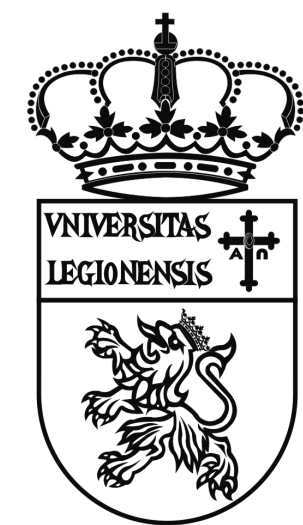

Universidad de León

Facultad de Filosofía y Letras

Departamento de Patrimonio Artístico y Documental

\title{
EL SUSTRATO DE LA ANTIGÜEDAD "CLÁSICA" EN LA ESCULTURA ROMÁNICA HISPANA Tesis Doctoral
}

\author{
JOSÉ ALBERTO MORÁIS MORÁN \\ Bajo la dirección de la Prof. Dra. E. Fernández González
}

León, 2009 



\title{
El sustrato de la ANTIGÜedad "Clásica" en la ESCULTURA ROMÁNICA HISPANA
}

\author{
ÍNDICE
}

1. INTRODUCCIÓN

2. ASPECTOS METODOLÓGICOS 1

2. 1. JUSTIFICACIÓN DEL TEMA......................................................................... 1

2. 2. EL MARCO CRONOLÓGICO .......................................................................... 7

2. 3. LÍMITES GEOGRÁFICOS .................................................................................. 9

2. 4. ASPECTOS METODOLÓGICOS ................................................................... 11

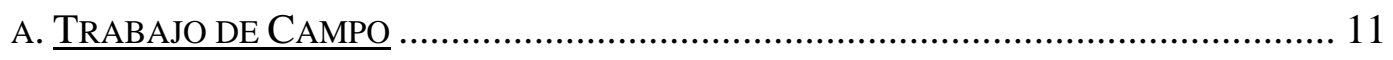

B. TRABAJO DE ARCHIVOS Y BIBLIOTECAS............................................................ 19

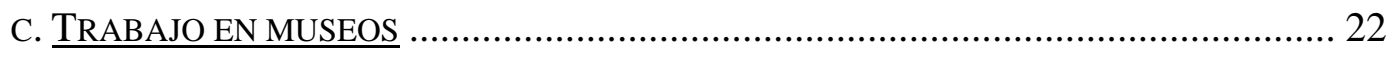

D. ESTANCIAS DE FORMACIÓN EN CENTROS ESPECIALIZADOS Y ASISTENCIA A

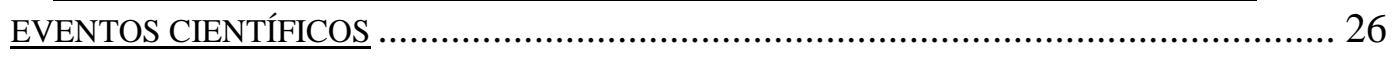

E. TRABAJO DE GABINETE ............................................................................ 33

\section{BLOQUE I}

1. 1. HACIA UNA "ARQUEOLOGÍA" DE LO CLÁSICO A TRAVÉS DE LA “MEMORIA" DE LA ANTIGÜEDAD. A MODO DE INTRODUCCIÓN

1. 2. LOS "RENACIMIENTOS” EN EL ARTE MEDIEVAL A TRAVÉS DE UN BALANCE HISTORIOGRÁFICO. 


\section{3. INFLUENCIA, IMITACIÓN, COPIA Y ARQUETIPO:}

A PROPÓSITO DE LAS RELACIONES ENTRE EL ARTE ANTIGUO Y

MEDIEVAL

1. 4. LA CONCIENCIA DE LA ANTIGÜEDAD EN LA EDAD MEDIA 89

A. LA "VOLUNTAD DE CONTINUIDAD" Y EL TRÁNSITO DE LA ANTIGÜEDAD TARDÍA A LA ALTA EDAD MEDIA. El ARTE "SUBANTIGUO" Y EL "PRERROMÁNICO”: PROBLEMÁTICA DE SUS NOMENCLATURAS

B. LOS “RENACIMIENTOS” DESDE EL ARTE ANTIGUO AL ARTE MEDIEVAL 100

1. CuAndo lo clásico gRIEGo es la ANTIGÜEDAD CLÁSICA PARA RoMA ...... 105

2. CONTINUDAD DEL PASADO GRIEGO EN LOS INICIOS DE LA EDAD MEDIA:

EL “RENACIMIENTO GRIEGO” DEL SIGLO V …............................................... 113

3. EL "RENACIMIENTO SIXTINO" .................................................................. 118

4. EL "RENACIMIENTO” CAROLINGIO ............................................................. 122

5. EL "RENACIMIENTO" OTONIANO .......................................................... 143

6. EL "RENACIMIENTO PALEOCRISTIANO": ROMA, MONTECASSINO Y CLUNY

BAJO LOS EFECTOS DEL ARTE CLÁSICO .......................................................... 164

C. ROMA, LA IDEA DE ROMA Y SU LEGADO DURANTE LA EDAD MEDIA ................. 192

1. LA IMAGEN DEL ORBE ANTIGUO Y SU PASO A LA EDAD MEDIA.

2. DE LA CIVITAS ANTIGUA A LA CIVITAS DEI: REUTILIZACIÓN CONCEPTUAL

E ICONOGRÁFICA

3. LA IMAGEN DE LA ROMA ANTIGUA A TRAVÉS DE LA MIRADA DE LOS

HOMBRES MEDIEVALES.

4. LA IMAGEN DE LA HISPANIA ANTIGUA EN LA EDAD MEDIA

2. 1. EL SPOLIUM IN SE Y LOS VALORES DE LA APROPIACIÓN DE MATERIALES ANTIGUOS. EL PRINCIPIO DE AUTORICTAS, LA VARIETAS Y LA VENUSTAS

2. 2. EL TRANSPORTE DE MATERIALES ANTIGUOS 286

2. 3. LA EXPOLIACIÓN DE SARCÓFAGOS ROMANOS EN LA HISPANIA MEDIEVAL

A. EL PRAETIOSO MARMORE Y SU EXPOLIACIÓN: A PROPÓSITO DEL SARCÓFAGO DE ITHACIO DE OVIEDO.....

B. DIGNIFICAR LA MEMORIA DE LOS DIFUNTOS: LOS SEPULCROS EXPOLIADOS POR FERNÁN GONZÁLEZ Y DOÑA SANCHA EN COVARRUBIAS. 
C. LA DIFUSIÓN DE LOS REPERTORIOS ORNAMENTALES. EL "ESCAMADO" AQUITANO Y EL SARCÓFAGO DEL CONDE SANTO

D. LA EXPOLIACIÓN DE SARCÓFAGOS DE FRISO HISTORIADO Y LA ADMIRACIÓN

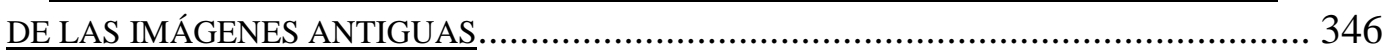

2. 4. ALGUNAS NOCIONES SOBRE EL SPOLIUM IN RE ........................... 368

3. EL ACANTO ROMANO Y EL CAPITEL CORINTIO. LOS

TRASPASOS DE UN ORDEN ROMANO A LA EDAD MEDIA 383

3. 1. LA PERVIVENCIA DEL CAPITEL CORINTIO EN LA ESCULTURA MEDIEVAL (siglos VIII-XII) .......................................................... 384

3. 2. PARA UNA "POÉTICA VEGETALIZADA" DEL ACANTO CLÁSICO DURANTE EL MEDIEVO.

3. 3. EL CAPITEL FIGURADO ROMÁNICO, UNA TIPOLOGÍA DE LA ESCULTURA ROMANA

\section{BLOQUE II}

1. RECUERDOS "CLÁSICOS" EN LA ESCULTURA ROMÁNICA HISPANA. A MODO DE INTRODUCCIÓN. 451

1. 1. SOBRE LA IMPORTANCIA DE LOS SARCÓFAGOS ANTIGUOS

EN LA FORMACIÓN DEL NUEVO LENGUAJE ESCULTÓRICO

1. 2. REFLEXIONES SOBRE LA FORTUNA DE ALGUNOS MONUMENTOS SEPULCRALES Y SARCÓFAGOS ANTIGUOS EN LA ICONOGRAFÍA MEDIEVAL

1. 3. LA ANÁSTASIS DE JERUSALÉN Y LA CRISTIANIZACIÓN DE LOS MONUMENTOS FUNERARIOS ANTIGUOS.

1. 4. EL EDÍCULO SOBRE LA TUMBA DE CRISTO Y SUS

FILIACIONES “ANTIQUIZANTES"

1. 5. LA IMAGEN DEL SANTO SEPULCRO EN LA EDAD MEDIA 494 


\section{EL SUSTRATO DE LA ANTIGÜEDAD CLÁSICA EN LA}

2. 1. UN CASO PARADIGMÁTICO DE INFLUENCIA DE LA ANTIGÜEDAD ROMANA SOBRE LA ESCULTURA ROMÁNICA: EL SARCÓFAGO DE HUSILLOS.

A. EL SARCÓFAGO ROMANO

B. DEL SARCófago ROMANO AL CAPITEL ROMÁNICO dE SAN MARTín DE FRÓMISTA

2. 2. EL SARCÓFAGO DE HUSILLOS Y SU LUGAR DENTRO DE LA ESCULTURA ROMÁNICA HISPANA

A. EL PROBLEMA DE LA PERSONALIDAD DEL ARTISTA Y EL “ATRIBUCIONISMO” .. 533

B. IMAGEN, ESCULTURA Y PÚBLICO: A PROPÓSITO DEL CAPITEL DE SAN

MARTÍN DE FRÓMISTA .

3. MOTIVOS CLÁSICOS EN LA ESCULTURA DE LA

CATEDRAL DE JACA Y SU ASIMILACIÓN EN EL ROMÁNICO ESPAÑOL (EL ÚLTIMO CUARTO DEL SIGLO XI Y LA PRIMERA MITAD DEL SIGLO XII)..

3. 1. INTRODUCCIÓN. ASPECTOS BIBLIOGRÁFICOS Y METODOLÓGICOS

3. 2. REPERTORIOS ORNAMENTALES E ICONOGRÁFICOS: TRASPASOS DEL ARTE ROMANO AL ROMÁNICO EN LA CATEDRAL DE JACA.

A. EL CAPITEL DE LOS DANZANTES Y LOS TOCADORES DE DOBLE AULOS

B. LA SERPIENTE: UN TEMA RECURRENTE DE LA ANTIGÜEDAD EN LA ESCULTURA ROMÁNICA HISPANA. EL EJEMPLO DE LA CATEDRAL DE JACA

C. MÁSCARAS Y PRÓTOMOS CEFÁLICOS: ENTRE LA TRADICIÓN SIMBÓLICA ANTIGUA Y EL DECORATIVISMO DEL ROMÁNICO......

D. LA CONCEPCIÓN DEL CUERPO. EL USO DEL DESNUDO Y LOS TEXTILES EN LA ESCULTURA JAQUESA.... 
F. MODELOS CLÁSICOS PARA LA ESCULTURA DEL ÁBSIDE SUR Y LA

REINTERPRETACIÓN DE LA ESCULTURA ARQUITECTÓNICA TARDOANTIGUA 668

G. EL TÍMPANO OCCIDENTAL Y LA ANTIGÜEDAD ROMANA TARDÍA 677

\section{ENTRE LA ASIMILACIÓN, LA REINTERPRETACIÓN Y LA DISOLUCIÓN DE LA CORRIENTE CLÁSICA JAQUESA. LOS TALLERES DE SANTIAGO DE COMPOSTELA Y SAN ISIDORO DE LEÓN (1075- 1147).}

\section{1. INTRODUCCIÓN. ASPECTOS BIBLIOGRÁFICOS Y} METODOLÓGICOS.

4. 2. REPERTORIOS ORNAMENTALES E ICONOGRÁFICOS EN LA CATEDRAL DE SANTIAGO DE COMPOSTELA

A. LA LLEGADA DEL “ESTILO FRÓMISTA-JACA” AL TALLER COMPOSTELANO........ 704

B. LA FACHADA DE LAS PLATERÍAS Y LA PUERTA FRANCIGENA: DEUDAS CON LO ANTIGUO

C. ROMA, UN MODELO DE PRESTIGIO

1. El PARADISUS DE LA CATEDRAL COMPOSTELANA Y LA ANTIGÜEDAD

2. LA COLUMNA HELICOIDAL EN LA CATEDRAL DE SANTIAGO

4. 3. OTROS ASPECTOS CLÁSICOS DE LOS ESCULTORES DE SANTIAGO DE COMPOSTELA

A. LOS ELEMENTOS TEXTILES EN ÁMBITOS ACUÁTICOS: UN PROBLEMA ICONOGRÁFICO SIN RESOLVER.

B. LAS MÁSCARAS Y LOS ROSTROS DE TRADICIÓN ANTIGUA: ALGUNAS HIPÓTESIS A PROPÓSITO DE LA “MUJER DEL CRÁNEO” Y LA NUMISMÁTICA.

C. EL PRECIOSISMO DE LOS TRABAJOS ESCULPIDOS INFLUENCIADOS POR LA PLÁSTICA ROMANA: LOS EJEMPLOS DE LOS NIMBOS Y “ESCAMADOS” DE ALGUNOS RELIEVES COMPOSTELANOS..

D. EL PROBLEMA DE LA ASIMILACIÓN DE LO CLÁSICO EN LOS TALLERES COMPOSTELANOS

4. 4. DIFUSIÓN Y DISOLUCIÓN DE LOS ELEMENTOS CLÁSICOS EN LA ESCULTURA ROMÁNICA HISPANA HASTA LA MITAD DEL SIGLO XII: EL EJEMPLO DE SAN ISIDORO DE LEÓN Y SUS ÁREAS DE IRRADIACIÓN 
A. ALGUNAS REFLEXIONES SOBRE LA DISPERSIÓN DE LOS MOTIVOS CLÁSICOS EN LAS PRODUCCIONES ARTÍSTICAS DE LA REAL COLEGIATA DE SAN ISIDORO DE LEÓN.

B. MULTIPLICIDAD DE FUENTES CLÁSICAS E IMPOSIBILIDAD DE MODELOS ÚNICOS: A PROPÓSITO DE LA ICONOGRAFÍA DE LOS LICURGOS

\section{BLOQUE III}

\section{EN TORNO AL AÑO 1150. EL PROBLEMA CRONOLÓGICO Y LA SELECCIÓN DE LOS MONUMENTOS Y SUS VESTIGIOS}

2. LA OBRA DEL "MAESTRO" DE CABESTANY .851

2. 1. EL PROBLEMA DEL ARTISTA Y SUS FUENTES

2. 2. LOS VESTIGIOS DE LA ANTIGÜEDAD COMO FUENTE

MATERIAL (SPOLIUM IN SE)

2. 3. LOS VESTIGIOS DE LA ANTIGÜEDAD COMO FUENTE DE INSPIRACIÓN (SPOLIUM IN RE)

\section{BLOQUE IV}

1. LAS ÚLTIMAS DÉCADAS DEL SIGLO XII Y EL AÑO 1200: LOS CRITERIOS DE DELIMITACIÓN CRONOLÓGICA Y EL PROBLEMA TERMINOLÓGICO.

\section{EL SUSTRATO CLÁSICO DE LA ESCULTURA}

TARDORROMÁNICA (1160-1200)

2. 1. INTRODUCCIÓN

A. LAS APORTACIONES DE LA ISLA DE FRANCIA Y EL TRASPASO DE FÓRMULAS ANTIGUAS. EL EJEMPLO DE LAS ESTATUAS COLUMNAS 
B. EL PROBLEMA DEL LLAMADO “ESTILO 1200”, TRAZADO DE UN PANORAMA GENERAL

1. EL “ARTE 1200” Y SUS PROBLEMAS. UNA SÍNTESIS INTRODUCTORIA .......... 920

2. EL PAPEL DE LO “CLÁSICO” EN LA FORMACIÓN DEL “ESTILO 1200”.............. 925

3. LA DIFUSIÓN DE FÓRMULAS CLÁSICAS EN TORNO AL AÑO 1200.

DEL ÁMBITO EUROPEO AL CASO HISPANO........................................................ 930

C. EL PROBLEMA DEL “ESTILO 1200” Y LAS ARTES HISPANAS ….......................... 950

D. EL “ARTE 1200” Y LA ESCULTURA MONUMENTAL. PARTICULARIDADES DE LA PENÍNSULA IBÉRICA EN LOS PROCESOS DE ASIMILACIÓN DEL SUSTRATO CLÁSICO

\section{BLOQUE V}

\section{BLOQUE VI}

\section{APÉNDICES}

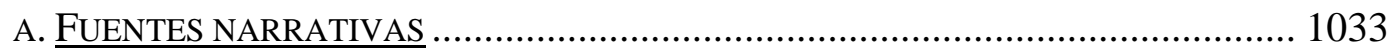

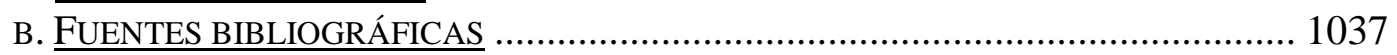

1. 3. APÉNDICE FOTOGRÁFICO _........................................................... 1159

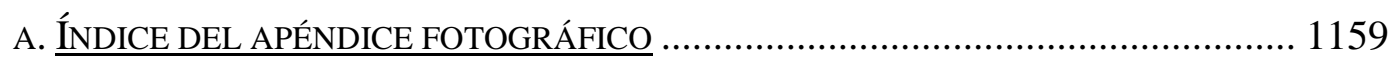

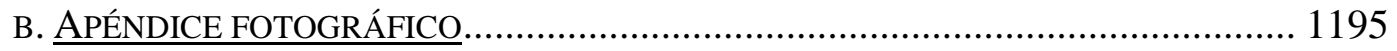




\section{BLOQUE VII}

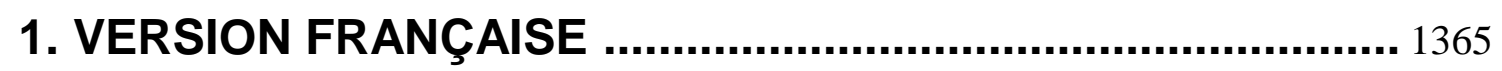

1. 1. TABLE DES MATIÈRES............................................................................ 1365

1. 2. RÉSUMÉ .......................................................................................................... 1373

1. 3. CONCLUSIONS .................................................................................................. 1381

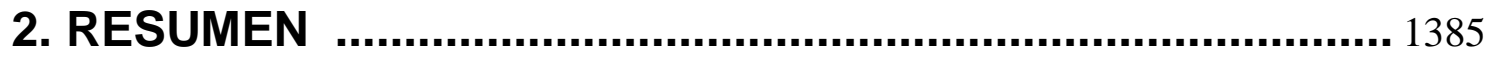




\section{INTRODUCCIÓN.}

En el apartado con el que iniciamos esta exposición, resulta obligado plantear una introducción dedicada a los aspectos generales previos, necesarios para encuadrar nuestra investigación. En este sentido se abordarán aquellas cuestiones relativas a la justificación del tema y al título con el que se define nuestro trabajo, el marco cronológico y los límites geográficos a los que se circunscribe y, sobre todo, aquellos aspectos relacionados con la metodología utilizada para su elaboración.

\section{ASPECTOS METODOLÓGICOS.}

\section{1. JUSTIFICACIÓN DEL TEMA.}

El estudio que ahora presentamos y que sometemos a su consideración para obtener el grado de Doctor se titula El sustrato de la Antigüedad "clásica" en la escultura románica hispana. La importancia de las fuentes antiguas a la hora de explicar algunos de los aspectos más importantes del arte románico, fue un tema tratado por los estudiosos de estas materias en multitud de ocasiones. Sin embargo, para el caso hispano en concreto, desde un primer momento se observó la inexistencia de un estudio global sobre el tema que ahondase en cuestiones más profundas y problemáticas.

Por lo que se refiere a todas aquellas aportaciones científicas que lo abordaron, mayoritariamente se trataba de menciones de carácter muy puntual, casi podríamos decir que aisladas, sin tener en cuenta el fenómeno desde la óptica en su contexto europeo.

Por estas razones nos pareció pertinente focalizar nuestras investigaciones hacia la recuperación, comprensión y transmisión de diversos recuerdos de la tradición antigua hacia el arte románico hispano, deteniéndonos, específicamente, en el estudio de los trabajos escultóricos contextualizados dentro de tal movimiento artístico.

Con la elección de este tema se pretendió, desde el primer momento, contribuir al conocimiento de un fenómeno extremadamente interesante dentro de la Historia del Arte Medieval, valorando todas aquellas aportaciones realizadas hasta la fecha y aportando nuevas vías de análisis que, evidentemente, se presentan como un conjunto de pensamientos abiertos a la reflexión, susceptibles de variar desde su génesis más profunda. 
Bajo estas premisas, el objetivo primordial que plantea nuestra Tesis Doctoral es el estudio del fenómeno de recuperación e influencia de la tradición "antiquizante" dentro de los siglos del románico; teniendo siempre como principal meta su contextualización dentro de un fenómeno tan global, como el marco geográfico donde se desarrolló.

La perdurabilidad de las tradiciones plásticas del pasado antiguo ofreció una base rica y prolija sobre la que asentaron las posteriores producciones plásticas cristianas.

Este SUSTRATO antiguo, como es obvio, se presentaba bajo múltiples formas. Así, parece indiscutible que todas las civilizaciones desarrolladas posteriormente a los siglos de la Antigüedad, tanto en Oriente como en Occidente, fueron deudoras de las tradiciones antiguas. Nadie duda de las repercusiones que sobre estos pueblos y territorios tendrían, por ejemplo, las producciones artísticas de tradición mesopotámica, egipcia, griega o romana, fundamentales para poder explicar la futura morfología de determinadas creaciones humanas, ya en época cristiana.

Resulta imposible afrontar todas cuestiones en un estudio de estas características, por lo que, desde un punto de vista metodológico, era necesaria una precisa acotación de todos estos aspectos.

En relación con ello, a propósito de la expresión "el sustrato de la Antigüedad clásica" que se utilizó para definir nuestra investigación, se partió de la base que defendía la importancia de un determinado resabio clasicista nacido en el seno de las culturas antiguas y que, posteriormente, fue transmitido al arte ulterior.

Sin embargo, el término "CLÁSICO” presenta unas connotaciones demasiado complejas por lo que fue necesario valorarlo y acotar su significado ${ }^{1}$. Según estos aspectos e intentando concretar el campo de trabajo, nuestro estudio se centra, preferentemente, en las producciones romanas de resabios "clásicos" y la influencia que posiblemente ejercieron sobre la escultura románica.

\footnotetext{
${ }^{1}$ En el epígrafe que titula nuestro estudio hemos optado por entrecomillar tal vocablo para dejar claro que somos absolutamente conscientes de la problemática conceptual que se esconde bajo este calificativo, utilizado, frecuentemente, como un término ambiguo, poco definido y abierto a todo tipo de reflexiones. A lo largo de las siguientes páginas valoraremos su problemática, intentaremos acotar el significado que nosotros le hemos otorgado para realizar nuestra investigación y, finalmente, se explicarán aquellos rasgos "clásicos" que hemos detectado dentro del arte románico de los reinos hispanos. Posteriormente, acotaremos los diferentes tipos de clasicismos localizados, sin embargo, desde el principio nos pareció prácticamente imposible encontrar un término conciso que formase parte del título de la Tesis Doctoral. Finalmente nos decantamos por el vocablo "clásico", a sabiendas de los problemas que dicha elección podía esconder, pero que se intentarán resolver a lo largo de los próximos capítulos.
} 
Todos los rasgos que contribuyen al desarrollo de un pueblo como civilización, y entre ellos incluimos, evidentemente, sus producciones plásticas, ofrecieron en su desarrollo un momento de máximo apogeo que, generalmente, suele coincidir con lo que los expertos definen como "periodo clásico" de su arte. Ante la imposibilidad de abordar todas las etapas "clásicas" del devenir de las formas artísticas realizadas en el transcurrir de los largos siglos de la Antigüedad, nos centramos en un periodo en concreto.

En la Tesis Doctoral, el sustrato de la Antigüedad "clásica" se refiere al periodo artístico desarrollado en el seno de la cultura romana de la órbita occidental. Todos conocemos que, antes que en Roma, las culturas orientales y la misma Grecia habían vivido sus etapas "clásicas" en la evolución de sus artes.

Aquí se analizarán aquellos aspectos del arte "clásico" desarrollados en el seno de la cultura romana y que los especialistas han encuadrado desde los últimos siglos de la República romana (siglos III y II a. C.), las centurias en las que se localiza el progreso pleno del Imperio y, finalmente, los últimos balbuceos de la tradición romana pagana en torno a los siglos III y IV d. de $\mathrm{C}^{2}$.

Las obras de tradición "clásica" realizadas en este arco temporal de casi siete siglos, serán las que focalicen nuestra atención en el transcurso del estudio. A pesar de ello, tales aspectos no son óbice para aludir, cuando fuese necesario, a otros ejemplos tomados de las culturas mesopotámicas y egipcias, así como los datados, por ejemplo, en época helenística.

En relación con lo afirmado, parece más que posible que ese "clasicismo" de tradición griega, reinterpretado ya por la plástica engendrada en el seno del periodo imperial pasó, evolucionado, al arte de la última etapa del Imperio romano ${ }^{3}$. Nos referimos al complejo arco temporal que los expertos han definido con la difícil

\footnotetext{
${ }^{2}$ Evidentemente aquí estamos adoptando la división tradicional que los expertos han ofrecido del desarrollo histórico, político y artístico de la civilización romana y, concretamente, aquellos momentos de mayor "clasicismo" que alcanzaron las artes a lo largo de las diferentes etapas de la historia romana. Cf.: I. MORENO, "El tiempo como categoría histórica: la periodización y las Edades de Roma", Minerva, 15, 2001, pp. 175-188 y J. M. VICENT GARCÍA y M. I. MARTÍNEZ NAVARRETE, "La periodización: un análisis histórico-crítico", Homenaje al prof. Martín Almagro Basch, vol. 4, 1983, pp. 343-352. Todos los aspectos relacionados metodológicamente con las cuestiones cronológicas se abordan en un apartado específico de esta introducción. Los que en estos momentos mencionamos corresponden, tan sólo, a las necesidades de justificación del título de nuestra Tesis Doctoral.

${ }^{3}$ Omitimos aquí la cita de las obras científicas que hemos consultado, pues en las páginas siguientes podrán encontrarse todas estas reflexiones más ampliadas. No obstante, véase: C. GARCÍA GUAL, "Roma y la herencia de la cultura griega", Roma. Senatus Populus Que Romanus, Madrid, 2007 pp. $363-$ 371 y J. ARCE MARTÍNEZ, "La "crisis" del siglo III d. C. en Hispania y las invasiones bárbaras", Hispania antiqua, 8, 1978, pp. 257-270.
} 
expresión de "arte de la Antigüedad tardía". Una nomenclatura problemática, y que también será abordada en su apartado correspondiente ${ }^{4}$.

Los último siglos de producción artística que comprenden la etapa final del mundo antiguo y el inicio de la era cristiana, representan uno de los momentos más ricos dentro de la Historia del Arte y es allí donde se localizan muchas de las obras más importantes, a la hora de explicar ciertos rasgos "clásicos" del arte medieval.

Advertimos entonces que la noción de arte "clásico" se utilizará teniendo en cuenta sus múltiples matices, sus dependencias con respecto a las artes de etapas anteriores y prestando especial atención a que, ese sustrato "clásico" de la etapa imperial romana, también fue traspasado, con formas diversas, a las artes tardoantiguas. El siguiente paso sería su absorción por parte de los artífices cristianos y su transmisión al arte medieval.

Una vez justificado parte del título que da nombre a nuestro estudio, hacemos notar que, centrándonos ahora en la época medieval, nuestra investigación se circunscribe al periodo cronológico en el que se desenvolvió el arte románico. Nuevamente los convencionalismos academicistas y la necesidad de utilizar un método de trabajo fiable nos llevaron a buscar una concreción dentro de los largos siglos del Medievo.

La dificultad de definir una periodización exacta y consecuente con la realidad histórica, así como la necesidad de utilizar una terminología lo más fiel posible a estos preceptos, fue la norma dominante a lo largo del estudio. Los problemas de los investigadores a la hora de concretar el marco temporal y delimitador del fin del mundo antiguo y la llegada del cristianismo; se repiten, nuevamente, en el momento de datar cronológicamente los siglos y años concretos en los que se gestaron las primeras formas de lo que, tradicionalmente, solemos conocer arte románico.

Al estudiar el sustrato "clásico" de la escultura ROMÁNICA, utilizamos nuevamente el consabido tópico cronológico, según el cual, el movimiento se desarrolló en los reinos hispanos, durante los siglos XI y XII.

Siguiendo una metodología idéntica a la aplicada para el periodo antiguo, los problemas surgidos a la hora de acotar el campo de actuación durante la época románica también son similares.

\footnotetext{
${ }^{4}$ Todas las nociones y expresiones derivadas de la aplicación de un método basado en la Teoría de los Estilos serán valorados a lo largo del estudio en su momento oportuno.
} 
Teniendo en cuenta la complejidad de acordar una fecha concreta sobre la que definir el inicio o la introducción de las primeras formas románicas en Hispania, resultó obligado acudir a las artes desarrolladas en estos territorios durantes los siglos IV al X. Dicho periodo, definido durante largo tiempo bajo la conflictiva expresión de "arte prerrománico", ofreció clarificadores ejemplos que poner en relación con la recuperación del legado “clásico” que parecía mostrar la escultura románica 5 .

Si con cierta unanimidad se consideraron los siglos XI y XII como referentes temporales en los que ubicar el desarrollo de las soluciones románicas, para definir las etapas finales de nuestro estudio volvimos a considerar la arquetípica y problemática, fecha del año 1200, por ser aquella en la que muchos especialistas vieron la posibilidad de, mediante ella, advertir la introducción de las nuevas formas góticas.

Todos somos conscientes del carácter convencional, así como artificial y sin justificaciones especiales dentro de la realidad artística hispana, que posee el año $1200^{6}$. Sin embargo son numerosos los expertos que suelen considerar, de manera práctica, este año como el punto y final de las experiencias románicas, aún conociendo plenamente la inercialidad de esta "estética del románico", en la que, soluciones, fórmulas y características de este movimiento, perduraron hasta bien entrado el siglo XIII. Aunque tal fenómeno se localice, más concretamente, en las zonas relativamente marginadas con respecto a los grandes centros innovadores en la asimilación de novedades artísticas.

Finalmente, el estudio del sustrato "clásico" de la escultura románica plantea la necesidad de acotar, una vez más, el ámbito de trabajo, una vez definido el marco cronológico. Resultaría inabarcable y, quizás, incomprensible, plantear un panorama general de la asimilación de los resabios "antiquizantes" dentro del arte románico en cualquiera de sus manifestaciones técnicas.

Siguiendo con esta necesidad de demarcación, obligatoria en todo tipo de estudios con estas características, centramos nuestra atención en las producciones escultóricas de carácter monumental. Desde un primer momento, pensamos que esta elección podía aportar mayor concreción a nuestras afirmaciones y ser más favorable a la hora de trazar un panorama más claro y verídico del desarrollo de este fenómeno.

\footnotetext{
${ }^{5}$ Nuevamente señalamos la crítica que se ha realizado al término "prerrománico". Sobre ello volveremos en las páginas posteriores. Cf.: I. G. BANGO TORVISO, "La tradición (Prerrománico)", Sancho el Mayor y sus herederos. El linaje que europeizó los reinos hispanos, 2 vols., Pamplona, 2006, vol. II, pp. 586-587.

${ }^{6}$ Para las cuestiones relativas al "estilo 1200" y las diversas corrientes historiográficas que lo valoraron, véase el apartado correspondiente del trabajo.
} 
El hecho de que nuestro trabajo tenga como objeto de estudio las producciones esculpidas no implicó, bajo ningún concepto, el olvido o la omisión de las restantes técnicas utilizadas por los artífices románicos. Así, se acudió, continuamente, a la orfebrería y a la escultura en materiales suntuosos. Igualmente, se tuvieron en cuenta la pintura mural y la ilustración del libro, todas ellas básicas para buscar los referentes en los que basar nuestras hipótesis, pero siempre tomando el desarrollo de la escultura románica como hilo conductor para todas nuestras reflexiones. 


\section{2. EL MARCO CRONOLÓGICO.}

En el apartado anterior adelantábamos, en el momento de explicar y justificar el título del estudio, determinadas cuestiones derivadas de la delimitación cronológica del mismo.

El establecimiento de unos límites concretos para fijar el momento de inicio y de finalización de un periodo artístico siempre es problemático.

Tradicionalmente han surgido graves problemas a la hora de deslindar y someter a las estrictas reglas de una periodización derivada de la aplicación de una metodología historicista, los postulados más propios de la Historia del Arte.

La comunidad científica parece estar de acuerdo en que, tanto la evolución de las fórmulas arquitectónicas como otra serie de manifestaciones plásticas románicas, no pueden acotarse mediante compartimentos estancos ni definidos mediante una circunscripción a un año determinado. Teniendo en cuenta estos factores, el desarrollo de nuestro estudio tendrá que enfrentarse a las etapas evolutivas, de transición o los periodos de adaptación, mediante los cuales, los diferentes territorios se fueron familiarizando con las novedades que afectaron a los lenguajes artísticos.

Con todo, un trabajo de las características como el que presentamos, se debe regir por un condicionamiento metodológico en el que parece obligado marcar una serie de hitos cronológicos a los que ceñir el inicio y finalización de nuestras reflexiones. Así, las delimitaciones cronológicas que rigen nuestra investigación no deben juzgarse bajo la óptica de un sistema rígido e inamovible.

Sin redundar en lo que ya hemos afirmado, el punto de partida para el análisis y valoración del arte antiguo toma con referencia la cronología, a veces variable, que los expertos han propuesto para diversas producciones plásticas datadas entre los siglos $\mathrm{V}$ y IV a. de C., sin que ello suponga la imposibilidad de aludir a otras anteriores, cuando ello fue necesario ${ }^{7}$.

En relación con el periodo antiguo $\mathrm{y}$, sobre todo, teniendo en cuenta la importancia que otorgamos al arte romano, cobrarán una importancia vital las obras de este momento, sobre todo dentro del arco temporal que comprende la etapa clásica del arte imperial hasta las producciones tardoantiguas, estimablemente datadas en su etapa

\footnotetext{
${ }^{7}$ Recordemos que, tradicionalmente, la República Romana se viene datando entre los años 509 a. C. y 31 a. C., el Principado abarcaría los años 31 a. C. al 284 d. C. y, finalmente, el Dominado acogería las fechas que van desde el 284 d. C. al 476 d. C., arco temporal de la Tetrarquía y la época constantiniana.
} 
final en torno al siglo IV de nuestra era, aproximadamente. Evidentemente, a pesar de que estas obras presentan, en ocasiones, lenguajes alejados de las fórmulas clásicas, en otras tantas, conservaron el ideario de las etapas anteriores y convirtieron estas tendencias clasicistas en una de las características esenciales de este tipo de manifestaciones.

El mismo razonamiento utilizamos para la acotación cronológica del periodo románico, tal y como ya se ha advertido.

Desde la célebre barrera temporal del año mil, hasta los últimos años del siglo XII, el ámbito hispano sufrió la implantación de la nueva corriente estética definidora de lo que llamamos románico.

Las primeras experiencias artísticas, introducidas lentamente a lo largo de todo el siglo XI, culminan en un desarrollo pleno que finaliza y se disuelve una vez traspasado el año 1200. No en vano, esta es la fecha que tomamos como referencia para la finalización del estudio, sin que este hecho signifique una ruptura total con las experiencias anteriores ante la difusión de los lenguajes definidos como góticos, ni que ello deba entenderse como una barrera cronológica indiscutible y rupturista. 


\section{3. LÍMITES GEOGRÁFICOS.}

En el momento de especificar los límites geográficos en los que encuadrar nuestro estudio, se optó por situarlo en el ámbito hispano. La movilidad de las fronteras propiciada por los cambios históricos, la mutabilidad de las demarcaciones administrativas de la España actual con respecto a las que vivieron estos territorios desde la Antigüedad hasta la época románica, complicaron esta tarea delimitadora.

Fruto de estos factores, resulta imposible establecer una limitación inequívoca, agudizada aún más, por la diversa e invariable implantación de las formas románicas en los diversos espacios que configuraron los territorios hispanos.

El hecho de que la división territorial de la Hispania romana sufriese cambios durante los siglos de la Alta y Plena Edad Media no es un tema menor. Su problemática se agudiza en casos como los de la Provincia de Lusitania y la zona oriental hispana, concretamente, en el Reino de Aragón y la Marca Hispana. Todas estas regiones poseen unas características especiales en cuanto a su relación con los restantes reinos hispanos, así como con el ámbito europeo. Sin duda se trata de aspectos fundamentales que acabaron por afectar a las manifestaciones artísticas.

Por todo ello no se siguió un criterio histórico cerrado que intentase definir las artes del periodo. De esta forma, por ejemplo, para el caso luso se acudió cada vez que fue necesario a todas aquellas producciones que ayudasen a explicar las características de la escultura románica y su enriquecimiento con las formas "clásicas" antiguas. En este sentido se prestó especial atención al área norte y las regiones del Duero, por su mayor riqueza en cuento a la cantidad de monumentos datados en época románica que se conservaron. Ello, sin olvidar tampoco, las regiones centrales y del sur, más ricas en obras romanas y tardoantiguas.

En el caso de la Marca Hispánica y las zonas catalanas, se aplicaron los mismos argumentos, sobre todo, tiendo en cuenta la importancia de estas áreas en relación con la recuperación del legado "clásico", desde el siglo X hasta la etapa final del siglo XII.

Finalmente, somos absolutamente conscientes de que esta demarcación presenta tantos inconvenientes como puntos a favor.

La acotación del tema ceñido al basto territorio hispano podría parecer, a priori, un criterio negativo a la hora de emprender nuestras labores investigadoras. Esta amplitud podía acabar generando un campo de estudio un tanto indefinido, inabarcable y generalista. Sin embargo, pensamos que un tema como el que aquí vamos a tratar, no 
tendría sentido limitándolo a un territorio o demarcación política de pequeña entidad. A ello tenemos que sumar que el fenómeno de la romanización fue completamente desigual en todos los territorios que configuraban la Hispania antigua e, igualmente, que no todas las regiones presentaron soluciones románicas de la misma índole, de igual desarrollo y evolución. Estos mismos parámetros han de tenerse en cuenta a la hora de valorar la asimilación de fórmulas "clásicas" dentro de la plástica medieval. Este carácter desigual en todos sus aspectos, pugnaba por acotación dilatada que permitiese obtener una visión completa y global del fenómeno.

Pensamos que el examen específico de esta tendencia recuperadora de lo "antiquizante" a través de un conocimiento global del territorio, ofrece mayores facilidades para definir los centros más representativos de esta tendencia y aquellos en los que la perdurabilidad de los valores "clásicos" se confundió con un simple traspaso inercial de soluciones desde la Antigüedad.

Por el contrario, presentar una visión de este tema adscrita a un territorio en concreto, por ejemplo, una Provincia o una Comunidad Autónoma definidas por la jurisdicción actual, podría ofrecer una visión parcial y sesgada de un movimiento excesivamente complejo.

En el mejor de los casos, creemos que el amplio territorio seleccionado ofrecía la suficiente variabilidad regional como para establecer un panorama comparativo que delatase los diferentes grados con los que fue asimilada la tradición "clásica", atendiendo a su diversidad dependiendo de las heterogéneas áreas geográficas y los disímiles marcos cronológicos. 


\section{4. ASPECTOS METODOLÓGICOS.}

La Tesis Doctoral que presentamos se elaboró, si intentamos realizar una sucesión de estadios coherentes y sintéticos, a través de cinco etapas interrelacionadas. El presente apartado pretende poner de relieve la realización de una intensa labor de campo, una exhaustiva labor de consulta y valoración crítica de toda aquella información a la que tuvimos acceso en diferentes archivos y bibliotecas. La tarea fue enriquecida mediante la realización de cuatro Estancias de Investigación en diversos Centros Extranjeros especializados en los variados campos de la civilización y el arte medieval. Estas fases del desarrollo de nuestra investigación, se vieron acompañadas, desde el inicio, a través del enriquecimiento de nuestra formación mediante la asistencia y participación en importantes foros científicos. Finalmente se desarrolló la labor de gabinete.

\section{A. TRABAJO DE CAMPO.}

Para el desarrollo de la actividad investigadora, resultó de gran importancia la visita, para el estudio in situ, a muchos de los monumentos que, más tarde, configurarían el corpus de las obras sobre las que se basan nuestros análisis.

Este aspecto presentó muchos problemas elementales. El primero de ellos era la amplitud territorial sobre los que se basa nuestro trabajo. El área hispana presentaba un conjunto casi inabarcable de edificios susceptibles de ser tenidos en cuenta para los futuros análisis. Ante un número ilimitado de obras como el que posee el románico hispano de los siglos XI y XII, se hizo necesaria una selección de las obras, las técnicas y los centros artísticos objeto de estudio.

Este primer problema provocó que la labor de campo se extendiese por todo el territorio hispano y por todas aquellas provincias que presentasen producciones artísticas en las que, hipotéticamente, se pudiera intuir una influencia de las obras antiguas.

A ello se sumó otro tema complejo. Al tratarse de una investigación centrada en el movimiento románico, era obligatoria la contextualización y comparación de las obras hispanas que íbamos a estudiar, con respecto a las conservadas en el ámbito europeo. Pronto entendimos que era, absolutamente necesario, el conocimiento de este 
fenómeno de recuperación de lo "clásico" pero desde la óptica de su encuadre con respecto a lo que, contemporáneamente, se venía realizando en la Europa románica.

Ligado de manera tangencial a estas cuestiones relativas al desarrollo de las tareas de campo, destacamos un tercer problema. Al tratarse de un estudio fundamentado, desde un punto de vista metodológico, en las pervivencias y filiaciones del arte románico con respecto al de la Antigüedad, era fundamental conocer exhaustivamente y realizar su correspondiente labor de campo en todas aquellas regiones, tanto hispanas como europeas, donde la pervivencia y conservación de los monumentos y obras de este periodo antiguo fueran, lo suficientemente explicitas y claras, como para poder argumentar su posible influencia sobre los artífices medievales.

Por esta causa se realizaron diversas sesiones de trabajo de campo en todos aquellos lugares, tanto hispanos como foráneos, donde existiesen obras antiguas de especial relevancia.

Tal y como se puede observar, las sesiones de trabajo de campo se extendían ampliamente, tanto desde el punto de vista del contenido, como desde las áreas geográficas en las que actuar.

Con todo, se partió inicialmente del caso hispano, realizando la visita a los principales monumentos románicos. En principio pensamos que debíamos conocer profundamente el corpus de obras románicas con las que íbamos a trabajar para, en un segundo momento, poder realizar todas las comparaciones pertinentes con respecto al corpus de obras antiguas.

Se prestó especial atención a la decoración escultórica conservada en los principales edificios románicos o, en su defecto, aquella realizada para otros centros menos importantes, pero que pudieran presentar una dependencia con respecto a la tradición "clásica" encontraban, así como otra serie de producciones que, en principio, pudieran enriquecer nuestros objetivos. Así, paralelo al interés que mostramos por la escultura, también fueron objeto de nuestra atención otros soportes y técnicas, tales como el mosaico, la pintura mural y la ilustración de códices manuscritos y todas aquellas obras englobadas bajo la expresión de "artes suntuarias".

En esta fase del trabajo de campo, se localizaron aquellos lugares que, en un principio, pudieran resultar enriquecedores para iniciar el estudio. A ello se sumó, en

\footnotetext{
${ }^{8}$ Para las obras conservadas en los diferentes museos y colecciones hemos dedicado un apartado específico en esta introducción.
} 
este momento de la investigación, la consulta de una breve selección bibliográfica muy específica sobre nuestro tema. Este hecho nos permitió poder comenzar a señalar, sobre el mapa, los focos artísticos que los especialistas habían considerado fundamentales para comprender el fenómeno de la influencia del arte antiguo sobre el románico.

Una vez concretados los lugares de interés, tanto hispanos como foráneos, se realizaron diversos viajes a cada uno de ellos entre el arco temporal que comprendió los años 2003 hasta el 2009. A lo largo de todo este periodo se conocieron los edificios y su decoración artística de manera directa.

En un segundo momento, el trabajo de campo se desarrolló siempre siguiendo el mismo esquema metodológico que detallamos a continuación:

1. Durante la visita se inspeccionaron ocularmente todas aquellas esculturas que ornaban los edificios, prestando atención a la manera en que estaban realizadas, su volumen, las soluciones tomadas por los artífices en la concepción de las mismas y, con especial interés, su iconografía figurada. Lo mismo ocurrió con algunos aspectos que podían ofrecer noticias o datos que nos hiciesen comprender tales manifestaciones esculpidas. Nos referimos, por ejemplo, a la misma arquitectura que albergaba dichas piezas, además de otros elementos, como las inscripciones.

2. En gran parte de los edificios se tomaron las medidas pertinentes, siempre y cuando la ocasión lo permitió. Ocasionalmente, se hicieron dibujos precisos de las esculturas. Prácticamente para la mayor parte de las veces tales bocetos no tuvieron especial validez, sin embargo, a la hora de poder reconstruir partes desaparecidas de los edificios o esculturas muy deterioradas, éstos diseños cobraron especial relevancia.

3. Un nivel fundamental del trabajo de campo lo constituyó la creación de un completo corpus fotográfico de las obras a estudiar. Se recopiló dicho material intentando seleccionar un repertorio de los temas iconográficos, lo suficientemente amplio, como para ofrecer una base segura para el análisis. En el fotografiado de las obras, nos interesaron, especialmente, ciertos detalles de las esculturas, así como panorámicas generales que facilitasen, a posteriori, el trabajo de gabinete.

Una vez obtenido el material fotográfico, este pasaba a formar parte de un base de datos informatizada en la que cada una de ellas era identificada convenientemente, seleccionando sus datos desde lo particular a lo general, empezando por el país al que 
dichas obras pertenecían, para luego concretar la provincia, el templo en el que se hallaban y, por ultimo, su ubicación dentro del espacio eclesiástico.

4. Una vez que el trabajo de campo se desarrollaba coherentemente, se completó con otras acciones que enriquecieron nuestros resultados. Nos referimos, concretamente, a las labores de comparación entre diversos materiales gráficos y algunos edificios.

En muchas ocasiones contábamos con planos y fotos antiguas publicadas por los diferentes especialistas dentro de los primeros trabajos que abordaron tales monumentos, en los inicios de la historiografía. Para tal cometido, nos trasladamos a los diversos lugares con este amplio material y así se pudo comprobar, in situ, si las obras continuaban en un estado similar al que presentaron en el momento de ser fotografiadas. Además, mediante los grabados y las fotografías antiguas, se pudieron desarrollar diversas tareas comparativas entre la realidad material de los sitios que visitábamos y la que habían conocido estos primeros investigadores. Ello ofreció resultados sorprendentes.

5. En último lugar, las sesiones de trabajo de campo ofrecieron la oportunidad de acceder a materiales de gran relevancia. En los edificios visitados, de manera muy ocasional, se pudieron adquirir algunas aportaciones científicas de tipo bibliográfico, actualmente descatalogadas. En estos lugares tuvimos la posibilidad de consultar diversos libros, artículos y otra serie de aportaciones difícilmente localizables. En otras tantas, ello nos permitió adquirir algunos ejemplares "raros" y ediciones descatalogadas dedicadas a los monumentos que visitábamos.

El trabajo de campo no se llevó a cabo de una manera igualitaria por toda la geografía hispana. En principio, se partió de aquellos ejemplos localizados en los centros que los especialistas habían considerado relevantes y representantes del fenómeno de recuperación de lo "clásico". Así, y sin ánimo de ser exhaustivos, se realizaron las pertinentes labores de fotografiado en lugares dispuestos a lo largo del territorio ${ }^{9}$. Mencionamos la importancia de las tareas realizadas en el ámbito gallego, concretamente, en la catedral de Santiago de Compostela, la catedral de Lugo y la de Orense. Del mismo modo, el trabajo de campo se desarrolló en el área castellanoleonesa, tomando como referencia centros fundamentales para el estudio del fenómeno,

\footnotetext{
${ }^{9}$ Evidentemente, citamos solo aquellos ejemplos más importantes. La nómina que aquí mencionamos no pretende ser detallada.
} 
tales como la basílica de San Isidoro, la iglesia de San Esteban de Corullón -ambas en la Provincia de León-, la iglesia y el claustro del monasterio de Santo Domingo de Silos o el de San Pedro de Arlanza, en Burgos. En la misma tesitura, fueron primordiales las labores realizadas en la Provincia de Palencia, con el trabajo de campo en la iglesia de San Martín de Frómista, en el monasterio de San Zoilo de Carrión de los Condes o en la iglesia de Santiago, en la misma localidad.

La región asturiana también proporcionó, con frecuencia, numerosos ejemplos que aportarían fructíferas noticias para nuestras investigaciones. En el caso de la ciudad de Oviedo, fueron fundamentales las jornadas de trabajo en la catedral del Salvador y, especialmente, en la Cámara Santa, por citar los ejemplos más señeros.

En esta nómina que ofrecemos merecen ser destacadas las provincias de Navarra, Aragón y Huesca.

En tales áreas, resultaron de gran importancia los resultados obtenidos en la catedral de Pamplona, la de Tudela, el monasterio de Leyre, las iglesias de Torres del Río y Eunate, o las de Estella y Sangüesa.

En Aragón, debemos subrayar la visita al castillo de Loarre, el monasterio de San Juan de la Peña, la iglesia de Santa María de Santa Cruz de la Serós y, sobre todos ellos, la labor de campo desempeñada en la ciudad de Jaca, especialmente en la catedral de San Pedro y la iglesia de Santiago, ambas en la misma localidad.

Idénticos trabajos se realizaron en muchos de los núcleos artísticos más importantes de la región catalana. Resultaría imposible enumerar todos aquellos lugares en los que se trabajó a lo largo de los últimos años, sin embargo, no nos resistimos a señalar las sesiones realizadas en la ciudad de Barcelona, en y otros núcleos más lejanos, como los monasterios de San Miguel de Cuxa, San Martín del Canigó o San Pedro de Rodas. A esta nómina sumamos la visita a las localidades de Lérida, Gerona o Tarragona. Por último, destacamos la importancia del trabajo de campo realizado en el monasterio de Santa María de Ripoll.

Dentro del ámbito europeo ${ }^{10}$, a lo largo de todos estos años han sido innumerables todos los lugares en los que se desarrollan estas labores ${ }^{11}$.

\footnotetext{
${ }^{10}$ Por razones metodológicas se atendió, preferentemente, al ámbito europeo. Sin embargo, en las ocasiones en que fue necesario no se excluyó la alusión a otros territorios pertenecientes al Imperio Romano, pero alejados de las áreas europeas. En muchas ocasiones se analizaron ejemplos artísticos localizados en los territorios romanizados orientales, así como los pertenecientes a la zona norte africana.

${ }^{11}$ Para el desarrollo de estas tareas fue esencial la realización de cuatro Estancias de Investigación en diversos Centros Extranjeros. Véase el apartado correspondiente de esta introducción dedicado a estos aspectos.
} 
Por su conexión y cercanía con el ámbito hispano, la antigua Lusitania fue objeto fundamental para el trabajo de campo, entre los años 2003 y 2009. En Portugal, se desarrollaron enriquecedoras sesiones en la ciudad de Lisboa, así como en otras ciudades. En las áreas del norte se visitaron diversos templos de la región del Alto Duero, distribuidos a lo largo de ciudades como Oporto, Braga, Braganza o Vila Real. La zona sur, por presentar una mayor riqueza de restos romanos y de altomedievales, será abordada en las páginas posteriores.

También muy conectada con el desarrollo del románico hispano, Francia fue objetivo de cuantiosos viajes en los que desarrollar el trabajo de campo, entre los años 2003 y 2007. Mencionamos la importancia de las zonas mediterráneas, con la visita a focos de la categoría de Toulouse, Aix-en-Provence, Marseille, Nîmes o Arles.

Se trabajó con igual metodología en el monasterio de Saint-Pierre de Moissac y las regiones pirenaicas, visitando con especial atención el área administrativa del Languedoc-Roussillon. Nuestros objetivos también se localizaron en las regiones de Aquitania, el Midi-Pyrénées, Limousin y, especialmente, en las regiones del PoitouCharentes. Evidentemente, la visita a la ciudad de Paris fue obligada.

Por su importancia en relación con la perdurabilidad de las formas de tradición "clásica" romana, Italia también objetivo de nuestro trabajo de campo. Partiendo de la ciudad de Roma, se desarrollaron diversos viajes. Tan sólo mencionamos las jornadas realizadas durante algunos meses del año 2006 que nos llevaron a estudiar los enclaves románicos más significativos ubicados en las regiones del Lazio, Umbría, Liguria, Toscana, Emilia-Romagna, Abruzzo y Marche. En un segundo momento se acometió con el desarrollo de nuestras tareas en las regiones del sur, concretamente, en las regiones de Puglia, Basilicata, Campania y Sicilia. Ésta última fue sometida a nuestros análisis en la última etapa que cerraba este estudio, durante el verano del año 2009.

A esta lista sumamos otros lugares conocidos mediante viajes realizados en periodos cortos. Así destacamos la visita a Croacia, en la que se prestó especial cuidado en valorar los monumentos de la ciudad de Split y, en particular, el palacio de Diocleciano.

Por último, en el año 2009 se realizaron varias jornadas repartidas a lo largo de los territorios que configuran la actual Grecia. Se viajó a la isla de Creta, así como a las regiones que configuran el Egeo Meridional, con la visita de las islas de Samos y Delos. Se desarrolló una visita exhaustiva a los principales templos medievales de tradición 
bizantina de la ciudad de Atenas, con las pertinentes jornadas en las regiones del Ática y el Peloponeso.

La segunda fase del trabajo de campo, después de finalizar con las labores de estudio en torno a las producciones artísticas románicas, se centró en el arte antiguo.

Siguiendo el mismo método, antes descrito para el arte románico, se partió del conocimiento de aquellos monumentos localizados en suelo hispano para, más tarde, acudir a los conservados en las áreas europeas ${ }^{12}$.

En lo relativo a los principales conjuntos hispanos de cronología antigua, se realizaron las pertinentes labores en los lugares que consideramos más importantes. Si durante la primera fase del trabajo de campo nos centramos en el área norte de la Península Ibérica, por ser allí donde se localizaban el mayor número de monumentos románicos; en este segundo momento, se sumaron también las áreas del sur, muy ricas en vestigios antiguos.

En el norte, se realizó la visita pertinente a la antigua provincia de la Gallaecia, visitando lugares tan importantes como la ciudad de Lugo (Lucus Augusti) o la ya citada de Braga (Bracara Augusta). Cabe mencionar, por ejemplo, la exhaustiva jornada realizada en el monumento que hoy conocemos como Santa Eulalia de Bóveda (Lugo).

En la región asturiana, se visitaron diversos sitios arqueológicos, algunos de los más ricos ubicados en la ciudad de Gijón y sus proximidades.

El mismo método fue seguido para la inspección ocular y la aplicación de la metodología de campo en la ciudad de León (Legio VII Geminae) o los interesantes vestigios de Astorga (Asturica). La mención de los lugares en los que trabajamos, dentro del área que actualmente conforma la Comunidad Autónoma de Castilla y León sería demasiado densa. Baste con citar el viaje realizado a las villas romanas de La Olmeda de Palencia, la de Baños de Valdearados en Burgos o los restos de la antigua Clunia, englobada igualmente en la provincia de la Tarraconensis.

En este periplo, se tuvo en cuenta la variabilidad de las fronteras de la Hispania del momento y los continuos cambias de los límites de la Tarraconensis, una de las provincias romanas más extensas.

\footnotetext{
${ }^{12}$ Tal y como ocurría con los análisis del románico europeo, también a la hora de valorar el arte antiguo, desde un punto de vista metodológico, se tuvieron en cuenta preferentemente los conjuntos localizados en Europa. Sin embargo y como es lógico, en cada caso particular se acudió, cuando fue necesario, a otros monumentos ubicados en otros lugares fuera del contexto europeo. Este es el caso, por ejemplo, del arte romano producido en los territorios orientales o el importante corpus de obras conservadas en África.
} 
El hecho de que algunas áreas del territorio norte de la Península, incluida parte de la Gallaecia y las regiones del Duero, formaran parte de esta división territorial, es un dato que no debemos olvidar. Así, paralelamente al desarrollo del trabajo de campo en la zona oeste, se acometieron idénticas labores en el oriente de la Península Ibérica, visitándose la antigua capital, Tarraco y otros núcleos importantes, como Ampurias.

Dentro de la Lusitania, tuvieron igual notabilidad las tareas desarrolladas en Lisboa (Olisippo) y el importantísimo conjunto conservado en la cercana Odrinhas. Los restos de la pintura mural del aula arqueológica de Troia de Setúbal, determinados monumentos de Faro, Mértola y Beja, también merecen ser citados. Por último y como capital de la Lusitania, fueron muy sistemáticos los trabajos desarrollados en Mérida (Emerita Augusta).

Dentro de la Hispania Ulterior, jugaron un papel preponderante en la configuración del corpus sobre el que basar nuestras investigaciones, las labores de campo realizadas en la ciudad de Córdoba, Sevilla (Hispalis) y Écija (Astigi), tres de los núcleos más importantes de la Baetica.

Con respecto a los lugares de la Galia donde centramos nuestros análisis, destacamos las respectivas sesiones de trabajo en las provincias de la Narbonensis, Aquitania, Celtica y la Galia Cisalpina.

En último lugar y no menos importante, destacamos las largas jornadas llevadas a cabo en la antigua península itálica, donde el número de monumentos visitados fue tan extenso que resultaría imposible recogerlos todos aquí. Nos limitamos a citar el viaje a las ciudades de Roma, Ostia y Nápoles, incluyendo aquí los sitios arqueológicos de Pompeya y Herculano.

Finalmente, queremos reseñar que, mediante el trabajo de campo desempeñado a lo largo de estos años, se pretendió tener un mejor conocimiento de la realidad material de la Europa románica, así como poder adquirir un conocimiento, lo suficientemente sólido sobre el arte antiguo, que permitiese crear una serie de reflexiones coherentes. 


\section{B. TRABAJO DE ARCHIVOS Y BIBLIOTECAS.}

Paralelamente al desarrollo de las acciones que antes enunciábamos, se llevó a cabo la consulta en los archivos y bibliotecas. Consideramos que se trata de uno de los momentos fundamentales del estudio, por ser en este nivel cuando se construyó la base teórica sobre la que fundamentar la investigación.

Por las características de la misma y, especialmente, por el periodo cronológico que nos ocupa, la labor realizada en los diferentes archivos tuvo gran relevancia. Sin embargo, prácticamente toda la documentación de este periodo histórico se encuentra, en la actualidad, publicada y editada críticamente, a través de la meticulosa labor de los especialistas. Este hecho propició que su consulta se realizase, mayoritariamente, en las bibliotecas o en el momento de acometer la labor de gabinete.

A pesar de ello, acudimos a diversos archivos localizados en España y en otros países, donde pudimos acceder a los manuscritos y documentos originales, bien para intentar cotejar y comprobar aquellas informaciones que sobre ellos habían realizado otros estudiosos, o bien para analizar directamente aquellos aspectos relacionados con la naturaleza de los mismos. En este sentido las sesiones de trabajo en los archivos permitieron acceder a determinados códices $\mathrm{y}$, en el caso de poseerlas, a las ilustraciones con las que fueron decorados.

Por ejemplo, citamos por su especial relevancia, la consulta de los fondos custodiados en la Médiathèque François Mitterrand de Poitiers, en Francia, o algunas consultas muy concretas y puntuales realizas en los Archivi Vaticani de la Ciudad del Vaticano.

En caso español, se prestó una atención más destacada a los fondos del Archivo Histórico Nacional, del Archivo-Biblioteca de la Real Academia de Bellas Artes de San Fernando y el Archivo del Museo Arqueológico, todos ellos en la ciudad de Madrid.

De la misma manera e intentando enriquecer nuestra investigación con aspectos más concretos, se consultó el Archivo de la Real Colegiata de San Isidoro, el Archivo Provincial o el Archivo Histórico Diocesano, todos en León.

Tal y como anunciábamos anteriormente, la mayor parte de la documentación hispana relativa al periodo que iba desde la Antigüedad romana a la Plena Edad Media, se encuentra ya editada, facilitando su consulta en las bibliotecas. Sin embargo, este hecho debilitó la posibilidad de aportar algún documento inédito sobre el que fundamentar nuestras pesquisas. 
El grueso del tiempo dedicado a la documentación de nuestro estudio recayó en la rigurosa y pormenorizada consulta de la bibliografía especializada en nuestro tema, así como otra que permitiese formarnos un criterio lo suficientemente estable como para poder pronunciarnos al respecto. En la persecución del máximo rigor científico, se procedió a la búsqueda de todas aquellas aportaciones publicadas por los expertos. En un primer momento las bibliotecas permitieron que, mediante la consulta de esta bibliografía científica, conociéramos las posturas y estudios más relevantes desde una visión historiográfica.

Al abordar un periodo como el románico, desde un primer momento fue necesario un conocimiento escrupuloso y meticuloso de las aportaciones científicas de los estudiosos extranjeros. Como veremos en el momento de realizar un estado de la cuestión al tema de estudio, la bibliografía específica cuenta con una basta nómina de aportaciones escritas en lengua francesa, italiana, alemana e inglesa que había que conocer concienzudamente.

La persistencia de la tradición "clásica" en el arte medieval fue un tema relevante que, desde muy temprano, preocupó a la historiografía de la órbita europea, mucho antes, incluso, que a la española. En relación con este aspecto el acceso a un gran número de bibliotecas internacionales fue ineludible.

Las bibliotecas francesas nos ofrecieron un importante catálogo al que acudir para encontrar este tipo de estudios. Se trabajó asiduamente en París, tanto en la Bibliothèque nationale de France como en otras ubicadas en la misma ciudad. Mencionamos así la Bibliothèque de l'Institut national d'Histoire de l'Art o la Bibliothèque du Musée national du Moyen-âge, Musée des Thermes et de l'Hôtel de Cluny.

Fuera de la capital francesa, una de las más importantes colecciones bibliográficas que ocupó nuestro tiempo de documentación, fue la Bibliothèque du Centre d'Etudes Supérieures de Civilisation Médiévale de Poitiers.

Del mismo modo, mencionamos aquellos centros más importantes y que nos aportaron infinidad de títulos primordiales para nuestro tema de trabajo. Este es el caso de la Bibliothèque Universitaire Centrale de Toulouse-Le Mirail o la Bibliothèque et Service Commun de la Documentation de l'Université Toulouse 1. Sciences Sociales, ambas en Toulouse.

También en suelo francés, destacamos las consultas realizadas en la Bibliothèque Universitaire de Lettres de l'Université Michel de Montaigne Bordeaux 3. 
Al igual que en el caso galo, también Italia posee ricos fondos relacionados con nuestro tema de investigación. En Roma, por aludir a los casos más importantes, se realizaron largas sesiones centradas en la consulta bibliográfica dentro de la Biblioteca G. C. Argan del Dipartimento di Storia dell'Arte de la Università de La Sapienza, la Biblioteca Hertziana. Istituto Max Plank per la Storia dell'arte o la Biblioteca di Archeologia e Storia dell'Arte del Palazzo di Venezia, también en Roma.

Por último, pero no menos importante, destacamos el trabajo realizado en Portugal. La cercanía con España y sus estrechas relaciones artísticas, ofrecieron interesantes datos obtenidos del examen riguroso de las fuentes bibliográficas. En la ciudad de Lisboa, dedicamos gran atención a los fondos conservados en la Biblioteca de História da Arte del Departamento de História da Arte, así como los de la Biblioteca Mário Sottomayor Cardia, de la Faculdade de Ciências Sociais e Humanas de la Universidade Nova, también en la capitel lusa.

En el caso español, la Biblioteca Nacional, en Madrid, fue uno de los primeros lugares a los que acudimos en esta fase del trabajo. Sin embargo, de igual ayuda nos sirvieron otros centros de la misma ciudad, tales como la Biblioteca de la Casa de Velázquez, la Biblioteca de la Universidad Complutense y la de la Universidad Autónoma, todas ellas en Madrid.

Fuera de esta capital, destacamos la Biblioteca Universitaria de Santiago de Compostela, la de la Universidad de Salamanca, así como la Biblioteca General San Isidoro de la Universidad de León.

Para finalizar, citamos otras sedes o fundaciones que permitieron continuar con nuestros objetivos. En Oviedo, se consultaron los fondos de la Biblioteca de la Universidad, acudiendo cuando fue necesario a los custodiados en la Biblioteca del Real Instituto de Estudios Asturianos, de la misma ciudad.

Tras esta larga lista de instituciones públicas y privadas, debemos alegar que, gracias a las sesiones realizadas en estos centros, pudimos acceder a la mayor parte de la bibliografía necesaria para la redacción de este trabajo. Sin embargo, cuando la consulta fue imposible en estos lugares, se acudió, esporádicamente, a los distintos servicios interbibliotecarios de las Universidades españolas, así como a los diversos catálogos informatizados y revistas electrónicas, accesibles a través de Internet. Ello permitió completar eficazmente la documentación de nuestras investigaciones, a pesar de que, tal y como señalaremos más adelante, somos conscientes de que muchos de estos trabajos y aportaciones científicas hayan podido ser obviadas, no sólo por el desconocimiento que, 
seguramente, tengamos hacia ellas, sino por la imposibilidad de abarcar todos los estudios publicados hasta la fecha.

\section{TRABAjo En Museos.}

Dentro de la enumeración de los principales lugares que contribuyeron a nuestra formación y preparación para realizar el posterior trabajo de gabinete, poseen un papel destacado todos aquellos museos, galerías y colecciones, tanto del ámbito público como privado, en los que se custodian piezas de gran valor artístico.

En el territorio francés, fueron indispensables las sesiones acometidas en las diversas colecciones del Musée du Louvre en Paris. En este caso concreto, como en los que citaremos más adelante, prestamos especial atención a los Departamentos y Secciones encargadas de custodiar las colecciones lapidarias, epigráficas y de esculturas, tanto antiguas como medievales. Dentro del museo parisino, mencionamos los Departamentos de “Antiquités Orientales”, “Arts de l'Islam”, “Antiquités grecques, étrusques et romaines", “objets d'art", así como las conservadas en el "Département des sculptures du Moyen Age, de la Renaissance et des Temps modernes”.

Ubicada también en París, jugó un papel primordial la colección del Musée national du Moyen-âge, Musée des Thermes et de l'Hôtel de Cluny y, particularmente, las custodiadas en las colecciones de "Antiquité et Haut Moyen Âge", "Monde roman", "Sculpture gothique", "Peintures, enluminures et vitraux" y "Orfèvrerie et ivoires".

En la ciudad de Toulouse, se analizaron exhaustivamente las obras del Musée des Augustins, prestando especial atención a los vestigios romanos y paleocristianos que allí se guardan, así como a la excepcional colección de esculturas procedentes de la basílica de Saint-Sernin de Toulouse, del monasterio de Notre-Dame de La Daurade o de la catedral de Saint-Étienne. A estos ejemplos debemos sumar otros vestigios provenientes de la región del Languedoc.

En la ciudad de Poitiers, nos interesaron las piezas expuestas en el Musée SaintCroix, con importantes restos trasladados de toda la región del Poitou-Charante. Se trata de piezas romanas, pero también de cronología cristiano-primitiva y medieval. Son dignos de mencionar los restos del Hipogeo de Dunes, muy interesantes para nuestro estudio. 
Tampoco debemos olvidar la visita realiza a la ciudad de Bordeaux, con las pertinentes tareas llevadas a cabo en la basílica de Saint-Seurin, incluida la espléndida colección de sarcófagos custodiada en la cripta del mismo edificio. En la misma ciudad, también se trabajó sobre las colecciones del Musée des Beaux-Arts.

En esta breve síntesis que presentamos, no podemos pasar por alto la fructífera visita a las colecciones presentes en dos lugares importantes para la cultura románica europea. La primera de ellas, es la formada a partir de los vestigios procedentes de la iglesia de Saint-Pierre de Cluny y que forman el Musée d'Art et d'Archéologie de l'abbaye de Cluny. La inspección ocular y el fotografiado de los capiteles procedentes de la girola de dicho templo fue una tarea primordial.

En el caso italiano, sin duda, las labores desarrolladas en los Musei Vaticani de la Ciudad del Vaticano fueron muy productivas. Las colecciones de sarcófagos romanos y cristianos del Museo Pío Cristiano, así como la infinidad de piezas de la más diversa índole artística, completaron convenientemente el corpus de obras sobre el que trabajar.

Desde el punto de vista de las obras custodiadas en museos y procedentes de la órbita pagana, es evidente que el más importante es el Museo Nazionale Romano, en todas sus sedes físicas de las Termas de Diocleciano, el Aula Ottagona, el Palazzo Máximo y el Palazzo Altemps.

A estos importantes museos sumamos otros, como el Museo Lateranense de Roma, la Galleria Borghese, la Galleria Barberini, la Galleria Corsini e Galleria Spada y la Galleria Nazionale D'Arte Antica. Finalmente, nombramos los Musei Capitolini, por la riqueza de sus colecciones y las obras romanas allí conservadas.

Fuera de la ciudad de Roma, remarcamos el Museo Archeologico Nazionale di Napoli, así como los sitios arqueológicos de Pompeya y Herculano.

Finalmente, mencionamos otros museos visitados y que se ubican a lo largo de la península itálica. Este es el caso del Musei della provincia di Ravenna, así como otros localizados en Firenze, Siena, Bari y Sicilia.

Junto con el Museé du Louvre de París y los Musei Vaticani de Roma, el tercer museo en importancia para el desarrollo de nuestro tema fue el British Museum de Londres, donde también se realizaron idénticas labores dirigidas a ampliar y enriquecer el corpus fotográfico y las fichas catalográficas de las piezas a tener en cuenta para realizar el estudio.

Por su importancia para conocer la cultura antigua, tanto griega como romana, fue cardinal la estancia realizada en Grecia. Allí se accedió a las colecciones recogidas 
en el Museo Arqueológico de Heraklion, en la isla de Creta. Dentro del mismo país, mencionamos las obras expuestas en la ciudad de Atenas, sobre todo, en el Nuevo Museo de la Acrópolis.

En última instancia queremos citar un caso excepcional formando por un conjunto de colecciones y museos dispersos por el territorio portugués. Las obras artísticas que forman tales centros presentan una especial relevancia para conocer el caso hispano. Así, en la ciudad de Lisboa se trabajó sobre las colecciones de escultura antigua y medieval del Museu Arqueológico do Carmo y el Museu Nacional De Arte Antiga, en la misma ciudad.

Del mismo modo, jugaron idéntico papel, las excepcionales muestras albergadas en la ciudad de Belém y su Museu Arqueológico, así como la substancial compilación epigráfica y de escultura romana, paleocristiana y altomedieval del sitio arqueológico sobre el que se fundó el Museu Arqueológico São Miguel de Odrinhas.

Por ultimo, queremos dejar constancia del viaje realizado para trabajar sobre las obras albergadas en el The Metropolitan Museum of Art's collection. The Cloisters, de la ciudad de New York.

En lo que se refiere al ámbito hispano, fueron muchos los centros visitados para realizar estas labores que explicamos. Tanto desde el punto de vista de las colecciones antiguas, como los configurados a partir de obras datadas en época medieval, España posee ricos fondos al respecto.

En Madrid, se realizaron sesiones organizadas a lo largo del tiempo en el Museo Arqueológico Nacional, muy prolijo en diversos objetos artísticos y esculturas provenientes de todas las regiones de España y que configuran la colección del "Departamento de Antigüedades Medievales".

En la ciudad de Toledo se encuentra el excepcional Museo de los Concilios y la Cultura Visigoda, fundamental para el conocimiento de la transmisión plásticas de fórmulas y soluciones de tradición antigua hacia la Edad Media hispana.

Fuera del centro peninsular, destacamos el examen de los Museos Provinciales de Lugo, Orense, Oviedo, León, Burgos, Palencia o Salamanca, así como el Museo Numantino de Soria.

No debemos olvidar que, en dichas ciudades, se custodian importantes colecciones de arte sacro, germen de los Muesos Diocesanos de las catedrales, a los que también se acudió con idénticos fines. 
Por la proximidad con nuestros objetivos y temas de análisis, se realizaron largas sesiones de trabajo en el Museo de la Real Colegiata de San Isidoro de León, sin duda, uno de los conjuntos medievales hispanos más completos.

De especial relevancia nos parecen las colecciones medievales que posee el Museu Nacional d'Art de Catalunya de Barcelona y, en la misma ciudad, del Museu Frederic Marès, donde se accedió a buena parte del corpus de obras románicas de las áreas orientales de la Península Ibérica.

Sin embargo, en el proceso de comparación de las obras antiguas con respecto a las medievales, también cobraron especial relevancia las jornadas de trabajo realizadas en varios museos y colecciones dedicadas al arte antiguo de las regiones del sur peninsular.

En este sentido debemos subrayar la importancia que posee el más significativo de los museos españoles centrados en estos objetivos. Nos referimos al Museo de Arte Romano de Mérida, uno de los centros que nos ofreció mas ayuda al respecto.

Además de lo expuesto, en Sevilla se visitó el Museo Arqueológico Provincial, mientras que en Córdoba se realizaron parejos trabajos en el Museo del Alcázar de los Reyes Cristianos. Por último y teniendo en cuenta la importancia de las piezas romanas y paleocristianas conservadas, citamos el Museo de Bellas Artes de Valencia y el Museo Arqueológico Provincial de Granada.

A través de todos ello se pudo conocer una nómina de obras lo suficientemente rica como para poder desarrollar posteriormente el trabajo de gabinete y la labor heurística. En todo caso, esto fue preciso dadas las características del propio trabajo. 


\section{ESTANCIAS DE FORMACIÓN EN CENTROS ESPECIALIZADOS Y ASISTENCIA A EVENTOS}

\section{CIENTÍFICOS.}

Dentro del proceso de documentación y formación que nos permitió adquirir la suficiente madurez como para acometer la elaboración del estudio, tuvieron una especial importancia las Estancias de Investigación realizadas en Centros Universitarios Extranjeros ${ }^{13}$.

Entre los meses de junio y octubre de 2006, se realizó una de las citadas estancias bajo la tutela del profesor Dr. Mario D'Onofrio, del Dipartamento de Storia dell'Arte de la Università La Sapienza de Roma (Italia). Tal actividad permitió el acceso a gran parte de la bibliografía más importante sobre el tema de análisis, así como la posibilidad de trabajar en algunas de las bibliotecas más completas sobre los asuntos relacionados con la Historia del Arte.

Entre junio y octubre del 2007 se realizó otra estancia de iguales características bajo la dirección del profesor Dr. Claudio Galderisi, en el Centre d'Études Supérieures de Civilisation Médiévale de Poitiers (Francia). La excelente biblioteca del centro y la importancia de su fototeca permitieron completar algunas partes fundamentales del estudio, así como mejorar nuestro conocimiento sobre determinados aspectos del románico galo. Tales labores permitieron dominar la suficiente información como para, posteriormente, establecer los paralelismos pertinentes con respecto al románico hispano.

De la misma forma, entre los meses de junio y agosto del 2008, se realizó, bajo la tutela de la profesora Dra. Adelaide Miranda del Departamento de História da Arte de la Universidade Nova de Lisboa (Portugal), una estancia de investigación que tuvo como principal objetivo perfeccionar nuestras nociones sobre algunos aspectos bibliográficos relacionados con el románico de las áreas lusitanas.

Finalmente, debemos mencionar la estancia de investigación realizada durante los meses de julio y agosto del 2009, en la Officina di Studi Medievali de la Universitá Degli Studi di Palermo (Italia), tutelada por el profesor Dr. Alessandro Musco ${ }^{14}$.

\footnotetext{
${ }^{13}$ Las estancias fueron realizadas a través del Programa de Becas de Formación del Profesorado Universitario (F.P.U) del Ministerio de Educación y Ciencia de España.

${ }^{14}$ La estancia investigadora que se llevó a cabo en Sicilia se desarrolló en el marco de la Beca de la Fundación del Patrimonio Histórico de Castilla y León.
} 
Las labores realizadas en estas estancias de investigación ofrecieron la posibilidad de acceder a los repertorios bibliográficos que, desde España, hubiera sido imposible consultar. La riqueza de las bibliotecas de estos centros, así como su excelente ubicación en lugares de vital importancia para la Historia del Arte, permitieron el buen desarrollo del trabajo de campo y en los museos, puesto que todas las ciudades ofrecen un basto panorama patrimonial muy rico sobre el que se pudo reflexionar ampliamente.

Paralelamente al desenvolvimiento de estas actividades investigadoras, las Becas de Formación del Profesorado Universitario (F.P.U) del Ministerio de Educación y Ciencia, así como la ofrecida por la Fundación del Patrimonio de Castilla y León permitieron, en todo caso, poder complementar nuestras labores investigadoras mediante la asistencia a cursos, seminarios, simposios, congresos y foros especializados de reconocido prestigio nacional e internacional.

De este modo, tras la realización de los Estudios de Doctorado con Mención de Calidad del Ministerio de Educación y Ciencia de España titulados: Las relaciones artísticas como vía de intercambio cultural. Mecenas, artistas y clientes e impartidos por el Departamento de Patrimonio Artístico y Documental de la Universidad de León durante los años 2003-2004; se obtuvo el título de Licenciado de Grado a través de la presentación de la Memoria de Licenciatura: La recuperación de la Ecclesiae Primativae Forma en la escultura del Panteón Real de San Isidoro de León.

En todo momento, las actividades descritas se desarrollaron paralelamente a la participación en actos científicos.

Desde una óptica nacional, se asistió, por ejemplo, al curso “Aproximación a los estudios de iconografía. Iconografía profana en la Edad Media”, en el Centro de Estudios Históricos, Fundación Sánchez Albornoz de Ávila ${ }^{15}$ o a los Cursos de verano Casado del Alisal "I Encuentros Jacobeos", celebrados en el Monasterio de San Zoilo en Carrión de los Condes de Palencia ${ }^{16}$.

En la misma línea, destacamos también la asistencia, entre otros, al Congreso Internacional "La Catedral de León en la Edad Media"17, al Congreso Internacional

\footnotetext{
${ }^{15}$ Fue impartido en esa localidad entre el 2 y el 6 de julio de 2001. Un año después participamos en el curso "Aproximación a los estudios de iconografía. Iconografía religiosa en la Edad Media", nuevamente, en el Centro de Estudios Históricos, Fundación Sánchez Albornoz de Ávila y celebrado en el mismo lugar, del 1 al 5 de julio de 2002.

${ }^{16}$ Organizados por la Universidad de Palencia.

${ }^{17}$ Organizado por el Departamento de Patrimonio Artístico y Documental de la Universidad de León, e impartido en esa ciudad, entre el 7 y el 11 de abril de 2003.
} 
“Orígenes de las Lenguas Romances en el Reino de León. siglos IX-XIr"18; al Congrés Internacional "El Camí de Sant Jaume $i$ Catalunya"19 y al IX Congreso de Estudios Medievales de la Fundación Sánchez-Albornoz, que en dicha ocasión versó sobre los "Fundamentos Medievales de los Particularismos Hispánicos" 20.

Además de los que aquí mencionamos, participamos igualmente en el VII Congreso Internacional de Estudios Jacobeos "Visitandum est: cultos y santos en el Codex Calixtinus" 21 ; en el Curso "La mujer en la cultura griega y latina", organizado por el Departamento de Estudios Clásicos de la Universidad de León ${ }^{22}$; en el X Congreso de Estudios Medievales “El Monacato en los reinos de León y Castilla (Siglos VII-XIII)",23 o en el Congreso Internacional "Monarquía y sociedad en el Reino de León de Alfonso III a Alfonso VII"24.

Deben ser destacados, por la importancia de las aportaciones allí realizadas y el enriquecimiento de algunas partes del presente estudio, el V Congreso Internacional Restaurar la Memoria. ARPA. "Patrimonio y Territorio",25; el Simposio Internacional "El legado de Al-Andalus. El arte andalusí en los reinos de León y Castilla durante la Edad Media",26; el Congreso Internacional "Monasteria y Territoria. Elites, edilicia y territorio en el mediterráneo medieval (siglos V-XI)",27 y el Simposio Internacional "Las relaciones entre los reyes hispanos y las Cortes europeas en la baja Edad Media. El intercambio artístico" ${ }^{28}$.

Durante este periodo continuaron realizándose tales actividades de manera regular. Así, pudimos continuar nuestra aproximación a estos temas mediante la asistencia a la Jornada de Estudio "El Libro de Alexandre: nuevas perspectivas",29, al II Simposio Internacional "L'església romànica, espai de les imatges" Internacional “Imagen y Apariencia”, organizado por la Universidad de Murcia ${ }^{31}$.

\footnotetext{
${ }^{18}$ Celebrado en León, del 15 al 18 de Octubre de 2003.

${ }^{19}$ Impartido en Barcelona, del 16 al 18 de Octubre de 2003.

${ }^{20}$ Impartido en León, del 15 al 18 de Diciembre de 2003.

${ }^{21}$ Celebrado en Santiago de Compostela, del 5 al 7 de octubre de 2004.

${ }^{22}$ Entre los días 2 y 5 de noviembre de 2004.

${ }^{23}$ Organizado por la Fundación Sánchez-Albornoz y celebrado en León del 26 al 29 de septiembre de 2005.

${ }^{24}$ Celebrado en León, del 25 al 28 de octubre de 2006.

${ }^{25}$ Celebrado en Valladolid, del 10 al 12 de noviembre de 2006.

${ }^{26}$ Celebrado en León, del 29 al 1 de diciembre de 2006.

${ }^{27}$ Celebrado en Madrid, del 18 al 20 de diciembre de 2006.

${ }^{28}$ Celebrado en León, del 27 al 29 de septiembre de 2007.

${ }^{29}$ Organizada por la Casa Velásquez y FRAMESPA-UMR 5136 (Toulouse) y celebrada en Madrid el 17 de octubre de 2007.

${ }^{30}$ Organizado por la Universidad Autónoma de Barcelona y el Grupo de Investigación Ars Picta. Tal evento se celebró en Barcelona entre el 20 y el 22 de noviembre de 2007. En dicho evento pudimos,
} 
Especial alusión merece nuestra participación en las "I Jornadas de Jóvenes Investigadores en Ciencias Humanísticas de la Universidad de León", que nosotros mismos organizamos en colaboración con otros miembros del Departamento de Patrimonio Artístico y Documental de la Universidad de León ${ }^{32}$.

Dentro de esta lista de actividades proyectadas a realizar la Tesis Doctoral, debemos remarcar, igualmente, la participación en otros foros más específicos sobre los temas que, más tarde, se tratarían en nuestras investigaciones.

Cabe recordar, por ejemplo, la asistencia al Seminario "Modos de reutilización en la Edad Media en los países del Mediterráneo occidental (ss. X-XIII),33, evento en el que se abordaron importantes cuestiones relacionadas con la reutilización de materiales antiguos durante los siglos medievales. En la misma línea señalamos la asistencia a la X Reunión Científica Internacional "El Humanismo y su pervivencia" "34 y al Congreso Internacional "Alfonso VI y su legado"35,

En todo caso, en estos últimos eventos se dio especial relevancia al tema de las repercusiones del arte antiguo y sus diferentes mecanismos de transmisión hacia el arte medieval, poniéndose destacada atención al fenómeno dentro de las artes plásticas románicas.

La participación en estos foros de carácter nacional vino pareja a la asistencia a otros eventos de semejante índole, pero desarrollados en los ámbitos europeos y que aportaron una visión mucho más completa sobre los temas de trabajo.

En relación con este hecho aludimos, por ejemplo, la asistencia a las prestigiosas Journées Romanes organizadas en la abadía de Saint-Michel de Cuxa (Francia), dedicadas a los temas: "Chrétiens et Musulmans, autour de 1100"36 y "Actualité de l'art antique dans l'art roman". Esta última fue especialmente concluyente para el tema que nos ocupa, pues entroncaba directamente con nuestras investigaciones ${ }^{37}$.

\footnotetext{
además, presentar el estudio que titulamos: "Dos templos, dos ciudades. Imágenes de la Iglesia en la iglesia".

${ }^{31}$ Se celebró en dicha localidad, entre el 19 y el 21 de noviembre del 2008.

${ }^{32}$ Celebradas en León, del 13 al 15 de noviembre de 2006.

${ }^{33}$ Organizado por la Casa de Velázquez de Madrid y celebrado en dicha ciudad del 27 al 28 de marzo de 2006.

${ }^{34}$ Organizada por la Universidad de León, del 19 al 20 de octubre de 2009.

${ }^{35}$ Celebrado en Sahagún, del 29 al 31 de octubre de 2009.

${ }^{36}$ Se celebraron entre el 8 y el 15 de julio de 2003 .

${ }^{37}$ Se celebraron entre el 6 y el 13 de julio de 2007.
} 
Del mismo modo, nos parece igualmente importante poner de relieve la participación en el Encuentro "O Corpo e o Gesto na Civilizaçao Medieval”38 y en el Congreso Internacional "Les abbayes martiniennes en Europe", celebrado en Tours $(\text { Francia })^{39}$.

Con los mismo objetivos asistimos a la LII Settimana Internazionale di Studio de la Fondazione Centro Italiano di Studi sull'Alto Medioevo donde se trabajó en torno al tema: "Comunicare e significare nell'alto medioevo" 40 . Un año después, regresamos al prestigioso centro para poder completar nuestros conocimientos sobre la civilización medieval a través de la LIII Settimana, que por entonces versó sobre el "Comportamenti e imaginario della sessualità nell alto medioevo" "41.

Para finalizar esta breve nómina que venimos elaborando, creemos que fue muy significativa, por la envergadura e importancia del tema abordado, la asistencia a las Internationale Tagung "Christliche Kunst im Umbruch. Hispaniens Norden im 11.Jahrhundert", celebradas en la Georg-August-Universitat de Göttingen, en Alemania $^{42}$.

Del mismo modo, asistimos a la Semaine d'Études Médiévales del Centre d'Études Supérieures de Civilisation Médiévale de Poitiers y en cuyas actividades, además de profundizar en diversas materias interdisciplinares ligadas al ámbito medieval, también se pudieron conocer, de primera mano, determinados monumentos tardoantiguos, románicos y góticos muy importantes de algunas regiones francesas ${ }^{43}$.

Además de la participación en estos eventos y reuniones científicas, análogamente, se nos brindó la posibilidad de poder presentar en estos foros algunas de nuestras aportaciones a estos temas.

Así, en el año 2006 publicamos el trabajo titulado "De lo pagano a lo cristiano en el arte románico hispano: a propósito de la iconografía de las aves afrontadas a la crátera de la vida", dentro del volumen de estudios que forman las Actas del XVI

\footnotetext{
${ }^{38}$ Fue organizado por la Universidade Nova de Lisboa. Facultade de Ciências Sociais e Humanas. Núcleo Científico de Estudos Medievais, en Lisboa, del 11 al 13 de noviembre de 2003.

${ }^{39}$ Fue organizado por la Université François-Rabelais de Tours y el CERMAHVA (Centre de Recherches sur les Mondes Antiques et sur l'Histoire des Villes et de l'Alimentation), entre el 7 y el 8 de noviembre de 2008.

${ }^{40}$ Impartida en Spoleto (Italia), del 15 al 20 de Abril de 2004.

${ }^{41}$ Impartida en Spoleto (Italia), del 31 de marzo al 5 de abril de 2005.

${ }^{42}$ Celebradas entre el 27 y el 29 de febrero de 2004.

${ }^{43}$ Celebradas en Poitiers (Francia), entre el 25 de junio y el 6 de julio de 2007. Por ejemplo, nos referimos a las clases prácticas a las que asistimos en la catedral de Poitiers, la iglesia de Notre-Dame-la-Grande de la misma ciudad, el hipogeo de Dunes y la denominada linterna de los muertos de Lisieux.
} 
Congreso Nacional de Historia del Arte del CEHA: La Multiculturalidad en las artes y en la arquitectura ${ }^{44}$.

Ese mismo año también fue publicado el estudio "Nuevas reflexiones para la lectura iconográfica de la Portada del Perdón de San Isidoro de León: el impacto de la Reforma Gregoriana y el arte de la tardoantigüedad", en la revista De Arte ${ }^{45}$.

Un año más tarde, en el 2007, contribuimos con el estudio titulado "Un arquetipo arquitectónico de la Antigüedad clásica en la edilicia Altomedieval asturleonesa: el vano de triple arcada", dentro del libro colectivo: Monarquía y sociedad en el Reino de León: de Alfonso III a Alfonso VII ${ }^{46}$.

Durante el año 2008 también fue publicado otro artículo, esta vez consagrado a estudiar las "Pervivencias de la Antigüedad Clásica en la Edad Media Hispana. El spolium in se: a propósito del cáliz de Doña Urraca", dentro de las Actas del XII Congreso Español de Estudios Clásicos $^{47}$; y, finalmente, en el año 2009 se presentó a la comunidad científica el Volumen Extraordinario de los Anales de Historia del Arte, donde publicamos un trabajo que llevó por título: "El valor clásico de la arquitectura asturiana (s. IX): la iglesia de San Julián de los Prados. Entre la tradición "antiquizante" hispanovisigoda y la carolingia" ${ }^{48}$.

Por otra parte, dentro del contexto científico europeo, pronunciamos la conferencia titulada "Gestures of pain in Spanish Romanesque sculpture. The Heroic Death: from Antiquity to the Middle Ages", en el marco del International Congress of the European Middle Ages (ca. 300-1500) Gestures and emotions, celebrado en Leeds

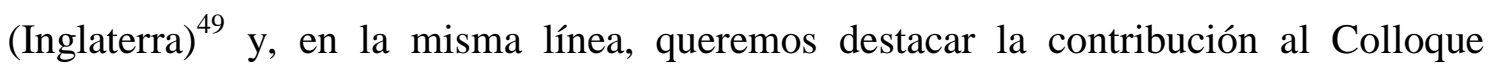
International et Pluridisciplinaire "Effets de style au Moyen Âge", donde leímos nuestro trabajo titulado: "Problématique autour du "style des joues bouffies" et de sa diffusion au sein de la sculpture romane hispano-languedocienne" ${ }^{, 50}$.

Por su relevancia y para finalizar, señalamos dos estudios que consideramos importantes. El primero de ellos, publicado en el año 2005, fue realizado en

\footnotetext{
${ }^{44} 2$ vols., Las Palmas de Gran Canaria, 2006, vol. I, pp. 383-391.

${ }^{45}$ De Arte, 5, 2006, pp. 63-86. Este trabajo nació a través de una conferencia, no publicada, que había sido leída en el I Congreso Internacional de Zamora, celebrado en dicha localidad entre el 4 y el 7 de julio de 2006.

${ }^{46} 2$ vols., León, vol. II, León, 2007, pp. 563-598.

${ }^{47}$ Valencia, 2008, pp. 120-129.

${ }^{48}$ La obra colectiva se llamó: Cien años de investigación sobre arquitectura medieval española, Madrid, 2009, pp. 233-246.

${ }^{49}$ Celebrado entre el 10 y el 13 de julio de 2006.

${ }^{50}$ Celebrado en Aix-en-Provence, del 28 al 31 de mayo de 2008.
} 
colaboración con el profesor Dr. Fernando Galván Freile y se tituló: "Microarchitectures dans les arts plastiques en Espagne autour de 1200 et leurs relations avec l'architecture monumentale". Se trata de una aportación que forma parte del libro Mikroarchitektur im Mittelalter. Ein gattungsübergreifendes Phänomen zwischen Realität und Imagination $^{51}$.

El segundo trabajo, que vio la luz en el año 2008, lo consideramos substancial dado el tratamiento que realizamos sobre el fenómeno de recuperación de las fuentes "antiquizantes" dentro de la escultura románica. Se trata del libro que titulamos: La recuperación de la Ecclesiae Primitivae Forma en la escultura del Panteón Real de San Isidoro de León ${ }^{52}$.

En realidad, todos los aspectos que anteriormente se han venido mencionando, tuvieron como principal objetivo preparar, ampliar y completar todos nuestros conocimientos sobre estas materias para, en última instancia, poder emprender la redacción definitiva del estudio que presentamos a su valoración para la obtención del grado de Doctor.

\footnotetext{
${ }^{51}$ Leipzig, 2008, pp. 479-497.

${ }^{52}$ León, 2008.
} 


\section{E. TRABAJO DE GABINETE.}

Una vez estuvieron recopilados, analizados y ordenados todos los datos y materiales obtenidos a través de las labores que hemos descrito anteriormente, se inició la labor propia de gabinete ${ }^{53}$. El objetivo principal en este período del trabajo era la redacción definitiva del texto que conforma nuestra Tesis Doctoral.

El trabajo de gabinete permitió la estructuración de todo el estudio a través de

\section{VII bloques temáticos ${ }^{54}$.}

Tras el pertinente índice y el desarrollo de la introducción, el Bloque I está dedicado al establecimiento de unas bases teóricas en las que se aclaran algunos conceptos que consideramos fundamentales para el estudio. Se abordaron ciertos términos, como el de "Renacimiento", en relación con el resurgimiento de las fuentes antiguas, así como otros conceptos como el de "influencia”, "imitación”, "copia” y "arquetipo", todos ellos cardinales para poder iniciar correctamente la investigación. En este punto se efectuó un balance historiográfico del tema, planteando un estado de la cuestión.

En este apartado de reflexiones teóricas también se valoraron fenómenos de índole conceptual, a partir del concepto de transmisión de fórmulas y soluciones artísticas desde los siglos de la Antigüedad tardía y la Alta Edad Media hacia el románico. Se prestó detallada atención a toda la serie de movimientos recuperadores de recuperación de lo "clásico", materializados a través de los diversos "renacimientos" sucedidos a los siglos medievales ${ }^{55}$.

Por último, en este bloque se insistió en el papel jugado por la ciudad de Roma y sus monumentos medievales, sus deudas con lo antiguo y, sobre todo, cómo su fisonomía y topografía, así como la idea nacida de su imagen como ciudad, fueron una fuente primordial para los artífices de la Edad Media.

En esa unidad que intentaba aclarar algunos conceptos teóricos, cabe destacar el análisis realizado sobre los fenómenos del spolium in se y el spolium in re.

\footnotetext{
53 Evidentemente, aunque dicha actividad se venía desarrollando desde el inicio mismo de la investigación, en este punto se puso mayor énfasis en realizarla.

${ }^{54}$ El último bloque está dedicado a la defensa de la Tesis Doctoral en lengua francesa, enfocada por obtener el título de Doctor Europeo. En este apartado se incluyen igualmente, la traducción a dicha lengua del índice y las conclusiones del trabajo.

${ }^{55}$ Se dejaron a un lado las manifestaciones artísticas clasificadas estilísticamente como góticas.
} 
En el Bloque II del estudio aplicamos estas deducciones teóricas sobre la realidad material de los siglos medievales. Tras una serie de apartados introductorios en los que se remarcó la importancia de las piezas y monumentos funerarios a la hora de explicar determinadas iconografías románicas, se abordó uno de los puntos más importantes del estudio.

Concretamente, nos referimos al grueso de la investigación, centrado propiamente en la escultura románica. Aquí se dedica un aparto íntegro al sarcófago de Husillos $^{56}$ y el papel que dicha obra jugó dentro de la historiografía específica sobre nuestro tema, así como su lugar dentro del desarrollo de la escultura románica hispana.

Dentro del tercer bloque se siguió siempre la misma metodología en cada uno de los apartados, elaborando sus pertinentes introducciones y balances bibliográficos y metodológicos de los temas a tratar. Primeramente, nos centramos de manera exclusiva en la escultura de la catedral de Jaca y sus dependencias con respecto a las fuentes antiguas. No se trató, en ningún caso, de realizar un estudio monográfico del edificio ni de su escultura. Así, se seleccionaron una serie de temas presentes en los capiteles y otros relieves del templo, basándonos en su posible subordinación con respecto a la escultura funeraria romana y paleocristiana.

Intentando huir de un estudio monográfico, cada uno de estos repertorios "antiquizantes" fue puesto en relación con otros ejemplos de cronología románica, ligados con edificios más alejados de la catedral jacetana. Siguiendo tales premisas se abordaron algunas de las esculturas de la iglesia del castillo de Loarre, Iguácel, Santa María de Santa Cruz de la Serós o Sos del Rey Católico.

En un segundo apartado de este tercer bloque los análisis se enfocaron al caso concreto de la escultura realizada para la catedral de Santiago de Compostela y la basílica de San Isidoro de León.

La metodología aplicada pretendía ofrecer una visión general del fenómeno de resurgimiento de la tradición "clásica" sin caer en regionalismos demasiado cerrados, de ahí que, se buscase abordar estos dos importantes edificios, íntimamente relacionados y con unos parámetros cronológicos similares, de una manera conjunta.

Se intentó trazar un discurso coherente, a la hora de acometer los análisis de la escultura de la catedral compostelana, tratando el tema de la difusión de diversas

\footnotetext{
${ }^{56}$ Madrid, Museo Arqueológico Nacional.
} 
soluciones adoptadas en la catedral jacetana y su repercusión a lo largo de las vías de peregrinación que llegaban a Santiago de Compostela.

Tanto para el caso de la catedral gallega como para el de la basílica de San Isidoro, se pretendió contextualizar aquellos elementos analizados dentro de un contexto amplio del románico hispano y europeo. No sólo se abordaron los rasgos estilísticos e iconográficos emparentados con la tradición "antiquizante", sino que se aludió, cuando fue necesario, a otros edificios ubicados en las mismas áreas geográficas que parecían poseer puntos en común a través de la irradiación de los motivos decorativos entre estos templos.

En este sentido, cabe destacar el caso de la escultura realizada en San Isidoro, muy influyente con respecto a la efectuada para otros núcleos, como son los de la iglesia leonesa de Santa María del Camino o del Mercado, las iglesias bercianas de San Esteban y San Miguel de Corullón o la de Santa Marta de Tera, en Zamora.

El Bloque III del estudio se localiza, aproximadamente, en la mitad del siglo XII, fecha en la que aún permanecían sin concluir, tanto la catedral de Santiago como la iglesia de San Isidoro de León. Se trataba de una fase en la que los fuertes ecos de la tradición "clásica" que hallábamos en los años finales del siglo XI y las primeras décadas del siguiente, se disolvían poco a poco y, en el mejor de los casos, se hacían repetitivos y estereotipados.

Buscando centrarnos en las áreas hispanas donde la presencia y el resurgir de fuentes antiguas fuese más claro y visible, para este bloque se decidió trasladar nuestra atención al ámbito oriental de la Península Ibérica.

La figura más significativa dentro del fenómeno de recuperación de las fuentes "clásicas" es la del "maestro" de Cabestany. En un primer apartado se abordó la problemática relativa a la "invención" de su figura, de las obras que se le atribuyeron y de las controversias derivadas del esclarecimiento de la supuesta red de escultores ligados a su figura. En el mismo contexto, se analizaron los fenómenos del spolium in se/in re dentro de las obras que los expertos han ligado a este artífice.

De esta forma, aunque a priori se pudiera pensar que nuestro discurso perdía linealidad y coherencia; abordar las labores escultóricas de una serie de artífices datados en la segunda mitad del siglo XII, nos permitía defender la idea de un fenómeno continuado y paralelo en gran parte de la Hispania románica. 
Dentro de este apartado, nuevamente, se constató la importancia de determinadas áreas francesas dentro de la formación de estos lenguajes "antiquizantes". Así, si en la primera parte del estudio se había remarcado el papel que tuvieron el Languedoc y la basílica de Saint-Sernin de Toulouse como epicentro del movimiento escultórico desarrollado en los últimos años del siglo XI y la primera parte del siglo XII; en el Bloque III se pretendió, además, afianzar la idea de que, una vez superada la arquetípica fecha del año 1150, la tradición "hispano-languedociana" continuó ofreciendo a los artífices de este momento unas fuentes de tradición "antiquizante" en las que basarse.

El Bloque IV culmina los análisis del fenómeno, centrándonos en la escultura producida más allá de las décadas de los años sesenta y setenta del siglo XII. Se tomó como punto y final el año 1200, aspecto plenamente justificado en su apartado correspondiente.

Persiguiendo una visión general del fenómeno, parecía obligado detenernos en las esculturas realizadas en la última etapa del románico. La razón fundamental que propició tal elección vino dada por la propia naturaleza de esta escultura, en la etapa final del siglo XII. El estudio del sustrato clásico en el tardorrománico pasaba por la valoración de los cambios sufridos en esta etapa dentro de las artes hispanas. Ahora tomaban peso otros centros, tanto a la hora de generar obras de calidad, como en el momento de buscar referentes foráneos que explicasen las fuentes antiguas seguidas por los artesanos.

La Isla de Francia, y el ambiente parisino, supusieron un buen punto de partida para explicar la renovación sufrida por la escultura de este periodo. En relación con ello, el tema central del Bloque se concentró en la problemática del conocido como "estilo 1200 " 57 .

Siguiendo con la metodología planteada para el resto del trabajo se llevó a cabo una síntesis introductoria y un exhaustivo estado de la cuestión. Se partió de la aparente unanimidad de la comunidad científica al defender la importancia de las fuentes antiguas para explicar el desarrollo de esta "estética del 1200". Tras unas breves reflexiones que intentaron perfilar las características de este arte en otras

\footnotetext{
${ }^{57}$ Debido a la ambigüedad del término, insistimos, nuevamente, en que somos muy conscientes de la complejidad que dicha nomenclatura encierra y por ello se dedicó un capítulo a valorar su utilización, las causas que propiciaron su creación y los detractores de tales teorías.
} 
manifestaciones plásticas, nos centramos en el caso concreto de la escultura desarrollada en el ámbito hispano.

El problema fundamental era intentar poner de relieve el gran cambio sufrido por los artistas y, en particular, sobre su manera de enfrentarse al legado antiguo. Ahora las fuentes se hicieron más complejas y dispersas, con un mayor bagaje y absorción de las experiencias artísticas llevadas a cabo por todo el ámbito europeo. A estas fuentes debemos sumar las traspasadas por la órbita oriental, hecho que acabó generando una apariencia estética de las artes muy peculiar.

Sin embargo, nos preocupó, especialmente, poner de manifiesto las dispares fuentes "clásicas" sobre las que se habían formado los artistas. Si durante los años finales del siglo XI y las primeras décadas del siguiente, la plástica romana, así como la de cronología paleocristiana y altomedieval, había sido importante; ahora, estos aspectos cambiaban. La corriente "hispano-languedociana", con puntos focales localizados en Toulouse, Jaca o Frómista, había fundamentado muchas de sus características en la tradición "clásica", absorbida a través del conocimiento de la escultura funeraria romana.

La escultura cercana al año 1200, tenía tal pluralidad de fuentes de tradición "antiquizante" que fue imposible diferenciarlas todas y concretar su origen. El sustrato romano de tradición oriental, tamizado bajo la esfera griega y su transmisión a través de los más amplios territorios europeos, ofreció un sustrato "clásico" muy peculiar, más complejo y en el que los sarcófagos romanos y la escultura de tradición imperial romana, tardoantigua y altomedieval no tuvieron todo el peso específico en la formación sus normas estéticas.

Una vez planteado el núcleo central del estudio, el Bloque $\mathbf{V}$ ofrece las conclusiones pertinentes. Se trata de un conjunto de reflexiones sintéticas de las principales aportaciones extraídas de la Tesis Doctoral. Sin duda, las entendemos como un punto de partida abierto a nuevas investigaciones que, esperamos poder realizar en el futuro y que, por lo tanto, no pretenden, bajo ningún concepto, poseer un carácter cerrado.

Finalmente, el Bloque VI contiene los apéndices derivados del estudio. Aquí, un apartado recoge el apéndice documental y de textos. Creímos conveniente seleccionar todos aquellos textos literarios, noticias, inscripciones, fragmentos de crónicas y fuentes de similar índole, que pudieran ayudar a esclarecer aquello que intentábamos argumentar desde el punto de vista teórico. 
En la segunda parte del Bloque VI se acopian, distribuídas a través de dos epígrafes diferentes, las fuentes narrativas y las bibliográficas. Siguiendo la metodología habitual en estos casos, se alfabetizaron todas las aportaciones científicas utilizadas para la elaboración del trabajo.

La última parte de este apéndice recoge los apartados consagrados al material fotográfico, precedidos por un índice de ilustraciones. 
La elaboración del presente trabajo se enmarca dentro de el Programa de Becas de Formación del Profesorado Universitario (F.P.U) del Ministerio de Educación y Ciencia de España y la Beca de Investigación de la Fundación del Patrimonio Histórico de Castilla y León. Dichas becas se aplicaron en el Departamento de Patrimonio Artístico y Documental de la Universidad de León. Agradecemos a todas las instituciones mencionadas la oportunidad y confianza mostrada al apoyar el desarrollo de esta investigación.

Del mismo modo, hacemos extensiva nuestra gratitud a los profesores y compañeros del citado Departamento, cuya ayuda y enseñanzas desinteresadas han sido constantes a lo largo de estos años.

Queremos destacar también nuestro reconocimiento para el Dr. Mario D’Onofrio del Dipartamento di Storia dell'Arte de la Università degli Studi di Roma La Sapiezna, el Dr. Claudio del Centre d'Études Supérieures de Civilisation Médiévale de Poitiers, la Dra. Adelaide Miranda del Departamento de História da Arte de la Universidade Nova de Lisboa y, finalmente, al Dr. Alessandro Musco, miembro de la Officina di Studi Medievali. Palermo de la Universitá Degli Studi di Palermo. La amable atención y el cálido recibimiento que nos mostraron en sus centros de investigación fueron fundamentales para poder desarrollar las Estancias de Investigación aludidas.

Por último, deseo dedicar un sentido recuerdo a la memoria del Dr. Fernando Galván Freile, sin cuyas atenciones, consejos y correcciones, este estudio jamás hubiera sido finalizado. Su marcha le privó ver concluido este trabajo que, desde el primer momento, impregnó de sabias enseñanzas, inculcándome el rigor científico y la pasión por el arte medieval que él poseía.

Finalmente, deseo expresar mi agradecimiento a la Dra. Etelvina Fernández González por su dirección del trabajo, sus acertadas indicaciones, sugerencias y sus importantes observaciones que, de una manera constante y dedicada, nos han permitido concluir la Tesis Doctoral que ahora presentamos a su consideración. 
BLOQUE I 


\section{BASES TEÓRICAS.}

\section{1. HACIA UNA “ARQUEOLOGÍA” DE LO CLÁSICO A TRAVÉS DE LA “MEMORIA” DE LA ANTIGÜEDAD. A MODO DE INTRODUCCIÓN.}

En torno a los años 1485 y 1488, Pedro Berruguete pintaba un cuadro titulado la Verificación de la Cruz, conservado actualmente en el Museo de Bellas Artes de Valencia (fig. 1). La obra, posiblemente creada en la localidad palentina de Paredes de Nava, recogía, por una parte, la tradición relativa a los acontecimientos narrados en diversas fuentes literarias de gran antigüedad, centradas en la invención de los vestigios de la Cruz de Cristo por parte de Helena, la madre de Constantino. Desde otro punto de vista, el tema servía de hilo conductor para unir una tradición pictórica "a lo moderno", con respecto a otra serie de experiencias, pudiéramos decir, pertenecientes a la tradición "clásica" 58 .

La obra del pintor castellano que aquí hemos seleccionado refleja correctamente la utilización de un tema iconográfico tomado de las mismas fuentes tardorromanas y difundido en algunas producciones de la Baja Edad Media y los albores del Renacimiento. En ella se muestra el momento exacto en el que la madre de Constantino presencia el descubrimiento de la Cruz de Cristo que, acompañada por aquellas que habían servido para crucificar a los ladrones, se muestra íntegra y elevada sobre un pequeño podio pétreo.

Resulta complejo, y además no es el objeto de estas palabras, poder llegar a demostrar si la inspiración del pintor se asentaba sobre un conocimiento de las fuentes documentales o literarias o, por el contrario, simplemente reproducía de manera inercial un tema iconográfico bien conocido durante los siglos medievales ${ }^{59}$.

Sin embargo, tal y como se advertirá en este estudio, la narración de la invetio crucis habría de tener una importancia sobresaliente dentro de las producciones artísticas medievales, tanto europeas como hispanas. Este hecho es fácilmente

\footnotetext{
${ }^{58}$ M. P. SILVA MAROTO, Pedro Berruguete, Valladolid, 1998; ID., "Pedro de Berruguete", Álbum, letras, artes, 70, 2002, pp. 54-61 e ID., "La iconografía como clave para la comprensión de la personalidad de Pedro Berruguete", Cuadernos de arte e iconografía, vol. 2, 4, 1989, pp. 134-141.

${ }_{59}$ Recuérdese, por ejemplo, el conocido ciclo pictórico desarrollado en la iglesia de los Santi Quattro Coronati de Roma.
} 
demostrable, tal y como demuestra, por ejemplo, el ciclo desarrollado en el bordado de la catedral de Gerona, por citar el caso más conocido y relevante al respecto ${ }^{60}$.

En lo relativo a la pintura de Berruguete queremos centrarnos en una figura en concreto. Se trata de uno de los "operarios" representados en la parte izquierda del lienzo. La figura se presentaba ataviada siguiendo la moda del momento, sin embargo, desde nuestro punto de vista, el rasgo más significativo es la herramienta que dicho personaje porta en sus manos y con la que, presumiblemente, ha llevado a cabo la "prospección arqueológica" que ha dado como resultado el descubrimiento de la vetusta reliquia.

La obra que hemos presentado, nos sirve de punto de partida para poder llevar a cabo una serie de reflexiones introductorias relacionadas con la percepción de lo "clásico" dentro de los siglos medievales. A partir de ellas, intentaremos acercarnos a dicho fenómeno a través de lo que se ha dado en llamar la "arqueología de lo clásico" en la Edad Media ${ }^{61}$.

El viaje realizado por la emperatriz Helena en torno al año 326 a Tierra Santa, le había permitido entrar en contacto con una de las zonas más importantes para la cristiandad. Su hijo, el emperador Constantino, se encontraba inmerso en la monumentalización del locus santo, allí donde se suponía que había sido enterrado el cuerpo de Cristo y que daría lugar a la famosa iglesia del Santo Sepulcro de Jerusalén ${ }^{62}$.

Según la tradición, la madre del emperador había ordenado a diversos “operarios" la "prospección" detenida y exhaustiva de la zona para poder sacar a la luz la famosa Cruz en la que había sido crucificado Cristo ${ }^{63}$.

El acto en sí es de una importancia extrema. Dejando a un lado las cuestiones teológicas, podemos constatar un especial interés, tanto por parte del emperador como de su madre, por llevar a cabo lo que pudiera ser definido como una de las primeras labores "arqueológicas" medievales que tendrían como principal interés recuperar un

\footnotetext{
${ }^{60}$ P. DE PALOL, "Elements clàssics en la iconografia del brodat de la Creació de la Catedral de Girona", Anals de d'institut d'estudis Gironins, XXII, 1974-1975, pp. 427-438 e ID., El Tapís de la Creació de la Catedral de Girona, Barcelona, 1986.

${ }^{61}$ Obsérvese que, a lo largo de este apartado usaremos las comillas para señalar la utilización del término -clásico-, pues se trata de una palabra de gran complejidad, tanto en la serie de acepciones que presenta, como en relación con los contextos en que se ha utilizado Cf.: S. SETTIS, El futuro de lo clásico, Madrid, 2006.

${ }^{62}$ En este estudio dedicamos un apartado al análisis de la iconografía de este edificio desde la Antigüedad tardía y su traspaso iconográfico a los siglos posteriores. Remitimos, por tanto, a dicho apartado para consultar la bibliografía sobre este tema en concreto.

${ }^{63}$ M. L. MARTÍNEZ y L. L. MARTÍNEZ, "Santa Elena y el hallazgo de La Cruz de Cristo", Comunicación y hombre: revista interdisciplinar de ciencias de la comunicación y humanidades, vol. 3 , 2007, pp. 39-50.
} 
elemento del pasado. Se trataba de una serie de restos enterrados y desaparecidos, pero cuyo rescate debía llevarse a cabo a través de estas labores de excavación.

En un estudio realizado por A. Schnapp, el autor dedicaba buena parte del mismo a reflexionar sobre la importancia que tendrían estas primeras acciones "arqueológicas" para poder comprender la importancia de lo "clásico" en los siglos medievales y su interés, muy temprano, por recuperarlo ${ }^{64}$.

El mismo Constantino, según recoge E. de Cesarea, había tenido el máximo cuidado a la hora de acondicionar el terreno sobre el que erigir la famosa Rotonda de la Anástasis. Así nos dice:

"Sin embargo, por lo divino de su espíritu no consintió que ese recinto mismo que acaba de mostrarse siguiera soterrado por toda suerte de material inmundo, acopiado fraudulentamente por los enemigos, y entregado al olvido y la ignorancia; tampoco transigió con la maldad de los culpables, antes invocado a Dios como su valedor, dicta la orden de limpiar aquella área, en la idea de que aquella parte especialmente contaminada por los enemigos debía, por su intervención, disfrutar de la magnificencia divina. Nada más dictarse la orden, todos los armatostes de la confusión fueron derribados y destrozados con todas sus estatuas de divinidades. No se detuvo sólo en esto la muestra de su celo, sino que una vez más ordena que los materiales de derribo, de piedra y de madera, sean recogidos y arrojados lo más lejos posible de la comarca (....)"65 (texto 1).

Resulta complejo defender un interés "arqueológico" de estas acciones, pues bien se pudiera tratar de un topos literario, según el cual se pretendió limpiar el lugar más santo de toda la cristiandad de cualquier resto pagano que pudiera encontrarse en el entorno. Sin embargo, queda claro mediante este fragmento que los constructores y artífices al servicio de la voluntad del emperador, llevaron a cabo un acondicionamiento

\footnotetext{
${ }^{64}$ A. SCHNAPP, La Conquête du passé. Aux origines de l'archéologie, Paris, 1993, en concreto, pp. 116118.

${ }^{65}$ E. DE CESAREA, Vida de Constantino (Introducción, traducción y notas de M. Gurruchaga), Madrid, 1994, Libro III, 27, p. 291 (texto 1). A lo largo del presente trabajo y, preferentemente en las partes introductorias, se han seleccionado algunos textos de gran interés para la comprensión de los temas abordados. En ocasiones, hemos optado por introducir los fragmentos que consideramos más importantes dentro del mismo texto. En otros momentos, debido a la extensión que presentaban, se ha resumido el contenido de los mismos, mientras que se optó por copiarlos íntegramente e introducirlos en su correspondiente apartado al final del estudio. A partir de ahora, se señalará en cada momento puntual si el fragmento utilizado en el texto se encuentra resumido y recogido de manera más amplia en dicho apartado, al final del estudio.
} 
del terreno del templo para, desde lo más profundo de la tierra, retirar cualquier vestigio "arqueológico" que provocase un recuerdo del pasado pagano.

Si en citada pintura de Berruguete remarcábamos el interés del obrero que portaba en sus manos la herramienta con la que, posiblemente, se había llevado a cabo la excavación de la que habrían surgido los restos de la Cruz, a través de otras fuentes, se puede llegar a constatar que el tema no fue en absoluto ajeno a otra serie de manifestaciones artísticas, tanto iconográficas como literarias.

En una de las miniaturas que decoran una copia moderna de La Leyenda Dorada, nuevamente se representó a Helena acompañada por diversos personajes de su cortejo $^{66}$ (fig. 2). La emperatriz, con gesto distintivo, señala la aparición nuevamente de las tres cruces lígneas. Las concomitancias son factibles al comparar dicha imagen con la tabla de Berruguete.

Sin embargo, en el caso del manuscrito la Cruz de Cristo aparece identificada por un elemento epigráfico que no ofrece dudas ni permitía la confusión con respecto a las otras dos, pertenecientes a los ladrones. Nuevamente aquí aparecen dos "operarios" que excavan el suelo con sus herramientas, a la búsqueda de tales reliquias ${ }^{67}$.

Con todo, a pesar de que este tema específico de la "prospección" dictaminada por la emperatriz no alcanzó gran difusión dentro de la plástica medieval, una ilustración del Sacramentario de Gellone, datada en el siglo VII, muestra nuevamente a un operario en plena labor de excavación (fig. 3). Con sus manos agarra fuertemente una especie de pico con el que intenta abrir el suelo. Las tres cruces del Gólgota se han representado esta vez inscritas en un clípeo, generando una imagen extraña dentro del repertorio iconográfico altomedieval. A pesar de ello, la ilustración a la que nos referimos ha sido identificada como el acto "arqueológico" de un hombre intentando penetrar la tierra para rescatar diversas reliquias del pasado ${ }^{68}$.

En relación con lo señalado, somos conscientes de que tales acciones deben ser valoradas en su justa medida. Evidentemente, tanto los hombres antiguos como los medievales, no utilizaron nunca la tierra como una fuente consciente de información científica que les permitiese recuperar los vestigios del pasado de una manera metódica. Sin embargo, las representaciones iconográficas de estas primeras "prospecciones arqueológicas", señalan claramente un interés por recuperar el recuerdo del pasado que,

\footnotetext{
${ }^{66}$ Paris, Bibliothèque nationale de France, Ms. 244, fol. 146.

${ }^{67}$ A. SCHNAPP, La Conquête du passé..., p. 17.

${ }^{68}$ Paris, Bibliothèque nationale de France, Ms. lat. 12048, fol. 76v. Sobre la obra, vid.: Ibidem, p. 484.
} 
en muchas ocasiones, se hallaba bajo la tierra.

En este sentido y en relación con estas cuestiones, G. Cantino Wataghin recoge en su clásico trabajo la imagen de la Invención de la Cruz proveniente de un texto litúrgico carolingio y que se ha datado en la primera mitad del siglo $\mathrm{IX}^{69}$ (fig. 4). A través de esta imagen se constata la importancia que tenían determinadas piezas del pasado cristiano que, ocultas bajo las ruinas de los siglos, debían salir a luz a través de diversos mecanismos, para pasar a formar parte de los tesoros de los grandes centros eclesiásticos. Algunas noticias del momento, como por ejemplo las narradas por Gregorio Magno, insisten en la importancia de estas labores de exploración del subsuelo, así como los tesoros susceptibles de ser hallados bajo él ${ }^{70}$.

Entre estos tesoros, parece claro que las reliquias de los santos y sus sepulcros debieron considerarse de los más venerados. Sin embargo, es lógico pensar que en tales excavaciones apareciesen otros de más diversa índole. La búsqueda de materiales paganos, tanto para su destrucción, como para su reempleo, así como el rastreo de los suelos catedralicios y las zonas adyacentes a los grandes conjuntos religiosos en busca de tales reliquias, permiten señalar este interés por el pasado.

La ilustración del libro medieval, tal y como hemos visto, nos ha legado buenos ejemplos de esta búsqueda de objetos y reliquias ocultos. La presencia de los obreros con sus herramientas, listos para penetrar en las entrañas de la tierra, la figura del clérigo o el mentor que dirige la "exploración", así como la imagen del mismo suelo horadado, fueron constantes en este tipo de imágenes. Se trataba de recuperar objetos "históricos" que legitimasen la conexión de la realidad de aquellos hombres medievales con la vivida por sus antepasados.

Así, una vez constatada la importancia de tal tradición desde el punto de vista artístico, se comprueba que ésta no fue ajena a la misma documentación escrita.

En relación con este interés del hombre medieval por aquello que se encontraba bajo sus pies, es muy interesante el extenso pasaje recogido en la Historia

\footnotetext{
${ }^{69}$ Vercelli, Biblioteca Capitulare, Ms. CLXV. El trabajo de esta investigadora es de suma importancia para poder comprender este fenómeno que relaciona diversas actividades emparentadas, aunque sea de lejos, con la tradición moderna de la arqueología y las acciones de búsqueda de reliquias emprendidas por los hombres medievales. Cf.: G. CANTINO WATAGHIN, "Archeologia e «archeologie». Il raporto con l'antico fra mito, arte e ricerca", Memora dell'antico nell'arte italiana, L'uso dei classici, vol. I, Turín, 1984, pp. 171-217, en particular, p. 182.

${ }^{70}$ Ibidem, p. 183, donde insiste en estos textos y la importancia de reflexionar sobre la relación existente entre el tesoro y la reliquia.
} 
Compostelana $^{71}$. El autor de esta importante fuente documental e histórica, narra el viaje del obispo Gelmírez a Portugal en los siguientes términos:

"Y así, inspirado por la divina gracia, después de marchar a Portugal, con la ayuda del Señor, realizó lo que a continuación se lee (...). En el año de la Encarnación del Señor 1102 el venerable padre Diego II de la sede compostelana de la iglesia de Santiago, con la ayuda de la divina gracia, en el segundo año de su episcopado decidió visitar, como es debido, las iglesias, capillas y heredades que en tierra de Portugal pertenecían jurídicamente a la iglesia compostelana (...). Tomó a algunas de las personas más relevantes de su iglesia y se encaminó a Portugal (...). $Y$ así, aquel día, el obispo de Santiago recibió la hospitalidad del arzobispo de Braga. Al día siguiente, después de saludar a los hermanos de esta iglesia y confortarlos con su bendición, el obispo se dirigió en compañía del arzobispo a la iglesia de San Víctor (...). Pero entretanto, al dar la vuelta por sus iglesias, visitarlas y celebrar en ellas misas solemnes, cuando contemplaban los cuerpos de muchos santos que, semienterrados en ellas, carecían del honor debido, lloraba con piadoso sentimiento y daba vueltas en su corazón movido por esta misma piedad a lo que después con la ayuda divina llevó a cabo, pues pensaba con ansia de qué manera podía sacar aquellas preciosas perlas de lugares tan inconvenientes y llevarlas a la ciudad de Compostela. (...). Luego tras entrar en la iglesia de San Víctor y celebrar allí una misa, ordenó que se cavara en la parte derecha del altar mayor. Fue descubierta allí un arca marmórea, fabricada con finura y admirablemente y que estaba bajo tierra. Al abrirla en presencia del señor obispo, encontraron dentro dos cajitas de plata. Y cuando las recibió el mencionado obispo con gran respeto, glorificando el nombre del Señor con salmos y oraciones, descubrió la de muchos santos. Tras cerrarlas y sellarlas con firmeza, las entregó a sus más fieles clérigos para guardarlas" ${ }^{, 72}$ (texto 2 ).

Uno de los aspectos más interesantes que se pueden deducir de este testimonio, a parte de constatar el llamado "pío latrocinio" llevado a cabo por el obispo compostelano, es la importante acción de llevar a cabo una prospección del suelo de la basílica en busca de las reliquias. Tal noticia documental carece de referentes iconográficos dentro de la plástica hispana, al menos que nosotros conozcamos. Sin

\footnotetext{
${ }^{71}$ Historia Compostelana (Emma Falque ed.), Turnholti, 1988, (reed. Madrid, 1994), pp. 94-99.

${ }^{72}$ Ibidem, pp. 96-97. Dada la extensión del texto original, hemos optado por transcribirlo de una forma resumida. Puede consultarse la versión integra en el apartado dedicado a los textos de este estudio (Texto 2).
} 
embargo, existen alguna serie de ejemplos en el ámbito europeo que permiten advertir la importancia de tales acciones.

El Evangeliario de Echternach, conservado en la Biblioteca Real de Alberto I de Bruselas, da buena cuenta de ello a través de dos miniaturas ${ }^{73}$ (fig. 5). En el manuscrito hallamos dos miniaturas en las que se ha representado a los cristianos en plena acción "arqueológica". En la primera de ellas, la escena se desarrolla en plena montaña, con varios personajes literalmente excavando el terreno en busca de las reliquias de San Esteban. En la segunda ilustración, los mismos personajes, nuevamente con picos y palas en sus manos, hallan los restos del santo (fig. 6). Lo más interesante de esta segunda obra es la manera en que el artífice ha materializado dichas reliquias, a través de la presencia de algunos sarcófagos pétreos, posiblemente de mármol.

La imagen de este códice carolingio nos trae a la memoria otras escenas similares del repertorio medieval, en las que se intentó materializar el mismo momento del hallazgo de las reliquias de algún personaje venerado del ámbito cristiano. En el caso de la escena del Evangeliario de Echternach, la manera de representar el posible mármol, con sus vetas coloreadas y los matices de texturas, no dejan de recordar el momento en el que se produce la inventio del sepulcro del apóstol Santiago, dentro de la miniatura del Tumbo A de la Catedral de Santiago de Compostela ${ }^{74}$ (fig. 7).

A través del referido texto de la Historia Compostelana, se constata en Hispania un interés por parte de la élites eclesiásticas por comprender aquellos vestigios históricos perdidos y para cuya recuperación era necesario "cavar", si utilizamos el verbo con el que se definió la acción emprendida por algunos personajes de la comitiva de Gelmírez en la iglesia de San Víctor de Braga.

Los ejemplos susceptibles de ser aludidos son numerosos. Al este respecto, una

\footnotetext{
${ }^{73}$ Bruxelles, Bibliothèque royale Albert I, Ms. 9428, fol. 158v y Bruxelles, Bibliothèque royale Albert I Ms. 9428, fol. 159v. Cf.: A. SCHNAPP, La Conquête du passé..., p. 48 y p. 107. Las ilustraciones se han datado en el siglo IX.

${ }^{74}$ Santiago de Compostela, Archivo de la Catedral, cód. 1, fol. 1v. Sobre la obra, véase: F. LÓPEZ ALSINA, "Le Tumbo (cartulaire) A de la cathédrale de Saint-Jacques", Europalia 85 España. Santiago de Compostela 1000 ans de Pèlerinage Européen, Santiago de Compostela, 1985, ficha catalográfica 36, p. 235. Se trata de una escena muy estudiada y sobre la que nos ocuparemos más adelante. La imagen ha tenido muchas interpretaciones, sobre todo en lo relativo a la morfología del lugar y su posible correspondencia con los textos y fuentes documentales que narran el momento del descubrimiento de la tumba del Apóstol. En este trabajo dedicaremos un apartado a analizar la importancia del mármol, así como su representación dentro de la iconografía medieval, por lo que abordaremos esta imagen en su momento de una manera más extensa. Vid. también: I. G. BANGO TORVISO, "El locus sanctus de Santiago de Compostela. Una nueva interpretación del escenario arquitectónico del santuario", El Camí de Sant Jaume i Catalunya, Barcelona, 2007, pp. 191-220, en concreto, p. 194. Esta miniatura en la que se representaron los tres sepulcros correspondientes a Santiago y a sus discípulos, debió realizarse después del año 1129. Para el autor, en dicha escena no se está reproduciendo en ningún caso, un marco arquitectónico real.
} 
miniatura del siglo XV en la que se representó la exhumación de las reliquias de San Humberto, muestra el momento exacto en el que un obispo, literalmente metido en una gran zanja que se ha excavado delante del altar de una iglesia gótica, saca, uno a uno, los huesos del santo (fig. 8). En tal labor le ayudan otros obispos, que con sumo cuidado colocan el fragmentado tesoro sobre la mesa de $\operatorname{altar}^{75}$.

La escena interesa por varios motivos. En primer lugar, refleja el acto mismo de excavar para obtener una serie de restos perdidos que interesa recuperar y que el tiempo se ha encargado de enterrar. Por otro lado, la imagen materializa igualmente lo problemático de comprender la noción de pasado que tenían los hombres medievales. Esta miniatura de época gótica, intenta reflejar un hecho histórico: el descubrimiento de unas reliquias, del que paradójicamente, a su vez, se tenía constancia de que había ocurrido en los tiempos lejanos del emperador Carlomagno.

El monarca aparece en la parte izquierda de la escena portando todos sus regalia, asistiendo al acto y verificándolo con su presencia. Creemos que tales imágenes ilustran bien el problema al que nos queremos referir y reflejan claramente el interés constante del hombre por recuperar, independientemente de los fines con los que utilizara sus descubrimientos, determinados vestigios de un pasado antiguo. El hecho de que siglos después, el mismo Roger van der Weiden utilizase nuevamente este tema para pintar un lienzo, representa claramente la importancia y la fuerza de la tradición de los fenómenos que hasta aquí analizados ${ }^{76}$ (fig. 9).

En relación con lo dicho, creemos que resulta imposible defender la voluntad arqueológica de estas acciones realizadas por los hombres del medievo. Sin embargo, desde otro punto de vista, la utilización de tales actos, pudieron haber sido realizados de una manera consciente para definir la memoria de un pasado, que de no recuperarse convenientemente, podía llegar a disiparse ${ }^{77}$.

La memoria era la facultad mental de poder recordar y rescatar del olvido una serie de acontecimientos que, utilizados convenientemente, podrían servir para

\footnotetext{
${ }^{75}$ Legenda de San Humberto, Paris, Bibliothèque national de France, Ms. 424, fol. 49. Sobre la miniatura, vid.: A. SCHNAPP, La Conquête du passé..., p. 118.

${ }^{76}$ El lienzo se conserva hoy en London, National Gallery. En este caso, el cuerpo del santo emerge intacto del subsuelo catedralicio, tal y como viene siendo habitual en este tipo de representaciones.

${ }^{77}$ Señalamos el término memoria en cursiva por utilizarlo según la acepción clásica de Cicerón y César, pues la manera con que fue usado por los clásicos, pasaría también a las fuentes documentales y literarias medievales. Cf. : M. SOT, "Mémoire, Antiquité, Renaissance, vues des IX ${ }^{\mathrm{e}}$ et $\mathrm{X}^{\mathrm{e}}$ siècles", La Mémoire de l'Antiquité dans l'Antiquité tardive et la Haut Moyen Âge, Paris, 2000, pp. 7-13.
} 
comprender el presente ${ }^{78}$. En el estudio mencionado de M. Sot, toma una importancia fundamental el concepto memoria, que es básico para comprender la recuperación del pasado a través de este mecanismo de selección de aquello que interesaba conservar para que formara parte de la memoria colectiva de una época, independientemente del uso que se le pretendiese dar a ese recuerdo ${ }^{79}$.

Tal acepción sería la que permitiese crear dos nociones que, según se ha señalado, parecen haber sido creadas en la misma Edad Media. Según el mencionado autor, "au Moyen Âge classique apparaîtra la distinction entre antiqua tempora et moderna tempora" ${ }^{\prime 80}$, que una vez llegado el siglo $\mathrm{XV}$, acabará por generar la famosa distinción entre los antiqui y los moderni ${ }^{81}$.

La Antigüedad había generado una serie de vestigios que los hombres posteriores a ella -ya fuesen cristianos de la Antigüedad tardía o altomedievaleshabían olvidado en forma de ruinas abandonadas. Éstas, se erigían ahora como claras representantes de ese pasado y suponían el mejor mecanismo de perpetuación de esta memoria. La recuperación de tales "reliquias" supuso llevar a cabo una práctica que tenía fines bien distintos a la que habían realizado con frecuencia los moderni en la misma ciudad de Roma. Pues ellos, de manera general, habían efectuado toda suerte de intentos por excavar y recuperar las maravillosas piezas artísticas de los antiqui, enterradas bajo los escombros de la ciudad eterna.

La antigüedad de los antiqui era vista por los nuevos cristianos como un periodo al que obligatoriamente había que referirse de una manera directa, pues a pesar de su marcado paganismo, era en él donde históricamente se ubicaba el nacimiento de la nueva religión. Es por ello que en las representaciones plásticas de época medieval tardía que hacían referencia a ese periodo del pasado cristiano, por ejemplo el de la época de Constantino, la Antigüedad se convertía en el marco obligado en el que

\footnotetext{
${ }^{78}$ En la introducción de su obra consagrada al estudio del concepto "clásico", el profesor Settis recoge una serie de reflexiones realizadas por el teórico Arnaldo Momigliano. Recuerda el investigador que éste último se preguntó al inicio de una lección ¿por qué se estudia historia antigua? Una de las respuestas que dio a tal cuestión fue la de "que las huellas del nuestro pasado (por ejemplo, en Italia) en la cultura, en la lengua, en los monumentos, en las instituciones, en el paisaje, son tan imponentes que nos dan curiosidad y nos obligan a estudiar el pasado para comprender una parte importante de nosotros mismos". Cf. : S. SETTIS, El futuro..., p. 9 y H. INGLEBERT, "La mémoire de l'histoire de Rome chez les auteurs latins chrétiens de 410 à 480", La Mémoire de l'Antiquité dans l'Antiquité tardive et la Haut Moyen Âge, Paris, 2000, pp. 57-66.

${ }^{79}$ C. MANCHO, "La memòria artística I l'oblit del passat", Art i Memòria. Pre-Actes, Barcelona, 2008, pp. 20-22.

${ }^{80}$ M. SOT, Op. cit., p. 9.

${ }^{81}$ El término modernus fue empleado ya por Casiodoro, pero no fue hasta los siglos XIII y XIV cuando se comenzó a hacer tal distinción entre antiqui y moderni. Cf.: SETTIS, El futuro..., pp. 78-79.
} 
desarrollar toda suerte de escenas religiosas. Es decir, cuando la Edad Media cristiana necesitó ubicar una escena o narración de un pasado lejano, aquel en el que supuestamente se habían ambientado y desarrollado las escenas y los acontecimientos históricos de la vida de Cristo, no hubo más remedio que utilizar la imagen de la Antigüedad pagana romana para enmarcar tales sucesos. Sobre todo si se les pretendía otorgar una carga de verismo y realidad.

En relación con ello, parece claro entonces que la Antigüedad es el argumento principal, al menos en cuanto al marco en el que se desarrolla, de la pintura realizada por Maso di Banco en torno al año 1336 sobre los muros de la capilla Bardi de Vernio, en la iglesia de la Santa Croce de Florencia (fig. 10). En ella se desarrolla el ciclo de la vida de San Silvestre, siendo la escena de la resurrección de los magos una de las más interesantes.

El ciclo, a pesar de estar pintado en una época relativamente tardía de la pintura medieval, ubicaba los acontecimientos de la vida de San Silvestre dentro del ambiente de la Roma del emperador Constantino. Uno de los rasgos más destacados viene definido por el escenario donde el santo lleva a cabo tal proeza, que se nos presenta completamente en un estado de ruinas, donde los vestigios aparecen desperdigados por doquier. Tal y como señala A. Schnapp, los ladrillos rojos de la Roma cristianaconstantiniana se oponen de manera rotunda al mármol blanco de la Roma antigua, la pagana $^{82}$.

El paisaje ruinoso sobre el que se desarrolla la acción, con el mismo emperador y el papa presidiendo el milagro del santo, muestra hasta que punto el arte medieval utilizó la memoria de la Antigüedad pagana para sus propios beneficios ${ }^{83}$. En la escena llaman poderosamente la atención las numerosas huellas de la ciudad romana, amontonadas por el suelo, además de los arcos fragmentados y agrietados. En palabras

\footnotetext{
${ }^{82}$ A. SCHNAPP, La Conquête du passé..., p. 125; J. BELTRÁN y F. GASCÓ, La Antigüedad como argumento, II vols., Sevilla, 1993-1995 y J. A. RAMÍREZ, "De la ruina a la destrucción arquitectónica (para una iconografía del caos)", La Multiculturalidad en la Artes y la Arquitectura, Las Palmas de Gran Canaria, 2006, pp. 526-553. El profesor Ramírez señala que esta obra que citamos debe ser considerada como la primera pintura de "ruina" del arte occidental. La escena ilustra un milagro del santo que resucita a los dos magos que yacen moribundos en el suelo, maltrechos por causa del aliento pestilente de un dragón que es atado por otros clérigos. Algunos autores han identificado la gran abertura en el suelo como la cueva en la que supuestamente habitaría el dragón. Lo que más nos interesa destacar, es que el autor realiza una lectura iconográfica de la "ruina" en la que ésta puede identificarse con la idea del mal y del desorden.

${ }^{83}$ S. PIGGOTT, Ruins in a Landscape. Essays in Antiquarianism, Edinburgh, 1976 y S. MARCHÁN FIZ, "La poética de las ruinas. Un capítulo casi olvidado en la historia del gusto", Fragmentos. Revista de Arte, 6, 1985, pp. 4-15. Sobre la idea de la ruina, su imagen y las diversas posibilidades de cómo pudo ser entendida por los hombres medievales, hablaremos en los capítulos posteriores.
} 
de A. Conti parecen mostrar una "atención arqueológica" a determinados detalles que configuran el ambiente en el que se enmarca parte de la comitiva que acompaña el santo y que se adentra en la tierra excavada ${ }^{84}$.

La ruina era utilizada como un elemento iconográfico que permitía a los artífices medievales ubicar sucesos pasados en el presente, a pesar de que seamos conscientes de que tales representaciones carecieron siempre de un riguroso valor "arqueológico". Sin embargo, aunque la manera en que éstas fueron concebidas por los hombres medievales y los del Renacimiento, es absolutamente opuesta, se podría defender que, en algunas ocasiones, pudieron compartir ciertos puntos en común.

Cuando en pleno siglo XV Andrea Mantegna pinta el San Sebastián del Museo del Louvre de París (fig. 11), parece claro que el pintor poseía un conocimiento mucho más "arqueológico" que el que presentaron los hombres medievales. Las ruinas de la pintura de Maso de Banco, o cualquiera de las miniaturas antes mencionadas, muestran una evidente ingenuidad al compararlas con el profundo conocimiento, ahora si pudiéramos decir sin prejuicios, "arqueológico", que muestra la obra de Mantegna. En su pintura de San Sebastián, la Antigüedad pasa de ser un mero escenario del argumento, tal y como era utilizada en las obras anteriormente citadas, para convertirse en el argumento mismo de la tabla ${ }^{85}$.

La pintura de Mantegna, realizada posiblemente entre los años 1459 y 1460, presenta a la figura del santo atada sobre un fuste de una columna de canon clásico. El ambiente ruinoso se materializa a través de los capiteles, esculturas, "fragmentos" de relieves y elementos ornamentales del más depurado arte romano, que se muestran dispersos por el suelo ${ }^{86}$. El gusto de la obra por la misma ruina ha cambiado, haciéndose ahora más complejo y desarrollando claramente una intención "arqueológica" de mostrar un tiempo pasado, lejano ${ }^{87}$.

\footnotetext{
${ }^{84}$ A. CONTI, "Giotto e la pittura italiana nella prima metà del Trecento", L'Arte Medioevale in Italia e nell'Occidetne europeo (L. Castelfranchi Vegas ed.), Milano, 1994, pp. 89-106, en concreto, p. 102.

${ }^{85}$ S. SETTIS, "Continuitá, distanza, conoscenza. Tre usi dell'antico", Memora dell'antico nell'arte italiana, Dalla tradizione all'archeología, vol. III, Turín, 1986, pp. 372-486, en particular, p. 380.

${ }^{86}$ Marcamos mediante las comillas el término "fragmento", por considerar que se trata de uno de los vértices para comprender algunas de las reflexiones que se realizarán en este estudio. La cultura antigua nos ha llegado fragmentada. La admiración de esos mismos "fragmentos" son, en parte, la base sobre la que se ha construido su conocimiento. El valor absoluto del "fragmento" se convertía, tal y como señaló en su día Theodor Wiesendgrund Adorno, en carácter constitutivo de la modernidad. En adelante el término "fragmento" se utilizará entendiéndolo como una "pieza" representante de la Antigüedad dentro de la misma historia. Cf.: S. SETTIS, El futuro..., p. 46.

${ }^{87}$ A. ESCH, "Reimpiego dell'antico nel Medioevo: la prospettiva dell'archeologo, la prospettiva dello storico", Ideologie e pratiche del reimpiego nell'alto medioevo, XLVI, vol. I, Spoleto, 1999, pp. 75-108, en particular, sobre la obra de Mantegna, pp. 106-108. La obra de este pintor ha sido destacada por el
} 
El uso que hace Mantegna de las pilastras decoradas a candelieri, la decoración clásica de los suelos, las esculturas agrietadas esparcidas por todo lugar, así como la columna sobre la que se muestra saeteado el santo, hablan de un interés preciso por representar la época "romana in cui visse Cristo" "88.

Algunos de estos vestigios, de eminente carácter "antiquizante",89, fueron utilizados como una suerte de disecta membra que, utilizados en diversos contextos, en ocasiones aludían a la memoria clásica y al periodo en el que supuestamente había sido martirizado Cristo ${ }^{90}$.

La columna de orden clásico sobre la que se muestra atado el San Sebastián de Mantegna, debe ser entendida en relación con este aspecto. A pesar de que se trata de un simple modelo iconográfico de gran difusión dentro de las artes de diversos periodos, no deja de llamar la atención su presencia en algunas obras medievales, donde alude claramente al recuerdo de lo antiguo a través de morfología all'antica.

Así se muestra, por ejemplo, la columna marmórea de La Flagelación que expone sobre sus brazos uno de los ángeles del conjunto pictórico realizado para el cascarón del ábside la catedral vieja de Salamanca (fig. 12). La obra, pintada tal y como atestigua el contrato que se ha conservado de hacia el año 1439 por los hermanos florentinos Dello, Nicolás y Sansón Delli, fue ejecutada también en colaboración con otros $\operatorname{artistas}^{91}$.

profundo conocimiento de las ruinas romanas, el interés y la precisión, casi académica, por reconstruir este ambiente del Renacimiento dominado por un "purismo anticuario".

${ }^{88}$ S. SETTIS, El futuro..., pp. 100-108 y J. M. MONTIJANO GARCÍA, "Iconografía y representación en Roma en el siglo XV: del emblema y la ruina a la figuración científica urbana”, Boletín de arte, 15, 1994, pp. 9-32. Por otra parte, sobre la intención de ubicar las escenas de la vida de Cristo dentro de las recreaciones del paisaje de la Roma antigua, en la que supuestamente éste había vivido, consúltese: A. ESCH, Op. cit., p. 107.

${ }^{89}$ La palabra "antiquizante" no aparece recogida en la última edición del Diccionario de la Real Academia de la Lengua Española. Sin embargo, dado que, de manera habitual, se viene utilizando en muchos trabajos dedicados a analizar la influencia de la Antigüedad clásica en el arte posterior, en nuestro estudio, la utilizaremos puntualmente entre comillas, siendo plenamente conscientes de este hecho.

${ }^{90} \mathrm{El}$ fenómeno al que aludimos rápidamente se hizo extensivo a otros pintores. Recuérdese el caso de la obra de Botticelli conservada en la National Gallery de Londres y datada entre los años 1470-1475. Se trata de una tabla en la que se representó la adoración de los magos y donde enmarcando toda la escena, el pintor colocó numerosas ruinas, entre las cuales destacan arcos, columnas, pilastras y diversos elementos arquitectónicos maltrechos, en clara alusión a su antigüedad. Cf.: L. CIRLOT, National Gallery, Barcelona, 2005, p. 61.

${ }^{91}$ F. J. PANERA CUEVAS, El retablo de la Catedral Vieja y la pintura gótica internacional en Salamanca, Salamanca, 1995, en concreto, pp. 167-191 e ID., "El retablo y las pinturas murales de la Capilla Mayor de la Catedral Vieja de Salamanca", La restauración del Retablo de la Catedral Vieja de Salamanca, Valladolid, 2000, pp. 55-225, en concreto, pp. 214-224. Resultan muy interesantes las relaciones que el autor establece entre los modelos iconográficos de estas pinturas y determinadas esculturas clásicas antiguas. En concreto, para el gesto del Cristo Juez del cascarón, trae a colación la escultura de una amazona herida de los Musei Capitolini de Roma. 
La columna clásica se convierte mediante su presencia en la escena, en un "fragmento" materializador del tiempo histórico en el que se había producido la passio de Cristo, es decir, el mundo antiguo. Así mismo, a la vez rememora una marcada tradición antigua que, según han señalado algunos autores para otros conjuntos de similar iconografía, parece evocar el valor expositivo con el que determinados arcos de triunfo romanos mostraban los trofeos y estandartes triunfales típicos de las batallas del mundo antiguo ${ }^{92}$ (figs. 13 y 14).

Con ello, no deja de resultar llamativa la tradición artística y literaria con la que el medievo va a revalorizar estos vestigios materiales del mundo antiguo. Así, queremos llamar la atención sobre un pasaje recogido en el Liber Sancti Jacobi en relación con la iconografía de la columna clásica como representante visual de la escena de La Flagelación de Cristo, así como su correspondencia con algunos fustes de mármol provenientes de diversas construcciones romanas. El texto dice:

"Asimismo se ha de implorar en el cementerio de dicha ciudad la protección de San Honorato, obispo, cuya solemnidad se celebra el 16 de enero. En su venerable y magnífica iglesia descansa el cuerpo de San Ginés, mártir muy preclaro. Pues hay un arrabal junto a Arles, entre los dos brazos del Ródano, que se llama Trinquetaille, en donde existe detrás de la iglesia una columna de magnífico mármol, muy alta y elevada sobre la tierra, a la que, según se cuenta, ataron a San Ginés y lo degolló la plebe fiel; y aún hoy aparece enrojecida por su rosada sangre"93 (texto 3).

A pesar de que resulte complejo poder atribuir un origen antiguo o considerar dicha pieza como un resto expoliado de época romana pagana, se podría entrever en este tipo de noticias una relación con las leyendas surgidas en torno a la columna de la

\footnotetext{
${ }^{92}$ M. A. CASTIÑEIRAS GONZÁLEZ, El Pórtico de la Gloria, Madrid, 1999, en concreto, p. 15. El autor entiende que la exposición de los Armi Christi, es decir, los instrumentos de la pasión de Cristo en un tímpano de gran formato como el que presenta el Pórtico de la Gloria de la catedral de Santiago de Compostela, tiene sus raíces ideológicas dentro del arte romano. En los arcos de triunfo, las victorias mostraban a los espectadores los objetos de botín de guerra, que eran entendidos como auténticos representantes de los triunfos de los emperadores. La adaptación del tema al ideario cristino pasó por la cristianización de estos objetos. Así, la columna, a veces seguidora de los modelos romanos, pasó a mostrarse en los brazos de los ángeles, que las exponen al espectador. No es de extrañar que, en muchas ocasiones, determinadas sedes presumiesen de albergar entre sus reliquias más insignes, un fragmento de fuste sobre el que supuestamente había sido azotado Cristo, tal y como observamos en la reliquia conservada en la iglesia romana de Santa Práxedes. Este y otros ejemplares son, en realidad, fragmentos marmóreos provenientes de las labores de expoliación de los edificios clásicos. Con todo, véase también: F. J. PANERA CUEVAS, El retablo de la Catedral..., p. 178. El autor recoge la teoría de L. Réau, según la cual, la iconografía de los Arma Christi posee un origen heráldico.

${ }_{93}$ Liber Sancti Jacobi Codex Calixtinus, (Traducción al castellano de A. Moralejo, C. Torres y J. Feo), Santiago de Compostela, 1944, (reed., Santiago de Compostela 2004), pp. 559-560.
} 
Flagelación. No en vano, desde otro orden de ideas, existen diversas alusiones medievales que nos han llegado sobre estos supuestos representantes antiguos de algunas columnas míticas. Es decir, en realidad se trataría de meros "fragmentos" descontextualizados del legado antiguo que, conservados, aludían a tiempo histórico $\operatorname{pasado}^{94}$.

Se percibe a través de estos ejemplos un interés constante por referirse a la Antigüedad, por manifestar, mediante una falso "método arqueológico", una citación directa hacia lo "clásico". Así, mediante estas conductas, la Edad Media llegará a convertirse en una auténtica especialista en realizar estas alusiones fragmentarias e inconexas o, tal y como explica el profesor S. Settis, en llevar a cabo "un citacionismo de tercera mano"95. El ejemplo anteriormente mencionado de los vestigios de las columnas es muy representativo al respecto.

Se trataría entonces de una visión de lo antiguo construida a través de un conocimiento fragmentado de la realidad artística, que se traducía, por fuerza, en una limitación a la hora de aludir a ese arte "clásico". Cuando a lo largo de los siglos posteriores a la disolución de las fórmulas romanas, los artistas quisieron sugerir un conocimiento de ese tipo de plástica, bastaba entonces con mencionar uno de esos "fragmentos", para materializar plenamente -o ubicar la escena- dentro de esa Antigüedad.

A este respecto, queremos señalar un ejemplo interesante tomado de las artes pictóricas españolas, en torno al año 1888. En este año se le encargó a Antonio Muñoz Degraín un lienzo en el que debía desarrollar el tema de la Conversión al cristianismo de Recaredo, durante la celebración del III Concilio de Toledo (fig. 15). En su obra, el pintor representó a la figura del monarca con suntuosa túnica y coronado por una diadema rematada por un cruz, abjurando de la doctrina de Adriano. Dentro de la misma

\footnotetext{
${ }^{94}$ Otros ejemplos medievales dan constancia de la importancia que habrían de llegar a tener tales piezas. Sin pretender establecer un paralelismo, puesto que no puede realizarse tal comparación ni desde el punto de vista simbólico, ni desde la función, queremos llamar la atención sobre el fuste marmóreo posiblemente reempleado de la catedral de León. Se trata de una pieza que formaría parte del conocido como Locus Apellationes y sobre el que parece hubo una intención de preservarlo y conservarlo dentro de un nuevo contexto gótico. El fuste, de medidas, talla y características que hacen pensar en un reempleo, llegó a adquirir fuertes valores simbólicos dentro de la fachada del templo. Se trata de un "fragmento" que emparentaba desde un punto de vista simbólico algunas ceremonias de impartición de justicia con una tradición anterior, alejada en el tiempo. Cf.: G. CAVERO DOMÍNGUEZ, E. FERNÁNDEZ GONZÁLEZ y F. GALVÁN FREILE, "Imágenes reales, imágenes de justicia en la catedral de León”, e-Spania, URL: http://e-spania.revues.org/document204.html, consultado el 3 de octobre de 2007.

${ }^{95}$ S. SETTIS, El futuro..., p. 24.
} 
escena, que se ambienta en un entorno religioso de gran suntuosidad, aparece la esposa del monarca, la reina Badda ${ }^{96}$.

A propósito del cuadro de Degraín se ha señalado que no había certidumbre sobre el lugar en el que se había celebrado tal Concilio y que tampoco eran abundantes los monumentos de la época visigoda conservados en Toledo. La nómina se empobrecía más incluso, al valorar los escasos vestigios presentes durante la segunda mitad del siglo XIX y de entre los más famosos, tales como los pertenecientes a la iglesia de Santa Leocadia, pocos eran los datos de interés.

Ante tal panorama, el pintor se vio obligado a indagar en la documentación necesaria para ambientar su historia de la manera que describe a continuación:

"Mas por desgracia, si conocemos las remotas civilizaciones de pueblos como la India y Egipto (...) las artes de los godos españoles, y en general, de la época bizantina, nos son más desconocidas por los escasos monumentos que de ellos nos quedan. Las coronas votivas de Guarrazar (Toledo), los mosaicos de San Vitale de Rávena (Italia) y los de Santa Sofía en Constantinopla, son los más importantes y los que me han servido principalmente para reconstruir la indumentaria de la época de Recaredo. En ellos aparecían confundidos los caracteres latinos arraigados de antiguo en nuestro pueblo, con la magnificencia de la corte de Bizancio, que introdujo en la suya Leovigildo (...)" ${ }^{, 97}$.

Dentro de la obra del artista decimonónico, llama la atención desde el punto de vista compositivo, la representación de un gran capitel marmóreo sobre el que voltea uno de los arcos de la basílica (fig. 16). La pieza se eleva por encima de la escena principal, dividiendo visualmente la composición en dos partes bien marcadas y otorgando a este elemento una importancia intencionada. Lo más destacado, es que la pieza recuerda claramente los modelos presentes en la basílica italiana de San Vitale de Ravenna, tal y como señalan los autores que han estudiado esta pintura. De hecho, "Así

\footnotetext{
${ }^{96}$ La pintura fue incluida en el programa decorativo del Salón de Conferencias del Senado. Cf.: M. CORTÉS ARRESE, "Acerca de la "invención" de Bizancio en el arte español: tres notas", Arte e Identidades Culturales, Oviedo, 1998, pp. 86-96, en particular, pp. 93-94.

${ }^{97}$ Ibidem, p. 93-94; F. WULFF ALONSO, "La Antigüedad en España en el siglo XIX", Arqueología fin de siglo: la Arqueología Española de la segunda mitad del siglo XIX, (M. B. Deamos y J. Beltrán Fortes coords.), Sevilla, 2002, pp. 119-15 y J. P. MUÑOZ HERRERA, "Toledo ante la mirada romántica: reflexiones en torno a una imagen", Cuadernos de arte de la Universidad de Granada, 27, 1996, pp. 147168.
} 
lo entendió Muñoz Degraín, quién pasó por alto que se trataba de un anacronismo: Recesvinto pertenecía a la centuria siguiente" ${ }^{98}$.

El capitel de tipo ravenante que aparece en la pintura depende de una tradición imaginaria no documentada en el Toledo en el que supuestamente se sitúa la escena. Más bien se trataría de una recuperación de los modelos presentes en la arquitectura oriental, tal y como se demuestra a través de los ejemplos de la iglesia de los Santos Sergio y Baco de Estambul o los realizados para San Demetrio de Tesalónica ${ }^{99}$.

Este aspecto tan particular de la pintura histórica española del siglo XIX, permite poner de relieve la tendencia anacrónica que determinados periodos mostraron hacia ciertos fragmentos de la Antigüedad clásica y tardía. Mediante el empleo instrumental de estas citas al mundo "clásico", se conseguía aludir a un momento histórico y a una época, aunque tal elemento no correspondiese en absoluto con la realidad material de dicho periodo.

Esta estética de lo "fragmentando", fundamentada en el citacionismo a las ruinas de la Antigüedad a través un legado "descontextualizado", tendría mucha fortuna en los siglos posteriores a la misma Edad Media.

Los grabados de Maarten van Heemskerck así lo atestiguan, pues en ellos encontramos, de manera reiterativa y continua, la alusión a un mundo antiguo destruido, pero que se reconoce a través de esas piezas ruinosas. La imagen en la que el autor reconstruye la vista del Puerto de Rodas con la mítica imagen del Coloso, da buena muestra de ello (fig. 17) ${ }^{100}$.

En el grabado al que nos referimos, una gigantesca cabeza perteneciente a una gran escultura, se muestra en estado ruinoso, asistida por diversos hombres que parecen intentar recomponerla o analizarla. Entre tanto, la ciudad de Rodas aparece cargada de monumentos de tradición clásica que se expanden por doquier. Sin duda, se trata de una

98 M. CORTÉS ARRESE, “Acerca de la “invención”...”, p. 94 y Constantinopla 1453. Mitos y Realidades (P. Bádenas, A. Bravo, I. Pérez Martín, E. Ayensa, J. S. Codoñer y M. Cortés Arrese eds.), Madrid, 2004.

99 E. KITZINGER, Byzantine Art in the Making. Main lines of stylistic development in Mediterranean Art. $3^{\text {rd }}-7^{\text {th }}$ Century, Cambridge, 1995, pp. 78-82.

${ }^{100}$ Erlangen, Universitätsbibliothek, Ms. 115, fol. 74v. Cf.: A. RED, voz "Heemskerck, Maarten Van", Enciclopedia dell'arte antica, classica e orientale, vol. III, Roma, 1960, p. 1127. Este pintor nacido en Holanda en el año 1498, ha pasado a la posteridad por mostrarnos un precoz tratamiento del género de las vistas, a través de la recreación de muchos lugares importantes del mundo antiguo. Sus visiones presentan un mundo en ruina, donde los restos de la Antigüedad se presentan fragmentados. En su obra, la individualidad de tales vestigios se convierte casi en símbolo de aquel pasado, pues, inconexos y aislados, enfatizan aún más su monumentalidad. En tal concepción del mundo antiguo, influyeron sus viajes a Italia, así como su pasión por los estudios de talante arqueológico. 
imagen fundamentada en el valor clásico de la ruina, así como en la construcción de un discurso a través del "fragmento" ". Su sola citación otorgaba a cualquier ambiente iconográfico con pretensiones paisajísticas de un prestigio bien marcado y reactivaba en el ideario colectivo toda una serie de valores de gran carga intelectual vinculados con las ruinas antiguas ${ }^{102}$.

Realizando una extrapolación forzada entre las obras artísticas, un diseño de Paulino de Venecia que tendremos oportunidad de valorar más adelante, insiste en la idea que estamos exponiendo (fig. 18). El dibujo, realizado en torno al año 1320, muestra los diversos fragmentos restantes de la desmantelada escultura del Coloso que originariamente se erigía en el área lateranense. Se trata de un documento excepcional que refleja perfectamente la representación de un mundo dislocado y desmembrado. Una visión de la Antigüedad parcial, derivada de un conocimiento disperso de todas aquellas obras que dicho tiempo había legado al medievo ${ }^{103}$.

Para concluir este apartado introductorio, debemos ser concisos a la hora de exponer algunas de las bases sobre las que se fundamenta este trabajo.

En primer lugar, dentro del presente estudio, al utilizar el concepto de lo "clásico", seremos, en la medida de lo posible, conscientes de la complejidad del término ${ }^{104}$. Siguiendo al profesor S. Settis, la utilización de esta voz a lo largo de las siguientes páginas aparece justificada por su valor "instrumental".

\footnotetext{
${ }^{101}$ M. MIGLIO, "Roma dopo Avignone. La rinascita politica dell'antico", Memoria dell'antico nell'arte italiana. L'uso dei classici, vol. I, Torino, 1984, pp. 75-111, en concreto, pp. 94-95 y F. HASKELL y N. PENNY, El gusto y el arte de la Antigüedad. El atractivo de la escultura clásica (1500-1900), Madrid, 1990. De entre las vistas creadas por Heemskerk, destaca aquella que recreaba el Campidoglio, con la loba de bronce sobre la fachada del Palacio de los Conservadores de Roma. Se ha datado el diseño entre los años 1534-1536.

102 En este sentido, tomarán gran importancia dentro del género del retrato, por ejemplo, los "fragmentos", de las esculturas o la arquitectura antigua. La introducción por parte del artista de alguno de estos vestigios, en forma de cornisas, bustos fraccionados, capiteles o cualquier obra artística clásica, dentro de los ambientes sobre los que se va a retratar a personalidades, tales como Rafael Grassi, Andrea Odón, Paolo Cornaro o Jacopo Strata, otorgaba a los retratados de un prestigio resuelto a través de este mecanismo de citación hacia lo antiguo. Véase, sobre el tema: C. FRANZONI, "Rimembranze d'infinite cose. Le collezioni rinascimentali di antichità", Memoria dell'antico nell'arte italiana. L'uso dei classici, vol. I, Torino, 1984, pp. 301-360.

${ }^{103}$ Roma, Biblioteca Marciana, Ms. lat. Zan. 399 (1610) fol. 98r. Sobre el diseño y los restos de la escultura, hoy conservados en los Musei Capitolini de Roma; vid.: S. ENSOLI, "I colossi di bronzo a Roma in età tardoantica: dal Colosso di Nerone al Colosso di Costantino. A proposito dei tre frammenti bronzei dei Musei Capitolini”, Aurea Roma. Dalla città pagana alla città cristiana, Roma, 2000, pp. 6690 .

${ }^{104}$ Nuestros limitados conocimientos en otras materias, en cierto modo, ajenas a la misma historia del arte, no nos permitirán poder reflexionar sobre los significados que las diferentes etapas de los siglos medievales dieron al término "clásico". Se trata de una cuestión vinculada a la filología, a la filosofía y la misma historia de las ideas estéticas. Para poder pronunciarnos sobre estas cuestiones, sería deseable poseer un alto conocimiento de las fuentes latinas y de la documentación relacionada con el tema. En
} 
“CLÁSICO” es, por sí sólo, un concepto estático, sin embargo, desde el punto de vista estético, acabó por designar también a ciertas tendencias visuales de la historia del arte. Sin embargo y a pesar de ello, tal concepto no tiene sentido y no se vuelve operativo sin un mecanismo dinámico de nostalgia y de iteración, sin una cierta pulsión, bien hacia el retorno hacia ese mismo "clasicismo", bien hacia su superación, con respecto a los demás periodos históricos. En otros términos, "clásico" y "clasicismo" forman parte de una pareja de conceptos que se explican y se legitiman mutuamente $(\ldots)^{\text {,105. }}$.

En todo caso y desde el punto de vista artístico, el concepto "clásico" será entendido como una categoría estética, es decir, como una constante histórica que se repite e "interesa a toda la civilización y a la cultura en su conjunto" cíclico y su comprensión como un mecanismo recurrente en la historia cultural de Occidente, llevarán a que tal categoría sea recuperada de manera reiterativa dentro de todo tipo de producciones artísticas, estéticas y de la más diversa índole ${ }^{107}$.

Tal fenómeno de recuperación de lo "clásico", a pesar de tener en el Renacimiento un respaldo teórico de una importancia extraordinaria mayor que en ningún periodo de la historia, habría de repetirse con asiduidad a lo largo de los siglos, tanto en los antiguos como en los modernos.

Ante tales premisas, se observará que, sin quererlo, nos adentramos entonces en la complejidad de un término cuya valoración radica en el conocimiento de sus fuentes filosóficas, filológicas y conceptuales y que, según la historiografía de nuestro tiempo,

definitiva, se trata de una labor complicada y con demasiados interrogantes que no podemos resolver aquí.

${ }^{105}$ Es evidente que las diferentes acepciones que ha recibido el término "clásico" poco tienen que ver con el origen etimológico y el significado que la palabra classicus poseía en latín. "No nació para definir fenómenos y épocas de la historia cultural, sino que pertenecía al lenguaje político y económico (por ejemplo, para designar las seis classes de ciudadanos romanos en el ordenamiento de Servio). El Classicus por excelencia era un ciudadano perteneciente a la classis más elevada de los contribuyentes fiscales; por traslación, un escritor del siglo II d. de C., Aulo Gelio, definía como "classicus scriptor, non proletarius" a un escritor de primer orden, no de la masa, o quizá mejor, digno de ser leído por los classici (los contribuyentes más ricos) y no por el pueblo". Sobre tal acepción, vid.: S. SETTIS, El futuro..., p. 81.

${ }^{106}$ E. D’ORS, Lo Barroco, Madrid, 2002, pp. 49-98; J. DE GARAY SUÁREZ-LLANOS, "Lo barroco, según E. D’Ors", Comentarios de textos literarios hispánico: homenaje a Miguel Ángel Garrido Gallardo (J. L. García Barrientos y E. Torre coords.), Madrid, 1997, pp. 181-202; J. PLAZAOLA, Modelos y teorías de la Historia del Arte, San Sebastián, 1987, pp. 56. La teoría defendida en su día por D’Ors, según la cual "se puede encontrar barroco por todas partes", acabó por definir el carácter cíclico del fenómeno de retorno a los clasicismos.

107 S. SETTIS, El futuro..., p. 96. El estudioso insiste en que la recuperación de lo "clásico", a veces reflejó el esfuerzo de legitimar el presente seleccionando en el pasado los modelos "exactos" a los que referirse. Según esto, lo "clásico" se podría hallar tanto "en la Roma de Augusto más que en la Atenas de Pericles", por citar una comparación bien expresiva realizada por el experto. 
habría de tener una importancia fundamental sobre las cuestiones relacionadas con la producción artística.

En concreto, el problema se agudiza al valorar la noción de revival ${ }^{108}$. De hecho, según las palabras de Argan, el revival se caracteriza por una revitalización de lo antiguo, pero sin que esa misma antigüedad sea el objeto a imitar. La recuperación de lo clásico alcanza cotas muy complejas para ser analizadas aquí. Según el autor:

"Se trataba de una valoración positiva del presente, al que se atribuía la fuerza de poder superar la inercia que conllevaba la tradición, para volver a conectar y a enfrentarse con lo antiguo. El efecto logrado pasaba por una toma de conciencia de la razón histórica del cristianismo, cuyo dogma, por consiguiente ya no sería en adelante sólo una cuestión de fe, sino una verdad histórica (...). De este modo se distinguía entre pasado histórico y pasado vivido o, lo que es lo mismo, entre antigüedad y pasado: nadie dudaba que la Edad Media era un pasado vivido, pero por esta misma razón constituía un vacío histórico; por encima de ella se alzaba un gran arco en cuyos extremos se encontraban lo antiguo y lo moderno" ${ }^{109}$.

Sus reflexiones pueden ayudar a entender la actitud de los hombres medievales ante los vestigios del mundo antiguo, independientemente de que estos fuesen materiales, intelectuales o de otra índole. Aún así, se deberá tener en cuenta que se trata de la aplicación de un método surgido en un momento histórico muy diferente, pero del que se pueden extraer argumentos extrapolables a la Edad Media.

Según entendió el mencionado teórico, "lo que concebimos como revival, tiene sus orígenes en el concepto ilustrado de taste -gusto- (...)" y que se puede relacionar con una cierta "intencionalidad poética"

Tal fenómeno ocupa el lugar de la clásica estructura binaria de la teoría y práctica y constituye la fuerza constante de todo el arte romántico. En este sentido:

“los revivals románticos están totalmente impregnados de la melancolía del exilio: se vive idealmente en otro tiempo, pero siempre con la forma de pensar del presente, y con un sentido de precariedad que impide una visión clara de aquel

\footnotetext{
108 G. C. ARGAN, "El revival", El pasado en el presente. El revival en las artes plásticas, la arquitectura, el cine y el teatro, Barcelona, 1977, pp. 7-66.

${ }^{109}$ Ibidem, p. 10.

${ }^{110}$ Ibidem.
} 
pasado en el que se ha buscado refugio, que no puede ser sustituido más que por el presente del que se está marginando" ${ }^{\text {.111. }}$

Mediante tales aspectos, pretendemos poner de relieve el hecho de que, determinadas imágenes producidas en consonancia con una percepción recuperadora del pasado "clásico", previsiblemente pudieron tener una intención poética. En este sentido, la ruina se nos presenta como un elemento importante y a tener en cuenta.

Según el profesor J. A. Ramírez, el tema de las ruinas debe ser considerado un asunto "clásico"112. Y no se trata de una defensa puntual de una teoría improbable, pues autores de la talla de S. B. Vranich, otorgaron un sentido similar a la imagen de las ruinas:

"En dos libros recientes (Rose Macaulay: Pleasure of Ruins y Paul Zucker: Fascination of Decay) se examinan a fondo los efectos que desde tiempos remotos, las ruinas han ejercido sobre la mente humana. Lo más curioso de notar es que no todas las épocas exhibieron igual sensibilidad ante las ruinas; tampoco se reaccionó de igual manera en diferentes países. La Roma imperial estuvo en escombros durante siglos sin que se percataran de ello los peregrinos a la ciudad de San Pedro, pues su reacción íntima ante las ruinas no se expresó durante casi toda la Edad Media. Es el espíritu humanístico el que descubre las ruinas como una herencia concreta de la gloria del pasado clásico, y son los arquitectos y arqueólogos los que primero las miden, estudian y describen"113.

Tal y como hemos expuesto en las líneas anteriores, en este estudio se intentará reflexionar sobre determinados aspectos derivados de tales premisas, interesándonos, en concreto, por las reacciones que pudieron mostrar los hombres medievales ante los vestigios "clásicos" de un pasado del que ya no participaban.

Como en otros periodos históricos, las ruinas fueron observadas y asimiladas dentro del ideario colectivo de los pueblos y las sociedades. Así lo certifican numerosos

\footnotetext{
${ }^{111}$ Ibidem, pp. 13-14.

112 J. A. RAMÍREZ, "De la ruina a la destrucción arquitectónica...", p. 526.

${ }^{113} \mathrm{~S}$. B. VRANICH, "La evolución de la poesía de las ruinas en la literatura española de los siglos XVI y XVII", Ensayos sevillanos del Siglo de Oro, Valencia-Chapel-Hill, 1981, pp. 765-768, en concreto, p. 765. Sobre las citadas obras a las que se refiere el autor, vid.: R. MACAULAY, Pleasure of Ruins, New York, 1967 y P. ZUCKER, Fascination of Decay, Ridgewood, 1968.
} 
documentos iconográficos y literarios y de entre los cuales, el ya citado diseño de Paulino de Venecia es uno de los más interesantes.

Según pensamos, a través de muestras como esta, no se pude seguir manteniendo y defendiendo el sentimiento de indiferencia ante la ruina que algunos autores han atribuido a los hombres medievales ${ }^{114}$.

La visión de lo “clásico" y la construcción de esta noción estética, aparecen ligadas íntimamente a la idea de las ruinas, cuya imagen forma parte y define este recurso intermitente y un periódico regreso a tal concepto. A través de tales elementos, según se ha advertido, se atestiguaba el final de determinados monumentos antiguos mutilados a lo largo de los siglos posteriores. Sin embargo, al mismo tiempo también, se "presagiaba su renacimiento" $"$.

Las ruinas supuestamente hubieron de ser un "testimonio tangible no sólo de la muerte de un mundo antiguo sino también de su intermitente y rítmica vuelta a la vida". Por eso, el sentido de éstas debe ser entendido como un vértice primordial dentro de la memoria cultural europea desde la Edad Media hasta hoy en día ${ }^{116}$.

114 M . GREENHALGH, "Ipsa ruina docent: l'uso dell'antico nel Medioevo", Memoria dell'antico nell'arte italiana, L'uso dei classici, vol. I, Torino 1984, pp. 113-167, en concreto, pp. 118-120. El autor recoge interesantes datos sobre el "descubrimiento" de algunas de estas ruinas en los siglos del medievo. Se trata de un estudio fundamental que demuestra que en dicho periodo la atención a las ruinas no fue menor.

${ }^{115}$ S. SETTIS, El futuro..., p. 101. Nos parece importante esta reflexión, en cuanto nos sirve para poder introducir el siguiente apartado de nuestro estudio, donde se analizará el fenómeno de los distintos "renacimientos" durante los siglos de la Edad Media.

${ }^{116}$ Ibidem, p. 102. 


\section{2. LOS "RENACIMIENTOS" EN EL ARTE MEDIEVAL A TRAVÉS DE UN BALANCE HISTORIOGRÁFICO.}

En el año 1987 Peter Burke publicaba un pequeño ensayo titulado El Renacimiento $^{117}$. En esta obra, breve en cuanto a su extensión pero contundente en sus afirmaciones, el autor escribía:

“(...) casi todas las características que se atribuyen al Renacimiento pueden encontrarse también en la Edad Media, época con la que se suele contraponer. Y sucede que esta simple oposición binaria entre la Edad Media y el Renacimiento, tan útil a efectos explicativos, es en muchos casos errónea" ${ }^{\prime 18}$.

Como suele ocurrir en estos casos, la distancia histórica y el discurrir del tiempo nos ofrecen la ventaja suficiente de poder analizar una idea tan contundente como esta, que el propio Burke defendía dentro del apartado de las conclusiones de su ensayo. Sin embargo, convencido de cual sería el desenlace de su obra, escribía al comenzar:

“(...) existen razones para afirmar que los llamados "hombres del Renacimiento" eran en realidad bastante medievales (...). Los medievalistas han reunido datos suficientes para afirmar que el Renacimiento no fue un acontecimiento singular. Existieron varios "renacimientos" en la Edad Media, especialmente en el siglo XII y en la época de Carlomagno. En ambos casos se produjo una combinación de logros artísticos y literarios, con un resurgimiento del interés por las enseñanzas clásicas, y también en cada uno de ellos los contemporáneos consideraron que la suya era una época de restauración, renacimiento o "renovación"119 (texto 4).

Mediante estas palabras Burke demostraba, desde el punto de vista historiográfico, dos aspectos fundamentales. En primer lugar, el cierto rechazo y su correspondiente crítica, al sistema ideológico defendido por el suizo Jacob Burckhardt y su apoteósica y trascendente obra La cultura del Renacimiento en Italia ${ }^{120}$.

\footnotetext{
${ }^{117}$ P. BURKE, El Renacimiento, Barcelona, 1999.

118 Ibidem, p. 97.

${ }^{119}$ Ibidem, pp. 12-13. Reproducimos literalmente el texto de Meter Burke por considerarlo necesario a la hora de poder abordar el tema de estudio a partir de las ideas expresadas, no por un medievalista, sino por un estudioso del arte producido entre los siglos XV y XVI.

${ }^{120}$ J. BURCKHARDT, La cultura del Renacimiento en Italia, Roma, 1860.
} 
En dicho ensayo, el citado investigador defendía que el Renacimiento -con $\mathrm{R}$ mayúscula- fue el gran acontecimiento cultural, artístico, económico y sociológico desde la caída del Imperio Romano y la disipación de los siglos de la Antigüedad. El fenómeno renacentista concebido por este planteamiento es un movimiento único, irrepetible y tan sólo vinculado en su momento inicial al ámbito italiano de finales del siglo XV y principios del XVI.

Sin embargo, la afirmación de Burke según la cual, "el Renacimiento de Burckhardt es un mito (...) es sinónimo de modernidad”, no deja lugar a dudas sobre su posicionamiento ante tales teorías ${ }^{121}$.

Así, la hipótesis de Burke parece mostrar una adhesión bastante clara con respecto a las ideas defendidas en su momento por E. Panofsky y materializadas sintéticamente en su famosa publicación del año 1960. Nos referimos, evidentemente, a su paradigmática obra titulada Renacimiento y renacimientos en el arte occidental ${ }^{122}$. Las ideas señaladas por el estudioso alemán en este texto, supondrían el punto y final a toda una serie de teorías, según las cuales, los fenómenos artísticos desarrollados en la Antigüedad clásica y la Edad Media estaban tan separados y distantes, los unos de los otros, que debían ser concebidos como movimientos estancos y sin relación posible.

Se rompía así con la división infranqueable de lo que él denominaba "megaperíodos", es decir, grandes momentos históricos amurallados e inconexos los unos con respecto a los otros ${ }^{123}$.

Tal grado de digresión, hacía necesario el establecimiento de un puente o salvoconducto intermedio entre ambos, de tal forma que, a través de tales planteamientos, la media aetas, el medium aevum o la media tempora, comenzasen a mostrarse y a ser entendidos, como meros calificativos didácticos y referenciales de tintes utilitaristas, y no como dogmas de fe inamovibles.

La Edad Media no suponía una ruptura en la sucesión histórico-artística, sino un pasaporte de unión inmediata entre unos siglos -y más importante aún, unas gentes-

${ }^{121}$ P. BURKE, Op. cit., pp. 8-9.

${ }^{122}$ E. PANOFSKY, Renaissance and Renascences in Western Art, Stockholm, 1960. Este texto puede ser considerado como uno de los referentes fundamentales a la hora de explicar el fenómeno de recuperación de formas clásicas durante la Edad Media occidental. Así mismo, es obligado punto de partida para las abundantes reflexiones que sobre el mismo tema serían realizadas dentro de la historiografía posterior. Para nuestro estudio, hemos trabajado con dos ediciones del mismo texto. Cf.: E. PANOFSKY, Renacimiento y renacimientos en el arte occidental, Madrid, 1985 e ID., Renacimiento y renacimientos en el arte occidental, Madrid, 2004. Por nuestra parte, utilizaremos preferentemente la edición más reciente, mientras que aquellos lugares en los que hayamos utilizado otras versiones, serán señalados puntualmente.

${ }^{123}$ E. PANOFSKY, Renacimiento y renacimientos..., p. 33. 
que en absoluto se sentían partícipes de periodos herméticos y finitos ${ }^{124}$. Según esto, la finitud de los periodos artísticos debía considerarse como una división artificial y controvertida, tan sólo útil a efectos prácticos. Es decir, teniendo en cuenta tales ideas y los posteriores planteamientos a los que han llegado las investigaciones de nuestro siglo, se trataría de un fraccionamiento eminentemente ambiguo y falsificado ${ }^{125}$.

A partir de esta nueva concepción, el Renacimiento dejaba de ser un "periodo" para convertirse en un "movimiento" "126, mientras que la Edad Media pasa a mantenerse unida al Renacimiento "por mil lazos; ya que la herencia de la Antigüedad clásica, por muy tenue que fueran a veces los hilos de la tradición, no llegó nunca a pederse de manera irrecuperable (...)"127.

El ámbito científico europeo inauguraba así una nueva tendencia historiográfica que buscaba redefinir los lenguajes, acotar las influencias y concretar la utilización de los conceptos y divisiones establecidas ${ }^{128}$.

A la hora de realizar una síntesis coherente sobre el tratamiento que las diversas tendencias historiográficas han dado a estos temas, merecen una mención destacada las diversas aportaciones realizadas por la historiografía ALEMANA. De sus escuelas y universidades nacería una basta producción literaria especializada en estos asuntos, pero que, debido a tal volumen, resulta imposible recoger de manera exhaustiva ${ }^{129}$.

En este mismo sentido, a la hora de realizar una aproximación historiográfica al tema, merece destacada mención el ámbito ANGLOSAJÓN.

Entre los más importantes, señalamos los trabajos de C. H. Haskins, The Renaissance of the Twelfth Century ${ }^{130} \mathrm{y}$ el de D. Miner, The survival of Antiquity in the

\footnotetext{
${ }^{124}$ Recordemos en este punto la frase de P. Burke: "existen razones para afirmar que los llamados "hombres del Renacimiento" eran en realidad bastante medievales". Cf.: P. BURKE, Op. cit., p. 12.

${ }^{125}$ E. SESTAN, "Tardo antico e alto Medievale: Difficoltà di una periodizzazione", Actas IX Settimane di Studio del Centro Italiano di studi sull'Alto Medioevo. Il passaggio dall'Antichità al Medieoevo in Occidente, Spoleto, 1962, pp. 15-37.

${ }^{126}$ P. BURKE, Op. cit., p. 97.

${ }^{127}$ E. PANOFSKY, Renacimiento y renacimientos... (1985), p. 38.

${ }^{128}$ Para el balance historiográfico que a continuación vamos a desarrollar, no se han seguido criterios de orden cronológico, sino geográfico. Más concretamente, se tendrá en cuenta la importancia que, según nuestro criterio, tienen dichas producciones artísticas dentro del panorama de la historiografía especializada en el tema. Se tendrán en cuenta los autores de diversas nacionalidades especialistas en estos temas, pero también aquellos foráneos que hayan dirigido sus investigaciones a un determinado área geográfica o país.

${ }^{129}$ En relación con los textos científicos publicados en lengua alemana, evidenciamos nuestros problemas para acceder a ellos, debido, en parte, a nuestro desconocimiento de este idioma. No obstante, tales carencias se han suplido gracias a las traducciones a las que hemos tenido acceso mediante diferentes vías. La más importante reside en las numerosas traducciones y reediciones que en los últimos años se han hecho de estos importantes textos de la historiografía germana.

${ }^{130}$ C. H. HASKINS, The Renaissance of the Twelfth Century, Cambridge, 1927.
} 
Middle Ages. The Greek tradition ${ }^{131}$, ambos centrados en analizar el impacto de la tradición clásica en las producciones medievales, concretamente en las del siglo XII. Igualmente indispensables resultan las aportaciones de D. Glass ${ }^{132}$ y la de R. L. Benson y C. Constable con su, Renaissance and Revewal in the Twelfth Century ${ }^{133}$, y que siguen estos mismo parámetros desde el punto de vista de la acotación cronológica.

Más conocidas para el historiador del arte se muestran las producciones científicas de M. Greenhalgh, sobre todo a partir de la publicación de su obra, The survival of Roman Antiquities in the Middle Ages ${ }^{134}$.

A partir de ella, el autor centrará sus estudios en el fenómeno de la expoliación de material clásico durante el medievo. Sus textos, la mayoría deudores de la tradición inglesa, han sido traducidos a otras lenguas, especialmente la italiana, lo que ha permitido un mayor acceso por parte del público a la serie de aportaciones nacidas de una de las personalidades más relevantes en el estudio del tema que aquí tratamos.

En otro orden de cosas y para finalizar este breve recorrido por las producciones científicas inglesas, merece obligada alusión la obra de F. Saxl ${ }^{135}$. Se trata del mismo autor que escribiría junto a E. Panofsky otra serie de textos de absoluta referencia ${ }^{136}$.

Sin embargo, si existe una obra indispensable en cuanto a su acotación sobre las materias relacionadas con el estudio de las artes plásticas y tratamiento puntual del ámbito inglés medieval, ese es el estudio de W. Oakeshott, titulado, Classical inspiration in Medieval Art ${ }^{137}$. Dicho texto, publicado en la fecha temprana de 1959, puede ser considerado como el precedente teórico de la obra de E. Panfosky. Su estudio, ciertamente completo desde el punto de vista iconográfico, analiza el resurgir de las fórmulas clásicas a lo largo de los diferentes estadios de la Historia del Arte, desde el "renacimiento" de Northumbria al acontecido en los territorios carolingios y desde la recuperación de estos ideales antiguos durante los siglos XI al XIII a la época tardogótica.

Dentro de la escuela FRANCESA y vinculados a los autores que se preocuparon de manera más especifica por el arte medieval de estos territorios, sin duda, el caso más

\footnotetext{
${ }^{131}$ D. MINER, The survival of Antiquity in the Middle Ages. The Greek tradition, Baltimore, 1939.

132 D. GLASS, The Renaissance of the Twelfth Century, Rhode Island, 1969.

${ }^{133}$ R. L. BENSON y C. CONSTABLE, Renaissance and Revewal in the Twelfth Century, Oxford, $1982 \mathrm{y}$ C. CONSTABLE, The Reformation of the Twelfth Century, Cambridge, 1996.

${ }^{134}$ M. GREENHALGH, The survival of Roman Antiquities in the Middle Ages, London, 1989.

135 F. SAXL, "Continuidad y variación en el significado de las imágenes", La vida de las imágenes, Madrid, 1989, pp. 11-20.

${ }^{136}$ F. SAXL y E. PANOFSKY, Classical Mythology in medieval art, New York, 1933.

${ }^{137}$ W. OAKESHOTT, Classical inspiration in Medieval Art, London, 1959.
} 
importante es el de J. Adhémar y su famoso Influences antiques dans l'art du Moyen $\hat{A}$ ge français $^{138}$. La obra supuso un hito fundamental y aún hoy resulta un magnifico ensayo en el que se valoraron, por primera vez y de manera global, las repercusiones que el arte galo-romano tuvo sobre las producciones artísticas románicas.

No es de extrañar que, siguiendo esta misma dicotomía planteada por este autor, surgieran otros estudios de similar naturaleza y de entre los que destacamos, las producciones científicas del profesor V. Lassalle ${ }^{139}$.

Sin embargo, dentro de este sucinto balance merecen ser mencionados otra serie de trabajos. Destacamos así las investigaciones realizadas por R. Rey, quién desde el año 1928 realizaría importantes aportaciones en este campo ${ }^{140}$. En relación con ello, parece que podemos considerar esta aportación, tanto desde el punto de vista ideológico como desde el metodológico, como antecedente directo de la obra de J. Adhémar.

Otro de los estudiosos importantes fue el profesor M. Durliat. Sus trabajos se presentan ciertamente más concretos y acotados a un determinado ámbito o región, además de no abordar directamente el tema de la recuperación de formas clásicas de una manera directa ${ }^{141}$. Dentro de la misma escuela nacional, también son significativos los estudios de R. Crozet, sobre todo, a través de sus contribuciones centradas en el legado clásico del arte románico francés ${ }^{142}$.

138 J. ADHÉMAR, Influences antiques dans l'art du Moyen Âge français; recherches sur les sources et les thèmes d'inspiration, Paris (1939), 1996. Se trata, sin duda, de otro de los primeros y más importantes estudios sobre la herencia de la Antigüedad en la Edad Media, aunque su restricción geográfica al ámbito francés no fueron suficiente como para que E. Panofsky escribiera al respecto: "A pesar de las limitaciones topográficas que su mismo título indica, el excelente estudio de J. Adhémar (...) merece contarse entre las discusiones generales de este problema". Cf.: E. PANFOSKY, Renacimiento y renacimientos..., p. 84, nota 1 .

${ }^{139}$ V. LASSALLE, L'influence antique dans l'art roman provençal, Paris, 1983. El autor, siguiendo a J. Adhémar, aplica su análisis sobre una clásica división de las artes plásticas, acotando el fenómeno sobre la arquitectura, la escultura y la pintura.

${ }_{140}$ R. REY, "Quelques survivances antiques dans la sculpture romane du Midi de la France", Gazette des Beaux-Arts, II, 1928, pp. 173-191. A pesar de tratarse de una obra tan precoz, desarrolló una serie de planteamientos que habrían de tener gran éxito dentro de la historiografía posterior. En este sentido, el autor apuntaba ya un fuerte legado clásico dentro de la escultura francesa, especialmente en obras de gran importancia como la Puerta Miègeville de Saint-Sernin de Tolouse, los relieves del deambulatorio del mismo edificio o los dinteles de Arles-sur-Tech o Saint-André-de-Sorède.

${ }^{141}$ M. DURLIAT, La sculpture romane de la route de Saint-Jacques. De Conques à Compostelle, Montde-Marsan, 1990 e ID., "Influences antiques sur la sculpture romane du Languedoc méditerranéen et de Catalogne”, Congrès National des Sociétés Savantes, 33, 1952, pp. 78-90. Con todo, la obra de M. Durliat es básica para el estudio del legado clásico en las producciones artísticas de la Edad Media. El autor nunca realizó un estudio específico sobre el tema, al menos de una manera amplia. Su obra, ya clásica, tiene muy en cuenta a la hora de abordar las relaciones de la escultura hispana románica con los focos franceses, la fuerte impronta clásica de ésta y sus deudas con el arte antiguo.

${ }^{142}$ R. CROZET, "Les survivances de la pensée et de l'art antique dans la peinture carolingienne", Mélanges d'histoire du Moyen Âge dédiés à la mémoire de L. Halphen, Paris, 1951, pp. 165-168; ID., "Survivances antiques dans l'architecture romane du Poitou, de l'Angoumois et la Saintonge", Mémoires de la société nationale des Antiquaires de France, 3, 1954, pp. 193-202 e ID., "Survivances antiques 
Por último, y por citar una obra pluridisciplinar y que tiene en cuenta los diferentes estadios sociales y políticos del periodo, aludimos al estudio de J. Verger, pues se trata de una aportación importante al analizar el ambiente en el que situar las diversas producciones artísticas del momento ${ }^{143}$.

Desde el ámbito ITALIANO, la literatura científica sobre el tema es muy densa y condicionada, en parte, por la fuerte deuda con lo clásico que presentan las obras artísticas conservadas a lo largo de toda la Península ${ }^{144}$.

Debemos a la profesora N. Dacos la autoría de una aportación titulada, Sopravvivenza dell'antico ${ }^{145}$. En ella se hace un excelente y riguroso balance historiográfico sobre el tema a través de los diferentes periodos artísticos de la historia. Según pensamos se trata de un brillante estado de la cuestión sobre el recuerdo y absorción de fórmulas clásicas en el arte de la Antigüedad tardía, además de servir de base para ciertas reflexiones que llevarían a cabo otros autores posteriores. Este es el caso, por ejemplo, de las contribuciones de la profesora A. M. Romanini ${ }^{146}$.

Finalmente, en entre los años 1984-1986, el profesor S. Settis dirigió la aportación colectiva más importante en relación con el tema del sustrato clásico del arte medieval, tanto desde las escuelas italianas como desde las europeas en general. Los tres volúmenes de Memoria dell'antico nell'arte italiana, pueden ser considerados como la obra de conjunto más completa, por enfocar cada volumen hacia un aspecto destacado dentro del fenómeno de la recuperación del mundo clásico ${ }^{147}$. El propio $\mathrm{S}$. Settis, a parte de su aportación a la magna obra que dirigía ${ }^{148}$, publicaría además otros

dans le décor roman du Poitou, de l'Angoumois et de la Saintonge, Bulletin Monumental, 114, I, 1956, pp. 7-33.

${ }_{143}$ J. VERGER, La Renaissance du XII ${ }^{e}$ siècle, Paris, 1996.

${ }^{144}$ Indicamos a continuación los títulos que, a nuestro juicio, son más significativos. Somos conscientes además de la existencia de multitud de obras que no conocemos y otras a las que no hemos podido tener acceso.

145 N. DACOS, "Sopravvivenza dell'antico", Enciclopedia dell'arte antica, classica e orientale. Supplemento1970, Roma, 1973, pp. 725-746.

146 A. M. ROMANINI, "Il concetto di classico l'arte medievale”, Romanobarbarica, I, 1976, pp. 203-242 e ID., "Il concepto di classico e l'alto medieoevo", Arte Medievale. Interpretazioni storiografiche (a cura di A. Peroni e M. Righetti), Spoleto, 2005, pp. 129-142.

147 Memoria dell'antico nell'arte italiana (a cura di S. Settis), 3 vols., Torino, 1984-1986; Memoria dell'antico nell'arte italiana, vol. I, L'uso dei classici (a cura di S. Settis), Torino, 1984; Memoria dell'antico nell'arte italiana, vol. II, I generi e i temi ritrovati (a cura di S. Settis), Torino, 1985 y Memoria dell'antico nell'arte italiana, vol. III, Dalla tradizione all'archeología (a cura di S. Settis), Torino, 1986. Evitamos en este repaso general mencionar cada uno de los artículos incluidos a lo largo de los tres volúmenes, a pesar de que consideramos a algunos de ellos como verdaderamente merecedores de aparecer dentro de este breve balance historiográfico. No obstante, las aportaciones incluidas en los tres volúmenes serán citadas convenientemente a lo largo de todo el texto cuando fuese necesario.

${ }^{148}$ S. SETTIS, “Continuitá, distanza...”, pp. 373-486. 
estudios de igual relevancia y siempre relacionados con diversos aspectos ligados a la recuperación iconográfica y material del mundo antiguo en los siglos medievales ${ }^{149}$.

Ya dentro de la década de los año noventa merecen ser destacadas, para finalizar, las aportaciones de A. Pensabene, quién enfocará sus indagaciones hacia la recuperación de la Antigüedad en época medieval, pero desde un punto de vista material, más que desde el intelectual, es decir, a través del fenómeno de la expoliación in $s e^{150}$. Para finalizar, no debemos olvidar otra serie de contribuciones llevadas a cabo por los profesores M. D’Onofrio ${ }^{151}$, B. Brenk ${ }^{152}$ y, especialmente, A. Quintavale ${ }^{153}$.

Hasta aquí, hemos citado algunas de las obras más importantes en relación con el tema que estudiamos. Se trata, a todas luces, de una selección necesariamente parcial, fruto de la necesidad de síntesis. Sin embargo, a través de las aportaciones mencionadas, creemos que hemos perfilado un panorama historiográfico lo suficientemente rico y representativo como para comenzar el estudio.

Resta, finalmente, analizar sucintamente el ámbito en el que se circunscribe nuestro estudio. Así, desde el punto de vista de la historiografía que se preocupó de los

\footnotetext{
${ }^{149}$ S. SETTIS, "Ineguaglianze e continuità: un'immagine dell' arte romana", Introduzione all'arte romana (J. Brendel ed.), Torino, 1982, pp. 161-200; ID., "Tribuit sua marmora Roma: sul reimpiego di sculture antiche", Lanfranco e Wiligelmo. Il duomo di Modena, Modena, 1984, pp. 309-317 e ID., "Les remplois", Patrimoine, temps, espace. Patrimoine en place, patrimoine déplacé. Actes des Entretiens du Patrimoine sous la présidence de F. Furet, Paris, 1997, pp. 67-86.

${ }^{150}$ A. PENSABENE, "Contributo per una ricerca sul reimpiego e il "recupero" dell'antico nel Medioevo. Il rimpiego nell'età marmorea", Rivista dell'Istituto Nazionale d'Archeologia e Storia dell'Arte, III, XII, 1990, pp. 5-138; ID., "Contributi per una ricerca sul reimpiego e il "recupero" dell'antico nel Medioevo. II. I portici cosmateschi a Roma", Rivista dell'Istituto Nazionale di Archeologia e Storia dell'Arte, 3, 14/15, 1991/1992, pp. 305-346; ID., "Il reimpiego nell'età constantiniana a Roma", Constantino il grande dall'antichità all'umanesimo. Colloquio sul cristianesimo nel mondo antico, vol. II, Macerata, 1993, pp. 749-768 e ID., "Reimpiego dei marmi antichi nelle chiese altomedievali a Roma", Marmi Antichi (a cura di G. Borghini), Roma, 1997, pp. 55-64.

${ }^{151}$ Desde hace años el profesor M. D'Onofrio ha venido publicando algunos trabajos donde analiza diversos aspectos de las producciones artísticas de época carolingia desde la óptica de las relaciones que éstas mantuvieron con el arte clásico romano y las repercusiones que tendrían sobre el arte posterior. Cf.: M. D'ONOFRIO, "La königshalle di Lorsch presso Worms", Roma e l'età carolingia, Roma, 1976, pp.131-138; ID., Roma e Aquisgrana, Roma, 1983; ID., "Tribuit sua marmora Roma: sul reimpiego di sculture antiche", Lanfranco e Wiligelmo. Il duomo di Modena, Milano, 1984, pp. 309-317 e ID., Rilavorazione dell' antico nel medioevo (a cura di Mario D'Onofrio), Roma, 2003.

${ }^{152}$ A pesar de pertenecer a la escuela germana, lo incluimos dentro del ámbito italiano debido a que muchos de sus estudios se ciñen al ámbito medieval italiano. Cf.: B. BRENK, "Suger Spolien", Arte Medievale, I, 1983, pp. 101-107; ID., "Spolia da Constantino a Carlomagno: estetica versus ideología", Architettura e immagini del sacro nella tarda antichità, Spoleto 2005, pp. 197-203 e ID., "Spolia e il loro effetto sull'estetica della varietas. Attorno al problema dei capitelli alternati", Architettura e immagini del sacro nella tarda antichità, Spoleto 2005, pp. 205-219.

153 A. C. QUINTAVALLE, "L'antico ritrovato", Medioevo. Immagini e idelogie. Atti del V Convengo Internazionale di Studi (a cura de A. C. Quintavale), Parma, 2002, pp. 23-45; ID., "Quei campi dei miracoli”, Rilavorazione dell'antico nel Medioevo (a cura di Mario D’Onofrio), Roma, 2003, pp. 15-28 e ID., Medioevo: il tempo degli antichi, Parma, 2006.
} 
temas HISPANOS, se acusa claramente la carencia de un análisis profundo y completo sobre la pervivencia y permanencia del sustrato antiguo en los siglos medievales.

Este hecho se hace aún más evidente al referirnos a la plástica del románico en concreto. Hasta la fecha, que nosotros conozcamos, no existe un estudio de conjunto en el que se tengan en cuenta estos aspectos generales a través de una visión de conjunto, no sólo desde un punto de vista meramente descriptivo, sino basado en el análisis global del fenómeno.

En este sentido, creemos necesario llevar a cabo una valoración de los aspectos artísticos más destacados, centrados no sólo en la vertiente iconográfica, sino también teniendo en cuenta otros elementos, tales como las mismas variantes estilográficas, por citar el aspecto que más nos interesa.

Creemos que, a la hora de abordar estas cuestiones, se deben tener en cuenta otra serie de indagaciones relacionadas con la propia arquitectura, las producciones librarias y las fuentes escritas. Hecho que, desde hace ya algunos años, la historiografía dedicada a los temas hispanos, viene teniendo muy en cuenta ${ }^{154}$.

Sin embargo, y a pesar de haber mencionado una cierta carencia en cuanto a los estudios dedicados al tema que nos ocupa, señalaremos a continuación los trabajos que, de una manera u otra, han hecho hincapié en las repercusiones del arte antiguo sobre las producciones posteriores.

Sin duda, la gran autoridad en relación con el ámbito hispano románico y el legado clásico es el profesor S. Moralejo. Dentro de su producción científica, el autor nunca abordó de manera concreta el tema, sin embargo, prácticamente en todos sus trabajos se adentra en la problemática que venimos tratando.

De una manera u otra, sus estudios se centraron en el fenómeno de la expoliación de material antiguo durante el medievo ${ }^{155}$, así como los procesos de asimilación estilística de la Antigüedad por parte de la escultura románica española ${ }^{156}$.

\footnotetext{
${ }^{154}$ I. G. BANGO TORVISO, "Crisis de una historia del arte medieval a partir de la teoría de los estilos. La problemática de la Alta Edad Media", Revisión del arte medieval en Heuskal Herria, 15, 1995, pp. 1528. El profesor Bango lleva a cabo una serie de reflexiones sobre la complejidad del concepto y la creación de una Historia del Arte fuertemente asentada sobre tales preceptos estilográficos. Nosotros, por nuestra parte, adelantamos que algunas de nuestras reflexiones, tendrán como punto de partida diversas cuestiones estilísticas, incluso antes que otras de índole iconográfica.

${ }^{155}$ S. MORALEJO ÁLVAREZ, "La reutilización e influencia de los sarcófagos antiguos en la España Medieval", Atti Colloquio sul reimpliego dei sarcofagi romani nel medioevo, Marburg, 1984 consultado en la reedición de su obra: Patrimonio artístico de Galicia y otros estudios, vol. II (A. Franco Mata dir.), Santiago de Compostela, 2004, pp. 279-288.

${ }^{156} \mathrm{~S}$. MORALEJO ÁLVAREZ, "Modelo, copia y originalidad en el marco de las relaciones artísticas hispano-francesas (siglos XI- XIII)", V Congreso Español de Historia del Arte, Barcelona, 1987, pp. 89-
} 
Continuadores en cierta medida de esta tendencia, podemos considerar los estudios de M. A. Castiñeiras. Sus aportaciones tampoco se centraron de manera concreta en el tema, pero, por el contrario, ha llegado a importantes conclusiones en lo relativo al sustrato clásico del arte medieval ${ }^{157}$.

Igualmente, y siempre en esta misma línea temática, debemos señalar los estudios del profesor I. G. Bango Torviso. Su producción científica aparece ligada a la recuperación, o más bien podríamos decir, continuidad ${ }^{158}$, de modelos bajorromanos en el arte de la Alta Edad Media. Dichos tipos nunca se perdieron, sino que sobrepasaron los diferentes estadios del tiempo sin solución de continuidad, como elementos que formaban parte de la conciencia colectiva de los artífices y productores de objetos artísticos y edificios. Así, son fundamentales las aportaciones vinculadas a la persistencia de elementos de tradición bajo imperial en la plástica y la arquitectura visigodas, en lo que se ha definido como el "mantenimiento del ordo gothorum"159.

Para finalizar este breve repaso, creemos que merecen obligada mención, por moverse siempre en el ámbito del arte prerrománico hispano y, en ocasiones, en su

112, consultado en la reedición de su obra: Patrimonio artístico..., vol. II, pp. 75-96; ID., "Le origini del programma dei portali nel romanico spagnolo", Atti del Convengo: Wiligelmo e Lafranco nell'Europa romanica, Modena, 1989, pp. 35-51, consultado en: Patrimonio Artístico..., vol. II, pp. 121-135; ID., "La sculpture romane de la cathédrale de Jaca. Etat des questions", Les Cahiers de Saint-Michel de Cuxa, 10, 1979, pp. 79-100, consultado en: Patrimonio Artístico..., vol. I, pp. 141-160.

157 M. A. CASTIÑEIRAS, "Las fuentes antiguas en el menologio medieval hispano: la pervivencia literaria e iconográfica de las Etimologías de Isidoro y del Calendario de Filócalo", Boletín del Museo Arqueológico Nacional, XIII, 1-2, 1994, pp. 77-100; ID., "Capitel románico inspirado na Orestíada do sarcófago de Husillos", Luces de Peregrinación, Santiago de Compostela, 2004, pp. 252-254. Centrándose más en la recuperación de iconografía tardoantigua cristiana por parte del arte de la Reforma Gregoriana y, en concreto, dentro de los ciclos escultóricos auspiciados bajo su influencia, véanse: ID., "Un adro para un bispo: modelos e intencións na fachada de Praterías", Sémata, Cultura, Poder y mecenazgo, 10, Santiago de Compostela, 1998, pp. 231-264; ID., "Roma e il programma reformatore di Gelmírez nella Catedrale di Santiago di Compostella", Medioevo: immagini e ideologie, Parma, 2002, pp. 211-226 e ID., "Un passaggio al passato: il portale di Ripoll”, Medioevo. Il tempo degli antichi, Parma, 2006, pp. 365-381.

${ }^{158}$ Señalamos aquí la importancia del concepto "continuidad", por ser uno de los puntos cruciales dentro de nuestros análisis y mediante el cual entendemos las fórmulas artísticas medievales como el resultado de una continuidad de aquellas existentes en el mundo bajorromano. Véase más adelante el correspondiente apartado donde abordamos el concepto.

${ }^{159}$ I. G. BANGO TORVISO, "El ocaso de la Antigüedad. Arte y Arquitectura en la Alta Edad Media hispánica”, Cataluña en la época carolingia. Arte y cultura antes del románico (siglos IX y X), Barcelona, 1999, pp. 175-185; ID., "El neovisigotismo artístico de los siglos IX y X: la restauración de las ciudades y templos", Revista de Ideas Estéticas, 1979, pp. 319-338; ID., "L'Ordo Gothorum et sa survivance dans 1’Espagne du Haut Moyen Âge", Revue de l'art, LXX, 1985, pp. 9-20; ID., "La cultura artística de la monarquía astur, la última manifestación de la Antigüedad", Astures (pueblos y cultura en la frontera del Imperio Romano), Gijón. 1995, pp. 175-187 e ID., "La creación artística como emblema de la teoría del estado en la monarquía visigoda y en la asturleonesa", Propaganda e poder. Congreso Peninsular de História da Arte, Lisboa, 2001, pp. 31-46. No obstante, sus aportaciones se han centrado preferentemente en la arquitectura. 
relación con los modelos clásicos, los estudios de P. de Palol ${ }^{160}$ y F. Marín Valdés ${ }^{161}$.

Como en el caso francés o italiano, diversos "hispanistas" han llevado a cabo diferentes reflexiones en las que aborda de una manera más parcial el tema. Nos referimos en este sentido a los trabajos de J. A. Ramos Rubio ${ }^{162}$ y M. E. Ibarburu Asurmendi ${ }^{163}$, por citar dos de los ejemplos más concretos.

Por último y por tratarse de una obra de carácter general, no se puede obviar la obra colectiva fruto de la celebración del X Congreso del CEHA, Los clasicismos del arte español. Este volumen es el único caso dentro de la historiografía hispana, del que tengamos constancia, en el que se ha intentado tratar de manera global el tema de la perdurabilidad del arte clásico a lo largo de toda la Historia del Arte ${ }^{164}$.

Como reflexión final para este apartado, queremos señalar que la pervivencia de fórmulas "antiquizantes" dentro de las artes y la arquitectura románica, se presenta como un tema sobre el que recientemente se ha insistido. A partir del año $2000 \mathrm{y}$, sobre todo, entre los años 2006 y 2009, algunos eventos científicos han abordado de manera monográfica determinados aspectos de vital importancia para comprender el fenómeno.

En este sentido, mencionamos las Jornadas de Estudio realizadas en la Casa Velázquez de Madrid, desarrolladas bajo el título Modos de reutilización en la Edad Media en los países del Mediterráneo occidental (siglos X-XIII), que deben ser citadas por la alta calidad de las aportaciones allí realizadas ${ }^{165}$.

Con todo, fue entre los años 2007 y 2008 cuando vieron la luz dos publicaciones de especial relevancia para el tema que nos ocupa. Nos referimos, en primer lugar, a la

\footnotetext{
${ }^{160}$ P. DE PALOL, "Elements clàssics en la iconografia del brodat..., pp. 427-438.

${ }^{161}$ F. MARÍN VALDÉS, "Los frontis de glorificación del prerrománico asturiano a la luz de algunas proyecciones de la Antigüedad Tardía", Cuadernos de arte e iconografía, VI, 1993, pp. 151-159 e ID., "Observaciones sobre la adopción de loci classici en el arte prerrománico asturiano: factores de continuidad", Actas VI Jornadas de Arte La Visión del Mundo clásico en el arte español, Madrid, 1993, pp. 30-59.

162 J. A. RAMOS RUBIO, "La herencia del mundo antiguo. Aportaciones a la iconografía de la Edad Media en la Diócesis de Palencia”, Hispania Sacra, LVII, 16, 2005, pp. 407-428. Nuevamente con una acotación geográfica bastante restringida que no permite al autor realizar conclusiones generales de interés.

${ }^{163}$ M. E. IBARBURU ASURMENDI, "La pervivencia de ilustraciones sobre temas astronómicos del mundo clásico, a través del ms. Vat. Reg. 123", V Congreso Español de Historia del Arte, Barcelona, 1986, pp. 29-37.

${ }^{164}$ Los clasicismos del Arte Español. Actas del X Congreso del CEHA, Madrid, 1994. El volumen recoge una serie de aportaciones centradas en la continuidad de los valores y formas clásicas durante los diferentes momentos de la Historia del Arte. Un marco cronológico tan amplio provoca que las referencias y estudios concretos sobre los siglos medievales, fueran, necesariamente, limitados.

${ }^{165}$ No tenemos constancia de que los trabajos de este evento hayan visto la luz a través de una publicación. Tan sólo nos remitimos a señalar que el tema de las expoliaciones de materiales poseen una importancia absoluta dentro de nuestro trabajo y la dedicación de unas Jornadas a su estudio, sigue incidiendo en la actualidad e interés que la comunidad científica muestra por este tema. Dicho acto se desarrolló en la Casa de Velázquez de Madrid, entre el 27 y 28 de marzo de 2006.
} 
celebración de las Jornadas Románicas de la abadía de San Miguel de Cuixá, que en la edición de ese año versaron sobre la Actualité de l'art antique dans l'art roman ${ }^{166}$.

Un año después, el Museu Nacional d'Art de Catalunya, en Barcelona, acogía la exposición titulada El Románico y el Mediterráneo. Cataluña, Toulouse y Pisa (11201180). El catálogo fruto de tal evento puede considerarse como una de las aportaciones colectivas recientes de mayor interés y calidad científica, centrada en el estudio de las relaciones entre el arte antiguo y el periodo medieval ${ }^{167}$.

Por último, tan sólo resta aludir a los pequeños trabajos que nosotros mismos hemos ido desarrollando en los últimos años y que han tenido como objetivo central poner de relieve el fuerte sustrato clásico que presentan las artes hispanas realizadas entre los siglos que transcurrieron entre lo que actualmente denominamos Alta y Baja Edad Media ${ }^{168}$.

\footnotetext{
${ }^{166}$ Durante la redacción de este apartado las actas en las que se verán publicadas todas las aportaciones realizadas en este evento no se habían hecho públicas para la comunidad científica. Las exposiciones de los expertos se desarrollaron en la abadía de Saint-Michel de Cuxa, entre el 6 y el 13 de julio de 2007.

${ }^{167}$ El Románico y el Mediterráneo. Cataluña, Toulouse y Pisa (1120-1180), Barcelona, 2008. Se trata de un volumen de estudios y fichas catalográficas en los que se pone de relieve la importancia del arte tardorromano del área tolosana e italiana, a la hora de explicar otras manifestaciones románicas localizadas en la Península Ibérica. Se trata de un estudio fundamental para nuestro trabajo y que citaremos en repetidas ocasiones a lo largo del texto.

${ }^{168}$ J. A. MORÁIS MORÁN, "De lo pagano a lo cristiano en el arte románico hispano: a propósito de la iconografía de las aves afrontadas a la crátera de la vida", La Multiculturalidad en las artes y en la arquitectura, 2 vols., Las Palmas de Gran Canaria, 2006, vol. I, pp. 383-391; ID., "Nuevas reflexiones para la lectura iconográfica de la Portada del Perdón de San Isidoro de León: el impacto de la Reforma Gregoriana y el arte de la tardoantigüedad", De Arte, 5, 2006, pp. 63-86; ID., "Un arquetipo arquitectónico de la Antigüedad clásica en la edilicia Altomedieval astur-leonesa: el vano de triple arcada", Monarquía y sociedad en el Reino de León: de Alfonso III a Alfonso VII, vol. II, León, 2007, pp. 563-598; ID., "Pervivencias de la Antigüedad Clásica en la Edad Media Hispana. El spolium in se: a propósito del cáliz de Doña Urraca", Actas del XII Congreso Español de Estudios Clásicos, (en prensa); ID., "El valor clásico de la arquitectura asturiana (s. IX): la iglesia de San Julián de los Prados. Entre la tradición "antiquizante" hispanovisigoda y la carolingia", Cien años de investigación sobre arquitectura medieval española, Madrid, 2009, pp. 233-246 e ID., La recuperación de la Ecclesiae Primitivae Forma en la escultura del Panteón Real de San Isidoro de León, León, 2008.
} 


\section{3. INFLUENCIA, IMITACIÓN, COPIA Y ARQUETIPO: A PROPÓSITO DE LAS RELACIONES ENTRE EL ARTE ANTIGUO Y MEDIEVAL.}

Las primeras palabras de W. Oakeshott al iniciar su obra Classical Inspiration in Medieval Art, eran las siguientes:

"The influence exerted by classical models on the art of the Middle Ages has been studied in a number of books and articles, and allusions to it are a commonplace in the histories of different periods in medieval art. For the most part, however, the difficulty of distinguishing such influences precisely, and of tracing them to any particular group of works, has been accepted as insuperable, and critics have been content simply to classify what they have noticed as due to some survival of the antique $^{169}$.

Se trata, sin duda, de un texto de singular importancia, no sólo por ser las palabras introductorias a la gran obra del autor, sino porque en apenas un párrafo utiliza varias veces uno de los términos más frecuentes y, a la vez, más problemáticos, que van a definir el mecanismo mediante el cual se relacionaron el arte antiguo y el medieval. Nos referimos, evidentemente, al fenómeno de la influencia.

Según el Diccionario de la Real Academia de la Lengua Española, la palabra INFLUENCIA significa concretamente:

“Acción y efecto de influir. Poder, valimiento, autoridad de alguien para con otra u otras personas o para intervenir en un negocio" ${ }^{170}$.

Por su parte, el Diccionario del Uso del Español aclara que la influencia debe ser entendida como una manifestación de una cosa en otra, con cierto tono superficial $^{171}$. De ambas definiciones deducimos que, la influencia presentará

\footnotetext{
${ }^{169}$ W. OAKESHOTT, Classical Inspiration..., p. 1. La negrita es nuestra y con ella pretendemos señalar la importancia que el autor va a otorgar a este vocablo. Por otra parte, a la hora de realizar las citas exactas o extractos de algunos de los textos y trabajos consultados para este estudio en lenguas extranjeras, éstas se realizarán preferentemente en castellano, siempre y cuando se pudiera haber accedido a la traducción del texto extranjero. En algunas ocasiones, no se han podido consultar los trabajos traducidos, por lo que nos hemos decantado por transcribirlos en sus lenguas originales. Creemos que no poseemos el criterio ni la autoridad suficiente como para realizar ninguna interpretación de ellos.

${ }_{170}$ Diccionario de la Lengua Española, Madrid, 2001, p. 863.

${ }^{171}$ M. MOLINER, Diccionario de uso del español H-Z, vol. II, Madrid, 1983, p.129.
} 
características indeterminadas, hasta cierto punto ambiguas, si las comparamos con otros fenómenos del tipo de la copia o la imitación.

Debemos señalar también que ninguna de las dos definiciones recoge acepciones relativas a las formas artísticas o a términos y conceptos derivados de ellas. Tales axiomas simplemente se limitan a relacionar la acción de imitar con el poder o la autoridad de una persona para con otra.

La Historia del Arte, por su parte, ha venido utilizando el término de manera polivalente y ambigua, sin restricción ni acotación ninguna y creemos que se trata de un punto esencial a tener cuenta, sobre todo si trabajos continuamente con la correspondencia entre dos periodos artísticos diversos.

A la hora de equiparar diferentes obras artísticas y establecer las repercusiones que unas pudieran tener sobre las otras, la influencia se presenta como el vocablo más manejable y estereotipado al que acudir para definir un tipo de fenómeno pocas veces acotado.

En las siguientes páginas intentaremos definir el significado que en este trabajo vamos a otorgar al concepto de influencia. A partir de ello, aclararemos en que medida entenderemos otros fenómenos derivados de tal aspecto. Nos referimos al entendimiento por parte de los artífices románicos de fenómenos tan diversos como la copia, la imitación y el arquetipo; todos ellos cruciales en el desarrollo de los análisis que vamos a efectuar.

Según nuestro criterio y puntualizando así en que condiciones utilizaremos esta noción, la influencia, hablando siempre desde el punto de la Historia del Arte, es un mecanismo mediante el cual, un determinado tipo de obra perteneciente a un movimiento artístico concreto, acaba manifestándose, de una manera u otra, en otras obras de diferente tipo. Somos conscientes que al posicionarnos con esta definición, nuevamente ambigua, nos vemos obligados a intentar acotar más el significado que le pretendemos otorgar.

Creemos que a través de un ejemplo particular podemos clarificar el concepto que estamos pretendiendo especificar.

El siglo IV de la era cristiana ha sido considerado por los especialistas como un siglo de "revolución" dentro de la historia de la edilicia, tanto civil como religiosa. La ciudad de Roma vivía en la primera mitad del siglo una fiebre constructiva reflejada en las numerosas obras que por estos momentos se estaban erigiendo. Así, San Giovanni in 
Laterano, la gran catedral de Roma, se encontraba en plena fase de construcción ${ }^{172}$ (fig. 19).

En el mismo periodo cronológico, otra serie de iglesias erigían sus muros en consonancia con los nuevos preceptos estéticos imperantes en el periodo, a saber, espacios internos diáfanos, articulación del muro a través de arcadas formadas por arcos de medio punto apoyados sobre grandes columnas de mármol -en muchas ocasiones fruto del expolio-, elaboración en algunas ocasiones de amplios cruceros, doble vertiente en la nave central y derrame de un solo trazo en las laterales, cubierta de madera, proliferación de las criptas, etcétera ${ }^{173}$.

Uno de los grandes hallazgos en cuestiones arquitectónicas durante este periodo, lo ofrece, en opinión de F. Guidobaldi, las experiencias edilicias que por estos momentos se llevaban a cabo en la gran iglesia de San Pedro del Vaticano, construida entre los años $330-340^{174}$. Según este autor, se trata del primer ejemplo constatado dentro de la arquitectura tardorromana cristiana, en la que la división de naves, rematadas a oriente por un enorme crucero, se llevó a cabo a través de la repetición continuada del arco de medio punto apoyado sobre columnas que recorrían de este a oeste los extremos de la nave central para llevar a cabo la generación de naves ${ }^{175}$.

Dentro del espacio y al mismo tiempo, se requirió una solución -y es ahí donde estriba la novedad- que proyectase un paño de muro que cerrase la larga hilera de arcos

\footnotetext{
${ }^{172}$ A pesar de que la iglesia de San Juan de Letrán debe ser considerada como un punto clave en la tendencia reformadora de la arquitectura de época tardoantigua, se trataba, en origen, de un edificio mucho más conservador que el de San Pedro de Roma, donde las novedades es cuestiones arquitectónicas eran mucho mayores. Cf.: H. BRANDEMBURG, Le prime chiese di Roma. IV-VII sécolo. L'inizio dell'architettura ecclesiastica occidentale, Milano, 2004, especialmente, pp. 92-95.

${ }^{173}$ R. KRAUTHEIMER, Roma. Proflio di una città. 312-1308, Roma, 1981, en especial, pp. 30-89 e ID. Arquitectura paleocristiana y bizantina, Madrid, 1984, particularmente, pp. 35-40.

174 Adelantamos en este punto, que a lo largo del trabajo se tendrán muy en cuenta tanto el arte como la arquitectura creados bajo el mandato del emperador Constantino. Ambos elementos van a ser utilizados constantemente para aludir, ejemplificar o explicar diversos aspectos del fenómeno de recuperación de formas clásicas por parte del arte cristiano. Consideramos que el arte del periodo constantiniano refleja de manera clara este aspecto, además de ser un tipo de arte inmerso aún en una sociedad eminentemente antigua, pero con una perspectiva ya cristiana. Cf.: H. BRANDEMBURG, Le prime chiese..., p. 95 y W. SESTON, "Hypothèse sur la date de la basilique constantinienne de Saint-Pierre de Rome", Cahiers Archéologiques, II, 1972, pp. 153-159. Según estos autores, en el año 337 se encontrarían finalizadas la cabecera y el arco triunfal del templo vaticano.

${ }^{175}$ El crucero de San Pedro ha sido señalado por varios autores como un elemento realmente innovador dentro del edificio. Se trata de una estructura ensalzadora de la tumba del apóstol, pero además "alejaba la tumba de Pedro de las masas de peregrinos", pues se cerraba con respecto a las naves principales a través de columnas torsas griegas de pórfido. Cf.: B. BRENK, "Il luogo di culto, sua accessibilità e suoi visitatori. La retorica dell'architettura di pellegrinaggio", Architettura e immagini del sacro nella tarda antichità, Spoleto 2005, pp. 119-142, particularmente, p. 123; M. A. CRIPPA, "La primera arquitectura cristiana. Siglos IV y V", El arte paleocristiano. Visión y espacio de los orígenes a Bizancio, BarcelonaMadrid, 1998, pp. 183-216, sobre todo, p. 189 y C. HEITZ, "More romano. Problèmes d'architecture et liturgie carolingiennes”, Roma e l'età carolingia, Roma, 1976, pp. 27-37, particularmente, pp. 29-30.
} 
construidos a cada extremo de la nave central (figs. 20 y 21). Sobre esos arcos se colocó un muro de cierre que, llegando hasta la cubierta, permitía no sólo el cierre de las naves, sino la inclusión de grandes ventanas que abarrotaban de luz la nave central, así como la posibilidad de incluir también un amplio programa pictórico sobre dicha superficie (fig. 22) ${ }^{176}$.

Este hallazgo supuso la creación de un auténtico hito dentro de la historia de la arquitectura. Pronto comenzaron a elevarse en la ciudad de Roma construcciones que de manera mecánica repetían el modelo de San Pedro del Vaticano, hasta convertirlo en una constante dentro de la arquitectura cristiana a partir de ese momento. Edificios tan importantes como la basílica de Santa Sabina, la de Santa Inés Extramuros o la de los Cuatro Santos Coronados, todos ellos en la ciudad de Roma, comenzaron a utilizar las arcadas de medio punto en la división de naves con la consiguiente elevación a través de un paño de muro sobre ellas ${ }^{177}$.

Lo más interesante al respecto, es que este conjunto de iglesias de la segunda mitad del siglo IV estaban siendo influenciadas, de manera concreta, por la iglesia de San Pedro. Se trataba de una influencia, puesto que tanto el ente emisor del concepto (la iglesia de San Pedro del Vaticano) como el ente receptor de tal idea (el resto de la arquitectura religiosa romana de la segunda mitad del siglo IV) compartían el mismo horizonte temporal y coexistían de manera paralela. La influencia presenta una cercanía cronológica entre el elemento que genera esa autoridad y aquel que se deja influenciar y persuadir.

Esta relación existente entre la iglesia de Santa Sabina de Roma y la del Vaticano, creemos, debe ser definida como influencia y no como imitación.

\footnotetext{
${ }^{176}$ F. GUIDOBALDI, "Sull'originalità dell'architettura di età costantiniana", XLII Corso di cultura sull'arte ravennate e bizantina. Seminario internazionale sul tema: Ricerca di Archeologia Cristiana e Bizantina, Ravenna, 1995, pp. 419-441, particularmente, pp. 423-430. El autor señala que dentro de la arquitectura clásica las pantallas formadas por galerías de arcos eran bastante frecuentes, sobre todo dentro de los foros y espacios públicos romanos, tales como la Casa de la Fontana, la del Specchio o la Casa degli Archi de Pompeya. Sin embargo, el gran reto de la arquitectura cristiana constantiniana fue adaptar tal estructura al interior de los templos, en detrimento del tipo arquitrabado utilizado normalmente. Ese paño, generalmente de ladrillo, y en el que se ubicarían ventanas, fue el soporte idóneo además para aplicar sobre él, recubrimientos musivos, pictóricos o marmóreos. Pone como ejemplos de este prototipo, la Anástasis de Jerusalén o el Octógono de Antioquía.

${ }^{177}$ G. MATTHIAE, Le chiese di Roma dal IV al X secolo, Roma, 1962, pp. 168-169. El autor afirma que, tanto la basílica de Santa Inés como la de los Santos Coronados, fueron obra de Onorio I (625-638). En el caso de esta última considera que el ábside es de factura posterior a la nave, datándolo posiblemente ya dentro del siglo IX. Con respecto a la basílica de Santa Sabina la cronología de fundación parece rondar el año 440. Sobre este aspecto, vid.: N. CHRISTIE, From Constantine to Charlemagne. An Archaeology of Italia A.D. 300-800, Cornwall, 2006, en particular, p. 102.
} 
La aclaración para poder pasar a definir las diferencias existentes entre influencia e imitación nos la ofrece el propio R. Krautheimer al hablar del impacto que supuso la construcción eclesiástica de San Pedro dentro de los demás edificios romanos:

“En el siglo IV, su planta se imitó en Roma, pero sólo una vez: en el santuario de San Pablo en 385. Fuera de Roma siguió siendo igualmente rara. Hasta el renacimiento carolingio no se haría uso común de la basílica con transepto continuo, tanto en Roma como al Norte de los Alpes"178.

Lo que intentamos decir es que, a nuestro juicio, toda la arquitectura romana del siglo IV recibió una influencia del modelo vaticano, pues determinados elementos existentes en su morfología pasaron a las nuevas construcciones. Sin embargo, en el caso concreto de la iglesia de San Pablo Extramuros, por poseer un mayor grado de similitud, cercanía cronológica e idéntica función en el uso de los espacios con respecto al modelo original -la iglesia de San Pedro- estaríamos ante un fenómeno de imitación, y no ante una simple influencia.

Según el Diccionario de la Real Academia de la Lengua Española, IMITACIÓN es:

"ejecutar algo a ejemplo o semejanza de otra cosa. Dicho de una cosa: Parecerse, asemejarse a otra. Hacer o esforzarse por hacer algo lo mismo que otro o según el estilo de otro" ${ }^{, 179}$.

Una de las diferencias fundamentales entre la influencia y la imitación, viene dada por el nivel o grado de repercusión y, sobre todo, de consciencia que el elemento de mayor autoridad ejerce sobre el de inferior importancia. Así, mientras la influencia se presenta como un fenómeno inconsciente, sobre todo por parte del elemento influenciable, la imitación es un acto del total consciencia. De tal manera que, mientras

\footnotetext{
${ }^{178}$ R. KRAUTHEIMER, Arquitectura paleocristiana..., p. 66 y pp. 533-534, nota 41. La iglesia de San Pablo extramuros, actualmente muy restaurada tras el gran incendio de julio de 1823, presentaba en origen un transepto continuo, a diferencia, por ejemplo, del uso de pequeñas capillas laterales que lo sustituían en la iglesia de San Juan de Letrán. Así, el transepto de San Pablo, a imitación directa del Vaticano, usaba este elemento como intersección con la nave central para ensalzar la edicola o memoria del mártir en cuestión. Cf.: H. BRANDEMBURG, Le prime chiese ..., p. 96 y R. KRAUTHEIMER, "La fondation de Saint-Paul-hors-les-murs", Idéologie de l'art antique. Du IV au XV siècle, Paris, 1995, pp. 11-24.

${ }^{179}$ Diccionario de la Lengua Española..., p. 848. Igualmente define imitación como: “imitación. Acción y efecto de imitar. Objeto que imita o copia a otro, normalmente más valioso.
} 
la influencia posee un carácter general y de alcance eminentemente superficial, la imitación es directa, contundente, eminentemente acotada a reproducir un modelo, aunque permitiéndose en ocasiones ciertas libertades y variaciones.

Parece claro que si a partir del modelo vaticano, muchas de las construcciones religiosas cristianas, no sólo de época tardorromana sino también las datadas en la Alta y Plena Edad Media, utilizaron este sistema de separación, se debió, no a un fenómeno de imitación directa de la iglesia de San Pedro del Vaticano. Su asiduidad dentro de este tipo de edificios habla de una influencia, pues es imposible que todos los constructores del momento conocieran de primera mano el modelo original de la iglesia vaticana. Es más, resulta difícil poder encontrar cualquier noticia fiable que certifique el impacto directo de morfología del templo vaticano sobre otras construcciones contemporáneas. Por ello, según pensamos, resulta más correcto definir tal fenómeno como una influencia, más que una imitación directa y consciente.

Cuando los artífices de la iglesia asturiana de San Julián de los Prados (fig. 23), incluyeron en su planta un gran crucero a modo de nave transversal, parece factible pensar, que no se trataba de una imitación directa de las formas constructivas de la arquitectura constantiniana, con las cuales no comparte muchos elementos en común ${ }^{180}$. Es decir, más bien podríamos hablar de una influencia lejana en cuanto no existen pruebas suficientes ni similitudes tan acusadas como poder defender una supuesta imitación inmediata de monumento romano ${ }^{181}$.

Tal y como es sabido, en el tránsito de la nave central de la iglesia asturiana hacia la estructura transversal, se construyó un elemento diferenciador y aislante a modo

\footnotetext{
${ }^{180}$ No es este el lugar más conveniente para recoger la abundante bibliografía sobre este edificio datado en la época de Alfonso II el Casto. Se menciona aquí a título de ejemplo y sirve tan sólo para la comprensión de los conceptos que venimos analizando. Algunos autores han relacionado la morfología de la iglesia asturiana con la arquitectura constantiniana, sobre todo, a la hora de explicar el uso del arco de medio punto en el edificio. En relación con estos aspectos, se ha escrito: "Si bien el transepto continuo de Santullano carece de paralelos coetáneos, existen lejanos antecedentes que se remontan al Bajo Imperio asociados a estructuras basilicales tanto paganas como cristianas. Así puede constatarse de Bulla Regia a San Pedro del Vaticano (...). La presencia de una nave cruzada de semejantes dimensiones, que consolida una singular disyunción entre el cuerpo axial y el espacio de cabecera, parece insertarse en la órbita del denominado "renacimiento constantiniano", fenómeno común al prerrománico y que tiene su principal baluarte en la renovación carolingia, vuelta hacia los prestigiosos modelos de la antigüedad tardía". Cf.: F. A. MARÍN VALDÉS y F. GIL LÓPEZ, San Julián de los Prados o el discurso de las dos ciudades, Oviedo, 1989, particularmente, p. 44 y p. 53. Véase también: R. KRAUTHEIMER, "The Carolingian revival of early Christian architecture", The Art Bulletin, XXIV, 1942, pp. 1-38.

181 J. A. MORÁIS MORÁN, "El valor clásico de la arquitectura asturiana...", (en prensa). Hemos reflexionado sobre lo problemático de defender una dependencia romana de tal elemento a través de la asimilación de las fórmulas clásicas carolingias, frente a las posturas que señalan un origen hispano del espacio transversal que algunos autores denominan transepto.
} 
de "arco-iconostasio" -si seguimos la expresión de F. Marín Valdés y J. Gil López-

(fig. 23 a). Este elemento debe ser entendido, según escriben, como:

“(...) tantos otros "loci classici” citados en el templo (...) obedece a la fascinación de la élites de la temprana Edad Media hacia el pasado imperial. Inclinadas a la recuperación de modelos romanos altamente representativos, saben conferirles un uso específico y un nuevo comportamiento textual”,"

Estos investigadores, al igual que el profesor I. Bango Torviso, han señalado las fuertes concomitancias existentes entre este arco y otros de época romana, concretamente con la Porta pretoria de Aosta o en el caso de la Hispania romana, con el arco de Medinaceli, en Soria (fig. 24).

En relación con lo dicho y aplicando a tal ejemplos las distinciones antes expuestas entre los dos conceptos que analizamos, creemos que nuevamente aquí podemos afirmar que el arco de triunfo hispanorromano de Medinaceli, debe ser entendido más como una influencia que como una imitación, a la hora de estudiar su materialización en la arquitectura asturiana. Ningún dato atestigua una copia consciente y directa, al menos que se conozca hasta la fecha. Se trataría más bien de la utilización de una fórmula que al perecer debió ser corriente entre determinadas obras tardoantiguas. Su uso dentro de otro espacio templario, esta vez geográficamente más alejado del arco de Medinaceli, nos habla de una pluralidad de fuentes no concretas que niegan la imitación directa y consciente que a veces se ha defendido para el caso asturiano.

\footnotetext{
${ }^{182}$ F. A. MARÍN VALDÉS y F. GIL LÓPEZ, San Julián de los Prados..., p. 44. Remarcamos que la aplicación del término "transepto" sobre este espacio del templo ha sido muy valorada y, a veces criticada, por la historiografía.

Por otra parte, también el término "iconostasio" ha sido valorado por los expertos. Se trata de un vocablo utilizado para referirse a determinadas estructuras de la arquitectura oriental y que responde a unas necesidades propias de la liturgia desarrollada en aquellas áreas. Más tarde, fue asimilado y aplicado sobre las construcciones hispanas y utilizado durante largo tiempo por los expertos. Sin embargo, hace ya varias décadas que se viene insistiendo en su carácter ambiguo y su disociación con respecto al valor que tuvieron las barreras litúrgicas dentro del contexto hispano, muy diferente al oriental. Sobre estos aspectos, véase: I. G. BANGO TORVISO, "Los expolios del paisaje monumental y la arquitectura hispana de los siglos VIII al XI. Reflexiones sobre el proceso constructivo de San Miguel de Escalada", De Arte, 7, 2008, pp. 7-50, en particular p. 30 e ID., "La vieja liturgia hispana y la interpretación funcional del templo prerrománico", VII Semana de Estudios Medievales, Nájera, 1997, pp. 61-120, en particular, p. 102. En el primer estudio el autor desestima la aplicación del término "iconostasis" sobre los edificios hispanos. De este modo, para el caso del templo de Escalada prefiere utilizar la expresión "puerta del coro", desechando también el uso de "cancel alto", que había defendido en el segundo de sus trabajos que aquí citamos.
} 
Nos referimos, concretamente, a la iglesia monástica de San Gião de Nazaré, en Portugal. El templo se ha datado en torno al siglo VII y nuevamente aquí se repite el esquema de paso central y dos ventanas laterales que caracterizarían tanto al arco hispanorromano como al de la iglesia de $\operatorname{los}_{\operatorname{Prados}}{ }^{183}$ (fig. 25). El esquema del arcodiafragma de esta iglesia puede ser entendido como una mera reinterpretación cristiana de un motivo de largo historial y usos diversos. Así, en palabras de A. Arbeiter:

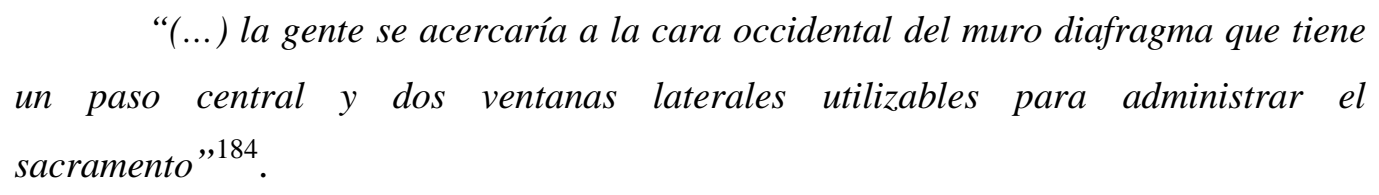

Los nuevos aspectos simbólicos, funcionales y litúrgicos adquiridos por esta estructura antigua durante la época medieval, hablarían entonces de una cierta dependencia indirecta con respecto al modelo original.

La aparente frecuencia con la que el mismo esquema se repitió en dos iglesias del prerrománico peninsular hispano, acusa el interrogante de las fuentes manejadas por los artífices de tales edificios y, sobre todo, sobre si existieron realmente unas intenciones imitativas conscientes o, por el contrario, se trata tan sólo de una manifestación inercial de una influencia puntual.

La fortuna del arco de medio punto o su variante monumental en forma de arco triunfal romano de tres vanos practicables, dentro de las artes medievales, nos permite asentar las bases para llevar a cabo la acotación semántica y utilitarista, del siguiente concepto que vamos a manejar. Se trata del fenómeno de la COPIA.

Si llevamos a cabo un rápido análisis de la perdurabilidad medieval de la estructura del arco de medio punto en su variante de arco triunfal romano, resulta patente que se trata de una fórmula que mantuvo alguno de los preceptos con los que se ligó en la Roma Imperial.

Desde su concepción como elemento dignificador, conmemorativo y de exaltación, en la Roma de los primeros tiempos, a baluarte y parapeto expositor de todo un repertorio de ideas y mensajes publicitados a través de la escultura, tal y como se

\footnotetext{
${ }^{183}$ H. SCHLUNK, "La Iglesia de San Gião, cerca de Nazaré. Contribución al estudio de las influencias de la liturgia en la arquitectura de las iglesias prerrománicas de la Península Ibérica”, Actas do II Congresso Nacional de Arqueología, Coimbra 1971, pp. 509-528.

${ }^{184}$ A. ARBEITER, "Los edificios de culto cristiano: escenarios de la liturgia", Repertorio de arquitectura cristiana en Extremadura: época tardoantigua y altomedieval (P. Mateos Cruz y L. Caballero Zoreda ed.), Mérida, 2003, pp. 117-230, particularmente, p. 220.
} 
hará en tiempos cristianos, la morfología del arco triunfal pasó sin solución de continuidad a lo largo de los siglos ${ }^{185}$.

El modelo, como todo, rápidamente fue asimilado por parte de los artífices y creadores de la nueva religión. A través de los diferentes mecanismos de influencia, imitación y copia, el arco de triunfo pagano fue reabsorbido, sobre todo dentro de las obras creadas en época constantiniana. Así, tal y como se ha señalado, la total cristianización del arco triunfal se produjo cuando el emperador Constantino mandó colocar sobre el arco de triunfo de la primitiva basílica de San Pedro del Vaticano la siguiente inscripción:

“PORQUE GUIADO POR TI EL MUNDO SE ELEVA TRIUNFANTE A LOS CIELOS, CONSTANTINO, UN VÍCTOR, TE EDIFICÓ ESTA SALA" ${ }^{186}$.

A partir de este momento, la figura del arco triunfal renacía para desarrollarse con su nuevo significado a lo largo de todo el arte posterior. Exactamente con la misma idea, mandaría Constantino colocar la gran cartela epigráfica sobre el ático de su arco en el foro romano:

\section{ARCV(S) TRIUMPHIS INSIGN (IS) ${ }^{187}$.}

Se trataba de un mensaje que publicitaba no el triunfo de algún emperador pagano, tal y como había ocurrido en la propia Roma durante siglos, sino el triunfo del cristianismo, sobre el propio paganismo ${ }^{188}$ (fig. 26). A partir de entonces, el arco de triunfo romano pasaba a ser el símbolo del triunfo de la iglesia. Ubicado a partir de este momento en los accesos a los presbiterios de las iglesias medievales, el arco de triunfo romano acaba influenciando y repercutiendo en la fisonomía de las cabeceras de los templos, incluidas las de época románica.

Esta reflexión que acabamos de realizar es básica para comprender las diferencias existentes entre la influencia y la imitación con respecto a la copia.

\footnotetext{
185 M. PAllotTinO, Voz "Arco onorario e trionfale", Enciclopedia dell'arte antica classica $e$ orientale, vol. I, Roma, 1958, pp. 588-599.

${ }^{186}$ S. KOSTOF, Historia de la arquitectura, vol. I, Madrid, 1988, especialmente, p. 450.

${ }^{187}$ CH. FRUGONI, "La antichità: dai Mirabilia alla propaganda politica", Memoria dell'antico nell'arte italiana. L'uso dei classici (A cura de S. Settis), vol. I, Torino, 1986, pp. 5-72, en particular, p. 21. La autora afirma que debe ser visto también como una victoria sobre la muerte.

${ }^{188}$ M. D’ONOFRIO, Roma e Aquisgrana..., particularmente, p. 61.
} 
Para ello, debemos acudir a un arco de triunfo cristiano de cronología avanzada, dotado de una gran monumentalidad y sobre el que se expuso un desarrollado programa iconográfico esculpido. Se trata del conocido Pórtico de la Gloria de la catedral de Santiago de Compostela ${ }^{189}$ (fig. 27). En dicho pórtico, y como cierre occidental del buque catedralicio, se levantó un macizo monumental a modo de westwerk formado por tres niveles, a los que el profesor S. Moralejo atribuyó una interpretación simbólica e iconológica. Según su teoría, existía en el conjunto una idea rectora que buscaba exaltar la Segunda Venida de Cristo, el Juicio Final y la posterior gloria de la Jerusalén Celeste. Partiendo de este planteamiento, lo mundano o terrestre quedaría representado por la llamada cripta o iglesia vieja, símbolo de la Tierra. El piso intermedio simbolizaría las puertas de la gloria, sintetizadas a través de los trabajos en escultura y, finalmente, el cielo, ubicado en la galería de la parte alta del pórtico donde el Agnus Dei esculpido en la clave de la bóveda evocaría la salvación eterna ${ }^{190}$. La obra, finalizada en el año 1188 , según consta en la inscripción del dintel de la puerta, presenta una hipotética lectura simbólica sin precedentes en el arte románico peninsular hispano. Por lo que respecta al nivel intermedio, el arco allí practicado se presentaría como una suerte de arco de triunfo que da acceso físico y simbólico a la Ciudad Sagrada o Jerusalén Celeste ${ }^{191}$.

La lejana relación de la triple arquería del Pórtico de la Gloria con los arcos de triunfo romanos, nos habla de su llegada al periodo medieval a través de una influencia, más que mediante una copia. Por el contrario, creemos imposible, al menos con respecto a las obras romanas conservadas de la Hispania antigua, argumentar una imitación directa de algún ejemplar de arco de triunfo al que los constructores y escultores

\footnotetext{
${ }^{189}$ La bibliografía sobre esta obra sobrepasaría en exceso la intención que tenemos al abordarla concretamente en este trabajo, pues se trata de un ejemplo a la hora de poder explicar determinadas cuestiones teóricas. De ahí que sólo hagamos referencia a las obras que hemos utilizado para tal efecto.

${ }^{190}$ S. MORALEJO ÁLVAREZ, "La imagen arquitectónica de la catedral de Santiago de Compostela", Atti del Convengo Internazionale di Studi: Il pellegrinatio a Santiago de Compostela e la letteratura jacopea, Perugia, 1985, pp. 37-61, consultado en la reedición: Patrimonio artístico..., vol. I, pp. 237-246 y M. A. CASTIÑEIRAS, El Pórtico de la Gloria..., sobre todo, pp. 51-55.

${ }^{191}$ S. SEBASTIÁN, Mensaje simbólico del arte medieval: arquitectura, iconografía, liturgia, Madrid, 1994, concretamente, p. 286 y E. FERNÁNDEZ GONZÁLEZ, "El arco: tradición e influencias islámicas y orientales en el románico del reino de León", Awrāq, 5-6, 1982-1983, pp. 221-242.

Recuérdese en este sentido la comparación realizada por M. Castiñeiras a propósito de la portada de Santa María de Ripoll, pues la similitud con un gran arco triunfal romano esculpido tiene sus precedentes lejanos en ejemplos de la Antigüedad romana como en la Porta Negra de Bensançon. Cf:: M. A. CASTIÑEIRAS GONZÁLEZ, El calendario medieval hispano (s. XI-XIV), Salamanca, 1996, pp. 83 у p. 247 e ID., "Un passaggio al passato: il portale di Ripoll", Medioevo: il templo degli antichi, Milano, 2006, pp. 365-381.

Con todo, la idea defendida por Castiñeiras ya había sido expuesta en 1971 por el profesor Christe. Cf. : Y. CHRISTE, "La colonne d'Arcadius, Sainte-Pudentienne, l'arc de Eginhard et le portail de Ripoll", Cahiers Archéologiques, XXI, 1971, pp. 31-42, especialmente, p. 40.
} 
compostelanos pudieron haber tenido acceso. Sin embargo, el prototipo triunfal del arco con tres pasos practicables, parapeto de exposición pública y puerta sagrada, no se perdió en la Hispania de finales del siglo XII ${ }^{192}$.

El llamado Pórtico del Paraíso de la catedral de Orense, a la vez de señalar una continuidad de los prototipos compostelanos, permite ejemplificar claramente las diferencias conceptuales que venimos señalando. Esta portada, íntimamente ligada al Pórtico de la Gloria, es claramente una copia directa de aquella, mientras que desde el punto de vista formal, tan sólo presenta una lejana influencia de los arcos de triunfo $\operatorname{romanos}^{193}$.

Traemos a colación este ejemplo, por mostrar, por un lado, una influencia de los arcos triunfales romanos, mientras que por el otro, el pórtico orensano parece ser una copia derivada de los trabajos en Compostela. Es decir, dos fenómenos diferentes que han ser definidos y entendidos no como sinónimos, sino más bien como conceptos derivados de los diferentes estadios y acercamientos de los artesanos románicos a las obras antiguas. Dicha diferenciación estribará en el grado de semejanza que presente con respecto al modelo primigenio y la conservación o distorsión de la forma que el elemento original tenía en el momento de ser sometido a reinterpretación ${ }^{194}$.

Por último, creemos necesario detenernos en un último concepto. El Diccionario de la Real Academia de la Lengua Española, al que acudimos nuevamente, define el término ARQUETIPO de la siguiente manera:

"Modelo original y primario en un arte u otra cosa. Punto de partida de una tradición textual. Representación que se considera modelo de cualquier manifestación

\footnotetext{
${ }^{192}$ Aludimos en este sentido a la comparación que hace M. Castiñerias entre los ángeles tenantes que, a modo de victorias, muestran mediante sus manos veladas los Armi Christi de la pasión. Se trata de los objetos de suplicio expuestos ante los ojos del espectador siguiendo un mecanismo iconográfico de raigambre romana y que el autor relaciona con la iconografía triunfal y los arcos honoríficos. Obsérvense las concomitancias desde el punto de vista compositivo con determinadas piezas tardoantiguas, como por ejemplo, con la placa del Metropolitan Museum de Nueva York, donde dos personajes nimbados presentan la cruz de Cristo mientras sujetan igualmente un libro. La pieza se ha venido datando en el siglo VI. Sobre dicha escultura, véase: C. METZGER, "Fragment de plaque de revêtement", Byzance. L'art bizantin dans les collections publiques françaises, Paris, 1992, ficha catalográfica 63, p. 116. Sobre la iconografía compostelana y su relación con el arte romano, véase: M. A. CASATIÑEIRAS, El Pórtico..., p. 15.

${ }^{193}$ M. CHAMOSO LAMAS, "La Catedral de Orense", Catedrales de España., vol. 1, 1994, pp. 121-216.

${ }^{194}$ A propósito del Pórtico compostelano y sus repercusiones sobre la escultura hispana contemporánea, M. Castiñeiras utiliza otro concepto para definir las relaciones e intercambios existes entre éste y el de la iglesia de Santa Maria de Noia, en La Coruña. En este templo, nuevamente se advierten semejanzas de índole estilística e iconográfica con respecto al Pórtico de la Gloria. En concreto, considera que la portada de Noia es un "eco" del conjunto santiagués y no una copia, categoría que otorgaría al de Orense. Cf.: M. A. CASTIÑEIRAS, El Pórtico..., en concreto, p. 81.
} 
de la realidad. Tipo soberano y eterno que sirve de ejemplar y modelo al entendimiento y a la voluntad de los humanos" $" 195$.

Esta definición puede ser entendida, desde la óptica de las producciones artísticas, como el modelo original y primario que genera un tipo supremo o prototipo ideal que con el tiempo se acabará convirtiendo en un modelo a seguir. Es decir, una imagen o forma que tras ser imitada y copiada a lo largo de los siglos adquiere, por una parte, un valor de perpetuidad en la historia de las imágenes, mientras que por otra, toma algunos valores que le son extrínsecos y que aportan a dicho elemento un nuevo carácter del que antes carecía: el valor y entidad como imagen perdurable y lista para ser transmitida hacia otros periodos históricos ${ }^{196}$.

Mediante este mecanismo germinador de la cultura visual, las artes plásticas medievales adquirieron un bagaje, adquirido mediante las vías de la influencia, la imitación y la copia. Se trata de fenómenos reiterativos que convierten a las imágenes en auténticos iconos de los cuales es imposible vislumbrar su origen y lugar de génesis y que hace también complicado poder llegar a concretar el lugar exacto del que provienen y el momento concreto en el que se disuelven dentro esa misma cultura visual de una época.

Para intentar clarificar estos aspectos, nos decantamos nuevamente por ilustrarlos a través de un ejemplo relacionado con el arte asturiano.

En un trabajo excelente publicado en el año 1993, el profesor F. Marín Valdés exponía alguna de sus ideas relacionadas con una estructura monumental utilizada por el arte asturiano durante el siglo $\mathrm{IX}^{197}$. Nos referimos al llamado frontis de glorificación, una estructura posiblemente tomada del arte antiguo y que, según se ha venido afirmando, reaparecería en el periodo medieval a través de una estructura de enmarque idónea para la celebración de determinados ceremoniales.

A la hora de materializarla, los constructores medievales la monumentalizarían en la mayoría de los casos a través de columnatas y arquerías ${ }^{198}$. Según lo afirmado

\footnotetext{
${ }^{195}$ Diccionario de la Lengua Española..., p. 141.

${ }^{196}$ J. A. MORÁIS MORÁN, "Imitación, copia y asimilación de arquetipos. Algunas reflexiones sobre los procesos de creación artística en el arte románico español: los tímpanos de Ruiforco y Matueca de Torío (León)", (en prensa).

${ }^{197}$ F. A. MARÍN VALDÉS, “Los frontis de glorificación...”, pp. 151-159.

198 J. A. MORÁIS MORÁN, "Un arquetipo edilicio...", pp. 582-587. La mayoría de los autores coinciden en señalar que entre los casos más conocidos de esta tipología estaría el llamado frontis del palacio de Diocleciano de Split, auténtica estructura de enmarque para las posibles apariciones del soberano. Dichas fórmulas fueron cuanto menos conocidas durante los siglos de la baja romanidad. Lo atestigua no sólo la
} 
hasta el momento, esta tipología arquitectónica presente, por ejemplo, en las dos fachadas cortas del belvedere de Ramiro I en el Naranco, repetida igualmente en las arquerías de la tribuna de la iglesia de Santianes de Pravia o, por ejemplo, reproducida fielmente en algunos de los templetes de las pinturas de San Julián de los Prados; hablan de la pertenencia de la imagen a la larga nómina de arquetipos iconográficos que presentan las producciones artísticas medievales hispanas ${ }^{199}$. Tal y como en su día argumentó F. Marín Valdés, la tardoantiguedad es la fuente de la que parece bebieron los constructores del siglo IX astur. No en vano, algunos ejemplos tan significativos como el mosaico hispano de Tossa del Mar, aquel en el que el senior se muestra en público enmarcado por un frontis de triple arquería similar al asturiano o antecedentes más lejanos, como los derivados del arco triunfal de Constantino en el foro romano, nos permiten intuir un posible origen de esta fórmula.

Como arquetipo que es, es difícil establecer el origen concreto del vano de triple arcada que hemos utilizado para ejemplificar estas reflexiones sobre tal vocablo. Su cristianización llegaría ya dentro de la arquitectura eclesiástica de la propia ciudad de Roma, donde el triple arco o pantalla de glorificación, dejaba de enmarcar el ceremonial de los emperadores para monumentalizar el acceso a determinadas partes nobles del edificio cristiano, tal y como vemos, por ejemplo, en las dos pantallas de fábrica erigidas en la nave central de la iglesia romana de la Santa Croce de Jerusalén ${ }^{200}$ (fig. 28).

$\mathrm{El}$ arte asturiano, baluarte indiscutible de la supervivencia de formas clásicas en el arte medieval hispano anterior a la llegada del románico, refleja mediante el uso de los frontis, un fenómeno que encontraremos de manera reiterativa a lo largo de toda la Edad Media. Determinadas fórmulas de eminente sentido clásico reaparecen en los edificios medievales como una suerte de disecta membra, de las que es muy difícil conocer su origen.

\footnotetext{
arquitectura monumental, sino también las demás artes. En este sentido, debe recordarse la representación realizada sobre el famoso Missorium de Teodosio, donde el monarca aparece representado bajo una arquitectura que recuerda la existente en el palacio croata. La fórmula se repetiría en los mosaicos de la iglesia de San Apolinar el Nuevo de Rávena con la famosa recreación del supuesto frontispicio del palacio de Teodorico. Sobre estos aspectos, véase: J. ARCE, "El Missorium de Teodosio I: Problemas históricos y de iconografía", El disco de Teodosio (M. Almagro Gorbea coord.), Madrid, 2000, pp. 281288 y G. FRANCOVICH, Il palatium di Teodorico a Ravenna e la cosiddetta "architettura di potenzo". Problema d'interpretazione di raffigurazioni architettoniche nell'arte tardoantica e altomedioevale, Roma, 1970.

${ }^{199}$ J. A. MORÁIS MORÁN, “Un arquetipo edilicio...”, pp. 592-595.

${ }^{200}$ R. KRAUTHEIMER, Corpus Basilicarum Christianarum Romae. Le basiliche cristiane antiche di Roma (sec. IV-X), vol. I, Città del Vaticano, 1937, particularmente, pp. 165-194 y J. A. MORÁIS MORÁN, "Un arquetipo edilicio...", p. 591.
} 
Las vías de llegada de tales elementos "antiquizantes" hasta ese ámbito propiamente medieval, así como su desarrollo, su repercusión y su posterior desaparición dentro de la historia de las formas estéticas, tienen en la influencia, la imitación, la copia y la repetición de arquetipos sus más representativos mecanismos de difusión. 


\section{4. LA CONCIENCIA DE LA ANTIGÜEDAD EN LA EDAD MEDIA.}

\section{A. LA "VOLUNTAD DE CONTINUIDAD” Y EL TRÁNSITO DE LA ANTIGÜEDAD TARDÍA A LA}

Alta EDAD MEDia. El ARTE “SUbANTIGUO" Y EL “PRERROMÁNICO”:
PROBLEMÁTICA DE SUS NOMENCLATURAS.

Durante el siglo XIX y una parte importante de la primera mitad del siglo XX, los estudiosos o conocedores de las producciones artísticas que ya por estos momentos se englobaban bajo el epígrafe de "arte medieval" serían, en parte, los responsables de fomentar la tendencia general que consideraba dicho periodo como "un siglo oscuro". Paralelamente a lo que ocurría dentro de la historiografía histórica, el arte del medievo era visto como un periodo decadente y muerto, un arte que materializaba una etapa intermedia entre dos "megaperiodos" brillantes.

En relación con esta idea, baste tan sólo con aludir a las primeras palabras que E. Mâle dedicaría al arte románico francés en su magna obra L'art religieux du XII en France, publicada, por primera vez, en el año 1922, para darnos cuenta de el grado de desprecio y carácter peyorativo que algunos sectores aún mantenían a la hora de afrontar los estudios medievales. El insigne autor escribía:

"La escultura monumental, olvidada después de siglos, reaparece en el siglo XI en el centro de Francia. Esta resurrección es uno de los fenómenos más curiosos de la historia: la humanidad reencontraba un secreto perdido y reiniciaba su camino"201. $^{\text {. }}$

Lejos de querer realizar una crítica a la importante obra de este especialista, traemos a colación sus palabras pensando que se trata de una prueba importante para comprender el fenómeno que vamos a tratar a continuación. Las palabras de Mâle son el reflejo de una tendencia que por estos momentos ya agonizaba pero que consideraba que el arte medieval y, en concreto, el anterior al siglo XI, había vivido una gran etapa de decadencia o, casi diríamos, muerte, de ahí que el autor afirme que el rebrote de escultura que vivió dicho territorio en el siglo XI podía considerarse como una resurrección.

\footnotetext{
${ }^{201}$ E. MÂLE, L'art religieux du XII en France, Paris, 1998, concretamente, p. 1.
} 
El investigador abordaba así el problema del "renacimiento" de una serie de prácticas realizadas en un periodo pasado, que hasta el momento se consideraban perdidas, pero que igualmente comenzaban a reaparecer dentro del panorama de las artes plásticas.

Así, E. Mâle continuaba su discurso preguntándose:

“Cómo se puede explicar que ese arte maravilloso de la escultura haya desaparecido durante más quinientos años?"202.

Sus argumentos son muy significativos a la hora de definir la postura que algunos investigadores mantendrían durante este momento en torno a este problema. Es evidente que las palabras de Mâle reflejan el final de una postura intelectual que habría de influir en muchos aspectos de la historiografía, potenciando el carácter inferior, fragmentario y débil de todo el arte medieval en general y, de manera especial, aquel que se había realizado entre los siglos VI-X.

Parece claro que la realidad artística no se correspondía en absoluto con la realidad científica que se defendía por estos momentos. Creer que la escultura medieval había llegado en el siglo XI a su máximo apogeo tras ciertos periodos de menor producción, era posible. Sin embargo, a la vista de lo conservado y a través de la deducción de lo que imaginamos que existió, actualmente los investigadores han conseguido sobrepasar esta postura y poder llegar a defender la existencia de una rica y evolucionada producción escultórica tras los siglos que siguieron al desmembramiento del Imperio Romano ${ }^{203}$.

El problema, sin embargo, era mucho más profundo. El desprecio existente hacia la escultura anterior a la llegada del románico, tenía su fundamento en otra serie de teorías históricas que, apoyadas por determinados sectores, defendían un ocaso de las fórmulas artísticas tras la caída de Roma. Nos referimos, concretamente, al tópico historiográfico que argumentaba la existencia de un conflicto muy marcado entre las

\footnotetext{
${ }^{202}$ Ibidem.

${ }^{203}$ E. FERNÁNDEZ GONZÁLEZ, "Hacia la renovación escultórica de la segunda mitad del siglo XI: Los ejemplos del sarcófago de San Martín de Dumio y de la pila bautismal de San Isidoro de León", De arte, 6, 2007, pp. 5-36.
} 
producciones artísticas generadas en el seno de los últimos siglos de dominio imperial romano y aquella paralela al crecimiento del cristianismo ${ }^{204}$.

Sin duda, en relación con estos aspectos, una de las obra clave que originó y apoyó estas corrientes interpretativas de este periodo tan concreto de la historia, fue la del profesor H. I. Marrou. Su estudio aún hoy sigue siendo básico a la hora de poder adentrarse en el complejo periodo que supuso la disolución de determinados aspectos de la organización política romana y el asentamiento de otros, derivados de la introducción de la nueva religión cristiana ${ }^{205}$.

Basándose en tales supuestos, deben entenderse algunas de las reflexiones realizadas por A. M. Romanini a la hora de reflexionar sobre el carácter "clásico" de determinadas producciones artísticas altomedievales. Según la autora, tales manifestaciones no deben ser consideradas como representantes de una estética "anticlásica" o degenerada. Por el contrario, cuando la especialista italiana lleva a cabo sus análisis, llega en muchos casos a concluir que el arte medieval occidental, una vez evolucionado, lograría "conquistar su propio clasicismo",206.

Aún con tales propósitos, la transformación de algunos de estos preceptos y su correspondiente reconsideración teórica tienen en el estudio de C. Homer Haskins, un antecedente primordial, sobre todo, si tenemos en cuenta que uno de sus más importantes estudios vio la luz en el año $1927^{207}$. Frente a la concepción de una civilización medieval cerrada y sin visos de evolución, marcada por el mito de la "Edad Oscura" con el que se venía considerando el espacio conformado entre el año 476 y el

\footnotetext{
${ }^{204}$ Dentro de la historiografía española, algunos estudiosos se han intentado aclarar la realidad histórica de este complicado periodo. El tránsito de una sociedad romana a otra cristiana, implicó toda una serie de modificaciones que tendrían ciertas repercusiones dentro del plano artístico. Cf.: F. J. GUZMÁN ARMARIO, "¿Germanismo o romanismo?: una espinosa cuestión en el tránsito del mundo antiguo a la Edad Media: el caso de los visigodos", Anuario de estudios medievales, 35, 1, 2005, pp. 3-24, en concreto, p. 4. El autor, siguiendo los trabajos de H. I. Marrou, prefiere utilizar el término "transformación", antes que el de decadencia o crisis. En este sentido, afirma: "no fue una caída en picado de la vida de los hombres de Occidente, sino una transformación tras el desmoronamiento de la estructura política y social del Imperio".

Por su parte, el profesor J. M. Blázquez, uno de los investigadores más autorizados en el tema, consideraba el final de la Antigüedad como un periodo evolutivo desde finales del siglo IV hasta aproximadamente el siglo VI, periodo en el que "las zonas periféricas del Imperio Romano, como Britania, Hispania, Norte de África, Egipto o Israel, abandonaron poco a poco los cánones artísticos vigentes en esas regiones hasta entonces, heredados del arte de Grecia y de Roma". Por su parte, el especialista, siguiendo a autores como Marrou y Vogt, aboga por la sustitución del concepto "decadencia" por el de "metamorfosis de una cultura". Cf.: J. M. BLÁZQUEZ, "Transformaciones sociales y descomposición de las formas artísticas en la Antigüedad clásica", Imágenes de la Edad Media, Madrid, 1987, pp. 25-37, en concreto, pp. 25-26.

${ }^{205}$ H. I. MARROU, Décadence romaine ou Antiquité tardive, Paris, 1977 y E. SESTAN, "Tardo antico...", pp. 15-37.

${ }_{206}$ A. M. ROMANI, "Il concetto di classico...", p. 130.

${ }^{207}$ C. HASKINS, The Renaissance of the Twelfth Century, Cambridge, 1927.
} 
1453, las nuevas vías de estudio intentaron presentar una novedosa concepción del siglo XII, diferente a la que se había ofrecido hasta el momento ${ }^{208}$. Ahora se pasó a poner de relieve la importancia que, durante estos siglos "oscuros" y, especialmente durante la duodécima centuria, habían tenido determinados centros artísticos e intelectuales. En ellos, tanto las bibliotecas como toda una extensa producción libraria, habían fomentado de manera evidente la total recuperación del latín culto, por citar uno de los catalizadores imprescindibles que explique el desarrollo cultural en este momento ${ }^{209}$.

Estas tempranas investigaciones comenzaron a cambiar la imagen de los "secoli oscuri $^{\text {"210 }}$, otorgándoles un cariz bastante diferente del que gozaban hasta ese momento. Aún con todo, durante la década de los setenta, un insigne historiador del arte como A. Grabar, utilizaba una expresión que acusaba y resumía muy bien el lugar que determinadas producciones artísticas de estos "siglos oscuros" había ocupado dentro de los círculos científicos y especializados en estas materias.

$\mathrm{Al}$ referirse al arte del periodo comprendido entre el final del mundo antiguo y la Plena Edad Media, A. Grabar se servía de la expresión "grande décadence", es decir, un arte que como él mismo reconocía, había sido valorado injustamente durante el siglo XIX, pero del que también habían salido creaciones originales ${ }^{211}$. Sin embargo, el contenido que él otorgaba a estas palabras tampoco estaba exento de cierto carácter peyorativo, pues al exaltar determinadas peculiaridades de esta plástica, que según él tan sólo eran entendibles por "nuestra época, más abierta a los ensayos de un arte abstracto", conseguía en algunos puntos un efecto contrario ${ }^{212}$.

Por una parte reconocía que se trataba de un arte que era necesario valorar, mientras que desde otro punto de vista nuevamente caía en el error de documentar dicha valoración rigiéndose por los cánones y formulaciones intrínsecas al arte clásico. Según pensamos, utilizar las mismas reflexiones o leyes estéticas que nos permitían comprender la escultura griega y romana, para poder acercarnos a la escultura longobarda, seguía siendo un método complicado y difícil de mantener.

\footnotetext{
${ }^{208}$ Ibidem, p. 4.

${ }^{209}$ Ibidem, pp. 93-152. Marrou dedica un capítulo a la recuperación del latín clásico durante este siglo XII. Es el momento en el que establecerá la clásica división formada por Trivium y el Quatrivium, sobre todo en relación con las artes liberales. Vid. también al respecto: S. SEBASTIÁN, Mensaje simbólico..., en concreto, p. 238.

${ }^{210}$ A. M. ROMANINI, "Il concetto di classico...", p. 130.

${ }^{211}$ A. GRABAR, "Le tiers monde de l'Antiquité à l'école de l'art classique et son rôle dans la formation de l'art du Moyen Âge", L'art paléochrétien et l'art byzantin, London, 1979, pp. 1-59, en particular, p. 3.

${ }^{212}$ Ibidem, p. 3.
} 
En el caso hispano, dentro de los estudios centrados en el análisis de la escultura de los siglos de la Antigüedad tardía, llamaba la atención en este sentido el calificativo utilizado por F. García Romo para definir las producciones artísticas datadas entre los siglos VII y VIII.

El autor, en relación con ello, se preguntaba:

"¿existe un arte visigodo? Adelantaremos que no creemos en la existencia de un estilo auténticamente visigodo (...) nadie parece creer en él (...) a juzgar por esas pequeñas iglesias campesinas y por los restos aludidos, la aportación estilística de los pueblos bárbaros invasores de la España romanizada, fue de escasa importancia. En el llamado arte visigodo ser reconocen, sobre todo, tradiciones romanas más o menos bastardeadas y aportaciones esporádicas del oriente cristiano",213.

La definición del arte hispanovisigodo como un arte bastardo derivado del arte romano imperial refleja, por un lado, la concepción tan alejada de lo clásico que se tenía de este arte, pero al mismo tiempo, ratificaba la absoluta dependencia de modelos romanos, si bien en muchos casos provinciales, pero romanos al fin y al cabo.

Tal y como observamos, todos estos autores acabarían por convertirse en los representantes teóricos de una problemática más profunda, obsesionada por acercarse a las producciones artísticas de época medieval a través de métodos y sistemas de valoración creados y definidos específicamente para el estudio de la escultura griega y romana.

El segundo problema vendría dado por la misma periodización del discurso histórico que veía en los siglos medievales un tiempo intermedio que servía de viaducto unificador de dos grandes épocas. La Antigüedad y el mismo Renacimiento se perfilaron durante el siglo XX como dos de los grandes momentos más brillantes y espectaculares en cuanto al desarrollo de las artes. La Edad Media quedaba relegada a un mero suceso de rango inferior que tan sólo supuso la ruptura de una serie de planteamientos estéticos de los cuales no participaba.

Sin embargo, tal y como apuntamos, la situación pronto cambió. Las aportaciones de profundo calado teórico desarrolladas, por ejemplo, por P. Burke, tendrían gran importancia en este sentido. En relación con ello, el concepto de

213 F. GARCÍA ROMO, La escultura del siglo XI (Francia-España) y sus precedentes hispánicos, Barcelona, 1973, en especial, pp. 103-104. 
Renacimiento pronto dejó de ser el hilo rector inquebrantable de muchas de las reflexiones de la historiografía contemporánea. A propósito de tal premisa, Burke llegará a considerar que:

“(...) no fue nada fortuito que el resurgimiento de la Antigüedad empezase en Italia, donde se produjeron los logros originales. No olvidemos que era Roma, y no Grecia, el objeto de mayor veneración; Virgilio más que Horacio, el Panteón más que el Partenón (...). Así no resulta fácil discernir si la inspiración clásica en el arte italiano de los siglos VII, XII o incluso en el XIV responde a una pervivencia o a un resurgimiento. Hablamos de Renacimiento cuando la imitación de la Antigüedad se convierte en algo cotidiano, meticuloso y consciente, pero en Italia, al contrario que en otros lugares de Europa, la tradición clásica nunca fue algo remoto"214.

Sus palabras nos parecen reveladoras, aún con independencia de que no compartamos absolutamente todo lo afirmado en torno a una cuestión sobre la que volveremos más adelante.

En el párrafo que acabamos de transcribir, escrito por el autor en el año 1989, se advierte el final de una secuencia de afirmaciones hechas por varios autores en periodos anteriores y en las que se viene a especificar algo que hoy en día parece obvio. La imposibilidad de seguir manteniendo vigente la división de periodos históricos estancos, artificiales y encorchetados, provocó una migración ideológica que pugnaba ahora por la concepción de esos periodos estancos como unas divisiones meramente funcionales, ideales para poder continuar utilizando el discurso científico y pedagógico anterior. Las barreras infranqueables y las nomenclaturas inamovibles que durante mucho tiempo habían regido el estudio de estas cuestiones caían para siempre ${ }^{215}$.

Desde el punto de vista de la Historia del Arte y su literatura científica, un estudioso de la talla de S. Settis, marcaba una tendencia dentro de la disciplina al

\footnotetext{
${ }^{214}$ P. BURKE, El Renacimiento..., p. 43.

${ }^{215}$ En relación con estos temas, recordamos que esta cuestión ocupó el grueso de las reflexiones realizadas en las Internationale Tagung Christliche Kunst im Umbruch. Hispaniens Norden im 11.Jahrhundert de la Georg-August-Universitat Göttingen. En estas Jornadas Internacionales tituladas "El Norte hispánico en el siglo XI. Un cambio radical en el arte cristiano" de la Universidad de Göttingen (Alemania), celebradas entre el 27 y el 29 de febrero de 2004, se debatió sobre la problemática de poder llegar a definir claramente los fenómenos que se producen dentro de la arquitectura y las artes plásticas, cuando una determinada manera de hacer llega a su fin y se disuelve, para ser sustituida por otra nueva. La cuestión sigue residiendo en llegar a determinar si se trata de un tránsito muy marcado y rupturista $\mathrm{o}$, simplemente, de una evolución lenta y con fuerte carácter evolutivo, no radical. Las Actas de dicho evento científico no han sido publicadas aún.
} 
publicar sus tres volúmenes sobre la memoria del mundo antiguo en el arte medieval, tal y como ya hemos señalado. Su contribución puede considerarse un punto de confluencia entre las ideas defendidas por Burke y las ya mencionadas de A. Grabar ${ }^{216}$.

Settis retomaba y actualizaba la conocida teoría de la "voluntad de continuidad" y potenciaba la idea de una Historia del Arte sin los arquetípicos muros divisorios con los que se suele identificar la misma sucesión de los estilos. El especialista decía al respecto:

“(...) cuando se pasa de las imágenes cristianas antiguas a las de la Edad Media destaca, en primer lugar, la parte considerable que hay en éstas de continuidad, ${ }^{217}$.

En este sentido, es importante la conclusión a la que estos autores llegaban con sus estudios, permitiendo el establecimiento teórico de una afirmación que habría de tener mucha aceptación en las investigaciones posteriores. La evolución metodológica producida, entre otros, por los autores hasta aquí mencionados, acabó por hacer más factible la teoría que hablaba no de un resurgimiento de las fórmulas clásicas dentro de las artes tardoantiguas, sino más bien una pervivencia de las mismas, tamizada a través de los condicionantes regionales. Esto es lo que debió suceder, por ejemplo, en el caso de Italia, donde la continuidad de las formas de tradición clásica en la arquitectura y las artes medievales, debe ser entendida siempre como una continuidad y no como un resurgimiento.

En tal renovación conceptualista de los estudios, pronto se "resucitaron" viejas tendencias expuestas hacia tiempo por los conocedores de estos temas. Esto mismo sucedió con los principios defendidos en su día por A. Riegl y su teoría basada en la "reconstrucción de las mentalidades" de cada época. Así, cuando los nuevos investigadores comenzaron a elucubrar sobre la posibilidad de perfilar la concepción y la visión que los hombres medievales pudieron haber tenido de la Antigüedad, los expertos se fijaron nuevamente en las afirmaciones realizadas por Riegl:

216 S. SETTIS, “Continuitá, distanza...", pp. 373-486 y A. GRABAR, Las vías de la creación iconográfica cristiana, Madrid, 1985, p. 139. Grabar entendía que se trataba de una voluntad deseada, ya que señalaba, "si recordamos la decadencia de las artes figurativas cristianas de los siglos oscuros del siglo VI al IX, hay buenas razones para subrayar esta voluntad de continuidad".

${ }^{217}$ A. GRABAR, Las vías de la creación..., p. 139. 
“(...) era una ficción llena de fantasía, imaginaban que el poder y grandeza del antiguo Imperio, era algo todavía existente o sólo esporádicamente interrumpido" $^{, 218}$.

Esta serie de reflexiones nos llevan al estado actual de la cuestión. Los investigadores entienden, con buen criterio, que el sistema divisorio de los periodos históricos y de los movimientos artísticos, realizado durante los siglos pasados, debe ser entendido como un fruto artificial de una determinada solución academicista y utilitarista, que facilitaba el conocimiento y la comprensión de la misma historia.

Una vez aceptado este hecho, parece que, al igual que los hombres del siglo XIX jamás sintieron que la invención de la locomotora, el desarrollo de las redes ferroviarias y la implantación de los nuevos métodos de producción relacionados con las industrias metalúrgicas, suponían el punto y final de la Edad Moderna y la "invención" de lo que actualmente conocemos como Edad Contemporánea, tampoco los hombres medievales de la Alta y Plena Edad Media se sentían muy diferentes a los que habían vivido varios siglos antes. Según se viene sosteniendo, nunca llegaron a ser conscientes del cambio que se había producido, ni de la importancia que tendría para las ciencias históricas la desmembración del Imperio Romano. Creemos que el mismo razonamiento o, uno de similares características, puede ser utilizado para justificar algunos aspectos relacionados con las artes y la arquitectura.

Para concluir este apartado, queremos hacerlo a través de la mención de dos aportaciones historiográficas que nos parecen altamente representativas de estas tendencias más actuales. La primera de ellas surge a partir de algunas de las investigaciones realizadas por la profesora H. Toubert. En sus estudios, la especialista llegará a utilizar de manera indiferente los términos de "arte antiguo" y "arte paleocristiano". A pesar de realizar tal acción con una justificación previa, este hecho refleja la tendencia actual a considerar que ambos periodos contaron con mayores puntos en común que diferencias. La investigadora defenderá de manera reiterativa, dentro de sus trabajos, la implantación de una "manera de ver" el arte del pasado romano. Según ella, sólo se llegará a comprender esta "voluntad de continuidad" que venimos estudiando, al entender el hecho de cómo los artistas románicos del siglo XII, se pudieron llegar a considerar a sí mismos como partícipes de un todo, de una etapa

\footnotetext{
${ }^{218}$ A. RIEGL, El culto moderno a los monumentos, Madrid, 1999, pp. 33. Se trata de una idea vertebral dentro de la tradición académica y metodológica en la que se había formado este estudioso.
} 
continúa, nunca fragmentada ${ }^{219}$.

En relación con este aspecto, el profesor I. Bango Torviso escribía:

“(...) el arte astur es una producción de la Antigüedad, o de la subantiguedad (...) no es que se inspirasen en la vieja tardorromanidad, sino que son todavía tardorromanidad inercial",220.

Creemos que tal afirmación representa plenamente la problemática a la que nos estamos refiriendo. Según nuestro criterio, su planteamiento es acertado y define claramente cómo se debe comprender la sucesión de movimientos artísticos dentro de la Hispania tardoantigua. En este sentido, pensamos igualmente que tal deducción puede hacerse extensible al denominado "arte prerrománico" hispano en general, desde las primeras obras catalogadas como visigodas durante los siglos VI y VII, hasta las producciones, a veces tamizadas por lo islámico, del siglo $\mathrm{X}$.

Reflexionar sobre lo problemático de las nomenclaturas enunciadas hasta aquí, así como las ideas que tales conceptos transmiten y representan es, sin duda, una tarea que sobrepasa los objetivos de este estudio. Las nociones de arte tardoantiguo, arte tardorromano, arte cristiano-primitivo, arte paleocristiano, arte romano de la Antigüedad tardía, son lo suficientemente complejas, para que se dude frecuentemente sobre su validez.

Tales complicaciones, ya fueron señaladas en su día por el mismo E. Panofsky en sus aportaciones al tema. Sin embargo, en el caso concreto de lo hispano, y en lo que respecta a nuestro estudio, consideramos importante las diferentes reflexiones que se han vertido sobre el término "prerrománico", que en nuestro caso específico, nunca llega a definir la marcada pluralidad y complejidad del fenómeno en la Península Ibérica.

La importancia del concepto es clara, pues será dentro del periodo que tradicionalmente venimos definiendo como "prerrománico" donde se localicen muchas

\footnotetext{
${ }^{219}$ H. TOUBERT, "Le renouveau paléochrétien à Rome u début du XII" siècle", Cahiers Archéologiques, XX, 1970, pp. 99-154, en especial, p. 99: "nous utiliserons indifféremment les deux termes, antique et paléochrétien. Nous devons, en effet, prendre le passé romain comme le voyaient les artistes romains du XII siècle, c'est-à-dire, comme un tout'. Consideramos este estudio como una de las aportaciones más interesantes en cuanto al fenómeno de recuperación de iconografía tardoantigua cristiana en el arte románico, sobre todo, por considerar que fue este tipo de producciones de las que, con mayor frecuencia, beberían los artistas de etapas posteriores.

${ }^{220}$ I. G. BANGO TORVISO, “El ocaso de la Antigüedad...”, en particular, p. 178.
} 
de las manifestaciones plásticas que servirían de hilo conductor entre los periodos antiguos y medievales.

Con todo, las razones prácticas empujan a una definición que aclare nuestra postura al respecto. Según lo afirmado, podemos entender que, el "arte prerrománico", además de concretarse mediante todas las características que tradicionalmente vienen siendo aceptadas como definitorias de tal movimiento, debe ser tenido en muy en cuenta por su fuerte vinculación con las manifestaciones de raigambre "clásica". Una característica que no le es extrínseca y que no ha adquirido mediante su contaminación con elementos externos, sino que forma parte de él de manera innata, en cuanto ese arte "prerrománico" se halla plenamente inmerso en la estética "clásica” tardoantigua.

Para finalizar queremos insistir en un último punto derivado de las teorías defendidas por E. Panofsky.

El autor se manifestó en varias ocasiones sobre la importancia de Hispania dentro de estos movimientos. Para él, lo "prerrománico hispano", a diferencia de lo que había ocurrido en otras regiones como la centroeuropea y todas aquellas que habían sucumbido al dominio carolingio, permanecía como un oasis incorrupto, donde la tradición clásica romana "pura” nunca llegó a perderse ${ }^{221}$.

Para definir este "estado de pureza" en cuanto a la conservación de los ideales y de las tradiciones artísticas y plásticas del arte romano, el autor utilizaba una expresión novedosa, acuñada en torno al año 1940 por E. Kitzinger. Nos estamos refiriendo al denominado arte "subantiguo",222.

La creación, definición y utilización del término "subantiguo" es básica, pues pretendía reafirmar que algunas de estas producciones anteriores al año mil, realizadas en la Península Ibérica, tenían como rasgo más marcado la conservación del clasicismo romano. Éste se mostraba inalterado, “puro”, frente a las diversas versiones, más "contaminadas" e imperfectas, que de él habían realizado recurrentemente entre otros, los mismos carolingios, por citar un ejemplo bien conocido.

A través de esta corriente "subantigua", lo "clásico" fue traspasado, si seguimos en todo momento lo señalado por Panfosky, sin solución de continuidad durante todos

\footnotetext{
${ }^{221}$ E. PANOFSKY, Renacimiento y renacimientos..., en especial, p. 85. Utilizamos el símil del oasis que el autor desarrolla en su texto original de forma brillante.

${ }^{222}$ E. KITZINGER, Early Mediaeval Art in the British Museum, London, 1940, p. 8.
} 
los siglos que configuraban el paso desde la Antigüedad tardía a la Alta Edad Media hispanas $^{223}$.

La idea, aunque brillante, merecerá ser reconsiderada desde sus puntos más esenciales para poder valorar si tales preceptos pueden mantenerse aún hoy en día.

\footnotetext{
${ }^{223}$ I. G. BANGO TORVISO, “El ocaso de la Antigüedad...”, pp. 175-185, en concreto, p. 178.
} 


\section{B. LOS “RENACIMIENTOS” DESDE EL ARTE ANTIGUO AL ARTE MEDIEVAL.}

En el presente apartado intentaremos abordar la inabarcable problemática de los diferentes "renacimientos" que la historiografía ha señalado a lo largo de la historia de las artes plásticas antiguas y medievales ${ }^{224}$. Somos conscientes de nuestras limitaciones a la hora de poder tratar de una manera correcta el gran número de movimientos renovadores que se produjeron durante los largos siglos de la Edad Media. Sin embargo, consideramos oportuno plantear un breve estado de la cuestión y analizar cada uno de estos "renacimientos" para poder entender finalmente la recuperación de fórmulas clásicas en la etapa románica hispana.

En este sentido, un trabajo publicado en 1982 por A. González Hernández, nos permite iniciar este repaso por los diferentes estados renovadores que vivieron las artes plásticas durante este periodo ${ }^{225}$. Sus afirmaciones reflejan la complejidad que presenta el proceso, la definición de sus características y la acotación y normalización del concepto a la hora de utilizarlo.

En relación con ello, determinados autores han considerado algunos periodos históricos y ciertas etapas culturales, como siglos de verdadera intención "renacentista", mientras que otros, han negado para esos mismos tiempos tal catalogación.

Este es el caso del autor que hemos señalado, quién, por ejemplo, considera que expresiones como la de "renacimientos medievales" están perfectamente justificadas dentro del estudio de la recuperación de la cultura clásica en las etapas posteriores a su disolución.

A. González Hernández puntualiza que otras expresiones de índole similar, tales como por ejemplo la de "renacimiento ostrogótico", no deben ostentar la misma consideración que la de "renacimiento medieval" por ser, según su criterio, una mera continuación de la romanidad. Igualmente opina sobre el conflictivo enunciado de "renacimiento céltico" o "renacimiento británico", pues considera que ambos deben ser excluidos de la lista de movimientos renovadores "por falta de tradición romana",226.

Tomando como ejemplo la postura del autor, se puede concluir que, mientras determinados sectores historiográficos aceptarán de manera canónica la utilización del

\footnotetext{
${ }^{224}$ La utilización del término entre paréntesis, señala las complejidades derivadas de la normativización de su uso, sobre todo a la hora de poder diferenciar tal fenómeno del Renacimiento. Tal término, con $\mathrm{R}$ mayúscula, es entendido en la actualidad como el movimiento desarrollado primero por el arte italiano, para más tarde difundirse por el ámbito europeo, entre los siglos XV y XVI.

${ }_{225}$ A. GONZÁLEZ HERNÁNDEZ, Los primeros renacimientos, Valencia, 1982, en especial, pp. 13-14.

${ }^{226}$ Ibidem, pp. 14-15.
} 
calificativo "renacimiento" para unos periodos, la vertiente opuesta lo desmentirá y lo negará, considerando que aquellas producciones artísticas que se presenten indisolublemente inmersas dentro de la tradición romana no deben ser marcadas bajo el epígrafe de "renacimiento", pues lógicamente se trata de un encadenamiento sin ruptura alguna.

A esta larga serie de problemas de naturaleza conceptual, debemos sumar otros no menos importantes. El más grave viene dado por las fuertes connotaciones restrictivas que la sociedad contemporánea ha a atribuido a la palabra "RENACIMIENTO", ya que, por lo general, su uso actual se encuentra casi limitado a todas aquellas producciones plásticas y arquitectónicas acotadas cronológicamente a los siglos $\mathrm{XV}$ o $\mathrm{XVI}^{227}$. A este problema se debe añadir otro factor discriminatorio $\mathrm{y}$ limitador, pues se ha entendido que tal movimiento se produjo específicamente y con mayor fuerza sobre algunos lugares muy concretos, como por ejemplo Italia y, a lo sumo, en el área de los Países Bajos ${ }^{228}$.

Tales ideas provocaron directamente la infravaloración de otros tipos de "renacimientos" que se habían producido a lo largo de los diferentes periodos históricos, quizás, por causa de su naturaleza menos definida.

Así, según apuntaba ya E. Panofsky, la causa de esta concepción peyorativa de los demás "renacimientos" fue, con respecto al Renacimiento italiano por ejemplo, el carácter meramente transitorio que estos tenían, mientras que el acaecido durante la etapa moderna fue, según nos dice, "total y permanente"229.

Entre tal tensión conceptual, semántica y terminológica, debemos situar el análisis del concepto "renacimiento" aplicado a los siglos medievales.

Parece claro que, avanzado el tiempo y paulatinamente a la desvinculación de las artes plásticas con respecto a los condicionamientos políticos de las áreas romanizadas ${ }^{230}$, los diferentes fenómenos de recuperación del ideario clásico no cesaron

\footnotetext{
${ }^{227}$ M. D. CAMPOS SÁNCHEZ-BORDONA, El arte del renacimiento en León: las vías de difusión, León, 1992, pp. 11-22.

${ }^{228}$ M. MOLINER, Op. cit., p. 996. En la voz de este Diccionario de insiste en tales factores.

${ }^{229}$ E. PANOFSKY, Renacimiento y renacimientos..., (1985), en especial, p. 164.

${ }^{230}$ No debemos olvidar que el alcance del fenómeno renovador tuvo diferentes grados dependiendo del lugar geográfico en el que se desarrollaba. Así, el legado de la Antigüedad clásica se mostraría de manera más evidente en Italia, donde nunca llego a perderse. Allí el proceso de herencia se llevó cabo bajo un "hábito de pensar en términos romanos", tal y como se ha señalado. Cf.: S. KOSTOF, Op. cit, pp. 551552; E. PANOFSKY, Renacimiento y renacimientos..., p. 85 y J. ARCE, “Arte romano en Hispania”, El arte de España. Altamira y los orígenes del arte español, vol. I, Barcelona, 2002, pp. 43-80, particularmente, p. 73. Estos expertos hablan sobre la importancia del germen local que el arte antiguo tuvo en cada territorio y su influencia en el arte alto medieval. Así, en lugares como Italia, el Norte de
} 
de sucederse en forma de rebrotes, más o menos continuos, ya fuese en su vertiente innovadora y continuista a través del renacimiento o, en su forma más conservadora, a través de una simple renovación.

La incorrección e indefinición con que habitualmente se han venido usando estos conceptos, sin aclararlos inicialmente y delimitarlos dentro de los estudios especializados en la materia, ha provocado que muchos de los movimientos de recuperación de los ideales clásicos acaecidos en el periodo medieval se hayan visto sumergidos en una indeterminación grave.

Son numerosos los periodos históricos, y con ellos las producciones artísticas nacidas en tales momentos, en los que la palabra "renacimiento" se utilizó para definir cualquier recuperación del pasado. Sin embargo, se advierte una necesidad de matizar su uso, de hacerlo más concreto y restringido.

El concepto "renacimiento" se presta a una utilización ambigua y fácil, perfilada por unos contornos difusos y en los que cualquier recuerdo del pasado se define mecánicamente mediante tal calificativo, sin entrar a valor el alcance de tal recuperación.

Por citar algunos ejemplos bien significativos, recuérdese, por ejemplo, el caso del supuesto "renacimiento" romano de los siglos V y VI. Mientras que para algunos autores se trataría de una clara recuperación de fórmulas clásicas de claro talante "renacentista", otros, sin embargo, prefieren incluirlo simplemente bajo el concepto de renovación. Es evidente que tales posturas acaban provocando una confusión total a la hora de utilizar dichos vocablos ${ }^{231}$.

Sin embargo, intentando salvar esta ambigüedad en el uso del terminológico, algunos especialistas señalaron cómo las últimas producciones del arte antiguo que intentaron recuperar los ideales del arte clásico, ya fuesen las adscritas al primer arte cristiano, al arte de los pueblos invasores -y, entre ellos, evidentemente, los visigodoso el arte producido en la ciudad de Roma desde el siglo V al VIII, deberían englobarse bajo un fenómeno de "renacimiento" y no de RENOVATIO.

África, España y la Galia meridional, existió durante el periodo que comprende el fin de la Antigüedad y los inicios del medievo, una fuerte tradición clásica autóctona que influyó decisivamente en la formación del nuevo estilo. Tal aspecto serviría de base generadora de lo que Panofsky calificó en su día como el "estilo subantiguo".

${ }^{231}$ F. MASSIP BONET, Prerrománico y románico, vol. 2, Barcelona, 1997, p. 579. El autor alude a una cierta renovatio para referirse al arte de Roma, la Galia y la España de la etapa visigótica, utilizando un concepto diferente al de "renacimiento" para señalar esta vuelta hacia lo clásico, como fenómeno precedente del "renacimiento" carolingio y, englobado en el arte de la Antigüedad tardía. La utilización de tales términos resulta problemática y compleja a la vista de la definición que hace de los mismos. 
Según estos autores, este hecho es factible si tenemos en cuenta que todas estas obras artísticas fueron reinterpretadas bajo las formas y leguajes antiguos, para readaptarlos a unos usos novedosos y que, por lo tanto, basaban todos sus planteamientos conceptuales en la misma idea de regeneración de lo antiguo para crear algo nuevo. Según esto, no existiría, en principio, ningún problema para poder englobar este tipo de obras bajo el título de "renacimiento", es decir, volver a nacer y, consecuentemente, hacerlo de forma totalmente renovada.

Las dificultades a la hora de poder aplicar correctamente el calificativo de "renacimiento" o de renovación sobre las artes medievales y, en concreto, sobre las de la Alta Edad Media europea e hispana, quedan patentes a la hora de abordar la problemática de la recuperación de lo clásico en el ámbito carolingio.

Según se ha venido señalando, la expresión más correcta para definir este fenómeno del ámbito centroeuropeo del siglo IX, vendría concretada por el uso normativo del término renovatio. Tales argumentos defienden su entendimiento como un fenómeno de "rapprochements" que podría coexistir sin problemas con otra serie de acepciones como las de renovare o redintegrare ${ }^{232}$.

Llegados a este punto, se debe señalar claramente que, la principal diferencia existente entre la acepción de renovatio con respecto al término "renacimiento", viene dada nuevamente por la concepción semántica que dicha nomenclatura ostenta. En este sentido, generalmente se viene entendiendo que la renovación implica una vuelta o revalidación de "una cosa decaída, envejecida y olvidada" y que desde el punto de vista de su enunciación, en ningún caso se incluye ni menciona su capacidad de aportar alguna novedad ${ }^{233}$.

Según la definición dada en su día por M. Moliner, renacimiento es "nacer de nuevo. Adquirir nuevas fuerzas o ánimos" ${ }^{234}$. Este hecho, aplicado sobre las diferentes artes visuales, acusa ciertas concomitancias con la definición y el entendimiento que del término tuvo en su día E. Panofsky. Para el autor, no existió un único "renacimiento", sino más bien una constante tendencia renovadora a lo largo de los últimos milenios de

\footnotetext{
${ }^{232}$ E. PANOFSKY, Renacimiento y renacimientos..., p. 85 y S. SEBASTIAN, Mensaje simbólico..., pp. 190-191. El investigador utiliza concretamente estos conceptos que nosotros asumimos para nuestro discurso. En relación con ello, resulta llamativa la postura del profesor S. Sebastián. El autor español considera, al contrario que Panofsky, que la renovatio carolingia debe definirse como un "renacimiento", si bien se advierte claramente su uso más como un sinónimo de renovación. Este hecho insiste nuevamente sobre la conflictividad y la confusión en el uso de dicha terminología.

${ }^{233}$ M. MOLINER, Op. cit., p. 998.

${ }^{234}$ Ibidem, p. 996.
} 
la civilización occidental, en las que las fórmulas clásicas nacían de nuevo de manera intermitente ${ }^{235}$.

Se trataría, siguiendo tales posturas, de ciertos rebrotes de la cultura antigua que despuntaban entre un panorama artístico muy heterogéneo. Un regreso de las artes visuales hacia los fundamentos del pasado, donde se entendía que se encontraban los momentos más espectaculares de las producciones artísticas.

La multipluralidad de "renacimientos" que los citados investigadores se han encargado de señalar a lo largo del tiempo, se nos muestran evidentes dentro del caso medieval, donde éstos llegarían a ser innumerables. Se trataría de un mismo fenómeno que pretendía inútilmente acotar un movimiento definido por infinitas posibilidades ${ }^{236}$.

Desde los inicios historiográficos centrados en el tema, tal pluralidad obligará a una acotación de análisis, señalando los casos más significativos de cada uno de estos "renacimientos" desarrollados dentro del ámbito cronológico medieval de una manera concreta. Tan sólo a través de lo específico y de la puntualización de cada fenómeno por aislado, se llegará a una visión de conjunto del fenómeno. Sobre todo si tenemos en cuenta que ya desde la misma Antigüedad estos "renacimientos" del pasado aparecen documentados de manera clara y cargados con una gran voluntad y consciencia. Aquellos hombres, según se deduce de las obras que nos han legado, se sintieron en ocasiones partícipes de diversas etapas renovadoras, que aplicadas de una manera continuada y asentadas sobre un aparato ideológico definido, acabarían materializándose en los diferentes y muy diversos "renacimientos" medievales de los que tenemos constancia durante los siglos posteriores a la disipación del mundo antiguo.

\footnotetext{
${ }^{235}$ E. PANOFSKY, Renacimiento y renacimientos..., (1985), pp. 38-39.

${ }^{236}$ P. BURKE, Op. cit., p. 13.
} 


\section{CUANDO LO CLÁSICO GRIEGO ES LA ANTIGÜEDAD CLÁSICA PARA ROMA.}

En uno de los estudios más completos sobre el fenómeno de la expoliación material y conceptual de lo clásico en las artes de los siglos posteriores a la caída del mundo antiguo, la autora L. de Lachenal dedicaba el primer apartado de su investigación a la reutilización de materiales antiguos en la época Imperial romana ${ }^{237}$.

La investigadora iniciaba su exposición documentando el proceso de "restauración" del llamado Porticus Octaviae de Roma. Según recogía, tal acción conservadora había sido impulsada por el mismo Alejandro Severo y en su desarrollo se había tenido como principal objetivo la reutilizaron y reintegración de múltiples materiales "antiguos" dentro de un edificio que, desde un punto de vista cronológico, también pertenecía a la Antigüedad ${ }^{238}$.

La idea rectora de tal acción, parecía dirigida de manera unánime, a respetar en la medida de lo posible los restos materiales heredados desde la misma Edad Augustea y ahora incorporados a las construcciones creadas ex novo ${ }^{239}$.

Este dato, seleccionado de entre los muchos posibles dentro del fenómeno de la expoliación material de la edilicia y la escultura del mundo antiguo, refleja el enorme respeto y admiración que el pueblo romano guardaba hacia la figura de Augusto.

Llegados a este punto, son de obligada referencia las investigaciones llevadas a cabo por P. Zanker en relación con lo que él ha dado en llamar el "renacimiento augusteo". El fenómeno, vinculado de manera recurrente a la figura del emperador, tenía como principal objetivo tomar como modelo el pasado que los mismos romanos consideraban como propio. Así, durante su mandato, el arte romano apelaría de manera consciente a un tipo de producciones artísticas que consideraban como representantes de las glorias de su mismo pasado. Por consiguiente, el modelo que tomaron como

\footnotetext{
${ }^{237}$ L. DE LACHENAL, Spolia. Uso e reimpiego dell'antico. Dal III al XIV secolo, Milano, 1995, concretamente, pp. 11-30. Véase igualmente el apartado de este trabajo donde analizamos el fenómeno de la expoliación material y la expoliación intelectual o, lo que es lo mismo, el spolium in se y el spolium in re.

${ }^{238}$ Señalamos entre comillas aquí el concepto de "antiguo", para dejar constancia de lo paradójico que resulta señalar el hecho de cómo para los mismos romanos, que según nuestros criterios actuales son eminentemente antiguos, existía otra "Antigüedad" anterior a ellos y a la cual consideraban su pasado más inmediato al que mirar en busca de aquellos argumentos que les permitiesen conocer su presente. Se trataría de una Antigüedad que miraba hacia su propia "antigüedad".

${ }^{239}$ L. DE LACHENAL, Op. cit., p. 11.
} 
referente para tal acción, no podía ser otro que el arte clásico griego del siglo $\mathrm{V}$ a d. $\mathrm{C}^{240}$.

Según se entiende bajo la óptica actual el arte augusteo, éste se engloba, sin dudas, dentro del "megaperiodo" correspondiente al mismo arte antiguo y, más concretamente, se le suele englobar bajo el epígrafe de "arte clásico".

El mecanismo fue similar para las artes patrocinadas bajo el mandato de este emperador, pues tal y como se viene aceptando, este tipo de producciones tenían también su referente cultural y artístico en otro periodo distinto al que ellos estaban viviendo. La Grecia del siglo V debió ser igual de clásica para nosotros que para los coetáneos a la época de Augusto, convirtiéndose en el tipo y el arquetipo al que emular $\mathrm{y}$, en ocasiones, expoliar materialmente. El arte romano, tomando como base tales referentes, vivió una renovación orientada hacia la cultura griega, buscando una apropiación de fórmulas artísticas traducidas en un amplio programa de renovación y "saneamiento" de la sociedad romana, por utilizar la expresión señalada por P. Zanker $^{241}$.

La consciencia histórica y del devenir cronológico, nos otorga la posibilidad de realizar una reflexión justificada por nuestra distancia temporal con respecto a tales sucesos. Los mismos romanos no fueron nunca conscientes de que las futuras sociedades que les sucedieron, les verían a ellos como representantes igualmente clásicos del mundo antiguo, en un nivel bastante similar al que para los romanos ostentaban esos mismos griegos a los que decidieron imitar. En este mismo sentido, parece lógico afirmar que la sociedad romana de tal periodo, nunca podría haber llegado a imaginar que bajo el epígrafe de "arte clásico" las sociedades actuales llegarían a englobar de igual manera, tanto el arte griego del siglo $\mathrm{V}$ a. de $\mathrm{C}$, como el producido en la Roma del siglo I d. de C. Nuevamente se acusa el carácter artificial y los varemos "inventados" que rigen nuestra concepción intelectual de estos temas.

La conducta del emperador puede ser entroncada, según nuestra opinión, en una tendencia habitual durante la Antigüedad, según la cual, las diversas sociedades irían rescatando paulatinamente los ideales artísticos más destacados de cada momento

\footnotetext{
${ }^{240}$ P. ZANKER, Augusto y el poder de las imágenes, Madrid, 1992, pp. 234-235 e ID., Un'arte per l'impero. Funzione e intenzione delle immagini nel mondo romano, Milano, 2002, en especial, p. 108. El experto define tal movimiento mediante la expresión renovatio augustea.

${ }^{241}$ Esta situación que venimos señalando se producía en una fecha levemente posterior a la batalla de Accio, es decir, en torno al año 28 a. de C. Augusto llevará a cabo una serie de reformas de carácter institucional y público, mediante las cuales pretendería proyectar una imagen de "reconstructor" del estado romano. Cf.: P. ZANKER, Augusto y el poder..., p. 128.
} 
histórico. Mediante tales conductas mostraban un interés extremo por la vuelta a los modelos clásicos de lo que ellos consideraban como su propia "Antigüedad" y ello, muy a pesar de que, basándonos en nuestra perspectiva histórica y cronológica, ésta estuviese tan próxima y cercana a los romanos como nunca más habría de ocurrir con respecto a ningún periodo posterior de la civilización occidental ${ }^{242}$.

El mecanismo utilizado por este emperador para reactivar esta suerte de renovatio de los modelos antiguos dentro de la misma Antigüedad, permite argumentar un prólogo estable para las conductas de los hombres medievales.

Mediante estas acciones emprendidas por Augusto, relacionadas casi siempre con la prosperidad de algunos aspectos vinculados con la política, la sociedad y también con las mejoras urbanas y edilicias, además se pretendía "construir" una imagen de monarca benefactor, sabio y condescendiente para con su pueblo. Desde este punto de vista, la opinión defendida por L. de Lachenal nos parece acertada, en cuanto detecta cierta continuitas imperii entre algunos valores políticos y estratégicos del mundo antiguo con respecto al ámbito medieval ${ }^{243}$. Parece claro que las cuestiones artísticas siguieron los mismos derroteros.

Sirva de ejemplo, en este sentido, la conocida admiración que el emperador Pompeyo (106-48 a. de. C) sentía por Alejandro Magno. Tal devoción, llevó a dicho personaje a mandar retratarse, de manera oficial, con el mismo peinado con el que aparecía el mismo Alejandro dentro del basto corpus de efigies míticas que por estos tiempos nutrían los cánones de la estética romana ${ }^{244}$.

A este respecto, escribe P. Zanker:

“(...) el retratado se ve a sí mismo como un nuevo Alejandro (...) el peinado anastole - lleva en la imagen el título de Magnus con el que Alejandro distinguiera su

\footnotetext{
${ }^{242}$ S. MADDALO, In Figura Romae. Immagini di Roma nel libro medioevale, Roma, 1990, particularmente, p. 33. La profesora Maddalo realiza algunas reflexiones con respecto a esta admiración de las diferentes fases históricas hacia las manifestaciones artísticas de Roma y sus monumentos. Cf:: S. MADDALO, In Figura Romae. Immagini di Roma nel libro medioevale, Roma, 1990, particularmente, p. 33.

${ }^{243}$ L. DE LACHENAL, Op. cit., p. 12.

${ }^{244}$ P. ZANKER, Augusto y el poder..., p. 30. Recogemos este dato de la obra del autor por considerar que es bien representativo de esta idea y porque además sirve para corroborar la admiración que sentían determinados personajes de la Roma Republicana por las personalidades más distinguidas del mundo helenístico. Es decir, los personajes del pasado buscaron sus referentes en la cultura que ellos consideraban como germen de su propio presente.
} 
nombre ${ }^{, 245}$.

Esta utilización y apropiación de determinados aspectos del periodo más clásico de la historia, según la visión que de ésta tenían los romanos de la época Republicana de Pompeyo y de la Roma Imperial de Augusto, servirían para que los diferentes emperadores intentasen, mediante sus acciones, una equiparación con respecto a las más insignes personalidades representantes de eso que se ha dado en llamar "saecula aurea". Las obras emprendidas por Trajano, Adriano y el propio Marco Aurelio son los representantes materiales más evidentes de tales voluntades ${ }^{246}$.

Desde otro orden de cosas, tales conductas tendrían cierta continuidad. No en vano y andando el tiempo, concretamente en época ya cristiana, el emperador Constantino mandaría colocar dentro del programa iconográfico de su famoso arco del foro romano, las efigies de Trajano, Adriano y Marco Aurelio en plena oratio. Lo más interesante respecto a esta noticia es que no sólo fue una alusión iconográfica o intelectual a tales monarcas, sino también material y física. En su intento por revivir los gloriosos saecula aurea, el emperador también ordenó colocar ciertos relieves expoliados y reempleados de las construcciones de aquellos emperadores y a las que, por cierto, generalmente tan sólo tenían plena libertad de acceso para su uso los canteros $\mathrm{y}$ artífices activos bajo la voluntad del emperador ${ }^{247}$.

El amplio programa reformador de Augusto, así como aquel seguido por otros que le imitaron, incluía una proyección de un emperador benévolo con sus súbditos, a los que dedicaba la construcción de grandes obras civiles y públicas erigidas con la única finalidad de servir para uso de la plebe, sin duda los "destinatarios material" de ese fenómeno definido como la Edad de Oro ${ }^{248}$.

Para la Roma de Augusto el pasado clásico era el pasado griego. Evidentemente no se sentían participes de ninguna renovación ni cambio de gran trascendencia, y menos desde el punto de vista de las artes plásticas. La copia minuciosa y exacta que se

\footnotetext{
${ }^{245}$ Ibidem, p. 29 e ID., "Las representaciones del soberano", Roma. Sentaus Populus Que Romanus, Madrid, 2007, pp. 373-383.

${ }^{246}$ L. DE LACHENAL, Op. cit., p. 15; M. BENDALA GALÁN, "La paz augustea y la romanización", En el año de Trajano. Hispania. El legado de Roma, Zaragoza, 1998, pp. 127-138; A. M. CANTO, "Saeculum Aelium, saeculum Hispanum: Poder y promoción de los hispanos en Roma", En el año de Trajano. Hispania. El legado de Roma, Zaragoza, 1998, pp. 209-224 y J. BELTRÁN FORTES, "El esplendor de un imperio: la época de Trajano", En el año de Trajano. Hispania. El legado de Roma, Zaragoza, 1998, pp. 225-238.

${ }^{247}$ B. BRENK, "Spolia da Constantino...", p. 198.

${ }^{248}$ P. ZANKER, Augusto y el poder..., p. 129.
} 
llevó a cabo en el foro romano de las cariátides del Erecteion de Atenas y que el emperador mando colocar sobre el ático de la gran columnata de dicho espacio público, seguramente no fue vista como símbolo alguno de renovación artística por los artífices del momento. Por el contrario, hoy creemos que se trataba de una cita al pasado clásico en toda regla ${ }^{249}$.

El gesto poseía unos fines políticos que instrumentalizaban el pasado glorioso o mejor, mitológicamente glorioso, de Grecia, proyectando una imagen de las artes que buscaba de manera clara la equiparación con la autoridad de las artes del periodo de Fidias.

Sin embargo, para los artistas del momento, carentes de nuestra perspectiva histórica, tales hechos quizás supusieron simplemente una especie de exhuberancia arqueológica, tal y como se ha definido en ocasiones. En este sentido, esta es la posibilidad que debemos manejar para poder llegar a intuir el sentimiento que impulsó a M. Emilio Scauro a hacer traer y colocar, por orden suya, cuatro columnas de mármol importadas de Grecia para ocupar un lugar preferente en el atrio de su casa, que rápidamente, y esta vez intuimos que con una intención más ideológica y simbólica, fueron reubicadas por orden de Augusto en la scaenae frons del teatro Marcello de Roma $^{250}$.

Esta serie de conductas que venimos explicando tuvieron sus frutos. El arte del periodo, que daría resultados tan indiscutiblemente clásicos como el Ara Pacis, ha sido considerado por todos los estudiosos ulteriores como un claro representante de este "renacimiento" de las artes (fig. 29). Los motivos iconográficos más difundidos en las obras creadas bajo este movimiento han sido señalados de manera reiterativa. Entre ellos destaca, por ejemplo, la absoluta proliferación de grutescos, candelieri y todo tipo de ornamentación vegetal, que pasarían al arte posterior de manera recurrente y arquetípica como símbolo de tiempos de bonanza (fig. 30). Que los repertorios de imágenes utilizados para lograr esta transformación social acabaron por convertirse en sellos visibles de la exaltación de la renovación política y social, así como de su abundancia y su riqueza, lo certifican algunas monedas de época augustea en las que se representaron, por ejemplo, algunos manojos de espigas, símbolo de fecundidad y

\footnotetext{
${ }^{249}$ Ibidem, pp. 299-300.

${ }^{250}$ P. ZANKER, Un' arte per l'impero..., p. 29.
} 
engendro productivo ${ }^{251}$.

Las provincias del Imperio tampoco escaparon a la perpetuidad de estos símbolos de renovación. Aludimos en este sentido a la placa marmórea conservada en el Museo Nacional de Arte Romano de Mérida y en la que nuevamente se reproduce la iconografía de las espigas, acompañado por la inscripción AESTAS. Según se ha venido insistiendo, tal imagen aludiría intencionadamente a esta "tiempo de fertilidad", materializada por la iconografía de ciertos elementos ligados a los campos y a las cosechas en plena germinación ${ }^{252}$ (fig. 31).

Concluyendo, podemos afirmar que el "renacimiento" dirigido por Augusto se caracterizó por la exaltación absoluta de la pietas del monarca a través de su publia magnificentia, así como por la explotación de la plástica artística y de la arquitectura como transmisores materiales que reflejasen esta etapa de bonanza social. Sin embargo, en relación con este breve recorrido por los diferentes "renacimientos" de la historia artística antigua y a pesar de que tendremos que analizar aún muchos fenómenos de índole similar hasta llegar a las etapas medievales, creemos bien significativas las palabras escritas por F. Marín Valdés a la hora de compararlas con el fenómeno antes señalado en la Roma Imperial:

"Los reyes godos de Oviedo, modesta sede de un nuevo arranque, no representaron una excepción. Puesto que en la ideología del poder durante el primer medievo el modelo imperial cristiano carece de alternativa, cada príncipe, en la medida de sus posibilidades, aspira a asumir y a reanudar las funciones privativas de un emperador a pequeña escala, emulando con su política edilicia el esplendor y la prodigalidad de los antiguos césares" 253 .

\footnotetext{
${ }^{251}$ P. ZANKER, Augusto e il potere delle immagini, Roma, 2006, en concreto, pp. 98-99. En este caso, hemos manejado, de manera puntual, una edición diferente hasta la que en este momento se ha venido señalando. Se trata de algo meramente ocasional, pues en lo sucesivo, a la hora de citar tal estudio, se hará siempre a través de la versión ya señalada en castellano.

${ }^{252}$ M. CRUZ VILLALÓN, "El taller de escultura de Mérida. Contradicciones de la escultura visigoda", Visigodos y omeyas. Un debate entre la Antigüedad tardía y la Alta Edad Media, Madrid, 2000, pp. 265278; ID., Mérida visigoda. La escultura arquitectónica y litúrgica, Badajoz, 1985, en concreto, pp. 35-36; M-P. GARCÍA-BELLIDO, "Dalla moneta iberica alla moneta ispanica", Hispania Romana. Da terra di conquista a Provincia dell'imperio (J. Arce, S. Ensoli, E. La Rocca coord.), Roma, 1997, pp. 31-43, en concreto, p. 37 y P. C. DÍAZ, "Urbes in rure: I pacieri della campagna e della natura", Hispania Romana. Da terra di conquista a Provincia dell'imperio (J. Arce, S. Ensoli, E. La Rocca coord.), Roma, 1997, pp. 283-294.

${ }^{253}$ F. MARÍN VALDÉS, “Observaciones sobre la adopción...”, en particular, p. 20.
} 
No es este el apartado correcto para abordar el hecho de cómo algunos monarcas medievales tomaron, en ocasiones, algunos aspectos del supuesto programa reformador de emperadores como Augusto. Sin embargo, algunas premisas que más adelante abordaremos con cierto detenimiento, asientan sus bases sobre esta idea. Se trataba de recuperar determinados perfiles que habían servido en el mundo antiguo para la configuración de la imagen mental del buen gobernante y ponerlos al servicio constructor de la imagen del monarca medieval ${ }^{254}$.

En este sentido, aunque mucho menos significativo y conscientes de que puede tratarse de un ejemplo forzado, en cuanto alude a una intitulatio más bien de carácter arquetípico que verídica, es la alusión que se va a hacer de determinados monarcas dentro de las fuentes que nos ha legado la Hispania medieval.

El título de imperator, ciertamente ambiguo y alejado de las connotaciones romanas que posee tal nomenclatura, fue utilizado para hacer referencia al mismo rey Alfonso VI. Quizás podría valorarse el alcance de tal utilización, codificada bajo el lejano recuerdo que tal categoría había tenido durante la Antigüedad ${ }^{255}$.

No en vano, tal y como había hecho Pompeyo Magno equiparándose al gran héroe helenístico, tampoco fueron aislados los casos en los que monarcas medievales buscaron, en una especie de precoz espejo de príncipes, verse reflejados en las figuras de algunos reyes del pasado más emblemático. Desde otro punto de vista, no debemos olvidar que, en ocasiones podrían documentarse los ejemplos de monarcas que se vieron reflejados, al igual que los emperadores del mundo antiguo, en las figuras de otros monarcas célebres, cuya vida y figura servían de modelo para gestar otros discursos que comparar con las personalidades del medievo.

Este es el caso de la figura de Alejandro Magno. En el caso hispano, algunos investigadores han señalado, no sin riesgo, como el famoso capitel ubicado en la girola de la catedral de Santiago de Compostela con la representación del monarca Alfonso VI, puede ser valorado teniendo en cuenta estas hipótesis inestables. En este caso concreto, el monarca se acompaña de otra pieza esculpida en la que se incluyó el tema de la Ascensión de Alejandro a los cielos. Esta imagen, tal y como es sabido, fue vista

\footnotetext{
${ }^{254}$ P. ZANKER, "Las representaciones del soberano...", pp. 373-383.

${ }^{255}$ Somos conscientes de que se trata de una extrapolación sin fundamento y que sobrepasa, con mucho, nuestra capacidad de análisis en relación con el estudio de este término. Se trata de una cuestión sintáctica y epistemológica sobre la cual habría que volver, en busca de las "voluntades" que tales acepciones podrían tener al aplicarlas sobre los soberanos medievales.
} 
durante los siglos medievales como un auténtico arquetipo de soberbia, que recordaba al espectador más cultivado la altivez y jactancia del monarca antiguo.

El paso más complejo de esta teoría defiende la posibilidad de poder identificar la efigie del mismo Alfonso VI, representada sobre el capitel, como una alegoría simbólica de la figura del monarca macedonio.

Como es bien sabido, la imagen de Alejandro Magno del capitel contiguo serviría, insistimos que de manera hipotética, para llamar la atención sobre determinados aspectos de la personalidad de este rey medieval. Se trataría de una alusión, no exenta de crítica, de la soberbia del rey helenístico, entendida ahora como un reflejo real de aquella que supuestamente había dominado la figura del monarca hispano $^{256}$.

Aún teniendo en cuenta estas hipótesis de trabajo para la identificación de determinados temas de la escultura románica hispana y su vinculación con los posibles rebrotes clasicistas, somos plenamente conscientes de que deben ser tomadas con cierta cautela. Lejos de contar con el criterio acertado que nos permita pronunciarnos con respecto a estas identificaciones, lo más interesante, según creemos, estriba en poder reflexionar sobre la importancia de determinados arquetipos intelectuales del mundo antiguo y sus repercusiones en la misma Edad Media.

El hecho de que los monarcas medievales vieran en sus antepasados antiguos más lejanos un modelo a imitar, parece claro. Faltaría tan sólo poder concretar estas premisas de un modo justo, centrándose en personalidades regias concisas y esperando poder progresar en el conocimiento de la imagen antigua del poder y su asimilación a lo largo de los diferentes "renacimientos" de la cultura griega y romana que sucedieron en la etapa medieval.

\footnotetext{
${ }^{256}$ Tanto el capitel de la Ascensión de Alejandro como el del monarca Alfonso VI, pertenecen a la primera campaña constructiva de la catedral de Santiago de Compostela. Se han venido datando entre el año 1078, en el que se iniciarían las labores constructivas de la cabecera y la fecha de 1080, en las que, parece ser, se produciría una detención de los trabajos realizados bajo el auspicio del obispo Diego Peláez. Cf.: V. NODAR FERNÁNDEZ, La inicios de la catedral románica de Santiago: El ambicioso programa iconográfico de Diego Peláez, Santiago de Compostela, 2005, en particular, pp. 10-35; ID., "Alejandro, Alfonso VI y Diego Peláez: una nueva lectura del programa iconográfico de la Capilla del Salvador de la Catedral de Santiago", Compostellanum, XLV, 3-4, 2000, pp. 617-648; F. ESPAÑOL BRERTRÁN, "El sometimiento de los animales al hombre como paradigma moralizante de distinto signo: la "Ascensión de Alejandro" y el "Señor de los animales" en el románico español", Originalidad, modelo y copia en el arte medieval español (F. Español Bertrán y J. Yarza Luaces coord.), Barcelona, 1987, vol. 1, 1987, pp. 49-64 y D. RICO CAMPS, Las voces del románico. Arte y epigrafía en San Quirce de Burgos, Murcia, 2008, concretamente, p. 15.
} 
2. Continuidad del Pasado GRIEgo en los inicios De LA EdAd Media: EL “RENACIMIENTO GRIEGO” DEL SIGLO V.

La admiración por la Antigüedad grecorromana que hemos señalado anteriormente dentro de la predisposición recuperadora vivida por la misma sociedad romana de la época de Augusto y sus sucesores, debe ser vista como un rebrote inicial de una tendencia más compleja.

El respeto que los romanos mostraban hacia las obras griegas, sobre todo escultóricas, explica todo el sistema de reproducción de piezas sobre el que se asienta buena parte de nuestro conocimiento del corpus estatuario griego, la mayor parte perdido.

El hecho de que actualmente conozcamos muchas de los trabajos griegos se debe, sin duda, a estas copias romanas. El sistema de reproducción exacto y fidedigno sobre el que se basaban tales duplicados, ofrece muchos campos de reflexión sobre los que poder medir la importancia del arte griego, tanto para los artífices romanos como para los de etapas posteriores ${ }^{257}$.

La reflexión sobre tales modelos, lo habitual de su difusión mediante los sistemas de copia o imitación, así como otras diversas causas, permiten explicar el

\footnotetext{
${ }^{257}$ Es importante tomar consciencia del alcance de estas ideas. Mediante diversos métodos y, en concreto, a través de aquel que se ha definido como la llamada "Arqueología del Arte", se pudo llegar a tener un conocimiento bastante detallado de la escultura griega perdida a través de las copias romanas. Se trata de un sistema muy utilizado por los historiadores del arte antiguo de la órbita alemana durante el siglo XIX. Mediante él, se posibilitó la reconstrucción de la historia del arte clásico helénico teniendo en cuenta las obras, sobre todo escultóricas, que no habían llegado a nosotros.

Este sistema de la Archäologie der Kunst o "Arqueología del arte", también denominada "Arqueología filológica", permitía a través de su utilización recuperar el conocimiento de obras de arte perdidas. Las fuentes para llevar a cabo esta teoría eran dos principalmente.

El primero recaía en el análisis de la documentación en todas sus variantes: histórica, literaria, etcétera; mientras que el segundo caso, y el que más nos interesa a nosotros, es aquel que mediante el análisis de los monumentos posteriores conservados, se podía llegar a perfilar una historia del arte de los monumentos perdidos. En el caso del conocimiento de la escultura griega, la clave estaba en el estudio de las copias realizadas en época romana, tal y como venimos señalando. Mediante la Arqueología del arte, se podía llegar a "re-construir" un corpus perdido y "construir" así uno nuevo.

Con frecuencia se suele traer a colación el ejemplo de las esculturas de Policleto o Mirón, de las que no ha sobrevivido ningún original, pero de las que podemos llegar a tener una idea a través de sus copias.

Sobre todos estos aspectos, véase: S. SETTIS, El futuro..., pp. 44-45; G. LIPPOLD, voz "Copie e copista", Enciclopedia dell'arte antica classica e orientale, vol. II, Roma, 1959, pp. 804-810; PH. SÉNÉCHAL, "Originale e copia. Lo studio comparato delle statue antiche nel pensiero degli antiquari fino al 1170", Memoria dell'antico nell'arte italiana. Dalla tradizione all'archeologia (S. Settis dir.), vol. III, Torino, 1986, pp. 149-180 y O. ROSSI PINELLI, "Chirugia della memoria: scultura antica e restauri storici”, Memoria dell'antico nell'arte italiana. Dalla tradizione all'archeologia (S. Settis dir.), vol. III, Torino, 1986, pp. 181-250.
} 
porqué de esta tendencia continuista a la hora de justificar esta serie de rebrotes recuperadores de ciertos aspectos de la plástica griega en Occidente ${ }^{258}$.

Sin embargo, tal y como señala, por ejemplo, A. Grabar, esta influencia del arte grecorromano llegó más allá de un momento muy puntual y concreto de la civilización romana del siglo I a de C. Así, en pleno siglo V de nuestra era, encontramos en Bizancio y, por correspondencia, en Ravenna, un nuevo renacer de la tradición artística griega que permite trazar una voluntad de continuidad en lo referente a la preservación de los valores artísticos de la Antigüedad más clásica.

En particular, nos referimos al denominado como "renacimiento pictórico grecorromano", que tiene como principal elemento definidor la recuperación de una forma de pintar basada en la recreación ilusionista de ambientes arquitectónicos, muy difundidos dentro de la pintura helenística. Esta "pintura de arquitecturas", tal y como la definiría el autor, tendría su máximo exponente en obras paradójicamente realizadas en mosaico, tal y como vemos, por ejemplo, en la iglesia de San Jorge de Salónica ${ }^{259}$ o en el Baptisterio de los Ortodoxos en Ravenna ${ }^{260}$ (fig. 32).

Tanto las "microarquitecturas" realizadas en mosaico para el templo de Salónica como las más occidentales de la Península Itálica, traducen la recuperación de una práctica bien documentada en la Antigüedad griega, donde fue frecuente la emulación de grandes estructuras arquitectónicas que enmarcaban espacios de carácter público y privado $^{261}$. En el caso de Ravenna, tales soluciones se observan no sólo de manera reiterativa en el citado baptisterio de los Ortodoxos ${ }^{262}$, sino también el pequeño mausoleo de Gala Placidia, donde, además de los fondos dorados y azules en los que se

\footnotetext{
${ }^{258}$ S. SETTIS, El futuro..., pp. 44-45. El especialista analiza la importancia que los romanos otorgaron a las obras griegas, por considerar que eran modelos ideales de un pasado que ellos mismos consideraban "clásico".

${ }^{259}$ A. GRABAR, "A propos des mosaïques de la coupole de Saint-Georges a Salonique", Cahiers Archéologiques, XVII, 1977, pp. 59-81.

${ }^{260}$ F. GALTIER MARTÍ, La iconografía cristiana en el arte cristiano del primer milenio. Perspectiva y convención; sueño y realidad, Huesca, 2001, en especial, pp. 49-50; L. DE LACHENAL, Op. cit., pp. 4960 y A. M. ROMANINI, "Il concetto...", pp. 130-134. Más específicamente, la profesora Romanini afirma sobre las pinturas de Castelseprio, datadas con ciertas dudas entre los siglos VII-VIII, que suponen un ejemplo de continuità de la tradición de pinturas arquitectónicas de claro influjo helénico.

${ }^{261}$ En el caso de la pintura conservada de época griega, la problemática es mayor, debido a la carencia de ejemplos bien conocidos y lo suficientemente representativos como para obtener conclusiones seguras. Para la pintura romana, véase: L. ABAD CASAL: La pintura romana en España, 2 vols., Cádiz, 1982 y M. ANDALORO, La pittura medievale a Roma 312-1431. Corpus. L'Orizzonte tardoantico e le nuove immagini, vol. I, Roma, 2006, en concreto, pp. 37-77. Véase también, la obra colectiva titulada: Pompeya. Historia, Vida y Arte de la ciudad sepultada (M. Ranieri Panetta, ed.) Barcelona, 2004.

${ }^{262}$ Es muy significativo como en este edificio centralizado los muros fueron decorados, además, con arquitecturas realizadas en estucos que reproducían exedras enmarcadas por arcos de medio punto, bajo los que se cobijaban figuras togadas de actitud y formas realmente clásicas.
} 
colocaron diversas representaciones de los apóstoles, también se incorporaron aquí las clásicas exedras con entablamentos de morfología "antiquizante" de la tradición griega $^{263}$.

El caso más conocido de esta recuperación del viejo arte grecorromano, tal y como lo define el profesor F. Galtier Martí, se percibe en la imagen de la fachada del palacio de Teodorico en Ravenna, representando sobre los muros de la iglesia de San Apolinar el Nuevo. Y todo ello, muy a pesar de que la imagen se aparta del carácter fantástico de algunas de las arquitecturas anteriormente citadas (fig. 33).

La morfología de este palatium, basada prácticamente en el modelo imperial contantinopolitano $^{264}$, encontró su materialización más factible a través de la explotación de estas fórmulas iconográficas de tradición griega, aunque tamizadas consecuentemente bajo la impronta de lo "bizantino"265.

Al señalar este ejemplo de recuperación de las fórmulas helenísticas de la pintura de arquitecturas dentro de las artes de los siglos posteriores, queremos poner de relieve la continuidad de tal tendencia con respecto al impacto del arte griego sobre el romano. Tal pervivencia es la prueba más verídica para abordar el "renacimiento" de época augustea y su posterior revalorización durante el siglo $\mathrm{V}$ de nuestra era, tanto en Oriente como en Occidente.

Para finalizar este breve repaso que hemos intentado esbozar, no podemos eludir un ejemplo hispano de la Alta Edad Media que siempre se ha señalado y juzgado como muy representativo de este movimiento.

Según determinados especialistas, algunas de las producciones realizadas en la Hispania del siglo IX debieran considerarse como el último ejemplo de esta directriz recuperadora y conservadora de la tradición iconográfica y pictórica greco-helenística. Nos referimos, concretamente, a las pinturas murales de la iglesia de San Julián de los Prados, en Oviedo.

\footnotetext{
${ }^{263}$ Recuérdese, por ejemplo, la representación del mueble con el libro abierto en el que se plasmó mediante una inscripción, también realizada en mosaico, la identificación del mismo como el Evangelio según Marcos. Las soluciones de espacio y perspectiva nuevamente se remontan a los prototipos griegos. Cf.: F. X. BARTL y J. BOEHRINGER, Ravenna, San Vitale, Sant'Apollinare in Classe, Baden-Baden 1959.

${ }^{264}$ L. DE LACHENAL, Op. cit., pp. 50-52. Véase el completo análisis que hace de él y de los materiales utilizados para su construcción.

${ }^{265}$ G. DE FRANCOVICH, Il palatium de Teodorico..., pp. 5-11. Sobre las fuentes tardoantiguas en relación con la representación del palacio de Ravena y determinados aspectos de la pintura asturiana del siglo IX, vid.: J. A. MORÁIS MORÁN, “Un arquetipo edilicio...”, pp. 582-589.
} 
En el conjunto mural que decora el templo, encontramos un resumen de toda la actividad pictórica mural de la tardorromanidad, sintetizada en un programa de claro sentido pagano-imperial y en el que algunos autores han querido ver incluso ciertas concomitancias con lo cristiano ${ }^{266}$ (fig. 34).

Independientemente del significado iconográfico de las pinturas asturianas, tema que, por otra parte, no debemos abordar en este punto, la pervivencia de modelos antiguos en los comentados frescos puede considerarse uno de los casos más excepcionales y representantes del último coletazo de la transmisión directa de modelos clásicos hacia el medievo.

Según señalaran en su día F. Marín Valdés y J. Gil López, tal repertorio recrea algunos aspectos de las prácticas greco-helenísticas, tanto del siglo V, como otras documentadas en épocas anteriores. Así dicen:

"El clasicismo de los frescos asturianos se inscribe en un dilatado contexto que engloba diversos ámbitos de corte, como las artes del color del imperio carolingio-del pórtico de Lorsch al Evangeliario de Saint-Médard de Soissons- en cuyos procedimientos representativos también aflora un deliberado retorno, una lectura paralela de la romanidad (...) sus antecedentes pueden rastrearse desde los esquemas decorativos de la pintura pompeyana -Villa de los Misterios en Pompeya, Boscorealea las ya tardías de la Basílica de Junios Bassus y Contanza de Roma (...) el recurso fue incorporado en ámbitos bizantinos, como lo atestiguan las fundaciones imperiales de Salónica (Hagios Demetrios) y Rávena (San Vital)"267.

Creemos que tales posturas resumen bien el fenómeno que intentamos ejemplificar y que habla de una tradición bien perfilada y continua, basada en un interés por recuperar el arte griego de tamiz helenístico. Lo sucedido entre los siglos V y IX de

\footnotetext{
${ }^{266}$ H. SCHLUNK y M. BERENGUER, La pintura mural asturiana de los siglos IX y X, Oviedo, 1957 e I. RUÍZ DE LA PEÑA GONZÁLEZ, El Legado de Magín Berenguer (1918-2000), arte medieval asturiano, Oviedo, 2008, pp. 49-69.

${ }^{267}$ F. MARÍN VALDÉS y J. GIL LÓPEZ, Op. cit., en particular, pp. 62-64 y p. 76; F. GALTIER MARTÍ, La iconografía arquitectónica..., pp. 49-50 y X. BARRAL I ALTET, "La representación del palacio en la pintura mural asturiana de la Alta Edad Media", Actas del XXIII Congreso Internacional de Historia del Arte, España entre el Mediterráneo y el Atlántico, Granada, 1973, pp. 293-301, en especial, p. 299. Por su parte, los profesores Marín y Gil apoyan una lectura de estas arquitecturas en clave cristiana, como una alusión a la Jerusalén Celeste, mientras que el profesor Barral cree que se trataría de una serie de fórmulas que se mantendrían de manera indistinta tanto en Occidente como en Bizancio hasta el siglo VIII, mostrando, preferentemente, un carácter más pagano.
} 
nuestra era así lo sugiere ${ }^{268}$.

268 En relación con la importancia del arte greco-helenístico y su impacto sobre las artes plásticas medievales, remitimos al último capítulo de este trabajo, donde se aborda el tema del denominado "estilo 1200" o, lo que es lo mismo, la relación del arte románico de los años finales del siglo XII con respecto a las prácticas bizantinas. Tal y como veremos, ésta fue una de las vías más claras de asimilación y llegada de elementos clásicos a la Europa occidental. 


\section{EL “RENACIMIENTO SIXTINO”.}

Fue R. Krautheimer el que acuñó, en torno al año 1961, la expresión de "renacimiento sixtino"269. El autor la utilizaba para referirse a la renovación que vivió la ciudad de Roma en la segunda mitad del siglo V, tras la invasión del visigodo Alarico y el saqueo de la ciudad en torno al año 410.

Como en los casos anteriormente mencionados, nuevamente asistimos a una programación muy meditada de un mandatario para proyectar sobre su pueblo la imagen de una recuperación y de una reconstrucción de un pasado glorioso. En el caso de este "renacimiento sixtino", la principal figura implicada en tal acción fue el Papa Sixto III (432-440), quién elaboraría una serie de medidas premeditadas proyectadas hacia unos fines muy concretos, generalmente dirigidas a otorgar a la ciudad de Roma un nuevo esplendor, tras una larga etapa de "decadencia" cultural y política ${ }^{270}$.

La aparición de una nueva aristocracia romana de elevada cultura y consumidora de una estética plástica refinada, llevó al poder religioso de la gran urbs a buscar un nuevo referente artístico al que emular. $\mathrm{El}$ arte y la arquitectura del momento miraron nuevamente hacia la Antigüedad clásica, generando un nuevo rebrote de clasicismo que debe ser tenido muy en cuenta en este análisis que venimos desarrollando.

Nuevamente fue la necesidad de un pueblo por autoafirmarse y por reivindicar su puesto dentro del devenir histórico que configura la memoria del pasado, los que llevarían a activar los sistemas de recuperación de tal memoria de una manera reiterativa $^{271}$. Tales aspectos, traducidos al lenguaje de las artes plásticas, tendrían consecuencias muy significativas ${ }^{272}$.

A partir de este momento, el patrocinio de obras salidas de las órdenes y dictámenes "sixtinos", llegarán a configurar una estética que, según se ha venido aceptando, tendría un fuerte carácter clásico de rasgos propios.

La primera gran construcción ligada a estos supuestos ideológicos y estéticos, que supuestamente configurarían este nuevo "renacimiento", se vio materializada en la iglesia de Santa Sabina de Roma. Fue levantada en torno el año 432, utilizando diversas soluciones de gran clasicismo. Entre ellas, se han destacado, por ejemplo, la herencia de

\footnotetext{
${ }^{269}$ R. KRAUTHEIMER, “The Architecture of Sixtus III: a fifth Century Renascence?”, Essays in Honor of E. Panofsky (M. Meiss ed.), New York, 1961, pp. 291-302. Para este estudio hemos utilizado diversas versiones del artículo. En cada momento concreto se señalarán cuales.

${ }^{270}$ N. CHRISTIE, $O p$. cit., en particular, p. 89.

${ }^{271}$ C. MANCHO, "La memòria artística...", pp. 20-22.

${ }^{272}$ R. KRAUTHEIMER, Arquitectura paleocristiana ..., p. 107.
} 
ciertos aspectos constructivos derivados de la edilicia romana pagana, sobre todo la referente a las basílicas.

En concreto, en Santa Sabina se percibe una búsqueda del espacio interno, matizado a través de la luz filtrada por los grandes ventanales abiertos sobre los paños de muro de los extremos de la nave central, así como la utilización de veinticuatro columnas expoliadas de edificios clásicos. Estos rasgos y otros similares, convierten al edificio en un ejemplo refinado y coherente, digno representante de la llamada estética del "renacimiento sixtino",273.

Los siguientes edificios donde se puede rastrear la pujanza patrocinadora de Sixto III y el reflejo de una Roma que intentaba recuperar un status perdido, fueron los complejos eclesiásticos de San Pedro in Vincoli y la restauración a la que en el año 441 fue sometida la gran basílica de San Pablo Extramuros ${ }^{274}$. En la primera, los recuerdos clásicos llegan a ser tales que, como caso excepcional en el mundo paleocristiano, se utilizó el orden dórico en la separación de naves, mientras que, en el segundo, se recurrió a una decoración con finos estucos y frescos, siguiendo el modelo de Santa Maria Maggiore de la misma ciudad ${ }^{275}$.

No en vano, esta última ha sido considerada por la historiografía más especializada como la gran creación del "movimiento sixtino" y en la que se definieron todos los aspectos de tradición clásica que más tarde reaparecerían en la arquitectura religiosa de la ciudad eterna.

Así las cosas, según R. Krautheimer, la basílica de Santa Maria Maggiore de Roma se presenta como el ejemplo más evidente de la recuperación del arte clásico desarrollado bajo el mandato de Trajano.

Tal afirmación es de una importancia vital. Mediante el establecimiento de estas relaciones, se ha podido explicar, por ejemplo, el uso dentro del edificio de un sistema arquitrabado materializado por un entablamento, que recorre de manera monumental el templo ${ }^{276}$.

\footnotetext{
${ }^{273}$ L. DE LACHENAL, Op. cit., pp. 32-35 y M. GREENHALGH, The survival of Roman..., en concreto, p. 95.

${ }^{274}$ R. KRAUTHEIMER, “La fondation de Saint-Paul...", en particular pp. 18-21 y M. GREENHALGH, The survival of Roman..., p. 94. Los autores confirman que, además, el edificio fue erigido sobre una antigua estructura pagana, concretamente una domus.

${ }^{275}$ L. DE LACHENAL, Op. cit. p. 37 y M. GREENHALGH, The survival of Roman..., p. 113. Recordemos aquí que, además, el edificio fue construido físicamente al lado de un complejo termal, de donde se pudieron tomar buen parte de los materiales para su construcción.

${ }^{276}$ R. KRAUTHEIMER, Arquitectura paleocristiana..., pp. 103-104.
} 
Exactamente lo mismo ocurrió con la decoración del espacio arquitectónico. Para sus mosaicos, el "renacimiento sixtino" tomó como fuente de inspiración un emblema iconográfico del arte romano de tradición pagana. Se trata de los relieves de las columnas de Arcadio en Constantinopla, que a pesar de su paganismo, poseían un marcado carácter triunfal. Sin embargo, el hecho fue tan sólo posible a través de una fuerte reinterpretación de estos símbolos romanos, ahora acomodados a la situación religiosa y política vivida en la Roma del siglo V. Ante tales perspectivas, las imágenes dejaban al margen su pasado meramente imperial, para ser entendidas ahora como símbolo del poder de Dios en la tierra ${ }^{277}$.

Sin embargo, además de todo lo afirmado, existió una última aportación del "renacimiento sixtino" al panorama romano de las artes del periodo. Se trata de las experiencias vividas en la iglesia de Santo Stefano Rotondo, nuevamente en Roma. El templo, aunque construido por el papa Simplicio (468-483) en la segunda mitad del siglo $\mathrm{V}$, supone la reelaboración del prototipo centralizado tardorromano, dotado ahora de un resignificación cristiana muy en la línea de las "mutaciones conceptuales" que se vienen exponiendo.

En la construcción se percibe, de nuevo, el uso del arquitrabe en el interior, de gran recuerdo clásico. A ello debemos sumar las conexiones que se han establecido entre su planta y determinados ninfeos de las villae romanas o, incluso, los parentescos con alguno de los pabellones de la villa de Adriano.

En este sentido, resulta de extrema importancia la teoría vertida por F. Guidobaldi, en la que justifica el uso de algunos elementos clásicos en Santo Stefano. Según el experto, el arquitrabe del edificio, por citar un elemento bien visible, podría explicarse a través de la presencia patrocinadora de miembros de la familia imperial con gran nivel cultural. Así, la relación de Gala Placidia y Eudoxia, la mujer de Arcadio con respecto al templo, permitirían demostrar tales hipótesis ${ }^{278}$.

Para finalizar, en lo referente a la utilización de arquitrabes en estas construcciones, también se suele aludir con frecuencia a su presencia en otro de los edificios más importantes de la ciudad de Roma, el baptisterio de San Giovanni

277 A. GRABAR, Las vías de la creación..., p. 52 y L. DE LACHENAL, Op. cit., p. 38. La combinación en Santa María la Mayor de mosaicos, mármoles de reempleo y frescos, no tendría otra fuente de inspiración más clara que la de las termas imperiales o la basílica de Magencio, ubicadas geográficamente muy cerca de este edificio.

${ }^{278}$ F. GUIDOBALDI, voz "Roma. De Constantino...", particularmente, p. 66 y R. KRAUTHEIMER, Arquitectura paleocristiana..., en particular, pp. 105-107. Parece que el edificio fue construido entre los años 468 y 483. Estos autores, además de emparentarlo con la arquitectura civil antigua, remontan su prototipo a los modelos de la Anástasis de Jerusalén, del siglo IV. 
Laterano. A pesar de no ser este el lugar ideal para reflexionar sobre este tipo de arquitectura, aquí Sixto III respetó al máximo la sagrada estructura constantiniana para llevar a cabo una reforma de engrandecimiento. El octógono más famoso de la ciudad, en parte modelo inspirador de la estructura de San Stefano Rotondo, fue enmascarado siguiendo los planteamientos de este "renacimiento" y adoptando nuevamente las soluciones empleadas por la arquitectura arquitrabada de tradición clásica.

En el año 432 se remozó la estructura interior del baptisterio añadiendo otra vez un arquitrabe (fig. 35). El respeto escrúpulo por las formas anteriores, consideradas ya por entonces antiguas y la reinterpretación de los tholoi clásicos que aquí se practicó, parecen intentar preservar las ideas rectoras del tiempo Constantino ${ }^{279}$. Es decir, nuevamente las artes romanas vivían una etapa de esplendor renacentista en un siglo $\mathrm{V}$ que miraba, una vez más, al pasado.

\footnotetext{
${ }^{279}$ R. KRAUTHEIMER, Arquitectura paleocristiana ..., en concreto, p. 105 y M. GREENHALGH, The survival of Roman..., p. 98. El baptisterio de San Juan de Letrán fue fundado junto con la basílica en el año 313, por el emperador Constantino. La erección de la basílica de San Pedro se dilataría entre los años 320-329.

Vid. también: L. DE LACHENAL, Op. cit., p. 16 y p. 36. La autora afirma que el remoce sixtino llevó a cabo una fusión de la planta octogonal constantiniana y el trazado centralizado típico de los mausoleos romanos tardoantiguos. Además, la decoración marmórea añadida sobre este momento, perduró visible e intacta hasta el año 1588 en el que se recubrió con unas soluciones acordes con la estética del momento.
} 


\section{EL “RENACIMIENTO” CAROLINGIO.}

En uno de los textos más interesantes escritos en torno a las producciones artísticas y edilicias creadas en la época de Carlomagno y su relación con prototipos tardorromanos cristianos, el profesor M. D’Onofrio reflexionaba sobre la figura del emperador romano-cristiano y la transposición de tal modelo a la figura política del emperador carolingio ${ }^{280}$. En general, la historiografía más autorizada sobre el tema da por correcta la interpretación, según la cual, muchas de las acciones políticas llevadas a cabo por Carlomagno, pretendían vincular su figura con la iglesia romana, pero, sobre todo, con el pasado romano.

El texto de Eginhardo, siempre tan socorrido, no cesa de dar pequeñas noticias en las que la figura del emperador aparece ligada, de manera consciente, con el pasado imperial de la civilización romana. Tales hechos son perceptibles, por ejemplo, en una noticia aparentemente intranscendente recogida por el biógrafo, en la que se dice:

"Rechazaba las indumentarias de otras naciones aunque fueran bellísimas, y jamás consintió llevarlas excepto una vez, en Roma (...) entonces se cubrió con una larga túnica y con una clámide y llevó también un calzado a la moda romana"281 (texto 5).

Nuevamente se percibe tal idea, de manera más oficial, en la noticia en la que se relata la coronación del emperador en la misma ciudad de Roma. El día 25 de diciembre del año 800, Carlomagno, antes del oficio, fue coronado por el papa León en la iglesia más importante de toda la cristiandad. Todos los allí presentes lo aclamaron como Carlos Augusto y emperador de los romanos ${ }^{282}$.

\footnotetext{
${ }^{280}$ M. D’ONOFRIO, Roma e Aquisgrana..., particularmente, p. 20. Recuérdese que ya hemos insistido con anterioridad sobre la concepción del poder imperial romano y su influencia sobre la que se tendrá durante los siglos medievales de los monarcas.

${ }^{281}$ EGINHARDO, Vida de Carlomagno (A. De Riquer ed.), Barcelona, 1986, p. 93.

Sobre la obra de Eginhardo y su clara inspiración con respecto a los textos clásicos, especialmente la obra de Suetonio, coinciden casi todos los autores. Cf.: D. SCHALLER, "Poetic rivalries at the Court of Charlemagne", Classical influences on European Culture A. D. 500-1500, Cambridge, 1971, pp. 151-157, particularmente, p. 151.

${ }_{282}$ Ibidem, p. 103, nota 3. Se describe además como el papa se arrodillaría ante el nuevo imperator, siguiendo un estricto protocolo imperial que se remontaba a la época de Diocleciano.
} 
Se trataba del final de una serie de viajes que le habían llevado a Roma en el año 775 , en el 781, en 787 y finalmente en el $800^{283}$. Eginhardo plasma nuevamente el acontecimiento afirmando:

“(...) Yendo a Roma por este motivo, para restablecer la situación de la Iglesia, que estaba demasiado alterada, paso todo el invierno allí. Entonces fue cuando recibió el título de emperador y augusto; en un principio mostraba ante esto una actitud tan hostil que afirmaba que no habría entrado en la iglesia aquel día, aunque era una gran festividad, si hubiera podido saber de antemano la decisión del pontífice. Pero soportó con gran paciencia la envidia de los emperadores romanos que estaban indignados por el título que había asumido (.... $)^{284}$ (texto 6).

A pesar de que muchos historiadores, tal y como ha señalado A. de Riquier, defendieron el hecho de que la coronación fue una acción programada por el propio papa León y no por el emperador ${ }^{285}$, la noticia debía ser conocida en toda Roma, habida cuenta de la realización del mosaico de San Giovanni Laterano, obra encargada explícitamente por el papa León III un poco antes del año 800 y proyectada en vista de tal coronación ${ }^{286}$.

Son muchas las causas que se han señalado como responsables de esta mira hacia el pasado romano que realizó el mundo carolingio, aunque, sin duda, la más importante llegó desde la necesidad de reestructuración imperante en buena parte de las estructuras socio-políticas del imperio franco-germánico. Tales aspectos devendrían no sólo en una renovación artística, al fin y al cabo un tema de carácter menos influyente dentro del medio histórico y social, sino que la reforma pasaría por la total modificación del sistema administrativo, la liturgia, la lengua y gran parte de los aspectos de la cultura en general ${ }^{287}$.

\footnotetext{
${ }^{283}$ N. CHRISTIE, Op. cit., particularmente, pp. 53-55.

${ }^{284}$ EGINHARDO, Op. cit., pp. 103-104.

285 Ibidem.

${ }^{286}$ M. D’ONOFRIO, Roma e Aquisgrana..., p. 24 y p. 32, nota 19. En el ábside de la catedral de Roma fue representado el emperador recibiendo el lábaro constantiniano, en forma de bandera, por mano de San Pedro, mientras que el papa León recibía el palio. El autor data el mosaico concretamente en el año 795, fecha de la elección del mencionado Sumo Pontífice. La misma iconografía se repetiría en la iglesia de Santa Susana, tal y como señala el investigador.

${ }^{287}$ A. GONZÁLEZ HERNÁNDEZ, Los primeros renacimientos..., pp. 85-89. El especialista señala el papel jugado por diversos intelectuales de la corte carolingia, entre los que destacarían, Pedro de Pisa, Paulino, Pablo el Diacro, Clemente, Dungal o Alcuino de York, sin duda llamados a la corte siguiendo la búsqueda de un ambiente culto. La prueba de ello nos la ofrece el mismo sistema educativo elegido por Carlos Martel para el monarca Pipino.
} 
Sin embargo, como en todo periodo renovador, uno de los aspectos más necesarios para su desarrollo fue la necesidad de gestar una base sobre la que asentar tales cambios. En este sentido, mencionamos brevemente las aportaciones de J. Hubert, defensor de la figura y política de Pipino III y de lo que él mismo ha catalogado como "prérenaissance carolingienne" 288.

El autor considera que, antes de que se produjeran en este ámbito todas las innovaciones artísticas que caracterizan el periodo de Carlomagno, ya durante el siglo VIII el círculo de Chrodegang, obispo de Metz y fundador de la abadía de Lorsch, se patrocinaron algunas obras que pueden ser consideradas como iniciadoras de esta recuperación de lo antiguo ${ }^{289}$.

Las fuentes escritas no dejan lugar a duda sobre la posibilidad de definir el papel y la figura de Carlomagno dentro del desarrollo de tal "renacimiento" de las artes. Basta tan sólo con recoger el siguiente fragmento de la biografía del emperador:

“(...) hizo construir en Aquisgrán una basílica de excepcional belleza que ornó con oro, plata, candelabros y con balaustradas y puertas de bronce macizo. Y como no podía procurarse de otro sitio las columnas y los mármoles para la construcción de la basílica, mandó que se trajeran de Roma y Rávena" ${ }^{290}$ (texto 7).

No insistiremos aquí en la labor de expoliación de los artífices carolingios pues se abordará el tema en el correspondiente apartado de este trabajo, pero apuntamos ya que, más que una admiración arqueológica hacia las piezas antiguas, el imperio de Karolus rastreó el panorama arqueológico romano y foráneo, en busca de piezas que reutilizar con determinados valores intelectuales y simbólicos, más que meramente utilitaristas.

Vid. también: E. PANOFSKY, Renacimiento y renacimientos..., pp. 86-88; M. D’ONOFRIO, Roma e Aquisgrana..., p. 35 y p. 47, nota 1; A. GONZÁLEZ HERNÁNDEZ, Los primeros renacimientos..., p. 93 y S. SEBASTIÁN, Mensaje simbólico..., pp. 190-191. Los autores ponen un énfasis especial en las fuentes clásicas de este ambiente culto, ya que, mientras que Eginhardo tomaba como base la obra de Suetonio; Lupo de Ferrières cotejaba y corregía textos clásicos. Tampoco debemos olvidar la importancia relevante que tendrían los personajes hispanos, pues mencionan el caso de Félix de Urgell.

${ }^{288}$ J. HUBERT, "Les prémisses de la Renaissance carolingienne au temps de Pépin III", Nouveau recueil d'études d'Archéologie et d'histoire. De la fin du monde antique au Moyen Age, Paris, 1985, pp. 225-234, sobre todo, p. 227 e ID., "Rome et la Renaissance carolingienne", Nouveau recueil d'études d'Archeólogie et d'histoire. De la fin du monde antique au Moyen Age, Paris, 1985, pp. 235-244, particularmente, p. 238.

${ }^{289}$ J. HUBERT, “Les prémisses...”, pp. 225-226.

${ }^{290}$ EGINHARDO, Op. cit., pp. 99. 
No pretendemos someter al fenómeno del "renacimiento carolingio" a un análisis exhaustivo, por escaparse del objetivo central de nuestros análisis. Además, la complejidad del tema hace que tampoco podamos aportar novedades al respecto y que nuestro control de la materia sea tan alejado del deseado que no podríamos desarrollar un balance satisfactorio. Sin embargo, un breve repaso a determinadas cuestiones nos ayudará a ejemplificar la situación de la Europa central durante los siglos VIII y IX, como marco y base para el desarrollo del arte europeo e hispano coetáneo, en cierta manera, preludio del posterior movimiento románico.

S. Kostof, en su manual sobre la historia de la arquitectura y, a propósito del estudio de la Capilla Palatina de Aquisgrán, llevaba a cabo una comparación muy significativa (fig. 36). El autor emparentaba el edificio más conocido creado bajo el mandato de Carlomagno, con uno de los más importantes conjuntos hispanos del siglo VIII. Nos referimos a la pequeña iglesia de San Pedro de la Nave, en Zamora.

A este respecto escribía:

"Ambos edificios sienten indiferencia por las unidades clásicas, algo típico en la arquitectura medieval temprana (...). San Pedro de la Nave no puede ser considerada de ningún modo sucesora de las basílicas romanas o paleocristianas. Ambos edificios no son coherentes de la composición total, con masa general desmenuzada, compartimentadas, interior fragmentando que se aleja del respeto romano por la cohesión espacial ${ }^{291}$.

Evidentemente no podemos estar de acuerdo con esta posición, que para el caso de la iglesia visigoda, ya argumentaremos más adelante. En lo referente a la Capilla Palatina de Aquisgrán, ya E. Panofsky estableció su dependencia con respecto a la arquitectura de sustrato clásico del siglo $\mathrm{V}$ y, más concretamente, con respecto a San Vitale de Ravenna ${ }^{292}$.

Se trataría de un prototipo que, como bien han señalado, entre otros, la profesora M ${ }^{a}$ C. Muñoz Párraga, se había venido adoptando entre las clases sociales acomodadas de la baja romanidad como forma preferencial para los oratorios privados ${ }^{293}$.

\footnotetext{
${ }^{291}$ S. KOSTOF, Op. cit., vol. I, pp. 475-481.

${ }^{292}$ E. PANOFSKY, Renacimiento y renacimientos..., pp. 89-90.

293 M. C. MUÑOZ PÁRRAGA, "Las Capillas Palatinas", Maravillas de la España Medieval. Tesoro sagrado y monarquía, León, 2001, pp. 55-61, en concreto, p. 55. La autora recoge, además, la donación de las reliquias de San Esteban que haría el Papa León III en el año 800 en Aquisgrán, paradójicamente el año de la coronación de emperador. Este ambiente culto y elitista nunca dejó de apreciar las piezas
} 
Prototipos para el edificio de Karolus los ofrece la arquitectura romana oriental desde el siglo IV al VIII, tal como ha apuntado la profesora E. Fernández González, a través de la que, se supone, pudo ser una de las primeras capillas palatinas de la historia de la arquitectura, es decir el Octógono Dorado de Antioquia que había sido levantado contiguo al palacio imperial de las isla del Orontes, en torno al año $327^{294}$.

Más cercanos en el tiempo, en torno al siglo VIII, se ubicarían el oratorio de la Santa Virgen de Pharo o el Santuario dedicado a la Virgen de Hagios Soros en el recinto imperial de Blanquernas, en la ciudad de Bizancio ${ }^{295}$. La hipótesis de la utilización de fuentes bizantinas para la formación y el enriquecimiento de este tipo de estructuras, viene avalada por sus semejanzas formales con el Chrysotriklinos del palacio imperial de Constantino, la iglesia de los Santos Sergio y Baco o el Santo Sepulcro de Jerusalén ${ }^{296}$. Parece claro entonces, que la construcción carolingia goza de tantos referentes clásicos, que resultaría imposible enumerarlos todos aquí.

En este mismo sentido, nuevamente todos los expertos concuerdan en señalar los antecedentes directos de obras clásicas para la famosa Capilla Palatina del emperador en Aquisgrán, donde, tal y como hemos visto, se ponía especial énfasis en asimilar y recoger las experiencias artísticas de las dos ciudades más importantes del orbe cristiano: Roma y Bizancio ${ }^{297}$.

En relación con ello, creemos conveniente traer a colación nuevamente las palabras de su biógrafo para poder intuir el ambiente en el que se estaba produciendo este "renacimiento" de las artes y, sobre todo, para constatar la importancia que poseen

antiguas. Lo demuestra el hecho de que el propio papa León III se haría enterrar, tras su muerte $(\dagger 816)$, en un sarcófago paleocristiano con el frente decorado con las imágenes de Cristo y los Apóstoles. Sobre la pieza, vid.: F. ALTO BAUER, "Sarcofago paleocristiano riutilizzato per Leone III", Carlo Magno a Roma, Roma, 2001, ficha catalográfica 11, pp. 122-123.

${ }^{294}$ E. FERNÁNDEZ GONZÁLEZ, "Estructura y simbolismo de la Capilla Palatina y otros lugares de peregrinación: los ejemplos asturianos de la Cámara Santa y las Ermitas del Monsacro", Las peregrinaciones a Santiago de Compostela y San Salvador de Oviedo en la Edad Media, Oviedo, 1990, pp. 335-397.

S. SEBASTIÁN, Mensaje simbólico..., p. 194 y E. FERNÁNDEZ GONZÁLEZ, "Estructura y simbolismo...", especialmente, p. 339-340. Según recoge la autora, el oratorio de Pharo es obra de Constantino Coprónimo (745-768). Con respecto al santuario de Hagios Soros, es conocido por custodiar una reliquia del Omophorium o velo mortuorio de la Virgen.

${ }^{296}$ L. DE LACHENAL, Op. cit., p. 118.

${ }^{297}$ La cronología que se le viene atribuyendo al edificio viene avalada por la carta que Alcuino de York escribiría con data de 22 de julio del año 798 a una dama de la corte y en la que se puede deducir que la mayor parte de la obra estaba terminada. Cf.: L. FALKENSTEIN, "Charlemagne et Aix-la-Chapelle", Byzantion, 61, 1991, pp. 230-289, en concreto, p. 237

Vid. también: S. KOSTOF, Op. cit., vol. I, p. 478 y G. SIEFFERT, “A propos de l'église d'Ottmarsheim. Les imitations de la Chapelle palatine a Aix-la-Chapelle”, Cahier de l'art médiéval, V, fascicule II, 1968 (1969), pp. 29-70, en concreto, p. 30. El primer autor da la fecha de 792 para su construcción, mientras que el segundo defiende los años 796-805. 
las dos ciudades antes mencionadas como centros neurálgicos en el desarrollo y la difusión de determinadas estéticas antiguas.

Se trata de un fragmento de la parte final de su biografía, cuando Karolus princeps ya había muerto. En ella se nos dice:

"Había decidido hacer un testamento para instituir herederos (...). Entre otros tesoros y riquezas consta que figuran tres mesas de plata y de ellas de oro de gran tamaño y peso. Decidió y dispuso que una de ellas, la de forma cuadrangular y que lleva un trazado de la ciudad de Constantinopla, fuera enviada, entre otras ofrendas previstas para este fin, a Roma, a la basílica del bienaventurado apóstol Pedro: otra, de forma redonda, en la que está representada la ciudad de Roma, que fuera donada al episcopado de la iglesia de Rávena (...)" (texto 8) ${ }^{298}$.

Sin ánimo de ser exhaustivos con respecto a esta cuestión, la fundación de la Capilla Palatina de Aquisgrán junto con el resto del conjunto palatino, supuso la repetición del conocido esquema de las villae galorromanas, citado por las crónicas como el hiemare o, lo que es lo mismo, el palatium de invierno ${ }^{299}$. El artífice encargado de construir la capilla palatina fue Eudes de Metz que logró crear un espacio donde, como era normal, imagen política y religiosa se entremezclaban mediante una edilicia absolutamente teatral y escenográfica, digna de la concepción antigua más absoluta del espacio $^{300}$.

Dejando a un lado las cuestiones relativas a estas obras arquitectónicas, el arte del periodo se encuentra plagado de alusiones directas al mundo clásico. Baste tan sólo con mencionar, por ejemplo, la reproducción en bronce que los talleres cortesanos

\footnotetext{
${ }^{298}$ EGINHARDO, Op. cit., p. 117. También se incide en este aspecto, en: M. A. CASTIÑEIRAS, El calendario medieval..., en especial, pp. 273-274. El último autor destaca el clasicismo de las imágenes del planisferio celeste dentro del trono que Carlos el Calvo donó a la basílica de San Pedro de Roma.

${ }^{299}$ L. FALKENSTEIN, "Charlemagne et Aix-la-Chapelle...", pp. 231-289, en particular, pp. 233-235. Recoge la noticia de que, según Eginhardo, el emperador habría elegido como residencia Aix-la-Chapelle debido a su predilección por las aguas termales y la natación. En ella se establecería de manera continuada en torno al año 795, una vez trasladado allí el prestigioso tesoro de Avares.

${ }^{300}$ G. SIEFFERT, Op. cit., en particular, p. 30 y M. D'ONOFRIO, Roma e Aquisgrana..., p. 155. Sobre los valores de la arquitectura a disposición de la imagen del monarca, vid.: G. LORENZONI, "Per una possibile lettura simbolica del presbiterio nell'architettura paleocristiana", Arte d'Occidente. Temi e Metodi, Studi in onore di Angiola Maria Romanini. Arte, I, Roma, 1999, pp. 1- 6, en especial, pp. 1-2. Sobre la luz y su utilización en los edificios antiguos y por derivación en la Capilla de Carlomagno, vid.: P. DUBOURG-NOVES, "Des mausolées antiques aux cimborios romans d'Espagne. Évolution d'une forme architecturale", Cahiers de Civilisation Médiévale, 4, 1980, pp. 323-359, en particular, p. 339, nota 96.
} 
carolingios llevarían a cabo de la famosa loba capitolina de Roma (figs. 36 y 36 a), que desde bien temprano ocupó un lugar destacado en San Giovanni Laterano ${ }^{301}$.

En este mismo sentido, es sabido que en los alrededores de la gran catedral de Roma y su famoso Triclinium, erigidos ambos en época de Constantino ${ }^{302}$, presentaba en estos momentos una suerte de "gabinete de maravillas" formado por múltiples objetos expoliados y que, poco a poco, habían ido engrosando las colecciones imperiales. Entre este conjunto de piezas, auténticas "reliquias" que animaban al espectador romano a continuar participando de una Antigüedad de la que nunca se habían separado, es donde encontraríamos la ya mencionada loba capitolina (fig. 37) y, sobre todo, la famosa escultura ecuestre de Marco Aurelio (fig. 38) ${ }^{303}$.

La famosa obra en bronce con el emperador a caballo, recogía una de las fórmulas icónicas más desarrolladas durante los siglos clásicos, sobre todo en época romana. Había sido utilizada para representar la imagen del soberano todo poderoso y, según se ha constatado, la Edad Media mostró una gran aceptabilidad a tal prototipo, que llegará a asimilar y desarrollar de manera propia.

Las diversas connotaciones que tal imagen poseía desde el antiguo, aparecen enriquecidas además a través de otras ideas ligadas a su entidad y prestigio como arquetipo iconográfico. No en vano, cuando C. Plinio se pronunciaba sobre este tipo de representación en su famosa Historia Natural, lo hacía en los siguientes términos:

“(...) Más las estatuas de personas a cavallo son celebradas de los romanos, haviendo sin duda seguido el exemplo de los griegos. Pero ellos sólo las dedicavan esculpidas o cinceladas a aquellos que havían sido vencedores en cosas sagradas.

\footnotetext{
${ }^{301}$ W. BRAUNFELS, "La cour d'Aix-la-Chapelle et sa culture", Charlemagne. Oeuvre, Rayonnement et Survivances, Aix-la-Chapelle, 1965, pp. 17-30, en particular, p. 20 y S. SEBASTIÁN, Mensaje simbólico..., pp. 191-192.

${ }^{302}$ Sobre la adopción por parte de Carlomagno del modelo lateranense del Triclinium, compuesto de un gran atrio, un aula para el monarca al modo de la sala de recibimientos de los Papas en el Laterano y un oratorio, véase: J. HUBERT, J. PORCHER y F. W. VOLBACH, L'Impero carolingio, Milano, 1968, particularmente, pp. 39-40; V. H. ELBERN, "L'Orfèvrerie", Charlemagne. Oeuvre..., pp. 357-362, en particular, p. 361 y N. CHRISTIE, Op. cit., pp. 98-99.

${ }^{303}$ A través de varios grabados de diferentes épocas sabemos que durante la tardoantigüedad y el primer medievo, estas obras eran admiradas libremente alrededor del complejo lateranense. La colección de imágenes a las que aludimos se remonta a la época de Constantino. El profesor B. Brenk ya aludió en su día al "coleccionismo de estatuas" llevado a cabo por el emperador, poniendo el ejemplo del arco de triunfo que mandó erigir en el foro y el del hipódromo de Constantinopla, considerados como "una suerte de museo abierto de la estatuaria antigua". Cf.: B. BRENK, "Committenza e retorica", Arti e storia nel Medioevo. Del construire: tecniche, artista, artigiani, committenti (E. Castelnuovo coord.), vol. II, Torino, 2003, pp. 3-42, en particular, pp. 12-13 y R. KRAUTHEIMER, Profilo de una città..., pp. 241242.
} 
Pero después también a los que huviesen vencido en carros de dos cavallos o de quatro (...) $)^{304}$ (texto 9).

Siguiendo con las palabras de este mismo autor, en el siguiente capítulo de su obra pasa a decir:

"Destas estatuas está la de Rómulo, sin vestidura, como la de Camilo en Rostra. Y delante del templo de los Cástores estuvo la estatua de Q. Marcio Trémulo, puesta a cavallo y togada (...),305.

No es preciso insistir en la importancia que dicha imagen iba a adquirir durante toda la Edad Media, así como el respaldo teórico que las fuentes muestran mediante textos de estas mismas características. El icono del imperator a caballo fue visto durante los siglos medievales, no cómo la imagen pagana de un mandatario, sino como la efigie del primer emperador cristiano: Constantino a modo triunfal, como Miles $D e i^{306}$.

El ejemplo de esta iconografía clásica, traspasada y reinterpretada por el mundo cristiano, ha sido tan frecuentemente abordado, que constata claramente su evolución dentro de la historia de las imágenes, desde su génesis antigua hasta su desarrollo medieval.

\footnotetext{
${ }^{304}$ C. PLINIO SEGUNDO, Historia Natural de Cayo Plinio Segundo (Traslada y anotada por el doctor F. Hernández (Libros primero a vigésimo quinto) y por J. De Huerta (libros vigésimo sexto a trigésimo séptimo), Madrid, 1998, en concreto, p. 1072. ${ }^{305}$ Ibidem, p. 1073.

${ }^{306}$ R. CROZET, "Le thème du cavalier victorieux dans l'art roman de France et d'Espagne", Príncipe de Viana, 124-125, 1958, pp. 125-143, en especial, p. 125 y p. 127; M. CH. DARAS, "Reflexións sur les statues équestres représentant Constantin en Aquitaine", Bulletin de la Société des Antiquaires de l'Ouest, $2^{\circ}$ trimestre, 1969, pp. 151-157; A. ARBELLOT, Mémoire sur les statues équestres de Constantin placées dans les églises de l'Ouest de la France, Limoges, 1885, pp. 10-29; S. SEBASTIÁN, Mensaje simbólico..., p. 192; P. ZANKER, Augusto y el poder..., en particular, p. 45; A. GRABAR, Las vías de la creación..., p. 46.

Ya durante el mundo antiguo la efigie a caballo aparecía vinculada al triunfo, tal y como sucedía dentro del imaginario heroico del mundo helenístico y macedónico. Incluso el emperador César, intentando superar el arte de Pompeyo, mandaría colocar una escultura ecuestre de Alejandro Magno, con la puntual decisión de sustituir el retrato del héroe macedonio por el suyo mismo.

Desde otro orden de cosas, otras imágenes completaban el programa constantiniano de exaltación del monarca victorioso. A este respecto, mandó colocar en el vestíbulo de su nuevo palacio en Constantinopla, la efigie esculpida de sus hijos y la de él mismo, como triunfadores victoriosos sobre una dragón rampante a sus pies. El tipo iconográfico se repetiría, siglos después, dentro de la placa ebúrnea de Harrach, de la Escuela de la Corte de Carlomagno. Cf.: H. SCHNITZLER, "Diptyque de Genoels Elderen", Charlemagne. Oeuvre..., ficha catalográfica 534, pp. 345-346 y L. NEUMAN DE VEGVAR, "The origin of the Genoels-Elderen ivories", Gesta, 1990, XXXIX/1, pp. 8-24.
} 
A partir de la imagen de Marco Aurelio, de la cual incluso el propio Constantino hizo ya una réplica en el Augusteion de Constantinopla, los ejemplos comienzan a multiplicarse ${ }^{307}$.

El "renacimiento carolingio" se sirvió de tal icono para explotarlo y adaptarlo a las necesidades del emperador. Es bien sabido que, bajo su mandato, se hicieron traer desde Rávena todo tipo de materiales constructivos de expoliación -fustes, basas, capiteles- ${ }^{308}$, pero, además, hizo llevar a su palacio en Aquisgrán, en torno al año 801, una escultura ecuestre realizada en bronce del rey ostrogodo Teodorico ${ }^{309}$.

A través de este mismo proceso de "apropiación" iconográfica, reaparecería este icono romano materializado en la conocida esculturilla de bronce del Museo del Louvre (fig. 39). En ella, el retrato del emperador antiguo se tomaba como referente a la hora de crear una nueva imagen, de la cual explotar sus valores auto-legitimadores ${ }^{310}$.

Se trata de una pequeña pieza que, originariamente, se encontraba en la catedral de Metz y que desde un punto de vista formal, sintetiza toda una serie de largas enseñanzas antiguas y otras experiencias ya de cronología carolingia ${ }^{311}$. En este sentido, el prototipo de monarca, a modo del soldado de Dios, sobre caballo y acabando con el mal, tenía su prototipo más cercano en las mismas imágenes que hipotéticamente decorarían el llamado arco de Eginhardo y cuya decoración conocemos a través de unos diseños de época moderna, tal y como veremos más adelante (fig. 40).

En su estudio sobre la pieza, D. Gaborit-Chopin aludía a otra serie de jalones clásicos que pudieron haber configurado el tipo germánico. En concreto, mencionaba la

\footnotetext{
${ }^{307}$ Para un breve análisis de la iconografía del emperador a caballo y su traspaso al arte medieval en forma de caballero victorioso, véase: G. BOTO VARELA, La memoria perdida. La catedral de León (917-1255), León, 1995, en concreto, pp. 102-103; M. RUIZ MALDONADO, El caballero en la escultura románica de Castilla y León, Salamanca, 1986, pp. 71-72; E. FERNÁNDEZ GONZÁLEZ, La escultura románica en la zona de Villaviciosa (Asturias), León, 1982, p. 118; ID., "Escenas cinegéticas en el románico de Villaviciosa (Asturias)", Boletín del Instituto de Estudios Asturianos, 105-106, 1982, pp. 167-179 e I. RUIZ DE LA PEÑA GONZÁLEZ, "Un tema iconográfico en torno al 1200 la dama y el caballero", Actas del VIII Congreso de Estudios Medievales; Fernando III y su tiempo (1201-1252), León, 2003, pp. 437-467.

308 M. D’ONOFRIO, Roma e Aquisgrana..., pp. 112-114. Apunta, además, otros posibles lugares de origen para estas piezas "robadas". Entre otros Nîmes, Verdún, Arles y Marsella.

309 W. BRAUNFELS, "La cour d'Aix-la-Chapelle et sa culture", Charlemagne. Oeuvre..., particularmente, p. 20; M. GREENHALGH, The survival of Roman..., p. 213 y L. FALKENSTEIN, "Charlemagne et Aix-la-Chapelle...", en concreto, pp. 247-248. El profesor Falkenstein afirma que es difícil precisar en que lugar exacto dentro del recinto palatino mandó colocar el emperador tal escultura. Recoge una noticia del año 1844, en la que se afirma que pudo haber estado situada delante del porche existente entre la gran halle y la iglesia de Nuestra Señora.

310 J. M. NIETO SORIA, Ceremonias de la realeza. Propaganda y legitimación en la Castilla Trastámara. Madrid, 1993, particularmente, p. 73.

311 W. BRAUNFELS, "La statuette équestre de Charlemagne", Charlemagne. Oeuvre..., ficha catalográfica 29 a y b, pp. 39-40. Data la obra después del año 810, en un periodo tardío del arte de la corte de Aquisgrán, emparentando su estilo con las esculturas ebúrneas de los talleres de Metz.
} 
estatua ecuestre conservada en el Museo Nacional de Nápoles e identificada como Marcus Nonius Balbus ${ }^{312}$.

Al recurrir a estos modelos de larga tradición, el "renacimiento carolingio" se conectaba con un pasado del que quería seguir participando y, al mismo tiempo, activaba toda una serie de mecanismos que permitían determinadas asimilaciones con las artes plásticas de la Antigüedad.

La escultura ecuestre de Carlomagno hacia clara referencia al prototipo definido por el arte constantiniano y la imagen del Miles Dei, conducta que, además, se documenta en otros monarcas, tales como el mismo Lotario, Luís el Piadoso o el propio Carlos el Calvo, quienes parecen mostrar idénticas pretensiones ${ }^{313}$.

Durante todo el periodo alto y plenomedieval, la imagen de Constantino o, extrapolando tal hecho al siglo IX, la de Carlomagno, aparecía como símbolo del poder de la iglesia y la reencarnación de sus ideales en una figura terrestre como la que supone el soberano. Para explicar tal hecho, creemos necesario aludir a un ejemplo localizado dentro del ámbito hispano.

Se trata de las representaciones de la figura de Constantino dentro del Codex Albeldense, realizado posiblemente en la décima centuria ${ }^{314}$. Las imágenes, realizadas un siglo después que la escultura carolingia, justifican su aparición en el inicio de los textos sinodales de dicho códice, ocupados de defender la organización de la comunidad eclesiástica $^{315}$.

La aparición de tal personaje en esta obra debe incluirse dentro de la amplia nómina de producciones artísticas, de la más diversa variedad, en las que se incluyó el tema. Baste con recordar, por ejemplo, su presencia en determinadas fachadas de época románica.

A este respecto, citamos el conocido caso de la fachada de la iglesia de Santa María la Real de Sangüesa o la de Santa María de Carrión de los Condes, las cuales atestiguan su difusión en el ámbito hispano. Sin embargo, el mayor número de este tipo de representaciones se localiza dentro del románico francés, siendo el caso de Notre-

\footnotetext{
312 Napoli, Museo Archeologico Nazionale. Cf. : D. GABORIT-CHOPIN, La statuette équestre de Charlemagne, Paris, 1999, en concreto, pp. 22-35.

313 Ibidem, p. 37.

${ }^{314}$ El Escorial, Biblioteca del Real Monasterio, Ms. 976, fol. 71v y fol. 133v.

315 E. FERNÁNDEZ GONZÁLEZ y F. GALVÁN FREILE, "Iconografía, ornamentación y valor simbólico de la imagen”, 976 Códice Albeldense, Madrid, 2002, pp. 205-277, en especial, p. 254 y M. HERRERO DE LA FUENTE y J. A. FERNÁNDEZ FLÓREZ, "El códice albeldense (o Vigiliano) de la Biblioteca del Real Monasterio de El Escorial, Ms. D.I.2.”, Los manuscritos visigóticos: estudio paleográfico y codicológico (C. García Turza coord.), 2002, pp. 117-174.
} 
Dame-la-Grande de Poitiers o el conjunto de caballeros victoriosos de Parthenay-leVieux, Civray o Chateauneuf, los más llamativos ${ }^{316}$.

La iconografía del emperador ecuestre y su reinterpretación como el soldado de Dios durante la etapa medieval, es el ejemplo más claro de una imagen nacida en el seno del mundo antiguo y absolutamente reelaborada durante la etapa románica. Su sustrato clásico se diluía lentamente según avanzaba el desarrollo de la misma imagen, fruto de una continua reinterpretación de significados y significantes.

En relación con ello, podemos afirmar que, ya a partir del siglo XI y salvo contadas excepciones, la imagen del emperador Marco Aurelio a caballo o, en su defecto, la falsamente considerada como efigie de Constantino, pasaron a ser interpretadas como la prototípica escena del caballero durante la batalla o triunfante después de ella ${ }^{317}$.

Sin embargo, a lo largo del camino que hemos trazado desde su origen romano hasta la llegada a los albores de la plena Edad Media, sin duda, tuvo un gran papel el fenómeno de la recuperación de lo clásico por parte de los carolingios. Es ahí donde estriba la importancia de este ejemplo a la hora de comprender su desarrollo posterior.

Regresando nuevamente a la nómina de copias de diversas obras antiguas realizadas en Aguisgrán, deberemos sumar además aquellas obras originalmente antiguas, que habían sido trasladadas físicamente a su nuevo emplazamiento.

Así, mediante tal conjunto escultórico, el programa según el cual se pretendía realizar una síntesis del ambiente artístico de la corte bizantina y el desarrollado en el área del Laterano, parecía hacerse realidad en la ciudad carolingia.

No es preciso incidir en las pretensiones, más que intencionadas, de Carlomagno, por reproducir en Aquisgrán el modelo de la residencia romana de los pontífices, tal y como ha señalado L. Falkenstein en algunos de sus estudios ${ }^{318}$. Tal acción, se vería completada por la inclusión en el recinto palatino de otra serie de "caprichos" ciertamente normales dentro de la aristocracia romana y oriental. Nos

\footnotetext{
${ }^{316}$ R. CROZET, "Le thème du cavalier...", en particular, pp. 129-137. El autor recoge estos ejemplos y documenta bien aquellos que hemos perdido, como por ejemplo, el que un día decoró la iglesia de Poitiers.

${ }^{317}$ E. FERNÁNDEZ, "Héroes y arquetipos en la iconografía medieval", Los héroes medievales, 1, 1994, pp. 13-52 y R. ALONSO ÁLVAREZ, "De Carlomagno al Cid: la memoria de Fernando III en la Capilla Real de Sevilla", Actas del VIII Congreso de Estudios Medievales. Fernando III y su tiempo (12011251), León, 2003, pp. 471-488, especialmente, pp. 472-474.

${ }^{318}$ L. FALKENSTEIN, Der Lateran der Karolingischen Pfalz zu Aachen, Köln, 1966, en particular, pp. 32-90 e ID., "Charlemagne et Aix-la-Chapelle...", concretamente, pp. 250-266.
} 
referimos al denominado en las fuentes como brogilus o, lo que es lo mismo, el recinto destinado a encerrar todo tipo de bestias exóticas ${ }^{319}$.

Si las referencias a uno de los puntos focales de la Roma papal está ya clara, parece evidente que la gran iglesia de la cristiandad, San Pedro del Vaticano, tampoco escapó a la expoliación -si bien ideológica-por parte de la corte de Carlomagno.

No es preciso incidir en la profunda recuperación de las fórmulas, tanto arquitectónicas como plásticas, del arte romano de entre los siglos IV y V que se llevó a cabo en el imperio carolingio. El estudio de R. Krautheimer sobre el tema sigue estando en absoluta vigencia ${ }^{320}$.

En él, tal y como hemos puntualizado, el autor defiende la recuperación intencionada de las formas de la arquitectura paleocristiana romana durante el siglo IX. Así, tales pretensiones se observarían, por ejemplo, en la abadía de Saint-Denis de Pipino, iniciada en el año 754 y consagrada por Carlomagno en el 775, o, a través de otros ejemplos, como la definitiva recuperación de los prototipos romanos que parece mostrar la abacial de Fulda ${ }^{321}$.

Si tal y como se ha apuntado, el modelo primigenio que siguieron estas iglesias de Saint-Denis, Fulda o ya dentro de Italia, las de Santa Prassede o Santa Cecilia, fue el de la basílica de San Pedro del Vaticano y la de San Pablo Extramuros, no faltarán tampoco referencias directas, desde el punto de vista plástico, a otras pieza de reconocido prestigio en la Roma de este momento.

Según se ha dicho, dentro del "renacimiento carolingio" tiene una posición relevante, en cuanto a los valores ideológicos que representa, la recuperación de uno de los iconos más importantes del arte paleocristiano romano. Nos referimos a la famosa fuente con forma de piña que se localizaba en el atrio de la basílica vaticana (fig. 41) ${ }^{322}$.

\footnotetext{
${ }^{319}$ Ibidem, p. 252. El autor alude al famoso elefante de Abboul Abas del califa de Bagdad Haroun-alRachid, como un caso concreto de esta predilección real por los animales exóticos.

${ }^{320}$ R. KRAUTHEIMER, "Le renouveau carolingien de l'architecture paléochrétienne", Idéologie de l'art antique. Du IV au XV siècle, 1995, pp. 27-83.

${ }^{321}$ Ibidem, pp. 29-36.

${ }^{322}$ El conocido diseño de Philippe de Winghe nos ofrece datos iconográficos al respecto, pues en él se representó el atrium vaticano en torno a la fecha de 1590. Aún por entonces, se conservaba en el recinto un pequeño tabernáculo de bronce que albergaba y protegía la llamada pigna aurea. Además podemos obtener más información al respecto, pues según F. Cabrol y H. Leclercq y basándose en el Liber Pontificalis, dicha estructura poseía ocho columnas y un pequeño cántaro bajo el comentado edículo. Cf. : F. CABROL y H. LECLERCQ, voz "Canthare", Dictionnaire d'Archéologie Chrétienne et de liturgie, vol. 2-II, Paris, 1914, cols. 1983-1986.

A este respecto, son fundamentales también las noticias recogidas en los numerosos Mirabilia urbis Romae. Uno de los más interesantes al respecto, es el escrito por Pierre Mallius, ya que describe la fuente vaticana en los siguientes términos: "Cantarum columnis porphireticis ornatum, quae tabulis marmoreis cum griphonibus conexae, pretioso celo aureo coopertae (sunt) cum floribus et delfines aereis et
} 
Esta importante escultura realizada por los broncistas romanos en los siglos de la Antigüedad tardía, fue tomada como modelo para realizar una pieza de similares características dentro de la corte de Carlomagno.

La historiografía ha debatido frecuentemente sobre el origen de esta pieza. Para unos, se trataría de un bronce íntegramente romano, de época pagana, expoliado en la etapa carolingia y al que se le añadió una base en tiempos otonianos ${ }^{323}$.

Para otros, la piña sería una fundición de datación íntegramente carolingia, a la que más tarde se le añadió una base otoniana. Por último, otros expertos han considerado que, en realidad, se trataría de una escultura enteramente otónida ${ }^{324}$. Independientemente de las circunstancias que rodean la factura de tal pieza, parece claro que desde el principio estuvo ubicada en el atrium de la Capilla Palatina. Además, si aceptamos la teoría expuesta por W. Braunfels, se trataría muy posiblemente de una escultura romano-pagana totalmente reinterpretada, desde el punto de vista simbólico, a través de un buscado parentesco con el modelo cristiano.

Además de ello, el añadido de una base en la que se representaron las personificaciones de los cuatro ríos del paraíso acompañados por una inscripción, refrenda tales hipótesis (fig. 42) ${ }^{325}$. Dicha inscripción, así como las personificaciones

deauratis aquas fundentibus: in medio cantari est pinea aerea (...)". Cf. S. AINI, "Mirabilia Urbis Romae", Romei \& Giubilei. Il pellegrinaggio medievale a San Pietro (350-1350) (M. D'Onofrio coord.), Milano, 1999, pp. 199-204 y F. CABROL y H. LECLERCQ, voz “Canthare...”, cols. 1983-1986.

${ }^{323}$ No debemos olvidar que, durante la Antigüedad pagana, la piña estuvo presente dentro de los programas iconográficos utilizados generalmente con fines funerarios. Un símbolo mortuorio que se relacionaba con la perennidad del árbol del que provenía dicho fruto, así como con la ansiada inmortalidad y acceso a la vida eterna del difunto. Esta fue la causa de que diversos edificios funerarios romanos tuviesen como remate una estructura que formalmente evocaba la forma de una piña. Recuérdese, dentro del caso hispano la llamada Torre Ciega de Cartagena, construida en torno al siglo I a. C. Esta torre funeraria, hoy prácticamente desaparecida, poseía un cuerpo superior troncocónico rematado por una semiesfera que, en realidad, podía haber intentado imitar una piña.

En la misma línea, por ejemplo, fue concebida la torre de Saint-Front de Périgueux, un edificio medieval con claro gusto "antiquizante", que parece evocar los modelos romanos. Según Dubourg-Noves, este edificio francés estaría originariamente rematado por un cuerpo tripartito cuadrangular sobre el que se colocaría un tholos con remate en forma de piña.

Estas y otras noticias, justificarían la posibilidad de que los artistas carolingios tomasen la pieza de alguna construcción romana y la hubieran reutilizado. No debemos olvidar, como ya en época paleocristiana, la propia madre de Constantino había sido enterrada en un mausoleo ubicado en la Subaugusta o Fundus Lauretum. Se trataba de un edificio que poseía una cúpula totalmente cubierta con ánforas que permitían y facilitaban la consolidación del opus coementicium. Con el tiempo, se le comenzó a denominar Tor (re) Pignattara, topónimo descriptivo de las similitudes que tales soluciones presentaban con una piña. Cf.: L. ABAD CASAL, El arte funerario hispanorromano, Madrid, 1991, ficha catalográfica 4; P. DUBOURGNOVES, Op. cit., p. 328 y H. BRANDENBURG, Le prime chiese..., en particular, p. 56.

${ }^{324}$ W. BRAUNFELS, "Pomme de pin", Charlemagne. Oeuvre..., ficha catalográfica 3, p. 25.

${ }^{325}$ Ibidem, p. 25. El profesor Braunfels transcribe íntegramente el texto de la base de la piña, matizando que el tercer verso se trataría de un añadido del siglo XIX:

"Dant orbi latices quae incremente gerentes

Fertilis Eyfrates velox ut missile Tygris

Phison auriferis Gehon sed mitior undis 
fluviales, dotarían a la pieza de un resignificación en clave salutífera relacionada con la imagen de la fons vitae, en la que la idea de inmortalidad y perennidad, así como la de bautismo y acceso al locus amoenus o paradisus, serían las principales premisas rectoras desde el punto de vista iconológico ${ }^{326}$.

Con estas pretensiones, fueron incluidas varias decenas de ramas de pino con piñas entre la hojarasca del programa iconográfico del mausoleo constantiniano de Santa Constanza de Roma, un claro arquetipo de la asunción de las fórmulas “antiquizantes" y la estética clásica en pleno siglo IV (fig. 43) 327.

$\mathrm{Si}$ en este sentido las fuentes romanas parecen claras, tampoco es nada desdeñable el dato que nos ofrecen F. Carbol y H. Leclercq, a propósito de la gigantesca piña de bronce colocada durante el siglo IX en el atrium de la gran basílica palatina de Constantinopla. Tal elemento se mostraría elevado encima de dos cántaros, sobre los que, a su vez, vertía agua. Se trata de un hecho que incorporaba, nuevamente, esta fuente al tema de la purificación del cuerpo y el alma cristianos y que conformaría parte de la nómina de ejemplos localizados en este área. En este mismo sentido, sabemos que la basílica de Santa Sofía de Constantinopla, tras la reconstrucción de Justiniano, presentaba un gran atrio donde, otra vez, una piña vertía agua sobre un gran vaso de mármol $^{328}$.

A través de la utilización de tales elementos, en ocasiones piezas de nueva fundición y en otras, expoliados de edificios antiguos, la corte carolingia alcanzaba cotas de absoluto clasicismo en su proyecto consciente de evocar la Roma imperial. No

Auctori grates canit Udalrich pius abbas”.

\footnotetext{
${ }^{326}$ En relación con estos aspectos, se debe recordar la importancia que dicha iconografía de la Fuente de la Vida va a tener dentro de las producciones manuscritas carolingias. Baste con citar la célebre representación del Evangeliario de San Médard de Soissons, Paris, Bibliothèque nationale de France, Ms. lat. 8850, f. 6 v. Cf.: T. VELMANS, "Quelques versions rares du thème de la Fontaine de Vie dans l'art paléochrétien”, Cahiers Archéologiques, XIX, 1969, pp. 29-43, en especial, p. 34 ; M. BESSEYRE, "La fontaine de vie", Trésors carolingiens. Livres manuscrits de Charlemagne à Charles le Chauve, Paris, 2007, pp. 90-91 y M-P. LAFFITTE, "Évangiles de Saint-Médard de Soissons", Trésors carolingiens..., ficha catalográfica 10, pp. 97-100, en especial, p. 97.

${ }^{327}$ Los mosaicos de este edificio centralizado son sobradamente conocidos. Así, la bóveda anular que circunscribe el edificio, fue decorada con todo tipo de iconografías funerarias de tradición romana, pero con absoluta incorporación de temas paganos. Además de las aves bebiendo de la crátera de la vida y otros objetos de diversa índole, el mosaico se ve salpicado por decenas de piñas en alusión directa a la inmortalidad de la difunta para la que dicho edificio fue construido. Cf.: A. AMADIO, I mosaici di Santa Constanza, Roma, 1984.

${ }^{328}$ F. CABROL Y H. LECLERCQ, voz “Canthare...”, especialmente, col. 1963.
} 
debe resultar llamativo entonces que Aquisgrán, pronto comenzase a ser denominada en las fuentes como la "Segunda Roma"329.

Sin embargo, el rastreo de fuentes clásicas sobre las diversas producciones carolingias puede ir más allá. En concreto, la evocación de la arquitectura constantiniana del siglo IV fue una de las vías que más van a explotar los artífices activos durante este periodo.

Se trata de una idea que, rápidamente, se expandiría por todo el imperio carolingio, tal y como atestiguan, por ejemplo, las soluciones en planta que se observan en las abaciales de Fulda (fig. 44) o Seligenstadt, herederas en todo caso de fórmulas romanas de siglos pasados. En relación con la arquitectura construida durante el siglo IX en la misma Roma carolingia, deben señalarse las basílicas de Santa Prassede o Santo Stefano degli Abessini, las cuales nuevamente retoman estos principios edilicios. Parece claro que todo el imperio conocía y se esforzaba, de una manera consciente, por "resucitar" los modelos de la última arquitectura antigua romana ${ }^{330}$. Tal y como veremos más adelante, dentro de este breve análisis que estamos realizando sobre los diferentes "renacimientos" de las artes plásticas y la arquitectura alto y pleno medievales, el fenómeno volvería a producirse con fuerza ya en la época madura del medievo, concretamente en los años finales del siglo XI.

Fue entonces cuando, potenciado por la Reforma Gregoriana, se volvió de nuevo la vista al mundo paleocristiano en busca de referentes en los que abastecerse e inspirarse. Tal y como veremos, de la misma forma que Carlomagno reproducía fielmente la planta y las formas decorativas de la basílica de San Pedro en sus fundaciones centroeuropeas, el arte románico tampoco escapó a esta tendencia de hacer revivir aquel edificio. Sirva de ejemplo, para clarificar la cuestión en este breve avance, la intención "arqueológica y recuperadora" que acusa la planta de la abadía de Cluny, especialmente evidente en su segunda fase constructiva. Tal y como se ha dicho, la planta de Cluny II podría ser englobada dentro del fenómeno que H. Toubert ha definido como el "renacimiento paleocristiano" del siglo $\mathrm{XI}^{331}$.

En relación con estos aspectos, merece especial mención un diseño del siglo

\footnotetext{
${ }^{329}$ M. GREENHALGH, The survival of Rome..., p. 105 y P. LASKO, Arte sacro. 800-1200, Madrid, 1999, pp. 36-37. Según P. Lasko, el hecho de que la piña carolingia poseía idénticas funciones a la existente en San Pedro del Vaticano, lo demuestran las pequeñas salidas de agua que la perforan.

${ }^{330}$ R. KRAUTHEIMER, “Le renouveau carolingien..., en particular, pp. 28-29.

${ }^{331}$ A. BAUD, Cluny. Un grand chantier médiéval au Coeur de l'Europe, Paris, 2003, en concreto, p. 87 y H. TOUBERT, "Le renouveau paléochrétien...", pp. 99-154. Remitimos, así mismo, al análisis del concepto que hacemos nosotros en este estudio en el apartado pertinente.
} 
XVII, en el que algún autor reprodujo fielmente un objeto de orfebrería catalogado como perteneciente a la "escuela de trabajos en metal de la corte de Aquisgrán" y que no ha llegado hasta nosotros. Tal diseño ha sido la única fuente precisa para poder hablar de lo que la crítica historiográfica considera uno de los objetos más importantes de la plástica de este "renacimiento carolingio". Nos referimos al llamado arco de

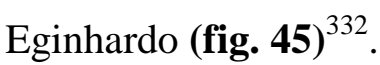

\section{AD TROPAEUM AETER \\ NAE VICTORIAE SVSTI \\ NENDUM EINHARDVS \\ PECCATOR HVNC AR \\ CVM PONERE AC DEO \\ DEDICARE CVRAVIT}

Esta fue la inscripción que el biógrafo de Carlomagno mandó colocar en la cartela del ático de la pequeña maqueta que reproducía, en miniatura, un arco de triunfo a la manera romana ${ }^{333}$. Se trataba de una pieza de madera revestida de plata, que mostraba el epígrafe a la manera de la cartela existente en el arco de Constantino, en Roma. No en vano, tal y como ha señalado el profesor P. Henriet, el arco en miniatura y la posible cruz montada que debió existir sobre su ático, así como su iconografía, representan un claro ejemplo de la asociación iconográfica del Miles Dei cristiano con respecto a la figura del emperador antiguo ${ }^{334}$.

El arco ofrecía una nueva alusión al arte antiguo romano, bien a través de su vertiente pagana -recuérdese que también de un único ojo es el arco de Tito en el foro romano- o bien, a través de su vertiente cristiana, representada por el arco de Constantino. Lo que parece claro es que, la disposición y composición del objeto suntuario debió obedecer al esquema de un arco de triunfo y, muy posiblemente, alguno desaparecido de entre los que se erigían en la ciudad de Roma ${ }^{335}$.

\footnotetext{
${ }^{332}$ Paris, Bibliothèque nationale de France, Ms. Franç. 10440, fol. 45 r. Cf.: W. BRAUNFELS, “L'arc de triomphe d'Eginhard", Charlemagne. Oeuvre..., ficha catalográfica 9 y 9 b, pp. 29-30. El autor data la obra en metal, hipotéticamente, entre los años 815-830.

333 Ibidem, p. 29 y M. D’ONOFRIO, Roma e Aquisgrana..., pp. 45-46. El profesor M. D’Onofrio destaca el valor didáctico y edificatorio que poseían muchas de estas superscriptiones dentro de las artes carolingias.

${ }^{334}$ P. HENRIET, "Mille Formis Daemon. Usages et fonctions de la croix dans l'Hispania des IX $-\mathrm{XI}^{\mathrm{e}}$ siècles", Guerre, Pouvoirs et Idéologies dans l'Espagne Chrétienne aux alentours de l'an mil (T. Deswarte y Ph. Sénac dirs.), Turnhout, 2005, pp. 163-18, en especial, p. 167.

${ }^{335}$ F. GALTIER MARTÍN, La iconografía arquitectónica ..., p. 141.
} 
Por otra parte, según J. Hubert, dicho objeto habría de tener las funciones de un relicario, tratándose muy posiblemente de una donación hecha por el propio Eginhardo a la abadía de San Servatius de Mastrich ${ }^{336}$. Nuevamente, al igual que el resto de símbolos tomados del arte clásico, observamos en esta obra una nueva resignificación de su simbolismo inicial, pues,

“(...) fue dedicado a celebrar la victoria de Cristo sobre la muerte. Destinado a soportar el trofeo de la eterna victoria, como afirma la inscripción, la cruz de orfebrería se erigiría sobre un zócalo situado en el coronamiento, allí donde en los arcos antiguos figuraba el arco triunfal ${ }^{337}$.

La idea rectora del programa iconográfico pretendería exaltar el triunfo del reino de Dios a través de una historia de la redención tras la muerte. En este sentido, creemos que, tal y como apunta C. Frugoni, el arco debe ser entendido como el triunfo o victoria de Cristo, no sólo sobre el paganismo, sino también sobre la muerte ${ }^{338}$. Sin embargo, a pesar de compartir tales opiniones, creemos que es posible igualmente entrever el recuerdo funerario y conmemorativo que diversos arcos triunfales tuvieron durante el mundo antiguo y que, posiblemente, aparecen contenidos en la pieza de Eginhardo ${ }^{339}$. En esta misma dirección, conviene recordar la vieja teoría que defendía como el emperador Tito pudo haber sido enterrado en relación con uno de estos arcos honoríficos.

Lo más destacado es que, tal enterramiento, no sólo se debió producir desde un punto de vista meramente estructural, sino que, literalmente, pudo haber sido inhumado dentro de su arco de triunfo, en la Velia del foro romano (fig. 46). De ser cierta esta hipótesis, se trataría de la primera tumba del Caesar, antes de que su cuerpo fuera llevado definitivamente al Templum Gens Flaviae, que albergó de manera permanente

\footnotetext{
${ }^{336}$ Se trataría, así mismo, de una estructura que serviría de pie a una supuesta cruz de Cristo, al mismo tiempo que albergaría en su interior una reliquia del lignum crucis. Cf.: J. HUBERT, J. PORCHER y F. W. VOLBACH, Op cit., pp. 35-37; W. BRAUNFELS, "L'arc de triomphe...", p. 29.

La donación debió realizarse concretamente en el año 828 tal y como se defiende en: L. DE LACHENAL, Op. cit., p. 127.

${ }^{337}$ F. GALTIER MARTI, La iconografía arquitectónica ..., p. 142.

${ }^{338}$ C. FRUGONI, "La antichità: dai Mirabilia...", en particular, p. 21.

${ }^{339}$ Y. CHRISTE, "La colonne d'Arcadius...", pp. 31-42. Véanse, especialmente, las concomitancias que establece con la portada de Santa María de Ripoll, en cuanto al uso simbólico de las imágenes y su emplazamiento sobre el mismo arco.
} 
sus cenizas ${ }^{340}$. Se trataría, por tanto, de un arco que, además de su carga simbólica alusiva al triunfo, también materializaría otra serie de connotaciones de tipo funerario.

Otro arco, esta vez de fábrica, se nos presenta como parada obligada en cualquier recorrido a través del estudio del carácter "antiquizante" del arte carolingio. Nos referimos al pórtico de Lorsch (fig. 47), redefinido de manera acertada como una Torhalle Königshalle, ya que tal estructura lleva cabo una síntesis arquitectónica de varias tipologías constructivas ${ }^{341}$.

Aquí se fusionaban, por un lado, el aula regia de origen romano y, por el otro, la laubiae de tradición bárbara ${ }^{342}$. Sin embargo, tampoco parece descabellado apuntar una posible relación remota con respecto a otro de los grandes edificios constantinianos, esta vez, ubicado en la capital oriental del Imperio. Nos referimos, concretamente, a la sala de audiencias, la llamada "Chalkê", del Gran Palacio de Constantinopla, que construyó el emperador en su recinto palatino y que, según se ha argumentado, tendría funciones similares a las defendidas para el arco de Lorsch.

Esta última hipótesis es ciertamente lógica y permite entender la estructura de dos pisos y con función de pórtico o porche, que, según ha estudiado L. Falkenstein, había sido erigida a su semejanza en uno de los espacios abiertos existentes en el recinto anterior a la gran iglesia de Nuestra Señora ${ }^{343}$.

Algunos autores y, entre ellos, M. D’Onofrio o L. Lachenal, apoyan la influencia directa de otras obras de cronología romana sobre el conocido pórtico alemán. En concreto, señalan las concomitancias con respecto al arco de triunfo de Constantino (fig.

\footnotetext{
340 J. ARCE, Funus Imperatorum. Los funerales de los emperadores romanos, Madrid, 1988, en particular, pp. 80-82 y L. DE LACHENAL, Op. cit., p. 127. El profesor Arce recoge la teoría de Hartleben, según la cual, Tito habría sido enterrado en el ático de su arco de triunfo. Más concretamente, en una cámara creada para albergar sus cenizas. Por su parte, la profesora Lachenal, también apunta determinados parentescos entre la pieza de Eginhardo y el arco de Tito, sobre todo, en lo referente a la tabula ansata sobre la que se dispuso la inscripción.

${ }^{341}$ La abadía en la que se ubica el edificio había sido fundada en el año 763 por el rey Chrodegang, destacando dentro del recinto, sobre todo, la iglesia conventual dedicada a San Nazario. Cf.: J. HUBERT, "Rome et la Renaissance...", especialmente, pp. 239-240.

${ }^{342}$ La bibliografía sobre el llamado Pórtico de Lorsh es abundante. Sin pretender realizar un estado de la cuestión, citamos los trabajos que hemos consultado al respecto. Vid.: L. DE LACHENAL, Op. cit, p. 111; F. GALTIER MARTÍ, La iconografía arquitectónica..., en especial, p. 177; R. SILVA, "Et domuncula, in qua sedebatur ad iudicantum, erat in media porticu. Alcune cosiderazioni sulla Königshalle di Lorsch", Arte d'occidente. Temi e metodi. Studi in onore di Angiola Maria Romanini, vol. I, Roma, 1999, pp. 41-47 y H. SCHEFERS, “Die „Köngshalle”, Weltkulturerbe Kloster Lorsch das Mittelalter erwacht, Regensburg, 2003, pp. 12-15. Según se desprende de estos estudios, la laubiae es una estructura arquitectónica que se desarrolló, sobre todo, en el ámbito longobardo y que, tradicionalmente, estaba formada por dos pisos. .

${ }^{343}$ L. FALKENSTEIN, "Charlemagne et Aix-la-Chapelle...", particularmente, p. 249.
} 
48), sobre todo en lo referente a la distribución espacial de los vanos inferiores ${ }^{344}$. A tales ideas debemos sumar las defendidas por S. Kostof, quién argumenta que se trataría, más concretamente, de una evocación del acceso monumental de alguna ciudad romana, guardando especial parecido, por ejemplo, con el que poseía la muralla de Aureliano en la misma Roma ${ }^{345}$.

Otros aspectos sobradamente conocidos de la estructura de Lorsch, como la utilización de un repertorio escultórico y decorativo de primera categoría, el uso ilusionista de la alternancia policroma de los materiales, así como otra serie de elementos plásticos, podrían tener sus precedentes directos en edificios gallo romanos de gran importancia, tomados posiblemente como modelo. Cabe señalar, a título de ejemplo, la torre Römerturm de Colonia o los sistemas decorativos utilizados en el baptisterio de Saint-Jean de Poitiers (fig. 49) ${ }^{346}$.

A través de la continuidad en la utilización de estos sistemas decorativos, se podría defender un interés, por parte del "renacimiento carolingio", de evocar el mundo romano a través de la aplicación de técnicas a lo more romano, hecho que habla, además, de una cierta continuidad de formas desde la caída del Imperio hasta el propio siglo IX, en una suerte de hilo conector que jamás llegó a perderse ${ }^{347}$.

En este sentido, resulta muy interesante señalar la importancia de la estética del color en la concepción de la estereotomía de algunas construcciones de cronología carolingia. Se trata de una solución que volvía a servir como un puente de unión entre la tradición romana y la que luego continuaría dentro de la misma arquitectura románica, donde tampoco faltarán ejemplos en los que se utilizarán tales técnicas.

Para finalizar, es posible concluir que, la observación directa de los monumentos antiguos por parte de los arquitectos carolingios que, susceptiblemente, pudieron conocer obras de la envergadura del propio baptisterio de Poitiers o las importantes

\footnotetext{
${ }^{344}$ M. D'ONOFRIO, “La königshalle di Lorsch presso Worms”, Roma e l'età carolingia, Roma, 1976, pp. 131-138, en particular, p. 132; ID., Roma e Aquisgrana..., p. 61 y L. DE LACHENAL, en con concreto, p. 111.

${ }^{345}$ S. KOSTOF, Op. cit., particularmente, pp. 485-486.

${ }^{346}$ L. DE LACHENAL, Op. cit., p. 112. Lachenal data la torre romana en torno al siglo I-II, mientras que, da las fechas del siglo V-VI para el baptisterio de Poitiers. Véase también: E. FERNÁNDEZ GONZÁLEZ y F. GALVÁN FREILE, "Pintando arquitecturas/arquitecturas pintadas: las construcciones figuradas en el Códice Albeldense", De arte, 7, 2008, pp. 51-60. Los autores insisten en la importancia de los juegos de policromía y los valores plásticos de los monumentos altomedievales, sobre todo, en sus decoraciones exteriores.

${ }^{347}$ C. HEITZ, "More romano...", pp. 27-37; ID., "Bâtir et célébrer more romano", Les Cahiers de SaintMichel de Cuixà, XXVI, 1995, pp. 57-66; O. DOPPELFELD, "More Romano. Die beiden Karolingischen Domgrundrisse von Köln”, Kölner Domblatt, VIII-IX, 1954, pp. 33-61 y E. FERNÁNDEZ GONZÁLEZ y F. GALVÁN FREILE, "Pintando arquitecturas...", en concreto, p. 54.
} 
murallas romanas de Le Mans, bien significativas en este mismo sentido (fig. 50) (48 $^{348}$

Volviendo en última instancia a las fuentes utilizadas por los constructores del pórtico de Lorsch, debemos ver en esta "laubia cum solarium" una especie de templete exento ubicado en el lado oeste del basto atrio que precedía a la iglesia abacial. Emplazado nuevamente en este lugar, tal edificio seguía, en todo caso, la ubicación de aquella estructura que, de igual manera, se situaba en el espacio existente entre la Capilla Palatina y la halle del conjunto palatino ${ }^{349}$.

Nuevamente el "renacimiento carolingio" explotaba conceptos tan clásicos como la eurytmia y la symmetria para generar un edificio digno del adeventus del soberano a la abadía ${ }^{350}$, evocador, sin duda, de ese concepto bien definido de la llamada architettura di potenza que, tradicionalmente, se ha venido aplicando sobre las construcciones tardoantiguas ${ }^{351}$.

El pórtico carolingio pudo ser concebido con una finalidad glorificadora y de exaltación, al modo de los grandes arcos triunfales estructurados siguiendo el esquema del frotis de glorificación antiguo ${ }^{352}$.

Para concluir, queremos aludir a las magnificas pilastras adosadas a los paños de muro del piso superior del pórtico (fig. 51), pues, sólo con su presencia, aluden por sí mismas al gran conocimiento que tenían los artífices carolingios de la arquitectura clásica $^{353}$.

Ligadas a estas exquisitas esculturas pétreas, reaparecen las réplicas en bronce que se observan en las rejas y canceles ubicados en la capilla palatina de Aguisgrán y que cerraban el octógono de dicho espacio (fig. 52).

Las concomitancias entre ambos trabajos nos revelan las fuentes utilizadas por artistas que trabajan, de manera independiente, los más variados tipos de materiales ${ }^{354}$.

\footnotetext{
348 A. BONNERY, "Matériaux et couleurs dans les églises romanes du Languedoc", Les Cahiers de Saint-Michel de Cuixà, XXVI, 1995, pp. 109-123, en especial, p. 121.

${ }^{349}$ R. SILVA, Op. cit., pp. 42-43; S. KOSTOF, Op. cit., p. 485 y L. FALKENSTEIN, "Charlemagne et Aix-la-Chapelle...", particularmente, p. 245.

350 Son muchos los autores que han vinculado el edificio con funciones palatinas y regias. Sobre todo, relacionándolo con las visitas a la abadía y el recibimiento en tal estructura. Véase: L. DE LACHENAL, Op. cit., p. 113 y M. D'ONOFRIO, Roma e Aquisgrana..., pp. 72-75.

${ }^{351}$ G. DE FRANCOVICH, Il palatium di Teodorico..., especialmente, pp. 5-20 y M. D'ONOFRIO, Roma e Aquisgrana..., p. 77.

${ }^{352}$ F. MARÍN VALDÉS, “Los frontis de glorificación...”, en especial, p. 151.

${ }^{353}$ Compárese la semejanza entre el uso de las pilastras en Lorsch y el que se hace en el ábside de la iglesia de Santa Inés en Roma, perteneciente al conjunto de la basílica de Santa Inés y el mausoleo de Santa Constanza.

${ }^{354}$ W. BRAUNFELS, "Les huit grilles des tribunes de la chapelle palatine", Charlemagne. Oeuvre..., ficha catalográfica 6, pp. 27-28. Inicialmente estaban doradas e imitan formas habituales dentro de los
} 
Mediante estos trabajos del bronce y el mármol, ambos concebidos durante toda la Antigüedad como materiales de gran prestigio material, cerramos el capítulo perteneciente al "renacimiento carolingio". Sin embargo, no debemos olvidar que, en un corto paréntesis cronológico, el bronce volverá a prodigar un conjunto de obras de tendencia igualmente clásica, dentro de lo que tradicionalmente se dio en llamar como el "renacimiento otoniano". 


\section{EL “RENACIMIENTO” OTONIANO.}

La llamada "segunda renovatio" o lo que, tradicionalmente, se ha definido como el "renacimiento otoniano" 355 , bien podría haberse iniciado con la noticia del 28 de enero del año 814 que nos transmite Eginhardo:

"Su cuerpo fue lavado y compuesto según el rito solemne, fue llevado a la iglesia e inhumado en medio de la gran aflicción de todo el pueblo. Se dudó en un principio sobre el lugar en donde debía ser depositado porque él, en vida, no había dispuesto nada al respecto. Finalmente, todos decidieron que el sitio más digno de que fuera enterrado era la basílica que él mismo había hecho construir, a sus expensas, en este lugar, por amor a Dios y a Nuestro Señor Jesucristo y en honor a su santa Madre, siempre Virgen. Allí fue sepultado el mismo día de su muerte y sobre la tumba se construyó un arco dorado con su imagen y con una inscripción; el texto que fue grabado es el siguiente:

EN ESTE SEPULCRO YACE EL CUERPO

DE CARLOS, MAGNO Y ORTODOXO EMPERADOR

QUE NOBLEMENTE AMPLIÓ EL REINO DE LOS FRANCOS

Y LO QUE GOBERNÓ FELIZMENTE DURANTE XLVII AÑOS

MURIÓ SEPTUAGÉNARIO EN EL AÑO DEL SEÑOR DCCCXIV

EN LA VII INDICCIÓN EL DÍA V ANTES DE LAS CALENDAS

DE FEBRERO (texto 10) ${ }^{356}$.

\footnotetext{
${ }^{355}$ W. OAKESHOTT, Classical inspiration...., pp. 58-75. Así lo definió este autor en el año 1959.

${ }^{356}$ EGINHARDO, Op. cit., pp. 109. Al morir Carlomagno, fue enterrado en esta tumba que nos describe su biógrafo. Parece absolutamente claro que constaba de una efigie del gobernante. La mitología posterior se encargaría de describir y reconstruir de maneras diversas y, en ocasiones, poco veraces, su forma y el aspecto. Los mecanismos ideológicos medievales, en cuanto a la formación del arquetipo heroico, imaginaron una efigie del monarca incorrupto, entronizado y ataviado con las vestiduras e insignias de poder.

Señalamos, en este sentido, una pieza datada, con dudas, en el siglo XI y que representa la tipología que estamos señalando con el monarca en actitud sedente y con los regalia. Se trata de la representación de Carlomagno de la abadía de San Juan de Münster. La pieza ha sufrido diversos avatares, sin embargo, debido al prestigio que debió tener, fue restaurada en época gótica imitando el estilo arcaico de la escultura. Se muestra con túnica, fíbula, brazalete, corona y el mundus. Sobre la figura, vid.: D. GABORIT-CHOPIN, Regalia. Les instruments du sacre des Rois de France. Les "Honneurs de Charlemagne", Paris, 1987, en particular, pp. 9-16 y W. BRAUNFELS, "Statue de Charlemagne de StJohann de Münster", Charlemagne. Oeuvre..., ficha catalográfica 30, p. 41.

Para una hipotética reconstrucción de la tumba del monarca carolingio, vid.: F. CABROL y $\mathrm{H}$. LECLERCQ, voz "Charlemagne", Op. cit., vol. 3-I, cols. 656-803, en particular, cols. 793-794.

En relación con las posibles repercusiones que la tumba del monarca carolingio tuvo sobre los catafalcos funerarios medievales hispanos, vid.: R. ALONSO ÁLVAREZ, "De Carlomagno al Cid...", concretamente, pp. 472-474. El tema también ha sido estudiado, aunque centrándose en piezas más
} 
Con la muerte de Carlomagno y la sucesión a favor de su hijo Ludovico, en una ceremonia de coronación ante la Curia de Roma y siguiendo nuevamente la tradición tardoantigua, se iniciaba una nueva era marcada por los cambios ${ }^{357}$.

Un dato a tener en cuenta a la hora de hacer un balance del camino que tomaron las artes plásticas tras la muerte de Karolus, fue la exhumación del cadáver del emperador que llevaría a cabo Otón III. En plena Capilla Palatina y, con un ambiente de máxima conmoción y respeto, el cuerpo fue cambiado de ubicación, para pasar a ocupar un nuevo sarcófago, tras la destrucción del anterior por los normandos en el año $881^{358}$. El sarcófago elegido para el nuevo sepelio fue nuevamente expoliado de entre las colecciones escultóricas romanas, presentando en el frente un tema tan pagano como el del rapto de Proserpina (fig. 53) ${ }^{359}$.

Se trataría de una pieza trasladada, hipotéticamente, desde Italia a Aquisgrán, aún con el propio emperador vivo y que seguro había formando parte de las abundantes partidas de obras que desde diferentes lugares llegaban a centroeuropa. Con todo, aún no siendo un unicum, es un caso excepcional, en cuanto se conoce el lugar del que provenía originariamente el sarcófago ${ }^{360}$.

Estas acciones, acompañadas de otras que analizaremos en breve, nos hacen suponer que, a partir de la muerte de Carlomagno y el advenimiento de la llamada era de los "Otones", el arte centroeuropeo de los albores del año mil no sucumbió al olvido del arte clásico ${ }^{361}$.

tardías, en: T. LAGUNA PAÚL, "Memorias sepulcrales de las Sauninas, Laboratorio de Arte, 12, 1999, pp. 27-38

${ }^{357}$ L. DE LACHENAL, Op. cit., en particular, p. 129.

${ }^{358}$ M. SPRINGER, "Die Wiederverwendung Antiker Sarkophage", Kunst und Kultur der Karolingerzeit. Kart der Grobe und Papst Leo III in Paderborn, vol. II, Mainz, 1999, ficha catalográfica X. 41, pp. 758763, particularmente, pp. 760-761 y R. ALONSO ÁLVAREZ, "De Carlomagno al Cid...”, p. 473.

${ }^{359}$ Era el año 998 cuando, tras una peregrinación documentada a la Capilla Palatina, ordenó, el 18 de mayo y con la festividad de Pentecostés, buscar la tumba de su glorioso ancestro. Se ha querido ver este acto como un intento, por parte de la dinastía otoniana, de iniciar la nueva renovatio imperii. Sobre ello, véanse: J. ADHÉMAR, Op. cit., p. 78; L. DE LACHENAL, Op. cit., p. 148; R. CASSANELLI, "I resti di un grande patrimonio architettonico", L'arte dell'anno mille in Europa 950-1050, Milano, 2000, pp. 3540, en particular, p. 35 y J-P. CAILLET, "Le pape et l'empereur...", p. 69.

360 W. BRAUNFELS, "Le sarcophagi de Charlemagne", Charlemagne. Oeuvre, Rayonnement et Survivances, Aix-la-Chapelle, 1965, ficha catalográfica 7, p. 28. Desde otro punto de vista, este hecho corrobora el aprecio que los grandes monarcas medievales tuvieron hacia los sarcófagos de la Antigüedad y su preferente deseo de ser inhumados en aquellos más espectaculares, quizás debido a su perfección técnica. Cf.: F. A. MARÍN VALDÉS, "Observaciones sobre la adopción...", en especial, p. 22 y S. MORALEJO ÁLVAREZ, “La reutilización...”, en particular, p. 187.

${ }^{361}$ W. OAKESHOTT, Classical Inspiration...., pp. 62-67. 
A continuación y basándonos en dos ejemplos extraídos de la ilustración del libro, pensamos que es posible ejemplificar algunas de las características más especiales del "renacimiento otoniano".

El primero de ellos, es una miniatura proveniente del Sacramentario de Metz, obra presumiblemente creada bajo el patrocinio de Carlos el Calvo, en torno al año $869^{362}$ (fig. 54). En ella, se representó la figura de Cristo como señor del mundo, inscrito en la mandorla mística y flanqueado por dos serafines. El tono "antiquizante" vendría dado por la representación, a los pies de esa misma mandorla, de dos personificaciones que se han identificado como Océano y Tierra ${ }^{363}$.

En este sentido, la presencia de estas personificaciones en otras obras coetáneas, señala cierto continuismo en relación con la percepción del mundo clásico durante la etapa otoniana. Recuérdese, en relación con lo afirmado, la placa ebúrnea que cubría originariamente el Codex Aureus de San Emmeram de Ratisbona, perteneciente a Carlos el Calvo, en un primer momento, ya que pronto pasó a formar parte de la cubierta del Perikopon de Enrique $\mathrm{II}^{364}$.

Esta iconografía, absolutamente pagana y derivada de los ciclos icónicos romanos, tiene su mejor antecedente en aquellas imágenes de los emperadores en los que se mostraban como dominadores del orbe. Un cosmos que se materializaba, en algunas ocasiones, a través de la figura de caelum, mientras que, en otras, lo hacia mediante las imágenes de Tellus, Okeano o los mismos Sol y la Luna.

Todas ellas, a pesar de su alta carga pagana, fueron reabsorbidas por el imaginario cristiano $\mathrm{y}$, en este sentido, consideramos que, las artes carolingias y otonianas fueron el viaducto que permitió conectar aquellos siglos de la Antigüedad tardía con los de la Alta y Plena Edad Media, de ahí la importancia que les otorgamos.

\footnotetext{
${ }^{362}$ Paris, Bibliothèque nationale de France, Ms Lat. 1141, fol. 6.

${ }^{363}$ La obra pudo haber sido realizada en Corvey o incluso en Saint-Denis, ingresando en el siglo XVII en el tesoro de la catedral de Metz. Se ha ligado su factura a la Biblia de San Pablo Extramuros, donde nuevamente aparece un posible retrato del monarca. Vid. sobre la obra: M-P. LAFFITTE, "Sacramentaire de Charles le Chauve (?), fragment", Trésors carolingiens..., ficha catalográfica 18, pp. 117-118.

${ }^{364}$ München, Bayerische Staatsbibliothek, Ms. 30, fol. 34v.

La fortuna de este esquema, según el cual, Tierra y Océano se colocan en la parte baja de la composición de la miniatura, mientras que, arriba, se ubica la escena sagrada en cuestión, tuvo su asimilación por parte de otro gran personaje conocedor de lo clásico. Nos referimos al abad Bernardo de Hildesheim que, tal y como veremos más adelante, patrocinó algunas obras que se muestran cargadas de recuerdos del mundo antiguo. Sobre la obra, vid.: M-P. LAFFITTE, "Sacramentaire de Charles le Chauve...", p. 118 y L. DE LACHENAL, Op. cit., p. 135. Sobre los aspectos clásicos de las obras del abad Bernardo, consúltese: L. E. STAMM-SAURMA, "Die ,autorictas" des Zitates in der bernwardinischen Kunst", Bernwardinische Kunst. Bericht über ein wissenschaftliches Symposium in Hildesheim vom 10.10 bis 13.10.1984, Göttingen, 1988, pp. 105-126, en especial, pp. 112-113.
} 
El caso del Sacramentario de Carlos el Calvo lo atestigua. Aquí, las personificaciones de Tellus y Oceano parecen evocar los textos de Dionisio Pseudopagita, en los cuales, se aborda el tema de estas personificaciones como representantes del mundo cristianizado ${ }^{365}$. Su origen antiguo parece fuera de toda duda, sobre todo, teniendo en cuenta la gran difusión de estos temas en Roma y de los que, por ejemplo, la representación de Tellus amantando a dos putti del Ara Pacis, es tan sólo el caso más conocido.

Con ese sentido han sido colocados en la miniatura a la que nos venimos refiriendo, como evocadores de una suerte de mappa mundi sobre el que gobierna la Maiestas Domini. Es, por así decirlo, una materialización del cosmos, representado por las figuras angélicas, que también se encuentran bajo su dominio.

El "renacimiento otoniano" supo transformar y reactivar esta iconografía, aunque si bien, parece claro que ya se encontraba presente dentro de otras obras de cronología anterior. Ya hemos aludido al caso de las personificaciones de los ríos fundidas a los pies de la pigna del atrio de la Capilla Palatina de Aquisgrán. Reproducen, con ligeras variantes, el prototipo iconográfico de la figura que se recuesta bajo la mandorla de la ilustración del citado Sacramentario de Metz (fig. 55). Es decir, actitud recostada del personaje, uso de ropajes “antiquizantes" y, lo más destacado, jarrón inclinado del que vierte el agua del río al que personifica. En el ejemplar de Aquisgrán, se trataba de una alusión a los ríos del Paraíso, mientras que, en la miniatura, la personificación descansa sobre una figura monstruosa, quizás alusión directa a los monstruos desconocidos que habitan las profundidades del mar.

Derivado de tales argumentos, traemos a colocación otra imagen fundamental para entender el mecanismo de apropiación que estaban realizando las artes del periodo carolingio y otoniano. Nos referimos, específicamente, a la personificación de Tellus en forma de Abundantia existente en la parte inferior del Missorium de la Real Academia de la Historia, en Madrid, también conocido como disco de Teodosio (fig. 56).

En esta extraordinaria pieza de metal, nuevamente aparece la figura semidesnuda, rodeada de putti saltarines. Se le ha considerado como una representación ligada directamente con el soberano, que aparece en la parte alta del Missorium y que

\footnotetext{
${ }^{365}$ L. E. STAMM-SAURMA, “Die ,autorictas”...”, pp. 112. El autor afirma que el texto llegó a la abadía de Saint-Denis en el año 835, en una versión griega y que fue traducida al latín por el irlandés Juan Scoto Erígena.
} 
habla de la estrecha relación que dichas iconografías mantuvieron con la plástica imperial.

Sobre este aspecto, no es preciso insistir, pues la importancia que allí tuvieron las personificaciones de fenómenos naturales, aquellas relativas a territorios o conceptos mucho más abstractos y complejos, siempre frecuentes a la hora de exaltar la figura del emperador, es un tema sobradamente conocido ${ }^{366}$.

Lo que intentamos explicar a través de estos ejemplos, es que, tras la disolución de diversos contenidos ideológicos y simbólicos referidos a la interpretación de las imágenes clásicas, el arte carolingio y otoniano serían los encargados de servir de nexo unificador entre esas imágenes antiguas y las que habrían de traspasarse a la Edad Media. En el caso que nos ocupa, la personificación de Tellus o, lo que es lo mismo, la Diosa Madre, acabó transformándose durante el periodo medieval en otro símbolo bien diferente.

El camino recorrido por la imagen de Tellus hasta convertirse en Terra Mater, refleja claramente la "migración" de este tipo de representaciones. Pero es, sin duda, su evolución desde su génesis en el mundo romano a su entendimiento como la personificación de la Lujuria durante los siglos medievales, el aspecto más llamativo.

El mecanismo más habitual en este tipo de casos, pasa por el estudio de un motivo clásico que es tomado por el artista medieval y reelaborado desde el punto de vista del significado ${ }^{367}$. De tal manera que, un mismo significante -con las variantes normales que supone la evolución de una imagen a lo largo de los siglos-, puede albergar diferentes significados ${ }^{368}$.

Así, la diosa benefactora que antaño daba de mamar a sus criaturas, pasaba a ser entendida bajo el prisma ideológico medieval como símbolo de la Lujuria, personificada en la mujer atormentada a la que diversos reptiles y batracios le succionan los pechos ${ }^{369}$.

\footnotetext{
${ }^{366}$ Nos referimos, por ejemplo a las representaciones de las Provincias, conocidas también por la miniatura carolingia, pero también, a la alusión directa de la fecundidad, la abundancia y la prosperidad. Tales preceptos, fueron representados, en ocasiones, por la figura de Tierra amamantando a sus crías, en una suerte de materialización de las ansiadas épocas de bonanza comercial y agrícola.

Sobre el conocido como "disco" de Teodosio, vid.: J. ARCE, "El Missorium de Teodosio...", pp. 281288 y J. ARCE, "Missorium di Teodosio", Hispania Romana Da Terra di Conquista a Provincia dell'Impero, Roma, 1997, ficha catalográfica 285, p. 444.

${ }^{367}$ M. A. CASTIÑEIRAS GONZÁLEZ, Introducción al método..., pp. 104-105.

${ }^{368}$ Este doble significado para un mismo significante encaja con lo que Panofsky definió como "principio de disyunción", una expresión que intenta referirse a un fenómeno mediante el cual, en la Edad Media, se otorgaba una significación no clásica a una forma o modelo que sí pertenecían al ámbito clásico. Cf.: E. PANOFSKY, Renacimiento y renacimientos..., pp. 136-137.

369 J. LECLERCQ-KADANER, "De la Terre-Mère à la Luxure. A propos de la "migration des symboles", Cahiers de civilisation médiévale, 69, XVIII, 1975, pp. 37-43 y V. R. NODAR FERNÁNDEZ, "De la
} 
Este hecho que documentamos dentro de la plástica anterior al año mil, también tendrá sus consecuencias en el periodo románico, donde encontramos casos excepcionales y alejados de toda duda en cuanto a su significación. Recuérdese, por ejemplo, la imagen de la Diosa de la Naturaleza del Rollo Exultet de Bari ${ }^{370}$, donde tal iconografía conserva su primitivo significado, sin reelaborar desde el punto de vista simbólico (fig. 57). Aquí, el artista ha sabido mantener intacto el significado de la imagen, demostrando su capacidad para contextualizar y salvaguardar su sentido primigenio, aún en un ambiente puramente medieval.

Retomando el tema de las dos personificaciones del manuscrito carolingio, creemos que el ambiente en el que se gestaron, dentro del "renacimiento otoniano", fue muy influyente para las producciones artísticas posteriores. La idea de exaltar la figura de la Maiestas, o en su vertiente más críptica, a través de la presencia de la imagen del Agnus Dei o la de cualquier otro elemento cristológico, habla de un interés por aludir a la imago del mundus, según la visión que de éste tenía la mentalidad cristiana.

Conviene no olvidar en este sentido y aunque incidamos más adelante sobre ello, como las personificaciones de los cuatro ríos del paraíso vertían sus aguas a los pies de la basa antica de la columna atribuida a Bernardo de Hildesheim (fig. 58). Se trata de una clara vinculación con las representaciones documentadas en la misma piña de bronce de Aquisgrán o, en miniatura, a través de la imagen del Oceano del Sacramentario de $\mathrm{Metz}^{371}$.

La visión clásica del mundo dominado por las deidades más variadas era reinterpretada ahora a través de la exposición del triunfo de Cristo sobre los cuatro puntos cardinales. En ambos casos, se trataba de exaltar un emblema cristológico de raíces eminentemente tardoantiguas, pero materializadas a través de dichas personificaciones.

Con todo, tal tradición no se documenta únicamente dentro de las artes plásticas. El mismo texto de Isidoro de Sevilla ya menciona dichos ríos dentro de un ambiente

Tierra Madre a la Lujuria: a propósito de un capitel de la girola de la Catedral de Santiago", Sémata, 14, 2002, pp. 335-347.

${ }^{370}$ Bari, Museo della Cattedrale, Ms. Lat. 6, III, f. 83 r. En la imagen, Tierra aparece vestida con túnica, mientras que de su cabeza surgen varias ramificaciones vegetales. A su vez, la personificación sujeta con las dos manos sendos tallos vegetales, en alusión directa a su carácter benefactor con respecto a la misma tierra de la que nace.

${ }^{371}$ W. OAKESHOTT, Classical Inspiration..., p. 67. El caso de las producciones de tono tan clásico salidas de los talleres ligados a Bernardo y la iglesia de San Miguel de Hildesheim, serán analizados detenidamente más adelante, donde se recogerá la bibliografía utilizada para esta cuestión. 
totalmente cristiano, hecho que nos debe servir de base para defender una difusión compleja de tal imagen, incluso dentro de los ámbitos cultos de la Europa central.

A este respecto escribió el santo hispalense:

"El paraíso es un lugar situado en tierras orientales, cuya denominación, traducida del griego al latín quiere decir "delicias". La combinación de ambos nombres nos da "El Jardín de las Delicias". Allí, en efecto abunda todo tipo de arboledas y de frutales, incluso el "árbol de la vida". No existe allí ni frío ni calor, sino una templanza constante. De su centro brota una fontana que riega todo el bosque, y se divide en cuatro ramales que dan lugar a cuatro ríos distintos",372.

Lo más interesante para nuestro objetivo, reside en poder llegar a valorar el grado de impacto que tales tradiciones ejercieron sobre las artes hispanas. El problema de la filiación de algunos motivos de tradición carolingia con las obras románicas de la Península Ibérica es una cuestión compleja y demasiado extensa como para poder desarrollarla aquí. Sin embargo, algunos autores han señalado reiteradamente la correspondencia que es posible establecer entre diversos ciclos hispanos y toda esta serie de repertorios de personificaciones que hemos venido señalando dentro de las artes centroeuropeas.

Aludimos, por ejemplo, al caso de la catedral de Santiago de Compostela y su desaparecida fachada norte, la denominada como Porta Francigena ${ }^{373}$. Allí, según estudió el profesor M. A. Castiñeiras, fue esculpido, en los inicios del siglo XII, un menologio donde las doce personificaciones clásicas del arte romano configurarían el primer ciclo de este tipo documentado dentro de una fachada monumental esculpida en Hispania. Según el investigador, tal conjunto debe ser valorado, además, por la

\footnotetext{
${ }^{372}$ ISIDORO DE SEVILLA, Etimologías (Edición bilingüe preparada por J. Oroz Reta y M. A. Marcos Casquero), 2 vols., Madrid, 1983, vol. II, en especial, p. 167. También se aborda este texto en: S. SEBASTIÁN LÓPEZ, "La visión del cosmos medieval", Revista del Departamento de Historia del Arte, 6, 1986, pp. 73-81, en particular, pp. 73-74.

${ }^{373} \mathrm{La}$ fachada norte románica de la catedral fue desmontada en torno al año 1757, para llevar a cabo la construcción de la estructura barroca que hoy contemplamos. Cf.: S. MORALEJO ÁLVAREZ, "El patronazgo artístico del arzobispo Gelmírez (1100-1140): su reflejo en la obra e imagen de Santiago", Atti del Convengo Internazionale di Studi Pistoia e il Cammino di Santiago, Una dimensione europea nella Toscaza medioevale, Nápoles, 1984, pp. 245-272, consultado en la reedición: Patrimonio Artístico..., vol. I, pp. 289-299; ID., "La imagen arquitectónica...", pp. 237-246; M. A. CASTIÑEIRAS GONZÁLEZ, "La catedral románica: tipología arquitectónica y narración visual", Santiago, la Catedral y la memoria del arte, Santiago de Compostela, 2000, pp. 39-96, especialmente, p. 59 y S. FERNÁNDEZ PÉREZ y V. NODAR, "Un proyecto de reconstrucción hipotética de las portadas del transepto de la Catedral de Santiago en época de Diego Gelmírez", Compostellanum, XLVIII, 1-4, pp. 605-613.
} 
importancia que supone que una serie de temas como estos, decorasen el acceso a una basílica de tipo martirial ${ }^{374}$.

La única pieza conservada de tal conjunto, la laja en la que se representó el mes de febrero (fig. 59), ha sido vinculada por algunos autores a esta corriente "antiquizante" nacida en el seno de las artes plásticas carolingias y en la que, insistimos, la inclusión de estas personificaciones servía para expresar la idea de espacio y tiempo dentro del orbe cristiano, a través de soluciones de morfología pagana ${ }^{375}$.

Continuando dentro del ámbito hispano, encontramos que la influencia de la tradición carolingia en el uso de estas personificaciones no fue algo excepcional. En este sentido, el llamado Tapiz de la Creación de la catedral de Gerona, muestra dentro de su repertorio iconográfico, ciertos ecos de algunas de las ideas que hallábamos dentro de la corte otoniana. Nuevamente se incluyó en el bordado la representación de los ríos del Paradisus recostados en actitud muy clásica y portando los consabidos jarros mediante los que vierten el agua (fig. 60) ${ }^{376}$.

Tal y como señalara en su día W. C. Webster, se trata de un ciclo directamente dependiente del texto de Isidoro de Sevilla, en donde las personificaciones de los meses y los ríos complementan diversas escenas ligadas a la Historia de la Humanidad, cobrando especial importancia, aquellas relativas al pasaje del Génesis ${ }^{377}$.

La Maiestas Domini del bordado, al igual que en la miniatura carolingia, aparece ocupando la parte central del bordado, rodeada por todas las demás escenas, en una

\footnotetext{
${ }^{374}$ La confirmación de la existencia de tal menologio con la representación de los doce meses a través de sus doce correspondientes personificaciones, nos la ofrece el propio texto del Códice Calixtino: “(...) Sin embargo, sobre la puerta que está a la izquierda, según se entra a la catedral, está esculpida en el tímpano la Anunciación de la santísima Virgen María. Háblale también allí el ángel Gabriel. En cambio, a la izquierda de la entrada lateral sobre las puertas se ven en relieve los meses del año y otras muchas hermosas alegorías". Cf.: Liber Sancti Jacobi..., pp. 595-596.

${ }^{375}$ Sobre esta laja con la personificación de febrero y su relación con la tradición carolingia, véase: J. CAUCCI, "Maestro de las Platerías (Maestro Esteban?), L'inverno (Mese di Febbraio)", Romeo \& Giubilei..., ficha catalográfica 178, p. 387; M. A. CASTIÑEIRAS GONZÁLEZ, El calendario medieval..., en especial, pp. 24-78; ID., "Un adro para un bispo...", pp. 231-264 e ID., "Las fuentes antiguas...", pp. 77-100.

${ }^{376}$ P. DE PALOL, El Tapís de la Creació...., en concreto, p. 102 y M. A. CASTIÑEIRAS, El calendario medieval..., p. 119. Los autores señalan algunos ejemplos de cronología carolingia, tanto en miniatura como en marfil, en relación con el bordado. Sobre todo, inciden en la filiación del estilo de la pieza en comparación con algunas miniaturas del siglo IX. Concretamente, el profesor Castiñeiras, defiende un origen carolingio para el motivo del Annus circunscrito por un círculo completo y rodeado, además, tanto por los meses del año, como por los símbolos del zodiaco.

377 J. C. WEBSTER, The labours of the months in antique and medieval art, Princeton, 1938, particularmente, pp. 79-81; A. A. NASCIMENTO, "The image of time: European Manuscript Books", The image of Time. European Manuscript Books, Lisboa, 2000, pp. 11-25, especialmente, p. 15 y M. A. CASTIÑEIRAS GONZÁLEZ, "La iconografía de los planetas en la Cataluña de los siglos XI-XII", Annals de l'Institut d'Estudis Gironins, XXXV, 1995, pp. 97-122.
} 
especie de dominio terrenal y celestial, representado igualmente por las personificaciones del Sol y de la Luna.

Webster ya confirmó hace tiempo una dependencia muy marcada con respecto a los modelos clásicos ${ }^{378}$. Los mismos que, por citar un caso bien conocido, se estaban utilizando en los scriptoria otonianos durante el gobierno de Carlos el Calvo, tal y como demuestra el folio 192 de un Sacramentario proveniente de Fulda ${ }^{379}$.

En dicha obra, además de las personificaciones de Aion, de los meses y las estaciones, aparece, además, el busto de Día, personificado junto a la Noche dentro de medallones ${ }^{380}$.

Los breves ejemplos vistos hasta el momento, nos permiten afirmar que, las artes del periodo comprendido entre la muerte de Carlomagno y el año mil, devendrían en otra oportuna renovación de fórmulas iconográficas, nuevamente vinculadas a lo antiguo. Además, tales hechos permiten observar la enorme trascendencia que para lo hispano tendrían algunas de estas representaciones. La imagen de los cuatro ríos personificados a través de jóvenes con clámides atadas mediante fíbulas, pasarían con total fidelidad a las artes hispanas de finales del siglo XI.

Así, de la misma forma que Océano y Tellus representaban el cosmos sobre el cual reinaba la Maiestas o, de forma que los cuatro ríos de la basa de la columna de Hildesheim y la que sujetaba la piña de bronce en Aquisgrán, aludían al triunfo sobre los cuatro puntos cardinales, aún a finales del siglo XI se percibe una continuidad de tal iconografía $^{381}$.

Nos referimos, por citar un caso conocido, a la arqueta de los marfiles de San Isidoro de León (fig. 61) donde, nuevamente, la iconografía de los jóvenes efebos con clámides y vertiendo agua a través de las ánforas, reaparece junto a diversas imágenes

\footnotetext{
${ }^{378}$ J. C. WEBSTER, The labours of the months..., pp. 82-83. Aunque desde el punto de vista estilístico conectaba la pieza de Gerona con la manera de hacer del Sur de Francia, especialmente con la escultura del Languedoc, el autor dio mayor peso a la miniatura antigua que, según él acabaría por inspirar a los artífices de la pieza textil

Por otra parte, la fórmula compositiva que ubica a las personificaciones de los meses alrededor de la figura central de Annus o, en su vertiente menos clásica, la Maiestas, fue bien conocida durante la época románica. Según el profesor A. Nacimiento, la distribución iconográfica presente en el bordado catalán podría equiparse a determinadas páginas miniadas, algunas de ellas pertenecientes al Sacramentario de Fulda, Göttingen, Niedersächsische Staats-und Universitätsbibliothek, Ms. Cod. Theol. 231, f. 250 v. Cf.: A. A. NASCIMENTO: "The iconography of the year: imagery and astrological dominance", The image of Time..., pp. 116-123, en concreto, p. 123.

${ }_{379}$ Berlin, Staatsbibliothek, Preussischer Kulturbesitz, Ms. theol. lat. 192, fol. 192v. Cf.: L. DE LACHENAL, Op. cit., p. 149 y J. C. WEBSTER, Op. cit., pp. 49-50. La obra fue incorporada, posteriormente, a un manuscrito del siglo XIII.

${ }^{380}$ L. DE LACHENAL, Op. cit., p. 150.

${ }^{381}$ La misma iconografía se repetiría en la gran techumbre de la iglesia de San Miguel de Hildesheim donde, nuevamente, aparecen los ríos con clámides vertiendo agua mediante las ánforas.
} 
sagradas (fig. 62) ${ }^{382}$. Entre ellas, destaca el Agnus Dei, flanqueado por los cuatro ríos, triunfante sobre el Paraíso, que aquí estaría personificado a través de estas cuatro figuras clásicas.

No creemos necesario insistir en las opiniones de los especialistas sobre muchos de los aspectos que muestra el tesoro de San Isidoro y su marcada relación con los ambientes artísticos centroeuropeos ${ }^{383}$.

Sin embargo, en el caso concreto de la arqueta antes citada, existen paralelismos de tipo iconográfico que permiten poder conectar el programa desarrollado sobre la pieza con otras producciones suntuarias de cronología anterior. Así, por ejemplo, las artes del metal germanas, tantas veces aludidas como posibles fuentes de los creadores de las obras que configuran el tesoro de la Real Colegiata leonesa, permiten establecer ciertas comparaciones.

En este sentido, destacamos la relación del programa que presenta la caja de marfil con, por ejemplo, la tapa del Evangeliario estudiada por D. Kötzsche (fig. 63). En ella, los cuatro ríos del paraíso flanquean la imagen triunfal del Agnus Dei ubicado en la parte central de la composición ${ }^{384}$.

Mediante este ejemplo, podemos explicar la pervivencia de muchos de estos elementos transmitidos a través de esta "segunda renovatio otoniana" que, pesar de la complejidad de presentarse como un periodo obscurum, siguiendo el adjetivo utilizado por L. de Lachenal, puede ofrecer ciertas luces al respecto ${ }^{385}$.

La segunda mitad de siglo a la que nos venimos refiriendo, puede ser descrita como un debate continuo entre las tradiciones "antiquizantes" derivadas de la asimilación de los modelos que regían las artes plásticas de la corte carolingia y las nuevas formas que ya por entonces comenzaban a intuirse. Las mismas que llevarían a

\footnotetext{
${ }^{382}$ La iconografía del muchacho desnudo o semidesnudo, en ocasiones, en forma de personaje maduro sosteniendo un ánfora y vertiendo agua, fue utilizada de manera habitual dentro del arte clásico. Véase, por ejemplo, el uso que se hace de dicho arquetipo para representar la imagen de Aquarius (f. 48 v.) o la de Eridanus (f. 68 v.) en el llamado Códice Aratus, Leiden, Bibliotheek der Rijksuniversiteit, Ms. Voss. Lat. Q. 79

Sobre esta obra, vid.: F. MÜTHERICH, "Die Bilder des Leidener Aratus", Studies in Carolingian Manuscript Illumination, London, 2004, pp. 147-265, en concreto, p. 218 y p. 228 y W. C. M. WÜSTEFELD, W. NOEL y K. VAN DER HORST, "Madrid Astronomical-Computistical Manual", The Utrecht Psalter in Medieval Art. Picturing the Psalms of David (K. van der Horst, W. Noel y W. C. M. Wüstefeld ed.), London, 1996, pp. 198-199.

${ }^{383}$ E. FERNÁNDEZ GONZÁLEZ, "Hacia la renovación escultórica de la segunda mitad del siglo XI: Los ejemplos del sarcófago de San Martín de Dumio y de la pila bautismal de San Isidoro de León", De arte, 6, 2007, pp. 5-36.

${ }^{384}$ D. KÖTZSCHE, "Platte Von Einen Buchdeckel", Rhein und Maas. Kunst und Kultur 800-1400, Köln, 1972 , ficha catalográfica 20, p. 258

${ }^{385}$ F. MASSIP BONET, Prerrománico y románico, Barcelona, 1997, vol. IV, en especial, p. 581.
} 
las artes plásticas en el cambio de siglo hacia el románico y las que explican la atención que hemos prestado a estos fenómenos como "preparatorios" de lo que, más tarde, podrá observarse, con muchos matices, en los siglos XI y XII ${ }^{386}$.

El papel jugado por el impulsor de este movimiento, el emperador Otón III, debe ser valorado en cuanto ofrece datos sobre la manera de asumir el pasado durante estos años. De ascendencia bizantina, debido a que su madre había sido princesa de Bizancio, algunos autores han señalado que las producciones del periodo presentan una vinculación más cercana al clasicismo de tipo romano oriental que propiamente al romano de Occidente ${ }^{387}$.

Desde su coronación en Aquisgrán en el año 983, con apenas trece años y tras recibir la noticia de la muerte del rey Otón II, la reina Teophanum como regente, su abuela Adelaida, Willigis de Maguncia y Bernardo de Hildesheim, entre otros, se encargaron de su educación ${ }^{388}$.

Ante tales circunstancias, quedaban marcadas las pautas para una nueva renovatio Imperii Romanorum, que tomaba como referencia directa el antiguo imperio de Carlomagno. El nuevo soberano, con el tiempo, llevaría a cabo un replanteo político e ideológico en torno al carácter del poder real dentro de su dinastía. Veremos, en este sentido, como haciendo uso de las artes, el nuevo soberano proyectará una imagen de investidura de poder por partida doble, desde el punto de vista real, pero también, desde el sacerdotal. Ello explica, según palabras del profesor E. Palazzo, "el deseo del emperador otoniano de renovar con la tradición imperial carolingia y de situarse como heredero legítimo del imperio romano" 389.

En consonancia con estos planteamientos ideológicos, el periodo se encuentra plagado de expoliaciones cuyo origen parece hallarse en algunos edificios clásicos romanos y ravenantes, que pasaron a ocupar nuevos lugares de especial relevancia. Así, siguiendo el ejemplo de la Capilla Palatina de Aquisgrán, durante esta "segunda renovación", el palacio de la dinastía otónida en Quedlinburg o la iglesia dinástica en Magdeburg, volvieron admitir entre sus muros todo tipo de materiales de acarreo ${ }^{390}$.

\footnotetext{
${ }^{386}$ L. DE LACHENAL, Op. cit., p. 148.

${ }^{387}$ W. OAKESHOTT, Classical Inspiration..., pp. 65-67.

${ }^{388}$ L. CASTELFRANCHI VEGAS, “L'arte ottoniana e l'anno Mille”, L'arte dell'anno mille..., pp. 1334, en especial, p. 19.

${ }^{389}$ E. PALAZZO, Les sacramentaires de Fulda. Étude sur l'iconographie et la liturgie à l'époque ottonienne, Münster, 1994, específicamente, pp. 163-164.

${ }^{390}$ R. CASSANELLI, "I resti di un grande patrimonio...", en particular, p. 36.
} 
El círculo en el que se había formado y crecido el monarca explica el carácter que tendrán las artes creadas bajo su auspicio. A parte de los citados hasta el momento, cobrarían en su reinado gran importancia figuras como la de Gerberto de Aurillac ${ }^{391}$. Pero fue, sin duda, el obispo Bernardo de San Miguel de Hildesheim (993-1022), el personaje más destacado desde el punto de vista no solamente político e intelectual, sino también artístico ${ }^{392}$.

Nos interesa detenernos en su figura, pues las artes patrocinadas por él se nos presentan plagadas de citas a la tradición clásica, tan sólo explicables desde el punto de vista de su exquisita formación, adquirida en, gran parte, a través de su terrena vagatio, tal y como algunos especialistas suelen definir su periplo a través de los lugares más emblemáticos de la Europa de su tiempo.

Los viajes que llevó a cabo en vida formarían buena parte de sus impresiones respecto a las artes plásticas y su función dentro del espacio sagrado, le retribuirían una importante comprensión del mundo antiguo y le otorgarían la facultad de saber utilizar tales citas al clasicismo como un sistema efectivo y al que recurrir a la hora de dotar de un fuerte contenido simbólico todas sus creaciones.

En el año 980, aún reinando Otón II, un cortejo formado por el propio monarca y la reina Teofano se desplaza a la ciudad de Roma. El obispo se encontraba entre ellos ${ }^{393}$. En noviembre del año 1000, veinte años después, regresaría a la caput mundi, ya acompañado por su joven alumno, el emperador Otón III $^{394}$. Finalmente, en el 1010 fundaría su gran empresa: la iglesia de San Miguel de Hildesheim.

Se trata un edificio de aspecto monumental con dos volúmenes contrapuestos al este y al oeste, explotando con eficacia la fórmula de los ábsides contrapuestos (fig. 64) ${ }^{395}$. Al oeste, se construyó una cripta, mientras que a los pies, en el espacio restante,

\footnotetext{
${ }^{391}$ J-P. CAILLET, "Le pape et l'empereur en l'an mil", L'Europe de l'an mil (P. Riché dir.), La Pierrequi-Vire, 2001, pp. 61-71, en particular, p. 63.

L. CASTELFRANCHI VEGAS, "L'arte ottoniana...”, p. 19; L. DE LACHENAL, Op. cit., p. 146.

${ }^{392}$ L. CASTRELFRANCHI VEGAS, "Hildesheim e Bernoardo", L'arte dell'anno mille ..., pp. 125-130.

${ }^{393}$ Ibidem, p. 125.

${ }^{394}$ Sobre esta cuestión y la situación de Roma en el año 1000, véase: J-P. CAILLET, "Le pape et l'empereur....", pp. 64-66.

${ }^{395}$ G. BINDING, "Bischof Bernward von Hildesheim -architectus et artifex?", Bernwardinische Kunst..., pp. 27-47. Se trataba de una solución difundida en la etapa romana tardía. La monumentalización de espacios a occidente, en ocasiones con fines funerarios, fue un recurso conocido, sobre todo, en África del Norte y España. Difundidas, sobre todo, a partir de la caída del Imperio, son de destacar, las estructuras contrabsidiadas de Orléansville, sin duda, las más conocidas. En el caso hispano, también se utilizó tal estructura, influenciando así mismo la costumbre de enterramiento al occidente de los edificios, donde, en origen, se habían ubicado dichos ábsides. Cf.: P. DE PALOL, Arte paleocristiano en España, Barcelona, 1968, en especial p. 306; I. G. BANGO TORVISO, "El espacio para enterramientos privilegiados en la arquitectura medieval española", Anuario del Departamento de Historia y Teoría del Arte, vol. IV, 1992,
} 
sería enterrado el propio obispo, rememorando algunos de los espacios funerarios más importantes de la Antigüedad tardía y demostrando un buen conocimiento de la edilicia de época paleocristiana.

En este sentido debemos recordar como, por ejemplo, la iglesia de San Bonifacio de Fulda (fig. 65), datada entre los siglos VIII y IX, presentaba nuevamente un transepto de gran tamaño, quizás evocador del de San Pedro del Vaticano (fig. 66). Por su parte, el nuevo templo fundado en Hildesheim, manifestaba en planta dos ábsides contrapuestos, que tal y como apunta M. D’Onofrio, deben ser vinculados más a la tradición hispana y norteafricana que a la puramente romana ${ }^{396}$. Se trata de un dato que aún la historiografía debe sopesar y valorar en su justa medida, insistiendo en la posibilidad de los intercambios entre las provincias más occidentales y las partes centrales del Imperio, incluso, mucho más allá de su desmembramiento.

Volviendo a San Miguel de Hildesheim, su altar sería transformado, siguiendo la tipología de los lugares de enterramiento para los mártires tardoantiguos, en un sepulcro-altar, que se dedicó a San Miguel ${ }^{397}$. Así mismo, alrededor de tal espacio se creó un recinto a modo de deambulatorio que permitía girar en torno al lugar santo donde descansaría el obispo. Todo ello, recopilando, una vez más toda, la tradición constructiva del llamado more romano, tal y como ha señalado C. Heitz ${ }^{398}$.

Decoró su iglesia mediante unas grandes puertas fundidas en bronce ${ }^{399}$, herederas, no sólo de la tradición de la escultura en este material que tan buenos resultados había dado a sus predecesores antiguos y carolingios, sino que, además, evocó nuevamente la técnica escultórica por antonomasia de la Roma Imperial (fig. 67). Ante sus ojos tenía presentes los modelos de las puertas lígneas de Santa Sabina de Roma o las de San Ambrosio de Milán ${ }^{400}$ y otra serie de repertorios dentro de la

pp. 93-132, especialmente p. 102; A. MARTÍNEZ TEJERA, "El contraábside en la Arquitectua de Repoblación”, Repoblación y Reconquista, Aguilar de Campoo, 1991, pp. 149-161. En lo referente a esta tipología del ábside contrapuesto, A. Arbeiter insiste en que no es exclusiva de la arquitectura eclesiástica y da ejemplos romanos de villas donde ya aparece. Cf.: A. ARBEITER, "Los edificios de culto cristiano...", especialmente, pp. 189-193.

${ }^{396}$ M. D’ONOFRIO, Roma e Aquisgrana..., p. 90.

397 J-P. CAILLET, “Architecture et décor monumental”, L'Europe..., pp. 77-255, en particular, p. 212. El autor relaciona esta solución con la existente en San Pedro del Vaticano.

${ }^{398}$ C. HEITZ, "More romano...", p. 33.

${ }^{399}$ Véase la obra colectiva titulada: Le Porte di bronzo dall'antichità al secolo XIII (S. Salvatorino dir.), 2 vols., Roma, 1990. Además, vid.: D. GABORIT-CHOPIN, "Les arts précieux en l'an mil”, L'Europe..., pp. 321-364, en concreto, pp. 347-348. Según este último autor, las puertas estarían acabadas en 1015, listas para ser colocadas sobre el acceso a la basílica desde el gran macizo occidental.

${ }^{400}$ L. CASTELFRANCHI VEGAS, "Hildesheim e Bernoardo...", en particular, p. 126 y D. GABORITCHOPIN, "Les arts précieux...”, en concreto, p. 345. El profesor Gaborit-Chopin alude a las puertas de 
metalurgia romana; como por ejemplo, la tantas veces mencionada escultura de Marco Aurelio, la loba capitolina o las puertas romanas de Mainz ${ }^{401}$.

A todo ello, debemos sumar la utilización de otra serie de recursos iconográficos presumiblemente ligados a la miniatura y los libros manuscritos, y que tantas veces han sido señalados como preservadores de la tradición clásica ${ }^{402}$. En este sentido, V. S. Kaspersen ha apuntado ciertas concomitancias entre la distribución de las imágenes en los paneles de bronce de Hildesheim y la manera en que se han colocado las figuras en determinadas ilustraciones del Cotton-Génesis de Viena ${ }^{403}$. Una teoría que, por otra parte, ya había señalado W. Oakeshott al defender las similitudes que presentaban las puertas con la narración compartimentada de la Biblia Vivien ${ }^{404}$.

\section{AN(NO) DOM(INICE) INC(ARNATIONIS) MXV B(ERNWARDUS) EP(ISCOPUS) DIVE MEM(ORIE) \\ HAS VALVAS FUSILES \\ IN FACIE(M) ANGELICI TE(M)PLI OB MONIM(EN)T(UM) SUI FEC(IT) SUSPENDI ${ }^{405}$.}

Ésta fue la inscripción que Bernardo mandó colocar sobre las puertas de bronce que daban acceso a la gran nave de la iglesia de San Miguel y, mediante la cual, utilizaba nuevamente el mecanismo de la donatio de tradición imperial romana, para potenciar su figura y su propia imagen para la posteridad ${ }^{406}$.

Con todo, a parte de todas las fuentes señaladas para el enriquecimiento y la formación de los talleres de broncistas activos bajo sus órdenes, se deben sumar otra serie de aportaciones ligadas al ámbito carolingio. En este sentido deben ser vistos los

bronce de la catedral de Mayenza, de época de Willigis (975-1011) y al candelabro de Essen de la abadesa Matilde, como precedentes de estas obras de bronce monumentales.

${ }^{401}$ M. GREENHALGH, The survival of Roman..., p. 242.

402 O. PÄCHT, La miniatura medieval. Una introducción, Madrid, 1987, en particular p. 16.

${ }^{403}$ Wien, Österreichische, Nationalbibliothek, Codex Vindobonensis theol. Graec. 31.

V. SØREN KASPERSEN, "Cotton-Genesis, die Toursbibeln und die Bronzetüren -Vorlage und Aktualität”, Bernwardinische Kunst..., pp. 79-103, particularmente, pp. 82-85 у M-O. GERMAIN, “Genèse, dite Genèse de Cotton”, Byzance. L'art byzantin dans les collections publiques françaises, Paris, 1992, ficha catalográfica 96, p. 142. Se han datado las miniaturas del códice en torno al siglo V, concretamente en los años finales. Además, los especialistas han relacionado la miniatura de la Creación de las plantas, con un herbario de la Antigüedad tardía. En ella, Cristo imberbe aparece junto a la personificación de las Horas, personajes otra vez de clara tradición clásica.

${ }^{404}$ Paris, Bibliothèque nationale de France, Ms. lat. 1. Cf.: W. OAKESHOTT, Op. cit., particularmente, p. 68.

${ }^{405}$ Se analiza la inscripción en: V. D. VON DER NAHMER, "Die Inschrift auf der Bernwardstür in Hildesheim im Rahmen Bernwardinischer Texte”, Bernwardinische Kunst..., pp. 51-70, en especial, pp. 51-53.

406 L. CASTELFRANCHI VEGAS, "Hildesheim e Bernoardo...", p. 126. La autora ve en dicha inscripción, un presagio, bien anticipado, de la muerte del propio obispo. 
dos mascarones leoninos de clara tradición romana que presentan las puertas y que, evocan los tipos que antaño había mandado fundir Carlomagno sobre las existentes en la Capilla Palatina (figs. 68 y 69) ${ }^{407}$.

No era la primera vez que el obispo Bernardo mostraba su admiración por el arte tardoantiguo, tanto el realizado por paganos, como el creado para las primeras comunidades cristianas. Obras como la cátedra de Maximiano le valdrían para "apoderarse" del anagrama paleocristiano que mostraba la silla ebúrnea y aplicarlo sobre sus propias obras (figs. 70 y 71) ${ }^{408}$. Sin embargo, pronto mostró preocupación, como buen "anticuario", por obras de mayor amplitud ideológica ${ }^{409}$.

El 29 de septiembre de 1022, un mes antes de su muerte -que le llegó el día 20 de noviembre-, el obispo donaba a la iglesia de San Miguel su última obra: una columna de bronce $e^{410}$ (fig. 72). Se trataba de una pieza maciza fundida en este metal y con forma de columna, pero era en realidad, un gigantesco candelabro para colocar el cirio pascual. Alrededor de su fuste y mediante una distribución en espiral, se relataban los sucesos alusivos a la vida de Cristo.

No es preciso volver sobre su clara evocación de modelos romanos, esta vez de tono totalmente pagano, pues todos los autores coinciden en afirmar que Bernardo

\footnotetext{
${ }^{407}$ Dichos prótomos cefálicos recuerdan, claramente, a los trabajos en bronce pertenecientes a la nave de Nemo, hoy conservados en el Museo Nacional de Arte Romano de Roma. Las piezas en bronce del barco, hundidas durante siglos en un lago, tienen entre su haber varias agarraderas y otros utensilios navales con cabezas de león que recuerdan los modelos usados durante el siglo IX. Sin embargo, debemos pensar también en la posibilidad de que fueran tomados de cualquier tipo de obra, ya fuese en bronce o mármol, pues fue un motivo muy recurrente dentro del arte romano. La tradición iconográfica se perpetuaría a través de los marfiles del siglo IV, donde observamos, como en la mayoría del mobiliario imperial, reaparecen dicha cabezas de león en forma de agarraderas, tal y como se fundirán en las puertas del siglo IX. Cf.: G. LUGLI, voz "Lago di Nemo", Enciclopedia dell'arte antica classica e orientale, vol. VI, Roma, 1963, pp. 406-409; D. GABORIT-CHOPIN, "Feuillet inférieur d'un diptyque du cónsul Areobindus", Byzance. L'art byzantin dans les collections publiques françaises, Paris, 1992, ficha catalográfica 12, pp. 49-50; ID., "Feuillet supérieur d'un diptyque du consul Areobindus", Byzance..., ficha catalográfica 13, pp. 50-51; ID., "Diptyque du cónsul Anastasius", Byzance..., ficha catalográfica 15, pp. 54-56 e ID., "Feuillet inférieur d'un diptyque du cónsul Magnus", Byzance..., ficha catalográfica 16, pp. 56-58. En cada una de las piezas se repite el mismo prototipo de cabeza de felino con anilla, supuestamente de metal, que agarra con las fauces.

${ }^{408}$ W. OAKESHOTT, Classical Inspiration..., en concreto, pp. 67 y 76; D. GABORIT-CHOPIN, "Les ivoires du V $\mathrm{V}^{\mathrm{e}}$ au VIII ${ }^{\mathrm{e}}$ siècle", Byzance..., Paris, 1992, pp. 42-45, en concreto, p. 43; L. DE LACHENAL, Op. cit., p. 148 y D. GABORIT-CHOPIN, "Les arts précieux...", en especial, p. 327. Tan sólo citamos, brevemente, el reempleo de placas de marfil que se llevó a cabo sobre el ambón de la Capilla Palatina de Aquisgrán, donde en pleno espacio sagrado, fueron colocadas las imágenes de Baco, Venus, un sátiro y Marte, lo que en opinión de Oakeshott, verifica que la irrelevancia del tema era tal, que sólo importaba la riqueza que mostrasen las piezas, más valoradas cuanto más antiguas.

Según la profesora Lachenal, se trataría de unas placas del siglo VI, mientras que las del púlpito de la Capilla Palatina, se podrían emparentar, según Gaborit, con determinadas obras de Alejandría.

${ }^{409}$ M. GREENHALGH, The survival of Roman..., p. 162. Utilizamos dicho término siguiendo a este autor.

${ }^{410}$ L. CASTELFRANCHI VEGAS, "Hildesheim e Bernoardo", p. 128 y M. GREENHALGH, The survival of Roman..., en particular, p. 118.
} 
estaba influenciado por las grandes columnas honorarias de la ciudad de Roma ${ }^{411}$. Desde la propia base de la columna (fig. 73), directamente emparentada con los perfiles diseñados por Vitruvio para los Libros de Arquitectura (fig. 74), hasta detalles más pequeños como, nuevamente, las personificaciones de los cuatro ríos del Paraíso colocados sobre esa misma base; todo evocaba el prototipo de monumento conmemorativo imperial ${ }^{412}$.

Todas estas alusiones directas al mundo romano, cobraban en este ámbito otro sentido. Ahora, el valor de exaltación aplicado antaño sobre las figuras de los emperadores romanos mediante este tipo columnas honoríficas, era sustituido por una nueva figura: la del Salvador. Los actos heroicos de los guerreros romanos y las victorias del Imperio sobre los enemigos, eran suplantados por la narración de los acontecimientos de la vida de Cristo. Si la columna Trajana, modelo seguro de inspiración según W. Oakeshott, mostraba, entre sus figuraciones, una personificación del Danubio (fig. 75), el ideario otoniano transformaba tal imagen en el río cristiano por excelencia, es decir, el Jordán ${ }^{413}$ (fig. 76). Allí donde antes descansaba la figura el emperador, en lo más alto, junto a las victorias, ahora se encontraban las cortes $\operatorname{angélicas~}^{414}$.

Con todos estos datos, son muchos los especialistas que se han aventurado a señalar que la columna pudo conmemorar la visita a Roma llevada a cabo por el obispo en el año 1001. Mediante ella, supuestamente, el prelado pudo celebrar la obtención de los derechos del convento de Gandersheim, por los cuales disputaba con su gran enemigo el arzobispo Willigis de Maguncia.

Al menos estas son las hipótesis defendidas por E. Panofsky, quién, en relación con este tema, apuntaba hace tiempo:

\footnotetext{
${ }^{411}$ W. OAKESHOTT, Classical Inspiration..., pp. 68-69.

412 N. P. PAGLIARA, "Vitruvio da testo a canone", Memoria dell'antico..., Dalla tradizione all'archeologia, vol. III, Torino, 1986, pp. 7-85, en especial, pp. 8-12. El autor corrobora la posesión de un ejemplar del libro de Vitrubio en las manos del obispo Bernardo. Además, a su muerte, dejó a la iglesia de San Miguel, entre otras muchas donaciones, un ejemplar de este texto. El conocimiento en Hildesheim de los Libros de Arquitectura no debe ser visto como algo extraordinario. Ya durante el siglo IX encontramos piezas artísticas donde claramente se puede alegar una influencia de tal obra. El profesor Pagliara menciona también el caso de Alcuino de York, que en una misiva escrita entre los años 801-804, plantea algunas cuestiones expuestas en los Libros II y IV del texto de Vitrubio.

413 W. OAKESHOTT, Classical Inspiration..., p. 69. La alusión al río Jordán a través de una personificación y colocado dentro de las escenas de la vida de Cristo, aparece también en los marfiles del siglo VI, tal y como demuestra por ejemplo, la placa del Museo de Bellas Artes de Lyon. En esta pieza, la figura de Jordán es pisoteada, como es habitual, por Juan Bautista. Además, en la parte alta aparecen, en un tamaño bastante destacado, las personificaciones del Sol y la Luna. Toda la pieza se podría emparentar, según Gaborit, con la escena del bautismo de Cristo en el trono de Ravenna. Cf.: D. GABORIT-CHOPIN, "Plaque: baptême du Christ", Byzance..., ficha catalográfica 25, p. 72.

${ }^{414}$ L. CASTELFRANCHI VEGAS, "Hildesheim e Bernoardo...", p. 128.
} 
“(...) quizá no sea demasiado atrevido suponer que este monumento único, trazado a imitación de las columnas triunfales de Roma, conmemore, además de la devoción de San Bernwardo, el éxito más resonante de su carrera administrativa" ${ }^{415}$.

Según se ha dicho, esta interpretación cristiana de uno de los iconos más importantes del mundo romano, como el que supone la columna historiada helicoidal, se convirtió pronto en el centro de diversas procesiones y actos litúrgicos, modificando, desde el punto de vista ideológico, el espacio que la circundaba dentro de la propia basílica de San Miguel. De tales hechos dejan constancia las numerosas noticias conservadas al respecto y sobre las que no es posible detenernos exhaustivamente ${ }^{416}$.

La obra artística de este personaje habla por sí sola. Su conocimiento del arte clásico parece claro y es por ello que, omitimos aquí la larga lista de evidencias que prueban una intencionalidad política, ideológica y estética del uso de fórmulas clásicas dentro de la corte otoniana durante la época de Bernardo.

Aludimos, en última instancia, a la reflexión realizada por W. Oakeshott, en la que imagina al obispo Bernardo en la ciudad de Roma admirando con ojos entusiastas el legado de un pasado que en esos momentos parecía en decadencia. Las ruinas de Roma, solo adquiribles mediante pequeñas expoliaciones, también podían llegar a la corte centroeuropea mediante los cientos de objetos que, desde la ciudad eterna, se llevaban para ser engastados en cruces, antipendia, relicarios y cubiertas de libros litúrgicos ${ }^{417}$.

No nos deja de venir a la memoria en este sentido, el texto redactado por otro gran "coleccionista" de estos pequeños fragmentos de la Roma Imperial. El mismo abad Suger de Saint-Denis escribiría:

"Para adorar la cruz (...) habríamos dedicado, de haber sido posible, toda la devoción de nuestro pensamiento a embellecerla (...). Pero porque no pudimos hacer lo que quisimos (...). De ahí que buscamos nosotros mismos por nuestro entorno a

\footnotetext{
415 E. PANOFSKY, Renacimiento y renacimientos..., p. 99 y D. GABORIT-CHOPIN, "Les arts précieux...", p. 348. Los autores apoyan la dependencia con respecto al modelo trajano.

${ }^{416}$ E. PALAZZO, Les sacramentaires de Fulda..., pp. 161-162. Palazzo afirma que, gracias a la rica documentación de la iglesia de San Miguel de Hildesheim, podemos afirmar que, la columna era el centro de la organización litúrgica del lugar y del espacio eclesiástico, así como de las procesiones que se realizaban en torno a ella. En relación con la narración helicoidal o en espiral, M. Schapiro alude a su importancia dentro de la Alta Edad Media. El autor pone el ejemplo del Rollo Josué del siglo X, donde nuevamente se utiliza esta peculiar forma de distribuir las escenas. Además de emparentarlo con las columnas de Marco Aurelio y Trajano, afirma que el manuscrito, como aquellas, posee un fuerte carácter imperial y militar, disipado bajo su contenido religioso. Cf.: M. SCHAPIRO, Estudios sobre el arte de la Antigüedad tardía, el cristianismo primitivo y la Edad Media, Madrid, 1987, en particular, pp. 59-61.

${ }^{417}$ W. OAKESHOTT, Classical Inspiration..., p. 73.
} 
través de nuestros mensajeros abundancia de perlas y piedras preciosas, y preparamos material de aderezo en oro y piedras preciosas lo más hermosos que pudimos hallar; mandamos venir de diversos lugares a expertos artesanos que trabajando con diligencia y cuidado levantaron la cruz (...). He aquí que unos monjes de tres abadías (...) entraron en nuestro habitáculo contiguo a la iglesia y nos ofrecieron en venta una cantidad tal de piedras preciosas que no esperábamos encontrar ni en diez años, a saber, jacintos, zafiros, rubíes, esmeraldas y topacios" (texto 11).

Para finalizar, debemos aludir nuevamente a las palabras que E. Panofsky dedica al "renacimiento otoniano". En relación con dicho fenómeno, afirma:

“Con sólo relativamente pocas y bien fundadas excepciones, la renovación de hacia 970-1020 se inspiró únicamente en fuentes paleocristianas, carolingias y-cosa muy importante-, bizantinas" 419 .

En este sentido, no podemos estar totalmente de acuerdo con esta idea, pues creemos que las obras de este periodo bebieron, así mismo, de otra serie de fuentes más lejanas en el tiempo y vinculadas concretamente al arte romano de época imperial. La columna de Bernardo es una prueba irrefutable de ello, del mismo modo que lo son los diferentes disecta membra clásicos que pueblan la plástica de su momento ${ }^{420}$.

Con Otón III y la figura del abad Bernardo, cerramos la etapa del "renacimiento otoniano". Una periodo donde la figura del emperador intentó, por algún momento, emular el verso: Roma caput mundi dentro del programa de renovatio Imperii Romanorum, en el que el monarca, tal y como ya hemos apuntado, explotaba al máximo todos los recursos que tenía a su alcance para "construir" una imagen bien perfilada del buen gobernante, a la manera de los emperadores romanos.

La concepción del poder que presentaban estos nuevos emperadores, tuvo su plasmación más perfecta dentro de una representación en la que, Otón III, aparecía

\footnotetext{
${ }^{418}$ El abad Suger, Sobre la abadía de Saint-Denis y sus tesoros artísticos (E. Panfosky ed.), Madrid, 2004, pp. 73-75.

${ }^{419}$ E. PANOFSKY, Renacimiento y renacimientos..., en concreto, p. 98.

${ }^{420} \mathrm{El}$ autor señalaba sus dudas con respecto a las fuentes que tomó Bernardo para la columna, pues afirma sobre ella: es "uno de los casos excepcionales de influencia clásica directa en el arte otoniano". Cf. Ibidem, p. 98.
} 
entronizado como la Sagrada Majestad, con el mundus sobre su mano y un trono sujetado por la personificación de Terra ${ }^{421}$.

Su figura aparece circunscrita dentro de una mandorla, elemento que, tal y como señala H. P. L'Orange, es "the holy radiant of gods and divinely possessed men" ${ }^{422}$.

Se trataba de una asimilación del emperador con la figura de Cristo hasta hacerse presentar utilizando los mismos recursos iconográficos que se venían usando para plasmar la imagen de la Maiestas cristiana. Las soluciones, derivaban, tal y como apuntamos, de la imaginería de los emperadores romanos paganos, los cuales, a través de la apropiación de las iconografías de Sol, Júpiter o Serapis, mostraban al resto de los mortales la proyección de poder que realmente querían ofrecer ${ }^{423}$.

La figura estaría acompañada, según L. Castelfranchi, por una inscripción sobrepuesta al velo que sujetan los símbolos del tetramorfos y que publicitaría:

\section{HOC AUGUSTE LIBRO TIBI COR INDUAT OTTO ${ }^{424}$.}

Tal elemento, según se ha dicho, claramente nos habla de la identificación del monarca medieval con Augusto, por una parte, y con la mismísima Maiestas Domini, por la otra, rememorando de este modo, las soluciones dadas ya por la escultura constantiniana. En especial, se suelen invocar los ciclos del mismo arco de Constantino, en los que se colocó la efigie del emperador en tamaño jerárquico, de gran tamaño y en el centro de la composición, "ejemplo de la revolución tetrárquica de las artes figurativas" del periodo ${ }^{425}$.

Un monarca que, entre sus representaciones más conocidas, ofrecía la imagen de las personificaciones de las provincias vencidas, probablemente las eslavas, mientras

\footnotetext{
${ }^{421}$ Evangeliario de Liuthar, Aachen, Domschatz, Ms. 33 f. 16 r. La personificación de Terra, a la manera de una especie de atlante, aparece nuevamente, esta vez en marfil, en la cubierta del Codex Aureus Epternacensis, de la Germanisches Nationalmuseum de Nüremberg. Sin embargo en esta ocasión, esta figura clásica del arte romano sujeta no el trono del emperador, sino la propia cruz de Cristo, detalle que nos da idea de la identificación con la figura de la Maiestas cristiana que en estos momentos esta llevando a cabo la plástica otoniana bajo el gobierno de Otón III. Cf.: L. CASTELFRANCHI VEGAS, "Egberto, Treveri e la Lotaringia", L'arte dell'anno mille ..., pp. 73-85, particularmente, p. 81.

${ }^{422}$ H. P. L'ORANGE, Apotheosis in Ancient Portraiture, New York, 1982, particularmente, p. 119.

${ }^{423}$ P. ZANKER, "Las representaciones del soberano...", p. 376 y H. P. L'ORANGE, Op. cit., pp. 111128. El último autor dedica un capítulo en el que analiza la transmisión de la forma de representación de los dioses paganos a las efigies de los emperadores de la Antigüedad tardía y la Alta Edad Media.

${ }^{424}$ L. CASTELFRANCHI VEGAS, "Reichenau e la miniatura ottoniana", L'arte dell'anno mille..., pp. 49-64, especialmente, p. 60.

${ }^{425}$ G. LORENZONI, "Aspetti del Tardoantico: Diocleziano e Constantino", Aspetti e problemi del Medioevo artistico. Le origini, Torino, 1969, pp. 1-39, en concreto, pp. 13-14.
} 
enmarcaba su figura bajo unos cortinajes efectistas de clara vocación clásica ${ }^{426}$. No en vano, no han faltado autores, como por ejemplo G. Cames, que hayan propuesto una ubicación de la escena que aquí estudiamos en el palacio romano del emperador, en el Aventino de Roma, señalando el interés por explotar consecuentemente cualquier rasgo de este tipo que enriqueciese y otorgase un mayor prestigio a la figura del gobernante ${ }^{427}$.

Al fin y al cabo, sería Otón III el donante de la llamada cruz de Lotario, que el monarca donaría a la catedral de Aquisgrán. En dicha pieza, allí donde hubiera aparecido la imagen de Cristo dentro de la orfebrería más convencional, fue colocada una gran gema donde estaba representado en busto el emperador Augusto ${ }^{428}$ (fig. 77).

Con esta excelente pieza de orfebrería, queremos cerrar este breve capítulo de la recuperación de la Antigüedad en los albores del año mil. El "renacimiento otoniano" llegaba a su fin, dejando una gran estela de piezas artísticas de primer orden. El antecesor del emperador, el monarca Otón II había fallecido de malaria en la misma ciudad de Roma en torno al año 983. A su muerte, su cadáver fue depuesto con grandes fastos en el atrio de la basílica de San Pedro del Vaticano bajo un coopertorium traído expresamente desde el mausoleo de Adriano. El dato es bien significativo y no precisa de comentarios.

La tradición clásica alimentó buena parte de las intenciones de estos emperadores a la hora de proyectar su imagen al pueblo, incluso más allá de la muerte. En este mismo sentido, nuevamente las fuentes también especifican que, tras la muerte de su sucesor, el emperador Otón III había sido inhumado en la catedral de Aquisgrán, en un vasca di rosso antico, noticia que, según L. De Lachenal, alude directamente a un

\footnotetext{
${ }^{426}$ Ibidem.

${ }^{427}$ G. CAMES, "Otton III et ses hauts dignitaires sur les miniatures de Bamberg et de Munich. Un essai d'identification”, Scriptorium, XVI, 2, 1962, pp. 231-238, en particular, pp. 238 ; F. MÜTHERICH, "Das Kaiserbild", Das Evangeliar Ottos III. Clm 4453 der Bayerischen Staatsbibliothek München (F. Mütherich y K. Dachs ed.), München, 2001, pp. 31-35, en particular, p. 31; J-P. CAILLET, "Le pape et l'empereur...", p. 66 y A. GRAF, Roma nella memoria e nelle immaginazioni del Medio Evo, Roma, 1923, en concreto, pp. 88-92. Según estos autores, se trataba de una construcción que se ubicaba al sur del Palatino, entre las iglesias de Santa María in Pallara y Santa Cesárea. En todo caso, tanto el mismo Aventino como el Palatino de Roma, habrían de provocar un fuerte impacto sobre los visitantes de la ciudad, así como en las descripciones hechas a través del género de los Mirabilia, tal y como estudió en su día A. Graf.

La obra de este autor, publicada en una fecha muy temprana, será fundamental para nuestro estudio, por presentar un análisis del género descriptivo por excelencia de los monumentos de Roma, así como por abordar las cuestiones más significativas en relación con la idea que de la misma ciudad tenían los hombres medievales.

${ }^{428}$ L. DE LACHENAL, Op. cit., pp. 147-148. La autora plantea la posibilidad de que fuera incluida dentro de la pieza por su posible identificación con Constantino. Vid. también: L. CASTELFRANCHI VEGAS, "Corone e crocifissi", L'arte dell'anno mille..., pp. 108-115, en especial, p. 114. Según Castelfranchi, la inclusión de la pieza en una cruz procesional se trataría de un intento más por marcar una continuidad entre el pasado y el presente de la dinastía.
} 
spolium y que, nuevamente, vuelve a insistir sobre la recuperación del mundo clásico en una cronología que anunciaba la inminente llegada de las formas románicas ${ }^{429}$.

${ }^{429}$ L. DE LACHENAL, Op. cit., p. 153 y X. DECTOT, Pierres tombales médiévales: Sculptures de l'audelà, Paris, 2006. p. 19.

Otón III muere de un brote de malaria en enero de 1002, en Paterno. Fue llevado a la Capilla Palatina de Aquisgrán. Algunos años después, aún el papa Sergio IV, que había sido en vida amigo del emperador, compuso una lápida para uno de los pilares de San Juan de Letrán, con una serie de versos en los que señalaba a Otón como "cabeza de Roma, caput mundi". Cf.: J-P. CAILLET, "Le pape et l'empereur...", particularmente, p. 71 y N. CHRISTIE, Op. cit., p. 100. 


\section{El “RENACIMIENTO PALEOCRISTIANO”: Roma, MonteCASSinO y Cluny BAJO los EFECTOS DEL ARTE CLÁSICO.}

Hasta el momento, hemos analizado, a grandes rasgos, algunos de los movimientos renovadores y de vuelta al pasado, más señeros, mejor documentados y más influyentes para las artes plásticas, que desde la Antigüiedad se venían desarrollando en el seno de los focos de creación más activos de la Europa tardoantigua y de la Alta Edad Media.

En este apartado, una vez señalada la complejidad del fenómeno entre los carolingios y los otonianos, nos centraremos en otro fenómeno fundamental para entender este devenir ideológico que asentará las bases para comprender el caso hispano de los siglos XI y XII.

Según ha señalado la historiografía especializada, el "renacimiento paleocristiano del siglo XI" debe ser entendido como otro jalón más en la larga lista de "renacimientos" que tendrían repercusiones lo suficientemente importantes como para ser incluidos dentro de este sucinto balance.

Para abordar dicho concepto y las implicaciones que tuvo sobre las producciones artísticas y arquitectónicas, aludimos a una reflexión realizada por F. Gandolfo, a propósito de este término, y en la que considera el arte otoniano como un intento, muy definido, por llevar a cabo una regeneración del imperio cristiano.

Sus fuentes, según este autor, eran el arte antiguo, pero, sobre todo, aquellas obras de raigambre cristiana y datadas en época tardoantigua ${ }^{430}$. Las bases de tal tendencia se verán ampliadas a partir de la segunda mitad del siglo XI, adquiriendo gran fuerza en las últimas décadas del siglo y en las primeras del siguiente. El objetivo de este supuesto "renacimiento" tendría una directriz clara: recuperar el arte paleocristiano creado en la baja romanidad.

"La imitación del modelo de San Pedro de Roma asumirá un fuerte valor simbólico en la iglesia madre de la orden cluniacense; la abadía de Cluny en su tercera fase de construcción"

\footnotetext{
${ }^{430}$ F. GANDOLFO, "Il romanico in Alta Italia", L'Arte Medievale in Italia, Firenze, 1988, pp. 285-356, en particular, p. 330.

${ }^{431}$ A. C. QUINTAVALE, "Riforma Gregoriana...", particularmente, p. 244: "l'imitazione del modelo de San Pietro a Roma assume un forte valore simbolico nella chiesa madre dell'orde cluniacense, l'abbadia de Cluny, nella sua terza edificazione".
} 
Estas palabras de A. Quintavale, reflejan y resumen, perfectamente, una de las ideas básicas de este fenómeno, pero sobre todo, insisten sobre dos de los puntos focales desde los que se va a iniciar tal movimiento; por una parte, la Roma paleocristiana de San Pedro y por el otro, uno de los centros de la cristiandad más importantes del siglo XI. Nos referimos a la Maior Ecclesia, es decir la abadía borgoñona de Cluny.

Hablar de la Roma de los siglos XI y XII, así como de la abadía de Cluny, supone insertar nuestro discurso en la etapa del románico pleno. Tal tarea implica, además, poder contextualizar las acciones antes mencionadas que se habían llevado a cabo desde época antigua en relación con la revisión de determinados conceptos del arte clásico, dentro de la fase pleno medieval, objeto de este trabajo.

Ya hemos señalado como R. Krautheimer había definido el llamado "renacimiento sixtino" y sus consecuencias sobre las artes. Las iglesias de nueva construcción por aquel momento, San Pablo Extramuros (ca. 385) o Santa Maria Maggiore (ca. 433-440), por poner dos de los ejemplos más espectaculares, suponían la vuelta de la arquitecta a un clasicismo perdido. Tal sistema comparativo permitía emparentar dichas estructuras con modelos romanos imperiales datados entre los siglos I al III y, sobre todo, con aquellos gestados durante el mandato de Trajano ${ }^{432}$. El propio Krautheimer había descrito un fenómeno similar durante el siglo IX carolingio y en el que, en un intento por llevar a cabo la renavatio romani imperii, Carlomagno y otra serie de figuras como las de el papa Pascual I (817-824) y el papa Gregorio IV (827844), promovieron obras en la que primaba la recuperación de los valores plásticos del primer arte cristiano ${ }^{433}$.

La continuidad ideológica y la persistencia de intenciones en relación con este tipo de recuperaciones parecen evidentes.

Sería entonces, en la misma ciudad de ROMA y dos siglos después del movimiento carolingio, cuando se producía la llegada al solio del papa Pascual II (10991118) y con él, este "supuesto renacimiento paleocristiano" 434.

Por lo general, se suele considerar de vital importancia para abordar este concepto, el estudio publicado en el año 1970 por H. Toubert ${ }^{435}$. En él, la autora se

Para una síntesis de determinadas "copias" del modelo vaticano, vid.: H. L. KESSLER, "Caput et speculum onmium ecclesiarum: Old St. Peter's and church decoration in medieval latium”, Old St. Peter's and church decoration in medieval Italy, Spoleto, 2002, pp. 46-73, en particular, pp. 52-54.

${ }^{432}$ R. KRAUTHEIMER, Arquitectura paleocristiana..., pp. 103-104 y B. BRENK, "Spolia e il loro effetto...", pp. 205-206.

433 R. KRAUTHEIMER, "Le renouveau carolingien...", pp. 39-46 y F. GALTIER MARTÍN, La iconografía arquitectónica..., pp. 312-313.

${ }^{434}$ F. GANDOLFO, "Il romanico...", p. 330. 
centraba en el caso concreto de la ciudad de Roma, sobre todo, en las producciones artísticas desarrolladas entre los últimos años del siglo XI y los primeros veinte años del siglo XII, que era donde, según la mencionada estudiosa, llegamos a percibir tal fenómeno.

Según la teoría, entre los motivos iconográficos que durante este periodo se iban a utilizar, se advertía una recuperación directa de elementos derivados del primer arte cristiano, "une recrudescence", como llegará a afirmar, en cuanto al uso de determinados temas, cuyo uso había decrecido durante este siglo ${ }^{436}$.

A partir de esta tesis, la autora plantearía un panorama de las artes durante este periodo $^{437}$. Entendía que, para su estudio, existían dos términos que se debían utilizar de manera indiferente. Estos dos conceptos eran los de arte antiguo y arte paleocristiano, algo que demuestra lo que ya hemos señalado con anterioridad; la auténtica filiación y deuda que el primer arte cristiano tuvo con la Antigüedad clásica ${ }^{438}$. Es decir, las artes de ambos periodos pudieron haber sido vistas por los hombres del medievo como pertenecientes a un fenómeno común, como un todo, esto es, formando parte de una continuidad $^{439}$.

Posteriormente, autores como A. C. Quintavale o F. Gandolfo, relacionarían esta tendencia retrospectiva hacia el arte "arcaico" del primer cristianismo con otro gran fenómeno que, habiéndose iniciado años atrás, seguía teniendo por estos momentos un gran desarrollo. La implantación de la liturgia romana a través de la Reforma Gregoriana, que desde Roma y desde la abadía de Cluny, en Francia, se intentaba llevar a cabo, pasaba por el intento de lograr una homogenización de recursos e intereses, a través, sobre todo, de la orden cluniacense ${ }^{440}$.

\footnotetext{
${ }^{435}$ H. TOUBERT, “Le renouveau paléochrétien... ”, pp. 99-154.

${ }^{436}$ Ibidem, p. 105.

${ }^{437}$ H. TOUBERT, "Rome et le Mont-Cassin. Novelles remarques sur les fresques de l'église inférieure de Saint-Clement à Rome", Dumbarton Oaks Papers, 30, 1976, pp. 1-33; ID., "Un fresque de San Pedro de Sorpe (Catalogne) et le thème iconographique de l'Arbor Bona-Ecclesia, Arbor Mala-Sinagoga", Cahiers Archéologiques, XIX, 1969, pp. 167-189 e ID., "Didier du Mont-Cassin et l'art de la Réforme Grégorienne. L'iconographie de l'Ancien Testament à Sant'Angelo in Formis", Desiderio di Montecassino e l'arte della Reforma Gregoriana, (F. Avagliano ed.), Mont-Cassin, 1997, pp. 17-105.

${ }^{438}$ H. TOUBERT, "Le renouveau paléochrétien...", p. 99. Nos parece interesante recoger las palabras exactas utilizadas por la investigadora: "Nous utiliserons, dans cette étude, sur renouveau paléochrétien au XIIe siècle, indifféremment les deux termes, antique et paléochrétien".

${ }^{439}$ En este estudio ya hemos señalado la importancia que daba E. Panofsky al concepto "voluntad de continuidad".

${ }^{440}$ Recogemos algunos de los trabajos más significativos respecto al tema que nos ocupa. No pretendemos realizar un estado de la cuestión, sino citar aquellos estudios que ofrecen la posibilidad de obtener un reflejo histórico que explique un movimiento artístico como este. Véanse, por ejemplo: G. MICCOLI, "Ecclesiae Primitivae Forma", Studi Medievali, II, 1960, pp. 470-498; O. CAPITANI, "La Riforma gregoriana e la lotta per le Investiture nella recente storiografia”, Cultura et Scuola, 6, 1962-
} 
El fenómeno, especialmente patente en Roma, habría de iniciarse con la personalidad de León de Ostia, muerto en el año 1115 y quién aparece como una de las cabezas pensantes del entorno de la basílica de San Clemente de Roma. Totalmente inmerso en el ambiento reformador gregoriano, debe ser considerado como uno de los impulsores de esta Ecclesiae Primitivae Forma, que ya en torno al año 1060 había contaminado a otro centro fundamental dentro de este "renacimiento": la abadía de Montecassino $^{441}$. Lo que parece claro, es que este nuevo renacer del arte se debió a un círculo de prelados cultivados que, con el tiempo, acabarían patrocinando diversas obras con una clara vocación imitativa del pasado paleocristiano. Entre ellos destacaron, Anastasio IV, Calixto II, el cardenal Pedro de León, el que sería futuro Anacleto II y, sobre todo, Pascual $\mathrm{II}^{442}$.

Dentro de tal pensamiento, la explotación de la imagen como medio para transmitir conceptos ideológicos -hecho que, por otra parte, nunca se había perdido desde la Antigüedad romana- alcanzó un grado de desarrollo como hasta entonces no había hecho. Como en la Antigüedad, la nave central de los nuevos templos que por estos momentos se erigían, mostraba una diafanidad comparable a la gran arquitectura civil romana, bien representada, por ejemplo, en la basílica Ulpia de Roma ${ }^{443}$. El modelo arquitrabado, de clara vocación clásica, había sido utilizado convenientemente

1963, pp. 108-115; H. E. COWDREY, The Cluniacs and the Gregorian Reform, Oxford, 1970; E. KITZINGER "The Gregorian Reform and the visual arts: a Problem of Method", Transactions of the Royal Historical Society, V, 22, 1972, pp. 87-102 y W. WEISBACH, Reforma religiosa y arte medieval. La influencia de Cluny en el románico occidental, Madrid, 1949. La obra de Weisbach es indispensable, a pesar de su fecha temprana, para obtener una visión general de los cambios que la Reforma Gregoriana produjo sobre las artes. Es interesante la visión que plantea a través del análisis concreto de los diferentes territorios geográficos, entre los cuales incluye España.

En el año 2007 vio la luz la monografía titulada: Roma e la Riforma gregoriana. Tradizioni e innovazioni artistiche (S. Romano e J. Enckell Julliard ed.), Roma, 2007. Se trata de la última gran aportación bibliográfica al tema, con conclusiones importantes. Sobre ellas volveremos al finalizar este apartado.

${ }^{441}$ H. TOUBERT, "Le renouveau paléochrétien...", p. 152 y nota 201. Este personaje sería monje de la abadía de Montecassino hasta los catorce años. Fue un personaje culto, bibliotecario de la abadía y miniaturista de libros, que acabó siendo nombrado obispo de Ostia.

${ }^{442}$ M. RIGHETTI TOSTI-CROCE, voz "Roma. Secolo 12", Enciclopedia dell'arte medievale, vol. X, Roma, 1990, pp. 85-96.

${ }^{443}$ Recordemos como ya durante el "renacimiento sixtino" se había tomado como referente este edificio, en concreto, para levantar el alzado de la basílica de Santa María la Mayor, donde se utilizó el doble orden. Este elemento de la arquitectura de Trajano, junto con otros modelos más lejanos, como la basílica de Septinio Servero en Leptis Magna o el hall de audiencias del palacio de Domiciano, se convirtieron en modelos a seguir durante esta recuperación de la arquitectura clásica del siglo $\mathrm{V}$ y de la que ya hemos hablado. Cf.: R. KRAUTHEIMER, "The Architecture of Sixtus III...”, en concreto, p. 294. Se trata de una segunda revisión, ahora durante la cronología románica, de los mismos modelos sobre los que habían vuelto, a su vez, los carolingios y otonianos. 
dentro del gran edificio cristiano de Roma, San Pedro del Vaticano, donde un largo arquitrabe recorría, desde la puerta occidental, toda la nave central del edificio ${ }^{444}$.

Sin embargo, el aspecto más llamativo era el destacado programa iconográfico distribuido sobre las diferentes partes del edificio. La imagen retomó en San Pedro del Vaticano el gran valor propagandístico que había tenido en la Roma de los emperadores paganos, un medio de expresión de poder y de conceptos políticos e ideológicos muy complejos.

Desde el acceso al atrio vaticano, en cuyo extremo oriental era visible la gran fachada de la iglesia decorada con un gran mosaico, se percibía esta intencionalidad ${ }^{445}$ (fig. 78). A lo largo de todo el edificio se podían contemplar otra serie de imágenes realizadas a través de la técnica del fresco y, sobre todo, en mosaico, donde se mostraban diversos retratos de algunas autoridades papales. Sin embargo, en una de las partes más importantes del templo, el transepto, tal y como se ha constatado a través de dibujos, grabados y descripciones, lo más destacado era la existencia de un gran programa iconográfico que narraba algunos aspectos de la vida y el martirio del santo $^{446}$. Se trataba de una llamada de atención, por parte del papado, a los fieles que accedían -hasta el lugar al que se les estaba permitido- a venerar la tumba del mártir ${ }^{447}$.

Aquí, nuevamente, se elaboró otro gran mosaico que recorría todo el transepto y que se extendía al arco triunfal, dando paso a la cabecera del templo ${ }^{448}$.

Por su parte, Kessler vuelve a insistir en su trabajo sobre la gran inscripción o titulus realizada en torno al año 324 y en la que se decía:

\footnotetext{
${ }^{444}$ P. SILVAN, "L'architettura della basílica medievale di San Pietro", Romei \& Giubilei..., pp. 249-261.

${ }^{445}$ La datación que se ha dado a tal conjunto es tardía. Parece ser que, el mosaico de la fachada principal del edificio, fue realizado bajo el pontificado de Gregorio IX (1227-1241) y reproducía un modelo anterior datado entre los años 423-448, de época del papa León Magno. Se ha señalado también que, es posible, que en la obra del siglo XIII aún se mantuviesen partes del trabajo musivo del siglo V. Cf.: H. L. KESSLER, "La decorazione della basilica medievale di San Pietro", Romei \& Giubilei..., pp. 263-270, en concreto, p. 263.

${ }^{446}$ Ibidem, p. 265.

${ }^{447}$ Sería en el transepto donde se agruparían las masas de peregrinos y fieles que visitaban el lugar sagrado. En ocasiones, y dependiendo del desarrollo litúrgico, el espacio era destinado al clero de manera exclusiva. Cf.: M. A. CRIPPA, "La primera arquitectura cristiana...", en particular, p. 189.

Desde otro orden de cosas, la introducción del transepto supuso, además, una novedad con respecto a la arquitectura pagana y la planta de las basílicas, puesto que esta estructura no tiene precedentes dentro de los edificios paganos, por lo que debe ser considerada como una de las grandes aportaciones de la edilicia constantiniana a la historia de la arquitectura cristiana medieval. Cf.: A. M. ROMANINI, L'arte medievale..., en concreto, p. 40.

En un primer momento, la tumba apostólica se mostraba descubierta delante del transepto, sin una protección específica. Sin embargo, en época del papa Gregorio Magno, se construyó una cripta anular, que, en el medio y mediante un pasillo, comunicaba directamente con tal enterramiento. A dicha cripta se accedía a través de dos escaleras al norte y sur del coro. Finalmente, sobre la antigua construcción se mandó construir un altar. Cf.: B. BRENK, "Il luogo di culto...", p. 124.

${ }^{448}$ R. KRAUTHEIMER, Arquitectura paleocristiana ..., en concreto, p. 66.
} 


\section{"QUOD DUCE TE MUNDUS SURREXIT IN ASTRA TRIUMPHANS/ HANC COSTANTINUS VICTOR TIBI CONDIDIT AULAM"449.}

A lado aparecería el propio emperador presentando una maqueta del templo en las manos y ofreciéndosela al mártir y patrón del templo ${ }^{450}$ (fig. 79). El ábside, en cambio, tal y como señala M. Andaloro, durante los primeros tiempos en los que el edificio fue abierto al público, no presentaba imágenes en su bóveda de horno, sino que se mostraba absolutamente cubierto de láminas de oro, supuestamente aplicadas a través de teselas ${ }^{451}$.

Muchos años después, concretamente en torno al año 1128, era consagrada la nueva construcción medieval de San Clemente de Roma. Un edificio que, literalmente, había aplastado a su homónimo antecesor, quedando por entonces oculto bajo la cimentación altomedieval $^{452}$. El elemento que más nos interesa destacar del conjunto es el gran mosaico absidial (fig. 80), pues en él, se adosó un complejo programa iconográfico hecho mediante la técnica del mosaico y que ha sido analizado como el mejor representante del "renacimiento paleocristiano" de este siglo XI.

Como en su día se hubiera hecho en las grandes fundaciones constantinianas, la técnica por excelencia utilizada para realizar la decoración del edificio fue el trabajo musivo, sin duda, una de las artes de mayor tradición durante toda la Antigüedad.

\footnotetext{
${ }^{449}$ S. KOSTOF, Op. cit., p. 450 y H. L. KESSLER, "La decorazione della basilica...”, p. 266. Los autores la traducen en los siguientes términos: "Porque guiado por ti el mundo se eleva triunfante a los cielos, Constantino, un víctor, te edificó esta sala".

${ }^{450}$ H. L. KESSLER, "La decorazione della basilica...", p. 266. El investigador señala que, posiblemente, el modelo en miniatura de la iglesia, muy habitual dentro de los trabajos musivos romanos a partir de este momento, quizás fue añadido posteriormente. Para la datación de esta parte del edificio antes del año 337, véase: H. BRANDEMBURG, Le prime chiese..., pp. 92-95.

${ }^{451}$ M. ANDALORO, "I seculi della clandestinitá. Lo spazio del culto", L'Arte Medievale in Italia, Firenze, 1988, pp. 49-74, particularmente, p. 66 y P. SILVAN, "L'architettura della basílica...", en particular, p. 251. Silvan atribuye esta cubrición de oro al tiempo de Silvestro I. La Hispania cristiana tardoantigua también conoció soluciones similares dentro de sus construcciones. Baste con recordar la cubrición de teselas doradas que presentaba, según A. M. Martínez Tejera, la cúpula del mausoleo de la villa de Centcelles. Un espacio nuevamente repleto de connotaciones funerarias. Cf.: A. MARTÍNEZ TEJERA, "Arquitectura cristiana en Hispania durante la Antigüedad Tardía (siglos IV-VIII) (I)", Gallia e Hispania en el contexto de la presencia "germánica" (ss. V-VII): Balances y perspectivas: Actas de la Mesa Redonda hispano-francesca, Madrid, 2005, pp. 109-187, en especial, p. 118.

Más adelante insistiremos en otros casos, como por ejemplo, en el ábside de la iglesia de La Dorada de Toulouse y su importancia dentro de la época medieval.

${ }^{452}$ M. R. TOSTI-CROCE, voz "Roma. Secolo $12^{\circ}$...", en concreto, p. 85; G. MATTHIAE, Mosaici medioevali delle chiese di Roma, 2 vols., Roma, vol. I, 1967, en especial, p. 279 y F. GUIDOBALDI, San Clemente gli edifici romani, la basilica paleocristiana e le fasi altomedievali, Roma, 1992, en especial, pp. 128-156.
} 
Tal y como veremos, con este edificio quedaba inaugurada en Roma una nueva tendencia artística que tendrá como medio de trabajo técnico el mosaico. Será en dichas producciones, junto con algunos frescos, donde todo un repertorio de imágenes “antiquizantes" se desplegará ante los ojos del público medieval.

Para comprender este revival de la técnica romana por excelencia, debemos acudir brevemente a Montecassino. Allí, el abad Desiderio (1058-1087) desarrollaba una serie de acciones destinadas, en parte, a potenciar el desarrollo de la Reforma Gregoriana y la implantación de sus preceptos más señeros ${ }^{453}$. Su famosa abadía, consagrada en $1071^{454}$, ha sido vista como una representante fundamental de este fenómeno, pues, partiendo de la planta de San Pablo Extramuros, reutiliza todo tipo de ricos mármoles para elevar el edificio y dotarlo de todo el mobiliario litúrgico (fig. 81). Nuevamente se colocó en el interior del edificio un gran titulus en el que se publicitaba su labor como promotor, siguiendo el ejemplo del propio Constantino en el Vaticano ${ }^{455}$. La imagen recuperaba en la basílica desideriana sus antiguas funciones, pues el programa allí expuesto, ha sido comparado con la distribución que, de igual manera, se realizaba dentro de las basílicas civiles romanas ${ }^{456}$. En este sentido, L. de Lachenal entiende la obra románica de Desiderio como una puesta al día de los valores del arte romano paleocristiano de los siglos IV y VI. Aunque, también debemos afirmar, que no han faltado autores que matizasen convenientemente esta serie de ideas atribuidas a la

\footnotetext{
${ }^{453}$ En torno al año 1066, el abad comenzaría la labor de construcción de la basílica, apoyado por la figura, tantas veces citada, de León de Ostia. Dicho personaje, mandaría al abad, no sólo adquirir para la propia basílica todo tipo de objetos bizantinos, sino que, explicitó, que los artistas también debían haberse formado en las artes de este tipo. Cf.: H. E. J. COWDREY, "Desiderio abate di Montecassino", L'età dell'abate Desiderio, (a cura di F. Avagliano y O. Pecere), Montecassino, 1992, pp. 17-32, en particular, p. 17; ID., The Age of Abbot Desiderius, Oxford, 1983; H. BLOCH, Monte Cassino in the Middle Ages, Rome, 1986; L. DE LACHENAL, Op. cit., pp. 158-160; H. TOUBERT, "Le cycle de l'Ancien Testament à Sant'Angelo in Formis. L'idéal de renovatio grégorienne et l'art du Mont-Cassin au temps de Didier", Un art dirigé. Réforme grégorienne et iconographie, Paris, 1990, pp. 94-148, en concreto, p. 96; ID., "Rome et le Mont-Cassin: nouvelles remarques sur les fresques de l'église inférieure de Saint-Clément de Rome", Un art dirigé..., pp. 193-238, en particular, p. 193.

Otros autores también han incidido sobre la llegada de artistas y objetos bizantinos a Italia gracias al empeño del abad. Cf.: V. VON FALKENHAUSEN, "Montecassino e Bisanzio dal IX al XII secolo", L'età dell'abate..., pp. 69-107 y H. BLOCH, "Monte Cassino, Byzantium and the West in the Earlier Middle Ages", Dumbarton Oaks Papers, 3, 1946, pp. 163-224.

${ }^{454}$ H. E. J. COWDREY, "Desiderio abate...", en particular, pp. 18-19. Fue consagrada el día 1 de octubre de 1070, teniendo como patrón a San Benito.

${ }^{455}$ M. GREENHALGH, The survival of Roman..., p. 164 y H. TOUBERT, "Le cycle...", p. 97. Ambos autores consideran la acción de Desiderio como una paráfrasis del texto constantiniano.

${ }^{456}$ L. DE LACHENAL, Op. cit., pp. 164-208 y H. E. J. COWDREY, "Desiderio abate...", en concreto, p. 21. Los autores coinciden en señalar la importancia de las labores de expoliación de los materiales antiguos llevada a cabo por el abad, quién se trasladaría a Roma para hacerse con columnas y otros elementos salidos de las ruinas de la ciudad.
} 
Reforma Gregoriana, para explicar toda la recuperación clásica que en estos momentos se producía en MONTECASSINO, tal y como expone F. Gandolfo ${ }^{457}$.

La técnica del mosaico, perdida en Italia durante siglos, era recuperada por los artífices que trabajaban a las órdenes del abad en Montecassino. En este mismo ambiente se movía el cardenal Anastasio, amigo de León de Ostia durante largo tiempo y que, además, va a ser el promotor del gran mosaico clementito. Por ello, en este sentido, quedarían explicadas las similitudes ideológicas existentes entre ambas obras $^{458}$.

El problema más importante, para el caso del arte patrocinado por Desiderio, reside en los pocos datos absolutamente seguros que conservamos. Parece claro que la idea rectora de todo su programa artístico estaba vinculada a recuperar un pasado que consideraba glorioso y que no era otro que el de la Roma paleocristiana de Constantino. En este sentido, el "renacimiento paleocristiano" del siglo XI tuvo en las grandes fundaciones constantinianas sus modelos a seguir, pues en relación con el edificio "casinense", se puede defender que la fuente de inspiración, sobre todo desde el punto de vista de la planta, recaía sobre las basílicas romanas, tal y como hemos señalado ${ }^{459}$.

No debe parecer extraño que la estudiosa compare el fenómeno del "renacimiento paleocristiano" con aquel llevado a cabo por Carlomagno y la dinastía otónida en su intento de potenciar una renovatio imperii ${ }^{460}$.

Desde el punto de vista de las decoraciones pictóricas y musivas conservadas en la propia abadía de Montecassino, son pocos los datos seguros. H. Toubert ha conseguido dibujar un perfil aproximativo de lo que pudieron ser los temas y las fuentes que en su día ornaron las paredes de la basílica de Desiderio, a través del amplio programa pictórico existente en la cercana iglesia de Sant'Angelo in Formis. Un templo que, ya desde el año 1072, estaba en manos del abad y que, según parece ser, debe su gran ciclo de pinturas "antiquizantes" a su influencia ${ }^{461}$.

\footnotetext{
${ }^{457}$ F. GANDOLFO, "La pintura romana tra XI e XII secolo e 1'Antico", Roma, centro ideale dell cultura dell'Antico nei secoli XV e XVI. Da Martino V al Sacco di Roma 1417-1527, Milano, 1985, pp. 21-32, en particular, p. 26. Sobre la controversia de si este "arte de la reforma", llegó antes a Roma o la abadía con Desiderio, vid.: H. TOUBERT, "Le cycle...", en concreto, pp. 135-136 e ID., "Rome et Mont-Cassin...", pp. 193-194.

${ }^{458}$ H. TOUBERT, "Le renouveau paléochrétien...", p. 152 y M. GREENHALGH, The survival of Roman..., p. 128.

${ }^{459}$ H. TOUBERT, "Le cycle...", p. 97.

${ }^{460}$ Ibidem, p. 133.

${ }^{461}$ Ibidem, pp. 96-97. H. Toubert afirma que los pocos restos conservados de la basílica primitiva presentan, igualmente, formas muy clásicas en cuanto a su estilo.
} 
Las fuentes de Sant'Angelo, como debieron ser en su día las de San Benito de Montecassino, estaban en los grandes ciclos de las basílicas paleocristianas romanas, especialmente, en los programas de San Pablo Extramuros y San Pedro del Vaticano ${ }^{462}$.

Desde otras perspectivas, la experta llama la atención ante un nuevo resurgimiento o renacimiento, de una fuente iconográfica que ya hemos aludido en este estudio. Concretamente, insiste en la recuperación de las obras miniadas del siglo V y la adopción, otra vez, de fórmulas iconográficas de la Antigüedad tardía que ya habían sido utilizadas en el Génesis Cotton y en la, más tardía, Biblia Vivian ${ }^{463}$.

Este ambiente que Toubert califica de "reformador y cristiano primitivo", y que, buscaba, mediante las técnicas del mosaico y el fresco, se ve reflejado, a nuestro modo de ver, por un texto fundamental que pone de relieve las fuentes que estaban tomando los participantes de este "renacimiento". Así, íntimamente ligadas a estas ideas, sirvan las siguientes palabras de Aureliano Prudencio, escritas en el siglo V:

“El lugar de la su tumba está ahora en Mérida (...). Aquí, donde el brillo de relucientes mármoles, traídos de fuera y del propio país, llena de esplendor su templo santo, el suelo venerable guarda en su seno sus reliquias y sagradas cenizas. Los techos relucientes brillan, además, al rojo vivo desde los artesonados dorados, los mosaicos llenan de colorido el pavimento (...). El altar que se ha levantado sobre ellos. Ella, colocada allí a los pies de Dios (...)"464 (texto 12).

Prudencio, entre tópicos literarios y realidades difícilmente probables, nos muestra el auténtico valor de la arquitectura tardoclásica. A través de esta descripción

\footnotetext{
${ }^{462}$ Ibidem, pp. 97. Son muchas las pruebas que aporta la autora en su estudio, realizando un recorrido por los temas más significativos de la iglesia de Formis e incidiendo en los veterotestamentarios. A través de estos, hace una relación con los que pudieron existir en la basílica de San Pedro del Vaticano y de San Lorenzo Extramuros. Véase, además: H. L. KESSLER, "La decorazione della basilica...", en concreto, pp. 265-267 y G. OROFINO, "Montecassino", La pittura in Italia. L'Altomedioevo, Milano, 1994, pp. 441-461, en especial, p. 444. Orofino llega, incluso, a utilizar nuevamente la expresión "renacimiento desideriano".

463 Wien, Österreichische, Nationalbibliothek, Codex Vindobonensis theol. Graec. 31 y Paris, Bibliothèque nationale de France, Ms. lat. 1.

Debemos destacar que, nuevamente, se está recurriendo a prototipos muy conocidos y que habían sido la base para obras de primera categoría dentro de algunos "renacimientos" pasados. En este sentido, ya se ha apuntado la posible influencia que estas miniaturas ejercieron sobre las puertas de bronce de la basílica de Hildesheim. Sobre este tema, vid.: H. TOUBERT, "Le cycle...", en concreto, pp. 104-117.

${ }^{464}$ Obras completas de Aurelio Prudencio, (A. Ortega ed.), Madrid, 1981, pp. 539-540.

Se analizan el texto, así como otras ideas relacionadas con el problema de la luz y la venustas dentro de la descripción de Prudencio, en: I. VELÁZQUEZ SORIANO, "Aedificiorum Venustas: la recepción de un término clásico en Isidoro de Sevilla (Etym., XIX 11)", Antigüedad y cristianismo: Monografías históricas sobre la Antigüedad tardía, 14, 1997, pp. 229-248, en concreto, p. 46.
} 
que realiza del mausoleo de Santa Eulalia en Mérida, parece más fácil entender los valores estéticos de los que estaban impregnadas estas construcciones. En este sentido, no deja de recordarnos las numerosas reformas y arreglos que los diferentes comitentes llevaron a cabo, por ejemplo, en la basílica constantiniana del Vaticano. A fin de cuentas, podemos defender que, el modelo de basílica funeraria o martirial debía tener, en cuanto a preceptos estéticos, una misma dirección en la tardía Antigüedad hispana y la de la propia ciudad de Roma, sin duda, participantes de una misma voluntad $\operatorname{artística~}^{465}$.

De esta forma, poniendo de relieve las palabras de Prudencio, tiene mayor sentido el anteriormente comentado mosaico del ábside de la basílica de San Clemente. $\mathrm{Su}$ composición iconográfica aparece distribuida alrededor de un motivo central: el Crucificado. De la base de la cruz nace la gran Viña del Señor, en realidad acanto, que se expande por todo el cascarón del ábside a través de diferentes roleos y zarcillos en espiral y, entre cuyas hojas, se colocaron todo tipo de imágenes que "habitan" este ambiente vegetal $^{466}$ (fig. 82).

Todo el repertorio iconográfico más antiguo se desplegaba en esta obra: guirnaldas, meandros griegos, veneras, candelieri o grutescos, aves en el paraíso, cráteras, cornucopias, mascarones, delfines, caracoles y un extenso repertorio de figuras aparentemente desconocidas entre el imaginario medieval hasta ese momento ${ }^{467}$.

Teniendo en cuenta estas pruebas, $\mathrm{H}$. Toubert ha calificado todo este repertorio como una "pédanterie archéologique"468 y, en este sentido, parece realmente arqueológica, pues, en realidad, las fuentes de las que bebían los artistas del mosaico estaban bajo la propia obra medieval, es decir, en el mosaico y las pinturas paleocristianos de la iglesia inferior de San Clemente ${ }^{469}$.

\footnotetext{
${ }^{465}$ Sobre las continuas reformas dentro del edificio vaticano, muchas de ellas vinculadas a las mejoras de los programas iconográficos pintados y musivos, vid.: P. SILVAN, "L'architettura della basílica...", pp. 251-257.

${ }^{466}$ G. MATTHIAE, Mosaici medioevali..., en particular, pp. 279-288 y L. DE LACHENAL, Op. cit., p. 219. Se trata de uno de los elementos más importantes dentro del conjunto, pues habría de tener gran trascendencia posterior. Los modelos que estaban tomando, nuevamente, eran antiguos. Según apunta Matthiae, tanto el sarcófago de Constantina, como el ábside del nathex de San Juan de Letrán, otra vez con decoración vegetal en espiral, fueron recuperados en esta versión de la Viña del Señor en pleno siglo XII. Recordemos, que el mosaico lateranense se había adscrito al "renacimiento sixtino".

${ }^{467}$ M. MIRABELLA ROBERTI, "La symbologie paléochrétienne prélude a la symbologie médiévale", Cahiers de Saint-Michel de Cuxa, 12, 1981, pp. 181-187, en concreto, pp. 181-182.

${ }^{468}$ H. TOUBERT, "Le renouveau paléochrétien...", p. 105 y M. GREENHALGH, The survival of Roman..., en concreto, p. 166. Véase como Greenhalgh repite el mismo adjetivo utilizado por Toubert.

${ }^{469}$ H. TOBUERT, "Rome et le Mont-Cassin...”, pp. 196-212. La autora analiza los frescos románicos de la iglesia inferior de San Clemente, pintados directamente sobre los muros de la basílica del siglo IV. Data tales pinturas en los años finales del siglo XI y principios del siguiente, afirmando, además, que
} 
En el arco triunfal, flanqueando a las figuras del Crucificado, la de San Juan y la de María, fueron colocados los apóstoles y mártires Lorenzo y Pablo, a la izquierda, y Pedro y Clemente, a la derecha. Todos ellos fueron colocados sobre los objetos de suplicio que les habían llevado a la muerte.

Las fuentes de las que parecen beber los artistas estaban nuevamente en la Roma cristiana del "renacimiento sixtino", pues, tal y como se ha indicado, este valor de exposición de los objetos de castigo de los mártires, había sido una de las imágenes clave del mosaico de Santa Maria Maggiore y de allí la tomaron ${ }^{470}$. Además de lo mencionado, debemos añadir la infinidad de alusiones al mundo clásico veladas bajo figuras aparentemente reinterpretadas bajo significados cristianos. Así, a las naturalezas muertas, pavos reales, copas y cornucopias de la abundancia, erotes voladores y demás imaginario antiguo, debemos añadir la representación de escenas fluviales de claro gusto helenístico y diversos personajes realizando tareas agrícolas, en una especie de revisión del prototipo virgiliano de la vida pastoril ${ }^{471}$.

Otro dato interesante en este sentido, es la utilización física de diversos objetos expoliados de algún edificio antiguo dentro de la basílica. Según se ha defendido, el trono episcopal del templo, la llamada cátedra del papa Anacleto II, datada en torno al año 1120, presenta en su estructura materiales expoliados del arte tardoantiguo. En concreto, se trataba de mármoles datados en el siglo IV, tomados de la cantera que los artífices tenían bajo sus pies, es decir, de la basílica paleocristiana ${ }^{472}$.

muchos de los elementos presentes dentro del programa iconográfico habían sido tomados a su vez de los mosaicos de Santa María Mayor u obras miniadas como el manuscrito De Universo de Rábano Mauro, miniado en Montecassino.

Sobre el repertorio de pinturas de la basílica inferior, vid.: C. BERTELLI, "La pintura medievale a Roma en el Lazio", La pittura in Italia..., pp. 206-241, en especial, pp. 219-228 y X. BARRAL I ALTET, "Il mosaico parietale", La pittura en Italia..., pp. 462-478, en especial, p. 467. También el profesor Barral apoya la teoría de que el mosaico se llevó a cabo a partir de un modelo preexistente.

${ }^{470}$ Con tal representación se dio una mayor importancia a la figura del Papa Gregorio VII. Se le representó como doctor de la iglesia, resaltando su labor en la homologación ritual que, desde Roma, se divulgaba, pero con la peculiaridad de aparecer vestido, no como obispo, sino como monje. A su vez, las fuentes clásicas de los mosaicos de Santa María Mayor han sido señaladas por A. Grabar, quién considera que fue la columna de Arcadio erigida en Constantinopla la que sería tomada como modelo, hecho visible, sobre todo, en las similitudes de colocación de la iconografía en la columna y en la basílica. Cf.: G. MATTHIAE, Le chiese di Roma..., pp. 142-143; H. TOUBERT, "Le renouveau paléochrétien...", p. 149 y pp. 152-153, especialmente, nota 205, de p. 153 y A. GRABAR, Las vías de la creación..., en especial, p. 52.

${ }^{471}$ G. MATTHIAE, Mosaici medioevali..., en particular, pp. 287-288 y p. 290.

${ }^{472}$ El fragmento más significativo es aquel en el que se observa una inscripción que se refiere al santo mártir y patrón de la basílica. Cf.: F. GANDOLFO, "Reimpiego di sculture antiche nei troni papali del 12 secolo", Atti della Pontificia Academia Romana di Archeologia: Rendiconti, 47, 1974-1975, pp. 203-218; L. DE LACHENAL, Op. cit., en concreto, pp. 217-218 y H. TOUBERT, "Rome et Mont-Cassin...", en especial, p. 198. 
Con esta breve alusión a las obras emprendidas por Desiderio en Montecassino y la participación de los mosaistas de San Clemente en el mismo fenómeno del "renacimiento paleocristiano", podemos llegar a la conclusión, apuntada por J. Cowdrey, de que, con tales acciones, nos encontramos posiblemente ante una nueva muestra de primer orden de la renovatio de la iglesia, pero en un sentido de recuperación constantiniana a través del regreso al arte dell'antico Impero romano que tenían tras sus espaldas ${ }^{473}$.

Esta explotación de los valores antiguos dentro del espacio religioso medieval acaecida en San Clemente, no era un caso aislado. Por los mismos años, dentro de la basílica de Santa María in Cosmedin, consagrada el 6 de mayo de 1123 por el obispo Gerlasio II, encontramos acciones similares. El pontífice mandaría grabar su nombre junto con el de Calixto II, en la mesa de altar y la silla episcopal, donde también observamos la introducción de spolia antiguos ${ }^{474}$.

Así mismo, los ejemplos similares que tenemos documentados, en el periodo comprendido entre la consagración de la iglesia de Desiderio en el año 1057 y hasta el pontificado de Anastasio IV (1153-1154), han potenciado, justificadamente, que el ambiente artístico de la ciudad de Roma haya sido redefinido bajo el concepto de "renacimiento paleocristiano".

Al observar los reempleos de material romano de la columnata de Santa María del Trastevere, rápidamente podemos deducir la razón por la que fueron rescatados de las ruinas de la ciudad. Lejos de ver en ellos solamente un símbolo del poder del Imperio Romano, otorgaban la posibilidad de dotar a las nuevas construcciones con piezas de primer orden, en cuanto a la técnica que mostraban.

Los fustes de pórfido del arco triunfal de la basílica, los de mayor diámetro dentro de las columnas expoliadas de Roma y los bellos capiteles jónicos procedentes de las termas de Caracalla, hablan por sí solos ${ }^{475}$. Además, aquí se introduce otra vez uno de los valores plásticos más explotados por las construcciones tardoantiguas de sello cristiano. Nos referimos a la varietas o la alternancia de materiales de diferente

\footnotetext{
${ }^{473}$ H. E. J. COWDREY, “Desiderio abate...", en concreto, p. 30.

${ }^{474}$ H. TOUBERT, "Le renouveau paléochrétien...", p. 100 y nota 4 y L. DE LACHENAL, Op. cit., particularmente, p. 216.

${ }^{475}$ D. KINNEY, "Spolia from the Baths of Caracalla in Santa Maria in Trastevere", Art Bulletin, 68, 1986, pp. 379-397 e ID., "The concept of spolia", A Companion to Medieval Art: Romanesque and gothic in Northern Europe (C. Rudolph ed.), Oxford, 2006, pp. 233-252.
} 
procedencia, color y forma que, distribuidos de diversas maneras, buscaban generar valores estéticos de primera categoría ${ }^{476}$.

Así, en la basílica de Santa María del Trastevere se colocaron en alternancia con las dos galerías de capiteles jónicos de las columnatas de la nave central, sendos capiteles corintios que daban fin a tales columnatas y abrían paso al presbiterio, en una acción expoliadora que difícilmente se justifica mediante la arbitrariedad ${ }^{477}$.

Saliendo fuera del ambiente italiano, parece que tal tendencia se mantuvo.

En torno al 1083, el abad Desiderio daba la bienvenida en su abadía de Montecassino, al abad Ugo de Cluny, "honorifice ut tantum decebat virus", tal y como señala J. Cowdrey. A partir de este momento, las dos congregaciones entraban a formar parte de una societas monastica ${ }^{478}$.

Lo más importante, en relación con esta cuestión, es que el mismo estudioso de la abacial "cassinense", señalaría en reiteradas ocasiones la posibilidad de que los contactos monásticos entre Montecassino y Cluny hubieran repercutido en otros aspectos más allá de los meramente políticos y litúrgicos. Se refería, especialmente, a la posibilidad de ciertos intercambios entre la tercera iglesia de CLUNY, patrocinada por el abad Hugo, y la misma basílica de Montecassino ${ }^{479}$.

Las relaciones entre Cluny y la abadía italiana habían sido importantes en tiempos pasados. Señalamos, por ejemplo, la visita realizada por el abad Odilón, en el año 1027, cuando el por entonces, abad Teobaldo (1022-1035), pedía de manera deseosa al abad cluniacense que hiciese la donación de una reliquia de San Mauro, discípulo de San Benito en Italia. La petición que se vería concedida siete años después con la llegada a Montecassino de un integrum bracchii del santo ${ }^{480}$. Estos acercamientos y otros tantos no mencionados, han llevado a establecer una relación directa entre estos dos grandes focos de la Reforma Gregoriana que fueron Montecassino y Cluny.

La abadía de Cluny había sido fundada en el año 931 por Odón (927-942), un

\footnotetext{
${ }^{476}$ B. BRENK, "Spolia e il loro effetto...", especialmente, pp. 209-210. No incidimos aquí en el término, pues será tratado ampliamente a la hora de abordar el concepto de expoliación en el arte medieval. Sobre un interés político en el uso del pórfido como material de prestigio, vid.: L. FAEDO, "I porfidi: imagines di potere", Aurea Roma..., pp. 61-65.

${ }^{477}$ L. DE LACHENAL, Op. cit., p. 225 y F. GANDOLFO, "Il romanico...", en concreto, p. 332.

${ }^{478}$ H. E. J. COWDREY, "Desiderio abate...", en particular, p. 28.

${ }^{479}$ Ibidem, p. 30 y N. CILENTO, "L'opera di Desiderio abate cassinese e pontífice peri il rinnovamento della chiesa dell'Italia meridionale nell'età gregoriana", L'età dell'abate..., pp. 120-190 y p. 161. Sin embargo, Cilento señala ciertas concomitancias entre el la arquitectura de Montecassino y la iglesia de Cluny II, y no III, como en ocasiones ha defendido H. E. Cowdrey.

480 A. O. CITARELLA y H. M. WILLARD, "Le relique e la loro disposizione nelle chiese di Montecassino nell'età di Desiderio e Odoresio I”, L'età dell'abate..., pp. 441-466, en concreto, p. 462.
} 
momento primordial definido por A. E-Brandenburg, como la creación del imperio cluniacense. Tras la sucesión en el cargo de abad de personajes tan conocidos como Mayoldo (948-994) u Odilón (994-1049), Cluny se convierte en el gran centro religioso y artístico de la Europa medieval. La regla adoptada sería la establecida por Benito de Nursia $(† 550)$ para su abadía, en Montecassino ${ }^{481}$.

Será con el abad Hugo de Semur (1049-1109), cuando el monasterio alcance su etapa más próspera. No en vano, fue con él cuando se inició la reconstrucción del monasterio y la edificación de la nueva iglesia ${ }^{482}$.

El nuevo proyecto, apoyado por Gregorio VII, pareció constituirse como un auténtico codificador de ciertos aspectos de la cristiandad del momento ${ }^{483}$. Si a ello sumamos las complejas necesidades de una suntuosa liturgia, basada en la religiosidad colectiva, los espacios comunales, la meditación y una refinación máxima en lo referente al ritual, parece clara la necesidad de un espacio arquitectónico de extrema complejidad para llevar a cabo tal desarrollo y que, además, diese cabida a los más de doscientos cincuenta monjes que se han llegado a cuantificar durante este momento, además de los fieles ${ }^{484}$.

La crítica historiográfica especializada en este tema ha datado la iglesia abacial de Cluny III, en torno a los años 1080-1130, emparentándola con el movimiento arquitectural desarrollado en toda Europa y que crearía edificios como los de SaintSaturnin de Toulouse, Saint-Martial de Limoges, Sainte-Foy de Conques o la catedral de Santiago de Compostela, en España, todos ellos equiparables, de una manera u otra, en formas y soluciones con la abadía borgoñona ${ }^{485}$.

\footnotetext{
${ }^{481}$ A. E-BRANDENBURG, L'abbaye de Cluny, Paris, 1981, pp. 5-8; N. HUNT, Cluny under Saint Hugh 1049-1109, London, 1967, en concreto, pp. 19-24; PH. DIXON, M. JONES y G. MEIRION-JONES, "L’abbaye de Cluny", La ville de Cluny et ses maisons. XI $-X V^{e}$ siècles, Paris, 1997, pp. 55-75, en particular, p. 55.

Es interesante destacar como son varios los autores que señalan una dependencia de la abadía con respecto a Roma, desde el primer momento mismo de la fundación. Cf.: P. PIVA, "Cluny: l'abbazia di Maiolo e Odilone (950-1050), L'arte dell'anno mille in Europa, 950-1050 (L. Catelfranchi Vegas ed.), Milano, 2000, pp. 152-160, en particular, p. 152.

${ }^{482}$ A. E-BRANDENBURG, L'abbaye..., concretamente, p. 8 y K. J. CONANT, Cluny..., en especial, p. 69. Conant menciona el viaje que en ese mismo año de 1049 realizará el abad Hugo a Roma, donde tendría una audiencia con el papa León IX.

${ }^{483}$ K. J. CONANT, Cluny..., particularmente, pp. 21-25.

484 PH. DIXON, M. JONES y G. MEIRION-JONES, Op. cit., en concreto, p. 61 y A. EBRANDENBURG, L'abbaye..., p. 11.

No es preciso ahondar en toda la serie de reformas litúrgicas y de índole religiosa que el movimiento cluniacense va a llevar a cabo dentro de su orden. Mencionaremos, brevemente, la introducción, por parte de Odilón, de la conmemoración del día de todos los fieles difuntos el 2 de noviembre o la implantación, por parte del abad Hugo, de una liturgia para el jueves precedente a Pentecostés.

${ }^{485}$ Fue consagrada el 24 de octubre de 1130 por el papa Inocencio II, sin embargo, aún las partes más occidentales del edificio estaban sin acabar. En tales obras, debió jugar un especial papel el monarca
} 
La fábrica de San Pedro y San Pablo de Cluny, tal y como señala A. EBrandenburg, debe ser vista como el germen renovador de las formas artísticas del occidente cristiano $^{486}$.

El impulsor de una parte importante de las obras, el abad Hugo, entraría en contacto con las experiencias llevadas a cabo en algunos conjuntos eclesiásticos de la misma ciudad de Roma. El mismo pontificado romano, reafirmando las buenas relaciones con la iglesia de Cluny, concedería a la abadía una protección especial otorgándole la libertas Romana, es decir, una serie de exenciones que favorecerían a las dos abadías a partir de estos intercambios. Desde de este momento, la documentada relación entre los dos centros será la que permita explicar algunas similitudes existentes entre algunos elementos de ambos proyectos ${ }^{487}$.

A. Baud, en un estudio ya citado sobre el edificio, titula uno de los apartados con el significativo epígrafe de 'L'influence de l'Antiquité dans la construction de la Maior Ecclesia ${ }^{488}$. Se centra en una serie de aspectos constructivos del templo que relaciona con otros de índole clásica, llegando, así mismo, a la conclusión de que los constructores del edificio estaban claramente inspirados por un modelo antiguo sobre el que debieron reflexionar. La distribución interior a través de pilastras, la articulación de los muros, el uso de cierto tipo de aparejo, así como su decoración escultórica, han sido los elementos que le permitían llegar a esta interesante conclusión.

Al analizar los alzados conservados del transepto perteneciente a la tercera iglesia, ponía de relieve el uso de la articulación tripartita de los diferentes niveles,

hispano Alfonso VI de Castilla. Los diferentes autores, basándose en su testamento y la famosa donación anual que realizaba este monarca, doblando la cantidad concedida por su padre, el rey Fernando I, pusieron de relieve tales aspectos.

A ello se deben sumar otros datos relevantes, como por ejemplo, la carta del mismo soberano al abad de Cluny donando una cantidad de dinero para la "eclessiae quam edificatis". Con todos estos datos, se suele considerar el año de 1085 como muy fiable para señalar las obras de la abadía, que se encontrarían en pleno desarrollo. Cf.: K. J. CONANT, Cluny..., en concreto, pp. 20-59; A. E-BRANDENBURG, L'abbaye..., p. 27; A. BAUD, Op. cit., en concreto, p. 37 y F. SALET, "Cluny III", Bulletin Monumental, CXXXVI, 1968, pp. 235-292, en especial, pp. 236-237.

Sobre los datos relacionados con el ámbito hispano y el monarca, véanse, entre otros: J. PÉREZ GIL y J. J. RIVERA BLANCO, "Sahagún y Cluny: vidas paralelas", Los grandes monasterios benedictinos hispanos de época románica (1050-1200), 2007, pp. 87-120; C. COSMEN ALONSO, M. V. HERRÁEZ ORTEGA y M. VALDÉS FERNÁNDEZ, “Alfonso VI y el monasterio de Sahagún: nuevos testimonios sobre la construcción del templo monástico", De arte, vol. 5, 2006, pp. 29-41; A. LINAGE CONDE, Alfonso VI, el rey hispano y europeo de las tres religiones (1065-1109), Burgos, 1994 y A. M. PÉREZ RODRÍGUEZ, "Leyenda y realidad en dos textos cluniacenses sobre Alfonso VI", Memoria, mito y realidad en la historia medieval, Nájera, 2003, pp. 417-430.

${ }^{486}$ A. E-BRANDENBURG, L'abbaye..., pp. 27-30.

487 A. BAUD, Op. cit., en especial, p. 34 y H. E. J. COWDREY, "Cluny et Rome”, Revue Mabillon, 66, 1994, pp. 258-264.

${ }^{488}$ A. BAUD, Op. cit., pp. 85-84. 
señalando que se trataba de un rasgo muy común de la arquitectura antigua, presente, reiteradamente, en ciertas construcciones de la Galia y de donde, posiblemente, tomaron el modelo ${ }^{489}$.

La referencia a la Roma antigua, especialmente aquella vinculada al primer apóstol y a los santuarios erigidos durante la época de Constantino, fueron, según la mencionada autora, los modelos de inspiración utilizados fundamentalmente por Hugo de Semur para proyectar su templo ${ }^{490}$. Ello relaciona directamente las producciones artísticas de las que venimos hablando con el fenómeno del "renacimiento paleocristiano", señalando ciertas semejanzas entre el plano seguido dentro de la basílica de San Pedro de Cluny (fig. 83) y las fundaciones, tantas veces mencionadas, de San Pedro del Vaticano (fig. 84), San Juan de Letrán o San Pablo Extramuros.

Lo más significativo al respecto, es que, tales hipótesis, llevarán a la mencionada estudiosa a calificar, quizás de manera excesiva, la iglesia abacial de Cluny y el conjunto de dependencias que la rodearon como una "nouvelle Rome"491.

Con todo, estas ideas seguían de cerca lo que en su día había planteado el mismo K. J. Conant, quién consideraba que determinados aspectos de la gran fábrica de la tercera iglesia de Cluny, dependían, en cierto modo, de la arquitectura clásica, sobre todo en relación con su configuración y planimetría. El investigador señalaba las teorías expuestas en De Architectura de Vitruvio como uno de los referentes básicos que los supuestos arquitectos Gunzo y Hezelon habían tenido en cuenta a la hora de distribuir las proporciones y los espacios del recinto templario ${ }^{492}$.

La historiografía posterior al estudio de Conant, hizo suya la teoría, según la cual, las medidas y proporciones de la abacial III de Cluny, emparentaban directamente con las presentes en la vieja basílica constantiniana de San Pedro en Roma ${ }^{493}$.

\footnotetext{
489 Ibidem, p. 87.

${ }^{490}$ Ibidem, pp. 165-170. Véase también: W. WEISBACH, Op. cit., en concreto, p. 20. El autor también apoyó esta cuestión en una fecha más temprana, relacionando esta recuperación de formas con el mismo movimiento de la Reforma Gregoriana, en el que, supuestamente, se tuvo cierta preferencia por este tipo de soluciones all'antica.

${ }^{491}$ W. WEISBACH, Op. cit., en concreto, p. 172.

${ }^{492}$ K. J. CONANT, Cluny..., en especial, pp. 78-79. Lleva a cabo una serie de reflexiones y conjeturas asentadas en los datos que nos han llegado para poder adjudicar la obra a estos dos personajes, a pesar de ser una teoría bastante arriesgada y sin la fiabilidad de un documento preciso que lo especifique. El mismo autor señala, además, la referencia concreta del capítulo exacto que, hipotéticamente, habrían seguido los constructores del edificio con respecto a la obra vitruviana. En concreto, habla del Libro VI, capítulo III, 3, que, según él, debió ser la base para la concepción de algunas estructuras arquitectónicas. ${ }^{493}$ Ibidem, p. 80 y A. BAUD, "La place des morts dans l'abbaye de Cluny. État de la question", Archéologie médiévale, vol. 29, 1999, pp. 99-114.
} 
Sin embargo, aunque la idea parece en primer momento sugestiva, consideramos que debemos ser más cautos en cuanto a determinadas afirmaciones.

Si bien es cierto que los ejemplos aportados anteriormente hablaban de una clara voluntad de imitar este arquetipo arquitectónico tardoantiguo, este hecho, tan sólo se ha probado en relación con las producciones de época carolingia. Recuérdese, por ejemplo, la filiación romana defendida para la abacial de Fulda, así como otra serie de ejemplos, alegados, en su mayor parte, por investigadores tan reconocidos como el mismo C. Heitz $^{494}$.

Por ello, a pesar de la existencia de una serie de repertorios anteriores que justifiquen el establecimiento de tales dependencias, tal planteamiento no sirve para explicar ciertos aspectos de la basílica románica construida en Cluny. En todo caso, el hecho de que la arquitectura carolingia asimilara de manera tan clara la propia arquitectura tardoantigua, debe ser entendido como algo extraordinario para tal periodo y no como un argumento más para poder establecer las mismas deducciones a un fenómeno desarrollado en torno al siglo XII y que, evidentemente, tuvo un alcance mucho menor.

Lo que se muestra indiscutible son las pervivencias clásicas que reaparecen en el edificio borgoñón. Recordemos, por ejemplo, como las columnas del deambulatorio eran de mármol antiguo, posiblemente de Carrara o del Pentélico, o como, mucha de la piedra con la que posteriormente se construyó, era fruto de la expoliación de un monumento romano del valle de Saône.

Así mismo, la utilización dentro el edificio de pilastras corintias acanaladas (fig. 85), rememora un recurso característico de las obras romanas, tal y como se observa en el famoso arco romano de Autun (ca. 100 d. de C.) (fig. 86), motivo que acabaría por convertirse en un elemento común dentro de las construcciones de la Borgoña románica. Del arco romano pasarían, no sólo a los alzados de la misma abacial de Cluny, sino que articularán también las naves de la misma catedral de Autun, otorgando a estas obras un fuerte sabor clásico ${ }^{495}$. Allí servirían de elemento dinamizador del triforio y dividirían

\footnotetext{
${ }^{494}$ Las pervivencias carolingias de tipo cultual se mantuvieron dentro del espacio templario de la Maior Ecclesiae, mucho más allá de las épocas anteriores al año mil. Recordemos la existencia de una capilla dedicada al arcángel San Gabriel en lo alto de una de las torres del brazo sur del transepto, que parece rememorar una tradición bien asentada entre los carolingios. Cf.: C. HEITZ, Recherches sur les rapports entre architecture et liturgie à l'époque carolingienne, Paris, 1963 y K. J. CONANT, Cluny..., particularmente, p. 93.

${ }^{495}$ Sobre el uso de spolia en la abacial de Gunzo, véase: K. J. CONANT, Cluny..., p. 85. Sobre la fortuna de los motivos del arco romano de Autun, consúltese: W. OAKESHOTT, Classical Inspiration..., p. 91. En relación con ello, R. Oursel ha llamado la atención sobre la importancia de Autun como zona
} 
los muros superiores de la puerta esculpida en la parte occidental del recinto, si atendemos a los casos más llamativos.

Creemos que la distribución en planta de Cluny III, a través de su enorme buque de cinco naves terminadas en un transepto, es un claro ejemplo de perpetuación de un arquetipo arquitectónico a lo largo de la Edad Media ${ }^{496}$. Por entonces, debía ser ya un recurso cuanto menos conocido dentro de los ambientes eclesiásticos. El caso de la abadía borgoñona contribuyó de manera clara a fomentar su perdurabilidad como arquetipo, más allá de las evocaciones llevadas a cabo durante la época carolingia y otoniana. Se trataba de una forma de prestigio y recuerdo de la basílica del primer apóstol en Roma, pero no de una influencia directa. La inclusión de un amplio transepto articulado a través de dos absidiolos semicirculares y de un gran nartex a occidente, hablan de una relación morfológica innegable con la edilicia imperial romana de patrocinio cristiano, siempre dispuesta a explotar los valores de los espacios públicos abiertos $^{497}$. Falta por comprobar si también existió esa misma herencia desde el punto de vista iconográfico.

Uno de los apartados más conflictivos a la hora de alegar una inspiración clásica para la gran iglesia europea de finales del siglo XI y los inicios del XII, es el de su escultura y el de su pintura. A partir de los datos históricos, grabados y descripciones conservados, podemos alegar que existía en el edificio una vocación por desarrollar un complejo programa iconográfico que se expandiría a través de las naves, los capiteles,

romanizada y las continuas relaciones que la urbe estableció con Roma, hasta el punto de considerarse "hermana y émula" de la ciudad eterna. El autor resalta el papel jugado por el obispo Esteban, hijo del Señor Jocerand de Bagé, en Bresse. Fue nombrado en 1112 obispo de la diócesis de Autun, que acabaría por perpetuar los derechos de la sede a través de la acogida, por dos veces, de los papas Calixto II e Inocencio II, entre los años 1119 y 1130. Cf.: R. OURSEL, La arquitectura románica, Madrid, 1987, p. 36.

496 A. BAUD, "La troisième église abbatiale de Cluny modèle ou prototype?", Paray-le-Monial, Brionnais-Charolais: le renouveau des études romanes en Bourgogne du Sud, Paray-le-Monial, 200, pp. 337-345.

${ }^{497}$ Además del transepto mayor, recordemos que la abadía poseía otro de menor tamaño que anticipaba el espacio al que nos referimos. Dicha estructura se ha datado entre los años 1095-1097. En todo caso, tal estructura estaría terminada antes de la muerte del obispo de Pamplona, Pedro de Roda (†1115), que consagrará la obra.

En cuanto al gran nartex del templo, eminentemente vinculado con la arquitectura paleocristiana, hoy solo es visible a través de grabados. Se trataba de un espacio formado por ocho naves que remataba a oriente mediante la fachada occidental de la iglesia. A pesar de tratarse de un espacio con gran tradición dentro de los recintos cristianos, en el caso de Cluny III las procesiones pasaban del claustro a la vieja galilea. Desde allí, atravesaban la Porta Galilea y llegaban a la nave del templo, por lo que este recinto al que nos referimos tan sólo servía para realizar las salidas y entradas solemnes. Cf.: K. J. CONANT, Cluny..., en concreto, pp. 93 y 112 y F. SALET, “Cluny III...”, especialmente, p. 247. 
los ábsides y las fachadas ${ }^{498}$.

Poco o casi nada de lo conservado dentro del edificio puede ser explicado y defendido sin dudas. A pesar de ello, ciertos datos parecen reafirmar un intento por regresar a determinados mecanismos de utilización de la imagen, propios de la baja romanidad.

Es sabido que en el centro del gran ábside de la iglesia se mostraba pintada una gran imagen del Pantocrátor, rodeado del tetramorfos ${ }^{499}$. Que al menos, el portal occidental, presentaba una gran fachada totalmente esculpida, y que, sobre todo, el deambulatorio del edificio se decoró con un repertorio de capiteles figurados que afortunadamente se han conservado tras el declive del templo ${ }^{500}$.

Allí fueron representados, sobre las diez columnas del deambulatorio (fig. 87) y en un estilo indiscutiblemente "antiquizante", algunos capiteles corintios habitados por personajes desnudos vestidos con clámides clásicas atadas con nudo. Como sería habitual dentro de los programas artísticos romanos, en Cluny, se introduce un elemento fundamental para el desarrollo del discurso iconográfico: las personificaciones ${ }^{501}$.

Entre otras imágenes, se esculpieron las representaciones humanas de los vientos (fig. 88), donde:

\footnotetext{
${ }^{498}$ A. ERLANDE-BRANDENBURG, "Iconography de Cluny III", Bulletin Monumental, CXXVI, 1986, pp. 293-322.

${ }^{499}$ Son escasos los restos pictóricos que hoy se pueden observar en el edificio, más allá de determinados repertorios geométricos. En todo caso, no podemos apoyar la idea desarrollada por A. Baud, aunque para nuestros objetivos se presentaría como una posibilidad tentadora. Según la autora, y aludiendo al ejemplo de Sant'Angelo in Formis, el repertorio iconográfico pintado en este templo, sería una hipotética vía de análisis que ayudaría a imaginar lo que, en realidad, pudo existir en la abadía borgoñona.

Ya en su día Conant alegó una relación con ese ejemplo básico del "renacimiento paleocristiano" que fue la iglesia de Formis y su predecesora, la de San Benito de Montecassino. Cf.: A. BAUD, Cluny..., p. 126 y K. J. CONANT, Cluny..., en concreto, p. 101. Véase también: G. FERNÁNDEZ SOMOZA, "Cluny y el arte de la pintura en tiempos del románico. La imagen pictórica del edificio medieval", Alfonso VI y su época II. Los horizontes de Europa (1065-109), León, 2008, pp.53-72.

${ }^{500}$ La cronología que se ha dado para los capiteles se inscribe dentro del arco temporal de los años 11001120. Cf.: A. E.-BRANDEMBURG, L'abbaye..., en concreto, p. 56; F. SALET, Cluny et Vézelay. L'oeuvre des sculpteurs, Paris, 1995, en especial, p. 17 y PH. DIXON, M. JONES y G. MEIRIONJONES, Op. cit., en concreto, p. 61.

Sobre la decoración escultórica de algunos edificios cluniacenses de carácter civil, donde pilastras acanaladas y florones clásicos se muestran como motivos recurrentes, véase: P. GARRIGOU GRANDCHAMP, J-D. SALVÈQUE, B. MAURICE-CHABARD, "La sculpture civile clunisoise", La ville de Cluny et ses maisons. XIe-XVe siècles, Paris, 1997, pp. 178-206, en particular, pp. 194-196.

En este apartadado nos centraremos, brevemente, en el tema de los capiteles de la girola, los más clásicos de los conservados. Sin embargo, aunque de factura más tardía, recuérdese el bello y "antiquizante" frontal de altar formado por clípeos con florones, de clara vocación romana.

${ }^{501}$ K. J. CONANT, Cluny..., pp. 87-89. Durante el siglo XIX se afirmaba que eran sólo ocho las columnas que soportaban el volteo de la bóveda que configuraría el deambulatorio e, incluso, se llegaría a insistir en que dichas piezas provenían de Grecia. Cf.: M. F. CUCHERAT, Cluny au onzième siècle. Son influence religieuse, intellectuelle et politique, Paris, 1850, en especial, p. 129.
} 
“(...) parece evidente que un hombre con clámide así, parece un personaje clásico y que sólo podemos explicar sus gestos a través de una copia de una obra antigua" ${ }^{„ 502}$.

En este sentido, es fundamental la precisión con la que F. Salet defiende que, tal imagen, se trata más bien de la representación de un genio del viento, tal y como se concibieron, por ejemplo, dentro del programa iconográfico del bordado de Gerona (fig. 89). Quizás, en Cluny, haya pervivido el eco del uso de tales imágenes galorromanas, tal y como se ha señalado para el bordado de Gerona. En todo caso, algunos aspectos permiten apuntar que, el genio aquí representado, intenta cerrar con sus manos un panier d'osier, aunque la ausencia de las demás personificaciones no asegura hablar de un conjunto iconográfico alusivo a los vientos en concreto. La problemática en cuanto a la identificación y el origen de tales imágenes se encuentra, en parte, abierta ${ }^{503}$.

Otro conjunto de personificaciones, en este caso alusivo a las Virtudes, también se incluyeron en el conjunto de esculturas que decoraban la girola del templo, acompañadas, entre otras, por las Artes Liberales. En todas estas iconografías se introdujo, de manera bien clara, una cartela explicativa a modo de tituli y que, han servido, para poder llegar a reconocer buena parte de las fuentes en las que, posiblemente, se inspiró el programa. En este sentido, el "renacimiento paleocristiano" toma más justificación, si cabe, con la elección premeditada de un texto de carácter tan clásico, como el escrito en el siglo V por el mismo A. Prudencio. Nos referimos, concretamente, a la Psicomaquia que, según se ha venido manteniendo, sería la fuente para el texto que acompaña a estas personificaciones ${ }^{504}$.

Además, en el caso de la escultura de la iglesia, nuevamente se incluyó dentro de un recinto sagrado un capitel dedicado a los árboles y los ríos del paraíso. Se ha señalado, por ejemplo, la atribución simbólica que se le ha dado a determinados

\footnotetext{
502 "Il me paraît évident que cet homme à chlamyde est un personnage à l'antique et que seule l'imitation d'une oeuvre de l'Antiquité peut expliquer son aparéense et ses gestes". Cf.: F. SALET, Cluny et Vézelay..., en concreto, p. 28-34.

${ }^{503}$ S. BIAY, "Entre l'oeil et la main: le concept de maitre sculpteur appliqué aux chapiteaux du rondpoint de Cluny III et aux portails de la nef de Vézelay", À l'ombre des mots: dire et penser le Moyen Âge, Poitiers, 2007, http://janua.blog4ever.com/blog/lirarticle-68850-380168.html, consultado el 10 de agosto de 2008.

${ }^{504}$ F. SALET, Cluny et Vézelay..., pp. 34-42. La autoría hispana de los textos, atribuidos a Prudencio, llevó a Conant a defender, cuanto menos de forma inestable, una relación entre la elección de los temas y la huella del patrocinio que va a tener en el edificio la figura del rey castellano Alfonso VI. De ascendencia hispana son, según el autor, los arcos polilobulados que enmarcan algunas ventanas del triforio. Tales referencias a lo hispano, según el experto, serían reflejo de la fuerte influencia de la dinastía de Fernando I sobre el edificio y que, además, se verificaría con la dedicación de los altares de San Vicente y Santiago en el propio espacio templario. Sin duda, se trata de propuestas sugestivas, pero difícilmente demostrables con seguridad. Cf.: K. J. CONANT, Cluny..., en concreto, pp. 80-81.
} 
vegetales que aparecen representados en tales piezas, como por ejemplo, las alusiones a la vida y la redención a través de la viña, la higuera como símbolo de Justicia divina, el olivo como representante de la gracia y, finalmente, el manzano, el árbol de la Ciencia y del Pecado 505 .

A los lados, y entre dichos vegetales, los escultores emplazaron las cuatro personificaciones de los Ríos del Paraíso, Ghéon, Physon, Tigris y Eufrates, con sus cuernos de la abundancia en la mano y de los que fluyen las aguas paradisíacas ${ }^{506}$.

Finalmente, otro capitel de los más bellos que ha conservado el conjunto, es aquel que muestra las personificaciones de los Ocho Tonos musicales, dotados con sus atributos propios y, nuevamente, acompañados por las citadas cartelas explicativas ${ }^{507}$.

La escultura de la abadía borgoñona realizada durante esta tercera fase, ha sido definida como una clara materializadora de este "renacimiento" que venimos señalando. Su puesto dentro de la serie de "renacimientos" aquí estudiados, abre el panorama artístico de la Plena Edad Media al estudio de sus posibles fuentes y contactos con lo clásico. Tanto la abadía de San Benito de Montecassino, como la de San Pedro y Pablo de Cluny, pueden servir de ejemplo a la hora de hablar de una consolidación de las artes plásticas románicas, una vez iniciada su andadura tras la superación de la barrera del año mil, pero teniendo como principal elemento definitorio, su marcado carácter retrospectivo hacia las artes antiguas. Sobre todo, cobrará especial relevancia, tal y como veremos, la escultura, que se convertirá en una de las técnicas en las que, de una manera más clara, se observarán tales pervivencias.

Finalizamos aquí, en los inicios de la arquitectura y las producciones plásticas del románico, el repaso a los principales "renacimientos" en el ámbito europeo, para tratar el caso específico de la Península Ibérica, de una manera más particular. Así, en el apartado correspondiente, analizaremos los principales "renacimientos" del arte antiguo a lo largo de los siglos comprendidos desde la Antigüedad tardía a los inicios de la Plena Edad Media, tomando como ejemplo concreto el caso hispano.

\footnotetext{
${ }^{505}$ No insistiremos en la recuperación que, de manera paralela, se había hecho durante este "renacimiento paleocristiano" del simbolismo de determinados vegetales. El caso de la "viña" de acantos de San Clemente de Roma lo atestigua. Cf.: H. TOUBERT, "Un fresque de San Pedro de Sorpe...", pp. 167-189 y F. SALET, Cluny et Vézelay..., en concreto, p. 42.

${ }_{506}$ A. BAUD, Cluny..., en especial, pp. 87-88.

${ }^{507}$ K. J. CONANT, Cluny..., p. 89. El estudioso llega a señalar, a modo de hipótesis, que Gunzo y Hezelon, pudieron ser los posibles mentores del programa, debido, en parte, a su alto nivel cultural y al conocimiento documentado de las artes musicales. Nuevamente se trata de una teoría sugestiva, pero difícil de mantener.
} 
Poner punto y final a este análisis que venimos desarrollando, tomando como referencia los ejemplos de ciertas construcciones de ROMA, MONTECASSINO y CLUNY, así como el llamado "renacimiento paleocristiano" puede parecer ciertamente artificial y erróneo.

Sin embargo, tal decisión aparece justificada, en cierta medida, por la importancia que estos centros van a tener dentro de la difusión en toda Europa de los lenguajes románicos, pues, frecuentemente, han sido señalados como los casos concretos y evidentes de la difusión de las nuevas corrientes estéticas.

Finalizar este balance, a través del caso concreto de la escultura, la mayor parte perdida, de la abadía de Cluny III, es una acción premeditada. La exaltación, tan clásica, que se hace en el deambulatorio del edifico, de algunos temas como los de las personificaciones, reflejan varios aspectos relacionados con la gran trascendencia que el arte antiguo tendría sobre las producciones románicas.

Bien es verdad que, paralelamente a las experiencias de Cluny, e incluso en una cronología más temprana, se estaba explotando ya con el mismo éxito el uso de imágenes esculpidas formando un programa iconográfico dentro de las cabeceras y fachadas de algunos edificios.

Sin embargo, el caso de Cluny se presenta revelador, pues aquí, la escultura pasó de ser un mero ornamento, a convertirse en una explotación de la imagen en favor de una autoritas antiquorum ${ }^{508}$. La imagen cobra una especial importancia. Se coloca en la parte más señera del espacio templario, a pesar de poseer un origen eminentemente pagano, y no especialmente recomendada para los ámbitos cristianos. El ábside de la iglesia borgoñona continuaba teniendo fuertes valores heredados de la tradición romana. Tal uso, permaneció inalterable dentro de los mismos espacios de la arquitectura románica en general y, en el caso particular de Cluny, estos aspectos explotaban sabiamente el fuerte valor visual de la iconografía.

No en vano, el ábside era la culminación más notable del eje longitudinal del templo, heredero, así mismo, de la distribución romana de las salas oficiales y los templos civiles. Allí, esta era el área para las efigies de los dioses y, a partir del nombramiento de Augusto como divus, pasó a ser la zona donde se colocaba el emperador, por lo que la carga simbólica del ábside, así como de los programas visuales

\footnotetext{
${ }^{508}$ S. SETTIS, “Continuità, distanza...”, en particular, p. 384. Tomamos la expresión del citado autor.
} 
que en torno a él se desarrollarían, debían ser indispensables dentro del desarrollo ceremonial. La época medieval continuaría con tales tradiciones, aunque parcialmente.

Ahora el ábside pasaba a ser el eje del espacio congregacional, del espacio de Cristo, el único rey dominador del mundo. Tan sólo los presbíteros accederían a tal lugar y, en ocasiones, sentados bajo la bóveda, emularían la asamblea celestial que frecuentemente se representaría en la parte superior ${ }^{509}$. De ahí, la habitual tradición de colocar sobre tales recintos los más completos y variados programas iconográficos dispuestos a evocar una imago mundi, en ocasiones, ideada bajo parámetros antiguos ${ }^{510}$.

La representación de la personificación de los ríos del paraíso o la de los tonos musicales, materializada bajo la mano de un escultor o escultores de primer orden, utilizaba de manera consecuente esta "estética antiquizante". La ubicación de tales capiteles conformando un programa común en correspondencia con los frescos, hipotéticamente, trazados en el interior del recinto, así como otra serie de elementos hoy perdidos, como textiles, candelas, obras de orfebrería y demás muebles litúrgicos, ofrecían, sin duda, una imagen preconcebida e ideada para ser proyectada sobre un público. Debiéramos pensar en la importante deuda que presentan algunos de estos objetos y su valor plástico dentro del templo, en relación con los espacios eclesiásticos de la Antigüedad tardía.

Nuevamente nos hallamos ante uno de los valores más destacados de la arquitectura y las artes clásicas. Se trata de la necesidad de proyectar sobre el espectador una imagen diseñada con el único fin de provocar una reacción sobre tal receptor. En relación con ello, el espectador de la arquitectura tardoantigua, ha dejado pruebas escritas de sus sensaciones y sensibilidades ante tales proyecciones.

"Una vez que el pueblo ha descansado, al empezar la hora segunda se reúnen todos en la iglesia mayor, que está en el Gólgota. Cuál sea el ornato aquel día en la Iglesia o en la Anástasis o en la Cruz o en el Belén, me ha parecido inútil escribíroslo. Allí no ves más que oro, piedras preciosas y seda; porque si miras los tapices, son de seda bordada de oro; si miras las cortinas, son también de seda bordada de oro. Todo el servicio de culto divino que se ve aquel día es de oro con piedras preciosas incrustadas. Y el número o valor de los cirios, candelabros o

\footnotetext{
${ }^{509}$ S. KOSTOF, Op. cit., p. 443.

510 M. ANDALORO y S. ROMANO, "L'immagine nell'abside", Arte e iconografia a Roma da Costantino a Cola di Rienzo, Roma, 2000, pp. 93-132 y M. A. CASTIÑEIRAS, El calendario medieval..., en especial, p. 251
} 
lámparas y de toda clase de objetos de culto, ¿puede acaso apreciarse o escribirse? Y ¿qué diré de la ornamentación de la fábrica misma, que Constantino, bajo la vigilancia de su madre, en cuanto se lo permitieron las riquezas de su reino, decoró con oro, mosaicos y mármoles preciosos, tanto la iglesia mayor como la Anástasis y la Cruz y los demás lugares santos de Jerusalén?"511 (texto 13).

El valor que durante toda la Antigüedad había poseído la imagen de la arquitectura y las artes plásticas que la engalanaban, patente, de manera clara, en el texto de Egeria, parece adquirir durante el románico sus cotas de máximo desarrollo. Se trata de la asimilación clara de algunos de los preceptos estéticos más difundidos durante la Baja Antigüedad ${ }^{512}$.

En este sentido, el arte medieval supo asimilar eso que A. Grabar dio en llamar “imágenes y ciclos gubernamentales" y que habían sido la dirección rectora de buena parte del desarrollo y concepción de los programas icónicos del mundo romano. La voluntad de explotar la imagen con un fin político, militar, judicial o, a grandes rasgos, ideológico, fue una práctica corriente en las artes patrocinadas por los emperadores y los agentes del imperio y que sería asimilada por la Iglesia desde el fin del mundo antiguo $^{513}$.

Fue también el mismo A. Grabar el que, a propósito de la herencia clásica de los sistemas iconográficos cristianos y los modos de desarrollo del lenguaje de las imágenes en tal periodo, escribiera:

"En la época en que las fachadas de las iglesias sólo alojaban esculturas iconográficas, en los tímpanos y los dinteles de los pórticos, la iconografía esculpida invadía también los interiores de ciertas basílicas, tanto en Borgoña como en el mediodía de Francia, en Italia y en España, y en seguida en todos los países de la Europa Occidental. Recogiendo un uso antiguo, pero superando inmediatamente los modelos romanos, los personajes y las escenas cristianos se labraron sobre los capiteles. Estos emplazamientos resultaban poco favorables para la iconografía, debido a la forma del capitel y a que una gran parte de esos capiteles historiados estaban tan altos y con poca luz que los fieles no podían analizar y comprender las

\footnotetext{
${ }^{511}$ EGERIA, Op. cit., p. 269.

${ }_{512}$ R. KRAUTHEIMER, Arquitectura paleocristiana..., p. 77.

${ }^{513}$ A. GRABAR, Las vías de la creación..., p. 16.
} 
imágenes. Por tanto, no se les encomendaba una enseñanza teológica y sólo muy raramente servían para ese fin ${ }^{, 514}$.

Con esta reflexión entramos de lleno en la complicada e interminable cuestión del valor y la lectura que, durante la Edad Media, se le dio a determinadas imágenes expuestas en fachadas y capiteles. Traemos el texto de Grabar a colación, debido a la importancia, por ejemplo, que tuvieron los capiteles de la abacial de Cluny III dentro del espacio de la girola del edificio. Con un programa tan complejo, en cuanto a su lectura iconográfica, y la importancia de los elementos epigráficos para la clarificación de las escenas, creemos que es posible afirmar que, en determinadas ocasiones, la imagen mantuvo su valor de elemento transmisor, tal y como había ocurrido durante el arte romano. Los capiteles de las iglesias románicas eran vistos, en ocasiones, como elementos transmisores de imágenes y contenidos, a pesar de la continua sobreexplotación que numerosos especialistas han venido realizando sobre tal precepto y que ha provocado un rechazo de estas posturas. Las obras esculpidas eran, por su misma presencia dentro del edificio, susceptibles de ser analizadas $\mathrm{y}$, sobre todo, valoradas desde el punto de vista de su calidad técnica, desde la óptica de sus materiales, desde su significado, etcétera.

El texto, tantas veces citado, de Eusebio de Cesarea, sirve para ejemplificar tales posturas y documenta la posición que tomaba, en este caso concreto, el hombre medieval frente a la obra artística. Así nos dice:

"Los pórticos que daban a la fachada de la basílica gravitaban sobre columnas gigantescas; los interiores elevándose sobre pilastras. Tres poternas bien orientadas al levante daban recibimiento al gentio que penetraba en el interior. En frente de éstas, cual epicentro de todo el conjunto, hallábase el ábside, colocado en el extremo de la basílica; lo ceñían doce columnas, de cifra igual a los apóstoles del Salvador; tenían sus capiteles ornamentados con enormes cráteras de plata que el mismo emperador había donado (...)" ${ }^{\text {515 }}$ (texto 14).

Parece claro, según el texto, que en determinadas ocasiones, los capiteles, independientemente de su forma y material, eran observados por los visitantes de los

\footnotetext{
${ }^{514}$ Ibidem, en concreto, p. 185.

${ }^{515}$ E. DE CESAREA, Vida de Constantino (Introducción, traducción y notas de M. Gurruchaga, Madrid, 1994), Libro III, 38-39, pp. 297-298.
} 
templos, en cuanto objetos esculpidos y decorados con imágenes. Sin embargo, a pesar de ello, la historiografía especializada en estas cuestiones, sobre todo durante el siglo pasado, abusó del método que defendía la posibilidad de someter a una lectura simbólica e iconográfica tales piezas. Las imágenes fueron vistas como medio de comunicación y, según algunos, como el medio más fiable para la difusión de los dogmas cristianos. Tal acepción provocó, en continuadas ocasiones, la "sobrelectura" de determinados temas, centrándose, sobre todo, en el caso problemático de las reacciones que el espectador mostraría frente a la obra artística ${ }^{516}$.

La cuestión de la Biblia pauperum o de los iletrados, debe ser vista, según creemos, a través de una necesidad, por parte de la Iglesia, de transmitir un mensaje. Durante la Antigüedad cristiana tal hecho se llevó a cabo a través de los sistemas que tenían a su alcance, es decir, mediante el tratamiento de los lenguajes figurativos heredados del arte romano. Los grandes monumentos constantinianos, haciendo uso de esa concepción romana de la imagen, habían hecho eclosionar este desarrollo iconográfico dentro de sus construcciones más emblemáticas. La decoración aplicada sobre los muros y otros soportes en las basílicas de San Pedro del Vaticano o San Pablo Extramuros, así parecen confirmarlo. Sin embargo, tal y como señala Kessler, fue en todo caso una reflexión de miras muy complejas realizadas por estos cristianos, a partir del mismo arte antiguo, que siempre se consideró como aquel al que se debía mirar en busca de determinados recursos ideológicos ${ }^{517}$.

En el caso de la utilización de tales sistemas durante el auge del movimiento románico, parece que su origen debe buscarse, nuevamente, en un intento por recuperar los mecanismos nacidos de experiencias anteriores que nunca se habían perdido y que se habían conservado desde aquella Antigüedad tardía hasta la Plena Edad Media. El caso de la iconografía de la cabecera de Cluny III así lo insinúa. La imagen de fuerte sustrato "antiquizante" se aunaba con los nuevos recursos medievales, para, a partir de las enseñanzas del arte romano, generar nuevas vías de creación artística ${ }^{518}$.

Para finalizar, queremos puntualizar una última cuestión.

\footnotetext{
${ }^{516}$ Nos referimos al abusivo uso, entre otras, de la famosa carta de Gregorio Magno (540-604) escrita al obispo de Marsella, en la que defiende la imagen, por creer que esta desempeña una función importante a la hora de dar instrucción a los iletrados. Sobre esta cuestión, véase: M. BARASCH, Teorías del Arte. De Platón a Winckelmann, Madrid, 1999, en concreto, p. 63; A. GRABAR, Las vías de la creación..., en especial, p. 167 y H. L. KESSLER, "Pictures as scripture in fifth-century churches”, Old St. Peter's..., pp. 15-43, en especial, pp. 41-43.

${ }_{517}$ H. L. KESSLER, "Pictures as scripture...", pp. 15-43, en concreto, pp. 18-19.

518 A. C. QUINTAVALLE, "Riforma Gregoriana...", en particular, p. 244.
} 
El caso que hemos utilizado en este apartado para ejemplificar estas cuestiones, es extrapolable a otros conjuntos de similar cronología. Sin embargo, el evidente contenido clásico y la inspiración, aparentemente directa, de modelos romanos, permiten justificar la perdurabilidad de estos sistemas de narración a través de la imagen y de sus mecanismos de explotación, por parte del arte románico.

A partir de este momento y teniendo en cuenta que, en todo caso, nos hemos referido a una cronología concretada en el tránsito del siglo XI al XII, creemos que fue la técnica escultórica la que, de manera más evidente, mostró su dependencia con respecto a lo clásico. En el desarrollo de tales mecanismos, el periodo no recuperó su voluntad de transmitir mensajes a través de la imagen, tal y como frecuentemente se ha venido afirmando. Se trata más bien de una cierta continuidad en la experimentación con tales métodos de narración y transmisión de contenidos, que una recuperación, pues tal y como es sabido, el fenómeno nunca había llegado a perderse desde el mismo periodo antiguo.

El desarrollo de la escultura monumental en las fachadas y en el edificio en general, reinventaba los valores de difusión de las imágenes de poder utilizados por los artífices del imperio romano ${ }^{519}$. Ello explicaría, por ejemplo, porqué en aquellos edificios donde la escultura adquirió un temprano desarrollo, acompañado, generalmente, por un fuerte aprovechamiento de la capacidad narrativa, este tipo de técnica se encuentra indisolublemente ligada a determinados preceptos clásicos.

En los casos en los que tenemos constancia clara de los artistas que trabajaron en dichas fábricas, las voces más especializadas han sabido emparentar, de una manera $\mathrm{u}$ otra, tales esculturas con la tradición antigua. Recordamos, para finalizar, no solo el caso de los escultores o escultor de los capiteles de la girola de Cluny, sino otros jalones de una lista que, nuevamente, vuelve a ser densa.

Valores clásicos y dominio de la capacidad de narración a través de un estilo "antiquizante", serán los que encontremos dentro de otros focos activos en este momento. Baste citar, por ejemplo, los tempranos trabajos decorativos en Saint-Saturnin

\footnotetext{
${ }^{519}$ M. A. CASTIÑEIRAS GONZÁLEZ, “Arte románico y reforma eclesiástica”, Las religiones en la historia de Galicia (M. V. García Quintela), Santiago de Compostela, 1996, pp. 307-332; M. MELERO MONEO, "La propagande poitico-religeuse du programme iconographique de la façade de Sainte-Marie de Ripoll", Cahiers de Civilisation Médiévale, vol. 182, 2003, pp. 135-157 y X. BARRAL I ALTET, "Propaganda eclesiástica y poder feudal. El orden del mundo en las fachadas románicas", Propaganda y Poder, Oporto, 1999, pp. 57-70, en especial, p. 59.
} 
de Toulouse y el círculo de artífices activos bajo la figura de Bernardo Guilduino ${ }^{520}$. Idénticas características, con respecto a la filiación con lo clásico, presenta, por ejemplo, el foco de escultores que trabajaban en la catedral de Jaca, otra vez, en una fecha muy temprana.

En este mismo sentido, es en el año 1100, cuando se viene documentando el trabajo de los escultores del transepto de la catedral de Santiago de Compostela y, antes, por ejemplo, los artífices de posible vocación antigua y tradición paleocristiana, del conjunto de esculturas del Pórtico de San Pedro de Teverga y del Panteón de San Isidoro de León ${ }^{521}$.

A partir de tales experiencias, tal y como veremos, los lenguajes de ascendencia "antiquizante" y el uso de la imagen como medio de expresión de conceptos complejos, irían unidos de manera bien eficaz.

${ }^{520}$ TH. W. LYMAN, “ La table d'autel de Bernard Gilduin et son ambiance originelle”, Les Cahiers de Saint-Michel de Cuxa, vol. 13, 1982, pp. 53-73.

${ }^{521}$ En lo referente a cada uno de estos focos escultóricos, no realizamos ninguna mención bibliográfica aquí, pues cada uno de ellos se abordará más adelante y será en ese momento cuando se incluirán las notas bibliográficas pertinentes. 


\section{ROMA, LA IDEA DE ROMA Y SU LEGADO DURANTE LA EDAD MEDIA.}

Roma, además de ser un lugar físico, es también un concepto, un mito, una idea, un signo de distinción, de poder, de riqueza y de lujo, desde la misma Antigüedad hasta hoy en día. Cada uno de estos factores, extrínsecos en principio a cualquier lugar geográfico, han ido con el tiempo sumándose a la larga lista de adjetivos y calificativos aplicables a la ciudad de las ciudades. Su simple mención evoca la idea de urbs por antonomasia, tan sólo equiparable en autoridad a otras míticas ciudades como Jerusalén, Constantinopla, Babilonia o, en última instancia, la etérea Ciudad Celeste.

Desde la misma mentalidad cristiana, el concepto de urbe y capital del Imperio Romano, fue asimilado rápidamente por parte de las élites más pujantes, quienes, a través de la apropiación de los monumentos paganos de los emperadores y la ocupación física de aquellos territorios, reinterpretaron el concepto de ciudad imperial, readaptándolo a sus propios valores políticos, económicos e ideológicos. Si Roma fue capital del Imperio Romano, pronto pasó a ser la capital del Imperio Cristiano ${ }^{522}$.

Nada escapó a este método de reelaboración. Hasta la propia ruina de la ciudad romana fue sometida a un proceso de reinterpretatio christiana, por parte del nuevo ente político dominador de la urbe. Los fragmentos materiales de aquel poder en declive, es decir, templos, mausoleos, fustes, capiteles, cornisas, esculturas de todo tipo, sillares y un largo etcétera, pronto volvieron a configurar una nueva identidad, ahora cristiana, de una nueva ciudad.

Como capital de la nueva religión, pronto comenzaron a acudir a ella multitud de viajeros, curiosos y, sobre todo, peregrinos deseosos de comprobar físicamente la magnificencia del poder de la civitas que había acogido el cuerpo de tantos emperadores y, a la vez, de tantos mártires. El viaje se hizo entonces indispensable y, a partir de este momento, nacía con él un nuevo concepto que definía a todos aquellos viajeros que acudían a venerar las santas reliquias y el pasado glorioso de aquella ciudad.

Así, los términos de romipetae o romeo, tal y como ha señalado C. Nardella, sirvieron pronto para designar a este nuevo público del arte ${ }^{523}$. Y como todo lugar de peregrinaje, la ciudad eterna desarrollaba una reinterpretación de la mejor arquitectura civil romana para adaptarla a sus necesidades. Nacía así, eso que se ha dado en llamar

522 Il fascino di Roma nel Medioevo. Le «Meraviglie di Roma» di Maestro Gregorio (C. Nardella ed.), Roma, 1998, p. 9. A partir de este momento citado como: C. NARDELLA (ed.), Op. cit.

${ }_{523}$ C. NARDELla (ed.), Op. cit., p. 12. Véase la obra colectiva titulada: Romei \& Giubilei. Il pellegrinaggio medievale a San Pietro (350-1350) (a cura di M. D’Onofrio). 
"arquitectura de peregrinación" y de la que, según parece, Constantino fue el primer patrocinador $^{524}$. Siglos más tarde, Cluny se convertiría en punto indispensable en el cruce de caminos desde el norte de Europa y Roma, explotando, de igual manera, las experiencias artísticas y arquitectónicas de la Antigüedad ${ }^{525}$.

${ }^{524}$ B. BRENK, "Il luogo di culto...", p. 121. El autor considera que los edificios patrocinados por el emperador en Roma, pero sobre todo en Oriente: Santo Sepulcro, iglesia de la Natividad de Belén, la iglesia Eleona en el Monte de los Olivos y la de los Apóstoles en Constantinopla, configurarían la lista de un fenómeno que define como "arquitectura de peregrinaje internacional". En la actualidad, la expresión ha recibido fuertes críticas, sobre todo a la hora de aplicar el concepto de "iglesia de peregrinación" sobre la mismas iglesias románicas.

${ }^{525}$ C. NARDELLA (ed.), Op. cit., p. 12. 


\section{LA IMAGEN DEL ORBE ANTIGUO Y SU PASO A LA EDAD MEDIA.}

En esta nueva tesitura social en la que la peregrinación a los lugares santos se convirtió en un fenómeno de grandes repercusiones, es donde debemos buscar los ejemplos que clarifiquen el papel jugado por la ciudad de Roma, en cuanto a ciudad real, y su lugar en relación con la imagen que de ella se va a tener a lo largo de los siglos medievales. En este sentido y derivada directamente de esta premisa, la imagen mítica de la ciudad tendrá en sus ruinas y en el mismo arte antiguo, un elemento de gran interés a la hora de construir tal idea.

Todo viaje que se precie necesita de un mecanismo o fórmula que permita recordar lo visto y lo vivido. Nacerán pronto las descripciones que, de manera minuciosa, se detendrán en aquellos elementos más importantes de la ciudad. Se trata del documento más fiable a la hora de poder sopesar las percepciones, interpretaciones y valoraciones de las obras clásicas vistas ante los ojos de las gentes que visitaron Roma durante los siglos posteriores a la desmembración del Imperio. Encontraremos, si citamos dos de los casos más conocidos, a personajes como la monja Egeria, viajera del siglo IV o Benjamín de Tudela, que llevó a cabo su periplo a finales del siglo XII ${ }^{526}$.

En ocasiones, los autores de tales fuentes se nos mostrarán anónimos, tal y como vemos en el Itinerario de Einsiedeln, escrito entre los siglos VIII o IX en el monasterio suizo del mismo nombre o, en otras, relatados por personajes que pondrán especial atención en dejar clara constancia de la idea que se han formado de la misma ciudad, una vez finalizado el viaje.

Se producía entonces el nacimiento de los denominados Mirabilia. Un nuevo género literario que habría de mantenerse en boga durante toda la Edad Media ${ }^{527}$. Para comprender realmente lo que debemos entender por este tipo de obras, a veces mal definidas e interpretadas, seguimos a la profesora S. Maddalo, quién afirma:

\footnotetext{
${ }^{526}$ M. MAÑE RODRÍGUEZ, "La época de los viajeros y el redescubrimiento: la memoria del Próximo Oriente y los primeros viajeros: Egeria. Cartas de una peregrina a Tierra Santa (381-384 d.C.): reseña bibliográfica", La aventura española en Oriente (1166-2006) (J. M. Córdoba Zoilo y M. C. Pérez Díez, coords.), Vol. 1, 2006, pp. 53-54.

${ }^{527}$ Se ha venido considerando el Itinerario de Einsiedeln como uno de los más antiguos. Se cree que fue realizado en griego por un anónimo discípulo de Valafredo Strabon, quién se centrará, sobre todo, en recopilar fielmente algunas inscripciones, para, al mismo tiempo, describir la ciudad de Roma. Sobre ello, vid.: A. GRAF, $O p$. cit., en especial, p. 45; C. NARDELLA (ed.), Op. cit., pp. 15-16 y R. SANTAGELI VALENZANI, "Le più antiche guide romane e l'itinerario di Einsiedeln", Romei \& Giubilei..., pp. 195198.
} 
“(...) el término mirabilia, indica una tipología textual muy variada y la vez suficientemente homogénea: elementos de edificios sacros y profanos y de monumentos antiguos (...) Se trata de las guías del peregrino, la relación del viaje, el recuerdo de Roma y la narración de sus míticas leyendas, las descripciones, a veces fantasiosas, de los monumentos medievales y de los vestigios de la Roma antigua" ${ }^{, 528}$.

A partir de este momento, las ruinas de la ciudad, sus monumentos más importantes y sus lugares más emblemáticos, pasaron a formar parte de descripciones de viajeros que, a través des sus ojos, no han legado la imagen que por estos momentos se tenía de tales ciudades ${ }^{529}$.

El texto se convierte en el documento al que recurrir como único testigo directo y reflejo difuso del recuerdo de un mundo pasado. Las ciudades, sus símbolos, sus obras y edificios, algunos perdidos para siempre, causaron impacto en estos hombres y la manera en que hoy podemos llegar a percibir tales sensaciones, pasa por el análisis de tales textos. Aunque, igualmente se deba ser extremadamente cauto a la hora de valorarlos, debido, sobre todo, a su fuerte carácter fantástico.

Ya hemos aludido anteriormente al famoso Mirabilia de Pierre Maillius y su descripción de diferentes partes de la ciudad. Sin embargo, los primeros ejemplos del género, al menos que hayamos conservado, pertenecen al siglo XII.

En este sentido, posee especial relevancia, el Liber Politicus, redactado por Benito, un canónigo de la basílica de San Pedro de Roma. Sin embargo, avanzando el tiempo, los ejemplares se hicieron cada vez más numerosos, aumentando cuantitativamente los ejemplos escritos $\mathrm{y}$, por consecuencia, los que llegaron hasta nosotros $^{530}$.

La Historia Natural de Plinio, ofrecía ya en fecha temprana, un precoz ejemplo de este género, si es que lo podemos considerar asi ${ }^{531}$. Algunas de sus palabras aludían a determinadas maravillas de la urbs augusta, por ejemplo:

\footnotetext{
${ }^{528}$ S. MADDALO, In Figura Romae..., pp. 28-29: "il termine Mirabilia si è soliti indicare una tipologia testuale molto varia, se pure suficientemente omogenea: elenchi di edifici sacri e profani e di monumenti antichi (...) le guide per pellegrini, le relazioni di viaggio, i ricordi di Roma e i racconto delle sue mitiche leggende, le descrizioni, spesso fantasiose, dei monumento medioevali e delle vestigia della Roma antica".

${ }_{529}$ Véase el capítulo del estudio de A. Graf titulado "Le rovine di Roma e i Mirabilia", donde analiza la forma de ver las ruinas por parte de los peregrinos que llegaban a Roma. Cf.: A. GRAF, Op. cit., pp. 3460, en particular, p. 43.

${ }^{530}$ C. NARDELLA (ed.), Op. cit., en concreto, p. 17 y S. AINI, Op. cit., pp. 199-204.

${ }^{531}$ Somos conscientes de las diferencias existentes entre el género utilizado por los redactores de los Mirabilia y los textos de Plinio, así como de lo problemático de poder considerar algunos fragmentos de
} 
"Pero conveniente es pasar a contar las cosas admirables de nuestra ciudad (Roma) y hazer mención de los hombres que en novecientos años han sido de sutil ingenio (...) Algunas veces reciben las ondas del río Tibre, que infundido por ellos los haze bolver atrás, y pelean dentro los ímpetus de las aguas, y estrivando la firmeza de los conductos resiste. Llevan las aguas por dentro piedras grandes y de grande peso, sin quedar vencidas las causas de la obra. Reciben golpes de las ruinas que encima se hunden o se derriban con incendios ${ }^{" 532}$ (texto 15).

Parece claro que, ya por estos momentos, las ruinas de la gran ciudad y las consecuencias del paso del tiempo sobre la misma, atraían la atención de aquellos que escribían sobre ella. La ruina se convertía en un objeto para observar y admirar, entendiendo tal fenómeno como integrante del acto mismo de destrucción, no hacia su desaparición, sino hacia la reafirmación de su magnificencia. El objeto material representante de aquel pasado se desintegraba mientras que, de una manera proporcional, se incrementaba la imagen mítica del mismo.

Es en el siglo XI cuando se documenta uno de los textos más llamativos a la hora de expresar la relación del hombre medieval con respecto a la ruina de Roma. Se trata del texto escrito por Ildefonso de Lavardin (1056-1133), primero obispo de Le Mans y, más tarde, de Tours.

Dicho personaje, ante la decadencia y el desmembramiento de la gran ciudad escribía:

"Nada se puede enfrentar a ti, o Roma, sin embargo ahora te muestras casi en ruina completa y por el contrario son tus ruinas las que muestran que grande fuiste estando íntegra" ${ }^{, 533}$.

\footnotetext{
su obra como tales. Se trata, tan sólo, de un ejemplo que sirve para poder explicar que tal tendencia había sido utilizada ya en el mundo antiguo.

${ }^{532}$ C. PLINIO SEGUNDO, Op. cit., pp. 1115-1116. Es interesante destacar que, de igual manera, se ha señalado la situación totalmente ruinosa que mostraban algunas partes de la ciudad durante el siglo X, especialmente el cauce del río Tiber, que arrastraba a menudo "i rospi e le serpi". Cf.: A. GRAF, Op. cit., p. 37.

${ }^{533}$ Hildeberti Cenomanensis Carmina minora (A. Brian Scott ed.), Leipzig, 1969, p. 36 . El fragmento dice textualmente: "Nulla si può mettere a confronto con te, o Roma, nonostante tu sia quasi tutta in rovinal e pur in rovina mostri quanto grande saresti stata integra"/ "Par tibi, Roma, nihil, cum sis prope tota ruina, / quam magna fueris integra, fracta doces".

Sobre el texto, véase también: S. MADDALO, In Figura Romae..., p. 3; A. GRAF, Op. cit., en concreto, p. 25 y S. SETTIS, "Continuità, distanza...", en concreto, p. 377. El texto de Lavardin debió ser compuesto antes del 1130-1140, fechas en las que se ha barajado la muerte de este obispo que, mediante
} 
Sin embargo, además de las ruinas, también centró la atención de estos autores y sus escritos, el estado anterior y el proceso mediante el cual, algunas de estas construcciones y obras realizadas en la misma ciudad, habían llegado a mostrar tal apariencia. No en vano, la creación durante los siglos del medievo de este género literario y la posibilidad de rastrear sus orígenes y antecedentes dentro de la misma Antigüedad, señala un interés continuo por conocer, difundir y asimilar el conocimiento de las obras de arte y las maravillas creadas por la mano del hombre.

La literatura cristiana tomó el concepto y lo explotó desde época muy temprana. Este fue el caso, por ejemplo, de los textos que nos ha legado la amplia producción de Prudencio, quién visitó la ciudad de Roma en el siglo IV, dejando constancia de tal hecho a través de una serie de bellas descripciones de sus lugares más significativos. Si bien, la mayor parte de los ejemplos expuestos por el autor cristiano no corresponden a narraciones centradas en la ciudad de Roma, es cierto que se advierte plenamente la utilización dentro de sus recursos literarios y lingüísticos de idénticos mecanismos de exaltación y descripción de determinadas producciones artísticas, anticipando el discurso utilizado para los Mirabilia ${ }^{534}$.

Sin embargo, este caso concreto es extrapolable a otros tantos. En consonancia con ello, por ejemplo, cuando en su Itinerario, Egeria escribe sobre el palacio del rey Abgar, se percibe claramente la utilización de estos mismos recursos narrativos y, sobre todo, una posible similitud en cuanto a sus objetivos en el uso de los mismos:

"Y así me llevó primero al palacio del rey Abgar, donde me mostró su estatua de mármol, grande y muy parecida a él, según ellos decían, tan brillante que parecía de perlas; en el rostro de Abgar, mirando de frente, se veía haber sido realmente varón muy sabio y honorable (...). Cerca de allí había otra estatua también de mármol, que dijo ser la de Magno, hijo de Abgar, la cual también tenía un aspecto gracioso. Luego entramos en la parte interior del palacio. Había allí fuentes llenas de peces, cuales yo nunca había visto: tan grandes, tan lustrosos y de tan buen sabor. La ciudad no tiene actualmente más agua que la que sale del palacio, que es como un gran río de plata (...)." ${ }^{, 535}$ (texto 16).

\footnotetext{
un poema elegíaco, se lamenta de la destrucción de la gran ciudad. Debemos señalar que durante mucho tiempo se creyó que el texto había sido escrito por un poeta clásico.

${ }^{534}$ M. MAYER I OLIVÉ, "Fuentes hispanas para los contactos con la iglesia de Roma", Ecclesiae Urbis. Atti del Congresso Internazionale di Studi sulle chiese di Roma (IV-X secolo) (F. Guidobaldi y A. G. Guidobaldi coords.), vol. I, Cittá del Vaticano, 2002, pp. 159-168, en especial, p. 162.

${ }^{535}$ EGERIA, Op. cit., p. 237.
} 
Su descripción señala un interés muy temprano, por parte de estos primeros autores cristianos, hacia la valoración de las obras, independientemente de su carácter eclesiástico o no, que tienen ante los ojos. Resulta evidente que la serie de descripciones hechas por la monja están casi siempre destinadas a exaltar la realidad material de los lugares santos y no exclusivamente aquellos relacionados con la ciudad de Roma. Sin embargo, los textos también muestran cierta sensibilidad hacia otra serie de obras más específicamente artísticas, tal y como se observa, por ejemplo, a través de la valoración que lleva a cabo de algunas de las esculturas que tiene ante los ojos.

En el caso de la descripción de la monja Egeria que acabamos de ver, no lo olvidemos, escrito en una fecha muy temprana, llama la atención el parentesco que presenta con algunos de los mejores textos que se han incluido categóricamente dentro del género medieval de los Mirabilia, incluso aquellos de datación mucho más tardía. En este sentido, por ejemplo, merece ser citado el llamado Liber Imperiale, que aparece incluido en el texto titulado De Roma prisca et nova varii auctores, publicado por Giacomo Mazochio en la propia Roma en torno al año 1523. En dicha fuente, a la hora de describir los Pallatium majus del Palatino de Roma, el autor nos dice:

“El Palacio Mayor (...) está en el medio de Roma y era un palacio (...) redondo (...) con cincuenta bellísimos palacios, de belleza similar tanto los unos como los otros (...) decorados con bellísimos pórfidos y mármoles de diversos colores, en el medio al interior, tenía un lago, donde había todo tipo de peces (...)"536 (texto 17).

Desde un punto de vista formal, se observan ciertas concomitancias entre el texto de la monja y el recogido en el Mirabilia renacentista. Tal fenómeno puede explicarse a través de una transmisión estereotipada o a través del uso de fórmulas literarias repetitivas, que consiguen, finalmente, que ambas fuentes puedan encontrarse en un determinado punto. Sin pretender equiparar ambos textos, llama la atención que la monja Egeria, a pesar de no componer plenamente un Mirabilia, apunte ciertos rasgos y maneras habituales del género.

Desde otro punto de vista, el número de autores que escribirían sobre Roma y sus monumentos iría incrementando con el paso del tiempo. Ejemplos como los de Amato de Montecassino (†1093), que elaboraría un poema dedicado a los apóstoles Pedro y Pablo, no dejarán de mostrar referencias exactas al gran prestigio de la urbs

${ }^{536}$ A. GRAF, Op. cit., pp. 90-92. Véase el texto 17 de nuestro Apéndice de Textos. 
romana, a pesar de que su obra no pueda ser considerada estrictamente como perteneciente al género de los Mirabilia ${ }^{537}$.

Otros personajes, como por ejemplo Bernardo de Morlas, monje de la abadía de Cluny, escribiría en la primera mitad del siglo XII reflexiones ciertamente interesantes en este sentido:

"Est modo mortua Roma superflua; quando resurget? Roma superflui, afflua corruit, arida, plena; Clamitat et tacet, eregit et jacet, et dat egena" 538.

Sus palabras, sumadas a las vertidas por Amato de Montecassino, revelan el conocimiento y la exaltación simbólica de la ciudad más emblemática de la Antigüedad occidental.

La imagen que el hombre medieval tuvo del mundo antiguo y de las grandes ciudades y obras artísticas que configuraron el panorama de ese periodo, es difícil de precisar en la actualidad $^{539}$. Sin embargo, las referencias fueron frecuentes y éstas deben ser vistas por parte del hombre contemporáneo, como un mecanismo que facilite la comprensión y el análisis de la percepción de ese mundo antiguo, analizado bajo el prisma del hombre del medievo. A través de las descripciones, de la literatura y de fuentes diversas, es posible acercarse a la percepción de lo antiguo y de lo clásico, según la manera de mirar el arte antiguo que tenía el mismo hombre medieval.

Con todo, resulta extremadamente arriesgado poder valorar el alcance y complejidad de tal percepción de la realidad antigua, de las grandes ciudades romanas, así como de la propia definición de ciudad y de sus construcciones más significativas. Es nuevamente complejo poder delimitar cuales de las obras datables en el periodo antiguo se mantuvieron en uso, si conservaron tal funcionalidad durante los siglos

\footnotetext{
${ }^{537}$ Ello demuestra, además, la gran estima que el entorno de la abadía casinenese sentía hacia la ciudad de los emperadores, así como hacia sus vestigios materiales. Cf.: A. GRAF, Op. cit., en concreto, p. 11.

${ }_{538}^{538}$ Ibidem, p. 31.

${ }^{539}$ M. CLAVERIA NADAL, "El sarcófago romano. Cuestiones de tipología, iconografía y centros de producción”, El sarcófago romano. Contribuciones al estudio de su tipología, iconografía y centros de producción, Murcia, 2001, pp. 19-50, particularmente, p. 27. La profesora Claveria señala que el sarcófago antiguo, desde siempre, estuvo emplazado al aire libre, de una manera preferentemente expositiva "en extensas zonas cementeriales que flanqueaban la red viaria que conducía a la ciudad". Desde la Antigüedad tardía dichas piezas se aglutinaban alrededor de las cella memoriae o en torno a los monumentos funerarios o enterramientos en las propiedades suburbanas, modificando profundamente el panorama geográfico y visual de tales territorios. Estos datos deben servir para reflexionar sobre el papel jugado por las piezas en relación con el estudio del paisaje monumental de los siglos antiguos y medievales.
} 
medievales, con qué sentido se las utilizó y que valor se les otorgó. El panorama de las urbes antiguas fue bien distinto al que rodeó la vida cotidiana de los hombres de los siglos medievales. Muchos de estos "fragmentos" de la Antigüedad fueron reutilizados para amoldarse y adaptarse a los nuevos entramados urbanos de los siglos posteriores a la disipación del poder imperial romano. Sin embargo, sus símbolos artísticos más contundentes se mantuvieron, en ocasiones, intactos y aparentemente fueron respetados.

En otras ocasiones, fueron sometidos a reinterpretaciones, tanto físicas como intelectuales, que servirían como medida preservadora de las obras y que evitaron su destrucción. Tal actitud de veneración y respeto hacia un pasado antiguo, se transformaba esporádicamente en un sentimiento de admiración hacia los restos de esa Antigüedad. Su deseo de sentirse continuadores de ese pasado lejano, que no perdido, llevaría a determinados hombres medievales a exaltar la imagen de la ciudad romana, de sus edificios y de las obras que un día la decoraron, como un referente cultural de gran prestigio ideológico.

En otras ocasiones, esta suerte de disecta membra legados a la Edad Media desde el mundo antiguo, fueron vistos como un mero reempleo material y de economía de trabajo, aunque otras tantas, recibieron una reactivación ideológica de gran alcance.

Sin embargo, independientemente de tales circunstancias, la Antigüedad nunca fue negada. Sus vestigios eran la base y cimentación de una cultura que no se sentía heredera de tal pasado, sino continuadora del mismo. Los cimientos de los antiguos templos sirvieron de base para los nuevos. Se trataba de una base material que, exprimiendo al máximo tal argumentación, permite hablar desde un punto de vista metafórico, de una reutilización ideológica de tales cimientos.

La geografía de la Europa romanizada, durante toda la Edad Media, se encontraba plagadas de citas textuales de ese mundo antiguo. El hombre medieval, como el de los demás periodos del devenir histórico, no se mantuvo pasivo hacia tales restos materiales. Como hoy, en ocasiones el hombre admiró y describió su impresión ante tales obras, mientras que en otras, se mantuvo completamente ajeno -quizás de manera inconsciente por desconocer la función y significado de tales "restos" de una cultura de la que participaba, pero de la que desconocía el origen-.

Parece claro que la imagen más difundida durante todo el periodo medieval en relación con los ambientes urbanos de mayor prestigio, fue la de la ciudad de Roma. Sin embargo, otros núcleos como los de Constantinopla, Ravenna, Jerusalén y los ya más 
lejanos de Bagdad o Samarcanda, también recibieron atención por parte de los hombres medievales.

El viaje se convertirá, en la mayoría de las ocasiones, en una fuente fundamental para conocer, de primera mano, la visión que se tenía de la Antigüedad. No en vano, el mundo concebido de manera científica, era un espacio físico donde la urbe y las vías de comunicación, junto con los accidentes geográficos y los fenómenos naturales, configuraban la imagen que de él se tendría. La visión científica, apartada en cierta medida de la concepción del mundo teológico, será una imagen donde las ruinas de la Antigüedad, entre otros muchos elementos, contribuían a construir y definir su morfología e imagen.

A pesar de su fórmula simplificada, la imagen del Mappa Mundi datada en el siglo VIII del De natura rerum de Isidoro de Sevilla, define claramente la forma que se le otorgaba al espacio en el que habitaba el hombre, que se relacionaba con un concepto, en cierta medida, urbano ${ }^{540}$ (fig. 90).

Se trata, según S. Gianmaria, de un códice redactado durante el siglo VII en Italia, quizás en la misma Roma. En los folios 63 v. y 64 r. fue miniada la imagen de un mappa mundi que, según se ha dicho, se trata muy posiblemente de una de las imágenes más antiguas que ha llegado hasta nuestros días de la imagen de la tierra, según la concepción que de ella se tenía en la Alta Edad Media.

No deja de resultar llamativo que, aquí, nuevamente las fuentes utilizadas para elaborar tal imagen vuelvan a ser antiguas, pues tal y como se ha demostrado, parece inspirarse en las teorías cosmográficas de Tolomeo, pero reinterpretadas bajo el prisma teológico del mundo cristiano ${ }^{541}$. Así, ocupa un lugar privilegiado dentro del orbe, la imagen de Jerusalén, la ciudad santa por excelencia, que aparece amurallada a través de un recinto estrellado. Este hecho, tan sólo lo comparten otras dos ciudades; los grandes centros de Constantinopla y Roma, que nuevamente aparecen señalados bajo la forma de unos rudimentarios bastiones defensivos estrellados, tal vez en una alusión imaginativa de los recintos amurallados de tales ciudades.

\footnotetext{
${ }^{540}$ Roma, Biblioteca Apostólica Vaticana, Vat. Lat. 6018, fols. 63v-64r. Cf.: S. MADDALO, In Figura Romae..., en concreto, p. 86.

${ }^{541}$ S. GIANMARIA, "Isidoro di Siviglia, De natura rerum", Romei \& Giubilei..., ficha catalográfica 11, p. 287. El autor que realizó tal imagen tenía un buen conocimiento de las regiones orientales, tal y como acredita el detallismo a la hora de señalar los núcleos urbanos de Ebron, Jericó o diversos accidentes geográficos, como el monte Sinaí, el río Jordán y el mar muerto. Menos familiar le resultaba la India, aunque señala con todo acierto el río Ganges.
} 
No pretendemos en ningún caso justificar la forma de tales imágenes mediante la posibilidad de una evocación arqueológica de las murallas. Simplemente, apuntamos que, muy posiblemente se trate de una evocación simbólica de tales espacios, donde la presencia de los vestigios amurallados de las ciudades romanas debía formar parte habitual del panorama que contemplaban los hombres de los siglos medievales. Un espacio donde la ciudad era el elemento que definía claramente y servía para identificar esos mismos espacios ${ }^{542}$.

No en vano, sería el propio Isidoro de Sevilla el que dirá:

"Ciudad es un grupo de hombres ligados por un vínculo social, así llamada a causa de sus ciudadanos que son los que la habitan. En cambio, por urbe se entiende simplemente los muros, con civitas, en cambio, no se entiende la piedra, sino los hombres que la habitan"543.

Parece claro que la concepción del hábitat humano comprendido por una realidad urbana en la que habitan los hombres, debe emparentarse igualmente con la concepción teológica del mundo en vigor durante el periodo medieval. Dicha concepción de la vida humana, vinculada en muchos casos al ambiente urbano, preocupó tanto autores antiguos como medievales.

Plinio, en su Historia Natural, ya muestra su interés por las dimensiones de la ciudad de Roma y algo similar ocurrirá con la mayoría de los autores cristianos medievales, que a través de sus descripciones nos mostrarán su interés por la morfología de la ciudad de los emperadores ${ }^{544}$.

\footnotetext{
${ }^{542}$ Es evidente que en el mundo antiguo existieron cientos de ciudades que poseían un recinto amurallado con formas diversas e irregulares, que se alejan de la imagen estrellada que propone el autor del siglo VIII en esta miniatura. Sin embargo, baste recordar los recintos amurallados con forma de estrella de algunas ciudades como la de Sforza en Italia, u otros ejemplos conservados en Portugal, para demostrar la posible inspiración real de estas imágenes, sometidas, sin duda alguna, a la reinterpretación imaginativa de los autores medievales. Cf.: X. BARRAL I ALTET y R. NAVARRO SÁEZ, "Las representaciones de murallas en los mosaicos romanos de Hispania: un motivo de orla itálico", Boletín del Seminario de Estudios de Arte y Arqueología, vol. 40-41, 1975, pp. 503-522 y S. MADDALO, In Figura Romae..., pp. 86-87.

${ }_{543}^{54}$ ISIDORO DE SEVILLA, Op. cit., p. 88.

${ }^{544}$ R. VALENTINI y G. ZUCCHETTI, Codice Topografico della Città di Roma, 2 vols, Roma, 1940, vol. I, en concreto, pp. 3-8. Los autores recogen el texto y llevan a cabo un análisis de la problemática en torno a las dimensiones de la ciudad y los edificios que configuraban el espacio urbano en época de Plinio. La obra que hemos citado aquí, ha sido fundamental para elaborar este apartado de nuestro trabajo. Se observará una cita constante de ella, a través de las diferentes voces, documentos y transcripciones, que los autores han seleccionado, de manera crítica, de entre las muchas fuentes que manejaron en su día.
} 
No en vano, fue Plinio el que otorgó un lugar privilegiado a la famosa planta de Roma que, hipotéticamente, había sido esculpida sobre diversas placas de mármol durante la época de Septimio Severo (fig. 91). Se trataba de una planta de la ciudad inspirada, a su vez, en otro ejemplo datado durante el mandato del emperador Augusto. La pieza, labrada sobre mármol, estaba colocada en el Forum Pacis de Vespasiano, en la parte externa del edificio. Además de señalar los principales inmuebles de la ciudad, presentaba áreas coloreadas a través de mármoles de diferentes tipos, que marcaban las diversas partes de la gran urbe: fuentes, ninfeos, acueductos, calles, pórticos, templos, teatros y diversas zonas, como el Palatino o el Aventino, aparecían aquí con todo lujo de detalles $^{545}$.

Son muchos los autores que han propuesto esta carta del pórtico, actualmente conocida como "planta de Vespasiano" como el modelo original y del que derivarían muchos de los mapas de la Antigüedad tardía, tanto pagana como cristiana ${ }^{546}$. En este sentido, cuando esta gran placa de mármol polícromo a la que nos estamos refiriendo, fue colocada sobre la parte frontal del templo, a la vista de todo el público romano, se estaban asentando algunos precedentes que más tarde encontraremos en el mismo ámbito medieval, donde este valor expositivo de las obras cartográficas no fue desconocido.

En relación con ello es posible citar algunos ejemplos. La utilización de la imagen de la urbe materializada, por ejemplo, a través de una carta, del orbe o mediante un mapa, había sido usada ya por el mismo papa Zacarías durante los años centrales del siglo VIII. Tal personaje mandó pintar sobre su triclinium, cercano al Letrán, una imagen del orbis terrarum. Por su parte, también el propio Teodulfo de Orleáns denominará totius orbis depicta figura, a la carta geográfica representada en la mesa de su palacio episcopal, en la misma ciudad ${ }^{547}$.

Se trata de algunos ejemplos bien conocidos y que pueden ser considerados como precedentes de otra serie de obras de gran prestigio. En este sentido, merece la pena recordar las citadas mesas de oro y plata descritas en el testamento de Carlomagno y sobre las que volveremos en breve.

\footnotetext{
545 Ibidem, pp. 49-58. El edificio romano se encontraría colocado donde hoy se ubica la iglesia de los Santos Cosme y Damián, en el foro de Roma. Por razones que se desconocen, las piezas acabaron sepultadas bajo los cimientos del edificio romano, para ser finalmente descubiertas en época del papa Pío IV (1562), época en la que se llevaron a cabo diversas obras en la iglesia.

${ }^{546}$ P. GAUTIER DALCHÉ, La descriptio mappe mundi de Hugues de Saint-Victor, Paris, 1988, en concreto, p. 62, nota 8

${ }^{547}$ Ibidem, pp. 90-92.
} 
Tal relación de dependencia entre los modelos clásicos y los medievales, viene reafirmada, igualmente, en cuanto a la creación de modelos cartográficos y cosmográficos, pues aquellos realizados en la misma Edad Media, tenían un claro origen antiguo. Determinados autores cristianos, algunos de ellos activos durante los últimos siglos del Imperio, como Martianus Capella, Iulius Honorius o el mismo Orosio, se inspirarán indiscutiblemente en dicha tradición ${ }^{548}$.

Las visiones del mundo que plantearán tanto los autores cristianos como los antiguos, tendrían, a veces, cierta intencionalidad científica. En otras ocasiones, el objetivo sería voluntariamente simbólico, primando un interés por resaltar aspectos concernientes, de una manera más concreta, sobre los temas religiosos y culturales, que en relación con los meramente geográficos.

En otros casos, la visión simbólica y la topográfica se entremezclaban de manera confusa, sirviendo tal mecanismo como base para la reflexión sobre los pueblos y las gentes que habitaban sobre el mundo ${ }^{549}$.

Lo que pretendemos exponer con tales datos, es la voluntad de todos los autores por dejar constancia del conocimiento del mundo y de sus elementos más señeros, entre los cuales se encontraban numerosos restos y vestigios de época antigua. De ahí el interés que puedan ofrecer tales fuentes.

Tal y como hemos visto, en la representación del manuscrito de Isidoro de Sevilla del siglo VIII, la concepción del espacio terrestre se lograba a través de la forma de la esfera. Una esfera inmóvil creada por Dios, que se mantenía estática en el centro del Universo. La tierra, siempre rodeada por agua, tiene un eje central: la Civitas Hierosolimitana ${ }^{550}$. Una imagen circular, de claras resonancias clásicas, que reaparecía cargada de simbolismo y que sería explotada de manera frecuente por parte de la imaginería medieval cristiana $^{551}$.

\footnotetext{
${ }^{548}$ Martianus Capella escribiría su De nuptiis Philologiae et Mercurii centrándose en algunos aspectos geográficos del mundo. Honorius realizó la obra titulada Cosmographia, seguramente en una fecha posterior al año 312 y también se centraba en el mismo tema, así como sobre el análisis de los habitantes que vivían sobre las diversas partes de la tierra. Este autor sería conocido además a través de sus conocidas palabras sobre la insulae Hippopodes, por citar el ejemplo más famoso. También Orosio y su Historiae adversus paganos se preocupaba por las diversas regiones del mundo. Todos ellos asentarían las bases para tratados posteriores en los que los autores medievales llevarían a cabo un estudio de similares características sobre la geografía del plantea. Cf.: P. GAUTIER DALCHÉ, La descriptio mappe mundi..., en concreto, pp. 66-72.

${ }^{549}$ S. MADDALO, In Figura Romae..., en especial, pp. 5-50.

${ }^{550}$ S. GIANMARIA, "Isidoro di Siviglia...", p. 287.

${ }^{551}$ A través de la representación del mundus sostenido por el Pantocrátor o, en su versión política, dentro de la imagen de los regalia como atributo del soberano, por citar los casos más evidentes.
} 
En relación con tales aspectos, debe recordarse el caso ya mencionado de las famosas mesas del testamentum de Carlomagno, donadas respectivamente a la iglesia de San Pedro de Roma y a la ciudad de Ravenna. En ellas parece que se mandó colocar la imagen de la ciudad de Constantinopla, representada a través de un cuadrado y la de Roma, a través de un círculo.

La tercera mesa, según Eginhardo, era:

“(...) mucho más hermosa y más pesada que las otras, que lleva grabado en un dibujo fino y pequeño el mapa del mundo entero bajo la forma de tres círculos concéntricos" $" 552$ (texto 8).

Aunque la representación del siglo VIII dista en algunos detalles respecto a la descripción dada por el autor carolingio, parece que las dos obras dependían de las mismas fuentes artísticas. La continuidad en la utilización de esta tradición clásica, parece perpetuarse en el siglo XI, donde observamos que, tanto la representación del Santo Sepulcro, como la de la Jerusalén Celeste, se definían nuevamente a través de la figura del círculo. Éste elemento, permite a su vez, circunscribir el edificio funerario constantiniano y el Cordero Apocalíptico en su interior, tal y como demuestran algunos ejemplos de dicha cronología. Según se ha señalado, tales fórmulas parecen seguir, a grandes rasgos, la usanza clásica atestiguada ya en las Etimologías de Isidoro de Sevilla, según las cuales, "annum autem quasi anum dici quidam putant, id est circulum",553.

En el caso hispano, dicha tendencia se repetirá de manera milimétrica. La centralidad del mundus, su carácter estático, rodeada completamente por las aguas y teniendo como centro más importante la ciudad de Jerusalén, son características que encontraremos en la conocida imagen del Beato de Liébana (ca. 1047) ${ }^{554}$ (fig. 92). En la Explanatio in Apocalipsim, posiblemente realizada por Facundus bajo el patrocinio de los reyes Fernando I y Sancha, la visión del mundo que se plantea parece totalmente contaminada por la tradición clásica, según la cual, éste se dividía a través de los territorios de África, Asia y Europa, acompañados, en muchos casos, por la

\footnotetext{
${ }^{552}$ EGINHARDO, Op. cit., pp. 117. Se trata del texto 8 del apéndice de textos.

${ }^{553}$ En concreto nos referimos a la imagen del Santo Sepulcro de Berlin, Nationalbibliothek, Ms 458, f. 4 v. y a la imagen de la Jerusalén Celeste del Apocalipsis de Valenciennes, Bibliothèque Municipale, Ms 99, f. 38 r. Sobre ambas imágenes, véase: CH. FRUGONI, Una lontana città..., en concreto, pp. 18-19.

${ }^{554}$ Madrid, Biblioteca Nacional, vit. 14-2, cc. 63v-64r. Cf.: J. WILLIAMS, Early Spanish Manuscript Illumination, New York, 1977 e ID., The illustrated Beatus: a corpus of the illustrations of the commentary on the Apocalypse, Introduction, vol. I, London, 1994, pp. 51-53.
} 
representación del Nilo y el mar Mediterráneo. En relación con la imagen, destaca, en el lado derecho, la representación de la "deserta terra vicina solis ab ardore incognita nobis", una solución improvisada para obtener la imagen de un continente que desconocían y que ocupaba todo el hemisferio astral.

Nos interesa destacar, sobre todo, la representación más importante de la carta que venimos comentando. Se trata de la ciudad de Jerusalén que, junto con la imagen del paradisus de Adán y Eva, ocupa la parte alta del mundo, es decir, el oriente ${ }^{555}$. Se trata de una microarquitectura idealizada y fantástica, pero que recoge la tradición clásica de colocar a la urbe en el centro del mundo conocido, como representante del devenir histórico humano y, tal y como ocurrirá en infinidad de ejemplos, con el establecimiento físico de la ciudad de Roma. El mismo sistema de representación clásica aparece, por citar un caso concreto, en el famoso mosaico de la iglesia de San Jorge en Madaba, en Jordania, que se ha venido datando en torno al siglo VI (fig. 93).

En dicho mosaico, la ciudad de Jerusalén aparece representada a vista de pájaro, siguiendo modelos bien conocidos dentro de la pintura romana ${ }^{556}$. La ciudad se abriga bajo un recinto amurallado regular de forma más o menos ovoide. El centro topográfico vuelve a ser nuevamente el Santo Sepulcro, que marca un eje axial con el cardo de la ciudad. Las fuentes para esta obra han sido detectadas en el ámbito cartográfico helenístico-romano y su importancia estriba en la gran influencia que ejercerá sobre el arte medieval, tal y como han señalado, entre otros M. Piccirillo ${ }^{557}$.

La gran construcción constantiniana de la Anástasis, con su cúpula central representada en el mosaico mediante teselas amarillas, marca claramente el eje compositivo de la obra y recoge muchas de las características del sistema de representación geográfico y topográfico de las artes plásticas clásicas.

Sin embargo, de las tres ciudades más importes del mundo cristiano: Jerusalén, Roma y Constantinopla, la ciudad de los emperadores pronto adquirió un lugar

\footnotetext{
555 A. TRIVELlONE, "Beato di Liébana, Explanatio in Apocalipsim", Romei \& Giubilei..., ficha catalográfica 12, p. 288.

${ }^{556}$ Recuérdese también la famosa representación del anfiteatro de la casa del gladiador Actius Anicetus de Pompeya, hoy dentro de la colección del Museo Arqueológico de Nápoles, donde también se utiliza este sistema de captación de la imagen urbana. El espectador puede acceder a los hechos desarrollados en el interior del edificio gracias a una fórmula que mezcla la visión frontal y una vista "en picado" de la escena. Se ha venido datando poco después del año 59 d. de C. Vid.: E. SALZA PRINA RICOTTI, "Peinture et vie quotidienne", Jeunesse de la beauté. La peinture romaine antique, Paris, 2001, pp. 43-49 y F. GALTIER MARTÍ, La iconografía arquitectónica..., en concreto, p. 39.

${ }_{557}$ M. PICCIRILLO, "La città di Gerusalemme", Romei \& Giubilei..., ficha catalográfica 16, p. 291.
} 
destacado, que llegaría incluso a superar en grandeza a la urbe en la que se encontraba el Santo Sepulcro.

Roma acabaría imponiendo su imagen sobre los centros religiosos de peregrinación. Los mappa mundi de los siglos medievales señalaban la importancia de Jerusalén, pero Roma, a pesar de no poseer el memorable lugar donde había descansado el cuerpo muerto de Cristo, utilizó su pasado glorioso para atraer a las masas que visitaban la ciudad, a veces con motivos nada religiosos y totalmente desvinculados de la veneración de las reliquias de San Pedro ${ }^{558}$.

La ciudad de Constantinopla habría de perder durante los siglos medievales el rango que algún día, ya en el pasado, había ocupado dentro de los itinerarios y las representaciones cartográficas.

Tal aspecto viene ratificado gracias a la obra y las miniaturas de Salustio, datadas en torno al siglo XII ${ }^{559}$. Entre sus escritos se ha destacado la imagen del orbe, nuevamente circular y divido en tres partes, tal y como era habitual durante el mundo antiguo $^{560}$ (fig. 94). Llama la atención el hecho de que, en la parte alta, la imagen de Jerusalén se muestre monumentalizada a través de un edificio coronado por una estructura abierta al cielo, mientras que, en el lado izquierdo, se observa la representación de una Roma absolutamente simplificada. Por el contrario, constatada la presencia de Jerusalén y Roma en tal miniatura, no existe ni rastro de la ciudad de Constantinopla.

El conocido como primer tratado de geografía de la Edad Media, la Descriptio Mappe Mundi de Hugo de San Víctor, fue hipotéticamente compuesto entre los años $1128-1129^{561}$. A pesar de que el texto ha llegado hasta nosotros, sin embargo, ni rastro ha perdurado de la posible imagen que acompañaría a esta descripción del mundo. Presumiblemente, y tal y como era costumbre en este tipo de obras, el autor llevaría a

\footnotetext{
${ }^{558}$ Ese es el caso del magister Gregrio que en su famoso Mirabilia, ya citado, se detiene en describir otras obras antes que fijarse en aspectos meramente religiosos. Sobre este personaje y sus escritos volveremos más adelante. Véase también: J. SUMPTION, Monaci suntuari pellegrini. La religione nel Medioevo, Roma, 1981, en particular, pp. 29-53.

${ }^{559}$ Este es el caso, por ejemplo, del Orbe tripartito de Salustio, De bello Iughurtino, Roma, Biblioteca Apostolica Vaticana, Reg. Lat. 571, f. 71 v. Cf.: M. A. CASTIÑEIRAS GONZÁLEZ, "Topographie sacrée, liturgie pascale et reliques dans les centres de pèlerinage: Saint-Jacques-de-Compostelle, SaintIsidore-de-León et Saint-Étienne-de-Ribas-de-Sil”, Les Cahiers de Saint-Michel de Cuxa, 34, 2003, pp. 27-49, en concreto, p. 27 y S. MADDALO, In Figura Romae..., pp. 86-89.

${ }^{560}$ El caso más significativo, en cuanto a sintético, lo representa la imagen del mundus de las Etimologias de Isidoro, London, British Library, Royal Ms. 6. C. I. f. 108 v. Cf.: P. D. A. HARVEY, Medieval Maps, London, 1991, en especial, p. 21. El autor lo data en el siglo XI.

${ }^{561}$ P. GAUTIER DALCHÉ, La descriptio mappe mundi..., en concreto, pp. 11-17. El autor analiza la problemática de la autoría, lugar de redacción y cronología de la obra, de la que existen diferentes copias manuscritas.
} 
cabo la redacción de tal texto delante de una imagen pintada del orbe, utilizando un recurso ya documentado dentro de diversos textos datados en época tardoantigua. La obra del propio Isidoro de Sevilla es, en relación con ello, un buen ejemplo ${ }^{562}$.

A pesar de que la imagen que Hugo de San Víctor tuvo posiblemente delante de sus ojos se ha perdido, P. Gautier Dalché propuso en su día la comparación entre el texto del siglo XII y una representación figurada que parecía corresponderse, en algunos puntos, con la fuente escrita. Se trata de la imagen del orbe realizada dentro de un manuscrito conservado en la Bayerische Staatsbibliothek ${ }^{563}$ (fig. 95).

La descripción hecha en este primer "tratado geográfico" de la Edad Media, coincide, hasta en los más pequeños detalles, con la imagen del citado códice de Munich. Para nuestros objetivos, lo más interesante, reside en señalar el recuerdo de la Antigüedad dentro de la carta, materializado a través de la imagen de diversos monumentos antiguos que los autores medievales tenían aún delante de sus ojos. Su parentesco y dependencia con respecto a la imagen del mundo utilizada en los diferentes manuscritos y tratados cosmológicos de época clásica, viene apoyado por la presencia de las personificaciones de los vientos que rodean el orbe.

La ciudad de Jerusalén, un edificio centralizado rematado por una cruz y flanqueado por dos grandes torres, se ubica prácticamente en el centro, junto al monte Libanus y el río Jordán. Todo ello cercano al monte Sinaí, que aparece representando al lado del Tigris y el Eúfrates. La ciudad de Roma se sitúa en la parte inferior de la península italiana, separada del lado sur a través de un macizo montañoso escarpado y que, claramente, puede identificarse con los Apeninos que dividen en dos el territorio:

"Italia regio Romanorum a circio in eurum extensa habet ab affrico

Turrenum mare et a borea Adriaticum sinum; ab occidente autem obicibus Alpium obruitur (...).

Nona uero provincia in Alpibus Apenninis est sita. Decima autem Emilia nominatur.

\footnotetext{
562 Ibidem, p. 20. El experto señala la utilización de la expresión "depingere, mappa mundi depingitur". Sobre la utilización por parte de Isidoro de Sevilla de alguna imagen pintada que complementase el texto escrito, véase: M. A. CASTIÑEIRAS GONZÁLEZ, El calendario medieval..., en concreto, pp. 20-34 Recordemos que, de igual manera, la obra manuscrita realizada por la monja Egeria debió poseer también miniaturas. Tal deducción solamente es entendible a través de la utilización que hace la autora de expresiones como "ha sido edificada esta iglesia, que veis", refiriéndose al edificio que albergaba la tumba de Job. Sobre el tema, vid.: F. GALTIER MARTÍ, La iconografía arquitectónica..., en especial, p. 97 y p. 222.

563 München, Bayerische Staatsbibliothek, Clm. 10058, f. 154 v. Se trata de una miniatura fechada en el siglo XII y que se cree originaria del norte de Francia. Ocupa una parte preeminente del libro XIV de la enciclopedia consagrada al orbis. Cf.: P. GAUTIER DALCHÉ, La descriptio mappe mundi..., en concreto, pp. 81-83 y P. D. A. HARVEY, Op. cit., pp. 22-23.
} 


\section{Hec incipit inter Alpes Appeninas et pergit iuxta Padi fluenta versus \\ Rauennam, et hec locupletibus urbibus decoratur Placentia, Parma, Bolonia \\ et Cornelii Foro, quod modo Castrum Imolas appellatur ${ }^{\text {"564. }}$.}

La ciudad de Roma era para los artistas creadores de esta imagen un edificio simplificado y desprovisto de todo detalle. Tan sólo merece la pena destacar el hecho de que la ciudad aparezca asentada sobre el río Tiber, que atraviesa el espacio urbano mediante un túnel abierto en la muralla de la urbe (fig. 96). Nuevamente los accidentes y formaciones naturales, que desde el mundo antiguo habían señalado la ubicación de ciertos lugares y zonas geográficas, eran utilizados por los artífices medievales para realizar idénticas acciones.

El precedente directo, desde el punto de vista conceptual, se encuentra en el Mappa Mundi del Beato de Burgo de Osma ${ }^{565}$ (fig. 97).

En esta obra hispana se representó, otra vez, la península italiana rodeada por las aguas, mientras que en el centro de la misma emerge un edificio con tres torres y puertas laterales que cobijan la cabeza de San Pedro (fig. 98). Al otro lado y separados nuevamente por el río Tiber, el "retrato" de San Pablo. De nuevo vuelve a ser un accidente geográfico el elemento que define a un núcleo urbano o a una determinada región ${ }^{566}$. Este rasgo de la ciudad imperial se mantendría hasta fechas más tardías en otras obras, donde el modelo presente en el Beato de Burgo de Osma parece perpetuarse.

Para finalizar este repaso que hemos realizado en torno a la imagen del orbe, según los hombres del medievo y la utilización de fuentes clásicas, conviene mencionar el conocido como Itinerario de Matthew Paris. Se trata de una pieza de pergamino, supuestamente miniada por el monje Matthew en Inglaterra, alrededor de los años 12501269 y en la que se representó una suerte de itinerario que marcaba el camino a seguir para el desarrollo de la peregrinación desde Londres hasta Roma.

\footnotetext{
${ }^{564}$ P. GAUTIER DALCHÉ, La descriptio mappe mundi..., pp. 156-157. Señalamos aquí una constante dentro de la representación geográfica, en relación con la imagen de la península de Italia y la de España, separadas a través de los Apeninos y de los Pirineos.

${ }_{565}$ Burgo de Osma, Biblioteca de la catedral, cod. 1, ff. 34 v-35 r. Se ha datado en el siglo XI.

${ }^{566}$ En el caso de la imagen del Beato de Burgo de Osma, se trata de una representación del proceso evangelizador a través de la presencia de la efigie de los apóstoles, aludidos mediante sus cabezas. Véase la importancia que adquiere el Tiber en otros ejemplos recogidos por la profesora Silva Maddalo. Cf.: S. MADDALO, In Figura Romae..., en especial, pp. 91-99 y J. WILLIAMS, The illustrated Beatus..., vol. I, pp. 51-53.
} 
Se representaron en cinco páginas cosidas y a través de un fino dibujo coloreado mediante la técnica de la acuarela, los principales centros urbanos que el peregrino debía traspasar hasta llegar a la ciudad de San Pedro. La representación de Roma adquiere unas cotas importantes, pues el autor llega a figurarla hasta dos veces. Lo más interesante es que, en la segunda imagen de la urbe, cosida marginalmente al pergamino principal a través de un añadido, se representó la ciudad en formato rectangular, amurallada y con un rótulo de grandes dimensiones en el que se lee fácilmente la palabra "Roma" (fig. 99).

El modelo de la miniatura hispana del siglo XI que hemos analizado anteriormente, se repite aquí. El Tiber vuelve a dividir la ciudad en dos partes, separando la gran iglesia de San Pedro del Vaticano y la de San Pablo, aunque si bien, en esta obra, se percibe la ausencia de las inocentes simplificaciones cefálicas de los Apóstoles. Además, tal y como ocurría en el arte clásico, se puso especial énfasis en representar las puertas de la ciudad, sobre todo simbolizadas a través de la Porta Lumbardi, desde la que nacía la vía Francigena ${ }^{567}$.

Las obras hasta aquí mencionadas, ilustran la importancia de las fuentes romanas a la hora de analizar la visión que del orbe y de sus ciudades tuvieron los artífices medievales. Así, una vez estudiado el caso general de las representaciones de los mapamundis, en las páginas que siguen, aplicaremos los mismos razonamientos para explicar las imágenes medievales de las ciudades, tampoco exentas de un marcado carácter "antiquizante".

\footnotetext{
${ }^{567}$ London, British Library, Ms. Royal 14 C. VII. Cf.: P. MATHIS, "Matthew Paris, Itinerario", Romei \& Giubilei..., p. 289 y S. MADDALO, In Figura Romae..., pp. 96-98. El sustrato clásico de la obra se confirma al leer la inscripción realizada por el monje Mateo Paris, en la que cuenta los orígenes mitológicos de la ciudad, tal y como eran narrados en época virgiliana, remontándose desde la Enea a la ciudad de Troya.
} 
2. De la civitas antigua a la Civitas DeI: Reutilización CONCEPTUAl E ICONOGRÁFICA.

En el apartado que ahora iniciamos, se pretende realizar una visión del concepto de la ciudad antigua, desde el punto de vista de las artes visuales y cómo tales premisas acabaron por ser adoptadas a la hora de recrear plásticamente las principales ciudades de la cristiandad.

Por lo tanto, se advertirá, que el discurso se desarrolla en torno al concepto de muralla y su papel como definidora de la civitas. A partir de tales premisas, se estudiarán los aspectos que la ciudad real acabó por traspasar a la ciudad ideal o Jerusalén Celeste para, finalmente, aludir a las fuentes que los medievales utilizaron para "inventar" el carácter rico y dorado de esa urbe mítica. En la última parte del apartado se observará que tales prototipos son deudores, a su vez, de la imagen que el mundo medieval va a tener de la ciudad de Roma.

Tal y como ya hemos señalado, la MURALLA y las puertas de acceso a los recintos urbanos fueron desde la Antigüedad símbolo de la ciudad urbanizada, civilizada y desarrollada. Además, en el caso de Roma, este hecho alcanzó cotas monumentales, deudoras, tal vez, del concepto isidoriano de la urbe, que generalmente se vinculada siempre con la muralla y con la organización del recinto infra/extra muros. El autor visigodo, tal y como se ha venido aceptando, definía la urbs a través de los muros que circunscribían el espacio en el que habitaban todos los ciudadanos.

En este contexto se entienden bien las palabras escritas por el rabino Benjamín de Tudela en su conocido Itinerario ${ }^{568}$. El autor, una vez iniciado su periplo mundial desde tierras navarras, señala, aún dentro de las fronteras de Hispania, un elemento que a él le resulta llamativo de la ciudad de Tarragona. En concreto, sus palabras se referían a la antigüedad que los vestigios de la propia ciudad parecían mostrar y sobre todo, sus “edificios ciclópeos”, cuya factura atribuye a la civilización griega ${ }^{569}$.

\footnotetext{
${ }^{568}$ Benjamín de Tudela "de la tierra de Navarra" y nativo de la ciudad de Tudela, tal y como él mismo se encarga de señalar al iniciar su Itinerario, desarrollaría un viaje a través de distintos puntos de la geografía mundial y los plasmaría en un texto, donde relata todas las impresiones y datos relativos a tal viaje. Se ha considerado una obra posiblemente datada en torno al año 1173, tal y como se específica en la propia fuente: "Y trájose consigo este libro a su regreso a tierras de Castilla en el año cuatro mil novecientos treinta y tres (ca. 1173). Cf.: BENJAMÍN DE TUDELA, Libro de Viajes de Benjamín de Tudela (J. R. Magdalena Nom de Déu ed.), Barcelona, 1989, en concreto, p. 55. También se hace un breve análisis de la figura del rabino navarro en: A. GRAF, Op. cit., p. 106, donde señala que el viaje fue realizado entre los años 1160 y 1173.

${ }^{569}$ B. DE TUDELA, Op. cit., p. 56.
} 
Interesa destacar su visión de la ciudad, donde lo más importante, a parte de la comunidad de judíos influyentes que moraban en ella, es la vetustez de las construcciones, que otorgaban al territorio cierto prestigio y abolengo ${ }^{570}$. Sin embargo, no resulta una cuestión fundamental discernir si el rabino acierta o no al identificar la civilización que habría de construir las obras que describe en la Tarraconensis, creemos que el dato más relevante estriba, simplemente, en la voluntad de señalar que, a través de su atribución griega, se muestra una intención directa por exaltar su antigüedad.

Las murallas de época antigua, en muchos casos totalmente intervenidas en época medieval, seguirían en la mayoría de los casos el trazado romano, reaprovechando igualmente los materiales de dichas construcciones.

En relación con ello, si atendemos a la noticia transmitida por el Códice de Roda, se parecen ratificar tales hipótesis. El texto inicia su explicación sobre algunos aspectos relativos a los monarcas de la ciudad de Pamplona a través de una exaltación de la misma ciudad romana, que constituyó a su vez, el prestigioso núcleo sobre el que se desarrollará, en época medieval, la ciudad de esta misma cronología. Así se nos dice:

“(...) se alza inmenso con sus torres muradas de un grosor cifrado en sesenta y tres pies, una altura de ochenta y cuatro, un recinto urbano con mil diestros (...). Pamplona en lengua griega se interpreta en latín como puerta de todos (...) la fuerza que la opulenta Roma haya comunicado a los monarcas, no deja de infundirla Pamplona a los suyos" ${ }^{, 571 .}$

El texto deja claras varias cuestiones. La primera, la importancia que las murallas romanas tuvieron dentro de las ciudades medievales, tanto desde el punto de vista de la expoliación de materiales como desde el reaprovechamiento de las mismas para la erección de las nuevas construcciones. Desde una segunda valoración, se insiste en el interés político e ideológico que los cronistas y, a través de estos, sus mentores, los

\footnotetext{
${ }^{570}$ También hemos consultado la edición inglesa realizada por M. Nathan. Este autor realiza una serie de introducciones y apuntes en forma de notas a la edición, en las que ofrece datos diferentes y más amplios que la edición castellana. A partir de este momento se citará normalmente la obra en castellano, salvo en aquellos casos que se especifique lo contrario.

En relación con las obras en la Tarraconensis, el autor inglés apunta que, posiblemente, se trata de piedras prehistóricas que configurarían los muros de la ciudad o, posiblemente, vestigios de diversas construcciones hispanorromanas, tales como acueductos, monumentos funerarios o anfiteatros. Cf.: BENJAMÍN DE TUDELA, The Itinerary of Benjamín de Tudela (M. Nathan Adler ed.), London, 1909, en particular, p. 2.

${ }^{571}$ I. G. BANGO TORVISO, “La vieja ciudad...”, en concreto, pp. 68-70.
} 
monarcas y patrocinadores, tuvieron por ligarse a la mítica ciudad de Roma y su prestigio $^{572}$.

Desde otro orden de cosas, parece claro que no fue sólo un reempleo físico de las murallas lo que más destacó dentro del periodo medieval, puesto que nuevamente encontramos ejemplos iconográficos de este periodo donde se advierten estos hechos. La muralla, como desde la Antigüedad, pasó a ser la imagen de la ciudad, llegando, en ocasiones, a simplificarse de manera absoluta a través de la presencia única de unos cuantos sillares escuadrados formando un muro ${ }^{573}$. Así la veremos representada, por ejemplo, en la fachada de las Platerías de la catedral de Santiago de Compostela, donde se nos muestra bien definida a través del epígrafe CIVITA, en alusión a un muro de sillares que, junto con un portón trabajado con piezas de madera y metal, servirán para enmarcar la urbe en la que Cristo recibe las tentaciones demoníacas ${ }^{574}$ (fig. 100).

Las murallas romanas, resistiendo al paso del tiempo dentro de las tramas urbanísticas medievales, acabaron por configurar la iconografía de la ciudad medieval. Y si bien Isidoro de Sevilla había señalado su carácter necesario dentro de la convivencia urbana, desde el punto de vista de Benjamín de Tudela, se insistirá en aquellos casos donde tal elemento no se mostrase como definidor de la ciudad. En concreto, señala tal anomalía, por ejemplo, ante la inexistencia de recinto amurallado en la ciudad de Pisa, donde nos aclara: “(...) no está circundada por muralla alguna $(\ldots)^{, 575}$.

Podemos señalar, a grandes rasgos, que el panorama de la ciudad medieval no debía discernir mucho en cuanto a su semejanza con la morfología urbanística que mostraban las ciudades en la época romana. La muralla seguía teniendo una importancia fundamental en la imagen de la ciudad, incluso en relación con los lugares más importantes de la misma. Recordemos las palabras de Prudencio al referirse al lugar del enterramiento de Santa Eulalia:

\footnotetext{
${ }^{572}$ En este punto somos conscientes de que, en infinidad de casos y ejemplos, la alusión a Roma forma parte de una explotación de tipo formulario, de tono mítico, más que una realidad factible de querer emparentarse con la famosa urbe.

573 E. FERNÁNDEZ GONZÁLEZ y F. GALVÁN FREILE, "Iconografía, ornamentación y valor simbólico de la imagen”, 976 Códice Albeldense, Madrid, 2002, pp. 205-277.

${ }^{574}$ M. VACCARO, "Le sculture di Platerías nella storiografia del XX secolo: II. Dagli studi iconografici alla valutazione funzionale", Compostellanum, vol. 52, 3-4, 2007, pp. 471-510.

575 B. DE TUDELA, Op. cit., p. 59: "Desde alli a Pisa hay dos jornadas. Es una ciudad muy grande y en ella hay unas diez mil torres en sus casas para luchar en los momentos de discordia; todos sus habitantes son valerosos, no tienen rey ni príncipe que los domine, sino lo Cónsules que ellos nombran. En la ciudad hay como unos veinte judios, a cuya cabeza están: R. Moisés, R. Jaím y R. José. No está circundada por muralla alguna y a unas seis millas lejos del mar. Se sale y entra a ella en barco por el río que atraviesa la ciudad".
} 
"El lugar de su tumba está ahora en Mérida, colonia ilustre de la Vetonia, por la que pasa el famoso río Ana (Guadiana) y cuyas bellas murallas baña raudo con sus verdeantes ondas"

La identificación de la ciudad se lleva a cabo, entre otros, a través de la exaltación de sus murallas, como uno de los elementos más importantes.

La descripción de la muralla romana de la ciudad de Mérida, como identificativo nuclear de la propia urbe, a través del texto del siglo IV de Prudencio, se constata nuevamente a través de otra fuente. Se trata de una inscripción, hoy perdida, pero que ha llegado a nosotros a través de una copia en un manuscrito del siglo VII. En este epígrafe se decía:

"En el tiempo actual del poderoso rey Eurico, a quién Dios ordenó conquistar tierras, éste, magnánimo, puso todo su empeño en dar a conocer su nombre; y el noble cortesano Salla también añadió honores a un antiguo nombre, puesto que después de renovar las fuertes murallas de la ciudad (de Mérida) no dudó en realizar otra obra prodigiosa (...),577 (texto 18).

Estos datos prueban la importancia que las murallas romanas habrían de tener en la configuración ideológica de la imagen de la ciudad, sobre todo, en cuanto a la relación que, en muchas ocasiones, tenían las zonas periféricas de las ciudades y sus murallas. Dichos lugares gozaron de gran importancia gracias a las tumbas de los santos que se erigían cercanas a los espacios amurallados. Se trataba, por lo general, de aquellos sitios en los que habían recibido el martirio y muerte y que, tanto las fuentes como los testigos arqueológicos, se encargan de ubicar en las afueras de las ciudades,

\footnotetext{
${ }^{576}$ A. DE PRUDENCIO, Op. cit., pp. 539-540.

577 J. VIVES, Inscripciones cristianas de la España romana y visigoda, Barcelona, 1969, en especial, pp. 126-127. Sobre dicha inscripción volveremos más adelante, debido, sobre todo, a que se trata de una fuente fundamental para analizar diversos fenómenos constructivos, tales como la ruina y la reparación de diversas construcciones. Agradezco al Dr. D. Santiago Domínguez del Departamento de Patrimonio Artístico y Documental de la Universidad de León, la traducción al castellano de este epígrafe y toda la ayuda prestada en cuanto al tratamiento de las fuentes latinas.

También se alude al contenido de esta inscripción, en: A. M. MARTÍNEZ TEJERA, "Arquitectura cristiana...", en especial, p. 83 y J. ARCE, "Agusta Emerita en los siglos IV-V d. C.: la documentación escrita", Anejos de Archivo Español de Arte (P. Mateos Cruz y L. Caballero Zoreda ed.), XXIX, 2003, pp. 121-131, en particular, pp. 122-124. El profesor Arce recoge una inscripción proveniente del circo romano de Mérida, datada en época de Constantino. Lo más destacado es el calificativo que se utiliza para hablar del estado ruinoso de la obra romana, a través de la expresión "vetustae conlapsum", que guarda un parecido conceptual con la utilizada para la inscripción del puente emeritense.
} 
cercanas a las murallas. Por otra parte, tal conducta simplemente seguía la ley vigente durante todo el mundo antiguo romano, donde los enterramientos dentro de los recintos amurallados estaban, por lo general, prohibidos $^{578}$.

La periferia urbana, delimitada a través de la propia muralla, separadora de los ámbitos regidos mediante la jurisdicción y aquellos que no lo estaban, fue escenario en, muchas ocasiones, del martirio de los nuevos defensores de la religión cristiana. Su muerte fue llevaba a cabo en la parte exterior de tales recintos, arrojando sus cuerpos muertos sobre el vacío que ofrecía el muro protector de la ciudad, tal y como por ejemplo, se sabe que ocurrió con los despojos de los santos Vicente, Sabina y Cristeta $^{579}$.

Los cuerpos fueron lanzados fuera de los muros de la ciudad, como si dichas construcciones representasen el límite diferenciador entre el espacio regido por las leyes de los hombres y aquel abierto al albedrío de actuación. En este sentido, el lugar de la muerte de estos primeros mártires será la razón fundamental que explique la ubicación y la elección de asentar las basílicas funerarias y martiriales en el alfoz de las ciudades, patrocinadas en torno a las emergentes ecclesiae. No en vano, tras la constitutio dictada por Máximo en el 386 se autorizó el desarrollo del culto dedicado a tales mártires allí donde se encontrase su sepultura, monumentalizada a partir de este momento a través de la fórmula del martyrium ${ }^{580}$.

En este sentido, la muralla de la ciudad romana de la Antigüedad tardía, se convertía en un referente dentro de la realidad espacial cristiana. Un elemento constructivo, que fue asimilado por los cristianos, no sólo desde el punto de vista defensivo sino, tal y como venimos explicando, ideológicamente, pues marcaba el lugar donde los santos mártires debían descansar. No debemos olvidar además, que durante los siglos IV y V, el lugar de veneración de las reliquias de estos primeros mártires estaría aún colocado espacialmente dentro de los propios recintos amurallados, pues tal y como se deduce de la ley del 30 de julio de 381, dictada por el praefectus de

\footnotetext{
${ }^{578}$ A. M. MARTÍNEZ TEJERA, “Arquitectura cristiana...”, en concreto, p. 112.

${ }^{579}$ W. GOLDSCHMIDT, "El sepulcro de San Vicente de Ávila”, Archivo Español de Arte, 34, 1936, pp. 161-170; D. RICO CAMPS, El románico de San Vicente de Ávila (estructuras, imágenes, funciones), Murcia, 2002, en especial, pp. 291-336 y S. SILVA Y VERÁSTEGUI, "Los sepulcros de los santos en la Alta Edad Media en España: aportaciones de la iconografía a la literatura hagiográfica”, Memoria Ecclesiae, XXV, 2004, pp. 199-214, en particular, pp. 204-205. Véase la fuente que sirvió para inspirar el ciclo del conocido cenotafio en: Pasionario Hispánico, (Introducción, edición, crítica y traducción de P. Priesco Chueca), Sevilla, 1995, pp. 214-225.

580 A. GRABAR, Martyrium: recherches sur le culte des reliques et l'art chrétien antique, 2 vols., London, 1972 y A. M. MARTÍNEZ TEJERA, “Arquitectura cristiana...”, en particular, pp. 109-111.
} 
Constantinopla, se prohibía el enterramiento en el interior de las ciudades. Si la prohibición se llevaba a cabo es porqué durante este momento aún la costumbre de realizar tal acto se seguía practicando ${ }^{581}$.

A este respecto y centrándonos en el caso de la Península Ibérica, el Canon XVIII del primer Concilio de Braga (ca. 561) recogerá:

"Del mismo modo tuvimos por bien que de ningún modo sean enterrados los cuerpos de los difuntos en el interior de la "basílica de los santos" sino que de forma obligatoria, siempre y cuando no sea incompatible, se haga fuera, cerca de los muros de la misma. Pues si este privilegio ha sido hasta ahora firmemente conservado por las ciudades - el de que de ningún modo sean enterrados los cuerpos de los difuntos dentro del espacio delimitado por sus murallas" ${ }^{\$ 582}$.

La Passio de los mártires Vicente, Sabina y Cristeta, con el posterior deshecho de sus cuerpos fuera del recinto amurallado, habla sobre la posibilidad de valorar su martirio en relación con el espacio limítrofe que separaba, mediante la muralla, el fin de la ciudad.

Los datos aportados en este sentido por A. Prudencio, a la hora de hablar sobre el lugar en el que se hallaba el martyrium de San Hipólito, vuelven a utilizar la muralla romana como un elemento indicador de su situación geográfica con respecto al espacio urbano:

"Y cuando, contadas todas las partes, estuvo completo aquel que había sido el conjunto de su cuerpo entero (...), se elige un lugar para emplazar la tumba; dejan la desembocadura del Tiber, Roma gusta a todos, para que ella sea la que retenga las cenizas santas. No lejos del final de la muralla, junto a la ajardinada explanada del pomerio, se abre una cripta de recónditas cavernas. Un camino en pendiente, con escalones en caracol, nos enseña a ir hasta la parte secreta de la cripta a través de pasos subterráneos, aunque se halle retirada la luz. Pues la claridad del día alcanza las primeras puertas de la entrada hasta la abertura superior de la escalera e ilumina

\footnotetext{
${ }^{581}$ A. M. MARTÍNEZ TEJERA, “Arquitectura cristiana...”, en concreto, p. 112.

${ }^{582}$ Concilios Visigóticos e Hispanorromanos, (J. Vives ed.), Barcelona, 1963, en especial, p. 75. Lo dictaminado en este famoso canon XVIII del primer Concilio de Braga tendría grandes repercusiones dentro de la edilicia cristiana, sobre todo en el ámbito hispano, donde dicha prohibición se acató de manera más o menos rigurosa. Para un análisis de esta cuestión, véase: I. G. BANGO TORVISO, "El espacio para enterramientos...", pp. 93-132 y L. ARIAS PÁRAMO, Prerrománico asturiano: el arte de la monarquía asturiana, Gijón, 1999, en especial, p. 110.
} 
abajo el umbral del vestíbulo. Después, cuando, avanzando fácilmente, va apareciendo, cada vez más densa, la oscura noche a través de la incierta galería del recinto, se encuentran en ella aberturas hechos en lo alto del techo, que proyectan rayos luminosos sobre los subterráneos. Aunque a uno y otro lado los estrechos atrios bajo pórticos sombríos formen rincones dudosos, sin embargo, por los agujeros de la bóveda penetra luz copiosa hasta las cóncavas entrañas de la montaña excavada (...). A estos escondidos lugares se ha confiado el cuerpo de Hipólito, en el lugar junto al cual se ha colocado un altar consagrado a Dios. Aquella mesa distribuidora del Sacramento, y que fue puesta al mismo tiempo como fiel guardiana de su mártir, guarda en el sepulcro los huesos (...) ${ }^{, 583}$.

Parece claro que el texto de Prudencio insiste sobre el lugar dispuesto para el enterramiento de Hipólito, como un espacio no urbanizado cercano al final de la muralla. Es posible que se tratase de un lugar que, siguiendo la legislación romana, estuviese extramuros del recinto amurallado de Roma, como otros tantos martyria ubicados en los suburbia y que, por este momento proliferarán ${ }^{584}$.

Con tales datos, no se debe menospreciar la importancia que la imagen de la muralla, generalmente romana, va a adquirir para los cristianos.

El caso concreto del famoso cenotafio de los santos Vicente, Sabina y Cristeta, en la iglesia de San Vicente de Ávila, permite arrojar algo de luz sobre estos aspectos. El profesor D. Rico Camps defendió en su día la evocación de determinadas partes del recinto mural romano y medieval de la ciudad abulense, dentro de las complejas microarquitecturas del cenotafio. En concreto, aludía a una de las puertas de la muralla de la ciudad romana (fig. 101) que, posiblemente, inspiró el enmarque monumental arquitectónico de la Maiestas de uno de los lados cortos de la "arqueta pétrea" 102 y 102 a).

\footnotetext{
${ }_{583}$ A. PRUDENCIO, Op. cit., p. 707.

${ }_{584}^{584}$ A. M. MARTÍNEZ TEJERA, “Arquitectura cristiana...”, en concreto, pp. 116-123.

${ }^{585}$ D. RICO CAMPS, El románico de San Vicente..., en especial, pp. 291-336. El sepulcro se encuentra en la nave de la epístola de la iglesia de San Vicente de Ávila. Su alta calidad escultórica, así como el amplio desarrollo iconográfico con el que se narra el martirio de los tres santos, le han hecho ser el objeto de algunos estudios. Recogemos aquí algunos de los trabajos que han tratado de manera más concreta el sepulcro: M. GÓMEZ-MORENO, Catálogo Monumental de la Provincia de Ávila (A. de la Morena y T. Pérez Higuera eds.), 3 vols., Ávila, 1983, vol. I, pp. 145-146; W. GOLDSCHMIDT, "El sepulcro de San Vicente...", pp. 161-170; S. SILVA Y VERÁSTEGUI, "Los sepulcros de los santos...", en particular, pp. 204-205 y Z. ESCUDERO NAVARRO, J. GARCÍA ÁLVAREZ y A. LEÓN LÓPEZ, "Milagro en color. El cenotafio de San Vicente, en la basílica de los Santos Mártires de Ávila”, Patrimonio, 33, 2008, pp. 28-34. En esta última aportación que citamos, los autores analizan el proceso de restauración de la pieza, pues, gracias a las labores de la Fundación del Patrimonio de Castilla y León se ha recuperado la policromía que originariamente poseía.
} 
De ser cierta esta teoría, la muralla romana habría jugado un papel excepcional en la elaboración del cenotafio, pues no sólo desde el punto de vista de las fuentes textuales ya se alude a la muerte de los tres hermanos en los aledaños de la muralla romana, sino que, además, teniendo en cuenta esta idea, algunas partes de la misma muralla antigua habrían de inspirar determinadas formas del sepulcro del sepulcro medieval.

La imagen de la ciudad medieval, podemos afirmar, fue deudora de gran parte de los sistemas representativos utilizados en la configuración de la imago de la urbe clásica. Quizás, en el caso de las murallas, tanto las imágenes del arte antiguo como las del medievo, acabarían por configurar un tópico, según el cual, la metrópoli mostraría a través de las murallas, la imagen de poder, fortaleza bélica y defensiva que poseía.

Si el viajero Benjamín de Tudela exaltaba las ciclópeas construcciones de la Tarraco antigua o declaraba al gran monarca Antíoco como el "rey constructor" seguidamente de la descripción de la muralla que circundaba el recinto urbano por él construido; es porqué, la muralla, se había convertido en un elemento indispensable dentro de la imagen de las ciudades romanas y, por contaminación, de las medievales ${ }^{586}$. No en vano, ese mismo prestigio que la muralla tuvo durante la Antigüedad, pasó de manera intacta a la hora de recrear la ciudad más poderosa e indestructible del devenir histórico de todos los tiempos: la muralla de la Jerusalén Celeste.

La Ciudad, nos dice el texto bíblico:

“(...) tenía un muro grande y alto y doce puertas" (Apoc. XXI, 12) y "estaba asentada sobre una base cuadrangular y su longitud era tanta como su anchura" (Apocalipsis, XXI, 16).

Parece claro que, en su origen, las fuentes de las que se surtieron este tipo de evocaciones, estaban emparentadas con las imágenes arquitectónicas de pinturas, mosaicos y manuscritos, tanto de época romana como paleocristiana ${ }^{587}$. Además, tal y como ha señalado la profesora E. Fernández González, no sólo podemos atribuir un

\footnotetext{
${ }^{586}$ B. DE TUDELA, Op. cit., en concreto, pp. 55-56.

${ }^{587}$ M. EHRENSPERGER-KATZ, "Les représentations de villes dans l'art Chrétien avant l'an mil", L'information d'Histoire de l'art, 3, 1964, pp. 130-132; F. GALTIER MARTI, La iconografía arquitectónica..., pp. 251-264 y G. BOTO VARELA, "Ciudades escatológicas fortificadas. Usos perspectivos en los beatos de Girona y Saint-Sever", Locus Amoenus, 2, 1996, pp. 15-30, en concreto, p. 20-32. El profesor Boto se centra, sobre todo, en el problema de la representación arquitectónica de las microarquitecturas hispanas de la Alta Edad Media, poniéndolas en relación con algunos precedentes clásicos y orientales.
} 
origen clásico para determinadas arquitecturas medievales representantes de la Jerusalén Celeste $^{588}$. El fenómeno es extensible a otro tipo de temas, tales como, por ejemplo, la representación "microarquitectónica" de las Siete Iglesias de Asia, donde los modelos romanos musivos de determinadas villae norteafricanas, acabarían por marcar los parámetros a seguir para las evocaciones medievales de tales iglesias, tal y como observamos, por ejemplo, en las arquitecturas pintadas en las bóvedas del Panteón de San Isidoro de León ${ }^{589}$.

En relación con estos temas que abordamos, G. Boto puso de relieve la importancia del llamado Corpus Agrimensorum ${ }^{590}$. Se trata de uno de los catálogos cartográficos romanos conservados más ricos desde un punto de vista iconográfico, pues presenta diversas imágenes en las que se muestra un interés absoluto por representar y captar la imagen de la ciudad. Son de destacar diversas representaciones de murallas, circundando las urbes por los cuatro costados $\mathrm{y}$, generalmente, dispuestas a través de una síntesis de algunos paños murarios de los recintos. Los mayores grados de abstracción se muestran al concebir tales espacios, representando, tan sólo, la parte delantera y trasera de estas construcciones. Además de torres, cubiertas y puertas, destaca entre el repertorio utilizado en este códice, la representación de diversos espacios centrales rodeados por murallas, a modo de plazas (fig. 103).

Las imágenes realizadas en concreto para este Corpus Agrimensorum deben ser entendidas claramente como uno de los muchos ejemplos a los que posiblemente los artistas medievales tuvieron acceso, para recrear, plásticamente, la imagen de la Ciudad Santa o Jerusalén Celeste ${ }^{591}$.

En algunos casos, resulta complejo poder señalar el modelo concreto y la obra exacta utilizada por los artífices medievales. Los ejemplos conservados en la actualidad muestran, en la mayoría de los casos, tan sólo el recuerdo de la obra que los inspiró, pues el modelo original o primigenio se ha perdido irremediablemente. Así, la imagen

588 E. FERNÁNDEZ GONZÁLEZ y A. MIGUÉLEZ CAVERO, "Die Mikroarchitekturen in den Darstellungen Der "Sieben Gemeinden Von Asien" in den Ikonographischen Zyklen der Apokalypse im Spanischen Mittelalter", Mikroarchitektur im Mittelalter. Ein gattungsübergreifendes Phänomen zwischen Realität und Imagination, Leipzig, 2008, pp. 455-476, particularmente, p. 473.

${ }^{589}$ G. LÓPEZ MONTEAGUDO, "Modelos clásicos para las pinturas de San Isidoro de León”, La visión del mundo clásico en el arte Español, Madrid, 1993, pp. 25-35.

${ }^{590}$ Wolfenbüttel, Herzog August Bibliothek, Corpus Agrimensorun Romanorum, cod. guelf. 36.23A, f. $56 \mathrm{v}$.

${ }^{591}$ G. BOTO VARELA, “Ciudades escatológicas...", en concreto, p. 20 y nota 21. Este ejemplar al que alude el autor fue redactado posiblemente entre los siglos V y VI, a través de una copia del siglo I o principios del siglo II. Todas las arquitecturas representadas utilizan fórmulas estereotipadas, pero que, muy posiblemente, tuvieron una continuidad e influencia en otra serie de piezas de la misma índole, sobre todo de época medieval. 
de la ciudad romana, configurada externamente a través de sus murallas y sus puertas de acceso, acabaría por ser reinterpretada de manera parcial y siempre a través de una visión reduccionista y artificial, motivada, en parte, por un conocimiento fragmentario de este tipo de imágenes. En este sentido, si comparamos cualquier tipo de representación medieval alusiva a la Jerusalén Celeste con alguna de las obras monumentales vinculadas a las estructuras murarias de las ciudades romanizadas más importantes, los resultados, cuanto menos, siempre van a ser fructíferos.

J. Adhémar, a propósito de la puerta romana de Tréveris (fig. 104), analizó la fuerte consistencia que tal construcción tenía como imagen de poder. Se trataba del acceso a la ciudad desde época antigua, para pasar a ser completamente reutilizada durante los siglos medievales, como basílica de la ciudad ${ }^{592}$. Este monumento, colocado en la desembocadura de una gran vía de comunicación, pudo, durante el transcurso de los años, ser admirada por diversos viajeros, visitantes y artistas de diferentes lugares, lo que sin duda contribuyó a la difusión de su imagen, además de incrementar su importancia como arquetipo constructivo.

Los paralelismos que se han establecido entre esta construcción romana y otra serie de piezas medievales, deben ser vistos como una clara reinterpretación de las fórmulas de representación urbanas existentes durante la época clásica, por parte de los artistas medievales. En el caso concreto de la pila bautismal hispana de Redecilla del Camino, en Burgos (fig. 105), se ha defendido una clara intención "antiquizante" y de fuerte contenido simbólico ligada a la idea de la Jerusalén Celeste ${ }^{593}$. Lo más llamativo, es la serie de puntos en común que la pieza medieval guarda con respecto a la puerta romana de Tréveris.

Resulta evidente que, en ningún caso, pretendemos defender una copia directa del modelo antiguo por parte del artista medieval. Simplemente insinuamos el hecho de cómo el escultor románico participaba de una larga tradición iconográfica perfectamente asentada dentro de los sistemas de representación arquitectónicos.

Nuevamente la ciudad romana era el referente cultural, social y surtidor de modelos artísticos que se debían seguir. Para el caso concreto del escultor de Burgos, lo más complicado es poder llegar a concretar el modelo exacto al que tuvo acceso, poder diferenciar si éste se encontraba en el momento de su conocimiento en un estado "puro"

\footnotetext{
${ }^{592}$ J. ADHÉMAR, Influences antiques..., p. 60.

593 G. BILBAO LÓPEZ, Iconografía de las pilas bautismales del románico castellano. Burgos y Palencia, Burgos, 1996.
} 
o ya "contaminado", tamizado y evolucionado con respecto al original romano. Tales aspectos, hacen imposible poder llegar, actualmente, a discernir cual fue el modelo que se siguió y, sobre todo, poder reconstruir su imagen ante su eminente pérdida ${ }^{594}$.

Retomando la importancia que Prudencio va a otorgar a la imagen de la ciudad en su texto, en aquel pasaje en el que escribe: "Antigua madre de paganos templos, Roma, ya consagrada a Cristo, bajo la guía de Lorenzo victoriosa, de culto bárbaro y gentil triunfas" ${ }^{, 595}$, queda patente la manera en que las fuentes defendían la eminente cristianización de la ciudad de Roma $-\mathrm{y}$, por extensión, de otras muchas ciudades paganas- que, a partir de este mecanismo, dejaban de representar a la ciudad del Imperio para pasar a inspirar la morfología de la ciudad imaginada o JERUSALÉN CELESTE.

A través de este fenómeno, bien estudiado en su día por S. Maddalo, se entendía que, en determinadas imágenes que intentaban materializar la Civitas Dei, no se había acudido a ciertos modelos estereotipados e inexistentes, sino que, en tal labor, se habían tomado aquellos que dependían directamente de la realidad misma.

Este aspecto se advierte fácilmente a través de la ilustración en la que aparece la imagen de la Jerusalén Celeste sobre la figura de San Agustín, en el incipit en el que el autor cristiano se muestra representado como escriba del texto De Civitate Dei (fig. 106). En esta miniatura, la imagen de Roma ha servido de modelo directo para inspirar otra ciudad, la ficticia, la inexistente. La urbs eterna de la Antigüedad, era entendida por los artistas medievales, no como ciudad física, sino como un espacio ideal, con el suficiente prestigio como para poder representar la Ciudad Santa; y todo ello, a pesar de poder reconocerse entre sus construcciones, obras tan identificables como el castillo de San Ángelo, la columna trajana o el mismo Panteón ${ }^{596}$.

Nuevamente la representación figurativa de la ciudad romana pagana se entremezclaba con la evocación de la ciudad cristiana. Un binomio que refleja la dualidad en cuanto a la intención de las representaciones "microarquitectónicas", siempre en continuo debate entre la imagen real y la simbólica, entre las posibles lecturas "arqueológicas" y otras más superficiales.

\footnotetext{
${ }^{594}$ F. GALVÁN FREILE y J. A. MORÁIS MORÁN, "Microarchitectures dans les arts plastiques hispaniques autour de 1200 et leurs relations avec l'architecture monumentale", Mikroarchitektur im Mittelalter. Ein gattungsübergreifendes Phänomen zwischen Realität und Imagination, Leipzig, 2008, pp. 479-497, en concreto, p. 488.

595 AURELIO PRUDENCIO, Op. cit., p. 493.

${ }^{596}$ Paris, Bibliothèque Sainte-Geneviève, Ms. Lat. 218, f. 2r. Cf.: S. MADDALO, In Figura Romae..., p. 76. La obra es obra del artista Nicolás Polani.
} 
No sería la primera vez que ocurriría tal hecho dentro de las artes plásticas de la Edad Media. La asociación entre ciudades reales e imaginadas y, por extensión, entre la Roma antigua y determinadas ciudades medievales, fue algo recurrente. Señalamos, dentro del caso hispano, las idénticas fuentes que, hipotéticamente, parecen compartir, dos de las representaciones más famosas de la iconografía arquitectónica. Nos referimos, en concreto, a la imagen de la Civitatis Regia Toletina del Códice Albeldense y la, identificada por algunos autores, como evocación arquitectónica de la Jerusalén Celeste de las pinturas de la iglesia de San Julián de los Prados en Oviedo ${ }^{597}$.

Los diversos motivos utilizados en ambos ejemplos, sobre todo, en relación con el uso del color y de la vocación cromática de los muros y las diversas estructuras de ambos conjuntos, nos hablan de un modelo común para ambas.

Tanto la policromada muralla de la ciudad de Toledo del manuscrito (fig. 107), como las arquitecturas pintadas de la iglesia de Alfonso II el Casto (fig. 108), hablan de la importancia de la muralla y de la imagen de la ciudad durante la Alta Edad Media hispana a través de un conocimiento absoluto de la plática de tradición antigua. Nuevamente las murallas romanas de las viejas urbes, hipotéticamente pintadas, aportaban el modelo a seguir para la miniatura medieval, que en esta ocasión pudiera servir como prueba arqueológica que verifique el uso de estucos pintados en los recintos amurallados $^{598}$.

No podemos detenernos en tales aspectos, pero parece claro que, tanto la arquitectura, como la escultura de toda la Antigüedad tardía y la Edad Media, fueron siempre concebidas para estar absolutamente pintadas ${ }^{599}$. Restaría al respecto, poder llegar a concretar la importancia jugada por tales revocos y policromías en la configuración de la iconografía de la ciudad medieval, así como sus repercusiones sobre otro tipo de expresiones, por ejemplo dentro de los frescos de Santullano ${ }^{600}$. Algunas

\footnotetext{
${ }^{597}$ El Escorial, Real Biblioteca del Monasterio, Ms. d. 1.2, fol. 142r.

${ }^{598}$ La imagen ha sido estudiada de manera exhaustiva en: E. FERNÁNDEZ GONZÁLEZ y F. GALVÁN FREILE, "Iconografía, ornamentación...", en concreto, pp. 205-277; ID., "Un ejemplo de topografía urbana en el siglo X: la visión de la ciudad de Sevilla en el códice Emilianense", Homenaje a Joaquín González Vecín, León, 2005, pp. 137-147 e ID., "Pintando arquitecturas/arquitecturas pintadas...", pp. 5160 .

${ }^{599}$ I. G. BANGO TORVISO, "Cuando los edificios eran de colores”, Descubrir el arte, 100, 2007, pp. 196-200; F. GALTIER MARTÍ, “Aproximación a un nuevo tema: la pintura de exteriores románicos”, Actas del VII Congreso Internacional de Estudios Pirenaicos, Jaca, 1983, pp. 5-15.

${ }^{600}$ En los muros exteriores de la iglesia de San Julián de los Prados, en Oviedo, se han detectado varios vestigios de revoques, que dan idea y verifican la utilización de tal solución decorativa, tanto en el interior como en el exterior del templo. Cf.: H. SCHLUNK y M. BERENGUER, Op. cit., pp. 161-168; L. ÁRIAS PÁRAMO, Prerrománico asturiano..., pp. 44-94 e I. RUÍZ DE LA PEÑA GONZÁLEZ, El legado de Magín Berenguer..., pp. 20-45.
} 
piezas esculpidas que nos han llegado desde época tardoantigua, deben ser tenidas en cuenta a la hora de poder analizar los intercambios entre lo existente en el medio artístico real y aquello que más tarde se evocaría en pinturas o miniaturas.

En relación con ello, recuérdese, por ejemplo, el cancel proveniente de la basílica de Cabeza del Griego, en Uclés (fig. 109), el cual muestra un repertorio decorativo que, algunos autores, entre ellos A. Arbeiter y S. Noack, han relacionado con las pinturas que ornan la bóveda del ábside central de Santullano ${ }^{601}$ (fig. 108).

La relación entre el objeto esculpido, la representación ficticia de lo posibles estucos que decoran las murallas de la miniatura del Codex Albeldense $e^{602}$ y la pintura de San Julián de los Prados, llevan claramente a reflexionar sobre el papel jugado por la misma ciudad antigua, su morfología, la estética y la decoración de sus edificios, así como su supuesta influencia sobre las artes medievales.

Si la ciudad romana tiene muros pintados, la ciudad de Dios también. Del mismo modo que la Ciudad de Dios es Roma en el códice de Nicolás Polani, los techos abovedados de San Julián aluden a diversas fórmulas decorativas de las ciudades del bajo imperio, a su realidad material ${ }^{603}$. Estas bóvedas que cubren la casa de Dios, nuevamente vuelven a ser bóvedas romanas con decoración all'antica. La urbs cristiana y la romana vuelven a entrelazar sus morfologías sin posibilidad de separación. Ambas ciudades, la imaginada y la real, la cristiana y la pagana, se entremezclan en un discurso de las dos ciudades, parafraseando el título del estudio de F. Marín Valdés y J. M. Gil López y en las que, según parece, resulta difícil establecer los límites entre lo real y lo imaginado.

\footnotetext{
${ }^{601}$ Se trata de una pieza datada en el siglo VI. Actualmente se conserva en el Monasterio de Uclés, en Cuenca. Cf.: R. BARROSO CABRERA y J. MORÍN DE PABLOS, "Fórmulas y temas iconográficos en la plástica hispanovisigoda (siglos VI-VIII). El problema de la influencia oriental en la cultura material de la España tardoantigua y altomedieval", Visigodos y Omeyas. Un debate entre la Antigüedad tardía y la Alta Edad Media, Madrid, 2002, pp. 279-306; H. SCHLUNK y M. BERENGUER, Op. cit., en concreto, pp. 39-40; S. NOACK-HALEY, "Tradición e innovación en la decoración plástica de los edificios asturianos", III Congreso de Arqueología Medieval Española, Oviedo, 1992, pp. 174-184; L. ÁRIAS PÁRAMO, Prerrománico asturiano..., en concreto, pp. 90-91 y J. GARCÍA NISTAL, "La memoria de la Antigüedad en las armaduras de cubierta y sus diferentes vías de difusión. Reflexiones sobre la historia de los ornamentos", Art i Memoria (en prensa).

${ }^{602}$ El Escorial, Real Biblioteca del Monasterio, Ms. d. 1.2, fol. 142r.

${ }^{603}$ Algunas de las murallas más importantes de las ciudades romanas hispanas poseían una variada decoración pictórica, aplicada sobre las diversas capas de estucos que se habían realizado con anterioridad. Los motivos decorativos se centrarían en las zonas más emblemáticas de los accesos a las ciudades y, en la mayoría de las ocasiones, se trataría de simples elementos geométricos repetitivos, pero de gran colorido. Para el caso de la ciudad de León y la pintura de su muralla, véase: M. L. GONZÁLEZ FERNÁNDEZ, R. FERNÁNDEZ ORDÁS, J. C. ALVAREZ ORDÁS, P. RODRÍGUEZ GONZÁLEZ y J. M. VIDAL ENCINAS, "Un asunto superficial: el revoco decorativo del recinto amurallado romanomedieval de León", De arte, 1, 2002, pp. 11-20.
} 
Las arquitecturas pintadas de San Julián de los Prados, a las que volveremos de manera recurrente a lo largo de este trabajo, presentan, a través de una visión parcial de las mismas, continuos recuerdos de la ciudad romana. La Civitas Dei evocada en este conjunto mural y la verdadera ciudad del Oviedo, anterior al año mil, aluden a otra urbe que entonces contaba ya con un pasado esplendoroso. Nos referimos a la ciudad de Toledo. Dos ciudades, las dos reales, pero al mismo tiempo, las dos igualmente imaginadas en las arquitecturas de la iglesia asturiana. La barrera existente entre la ciudad ficticia y la verídica se difumina a la hora de simbolizar la Jerusalén Celeste, por un lado, y la terrenal, por el otro ${ }^{604}$.

Palatium y civitas se entremezclan, las alusiones a la urbe de Dios y a la real, se intercalan para exaltar, en el Oviedo del siglo IX, la idea de sede regia. La miniatura del Códice Vigilano utiliza nuevamente el mismo mecanismo, según el cual, el pasado clásico y la ciudad antigua, la romana, sirven como elemento de prestigio y de reactivación de los valores intrínsecos a las artes áulicas del periodo medieval ${ }^{605}$.

La fórmula sería explotada con éxito dentro del arte medieval. Mediante este sistema de apropiación de la imagen de la ciudad antigua, es decir, la romana, el hombre medieval mostraba su interés y la idea que poseía de la ciudad antigua por excelencia, Roma. La sola citación de estos elementos de tradición "antiquizante" relacionaba las obras y las construcciones patrocinadas por los monarcas medievales con aquellas que, desde antiguo, habían erigido los grandes emperadores.

La figura del rey constructor, de la que hablaba anteriormente Benjamín de Tudela, parece configurada a través de los sistemas ideológicos e intelectuales que antaño habían definido el perfil de los emperadores constructores al servicio de su pueblo.

\footnotetext{
${ }^{604}$ Evidentemente no se está afirmando, en ningún caso, que tales representaciones intentasen copiar literalmente ninguna construcción, ni de Oviedo ni de Toledo. Cf.: I. G. BANGO TORVISO, "Las imágenes en los templos medievales. Del aniconismo a la intención docente. Las tres posturas tradicionales de la Iglesia”, La Enseñanza en la Edad Media (J. I. de la Iglesia Duarte ed.), Logroño, 2000, pp. 357-82.

${ }^{605}$ F. A. MARÍN VALDÉS, y F. GIL LÓPEZ, San Julián de los Prados..., en especial, pp. 56-67. Recuérdese, en este sentido, como se utiliza el mismo recurso en la fachada de Notre-Dame-la-Grande de Poitiers, donde se representó, en el friso colocado sobre la puerta y dentro de las escenas de la infancia de Cristo, la visitación de Isabel a María. La escena del abrazo se desarrolla entre dos estructuras arquitectónicas de gran tamaño que han sido identificadas como las dos ciudades: la representante del Antiguo Testamento y la del Nuevo. Su simbolismo viene apoyado por la colocación, al lado de la representación de la ciudad veterotestamentaria, de la figura de un dragón, símbolo del mal y de una basílica coronada por una cruz sobre la ciudad neotestementaria. Cf.: M-Th. CAMUS y C. ANDRAULTSCHMITT, Notre-Dame-la-Grande de Poitiers. L'ouvre romane, Paris, 2002 y M-Th. CAMUS, "Des Images à lire, méditer, admirer", Notre-Dame..., pp. 249-307.
} 
Nuevamente nos encontramos ante una tradición donde la ciudad y sus obras traducen al espectador la imagen de sus gobernantes. En este sentido, la Civitatis Regia Toletina del Códice Albeldense, cuyos muros evocan la tradición cromática con la que el arte tardorromano decoraría estos espacios, tiene el mismo valor simbólico que la Civitas Ravenne del gran mosaico de San Apolinar Nuevo (fig. 110). Dos ciudades nuevamente, una real, la Ravenna del siglo de Teodorico y otra imaginada, la de Roma.

La iconografía arquitectónica de los mosaicos de Ravenna, en concreto la del famoso palacio y la ciudad que venimos comentando, han sido incluidas por $\mathrm{Ch}$. Frugoni dentro del programa ideado por Teodorico para recuperar en su ciudad la idea de la gran capital del mundo antiguo, es decir, Roma. La actividad edilicia y de patrocinio de las artes llevadas a cabo por el monarca, demuestran el sentido del argumento, sobre todo, al estar únicamente encaminadas a emular ciertos aspectos relacionados con la misma ciudad de Roma, la ciudad de la memoria. Su empeño por restaurar el acueducto de Trajano en la ciudad, habla de un interés inicial de tipo económico, pero no exento de aspiraciones ideológicas y culturales, en un segundo momento ${ }^{606}$.

Como en el manuscrito de Toledo, el tituli que señala el comienzo de la urbe en Ravenna, la ciudad, se enmarca por estructuras defensivas y aparece colocado sobre los sillares de la muralla. Los bloques dorados de la ciudad de Teodorico entroncan, nuevamente, con la ciudad ideal, la Jerusalén Celeste, donde la riqueza de los materiales y de los brillos, vuelven a convertirse en un topos de la arquitectura medieval, pero de clara herencia antigua.

Los datos aportados por el Apocalipsis, entre los cuales se nos dice que: “(...) la plaza de la ciudad era de oro puro, como vidrio transparente" (Apocalipsis, XXI, 21), serán la fuente inspiradora de muchas de las materializaciones plásticas de estas imágenes. Sin embargo, todo parece indicar que se trata de un recurso heredado del periodo antiguo romano.

\footnotetext{
${ }^{606}$ Véase el capitulo dedicado por Ch. Frugoni al tema y que titula "Le città della memoria, un sogno sui mosaici". Cf.: CH. FRUGONI, Una lontana città. Sentimenti e immagini nel Medioevo, Torino, 1983, en concreto, pp. 34-60. La autora considera que Roma se convirtió, durante el mandato de Teodorico, en el punto de referencia cultural. Además, alude a la contaminación ideológica que venimos señalando entre el mito de la ciudad terrestre y la celeste. En este caso, compara determinadas noticias documentales y textuales del ambiente cultural de la ciudad de Teodorico con la recreación de una Nueva Jerusalén Celeste. Las fórmulas utilizadas iban desde, la exaltación de la figura del monarca dentro de la constructio civitatis, representada en los mosaicos de San Apolinar por la ciudad amurallada con el puerto y el palacio real, hasta la recuperación de material expoliado de la propia ciudad de Roma. Sobre el mosaico del palacio en San Apolinar, vid.: G. DE FRANCOVICH, Il palatium de Teodorico..., pp. 5-55.
} 
El brillo absoluto de los sillares del mosaico de Ravenna, a medio camino entre la ciudad imaginada y la real, entroncan con las mejores descripciones del género de viajes, donde, tal y como ya hemos ejemplificado, a través de textos como los de Egeria o Prudencio, el ORO y el BRILLO de las ciudades tardoantiguas hacían que la percepción estética de tales urbes o construcciones, se debatiese entre la realidad y la fantasía.

La ciudad romana, según el ideario medieval, era una ciudad de oro. La concepción, aunque pueda parecer irreal, estaba refrendada por las fuentes, pues textos como el Opusculum de mirabilibus novae et veteris Romae de Francesco de Albertinis $^{607}$, ofrecían una imagen de la ciudad totalmente basada en la exhibición de sus riquezas y del oro a través de las estatuas macizas, los mosaicos y los techos dorados. Las famosas ruinas de la Domus Aurea de Nerón, el castellum aureum o el arcus panis aurei, acabarían por confirmar esta idea donde la ciudad eterna era también la ciudad dorada ${ }^{608}$. El cristianismo tomó este concepto de ciudad imperial que basaba su poder en la suntuosidad de sus muros y del resto de sus construcciones, de una manera integral.

En este sentido, el Peristephanon de Prudencio, en aquella parte que dedica al martirio de los apóstoles Pedro y Pablo, da prueba de esta perpetuación de la imagen del oro dentro de la ciudad tardoantigua, así como su posterior traspaso al ámbito medieval. En relación con ello nos dice:

“En la otra parte, la vía Hóstiense conserva el sepulcro de Pablo (...). Un príncipe bueno (¿Honorio?) dedicó esta mansión e hizo decorar el recinto con grandes riquezas. Con planchas de oro recubrió las vigas, para que el interior fuese toda la luz dorada, como la del sol al amanecer. Hizo poner bajo los dorados artesonados columnas de mármol de Paros, que allí aparecen hermosas en cuatro filas. La arcadas de la bóveda ordenó exornar después variadamente con mosaicos de magnífico vidrio de color verde (...)" ${ }^{, 609}$ (texto 19).

Ya hemos aludido al texto de Eusebio de Cesarea, quién al describir algunos aspectos del Santo Sepulcro de Jerusalén, señalaba la magnificencia de los grandes

\footnotetext{
${ }^{607}$ A. GRAF, Op. cit., pp. 121-122. Albertinis fue un erudito pensador romano que vivió entre los años 1470-1520.

${ }^{608}$ Ibidem. El autor lleva a cabo un análisis de todas estas fuentes y obras citadas.

${ }^{609}$ A. PRUDENCIO, Op. cit., pp. 721-723.
} 
capiteles de plata que poseía el edificio (texto 14). En relación con ello, creemos que este tipo de noticias, datadas todas ellas en época tardoantigua, asentarían la base que permitió la creación de un topos de la urbs dorada, que habría de pasar íntegro a los viajeros medievales.

Así, cuando Benjamín de Tudela visita Constantinopla a finales del siglo XII, nos dice:

"El perímetro de la ciudad de Constantinopla es de diez y ocho millas, la mitad sobre el mar y la otra mitad sobre el continente. Se asienta sobre dos brazos de mar; uno que viene del mar de Rusia y el otro del mar de España. Vienen aquí todos los mercaderes de Babel y de todo el país de Sinar, de Persia y de Media, de todo el reino de Egipto, de la tierra de Canaán, del reino de Rusia, de Hungría, de Patzinakia, de Jazaria, del país de Lombardía y de España (...). Hay allí tantas iglesias como número de días tiene el año (...). En el interior de la iglesia hay columnas de oro y plata e incontables lámparas de plata y oro (...)"610.

Además, el autor describe otra serie de partes de la ciudad y de determinados edificios, como por ejemplo, el gran palacio llamado Blachernae, que él atribuye al patrocinio del rey Emmanuel. En la descripción que hace el rabino medieval están presentes algunos de los arquetipos utilizados para concebir la ciudad imaginada por los artistas musivos de Ravenna en una voluntad por emular a Roma.

En relación con ello, Benjamín de Tudela continúa escribiendo sobre el mítico palacio de las Blanquernas, diciéndonos:

"El rey Manuel construyó un gran palacio, para el trono de su reino, sobre la orilla del mar, a más de los que edificaron sus antecesores, y lo llamó Blachernes. Recubrió de oro y plata pura las columnas y los muros, pintando sobre ellos las guerras que él mismo realizó. Allí hay un trono de oro y piedra noble, hizo pender una corona áurea de una cadena de oro sobre el trono, estando situado su asiento preciosamente bajo ella; en la corona hay incontables piedras preciosas, tantas que, por la noche, no es necesario poner allí lámparas, pues todos ven la luminaria que

\footnotetext{
${ }^{610}$ B. DE TUDELA, Op. cit., pp. 66-67.
} 
desprende la luz de las piedras preciosas. Y hay tantos edificios allí que no pueden ser enumerados" $" 611$.

La ciudad irreal se mezcla con la real, y tanto Roma como Constantinopla servían, en opinión de Ch. Frugoni, como arquetipos visuales e intelectuales que tenían en mente los artistas de Teodorico dentro de este programa de reconstrucción del nuevo estado $^{612}$.

En el caso de las fuentes hispanas, aunque nunca tan enfáticas y prolijas en datos, parece que, a la hora de realizar tales alusiones de edificios y de elementos constructivos, la idea de riqueza y suntuosidad tampoco dejó de utilizarse. El siguiente extracto del Codex Calixtinus refleja bien tales aspectos:

"Luego, pues, devastando las tierras de España, llegó a la villa que vulgarmente se llama Orniz (actual San Román de Hornija), en la que había una bellísima y muy buena basílica de San Román con riquísimos paños y códices, cruces de plata y telas bordadas de oro. Y al llegar a ella el inicuo Almanzor robó cuanto en ella encontró y de igual suerte devastó la villa. Y habiéndose albergado con sus ejércitos en esta villa, cierto capitán de sus huestes que entró en la iglesia vio las bellísimas columnas de piedra que sustentaban el techo de la iglesia y cuyos capiteles estaban plateados y dorados, y estimulando por su odio y crueldad, clavó una cuña de hierro entre una columna y su basa. Y al golpear fuertemente aquella cuña con un martillo de hierro, tratando de derrumbar toda la iglesia, el hombre se convirtió en piedra por providencia de Dios. Y esta piedra con forma humana subsiste hasta el día en la misma iglesia y tiene el mismo color que tenía la túnica del sarraceno entonces. También suelen contar los peregrinos que allá van a rezar, que la piedra hiede" 613 (texto 20).

El texto, aunque lejano ya de la tradición tardoantigua, recurre a los tópicos ya mencionados para describir la fábrica cristiana, que, además de presentar una riqueza

\footnotetext{
${ }^{611}$ Ibidem, p. 67. Además, el autor dedica una serie de líneas a exaltar las riquezas del trono del monarca, absolutamente cubierto con oro y piedras preciosas. Alude, igualmente, a la imagen de la ciudad totalmente cubierta con oro, púrpura y otros materiales.

${ }^{612}$ CH. FRUGONI, Una lontana città..., en concreto, pp. 36-39 y p. 49. La autora aborda el problema de las representaciones perdidas en los mosaicos de Ravenna. Sobre todo, se centra en la imagen destruida de Teodorico, figurado, posiblemente, como un emperador bizantino en su presunto retrato realizado para la iglesia de San Apolinar. Según la autora, aparecería entre la personificación de Roma y la de la misma ciudad de Ravenna, supra portam et in fronte regiae quae dicitur ad Calchi, es decir, el famoso Chalke construido por Constantino en la ciudad.

${ }^{613}$ Liber Sancti Jacobi..., p. 519, (texto 20).
} 
desbordante, se muestra como bastión y refugio de la fe, infranqueable por los enemigos del Islam que perecen en su intento por destruir dicho templo ${ }^{614}$.

A través de estas descripciones, podemos deducir que, la ciudad que describen los primeros autores cristianos, es una ciudad dorada, rica en materiales, siguiendo el modelo de las urbes antiguas. La idea pasó integra a las representaciones plásticas del medievo, donde la muralla de Ravenna en el mosaico de Teodorico y la ciudad con muros policromados del Códice Albeldense, explotan claramente, y con éxito, este tópico.

Sin embargo, entre estas obras que mencionamos, realizadas supuestamente entre el siglo V y el siglo X, el tema de la ciudad, su decoración y la exaltación de los ricos materiales a la hora de representarla en la artes plásticas, tendrá dos estadios fundamentales que debemos señalar.

Por una parte, el siglo IX carolingio, nexo inexcusable entre la tradición clásica romana y la Alta y Plena Edad Media europea, reabsorbió el concepto y explotó los valores del oro y la magnificencia de los materiales de la exégesis clásica, en favor de la exaltación de la urbe cristiana. A este respecto y en relación con el patrocinio real de los monarcas dentro de la basílica altomedieval de Saint-Denis, la documentación sostiene:

"Dagoberto, el rey glorioso (...) ordenó en un impulso de amor digno de admiración que se construyera la basílica de los santos con real magnificencia. Una vez construida la basílica con una maravillosa variedad de columnas de mármol, la enriqueció de forma incalculable con tesoros abundantes en oro purísimo y plata, y mandó cubrir paredes, columnas y arcos con tapices tejidos en oro y adornados con abundantes perlas (... $)^{615}$ (texto 21).

El lejano recuerdo de la urbe antigua se vislumbra aún en estas palabras, ahora dirigidas a exaltar la ciudad de Dios que, siguiendo similares mecanismos, se utilizaría también dentro de las fuentes escritas de la Alta Edad Media hispana, igualmente datadas en el siglo IX.

Nos referimos a las Crónicas Asturianas y, específicamente, a la Crónica Albeldense. Su autor, escribió en torno a la figura de Alfonso II el Casto (791-842):

\footnotetext{
${ }^{614}$ Obsérvese, nuevamente, la utilización del tópico de los capiteles plateados que muestra esta fuente medieval, como elemento claramente heredado de los textos de la Antigüedad tardía.

${ }^{615}$ E. PANOFSKY (ed.), El abad Suger..., en concreto, p. 103.
} 
“(...) reinó 51 años (...). Este construyó en Oviedo el admirable templo de San Salvador y los Doce Apóstoles (...). También erigió la basílica de San Tirso, admirable edificación, con numerosos ángulos; y todas estas casa del Señor las adornó con arcos y con columnas de mármol, y con oro y plata, con la mayor diligencia y junto con los regios palacios, las decoró con diversas pinturas; y todo el ceremonial de los godos, tal y como había sido en Toledo, lo restauró por entero en Oviedo, tanto en la Iglesia como en el Palacio",616 (texto 22).

Siendo plenamente conscientes de que en ambas noticias existe un uso repetitivo y reiterativo de diversos topos literarios sin correspondencia con la realidad, al menos, de una manera directa y en relación con el caso asturiano, nuevamente la urbe toledana, amurallada y siguiendo el esquema exegético de la Jerusalén Celeste, se convierte en el referente "antiguo" para recuperar, mediante el patrocinio artístico, el recuerdo de las más grandes ciudades de la Antigüedad. Se trata de las mismas soluciones que explican la presencia de las arquitecturas imaginadas de las representaciones de Santa Maria Maggiore, Santa Prassede y Santa Prudenciana, todas ellas en Roma o, incluso, de la propia civitas de Ravenna ${ }^{617}$. Su modelo común: la Roma ideal. La Roma pagana del oro que brillaba en los mejores edificios del arte imperial, tales como en el Coliseo romano:

"El Coliseo era un templo de suma grandeza y altura (...) en el dicho templo, entre los muros había muchas capillas laterales con infinidad de estatuas, las cuales eran de oro, otras de cristal (...) venían gentes de todo el mundo a hacer en el dicho templo el sacrificio (...) hecha la ofrenda a Giove, iban a aquella capilla donde estaba su ídolo (...). Era tanto el oro y las piedras preciosas que había en aquel lugar que sería imposible contarlo" ${ }^{, 618}$.

\footnotetext{
${ }^{616}$ Crónicas Asturianas (J. Gil Fernández, J. L. Moralejo y J. I. Ruiz de la Peña, eds.), Oviedo, 1985, Crónica Albeldense, pp. 248-249.

${ }^{617}$ F. MARÍN VALDÉS y J. M. GIL LÓPEZ, Op. cit., en especial, p. 77.

${ }^{618}$ El texto pertenece al Libro Imperiale y aparece editado en: A. GRAF, Op. cit., en concreto, pp. 98100. Debemos señalar la confusión que en estos momentos existía con respecto al edificio, pues se le consideraba un templo: "Culiseo era uno tempio di somma grandeza ed alteza (...). Nell detto tenpio fralle dette mura erano molte chapelle chon infinite statue, et quale erano d'oro, et qual di cristallo (...) Venivano le genti di tutto el mondo a fare nel detto tenpio sacrificio (...) e fatta l'oferta a Giove, andavano a quella chapella dove stava el suo iddyo (...). Era tanto l'oro e le pietre preziose che erano nello detto luocho donate che seria impossibile a rachontallo (...)".
} 
La concepción que el hombre medieval tuvo de la ciudad de Roma como gran urbe dorada, tiene su justificación, entre los muchos posibles, en este texto que narra la grandeza y maravillas del Coliseo. No en vano, los viajeros medievales que acudían a la ciudad de los emperadores podían observar, colocada al lado de la arquitectura más famosa de la Roma antigua, la figura de un gran coloso:

“(...) que algunos creen estatua del Sol, y otros dicen imagen de Roma (...) en la mano derecha porta un globo, en la izquierda una espada: el globo representa el mundo, la espada la virtud guerrera (...). Esta estatua de bronce, todo dorada con oro imperial, brillaba en la oscuridad. La cosa más sorprendente en relación con esta escultura, es que giraba junto con el sol con movimiento constante y uniforme, dando la cara siempre al sol: motivo por el cual se cree imagen del Sol"619.

La imagen del Sol en forma de escultura personificada que cree ver el magister Gregorio, es la imagen del poder de esa misma Roma. El dorado del oro recubriendo la escultura simboliza el control de los astros, puestos bajo el poder imperial de la ciudad. Nuevamente se trata de una idea arraigada en la tradición literaria clásica, sobre todo, vinculadas con algunas noticias que nos han llegado en relación con la figura del gran rey antiguo Corroes de Persia.

Este monarca pasó a la historia por ser el gran usurpador de la cruz que, queriendo ser adorado por las deidades, hizo construir una torre de plata, en la que mandó colocar una personificación del Sol, otra de la Luna y una de las Estrellas, además de otros elementos. También ideó algunos mecanismos móviles, mediante los cuales, podía disparar agua a través de un surtidor colocado en lo alto de una gran torre, de tal manera que emulase la lluvia, que solía acompañar, además, de fuegos de artificio que emulaban rayos y truenos ${ }^{620}$.

Una torre de plata, capiteles dorados, vigas cubiertas de teselas de oro, columnas

\footnotetext{
${ }^{619}$ Estas son las palabras recogidas por magister Gregorio en relación con su viaje a Roma durante el siglo XII. Cf.: C. NARDELLA (ed.), Op. cit., pp. 153-155: "che alcuni credono statua del Sole, altri dicono immagine di Roma (...) nella mano destra portava un globo, nella sinistra una spada: il globo rapprsentava il mondo, la spada la virtù guerriera (...). Questa statua di bronzo, tutta dorata con oro imperiale, brillava nelle tenebre. La cosa più miracolosa a proposito di questa statua era che si girava assieme al sole con moto constante e uniforme, rivolgendo sempre la faccia verso il sole; pero questo motivo Mopti la credevano immagine del Sole".

El magister Gregorio habla de esta escultura colocada en los aledaños del Coliseo y además narra su posterior incendio: "Da quel vigoroso incendio rimasero tuttavia salvi la testa e la mano destra col globo che ora, posti su due colonne di marmo davanti al palazzo del papa, offrono stupendo spettacolo a chi le guarda". Cf.: Ibidem, p. 153.

${ }^{620}$ A. GRAF, Op. cit., p. 100.
} 
de vidrio, muros de jaspe que asemejan piedras preciosas; en definitiva, una ciudad irreal, donde tan sólo es verídica su ansia de poder visual, un poder sobre la imagen artística y el recuerdo que de ella, de Roma, habría de quedar en la memoria colectiva medieval, mucho más fijado que la pervivencia de su esplendor político.

Si atendemos a estas descripciones y a las noticias que, hasta aquí, se han examinado, rápidamente podemos establecer una clara vinculación con otros textos de mayor importancia para los siglos medievales. Sin duda, el más conocido es el párrafo bíblico en el que se describe la Jerusalén Celeste y en el que se analizan sus diversas estructuras, materiales y las puertas de acceso al bastión amurallado que, según el ideario medieval, la configuraban.

A este tipo de tradición textual, se pueden añadir otras. Por ejemplo, la recogida en el Codex Calixtinus de la catedral de Santiago de Compostela, donde podemos leer:

“(...) por las doce piedras preciosas engastadas en el pectoral de Aarón (Éx. 28, 15), por los doce panes de la proposición (Lev. 24, 5), por los doce exploradores enviados por Moisés a la tierra de promisión (Núm. 13, 2), por las doce piedras de que fue hecho el altar (Éx. 24, 4) (...). También por el Nuevo Testamento (Mat. 14, 29; Marc. 6, 43; Juan 6, 13) están indicados en los doce cuévanos de los pedazos, en los doce nombres que vio San Juan en el Apocalipsis escritos sobre la puerta del Jerusalén celestial y en las doce hiladas del muro de la misma ciudad (Apoc. 21, 1214 y $19-20)^{\prime 621}$ (texto 23).

Tal y como señalara en su día Ch. Frugoni, las concomitancias formales, ideológicas e iconográficas, establecidas por el imaginario medieval entre la ciudad real -ya fuese Roma, Constantinopla o cualquier gran centro urbano del Imperio- y la ciudad imaginada, es decir, la Jerusalén Celeste, fueron muy estrechas.

Además del recinto amurallado, la importancia de las puertas que definían el entramado urbano de la ciudad de Roma durante la Antigüedad, también pasó a la Edad Media. Si observamos la descripción del monje Gregorio en torno a este aspecto, parece claro que, la disposición y el nombre de ellas era bien conocido para el público de los siglos medievales. En relación con ellas, nos informa:

${ }^{621}$ Liber Sancti Jacobi..., pp. 30-31. 
"Le porte di questa città sono quattordici e si chiamano: porta Aurea, porta Latina, porta Sacra, porta Salaria, porta Marcia, porta Livia, porta Collatina, porta Flaminia, porta Numanzia, porta Appia, porta Tiburtina, porta Aquileia, porta Asinaria" ${ }^{622}$.

Sin duda, fue el mundo romano el que mejor supo explotar la imagen de la puerta como representante del poder y el abolengo de una ciudad. Dicha iconografía acabó por transformarse en un estereotipo en el que, la sola imagen de la muralla abierta mediante un gran portón, aludía a la ciudad de Roma. También en las descripciones o ekphrasis de época medieval, se advierte la existencia de un topoi, de clara raíz clásica, en el que la puerta de acceso a la ciudad se transforma en un elemento indispensable para la gestación de la imagen simbólica de la misma.

Paralelamente al texto de Gregorio, el hispano Benjamín de Tudela llama la atención sobre las cuatro grandes puertas de la ciudad de Jerusalén:

"Hay en Jerusalén cuatro puertas: la puerta de Abrahán, la puerta de David, la puerta de Sion y la puerta de Josafat, es decir, la puerta de Yehosafat, delante del templo que había en los días de antaño"623.

Con todo, en relación con el papel jugado por las murallas, las puertas y la exaltación de los materiales ricos en relación con la idea y la imagen de la ciudad en el tránsito de la Antigüedad a la Edad Media, creemos interesante aludir a una obra plástica muy expresiva.

Se trata de una miniatura realizada por Lamberto de San Omer, incluida en el llamado Liber Floridus y datada en la segunda mitad del siglo XII ${ }^{624}$ (fig. 111). En ella, observamos como la CIUDAD CELESTE posee una forma decididamente circular, sobre la que se elevan doce grandes torreones. El gran macizo central coincide con la gran puerta de acceso a la Ciudad. Lo más destacado de la imagen es el fuerte sentido simbólico que se le otorga al muro, en el que es visible, con todo detalle, el despiece de los sillares y la estereotomía. Según recoge Ch. Frugoni en su estudio, la importancia de este ejemplo estriba en que se trata de una imagen heredera de las vistas amuralladas

\footnotetext{
${ }^{622}$ C. NARDELLA (ed.), Op. cit., p. 147.

${ }^{623}$ B. DE TUDELA, Op. cit., pp. 77.

${ }^{624}$ Wolfenbüttel, Braunschweigische Landesbibliothek, Ms. Gud. Lat. I, f. 43v. Cf.: CH. FRUGONI, Una lonta città..., p. 12.
} 
acuñadas sobre las monedas de época clásica, especialmente dentro de las producciones numismáticas romanas.

Sin embargo y más importante aún, resulta la compleja serie de epígrafes identificativos colocados sobre las altas torres de esta miniatura. En ellos se puede leer cada uno de los materiales de los que están hechas las construcciones, siguiendo siempre el texto apocalíptico:

"La ciudad santa, Jerusalén (...) la rodeaba una muralla grande y alta con doce puertas, y sobre las doce puertas, doce ángeles y nombres escritos, que son los nombres de las doce tribus de Israel: de la parte de oriente, tres puertas; de la parte del norte, tres puertas; de la parte del mediodía, tres puertas; y de la parte de poniente, tres puertas. El muro de la ciudad tenía doce hiladas, y sobre ellas los nombres de los doce apóstoles del Cordero (...) la ciudad estaba asentada sobre una base cuadrangular y su longitud era tanta como su anchura (...) su muro era de jaspe, y la ciudad de oro puro, semejante al vidrio limpio; y las hiladas del muro de la ciudad eran de todo género de piedras preciosas" (Apocalipsis, XXI, 9-22).

Sin duda, se trata del texto más representativo de la Edad Media en relación con los temas aquí tratados. Además, nos sirve, eficazmente, para poder concluir este apartado en el que hemos llevado a cabo una serie de reflexiones proyectadas a señalar la importancia de la ciudad de Roma, de sus monumentos, de su configuración y sobre todo, de la idea de la Roma antigua que se había formado en el subconsciente colectivo, durante los siglos posteriores al desmembramiento del Imperio Romano.

El texto es lo suficientemente conocido como para no tener que detenernos en su comentario. La descripción y la mención del jaspe, el zafiro, la calcedonia, las esmeraldas, sardónices, cornalina, crisolito, berilo, topacio, crisoprasa, jacinto y amatista, aparecen fielmente identificadas en la obra de Lamberto que acabamos de mencionar. Sus nombres campean en lo alto de las torres-puerta, sobre los tejados rematados en cruces que configuran la forma de esta Ciudad Eterna.

Las fuentes para este tipo de representaciones deben buscarse en la propia ciudad física y, más concretamente, en las ciudades de la Antigüedad. Si comparamos la imagen anterior del siglo XII con la ilustración de un mapa de la ciudad real de Jerusalén, conservado en Cambrai, observamos que, ésta, se circunscribe mediante un 
recinto amurallado almenado ${ }^{625}$ (fig. 112). Nuevamente se puso especial énfasis en captar la imagen de las puertas de la ciudad y, otra vez, se identificó cada torre-puerta mediante su correspondiente nombre, aquí en forma de topónimos verídicos de cada lugar de la urbe. Leemos con claridad, por ejemplo, el nombre de Porta S. Stephani o Turris David, entre otros ${ }^{626}$.

El simbolismo y la carga icónica y política que las puertas de las ciudades habían tenido durante la Antigüedad, fue absorbido de manera completa por el imaginario medieval, tal y como vimos dentro de la iconografía del cenotafio de San Vicente de Ávila, por citar un ejemplo hispano.

Sin embargo, pronto la reinterpretación del término adquirió valores sorprendentes, pues lo que un día supuso el acceso monumentalizado a las grandes ciudades, pronto pasó a ocupar un lugar preeminente dentro de un tipo muy específico de producción artística. Nos referimos, en concreto, a la arquitectura religiosa.

Las puertas de los templos medievales, sobre todo en época románica, absorbieron las experiencias clásicas, para explotar la imagen de acceso a un recinto monumental y poderoso, tal y como en su día había ocurrido con las puertas romanas. Por ello, no es de extrañar que, en numerosas ocasiones, la puerta de las iglesias de muchas basílicas y templos hayan sido comparadas con las puertas de acceso a las grandes ciudades romanas, que aún durante los siglos medievales, se mantenían en pie.

Hemos mencionado ya el caso paradigmático de las repercusiones plásticas de la puerta romana de Autun sobre la arquitectura románica de la ciudad. No es menos significativo el caso hispano, donde tal y como ha demostrado la profesora E. Fernández González, para el ejemplo concreto de la fachada del Obispo de la catedral de Zamora, las relaciones con el arte antiguo más clásico se muestran evidentes. La autora alude al recuerdo de ejemplos paradigmáticos de la edilicia clásica como el vestíbulo del Palacio de Cosroes o el arco de Septimio Severo, como referentes ideales ${ }^{627}$.

Para el caso de la gran portada monumental del Perdón, en la basílica de San Isidoro de León, también el profesor I. G. Bango ha propuesto una fuente, más que

\footnotetext{
${ }^{625}$ Cambrai, Médiathèque Municipale, Ms. 437.

${ }^{626}$ P. LAVEDAN, Représentation des villes dans l'art du Moye Âge, Paris, 1954, en concreto, pp. 11-12; M. LÉVY-RUBIN, "The Crusader Maps of Jerusalem", Knights of the Holy Lands, Crusader Kingdom of Jerusalem, Jérusalem, 1999, pp. 231-237 y M. PICCIRILLO, "Jérusalem et la basilique du SaintSépulcre", Les Croisades. L'Orient et l'Occident d'Urbain II à Saint Louis, 1096-1270, Milan, 1997, pp. 233-242. Los autores han datado el plano en torno a los años 1150-1170. Se pueden identificar cuatro puertas con los nombres de San Esteban, Puerta Sión, Puerta David y la Puerta Josaphat.

${ }^{627}$ E. FERNÁNDEZ GONZÁLEZ, "Presencia de Oriente y Occidente en la Portada del Obispo de la Catedral de Zamora", Estudios Humanísticos, 1988, León, pp. 225-274.
} 
posible, pero hoy perdida, relacionada con alguna de las puertas monumentales de acceso al recinto amurallado de la ciudad romana de León, la Legio VII Geminae ${ }^{628}$.

Idéntico origen romano, evidente desde el punto de vista iconográfico y simplemente formal, es el que posee la portada esculpida de Santa María de Ripoll, que según M. A. Castiñeiras, tendría su referente más cercano en la puerta romana de la ciudad de Bensançon ${ }^{629}$.

Siempre dentro del área hispana, el caso más paradigmático lo ofrece la puerta de las Platerías de la catedral de Santiago ${ }^{630}$. Tal y como es sabido, tanto la portada sur del templo que hoy contemplamos, como la norte, la conocida como Porta Francigena, fueron concebidas mediante una gran entrada geminada que permitía el acceso al templo (fig. 113). Independientemente de los problemas cronológicos que pudiera suscitar tal conjunto, parece clara su dependencia con respecto a la gran puerta de los Condes de la basílica de Saint-Sernin de Toulouse, en la que también se utilizó la misma solución ${ }^{631}$ (fig. 114).

El posible parentesco para el origen de tal motivo nuevamente se encuentra dentro del arte romano, especialmente el de la Galia, siempre más rico en cuanto a piezas conservadas. La grandiosa puerta de Augusto, imbricada en la muralla de la ciudad de Nîmes, presenta dos arcos de medio punto por los que se accedía al interior (fig. 115). La construcción, datada por una inscripción en el año 16 a. de C., formaría parte de una muralla con más de noventa torres de diversas formas y nueve puertas

\footnotetext{
${ }^{628}$ I. G. BANGO TORVISO, “Arquitectura y escultura”, Historia del Arte en Castilla y León. Arte Románico, II, Valladolid, 1994, pp. 9-212, especialmente, p. 68. Véase también: C. COSMEN ALONSO, Dos iglesias románicas..., pp. 10-35. La profesora Cosmen defendió en su momento la fuerte impronta e influencia que ejerció la puerta del Perdón de San Isidoro, sobre la puerta de la iglesia de San Miguel de Corullón,

${ }^{629}$ La llamada Porta Negra de Bensançon poseía, al igual que Ripoll, un amplio programa iconográfico relativo a los meses del año personificados. Además, otra serie de detalles, como el uso del escamado y de una clara intención publicitaria del lenguaje escultórico, permiten hablar de ciertas concomitancias entre ambas obras. Véase al respecto: M. A. CASTIÑEIRAS GONZÁLEZ, El calendario medieval..., en especial, pp. 83 у 247; ID., “Un passaggio al passato...", pp. 365-381; Y. CHRISTE, "La colonne d'Arcadius...", especialmente, p. 40; X. BARRAL I ALTET, "Propaganda eclesiástica y poder feudal...", particularmente pp. 61-62; M. MELERO MONEO, "La propagande politico-religieuse...", pp. 135-157 e I. LORÉS I OTZET, “La decoración escultórica en el monasterio...”, pp. 167-190.

${ }^{630}$ No recogemos aquí ningún trabajo específico sobre la portada, ni realizamos una valoración bibliográfica, ya que será una cuestión que llevaremos a cabo a la hora de abordar el análisis de determinadas cuestiones relativas al carácter clásico del foco escultórico santiagués.

631 E. VERGNOLLE, L'art roman en France, Paris, 1994, p. 191 y J. M. ANETTE, The Porte des Comtes atelier of Saint-Sernin in Toulouse and the Romanesque sculpture of southwest France, University of North Carolina at Chapel Hill, 1992, en concreto, pp. 120-123.

Señalamos, para el caso hispano, la desaparecida fachada de la catedral de Pamplona y que también se ha vinculado, por una parte, al foco santiagués y, por otra, a un posible maestro ligado con la tradición clásica. Sobre esta obra navarra volveremos en las páginas siguientes.
} 
monumentales ${ }^{632}$. Los lugares donde antaño se colocaron dos nichos rectangulares, quizás con el fin de recibir algunas estatuas, son ocupados en la puerta de los Condes de Toulouse, por sendos relieves, en forma de nicho bajo arco de medio punto, donde se colocaron dos figuras esculpidas ${ }^{633}$.

Si el origen romano de la distribución general de las portadas de Toulouse y Compostela se presenta como una posible vía de estudio, también lo es la importante influencia que el prototipo ejercerá sobre la iconografía románica. Del concepto arquitectónico real, se pasaba, una vez más, a un concepto ideal e imaginario, reflejado por la escultura del momento.

Si observamos la representación de la ciudad maldita, Babilonia, en uno de los capiteles del claustro de Moissac, la representación de la ciudad se llevó a cabo a través de un arco geminado, que evoca, claramente, por un lado, la estructura amurallada romana de Nîmes y, por el otro, la reinterpretación románica de la puerta de la basílica de Toulouse ${ }^{634}$ (fig. 116).

Para concluir, queremos señalar que, según lo expresado en este apartado, parece claro que las relaciones existentes entre la ciudad de Roma antigua o, por extensión, de cualquier ciudad romanizada del Imperio, acabó por generar un prototipo iconográfico durante los siglos medievales que definió la imagen de otra serie de ciudades importantes para el ideario cristiano. Sin duda, la más significativa y la que más se beneficiará de las experiencias realizadas por los artífices de la Antigüedad, fue la Jerusalén Celeste.

La ciudad de ROMA fue para los autores cristianos una conglomeración de hechos, ideas, obras y sucesos a los que no se mostraron pasivos. El fenómeno no sólo se puede hacer extensible al caso de la Jerusalén Celeste, pues sabemos que, a la hora de concretar la imagen de Babilonia, los primeros cristianos tomaron el modelo de la Roma imperial pagana, como ciudad del pecado, de ahí que en los pasajes dedicados a narrar la destrucción de la ciudad, muestren el deseo de que también ésta sea destruida e incendiada ${ }^{635}$.

De nuevo se muestra patente la ambigüedad que los primeros cristianos

\footnotetext{
${ }^{632}$ R. PEYRE, Nîmes, Arles, Orange, Saint-Rémy, Paris, 1903, pp. 26-27.

${ }^{633}$ M. DURLIAT, "L'apparition du grand portail roman historié dans le Midi de la France et le Nord de 1’Espagne”, Les Cahiers de Saint-Michel de Cuxa, 8, 1977, pp. 7-24, en concreto, pp. 11-16. El experto fecha la puerta de Comtes, en torno al año 1090. El autor francés identifica las figuras colocadas en los relieves laterales como dos de los discípulos de San Saturnino, Papoul y Honest, que flanquearían, a su vez, a la efigie del mártir al que se dedica el edificio.

${ }^{634}$ Q. CAZES, M. SCELLES y G.-M. RENIE, Le cloître de Moissac, Bordeaux, 2001.

${ }^{635}$ F. GALTIER MARTÍ, La iconografía arquitectónica..., p. 423.
} 
mostrarán hacia el pasado pagano. Por un lado, se percibe cierta admiración y continuismo, mientras que, por el otro, se advierte un claro rechazo. Con todo, lo más importante y con la idea que queremos concluir, es que la ciudad de Roma no dejó indiferente al artista medieval. Sus monumentos arruinados le ofrecían una cantera interminable de modelos que se transmitirían mucho más allá de los centros más prestigiosos del occidente cristiano.

El modelo de portada bífora que acabamos de comentar, parece perpetuarse en la memoria visual de los escultores activos durante los primeros años del siglo XII, a través de la imagen de Jerusalén representada, por ejemplo, en otro de los capiteles del claustro mencionado. Dos arcos bastan para representar el acceso monumental al recinto amurallado de la ciudad. Sin embargo, el arquetipo se extiende rápidamente, pues lo encontramos nuevamente como imagen física del Santo Sepulcro en un capitel de SaintPierre de Mozac, a través de un pequeño templo de dos pisos custodiado por los somnolientos guardianes ${ }^{636}$ (fig. 117).

Debiéramos preguntarnos ante este tipo de imágenes, cual es el grado de dependencia de la obra plástica con respecto al modelo real y, sobre todo, cual es el papel jugado por las construcciones antiguas en cuanto a la génesis de tales iconografías. La tarea se complica al observar, por ejemplo, la distribución de la fachada de acceso al edificio del Santo Sepulcro de Jerusalén (fig. 118). Si bien se trata de una fachada tardía y rehecha en las numerosas remodelaciones del conjunto, cabría preguntarse si las semejanzas con las fachadas de algunas de la más importantes iglesias de peregrinación del occidente cristiano, es tan sólo fruto de la casualidad o existen otras razones que hoy se nos escapan ${ }^{637}$.

La morfología arquitectónica que configuraba la topografía urbana de las ciudades romanas, especialmente la de Roma, acabó por entenderse dentro de la cultura medieval como un signo de poder. Por extensión, las puertas y las murallas de las urbes antiguas, gracias a su suntuosidad y vetustez, fueron reabsorbidas frecuentemente por los artífices románicos, reinterpretándolas y otorgándoles nuevos significados, tanto desde el punto de vista físico, como desde el plástico.

Estas resonancias de tan compleja índole en cuanto a su significado clásico,

\footnotetext{
${ }^{636}$ P. MATHIS, "Capitello con tre donne al sepulcro", Romei \& Giubilei..., ficha catalográfica 179, p. 387.

${ }^{637}$ Obsérvese que la distribución del acceso a través de dos arcos geminados, con sus correspondientes en la parte alta de la fachada, utiliza idénticas soluciones a las creadas en la fachada de Platerías de Santiago de Compostela.
} 
pasarán al intelecto medieval, a veces, bajo tintes apocalípticos. Si leemos detenidamente el texto recogido en el Codex Calixtinus de la catedral de Santiago, la función de la puerta, antes elemento diferenciador entre la urbs y el campo, si seguimos la definición dada por Isidoro de Sevilla, pasará en los siglos medievales a separar lo profano de lo sagrado:

"Las puertas de esta basílica nunca se cierran, ni de día ni de noche; ni en modo alguno la oscuridad de la noche tiene lugar en ella; pues con la luz espléndida de las velas y cirios, brilla como el mediodía"638 (texto 24).

Unas puertas tan importantes, aquellas que daban paso a las basílicas medievales, debían, cuanto menos, poseer un rango de prestigio que, en ocasiones, sólo la imitación de la Antigüedad podía otorgarles. Los modelos a seguir estaban en la misma ciudad en la que se construían ahora los nuevos edificios, fundamentados sobre las estructuras romanas preexistentes que ayudaban, mediante este reempleo físico de la civitas, a construir la imagen mental cristiana de la otra urbe, la Civitas $D e i^{639}$.

${ }^{638}$ Liber Sancti Jacobi..., p. 192.

${ }^{639}$ Es por ello que, por ejemplo, encontraremos gran cantidad de materiales antiguos reempleados en los accesos de los templos. El caso más significativo lo presenta la puerta de entrada a la basílica de Santa María in Trastevere, cuyas lajas de tema vegetal provienen de las termas de Caracalla, al igual que muchos de sus capiteles. Cf.: D. KINNEY, "Spolia from the Baths...”, pp. 379-397. 


\section{LA IMAGEN DE LA ROMA ANTIGUA A TRAVÉS DE LA MIRADA DE LOS HOMBRES}

MEDIEVALES.

En las páginas precedentes hemos señalado la importancia de reflexionar sobre las relaciones existentes entre la imagen de la ciudad de Roma antigua, con sus construcciones y monumentos más señeros, y la formación de la iconografía de las ciudades medievales.

En este apartado se abordará otro tema complejo, no sólo desde el punto de vista de la gran cantidad de fuentes existentes que lo abordan, sino también, en relación con su carácter subjetivo.

Los hombres medievales que comprobaron con sus propios ojos el aspecto que presentaba la ciudad de Roma durante los siglos en los que vivieron, dejaron claro testimonio sobre su estado, su forma, la distribución de sus edificios y de sus esculturas. Se trata, por lo general, de testimonios escritos de gran valor que, en ocasiones, hablan de monumentos hoy perdidos. El problema reside, una vez más, en poder atribuir un carácter verídico a tales descripciones y a las posibles lecturas simbólicas realizadas sobre las obras que tenían ante sus ojos ${ }^{640}$.

Uno de los textos más conocidos y más útiles a la hora de comprender el conocimiento y la concepción que del arte clásico y de las ruinas de la ciudad de Roma, tuvieron los hombres de la Plena Edad Media, fue el Mirabilia del maestro Gregorio, tal y como ya hemos señalado reiteradamente. Pocos datos conocemos de este magister que, en un momento determinado, viaja a la caput mundi. Se ha señalado su posible procedencia inglesa y su dependencia a cualquier estructura eclesiástica, pero ninguna de estas suposiciones están del todo claras ${ }^{641}$. Lo más interesante de su escrito, son, sin duda, las descripciones que de los diferentes monumentos de la ciudad de Roma va a realizar. Sus palabras sirven, por una parte, para reconstruir un pasado artístico hoy casi

\footnotetext{
${ }^{640}$ Resulta imposible poder realizar un balance completo y representativo de todos aquellos textos y fuentes, de diversa índole, en los que se ha prestado atención a la ciudad de Roma y sus monumentos. Señalamos, en este sentido, que hemos seleccionado una serie de textos, autores y obras escritas, de carácter literario y documental, que consideramos representativas a la hora de otorgar una visión completa del tema. Seguramente se observe la omisión de otras muchas noticias y textos, pero debido a la necesidad de acotar el tema, los hemos reducido, centrándonos en aquellos que consideramos de mayor importancia.

${ }^{641}$ El texto ha sido considerado como el primer Mirabilia. Por su parte, M. Barash da por seguro su origen inglés, en especial de Oxford, mientras que lo data cronológicamente en el año 1200. Cf.: C. NARDELLA (ed.), Op. cit., pp. 24-29; A. GRAF, Op. cit., p. 48 y M. BARASH, "Le Beau ou le démoniaque: le regard du spectateur médiéval sur la statuaire classique", Histoire de l'histoire de l'Art de l'Antiquité au XVIIIe siècle, vol. I, Paris, 1995, pp. 97-117, en concreto, pp. 101-102.
} 
perdido en su totalidad, además de permitirnos, desde otro punto de vista, intuir las sensaciones que la obra antigua provocaba en el espectador de los siglos medievales.

En relación con ello, al leer algunos de los conocidos pasajes que Plinio dedica a la ciudad de Roma, queda clara la grandilocuencia que, en la edad clásica, debía presentar la ciudad y explica, a su vez, la impresión que la gran urbe provocó en los espectadores medievales, donde los textos del autor fueron bien conocidos.

En este sentido, por ejemplo, destacamos el párrafo en el que Plinio describe algunos de los colosos más conocidos del mundo antiguo:

"Tal es en el Capitolio la estatua de Apollo (...), que tiene treinta brazas de largo y costó de hechura ciento y cincuenta talentos. Tal es en el campo Marcio el Júpiter que dedicó el emperador Claudio, a quién llaman Pompeyano, por estar junto al teatro de Pompeyo; tal es también el de Tarento, el qual hizo Lisipo de quarenta brazas. Havía en él una cosa admirable, que, según dizen, se movía con una mano y ningunas tempestades le hazían perder su firmeza (tal era el orden con que estava fijado)" ${ }^{\text {642 }}$ (texto 25).

El pasaje nos recuerda a las palabras que utilizará, ya en época medieval, el monje Gregorio para referirse al movimiento del gran Colosseo, adyacente al edificio al que daría nombre. Cuando el autor habla en su texto de la escultura, lleva a cabo una descripción casi "arqueológica" de ella, pues lo que en realidad evocan sus palabras, son los pocos restos que ya por su época quedaban de otra efigie, posiblemente dedicada a Constantino. De la obra, tan sólo restaban una serie de fragmentos esparcidos delante del palacio del Laterano, que el clérigo se encarga de identificar y relacionar con la escultura colosal de Nerón. Sin embargo, tal y como se ha dicho, el autor medieval, que tenía ante sí los vestigios materiales de la Roma pagana, lleva a cabo en este punto una identificación errónea.

A través de tal noticia, queremos señalar la problemática a la que se enfrentó el hombre medieval a la hora de poder llegar a comprender, con seguridad, diversos aspectos relacionados con las piezas romanas que tenía ante su mirada.

Generalmente, estas fuentes se encuentran plagadas de datos falsos, no históricos y empapados de leyendas, que los autores iban añadiendo a sus escritos. Sin embargo, desde otro orden de cosas, el texto de Gregorio muestra un buen conocimiento de esa

${ }^{642}$ PLINIO, Historia Natural..., p. 1074. 
misma Antigüedad. Según se ha dicho, la denominación que utiliza para designar esta escultura, imago Colosei, parece estar inspirada en la descripción hecha por Suetonio de la misma pieza ${ }^{643}$.

Con todo, la noticia nos muestra como, en ocasiones, la realidad material a la que estos hombres tuvieron acceso, no debía distar mucho de la que el espectador actual tiene, pues, en relación con ello, parece claro que el monje no vio muchos más fragmentos de esta escultura colosal de los que hoy conservamos ${ }^{644}$.

Lo realmente significativo, es que, la imagen de una Antigüedad fragmentada y ruinosa interesaba aún a los espectadores medievales. En torno a los años 1330-1340 Paulino de Venecia escribe su Compendium. En una de las imágenes que acompañan al texto podemos observar la gran explanada del Laterano, cerrada en uno de los laterales por la muralla romana (fig. 119). En el medio de este "museo abierto" el artista diseñó la imagen ecuestre de Marco Aurelio, tal y como se encontraba antes de su traslado al Campidoglio, así como los restos de la posible escultura colosal de Constantino, es decir, su cabeza y una mano sujetando el globo ${ }^{645}$.

También Benjamín de Tudela, tantas veces mencionado, se hace eco de la misma noticia al describir la explanada del Laterano. En los alrededores de este espacio constata la conservación de dos columnas de bronce, que él atribuye al Templo de Salomón. Así nos dice:

"Ante San Juan de Letrán está esculpido en piedra Sansón, con una lanza en la mano. Así mismo Absalón, hijo de David; también Constantino el Grande, quien construyera Constantinopla -pues en su nombre se llama (así)-, está esculpido en cobre, y su caballo recubierto de oro. Hay además, en Roma otros muchos edificios y cosas que nadie podría enumerar aquî,646.

Parece claro que, el viajero partido de Navarra estaba contemplando ante sus ojos, tal y como apunta M. Nathan Adler, entre otras, la escultura ecuestre de Marco

\footnotetext{
${ }^{643}$ Los fragmentos de esta escultura colosal, fueron vistos por el maestro Gregorio en la explanada del Letrán. Sin embargo, tras su traslado, hoy se conservan en los Musei Capitolini de Roma.

${ }^{644}$ C. NARDELA (ed.), Op. cit., en concreto, pp. 90-92 y pp. 153-155.

${ }^{645}$ Roma, Biblioteca Apostolica Vaticana, Ms. Vat. Lat. 1960, f. 270v. Cf.: S. MADDALO, In figura Romae..., en especial, pp. 24-33.

El autor medieval de la pieza realizó, través de la técnica de la acuarela, una visión cenital de la ciudad de Roma. Realizaría además otras versiones, de las cuales se conserva una en Paris, Bibliothèque nationale de France, Ms. Lat. 4939, f. 27r. y otra en Roma, Biblioteca Nazionale Marciana, Ms. Lat. Z. 399, f. 98r.

${ }^{646}$ B. DE TUDELA, Op. cit., p. 61.
} 
Aurelio $^{647}$.

Tanto los autores antiguos, como medievales, observaron detenidamente la obra de arte y reflexionaron, de una manera u otra, sobre su mensaje. En este sentido, Plinio nos dice sobre una escultura:

"En nuestra edad se vio en el Capitolio, antes que se quemase haviéndole puesto fuego los Vitelianos, que en la capilla de Juno havía un perro de bronce que se estava lamiendo su llaga, del qual su admirable figura y natural semejanza del verdadero, no sólo se entiende por haver sido dedicado a aquel lugar (...)”648 (texto 26).

Parece claro, que la capacidad para comentar las obras y plasmar en escritos sus impresiones, fue una tradición clásica que continuaron los hombres del medievo. A través de los diferentes grados de formación, en ocasiones, estos autores sometían la obra antigua a duras críticas. Por lo general, los literatos cristianos solían ver ante sus ojos, bellas y sugestivas imágenes desnudas y rebosantes de erotismo y que, evidentemente, eran susceptibles de acabar siendo rechazadas.

En este sentido, M. Barash ha señalado como el espectador medieval llevaba a cabo el rechazo de estas representaciones, condenándolas $\mathrm{y}$, en ocasiones, destruyéndolas. Se trataba de una moralización del legado clásico, entendido como enteramente pagano y sin ningún motivo digno para ser conservado ${ }^{649}$.

Si Roma debía ser destruida de igual manera que Babilonia por estar "embriagada con las sangre de los mártires de Jesús" (Apoc. XVII, 6), también debía acabarse o, al menos, repudiar todo aquello que simbolizase la propia ciudad de Roma. Ello pasaba, indudablemente, por destruir su legado artístico.

Cuando los hombres medievales de determinados ambientes cultos expresaban su opinión acerca del arte clásico, los discursos, podían ser de caracteres muy dispares. Dentro de las noticias ofrecidas por magister Gregorio, al hablar de la imagen de Venus colocada en los anejos del teatro de Eraclea, justifica su loa afirmando que lo hace por la increíble belleza de su aspecto. Así, escribe:

\footnotetext{
${ }^{647}$ M. N. ADLER, Op. cit., p. 7, nota 2.

${ }^{648}$ PLINIO, Historia Natural..., p. 1074.

${ }^{649}$ M. BARASH, "Le Beau ou le démoniaque...”, pp. 97-117.
} 
"Questa immagine fu dedicata dai Romani a Venere, nella forma in cui, secondo la leggenda, si dice che la dea si sia mostrata a Paride, nuda, in un'audace gara assieme a Giunone e Pallade. Il temerario giudice guardandola disse: A parer nostro Venere le vince entrambe. Questa immagine è fatta di marmo di Paro con un'arte talmente meravigliosa ed indicibile da sembrare una criatura viva piuttosto che una statua: simile a donna che arrossisca della sua nudità, essa ha il viso cosparso di un colore rosso. E sembra propio a chi guarda che sul volto candido come la neve di quella statua scorra il sangue. Per il suo meraviglioso aspecto e non so per quale magica seduzione fui costretto a tornare a guardarla tre volte, anche se distava due stadi dal mio allogio" ${ }^{650}$.

Parece claro, a propósito de las palabras de Gregorio, que el espectador medieval podía, si su nivel cultural se lo permitía, aproximarse a la valoración crítica de una obra de arte clásica y mostrar así sus pareceres respecto a ella. Exalta su perfección técnica, el material del que estaba hecha, su belleza y, sobre todo, su proximidad con la realidad, característica que, tal y como ya hemos señalado, también valoraba Plinio, a propósito del perro de bronce de la capilla de Juno, en el Capitolio (texto 26).

Una planta de la ciudad de Roma datada entre los años 1418-1420 y atribuida al Maestro de Orosio, muestra la posible imagen que Gregorio tenía antes sus ojos: la estatua marmórea de Venus erigida sobre un pedestal cercano al teatro de Eraclea, además de otros vestigios de la Antigüedad romana ${ }^{651}$ (fig. 120). Expuesta sobre su pedestal, se presentaba como verdadera joya persuasoria ante los ojos del público medieval, exuberante, perfecta y, sobre todo, demoníacamente pagana ${ }^{652}$.

Sin embargo, sus palabras reflejan la pasión que, en ocasiones, suscitó tal tipo de producciones. La imagen desnuda de Venus se prestaba fácilmente a una reinterpretación medieval que la llevaría a convertirse en la imagen de Eva, tal y como atestiguan algunas obras donde las similitudes con la desnudez antigua son evidentes. Tales datos, evidencian que, aunque denostada por su apariencia sexual, fue vista

\footnotetext{
${ }^{650}$ C. NARDELLA (ed.), Op. cit., pp. 157-159.

${ }^{651}$ Roma, Colección particular. Cf.: A. P. FRUTAZ, Le piante di Roma, 3 vols., Roma, 1962, vol. I, fig. 150 y C. NARDELLA (ed.), Op. cit., p. 68. Resulta problemático pronunciarse sobre el lugar de origen donde se encontraba tal escultura. El maestro Gregorio alude que se hallaba cerca del monumento de los Dióscuros del Quirinale. En el siglo XVII fue encontrada en esa zona una escultura de mármol de Pharos, embutida dentro de un muro.

${ }^{652}$ C. NARDELLA (ed.), Op. cit., p. 68. No en vano, el autor del mirabilia tomó como referencia un verso de Ovidio para el pasaje que escribió.
} 
igualmente con ojos expectantes por los artistas del medievo ${ }^{653}$. Aunque, de nuevo bajo un sentimiento ciertamente ambiguo.

El conocimiento de esta deidad clásica romana durante los siglos medievales y su utilización para fines cristianos, parece claro. Uno de los sermones recogidos en el Codex Calixtinus de la catedral de Santiago de Compostela habla de Venus en los siguientes términos:

"No te dejes de Venus vencer ni tampoco del vino,

Pues de la misma forma Venus y el vino dañan.

Venus enerva las fuerzas y Baco a su vez, excesivo,

Entorpece el paso, debilitando los pies.

Muchos, movidos de un ciego amor, descubrieron secretos,

Y la demente embriaguez nunca los supo guardar.

Muchas veces Cupido ha llevado a la guerra funesta;

Muchas las manos mueve Baco a la guerra también.

Venus fatal a Troya perdió con la lucha homicida,

Y a los Lapitas tú, Baco, perdiste fatal.

Y cuando, en fin, por aquélla o por ésta enloquecen los hombres,

Toda vergüenza y bondad huyen con todo temor.

Ponle ferretes a Venus, con lazos sujeta a Lieo,

Para que con sus dones ni ella te dañe ni él.

Cálmete el vino la sed y feliz creadora de hijos

Venus te sea: saltar límites tales daña",654 (texto 27).

El texto muestra hasta que punto la imagen de la divinidad antigua era sometida a crítica y ejemplificada como parábola moral para llamar la atención sobre determinados pecados. Sin duda, la escultura femenina desnuda permaneció en el imaginario colectivo durante los siglos del románico. De tal forma que, si bien un determinado público se mostraba preparado para exaltar la perfección técnica de las imágenes que la representaban, así como la grandeza de su mito, otras veces hallamos un uso interesado por parte del cristianismo que llegará a reinterpretar doblemente el tema, haciendo de la imagen de Venus una alusión a la Lujuria, como personificación de

\footnotetext{
${ }^{653}$ E. PANOFSKY, Renacimiento y renacimientos..., p. 112.

${ }^{654}$ Liber Sancti Jacobi..., p. 205.
} 
$\operatorname{los} \operatorname{vicios}^{655}$.

Un ejemplo muy expresivo en relación con el tema, nos permite intuir hasta que punto la imagen de Venus llegó a desvirtuarse durante la Edad Media, a través de su conocimiento incompleto.

Según E. Panofsky, fue habitual que, durante estos siglos, la concham marinan de la que supuestamente saldría la diosa y que, en determinadas ocasiones, portaba en su mano, fue leída por algunos medievales como aucam marinam, lo que llevó a representarla saliendo de entre las olas con una oca sostenida por el cuello. El equívoco llegará a ser tal que, de la concham marinam se terminó por comprender canam laminam, es decir pizarra. Este grave error explicaría la imagen del Ovide moralisé de la Biblioteca de Copenhague, donde Venus sale de las aguas asiendo una pizarra que muestra al viento, en el lugar donde algún día hubo una venera ${ }^{656}$ (fig. 121).

Lo que demuestran estos hechos es la importancia que adquirió la imaginería antigua dentro de las ciudades medievales. La imagen de Venus que ve Gregorio, es el caso más conocido de un hecho difícil de demostrar: la cotidianeidad de tales imágenes, el interés por conocer su historia, su significado y su puesto dentro de una sociedad pasada. Su inclusión dentro de los sermones eclesiásticos, en las diversas historias y leyendas creadas y difundidas en época medieval, justifica y explica un interés por acercarse a dichas imágenes.

Por otro lado, nos ayudan a obtener una visión, aunque sesgada, de la imagen que la Antigüedad, ya difusa, proyectaba sobre la mentalidad de los siglos posteriores. La forma, belleza y perfección de algunos de estos fragmentos de la Antigüedad, despertaba sentimientos enfrentados, que provocarían la comprensión de la imagen como un elemento simplemente exótico, mientras que, en otras ocasiones, sería entendida como contenedora de una misteriosa fuerza que le llevará a ser demonizada.

Creemos perfectamente plausible hacer extrapolable el caso de la imagen de Venus a otra serie de esculturas romanas, de las cuales, hemos perdido casi todos los datos.

El público medieval fue consciente de la importancia y de la grandeza de estas obras y por eso las utilizó para poder emular aquel periodo pasado, siempre rigiéndose bajo los parámetros de su propia conveniencia. Se trataba de explotar una época, unas obras y una ideología, a pesar de que ello implicase una citación al mundo pagano. Así,

\footnotetext{
${ }^{655}$ E. PANOFSKY, Renacimiento y renacimientos..., en especial, p. 136 y p. 171.

${ }^{656}$ Copenhague, Det Kongelige Bibliotek, Ms. Thott 399, $2^{\circ}$, fol. 9 v. Cf.: Ibidem, pp. 140-141.
} 
si para demostrar la caída de Roma y la destrucción del paganismo bajo la nueva religión cristiana, se tenía que llevar a cabo una alusión casi "arqueológica" hacia el arte clásico, ésta se hizo con total impunidad.

En una tabla veneciana conservada hoy en la Staatsgalerie de Sttutgart y que se ha datado en torno al año 1400, se representó la Encarnación de Cristo dentro un clípeo (fig. 122). En la parte baja de la obra se dispusieron dos grupos de figuras separados por una "antiquizante" fuente sustentada por personajes desnudos. El tema en cuestión, plasma la visión del emperador Augusto, quién, acompañado por un Sibila, observa el fenómeno celestial. Se trata de la expresión de la grandeza de Cristo, la derrota definitiva del paganismo y la destrucción de todo aquello que a él apareciera ligado.

Ante la manifestación divina, el emperador se postra en el suelo de rodillas, a modo de orante cristiano y mostrando su sumisión hacia la nueva religión triunfante. $\mathrm{Su}$ plegaría da los resultados esperados. La arquitectura monumental del lado izquierdo, que representa el palacio imperial del emperador, permanece en pie, mientas que la construcción del lado derecho, el templo de la Paz, se desmorona y desquebraja por momentos. Roma había caído y, con ella, sus símbolos e ídolos paganos ${ }^{657}$.

A parte de las arquitecturas fantásticas con las que se recrean los edificios romanos, llama la atención la veracidad con la que se representó el ábside del templo de la Paz, más acorde con la definición de un templo cristiano que con una obra antigua. Sin embargó, este espacio se decoró totalmente para simular una pintura al fresco en la que se pueden apreciar perfectamente una serie de soluciones antiguas donde, roleos, acantos y putti son los elementos más destacados. Sin embargo, todos estos frescos se muestran ahora arruinados y arrasados por la nueva religión que triunfaba en Roma. Es la ruina de la ciudad pagana y de su arte, lo que, andando el tiempo, acabaría por aludir a la destrucción no sólo artística del Imperio, sino también ideológica, política y social.

Para concluir este breve apartado, aludimos a las palabras del hispano Prudencio, pues reflejan de manera clara la idea que los autores cristianos tendrían de la Roma pagana:

\footnotetext{
${ }^{657}$ S. MADDALO, In Figura Romae..., pp. 5-7 y S. SETTIS, "Continuitá, distanza...", en especial, pp. 377-378. Todas las arquitecturas de la pintura están estereotipadas, al menos desde el punto de vista estilístico. Son fórmulas no reales, idealizadas y que no corresponden, en absoluto, con los planteamientos arquitectónicos del arte de la época de Augusto. Incluso los ropajes y otra serie de detalles, completamente medievales, hablan de una puesta al día de las fórmulas plásticas, alejadas del periodo en el que supuestamente se ubica la escena, es decir, la Roma imperial de Augusto.
} 
"Los días pase en himnos de continuo y no haya noche alguna sin que el Señor celebre; luche contra las herejías, la fe católica descubra; Templos y cultos de los paganos menosprecie; ruina, Roma, a tus ídolos infiera; canciones a los mártires consagre, loanzas diga a los apóstoles" ${ }^{\text {658 }}$.

Tal y como hemos venido afirmando, el pasado pagano, en muchas ocasiones negado y utilizado para engrandecer la nueva religión, no dejó de ser un tema central dentro de este tipo de reflexiones. El objeto de las mismas, como no podía ser de otra manera, se fundamentó en todas aquellas construcciones, esculturas, pinturas y una larga lista de producciones artísticas que, legadas por el paso del tiempo a las sociedades medievales, estuvieron siempre al alcance de la mirada de sus ojos.

${ }^{658}$ A. PRUDENCIO, Op. cit., p. 7. 


\section{LA IMAGEN DE LA HiSPANIA ANTIGUA EN LA EDAD MEDiA.}

Después de haber apuntado algunas reflexiones sobre la representación de la ciudad de Roma, del arte romano y de su poder, según la concepción que de ellos se tenía durante la Edad Media, creemos posible aplicar algunas de estas consideraciones sobre el caso concreto de la Península Ibérica.

El arte antiguo producido en la Hispania clásica tuvo menos fortuna dentro de las representaciones plásticas y las referencias textuales realizadas durante los siglos del Medievo hispano. Parece claro que, la riqueza monumental conservada en la propia capital del Imperio no debe, en ningún caso, parangonarse con la que nos ha legado el arte hispanorromano ${ }^{659}$. Sin embargo, determinados datos nos pueden ayudar a comprender varios problemas a los que debemos enfrentarnos a la hora de estudiar este fenómeno.

Por una parte, el enorme estado fragmentario del arte hispanorromano que ha llegado hasta nosotros, acompañado nuevamente de un incompleto corpus de obras de la Alta Edad Media hispana, complica enormemente la tarea de poder rastrear e indagar en la imagen que de la Hispania antigua se tuvo durante los siglos medievales. Un arte fragmentario implica, necesariamente, un análisis parcial y expuesto a conclusiones muy abiertas.

Otro de los problemas viene dado por las fuentes. En ocasiones, la aparente riqueza de referencias a la Hispania romana en los propios textos antiguos, así como en los medievales, no se detiene de manera exhaustiva en llevar a cabo un análisis de las obras, citándolas brevemente y sin interesarse por las cuestiones artísticas. En otras ocasiones, la obra que se describe ha desaparecido y no queda en el territorio actual ningún vestigio de lo que las fuentes atestiguan ${ }^{660}$.

Por último y abreviando, se presenta el problema del análisis de los textos y el uso de elementos vinculados a la tradición literaria. Muchas veces, las obras citadas derivan directamente del uso reiterativo de topos literarios que se reutilizan para aderezar la narración, presentando la duda de si en realidad la obra que se está señalando existió o es, simplemente, fruto de la inventiva del autor. Con todo, a pesar de

\footnotetext{
${ }^{659}$ T. NOGALES BASARRATE, "Ritratti di provinciali. Immagini dei nuovi coloni nelle nuove colonie", Hispania Romana Da Terra di conquista a Provincia dell'Impero, Milano, 1997, pp. 112-115.

${ }^{660}$ C. GODOY FERNÁNDEZ, "Calagurris, centro de culto martirial de los santos Emeterio y Celedonio. Observaciones sobre la restitución arquitectónica de la memoria martyrum a partir de Prudencio", Kalakorikos, 5, 200, pp. 87-102.
} 
todos los problemas señalados, consideramos interesante intentar perfilar la posible imagen del mundo antiguo en la Edad Media hispana.

A propósito de Hispania, nos dice Plinio:

"Nueva parte de tierra que tracto, la cual está como levantada del Océano que la cerca, tiene su mayor longitud desde oriente a occidente, conviene a saber, desde la India hasta las Columnas de Hércules, consagradas en Cádiz, de ocho cuentos y 578 mil pasos, según le parece a Artemidoro, y según, Isidoro, nueve cuentos y 818 mil. Añade más Artemidoro: desde Cádiz, en el circuito del cabo de San Vicente, hasta el de Finisterre, por donde se extiende más largamente la frente de Hespaña, 891 mil $^{\text {"661 (texto 28). }}$

Las palabras del autor romano son fundamentales para comprender algunos aspectos que acabarán codificándose dentro de las alegorías iconográficas y alusiones plásticas de los territorios de la Península Ibérica durante la Edad Media y que se convertirían, por evidentes, en habituales dentro de las descripciones de los autores medievales.

En relación con ello merece la pena destacar las palabras que el autor de la Crónica Albeldense dedica al territorio:

"España se llamó antes Iberia por el río Ebro; luego fue denominada España por (H)íspalo. También es verdaderamente llamada (H)esperia por el (H)espero, la estrella de occidental. Está dividida entre África y Galia, cerrada al Septentrión por los montes Pirineos, y rodeada por todas las demás partes por el mar, igual en lo salubre de su clima, fecunda en todo género de frutos, riquísima en recursos de piedras y metales" ${ }^{\text {662 }}$ (texto 29).

A pesar de la diferencia entre las definiciones, diversos datos comienzan a ser interesantes para comprender los elementos que acabarán por definir la representación y la imagen que los autores medievales van a tener de la Hispania antigua.

La primera de las peculiaridades que destacan es la importancia del mar dentro de la geografía hispana. El mismo Plinio reiterará tal afirmación varias veces dentro de su texto:

${ }^{661}$ PLINIO, Historia Natural..., en concreto, p. 134.

${ }^{662}$ Crónicas Asturianas..., "Crónica Albeldense”, p. 224. 
"Después de Italia, fuera de los lugares fabulosos de la India, tengo por cierto tener el primer lugar España por todas las partes que está rodeada de mar" ${ }^{\text {663. }}$.

Tal aspecto estará, desde un principio, bien claro para los artífices medievales, que plasmarán la imagen de la Península Ibérica emergiendo de las aguas, al igual que harán con otra serie de istmos ${ }^{664}$.

La cercanía de la Provincia con respecto a la capital del Imperio, practicable relativamente rápido a través de la navegación por el Mediterráneo ${ }^{665}$, propició que todos los autores, tanto antiguos como medievales, expresaran su interés, no sólo por el mar y los océanos que rodeaban el territorio, sino también por los ríos, los canales y las naves que por ellos discurrían:

"La serie de canales que han abierto por doquier, ayudan al tráfico y a las relaciones, tanto entre ellos mismos como con los forasteros. Del mismo modo, también en la pleamar se utilizan los brazos confluentes cuando los istmos que los separan se hacen navegables al quedar anegados. Las naos pasan entonces de los ríos a los esteros, y viceversa. Todo el tráfico se hace con Italia y Rhóme"666 (texto 30).

Datos como estos ayudan a explicar la concepción que los autores más modernos tendrán sobre las relaciones entre la Provincia y la metrópoli, donde se evidencia una romanización que, aunque desigual, afectó de manera profunda a los más diversos territorios de Hispania:

"Después de esto, unas gentes extrañas que se llamaban almonizos expulsaron a los griegos y reinaron en España durante cuarenta años. Después llegaron numerosos ejércitos desde Alemania y las islas cercanas y expulsaron a los almonizos y reinaron entre los hispanos durante mucho tiempo hasta que los

\footnotetext{
${ }^{663}$ PLINIO, Historia Natural..., p. 1142.

${ }^{664}$ P. LIVERANI, "L'immagini della Hispania", Hispania Romana Da Terra di conquista a Provincia dell'Impero, Milano, 1997, pp. 93-98 y M. ALMAGRO-GORREA, "Hispania a la llegada de Roma", Hispania. El legado de Roma, Zaragoza, 1998, pp. 37-50.

${ }^{665}$ W. TRILLMICH, "Il modello della metropoli", Hispania Romana Da Terra di conquista a Provincia dell'Impero, Milano, 1997, pp. 131-141 y J. A. ABÁSOLO, "Las comunicaciones", Hispania. El legado de Roma, Zaragoza, 1998, pp. 151-158.

${ }^{666}$ A. GARCÍA Y BELLIDO, España y los españoles hace dos mil años según la geografía de Strábon, Madrid, 1945, p. 86.
} 
cartagineses pasaron desde África y sometieron una gran parte de España. Como en un principio resultó muerto Amílcar mientras asediaba Sagunto, Aníbal, el más valeroso rey de los cartagineses, reanudó más tarde el asedio y conquisto la fortaleza de Sagunto, que no es Sigüenza sino que es Murviedro, es decir, Muro Viejo, cerca de Valencia, con la que los romanos, que ya llevaban largo tiempo de hegemonía, tenían un trato de amistad y por ello la llamaban Segunda Roma" $" 667$ (texto 31).

Tal y como vemos, el calificativo de "Segunda Roma" utilizado por B. Morer de Torla en su escrito, aunque exagerado y teñido con ciertos matices estereotipados, demuestra la concepción que tendrían determinados escritores sobre algunas ciudades hispanorromanas. El caso aquí mencionado de Murviedro es bien significativo.

Se trataba de unas ciudades conectadas a través del mar y que mantenían profundas relaciones comerciales de todo tipo de objetos, entre ellos los artísticos. Algunas noticias nos informan sobre determinados personajes que desarrollaban tales actividades en relación con el ámbito hispano de la Antigüedad ${ }^{668}$.

Sabemos así que, Mummio, el destructor de Corintio, fue además un gran expoliador de obras griegas que transportaba a la ciudad de Roma, unas veces, y que donaba a las Provincias en otras ocasiones. Uno de esos traslados de piezas se ha documentando en relación con la ciudad de Itálica, que sería la destinataria de varias de estas obras que debieron ser trasladadas y llegar a suelo hispano mediante los navíos, tal y como atestigua una inscripción estudiada por J. $\mathrm{M}^{\mathrm{a}}$ Blázquez ${ }^{669}$.

A la hora de plasmar plásticamente tales aspectos, por ejemplo, dentro de la ya mencionada Descriptio Mappe Mundi de Hugo de San Víctor, la imagen de Hispania aparece nuevamente vinculada al mar, donde nos informa a propósito del Tyrrenum:

"Tyrrenum dicitur mare illud, quod inter Hispaniam et Africam per mediam terram ab occidente contra orientem cursum suum dirigit usque Alexandriam et Pelusium, et inde reflectitur in obliquo ad septentrionem disterminans orbem terre in tres partes, Africam scilicet, Europam et Asyam, et peruenit usque ad ostium Thanais

\footnotetext{
${ }^{667}$ B. MORER DE TORLA, Crónica (Additiones a De Rebvs Hispaniae de Rodrigo Jiménez de Rada (J. Fernández Valverde ed.), Zaragoza, 2002, pp. 76-77.

${ }_{668}$ W. TRILLMICH, "Las ciudades hispanorromanas: reflejos de la metrópoli”, Hispania. El legado de Roma, Zaragoza, 1998, pp. 163-174.

${ }^{669}$ J. M. BLÁZQUEZ MARTÍNEZ, "El comercio de obras de arte en la Hispania romana", Goya, 143, 1978, pp. 254-265, especialmente, p. 256. Apunta que algunas obras de los Museos Arqueológicos de Jaén, Cádiz y Granada, pueden pertenecer a estas donaciones de obras helenísticas realizadas por parte de Mummio.
} 
fluminius, licet ex adiacentibus prouinciis uel ciuitatibus diuersis in partibus diuersis uocabulis appelletur, ut contra Hispaniam Hispanicum mare, contra Libiam Libicum, contra Galliam Narbonensem Gallicum, contra Siciliam Siculum ${ }^{\text {670 }}$.

Como vemos, la imagen que poco a poco ser formará de Hispania aparece vinculada al mar y la navegación, pero también a las ricas tierras fértiles, pobladas de animales dispuestos a ser cazados ${ }^{671}$. Será el propio Strabon el que incida en este aspecto benévolo del clima peninsular:

"La pureza del aire y la dulce influencia del zéphyros son, en efecto, caracteres propios de Ibería, que vuelta por completo al lado del Occidente, posee un clima verdaderamente templado. Además está situada en los últimos confines de la tierra habitada, es decir, en los mismos lugares donde la fábula -como hemos dichoha colocado el Háides (...)" ${ }^{\circ 72}$ (texto 32).

Los grandes páramos abiertos a la práctica de la caza por parte de los terratenientes de la Antigüedad tardía hispana, acabaron no sólo por generar fuentes de primer orden desde el punto de vista literario, sino también artístico. La caza en esos valles fértiles de los que hablan los autores clásicos convirtieron a Hispania en un destino frecuente donde llevar a cabo grandes batidas ${ }^{673}$.

No vamos a detenernos aquí en las imágenes realizadas para el gran mosaico de Centcelles, por ejemplo, o de la fama que las reses equinas alcanzaron entre la nobleza y las clases pudientes romanas. En relación con ello, baste citar una inscripción conservada hoy en el Museo de León, que da buena cuenta sobre estos aspectos y donde se nos dice:

“Consagrado a Diana; Quinto Tulio Máximo, legado de Augusto de la legión VII Gemina Feliz. Delimitó las llanuras del campo y las dedicó a las divinidades y te levantó un templo, Delia, Virgen Triforme, Tulio, natural de Libia, jefe de la legión

\footnotetext{
${ }^{670}$ H. DE SAN VÍCTOR, Op. cit., en concreto, pp. 135-136. Vuelve a retomar el tema en los versos 335340 , de la p. 145 de la edición del texto.

${ }^{671}$ J. M. BLÁZQUEZ, "Los productos de la tierra”, Hispania. El legado de Roma, Zaragoza, 1998, pp. 95-102.

${ }^{672}$ A. GARCÍA Y BELLIDO, España..., p. 114.

${ }^{673}$ E. CERRILLO MARTÍN DE CÁCERES, "Los campos de Hispania”, Hispania. El legado de Roma, Zaragoza, 1998, pp. 343-352.
} 
íbera, para conseguir herir a las cabras veloces, a los ciervos, a los jabalies de cerdas erizadas, a la progenie de caballos salvajes para competir en carrera y derribarlos con la lanza bien llevando a pie las armas o arrojándolas desde un caballo íbero. Dedica a Diana los colmillos de los jabalíes que mató Máximo, como hermoso testimonio de su valor. Dedica a Diana Tulio los cuernos de los ciervos de la elevada frente, a los que venció en la llanura del páramo, montando un fogoso caballo de cascos resonantes" ${ }^{\text {,674 }}$ (texto 33).

Documentos como este, señalan claramente determinados aspectos que, andando el tiempo, acabarán por configurar la imagen textual e iconográfica que los autores de la Antigüedad y la Edad Media tendrán de Hispania.

Una geografía eminentemente fluvial y mayoritariamente marítima, serían elementos que, de una manera u otra, repercutirían dentro de la forma de representar iconográficamente las ciudades antiguas por parte de los artífices medievales. No en vano, estos autores que dedicarán algunas palabras a las urbes asentadas en los territorios de la Península Ibérica, eran conscientes de que, cuanto menos, las piedras que estaban contemplando tenían siglos de historia. Ya hemos aludido, en este sentido, a los "ciclópeos edificios griegos" que el viajero Benjamín de Tudela señala para la ciudad de Tarragona.

$\mathrm{Si}$ el viajero navarro es capaz de señalar un pasado griego para tales construcciones, incluso a pesar de lo arriesgado de tal tarea de identificación y adjudicación estilística de los vestigios antiguos que tiene ante sus ojos, parece que su interés por describir y analizar esos muros tiene sus precedentes directos en otra serie de reflexiones realizadas por diversos autores antiguos.

En concreto, parece continuar la tradición literaria desarrollada por Strábon, quién señalaba diversas fundaciones griegas en las costas de Hispania diciendo:

"Partiendo de la región del Kálpe, cruza la Bastetania y el país de los oretanoí una cordillera cubierta de densos bosques y corpulentos árboles (...). En la costa la primera ciudad es Málaka, que dista tanto de Kálpe como ésta de Gádeira; en ella hay un emporio, que usan los nómadas que viven en la costa opuesta, y grandes talleres de salazón. Algunos creen que es la misma Maináke, que la tradición dice haber sido la última de las ciudades de los phókaioi hacia el Occidente; pero no

\footnotetext{
${ }^{674}$ M. A. RABANAL ALONSO y S. GARCÍA MARTÍNEZ, Epigrafía romana de la Provincia de León: Revisión y actualización, León, 2001, en concreto, pp. 85-89.
} 
es así, pues ésta se halla más lejos de Kálpe, y los vestigios de sus ruinas demuestran ser una ciudad griega, mientras que Málaka está más cerca y presenta planta fenicia" ${ }^{\circ 75}$ (texto 34).

Cuando Strábon habla de la ruinosa Maináke, se refiere a la colonia fundada en el siglo VII por los coceos, tal y como apunta A. García y Bellido. Se trataba de una de las colonias más alejadas de la Hélade que, con fines comerciales, mantuvo grandes relaciones con los tartessos, sobre todo en lo referente al comercio de los metales ${ }^{676}$.

Estas colonias griegas primero, y más tarde las romanas, se caracterizaron siempre por su estrecha vinculación con el mar, tal y como se encargan de señalar, de manera reiterativa, las fuentes. Tal situación acabó generando un tipo de construcciones que habrían de tener gran fortuna dentro de las representaciones topográficas y cartográficas medievales, así como dentro de las descripciones geográficas que se realizaban de todos estos lugares de gran importancia para el comercio marítimo de la Antigüedad hispana. Nos estamos refiriendo, concretamente, a los faros.

Las palabras de Strábon son claras al describir una de estas monumentales construcciones que dominaban las costas de Hispania:

"Sigue el puerto llamado de Menestheús (...). Inmediatamente después se halla la desembocadura del Baítis, dividida en dos brazos (...). Allí es donde se encuentra el oráculo de Menstheús y donde se alza el Kaipíonos Pyrgos, construido sobre rocas a las que circundan las olas, obra admirablemente hecha y destinada, como el Pháros, a evitar la pérdida de los navegantes (...) sus proximidades están sembradas de escollos, se hizo necesaria una señal perceptible de lejos. De aquí remontando el Baítis, está la ciudad de Eboúra y el santuario de Phosphóros, llamado también Lux Divina"677 (texto 35).

El faro al que se alude, el Kaipíonos Pyrgos, o Caepinonis Monumentum, fue una construcción levantada por Q. Servilius Carpio, cónsul de Hispania entre los años 140-139 a. de C., para que los navegantes que habían de entrar en el Guadalquivir pudiesen evitar los escollos del islote de Salmedina. La figura y la silueta de tal

\footnotetext{
${ }^{675}$ A. GARCÍA Y BELLIDO, España ..., p. 142.

${ }^{676}$ L. DIEGO BARRADO, Nacido del Fuego. El arte del hierro románico en torno al Camino de Santiago, Zaragoza, 1999, en concreto, pp. 5-10 y F. J. SÁNCHEZ-PALENCIA y A. OREJAS, "Minería en la Hispania Romana", Hispania. El legado de Roma, Zaragoza, 1998, pp. 103-112.

${ }^{677}$ A. GARCÍA Y BELLIDO, España ..., pp. 70-72.
} 
construcción debía ser imponente a la vista de los navegantes, evocando otra serie de imágenes que no debieron de resultar extrañas dentro de la morfología de las costas que bañaban la geografía marítima del mundo antiguo.

Se trata de una noticia que rememora otra serie de ejemplos de este tipo, en los que los grandes FAROS acabarían por convertirse en auténticos "símbolos" representantes de algunos puertos, ciudades y territorios. En este sentido, conviene mencionar el ejemplo del faro más conocido de toda la Antigüedad, el de Alejandría.

Su forma monumental, su factura, las grandes murallas que lo rodeaban y la luz que proyectaba sobre el mar, fueron los elementos más destacados y más conocidos por los hombres medievales. En este sentido, la noticia de su existencia llegó incluso a los oídos del viajero de Tudela, quién dedica también unas palabras a dicha construcción ${ }^{678}$. Ejemplos como estos, dan buena cuenta del fenómeno que intentamos explicar. En determinadas ocasiones, algunos de los monumentos más insignes del mundo antiguo, pasaron a la memoria de los hombres medievales ${ }^{679}$. A través de ellos, se situaban y se identificaban determinados territorios, regiones y espacios geográficos ${ }^{680}$. Servían, en otras ocasiones, para situar el desarrollo de determinados acontecimientos políticos e históricos, transformándose en auténticos "iconos" referenciales del devenir histórico antiguo en plena Edad Media.

Dentro del caso hispano, es interesante una noticia extraída de las Crónicas Asturianas. Concretamente, la versión Rotense, sostiene, al narrar la lucha contra los normandos:

"Por el mismo tiempo el pueblo de los normandos (...) vino con una armada a nuestras tierras. Ante su llegada, el ya dicho rey Ramiro congregó un gran ejército, y en el lugar que se llama Faro de Brigancio les plantó batalla; allí dio muerte a gran cantidad de ellos y sus naves las aniquiló por el fuego" $" 681$ (texto 36).

\footnotetext{
${ }^{678}$ B. DE TUDELA, Op. cit., p. 75. Véase también: L. ROCCHETTI, voz "Alessandria", Enciclopedia dell'arte antica classica e orientale, vol. I, Roma, 1958, pp. 204-218. Rocchetti señala que la famosa torre luminosa, levantada bajo las órdenes de Ptolomeo II de Postratos de Cnido, fue considerada, desde la Antigüedad, como una de las maravillas del mundo. La ciudad de Alejandría se encontraba físicamente enfrente de la isla de Faro, donde se hallaba tal estructura que acabaría dando el nombre a la isla. A parte de los dos puertos naturales con los que contaba la ciudad, el de Eunosto y el situado al este, el Gran Puerto, ésta se unía mediante una larga "diga" a la isla donde se levantaba el faro.

${ }^{679}$ S. M. ORDÓÑEZ AGULLA, "El Faro de Gades y las fuentes medievales", II Congreso peninsular de História antiga, Coimbra, 1993, pp. 247-278.

${ }^{680}$ B. GIARDINA, "La rappresentazione del faro nelle emissioni numismatiche del mondo antico", Rivista italiana di numismatica e scienze affini, 108, 2007, pp. 145-168.

${ }^{681}$ Crónicas Asturianas..., A. III Rotense, 23, p. 216.
} 
La noticia refleja un hecho que debió ser habitual en el norte de la Península Ibérica; la lucha contra el enemigo que asediaba Hispania desde los países nórdicos y atracaba en los puertos de Asturias, Galicia y Cantabria. En el caso de esta noticia recogida en el siglo IX, el marco para la batalla es el desconocido Faro de Brigantio, que, ocasionalmente, la historiografía ha señalado en relación directa con la famosa Torre de Hércules de La Coruña ${ }^{682}$.

Así, según J. Gil Fernández, J. L. Moralejo y J. I. Ruiz de la Peña, la batalla se llevaría a cabo en el acantilado custodiado por dicha construcción. La posteriormente conocida como Torre de Hércules, erigida en época romana, servía a los autores medievales que nos han legado esta noticia para ubicar una batalla. El monumento antiguo atestiguaba mediante su propia vetustez, los acontecimientos históricos desarrollados en época medieval. Un edificio que, según los mencionados autores, habría de recordarse aún a través de la supervivencia posterior del arciprestazgo de Faro $^{683}$.

A pesar de que la Crónica narra tales acontecimientos históricos sin demasiados detalles, generalmente se ha venido aceptando que ésta se produjo en las actuales costas gallegas y que el faro romano que se cita, no es más que la actual Torre de Hércules. Sin embargo, en este punto las noticias no son concluyentes y la alusión toponímica a Brigantio no clarifica en absoluto tal problemática.

En cuanto a la existencia material de esta construcción, su forma y sus características identificativas, las fuentes silencian todos los datos, al menos, de los que nosotros disponemos más allá de la supuesta identificación que se haga del monumento en relación con la actual torre gallega ${ }^{684}$.

Sin embargo, sin adentrarnos en tales problemas, resulta muy significativo que, aún en el periodo medieval, la ubicación física de tales hechos se realizase mediante tal construcción antigua.

\footnotetext{
${ }^{682}$ P. LATORRE GONZÁLEZ-MORO y L. CABALLERO ZOREDA, "El faro de La Coruña, llamado la Torre de Hércules", Hispania. El legado de Roma en el año de Trajano, Zaragoza, 1998, pp. 453-457.

${ }^{683}$ Crónicas Asturianas..., p. 217, nota 102. En torno al lugar surgió, además, el llamado Camino de Faro, una ruta alternativa al Camino Inglés, que discurría entre los puertos del Golfo Ártabro y Santiago. Debe el nombre a su punto de partida, el antiguo arciprestazgo de Faro, que abarcaba, fundamentalmente, los actuales municipios de A Coruña, Culleredo y Arteixo.

${ }^{684}$ P. LATORRE GÓNZALEZ-MORO y L. CABELLERO ZOREDA, Op. cit., p. 456.
} 
Si observamos la representación del mundus incluida en el Beato de Burgo de Osma y a la que ya hemos aludido anteriormente, observamos algunos datos de interés en relación con esta cuestión ${ }^{685}$.

La península italiana se separa de la Ibérica a través de un fino hilo de agua que muy posiblemente representa el Mar Mediterráneo. En la miniatura se observa, de manera clara, la identificación mediante un tituli del territorio de Gallecia, en la que se incluyó una imagen de la construcción religiosa más conocida en toda la Hispania medieval, al menos, teniendo en cuenta esta representación en concreto. Nos referimos a la catedral de Santiago de Compostela, materializada aquí mediante una pequeña microarquitectura que cobija la cabeza del apóstol (fig. 123). En un cercano lugar, desde un punto de vista geográfico a la Gallecia que nos ubica el mapa, leemos claramente la palabra Asturias, nuevamente designada mediante una cartela explicativa. Un epígrafe que no deja lugar a dudas de la región de Hispania que el artífice está intentando representar a la hora de sintetizar una imagen de la misión evangelizadora.

Nos interesa destacar este hecho, porqué anexo a dicho topónimo, el miniaturista erigió una gran torre. Se trata de una construcción de perfil posiblemente circular, rematada por una cubierta cónica. Nuevamente la leyenda no deja lugar a dudas de que nos encontramos ante un Faro. Se trata, posiblemente, de una representación arquetípica alejada de lo real, pero que reproduce este monumento tan singular de la geografía marítima de estas regiones durante el siglo XI y que, presumiblemente, se habría conservado desde época romana ${ }^{686}$. Queda la duda de saber si lo que se intentó representar fue exactamente el citado faro de Brigantio que citan las Crónicas o, por el contrario, se trata de otra construcción.

Aún con todo, el profesor Bango ya resaltó en su momento la importancia de esta imagen que identifica, sin dudas, con el faro de La Coruña, destacando también el

\footnotetext{
${ }^{685}$ Burgo de Osma, Biblioteca de la catedral, cod. 1, ff. 34 v-35r. Cf.: A. BALIL, "El códice de Beato de Liébana en Burgo de Osma: notas sobre su mapa y las representaciones de faros en el mismo", Celtiberia, 28, 1978, pp. 7-12; S. MORALEJO ÁLVAREZ, "El mundo y el tiempo en el Beato de Osma", El Beato de Osma. Estudios, Valencia, 1992, pp. 151-179; J. WILLIAMS, The illustrated Beatus: a corpus of the illustrations of the commentary on the Apocalypse. Introduction, vol. I, London, 1994, pp. 50-52; X. BELLO DIÉGUEZ, "La Torre de Hércules y la leyenda", Ciudad. Ciudad y Torre. Roma y la Ilustración, La Coruña, 1991, pp. 145-149; A. FUENTES, “Aproximación a la ciudad hispana de los siglos IV y V d. C.", Congreso Internacional de la historia de Teodosio, Salamanca, 1997, pp. 477-496 у TH. HAUSCHILD, “Torre de Hércules (prov. La Coruña). Leuchtturm”, Denkmäler der Römerzeit, Hispania Antiqua, Maguncia, 1993, p. 300.

${ }^{686}$ S. MADDALO, In Figura Romae..., en concreto, p. 91 y A. BALIL, "El códice de Beato...”, pp. 7-9.
} 
hecho de que coexista con el de Alejandría, otro ejemplar de los dos que minió el $\operatorname{artífice~}^{687}$.

Sin pretender aclarar en ningún caso este problema, lo más interesante es poder reflexionar sobre la importancia que los monumentos antiguos seguían teniendo para los hombres del medievo. En ocasiones, estas obras de ingeniería se continuaban utilizando, de manera que, a pesar de que se trataba de estructuras que habían llegado a los siglos medievales maltrechas, aún podían seguir cumpliendo su función.

Su monumentalidad, su vetustez y, sobre todo, el continuado uso de las mismas desde la época romana, permitieron tal hecho. Creemos que esa fue la causa que llevó a introducir tal elemento dentro de la imagen del mundus que nos ofrece este Beato y, sobre todo, la que llevará a compararlo en monumentalidad con la misma catedral de Santiago de Compostela.

Ya hemos mencionado el famoso mappamundi de Hereford (fig. 124), realizado en Inglaterra en los últimos años del siglo XII ${ }^{688}$. Se trata de una obra de gran formato que, a través de la representación del orbe, aporta variados datos de tipo cosmológico, etnográfico, geográfico, histórico, teológico e incluso zoológico, relativos a la concepción del mundo en torno al año 1200. Se trata de una obra de gran interés para abordar la imprecisa idea que de la Antigüedad se tenía en dicho periodo, sobre todo, en lo relativo al conocimiento de los monumentos más importantes que salpicaban la geografía mundial durante toda la Edad Media ${ }^{689}$.

Las fuentes en las que se basó el miniaturista, nuevamente vuelven a ser clásicas. Sobre todo, se ha destacado la influencia de la obra de Plinio y del Itinerario de Antonino, compuesto por varios anónimos y que narra los viajes de algunos emperadores, como por ejemplo, Caracalla ${ }^{690}$.

En la magna obra, la Península Ibérica aparece dividida en dos partes, la Hispania inferior y la citerior, identificadas mediante dos tituli, de los más de mil que presenta toda la ilustración ${ }^{691}$ (fig. 125). Tal aspecto se ha ligado, por ejemplo, a los parámetros clásicos que en su día había seguido el mismo Isidoro de Sevilla.

\footnotetext{
${ }^{687}$ I. G. BANGO TORVISO, "La cultura enciclopédica”, Sancho el Mayor y sus herederos. El linaje que europeizó los reinos hispanos, 2 vols., Pamplona, 2006, vol. I, pp. 96-107.

${ }^{688}$ Hereford, Cathedral Library.

${ }^{689}$ S. D. WESTREM, The Hereford Map, Turnhout, 2001, en especial, pp. XV-XXVIII; ID., "Lessons from Legends on the Hereford Mapamundi", Barber and Harvey, 91, 1991, pp. 30-67 y P. D. A. HARVEY, Op. cit., en especial, pp. 28-29.

${ }^{690}$ S. D. WESTREM. The Hereford Map..., p. XXIX.

${ }^{691}$ Ibidem, p. 327 y p. 333.
} 
En el lado oeste del istmo, abierta al mar, aparece identificado el territorio de Compostrina, es decir Compostela, que se sitúa al lado del templum Sancti Iacobi que en la imagen viene representado por una suerte de arquitectura fantástica que asemeja la forma de un gran altar rematado por un sagrario ${ }^{692}$. Justo en la parte inferior de dicho espacio aparece, monumental, una enorme torre de fábrica de cuya parte superior surgen potentes llamaradas de fuego. Se trata de un faro y su cartela identificativa se refiere a él con el siguiente término: Perona (fig. 126).

Para S. D. Westrem se trata, posiblemente, del faro de la zona de Padrón, cercana al río Ulla y que aparece ligada a la nave maravillosa que transportó el cuerpo del Apóstol desde Jerusalén a la costa de Iberia ${ }^{693}$. Es evidente que a través de esta pequeña representación de un faro, posiblemente estereotipada, no podemos llevar a cabo una lectura "arqueológica" que permita poder intuir la forma originaria de tal construcción. Sin embargo, nos interesa más destacar que la construcción romana aún a finales del siglo XII y principios del XIII, debía dominar el imaginario de las gentes que habitaban y visitaban dichas zonas ${ }^{694}$.

La construcción romana, por su grandeza y su función dentro de las costas de Ibería, repite en el códice de Hereford la misma apariencia que encontramos en otros grandes faros de la Antigüedad, como por ejemplo el propio faro de la ciudad de Pharos. Esta gran torre mandada construir por el rey Ptolomeo II en una isla cercana a la ciudad de Alejandría, aparece mencionada en el mapa con el nombre de Tafnus civitas ${ }^{695}$ (fig. 126 a).

Creemos que el faro representado en el Beato de Burgo de Osma y el que aparece en el mapa inglés, representan la misma construcción. Debió ser una obra monumental y de gran prestigio en el mundo antiguo y medieval. No sólo por el lugar que ocupó en la cartografía de los siglos XI y XIII, sino porqué en toda la iconografía arquitectónica existente dentro del mapa de Hereford, sólo son dos los grandes faros mencionados: el de Pharos y el de las costas de Iberia.

\footnotetext{
${ }^{692}$ Ibidem, pp. 326-327.

${ }^{693}$ Ibidem, p. 326. El autor alude a las posibles identificaciones con otro tipo de regiones como, por ejemplo, El Ferrol o La Coruña, alegando su importancia debido al intenso comercio marítimo y de peregrinos que tenía la zona, especialmente procedentes de Inglaterra.

${ }^{694}$ Debemos tener en cuenta que, este tipo de obras, se realizaban casi siempre copiando otra serie de modelos, lo que debe servir para afirmar que su presencia en estos mapas tardíos no implica necesariamente que por estos momentos tales construcciones se mantuviesen en pie, pues bien pudieron haberse incorporado al repertorio iconográfico posterior, tan sólo a través de la copia de modelos de obras ya desaparecidas en tiempos medievales.

${ }^{695}$ S. D. WESTREM, The Hereford Map..., pp. 174-175.
} 
En el resto de las regiones del mundo son tan sólo pequeñas torres o fortificaciones que no aluden más que a pequeños edificios. Sólo el faro de la isla cercana a Alejandría y el faro hispano presentan un tamaño considerable y una gran hoguera en la parte posterior del edificio, siguiendo modelos bien conocidos en la iconografía romana, tal y como atestigua el sarcófago de mármol del Museo Nacional de Roma ${ }^{696}$ (fig. 127). Nuevamente vemos que dos de las grandes obras de la Antigüedad perduraban en el imaginario de los hombres medievales ${ }^{697}$.

Tal y como vemos, la representación del faro hispano surge derivada del interés que por los ACCIDENTES GEOGRÁFICOS mostraron los autores del mundo antiguo y medieval. Ya hemos mencionado que ríos, mares, océanos, ciudades y, sobre todo, montañas, eran indicadores de la realidad espacial en la que se movían los hombres, tal y como ocurre en la actualidad. En este sentido, todos los autores que se detienen en hablar de Hispania, aluden a la gran barrera natural que hay que atravesar para llegar a ella por tierra: los Pirineos.

De esta forma, en el capítulo dedicado a Hispania, Hugo de San Víctor inicia su exposición en los siguientes términos:

"Hispania undique circumsepta est Mari et montibus, ab oriente et septentrione Pireneis montibus, ab austro mari Tyrreno, ab occidente occeano" ${ }^{\prime 698}$.

La Crónica Albeldense, tal y como hemos dicho, también especificaba que mediante esta cadena montañosa la Península Ibérica se separaba de la Galia ${ }^{699}$. La barrera defensiva más grande que separaba Iberia del resto de Europa, no pasó desapercibida para todo aquel que desease entrar en el territorio, incluso para la guerra.

Así, Eginhardo ya dejaba claro que para atacar España, Carlomagno entró en el territorio:

“(...) con el mayor contingente bélico que pudo. Atravesó el desfiladero de los Pirineos, aceptó la rendición de todas las fortalezas y castillos que encontró a su

\footnotetext{
${ }^{696}$ Roma, Museo Nazionale Romano. Se trata de un sarcófago en cuyo lado izquierdo se representó una imagen femenina que en la mano sustenta un faro muy semejante al que fue representado en el mapa inglés. Además, en el frente de dicho sarcófago aparecen otras representaciones, como África, fácilmente identificable a partir de su tocado en forma de colmillos y orejas de elefante.

${ }^{697} \mathrm{~J}$. ADHÉMAR, Influences antiques..., sobre todo, pp. 52-53. El investigador documenta la existencia de una serie de pirámides romanas construidas en Varèse, en el Angoumois, que durante la época medieval y moderna fueron denominadas por los habitantes de la zona como "les Faniaux".

${ }^{698}$ H. DE SAN VICTOR, Op. cit., en concreto, pp. 154-156.

${ }^{699}$ Crónicas Asturianas..., "Crónica Albeldense”, p. 224.
} 
paso y volvió con el ejército sano y salvo si se exceptúa que, a su regreso, tuvo ocasión de experimentar algo la perfidia vasca en las mismas cumbres de los Pirineos" 700 (texto 37).

Tales aspectos acabaron por repercutir desde el punto de vista iconográfico. Así aparecen representados en el Orbe Tripartito de un códice del siglo XI, a través de unas pequeñas protuberancias señaladas mediante la palabra Pirineus, enfrentados a la magnificencia con la que se han representado los Alpes ${ }^{701}$.

Una forma mucho más geométrica presentan las montañas hispanas en la Descriptio orbis terrae de la Prefatiuncula in Orosio de passionibus omnium paganorum seu hereticorum, datada en el siglo $\mathrm{XIV}^{702}$ (fig. 128). El orbe se muestra completamente circular y rodeado por las aguas. Nuevamente se divide en las tres partes del mundo conocido: Asia, Europa y África. A parte de señalar las grandes ciudades de Jerusalén, Constantinopla y Roma, existe un aspecto fundamental: la gran cadena montañosa que se ha representado es la de los Pirinei Montes. Dichas montañas separan Hispania del resto de Europa, cuya capital es, según lo representado, Roma.

En el caso del mapamundi de Hereford, nuevamente la gran barrera montañosa sirve de separación con respecto a la Galia y, adosado a ella, podemos ver las ciudades de Pamplona y Palencia, a pesar de que, sin duda, se trata de un mal cálculo del $\operatorname{artífice~}^{703}$.

Igualmente se repite la imagen de una montaña elevada con vegetación, que nace de ella, en el Beatus de la British Library de Londres, que enlaza con otra gran cadena montañosa que separa Hispania de la Galia y más concretamente, Narbona y Tarragona. En este caso la identificación es segura gracias a la inscripción: Mons Pirineis $^{704}$.

La importancia que los Pirineos tuvieron durante la Edad Media dentro de la ilustración de mapas, se corresponde con el valor que los autores clásicos le habían dado a dicho territorio.

Ya Plinio escribía sobre ellos:

\footnotetext{
${ }^{700}$ EGINHARDO, Op. cit., p. 65.

${ }^{701}$ Leipzig, Universitaetsbibliothek, Ms. XI, f. 184 v. Cf.: S. MADDALO, In Figura Romae..., pp. 88-91.

702 Roma, Biblioteca Apostolica Vaticana, Vat. lat. 7318, f. 3 v. Cf.: Ibidem, p. 91. Se trata de la Descriptio orbis terrae de la Prefatiuncula in Orosio de passionibus omnium paganorum seu hereticorum.

${ }^{703}$ S. D. WESTREM, The Hereford Map..., pp. 283-285.

${ }^{704}$ British Library, Additional Ms. 11695, ff. 39 v-40r. Cf.: P. D. A. HARVEY, Op. cit., p. 23. Es muy llamativo como se utiliza el mismo modelo para representar diversos accidentes de la geografía del mundo. Son idénticas a los Pirineos, por ejemplo, el Mos Libanus y otra serie de montañas de África o la India.
} 
"Pero a la honra del pueblo romano toca, y no a la de un hombre solo, nombrar en este lugar todas las victorias, los títulos y triumphos del Magno Pompeyo, con las cuales no solamente igualó la fama de las hazañas de Alexandro Magno, pero cuasi las de Hércules y del padre Libero (...). Entró en Roma en carro triunfal, lo que no havía hecho otro ninguno antes de él. Y después, pasado a occidente y levantados en el Pyrineo muchos tropheos, juntó a sus victorias 866 pueblos que ganó desde los Alpes hasta los fines de la Hespaña Ulterior",705 (texto 38).

Plinio cita en este texto la construcción en los Pirineos de una serie trofeos en conmemoración de las victorias del emperador Pompeyo, que, según nos dice también, habría logado conquistas en la propia Hispania. Pudiera parecer un dato irrelevante, si no fuera porqué, más adelante, el propio autor explica con detenimiento las características de algunas de las obras creadas para tales conmemoraciones:

"Para que esto más claramente se conozca, pondré abaxo las palabras de los mismos actos de los triunfos de Pompeyo. En el tercero triunfo, pues, el qual tuvo el día de su nacimiento y último de octubre (...). Y para que no pongan duda en esto, ninguna piedra preciosa ha llegado hasta hoy a esta grandeza y tamaño. Huvo en aquel triunfo una luna de oro de treinta libras y tres lechos triclinares para comer; vasos de oro y piedras preciosas para nueve aparadores; tres estatuas de oro, de Minerva, Marte y Apolo; coronas de perlas, treinta y tres; un monte de oro cuadrado con ciervos y leones y frutas de todos géneros, y rodeada una vida de oro; un mucho hecho de perlas, en cuyo capitel estava un relox; una estatua de Cneo Pompeyo, de perlas (...). ¿Así quieren que parezcas prodigioso? ¿Por ventura no es más parecida a ti aquella imagen que pusiste sobre los montes Pirineos?",706 (texto 39).

Este ejemplo pone en evidencia, una vez más, el problema de la desaparición de algunas de las obras más señeras de la Antigüedad que, llegadas a los siglos del medievo, ya fuese a través de un conocimiento directo justificado por la conservación de las mismas o, a través de diversas fuentes documentales, literarias o artísticas, les permitieron crearse un juicio propio más completo del que tenemos en la actualidad.

\footnotetext{
${ }^{705}$ PLINIO, Historia Natural..., pp. 327-328.

${ }^{706}$ Ibidem, p. 1126.
} 
Su posterior destrucción y pérdida, hacen imposible poder reconstruir su apariencia y su importancia para las sociedades posteriores. Tan sólo esta breve mención, nos permite conjeturar con el valor que dicha imagen pudo tener en su momento, colocada en un lugar bien visible, en el límite de la frontera que toda persona que deseaba entrar a Hispania debía atravesar. Sin duda, la imagen debió ser impactante o, por lo menos, gozar de cierta relevancia. Sin embargo las fuentes iconográficas medievales que nosotros hemos manejado silencian cualquier dato ${ }^{707}$.

Con todo, no debemos tomar los datos aportados por Plinio como meramente anecdóticos. En este sentido, el autor afirma que el trofeo de los PIRINEOS se levantó para conmemorar unas hazañas tan importantes como las del propio HÉRCULES. Se trata de un dato revelador, pues a través de él, las fuentes antiguas y medievales conectaban esta trascendental figura de la Antigüedad con la Península Ibérica.

Su figura aparece envuelta en las brumas de la mitología y es por ello que resulta difícil aportar datos precisos. Todos aquellos autores que, de una manera más o menos amplia, llevan a cabo una descripción de Iberia, aluden de manera reiterativa a un monumento antiguo que debió tener una importancia vital dentro del imaginario de la época.

Tal monumento, nos dice Strábon, se hallaba en la parte meridional de la Península:

"La primera parte de ellas, es como decíamos, el Occidente; es decir, Ibería; ésta, en su mayor extensión, es poco habitable (...). La región septentrional es muy fría por ser accidentada en extremo (...). La meridional casi toda ella es fértil, principalmente la de fuera de las Stélai, ${ }^{\text {708 }}$ (texto 40).

La noticia es importante en cuanto se refiere a las Stélai que, según García y Bellido, se trataría del nombre con el que los griegos conocían, desde antiguo, al Estrecho de Gibraltar, Herákleioi o Herakléous (de Hércules). Según el autor, Stélai significa "columnas", es decir, el nombre latino de Columnae Herculis. El topónimo señala uno de los mitos más arraigados en relación con la Península Ibérica, en la cual,

\footnotetext{
${ }^{707}$ P. LIVERANI, Op. cit., p. 93-94. El autor pone de relieve la importancia de este tipo de monumentos y sus repercusiones sobre las artes plásticas, especialmente la numismática. Menciona el famoso trofeo de Augusto en Lugdunum Convenarum, hoy Saint Bertrand de Comminges.

${ }^{708}$ A. GARCÍA Y BELLIDO, España ..., pp. 54-56.
} 
según la leyenda, Hércules alzó dos columnas, una enfrente de la otra, como término de sus hazañas legendarias por el extremo occidental del mundo ${ }^{709}$.

Otra vez Plinio confirma la noticia:

“(...) la cual está como levantada del Océano que la cerca (la Península Ibérica), tiene su mayor longitud desde oriente a occidente, (...), desde la India hasta las Columnas de Hércules, consagradas en Cádiz" ${ }^{, 710 .}$

A partir de la Antigüedad el territorio adyacente a Gibraltar aparece citado frecuentemente por aquellos autores medievales que tratan el tema. Se trata nuevamente del traspaso de una tradición antigua a las fuentes medievales.

Así, por ejemplo, Hugo de San Víctor aclara:

"Prima igitur insula est Gades, sita in ipso ostio unde mare Mágnum ab océano diriuator, inter Auennam Hispanie montem a septentrione et Calpem montem Africe ab occidente, habens ciuitatem eiusdem nominis, deinde alie tres, que similiter Gades dicuntur, ubi sunt columpne Herculis" ${ }^{, 711 .}$

La noticia nos parece interesante, pues el autor medieval alude directamente a este punto extremo entre los dos continentes. Se trata, según P. Gautier Dalché, del mons Auenna de África -el monte Abila del que habla Plinio- y que se viene identificando como el monte Acho, cerca de Ceuta. El otro monte es el Calpe, es decir, Gibraltar $^{712}$.

La noticia, que en un primer momento pudiera parecer simplemente anecdótica, no lo es, en cuanto, durante la Edad Media, los copistas de manuscritos llegarían a "inventar" y reproducir con total fidelidad las famosas columnas de Hércules. Muy a pesar de que, en ocasiones, no tuvieran ningún tipo de dato fiable que les confirmase su existencia, su forma, su ubicación y su número, que oscilará de manera remarcable, dependiendo de la fuente utilizada por el artista.

\footnotetext{
${ }^{709}$ Ibidem, p. 57, nota 3.

${ }^{710}$ PLNIO, Historia Natural..., p. 134.

${ }^{711}$ H. DE SAN VICTOR, Op. cit., en concreto, p. 136.

${ }^{712}$ Ibidem, p. 162, nota 8 .
} 
En el manuscrito, ya citado, de la Bayerische Staatsbibliothek de Munich y que, tal y como hemos apuntando, guarda una semejanza más que evidente con el texto de Hugo de San Víctor, es interesante en este sentido ${ }^{713}$.

En dicha imagen fue representada, con total nitidez, la Península Ibérica, separada de Aquitania por los Pirineos. Dividida con respecto a Iberia por el mar, aparece África y, entre ambas, las representación, absolutamente convencional e idealizada de las columnas de Hércules ${ }^{714}$ (fig. 129). De hecho, existe otro dato interesante en el texto de San Víctor, ya que es el único que se conoce en el que se ponen en relación directa las tres columnas de Hércules con las tres islas del Gades ${ }^{715}$. Resulta un dato llamativo si se tiene en cuenta que esto tiene su reflejo en la ilustración de Munich ${ }^{716}$.

Para representar las tres columnas antiguas se marcaron, dentro del manuscrito, tres líneas rojas justo enfrente de las costas de ambos continentes.

Nuevamente será en el manuscrito de Orosio, titulado Descriptio orbis terrea, donde hallamos una representación de las columnas de Hércules ${ }^{717}$. Si Europa y África se separan mediante el Mediterraneum mare, encontramos, junto al Mons Athlas, situado en el continente africano, tres pequeños símbolos marcados en tinta negra que se identifican con el término Gades. Anexo a ellos aparece otro símbolo del mismo tipo denominado por el artífice como Herculis, es decir, el conjunto iconográfico debe ser entendido como el Gades Herculis (fig. 130).

Mucho más lograda es la imagen del mapa Hereford. La costa de Iberia que mira hacia África aparece ocupada por dos grandes edificios identificados como Valencia y Córdoba. Nuevamente aparece el monte Acho. Tras él, el estrecho de Gibraltar. La costa africana destaca por la presencia del Mons Capel o el Peñón ${ }^{718}$.

Finalmente, flotando sobre el mar que divide los dos continentes, fueron representadas las Gades Herculis o, tal y como las identifica S. D. Westrem, las

\footnotetext{
${ }^{713}$ Münich, Bayerische Staatsbibliothek, Clm 10058, f. 154 v. Cf.: P. D. A. HARVEY, Op. cit., p. 23.

${ }^{714}$ H. DE SAN VICTOR, Op. cit. p. 82. Debemos mencionar, a este respecto, como el propio Orosio no llega a mencionar nunca la ciudad de Gades. Véase también: Y. JANVIER, La géographie d'Orose, Paris, 1982, en concreto, p. 255.

715 Aún hoy en día existen desacuerdos para localizar estas islas, ya que, incluso, algunos autores prefieren afirmar que la primera fundación de la ciudad de Cádiz estuvo en una isla. Cf.: L. PÉREZ VILATELA, Lusitania: Historia y Etnología, Madrid, 2000, en concreto, p. 43.

${ }^{716}$ H. DE SAN VICTOR, Op. cit., p. 162, nota 9 y L. PÉREZ VILATELA, "Los nombres del mar de más allá de las columnas de Hércules en la Antigüedad", El Estrecho de Gibraltar, Ceuta, 1995, pp. 165-178.

717 Descriptio orbis terrae de la Prefatiuncula in Orosio de passionibus omnium paganorum seu hereticorum, Roma, Biblioteca Apostólica Vaticana, Vat. lat. 7318, f. 3 v.

${ }^{718}$ S. D. WESTREM, The Hereford Map..., p. 335 y p. 371.
} 
Columnas de Hércules (Fig. 131). Aquí se observan ya perfectamente dos grandes columnas que ponían punto y final a las hazañas del héroe dentro del mundo conocido $^{719}$. Y así pasarán al ejemplo más desarrollado de este tipo de iconografía: el que presenta el mapa del mundo de Ranulf Higden.

Fue este un monje proveniente de Chester, que durante el siglo XIV llevó a cabo una compilación de la historia universal acompañada de una representación del orbe. En el mar, separando Europa de África, nuevamente emergen las dos míticas columnas, ahora perceptibles hasta en los más mínimos detalles, con sus basas, fustes y capiteles simples $^{720}$ (fig. 132).

Los ejemplos hasta aquí señalados, reiteran todo aquello que hemos venido afirmando, sobre todo en relación con la perdurabilidad de una noticia nacida en el seno de los autores de la Antigüedad y traspasada a la Edad Media. Es más, la referencia fue reelaborada por los artistas medievales, y enriquecida, aportando una serie de fórmulas iconográficas que seguramente, de haberse conservado ejemplos miniados de época romana, reproducirían también estas fuentes clásicas.

Las dos grandes columnas de Iberia pasaban así a formar parte de otra serie de obras clásicas, reales o ficticias, que esparcidas por todo el mundo, habían servido de elemento identificador de determinadas partes del orbe. Así, por ejemplo, es bien conocido el caso de la gran columna representada sobre el mosaico de Madaba, en Jordania (fig. 133). Aquí, tras el paso de muralla, se da inicio, mediante una gran plaza, al cardo columnado que se muestra flanqueado por sendos pórticos. Esa plaza cercana a la puerta norte de la ciudad presenta, según dicha representación, una gran columna votiva. Nuevamente observamos la importancia de tal elemento para la identificación de un lugar, pues tras la Porta de Damasco o Porta di Sichem, se da paso a la plaza Bab al'Amud, en árabe, Puerta de la Columna ${ }^{721}$.

En la Antigüedad clásica romana ocurrió exactamente lo mismo. Citamos, a modo de ejemplo, el caso más conocido de la ciudad de Roma, donde la Piazza della

\footnotetext{
${ }^{719}$ Ibidem, pp. 426-427.

${ }^{720}$ P. D. A. HARVEY, Op. cit., pp. 33-34.

${ }^{721}$ M. PICCIRILLO, Op. cit., p. 291; P. D. A. HARVEY, Op. cit., en especial, p. 10 y G. MENÉNDEZPIDAL, Hacia una nueva imagen del mundo, Madrid, 2003, p. 30. Los autores consideran que de esta plaza de la Columna nace la gran avenida porticada que corre hasta el este de la ciudad, tan sólo interrumpida por la calle abierta tras la Puerta Oriental. Recordemos que este esquema cartográfico de la ciudad presenta muchos de los convencionalismos de las representaciones topográficas del mundo clásico. Se ha datado en torno al siglo VI.
} 
Colonna retoma el nombre de su monumento más célebre, la gran columna conmemorativa de Marco Aurelio ${ }^{722}$.

Sin embargo, los ejemplos pueden extrapolarse a toda la geografía provincial romana, donde los topónimos geográficos actuales, guardan el recuerdo de un monumento o estructura antigua que acabó por "fosilizarse" dentro de la propia palabra que definía al lugar. Así por ejemplo, la iglesia hispana de San Juan de Baños reflejaría su cercano asentamiento a unos desaparecidos balnea, Sainte Amelie-les-Bains, su conexión con las termas romanas construidas en su entorno, la iglesia de Notre-Damedes-Arènes, su erección sobre la arena de la ciudad de Narbona, y así sucesivamente ${ }^{723}$.

Sin embargo, si dentro del panorama de algunas ciudades este tipo de columnas conmemorativas podía ser más o menos habitual para las gentes que habitaban en ella, el cristianismo supo aprovechar su contenido ideológico y sacar el máximo contenido "moral" a este tipo de monumentos de la Antigüedad.

Apuntamos un ejemplo hispano, en el que las míticas columnas de Hércules aparecen integradas en un sermón del Codex Calixtinus:

“Eres feliz, porque en el clima eres semejante al Paraíso; pero eres más dichosa, porque has sido encomendada al paraninfo del cielo. En otro tiempo fuiste célebre por las columnas de Hércules, según vanas leyendas, más ahora con más felicidad te apoyas en la columna firmísima de Santiago"724 (texto 41).

A propósito de este texto, se ha señalado la importancia de las Columnas de Hércules en Gibraltar, en relación con los posibles ecos de otra columna famosa de la Hispania antigua, la actual Torre de Hércules, que desde Dion Casio y, sobre todo, Orosio, fue bien conocida. Así, durante la Edad Media acabará teniendo una notable

\footnotetext{
${ }^{722}$ VV. AA., La colonne Aurélienne. Autour de la colonne Aurélienne. Geste et image sur la colonne de Marc Aurèle á Rome (J. Scheid et V. Huet eds.), Thurnhout, 2000. En especial, véase: V. HUET, "La colonne Aurélienne: contexte spatial et historiographie”, La colonne ..., pp. 107-127.

La columna fue, durante largo tiempo, considerada como obra de Antonino Pío y Faustina, debido, sobre todo, a la errónea inscripción que mandó colocar en la base del conjunto el papa Sixto Quinto y que les adjudicaba la obra. Fue levantada sobre el Campo de Marte, a la izquierda de la Vía Flaminia, con el templo de Adriano y el Ara Pacis. La plaza estaba rodeada, quizás, por pórticos y por el Templo de Divus Marcus. Su fin era salvaguardar y monumentalizar el lugar en el descansarían las cenizas de los Antoninos. Ya hemos hablado, anteriormente, del uso conmemorativo que durante la Edad Media se le dio a determinadas columnas, la más famosa, la patrocinada por Bernward de Hildesheim.

${ }^{723}$ J. ADHÉMAR, Influences antiques..., en concreto, pp. 46-49. El experto alude al término Fains o Fain, que recordaría el asentamiento anterior de un templo (fanum) o a nombres como los de "Campos de Piedra" o el "Campo de las Columnas" en Vieu, donde los fustes antiguos fueron expoliados dentro de la torre campanario de una nueva iglesia.

${ }^{724}$ Liber Sancti Jacobi..., p. 169.
} 
reputación como referencia necesaria en la navegación atlántica, con su consecuente derivación en fantasías y mitos ${ }^{725}$.

No podemos detenernos en la fortuna que el motivo antiguo alcanzó en las fuentes medievales, de las que, la Crónica del Moro Rasis, Ximénez de Rada, Alfonso X, Leomarte y Raoul le Fêvre, son los casos más conocidos.

En su día el profesor S. Moralejo señaló la importancia de estos monumentos antiguos dentro de la configuración de la imagen de la Antigüedad en el pensamiento medieval. Tales vestigios adquirían la condición de "monumentum", si utilizamos el término actual o, mirabilia, si le aplicamos la categoría más difundida durante los siglos de la Edad Media ${ }^{726}$.

Podemos afirmar entonces que, se trata de la utilización de un mito antiguo con fines cristianos, es decir, una reinterpretación de la historia adaptada a la conveniencia del pensamiento medieval. Tal y como será frecuente dentro de los textos de este momento, Cristo y lo apóstoles serán, a menudo, equiparados con una columna, como símbolo de fuerza, vigor y firmeza. En el caso hispano, además, parece que tal elemento se ligó, en algunas ocasiones, con el monumento antiguo que aquí hemos analizado.

Incluso si leemos el comentario realizado por el árabe al-Barkri con respecto a la geografía peninsular, observamos, igualmente, un conocimiento cercano de algunas de las grandes obras romanas de la Antigüedad hispana. En este sentido nos informa:

"Los antiguos dividieron al-Andalus de maneras distintas. Constantino la fraccionó en seis partes, colocando la primera en (la Galia, con sede metropolitana en) la ciudad de Narbona, confín entre la Galia y al-Andalus (...), la segunda (la Gallecia, con sede) en la ciudad de Braga(...), la tercera (la Celtiberia, con sede) en la ciudad de Tarragona (...), la cuarta (la Cartaginenses) con sede en la ciudad de Toledo(...), la quinta (la Lusitania) con sede en la ciudad de Mérida (...), la sexta (la Bética) con sede en la ciudad de Sevilla (...) el territorio de al-Andalus es triangular, con uno de sus vértices en el lugar donde está el "ídolo de Cádiz" (...) frente al monte de África llamado Atlas (Adlabiya)(...); el vértice segundo está al oriente de al-Andalus, entre la ciudad de Narbona y la ciudad de Burdeos(...) siendo la entrada a al-Andalus desde

\footnotetext{
${ }^{725}$ Ibidem, nota 242.

${ }^{726}$ A. BALIL, Op. cit., pp. 7-12; S. MORALEJO ÁLVAREZ, "El mundo y el tiempo...", pp. 151-179; M. C. DÍAZ Y DÍAZ, Visiones del más allá en Galicia durante la Edad Media, Santiago de Compostela, pp. 247-248 y J. J. MORALEJO ÁLVAREZ, "De griegos en Galicia”, Epieikeia. Homenaje al Profesor Jesús Lens Tuero (M. Alganza et alt. eds.), Granada, 2000, pp. 327-358.
} 
Europa (...); el tercer vértice está donde el mar gira de norte a oeste y se encuentra el "faro" (de Hércules)",727.

La figura mitológica de Hércules y sus Columnas sobrepasaron los límites de la iconografía más clásica para asentarse en la Edad Media, tanto cristiana como musulmana, tal y como se puede observar. Su supuesta obra conmemoraba y rememoraba su memoria hasta el confín del mundo civilizado. Sin embargo, los hombres del medievo, seguidores en todo caso de la tradición antigua, copiaron el motivo de manera estereotipada y sin reflexionar profundamente sobre la problemática de su real existencia o no. Según pensamos, se puede alegar de manera segura, una simple transmisión formal de la fórmula, desde las ilustraciones cartográficas tardoantiguas hasta la etapa medieval.

El fenómeno que hemos estudiado en relación con la exaltación de la memoria antigua de la ciudad de Roma, de la de Jerusalén o de Bizancio y su traspaso a los siglos medievales, tiene su referente en ciertos aspectos relacionados con la imagen medieval de la Hispania antigua. En relación con ello, encontramos pequeños fragmentos aislados, desde el punto de vista iconográfico y textual, que nos hablan de unos artistas medievales conocedores de la geografía clásica y de sus sistemas de representación más comunes.

La obra antigua se convierte, durante la Edad Media, en una especie de:

“(...) monumento 'no intencionado' (...) dado que los autores de estas obras (antiguas), que hoy se nos presentan como monumentos históricos, en general sólo pretendían satisfacer ciertas necesidades prácticas o ideales propias, de sus contemporáneos o, como mucho, de sus sucesores más inmediatos, y que seguramente no pensaban en dejar a las generaciones de siglos posteriores testimonios de la vida y la creación artística y cultural propias" ${ }^{, 728}$ (texto 42).

\footnotetext{
${ }^{727}$ M. J. VIGUERA MOLINS, "Esplendor y decadencia de al-Andalus: de la invasión musulmana a la toma de Granada", España Medieval y el legado de Occidente, Barcelona, 2005, pp. 37-60, en especial, p. 38.

${ }_{728}$ A. RIËGL, El culto a los monumentos modernos, Madrid, 1999, en concreto, pp. 28-29. El autor utiliza el término "monumento" y nosotros lo tomamos siendo conscientes de lo problemático de aplicar tal acepción a la manera en que los medievales observaban la obra clásica. Nos apoyamos, en este sentido, en el estudio de la edición del Codex Calixtinus, donde los investigadores utilizan esta misma palabra para señalar este fenómeno, siendo conscientes de su ambigüedad. Cf.: Liber Sancti Jacobi..., p. 169 , nota 242.
} 
Sin embargo, aunque el uso del concepto "monumento" para definir la actitud de los hombres del periodo medieval hacia las producciones artísticas antiguas, no es el correcto, la admiración por tales obras durante este momento, fue el primer paso de la civilización occidental para convertirlas en monumentos propiamente dichos. Fueron los hombres medievales quienes comenzarían a atribuir determinados valores nuevos a dichas piezas clásicas; valores relacionados con lo mitológico, con lo político y con lo ideológico.

La presencia de las Columnas del Hércules en la ilustración y la literatura medievales, habla de un uso intencionado, más bien "pseudohistórico", de las obras de arte del pasado. La construcción antigua identificaba un lugar y la sóla referencia a dicho objeto significaba aludir a ese territorio donde se hallaba la obra.

Así, la obra de arte antigua pasó a representar, en ocasiones, a la misma Antigüedad. Cuando un hombre medieval como el monje Gregorio llevaba a cabo la descripción de una simple loba de bronce colocada cerca del Patriarchium, lo hacía en los siguientes términos:

"Nel portico davanti al palazzo d'inverno del papa vi è ache l'immagine broncea di quella lupa che si dice abbia nutrito Romulo e Remo; ma questa è una favola. Infatti Lupa fu una donna di grande bellezza, al tema dell'antica Roma. Costei trovò Romulo e Remo gettati nel Tevere e li allevò como figli propi (...) questa lupa di brozo cerca di azzannare un ariete, anch'esso di bronzo, che posto davanti al predetto palazzo emette dalla boca un zampillo d'acqua per un analogo scopo, ma ora non più, perché, spezzatisi i piedi, fu portata via dal luogo che prima ocupava"729.

La sóla imagen de una loba de bronce podía representar ya durante la Edad Media, tal y como ocurre hoy, a la gran capital del mundo clásico. Ya hemos mencionado la evocación directa de la ciudad de Roma a través de la copia de esta imagen durante el imperio carolingio. En este sentido, es interesante aludir al ejemplo expuesto por S. Settis, quién a propósito de un marfil carolingio en el que fue figurada la crucifixión de Cristo, alude a este sistema de cristianización de las obras de arte

\footnotetext{
${ }^{729}$ C. NARDELLA (ed.), Op. cit., p. 94 y p. 173 y R. TURCAN, L'art romain dans l'histoire. Six siècles d'expressions de la romanité, Paris, 1995, en especial, pp. 18-19. La obra que describe el maestro Gregorio es la pieza de bronce que hoy podemos contemplar en los Musei Capitolini de Roma. La primera mención de esta escultura dentro de las colecciones de objetos que estaban colocados en los alrededores del Laterano, datan del siglo X y están ligadas al desarrollo de ceremonias de impartición de justicia.
} 
paganas, que con el paso del tiempo, acabaron por convertirse en representantes de la Antigüedad clásica de una ciudad, en este caso Roma (fig. 134).

En la pieza de marfil se observa claramente al REX IVDEORUM flanqueado por la MVLIEREN y el DISSIPVLECCE, siguiendo el sistema habitual de representaciones de esta índole. Sin embargo, bajo la cruz, el artífice introdujo la imagen de una loba amamantando a dos niños. La inscripción disipa cualquier duda: ROMVLVS ET REMVLVS A LVPA NVTRITI ${ }^{730}$. Settis ha interpretado la escena como una reiteración del triunfo del crucificado sobre el paganismo de la ciudad de Roma, representado mediante la loba y los gemelos ${ }^{731}$.

Para concluir este apartado, queremos aludir finalmente a una obra creada en el ambiente cortesano del rey Alfonso X El Sabio. Sus famosas Cantigas de Santa María, fuente iconográfica de gran riqueza, presentan una imagen fundamental para comprender el fenómeno que hasta aquí hemos intentado analizar.

En una de las miniaturas se representó una escena enmarcada por un entorno totalmente urbano ${ }^{732}$ (fig. 135). En ella, una mujer judía es condenada a ser despeñada tras cometer una falta. Para concretar el lugar exacto en el que se desarrolla la acción, el miniaturista aludió a un monumento de la Antigüedad romana sobradamente conocido durante el medievo: el acueducto de la ciudad de Segovia (fig. 136). La inclusión de este monumento en la escena ratifica la idea de que determinadas obras de la Antigüedad, en este caso romana, presentaban tal monumentalidad y senectud, que los espectadores medievales llegaron a identificar el lugar en el que se encontraban tales obras, con el mismo término físico en el que éstas se hallaban ${ }^{733}$.

El acueducto romano de Segovia, icono indiscutible de la ciudad, ejercería sobre los hombres medievales una cierta impresión inmemorial. La misma presencia de la obra durante siglos en el imaginario colectivo, acabaría por convertir dicho monumento en un elemento cotidiano dentro de la convivencia diaria en la urbs.

\footnotetext{
730 S. SETTIS, "Continuità, distanza...", p. 436 y D. GABORIT-CHOPIN, Ivoires du Moyen Age, Fribourg, 1978, en especial, pp. 92-93. El llamado díptico de Rambona, se ha datado en torno al siglo X y se conserva en Roma, Musei Vaticani.

${ }^{731}$ Sobre el uso de personificaciones de localidades, fenómenos naturales, emociones humanas y conceptos abstractos a través de las artes plásticas durante el imperio carolingio, vid.: E. PANOFSKY, Renacimiento y renacimientos..., en especial, pp. 94-95.

${ }_{732}^{733}$ El Escorial, Biblioteca del Monasterio, Ms. 107, f. 154r.

${ }^{733}$ No es la primera filiación con lo antiguo que se ha señalado en la obra promovida por Alfonso X el Sabio. En relación con el púlpito marmóreo de Nicolás de Siena, datado entre los años 1248 y 1260, aproximadamente, las Cantigas, tal y como ha señalado E. Castelnuovo, describen en términos casi místicos tal pieza, exaltando el mármol con el que está hecho. Cf.: E. CASTELNUOVO, "Indigeni sassi", Niveo de marmore. L'uso artistico del marmo di Carrara dall'XI al XV secolo, Genova, 1992, en especial p. 18.
} 
Los artífices medievales, sometiendo la pieza antigua a una nueva lectura, reelaboran la imagen clásica, readaptándola a los nuevos contextos. Ello explica, por ejemplo, la utilización dentro de la miniatura de esta cantiga, del arco de herradura, que evidentemente no se materializó en ninguno de los arcos de medio punto que configuran el acueducto romano segoviano. El fenómeno en ningún caso fue desconocido dentro de otras producciones artísticas y arquitectónicas de los siglos medievales hispanos, ya que, tal y como se ha señalado, cuando los constructores de la mezquita de Córdoba plantearon el sistema de distribución de los arcos de dicho espacio, miraron nuevamente hacia el pasado romano en busca de inspiración ${ }^{734}$ (fig. 137). En concreto, se ha defendido la posible evocación, dentro de la mezquita, de los sistemas constructivos desarrollados por los ingenieros romanos para el acueducto de los Milagros de Mérida $^{735}$ (fig. 138).

Es difícil, en un estado tan fragmentando del conocimiento de estas obras, poder llegar a vislumbrar con claridad qué significó el arte antiguo para los hombres del medievo.

Seguramente, en ocasiones, de la misma manera que se sentían partícipes de una continuidad histórica -según una concepción teológica del mundo- perpetuada desde antiguo, también desde el punto de vista de las artes podríamos alegar tal prolongación. En ocasiones, la expoliación y uso de las obras de arte antiguas por parte de los medievales, atestigua una incapacidad para diferenciar entre una producción artística pagana y otra propiamente cristiana ${ }^{736}$. En otras, parece que la valoración de esa obra clásica se fundamentaba a través de una simple valoración técnica, en la que primaban las características de su factura antes que las de su contenido simbólico.

Sin embargo, lo que parece claro es que el arte antiguo -y especialmente el arte romano- no dejó, en ningún caso, indiferente al espectador medieval. Incluso sus ruinas y la expoliación de ese pasado esplendoroso fue un fenómeno seguido de cerca por el hombre de esta época.

Desde el lamento ante la decadencia cultural de la Roma anterior al siglo X, llevado a cabo por Arnulfo en el Sínodo de Reims, hasta el texto ya comentado de Hildeberto de Laverdin, obispo de Le Mans entre el 1097 al 1125, se da buena cuenta

\footnotetext{
${ }^{734}$ A. FERNÁNDEZ PUERTAS, "Mezquita de Córdoba: Abd al-Rahman I (169/785-786). El trazado proporcional de la planta y alzado de las arquerías del oratorio. La qibla y el mihrab del siglo VIII", Archivo Español de Arte, 81, 324, 2008, pp. 333-356.

${ }^{735}$ C. FERNÁNDEZ CASADO, Acueductos romanos en España, s.l., 1972 y J. CUÉLLAR LÁZARO, España romana: arquitectura romana en España, Madrid, 1998.

${ }^{736}$ E. PANOFSKY, Renacimiento y renacimientos..., en concreto, p. 90.
} 
del estado ruinoso de la ciudad de Roma, así como de la admiración por esos mismos vestigios $^{737}$. Sin embargo, en sus palabras se exalta la ruina como prueba de la magnificencia que algún día tuvo la ciudad y con ella su arte ${ }^{738}$.

Desde la ruinosa Roma, hasta la decadencia de sus provincias, los disecta membra de esa Antigüedad acabarían por suscitar todo tipo de reacciones en el hombre medieval, que veía antes sus ojos multitud de trazas que en la mayoría de los casos no llegaba a comprender ${ }^{739}$.

Para finalizar, algunas de las palabras escritas por el abad Suger al respecto, reflejan bien la actitud del hombre del medievo ante la Antigüedad:

“Actuando de este modo, me preocupaba en primer lugar la conveniencia y coherencia de la obra antigua y la nueva, a saber, de dónde íbamos a sacar columnas de mármol o parecidas al mármol, y de tanto pensar, preguntar, buscar por diversas regiones del remoto mundo y no encontrar nada, sólo un hecho ocupaba la mente y el espíritu de los trabajadores, a saber, que de la Ciudad (pues en Roma, en el palacio de Diocleciano y en otras termas, las habíamos visto a menudo admirables), cruzando el mar Mediterráneo con una flota segura, luego el mar de Inglaterra y el tortuoso recorrido del río Sena, las consiguiéramos con gran gasto por parte de los amigos e incluso con el pago a los enemigos sarracenos cercanos" ${ }^{740}$ (texto 43).

Se trata de una relación de conveniencia, en la que las piezas son vistas de una manera u otra, ya sea desde el punto de vista material o intelectual, como pequeños tesoros dignos de ser recuperados. Una admiración que llevará a buscar, por todos los medios, una coherencia entre la obra de arte antigua y la medieval. Esa conveniencia, tan sólo era posible a partir de un hecho fundamental: la ruina de Roma y su Imperio. Sobre sus cimientos ideológicos y también materiales, asentó el cristianismo la base para sus experimentaciones plásticas.

\footnotetext{
${ }^{737}$ A. GRAF, Op. cit., pp. 35-39 y E. PANOFSKY, Renacimiento y renacimientos..., pp. 122-123.

${ }^{738}$ A. LABBÉ, "La poétique des ruines dans quelques chansons de geste", Littératures, 36, 1997, pp. 532, en especial, p. 7.

${ }^{739}$ Ibidem, pp. 8-13. El investigador analiza la problemática de las ruinas romanas en la Galia, tales como los monumentos romanos de Orange, de Arles o Nîmes, así como la necrópolis de los Alyscamps, en la formación de un tópico literario fundamental para la Chanson de gesta. Diversas batallas y otras acciones se acabarían desarrollando entre ambientes romanos en ruina que ayudaban a dotar a tales obras de un carácter más épico, mientras que los restos del anfiteatro de Burdeos, por ejemplo, acabarían por ser transformados en un el palais Gallien, lugar, si cabe, más legendario para el devenir de la acción.

${ }^{740}$ E. PANOFSKY (ed.), El abad Suger..., p. 107 y p. 238. En este punto Panofsky defiende una posible inspiración en La Odisea o, al menos, un conocimiento por parte de Suger de este texto.
} 


\section{EL SPOLIUM CLÁSICO EN LOS SIGLOS MEDIEVALES.}

\section{1. EL SPOLIUM IN SE Y LOS VALORES DE LA APROPIACIÓN DE MATERIALES ANTIGUOS. EL PRINCIPIO DE AUTORICTAS, LA VARIETAS Y LA VENUSTAS.}

Son muchos los autores que han propuesto una definición para el término spolium. Sin embargo, comenzaremos con aquella que nos ofrece exactamente el Diccionario del Uso del Español, donde se nos dice que:

"Expoliar significa etimológicamente apropiarse y despojar a alguien o algo, mediante cualquier método que generalmente es forzado, de aquello que le pertenece $^{, 741}$.

Sin embargo, para este trabajo nos ceñiremos a las precisiones terminológicas y semánticas realizadas por algunos especialistas, que han preferido acotar su significado enfocándolo hacia su contenido desde el punto de vista artístico y arquitectónico. Así, entre los más importantes estudiosos del tema, se encuentra J. Alchermes, quién entiende que la expoliación se puede entender:

“(...) in this study both as the integral adaptation of buildings and as the reuse of construction materials salvaged from structures for erection elsewhere, was widely practiced in late antique cities" ${ }^{, 742}$.

Su importancia y periodicidad dentro de la época propiamente romana viene acreditada por la existencia de una legislación específica sobre el tema, que funcionaba ya desde la misma Antigüedad.

El término latino spolia ha sido ligado, dentro de la historiografía moderna, a la acción del reempleo de todo tipo de piezas materiales provenientes de un lugar diferente

\footnotetext{
${ }^{741}$ M. MOLINER, Diccionario de uso del español H-Z, vol. II, Madrid, 1983, p. 1260.

${ }^{742}$ J. ALCHERMES, "Spolia in Roman Cities of the Late Empire: Legislative Rationales and Architectural Reuse", Dumbarton Oaks Papers, 48, 1994, pp. 167-178, en concreto, p. 167.
} 
-desde el punto de vista cronológico, estilístico y funcional- al que tenían dichos elementos en el momento en que fueron concebidas ${ }^{743}$.

Sin embargo, la complejidad de tal acepción entraña diferentes formas de comprender el fenómeno de la expoliación. Así, parece evidente que la reutilización de piezas de cualquier tipo de material y condición, así como incluso de edificios enteros, fue una práctica habitual que se remonta a los orígenes de la civilización humana.

En la época romana, que es la que nos interesa, observamos de manera habitual el desarrollo de tal práctica. En unas ocasiones aparece ligada a la propia acción restauradora de los monumentos, que llevaba pareja una reutilización física de los mismos; tal y como vemos, por ejemplo, en la selección de objetos expoliados que realizará Alejandro Severo para la restauración del Pórtico de Octavia o la reutilización de materiales tomados del Forum Suarium y usados para completar los trabajos de la Basílica Iulia, en torno al año $377^{744}$.

Sin embargo, durante el Bajo Imperio la palabra spolia no se utilizó en este sentido, pues ya durante la época Imperial y también durante la Republicana, dicho concepto jamás había sido entendido en el sentido con el que hoy lo utilizamos. La acepción "spoliata (e)" se muestra entonces como un vocablo raro y que tan sólo se podrá documentar dentro de un campo muy específico de la legislación romana ${ }^{745}$.

Queda atestiguado, por lo tanto, la utilización del término desde un punto de vista jurídico. Sin embargo, la no normativización del concepto dentro de la lengua latina, no implica, bajo ningún concepto, que tales prácticas no se desarrollaran con total normalidad y cotidianeidad.

En relación con este tema, se suele señalar el ejemplo concreto del conocido como arco de Portogallo, en la vía Lata de Roma. Dicha construcción conectaba con el recinto donde se hallaba, en sus orígenes, el Ara Pacis y servía de acceso monumental al Campo Marzio. Su patrocinador, Aureliano, llevó a cabo el reempleo de diversas piezas de época antonina que reintegró en la nueva obra, asentando así el precedente para otros tipos de spolia realizados en las épocas posteriores ${ }^{746}$.

\footnotetext{
${ }^{743}$ C. DU FRESNE DU CANGE, Glossarium mediae et infimae latinitatis, vol. VII, Niort, 1886, p. 560. ${ }^{744}$ M. GREENHALGH, The survival of Roman..., p. 145.

${ }^{745}$ En relación con ello se ha afirmado: "The rulers and residents of the cities of the Late Empire did not employ the word in this sense. In the imperial laws that are the principal object of this study, as well as in all other texts of the Republic and Empire, the noun spolia never refers to architectural reuse. Spoliata (e), the related participle, appears just twice in the legislation". Cf.: J. ALCHERMES, Op. cit., p. 167.

${ }^{746}$ L. DE LACHENAL, Op. cit., pp. 11-12 y pp. 40-120. La autora aborda dicho fenómeno desde un punto de vista global y que ayuda a comprender la dimensión que alcanzó este tipo de práctica durante la Edad Media.
} 
Tales prácticas acabarían por asentar otras nuevas conductas de la misma índole. Nos referimos, por ejemplo, a la expoliación de los relieves reutilizados por Constantino para ser incrustados en su arco de los foros imperiales ${ }^{747}$.

El arco de Constantino y sus numerosos spolia son el mejor ejemplo a la hora de definir esta práctica. Tal hecho ha suscitado, además, una conocida "polémica" historiográfica, provocando un gran debate que se ha centrado en la complejidad del fenómeno del reempleo de materiales artísticos durante la Antigüedad tardía y su posterior traspaso a la Edad Media.

En el caso de Constantino, la acción llevada a cabo fue analizada desde diferentes puntos de vista por parte de los expertos. Así, es de destacar, por ejemplo, la postura tomada por B. Berenson, quién veía tal reutilización como un lógico reflejo de la problemática social, económica y civil que atravesaba la Antigüedad tardía, hundida en una catástrofe económica sin precedentes en el Imperio Romano ${ }^{748}$. La idea fue seguida por otros autores, como el propio F. W. Deichmann quién defendió similares argumentos para explicar la reiterativa apropiación de piezas anteriores dentro de las nuevas obras de época constantiniana ${ }^{749}$.

La decadencia de la fuerza política romana durante este periodo, así como otra serie de causas que desembocarán finalmente en la caída del sistema político del Imperio, servirían, según estos autores, para explicar la necesidad de recurrir a una cantera abierta, como la que suponía la misma ciudad de Roma en torno al siglo IV. Veían en dichas acciones una solución para saciar una creciente necesidad, eminentemente ligada a factores de índole productivo y económico.

Sin embargo, paralelamente, otra serie de autores enfocarán sus investigaciones hacia el factor ideológico y el denominado "principio de autorictas". Sin duda, fueron

\footnotetext{
${ }^{747}$ M. D'ONOFRIO, Roma e Aquisgrana..., pp. 60-70; L. DE LACHENAL, Op. cit., en concreto, pp. 1415 y R. TURCAN, L'art romain..., pp. 350-354.

Recordemos como el célebre arco fue dedicado al Senado de Roma en el año 315, representando una victoria sobre el paganismo, en este caso materializado por la figura de Magencio que el propio Constantino habría de vencer ante las puertas de la ciudad en la batalla del 312. Se ha considerado esta obra como un final y, a la vez, un comienzo. Los paneles de la captura de los dacios y los grandes frisos fueron expoliados del foro de Trajano, mientras que los tondos pertenecen a un monumento de Adriano y al Arco de Marco Aurelio. Sus fuentes estaban, según se ha defendido, en otro tipo de expoliación, de índole ideológica, pues se suele señalar, con cierta frecuencia, la basílica Iulia, el arco de Tiberio, las columnas tetrárquicas y el arco de Septinio Severo como otras fuentes a tener en cuenta.

${ }_{748}$ B. BERENSON, The Arch of Constantine, or the Decline of Form, New York, 1954, pp. 13-14.

${ }^{749}$ F. W. DEICHMANN, Die Spolien in der spatantiken Architektur, Munich, 1975, en especial, p. 95 y B. BRENK, "Spolia da Constantino...", en especial, p. 197. Los autores afirman que fueron dos razones fundamentales las que produjeron un crecimiento importante de las piezas conservadas durante la Antigüedad Tardía. Por una parte, el cambio de actitud estética antes las producciones artísticas y, por otra, el declive y el empobrecimiento económico.
} 
los estudios de R. Krautheimer los que iniciaron esta tendencia que, de alguna manera, se enfrentaba a las teorías anteriores. Así, en un trabajo del que ya hemos hablado anteriormente en el que autor se centraba en el estudio del "renacimiento sixtino",750, defendía la postura contraría. Según sus teorías, la reutilización de materiales durante el periodo constantiniano y en las épocas posteriores, debía ser analizada bajo una óptica donde el simbolismo y la intencionalidad del expolio debían regir la explicación de tal acción.

Con todo, serán los estudios de B. Brenk los más destacados e imprescindibles en esta materia. La década de los años setenta y ochenta supuso la revalorización del concepto, entendido desde una óptica estética e ideológica. Se trataba de definir y clarificar algunos conceptos fundamentales para poder comprender la manera con la que los medievales se apropiaron de las obras de arte clásico. Entre esta nueva terminología, resaltaron pronto términos tales como varietas o venustas, que aplicados al fenómeno de la expoliación, adquirían ahora unos valores nuevos ${ }^{751}$.

Desde el ámbito italiano apoyaron esta idea. Por citar los trabajos más reconocidos, aludimos a aquellos realizados por el profesor M. D'Onofrio, quién ya en el año 1983 escribía:

"L'impiego del material antico visto come preziosa testimonianza di un glorioso passato significava riconoscimiento della sua qualità artistica e rinnovamento di questa come corrispondente estetico delle politicio-religiosa rinascita romani imperii" $^{, 752}$.

Son igualmente importantes los estudios efectuados por S. Settis, quién tal y como veremos, aportará también una interesante definición sobre el concepto de spolium, aplicándolo, sobre todo, a la recuperación de piezas en época románica ${ }^{753}$.

En esta misma línea argumental se encuentran las aportaciones de A. Pensabene, quién desde los años ochenta centró sus investigaciones en este campo, especializándose en las producciones artísticas realizadas en suelo italiano ${ }^{754}$.

\footnotetext{
${ }^{750}$ R. KRAUTHEIMER, “The Architecture of Sixtus III...”, pp. 291-302.

${ }^{751}$ B. BRENK, "Spolia. Da Contantino...", pp. 197-202; ID., "Spolia e il loro effetto...", pp. 205-219 e ID., "Suger Spolien", Arte Medievale, I, 1983, pp. 101-107.

${ }_{752}^{7}$ M. D'ONOFRIO, Roma e Aquisgrana ..., en concreto, p. 114.

${ }^{753}$ S. SETTIS, "Continuità, distanza...", pp. 391-401; ID., "Les remplois", Patriomoine, temps, espace. Patrimoine en place, patrimoine déplacé. Actes des Entretiens du Patrimoine sous la présidence de F. Furet, Paris, 1997, pp. 67-86 e ID., "Tribuit sua marmora Roma: sul reimpiego di sculture antiche", Lanfranco e Wiligelmo. Il duomo di Modena, Modena, 1984, pp. 309-317.
} 
Del mismo modo, aparte del estudio de L. de Lachenal ya citado, las aportaciones de A. Peroni se encuentran entre las más reconocidas respecto al tema, sobre todo, por abordar cuestiones relativas a la escultura ${ }^{755}$. Completan este breve recorrido por los estudios más representativos, las contribuciones puntuales llevadas a cabo por F. Rebecchi, M. Righetti Tosti-Croce, S. Ciranna o F. Franzoni ${ }^{756}$.

Para finalizar este apresurado repaso de las investigaciones sobre la expoliación de materiales clásicos, destacamos la obra, ya citada, de M. Greenhalgh, que completa el panorama junto con los trabajos de B. Ward-Perkins, P. C. Claussen o D. Kinney, entre otros ${ }^{757}$.

Dentro del caso hispano, se advierte la carencia de un trabajo que aborde de manera específica este fenómeno de la expoliación y que, aunque en el caso de Hispania fue menos habitual que dentro de los territorios italianos y de la Galia, también nos legará algunos ejemplos muy representativos.

En relación con ello, aludimos a los trabajos del profesor S. Moralejo, el hispanista que más aportaciones ha realizado sobre este tema. Para completar esta

\footnotetext{
${ }^{754}$ A. PENSABENE, "La decorazione architettonica, l'impiego del marmo e l'importazione di manufatti orientali a Roma, in Italia e in Africa (II. d. C). Società romana e impero tardoantico", Le merci $e$ l'insediamenti (A. Giardina coord.), Roma-Bari, vol. III, 1986, pp. 285-429; ID., "Contributo per una ricerca sul reimpiego...", pp. 5-138; ID., "Il reimpiego nell'età constantiniana a Roma", Constantino il grande dall'antichità all'umanesimo. Colloquio sul cristianesimo nel mondo antico, vol. II, Macerata, 1993, pp. 749-768 e ID., "Reimpiego dei marmi antichi nelle chiese altomedievali a Roma", Marmi Antichi (G. Borghini coord.), Roma, 1997, pp. 55-64.

${ }^{755}$ A. PERONI, "Acanthe remployée et acanthe imitée dans les cathédrales de Modène, Ferrate et Pise", L'Acanthe dans la sculpture monumental de l'Antiquité à la Renaissance, Paris, 1993, pp. 313-326 e ID., "Architettura ottoniana e architettura romanica alla luce del reimpiego dell'antico", Mittellatenisches Jahrbuch, 35, 2000, pp. 205-225.

${ }^{756}$ F. REBECCHI, "Il reimpiego di materiali antico nel Duomo di Modena", Lanfranco e Wiligelmo..., pp. 319-353; M. RIGHETTI TOSTI-CROCE, "Tra spolia e modelli altomedievali: note su alcuni episodi di scultura cistercense", Arte d'Occidente. Temi e Metodi, Studi in onore di Angiola Maria Romanini. Arte, 3 vols., Roma, 1999, vol. I, pp. 381-389; S. CIRANNA, "La lectura architettonica degli spolia nelle chiese di Roma", Ecclesiae Urbis. Atti del Congresso Internazionale di Studi sulle chiese di Roma (IV-X secolo) (F. Guidobaldi y A. G. Guidobaldi), vol. II, Cittá del Vaticano, 2002, pp. 895-874; C. FRANZONI, "Presente del passato: le forme classiche nel Medioevo", Arti e storia nel Medioevo, vol. II, Torino, 2003, pp. 329-359; D. DRAPER, "Canterbury Cathedral: Classical Columns in the Trinity Chapel?", Architectural History. Essays in Architectural History Presented to John Newman, 44, 2001, pp. 172-178, en concreto, p. 176 e Y. KUSABA, "Henry of Blois, Winchester, and the Twelfth-Century Renaissance", Winchester Cathedral: Nine Hundred Years (J. Cook ed.), 1993, pp. 69-80.

${ }^{757}$ B. WARD-PERKINS, From Classical Antiquity to the Middle Ages: Urban Public Building in Northern and Central Italy, A.D. 300-850, Oxford, 1984; P. C. CLAUSSEN, "Marmi antichi nel medioevo romano. L'arte dei Cosmati”, Marmi antichi (G. Borghini coord.), Roma, 1989, pp. 65-79; ID., "The concept of spolia", A Companion to Medieval Art: Romanesque and gothic in Northern Europe (C. Rudolph ed.), Oxford, 2006, pp. 233-252 y A. CUTLER, "Reuse o use? Theoretical and practical attitudes toward objects in Early Middle Ages", Ideologie e pratiche del reimpiego nell'Alto Medioevo, XLVI, Spoleto, 1999, pp. 1055-1079.
} 
nómina, recordamos aquellos elaborados por F. Marín Valdés, centrados en el spolium dentro del arte prerrománico asturiano ${ }^{758}$.

Más recientemente, retomaron el tema, investigadores como M. A. Castiñeiras, quién aceptará los dos tipos de expoliaciones habituales, siguiendo las teorías italianas $^{759}$, así como la profesora M. T. López de Guereño, quién abordó el tema de los spolia dentro de la orfebrería, centrándose en reino de Asturias ${ }^{760}$.

Tal y como hemos adelantando al principio de este apartado, la expoliación de materiales comenzó ya dentro de la propia Antigüedad. La legislación vigente en la época de Teodosio II, en relación con la construcción y, sobre todo, la destrucción de obras y edificios para obtener materiales que aprovechar a la hora de erigir otros, ha sido señalada como el inicio de la regularización de tal práctica. Se buscaba, de alguna manera, preservar y proteger el ornatus de las urbes imperiales, es decir, de evitar la destrucción de todo aquel conjunto -edificios y su decoración- que configuraban la imagen de las ciudades ${ }^{761}$.

Parece claro que, aunque el conocimiento sobre la protección de estas obras durante la Antigüedad es amplio, no podemos llegar a concretar el alcance que tuvo tal medida y a que tipo de obras afectó. En este sentido, A. Riëgl afirmaba en su conocido ensayo que, una obra tan emblemática como la columna trajana, debía, a todas luces, carecer de protección alguna durante la Edad Media, época en la que incluso se llegó a mutilar la pieza.

Sin embargo, alude a una "supervivencia de los restos del patriotismo de la antigua Roma, que los romanos medievales nunca llegaron a perder por completo", para explicar su conservación ${ }^{762}$ (texto 44).

El hecho de que durante la Antigüedad existieran leyes como las aprobadas en época de Teodosio II, no implica, en ningún caso, una respetuosa conservación de las piezas clásicas, ya que, tal y como afirma A. Riegl, no se trataba de un culto al monumento sino tan sólo:

\footnotetext{
${ }^{758}$ F. MARÍN VALDÉS, “Observaciones sobre la adopción...”, pp. 13-23. Sobre la obra del profesor Moraleja, remitimos al apartado en el que hemos realizado un estado de la cuestión sobre la historiografía dedicada a abordar la influencia y repercusiones del arte antiguo en la Edad Media hispana.

${ }^{759}$ M. A. CASTIÑEIRAS, "Capitel románico inspirado na Orestíada do sarcófago de Husillos", Luces de Peregrinación, Santiago de Compostela, 2004, pp. 252-254 e ID., "La reutilización de piezas romanas y medievales en Galicia", Brigantium, 6, pp. 77-90.

${ }^{760}$ M. T. LÓPEZ DE GUEREÑO, "La cruz y el crucificado en la Edad Media hispana", Maravillas de la España medieval. Tesoro sagrado y monarquía, 2 vols., León, 2001, vol. I, pp. 371-381.

${ }^{761}$ J. ALCHERMES, Op. cit., p. 169.

${ }^{762}$ A. RIEGL, Op. cit., en concreto, pp. 32-34 y J. ADHÉMAR, Influences antiques..., p. 94. Adhémar afirma que la columna trajana gozaba de protección por parte del senado desde el año 1162.
} 
“(de un) culto a ideas vivas, sobre todo religiosas, que como tales no poseían ningún valor rememorativo (monumental), sino un valor muy real de contemporaneidad" ${ }^{, 763}$.

Sin embargo, en este sentido son relevantes los ejemplos esgrimidos por B. Ward-Perkins, a propósito de la restauración de obras clásicas romanas en los últimos tiempos de la Antigüedad. Así recoge, por ejemplo, el deseo de llevar a cabo una mejora en el área del Aventino, sobre todo, en lo concerniente a la conservación de los baños y de la Basilia Iulia. Dentro de estos casos, podría incluirse también, la reparación llevada a cabo en el año 484 del mismo Coliseo, mediante una financiación privada ${ }^{764}$.

La conservación de estas estructuras, primeramente, respondía a razones donde primaba el interés funcional por seguir explotándolas. Cuando durante estos momentos se acomete la restauración del acueducto que surtía de agua la zona vaticana y, en concreto, la gran fuente central de atrio en el que se hallaba la famosa pigna, se hizo, sin duda, por razones de interés funcional y no simbólico o, al menos, éstas estaban en un segundo plano $^{765}$.

Las restauraciones de acueductos, termas, baños y puentes durante los siglos IV y $\mathrm{V}$, deben ser vistas no como un deseo de rememorar una Antigüedad esplendorosa, sino como un interés en seguir utilizando diversas construcciones que hacían la vida más cómoda dentro de las viejas ciudades. Si Ward-Perkins documenta multitud de ejemplos de este tipo de actividades en el ámbito italiano, tampoco en la Hispania tardorromana fueron desconocidas tales actuaciones.

Una inscripción colocada sobre el puente romano de Mérida, de la que ya hemos hablado, refleja bien este fenómeno que recorría hasta los rincones más lejanos de las provincias romanas:

“La ruinosa antigüedad había deshecho las antiguas moles (de piedra). La obra se mantenía caída y rota por la vejez. El puente sobre el río había perdido su uso. En el tiempo actual del poderoso rey Eurico, a quién Dios ordenó conquistar tierras, éste, magnánimo, puso todo su empeño en dar a conocer su nombre; y el noble cortesano Salla también añadió honores a un antiguo nombre, puesto que después de renovar las fuertes murallas de la ciudad (de Mérida), no dudó en

\footnotetext{
${ }^{763}$ Ibidem, pp. 40-41.

${ }_{765}^{764}$ B. WARD-PERKINS, From Classical Antiquity..., pp. 42-44.

${ }^{765}$ Ibidem, en concreto, pp. 136-142.
} 
realizar otra obra prodigiosa. Construyó los arcos del puente, los asentó con firmeza en lo profundo del río y remató una obra admirable, que imitaba la de un primer constructor. Además, el afecto de Zenón, obispo (de Mérida), le persuadió para fortificar en gran medida un bastión. La ciudad augustea (de Mérida) permanecerá dichosa por los siglos gracias al empeño del citado noble y del citado obispo" ${ }^{, 766}$ (texto 45).

Esta inscripción hispana refleja bien la situación que vivían muchas de las obras romanas durante estos tiempos. La ruinosa uetustas había privado de su función al viejo puente que, gracias a la labor del rey Eurico, volvió a recuperar su primitiva imagen. La restauración se hizo imitando el primer modelo, lo cual refleja bien el fenómeno que venimos señalando: las viejas estructuras eran conservadas por su función, pero respetando el valor que sus antepasados les habían otorgado ${ }^{767}$.

Lo que parece más o menos claro es que, con la llegada al poder de Constantino, la explotación de los grandes edificios clásicos en busca de materiales que poder incluir en las nuevas construcciones se convirtió en una práctica habitual.

La continua recurrencia, por parte del princeps, a los trabajos de sus antepasados, Trajano, Adriano o Marco Aurelio, se ha visto como un intento de aludir a los saecula aurea ${ }^{768}$. Advertimos, por lo tanto, unos intereses políticos en tales conductas que vendrían a completar las intenciones de reutilización meramente utilitaristas $^{769}$.

Gran parte de las obras activas en la Roma de los años 315 al 400 presentan, dentro de su fisonomía, materiales de acarreo. Sin embargo, la manera en que dichas piezas eran colocadas dentro de los espacios templarios, no puede argumentarse mediante una pretendida libertad y arbitrariedad.

En San Pablo Extramuros, por citar un ejemplo concreto, las piezas expoliadas fueron dispuestas buscando valores cromáticos y de alternancia de materiales, de tal

\footnotetext{
${ }^{766}$ J. VIVES, Inscripciones cristianas..., en concreto, pp. 126-127. Véase el texto original en el apéndice documental de este trabajo, texto 45.

${ }^{767}$ B. WARD-PERKINS, From Classical Antiquity..., p. 24; J. ARCE, "Agusta Emerita en los siglos IVV d. C.: la documentación escrita", Anejos de Archivo Español de Arte (P. Mateos Cruz y L. Caballero Zoreda ed.), XXIX, 2003, pp. 121-131, en particular, pp. 122-123 y A. M. TEJERA, "Arquitectura cristiana...", p. 125. Tejera señala la importancia del obispo Zenón como restaurador de las murallas y del puente de Emerita Augusta.

${ }_{768}^{76}$ L. DE LACHENAL, Op. cit., p. 15.

${ }^{769}$ P. ZANKER, Augusto y el poder..., en concreto, p. 42. Zanker recoge la reutilización de material realizada por el emperador Sila durante la construcción del Templo de Iuppiter Optimus Maximus, apropiándose de las columnas del Olympieion de Atenas, con el consabido desajuste entre el frontón y los propios fustes, además de las desigualdades de material, color y proporción.
} 
manera que se establecía un juego entre los capiteles creados ex novo y los $\operatorname{expoliados}^{770}$.

El mismo fenómeno encontramos en el arco de Constantino donde los mármoles fueron colocados buscando explotar las gamas cromáticas, dependiendo, sobre todo, de la propia naturaleza del material. Los artífices al servicio del patrocinio imperial alternaron entonces mármoles de Proconnesos y de Carrara ${ }^{771}$.

Se trataba de una apropiación física de la pieza pero dotándola de unos valores intelectuales. Pues tal y como ha apuntado B. Brenk, el valor de la varietas, surgido a través de la reutilización de materiales expoliados, buscaba activar determinados valores estéticos inherentes a tales piezas, cargadas de belleza técnica pero también de fuerza política. Encontramos dentro del arte del periodo, una variedad en el uso de los materiales "robados", donde los capiteles se alternan según su orden, pero también según su material y procedencia. Siguiendo, en todo caso, juegos cromáticos sobradamente conocidos dentro de la arquitectura greco-romana, sobre todo durante el siglo II a. de C. ${ }^{772}$.

Sin embargo, el canon de construcción se rompió. La introducción de piezas preexistentes propició desajustes en los nuevos edificios y en las estructuras donde iban a parar tales fragmentos.

Con todo, tampoco debemos mitificar la labor conservadora y exaltadora de la arquitectura que, al parecer, movía la voluntad constructora imperial. Ya el texto de Eusebio de Cesarea, al narrar la construcción del Santo Sepulcro, nos informa:

"No paró aquí la diligencia del emperador; sino que ordenó que las piedras y las maderas del edificio fueran derribadas y arrojadas fuera de los límites del territorio: lo cual fue cumplido, apenas mandado. Aun después de hecho esto, no quedó contento el emperador. Movido por una especia de inspiración divina, mandó que, ahondado el lugar hasta lo más profundo, el suelo mismo, como contaminado por los sacrificios de los demonios, fuera llevado muy lejos con los escombros amontonados", 773 (texto 46).

\footnotetext{
${ }^{770}$ B. BREK, "Spolia e il loro...", en especial, pp. 207-210.

${ }^{771}$ B. BRENK, "Committenza e retorica", Arti e storia nel Medioevo. Del construire: tecniche, artista, artigiani, committenti (E. Castelnuovo, ed.), vol. II, Torino, 2003, pp. 3-42, en concreto, pp. 10-11.

772 B. BRENK, "Spolia e il loro effetto...", en especial, p. 206. Atestigua un uso de la alternancia de capiteles, ya durante la época de Augusto.

${ }^{773}$ E. DE CESAREA, Vida de Constantino..., Libro III, 27, p. 291.
} 
Los materiales de los que habla el texto pertenecían al templo de Afrodita, en Jerusalén, y debían aparentar tanta calidad como para ser reaprovechados. El profesor B. Brenk explica así tal acontecimiento:

"pens`che i materiali construttivi pagani di Gerusalemme erano impuri e si astenne dal riusarli nuevamente" ${ }^{, 774}$.

Lo que parece claro es que el valor estético de la varietas, con el que se iniciaba buena parte del fenómeno de la expoliación en la Antigüedad tardía, no negaba tampoco el viejo concepto vitruviano de la "variedad" como elemento integrante de la simetría. La varietas, característica estética inseparable de la mayor parte de las producciones medievales, suponía una continuación con determinados valores del arte clásico pero, a la vez, una renovación de los mismos, siempre, eso sí, a expensas de lograr valores inherentes a la obra romana como la sublimitas o la magnificentia ${ }^{775}$.

Las razones económicas utilizadas para explicar tales reempleos serían entonces inferiores si se comparaban con las ideológicas, que toman fuerza en el intento por autoproclamar una suerte de autorictas ${ }^{776}$. No en vano, muchas de las piezas reutilizadas provenían de lugares tan lejanos que resultaba mucho más costoso llevarlas al lugar donde eran requeridas, que solicitar a los talleres imperiales que las realizasen ex novo.

Parece claro que existieron otras razones que expliquen este traslado masivo de todas estas piezas a través de los medios más dispares. Es conocida, por ejemplo, la problemática que estas obras conllevan, no sólo para su transporte, sino por todo el trasfondo político e histórico que se esconde tras ellas.

Así por ejemplo, sabemos, a través de los textos, que cuando el emperador Justiniano inició la construcción de Santa Sofía de Constantinopla, proclamó una orden mediante la cual pedía que desde todas partes del Imperio se enviasen todo tipo de piezas para la construcción de su nuevo templo:

\footnotetext{
${ }^{774}$ B. BRENK, "Spolia da Constantino...", particularmente, pp. 200-201 e ID., "Il luogo di culto...", p. 131. El autor se centra en el caso de la iglesia de Eleona, erigida sobre la tercera grotae relacionada con la vida de Cristo, en la que, el Maestro, supuestamente había enseñado a sus discípulos.

${ }^{775}$ B. BRENK, "Il luogo di culto...", p. 219; C. HEITZ, "Mathématique et architecture. Proportions, dimensions systématiques et symboliques dans l'architecture du haut Moyen Âge", Musica e arte figurativa nei secoli X-XII, Todi, 1973, pp. 167-193 e ID., "Vitruve et l'architecture du Haut Moyen Âge", La cultura antica nell'Occidente latino dal VII all'XI secolo, XXII Settimana di Studio del Centro di Studio sull'Alto Medioevo, Spoleto, 1975, pp. 725-757.

776 S. SETTIS, “Continuità, distanza...”, en especial, p. 391.
} 
“(...) buscaran columnas, vigas, paneles y placas de jaspe, cancelas y todo material apropiado para la erección de un templo. Y cuantos recibieron la orden enviaron por mar al emperador Justiniano materiales procedentes de templos paganos, antiguas termas y palacios de todas las regiones, del este y del oeste, del norte y del sur y de todas las islas" ${ }^{\text {777. }}$.

Noticias como esta que ofrecemos, permiten introducir las reflexiones que realizaremos en el siguiente apartado.

777 J. M. EGEA, Relato de cómo se construyó Santa Sofía. Según la descripción de varios códices y autores, Granada, 2003, pp. 81-83. 


\section{2. EL TRANSPORTE DE MATERIALES ANTIGUOS.}

Uno de los aspectos que parece más claro, en cuanto al fenómeno de la expoliación in se, fue el de los traslados de materiales desde aquellos puntos en los que se hallaban, físicamente, hasta el lugar donde serían reutilizados.

Las diversas noticias que hemos recogido parecen señalar de manera clara el interés por transportar largas series de materiales que llegaban desde los lugares más alejados. A través de diversos sistemas de transporte, tanto terrestres, como marítimos, $\mathrm{y}$, en ocasiones muy costosos, las piezas recorrían largas distancias para finalmente cumplir otras funciones alejadas de la plaza original que en su día ocuparon.

A parte de conseguir materiales que engrandecerían los nuevos edificios, de hacer avanzar la obra de una manera más rápida gracias a un ahorro de esfuerzos y trabajos, las piezas expoliadas se vincularon pronto con otros valores más complejos.

Sabemos, por ejemplo, que tras la orden dada por el emperador Justiniano, una viuda de la ciudad de Roma llamada Marcia, envió a Constantinopla, mediante una balsa, una dote de ocho columnas. En el texto se especifica que, además, se trataba de una serie de piezas provenientes del templo de Helios construido por Aureliano en Roma. Todo ello, a cambio de la salvación de su alma, tal y como nos indica:

"Envío unas columnas iguales en altura, diámetro y peso por la salvación de mi alma",778.

Un caso bien documentado es el de Henry de Blois (1129-1171) que, según J. Adhémar, sentía auténtica pasión por el arte de la Antigüedad clásica. Esa admiración le llevaría a realizar un viaje desde Ostia a su tierra natal en un navío cargado de mármoles y piezas artísticas de época romana ${ }^{779}$.

En otras ocasiones, las piezas eran, incluso, marcadas por los propios mercaderes, que se encargaban de su compra-venta y de su traslado. Al menos esta es la razón que se ha utilizado como argumento, por ejemplo, para explicar el grafito de una

\footnotetext{
778 J. M. EGEA, Op. cit., p. 83.

779 J. ADHÉMAR, Influences antiques..., p. 95; S. SEBASTIÁN, Mensaje simbólico..., pp. 235-236 y C. FRANZONI, Op. cit., p. 357. El profesor Franzoni data este testimonio en torno al año 1150, equiparándolo con la noticia de John de Salisbury, igualmente interesado por este tipo de expoliaciones.
} 
de las columnas de Santa Sabina en el Aventino de Roma, quizás provenientes de un templo pagano del siglo II dedicado a Giunone ${ }^{780}$.

El transporte de estas piezas no deja de recordarnos las palabras del abad Suger, quién, mediante el texto que ya hemos mencionado, dejó constancia del enorme problema que suponía acarrear unas columnas desde las termas de Diocleciano de Roma hasta París, a través del mar Mediterráneo, pasando por el mar de Inglaterra y remontando el Sena hasta la cantera de Saint-Denis ${ }^{781}$.

Sería imposible recoger todas las noticias que han llegado hasta la actualidad de este tipo de acciones, que se nos muestran, unas veces, documentadas de manera rigurosa por las crónicas o la documentación y en otros casos, envueltas por un aire mítico y de leyenda. No en vano, una serie de ejemplos significativos podrán dar una idea del fenómeno.

Recordemos, brevemente, la narración de la travesía del caballero inglés Harpin de Thornley, quién en 1145 realizó a caballo el camino que iba desde Roma hasta Durham, cargado con un bloque de mármol "preciose qualitate generis" que, finalmente, dedicaría al patrono local Saint Cuthbert ${ }^{782}$; o, el conocido caso de Gauzlin, abad de Saint Benoît-sur-Loire, quién compró en Roma un bello mosaico de mármol, así como otra serie de materiales de pórfido para ornar los altares de su abadía. Entre una de las acciones más significativas, se cuenta el hecho de llevarse consigo a Francia al mosaista Rodolfo, para que realizase diversas obras ya en suelo francés ${ }^{783}$.

En el caso hispano, las noticias son menos claras según nos acercamos a los siglos del románico, sin embargo, si atendemos a determinados hechos documentados en la catedral de Santiago de Compostela, se puede llegar a intuir el alcance de tal fenómeno dentro de la Hispania medieval.

El siguiente texto es una de las pruebas fundamentales que certifican la práctica de la expoliación de materiales de la Antigüedad en el arte medieval hispano. Así, se nos dice:

\footnotetext{
${ }^{780}$ B. BRENK, "Spolia da Constantino...", p. 200, nota 14.

${ }^{781}$ Nuevamente el mar Mediterráneo se convierte en la vía de influencia más importante en relación con la difusión de piezas artísticas y formas. Cf.: X. BARRAL I ALTET, “Apropiación y recontextualización de lo antiguo en la creación artística románica mediterránea”, El románico y el Mediterráneo..., pp. 171179.

${ }^{782}$ L. DE LACHENAL, Op. cit., p. 230.

${ }^{783}$ J. ADHÉMAR, Influences antiques..., p. 97. Dentro del caso francés, es también muy conocida la figura de Heiricus y su continuo traslado de mármoles desde Marsella a Auxerre, tal y como señala, en: E. PANOFSKY (ed.), El abad Suger..., pp. 238-239.
} 
"En el nombre de Nuestro Señor Jesucristo, fue edificado el templo de San Salvador y Santiago Apóstol en el lugar del Arca Marmórea en territorio de Galicia, por disposición del gloriosísimo príncipe Alfonso (...) dispusimos edificar la casa del Señor y restaurar el templo que está en el túmulo del sepulcro del Apóstol, que en otro tiempo el señor Alfonso el Magno de excelentísimo recuerdo, había construido pobremente de piedra y barro. Nosotros, impulsados ciertamente por la inspiración divina, con nuestros súbditos y familia trajimos al santo lugar de España por entre las muchedumbres de los moros las piedras de mármol que sacamos de la ciudad de Eabaca, que nuestros antepasados transportaron por mar en naves y con las que edificaron bellas casas, que permanecían destruidas por los enemigos. Por ello también se restauró con estos mismos mármoles la puerta principal de la parte occidental, sin embargo encontramos los dinteles del asiento de la puerta tal como había sido en el antiguo asentamiento, esculpidos con admirable trabajo. Construimos la puerta de la izquierda junto al templo de Juan el Bautista y Mártir, a quien del mismo modo la dedicamos, y pusimos seis columnas enteramente de piedra con otros tantos basamentos donde fue construida la bóveda de la tribuna, incluso trajimos de una ciudad de Portugal, transportadas en naves, otras columnas esculpidas, sobre las que fueron levantadas dieciocho columnas, junto con otras

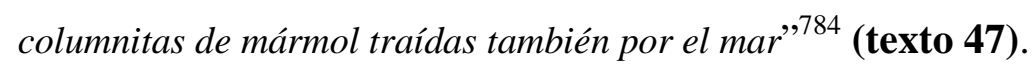

El texto narra la ampliación del templo dedicado al apóstol que Alfonso II (791842) había construido para magnificar el lugar en el que había sido hallado el cuerpo del predicador. Sin embargo, la pequeña basílica construida, tal y como se señala en la fuente, de barro y piedra, pronto se quedó pequeña. A partir de este momento, durante la época de Alfonso III el Magno (866-910) se decide acometer el engrandecimiento de la estructura, que sería consagrada el 6 de mayo del año $899^{785}$.

El pasaje, además de ofrecer estos datos, insiste también en el problema de los transportes de materiales que, según se nos dice, provenían concretamente de varios lugares de Portugal. La noticia hace especial hincapié en aclararnos que se trataba de mármoles prestigiosos, por haber sido utilizados ya por sus honorables antepasados.

A parte de hacer una valoración estética sobre los mismos, se advierte que los mármoles expoliados tenían como finalidad ser colocados en la parte occidental del

\footnotetext{
${ }^{784}$ A. LÓPEZ FERREIRO, Historia de la Santa Iglesia, vol. I, Santiago de Compostela, 1978, pp. 50-51.

${ }^{785}$ I. G. BANGO TORVISO, Arte prerrománico..., en especial, p. 274; ID., "El locus sanctus de Santiago de Compostela...", pp. 191-220 y ARBEITER, "Santiago de Compostela (Prov. A Coruña), Ausgrabungen unter der Kathedrale", Christliche Denkmäler des frühen Mittelalters vom 8. bis ins 11. Jahrhundert, Mainz-Rheim, 1999, pp. 216-224.
} 
templo, es decir, en el acceso. Finalmente se especifica el uso de varios spolia de mármol, ya tallados, en forma de columnas, que tras ser traídas por mar, acabaron siendo dispuestas en el nuevo templo.

Tal noticia permite intuir la apreciación que los hombres medievales sentían, también en territorio hispano, por este tipo de materiales. El dato sirve para integrar el ejemplo de la basílica compostelana en la lista que de este tipo de conductas se llevaron a cabo dentro del arte promovido bajo los auspicios de la monarquía asturiana ${ }^{786}$.

En todo caso, la expoliación de lajas marmóreas de edificios antiguos con la finalidad de ser dispuestas en los flancos de las puertas, no era una conducta exclusiva del arte hispánico. Este caso no deja de tener ciertas concomitancias con otros ejemplos atestiguados en la ciudad de Roma.

Baste con citar el dintel y los flancos de la puerta de Santa Sabina, el dintel de la capilla de San Zenone de Santa Práxedes, ambas en Roma, y la misma pieza de la iglesia de San Salvador de Spoleto, así como determinados fragmentos de la puerta de San Raniero, en Pisa ${ }^{787}$.

La puerta de la basílica compostelana, al igual que en los casos italianos que mencionamos, fue considerada un lugar privilegiado y, en ocasiones, disputado como zona de enterramiento. Por lo tanto, ha de entenderse que se pensase en él como un lugar perfecto para colocar las piezas mejor trabajadas y aquellas que gozaban de mayor valor. En el caso de Roma, su uso queda justificado por la calidad técnica de todos esos fragmentos romanos de talla muy delicada, que engrandecían los accesos a las basílicas. Para el caso hispano, el interés por exhibir las piezas obtenidas de los trabajos de spolia queda evidenciado a través del texto comentado e, igualmente, mediante otros ejemplos posibles.

\footnotetext{
${ }^{786}$ Analizaremos estos aspectos en el apartado correspondiente al arte prerrománico hispano y su legado clásico, como preludio a los siglos del románico.

${ }^{787}$ L. DE LACHENAL, Op. cit., en concreto, p. 34; A. GRABAR, Las vías de la creación..., p. 133. Para el caso de Santa Prudenciana, vid.: M. GREENHALGH, The survival of Roman..., p. 50; B. BRENK, voz "Architrave", Enciclopedia dell'Arte..., vol. II, Roma, 1994, pp. 411-414 y M. SALMI, "San Salvador di Spoleto, il tardo antico e 1'Alto Medioevo", Actas IX Settimane di Studio del Centro Italiano di studi sull'Alto Medioevo. Il passaggio dall'Antichità al Medieoevo in Occidente, Spoleto, 1962, pp. 497-520.

En relación con estos temas, el profesor Brenk destaca la peculiaridad de la pieza de Santa Prudenciana, de factura clásica pero expoliada y readaptada a su nueva ubicación medieval. Sin embargo, ello necesitó de la pericia del escultor románico que llevó a cabo una "copia" de los motivos clásicos romanos del frente, en los laterales cortados del entablamento. Desde la decoración más geométrica, a la vegetal, el artífice supo interpretar, a su manera, la obra antigua, a través de un lenguaje y técnicas distintos.
} 
El caso que comentamos de Compostela no fue único. Del mismo modo, la puerta fue señalada como un lugar importante por los constructores y escultores que trabajaban al servicio del arte áulico de Ramiro I.

Las jambas de la iglesia de San Miguel de Lillo, sobre las que habremos de volver más adelante, han sido consideradas como uno de los ejemplos más representativos del arte asturiano, en torno a la delimitación del espacio de acceso con materiales, iconografías u otro cualquier elemento distintivo.

El presunto modelo seguido en esta ocasión fue un díptico consular romano, que ofreció la base necesaria para inspirar al artífice de las jambas. Queda claro entonces, el interés por reaprovechar "materiales" ya fuese de una manera física, como en Compostela o, en su vertiente intelectual, como en Lillo ${ }^{788}$.

Al observar los ejemplos mencionados en la basílica prerrománica de Santiago de Compostela, el llevado a cabo en el Oviedo del siglo IX y, posteriormente, los citados en la Roma medieval, cabe aludir a otros igualmente sugestivos.

Existen bastantes casos documentados de grandes lajas con decoración vegetal de finos roleos y zarcillos esculpidos sobre el mármol, algunas de ellas expoliadas de obras antiguas y otras, simplemente imitadas en la etapa medieval. Lo que resulta indiscutible, es que, como en los casos citados, ocuparon lugares preeminentes dentro de las fachadas, evocando, claramente, algunas soluciones practicadas en las puertas de la etapa imperial romana.

En ellas encontramos el uso de grandes jambas y dinteles bajo cornisas elegantemente esculpidas, tal y como observamos, por ejemplo, en los flancos marmóreos de la gran puerta de acceso al edificio de la Eumachie en la ciudad de Pompeya $^{789}$ (fig. 139).

En relación con tales imágenes, debiéramos reflexionar sobre el origen y los modelos seguidos para las enormes placas esculpidas con motivos vegetales de la basílica de San Prudencio de Armentia (fig. 140), donde fueron colocadas, a lo largo de los flancos, unas lajas decoradas con motivos "antiquizantes" que aluden claramente a la tradición clásica. Al igual que en el quicio de la puerta compostelana, los materiales de mejor calidad y factura flanquean el acceso a los recintos sagrados.

\footnotetext{
${ }^{788}$ No recogemos aquí la bibliografía que hemos manejado sobre las jambas de Lillo y la escultura de época asturiana, ya que se tratará el tema dentro de un apartado posterior.

${ }^{789}$ E. GRIMAL, Pompéi, Paris, 1992, pp. 23-90.
} 
Resulta difícil establecer un modelo concreto para estas piezas, pero en este sentido, ocurre exactamente el mismo fenómeno con la escultura del interior del templo, a la que se le han señalado habitualmente conexiones con la estatuaria antigua. Con todo, tan sólo podemos afirmar que dichos trabajos poseen un recuerdo clásico, no sólo en su realización sino, incluso, en el emplazamiento elegido ${ }^{790}$.

Dentro de esta serie de reflexiones realizadas en torno a la ubicación de los materiales expoliados en el edificio prerrománico de Compostela, merecen especial atención, los escasos fragmentos conservados en la portada occidental de San Pedro de Rodas. Aunque volveremos más adelante sobre la cuestión, aún permanecen in situ dos segmentos de los relieves que flanqueaban el acceso al interior de la iglesia. Nuevamente se trata de un trabajo en mármol de primer orden que, además, posee una decoración de zarcillos en los que fueron colocadas pequeñas cabezas que habitan, siguiendo modelos clásicos, ese ambiente vegetal (fig. 141).

No en vano, la paternidad de estos trabajos escultóricos se ha ligado al anónimo "maestro" de Cabestany, al que, como veremos, se le han atribuido grandes conocimientos de la escultura clásica y que, en ocasiones, llegará incluso a expoliar físicamente ${ }^{791}$.

Pero regresemos finalmente al caso compostelano. La intención de los constructores de la obra emprendida por Alfonso III al colocar dicho material de acarreo en la parte más destacada del templo, parece señalar cierta continuidad de una tradición antigua, que tendría su prolongación en la Hispania medieval.

\footnotetext{
${ }^{790}$ M. RUIZ MALDONADO, Escultura románica alavesa: el foco de Armetia, Bilbao, 1991, en especial, pp. 89-114. La autora analiza los relieves empotrados en el pórtico de la iglesia en los que fueron representados Cristo y los apóstoles. La figura de Cristo, así como los ángeles que lo flanquean, presentan una serie de rasgos que los emparientan con la tradición clásica. Tales rasgos se acusan, por ejemplo, en las figuras semidesnudas de los ángeles.

Otro relieve del mismo edificio, muy deteriorado y que, supuestamente, posee una representación de la Adoración del becerro de oro, parece recordar diversos aspectos de la escultura antigua de sarcófagos, como el uso de velos y telas, escorzos y un dinamismo de la escena poco habitual en la escultura del periodo. Cf.: J. J. LÓPEZ DE OCARIZ Y ALZOLA, "El temor al infierno hacia 1200. Análisis iconográfico de la Anástasis de Armentia (Álava)", Alfonso VIII y su época, Madrid, 1992, pp. 253-269, en concreto, pp. 260-261.

${ }^{791}$ El caso de la filiación clásica del denominado "maestro" de Cabestany se aborda en un apartado de este trabajo dedicado a la influencia de la Antigüedad dentro de la escultura románica hispana. Sobre el comentado relieve vegetal, véase: I. LORÉS I OTZET, El monestir de Sant Pere de Rodes, Barcelona, 2002, en particular, pp. 105-113. Este tipo de fenómenos dentro de la Marca Hispánica parecen, hasta cierto punto, lógicos y justificables a través de la continuación del trabajo y el reempleo del mármol dentro de los talleres del Rosellón, a los que, por cierto, M. Durliat atribuía una vinculación con la eboraria carolingia de recuerdo clásico. Cf.: M. DURLIAT, "Les débuts...", p. 101 y A. MILONE, "El Maestro de Cabestany: notas para un replanteamiento", El románico y el Mediterráneo. Cataluña, Toulouse y Pisa. 1120-1180, Barcelona, 2008, pp. 181-191.
} 
Durante los siglos del románico, tal y como veremos, se puede documentar este reempleo de piezas marmóreas de cronología romana.

Son muchos los autores que han querido ver en estos traslados físicos de las piezas un intento por fomentar y recrear un prestigio relacionado con la sola propiedad de la obra por parte de su dueño. Ello explicaría la reintegración de todo este material dentro las partes más perceptibles de los edificios y de las obras suntuarias, en el caso, sobre todo, de los trabajos con materiales preciosos.

Los especialistas y conocedores del tema, como por ejemplo el profesor B. Brenk, han señalado un interés por parte de los "expoliadores" en refrendar su imagen política y social a través del reempleo de tales piezas, argumento que serviría, igualmente, para justificar estos traslados de material de acarreo.

El autor, a través del caso concreto de la edilicia de la etapa de Teodorico en Ravenna, señala otra serie de fenómenos ciertamente interesantes. En esta ciudad, explica, casi no se llevaron a cabo expoliaciones de material romano, pues casi todas las piezas, entre ellas capiteles, fustes, basas, arquitrabes y mobiliario litúrgico, fueron creadas ex novo en la ciudad de Constantinopla y trasladados a los nuevos edificios. Sin embargo, donde si se patentizan con frecuencia este tipo de reempleos fue en el famoso palacio del emperador en la misma Ravenna, hecho que ha permitido argumentar un interés por prestigiar su persona y sus empresas a través de una conexión con la Roma imperial $^{792}$.

Sin embargo, son conocidos numerosos ejemplos donde las obras clásicas fueron vistas como simples fragmentos tomados de la gran cantera abierta que suponía el arte de la Antigüedad. En estos casos, la recuperación de materiales para las construcciones se realizaba independientemente de su pasado y su valor dentro de la historia.

Las fuentes apoyan textualmente estos hechos, donde las "preciosissimis et politis lapidibus" acarreadas de un templo romano que se encontraba en el Forum Vetus de la ciudad de Lyon, sirvieron para construir la cimentación de la nueva catedral medieval. A pesar de que las grandes piedras de mármol estaban decoradas con inscripciones romanas, el obituario de la catedral insiste en que la construcción del

\footnotetext{
792 B. BRENK, “Spolia da Constantino...”, p. 202 y CH. FRUGONI, Una lontana città..., pp. 39-51. La profesora Frugoni trata ampliamente el tema de la actividad edilicia durante la época de Teodorico en la ciudad de Rávena. Su labor constructora se basó en la restauración de las obras de Trajano, potenciando la faceta de emperador constructor y creador de una obra para el pueblo, siempre teniendo en cuenta la belleza de las construcciones pasadas y las aportaciones de los talleres bizantinos. Con estas premisas, hace una lectura del conjunto de obras musivas patrocinadas por el emperador medieval, dispuestas, según la autora, a lograr una semejanza desde un punto de vista material, entre la civitas Ravennae y la civitas Classis, con la ciudad de Roma.
} 
ábside, acometida en el año 1107 por Gaucerand, se llevó a cabo con estas "politis lapidibus",793.

Por la misma época, se ha datado el reaprovechamiento de material romano para crear la cimentación de los pilares románicos de la catedral de Santiago de Compostela. En este caso, un ara romana, de gran formato, con una inscripción en letras capitales servía como material de relleno para estos cimientos. Parece claro que, en ningún caso, se pensó en la función estética de esta obra, oculta bajo la tierra y tan sólo visible a partir del momento en que se excavó el suelo catedralicio (fig. 142). Perfectamente escuadrada dentro de los muros de cimentación del edificio, sin ningún tipo de consideración ni respeto hacia lo antiguo, fue colocada tan sólo por su valor funcional, pues este ara pétrea dedicada a Júpiter evitaba el hecho de tallar un nuevo sillar ${ }^{794}$.

La operación se repite en el templo de San Miguel de Escalada, en León ${ }^{795}$. Un epígrafe que ha sido datado en torno a los siglos IV o $\mathrm{V}$ de nuestra era, fue reutilizado como cimacio sobre uno de los capiteles de la arcada de separación de naves de la iglesia (fig. 143). En dicha inscripción, estudiada por el profesor V. García Lobo, se dice:

"Aquí está sepultada (Valeria) esposa de Montano; séate la tierra leve benigna. ¡O mi muy amada; Podías, si el tiempo no te hubiera vencido, educar a

\footnotetext{
${ }^{793}$ J. ADHÉMAR, Influences antiques..., p. 55 y nota 2. Lo que demuestra un total descuido por parte de los constructores en proteger y conservar tales piezas.

${ }^{794}$ M. CHAMOSO LAMAS, "Excavaciones arqueológicas en la catedral de Santiago (tercera fase)", Compostellanum, II/4, 1957, pp. 575-624.

795 A. MARTÍNEZ TEJERA, El templo del monasterium de San Miguel de Escalada: "arquitectura de fusión" en el reino de León (siglos X-XI), Madrid 2005, en concreto, pp. 61-93; I. G. BANGO TORVISO, Arte prerrománico..., pp. 244-346 e ID., "Los expolios del paisaje monumental...", pp. 7-50. El profesor Bango alude a la fecha de la consagración realizada por el obispo Genadio en el año 913. Sin embargo, ya planteaba sus dudas respecto a la morfología del edificio y a la fecha y tiempo de ejecución de las obras, en un periodo cronológico tan pequeño como al que alude la inscripción. A partir de ello, el autor defenderá una datación más tardía. Las obras de Sabarico y el aumento de reliquias llevarán a una nueva consagración a finales de siglo XI. La inscripción, hoy desaparecida, que ha servido para datar el edificio, fue recogida ya en su día por M. Risco.

Sobre ella, vid.: S. NOACK-HALEY, "San Miguel de Escalada (Prov. León) dreischiffige Basílika mit eingeschriebenem, dreigeteiltem Transept, drei Apsiden und Südportikus. -Weihe 913, Portikus um 930940 und romanisch", Christliche..., pp. 262-270, en concreto, p. 262 y N. RODRÍGUEZ SUÁREZ, "La inscripción fundacional de San Miguel de Escalada. Un acercamiento atrevido", Paleografía I: la escritura en España hasta 1250 (J. A. Fernández Flórez y S. Serna Serna, coord.), Burgos, 2008, pp. 173187.
} 
nuestros hijos al menos durante otros fecundos cinco años; pero la corriente del agua, cogiéndote, te llevó con toda facilidad..."796 (texto 48).

Los puntos suspensivos indican una laguna insalvable, la generada por el propio capitel altomedieval que, apoyado sobre la inscripción, no permite seguir leyendo, tal vez en un indicador absoluto de la poca preocupación que el constructor mostró ante la pieza clásica.

Este tipo de spolia parece mostrar las posibles variantes a la hora de valorar el respecto del artista medieval hacia la obra clásica. Por una parte, existieron piezas de calidad que, apreciadas por los artífices, pasaron a formar parte visible de las construcciones, quizás en un deseo de enfatizar dichas piezas como continuadoras de una tradición y de un pasado antiguo y prestigioso.

Sin embargo, en otras ocasiones, tal y como vemos con las expoliaciones de Santiago y León, las piezas son colocadas de manera arbitraría e, incluso, invisible a la vista del espectador, enterradas bajo los cimientos, demostrando un desentendimiento absoluto de lo que significaban. Los reempleos de numerosas inscripciones romanas en otra serie de construcciones medievales, como las realizadas en la iglesia de Santa Lucia del Trampal, la basílica del Gatillo o en la pequeña iglesia rural de Ibahernando, en Cáceres, certifican un cierto tono arbitrario a la hora de decidir la colocación de tales obras.

En este sentido, afirma el profesor A. Arbeiter:

"La diligencia palpable en su redestinación a las iglesias y en su colocación allí con el epígrafe hacia arriba parece delatar cierta intención de transferir estos testimonios del paganismo superado a la servidumbre del culto cristiano"797.

Adoptando, a veces, la forma de canceles, tal y como vemos en la iglesia de El Gatillo o, sirviendo, en otras, de gran losa de acceso al sanctuarium altaris, como en Ibahernando, las inscripciones romanas se colocaban como pequeños fragmentos de una Antigüedad, en ocasiones, no comprendida. Sin embargo, en el caso de la pieza de de Cáceres, su ubicación en un lugar privilegiado, habla nuevamente de un interés por

\footnotetext{
${ }^{796}$ GARCÍA LOBO, V., Las inscripciones de San Miguel de Escalada. Estudio crítico, Barcelona, 1982, en concreto, p. 60. Véase también: M. A. RABANAL ALONSO y S. MARÍA GARCÍA MARTÍNEZ, Op. cit., p. 30 e I. G. BANGO TORVISO, "Los expolios del paisaje monumental...", pp. 7-50.

${ }^{797}$ A. ARBEITER, "Los edificios de culto cristiano...", especialmente, p. 213.
} 
mostrar las piezas en las zonas importantes y visibles de los templos, tal y como ocurría con los spolia transportados en barco desde Eabaca y diversas zonas de Portugal, hasta Santiago de Compostela ${ }^{798}$.

Tras los ejemplos desarrollados, creemos estar en posición de abordar la definición exacta y utilitaria de este fenómeno que hemos venido tratando hasta el momento. A la enunciación dada por el Diccionario de la Lengua Española, debemos sumar otra serie de axiomas ofrecidos por los especialistas en el tema.

Para B. Brenk, la palabra spolia debe ser definida teniendo en cuenta su acepción latina, donde literalmente significaba "pelliccia asportata de un animal", tal y como señala. Desde los primeros momentos se asoció a los botines de guerra o las expoliaciones hechas por los soldados tras la destrucción de un territorio o una ciudad. Sin embargo, las etapas modernas han relacionado el término spolia con toda aquella acción que tiene como fin la reutilización de una construcción arquitectónica que proviene de un edificio demolido ${ }^{799}$.

A través de estas palabras y los ejemplos antes analizados, entendemos que, durante la Edad Media, existió una conducta frecuente, según la cual, determinadas piezas provenientes de obras arquitectónicas y artísticas de cronología antigua, eran reempleadas y reintegradas en los nuevos conjuntos que se estaban creando. Se trataría, por lo tanto, de una utilización física de estas piezas en nuevo contexto medieval ${ }^{800}$.

Los materiales acarreados de antiguas fundaciones, tales como bloques pétreos y sillares, todo tipo de elementos escultóricos, columnas, mosaicos, inscripciones, sarcófagos y relieves, gemas y materiales preciosos, y, evidentemente, textiles, eran reutilizados en una época y un periodo cronológico distinto para el que algún día habían

\footnotetext{
${ }^{798}$ Ibidem, p. 203 y p. 213. La placa de Ibahernando se reempleó en esta iglesia rural levantada en torno al año 635 en honor de Santa María. Se trata de una construcción rústica que pudo ser patrocinada por un latifundista $\mathrm{o}$, incluso, por una comunidad rural muy reducida. A la pieza se le realizaron sendas ranuras que, además, y estamos hablando ya de un segundo reempleo, permitían la inserción en ellas de una pareja de placas de cancel.

Sobre la desconocida ciudad de Eabaca, vid.: C. SÁNCHEZ ALBORNOZ, Estudios críticos sobre la historia del Reino de Asturias: origen de la nación española, Oviedo, 1975, pp. 813-819.

${ }^{799}$ Véase la clarificadora comparación que establece el autor entre el fenómeno de la expoliación de materiales antiguos durante la Edad Media y el ejemplo de un caníbal, que no devora a sus enemigos por hambre, sino como manera de reafirmar y legitimar su poder. Cf.: B. BRENK, "Spolia da Constantino...", en especial, p. 197. Sobre el concepto, también véase: A. ESCH, "Zur Wiederverwendung antiker Baustucke und Skulpturen im mittelalterlichen Italien", Auchiu fur Kulturgeschichte, 51, 1969, pp. 1-33.

${ }^{800}$ S. SETTIS, "Distanza, continuità...", pp. 373-486; J. ALCHERMES, Op. cit., pp. 167-168; M. GREENHALGH, The survival of Roman..., particularmente, pp. 145-181 y M. A. CASTIÑEIRAS, "Capitel románico...", particularmente, p. 252.
} 
sido concebidos ${ }^{801}$.

Sin embargo, las reutilizaciones físicas de las piezas o, de una manera más científica, spolia in se, pueden tener, además, diferentes tipos de nomenclaturas dependiendo de algunas de sus características esenciales.

En este sentido es muy interesante la matización que realiza I. Rilliet-Maillard al abordar la producción de sarcófagos durante el mundo romano en las diferentes partes de las provincias del Imperio y su posterior reutilización ${ }^{802}$. La autora aclara en su estudio que, dentro de la propia expoliación in se y teniendo muy en cuenta los diferentes avatares de las piezas, se podría llegar a discernir otra serie de vocablos aplicables a la hora de concretar y definir el fenómeno.

En el caso de los sarcófagos reutilizados para enterramientos posteriores, las piezas, a parte de ser un spolium in se, también puede albergar otros matices conceptuales.

Según se ha defendido, existieron, además, otra serie de reempleos que se podrían definir bajo las expresiones de "utilización secundaria" y "utilización terciaria", si acudimos a las distinciones más específicas que realiza la estudiosa.

Para I. Rilliet, la utilización secundaria de un sarcófago expoliado se produce cuando ésta se lleva a cabo por personas ajenas a la familia del primer difunto que ocupó el sarcófago, y que, a veces, implicaba el transporte de la pieza a lugares muy alejados de su origen inicial ${ }^{803}$.

Por el contrario, la "utilización terciaria" supone un nivel más marcado y profundo de expoliación. En ella, el sarcófago y, de una manera más general, cualquier pieza antigua, pierde todos los fines para los que fue concebido, pasando a cumplir otras funciones. El caso más representativo lo supone la utilización terciaria de un sarcófago en un nuevo contexto con funciones de abrevadero, recipiente, relleno en un muro o piscina litúrgica, por ejemplo ${ }^{804}$.

Hasta aquí, hemos intentado realizar una breve síntesis del fenómeno de la expoliación y reutilización de piezas antiguas en el ámbito medieval, tanto desde el punto de vista de su acarreo, como sobre su integración en las nuevas construcciones.

${ }^{801}$ M. GREENHALGH, The survival of Roman..., pp. 145-201. El investigador dedica dos extensos capitulos de su obra a estudiar todo tipo de expoliaciones. Lo hace de una manera global y con ejemplos muy variados pertenecientes a distintas zonas geográficas.

${ }^{802}$ I. RILLIET-MAILLARD, "Productions des...", en concreto, p. 182. Las piezas serán reempleadas, si seguimos siempre la definición dada para el spolium in se, sobre todo de manera física, dejando la asimilación intelectual de la obra en un segundo plano.

${ }^{803}$ Ibidem.

${ }^{804}$ Ibidem. 
Se trata, claramente, de una síntesis muy simplificada y que ha tenido como objeto de análisis una serie de ejemplos muy concretos.

Somos conscientes de la abundancia de piezas susceptibles de ser mencionadas, sin embargo, se ha optado por seleccionar aquellas que, según nuestro criterio, mejor podían exponer tal cuestión.

Fue un fenómeno universal a todas las áreas geográficas y periodos cronológicos, aunque desigual en relación con los principios ideológicos y teóricos que propiciaron tales reempleos. Sin embargo, resulta bien llamativo el hecho de que ni las grandes piezas artísticas del mundo antiguo escaparon a este tipo de acciones. Así, debe recordarse, para finalizar, el caso paradigmático del sarcófago de Santa Elena, la madre de Constantino, que tras ser profanado en el año 1154, sirvió de sepultura al papa Anastasio IV (1153-1154), quién lo trasladaría desde el mausoleo de Tor Pignattara hasta la iglesia de San Giovanni Laterano ${ }^{805}$. Parece claro, por lo tanto, que si hasta la gran tumba de la madre del emperador Constantino fue reutilizada durante los siglos del medievo, cualquier pieza podía ser susceptible de tener la misma fortuna.

\footnotetext{
${ }^{805}$ X. DECTOT, Pierres tombales..., en concreto, p. 15. Se trata del soberbio sarcófago conservado actualmente en los Musei Vaticani de Roma. La temática de la obra, datada en los siglos finales de la Antigüedad, habla de una continuidad absoluta de la iconografía pagana dentro de las realizaciones cristianas. Destacan las escenas de guerra que muestran a los soldados romanos victoriosos a caballo, triunfantes, venciendo a las tropas bárbaras, que se sitúan, como era habitual dentro de estos ciclos, esclavizados a los pies de sus verdugos.

Los diferentes autores han defendido la ocupación inicial de la obra dentro del gran nicho del mausoleo romano. Así mismo, se suele aludir a la donación del emperador Constantino de un gran altar que se colocaría en el ábside de la basílica anexa, para poder celebrar así, la eucaristía cerca del catafalco de su madre.

Desde otro punto de vista, cabe destacar, que el pontificado de Anastasio IV, duró tan sólo un año, pero que fue tiempo necesario para poder apoderarse de esta pieza tan importante desde el punto de vista simbólico. Cf.: H. BRANDENBURG, Le prime chiese..., p. 56; L. DE LACHENAL, Op. cit., en concreto, pp. 224-225 y J.-P. CAILLET y H. NILS LOOSE, La vie d'éternité. La sculpture funéraire dans l'Antiquité chrétienne, Paris, 1990, en concreto, p. 8 y p. 49.
} 


\section{3. LA EXPOLIACIÓN DE SARCÓFAGOS ROMANOS EN LA HISPANIA MEDIEVAL.}

Las piezas más numerosas dentro del fenómeno de las expoliaciones que se van a llevar a cabo, tanto a nivel europeo como dentro del ámbito hispano medieval, fueron los sarcófagos. Para el caso español, tal y como veremos, se pueden señalar, además, unas características específicas, fruto, sin duda, de la situación política y social que vivía la Hispania de la Alta y Plena Edad Media.

El panorama que debían presentar las ciudades durante la Antigüedad tardía y los siglos medievales es una cuestión fundamental para poder abordar este tema ${ }^{806}$.

En relación con ello, es bien expresivo el célebre párrafo que nos ha legado el autor del Codex Calixtinus, a la hora de narrar aquel panorama que el hombre medieval tenía ante sus ojos. Así nos dice:

"Luego se ha de visitar junto a la ciudad de Arles un cementerio en el lugar llamado Alyscamps, para rogar por los difuntos con rezos, salmos y limosnas, según costumbre. Su longitud y anchura es de una milla. Tantas y tan grandes tumbas de mármol colocadas sobre la tierra no pueden encontrarse en cementerio de parte alguna, excepto en éste. Tienen esculpidos diversos motivos e inscripciones latinas y son antiguas por su redacción ininteligible. Cuanto más lejos se mira, tanto más lejos se ven sarcófagos. En este mismo cementerio existen siete iglesias (...). Pues allí descansan los cuerpos de muchos santos mártires y confesores, cuyas almas gozan ya en la paradisíaca morada. Su conmemoración suele celebrarse el lunes después de la octava de Pascua" ${ }^{807}$ (texto 49).

\footnotetext{
${ }^{806}$ M. C. COSMEN ALONSO, "Noticias sobre la reconstrucción arquitectónica en la Diócesis de León durante el siglo X", La Multiculturalidad en las Artes y en la Arquitectura, Las Palmas de Gran Canaria, 2006, pp. 599-607. La autora ha realizado una serie de trabajos donde analiza la importancia de las obras artísticas de los siglos de la Antigüedad para la construcción de otra serie de estructuras medievales. Se centra en la documentación y en las fuentes a la hora de poner de relieve este fenómeno del spolium in se, sobre todo, en relación con la reutilización de cimientos, fustes, capiteles y otra serie de elementos arquitectónicos y escultóricos tomados. Estos debieron provenir, concretamente, de las villas romanas, de los templos y de todo el panorama arquitectónico que suponía una auténtica cantera abierta donde tomar las piezas.

${ }^{807}$ Liber Sancti Jacobi..., p. 560-561. Para una imagen evocadora de tal paisaje, véase el grabado de E. Eduinent, del año 1789, publicado por J.-F. de Noble Lalauzière. Cf.: J.-F. DE NOBLE LALAUZIÈRE, Abrégé chronologique de l'histoire d'Arles, Arles, 1808 y P.-A. FÉVRIER, "Arles, Les Alyscamps. Nécropole orientale", Les premiers monuments..., pp. 118-120, concretamente, p. 119.
} 
Se trata de un texto significativo y fundamental para comprender el fenómeno que vamos a analizar.

El autor del escrito tiene ante sus ojos los restos de una Antigüedad pasada, inmersa ahora dentro de los siglos de la Edad Media. Los sarcófagos paganos y paleocristianos utilizados en origen para dar cobijo a toda una serie de personajes, hoy la mayoría desconocidos, pasaban a ser reutilizados para albergar las tumbas de los mártires, de los santos y de cualquier persona muerta al amparo de Dios ${ }^{808}$.

El fenómeno de la expoliación de estos materiales de la Antigüedad tardía cristiana, vino acompañado por la continuidad de las mismas prácticas funerarias romanas de época Imperial. En este sentido, cuando un individuo deseaba pervivir como tal, tras la muerte, necesitaba que alguien recordara su existencia.

La desaparición de su ánima le llevaría a formar parte de los dii inferi, es decir los manes, que podían ser perniciosos para los hombres. Ello conllevó que, también durante las primeras expresiones del arte paleocristiano, se buscase materializar la pervivencia de la memoria aeterna a través de determinadas formas ${ }^{809}$. Una de las soluciones más significativas y utilizadas fue la de crear estos sepulcros y monumentos funerarios con inscripciones, que serían entendidos como representantes y evocadores de la memoria del difunto.

En la definición de este fenómeno de la expoliación de sarcófagos durante los últimos siglos de la Antigüedad, tuvieron gran peso algunos aspectos relacionados con el ambiente jurídico y legislativo del momento.

Un monumento sepulcral o un sarcófago no es un lugar sagrado:

"Sacro es pues sólo el lugar exacto donde reposan los restos, lo demás, sea grande o pequeña la tumba, es sólo un testimonio destinado a conservar la memoria del difunto" ${ }^{, 10}$.

\footnotetext{
${ }^{808}$ I. SÁNCHEZ RAMOS, "La incidencia del cristianismo en el mundo funerario romano cordubense", Espacio y usos funerarios en el Occidente romano (D. Vaquerizo ed.), Córdoba, 2002, vol. 2, pp. 325342. El autor insiste en la proliferación de necrópolis y basílicas, ecclesiae, extramuros de las ciudades romanas desde el siglo III, señalando, por ejemplo, el caso de Córdoba. Esto hecho es, entre otras, una de las razones por las que, a partir de este momento, se reactiva la producción de sarcófagos decorados con una rica iconografía cristiana, así como el aumento de la reutilización de los ya existentes.

${ }^{809}$ F. DE VISSCHER, Le droit des tombeaux romains, Milano, 1963, en concreto, pp. 20-99; F. CUMONT, Recherches sur le symbolisme funéraire des romains, Paris, 1942; ID., Lux perpetua, Paris, 1949 y J. REMESAL RODRÍGUEZ, "Aspectos legales del mundo funerario romano", Espacios y usos funerarios..., pp. 369-378, en particular, pp. 370-372.

${ }_{810}$ J. REMESAL RODRÍGUEZ, Op. cit., p. 372.
} 
La legislación permitía realizar todo tipo de actividades, como por ejemplo, la compra y venta de los cenotafios y los monumentos sepulcrales no ocupados, pues tales elementos no eran considerados sagrados, ya que tal categoría sólo correspondía al lugar material en el que se hallaban los restos físicos del cadáver.

Ello implica que, desde época romana, cuando la memoria de un difunto se disolvía, ya fuese porque sus herederos habían desaparecido, porqué no hubiese restos de su existencia material en la tierra o por la no identificación de la tumba con su ocupante en particular; las tumbas, monumentos funerarios y demás lugares ligados a la muerte, fueron reutilizados.

Ya Plinio había tratado estas cuestiones en su obra. Entre ellas, nos interesa destacar la noticia en la que nos aclara:

"No se solía usar antiguamente entre los romanos quemar los cuerpos de los hombres, sino enterrarlos. Más de que vieron que los que se havían, en tiempo de guerras prolixas, enterrados, se desenterravan, ordenaron que sirviese el fuego de la sepultura, aunque ciertos linajes guardaron la costumbre antigua, y ansí no se escribe haverse quemado hombre en la familia de los Cornelios antes de Sylla, dictador. El cual, porqué havía hecho desenterrar el cuerpo de Cayo Mario, temiendo que conforme a la ley del Talión no se hiziese con él, ansí quiso que le quemasen" ${ }^{\prime 11}$ (texto 50).

El texto de Plinio, siempre rico en noticias, alerta ya sobre la problemática de la expoliación de sarcófagos y el cambio de costumbres funerarias a causa de esta práctica. A su vez, la visión descrita por el autor del Codex Calixtinus sobre la gran necrópolis de los Alyscamps de Arles, nos habla de un panorama donde la convivencia con estas piezas artísticas -simples lápidas de piedra, en muchos casos- era frecuente. Extramuros de las viejas ciudades, se extenderían las grandes necrópolis cristianas, frecuentemente constituidas a través de materiales expoliados romanos ${ }^{812}$.

La constitutio dictada por Máximo en el año 386 ordenaba que los cuerpos de los mártires fueran venerados allí donde se hallaba su sepultura, por lo que, a partir de este momento, dicho lugar se presentaba como propicio para la erección de los martyria, que a partir de entonces empezarán a multiplicarse. Sin duda, con ello también

\footnotetext{
${ }^{811}$ PLINIO, Historia Natural..., p. 348.

${ }^{812}$ A. MARTÍNEZ TEJERA, “Arquitectura cristiana...”, en especial, pp. 109-110.
} 
aumentaron las labores de reempleo de materiales ${ }^{813}$.

Nacía así el deseo, por parte de los primeros cristianos, de enterrarse alrededor de las tumbas de los grandes mártires, siguiendo la tradición pagana, según la cual, las zonas anexas a los heroa de personajes importantes eran objeto frecuente de continuas disputas por ocupar tal lugar ${ }^{814}$. Tras la tendencia habitual entre los siglos II y III, la Edad Media continuó enterrando a sus difuntos en estas zonas comunes que eran vigiladas por el administrador de la iglesia. Era el momento en el que surgía el concepto de coementerium, definido por un término nuevo, sin connotaciones paganas, que significaba literalmente "dormitorio" ${ }^{815}$.

Pero además, si atendemos a la noticia del Codex Calixtinus antes analizada, hay un elemento que, junto con los sarcófagos, se convirtió en recurrente dentro del panorama de este periodo, tanto desde el punto de vista de las expoliaciones como desde su interés para el espectador medieval.

Nos estamos refiriendo a los relieves e inscripciones que, como se nos dice:

“(...) tienen esculpidos diversos motivos e inscripciones latinas y son antiguas por su redacción ininteligible" (texto 49).

No debe resultar extraño que el viajero de época románica llame la atención sobre los caracteres de estos epígrafes romanos que yacían sobre el cementerio de Arles. La memoria del difunto romano, como hemos dicho, permanecía viva mientras hubiese alguien que recordase su nombre y su existencia. Las tumbas en forma de amontonamiento de piedras, con forma de estela, fragmento de ánfora o monumento de gran tamaño, también corrían el peligro de poder caer en el olvido sin una inscripción que ligase aquel lugar con el nombre de un difunto en particular $^{816}$.

Según ha señalado J. Remesal:

\footnotetext{
${ }^{813}$ Ibidem, p. 111.

${ }^{814}$ F. CABROL y H. LECRECQ, voz "Martyrium”, Dictionnaire d'archéologie Chrétienne et de liturgie, vol. X-II, Paris, 1932, cols. 2512-2523; A. GRABAR, Martyrium: recherches sur le culte..., pp. 16-23 y I. VELÁZQUEZ, "Baselicas multas miro opere construxit (VSPE 5.1.1). El valor de las fuentes literarias y epigráficas sobre la edilicia religiosa en la Hispania Visigoda”, Hortus Artium Medievalium, vol. 13/2, Zagreb-Motovum, 2007, pp. 261-270.

${ }^{815}$ Se abandona el término panteón, al menos durante los primeros siglos de la Alta Edad Media, por sus connotaciones paganas, que vinculaban dichos lugares a las divinidades romanas. A partir de este momento el accubitorium, derivado del término accumbere, literalmente "yacer", empezarán a utilizarse con más frecuencia. Cf.: J. A. IÑíGUEZ, Síntesis de Arqueología Cristiana, Ávila, 1977, en particular, p. 22.

${ }^{816}$ C. TREFFORT, “Inscrire son nom dans l'espace liturgique à l'époque romane", Cahiers de SaintMichel-de-Cuxa, XXXIV, 2003, pp. 147-160.
} 
"La inscripción sobre una tumba con las indicaciones de «hic situs est o sit tibi terra levis» lleva implícito que el caminante al leer el nombre del difunto y las fórmulas que le acompañen, evoque al difunto y de esa forma a su recuerdo"817.

Es por ello que, cuando el viajero llevaba a cabo un intento de lectura de tales inscripciones, no hacía otra cosa que rememorar una tradición romana que llevaba siglos practicándose, sobre todo delante de aquellas tumbas ubicadas en los cruces y aledaños de los caminos públicos ${ }^{818}$.

La Antigüedad tardía ofrece ejemplos escritos de gran valor sobre este aspecto, en especial, dentro de la obra de Prudencio. Ya hemos aludido a la importancia que el autor da a los sepulcros dentro de sus reflexiones, sobre todo, en relación con su visita a Roma $^{819}$. Sin embargo, el pasaje más llamativo, por reiterar el valor que estos primeros cristianos daban al monumento funerario y las inscripciones en particular, es aquel en el que se expone:

"Innumerables cenizas de santos he visto en la ciudad de Rómulo, joh Valeriano, consagrado a Cristo!. Me preguntas las inscripciones grabadas en los sepulcros y los nombres grabados de cada uno de los santos: difícil es que yo pueda recorrer toda su lista (...). Muchísimos sepulcros con menudas inscripciones, proclaman el nombre del mártir, o algún epitafio; también hay, sin embargo, muchas losas de mármol cubriendo tumbas silenciosas que sólo indican el número de mártires. Se puede saber qué cantidad de cuerpos de héroes reposan en sepulcros comunes, aunque no puedes leer ninguno de sus nombres. Recuerdo haberme enterado de que bajo una misma piedra hay alli enterradas las reliquias de sesenta mártires (...... Mientras voy recorriendo con mis ojos y busco entre los sepulcros si acaso hay en alguna parte ocultas inscripciones de antiguas hazañas (...)" ${ }^{\# 20}$ (texto 51).

\footnotetext{
${ }^{817}$ J. REMESAL RODRÍGUEZ, Op. cit., en concreto, p. 8.

${ }^{818}$ En este sentido, se debe interpretar la inscripción visible sobre el sarcófago 6 del cementerio de la iglesia de Saint-Pierre de Narbonne, que presenta un frontal decorado con estrígiles. En el centro, fue esculpida una victoria ligada a la inscripción, cincelada sobre el mármol, que dice: LEGE FELICITER, es decir, "buena suerte para el lector". Cf.: Y. SOLIER, "Narbonne, Édifice à abside du cimentière SaintPaul", Les premiers monuments chrétiens de la France. 1. Sud-Est et Corse, Paris, 1995, pp. 39-42.

${ }^{819}$ Recuérdese, por ejemplo, el momento en el que, al tratar el problema de la resurrección, dice: "Yo creo firmemente (y no es vana mi fe) que los cuerpos viven a modo de las almas, (...). Esta esperanza misma guarda al cuerpo mío; forzado ahora a reposar oliente en fúnebre sarcófago, Cristo, mi guía, resucitado de la misma tierra, lo llama a las estrellas ardorosas". Cf.: A. PRUDENCIO, Op. cit., p. 699.

${ }^{820}$ Ibidem, p. 47.
} 
Tanto el espectador tardorromano como el medieval sienten la misma atracción hacia los monumentos funerarios, donde es perceptible el sentimiento de respeto y admiración por tales obras. Así, aunque en muchas ocasiones las finas capitales romanas labradas sobre mármoles escaparan al entendimiento de los medievales, no debemos desechar la posibilidad de ver en su reutilización una manera directa de aludir a un pasado que, en la Plena Edad Media, se veía evidentemente lejano, pero, al fin y al cabo, como formando parte del devenir de la historia cristiana. Su atribución como lugar de descanso de estos primeros mártires parece clara, aún a pesar de tratarse, en ocasiones, de epitafios paganos.

A propósito de tales argumentos, creemos representativo volver sobre el spolium in se de la iglesia leonesa de San Miguel de Escalada. Esta inscripción romana, reutilizada como cimacio en época medieval, se colocó hacia abajo, siendo aún visible parte de su mensaje, tal y como hemos señalado.

Podría pensarse que, en tal reutilización, más allá de buscar una lectura de sus caracteres, tan sólo se valoró el material. Sin embargo, esas grafías, por antiguas e ininteligibles, convertían dicha pieza en un fragmenta docta. Una suerte de vestigio precioso de aquel pasado lejano que, simplemente por su decoración, debía figurar expoliado dentro de la construcción medieval ${ }^{821}$.

El reempleo de inscripciones romanas funerarias, perfectamente escuadradas dentro de la sillería de la catedral de Módena, habla de un interés por hacer visibles dichas escrituras, dentro de un ambiente de continuas referencias a la Antigüedad, tal y como han señalado, por ejemplo, F. Rebbecchi o M. Greenhalgh ${ }^{822}$.

El reempleo de materiales funerarios, tanto de epígrafes como de sarcófagos, fue

\footnotetext{
${ }^{821}$ Se trataría de un fenómeno muy parecido al que se constata en ciertas piezas románicas decoradas con motivos de tradición islámica y que los expertos han hecho derivar de una influencia de las escrituras árabes, tales como la cúfica. Sin embargo, los artesanos medievales, tal y como es sabido, convirtieron estos elementos escritos en meros elementos ornamentales. Cf.: I. RUÍZ DE LA PEÑA GONZÁLEZ, “Arquetas musulmanas para mártires cristianos", Correspondencia e integración de las artes. Actas del XIV Congreso Nacional, Málaga, 2006, pp. 151-168 y N. RODRÍGUEZ SUÁREZ, "Multiculturalidad artística a través de la epigrafía”, La Multiculturalidad..., pp. 447-452.

${ }^{822}$ F. REBBECCHI, Op. cit., pp. 219-353. Recordemos, que es el mismo ambiente en el que trabajaría el maestro Wiligelmo de Módena, en torno al año 1170, para crear esculturas tan "antiquizantes" como los famosos erotes apoyados sobre columnas acompañados de un ibis.

Véase también: E. PANOFSKY, Renacimiento y renacimientos..., en especial, p. 149; $\mathrm{M}$. GREENHALHG, The survival of Roman..., en concreto, pp. 70-72 y L. DE LACHENAL, Op. cit., pp. 192-193. Por lo general, se suele advertir que tales reempleos no pueden ser vistos como una medida de ahorro de trabajo y presupuesto. Con todo, continúa siendo complicado atribuir una valoración intelectual de estas piezas epigráficas de la torre denominada Ghirlandina, sobre todo, por la altura a la que fueron dispuestos los fragmentos, ilegibles desde abajo. Sin embargo, se reconoce que en tal expoliación, podemos ver un interés por exhibir las piezas como pertenecientes al pasado de la Antigüedad romana de la ciudad.
} 
tan frecuente, que hasta los recintos amurallados de las grandes ciudades presentaban, en muchas partes de su perímetro, todo tipo de materiales marmóreos de diferentes épocas reaprovechados a modo sillares.

En ocasiones, se trata de una simple "reutilización terciaria", si utilizamos la expresión de I. Rilliet, sin embargo, en otras tantas, existió un valor de conservación y, sobre todo, de exhibición de tales piezas.

Se puede concluir entonces, que el comercio de obras funerarias debió ser habitual en los últimos siglos del mundo antiguo y los inicios de la Edad Media. La noticia, por ejemplo, de la muerte de Teodosio, el hijo de Ataulfo y Gala, narrada por Olympiodoro de Tebas, concreta que fue enterrado en un sarcófago de plata, pero que sus restos fueron trasladados a un oratorio situado fuera de la ciudad de Barcino en torno al año $415^{823}$. Se deduce en este sentido, un importante movimiento y tráfico de los restos de los santos y mártires, así como de sus sepulturas, durante este periodo, que parece tener sus raíces en la tardía romanidad.

Son muchos los ejemplos que podríamos apuntar en relación con los sarcófagos, tanto paganos como paleocristianos, reaprovechados durante la Alta y Plena Edad Media. Señalaremos, a continuación, algunos de los casos más significativos que permitan comparar y completar la visión del spolium in se dentro del contexto hispano, centrándonos posteriormente, en analizar el lugar que tal fenómeno tuvo en relación con lo europeo.

Uno de los más sobresalientes, por cuanto problemático, es el del sepulcro romano reempleado por Carlomagno. Generalmente se suele admitir que este sarcófago con la representación del rapto de Proserpina en el frente sirvió de sepultura para el monarca carolingio, sin poseer muchos datos más seguros para defender una adjudicación indudable (fig. 144).

Ya hemos aludido al párrafo donde Eginhardo relata los últimos días del emperador y donde deja constancia de lo improvisado de la decisión de enterrarlo en la basílica el mismo día de su muerte. Ni el arco dorado con su efigie, ni la inscripción que supuestamente tenía el monumento, demuestran que se tratase de un verdadero spolium in $s e^{824}$.

Sin embargo, la historiografía ha venido repitiendo de una manera, más o menos consensuada, la atribución de esta pieza romana al monarca, sobre todo, a través de

\footnotetext{
${ }^{823}$ A. MARTÍNEZ TEJERA, “Arquitectura cristiana...”, en especial, p. 127.

${ }^{824}$ Véase el texto 10 del apéndice documental de este estudio.
} 
reconstrucciones como la que en su día propusieron F. Carbrol y H. Leclercq $^{825}$ (fig. 145).

Otros ejemplos atestiguan una continuidad de esta tradición en suelo francés, como la expoliación de un sarcófago que narraba la escena del paso del mar rojo, reempleado por Luís el Piadoso en su enterramiento de San Arnaldo de Lieja o aquel en el que se sepultó a San Mauro, obispo de Marsella y que tenía representada una escena báquica $^{826}$.

Además, fue el mismo J. Adhémar, pionero en este tipo de estudios en el ámbito francés, quién ofrecerá una lista bien completa sobre este tipo de obras expoliadas. A las anteriores, debemos sumar también, el ejemplar del cónsul Joven de Reims, originariamente en San Nicasio y que se hallaba empotrado contra un muro de dicho templo, el de Santa Aphrodise de Béziers, quién fue enterrada en un gran sarcófago de mármol gris con escenas cinegéticas u otra serie de casos conocidos, como los del sarcófago de Saint-Hilaire-de-Melle, embutido sobre la puerta de acceso a Notre-Damede-Orange o el de Saint-Benoît-de-Cessieu ${ }^{827}$.

La lista es cuantiosa, sobre todo, teniendo en cuenta la gran romanización sufrida por buena parte de la Galia. Los personajes pudientes adquieren las esculturas buscando una perpetuación de su memoria a través de la obra clásica. Así, si en ámbito francés la nómina de expoliaciones es amplia, el caso italiano presenta una expoliación tan abundante de sarcófagos que sería imposible recogerlos todos. Nada extraño, por otra parte, si tenemos en cuenta sus especiales circunstancias históricas y artísticas.

Destacamos, por conocido, el caso de la comitissa Matilde, quién a finales del siglo XI, retomará el interés por recuperar piezas funerarias romanas. En este sentido, en una acción totalmente premeditada, se encargará de buscar cuatro sarcófagos antiguos de mármol, trasladarlos hasta la iglesia de San Apolunio de Canossa y dar en ellos digna sepultura a sus antepasados ${ }^{828}$.

${ }^{825}$ F. CABROL, y H. LECLERCQ, voz "Charlemagne...", en particular, cols. 793-794; J. ADHÉMAR, Influences antiques..., en concreto, p. 78; M. SPRINGER, "Die Wiederverwendung Antiker Sarkophage", Kunst und Kultur der Karolingerzeit. Kart der Grobe und Papst Leo III in Paderborn, vol. II, Mainz, 1999, ficha catalográfica X. 41, pp. 758-763, particularmente, pp. 760-761 y R. ALONSO ÁLVAREZ, "De Carlomagno al Cid...", pp. 472-474. De ser cierta esta hipótesis, quedaría demostrada, una vez más, la pasión que el mundo carolingio sintió por las piezas romanas.

${ }^{826}$ J. ADHÉMAR, Influences antiques..., pp. 79-79, nota 5.

827 Ibidem, en concreto, pp. 78-81.

${ }^{828}$ L. DE LACHENAL, Op. cit., pp. 183-184. La autora dedica un apartado a analizar la importancia de esta figura política de la Italia medieval. Sobre todo, en relación con la apropiación de piezas artísticas antiguas dentro de los edificios que ella promovió y que tuvo como objetivo más frecuente toda clase de epígrafes, lápidas y sarcófagos. A parte, recoge otra serie de datos interesantes, como el patrocinio de una 
Hacer una relación exacta desde un punto de vista cuantitativo de este tipo de spolia a nivel europeo e hispano, desviaría la atención de nuestro trabajo ${ }^{829}$. En los siguientes apartados se tratarán algunas de estas piezas que fueron "rescatadas" de entre los vestigios antiguos para otorgarles nuevas funciones y explotar su presencia a través de otras vías.

El caso hispano presenta, de igual modo que el europeo, una amplia nómina de obras reempleadas. Su análisis y estudio puede ofrecer una idea de cómo se vivió tal fenómeno en la Hispania medieval.

Teniendo en cuenta estos factores, la literatura científica centrada en temas hispanos ha generado una base, lo suficientemente estable y amplia, como para poder iniciar una serie de reflexiones al respecto.

En particular, nos referimos al estudio realizado por el profesor S. Moralejo, publicado en el año 1984, y que sigue estando en plena vigencia ${ }^{830}$.

A parte de ello, recientemente, M. Claveria Nadal ha dedicado varios estudios al tema, a veces centrados en el ámbito catalán, pero que suponen un acercamiento actualizado a este tipo de actuaciones y que pueden ser tomados como base para el inicio de nuestra exposición ${ }^{831}$.

rotonda, en torno al año 1083, dedicada a San Lorenzo en Mantova, de clara inspiración paleocristiana y que se ha llegado a comparar con los mausoleos tardoantiguos o con la morfología del Santo Sepulcro.

${ }_{829}$ Nos hemos decantado por evitar realizar una lista de todos aquellos sarcófagos romanos reutilizados en época medieval en Hispania, debido al gran número de piezas existentes y, sobre todo, por tratarse de una tarea excesivamente ambiciosa. Por ello, se ha optado por seleccionar los ejemplares más significativos y sobre todo, aquellos cuya expoliación propició otra serie de fenómenos artísticos relacionados con dicha acción. Se advertirá, por tanto, la ausencia de muchos ejemplos que, de manera consciente o, quizás por la incapacidad de conocer todo el repertorio de esculturas expoliadas españolas, se han omitido.

Véase también la obra colectiva titulada: Matilde e il tesoro di Canossa tra castelli, monasteri e città. Catalogo della mostra (a cura di A. Calzona), Milano, 2008.

${ }^{830}$ S. MORALEJO ÁLVAREZ, "La reutilización...", pp. 279-288.

${ }^{831}$ M. CLAVERIA, "El sarcófago romano. Cuestiones de tipología, iconografía y centros de producción", El sarcófago romano. Contribuciones al estudio de su tipología, iconografía y centros de producción, Murcia, 2001, pp. 19-50; ID., Los sarcófagos romanos de Cataluña, Murcia, 2001 e ID., "La reutilización de sarcófagos romanos en Cataluña”, Anmurcia, 13-14, 1995 pp. 34-60. 


\section{A. EL PRAETIOSO MARMORE Y SU EXPOLIACIÓN: A PROPÓSITO DEL SARCÓFAGO DE ITHACIO}

DE OVIEDO.

Una de las expoliaciones más importantes y mejor documentadas, en relación con el ámbito geográfico de la Hispania medieval, es la que representa el sarcófago denominado de Ithacio y que actualmente se conserva en la catedral de Oviedo ${ }^{832}$ (fig. 146). De dicho sepulcro, conservamos tan sólo la lauda, habiendo desaparecido en un momento no concretado la cista.

Una de las primeras menciones que se ha documentado sobre la obra, fue la realizada por L. A. Carballo en torno al año 1695. El autor hacía, ya por entonces, algunas aclaraciones sobre la pieza que resultan de gran interés ${ }^{833}$. Su testimonio es fundamental para poder hablar de esta expoliación, pues alude y especifica, exactamente, el lugar en el que se encontraba el sarcófago durante la etapa moderna.

En concreto, se hallaba en el famoso Panteón funerario que la monarquía asturiana había construido en la parte occidental de la basílica de Santa María, fundada por el rey Alfonso II el Casto ${ }^{834}$.

\footnotetext{
${ }^{832}$ La bibliografía en la que se ha tratado o se ha citado la pieza es numerosa. Recogemos, tan sólo, los trabajos consultados para la realización de esta investigación. Cf.: T. ULBERT y S. NOACK-HALEY, "Lid for the sarcophagus of Ithacius", The Art of Medieval Spain 500-1200, New York, 1993, ficha catalográfica 1, p. 45; A. SUÁREZ SARO, "Tapa del Sarcófago de Ithacio", Orígenes, arte y cultura en Asturias siglos VII-XV, Oviedo, 1993, ficha catalográfica 59, pp. 87-88 y S. VIDAL, "Tapa de sarcófago de Ithacius", La escultura hispana de la Antigüedad tardía, Murcia, 1995, ficha catalográfica B25, pp. 87-91.

${ }^{833}$ A. L. DE CARVALLO, Antigüedades y cosas memorables del Principado de Asturias, Oviedo, 1988, (facsímil de la edición de 1695), en especial, p. 255.

${ }^{834}$ El reinado de este monarca se ha establecido entre los años 791-842. A él se debe esta estructura que ha sido considerada como el primer gran Panteón regio documentado en la Alta Edad Media hispánica. Cf.: C. ABAD CASTRO, "Espacios y capillas funerarias de carácter real", Maravillas de la España Medieval. Tesoro sagrado y monarquía, vol. I, León, 2001, pp. 63-71, en concreto, p. 63.

Dicho panteón, inmerso en el cuerpo de naves de la basílica, serviría para dar cobijo a los cuerpos de los reyes de la monarquía asturiana. La basílica formaría, a su vez, parte de un gran grupo catedralicio configurado por la gran iglesia de San Salvador y los Doce Apóstoles y la iglesia de San Tirso. La catedral prerrománica de Oviedo, dedicada a Santa María, donde se encontraba el sarcófago que estudiamos, desapareció en los inicios del siglo XIV, cuando se comenzó la construcción del templo gótico que hoy vemos. Cf.: A. ARBEITER, voz "Asturie", Enciclopedia dell'arte ..., vol. II, pp. 674-675; I. G. BANGO TORVISO, Arte prerrománico hispano..., p. 467; ID., "El espacio para enterramientos...", p. 100; R. ALONSO ÁLVAREZ, "Los enterramientos de los reyes visigodos", Fundamentos medievales de los particularismos hispánicos. IX Congreso de Estudios Medievales Fundación Sánchez Albornoz, León, 2005, pp. 361-375, en concreto, pp. 363-366.

En el estudio realizado por R. Alonso, se lleva a cabo un análisis exhaustivo de la problemática en torno a la existencia, poco documentada, de una tradición anterior de enterramientos en panteones. Así, se afirma: "La convicción de que los monarcas visigodos dispusieron de un panteón dinástico en la ciudad de Toledo, capital del reino, ha sido capaz de imponerse incluso a la absoluta carencia de testimonios que prueben su existencia". Centrándose en las fuentes documentales y cronísticas, realiza una crítica de la historiografía tradicional, cuestionando incluso la existencia, al menos a través de la documentación, del Panteón dinástico toledano, que supuestamente se ubicaría en la iglesia de Santa Leocadia.
} 
Si para la estructura funeraria asturiana se han alegado precedentes tardoantiguos, en concreto relacionados con la estructura de la habitatio sepulcri de la iglesia toledana de Santa Leocadia y otra serie de obras tardorromanas, no menos significativa es la presencia de esta pieza dentro del recinto. Ello implica que, anteriormente a la destrucción del Panteón en época moderna, esta capilla del rey Casto conservó el sarcófago clásico entre sus muros, aunque aún hoy en día se nos siga escapando la seguridad de poder atribuir tal pieza a una personalidad concreta.

Se trata de la lauda de un sarcófago realizada en mármol blanco, de doble vertiente, que ha sido objeto de muchas hipótesis en cuanto a su datación y, sobre todo, su filiación. La cubierta aparece decorada mediante una serie de roleos o zarcillos vegetales de gran clasicismo. En la parte superior se cinceló una bella inscripción en capitales romanas clásicas en la que se dice:

“INCLVSIT TENERVM PRAETIOSO MARMORE CORPVUS AETERNAM IN SEDEM NOMINIS ITHACII" ${ }^{, 835}$.

Dicho epígrafe ha sido la causa de que algunos autores hayan barajado la posibilidad de que, en origen, se pudiera tratar de la tumba de un niño, sobre todo por la utilización del adjetivo "tenerum", es decir, joven.

En este sentido, el propio Carballo pensaba que "esta sepultura es de un infante o chiquito y moçuelo de pocos años", por lo que, a partir de él y tomando como base sus argumentos, serían muchos los especialistas que apoyaron esta hipótesis ${ }^{836}$.

El gran problema se presentaría a la hora de concretar la cronología de la obra, que ha oscilado entre los siglos V y VI. Con todo, el dato que más nos interesa es aquel que insiste en su reutilización durante el siglo IX. En concreto, S. Moralejo apuntó la posibilidad de que hubiera servido de tumba al mismo rey Alfonso III el Magno que, hipotéticamente, habría sido la persona encargada de llevar a cabo esta expoliación in se del sarcófago, dentro del Panteón ovetense ${ }^{837}$.

De ser cierta la hipótesis del profesor Moralejo, la tapa del sarcófago hubo de

\footnotetext{
835 J. VIVES, Op. cit., en especial, p. 92 y F. DIEGO SANTOS, Inscripciones medievales de Asturias, Gijón, 1993, p. 23.

${ }^{836}$ S.VIDAL, "Tapa de sarcófago...", p. 88; T. ULBERT y S. NOACK-HALEY, Op. cit., p. 45 y F. DIEGO SANTOS, Op. cit., p. 23.

${ }^{837}$ S. MORALEJO ÁLVAREZ, "La reutilización...", pp. 187-188. La teoría, sin duda, sugestiva, presenta la problemática de no tener todo el respaldo documental por parte de las fuentes para poder afirmar si realmente se expolió esta pieza clásica con tales fines.
} 
compartir espacio con otra serie de monumentos funerarios, tal y como por ejemplo, pudo haber sido el de Alfonso II el Casto, que tal y como nos dice la Crónica ad Sebastianum:

"Y así, tras haber llevado por cincuenta y dos años casta, sobria, inmaculada, piadosa y gloriosamente el gobernalle del reino, amable para Dios para los hombres, dejó marchar al cielo su glorioso espíritu. Más su cuerpo, sepultado con unas exequias llenas de veneración en la ya nombrada Iglesia de Santa María, por él fundada, en un túmulo de piedra, descansa en paz ${ }^{, 838}$ (texto 52).

En relación con la iconografía de la pieza, pudiéramos pensar que fue, en cierta medida, comprendida en el momento de su expoliación ya que alude a varios aspectos ligados a la salvación y a la vida paradisíaca en el más allá, es decir, en el locus amoenus o Jardín Celestial ${ }^{839}$.

La inclusión de dos pares de cráteras de las que beben las aves y de las que, a la vez, nacen dos árboles de la vida, tenía ya por entonces larga tradición iconográfica fúnebre, tanto en el seno de la cultura visual del Bajo Imperio, como durante el primer cristianismo. Además, es muy expresiva la introducción, mediando entre los dos grupos de aves, del símbolo criptomórfico cristiano por excelencia, es decir, el crismón ${ }^{840}$.

La alusión paradisíaca, perfecta para cualquier ambiente funerario, continúa en las otras partes de la lauda. Así, en los laterales se extienden, nuevamente, las formas vegetales entrelazadas y entre las cuales se colocaron pequeños motivos, como por ejemplo, el de una crátera flanqueada por aves, que parecen ocupar el lugar destinado a

${ }^{838}$ Crónicas asturianas..., A. III “A Sebastián”, 22, p. 215.

839 H. J. L. DE GRIMOUARD DE SAINT-LAURENT, "Étude sur une série d'anciens sarcophages", Revue de l'Art chrétien, II, vol. IV, 1877, pp. 1-39, en especial, p. 32. El autor ya señalaba en el año 1877 la importancia que habría de tener este tipo de iconografía dentro de la escultura cristiana. Sobre todo, hacía alusión a las teorías vertidas por San Paulino y su referencia al "celeste nemus paradisi", para explicar la presencia de diversos árboles, palmeras y vegetación, dentro de este tipo de producciones. También insiste en el papel que tienen las aves dentro de este tipo de iconografía, representadas, a veces, bebiendo de la crátera, picoteando la propia vegetación o flanqueando el símbolo de Cristo, ya sea en forma de crismón o de cruz rampante.

${ }^{840}$ El sistema compositivo de la escultura no presenta grandes novedades en este sentido, pues se trata de una fórmula muy arraigada en el arte paleocristiano. El crismón del que penden el alpha y la omega, está circunscrito por una estructura circular entrelazada que se sobre eleva, a su vez, gracias a una columna de fuste de gran éntasis, capitel vegetal de tres hojas y una basa simple.

Un buen ejemplo con la representación del crismón entre pámpanos de vid que nacen de una crátera, esta vez sin aves, es el de la iglesia de San Mauricio, en Vienne. Cf.: P. PALOL, Arte paleocristiano en España, Barcelona, 1968, en concreto, p. 324 y M. EDMOND LE BLANT, Les sarcophages chrétiens de la Gaule, Paris, 1886, en especial, p. 22. Aclaramos, además, que este trabajo que citamos realizado por Le Blant, será fundamental para nuestro trabajo, pues se trata de la primera gran compilación realizada de los sarcófagos romanos cristianos conservados en suelo francés. 
las asas del objeto.

Tal y como ya hemos expuesto en otras ocasiones, la iconografía de esta crátera, no desentona, ni con el acento escatológico y salvífico de la pieza, ni con la teoría que defiende que, en origen, fuese realizada para un niño ${ }^{841}$.

El motivo incide en el mensaje general del programa iconográfico, basándose, fundamentalmente, en la tradición que consideraba al vaso como el símbolo del cuerpo $^{842}$.

En este sentido, creemos posible que la imagen de la crátera y las aves aluda al propio alma, encerrada dentro del cuerpo que, tras la muerte, emprende su huida hacia el más allá mediante las alas que, ocasionalmente, mencionan las teorías neoplatónicas $^{843}$.

Sin embargo, parece que la elección y la expoliación de la pieza estuvieron vinculadas a la posible creencia de que se trataba de una obra perfecta desde el punto de vista iconográfico, debido no sólo a las imágenes que presentaba, sino también al prestigio artístico que proyectaba la escultura clásica.

De esta manera, son muchos los autores que insisten en afirmar su gran calidad y sus vinculaciones con el ambiente escultórico de Ravenna ${ }^{844}$. Tales datos, pueden llevarnos a pensar que dicha obra fuese valorada de igual manera, tanto por su mensaje figurativo como por su fina labra.

Recordemos, por ejemplo, la expoliación llevada a cabo por Drausín, obispo de Soissons, en torno al año 680. Para su enterramiento utilizó una pieza aquitana paleocristiana que, igualmente, poseía en el frente una imagen del crismón rodeada de

\footnotetext{
${ }^{841}$ J. A. MORÁIS MORÁN, "De lo pagano a lo cristiano en el arte románico hispano: a propósito de la iconografía de las aves afrontadas a la crátera de la vida", La Multiculturalidad en las artes y en la arquitectura, 2 vols., Las Palmas de Gran Canaria, 2006, vol. I, pp. 383-391.

${ }^{842}$ J. A. MARTIGNY, voz "Vasos sagrados", Diccionario de Antigüedades cristianas, Madrid, 1894, pp. 826-830.

${ }^{843}$ Sobre la importancia de los textos de Platón para la configuración del tipo iconográfico del ave como representante del alma del difunto, vid.: J. A. MORÁIS MORÁN, "De lo pagano...", pp. 383-384.

Parece plausible, además, poder reafirmar la hipótesis de que se trate del enterramiento de un niño, ya que según nos dice Martigny, el cantharus alado debe considerase "como un presagio de elección y de santificación", lo que explicaría entonces que el motivo aparezca "adornando la tumba de un niño, lo que sucede con bastante frecuencia". Cf.: J. A. MARTIGNY, Op. cit., en particular, p. 825.

${ }^{844}$ P. DE PALOL, Arte paleocristiano..., p. 324 y M. EDMOND LE BLANT, Les sarcophages..., en concreto, pp. 15-16.

Le Blant ya señalaba la frecuencia con la que aparecerán dentro de este tipo de esculturas la imagen del crismón, rodeada de vegetales. Alude, especialmente, al ejemplo conservado en Notre-Dame-desSoissons. Una pieza del siglo IV que custodió los restos mortales de San Drausín. Posee esculpido el monograma de Cristo, que aparece entre una gran viña de pámpanos. Sobre esta escultura volveremos más adelante.
} 
elementos vegetales, demostrando la predilección por el tema dentro de las más altas esferas sociales del medievo ${ }^{845}$.

Sin embargo, las razones de la expoliación del sarcófago de Ithacio pueden plantear nuevas vías de estudio. La reutilización de la pieza clásica de característico ambiente vegetal, anuncia cierta predilección dentro del ámbito cortesano ovetense por este tipo de decoración "antiquizante", presente también, en otra serie de piezas expoliadas $^{846}$.

Tal interés se observa, de manera patente, en una gran joya de la escultura asturiana como la que suponen las dos pilastras de mármol empotradas en la parte interna de los laterales del ábside central de San Julián de los Prados ${ }^{847}$ (fig. 147).

El interés por recuperar una pieza antigua donde la vegetación se muestra con tal fuerza y exhuberancia, anticipa, claramente, el otro tipo de expoliación al que nos referiremos, la denominada como expoliación in re.

En relación con ello, las pilastras del santuario del rey Casto, en Oviedo, muestran una absoluta contemplación de los motivos geométricos y vegetales, de determinadas obras clásicas, sobre todo mosaicos, estucos y pinturas murales ${ }^{848}$. Estos apoyos rematan, a su vez, en un friso de doble piso de acanto que nos habla de un interés por estas producciones artísticas de temática vegetal ${ }^{849}$.

Se trata de un interés por lo vegetal ya manifestado dentro de las producciones prerrománicas hispanas de época anterior, tal y como demuestran, los fragmentos de estuco conservados en la iglesia de San María de Melque, muy a pesar de encontrarse

${ }^{845}$ J.-P. CAILLET y H. NILS LOOSE, Op. cit., en especial, p. 13, p. 103 y p. 108. Los autores datan la pieza aquitana en la segunda mitad del siglo VI. Se conserva actualmente en Paris, Musée du Louvre. Otra pieza que señalan dentro de la acción expoliadora, es el llamado sepulcro del arzobispo Teodoro, conservada en la iglesia de San Apolinar de Rávena. Se trata de un sarcófago en mármol con la cubierta de perfil semicircular y en cuyo frente se esculpió un crismón central flanqueado por dos aves, en este caso, pavos reales. Nuevamente se repite aquí el ambiente vegetal en el que habitan otras aves. Se ha venido datando en torno al siglo $\mathrm{V}$.

${ }^{846}$ En este momento, tal y como señalamos, empezamos a abrir diferentes vías de estudio con respecto al fenómeno de la expoliación. Pasamos de la constatación simple y evidente de los reempleos materiales y físicos, a una reelaboración conceptual de los motivos clásicos o, tal y como veremos en su apartado correspondiente, el fenómeno definido como spolium in re.

${ }^{847}$ Se trata de dos pilastras o jambas con capitel corintio, sin duda, expoliadas. Tal hecho, se constata a través de los recortes que presentan. Parece que se trataría de unas piezas datadas en la Antigüedad tardía, pues el tema que presentan fue bien conocido dentro de la plástica hispanorromana. Cf.: L. ÁRIAS PÁRAMO, Prerrománico asturiano..., pp. 52-54 y J. GARCÍA NISTAL, Op. cit., (en prensa).

${ }^{848}$ L. ÁRIAS PÁRAMO, Prerrománico asturiano..., p. 53. El autor resalta la importancia de las esculturas por presentar un motivo semejante al que posee otro fragmento marmóreo hallado bajo el suelo de la catedral de Oviedo. Tal composición se repitió en la pintura de las bóvedas de los ábsides.

849 Véase sobre la comentada pilastra de San Julián de los Prados: S. NOACK-HALEY, "Oviedo (Asturien), San Julián de los Prados (Santullano), Pilaster der Hauptapsis. -8 Jh.?”, Christliche..., p. 124; ID., “Tradición e innovación...”, pp. 174-184 y F. MARÍN VALDÉS y J. GIL LÓPEZ, San Julián de los Prados..., en especial, p. 48. 
hoy casi totalmente perdidos ${ }^{850}$ (fig. 148).

Allí, aún permanece in situ un pequeño segmento en estuco de lo que un día fue una frondosa orla vegetal que recorría el intradós de uno de los arcos del edificio. Una composición formada por roleos que, a modo de zarcillos, se enroscan sobre su propio eje central.

Es por ello que, A. Arbeiter y S. Noack-Haley, han señalado reiteradamente paralelismos con respecto a las producciones de Ravenna, sobre todo, emparentándola con un estuco de la iglesia de San Vitale ${ }^{851}$.

Además, el trabajo en estuco hispano, parece participar claramente de una larga tradición romana en la que este tipo de recursos fueron muy utilizados. Citamos, por ejemplo, el caso del estuco de la iglesia de Saint-Victor de Marsella, donde se utilizó el tema vegetal para decorar el intradós de un arco, mediante una composición de zarcillos con uvas que, desde un punto de vista formal, recuerda la solución ofrecida en Melque $^{852}$ (fig. 149).

La expoliación in se del sarcófago de Ithacio en las postrimerías del siglo VIII o durante el siglo IX en la nueva Oveto, regia sedes, habla de un interés y observación de las mejores esculturas vegetales de la tardoantiguedad romana.

De la misma manera que en el ámbito romano las representaciones vegetales habían inundado las mejores obras de patrocinio imperial, recuérdese la frondosa vegetación del Ara Pacis del Campo Marcio; también la Edad Media supo aprovechar tales experiencias artísticas. Así, si por ejemplo, el visionado y admiración de los relieves del Ara sirvieron a los talleres de mosaistas de San Clemente de Roma, tal y como defiende S. Romano, para poder recrear la "viña" del Señor habitada por sus criaturas en el cascarón del ábside, también en el caso del pequeño reino asturiano podemos señalar un mismo interés por explotar, desde un punto de vista estético, estas imágenes vegetales ${ }^{853}$.

\footnotetext{
${ }^{850}$ Para una contextualización de esta técnica en la Europa medieval, vid.: CH. SAPIN, "Stucs et décors de l'Antiquité tardive", Le Stuc. Visage oublié de l'art médiéval, Poitiers, 2005, pp. 101-105.

${ }^{851} \mathrm{La}$ decoración vegetal realizada en estuco a la que nos estamos refiriendo presenta hoy un estado fragmentado. En el intradós del arco, en los salmeres y acentuando su forma de herradura, fue realizada una cenefa de pequeños roleos en serie, enmarcados por una fina moldura. Datan la decoración entre los siglos VIII y IX, proponiendo, además, una conexión con un mosaico de la mezquita de Damasco. Cf.: S. NOACK-HALEY, "Santa María de Melque (Prov. Toledo), Reliefs. -8. -9. Jh.?”, Christliche ..., pp. $92-$ 94.

${ }^{852}$ CH. SAPIN, "Marseille (Bouches-du-Rhône). Abbaye Saint-Victor", Le Stuc..., p. 125. El autor data la decoración en torno al siglo V.

${ }^{853}$ Ya hemos tratado anteriormente la problemática de los mosaicos de la iglesia de San Clemente de Roma, a propósito del problema del "renacimiento paleocristiano". Sobre la comparación y posible deuda
} 
Con la posible reutilización del sarcófago de Ithacio en el Panteón ovetense, se reafirma y se explica el clasicismo, no sólo de las pilastras del ábside de Santullano, sin parecido aparente desde el punto de vista formal con la pieza funeraria; sino que, además, se pone de manifiesto una continuidad con respecto a la plástica visigoda en el interés de introducir estas notaciones antiguas dentro del interior de los templos, como ocurría con el estuco del intradós de Santa María de Melque.

A partir de esta escultura, pensamos que se pueden llevar a cabo otra serie de reflexiones sobre el tema.

El caso de las piezas marmóreas expoliadas y transportadas, según las fuentes, desde Portugal a la catedral de Alfonso III en Santiago de Compostela, debe ser visto como un claro antecedente de tales acciones.

La admiración por dicha escultura vegetal y el marcado interés por reinterpretarla, vuelve a mostrarse en la parte occidental de la iglesia de San Miguel de Lillo $^{854}$.

Allí, en época de Ramiro I, tal y como explicaremos más adelante, fueron colocadas de manera vertical una serie de placas labradas, flanqueando el acceso a la tribuna $^{855}$ (fig. 150). Tal y como veremos, las experiencias plásticas desarrolladas aquí, en relación con el uso de lajas vegetales en los flancos e inmediaciones de las puertas, habría de tener cierta fortuna en el arte románico hispano. El ejemplo, ya descrito, del foco de Armentia, es bien expresivo ${ }^{856}$.

de los talleres musivos que trabajaron en el ábside de la iglesia y los relieves de mármol de época de Augusto, véase: S. ROMANO, "La chiesa triunfante (1100-1143), Riforma e tradizione 1050-1198. La pintura medievale a Roma 312-1431 Corpus Atlante (M. Andaloro y S. Romano ed.), VI vols., Roma, 2006, vol. IV, pp. 163-182, en especial, pp. 167-168. La profesora S. Romano apunta, además de las clásicas teorías que hacen derivar dicha iconografía de la existente en el absidiolo del nartex de la iglesia de San Juan del Letrán y del mosaico inferior de la basílica de San Clemente, otra serie de hipótesis. En este sentido defiende la posible reutilización de teselas de dicho mosaico "abandonado" en la obra nueva de la parte superior del conjunto. Pero, sobre todo, llama la atención en relación con la posibilidad de un visionado de las placas del Ara Pacis en esta obra de la Roma de Pascual II, que habrían sido utilizadas como modelo inspirador.

${ }^{854}$ Aún a pesar de que, actualmente, sea allí donde se conserven estas obras, se debe tener sumo cuidado en realizar afirmaciones al respecto, sobre todo, porque, es posible, que el templo sufriera algún tipo de remodelación, ya en época medieval, en su área más occidental, donde se encuentran tales esculturas. Cf.: C. GARCÍA DE CASTRO VALDÉS, "San Miguel de Lillo: Campaña de excavaciones arqueológicas 1991: II análisis de materiales”, Boletín del Real Instituto de Estudios Asturianos, 51, 150, 1997, pp. 4774.

${ }^{855}$ S. NOACK-HALEY, "San Miguel de Liño bei Oviedo (Asturien), erhaltenes westliches Drittel der Basilika mit später angefügter Apsis. -848 geweiht", Christliche..., pp. 143-149, concretamente, p. 146.

${ }^{856}$ La teoría que hasta aquí hemos expuesto y que relacionan claramente algunos de estos motivos de las piezas asturianas con la tradición de sarcófagos vegetales de época romana y tardoantigua, fue ya defendida en su día por otros autores. Cf.: S. NOACK-HALEY, “Tradición e innovación...”, pp. 174184. La autora insistía en la relación entre las placas esculpidas de Lillo y el desarrollo vegetal del sarcófago de Ithacio. 
De ser cierta la afirmación de Carvallo, la permanencia física de la lauda marmórea de Ithacio en el Panteón asturiano, supondría el antecedente directo para otros ejemplos de similares características, donde los monumentos funerarios decorados con temática vegetal recreando una suerte de paradisus, fueron frecuentes.

De un estilo y factura mucho más tosco, pero con igual vocación "antiquizante" se puede considerar la lápida de época románica de Pedro I de Aragón (1094-1104), en el Panteón de Nobles de San Juan de la Peña, fechada en torno al año 1104. En ella se conjugan, de la misma forma que en el ejemplo ovetense, decoración vegetal de tono antiguo e iconografía zoomorfa ${ }^{857}$.

Con la posible presencia de la pieza tardoantigua de "PRAETIOSO MARMORE" en pleno siglo IX asturiano, la recuperación de lo antiguo queda puesta de manifiesto. Los grandes campos santos y lugares funerarios de la Galia paleocristiana y altomedieval, habían participado en idénticas experiencias mediante el uso de la vegetación clásica. Los ejemplos salidos de los talleres aquitanos, muchos de ellos conservados en Toulouse, Musée des Augustins o en la nave de la iglesia de Moissac, por ejemplo, parecen señalar cierta predilección por el uso del tema ${ }^{858}$.

Retomando la tradición romana imperial, donde el lugar funerario aludía al locus amoenus a través de todo tipo de vegetación, real y ficticia, la pieza asturiana es una clara metáfora de la habitual decoración helenística vegetal que impregnaba este tipo de producciones $^{859}$.

La reinterpretación cristiana de tales topos, debida, en parte, a Isidoro de Sevilla, convertía el edén paradisíaco en el lugar perfecto para el descanso eterno ${ }^{860}$;

\footnotetext{
${ }^{857}$ J. MARTÍNEZ DE AGUIRRE, "La memoria de la piedra: sepulturas en los espacios monásticos hispanos (siglos X y XII)", Monasterios románicos y producción artística, Aguilar de Campoo, 2003, pp. 133-159, particularmente, p. 143; A. I. LAPEÑA PAÚL, "Lauda sepulcral atribuida a la tumba de Pedro I de Aragón", Sancho III el Mayor y sus herederos. El linaje que europeizó los reinos hispanos, 2 vols., Pamplona, 2006, vol. I, ficha catalográfica 131, pp. 367-368 y S. SILVA Y VERÁSTEGUI, "Los sepulcros de los santos...", en especial, p. 151.

Vid. también: S. MORALEJO ÁLVAREZ, "La sculpture romane de la cathédrale de Jaca. État des questions", Les Cahiers de Saint-Michel de Cuxa, 10, 1979, pp. 79-100, consultado en la reedición: Patrimonio artístico..., pp. 21-46, vol. I, pp. 141-160, en particular, p. 150, nota 45. Moralejo atribuye al monarca Pedro I el uso de una joya o entalle helenístico en su capa, hecho que vuelve a poner de relieve la importancia de las obras antiguas en relación con el rey.

${ }^{858}$ Además de este tipo de escultura, la temática vegetal fue habitual en la decoración de los mosaicos y laudas sepulcrales durante los primeros siglos del cristianismo. Por citar algunos ejemplos conocidos, a parte de los propiamente hispanos que trataremos más adelante, son de destacar los pavimentos de las iglesias de Mopsuestia, en Turquía, de la época de Teodosio o el hallado en el martyrium de Seleucia, Antioquía, donde los artistas intentaron recrear, de manera verídica, árboles, arbustos y numerosas aves, sugiriendo simbólicamente el Paradisus. Cf.: J. BECKWITH, Arte paleocristiano..., pp. 71-73.

${ }^{859}$ J. ARCE, Funus Imperatorum..., p. 72.

${ }^{860}$ Es conocida la definición que hace Isidoro de Sevilla del Hortum deliciarum. Un lugar lleno de vegetación germinada gracias a un ambiente templado, sin frío ni calor, y en cuyo centro existía una
} 
rememorando los mejores tiempos de la Edad de Oro de la poesía virgiliana ${ }^{861}$.

Según P. Sauron, la reinterpretación de los temas vegetales de época antigua, especialmente romana, dentro de las diversas producciones artísticas medievales, debe ser vista como uno de los ejemplos más claros de la expoliación del material antiguo. En el caso del sarcófago de Ithacio, el primer motivo evidente para su recuperación, pasaba por un indudable ahorro de trabajo y de costes. Una pieza ya labrada implicaba no realizar otra.

Sin embargo, ello no desacredita otra serie de valores que tal acción puede llevar implícita. El spolium in se de la lauda, permitió a los artífices asturianos entrar en contacto directo con la pieza antigua. Observar la manera en que estaba trabajada, su factura y su iconografía. Creemos que, en conjunto, estas fueron las razones que explicarían su reutilización, sin tener que reducirlas simplemente a motivos de conservación.

Ahora bien, esta clase de expoliación se convertía en la base para el desarrollo del otro tipo de reutilización que veremos más adelante. Mediante la reinterpretación de los motivos clásicos de la lauda, así como del reempleo de otras piezas clásicas con similares características, se puede fundamentar la posibilidad de defender, a su vez, un spolium in re para las obras antes mencionadas.

Con todo, a parte del contenido simbólico que implicaba recuperar una pieza antigua, creemos posible reflexionar, a partir de tal ejemplo, sobre otra serie de fenómenos paralelos.

Hablar y atribuir al hombre medieval una serie de capacidades reflexivas sobre diversos aspectos estéticos de las obras clásicas, resulta complejo y difícilmente demostrable.

Cuando el artífice de la escultura que decora la obra realizó el epígrafe que anteriormente hemos transcrito, puso especial cuidado en señalar y adjetivar su trabajo. El joven Ithacio fue cobijado bajo un "PRAETIOSO MARMORE", un calificativo que

fuente de la que nacían los cuatro ríos del paraíso, que regaban, además, todo el vergel: “El paraíso es un lugar situado en tierras orientales, cuya denominación, traducida del griego al latín quiere decir “delicias". La combinación de ambos nombres nos da "El Jardín de las Delicias". Allí, en efecto abunda todo tipo de arboledas y de frutales, incluso el "árbol de la vida". No existe allí ni frío ni calor, sino una templanza constante. De su centro brota una fontana que riega todo el bosque, y se divide en cuatro ramales que dan lugar a cuatro ríos distintos". Cf.: ISIDORO DE SEVILLA, Op. cit., vol. II, p. 167. Vid. también: S. SEBASTIÁN LÓPEZ, "La visión del cosmos medieval", Revista del Departamento de Historia del Arte. Universidad de Córdoba, 6, 1986, pp. 73-81, en especial, pp. 73-74.

${ }^{861}$ T. VELMANS, "Quelques versions...", p. 40; F. A. MARÍN VALDÉS, "Observaciones sobre la adopción...”, pp. 22-23 y J. MARTÍNEZ DE AGUIRRE, “La memoria de la piedra...”, p. 143. 
tendrá larga trayectoria dentro de las fuentes medievales, a veces atestiguando una realidad material y, otras tantas, formando parte de una larga serie de topoi.

Las mejores piezas, las más bellamente labradas y aquellas que presentasen un carácter más suntuoso, serían, sin duda, las más fuertemente disputadas como enterramiento por parte de las élites poderosas durante los siglos del medievo ${ }^{862}$. El principio de autorictas mediante el cual, una pieza antigua otorgaba cierta dignidad a quién descansaba en ella, parece susceptible de ser aplicado también en el caso hispano $^{863}$.

La inscripción presente en la pieza de Oviedo, transcrita en las páginas anteriores, utiliza un calificativo que habría de convertirse en recurrente y arquetípico durante los siglos medievales. Tal y como veremos, la alusión de las fuentes documentales, cronísticas y epigráficas a diversas piezas, generalmente romanas, mediante expresiones como "praetioso marmore" o "preciosissimis et politis lapidibus", pasarían de convertirse en referentes de la realidad material de los últimos siglos del mundo antiguo a un tópico literario, mediante el cual, señalar el abolengo del que, quizás, carecían muchas piezas ${ }^{864}$.

Parece fuera de toda duda que el material por excelencia durante las épocas clásicas para realizar esculturas fue, además del bronce, el mármol. Sus excelentes resultados a la hora de ser trabajado y su acabado estético, lo convertirían en el material más deseado con el que configurar la última morada para el descanso eterno. No en vano, los grandes autores romanos ya contemplaban y describían las ventajas de su utilización dentro de sus escritos.

Vitruvio, por su parte, dice:

"No en todos los países existe la misma especie de mármol; en ciertos lugares se encuentran bloques salpicados de granitos transparentes, como si fueran de sal, que mojados y molidos son de gran uso para el enlucido. Por el contrario, donde no se le encuentra, se mojan y se muelen los pedazos o astillas que saltan al

\footnotetext{
${ }^{862}$ S. SETTIS, "Distanza, continuità...", en especial, p. 390. Settis calificará a este tipo de élite expoliadora de lo antiguo como "mercaderes", recogiendo el ejemplo, ya aludido, de H. de Blois, John de Salisbury o Ricardo de Ware, abad de Westminster y al que se le atribuye una compra de mármoles de Taso para trasladarlos a Inglaterra.

${ }^{863}$ S. MORALEJO ÁLVAREZ, "La reutilización...", pp. 15-29 y M. V. HERRÁEZ ORTEGA, C. COSMEN ALONSO, E. FERNÁNDEZ GONZÁLEZ y M. VALDÉS FERNÁNDEZ, "La formación de un monasterio románico", Esplendor y decadencia de un monasterio..., pp. 56-62.

${ }^{864} \mathrm{Se}$ aborda el tema de la venustas en época medieval, sobre todo en relación con el mármol, en: I. VELÁZQUEZ, Op. cit., pp. 247-248.
} 
trabajar el mármol, y después de cernidos se los emplea en las obras (...)"865 (texto 53).

En el caso de Plinio, la utilización del mármol se convierte en una manera de ensalzar la labor constructora de un emperador dentro de la ciudad de Roma y sirve para explicar el posterior uso iconográfico y textual de las alusiones al mármol, siempre presentes a la hora de engrandecer las obras de los grandes personajes.

"Pero Agripa, siendo edil, añadió a ésta el agua virgen, y haviendo dado corriente y enmendado las demás, hizo setecientos lagos, y fuera déstos ciento y cinco fuentes que corrían y ciento y treinta arcas y otras muchas obras magníficas; sobre estas obras puso trescientas estatuas de bronce, o de mármol y quatrocientas colunas de mármol, y todas estas en el espacio de un año" 866 (texto 54).

En esta ocasión, la materia marmórea sirve al autor para engrandecer, más si cabe, la crónica en la que exalta la labor constructiva del emperador Agripa, a través del ensalzamiento del material utilizado en la construcción.

Los literatos del primer cristianismo parecen prestar igual atención al uso del mármol dentro de las obras funerarias, especialmente, en los sarcófagos. La monja Egeria, siempre atenta a detalles de índole artística, recoge varias noticias interesantes para poder recrear la imagen de las ciudades durante los últimos años de la Antigüedad. A propósito de su visita a la ciudad de Edesa, la viajera nos relata la visión que tiene de la urbe y de sus templos. En relación con los sepulcros que ve y sobre el panorama artístico que le rodea, nos dice:

"Partiendo de nuevo de allí, llegamos en nombre de Cristo nuestro Dios a Edesa; donde una vez llegados nos dirigimos inmediatamente a la iglesia y al sepulcro de Santo Tomás. La iglesia que hay allí es grande, muy hermosa y de nueva

\footnotetext{
${ }^{865}$ M. L. VITRUVIO, Los Diez Libros de Arquitectura, (A. Blánquez ed.), Barcelona, 2000, pp. 185-186. Sobre la preocupación por los diferentes tipos de materiales con los que se podía esculpir un sarcófago, también Plinio da algunas noticias interesantes, sobre todo, en relación con la acción de determinadas piedras sobre los restos de los difuntos en descomposición: "Dizen que la piedra de la isla de Sciro, estando entera, anda por encima del agua y la misma, desmenuzada, se hunde. En Also, de Troya, la piedra sarcóphago se corta con vena, que se hiende a la larga. Los cuerpos de los difuntos, encerrados en ella, es cierto que se consumen dentro de quarenta días, si no es los dientes. (...) En Licia y en el Oriente hay piedras desta naturaleza que, ligadas a los vivos, roen también sus cuerpos". Cf.: PLINIO, Historia Natural..., p. 1118.

${ }^{866}$ PLINIO, Historia Natural..., p. 1117.
} 
planta (...). Vi, pues, en esa ciudad muchos sepulcros y santos monjes, viviendo unos junto a los sepulcros, otros lejos de la ciudad en monasterios que tienen en los

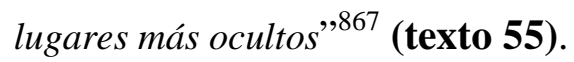

Su descripción no deja de recordar la que, siglos después, nos ofrecería el peregrino del Codex Calixtinus al hablar sobre el cementerio de Arles y de la vista que ofrecían las piezas funerarias desperdigadas por doquier.

Sin embargo, la noticia más interesante que nos ofrece Egeria viene dada ante la visita al sepulcro del rey Abgar, a propósito del cual, nos relata:

"Mostrónos además el santo obispo el sepulcro de Abgar y de toda su familia, muy hermoso pero hecho a la manera antigua"868.

Quizás, se pueda interpretar el calificativo utilizado por la monja en su descripción, como una manera de expresar la utilización de alguna técnica relacionada con el trabajo del mármol, posiblemente esculpido de manera detallada.

Si el carácter praetioso del sarcófago de Ithacio, parece lógico al contemplar la delicada talla de la obra, otra serie de noticias relativas al sepulcro y al lugar funerario en el que descansaba el apóstol Santiago, resultan mucho más problemáticas a la hora de llevar a cabo una lectura sobre ellas.

Nos estamos refiriendo a la serie de noticias que envuelven el relato del viaje marítimo, la traslación de los restos mortuorios y la posterior monumentalización del lugar donde descansarían los restos del apóstol. Se trata, al fin y al cabo, de noticias inciertas, pero que siempre tienen un denominador común, al especificar que el mármol era el material con el que estaban trabajando los escultores.

Si seguimos los acontecimientos narrados en la Historia Compostelana, se menciona específicamente el material que cubrió la primera tumba del apóstol:

"Pero sus discípulos, a los que él había ordenado en vida que llevaran su cuerpo a Hispania para enterrarle, recogieron el cuerpo con la cabeza durante la noche (...) llegaron hasta la orilla del mar con paso apresurado y, al buscar allí un

${ }^{867}$ EGERIA, Op. cit., p. 235. Vid. también: J. L. MONTERO FENOLLÓS, "De Gallaecia a Oriente: monumentos y lugares visitados por Egeria en su peregrinación por la Mesopotamia del siglo IV d.C.", Aulas no camiño: diálogos nun camiño da cultura europea (J. Leira López-Vizoso coord.), A Coruña, 2007, pp. 255-274.

${ }^{868}$ EGERIA, Op. cit., p. 241. 
barco para hacer el viaje a Hispania, encontraron en la playa una nave que les había sido preparada por Dios, en la cual se hicieron a la mar (...), arribaron a bordo del afortunado navío primero al puerto de Iria y luego llevaron el venerable cuerpo al lugar que entonces se llamaba "Liberum donum" y que ahora se llama Compostela, donde los sepultaron siguiendo el rito eclesiástico bajo unos arcos de mármol”,869

(texto 56).

Por su parte, el documento conocido como la Concordia de Antealtares, narra la serie de acontecimientos extraordinarios que llevarían al descubrimiento de la mítica tumba del apóstol. El texto vuelve a insistir en la calidad marmórea de la tumba:

“(...) habian visto muchas veces unas luminarias, que brillaban de noche en el bosque que, por el mucho tiempo transcurrido, había crecido sobre la tumba de Santiago, y que alli se les habían aparecido ángeles con frecuencia. Cuando escuchó esto (el obispo), él mismo se dirigió al lugar donde aquéllos aseguraban que habían visto tales cosas, y efectivamente contempló con sus propios ojos las luminarias que brillaban allí (...), se dirigió rápidamente al referido bosquecillo y mirando alrededor con cuidado encontró entre los arbustos y malezas una pequeña casa que tenía dentro una tumba de mármol. (....”870 (texto 57).

A partir de estos datos, sumados a otros tales como las supuestas losas de mármol que, teóricamente, habría visto el obispo Teodomiro, la historiografía ha intentado entender y aclarar algunos datos relativos a su construcción y el material del que estaba hecho tal monumento.

\footnotetext{
${ }^{869}$ Historia Compostelana..., p. 68.
}

Sobre el tema del sepulcro apostólico, véase: I. G. BANGO TORVISO, "El Locus Sanctus de Santiago...", en concreto, p. 193; J. GUERRA CAMPOS, "El descubrimiento del cuerpo de Santiago en Compostela. Según la "Historia de España" dirigida por Menéndez Pidal. Nota bibliográfica", Compostellanum, I/2, 1965, pp. 513-551 e ID., "La tumba Apostólica de Santiago de Compostela a la luz de las excavaciones recientes", Compostellanum, I/4, 1956, pp. 886-896.

${ }^{870}$ E. FLÓREZ, España Sagrada. Teatro geográfico-histórico de la iglesia de España, 48 vols., Madrid, 1953, vol. VIII, pp. 1754-1862. En este sentido, queremos hacer referencia a la Historia Compostelana, donde se da otra versión de los acontecimientos en los siguientes términos: "En tiempos del serenísimo rey don Alfonso el Casto fue revelado por los ángeles a un anacoreta llamado Pelayo que muy cerca de donde él vivía se hallaba enterrado el cuerpo del Apóstol Santiago. Luego, muchos fieles de la vecina iglesia de San Félix de Lobio vieron luces en el sitio indicado. Avisan de ello al obispo de Iria Teodomiro, el cual, después de tres días de ayuno, encontró el sepulcro del bienaventurado Santiago cubierto de losas de mármol" (texto 58). Cf.: Historia Compostelana..., p. 70.

La noticia se vuelve a repetir en la descripción hecha por el Codex Calixtinus en torno a la tumba: "Pero puesto que aquí hemos tratado de las características de la iglesia, trataremos ahora del venerable altar del Apóstol. En la referida y venerable catedral yace honoríficamente según se dice el venerado cuerpo de Santiago, guardado en un arca de mármol, en un excelente sepulcro abovedado, trabajado admirablemente y de conveniente amplitud, bajo el altar mayor, que se levanta en su honor" (texto 59). Cf.: Liber Sancti Jacobi..., p. 600. 
Las dudas surgieron al debatir sobre su forma, de si realmente había sido un edículo o una arquitectura construida mediante arcos y bóvedas, de si, efectivamente, este primer lugar de descanso del cuerpo del apóstol tras su viaje marítimo, había sido realizado en piedra, de si se trataba de un pequeño edículo o "casilla", de una simple lápida o de una construcción más compleja. Lo que parece claro es que, las fuentes repiten de manera reiterativa que se trataba de una obra en mármol ${ }^{871}$.

Más complejo resultaría poder llegar a demostrar una supuesta expoliación de materiales antiguos que, a la luz de los textos que hemos manejado sobre la construcción de la basílica prerrománica, pudiera ser bien factible ${ }^{872}$.

No vamos a insistir en el carácter reiterativo de los datos existentes en torno al sepulcro del apóstol y a la misma construcción de la basílica, donde se nos informa que el mármol fue un material muy solicitado.

La Crónica de Sampiro alude también al mármol, sin embargo, para referirse esta vez a determinados aspectos de la construcción de la nueva basílica:

"Entonces este rey construyó en Galicia de Compostela la iglesia que sobre el cuerpo del beato apóstol Jacobo había contribuido el rey don Alfonso el Magno, pequeña, de piedras y obras de barro, y la construyó muy hermosísima de cal y

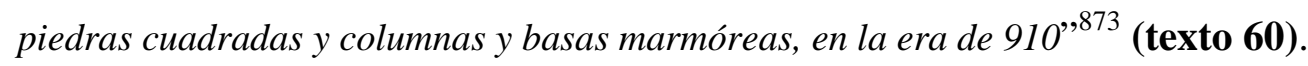

La utilización de estos datos no debe causar sorpresa pues, a medida que nos acercamos a la época románica, las fuentes acabaron por convertir las citas a las obras marmóreas, en un auténtico tópico, de tal manera que, para ensalzar la obra de los monarcas y los grandes patrocinadores, se utilizó este recurso que acabó siendo, prácticamente, de índole literaria. Así, se contraponía la obra en madera y barro a las nuevas empresas, siempre convertidas en obras admirables y construidas en mármol o piedra $^{874}$.

\footnotetext{
${ }^{871}$ I. G. BANGO TORVISO, "El Locus Sanctus de Santiago...”, p. 195 y C. TORRES RODRÍGUEZ, "Arca Marmórea", Compostellanum, II/2, 1957, pp. 323-339.

${ }^{872}$ I. G. BANGO TORVISO, "El Locus Sanctus de Santiago...", p. 197. El autor defiende la teoría de una expoliación in se de un viejo mausoleo romano, pues nada seguro existe para poder afirmar que tal enterramiento se hubiera realizado sobre una estructura preexistente cristiana.

${ }^{873}$ J. PÉREZ DE URBEL, Sampiro, su Crónica y la Monarquía leonesa en el siglo X, Madrid, 1952, p. 278.

${ }^{874}$ El tópico se repite en muchos textos del momento. Recuérdese, a modo de ejemplo, el paso de la construcción en barro de la basílica de San Juan y San Pelayo de León, patrocinada por Alfonso V (9991027) a la obra pétrea posterior. Con la llegada del monarca al trono y, tras la invasión de Almanzor, se inicia la reconstrucción de los edificios y dependencias palatinas y eclesiásticas, comenzando por su
} 
En relación con ello, recuérdese, siguiendo esta misma idea, como el autor de la Crónica Rotense, señalará con énfasis las construcciones realizadas por el monarca asturiano Ramiro I, destacando de ellas algunos datos de gran valor. Así nos dice:

"El príncipe Ramiro ya tantas veces nombrado se vio muchas veces acosado por las guerras civiles (...). Después de que descansó de las guerras civiles, edificó muchos edificios de piedra y mármol, sin vigas, con obra de abovedado, en la falda del Monte Naranco, a sólo dos millas de Oviedo (...). Tras el séptimo año de reinado, murió de muerte natural y descansa en su tumba en Oviedo" ${ }^{875}$ (texto 61).

El párrafo permite reiterar esta idea, según la cual, el mármol, la materia con la que los emperadores habían construido sus ciudades, se convertía en el elemento obligado en toda construcción y sobre todo, necesario en cualquier tipo de crónica o fuente que se detuviese en ensalzar tales obras y el patrocinio las mismas por parte de su mentor $^{876}$.

Aludiendo a un ejemplo más alejado en el tiempo, el abad Suger, como no podía ser de otra manera, nos aporta un buen número de noticias al respecto, pues la inscripción que mandó grabar en el cuello de su famoso águila, no deja lugar a dudas sobre la valoración del material:

"Ésta piedra es merecedora de ser encerrada en oro y gemas; era mármol, pero ésta montura la hace más preciosa que el mármol" $\$ 777$ (fig. 151).

traslado a la zona noroeste de la ciudad. Es en este momento, cuando se produce la desaparición del originario monasterio de San Salvador, ahora sustituido por la iglesia de San Juan Bautista, anexa al antiguo monasterio de S. Pelayo. Posteriormente, el rey Fernando I y su esposa Sancha, llevarían a cabo una construcción de piedra, sustituyendo la obra pobre y de ladrillo que especifican las fuentes, por otra hecha en cantería. De esta serie de obras hoy tenemos pocos datos, pues tras la reforma de la iglesia de San Juan Bautista y su nueva advocación a Isidoro de Sevilla, la obra que describen las crónicas acabó por desaparecer. Cf.: E. MARTÍN LÓPEZ, "Las inscripciones del Panteón de San Isidoro de León. Particularidades epigráficas", Escritos dedicados a José María Fernández Catón, León, 2004, pp. 941972, sobre todo, p. 948 y C. ABAD CASTRO, "Espacios y capillas funerarias...”, p. 64.

${ }^{875}$ Crónicas asturianas..., A. III Rotense, 24, p. 216.

${ }^{876}$ F. MARÍN VALDÉS y J. GIL LÓPEZ, San Julián de los Prados..., en especial, p. 14 y V. NIETO ALCAIDE, "La imagen de la arquitectura asturiana...", pp. 11-34. Los autores consideran que dentro del ciclo cronístico de Alfonso III, se registra un cierto tono admirativo hacia las obras del rey Casto, sobre todo en lo relativo a exaltar determinados valores estéticos, frente a los logros de carácter constructivo que se destacan más en la parte de la obra dedicada a explicar las obras de la época de Ramiro I. En los pasajes dedicados a los monumentos de Alfonso I, afirman, se destacan más el uso de mármoles y materiales de carácter suntuario, claramente vinculados a exaltar el carácter áulico de las empresas realizadas bajo su auspicio.

${ }^{877}$ INCLUDI GEMMIS LAPIS ISTE MERETUR ET AURO MARMOR ERAT, SED IN HIS MARMORE CARIOR EST. Cf.: D. GABORIT-CHOPIN, “Aigle de Suger”, La France romane au temps des premiers 
Según F. Crivello se trataría de un vaso de pórfido labrado en Egipto o, quizás, con más acierto, en la Roma Imperial y que el abad decide elevar de categoría material al colocarle una sobremontura de oro ${ }^{878}$. El mismo Suger nos relata, paso a paso, este famoso spolium in se, datado entre los años 1122-1147:

\begin{abstract}
"Igualmente depositamos en este lugar unas vinajeras de cristal que habíamos destinado en nuestra capilla privada al servicio diario del altar. E igualmente adaptamos al servicio del altar un vaso de pórfido, obra admirablemente labrada por la mano del escultor y el pulidor, el cual había permanecido durante muchos años en un baúl de papeles, transformando su forma inicial de un ánfora en la de un águila mediante la adición de oro y plata; en él hicimos inscribir estos versos: Esta piedra merece ser incluida entre las piedras preciosas y el oro. Era de mármol, pero en este marco es más valiosa que el mármol ${ }^{\text {,879 }}$ (texto 62).
\end{abstract}

El texto del abad parisino es realmente significativo, pues es uno de los pocos ejemplos conocidos en los que, el autor medieval, consciente del valor de una pieza artística, que no por casualidad es de mármol, puede ser reutilizada para adoptar otro tipo de funciones, engrandeciéndola y enriqueciéndola a partir de la añadidura de nuevos elementos. Además, sus palabras finales resumen, brillantemente, el aprecio que durante el medievo se tuvo a dicha materia.

Los ejemplos documentales y epigráficos en los que se deja claro que el material utilizado para ciertas producciones era el mármol, y no otro, son, en cierta medida, numerosos:

"Bajo este mármol sepultado está Esteban, abad egregio, eximio en las costumbres, varón verdadero del Señor, severo de materia de disciplina, discreto,

capétiens (987-1152), Paris, 2005, p. 347 y F. CRIVELLO, "Le opere: colori, materiali, artefici", Arti e storia nell Medioevo, vol. II, Torino, 2003, ficha catalográfica 16, p. 427. Para el primer autor, se trataría de una pieza de procedencia clásica, transformada por orfebres franceses que trabajaban para el abad. Aunque sólo se conserva una pieza de estas características, según diversas noticias, habría de estar acompañada por otro vaso de ágata, también clásico, pero hoy desaparecido.

${ }^{878}$ F. CRIVELLO, "Le opere: colori...", p. 427, ficha catalográfica 16 y L. FAEDO, Op. cit., pp. 61-65.

El profesor Faedo estudia la importancia del material, a la hora de utilizarlo como verdadero elemento de poder y prestigio. A través de piezas tan conocidas como el grupo escultórico de los Tetrarcas de San Marcos de Venecia, la escultura del Jardín de Boboli en Florencia y el sarcófago de Constantina de Santa Constanza, analiza y estudia el interés por la utilización del pórfido como material escultórico de gran prestigio.

${ }^{879}$ E. PANOFSKY (ed.), El abad Suger..., p. 95. 
sabio, sobrio y sufrido, de gran honestidad y también varón de grande piedad mientras le fue dado vivir. La nación francesa nos dio una guía para los jóvenes y un admirable modelo para los ancianos. Se rindió a la frágil senectud en la fiesta de San Gervasio, que el excelso poder de Dios le sea propicio. Toma cien años, añade siete veces diez, júntales mil y sabrás la era que fue. El diecinueve de junio murió el abad Esteban. Pelayo Fernández mandó hacer la inscripción y Pedro la grabo ${ }^{880}$ (texto 63).

La trascripción que acabamos de hacer corresponde a un epígrafe colocado en la iglesia berciana de Santiago de Peñalba. Gracias a su bello juego de palabras, sabemos que fue esculpida en el año $1137^{881}$. No importaba demasiado si la piedra utilizada para crear esta inscripción fuera verdaderamente de mármol o no, lo realmente substancial era señalar, dentro de los tópicos habituales en los que se glosaban sus excelencias como abad, que su cuerpo había sido "sepultado" bajo una losa de mármol.

De esta forma, parece factible que, las numerosas alusiones al mármol recogidas por los escritores medievales, podrían ser leídas teniendo en cuenta varios factores.

Primeramente, resulta lógico pensar que el aprecio que sentían hacia este material, residía en el prestigio que había tenido dentro de las obras antiguas, pues muchas de esas piezas tan valoradas, provenían directamente de los monumentos expoliados. Además, aunque se puede alegar que todas estas afirmaciones tan sólo reiteran el uso de diversos tópicos literarios, según los cuales las tumbas de los santos debían ser descritas como las más ricas desde un punto de vista material; es ese mismo carácter tópico el que nos autoriza para creer que el mármol era valorado más allá de su mera consideración material y visual.

El mármol era sinónimo de prestigioso, era la materia más excelente de las obras del mundo antiguo. Los hombres medievales eran conscientes de que el "praetioso marmore" otorgaría mayor honorabilidad a sus sepulturas, aunque en la mayor parte, evidentemente, habían sido creadas ex novo y su origen no correspondía

\footnotetext{
${ }^{880}$ M. GUARDIA PONS, "Scariphare et pingere en la Edad Media", Patrimonio, 33, 2008, pp. 51-58. La obra fue encargada por el undécimo abad de la comunidad de Peñalba, sucesor del fallecido Esteban. En el contraábside del edificio, datado en el siglo X, se lee STFANUS, por lo que es posible que aluda al lugar donde fue enterrado Esteban, aunque su lápida se encuentre hoy en el acceso al templo desde la puerta norte.

${ }^{881}$ Ibidem, pp. 53-54. Según la profesora M. Guardia, se trataría de ricos versos leoninos en los que las dos últimas sílabas del primer hemistiquio riman con las dos últimas del segundo. Véase también, sobre esta inscripción: A. ÁLVAREZ, "El epitafio del abad Esteban de Santiago de Peñalba", AnMal Electrónica, 24, 2008, pp. 1-14.
} 
verdaderamente con tales labores de expoliación.

Cuando durante la Alta Edad Media, se produce el traslado de los restos de San Froilán a la catedral de León, las fuentes documentales se reafirman, otra vez, en el uso tal calificativo, para señalarnos que el santo fue depositado en un sarcófago pétreo de factura preciosa ${ }^{882}$.

Según ha sugerido R. Sánchez Ameijeiras, a propósito de tal noticia, es posible, a juzgar por la manera en que las fuentes se refieren a dicha pieza, que se tratase de una obra expoliada y, además, posiblemente de mármol. La autora incluso se ha aventurado a identificar un fragmento de sarcófago marmóreo conservado en el Museo Catedralicio de León, de cronología posiblemente paleocristiana y decorado mediante un friso de estrígiles, como el último resto conservado de tal sepultura ${ }^{883}$.

De ser cierta la hipótesis de la investigadora, nos encontraríamos ante un nuevo ejemplo de sarcófago expoliado y además, ante un nuevo caso dentro de las fuentes textuales medievales, en las que para referirse a una pieza antigua reutilizada, se utiliza el calificativo de praetiosa ${ }^{884}$.

Sin embargo, al problema literario, semántico y etimológico de la utilización de estos calificativos, debemos sumar otros, relacionados con la iconografía artística.

Se trataría entonces de atestiguar la continuidad de una tendencia ya documentada desde época paleocristiana, donde, a la hora de representar un sarcófago en miniatura, como es lógico, se recurría a los modelos más cercanos.

Así, los artífices medievales, en el momento de recrear una imagen de la tumba de un santo o materializar, desde el punto de vista iconográfico, un sepulcro al que querían dotar con cierta imagen vetusta, se recurrió, reiterativamente, a la modelos que ofrecían los monumentos funerarios del mundo antiguo.

Así lo vemos, por ejemplo, en un sarcófago conservado en Le Mas-SaintAntonin, cerca de Pamiers, donde en la parte central de la pieza se representó una

${ }^{882}$ G. BOTO VARELA, "Sobre reyes y tumbas en la catedral de León: discursos visuales de poder político y honra sacra”, La Catedral de León en la Edad Media, León, 2004, pp. 305-365.

${ }^{883}$ R. SÁNCHEZ AMEIJEIRAS, "Una empresa olvidada...", p. 402, nota 36. La autora escribe: "En la sala de piedra de la catedral de León se conservan restos de un sarcófago estrigilado. Como mera hipótesis cabría preguntarse si no podría haber correspondido a un sarcófago romano reutilizado para albergar los restos de Froilán. La singularidad del epíteto "praetioso" recuerda a otras referencias a sarcófagos antiguos reutilizados en el siglo X, percibidos por los contemporáneos como piezas singulares y excepcionales".

${ }^{884}$ J. ADHÉMAR, Influences antiques..., pp. 51-55. El autor menciona también el caso de las lapidibus precioccisimis utilizadas para la construcción de la catedral de Lyon o, por ejemplo, como en la región de Vienne, el palacio de Canaux, antiguo asentamiento de unos baños romanos, que durante el siglo XI fueron usados por la corte de Boson, rey de Provenza, fueron rebautizados con el revelador nombre de Palacio del Espejo, a causa de las placas de mármol verde que recubrían los muros. 
escena de resurrección. El Señor, mediante la imposición de su mano sobre el cadáver de un difunto que aparece colocado sobre un sepulcro, obra el milagro. La morfología de tal pieza presenta muchas de las características habituales de los sarcófagos de época romana y paleocristiana. Así, fueron esculpidas unas estrígiles muy bien definidas, siguiendo el repertorio habitual de los talleres de sarcófagos del sudoeste francés ${ }^{885}$.

Nuevamente se corroboraba que los enterramientos de la Antigüedad fueron los objetos más codiciados para su reutilización. Su imagen pasaría, imperturbablemente, a través de las fuentes textuales, pero también mediante las iconográficas.

Según la profesora M. Melero, tal premisa se deduce si analizamos una obra tardía, datada en el primer cuarto del siglo XIII. Se trata de un capitel de la catedral de Lérida, en el que fue esculpida la escena de la traslatio por mar, de los restos del apóstol a Galicia (fig. 152). En la imagen apreciamos, claramente, una barca sin remos y sin vela que navega a través de las olas. En su interior el artista representó un sarcófago, cuyo frente fue completamente decorado con estrígiles ${ }^{886}$.

Con todo, aunque en las fuentes alusivas a la traslación por mar de los restos del apóstol, no se define bien el tipo de material con el que estaba labrada tal pieza, es posible que haya existido cierto interés por dotar de un rango y una relevancia a la imagen de tal obra. Los modelos a los que se recurría a la hora de representar la tumba de un personaje que había vivido en un tiempo remoto, eran, generalmente, modelos romanos.

No fue un caso excepcional, pues durante toda la época románica el motivo de las estrígiles se convirtió en una nota alusiva a la antigüedad de los sarcófagos que albergaban los restos de los santos ${ }^{887}$. El caso de Lérida, por su datación tardía, alude a la cotidianeidad con que estas piezas eran reutilizadas y a la persistencia de esta predisposición.

\footnotetext{
${ }^{885}$ M. EDMOND LE BLANT, Les sarcophages..., en especial, p. 137. Se trata, por lo tanto, de una prueba más que permite documentar una práctica muy difundida desde la propia época paleocristiana y la Antigüedad tardía y que pasaría, de una manera más o menos definida, hasta los siglos medievales. Una tradición artística que se heredó desde el periodo clásico y que de manera continúa se siguió practicando. ${ }^{886}$ M. MELERO MONEO, "Traslatio Santi Jacobi: Contribución al estudio de su iconografía”, Los Caminos y el Arte. Caminos y Viajes en el Arte. Iconografía, vol. III, Santiago de Compostela, 1989, pp. 71-93, en especial, pp. 75-76 y p. 77, nota 26. Dentro del mismo ciclo, podemos observar la escena en la que el sarcófago del Apóstol, ya en el interior de la basílica, aparece asentado sobre columnas, visible a través de unas cortinas descorridas que, además, sirven como elemento dignificador y configurador de un espacio teatralizante. Sobre él, fue esculpida una cruz que la autora ha relacionado con la ofrecida por Alfonso III a la tumba de Santiago, en el año 874.

${ }^{887}$ Veremos, más adelante, que el motivo se convirtió en un tipo recurrente dentro del taller activo en La Daurade de Toulouse, tal y como atestiguan los capiteles conservados en el Museo de los Agustinos de la misma ciudad.
} 
Remarcando el pretendido carácter "antiquizante" de la tumba, la expoliación de los sarcófagos antiguos llegó a límites de fuerte carga ideológica. En este sentido, S. Moralejo ya analizó en su día la expoliación de un sarcófago paleocristiano, nuevamente decorado en su parte frontal con estrígiles. La pieza, extrañamente, no sirvió para cobijar un cuerpo de un santo o de alguna personalidad importante del ámbito cristiano hispano, tal y como pudiera pensarse en un primer momento. Fue dispuesta para recibir el mismo cuerpo de Cristo, evidentemente, de una manera simbólica (fig. 153).

Se trata de una obra conservada en la catedral de Tarragona y que, presumiblemente, fue expoliada en torno al siglo $\mathrm{XV}$, para formar parte de un conjunto escultórico lígneo que representaba el Santo Entierro, justo en el momento en el que el cuerpo de Cristo era depositado en el sarcófago, tras la depositio de la cruz.

La pieza, una obra de mármol datada en torno al siglo IV o V, tal y como señala M. Claveria, formó parte, a partir de entonces, de este conjunto de esculturas en madera policromada de época tardogótica. Su perfecta expoliación e integración dentro de la escena, refleja de manera perfecta el aprecio que se llegó a tener por tales piezas durante los siglos medievales donde, incluso, fueron susceptibles de llegar a materializar la misma santa tumba ${ }^{888}$. La pieza tardoantigua, totalmente integrada dentro del grupo escultórico, no deja de proporcionar ciertas cotas de teatralidad al conjunto, donde para aludir a la tumba venerable y anciana de Cristo, se recurrió a una verdadera pieza antigua estrigilada.

Sin embargo, la tendencia de evocar la tumba sagrada de Cristo a través de un sarcófago antiguo, estuvo más arraigada de lo que en un primer momento se pudiera pensar.

El profesor S. Settis ya aludió en su día a un lienzo datado en torno al año 1485 y que él adjudicada al pintor Bartolomeo Bonascia ${ }^{889}$. La pintura muestra la escena en la que Cristo en Piedad, aparece flanqueado por San Juan y la Virgen María, mientras su cuerpo se coloca en el interior de un sarcófago (fig. 154). El autor insistía en el carácter antiquizante de dicho sepulcro, presumiblemente labrado en mármol y decorado en su

\footnotetext{
${ }^{888}$ M. CLAVERIA, "La reutilización....", p. 246. La investigadora alude a una primera función de la pieza, antes de pasar a formar parte del conjunto gótico. Según nos dice, pudo utilizarse como fuente, algo que se deduce gracias a los agujeros que se le practicaron. También señala la importancia del conjunto medieval, que debió utilizarse para la realización de los Oficios de la Pascua, "idónea (la pieza) para ejercer de divino sepulcro", escribía la autora. En el año 1494 se le añadió un blasón perteneciente a A. Barceló, lo que reafirma el alto grado de expoliaciones a las que fue sometida la obra.

${ }^{889}$ Modena, Galleria Estense.
} 
frente con dos parejas de grifos. A la pieza se le han buscado referentes dentro del arte romano, que pudieron finalmente inspirar al pintor renacentista ${ }^{890}$.

Pero los precedentes de esta tendencia que identificaba la tumba de Cristo con un sarcófago clásico se pueden rastrear ya en épocas anteriores. Si bien el caso de la pintura italiana es excepcional, en cuanto a su claro reflejo de fuentes antiguas, el sarcófago expoliado en el conjunto escultórico de la catedral de Tarragona, no deja de ser menos expresivos, pues aquí no se aludió a una pieza antigua para materializar la tumba, sino que la obra romana, "es" la propia tumba.

En este sentido, y en una cronología más temprana, volvemos a encontrar una representación del sepulcro de Cristo con clara forma romana.

Se trata de dos piezas de marfil conservadas en Salerno ${ }^{891}$. Ambas obras han sido datadas a finales del siglo XI por D. Gaborit-Chopin. En la primera, se representan las escenas relativas a la Crucifixión y el Santo Entierro, de tal forma que el sepulcro en el que está depositado el cuerpo de Cristo, presenta un frente estrigilidado y decorado en el centro con un gran clípeo (fig. 155). El sarcófago antiguo vuelve a repetirse en la pieza siguiente, donde las Marías visitan un sepulcro monumentalizado mediante una gran arquitectura, pero que guarda, en su interior, casi a modo de preciosa reliquia, el mismo sarcófago estrigilado ${ }^{892}$ (fig. 156).

Los ejemplos se repiten de manera mecánica. En una cronología aún más temprana, entre los años 817-824, se han venido datando las pinturas del transepto norte de la iglesia romana de Santa Prassede. Allí, inmerso dentro de las escenas hagiográficas que narran la vida de San Claudio, Santa Basilisa, San Mauro y San

\footnotetext{
${ }^{890}$ S. SETTIS, “Continuità, distanza...", en concreto, p. 480. En este mismo sentido, son interesantes las piezas estudiadas en: M. EDMOND LE BLANT, Les sarcophages..., en especial, pp. 55-58. A propósito de la utilización de la imagen del grifo dentro de la iconografía funeraria cristiana, señala una pieza de mármol vinculada al ámbito aquitano, hallada en una casa de Charenton. En ella, dos grifos aparecen afrontados a un gran vaso central, imaginería muy conocida en los sepulcros cristianos. Sin embargo, en este caso, parece que los escultores de la pieza aquitana tuvieron a mano otra pieza clásica que les sirvió para copiar el motivo. Se trata del sarcófago pagano de Arles, transportado al Museo de Marsella. En él, se enterró en el siglo IV un importante personaje que eligió esta pieza romana para darse sepultura. Se trataba de Flavius Memorius, un antiguo Protector del servicio imperial. Se ha fechado la pieza romana en el siglo III d. de C. El mismo autor afirma que la obra fue entonces expoliada a través de dos formas, una, mediante el spolium in se, es decir, la obra romana pagana sirvió de tumba nuevamente para un personaje cristiano. La otra forma de expoliación, haría que los talleres cristianos interpretaran, a su manera, dicha iconografía dentro de la pieza de Charenton, es decir, un spolium in se.

${ }^{891}$ Salerno, Museo Diocesano.

${ }^{892}$ D. GABORIT-CHOPIN, "Panneau central d'un triptyque: Crucifixion; Saintes Femmes au tombeau", Ivoires..., ficha catalográfica 60, pp. 210-212. Llama la atención que el Santo Sepulcro sea evocado aquí mediante un sarcófago antiguo, pero además, a través de otro recurso habitual dentro de este tipo de recreaciones: la gran torre-linterna con tejado escamado, que como veremos, no guarda menos relación con diversas fórmulas clásicas que el sarcófago estrigilado.
} 
Giasone, se representó, nuevamente, un sarcófago marmóreo decorado con estrígiles. Una fecha tan prematura, hace pensar en una continuidad dentro de esta forma de representación iconográfica, la misma continuidad que muestra el reempleo de estas $\operatorname{piezas}^{893}$.

Según los visto hasta aquí, se puede afirmar que, durante la Alta Edad Media, a la hora de representar un sepulcro venerable, se intentaba por medio de las artes plásticas, recrear su antigüedad, en este caso, a través de la imagen arquetípica de los sarcófagos estrigiliados. No en vano, esta fue la tipología de sarcófago más difundida y la que mayor número de piezas ofrece dentro del fenómeno de la expoliación. En el caso, por ejemplo, de la zona del Rosellón, de los Pirineos Orientales y en el ámbito catalán, la utilización de esta iconografía es plenamente justificable, habida cuenta del número de sarcófagos y mármoles, de todo tipo, reutilizados por los grandes talleres de marmolistas de estas regiones ${ }^{894}$.

Un ejemplo interesante al respecto, es el que presenta la serie de capiteles que han llegado a nosotros del famoso monasterio de La Daurade, en Toulouse, y que atestiguan esta contaminación entre la escultura románica y las piezas antiguas legadas por un panorama monumental especialmente rico en este tipo de obras antiguas ${ }^{895}$.

Dentro del conjunto de capiteles conservados hoy en el Musée des Augustins de la misma ciudad, podemos observar dos ejemplares especialmente relevantes para nuestro propósito. El primero de ellos, es aquel procedente del claustro que narra la escena de la Resurrección de Cristo, representada mediante la salida del sarcófago. El segundo capitel, posee esculpida la escena en la que San Juan descubre el sepulcro vacío. Finalmente, el tercer capitel representa la visita de las tres Marías al Santo Sepulcro.

En todos ellos ha sido representado un sepulcro elevado sobre pequeñas columnillas con un frontal totalmente esculpido con estrígiles clásicas. Creemos,

\footnotetext{
${ }^{893}$ Los frescos a los que nos referimos han sido datados por M. Andaloro, dentro del pontificado del papa Pascual I (817-824). La escena en cuestión narra el sepelio de Giasone y Mauro por parte de su madre Hilaria. Cf.: M. ANDALORO, "Santa Prassede", La pintura medievale a Roma 312-1431. Atlante percorsi visivi, VI vols., Roma, 2006, vol. I, pp. 295-306, en concreto, p. 297. Consúltese también una breve referencia en: J.-P CAILLET, L'art carolingien, Paris, 2005, pp. 101-102.

${ }^{894}$ M. CLAVERIA, "La reutilización de sarcófagos...”, pp. 241-250.

${ }^{895} \mathrm{Tal}$ y como es sabido, el famoso monasterio de La Dorada de Toulouse, fue destruido en el año 1761 para dejar paso a otra construcción. Su nombre vendría dado por el gran mosaico de teselas doradas que, hipotéticamente, decoraba el ábside del edificio. Cf.: J. CAILLE, Sainte-Marie La Daurade à Toulouse. Du sanctuaire paléochrétien au grand prieuré clunisien médiéval, Paris, 2006, en especial, pp. 55-89. En dicho edificio se encontraba el gran claustro de capiteles esculpidos que también fue demolido con el resto de las dependencias.
} 
además, que para revalorizar el material, el escultor decoró los bordes con un perlado que da sensación de mayor riqueza (fig. 157).

La alusión al mundo clásico parece clara en un taller donde este tipo de esculturas fueron sobradamente conocidas. No en vano, todos los estudiosos y especialistas del tema coinciden en señalar el carácter "antiquizante" de su estilo, inspirado en los monumentos funerarios romanos que invadían la propia ciudad de Toulouse y las regiones de Aude, los Pirineos Orientales, Arriège y el Alto Garona ${ }^{896}$.

El sepulcro en el que tenía que descansar el cuerpo muerto de Cristo, debía aparentar ser una pieza de ancianidad venerable.

Este afán de identificar claramente el Locus Sanctus con la pieza antigua, llevó a los pintores de la pequeña capilla de Liglet, en el Poitou, a señalar, mediante una inscripción, que la escultura estrigilada de mármol allí representada, no era otra cosa que el SEPVLCRVM DOMINI ${ }^{897}$.

Para concluir, debemos señalar que, a través del epígrafe presente en el sarcófago de Ithacio de Oviedo, se han realizado una serie de reflexiones que nos llevan a pensar en la posibilidad de que los sarcófagos antiguos, particularmente, aquellos decorados con estrígiles y realizados en mármol, proyectaron una imagen que otorgaba cierta importancia y prestigio, a aquellos que se enterrasen en ellos. El fenómeno se localiza, de manera clara, durante el periodo medieval.

\footnotetext{
${ }^{896}$ TH. W. LYMAN, "Reused marble...", en especial, p. 223 y pp. 225-229 e ID., "Arts somptuaires et art monumental. Bilan de influences appliques pré-romanes sur la sculpture romane dans le sud-ouest de la France et en Espagne", Les Cahiers de Saint-Michel de Cuxa, IX, 1978, pp. 115-124. La difusión de la escultura románica de la zona tolosana y del Rosellón, debe entenderse dentro de la organización de los talleres de marmolistas. En este sentido el autor señala que, algunas de las placas rectangulares utilizadas como material escultórico dentro de los talleres de Moissac o San Saturnino de Toulouse, proceden, en origen, de canteras pirenaicas, apuntando la posibilidad de que se trate de mármol expoliado. Ello acabaría reflejándose, por ejemplo, en las expoliaciones, bastante numerosas, de piezas antiguas dentro del mobiliario litúrgico que presentan algunos de estos templos. Baraja incluso la posibilidad de que las famosas placas empotradas en el ábside de San Saturnino, pudieran provenir de los trabajos de reempleo. Sobre este tema. Para una breve mención sobre el ciclo de la Pasión de la Dorada, véase: E. VERGNOLLE, L'art roman en France, Paris, 1994, pp. 261-262, quién data las obras de este claustro tras la finalización del de Moissac. Hace hincapié en la paralización de los trabajos en La Dorada entre los años 1130-1135.

${ }^{897}$ Las pinturas de la capilla de Liglet se han datado en torno a los años 1176-1188. Actualmente se la denomina la capilla de San Juan, aunque esta no fuese su advocación primigenia. El programa está formado por escenas de la vida de Cristo, entre las que destacan, la Natividad, la Crucifixión y las Santas Mujeres ante el sepulcro. Éste aparece señalado, además, a través de la inscripción en una filacteria que sujeta un profeta en la que se nos dice: LAPIDEM QUEM REPROBAVERUNT. Se trata de una alusión al comentario de San Bruno en la Expositio in Psalmos: "Quod est dicere: per reprobationem Christi, firmissimi lapidis, me salvasti, sine quo fundamento nemo potest seo Deo templum per virtutes et opera bona aedificare...".

Esta precisión al aclarar que se trata del sepulcro de Cristo, aparece también en las pinturas de la iglesia de Saint Savin-sur-Gartempe, donde, nuevamente, se reproduce el cartel explicativo de SPVLCRVM DOMINI. Cf.: R. FAVREAU, "Peinture et épigraphie", Peintures romanes, Poitiers, 1988, pp. 41-49, especialmente, p. 45.
} 
Por otra parte, siendo conscientes de que, en muchos casos, su puesta en valor se fundamentó en simples topos arraigados y reiterados dentro de las fuentes y la tradición literaria, creemos que, la alusión a la utilización del mármol, independientemente de que, en ocasiones, tal aspecto no fuera del todo real, hablan del aprecio que se sintió por dicho material. Además, mediante su presencia, ya fuera física o meramente iconográfica, se fundamentaban las bases necesarias para citar y aludir al prestigio, la antigüedad y la magnificencia que su uso otorgaban. 


\section{B. DIGNIFICAR LA MEMORIA DE LOS DIFUNTOS: LOS SEPULCROS EXPOLIADOS POR FERNÁN}

\section{GONZÁLEZ Y DOÑA SANCHA EN COVARRUBIAS.}

En el apartado anterior nos centramos en el prestigio que parecieron alcanzar, en época medieval, diversos elementos ornamentales nacidos y difundidos en el seno de la escultura de sarcófagos romanos de época tardía.

Parece claro que, si dentro de la tradición visual medieval, hasta la tumba de Cristo era susceptible de mostrar tal decoración, no será extraño que, este tipo de piezas, estuvieran muy solicitadas por parte de las altas personalidades de la sociedad de tal periodo.

Este es el caso de los dos receptáculos funerarios conservados, actualmente, en la Colegiata de los santos Cosme y Damián de Covarrubias, en Burgos.

Se trata de dos sarcófagos que, según se viene aceptando tradicionalmente, albergarían los restos del conde castellano Fernán González (†970) y su esposa, la noble doña Sancha (†959), y que, en origen, habrían sido custodiados en el mismo monasterio de San Pedro de Arlanza, hasta su posterior traslado, en el año 1841, a la mencionada Colegiata $^{898}$.

La pieza más interesante es la que perteneció a la noble. Se trata de un sarcófago esculpido sobre un bloque de mármol de cronología romana y que, potencialmente, fue expoliado de la misma Clunia (fig. 158). La parte del frente presenta una decoración esculpida de finas estrígiles que enmarcan otros temas iconográficos ${ }^{899}$.

La parte central del frontal de la pieza presenta, además de estos dos grupos de estrígiles, dos escenas pastoriles ubicadas en los extremos del conjunto. Así mismo, lo más destacado, es la presencia, entre dicha decoración, de un gran clípeo en el que se

\footnotetext{
${ }^{898}$ J. A. MORÁIS MORÁN, "La construcción del pasado...”, (en prensa). Remitimos a nuestro estudio, donde hemos tratado ampliamente el caso concreto de estas dos obras, así como la bibliografía especializada que las han abordado.

${ }^{899}$ P. BATLLE HUGUET, “Arte Paleocristiano”, Ars Hispaniae, Madrid, 1947, pp. 183-223, en concreto, p. 211 y A. BALIL ILLANA, "Arte de la época romana", Historia del Arte en Castilla y León. Prehistoria, Edad Antigua, Arte Prerrománico, 5 vols., Valladolid, 1994, vol. I, pp. 69-102.

Desde otro orden de cosas, está claro que son muchos los autores que señalan la reutilización de estos dos sarcófagos romanos por parte del conde de Castilla Fernán González y su mujer Doña Sancha, durante el siglo X. En este sentido, se ha señalado un aspecto interesante, pues se trata de un spolium in se realizado por parte de un noble y no de un monarca, como habitualmente ocurrirá. El ambiente castellano vivió, durante este periodo, un momento brillante en cuanto a la expoliación de sarcófagos antiguos. Aunque no fue, tal y como se ha demostrado, un fenómeno exclusivo de estos territorios. Cf.: S. MORALEJO ÁLVAREZ, "La reutilización...", pp. 278-288; S. SILVA Y VERÁSTEGUI, "Los sepulcros de los santos...", p. 151; M. A. CASTIÑ̃EIRAS, "La actividad artística en la antigua provincia de Mondoñedo: del Prerrománico al románico", Estudios Mindonienses, 15, 1999, pp. 287-342, en especial, pp. 292-293 y M. CLAVERIA NADAL, "La reutilización de sarcófagos...", pp. 241-250.
} 
han insertado dos figuras. Se trata del clásico retrato en pareja, habitual dentro de este tipo de obras ya desde etapa romana y que pasó a la escultura cristiana directamente ${ }^{900}$. En la parte baja de la composición, emulando sustentar la estructura circular, se representó a Caelum ${ }^{901}$.

El sarcófago, tal y como se viene aceptando, serviría de última morada a la noble esposa de Fernán González, sepultado junto a ella en el monasterio de San Pedro de Arlanza. Sin embargo, lo más llamativo de todo es que, incluso el propio conde, utilizaría como sepultura, al igual que su mujer, otro sarcófago de mármol ${ }^{902}$.

${ }^{900}$ La historiografía especializada, señalaba ya en el año 1877 algunos de estos aspectos, a propósito de la pareja ubicada en un clípeo central, de una pieza del siglo IV, conservada en la basílica de San Pablo Extramuros de Roma. Se trata del esquema en el que el marido porta un rollo en la mano y ella, a veces con gesto afectuoso, le abraza. La interpretación que se ha hecho del rollo, como contenedor del contrato matrimonial de ambos personajes, es quizás demasiado inestable. En la pieza italiana, el medallón aparece sujeto por dos genios, herederos de la tradición pagana y que pasarán al ejemplo burgalés en forma de la personificación de Caelum. Cf.: H. J. L. DE GRIMOUARD DE SAINT-LAURENT, Op. cit., en concreto, pp. 3-4 y J.-P. CAILLET y H. NILS LOOSE, Op. cit., en especial, p. 14. Los autores recogen otro ejemplar datado en torno al año 320, en el que dentro de un clípeo, fueron representados otra vez los esposos, ella con el mismo ademán y él sujetando nuevamente el rollo. Sin embargo, aquí han desaparecido las figuras de los erotes que en la otra pieza sujetaban el tondo.

901 Véase, como dicha distribución de las imágenes, totalmente apegada a la tradición pagana, fue sabiamente adoptada por los talleres paleocristianos. Así, un sarcófago conservado en la cripta de San Víctor de Marsella, y proveniente del cementerio denominado del Paraíso, presenta una distribución iconográfica que sigue los mismos parámetros. Un frontal decorado con estrígiles que, a su vez, está flanqueado por dos escenas laterales que enmarcan, así mismo, una central. Si en los bordes se talló la escena del milagro de la roca y a Moisés tomando las tablas de la Ley, en el centro aparece el retrato del comitente dentro de un clípeo. En la parte baja, allí donde en la pieza pagana se colocó la figura de Caelum, ahora aparece el joven Jonás, tumbado bajo el árbol con frutas. Sobre la pieza, vid.: M. EDMOND LE BLANT, Les sarcophages..., en concreto, p. 40. Para la pieza burgalesa, vid. : E. VALDEZ DEL ÁLAMO, "Lament for a lost...", p. 314. La autora considera que, tapa actual del sarcófago es de factura medieval, ya que los vegetales que la decoran son de una realización más tosca que el resto del conjunto.

902 S. SILVA Y VERÁSTEGUI, "Los sepulcros de los santos...", en concreto, p. 151; M. A. CASTIÑEIRAS GONZÁLEZ, "Sarcófago da Orestíada", Luces de Peregrinación, Santiago de Compostela, 2004, pp. 248-250.

Sobre este caso tan interesante de expoliación de dos sarcófagos, por parte de una pareja de nobles, debiéramos preguntarnos en que lugar exacto del monasterio de San Pedro de Arlanza fueron colocadas originariamente tales piezas. Su rango y su abolengo bien pudieran hacerlas merecedoras de un lugar privilegiado en tal recinto. No es este el lugar indicado para llevar a cabo un análisis de la problemática existencia de un posible panteón o sala funeraria ubicada al occidente de este templo. Señalamos al respecto la sugestiva hipótesis desarrollada en: M. V. HERRÁEZ ORTEGA y M. D. TEIJEIRA PABLOS, "El cuerpo occidental de la iglesia de San Pedro de Arlanza. Propuesta de reconstrucción histórica", De Arte, 2, 2003, pp. 7-27, especialmente pp. 13-14. Las autoras consideran factible la posibilidad de que el noble castellano fuese enterrado en una estructura de planta cuadrangular y, por lo tanto, similar a los grandes panteones astur-leones, ubicados en el occidente del edificio, como es el caso del de San Isidoro de León o el desaparecido de San Benito de Sahagún. Señalan la ubicación del sepulcro siguiendo las palabras escritas por el abad don Gonzalo de Arredondo. Dicho personaje, en su Crónica del Bienaventurado Catholico Caballero el conde Fernán Gonçalez, del año 1515, señala que el sepulcro de mármol del noble fue colocado en el fin de la iglesia, hasta su posterior traslado al interior del templo, en el año 1274.

Véase también: C. COSMEN ALONSO, E. FERNÁNDEZ GONZÁLEZ, M. V. HERRÁEZ ORTEGA y M. VALDÉS FERNÁNDEZ, "La renovación del monasterio en el reinado de Alfonso VI", Esplendor y decadencia de un monasterio medieval. El patrimonio artístico de San Benito de Sahagún, León, 2000, pp. 67-62 y C. COSMEN ALONSO, M. V. HERRÁEZ ORTEGA y M. VALDÉS FERNÁNDEZ, 
Con todo, aún se duda de la cronología de esta segunda escultura funeraria pues, a pesar de que durante mucho tiempo fue considerada romana, todo parece indicar que se trata, en realidad, de una renovación medieval ${ }^{903}$.

Como vemos, nos encontramos ante dos magnates pertenecientes a la nobleza castellana que, a finales del siglo $\mathrm{X}$, deciden elegir como lugar de enterramiento, al menos de manera segura, una pieza expoliada de alguna villa romana de la región ${ }^{904}$. El prestigio del mármol queda de nuevo patente dentro de esta acción. El sepulcro del conde, totalmente liso, de buena factura y presumiblemente inspirado en otro anterior, lo hicieron valedor de ostentar el privilegio de conservar los restos mortuorios del noble.

En cambio, el de su esposa presentaba las habituales escenas de pastoreo, típicas dentro de las obras clásicas helenísticas y romanas, sobre todo, en el contexto de la Alejandría de los Ptolomeos ${ }^{905}$. Los ambientes campestres, acompañados por rebaños de animales y el pastor que se hace cargo de ellos, se presentaban ante el espectador medieval como una suerte de imagen ligada al pasado. Es difícil plantearse si a la hora de elegir el sarcófago, primaron las razones de economía del trabajo y el valor material de la pieza ya trabajada e íntegramente labrada en mármol o aquellas ligadas a la rica iconografía que presentaba, de alto valor estético.

Esta tradición de conectar la imaginería pastoril con un monumento funerario, pasaría, a grandes rasgos, a la época medieval. Su carácter bucólico, ligado a la Edad de Oro virgiliana, así como una iconografía repleta de notas idílicas, rápidamente fueron reinterpretados dentro del contexto cristiano a través de la imagen del buen pastor que guiaba y protegía al rebaño, en una alusión directa al Paraíso o, incluso, dentro de la misma escena de la Anunciación a los pastores. En este sentido, parece claro que, la dedicación de una de las bóvedas pintadas en el recinto funerario del Panteón Real de San Isidoro de León, a narrar, con todo detalle, dicha escena, habla de un conocimiento de las fuentes clásicas durante los siglos del románico hispano en lo referente a este

\footnotetext{
"Alfonso VI y el monasterio de Sahagún. Nuevos testimonios sobre la construcción del templo monástico", De Arte, 5, 2006, pp. 29-41.

${ }^{903}$ J. A. MORÁIS MORÁN, "La construcción del pasado...", (en prensa).

${ }^{904}$ Ibidem, (en prensa). En el trabajo que citamos desarrollamos las teorías concretas sobre la posibilidad de que el sarcófago original del noble, aquel que custodió su cuerpo antes de que fuera sustituido por la pieza que hoy observamos, fuera también de cronología romana.

${ }^{905}$ A. BALIL ILLANA, "El arte de la época romana...", p. 90.
} 
tema, donde como en la literatura clásica, la vida pastoril se contemplaba como un anticipo en el disfrute del paraíso ${ }^{906}$.

Estas imágenes, de sustrato clásico muy marcado, estuvieron bastante difundidas en los siglos de la Antigüedad tardía. Baste señalar, por ejemplo, el llamado sarcófago de la pesca, conservado en el Musée de Brignoles. Allí, se esculpió en el frente de la pieza, la figura del filósofo, acompañado por una orante y el Buen Pastor. Sin embargo, en el lado izquierdo aparece otra escena, aparentemente pagana: una pastorada con una figura que, además de cuidar el rebaño, practica la pesca. La ambigüedad de tal escena hace complicado poder decantarse por una intencionalidad cristiana o pagana de la escena pastoril ${ }^{907}$. Se trata de la misma ambigüedad iconográfica, que duda entre un contenido pagano y cristiano, que la que encontramos desde el siglo III, por ejemplo, en un sarcófago conservado en San Sebastián de Roma, lindando con la vía Appia. La

\footnotetext{
${ }^{906}$ Las pinturas del Panteón de San Isidoro de León fueron datadas, durante algún tiempo, en torno a los años 1164-1188. Posteriormente, tras el estudio del profesor Williams, se ha venido aceptando una datación más temprana, en torno a los inicios del siglo XII. Cf.: O. DEMUS, "The First Romanesque Beatus Manuscripts and the Liturgy of Death", Estudio de los Códices del Comentario al Apocalipsis de Beato de Liébana, Madrid, 1979-1980, vol. I, pp. 320-328; J. WILLIAMS, "San Isidoro in León: Evidence for a New History", The Art Bulletin, 55, 2, 1973, pp. 171-184; R. WALKER, "The Wall Paintings in the Panteón de los Reyes at León: A Cycle of Intercession”, The Art Bulletin, 82, 2, 2000, pp. 200-225, en concreto, p. 116.

De todas las hipótesis barajadas, cabe destacar aquella expuesta por R. Walter. Según la autora, es digna de remarcar la importancia que se le ha otorgado al tema de la Anunciación a los Pastores, dentro del ciclo. Conecta la elección de dicha iconografía con la costumbre pagana de decorar sarcófagos y lugares funerarios con diversas escenas de pastoreo, ligadas a la idea de locus amoenus. Además, incluso se han reinterpretado en las pinturas el mito del pastor bucólico portando un instrumento musical, recuerdo del Orfeo pastor y músico. Las notas paisajísticas tampoco faltan en la pintura románica. Todo ello permite suponer un conocimiento de las fuentes clásicas dentro de este conjunto, en relación con las escenas de pastoreo. Por todo esto, pensamos que, idénticas razones, se pueden defender para explicar la elección de sarcófago romano que serviría de tumba a doña Sancha en San Pedro de Arlanza.

Sobre las fuentes clásicas de los murales leoneses, véase: M. A. CASTIÑEIRAS GONZÁLEZ, "El programa enciclopédico...", pp. 657-694 y J. WETTSTEIN, La fresque romane. La route de SaintJacques, de Tours a León. Etudes comparatives II, Genève, 1978, particularmente, p. 112,

Este último autor, a la hora de buscar paralelismos entre la escena de pastores de León y otras obras, acude al famoso plato argento conservado en el Ermitage y datado en el siglo IV, donde también se representó una bella escena bucólica de pastores. El dato vuelve a poner de manifiesto el interés que todos los especialistas han mostrado por hacer depender la bóveda del Panteón leonés con respecto a los modelos clásicos.

907 J.-P. CAILLET y H. NILS LOOSE, Op. cit., pp. 42-45. La pieza proviene de La Gayole, en la Costa Azul francesa y fue esculpida en mármol. Los autores datan la obra en el siglo III. Son importantes las reflexiones que llevan a cabo sobre la problemática de llegar a discernir, en algunos ejemplos, la finalidad iconográfica de las piezas, desde una vertiente pagana o cristiana. Aluden al conocido ejemplo del Buen Pastor, que siempre ha despertado muchas controversias. Reflexionan sobre la iconografía griega arcaica del hombre portando a hombros un animal para transportarlo al sacrificio, que, finalmente, se transformará en la figura de Hermes, que tomaría el sujeto para dotarlo de un sentido funerario. Sin embargo, las escenas pastoriles y campestres, como la que muestra el sarcófago de Covarrubias, siempre llevarían consigo un aire bucólico de tipo helenístico. Cf.: I. MATEO, "Temas paganos cristianizados", Actas VI Jornadas de Arte. La Visión del Mundo clásico en el arte español, Madrid, 1993, pp. 37-48, en concreto, p. 45; S. SEBASTIÁN, Mensaje simbólico..., en particular, pp. 140-141 y M. MIRABELLA ROBERTI, “La symbologie paléochrétienne...”, pp. 181-187, en especial, p. 184.
} 
escena del pastor aparece junto a la imagen de una mujer que porta un niño en sus brazos. Para A. Grabar la imagen no deja de ser pagana, pero la expoliación del motivo por los cristianos, pronto acabaría por convertir dicha iconografía en la imagen de la theotolos hodigitria, enmarcada en un ámbito paradisíaco que se suele concretar con la

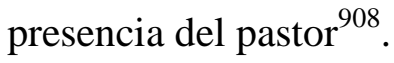

En definitiva, podemos afirmar que, las tumbas de los santos, reyes y hasta el propio enterramiento de Cristo, como hemos visto, mantendrían durante la etapa alto y pleno medieval, su forma clásica, decorada a veces con estrígiles o con cualquier motivo que recordase la tradición clásica, como escenas de pastoreo o, por ejemplo, las escamas, tal y como veremos de seguido.

Este último caso de los expoliados sarcófagos de Fernán González y su esposa, hablan, además, de un intento de preservación, conservación y cuidado de las piezas, que habrían de pasar desde su emplazamiento primitivo, en la hipotética cámara funeraria de la iglesia de Arlanza, hasta la actual Colegiata de Covarrubias ${ }^{909}$. La buena calidad de ambos ejemplares y, en especial, el de la esposa, además de su visible antigüedad, llamarían la atención de los viajeros y visitantes, y no sólo medievales ${ }^{910}$.

Lo que parece claro es que, determinadas piezas antiguas y paganas, gozaron de gran admiración y respeto durante el periodo que nos ocupa. Las reliquias se colocaron preferentemente en aquellos cofres, arquetas o sarcófagos que ostentaban un mayor grado de antigüedad, pensando que, ambas en conjunto, otorgarían a quién las custodiase una mayor autoridad ${ }^{911}$.

Creemos que, dentro de la construcción de una memoria o una identidad, -acción innata al ser humano y común a todos los periodos históricos-, estas piezas jugaron un papel destacable. Los dos sarcófagos reutilizados para dar cobijo a los restos de la pareja de nobles castellanos, permiten realizar una serie de reflexiones más allá del mero estudio formal de las piezas. Parece que desde los orígenes, hubo un interés inicial

\footnotetext{
${ }^{908}$ A. GRABAR, Las vías de la creación..., en concreto, p. 43.

${ }^{909}$ M. V. HERRÁEZ ORTEGA y M. D. TEIJEIRA, “El cuerpo occidental...”, pp. 11-14.

910 A. DE MORALES, Crónica General..., p. 351. El viajero de época moderna, tras enumerar los ejemplos de enterramientos reales de Oviedo, León y el monasterio de San Zoilo, en Carrión de los Condes, también afirma "Así hallamos también en lo muy antiguo de España los sepulcros de los grandes señores, como el Cid, el Conde Fernán González...".

${ }^{911}$ La calidad técnica era una razón decisiva para llevar a cabo tales acciones, incluso si se trataba de piezas no cristianas. Cf.: I. RUIZ DE LA PEÑA GONZÁLEZ, "Arquetas musulmanas para mártires cristianos: la traslación de Santa Eulalia de Mérida al relicario ovetense", Correspondencia e integración de las Artes, Málaga, 2006, pp. 151-168.
} 
en conservarlas y que explica su supervivencia más allá de los numerosos traslados que sufrieron a lo largo de los siglos ${ }^{912}$.

Incluso durante las posteriores épocas gótica y moderna, cuando los medios económicos y artísticos hubieran permitido renovar ambas sepulturas, se prefirió conservar la antigua pieza de doña Sancha, introduciendo ligeras consolidaciones que, lejos de modificar su apariencia, reafirmaron la pertenencia a la pareja de nobles ${ }^{913}$.

Es más, cotejando este tipo de acciones expoliadoras con otra serie de pruebas, por ejemplo las literarias, se puede llegar a intuir la complejidad del fenómeno. En este sentido, la redacción posterior del Poema dedicado al noble ${ }^{914}$, insisten en un interés general por mitificar su figura, de tal manera que la construcción de una memoria histórica en relación con la figura del conde castellano que observamos desde el punto de vista literario, se podría haber completado a través del spolium de las obras romanas $^{915}$.

La utilización de estas piezas como última morada para los restos sin vida de Fernán González y su esposa, pretendió darles el cobijo más digno posible y, sobre todo, otorgar un prestigio, una honorabilidad y una autoridad política al monasterio elegido para su eterno descanso. El ejemplo nos permite poner de relieve la importancia que durante el siglo $X$ tendrá la familia Fernán González, de la que sabemos por ejemplo, que Flamola, casada con Gundisalvo Telliz, tendría de esta unión una hija llamada Munia, la posterior esposa del conde Gonzalo Fernández, fundador de la ciudad de Lara y padre del futuro conde Fernán González ${ }^{916}$.

Fruto del patrocinio nobiliario que desarrolló la dinastía, hemos conservado obras tan importantes como la iglesia de Quintanilla de las Viñas, así como otras

\footnotetext{
912 J. A. MORÁIS MORÁN, "La construcción del pasado...”, (en prensa). Según hemos defendido, sería en uno de esos traslados donde, hipotéticamente, el sarcófago de Fernán González sufriría unos daños irreparables, hasta el punto de tener que ser sustituido por otra escultura de cronología medieval.

${ }^{913}$ Creemos que esta fue la causa de la incorporación en época gótica de cuatro pies zoomórficos sobre los que, actualmente, se elevan los sarcófagos. Ello habla de un interés continuo por conservar los sepulcros en buen estado. Igualmente cabe señalar la realización de los epígrafes decimonónicos que, de manera clara, defienden la atribución de los sarcófagos a Fernán González y su esposa. El estudio de estos apeos en forma de felinos así como las inscripciones, aún a pesar de ser posteriores, no ha recibido la atención necesaria por parte de los especialistas.

${ }_{914}$ Estos recursos literarios utilizados, no están exentos de cierta influencia del género épico antiguo. Cf.: Poema de Fernán González (J. Victorio, ed.), Madrid, 1981 y Poema de Fernán González e Hispano Diego García, (José Hernando Pérez, ed.), Salamanca, 2001.

${ }_{915}$ Los ejemplos de este tipo de conductas son innumerables. Recuérdese, el caso concreto del sarcófago utilizado como tumba de Carlomagno, con el tema de Proserpina, o incluso, hasta el sarcófago romano de la catedral de Astorga, atribuido de una manera poco fiable al monarca Alfonso III el Magno de Oviedo. Cf.: R. ALONSO ÁLVAREZ, "De Carlomagno al Cid...", pp. 471-488.

916 J. PEREZ DE URBEL, "La antiquísima iglesia de Santa María de las Viñas, monumento de gran interés”, Enciclopedia Espasa-Calpe, Apéndice, 8, Madrid, 1978, pp. 1129-1130.
} 
noticias documentales que nos informan de las continuas donaciones de tejidos, marfiles o metales, preciosas manufacturas, al fin y al cabo, que eran entregadas a aquellos centros monásticos de los que eran benefactores ${ }^{917}$. Sin duda, tales actividades permitían al linaje continuar una política de donaciones que perpetuaba la memoria de la familia que, desde tiempos inmemoriales, se venía potenciado a través de estas acciones. La exposición pública de este tipo de piezas, incluidos los sarcófagos romanos, activaba en la memoria de todos aquellos viajeros y visitantes la toma de conciencia con un pasado no conocido y lejano, que había que respetar y venerar.

A través de la memoria de estos difuntos, materializada mediante los dos sarcófagos, se "construían" un pasado histórico y otro político, en el que las piezas artísticas debieron jugar un papel significativo.

\footnotetext{
${ }^{917}$ M. CRUZ VILLALÓN, “Quintanilla de las Viñas en el contexto del arte altomedieval. Una revisión de su escultura", Sacralidad y Arqueología, Murcia, 2004, pp. 101-135, en concreto, p. 121 e ID., “Quintanilla de las Viñas y el arte cordobés”, Norba-arte, XXII-XXIII, 2002-2003, pp. 341-349.
} 


\section{LA DIFUSIÓN DE LOS REPERTORIOS ORNAMENTALES. EL "ESCAMADO" AQUITANO Y EL SARCÓFAGO DEL CONDE SANTO.}

En las páginas anteriores hemos señalado como las estrígiles fueron uno de los temas predilectos por parte de los talleres de sarcófagos de la Antigüedad tardía aunque, si bien, dentro del repertorio iconográfico existió una gran variedad de motivos, de los cuales, tan sólo algunos pasarían a la escultura de época románica.

La facilidad para poder reproducir de una manera seriada este sistema decorativo, basado en la simple repetición mecánica del mismo, favoreció su difusión dentro de la decoración de las piezas. Entre la lista de motivos más utilizados, el de las escamas va a ser uno de los más apreciados. El escamado recubrirá, desde el mundo romano imperial hasta la disipación de los talleres de sarcófagos de la Antigüedad, todo tipo de objetos: placas de canceles, sillares de edificios, cubiertas de los templos y, por supuesto, sarcófagos.

Es sabido que el sistema decorativo arraigó con fuerza en una determinada región de la Galia, sobre todo, aquella vinculada a los talleres que trabajaban en la zona de Aquitania, pero también, en el entorno de otras ciudades, como las de Toulouse, Agen, Auch y, en general, todo el sur de la Francia, hasta la zona noroeste del Poitou ${ }^{918}$.

El Codex Calixtinus, siempre tan abundante en referencias, da un dato especialmente relevante sobre esta cuestión. A propósito de la tumba de San Gil, dice:

"Las cubiertas del arca por arriba están labradas por ambas partes en forma de escamas de peces. En su ápice hay engarzados trece cristales de roca, unos a modo de escamado, otros en forma de manzanas o granadas. Hay un enorme cristal en forma de pez grande, de trucha seguramente, erguido, con la cola vuelta hacia arriba" 919 (texto 64).

La noticia informa del aprecio que se le va a tener durante los siglos del románico a este tipo de producciones que, por lo general, habían perdurado de época romana y paleocristiana y que presentaban entre los motivos más comunes, por ejemplo, arcos, vegetales y crismones, mientras que, en otros casos, determinadas partes del sarcófago se cubría con este motivo tan característico que asemeja al escamado de un

\footnotetext{
918 J.-P. CAILLET y H. NILS LOOSE, Op. cit., pp. 40-77 y p. 112.

${ }^{919}$ Liber Sancti Jacobi..., p. 563.
} 
pez. El caso que mencionamos de la arqueta relicario del santo francés, es bien representativo.

La tradición del motivo se documenta en multitud de obras romanas. Sin ánimo de ser exhaustivos, señalamos, por ejemplo, el motivo del escamado representado sobre el petril de mármol que cierra el jardín recreado en las pinturas de la villa Iulia Livia, hoy conservadas en el Museo Nacional de Roma ${ }^{920}$.

Su presencia dentro del arte romano justificó sobradamente la reutilización del motivo por parte de los tallares de sarcófagos al servicio de los primeros cristianos. De igual impronta clásica que las estrígiles, tal elemento pronto acabaría por convertirse en una alusión directa a este tipo de sarcófagos, que tanta difusión habían tenido y de los cuales, tantos ejemplos nos han llegado.

Dentro del caso hispano y, concretamente, en el ámbito gallego, sería Osorio Gutiérrez II, el llamado Conde Santo, el encargado de expoliar durante el siglo X un sarcófago antiguo de este tipo (fig. 159). Se trata, concretamente, de una obra datada en torno al siglo $\mathrm{VI}^{921}$, de mármol gris y que, según parece, sería el lugar elegido como última morada por el noble para descansar en el monasterio de San Salvador de Lourenzá, en Lugo ${ }^{922}$.

Las razones de tal acción parecen obvias: se trata de una pieza de mármol que ya estaba tallada, de buena calidad y que se presentaba a una fácil reutilización. Sin embargo, vemos en este hecho una serie de razones que van más allá de unos fines meramente utilitaristas. La pieza debió ser transportada, posiblemente, desde talleres

\footnotetext{
${ }^{920}$ Roma, Museo Nazionale Romano. Se trata de una serie de pinturas al fresco que decoraban una de las estancias de dicha villa. En ellas, fue representado un gran jardín con todo tipo de plantas, árboles y pájaros, cerrados a través de una cerca, posiblemente pétrea, que sirve, además, para enmarcar la escena y dotarla de mayor ilusionismo. Cf.: E. DE CAROLIS, "La Casa Pompeyana", Pompeya..., pp. 242-257, en particular, p. 245; A. CIARALLO, "La flora y la fauna", Pompeya..., pp. 302-313, en concreto, p. 310. Sobre la ornamentación de las villas de otium de la aristocracia tardorrepublicana, véase: S. ADAMO MUSCETTOLA, "El mobiliario doméstico", Pompeya..., pp. 258-285.

${ }^{921}$ H. SCHLUNK, "Los monumentos paleocristianos en Gallaecia, especialmente en la provincia de Lugo", Actas del Coloquio Internacional sobre el Bimilenario de Lugo, Lugo, 1977, pp. 193-236, en concreto, p. 196 y S. MORALEJO ÁLVAREZ, "La reutilización...", p. 189.

${ }_{922}$ Se conserva actualmente en la capilla de Santa María de Valdeflores. Sobre este expolio, vid.: M. A. CASTIÑEIRAS, "Sarcófago...", en concreto, p. 250 e ID., "La actividad artística...", en especial, pp. 292-293. Dicho monasterio perteneció, desde la fundación, a la regla de San Benito. Sin embargo, tanto el fundador, el mismo Osorio Gutiérrez, como la fecha de fundación del monasterio, hoy por hoy, presentan dudas. El sarcófago se labró en todas sus caras, menos en el fondo y en el frente. Esta parte es la que posee decoración de estrígiles que dan paso a un clípeo central con la imagen del crismón. Posee, además, una cubierta de cuatro vertientes totalmente decorada con escamas y sogueado en las aristas. Por su parte, M. Castiñeiras realiza un resumen sobre las posturas que tomaron los autores respecto a su procedencia. Así, mientras H. Schlunk se decantaba por un origen aquitano, P. de Palol prefería vincular la pieza con el ámbito tolosano.
} 
aquitanos, a juzgar por la exclusividad de la obra dentro del ámbito gallego, donde no se han documentado más piezas de este tipo ${ }^{923}$.

Con todo, atendiendo a los datos ofrecidos en su momento por Yepes, la importancia de la pieza, así como su carácter valioso, llevarían a crear una serie de leyendas emparentadas con la más pura literatura jacobea, que intentaban prestigiar, aún más, el origen del sepulcro:

"Está en una hermosa capilla, assentada entre dos iglesias, vna la del Couento, que se llama San Saluador, de donde la casa toma el apellido de San Saluador de Lorençana (...). La capilla à donde està el cuerpo del santo tiene de largo cuarenta pies, y de ancho veynte y tres; en la testera, o cabecera della, que topa con la Iglesia de los monjes, se haze una manera de cuenecita, à la qual baxa por tres gradas, veese alli un arco de hermosa canteria, donde está metido el sepulcro del santo Conde, levantado sobre dos columnas: porque la gente (que con gran deuocion le va à visitar) se pone debaxo, y gustan de topar con la cabeça, y con las manos en la santa arca: la cual está agujereada por dos partes, y en cada vna se vee el circulo, del tamaño de un real de ancho, tienen deuocion, de meter por alli los dedos, y encuentran con vna caxa de madera, en donde està el rico deposito. A los lados de este sepulcro estan dos hornacinas, en la vna es fama que estan los hijos, y nietos; y descendientes del Conde (...). Sobre la cueuecita que dixe arriba, donde estauan los sepulcros, se muestran vn corredor encima del mismo arco con sus varandas, y valaustres plateados, y en la pared se ve otra hornacina a la traça que diximo era la del Conde Santo, y en ella está encaxado un Altar, con vn deuoto Crucifixo, y que salen de ordinario las Missa, que piden los romeros, y peregrinos, que digan en honor del santo (...). Algunos afirman, que el santo Conde don Ossorio Gutiérrez le embió desde la Tierra Santa, y que le compró a vnos infieles en el puerto de Iapha, el qual tenían hecho para vn Rey Moro, y que costo al santo quinientos sueldos. También añaden, que milagrosamente vino por el mar, y aportó a Galizia, y después quando el santo boluio de su peregrinación, le hizo del puerto llevar a san Saluador de Lorençana. Como las cosas milagrosas se fundan en la potencia de Dios, la qual es infinita, aunque la maravillas sean estupendas, y prodigiosas, en quanto

${ }^{923}$ M. A. CASTIÑEIRAS, "Sarcófago...", en especial, p. 294 e ID., "La reutilización de piezas romanas...", pp. 77-90. El autor señala como el sarcófago puedo ser trasladado en fecha temprana, en torno a la segunda mitad del siglo V. Sin embargo, si seguimos las teorías expuestas por H. Schlunk, se trataría de un traslado realizado directamente en el siglo $\mathrm{X}$, dentro de las crecientes relaciones entre Galicia y Francia. 
estriuan en su omnipotencia, son dignas de creerse" ${ }^{\text {924 }}$.

Las razones de tal traslado e incluso la misma decisión de enterrarse en él deben buscarse, nuevamente, en la propia forma de la pieza. Su decoración escamada debía ser bastante familiar dentro de los talleres de esculturas medievales, donde, tal y como veremos más adelante, el motivo se desarrolló de una manera considerable. Pero además, las escamas, que ya se habían utilizado en la decoración del monumento funerario de San Gil, por citar el caso antes mencionado, tenían el suficiente prestigio como para hacer llegar esta pieza desde tan lejos.

En relación con esto, si observamos con detenimiento al panorama artístico gallego, una obra tardía, datada ya en el siglo XVI, es decir, en plena introducción de las formas del llamado Renacimiento en España, presenta una razón de peso para poder justificar lo aquí afirmado.

Se trata del llamado frontal de Santa Eufemia de la catedral de Orense, en el que encontramos desarrollado un ciclo que alude a la vida y pasión de la santa (fig. 160). La representación de su sepulcro no deja lugar a dudas, se trata de una evocación clásica de la forma que en su día pudo tener el sepulcro de la santa ${ }^{925}$. El artista "moderno" realizó un sarcófago, aparentemente de mármol, sobreelevado mediante columnas entorchadas, y con una cubierta decorada mediante una red reticulada que recuerda, en su forma, a los sepulcros escamados del tipo aquitano, semejantes a los del tipo expoliado para el Conde Santo ${ }^{926}$.

El sepulcro representado en el frontal de la catedral de Orense, corresponde a una tipología muy desarrollada durante la Edad Media, especialmente, durante los siglos XI al XIII y que, por diversas razones, elevaba los sarcófagos mediante columnillas.

\footnotetext{
${ }^{924}$ A. YEPES, Crónica General de la Orden de San Benito (1615), Biblioteca de Autores Españoles, 124, Madrid, 1960, vol. II, p. 356.

${ }^{925}$ Es posible, que se trate de un mero convencionalismo sin ningún tipo de valor arqueológico, pero lo más destacado es que, para aludir a la antigüedad del lugar en el que había sido colocado el cuerpo de la santa, no hubo una solución más eficaz que reproducir una pieza de tradición romana o paleocristiana, con la parte superior del sarcófago decorada con escamas.

${ }^{926}$ No de es de extrañar que la pieza de metal colocada en el actual mausoleo del apóstol Santiago, en Compostela, de cronología contemporánea, reproduzca de manera "neopaleocristiana" un sarcófago decorado con todo este tipo de repertorios de tradición romana cristiana, entre los que destacan, el escamado. Lo mismo ocurre con el tríptico de la predicación, traslación y sepultura conservado en la sacristía de la misma catedral, obra de Modesto Brocos. Se trata de una obra de cronología moderna que vuelve a utilizar el tipo aquitano de sarcófago para aludir a la tumba del Apóstol. Cf.: R. OTERO TÚÑEZ, "La Edad Contemporánea", IX Centenario de la Catedral de Santiago de Compostela, Santiago de Compostela, 1977, pp. 381-422 y J. GUERRA CAMPOS, "El sepulcro de Santiago", IX Centenario..., pp. 13-86, en concreto, p. 36.
} 
La primera de ellas, obviamente, era la de proteger la sepultura del alcance de los peregrinos, que ansiosos de llevar a cabo el contacto con las reliquias, tocaban sin cesar este tipo de piezas, hasta en la mayoría de los casos acabar desgastándolas. Las columnas que elevaban este tipología de sarcófagos, en muchas ocasiones, de reempleo, permitían a los peregrinos realizar todo tipo de movimientos libres alrededor de los sepulcros, de tal manera que, incluso, se llegaron a crear rituales vinculados a la elevación de las santas reliquias, tal y como sucedía, entre otros, con el sepulcro de Santa Radegunda de Poitiers ${ }^{927}$.

El llamado Breviario de Anne de Prye ${ }^{928}$, presenta una imagen en la que los enfermos y los tullidos obtienen la curación al pasar bajo la estructura. Incluso, algunos de ellos, tocan las columnas en busca de la sanación ${ }^{929}$. Inmerso en esta misma tradición, se presenta el capitel de Saint-Severin de Bordeaux, donde el sepulcro del santo fue representado elevado sobre columnillas ${ }^{930}$.

\footnotetext{
${ }^{927}$ El sepulcro se conserva en la iglesia homónima de dicha ciudad. Se trata de un bello sarcófago de mármol negro elevado sobre dos pilastrones de época gótica, añadidos cuando se acometió un saneamiento del lugar. Sin embargo, seguramente precedan a otras columnas encargadas de desarrollar la misma función, elevar la sepultura para dignificarla y evitar su deterioro. Los peregrinos visitantes del sepulcro están atestiguados por el biógrafo de la santa ya desde el siglo VII, aunque sus restos no estaban aún localizados durante la consagración documentada del año 863. Tras diversos avatares, entre ellos el incendio del templo en el año 955 y su consecuente estado de ruina, reaparece en una fosa la tumba de la santa cubierta de tierra. Su descubrimiento marca el inicio de la construcción románica.

El sarcófago actual no puede datar, según M.-Th. Camus, del siglo VI, pues la crónica narrada por Gregorio de Tours sobre la inhumación del cuerpo habla de una pieza de madera. Posiblemente, pertenezca a la segunda mitad del siglo IX, cuando se produjeron diversas reparaciones en el templo. El sarcófago se eleva sobre un rico cimacio decorado con entrelazos vegetales. Tanto la basa como el sepulcro pueden pertenecer a cronologías diferentes, según la autora. Cf.: M.-TH. CAMUS, "L’Eglise: la construction romane", La vie de Sainte Radegonde par Fortunat (R. Favreau dir.), Poitiers, 1995, pp. 254-257; M. LAVERRET, "L'iconographie de Sainte Radegonde dans les manuscrits", Bulletin de la Société des Antiquaires de l'ouest et des Musées de Poitiers, 5, II, 1988, pp. 85-112; R. FAVREAU, "Le culte a Sainte Radegonde", La vie de Sainte Radegonde..., pp. 5-20, en especial, pp. 10-13 y P. SKUBIZEWSKI, "Le tombeau de Sainte Radegonde et la croix de son sarcophage", Le Supplice et la Gloire. La Croix en Poitou, Poitiers, 2000, pp. 33-35.

Véase también: M. EDMOND LE BLANT, Les sarcophages..., en especial, pp. 16-17. El autor llamaba la atención sobre la realización de tal práctica: "D'après un ancien usage, encore conservé à Poitiers pour le tombeau de Sainte Radegonde, les fidèles détachaient du sépulcre de Saint Drausin une poudre qu'ils emportaient comme un précieux remède. Les pèlerins affluaient au sanctuaire où se trouvait cette tombe, et plusieurs textes du moyen âge constatent qu'avant de combattre en champ clos, nos pères venaient y passer une nuit en prière". Se refiere a la acción llevada a cabo en torno al sepulcro de San Drausin, que él mismo atribuye al ámbito aquitano o del suroeste de Francia.

${ }_{928}$ Poitiers, Trésor de la Cathédrale, Ms. non coté, fol. 305v. Cf.: M. LAVERRET, Op. cit., p. 109. Se ha datado entre los años 1484 y 1500 y posee cincuenta miniaturas e iniciales historiadas.

${ }^{929}$ Sobre este rito y la comentada ilustración, véase: F. ESPAÑOL BERTRÁN, "Santo Domingo de la Calzada: el cuerpo santo y los escenarios de su culto", La cabecera de la catedral calceatense..., pp. 209282, en concreto, pp. 259-260 y M. LAVERRET, Op. cit., p. 110. La profesora Español relaciona esta miniatura y el ritual que en ella se recoge con otra serie de sepulcros, tanto hispanos como foráneos. Entre ellos, es bien significativo que aluda al ejemplo del sarcófago del Conde Osorio y al texto de Yepes, ya analizados.

${ }_{930}$ En este caso, con la peculiaridad de que la efigie muerta del difunto se ha extrapolado al exterior del sarcófago y se muestra adosada a él. Salvando las distancias, se adopta en el caso francés una solución
} 
Sin embargo y en relación con nuestro tema, resulta más representativa una pintura sobre tabla realizada por Josse Lieferinxe, que se ha datado en torno a los años 1497-1499 (fig. 161). En ella, se representó el interior de una iglesia con un sepulcro sobreelevado mediante cuatro columnas clásicas. Alrededor, decenas de peregrinos oran y veneran las santas reliquias, mientras uno de ellos, incluso, llega a ponerse de cuclillas para tocar el sarcófago que se eleva sobre la cabeza de los fieles, ansiosos de una curación que se lograría mediante el contacto físico con las reliquias, tal y como veíamos en la miniatura francesa.

Lo más destacado de la pintura italiana, es que, posiblemente, representa una pieza de orfebrería con una cubierta escamada.

Podemos concluir al respecto que, aunque se puede alegar una fecha tardía para la pieza que el artista "moderno" ha intentado representar, puesto que no fueron desconocidas en época gótica y posteriormente, la cubierta escamada que presenta el sarcófago o la arqueta que custodia tales reliquias, podría evocar el carácter antiguo del sepulcro original $^{931}$.

Sin embargo, si la representación del sepulcro de Santa Eufemia en Orense y la expoliación del sarcófago aquitano por parte del Conde Santo, demuestran un interés por conservar los sepulcros antiguos en el ámbito hispano de la Edad Media, también dichas imágenes ratifican su puesto dentro del ámbito europeo, donde esta tendencia fue habitual.

En un capitel historiado fechado en época románica y perteneciente al conjunto escultórico de la cripta de Saint-Denis de París, fue representada, dentro del ciclo dedicado a la vida del santo, la escena de su traslación. En la imagen puede verse como se ha captado el momento en el que, delante de una muchedumbre, un animal de carga tira de un carro sobre el que están emplazadas las reliquias del santo. A pesar de que la escultura se ha datado en época románica, el sepulcro que se ha representado sigue los

parecida a la que se observa en el monumento funerario del obispo Rodrigo Jiménez de Rada. Cf.: X. DECTOT, Pierres tombales..., en especial, p. 24 y C. BANGO GARCÍA, "Rodrigo Jiménez de Rada, arzobispo de Toledo", Sancho el Mayor y sus herederos. El linaje que europeizó los reinos hispanos, 2 vols., Pamplona, 2006, vol. I, pp. 231-233.

${ }^{931}$ Roma, Galleria Nazionale d'Arte Antica di Palazzo Barberini. La tabla formaría conjunto con otra serie de piezas de una predela de altar dedicada a la vida de San Sebastián y San Roco, realizadas para la iglesia de Notre-Dame-des-Accoules, en Marsella. El pintor francés, de formación flamenca e influencia del quattrocento italiano, desarrolló su obra en esa ciudad, así como en Aix-en-Provence. Esta obra le daría el sobre nombre de el maestro de San Sebastián. Cf.: T. STRINATI, Romei \& Giubilei..., ficha catalográfica 190, p. 394. 
parámetros de la estatuaria funeraria de los sarcófagos de finales del siglo IV y el siglo VI.

La cista de este capitel alberga una representación del arca de las reliquias decorada mediante una serie de arquerías, mientras que la parte superior de la pieza fue decorada mediante un escamado de tipo paleocristiano ${ }^{932}$ (fig. 162).

La escena alude, claramente, a un intento por dignificar el lugar de reposo de los restos del santo, pues tal y como ocurría en el capitel ya mencionado de la catedral de Lérida, existe un interés marcado por aludir a los sarcófagos antiguos a través de estas imágenes, incluso cuando los textos silencian cualquier dato sobre la decoración de estos contenedores materiales, mediante los cuales, se llevarían a cabo dichas traslaciones, tal y como vemos por ejemplo, en el caso de los restos del apóstol Santiago ${ }^{933}$.

Sobre la fortuna de estos motivos derivados del arte antiguo y heredados por la plástica románica peninsular, trataremos de manera más profunda en el apartado correspondiente. Sin embargo, queremos avanzar que, a la hora de analizar diferentes monumentos sepulcrales que forman parte del corpus de la escultura funeraria de los siglos XI y XII, el uso de estos repertorios no fue desconocido.

En este sentido, no se debieran obviar las conexiones y, en muchas ocasiones, evocaciones, de tales piezas clásicas dentro de la escultura medieval, tal y como ha señalado X. Dectot. Según este autor, el caso del cenotafio de San Vicente de Ávila muestra una clara herencia de toda una tradición iconográfica y arquitectónica inmersa en el arte de la Antigüedad, que se manifiesta aquí, por ejemplo, a través del uso de frisos continuos narrando escenas. A ello debemos sumar, sobre todo, el recuerdo del escamado, que recubre, a modo de tejas, las vertientes que forman los tejados del

\footnotetext{
${ }^{932}$ E. VERGNOLLE, L'art roman..., en concreto, pp. 24-25. El tipo de cubierta encuentra paralelos dentro de la escultura de mármol salida de los talleres de los Pirineos, como por ejemplo, en el llamado sarcófago de los Apóstoles conservado en el Museo de los Agustinos de Toulouse, datado en la segunda mitad del siglo V o inicios del siglo VI, con la tapa escamada. Igualmente, aunque con una talla más modesta y con las escamas incisas, cabe mencionar un sarcófago datado entre el siglo IV y el siglo V, hoy conservado en la iglesia de San Seurin de Burdeos. Se aborda el problema cronológico de los talleres del suroeste de la Galia, en: J.-P. CAILLET y H. NILS LOOSE, $O p$. cit., en concreto, pp. 102-104.

${ }^{933}$ M. MELERO, "Traslatio Santi Jacobi...”, p. 76 y J. LACOSTE, "Découvertes dans la cathédrale de Lérida", Bulletin Monumental, 132-1, 1974, pp. 231-234. La profesora Melero ya señalaba, con respecto al capitel de Lérida que, a pesar de que las fuentes sobre dicha escena nunca citan la presencia de ningún sarcófago, en la serie de capiteles de Lérida, fueron representados dos tipos de piezas. El primero, durante la traslación marítima, el cuerpo reposa sobre un sarcófago estrigilado. La segunda vez, en aquella escena en la que se muestra la tumba del apóstol entre cortinas, el sarcófago aparece elevado sobre columnillas, pero esta vez sin la presencia del motivo clásico.
} 
cenotafio y que tendrían como modelo lejano, los escamados de las famosas linternas de los muertos galorromanas ${ }^{934}$.

A pesar de ello, somos conscientes de que se trata de una emulación de las losas o tejas de la cubierta del edificio, antes que una alusión a este tipo de escamado. Sin embargo, creemos que, partiendo de estas hipótesis, las vías de estudio son realmente prometedoras $^{935}$.

Tal y como se estudiará en su apartado correspondiente, el motivo del escamado pasó directamente a la escultura románica y, a veces, con gran éxito. Tampoco es de extrañar que, ligado a los talleres de la catedral de Santiago y cercanos en todo caso a las soluciones utilizadas para el sepulcro conservado en el monasterio de Lourenzá, se documente una utilización del motivo del escamado en numerosas piezas pertenecientes a la desaparecida puerta norte o Francigena y en otras, realizadas para la puerta de Platerías $^{936}$.

Siguiendo estos mismos planteamientos, las esculturas de la zona tolosana, adscritas a los talleres de Saint-Saturnin de Toulouse, siempre tan vinculados a las producciones de sarcófagos romanos, tampoco obviaron el motivo dentro de sus repertorios más frecuentes ${ }^{937}$. Sin duda, los sarcófagos fueron los referentes más importantes para explicar este tipo de traspasos hacia los repertorios románicos.

\footnotetext{
${ }^{934}$ Véase el apartado correspondiente de este mismo trabajo en el que se analiza la influencia de los sepulcros y obras de la Antigüedad y del primer arte cristiano, sobre todo, de las piezas funerarias, sobre la escultura de cronología románica. Sobre el carácter clásico de algunos monumentos funerarios hispanos, véase: X. DECTOT, Pierres tombales..., en concreto, p. 24.

${ }^{935}$ F. GALVÁN FREILE y J. A. MORÁIS MORÁN, Op. cit., pp. 480-482. Recordamos, por ejemplo, que este tipo de escamados ya estaban presentes en la arquitectura monumental, tal y como se observa en las cubiertas de los cimborrios de la zona del Duero. Su presencia dentro de la escultura, particularmente a través de las microarquitecturas, tiene representantes tan expresivos como los que se ven en algunas de las piezas pertenecientes al coro pétreo de la catedral compostelana.

${ }_{936}$ Nos detendremos en ello más adelante. Mencionamos su uso dentro, por ejemplo, de la escultura de la mujer del cráneo, la escena de Dios Padre con Adán o la lastra colocada al lado de la Eva amantando a Caín, que muestra, claramente, este tipo de decoración, a pesar de que, en muchos casos, las escamas se han realizado de una manera más "vegetal". Cf.: J. M. PITA ANDRADE, "La arquitectura románica", IX Centenario..., pp. 89-162.

${ }^{937}$ Por ejemplo, el escamado se repite, colocado en la base del relieve de los signos del león y el cordero, del Museo de los Agustinos de Toulouse, en una posición idéntica a la que presentan algunas piezas de Santiago. Parece lógico pensar que, el motivo, fue tomado de estas piezas romanas difundidas en Aquitania y los Pirineos. Cf.: J. LACOSTE, Les Maîtres..., p. 27.
} 


\section{LA EXPOLIACIÓN DE SARCÓFAGOS DE FRISO HISTORIADO Y LA ADMIRACIÓN DE LAS} IMÁGENES ANTIGUAS.

En los apartados anteriores se ha señalado la importancia que tuvieron algunos elementos decorativos que los artífices medievales tomaron de los sarcófagos romanos.

Se trataba de explotar al máximo tales recursos que, en ocasiones, se utilizaban independientemente de su origen y función original.

En el presente bloque se abordarán otra serie de piezas también relacionadas con el ámbito funerario, que serán tomadas como punto de partida para otras reflexiones centradas en manifestar la importancia para la formación de los artistas medievales. Así, si hasta el momento hemos señalado un interés por la expoliación de piezas decoradas con motivos de diversa índole, creemos que, para nuestro objetivo, será más revelador centrarse en aquellos sarcófagos que presentan una profusa decoración iconográfica. En concreto, hablamos de aquellas obras romanas que mostraban en sus frentes y cubiertas grandes ciclos figurativos.

Dentro del ambiente hispano existe un ejemplo paradigmático a la hora de abordar tales cuestiones y que en los últimos años ha adquirido una importancia quizás abusiva y excesivamente explotada.

Nos referimos al sarcófago romano, documentado, por primera vez, en la iglesia de Santa María de Husillos, en Palencia ${ }^{938}$.

La obra es bien conocida. Se trata de una pieza, actualmente carente de cubierta, que presenta todo el frontal y los lados cortos decorados mediante un friso historiado de tema mitológico (fig. 163). En el frente se ha narrado la historia de Orestes quién, dominado por la furia, ante el engaño que su madre Clitemmenestra lleva a acabo con el joven Equistes, decide vengar la memoria de su padre matando a su progenitora. El parricidio se lleva a cabo en un ambiente palatino representado simbólicamente

\footnotetext{
${ }^{938}$ Somos conscientes del carácter reiterativo y, en cierto modo, manido, que presenta este ejemplo de Husillos. Nos interesa señalar que, en este apartado general, dedicado al expolio in se, incluimos esta pieza por tratarse de una de las más importantes, tal y como de manera continua ha señalado la historiografía especializada. El sarcófago de Husillos fue una obra reutilizada como sepulcro en etapas posteriores a las de su creación, de ahí que pueda englobarse en este bloque. Señalamos que, a la hora de analizar la fortuna de los motivos e iconografía antiguos de esta pieza en la escultura románica hispana, volveremos a abordar el tema de una manera detenida. Será en este momento donde recojamos toda la bibliografía manejada sobre tal cuestión. Se trata, por lo tanto, de una obra que debe ser valorada a la hora de estudiar el fenómeno del spolium in se y, del mismo modo, en el momento de realizar las reflexiones pertinentes sobre los spolia in re, pues tal escultura representa de manera evidente estas dos vertientes. Finalmente, queremos justificar su inclusión en diferentes partes de nuestro trabajo, debido al excelente conocimiento que se tiene de la obra funeraria y de sus características, así como de su importancia para la formación de muchas de las imágenes creadas por los escultores románicos.
} 
mediante las cortinas y el mobiliario. En la narración del friso, si realizamos una lectura desde la derecha hacia el lado izquierdo, se observa a las Furias durmiendo y al joven Orestes, que entra en la escena portando la daga que dará muerte a su madre. La parte central muestra la ira del efebo, que arremete con fuerza contra el amante de su madre, tirándolo al suelo. El escultor romano ha captado perfectamente el terror de los criados que, asustados, evitan el horror del suceso tapándose los ojos con las manos u ocultándose detrás de los muebles de palacio. Tras el asesinato, las Furias despiertan de su letargo, arremetiendo contra Orestes mediante serpientes que lanzan sobre su cuerpo atlético y que aquí han sido vistas como el símbolo del arrepentimiento.

En los laterales, esculpidos en un relieve de menor volumen, se narra la continuación de la escena principal, con la visita del joven al Oráculo de Delfos. La parte trasera de la pieza fue dejada sin trabajar, posiblemente para poder adosarla contra un muro.

Se considera una de las grandes obras del arte romano conservadas en suelo hispano. Datado en época adrianea, el propio García y Bellido supuso que habría sido trasladada directamente desde los talleres romanos a través del intercambio comercial entre Hispania y "los buques que llevaban alimentos a Ostia"939.

Entre los argumentos esgrimidos está la presencia en Tarragona durante un invierno de la propia figura del emperador Hadriano, quién, además de llevar a cabo varias obras de restauración en diversos templos, potenció un arte bajo el auspicio imperial, que colocó las producciones artísticas de la Hispania romana a la altura de las demás provincias del Imperio ${ }^{940}$.

La pieza se mantuvo, más o menos intacta, hasta el siglo $\mathrm{X}$, llegando casi íntegramente, a juzgar por el buen estado que presenta en la actualidad. Sin embargo, no sabemos fehacientemente el lugar en el que fue colocada tras su traslado, en que

\footnotetext{
939 A. GARCÍA Y BELLIDO, Arte Romano, Madrid, 2004, en concreto, pp. 411-413; ID., "La Hispania de Hadriano", Homenaje a Conchita Fernández Chicarro, Madrid, 1982, pp. 301-317, en concreto, p. 306; ID., Esculturas romanas de España y Portugal, Madrid, 1949, pp. 212-213 y J. M. BLÁZQUEZ MARTÍNEZ, "Panorama general de la escultura romana en Cataluña", Problemas de la Prehistoria y de la Arqueología Catalanas. II Symposium de Prehistoria Peninsular, Barcelona 1963, pp. 225-245, en concreto, p. 243. Los especialistas destacan que, si bien el ámbito de Tarraco habría de convertirse en el gran centro de producción de sarcófagos romanos de la Hispania tardo antigua, su irrupción dentro del campo de la escultura fue tardía.

${ }^{940}$ Sobre el desarrollo de la escultura hispanorromana en una época paralela a la fabricación del sarcófago romano de Husillos, véase: A. GARCÍA Y BELLIDO, "La Hispania...", en concreto, pp. 305-306 y J. J. MENCHON BES, "Tarragona, la antigua ciudad romana y la construcción de una ciudad medieval", $E l$ románico y el Mediterráneo..., pp. 47-53.
} 
circunstancias estuvo hasta tal fecha y, ni siquiera, cuantos cuerpos albergó hasta el momento de su traslado al Museo Arqueológico de Madrid, donde hoy se halla.

Parece ser que, durante los siglos medievales, fue sometida a diversas acciones expoliadoras por parte de los "admiradores" del excelente trabajo que mostraba en su frente. En concreto, se ha señalado al conde de Monzón, Fernando Ansúrez, que fue también el fundador de la colegiata de Santa María de Husillos, entre los años 960 y $967^{941}$.

Allí, reempleada contra el muro de este templo, la vieron, posiblemente, los participantes en el Concilio del año 1088 que se desarrolló en este espacio eclesiástico $^{942}$. Sobre la influencia que dicha pieza tuvo en la escultura románica y sobre las investigaciones llevadas a cabo por el profesor S. Moralejo en relación con ella, hablaremos más adelante ${ }^{943}$.

Sin embargo, destacamos en último lugar el reciente estudio realizado por F. Prado-Vilar, en el que desarrollan ciertos puntos novedosos en relación con la importancia de la pieza funeraria y su influencia sobre la escultura románica hispana. El citado investigador defiende nuevas teorías en relación con la interpretación de la escultura de Frómista, a pesar de no tener en cuenta que la sucesión de los trabajos decorativos entre dicha localidad palentina y la catedral de Jaca no es una cuestión tan simple y cerrada, y de la que, frecuentemente, se ha discutido mucho. Además, resulta complejo poder llegar a perfilar una psicología de los espectadores medievales que llegaron a ver el sarcófago de Husillos, ni tan siquiera a título de hipótesis, ya que, reconstruir la realidad intelectual de aquellos hombres y su reacción ante la escultura clásica no posee respaldo alguno en la metodología científica ${ }^{944}$

\footnotetext{
${ }^{941}$ M. A. CASTIÑEIRAS GONZÁLEZ, "Sarcófago...”, pp. 248-250 y D. OCÓN ALONSO, "Los modelos clásicos de la escultura monumental española: de fines del siglo XI a fines del siglo XII", Actas del X Congreso del CEHA, Los Clasicismos del Arte Español, Madrid, 1994, pp. 67-73.

942 J. L. HERNANDO GARRIDO, "La escultura románica en Palencia: un balance historiográfico", Palencia en los siglos del románico, Aguilar de Campoo, 2002, pp. 11-35, particularmente, pp. 14-15. El especialista apoya la hipótesis de la reutilización medieval por parte del conde de Monzón.

${ }^{943}$ S. MORALEJO ÁLVAREZ, "La reutilización...", pp. 279-288 e ID., "Sobre la formación del estilo escultórico de Frómista y Jaca", Actas del XXIII Congreso Internacional de Historia del Arte, Madrid, 1976, pp. 227-233.

${ }^{944}$ F. PRADO-VILAR, "Saevum facinus: Estilo, genealogía y sacrificio en el arte románico español", Goya, 324, 2008, pp. 173-199 e ID., "Lacrimae rerum: San Isidoro de León y la memoria del padre", Goya, 328, 2009, pp. 195-221. El autor defiende una nueva interpretación del famoso capitel inspirado en el sarcófago de Husillos de la iglesia románica. En concreto, piensa que podría tratarse del tema de Caín y Abel y defiende una serie de parentescos y dependencias genealógicas nacidas en Frómista y asimiladas, posteriormente, en Jaca y San Isidoro de León. Tal y como señalamos recientes estudios han dudado de las clásicas relaciones y cronologías establecidas por la historiografía. Cf. M. A. CASTIÑEIRAS, M. A. CASTIÑEIRAS GONZÁLEZ, "Verso Santiago? La scultura romanica da Jaca a Compostella", Medioevo: l'Europa delle cattedrali, Milano, 2007, pp. 387-396.
} 
Fuera ya de la época medieval, el sarcófago antiguo siguió impresionando a aquellos que lo contemplaban. A. de Morales, en su famoso Viage, dedica especial atención a esta obra. $\mathrm{Al}$ respecto nos dice:

"De género bien distinto es la joya que hoy se envanece la iglesia de Husillos; un sepulcro pagano de procedencia desconocida, de piedra compacta y pulida como el mármol, de primor comparable al de las más esquisitas antigüedades romanas. El significado de la escena, esculpida de más de medio relieve en la delantera de la urna, no se atina fácilmente: una joven difunta tendida en el centro y junto á ella de pié un robusto mancebo, á los estremos dos mujeres reclinadas, personas de ambos sexos con grandes tendidos como para cubrir el cadáver, revelan bien una ceremonia fúnebre, pero no es tan cierto que figuren el combate de los Horacios y la muerte de su hermana á manos del último, ni menos la paz entre Sabinos y Romanos por mediación de sus hijas y esposas. Siglos hace que artistas y viajeros admiran aquella obra maestra, sin que se sepa donde y cuándo fue hallada, ni como vino á tan escondida soledad: solo parece que el sepulcro, lo mismo que el del Rey Monge en Huesca, el de Itacio en el panteón real de Oviedo, el atribuido al rey Alfonso en la catedral de Astorga, encierra restos de algún personage muy distinto de aquel para quien se labró con mil años de anterioridad. Con la perfección del arca contrasta lo tosco de la cubierta, añadida sin duda al destinarla á su actual empleo; mas carece de epitafio que permita asegurar si yace alli el conde fundador ó alguno de sus descendientes"945 (texto 65).

Las palabras del autor sirven para constatar la presencia de la pieza en el templo durante la época moderna, así como para demostrar que, en origen, el sarcófago poseía una cubierta. Sin embargo, estas líneas nos llevan a pensar también que ya por este momento dicha cubierta medieval había sustituido a la original romana, a juzgar por el carácter "tosco" que, según el viajero, presentaba en el momento de examinarla ${ }^{946}$.

Con todo, pensamos que tales reflexiones, realizadas en una fecha precoz, reflejan un buen conocimiento del fenómeno de la expoliación in se, pues, el mismo erudito, llega a comparar el caso de Husillos con otros ejemplos de similar índole, tales como el ya mencionado sarcófago de Ithacio de Oviedo y otros que abordaremos

945 A. DE MORALES, Viaje a los reinos de León, y Galicia, y Principado de Asturias, (1765), Oviedo, 1977, pp. 109-110.

${ }^{946}$ Las dudas son complicadas de solucionar. Es posible, también, que nunca llegara poseer cubierta, aunque parece ilógico mantener tal hipótesis. 
brevemente. Se deduce también, que durante la época en la que Morales realizó su obra, era obvio que en la Edad Media hispana el fenómeno del spolium se había desarrollado de una manera, más o menos generalizada, con un volumen de piezas expoliadas nada despreciable.

En los siglos posteriores, sobre todo a través de las palabras de José María Quadrado, parece que el texto de A. de Morales se tuvo muy en cuenta. En este sentido se dice:

"Por larga y minuciosa que sea la relación que de esta urna hace Morales, no sabemos abreviarla una línea. Y estando ella, dice en sus Anales, labrada como se dirá, tiene la cubierta tumbada de una piedra tosca y lisa y tan groseramente labrada que parece se hizo de aquella manera para que la labor de la caja de abajo pareciese mejor. En la haz desta caja está esculpido de más que medio relieve el fin de la historia de los Horacios y Curiacios (...) la excelencia de la escultura se pude sumar con lo que dijo el famoso Berruguete, después de haber estado gran rato como atónito mirándola: ninguna cosa mejor he visto en Italia (...). Toda la escultura está muy conservada sino es una sola figura al un lado, que a lo que yo creo por estar muy relevada quitó algún grande artífice para llevarse algo de aquella maravilla. $Y$ no se espante nadie como me detengo tanto en celebrar una piedra (...). Y á lo que yo creo debe ser sepultura de aquel conde Fernando Ansurez fundador, que aviendo avido esta rica antigualla de romanos, quiso sirviese para su sepultura. De romanos digo que es, pues para sepultura de ningún cristiano cierto que no se hiciera con tan profana historia"947 (texto 66).

En el Viaje Santo, donde se expresan, casi en iguales términos estas reflexiones, se añade que, la obra:

“(...) es de ocho pies de largo y tres y medio de alto y otro tanto de ancho, que dentro hay huesos, y que tal vez tenga algunas letras el lado de la urna arrimado a la pared, que está liso según se juzga por lo que se puede tocar"948.

Las palabras de José María Quadrado, a propósito del sarcófago, son reveladoras. A parte de reiterar la presencia de una cubierta hoy inexistente, retoma la

${ }^{947}$ J. M. QUADRADO, Recuerdos y bellezas de España. Palencia, (1865), Valladolid, 1989, pp. 109111.

${ }^{948}$ A. DE MORALES, Viaje a los reinos de León..., pp. 110. 
errónea explicación iconográfica de las escenas que llevaron a cabo algunos autores de época moderna. Además, sus reflexiones contextualizan el valor del sarcófago, que se ve refrendado por las menciones que, supuestamente, realizaron personajes de gran relevancia durante aquel tiempo sobre la pieza. Las citas de Berruguete y el cardenal Poggio se convierten en señales que ayudaban a prestigiarla.

La identificación de la obra como romana y la atribución de este reempleo al conde Fernando Ansúrez, cierran las noticias más interesantes que estos autores dedicaron a la pieza.

Sin embargo, el recorrido histórico de la escultura fue largo. A partir del año 1844, la Comisión de Monumentos de la ciudad de Palencia, con Justo María Velasco a la cabeza, inicia el informe que se enviaría al Ministro de la gobernación de la Península. En dicha documentación, se destacaba la existencia de tal sarcófago ${ }^{949}$. A pesar de todas las medidas llevadas a cabo para su puesta en valor y conservación en el nuevo museo que se pretendía crear en Palencia, en el año 1852, el sarcófago aún permanecía en Husillos ${ }^{950}$.

Un documento generado a raíz de estas acciones enfocadas a conservar la pieza de Husillos, hasta la fecha inédito, narra excelentemente la situación en que la escultura romana se debía encontrar a mediados del siglo XIX:

"Tampoco pertenece al Estado, el precioso Monumento que se conserva en una capilla, bastante obscura, de la Iglesia Parroquial de este pueblo. Consiste aquel en un antiguo sepulcro de mármol blanco, sin tapa alguna que lo cubra; su largo ocho pies, y tres de ancho y altura. En su frente está esculpida de más de bajo relieve, la terminación del Justo encono y deseos de venganza de Sabinos contra los Romanos; en el lado opuesto hay figuras en acción de sacrificio; y en otro lado están

\footnotetext{
${ }^{949}$ Madrid, Archivo de la Real Academia de las Bellas Artes de San Fernando, sig. 7-7/2, Monumentos en General, Informe de Justo María Velasco adjunto a oficio del jefe político de la provincia de Palencia al Ministro de la Gobernación de la Península, 30 de junio de 1844 y la Descripción Artístico-Arqueológica de los Monumentos de Bellas Artes que aún subsisten y pertenecieron a las Comunidades Religiosas suprimidas de la provincia de Palencia. Tras este primer paso, se produce la contestación del ministro de la Gobernación, el día 20 de noviembre de 1844, en la que se recomienda el traslado a Palencia de la obra para que sirva de base al naciente museo que se intentaba crear en dicha ciudad. El Oficio del Gobernador Civil de Palencia remitido al presidente de la Comisión Central de Monumentos de 3 de agosto de 1845, da inicio a las acciones que culminarán con el traslado del sepulcro a Palencia. Las noticias documentales ofrecidas en torno al sarcófago de Husillos nos han sido facilitadas íntegramente por D. Enrique M. Lombó, al que mostramos nuestro agradecimiento.

${ }^{950}$ Hecho que se deduce de la tramitación del Oficio de la Comisión de Monumentos de Palencia al Ministro de Fomento (Presidente de la Comisión Central) de 18 de agosto de 1852, en la que se vuelve a incluir el sarcófago entre los monumentos a conservar de la provincia de Palencia.
} 
depositando en un sepulcro una urna dentro de la que se debían conservar las cenizas de algún héroe.

El célebre pintor escultor y arquitecto Alonso Berruguete, quedo admirado contemplando la excelencia de la ejecución, y los conocimientos profundos de la belleza ideal que rebelaba esta urna, asegurando que "competía con las mejores obras que había visto y estudiado en Italia y que ninguna había hallado mejor". También el Cardenal Paggio habiéndola visto dijo al secretario Gracias Padre, "Esta urna merecía estar en Italia en medio de las más preciosas antigüedades que allí se conservan, pues que su mérito la hace digno rival de aquellas (...). Este singular monumento dejará de existir muy pronto, si nuestro ilustrado Gobierno no exige que sea trasladado a la Capital, depositándole y al cuidado de algún cuerpo facultativo, tal como la Sociedad económica. Es facilísima su total inexistencia; pues que estando colocado a la altura sobre el pavimento de la iglesia, llegan a él con gran facilidad los muchachos, y estos, no sólo en las noche de Miércoles y Jueves Santo con gruesas piedras, hacen gala de la fuerza de sus puños, sino que a competencia se proponen hacer amputaciones en las bellas figuras que aquella antigüedad presenta en sus tres lados; deshaciendo en un solo instante una preciosidad que costó muchas fatigas y estudios a su autor. El centro o interior de este sarcófago sirve en la actualidad de depósito a muebles inservibles de la Iglesia ¿Qué ratos tan fatales para el viajero instruido, al hallar en estado tan triste y descuidado, preciosidades como esta que no tiene precio!"951.

La mención que realiza el autor de este documento administrativo de las continuadas agresiones que sufrió el sarcófago, explicarían algunas de las pérdidas y daños que muestra hoy en día, así como la mutilación de algunos de los miembros de ciertas figuras.

Finalmente, tras estos acontecimientos, en el año 1870 el sarcófago deja su emplazamiento original para ser transportado definitivamente al Museo Arqueológico de Madrid ${ }^{952}$ :

"En cumplimiento de los dispuesto por S. A. el Regente del Reino en orden comunicada por el Excelentísimo Sr. Ministro de Fomento con fecha 8 de noviembre

\footnotetext{
${ }^{951}$ Madrid, Archivo de la Real Academia de Bellas Artes de San Fernando, sig. 7-7/2, Monumentos en general, Informe de Justo María Velasco adjunto a oficio del Jefe Político de la Provincia de Palencia al Ministro de la Gobernación de la Península de 30 de junio de 1844.

${ }^{952}$ Toda esta serie de noticias documentales se ampliarán más adelante, cuando se aborde el estudio de la pieza de manera más profunda.
} 
último, tengo el honor de acompañar adjunto el talón de consignación en el ferrocarril del Norte del Sepulcro Romano que existía en la Iglesia de Husillos en esta provincia, y la cuenta de los gastos ocasionados en la misma, esperando que $V$. S. se servirá acusarme recibo de dicho Sepulcro que va perfectamente encajonado y embalado y abonar el importe de la referida cuenta a cargo de los gastos de material del Museo que tan dignamente dirige, según está determinado en dicha disposición de S. A.

Dios guarde a V. S. muchos años. Palencia, 21 de diciembre de 1870",953.

El spolium in se llevado a cabo por este noble en la abadía de Husillos, reitera, nuevamente, el interés de los hombres medievales por las obras romanas. Sin embargo, aquí parece claro que, ni los espectadores del siglo $\mathrm{X}$, ni los pleno medievales, ni incluso las gentes cultivadas y "modernas" como A. de Morales o J. M. Quadrado comprendieron la escena.

Se podría deducir, con cautela, que el tema representado en el frente del sarcófago no fue la razón principal por la que se realizó tal expoliación, pues la historia en él contada no fue entendida de manera íntegra. La compleja distribución de las figuras, la problemática sucesión de las escenas y la acción encadenada a lo largo del friso, hacen imposible defender una comprensión que justifique su reutilización, tanto en época medieval como en los siglos posteriores. Aunque, tal y como señalamos, tal afirmación nos sigue presentando algunas dudas.

Parece claro que, a pesar de ofrecer un tema pagano tomado de la mitología clásica, en el que varias figuras se muestran desnudas, los espectadores medievales no llevaron a cabo ningún tipo de censura o damnatio nuditatis con respecto a tales imágenes.

Los avatares vividos por esta pieza funeraria romana durante los siglos medievales, aunque recogidos por toda una serie de noticias documentales y literarias vagas y difusas, parecen señalar un posible reaprovechamiento de la cista del sarcófago en la Edad Media. El hecho de que haya llegado hasta nosotros, permite asegurar, en cierto modo que, a lo largo de los siglos recibiera diferentes cuerpos y funciones diversas. Una de ellas, la de "trastero", llevó a guardar algunos muebles viejos y otros objetos dentro del sarcófago, tal y como recoge el documento antes transcrito.

\footnotetext{
${ }^{953}$ Madrid, Archivo del Museo Arqueológico Nacional, Expediente 9 de 1870, Oficio del Gobernador Civil de la Provincia de Palencia al Director del Museo Arqueológico Nacional, 21 de octubre de 1870.
} 
El simple aprecio al mármol, su apariencia suntuosa y el deseo de perpetuar la memoria a través de un lecho funerario que conectase el tiempo vivido por el "expoliador" con aquel pasado más célebre, son razones suficientes para justificar e insinuar tal reutilización ${ }^{954}$.

Tal y como veremos, tanto en el caso hispano, como en el ámbito europeo, las expoliaciones de sarcófagos decorados con amplios programas iconográficos gozaron de amplia fortuna. Si el llamado conde de Monzón se enterró en esta pieza expoliada de la Orestíada ${ }^{955}$, no faltarán ejemplos igualmente significativos.

Señalamos el caso de la princesa italiana Beatriz de Lorena, madre de Matilde de Canossa, que decidió ser inhumada en la catedral de Pisa en torno al año 1076, a pesar de que ésta se encontraba aún en construcción. La pieza elegida narraba en el frente el mito de Fedra e Hipólito y parece ser que las causas de su elección indican la necesidad de aludir y emular mediante el uso de estas piezas, a una romanitas que a finales del siglo XI, por varias razones que iremos explicando, estaba en auge ${ }^{956}$.

Creemos que idénticos motivos pudieran explicar, de una manera general, la expoliación de la obra de Husillos.

El valor de la imagen que mostraban estos frentes decorados con ciclos corridos, así como el entendimiento y la comprensión de los mismos por parte de los escultores medievales, es difícil de precisar. Se trata de un problema que surge al analizar otro de los casos paradigmáticos de expoliación material de un sarcófago durante la Edad Media. Nos referimos, concretamente, al sepulcro romano de la iglesia de San Pedro el Viejo de Huesca (fig. 164).

Dicha obra, expoliada, hipotéticamente, como enterramiento del monarca Ramiro I el Monje, daría cobijo a su nuevo ocupante en una fecha posterior al 1157, en la que dicho rey muere.

\footnotetext{
${ }^{954}$ L. ÁRIAS PÁRAMO, Prerrománico Asturiano..., en especial, pp. 70-71. El investigador, a propósito de la tradición clásica del arte astur, escribe: "se cuidaba especialmente el elemento clásico como tradición de alcurnia, por así decirlo, que había que cultivar".

${ }^{955}$ Las noticias que aseguren este reempleo son, como casi siempre suele ocurrir, dudosas y poco claras.

${ }^{956}$ Beatriz de Lorena fue la segunda esposa de Bonifacio, marqués y duque de Tuscia. Fruto del matrimonio nació la futura condesa Matilde, en el año 1046. Cf.: S. SETTIS, "Continuità, distanza...", en especial, pp. 395-396; L. DE LACHENAL, Op cit., pp. 153-154 y E. PANOFSKY, Renacimiento y renacimientos..., pp. 223-224. Panofsky aporta una noticia interesante. Parece que las escenas de drama, lucha y diversos acontecimientos bélicos, de cacería o de enfrentamiento personal, tal y como ocurre en el tema de la pieza de Husillos, tuvieron especial impacto sobre los artistas medievales. Recoge la influencia ejercida por un sarcófago que narra la muerte de Meleagro y el Llanto de sus allegados ante el drama, sobre el arte de Giotto y Nicola Pisano. Véase así mismo: F. GALVÁN FREILE, "Representaciones bélicas en el arte figurativo medieval: particularidades del caso hispano", Memoria y civilización. La violencia en la Historia, 2, 1999, pp. 55-86.
} 
En su frontal se esculpió una escena de gran tradición dentro del arte romano, tanto desde el punto de vista compositivo, como desde el iconográfico. En el centro de la cista se colocó una imago clipeata sujeta por genios alados que sirve de punto intermedio entre las imágenes de Neptuno y Amphitrite. A los lados, se representaron las personificaciones de Hypnos y Thanatos, los dioses del sueño y la muerte respectivamente ${ }^{957}$.

La "expropiación" de esta pieza de "segunda mano" demuestra el carácter aleatorio que van a presentar muchas de estas acciones, donde esculturas de evidente sentido pagano eran expoliadas por comitentes cristianos. Además, en este caso, la pieza mostraba una iconografía de las personificaciones antiguas de los dioses relacionados con la muerte que hacían complicada una posible resignificación de la imagen en la búsqueda de un nuevo sentido cristiano.

Sin embargo, lo aparentemente fortuito de estas intenciones, se enfrenta al marcado interés que se tuvo, en ocasiones, por aludir a la iconografía pagana mediante el reempleo de estas obras.

Así, L. de Lachenal ha señalado, en relación con una placa colocada sobre la puerta de acceso a la catedral románica de Calvi Vecchia, cerca de Nápoles, el interés por "exponer públicamente" este tipo de iconografía clásica en época medieval ${ }^{958}$. A pesar de mostrar una iconografía pagana basada en el thiasos marino y, aparentemente, presentarse como una imitación de una obra antigua hoy no localizada, fue colocada en la parte alta de la puerta a modo de dintel. La decisión de ubicar la pieza en un lugar tan importante dentro del templo, debe ser vista como algo no casual ni aleatorio. Sin embargo, se nos escapan las razones concretas que expliquen la elección de tal emplazamiento.

Regresando al sarcófago de Ramiro I el Monje, es posible que la figura central colocada dentro del clípeo pudiera haber sido sometida a diversas interpretaciones durante los siglos siguientes a tal expoliación ${ }^{959}$. Sin embargo, a veces no era necesaria

\footnotetext{
${ }^{957}$ M. DURLIAT, “Sculpture romane à...”, en especial, p. 394 y S. C. SIMON, "Iconografía de un capitel del claustro de la Catedral de Jaca", Actas del XV Congreso de Historia de la Corona de Aragón, Jaca en la Corona de Aragón (siglos XII-XVIII), vol. III, Zaragoza, 1994, pp. 223-436, en concreto, p. 394.

${ }^{958}$ La pieza presenta un friso continuo donde fueron representadas, a los lados, dos imágenes de Nereidas, con sus habituales velos volando sobre la cabeza, mientras que en el centro, dos Tritones sujetan el clípeo en el que se inscribe la figura del difunto. La pieza, bastante ruda, ha sido datada en torno a los siglos VIII o IX, aunque se trata de una copia de una escultura romana. Cf.: L. DE LACHENAL, Op. cit., en especial, p. 90.

${ }_{959}$ S. MORALEJO ÁLVAREZ, "La reutilización...”, pp. 197-203. El experto llega a insinuar la posibilidad de que, durante los siglos medievales, la pareja retratada sobre el sarcófago romano de
} 
ni tan siquiera la presencia de la efigie antigua del difunto para que tal hecho pudiese ocurrir.

Un sepulcro conservado actualmente en el Camposanto de Pisa muestra en su frente dos grandes genios alados sujetando un clípeo vacío, posiblemente inacabado o quizás rehecho en la época en la que la pieza fue reutilizada como sepulcro de Gallo Agnello. En este sarcófago en concreto, si no existía ningún rasgo o imagen que aludiese a la personalidad del difunto allí encerrado, se recurría a todo tipo de soluciones que permitiesen establecer tal conexión. En esta escultura, por ejemplo, se colocó una simple inscripción que dejaba constancia de la relación entre el sepulcro y su ocupante $^{960}$.

Dentro de la lista de algunas de estas obras expoliadas que presentan amplios programas iconográficos, es de estacar, el sarcófago paleocristiano de la catedral de Astorga, localidad en donde se conservó hasta su traslado desde la localidad de San Justo de la Vega (fig. 165). Nuevamente se trata de una pieza de friso continuo datada en una fecha no posterior al año $315^{961}$.

De derecha a izquierda, se esculpieron las escenas relativas a la resurrección de Lázaro, la captura de Pedro, el milagro de la roca y el agua, Adán y Eva ante el árbol del pecado, el milagro de los panes y los peces y, finalmente, el sacrificio de Isaac ${ }^{962}$.

Entre los datos más importantes expuestos por los especialistas que han estudiado el sarcófago, destaca su hipotética dependencia con respecto a algún taller de la ciudad de Roma. Se ha destacado, igualmente, su exquisita factura que, según se ha dicho, sería una de las causas principales que motivaron su elección como tumba provisional del monarca Alfonso III el Magno ${ }^{963}$.

Covarrubias y atribuido como enterramiento de doña Sancha, pudiera haber sido vista como el matrimonio de nobles castellanos. Se trata de una hipótesis sugestiva pero arriesgada.

960 E. PANOFSKY, Renacimiento y renacimientos..., en concreto, pp. 218-219. El autor analiza las repercusiones que la pieza romana pudo tener además dentro del conjunto de pinturas murales realizadas hacia 1350 por Francesco Traini, en el Camposanto y que representan el Triunfo de la Muerte. La imagen frontal del sarcófago pudo inspirar varios de los putti que aparecen en este conjunto, sobre todo, aquellas en las que los dos angelotes sujetan con sus manos una gran filacteria, reinterpretación de la imago clipeata del sepulcro romano.

961 I. M. GABRIEL PÉREZ, "El Sarcófago de San Justo de la Vega (Astorga, León)”, Revista de arqueología, 29, 327, 2008, pp. 24-33.

${ }^{962}$ Se trata de un programa iconográfico bien conocido dentro de los repertorios de talleres productores de sarcófagos de la ciudad de Roma, ya desde el siglo IV. Cf.: H. J. L. DE GRIMOUARD DE SAINTLAURENT, Op. cit., pp. 7-9. La alusión a la creación, la caída y la promesa de redención, eran vistos como referentes y síntesis del ideario cristiano.

${ }^{963}$ La pieza acabó finalmente siendo trasladada al Museo Arqueológico Nacional en el año 1869. Sobre ella, véase: M. SOTOMAYOR, Op. cit., p. 19; S. MORALEJO ÁLVAREZ, “La reutilización...”, p. 187; A. OEPEN, "Rasgos generales del sarcófago paleocristiano en Hispania. Bases para la redacción de un primer Corpus", El sarcófago romano..., Murcia, 2001, pp. 257-272; J.-P. CAILLET y H. NILS LOOSE, 
Según señalara el profesor E. Carrero Santamaría, debió de gozar de gran fortuna dentro del panorama de obras artísticas de la catedral de Astorga, dada su veneración dentro de una de las capillas medievales del claustro del templo. El mismo autor señala que, la expoliación in se, pudo potenciar su función como elemento recordatorio y ensalzador de la memoria y el recuerdo de la personalidad del monarca dentro de la catedral. En torno a él, se desarrollaban diferentes procesiones capitulares en remembranza del rey que, tal y como ha defendido dicho experto, aparecen recogidas en los Libros de Aniversarios asturicenses ${ }^{964}$.

En este caso, a las razones de riqueza y prestigio de la pieza antigua, cabe alegar que se trate también de una obra enteramente cristiana y que desarrolle un programa más asequible al espectador medieval que el que presentaba, por ejemplo, la complicada historia de Orestes. Las imágenes del frontal del sarcófago de la catedral de Astorga podían ser, en parte, comprendidas por aquellas personas que tuviesen un contacto visual con la obra. La expoliación de piezas de igual temática e iconografía en lugares muy diversos, podría justificar tal aspecto.

En relación con ello, baste mencionar el famoso sarcófago paleocristiano conservado en la iglesia de San Ambrosio de Milán y que fue reempleado en torno al año 1200 como base para el ambón románico del templo (fig. 166).

Su emplazamiento y los temas cristianos que presenta la obra, desarrollados a lo largo de escenas completamente plagadas de figuración, así como el hecho de que se trate de una importante obra tardoantigua, evidencian el interés y las razones por expoliarla durante los inicios de la Baja Edad Media ${ }^{965}$.

Nuevamente resulta complejo poder llegar a vislumbrar el significado que los hombres medievales otorgaron a la pieza paleocristiana y a su iconografía, así como los niveles de lectura a los que fue sometida. Lo que parece claro, es que la figuración

Op. cit., en concreto, p. 19; T. MAÑANES PÉREZ, Op. cit., pp. 253-254 e I. M. GABRIEL PÉREZ, $O p$. cit., pp. 24-33. El sarcófago fue mencionado ya por A. de Morales en el año 1527, en la capilla de San Cosme de la Claustra, en Astorga. Volvió a documentarse, más tarde, en San Justo de la Vega, para, finalmente, ser trasladado a Madrid, tal y como hemos señalado.

${ }^{964}$ E. CARRERO SANTAMARÍA, "El confuso recuerdo de la memoria", Maravillas..., pp. 85-93, en concreto, p. 93, nota 69.

965 J.-P. CAILLET y H. NILS LOOSE, Op. cit., en concreto, p. 7, p. 52 y pp. 112-114. La pieza, proveniente de un taller romano, es datada por los autores en torno al año 390. Las escenas que narra, ascensión de Elías, el pecador original, Moisés recibiendo las tablas de la Ley, etcétera, permiten suponer una expoliación más allá de lo mera funcionalidad funeraria. Citan también una pieza del año 340 que, aunque expoliada en el año 1819, sirve para atestiguar una continuidad de esta costumbre. Se trata de un sarcófago proveniente de la necrópolis de los Alyscamps. Desde el año 1724 se conserva en la catedral de San Trófimo de Arles, pero tan sólo fue en el siglo XIX cuando paso a ser transformado en mesa de altar que, además, se enmarcó mediante dos columnas también romanas. 
antigua llamó la atención de los escultores medievales y las expoliaciones in se realizadas se desarrollaban siguiendo criterios que valoraban también la técnica. La riqueza del material se vería aumentada al observar la destreza del escultor a la hora de materializar las figuras.

En el año 1911, M. E. Bonnet publicaba un pequeño trabajo donde señalaba el caso peculiar de un conjunto de sarcófagos antiguos expoliados, pertenecientes todos ellos, al ámbito hispano. Se refería, en concreto, a las piezas antiguas reutilizadas en Tarragona y Gerona durante el Medievo ${ }^{966}$.

El autor, a parte de hacer derivar tales obras de los talleres aquitanos de la Galia y señalar la riqueza de las piezas conservadas en suelo catalán, aludía al fenómeno que estamos analizando, al contabilizar los seis sarcófagos paleocristianos y otros dos de tema pagano reaprovechados entre los muros de la iglesia de San Félix de Gerona ${ }^{967}$.

La mayoría de los especialistas han datado las piezas entre los siglos IV y V, destacando, entre ellas, aquella que presenta una cista decorada con estrígiles y con las figuras de Pedro y Pablo, que parecen recibir el alma del difunto ${ }^{968}$.

De manera general, las piezas vuelven a presentar la típica decoración de estrígiles que recorren todo el frente de las cistas $\mathrm{y}$, en ocasiones, muestran excepcionalmente la representación de la orante en el centro, en la vesica piscis. La imagen del Buen Pastor se incluye dentro del repertorio iconográfico, en uno de los ejemplares, por partida doble. Se trata de modelos de larga tradición, como aquel que muestra la clásica composición de un hombre portando el cordero sobre los hombres, con una jarra en la mano ${ }^{969}$.

Pero sin duda, han sido dos, las piezas que más han llamado la atención de los especialistas. La primera de ellas, es el llamado sarcófago de la historia de Susana, inspirado en la narración veterotestamentaria y resuelto a través de cinco escenas ${ }^{970}$. El

\footnotetext{
${ }^{966}$ M. E. BONNET, Les sarcophages chrétiens de l'église St-Félix de Gérone et l'école arlésienne de sépulture funéraire, Paris, 1911.

${ }^{967}$ Ibidem, p. 3; J. BONET Y SISÓ, Sarcófagos romano-cristianos esculturados que se conservan en Cataluña, Barcelona, 1895 y P. DE PALOL, Arte paleocristiano..., pp. 104-110.

${ }^{968}$ E. LE BLANT, Étude sur les sarcophages chrétiens antiques de la ville d'Arles, Paris, 1878; ID., Les sarcophages..., p. 156; X. BARRAL I ALTET, “Apropiación y recontextualización...”, pp. 177-179 y A. MILONE, "El Maestro de Cabestany...”, pp. 182-183.

${ }^{969}$ M. E. BONNET, Op. cit., p. 9. La autora identifica el animal que aparece al lado de uno de los pastores como un perro.

${ }^{970}$ J.-P. CAILLET y H. NILS LOOSE, Op. cit., en concreto, p. 59. Los investigadores han datado la pieza en torno al año 325, como perteneciente a un taller romano. El desarrollo iconográfico de esta obra es bien conocido. De derecha a izquierda se suceden las escenas según el texto bíblico. En primer lugar, aparece Susana entre dos árboles, símbolo del espacio ajardinado donde se produce el encuentro con los viejos que la vigilan. La comparecencia de Susana ante el juez Daniel, ubicados ambos bajo una
} 
segundo, es aquel que muestra, entre diversas iconografías arquetípicas como el sacrificio de Isaac y la multiplicación de los panes y los peces, la imagen de Cristo pisoteando al áspid ${ }^{971}$.

Los sarcófagos han sido encastrados entre los muros del templo en una fecha presumiblemente no anterior al siglo XIV. Es llamativo como las piezas no se han colocado de manera aleatoria, pues aquellas que muestran un contenido pagano fueron distribuidas lo más lejos posible del altar y en la parte baja, mientras que las que narran sucesos eminentemente cristianos, se han colocado en un espacio más privilegiado ${ }^{972}$.

Evidentemente se trata de una expoliación selectiva de las esculturas que, además, desarrollan una suerte de "topografía del spolia" donde, con las piezas "rescatadas", los artífices recreaban una voluntad de relegar al margen los sarcófagos de contenido pagano, mientras que, aquellas indudablemente cristológicas, se exponían en un lugar bien visible ${ }^{973}$.

Esta disposición tan cercana del altar que presentan las piezas romanas, tanto paganas como cristianas, de la iglesia de San Félix de Gerona, nos trae a la memoria la expoliación ya comentada de Saint-Trophime de Arles, donde en época moderna, un sarcófago de doble friso se transformó en antipendia para cubrir la parte delantera de un altar, quizás, en una intención de acercar una obra de temática cristiana al lugar más importante del templo.

Este no fue el único caso en el que se produjo una expoliación de una escultura pagana romana en alguna de las zonas más importantes de los templos cristianos. El profesor S. Moralejo ya documentó en su día la reutilización de una losa marmórea romana como base para una mesa de altar que, además, presentaba una inscripción cincelada. Este epitafio pagano, incorporado al mobiliario litúrgico de la iglesia de San

microarquitectura que, posiblemente, simboliza la basílica donde se narra la escena. Daniel dicta sentencia favorable e impone la mano de la absolución sobre la cabeza de la joven. Finalmente, los dos viejos salen de la escena. Se ha destacado de la pieza la nota paisajística de los dos árboles, la simetría de las escenas y el tocado que porta Susana, además de la silla sobre la que Daniel imparte su veredicto, representada a la manera romana.

971 Esta iconografía, única dentro del ambiente de la escultura paleocristiana hispana, ha sido habitualmente citada en los estudios de la pieza. Cf.: J.-P. CAILLET y H. NILS LOOSE, Op. cit., en concreto, pp. 64-65. Nuevamente se trata de un sarcófago importado de Roma y datado en el siglo IV.

972 Ibidem, en concreto, p. 17 , pp. 58-59 y p. 113. Es llamativo como los autores llegan a insinuar, incluso, la posibilidad de que tal disposición corresponda a una intencionalidad ligada a un posible programa simbólico.

${ }^{973}$ No debe parecer una excepción pues, tal y como veremos en este trabajo, la filiación entre los motivos de la escultura románica y la clásica, se hace más evidente allí donde los temas han sido relegados al margen, quizás, un espacio de mayor libertad creativa. En relación con una intencionalidad bien estudiada a la hora de reubicar las piezas romanas en los espacios cristianos, recordemos el análisis que se ha desarrollado en este estudio sobre el concepto de la varietas. 
Paio de Antealtares, refleja claramente la pericia de los escultores románicos, quienes supieron hacer convivir la pieza clásica con los cuatro apeos del altar en forma de estatuas columnas con la representación de los Apóstoles ${ }^{974}$.

Este ejemplo, junto con los sarcófagos reempleados en Gerona, señala cierta continuidad del fenómeno en suelo hispano. Las piezas eran recuperadas conscientemente y colocadas en los nuevos lugares, aunque no podamos señalar si tal acción venía acompañada por una actividad reflexiva profunda. Lo que se puede mantener, con mayor seguridad, es que tales conductas se documentan incluso más allá de la etapa románica.

Del siglo XIII se ha datado el spolium de un sarcófago antiguo de una cronología próxima al siglo IV, sobre una de las puertas laterales de la catedral de Tarragona ${ }^{975}$ (fig. 167).

Allí, embutido dentro de la cantería gótica y compartiendo espacio con los maineles y calados góticos, aparece el friso corrido de tipo constantiniano que narra diversas escenas, entre las cuales, la más destacada es la que muestra la entrada en Jerusalén de Cristo, ubicada en un lateral de la composición ${ }^{976}$.

Se puede remarcar, en relación con su reubicación en dicho acceso, que se trata de una recolocación con clara intención publicitaria y exhibicionista. Su expoliación en un lugar tan visible no fue casual, pues el tema de la entrada de Cristo en Jerusalén, siendo recibido por sus fieles, así como la exaltación del Cristo "hacedor" de milagros, se ajusta perfectamente a los grandes temas de la escultura medieval seleccionados, en ocasiones, para decorar los accesos y las portadas ${ }^{977}$.

\footnotetext{
974 El altar se encuentra en la actualidad desmantelado. Las columnas se reparten entre el Museo Arqueológico Nacional de Madrid y el Fogg Museum de la Universidad de Harvard. La que representaba la figura de San Juan, hoy se encuentra desaparecida. Cf.: S. MORALEJO ÁLVAREZ, "Altar support with Apostles Matthew, Simon, and Judas", The art of the medieval Spain. 500-1200, New York, 1993, ficha catalográfica no 93, pp. 214-215 y J. YARZA LUACES, “Artes figurativas románicas en Galicia antes de 1150”, Románico en Galicia y Portugal, A Coruña, 2001, pp. 57-87, en concreto, p. 77. J. Yarza data las piezas en la segunda mitad del siglo XII (1152), sin embargo, muestra sus dudas con respecto a su proveniencia y su función como apoyos de una mesa de altar, alegando que son demasiado altas.

${ }^{975}$ S. MORALEJO ÁLVAREZ, "La reutilización...", en especial, p. 194. La pieza ha sido datada por este autor entre los años 390-395. Nuevamente es una importación romana.

${ }^{976}$ A dicha escena le acompañan otras alusivas a los milagros de Cristo, como la curación del criado del centurión o de los hijos del funcionario real, además de la curación del paralítico, representada en el centro de la parte frontal.

977 E. CONDE GUERRI, "La iconografía de los milagros de Cristo en los sarcófagos paleocristianos como prototipo del "nuevo héroe", El sarcófago romano..., pp. 273-281, en especial, pp. 274-275. La autora defiende la importancia que tuvieron las escenas salutíferas y sanatorias dentro de la formación de la figura de Cristo reencarnando la imagen del nuevo héroe. Insiste, igualmente, en la utilización de un mecanismo clásico, explotado por el cristianismo para configurar tal imagen de Cristo. En este sentido, la colocación de estas escenas dentro del ámbito de una puerta, aludirían al anticipo del cielo en la tierra,
} 
La puerta de entrada al templo adquiere, con la colocación de este sarcófago clásico, connotaciones ligadas a la exaltación de la figura de Cristo y su dominio. El vano toma tintes simbólicos, convirtiendo un fragmento de la Antigüedad paleocristiana en un indicador y evocador del triunfo de Cristo ante las puertas de Jerusalén o, lo que es lo mismo, el triunfo del fiel cristiano ante la Nueva Ciudad Santa, materializada aquí por el templo al que se accede mediante esta suerte de Porta Coeli.

Este mismo fenómeno se percibe, por ejemplo, dentro de la magnífica portada de la iglesia italiana de San Leonardo al Frigido, realizada entre los años 1170-1180. En el dintel de tal estructura se figuró la escena de Cristo entrando en Jerusalén, con una distribución iconográfica en friso, con las figuras presentando una marcada isocefalia y sobre, todo, un relieve que permite relacionarla, desde el punto de vista formal, con el frontal de algún sarcófago paleocristiano ${ }^{978}$.

Volviendo finalmente al caso catalán, la presencia en este lugar tan importante de una pieza romana servía, en parte, para reiterar la antigüedad de la propia sede tarraconense, presentando una prueba material que atestiguase la longevidad de la diócesis, dentro del panorama de la cristiandad hispana.

Para el caso del sarcófago de Tarragona, ya en el año 1886, M. Edmond Le Blant conectaba su iconografía con algunos ejemplos conservados en la Galia. Desde una vertiente iconográfica, señalaba la difusión que había tenido en dicho área, por ejemplo, el uso del mismo tipo de distribución de las escenas en el frente del sarcófago. La tabla central de estas piezas, se presentaba dividida en dos registros, hecho que tiene su paralelo más cercano en otro sarcófago coetáneo en el tiempo y conservado en la antigua iglesia de San Venerando de Clermont ${ }^{979}$.

El autor hace una equiparación entre la obra empotrada en la fachada de la catedral de Tarragona y otros ejemplos, como son aquellos conservados en la ciudad de Roma, en la localidad francesa de Die, cerca de Grenoble, en Arles y en la región de

materializado a través de los milagros de Cristo pero, sobre todo, a su triunfo, representado por su entrada en la Ciudad Santa.

${ }^{978}$ New York, The Cloisters. Metropolitan Museum of Art. Cf.: CH. T. LITTLE y T. B. HUSBAND, “Two Italian Church Portals", The Metropolitan Museum of Art. Europe in the Middle Ages, New York, 1987, pp.68-71.

${ }^{979}$ La iglesia de Saint-Vénérand de Clermont aparece ya citada a propósito de su alto número de sarcófagos en los textos de Gregorio de Tours. Además, a pesar de las destrucciones sufridas en el templo durante la Revolución, conocemos datos, más o menos, seguros. Gracias a los diseños del anticuario francés Tersan, datados en torno al año 1819, así como a la descripción topográfica que realiza de la ubicación de las piezas, actualmente se ha podido llegar reconstruir su colocación dentro del recinto. Cf.: M. EDMOND LE BLANT, Les sarcophages..., en especial, pp. 59-60. 
Vienne ${ }^{980}$. Sin embargo, además de ello, Le Blant alude a otro pequeño fragmento encastrado sobre los muros de la catedral de Clermont. Se trata de una pieza fragmentada de mármol, con seis personajes y una posible ascensión de Cristo a los cielos.

Sin embargo, lo más destacado es que, en una fecha tan precoz, el autor ya señalaba un posible paralelismo entre la pieza expoliada en Clermont y la de Tarragona $^{981}$.

Con todo, la solución de recolocar estas piezas clásicas en los umbrales de las puertas de acceso a los templos medievales, fue menos excepcional de lo que a primera vista se pudiera pensar. En relación con ello, sabemos, por ejemplo, que la tumba de Syagrius fue reutilizada como dintel de la puerta del claustro de la iglesia de Médard de Soissons o, por ejemplo, que otro sarcófago decorado en su frente con dos genios alados que sujetan un medallón a modo de imago clipeata, se reinstaló en el acceso a la iglesia de Notre-Dame-de-Orange ${ }^{982}$.

Sin embargo, si se pueden alegar razones de índole material y simbólicas para la estas expoliación, es importante señalar la dialéctica establecida entre la imagen de la puerta y la propia iconografía arquitectónica que hallaremos dentro de algunas de estas piezas.

Según se ha dicho, parece que esta es la intención de los denominados como sarcófagos "a las puertas de la ciudad" "983. En este trabajo de principios del siglo XX, M. Lawrence, ya mencionaba los ejemplos más significativos de esta tipología que establecían una conexión entre la imagen de la puerta y el propio sepulcro. Desde las piezas conservadas en la catedral de Ancona o Tolentino, hasta la decadencia del tipo iconográfico dentro de la escultura provincial de la Galia, tal y como atestiguan el sarcófago de Saint-Sauveur de Aix-en-Provence o el de Saint-Victor de Marsella. A la vista de tales piezas se puede defender un papel preponderante en la configuración de la imagen de la puerta, sin duda, evocando las producciones paganas donde el acceso al

\footnotetext{
${ }^{980}$ Ibidem, p. 63.

981 Establece, además, conexiones con la catedral de Génova, donde igualmente se puede observar este fenómeno de la expoliación de piezas. Cf.: Ibidem, p. 67.

982 J. ADHÉMAR, Influences antiques..., en especial, p. 79, nota 4. El autor también señala el caso del sarcófago colocado sobre la entrada de la iglesia de San Benito de Cessieu. Se trata de una pieza que, además, posee una inscripción en capitales romanas. Cf.: Ibidem, pp. 79-80.

983 M. LAWRENCE, "City-Gate Sarcophagi", The Art Bulletin, 10, 1, 1927, pp. 1-45. El caso más conocido que explota este juego dialéctico entre la imagen de la puerta de acceso al templo cristiano y la puerta de la ciudad, es el del sarcófago de San Ambrosio de Milán, del que ya hemos hablado. La autora data la pieza a mediados del siglo IV.
} 
Hades como referente al tránsito del difunto hacia el más allá se marcaba mediante la imagen de un vano ${ }^{984}$.

Siguiendo estas mismas líneas de reempleo, la pieza de Tarragona pasa de ser un sarcófago a, mediante el spolium in se, convertirse en un disecta membra y objeto praetioso que, como las pequeñas gemas romanas engastadas en las cruces y objetos de orfebrería prerrománicos y románicos, salpican las producciones artísticas con el único fin de otorgarles abolengo, prestigio, riqueza y ancianidad.

Siguiendo el concepto usado por I. Rilliet, de su función original como contenedor de restos humanos, el sarcófago pasa a poseer una "función terciaria", que lo transforma en una suerte de dintel figurado tardoantiguo dentro de un edifico gótico. Una nueva relación entre imagen ficticia y lugar físico, que establece un juego dialéctico entre la imagen de entrada a la Jerusalén real y el acceso a la Celeste, simbolizada por la propia puerta material de la iglesia. Función, sin duda, para la que los artífices romanos que lo esculpieron jamás pensaron ${ }^{985}$.

Para concluir el apartado dedicado al spolium in se, de este trabajo, aludimos al capitulo del libro de M. Greenhalgh titulado "Precious marbles" 986 . Su estudio deja patente la importancia que llegaron a adquirir durante la Edad Media las producciones y trabajos en mármol salidos de los talleres durante la Antigüedad tardía. Fue esa misma Antigüedad, la que sirvió de cantera material para los nuevos artistas. Una vez cerrados

\footnotetext{
${ }^{984}$ Sobre las piezas francesas y la derivación de la iconografía de las puertas de la ciudad en los frontales de los sarcófagos citados, véase: Ibidem, en especial, pp. 13-16.

Para el caso de la tipología de sarcófagos con representaciones de la Puerta del Hades, se ha conservado en suelo hispano una pieza de primera calidad con la representación de tal tema. Se trata del conservado en Córdoba. Fue hallado en la necrópolis del Brillante en el año 1958 y hoy se expone en el Alcázar de los Reyes Cristianos. La obra, posiblemente de importación desde los talleres de Roma, atestigua la importancia del tema y su larga difusión en el occidente romano. Se ha venido considerando de época tardoseveriana, aunque parece ser que los retratos en él esculpidos, son de factura posterior. Cf.: J. BERTRÁN FORTES, Los sarcófagos romanos de la bética con decoración de tema pagano, Málaga, 1994, en concreto, pp. 93-111.

En otras ocasiones, a pesar del que el sarcófago fue esculpido aludiendo directamente a la puerta del Hades del ideario romano, los artífices cristianos llevarían a cabo una reelaboración escultórica de las piezas, añadiendo, por ejemplo, diferentes símbolos cristianos delante de estos vanos para, de alguna manera, cristianizar el símbolo. En este sentido fueron esculpidas las cruces del sarcófago de Marco I Pío, de San Francisco de Carpi. Sobre la pieza, consúltese: A. C. QUINTAVALE, "Quei campi dei miracoli", Rilavorazione dell'antico nel Medioevo (M. D'Onofrio ed.), Roma, 2003, pp. 15-28, especialmente, p. 21 y M. GARGIULO, "Sarcofago architettonico di un centurione", Rilavorazione..., ficha catalográfica 6, pp. 38-39.

${ }_{985}$ I. RILLIET-MAILLARD, Op. cit., en concreto, p. 182.

${ }^{986}$ M. GREENHALGH, The survival of Roman..., pp. 119-144. El autor analiza la importancia de los materiales marmóreos reempleados durante la Edad Media. El mármol, según el indica, fue un material preciado y de relativa popularidad. Recoge los principales ejemplos de expoliaciones marmóreas a través de los textos más importantes de Francia, Italia e Inglaterra, pero omite, casi siempre, las alusiones a España. De hecho, no dedica ninguno de los apartados del libro a desarrollar un estudio del fenómeno, tal y como hace con los demás territorios.
} 
los grandes talleres de la ciudad de Roma, la técnica de esculpir dicho material decayó o, al menos, la destreza y el sistema de producción seriado con el que habían trabajado los escultores antes de la desmembración del Imperio Romano ${ }^{987}$. Era el momento de reemplear las piezas que dichos obradores habían creado y, era el tiempo también, de competir por lograr apropiarse de alguna de estas preciadas obras.

A propósito del enterramiento del senador Hilario de Dijon, los investigadores J.-P. Caillet y H. Nils Loose señalan:

“(...) un propos de Grégoire de Tours sur le tombeau du sénateur Hilarius de Dijon s'avère très significatif: "lorsque mourut ce personnage, on le déposa dans un sépulcre de marbre de Paros sculpté et dont la magnificence atteste la haute position qu'Hilarius occupait en ce monde"; peu importe, ici, que l'identification du matériau ait été correcte; mais on note en revancha que le chroniqueur accorde toute son attention à l'aspect somptuaire et, implicitement, à la conformité aux usages Anciens, sans seulement évoquer la nature des représentations figurées" ${ }^{\text {988 }}$.

Según el criterio de los autores y, a través de las fuentes señaladas, se entiende bien el calificativo de praetioso utilizado por el cronista medieval al referirse al posible sepulcro expoliado de San Froilán en la catedral de León y con el que iniciábamos esta exposición. Tal expresión, independientemente de la identificación de alguno de los fragmentos marmóreos conservados en el entorno catedralicio con la pieza romana, parece formar parte de un uso tópico del adjetivo dentro del arte antiguo y medieval. El caso del sarcófago de Ithacio así lo garantiza.

Se pueden aducir idénticos argumentos para explicar la intención de un artífice de época moderna al embutir un busto romano, con pedestal incluido, en el muro de la torre campanario de la pequeña iglesia de Quintana del Marco, en León (fig. 168).

Se trata de una pieza de excelente calidad que muestra el retrato de un personaje barbado, con palludamentum de voluminosos pliegues y semblante grave. Se ha identificado la figura como una efigie de Marco Aurelio, que presenta paralelos con otros ejemplos hallados en Hispania, como el retrato de Antonino Pío, el de Adriano o el de Lucio Vero.

\footnotetext{
${ }^{987}$ Ibidem, p. 134.

988 J.-P. CAILLET y H. NILS LOOSE, Op. cit., p. 109.
} 
Estos aspectos, ligado a su carácter suntuario -obsérvese el efecto que causa una pieza romana de primerísimo orden empotrada sobre un muro de factura tosca y rural como el que presenta la torre-, explican sobradamente la intención de este spolium in se. Pero creemos que la causa fundamental que llevó a su reutilización y que además le salvó de la destrucción, fue la creencia de que esta figura barbada era en realidad una imagen del apóstol San Pedro, a quién, además, está dedicada la iglesia donde fue reutilizado $^{989}$.

Es muy significativo como esta pieza, rara dentro de las aparecidas en la provincia de León, justifica aún más su reutilización. En una zona donde la escultura no alcanzó el desarrollo que obtuvo en otros centros romanizados de la Península, las pocas piezas que aparecían, debían ser vistas como verdaderos tesoros ${ }^{990}$. No en vano, este hecho ya fue señalado en su día por S. Moralejo, a propósito de la distribución de los spolia in se a lo largo de toda la geografía hispana. Según el autor, el gran número de expoliaciones de sarcófagos durante la Edad Media, se dio en el norte, precisamente allí donde la romanización había tenido un alcance menor si se le comparaba con otras zonas del sur peninsular ${ }^{991}$.

$\mathrm{Su}$ idea refuerza el argumento, según el cual, las piezas romanas conservadas debían ser vistas como obras excepcionales. El busto romano de Quintana se exhibe en la parte alta, mostrándose como un "trofeo", siguiendo una costumbre que se documenta ya desde la época románica, donde las cabezas de esculturas clásicas decoraban las partes altas de las fachadas. Recordemos en este sentido el famoso busto expoliado y embutido sobre el campanario de la catedral de Capua ${ }^{992}$.

\footnotetext{
989 T. MAÑANES PÉREZ, "La escultura romana en la provincia de León", Butlletí de la Reial Acadèmia Catalana de Belles Arts de Sant Jordi, XVI, 2002, pp. 193-285, en concreto, pp. 229-233 y F. REGUERAS GRANDE, P. YAGÜE HOYAL y R. MARCOS FIERRO, Rapto y Rescate del Héroe. El mosaico de Hilas y las ninfas. Museo de León, León, 1994, en concreto, p. 16. Para estos autores la personalidad que retrata el busto sería desconocida. Apoyan la posibilidad de que por sus rasgos físicos y la fórmula empleada para el retrato, fuera identificado en el momento de su expoliación como San Pedro. Los ejemplos son numerosos en cuanto al reempleo de cabezas romanas a las que se les dio otro tipo de significación. Una cristianización que las conservó y evitó su desaparición. Véase, por ejemplo, la reutilización de una cabeza romana en los muros de la iglesia de Saint-Maurice de Vienne. Cf.: J. ADHÉMAR, Influences antiques..., p. 83.

${ }^{990} \mathrm{Se}$ ha señalado, frecuentemente, que la romanización de la provincia de León, en términos culturales, se produjo más, desde el punto de vista de la escritura, sobre todo atestiguada por un gran número de inscripciones que han llegado hasta nosotros. Por el contrario, son pocas las piezas esculpidas que se han contabilizado.

${ }^{991}$ S. MORALEJO ÁLVAREZ, “La reutilización...”, pp. 187-188.

992 El busto romano de Capua guarda ciertas analogías, en cuanto a las formas de llevar a cabo la expoliación, con la pieza de León. El campanile de la catedral italiana se ha datado en la segunda mitad del siglo XII. Allí, además de reemplearse dicha pieza, se utilizaron otra serie de relieves, inscripciones, columnas y cipos antiguos que también fueron embutidos sobre los muros. Cf.: L. DE LACHENAL, $O p$. cit., p. 171.
} 
En los territorios hispanos, la provincia de Burgos y, concretamente, las áreas lindantes con la localidad de Peñaranda de Duero son un claro ejemplo de expoliación y reempleo de infinidad de vestigios escultóricos datados entre la etapa romana y los siglos visigodos ${ }^{993}$.

Sin duda, este tipo de expoliaciones reflejan las nuevas interpretaciones y funciones que sus expoliadores otorgaban a tales obras, a veces ligadas con el simbolismo apotropaico y protector que habían tenido durante la Antigüedad y, en otras ocasiones, por identificarse con algún santo o mártir ${ }^{994}$.

Finalizamos este apartado aludiendo a la famosa carta de Foulcoie de Beavais a su amigo y confidente el abad Hugo I de Semur, abad de Cluny durante el siglo XI y en la que, precisamente, el tema principal sobre el que versa la misiva es torno a una cabeza romana. El texto dice:

"Meldis erat murus celebratus, teste ruina. Tempore praeterito nomine perstat adhuc/ Quem Martis fanum veteres dixere coloni. Martis adhunc fanum saxa, colone, vocas;/ Quem sic dicebas nec rem dicendo tenebas,/ Res inventa dedit nominis indicium/ Hoc in semiruto dum ruricolonus araret/Invenit effigiem, fit velut effigiem/ Nulli par nostro sculptum caput invenit unum, / Nulli quod vivat quodque figuret homo. Horrendum caput, et tamen hoc horrore deocorum;/ Lumine terrifico, terror et ipse decet./ Ritibus, ore fero, feritate sua speciosum. Deformis formae forma quod apta foret./ Tunc prius ingresso fines mihi fertur imago,/ Ut conjectarem quid, cui, cujus erat./ Auditoque loci corrupto nomine lingua/ Vulgi, dumque locum dum caput intueor,/ Neglectum sed utrumque licet, sed utrumque decorum,/ Rem docuere locus nomen et acre caput/ Hic Martis fanum locus est, Martisque profanum/ Hoc caput est, error quem putat esse deum/ Olim dum valuit sic conjectando probavi,/ Olim secta timor dum peperere deos/ Immo non valuit nec debuit ille valere/ Quod

\footnotetext{
993 J. L. HERNANDO GARRIDO, "Ermita del Santo Cristo", Enciclopedia del románico en Castilla y León. Burgos, vol. IV, Aguilar de Campoo, 2002, pp. 2746-2754.

${ }^{994}$ No vamos a incidir en la costumbre antigua de proteger los recintos sagrados y funerarios con cabezas humanas y zoomórficas. Señalamos, a título de ejemplo, dos sarcófagos paleocristianos que, creemos, por su cercanía temporal con la Edad Media, pudieron ser los que más influyeron en este tema. Por ejemplo, un gran sarcófago con dos cabezas humanas esculpidas en los bordes de la tapadera se conserva en San Víctor de Marsella o, el ejemplar fragmentado del Museo de Avignon, con un rostro de perfil que algunos autores han identificado con San Ginés. Cf.: M. EDMOND LE BLANT, Les sarcophages..., p. 43.

En este sentido, resulta importante la cabeza esculpida en el flanco derecho, bajo el nicho en el que se encuentra la imagen de María, de la fachada del obispo de la catedral de Zamora. No se trata de una pieza de expoliación, sino una escultura cronológicamente contemporánea a la portada. Su simbolismo y las complicadas lecturas a las que han sido sometidas dichas piezas, hablan de una herencia clásica que atribuía todo tipo de cualidades y leyendas a los vestigios cefálicos de este tipo. Sobre la fachada del obispo de la catedral de Zamora, véase: E. FERNÁNDEZ GONZÁLEZ, "Presencia de Oriente y Occidente...", pp. 225-274.
} 
res, quod ratio, quod probat iste locus/ Esse deum ratione caret cui contulit essel Effigiale manus, materiale lapis./ Nil agit os, oculum, manus et pes, nariz et auris;/ Ars dedit effigiem, non dedit officium" $"$.

Tal y como se describe, el descubrimiento de una cabeza de Marte, cerca de Meaux, es una prueba del interés mostrado por algunos personajes del mundo medieval hacia las obras clásicas. Foulcoie, archidiácono de Beauvais, representa bien esta idea que venimos desarrollando. Una conducta de admiración, extrañeza, valoración y, finalmente, de posible explotación hacia las obras antiguas.

Cuando a finales del siglo XI los allegados del abad Isarn de Marsella, deciden monumentalizar la tumba de este personaje muerto en el año 1049, pagaron a un escultor que decidió tomar un sarcófago antiguo y utilizarlo como base para la nueva pieza medieval, es decir, llevó a cabo un spolium in se $e^{996}$ (fig. 169).

No contentos con tal cita material del pasado, se decidió tomar como modelo para la nueva escultura una lápida romana que posiblemente se hallaba en el cementerio de Saulieu ${ }^{997}$ (fig. 170). Es decir, a parte de la primera expoliación física de un material clásico dispuesto como base para la nueva escultura medieval, los creadores de la obra llevaron a cabo una segunda expoliación. A través de la observación de una pieza romana, se reinterpretaban aquellas formas a través de un nuevo lenguaje medieval. A este tipo de expoliación que citamos en segundo lugar, se le ha venido denominado spolium in re, un concepto que ahora pasamos a analizar.

\footnotetext{
995 Beauvais, Bibliothèque Municipale, Ms. 6121. Cf. : M. A. BOUTEMY y F. VERCAUTEREM, "Foulcoie de Beauvais, et l'intérêt pour l'archéologie antique au $\mathrm{XI}^{\mathrm{e}}$ et au XII siècle", Latomus, I, 3, 1937, pp. 173-186 y J. ADHÉMAR, Influences antiques..., pp. 311-312.

${ }^{996}$ X. DECTOT, Pierres tombales..., en concreto, pp. 26-27. El autor justifica tal actuación por la importancia que tuvo este personaje dentro de la construcción de la iglesia de San Víctor de Marsella y, sobre todo, en la introducción de la Reforma Gregoriana en dicho ámbito. Véase también: J.-R. GABORIT, "Dalle funéraire de l'abbé Isarn", La France romane..., ficha catalográfica 178, p. 240, donde señala la forma, un tanto peculiar, del sepulcro, con las extremidades redondeadas, tipo bacellinato. Se trata de una tipología muy difundida entre los siglos II y III, pero de la cual no se han encontrado prototipos anteriores en Marsella. El gran epitafio que presenta la pieza donde se dan noticias exactas de la muerte del difunto, esta trazado, así mismo, en unas bellas capitales cuadradas.

Por último, señalamos un sarcófago paleocristiano conservado en el Museo de Autun, que presenta, igualmente, una forma similar a la del sepulcro de Isarn, con los bordes de la tapadera redondeados. Cf.: M. EDMOND LE BLANT, Les sarcophages..., en concreto, p. 3.

997 J. ADHÉMAR, Influences antiques..., en concreto p. 236 y P. DESCHAMPS, Étude sur la renaissance de la sculpture en France a l'époque romane, Paris, 1925, en concreto, pp. 68-69. P. Deschamps se pronunciaba sobre el monumento sepulcral de Isarn, planteando la posibilidad de que el artífice medieval, conocedor de sus propias limitaciones como escultor, hubiese colocado conscientemente la gran lápida sobre la que se emplaza la inscripción, para evitar así esculpir el cuerpo de la figura y la propia vestimenta.
} 


\section{4. ALGUNAS NOCIONES SOBRE EL SPOLIUM IN RE.}

Según el profesor S. Settis, un spolium in re consiste en:

“(...) il reimpiego admirativo di stili, motivi e temi precedente, che siattua attraverso l'imitazione (...) una spoliazione concettuale ed eclettica: non un trasporto fisico, 998 .

Se trata, por lo tanto, de un nuevo empleo, esta vez admirativo, de las obras, motivos y formas de una obra antigua durante el periodo medieval. La expoliación deja de ser meramente material para pasar a ser conceptual e ideológica. Ahora existe una reinterpretación de los motivos tomados del arte clásico, no una apropiación del material $^{999}$. Nuevamente se verifica una actitud de respeto y admiración hacia el arte clásico, que sigue considerándose como signo de alcurnia y distinción, según el conocido "principio de autorictas" pero, sobre todo, continuó siendo visto como una "cantera abierta" inagotable de ideas a las que recurrir ${ }^{1000}$.

El concepto, que en un primer acercamiento parece simple, presenta un contenido y unas complejidades mayores que las que hemos señalado para el primer tipo de expoliación, el spolium in se.

Cuando el artífice medieval se enfrentaba a una pieza clásica, las actitudes y reacciones que mostraba podían ser muy variadas y el elemento subjetivo, definidor de tal conducta, acabará por presentarse como un factor difícil de analizar.

De entre las muchas posibilidades, el artista podía absorber el motivo clásico, siendo conocedor de su bagaje y significado y utilizándolo de la misma forma con la que se había comprendido durante toda la Antigüedad. Desde otra perspectiva, podía enfrentarse al modelo antiguo, copiando tan sólo el significante clásico, pero dotándolo de un nuevo significado que, generalmente, estaba ligado a ciertas premisas cristianas aplicadas sobre la imagen mediante la reinterpretación.

\footnotetext{
998 S. SETTIS, “Continuità, distanza...”, en concreto p. 401 y M. A. CASTIÑEIRAS GONZÁLEZ, “Capitel románico...", en concreto p. 252. M. Castiñeiras lo define como "a utilización física dunha peza antiga nun novo contexto medieval".

${ }^{999}$ A. C. QUINTAVALE, "Quei campi...”, pp. 21-25.

1000 Ahora no material, sino también intelectual. Este concepto aparece ligado a la legitimación política que las obras de arte antiguo otorgaban a quién las poseyese e hiciese uso de ellas. Cf.: S. MORALEJO ÁLVAREZ, “La reutilización...”, pp. 188-189.
} 
En último lugar, el artista medieval podía "copiar" de manera mecánica una obra clásica, tan sólo atraído por su belleza, por su exotismo o, simplemente, por su tema, sin saber realmente de lo que se trata, pero reproduciéndolo sin otra función que realizar un mero ejercicio evocador del modelo.

De todos estos comportamientos mencionados, el más habitual fue aquel en el que el artífice medieval copiaba el motivo clásico, pero dotándolo de un nuevo significado. Se conservaba el significante pero el significado variaba, su contenido dejaba de ser comprensible si se le continuaban aplicando los varemos conceptuales y de comprensión utilizados por los espectadores del arte antiguo. La conducta, así definida, encaja perfectamente con la expresión utilizada por E. Panofsky para definir tal fenómeno. Nos referimos al denominado como "principio de disyunción"

Dos ejemplos al respecto pueden clarificar esta idea. El primero de ellos, datado cronológicamente en el siglo IX, se desarrolló dentro del arte prerrománico asturiano, auténtico nexo de unión entre la Antigüedad tardía y el arte del primer románico hispano.

Cuando Ramiro I (842-850) manda construir y decorar la iglesia de San Miguel de Lillo, en el monte Naranco, las líneas del "programa" que se iba a seguir en tal tarea, creemos, estaban perfectamente pensadas y previstas:

“Ramiro reinó siete años (...). En el lugar de Liño construyó una iglesia y palacios, con admirable bóveda" ${ }^{1002}$.

Los motivos utilizados en las tareas de decoración pictórica y escultórica del templo así parecen indicarlo, aunque, en verdad, las Crónicas silencian cualquier alusión al programa esculpido, mientras se detienen de manera más prolija en lo arquitectónico $^{1003}$.

1001 E. PANOFSKY, Renacimiento y renacimientos..., pp. 136-137 y M. A. CASTIÑEIRAS, Introducción al método iconográfico, Barcelona, 2005, en concreto, pp. 104-108. Recoge el conocido texto escrito por F. Saxl y E. Panfosky en el que dicen: "Como dos desafortunados enamorados de una película que esperan volver juntos, forma y tema clásico se separan", en relación con el "principio de disyunción". Además, Castiñeiras establece tres categorías, siguiendo a J. Bialostocki, en relación con los grados de contaminación que se producen en la iconografía desde su transmisión del mundo clásico al medieval.

${ }^{1002}$ Crónicas Asturianas..., "Crónica Albeldense”, 10, p. 249.

${ }^{1003}$ I. G. BANGO TORVISO, Arte prerrománico..., en concreto, pp. 261-263 y V. NIETO ALCAIDE, "La imagen de la arquitectura asturiana de los siglos VIII y IX en las crónicas de Alfonso III", Espacio, Tiempo y Forma, Madrid, VII, 2, 1989, pp. 11-34. Se ha llamado la atención sobre este aspecto, donde la alta calidad de las producciones arquitectónicas del reinado de Ramiro I, conllevaron a que las Crónicas 
A propósito de la obra escultórica del templo, escribía I. G. Bango Torviso:

“(...) la decoración escultórica no tiene la calidad del proyecto arquitectónico. Es una escultura efectista, pero tosca y de limitados recursos, labrada con los bordes redondeados y con representación de detalles mediante un grafismo lineal inciso" ${ }^{, 1004}$.

En el acceso a dicha iglesia, ubicadas flanqueando el acceso al edificio, se colocaron dos grandes jambas en las que se esculpieron una serie de imágenes de importante contenido ideológico ${ }^{1005}$. Cada una de las piezas presenta tres imágenes distribuidas de manera vertical a lo largo del machón y, separadas, las unas con respecto a las otras, mediante dos franjas de sogueado con cuatro florones interiores en cada una. En lado contrario del flanco de la puerta se colocó una pieza de similares características, tan sólo diferenciada en los mínimos detalles.

Todos los autores coinciden en señalar que el motivo que inspiró a los escultores medievales fue un díptico consular tardorromano ${ }^{1006}$. Los artífices asturianos del siglo IX habrían llevado a cabo, hipotéticamente, un spolium in re de los motivos que admiraron sobre una de estas piezas ebúrneas, habituales dentro de la imaginería consular romana $\mathrm{o}$, al menos, esta es la premisa que se deduce al observar detenidamente la iconografía que muestran las jambas de esta iglesia de Lillo ${ }^{1007}$.

resalten más estos aspectos que otros de índole decorativa, tal y como ocurre en los pasajes dedicados a las obras de Alfonso II.

${ }^{1004}$ I. G. BANGO TORVISO, Arte prerrománico..., p. 263. Respecto a este tipo de escultura, ciertamente deudora de modelos clásicos, pero resuelta finalmente de un modo un tanto provinciano y popular, ya puntualizó en su día G. Lorenzoni, afirmando que se le debía prestar especial atención por ser el germen sobre el que se asentarían las experiencias del primer arte románico. Estas obras, sermo vulgaris, como él lo califica, explicarán buena parte del contenido clásico de la escultura alto y pleno medieval. Cf.: G. LORENZONI, “Aspetti del Tardoantico...", p. 20.

1005 Ya hemos insistido en que, es posible, que esta parte occidental del edificio fuese removida o intervenida ya en la misma época medieval.

${ }^{1006} \mathrm{La}$ pieza ha sido tratada de manera reiterada por parte de los estudiosos. Recogemos tan sólo los trabajos consultados para su estudio: A. BONET CORREA, Arte prerrománico asturiano, Barcelona, 1967, en especial pp. 152-153; P. GARCÍA TORAÑO, "Los dípticos consulares y el ramirense", Boletín del Instituto de Estudios Asturianos, 35, 1981, pp. 837-848; V. NIETO ALCAIDE, Arte Prerrománico Asturiano, Salinas, 1989, pp. 131-135 y pp. 144-149; I. G. BANGO TORVISO, Arte prerrománico..., p. 240-241; L. ARIAS PÁRAMO, Prerrománico asturiano..., pp. 176-177; F. GALVÁN FREILE, "Iconografía del soberano en la Alta Edad Media Hispana: Propaganda y Legitimación", Sacralités Royales en Péninsule Ibérique: formes, limites, modalités (VII-XV siècle), (en prensa) у C. BERTELLI, voz "Anastasio I", Enciclopedia dell'arte antica classica e orientale, vol. I, Roma, 1958, p. 342.

1007 A. BONET CORREA, Arte prerrománico..., p. 152. En la escultura de la iglesia de Lillo la influencia bizantina está patente dentro de la decoración de las basas, en los sogueados de los collarinos, las roscas de las puertas de acceso a la tribuna y los mismos capiteles imposta. Según el autor, se trataría de una influencia bizantina y oriental, ligada a las corrientes ultra pirenaicas de raigambre carolingia, proponiendo el ejemplo de la iglesia de Germigny-des-Prés, en Francia, como referente comparativo. 
Resulta extremadamente complejo poder llegar a señalar el modelo clásico exacto que hubo de servir como referente inspirador para la pieza asturiana. Con todo, cabe la posibilidad de poder numerar diversas obras que contienen algunos motivos iconográficos susceptibles de ser comparados con aquellos representados en Oviedo. En este sentido, todos los investigadores han coincidido en señalar los dípticos ligados a la figura de Areobindus como posibles fuentes inspiradoras para la obra, a pesar de que una adjudicación segura del modelo utilizado resulta arriesgada en exceso ${ }^{1008}$.

El gran número de copias y variantes de estas obras de marfil, tan sólo permite hablar de una posible influencia sobre la escultura asturiana de estas piezas romanas ligadas a la personalidad del cónsul. Su facilidad a la hora de ser transportadas y su utilización entre las capas más altas de la sociedad, especialmente dentro del ambiente eclesiástico y regio, a la hora de realizar presentes e intercambios de regalos dentro de todos los ceremoniales de agasajo y recibiendo, han centrado siempre la atención de los especialistas a la hora de buscar posibles modelos que se hubieran transmitido a la plástica medieval.

Entre los dípticos de San Petersburgo, Zurich, París y Bensançon, por citar los ejemplos más conocidos, ninguna de las piezas presenta una total correspondencia con la escultura de Lillo. Tal aspecto debiera autorizar para poder hablar tan sólo de una “evocación” de los modelos ebúrneos ligados con los dípticos consulares, pero no de una copia, en el sentido más estricto del concepto ${ }^{1009}$.

En el marfil de Zurich, una de las fuentes más próximas a la obra asturiana, según la mayoría de los autores, el cónsul se muestra como Magister Militium portando todas sus insignias y presidiendo el inicio de los juegos circenses desde su sella

${ }^{1008}$ D. GABORIT "Diptyque d'Areobindus", Ivoires médiévaux..., ficha 7, pp. 45-47; L. ARIAS PÁRAMO, Prerrománico asturiano..., pp. 176-177 y C. BERTELLI, voz "Aerobindo", Enciclopedia dell'arte antica classica e orientale, vol. I, Roma, 1958, pp. 601-603. Tal y como señalan los autores, de entre los cincuenta dípticos conservados y datados alrededor del siglo VI, más de siete han sido adjudicados a la figura de Areobindus. Aerobindo fue cónsul de Oriente en torno al año 506. Hijo de Dagalaifo y perteneciente a una pujante familia, había contraído matrimonio en el 480 con Anicia Giuliana, nieta de Valentiniano III. En el 503, como magister militium per Orientem, combatió contra los persas. El autor recoge las representaciones más importantes ligadas a la figura de Aerobindo. En este sentido, destacan las piezas ebúrneas conservadas en Zurich, Besançon, en el Museo de Cluny de Paris, en el Archivo del Duomo de Lucca, en la Colección Trivulzio de Milán y el Museo del Louvre de Paris.

1009 D. GABORIT-CHOPIN, "Diptyque du Cónsul Aréobindus", Ivoires du Moyen Age..., ficha 28, p. 182. El autor analiza la pieza conservada en la Zürich, Stadtbibliothek, desde el 1787, que es con la que más frecuentemente se han emparentado las esculturas asturianas.

Lo más destacado es la inscripción que aparece en la tabula ansata, donde se dice: FLAVIUS AEROBINDUS DAGALaifus AEROBINDVS VIR Inlustris. Tal epígrafe ha permitido datar la pieza en el año 506, ubicar su realización en Constantinopla e identificar al magistrado representado en ella con la figura de Areobindus. Cf.: C. BERTELLI, voz "Aerobindo", Op. cit., pp. 601-603. Este último autor destaca las diferencias estilísticas entre todas las piezas e, incluso, entre las hojas de un mismo conjunto. 
curulis $^{1010}$. Las dos hojas que configuran la pieza son, aparentemente, idénticas y tan sólo se diferencian, la una con respecto a la otra, a través de pequeños detalles ${ }^{1011}$. Con la mappa en la mano, da inicio a los juegos, que el escultor ha representados en la parte baja de la placa, allí donde leones, luchadores, domadores y saltimbanquis, inician el espectáculo dentro de un anfiteatro.

Las piezas del Museo del Ermitage, de las Termas de Cluny en Paris o la conservada en el Museo de Bellas Artes de Bensançon, repiten el mismo prototipo. Todas ellas, a través de sus iconografías, configuran el tipo que se ha denominado " $a$ tribunal d'amphithéâtre" y en el que siempre aparece la figura del cónsul presidiendo, desde la parte alta, las escenas de lucha y diversión ${ }^{1012}$.

La escena superior de la escultura de Lillo sigue de manera canónica las representaciones clásicas, donde el cónsul aparece sobre la sella y los pies apoyados sobre un escabel, sin tocar el suelo. Le flanquean dos personajes que, desde un segundo plano, acompañan al cónsul en el palco ${ }^{1013}$. Los artífices del siglo IX asturiano se aseguraron de introducir en la representación todos aquellos elementos habituales dentro de este tipo de imágenes. Aparece, nuevamente, el gran cónsul con la mappa en la mano. Sobre el pecho de dicha figura se han llevado a cabo una serie de incisiones y

\footnotetext{
${ }^{1010}$ Es muy significativo como la obra de Lillo, a pesar de su carácter un tanto arcaico, se ha prestado especial significado a representar detalles aparentemente menos importantes. El cetro que porta la figura asturiana, así como la sella, son los elementos más importantes para identificar la figura del cónsul. De ahí que se repita en todas las piezas de esta misma índole iconográfica. Cf. : D. GABORIT-CHOPIN, Ivoires du Moyen Age..., p. 24. El autor señala que tales aspectos irían adquiriendo una importancia fundamental en las composiciones, tal y como vemos en el díptico del emperador Félix, datado en el año 428, posiblemente efectuado en Roma y conservado en Paris, Bibliothèque nationale de France, Musée des Monnaies, Médailles et Antiques.

${ }^{1011}$ El profesor I. Bango ya detectó en su momento la forma un tanto curva de las piezas pétreas asturianas, sugiriendo, incluso, una deuda con respecto a las formas que frecuentemente poseen los colmillos de marfil sobre los que se solían realizar los trabajos escultóricos romanos: "Será por pura coincidencia, pero la reproducción es tan mimética que, como los modelos en marfil, una de las jambas se incurva hacia dentro siguiendo la forma que muchas hojas eborarias lo hacen condicionadas por la curva del colmillo del que procede el material empleado": Cf.: I. G. BANGO TORVISO, Arte prerrománico..., en concreto, p. 240.

${ }^{1012}$ D. SANDRON "Feuillet d'un diptyque du cónsul Areobindus", Musée national du Moyen Age Thermes de Cluny, Paris, 1993, ficha 130, p. 112.

${ }^{1013}$ En la representación de la jamba, las dos figuras que lo flanquean han sido representadas constreñidas contra los marcos vegetales, mientras la figura central presenta una mayor definición del volumen del cuerpo. Ello se ve reflejado también en la pieza de San Petersburgo. En esta obra se observa, en primer plano, la figura del cónsul acompañado de otros personajes. El dato más importante es que, debido a todo el aparato de regalia que porta y sumado a la parafernalia de la sella curulis, los acólitos han quedado casi ocultos en el fondo de la escena. Cf.: S. NOACK-HALEY, "San Miguel de Liño bei Oviedo (Asturien), Reliefplatten der Portallaibungen. -Gegen 848”, Christliche..., pp. 152-153.
} 
motivos que, quizás, aludan a la rica ornamentación de la trabea picta que portaban los emperadores en este tipo de $\operatorname{actos}^{1014}$.

El peculiar tocado con el que aparecen las figuras de estas jambas, nuevamente se relaciona con las representaciones ebúrneas del siglo $\mathrm{V}$, donde esta especie de casquete, a veces escamado, evocaba los bucles capilares con el que durante la tardoantiguedad se habían mostrado algunas figuras y cuyo recuerdo aún se percibe en las tres retratos ${ }^{1015}$ (figs. 171 y 172).

Debajo de la escena superior, se distribuyó la escena circense. Ambas se separan mediante un sistema decorativo posiblemente tomado de las artes suntuarias realizadas en marfil. Se dispuso en este sentido una banda con bordes sogueados, tan habituales en la decoración asturiana, sobre la que se colocaron cuatro rosetas. Se trata de una reinterpretación del motivo clásico que aparece frecuentemente dentro de estas producciones, tal y como se observa, por ejemplo, en el llamado Díptico del cónsul Apion, procedente de Constantinopla y datado en torno al año 539, aunque en la actualidad se conserve en el tesoro de la Cámara Santa de la catedral de Oviedo ${ }^{1016}$.

Aunque la pieza fuera trasladada a la ciudad en una época posterior a la de realización de las jambas, nos habla de una continuidad en el conocimiento de este tipo de plástica, que nunca fue ajena al acervo cultural del Reino de Asturias.

\footnotetext{
${ }^{1014}$ La serie de pliegues colocados sobre el pecho de la figura central de Oviedo hablan de una observación de este tipo de representaciones en las que los emperadores portaban este rico elemento que se solían cruzar a la altura del pecho, tal y como vemos representada en la imagen de San Petersburgo, en la pieza del Museo de las Termas de Cluny o en otras, como la del Museo de Berry, en Bourges. Cf.: D. GABORIT-CHOPIN, "Diptyque d'Areobindus", Ivoires médiévaux..., ficha 7, pp. 45-47 e ID., "Diptyque: Sénateur présidant les jeux du cirque", Ivoires médiévaux..., ficha 6, pp. 43-44, en concreto, p. 44. La presencia de la mappa o pañuelo con el que el emperador daba comienzo a los juegos fue un elemento muy conocido dentro de este tipo de obras. En relación con ello, D. Gaborit señala un marfil datado en el siglo $\mathrm{V}$ y procedente de la Galia. El autor analiza la forma de la mappa, afirmando que, en realidad, se trata no de este elemento, sino más bien de la representación misma de un díptico de marfil decorado con vegetales, que el emperador sujetaría, hipotéticamente, con su mano.

${ }^{1015}$ Es el tipo de peinado en "boule". Cf.: D. GABORIT-CHOPIN, "Diptyque d'Areobindus", Ivoires médiévaux..., ficha 7, pp. 45-47; D. SANDRON, Op. cit., p. 112 y D. GABORIT-CHOPIN, Ivoires $d u$ Moyen Age, Fribourg, 1978, pp. 19-20. La pieza más representativa en la que se utilizó este tipo de tocado es aquella en la que se esculpió a Adán entre los animales del paraíso terrestre y que hoy se conserva en Firenze, Museo del Bargello. Se ha datado, también, en el siglo VI.

${ }^{1016}$ D. GABORIT-CHOPIN, Ivoires du Moyen Age..., p. 28. El cónsul fue representado sólo en el interior de un clípeo, con la mappa circensis en una mano y el cetro en la otra. A los lados, dos grandes florones de complicadas hojas ornamentan la composición. La Cámara Santa, elevada posiblemente durante el reinado de Alfonso II, debe ser entendida como aquel lugar dónde se custodiaban las piezas más preciadas, además de coincidir "con los restantes oratorios privados europeos en la síntesis de su doble funcionalidad de relicario y uso regio". Cf.: E. FERNÁNDEZ GONZÁLEZ, "Estructura y simbolismo...", en especial, p. 345. A pesar de que no conozcamos todas las piezas que allí se guardaron durante siglos, se supone que el repertorio de obras sería amplio, al igual que la posibilidad de tomar de ellas infinitos repertorios iconográficos y ornamentales. No podemos asegurar que el modelo tomado para las jambas de Lillo hubiera salido de alguna pieza que formaba parte de este tesoro, pero la hipótesis sería factible.
} 
Recuérdese, en relación con estas noticias, como está documentado el viaje que entre los años 1293 y el 1308 realizó el canónigo ovetense Gaufrido a Roma, donde según parece, adquirió esta pieza que rápidamente pasó a endosar la lista de tesoros conservados en la capilla palatina de Alfonso II el Casto. A este caso, debemos sumar también, el del llamado díptico de Gundisalvo, fechado entre el 1162 y el 1174 y que también debió ser considerado como una joya de gran aprecio ${ }^{1017}$.

Todas las noticias apuntan a una tradición en torno a la adquisición, la conservación y la admiración de este tipo de obras dentro de la corte ovetense durante los siglos medievales.

A través de estas producciones nacerían toda una serie de motivos que, tomados del repertorio clásico, eran ahora reinterpretados. El caso más llamativo es el de las carnosas rosáceas presentes en el díptico de Apion, materializadas con toda la fuerza de la plática tardoantigua. Su esquematización en las jambas de Lillo refleja la complejidad a la que se enfrenta el escultor medieval a la hora de intentar evocar los complicados modelos romanos, que los artífices clásicos habían resuelto con gran pericia técnica ${ }^{1018}$.

Dentro de estas composiciones, la división entre escenas se realiza, en la mayoría de los casos, mediante un muro combado que alude a la arena del anfiteatro en la que se desarrollan los juegos que el monarca acaba de inaugurar. Por su parte, A. Bonet Correa describía así la imagen:

"Las escenas de circo con el saltimbanquis haciendo un ejercicio por los aires sobre un palo y el domador con el látigo excitando a un león levantado sobre sus patas traseras" $" 1019$.

Tal descripción alude a la escena que reproduce los clásicos juegos que se desarrollaban en la arena romana, donde los malabares realizados ante animales peligrosos, generalmente felinos, escenas de cacería y luchas en la que, finalmente, se

1017 P. GARCÍA TORAÑO, Op. cit., p. 842 y E. FERNÁNDEZ GONZÁLEZ, "Estructura y simbolismo...", pp. 335-398.

${ }^{1018}$ Idénticas rosetas aparecen en otra pieza del British Museum. Se trata de la imagen del Arcángel, traída de Constantinopla y datada en el siglo VI. Cf.: D. GABORIT-CHOPIN, Ivoires du Moyen Age..., p. 30. Evidentemente, no señalamos con ello una dependencia directa entre las piezas señaladas y los motivos esculpidos de Lillo, pues se trata de una afirmación que no podemos realizar con seguridad.

${ }^{1019}$ A. BONET CORREA, Arte prerrománico..., en concreto, p. 152. 
les daba muerte, fueron habituales dentro de estos repertorios, englobados dentro del tema de la venatio ${ }^{1020}$.

El referente más cercano para el funambulita que realiza cabriolas con el palo, aparece en el marfil de San Petersburgo, donde observamos, dentro de la gran amalgama de personajes y animales, como uno de ellos se levanta sobre su propio cuerpo con las piernas hacia delante, apoyándose sobre una pértiga ${ }^{1021}$. Mientras tanto, otro domador lanza un golpe al aire con el látigo, para amansar a un felino que, sobre las patas traseras, hace equilibrio para mantener en el aire un utensilio que tiene colocado sobre el hocico ${ }^{1022}$.

En el registro inferior se repitió, en ambas jambas, la escena que hemos analizado al principio.

A todos estos elementos tenemos que sumar la propia distribución vertical de las escenas, siguiendo la forma de las hojas ebúrneas y su duplicado, casi exacto, habitual dentro de este tipo de obras ${ }^{1023}$.

Además, ese carácter vertical, recuerda a otro tipo de producciones muy arraigadas en el ámbito hispano, a pesar de que las concomitancias no sean tan evidentes.

Nos referimos a las laudas sepulcrales, donde encontramos referentes que aluden a un mismo origen del motivo vegetal que enmarca las jambas asturianas. Si observamos, por ejemplo, la conocida lauda de Ampelius, podremos constatar la utilización de una cenefa vegetal en la que también se han colocado pequeños elementos

\footnotetext{
${ }^{1020}$ D. GABORIT-CHOPIN, "Diptyque: Sénateur présidant les jeux du cirque", Ivoires médiévaux..., ficha 6 , pp. 43-44.

${ }^{1021}$ S. NOACK-HALEY, “, “San Miguel de Liño bei Oviedo (Asturien), Reliefplatten...”, en concreto, p. 152.

${ }^{1022}$ Se trata de un objeto en forma de U, posiblemente ligado a algún tipo da artilugio como los que aparecen en la arena de la pieza del Ermitage y que algunos autores interpretan como un redil o elemento de delimitación para los animales. También en la hoja del díptico de las Termas de Cluny podemos observar varios de estos instrumentos que, por lo general, adquieren forma de cubos o esferas. Obsérvese el famoso ejemplo de París, en el que un oso intenta escapar de un gazapo metálico que le apresa la pata y al que muerde con ganas para intentar escapar. En esta misma idea fue representada la semiesfera estrellada del díptico del siglo V de la Galia, conservado en el Louvre, donde bajo una tribuna en forma de venera, el cónsul observa como dos osos pelean haciendo malabares, mientras otro personaje intenta capturar un animal por el cuello mediante una cuerda. Cf.: D. GABORIT-CHOPIN, "Diptyque: Sénateur présidant les jeux du cirque", Ivoires médiévaux..., ficha 6, pp. 43-44.

1023 D. GABORIT-CHOPIN, Ivoires du Moyen Age..., p. 25. El experto señala como elemento fundamental dentro de este tipo de piezas la composición vertical, adecuándose a la forma que poseen los cuernos de marfil de donde se obtenían las placas para realizar este tipo de trabajos. Pone el ejemplo de San Petersburgo como clásico dentro de este tipo de organización, afirmando que fue habitual dentro de las piezas datadas entre los siglos V y VI. La misma disposición se observa, por ejemplo, en el marfil de Dionysos y Selene procedente de Italia y conservado en el tesoro catedralicio de Sens. En este sentido, debe recordarse como el profesor I. Bango defendía estas mismas características para las jambas de Lillo.
} 
que recuerdan a las gemas y piedras preciosas representadas entre los vegetales de los mosaicos y las pinturas de época imperial ${ }^{1024}$ (figs. 173 y 174). En el caso de Oviedo, el recuerdo de este tipo de cenefas vegetales o guirnaldas cargadas de frutas, joyas o, diversos objetos, incluso seres vivos, perdura, de manera sintética, en la colocación de dos margaritas en las partes exteriores de las jambas, además de cuatro piñas en las esquinas de la pieza ${ }^{1025}$.

I. G. Bango Torviso, siguiendo a H. Schlunk, consideraba que:

$$
\begin{aligned}
& \text { “(...) al igual que en ciertas iglesias palatinas orientales existen } \\
& \text { representaciones de cacerías y escenas circenses, estas imágenes figurarían con } \\
& \text { igual significación"1026. }
\end{aligned}
$$

Recientemente, el profesor F. Galván Freile ha llamado la atención sobre la disposición geográfica de este spolium in re, dentro del espacio templario asturiano, bajo la tribuna y ante las puertas del edificio, a la manera bizantina ${ }^{1027}$.

Parece claro que, cuando los artífices de Lillo recurrieron a un díptico en marfil monumentalizando en piedra las dos hojas que lo componían, lo hacían siendo conscientes de que iban a ser contempladas por las gentes vinculadas al ámbito palatino. La mejor manera de exaltar la figura del monarca, fue a través de una expoliación de la iconografía y las formas clásicas de un díptico. Como apunta el profesor Bango, la inspiración en este tipo de producciones, conmemora y perpetúa, plásticamente, el periodo de mandato de un cónsul. Se trata de una alusión al monarca y de un uso de las formas antiguas como mecanismo legitimador de una dinastía ávida por contextualizar sus raíces en el pasado.

\footnotetext{
${ }^{1024}$ Esta tendencia de salpicar las orlas vegetales con pequeñas piedras de cristal de roca, emulando joyas o camafeos, perduró también dentro de la miniatura carolingia, donde incluso se representaban en tales piezas, pequeñas iconografías, sin duda, imitando los camafeos incisos de época romana. En el caso hispano, el mosaico de Valeria, presenta igualmente una cenefa que enmarca la escena vertical representada en el centro. Dicho enmarque se llenó de motivos geométricos, aquí mucho más barrocos en su efecto final.

${ }^{1025}$ Recuérdense el intradós de algunos arcos pintados en Santullano o Valdediós. H. SCHLUNK y M. BERENGUER, Op. cit., pp. 48-52.

${ }^{1026}$ I. G. BANGO TORVISO, Arte prerrománico..., en concreto, p. 241.

${ }^{1027}$ F. GALVÁN FREILE, "Iconografía del soberano..." (en prensa). Apoya las semejanzas con respecto a la pieza de Zurich. Con todo, debemos advertir como diversos estudios, ya citados, llamaban la atención sobre los numerosos indicios que permiten suponer ciertas reformas e intervenciones dentro de la parte occidental del templo de Lillo. No se puede descartar que las jambas hubieran sido recolocadas o movidas con respecto al lugar en el que actualmente las observamos.
} 
Un "programa" de connotaciones áulicas, pero con un sentido de la exhibición pública de la imagen, que anuncia el éxito que la escultura en portada habría de obtener dos siglos después.

No en vano, y para finalizar con la reinterpretación en las jambas de Lillo, hacía mucho tiempo que las imágenes de gladiadores y escenas circenses venían ocupando los lugares más destacados de los accesos públicos, de los edificios y las ciudades de la Antigüedad:

"El emperador Nerón havía mandado pintar un coloso o figura suya de ciento y veinte pies, en un lienzo incógnito hasta ese tiempo. Esta pintura, estando ya acabada en los huertos Laminados encendida con un rayo, se quemó con la mejor parte de los huertos. Un liberto suyo, queriendo hazer en Anthio los juegos de los gladiadores, cubrió de pintura las puertas públicas, como todos saben, puestos los retratos al natural de todos los gladiadores (...)"1028 (texto 67).

Casi dos siglos después de esa primera experiencia de la escultura en portada que suponen las jambas de San Miguel en el monte Naranco de Oviedo, se estaba esculpiendo el tímpano de la fachada del Perdón de la Basílica de San Isidoro de León ${ }^{1029}$. Las fuentes para dicha obra, variadas y complejas, se han reducido, generalmente, a la famosa puerta de Miègeville, sin que ésta, además, tenga establecida una cronología segura ${ }^{1030}$.

Sin embargo, ya en el año 1984, el profesor S. Moralejo llamó la atención sobre una pieza que consideramos básica para entender alguna de las imágenes que aparecen, tanto en la portada leonesa, como en la de Toulouse y a la que no se le ha prestado la

${ }^{1028}$ PLINIO, Historia Natural..., p. 1092.

${ }^{1029}$ J. A. MORÁIS MORÁN, "Nuevas reflexiones para la lectura iconográfica de la Portada del Perdón de San Isidoro de León: el impacto de la Reforma Gregoriana y el arte de la Tardoantigüedad", De Arte, 5, 2006, pp. 63-86, en concreto, p. 63. En dicho estudio recogemos las menciones más importantes de la literatura científica, hechas en relación con dicha portada.

${ }^{1030}$ Para un balance de la problemática cronológica de la escultura de dicha portada y su puesto dentro de las producciones del llamado "estilo hispano-languedociano", véase: M. POZA YAGÜE, "Entre la tradición y la reforma. A vueltas de nuevo con las portadas de San Isidoro de León", Anuario del Departamento de Historia y Teoría del Arte, XV, 2003, pp. 9-28, en especial p. 20. La autora se posiciona a favor de una fecha anterior para la portada hispana en detrimento de la escultura de Toulouse. Según la autora, la fecha del 1112, se puede tomar como válida para datar el conjunto leonés, es decir, supuestamente anterior a la fecha tradicionalmente aceptada para la portada Miègeville. En este sentido escribía: "todos los elementos y particularidades iconográficas de los tímpanos legionenses que se hacían derivar de la Porte Miègeville (ca. 1115) desde antiguo (...) tendrían su origen primero en estas portadas hispanas. Desde ahí habría partido el influjo hacia la tolosana, y no al contrario". En este apartado no nos adentraremos en cuestiones cronológicas, por tratarse de un simple ejemplo que clarifique el concepto del spolium in re que venimos tratando. 
atención que merece. Afirmaba el autor que para la escultura de ambas portadas, se había tenido en cuenta como posible modelo, una obra ligada, nuevamente, a los trabajos ebúrneos de la Antigüedad ${ }^{1031}$.

En dichas esculturas, al igual que en las jambas colocadas durante el siglo IX en el acceso a la iglesia de Lillo, la fuente de inspiración fue un marfil tardo clásico, datado en torno al siglo V. Nuevamente la cautela hace necesario hablar de una "evocación" y no de una copia directa, pues, es imposible poder afirmar que fuese realmente una pieza concreta la que se tuvo en cuenta a la hora de esculpir el tímpano leonés. S. Moralejo se refería, particularmente, al llamado díptico Symmachi, una pieza de raigambre imperial en la que fue representada una compleja iconografía de apotheosis de un emperador ${ }^{1032}$.

Lo más destacado para nuestro objetivo es la imagen que se representó en la parte alta de la composición (fig. 175). Se trata de la materialización de la llamada elevatio ad sidera, según la cual, el emperador dejaba de ser hombre material para pasar a ser divus. En su divinización y abandono de este mundo corporal, aparece ayudado por dos Aiones, que lo impulsan con sus manos, a lo más alta del firmamento, donde le esperan diversas personificaciones cosmológicas. El emperador pasaba a formar parte de una nueva órbita, la celeste, representada aquí por los signos del zodíaco ${ }^{1033}$.

No es el momento de profundizar en las fuentes clásicas de la escultura desarrollada en los últimos años del siglo XI y los primeros decenios del XII, pues dedicaremos un apartado de este trabajo para abordar tal cuestión. Avanzamos que todos los especialistas han buscado, tanto para la portada de León, como para la de Toulouse, una serie de fuertes dependientes de los trabajos en marfil ${ }^{1034}$.

Los artistas de las fachadas del Perdón y Miègeville, siempre vinculados con ciertas tendencias "antiquizantes", realizaron un spolium in re de los motivos hallados sobre una obra en marfil, posiblemente, ligada a la hoja de un díptico consular

\footnotetext{
${ }^{1031}$ S. MORALEJO ÁLVAREZ, “Modelo, copia...”, en concreto, pp. 98-100.

${ }^{1032}$ London, British Museum.

${ }^{1033}$ J. ARCE, Funus Imperatorum. Los funerales de los emperadores romanos, Madrid, 1988, p. 153. Las escenas de apotheosis imperiales fueron frecuentes dentro de la iconografía antigua. Nos interesa más destacar su uso también dentro de la iconografía de los arcos triunfales, antecedentes directos de las portadas esculpidas románicas. Baste citar, por ejemplo, el relieve de apotheosis de Septimio Severo representado junto a Julia Domna en el relieve del arco de este emperador en Leptis Magna. Sobre la obra, vid.: H. P. L'ORANGE, Apotheosis in ancient portraiture, New York, 1982, en concreto, pp. 78-79 y J. ARCE, "Imparatori divinizzati”, Aurea Roma ..., pp. 244-248.

${ }^{1034}$ S. MORALEJO ÁLVAREZ, "Modelo, copia...", p. 96; M. DURLIAT, "Les origines de la sculpture romane á Toulouse et á Moissac", Cahiers de civilisation médiévale, XII, 1969, pp. 349-363, en especial, p. 360; Q. CAZES y M. SELLES, Le cloittre de Moissac, Bordeaux, 2001, en especial pp. 23-24 y J. A. MORÁIS MORÁN, "Nuevas reflexiones...”, en concreto, pp. 70-71.
} 
semejante al de Symmachi. Sin embargo, afirmar que fue, concretamente, la pieza londinense el modelo que se tuvo en mente para tal tarea, sería demasiado arriesgado.

A la hora de expoliar el motivo clásico, los autores románicos conservaron el recuerdo plástico de la labra de este material, materializado, sobre todo, a través de las líneas suaves pero con volúmenes marcados que refleja este tipo de escultura. La luz, tal y como señaló en su día H. Focillon, resbala suavemente a través de dichas superficies y pliegues, que reflejaban, claramente, la observación cotidiana de los trabajos realizados con materias blandas ${ }^{1035}$.

La imagen colocada en la placa exterior izquierda del tímpano del Perdón de San Isidoro, conserva el recuerdo de un tipo iconográfico no habitual dentro de la iconografía románica hispana ${ }^{1036}$ (fig. 176).

Ya nos hemos detenido en alguna ocasión, sobre este tipo de representación tan peculiar donde, la escena de la Ascensión de Cristo, se completa con la presencia de los ángeles, que le ayudan en su tránsito. Se trata de un impulso físico y material, pues éstos incluso llegan a tocarlo.

Según se ha dicho, se trata de una imagen de la ascensión, heredada de la iconografía imperial helenística, donde la figura del emperador es ayudada por diversos genios en la Ascensión ${ }^{1037}$. A pesar de que en el ámbito hispano la manera más habitual de representar la Ascensión de Cristo fue a través de una mandorla, aquí, como en la portada tolosana, se tomó el prototipo del marfil ${ }^{1038}$.

Lo que intentamos explicar es que se llevó a cabo un spolium in re del motivo clásico, pero adaptándolo a las nuevas formas y simbolismos del momento. En esta reconversión de la imagen pagana perduraron las formas y el recuerdo del estilo surgido a partir del trabajo en marfil, pero, además, se conservó también la postura de los

1035 H. FOCILLON, La escultura románica: investigaciones sobre la historia de las formas, Madrid, 1987, pp. 206-207.

${ }^{1036} \mathrm{Se}$ ha señalado, incluso, que la tripartición del tímpano en tres placas responde a un reflejo de los modelos eborarios que se estaban manejando, pues, como ya hemos apuntado, para el caso de los marfiles que pudieron inspirar a los escultores de Lillo, la división de las escenas y las piezas a modo de dípticos o trípticos, fue bien conocida. Cf.: S. MORALEJO ÁLVAREZ, “Modelo, copia...”, pp. 98-100.

${ }^{1037}$ Se opone este tipo de Ascensión a la llamada oriental o de tipo sirio, donde jamás existe un contacto físico con el cuerpo del ser en tránsito. Por el contrario, se trata de una acción que, generalmente, realiza por sus propias fuerzas o enmarcado en un ámbito celeste y mayestático, materializado a través de la mandorla mística. Cf.: S. TSUJI, "Les Portes de Sainte Sabine. Particularités de 1'Iconographie de l'Ascension", Cahiers Archéologiques, XIII, 1962, pp. 13-28, en concreto, pp. 16-18; A. GRABAR, "L'iconographie du Ciel dans l'art Chrétien de 1'Antiquité et du Haut Moyen Âge", Cahiers Archéologiques, 30, Paris, 1982, pp. 5-24, especialmente, p. 11; ID., Las vías de la creación..., pp. 42-43 y A. BONNERY, "Le thème de l'Ascension dans les ivoires du Moyen Âge", De la création à la restauration, Toulouse, 1992, pp. 293-304.

${ }^{1038}$ Evidentemente, este rasgo no es dogmático, pues también existen muchos ejemplos en los que, en ocasiones, no aparece la estructura almendrada o mandorla. 
antiguos Aiones, ahora transformados en ángeles. En ambas imágenes, tanto en la clásica como en la románica, los seres alados sujetan a la figura en ascensión por las piernas y lo impulsan con sus manos hacia arriba. En ambas piezas, el artista ha tenido el mismo problema a la hora de introducir en escena las alas y así, mientras que en la obra romana una de ellas inunda el espacio destinado al zodiaco, en León, es el propio Cristo el que toma las alas con sus propias manos ${ }^{1039}$.

Todo fue cristianizado en esta nueva interpretación de la imagen. Los Aiones, ahora se conciben vestidos y sus rostros humanizados y desprovistos de cualquier rasgo pagano. Enmarcando esta placa y solo en esta escena, aparece una inscripción:

\section{(Cruz) ASCENDO AD PATREM MEVM ET PATREM VESTRVUM ${ }^{1040}$.}

Llama la atención que dicha inscripción recorra la moldura relativa a esta imagen y no al resto, a pesar de que hubiera sido fácil una relativa continuación de la misma. Debiéramos preguntarnos, aunque seamos conscientes de lo problemático de la idea y de que, realmente, es poco probable encontrar una respuesta segura, si la colocación aquí del epígrafe no responde a un deseo consciente de reafirmar el contenido de la escena a favor de una identificación segura con un modelo que, en principio, no estaría tan claro dentro del imaginario cristiano. La respuesta, tal y como decimos, es compleja.

Además de todos estos aspectos, como en las jambas de San Miguel de Lillo, se han conservado en la fachada leonesa otra serie de elementos que hablan de una deuda con las producciones en marfil. Véanse, en este sentido, las rosetas colocadas sobre las placas de San Pablo y San Pedro empotradas en los laterales del conjunto y sobre las

\footnotetext{
${ }^{1039}$ Otros pequeños detalles han perdurado dentro de la escultura románica, fruto del recuerdo de la pieza clásica. Por ejemplo, la lateralidad en la colocación del cuerpo ascendente de Cristo, muy habitual dentro de este tipo de ascensiones a la romana.

${ }^{1040}$ La traducción para este texto es la siguiente: "Me elevo a Dios que es mi padre y el vuestro (Juan, XX, 17)". El texto, en ocasiones, aparece ligado al Bautismo, a la Ascensión y a la Resurrección. Cf.: Y. LABANDE-MAILFERT, "Les peintures murales. Le programme roman", Le Baptistère Saint-Jean de Poitiers, Poitiers, 2004, pp. 45-53, en especial, pp. 48-49 y p. 58, nota 1. Según la autora, la misma leyenda fue colocada dentro del conjunto mural de dicho baptisterio, junto a la figura de un Cristo en mandorla flanqueado por ángeles y rodeado de los apóstoles. El texto completo de las pinturas de Poitiers, datadas en el siglo XII, dice así: ASCENDO AD PATREM (MEVM E) T PATREM (VESTRUM, DEVM MEVM ET DEVM VESTRVM). VI (RI G) A (LIL) EI (QVID S) TA (TIS ASPICIENT) ES IN CELVM? HIC IHESVS QVI ASVMTVS EST A VOBIS.
} 
que ya llamó la atención en su día la profesora E. Fernández González, como derivadas de las técnicas escultóricas del marfil ${ }^{1041}$.

Por su parte, la elevación a los cielos siguiendo este prototipo iconográfico expoliado del arte clásico, aparece en algunas piezas ebúrneas de época carolingia, para las que, nuevamente, se ha apuntado una filiación con la plástica romana. En tales piezas, generalmente se representó el contacto físico entre la dextera dominum y la mano de Cristo, por lo que su concepción es diferente a la fórmula que venimos tratando. Una placa conservada en el Museo de las Termas de Cluny y fechada a finales del siglo X, muestra a Cristo ascendiendo con larga túnica o colobium. En su tránsito, agarra la mano de Dios Padre, mientras dos ángeles enmarcan su ascensión. Sin embargo, no llegan a tocarle ${ }^{1042}$.

El resto de cuestiones relativas al supuesto lugar, la cronología y la iconografía que presentaba el objeto artístico antiguo, hipotéticamente, tomado por los escultores románicos para llevar a cabo este spolium in re, caen dentro de las meras conjeturas.

San Isidoro de León fue uno de los centros más importantes en cuanto a la producción y acopio de objetos de índole suntuario, como los marfiles. No sería extraño que alguna de estas piezas en circulación pudiera haber sido tomada como modelo para llevar a cabo esta paráfrasis de la obra clásica.

Con este ejemplo terminamos el capítulo dedicado a la definición y ejemplificación de los diferentes tipos de spolia.

Así las cosas, tal y como advertimos en el apartado dedicado al estudio de los reempleos físicos de piezas dentro de las obras románicas, se han seleccionado una serie de ejemplos muy conocidos y, lo suficientemente claros, como para poder exponer y aclarar el fenómeno. La discriminación de motivos provoca el olvido de ejemplos que se podrían incluir en esta nómina que aquí presentamos, pero la necesidad de claridad y síntesis obliga a ello.

En los siguientes apartados, aplicaremos dicho concepto a las producciones artísticas, especialmente escultóricas, del ámbito románico hispano. Será en la escultura donde, creemos, fue más evidente la repercusión del mundo clásico y de la que,

${ }^{1041}$ E. FERNÁNDEZ GONZÁLEZ, San Isidoro de León, Madrid, 1991, p. 28 y TH. MARTIN, "Una reconstrucción hipotética de la portada norte de la Real Colegiata de San Isidoro, León", Archivo Español de Arte, 81, 324, 2008, pp. 357-378. Además, hemos tratado ampliamente el tema en: J. A. MORÁIS MORÁN, "Nuevas reflexiones...", en concreto, p. 72.

${ }^{1042}$ Paris, Paris, Musée national du Moyen Age. Thermes et Hôtel de Cluny. Cf. : D. SANDRON, "Plaque d'une reliure: Crucifixion, avec Saintes Femmes au tombeau, Ascension et Parousie", Musée national..., ficha 136, p. 116. La obra proviene de Colonia y desarrolla un programa escatológico alrededor de la cruz, que aparece en la parte central de la placa. 
aparentemente, resulta más factible poder buscar modelos concretos o cercanos de inspiración. El spolium in se o in re, serían los dos mecanismos más frecuentes que el medievo utilizó para poder seguir participando de esa Antigüedad nunca olvidada, tal y como intentaremos explicar de manera más profunda a lo largo del estudio ${ }^{1043}$.

${ }^{1043}$ Tal y como se puede advertir, la extensión del apartado dedicado al estudio de la expoliación in re es menos extenso y profundo que el que hemos dedicado para abordar el otro tipo de expoliación. Las causas son de índole metodológica pues, tal y como ya hemos señalado, dentro del ámbito hispano, la mayor parte de los ejemplos que vamos a encontrar hablan de la reinterpretación de las piezas clásicas y no de su expoliación material en forma de spolium in se. Por ello, en los apartados posteriores se insistirá, sobre todo, en la reinterpretación de los motivos clásicos por los escultores románicos, razón última por la que aquí se ha decidido aportar tan sólo una serie de reflexiones muy breves y sumarias que se ampliarán en las siguientes páginas. 


\section{EL ACANTO ROMANO Y EL CAPITEL CORINTIO. LOS TRASPASOS DE UN ORDEN ROMANO A LA EDAD MEDIA.}

Realizar un balance sobre la importancia que el capitel corintio tuvo durante los siglos medievales y su dependencia con respecto al mundo clásico, resulta una tarea de extrema complejidad ${ }^{1044}$. A pesar de ello, en este apartado intentaremos realizar un acercamiento a la problemática de la recuperación de este tipo de capitel durante la Edad Media, aunque, si bien, somos conscientes de que, desde un punto de vista formal, podríamos hablar más bien de una continuación en su uso, puesto que su utilización jamás dejó de realizarse.

El capitel corintio y, antes que él, toda la serie de motivos vegetales derivados de las diferentes gamas y especies de la hoja de acanto, fue uno de los más utilizados dentro de las producciones escultóricas y arquitectónicas del mundo antiguo. Su traspaso a la Edad Media no fue tal, puesto que se trata de uno de los pocos motivos del que jamás se tuvo constancia de su desaparición y del que, además, parece claro que, junto con el capitel historiado, se habría de convertir en el predilecto de los obradores medievales.

${ }^{1044}$ El problema es mucho mayor si se tiene en cuenta que, la utilización del motivo del acanto y, por derivación, del capitel corintio, a lo largo de toda la historia del arte fue recurrente y bastísima. 


\section{1. LA PERVIVENCIA DEL CAPITEL CORINTIO EN LA ESCULTURA MEDIEVAL (siglos VIII-XII).}

Si atendemos a la reflexión realizada por el profesor I. Bango Torviso sobre la problemática del capitel durante la Edad Media hispana, en una de las conclusiones a las que llega, defiende que:

"A pesar de los esfuerzos que se han hecho por sistematizar una tipología de capitel hispano durante los siglos VI y VII no se ha llegado a ningún resultado concreto. No es posible señalar una evolución de formas; lo único que se puede verificar es una serie de mutaciones continuas, absolutamente espontáneas, que no terminan por concretarse en una evolución consecuente. Como este es un fenómeno propio ya de la arquitectura del siglo IV en zonas periféricas del Imperio, resulta más difícil la creación de series tipológicas y propuestas cronológicas con una cierta lógica de producción. Es un campo de investigación que, como no aparezcan nuevos métodos de trabajo, poco es lo que se puede decir de manera segura" ${ }^{1045}$.

Partiendo de tales premisas parece, a priori, extremamente complejo poder llegar a establecer una serie de vías seguras para la reflexión de dicha perdurabilidad. Sin embargo, pensamos que el capitel corintio fue uno de los elementos de la tradición antigua que con mayor homogeneidad pasaría al arte de la Edad Media. La expoliación del motivo, en sus dos variantes, obliga necesariamente a desarrollar un capítulo que aborde el tema.

El capitel corintio, reinterpretado hasta la saciedad a través del spolium in re, no se convirtió en una mera cita mecánica a esa Antigüedad, vacía de contenido y con

1045 I. G. BANGO TORVISO, Arte prerrománico..., en concreto, p. 76. Las palabras del autor están enmarcadas en el estudio de las características generales del arte de la época visigoda, a propósito, por lo tanto, de la escultura alto medieval hispana.

Sobre el tema, véase también: J. CABANOT, "Constitution d'une banque de donnes sur les chapiteaux corinthiens et dérivés du corinthien: méthodes et perspective", L'acanthe dans la sculpture monumentale de l'Antiquité à la Renaissance, Paris, 1993, pp. 9-25. Las actas de este Coloquio celebrado en la Universidad de La Sorbonne en octubre de 1990, se presentan como una de las aportaciones más interesentes en cuanto a la perdurabilidad en el uso del capitel corintio y el acanto durante los siglos medievales. En este sentido, es fundamental para abordar el tema, la obra de conjunto, fruto del Coloquio Internacional organizado en 1987 por la Casa Velásquez, el Instituto Arqueológico Alemán de Madrid, el Instituto Hispano Árabe de Cultura y el Museo Arqueológico Nacional. La publicación fue titulada: Coloquio Internacional de Capiteles Corintios Prerrománicos e Islámicos (ss. VI-XII d. C.), (P. Cressier, Ch. Ewert y J. Zozaya ed.), Madrid, 1992.

Por último, véase también: M. A. GUTIÉRREZ BEHEMERID, "Sobre la sistematización del capitel corintio en la Península Ibérica”, Boletín del Seminario de Estudios de Arte y Arqueología, 48, 1982, pp. $25-44$. 
intenciones tan sólo decorativas. Su presencia dentro de los conjuntos medievales, permite plantear otra serie de hipótesis relacionando su expoliación in se $\mathrm{y}$ sus intenciones simbólicas, propagandísticas y cargadas de reflexión intelectual.

Por todo ello, creemos que no se podría dejar, en ningún caso, de aludir a este elemento y su perduración en la escultura de los siglos medievales.

La cuestión que más nos interesa remarcar, en relación con la morfología del capitel corintio de cronología medieval, no es aquella enfocada al esclarecimiento y la creación de un código o sistema metodológico que permita configurar un panorama de la producción de este tipo de obras en la geografía hispana. Tampoco se ha buscado el establecimiento de criterios de datación cronológica o de diferenciación estilística de las piezas a través de los diferentes periodos históricos.

En este apartado nos centraremos en el uso del capitel en cuanto a su dependencia con respecto a los modelos clásicos y en los factores de continuidad que se establecieron entre las obras escultóricas de la Antigüedad tardía y las de la Plena Edad Media. Por último, el aspecto más interesante sobre esta cuestión, reside en poder llegar a perfilar una lista de "intenciones", en cuanto a su uso, por parte de los artistas medievales, aunque si bien, tal cuestión, como siempre, resulte muy problemática.

El caso del capitel corintio se presenta como el más revelador dentro de la escultura y la arquitectura de épocas prerrománica y románica. Tal aspecto, no sólo deriva de su representatividad desde un punto de vista cuantitativo, sino que también, y ello es más importante, por su íntima relación con respecto a los modelos clásicos. La frecuencia de su inclusión dentro de los edificios medievales habla de una cierta continuidad con respecto a los tiempos romanos, donde este tipo de capitel fue uno de los más utilizados ${ }^{1046}$. La abundancia de piezas y la gran difusión que adquirió, pronto llevaron al capitel corintio a mostrarse como un elemento de fácil acceso, tanto desde un punto de vista admirativo como meramente instrumental.

La supuesta familiaridad y la convivencia cotidiana entre este tipo de esculturas y los mismos escultores medievales, vuelve a poner de relieve el debate entre la expoliación intelectual y la material, a las que fueron sometidos miles de estos ejemplares. Por una parte, es lógico pensar en que ante, un capitel corintio descontextualizado de su emplazamiento original, el escultor medieval viese en él una posibilidad de reutilización funcionalista; pero, del mismo modo, en determinados

${ }^{1046}$ P. GROS, "Situation stylistique et chronologique du chapiteau corinthien de Vitruve", L'acanthe..., pp. 27-37. 
momentos, parece claro que su apropiación y reubicación dentro de los nuevos espacios, materializaba una alusión directa a un arte de calidad y prestigio, que tan sólo poseían las producciones clásicas.

En el caso hispano, como en el resto de las zonas más o menos romanizadas, la expoliación de capiteles corintios antiguos fue frecuente. En su día, P. de Palol ya señaló el aprecio que los visigodos habían mostrado hacia estas obras romanas y la predilección que manifestaron estos primeros escultores del medievo hacia la plástica clásica, patente, sobre todo, en el intento de dominar y emular las destrezas técnicas romanas a la hora de recrear los complicados motivos vegetales ${ }^{1047}$.

Ello llevó, desde los siglos VI al VIII, ha una tendencia recuperadora, por una parte y, continuista, desde la otra, en la que se documenta claramente un interés por incorporar dichos capiteles dentro de las construcciones erigidas ex novo ${ }^{1048}$.

El caso de la basílica de San Vicente de Córdoba, hoy bajo la actual mezquita, debió ser un caso bien paradigmático. Los bellos capiteles reempleados hoy en el edificio HISPANOMUSULMÁN, corresponden, en algunas partes, a las labores de expoliación llevadas a cabo sobre el edificio visigodo anterior ${ }^{1049}$.

Estas piezas muestran, a las claras, el gran aprecio de los talleres godos por las formas clásicas, en todo caso, continuadoras de ciertas tendencias “antiquizantes", por mucho que determinados ejemplares se presenten impregnados de cierto tono provincial $\mathrm{y}$, en otros tantos, ligados a las mejores experiencias plásticas del arte del Impero Romano.

Cuando los constructores de la mezquita cordobesa que trabajaban en la fase constructiva patrocinada por Abd al-Rahman I, decidieron incluir estas piezas godas en

\footnotetext{
${ }^{1047}$ P. DE PALOL, Arte hispánico de la época visigoda, Barcelona, 1968, en concreto, p. 106. El autor incide en el aprecio que la plástica hispano visigoda va a mostrar por todo el repertorio de elementos vegetales pertenecientes a la tradición clásica, como por ejemplo, el capitel corintio, el uso de zarcillos y roleos, así como la pervivencia del interés por incluirlos en la decoración de los espacios más privilegiados del edificio.

1048 J. M. HOPPE, "Quelques observations personnelles sur le rencontre "escultura decorativa tardorromana y altomedieval en Hispania", Escultura decorativa tardorromana y altomedieval en la Península Ibérica, Madrid, 2007, pp. 415-420 y L. J. BALSEMADA MUNCHARAZ, "Algunos problemas de la escultura visigoda toledana", Escultura decorativa tardorromana y altomedieval en la Península Ibérica, Madrid, 2007, pp. 275-300.

${ }^{1049}$ P. MARFIL RUÍZ, "Arqueología. La Basílica de San Vicente: En la Catedral de Córdoba", Arte, arqueología e historia, 14, 2007, pp. 185-196 y S. NOACK-HALEY, "Los capiteles de la mezquita de Madinat al-Zahra", Cuadernos de Madinat al-Zahra: 5, 2004, pp. 413-443.
} 
las nuevas estructuras, estaban movidos, en cierto modo, por una fascinación por lo clásico, idéntica a la que tenían los visigodos ${ }^{1050}$.

La participación de ambas culturas en la explotación de los referentes clásicos romanos a la hora de crear sus propias culturas visuales está fuera de toda duda. Ambos permanecían empapados de un fuerte sustrato clásico sobre el que se habían asentado sus artes y será esa misma comprensión del arte antiguo la que justificará este tipo de reempleos, tanto físicos como intelectuales. No sería de extrañar que, muchos de los capiteles visigodos expoliados en la mezquita de Córdoba, hubieran sido considerados, en el momento de tal reempleo, como producciones de cronología romana ${ }^{1051}$.

En este sentido, es muy significativo señalar que el prototipo de capitel corintio utilizado durante el periodo emiral, es decir, aquel que engloba, principalmente, los reinados de Abd-al-Rahmān I y el de Abd-al-Rahmān II, va a presentar en sus rasgos más destacados, una total continuidad con las formas visigodas ${ }^{1052}$. Incluso, tratándose de capiteles esculpidos dentro de los mismos talleres andalusíes, la forma utilizada no varió mucho de la morfología del capitel corintio utilizada en la Antigüedad por los diferentes focos escultores hispanorromanos ${ }^{1053}$.

Sin duda, la expoliación in re o reinterpretación del prototipo de capitel corintio de época VISIGODA, buscaba, claramente, emular y continuar con una tradición romana. Desde el punto de vista del otro tipo de expoliación, la material o spolium in se, los ejemplos que permiten documentar tales acciones son abundantes.

${ }^{1050}$ P. CRESSIER, "El renacimiento de la escultura de capiteles en la época emiral: entre Occidente y Oriente", Cuadernos de Madinat al-Zahra, 3, pp. 165-187.

1051 J. M. BLÁZQUEZ MARTÍNEZ, "La herencia clásica en el Islam: Qusayr' Amra y Quart al-Hayr alGarbi”, Europa y el Islam (G. Anes ed.), Madrid, 2003, pp. 45-142. El autor aborda la problemática de un sustrato profundamente clásico que tiene su expresión más clara en algunas de las pinturas de dichos monumentos, relacionadas, desde un punto de vista técnico, iconográfico y estilístico, con determinados planteamientos romanos.

Véase también: M. ALMAGRO et alii, Qusayr'Amra. Residencia y baños omeyas en el desierto de Jordania, Madrid, 1975, en concreto, pp. 30-72. Estos autores señalaban, de manera muy marcada, la dependencia que estas pinturas presentaban con respecto al arte romano. A parte de la propia técnica constructiva de los edificios que forman el conjunto de Qusayr'Amra, enteramente romana y basada en el uso del opus signimun, señalaban, además, parentescos relacionados con lo iconográfico.

Sobre el expolio de las piezas citadas en la mezquita, vid.: P. DE PALOL, Arte hispánico..., en concreto, p. 92. El profesor Palol relacionaba algunos de estos capiteles con modelos procedentes de la Bética, datados entre los siglos IV y V.

${ }^{1052}$ H. TERRASE, "La reviviscence de l'acanthe dans l'art hispano-mauresque sous les almoravides", $A l$ Andalus, XXVI, 1961, pp. 426-435, en especial, p. 427. El autor afirma que la mayor parte de los capiteles utilizados en el oratorio del primer emir omeya, Abd-al-Rahmān I, provienen del reempleo de obras romanas y visigodas.

${ }^{1053}$ P. CRESSIER, "Historias de capiteles ¿Hubo talleres califales provinciales?”, Cuadernos de Madinat al-Zahra, 5, 2004, pp. 355-375. 
En todo caso, queda patente un interés común durante los últimos siglos de la Antigüedad y el inicio de la Alta Edad Media por continuar una tradición de reproducción fiel de estos modelos romanos, así como la recuperación de las piezas ya esculpidas que, desde los edificios hispanorromanos, pasarían a formar parte de las nuevas construcciones, tanto visigodas en un primer momento, como islámicas, en una época posterior ${ }^{1054}$.

Con todo, existe un problema mayor en relación con estas cuestiones. Los ejemplos conservados de la realidad edilicia visigoda se muestran en ámbitos geográficos variados $\mathrm{y}$, a veces, alejados de la corte toledana, cuando no, asentados sobre aquellos lugares que acabarían siendo dominados por el Islam. Por ello, a pesar del conocimiento tan sesgado que poseemos de la arquitectura visigoda, se puede señalar aún la existencia de algunos ejemplares de capiteles corintios romanos expoliados y reintegrados en las columnatas de estos templos, de carácter ciertamente más provinciano.

Este el caso, por ejemplo, de la iglesia de San Juan de Baños, en Palencia, donde se conserva, al menos, un capitel posiblemente antiguo fruto del spolium. Se trata del primero de la arcada izquierda desde el presbiterio, según señaló en su día, P. de Palol.

Además, este capitel romano no sólo otorgó la posibilidad de ahorrar los materiales y los esfuerzos económicos y de trabajo que implica reemplear una pieza ya fabricada, sino que, sirvió además, como modelo inspirador del resto de capiteles de la iglesia. Tal hecho indica no sólo una valoración admirativa por el corintio romano, sino, además, un intento por emularlo ${ }^{1055}$.

${ }^{1054}$ P. CRESSIER y P. MARINETTO SÁNCHEZ, "Les chapiteaux islamiques de la Péninsule Ibérique et du Maroc de la renaissance émirale aux almohades", L'acanthe ..., pp. 211-246, en concreto, pp. 212-213 y P. CRESSIER, "Les chapiteaux de la grande mosquée de Cordoue (oratoire d' Abd-al-Rahmān I et d' Abd-al-Rahmān II) et la sculpture de chapiteaux à l'époque émirale. Première partie", Madrider Mitteilungen, 25, 1984, pp. 216-281. Los autores señalan una total continuidad con respecto a los talleres visigodos. Afirman que, ocasionalmente, resulta extremadamente difícil poder llegar a discernir con claridad a quién pertenece la labra de determinadas piezas, puesto que la mano de obra de los talleres emirales y la activa en los visigodos, tenían en los modelos romanos su objeto de inspiración común. Por ejemplo, el tipo de acanto utilizado en la Mezquita de Córdoba, es realmente variable. Incluso, dentro de las etapas de construcción bien definidas, como la de Abd-al-Rahmān II, las tipologías son muy heterogéneas, una característica muy clara de los capiteles de cronología tardoantigua, sobre los que, es imposible poder llegar a crear un método definitorio de tipologías.

${ }^{1055}$ P. DE PALOL, Arte hispánico..., pp. 108-118. Muy interesante resulta la comparación entre la tipología de capitel empleada en la iglesia de Baños y otra serie de esculturas medievales en las que se ha señalado una dependencia directa con respecto a los modelos clásicos. Así, por ejemplo, la distribución de las hélices y las volutas que hallamos en algunos capiteles de la iglesia de Santa María in Domnica o Santa Práxedes de Roma, datados en el siglo IX, presentan algunas semejanzas con los ejemplares visigodos. Según J. Raspi-Serra, este tipo de capitel tan clásico que encontramos en las iglesias romanas del siglo IX, han sido considerados como copias exactas realizadas por los talleres medievales romanos de las obras de época antigua. Cf.: J. RASPI-SERRA, "Le chapiteau d'acanthe en Italie entre le $\mathrm{V}^{\mathrm{e}}$ siècle 
Los edificios de la Hispania romana debieron ser buenos proveedores de dichos materiales, a juzgar por su reempleo en otra iglesia datada dentro de cronología visigoda $^{1056}$. A pesar de su marcado carácter provincial, el templo de San Pedro de Balsemaõ, en Portugal, posee al memos cuatro capiteles romanos expoliados, otra vez de tipo corintio ${ }^{1057}$.

Tales ejemplos atestiguan la utilización de diferentes piezas romanas dentro de los templos visigodos, donde se mantendrá la tradición clásica en la utilización del corintio, a pesar de que, como es lógico, la concepción y morfología de dicho capitel fueran sometidas a una fuerte reinterpretación de los modelos antiguos. Tal hecho llevará a reinventar las fórmulas romanas de una manera totalmente diferente a cómo se habían concebido en el mundo clásico.

Las volutas de las piezas perderán entonces su carácter exento, las proporciones se modifican, el caulículo se descompone y todas las formas vegetales se abstraen y geometrizan dependiendo de soluciones más o menos caprichosas ${ }^{1058}$.

La tendencia que acabamos de señalar para la escultura visigoda, también se produjo de una manera más directa, si cabe, dentro de las producciones artísticas foráneas. Los territorios que configuraban la Galia se mostraban como buenos proveedores de piezas para los nuevos recintos medievales. Sin intención de llevar a cabo un catálogo donde se señalen todas aquellas expoliaciones de piezas importantes, se podrían citar algunos casos que pudieron provocar un impacto, más o menos marcado, en la escultura de los siglos posteriores al año mil.

et le $\mathrm{X}^{\mathrm{e}}$ siècle", L'acanthe..., pp. 175-188, en concreto, p. 182. Ello deja claro que el prototipo de capitel visigodo debe ser considerado como un producto totalmente inmerso en el arte romano, a pesar de las mutaciones propias del tipo.

${ }^{1056}$ Evidentemente, los ejemplos susceptibles de ser mencionados son incontables. Sin embargo, citamos aquellos casos que nos han parecido más significativos para poder ofrecer una visión general del fenómeno.

${ }^{1057}$ P. DE PALOL, Arte hispánico..., pp. 130-134. Además de dicho ejemplo, el autor también recoge el conocido y espectacular caso de la iglesia de Idanha-a-Velha, donde las once columnas del templo presentan capiteles expoliados, que en este caso no son más que diferentes basas romanas que se colocaron invertidas para sustituir al capitel. La fuerte romanización de estas zonas debió ayudar en esta predilección por lo clásico.

Para Puig i Cadafalch, gran defensor de la continuidad plástica entre la escultura realizada bajo el dominio visigodo y la creada en la Asturias del siglo IX, la obra escultórica de San Juan de Balsemaõ presenta un punto de partida para otras producciones posteriores. En concreto, relaciona la escultura de este edificio visigodo con la de la iglesia asturiana de San Miguel de Lillo. Cf.: J. PUIG I CADAFALCH, L'art wisigothique et ses survivances: recherches sur les origines et le développement de l'art en France et en la Espagne du IVe au XIIe siècle, Paris, 1961, en concreto, p. 123.

${ }^{1058}$ I. G. BANGO TORVISO, Arte prerrománico..., en particular, p. 76. 
Un edifico tan señero dentro del panorama arquitectónico de la Antigüedad tardía galorromana, como es el baptisterio de Saint-Jean de Poitiers, puede dar buena cuenta de ello.

Dentro de las más importantes fases de construcción y remozamiento del recinto, se pueden constatar idénticas labores expoliadoras que, en cierta medida, coinciden con las desarrolladas en la Hispania visigoda ${ }^{1059}$. Se trata, además, de una obra que nos permitirá definir algunas de las premisas sobre las que asentaremos las afirmaciones que aquí se realizarán y que tienen como objetivo primordial analizar las relaciones que el capitel corintio clásico va a mantener con la escultura de los siglos XI y XII.

Durante la época MEROVINGIA, en la que dicho baptisterio sufre una reforma, parece ser que se reintegraron dentro del edificio una amplia gama de capiteles, todos ellos corintios, de diferente tipo, material y procedencia. Según M.-Th. Camus, se trataría de piezas elaboradas con mármol pirenaico, aunque la autora expresaba sus dudas afirmando que, posiblemente, fuesen en realidad piezas reempleadas, cuya cronología iría desde la época propiamente paleocristiana hasta el mismo siglo VII ${ }^{1060}$.

Sin embargo, lo que resulta más interesante en este sentido, es poder constatar la admiración que los constructores mostraban hacia este tipo de capitel corintio, pues en relación con su expoliación, se ha insistido fuertemente en la voluntad expresa, por parte de los constructores, de recoger aquel número más elevado posible de piezas de un mismo género. Tales elecciones marcarían profundamente el devenir de la escultura románica posterior.

La profesora M.-Th. Camus, a propósito de estas reflexiones, plantea un panorama del Poitou muy vinculado a las fórmulas artísticas galorromanas, que habrían

\footnotetext{
${ }^{1059}$ El baptisterio de San Juan de Poitiers se insertaba dentro del grupo episcopal del núcleo urbano de la ciudad, ya desde el siglo IV. El edificio fue construido sobre una gran domus romana, ligado a un sistema de calefacción del agua de tipo termal, que habla de unas causas bien interesadas en la elección del recinto. Cf.: B. BOISSAVIT-CAMUS, "L'environnement du Baptistère", Le Baptistère..., pp. 3-34, especialmente, p. 5.

${ }^{1060}$ Se trata de un amplio número de capiteles, dieciocho, en concreto, que presentan una tipología tan amplia que ha sido difícil establecer conclusiones cerradas con respecto a ellos. Lo que si parece claro es que hubo una tentativa de reunir piezas corintias y de reinsertarlas dentro del edificio de una manera no arbitraría. Cf.: M.-TH. CAMUS, Sculpture romane du Poitou. Les grands chantiers du XI siècle, Paris, 1992, en concreto, pp. 58-62. Sin embargo, la autora recoge las diferentes posturas que han suscitado dichas obras, desde su consideración como piezas reempleadas ya en época paleocristiana o, propiamente, esculpidas para el baptisterio durante el mismo siglo VII.
} 
de tener repercusiones en uno de los fenómenos más importantes dentro de la escultura del siglo XI.

Nos estamos refiriendo al movimiento que se ha dado en llamar el "renacimiento del capitel corintio", cuyas características abordaremos más adelante ${ }^{1061}$. Sin embargo, tales reflexiones ponen de relieve el papel jugado por el arte prerrománico a la hora de legar formas y piezas que garantizaron el éxito que tuvo dicho orden durante la Edad Media. En el caso hispano, la situación puede presentar unas características ligeramente similares.

Si durante los siglos VI al VIII se pueden documentar estas expoliaciones de piezas dentro del entorno de las construcciones visigodas, parece ser que, una vez adentrados en el siglo IX, tal costumbre parece proseguir, si bien, en un grado menor. Un caso bien interesante lo ofrece la misma cultura ASTURIANA. Se trata de un territorio inmerso plenamente en los valores plásticos de la baja romanidad y poseedora de centros, más o menos romanizados, como fue el caso de la ciudad de Gijón. En tal ambiente, era de esperar una recurrencia hacia las obras del pasado para buscar su reintegración dentro de las nuevas producciones ${ }^{1062}$.

En ocasiones, los especialistas han señalado que, para el caso de la arquitectura y la escultura asturianas, anteriores al año mil, no se llevó a cabo, al menos que se tenga constancia plena, ninguna expoliación in se de un capitel corintio romano, la cuestión no puede simplificarse tanto.

Tal y como hemos señalado, resulta extremadamente problemático poder discernir a través de un método seguro, si dentro de todos los capiteles corintios que actualmente conserva la edilicia asturiana, alguno de ellos pudiera tener una cronología romana, a pesar de su apariencia provincial.

Que los escultores altomedievales de este área fueron fieles a la tradición visigoda en el uso del capitel corintio, parece claro ${ }^{1063}$. Dentro de un edificio íntegramente impregnado por el sustrato clásico, como el que representa la iglesia de San Julián de los Prados, los artífices dejaron constancia de tal interés por las piezas romanas y su integración en el nuevo espacio medieval, a través de una serie de reempleos ${ }^{1064}$.

\footnotetext{
${ }^{1061}$ Ibidem, pp. 58-78.

${ }^{1062}$ C. FERNÁNDEZ OCHOA, "Le terme di Gijón (Asturie)", Hispania Romana. Da terra di conquista a provincia dell'Impero, Milano, 1997, pp. 181-187.

${ }_{1063}$ A pesar de que, sus modelos, formas y ejecución, sean tan variables y diferentes.

${ }^{1064}$ J. A. MORÁIS MORÁN, "El valor clásico de la arquitectura...", (en prensa).
} 
Dentro de este templo, según se ha afirmado, se han conservado diversas piezas que parecen no pertenecientes a los talleres asturianos del siglo IX. En concreto, se ha señalado uno de los capiteles expoliados en una de las arcadas ciegas de la capilla central del ábside del edificio. Sin embargo, este ejemplo que mencionamos es problemático.

Así, mientras que para algunos autores, como por ejemplo, A. Bonet Correa, se trataría de un empleo consciente del capitel corintio romano dentro de una arquitectura deseosa de lograr un abolengo "antiquizante"; para otros, no pasaría de una simple reintegración de una pieza visigoda ${ }^{1065}$.

En concreto, entre los defensores de esta última teoría, se encuentra A. Arbeiter, quién considera que este capitel corintio de Santullano debe emparentarse más con la tradición escultórica visigoda que considerarlo un spolium in se de época romana. El autor llegará incluso a identificar, quizás de manera arriesgada, la iglesia de Santa María de Bamba como el lugar exacto del que pudo llegar el capitel ${ }^{1066}$.

De ser ciertas estas afirmaciones, el capitel ubicado bajo la arquería ciega de la cabecera de San Julián de los Prados debió ser, supuestamente, transportado desde otro lugar para integrarlo en el conjunto de esculturas de cronología posterior que nos muestra el templo.

Con todo, según F. Marín Valdés, la acción expoliadora que parece documentarse a través de este capitel corintio, debe ser llevada más allá. Para el autor, el caso de esta pieza y el de otras que parecen datables en las mismas cronologías, merecen ser analizadas desde la perspectiva de un reempleo simbólico y no meramente utilitarista.

Según menciona el investigador, a la hora de decantarse por la nueva ubicación de la pieza, los artífices debieron tener en cuenta diversos factores. Se trataría, si seguimos su teoría, de un intento de regularizar la colocación de las piezas, buscando una alternancia compositiva heredada de la más perfecta arquitectura antigua y que demuestra la concienzuda labor selectiva de las obras que se pretendían expoliar, así como el futuro lugar en el que colocarían.

\footnotetext{
${ }^{1065}$ A. BONET CORREA, Arte prerrománico..., en especial, p. 58. El autor defiende que la pieza en cuestión es un capitel romano esculpido en época tardía. También se aborda el problema, en: F. A. MARÍN VALDÉS, "Observaciones sobre la adopción...”, pp. 15-16.

${ }^{1066}$ A. ARBEITER, voz "Asturie", Enciclopedia dell'Arte Medievale, vol. II, Roma, 1992, pp. 672-681, en particular, p. 677 y G. CIOTTA, "La chiesa prerrománica asturiana di San Julián de los Prados a Oviedo. Iconografía, sistemi construttivi e partiti decorativi”, Arte d'Occidente..., vol. I, 1999, pp. 49-59, particularmente, p. 51.
} 
En el caso de los capiteles de Santullano, según afirma, se buscó una alternancia y una disposición de los mismos por pares, buscando la simetría y una cierta concordancia en el estilo y la estructura del corintio ${ }^{1067}$.

Si la teoría del autor es correcta, esta singular manera de distribuir los capiteles corintios dependiendo de su forma, cronología y material, permitiría englobar la escultura asturiana dentro del concepto de varietas, defendido, tal y como ya se ha explicado, por B. Brenk ${ }^{1068}$.

La multiplicidad de piezas de diferente origen, fruto de los trabajos de expoliación, había dominado parte de la mejor arquitecta de patrocinio cristiano durante los últimos siglos de la Antigüedad, según hemos explicado reiteradamente ${ }^{1069}$. Con tal acción, la arquitectura asturiana, heredera de la tradición visigoda, continuaba realizando una práctica arraigada desde los primeros tiempos de la edilicia cristiana ${ }^{1070}$.

Si el problema de la procedencia del capitel del ábside de Santullano no está clarificado del todo, parece seguro que el tipo de corintio utilizado se puede emparentar, perfectamente, con el difundido largamente en las provincias romanas durante los últimos siglos del Imperio ${ }^{1071}$. Quizás ello pueda explicar este hecho, de una manera más convincente, pues, según pensamos, más que de una expoliación romana, se podría hablar de cómo el escultor del siglo IX asturiano, pudo tomar como modelo para su escultura algún tipo de corintio de tipo provincial hispanorromano, y que, en ocasiones estaban muy alejados de los modelos más clásicos.

Sin embargo, la utilización y la valoración de este tipo de capitel en el arte asturiano fue más allá de lo que aquí se ha señalado. Siguiendo, nuevamente, a F. Marín Valdés, es posible que el uso y la importancia dados al capitel corintio dentro del ábside de San Julián, hubiese asentado las bases para determinadas experiencias posteriores.

Así, en el aula palatina de Ramiro I, el uso del corintio alcanza niveles importantes ${ }^{1072}$. En este sentido, lo más interesante en relación con esta cuestión, es

\footnotetext{
${ }^{1067}$ F. A. MARÍN VALDÉS, “Observaciones sobre la adopción...”, pp. 15-17.

1068 B. BRENK, "Spolia e il loro effetto...", en concreto, p. 210.

1069 Ibidem, p. 213 y P. SILVAN, "L'architettura della basílica...", particularmente, p. 250. Recuérdense los ejemplos de los expolios producidos en las fundaciones constantinianas, como por ejemplo, en el baptisterio de San Juan de Letrán y en otra serie de edificios relacionados con el "renacimiento sixtino". ${ }^{1070}$ F. GUIDOBALDI, voz "Roma...", en concreto, p. 72.

${ }^{1071}$ J. RASPI-SERRA, "Le chapiteau d'acanthe en Italie entre le $\mathrm{V}^{\mathrm{e}}$ et le $\mathrm{X}^{\mathrm{e}}$ siècle", L'acanthe..., pp. 175188 y A. PRALONG, "Remarques sur les chapiteaux corinthiens tardifs en marbre de Proconnèse", L'acanthe..., pp. 133-146.

${ }^{1072}$ I. G. BANGO TORVISO, Arte prerrománico... en concreto, p. 264 y V. NIETO ALCAIDE, Arte Prerrománico..., especialmente, pp. 134-140. En la actualidad, aún persiste el problema de identificación y de utilización de una nomenclatura correcta sobre el uso y función de este edificio. En ocasiones, se le
} 
como el profesor V. Nieto realiza una lectura simbólica del capitel corintio dependiendo del lugar exacto que, desde un punto de vista físico, ocupan las piezas en el recinto. Para él, aquellos capiteles "decididamente clásicos" del conjunto, han sido colocados, de manera intencionada, en los exteriores de la construcción, en las fachadas cortas del edificio, allí donde encontramos una proyección visual del capitel corintio, que por cierto, en este caso, son los mejores del tipo que, supuestamente, se llegaron a esculpir dentro de los talleres asturianos.

Somos conscientes de que resulta difícil defender y aceptar un uso consciente de las piezas en relación con el espacio en el que iban a ser dispuestas. Sin embargo, parece plausible que, allí, en las fachadas del aula regia, se tuvo un interés especial por mostrar este tipo de orden corintio ${ }^{1073}$.

En este sentido, V. Nieto Alcaide ha manifestado el fuerte parentesco de la articulación de la fachada con respecto a la arquitectura de glorificación según se concebía en el mundo romano, y de la que, por ejemplo, los arcos de triunfo son la mejor expresión. Es en dicha fachada, donde se han concentrado los elementos escultóricos más interesantes y con un valor plástico mejor definido, tal y como ocurría, en los espacios del mundo antiguo. En este sentido, serán tales aspectos los que permitan explicar la colocación de las bellas fajas pétreas que los escultores remataron con sendos clípeos, a su vez decorados iconográficamente y que aluden, una vez más, a fórmulas muy explotadas dentro del arte romano imperial.

Es en este lugar, donde, tal y como señala el autor, se colocaron los capiteles “decididamente clásicos" y donde tales piezas adquieren un valor importante dentro de la distribución geográfica del recinto. Se trata de soluciones que parecen anunciar recursos escultóricos muy interesantes, que se documentarán en construcciones de cronología posterior. Tal y como veremos, el capitel corintio llegará a servir de

ha definido como belvedere, mirador, recinto o sala de fiestas, dependencia o aula perteneciente a un conjunto palatino, hoy perdido, e incluso, sala del trono, así como una larga lista de posibles funciones.

${ }^{1073}$ No vamos a incidir en el valor que la historiografía ha dado a este tipo de fachada con su correspondiente triple arco. La mayoría de los autores le han buscado paralelos romanos o vinculados al arte clásico. Cf.: I. G. BANGO TORVISO, Arte prerrománico..., en concreto, pp. 242-243. Según el autor, el prototipo constructivo tendría su origen en las fórmulas romanas que definiera al templo de Clitunno, en Trevi (Italia), por citar el ejemplo más evidente. Ambos edificios comparten una fachada dividida en dos niveles, edículos de acceso laterales, y sobre todo, una exaltación del concepto de fachada que cobra valores vinculados a la denominada arquitectura de "potenzo".

Sobre esta cuestión, véase también: J. A. MORÁIS MORÁN, "Un arquetipo...”, pp. 582-589. En cuanto a la tipología de los capiteles del aula de Ramiro I, a pesar de las diferencias en cuanto a su morfología, es interesante atestiguar una cierta continuidad en el uso de la hoja de gran tamaño distribuida en dos pisos, tal y como se nos muestra, en algunos de los capiteles de la nave de San Miguel de Escalada, que utilizan nuevamente el mismo tipo de hoja. Sobre tales aspectos, véase también: I. G. BANGO TORVISO, "Los expolios del paisaje monumental...", pp. 7-50. 
elemento demarcador y a señalar, mediante su presencia, determinadas partes importantes y privilegiadas de los espacios templarios ${ }^{1074}$.

El uso del capitel corintio atravesará los siglos de la Alta Edad Media sin solución de continuidad, perpetuándose como uno de los elementos del repertorio ornamental antiguo con más fortuna dentro de la escultura posterior ${ }^{1075}$. La inspiración clásica de ciertos capiteles datados en el SIGLO X, habla por sí sola. En los albores del año mil y entremezclándose con soluciones arquitectónicas que anuncian lo románico, nuevamente hallamos una pervivencia en su forma, en su uso y, quizás, en su significado.

Con un propósito estético que parece recuperar cierto abolengo de elegancia y prestigio, se muestran los capiteles de la puerta bífora de Santiago de Peñalba, en León. Se trata de unas piezas de mármol que, junto con las de San Miguel de Escalada, son el mejor exponente de la pervivencia en el uso de este orden clásico, aún a pesar de tratarse de centros de cierto matiz rural ${ }^{1076}$.

En relación con tales piezas, muchos autores han señalado un parentesco con producciones artísticas ligadas a los dominios de Al-Andalus. Sin embargo, desde nuestro punto de vista, compartimos la opinión de I. Bango, según la cual, la morfología que van a presentar los capiteles de tradición corintia durante el siglo $\mathrm{X}$, más que una fuerte conexión con modelos andalusíes, "se debe fundamentalmente al léxico decorativo de los capiteles tardorromanos del área mediterránea" que poseían una larga trayectoria dentro de la historia de los edificios tardoantiguos ${ }^{1077}$.

Sin embargo, más allá del posible origen del que fuera tomada dicha tipología, nos interesa destacar su empleo admirativo a la hora de utilizar el acanto clásico dentro de los templos cristianos. Desde las pilastras visigodas, donde el leguaje puramente romano se mantenía, hasta esa pieza de excelencia máxima que supone la pilastra de

\footnotetext{
${ }^{1074}$ V. NIETO ALCAIDE, Arte Prerrománico..., p. 13.

${ }^{1075}$ F. GARCÍA ROMO, La escultura del siglo XI..., en particular, p. 134. El investigador concede una importancia vital al capitel clásico corintio, especialmente, aquel ligado a los talleres de las provincias, que, según el autor, serán los que ofrezcan una mayor fuente de inspiración para los talleres románicos. Véase también: E. DOMÍNGUEZ PERELA, "Los capiteles del pórtico de Escalada, entre la tradición clásica y la bizantina, lo islámico y la creación local", V Congrés espanyol d'història de l'art, (F. Español Bertrán y J. J. Yarza Luaces), vol. 1, Barcelona, 1987, pp. 65-76 y J. A. DOMINGO MAGAÑA, Capiteles Tardorromanos y Altomedievales de Hispania (ss. IV-VIII dC), Barcelona, 2007.

${ }^{1076}$ M. GUARDIA PONS, "De Peñalba de Santiago a Berlanga de Duero: la pintura mural de los siglos X y XI en el reino de León y en Castilla. ¿Un espejo del al-Andalus?”, El legado de Al-Andalus. El arte andalusí en los reinos de León y Castilla durante la Edad Media (M. Valdés Fernández coord.), León, 2007, pp. 115-156.

1077 I. G. BANGO TORVISO, Arte prerrománico..., p. 337. Sobre la problemática de algunos capiteles romanos y visigodos expoliados en la mezquita de Córdoba, así como su influencia dentro de los tipos utilizados en el mismo recinto, véase la parte inicial de este trabajo.
} 
mármol adosada al testero de San Julián de los Prados (fig. 177); la manera de esculpir la hoja de acanto y distribuirla dentro de los espacios sacros, parece tener una continuidad desde la época hispanorromana hasta el medievo ${ }^{1078}$.

En relación con lo expuesto, baste recordar, por ejemplo, la distribución superior de las hojas de acanto de las pilastras de Mérida, datadas, la mayoría, en torno al siglo VI. El desarrollo del vegetal, materializado de una manera carnosa y de gran tecnicismo escultórico, representa la base sobre la que se asentarán otra serie de obras del mismo calibre. Los especialistas han señalado las masas vegetales presentes en los capiteles apilastrados del oratorio de San Fructuoso de Montelios, en torno al año 656 (fig. 178), como claras deudoras de esta expoliación in re de todos los motivos del acanto presentes en las piezas romanas ${ }^{1079}$. El aprecio por este tipo de decoración vegetal continuará en los siglos posteriores.

Así, observamos una idéntica concepción de este desarrollo del corintio en forma de capitel apilastrado de la citada pilastra de Santullano en algunos de las piezas de la iglesia de Santa María de Bamba, en Valladolid ${ }^{1080}$.

Todas estas esculturas de tipo corintio que encontramos decorando algunos de los espacios de la arquitectura prerrománica hispana tienen sus modelos referenciales en la misma plástica hispanorromana. En otras ocasiones, las piezas no emulan aquellos modelos, sino que se opta por sustituirlas por piezas verdaderamente romanas.

Debe recordarse, en este sentido, el capitel expoliado del extremo derecho de la ventana suprabsidal de la cabecera de San Tirso de Oviedo (fig. 179), y que, según se ha

${ }^{1078}$ Es muy significativo como, convencido de toda continuidad de los valores artísticos del arte y la arquitectura de la Antigüedad clásica dentro de las producciones asturianas, Puig i Cadalfalch defenderá como las famosas pilastras de mármol con capitel de acanto y cuerpo decorado con casetones y vegetales de Santullano, corresponde, igualmente, a la misma tradición de esculpir este tipo de elementos, documentada en la época visigoda. Cf.: J. PUIG I CADAFALCH, L'art wisigothique..., p. 122.

1079 P. DE PALOL, Arte Hispánico..., en concreto, pp. 36-37 y T. HAUSCHILD, "Arquitetura em Portugal sob o domino dos visigodos", XXXIX Corso di cultura sull'arte ravennate e bizantina. Aspetti e problemi di archeologia e storia dell'arte della Lusitania, Galicia, e Asturie tra Tardoantico e Medioevo, Ravenna, 1992, pp. 387-495, especialmente, pp. 394-396.

En referencia a San Fructuoso, recuérdese el friso vegetal apilastrado que recorre perimetralmente el edificio. En general, es difícil referirse a este oratorio, debido a la problemática que los especialistas han mostrado a la hora de estudiar su cronología, función y relación con otros conjuntos arquitectónicos supuestamente coetáneos.

El profesor Bango alude a la problemática cronológica, con heterogéneas dataciones que lo han llevado a pertenecer a la arquitectura del siglo VII, a la de la décima centuria e, incluso, hasta el siglo XI. Según su opinión el edificio que hoy vemos es la obra original del año 656, año en el Recesvinto mandó construir un templo donde el cuerpo del santo fuese enterrado. El autor señala también la expoliación de piezas romanas que se reintegraron en la nueva construcción. Cf.: I. G. BANGO TORVISO, Arte prerrománico..., en especial, pp. 114-116.

1080 Sobre la pilastra de Santa María de Bamba, vid.: S. NOACK-HALLEY, "Santa María de Bamba (Prov. Valladolid), Pilaster-kapitell und Kircheninneres. -2. Drittel 10. Jh.”, Christliche..., en concreto, pp. 285-290. La autora defiende un recuerdo más directo de la tradición islámica. 
dicho, podría tratarse de una pieza romana de reempleo ${ }^{1081}$. Con todo, tal y como venimos señalando, nos parece más interesante indagar sobre la elección tan continuada de este tipo de orden dentro de los templos asturianos y sus repercusiones sobre el arte hispano medieval posterior. En relación con la pieza de San Tirso, llama la atención el grado de parentesco que presenta con respecto al prototipo de capitel apilastrado que aparece ya en torno al 28 a. de C. en el Apollon in Circo y que recoge G. Sauron en su especializado trabajo sobre el corintio en la época antigua ${ }^{1082}$.

De igual modo, se presentan los dos capiteles conservados en San Román de Hornija, con un indiscutible recuerdo de fórmulas romanas ${ }^{1083}$. Sin embargo, a pesar de conservar de manera canónica, si seguimos los parámetros de la teoría vitruviana, la roseta sobre el astrágalo y la distribución de dos pisos del acanto, otros elementos han sido mutados de manera evidente, perdiendo su sentido más doctrinal.

Así, al observar estos modelos del siglo X, se entienden bien las palabras escritas en un estudio publicado por G. Gaillard en el año 1925 y en el que definía esta tipología de capitel, del que afirmaba que poseían "formas degeneradas del capitel visigodo"1084.

Sin embargo, más que desde un punto de vista técnico, estas obras hablan de un interés por mantener y, sobre todo, evocar, las formas clásicas ${ }^{1085}$.

Una de las grandes controversias historiográficas vinculadas a la historia del arte del siglo X, es la noción y concepto de lo "mozárabe". El debate, de gran importancia para la literatura artística, puede hacerse extensible a la problemática de los capiteles

\footnotetext{
${ }^{1081}$ I. G. BANGO TORVISO, "Los expolios del paisaje...", en particular, p. 37.

${ }^{1082}$ G. SAURON, "La promotion apollinienne de l'acanthe et la définition d'une esthétique classique à l'époque d'Auguste", L'acanthe..., pp. 75-97, en concreto, p. 77. El capitel de pilastra al que alude, representa un prototipo muy difundido dentro del clasicismo ateniense. Será el motivo por el que los romanos demandarán, de manera habitual, este tipo de piezas a los talleres griegos. El autor considera que, desde estos momentos, el acanto ocupó dentro de estos capiteles de pilastra un lugar privilegiado en las producciones neoáticas. Salvando las distancias en el tiempo, es significativo observar como el prototipo de capitel apilastrado se mantendrá en las obras más "antiquizantes" de la Edad Media. Recuérdese, por ejemplo, la articulación superior del pórtico de Lorsch donde, nuevamente se recurre a esta tipología de piezas, siempre de gran apariencia clásica. En la misma línea, tal y como ya hemos señalado en este trabajo, el capitel corintio aparecía incorporado dentro de otras artes ajenas a la escultura en piedra, tal y como se observa, en la magnífica rejería de Aix-la-Chapel. Cf.: F. HERBER-SUFFRIN, "L'acanthe dans le décor architectural carolingien", L'acanthe..., pp. 189-210.

${ }^{1083}$ Para este edificio dedicado a San Román y que habitualmente se ha comparado con las soluciones tomadas en Santa María de Bamba, I. Bango propone un prototipo anterior visigodo que serviría, además, de modelo a otros templos coetáneos. Cf.: I. G. BANGO TORVISO, Arte prerrománico..., en especial, pp. 351-353.

${ }_{1084}$ G. GAILLARD, Premiers essais de sculpture monumental en Catalogne au $X^{e}$ et $X I^{e}$ siècles, Paris, 1938, p. 103.

${ }^{1085}$ I. G. BANGO TORVISO, “Los expolios del paisaje...," pp. 34-49.
} 
corintios facturados en este periodo ${ }^{1086}$. En los estudios más tempranos se llamaba la atención sobre el fuerte carácter "morisco" que tendrán algunos de estos capiteles corintios esculpidos en la Hispania de la décima centuria.

En este sentido, recuérdense los trabajos, por ejemplo, de G. Gaillard o J. Puig i Cadafalch, donde se defenderán de una manera rotunda las filiaciones y dependencias entre algunas obras esculpidas en este siglo y aquellas realizadas en el ámbito de AlAndalus.

En estos trabajos se valoraba una hipotética impronta omeya e "hispanomorisca", siguiendo el concepto utilizado por determinados autores y que impregnaría de manera marcada a este tipo de obras. Por ejemplo, al referirse a los capiteles de San Bartolomé de la Cuadra, G. Gaillard defendería un parentesco con la forma de algunas de otras producciones propiamente catalanas, como por ejemplo, los capiteles conservados en Ripoll y Cornellà (fig. 180), también de orden corintio ${ }^{1087}$. Sin embargo, a pesar de que el autor aceptó, en un primer momento, una posible dependencia de los modelos hispanorromanos, tamizados bajo la herencia visigoda, finalmente acabó defendiendo la participación de tales esculturas en la tradición andalusí. Resumiendo en exceso su aportación, G. Gaillard afirmaría que tales capiteles corintios, tan sólo se limitarían a perpetuar el "modelo omeya de Ripoll", según la expresión del propio autor ${ }^{1088}$.

Tendencias como estas, que conectaban obras de vital importancia para el siglo X, como por ejemplo los capiteles de Sant Pau del Camp, Santa María de Ripoll, San Mateu de Bagues o los excelentes corintios de Cornellà de Llobregat, con las formas

\footnotetext{
${ }^{1086}$ I. G. BANGO TORVISO, Arte prerrománico..., en especial, pp. 188-198 y pp. 219-226 e ID., "Un gravísimo error en la historiografía española, el empleo equivocado del término mozárabe", El legado de Al-Andalus. El arte andalusí en los reinos de León y Castilla durante la Edad Media (M. Valdés Fernández coord.), León, 2007, pp. 73-88. Se trata de un complejo término cuyo análisis no vamos a realizar aquí, pues escapa de los límites de este estudio.

${ }^{1087}$ La citada iglesia de San Bartolomé se encuentra en la localidad homónima, cercana a Barcelona.

${ }^{1088}$ G. GAILLARD, Premiers essais..., en concreto, pp. 83-85 y J. PUIG I CADAFALCH, Le premier art roman. L'architecture en Catalogne et dans l'occident méditerranéen aux $X^{e}$ et XI siècles, Paris, 1928, especialmente, pp. 11-37. Para G. Gaillard, los capiteles de San Bartolomé de la Cuadra debían ser emparentados también con las obras de San Pedro de les Puelles, en Barcelona. Para todos ellos, incidía en una tradición en la representación de los elementos vegetales ligada a diversas obras del ámbito cordobés. Idéntica postura mostrará J. Puig i Cadafalch, quién considerará que las aportaciones de AlAndalus sobre el arte medieval cristiano del siglo X catalán fueron cruciales. Dedica un capítulo de su obra titulado "La culture arabe et mozarabe des $\mathrm{IX}^{\mathrm{e}}$ et $\mathrm{X}^{\mathrm{e}}$ siècles en Catalogne et son influence en France", y en él defiende este parentesco con las formas meridionales, tal y como las designa, que tendrán repercusiones dentro de toda la escultura y la arquitectura catalana del periodo.
} 
artísticas de Al-Andalus, ejercieron una influencia importante sobre las posturas de parte de la historiografía especializada que estudiaría dichas piezas ${ }^{1089}$.

Es evidente que estos primeros autores señalaban la importancia que para el capitel corintio del siglo $\mathrm{X}$ tendría el mundo clásico, ya fuese desde la misma óptica "antiquizante" romana o, a través del tamiz clásico de reinterpretación omeya. En este sentido, escribía G. Gaillard:

"La inspiración de los marmolistas pirenaicos no es única; junto con las fuentes hispano-moriscas, que son las más importantes, también encontramos algo que no debe sorprender, la influencia de la decoración antigua y la de los marfiles y manuscritos carolingios" 1090 .

A pesar de que dichos capiteles corintios han sido tradicionalmente datados en el siglo $\mathrm{X}$ y se les ha hecho depender de manera inmediata con respeto a fórmulas hispanomusulmanas, en la actualidad, se cree que tales dataciones son dudosas y tales filiaciones rebatibles ${ }^{1091}$. Estos ejemplares de capitel corintio, denominados de manera inercial como "califales", podrían, según estos recientes estudios, haber sido realizados ya durante los primeros decenios del siglo $\mathrm{XI}^{1092}$.

\footnotetext{
${ }^{1089}$ A dichos capiteles debemos sumar obras importantes en el estudio del surgimiento de la escultura románica, tales como son los dinteles de Saint-André-de-Surede y Saint-Genis-des-Fontaines, así como sus respectivas ventanas marmóreas, la cátedra pétrea y la mesa de altar de la catedral de Gerona o, incluso, los capiteles de San Pedro de Rodas. Todos ellos, debían ser considerados como obras de recuerdo clásico, a veces tamizadas por la influencia de las artes suntuarias y la miniatura carolingia, pero totalmente dependientes, en sus características más elementales, de las artes de Al-Andalus. Cf.: G. GAILLARD, Premiers essais..., en concreto, pp. 50-101.

Para un estudio actualizado sobre las piezas de Ripoll, Bages y Cornellà de Llobregat, véase: S. NOACKHALLEY, "Katalonien, Kapitelle: c. d. Ripoll (Prov. Girona), Kapitelle in der Kloster-kirche Santa Maria und im Arxiu-Museu Folklòric Parroquial. -Zweite Hälfte 10. Jh. e. Kapitell. -Zweite Hälfte 10. Jh. Aus Sant Mateu de Bages (Prov. Barcelona). Museu de Manresa. f. g. Cornellà de Llobregat (Prov. Barcelona), Kapitelle am Rathaus. -Zweite Hälfte 10. Jh.”, Christliche..., en concreto, pp. 409-413; M. PAGÈS I PARETAS, voz "Santa María de Cornellà", Catalunya romànica ..., vol. XX, Barcelona, 1992, p. 354 y X. BARRAL I ALTET, “Apropiación y recontextualización...”, pp. 171-173.

${ }^{1090}$ G. GAILLARD, Premiers essais..., en especial, pp. 52-55. El experto, además relaciona los motivos vegetales de varias piezas catalanas y del Rosellón, con la tradición hispanomusulmana, sobre todo, del ámbito cordobés, como los mosaicos de la mezquita de Córdoba y de Medina Azahara, a pesar de que señala ciertas diferencias en el trabajo del mármol desde el punto de vista técnico.

${ }^{1091}$ Recientemente una serie de investigadores han retomado el tema de manera crítica. Cf.: J. CAMPS I SÒRIA, C. MANCHO e I. LORÉS I OTZET, "L'escultura preromànica", Del Romà al Romànic. Història, art i cultura de la Tarraconense Mediterrània entre els segles IV i X, Barcelona, 1999, pp. 416423.

${ }^{1092}$ I. LORÉS I OTZET, El monestir..., en concreto, p. 57. La autora afirma que la datación tradicional de los capiteles de Ripoll se ha venido apoyando en un supuesto reempleo de dichas piezas en el edificio promovido por el abad Oliba. Según su criterio, tal afirmación no cuenta con argumentos de peso que sirvan para datarlos en una fecha anterior al año 1000, pudiendo ser perfectamente incluidos dentro de los trabajos escultóricos realizados en dicho territorio, más allá del cambio de milenio.
} 
Por su parte, el profesor I. G. Bango Torviso considera que los capiteles catalanes:

\section{“(...) muy descontextualizados de un marco arquitectónico concreto,} muestran viejos esquemas de dos órdenes de hojas y caulículos con formas de palmeta, siguiendo prototipos bien documentados por toda la España del siglo X. En este sentido el capitel de Ripoll es una muestra significativa"1093.

Finalmente, frente a las tendencias historiográficas iniciadas en los primeros años del siglo XX e, incluso ya antes, en las que se consideraba el capitel corintio del siglo X como un remedo o copia de los prototipos existentes en Al-Andalus, en la actualidad, se vienen aceptando otro tipo de filiaciones ${ }^{1094}$. De esta forma, en la actualidad, la mayoría de autores ya no los hacen derivar de modelos hispanomusulmanes. Se trataría, supuestamente, de una serie de capiteles de acusado bizantinismo, pero que tan sólo retoman motivos ya difundidos con gran éxito dentro de la escultura, una vez más, tardorromana ${ }^{1095}$.

Así, tal y como ha señalado G. Mallet, la complejidad de estas obras corintias datadas dentro del arte prerrománico catalán, hace que resulte difícil llevar a cabo un análisis riguroso, sobre todo, teniendo en cuenta que se trata de una escultura en extremo no unitaria y muy original ${ }^{1096}$.

Será X. Barral i Altet, el autor que romperá con esta dinámica de filiación con los modelos califales, considerando la posibilidad de que los capiteles corintios del

${ }^{1093}$ I. G. BANGO TORVISO, Arte prerrománico..., p. 398.

${ }^{1094}$ J. PUIG I CADAFALCH, Le premier art..., en especial, pp. 31-37. El investigador defendía dicho "mozarabismo" no sólo en las producciones arquitectónicas del centro de la Península Ibérica, sino también, de una manera intensa en el ámbito catalán. Explicaba la difusión de tales fórmulas a través de las vías de peregrinación que unían territorios tan alejados de Francia y Cataluña como las zonas Duero y Cantabria, León, Astorga, el valle de Tera, el Órbigo y el Esla. El autor, que señaló paralelismos entre las iglesias del siglo X del ámbito castellano con otras catalanas, consideraba tales vías como una causa suficiente para hablar de una filiación "mozárabe" entre ambos territorios.

${ }^{1095}$ I. G. BANGO TORVISO, Arte prerrománico..., particularmente, p. 337.

${ }^{1096}$ G. MALLET, "La sculpture préromane en Catalogne: l'exemple des chapiteaux. État d'une question controversée", Saint-Guilhem-le-Desert dans l'Europe du Haut Moyen Age, Amis de Saint-Guilhem-leDésert, 2000, pp. 175-181 y nota 1. La autora plantea un breve estado de la cuestión en torno a la problemática de la escultura prerrománica catalana y en relación, también, con los capiteles a los que hemos aludido. En cuanto a la definición del arte del periodo, rechaza la utilización del concepto arte visigodo para el territorio catalán. Del mismo modo, destaca el uso incorrecto del concepto "mozárabe" para dichas producciones.

En este sentido, sigue los planteamientos definidos en su momento por el profesor Barral, quién plantea, incluso, a propósito del capitel de Ripoll, la posibilidad de que estemos ante piezas inacabadas en la mayoría de los casos y que sus hojas lisas fueran concebidas para albergar decoración pictórica. La teoría, aunque sugestiva, resulta difícil de demostrar. Cf.: X. BARRAL I ALTET, L'art pre-romànic a Catalunya. Segles IX-X, Barcelona, 1981, en concreto, pp. 9-15. 
ámbito catalán, podían ser vistos como un intento, común dentro del arte prerrománico, de recuperar el capitel clásico romano ${ }^{1097}$. A partir de este momento, se barajará la posibilidad de que este tipo de corintio hubiera pasado a los escultores de finales del siglo X y principios del siglo XI, a través de una herencia de la Antigüedad tardía y no por los contactos con lo hispanomusulmán.

Por su parte, E. Vergnolle, una de las grandes especialistas en el tema, vinculará este tipo de producciones catalanas tan tempranas con el prototipo de capitel de hojas lisas romano y para el cual alude a un ejemplo concreto conservado en Ostia que, según explica, podría ser un antecedente lejano de estas piezas ${ }^{1098}$.

La tesis propuesta por esta especialista, resulta de una importancia absoluta para el análisis del corintio desde la época tardoantigua hasta los albores del año mil, así como de sus repercusiones dentro del románico. A través de los ejemplos de un capitel del Coliseo romano, en el que se utilizaron dos registros de hojas totalmente lisas, así como varios ejemplares datables entre el siglo III y el IV d. de C., la autora establece algunas conclusiones de gran interés (fig. 181).

El tipo de capitel vegetal con hojas lisas, difundido de manera, más o menos, reinterpretada en la escultura medieval hispana, podría tener sus antecedentes más próximos dentro del arte romano, antes incluso, que en lo hispanomusulmán ${ }^{1099}$.

Sin embargo, lo que parece claro es que, conservando la morfología clásica con la que se había concebido el capitel corintio en la escultura visigoda o, por el contrario, desvirtuando en exceso tal fórmula; el capitel corintio romano traspasa las barreras del año mil y se adentraba por completo en la arquitectura y la escultura románica de toda Europa. Sin embargo, creemos que más que adentrarse, lo único que hizo tal elemento antiguo fue consolidar su larga trayectoria que, desde la más remota Antigüedad, le había llevado a salvar todos los periodos artísticos existentes -dentro del arte occidental- desde su nacimiento.

Tal y como observamos, el paso del año mil se presenta complejo a la hora de establecer conclusiones claras en cuanto a la hora de definir la fortuna del capitel corintio. Lo que si parece seguro de defender, es que no perdió nunca su prestigio. Son muchos los autores que han señalado una recuperación consciente y directa de los

\footnotetext{
1097 Ibidem, pp. 113-120.

1098 E. VERGNOLLE, "Réflexions sur les chapiteaux à feuilles lisses à propos de Saint-Sever", SaintSever. Millénaire de l'abbaye, Mont-de-Marsan, 1986, pp. 184-197, en concreto, pp. 189-190.

${ }^{1099}$ Tal y como hemos advertido, resulta complicado establecer conclusiones cerradas o seguras sobre las diferentes tipologías, usos y filiaciones de los capiteles, debido a su disparidad y, sobre todo, irregularidad en cuanto a su morfología.
} 
modelos clásicos romanos del corintio a partir del cambio de siglo, una vez ya en las etapas del ROMÁNICO.

En este sentido E. Vergonlle ya señaló en su día el conocimiento de las fórmulas vitruvianas que los escultores medievales demostraron a través del uso de este tipo de capitel $^{1100}$.

Por su parte, M. Durliat englobaría este hecho dentro del fenómeno que bautizó como "renaissance corinthienne" y que es tan sólo, según defendió, un reflejo de la fiebre restauradora de tal motivo dentro de la escultura románica. Según su teoría, a la hora de analizar la recuperación del corintio en la etapa medieval, no debemos caer en el error de considerar tal restitución de una manera reducida al mismo capitel corintio, ya que dentro de tal fenómeno se puede englobar igualmente la recuperación de capiteles de hojas lisas, no menos antiguas y que también habían sido utilizadas con asiduidad por los escultores romanos ${ }^{1101}$.

La historiografía francesa exaltará de manera importante la escultura del SIGLO XI, en lo que a la recuperación del corintio respecta. En este sentido, el caso paradigmático en tal renacimiento, fue el de la torre-pórtico de San Benoît-sur-Loire. Según lo expuesto por E. Vergnolle, en su clásico estudio del año 1985, la gran obra arquitectónica y escultórica de dicha estructura muestra, claramente, este tipo de resurgimiento brutal del corintio clásico y de la iconografía en el capitel historiado. Según señaló, la torre-pórtico debió ser iniciada en torno al mandato del abad Gauzlin (1004-1030) y en ella se incluirían los más bellos capiteles corintios "antiquizantes" realizados por artífices románicos hasta el momento ${ }^{1102}$.

Sus ideas iban mucho más allá, al considerar a UMBERTVS, como el escultor de los capiteles más clásicos del conjunto. La firma de este personaje sobre uno de ellos, le sirvió de base para identificarlo como el artífice material de toda la obra, tanto

${ }^{1100}$ E. VERGNOLLE, Saint-Benoît-sur-Loire et la sculpture du XI siècle, Paris, 1985, en especial, pp. 65-68; ID., "Chapiteaux corinthisants de France et d'Italie (IX ${ }^{\mathrm{e}}-\mathrm{XI}^{\mathrm{e}}$ siècles)", Romanico padano. Romanico europeo, Parma, 1982, pp. 339-350; ID., "Réflexions sur les chapiteaux... ", pp. 184-197; ID., "Fortune et infortunes du chapiteaux corinthien de le monde roman", Revue de l'art, 90, 1990, pp. 21-34; ID., L'art Roman en France. Architecture-Sculpture-Peinture, Paris, 1994; ID., "La colonne à l'époque romane. Réminiscences et nouveautés", Cahiers de Civilisation Médiévale, 41, 1998, pp. 141-174 e ID., "Recherches sur quelques séries de chapiteaux romans", L'Information de l'histoire de l'art, 20, 1975, pp. 30-59. La autora sigue siendo, aún hoy día, una autoridad en el estudio del capitel corintio durante los siglos del románico, así como de sus filiaciones clásicas.

${ }^{1101}$ M. DURLIAT, La sculpture romane de la route..., p. 12. El experto utiliza y define la expresión "renacimiento corintio".

${ }^{1102}$ A. DE FLEURY, Vie de Gauzlin, Abbé de Fleury. Vita Gauzlini Abatís Floriacensis Monasterio (R.H. Bautier y G. Labory ed.), Paris, 1969, p. 32. 
escultórica como arquitectónica ${ }^{1103}$. Todos estos aspectos le permitirían razonar e identificar tal figura como representante de una corriente cultural recuperadora de formas clásicas, que reflejaban un buen conocimiento de los principios constructivos expuestos en De Architectura de Vitruvio. La autora llegará a conectar algunos de los elementos de la escultura de dicho pórtico con diversas fuentes de marcado sustrato clásico, fruto, tal y como defendía, de una experta observación de la estatuaria clásica $^{1104}$.

Se trata, sin duda, de un estudio de gran relevancia a la hora de abordar el "renacimiento" del corintio en el arte románico. Sin embargo, algunos autores mostrarían su disconformidad con la temprana fecha propuesta por la autora para todas estas esculturas, entre ellos, el mismo M. Durliat ${ }^{1105}$.

El autor encabeza la inconformidad mostrada por ciertos especialistas a la hora de apoyar una datación tan temprana para los capiteles corintios de Saint-Benoît. En concreto, en contra de la datación dada por E. Vergnolle de los años 1026-1030, actualmente, se viene considerando la posibilidad de que las obras se hubiesen iniciado con el abad Gauzlin, pero no habiéndose finalizado el conjunto hasta el mandato del abad Guillermo (1067-1080) ${ }^{1106}$.

Aunque el tema cronológico no es una cuestión fundamental para nuestro cometido, es importante a la hora de poder abordar el tema de la perdurabilidad y recuperación del capitel corintio durante el románico. Durante mucho tiempo el gran conjunto de exquisitos capiteles "antiquizantes" de la torre-porche fueron considerados como los únicos representantes de tal "renacimiento corintio", sin embargo, a la vista de la gran la problemática cronológica que presenta el conjunto, la situación no muestra una solución tan clara.

\footnotetext{
${ }^{1103}$ E. VERGNOLLE, Saint-Benoît..., en concreto, pp. 114-117. La autora llega a considera a Umbertus como el princeps artificium que aparece nombrado en las fuentes documentales de época de Gauzlin.

${ }^{1104}$ Ibidem, pp. 81-117. Véase la comparación que hace entre el famoso sarcófago de tema cinegético y el capitel del cazador de la torre francesa, o la teoría en la que defiende influencias directas de capiteles constantinopolitanos, conocidos a través de supuestos viajes, para explicar el capitel con prótomos de corderos de uno de los capiteles del recinto. Realiza una comparación entre la situación de Gauzlin y la del abad Desiderio de Montecassino, quién contrató artífices bizantinos para realizar sus obras.

${ }^{1105}$ M. DURLIAT, "La sculpture du XI ${ }^{\mathrm{e}}$ siècle en Occident", Bulletin Monumental, 125, II, 1994, pp. 129-213, en especial, pp. 129-131.

${ }^{1106}$ Sobre toda la problemática de la cronología de la torre-pórtico, véase: Ibidem, pp. 176-177. M. Durliat alude a diversas fuentes del siglo XI en las que se menciona que la torre de Gauzlin se mostraba incompleta en torno al año 1030.
} 
Con todo, volveremos posteriormente sobre el tema de la torre-pórtico francesa, a la hora de definir el papel que jugó con respecto al desarrollo de este tipo de capitel dentro de la escultura románica hispana.

En el caso de la Península Ibérica, tras las experiencias desarrolladas en torno al siglo X, el capitel corintio se mantiene. Sin embargo, durante los primeros decenios del siglo XI es complejo citar un conjunto escultórico completo donde la asimilación de formas clásicas sea plena. Sin embargo, la no abundancia de estos ejemplos no justifica una negación con respecto a la participación de Hispania dentro de este "renacimiento del corintio", una vez traspasado el cambio de milenio.

En el mes de octubre del año 1022 se produce la "consecrationem novae ecclesiae Sancti Petri Rodensis"1107. A pesar de la problemática que hemos señalado para poder averiguar exactamente que papel tuvieron Tassi y su hijo Hildesind, respectivamente, en la construcción de cada una de las partes del edificio que hoy contemplamos, parece, según las últimas posturas historiográficas, que tanto la escultura

${ }^{1107}$ M. DURLIAT, "La Catalogne et le premier art roman", Bulletin Monumental, 147-I, 1989, pp. 209238 , en concreto p. 214. El autor alude al documento del año 878 y le sirve para hablar ya de un establecimiento monástico en el lugar. Menciona al abad Tassi como el promotor de la transformación de la cella originaria en monasterio. Tras la muerte de éste, en el 995, continua su labor su hijo Hildesinde, que llegará a ser abad de Rodas y obispo de Elna. El monasterio aparece bajo la protección del conde de Ampurias-Rosellón, Gausfred, hasta el 991, en el que muere Hildesinde. En el año 1022 se consagra la nueva iglesia, según afirma M. Durliat, con la asistencia del obispo de Cardona, el de Gerona, el de Osona y, finalmente, el propio abad Oliba. La obra aún no estaría terminada en el 1038, cuando continúan haciéndose donaciones para los trabajos en el edificio.

La datación de San Pedro de Rodas supone, nuevamente, una tarea de gran complejidad. Puig i Cadafalch no la incluye siquiera en su investigación sobre el arte románico catalán del siglo XI, por considerar que se trataba de una obra posterior, además de no encajar con su definición general del estilo en este periodo. Cf.: J. PUIG I CADAFALCH, Le premier art roman..., p. 33.

Por su parte, Gaillard remarcará nuevamente el carácter omeya de la escultura del edificio. Aborda el estudio de los capiteles, datándolos también dentro del siglo XII. Sin embargo, a la hora de emparentar la escultura de la iglesia, ya hace una diferenciación clave, pues al analizar los capiteles corintios, con cierta condescendencia, alude a una posible fuente antigua, para finalmente englobarlos dentro de una influencia cordobesa. Con todo, la datación del edifico vuelve a presentar numerosos problemas. Cf.: G. GAILLARD, Premiers essais..., en concreto, p. 101. Véase también: F. HERNÁNDEZ, "Un aspecto de la influencia del arte califal en Cataluña (Basas y capiteles del siglo XI)", Archivo Español de Arte y Arqueología, 1930, pp. 21-49 y G. GAILLARD., "Éléments andalous et carolingiens dans l'architecture et la sculpture de Saint-Pierre de Roda", Cahiers de Saint-Michel de Cuixa, 1979, pp. 129-139.

Otros trabajos más recientes, presentan completas actualizaciones bibliográficas. Cf.: I. LORÉS I OTZET, "Sant Pere de Rodes. Consideracions sobre la cronologia de l'església", Actes del congrés internacional Gerbert d'Orlhac, Vic, 1999, pp. 287-303; I. LORÉS I OTZET y J. CAMPS I SÒRIA, "El Port de la Selva. L'escultura de Sant Pere de Rodes", Catalunya Romànica. IX: Empordà II, Barcelona, 1990, pp. 703-728; I. LORÉS I OTZET, "L'église de Sant Pere de Rodes un exemple de renaissance de l'architecture du XI ${ }^{\mathrm{e}}$ siècle en Catalogne", Les Cahiers-de-Saint-Michel de Cuxa, XXXII, 2001, pp. 21-39 e I. LORÉS I OTZET, El monestir..., en concreto, pp. 33-83.

Sobre la problemática de la disociación entre arquitectura y escultura dentro del edificio y la posibilidad de considerar tal conjunto de capiteles como pertenecientes a los últimos años del siglo X, véase: $\mathrm{G}$. MALLET, "La sculpture préromane...", en concreto, p. 177. 
de las naves, como la de la gran portada, deben llevarse hasta el periodo comprendido entre los años 1030 y $1050^{1108}$.

Se trata, sin duda, de una fecha muy temprana, que introduce al ámbito hispano dentro las mejores producciones escultóricas de la Europa coetánea. Pero más importante resulta, sin duda, el uso que dentro del espacio templario se va a hacer del capitel corintio. El corpus de capiteles esculpidos para el edificio habla de una recuperación consciente y una observación directa de piezas clásicas romanas ${ }^{1109}$ (fig. 182).

En los varios estudios que ha dedicado a analizar la escultura del templo, la profesora I. Lorés i Otzet señala que los capiteles de mármol que hallamos en el interior del conjunto deben emparentarse más con la tradición romana que con la propiamente califal. En concreto, supone una deuda y contaminación con los modelos de la época augusta, representados, concretamente, por los capiteles de la Maison Carré de Nîmes ${ }^{1110}$ (fig. 183).

Podemos afirmar que, a través de los bellos capiteles corintios de la iglesia de San Pedro de Rodas, Hispania participaba de manera plena dentro del movimiento de recuperación de lo clásico y, en concreto, del capitel corintio, que marcaría buena parte de las esculturas datadas en el siglo XI.

A parte de todo lo expuesto, de entre las afirmaciones que realiza la profesora Lorés sobre esta escultura, nos interesa destacar aquella donde expone:

“(...) a Sant Pere de Rodes, també hi devia haver algun element de tancament per a separar ambdós àmbits. Però el que ens ha arribat avui és només la diferenciació a partir de l'alçat de la nau. I en aquest alçat, la disposició estratègica

\footnotetext{
${ }^{1108}$ I. LORÉS I OTZET, El monestir..., particularmente, p. 81. La autora cree que los capiteles de las naves fueron realizados un poco antes de esta fecha, en la cual, fue finalizado el edificio. Propone el 1030 para los capiteles del buque central.

${ }_{1109}$ M. DURLIAT, "La Catalogne...,", en concreto, p. 134. Obviamos cualquier referencia a la magnifica arquitectura del edificio, donde la inteligente y original articulación de los pilares de separación de naves, el uso de los órdenes superpuestos, así como una complicada cabecera, sitúan al edificio dentro de las mejores obras del ámbito europeo.

${ }^{1110}$ I. LORÉS I OTZET, El monestir..., en concreto, pp. 58-60 e ID., "L'église de Sant Pere de Rodes...", en especial, pp. 34-35. La autora desvincula el tipo de corintio usado en la iglesia catalana con respecto a los ejemplares de Ripoll, Vic o Cornellà de Llobregat.

Vid. también: V. LASSALLE, "Les chapiteaux corinthiens de Sant Pere de Rodes et leurs semblables ou dérivés du Roussillon et du Languedoc", Le Roussillon de la Marca Hispanica aux Pyrénées-Orientales (VIII'-XX siècles), Perpinyà, 1995, pp. 381-409 y M. DURLIAT, "La Catalogne...", en especial, pp. 217 218. Los autores aún defendían una filiación con respecto a los prototipos islámicos de los capiteles de Rodas, apostando, además, por el parentesco de la escultura con las obras de Ripoll, Vic o San Mateu de Bages, entre otros.
} 
de l'escultura també contribueix a la diferenciació de la part més pròxima a l'absis principal en relació amb la meitat occidental. L'ús des capitells corintis només en aquests pilars amb doble ordre $i$, precisament, la seva ubicació en la columna inferior i a la cara més visible del pilar des de la nau, són elements prou indicatius del fet que l'escultura $i$, concretament, el capitell corinti és l'altre gran recurs al servei de la jerarquització de l'espai i la diferenciació de les seves funcions" ${ }^{1111}$.

Con estas palabras, según nuestro punto de vista de una importancia vital, la autora consideraba que los capiteles corintios de mármol colocados en los dos tramos de la nave central, tras el crucero, sobre las columnas inferiores apoyadas sobre los gigantescos estilóbatos salientes, tendrían una función específica, aparte de la ornamental $^{1112}$ (fig. 184).

Se trata de una distribución "estratégica" del capitel corintio, pues en los dos restantes tramos de la nave, al occidente, no se incluyó este orden doble, ni tampoco el estilóbato en forma de T, lo que ha sido visto, por parte de la investigadora, como un intento de demarcar la zona privilegiada anexa al crucero.

A pesar del carácter monumental y la originalidad de tal solución, ya hemos señalado en este apartado como el valor expositivo del capitel corintio en las partes más nobles del edificio tenía larga tradición en las artes plásticas hispanas, antes de las soluciones mostradas en Rodas.

Ya hemos insistido en el ejemplo de las dos fachadas cortas del aula del Naranco, en Oviedo, donde los capiteles corintios "decididamente clásicos" servían de apoyo al volteo de la triple arcada de fuertes resabios clasicistas ${ }^{1113}$.

Sin embargo, tal recurso se puede rastrear, incluso, en cronologías anteriores. Recuérdese, en este sentido, los dos pares de capiteles corintios colocados sobre las columnas de acarreo que marcan el paso al presbiterio de la iglesia gallega de Santa Comba de Bande ${ }^{1114}$ (fig. 185).

\footnotetext{
${ }^{1111}$ I. LORÉS I OTZET, El monestir..., en especial, pp. 59-60.

${ }^{1112}$ I. LORÉS I OTZET, "L'église de Sant Pere de Rodes...”, p. 35.

1113 Ésta disposición intencionada de las piezas corintias en el espacio templario del palacio de Ramiro I fue defendida en su día en un estudio del profesor Marín. Cf.: F. A. MARÍN VALDÉS, "Observaciones sobre la adopción...", pp. 15-17.

${ }^{1114}$ Se trata de dos capiteles de época visigoda, según P. Palol, colocados junto a otros dos asturianos, reintegrados en el edificio durante la remodelación que sufrió en el siglo X. Cf.: P. DE PALOL, Arte hispánico..., en concreto, p. 98. Por su parte, I. Bango afirma: "dos pares de columnas romanas reaprovechadas, con absoluto desprecio por la semejanza de piezas e incluso por la proporción". Cf.: I. G. BANGO TORVISO, Arte prerrománico..., en concreto, p. 106.
} 
Una intención semejante parece que movió a los artífices activos en la iglesia de San Juan de Baños a la hora de ubicar un capitel romano, el único de esta categoría entre todas las piezas del templo que, fue colocado, según creemos, concienzudamente anexo a la capilla central, tal y como ya hemos señalado ${ }^{1115}$.

Este hecho indica una revaloración del corintio dentro de los edificios hispanos medievales que se remonta a la Antigüedad tardía y donde eran utilizados para marcar los espacios más importantes. El caso de San Pedro de Rodas es especialmente significativo, sobre todo, por razones de monumentalidad y de precocidad ${ }^{1116}$. Tan sólo después de observar los problemas de datación que han rodeado a la iglesia de Rodas se entienden las despectivas palabras utilizadas por G. Gaillard hacia la escultura catalana de finales del siglo X y principios del XI:

"Les chapiteaux de Sant Miquel de Fluvia et de la cathédrale d'Elne son peu de chose à côte de ceux de Saint-Germain-des-Prés, de Saint-Benoit-sur-Loire ou de la chapelle des Rois de León, por exemple" ${ }^{1117}$.

El autor ni siquiera llega a tener en cuenta el caso de los corintios de la iglesia de Rodas, catalogada en este momento dentro de una cronología mucho más tardía.

Sin embargo, reflexionando sobre sus palabras, resulta interesante la comparación que realiza el autor ya a comienzos de siglo. El investigador alude a que la

\footnotetext{
${ }^{1115}$ Los estudios que han puesto de manifiesto el valor político del ornamento vegetal en el arte antiguo son numerosos. En concreto, una de las aportaciones más importantes es la realizada por G. Sauron, quién se centra en la importancia del motivo del acanto en el Ara Pacis, como símbolo de la Edad de Oro de la dinastía. El autor dedica un capítulo al estudio de la transmisión de la "fecunda tradición inaugurada por la obra maestra imaginada por Augusto" sobre las representaciones de acanto en la Edad Media. Cf.: G. SAURON, L'Histoire végétalisée. Ornement et politique à Rome, Paris, 2000, en concreto, pp. 28-29.

${ }^{1116}$ No vamos a profundizar más en otras cuestiones. Sin embargo, la iglesia catalana presenta, dentro de su escultura, otra serie de motivos, desligados del capitel corintio, como los entrelazos y las palmetas que, según las últimas investigaciones, deben ser situados incluso antes que obras tan señeras como la escultura de la cabecera y el transepto de Santa Fe de Conques, por ejemplo. Cf.: I. LORÉS I OTZET, $E l$ monestir..., en concreto, p. 69.

Sobre un paralelismo entre los entrelazos de Rodas y la escultura de Conques y Saint-Gérau de Aurillac, véase: M. TH. CAMUS, Sculpture romane ..., en concreto, pp. 260-262.

Desde otro orden de cosas, actualmente se tiende a emparentar la escultura de los capiteles de la iglesia de Rodas con el trabajo de los mármoles del Rosellón, especialmente, con los centros de Saint-André-deSurede y Saint-Genis-des-Fontaines, así como con los de Saint-Jacques de Béziers, Lespignan i Agde o Santa Maria de Alet. Cf.: J.-C. FAU, "Les chapiteaux de l'église et du cloître de Conques", Mémoire de la Société Archéologique du Midi, XXIV, 1956, pp. 33-312 e ID., "Un décor original: l'entrelacs épanoui en palmette sur les chapiteaux romans de l'ancienne Septimanie", Cahiers de Saint-Michel de Cuxa, 1979, pp. 129-139.

${ }^{1117}$ G. GAILLARD, Premiers essais..., en concreto, p. 101.
} 
utilización del capitel corintio en determinados edificios franceses puede ser entendida en el contexto escultórico de otra serie de obras hispanas.

En concreto, se refería a los capiteles corintios realizados para el Panteón Real de San Isidoro de León, que el especialista menciona y en los que hallamos, nuevamente, una clara intención de recuperar los modelos "antiquizantes" que configuren la decoración de un espacio "acantizado", si seguimos el neologismo utilizado por G. Sauron ${ }^{1118}$.

Los escultores activos en el taller que decoraría el recinto funerario leonés, tenían pleno conocimiento de la morfología del capitel corintio, que utilizaron repetidas veces, inmerso dentro de un programa iconográfico más complejo ${ }^{1119}$.

1118 G. SAURON, L'Histoire végétalisée..., p. 38. Señala que toma el término de un estudio Th. Kraus, del año 1953.

${ }^{1119}$ La bibliografía sobre el Panteón Real es muy abundante, sin embargo recogemos aquella que más se ha centrado en las cuestiones escultóricas: J. E. DÍAZ-JÍMENEZ Y MOLLEDA, "San Isidoro de León", Boletín de la Sociedad Española de Excursiones, vol. XXV, 1917, pp. 81-98; M. GÓMEZ MORENO, Catálogo Monumental de España: Provincia de León, Madrid, 1925; A. K. PORTER, Spanish Romanesque Sculpture, New York, 1928, (reed. 1969); G. GAILLARD, Les débuts de la sculpture espagnole. León-Jaca-Compostelle, Paris, 1938; F. GARCÍA ROMO, "Los pórticos de San Isidoro de León y de Saint-Benoît-sur-Loire y la iglesia de Sainte-Foy de Conques (Estudio comparativo de sus capiteles)", Archivo Español de Arte, 111, 1955, pp. 207-236; D. ROOB, "The capitals of the Panteón de los Reyes de San Isidoro de León", The Art Bulletin, XXVIII, 3, 1945, pp. 165-174 y R. SALVINI, "Il problema cronológico del portico de San Isidoro de León e le origine della Scultura romanica in Spagna", Actas del XXIII Congreso Internacional de Historia del Arte, vol. I, Granada, 1976, pp. 465-475.

El profesor Williams realizó una de las aportaciones más importantes dentro de la historiografía del conjunto, defendiendo un cambio cronológico, generalmente, aceptado por la mayoría de los expertos. Cf.: J. WILLIAMS, "Evidence for a New History", The Art Bulletin, vol. 55, 1973, pp. 170-184 e ID., "A source for the capitel of the offering of Abraham in Panteón of the King in León", Scritti di Storia dell'Arte in onore di Roberto Salvini, Firenze, 1980, pp. 25-28.

Véase también: A. VIÑAYO, León roman, Yonne, 1972; ID., Panteón de San Isidoro de León, León, 1979; ID., León y Asturias, La España románica, Madrid, 1987; ID., San Isidoro de León. Panteón de los Reyes. Albores románicos: arquitectura, escultura y pintura, León, 1995; ID., "Real Colegiata de San Isidoro de León”, Enciclopedia del románico en Castilla y León. León, Aguilar de Campoo, 2002, pp. 534-566; B. ANNE ORR, The sculptural program of the Royal Collegiate Church of San Isidoro in Leon, The Ohio State University, 1988; S. MORALEJO ÁLVAREZ, "Le origini del programma dei portali nel romanico spagnolo", Wiligelmo e Lanfranco nell'Europa romanica, Atti del Convengo Willigelmo e Lanfranco nell'Europa romanica, Modena, 1989, pp. 35-51, en Patrimonio Artístico..., vol. I, pp. 121135; E. FERNÁNDEZ GONZÁLEZ, San Isidoro de León, Madrid, 1992; I. G. BANGO TORVISO, "Arquitectura y escultura", Historia del Arte de Castilla y León. Arte románico, vol. II, Valladolid, 1994, pp. 9-212; M. VALDÉS, "El Panteón Real de la Colegiata de San Isidoro de León”, Maravillas de la España Medieval. Tesoro sagrado y monarquía, vol. I, León, 2001, pp. 73-84; E. MARTÍN LÓPEZ, "Las inscripciones del Panteón de San Isidoro de León. Particularidades epigráficas", Escritos dedicados a José María Fernández Catón, León, 2004, pp. 941-972; R. SÁNCHEZ AMEIJEIRAS, “The Eventful Life of the Royal Tombs of San Isidoro in León”, Church, State, Velum and Stone. Essays on Medieval Spain in Honor of John Williams, T. Martin Y J. Harris (ed.), Leiden-Boston, 2005, pp. 489-530.

Recientemente ha llevado a cabo un completo estado de la cuestión en: A. GARCÍA MARTÍNEZ, "El Panteón de S. Isidoro de León: Estado de la cuestión y crítica historiográfica”, Anuario del Departamento de Historia y Teoría del Arte, vol. XVI, 2004, pp. 9-16 e ID., "Aproximación crítica a la historiografía de San Isidoro de León”, Estudios Humanísticos. Historia, IV, 2005, pp. 53-93.

Las síntesis más actualizadas en relación con el conjunto artístico en: E. FERNÁNDEZ GONZÁLEZ, "Reflexiones sobre la evolución hacia el románico de las fórmulas artísticas altomedievales, en el ámbito astur-leonés, en la undécima centuria”, Internationale Tagung: Christliche Kunst im Umbruch Hispaniens 
El recinto funerario ubicado a los pies de la basílica de San Isidoro de León, durante mucho tiempo se había venido datado en torno al año 1063, mencionando como patrocinadores del espacio al rey Fernando I y a su esposa la reina doña Sancha. Sin embargo, tras las investigaciones desarrolladas por J. Williams, principalmente, obtenidas a través de las excavaciones llevadas cabo durante el verano de 1969 en recinto, se comenzaron a barajar otra serie de teorías relativas a dicha datación cronológica $^{1120}$.

La obra que hoy contemplamos ha sido considerada como una de las experiencias escultóricas más importantes dentro de los orígenes y formación del estilo románico en suelo peninsular. El conjunto de capiteles que decoran la estructura arquitectónica del recinto, presentan diversos motivos que van, desde los simples capiteles vegetales, hasta la introducción de algunas escenas iconográficas.

En síntesis, tanto la estructura arquitectónica del Panteón, como su decoración, han sido puestas en relación, de manera sucesiva, con la torre-pórtico de Saint-Benoîtsur-Loire $^{1121}$. Es este dato el que nos ha movido a introducir el ejemplo leonés en el discurso que venimos desarrollando pues, tal y como señalamos, la famosa torre-pórtico francesa se había convertido en uno de los puntos focales en el desarrollo de este citado "renacimiento corintio".

Con todo, actualmente, la mayoría de los especialistas parecen afirmar con unanimidad, que dicho recinto sería la última materialización heredera de la tradición de

Norden im 11. Jahrhundert, Göttingen, 27-29 de febrero de 2004, (en prensa); T. MARTIN, Queen as king: politics and architectural propaganda in twelfth-century Spain, Leiden, Boston, Brill, 2006, pp. 2435; ID., "Decorar, aleccionar, aterrorizar: escultura románica y gótica", Real Colegiata de San Isidoro: relicario de la monarquía leonesa (C. Robles García y F. Llamazares Rodríguez), León, 2007, pp. 104143; G. BOTO VARELA, "Arquitectura medieval: configuración espacial y aptitudes funcionales", Real Colegiata de San Isidoro: relicario de la monarquía leonesa (C. Robles García y F. Llamazares Rodríguez), León, 2007, pp. 50-103; F. PRADO-VILAR, "Saevum facinus...”, pp. 173-199 e ID., “Lacrimae rerum...", pp. 195-221.

Por ultimo, centrado en diversos aspectos iconográficos de la escultura del recinto funerario, véase: J. A. MORÁIS MORÁN, La recuperación de la Ecclesiae..., pp. 161-198.

${ }^{1120}$ J. WILLIAMS, "Evidence for...", en concreto, pp. 180-183. Los frescos del recinto funerario, datados cronológicamente durante años en torno a la figura de Fernando II (1157-1188), también recibieron una nueva fecha de realización.

${ }^{1121}$ M. Durliat, entre otros, se refería a la estructura funeraria de San Isidoro con las siguientes palabras: "se trata de una adaptación para un uso funerario de las bellas torres del tipo de Saint-Benoît-sur-Loire o Saint-Hilaire de Poitiers, teniendo como única diferencia con respecto a estos modelos, que el caso de León no está abierto al exterior". Cf.: M. DURLIAT, La sculpture romane de la route..., concretamente, pp. 185-186. La teoría expuesta por Durliat tendría seguidores dentro de los estudios dedicados a esta obra. Aún en el año 2002, se utilizaba el término westwerk para definir la estructura occidental de San Isidoro. Cf.: M. A. CASTIÑEIRAS GONZÁLEZ, "El Programa Enciclopédico de la Puerta del Cielo en San Isidoro”, Compostellanum, vol. XLV, 3 y 4, 2002, pp. 657-694, en concreto, p. 658. 
los panteones hispanos visigodos y asturianos ${ }^{1122}$. En consecuencia, su definición como torre-pórtico, siguiendo los modelos franceses, se presenta, a todas luces, como una solución inválida y problemática ${ }^{1123}$.

La reforma llevada a cabo en época románica generaría un espacio porticado, pero totalmente privado, sin acceso para el público. Este es un aspecto fundamental de las torres-pórtico francesas y los westwerk carolingios y, por lo tanto, acerca al conjunto leonés a las fórmulas típicamente hispanas ${ }^{124}$. En definitiva y cerrando esta cuestión, recogemos las palabras escritas por el profesor M. Valdés en relación con dicho espacio:

\section{“(...) no es una torre-pórtico de tradición francesa o un westwerk imperial.}

Las razones de similitud son formales, no conceptuales (...) el arte hispánico de la Alta Edad Media está jalonado con ejemplos de construcciones occidentales con función funeraria, como Santa María del Rey Casto de Oviedo, que como el Panteón de San Isidoro, fue lugar de silencio y sosiego (...), y no de trasiego parroquial"1125.

Si desde el punto de vista arquitectónico el Panteón Real de San Isidoro de León refleja, en pleno siglo XI, una larga tradición de enterramientos atestiguadas desde época tardoantigua dentro de la arquitectura hispana ${ }^{1126}$; desde el análisis de su

${ }^{1122}$ E. FERNÁNDEZ GONZÁLEZ, San Isidoro de León..., p. 10 e ID., "Reflexiones...”, (en prensa).

${ }^{1123}$ La torre de San Isidoro se encuentra colocada en eje desviado con respecto al Panteón, no sobre él. La única estructura superior hoy conservada sobre el recinto funerario es la tribuna, posiblemente de cronología posterior. Por lo tanto, no se trataría de una torre-pórtico, de progenie francesa.

${ }^{1124}$ H. SCHLUNK y J. MANZANARES, Op. cit., especialmente, p. 304. Para estos autores, tanto el Panteón de León, así como la estructura occidental de San Pedro de Teverga, estaban emparentados con la tradición carolingia. El paralelo más cercano, según estos autores, estaría en el westwerk de la iglesia de Corvey, del año 875. Teorías como estas, acabarían por fosilizarse dentro de la misma historiografía. Así, a partir de ellas, cualquier cuerpo occidental de los edificios altomedievales hispanos eran emparentados, de manera automática, con las experiencias de época carolingia. Recuérdense, por ejemplo, las filiaciones que se realizarán con el espacio occidental de San Miguel de Lillo, ligado por M. Cuadrado con las tradiciones centroeuropeas. Cf.: M. CUADRADO SÁNCHEZ, Arquitectura palatina del Naranco, Madrid, 1991, en concreto, p. 26. Sobre el tema, véase: F. GALTIER MARTÍ, "Le corps occidental des églises dans l'art roman espagnol du XI $\mathrm{e}^{\mathrm{e}}$ siècle: problèmes de réception d'un modèle septentrional", Cahiers de Civilisation Médiévale, XXXIV, I, 1991, pp. 297-307; J. L. SENRA GABRIEL Y GALÁN, "En torno a las estructuras occidentales de las iglesias románicas: formulación arquitectónica y funcional de las galileas (ca.1030-1150)", Espacios y estructuras singulares del edificio románico (P. L. Huerta Huerta), Aguilar de Campoo, 2008, pp. 121-155; F. ESPAÑOL BERTRÁN, "Los Descendimientos hispanos", La Deposizione lignea in Europa. L'immagine, il culto, la forma, MilanoPerugia, 2004, pp. 511-554, en particular, pp. 543-546 e ID., "El escenario litúrgico de la catedral de Girona (s. XI-XIV)", Hortus Artium Medievalium, vol. 11, 2005, pp. 213-232.

${ }^{1125}$ M. VALDÉS FERNÁNDEZ, "El Panteón de la Real Colegiata...", particularmente, p. 78. Este carácter cerrado y silencioso que se viene defendiendo para el Panteón leonés, no distaría mucho de la propia arquitectura funeraria paleocristiana, por ejemplo, las catacumbas, pues dichos espacios nunca fueron lugares públicos, ni de reunión y mucho menos, lugares de refugio, tal y como de manera confusa, han señalado algunos autores. Cf.: J. A. IÑíGUEZ, Síntesis de Arqueología..., en concreto, p. 24.

${ }^{1126}$ I. G. BANGO TORVISO, “El espacio para enterramientos...”, pp. 93-132. 
escultura, creemos que, la introducción del capitel vegetal de tradición corintia debe ser analizada teniendo en cuenta este mismo fenómeno, que también se desarrollaba en otros focos europeos de gran importancia.

Desde un punto de vista eminentemente formal, la escultura del recinto entra de lleno en la definición que en su día dio M. Durliat sobre el "renacimiento corintio", ya que, desde los estudios más tempranos, la mayoría de los autores que hacían depender la estructura del Panteón leonés con respecto a las torres porche de SaintBenoît-sur-Loire y Saint-Hilaire de Poitiers, también apoyaron la dependencia de toda la escultura del espacio con respecto a modelos vegetales franceses ${ }^{1127}$.

Para nuestro objetivo, los aspectos más interesantes residen en remarcar la participación de este movimiento escultórico del románico hispano, por lo general de una datación cronológica temprana, dentro de la recuperación del acanthus mollis de tradición antigua, siguiendo la estela de los mejores talleres europeos ${ }^{128}$ (figs. $186 \mathbf{y}$ 187).

Los capiteles del recinto funerario más importante de la PLENA EDAD MEDIA hispana, presentan todo tipo de decoración vegetal. Es evidente que la mayoría

1127 P. DESCHAMPS, "Etudes sur les sculptures des Sainte-Foy de Conques et de Saint- Sernin de Toulouse et leurs relation avec celles de Saint-Isidore de León et Saint-Jacques de Compostelle", Bulletin monumental, C, 1941, pp. 235-264; PH. VERDIER, "La sculpture du clocher-porche de Saint-Benoît-surLoire dans ses rapports ave l'Espagne califale et mozarabe”, Études Ligériennes, Auxerre, 1945, pp. 327336; F. GARCÍA ROMO, "Los pórticos de San Isidoro...", pp. 207-236; J. CABANOT, "Le décor sculpté de la basilique de Saint-Sernin de Toulouse", Bulletin Monumental, CXXXII, 1974, pp. 99-145; M. DURLIAT, "Les débuts de la sculpture romane dans le midi de la France et en Espagne", Cahiers de Saint-Michel de Cuxa, 1978, pp. 104-105 e ID., "Les débuts de la sculpture romane dans le Midi", Cahiers de Saint-Michel de Cuxa, 1977, pp. 101-114.

${ }^{1128}$ M. DURLIAT, "La sculpture...", en concreto, pp. 176-177. Si aceptamos las dataciones del autor para la torre-pórtico de Saint-Benoît, las esculturas ligadas a Umbertus deben pertenecer a un periodo comprendido entre el mandato de Gauzlin (1004-1030) y el del abad Guillermo (1067-1080), tal y como ya hemos señalado a lo largo de este trabajo.

Para el caso de Saint-Hilaire de Poitiers y su torre-pórtico, hoy absorbida por el cuerpo de la nave del evangelio, el autor francés dedica un amplio apartado a tratar la problemática del uso del corintio en esta iglesia poitevina. El gran templo, donde uno de los elementos más destacados son los enormes y "antiquizantes" capiteles de dicho espacio, fue patrocinado por la estirpe de los Guillermos. Se ha atribuido a la condesa Inés de Borgoña, muerta en el año 1068, un papel importante en el empuje de la obra. La torre y su escultura fueron datadas entre los años 1020-1030.

Se trata de una cronología igual de precoz que la otorgada, en un primer momento, a la escultura de SaintBenoît. La estudiosa aludía a la consagración de la iglesia de Saint-Hilaire el 1 de noviembre de 1049 y a una serie de indicios que hacían retrasar la cronología de la torre hasta esas fechas. Cf.: M.-TH. CAMUS, "Tours-porches et fonction d'accueil dans les églises du Poitou au XI siècle", Avant-nefs et les d'accueil dans l'église entre le IVe et le XIIe siècle, Auxerre, 1999, pp. 260-280, en concreto, pp. 261-263 e ID., Sculpture romane..., concretamente, pp. 79-86.

Sin embargo, nuevamente en el año 1994, M. Durliat reconoció una datación excesivamente temprana sobre tales obras. Así, el autor propuso la fecha de la muerte de la condesa Inés, en 1068, como clave, en el desarrollo de estos trabajos. En todo caso, se trataría de una escultura que sólo sería posible incluirla, según su opinión, entre los años 1040-1070. Cf.: M. DURLIAT, "La sculpture...”, en concreto, pp. 186190. 
de elementos no son acantos, pues encontramos gran cantidad de palmetas y entrelazos de diversa índole ${ }^{1129}$. Sin embargo, algunos autores coinciden en afirmar que dichas experiencias escultóricas deben ser vistas como un intento de recuperación de las formulas romanas, siguiendo vías similares a las utilizadas por los mismos momentos en suelo francés. Se repite aquí la fascinación por lo vegetal, pero no sólo por la palmeta, sino también por los apomados, las volutas de gran volumen y todo un repertorio de temas de gran tradición dentro de la historia de las formas (fig. 188).

En palabras de G. Sauron, la recuperación de estos repertorios vegetales de tipo clásico, supone una vuelta hacia la "estética de lo ornamental" que, en el mundo antiguo, había nacido en el seno de la misma "estética apoliniana" "1130.

Los prótomos animales definidos por E. Vergnolle como eminentemente clásicos, para el caso de Saint-Benoît, aparecen también en la escultura del Panteón, en forma de prótomos cefálicos de gran prominencia ${ }^{1131}$. Si el taller de Umbertus, conocedor y observador de los sarcófagos paleocristianos, había introducido sobre un capitel una escena cinegética inspirada en la escultura antigua, también encontramos dentro del Panteón hispano una escena del mismo tipo ${ }^{1132}$. Se trata del capitel en el que un hombre alancea un felino en plena cacería, que corrobora, además, la importancia de las escenas cinegéticas de carácter antiguo dentro de los ámbitos y obras funerarias de Edad Media ${ }^{1133}$.

Las conexiones entre la escultura de ambos edificios, son más de índole temática que meramente estilística, pues desde el punto de vista formal, los capiteles figurados y

\footnotetext{
${ }^{1129}$ Es bien sabido que durante los siglos medievales, especialmente, durante la Alta y la Plena Edad Media, los escultores reinterpretaron el motivo del acanto a través de muy diversas soluciones, algunas de ellas sin ningún tipo de parecido con los modelos del acanto romano. Los vegetales se abstrajeron al máximo, los zarcillos se geometrizaron y toda la decoración sufrió una mutación muy marcada, fruto del cambio de técnicas, de una evolución en el tratamiento de los materiales y toda una serie de causas sobre las que no vamos a insistir. Todo ello provocó que, aún inspirándose en modelos romanos, los resultados que obtuvieron los artistas medievales se separasen del tipo corintio clásico. En este ámbito es donde surgirían expresiones tales como la de "capitel corintio degenerado". Cf.: G. SAURON, L'Histoire végétalisée..., en particular, pp. 222-230.

${ }^{1130}$ Ibidem, pp. 127-177. El autor incluye un capítulo titulado la "Historia vegetalizada por la poesía", en el que realiza una serie de reflexiones sobre la importancia de la literatura virgiliana en el desarrollo de este tipo de producciones.

${ }^{1131}$ E. VERGNOLLE, Saint-Benoît..., en concreto, p. 81.

${ }^{1132}$ Se analizan algunas de las posibles fuentes romanas para el capitel del cazador de San Isidoro en: J. A MORÁIS MORÁN, La recuperación..., pp. 130-132.

${ }^{1133}$ Señalamos, entre otros repertorios, obras como el mosaico de la gran cacería de Piazza Armerina. Ya en el caso hispano, el mosaico de la villa romana de Cardeñajimeno o del Hinojal en Badajoz, son ejemplos donde, nuevamente, aparece la caza del felino con lanza. El paralelismo más cercano, es el del sarcófago del Musée des Augustins, en Toulouse, donde un cazador vestido con túnica corta espeta una lanza a un felino de una manera muy similar a la pieza del panteón. Sobre dichas cuestiones, véase: J. A. MORÁIS MORÁN, La recuperación..., pp. 130-146.
} 
aquellos vegetales de Saint-Benoît-sur-Loire y los de Saint-Hilaire de Poitiers, acusan mayores diferencias que similitudes ${ }^{1134}$.

Sin embargo, en lo que si coinciden todos los recintos, es en el marcado clasicismo de sus capiteles que, además, en el caso de los tallados para el Panteón de San Isidoro muestran una pervivencia de ciertos elementos de la plástica hispana de los siglos anteriores ${ }^{1135}$.

Desde otro punto de vista, aparte de E. Vergnolle, ya la profesora M.-Th. Camus establecería una filiación directa entre algunos de los corintios del Poitou, especialmente los de Saint-Hilaire de Poitiers y Saint-Savin-sur-Gartempe, con otras obras más tardías, cercanas al final del siglo XI. En concreto, la relación se producía, según la autora, con algunos capiteles de Saint-Sernin de Toulouse, donde nuevamente se observaba esta tendencia "antiquizante" 1136 (fig. 189).

Las conexiones de estos modelos con otras obras importantes del románico francés, en las que se ha señalado la admiración de capiteles clásicos, han sido abundantes, tal y como demuestran las teorías defendidas por J. Cabanot, quién defenderá ciertas relaciones entre los capiteles vegetales del Panteón leonés y los de la abadía de Saint-Sever. En ambos, los grandes parentescos con respecto a los talleres tolosanos son evidentes ${ }^{1137}$.

La dualidad existente entre el capitel clásico antiguo y sus reinterpretaciones medievales llega a mostrar parecidos evidentes y relaciones directas que, en ocasiones, son factibles a través de la comparación formal entre las esculturas de ambos $\operatorname{periodos}^{1138}$.

\footnotetext{
${ }^{1134}$ F. GARCÍA ROMO, La escultura del siglo XI..., p. 247. Con todo, según el autor, la escultura del Panteón posee ciertos puntos en común con lo francés, hasta el punto de defender una cronología paralela con respecto a Saint-Benoît-sur-Loire, por ejemplo.

${ }^{1135}$ E. FERNÁNDEZ GONZÁLEZ, San Isidoro de León..., p. 12. La aludía al recuerdo de las fórmulas visigodas.

Véase también: F. GARCÍA ROMO, La escultura del siglo XI..., pp. 251-253 e ID., Un taller escultórico de influjo hispano-musulmán en Loire medio (entre 1031-1050)", Al-Andalus, 1, vol. 25, 1960, pp. 189200. El investigador aún emparentaba diferentes aspectos de la escultura, sobre todo los capiteles vegetales, con la tradición "mozárabe", tal y como él mismo defendía, señalando ese "mozarabismo", no sólo para el caso de León, sino también para los franceses.

${ }_{1136}$ M.-TH. CAMUS, Sculpture romane..., en especial, pp. 240-245 y p. 307, nota 35.

1137 J. CABANOT, "Le décor sculpté de la basilique Saint-Sernin de Toulouse", Bulletin Monumental, 132-1, 1971, pp. 99-145, en concreto, p. 110-111; ID., "La construction de l'abbatiale de Saint-Sever. État des questions", Saint-Sever Millénaire de l'abbaye, Mont-de-Marsan, 1986, pp. 145-161, especialmente, pp. 158-159 y J. LACOSTE, Les maîtres de la sculpture romane dans l'Espagne du pèlerinage à Compostelle, Bordeaux, 2006, en concreto, p. 46. Este último autor establece una filiación directa entre los primeros capiteles del taller de Toulouse que trabaja en la basílica de Saint-Saturnin, con los del Panteón.

1138 A. MILONE, "Taller de Rainaldo. Capitel con amorcillos y guirnaldas", El románico y el Mediterráneo..., ficha catalográfica 54, p. 309; G. TEDESCHI GRISANTI, "Capitel compuesto antiguo",
} 
Un ejemplar procedente del Duomo de Pisa debe ser valorado, tal y como se ha señalado, como una copia, casi perfecta, de una pieza antigua (fig. 190). Se trata de un tipo compuesto en el que la reflexión sobre la hoja de acanto a través del visionado de los modelos romanos, genera una producción plástica de primer orden dentro de los repertorios románicos del SIGLO XII, que plantea la problemática de poder llegar, incluso, a pensar que se trata de una obra propiamente antigua ${ }^{1139}$.

Dentro del caso hispano, la producción de capiteles romanos mostrará todas las variantes tipológicas habituales en un arte que se debate entre la creación propia de tono provincial y los modelos más selectos tomados de la metrópoli. En relación con ello, queremos detenernos un capitel romano proveniente de la ciudad de Soria ${ }^{1140}$ (fig. 191).

Al comparar algunos detalles que presenta dicha escultura con otros capiteles de tipo corintio, realizados en época románica, creemos que las posibles concomitancias insinúan ciertas relaciones entre las facturas antiguas y las medievales. El escultor del capitel hispanorromano, pudo contar con idénticas limitaciones instrumentales en el manejo de las herramientas que pudieran explicar la utilización de soluciones similares a la hora de resolver la pieza.

Al analizar uno de los capiteles vegetales del Panteón de San Isidoro de León (fig. 192), inmerso en una tradición muy similar a la que presentan determinadas piezas de la basílica de Saint-Sernin de Toulouse, se observan relaciones directas con respecto al capitel romano, en cuanto a la distribución del follaje en la cesta, la morfología de las hojas y la manera en que fueron talladas. Más allá de este parentesco formal que señalamos, atestiguar otro tipo de relación segura entre ambas piezas, caería en el mero campo de las hipótesis.

La defensa de las fuentes clásicas para algunos de estos capiteles románicos, fue señalada en su día por el profesor M. Valdés, al estudiar la escultura del Panteón leonés. El autor, aludía al carácter homogéneo del taller que trabajará en el recinto, que:

“(...) conjugó por un lado la recuperación de los modelos clásicos, el capitel compuesto con acantos y volutas, más el astrágalo decorado con pares de anillos que

El románico y el Mediterráneo..., ficha catalográfica 56, p. 311 y J. ANTON REMOLÀ, "Capitel corintio de la antigua Tarraco", El románico y el Mediterráneo..., ficha catalográfica 81, p. 358.

1139 A. MILONE, "Taller de Guglielmo (doc. 1158/ 1159-1165). Capitel compuesto", El románico y el Mediterráneo..., ficha catalográfica 51, p. 306.

${ }^{1140}$ Soria, Museo Numantino. 
recuerda modelos emeritenses y asturianos; es, en definitiva, la superación de los estilizados modelos del siglo X y principios del XI ${ }^{, 1141}$.

En este sentido, compartimos de manera absoluta tal postura. Los modelos de capitel corintio desarrollados en tal espacio, a pesar de ser calificados por A. Viñayo como "arcaicos y rudos" 1142 o de presentar una clara deuda con la escultura del siglo X, tal y como ha propuesto S. Noack-Haley, son piezas de clara deuda con lo romano, pero materializados bajo un fuerte sentido reinterpretativo ${ }^{1143}$.

Las experiencias recuperadoras del corintio antiguo, tenían en San Isidoro de León, antecedido por el caso de San Pedro de Rodas en más de medio siglo, los dos ejemplos hispanos más precoces, monumentales y que hayan llegado hasta nosotros completos, en relación con este movimiento.

De lo afirmado hasta aquí, podemos concluir que, en la década que iba desde el año 1080 al 1100, algunas de estas producciones románicas hispanas, se equiparaban a los grandes talleres europeos en cuanto a calidad y, sobre todo, en lo referente a un interés por monumentalizar el capitel corintio.

A partir de este momento y, según se viene aceptando mayoritariamente por la crítica historiográfica, podemos hablar de un despegue de los talleres románicos en Hispania. Los últimos años del siglo XI y, a partir de aquí, todo el siglo XII posterior, suponen la reactivación de la escultura monumental, nunca olvidada, por otra parte ${ }^{1144}$.

Este es el momento en que, paralelamente o, incluso antes de la construcción del Panteón de San Isidoro de León o la estructura occidental de San Pedro de Teverga, se daba inicio a la cabecera de la catedral de Santiago de Compostela.

A finales del siglo XI se trabaja también dentro de otra larga serie de edificios donde la escultura cobró una importancia fundamental, tales como la catedral de San Pedro de Jaca y otra serie de templos del ámbito navarro y aragonés, en la iglesia palentina de San Martín de Frómista o en la de San Zoilo, en el monasterio de Carrión de los Condes ${ }^{1145}$.

\footnotetext{
${ }^{1141}$ M. VALDÉS FERNÁNDEZ, "El Panteón Real...”, en concreto, p. 78.

1142 A. VIÑAYO, "Real Colegiata...", p. 549.

${ }^{1143}$ Sobre el carácter "mozárabe" de la escultura del Panteón, vid.: F. GARCÍA ROMO, La escultura del siglo XI..., en especial, p. 251-253 y S. NOACK-HALEY, "Capiteles mozárabes", Coloquio internacional de capiteles prerrománicos e islámicos (s. VI-XII), Madrid, 1990, pp. 37-52.

${ }^{1144}$ I. LORÉS I OTZET, "Actualización de los edificios: nuevas construcciones e incorporación de la escultura”, El románico y el Mediterráneo..., pp. 121-131.

${ }^{1145}$ M. DURLIAT, "Les débuts...", en concreto, p. 107. El investigador señala también los casos de San Salvador de Leyre, Santa María de Ujué y Santa María de Iguácel, como pioneros en el desarrollo de la
} 
En todos estos edificios se mantendrá, con más o menos variantes, el uso del capitel corintio. Algunos de ellos presentan la típica división de hojas planas y desnudas que se giran sobre si mismas rematando en apomados, como por ejemplo vemos, en las partes bajas del transepto de la catedral de Santiago ${ }^{1146}$. En otros lugares del edificio, como en los brazos del transepto, el capitel corintio muestra hojas nervadas muy carnosas y voluptuosas, que se emparientan, tanto con los ejemplos de Toulouse, como con los del mismo Panteón leonés ${ }^{1147}$. En el resto de edificios observamos una tendencia semejante, donde, a parte del desarrollo de capiteles historiados, se introdujeron también buenos ejemplares del tipo corintio.

Sin embargo, si en los casos citados la concepción del capitel siguió ligada a modelos romanos, en gran medida evolucionados y reinterpretados por los escultores románicos, creemos que, tras el cambio de siglo, su morfología y utilización cambió.

La posibilidad de explicar tal hecho a través de una supuesta consciencia premeditada de la utilización de este tipo de capitel, durante el siglo XII, es complicada. Más allá de los objetivos meramente ornamentales, a partir de la eclosión de la escultura figurada, fue ésta la que pasó a ocupar la mayor parte de las cestas de los capiteles. El uso del corintio se mantuvo, pero sin otorgarle los valores simbólicos que durante el siglo XI había tenido. Aparece ahora con propósitos ornamentales más evidentes y sólo será dentro de los talleres con tendencia a lo "antiquizantes", donde el recuerdo de las formas clásicas señalará un interés a la hora de abordar su elaboración simbólica.

escultura dentro del ámbito peninsular, sin embargo, en cuanto a la concepción del capitel corintio, dichas experiencias no llegaron a los niveles de clasicismo de otros territorios, como el catalán o el leonés. Véase también: A. GÓMEZ GÓMEZ, "La escultura románica en Navarra...", pp. 85-86. Se realiza un breve balance de las teorías vertidas sobre los capiteles de la cripta de Leyre, además de señalar el parentesco que, generalmente, se ha defendido con respecto a los de Ujué.

${ }^{1146}$ E. VERGNOLLE, "Réflexions sur les chapiteaux...", pp. 186-192. La autora explica el origen romano del tipo de capitel de hojas planas y marcadas volutas. Dichos ejemplares, que ella analiza a través de los existentes en Saint-Sever, presentan en la cesta una serie de motivos vegetales muy someros, lo que ha dado la posibilidad de hablar de una cierta premura en su labra y del hecho de que, algunas piezas, no fuesen acabadas de manera completa. Como precedentes de este tipo de capitel, la autora propone varios capiteles de Ostia y Cartago, así como ejemplos del Tabularium de Roma, datados sobre el 78 a. de C. Incide también en la gran difusión que logro el tipo, aludiendo a su fortuna sobre los talleres del Cluny, Saint-Benoit-sur-Loire, Toulouse e, incluso, Jaca.

Sobre la datación de los capiteles de Saint Sever, véase: J. CABANOT, "La construction de l'abbatiale...", en especial, pp. 158-159. Se compara directamente con los ejemplares de Santiago de Compostela y los del Panteón de San Isidoro de León.

1147 Sobre la cabecera de la catedral de Santiago de Compostela y su decoración esculpida, véase: V. R. NODAR FERNÁNDEZ, La inicios de la catedral románica de Santiago: El ambicioso programa iconográfico de Diego Peláez, Santiago de Compostela, 2005, pp. 5-40. 
En relación con ello, se deben recordar los magníficos capiteles corintios esculpidos durante la segunda mitad del siglo XII ${ }^{1148}$, en el entorno del denominado "maestro" de Cabestany, con ejemplares tan representativos como los de la iglesia francesa de Rieux-Minervois o San Pedro de Galligans, ya en suelo hispano ${ }^{1149}$.

Por ello, se puede afirmar que, dentro de determinados talleres, donde la tradición clásica y el conocimiento de modelos antiguos eran patentes, el capitel corintio continuó manteniendo su morfología. En este sentido, ya W. Goldschmidt señalaba, en 1937, la fuerte impronta clásica y el amplio abanico de fuentes antiguas que, por ejemplo, llevaron al taller de la iglesia de San Vicente de Ávila (ca. 1170-1180) a concebir una escultura repleta de alusiones a la romanidad ${ }^{1150}$. El autor equiparaba dicha escultura a la del "maestro" Mateo y su Pórtico de la Gloria, afirmando, incluso, que ésta poseía algunas características que la hacían superior ${ }^{151}$.

Dicho taller generará algunos de los más perfectos capiteles corintios del románico hispano de cronología más avanzada (fig. 193). Sus fuentes, tal y como ha

\footnotetext{
${ }^{1148}$ En relación con las producciones plásticas de mediados del siglo XII, véase: F. GARCÍA ROMO, La escultura del siglo XI..., en concreto, p. 219. El autor considera que ese renacimiento de la Antigüedad, visible dentro de la escultura de finales del siglo XI, llegó a su apogeo en torno al año 1140, sin explicar bien las causas y ejemplos que le llevan a fijar tal fecha.

${ }^{1149}$ No tratamos extensamente la problemática en torno al "maestro" de Cabestany y su círculo artístico, ya que se dedicará un apartado de este mismo estudio a su análisis. En concreto, sobre los capiteles de Rieux, A. Bonnery ha remarcado, últimamente, la fecha de 1154 como terminus ante quem de la escultura del edificio. Define, así mismo, los capiteles corintios a través del concepto "estilo depurado" o "estilo pseudo-clásico" y señala un muy buen conocimiento de la escultura clásica por parte de la persona que labró dichas piezas, incluso para las que siguen el prototipo de capitel clásico. Cf.: A. BONNERY, "L'église Sainte-Marie de Rieux-Minervois", Le maître de Cabestany, Saint-Leger-Vauban, 2000, pp. 3247, en concreto, p. 32. Sobre su marcado clasicismo a la hora de esculpir capiteles corintios, véase también: O. POISSON, "Un sculpteur anonyme du XII" siècle", Le maître..., pp. 7-15. El profesor Poisson relaciona los capiteles atribuidos a este maestro con los de la catedral de San Pedro de Maguelone, los de la nave de la catedral de Carcasonne, los de Santa-Marie d'Alet o los de Santiago de Béziers.

Véase también: I. LORÉS I OTZET, El monestir..., en especial, p. 58 y J. CAMPS I SÒRIA e I. LORÉS I OTZET, "Sant Pere de Galligants", Le maître..., pp. 28-31. Los autores señalan algunos de estos edificios como fuente para los artistas que esculpieron los clásicos corintios de Rodas y aluden al año 1131 como una fecha posible para datar la actividad de este taller.

${ }^{1150}$ En la actualidad, la denominación de "maestro" de Ávila, establecida el profesor Andrade, es la más acertada, tras haber considerado que la atribución de tales obras al famoso "maestro" Fruchel, era insostenible. Cf.: P. ANDRADE, Los maestros de Oviedo y Ávila, Madrid, 1955, en especial, p. 17; M. M. VILA DA VILA, Ávila Románica. Talleres Escultóricos de Filiación Hispano-Languedociana, Ávila, 1990; D. RICO CAMPS, El románico de San Vicente de Ávila (estructuras, imágenes, funciones), Murcia, 2002, en concreto, pp. 95-102. El profesor Camps es muy crítico con la teoría de Fruchel, que en su día defendió, sobre todo, G. Ramos. Cf.: G. RAMOS, "En torno a Fruchel", Boletín del Seminario de Arte y Arqueología de la Universidad de Valladolid, XL-XLI, 1975, pp. 189-199. La autora se respaldaba en el documento fechado en el año 1192. A él atribuye una actividad, no sólo en Ávila, sino también en Toledo, Zamora y Carrión de los Condes, además de Palencia. Sin duda, se trata de un repertorio de obras bastante extenso como para poder demostrar la atribución directa con una figura de la que restan pocas y fragmentadas noticias documentales.

${ }^{1151}$ W. GOLDSCHMIDT, "The West Portal of San Vicente at Ávila", The Burlington Magazine for Connoisseurs, 71, 414, 1937, pp. 110-123, en concreto, p. 123. La cronología de dicho portal que damos aquí, es la propuesta, recientemente, en: J. LACOSTE, Les maîtres..., en concreto, p. 164.
} 
apuntado recientemente J. Lacoste, se rastrean en la Antigüedad, pero no a través de la observación de obras locales hispanorromanas, sino que, a dichas filiaciones, se deben sumar también las influencias que el arte galorromano había ejercido sobre los escultores románicos activos en dichos territorios.

Se trataría entonces de la creación de un motivo clásico fundamentado mediante dos vías. La primera, vendría dada de las repercusiones que el arte antiguo de la Galia, había tenido sobre el arte románico francés, visible, sobre todo, a través del marcado clasicismo que encontraremos dentro de los repertorios escultóricos del ámbito borgoñón. La segunda premisa, será la llegada de este motivo del capitel corintio a la Hispania medieval. Sin embargo, los escultores que trabajaban en este territorio no mirarán a los vestigios hispanorromanos, sino que simplemente mostrarán una asimilación de los motivos clásicos de la Galia, reinterpretados allí por artistas medievales $^{1152}$.

La escultura de Borgoña, en concreto, la realizada para la iglesia de Saint-Lazare de Avallon (ca. 1160-1170) o la de la iglesia de Notre-Dame de Vezelay (ca. 1130), se ha presentado como el referente directo para estas producciones hispanas de los citados ejemplos abulenses ${ }^{1153}$.

Mediante algunas de estas producciones, en concreto, a través de determinados ejemplares de capiteles corintios distribuidos en la fachada occidental y en las torres de la iglesia de San Vicente de Ávila (fig. 193), el uso del capitel corintio hispano se equiparaba al fenómeno que años atrás había hecho revivir los órdenes clásicos, casi de manera "arqueológica", en edificios tan importantes, como la tercera fase de Cluny y en gran parte de la escultura ubicada en los grandes narthex borgoñones ${ }^{154}$.

Podemos concluir que, en el momento de producirse el desarrollo de la escultura en los capiteles románicos peninsulares, el tipo corintio nunca dejó de utilizarse. Es verdad que, en determinados ámbitos más apegados a la romanización, como San Pedro de Rodas, su uso, además de ser más monumental, se mostró también cargado de fuertes resonancias simbólicas. En otros casos, como en la catedral de Jaca, los modelos más

\footnotetext{
${ }^{1152}$ Sobre estas cuestiones, remitimos a la última parte de este estudio.

1153 J. LACOSTE, Les maîtres..., en especial, pp. 137-164. El autor propone algunas piezas del Museo Arqueológico de Ávila, en concreto, un centauro de mármol romano, como algunas de las obras que los escultores del foco abulense pudieron conocer, a parte de las consabidas filiaciones con la escultura antigua de la zona de la Saintogne y del oeste de Francia. Establece una dependencia de los talleres hispanos con respecto a otros edificios, como por ejemplo, Saint Bénigne de Dijon o Saint-Lazare de Autun. Los parentescos ya fueron expuestos en su día por otros autores. Cf.: W. GOLDSCHMIDT, "The West Portal...”, especialmente, p. 120 y D. RICO CAMPS, El románico de San Vicente..., pp. 184-202. ${ }^{1154}$ F. SALET, "Cluny III...”, pp. 235-292 y J LACOSTE, Les maîtres..., p. 160.
} 
clásicos corresponderían a la escultura figurada, pero sin obviar nunca el uso del corintio.

Hasta llegar, finalmente, a los últimos años del siglo XII, donde la mayoría de los capiteles se ven inundados por la introducción en las cestas de profusas escenas narrativas cargadas de imágenes e iconografía. Pero, incluso a partir de este momento, el recuerdo y la intención de incluir al capitel corintio dentro de los ciclos escultóricos, a veces, con un cierto sentido meramente decorativo, no dejó nunca de ser bien patente. 


\section{2. PARA UNA "POÉtiCa Vegetalizada" Del aCANTO CláSico DURANTE EL MEDIEVO ${ }^{1155}$.}

El 30 de enero del 9 a. de C. se dedicaba el llamado Ara Pacis en Roma. Para la decoración de dicha estructura, como es sabido, se utilizó, a lo largo de todo su perímetro, una decoración basada en diferentes motivos vegetales y animales, además de otras iconografías relativas a determinados ceremoniales y alegorías ${ }^{156}$. Entre los diferentes motivos vegetales utilizados, el acanto fue el más importante y el que cubriría la mayor parte del templete. Además de los numerosos zarcillos que se despliegan alrededor de todo el muro, se incluyeron otra serie de vegetales, tales como vides o laurel, que adquieren la forma y la disposición morfológica del mismo acanto, emulando, tanto su forma como textura, tal y como señaló en su día P. Zanker ${ }^{1157}$.

El ambiente vegetal esculpido sobre tal estructura asentó la nueva concepción que, de la imagen vegetal, se tendría en el mundo antiguo y, supuso, además, el inicio de una tradición icónica que disfrutaría de larga fortuna durante los siglos medievales ${ }^{1158}$. A partir de este momento, cualquier elemento vegetal representado plásticamente, podía ser susceptible de una interpretación en clave iconográfica y ser dotado de una serie de significaciones simbólicas.

El origen de esta tendencia tiene en el Ara Pacis de Roma y, por extensión, dentro del arte clásico romano, su mejor representante. Aquí el acanto se convirtió, tal y como ha señalado G. Sauron, en un auténtico símbolo de fecundidad de la naturaleza, sintetizada a través de exuberantes roleos y zarcillos cargados de jugosas hojas. El origen intelectual de tal repertorio tenía en los textos virgilianos su mejor apoyo teórico, tal y como ha defendido el autor ${ }^{1159}$.

\footnotetext{
${ }^{1155}$ Utilizamos la expresión ideada por G. Sauron, pues creemos que "inventa" una serie de conceptos y neologismos que expresan bien los fenómenos a los que se intenta referir, como por ejemplo, la “acantización”. Cf.: G. SAURON, L'Histoire végetalisée..., pp. 126-127.

${ }^{1156}$ D. CASTRIOTA, The Ara Pacis Augustae and the imagery of abundance in later Greek and early Roman imperial art, Princeton, 1995, pp. 10-58.

${ }^{1157}$ P. ZANKER, Augusto y el poder..., pp. 234-235. Se defiende el valor simbólico e iconográfico, así como la utilización política de estas imágenes vegetales que, colocadas sobre los edificios de patrocinio imperial, buscaban potenciar la idea de un estado en paz asentado en tiempos de bonanza. Véase también: G. SAURON, L'Histoire végétalisée..., en concreto, pp. 28-29. Se estudia el ejemplo del Ara Pacis y el valor político de su decoración vegetal. El autor apoya la teoría que defiende un intento por volver a la Edad de Oro, a través de estas imágenes.

${ }^{1158}$ CH. FRUGONI, "Alberi (in paradiso voluptatis)", L'ambiente vegetale nell'alto Medioevo (XXXVII settimana di studio del Centro italiano di studi sull'Alto Medioevo, Spoleto, 1990, pp. 725-762 y G. SAURON, L'Histoire végetalisée..., p. 100.

${ }^{1159}$ G. SAURON, "La promotion apollonienne de l'acanthe et la définition d'une esthétique classique à l'époque d'Auguste", L'acanthe..., pp. 75-97. Se trata de una aportación indispensable en relación con
} 
Es importante destacar que, para expresar ese retorno a la Edad de Oro de la que hablaba Virgilio, los talleres neoáticos, sobre todo a partir del siglo I a. de C., comenzarán a trabajar de manera habitual fuera del ámbito ateniense. Su signo más destacado, el uso del vegetal -y, en especial, del acanto-, se convirtió en un elemento habitual dentro de la decoración de muros, cornisas, capiteles y entablamentos, además de engalanar también los objetos muebles, las esculturas y los relieves. El acanto, derrochando una exhuberancia máxima, se entremezclaba con los pámpanos y hojas de vid de la tradición dionisíaca, permitiendo que todo tipo de seres mitológicos, putti, aves, candelieri y una alta gama de objetos suntuosos, configurasen una imagen cotidiana dentro de las artes plásticas de la Roma Imperial ${ }^{1160}$.

Poca fortuna cabía esperar para motivos tan aparentemente paganos dentro de la iconografía medieval. Con todo, partiendo de la aplicación de ciertas reflexiones simbólicas sobre la representación del acanto romano, creemos que se puede establecer una conexión entre esta intención clásica de utilizar determinados elementos vegetales con fines simbólicos y su traspaso a los espacios eclesiásticos cristianos.

Ya hemos señalado las brillantes reflexiones realizadas por la profesora $\mathrm{S}$. Romano a propósito del papel jugado por el Ara Pacis en la formación de algunos motivos vegetales presentes dentro de las producciones artísticas del medievo romano.

En concreto, aludía a la posibilidad de plantear ciertas hipótesis con respecto a las fuentes utilizadas por los mosaistas de Roma que trabajaron en el ábside de la iglesia superior de San Clemente.

Sobre la iconografía y las características del mosaico del ábside de este templo no es preciso insistir. Según se ha dicho, los dos talleres que aplicaron dicho mosaico estuvieron, posiblemente, dirigidos por una personalidad culta y conocedora de complejas ideas teológicas y espirituales, que le hubieron de llevar a programar un ciclo icónico de enorme complejidad. Fueron H. Toubert y E. Kitzinguer, los dos primeros estudiosos en señalar que su iconografía formaba parte de un fenómeno, denominado

este tema pues, partiendo de las premisas dadas en su día por P. Zanker, aporta una serie de matices sobre el simbolismo de lo vegetal en los edificios clásicos. Hoy se ha llegado al consenso de que la decoración fantástica y rica que se muestra sobre muchos edificios de la época de Augusto, poseen un trasfondo importante desde el punto de vista político. Se buscaba potenciar y publicitar una nueva etapa, la nueva Edad de Oro, que se lograría a través del uso del acanto en todas las promociones imperiales, tanto en los capiteles, como en los frisos de los templos, creando casos tan espectaculares como el del Templo Mars Ultor de Roma, por ejemplo. Cf.: P. VIRGILIO MARÓN, Bucólicas; Geórgicas (Introducción, notas y traducción de B. Segura Ramos), Madrid, 1983, pp. 8-13 y pp. 30-36. En especial caben destacar las Bucólicas II y III.

${ }^{1160}$ G. SAURON, "La promotion apollonienne...", en especial, pp. 78-89 y N. DACOS, La découverte de la Domus Aurea et la formation des grotesques dans la Renaissance, London, 1969, pp. 29-50. 
desde entonces, como "renacimiento paleocristiano" "1161. A partir de este momento, la historiografía aceptaría de manera consensuada el uso del término, tal y como ya hemos señalado ${ }^{1162}$.

A lo largo de toda la bóveda del ábside se desarrolla la representación de una gran viña, identificada mediante la siguiente inscripción:

ECCLESIAM CRISTI VITI SIMILABIMUS ISTI/ DE LIGNO CRUCIS IACOBI DENS IGNATIIQ(UE)/ IN SUPRASCRIPTI REQUIESCUNT CORPORE CRISTI/ QUAM LEX ARENTEM SET CRUS FACIT E(SS)E VIRENTE(M) ${ }^{1163}$.

Dicho epígrafe presenta una importancia fundamental, pues además de identificar la exuberante y variada vegetación del conjunto con la vid, alude a la presencia de la reliquia de la cruz. Este hecho ha servido, incluso, para desarrollar la hipótesis de la posible existencia de una cavidad en el interior del propio mosaico en la que, supuestamente, se habría de colocar la citada reliquia ${ }^{1164}$.

${ }^{1161}$ E. KITZINGER, "The Gregorian Reform and the visual arts: a problem of method", Transactions of the Royal Historical Society, V, 22, 1972, pp. 87-102. El autor desarrollaba la teoría de que el mosaico de la basílica clementina había sido concebido por artistas orientales y, más concretamente, bizantinos. En este sentido, aludía al ejemplo de Desiderio de Montecassino y la búsqueda de artífices bizantinos para llevar a cabo el mosaico de la renovada abadía de San Benito. A partir de sus ideas, parte de la historiografía, compartiría que el mosaico de San Clemente poseía un fuerte componente bizantinizante. Cf.: S. RICCIONI, "Signi epigrafici e sistema illustrativi alla greca nel mosaico di San Clemente a Roma", Medioevo mediterraneo: l'Occidente, Bisanzio e l'Islam dal tardoantico al secolo XII (a cura di A.Quintavalle), Parma, 2007, pp. 121-140 y H. TOUBERT, "Le renouveau paléochrétien...", pp. 9-154. La autora llamaba la atención sobre la posible inspiración de este mosaico en otro anterior ubicado en la basílica inferior, además de señalar diferentes iconografías all'antica tomadas de repertorios bien conocidos en la Roma paleocristiana, como putti, cráteras, escenas de género variadas, pastoradas y, sobre todo, un simbólico ambiente vegetal.

Para un estado de la cuestión actualizado, véase: S. RICCIONI, Il mosaico absidale di San Clemente a Roma. Exemplum della Chiesa riformata, Spoleto, 2006 y J. CROISIER, "I mosaici dell'abside e dell' arco absidiale della Chiesa superiore di San Clemente. 1118 ca.", Riforma e Tradizione (S. Romano dir.), Roma, 2006, pp. 209-218. La mayor parte de los autores datan la obra entre los años 1115 a 1120 , bajo el pontificado de Pascual II e íntimamente ligada a la consagración en el 1071 de la basílica de San Benito de Montecassino, donde sí parece clara la intervención de artífices bizantinos.

${ }^{1162}$ Remitimos al apartado en el que hemos analizado la problemática del "renacimiento paleocristiano", tanto romano como casinense, además de las reflexiones apuntadas a propósito de la reutilización del sarcófago de Ithacio de la catedral de Oviedo, en relación con el uso de temas vegetales y su fortuna en los siglos medievales. Sin embargo, mencionamos, otra vez, el famoso mosaico romano, por ser una pieza ineludible para el estudio del tema.

${ }^{1163}$ U. NILGEN, "Texte et image dans les absides des $\mathrm{XI}^{\mathrm{e}}-\mathrm{XII}^{\mathrm{e}}$ siècles en Italie", Epigraphie et iconographie (R. Fravreau dir.), Poitiers, 1996, pp. 153-165.

${ }^{1164}$ W. TELESKO, "Ein Kreuzreliquiar in der Apsis? Überlegungen zum Konzept der mittelalterlichen Apsisdekoration von San Clemente in Rom", Römische historische Mitteilungen, 36, 1994, pp. 53-79; A. DIELT, "Die Relikarium in Apsismosaik von San Clemente in Rom", Patrum Romanum, 1997, pp. 97111.

En fechas más recientes, la teoría ha sido desmentida, ya que, mediante los trabajos de consolidación realizados sobre el mosaico, se ha concluido que no existe ningún tipo de cavidad ni modificación alguna 
Para nuestro objetivo, lo más destacado del conjunto es la recreación de la imagen de la viña, que aquí nace de una gran planta de acanto ${ }^{1165}$. Tal elemento, sirve de base para la elevación de la cruz, que se nos presenta como auténtico arbor vitae y donde se muestra al crucificado rodeado de doce palomas, en una clara alusión a los mártires $^{1166}$ (fig. 194).

Ya hemos reflexionado sobre las concomitancias existentes entre el simbolismo de tales elementos vegetales y otra serie de piezas embebidas en la tradición iconográfica dionisíaca. En concreto, se ha aludido a la importancia del sarcófago de Constantina, en Santa Constanza de Roma y el llamado "renacimiento sixtino". Sin embargo, a partir de tales premisas, deberíamos preguntarnos sobre la fortuna de esta obra en el arte posterior, sobre su impacto en las producciones coetáneas y, en relación con ello, si esta iconografía de fuerte sustrato clásico fue difundida más allá de la Roma "reformada" del siglo XII.

Parece claro, que el mosaico guarda parecidos razonables con aquel conservado en el pequeño ábside de San Giovanni Laterano (fig. 195), traído a colación siempre que se trata la problemática de esta iconografía ${ }^{1167}$. Pero además, creemos que las connotaciones simbólicas del acanto y, por extensión, de la viña del Señor, adquirieron pronto unos valores importantes durante la Edad Media, siempre con cierta dependencia de las experiencias artísticas antiguas.

Ejemplos como el del llamado cáliz de Antioquía (fig. 196), cuya copa aparece totalmente cubierta con una abundante parra cargada de racimos de uva, deben ser vistos como la base sobre la que se asentará la reinterpretación iconográfica cristiana de tal elemento ${ }^{1168}$. La herencia antigua de dichas representaciones puede ser analizada de

sobre las teselas que configuran la imagen de la cruz, en la que, hipotéticamente, se encontraría este relicario. Cf.: J. CROISIER, Op. cit., p. 217.

1165 G. SAURON, "La promotion apollinienne...”, pp. 89-90 y J.-C. BONNE, "De l'ornement à l'ornamentalité: la mosaïque absidiale de San Clemente de Roma", Le rôle de l'ornement, Paris, 1997, pp. 103-119. Se señala como rasgo característico de la simbología vegetal del mundo antiguo, la simbiosis de varios vegetales, entre ellos, el acanto y la vid, que uniéndose, generan la imagen de un rico ambiente vegetal, susceptible de una lectura simbólica.

${ }^{1166}$ G. MATTHIAE, Mosaici medioevali..., en particular, pp. 279-280 y H. TOUBERT, "Un fresque de San Pedro de Sorpe...", pp. 167-189.

1167 M. ANDALORO, La pittura medievale a Roma 312-1431. Atlante Perocorsi Visivi. Suburbio, Vaticano, Rone Monti, vol. I, Roma, 2006, p. 205. La profesora Andaloro data el mosaico del atrio del Letrán dentro del pontificado de Sixto III (432-440). No es preciso incidir en que, dicha obra, con el tema de la viña de acanto, muestra, otra vez, diversos seres que habitan dicha vegetación, ocupando uno de los ábsides conservados de este atrio que antecedía al espacio bautismal.

1168 New York, The Cloisters. Metropolitan Museum of Art. Cf.: CH. T. LITTLE y T. B HUSBAND, "Early Christian Silver", The Metropolitan Museum of Art. Europe in the Middle Ages, New York, 1987, pp. 30-31 y J. M. BLÁZQUEZ MARTÍNEZ, "La herencia clásica...”, especialmente, p. 60. Según el 
manera exhaustiva para poder constatar la fortuna que dicho tema va a tener en los siglos medievales, ya que, al examinar algunas producciones artísticas de dicha época, se observa que el tema de la viña eucarística del Señor y las escenas derivadas de éste, presentan, ocasionalmente, una significativa filiación con los modelos y formas de la Antigüedad clásica.

Durante este periodo no resulta difícil encontrar ejemplos en los que se utilizó la temática vegetal para decorar todo tipo de espacios y objetos litúrgicos. En la mayoría de las ocasiones el tema vegetal aparecía vinculado a diversas escenas derivadas del repertorio dionisiaco. En otras tantas, aludía, simplemente, a la idea de fertilidad y fecundidad, relacionado con la personificación de la Tierra Madre o Tellus, para aparecer, finalmente, en todas aquellas escenas de índole agrícola, ya fuese representando simples ciclos campestres, aludiendo a la personificación de los meses y las estaciones o, relacionado con la evocación del paraíso ${ }^{1169}$.

Así, hallamos representado el tema a partir del siglo IV a. de C., tal y como atestigua, por ejemplo, una cerámica ateniense conservada en Munich. En ella fue representado Dionisos navegando sobre una nave de cuyo mástil nace una gran cepa cargada de racimos de uvas ${ }^{1170}$. Del mismo periodo, y en torno al siglo III a. de C., se ha datado la cratera de bronce de Deverni. En ella, se han simbolizado, cubriendo el fondo en el que se distribuyen los personajes, una serie de cepas de las que penden idénticas hojas de parra ${ }^{1171}$.

Este gusto por el ambiente vegetal del mundo antiguo griego, pasaría, iconográficamente, casi intacto al repertorio artístico romano. Los repertorios de vegetación decorando todo tipo obras, llevaron a utilizar, casi de manera indiferente y abstracta, toda suerte de vegetales. Así, observamos como, por ejemplo, el acanto de algunas representaciones plásticas llega a transformarse en laurel o, como de sus hojas

estudio de la obra en el catálogo del museo donde se conserva, el cáliz pudo haber sido realizada en Siria, en torno al siglo VI d. de C.

${ }^{1169}$ No es preciso señalar una vez más el caso del Ara Pacis, donde se incluyeron tales representaciones.

${ }^{1170}$ Münich, Antikensammlung. La pintura de esta cerámica es obra de Execias, conocido alfarero y pintor. Su trabajo se caracteriza por el uso de un estilo elegante pero vigoroso. La barca navega sobre un fondo de barniz rojo en el que flotan varios delfines de diseño esquemático. Cf.: G. M. A. RICHTER, $E l$ arte griego, Barcelona, 1990, p. 334 y p. 337.

${ }^{1171}$ Saloníki, Museo Arqueológico. Se trata de una de las grandes obras del arte helenístico. El programa iconográfico se centra en la temática dionisíaca, con Ariadna y las Ménades. Cf.: P. BRUNEAU, "Greek Art", Sculpture. From Antiquity to Middle Ages (G. Duby y J-L. Daval, edits.), Köln, 1999, pp. 11-113, en particular, p. 86. Observamos como la temática es similar a la que encontraremos, después, cristianizada en el cáliz de Antioquía. 
nacen las cepas de las colgarán los racimos de uvas, sin ningún tipo de respeto por la realidad natural de la planta ${ }^{1172}$.

En dicho ambiente báquico es, quizás, donde se tenga que rastrear el origen mismo del tema. La viña, a veces mezclada con todo tipo de vegetales, servirá de base para la reinterpretación cristiana, que verá en dicha imagen una manera de aludir a los diferentes preceptos de la vida cristiana. Tales elementos serán dotados de un nuevo contenido eminentemente cristológico, alusivo a la comunidad de fieles que viven al amparo de Cristo. Éste sería aludido mediante la propia viña que, madura, generará el vino, auténtica alusión a la sangre demarrada, tal y como se encargarían de difundir las interpretaciones hechas por el texto bíblico y los padres de la iglesia.

En el caso de la inscripción antes citada de San Clemente de Roma, la identificación es clara. El problema surge, no a través de los textos, sino a la hora de abordar el significado de la propia imagen. Los artistas medievales llegarían a crear auténticos jardines de variadas especies para poder aludir a todo ese ambiente, siempre presente en la propia historia bíblica. En ocasiones, tales elementos se muestran vinculados a un determinado carácter negativo, mientras que, en otras, se presentarían como el recurso perfecto para poder aludir al paradisus ${ }^{1173}$.

En el caso del ábside romano, la vegetación se convierte en el espacio material para la humanidad, representado aquí por las escenas de género. Cristo crucificado se muestra como representante de la Iglesia protectora de la comunidad cristiana, que será guiada, en todo momento, hacia la salvación ${ }^{1174}$. Si en el caso del mosaico romano la labor evangelizadora se cita a través de las imágenes de los clérigos que "habitan" dicha viña, en el ejemplo del cáliz de Antioquía -casi nunca citado al abordar el estudio iconográfico del ábside-, la viña del Señor protege a los mismos evangelistas ${ }^{1175}$.

\footnotetext{
1172 G. SAURON, "La promotion apollinienne...", en especial, p. 89. Se incide en la importancia que tuvieron los talleres neoáticos de Pompeya o Delos en la difusión de tales imágenes, base iconográfica del programa iconológico difundido por el arte de Augusto.

${ }_{1173}$ CH. FRUGONI, Una lontana città..., en especial, pp. 126-128 e ID., "Alberi (in paradiso voluptatis)...", pp. 725-762. La profesora Frugoni ha definido bien este ambiente vegetal de origen bíblico. El campo, el bosque o el huerto, se convirtieron, gracias a los textos de época medieval, en auténticos referentes de las escenas bíblicas. El trabajo campestre, al que fueron condenados los Primeros Padres y la punición divina, fueron relacionados con versos muy explícitos sobre este ambiente natural por varios intelectuales cristianos. En otras ocasiones, tal y como llama la atención la autora, la naturaleza vegetal se convierte en el lugar para la fe y la exaltación de la figura mariana a través de la imagen de hortus deliciarum, mientras que, en otras, alude al espacio inmaterial para la visión de Dios, la manera evidente de reflejar el lugar inmaterial perfecto.

${ }^{1174}$ J. CROISIER, Op. cit., p. 217.

${ }^{1175}$ CH. T. LITTLE y T. B HUSBAND, "Early Christian Silver...”, pp. 30-31 y J. M. BLÁZQUEZ, "La herencia clásica...”, en concreto, p. 60.
} 
Parece que ambas piezas comparten ciertas semejanzas desde un punto de vista conceptual.

El cáliz y el mosaico aquí citados, atestiguan una continuidad directa entre la tradición simbólica vegetal del mundo antiguo y la interpretación que a dichos elementos se le dio durante los siglos medievales. Ambas piezas permiten asegurar también que, dicha decoración, dejó de ser tal, justo en el momento en el que, el lugar sobre el que tales elementos ornamentales se disponían, pasaron a considerarse como espacios preeminentes ${ }^{1176}$. Un ábside o un cáliz, justifican, sobradamente, el uso de vegetales simbólicos en tales elementos, a pesar de que el tipo de planta no esté bien definida, tal y como ocurre con el acanto-vid de San Clemente de Roma.

Con todo lo afirmado hasta el momento, se pretende señalar que la representación artística de un elemento vegetal durante los siglos medievales, se caracterizó por su fuerte carácter polivalente. Su parecido con lo real, por otra parte, principio fundamental de las teorías de representación artística del mundo antiguo, dejó de ser, durante el medievo, razón primera a la hora de ser representado. Sin embargo, su colocación sobre el lugar de acceso de los catecúmenos, como por ejemplo, se observa en el caso del ábside laterano o, sobre las ventanas del baptisterio de los Ortodoxos de Ravenna, hablan de una intencionalidad en explotar la plástica de lo vegetal, siempre a la manera clásica ${ }^{1177}$.

En otras ocasiones, la imagen vegetal se convierte en el elemento por excelencia de la decoración de los espacios funerarios. Desde la Antigüedad, la viña, el acanto, el pino y una larga lista de especies, configuran el marco para el descanso eterno y la resurrección. Recuérdense, los ramajes de pino con piñas representados en el mausoleo imperial de Santa Constanza de Roma ${ }^{1178}$. El origen de tal tradición vuelve a ser, nuevamente, la pintura romana, donde las tumbas y lugares funerarios presentaron, en multitud de ocasiones, este tipo de decoración, tal y como vemos, por ejemplo, en el llamado columbario de Pomponius Hylas. En este recinto, además de una profusa decoración vegetal de pámpanos y hojas de vid, fueron incluidos erotes vendimiadores y

\footnotetext{
1176 A. PERONI, “Acanthe remployée...”, en concreto, p. 326. Se incide en la importancia de valorar el lugar exacto de la colocación física de los vegetales para defender sus posibles contenidos simbólicos.

${ }^{1177}$ El baptisterio de los Ortodoxos presenta, entre su profusa iconografía, la imagen de la viña de acanto que, a modo de roleos, se desenvuelve y permite que, bajo su carnosa forma, nazca la cruz. Véase el ejemplo de la imagen ubicada sobre los vanos del edificio, cuya resolución se podría emparentar con las desarrolladas en la iglesia de San Clemente y el ejemplo del narthex del Letrán. Cf.: F. W. DEICHMANN, Ravenna, Hauptsadt des spätantiken Abendlandes, Wiesbaden, 1969, pp. 120-140.

${ }^{1178}$ A. GRABAR, Le premier art..., pp. 160-192.
} 
aves habitando la hojarasca. Entre dichos elementos, y como recuerdo de la tradición báquica, fue representada una pequeña mascara teatral del dios ${ }^{1179}$.

Adelantamos que tal tradición iconográfica será fundamental para el arte cristiano posterior. De este tipo de repertorios descenderán, entre otras, las famosas columnas vaticanas colocadas en el ábside de la basílica constantiniana y cuyo estudio, en relación con Hispania, abordaremos más adelante.

En el ámbito de la Península Ibérica, dicha tradición iconográfica fue conocida. Ya hemos aludido al empleo del acanto en el sarcófago de Ithacio en Oviedo, así como su posible expoliación in re durante la época medieval. El friso vegetal que recorre la cubierta de la pieza funeraria, servía como escenario perfecto para la introducción de las aves y las cráteras del agua paradisíaca o de la resurrección. En el caso asturiano, el simbolismo vegetal, de fuerte recuerdo clásico, va más allá. El caso de los dos frisos que flanquean el acceso a la tribuna de San Miguel de Lillo, la cenefa enmarcada por piñas y posibles piedras preciosas de las jambas, los capiteles corintios del aula regia de Ramiro I o, los vasos de los que nacen las guirnaldas que recorren el intradós pintados de los arcos en San Julián de los Prados, entre otros, suponen un uso consciente de estos motivos, aún muy apegados a la tradición romana ${ }^{1180}$.

Sin embargo, creemos que se puede ir más lejos, pues tal hecho atestigua un conocimiento muy temprano de tales fórmula dentro de la Península Ibérica y un gran precedente para la plástica románica. En este sentido, es muy interesante la comparación que hace S. Noack-Haley, a propósito de las pinturas conservadas en San Salvador de Valdediós (fig. 197). Los zarcillos de gruesos tallos rematados en hojas, bastante difíciles de identificar, pero que podrían aludir formalmente a la vid, se enrollan sobre sí mismos y se distribuyen a lo largo de la bóveda de cañón. El parentesco iconográfico con las pinturas de los baños omeyas de Qusayr 'Amra de Jordania, que propone la investigadora, nos parece factible ${ }^{1181}$ (fig. 198).

Por otro lado, las pinturas omeyas, datadas en el siglo VIII, conservan aún toda su fuerza clásica, heredera de una tradición continuada con lo romano, donde la vid, la

${ }^{1179}$ F. GHDINI y M. SALVADORI, "Tradizione e innovazione nelle picture di vigne e giardini nel repertorio funerario romano", La peinture funéraire antique $I V^{e}$ siècle av. J.-C.-IV siècle apr. J.-C. (A. Barbet ed.), Paris, 2001, pp. 93-98, en particular, p. 93-94.

${ }^{1180}$ H. SCHLUNK y M. BERENGUER, Op. cit., pp. 10-35 e I. RUIZ DE LA PEÑA GONZÁLEZ, El legado de Magín Berenguer..., p. 68.

1181 S. NOACK-HALEY, "San Salvador de Valdediós (Asturien), Wand- und Gewölbemalereien des Mittelschiffes, der Hauptapsis und des südlichen Emporennebenraumes. -Gergen 893”, Christliche..., pp. 175-179, en concreto, p. 178. 
granada y otros vegetales, presentaban la suficiente carga simbólica como para poder ubicarse acompañando y completando otros repertorios ${ }^{1182}$.

La referencia a la eucaristía hace posible, en este caso, la colocación de este motivo en un lugar cercano al ábside de San Salvador de Valdediós, así como en el intradós de los arcos de separación de las naves del templo. Además, tal producción se convierte en un antecedente bastante revelador, preludio de las experiencias que se van a producir más allá del año mil ${ }^{1183}$.

En este sentido, creemos que la tradición antigua de atribuir una significación simbólica a determinados vegetales -siendo el más importante el caso del acantocontinuó, sin ruptura, durante la Edad Media. Su utilización consciente fue vista como un signo de autorictas y marca de Antigüedad, si seguimos la idea defendida por A. Peroni $^{1184}$.

La proliferación de la temática vegetal dentro de la plática románica hispana, presenta ejemplos verdaderamente clarificadores. Aludimos, en este sentido, a la famosa puerta del Obispo de la catedral de Zamora. De ella se han destacado los fuertes vínculos que mantiene con la tradición clásica, sobre todo, desde un punto de vista estructural $^{1185}$. Sin embargo, además de todas las conexiones que la arquitectura mantiene con la tradición constructiva antigua, queremos destacar un hecho que refrendaría tales fuentes.

En los dos nichos laterales, en los que fueron incluidas las dos únicas escenas con iconografía de la portada, se representaron, en el de la izquierda, las figuras de San Pablo y San Juan, ambos con agitadas túnicas y en actitud de movimiento, avanzando hacia la puerta del templo, que se ubica en el flanco central ${ }^{1186}$. En el nicho de la

\footnotetext{
${ }^{1182}$ Desde otro orden de cosas, se trata de la decoración vegetal que J. M. Blázquez identifica como una plata de vid, que se enredada sobre si misma y sobre un gran jarrón central gallonado. Nuevamente el autor le otorga un carácter ligado a la figura de Dionisos, el gran dios de la inmortalidad, incidiendo en la importancia que las imágenes de vendimia y la propia planta, tendrían sobre el primer arte cristiano. Alude al caso del sarcófago de Santa Constanza y el conservado en San Lorenzo de Roma, también con el tema de vendimia. Cf.: J. M. BLÁZQUEZ MARTÍNEZ, "La herencia clásica...", pp. 58-60.

${ }^{1183}$ Recuérdese el caso de las pinturas de la cripta de Saint-Étienne d'Auxerre. Las obras del recinto debieron comenzar en el año 1030, por lo que las pinturas deben ser un poco posteriores. Lo más destacado es el uso de elementos vegetales colocados sobre el intradós del deambulatorio y que recuerdan, en su disposición, a los ejemplos asturianos. Cf.: V. ROSSIGNOL, "Les débuts de la polychromie romane en Bourgogne", Edifices \& Peintures aux IV ${ }^{e}-X I^{e}$ siècles (Ch. Sapin dir.), Auxerre, 1994, pp. 125-134, en concreto, p. 131.

${ }_{1184}$ A. PERONI, “Acanthe remployée....", en concreto, p. 313.

${ }^{1185}$ E. FERNÁNDEZ GONZÁLEZ, "Presencia de Oriente y Occidente...”, pp. 225-274.

${ }^{1186}$ Las figuras han sido identificadas por los artífices románicos mediante epígrafes. Mientras San Pablo se mantiene estático, la figura de San Pedro se gira en un ademán bien naturalista, agarrando el libro que su compañero expone abierto al espectador. Ambas figuras, por su uso expresivo de lo gestual y el movimiento de las túnicas, han sido emparentadas con la escultura del ámbito borgoñón. Sobre todo, con
} 
derecha, ubicada nuevamente bajo un arco, aparece la imagen de la Virgen con el Niño, sedente y mayestática (fig. 199).

Se han destacado, entre otros elementos, el complejo mueble sobre el que se sienta la figura y el baldaquino que la dignifica. Se trata de una estructura muy barroca cuya arquivolta aparece decorada con una cenefa vegetal, posiblemente de acanto. Sin embargo, dicha decoración resulta pobre en comparación con la exquisita guirnalda que envuelve la escena.

Si comparamos los dos nichos sobre los que se colocan las escenas que acabamos de describir, aquel en el que aparecen los apóstoles se realizó sobrio y sin ningún tipo de decoración, apoyado sobre dos capiteles corintios excesivamente esquemáticos $^{1187}$. Por el contrario, tanto la rosca del nicho, como su intradós, así como la moldura sobre la que se apoya la escena de la Virgen, en el lado derecho, rebosan exotismo en cuanto a la distribución de los vegetales. Además, los capiteles de este lado, de bellas hojas corintias, presentan una fina labra de recuerdo clásico.

Creemos que, en esta ocasión, no sería aventurado señalar una cierta intencionalidad en el uso simbólico del acanto antiguo.

En otro orden de cosas, más complicado resulta poder sostener, con seguridad, otra serie de concomitancias que se han señalado entre esta imagen y el arte antiguo. Al analizar el trono sobre el que se presenta la figura de la Virgen, se observa que su escabel presenta una serie de arcuaciones decorativas que recorren el mueble. Algunas teorías han querido ver en este elemento decorativo la materialización de la imagen de un acueducto romano ${ }^{1188}$.

Según G. Ramos, la lectura de la imagen sería del siguiente modo: la figura mariana es representada aquí siguiendo el sermón de la Natividad de la Bienaventurada Virgen María de San Bernardo. En dicho texto, se compara a María con un acueducto,

los trabajos realizados en la iglesia de La Charité-sur-Loire, por ejemplo. La cronología establecida para ella aparece ligada al grueso de las obras llevadas a cabo en el templo durante el mandato del obispo Esteban (1150-1175) que, junto con la inscripción de consagración del templo en el año 1174, se proponen como las datas más oportunas para dichas esculturas. Cf.: J. LACOSTE, Les maîtres..., en especial, pp. 190-191 y W. GOLDSCHMIDT, “The West Portal...”, pp. 110-123. Se ha emparentado el estilo de dichas esculturas con la misma tendencia de recuperación de lo antiguo que muestra el denominado como "maestro" de Ávila, activo en la iglesia de San Vicente de la misma ciudad.

${ }^{1187}$ Los dos capiteles corintios sobre los que se apoya el nicho de la parte izquierda son del mismo tipo y ejecución que el resto de capiteles de toda la fachada. Se trata de un tipo de factura bastante simple, de dos pisos de grandes hojas que se giran sobre si mismas. Además, muestran un orden compuesto, que remata la cesta en dos grandes volutas. Son piezas bastante secas en cuanto a la captación del vegetal, pero, en conjunto, logran un efecto monumental, que concuerdan con la sobriedad de la decoración, abstracta y geométrica, del resto de la fachada.

${ }^{1188}$ Se defiende esta teoría, en: G. RAMOS DE CASTRO, El arte románico en la provincia de Zamora, Zamora, 1977, en concreto, p. 107. 
por el que corren las aguas de la Gracia divina que alimentan el vergel de acanto clásico que enmarca y desborda toda la escena. Se trata del,

“(...) jardín de las delicias que la corriente divina no sólo hace florecer, sino que recorre y mana dejando por todas partes su perfume, es decir, todos los dones de la gracia divina" 1189 .

Los defensores de estas posturas, han señalado que el modelo más cercano al que debieron acudir los artífices para crear esta imagen de un acueducto, estaba en la ciudad de Segovia. Sin embargo, a pesar de aceptar plenamente el fuerte sustrato clásico de la fachada desde un punto de vista arquitectónico, creemos que en este aspecto en concreto, la teoría resulta en exceso insegura y muestra la carencia de argumentos serios que la apoyen ${ }^{1190}$.

Con este ejemplo en concreto, volvemos a poner de relieve la peligrosidad argumental a la hora de relacionar y hacer depender determinados motivos del arte románico con respecto a las fuentes antiguas.

Volviendo al tema de la decoración vegetal de las esculturas de esta Puerta del Obispo, el recurso de dotar de un contenido simbólico a determinados vegetales para acompañar la escena, vuelve a recordar fórmulas clásicas. Se trata de un uso del acanto que sólo se explica atribuyendo a los artistas un conocimiento de las fuentes clásicas que, claramente, manejaron a la hora de materializar la configuración arquitectónica de la fachada ${ }^{1191}$.

Su utilización aquí no deja de recordar otras soluciones parecidas usadas dentro del ámbito románico europeo. Los artistas, conocedores del valor alegórico del acanto, no dudarán en recurrir a piezas expoliadas de edificios romanos para proveerse de tales imágenes. Los ejemplos de las esculturas de Pisa, Módena y Ferrara, atestiguan un interés por la observación, por la expoliación -tanto in re como in se- y por la

\footnotetext{
${ }^{1189}$ SAN BERNARDO, Obras completas de San Bernardo (ed. preparada por los monjes cistercienses), Madrid, 1986, vol. IV, p. 431.

${ }^{1190}$ No podemos, de ninguna manera, apoyar tal hipótesis, puesto que, basándonos en este método utilizado por la autora, gran parte de las arcuaciones o arquillos presentes en la orfebrería y el mobiliario de época medieval, por citar los casos más relevantes, serían susceptibles de poseer una misma lectura.

${ }^{1191}$ El efecto óptico conseguido en la guirnalda se aproxima bastante a un determinado sistema compositivo utilizado para el acanto, que dota a la estructura vegetal de cierto dinamismo, movimiento y gran volumen. Este efecto estético, un tanto barroco, ha sido definido mediante la expresión "acanthe fouettées par le vent". Cf.: E. GRABINIER y L. PRESSOUYRE, "Chapiteaux à feuilles d'acanthe fouettées par le vent", L'acanthe..., pp. 357-392.
} 
admiración de este tipo de vegetal ${ }^{1192}$. Su inclusión dentro de la obra del "antiquizante" Wiligelmo habla de una reinterpretación del acanto en relación con el jardín paradisíaco y el acceso al él mediante la Porta Coeli, en una función similar a la utilizada por los vegetales de la Puerta del Obispo de la catedral de Zamora.

Los escultores medievales se sintieron tan seducidos por dichas soluciones, que no sólo reactivaron su contenido simbólico, sino que, además, indicaron con claridad al espectador la calidad y delicadeza de sus representaciones.

Con esta intención, se ha señalado el epígrafe de la llamada puerta del Zodíaco de la catedral de Ferrara, donde un tal Nicholaus, hipotéticamente, escribiría entre la compleja decoración de acanto:

\section{FLORES CVM BELVIS.}

Se ha leído tal epígrafe como un intento por dejar constancia de la belleza del tema, que con tanta habilidad había esculpido ${ }^{1193}$. Creemos que el uso de tal decoración dentro de la portada de Zamora debe ser entendido en la misma dirección ${ }^{1194}$.

\footnotetext{
${ }^{1192}$ Recuérdese, que se ha señalado el año 1090 como el de la colocación de la primera piedra de la catedral de Módena. La cuestión del uso de piezas expoliadas dentro de su obra se ha sugerido, pero se mantiene aún abierta con serias dudas. Cf.: A. PERONI, "Acanthe remployée...", en concreto, p. 314. Sobre la figura de Wiligelmo de Módena, presunto expoliador de este acanto, existe una abundante bibliografía. Cf.: E. REGINA KNAUER, "Tribuerunt Sua Marmora Provinciae. Beobachtungen zu antiken Vorbildern Von Wiligelmus Genesis-Fries an der Domfassade in Modena und zu den sog. Metopen", Zeitschrift für Kunstgeschichte, 50, 2, 1987, pp. 153-186; S. SETTIS, "Tribuit sua marmora Roma: sul reimpiego di sculture antiche", Lanfranco e Wiligelmo. Il duomo di Modena (M. Armandi ed.), Milano, 1985, pp. 309-317 y F. REBECCHI, "Il reimpiego di materiali antico nel Duomo di Modena", Lanfranco e Wiligelmo..., pp. 319-353.

${ }^{1193}$ F. REBECCHI, "Il reimpiego di materiali...", p. 320. Se ha documentado al escultor Nicholaus dentro de la catedral de Ferrara en torno al año 1135. Nuevamente continúa abierto el debate sobre esta pieza de mármol decorada con acanto y ubicada en la portada del templo.

${ }^{1194}$ En el caso hispano, tal y como ha señalado H. Toubert, la iconografía de María apareció ligada, de una manera, más o menos frecuente, a este simbolismo relativo a lo vegetal. Así, la autora señala un ejemplo muy significativo. Se trata del fresco de San Pedro de Sorpe, en el que fue representada la figura de María sedente con el Niño. Además del friso vegetal de la parte alta de la composición, la imagen mariana aparece flanqueada por dos árboles o matojos. El de la derecha se muestra absolutamente vivo, con frondosas ramas cargadas de hojas y frutos de colores vivos, mientras que, en el lado opuesto, el vegetal aparece totalmente seco, con ramas esqueléticas y de frutos marchitos. Las ramas enfermas adquieren aquí la forma de un candelabro de siete brazos. Sin duda, se trata de la alusión, mediante los vegetales, a la Iglesia triunfante de Cristo, de fuertes raíces y hojas vivas, tal y como ocurría en el mosaico de San Clemente. Por el contrario, el otro vegetal, muerto y desechable, alude a la Sinagoga infiel. Como vemos, se trata de un complejo simbolismo vegetal que se utiliza aquí, nuevamente, acompañando a una imagen de María. Debiéramos preguntarnos sobre las fuentes utilizadas por el taller de pintores que llevó a cabo tal obra pues, tal y como se ha señalado en alguna ocasión, las influencias clásicas se muestran bien marcadas en otras escenas del ciclo pictórico del templo. Sobre la lectura de los dos vegetales, véase: H. TOUBERT, "Un fresque de San Pedro de Sorpe...", pp. 167-189, especialmente, p. 178 y M. DURLIAT, Espagne romane..., en concreto, p. 206. Sobre la influencia clásica dentro de la escena de la Anunciación de este ciclo pictórico, consúltese: C. MANCHO I SUÁREZ, "La Anunciación
} 
Para concluir este apartado dedicado a la utilización y algunos de los significados atribuidos al acanto en la época medieval, debemos afirmar que, dicha interpretación, al igual que la mayoría de los motivos zoomórficos y fitomórficos representados dentro de los programas escultóricos de época románica, presentan varios problemas. El primero de ellos es la imposibilidad de aplicar dicha regla de una manera sistemática a todo tipo de decoración vegetal sin tener en cuenta el contexto en el que se encuentre. Pero, además, al igual que la iconografía animal y de otra índole, sometidas, en ocasiones, a una sobrelectura muy forzada por parte de los estudiosos, parece lógico pensar que, no todas estas representaciones tuvieron forzosamente un contenido e intención ideológica $^{1195}$.

Los ejemplos paradigmáticos del ábside San Clemente ${ }^{1196}$, así como el de su modelo antecesor del Laterano, u otra serie de obras, como la copa del Metropolitan Museum o el fresco de Sorpe, atestiguan una continuidad en el uso de esta tradición. Creemos que también se presenta como factible, dentro de esta misma tendencia, el caso de la catedral de Zamora. Sin embargo, demostrar tales atribuciones simbólicas se presenta como una tarea compleja y problemática.

Recordemos por ejemplo, el caso de la atribución alegórica que R. Bartal llevó a cabo a través del análisis de un lirio esculpido dentro del conjunto de vegetales que decoran los capiteles del Panteón de San Isidoro de León ${ }^{1197}$. Según la citada investigadora, se trataría de una alusión al mundo funerario, donde este tipo de vegetales, aparecen de manera frecuente. Sin embargo, la imposibilidad de demostrar tal afirmación de una manera rotunda reclama cierta cautela.

De la misma manera, resulta incierta la lectura que podemos realizar, en un primer acercamiento, del tímpano colocado en la puerta occidental de la iglesia de Coustouges, en el Vallespir de los Pirineos Orientales (fig. 200). Se trata de una fachada vinculada a la órbita del "maestro" de Cabestany y en la que se representaron gran profusión de seres y elementos aparentemente ornamentales. El tímpano, sin embargo,

de San Pere de Sorpe, un ejemplo matizado de continuidad", Los clasicismos del Arte Español, Madrid, 1994, pp. 59-66.

${ }^{1195}$ G. BOTO VARELA, Ornamento sin delito. Los seres imaginarios del claustro de Silos y sus ecos en la escultura románica peninsular, Burgos, 2001, pp. 32-33 y pp. 121-170 e ID., "Seres teriomóficos en los claustros de Girona y Sant Cugat", Annals del Institut d'Etudis Gironins, XXXIII, 1994, pp. 291-320.

1196 C. MANCHO, "Los grandes conjuntos de pintura mural del siglo XII", El románico y el Mediterráneo..., pp. 169-167, en concreto, p. 161. El autor señala su puesto dentro de la formación de esta estética clásica para lo medieval.

${ }^{1197}$ A. DE EGRY, "Símbolos funerarios en monumentos románicos españoles", Archivo Español de Arte, 4, 1971, pp. 9-15. 
fue decorado mediante tres filas de roleos que se entrelazan y circunscriben un motivo floral interior, tal vez una hoja. La visión de conjunto genera la sensación de un tapiz vegetal en el que los doce roleos se prestan a una fácil lectura simbólica. La alusión a los doce apóstoles y la relación con los programas iconográficos en los que la viña sirve de marco para la aparición de las figuras apostólicas, podría ser factible.

Sin embargo, los problemas señalados para este tipo de decoraciones y las posibilidades de atribuirles una serie de intenciones simbólicas, obligan a mantener una interpretación segura como una cuestión pendiente o reducida a un primer nivel iconográfico, entendido desde una óptica meramente decorativa ${ }^{1198}$.

La posibilidad de aludir a la Porta Coeli a través de este sistema de representación vegetal, tal y como hemos señalado, fue explotada en los talleres más "antiquizantes" del románico europeo. No sería arriesgado pensar en una posibilidad de lectura en esta dirección para la portada de Coustouges, atribuida, igualmente, al clásico círculo del "maestro" de Cabestany ${ }^{1199}$.

Con todo, este tipo de red vegetal que se enmaraña hasta el punto de crear una pantalla a modo de tapiz, ocupó el acceso de algún templo más, dentro del corpus de las fachadas románicas hispanas.

En este sentido, destacamos la puerta de la iglesia de Cervatos, en Santander (fig. 201), donde observamos una profusión decorativa de palmetas entremezcladas con roleos que se extiende por todo el tímpano. En el medio de tal portada se colocaron tres pares de leones afrontados, de una factura inferior a la delicada vegetación del tímpano $^{1200}$.

\footnotetext{
${ }^{1198}$ La iglesia fue consagrada, según recoge M. Durliat, el año 1142, si bien, algunas partes del templo no pertenecen a dicha cronología, pues son más tardías. Entre los diferentes vegetales identificados que se expanden por toda la escultura del templo, son de destacar las piñas y uvas. Sin embargo, para el autor todo este tipo de vegetación no poseía, en absoluto, ningún contenido simbólico. Se trata, como dice el autor, "de un artista original más atento al estudio de la naturaleza que a los libros santos". Reconoce para esta portada en concreto la vinculación con modelos clásicos. Cf.: M. DURLIAT, La sculpture romane en Roussillon. Le maître de Cabestany. Coustouges. Le monestir del Camp. Espira-de-l'agly, Perpignan, vol. IV, 1954, en concreto, pp. 51-56 y L. CARRIÈRE, "Les portails des églises et des chapelles du haut et du moyen Vallespir (XII $-\mathrm{XIII}^{\mathrm{e}}$ siècles)", Les Cahiers de Saint-Michel de Cuxa, XXXII, 2001, pp. 207-217, en concreto, pp. 211-23. L. Carrière señala que el tipo de material empleado para su realización es una especie de travertino. Su buena conservación se debe al añadido de un portal en el occidente del edificio, que sirvió de protección al conjunto.

${ }^{1199}$ A. MILONE, “El Maestro de Cabestany...", pp. 181-191.

${ }^{1200}$ J. LACOSTE, Les maîtres..., en concreto, p. 66. J. Lacoste compara la representación de esta iglesia con los motivos de palmetas tan difundidos en Al-Andalus. Propone un recuerdo de las yeserías y estucos aplicados en la decoración de celosías, citando el caso concreto de la decoración de Medina Azahara.

Véase también: M. DURLIAT, La sculpture romane en Roussillon. Le maître..., p. 56. Se defiende un sentido meramente decorativo y sin ninguna intención didáctica ni pedagógica para este tipo de portadas con decoración vegetal, sobre todo para la de Coustouges.
} 
Para finalizar, queremos referirnos al posible acanto representado sobre la cesta de un capitel proveniente del claustro de la catedral de Pamplona y del que, generalmente, se han señalado sus fuertes nexos con la tradición antigua ${ }^{1201}$ (fig. 202).

En los ángulos de dicha pieza y colocados entre las hojas de acanto, aparecen cuatro figuras, hoy bastante deterioradas ${ }^{1202}$. Es posible, según ha propuesto J. Lacoste recientemente, que se trate de una representación de los cuatro evangelistas que, según parece, se muestran como escribas ${ }^{1203}$.

Por otra parte, hace años se defendió la posibilidad de que, entre dicho conjunto de capiteles con tendencia a lo clásico, también su hubiera incluido una representación de las personificaciones de los cuatro ríos del paraíso ${ }^{1204}$.

Basándose en tales pruebas, todos los autores han coincidido en señalar el fuerte recuerdo antiguo de estas obras. Creemos, además, que aquí el acanto, al mismo tiempo que se utiliza como un mero elemento ornamental, podría haber sido concienzudamente representando con un interés simbólico, quizás ligado a la explotación de ciertos modelos antiguos. Sin embargo, se trata de una intencionalidad que hoy se nos escapa, debido, principalmente, a su conservación y a su actual descontextualización ${ }^{1205}$.

\footnotetext{
${ }^{1201}$ Pamplona, Museo de Navarra. Se trata de un capitel que presenta una estructura de doble cesta. En el medio de ambas, se representó una hoja de acanto que se desdobla hacia las cestas de ambos lados, mediante un eje central que une los dos capiteles. La parte superior fue decorada con una cenefa en forma de meandro clásico. La pieza muestra una clara influencia de modelos antiguos. Cf.: M. MELERO MONEO, La escultura románica en Navarra, Madrid, 1991, pp. 6-12; ID., "La escultura del claustro de Pamplona", Sancho el Mayor y sus herederos. El linaje que europeizó los reinos hispanos, 2 vols., Pamplona, 2006, vol. II, pp. 911-920; ID., "Capitel vegetal doble y exento con hojas, animales y cuatro personajes", Sancho el Mayor..., vol. II, ficha catalográfica 272, p. 935 e ID., "Navarra y Aragón en las décadas centrales...", p. 100.

El tipo de corintio representado en el capitel, es del llamado "acanto movido por el viento" y presenta algunas similitudes con la representación que de este tipo de vegetales hará Nicola Pisano en la catedral de Siena, especialmente, en el claustro. Sobre esta cuestión, véase: E. GRABINIER y L. PRESSOUYRE, Op. cit., en especial, p. 377.

${ }^{1202}$ Se trata del llamado capitel "de los evangelistas", si bien la identificación no es segura, pues se ha llevado a cabo a través del hecho de que una de las figura parece escribir sobre una tablilla. Sobre la pieza, consúltese: J. MARTÍNEZ DE AGUIRRE, "El segundo tercio del siglo XII", El arte románico..., pp. 115-164, en especial, p. 123. El referido autor afirma que el resto de las figuras desmienten su identificación como tales evangelistas.

${ }^{1203}$ J. LACOSTE, Les maîtres..., en concreto, p. 77. Se plantea dicha teoría pero señalando la problemática conservación de la pieza. Señala, además, que el recuerdo clásico de esta escultura, conectaría con la tónica dominante en el sudoeste de Francia, en especial, con los talleres de escultura románica de la Saintogne y el Poitou que, en torno a la segunda mitad del siglo XII, recuperarán diversas fórmulas clásicas.

${ }^{1204}$ M. ARAGONÉS ESTELLA, "El desaparecido capitel de los Ríos del Paraíso de la catedral románica de Pamplona", Archivo español de arte, 68, 272, 1995, pp. 410-418.

${ }^{1205}$ Al uso de tal elemento vegetal debemos sumar la introducción de otra serie de figuras, como por ejemplo, los leones con su presa, cabras, aves, venados y diversas aves. Cf.: J. MARTíNEZ DE AGUIRRE, "El segundo tercio...", p. 123.
} 


\section{3. EL CAPITEL FIGURADO ROMÁNICO, UNA TIPOLOGÍA DE LA ESCULTURA ROMANA.}

Además de las portadas y los muros del templo, la iconografía esculpida durante el periodo románico inundó otro tipo de elementos que, en cierta medida, serán los que más éxito cosecharían dentro de los talleres de escultura. Nos referimos, evidentemente, a los capiteles.

Sin duda, como elemento estructural de la construcción, su uso parece obligado, en un primer momento, por razones meramente funcionales. Sin embargo, acabaría por convertirse en el lugar ideal sobre el que colocar las imágenes, en parte, gracias a su visibilidad y a que permitía todo tipo juegos simbólicos relacionados con su distribución geográfica dentro de los recintos templarios.

Parece claro que el capitel esculpido con imágenes no fue una invención excepcional del periodo románico. Al menos, desde el punto de vista formalista, sus características esenciales se encontraban ya dentro de la escultura romana y será a partir de tales modelos de donde los primeros artistas medievales tomen su morfología. Generalmente, se ha venido repitiendo de manera reiterada que el capitel como soporte para las imágenes fue el gran hallazgo de la plática románica, cuando, en realidad, su éxito dentro de tal periodo refleja más bien la continuación de una tradición antigua.

Son muchos los expertos que han insistido en la importancia que el capitel con iconografía tenía, antes incluso, de que este alcanzara el estatus al que llegó durante los siglos XI y XII. Desde estas posturas, H. Focillon, entre otros, defendió la importancia que tendrían los repertorios romanos en la configuración del capitel románico, al menos, para las producciones artísticas del ámbito occidental ${ }^{1206}$.

Sin embargo, la investigadora que más estudios ha dedicado al tema, la profesora E. Vergnolle, de manera continuada ha defendido tales conexiones, insistiendo en tal herencia y proponiendo numerosos ejemplos de capiteles con imágenes salidas de los talleres imperiales romanos, así como las deudas contraídas por la escultura medieval hacia este tipo de producciones $^{1207}$.

\footnotetext{
${ }^{1206}$ H. FOCILLON, La escultura románica ..., en especial, p. 127.

1207 E. VERGNOLLE, Saint-Benoît..., pp. 65-69 y pp. 246-247. Se destaca, especialmente, el uso de prótomos, apliques, cabezas zoomórficas y humanas, así como bustos, que de manera frecuente aparecen entre la vegetación de los capiteles clásicos. Ya hemos señalado como la autora remarcó en su día la fuerte recuperación del capitel corintio, así como el uso del capitel con iconografía dentro de la torre porche de Saint Benoît-sur-Loire.
} 
En esta misma línea, M. Durliat señalaba un aspecto muy significativo en relación con el uso del capitel con iconografía figurada dentro del mundo antiguo y el medieval. De la misma manera que E. Vergnolle insistía en la primicia de Saint-Benoîtsur-Loire en el uso de esta tipología dentro de un determinado movimiento del románico francés, Durliat insistió sobre la necesidad de matizar tales afirmaciones. Según sus estudios, la torre-porche mencionada, así como otras de la región del Poitou, incluían dentro del repertorio de capiteles esculpidos, algunos ejemplares de gran calidad en los que, la figura humana y la figuración se podían documentar en una fecha muy temprana. Lo más interesante para nuestro objetivo, es que el autor señalaba en su estudio, con justicia, que la primicia en este tipo de representaciones estaba dentro del corpus escultórico conservado en el ámbito hispano de la Alta Edad Media. El investigador se refería al capitel conservado en el Museo Arqueológico de Córdoba, datado en el siglo VII y en cuya cesta fueron esculpidas, por las cuatro caras, las efigies de los cuatro evangelistas $^{1208}$ (fig. 203).

En relación con esta pieza, I. G. Bango Torviso ha señalado la importancia de dicha obra, estudiándola en relación con otras, tales como las producciones esculpidas de la iglesia de Quintanilla de las Viñas y de San Pedro de la Nave, así como la pilastra de San Salvador de Toledo. Todas estas imágenes, datadas entre los siglos VII y VIII, son los ejemplos más antiguos, conocidos en el continente europeo, de representación de imágenes esculpidas en formato más o menos monumental y, especialmente, dentro de la cesta de un capitel ${ }^{1209}$.

\footnotetext{
${ }^{1208}$ M. DURLIAT, "La sculpture...", particularmente, pp. 166-167. Además, cita el caso de las experiencias iconográficas de la iglesia visigoda de San Pedro de la Nave y los vestigios del programa iconográfico de Quintanilla de las Viñas, en Burgos. El investigador destacaba la gran coherencia, tanto estilística como iconográfica, de estos primeros balbuceos de la escultura monumental a nivel Europeo. Señalaba, como dato fundamental, la irrupción de los musulmanes en la Península Ibérica que provocaría el fin de estas ricas experiencias.

Para un balance del tema de los evangelistas con acotaciones cronológicas, véase: M. MIRABELLA ROBERTI, "La symbologie paléochrétienne...", en especial, p. 185. Se documentan los primeros ejemplos en el siglo IV.

${ }^{1209}$ I. G. BANGO TORVISO, Arte prerrománico..., en concreto, pp. 556-559. Se defiende que, por ejemplo, las imágenes del capitel cordobés, en las que se utiliza la fórmula iconográfica de los evangelistas en busto, vestidos con clámides sujetas con fíbulas y nimbados, está en relación con ciertas imágenes de origen copto. Dichos tipos llegarían al ámbito hispano, otorgándole, en este sentido, la primicia en el tipo de representación iconográfica que estamos abordando, pues las efigies fueron colocadas en la parte central de la cesta, flanqueadas por hojas de acanto y cobijadas bajo una gran roseta que, siguiendo en todo caso modelos romanos, se coloca en la parte alta del capitel. El rostro de las figuras fue raspado, según se ha dicho, por los musulmanes, una vez que el capitel fue expoliado. Sobre la iglesia de San Pedro de la Nave, véanse, además: H. SCHLUNK, "Estudios iconográficos en la iglesia de San Pedro de la Nave", Archivo Español de Arte, 171, 1970, pp. 245-267; R. CORONEO, "I capitelli di San Pedro de la Nave", Medioevo: immagine e racconto. Atti del Convegno internazionale di studi, Parma, 2000, pp. 130-141; J.-M. HOPEE, "Ensayo sobre la escultura de San Pedro de la Nave", La
} 
Sin embargo, a pesar de la riqueza de los mensajes iconográficos que la plástica visigoda llegó a desarrollar en ámbito hispano, finalmente, M. Durliat acabará afirmando que, dichas primeras expresiones realizadas sobre la cesta de un capitel, no debían compararse con el caso del románico francés, pues el uso del capitel historiado en San Benoît-sur-Loire:

\author{
“(...) era infinitamente más rico que toda la totalidad de la producción \\ conservada de época visigoda" $" 1210$.
}

Evidentemente, no compartimos tal afirmación, pues la plástica visigoda, enraizada 0 , mejor aún, enteramente partícipe de ciertas tradiciones romanas, fue pionera en el desarrollo del capitel historiado, mucho antes de que el supuesto taller de Umbertus llegara a explotar con tanta facilidad todos estos recursos escultóricos antiguos. Otro tema diferente sería otorgar a cada una de estas producciones el lugar exacto que ocuparían en del desarrollo de la misma escultura románica.

Así, a pesar de la primicia hispana, de lo que no cabe duda es de la posibilidad de que ambas experiencias compartieran unos mismos orígenes e idénticos horizontes. La Antigüedad romana contaba con suficientes y significativos ejemplos como para poder asentar las bases para el desarrollo del capitel historiado en época medieval. En esta línea, R. Turcan ha señalado un gran número de piezas de datación romana en las que la cesta del capitel, casi siempre con decoración vegetal, también da cobijo a diversas figuras humanas e imágenes diversas. Creemos que en tales esculturas es donde se debe rastrear el origen de tal tendencia.

En este sentido, son de destacar las esculturas de época severiana (193-235) pertenecientes a las famosas y expoliadas termas de Caracalla, en las que, las partes principales del capitel, aparecen ocupadas ya por la figura humana. En este sentido se

iglesia de San Pedro de la Nave (Zamora), 2004, pp. 323-425; S. VIDAL ÁLVAREZ, "La transmisión iconográfica en la escultura hispánica de la Antigüedad tardía. Vigencia y discontinuidad de modelos", Escultura tardorromana y altomedieval en la Península Ibérica, Madrid, 2007, pp. 11-46; L. J. BALMASEDA MUNCHARAZ, "Algunos problemas de la escultura visigoda toledana", Escultura tardorromana y altomedieval en la Península Ibérica, Madrid, 2007, pp. 275-299.

Sobre la problemática de algunos elementos escultóricos de Quintanilla de las Viñas, consúltese: M. A. SEPÚLVEDA GONZÁLEZ, "Los anagramas y el programa iconográfico de Quintanilla de las Viñas: una hipótesis de interpretación”, La España Medieval, Madrid, 1986, vol. V, pp. 1217-1248 y M. CRUZ VILLALÓN, "Quintanilla de las Viñas en el contexto del arte altomedieval: una revisión de su escultura", Antigüedad y cristianismo: Monografías históricas sobre la Antigüedad tardía (J. M. Blázquez Martínez y A. González Blanco, coords.), vol. 21, Murcia, 2004 pp. 101-136.

${ }^{1210}$ M. DURLIAT, "La sculpture...", en especial, p. 167. Se señala la poca probabilidad de que los escultores de la torre-pórtico hubieran podido conocer estas primeras experiencias hispanas. 
observa la presencia de Marte, Baco o la diosa Fortuna, acompañada por putti que portan guirnaldas (fig. 204). En otro ejemplo del mismo tipo se documenta la presencia de la personificación de las estaciones (fig. 205). Se trata de piezas datadas entre los años 212-216 d. de C. y que fueron concebidas para decorar el ambiente del frigidarium de estas termas.

En otro ejemplar se constata la representación de la figura de Hércules, según el tipo Farnesio, en compañía de varias Ninfas. Se trata de esculturas de gran clasicismo que, originariamente, aparecían encuadrando los pequeños nichos semicirculares de la natatio o piscina del recinto y que demuestran que, evidentemente, desde un primer momento fueron concebidos para ser expuestos públicamente ${ }^{1211}$.

Aparte de los ejemplos existentes en las termas de Caracalla de Roma, se documenta una misma tipología de capitel en las llamadas termas alejandrinas de la misma ciudad. En dicho conjunto, datado entre los años 225-227 d. de C., un capitel muestra una escena en la que cinco atletas llevan a cabo diversas actividades deportivas $^{1212}$.

Sin duda, lo más destacado en relación con dichas esculturas, a parte de la importancia que toma aquí la figura, es la propia composición del capitel romano. Se trata, en los ejemplos citados, de un tipo, generalmente, de gran tamaño y volumen, en ocasiones compuesto y que presenta grandes volutas. Las figuras, siempre concebidas en un relieve muy marcado, se unen a la cesta del capitel de manera sutil pues, en ocasiones, casi llegan a alcanzar el bulto redondo. Una de las características importantes que se percibe en estas piezas, es el uso del vegetal, sobre todo el acanto, para, de alguna manera, generar el ambiente necesario donde posteriormente se esculpirán las figuras. Este hecho es importante pues, tal y como veremos, las primeras experiencias de capitel historiado durante la Alta Edad Media presentarán idénticas soluciones, donde la figura se recorta sobre un fondo vegetal o, en ocasiones, simplemente se deja enmarcar por tal elemento ${ }^{1213}$.

${ }^{1211}$ R. TURCAN, L'art romain dans l'histoire. Six siècles d'expressions de la romanité, Paris, 1995, en especial, pp. 251-279. Los ejemplos de este tipo de capitel son abundantes. El autor señala otro con cesta historiada, descubierto en el 1872 en el Palatino de Roma. La escena narrada, bastante compleja, representa al águila Elagabal entre Atenea y Juno, formando una tríada que, además, es acompañada por una Victoria y Tellus. Cf.: S. DONADONI, G. GARBINI y G. MATTHIAE, voz "Capitello", Enciclopedia dell'arte antica classica e orientale, vol. II, Roma, 1959, pp. 321-326, en concreto, p. 326 y A. GARCÍA Y BELLIDO, Arte Romano..., sobre todo, pp. 533-537.

${ }^{1212}$ Roma, Musei Vaticani. Concretamente, se trata de la pieza que sirve de base para la famosa pigna del Cortile del Museo. Cf.: Ibidem, pp. 276-277.

${ }^{1213}$ Recuérdese el ejemplo del capitel visigodo conservado en Córdoba. Las figuras evangélicas aparecen enmarcadas por unas hojas de acanto. Además, los bustos han sido colocados en eje con respecto al botón 
Un aspecto bien destacado, es que, dentro de la tipología de capitel historiado romano, se han constatado también diversas alteraciones en el canon de las figuras con el único fin de adecuarlas al marco de la cesta. Este hecho, señalado como una peculiaridad de la escultura de época medieval, parece, según tales afirmaciones, que no fue tan exclusivo.

Las figuras romanas fueron deformadas conscientemente teniendo en cuenta la altura exacta a la que iban a ser colocados los capiteles. Dicho con otras palabras, se siguió uno de los principios defendidos posteriormente, como básicos, según la concepción de la figura durante la época románica, aquella que aseguraba que los escultores medievales la adaptaban al marco sobre el que se desarrollaba y al que se constreñía ${ }^{1214}$.

Estas experiencias romanas en las que se utilizaba el capitel figurado, continuaron otorgando un puesto fundamental al acanto dentro del desarrollo de las escenas. Así, como si de un traspaso de fórmulas se tratase, algunos de los primeros ejemplos señalados por los investigadores como pertenecientes a la cronología románica y en los que se documentaba esta utilización de la imagen, ésta se mostrará acompañada por todo tipo de decoración vegetal. Con esta solución se presentan los capiteles del Museo Cívico de Brindisi y otro conservado en el Museo Arqueológico de Nîmrud, en Irak, y que recoge E. Vergnolle, a la hora de analizar el traspaso del capitel figurado romano al mundo románico ${ }^{1215}$.

Las experiencias hispano visigodas y, más tarde, las realizadas en el taller de Umbertus en Saint-Benoît-sur-Loire, por citar los ejemplos que han servido de base para este discurso, hablan de una continuidad exacta entre las obras romanas y las medievales. Sin embargo, parece claro que desde el siglo VII, en el que se han datado las obras de San Pedro de la Nave, las Viñas y el capitel de Córdoba y la cronología propuesta para la torre pórtico francesa, existieron otra serie de avances en materia escultórica que permitieron llegar a tal desarrollo.

floral superior, hecho que también se observa en la estatuaria romana. Incluso, otros detalles, como por ejemplo el uso de gotas u ovas dentro de la cesta, en combinación con las figuras -hecho que, por ejemplo, vemos en el capitel de las termas alejandrinas y conservado en el Vaticano-, se mantiene en el capitel hispano. Aquí, la parte alta de la pieza conserva una especie de acanaladuras de pequeño tamaño que indican un claro recuerdo clásico.

${ }^{1214}$ R. TURCAN, L'art romain..., en concreto, pp. 276-277.

1215 A parte de los ejemplos expuestos, recoge otros, como por ejemplo, un capitel de la catedral de Tréveris, así como otro del Museo Arqueológico de Florencia. En todas estas piezas, de la parte central de la cesta del capitel emerge un busto o cabeza humana, que pasa a ser el centro compositivo de la escultura. Cf.: E. VERGNOLLE, Saint-Benoît..., en concreto, pp. 246-247. 
Durante los siglos VIII al X, la escultura figurada en la cesta de los capiteles no fue tan frecuente como lo será a partir del siglo XI. Sin embargo, su uso no se perdió. Así, si durante el siglo IX europeo son bastantes los testimonios que nos hablan de una posible continuidad en la utilización de imágenes figurativas dentro de las cestas de los capiteles, los restos materiales conservados no son tan significativos, por ejemplo, como lo son las decenas de piezas de esta tipología representadas en el libro manuscrito, por citar un ejemplo revelador. De esta manera, si durante la Antigüedad romana la figura humana que emergía de un capitel de acanto está perfectamente asentada desde un punto de vista iconográfico, será, sin duda, dentro de las artes del color de época carolingia donde este tipo de solución romana conocerá gran éxito.

En dichos manuscritos son innumerables los ejemplos representados donde la cesta del capitel es ocupada por una figura humana, a veces reducida a una simple máscara y, en otras, incluso a una figura animal de cuerpo entero ${ }^{1216}$. A parte de los ejemplos carolingios que son bien conocidos, son de destacar otros pertenecientes ya al siglo X, como por ejemplo, el capitel que representa en su cesta el cuerpo íntegro de un toro, en la llamada Primera Biblia de Saint-Martial de Limoges ${ }^{1217}$.

El siglo $\mathrm{X}$ hispano, tan poco fructífero en escultura figurada conservada, ofrece uno de los ejemplos más importantes del uso del capitel historiado dentro del desarrollo del tipo a nivel europeo ${ }^{1218}$.

Nos referimos al excepcional capitel perteneciente al claustro de Sant Benet de Bages $^{1219}$ (fig. 206). En la estructura troncopiramidal de la cesta, se esculpió, por primera vez en un capitel hispano, del conjunto de piezas del siglo X conservadas, diversas figuras humanas presumiblemente integradas en una escena. Entre ellas, se ha

\footnotetext{
1216 T. SAUVEL, "Le chapiteau dans les manuscrits carolingiens", Bulletin Monumental, 106, 1948, pp. 8-49. El autor defiende una continuidad entre la tipología de capitel empleada durante la Antigüedad y los tipos representados en diferentes manuscritos datados entre los siglos VIII y XI. Los más difundidos son aquellos que poseen una cesta decorada con vegetación corintia, sin embargo, los casos de decoración figurada también son frecuentes. Véase también: R. CROZET, "Les survivances de la pensée et de l'art antiques dans la peinture carolingienne", Mélanges d'Histoire du Moyen Âge dédiés à la mémoire de Louis Halphen, Paris, 1951 pp. 165-168. Donde se insiste en el uso, dentro de los manuscritos, de atlantes y de otra serie de motivos clásicos.

${ }^{1217}$ Paris, Bibliothèque nationale de France, Lat. 5, fol. 132. Cf.: T. SAUVEL, Op. cit., pp. 37-38.

${ }^{1218}$ Los pocos restos conservados de escultura pétrea del siglo X en esta zona geográfica española y en los que aparezcan figuras humanas, se reducen al conocido relieve de San Cebrián de Mazote, en Valladolid, donde se representaron dos personajes muy esquemáticos al lado de una construcción acastillada y otra pieza proveniente de Santa María de Retortillo, entre los pocos ejemplares que podamos mencionar.

${ }^{1219}$ G. GAILLARD, Premiers essais..., en concreto, pp. 31-39. Se trata de un capitel reaprovechado dentro del conjunto claustral datado en el siglo XIII. La cronología que da el autor aparece vinculada al año 972, momento en el que, presumiblemente, se consagra el monasterio. Al menos uno de los capiteles de tal obra llegó a nosotros a través de este reempleo.
} 
señalado la presencia de una Maiestas, así como de un personaje orante y de una Anunciación, mientras que la última cara aparece cubierta con hojas vegetales ${ }^{1220}$.

Lo más importante en este sentido es que, tanto los autores de principios del siglo XX, como los actuales, coinciden en señalar que se trata de una de las primeras tentativas de utilizar la escultura figurada de manera monumental sobre la cesta de un capitel a nivel hispano. Se trata, por lo tanto, de un ejemplo realmente precoz de la utilización del capitel historiado dentro de la Cataluña condal y sin comparación conocida dentro de los reinos del noroeste hispano durante esta cronología.

Es por ello que algunos autores definieron este tipo de plástica y el periodo en el que se desarrolló con la expresión "siglo de renacimiento". Así, F. García Romo señaló en su día la importancia del siglo X hispano, donde la utilización de la figura humana no llegó a disiparse completamente. El estudioso consideraba la escultura de este siglo como crucial, en cuanto a la utilización continuada de la forma humana desde la Antigüedad hasta una vez traspasado el año mil. Así escribía:

“(...) podemos decir que (...) ya desde comienzos del siglo $X$ hay un renacer no sólo de la escultura sino de la figura humana, que constituye el prólogo de la escultura propiamente románica"1221.

Por su parte, el profesor I. G. Bango Torviso, señalaría la importancia del siglo $\mathrm{X}$ en cuanto a la supuesta continuidad de tradiciones plásticas de época visigoda, resaltando que:

\footnotetext{
“(...) en la décima centuria hay un renacimiento de las formas hispanovisigodas, tras el paréntesis asturiano" ${ }^{1222}$.
}

\footnotetext{
${ }^{1220}$ X. BARRAL I ALTET, "Sant Fruitós de Bages: Sant Benet de Bages, El claustre", Catalunya romànica. Bages, IX, Barcelona, 1984, pp. 431-438 y G. MALLET, "La sculpture prérromane...", en concreto, pp. 177-178.

${ }^{1221}$ F. GARCÍA ROMO, La escultura del siglo XI..., pp. 211-216.

${ }^{1222}$ I. G. BANGO TORVISO, “Arquitectura de la décima centuria: ¿repoblación o mozárabe?”, Goya, 122, 1974, en especial p. 73. Con todo, pensamos que la importancia de los ensayos en Cataluña queda atestiguada por una continuidad mucho más rica del uso de la escultura monumental. A partir del ejemplo de Bages, se podrían señalar también otra serie de obras que continúan esta tradición en la figuración humana o, simplemente, iconográfica. Recuérdense, por ejemplo, los importantes dinteles de Saint-Genísdes-Fontaines y Saint-Andre-de-Surede, ya comentados, así como otras piezas, como la cátedra de Gerona, donde la figuración alcanza cotas sin equivalentes en Castilla o Asturias.
} 
Se constata, por lo tanto, una continuidad en el uso del capitel figurado desde la época romana hasta el final del siglo $\mathrm{X}$ que, a pesar de tratarse de un periodo de cambio y transición -no exento de ciertas visiones apocalípticas- debe incluirse también dentro de la ya larga lista de "renacimientos" de las producciones plásticas que hemos venido señalando ${ }^{1223}$.

Sin embargo, el gran desarrollo del capitel figurado se produciría en el siglo XI, donde ya no se abandonaría su uso durante todo el periodo románico. Ahora dicho elemento se transforma en el emplazamiento ideal en el que colocar la imagen, en el lugar privilegiado, tras la portada, para ubicar los diferentes programas narrativos ${ }^{1224}$. Pasaba a tener una importancia con referente dentro del espacio construido, hecho que, por otra parte, no había perdido durante toda la Antigüedad tardía y la Alta Edad Media.

Ya hemos señalado a través de diferentes textos y autores la importancia que los capiteles tenían en las ekphrasis de los primeros autores cristianos. El caso del relato de Egeria es realmente significativo, pues la monja viajera llega a describir, perfectamente, tras la visita a algunos monumentos, el material con el que habían sido labrados los capiteles de diferentes construcciones.

El ejemplo recogido por R. Favreau, de un capitel de la iglesia de Notre-Dame de Bréville (Poitou-Charentes) (fig. 207), que se ha venido datando en el siglo XII, es muy representativo. Sobre la cesta, un tal Guillermo mandó colocar la siguiente inscripción:

"SIC CAPITRELLUM WILELMUS D DII TSTUM"

\footnotetext{
${ }^{1223}$ E. BENITO RUANO, "El mito histórico del año mil", Revista de Estudios Humanísticos, 1, 1979, pp. 11-31; P. RICHÉ, "Quelques réflexions sur un nouveau grand siècle", $X^{e}$ siècle. Recherches Nouvelles. Contribution au Colloque Huges Capet 987-1987. La France de l'an mil, Paris, 1987, pp. 5-7; M. SOT, "Mémoire, Antiquité, Renaissance, vues des $\mathrm{IX}^{\mathrm{e}}$ et $\mathrm{X}^{\mathrm{e}}$ siècles", La mémoire de l'Antiquité dans l'Antiquité tardive et le Haut Moyen Âge, Paris, 2000, pp. 7-13 y X. BARRAL I ALTET, "El mito de los terrores del año mil y el arte románico", Alfonso VIII y su época, Madrid, 1992, pp. 393-396.

${ }^{1224}$ Sobre la problemática de otorgar un valor didáctico a las escenas representadas sobre los capiteles románicos ya hemos aludido anteriormente. Cf.: A. GRABAR, Las vías de la creación..., en concreto, $\mathrm{p}$. 185; J. L. HERNANDO GARRIDO, "Los grandes talleres escultóricos en los monasterios románicos castellano-leoneses", Los monasterios románicos, Aguilar de Campoo, 2001, pp. 45-72, en concreto, p. 49 y TH. MARTIN, "Decorar, aleccionar...", pp. 104-143.

Por nuestra parte, hemos trascrito ya en este trabajo un fragmento tomado del estudio de Grabar que consideramos bastante clarificador sobre su postura, en relación con esta cuestión. Además de ello, queremos remarcar el estudio de J. Hernando, ya que señala el carácter restrictivo de algunos programas artísticos, como por ejemplo de los claustros, realizados no para ser vistos públicamente.
} 
Es decir, "así Guillermo dona este capitel"1225. Si bien se trata de una escultura sin figuración, la obra muestra la importancia que pasaron a tener durante este periodo dichos elementos, en inicio arquitecturales y, más tarde, ornamentales. Eran entendidos, posiblemente, como simples elementos englobados dentro de la construcción y por lo tanto, meramente arquitectónicos, para, posteriormente ser susceptibles de contener un mensaje, de la índole que fuese ${ }^{1226}$. La importancia que adquirieron durante los siglos siguientes está fuera de toda duda.

Por lo tanto, será a partir de este momento, cuando observemos el gran desarrollo de los elementos decorativos y figurativos dentro de las cestas de los capiteles. En este sentido, a parte de las experiencias llevadas a cabo durante el siglo X en el ámbito catalán, ya entre los años 1050 y 1100, observamos el incremento de tal práctica dentro de los talleres más precoces del ámbito hispano.

Los ejemplos, un tanto arcaizantes, de la cripta de San Salvador de Leyre, destacan por la monumentalización de la fórmula del capitel esculpido, pero con la excepción de que tan sólo se trata de decoración geométrica, muy esquemática y reticente a la hora de introducir las formas figurativas ${ }^{1227}$. Con todo, el recuerdo vago de la voluta clásica permanece inalterable.

${ }^{1225}$ R. FAVREAU, Corpus..., 22, ficha 11, p. 45. El autor propone dos interpretaciones de la inscripción del capitel. La primera, es la que hemos señalado. La segunda diría: “Así, yo, Guillermo, yo doné este capitel".

${ }^{1226}$ Ya hemos señalado en este trabajo diversos ejemplos de capiteles y, sobre todo, fustes de columnas entregados a la construcción de los templos mediante simples donaciones. Sin embargo, el acto no está exento de un gran valor simbólico, extensible, ciertamente, a las piezas que se donaban.

${ }^{1227}$ G. GAILLARD, "La sculpture du XI ${ }^{\mathrm{e}}$ siècle en Navarre avant l'influence des pèlerinages", Bulletin Monumental, CXIII, 1955, pp. 237-249. El experto ya señalaba su carácter elemental, donde la figura humana no alcanzará aún la importancia que se verá posteriormente. En el caso de los capiteles de la cripta de Leyre, se observa como, sobre un capitel de volutas un tanto abstractas, fue colocado un cimacio con una serie de rostros humanos. Para G. Gaillard dichos ejemplos tenían un origen similar al del conjunto de capiteles de San Martín del Canigó o la iglesia de Eus, en los Pirineos Orientales.

Véase también: A. GÓMEZ GÓMEZ, "La escultura románica en Navarra; Álava y su entorno", Revisión del Arte Medieval en Euskal Herria, 15, 1996, pp. 83-101, en concreto, pp. 83-85. El autor señala los comienzos del arte románico en Navarra con la primera consagración de Leyre, en el año 1057, incidiendo en que, de manera habitual, se atribuye al rey Sancho III el Mayor (1004-1035) el inicio de la obra. Remarca la problemática, aun sin esclarecer, de la procedencia y explicación lógica de los capiteles de la cripta del edificio.

Consúltese también: M. MELERO MONEO, La escultura..., p. 6. La autora defiende que los capiteles, primero colocados sin esculpir, fueron finalizados en una fecha cercana al 1098, en la que se produce la segunda consagración del edificio.

Por último, véase: T. BIURRUM Y SOTIL, Op. cit., especialmente, pp. 63-69. Se señala la existencia en Leyre de "dos construcciones románicas, efectuadas en diversos reinados, cuando el monasterio fue diversamente regido, y por ende, con sujeción a distintos métodos arquitectónicos". Se insiste en la importancia de la segunda fecha de consagración del edificio, el 24 de octubre de 1098. Además, se considera que la solución propuesta de aprovechar el desnivel del terreno para introducir una cripta bajo el área presbiterial, debe su origen a la influencia cluniacense. Sobre los capiteles del recinto escribía el autor: "parecen como hincados, sin basa en el pavimento, unos monstruos obesos andando sobre zancos 
Sin embargo, lo que si atestiguan los capiteles de San Salvador de Leyre, es una continuidad en la tradición prerrománica ${ }^{1228}$. Ya G. Gaillard señalaba las concomitancias entre determinados capiteles de la cripta navarra y los esculpidos en la iglesia asturiana de San Salvador de Valdediós. Se trata, en concreto, de la utilización de un capitel de gran volumen, que presenta una decoración estriada que recorre, de arriba hacia abajo, la cesta, generando en las esquinas una forma muy similar a una hoja vegetal $^{1229}$.

El uso del capitel con decoración estriada durante los primeros decenios del siglo XI no debe sorprender. Lo hallamos en un edifico fundamental a la hora de explicar el comienzo de la escultura figurativa sobre los capiteles hispanos del siglo XI. Nos referimos a los ejemplares de la iglesia asturiana de San Pedro de Teverga ${ }^{1230}$. Las primeras noticias del edificio se sitúan en torno al año $1069^{1231}$.

A pesar de ser un edificio muy reformado, su escultura puede ser considerada como una de las primeras experiencias pioneras en la creación de un conjunto de capiteles con un mensaje, en cierta manera, unitario. Tanto en la iglesia, como en el posible recinto funerario construido en la parte occidental del conjunto, se colocaron grandes capiteles con decoración figurada ${ }^{1232}$.

Con todo, y teniendo en cuenta que se trata de obras con una compleja lectura iconográfica, aún no interpretada completamente, son reconocibles dentro del conjunto las imágenes de la orante, acompañada por peces y espigas de trigo o, quizás, palmas, además del Cordero que se enfrenta a un posible felino que pisotea la Cruz. Entre ellos

(...) llegan con su astrágalo o collarín hasta el suelo. Otros hay de forma embrionaria, como el muñón de un miembro amputado para recibir los arcos o fajas de sección notablemente peraltada".

1228 A. GÓMEZ GÓMEZ, "La escultura románica en Navarra...”, particularmente, p. 85. Se recogen las conexiones defendidas con la escultura visigoda, asturiana y carolingia, entre otras.

${ }^{1229}$ Sobre el parentesco de la escultura de Leyre, con obras visigóticas y asturianas, véase: G. GAILLARD, "La sculpture du XI ${ }^{\mathrm{e}}$ siècle en Navarre...”, en especial, p. 242.

${ }^{1230}$ G. FERNÁNDEZ BALBUENA, "La Colegiata de San Pedro de Teverga", Arquitectura, III, 1920, pp. 223-227; H. SCHLUNK y J. MAZANARES, "La iglesia de San Pedro de Teverga y los comienzos del arte románico en el Reino de Asturias y León”, Archivo Español de Arte, 96, 1951, pp. 277-305; J. M. GARCÍA LANA, El concejo de Teverga y la insigne Colegiata de San Pedro, Palencia, 1952; A. BONET CORREA, Prerrománico..., en concreto, pp. 242-255; R. ALONSO ÁLVAREZ, "La Colegiata de San Pedro de Teverga. La "imagen medieval" de un edificio reformado", Asturiensia Medievalia. Homenaje a Juan Uria, Oviedo, 1995, pp. 225-242 y E. FERNÁNDEZ GONZÁLEZ, "Reflexiones sobre la evolución..." (en prensa).

La última aportación, de la que tenemos constancia, en relación con el tema, en: M. FERNÁNDEZ PARRADO, "Colegiata de San Pedro de Teverga", Enciclopedia del románico en Asturias, vol. II, Aguilar de Campoo, 2006, pp. 960-972, en concreto, p. 970.

1231 A ello se suma la inscripción del año 1076, donde se alude a una sepultura dentro de dicha construcción. Sobre el posible enterramiento de algunos miembros de la nobleza asturiana en la estructura occidental, véase: E. FERNÁNDEZ GONZÁLEZ, "Reflexiones sobre la evolución...”, (en prensa).

1232 C. CID PRIEGO, Arte Prerrománico de la Monarquía Asturiana, Oviedo, 1995, p. 359. 
se incluyeron también las figuras de un caballo, que se repite hasta cuatro veces, entre otros seres y escenas. No es el objetivo de este trabajo analizar la compleja iconografía de dichos capiteles, por lo que, tan sólo señalamos que es muy llamativo como en el resurgir de la plática figurativa, los motivos seleccionados para ocupar las grandes cestas de dichas obras, parecen tomados, casi todos, de las artes escultóricas funerarias de tradición antigua ${ }^{1233}$.

La imagen de la orante y lo símbolos eucarísticos, el caballo -elemento vinculado fuertemente a los programas iconográficos funerarios de la Antigüedad- y todos las demás figuras, aluden a la tradición iconográfica paleocristiana, posiblemente tomada del repertorio utilizado dentro de los sarcófagos ${ }^{1234}$.

En este sentido, es muy llamativo como A. Grabar, al estudiar algunas de estas imágenes utilizadas en contextos muy diferentes al de Teverga, aludía a su fuerte dependencia con respecto a los programas iconográficos paleocristianos ${ }^{1235}$. Igualmente, J. Beckwith señaló, en su día, la importancia que la dualidad de temas paganos y eminentemente cristianos, tenía dentro de los primeros programas de imágenes representados en los espacios utilizados para el desarrollo de la nueva religión ${ }^{1236}$.

Sobre la introducción de elementos de tradición pagana dentro de la escultura de San Pedro de Teverga no es preciso incidir, pues lo han hecho suficientemente todos los autores que han abordado el tema. Sin embargo, este dato apoya la idea de una posible deuda con respecto a los modelos paleocristianos y, concretamente, los presentes en los sarcófagos ${ }^{1237}$.

\footnotetext{
${ }^{1233}$ E. FERNÁNDEZ GONZÁLEZ, "Hacia la renovación escultórica de la segunda mitad del siglo XI. Los ejemplos del sarcófago de San Martín de Dumio y de la pila bautismal de San Isidoro de León", De Arte, 6, 2007, pp. 5-36. La citada autora analiza algunos de los factores y condicionantes que llevaron a este resurgir de la plástica escultórica.

${ }^{1234}$ Se trata de una afirmación que realizamos sin haber llevado a cabo un análisis profundo y concienzudo del conjunto.

${ }^{1235}$ A. GRABAR, Las vías de la creación...., en concreto, p. 40 y M. MIRABELLA ROBERTI, "La symbologie paléochrétienne...", en especial, pp. 182-183. Se insiste, entre otros aspectos, en la figura de la orante, incidiendo en la importancia del gesto, en cuanto imagen alegórica de la piedad, además de clara referencia a la plegaria. También se apunta que la imagen del pez debe ser vista como una alusión al alma del cristiano. Dichos autores señalan la idoneidad de tales iconos para ser colocados en baptisterios, recintos funerarios y, sobre todo, sarcófagos.

${ }^{1236}$ J. BECKWITH, Arte paleocristiano..., en especial, pp. 33-36. Se alude al uso de temas paganos, como las cacerías, entremezclados con otros de claro simbolismo cristiano. El autor pone el ejemplo de los mosaicos de Santa Constanza de Roma y del Mausoleo de Centcelles, como representantes de este dualismo iconográfico entre escenas paganas y cristianas.

${ }^{1237}$ M. FERNÁNDEZ PARRADO, "Colegiata de San Pedro...", en concreto, p. 970; P. DE PALOL, Arte paleocristiano..., particularmente, p. 46 y A. FUENTES DOMÍNGUEZ, Arte paleocristiano, Madrid, 1991, en concreto, p. 4.
} 
Como en los mejores programas catacumbarios y de monumentos sepulcrales, la escultura de Teverga está enraizada en la mejor tradición de las llamadas oraciones fúnebres, es decir, en relación con los ciclos de la commendatio animae, fuente que, además, según el profesor M. Valdés, ya había servido de base para la gestación del conjunto de capiteles del Panteón de San Isidoro de León, fuertemente emparentado con el caso asturiano ${ }^{1238}$.

Con todo, afirmar que el programa o las imágenes de los capiteles de San Pedro de Teverga forman parte de un tipo de iconografía ligada a lo funerario, es algo, en cierta manera, factible y de lo que todos los autores parecen hoy estar de acuerdo. En contra de ello, más arriesgado resulta poder afirmar que la fuente directa para algunos motivos del recinto, fue el frente de un sarcófago antiguo, sobre todo, sin tener el referente o modelo exacto que, hipotéticamente, se copió.

Lo más importante para nuestra tarea es poder llegar a señalar que, en una fecha estimada entre los años 1060 y 1070 se estaba llevando a cabo en Asturias una experimentación paralela a la realizada en San Isidoro de León ${ }^{1239}$.

Las concomitancias defendidas entre la escultura del Panteón leonés y el arte funerario de época paleocristiana es una vía de análisis aún por explorar y que puede ofrecer resultados muy ricos ${ }^{1240}$. Baste con mencionar, por ejemplo, los paralelismos establecidos entre el capitel del sacrificio de Isaac del mismo recinto leonés con el sarcófago de la iglesia de Saint-Orens de Auch y sobre el que, ya llamó la atención, M. Durliat $^{1241}$.

Estos paralelismos entre las obras esculpidas de la Antigüedad cristiana y la escultura emergente más allá de mediados del siglo XI, permiten indagar sobre el papel

\footnotetext{
${ }^{1238}$ M. VALDÉS FERNÁNDEZ, "El Panteón Real...", p. 79 y p. 84, nota 64. El autor señala la oración "Libera, Domine, aiman eius, sicut liberasti Eliam de communi morte mundi", en relación con la iconografía pintada del recinto.

Véase también: A. DE EGRY, Op. cit., en particular, p. 11. Por su parte, la citada experta definía con estas palabras el fenómeno: "es un ejemplo evidente, del esfuerzo realizado, para traducir plásticamente las oraciones pronunciadas por los moribundos y las palabras de una ceremonia funeraria". Sobre la importancia de la comendatio animae, dentro de los programas artísticos, véase: A. GRABAR, Las vías de la creación..., en especial, p. 20.

${ }^{1239}$ Somos conscientes de que, aún hoy en día, continúan las disputas en relación con la datación cronológica del edificio. Cf. G. BOTO VARELA, "Arquitectura medieval: configuración espacial y aptitudes funcionales", Real Colegiata de San Isidoro: relicario de la monarquía leonesa (C. Robles García y F. Llamazares Rodríguez coords.), León, 2007, pp. 50-103.

1240 J. A. MORÁIS MORÁN, La recuperación..., pp. 181-202.

${ }^{1241}$ Toulouse, Musée des Augustins. Cf.: M. DURLIAT, La sculpture romane de la route..., pp. 241-242, y D. CAZES, "Sarcófago paleocristiano llamado de Saint-Clair", El románico y el Mediterráneo..., ficha catolográfica 67, pp. 330-331.
} 
jugado por los sarcófagos, en la formación del lenguaje artístico y, sobre todo, en el desarrollo del capitel historiado ${ }^{1242}$.

En algunos capiteles de Teverga, se observa una tendencia que también se da en los capiteles, por ejemplo, de la resurrección de Lázaro y la curación del Leproso, del Panteón de San Isidoro de León. Se trata de la narración en friso continuado de la escena, que recorre perimetralmente la cesta del capitel, colocando a las figuras unas junto a otras, sin divisiones $\mathrm{y}$, en algunas ocasiones, situándolas todas a una misma altura $^{1243}$. Las escenas se suceden sin separación o, cuando se trata de simples figuras, se muestran colocadas de frente, sobre un fondo liso y dando la impresión de que están recortadas sobre el mismo. Este aspecto compositivo del capitel historiado románico, podría ser visto como una herencia del sistema de colocación de las figuras que los artífices romanos utilizaban para los frentes de los sarcófagos. Se trata de una hipótesis sobre la que han llamado la atención, continuadamente, muchos autores ${ }^{1244}$.

El fenómeno es especialmente visible en algunas de las esculturas románicas producidas por otro taller hispano, activo unos pocos años después que el de Teverga o León. Nos referimos a los capiteles realizados para la fábrica de Santiago de Compostela, donde se esculpieron, en concreto, dos capiteles en las que se narra el martirio de Santa Fe y que se han venido datando entre los años 1090-1100 ${ }^{1245}$.

Los dos capiteles, de gran formato, presentan la cesta totalmente ocupada por las figuras, que se van colocando, una tras otra, sin elementos separadores, recorriendo los tres lados visibles del capitel. El origen de la composición se halla, posiblemente, sobre

\footnotetext{
${ }^{1242}$ E. FERNÁNDEZ GONZÁLEZ, “Hacia una renovación escultórica...”, p. 9.

${ }^{1243} \mathrm{Si}$ bien se trata de una solución muy recurrente dentro de la escultura románica, en algunos de estos ejemplares es especialmente evidente.

${ }^{1244}$ P. DE PALOL, El Tapís..., en particular, p. 127 y X. BARRAL I ALTET, "Propaganda eclesiástica y poder feudal. El orden del mundo en las fachadas románicas", Propaganda y Poder, Congreso Peninsular de História da Arte, Lisboa, 1999, pp. 57-70, en especial, p. 62. Estos autores consideran que este rasgo es típico de la narración en friso del arte romano y los relacionan con las soluciones adoptadas por los talleres romanos de sarcófagos, durante la época constantiniana y preconstantiniana.

${ }^{1245}$ La cronología del capitel del martirio de Santa Fe, ubicado en el acceso de la capilla homónima de la catedral de Santiago de Compostela, así como otro capitel de composición similar, colocado en el brazo sur, tras el deambulatorio, deben ser datados poco antes del inicio de la campaña constructiva del obispo Diego Gelmírez. Cf.: J.-C. FAU, "À propos du chapiteau de la condamnation de Sainte Foy, à SaintJacques de Compostelle et à Sainte-Foy de Conques", Les Cahiers de Saint-Michel-de Cuxa, XXXI, 2000, pp. 47-57, especialmente, p. 48. Dicho autor propone el año 1105 como presunta fecha en la que el capitel estaría ya emplazado en su lugar, pues sería en esa data cuando el obispo de Pamplona consagraría el altar dedicado a la santa.

Sobre dichas obras, véase también: J. LACOSTE, Les maîtres..., en especial, pp. 12-15 y M. A. CASTIÑEIRAS, "Los santos viajan: la circulación de objetos y modelos artísticos en el camino", "Visitandum est": santos y cultos en el Codex Calixtinus (P. G. Caucci von Saucken coord.), Santiago de Compostela, 2005, pp. 63-90. Los autores aluden al papel jugado por Santa Fe de Conques en la formación del estilo escultórico del taller santiagués, además de insistir en la figura de Diego Peláez.
} 
el frente de un sarcófago, donde las figuras adquieren una dimensión de conjunto, equiparándose en apariencia a las imágenes de grupos o colectivos y mostrando, a veces, una marcada isocefalia ${ }^{1246}$.

Sin embargo, el tema del posible origen de tales composiciones dentro de los sarcófagos antiguos se adentra de lleno en la problemática de la relación entre la escultura románica creada más allá del 1100 y el mundo clásico. Si los ejemplos de cronología prerrománica declaran una continuidad en el uso de las imágenes dentro de los capiteles datados en tales fechas, tras el año mil, observamos, gracias a los ejemplos del Canigó, San Pedro de Rodas o San Salvador de Leyre, entre otros, que, a pesar de tratarse de conjuntos todos ellos donde las figuras humanas o los prótomos cefálicos nunca adquieren un valor monumental, si que denotan una cierta continuidad en la figuración del capitel.

A todas estas experiencias debemos sumar aquellas llevadas a cabo en los ejemplos tempranos de Santa María de Ujué e Iguácel donde, nuevamente, la figura humana aparece sobre la cista del capitel, no sin ciertas dosis de clasicismo. Más tarde vendrían los ya comentados capiteles del Panteón de San Isidoro de León, de Teverga y, finalmente, otros ejemplos presentes en la catedral de Jaca y San Martín de Frómista, así como la primera campaña constructiva de la catedral de Santiago de Compostela. Sin embargo, tales experiencias, por presentar un uso monumental de la figuración y, en muchas ocasiones, con gran vinculación con lo clásico, merecen un capítulo a parte ${ }^{1247}$.

\footnotetext{
1246 A. GRABAR, Las vías de la creación..., p. 75.

1247 Los ejemplos citados aquí corresponden, simplemente, a una serie de hitos historiográficos bien conocidos que, a pesar de trazar un panorama en exceso tópico y reducido, sintetizan bien el panorama que queremos esbozar como preludio del análisis de otra serie de ejemplos más concretos.
} 
BLOQUE II 


\section{RECUERDOS “CLÁSICOS” EN LA ESCULTURA ROMÁNICA HISPANA. A MODO DE INTRODUCCIÓN.}

A la hora de abordar el tema principal que este estudio tiene como objeto, creemos que resultan necesarias una serie de aclaraciones previas al respecto.

En el presente apartado se tratará de analizar de una manera más profunda la influencia que el arte de época romana ejerció sobre la escultura realizada en la Península Ibérica entre los siglos XI y XII ${ }^{1248}$.

El arco temporal que tomamos como referencia para el estudio dentro de los innumerables siglos de la Antigüedad, comprende las producciones datadas, en su mayor parte, en la época clásica imperial, es decir, entre los siglos I a. de C. y II d. de C. De una manera más precisa, se tendrán también muy en cuenta aquellas esculturas realizadas durante los últimos siglos de dicho periodo, que de una manera más evidente acabarían por "contaminar" las producciones cristianas de la Alta y Plena Edad Media $^{1249}$.

Nos interesará, especialmente, citar aquellos ejemplos romanos, tanto los producidos en la propia metrópoli de Roma, como aquellos que fueron ejecutados en las provincias, debido básicamente al clasicismo fuertemente variable que van a presentar dichas producciones ${ }^{1250}$. Será en tales ejemplos donde se hallarán los modelos más próximos, tanto desde un punto de vista iconográfico y, en ocasiones, incluso estilístico, que habrían de inspirar a los escultores románicos.

En tal discurso, resulta patente la práctica desaparición de los grandes conjuntos de pintura mural romana, especialmente en la Península Ibérica, que hacen muy problemático poder llegar a establecer una red de dependencias y relaciones de todo tipo entre las obras antiguas y medievales. Este aspecto se hace igualmente presente ante la conservación, más bien fragmentaria, de otro tipo de producciones como pueden ser las textiles, las suntuarias o las pertenecientes a la ilustración del libro. Así, teniendo en cuenta estas premisas, creemos que la escultura romana será la que de una manera más

\footnotetext{
1248 Hemos señalado repetidamente que nos centraremos, de una manera más concreta, en las producciones escultóricas, tanto antiguas como románicas. Para ser más concisos, los ejemplos a los que aludiremos serán tomados preferentemente del arte romano, con el que creemos que resulta más fácil establecer y demostrar ciertas relaciones.

1249 A. NOBRE DE GUSMÃO, "Introduction", Portugal Roman. Le Nord du Portugal, La Pierre-QuiVire, 1987, pp. 15-18, en particular, p. 15. El autor insiste en la importancia del arte romano tardío y el prerrománico para la formación del arte románico portugués.

${ }^{1250}$ A. GRABAR, "Le tiers monde de l'Antiquité à l'école de l'art classique et son rôle dans la formation de l'art du Moyen Âge", L'art paléochrétien et l'art byzantin, London, 1979, pp. 1-59.
} 
directa acabaría por influir a los escultores medievales y será entonces, a través de esta técnica, donde hallemos los ejemplos más representativos con los que justificar estas relaciones entre el mundo antiguo y el medievo.

Resulta evidente que, en ningún caso, se niega la posibilidad de que además de las fuentes escultóricas, los artistas románicos acudieran también a otra serie de ejemplos artísticos pertenecientes a la arquitectura y a otra serie de producciones, como por ejemplo, los mosaicos o los marfiles, a la hora de buscar los modelos inspiradores $^{1251}$. Nosotros mismos, en el desarrollo de la investigación aludiremos, cuando sea necesario, a diversos ejemplos tomados de la arquitectura, la pintura y las artes suntuarias. La acotación de este estudio a la técnica escultórica de época romana y sus repercusiones sobre la realizada en época románica, responde a la facilidad con la que demostrar la afinidad entre los modelos y las técnicas. Es factible hasta cierto punto afirmar que los artistas medievales pudieran haber accedido más fácilmente al corpus de obras esculpidas que propiamente a otra serie de repertorios, como por ejemplo, los representados por la pintura o los trabajos musivarios que, muy posiblemente, ya por entonces habían perecido en la mayoría de las ocasiones bajo los estratos -tanto físicos como temporales- de la historia ${ }^{1252}$.

El panorama de obras artísticas que los hombres de los siglos del románico podían vislumbrar estaba ligado, mayormente, a la escultura, lo que ofrece un mayor campo de estudio en relación con el tema que nos ocupa ${ }^{1253}$. Es posible que, en este proceso, cuando el artista medieval abordaba visualmente una escultura antigua, lo hiciese siendo consciente de lo problemático que resultaba acceder a otra serie de producciones menos viables ${ }^{1254}$. Ello no quiere decir en ningún sentido que, en muchas ocasiones, las filiaciones entre las obras medievales y las antiguas no estén exentas de grandes paralelismos con otra serie de producciones menos vinculadas a la escultura,

\footnotetext{
${ }^{1251}$ Resultaría imposible poder abarcar de una manera concreta la serie de dependencias que el arte medieval presenta con todas las técnicas utilizadas en el arte antiguo, desde la misma arquitectura hasta la pintura.

${ }^{1252}$ Debemos tener en cuenta que, aunque de manera generalizada, al hablar de la influencia del arte antiguo sobre el románico se suele pensar en obras de arte de gran calidad, esta cuestión no debió de ser del todo exacta. El panorama de obras antiguas al que debieron acceder los artífices posteriores, supuestamente, estuvo formado por obras de factura provincial.

${ }^{1253}$ Creemos que, posiblemente, la familiaridad que tenían los artífices con respecto a las obras esculpidas es comparable tan sólo a la influencia que debió ejercer la propia arquitectura, cuyas obras monumentales servirían para enriquecer el panorama artístico de la Antigüedad tardía y la Edad Media, así como para ofrecer toda una amplia gama de materiales que expoliar. Cf.: J. ALCHERMES, "Spolia in Roman Cities...", pp. 167-178 y J. M. BLÁZQUEZ MARTÍNEZ, "El urbanismo en Occidente", Homenaje a Manuel de los Santos, Albacete, 1988, pp. 179-183.

${ }^{1254}$ Pensamos, por ejemplo, en aquellas piezas que configurarían los tesoros imperiales.
} 
como, por ejemplo, la influencia de los trabajos en metal o las anteriormente aludidas esculturas en marfil.

Los aspectos puestos de relieve hasta aquí, permiten poder insistir sobre la posibilidad de que la técnica escultórica fuese una de las más valoradas por los hombres medievales, sobre todo gracias a sus razones de accesibilidad. Su valoración traducía los fines utilitaristas, pero también estéticos y artísticos con los que era observada. Al contrario que la arquitectura, la mayor parte de las esculturas antiguas eran vistas desde un sentido meramente práctico. Mientras que un elemento arquitectónico romano, como por ejemplo, un acueducto o un templo, podían ser utilizados con una función más o menos semejante a la que tenían cuando fueron concebidos ${ }^{1255}$, las esculturas poseían, además, un valor añadido. Eran objetos reutilizables y, sobre todo, en la mayoría de los casos, incluso transportables. Si la arquitectura antigua sirvió como cantera para poder obtener materiales de buena calidad para las nuevas construcciones medievales, la escultura ofreció, casi siempre, la posibilidad de su expoliación, tanto in se como in re. Al menos, parece relativamente más fácil poder señalar una expoliación in re dentro de modelos relativos a la escultura que, propiamente, a la arquitectura, aunque dudemos en esta afirmación que abordaremos más adelante.

Otra de las razones que podrían justificar esta acotación al estudio de la escultura en nuestro análisis, es el de su contexto. La escultura sobre piedra podía ser vista en contextos de más diferente índole que la misma pintura o la arquitectura. Mientras que la pintura romana pereció con los muros que le servían de soporte, en la mayoría de los casos, la escultura, además de presentar una resistencia material mayor, fue trasladada de una manera continuada, tanto por tierra como por mar. Se trata, por lo tanto, de un aspecto que ofrece múltiples ventajas que entroncan directamente con nuestras afirmaciones anteriores sobre la importancia de las expoliaciones de sarcófagos antiguos para enterramiento de personalidades medievales. Puede ser considerada como una de las pocas producciones artísticas antiguas que entraron, de manera más o menos regular, dentro de los espacios eclesiásticos cristianos, independientemente del material en el que estuviesen realizadas y de si la iconografía que presentaban era pagana o de otra índole.

\footnotetext{
${ }^{1255}$ En el caso contrarío, para transformar en templos cristianos todas estas estructuras, las reformas debían ser severas y, en ocasiones, tan sólo acababan siendo reutilizables ciertas partes más funcionales, como por ejemplo, las columnas o los capiteles, antes que los perímetros murales.
} 
Atendiendo a estas razones, hemos dividido el presente apartado en dos grandes bloques que tienen en cuenta, sobre todo, diversas cuestiones de índole cronológica y, sobre todo, estilística.

El primero de ellos se analiza la influencia de la escultura clásica romana realizada entre la época imperial y la tardoantigua sobre las producciones esculpidas de la Península Ibérica, aproximadamente, entre los años 1050 y 1150 . Se trata de un periodo de cien años que hemos acotado teniendo en cuenta la datación que se ha venido dando a los principales edificios construidos en suelo hispano durante el periodo románico.

Somos conscientes de lo arbitrario de tal elección, al menos teniendo en cuenta la naturaleza misma que rige la evolución y el desarrollo de los supuestos estilos artísticos en los que se ha venido dividiendo la misma historia del arte y en los que la acotación cronológica con intenciones matemáticas exactas se ha venido desechando desde hace algún tiempo ${ }^{1256}$.

Tomamos la fecha de 1050 en un sentido más práctico que rigurosamente simbólico. Los casos ya mencionados de San Pedro de Rodas y, tras él, otra serie de ejemplos distribuidos a lo largo de la geografía hispana, tales como los de Leyre o Ujué, presentaban interesantes desarrollos escultóricos decorando los edificios, de tal manera que, según creemos, deben ser tenidos en cuenta a la hora de acotar el inicio de nuestro discurso.

Por ejemplo, en relación con estos casos, veinte o treinta años después de la finalización de la iglesia de Rodas, posiblemente se estaba trabajando ya en la escultura que presentan los capiteles de la iglesia de San Pedro de Teverga. La fecha que se ha venido dando a tales trabajos, marca claramente la renovación que la escultura estaba sufriendo en torno al ecuador del siglo XI, o al menos eso se podría afirmar a juzgar por los monumentos conservados actualmente ${ }^{1257}$.

En un reciente artículo, la profesora E. Fernández González abordaba la problemática de la escultura datada más allá de esta mitad del siglo XI. En él señalaba la profunda complejidad del periodo, su carácter fragmentado, la imposibilidad de

\footnotetext{
${ }^{1256}$ I. G. BANGO TORVISO, “Crisis de una historia del arte...", pp. 15-28.

${ }^{1257}$ Este es el motivo por el que, en cierta medida, se haya obviado la escultura y las producciones artísticas de época anteriores a estas fechas intermedias del siglo XI, pues en este estudio no se podría llevar a cabo un análisis completo de todas las producciones datadas en una época anterior al año mil. Con todo, somos conscientes de la visión un tanto simple que se puede ofrecer tomando como punto de partida una fecha aleatoria como la que ofrecemos, pero practicable desde un punto de vista metodológico.
} 
encontrar ejemplos datados de una manera fiable y, sobre todo, del gran paso que se observará desde las fórmulas, más bien conservadoras, que ofrecerá la escultura hispana anterior a este momento, hacia unas formas mucho más homogéneas, ricas y complejas desde un punto de vista iconográfico. La experta iniciaba su exposición haciendo una valoración de esta plástica, teniendo como punto de partida la mitad de siglo y ello nos parece acertado por insistir en la importancia de tales fechas para comprender la evolución que explicará el desarrollo de la escultura románica en épocas posteriores ${ }^{1258}$.

En relación con los motivos por los que se ha partido de estas fechas, si seguimos las dataciones propuestas por el profesor S. Moralejo, aceptadas por M. Durliat más tarde y retomadas actualmente por J. Lacoste, por citar los autores que más trabajaron este periodo, la franja cronológica comprendida entre los años posteriores a la segunda mitad del siglo XI (1070-1090) y toda la primera mitad del siglo XII (11001150/1160), puede ser considerada como la primera gran etapa del arte románico español $^{1259}$. Será en este arco temporal cuando se inicien muchas obras ligadas a los grandes centros del Camino de Santiago, desarrollando un arte que, en ocasiones, se ha definido como "hispano-languedociano". Es entre estas vías que recorren los caminos de peregrinación a los grandes centros, como Santiago de Compostela o San Salvador de Oviedo y que enlazaban con otros lugares de mayor relevancia, como por ejemplo, San Pedro de Roma, donde hallaremos los mejores ejemplos de la escultura a la que nos estamos refiriendo.

Durante esta etapa se abren los talleres de San Martín de Frómista y de la catedral de Jaca. Paralelamente, se inician las obras en la catedral de Santiago y otra larga nómina de edificios, como los de Loarre e Iguácel, San Isidoro de León, Carrión de los Condes, San Benito de Sahagún o la catedral de Navarra, por citar los más emblemáticos y conocidos. En todos estos centros se trabajará en el tránsito entre los siglos XI y XII y, en algunos incluso, más allá del año 1150. Sin embargo en todos, y como elemento homogéneo, se han apuntado unos nexos unificadores dentro del

\footnotetext{
1258 Sobre los importantes cambios que sufrió la escultura en estas fechas, véase: E. FERNÁNDEZ GONZÁLEZ, "Hacia la renovación escultórica...”, pp. 5-36 y A. NOBRE DE GUSMÃO, "Introduction...", pp. 15-18. Este último autor insiste en esta misma circunstancia, reafirmando la importancia de la etapa final de siglo XI, como fecha clave para la renovación de las formas escultóricas. También, consúltese: C. A. FERREIRA DE ALMEIDA, Arquitectura Românica de entre Douro e Minho, 2 vols, Porto, 1978, vol. II, en concreto, p. 137. El autor, siguiendo a Durliat, insiste en el siglo XI como una época fundamental para el desarrollo de la escultura monumental románica.

${ }^{1259}$ Insistimos en que se trata, en gran medida, de una serie de fechas simbólicas y discutibles, tomadas tan sólo como mero punto de partida para iniciar el análisis.
} 
"fenómeno hispano-languedociano"1260. Será en esta primera gran corriente de la escultura románica hispana donde todos los autores coincidan en señalar una fuerte dependencia con respecto a los modelos clásicos. De ahí que el primer apartado de este bloque se centre en este tipo específico de escultura que va a emerger entre los centros franceses de Toulouse, Moissac, Cahors, Agen o Auch y otra serie de templos hispanos, como los anteriormente mencionados.

A grandes rasgos, se intentará demostrar el hecho de cómo estos talleres, tomaron gran parte de los modelos que estaban manejando y ciertas formas del estilo de la escultura funeraria de época romana, sin excluir una dependencia con respecto a otro tipo de producciones artísticas.

Como veremos, el famoso ejemplo del sarcófago de Husillos y toda la importancia que su iconografía y estilo habrían de tener para el desarrollo de la escultura románica hispana desde finales del siglo XI y más allá, incluso, de la mitad de siglo XII, es tan sólo el ejemplo más evidente y mejor conocido de los conservados.

La escultura surgida a partir de estos focos posee un gran recuerdo clásico, pero sus fuentes no parecen provenir ni de la pintura ni de las grandes esculturas monumentales, sino que, según se verá, éstas pueden rastrearse de una manera más clara dentro de piezas con fines funerarios, como los sarcófagos.

Por lo tanto, concluimos que desde las primeras experiencias desarrolladas más allá de la primera mitad del siglo XI hasta la disolución de esa fórmula "hispanolanguedociana", ya durante la segunda mitad del siglo XII, una de las principales vías de estudio en relación con la tradición clásica de la escultura románica debe buscarse dentro de los repertorios ligados a la escultura funeraria ${ }^{1261}$.

Por el contrario, el tercer bloque en el que se divide nuestro estudio, corresponde a la escultura hispana de época románica que se ha datado más allá de la segunda mitad del siglo XII. En esos años, las fórmulas y los talleres abiertos alrededor del año 1100 se disolvían y desaparecían. Su disipación vendría provocada por el agotamiento mismo de

\footnotetext{
${ }^{1260}$ S. MORALEJO ÁLVAREZ, "Arte del Camino de Santiago...", pp. 137-144 e ID., "Modelo, copia y originalidad...", pp. 75-96. Consúltese, también: J. A. MORÁIS MORÁN, "Autour du "style des joues gonflées" et de sa diffusion au sein de la sculpture romane hispano-languedocienne", Effets de style au Moyen Âge Colloque international et pluridisciplinaire organisé par le CUER MA/EA 2207, Aix-enProvence, 2008, (en prensa).

${ }^{1261}$ Resulta muy llamativo el ejemplo que se estudia en: C. A. FERREIRA DE ALMEIDA, Arquitectura Românica..., vol. II, en concreto, p. 144. Señala que la proliferación dentro de la escultura de tímpanos portugueses de la iconografía de las cruces o las aves afrontadas a vegetales, algunas de ellas datadas entre los siglos XII y XIII, pueden tener, a pesar de haber perdido prácticamente su simbolismo, un origen procedente de las piezas funerarias. Esta idea insiste en la importancia de este tipo de arte a la hora de buscar el origen de muchas imágenes frecuentes en la escultura medieval.
} 
tal fórmula, enormemente difundida y, especialmente, por la finalización de los trabajos en los edificios. Todos los centros anteriormente citados estaban más o menos activos entre el primer y el segundo decenio del siglo XII. Parece evidente que, una vez cerrados tales talleres o finalizadas las obras de los diferentes núcleos de creación, el llamado "estilo hispano-languedociano" acabara muriendo ${ }^{1262}$.

En relación con estos aspectos, tomamos nuevamente otra fecha como punto de partida que ponga límite a los análisis realizados en este bloque. El año 1150, de una manera aproximada, se da inicio al desarrollo de otra gran corriente del románico hispano o, para ser más acertados, a las corrientes de la escultura de la segunda mitad del siglo XII.

Ejemplos como los de Santa María la Real de Sangüesa o Uncastillo, la escultura realizada en la catedral de Santo Domingo de la Calzada o en el claustro de Silos, así como la decoración de San Vicente de Ávila, algunas obras del entorno de Aguilar de Campoo, la catedral de Zamora o la catedral vieja de Salamanca, son representantes de estas nuevas corrientes escultóricas que se producirán en la Península. Tras ellos, se construiría el cierre monumental a la escultura románica en nuestro país, con el ejemplo del Pórtico de la Gloria y la figura de Mateo, así como el caso del apostolado de la Cámara Santa de Oviedo ${ }^{1263}$.

\footnotetext{
${ }^{1262}$ Recuérdese, por ejemplo, como los talleres de San Isidoro de León, buenos representantes de estas experiencias escultóricas ligadas a determinadas fórmulas "antiquizantes" del Languedoc, pero reinterpretadas bajo lenguajes propiamente hispanos, debieron tener su punto y final en torno al año 1147. El dato se suele tomar de la noticia que presenta la consecratio del templo, del 6 de marzo de 1147 y que se señala como fecha indudable para el fin de las obras en el edificio. Con todo, es verdad que, tal y como se ha venido señalando, ello no implicó el cierre de la fábrica, pues aún se documentan artífices trabajando en fechas posteriores. Sobre la inscripción, véase: V. GARCÍA LOBO, "Las inscripciones medievales de San Isidoro de León. Un ensayo de Paleografía epigráfica medieval", Santo Martino de León. Ponencias del I Congreso Internacional sobre Santo Martino en el VIII centenario de su obra literaria (1185-1985), León, 1985, pp. 373-397, en especial, p. 386. Sobre los trabajos en la basílica más allá de esta fecha ya se llamó la atención en su día en: C. COSMEN ALONSO y M. V. HERRÁEZ ORTEGA, "Fernando II: promotor del Camino de Santiago en León", Imágenes y promotores en el arte medieval: miscelánea en homenaje a Joaquín Yarza Luaces, 2001, pp. 79-87, en especial, p. 82. Véase, además: J. A. MORÁIS MORÁN, "Imitación, copia...", (en prensa). Más significativo es el caso de la catedral de Santiago de Compostela. Las obras en el edificio no se concluyeron de manera más o menos exacta hasta finales del siglo XII, cuando se colocan los dinteles del cierre occidental o Pórtico de la Gloria. Sin embargo, hacía mucho tiempo que este "estilo" "hispano-languedociano" había desaparecido dentro de los talleres abiertos en el edificio. A pesar de que durante largo tiempo había sido la tendencia escultórica más importante dentro de tal construcción. Cf.: H. KARGE, "De Santiago de Compostela a León: modelos de innovación en la arquitectura medieval española. Un intento historiográfico más allá de los conceptos de estilo", Cien años de investigación sobre arquitectura medieval española, Madrid, 2009, pp. 165-198. El citado autor expone una serie de nuevos planteamientos en lo relativo a las fases constructivas del templo compostelano.

${ }^{1263}$ Evidentemente, los ejemplos aquí aludimos resultan en exceso fragmentarios y de una visión muy simplista que parece caer casi en lo tópico. Sin embargo tan sólo pretenden explicar y justificar la división efectuada para la realización de este trabajo.
} 
Para concluir esta introducción, queremos adelantar, finalmente, otra serie de ideas. Si durante la segunda mitad del siglo XI y la primera del XII se puede advertir una cierta predilección por la escultura funeraria clásica en cuanto a los modelos utilizados por los artífices, a partir de la segunda parte del siglo XII las fuentes parecen ser otras bien diferentes. No queremos ser tajantes y negar la posibilidad de que en un determinado momento también en este periodo otros artistas o talleres se inspiraran en piezas de este tipo. Tan sólo señalamos que, de manera más o menos generalizada, las fuentes cambiaron, pasaron a ser otras y aunque tenemos documentados ejemplos de primer orden que hablan de la admiración de sepulcros romanos durante la segunda parte del siglo XII, los artífices románicos prefirieron otras vías de ensayo más amplias y, quizás, más ricas y complejas, ligadas la mayor parte de las veces a la escultura monumental romana, tal y como puntualizaremos en su debido momento.

Si durante la primera etapa señalada las fuentes se ligaban a obras funerarias y la plástica muestra una relación con la zona de los Pirineos, la del Rosellón, el Languedoc o Aquitania, los nuevos talleres hispanos de la segunda mitad del siglo XII hablan de una conexión más estrecha con Provenza, Auvernia y, sobre todo, con Borgoña ${ }^{1264}$. El románico que se desarrollaría ahora en Hispania, como aquel datado en el siglo XI, presenta ciertas relaciones con la romanidad, tanto provincial como metropolitana. Sin embargo, es una relación dependiente de una escultura de mayores pretensiones, que mira con admiración los grandes bustos, los retratos y las efigies clásicas esparcidas por las zonas más romanizadas de la Galia y del noreste peninsular hispano.

A ello se suma la problemática del denominado "estilo 1200", al que de una manera general se ha relacionado con ciertas tendencias "antiquizantes", sin definir en muchas ocasiones de cuales se trataba. Ello ha provocado que de manera mecánica se aluda a estas obras tan sólo como aparentemente clásicas, sin matizar sí de lo que realmente se trata es de una alusión a la obra clásica romana, a la perteneciente a la Antigüedad tardía, si pretendía, por ejemplo, evocar un referente clásico tamizado bajo la plástica bizantina u otra larga lista de posibilidades que iremos analizando. Lo que parece claro es que este tipo de escultura posee una tendencia al fuerte contraste de volúmenes, ahora rotundos, el uso del pliegue como instrumento de exhibición tenaz de la habilidad con el cincel, así como un retorno evidente a los modelos romanos en el uso del capitel corintio, si citamos los aspectos más destacados de este tipo de trabajos. ${ }^{1264}$ Tales afirmaciones serán abordadas en un capítulo dedicado al tema. Será allí donde se recojan los
trabajos que respalden tales hipótesis. 
Se trata, por lo tanto, de dos tendencias muy diferentes a la hora de mirar a la Antigüedad. La primera, ciertamente más "ingenua", si se puede utilizar aquí el concepto, y más admirativa. La segunda, más consciente de que los modelos que se copian son armas de prestigio y de autoridad. Si los maestros hispanos que copiaron el sarcófago de Husillos lo hicieron por considerar que se trataba una pieza digna de ser conservada y a la que se le podían "robar", de alguna manera, unos cuantos fragmentos realizando una expoliación in re, los escultores tardíos del románico de San Vicente de Ávila, por ejemplo, admiraron las piezas clásicas con una intención más "arqueológica" de reproducir con la mayor semejanza posible el modelo que copiaban sobre la piedra, ahora en época medieval.

Pensamos que son dos maneras muy diferentes de enfrentarse a un mismo pasado, que mediante diversas y riquísimas vías de experimentación, darían múltiples y espléndidos resultados. 


\section{1. SOBRE LA IMPORTANCIA DE LOS SARCÓFAGOS ANTIGUOS EN LA FORMACIÓN DEL NUEVO LENGUAJE ESCULTÓRICO.}

Antes de abordar el tema concreto de las relaciones entre la escultura románica hispana y la realizada sobre diferentes producciones esculpidas de índole funeraria, creemos importante señalar algunos aspectos.

Sobre la importancia que los monumentos funerarios tuvieron durante el mundo antiguo y el medieval, su respeto, su conservación y su reempleo, así como sobre su tipología, ya hemos incidido de manera más detallada en este estudio. En relación con este tema, también se ha abordado la imagen que se tenía durante la época medieval de dichas piezas antiguas, donde las alusiones al mármol, así como a su decoración de estrígiles y de escamas eran utilizadas para recrear cualquier tipo de imagen que intentase representar un sarcófago antiguo, a pesar de hacerlo en época medieval. Los pequeños sarcófagos plasmados en la plástica románica señalaban un interés por mantener y reproducir la imagen antigua de tales piezas, así como dotarlos de un cierto abolengo prestigioso.

Los monumentos funerarios $\mathrm{y}$, por extensión, los sarcófagos, debieron ser considerados como elementos de respeto, en cuanto aludían a las personas que los habían construido y mandado esculpir para prestigiar y perpetuar la imagen de un ser que ya no estaba vivo. Este hecho, entre otros, marcaría este tendencia de conservar tales piezas y, en ocasiones, el lugar en el que se custodiaban ${ }^{1265}$.

Todas estas razones podrían explicar la perduración y conservación de estos sarcófagos durante los siglos medievales, pues se consideraba que la causa primera que explicaba la existencia de un monumento funerario era la de prestigiar, perpetuar y hacer más digna la partida del ser querido o de aquel que había comandado la construcción de tal obra. El intento de perpetuación de la memoria de la persona muerta haría que dichas obras llegaran en gran número a la época medieval. Así, no afirmando, en ningún caso, que durante la etapa románica no se hayan producido destrucciones de monumentos funerarios antiguos, creemos que, por el hecho de existir ese respeto hacia estas obras, éstas quizás recibieron menos el ataque de manos destructoras.

\footnotetext{
1265 M. F. SOARES PATROCÍNIO, Um lugar para o passado: A Arte e o Antigo, Évora, 1999, en concreto, pp. 11-12. El autor insiste en la importancia del pasado y de la búsqueda de toda una serie de mecanismos, tanto intelectuales como artísticos, que sirviesen para fomentar la memoria histórica de las sociedades.
} 
Otra causa importante que podría explicar esta facilidad de acceso para la admiración de los sarcófagos antiguos por parte de los artistas medievales, viene dada por la propia fecundidad del arte funerario. En una sociedad como la romana donde la idea de perdurabilidad era la base del sistema ideológico religioso y, en otra sociedad como la cristiana donde, heredera de ésta, el descano eterno a la espera de un juicio final se debería llevar a cabo de la manera más digna posible, la monumentalización de los lugares de enterramiento convertirían a este tipo de obras en las más frecuentes dentro de los sistemas de producción escultórica y arquitectónica ${ }^{1266}$.

Todos estos aspectos han llevado a la mayoría de los especialistas a señalar el arte funerario de época romana como una de las producciones artísticas que más habrían de influir en la formación de algunos aspectos de la escultura medieval europea ${ }^{1267}$. Es algo evidente que el arte funerario siempre estuvo predispuesto a poseer una marcada voluntad de continuación con el pasado y de cita y evocación de éste, en cuanto que, por su propia naturaleza, busca un claro recuerdo manifiesto del pasado. Del pasado de una estirpe, de una familia, de una comunidad o, simplemente, de una persona, lo que parece claro es que, la abundancia de piezas conservadas tiene en estos argumentos alguna razón de ser.

El panorama artístico que debieron observar los escultores románicos debió ser bien distinto al existente actualmente. Los sarcófagos y los sepulcros convivirían cotidianamente con aquellos hombres medievales, tal y como refleja el texto, ya recogido, del Codex Calixtinus donde se insiste en que "cuanto más lejos se mira, tanto más lejos se ven sarcófagos" (texto 49).

El monumento funerario adquiría una dimensión fundamental dentro del imaginario antiguo y medieval, en los que la imagen iconográfica de un sarcófago evocaba, mediante su sola presencia, los valores de prestigio, dignidad y respeto, ansiados para el recuerdo de los venerables personajes que allí se sepultaban.

\footnotetext{
1266 J. REMESAL RODRÍGUEZ, Op. cit., pp. 369-378.

1267 J. GARDNER, “Arnolfo di Cambio and Roman Tomb Design”, The Burlington Magazine, vol. 115, 844, 1973, pp. 422-439.
} 


\section{2. REFLEXIONES SOBRE LA FORTUNA DE ALGUNOS MONUMENTOS SEPULCRALES Y SARCÓFAGOS ANTIGUOS EN LA ICONOGRAFÍA MEDIEVAL.}

Aunque pudiera parecer que el presente epígrafe nos aleja del tema en cuestión, creemos que resulta fundamental dedicar una serie de reflexiones, necesarias para poder comprender el fenómeno al que nos venimos refiriendo. Durante la Antigüedad existieron diferentes tipos de monumentos sepulcrales, materializados en todas sus variantes en forma de sarcófagos, cenotafios, torres funerarias, mausoleos, tholos, esculturas, ánforas y una larga lista de tipologías que perdurarían durante la etapa románica.

Entre los ejemplos más conocidos de este tipo de obras funerarias debemos destacar el supuesto lugar en el que había sido enterrado Cristo, es decir, la rotonda de la Anástasis de Jerusalén y aquel que daba cobijo a los restos del apóstol San Pedro, bajo la famosa pérgola de San Pedro del Vaticano. Sin embargo, la lista se remonta propiamente a la Antigüedad más remota, donde el propio templo de Salomón y otra serie de edificios acabarían por establecer las pautas sobre las que asentar la configuración arquetípica de la imagen que, desde el punto de vista iconográfico, habrían de tener los monumentos sepulcrales ${ }^{1268}$.

A la hora de poder analizar la influencia que la escultura romana funeraria realizada para los sarcófagos ejerció sobre las producciones románicas, creemos fundamental abordar antes la imagen que estos monumentos funerarios de la tradición clásica y tardoantigua proyectarían sobre los mismos creadores medievales. No en vano, a la hora de poder explicar, por ejemplo, las columnas torsas esculpidas para la puerta Francigena del brazo norte de la catedral de Santiago de Compostela, habrá que recurrir a algunos de los modelos utilizados en la plástica de tradición fúnebre de los periodos antiguos, así como al citado templo de Salomón. Se trata de modelos funerarios prestigiosos, que pasarían al imaginario medieval de manera un tanto fragmentaria, sin embargo, como símbolos de autoridad que representaban, estos monumentos serán retomados en más de una ocasión por los artífices románicos para evocar el prestigio

\footnotetext{
${ }^{1268}$ La bibliografía sobre el conocido templo de Salomón es bastísima. Remitimos a una pequeña selección de obras donde se abordan estas cuestiones con extensas referencias bibliográficas. Cf.: W. J. HAMBLIN y D. ROLPH SEELY, El Templo de Salomón: historia y mito, Madrid, 2008.
} 
antiguo que poseían estas tumbas y poder aplicárselo a las nuevas creaciones medievales.

Como veremos, a la hora de representar iconográficamente los enterramientos cristianos más importantes, los modelos que se van a utilizar, nuevamente hablan de un conocimiento de las obras antiguas, tanto los sarcófagos como las tumbas de fábrica.

En este sentido, debemos señalar, una vez más, el papel jugado por el arte y la arquitectura de los siglos IV y V. Se trata, evidentemente, de una nueva concepción estética y funcional de los edificios, así como de su decoración que, a pesar de estar enteramente embebidos dentro de una sociedad cristiana, presentan una enorme deuda con el pasado clásico legado por el arte antiguo. En este mismo estudio hemos señalado también la importancia que para la arquitectura cristiana de los siglos medievales tendrían las experiencias en el campo de la construcción llevadas a cabo bajo el patrocinio de Constantino dentro de la edilicia tardoantigua. Tal y como ya hemos afirmado, la teoría expuesta por B. Brenk sobre la importancia de las fábricas constantinianas en la formación de lo que después se ha dado en llamar "arquitectura de peregrinación", resulta convincente ${ }^{1269}$.

Sin embargo, el fenómeno resulta mucho más complejo. Los edificios levantados por Constantino, tanto dentro del Imperio de Occidente como en la parte oriental, recogían de manera sabia todas las experiencias anteriores romanas en materia constructiva $^{1270}$. A las experiencias antiguas se añadían ahora las innovaciones y el ensayo con nuevas estructuras, materiales y concepciones espaciales ${ }^{1271}$. Se levantaron durante este periodo diversas edificaciones fundamentales para la historia de la arquitectura, y que acabarían por generar también una particular iconografía arquitectónica de estos monumentos. Así, el mismo Santo Sepulcro de Jerusalén, la basílica de San Pedro en Roma, el mausoleo de Santa Elena en la misma ciudad o la tumba de Gala Placia de Ravenna, son los ejemplos más conocidos de esta nueva

\footnotetext{
${ }^{1269}$ B. BREK, "Il luogo di culto...", en especial, p. 121.

${ }^{1270}$ Pensamos que la figura de Constantino es fundamental para poder entender la formación de la plástica cristiana, sobre todo teniendo en cuenta su deuda con el arte romano. El arte funerario producido en este periodo es de vital importancia para nuestro estudio, de ahí que en este apartado nos detengamos en el análisis de algunos aspectos relacionados con el arte creado bajo sus auspicios.

${ }^{1271}$ Un aspecto bien definido dentro de la arquitectura antigua era la explotación de los valores interiores de los edificios. Recuérdense las experiencias magistrales de arquetipos constructivos como el Panteón de Roma o la Domus Aurea de Nerón, por citar los ejemplos más significativos. La arquitectura de época constantinina, adaptó todos estos elementos a su propio interés, reactivando el valor interior de las construcciones y utilizando el simbolismo arquitectónico y escultórico de la misma manera que lo habían hecho los constructores y artífices de época imperial. Sobre el concepto del espacio en la arquitectura romana y su traspaso a la época de Constantino, véase: S. BETTINI, Lo spazio architettonico da Roma a Bisanzio, Bari 1992, en especial, pp. 57-87.
} 
manera de construir. A ellos debemos sumar, también, aquellos erigidos dentro del ámbito oriental, como la iglesia de la Natividad en Belén, la iglesia Eleona del Monte de los Olivos o la de los Apóstoles en Constantinopla, por citar tan sólo los ejemplos más significativos al respecto $^{1272}$.

Todas estas construcciones acabarían por reorganizar la concepción del propio espacio sagrado de los templos dentro de la historia de la arquitectura existente hasta este momento. Junto con ellos, el arte de Constantino trajo pareja una renovación de los lenguajes figurativos que decorarían tales espacios, así como los mismos sarcófagos. Todo ello, tal y como es bien conocido, apoyado sobre una reorganización religiosa y política, que tenía como fin más destacado el fortalecimiento de la iglesia y la autoridad de la nueva religión ${ }^{1273}$.

Sin embargo, como bien señalara en su día R. Krautheimer, el emperador tan sólo se convirtió al cristianismo en su lecho de muerte. Noticias como estas, señalan claramente la importancia de la romanidad pagana dentro de su mandato. El simple hecho de que la más famosa de las visiones del emperador, aquella que tuvo en los momentos previos a la batalla de Puente Milvio, en Roma, y mediante la cual le fue revelado el triunfo de la nueva religión, fuese un remedo de la mitológica visión de Apolo en la historia pagana, muestra bien a las claras los fundamentos de la nueva religión, íntegramente sumergida en un ambiente no cristiano ${ }^{1274}$.

Sin embargo, para lo que afecta a nuestro estudio, el aspecto más destacado vino ligado a la arquitectura de índole funeraria. Los grandes cambios experimentados en la concepción de los espacios funerarios durante la Roma antigua se produjeron antes que todas estas experiencias aportadas por Constantino, concretamente, entre los siglos I y II d. de C. Fue justo durante estos siglos cuando el concepto de espacio cambió, surgiendo lo que se ha dado en llamar, desde un punto de vista espacial, las "tumba/templo". Solo a partir de esta cronología, los arquitectos romanos comenzaron a levantar construcciones funerarias perfectas y, conscientemente, adaptadas para albergar no sólo un culto familiar en homenaje al difunto enterrado, sino la posibilidad de realizarlo dentro de un mismo recinto con la asistencia de un mayor número de personas. Mientras que los anteriores edículos o lugares funerarios romanos eran tan sólo representantes del

\footnotetext{
1272 B. BRENK, "Il luogo de culto...”, pp. 119-123.

${ }^{1273}$ R. KRAUTHEIMER, Arquitectura paleocristiana ..., en concreto, p. 43.

1274 Sobre la cristianización del mito de Apolo dentro del ideario cristiano, a través de la visión de Constantino y la cristianización del tema del héroe clásico, véase: E. FERNÁNDEZ GONZÁLEZ, "Héroes y arquetipos...", en concreto, p. 14, nota 3.
} 
recuerdo del difunto a modo de epitafio, pronto comenzaron a poder albergar en su interior también los restos mortuorios del difunto.

Ahora se comienzan a erigir edificios dedicados a exaltar el recuerdo del difunto, su titularidad en relación con tales edificaciones, así como la proyección de su dignitas en virtud de su labor patrocinadora. El gran cambio se produce cuando las nuevas construcciones de este tipo adquieren fuertes valores expositivos, relacionados con el carácter público que estas comenzaron a tener ${ }^{1275}$. Las zonas abiertas, con grandes puertas y la utilización de escalinatas de acceso, permitían una mejor comunicación entre el monumento y el exterior ${ }^{1276}$. Sin duda, la arquitectura funeraria, a partir del siglo II d. de C., se hizo más pública, de igual manera que también se harían más públicos los mecanismos mediante los cuales publicitar la imagen del difunto allí enterrado o conmemorado. Nos estamos refiriendo a la iconografía y la decoración de tales estructuras, que a partir de este momento, alcanzarán un desarrollo mayor, habida cuenta del nuevo público que podría contemplar dichas imágenes.

Debemos ver en esta "democratización" de los espacios funerarios, un gran preludio para las experiencias de la llamada arquitectura de peregrinación con las que se identificará la época constantiniana. La gestación de espacios diáfanos, la utilización de una red espacial dentro del edificio para la circulación de fieles, la monumentalización de las zonas más importantes de los recintos, la división y la compartimentación del espacio a través de canceles, columnas y otra serie de elementos, hablan a las claras de la voluntad pública que presenta esta nueva arquitectura. En relación con la otra parte fundamental de este proceso, la relacionada con los temas iconográficos y la profusión de los programas dentro del templo, nos ocuparemos más adelante.

La arquitectura funeraria de época constantiniana fue proyectada, generalmente, con una evidente intención pública. A ello responde la tipología abundantemente explotada durante este periodo, según la cual, el lugar sobre el que se hallaba el resto del difunto, ya fuese santo o mártir, es decir el martyria, era combinado con la estructura basilical en la que realizar el culto ${ }^{1277}$. Según S. Kostof, la solución debe explicarse, en

\footnotetext{
1275 C. A. FERREIRA DE ALMEIDA, Arquitectura Românica..., vol. II, en concreto, p. 158. El trabajo analiza algunos de estos aspectos, en concreto, la importancia de la imagen y las propiedades profilácticas y "mágicas" que durante el primer cristianismo se le atribuyeron, sobre todo, en el ámbito funerario.

${ }^{1276}$ Véanse las interesantes reflexiones que se desarrollan en: P. GROS, L'architecture romaine du début du III siècle av. J.-C. à la fin du Haut-Empire. Maisons, palais, villas et tombeaux, Paris, 2001, vol. 2, en concreto, pp. 444-454.

${ }^{1277}$ Desviaría la atención de nuestro trabajo el estudio pormenorizado del concepto del martyria dentro de la arquitectura tardoantigua, no obstante remitimos a una breve selección bibliográfica. Cf.: A. GRABAR, Martyrium. Recherches sur le culte des reliques et l'art chrétien antique, 2 vols. Paris, 1946. El autor
} 
parte, por razones prácticas, pues al tratarse de lugares públicos y de gran afluencia de fieles, se necesitaba un espacio que pudiese estar preparado para tales fines. No en vano, será en la época constantiniana cuando observemos un crecimiento ciertamente importante en la construcción de este tipo de obras, que ahora incluso inundaban los extrarradios de las ciudades, más allá de la cinta muraria. Se trataba de estructuras que se asociaron, de manera simultánea, a las necrópolis y que con el paso del tiempo serían el germen de las grandes construcciones de época medieval ${ }^{1278}$.

Dentro de este ambiente, impregnado de fórmulas del pasado e introduciendo importantes novedades que posteriormente se harían frecuentes dentro de la arquitectura románica, debemos entender la construcción de dos de las grandes obras más importantes y con mayor prestigio para el mundo medieval de este periodo. Nos referimos al Santo Sepulcro de Jerusalén y la basílica de San Pedro del Vaticano, en $\operatorname{Roma}^{1279}$.

muestra algunas ambigüedades con respecto a la definición del término. Entendemos que tras la constitutio de Máximo del año 386, en la que se daba orden de que todos los mártires fueran honrados allí donde se encontrase su sepultura, fue la fecha clave para poder comprender el fenómeno. Tras dicha ley comenzaron a prodigarse los martyrium y monumenta que permitían venerar las reliquias de tales personajes. Sobre el tema, véase también: C. BUENACASA PÉREZ, "La instrumentalización económica del culto a las reliquias: una importante fuente de ingresos para las iglesias tardoantiguas occidentales (siglos IV-VIII)", Santos, obispos y reliquias, (A. L. García Moreno, M. E. Gil Egea, S. Rascón Márquez, M. Vallejo Girvés ed.), Alcalá de Henares, 2003, pp. 123-140 y A. M. MARTÍNEZ TEJERA, "Arquitectura cristiana...", en concreto, p. 111. Este tipo de construcciones llegaron a tener gran aceptación en la Península Ibérica, a pesar de que la mayor parte de los ejemplos no llegaran hasta hoy. Sirva a modo de muestra el caso recogido en la passio de San Mancio. Se trata de un texto posiblemente realizado entre los siglos VII y VIII y contenido actualmente en el Legendario de Madrid, del siglo X. San Mancio, cristiano hispanorromano, había sido martirizado a finales del siglo VI o principios del siglo VII por los propietarios de una villa de la región de Évora. Su cuerpo fue enterrado indignamente, pero cuando la villa pasó a formar parte del dominio de los cristianos, su cuerpo fue rigurosamente transferido a un sepulcro digno. Allí fue erigido un templum que la fuente literaria describe perfectamente, con bellos mármoles, columnas, espaciosos atrios, una basílica para los fieles y todo tipo de decoración en mosaico. De tal estructura nada ha permanecido, pero queda claro que este tipo de construcciones debieron ser muy habituales, modificando monumentalmente el panorama de los extrarradios de las ciudades, favoreciendo, además, la prolijidad de modelos artísticos y formas con fuerte contenido estético. Se realiza una edición del texto en: J. M. FERNÁNDEZ CATÓN, San Mancio, culto, leyenda y reliquias. Ensayo de crítica hagiográfica, León, 1983, pp. 153-166. Véase también la valoración que se hace del mismo en: M. JUSTINO MACIEL, "A Arte de época classica (séculos II a. C.-II d. C), História da Arte Portuguesa, (P. Pereira dir.), Lisboa, 1995, vol. I, pp. 79-149 e ID., “A Arte da Antiguidade tardia (séculos III-VIII, ano de 711”, História da Arte..., vol. I, pp. 103-149, particularmente, pp. 136-137.

1278 Sobre la arquitectura funeraria con fines públicos en época constantiniana, consúltese: S. KOSTOF, Op. cit., en concreto, p. 447. El autor señala la importancia del uso de las cinco naves en Belén, así como el espacio del atrio que desembocaba en una estructura octogonal levantada sobre la gruta de la Natividad, evocando casi la forma de una caja pétrea de reliquias. Soluciones, más o menos similares, se seguirían dentro de la iglesia del Santo Sepulcro. Sobre las diferentes tipologías de martyria, en relación con su planta, véase: R. KRAUTHEIMER, Arquitectura paleocristiana..., en concreto, p. 40. El estudioso señala el uso de la planta central, sobre todo la trilobulada -cella trichorae-, en algunos ejemplos. Sobre la proliferación de martyria, con especial atención al caso hispano, consúltese: A. M. MARTÍNEZ TEJERA, “Arquitectura cristiana...”, en concreto, p. 116.

${ }^{1279}$ Sobre este último templo ya hemos llamado la atención en relación con el éxito de su planta y la difusión de su morfología dentro de la arquitectura medieval, en concreto, dentro del fenómeno del 
No es nuestro cometido estudiar dichos edificios. Sin embargo, creemos que se trata de dos obras fundamentales, ambas con fines mortuorios y ambas con sus respectivos monumentos fúnebres, de gran importancia para el mundo medieval. Tal y como veremos, en época románica estos dos edificios se convirtieron en arquetipos a seguir, no sólo desde su forma, sino también en lo referente a su decoración. Nos interesan por ser dos pruebas irrefutables de cómo la primera arquitectura medieval tomó como base la tradición eminentemente clásica y, sobre todo, ciertos rasgos de ese clasicismo, que acabarían por traspasarse al arte de época románica, incluso dentro del ámbito hispano.

"renacimiento paleocristiano", tanto de época carolingia como románica. Se ha decidido abordar estos dos ejemplos por que consideramos que representan bien la importancia que alcanzó en época tardoantigua la arquitectura funeraria cristiana. Estos dos edificios, con sus respectivos monumentos funerarios, podían ser visitados por los espectadores medievales, visionando muchas obras de carácter mortuorio que más tarde inspirarían otra serie de producciones de fuerte carácter clásico. 


\section{3. LA ANÁSTASIS DE JERUSALÉN Y LA CRISTIANIZACIÓN DE LOS MONUMENTOS FUNERARIOS ANTIGUOS.}

Bajo este epígrafe con el que iniciamos este apartado, ciertamente ambiguo e inabarcable para ser tratado de una manera completa, pretendemos desarrollar el estudio de la imagen que durante la etapa románica se tuvo del Santo Sepulcro de Jerusalén de época constantiniana.

Llevamos a cabo esta tarea para ahondar en la visión y la concepción que los artífices románicos tenían de tal insigne monumento de la Antigüedad tardía, completamente empapado de rasgos clásicos, para pasar, finalmente, a abordar la influencia que sobre la escultura peninsular de los siglos XI y XII tendrían otros monumentos funerarios de diversa índole.

Creemos que detenerse en alguno de estos aspectos, podría ser un prólogo obligado antes de pasar a analizar la influencia que determinadas imágenes esculpidas sobre los monumentos romanos ejercieron sobre la escultura románica. La iconografía habitual entre la decoración de estos sepulcros fue bien conocida, admirada, copiada y difundida durante los siglos medievales, especialmente durante la etapa románica, por lo que creemos que se trata de un tema importante.

Las noticias y la imagen que actualmente tenemos del Santo Sepulcro están claramente distorsionadas, sobre todo, por tratarse de un edificio muy reformado desde el punto de vista estructural, fruto de su problemática historia y que ha imposibilitado cualquier análisis seguro de la construcción. Sin embargo, en relación con ello, lejos de que este aspecto sea fundamental para nuestro objetivo, antes que la historia arquitectónica del monumento, nos interesa de manera más concreta la imagen que durante el románico se tuvo de este templo.

Una de los testimonios escritos más significativos con los que se puede iniciar esta serie de reflexiones, nos lo ofrece la carta de San Jerónimo escrita al presbítero Paulino $^{1280}$. En ella se habla sobre el solar en el que Constantino mandó construir un

\footnotetext{
${ }^{1280}$ Melitón de Sardes, Homilía sobre la Pascua, (J. Ibáñez Ibáñez y F. Mendoza Ruiz ed.), Pamplona, 1975, en concreto, pp. 186-220. Las noticias relacionadas con la existencia de obras de arte paganas de época romana en el recinto donde más tarde se levantaría el complejo del Santo Sepulcro, así como en toda la ciudad de Jerusalén, son abundantes.

Por otra parte, dentro de la narración hecha por Raúl de Caen en la llamada Gesta Tancredo in Expeditione Hierolymitana, el autor describe, por ejemplo, la expoliación de varias imágenes, posiblemente de Marte y Apolo por parte de Tancredo, que como arquetipo de cristiano fiel en lucha contra el paganismo, tiró y decapitó las esculturas paganas de materiales preciosos levantadas en la zona.
} 
monumento que exaltase el lugar donde había sido enterrado Cristo, especificando que, desde la época de Adriano hasta la erección del templo constantiniano, el lugar donde supuestamente se hallaba dicha la tumba había estado ocupado por una estatua de Júpiter $^{1281}$.

En otro orden de cosas, una de las noticias más conocidas al respecto, es la dada por Eusebio de Cesarea y en la que se confirma la obsesión de Constantino por derribar y arrojar fuera del territorio sagrado cualquier tipo de material pagano "contaminado por los sacrificios de los demonios" $" 1282$. Nos encontramos, aproximadamente, en el año 325, cuando, tras el Concilio de Nicea, se decidió levantar este gran monumento funerario que configuraría el complejo de la Anástasis ${ }^{1283}$.

Dejando a un lado estos datos, alrededor del supuesto lecho mortuorio de Cristo se levantaron tres grandes estructuras, siguiendo el prototipo de arquitectura pública antes señalado por S. Kostof: un martyrium, un gran atrio que englobaba la colina del Gólgota y, finalmente, la llamada rotonda de la Anástasis, que a modo de gran arqueta pétrea cubría la tumba de Jesús ${ }^{1284}$. El edificio fue consagrado el 13 de septiembre del año 335 , siendo descrita tal ceremonia por las fuentes con bastante exactitud ${ }^{1285}$.

Sobre su aspecto físico, son muchos los testimonios que nos han llegado. Baste con mencionar el texto de Egeria, donde se dice:

"Allí no ves más que oro, piedras preciosas y seda; porque si miras los tapices, son de seda bordada de oro; si miras las cortinas, son también de seda bordada de oro. Todo el servicio de culto divino que se ve aquel día es de oro con

Véase el texto completo en: RADULFUS CADOMENSIS, "Gesta Tancredo in Expeditione Hierosolymitana", Itinera ..., pp. 182-233, en concreto, p. 187.

${ }_{1281}$ J. IBAÑEZ IBAÑEZ y F. MENDOZA RUIZ, Op. cit., pp. 187-219.

${ }^{1282}$ E. DE CESAREA, Historia Eclesiástica..., vol. II, pp. 640-643 e ID., Vida de Constantino..., Libro III, 27, p. 291. Véase la trascripción en el texto 1 del apéndice de textos de nuestro estudio.

${ }^{1283}$ Para un excelente estado de la cuestión en relación con el tema del Santo Sepulcro, pero, sobre todo, a través de la imagen microarquitectónica de tal edificio, consúltese: F. GALTIER MARTÍ, La iconografía arquitectónica..., en concreto, pp. 218-250. En nuestro estudio seguiremos de cerca las noticias y reflexiones hechas por el autor.

${ }^{1284}$ Ibidem, p. 220, nota 7. El citado investigador realiza un estado de la cuestión sobre las fuentes más importantes para el estudio del edificio desde un punto de vista constructivo. Remitimos a estas páginas, pues consideramos que detenernos en el estudio de dichas fuentes desvaría la línea central del tema, centrado tan sólo en la imagen del edificio, no en él, desde un punto de vista material.

${ }^{1285}$ El edificio posteriormente sufrió muchos cambios. Desde el ataque de los persas en el año 614, la ocupación musulmana por los árabes en el 638, así como otra serie de acontecimientos, llevarán a una parcial y progresiva transformación del templo constantiniano, hasta su reconstrucción tras el año 1042. Nos interesan, por lo tanto, sólo las descripciones e imágenes elaboradas antes de la restauración románica del templo, por ser éstas las que ofrecen un reflejo del aspecto que tenía el edificio durante el siglo IV, inmerso plenamente en los lenguajes clásicos sobre los que se asentaría la tradición iconográfica medieval. Sobre tales cuestiones, vid.: Ibidem, en especial, p. 219. 
piedras preciosas incrustadas. Y el número o valor de los cirios, candelabros o lámparas y de toda clase de objetos de culto (...) Y ¿qué diré de la ornamentación de la fábrica misma, que Constantino, bajo la vigilancia de su madre, en cuanto se lo permitieron las riquezas de su reino, decoró con oro, mosaicos y mármoles preciosos, tanto la iglesia mayor como la Anástasis y la Cruz y los demás lugares santos de Jerusalén $?^{1286}$ (texto 13).

Eusebio de Cesarea también dedica unas palabras al recinto, quizás de una manera más exacta, señalando la presencia las puertas y un ábside rodeado por doce columnas con capiteles de plata ${ }^{1287}$ (texto 14).

A pesar de tener un carácter ciertamente tardío, pues se ha venido datando entre los años 1095-1127, es decir cuando el sepulcro constantiniano ya estaba muy remozado, la descripción realizada por Fulcherio de Chartres no deja dudas sobre el aspecto que tenía el conjunto hierosolimitano aún durante los siglos más avanzados de la Edad Media ${ }^{1288}$.

A este respecto nos dice el autor:

"La città di Gerusalemme si trova posta in luogo montagnoso (...). Verso ovest ha la Torre di David, che supplisce il muro della città in ambedue i lati; vi sta il Monte Sion a sud (...). Nella medesima città si trova il Tempio del Signore, costruito in forma rotonda, nel luego dove Salomone edificò prima un altro Tempio meraviglioso: sebbene il presente non sia per nulla da paragonarsi al primo, pure l'attuale è statu fatto con arte stupenda ed è dil bellísimo aspecto. La chiesa del Sepulcro del Signore è parimenti di forma rotonda, ma non fu completamente coperta, ma è sempre aperta, perchè dalla perizia d'un sapiente architetto fu fatto expresamente un foro, dalla cui alta apertura scende la luce. Per non ingannare chi legge queste cose, o in qualche modo le escolta, non sono capace, non so e nemmeno so dire tutto quello che è contenuto là, dentro (il Tempio); alcune cose sono certamente presenti, altre invence sono già passate. Nel centro del Tempio, quando

\footnotetext{
${ }^{1286}$ Itinerario de la Virgen Egeria..., p. 269.

${ }^{1287}$ E. DE CESAREA, Vida de Constantino..., Libro III, 38-39, pp. 297-298.

${ }^{1288}$ La figura de Fulcherio de Chartres se liga desde el año 1058 a la iglesia de Notre-Dame de Chartres. En el año 1097 embarca en Brindisi hacia Tierra Santa acompañando a su señor, Roberto, duque de Normandia y Stephan, conde de Blois y de Chartres. Ya en el 1099 se le documenta en Jerusalén. Su obra más importante es la llamada Historia de Jerusalén que consta de tres partes escritas entre los años 1095 y 1127. Cf.: F. CARTONENSIS, "Historia Hierosolymitana Gesta Francorum Iherysalem peregrinatium", Itinera Hierosolvmitana Crucensignatorum (saec. XII-XIII) (S. de Sandoli ed.), vol. I, Jerusalem, 1978, pp. 107-131.
} 
entrammo la prima volta, e dopo, quasi per quindici anii, notammo l'esistenza di una rocía naturalle nella quale s'immaginava che vi fosse l'arca dell'alleanza del Signore (...) In seguito, siccome quella rocía deturpava il Tempio del Signore, fu coperta con lastre di marmo, e là actualmente è statu posto un altare, e il clero vi ha adattato il coro, 1289 .

Dichos testimonios son fundamentales para comprender la historia del espacio sobre el que se erigió la tumba de Cristo, es decir aquel que se denominará como la Anátasis. Se trataba de una gigantesca rotonda, cortada por uno de los pórticos del narthex que la precedía y mediante los cuales se podía acceder al recinto a través de dos entradas. La enorme cúpula se elevaba sobre tres grandes galerías superpuestas ${ }^{1290}$. Las dos galerías inferiores eran de arcos apoyados sobre pilares y columnas, mientras que la tercera superior se abría mediante vanos de medio punto que, a su vez, ofrecían la posibilidad de generar un tambor lumínico hacia el interior de la construcción (fig. 208).

Sabemos por diversos testimonios, de entre los cuales ya hemos señalado el de Eusebio de Cesarea, que el recinto poseía doce columnas, entendidas ya como una alusión simbólica a los doce apóstoles, alternadas con seis pilares. Sobre éstas se colocarían los grandes capiteles corintios de plata, según citan los testimonios que se detienen en tal aspecto. Dicha estructura formaba una exedra desde el perímetro exterior y una rotonda casi completa de pilares y columnas en el interior. Esta fórmula generaba un espacio intermedio practicable y abierto, posiblemente transitable, que protegía el edículo central, que a su vez salvaguardaba la roca sagrada. Era la cueva en la que supuestamente había sido enterrado Cristo y que a su vez fue repicada por los arquitectos del siglo IV hasta aislarla y dotarla de una forma más o menos regular ${ }^{1291}$ (fig. 209).

${ }^{1289}$ Ibidem, pp. 111-113. Además, es muy significativo como el canónigo de Chartres menciona en su
texto las obras realizadas en el recinto por Adriano y a las que ya hemos aludido. El autor medieval se
refiere al emperador como Elio Adriano y dice sobre dichas labores: "L'imperatore Elio Adriano ornò
stupendamente questa città (Jerusalén) e abbellì convenientemente le strade e le piazze di pavimento.
Invence del nome di Gerusalemme, la chiamò Élia; per questi e altri fatti la città è gloriosa e venerabile".
${ }^{1290}$ La segunda galería estaba ocupada por la tribuna o Kathcoumena. Cf.: A. GRABAR, Martyrium...,
vol. I, en concreto, pp. 257-260. Es muy interesante como, basándose en algunos ejemplos plásticos que
más tarde analizaremos, se ha afirmado que la cúpula del edificio debió construirse de una manera un
tanto chaparra y que fue dorada al exterior, tal y como se representa en el mosaico de Madaba. Sobre ello,
véase: F. GALTIER MARTÍ, La iconografía arquitectónica..., en especial, p. 245 . También consúltese:
FULCHERIUS CARTONENSIS, Op. cit., en concreto, p. 111. Ésta última fuente señala que el templo no
fue completamente cubierto, dejándose una parte abierta para posibilitar la entrada de luz.
${ }^{1291}$ Todos los autores, tanto antiguos como medievales, insisten en introducir en sus escritos, el tema de
roca excavada. Por aludir a un ejemplo medieval, tomamos un texto anónimo, datado entre los años $1095-$
1108 y denominado Gesta Francorum Expugnantium Iherusalem. Según S. de Sandoli, se trata de un 
Se trataba de monumentalizar la tumba excavada a modo de hipogeo para poder protegerla mediante el famoso tegurium rotundum, una especie de edículo con dos partes bien diferenciadas ${ }^{1292}$. La primera, una estructura de ingreso cúbica, que antecedía a otra estructura mayor, con idéntica forma, pero monumentalizada por una cupulilla sobreelevada mediante once columnas torsas que se adosaban perimetralmente a tal elemento (fig. 210). A todo ello debemos sumar la existencia en el recinto de las lámparas, canceles, textiles y objetos suntuarios cuya existencia nos han hecho llegar los diferentes testimonios.

Desde los testigos más tempranos, datados entre los siglos IV y VI, a los más tardíos de época románica, todos coinciden en señalar la enorme riqueza del conjunto. Sobre todo, en lo relativo a columnas, capiteles, cortinajes, cirios y lámparas, además de canceles. En este sentido, aparte de las constantes referencias de Egeria y Eusebio de Cesarea a los canceles del edificio y al mobiliario litúrgico, también los hombres de la Plena Edad Media sintieron idéntica admiración por tales objetos.

Un ejemplo bien significativo al respecto lo ofrecen las noticias transmitidas por Alberto de Aquisgrán ${ }^{1293}$. El erudito nos dice sobre la rotonda de la Anástasis y el tegurium rotundum:

"Questo Tempio, detto del Signore, non è quell'antica e meravigliosa costruzione del re Salomone, perchè tutta la città di Gerusalemme fu distrutta dal re Nabucodonosor, e poi, Mopti anni prima dell'Incarnzione del Signore, il Tempio di Salomone fu distrutto dalle fundamenta e spogliato degli oranamenti e dei vasi sacri dal re Antioco. Di nuevo dopo l'Incarnazione, preavisándolo Gesù Signore,

texto donde se describe la ciudad de Jerusalén, así como la famosa leyenda del brote espontáneo de fuego sobre las candelas del Santo Sepulcro. La parte que más nos interesa destacar es aquella en la que el autor dice: "Sebenne non sia la prima costruzione di tutto il mondo nella seconda riedificazione fatta da Esdra, puer ha quattro ingressi, como li ebbe il primo Tempio. Si dice che in quel luogo si sia formato l'angelo che faceta strage del popolo, (per la qual causa) David pregava. Là ancora in mezzo al Tempio si mostra rozza ed elevata quella rocía sulla quale si fermò l'angelo". Cf.: ANONYMUS, "Gesta Francorum Expugnantium Iherusalem", Itinera ..., pp. 133-167, en concreto, p. 151. Simplemente tratamos de señalar que, en gran parte de estas noticias documentales, la roca se convertirá en el elemento más importante y digno de ser señalado.

${ }^{1292}$ F. GALTIER MARTÍ, La iconografía arquitectónica..., en concreto, p. 246.

${ }^{1293}$ Se trata de un personaje ligado al centro religioso de Aix-la-Chapelle. Son pocos los datos que nos han llegado sobre su biografía, pues incluso, se duda de los años de nacimiento y muerte. Fue canónigo de la iglesia de Notre-Dame de Aix y su obra más conocida es la Historia de la Expedición a Jerusalén, datada entre los años 1094 y 1120 . Actualmente se trata de un testimonio dudoso, pues el mismo autor señala en su obra que no fue testigo directo de todo lo narrado en su escrito, sin embargo, a pesar de todo, contaba con fuentes de primera mano. Para nuestro objetivo tan sólo nos interesa un dato de cierta irrelevancia, relacionado con algunos objetos litúrgicos que describe. Cf.: ALBERTUS AQUENSIS, "Historia Hierosolymitana", Itinera..., pp. 270-307, en concreto, p. 270-271. 
Gerusalemme fu talmente distrutta dalle fundamenta coi suoi abitanti dai generali romani Tito e Vespasiano, che secondo la parola del Signore non rimase che pietra sopra pietra (...) e ciò nello stesso luogo dove il pacifico Salomone mise l'antico tabernacolo di Dio (in un edificio coperto) di legno di cedro e di marmo bianco e in esso il Santo dei Santi. Nel centro di questo nuevo tabernacolo s'eleva una prominenza rocciosa di origine naturale, avente in larghezza una terza parte di higüero e due cubiti in altezza. In un lato vi sono degli scalini che conducono in basso a un luogo incanato; in altro lato, si dice da persone degne di FEDE che l'esaminarono, la rocía ha un'apertura di pietra, ma resta sempre chiusa. Ivi se crede da alcuni che ancora vengono conservati alcuni oggeti del Santo de Santi. (Alcuni) affermano che nel centro della volta del tempio attuale, che ora è ornato all'intorno sulla superficie dei muri con meravigliosi disegni, vi sia appesa una catena rotonda da cui suole sempre pendere un vaso artistico di splendido oro, del peso de circa duecento marche. Alcuni dicono che è un'urna d'oro, altri dicono che contiene il sangue del Signore, e altri affermano che ̀̀ nascosta la manna; e così quante sono le credenze, tante sono le varie interpretazioni" ${ }^{1294}$.

Las noticias aportadas por Alberto de Aquisgrán, aunque ofrecen ciertas dudas, también nos permiten configurar una idea de la imagen que tenían los hombres medievales sobre el recinto, de sus leyendas y de los elementos más característicos. Si su testimonio es una simple traslación de diferentes fuentes y un relato de una persona que jamás había visitado el templo, refleja bien a las claras que tipo de fuentes se estaban manejando y, sobre todo, la idea imperante en el imaginario colectivo de tal recinto.

A grandes rasgos, esta era la imagen arquitectónica del recinto bajo el que se hallaba excavada la tumba de Cristo. Lejos de ofrecer una visión al descubierto de la roca, el fiel percibía el espacio engrandecido a través de la cúpula, dorada al exterior, si damos por válida la representación del mosaico de Madaba o el de la iglesia de San Estefano en Umm al-Rasas, también en Jordania ${ }^{1295}$.

\footnotetext{
${ }^{1294}$ Ibidem, pp. 275-277.

${ }^{1295}$ Ya hemos hecho referencia anteriormente a este mosaico y recogido los trabajos consultados para la realización de este estudio. En dicha imagen la cúpula aparece dorada, marcando, como es natural, el eje de toda la composición del mosaico. El ejemplo musivo de la iglesia de San Estefano, datado en torno al siglo VIII, retoma nuevamente el tema de la visión aérea de Jerusalén "a vista de pájaro". Los modelos seguidos, se relacionan, según M. Piccirillo, con la escuela musiva de Madaba. Aquí se representó el Santo Sepulcro en el centro de la urbe, con una cúpula en forma cónica, cubierta de tejas, en este caso no doradas, que reafirma y resalta la centralidad física del recinto. Este testimonio quizás hable de un cierto carácter imaginativo a la hora de representar la cúpula del templo, pues dos mosaicos tan cercanos, no
} 
El recinto más importante de la cristiandad que acabamos de describir, construido por el emperador Constantino entre los años 325 y 335, aproximadamente, habría de proyectar una imagen absolutamente impactante para las artes pláticas del mundo medieval. Pero, además de ello, y en lo referente a nuestro trabajo, se trataba de una imagen de largo prestigio ya durante toda la Antigüedad que retomaba soluciones totalmente inmersas en el arte romano de la época Republicana e Imperial, que los artífices al servicio del emperador Constantino tan sólo dotaron de nuevos contenidos y simbolismos, ahora cristianos.

En relación con ello creemos necesario aludir a un ejemplo bien conocido. A la hora de idear el recorrido que debían realizar los fieles cristianos que visitaban el Santo Sepulcro, los arquitectos constantinianos llevaron a cabo la creación de una estructura en forma de exedra en el perímetro exterior y de rotonda casi completa en el interior. El espacio intermedio restante entre ambas fue ocupado por un pasillo o deambulatorio que permitía girar en torno al edículo que custodiaba la tumba de Cristo ${ }^{1296}$. Dicha solución no era nueva. Sus fuentes estaban arraigadas en la arquitectura funeraria más importante de época clásica, sobre todo, en relación con el culto a los héroes ${ }^{1297}$.

En un interesante artículo, E. La Rocca señala la importancia que la edilicia pagana tuvo en la formación de este tipo de estructuras que casi todos los autores vienen señalando como uno de los grandes hallazgos de la arquitectura cristiana. El culto a los restos mortales de los grandes héroes del mundo antiguo se realizaba a través de esta forma de rito giratorio. Para llevarlo a cabo, en ocasiones se disponían auténticas rotondas que permitiesen tal acción. Creemos que la continuidad de esta tradición dentro de la arquitectura constantiniana es evidente y es por ello que parece posible afirmar que la estructura en forma de deambulatorio que presenta el Santo Sepulcro rememore soluciones bien atestiguadas en la arquitectura antigua dispuesta para exaltar las figuras de los héroes paganos. En este caso, el mecanismo se ponía al servicio de la nueva religión y su nuevo "héroe", es decir Cristo ${ }^{1298}$.

ofrecen el mismo tipo de soluciones. Sobre la obra, véase: M. PICCIRILLO, "La città santa di Gerusalemme", Romei..., ficha 17, p. 292.

${ }^{1296}$ Veremos, más adelante, como esta solución de aparente exclusividad, fue implantada alrededor de la tumba del apóstol Pedro en Roma, pero sólo en época del papa Gregorio Magno. Abordaremos este aspecto en páginas sucesivas.

${ }^{1297}$ Como vemos, nuevamente las fuentes para comprender el edificio de Constantino están perfectamente documentadas en la Antigüedad más clásica.

1298 E. LA ROCCA, "Le basiliche cristiane "a deambulatorio" e la sopravvivenza del culto eroico", Ecclesiae Urbis. Atti del Congresso Internazionale di Studi sulle chiese di Roma (IV-X secolo) (a cura di Federico Guidobaldi e Alexandra Guiglia Guidobaldi), vol. II, Città del Vaticano, 2002, pp. 1109-1140. Tales conductas están bien documentadas, pues tal y como se sabe, las figuras de santos y mártires fueron 
Inmersos dentro de esta tradición, debe recordarse, por ejemplo, el carácter centralizado, derivado de la tradición helenística, que van a poseer los mausoleos más significativos del mundo antiguo. Desde el arquetípico mausoleo de Halicarnaso, hasta los posteriores de Augusto, construido sobre el 29 a. de. C, o el de Adriano. La fórmula del enterramiento ad tumuli, evidentemente realizado con soluciones muy diferentes a las tomadas en el Santo Sepulcro, hablan cuanto menos de una continuidad en el uso de tales estructuras centralizadas y la posibilidad de llevar a cabo un culto giratorio alrededor de ellas $^{1299}$.

exaltadas por el cristianismo siguiendo mecanismos existentes ya en el mundo pagano. El héroe antiguo fue cristianizado para proyectar una misma imagen de los santos cristianos, pero con unos fines bien distintos. Sobre el tema, véase : F. CABROL y H. LECLERCQ, voz "Actes des martyrs", Dictionnaire d'Archéologie Chrétienne et de Liturgie, vol. I, Paris, 1907, cols. 373-446. También véanse las reflexiones teóricas sobre las narraciones hagiográficas, en especial las passiones, que se realizan en: P. CASTILLO MALDONADO, Los mártires hispanorromanos y su culto en la Hispania de la Antigüedad Tardía, Granada, 1999, pp. 21-70; N. ZEEGERS VAN DER VORST, Les citations des poètes chez les apologistes chrétiens du II siècle, Lovaina, 1972 y I. SEVCENKO, "A shadow Outline of Virtue. The Classical Heritage of Greek Christian Literature (Second to Seventh Century), Age of Spirituality: A Symposium (K. Weitzmann ed.), New York, 1980, pp. 15-33. Consúltese también la obra colectiva: $D u$ héros païen au saint chrétien, Paris, 1997. Para el caso hispano, se deben destacar, igualmente, otros estudios. Cf.: J. SÁNCHEZ LASSO DE LA VEGA, "Héroe griego y santo cristiano", Ideales de la formación griega, Madrid, 1966, pp. 181-272 y A. BRAVO GARCÍA, "El héroe bizantino", Los héroes medievales..., pp. 101-142. También véase: J. PÉPIN, voz "Survivances mythiques dans le christianisme ancien", Dictionnaire des mythologies et des religions des sociétés traditionnelles et du monde antique $K$ Z, (Yves Bonnefoy coord.), 2 vols., Paris, 1981, vol. I, pp. 469-475, especialmente, p. 470 у A. PEDREGAL, "El culto a los mártires: una herencia de la advocación mágica de los héroes", Héroes, semidioses y daimines, Madrid, 1992, pp. 345-359. Sobre el reflejo de este fenómeno en las artes plásticas, vid.: E. CONDE GUERRI, "La iconografía de los milagros...", pp. 273-281. El autor se centra en el análisis de la figura de Cristo y su condición de "nuevo héroe" a través del proceso de reinterpretatio christiana que, tomando como referencia a los héroes del mundo antiguo, creará una nueva figura perfectamente acorde con los ideales cristianos. En el mismo sentido, vid.: J. L. SENRA GABRIEL Y GALÁN, "¿Hércules versus Cristo? Una posible simbiosis iconográfica en el románico hispano", Quintana, 1, 2002, pp. 275-283 y E. FERNÁNDEZ GONZÁLEZ, "Héroes y arquetipos...", pp. $13-52$.

${ }^{1299}$ El prototipo tiene su origen dentro de la arquitectura funeraria helenística del siglo I a. de C., donde una cinta muraria de ladrillo o sillería, albergaba en su interior la cámara mortuoria, que cubierta íntegramente por tierra, formaba al exterior la imagen de un túmulo. Dicho espacio era además cubierto con todo tipo de vegetación, especialmente árboles, que formarían al crecer el llamado bosque sagrado, ya mencionado de una manera simbólica por Platón en sus textos. Los ejemplos de la llamada Torre de Micara, cerca de Frascati, o la de Casal Rotondo, en Via Appia, datada entre los años 40-25 de nuestra era, hablan de la perdurabilidad del prototipo. En este tipo de estructuras los niveles o plataformas, el uso de balaustradas pétreas, así como la creación de una colina artificial superior que albergaba diferentes esculturas o efigies del emperador, suponen el anticipo de los modelos que servirán para representar la tumba de Cristo, donde, tal y como veremos, también aparecerán decorándola sobre plataformas y muros diversas imágenes y esculturas, sin duda, ligados a esta tradición iconográfica pagana. Sobre los enterramientos en túmulo, véase: P. GROS, L'architecture romaine..., vol. 2, en especial, pp. 422-435. No podemos recoger todos los ejemplos y la bibliografía dedicada a estudiar las copias, imitaciones y evocaciones del Santo Sepulcro en la Edad Media, pues trataremos el tema más adelante. Sirva a modo de muestra la menos conocida Charola Templaria de Tomar, en Portugal. Se trata de una fundación realizada por Gualdim Paris en torno al año 1160. Posee una planta centralizada inspirada en el Santo Sepulcro y los martiria paleocristianos, a pesar de que, posiblemente, se trata de un edificio de cronología muy avanzada en los siglos medievales. Cf.: P. PEREIRA, "O modo gótico (séculos XIII-XV). A Arquitectura (1250-1450), História da Arte..., vol. I, 1995, pp. 332-433. 
Con todo, es posible que, tanto desde un punto de vista ideológico, como desde el meramente artístico, la figura de Cristo y su monumento funerario, así como la de los santos mártires y sus martyria, aparezcan ligadas dentro de los espacios constantinianos a los héroes clásicos. Ello encaja bien dentro de la definición dada por A. Bravo García para la figura del héroe, sobre el que escribe:

“(...) un héroe es un varón ilustre y famoso, el que lleva a cabo una acción heroica, el personaje principal de todo poema épico y, finalmente, el protagonista de una obra literaria. Entendemos pues por héroe lo que, para los filólogos clásicos, vienen a ser los personajes de la épica oral más extendida en la Antigüedad griega, los personajes de la tragedia clásica, las grandes figuras de la historia que han pasado a la leyenda -un Alejandro Magno por ejemplo- y algunos otros personajes de ciertos géneros o subgéneros literarios, la prosa filosófica entre ellos" ${ }^{\prime 300}$.

La afirmación del autor es conveniente en relación con este aspecto, pues alude al origen que poseen los héroes cristianos medievales, es decir los mártires, relacionados de manera indisoluble con el arquetipo de los héroes antiguos y el culto de masas que, en ocasiones, estos personajes recibían. Ya hemos señalado en este sentido las ideas al respecto de B. Brenk y S. Kostof sobre los primeros ensayos de esta arquitectura denominada "de peregrinación" dentro de las nuevas construcciones levantadas por el emperador.

Un texto tardío, datado entre los años 1100 y 1115, escrito por Cafaro de Caschifelone, ofrece una visión bien significativa de cómo debía ser la afluencia de fieles en tales espacios ${ }^{1301}$. El autor describe, del siguiente modo, la peregrinación a Jerusalén de los duques Goffredo y de Roberto de Frisone:

"E mentre stavano entrando per la porta (della chiesa) del Sepolcro del Signore, i portinai (saraceni) subito impedirono l'ingresso fino a quanto ciascun (pellegrino) avesse dato, como'era d'uso, un solo bisanzio per l'ingresso. I Cristiani,

\footnotetext{
${ }^{1300}$ A. BRAVO GARCÍA, Op. cit., pp. 101-142.

${ }^{1301}$ Cafaro de Caschifelone nació en el año 1080 ó 1081 según nos indica S. de Sandoli. Su nombre le viene dado debido a la localidad de Caschifelone, hoy Castrofino de Polcevera, cerca de Génova. En el 1100 embarca rumbo a la Cruzada en Palestina. Sus textos fueron pensados inicialmente para formar parte de unos Anales Genoveses que escribiría desde el 1152 hasta el año 1163. Sin embargo, el texto que más nos interesa es el llamado De Liberatione Civitatum Orientis, escrito en el 1115 aproximadamente. Véase sobre esta cuestión: CAFARUS DE CASCHIFELONE, "De Liberatione Civitatum Orientis", Itinera..., pp. 330-345.
} 
che giungevano colà per pregrare, conoscendo la richiesta dei Saraceni, cominciavano a dare ciò che chiedevano" ${ }^{\prime 302}$.

Se trata de un dato aparentemente insustancial, quizás alterado en alguno de sus contenidos más básicos, sin embargo, no deja de ser llamativo el hecho de que para acceder al recinto, la manera más organizada de hacerlo sería haciendo fila, e incluso pagando, tal y como nos describe el autor. Es cierto que se trata de un texto tardío y modificado según los intereses de un cronista de las cruzadas, sin embargo, que tales monumentos recibían ya por estos momentos grandes masas de visitantes parece factible. También resulta lógico entonces, que los modelos que se tomaron para solventar tal afluencia de fieles fueran los ya conocidos dentro de la arquitectura romana, donde el culto a los héroes estaba lo suficientemente extendido y con estructuras constructivas lo suficientemente definidas, como para prodigar un modelo que los artífices cristianos supieron aprovechar perfectamente.

${ }^{1302}$ Ibidem, p. 317. 


\section{4. EL EDÍCULO SOBRE LA TUMBA DE CRISTO Y SUS FILIACIONES “ANTIQUIZANTES".}

Tras haber realizado algunas reflexiones sobre la problemática relativa a la estructura del recinto que albergaba la tumba de Cristo es necesario detenerse en la misma construcción que configuraba el tegurium rotundum y que incluía en su interior la roca dentro de la cual había sido sepultado Cristo. Con todo, antes de abordar la fortuna de la imagen del tegurium dentro del arte medieval, es preciso establecer los precedentes para este tipo de construcciones.

El uso de pabellones o templetes funerarios durante el mundo antiguo no fue, en absoluto, desconocido. Se trata de una fórmula configurada a través de un elemento cúbico o varios, en forma de antesala que, a su vez, se coronaban mediante edículos sobreelevados por columnas rematabas en cupulillas decoradas con gallones o escamas, entre otros elementos (fig. 210).

En este sentido, si observamos la reconstrucción propuesta por R. Krautheimer del tegurium rotundum de la Anátasis, se advierte que, el autor, a través de diferentes fuentes textuales e iconográficas, ha diseñado en la parte frontal del edículo una estructura compuesta por un cubo, al que se accede mediante una puerta. Ésta permite el acceso a una sala que antecede a otra, nuevamente de perímetro cuadrado, de mayor tamaño y sobre la que se colocó una cupulilla sobreelevada mediante columnas. Tanto los arcos que sustentan dicha cúpula, como los que se adosan al perímetro de la segunda sala, según su hipotética reconstrucción, son de medio punto ${ }^{1303}$.

El edículo funerario que protegía la tumba de Cristo, era una estructura de claras resonancias clásicas y que había servido en multitud de ocasiones para monumentalizar el lugar donde se hallaban los restos funerarios de una persona. En este sentido, si observamos, por ejemplo, el famoso relieve de la tumba de los Haterii (ca. 65-100), en la Labicana, no lejos de Roma, se percibe la representación de uno de estos templetes con funciones funerarias ${ }^{1304}$ (fig. 211).

\footnotetext{
${ }^{1303}$ R. KRAUTHEIMER, “The Constantinian Basilica”, Dumbarton Oaks Papers, 21, 1967, pp. 117-131; ID., "Constantine's Church Foundations", Akten des VII. Internationalen Kongresses für christliche Archäologie, Vatican City-Berlin, 1969, pp. 237-255 y G. T. ARMSTRONG, "Constantine's Churches: Symbol and Structure", The Journal of the Society of Architectural Historians, 33, 1, 1974, pp. 5-16.

${ }^{1304}$ Los relieves esculpidos pertenecientes a la tumba de Q. Haterius Tychichus, representan uno de los conjuntos de piezas en relación con su iconografía, más interesantes de la época romana. De temática íntegramente funeraria, entre las diversas placas que forman el conjunto, la más importante es aquella que muestra la imagen de un gran templo tetrástilo con escaleras, elevado sobre un alto podio. El templo representa la cámara funeraria, a través de una estructura clásica con frontón, sobre el que se ha colocado
} 
Posee una forma cúbica en la que se marcaron los sillares y sobre la que, a modo de pebetero, se colocó una especie de baldaquino con cubierta escamada que se eleva sobre columnillas. Evidentemente las diferencias en cuanto a su uso, su función y su representación con respecto al edículo de la Anástasis, son muy claras. Sin embargo, desde el punto de vista formal, la imagen guarda cierta conexión y demuestra la polivalencia, en época clásica, de este tipo de estructuras que podían cumplir las más variadas funciones.

Lo que si podemos afirmar es que la composición formada por un cubo de fábrica, que a modo de base servía para elevar otra estructura superior columnada y rematada por una cúpula, poseyó larga tradición en la arquitectura romana. Por ejemplo, y por aludir sólo a los casos más conocidos, recuérdese el llamado Ptolemaion de Lymira (siglo IV a. de C.), que nuevamente presenta, salvando las distancias, una estructura semejante ${ }^{1305}$ (fig. 212). El prototipo utilizado es del heroom, formado por un pabellón en forma de tholos y un basamento, que en el caso del Ptolemaion es monóptero.

El prototipo conoció gran éxito durante la Antigüedad romana, lo atestiguan la llamada tumba de Porta Nocera de Pompeya del siglo I a. de C. y la tumba de A.

la imagen de la difunta sobreelevada por cuatro capiteles corintios de gran formato. Sobre ellos se colocaron cuatro grandes águilas, en alusión directa a la apotheosis del fallecido. El resto del edificio, de una riqueza decorativa exuberante, presenta la imagen de los putti vendimiadores en los fustes de las columnas, mientras que la parte lateral se articula con pilastras decoradas a candelieri. Sobre el mismo tejado del edificio se colocó una recreación del interior de la cámara funeraria del templo, con la muerta colocada sobre el kliné, formando una escena bien conocida en el mundo antiguo. El resto de la iconografía se completa con una escena de construcción, donde cinco hombres trabajan con diversos utensilios. La escena ha recibido diferentes y muy complejas interpretaciones.

Sobre el tema en cuestión, véase: G. AMBROSETTI, Voz "Haterii, Monumento degli", Enciclopedia dell'arte antica classica e orientale, vol. III, Roma, 1960, pp. 1112-1114 y P. GROS, L'architecture romaine..., vol. 2, en concreto, pp. 446-448. Éste último autor se decanta por la posibilidad de que la escena de construcción no sea una traslación del texto vitruviano, sino una manera de aludir, simbólicamente, a la virtus del patrocinador, con un poder económico capaz de llevar a cabo grandes obras edilicias públicas, alegoría evidente de su prestigio y su riqueza.

Sobre la interpretación de la jaula colocada sobre la grúa y los obreros que parecen abrirla, P. Gros ve en ella la escena de la liberación del águila, fundamental dentro de la ceremonia de apotheosis.

En relación con dicho ceremonial, consúltese: J. ARCE, Funus imperatorem..., pp. 131-132. El investigador analiza dicho ceremonial en relación con diversos textos. Sirva de ejemplo el escrito por Dion Casio, en torno al siglo III, quién alude a la liberación del águila, tras la crematio de los restos mortales de Augusto, muerto en el 14 d. C y que se llevó a cabo en el lugar habitual, el Campo de Marte. Se trata de uno de los primeros ejemplos en los que se menciona explícitamente la aparición del águila, pasando a ser casi un tópico dentro de las descripciones de los funerales de otros emperadores como el de Pertinax y Septimio Severo, entre otros.

${ }^{1305} \mathrm{Se}$ trata de una estructura arquetípica dentro de la arquitectura funeraria en Asia Menor. Se ha datado en el siglo IV ó III a. de C. y presenta una tipología similar a la del monumento llamado de las Nereidas en Xantos, que nuevamente utiliza la conocida fórmula de basamento de sillares en forma de base para elevar sobre él un templete superior. Fue construido en honor de Ptolomeo II. Sobre dicha obra, véase: P. GROS, L'architecture romaine ..., vol. 2, en concreto, pp. 400-401. 
Murcius Obulaccus en Sarsina (Italia) de la misma cronología ${ }^{1306}$. En este sentido, los ejemplos señalados nos permiten afirmar que el tegurium rotundum de la Anástasis constantiniana, tan sólo retomaba la tipología de monumento funerario de tipo helenístico, formado por un edículo sobre podium, pudiéndose además completar con otra serie de elementos, como el llamado naïskos, nichos próstilos, columnatas, etcétera $^{1307}$.

Resulta extremadamente complejo poder atribuir una inspiración directa o cierta voluntad arqueológica a las imágenes creadas en la Edad Media del tegorium rotundum y, por extensión, de todo el conjunto del Santo Sepulcro. En uno de los trabajos más completos sobre las representaciones arquitectónicas de este tipo dentro, del ámbito anterior al año mil, realizado por F. Galtier Martí, el autor entendía que sometiendo dichas representaciones a un análisis riguroso y científico, éstas podían ser de una utilidad equiparable a los textos o a la investigación arqueológica ${ }^{1308}$.

Sin embargo, en lo referente a la imagen del Santo Sepulcro la tarea es complicada. La concepción que de este recinto se tuvo durante la época románica, se debatió entre una aparente representación inspirada en modelos reales y una distorsión fantástica de los mismos. En ocasiones, el complejo levantado por Constantino se esquematizaba y abstraía a través de la alusión simbólica a un solo elemento, como por ejemplo, una rotonda. En otras interpretaciones, el sepulcro, el tegorium rotundum, la rotonda de la Anátasis y otras estructuras se confundían y entremezclaban formando una imagen muy alejada de la realidad.

Sin embargo, si a la hora de levantar un edificio y una estructura protectora que albergara la sagrada roca, los arquitectos del siglo IV recurrieron a modelos de la Antigüedad romana, encontraremos, en ocasiones, esa misma voluntad "antiquizante" en algunas de las imágenes medievales que nos han llegado de dicho espacio.

Por ejemplo, la famosa imagen datada en torno al año 400, representada sobre el marfil de la Staatsbibliothek de Munich, presenta no menos complicaciones ${ }^{1309}$ (fig.

\footnotetext{
${ }^{1306}$ Ibidem, pp. 402-409. Algunos fragmentos de dicho monumento se custodian actualmente en Sarsina, Museo Archeologico Nazionale Sarsinate, de la localidad cercana a Rimini, en la región de EmiliaRomagna.

${ }^{1307}$ Ibidem, pp. 388-435. Véase el apartado dedicado por el autor a la llamada arquitectura funeraria del tipo "podium con edículo".

${ }^{1308}$ F. GALTIER MARTÍ, La iconografía arquitectónica..., en concreto, p. 450.

${ }^{1309}$ Se trata de una pieza donde fue representada la escena de Ascensión de Cristo a los cielos, ayudado por la mano de Dios Padre. Se ha datado a finales del siglo IV o principios del V. Abajo, junto a la bella representación del sepulcro, se colocaron las mirróforas, con el ángel presenciando la escena, junto con los guardianes somnolientos. La representación del Santo Sepulcro se lleva a cabo mediante una estructura cúbica, en la que se ha practicado una puerta entreabierta que presenta una decoración de
} 
213). A propósito de esta misma pieza, ya Galtier Martí señalaba "las dudas sobre los testimonios más inciertos de entre los que nos manejamos"1310, pues dicha representación presenta ciertas disonancias con respecto a la imagen real del edificio, que hablan del uso de otras fuentes, más allá de las reales, para la elaboración de la imagen del Santo Sepulcro.

Para C. Heitz sólo se podría explicar la imagen del edículo representado en el marfil de Munich a través de una influencia directa de la imagen real del tegurium rotundum $^{1311}$. Para otros autores, entre los que se encuentra F. Galtier Martí, la estructura aludiría no al templete interior que custodiaba la misma tumba de Cristo, es decir el tegurium, sino al mismo edificio del Santo Sepulcro, desde su vista exterior ${ }^{1312}$.

En todo caso, resulta complicado saber si el escultor del marfil quiso representar una visión del exterior de la Anástasis, materializada a través de la estructura superior que a modo de tholos evocaría la rotonda, o, por el contrario, demostrando un buen conocimiento de tal recinto, llevó a cabo una abstracción simbólica de la Anástasis. Tal hecho lo lograría a través de la alusión plástica al elemento más importante que se custodiaba en su interior, el pequeño edículo que conocemos mediante la hipotética reconstrucción de R. Krautheimer.

Creemos que se trata de una imagen arquetipo, que sin desvincularse totalmente de la realidad, toma elementos de diversas fuentes para, finalmente, reproducir una imagen, que vista por el observador medieval, no debía dejar lugar a dudas sobre su identificación. A la hora de representar un monumento funerario, los artífices del siglo $\mathrm{V}$ recurrieron al modelo más conocido, el tegurium rotundum, pero a este le añadieron otra serie de elementos habituales dentro de la arquitectura que conocían. El remate a modo de tholos que se coloca sobre el podio, se inspira directamente en el que, posiblemente, tuviera el edículo constantiniano, pero a ello se suman otras fuentes, todas ellas provenientes de la arquitectura romana, que ayudarían a una mejor comprensión del modelo.

\footnotetext{
placas, quizás insinuando que estas estaban realizadas en bronce. Sobre dicho podio se elevó una estructura a modo de templete, rematada por una cubierta cónica. Es de destacar la articulación de este elemento a través de diversos medallones o clípeos decorados con bustos que se intercalaron en las enjutas formadas por los arcos de medio punto, y que, reposando sobre unas columnillas dobles, permiten elevar dicha cubierta.

${ }^{1310}$ F. GALTIER MARTÍ, La iconografía arquitectónica..., en especial, p. 231, nota 39.

1311 C. HEITZ, "Sepulcrum Domini: Le sépulcre visité par les saintes Femmes (IX ${ }^{\mathrm{e}}-\mathrm{XI}^{\mathrm{e}}$ siècles)", Haut Moyen-Âge. Culture, Education et Société, Paris, 1981, pp. 389-400, en concreto, p. 390.

${ }^{1312}$ F. GALTIER MARTÍ, La iconografía arquitectónica..., en especial, p. 233.
} 
Por ejemplo, resulta imposible poder discernir si la galería abierta en el templete superior del marfil que venimos comentando, responde, en realidad, al tambor sobre el que se levantaba la gran cúpula del recinto y que se apoyaba, a su vez, sobre la Kathcoumena o galería con función de tribuna. Tal y como hemos señalado, este elemento aparece descrito en las fuentes abierto mediante una galería de ventanas de arco de medio punto. Si se trata de tal elemento o, por el contrario, es la imagen del pequeño edículo colocado sobre el tegurium rotundum, es una cuestión compleja de abordar.

Lo que parece evidente es que, desde el punto de vista del resultado iconográfico, las similitudes con los edículos funerarios romanos son evidentes. La complejidad del fenómeno se observa perfectamente tan sólo con contemplar el llamado mausoleo de Boemondo en Altavilla, en la ciudad italiana de Canosa ${ }^{1313}$ (fig. 214).

Tal y como observamos, el modelo seguido por este edículo funerario se encuentra dentro de la tipología del mausoleo imperial tardoantiguo ${ }^{1314}$. Parece claro que esta estructura construida en pleno periodo románico, es una clara evocación de las fórmulas funerarias romanas. $\mathrm{Su}$ parentesco, auque sólo sea desde el punto de vista formal, con la reconstrucción propuesta por Krautheimer para el tegurium constantiniano, parece más que evidente.

Tanto los artífices románicos encargados de elevar el mausoleo de Canosa, como aquellos que construyeron el tegurium de la Anátasis, manejaban las mismas fuentes. Un detalle que consideramos fundamental abre nuevas vías en el estudio de la representación de dichos monumentos funerarios. En esta dirección, L. de Lachenal ha señalado como el mausoleo románico se cerraba con dos puertas de bronce de gran formato. El primero de los batientes, de factura antigua, se acompañaba con otro, mandado fundir por el broncista Rogelio de Melfi, entre los años 1118-1120 ${ }^{1315}$. En dicha puerta se colocó una inscripción extraída de un poema realizado por el obispo

\footnotetext{
${ }^{1313}$ Este personaje murió de manera prematura en el año 1111. Para su descanso se dispuso una tumba monumental en el exterior de la catedral de Canosa, con la que se conectaba mediante un pasadizo compuesto también por una pequeña ante sala. Se han constatado dentro de este pequeño mausoleo numerosas expoliaciones de materiales romanos, tanto en columnas como capiteles. En su forma más simple se compone de una masa cúbica, que supone el cuerpo central del edificio, rematado en el centro por una cúpula. Los muros de la estructura se decoraron con mármol proconeso, dato que habla, una vez más, del interés por evocar formas clásicas. Cf.: F. TINÉ BERTOCCHI, Voz "Canosa di Puglia", Enciclopedia dell'arte antica classica e orientale Supplemento 1970, Roma, 1973, p. 179.

${ }^{1314}$ L. DE LACHENAL, Op. cit., en concreto, pp. 241-242.

${ }^{1315}$ Se trata de una localidad cercana a Canosa, en la provincia de Potenza, de la región de Basilicata.
} 
Alfano de Salerno, donde se exaltaba la figura del difunto como si de un héroe antiguo se tratase, casi a la manera de un semidiós ${ }^{1316}$.

Este dato nos parece fundamental. Se trataba de colocar dos grandes puertas fundidas en bronce a la manera de los grandes portones antiguos que desde tiempos inmemorables habían cerrado el acceso a los grandes templos romanos. En este sentido, hemos señalado que el marfil de Munich presentaba dos grandes puertas que, exprimiendo mucho la imagen, podían recordar, por su factura, la forma de dos hojas fundidas en bronce. Sin embargo, si recurrimos a otra representación del mismo ambiente constantiniano, observamos en lo relativo a las puertas una imagen crucial en este sentido. Se trata del relicario de marfil conservado en el British Museum y que representa la visita de dos Marías al sepulcro ${ }^{1317}$ (fig. 215). Los soldados durmiendo flanquean el acceso al recinto. Éste se ha representado visto de manera frontal, en "perspectiva inversa" si seguimos las palabras de F. Galtier, con dos grandes columnas sustentando dos capiteles corintios a cada lado de la puerta. Esta aparece entreabierta y, a pesar de su actual mutilación, presenta dos prótomos de león mordiendo la arandela, siguiendo modelos bien conocidos dentro del arte romano, sobre todo, dentro de la escultura en bronce. No cabe duda de que nos encontramos ante la representación de una puerta facturada en este metal, siguiendo los modelos iconográficos de la arquitectura imperial romana, como las existentes en el Panteón de Roma o las documentadas en el llamado templo de Rómulo, en el Foro de la misma ciudad ${ }^{1318}$.

La imagen que nos muestra el marfil del British está muy alejada de las descripciones dadas por todos los autores del recinto de la Anástasis, pues ninguno habla de tales puertas con cabezas leoninas. Dichos prótomos, colocados por el artista medieval sobre el lugar de acceso a la supuesta tumba donde había descansado Cristo, retoman el modelo de las puertas de bronce, por ejemplo, de Olinto, datadas en los años anteriores al 348 a. de C. y que presentaban ya dicha forma de cabeza de animal mordiendo la arandela ${ }^{1319}$. Fórmula que, por otra parte, gozaría de gran éxito durante todo el periodo románico ${ }^{1320}$.

\footnotetext{
${ }^{1316}$ Ibidem, en especial, p. 242.

${ }^{1317}$ El marfil se ha datado nuevamente entre los años 400-450. Cf.: F. GALTIER MARTÍ, La iconografía arquitectónica..., en concreto, p. 233.

${ }^{1318}$ Véase la siguiente obra colectiva: Le porte di Bronzo dall'Antichità al secolo XIII, (a cura di S. Salami), Roma, 1992. En cuanto a la puerta durante la época romana, consúltese la aportación realizada en: L. VLAD BORRELLI, "La porta romana”, Le porte di Bronzo..., pp. 1-18.

${ }^{1319}$ Se trata de uno de los modelos más antiguos conocidos. Uno de los ejemplares de dichas puertas de Olinto se conserva, actualmente, en el museo de Salónica. Cf.: E. MEYER, "Antike Türzieher", Festschrift E. V. Merckin, Waldsassen, 1964, pp. 80-89 y L. VLAD BORRELLI, Op. cit., en concreto, p.
} 
Si las fuentes coetáneas silencian cualquier alusión a dichas puertas de bronce y, sobre todo, a que éstas tuviesen decoración iconográfica, tal y como nos hace ver el marfil del British, debemos ver en ellas una interpretación del artista, quién, nuevamente, acude a modelos paganos para mostrarnos el acceso al lugar más sagrado de toda la cristiandad.

Para ello el artífice recurre a la conocida iconografía de la Puerta del Hades, difundida con éxito durante toda la romanidad sobre sarcófagos y pintura mural ${ }^{1321}$. Ello hace que las similitudes entre la puerta del marfil del British y este tipo de imágenes sean claras. Aludimos simplemente al conocido sarcófago, ya comentado en este trabajo, conservado en los Reales Alcázares de Córdoba, donde la parte central del frente aparece ocupado por esta puerta del Hades (fig. 216).

La imagen se representa a través de dos valvatae, supuestamente de bronce, decoradas con sendas cabezas leoninas, además de otros elementos, como placas y remaches que las hacen visualmente susceptibles de ser identificadas como puertas de bronce $^{1322}$.

En la pieza de mármol ocurre exactamente lo mismo que con la imagen ofrecida por el marfil de Munich, donde el acceso al edículo aparece marcado por dos puertas, esta vez cerradas. Sin embargo, otra vez aquí las alusiones al arte clásico son evidentes (fig. 217). Los clípeos que decoran la parte superior del templete, circunscribiendo las efigies de diversos personajes, tal vez magistrados, y, sobre todo, la colocación de un nicho con una escultura de un personaje togado sobre el umbral de acceso, rememoran soluciones antiguas.

Sin embargo, la fuente de tal imagen vuelve a ser, sin duda, la arquitectura funeraria romano-pagana. En concreto, la costumbre de colocar efigies del difunto en los accesos a tales construcciones para recordar su paso por la tierra, está atestiguado de

6. El motivo del felino y la arandela, de claro origen antiguo, fue bien explotado en el arte carolingio, en este sentido véase: H. FILLITZ, "Die Bronzetüren des Aachener Münsters", Le porte di Bronzo..., pp. 139-144.

${ }^{1320}$ L. DIEGO BARRADO, Nacido del Fuego..., en concreto, p. 51 y pp. 140-147.

${ }^{1321}$ L. VLAD BORRELLI, Op. cit., en concreto, p. 2. En este trabajo se hace un análisis etimológico del término puerta, vinculándolo a la acción de pasaje o transporte. Se alude, además, a otros ejemplos del mismo tipo de iconografía, entre ellos, el representado en una pieza ya tratada aquí. Nos referimos a la puerta de bronce esculpida sobre una de las lajas que formaban la decoración de la Tumba de los Haterii. Consúltese también: A. D. KARTSONIS, Anastasis. The making of a image, Princeton, 1986, en especial, p. 22. El mencionado autor analiza el papel de la llamada Puerta del Hades en relación con la iconografía de la Anástasis.

${ }^{1322}$ El sarcófago de Córdoba fue hallado en la necrópolis del Brillante en el año 1958. El tema que posee en el frente estuvo ampliamente difundido en los talleres occidentales y, específicamente, en los de la ciudad de Roma. Véase: J. BERTRÁN FORTES, Los sarcófagos romanos..., en concreto, pp. 93-110. El autor lo considera de época tardoseveriana. 
una manera muy expresiva por el relieve de la tumba de los Haterii, tantas veces recordado.

Ya Vitruvio había aludido a tal costumbre y a la importancia de la efigie del difunto, así como de otras escenas dentro de los recintos funerarios e, incluso, en el mismo ámbito familiar. A propósito de tal cuestión decía:

"De otra manera, acerca de los antiguos, en los patios estavan estas cosas para que fuesen vistas, no estatuas de artífices estrangeros ni de bronce o mármol, sino retratados en cera se ponían los rostros cada uno en su caxa, para que huviese imágenes que acompañasen las honras funerales y mortuorios de la familia, y siempre en muriendo alguno estava presente todo el pueblo o personas que havía havido en algún tiempo de aquel linaje, y los epitafios de sus nombres, honras y hechos discurrían con líneas al rededor de las imágenes pintadas, y los caxones se llenavan de libros y de memorias de las cosas hechas en el Magistrado"1323 (texto 67).

La imagen medieval en marfil que venimos analizando se inscribe dentro de esta tradición iconográfica de exposición de la imagen del difunto. Es extraño que de las fuentes documentales e iconográficas que nos han llegado hasta hoy en día, ninguna aluda a que en el acceso del tegurium rotundum o, por extensión, en el ambiente mismo de la Anátasis, existiesen imágenes decorando la tumba. Creemos que ello se explica por una contaminación directa del arte funerario romano, que es tomado por los artistas medievales para potenciar la imagen del sepulcro de Cristo, dotándola de una mayor conexión con los elementos de la realidad material coetánea. Parece claro que, de haber existido alguna imagen de Cristo o algún tipo de iconografía como la presente en el marfil de Munich, alguno de los visitantes del monumento nos lo habría hecho llegar.

Se trata de aportaciones hechas por los artistas, que pueden tener como fuente la realidad que les rodea, de tal manera que resulta factible que, ejemplos como el del llamado tholos de Sestino, en Toscana, ayuden a comprender las fuentes barajadas para la representación del Santo Sepulcro ${ }^{1324}$ (fig. 218).

Este tholos períptero de orden corintio, sustenta mediante las columnas que lo circunscriben un entablamento sobre el que se eleva una cúpula. El dato más interesante es el valor expositivo que alcanza aquí la imagen, pues en cada espacio del

\footnotetext{
${ }^{1323}$ PLINIO, Historia Natural..., p. 1087.

${ }^{1324}$ P. GROS, L'architecture romaine..., vol. 2, en concreto, pp. 407-409.
} 
intercolumnio fueron colocadas diferentes esculturas togadas, de una manera un tanto similar al ejemplo del marfil de Munich. Creemos que ambas imágenes están dentro de la misma tradición ${ }^{1325}$.

Sin embargo, pronto los artistas medievales comenzarán a enriquecer la imagen que venimos estudiando con nuevas aportaciones. La conocida hebilla conservada en el Musée de l'Arles Antique y procedente de la tumba de Cesáreo, obispo de la ciudad a comienzos del siglo IV, es uno de los ejemplares más conocidos y también más problemáticos ${ }^{1326}$ (fig. 219). En la imagen se plantea nuevamente el problema de llegar a discernir si se trata de una representación del tegorium rotundum visto desde el interior de la rotonda o una imagen del exterior del edificio. Para mayor complicación, flanqueando el edículo, se colocaron dos arcos, posiblemente alusivos a las arquerías que, apoyadas sobre columnas y pilares, circundaban esta especia de "mausoleorelicario".

La imagen del monumento, poco a poco, iniciaba su larga distorsión que le llevará a adoptar formas múltiples durante el periodo románico, alejadas de la realidad material que un día tuvo el edificio ${ }^{1327}$. En este sentido, la hebilla de Arles esquematiza al máximo el podio inferior con su puerta, reducida a la mínima expresión ahora, pero monumentaliza un elemento que será crucial en la imagen del Santo Sepulcro. Nos referimos a las columnas de grandes fustes y capiteles corintios, que algunas fuentes a las que hemos aludido, insisten en que eran de plata.

En lo referente a las columnas, prácticamente todas las imágenes que hemos consultado al respecto utilizan el tipo de fuste liso y en muy pocas ocasiones se representó el torso o helicoidal del tipo salomónico. En relación con este aspecto, F. Galtier Martí señaló en su día que, gracias a testimonios como el de la maqueta-relicario de Narbona ${ }^{1328}$, podemos concluir que, dentro del edificio se habían utilizado "una serie

\footnotetext{
1325 Ibidem, p. 409.

${ }^{1326}$ C. HEITZ, "Le sépulcre...", en concreto, pp. 391-392 e ID., La France pré-romane. Archéologie et architecture religieuse du Haut Moyen Âge, IV siècle- An Mille, Paris, 1987, en especial, pp. 30-60. El autor data la pieza en torno al siglo VI.

1327 Uno de los trabajos más importantes que han incidido en dicho aspecto es el realizado en: R. KRAUTHEIMER, Introduction à une iconographie..., en concreto, pp. 8-12. En él se alude a la pervivencia de la imagen y estructura del Santo Sepulcro dentro de edificios como los de San Miguel de Fulda, Paderborn, Lanleff y Cambridge. Señala que alguno de estos ejemplos es más una degeneración o eco del modelo que una verdadera evocación del mismo. Véase también: C. PÉQUIGNOT, "Vraies ou fausses imitations de l'Anastasis de Jérusalem aux XI ${ }^{\mathrm{e}}$ et XII ${ }^{\mathrm{e}}$ siècles", Les Cahiers de Saint-Michel de Cuxa, XXXI, 2000, pp. 119-133, en concreto, pp. 120-121. En él, se remarca la clara intención de evocar un mausoleo romano dentro del espacio de la Anástasis, así como el interés, por parte de algunas construcciones medievales, de evocar esa misma Antigüedad que reflejaba la construcción constantiniana. ${ }^{1328}$ Narbonne, Musée de Narbonne.
} 
de columnas torsas -en número de once, como refiere el patriarca Focio (...) soportaban dinteles rectangulares que daban reposo a un tejadillo o cúpula"1329 (fig. 220).

Sin embargo, la cuestión resulta problemática, sobre todo, en relación con la menor difusión de ejemplos iconográficos que muestren que dentro de tal espacio se utilizó la columna torsa. El llamado relicario del Santo Sepulcro de Narbona, presentaba una pronaos elevada por cuatro columnas, ambos elementos hoy perdidos, pero que coinciden con la reconstrucción hecha para el tegurium de Krautheimer, que antecedía al espacio centralizado. Este recinto, que cubría además dos ambientes, se marcaba a través de una cúpula rematada mediante una gran cruz. El primer espacio posee una forma de hemiciclo cubierto con bóveda de perfil avenerado, mientras que el otro, más oculto y profundo, serviría propiamente como lugar en el que colocar las reliquias. Los capiteles de la pieza son todos corintios, pero de los fustes nada sabemos, pues se han perdido $^{1330}$.

Sin embargo, ni el relicario de Narbona ni ninguna de las imágenes examinadas permite afirmar que dentro del edificio constantiniano se utilizaron columnas torsas de una manera categórica, puesto que en este punto las imágenes conservadas se presentan dispares, arbitrarias y cuestionables.

Sin embargo, entre tales testimonios, son las famosas ampollas de Tierra Santa, traídas a Occidente por peregrinos, viajeros y todo tipo de personajes, las que mejor ayudan a comprender este aspecto ${ }^{1331}$. Se trata de unos recipientes dispuestos para

\footnotetext{
${ }^{1329}$ F. GALTIER MARTÍ, La iconografía arquitectónica ..., en concreto, p. 246.

1330 A. BONNERY, "L'édicule du Saint-Sépulcre de Narbonne. Recherche sur l'iconographie de l'Anastasis", Les Cahiers de Saint-Michel-de-Cuxa, XXII, 1991, pp. 7-42 y A. TRIVELLONE, "Modelino del Santo Sepolcro di Gerusalemme", Romei..., ficha 18, p. 293. La pieza se ha venido datando en el siglo V y está esculpida en mármol de los Pirineos. Esta última autora señala que la pared abierta en el fondo de la pieza permitía introducir la mano hacia la cabecera del edículo, que estaba provista de una cámara con una banqueta de fábrica. Todo ello habla sobre la función de relicario de la obra, lo que ha llevado a la mayoría de los autores a señalar que se trata de una imagen que reproduce el tegurium rotundum.

${ }^{1331}$ A. GRABAR, Les ampoules de Terre Sainte (Monza-Bobbio), Paris, 1958, en concreto, pp. 13-15 y p. 50. El autor recoge y estudia el conjunto de ampollas mejor conservado de todo el Occidente cristiano. Nos referimos a las custodiadas dentro de los tesoros de San Juan de Monza y San Colombano de Bobbio, que de manera bastante extraordinaria nos ha legado tales piezas hasta nuestros días, debido, sobre todo, a su temprano ingreso dentro de los tesoros antes mencionados. Se trata de una serie de ampullae, generalmente hechas en plata $u$ otros materiales menos lujosos, como el vidrio, diversas aleaciones e incluso cerámica y que suelen presentar dos partes muy diferenciadas: el anverso y el reverso. En ambos lados la iconografía es siempre diferente. Además de analizar las imágenes y el estilo de tales obras, el citado estudioso aborda también la problemática de su uso y función, insistiendo en su carácter provincial, desde el punto de vista de la factura técnica, ligado, sin duda, a su uso local. Además de viajeros, participantes activos de las cruzadas y otra serie de personajes, dichas piezas se relacionan también con la realeza. El núcleo conservado en Monza es el más conocido. De manera tradicional se le ha ligando a una
} 
contener el aceite extraído de las lámparas que ardían dentro de los principales lugares de peregrinación en Tierra Santa y de los que tan buena cuenta nos han dado los autores de época paleocristiana.

Para el tema que nos ocupa, las más importantes son las ampollas que presentan, en alguno de sus lados, la representación del tema de la Resurrección de Cristo o el de la visita de las mirróforas al sepulcro vacío. Será dentro de estos ciclos donde hallemos las pertinentes evocaciones del Santo Sepulcro constantiniano ${ }^{1332}$. Uno de los aspectos que más nos interesa destacar de tales piezas, es que, al menos, en aquellas que presentan una mayor destreza técnica y atención a los detalles de la iconografía, muestran con claridad el uso del fuste helicoidal. El caso más excepcional lo representa la ampolla de Bobbio que porta el número de inventario 75 , sobre todo, en cuanto al desarrollo que muestra de los aspectos arquitectónicos ${ }^{1333}$ (fig. 221).

En dicha pieza, datada en la segunda mitad del siglo VI, se representó, por uno de sus lados, la escena de la Resurrección de Cristo. En ella encontramos la imagen del tegurium, vista desde el interior, que se circunscribe dentro de un círculo en el que se colocó la inscripción griega que dice: "Bendición del Señor de los santos lugares" ${ }^{1334}$. En el centro, dominando la escena, la imagen del Santo Sepulcro, desarrollado aquí como en ninguna de las otras piezas conservadas. La estructura más grande aparece elevada por cuatro grandes columnas torsas que sustentan capiteles, seguramente vegetales, que sirven para cobijar y, a su vez, dignificar el pequeño edículo que se sitúa debajo ${ }^{1335}$. A. Grabar señaló en su día que tal estructura superior, de forma arqueada,

donación de la reina longobarda Teodolinda, quién presuntamente las cedió a la basílica de San Juan Bautista en torno al año 595. Sin embargo, la adquisición y traslado de dichas piezas a Italia queda aún por aclarar. Sobre dicha cuestión, véase: R. CONTI, "Ampolla", Romei..., ficha 44, p. 309.

${ }^{1332}$ A. D. KARTSONIS, Op. cit., p. 20. El autor destaca el papel jugado por las mirróforas como "sinónimo" de la Resurrección. Sobre estos aspectos, ya se llamó la atención en su día, de una manera más extensa y completa, en: F. GALTIER MARTÍ, La iconografía arquitectónica..., en especial, pp. 228-229.

${ }^{1333}$ Señalamos el número de inventario para poder diferenciarla fácilmente del resto de piezas, todas de similares características. Se trataría de la pieza número 15 si seguimos los parámetros establecidos por Grabar. Cf.: A. GRABAR, Les ampoules..., en concreto, pp. 39-40 y A. GIGLI y G. VALENZANO, “Ampolla", Romei..., ficha 47, p. 311. Tomamos este ejemplo por tratarse del más significativo y el que muestra con mayor desarrollo, complejidad y evidencia, el uso de la columna torsa, además de otros elementos que pasamos, en breve, a comentar. Se trata también la pieza en: A. D. KARTSONIS, Op. cit., especialmente, pp. 20-21. El autor la compara con otra de similares características, presuntamente elaborada con el mismo molde y que se conserva en Washington, Dumbarton Oaks Research Library and Collection.

${ }^{1334}$ A. GRABAR, Les ampoules..., p. 39.

${ }^{1335}$ En esta pieza el uso de la columna torsa es evidente. Siguiendo en todo caso la numeración propuesta por A. Grabar, además de este ejemplo, presentan columnas de fuste torso las siguientes: conservadas en Monza los números 3, 5, 9, 13, 12, 14 y 15. Del mismo modo, presentan este mismo elemento las piezas numeradas como $3,4,5,6$, posiblemente 7 y la ampolla 15 que es la que tomamos como ejemplo. Hemos 
evocaba la gran cubierta del recinto, abierta con una serie de vanos, que arrojarían luz sobre al interior ${ }^{1336}$.

Lo más significativo de la pieza es que, si el resto de obras dejaban lugar a la ambigüedad sobre la composición y representación de tal estructura, en esta ampolla observamos una clara diferencia e independencia entre la estructura superior en forma de baldaquino y el verdadero tegurium, que aparece en forma de edículo debajo. Además de ello, las estilizadas columnas torsas elevan capiteles vegetales, tal vez corintios, aunque en este punto las ampollas conservadas presentan fórmulas bastantes variables $^{1337}$.

El edículo propiamente dicho, de menor tamaño, muestra un remate en forma de frontón que se repite en los demás ejemplos conservados. A este respecto, F. Galtier se refiere con las siguientes palabras:

“Al comparar las escenas de la Resurrección se puede determinar un modelo básico de edículo que, con algunas variantes, posee una fachada recta, con un frontón decorado con una especie de pétalos y coronados por una cruz" ${ }^{\text {1338. }}$.

Compartimos la opinión vertida por A. Grabar sobre tal estructura, pues creemos que los frontones decorados con este elemento vegetal en forma de pétalo, podrían ser la representación esquematizada de un perfil avenerado. La imagen tridimensional de tal estructura nos la ofrece, claramente, el edículo de Narbona. El perfil de concha se esculpió sobre el cuerpo anterior en forma de hemiciclo, que daba acceso al interior del relicario y que hoy, a pesar del mal estado de la pieza, es perfectamente visible ${ }^{1339}$. Además de ello, si seguimos la reconstrucción propuesta por A. Bonney, también encontraríamos esta decoración avenarada sobre el pórtico o pronaos, hoy perdido, que

incluido aquí las que no presentan dudas sobre el uso de este tipo de columnas, por ser los ejemplos que se han conservado mejor. Es posible, además, que otros casos más dudosos también las presentasen. No buscamos llevar a cabo un análisis pormenorizado de tales obras, simplemente remarcar la frecuencia con que la columna torsa apareció representada. La causa de tal repetición del prototipo de la columna de fuste torso quizás deba explicarse a través del uso de moldes y de una producción en serie que llevó a que muchas de las ampollas presenten características similares. Sobre este aspecto, véase: Ibidem, en concreto, pp. 13-20 y pp. 63-66.

1336 Ibidem, p. 39.

1337 Por ejemplo, la ampolla número 5, conservada en Monza, presta una especial atención a dichos capiteles, que el autor señala como posible derivación de una representación de vegetales del tipo acuático. Cf.: Ibidem, en especial, p. 22.

${ }^{1338}$ F. GALTIER MARTÍ, La iconografía arquitectónica ..., p. 230.

1339 A. TRIVELLONE, "Modelino....," p. 293. 
daba paso al ambiente interior ${ }^{1340}$. No es preciso insistir en el absoluto clasicismo de este elemento avenerado dentro de la arquitectura romana, así como en otra serie de representaciones "antiquizantes", donde las cáscaras de los ábsides ubicados en los espacios más nobles y más dignos utilizaron tal solución ${ }^{1341}$.

Su gran bagaje dentro de los espacios más dignos del mundo antiguo justifica su inclusión dentro de la imagen del edículo de la ampolla de Bobbio que comentamos. A parte de todo lo añadido, dentro de la pieza son de destacar otra serie de elementos importantes. Entre ellos la gran cruz que remata el frontón avenerado y que presenta la peculiaridad de estar, aparentemente, gemada y rodeada con ocho perlas ${ }^{1342}$.

La importancia de dicha cruz, es la razón por la que fue representada, con un tamaño tan desproporcionado, en un manuscrito conservado en Montpellier ${ }^{1343}$ (fig. 222). En dicho folio se recrea la imagen de Jerusalén a modo de gran rectángulo rodeado por la cinta muraria. Un tanto descentrado, en el margen inferior izquierdo, se

\footnotetext{
${ }^{1340}$ A. BONNERY, "L'édicule du Saint-Sépulcre...”, en concreto, p. 23. El autor se basa, así mismo, en las ampollas, para poder demostrar la utilización de este elemento dentro de la obra constantiniana.

${ }^{1341}$ Un aspecto muy importante, pero que desviaría la línea y el objetivo de nuestro trabajo, es la representación que hallamos de tal elemento dentro de las pinturas de Dura Europos. Nos referimos al llamado nicho de la Torah, datado alrededor del año 245. En el encontramos una estructura similar a la del sepulcro narbonés, con una cubierta de horno decorada con perfil avenerado. Sin embargo, creando un redundante juego espacial, sobre este nicho de fábrica, se pintó nuevamente, al fresco, la representación del tabernáculo. Se trata de una estructura que en fachada presenta cuatro columnas que, a pares, flanquean el edículo central, nuevamente rematado por este elemento avenerado. La imagen se acompaña por otra serie de representaciones. Así, a la izquierda se representó la gran menorah y el lulav y el etrog, mientras que, a la derecha, aparece el sacrificio de Isaac, que desde el punto de vista geográfico y litúrgico se liga al propio templo. Sobre dicha imagen, vid.: M. RONK-VAANDRAGER, Tabernacle, temple et Jérusalem Céleste. Premier, Deuxième et Troisième Temple? Etude d'iconographie biblique de la peinture du IX ${ }^{e}$ au XII siècle, 2 vols., Paris, 1996, en concreto, vol. I, pp. 401-402.

A dicha imagen debemos sumar, además, el conocido relieve de Cafarnaúm, en Israel, que representa el Arca de la Alianza transportada sobre un carro. El frontón de dicha arquitectura nuevamente vuelve a ser semicircular y presenta una estructura otra vez avenarada. Cf.: S. LOFFREDA, Recovering Capharnaum, Jerusalem, 1985, en concreto, pp. 10-50.

El elemento se repite dentro del mismo conjunto mural de Dura Europos, colocado sobre el acceso de otras puertas de menor importancia, como las presentes sobre las tres del tabernáculo, dentro de la escena de la consagración. Sobre la imagen, véase: M. RONK-VAANDRAGER, Op. cit., en especial, vol. I, pp. 130-132.

En dichas páginas se recoge la problemática técnica de la obra y el debate sobre su realización a secco o al fresco. En la escena de consagración del tabernáculo que comentamos, se representó, en tamaño jerárquico, a Aarón, vestido para el ceremonial. En concreto, tal estructura se ideó con la forma de un templo corintio clásico, con columnatas y rematado en frontón. Desde otro orden de cosas, se incide en la vinculación de las representaciones de las arquitecturas de las ampollas y las de los frescos de Dura Europos en: A. GIGLI y G. VALENZANO, Op. cit., p. 311.

${ }^{1342}$ Esta es la interpretación defendida en: Ibidem., p. 311. Por el contrario, para Grabar se trataría, sin embargo, de la representación de una serie de de elementos que sólo resaltarían el resplandor de tal pieza. Cf.: A. GRABAR, Les ampoules..., en especial, p. 39.

${ }^{1343}$ Montpellier, Archive Municipal, Situs Hierusalem, cod. H. 142, fol. 67 v. La miniatura se ha datado en el siglo XV. Sobre los elementos metálicos, como por ejemplo, los herrajes de la puerta representados en la obra, se incide en: L. DIEGO BARRADO, Nacido del Fuego..., en concreto, p. 114.
} 
ubicó un edículo cilíndrico rematado con una cúpula, tal vez escamada, que se acompañó por una inscripción que dice:

“(...) Qui fu trovata la Croce da Elena. Il Luogo del Calvario. Il Sepolcro del Signore. Qui Cristo fu spogliato. Qui fu coronato. Qui fu legato. Il centro del mondo. Il carcere del Signore" ${ }^{, 1344}$.

Una cruz remata la estructura e incide, así mismo, en la importancia que se debió dar a tal pieza ${ }^{1345}$. A dicho elemento tenemos que sumar las rejas que cerrarían el acceso al interior del templete y que en ocasiones llegarán a esquematizar y abstraer de tal manera la estructura, que serán dichos elementos los más reconocibles del conjunto ${ }^{1346}$.

A parte de todos los elementos clásicos señalados para dichas ampollas, es de destacar el fuerte carácter romano y bizantino que presentan tales producciones, tal y como ha señalado R. Conti ${ }^{1347}$.

Las ampollas de Monza y Bobbio, a pesar de su riqueza como fuente iconográfica, no permiten poder afirmar contundentemente que dentro de la estructura del Santo Sepulcro se utilizaran las famosas columnas torsas, perdurando la duda de saber cual fue la realidad material del lugar durante el siglo IV. Además, debemos tener en cuenta que, ni los testimonios literarios, ni las piezas artísticas que posteriormente representaron tal espacio, arrojan luz sobre este detalle. Debemos conformarnos con plantear su uso tan sólo respaldado por su aparición dentro de estas ampullae, donde aparecen claramente.

El uso de la columna torsa dentro de las ampollas parece mostrar una clara voluntad de evocar el pasado ${ }^{1348}$.

\footnotetext{
${ }^{1344}$ RADULFUS CODOMENSIS, Op. cit., en concreto, pp. 190-191.

${ }^{1345}$ Veremos como este tipo de solución se retomará en la basílica romana de San Pedro del Vaticano.

${ }^{1346}$ Sobre el tema de las rejas que cerraban el recinto y de su representación, vid.: A. GRABAR, Les ampoules..., en concreto, pp. 20-21, donde se analiza la ampolla número 3 de Monza. En ella se representó el edículo, que protegido por un ciborio, presenta un techo piramidal. La estructura aparece apoyada por cuatro columnas torsas. Lo más llamativo es como el autor identifica una especie de pérgola de la que pende una pieza textil. Son visibles las lámparas y, sobre todo, las rejas. En el interior del tegurium aparece una estructura semicircular, que se identifica con un arco. Éste da cobijo a otro elemento, un objeto rectangular que ha sido identificado como la piedra corrediza que cerraría la misma tumba de Cristo. Cf.: A. D. KARTSONIS, Op. cit., en concreto, pp. 20-23.

En las páginas escritas por el citado experto, se llama la atención sobre un relieve, ya citado, conservado en la Dumbarton Oaks Collection. Dicha pieza presenta la representación de un edículo coronado por una esfera en la que se grabó el signo de la cruz. Los capiteles de las cuatro columnas que elevan la cúpula de seis paños son nuevamente del tipo vegetal acuático. Bajo tal estructura se colocó una nueva imagen de la cruz y, además, una pequeña estructura que se ha identificado como la puerta de acceso al tegurium, bajo la cual se representó una forma romboidal, en alusión a la piedra tumbal.

${ }^{1347}$ R. CONTI, Op. cit., p. 309.
} 
La leyenda histórica, más que las fuentes artísticas, nos dice que las famosas columnas del Templo de Salomón (ca. 1000 a. de C.), pudieron haber sido del tipo torso, tal y como defiende M. Ronk-Vaandrager ${ }^{1349}$.

Sin embargo, al cotejar tales hipótesis con el texto bíblico, pronto surgen las dudas al respecto:

\section{“(...) Y comenzó Salomón á edificar la casa en Jerusalén, en el monte} Moria que había sido mostrado á David su padre (...).Estas son las medidas de que Salomón fundó el edificio de la casa de Dios. La primera medida fue, la longitud de sesenta codos; y la anchura de veinte codos. El pórtico que estaba en la delantera de la longitud, era de veinte codos al frente del ancho de la casa, y su altura de ciento y veinte: y cubriólo por dentro de oro puro. Y techó la casa mayor con madera de haya, la cual cubrió de buen oro, é hizo resaltar sobre ella palmas y cadenas. Así cubrió la casa, sus vigas, sus umbrales, sus paredes, y sus puertas, con oro; y esculpió querubines por las paredes. Hizo asimismo la casa del lugar santísimo, cuya longitud era de veinte codos según el ancho del frente de la casa, y su anchura de veinte codos: y cubrióla de buen oro que ascendía á seiscientos talentos. Y el peso de los clavos tuvo cincuenta siclos de oro. Cubrió también de oro las salas. Y dentro del lugar santísimo hizo dos querubines de forma de niños, los cuales cubrieron de oro (...) Hizo también el velo de cárdeno, púrpura, carmesí y lino, é hizo resaltar en él querubines. Delante de la casa hizo dos columnas de treinta y cinco codos de longitud, con sus capiteles encima, de cinco codos. Hizo asimismo cadenas en el oratorio, y púsolas sobre los capiteles de las columnas: é hizo cien granadas, las cuales puso en las cadenas. Y asentó las columnas delante del templo, la una á la mano derecha, y la otra á la izquierda; y á la de la mano derecha llamó Jachîn, y á la de la izquierda, Boaz (...)” (2 Crónicas, 3: 117).

Según las fuentes, eran dos piezas de bronce, de dieciocho codos de altura. La primera de ellas, Yakin aludiría a la firmeza, mientras que su pareja, Boaz era la materialización de la fuerza ${ }^{1350}$.

\footnotetext{
${ }^{1348}$ Para nuestro estudio resulta de vital importancia este tema del uso de la columna torsa dentro de los edificios constantinianos. Si en el caso del Santo Sepulcro, la afirmación de su existencia debe ser sostenida con cautela, para los ejemplos de San Pedro del Vaticano, tal y como veremos en breve, la certeza de su existencia es total.

${ }^{1349}$ M. RONK-VAANDRAGER, Op. cit., vol. I, en especial, pp. 212-228.

${ }^{1350}$ Las dos columnas serían trasladas a Babilonia desde Jerusalén, como botín de guerra, tras la toma de la ciudad por Nabuconodosor. Cf.: Ibidem, p. 212.
} 
La Antigüedad cristiana y la Edad Media no olvidarían tales antecedentes. Entre alusiones eminentemente históricas, casi siempre difuminadas por la leyenda, encontramos un recuerdo de dichas columnas, por aludir a un ejemplo de cronología medieval, en la desaparecida sinagoga de Worms, en Alemania. En dicho espacio se colocaron dos columnas datadas entre los años 1174 y 1175 con dos inscripciones. En ellas las palabras de Yakin y Boaz eran perfectamente legibles ${ }^{1351}$.

Las columnas del Templo de Salomón se convertirán pronto en auténticos representantes de un pasado prestigioso, ligado al monarca más importante de todos los tiempos, de ahí su éxito en la plástica medieval y de los siglos posteriores.

Sería complejo abordar las concomitancias y conexiones que presentan monumentos tan insignes como el Templo de Salomón, el tabernáculo y el Santo Sepulcro. Sin embargo, en lo referente a la fortuna de la columna torsa como representante de ese pasado mítico ligado a tales conjuntos, algunas imágenes pueden ayudar a perfilar el origen de tal tradición.

Por mencionar un ejemplo bien clarificador, destacamos la miniatura en la que se observa al rey David tañendo el arpa. Su efigie aparece colocada bajo una evocación esquematizada del tabernáculo ${ }^{1352}$. Lo más destacado para nuestro objetivo son las columnas que sujetan el arco carpanel, pues ambas sustentan un capitel corintio de clara tradición antigua, mientras que los fustes se decoran de manera efectista con una serie de elementos vegetales que, sin duda, evocan la forma de una columna torsa de tipo romano.

${ }^{1351}$ Ibidem, p. 228. La sinagoga fue bombardeada durante la Segunda Guerra Mundial, sin embargo, la autora publica unas fotografías donde se observan dichas columnas y sus inscripciones.

${ }^{1352}$ Saint-Gall, Siftsbibliothek, Cod. 22, fol. 66. La imagen se ha datado en el siglo IX. El tabernáculo funciona aquí como un mero marco para la escena, mostrándose en su vertiente fija. Cf.: Ibidem, p. 147. 


\section{5. LA IMAGEN DEL SANTO SEPULCRO EN LA EDAD MEDIA.}

De todo lo afirmado hasta aquí se puede concluir que la apariencia con la que los arquitectos constantinianos dotaron al Santo Sepulcro de Jerusalén fue una imagen claramente heredera de los mausoleos de tradición antigua. La forma centralizada, el sistema de circulación giratoria, el uso del capitel corintio dentro de los diferentes ambientes, así como la monumentalización del espacio a través de un edículo con no menos referencias "antiquizantes", hablan claramente de las fuentes que manejaron y de las que, obviamente, no se podían desprender, pues dichos artífices se encontraban propiamente formando parte de una sociedad aún inmersa en la Antigüedad tardía.

Lo más interesante para nuestro estudio es la pervivencia de todos esos elementos en la Edad Media. Desde el uso de la planta centralizada como recuerdo de la Anástasis construida por Constantino, hasta otros elementos más concretos, como por ejemplo el uso del orden corintio o la bóveda en forma de venera, se podría hablar de una continuidad de modelos romanos en la arquitectura del siglo IV realizada bajo el mandato del emperador ${ }^{1353}$.

Dentro del caso medieval, la importancia que tuvo el Santo Sepulcro como configurador de la imagen de otros tantos edificios, está sobradamente demostrada. En relación con ello, señalamos la iglesia francesa de Santa María de Rieux-Minervois, en el Languedoc francés, que ha sido relacionada, generalmente, con la centralidad de la Anátasis de Jerusalén, así como con otras obras de estos lugares de peregrinación (fig. 223). Nos referimos, en concreto, a la famosa rotonda erigida en el valle de Gehsemaní

\footnotetext{
${ }^{1353}$ Todos los autores coinciden en afirmar que existen niveles de acercamiento y comprensión de tal edificio por parte de los autores medievales, desde obras concienzudamente imitadoras del edificio, hasta otras construcciones que tan sólo consiguen evidenciar un lejano eco. Cf.: C. PÉQUIGNOT, "Vraies ou fausses imitations...", en concreto, pp. 119-121 y R. KRAUTHEIMER, Introduction à une iconographie..., particularmente, pp. 12-20. El autor recoge ejemplos tan significativos como el de la iglesia del Santo Sepulcro en Bolonia, su homónima en Pisa, el edificio de Northampton, el ya mencionado de Paderborn y la capilla de Krukenburg, así como otros tan interesantes como el de la capilla de San Miguel de Fulda. En cada obra las variantes pueden marcar diferencias irreconciliables con la estructura hierosolimitana, sin embargo, todos los edificios presentan un mismo origen e idénticas perspectivas simbólicas. El autor, en la segunda parte de su obra, hace derivar todas estas construcciones centrales, especialmente, los baptisterios de época medieval, de los grandes hitos arquitectónicos del mundo antiguo, como por ejemplo, la zona de los caldaria de Pompeya, así como de las existentes en la Roma de Caracalla y Constantino. En las pp. 56-59 señala la ductilidad de dicha fórmula, usada además de en estos edificios termales, en aquellos de carácter funerario. Enumera el ejemplo de la llamada Tor de'Schiavi, el Mausoleo de Elena en Roma, así como los de San Jorge de Salónica y, quizás, el Mausoleo de Constantino en Constantinopla. Los ejemplos se suceden con el Mausoleo de Diocleciano en Split o el de la familia Furia cerca de Tivoli, por citar los casos que recoge Krautheimer.
} 
que, claramente, se organizaba imitando la estructura espacial de la rotonda de Cristo en Jerusalén $^{1354}$.

En el edificio, además de la clara evocación "antiquizante" de modelos funerarios romanos tamizados bajo la cristianización constantiniana, encontramos otros aspectos que nos hablan de un profundo conocimiento de la Antigüedad. Sólo una figura tan conocedora de lo antiguo como la del "maestro" de Cabestany podía haber sido la encargada de esculpir los capiteles que ornan la iglesia, antes mencionada, de Riueux.

Lo que queremos señalar es que, dentro del arte románico, la imagen del Santo Sepulcro de Constantino no sólo se limitó a imitar, de una manera más o menos acertada, el prototipo funerario. En el caso de este templo, vinculado en primer lugar a la rotonda de la Virgen, que a su vez había tenía como su antecedente más directo la Anástasis, la escultura empleada refuerza ese uso de formas clásicas que se advierte desde el punto de vista arquitectural. Ya hemos aludido anteriormente a los capiteles de orden corintio del edificio, que configuran uno de los conjuntos más logrados y clásicos del románico europeo ${ }^{1355}$.

Jugando con una doble evocación clásica a través de las formas arquitectónicas y escultóricas, el artífice de la obra tomó como modelos más cercanos, para decorar este claro remedo de la arquitectura constantininana, los capiteles "antiquizantes" de la cercana iglesia de Sainte-Marie d'Alet, entre otros modelos ${ }^{1356}$.

\footnotetext{
${ }^{1354} \mathrm{El}$ ejemplo al que aludimos es meramente circunstancial, de ahí que no recojamos toda la bibliografía sobre el edificio y la escultura de este importante centro. En este mismo estudio dedicaremos un apartado completo para estudiar la figura del llamado "maestro" de Cabestany, sobradamente conocido por su fuerte conocimiento e influencia de lo clásico. A la hora de abordar su obra, incluiremos alguna de la bibliografía más importante relacionada con este edificio. Sobre la relación de la Anástasis y la rotonda mariana de la Virgen, así como el caso de la iglesia de Rieux. Cf.: A. BONNERY, "L'église de RiuexMinervois. Dimension symbolique de l'architecture. Sculpture", Les Cahiers de Saint-Michel de Cuxa, XXV, 1994, pp. 13-29, en concreto, p. 17.

${ }^{1355}$ A. BONNERY, "L'église Sainte-Marie...", en concreto, p. 32. El autor, tal y como hemos recogido en este estudio, data los capiteles en una fecha anterior al año 1154.

1356 O. POISSON, "Le Maître de Cabestany, sculpteur et architecte", Le maître..., pp. 154-163. El investigador plantea la posibilidad de que el mismo maestro, tan reconocido desde el punto de vista escultórico, hubiera podido ejecutar o, al menos participar, en las labores constructivas. Dicha teoría es muy sugestiva a la hora de poder apoyar nuestra idea sobre el conocimiento de lo clásico que presentaba el "maestro" de Cabestany, que le llevaría a trazar la forma de una rotonda mariana siguiendo modelos constantinianos o, lo que es lo mismo, derivados de la tradición romana imperial. No obstante, la idea de imaginar a tal artífice trabajando en las labores arquitectónicas es difícil de demostrar en el estado actual de las investigaciones. Véase también: A. BONNERY, "Sources de la sculpture romane en Languedoc. Les églises abbatiales de Caunes et d'Alet", Les Cahiers de Saint-Michel de Cuxa, XXIV, 1993, pp. 7991, sobre todo, p. 87. El autor habla de la similitud de formas con respecto a los edificios antiguos romanos. En relación con la escultura de Santa María d'Alet, se insiste, sobre todo, en las teorías que han relacionado la clásica escultura ubicada en el ábside de este ruinoso templo, con otra construcción romana dedicada a Diana. Muy interesante resulta, además, la articulación exterior de la cabecera, mediante
} 
El "maestro" de Cabestany fue un escultor formado en la tradición clásica que acabaría por inspirarse en los modelos romanos para crear sus obras, explotando, ricamente, el panorama monumental romanizado de aquellos lugares en los que más tarde estaría activo como escultor. El caso del templo centralizado de Riueux-Minervois es un buen ejemplo al respecto.

Sin embargo, la complejidad del fenómeno va más allá. Si el "maestro" de Cabestany evocó, de una manera u otra, el recuerdo de este tipo de edilicia funeraria tardoantigua ligada a los santos lugares, otros maestros, esta vez en Navarra, parecían conocer las mismas fuentes constantininanas ${ }^{1357}$.

Nos referimos al denominado Santo Sepulcro de Torres del Río ${ }^{1358}$. El edificio, de planta octogonal, presenta un ábside orientado y una espléndida bóveda de nervios entrecruzados ${ }^{1359}$. Del conjunto, nos interesa destacar la representación de la escena de

columnas adosadas y superpuestas, que el autor conecta con la tradición "romanista" de San Pedro de Roda. Cf.: I. LORÉS I OTZET, El monestir..., en especial, pp. 59-59 e ID., "L'église de Sant Pere de Rodes...", concretamente, p. 34. La autora ya establecía una conexión formal en el uso del corintio entre este edificio y el de San Pedro de Rodas. En la misma línea, véase.: O. POISSON, "Un sculpteur anonyme...", en concreto, pp. 7-15. El citado experto relaciona los capiteles de Minervois con los ejemplos de la catedral de San Pedro de Maguelone, los de la nave de la catedral de Carcasonne o los de Santiago de Béziers.

${ }^{1357}$ Citamos este caso, de entre los muchos posibles, para poder ejemplificar el fenómeno que estudiamos. En todo caso, somos conscientes que en tal discurso faltaría por definir de una manera exacta que tipo de relación existe entre el modelo medieval y aquel antiguo. Es decir, estos edificios medievales que parecen inspirarse en el Santo Sepulcro, en ocasiones, no pasaron de ser simples evocaciones de recuerdo lejano, siendo muy difícil poder llegar a discernir el grado de parentesco entre el modelo original y el medieval. En ocasiones, estas construcciones fueron realizados por artífices que, posiblemente, jamás habían visitado el Santo Sepulcro, explotando más los meros recuerdos de aquél, que realizando verdaderas copias del mismo.

${ }^{1358}$ La bibliografía sobre el edificio y su escultura es abundante. Señalamos las obras que hemos consultado para este aspecto en particular. En este sentido, véanse: P. E. ZORRILLA, "Otra iglesia de templarios en Navarra. El Santo Sepulcro de la villa de Torres", Boletín de la Comisión de Monumentos Históricos y Artísticos de Navarra, 1914, pp. 129-139; S. HUICI, "Iglesia de templarios de Torres del Río (Navarra), Boletín de la Comisión de Monumentos Históricos y Artísticos de Navarra, XV, 1924, pp. 4751; E. LAMBERT, "Les chapelles octogonales d'Eunate et de Torres del Río", Mémorial Henri Basset. Nouvelles études nord-africaines et orientales, Paris, 1928, pp. 1-8 y T. BIURRUM Y SOTIL, El arte románico en Navarra o las órdenes monacales, sistemas constructivos y monumentos cluniacenses, sanjuanistas, agustinianos, cistercienses y templarios, Pamplona, 1936. En esta última obra se trata el edificio de manera específica entre las pp. 648-660.

Véase también: J. MARTÍNEZ DE AGUIRRE, "Aproximación iconográfica a la iglesia del Santo Sepulcro en Torres del Río (Navarra)", Imágenes y promotores medievales en el arte medieval (M. L. Melero Moneo, F. Español Bertrán, A. Orriols i Alsina, D. Rico Camps eds.), Bellaterra, 2001, pp. 153165; ID., "Iglesias de plan central, encomiendas y otros templos del ámbito rural", El arte románico en Navarra $2^{a}$ edición, corregida y aumentada (C. Fernández Ladreda dir.), Pamplona, 2004, pp. 270-282 y J. MARTÍNEZ DE AGUIRRE y L. GIL CORNET, Torres del Río. Iglesia del Santo Sepulcro, Pamplona, 2004.

${ }^{1359}$ Para una reciente descripción del edificio, vid.: J. MARTÍNEZ DE AGUIRRE, "Iglesias de plan central...", en concreto, p. 272. También vid.: E. LAMBERT, "Les chapelles octogonales d'Eunate...", en concreto, p. 1. El autor francés señalaba una dependencia para la cúpula de los modelos hispanomoriscos, tal y como los define el autor. Por su parte, consúltese, igualmente: J. MARTíNEZ DE AGUIRRE y L. GIL CORNET, Op. cit., pp. 54-59. Los autores relacionan la cubierta con ejemplos conocidos, como la que presenta el Cristo de la Luz de Toledo. 
la visitatio sepulchri que fue esculpida en uno de los capiteles del edificio ${ }^{1360}$ (fig. 224). En concreto el ubicado en el lado derecho del ábside semicircular ${ }^{1361}$.

En la escultura, las tres mirrófonas se acercan al sepulcro vacío por la derecha del capitel que, entreabierto, deja ver, además, el sudario con el que se había amortajado a Cristo ${ }^{1362}$. Sobre dicho elemento se colocó, con una clara función de cobijo y de centralización, un gran arco rematado por una estructura turriforme de tres niveles. A dichos pisos se les practicaron grandes ventanas de medio punto ${ }^{1363}$.

La más reciente de las teorías, aquella defendida por el profesor J. Martínez de Aguirre, habla de un claro intento de evocar, en dicha imagen, la famosa rotonda de la Anástasis de Jerusalén. Sin embargo, no aquella de época constantinana, sino la resultante de las reformas llevadas a cabo a mediados del siglo XII. Según el autor, "la imagen que Occidente tenía del templo desde hacía siglos era la de un edificio con sucesivos niveles de arquerías en altura" ${ }^{1364}$.

Para el citado investigador la imagen que ofrece en altura esta representación del Santo Sepulcro está emparentada con esta tradición, que parece evocar la vista que Occidente tenía del mítico lugar hierosolimitano.

Sin embargo, desde nuestro punto de vista, creemos que la explicación a tal imagen es más compleja, sobre todo, desde el punto de vista de los modelos empleados, y más concretamente, de la larga tradición iconográfica que dicha representación posee. En este sentido, ya durante la cronología propuesta para la realización de la pieza navarra, mediados del siglo XII, la imagen del Santo Sepulcro había llegado a tal punto de distorsión que es imposible hablar de una relación directa con el modelo.

El ejemplo de Torres del Río refleja el final de una larga mutación que, tal y como ha señalado C. Heitz, se había iniciado, de una manera más evidente, dentro de las

\footnotetext{
${ }^{1360}$ Ya se identificaba la imagen como una representación del Santo Sepulcro en: T. BIURRUM Y SOTIL, Op. cit., p. 656.

1361 Véanse buenas imágenes de las plantas del edificio publicadas por Altadill en 1913, en: Ibidem, pp. 20-21.

${ }^{1362}$ Es muy significativo el hecho de cómo para representar el sepulcro de Cristo se recurrió a una decoración muy conocida en el ámbito hispano prerrománico. Nos referimos al sogueado que recorre la pieza y para el cual no debemos descartar un intento de evocación de fórmulas del pasado. Recuérdese, en este sentido, la famosa tapa del sarcófago de Ithacio de la catedral de Oviedo, ya tratada aquí. En ella también aparece el motivo recorriendo la superficie de la pieza.

1363 J. MARTÍNEZ DE AGUIRRE y L. GIL CORNET, Op. cit., pp. 62-63. Además, los autores siguen emparentando el estilo de las esculturas con diversas tendencias seguidas por los talleres languedocianos.

${ }^{1364}$ J. MARTÍNEZ DE AGUIRRE, "Iglesias de plan central...", en concreto, p. 275. Se reitera esta idea en: J. MARTÍNEZ DE AGUIRRE y L. GIL CORNET, Op. cit., p. 93.
} 
producciones plásticas de época carolingia y que tenía como elemento más destacado llevar a cabo una absoluta reinterpretación del modelo hierosolimitano ${ }^{1365}$.

Los siglos IX y X supusieron el inicio de este cambio radical dentro de la morfología de tal imagen. Los ejemplos en este sentido son extensísimos y su análisis pormenorizado no aportaría nada nuevo. Citaremos, por ejemplo, el marfil de la Walters Art Gallery de Baltimore, datado en el siglo IX o el más conocido del Museo Bargello de Florencia, de la misma cronología ${ }^{1366}$ (fig. 225). Se trata de dos piezas en las que se representó la escena del Sepulcro vacío visitado por las tres Marías. El rasgo que más nos interesa destacar es la representación de la famosa rotonda, concebida ahora como una gran torre de tres niveles superpuestos, abiertos con grandes ventanas y rematados por una cúpula semiesférica. La relación, al menos formal, entre tales imágenes y la recreación navarra parece factible.

La concepción de tal imagen dista mucho de los ejemplos tempranos de los siglos IV y V que hemos señalado. Parece claro que se trata de dos tipos muy diferentes de representaciones y de dos vías muy distantes en relación con las fuentes usadas. Las reformas del siglo XII acometidas en el recinto hierosolimitano no sirven para poder explicar la manera carolingia de recrear tal tipo e, igualmente, creemos que, tanto las representaciones de las ampollas o la del marfil de British, por ejemplo, beben de otras fuentes bien diferentes que la escultura de Torres del Río o las presentes en estos marfiles carolingios.

El proceso de desvirtualización máxima de la imagen había surgido a través de una contaminación entre la imagen real del edificio hierosolimitano y las construcciones nuevas que dentro de la arquitectura carolingia estaban surgiendo. C. Heitz ha señalado los ejemplos de la turris sancti salvatori de Saint-Riquier, así como otros ejemplos de San Miguel de Hildesheim y San Pantaleón de Colonia, para poder explicar la relación entre imágenes iconográficas e imágenes reales ${ }^{1367}$.

Sin embargo, parece posible alegar que tales ejemplos tienen dentro de la arquitectura funeraria romana sus más remotos orígenes. Las estructuras turriformes formadas por varios pisos, abiertos al exterior mediante vanos o simples arcuaciones, superpuestas, en ocasiones, guardan bastantes puntos en común con tales imágenes. A

\footnotetext{
1365 C. HEITZ, “Sepulcrum Domini...”, en concreto, pp. 391-393.

1366 Ibidem, pp. 391-399.

1367 Ibidem, véase, sobre todo, p. 394. Se insiste en el desarrollo de tales estructuras en relación con diversas ceremonias litúrgicas, entre las cuales, la más famosa es el drama del Quem quaeritis in sepulcro.
} 
pesar de ser diferentes en su concepción, si observamos la representación del Santo Sepulcro realizada en bronce sobre las famosas puertas de San Miguel de Hildesheim (fig. 226), se advierte que, nuevamente aquí, se ha recurrido al modelo de una torre funeraria romana ${ }^{1368}$.

Ya hemos señalado la importancia, la variedad y, sobre todo, el clasicismo de algunas de las fuentes manejadas por los artífices del bronce de Hildesheim. Creemos que la imagen del templete, clara evocación del Santo Sepulcro, es muy significativa. La construcción se coloca junto a la figura de Cristo que se representó sujetando con su mano izquierda el lábaro, mientras que la otra -en un claro gesto de redención- la ofrece a la figura de Adán, que se postra en el suelo ${ }^{1369}$.

Nuevamente creemos que se trata de un modelo arquitectónico tomado del arte antiguo. En concreto, al observar el mausoleo de Punico-Libio en Thugga, en el norte de África (fig. 227), parece que las comparaciones son más que posibles. Determinados elementos, como por ejemplo la misma cubierta cónica rematada a su vez por acroteras en los extremos y así como el remate de la parte superior de la estructura, la articulación del la torre a través de molduras y la marcada diferencia de niveles, hablan de un horizonte común para ambas estructuras ${ }^{1370}$.

La fortuna y conocimiento que de ellas se tuvo en todo el imperio romano está testificado por las decenas de ejemplos conservados y, de los cuales, también Hispania presenta alguna muestra. En concreto, consideramos dignas de mención, la llamada Torre Ciega de Cartagena o la torre funeraria de Albenga ${ }^{1371}$. Sin duda, el ejemplar más importante en este sentido es el de la famosa Torre de los Escipiones de Tarraco, datada en la primera mitad del siglo I. d. de C (fig. 228). Dicho monumento está formado por

\footnotetext{
${ }^{1368}$ B. GALLISTL, "Die Tür des Bischofs Bernward und ihr ikonographisches Programm", Le porte di Bronzo..., pp. 145-181; L. E. STAMM-SAURMA, "Die ,autorictas”...”, pp. 105-126 y G. BINDING, "Bischof Bernward...", pp. 27-47. Sobre estas puertas de bronce ya hemos tratado en este trabajo, por lo que referimos a la bibliografía recogida en el apartado bibliográfico.

${ }^{1369}$ El citado templete se eleva sobre un basamento de perfiles muy clásicos. Tras él, un primer cuerpo, quizás de planta cuadrada, representa la sala funeraria propiamente dicha, pues a ella se accede a través de una puerta, en la que se han representado, incluso, las bisagras, mostrando su factura metálica. Tras otra serie de molduras se eleva el segundo cuerpo, en el que se han practicado dos ventanas de medio punto. Finalmente la construcción remata en un tejadillo piramidal.

${ }^{1370}$ Sobre este de torres funerarias, véase: P. GROS, L'architecture romaine..., vol. 2, en especial, pp. 1415.

${ }^{1371}$ La Torre Ciega se ha datado en torno al siglo I a. de C. Aunque se trata de un edificio, hoy prácticamente desparecido, poseía un cuerpo superior troncocónico rematado por una semiesfera que, según se ha venido afirmando, bien podría haber tenido forma de piña. Sobre ella, vid.: L. ABAD CASAL, El arte funerario..., ficha 4.
} 
un podio sobre el que se proyectó un naïskos. Además incluía otros elementos de tipo escultórico acompañados de una tabula ansata con inscripción ${ }^{1372}$.

El modelo alcanzó igual difusión en las restantes provincias del Imperio. Desde la famosa Conocchia de Santa María de Capua Vetere, en Italia, hasta el llamado mausoleo de los Julii de Glanum ${ }^{1373}$ (fig. 229). Lo más importante es la importancia que dichas obras tendrán en cuanto a la formación de diversos tipos arquitectónicos medievales, generalmente, vinculados con funciones funerarias. De su éxito dentro de la ilustración del libro, por ejemplo, da buena cuenta la estructura representada en el conocido Salterio de Utrecht (fig. 230). Aquí se minió una estructura turriforme de tres niveles, de perímetro cuadrado que, además, presenta una serie de vanos practicados sobre los muros, siguiendo la tipología de las torres funerarias romanas que acabamos de señalar. Alrededor de tal construcción se representaron varias figuras, en concreto, el grupo más importante es aquel compuesto por dos personajes que meten con sus propias manos el cuerpo de un difunto dentro de un ataúd, incidiendo en la función mortuoria de dicha torre ${ }^{1374}$.

Imágenes como esta, certifican la continuidad de tradiciones y modelos con respecto al pasado, claradamente evocadores de lo clásico en el Salterio de Utrecht, donde todos los especialistas han coincidido en señalar una tendencia "antiquizante" en toda la larga serie de representaciones microarquitectónicas de la obra.

\footnotetext{
${ }^{1372}$ P. GROS, L'architecture romaine..., vol. 2, en concreto, p. 416. El autor habla de la posibilidad de que, en España, por su conexión con el ámbito norteafricano, este tipo de torre hubiera alcanzado gran desarrollo. A este respecto cita, además, los casos de la de Mengíbar en Jaén, la de Villajoyosa en Alicante y la de Daimuz en Valencia.

${ }^{1373}$ La primera se ha datado en el siglo I d. de C. y presenta una tipología similar a las que venimos señalando. Su peculiaridad revierte en el buen estado de conservación con el que ha llegado a nosotros, además de la complejidad de su estructura. El monumento funerario está formado por una torre concebida como una frons scaenae, donde los oculi, las arcadas, las columnas y el gran remate en forma de tholos, hablan de una derivación barroca del prototipo. Para el caso de la torre de la Galia, ubicada en Glanum, se han buscado referentes helenísticos. Se ha datado en época tardorrepublicana, en concreto, en los años 30-20 a. de C. Está formada por un arco quadrifrons y remate en varios niveles. Mientras que la parte más baja aparece articulada por varias molduras, la parte alta se forma por un primer nivel macizo, seguido de un segundo de mayor altura, tal y como observamos, por ejemplo, en la imagen del Santo Sepulcro de las puertas de Hildesheim. En ésta se colocó el arco de cuatro vanos antes señalado. Nuevamente, como en los ejemplos africanos, las columnas juegan un papel más articulador y decorativo que propiamente estructural. Un tholos de perímetro columnado remata la parte más elevada del monumento. Sobre ambas torres, véase: P. GROS, L'architecture romaine..., vol. 2, particularmente, pp. 485-422. Para la obra italiana, consúltese: G. LUGLI, voz "Appia, Via”, Enciclopedia dell'arte antica classica e orientale, vol. I, Roma, 1958, pp. 499-501.

1374 Paris, Bibliothèque Nationale de France, Ms. 47, 13, fol. 27v. Sobre la miniatura, consúltense: K. VAN DER HORST, W. NOEL y W. C. M. WÜSTEFELD, The Utrecht Psalter in Medieval Art. Picturing the Psalms of David, London, 1996, p. 30 y S. DUFRENNE, Les ilustrations du Psaltier d'Utrecht. Sources et apport carolingien, Paris, 1978, p. 39.
} 
Es difícil llegar a concretar hasta que punto las representaciones del Santo Sepulcro hechas durante el periodo carolingio, así como durante las sucesivas etapas del arte medieval, eran deudores de la imagen de estas torres funerarias o, por el contrario, más directamente herederas de la arquitectura real contemporánea a tales las piezas. En el caso de las obras ebúrneas del Barghello y de Baltimore, C. Heitz no ha dudado en emparentarlas, tal y como ya hemos señalado, con las obras arquitectónicas carolingias $^{1375}$.

Aunque es evidente que dichas torres pueden relacionarse con tales experiencias, tampoco es descartable la incidencia de modelos clásicos, tan bien comprendidos siempre dentro de la corte carolingia. Si analizamos, por ejemplo, la famosa placa de marfil conservada en la Staatsbibliothek de Munich, observamos que los paralelismos con dichas estructuras antiguas son posibles ${ }^{1376}$. En concreto, pensamos, por ejemplo, en el llamado mausoleo de Mactar, en Túnez, compuesto mediante la superposición de volúmenes puros. La colocación de la puerta de acceso en la parte baja, justo en el centro del cubo que sirve de base a la torre romana, se repite igualmente dentro de la pieza carolingia, así como el uso de columnas para articular el muro en el caso de la obra en marfil y de pilastras en la obra construida ${ }^{1377}$.

En ningún caso defendemos dependencias directas ni contactos reales entre ambas obras. Simplemente presumimos una cierta tendencia clásica en dicha representación, pues al observar otra serie de torres de la misma índole, las concomitancias, en cuanto a su aspecto formal, son significativas. Recuérdese en este sentido el mausoleo de Atban en Dougga (Túnez) sin duda, el ejemplo más espectacular y complejo de este tipo de torres funerarias compuestas por varios niveles ${ }^{1378}$. La formulación de la estructura repite los mismos parámetros que los anteriores ejemplos, es decir, una base sobre la que se eleva el monumento, compuesta por una escalinata y un primer nivel de forma cúbica que remata en cada esquina mediante una columna. Se trata de una solución que también se había dado en el marfil de Munich.

\footnotetext{
1375 C. HEITZ, “Sepulcrum Domini...”, en especial, p. 394 y p. 399.

1376 Se ha datado en el siglo IX. Véase un análisis de su iconografía en: S. FERBER, "Crucifixion Iconography in a Group of Carolingian Ivory Plaques", The Art Bulletin, 48, 1966, pp. 323-334, concretamente, pp. 323-324. En dichas páginas se señalan diferentes rasgos de la pieza, entre ellos la introducción de las personificaciones del Sol y de la Luna, flanqueando la escena de la crucifixión. También se incluyeron las personificaciones Oceanus y Terra, iconografía que, por otra parte, ya hemos analizado en este trabajo.

${ }^{1377}$ P. GROS, L'architecture romaine..., vol. 2, en concreto, pp. 407-417.

1378 Ibidem, especialmente, pp. 417-421.
} 
Sobre este primer nivel se superponen, a su vez, otros dos, articulados mediante columnatas, vanos y todo tipo de elementos, como pilastras adosadas, cornisas y diversas molduras. Finalmente, la obra se remata con una cubierta piramidal. Todas estas características hacen posible equiparar, formalmente, las torres funerarias romanas y estas representaciones del Santo Sepulcro que se estaban llevando a cabo durante los siglos IX y X, especialmente dentro de los diversos talleres carolingios y otonianos ${ }^{1379}$.

Observamos, por lo tanto, una continuidad entre la arquitectura funeraria romana y las representaciones que en época medieval se llevarán a cabo de la prestigiosa rotonda de la Anástasis. Así y, desde otro orden de cosas, la arquitectura funeraria de época romana sería también la fuente de inspiración de otra serie de estructuras muy desarrolladas también en los siglos del románico. Nos referimos, de manera particular, a las famosas linternas de los muertos que, derivadas nuevamente de modelos antiguos, serán punto de referencia para explicar la configuración de la imagen del Santo Sepulcro en los siglos del románico ${ }^{1380}$.

Regresando otra vez a la imagen esculpida en el capitel de Torres del Río, surgen una serie de reflexiones interesantes. La estructura colocada sobre el sarcófago vacío de Cristo guarda una relación directa con el centralismo evocado de manera física por la propia construcción para la que se esculpió tal pieza. El octógono que la iglesia de Torres del Río posee como planta, genera un espacio centralizado de lejanos orígenes

\footnotetext{
1379 J.-P. CAILLET, "Metz et le travail de l'ivoire vers l'an mil", Religion et culture autour de l'an mil. Royaume capétien et Lotharingie, (D. Iogna-Prat y J-Ch. Picard ed.), Picard, 1990, pp. 315-337, especialmente, pp. 315-318. El autor realiza un interesante estudio sobre un grupo de piezas con el tema de la crucifixión como elemento central, lo que, además, lleva parejo la representación, en la mayoría de las ocasiones, de la representación del Santo Sepulcro. En la misma línea, vid.: S. FERBER, Op. cit., pp. 327-333.

${ }_{1380}$ M. PLAULT, Les linternes des morts. Inventaire-Histoire et Liturgie, Poitiers, 1988. No se conoce con exactitud cual era la función exacta, desde el punto de vista simbólico, litúrgico y devocional que tenían las denominadas linternas de los muertos, pues las referencias a ellas dentro de la documentación medieval son muy escasas. Se sabe que la mayor parte de las ocasiones el edículo abierto y colocado en la parte superior permitía ubicar una candela, velas o cualquier elemento combustible y luminoso para poder recordar la memoria de los difuntos. Más problemático resulta analizar la función que poseían algunos altares que estas construcciones llevaban adosados algunas veces. Complejo, pero muy interesante en cuanto a su relación con el caso navarro, es la fortuna que desde el punto de vista iconográfico, formal y, sobre todo, constructivo, tuvieron dichos elementos, reinterpretados, en ocasiones, dentro de las partes más visibles del edificio. Recuérdese, por ejemplo, el conocido caso de las dos torrecillas laterales que flanquean la fachada occidental de Notre-Dame-la-Grande de Poitiers, emparentadas, posiblemente, con los modelos de linternas de los muertos conservados en Vienne, así como los de la Charante. Citaremos como casos más conocidos los de Cellefrouin, datada a finales del siglo XII o la de Fenioux, del mismo siglo. Señalamos las concomitancias que existen entre estas construcciones y los remates de algunas de las torres funerarias romanas ya aludidas. Sobre las linternas de muertos en Francia, véase: M. PLAULT, Les linternes des morts. Inventaire-Histoire et Liturgie, Poitiers, 1988, en concreto, sobre los casos citados, pp. 34-38.
} 
clásicos y siempre dentro de la órbita de lo funerario ${ }^{1381}$. Nuevamente algunos autores compararon el pequeño templete octogonal que remata la cúpula al exterior, con una de las mencionadas linternas de los muertos, con las que dicho elemento guarda ciertas semejanzas desde lo meramente formal ${ }^{1382}$.

Lo que parece claro, según nuestro punto de vista, es que las fuentes tomadas por el escultor navarro fueron variadas. La superposición de niveles abiertos mediante vanos y el remate a través de una cúpula fue una solución ya aplicada por los talleres ebúrneos carolingios, tal vez los auténticos modificadores de la imagen del Santo Sepulcro. El modelo usado en Torres del Río para nada sigue la tradición iconográfica utilizada, por ejemplo, por los artistas encargados de esculpir el marfil de Arles o el del Munich, datados ambos en el siglo V. Sin embargo tampoco se aparta en este sentido de la tradición antigua, lo que induce a pensar en la consciente recuperación de modelos clásicos para potenciar aún más el prestigio que debían tener la tumba de Cristo, y el edificio que la albergaba ${ }^{1383}$.

${ }^{1381}$ E. LAMBERT, “Les chapelles octogonales d'Eunate...”, particularmente, pp. 3-4. El citado autor ya aludía a su relación con las fórmulas arquitectónicas funerarias, especialmente las capillas cementeriales. Sobre todo y mucho más interesante para nuestro estudio, es la puntualización que de manera temprana hacía el autor, al señalar que, en el acceso del edificio, se encontraron diversos enterramientos con lujosas vestiduras y que formarían parte, supuestamente, de una cementerio que se colocaría en los alrededores del edificio. El autor recogía la noticia del siglo XVII dada por P. Moret.

Un trabajo más reciente en: J. MARTÍNEZ DE AGUIRRE, "Iglesias de plan central...”, en especial, p. 315, nota 318. El profesor Martínez de Aguirre recoge también la noticia, así como la ausencia de enterramientos en el interior del edificio. Dato sabido tras recientes excavaciones.

${ }^{1382}$ Ibidem, pp. 272-274. Se recoge, además, la otra solución que, en ocasiones, se le ha dado a este pequeño templete superior del edificio. La primera se ha ligado con la teoría del "faro de peregrinos", que mediante el uso del fuego permitiría guiar al caminante en su ida o venida desde Compostela. Para J. Martínez de Aguirre esta teoría carece de veracidad pues alude a problemas geográficos, pues según afirma, la situación del edificio no permite ser visto desde la distancia. La razón más convincente que aporta es la total ausencia de hollín o restos de piedra quemada dentro del edículo superior. También la teoría de la linterna de los muertos resulta problemática. En este sentido, véase el apartado titulado "Una arquitectura con significado: la imitación del Santo Sepulcro de Jerusalén”, en: J. MARTÍNEZ DE AGUIRRE y L. GIL CORNET, Op. cit., pp. 86-95.

También vid.: J. MARTÍNEZ DE AGUIRRE, "Iglesias de plan central...”, en especial, p. 274. El investigador escribe: "en cuanto a las linternas de muertos, no es descartable su uso como tal en relación con los difuntos de calidad enterrados en su entorno, dado que el uso de lámparas que recordaran a los muertos se documenta en la Navarra medieval. Pero el hecho de que la escalera sea un añadido lleva a poner en duda que fuese esta la finalidad buscada inicialmente".

Cayendo en cierta contradicción, véase también: J. MARTÍNEZ DE AGUIRRE y L. GIL CORNET, $O p$. cit., p. 91. En dichas páginas los autores afirman: "no consta que en Navarra existiesen usos o costumbres similares a las francesas en cuanto a la utilización de linternas de muertos en cementerios medievales", descartando, por tanto, el uso de tales linternas dentro del ámbito navarro.

${ }^{1383}$ Recuérdese que tras las campañas de excavación en el edificio de navarro, apareció en el subsuelo, en un nivel estratigráfico inferior al de la época de construcción del templo, una escultura de un crucificado, que había sido enterrado ex professo dentro de la parte central del octógono. Tal prueba sirvió a los expertos para potenciar la identificación arquitectónica que hacen con la evocación del Santo Sepulcro. Cf.: Ibidem, p. 93. 
Sin embargo las alusiones al mundo antiguo y paleocristiano realizadas en el capitel navarro no acaban aquí. La morfología utilizada para recrear el Santo Sepulcro, con precedentes dentro del arte románico hispano, estaba ciertamente enraizada en la tradición clásica.

Al observar la imagen del capitel de la iglesia se percibe que el edículo superior, colocado para potenciar la imagen centralizada del lugar, se superpone sobre otra estructura. Ciertamente se trata de un gran arco de medio punto que cubre toda la parte frontal del cuerpo de la escultura. Nuevamente las fuentes para este tipo de imágenes son romanas, de una manera más distante, y paleocristianas, más directamente.

En relación con esta imagen, varios años antes de la elaboración de este capitel, se esculpía dentro de la llamada Puerta del Perdón de San Isidoro de León, la imagen de la visita de las Tres Marías al sepulcro vacío, que un ángel señala con su dedo (fig. 231). Sobre esta figura se colocó un gran arco de medio punto apeado sobre sendas columnas de fuste torso perlado y capitel corintio. Se trata de una abstracción de la Anástasis de Jerusalén realizada a través de unos elementos arquitectónicos muy simples ${ }^{1384}$. Encontramos una disposición similar en una de las "antiquizantes" miniaturas de la Biblia de Ripoll donde, para representar el Santo Sepulcro, se siguió una solución $\operatorname{similar}^{1385}$.

El modelo seguido para tales representaciones, evocadoras de una arquitectura funeraria, se rastrea con facilidad dentro de la iconografía de los siglos V y VI, tal y como muestra, por ejemplo, el sarcófago hispano de Alcaudete, donde para poder representar la tumba de Lázaro se recurrió a un arco de medio punto apoyado, nuevamente, sobre dos columnas ${ }^{1386}$ (fig. 232).

El arco adquiere en estas representaciones, de la misma forma que ocurre en el capitel de la iglesia del Santo Sepulcro de Navarra, una dimensión alegoría que mantiene todo el simbolismo que tal elemento había tenido durante la época antigua. Parece, siguiendo estos ejemplos, que el arco de medio punto evocaba, aún en pleno siglo XII, la imagen del Santo Sepulcro.

\footnotetext{
${ }^{1384}$ E. FERNÁNDEZ GONZÁLEZ, “El arco...”, pp. 221-242.

1385 Città del Vaticano, Biblioteca Vaticana, Biblia de Farfa, fol. 370, Ms. Vat. Lat. 5729. Sobre esta cuestión, véase: A. M. MUNDÓ, Les Bíblies de Ripoll. Estudi dels Mss. Vaticà, Lat. 5729 I París, BNF, Lat. 6, Città del Vaticano, 2002 y M. J. GUDIOL, Els primitius. La miniatura catalan, Barcelona, 1955, pp. 86-111.

${ }^{1386}$ S. VIDAL, "La transmisión iconográfica en la escultura hispánica de la Antigüedad tardía. Vigencia y discontinuidad de modelos", Escultura decorativa tardorromana y altomedieval en la Península Ibérica, Madrid, 2007, pp. 11-46, en concreto, p. 27.
} 
Sin embargo, un último ejemplo en relación con el tema que venimos desarrollando, se presenta revelador. Nos referimos a la miniatura datada alrededor de 1213 y que aparece incluida en el último folio del comentario al Cantico dei Cantici de Honorio de Autun ${ }^{1387}$ (fig. 233).

En dicho folio se representó una imagen del complejo hierosolimitano antes de la reforma emprendida por los cruzados entre los años 1140-1149, de tal manera que, en la parte central de la hoja, aparece dibujada una gran estructura circular con otra de índole similar en el interior. Se trata de la famosa Rotonda de la Anástasis. Tal estructura aparece flanqueada, a la derecha y a la izquierda, por dos arcos de medio punto elevados sobre dos pares de columnas, uno de ellos dando cobijo a una inscripción, y otro, dignificando la imagen de la cruz. Finalmente, bajo ésta, se representó otra tercera arcada, en tamaño menor, sobre la que reposa el astil de tal $\operatorname{cruz}^{1388}$.

Todas las inscripciones que, a modo de explanatio, recorren los bordes del Santo Sepulcro y, sobre todo, aquellas que se colocan alrededor de los arcos, aluden de una manera directa a los lugares santos que Constantino había mandado construir anejos a la gran Rotonda. La manera que se tuvo de representarlos fue a través de grandes arcadas de medio punto elevadas sobre columnas, usadas aquí como abstracción de la construcción hierosolimitana del siglo IV ${ }^{1389}$.

\footnotetext{
${ }^{1387}$ Paris, Bibliothèque nationale de France, Cod. Ms. Turri, 2. Hoy se conoce gracias a una copia, datada en el siglo XIII, tal y como ya hemos señalado. Se recoge la imagen y el comentario a la misma en: ANONYMUS, "Qualiter sita est civitas hierosolymitana", Itinera..., pp. 1-5, especialmente, p. 4.

${ }^{1388}$ Lo más interesante de tal imagen son las explicaciones que acompañan a cada elemento. De esta manera, si seguimos la traducción propuesta, dentro de los dos círculos concéntricos que simbolizarían el Santo Sepulcro, se dice: "Questa è la gloriosa forma del Sepolcro del sommo Dio: la disengnò H. come egli stesso l'aveva atentamente osservata". La segunda de las inscripciones, colocada en el borde del gran círculo exterior dice: "Questa costruzione esterna è la più grande di tutte le chiese; fu dedicata alla Genitrice di Dio; nel centro contiene la grotticella della Tomba del Signore, la quale, come si vede nel disegno, è di forma rotonda". Para nuestro cometido las inscripciones más interesantes aparecen vinculadas a los arcos y la propia cruz. Sobre los brazos de ésta se escribió: "Sulla croce la morte della Vita fu la morte dell'iniqua Morte". En la mitad de la cruz se lee: "Qui è il luogo del Calvario". Bajo la arcada que flanquea el edículo de Cristo, por la izquierda, el miniaturista escribió, entre ambas columnas: "Qui fu trovata la Santísima Croce dalla Regina Elena". Cf.: Ibidem, p. 5.

${ }^{1389}$ Sobre este tema del arco o, en su derivación, las galerías de arcadas como elementos no sólo estructurales sino también simbólicos. Cf.: J. GARDELLES, "Recherches sur les origines des façades a étages d'arcatures des églises médiévales”, Bulletin Monumental, 136-I, 1978, pp. 143-133. El autor propone varios ejemplos, mayoritariamente tomados de la ilustración del libro y la pintura, para poder explicar el desarrollo de tales estructuras dentro de la propia arquitectura. Así mismo, alude al parentesco simbólico que existe entre algunas fachadas con arcos de medio punto y otra serie de representaciones, como por ejemplo las famosas imágenes apocalípticas del Beato de Magius, o ciertas imágenes representantes de la ciudad de Susa, tal y como se ve en el Beato de Gerona o el Templo del Beato de Navarra, por señalar los ejemplos más significativos.
} 
En este sentido, es factible entender que la serie de arcos de medio punto representantes del Santo Sepulcro de Jerusalén, guardan, además, bastantes puntos en común con otra serie de imágenes, relativas también al gran conjunto arquitectónico de la Anástasis. El fuerte peso de la imagen, su entidad y categoría como representante del propio Santo Sepulcro, además de su facilidad a la hora de la elaboración, servirían de gran ayuda a los artífices románicos, a la hora de representar no sólo la propia Tumba de Cristo, sino todo tipo de construcciones funerarias. Así, a modo de ejemplo, señalamos la imagen de la Rotonda hierosolimitana representada en el arcón de Carrizo de la Ribera, en León ${ }^{1390}$, donde el ángel señala el sepulcro vacío del tegururium rotundum, que se sintetiza mediante un arco de medio punto apoyado sobre columnas y capiteles $^{1391}$. Con una misma tipología, y datado varias decenas de años antes, fue representada la conocida imagen de la inventio del sepulcro del apóstol Santiago por Teodomiro ${ }^{1392}$. El sepulcro está formado por un arco de medio punto apoyado sobre capiteles y columnas, monumentalizado, además, por otra serie de construcciones inventadas, colocadas en las enjutas que forma el arco $^{1393}$. Todo ello de una manera un tanto simplista.

El prototipo gozará de gran difusión en el románico hispano, con ejemplos de gran belleza, tal y como nos ofrece, por ejemplo, un capitel de la catedral de Tarragona (fig. 234). En dicha escultura se representó el Santo Sepulcro, nuevamente bajo la forma de un gran arco de medio punto, que da cobijo al propio sepulcro de Cristo y que aquí se eleva sobre una gran columna. Del arco cuelgan dos lámparas, quizás incensarios, hecho que se asemeja a la realidad material del recinto, tal y como hemos señalado en repetidas ocasiones. Dentro del conjunto se integran los somnolientos vigías. Llama la atención de la pieza, sobre todo, la representación del pequeño sepulcrum domini,

\footnotetext{
${ }^{1390}$ Astorga, Museo Catedralicio.

${ }^{1391}$ El modelo del Santo Sepulcro utilizado en este tipo de representaciones, englobadas dentro de la estética que se ha dado en llamar de "estilo 1200", tenía ya por entonces una larga trayectoria. Los ejemplos más interesantes en este sentido, dentro del ámbito hispano, como por ejemplo, el existente dentro del conjunto de pinturas de Sigena, presenta una misma disposición, acorde con los modelos foráneos, tanto ingleses como Sicilianos. En el caso de las pinturas de Sigena, el lugar que cubre la tumba de Cristo y al que acuden la Marías, presenta, nuevamente, una forma de arco de medio punto, apoyado sobre columnas. Cf.: W. OAKESHOTT, Sigena..., p. 67.

1392 Santiago de Compostela, Archivo de la catedral, cód. 1, fol. 1v. Cf.: I. G. BANGO TORVISO, "El locus sanctus...", p. 194.

${ }^{1393}$ No es este el lugar indicado para poder abordar los puntos y conexiones que la miniatura posee con la realidad. Baste con citar la enorme problemática a la hora de analizar los textos y las fuentes que existentes al respecto.
} 
elevado sobre una gran columna con un capitel corintio desproporcionado y que hace juego con los otros dos que enmarcan la composición ${ }^{1394}$.

A parte de lo señalado, nos interesa insistir en el uso de la tipología de sepulcro elevado, del que ya hemos tratado aquí ${ }^{1395}$. El uso de las columnas de fustes monumentales con capiteles bien trabajados, así como la colocación del sepulcro sobre un capitel de apariencia bien clásica, no debe ser visto como un libre ejercicio por parte del escultor, pues ya hemos señalado la importancia que tuvieron las columnas, fueran lisas o torsas, en relación con estas piezas.

Si observamos, por ejemplo, la importancia que se le va a otorgar a la columna dentro de la representación del Santo Sepulcro del tímpano de la Puerta del Perdón de San Isidoro de León, parece claro que tal elemento jugó un papel fundamental en este tipo de representaciones (fig. 235). Aquí se esculpieron dos columnas torsas, con los fustes decorados de una manera preciosista a través de diversas bandas helicoidales adornadas con un perlado. Sin duda, la imagen de este tímpano trae a la memoria las descripciones, ya analizadas, de los diversos testigos que, a través de sus palabras, nos hicieron llegar la idea de la utilización de unas columnas preciosas dentro del espacio funerario. Si a ello sumamos el uso de los fustes torsos, frecuentes dentro de las ampollas de Monza y Bobbio, junto con unos capiteles corintios compuestos, parece que, nuevamente, se usaron unas fuentes ligadas a un remoto pasado constantiniano.

El uso de este tipo de columna, visible en la fidedigna representación del tegurium rotundum de un píxide ebúrneo conservado en el Metropolitan Museum neoyorquino (fig. 236), se relaciona directamente con el prototipo representado en la ampollas. En la pieza en cuestión, las mirróforas flanquean una triple estructura formada por tres arcos que rematan, a su vez, en sendas cúpulas ${ }^{1396}$.

\footnotetext{
${ }^{1394}$ S. LAMIA, "Souvenir, synaesthesia, and the sepulcrum Domini: sensory stimuli as memory stratagems", Memory and the Medieval Tomb, (E. Valdez del Álamo y C. Stamatis Pendergast), Cambridge, 2000, pp. 19-41, especialmente, p. 24. El autor señala, así mismo, la importancia que las estrígilas y otra serie de motivos clásicos, tuvieron dentro de este tipo de representaciones. En concreto, se centra el prototipo iconográfico del sepulcro decorado a través de una serie de círculos esculpidos, generalmente, en el frente de los sarcófagos, que representando el sepulcrum domini, hacen alusión a una suerte de fenestrella confessionis, mediante la cual, llevar a cabo una veneración de las reliquias a través del contacto. Al ejemplo de la catedral de Tarragona se pueden sumar otros, como por ejemplo, el representado en una de las fachadas de la catedral de Chartres, también dentro de la escena de la depositio del cuerpo de Cristo o en uno de los capiteles de la portada sur de la catedral de Notre-Dame de París, que nuevamente repite idénticas soluciones, con tres orificios en el frente.

${ }^{1395}$ Véase el ejemplo, ya citado, del sepulcro de Santa Radegunda en Poitiers, entre otros. Si bien, en el caso de la representación de Tarragona se trata de una simplificación del tipo.

${ }^{1396}$ F. GALTIER MARTÍ, La iconografía arquitectónica..., en especial, p. 233.
} 
El ejemplo propuesto del tímpano del brazo sur de San Isidoro de León, permite extraer ciertas conclusiones al respecto. Se trata, por una parte, de una creación original de los talleres románicos, que presenta múltiples fuentes. Es lógico pensar que la más cercana esté en la realidad misma. Las dos columnas representadas tienen, posiblemente, como modelo más cercano la arquitectura real. Se trata de un claro ejemplo que arroja luz sobre la clásica problemática de este tipo de representaciones, de las que siempre se duda sobre su valor arqueológico y a las que, generalmente, se les atribuye fuertes vínculos con lo imaginario e irreal.

Pues bien, es posible plantear la hipótesis de que, el artista que esculpió esta clásica columna, evocadora de las lejanas del tegurium, la copió de la realidad. En concreto, este modelo se puede observar en una serie de columnas, hoy descontextualizadas de su lugar original y reempleadas como pie del altar ubicado en el ábside sur del templo (fig. 237). Allí se colocaron varios fustes y capiteles quizás provenientes del desaparecido ábside central. En concreto, los fustes presentan la misma estructura que la imagen que analizamos, es decir, una pieza torsa con bandas helicoidales perladas. Se trata, por otra parte, de un claro ejemplo que nos habla de la buena fuente de información que, en ocasiones, pueden ofrecernos los ejemplos englobados dentro de la iconografía arquitectónica.

El análisis que hemos realizado de la iconografía del Santo Sepulcro y sus características dentro de las representaciones románicas, puede parecer un tanto alejado del objeto principal de este estudio. Sin embargo, creemos que la morfología e imagen de esta estructura de la época del emperador Constantino fue fundamental para el arte y, especialmente, para la escultura de épocas posteriores.

En primer lugar, pensamos que se trata de uno de los mejores ejemplos arquitectónicos tardoantiguos que reflejan una clara voluntad de perduración de los modelos romanos de tradición imperial. Esta premisa permite generar la hipótesis de que, a priori, la iconografía de este edificio dentro de las representaciones plásticas románicas, reflejó también esa adhesión con los modelos clásicos.

La idea de un espacio en forma de rotonda, evocaba, claramente, estructuras paganas relacionadas con los heroom antiguos, sin embargo, ello no imposibilitó su uso dentro de las imágenes cristianas de época medieval. Desde un punto de vista arquitectónico y también iconográfico, las características clásicas del recinto se perpetuaron a lo largo de toda la Edad Media. 
En segundo lugar, al tratarse de un monumento funerario, nos permite preparar el terreno para poder señalar en los capítulos siguientes, la importancia que, desde el punto de vista artístico, tendrán este tipo de producciones en cuanto a la absorción de modelos, formas, iconografía e, incluso, estilo, por parte de los artistas medievales, especialmente los románicos. Tal y como ya señalara P. de Palol en su día, el arte funerario, por todas sus características, va a ser el que, de manera más evidente, se convertirá en una vía de transmisión de fórmulas artísticas, en el sentido más amplio de la expresión. Ello anuncia la importancia que las piezas funerarias, especialmente los sarcófagos, van a tener para la formación de diversas corrientes clásicas, visibles en la escultura de los siglos XI y XII, especialmente.

No en vano, el Santo Sepulcro de Jerusalén, uno de los monumentos funerarios más importantes de la cristiandad, puede ser tomado como ejemplo vértice a la hora de poder explicar la importancia del arte funerario de tradición romana y su influencia sobre las artes que se producirían en tiempos posteriores. Estas razones son, entre otras, las que utilizamos para justificar su inclusión y amplio tratamiento en este estudio. 


\section{EL Sustrato de la ANTIGÜEdAd CLÁsica EN LA ESCULTURA ROMÁNICA PENINSULAR.}

Desde el siglo pasado los especialistas más cualificados y, en conjunto, toda la historiografía en general, ha venido señalando de manera reiterativa una constante influencia de la Antigüedad dentro de la formulación y desarrollo de lo que, de manera unánime, venimos denominando como "estilo románico".

Sin embargo, dicha influencia se nos presenta tan ambigua como dispersa, tan amplia, como poco definida, convirtiéndose, finalmente, en un concepto tópico al que acudir para hablar de todas aquellas producciones con cierto recuerdo clásico ${ }^{1397}$. En relación con ello, consideramos de extrema importancia llevar a cabo una serie de acotaciones y precisiones previas que permitan poder introducir y presentar el análisis que posteriormente llevaremos a cabo.

Al referirnos al sustrato de la Antigüedad clásica, estamos, de alguna manera, errando en este pretendido carácter concreto que buscamos conferir al estudio. Sin embargo, entendemos que, si bien todas las etapas históricas, y con ellas todos los movimientos artísticos adscritos y desarrollados en dichos períodos, tuvieron su momento de máximo esplendor y desarrollo; podemos deducir que, por lo general, dichos periodos coincidieron con las épocas que de manera habitual se han entendido como más clásicas dentro de su desarrollo como cultura.

Para nuestra tarea nos centraremos en un periodo concreto de la Antigüedad, algo obligado tratándose del tiempo histórico de mayores dimensiones y de mayor alcance en cuanto a la gran cantidad de siglos que abarca. A la hora de buscar los modelos, corrientes, iconografías y otra serie de relaciones entre dicho momento y la propia Edad Media, éstas habrán de estar preferentemente circunscritas a los siglos de la

\footnotetext{
${ }^{1397}$ Recientemente, hemos analizado este mismo fenómeno en relación con la tradición clásica de la arquitectura asturiana, en concreto dentro de la iglesia de San Julián de los Prados en Oviedo. También la arquitectura $\mathrm{y}$, por lo general, todas las artes hispanas del siglo IX asturiano han sido, una y otra vez, vinculadas de una manera reiterativa a la influencia de la Antigüedad, sin especificar qué tipo. Cf.: J. A. MORÁIS MORÁN, "El valor clásico de la arquitectura asturiana...", pp. 233-246. El trabajo, lejos de ser un riguroso estudio sobre la influencia clásica en la arquitectura asturiana, realiza un análisis historiográfico sobre el concepto de lo "clásico" utilizado por los diferentes especialistas a la hora de abordar el sustrato antiguo de la iglesia de San Julián de los Prados. Véanse también, algunas reflexiones sobre el concepto de lo clásico durante la Edad Media en: ID., La recuperación de la Ecclesiae..., pp. 10100 y M. L. REAL, "Inovação e resistência: dados recentes sobre a Antiguidade Cristã no Occidente Peninsular", IV Reunião de Arqueologia Cristã Hispânica, Barcelona, 1995, pp. 17-68.
} 
Antigüedad romana. De esta manera, nuevamente, acotamos el tema y el campo de búsqueda, restringiéndolo al ámbito romano ${ }^{1398}$.

Creemos que las conexiones que el arte románico mantuvo con el arte romano son más evidentes y fácilmente justificables que las que, de una manera más discreta y compleja, tendría con otra serie de movimientos, como los vinculados, por ejemplo, al ámbito oriental. Ya fuese desde su faceta griega o a través de otros mecanismos, el arte románico enlazó de una manera clara con las producciones orientales del ámbito egipcio, griego e, incluso, romano oriental ${ }^{1399}$.

Sin embargo, para evitar la dispersión y a pesar de que muchos de los motivos claramente clásicos del arte románico llegaron a través del contacto con estos centros orientales, nosotros nos centraremos en el arte romano desarrollado en las partes occidentales del imperio $^{1400}$. La proximidad geográfica y los paralelismos sociales, políticos y económicos, justifican tal decisión, que nos llevará a poder hallar argumentos más favorables, por ejemplo, para poder explicar las relaciones de determinadas obras del románico hispano, a través de los intercambios con el arte galorromano o con aquel desarrollado en la península italiana, más que con el existente en las zonas orientales del imperio.

La acotación geográfica lleva pareja una acotación cronológica. En busca de una mayor contingencia a la hora de establecer las dependencias entre el arte románico de la Península Ibérica y el arte de la Antigüedad romana, proponemos, también, una delimitación en el corpus de piezas tomadas del arte antiguo. Preferentemente se

\footnotetext{
${ }^{1398}$ La restricción o acotación que aquí realizamos, está justificada por la necesidad de trabajar sobre un campo delimitado y concreto. La Antigüedad tuvo muchos siglos y en ellos se produjeron multitud de movimientos y obras artísticas, por lo que creemos necesaria una limitación en el ámbito de trabajo. Queremos advertir, que ello no supondrá, en ningún caso, una delimitación tan forzada que no permita abrir las vías a otros periodos y producciones. En los casos necesarios acudiremos a las civilizaciones y el arte de Egipto, Mesopotamia y Grecia -simplificando de una manera muy limitada el panorama del arte antiguo-, en la búsqueda de los modelos iconográficos y estilísticos, siempre que la evidencia de pruebas justifiquen tal hecho.

${ }_{1399}$ Por citar un caso concreto, aludimos a la reflexión realizada por J. Rodrigues en relación con el tímpano de la iglesia románica de San Salvador de Ansiães, de finales del siglo XII. En dicha portada, se esculpió una imagen de Cristo acompañado por el tetramorfos, de una factura bastante ruda y alejada de los grandes movimientos escultóricos que inundaban la Península Ibérica por estos momentos. El autor reconoce ciertos detalles de tipo bizantino en el retrato de Cristo, ligándolo a la imagen del Pastor de tipo oriental. Cf.: J. RODRIGUES, "A escultura românica”, História da Arte Portugues..., vol. I, pp. 264-331, en concreto, p. 272. Este dato permite ejemplificar como la alusión al mundo bizantino, incluso para explicar determinados detalles, presentes en la escultura románica más "rural" son bastante frecuentes dentro de los estudios especializados en el tema.

${ }^{1400}$ Nuevamente en este sentido aplicamos el mismo sistema que hemos anunciado anteriormente. Así, siempre que sea necesario, tomaremos referencias de piezas y obras del ámbito romano oriental, por ser imposible obviarlas y negar la importancia que en muchos casos tendrían para la formación del arte románico, a pesar, sin embargo, de la complejidad de explicar su llegada a occidente, su difusión y la asimilación de sus fórmulas.
} 
tratarán las piezas datadas con posterioridad al siglo I. a. de C., aunque es evidente, tal y como venimos señalando, que siempre que fuese necesario tomaremos ejemplos anteriores, pudiendo llegar incluso, en los casos más excepcionales, a mencionar casos ligados cronológicamente al siglo $\mathrm{V}$ a. d. C.

Aunque en la mayoría de ocasiones se trate de piezas ya de nuestra era, conviene señalar que el repertorio más importante de obras aparecerá ligado a las producciones escultóricas de lo que, de manera generalizada, se ha denominado "época tardoantigua" ${ }^{, 1401}$. Creemos que circunscribir el tipo de análisis que vamos a realizar dentro de un arco cronológico que va desde los siglos I o II d. de $\mathrm{C}$ a los siglos IV y $\mathrm{V}$ d. de C., podría, finalmente, facilitar la tarea de rastreo de fuentes antiguas a la hora de poder explicar determinadas formas del arte románico.

Tras la delimitación geográfica y cronológica, parecía necesaria una delimitación técnica. La clásica división que presenta la Historia del Arte, en cuanto a su fraccionamiento según las técnicas artísticas, en arquitectura, escultura, pintura, artes del libro, etcétera, hace imposible llevar a cabo un análisis del fenómeno de una manera completa. En este sentido, con el fin de llegar a unas conclusiones más concretas, se ha optado, preferentemente, por centrarnos en los trabajos escultóricos.

Creemos que para el caso de la Península Ibérica, ámbito en el que se centra nuestro estudio ${ }^{1402}$, la manera más factible de poder demostrar algún tipo de relación y dependencia entre las artes romanas de época tardoantigua y las llevadas a cabo entre

\footnotetext{
${ }^{1401}$ H. I. MARROU, Décadence romaine ou Antiquité tardive, Paris, 1977. La obra, muy temprana tanto desde el punto de vista cronológico como desde el mismo método utilizado, sirvió para poder dotar a los siglos de la Antigüedad tardía de la importancia que tenían. Anteriormente a la aparición de la obra, el concepto de arte romano cristiano, ligado a los siglos de desmembramiento del Imperio Romano, no pasaban de ser una mera lista de obras estilísticamente "inferiores" y sin ningún tipo de importancia, salvo por su derivación de las producciones imperiales romanas. Desde el punto de vista de las artes plásticas y la "revalorización" de las producciones datables en los últimos años del Imperio Romano, sigue teniendo una importancia fundamental el estudio de Grabar: A. GRABAR, "Le tiers monde de l’Antiquité...", pp. 1-59. Los últimos siglos de la Antigüedad pasaban de ser un momento definido por la decadencia, a ser valorado en su justa medida.

Sobre la problemática de poder establecer una secuencia cronológica estable y sin conflictos entre la duración de la Antigüedad y el inicio de la Edad Media, consúltese: E. SESTAN, "Tardo antico e alto Medievale...", pp. 15-37.

${ }^{1402}$ Hemos señalado ya, que si bien el título de esta investigación tiene como objetivo las producciones de la Hispania románica, también se han tenido en cuenta aquellos casos importantes localizados en la actual división política de Portugal. Con todo, la escultura creada en este ámbito no puede desligarse de aquella realizada en Galicia, León o Castilla. Se analiza dicha cuestión en: J. RODRIGUES, "A Arquitetura românica", História da Arte Portuguesa..., vol. I, Lisboa, 1995, pp. 183-263, en particular, p. 189. El autor considera que el matrimonio de Don Henrique con Doña Teresa en el año 1096 es fundamental para explicar este tipo de relaciones. En lo referente a la imposibilidad de llevar a cabo un análisis separado entre las piezas y edificios ubicados en el ámbito portugués, con respecto al resto de Hispania, ya se llamó la atención en su día en: J. M. CAAMAÑO MARTÍNEZ, "Algunas consideraciones sobre arquitectura alto-medieval", Relaciones artísticas entre Portugal y España, Salamanca, 1986, pp. 65-69.
} 
los siglos XI y XII, es a través de una delimitación del tema al campo de la escultura. Las razones son varias. En primer lugar, la escultura ofrece mejor que ningún otro tipo de producción la posibilidad de poder comparar, de una manera directa, producciones datables en época antigua romana con las obras del periodo románico ${ }^{1403}$.

Los problemas de conservación de las piezas librarias o de los frescos de época hispanorromana han provocado que, a pesar de que las obras conservadas sean de gran interés, no sean lo suficientemente amplias en número como para poder llevar a cabo un estudio comparativo con las obras románicas. De hacerlo, se podría caer en el error de llevar a cabo un simple catálogo de motivos decorativos e iconográficos nacido de un corpus absolutamente fragmentado, como el que supone el arte hispanorromano, estableciendo relaciones quizás ficticias con la época medieval ${ }^{1404}$.

La discriminación de la arquitectura en este trabajo posee algunas razones de peso. En la mayoría de las ocasiones, el único mecanismo seguro que permite trazar ciertas conexiones entre la arquitectura de época antigua y la de época románica, fue el llevado a cabo mediante el spolium in se. Para nuestro estudio, más importante que establecer un catálogo de éstas piezas dentro del arte de los siglos XI y XII, sería la de poder definir las causas por las que dichos fragmentos antiguos fueron reutilizados. Por lo tanto, de centrarnos en cuestiones arquitectónicas, el estudio quedaría limitado por el vacío ideológico que presenta tal fenómeno, pues a pesar de que hemos señalado casos donde la admiración a la Antigüedad fue tal importante que justificó la expoliación de tales piezas, la mayoría de estos reempleos corresponden más a motivos funcionales que ideológicos.

Con todo, a través de este método restaría la vía comparativa, analizando que tipo de técnicas, composiciones y elementos de la arquitectura romana pasaron a la creada en época románica. Sin embargo, el problema que encontramos es la dificultad de poder asegurar una dependencia de tales motivos con respecto a los antiguos. Es bien sabido que la arquitectura hispanorromana contó con obras de primer orden, pero del

\footnotetext{
${ }^{1403}$ Por ejemplo, tanto la pintura como la ilustración del libro, ambas técnicas que alcanzaron un importante desarrollo durante la etapa medieval, podrían dar buenos resultados a la hora de indagar sus fuentes clásicas, si en el caso hispano y, por extensión, la Península Ibérica, se hubieran conservado muchos más ejemplos y un corpus lo suficientemente extenso como para poder establecer las pertinentes conexiones. Sirva de ejemplo el pobre panorama que, desde el punto de vista de los manuscritos iluminados, nos ofrece la Hispania romana. Ello pugna por una discriminación de estas técnicas en favor de la escultura, de la cual se han conservado muchos más ejemplos.

1404 J. A. MORÁIS MORÁN, "Investigar sin corpus...", (en prensa). En dicho trabajo abordamos la complejidad de trabajar sobre la influencia de las obras antiguas dentro de la escultura románica a través de un sistema comparativo basado en determinados corpus de obras artísticas muy incompletos.
} 
mismo modo, es notorio que, más que la escultura, la arquitectura románica presentó una serie de características universales y muy similares en unas regiones con respecto a otras. Esa universalidad hace más difícil poder delimitar la influencia de la arquitectura romana más allá de establecer unos puntos en común en la utilización de paramentos, técnicas similares, el uso del arco de medio punto o la columna. Las posibilidades en este sentido son menos ricas que las que hallaremos en las obras esculpidas.

La escultura desarrollada en la Hispania romana, presenta una mayor posibilidad de estudio en cuanto a las relaciones que establecería con la de cronología románica. Los sarcófagos, capiteles, relieves y otra serie de elementos esculpidos, como entalles, camafeos y piedras preciosas, eran susceptibles de una mayor y más rápida reutilización dentro de los edificios y obras medievales que los que presentan, por ejemplo, los motivos pintados, tanto en muros como en libros, sin duda, más difíciles de conservar y de reutilizar ${ }^{1405}$.

En este sentido, trabajar sobre el campo escultórico, ofrece una gran facilidad que no se puede observar en otros ámbitos. Una de las características más señaladas de la escultura hispanorromana es su absoluta dependencia con respecto al arte de Roma $^{1406}$. En el caso de la escultura esta posibilidad es más visible, debido a su facilidad para el traslado y su difusión, hecho que no posee, por ejemplo, la pintura sobre muros o la arquitectura. Esta disposición de la escultura antigua a ser trasladada y a "viajar" dentro de los intercambios comerciales, generalmente desarrollados por vía marítima a los importantes puertos existentes en las costas de la Península Ibérica, favoreció la llegada de piezas de gran valor y, sobre todo, la posibilidad de conocer otra serie de repertorios hasta entonces inéditos en nuestros territorios ${ }^{1407}$.

Además de poder participar así de la larga tradición escultórica de los talleres de la ciudad de Roma y por extensión de todo el Imperio, la elección de la técnica

\footnotetext{
${ }^{1405}$ Hemos analizado algunos aspectos de la reutilización de piedras preciosas antiguas dentro de determinadas piezas de cronología medieval en: J. A. MORÁIS MORÁN, "Pervivencias de la Antigüedad...", (en prensa). En dicho trabajo recogemos algunos de los ejemplos más importantes del ámbito hispano y su respectiva bibliografía.

${ }^{1406}$ Sobre las características hispánicas del arte romano conservado en la Península, véase, la breve, pero interesante aportación de J. Arce. Cf.: J. ARCE, "Arte Romano en Hispania", El Arte de España. Altamira y los orígenes del arte español, vol. I, Barcelona, 2002, pp. 43-80, en concreto, véanse las pp. 72-73. Para el caso de la Lusitania, consúltese: J. L. MARTINS DE MATOS, Subsídios para um catálogo da escultura Luso-romana, 2 vols., Lisboa, 1966, en particular, vol. 1, p. 8.

${ }^{1407}$ J. M. BLÁZQUEZ MARTÍNEZ, "El comercio de obras de arte...", en especial, pp. 257-260. En el estudio se alegan otra serie de motivos en relación con las facilidades que presenta la escultura de época romana a la hora de estudiar su difusión. En concreto, alude también a las copias de las piezas, generalmente sarcófagos y todo tipo de esculturas de bulto redondo y la posibilidad de poder llegar a conocer el patrimonio hoy desaparecido a través de éstas piezas actualmente conservadas.
} 
escultórica facilita el hecho de su rastreo dentro de las piezas existentes. Al tratarse, la mayoría de los casos, de obras de taller, generalmente seriadas, podemos acudir a ellas cuando dentro del corpus escultórico hispanorromano no encontremos piezas conservadas con estos mismos motivos ornamentales, estilísticos e iconográficos ${ }^{1408}$. Parece evidente que, si la mayoría de las piezas romanas conservadas en nuestro suelo, dependen de una manera directa o indirecta de las fabricadas en los talleres de la metrópoli, también podremos acudir a las piezas conservadas fuera de Hispania y salidas de esos mismo talleres, en busca de modelos posibles para emparentarlos con la escultura medieval de los siglos XI y XII. Por lo tanto, la escultura permite completar lagunas que puedan existir en el corpus de esculturas romanas de la Península ${ }^{1409}$.

Desde el punto de vista de la acotación cronológica a la época medieval, el estudio se dividirá en tres grandes bloques o apartados en los que se analizará el tipo de relación que dicha escultura románica mantuvo con el arte antiguo. En el primer apartado se ha pretendido abarcar las producciones escultóricas datadas entre el último cuarto del siglo XI y la segunda mitad del siglo posterior. Estaríamos hablando de todas aquellas esculturas datadas entres los años 1060-1080 aproximadamente, hasta las vinculadas al entorno del año $1150^{1410}$. La escultura del entorno de tal fecha recibe una atención que se materializa en el segundo bloque del estudio.

Por último, en un tercer bloque nos detendremos en valorar la relación de lo que se ha dado en llamar "arte 1200”, concretamente de su escultura, con las diversas filiaciones clásicas.

En realidad se trata de una delimitación convencional que iría desde la aparición de las primeras manifestaciones escultóricas románicas en el siglo XI, hasta una fecha como la relativa al entorno del año 1200, evidentemente, una elección más vinculada a un convencionalismo académico que a un periodo de cambio dentro de las artes románicas.

\footnotetext{
${ }^{1408}$ A la hora de plantearse el estudio de las producciones realizadas en época romana en la Península Ibérica y su relación con la metrópoli de Roma, será fundamental la obra colectiva, surgida de la exposición homónima: Hispania Romana. Da terra di conquista a provincia dell'impero (a cura di J. Arce, S. Ensoli y E. La Rocca), Roma, 1997. En particular, véase: W. TRILLMICH, "Il modello della metropoli”, Hispania Romana..., pp. 131-141. El autor plantea algunos aspectos básicos sobre la relación artística de la metrópoli con la provincia.

1409 J. M. BLÁZQUEZ MARTÍNEZ, "El comercio de obras de arte...", en especial, p. 257. No es cuestión de desarrollar un balance sobre la problemática de la escultura romana y de su habitual copia de piezas griegas. Sobre este aspecto, una breve síntesis en: M. BARASCH, Teorías del Arte..., en especial, pp. 28-29 y J. A. MORÁIS MORÁN, "Investigar sin corpus...”, (en prensa).

${ }_{1410}$ Tanto los límites cronológicos establecidos para estos tres bloques son, evidentemente, orientativos y han sido elegidos teniendo en cuenta la problemática existente dentro del arte románico, de poder asentar y definir barreras cronológicas inamovibles y fijas.
} 


\section{1. UN CASO PARADIGMÁTICO DE INFLUENCIA DE LA ANTIGÜEDAD ROMANA SOBRE LA ESCULTURA ROMÁNICA: EL SARCÓFAGO DE HUSILLOS.}

\section{A. EL SARCÓFAGO ROMANO.}

Dentro de las artes escultóricas hispanas no ha existido, hasta la fecha, un ejemplo que refleje de una manera más directa, evidente y comprensible, el fenómeno que aquí intentamos analizar. Creemos que para iniciar el impacto que la escultura clásica de época romana tuvo dentro del arte románico español, debemos comenzar por el paradigmático ejemplo del sarcófago de Husillos ${ }^{1411}$.

Dicha pieza, denominada así por la localidad de Husillos (Palencia) fue conservada hasta su traslado al Museo Arqueológico Nacional de Madrid en la iglesia de Santa María de la citada población palentina ${ }^{1412}$ (fig. 238). Ya en una publicación del año 1947, T. Aguirre describía así la escultura:

"El Museo Arqueológico Nacional guarda el magnífico sarcófago procedente de Husillos (Palencia) que desarrolla la leyenda de la venganza de Orestes, el hijo preferido de Agamenón y Clytemnestra, entregado a castigar en el cobarde Egisto y en su detestable madre el asesinato paterno. Comienza representando dormidas a las tres Furias, ejecutoras de las sentencias de los jueces de las almas, continúa en el centro con las figuras de Orestes y Pylades dando muerte a Egisto y Clytemnesta y arrancando las telas del trono usurpado, mientras la vieja nodriza horrorizada se cubre el rostro con la mano, y muestra en el lado derecho las Furias que disparan sus flechas y a Orestes que, cautelosamente para no despertar a

\footnotetext{
${ }^{1411}$ Somos plenamente conscientes de que, en la actualidad, la importancia que se le está otorgando al "fenómeno del sarcófago" de Husillos, sobrepasa, con mucho, las dimensiones del verdadero significado que pudo tener durante el periodo medieval. Cf.: F. PRADO-VILAR, "Saevum facinus...", pp. 173-199.

${ }_{1412}$ En las sucesivas páginas recogeremos toda la bibliografía que la pieza ha suscitado, mayoritariamente por parte de los medievalistas. Sin embargo, queremos señalar dos de los trabajos más interesantes en relación con la escultura. El sarcófago, que narra el mito de Orestes, tal y como explicaremos, halla sus paralelos iconográficos y estilísticos en los sarcófagos mitológicos de friso corrido producidos en Roma. Recogemos aquí las menciones realizadas por dos especialistas en escultura romana: A. GARCÍA Y BELLIDO, Esculturas romanas de España y Portugal, Madrid, 1949, en concreto, p. 217 у M. CLAVERIA NADAL, "El sarcófago romano en la tarraconense", IV Reunión sobre escultura romana en Hispania, Madrid, 2004, pp. 273-306, en concreto, p. 276. Se trata de dos aportaciones que recogen los datos más importantes sobre la pieza. Desde la ya temprana aportación de García y Bellido, hasta la más actual de M. Claveria, se viene admitiendo que se trata de una pieza, posiblemente, datable en el periodo antonino medio. Como veremos, algunos de los estudiosos del arte medieval optaran por otorgar a la pieza otras dataciones, generalmente, adscribiéndola al periodo de los severos.
} 
una aún dormida, con el gesto resuelto de haber hecho justicia, pasa ante la estatua de su padre. En el lado izquierdo representa el momento en que Minerva deposita su voto ante el tribunal de los Heliastas salvando a Orestes, cuyo corazón las Furias forzaron para que se presentara a exculpar su crimen, y en el costado derecho aparece Orestes prisionero. Estos salteados episodios del drama de Orestes y salvo la excepción del relieve de Petrogrado, son los mismos que en todos los sarcófagos de igual tema, de los cuales es el mejor ejemplar el conservado en el Museo de Letrán, perteneciente a los año 132 a 134 según la fecha de los ladrillos de la obra; el de Husillos guarda con él extraordinaria semejanza principalmente en las figuras de la línea inferior y tiene aunque menos correcto casi la misma distribución equilibrada y extraordinario movimiento, lo que fuerza a pensar que también corresponde a la época de Adriano" $" 1413$.

La descripción realizada por el autor dentro del volumen dedicado al arte hispanorromano de la colección Ars Hispaniae, es una de las primeras ocasiones en las que se abordaba, de manera científica, la pieza. En su aportación, el autor señalaba una idea que, a nuestro juicio, es fundamental para el estudio de la obra. El sarcófago pertenece a una abundante lista de piezas, todas ellas coetáneas aproximadamente en cuanto a su fecha de ejecución y, que presentan la particularidad de ostentar un mismo desarrollo iconográfico y unas mismas peculiaridades estilísticas en la parte frontal de todas ellas.

Se trata de un ejemplo bien significativo de la realidad existente en los talleres imperiales de la metrópoli romana, la ciudad de Roma, donde los artífices producían mecánicamente los motivos y modelos. T. Aguirre cita el ejemplo conservado en el Museo Lateranense de Roma y el de Petrogrado. A ellos debemos sumar, por ejemplo, la pieza conservada en los Musei Vaticani de Roma, que guarda un extraordinario parecido con la hallada en Palencia ${ }^{1414}$. Finalmente, debemos aludir al ejemplar

\footnotetext{
${ }^{1413}$ T. AGUIRRE, “Arte Romano”, Ars Hispaniae, vol. II, Madrid, 1947, pp. 11-179, en especial, p. 133. No debemos olvidar que fue durante el siglo II. d. de C. cuando se produce el afianzamiento de la inhumación de los cadáveres, es decir, a partir de este momento se comienza a multiplicar la producción de sarcófagos que comienzan a sustituir a las pequeñas urnas cinerarias para contener cenizas. Cf.: $\mathrm{M}$. CLAVERÍA NADAL, "El sarcófago...", concretamente, p. 22.

${ }^{1414}$ La pieza en cuestión vuelve a narrar la leyenda de Orestes en la parte delantera de la cista del sarcófago. Se trata de una pieza de mármol blanco, datada, generalmente, en torno a la primera mitad siglo II d. de C. Véase un breve análisis en: X. BARRAL I ALTET, "The Roman World", Sculpture. From Antiquity to the Middle Ages, (G. Duby y J-L. Daval eds.), Köln, 1999, pp. 147-237, en particular, p. 174. En su día, se apoyó la dependencia del ejemplar de Husillos con el del Laterano, en: J. M. BLÁZQUEZ MARTÍNEZ, "El comercio de obras de arte...”, en especial, p. 261.
} 
proveniente de la localidad francesa de La Gayole, cerca de Brignoles, aunque se encuentre en estado muy fragmentando ${ }^{1415}$.

Las copias de un mismo sarcófago debían realizarse de una manera seriada, independientemente del lugar al que posteriormente fueran transportadas. Aunque este hecho pudiera parecer evidente, pone de relieve un aspecto comentado con anterioridad. Así, parece factible la posibilidad de suplir la desaparición de algunas de estas piezas a través de otras existentes, a pesar de su lejanía con respecto a la ubicación de la obra románica con la que se pretende llevar a cabo tal comparación o vinculación.

Si en el caso que tratamos ahora, en concreto el del sarcófago de Husillos, la pieza hubiera desaparecido del corpus de sarcófagos hispanorromanos y nunca hubiéramos sabido de su existencia o conservación en medio de una zona tan rural como la palentina, parece que la posibilidad de establecer una dependencia de la escultura romana con respecto a la románica, se habría reducido de una manera considerable.

Sin embargo, a pesar de que éste hecho pudiera hablar negativamente en cuanto a la conservación y conocimiento de las piezas romanas que en su día existieron en la Península Ibérica, debemos, por otra parte, ser conscientes de que, esta manera de trabajo seriado, presenta también una gran ventaja. Gracias al sistema de copias con el que trabajaban los artífices de los talleres marmolistas romanos, una obra que durante la Antigüedad fue importada desde la ciudad de Roma a otras lejanas provincias del Imperio, pudo, según este mecanismo, haber sido transferida, igualmente, a Hispania.

Se trata de un factor fundamental, pues cuando establezcamos ciertas relaciones entre piezas conservadas en el ámbito italiano, otras vinculadas a la provincia galorromana u otras, por ejemplo, ligadas a las producciones romanas del norte de África, debemos ser conscientes de que era perfectamente factible el traslado de piezas y que, algunas poseedoras de las mismas características, podrían haber sido introducidas en la Península Ibérica ${ }^{1416}$. Tal y como observamos, esta tarea se complica si intentamos realizar la misma operación aplicando dicho método a otro tipo de producciones como la arquitectura o la pintura.

El sarcófago de Husillos debió llegar a la localidad, tal y como apunta, J. M. Blázquez, a través de esta fórmula, mediante la cual, "los sarcófagos llegaban ya

1415 Brignolles, Musée. Cf.: G. KOCH, "Zu dem verschollenen attischen Sarkophag aus La Gayole", Imago Antiqvitatis. Religions et iconographie du monde romain, Mélanges offerts à Robert Turcan (N. Blanc y A. Buisson ed.), Paris, 1999, pp. 291-297.

${ }^{1416}$ M. CLAVERÍA NADAL, "El sarcófago...", p. 25. Se rastrea el traslado de piezas desde estas regiones africanas a Hispania, precisando que, aunque el número de obras conservadas hoy sea escaso, los modelos nacidos a partir de este tipo de obras, sí que acabarían por estar ampliamente difundidos. 
tallados y eran la carga de retorno, igualmente, de los barcos que transportaban mercancías hispanas" ${ }^{1417}$.

Así, la escultura aparecería vinculada al ámbito hispano desde ese hipotético traslado que, presuntamente, si seguimos los parámetros habituales en relación con otras piezas, debió realizarse poco después de su ejecución en los talleres de la metrópoli ${ }^{1418}$. La mayoría de los especialistas tienden a datarla en torno al siglo II d. de C, es decir perteneciente a la época Antonina (150-170 d. de C.) ${ }^{1419}$.

Las menciones a la pieza se remontan hasta el siglo XVI, donde, tal y como es bien conocido, Ambrosio de Morales llevaría a cabo su descripción, cuando se encontraba in situ en la iglesia de Santa María de Husillos. El autor nos dice:

"En la haz desta caja está esculpido de mas que medio relieve el fin de la historia de los Horacios y Curiacios, pues está al principio la hermana muerta y allí su esposo y otra gente llorosa sobre la hermana, y entre ellos uno que no se le pareciendo mas que el colodrillo con la mano puesta en él representa mas tristeza que ningún rostro de los muy tristes que se parecen; con esto se puede creer quiso el artífice fuese este el Agamenon de Timantes, que cubriendo su pesar el buril lo muestra mayor el arte (...) Toda la escultura está muy conservada sino es una sola figura al un lado, que a lo

${ }^{1417}$ J. M. BLÁZQUEZ MARTÍNEZ, "El comercio de obras de arte...”, en particular, p. 261. Para el autor se trata de una pieza importada desde la ciudad de Roma. Resulta interesante la noticia ofrecida en: J. B. WARD-PERKINS, voz "Sarcófago...", en concreto, p. 700. El autor afirma que, en relación con el transporte marítimo de estas piezas, uno de los ejemplos más importantes es el del barco naufragado en Torre de San Pedro, cerca de Taranto, en torno a la primera mitad del siglo III d. de C. En sus bodegas se han localizado más de veinticuatro sarcófagos que viajaban desde Asia Menor hasta la misma ciudad de Roma. Ello nos habla de la importancia de la ciudad como gran exportadora, pero también, de la necesidad de importar otra serie de obras de lugares lejanos. El tránsito de las piezas queda nuevamente corroborado. Sobre la importancia del mar para difusión, tanto de obras como de fórmulas artísticas, en los diferentes territorios del periodo medieval, véase: M. ADELAIDE MIRANDA, "El Reino de Portugal, la promoción del conocimiento y de los viajes en la Edad Media a través del arte", El Mar de Portugal. Arte e Historia, La Laguna, 2002, pp. 17-39.

${ }^{1418}$ Se ha señalado también la importancia que dentro de este sistema tenían los escultores, no ya de la metrópoli, sino los de las mismas provincias que eran los encargados, una vez llegada la pieza desde su lugar original, de esculpir los rostros de los difuntos, que se habían dejado inacabados a la espera de poder personalizar las piezas. Sobre este tema, véase: J. ARCE, “Arte Romano...”, en concreto, p. 62.

${ }^{1419}$ Recogemos aquí las menciones y trabajos importantes que, a nuestro juicio, se han preocupado de manera explícita del sarcófago. A parte de la bibliografía ya mencionada, véanse: A. FERNÁNDEZ GUERRA Y ORBE, "Sarcófago pagano en la Colegiata de Husillos, recién traído al Museo Arqueológico Nacional”, Museo Español de Antigüedades, I, 1872, pp. 43-60; A. GARCÍA BELLIDO, Esculturas romanas..., en concreto, pp. 212-217; ID., Arte Romano, Madrid, 1972, en especial, pp. 430-439; M. A. CASTIÑEIRAS GONZÁLEZ, "Sarcófago de la Orestíada...”, pp. 248-255; A. BALIL ILLANA, "El arte de la época romana", El arte de España..., en especial, pp. 88-90 y F. PRADO-VILLAR, "Saevum facinus...", pp. 173-199. 
que yo creo por estar muy relevada quitó algún grande artífice para llevarse algo de aquella maravilla" ${ }^{1420}$ (texto 69).

La temprana descripción de la pieza llevada a cabo por A. de Morales, no deja de asombrar por lo completa que resulta. El autor, consciente en todo caso de que se trata de una pieza pagana, posiblemente elaborada, tal y como insinúa, dentro de alguno de los grandes talleres de Roma, no llegó a comprender bien la historia. A pesar de creer que en el frente se representó el tema de los Horacios y los Curiacios, lo más destacado es el gran valor e importancia que le atribuye, llegando a dar el nombre de Fernando Ansúrez como posible ocupante y expoliador del sarcófago, ya en época medieval ${ }^{1421}$.

Durante el siglo XIX la pieza continuó estando custodiada en la iglesia de Santa María de Husillos. Allí parece que la vio José María Quadrado ${ }^{1422}$ (texto 65).

En su análisis del sarcófago, el autor decimonónico presenta algunas variantes con respecto al autor moderno. Entre las más destacables, está la corrección que aporta a la descripción de A. de Morales, pues niega que se trate realmente de la leyenda de los Horacios. Además, y ello es importante, se muestra dubitativo a la hora de adjudicarle un origen y la manera en que pudo llegar a tal lugar. Sin embargo, al finalizar su mención sobre la pieza, nos ofrece una reflexión final sobre su importancia, al compararla con otros ejemplos expoliados que, al igual que el de Husillos, fueron reutilizados con un fin propagandístico y dignificador de la persona que había ocupado tal sarcófago en época medieval.

Sin embargo, a diferencia de Morales, Quadrado no se decide a desvelar el nombre de su nuevo ocupante “(...) mas carece de epitafio que permita asegurar si yace allí el conde fundador ó alguno de sus descendientes".

Con todo, el interés que la pieza suscitó a lo largo del tiempo aparece ratificado por otra serie de fuentes documentales. Así, en torno1844, Justo María Velasco, adjunto del Jefe Político de la Provincia de Palencia, redactaba un informe en el que ponía de relieve el extraordinario valor de la pieza, tal y como ya hemos señalado ${ }^{1423}$ (texto 70).

A pesar de las dificultades de los diferentes viajeros e historiadores para poder comprender las imágenes representadas en el frente de la cista de la pieza, actualmente,

\footnotetext{
${ }^{1420}$ A. DE MORALES, Viaje a los reinos de León..., p. 110.

${ }^{1421}$ Sobre dicha posibilidad nos ocuparemos más adelante.

1422 J. M. QUADRADO, Op. cit., pp. 109-110.

${ }^{1423}$ Madrid, Archivo de la Real Academia de Bellas Artes de San Fernando (A. R. A. S. F.), sig. 7-7/2, Monumentos en general, Informe de Justo María Velasco adjunto a oficio del Jefe Político de la Provincia de Palencia al Ministro de la Gobernación de la Península de 30 de junio de 1844.
} 
la historiografía acepta con unanimidad que nos encontramos ante la leyenda de Orestes, el héroe vengador de la muerte de su padre que, desde Homero, tendrá una importancia fundamental dentro de los grandes dramas de la tragedia antigua, sobre todo con Esquilo ${ }^{1424}$. Orestes, hijo de Agamenon y Clintemnestra, ayudado por su amigo Pilades, venga a su padre dando muerte a su madre y a su amante, el joven Egisto. La muerte de ambos, incluido el consabido parricidio, provoca la ira de los dioses, hasta que, con la ayuda de Minerva, finalmente le conceden el perdón ${ }^{1425}$.

Los lados cortos del sarcófago se completan con el tema del Juicio ante los Heliastas en el momento justo en el que se le otorga el voto favorable de Atenea, a la izquierda, mientras que a la derecha, se representó el recuentro del héroe Orestes con su hermana Ifigenia en Tauris ${ }^{1426}$.

Todos los especialistas coinciden en señalar la importancia de la pieza, por formar parte del conjunto de los sarcófagos más antiguos conservados y conocidos hasta la fecha en Hispania. El relieve historiado, colocado en la parte frontal a modo de friso, revela bien a las claras el gusto helenístico que impregnaba buena parte de las producciones escultóricas de época antonina. Las figuras desnudas mostrando unos cuerpos excesivamente musculados, el uso de reiterados escorzos y posturas ciertamente teatralizantes, la explotación de la luz como recurso modificador de la escultura y exaltador del relieve de músculos y textiles, permiten incluir dicha obra dentro de tal tendencia $^{1427}$.

\footnotetext{
${ }^{1424}$ Ello permitió que la iconografía de Orestes generase, a través de su trilogía, una serie de sucesivas reelaboraciones y ampliaciones del tema, pasando a ocupar buena parte de las producciones artísticas de época romana, donde el tema permaneció inalterable. Para un análisis completo de la historia de la "Orestíada", véase: R. GROUSSET y J. AUROYER, voz "Oreste”, Enciclopedia dell'arte antica classica e orientale, vol. IV, Roma, 1960, pp. 741-750, en especial, p. 741 y F. PRADO-VILLAR, Op. cit.

${ }^{1425}$ Se recoge ampliamente la leyenda en relación con la pieza palentina en: A. BALIL ILLANA, $O p$. cit., en concreto, p. 89 y F. PRADO-VILLAR, Op. cit.

${ }^{1426}$ A. M. CASTIÑEIRAS GONZÁLEZ, "Sarcófago da Orestíada...”, en concreto, p. 248.

${ }^{1427}$ Dichas características están tomadas, claramente, del ámbito helenístico, donde la escultura utilizará temas relacionados con la ira, la desesperación o la locura y, de manera más abundante, escenas relacionadas con la muerte. Se trata de una tendencia vigorosa, cuyo nacimiento aparece vinculado a la ciudad de Alejandría, donde este tipo de escultura adquirió gran desarrollo. Las composiciones suelen mostrar grandes grupos nutridos de figuras, frecuentes contorsiones y expresiones de gran carga emotiva, por lo que se ha relacionado tal tendencia con el llamado "estilo pergamés", que tuvo en las esculturas de los reyes de Pérgamo su máxima materialización. La vertiente helenística de la escultura griega, no sólo se limitó a extenderse por ciudades como Alejandría, Pérgamo o la Grecia continental, sino que llegaría más allá de Asia Menor, el norte de África o el sur de Italia. Véase, sobre estos aspectos: G. M. A. RICHTER, El arte griego..., en especial, pp. 116-184. Tal y como puede observarse, la calidad escultórica que observamos en la pieza de Husillos posee algunos puntos en común con esta serie de características. Ha incidido, igualmente, sobre la perdurabilidad de la estética helenística antigua en el ámbito medieval: N. DACOS, "Sopravvivenza...", en concreto, p. 728 y A. M. CASTIÑEIRAS GONZÁLEZ, "Sarcófago da Orestíada...”, en particular, p. 248.
} 
Sin embargo, si la pieza de Husillos ha ocupado un lugar preferente dentro de los estudios especializados en la escultura romana conservada en la Hispania de los siglos I o II d. de C., debemos estar de acuerdo en que, sin duda, ha sido desde los estudios de escultura románica donde a este sarcófago se le ha prestado mayor atención. 


\section{B. Del SARCófago ROMANO AL CAPITEl ROMÁNICO DE SAN MARTÍN DE FRÓMISTA.}

La figura más importante, en relación con este aspecto, fue el profesor Serafín Moralejo. En su ya clásico estudio del año 1973 el autor señaló la importancia que la pieza habría de tener en la formación de algunos de los rasgos de la escultura románica desarrollada en los últimos años del siglo XI en el norte de la Península Ibérica ${ }^{1428}$.

En concreto, la teoría que planteó el experto y que ya hemos recogido aquí, hablaba sobre la posibilidad de que el sarcófago romano que acabamos de estudiar hubiera sido tomado como modelo por parte de los artífices románicos para la creación de su obra escultórica. Se trataría de un spolium in re que, a finales del siglo XI, tendría su repercusión más importante en uno de los capiteles de la iglesia de San Martín de Frómista, en Palencia (fig. 239).

"El capitel conservado en el Museo Arqueológico de Palencia, ha de reconocerse en efecto, como señalé en otro lugar, una paráfrasis del sarcófago romano que por entonces se conservaba en Santa María de Husillos" ${ }^{, 1429}$.

El autor se refería a uno de los capiteles más importantes conservados en la iglesia de San Martín de Frómista. Concretamente, el colocado sobre la columna adosada el pilar sur del ábside central, que se eleva y se yuxtapone al muro de dicho espacio (fig. 240). Este capitel, junto con su columna, forma pareja con otro ubicado en el lado contrario, sirviendo ambos, de base para el asentamiento del arco triunfal que da acceso al presbiterio ${ }^{1430}$.

\footnotetext{
${ }^{1428}$ S. MORALEJO ÁLVAREZ, "Sobre la formación del estilo escultórico de Frómista y Jaca", Actas del XXIII Congreso Internacional de Historia del Arte, vol. I, Granada, 1973, pp. 427-434. Para el tema que aquí abordamos se trata de una de las aportaciones con mayor importancia, pues el autor, con gran agudeza e intuición, descubrió uno de los ejemplos más evidentes de la influencia de una pieza antigua sobre la escultura románica en el ámbito peninsular. Su estudio se reeditó en el homenaje dedicado al investigador: Patrimonio artístico de Galicia y otros estudios. Homenaje al Prof. Dr. Serafín Moralejo Álvarez, (A. Franco Mata dir.), 2 vols., Santiago de Compostela, 2004, vol. I, pp. 65-69. Los artículos del autor citados a lo largo de nuestro trabajo, dada su importancia para la historiografía que ha abordado el tema, se citarán a través de esta nueva reedición de sus estudios, a pesar de que, cada uno, fuera publicado en fechas y medios muy diferentes y dispares.

${ }^{1429}$ S. MORALEJO ÁLVAREZ, "San Martín de Frómista en los orígenes de la escultura románica europea", Patrimonio artístico..., vol. II, pp. 61- 64 e ID., "Sobre la formación...”, pp. 427-434.

${ }^{1430}$ A partir de este momento, queremos aclarar que, en ocasiones, a la hora de referirnos a determinados capiteles de este y otros edificios, se utilizará, preferentemente, la numeración establecida en su día por el profesor M. Durliat en su obra, La sculpture romane de la route de Saint- Jacques. De Conques à Compostelle, Mont-de-Marsan, 1990. La obra, cuya cita completa ya se realizó en este trabajo, sigue estando vigente aún después de dieciocho años de su publicación, a pesar de contar con algunos errores metodológicos, cronológicos y formales. Sin embargo, consideramos que es uno de los trabajos más
} 
Nadie, antes de este importante investigador, había logrado poder perfilar las fuentes seguidas para realizar tal escultura. Ni tan siquiera el mismo Émile Berteaux llegó a atinar con tanta agudeza sobre el modelo seguido y copiado en el capitel románico, pues el autor francés, tan sólo llegó a intuir un recuerdo de las fórmulas clásicas que explicarían algunos aspectos de la escultura de Frómista "difícilmente explicables sin el concurso de producciones clásicas ante los ojos del escultor"1431.

El capitel románico presenta una escena que, desde la aportación del profesor Moralejo, se viene aceptando como inspirada directamente en el sarcófago romano. La pieza, tal y como hemos apuntando anteriormente, había sido sometido a una expoliación in se durante el siglo X. Ahora, en los años finales del siglo XI, el escultor o escultores que trabajaban en el templo sometían a una reinterpretación intelectual, estilística e iconográfica, el sarcófago de época antonina. Se trataba de un spolium in re que permitía al escultor reinterpretar libremente la obra clásica.

En el capitel se esculpieron seis figuras, aparentemente desnudas, que se distribuyen a lo largo de las dos caras cortas y la parte frontal de la pieza (fig. 239). En la actualidad, dicha escultura se nos presenta muy mutilada y con algunas figuras fragmentadas, especialmente aquellas dos que, en origen, exhibían una desnudez plena en la parte frontal, sin duda, la más importante ${ }^{1432}$. Sin embargo, si la obra original,

brillantes y completos sobre la llamada "escultura de los caminos de peregrinación”, expresión, además, no exenta de problemática. Con todo, para referirnos a determinados capiteles, utilizaremos la numeración dada en su día por el autor. En concreto, para el capitel de la iglesia de Frómista inspirado en el sarcófago romano que venimos analizando, se trata del número 52. Véase, igualmente, la pequeña aportación realizada en: C. ARROYO PUERTAS, San Martín de Frómista, Palencia, 2002, en concreto, pp. 88-93. El autor incluye una planta del templo e identifica el mencionado capitel con el número 47. Sobre algunos aspectos de la obra de Durliat, véase: I. G. BANGO TORVISO, "La peregrinación jacobea: algunos aspectos de una mitificación cultural", Cuenta y razón del pensamiento actual, 112, 1999, pp. 20-23.

${ }^{1431}$ E. BERTEAUX, "La sculpture chrétienne en Espagne des origines au XIV siècle", Histoire de l'Art (A. Michel dir.), Paris, 1938, vol. I, pp. 214-295. Con buen criterio, el autor señaló la posibilidad de que el capitel se hubiera inspirado en alguna pieza antigua, pero no llegó a señalar cual. Este aspecto es ciertamente interesante, en cuanto a algunos aspectos que señalamos anteriormente en relación con la posibilidad de suplir la carencia o desaparición de algunas piezas perdidas a través de su sustitución por otras obras salidas de los mismos talleres de la ciudad de Roma. Si en un caso hipotético, el sarcófago de Husillos no hubiera llegado hasta nuestros días, hubiera cabido la posibilidad de recurrir a las copias contabilizadas del mismo sepulcro que en su día salieron de dichos talleres. Véase, en este sentido: A. M. CASTIÑEIRAS GONZÁLEZ, "Sarcófago da Orestíada...”, p. 248. Según el autor, se trataría de más de diez sarcófagos similares, tanto en tipología, como en temática. Sobre este "presentimiento", tal y como lo define Durliat y las reflexiones de Berteaux, consúltese: M. DURLIAT, La sculpture romane de la route..., en concreto, pp. 286-287.

${ }^{1432}$ No se tiene constancia en que momento se llevó a cabo su mutilación. Posiblemente se realizó cuando el capitel ya se había desmontado durante los trabajos de restauración. En la fotografía que se ha conservado aparece, aún sin dañar, por lo que se deduce que entre los planes de restauro estaría el volver a colocarla en su lugar original. Sobre el ambiente político de la Palencia decimonónica y los condicionantes religiosos que pudieron provocar tal actitud hacia el desnudo, véase.: J. L. HERNANDO GARRIDO, "La restauración de la arquitectura románica en Castilla y León a finales del siglo XIX: el 
actualmente conservada en el Museo de Palencia permite, aún hoy en su estado, vislumbrar la importancia y calidad de la escultura del capitel, la copia colocada en el lugar de donde fue retirada en su día dicha escultura, dentro del templo de San Martín, da buena idea del estado original que pudo presentar cuando fue realizada ${ }^{1433}$ (fig. 241).

Sin embargo, es gracias a la fotografía de J. Sanabria, publicada en 1901 por E. Serrano de Fatigati ${ }^{1434}$ (fig. 242), en la que podemos observar el estado original del capitel justo en el momento posterior a su desmonte para acometer con la famosa restauración realizada por M. Aníbal Álvarez y que modificaría todo el edificio durante los años finales del siglo XIX y los primeros del $\mathrm{XX}^{1435}$. Con todo, su restauración,

caso de San Martín de Frómista”, Perfiles del arte románico, Aguilar de Campoo, 2002, pp. 83-109. Para algunas reflexiones sobre esta damnatio nuditatis, véase: J. J. FERNÁNDEZ, "Capitel inspirado en La Orestíada", Los Caminos de Santiago. El arte en el periodo románico en Castilla y León, Valladolid, 2006, en particular, p. 318; G. BOTO VARELA, "La integración de las artes...", en concreto, p. 95 y F. PRADO-VILAR, Op. cit.

${ }^{1433}$ Una análisis de la fotografía citada y su comparación con la copia del capitel que sustituyó al original, han permitido a F. Prado realizar diversas hipótesis en cuanto a la identificación del tema esculpido, tal y como veremos. Cf.: Ibidem.

${ }^{1434}$ E. SERRANO FATIGATI, "Esculturas de los siglos IX al XIII. Astures, leonesas, castellanas y gallegas", Boletín de la Sociedad Española de Excursiones, IX, 1901, pp. 39-40. En su estudio, el autor ligaba estos motivos clásicos a las zonas romanizadas de la Galia, como Toulouse o Moissac.

${ }^{1435}$ No es este el lugar idóneo para recoger todas las publicaciones que han abordado, de una manera $u$ otra, el polémico tema de la restauración decimonónica de la iglesia. Algunos autores consideraron tal intervención como ejemplar y modelo a seguir. Vid.: M. VALDÉS FERNÁNEZ, Arquitectura y escultura románicas en León (siglos XI y XII), Astorga, 1985, particularmente, p. 38.

Sin embargo, por lo general, se ha venido criticando duramente esta intervención que, siendo justos, parece que salvó al edificio del derrumbe. Recogemos algunas publicaciones que contienen, además de diferentes estudios enfocados a analizar todo aquello relacionado con los trabajos restauradores, algunas aportaciones más centradas en diferentes aspectos artísticos y arquitectónicos. En este sentido, son de destacar dos obras colectivas que abordaron el tema que aquí tratamos.

La primera de ellas, nacida de la exposición celebrada en la propia iglesia de Frómista y que versaba sobre la conmemoración de la restauración, se tituló: Frómista 1066-1094. San Martín, centenario de una restauración, Palencia, 2004. Dentro del volumen, véase: J. L. SENRA GABRIEL Y GALÁN, "Origen, muerte y resurrección de la iglesia de San Martín de Frómista", Frómista 1066-1094..., pp. 21-37, en concreto, pp. 22 y 27 e ID., "La iglesia de San Martín de Frómista en vísperas de su transformación decimonónica”, Sautuola, VI Estudios homenaje al profesor Dr. García Guinea, 6, 1999, pp. 661-672. El experto define la intervención como "delito arqueológico". Fue una intervención que ya desde 1878 se consideraba premiosa, a juzgar por el avanzado estado de deterioro del edificio que obligó a que el párroco contratara un maestro de obras para retejar cubiertas y apuntalar muros.

En las mismas actas antes mencionadas, consúltese: J. RIVERA BLANCO, "San Martín de Frómista y la restauración española en el cambio del siglo XIX al XX”, Frómista 1066-1094..., pp. 71-90. El volumen que aquí comentamos finaliza con una selección bibliográfica actualizada, en las pp. 187-194.

La segunda obra que señalamos se titula: San Martín de Frómista, ¿paradigma o historicismo?, Palencia, 2005. Vid.: J. L. SENRA GABRIEL Y GALÁN, "La realidad material de la iglesia de San Martín de Frómista en el siglo XII: de 1066-1904”, San Martín de Frómista, ¿paradigma..., pp. 39-68, en concreto, pp. 43-45. En este trabajo se vuelve a criticar fuertemente la restauración. Además de estas investigaciones, mencionamos otras igualmente relevantes, como por ejemplo: P. NAVASCUÉS PALACIO, "La restauración monumental como proceso histórico: el caso español, 1800-1950", Curso de Mecánica y Tecnología de los edificios antiguos, Madrid, 1987, pp. 285-329; H. WESSEL, "Restauraciones decimonónicas en la iglesia de San Martín de Frómista", Compostellanum, XLVII, 3 y 4 , 2002, pp. 605-632; ID., "Neuere Erkenntnisse über die Kirche San Martín in Frómista und ihre Restaurierungen im 19. Jahrhundert, Mitteilungender Carl Justi Vereinigung e. V., 14, Jahrgang, 2002, pp. 37-67 y J. L. HERNANDO GARRIDO, “La restauración de la arquitectura románica...”, pp. 81-109. 
aunque ciertamente radical y artificial, "no cometió más excesos que (los llevados a cabo) en algunos de los grandes monumentos paradigmáticos de la Francia románica" ${ }^{1436}$.

Gracias a estos datos y a la conservación del capitel original, la obra que venimos señalando acabaría por convertirse en un auténtico hito de la escultura románica hispana y también en un importante jalón dentro de la historiografía especializada $^{1437}$.

Centrándonos concretamente en el capitel románico, la figura central, hoy completamente mutilada, copia directamente la figura vertebral que divide el friso de tipo helenístico del sarcófago romano en dos partes bien diferenciadas (figs. 243 y 244).

Se trata de Orestes que, desnudo, presenta la postura típica de los héroes clásicos y que generalmente se caracteriza por mostrar las piernas y los brazos abiertos

\footnotetext{
Más recientemente, se abordo el tema, en: I. G. BANGO TORVISO, "El paisaje monumental...", en concreto, p. 47. Resulta también indispensable, por ofrecer una visión de conjunto sobre el tema, el análisis realizado en: J. RIVERA BLANCO, De Varia Restauratione. Teoría e Historia de la restauración arquitectónica, Valladolid, 2002, en concreto, pp. 35-58.

${ }^{1436}$ I. G. BANGO TORVISO, "El paisaje monumental...", p. 47. Las palabras del investigador explican, claramente, la exagerada crítica que en los últimos años se ha hecho a tal restauración.

${ }^{1437}$ Todos los autores que han tratado el capitel o la escultura de la iglesia de San Martín, han retomado la teoría expuesta por Moralejo, apareciendo de manera obligada en todos los estudios. Vid.: M. A. GARCÍA GUINEA, "El arte románico en Palencia", Ciclo de conferencias sobre el románico y el Camino de Santiago, Palencia, 1983, pp. 83-108, de manera particular, pp. 84-85, donde expone su teoría de lo que él llama "el románico dinástico".

Véase también: ID., "El arte románico en Palencia", Historia de Palencia. Edades Antigua y Media, vol. I, Palencia, 1984, pp. 217-243, concretamente, pp. 221-223; S. SETTIS, "Continuitá, distanza...", particularmente, pp. 402-403; M. DURLIAT, La sculpture romane de la route..., en concreto, pp. 286287; I. G. BANGO TORVISO, "Arquitectura y escultura", Historia del Arte de Castilla y León. Arte románico, vol. II, Valladolid, 1994, pp. 84-95; H. BREDEKAMP, "Die nordspanische Hofskulptur und die Freiheit der Bildhauer", Studien Zur Geschichte der Europäischen Skulptur im 12./13. Jahrhundert, Frankfurt am Main, 1994, pp. 263-274, particularmente, pp. 266-277; M. DEL AMO Y DE LA HERA, "Capitel com nú clássico", O Románico e o Douro, Lisboa-Porto, 1998, pp. 182-184; J. L. HERNANDO GARRIDO, "Los grandes talleres escultóricos en los monasterios románicos castellano-leoneses", Los monasterios románicos, Aguilar de Campoo, 2001, pp. 47-71, en concreto, sobre el capitel, pp. 52-54; M. A. GARCÍA GUINEA, "San Martín de Frómista, paradigma del románico hispano", Perfiles del arte románico, Aguilar de Campoo, 2002, pp. 11-25; J. L. SENRA GABRIEL Y GALÁN, voz "Iglesia de San Martín (Frómista)", Enciclopedia del románico..., vol. II, Aguilar de Campoo, 2002, pp. 1035-1050; M. A. CASTIÑEIRAS GONZÁLEZ, "Capitel románico inspirado na Orestíada...", pp. 252- 254; H. BREDEKAMP y F. SEEHAUSEN, "Das Reliquiar als Staatsform. Das Reliquiar Isidors von Sevilla und der Beginn der Hofkunst in León”, Reliquiare im mittelalter, Berlin, 2005, pp. 139-164, concretamente, pp. 160-161; TH. MARTIN, "Escultura románica para un público laico: El "maestro de la Orestíada" de Frómista y sus contemporáneos", San Martín de Frómista, ¿paradigma..., pp. 71-83; J. J. FERNÁNDEZ, "Capitel inspirado en La Orestíada", Los Caminos de Santiago..., ficha catalográfica, p. 318 y G. BOTO VARELA, "La integración de las artes...", pp. 92-128. Recientemente se realizó una breve mención al tema en: M. DEL AMO Y DE LA ERA y F. J. PÉREZ RODRÍGUEZ, Museo de Palencia, Palencia, 2006, en concreto pp. 129-131. Destacamos, por su especial relevancia, los trabajos de: I. G. BANGO TORVISO "La arquitectura románica en Palencia", Enciclopedia del románico..., vol. I, Aguilar de Campoo, 2002, pp. 115-136, en concreto, pp. 116 y 123-126 e ID., "El paisaje monumental...", pp. 3350, en especial, p. 49. El estudioso incide en el grado de romanización de la zona palentina y en la importancia de este factor para poder comprender la escultura de Frómista.
} 
formando una $\mathrm{X}^{1438}$. El Orestes del sarcófago y la figura que lo imita en el capitel, realizan una contorsión violenta y absolutamente teatral, focalizada en la daga que ambas figuras portan en sus manos y que sirven al joven para acometer el parricidio, más tarde castigado por las Furias. Por el contrario, en la figura del capitel medieval ésta le sirve para dirigir su ira contra otro personaje que gira su rostro y se protege con la mano en ademán de terror. De igual manera que en el sarcófago romano, el artista románico consigue transmitir la torsión de un cuerpo en tensión, la cabeza se gira bruscamente en ambas composiciones, los cabellos ondean y se encrespan, siguiendo la clásica solución de la escultura helenística.

En el ejemplar romano, Orestes cruza su brazo derecho por delante de su torso para asir la daga y lo levanta en alto en actitud luchadora, mientras que la interpretación medieval de Frómista reproduce nuevamente idéntico gesto. Por otra parte, la mutilación sufrida por el sarcófago durante su estancia en la iglesia de Husillos, provocó la pérdida del miembro, así como la de la daga, que tan sólo se deja intuir en la laguna que muestra el relieve. El brazo izquierdo del Orestes del sarcófago también ha desaparecido, sin embargo, recurriendo a la copia existente, por ejemplo, en los Museos Vaticanos de Roma, podemos llegar a deducir que este brazo se encontraba colocado hacia abajo con el puño cerrado, en actitud de rabia y que, muy posiblemente, las telas que aún hoy vemos en el ejemplar conservado en Madrid, aludirían a algún tipo de túnica o textil que serviría para vestir al personaje (fig. 245).

Por el contrario, el maestro medieval obvió este aspecto y representó, tal y como se intuye en la fotografía de Serrano Fatigati y en el propio capitel original -aunque algo dañado- el brazo libre de todo elemento textil y en actitud acusadora hacia la figura contigua que porta una serpiente. Todos los demás detalles de esta figura central del capitel, hablan de una admiración total por la pieza clásica. Detalles como los cabellos y, especialmente, la semiflexión de la pierna izquierda que muestra el joven, presente en la escultura romana, ha sido realizada a la inversa en el capitel.

\footnotetext{
${ }^{1438}$ Se trata de una composición que tiene su origen en la figura de Orestes romana pero que presentará una larga trayectoria en la escultura románica de otros centros como los de la catedral de Jaca o San Isidoro de León. Al colocar las piernas tersas en aspa se genera una especie de diagonal a la que Moralejo definió en su día como crux decussata. Véase: S. MORALEJO ÁLVAREZ, "Sobre la formación...”, en concreto, p. 428. Es interesante como este juego de piernas y la transmisión del peso del cuerpo hacia ellas, con efectos en las partes altas y bajas del tronco de la figura, acabarían por convertirse en un recurso estético muy socorrido a la hora de representar el cuerpo masculino desnudo. Los artistas de los siglos XI al XIII, lo utilizarían con éxito en figuras tan importantes como el ángel Gabriel de la Visitación de Reims, donde tal y como señaló Panofsky, se ofrece "un contrapposto clásico disfrazado". Cf.: E. PANOFSKY, Renacimiento y renacimientos..., en concreto, p. 159.
} 
Estos aspectos y otros, son rasgos a tener en cuenta para asegurar que se trata de una copia de la obra romana ${ }^{1439}$. Otros detalles más precisos, como la fuerte demarcación de la musculatura a la altura del músculo psoasilíaco y el torso, hablan de la imposibilidad de poder atribuir al artífice románico tan aguda destreza mnemotécnica en la observación directa de la pieza antigua.

Sin duda, parece factible que el artífice románico observase la pieza al natural, pero más allá de retener todos estos detalles en la memoria, debió tomar algún tipo de apunte o realizar algún posible boceto in situ del relieve. Dicha hipótesis se justifica, fácilmente, a través de las grandes similitudes existentes entre ambas piezas ${ }^{1440}$.

Directamente ligadas a la representación central de Orestes, se esculpieron en el capitel otras dos figuras que, emplazadas en la parte frontal, parecen tomadas nuevamente del frente del sarcófago. A la izquierda, según el punto de vista del espectador, se representó una figura aparentemente femenina y de nuevo desnuda, que repite la posición de la figura de Orestes en cuanto se presenta con las piernas en aspa. Otra vez los músculos de estas extremidades recuerdan claramente el modelo romano.

Si las piernas de esta figura no aportan nada de especial al capitel, por ser un remedo de la postura que hemos encontrado en Orestes, la parte alta de dicha composición presenta ciertas peculiaridades. Según la foto de Serrano Fatigati y el capitel del Museo de Palencia, se trata de un hombre que, con su mano derecha, se protege el rostro, evitando así la actitud amenazante y atacante de Orestes. Además, la figura del capitel gira la cabeza al lado contrario, transmitiendo un gesto de horror ante la escena, mientras que con la mano izquierda intenta apartarse de la figura central.

\footnotetext{
1439 J. WIRTH, "Copie en miroir: copie au miroir?", Materiam Superabat Opus. Hommage à Alain Erlande-Brandenburg, Paris, 2006, pp. 265-277. El estudio analiza mediante ejemplos muy representativos este fenómeno. A través algunas piezas, como la estatuilla de Alejandro realizada en bronce y conservada en el Museo del Louvre y, por ejemplo, el diseño del hombre desnudo del Álbum de Villard de Honnecourt, ha establecido el estudio de las mutaciones que una composición sufre en el momento en que es copiada. La inversión de la postura de los miembros de las figuras es un rasgo muy corriente. El autor plantea series tan interesantes de modelos y copias como la de la figura de la Sinagoga de la catedral de Estrasburgo, la de la caja del abad Nantelme del tesoro de San Mauricio o la de la Sinagoga de la vidriera del coro de la iglesia de Santa Elizabeth de Marburg.

${ }^{1440}$ Recientemente se ha defendido dicha posibilidad en la que se imagina al escultor románico tomando apuntes delante de la pieza romana en: J. J. FERNÁNDEZ, "Capitel inspirado...", en concreto, p. 318: "Todo ello denota que el llamado maestro de Frómista habría visto, tomando presumiblemente notas y apuntes que utilizaría en futuros trabajos...". También se apoya la idea en: M. DEL AMO DE LA ERA, Op. cit., p. 182. El investigador afirma "debió tomar de él (del sarcófago) notas gráficas para su trabajo". En este sentido, consúltese también: J. A. MORÁIS MORÁN, "Imitación, copia...", (en prensa). En tal aportación, ya expusimos la posibilidad de argumentar, en ocasiones, e incluso tratándose de un medio eminentemente rural, la probabilidad de que este tipo de apuntes o notas en materias delebles, hubieran sido frecuentes.
} 
Parece claro que esta figura tiene su paralelo más destacado en la de la nodriza del sarcófago de Husillos ${ }^{1441}$. El personaje femenino romano, togado a la clásica, aparece en medio del friso aterrorizada ante el parricidio que Orestes está llevando a cabo. Al gesto de terror y miedo del sarcófago, debemos sumar, además, la incorporación de un ademán violento o de lucha, aportación claramente medieval del escultor.

La tercera figura que aparece representada en esta cara del capitel, se muestra arrodillada en el suelo y se introduce visualmente en la escena a través de una visión de medio cuerpo. Dicha efigie arremete contra la figura central de Orestes mediante una serpiente que porta en la mano derecha, mientras que, con la otra, se agarra con fuerza a un gran elemento textil que pende en medio de la escena y que sirve de separación entre la cara corta y la mayor del capitel. Es posible que este personaje tenga como referente directo la primera Furia que en el sarcófago aparece corriendo, agitada y asiendo una serpiente que embiste contra el mismo Orestes, tras el cortinaje que ocupa la mayor parte del lado derecho de la composición. El escultor románico nuevamente adapta la disposición del sarcófago al espacio restringido y deformado del capitel, lo que le lleva a solucionarlo mediante la figura de medio cuerpo.

La cara corta derecha del capitel, se separa, tal y como hemos dicho, de la cara larga, a través de un gran cortinaje. Dicho elemento textil aparece claramente copiado del sarcófago romano donde las cortinas dominan la composición en el momento en que se produce el asesinato, mientras las Furias comienzan su castigo infernal y un esclavo, atemorizado, se esconde tras un mueble del palacio. El ambiente palatino, acompañado además por estos muebles e, incluso, por una escultura sobre estípite, se completa con el gran cortinaje, tras el que corren las Furias con serpientes ${ }^{1442}$ (fig. 246).

En el capitel románico el cortinaje surge de una monstruosa máscara que parece vomitar este elemento textil ${ }^{1443}$ (fig. 247). El lugar en el que el escultor romano colocó

\footnotetext{
${ }^{1441}$ En su día ya se aludió al gesto de terror de este personaje y su reinterpretación en el capitel de Frómista. Vid.: S. MORALEJO ÁLVAREZ, "Sobre la formación...”, en concreto, p. 428.

${ }^{1442}$ La figura del esclavo representada en el sarcófago romano, de cuclillas y ocultándose tras un mueble atemorizado, también sería reinventada por parte de los escultores medievales, tal y como se observará en otra serie de relieves románicos. S. Moralejo aludió, por ejemplo, a la repercusión de tal figura en las columnas conservadas de la desmantelada Puerta Francígena de la catedral de Santiago de Compostela, donde "varias figuras en cuclillas, vistiendo exomis", parecen recordar la composición de la pieza romana. Vid.: S. MORALEJO ÁLVAREZ, "Sobre la formación...”, particularmente, p. 430.

${ }^{1443}$ A lo largo de éstas páginas indagaremos en la problemática, muy habitual dentro de la escultura de influencia antigua, en las que se representaron diferentes fluidos acuáticos que parecen mutarse y transformarse, en ocasiones, en textiles. Dicho elemento, lejos de ser trascendental, apunta un nuevo rasgo definitorio de este tipo de escultura de talante clásico.
} 
el nudo del gran telón, pasa a ser reinterpretado mediante el infinito imaginario fantástico del medievo, en una máscara.

Tras el cortinón, aparecen en la cara corta derecha de la pieza románica dos figuras desnudas (fig. 248). Son nuevamente hombres. El primero de ellos agarra una serpiente que lanza hacia la figura central, acto que realiza por debajo del telón, como si el artista hubiera intentado evocar diferentes niveles de profundidad en el campo del relieve escultórico. La solución está copiada íntegramente del relieve romano, donde la Furia pasa el brazo por debajo del textil, para alargarlo y atacar al joven del centro. La otra figura que le acompaña copia directamente la existente en el relieve antiguo. Aquí el escultor románico volvió a exagerar actitudes, gestos, cabellos y movimientos. Es muy significativo como, mientras en la pieza romana la figura tan sólo muestra el rostro por encima del cortinaje, en el capitel medieval el escultor incluyó un campo de visión más amplio y nos ofrece, nuevamente, un torso desnudo y un brazo que sobresale por encima del textil.

Por último, en la cara corta opuesta del capitel medieval (fig. 249), encontramos una nueva interpretación de una de las Furias del sarcófago. Su cuerpo vuelve a estar semioculto por los textiles, en clara copia de la pieza clásica. Incluso pudiéramos decir que se trata de la copia más fiel de la Furia que ataca a Orestes, ya que se han conservado pequeños detalles como la clámide que cubre la figura romana y que pasa íntegramente a la composición románica.

Según lo señalado hasta aquí, parece claro que el gran hallazgo del profesor Serafín Moralejo debe ser visto, tantos años después de su descubrimiento, como una de las pruebas más indiscutibles de la admiración que los escultores medievales sintieron hacia estas piezas antiguas. Pero además, queda patente su capacidad de síntesis y de reinterpretación, así como de adaptación al espacio físico que imponía el capitel medieval.

En nuestro estudio, no hemos encontrado ningún caso tan clarificador y evidente de una pieza romana que haya servido, tan a las claras, de fuente de inspiración para los artistas románicos. Su evidencia y rotundidad, han provocado que los estudiosos en el tema repitamos, una y otra vez, todo el discurso relacionado con ambas piezas. Además, tales hechos han proporcionado la base para generar serios debates historiográficos en torno a la figura del escultor medieval que visualizó y reinterpretó la pieza antigua, sobre su impacto, su comprensión y difusión de su influencia en las obras realizadas en los ambientes artísticos coetáneos, así como el grado de responsabilidad que debemos 
atribuir sobre la figura de este escultor anónimo en la difusión de las fórmulas clásicas que impregnarían, no sólo algunas de las esculturas de Frómista, sino las de otros centros cuyos talleres se encontraban activos de manera cronológicamente paralela. 


\section{2. EL SARCÓFAgO DE HUSILlOS Y SU LUGAR DENTRO LA ESCULTURA ROMÁNICA HISPANA.}

\section{A. EL PROBLEMA DE LA PERSONALIDAD DEL ARTISTA Y EL “ATRIBUCIONISMO”.}

Para comenzar a indagar en la personalidad de este escultor que en los años finales del siglo XI estaba llevando a cabo la realización de este capitel para la iglesia de Frómista, nos gustaría ejemplificar tal cuestión a través de la contraposición de dos posturas defendidas por dos de los más importantes especialistas en el campo que estamos abordando.

El profesor I. G. Bango Torviso, escribió en su día, al referirse a la escultura realizada en San Martín de Frómista:

"Los historiadores aceptan, rechazan o reinterpretan los datos documentales a partir de su propio análisis formal de la escultura, generalmente de metodología moreliana. De esta manera los estudios realizados con estos criterios no dudan en manipular la especulación documental en su propio interés (...). La investigación de la escultura puso de manifiesto enseguida la existencia del trabajo de varios artistas, de los que emerge, por su personalidad, el que se considera el maestro principal, caracterizado por el uso de recursos tomados de la escultura tardorromana. A partir de esta fuerte personalidad se han sugerido una serie de obras que podrían estar relacionadas con él, surgiendo así la personalidad del maestro de Jaca/Frómista o de Frómista/Jaca (....,"1444.

Tras realizar algunas reflexiones sobre las formas arquitectónicas y escultóricas de los templos de San Zoilo de Carrión de los Condes, de San Salvador de Nogal o de San Isidro de Dueñas, por ejemplo, el autor finaliza sus reflexiones refiriéndose a la escultura de estos focos con las siguientes palabras:

“Qué podemos decir de estos edificios en relación con los restos más o menos significativos conservados? En principio que en todos ellos hay formas que estilísticamente pueden ser de la época que se documenta. Algunas esculturas

\footnotetext{
${ }^{1444}$ I. G. BANGO TORVISO, "La arquitectura románica...”, en concreto, pp. 120-135. Recogemos este párrafo porque ilustra el fenómeno que queremos explicar a continuación, con el fin de compararlo, además, con las posturas ciertamente antagónicas que mantendrán otros autores.
} 
monumentales responden perfectamente al tercio final del siglo XI, pero se trata de obras que tienen en común un cierto aire estilístico e iconográfico, pero que no son el mismo taller ni mucho menos el mismo escultor" 1445.

El trabajo del profesor Bango, publicado en el año 2002, presenta una postura alejada de otro estudio, realizado por la profesora T. Martin y publicado en el año $2005^{1446}$. La autora, al analizar la escultura de la iglesia de Frómista, se refiere de manera reiterativa al escultor que denomina "maestro de la Orestíada" y realiza una serie de interesantes reflexiones sobre los aspectos que aquí estamos analizando.

"El maestro de la Orestíada, trabajó brevemente en Frómista antes de formar su equipo en Jaca. Allí su estilo es evidente en varios capiteles de la catedral de San Pedro. Su taller y la influencia artística de éste, salieron de la entonces capital aragonesa para llegar a lugares de gran importancia como el castillo de Loarre y las iglesias de Saint-Sernin de Toulouse, San Isidoro de León y Santiago de Compostela entre otros (...) Son varias las manos que se reconocen en la escultura de San Martín de Frómista, entre ellas la de un artista que se especializó en figuras simiescas en cuclillas (...) El "maestro de la Orestíada", hoy anónimo, tuvo que haber sido bien conocido en su medio a fines del siglo XI. No es casual que reconozcamos su "firma" entre las iglesias más importantes de su tiempo (...) En Jaca, León y Compostela, las esculturas del "maestro de la Orestiada" y de su equipo se encuentran en lugares preeminentes de las portadas principales" $" 1447$.

A continuación la autora enumera una serie de esculturas donde "el artista demuestra como se adaptan las formas romanas a la historia bíblica" tal y como se ve en la figura de Isaac de uno de los capiteles de la catedral de Jaca. Cita de seguido el ejemplo de León donde "el maestro y su taller pusieron su talento al servicio de la Puerta del Cordero". Igualmente, dicha personalidad "talló columnas marmóreas para el pórtico norte del transepto" de la Puerta de Azabachería de la catedral de Santiago de Compostela $^{1448}$.

\footnotetext{
1445 Ibidem, p. 122.

${ }^{1446}$ T. MARTIN, "Escultura románica...", en concreto, pp. 71-83.

1447 Ibidem, pp. 71, 74, 75 y 76.

${ }^{1448}$ El capitel en cuestión se encuentra situado en el portal meridional del lado sur del templo. Siguiendo la numeración establecida en: M. DURLIAT, La sculpture romane de la route..., en concreto, pp. 223242. Se trataría del capitel número 12.
} 
Como vemos, el panorama que plantea en su estudio la profesora Martin, se opone a la serie de reflexiones que, tal y como hemos señalado, defendió en su día el profesor Bango. Estas dos posturas, claramente antagónicas, en torno a la figura de este escultor o escultores que, tradicionalmente, se han venido definiendo bajo la expresión de "maestro de Frómista-Jaca" o según parece, ahora también conocido como "maestro de la Orestíada", refleja la complejidad del tema.

Resulta de una extrema inseguridad poder datar de manera exacta el periodo cronológico en el que el escultor trabajó en la iglesia de Palencia. En el estado actual de las investigaciones, son muchas las dudas que se ciernen sobre esta figura: ¿Cuál fue el alcance de su mano dentro de la escultura del edificio? ¿Se limitó a esculpir tan sólo el capitel que hemos venido analizando o, por el contrario, podríamos atribuir a su factura otros ejemplos dentro del mismo templo?. En este sentido, parece claro que deberíamos tener en cuenta que se trata del capitel de mayor calidad del conjunto y que los restantes distan bastante del perfecto acabado y resolución de éste que venimos comentando, por no enumerar la complejidad iconográfica y la clara voluntad "antiquizante" que no hallamos en otros ejemplares del mismo recinto.

De trabajar en Frómista entre los años 1080-1100 ¿esculpió tan sólo un único capitel como se ha afirmado?, ¿porqué se pierde su pista y su mano dentro del mismo edificio?, ¿cómo un capitel donde todas las figuras se mostraban totalmente desnudas y, en cierta medida castigadas, pudo ocupar un lugar tan preeminente dentro de este espacio? Y por otra parte, ¿es factible poder seguir manteniendo que fue un mismo escultor o un mismo taller el que, de manera paralela, trabajó en Frómista, para tras pasar a Jaca, acabar difundiendo su "estilo" por todo el norte peninsular e incluso llegar hasta las zonas del Languedoc?.

Todos estos interrogantes aún no han sido resueltos y creemos que tampoco nosotros podremos aportar mucha más luz a estos aspectos, teniendo en cuenta la situación actual de los estudios. Sin embargo, intentaremos llevar a cabo una serie de reflexiones sobre el tema, para poder perfilar, al menos, el grado de impacto que sobre la escultura coetánea tuvo la admiración por lo clásico que sentía el escultor del capitel de Frómista ${ }^{1449}$.

1449 Estos aspectos están derivados, lógicamente, de la metodología "atribucionista" preocupada en identificar a los autores de las obras, los talleres que pudieron formar, así como sus repercusiones en los diferentes medios artísticos. Véase: S. BIAY, "Entre l'œil et la main. Le concept de maître...", consultado en http://janua.blog4ever.com/blog/lirarticle-68850-380168.html, el día 10 de enero de 2009. El autor analiza algunas cuestiones relativas a la atribución de determinadas esculturas a maestros 
Los últimos trabajos publicados al respecto sobre el tema, entre los que se encuentran las aportaciones de J. Lacoste ${ }^{1450}$ y M. A. Castiñeiras González ${ }^{1451}$, continúan basándose en la eterna disputa cronológica ${ }^{1452}$. Independientemente del papel jugado por la iglesia de Frómista con respecto a la formación de los talleres activos en la catedral de Jaca, parece claro que, uno de los nexos más importantes que unifica ambas fábricas es el de su admiración y reinterpretación de las fuentes clásicas ${ }^{1453}$.

Más allá de las cuestiones cronológicas, el escultor que trabajó en el capitel de Frómista debió permanecer poco tiempo en el taller de la iglesia palentina, sobre todo, porque su manera de esculpir parece diluirse entre las otras manos que decoran el templo, sin duda, de peor calidad ${ }^{1454}$.

Con todo lo dicho hasta aquí, podemos perfilar, a grandes rasgos, un panorama al que habrían de llegar las influencias de este escultor que trabajó en Frómista, tal y como han venido señalando los diferentes autores. Independientemente de si su labor se centró primero en Palencia para pasar más tarde a Jaca, de si era sólo una persona o

concretos del románico borgoñón, especialmente, en el caso de la escultura de Cluny III. Para una reciente aportación sobre el problema del trabajo en los talleres de escultura del periodo románico, véase: A. C. QUINTAVALLE, "Medioevo: i modelli, un problema storico", Medioevo: i modelli, Milano, 2002, pp. 11-52.

${ }_{140}$ J. LACOSTE, Les maîtres..., en especial, pp. 9-58. En el trabajo se aborda el tema sin ahondar demasiado en estas problemáticas. Es importante destacar también la aportación realizada en: T. MARTIN, Queen as King..., en especial, pp. 81-91. Se abordan aquí algunos aspectos de la escultura de Frómista, pero siempre de manera indirecta al centrarse, sobre todo, en sus vinculaciones con la de la iglesia de San Isidoro de León.

${ }^{1451}$ M. A. CASTIÑEIRAS GONZÁLEZ, "Verso Santiago?...”, pp. 387-396.

${ }^{1452}$ La problemática sobre la cronología de la iglesia de San Martín de Frómista es demasiado extensa cómo para poder tratarla de manera rigurosa aquí. Nuestro cometido se aleja mucho de esta cuestión, que aunque muy importante, nos separa de la línea que pretendemos seguir. Son muchas las teorías vertidas en torno al año de inicio y al periodo de construcción del templo y la posibilidad de datar al escultor del capitel que aquí tratamos en un ámbito cronológico concreto. Por nuestra parte, las cuestiones cronológicas quedarán casi siempre y en la medida de lo posible desplazadas a un segundo plano, pues nos interesa, en primer lugar, establecer o definir las características del escultor, su relación con otros centros y, sobre todo, las fuentes clásicas que podemos deducir al observar su obra. Remitimos por lo tanto a la bibliografía recogida sobre el edificio en la que se aborda esta cuestión extensamente.

${ }^{1453}$ S. MORALEJO ÁLVAREZ, "La sculpture romane...", en particular, p. 145. El estudioso planteó en su día un resumen sobre las posturas historiográficas en torno a la formación de los talleres en Frómista y Jaca, defendiendo siempre la primicia de la iglesia de Frómista. Para el autor, el "estilo jaqués" no existiría antes del 1088, teniendo siempre en cuenta que, con anterioridad, se habían iniciado las obras en Frómista. El último trabajo dedicado a este aspecto del que nosotros tenemos constancia, hasta la fecha, es el realizado en: M. A. CASTIÑEIRAS, "Verso Santiago?...", en concreto, pp. 387-388. El investigador retoma la postura de M. Durliat, al dudar sobre lo prematuro de Frómista con respecto a Jaca.

1454 Se viene admitiendo, tradicionalmente, que en el año 1105 aproximadamente los maestros anteriormente activos en Frómista pasasen a desarrollar su labor dentro del taller de la catedral jacetana. Sobre esta hipótesis, véase: S. MORALEJO ÁLVAREZ, "La sculpture romane...", p. 145. Con una teoría contraria, consúltese: M. A. CASTIÑERIAS, "Verso Santiago?...”, p. 387. 
varias, lo que parece factible es que un único escultor que realiza un solo capitel dentro de un edificio no puede ser, él mismo, el generador y "creador" de ningún "estilo"

Se ha venido afirmando que su influencia se rastrea -incluso algunos autores han llegado a defender una misma mano ejecutora-, en lugares tan dispares como la catedral de San Pedro de Jaca ${ }^{1456}$, en los capiteles conservados procedentes Valdecal y Mave $^{1457}$, San Isidro de Dueñas ${ }^{1458}$, San Salvador de Nogal ${ }^{1459}$, la iglesia del monasterio de San Zoilo de Carrión de los Condes, todos en la provincia de Palencia ${ }^{1460}$, la iglesia de los santos Facundo y Primitivo de Sahagún ${ }^{1461}$, la de San Isidoro de León ${ }^{1462}$ o la catedral de Santiago de Compostela ${ }^{1463}$.

${ }^{1455}$ De la aplicación del método comparativo basado en el sistema "arqueológico" o de la "arqueología del estilo" entre las esculturas restantes de la iglesia de Frómista y el capitel inspirado en el sarcófago de Husillos, se deduce que éstas no fueron realizadas por la misma mano. El capitel al que nos referimos es único, el de mejor calidad dentro del recinto, pues los otros son bastante inferiores en cuanto a la pericia con la que fueron realizados. Creemos que existen más relaciones formales entre las restantes esculturas del templo entre sí mismas, que con el capitel. Se defiende la importancia del capitel de Frómista y el sarcófago, en cuanto a su papel dominante en la configuración estilística, en: F. PRADO-VILLAR, "Saevum facinus...", pp. 174-176.

${ }^{1456}$ S. MORALEJO ÁLVAREZ, "Sobre la formación...", pp. 432-433.

${ }^{1457}$ G. GUINEA, "El arte románico...", p. 93. El autor alude al conocido capitel en el que unos artesanos transportan una artesa, comparando dicho motivo con el capitel de Frómista, que más tarde, según señala, se repite, en Santillana del Mar.

${ }^{1458}$ Ibidem, p. 92. En esta aportación se afirma: "Evidentemente no hace falta mucho análisis para deducir que cuando se levantaba San Martín de Frómista, y por los mismos maestros, se construía San Isidro de Dueñas".

${ }^{1459}$ Ibidem, pp. 89-90. El autor da la fecha de 1063 para datar parte de la escultura de dicha iglesia, en relación con los cuales nos dice: "no parece haber duda, han sido tallados por las manos de quienes trabajaron en los de Jaca y Frómista".

${ }^{1460}$ J. L. SENRA GABRIEL Y GALÁN, "Algunas notas sobre la desaparecida iglesia románica del priorato cluniacense de Carrión de los Condes”, III Congreso de Historia de Palencia (Palencia 30-31 de marzo y 1 de abril de 1995), vol. IV, Palencia, 1996, pp. 439-451; ID., "La Portada occidental recientemente descubierta en el monasterio de San Zoilo de Carrión de los Condes", Archivo Español de Arte, 265, 1994, pp. 57-72 e ID., "Nuevos hallazgos románicos en el monasterio de San Zoilo de Carrión de los Condes (Palencia)", Archivo Español de Arte, 293, 2001, pp. 88-95.

${ }^{1461}$ El afán de atribuir una misma autoría a piezas y obras de la más diversa índole llega a límites exagerados y difíciles de demostrar. Vid.: J. L. HERNANDO GARRIDO, "Los grandes talleres...", en concreto, p. 52. El autor escribe: "lo más trascendental es señalar como en 1093 los escultores activos en Frómista fueron los responsables de labrar la lauda sepulcral de Alfonso Ansúrez...". Creemos que dicha afirmación es arriesgada y que, salvo ciertas concomitancias estilísticas, normales en este tipo de obras de similar cronología y geografía, no existe un parecido tan claro como para poder afirmar que el escultor del capitel de Frómista realizó también la lauda de Sahagún.

Su afirmación se basa en las indagaciones vertidas en su día en: S. MORALEJO ÁLVAREZ, "Lid of Alfonso...", ficha catalográfica 90, pp. 210-211. En este punto el autor, en ningún caso, habla de que se trate de dos piezas esculpidas por la misma mano.

${ }^{1462}$ La influencia del movimiento escultórico sobre la iglesia de San Isidoro ya fue estudiada en su día por diversos autores. Vid.: S. MORALEJO ÁLVAREZ, "Sobre la formación...", pp. 432-433 y R. SALVINI, La escultura románica en Europa, México, 1965, p. 59. Este último investigador alude a la zona aquitana y la basílica de Toulouse, así como el foco jaqués, como fuentes para entender la escultura de las naves del templo de San Isidoro en León. Consúltese también: F. GARCÍA ROMO, La escultura del siglo XI..., pp. 274-275. Aquí se incide en la importancia de lo que denomina el "maestro de León". Véase, finalmente: T. MARTIN, Queen as King..., pp. 90-91. La especialista defiende la teoría expuesta en su día por Moralejo, otorgándole la primicia a Frómista. El "maestro de la Orestíada" habría de pasar en torno al 1090 de Frómista a Jaca, donde, según la autora, la obra más característica que allí realizaría sería 
Desde la otra parte, la dirección contraria de su influencia llegaría a reflejarse dentro de la escultura de la iglesia del castillo de Loarre ${ }^{1464}$, alcanzando incluso a uno de los capiteles de las tribunas de Saint-Sernin de Toulouse ${ }^{1465}$. El movimiento se trasladaría más allá de la primera mitad del siglo XII, llegando a zonas más alejadas de las rutas jacobeas, tal y como se ha señalado ${ }^{1466}$.

Como vemos, el panorama es demasiado extenso como para poder defender una misma autoría, directa y segura, para todas las obras o, incluso, para poder hablar de un mismo taller. Creemos que a través del conocimiento que tenemos de este apartado de la historia del arte medieval, resulta difícil defender una red tan enmarañada de filiaciones y de trabajos de talleres que llegarían a recorrer todo el Camino de Santiago en dirección de ida y vuelta.

el capitel del Sacrificio de Abraham. La especialista vincula en todo momento la actividad de tal maestro con la escultura de San Isidoro. Según nuestro criterio, al analizar comparativamente el capitel de Jaca con respecto a las características más esenciales del capitel que copia el sarcófago de Husillos en Frómista, la supuesta obra clave del artífice, no encontramos puntos en común lo suficientemente relevantes como para creer que ambas piezas fueran esculpidas por la misma mano.

${ }^{1463}$ T. MARTIN, "Escultura románica...", en concreto, p. 76. Para la autora, el "maestro de la Orestíada" realizó también las columnas helicoidales de la Puerta Norte de la catedral de Santiago, afirmando "se inspiró no sólo en el sarcófago de Husillos, sino en sendas obras romanas". Nuevamente creemos arriesgado hablar de una misma mano trabajando en sitios tan dispares. Incluimos las derivaciones que de la escultura realizada a finales del siglo XI se han hecho a, por ejemplo, otros lugares como la de la iglesia leonesa de San Esteban de Corullón, que según se ha afirmado, es deudora de la corriente "Frómista-Jaca-Santiago". Cf.: C. COSMEN ALONSO, Dos iglesias románicas..., pp. 35-36 y pp. 92-93 e ID., El arte románico en León: diócesis de Astorga, León 1989, concretamente, pp. 20-34.

${ }^{1464}$ S. MORALEJO ÁLVAREZ, "Sobre la formación...", p. 433. El autor justifica tal filiación al comparar la composición de personajes agarrando telas, con los que en su día habían sido labrados en el frontal del sarcófago romano. Por otra parte, véase también: F. GARCÍA ROMO, "Orígenes y cronología de nuestro románico", Revista de Ideas Estéticas, 117, 1972, pp. 23-47, en concreto, pp. 32-33. Sobre este punto escribía: "El principal maestro de Jaca (el de las serpientes) es el mismo de Loarre, cabecera de Frómista y parte más antigua de las naves de San Isidoro, con sus portadas del Cordero y septentrional del crucero; quizás el de San Salvador de las Huertas se relaciona con el de las naves de Frómista; el de Platerías (maestro Esteban) lo es de la parte de las naves de San Isidoro con la portada del Perdón, de la de Platerías de Santiago, de la catedral de Pamplona ( y de la portada de Miégèville de Saint Sernin de Toulouse)".

${ }_{1465}$ Ibidem, p. 430. La teoría propuesta defiende que el comentado capitel de la tribuna de la iglesia francesa aparecía "como un descendiente de Orestes". Otros especialistas se han hecho eco de ello, tal y como expone en: J. L. HERNADO GARRIDO, "Los grandes talleres...", concretamente, pp. 52-54.

${ }^{1466}$ M. M. VILA DA VILA, Ávila Románica..., en especial, pp. 277-288. La investigación se centra, por ejemplo, en la difusión de algunos de los motivos de la puerta del Cordero de San Isidoro de León en la zona abulense. También consúltese: M. A. CASTIÑEIRAS, "Verso Santiago?...", p. 387. Basándose en cuestiones de parecidos estilísticos y noticias documentales, el autor ha defendido la expansión del supuesto "estilo" hasta alguno de los capiteles de la capilla mayor y, sobre todo, del pórtico occidental de la iglesia de Gerri de la Sal, en Cataluña. Sobre la mencionada puerta del Cordero de la basílica isidoriana, vid.: J. WILLIAMS, "Generationes Abrahae: Reconquest iconography in León", Gesta, XVI/2, 1977, pp. 3-4, reeditada en la traducción española en: ID., "Generationes Abrahae: iconografía de Reconquista en León", El tímpano románico: imágenes, estructuras y audiencias, Santiago de Compostela, 2003, pp. 155- 180. Consúltese también: J. YARZA LUACES, "I grandi programmi iconografici", Arti e storia nel Medioevo (E. Castelnuovo e G. Sergi eds.), Del vedere: pubblici, forme e funzioni, vol. III, Torino, 2004, pp. 85-143, concretamente, pp. 102-105. El profesor Yarza reafirma la teoría ofrecida en su día para la lectura del conjunto escultórico del Cordero. Sobre dicha portada se recogerá la bibliografía más destacada en el momento oportuno. 
El mítico maestro de Jaca y su nomenclatura, induce a una serie de reflexiones que entroncan con la esencia misma de la producción de obras artísticas durante el románico. Su hipotética actividad nos plantea dudas, por otra parte bien conocidas, en torno al sistema de establecimiento, distribución, organización y trabajo de los talleres de canteros, picapedreros, escultores y constructores, durante los siglos del románico.

El profesor Bango Torviso, uno de los especialistas más importantes en el ámbito hispano en relación con el desarrollo de los trabajos constructivos durante los siglos XI y XII y que ha centrado su atención, en ocasiones, en la manera en que dicha escultura se relacionaba con la arquitectura, siempre se ha mostrado crítico a este aspecto.

Sus palabras, en relación con esta cuestión, son muy concisas. Al referirse a la defensa de la existencia de este supuesto "maestro" trabajando en tantos lugares dispersos y generando un "estilo" propio, escribía:

"Desde el punto de vista de la técnica histórica la actuación parece correcta, y sin embargo ofrece importantes inconvenientes. El análisis de la evolución de la formas en un período en el que éstas han sido realizadas con unos recursos técnicos y modelos muy limitados, que suelen responder a una larga vigencia de los mismo, no ofrece ningún tipo de garantías. No es éste el momento de detenerse en una crítica exhaustiva del método, baste simplemente como ejemplo de las carencias que ofrece, el que un mismo objeto de estudio, las obras del llamado maestro de Frómista/Jaca, sean interpretadas con este criterio de manera diametralmente opuesta por dos investigadores de reconocido prestigio. El método además se ve estrechamente debilitado por el número considerablemente reducido de monumentos que pueden ser tenidos en cuenta en la estadística investigadora. Los más conspicuos defensores de estos criterios clasificatorios niegan que falten obras de referencia para realizar la teoría estilística del momento" ${ }^{, 1467}$.

Mediante sus palabras, el autor expresa, claramente, lo problemático que resulta seguir definiendo esta tendencia escultórica bajo la nomenclatura de "maestro de la Orestíada" o "maestro de las serpientes", sobre todo si tales acepciones son entendidas

1467 I. G. BANGO TORVISO, "La arquitectura románica....", en concreto, p. 120. Su postura, fuertemente crítica con la noción de estilo y su definición, quedó expuesta también en: ID., "Crisis de una historia del arte medieval a partir de la teoría de los estilos. La problemática de la Alta Edad Media", Revisión del arte medieval en Heuskal Herria, 15, 1995, pp. 15-28. Cuando el autor alude a los estudios de dos prestigiosos investigadores lo hace refiriéndose a los de M. Durliat y S. Moralejo. 
como los vértices fundamentales sobre los que se asiente la génesis de un hipotético "estilo" 1468 .

La persona que esculpió el capitel de Frómista sintió una admiración por la obra clásica, que si bien nos parece excepcional, no lo fue en un panorama donde los monumentos antiguos estaban más alcance de la vista de lo que hoy jamás podríamos imaginar $^{1469}$.

Las personalidades, algunas coetáneas, de Bernardo de Guilduino en Toulouse, el maestro de Platerías en Santiago de Compostela, Gilabertus en Autun, Wiligelmo de Módena, Biduino de Pisa o los más tardíos "maestros" de Cabestany, Mateo del Pórtico de la Gloria, Giraldus de Bourges o Nicola Pisano, son algunos nombres de estos escultores conocedores de lo antiguo. Sus obras, dotadas de gran complejidad en lo relativo a las fuentes que utilizan, hacen que las producciones ligadas a este supuesto maestro hispano de Frómista y Jaca, dejen de parecer elementos extraordinarios, para pasar, simplemente, a endosar una larga nómina de escultores europeos seducidos por el $\operatorname{arte~clásico~}^{1470}$.

En segundo lugar, de una manera parcial toda la historiografía especializada ha afirmado, con unanimidad, que las fuentes clásicas romanas pueden explicar muchas de las peculiaridades de la escultura de este supuesto "maestro" de Frómista.

Sin embargo, la extraordinaria y evidente admiración por lo clásico que presenta su obra, no fue inusual en este periodo. Más sorprendente, portentoso y algo en lo que el factor "suerte" ha tenido mucho que ver, es que el azar haya permitido que las dos obras necesarias para elaborar tal teoría comparativa entre lo antiguo y lo románico, se conservasen.

Creemos que la admiración por lo clásico de este escultor a finales del siglo XI, debe ser vista como un comportamiento hasta cierto punto habitual por parte de estos artífices. La problemática reside en que la mayoría de las fuentes que ellos utilizaron,

\footnotetext{
${ }^{1468}$ S. MORALEJO ÁLVAREZ, "Sobre la formación...,", p. 430. El especialista afirmaba: "Aunque en la mayoría de los casos no pueda hablarse propiamente de una dependencia morfológica, ha de tenerse en cuenta un probable influjo del sarcófago palentino en la proliferación o incluso génesis de dicha iconografía".

1469 Sobre tal aspecto, se hacen unas reflexiones interesantes en: S. KOSTOF, Historia de la arquitectura..., vol. 2, particularmente, pp. 473-474. Aquí se analiza la importancia de los viejos monumentos arquitectónicos y los miles de apilamientos romanos que se esparcían por doquier dentro de las ciudades tardoantiguas. También vid.: I. G. BANGO TORVISO, "Los expolios del paisaje monumental...", pp. 7-50.

${ }^{1470}$ M. A. CASTIÑEIRAS GONZÁLEZ, "Capitel románico...", en concreto, p. 252 y N. DACOS, "Sopravvivenza...", en concreto, p. 723. En relación con este trabajo, la profesora Dacos analiza la relación de la figura de Nicola Pisano con el arte clásico.
} 
hoy se han perdido, por lo que su comparación con las obras románicas es prácticamente imposible ${ }^{1471}$.

A la hora de analizar los restantes capiteles que presenta la iglesia de Frómista, se ha defendido, con cierta rotundidad, que este escultor reintérprete del sarcófago de Husillos, no ejecutó dentro del recinto otra obra de tan singulares características, señalando incluso la posibilidad, de que tan sólo hubiera trabajado en una parte muy concreta del templo ${ }^{1472}$.

En otro ejemplar del mismo edificio, aquel en el que se esculpió la fábula de la zorra y el cuervo (fig. 250), la factura del relieve se presenta ciertamente más tosca o, cuanto menos, no tan elegante y clásica como la presente en el capitel de la Orestíada. Con todo, el tema de esta pieza presenta idénticas conexiones con el mundo antiguo que aquel $^{1473}$. La mayoría de los expertos han defendido una clara dependencia de los textos clásicos, en concreto, de las Fábulas de Esopo. Aquí se representaron los dos animales siguiendo el relato clásico, pero con ciertas novedades y correcciones aportadas por la literatura romana, como es el caso de la reelaboración del texto por parte de Fedro ${ }^{1474}$.

Independientemente de la función pedagógica y moralizante del capitel de la fábula, se advierte en su realización un alejamiento de la manera clásica de esculpir que observamos en el capitel de la Orestíada. Creemos que no se trata, bajo ningún concepto, del mismo escultor $\mathrm{y}$, sin embargo, ambas personalidades comparten las mismas fuentes antiguas.

Se observa, en este sentido, que resulta poco seguro continuar afirmando que dichas fuentes clásicas y la admiración por el mundo antiguo que debían mostrar los artistas románicos, fue algo a lo que tan sólo tuvo acceso el escultor del capitel inspirado en la Orestíada.

\footnotetext{
${ }^{1471}$ J. A. MORÁIS MORÁN, "Investigar sin corpus...”, (en prensa).

${ }^{1472}$ En este sentido, algunos estudiosos han querido ver en el capitel de figuras humanas desnudas sobre leones una continuidad de la manera de hacer del escultor del capitel inspirado en la Orestíada romana. Sin embargo, este ejemplo es la excepción, pues su rastro se pierde dentro del resto de capiteles, de calidad técnica un tanto inferior.

${ }^{1473}$ Se trata del capitel número 34. Cf.: M. DURLIAT, La sculpture romane de la route..., p. 293. La pieza se sitúa rematando una de las columnas de la nave del evangelio, concretamente, en el tercer tramo de dichas naves.

${ }^{1474}$ J. L. SENRA GABRIEL Y GALÁN, “Origen, muerte y resurrección...”, en concreto, p. 34. El especialista considera que la obra presenta una carga simbólica indudable, ligada al tema de la soberbia y el cinismo del mundo, así como el ansia y la avaricia. Apunta que, quizás, en este ámbito cronológico de la Edad Media, la versión de Esopo hubiera sufrido ya una reinterpretación, de la que surgiría el Roman de Renard. Sobre la difusión del tema en época medieval, véase: L. HERRMANN, Les fables antiques de la broderie de Bayeaux, Bruxelles, 1964.
} 
El resto de escultores se acercaron a ese mundo antiguo de igual manera, tanto en su vertiente plástica a través de los trabajos del spolium in re, como en relación con otra serie de fuentes, como la literatura y la poesía. Su conocimiento amplio de las producciones antiguas queda demostrado por la utilización de la fábula de Esopo.

El mayor problema reside en la carencia de referentes y pruebas materiales. Muchas piezas, tanto romanas como medievales, que no han llegado a nosotros, diluyen y difuminan nuestra percepción del fenómeno, así como la posibilidad de rastrear las fuentes que pudieron manejar estos escultores.

Pongamos un ejemplo al respecto. Un bello capitel conservado en el Museo de Palencia (fig. 251), pero proveniente de la iglesia de Frómista, nos muestra a un hombre montado sobre los lomos de un león, mientras otro, aparentemente desnudo, se enreda con la vegetación que envuelve la parte alta de la escultura.

En las páginas anteriores, mencionábamos la escultura de época antonina y severa, de claros tintes helenísticos, como una de las fuentes más pródigas entre aquellas que habían estado ante los ojos de los escultores, a través de la presencia en tierra de campos del sarcófago romano de Husillos. Pero, ¿hubo más piezas de esta índole? La respuesta es compleja, sin embargo, al observar algunas producciones custodiadas en el Museo de Palencia, así como otras conservadas en diversas instituciones de Burgos o León se constata la gran importancia de la romanización.

Más difícil resulta poder demostrar un contacto de estas piezas antiguas con los artistas medievales y casi imposible, poder llegar a asegurar su posterior asimilación, su copia y su reinterpretación. A modo de ejemplo orientativo, que demuestre la problemática de la desaparición de piezas que en la actualidad no han llegado hasta nosotros y la posibilidad de errar al construir una historia del arte a través de un panorama fragmentado, proponemos la comparación del capitel del hombre montando un león con otra escultura de época clásica. Se trata de un capitel conservado en el Museo Arqueológico de Canosa de Puglia (fig. 252), en el que, una cabeza femenina surge de una serie de elementos vegetales que decoran la pieza ${ }^{1475}$. El rostro, de facciones ovales, destaca por el tamaño de los ojos, cuyos perfiles ser marcaron visiblemente ${ }^{1476}$.

\footnotetext{
${ }^{1475}$ Canosa di Puglia, Museo Civico Archeologico.

1476 Se trata de una ciudad italiana muy romanizada, sobre todo entre los siglos I-II d. de C. El mencionado capitel apareció durante las excavaciones realizadas en 1960 bajo la iglesia de San Leucio, dentro de los restos arqueológicos del templo de Giove Toro. Dicho templo recibió su nombre, a su vez, del hallazgo de los vestigios de una escultura dedicada a Giove y que hoy se conserva en el Museo de
} 
Un rasgo bien característico de esta escultura aparece definido por la cabellera que, dividida a través de una ralla alta en la cabeza, genera un peinado bien característico $^{1477}$. La obra, datada como el sarcófago de Husillos entre los siglos I y II d. de C., presenta grandes concomitancias formales con los rostros del capitel de Frómista. El aire helenístico de tales producciones, viene atestiguado, en el caso de la escultura italiana, por las fuertes oleadas de tal tendencia estética que sufrió la zona durante largos periodos.

Sin insinuar jamás una dependencia ni relación directas entre ambas piezas, los paralelismos morfológicos que hallamos entre ambas obras sirven de base para poder realizar una serie de reflexiones que ayuden a valorar la importancia que la historiografía ha otorgado al "maestro" de Frómista y al papel que éste jugó en el desarrollo de diversas corrientes del románico hispano.

En primer lugar, a la hora de plantear y defender una influencia o relación entre la escultura románica con la elaborada en época romana, debemos tener en cuenta que, dichos paralelismos, en ocasiones, dependen más de otros factores, que de una relación directa entre las piezas. Artistas diferentes, en espacios y tiempos disociados, pueden llegar a soluciones similares, a través de caminos muy diversos, sin la necesidad de que existan rasgos que las unan.

Desde otro orden de cosas, cuando se recurra por obligación, y debido, la mayor parte de las veces a una eminente e insalvable desaparición de muchas de las obras hispanorromanas, deberemos tener en cuenta que los artífices románicos bien pudieron conocer este tipo de obras, llegadas hipotéticamente a los territorios de la Península Ibérica a través de las vías ya antes mencionadas: importación, compra-venta de piezas o, simplemente, producciones hispanorromanas de talleres locales, inmersos íntegramente en los postulados estéticos y técnicos de la metrópoli ${ }^{1478}$.

Taranto. Sobre dicho templo y en una cronología posterior, se edificó otro dedicado a Minerva para, finalmente, ser ambos demolidos al elevarse la citada iglesia cristiana entre los siglos IV y V d. de C. Véase en este sentido: F. TINÉ BERTOCCHI, voz "Canosa di Puglia”, Enciclopedia dell'arte antica..., vol. Supplemento 1970, Roma, 1973, p. 179.

${ }^{1477}$ F. SCHETTINI, "Nuovi elementi per lo studio del romanico pugliese", Scritti di Storia dell'Arte in onore di Mario Salmi, vol. I, Roma, 1962, pp. 263-286.

1478 A la influencia de los talleres de la metrópoli, debemos sumar, además, el sustrato prerromano y el mismo germen local indígena, que se hallaban ya en la Península antes de la romanización. Vid.: J. ARCE, "Arte romano...", concretamente, p. 73. Más importante, si cabe, será la impronta que sobre la escultura hispanorromana dejarán las producciones artísticas del norte de África. Debemos recordar que la mayor parte de la escultura importada a Hispania, además de ser de temática preferentemente funeraria, provenía de tales regiones. Dicha corriente norteafricana, muy sensible en el arte hispano del periodo, se contraponía a la corriente llegada de Roma que, sin duda, era la más importante. En relación con ello, debemos recordar que los talleres hispánicos no empezaron a crear sus propias obras escultóricas hasta el 
Otra reflexión interesante aparece relacionada con la voluntad de copia y meditación sobre la obra clásica que los escultores románicos llevaron a cabo. Si en el caso del capitel de Frómista parece claro que se copió la pieza romana, debemos teorizar sobre la hipótesis, plausible, de que no fuera este un acto ajeno a los comportamientos cotidianos de los artistas y los talleres románicos. Debemos deducir, que si existió en un determinado momento un artista que reinterpretó la obra clásica y que, además, su reinterpretación sería seguida y asimilada por los talleres activos paralelamente, es factible que tal conducta fuese, cuanto menos, frecuente.

El capitel italiano que hemos comentado anteriormente y que guarda bastantes puntos en común, desde el punto de vista estilístico, con el de los leones de Frómista, no hace sino reflejar una admiración por la obra clásica. En concreto, se trataría de la asimilación de alguna escultura datable entre los siglos I o II d. de C. y relacionada con los valores estéticos helenísticos.

En relación con este tema, mencionemos, brevemente, el conocido ejemplo expresado magistralmente por la profesora E. Vergnolle a la hora de abordar el estudio de la escultura de la torre-porche de Saint-Benoît-sur-Loire ${ }^{1479}$. Aunque tal argumento parezca desviar la atención del tema que aquí estudiamos, creemos que es muy expresivo para comprender nuestra posición al respecto.

La autora, tal y como ya hemos apuntado, ha demostrado la posibilidad de que el taller activo en la famosa construcción hubiera tenido acceso a este tipo de capiteles que hemos explicado a colación del de Canosa. Ello lleva a pensar que tal actitud hacia lo clásico no fuera exclusiva del escultor de Frómista, sino que forme parte de un fenómeno global de atención a lo romano que sacudió algunos talleres de cierta relevancia hacia finales del siglo XI y principios del XII.

momento en que se produjo la decadencia de los centros productores de Roma, hecho que deberemos situar en torno al saqueo de la ciudad por Alarico, en el año 410. Vid.: P. DE PALOL, Arqueología cristiana...., en concreto, p. 289. Se incide en la cuestión de la comercialización de los sarcófagos en: J. B. WARD-PERKINS, voz "Sarcófago...,", de manera particular, pp. 699-700. El autor pone de relieve la importancia de los focos de Asia y el Proconeso, así como el de Roma. Rastrea su área de difusión, desde la misma Grecia, el Egeo, Siria, Cirenaica e Italia. En cuanto al caso de la Galia e Hispania, advierte que el comercio fue ciertamente menor. Sobre la importancia de la copia de piezas griegas dentro de los talleres romanos y su difusión por las provincias, consúltese: G. LIPPOLD, voz "Copie e copista...", pp. 804-810.

${ }^{1479}$ Sobre los estudios realizados por esta investigadora sobre el desarrollo del capitel corintio de inspiración clásica romana, en la escultura del románico, ya hemos hablado extensamente en las páginas anteriores. Sobre los capiteles de la iglesia véase: E. VERGNOLLE, Saint-Benoît-sur-Loire..., en concreto, pp. 26-100 e ID., "Un carnet de modèles...", pp. 23-56. La autora publica además una serie de diseños interesantes para poder rastrear la dependencia del capitel vegetal del que surge un busto, muy difundido en época romana, dentro de la escultura románica. 
Ambas piezas permiten, finalmente, indagar en la manera en que el artífice medieval se comportó ante lo clásico en Frómista. Según defendiera en su día S. Moralejo, la figura de Orestes con sus piernas y torso en forma de aspa fue un modelo de gran éxito en los talleres coetáneos. Al observar, por ejemplo, el capitel del sacrificio de Isaac de la catedral de Jaca ${ }^{1480}$, son muchos los autores que han afirmado que se trata de una clara copia, en algunos de sus detalles, del mismo sarcófago de la Orestíada de Husillos ${ }^{1481}$. Sin embargo, sabemos que éste tipo de solución, en la que se colocan las piernas en cruz para mostrar un admirable desnudo de las figuras, estuvo tan difundida dentro de estos talleres, que no es posible hacer derivar todos los ejemplos que reinterpretaron tal postura del mismo sarcófago.

De hacerlo, acabaríamos otorgando al sarcófago de Husillos un papel vertebral en la configuración de toda una serie de soluciones de la escultura románica, que realmente no posee ${ }^{1482}$. Resulta difícil imaginarse a toda una serie de escultores pertenecientes a los talleres de Jaca, León y Compostela acudiendo a la pequeña localidad palentina para observar al natural la pieza romana.

Según creemos, existieron diferentes grados de copia en relación con el sarcófago. El escultor del capitel de Frómista representa la copia más directa y exacta de la obra, mientras que las demás composiciones existentes al respecto, tan solo recuerdan vagamente el modelo original ${ }^{1483}$.

Tales premisas permiten afirmar que, mientras que el escultor de Frómista posiblemente realizó un visionado directo de la pieza antigua aplicando sobre la imagen el "principio de disyunción", los restantes escultores que siguieron el modelo, interpretaron la escultura antigua a través de la reelaboración realizada anteriormente por otro escultor románico ${ }^{1484}$. Tal hipótesis vendría demostrada, por ejemplo, a través

\footnotetext{
${ }^{1480}$ M. DURLIAT, La sculpture romane de la route..., pp. 238-240. Se trataría del capitel identificado con el número 12. Más adelante abordaremos el problema de la escultura de la catedral de Jaca y el clasicismo de sus formas, por lo que no recogemos aquí la bibliografía básica al respecto.

${ }^{1481}$ Algunos autores llegan a identificar el capitel del sacrificio de Isaac de Jaca con la misma mano que esculpió el capitel de la Orestíada de Frómista, afirmando que se puede datar dentro de la "última fase de este primer maestro de Jaca". Cf.: R. SALVINI, La escultura..., en concreto, pp. 56-57. Se trata de una observación complicada y difícil de demostrar, por otra parte.

${ }^{1482}$ F. PRADO-VILLAR, "Saevum facinus...".

${ }^{1483}$ La postura del Orestes del sarcófago romano pasó íntegramente a la figura del capitel de Frómista y, en menor grado, a la del Isaac de Jaca. Creemos que las figuras en la misma posición que encontramos en el relieve que representa el signo de Acuario en la Puerta del Cordero de León, alguno de los personajes desnudos que igualmente hallamos con postura similar en el interior de la misma iglesia y otra serie de figuras parecidas en la catedral de Santiago, no obedecen a una copia directa del modelo del sarcófago de Husillos, ni mucho menos fueron hechas por la misma mano.

${ }^{1484}$ E. PANOFSKY, Renacimiento y renacimientos..., en particular, pp. 141. Panofsky reflexiona sobre este mecanismo, mediante el cual, el artífice medieval, reinterpreta y reelabora una escena clásica ya
} 
de las pocas similitudes existentes entre, por citar dos casos evidentes, la postura del acuario de la Puerta del Cordero de San Isidoro de León y la figura de Orestes en el frontal romano ${ }^{1485}$.

Hemos de advertir que los procesos de transmisión de tales imágenes son extremadamente complejos. Primero se advierte la presencia del modelo original en el sarcófago de Husillos, pasando posteriormente a realizarse su primera reelaboración románica. Más tarde se produce la difusión de esta imagen "antiquizante" derivada del sarcófago, sin embargo, a partir de aquí las futuras reinterpretaciones parten de una imagen ya elaborada por un escultor románico. La fuente no es ya antigua, sino medieval, a pesar de que su origen continúa siendo clásico.

Si todo parece indicar que existieron fuentes clásicas para la elaboración de algunas de las esculturas de Frómista y, tal y como veremos, de las de Jaca, debemos pensar que los modelos antiguos no se transmitieron y difundieron por todos los talleres de una manera "pura", es decir, tomándolos directamente de las piezas romanas originales. Muchas de las similitudes que encontraremos entre algunos talleres y esculturas del mismo periodo con respecto a estos dos focos mencionados, responden más a interpretaciones de los mismos escultores coetáneos, realizadas sobre la reelaboración hecha por otros, que a una copia directa.

Se trataría de una reversión de una pieza clásica ya versionada a través de la copia de la obra románica que, a su vez, reinterpretaba el modelo romano, pero al que el escultor de esta segunda traslación ya no ha tenido acceso. Desde luego, cuesta imaginarse a los escultores del capitel de Isaac en Jaca o del relieve de Acuario de San Isidoro de León, acudiendo maravillados a tomar notas de la pieza romana de Husillos.

dada, generalmente, de origen mitológico, para acabar reinventando la historia, haciendo una mutación medieval a través de la figuración y el estilo. A partir de Panofsky, se realizaron una serie de reflexiones importantes en: S. SETTIS, “Continuità, distanza...”, pp. 373-486; M. A. CASTIÑEIRAS GONZÁLEZ, “Capitel románico...”, p. 252 e ID., Introducción al método..., en concreto, pp. 104-108.

1485 "En León, el maestro y su taller pusieron su talento al servicio de la Puerta del Cordero, la entrada mayor de la basílica. El toque particular del maestro se ve con más claridad en el relieve de Acuario, que se representa como un joven desnudo que vierte agua". Cf.: T. MARTIN, "Escultura románica...", en concreto, p. 76 e ID., Queen as King..., pp. 92-93. Según nuestro punto de vista, pretender que la placa con el símbolo de Acuario de la Puerta del Cordero pertenezca a la misma mano que el capitel que copia el sarcófago de Husillos en Frómista, supone plantear una visión simplista del desarrollo de la actividad escultórica durante los siglos XI y XII. Comparando las tres figuras desnudas del capitel de Frómista, del Isaac de Jaca y del Acuario de León, por no citar otros ejemplos del interior mismo de la basílica legionense o la catedral de Santiago, con el modelo original de Husillos, creemos que se ve, claramente, una dependencia real entre Frómista y el sarcófago romano y una simple derivación residual en los otros. No se puede hablar de copia directa del sarcófago, ni mucho menos de la misma mano trabajando en todos estos talleres. 
Bastaba con acudir a los modelos románicos -inspirados en la Antigüedad- que se encontraban ya lo suficientemente difundidos como para tener acceso a ellos.

Ello lleva, a su vez, a otro gran problema que se ha planteado alrededor de estas cuestiones. En ocasiones se ha sugerido la posibilidad de que en el momento en que el escultor románico tuvo acceso a la pieza romana y pensó en reproducir aquello que estaba viendo, éste comprendiera la historia que se narraba en la pieza, ya fuese de una manera total o, al menos, fragmentada.

En este sentido, M. Castiñeiras ha defendido, recientemente, la posibilidad de que el escultor hubiera entendido el motivo a la hora de copiarlo ${ }^{1486}$. También T. Martin ha insinuado la posibilidad de que el artífice románico "conociera la historia original de Orestes" y ello le llevase a reelaborarla ${ }^{1487}$.

Sin embargo, aunque interesantes, estas propuestas son complicadas. Resulta espinoso saber que grado de conocimiento de la escena romana tenía el escultor románico del capitel palentino y, sobre todo, debemos pensar que si llegó a comprender, aunque fuese indirectamente parte de la escena, es difícil que captase la turbulenta historia de Orestes al completo, tal y como ha apuntado S. Settis. En su reelaboración, el escultor eliminó de la escena las figuras fundamentales para comprender la historia, es decir, las de Pílades, Agamenón e incluso Clitemnestra, auténtica protagonista del drama $^{1488}$.

1486 "Gli autori hanno voluto vedere nel suo spolium in re una incomprensione del modello classico, che sarebbe stato variato nei suoi motivi e quindi reinterpretato come un'allegoria cristiana della lotta tra il bene e il male. Non dobbiamo dimendicare però che il tema delle Erinni che inseguono Oreste -tema principale del sarcofago de Husillos- era noto al ceto ecclesiastico più preparato dell'epoca". Cf.: M. A. CASTIÑEIRAS GONZÁLEZ, "Verso Santiago?...", en concreto, p. 388. El autor, apoyándose en los textos de Guibert de Nogent (1055-1125), especialmente en los de su biografía, alude a un pasaje en el que el Conde de Breteuil sufría en sueños el tormento de las Furias. También cita la figura de Giraldo de Beauvais, magister scholarum de la catedral de Santiago, que describe a la reina Urraca como una fera Erinis. El autor llega a plantear la posibilidad de que el escultor hubiera elegido esta escena para colocarla en el arco triunfal de la iglesia de Frómista, en alusión al tema del castigo. Lo relaciona con la fórmula paleográfica de condena que, en ocasiones, aparece en los documentos de donación, así como con el testamento de Doña Mayor. La hipótesis es sugestiva, pero según nuestra opinión, resulta difícil de demostrar. Anteriormente el mismo autor entendía que, cuanto menos, el maestro de Frómista entendió, desde un acercamiento superficial a la historia, la tragedia de un hombre perseguido por el mal. Véase igualmente sobre este punto: ID., "Capitel románico...", p. 252.

${ }_{1487}$ T. MARTIN, "Escultura románica...", en particular, p. 77.

${ }^{1488}$ S. SETTIS, "Continuità, distanza...", concretamente, pp. 402-403. El autor destaca lo pagano de la escena, incluso a través de la consabida "reinterpretación cristiana". Compartimos con él la afirmación de que, tanto artífice como público, no comprendieron en absoluto la esencia original de la historia. Anteriormente hemos mencionado que ni durante el siglo XVI con Ambrosio de Morales, ni más tarde en el XIX con J. M Quadrado, se llegó a averiguar que tipo de escena se representaba en el sarcófago, lo cuál es indicador de que, muy posiblemente, el espectador medieval, como la mayor parte del actual, no tenía tanta facilidad de comprensión de los temas clásicos. Véase: F. GARCÍA ROMO, La escultura del siglo $X I \ldots$, pp. 270-271. El investigador llegará a ser más radical afirmando que aquello que entendió el escultor medieval a la hora de realizar su capitel "era una libre fantasía, sin trabas iconográficas, o 
El escultor medieval quedó impresionado por las Furias y fue en ellas donde fijó su atención, siendo posible que la causa de tal admiración esté más emparentada con una familiaridad hacia ese determinado tipo de iconografía que a un conocimiento exhaustivo de las fuentes clásicas. Opinamos que la imagen de las Furias era susceptible de una rápida y evidente asimilación con la figura del pecado, de lo lujurioso y de la venganza. El atributo de las serpientes en manos de una mujer, tal y como se ha demostrado, era la materialización perfecta del pecado y de sus consecuencias, además de ser un tema inagotablemente repetido en los ambientes medievales ${ }^{1489}$.

La comprensión que realizó el artista románico de tal imagen, quedaba lejos de la que un día había ostentado dicho símbolo en la Antigüedad ${ }^{1490}$. El carácter ctónico y su función profiláctica y benefactora, relacionada, en ocasiones, con la fertilidad, se entendió durante los siglos medievales, la mayor parte de las veces, como una representación del mal y del pecado ${ }^{1491}$. El artista románico tomó de la pieza, mediante

capricho...". Consúltese también: L. GUERRINI, voz "Clitennestra”, Enciclopedia dell'arte antica classica e orientale, vol. II, Roma, 1959, pp. 721-723. Se analiza el origen mitológico del personaje, así como su importancia dentro del mito de Orestes. Clitemnestra era hija de Leda y Tíndaro, hermana de Timandra y Filonoe y gemela de Elena. Destaca el papel crucial que el personaje va a tener dentro del relato de Orestes, estudiando su representación en la parte frontal del sarcófago conservado en el Museo Lateranense de Roma.

1489 J. LECLERCQ-KADANER, "De la Terre-Mère à la Luxure. A propos de la "migration des symboles", Cahiers de civilisation médiévale, 69, XVIII, 1975, pp. 37-43. La investigadora habla de tal transposición de los símbolos desde la Antigüedad hasta la etapa medieval. Desde la historiografía española, véase: E. FERNÁNDEZ GONZÁLEZ, "Sobre la serpiente: aproximación a un tema iconográfico universal”, Ástura, 4, 1985, pp. 43-53 e ID., La escultura románica..., pp. 173-175. La profesora Etelvina Fernández insiste en la importancia del antiguo Oriente y el mundo clásico para poder comprender la difusión del tema en la Edad Media. En relación con la escultura de la primera fase de la girola de la catedral de Santiago de Compostela, anterior a los ejemplos que venimos comentando, consúltese también: V. R. NODAR FERNÁNDEZ, "De la Tierra Madre a la Lujuria: a propósito de un capitel de la girola de la Catedral de Santiago", Sémata, vol. 14, 2002, pp. 335-347.

${ }^{1490}$ Sin embargo, ello no quiere decir que el artista eliminase la esencia misma del tema, pues aquí no se percibe una negación de la concepción pagana del sujeto, ya que, al contrario, parece que fue uno de los aspectos que más interesó al artífice. No podemos, por tanto, estar de acuerdo con la afirmación realizada en: S. SEBASTIAN, Mensaje simbólico..., en concreto, p. 140. El especialista considera que los artistas cristianos "desechan figuraciones relativas a la mitología idolátrica y las figuraciones que en ese sentido idolátrico se perdieron, fueron tomadas y aceptadas por el cristianismo dotándolas de un sentido diferente". En el capitel el artífice conservó parte de esa figuración mitológica, a pesar de no haberla entendido plenamente.

${ }^{1491}$ No recogemos toda la bibliografía que hemos utilizado para el tema de la serpiente, ya que dicha tarea se realizará en el apartado que dedicamos más adelante a esta iconografía. Durante la Edad Media la figura clásica de Tellus o Gaia, como diosa genetrix y representante del principio de procreación, fue dotada de otra serie de significados, en relación siempre con el castigo, ahora en forma de mujer atormentada por serpientes, que le llegan a succionar los pechos. Cf.: J. LECLERCQ- KADANER, "De la Terre-Mère...", p. 41; A. GRABAR, "Le tiers monde de l'Antiquité...", p. 15 y P. ZANKER, Augusto y el poder..., p. 209. En las siguientes páginas se abordará el tema de manera amplia indagando en las fuentes clásicas y las repercusiones que esta imagen tuvo dentro de la escultura románica peninsular hispana. Consúltese también: M. A. CASTIÑEIRAS GONZÁLEZ, El calendario medieval..., en concreto, p. 47. En este punto se alude al valor benigno que desde antiguo se le había dado al mito de la Mater Genetrix, en parte gracias a la filosofía neoplatónica, que la entendía como una enviada de la divinidad y que, además, se encargaba de perpetuar las especies. 
el spolium in re, sólo aquellas imágenes que le interesaban para su cometido o aquellas a las que podía acceder intelectualmente a la hora de poder interpretarlas.

Tal supuesto, acabó materializándose a través del citado "principio de disyunción", donde las imágenes de las Furias pasaban al capitel palentino a través de una "visión incompleta y deformada", siguiendo las palabras de E. Panofsky ${ }^{1492}$.

El artista tan sólo llegó a un conocimiento muy primario de la imagen: la de un hombre atormentado, al que unas mujeres, símbolo del mal y el pecado en los siglos medievales, azuzaban con serpientes. El resto de figuras fueron eliminadas y con ellas cualquier posibilidad de atribuir al escultor un conocimiento de la narración mitológica y de la escena de una manera absoluta.

\footnotetext{
${ }^{1492}$ Recogemos uno de los párrafos que, a nuestro juicio, son más importantes del estudio del autor: " $L a$ Edad Media había dejado insepulta a la Antigüedad y alternativamente galvanizó y exorcizó su cadáver. El Renacimiento lloró ante su tumba y trató de resucitar su alma: y en un momento fatalmente propicio lo logró. Por eso el concepto medieval de la Antigüedad fue tan concreto y al mismo tiempo tan incompleto y deformado; mientras que el moderno, desarrollado gradualmente a lo largo de los últimos trescientos o cuatrocientos años, es completo y consecuente pero, si se me permite decirlo, abstracto. $Y$ por eso los renacimientos medievales fueron transitorios, mientras que en el Renacimiento fue permanente. Las almas resucitadas son intangibles, pero tienen las ventajas de la inmortalidad y la ubicuidad. De ahí que el papel de la Antigüedad clásica después del Renacimiento sea un tanto esquivo pero, por otra parte, omnipresente y mutable sólo a costa de una mutilación de nuestra civilización como tal (...)". Cf.: E. PANFOSKY, Renacimiento y renacimientos..., p. 173.
} 


\section{FRÓMISTA.}

La última cuestión que resta tratar en relación con este fenómeno, recae en el análisis de aquellos aspectos vinculados con el público al que iban destinadas estas imágenes.

En los párrafos anteriores hemos aludido a las diferentes actitudes del hombre del medievo a la hora de enfrentarse a las piezas antiguas. No volveremos a insistir más sobre tal cuestión; sin embargo, merece la pena recordar el fragmento de texto ya comentado del magister Gregorio que, en su visita a Roma, se quedaba prendado, a la vez que escéptico, ante la belleza de la escultura de una Venus de mármol colocada cerca del teatro de Eraclea ${ }^{1493}$.

La belleza de la obra antigua generaba un sentimiento extraño en el espectador medieval y fue ese mismo efecto el que llevó al clérigo a calificar dicha escultura como "demoníacamente pagana", tal y como ya hemos señalado anteriormente.

Uno de los estudiosos que mejor han abordado este tema es M. Barasch ${ }^{1494}$. Según sus teorías, a muchas de las imágenes conocidas a través de sus versiones escultóricas de época clásica durante el periodo medieval, se les otorgaban propiedades maléficas y demoníacas. El primero de los aspectos por los que eran atacadas venía definido por su pertenencia al imaginario pagano, tal y como, entre otros, señalaron Tertuliano o San Agustín. La belleza de tales figuras, conseguida a través de una técnica sobradamente depurada, como la que ostentaban los marmolistas clásicos, fue interpretada llena de connotaciones malignas, mágicas y, sobre todo, lujuriosas ${ }^{1495}$.

1493 C. NARDELLA (ed.), Op. cit., en especial, pp. 157-159. También se recoge el texto en: R. KRAUTHEIMER, Roma. Profilo di una città. 312-1308, Roma, 1981, p. 237. Aunque sin centrarse en el caso concreto de la imagen antigua comprendida como algo demoníaco durante la Edad Media, recientemente se ha abordado el tema del mal, analizando alguna de esta cuestiones, en: E. FERNÁNDEZ GONZÁLEZ, “A propósito del mal: posesiones y exorcismos en la plástica del medievo", L'Espai del Mal, Balaguer, 2005, pp. 117-142.

${ }^{1494}$ Para concluir este apartado dedicado al capitel de Frómista y a esta serie de reflexiones sobre la actitud del hombre medieval ante la pieza, queremos finalizar con algunas ideas en torno a la comprensión y entendimiento que dichos hombres tuvieron de la imagen. Sin centrarse en el ejemplo de Frómista, pero extrapolable a él, véanse: M. BARASCH, "Le Beau ou le démoniaque: le regard du spectateur médiéval sur la statuaire classique", Histoire de l'histoire de l'art de l'Antiquité au XVIII siècle, vol. I, Paris, 1995, pp. 97-117 e ID., Teorías del Arte..., en concreto, pp. 64-65.

1495 M. BARASCH, "Le Beau ou le démoniaque...", en particular, pp. 101-102. El autor toma nuevamente el ejemplo de la Venus descrita por el magister Gregorio así como el tema del espinario. Dichas esculturas ya han sido analizadas a través del texto del monje con anterioridad, por lo que no vamos a detenernos en ellas. 
El paso siguiente, desde el punto de vista ideológico, vendría dado por la actitud reinterpretativa de los artistas hacia estos iconos ${ }^{1496}$. En relación directa con este aspecto, cabe señalar que, durante mucho tiempo, se quiso ver en dichas imágenes, independientemente de su sustrato clásico o no, una fuente y herramienta indiscutible para la difusión del dogma y doctrina cristianos.

En relación con el caso concreto del capitel de la Orestíada se ha llegado a afirmar:

"Desde luego, los benedictinos que en la última década del siglo XI supervisaban la erección de los paramentos del nuevo templo de San Martín, lejos de rechazar, concedieron la incorporación del sorprendente capitel al umbral del presbiterio. Los destinatarios primeros no lo juzgaron indecoroso, dicho sea el calificativo de acuerdo con el alcance medieval de los conceptos latinos decor, lo que orna según conveniencia, y decus, la aplicación de elementos embellecedores a un objeto o un monumento a fin de otorgarle la dignidad apropiada (...) (el capitel) levanta acta de la actividad individual de un operario y colectiva de una sociedad que volvían su mirada hacia el deslumbrante legado romano, mientras planteaba nuevos requisitos a las imágenes de exposición pública" ${ }^{1497}$.

En la misma tónica, al examinar algunas de las características de la escultura del templo, en concreto, aquella realizada por este supuesto "maestro de la Orestíada", la profesora T. Martín afirma:

"Es evidente que el artista ha acertado de pleno al elegir una posición enormemente efectiva desde un punto de vista visual y, por añadidura, en su capacidad de comunicar un mensaje aleccionador al mayor número de gentes de todos los niveles culturales (...)"1498.

\footnotetext{
${ }^{1496}$ Sin olvidar tampoco la destrucción a la que fueron sometidas de manera sistemática multitud de obras antiguas, no sólo en época medieval, sino también ya bien avanzados los siglos de la modernidad. Sobre esta cuestión, vid.: J. ADHÉMAR, Influences antiques..., en especial, p. 46. El autor recoge el caso de la destrucción de una escultura de Venus que se encontraba, en torno al año 1760, en la sacristía del convento de la Visitación de Perigueux. Se incide sobre este aspecto de la destrucción y la repudia de los cristianos hacia los ídolos paganos en: M. GREENHALGH, "Ipsa ruina docent...", en concreto, p. 116.

${ }^{1497}$ G. BOTO VARELA, "La integración de las artes...", entre las más significativas, véanse las pp. 9497. El autor incide en el gran valor de la imagen en relación con la colección de capiteles del edificio. En concreto, denomina al capitel como un monumentum de su época. Alude a la comunidad de monjes y a los laicos como últimos destinatarios de tales imágenes.

${ }^{1498}$ T. MARTIN, “Escultura románica...”, p. 74.
} 
No es de extrañar que estos autores acudan a la famosa teoría del exemplum moralizante, por otra parte, tendencia muy habitual a la hora de entender parte del imaginario representado en los capiteles o, lo que es lo mismo, comprender su iconografía como contenedora de un mensaje susceptible de ser interpretado por el espectador $^{1499}$.

Con todo y regresando al tema que nos ocupa, sabemos, a través de diversas fuentes, que San Martín de Frómista no fue una iglesia de actividad parroquial en este momento ${ }^{1500}$. El acceso al templo cenobítico estaba restringido. La comunidad de monjes era el colectivo primero al que iba destinada la construcción, con su conjunto de capiteles incluido, mientras que los laicos, tal y como señala el profesor Bango, sólo podían acceder al interior del templo en festividades litúrgicas mayores, algo lógico tratándose de una iglesia no parroquial ${ }^{1501}$.

Según esto, resulta bastante difícil que la serie de imágenes expuestas en el interior del recinto fueran destinadas al conjunto de fieles.

En este sentido, M. Barasch, al analizar el valor doctrinal y moralizante de la escultura medieval, plantea una serie de cuestiones muy interesantes para poder comprender la función de estos repertorios icónicos, así como su deuda con el valor propagandístico que la imagen poseyó durante la Antigüedad.

El autor analiza la famosa carta escrita por Gregorio Magno al obispo de Marsella en la que se llevaba a cabo una defensa del uso de la imagen en el adoctrinamiento de los feligreses:

\footnotetext{
${ }^{1499}$ A pesar de que se han venido aceptando como válidas las lecturas de algunas imágenes medievales a través del mecanismo del exemplum, algunos autores han destacado como los núcleos cultos existentes en los diferentes ámbitos medievales, tenían un conocimiento limitado y selectivo de la filosofía antigua, además de una "deficiente perspectiva histórica y con criterios filológicos insuficientes". Cf.: A. GINZO FERNÁNDEZ, El legado clásico, Alcalá de Henares, 2003, en concreto, pp. 26-27. Estos aspectos han de ser tenidos en cuenta a la hora de atribuir ciertas capacidades intelectuales, en ocasiones excesivas, a dichos centros culturales.

${ }^{1500}$ Es difícil poder llegar a discernir si la concepción de los espacios eclesiásticos hispanos estuvo destinada, desde la concepción misma del templo, a albergar tan sólo a la comunidad eclesiástica o, si por el contrario, quedaba claro que en dicho espacio tendrían cabida también otro tipo de estratos sociales, tales como los relacionados con la corte y la nobleza. Sin duda, cada caso es particular y se deben tener en cuenta las peculiaridades sociales, geográficas, demográficas y económicas de los diferentes territorios. En este sentido, consúltese: E. FERNÁNDEZ GONZÁLEZ, La escultura románica..., pp. 70-89. La investigadora abordó el tema en relación con algunos pequeños núcleos asturianos, donde muchos de los templos, de reducidas dimensiones, fueron dispuestos tanto como iglesias monacales, como parroquiales.

${ }^{1501}$ I. G. BANGO TORVISO, "El paisaje monumental...", p. 47 y G. BOTO VARELA, "La integración de las artes...", en concreto, p. 97. Se trataría de una iglesia monasterial, tal y como se defiende, en: J. L. SENRA GABRIEL Y GALÂN, "Origen, muerte y resurrección...", p. 21.
} 
"las pinturas están hechas para la instrucción de los iletrados (...) no para ser venerados, sino sólo para educar las mentes de los ignorantes (...) para edificación de los incultos (...) la pintura informa al pueblo sin instrucción que la contempla"1502.

A partir de estas palabras, M. Barasch realiza una crítica profunda a la idea, según la cual, toda o gran parte de la escultura medieval tenía como objetivo máximo el adoctrinamiento y la educación de los espectadores que contemplaban tales imágenes. Inicia su teoría delimitando concretamente el significado del término "aprendizaje", afirmando que, por una parte, "puede aludir o bien a la adquisición de un conocimiento al que no se ha podido acceder previamente, o bien a la configuración de la estructura mental del que aprende" 1503.

Son muchos los historiadores del arte que, de una manera general y, tal y como vemos también para el caso del capitel de la Orestíada de la iglesia de San Martín de Frómista, han utilizado estos mismos argumentos para remarcar el valor didáctico del arte medieval. Barasch afirma sagazmente, que " $n i$ un solo rasgo relevante de este arte sugiere que las pinturas y esculturas estuvieran destinadas a ofrecer nueva información a este público" ${ }^{\prime 1504}$.

Creemos que la nueva imagen creada por el escultor del capitel de Frómista, basándose en la iconografía romana del sarcófago, era interpretada en un primer nivel iconográfico de una manera, más o menos acertada, por parte del público religioso. Se trataba de una clara alusión al pecado y los castigos. Sin embargo, la imagen no aportaba, en absoluto, nueva información a quién la contemplaba, por lo que en un sentido estricto estaba desposeída de un valor pedagógico o de aprendizaje.

\footnotetext{
${ }^{1502}$ M. BARASCH, Teorías del arte..., p. 63.

${ }^{1503}$ Ibidem, p. 64 y F. BRAVO, "Arte de enseñar, arte de contar. En torno al exemplum medieval", La enseñanza en la Edad Media (J-I. de la Iglesia Duarte coord.), Nájera, 1999, pp. 303-327, en concreto, p. 308. El investigador analiza algunos de los textos más importantes de San Agustín, en concreto su Doctrina Christiana, Rábano Mauro y su De Institutione Clericorum, Guillermo de Nogent y su obra Liber quo ordine sermo fieri debet, Alain de Lille y su Summa de arte praedicatoria o el ya citado Gregorio Magno. Todos ellos, afirma el autor, pueden ser considerados como precedentes del uso de la imagen como reflejo de las palabras. El especialista afirma que el hecho de que estos escritores medievales introdujesen en el sermón pequeñas narraciones destinadas a ilustrar aspectos diversos de la doctrina y a elevar el nivel cultural de los fieles, fue una de las causas que provocó la modernización del género del "siglo de oro", tal y como él lo denomina, refiriéndose al siglo XIII, así como la difusión del exemplum dentro de este tipo de textos.

${ }^{1504}$ Ibidem, p. 64.
} 
Pongamos un último ejemplo al respecto. Hemos aludido ya al magnifico conjunto de capiteles de la iglesia y recinto occidental de San Pedro de Teverga ${ }^{1505}$. Entre sus esculturas, algunas de ellas nos ofrecen razones suficientes como para creer que determinados motivos pudieron descender directamente de la iconografía paleocristiana habitual en los sarcófagos. Sin embargo, lo más importante, es que se trata de uno de los primeros conjuntos escultóricos románicos del arte hispano en el que, de manera excepcional en el siglo XI, se produce la recuperación de algunos valores expositivos y decorativos que la imagen había tenido durante la Antigüedad tardía ${ }^{1506}$.

En Teverga y, aunque salvando las distancias conceptuales y cronológicas, como en Frómista, la imagen reactiva los valores expositivos y decorativos, así como simbólicos, que había poseído durante los largos siglos pasados. En concreto, tal y como señaló en su día X. Barral i Altet, muchas de las experiencias en relación con el valor público de la imagen de época constantiniana, acabarían por pasar, a través de diferentes vías, a los artistas del periodo románico ${ }^{1507}$. De la misma manera que los grandes monumentos públicos del final del mundo antiguo habían publicitado, mediante

1505 No vamos a insistir en el problema de la introducción de la escultura figurativa en los capiteles historiados de la Antigüedad tardía y la Alta Edad Media hispanas. Remitimos al capítulo dedicado al capitel corintio medieval que hemos dedicado en este trabajo.

${ }^{1506}$ A propósito del valor expositivo de dichas piezas, T. Martin escribió en su día: "Dos ejemplos de mediados del siglo XI, la cripta de San Salvador de Leire (Navarra) y la iglesia de San Pedro de Teverga (Asturias), tienen capiteles pesados de poco relieve, casi todos de decoración vegetal o animal. Cuando aparecen figuras humanas suelen funcionar igual que los motivos vegetales, o sea, para decorar, no para atraer y aleccionar". Cf.: T. MARTIN, "Escultura románica...", particularmente, p. 72 e ID., "Un nuevo contexto...", en especial, p. 185 y p. 187.

La citada estudiosa teoriza sobre la capacidad del público medieval a la hora de interpretar las imágenes que se exponían en fachadas y capiteles. Además, basándose en el estudio clásico de J. Williams sobre la portada del Cordero de la basílica de San Isidoro, defiende la posibilidad de que la iconografía presente en este tímpano pudiera haber sido reinterpretada en época de la reina Urraca. Así dice "Como tal, las imágenes de la portada del Cordero fueron hechas para que le hablaran al espectador (...). Durante el reinado de Urraca sus súbitos pudieron haber hecho una nueva interpretación del tímpano de la portada del Cordero (...)".

Al margen de este ejemplo concreto, se debe recordar que, durante el siglo pasado, fueron muchas las lecturas historicistas y sociológicas que se realizaron de gran parte de las mejores obras escultóricas medievales. Con ello queremos exponer que, muchos especialistas, tendieron a ver representado dentro de los programas escultóricos de los grandes edificios del románico y del gótico a personajes ligados con la época en que dicha decoración fue realizada, así como a defender que algunos de los acontecimientos históricos y sociales también habían tenido cabida dentro de dichos programas. En la actualidad, los especialistas se muestran más cautelosos, llegando a plantear visiones más seguras.

Por ejemplo, y aunque circunscrito al ámbito gótico de la escultura de la catedral de León, la figura tradicionalmente identificada como Fernando III, entronizada y colocada sobre el Locus Apellacionis, ha sido entendida como la "representación de un soberano, sin personalizar; como alegoría de la monarquía; identificado por los atributos regios". Vid.: G. CAVERO DOMÍNGUEZ, E. FERNÁNDEZ GONZÁLEZ y F. GALVÁN FREILE, $O p$. cit., concretamente, pp. 57-58. Sin duda, este ejemplo refleja la tendencia actual a ser más reticentes a la hora intentar comprender las imágenes medievales a través de forzadas identificaciones con personalidades y acontecimientos históricos del momento.

${ }^{1507}$ X. BARRAL I ALTET, "Propaganda eclesiástica y poder feudal. El orden del mundo en las fachadas románicas”, Propaganda y Poder. Congresso Peninsular de História da Arte, Lisboa, 1999, pp. 57-70, particularmente, pp. 61-62. 
la imagen, todo tipo de mensajes, independientemente de la capacidad del espectador para interpretarlos, los escultores románicos recurrieron a esa Antigüedad "fragmentada" en busca de su inspiración iconográfica e ideológica ${ }^{1508}$. El ejemplo del sarcófago de Husillos es la prueba evidente.

1508 Un fenómeno paralelo al de la escultura se produce en la escritura epigráfica. Mediante las inscripciones y de la misma manera que había ocurrido en el mundo antiguo, se transmitían todo tipo de mensajes publicitarios que esperan un receptor que los interpretase y ello muy a pesar de que, dicha información, no era comprendida de manera absoluta por todos los que accedían a ella. Vid.: V. GARCÍA LOBO, Los medios de comunicación social en la Edad Media. La comunicación publicitaria, León, 1990, en concreto, pp. 10-20 y V. GARCÍA LOBO y E. MARTÍN LÓPEZ, "La escritura publicitaria en la Edad Media. Su funcionalidad”, Estudios Humanísticos (geografía, historia, arte), 18, 1996, pp. 125145. Más recientemente, se ha abordado el tema, poniendo especial énfasis en lo hispano, en: V. DEBIAIS, "Afficher pour convaincre: la construction et la promotion de la mémoire dans les inscriptions comme instrument de la propagande médiévale", Convaincre et persuader: communication et propagande aux XII et XIII e siècles, Poitiers, 2007, pp. 649-702, particularmente, pp. 674-679. En este punto el investigador se centra en el caso concreto de la basílica de San Isidoro de León. Agradezco en este punto la amabilidad del Dr. Vincent Debiais al informarme sobre la existencia del referido estudio. 


\section{MOTIVOS CLÁSICOS EN LA ESCULTURA DE LA CATEDRAL DE JACA Y SU ASIMILACIÓN EN EL ROMÁNICO ESPAÑOL (EL ÚLTIMO CUARTO DEL SIGLO XI Y LA PRIMERA MITAD DEL XII).}

\section{1. INTRODUCCIÓN. ASPECTOS BIBLIOGRÁFICOS Y METODOLÓGICOS.}

En el apartado que acabamos de cerrar, hemos puesto de manifiesto la problemática que surge a la hora de poder indagar en la actitud tomada, tanto por artistas como por espectadores, ante la obra escultórica. En concreto, en relación con el capitel de la Orestíada se ha planteado, generalmente, la posibilidad de que en su día su iconografía hubiera sufrido una "pseudomorfosis", es decir, la atribución a la imagen de un significado que no tenía en su origen clásico ${ }^{1509}$. Sin embargo, debemos ser cautos a la hora de pronunciarnos sobre el papel tomado por los aquellos que se situaban ante las imágenes medievales.

A partir de tales premisas, en el presente apartado abordaremos una de las problemáticas más complejas de nuestro estudio. Se trata del análisis de la filiación clásica que posee la escultura desarrollada en la catedral de San Pedro de Jaca y todas aquellas obras que, a su amparo, presentarían esos mismos resabios “antiquizantes"1510. Con ello, no estamos atribuyendo ni a los escultores ni a los espectadores de tales obras, la cualidad de reinterpretar dichas imágenes. En el caso del capitel de Frómista ya hemos apuntado que esta posibilidad es difícil. El artista se limitó a interpretar una serie

\footnotetext{
1509 El concepto de "pseudomorfosis" que aquí utilizamos lo hemos tomado teniendo en cuenta lo expuesto en: E. PANOFSKY, Estudios sobre iconología, Madrid, 1972, en concreto, pp. 94-98. Aunque el autor lo usa para referirse a determinadas imágenes creadas durante el Renacimiento de la etapa moderna. Véase también: G. BOTO VARELA, Ornamento sin delito..., en concreto, pp. 10-39. El autor lleva a cabo el estudio de la escultura del claustro del monasterio de Santo Domingo de Silos, haciendo hincapié en la problemática de atribuir un significado a los diferentes símbolos tanto fitomórficos como zoomórficos.

${ }^{1510}$ Hemos querido comenzar con el famoso capitel de Frómista primero para pasar después al foco jacetano, no por insinuar una prioridad cronológica del escultor palentino frente al foco aragonés. Sin embargo, al tratarse del ejemplo más evidente de copia de lo clásico romano, nos ha permitido apuntar una serie de reflexiones sobre la manera en que los artistas se enfrentaron a al recuerdo de la Antigüedad en la Península Ibérica durante este periodo tan concreto del siglo XI. En este apartado, tras abordar las cuestiones metodológicas e historiográficas sobre el edificio, se pasarán a estudiar aquellos elementos de tradición romana que se nos muestran en la escultura románica del templo. En determinados casos puntuales, se aludirá a otra serie de ejemplos pertenecientes a otras construcciones, a la hora de analizar las repercusiones que la escultura de la catedral de San Pedro pudo llegar a tener.
} 
de motivos que observó en el sarcófago pero sin llegar a comprender, en ningún caso, que se trataba de la compleja historia de Orestes.

La reinterpretación segura fue de índole estilística. El escultor del capitel, como todos los artistas que se enfrentan a las obras clásicas, llevó a cabo una paráfrasis medieval de las piezas antiguas. Finalmente, lo más problemático, resulta poder llegar a saber si, además, los artífices estaban atribuyendo connotaciones y contenidos nuevos acordes con el pensamiento medieval a estas nuevas imágenes que estaban generando.

Así, pensamos que tal cuestión se puede responder afirmativamente. Sin embargo, no debemos caer en el error de creer que dicha atribución o, siguiendo el concepto propuesto por E. Panofsky, esta supuesta "pseudomorfosis", se produjo en un grado elevado. Las Furias del sarcófago de Husillos pasaron a ser simples hombres azuzando serpientes, representantes directos del mal y del pecado, pero jamás les atribuyeron complicados simbolismos iconográficos relacionados con el medio social en el que comitentes y escultores trabajaban.

La escultura de la catedral de Jaca resulta extremadamente interesante a la hora de continuar indagando en estas cuestiones ${ }^{1511}$.

\footnotetext{
${ }^{1511}$ La bibliografía sobre la catedral de Jaca y la obra escultórica de otros edificios románicos en los que se puede advertir su influencia es abundante. En este lugar recogemos todos aquellos trabajos que hemos utilizado y consultado para la elaboración de nuestro estudio. Véanse: L. TORRES BALBAS, "La escultura románica aragonesa y el crismón de los tímpanos de la región pirenaica", Archivo Español de Arte y Arqueología, 6, 1926, pp. 287-291; A. KINGSLEY PORTER, "Spain or Toulouse? and Other Questions", The Art Bulletin, VII, 1924, pp. 2-25; ID., "The tomb of Doña Sancha and the Romanesque art of Aragón", Burlington Magazine, 45, 1934, pp. 165-179; G. GAILLARD, "Notes sur les tympans aragonais", Bulletin hispanique, XXX, 1928, pp. 193-203; ID., Les débuts de la sculpture..., pp. 87-119; M. GÓMEZ-MORENO, El arte románico..., en concreto, p. 74; W. WEISBACH, Reforma religiosa ..., en particular, pp. 133-279 y A. CANELLAS-LÓPEZ y A. SAN VICENTE, Aragon roman, La-Pierrequi-Vire, 1971.

Uno de los especialistas que mejor han abordado la problemática de la escultura de la Seo jaquesa es el profesor S. Moralejo. Vid.: S. MORALEJO ÁLVAREZ, "Aportaciones a la interpretación del programa...", pp. 173-198; ID., "Sobre la formación...", pp. 227- 233; ID., "La sculpture romane...", pp. 79-100. Véanse también: F. GARCÍA ROMO, "El problema de la personalidad del escultor románico: el maestro de Jaca (Jaca, Loarre, Frómista, León)", Mélanges offerts à René Crozet, vol. II, Poitiers, 1966, pp. 359-363; ID., "Nota sobre los posibles contactos entre la escultura de Jaca y la de Módena", Arte Lombarda, 1967, pp. 23-24; A. SENÉ, "Quelques remarques sur les tympans romans à chrisme en Aragón et Navarre", Mélanges offerts à René Crozet, vol. I, Poitiers, 1966, pp. 365-381; F. IÑíGUEZ, "La catedral de Jaca y los orígenes del románico", Pirineos, XXIII, 1967, pp. 179-200; J. M. CAAMAÑO MARTÍNEZ, "Restos del siglo XI en la iglesia de Santo Domingo de Jaca", Archivo Español de Arte, XV, 1942, pp. 112-113; ID., "En torno al tímpano de Jaca", Goya, 142, 1978, pp. 200-207; S. H. CALDWELL, The Introduction and diffusion of the Romanesque projecting single-portal unit in northern Spain, Ann Arbor, 1979 e ID., "Penance, Baptism, Apocalypse: The Easter Context of Jaca Cathedral's West Tympanum", Art History, 3, 1980, pp. 23-35.

Desde otro orden de cosas, se ha trabajado ampliamente el tema en: M. DURLIAT, "Les origines de la sculpture romane à Jaca", Comptes redus de l'Académie des inscriptions et belles- lettres, 1978, pp. 222235; ID., "Toulouse et Jaca", Homenaje a don José María Lacarra de Miguel, vol. I, Zaragoza, 1977, pp. 199-207; ID., La sculpture romane de la route..., en concreto, pp. 220-249; D. L. SIMON, "Le sarcophage de Doña Sancha à Jaca”, Les Cahiers de Saint-Michel-de-Cuxa, 1979, 10, pp. 107-124; ID.,
} 
Desde las primeras publicaciones referidas al conjunto escultórico de la catedral $^{1512}$, todos los especialistas han remarcado, unánimemente, las fuertes relaciones existentes entre la escultura de esta seo jaquesa y la misma iglesia de San Martín de Frómista.

Sin embargo, debemos ser cautos en tal afirmación. Los mayores parentescos que se pueden alegar entre las esculturas de Jaca y las de Frómista, tienen su mayor representación en los dos capiteles palentinos que hemos comentado con mayor detenimiento. Nos referimos al famoso capitel de la Orestíada y a aquel en que un joven aparece montando un león.

Para el resto de esculturas, aún compartiendo unos mismos lenguajes, fórmulas, rasgos estéticos y ejecución técnica de similares características, creemos que son coincidencias normales entre obras que se realizaron dentro del mismo arco cronológico

"Un chapiteau de cloître de la cathédrale de Jaca, représentant la psychomachie", Cahiers de SaintMichel-de-Cuxa, 12, 1981, pp. 151-159; ID., "El tímpano de la Catedral de Jaca", Jaca en la Corona de Aragón (siglo XII- XVIII), vol. III, Zaragoza, 1994, pp. 405-419; ID., "A Moses capital at Jaca”, Imágenes y promotores..., pp. 209-219; S. C. SIMON, "David et ses musiciennes: iconographie d'un chapiteau de Jaca", Les Cahiers de Saint-Michel-de-Cuxa, XI, 1980, pp. 239-248; ID., "Iconografía de un capitel del claustro de la Catedral de Jaca", Jaca en la Corona de Aragón (siglos XII-XVIII), vol. III, Zaragoza, 1994, pp. 223-436; D. OCÓN ALONSO, "Problemática del crismón trinitario", Archivo Español de Arte, 223, 1983, pp. 242-263; ID., Tímpanos románicos españoles: reinos de Navarra y Aragón, 2 vols, Madrid, 1987, vol. I, en concreto, sobre el tímpano de la catedral de Jaca, pp. 115-133; ID., "Ego sum ostium, o la puerta del templo como la puerta del cielo en el románico navarro-aragonés", Cuadernos de Arte e Iconografía, tomo II, 3, 1989, pp. 125-136 e ID., "El sello de Dios sobre la iglesia: tímpanos con crismón en Navarra y Aragón”, El tímpano románico. Imágenes, estructuras y audiencias (R. Sánchez Ameijeiras y J. L. Senra Gabriel y Galán coords.), Santiago de Compostela, 2003, pp. 75-101.

A tales trabajos de deben sumar otros que recogemos a continuación. Vid.: D. OCÓN ALONSO y P. RODRÍGUEZ ESCUDERO, "Los tímpanos de Jaca y Santa Cruz de La Serós, una pretendida relación modelo-copia”, Actas del V Congreso Español de Historia del Arte, Barcelona, 1984, pp. 259-263 y C. ENRÍQUEZ DE SALAMANCA, Jaca y el románico, León, 1983.

Más recientemente, se estudió el tema en: M. A. CASTIÑEIRAS, "Verso Santiago?...", en concreto, pp. 387-393 y J. LACOSTE, Les maîtres..., en concreto, p. 31-37. Son dignas de mención también todas aquellas aportaciones ligadas a la epigrafía del edificio, que siempre aportan datos fundamentales para la investigación sobre la escultura y la arquitectura. Vid.: J. VIVES, "Las leyendas epigráficas del tímpano de Jaca", Hispania Sacra, IX, 1956, pp. 391-394; A. DURÁN GUDIOL, "Las inscripciones medievales de la provincia de Huesca", Estudios de Edad Media de la Corona de Aragón, vol. III, Zaragoza, 1967, pp. 45-109, en particular, sobre el tímpano de Jaca y sus inscripciones, pp. 56-61; C. B. KENDALL, The Allegory of the Church. Romanesque and Portals and Their Verse Inscriptions, Toronto, 1998, en concreto, pp. 230-236; ID., "The Verse Inscriptions of the tympanum of Jaca and PAX Anagram", Mediaevalia, 19, 1996, pp. 405-434; F. ESTABAN LLORENTE, "Las inscripciones del tímpano de la Catedral de Jaca", Artigrama, 10, 1993, pp. 143-161; ID., "El tímpano de la catedral de Jaca (continuación)", Aragón en la Edad Media XIV-XV, 1999, pp. 451-472; R. FAVREAU, "Les inscriptions du tympan de la Cathédrale de Jaca", Académie des Inscriptions et Belles-lettres, 1996, pp. 535-560 y J. DEL HOYO, "El crismón de la catedral de Jaca y la pérdida de la conciencia lingüística", Analecta Malacitana, 6, 2000, consultado en http://www.anmal.uma.es/numero6/Hoyo.htm, el día 15 de noviembre de 2008 .

${ }^{1512}$ Uno de los mejores estados de la cuestión en relación con la bibliografía publicada sobre dicho edificio es el realizado en: D. L. SIMON, "A Moses...", en particular, p. 209. Con opiniones diferentes, véase: J. LACOSTE, Les maîtres...., en concreto, p. 348. En dicho estudio, a pesar de realizarse una aportación interesante para la bibliografía sobre el tema, no lleva a cabo una labor exhaustiva de actualización de lo escrito sobre la catedral y su escultura. 
y bajo circunstancias sociales, políticas e históricas muy similares. Más aún, pocos son los rasgos comunes que podremos señalar entre las esculturas de la catedral de Jaca y el resto del corpus escultórico de la iglesia de Frómista, si olvidamos, por un momento, los capiteles antes señalados ${ }^{1513}$.

En este apartado se abordará de una manera más directa la posible influencia de la escultura romana de los sarcófagos sobre el conjunto de capiteles conservados en el edificio catedralicio jaqués. Sin duda, las posibilidades de rastrear las fuentes clásicas y las vías de inspiración de lo antiguo se amplían, en este caso concreto, ante la existencia aquí de un mayor repertorio, tanto desde el número de capiteles ubicados en el templo, como desde su mayor calidad y diversidad iconográfica.

Una vez analizada la hipotética dependencia que el conjunto escultórico de Jaca mantiene con determinadas esculturas de la Antigüedad, se abordará la repercusión de los talleres jaqueses sobre aquellos centros próximos que fueron sensibles a su influencia.

La cronología de la catedral de Jaca y de su escultura han sido también problemáticas ${ }^{1514}$. Igual que en Frómista, las posturas nuevamente se enfrentan entre aquellos que pretender otorgarle una datación más temprana, frente a los que, incluso, defienden una cronología próxima al primer cuarto del siglo XII. En este sentido, es el trabajo de A. Ubieto Arteta el que, de una manera más corriente, se viene aceptando como referencial para este tipo de asuntos.

Tras demostrar que las famosas actas del Concilio de Jaca del año 1063 eran falsas, el autor realizó la misma tarea con otro documento ligado al rey Ramiro I de Aragón en el cual donaba a la catedral trece iglesias ${ }^{1515}$. A partir de estos datos concluía que "la revisión de los tres documentos que sirven para fechar la construcción de la

\footnotetext{
${ }^{1513}$ Ya hemos aludido a que las semejanzas de talla, de volúmenes y de composición existentes entre el resto de capiteles de Frómista con los de la catedral de Jaca, son fruto de unas maneras muy similares de trabajar la piedra, condicionadas por el uso de instrumentos rudimentarios y por una serie de cuestiones comunes dentro de un periodo cronológico tan igual como el que compartieron ambos talleres.

${ }^{1514}$ Desde un punto de vista cronológico, véase: A. UBIETO ARTETA, "L'art roman en Aragon au XIe siècle", L'Information d'histoire de l'art, IX, 1964, 4, pp. 158-160; ID., "La catedral románica de Jaca. Problemas de cronología", Pirineos, 59-66, 1961-1962, pp. 125-137 e ID., "El románico de la catedral jaquesa y su cronología”, Príncipe de Viana, XXV, 1964, pp. 187-200.

${ }_{1515}$ Con ello, desmantelaba las principales pruebas que, hasta ese momento, se habían tenido como seguras para llevar a cabo una datación del edificio. En relación con las actas del Concilio, decía el estudioso: "tal falsificación debió ejecutarse en Roma (...) entre abril de 1097 y mayo de 1098". Con respecto al documento en el que se citan los templos donados por el monarca, el investigador lo situaba "en la segunda mitad del siglo XIII y el 1300". Cf.: A. UBIETO ARTETA, "El románico de la catedral jaquesa...”, en particular, pp. 190-192.
} 
catedral de Jaca en el año 1063 nos permiten afirmar que éstos no constituyen una base documental segura" 1516 .

Algunos años más tarde, el profesor S. Moralejo, basándose en lo afirmado por A. Ubieto, publicaba en el año 1979, su estudio sobre la escultura románica del edificio, llegando a la conclusión de que los trabajos de construcción estarían en curso en torno al año 1094. Para ello, se basaba en el documento en el que la infanta Doña Urraca daba una serie de donaciones al templo utilizando la expresión ad laborem ${ }^{1517}$.

A partir de entonces, se comenzó a rechazar la datación primera del templo que defendía su cronología entre los años 1063-1070 aproximadamente, para pasar a dar como válida la fecha que iba desde el año 1077 al $1098^{1518}$.

Al igual que en relación con la escultura de Frómista, no es nuestro objetivo principal el de analizar pormenorizadamente una cuestión tan escabrosa y polémica como es ésta de la datación cronológica.

Regresando al hilo principal de nuestro trabajo, es bien significativo el hecho de que muchos autores hayan señalado, de manera rotunda, el fuerte clasicismo de su escultura, de una manera más evidente y fuerte, si cabe, que en el caso de San Martín de Frómista.

Al observar el conjunto de esculturas del templo se percibe aquí un panorama mucho más rico, más abundante, con modelos más dispares y, en definitiva, con fuentes más complejas. No estamos hablando de la simple copia de un sarcófago en concreto, sino de un pasó más allá. Se trata de la asimilación de la obra clásica, no como simple

\footnotetext{
1516 Ibidem.

1517 S. MORALEJO ÁLVAREZ, "La sculpture romane...", en concreto, p. 142 y M. DURLIAT, La sculpture romane de la route..., en particular, p. 141.

${ }^{1518}$ Uno de los estudiosos más críticos fue R. Salvini. Llegaría a afirmar que, en una fecha como la del 1063, la escultura llevada a cabo por el "maestro de Jaca", tal y como él mismo lo define, era inexplicable. Vid.: R. SALVINI, "Il problema cronologico...”, sobre todo, p. 467 y p. 475, nota 17.

Véase otro trabajo del mismo autor en: ID., La escultura..., p. 58. En él, el citado experto se muestra escéptico sobre la cuestión documental del Concilio y la donación de doña Sancha en el 1094. Todos estos aspectos le llevarán a afirmar que "por razones estilísticas (...) los capiteles del primer maestro de Jaca han de situarse, pues, en el primer decenio del siglo XII".

El mismo Ubieto tomaba los años 1076-1077, fecha del otorgamiento del Fuero de Jaca, como posible data para el establecimiento de la sede y, por lo tanto, una fecha propicia para el comienzo de la construcción. Según él, la obra estaría terminada en torno al año 1096, periodo en el que se decidió trasladar la sede a Huesca. Este traslado prematuro le serviría, además, para explicar el hecho de que algunos capiteles y la bóveda de la nave central aún estuviesen incompletos en ese momento. Vid.: A. UBIETO ARTETA, "El románico de la catedral jaquesa...", p. 195. Consúltese también: D. L. SIMON, “A Moses capital...”, pp. 209-219. Según se defiende en esta aportación, entre las fechas de 1070-1077, la obra catedralicia podría estar ya en activo, apoyando tal afirmación mediante la alusión a la figura del rey Sancho Ramírez, hijo de Ramiro I y la concesión del Fuero a la ciudad. También remarca el año 1077 como la fecha en la cual, el obispo de Aragón se comienza a denominar en la documentación como obispo de Jaca.
} 
objeto admirativo, susceptible de ser copiado, sino que casi podríamos hablar de una "digestión" de los modelos clásicos hasta el punto de convertirlos, no en breves copias, sino en la razón de ser de la propia escultura que practicaban.

En Jaca las fuentes no se limitan a un solo sarcófago, sino a una serie de modelos de gran alcance. A pesar de ello, si los sarcófagos fueron los elementos que más sirvieron como modelos de inspiración, a la vista de la obra románica, parece que, aquí, el abanico de fuentes se expande y abarca todo tipo de producciones, tanto paganas romanas como ya cristianas.

Estamos hablando, tal y como lo definió M. Durliat, de un "grand style antiquisant" ${ }^{\prime 1519}$. Se necesita, sin embargo, ser más precisos en tal afirmación.

Ya en su día el mismo F. García Romo llegó a comparar algunos de los rasgos de la escultura jaquesa con diversas fórmulas provenientes del mundo arcaico griego ${ }^{1520}$. Posteriormente, el mismo autor volvería sobre tal cuestión negando ahora la asimilación de prototipos bizantinos en dicha escultura. Se limitaba entonces, a definir tales resabios como simplemente "clásicos"

Lo que parece claro es que a finales del siglo XI la seo jaquesa podría estar completando su fábrica y decorándola a través de todo el conjunto de capiteles que hoy conservamos. Para poder concretar las fuentes antiguas que pudieron haber estado al alcance de estos escultores, debemos intentar extraer las posibles características comunes que hallamos en todo el conjunto de piezas.

A parte de la organicidad del desnudo, que llega a convertirse en un tema recurrente dentro de la iconografía utilizada, se ha destacado también el uso del cuerpo como elemento de experimentación escultórica, así como la reiteración del esquema quiástico de algunas partes del cuerpo. Los cabellos alborotados, las figuras colocadas en cuclillas, así como el omnipresente tema de la serpiente, permiten establecer los parámetros para comenzar a valorar toda una serie de piezas sobre las que rastrear tales

\footnotetext{
${ }^{1519}$ M. DURLIAT, “Les origines...”, en particular, p. 363.

${ }^{1520}$ F. GARCÍA ROMO, La escultura del siglo XI..., p. 273. No era la primera vez que ciertos rasgos un tanto clásicos de las obras prerrománicas y románicas del arte medieval europeo se explicaban a través del contacto con la plástica griega. El mismo Porter, al estudiar el famoso sarcófago del arzobispo Hincmar, muerto en el 882 en Epernay y trasladado posteriormente a Reims para ser enterrado en la iglesia de Saint-Remy, afirmó que algunos de los rasgos clásicos de las obras salidas de la corte de Carlomagno, presentaban una fuerte influencia griega. Vid.: A. K. PORTER, "The Tomb of Hincmar and Carolingian Sculpture”, Burlington Magazine, 287, 1927, pp. 75-91, en particular, p. 84.

${ }^{1521}$ F. GARCÍA ROMO, “Orígenes y cronología...”, concretamente, p. 44.
} 
filiaciones ${ }^{1522}$. En rasgos generales y con la intención de acotar nuestro campo de búsqueda, atenderemos, especialmente, a los siguientes tipos de obras artísticas:

1. Los sarcófagos fueron, hipotéticamente, algunas de las piezas que mejor podrían haber llegado al taller jaqués. Partimos de tales esculturas por ser éstas las que parece que, de una manera más frecuente, se pudieron conocer en el entorno en el que trabajaron estos artistas, a juzgar además, por la importancia demostrada que tuvo el sarcófago de Husillos en la configuración de los lenguajes escultóricos de Frómista.

- La primera fuente de importancia dentro del establecimiento de las características del "estilo" nacido en la seo jaquesa es, por deducción, el mismo sarcófago de Husillos. Creemos que los repertorios de éste sarcófago fueron conocidos también por los escultores que trabajaban en Jaca $^{1523}$. La gran variedad de reinterpretaciones que podemos observar en relación con la escultura romana de Husillos afianza la hipótesis. En muchas de las obras jaquesas se mantendrán, de manera regular, los ecos de aquella escultura, aunque jamás se evidenciará una copia tan directa como en Frómista. No debemos descartar tampoco, tal y como ya hemos dicho, la posibilidad de que los escultores de otros centros posteriores como el de San Isidoro de León y la catedral de Santiago de Compostela hubieran tenido acceso a estos repertorios clásicos a través ya de una segunda interpretación del sarcófago que habría sido realizada años antes, tanto por los talleres de Jaca como por otra serie de centros de menor importancia. Se trataría de una influencia de la Antigüedad romana llegada a través de la pieza de Husillos pero matizada y reinterpretada por el artista románico.

- Tal y como intentaremos demostrar, dentro de la variedad de repertorios que pudieron ser utilizados, parece que aquellas piezas ligadas al ámbito pagano funerario tuvieron gran relevancia. Generalmente se trata de sarcófagos datados entre los siglos I y III d. de C. Ellos darán la clave

${ }^{1522}$ M. A. CASTIÑEIRAS GONZÁLEZ, "Sarcófago da Orestíada...", p. 250. El autor cita alguna de estas características como definidoras de este tipo de escultura.

${ }^{1523}$ No es preciso insistir en la importancia que los autores han otorgado a tal sarcófago a la hora de explicar algunos aspectos de la escultura jacetana. Otra cosa muy diferente es defender un conocimiento directo y al natural, por parte de los escultores activos en este edificio, de la pieza de Husillos. 
para explicar la pervivencia de temas absolutamente paganos dentro del templo.

- El tercer conjunto de piezas necesarias para el estudio, son los sarcófagos cristianos, es decir, los denominados tradicionalmente como paleocristianos o cristiano primitivos ${ }^{1524}$. Entendemos por éstos todos aquellos ejemplares de temática cristiana que, generalmente, se suelen encuadrar entre los siglos IV y VI d. de C. Además, adquieren aquí una importancia fundamental para explicar ciertas peculiaridades de la escultura románica, los sarcófagos producidos en época constantiniana y post-constantiniana.

2. A parte de los sarcófagos y aquellas piezas relacionadas con el ámbito funerario, serán importantes, creemos, en la definición de las fuentes usadas por los artistas medievales, otras obras, generalmente marmóreas, pero de fines diferentes a los que posee un sarcófago. Hablamos, por ejemplo, de columnas de mármol y todo tipo de piezas concebidas para ser integradas dentro de los edificios, es decir, la llamada "escultura arquitectónica", de mobiliario pétreo formado por barrotes de cancel, pilastras y molduras, así como otra serie de elementos del mismo tipo. En este punto se observará que, dentro del mismo taller jaqués, los motivos, ciertamente ricos y abundantes, se verán enormemente incrementados dentro del panorama de la escultura románica hispana. Poco tiempo después, con la nueva generación de artífices activos, se percibe una ampliación de horizontes. El repertorio se enriquece aún más, pensamos, que por la incorporación de nuevas piezas al ideario que manejaban los nuevos escultores.

Durante el desarrollo de este apartado se podrá constatar que, a las piezas romanas a las que se venía concediendo una importancia fundamental en la formación de la cultura visual de los artífices, se deberán sumar, otra serie de repertorios de cronología más avanzada. Por citar un aspecto en concreto, veremos como algunas piezas ideadas para ser engastadas en los edificios, tales como por ejemplo, las placas de incrustación, tanto en mármol como en terracota, ofrecerán modelos a tener en cuenta a

${ }^{1524}$ C. A. FERREIRA DE ALMEIDA, “Arte paleocristã da época das invasões", História da Arte em Portugal. Arte da Alta Idade Média, vol. II, Lisboa, 1986, pp. 9-36; M. JUSTINO MACIEL, "Do Paganismo ao Cristianismo: Interacçoes e continuidades nos comportamentos culturais e artísticos", Psicología, 30, 2002, pp. 241-249 e ID., Antiguidade tardia..., en particular, pp. 53-54. El profesor Maciel se centra en el análisis de aquellos elementos ideológicos de tradición pagana romana heredados por la nueva cultura cristiana. 
la hora de establecer la dependencia entre el arte romano y el románico. La difusión que alcanzaron tales piezas durante los siglos de la Antigüedad tardía y, en ocasiones, su buena conservación, permite pensar en la hipótesis de que, en algún momento, pudieran ser copiadas por parte de estos escultores medievales.

3. El bronce, por su resistencia y a pesar de ser materia fácilmente licuable, resistió, al igual que la piedra, el paso del tiempo. Las pequeñas figurillas de este material, en tamaño generalmente reducido, pequeños exvotos, amuletos y diferentes adornos del ciudadano hispanorromano, pudieron, hipotéticamente, llegar hasta la época románica, ofreciendo a veces modelos para la escultura.

4. Aunque con menor incidencia, se citarán algunas obras numismáticas antiguas ciertamente interesantes, ya que presentan determinadas concomitancias con los rasgos de algunas de las esculturas románicas nacidas en este taller y difundidas posteriormente a otros centros. 


\section{2. REPERTORIOS ORNAMENTALES E ICONOGRÁFICOS: TRASPASOS DEL ARTE ROMANO AL ROMÁNICO EN LA CATEDRAL DE JACA.}

Tras la exposición de algunos aspectos de índole metodológica relativos a la cuestión bibliográfica y del método que se seguirá para abordar este capítulo del trabajo, se iniciará aquí el estudio de algunos de los rasgos más clásicos o susceptibles de presentar un origen antiguo, de la escultura presente en Jaca. En primer lugar, se reflexionará sobre la tradición clásica del motivo o imagen esculpida en las piezas que ornan el templo románico para, una vez analizado su posible origen, abordar su difusión y asimilación en otros focos escultórico activos dentro del románico peninsular hispano hasta la primera mitad del siglo XII, aproximadamente ${ }^{1525}$.

\footnotetext{
${ }^{1525}$ En relación con el orden establecido para el análisis de los capiteles, no se ha seguido en ningún caso la distribución espacial y física que presentan en el templo, pues realmente tal solución no ofrecería la posibilidad de agrupar algunas de estas imágenes según las necesidades mismas que va marcando su pertenencia a una y otra tradición clásica. Se tratará de analizar cada motivo iconográfico estableciendo la relación que pueda tener con otros de similares características. A la hora de citar cada pieza, tal y como venimos realizando a la largo de estas páginas, se utilizará la numeración ofrecida por M. Durliat. Somos conscientes de las carencias metodológicas que presenta este método seguido por el investigador francés, sin embargo, en su estudio se abordan prácticamente todas las piezas a las que nos referiremos aquí, otorgándoles un número de identificación y ubicándolas sobre un plano de la catedral. Aquellos ejemplos que en su día no recogió el investigador serán señalados en su momento preciso.
} 


\section{A. EL CAPITEL DE LOS DANZANTES Y LOS TOCADORES DE DOBLE AULOS.}

Para iniciar de una manera concreta el estudio de los motivos clásicos presentes en la escultura de este edificio, comenzamos con uno de los capiteles más problemáticos y complejos en cuanto a su desarrollo iconográfico ${ }^{1526}$ (fig. 253). La pieza fue colocada en el tercer tramo de las naves, integrada en uno de los pilares de la nave de la Epístola, es decir, en una situación preeminente del templo. Todo aquel que accediese al espacio sagrado por la puerta meridional sur del edificio y desease pasar a la nave central, lo hacia pasando por delante de esta escultura ${ }^{1527}$.

Se trata de un capitel adosado a un pilar que apoya sobre una columna (fig. 254). Presenta las tres caras decoradas, aunque el volumen más amplio de la cesta lo ocupa la escena frontal. En él, dos figuras que giran sus cabezas, la una hacia la otra, levantan los brazos como en actitud danzante, mientras que en las esquinas aparecen dos pequeños seres agachados tocando sendos instrumentos de viento. Las caras estrechas de la pieza, en los extremos, la ocupan dos cabezas monstruosas.

El centro de la composición aparece dominado, claramente, por estas dos figuras humanas, un hombre, el de la izquierda y una mujer a la derecha. Algunos autores han señalado, con ambigüedad, que se trataba de dos figuras jóvenes, que a modo de efebos se presentan al espectador insinuando ciertas partes de sus cuerpos semidesnudos. La joven exhibe su torso desnudo y son perfectamente identificables los senos, pues los "paños mojados" con los que se cubre, tan sólo llegan hasta la altura del vientre, cayendo hacia abajo y cubriéndole las piernas. Por el contrario, su compañero danzante presenta idénticos pliegues, que caen desde el hombro derecho, a modo de clámide, hacia abajo, dejando parte del torso y las piernas al descubierto.

La escena ha recibido todo tipo de interpretaciones por parte de los especialistas $^{1528}$. Sin embargo, el investigador que mayor atención le prestó al tema,

\footnotetext{
${ }^{1526}$ Se trata del capitel número 56. Cf.: M. DURLIAT, La sculpture romane de la route..., en concreto, p. 235.

${ }^{1527}$ Creemos que ha quedado clara nuestra postura con respecto a la relación que se formaba entre el espectador medieval y la escultura.

${ }^{1528}$ G. GAILLARD, Les débuts de la sculpture..., en concreto, pp. 104-105 y R. SALVINI, La escultura..., en especial, p. 56. El último autor mencionado identificaba el tema de este capitel como: "figurillas humanas entre figuras de ángeles, tal vez la alegoría del alma escoltada por los ángeles en su camino a través de los pecados del mundo, en la que la figura central se caracteriza por un espíritu de soberbia y de clásica nobleza de formas, o aquel otro, de los amorcillos u los niños, inspirado sin duda en algún sarcófago pagano (...) anima una poesía sustancialmente bucólica”. Consúltese también: W. WEISBACH, Reforma religiosa..., particularmente, p. 211, nota 186. En tal punto, el autor dio una lectura al capitel: "aparentemente las figuras responden a un prototipo antiguo, posiblemente un
} 
desde el punto de vista iconográfico, fue M. Durliat, quién explicó la imagen a través de una hipotética reinterpretación cristiana realizada por el escultor románico. Según esto, las dos máscaras laterales del capitel serían figuras demoníacas cristianas, mientras que las ondas sobre las que parecen danzar los dos efebos, aluden al mar, entendido aquí como símbolo de la muerte.

El autor toma un sermón de San Agustín donde se desarrolla esta idea en relación con las aguas, que le sirve, además, para justificar la presencia amenazadora de los monstruos en la escena. Cerrarían la composición los dos jóvenes, que tocando la doble flauta, aparecerían como símbolo de juventud, siempre según el investigador francés $^{1529}$.

La interpretación que acabamos de explicar, ha sido calificada, en su reciente publicación, por J. Lacoste como "perspicaz" $" 1530$. Sin embargo, desde nuestro punto de vista no podemos estar de acuerdo con algunos aspectos que, en su día, planteara el estudioso.

En primer lugar, el capitel parece recordar, en varios de sus detalles, las conocidas escenas acuáticas representadas, frecuentemente, dentro de la escultura romana de sarcófagos ${ }^{1531}$. En particular, el ambiente de ondas, claramente recordatorio de las escenas acuáticas, así como la presencia de la música y de los dos personajes bailando, aluden a tal tradición.

sarcófago. Pero en la interpretación cristiana se han convertido en una representación alegórica de la deshonestidad. Destaca el carácter pecaminoso del abrazo".

Véase también: M. A. CASTIÑEIRAS GONZÁLEZ, "Verso Santiago?...”, concretamente, p. 388. El especialista define la escena como de tipo marino y la relaciona con el sarcófago con el tema de las Nereidas de la iglesia de Ager, en Lérida. Como paralelo para las figuras tocando el aulos, afirma que tienen sus precedentes lejanos en la escena circense de la base de la columna de Teodosio, en Constantinopla.

${ }^{1529}$ M. DURLIAT, La sculpture romane de la route..., particularmente, p. 236. Durliat recoge el texto de San Agustín completo.

1530 J. LACOSTE, Les maîtres..., p. 35.

1531 La mayor parte de los autores coinciden en afirmar que la escena recuerda, desde la misma iconografía, composición y temática, los frisos corridos romanos de tema acuático. En concreto, se ha hablado de los temas ligados al thiasos marino, tal y como sagazmente reconoció S. Moralejo. El thiasos de la Antigüedad definía a la cofradía encargada de celebrar las fiestas en honor de una determinada divinidad, hecho que se realizaba a través de un séquito de personajes o cortejo que avanzaban en procesión. Sin duda, el ejemplo más conocido, entre este tipo de representaciones, fue el thiasos de Dionisos, sobre todo, por el gran tamaño que llegaban a alcanzar en la materialización plástica del tema las procesiones en su honor. El tema aparecía ligado también a las figuras de Poseidón y Anfítrite pero, sobre todo, a la figura de su vástago Tritón, quién en multitud de ocasiones, se representaba haciendo sonar un instrumento de viento. Fueron igualmente habituales dentro de las piezas que desarrollaron el tema, las escenas de danzas y bailes, así como la muestra explícita de todo tipo de celebraciones mediante el juego, la comida y la bebida. Sobre este tipo de representaciones, véase: F. CUMONT, Recherches sur le symbolisme funéraire des romains, Paris, 1966, en concreto, pp. 304-343 y pp. 414-421; M. I. RODRÍGUEZ LÓPEZ, "Pervivencias iconográficas del mundo clásico en los códices prerrománicos: la personificación del mar", III Coloquio de Iconografía, vol. III, Madrid, 1993, pp. 218-224, en particular, p. 219 y M. DURLIAT, La sculpture romane de la route..., pp. 235-236. 
Debemos recordar, así mismo, que dentro de los cortejos de thiasos marino de la iconografía romana, las personificaciones de los mares y océanos, así como las mismas hijas de Doris y Nereo, las denominadas "cincuenta o cien diosas inmortales", formaban, habitualmente, parte de estos cortejos, donde las figuras se mostraban en un ambiente acuático pero a la vez bucólico y donde la belleza de las composiciones era tan evidente, que su descripción se hizo habitual en los escritos de la Antigüedad ${ }^{1532}$.

Por otra parte, la presencia del medio marítimo en tales escenas, habla del carácter regenerador y de retorno a la vida que proporcionaban las aguas, si bien, en ocasiones, se trataba de aguas infernales que, presentes ya en los poemas homéricos, aludían a las zonas marinas de Océano, Styx, Aquenonte o Piriflegetonte. Dicho imaginario estaría en relación con la tradición antigua de que las almas difuntas cruzaban las corrientes de los océanos en busca del descanso eterno, siendo de entre todas estas narraciones la más conocida, aquella que narraba la llegada al Hades del alma de Patroclo, tras haber recibido sepultura por parte de Aquiles ${ }^{1533}$.

A la hora de intentar defender una lectura iconográfica del capitel, ya sea en clave pagana o bajo una reinterpretación cristiana, la tarea se complica. Las razones son las siguientes. Al analizar esta pieza, hemos aplicado algunas reflexiones realizadas en relación con el sistema de copia llevado a cabo por el escultor medieval sobre el sarcófago romano de Husillos. No podemos olvidar que, en Frómista, las figuras principales del sarcófago fueron eliminadas del capitel medieval, los textiles que formaban parte de la decoración palatina romana, fueron mutados completamente a través de una máscara inventada que parecía vomitar telas. Se llevó a cabo una reinterpretación tan profunda de todos estos elementos que mutó por completo el mensaje original que presentaba la pieza romana. Sobre estos aspectos no vamos a incidir más.

En el hipotético caso de que el escultor de Jaca hubiera tomado contacto con un sarcófago de tema dionisiaco o de thiasos marino, algo ciertamente factible, la distorsión a la que debió ser sometido el modelo original debió ser tan marcada, que

\footnotetext{
${ }^{1532}$ M. I. RODRÍGUEZ LÓPEZ, Op. cit., p. 219.

${ }^{1533}$ F. DÍEZ DE VELASCO, Los caminos de la muerte. Religión, rito e imágenes del paso al más allá en la Grecia antigua, Valladolid, 1995, concretamente, sobre el tema, p. 43. Por otra parte, el conocimiento de las fuentes clásicas en relación con la toponimia marítima parece que era claro en el ámbito hispano de este periodo. Véase el relato del traslado del cuerpo del Apóstol en una nave que tendrá como objetivo "evitar Escila y Caribdis, junto con la peligrosas Sirtes", los bancos de arena peligrosos tan temidos en el mundo antiguo y que provocaban catastróficos naufragios. Cf.: Historia Compostelana..., en concreto, p. 67.
} 
resultaría imposible poder realizar una lectura iconográfica comprensible de dicho capitel.

Así, elementos tan indicativos y originales como el agua que envuelve la escena, tampoco se nos presenta como un elemento muy fiable. Gran parte de la escultura de la catedral de Jaca, así como la de otros núcleos importantes como, por ejemplo, la realizada para la iglesia del castillo de Loarre, Iguácel o la catedral de Santiago de Compostela o San Isidoro de León, presentan este tema reiterativamente ${ }^{1534}$. Algunos capiteles aparecen enmarcados por figuras que parecen emerger de corrientes acuáticas llenas de ondulaciones, tal y como nos muestra, por ejemplo, un capitel de la catedral de Santiago de Compostela que ya se ha tratado en este trabajo y que, según se ha defendido recientemente, representaría la condenación de Santa $\mathrm{Fe}^{1535}$ (fig. 255).

Si embargo, el origen de tal imagen surgió, creemos, a través de un mecanismo de invención y distorsión muy similar al que llevó al escultor del capitel de Frómista a reconvertir unos textiles en una suerte de fluido que era vomitado por un mascarón y desarrollarlo alrededor de las figuras como si fuese un elemento textil.

No podemos afirmar, con seguridad, que este motivo de las ondulaciones que muestra la pieza de Jaca naciera directamente del sarcófago romano de Husillos. En aquel, resulta claro que se trata de textiles que ambientan y localizan la escena en un interior palatino. El segundo paso llegaría de la mano del escultor románico, que entendió dichas telas como un elemento hídrico en el capitel de Frómista. Finalmente, el tercer grado de interpretación del lejano motivo clásico, llega ahora de la mano de estos escultores jacetanos. Es posible que las ondulaciones de este capitel de los danzantes sean en el resultado de una segunda interpretación del motivo clásico, tomado no ya directamente del sarcófago mismo, sino de algún otro modelo propiamente románico.

Con todo, pensamos que en el caso de este capitel tampoco estamos ante unas ondas acuáticas auténticas. Simplemente debemos observar a los dos monstruos macrocefálicos colocados en las caras cortas del capitel, para constatar como ambos recogen con sus manos tales ondas como si de un textil se tratase (fig. 256). Las supuestas ondas marítimas que permitieron a M. Durliat interpretar la escena en relación

\footnotetext{
${ }^{1534}$ No recogemos la bibliografía relacionada con estos edificios, pues se hará más adelante.

1535 J.-C. FAU, “À propos du chapiteau de la condamnation...", pp. 47-57 y J. LACOSTE, Les maîtres..., p. 15. En este punto no se aportan grandes datos al tema, limitándose a identificar las presuntas ondulaciones marítimas con telas o cortinajes, lo que, además, permite al autor, reiterando por otra parte las posturas de varios de los estudiosos que han trabajado la escultura, sus relaciones con el foco jaqués.
} 
con el mar y los textos cristianos, no son tales o, al menos, no de manera íntegra, pues el hecho de que los monstruos las agarren desacredita, en parte, tal postura ${ }^{1536}$.

Pensamos que la explicación para el capitel de Jaca debe ser perfilada asentándonos sobre preceptos más sencillos. Aceptando una postura menos compleja, es posible que el escultor tomase este motivo de tradición clásica de un modelo ya románico que, habiéndose inspirado en el tema del sarcófago de Husillos, modificó la imagen de los textiles para convertirlas en fluidos.

Más complejo resulta aceptar el hecho de cómo el escultor románico, teniendo delante una obra antigua del tipo que hemos descrito, pudo tomar aquellos elementos que mejor convenían a la estructura del capitel o aquellos que, de una manera más fácil, pudo identificar, tal y como ocurrió con el artífice que copió el sarcófago de Husillos en Frómista. Otros elementos, como por ejemplo, los seres monstruosos de los laterales de este capitel de Jaca, fueron posiblemente tomados del imaginario o del repertorio medieval que tenía al alcance, siguiendo un mecanismo bien demostrado en este tipo de copias. Recordemos, por ejemplo, la invención esporádica de la máscara animal que escupe textiles o fluidos del capitel de Frómista, y que el escultor románico inventó a pesar de no existir en el original romano ${ }^{1537}$.

Parece claro, a través de lo expuesto hasta el momento, que los elementos textiles presentes en los sarcófagos romanos, sin referirnos única y exclusivamente a los que se muestran en el sarcófago de Husillos, fueron interpretados por los escultores

\footnotetext{
1536 Recordemos la extraña interpretación defendida en: J. J. FERNÁNDEZ, "Capitel inspirado...”, p. 318. En relación con la máscara del capitel de Frómista: "Se ha especulado con la representación de la condición humana caída, acechada por el pecado y por el mal, figurados en las serpientes que se acercan peligrosamente a los personajes desnudos; otros han pensando en la expulsión del Paraíso de Adán y Eva, aliviada no obstante con la esperanza de la purificación, simbolizada con la fuente en forma de cabeza de felino de la que, según esta interpretación, manaría el agua redentora (...)”.

Tal y como vemos, este elemento textil o acuático ha generado todo tipo de controversias y explicaciones, bastante alejadas del aquello que realmente se representó en la escultura, pues tal y como se ha visto, en Jaca, los monstruos no expulsan agua como surtidores, sino que realmente asen dicho elemento, ya sea acuático o textil. Por lo general, este tipo de piezas romanas que decoraban las salidas de aguas de los estanques y las fuentes durante la Antigüedad, solían presentar formas de todo tipo. El rasgo más significativo de estas piezas es que, normalmente, mostraban una boca de gran tamaño por donde se conducía el agua, es decir, creemos que el hecho de que estos seres agarren tal elemento con las manos no es suficiente prueba como para emparentarlos con estos surtidores de fuentes típicos romanos. Por citar un ejemplo bien representativo al respecto, véase la máscara viril de las termas de Santa María de Vitória de Ameixal, datado en el siglo II d. de C. Vid.: V. DE SOUZA, "Männliche Maske", Corpus Signorum Imperii Romani. Corpus der Skulpturen Der Römischen Welt. Portugal, Coimbra, 1990, ficha catalográfica 72 , p. 32.

${ }^{1537}$ No podemos estar de acuerdo tampoco con la supuesta intencionalidad cristiana de la pieza que se defendió en su día en: W. WEISBACH, Reforma religiosa... p. 221.
} 
románicos de este periodo, utilizándolos para organizar las composiciones y acentuar aquellos elementos más interesantes, como por ejemplo en el capitel de Frómista ${ }^{1538}$.

Con todo, buena parte de la problemática reside en poder discernir si el ambiente hídrico es tal o, simplemente, se trata de una serie de telas ondulantes agitadas por el movimiento del baile. Las representaciones antiguas del cortejo báquico estaban formadas, preferentemente, por Ménades que, configurando el thiasos o séquito, llevaban a cabo una serie de ritos y danzas orgiásticas ${ }^{1539}$.

No podemos descartar que las figuras representadas en el capitel hayan tenido su origen en una imagen de un thiasos báquico de Ménades y Sátiros. En dichas representaciones las participantes femeninas, como integrantes de las procesiones de ninfas, se iniciaban en los misterios báquicos a través de una serie de rituales ${ }^{1540}$. Según se ha dicho, una de las características artísticas más identificativas de tales figuras, fue la importancia que adquirieron las túnicas, el chiton o el peplos, generalmente representado con gran riqueza y abundancia textil. Tales elementos pululaban por el aire movidos por los bailes y el viento, mientras que, con sus propias manos remangaban para dejar a la vista, de una manera muy sensual, sus piernas y torsos ${ }^{1541}$.

E. Simon recoge en su análisis otra serie de características habituales en este tipo de representaciones de las ménades. Las escenas en las que aparecen se sitúan en ambientes salvajes y al aire libre, como por ejemplo, sobre el Parnaso, que eran lugares idóneos para matar en sacrificio a animales como el ciervo, panteras, linces y, más

\footnotetext{
${ }^{1538}$ S. MORALEJO ÁLVAREZ, "Sobre la formación...", en concreto, p. 428. El autor aludió a que dicho elemento debía ser identificado como un fluido "vomitado por una carátula de león", sin embargo, también incidía en la importancia del personaje que agarraba dicho elemento, proponiendo también la hipótesis del textil.

${ }^{1539}$ E. SIMON, voz "Menadi”, Enciclopedia dell'arte antica..., vol. IV, 1961, pp. 1002-1012. El especialista hace una excelente síntesis del tema iconográfico. En ella, precisa que esta serie de cortejos, relacionados con el culto báquico, tenían como rasgo característico dentro de las representaciones pláticas, el de situar la acción a través de una serie de notas paisajísticas, como por ejemplo, ramajes o rocas, así como con elementos relacionados con el agua, como ríos, lagos, olas, etcétera.

${ }^{1540}$ Parte de la información que nos ha llegado sobre estos aspectos se debe a la obra de Eurípides titulada Los Bacantes, donde se describen los rituales de bailes, danzas, juegos, práctica de la música, siempre dentro de ambientes de desenfreno sexual, practicado en lugares salvajes. Vid.: Ibidem, pp. 1002-1004.

${ }^{1541}$ En esta línea, queremos destacar el marfil conservado en Paris, Musée National du Moyen Âge Thermes et Hôtel de Cluny. En la pieza se representó la imagen de Ariadna, con uno de los senos descubiertos. Se trata de una pieza datada en torno al año $500 \mathrm{~d}$. de C, por lo tanto, plenamente integrada en el arte clásico de la Antigüedad tardía y que presenta, además, una serie de elementos iconográficos muy interesantes en relación con el capitel de Jaca.

La deidad del marfil es coronada por dos putti que mediante sus alas se elevan en vuelo para colocarle la corona. Aparece acompañada por dos figuras de menor tamaño, a la derecha un sátiro, habitual dentro de este tipo de cortejos, mientras que a la izquierda, se esculpió una figura femenina de menor tamaño que se ha identificado con una Ménade, que como en todo cortejo báquico acompaña a Ariadna. Cf.: J-P. CAILLET, "Groupe d'applique: Ariane, ménade, satyre et amours", L'antiquité classique, le haut moyen âge et Byzance au musée de Cluny, Paris, 1985, ficha catalográfica 50, pp. 110-111.
} 
raramente, leones. Los animales monstruosos y feroces también serán habituales en dichos thiasos, donde como afirma el autor, "il serpente, anch'esso un divoratore di carne viva, si avvinghia alle braccia, al corpo, alla testa delle menadi" ${ }^{1542}$.

En sus danzas colectivas eran acompañadas por los silenos que, junto a ellas, hacen sonar flautas, cémbalos, sistros y tambores, siempre en relación con el desarrollo del culto a Cibeles en torno al el siglo IV a. de C. Tales personajes, en conjunto, se presentan realizando dichas danzas en torno a la máscara de Dionisio, mostrando junto a ellos pequeñas panteras o animales fieros de rasgos felinos ${ }^{1543}$.

El momento más interesante en relación con esta iconografía típica de los sarcófagos con el tema de las ménades, aparece relacionado con la etapa clásica del arte griego. El thiasos se inunda de ménades danzantes acompañadas de querubines y niños que, en éxtasis salvaje, agitan y azuzan serpientes. A ello debemos sumar el hecho que de que, con el traspaso del tema al arte romano desde el siglo II. a. de C. y, sobre todo, en la época Republicana y durante la primera etapa Imperial, a la iconografía de las ménades y el inicio a los misterios báquicos, se añaden, además, aquellas relativas a la ceremonia nupcial. Ahora la ménade pasa a hacer las veces de esposa, mientras el sátiro representa al cónyuge en una unión materializada a través de la dextrarum iunctio ${ }^{1544}$.

Regresando al capitel de Jaca, cerrarían la composición los dos niños o putti tocando el aulos, muy frecuentes en las escenas de thiasos dionisiaco, tal y como ha estudiado E. Koppel. De manera específica en estas imágenes era habitual que algunos de estos putti se presentasen sin alas y tapados con una simple clámide que, sujeta por una fíbula, caería por la espalda formando numerosos pliegues. En otras ocasiones, constituirían un cortejo musical, es el denominado thiasos infantil u okomos, que aparecerá de manera reiterativa dentro de la escultura de los siglos II al IV d. de C. ${ }^{1545}$. En el caso del capitel románico, el escultor los ha colocado en cuclillas, formando una composición simétrica y enmarcando las dos figuras danzantes. Así, mientras que el de la izquierda exhibe su desnudez, el de la derecha es envuelto por los mismos paños

\footnotetext{
${ }^{1542}$ E. SIMON, Op. cit., particularmente, pp. 1004-1005. Se señala, además, como en estas procesiones báquicas, las serpientes se suelen representar también atadas alrededor de la cintura, a modo de cinturón, o en torno al cuello.

1543 Ibidem, p. 1008.

1544 Ibidem, p. 1011.

${ }^{1545}$ E. KOPPEL, "Sarcófago con cortejo de cupidos", Locvs Amønvs, 3, 1997, pp. 7-14, en concreto, p. 8 y p. 10. Analiza un sarcófago de una colección particular de Sevilla, conservado en el Palacio barroco de la Santa Cruz y que se ha emparentado con otro de iguales características conservado en los Museos Vaticanos.
} 
vaporosos y mojados que se arremolinan en torno al cuerpo de la mujer que baila ${ }^{1546}$ (fig. 257).

A pesar de todo ello, creemos que tales afirmaciones precisan de datos más exactos. En el caso del capitel de Jaca, el supuesto oleaje acuático ha llevado a buscar paralelos más fiables dentro de la iconografía de los thiasos marinos y, en particular, dentro de las imágenes de las nereidas.

Un sarcófago con este tema conservado en la iglesia parroquial de Àger, en Lérida, fue puesto recientemente en relación con el capitel de los danzantes de Jaca (fig. 258).

Ya en torno al año 1814 había llamado la atención de Félix Torres Amat, quién llegó a realizar un diseño que copiaba, a grandes rasgos, todos los detalles iconográficos de la pieza (fig. 259).

En general, resulta muy importante el cuidado que se muestra, dentro de este tipo de manifestaciones artísticas, a la anatomía y, más concretamente, al cuerpo femenino. Tanto las Nereidas de los extremos del frente del sarcófago de Áger, como las que aparecen junto a los tritones que sujetan el clípeo en el que se presenta el difunto, muestran un trabajo excelente en cuanto al a concepción del desnudo. El artista romano ha sabido captar los cuerpos sensuales en tensión y movimiento, trabajo que, además, acompaña con un impecable manejo del cincel a la hora de recrear el drapeado textil con el que se revisten las figuras ${ }^{1547}$.

La técnica de los "paños mojados", tan habitual en los sarcófagos de tipo marino donde el ambiente acuático ofrecía la posibilidad de hacer gala de la destreza técnica del

\footnotetext{
${ }^{1546}$ Se trata de una postura que habría de tener gran importancia dentro de los talleres románicos hispanos. Su origen, parece estar, otra vez, en el sarcófago de Husillos, donde el joven criado temeroso se escondía detrás de un mueble. Cf.: F. GARCÍA ROMO, La escultura del siglo XI..., particularmente, p. 272. La fortuna de la imagen de los putti durante la Edad Media, ya fue puesta de relieve en: E. PANOFSKY, Renacimiento y renacimientos...., en particular, pp. 217-219.

${ }^{1547}$ M. A. CATIÑEIRAS GONZÁLEZ, "Verso Santiago?...", p. 388. El diseño decimonónico se conserva en Madrid, Real Academia de la Historia (CAIB/9/3930/02(07), forma parte de un expediente remitido a la misma Academia por el autor. Sobre la pieza, véase también: M. CLAVERIA NADAL, "El sarcófago romano...", particularmente, pp. 34-38.

La importancia de los diseños realizados durante la etapa moderna y el siglo XIX, en general sobre determinadas piezas romanas, ha sido puesta de manifiesto en varias ocasiones por el profesor M. Justino Maciel. Cf.: M. JUSTINO MACIEL, J. M. PEIXOTO CABRAL y D. NUNES, "O sarcófago romano das Musas (Valado, Alfezeirão). Nova Leitura iconográfica e análise do mármore", Arqueologia e História, 55, 2003, pp. 63-70. Los autores publican un diseño realizado por el monje del monasterio de Alcobaça José de São Lourenço en el año 1780 del sarcófago romano de las Musas del Museo do Carmo de Lisboa.
} 
escultor, permitió durante la Antigüedad mostrar el desnudo de las figuras tamizado bajo las telas empapadas ${ }^{1548}$.

A tales aspectos debemos sumar la presencia de los dos pequeños músicos que otorgan a la escena cierto tono bucólico, algo alejados de una posible lectura en clave cristiana, a pesar de que fue una iconografía bastante difundida en determinados ambientes intelectuales de la época medieval ${ }^{1549}$.

Teniendo en cuenta estos aspectos, una serie de datos nos llevan a pensar que el escultor medieval, posiblemente, pudo conocer algún sarcófago de tema báquico. El recuerdo de los instrumentos de viento, más frecuentes dentro de la iconografía antigua, como la siringa, la oblica tibia, el odre, la cítara, el crótalo, el pendum y el aulos, se

${ }^{1548}$ Cabe citar, por su importancia dentro de la estatuaria antigua griega de época clásica, el conocido relieve que representa el nacimiento de Afrodita o, más comúnmente denominado, "Trono Ludovisi" que hoy se conserva en Roma, Museo Nazionale Romano. Palacio Altemps.

La pieza, llegada a nosotros en forma de dos relieves trípticos -el otro se conserva en Boston-, son la muestra más exquisita de este tipo de técnica. Se ha datado entre los años 470-460 a. de C. y se ha planteado la posibilidad de que, en origen, hubieran servido como frontales de altar. La imagen más importante, en relación con nuestro estudio, es la de Afrodita saliendo del mar, entre las suaves ondas acuáticas y la masa de guijarros. Dos figuras femeninas, posiblemente las Horas, la ayudan en tal acción. Aunque pudiera parecer que la pieza griega está demasiado alejada, tanto cronológica como estilística e iconográficamente del capitel románico, no debemos olvidar que, ambas comparten un mismo interés por representar el cuerpo desnudo insinuado bajo los "paños mojados". En ambas, las aguas se mezclan con las telas y, además, en los dos casos, enmarcando la escena central, se colocaron sendas personificaciones tocando el consabido instrumento de viento, el aulos. Si el escultor griego mostró su gran pericia al representar las túnicas de las Horas y la de la propia Afrodita, el artífice medieval intentó conseguir unos objetivos similares. Sobre el relieve griego, véase: G. M. A. RICHTER, El arte griego..., en concreto, pp. 102-107 y E. SIMON, Op. cit., p. 1009. El autor se centraba en el uso de este tipo de vestimentas transparentes y agitadas durante las danzas desde unas fechas aproximadas a los años 430-380 a. de C.

Véase, sobre el mismo tema: J. J. POLLIT, Op. cit., p. 278. El citado experto considera que se trata de una tradición neoática, donde se da, de manera habitual, lo que él define como "el estilo de paños agitados de fines del siglo $V$ '.

Por último, véase: V. DE SOUZA, "Unterteil eines Mänadenreliefs", Corpus Signorum..., ficha catalográfica 4, p. 10. El especialista analiza algunos aspectos de las fórmulas neoáticas de una escultura femenina del Museo Regional de Évora, donde, nuevamente, se hace gala de la técnica de los paños mojados.

1549 J. ARCE, Funus Imperatorum..., en concreto, p. 46. El autor habla de la utilización de los instrumentos de viento, ya fuesen tubae, lituus o los cornua, en diversas ceremonias fúnebres, perfectamente integrados en los cortejos y ofreciendo un tono melancólico a las escenas. En relación con la posibilidad de ver a estos dos putti como ángeles, tal y como se ha hecho más de una vez, parece claro, a nuestro modo de ver, que se trata de un motivo que no tiene ningún contenido cristiano. Es una iconografía tomada del vocabulario artístico romano y que será traspasada, en ocasiones, a las producciones medievales.

Consúltese también: W. TRONZO, "On the role of Antiquity in medieval art: Frames and framing devices", Ideologie e pratiche del reimpiego nell'Alto Medioevo, 2 vols, Spoleto, vol. 2, pp. 1085-1111, de una manera más concreta, pp. 1092-1093. El profesor Tronzo desarrolla esta idea en relación con la recuperación de iconografía clásica en el siglo XI, concretamente, en Roma y en relación con el llamado "renacimiento paleocristiano".

Sobre el conocimiento que de la imagen de los putti tenían abades y clérigos, centrándose, más concretamente, en la descripción realizada por el abad de Fleury sobre un vaso antiguo que tenía representado un erote, véase.: J. ADHÉMAR, Influences antiques..., en concreto, pp. 10-11 y p. 147. El estudioso ya aludió al importante valor de las escenas bucólicas de las figuras tocando la flauta y su claro origen antiguo. En la mayoría de las ocasiones, se las relaciona con las Églogas de Virgilio, donde los músicos, generalmente pastores, tocan la flauta a la sombra de un árbol. 
muestra aquí patente. Se podría pensar que pervive en esta escultura un recuerdo de estas escenas del thiasos, que en este caso, al ser infantil, pasa a denominarse $\operatorname{komos}^{1550}$.

Los rostros de los pequeños músicos, con los carrillos hinchados para hacer sonar los instrumentos, son un elemento recurrente dentro de la escultura de toda la catedral y que tendrá larga fortuna en el románico de principios del siglo XII ${ }^{1551}$. Se trata de un recurso estilístico muy utilizado en otro tipo de iconografías antiguas, como por ejemplo, la de los vientos, pero que acabará por convertirse en un rasgo característico de alguna de la escultura romana datada entre los siglos II y IV d. de C. ${ }^{1552}$.

Sin embargo, resulta de una complejidad extrema intentar poder rastrear algún otro origen para esta imagen de los tocadores de aulos pues, como es sabido, su inclusión en todo tipo de leyendas, mitos y obras artísticas, fue habitual durante la Antigüedad $^{1553}$.

A partir del interés por los "paños mojados" y por la experimentación con la representación anatómica del cuerpo, llaman la atención algunas afirmaciones que, a lo largo de los años, han acabado convirtiéndose en auténticos tópicos historiográficos.

En una obra muy interesante de K. Clark, publicada en el año 1956, el autor, al estudiar el tema del desnudo a lo largo de la historia del arte, afirmaba: "Ni siquiera hoy

\footnotetext{
${ }^{1550}$ E. KOPPEL, "Sarcófago con cortejo...", pp. 9-10; F. PORRAS ROBLES, "La pervivencia del mito de Orfeo en la iconografía del rey David: origen, significación simbólica y aproximación organológica", Cuadernos de arte e iconografía, 16, 32, 2007, pp. 301-332; D. OCÓN ALONSO, "Aspectos musicales en el arte románico y protogótico”, Musiker: cuadernos de música, 8, 1996, pp. 117-129; M. JULLIAN, "La lyre dans l'art roman. Transmission et diffusion par l'image d'un modèle antique à l'époque romane", Les Cahiers de Saint-Michel de Cuxa, XXXVII, 2006, pp. 43-58 y R. GONZÁLEZ HÉRRANZ, "Representaciones musicales en la iconografía medieval", Anales de Historia del Arte, 8, 1998, pp. 67-96. 1551 Hemos abordado tal peculiaridad dentro de la escultura románica en: J. A. MORÁIS MORÁN, “Autour du "style des joues gonflées..." (en prensa).

${ }^{1552}$ Recuérdese el soberbio sarcófago conservado en Roma, Museo Nazionale Romano. Palazzo Massimo alle Terme, y en el que se representó una batalla. La pieza ha sido datada en el siglo I a. de C. y entre toda la masa ingente de figuras en plena contienda destaca la del sonador de un enorme cuerno que, con gesto enérgico, insufla el aire para hacerlo sonar. Cf.: X. BARRAL I ALTET, “The Roman World...", p. 174. Sobre el traspaso de tal gesto a la imagen de los vientos, véase: J. ADHÉMAR, Influences antiques..., pp. 194-195. Abordaremos tal aspecto de los carrillos hinchados más adelante.

${ }^{1553}$ El doble aulos aparece ligado, entre otros, al mito de Marsias. El instrumento había sido creado, supuestamente, por Atenea ante la diosa Cibeles. Para demostrar su destreza en su manejo, la diosa comenzó a tocarlo y para poder verse, se acercó a la orilla de una laguna. Sin embargo, en el reflejo la imagen de Atenea comenzó a deformarse, por lo que, enfurecida y asustada, tiró el instrumento que acaba de crear a las aguas, maldiciendo a todo a aquel que lo encontrara. Marsias aparece en la historia descubriendo el instrumento. La maldición de Atenea se cumple, cuando Marsias, desafiando a Apolo en un duelo para demostrar quién de los dos componía la mejor melodía con el aulos, pierde y es atado a un árbol, donde es castigado por los dioses. Así se le representó en la conocida escultura conservada en Estambul, Museo Arqueológico, con varias copias custodiadas en otros museos, como el de Roma, Museo Nazionale Romano. Cf.: J. J. POLLITT, Op. cit., particularmente, pp. 199-200.
} 
podemos hojear a Petronio o a Apuleyo sin que nos escandalice un poco la forma absolutamente práctica con que el mundo antiguo aceptaba el cuerpo (...)"1554.

Más tarde, al referirse a la condición del cuerpo, el desnudo y su representación durante los siglos medievales escribía:

“el cuerpo (...) dejó de ser el espejo de la perfección divina y se convirtió en objeto de humillación y de vergüenza. El arte medieval entero es prueba de cuán completamente extirpó el dogma cristiano la imagen de la belleza corporal. Es de suponer que los seres humanos aún tenían conciencia del deseo físico; pero incluso en los temas iconográficos en los que el desnudo podía representarse apropiadamente, el artista medieval parece no mostrar ningún interés por los elementos del cuerpo femenino que nosotros hemos llegado a considerar como capaces de despertar inevitablemente el deseo. ¿Reprimía sus sentimientos de manera liberada? ¿O es nuestra propia complacencia del paisaje, parcialmente una consecuencia del arte, es decir, dependiente de una imagen creada por una sucesión de individuos sensibles? Al menos, no hay duda sobre el puritanismo de la tradición cristiana tal como la vemos, por ejemplo, en las primeras figuras desnudas independientes y de tamaño natural del arte medieval: el Adán y Eva de Bamberg. Sus cuerpos son tan poco sensuales como los contrafuertes de una iglesia gótica"1555.

La obra de Clark apareció en un momento muy temprano, una época en la que algunos aspectos del arte medieval, en parte denostados, iniciaban el camino que crearía algunos de los estereotipos más importantes sobre los que se definirían las supuestas características esenciales del arte de este periodo cronológico. Sin embargo, hoy creemos que es imposible mantener la idea que de que el arte románico estaba absolutamente despreocupado por captar las formas naturalistas del cuerpo.

Lejos de querer atribuir al pequeño capitel de la catedral de Jaca una excepcionalidad y calidad artística que, en parte, no posee, es justo afirmar que se trata de una muestra del valor que los escultores románicos otorgaron al cuerpo y a la captación del mismo. Dos figuras desnudas, tan sólo cubiertas con telas vaporosas que se entremezclan con ondas de recuerdo marítimo, son la prueba de ello. Sus cuerpos se mueven libres en el frente del capitel, al igual que los brazos, con los que se consigue realizar un bello juego compositivo. En particular, destaca la curvatura que se le ha dado

\footnotetext{
${ }^{1554}$ K. CLARK, El desnudo. Un estudio de la forma ideal, Madrid, 1981, en particular, pp. 297-298.

1555 Ibidem.
} 
a la figura femenina, donde los senos se muestran descubiertos como en las mejores esculturas clásicas. No podemos hablar, por lo tanto, de unas figuras "vergonzosamente desnudas, y que soportan humillaciones, martirios y torturas" ${ }^{\prime 556}$.

Sin intentar hacer una sobre lectura de tal imagen, pensamos que las figuras aquí representadas muestran su desnudez, alegres y bailarinas, de la misma manera que el Isaac del capitel de la portada meridional, ofrecerá orgulloso su cuerpo heroico, a la manera de los atletas en las imágenes de palestra del mundo romano, tal y como veremos.

Para finalizar este apartado, creemos necesario realizar una serie de reflexiones. En primer lugar, a la hora de analizar las fuentes clásicas del capitel de Jaca, se observará lo problemático de poder ofrecer ejemplos coherentes y factibles a la hora de establecer las comparaciones pertinentes entre la escultura medieval y la antigua. Sin duda, este es uno de los grandes riesgos que presente este estudio. El corpus de la estatuaria de sarcófagos romanos conservados en España se halla completamente fragmentado. Los ejemplos que han llegado hasta nosotros son perfectamente $\operatorname{conocidos}^{1557}$.

Presumiblemente el panorama fue mucho más rico que el presente y se podría pensar que alguna de esas obras, hoy perdidas, pudo ofrecer modelos suficientes que inspirasen a estos artistas románicos. Con todo, la pérdida de tales piezas no es razón suficiente como para negar una influencia clásica, pues tal y como hemos visto, la imagen que venimos estudiando presenta suficientes rasgos como para mantener tal posibilidad.

Consideramos que el método comparativo con el, generalmente, se han abordado estas cuestiones se torna restrictivo a la hora de plantear hipótesis serias. Ya hemos esbozado la posibilidad de invertir el método para, mediante los resabios clasicistas conservados en la escultura románica, generar diversas hipótesis que nos permitan deducir las piezas antiguas que los artífices pudieron tener a su alcance, muy a pesar de que estas hayan desaparecido.

\footnotetext{
${ }^{1556}$ Ibidem., en concreto, p. 299.

1557 Por citar los ejemplos más significativos, véanse los excelentes análisis llevados a cabo en: A. GARCÍA Y BELLIDO, Esculturas romanas de España y Portugal, Madrid, 1949; J. DE ALARCÃO, Roman Portugal, Warminster, 1988; V. DE SOUZA, Corpus Signorum..., pp. 3-67; M. JUSTINO MACIEL, J. M. PEIXOTO CABRAL y D. NUNES, "Os sarcófagos tardo-romanos do Museo Nacional da Arqueología. Novos dados para a sua Interpretação", O Arqueólogo Português, IV, 20, Lisboa, 2002, pp. 161-173 y J. L. DE MATOS, Inventário do Museu Nacional de Arqueologia. Colecção de Escultura Romana, Lisboa, 1995.
} 
Por ejemplo, antes de que S. Moralejo llevase a cabo el descubrimiento de la copia fiel del sarcófago de Husillos en Frómista, E. Berteaux ya había planteado la posibilidad de que el capitel citado hubiera tenido como base algunos ejemplos tomados de la estatuaria romana. El autor francés no conocía el sarcófago de la localidad palentina y optaba por sostener que la pieza que había dado origen e inspiración a la escultura de Frómista podía haber desaparecido. Ello no desacreditaba la posibilidad de intuir una influencia clásica.

Mediante este argumento queremos exponer que, a lo largo de las siguientes páginas, se observará el establecimiento constante de hipótesis, basadas, generalmente, sobre un horizonte de obras que no hemos conservado. Estas premisas se traducen, claramente, en una inseguridad a la hora de ofrecer paralelos posibles que, en muchos casos, se presentan escasos ${ }^{1558}$.

¿Hasta que punto es posible perfilar un panorama del arte antiguo, especialmente de su escultura, a través de la pervivencia de algunos de sus motivos dentro del arte medieval? La respuesta es compleja $\mathrm{y}$, sin duda, problemática. Al observar la decoración de los capiteles de la catedral de Jaca y comparándola con la realizada para la iglesia de San Martín de Frómista, se percibe un gran cambio. Ahora los modelos y fórmulas con las que se están trabajando son más amplios, más variados y ricos. Las fuentes a su alcance parecen más diversas. Quizás la explicación para este fenómeno esté relacionada con el incremento de piezas romanas que en el momento de llevar a cabo la decoración del edificio estaban al alcance de los escultores ${ }^{1559}$.

Regresando a la imagen de Jaca, a pesar de no contar con una pieza de tales características que nos de la clave y las razones suficientes como para emparentarla con la escultura románica, podría ser factible construir la hipótesis de que un sarcófago con

1558 J. A. MORÁIS MORÁN, "Investigar sin corpus...", (en prensa). Nos basamos, sobre todo, en el método desarrollado por los historiadores del arte antiguo de la órbita alemana del siglo XIX, que se dedicaron a reconstruir la historia del arte clásico griego a través del recuerdo que, de éstas, había pervivido dentro de las copias romanas. Se trata de la llamada Archäologie der Kunst o "Arqueología del arte", también denominada "Arqueología filológica". A través de tal base teórica se podía, en parte, recuperar el conocimiento de obras de arte perdidas. Véase, en relación con ello: S. SETTIS, El futuro..., pp. 44-45. Sobre la denominada "arqueología filológica", el autor señala que, aplicada a la escultura griega y sus copias romanas, fue utilizada en el siglo XIX para poder llegar a tener conocimiento de los originales griegos desaparecidos. Pone el ejemplo de las esculturas de Polícleto o Mirón, de las que no ha sobrevivido ningún original, pero de las que podemos llegar a tener una idea a través de sus copias. También consúltese: A. RIEGL, Stilfragen. Grundlegungen zu einer Geschichte der Oranmentik, Viena, 1983; ID., Spätrömische Kunstindustrie nach den Funden in Osterreich-Ungarn, Viena, 1901 у J. PLAZAOLA, Modelos y Teorías de la Historia del Arte, San Sebastián, 1987, en concreto, pp. 39-43.

${ }^{1559}$ Los investigadores han señalado, de manera recurrente, la importancia de estas piezas antiguas dentro del panorama monumental que debió existir durante los siglos medievales. Vid.: M. JUSTINO MACIEL, "Vectores da arte paleocrista em portugal nos contextos suévico e visigotico", XXXIX Corso di cultura sull'arte ravennate e bizantina, Ravenna, 1992, pp. 435-495. 
el tema de las Nereidas o, posiblemente, que desarrollase la iconografía de las Ménades en procesión báquica en forma de thiasos, pudiera haber estado ante los ojos de estos escultores.

El desnudo de la figura masculina y la belleza y sensualidad de la femenina, que en plena danza, llegan a tocarse, recuerda el tipo de iconografía de época romana donde la ménade y sátiro llevaban a cabo la dextrarum iunctio, tal y como hemos señalado ${ }^{1560}$.

Como mera hipótesis, cabría preguntarse por el origen de los dos seres monstruosos que aparecen en los laterales de tal composición, de rasgos eminentemente felinos y que, como ya hemos dicho, parecen descender de este tipo de repertorios del thiasos. Recordemos en éste sentido el magnífico sarcófago de tema dionisiaco de Cadenet, en Vaucluse (fig. 260). La pieza presenta, en su parte larga y las dos cortas, el desarrollo de un cortejo báquico de sátiros, ménades y otras deidades. Uno de los aspectos más destacados es la enorme cabeza de un gran león que se ha colocado en uno de los ángulos del sarcófago, junto a la figura de Baco y que rompe directamente con la narración corrida de las escenas. Es posible que algún elemento de similares características, en los que una cabeza de león o pantera dominase la composición de la pieza, a modo de prótomo de gran relieve, hubiese generado tal imagen, habida cuenta del gran desarrollo cefálico que presentan estos monstruos románicos ${ }^{1561}$.

Otro ejemplo bien significativo lo proporciona una pieza conservada en Roma, en la que fue representada una danza orgiástica de un Sátiro y una Ménade, que formando parte de una composición barroca, aparecen flanqueados por sendas máscaras leoninas. Bajo ellas, nuevamente aparecen las figuras de dos putti, esta vez cabalgando sobre dos panteras ${ }^{1562}$ (fig. 261).

Las piezas de similar índole que hemos consultado no ofrecen datos muy ricos que permitan realizar una comparación más segura. No obstante, pensamos que, muy

\footnotetext{
${ }^{1560}$ Napoli, Museo Archeologico Nazionale. La pintura, proveniente de Pompeya, es muy sugestiva al respecto. Sobre ella, véase: E. SIMON, Op. cit., en concreto, p. 1011.

${ }^{1561}$ R. TURCAN, Les sarcophages romains..., en concreto, pp. 235 y pp. 271-274 y H. LAVAGNE, "Le sarcophage à représentation dionysiaque de Cadenet (Vaucluse). Historiographie et problèmes d'iconographie", Imago Antiqvitatis..., pp. 297-313.

${ }^{1562}$ Città del Vaticano, Musei Vaticani. Creemos que esta pieza aporta otra prueba más para poder afirmar que las máscaras leoninas pudieron ser el origen de los monstruos felinos del capitel románico. Igualmente, la presencia de los niños en la escena, habla de la posibilidad de que el capitel de Jaca, hubiera tenido como base una composición similar. No debemos olvidar la enorme fortuna que los niños cabalgando leones van a tener dentro de los repertorios escultóricos de los talleres activos a finales del siglo XI y principios del XII. Más adelante, incidiremos sobre este aspecto, pero recuérdese, por ejemplo, el magnifico capitel de la iglesia de Loarre, donde una figura, aparentemente infantil, cabalga a horcajadas un posible león. Sobre la imagen de las panteras dentro de los cultos báquicos, en especial, su aparición junto a Dionisio, véase: J. J. POLLITT, Op. cit., en concreto, pp. 339-341.
} 
posiblemente, la figuración del capitel sea fruto de una reelaboración de motivos y temas muy variados, tomados quizás de varios sarcófagos diferentes. De ahí la imposibilidad de hallar una pieza que albergue el modelo original para todo el capitel jacetano.

Otro de los elementos más importantes y característicos de la pieza de Jaca, lo representan las telas. Éstas se convierten en el centro mismo de la composición junto con los danzantes y, teniendo en cuenta la difusión del motivo dentro de los talleres románicos hispanos, parece que fue uno de los elementos que más atrajo la atención de los escultores románicos.

Así, debemos afirmar que los cortinajes habían dominado, en muchas ocasiones, algunas de las piezas más importantes de la escultura de sarcófagos de época romana, tal y como aparecen en el mismo sarcófago de Husillos. Sin embargo, dicho elemento llegó a adquirir formas de lo más variado. El uso del llamado parapetasma que en ocasiones enmarcaba y servía de fondo para la imagen de los difuntos, así como de otra serie de funciones, casi siempre decorativas, convirtieron a estos textiles en elementos muy difundidos durante la época romana ${ }^{1563}$. Sustentado por los erotes, fue concebido desde antiguo como símbolo de la inmortalidad, para pasar con el tiempo a transformarse en un simple elemento decorativo de las escenas ${ }^{1564}$.

\footnotetext{
${ }^{1563}$ No debemos desdeñar la continua experimentación que los artistas de la Antigüedad van a desarrollar en torno a la representación de las telas. Además, una de las fuentes más importantes para los escultores medievales, en relación con este elemento, estará en las esculturas de época romana que servirán de continuo modelo para los artífices medievales. Consúltese al respecto: R. JULLIAN, "L'art de la draperie dans la sculpture romane de Provence", Gazette de Beaux-Arts, 1928, II, pp. 241-258, en concreto, p. 241. El especialista habla de la importante colección de sarcófagos romanos conservados en Narbona, pertenecientes, muchos de ellos, a la escuela de Arles y que serán el modelo de inspiración galorromano que tomen los escultores románicos de Provenza. Se incidirá en el tema a lo largo de las siguientes páginas.

${ }^{1564}$ M. CLAVERIA, "El sarcófago...", p. 38. La citada experta pone el ejemplo de uno de los sarcófagos conservados en el Museu d'Arqueologia de Catalunya, en el que se muestra la imagen de los esposos sobre este elemento textil. Sin embargo, tal elemento se usó de manera continua en los sarcófagos romanos para decorar los fondos y ambientar las escenas esculpidas.

Véanse algunos ejemplos recogidos en: R. TURCAN, Les sarcophages romains a représentations dionysiaques. Essai de chronologie et d'histoire religieuse, Paris, 1966, en concreto, véanse las pp. 72-81. Por su parte, F. Cabrol y H. Leclercq también reflexionan sobre este tipo de textiles o velos, movidos por el viento y colocados sobre las figuras a modo de capa o en la cabeza. Cf.: F. CABROL, y H. LECLERCQ, voz "Amours", Op. cit., vol. I, cols. 1618-1619. Los autores afirman que se trata de un símbolo de las divinidades marinas.

Por último, uno de los trabajos más interesantes a la hora de poner de relieve la importancia de las piezas textiles de época antigua en la configuración de estos modelos es el realizado en: M. D. DEL AMO, "El catapetasma en la plástica visigoda", IV Reunió d'Arqueologia Cristiana Hispànica, Barcelona, 1995, pp. 69-77. La autora recoge los diferentes simbolismos que se le atribuyeron durante la Antigüedad tardía hispana y la época visigoda a estos elementos textiles. Entendidos desde simples elementos decorativos de gusto bizantinizante, hasta ser dotados con otros significados relacionados con lo sagrado, la muerte $o$ los ambientes cortesanos.
} 
Para finalizar, quisiéramos citar un sarcófago en el que se representó, nuevamente, el tema de las nereidas y los tritones que aparecen distribuidos formando cinco parejas a lo largo del frente de la pieza. Se trata de un sarcófago de gran calidad, que nos interesa extremadamente, pues creemos que, sin defender lógicamente una copia directa de la pieza por el escultor románico de Jaca, existen argumentos suficientes como para emparentar algunas de las formas y recursos de la escultura románica con la estética antigua (fig. 262).

En primer lugar, llama la atención la manera con que fueron concebidos ciertos rasgos fisonómicos de las figuras. El escultor romano prestó atención al movimiento de los músculos en tensión, a los brazos y piernas y, de manera especial, a la relación espacial y física existente entre dos figuras que interactúan en el desarrollo de una escena de gran agitación (fig. 263). Tales hechos no fueron ajenos a las soluciones dadas por el escultor románico para el capitel.

El volumen de las cabezas de las figuras romanas, la concepción de ciertos detalles de los rostros y, por ejemplo, la manera con la que el escultor románico intentó materializar los cabellos de la figura masculina que aparecen movidos por la brisa que hace ondular las aguas y los textiles, tiene paralelos lejanos en el rostro de uno de los tritones de la pieza romana (figs. 264 y 265).

Con todo, creemos que el rasgo más significativo viene dado por la misma intención a la hora de otorgar cierta corporeidad a la masa muscular, utilizando un relieve contundente, pero blando, tal y como se constata en la manera de esculpir los torsos de las nereidas, con una ligera insinuación de los senos que también aparece en la escultura románica $^{1565}$.

El ambiente acuático en el que se desarrolla la escena del sarcófago romano, presenta las típicas ondulaciones hídricas que, en el caso concreto de esta pieza, apenas se realizaron en un relieve muy bajo, casi inciso. Las figuras femeninas romanas reposan sus pies desnudos para, en ocasiones, dejar caer las partes bajas de sus túnicas mojadas al agua. Los elementos textiles, túnicas y velos, se humedecen y se llegan a entremezclar con el agua, como si ambos elementos formase parte de un mismo motivo. Quizás sea en este tipo de soluciones de la estatuaria romana, a través de las que

${ }^{1565}$ N. ICARD-GIANOLIO y A. VIOLAINE SZABADOS, voz "Nereides", Lexicon Iconographicum Mythologiae Classicae, vol. VI, 1, Zürich-München, 1992, pp. 785-824, en particular, p. 796. Se trata de una obra conservada en Città del Vaticano, Musei Vaticani. Se ha datado en la segunda mitad del siglo II. 
debamos intentar explicar este complejo motivo románico que hemos venido señalando como tema recurrente dentro de la escultura del periodo ${ }^{1566}$ (fig. 262).

Tal y como se ha podido constatar, en el estudio de este primer motivo clásico que ofrece el capitel jacetano, necesariamente nuestros argumentos se han vertebrado sobre una metodología basada en el concepto mismo de "influencia" que, aplicado a este tipo de producciones tan dispersas, acaba por convertir las bases sobre las que asentamos nuestro discurso teórico en algo inestable y problemático. Del mismo modo, se han desarrollado diferentes vías de investigación totalmente hipotéticas, trabajando sobre la idea de que muchas de las fuentes antiguas no han llegado hasta nosotros y sabiendo, igualmente, de la problemática de acudir a otros repertorios más lejanos e inconexos, pero forzados ante la desaparición de buena parte de estos monumentos en la Hispania medieval.

Podemos concluir señalando que, las fuentes de las que pudo beber el escultor del capitel medieval, posiblemente, estaban emparentadas con la escultura romana pagana de friso continuo y, concretamente, aquella utilizada en la decoración de sarcófagos. El tema sobre el que se pudo basar la composición románica, pudo derivar de todo el repertorio iconográfico del thiasos, ya fuese en su vertiente marina, en relación con las imágenes de iniciación a los misterios y las procesiones báquicas o, en ultimo lugar, aquel que, en ocasiones, aparecía integrado por putti. Creemos que está fuera de toda duda, que el germen de estas imágenes ubicadas en pleno contexto sagrado de un templo medieval, tienen su precedente más instantáneo en las figuras de las Nereidas y Ménades, muy a pesar de que no conozcamos ningún ejemplar romano de este tipo en el área geográfica más cercana al entorno catedralicio de Jaca.

Siendo un poco más concisos, la cronología de las piezas romanas que, posiblemente, utilizaron estos artistas medievales, no debió ser anterior al siglo I. d. de C., por lo que creemos que se trata de una manera, ciertamente arriesgada y sin argumentos sólidos, de poder acotar el repertorio de piezas al que pudo acceder el

\footnotetext{
${ }^{1566}$ Ante la falta de otro ejemplo más cercano a la Península Ibérica, optamos por esta pieza romana que presenta múltiples semejanzas con el capitel de Jaca. En este sentido, creemos que el ejemplar de Àger, un poco más alejado, desde el punto de vista de las concomitancias formales, con la pieza románica, también debe ser tenido en cuenta a la hora de construir la hipótesis que permita deducir la pieza que estos artífices medievales pudieron haber consultado para inspirarse. Hubiera resultado fácil defender la posibilidad de que el modelo inspirador estuviese en la propia escultura hispanorromana de la Península, como en su día defendió R. Salvini.

Sin embargo, no se ha conservado, que conozcamos, ninguna pieza similar dentro del repertorio de la escultura provincial romana que permita establecer tantas comparaciones como las que ofrecen las dos obras antes comentadas. Para la teoría del autor mencionado, véase: R. SALVINI, La escultura ..., en concreto, p. 62.
} 
entorno de los talleres de Frómista y Jaca. Debemos recordar, en este sentido, que el sarcófago de Husillos también había sido datado por los expertos entre el siglo I y II d. de C.

Un último aspecto a tener en cuenta en relación con todo lo argumentado, habla de la relación, siempre tan compleja, entre la escultura de Frómista y Jaca. El capitel que acabamos de analizar es, sin duda alguna, uno de los más "antiquizantes" de todo el corpus de los realizados para la seo aragonesa. Sin embargo, en él no hallamos una sola huella o impronta directa que permita alegar que el escultor de tal pieza conoció el sarcófago de Husillos ${ }^{1567}$. Ni desde el punto de vista compositivo, ni desde el iconográfico, tal teoría se puede defender solidamente. Las conexiones que podemos establecer entre ambas piezas son, tan sólo factibles, porque ambas poseen un horizonte común que no es otro que los modelos de la Antigüedad romana, concretamente, los presentes en los sarcófagos, que tanto los escultores de Frómista como los de Jaca, compartieron. Ahora bien, sin restringir tal posibilidad de repertorios únicamente al legendario programa icónico del sarcófago de Husillos.

$\mathrm{Ni}$ en este capitel $\mathrm{y}$, podemos afirmar de manera general que, en ninguna de las esculturas conservadas en la catedral de Jaca, se advierte una copia tan directa del modelo palentino como la realizada por el escultor del capitel de Frómista. Hablando con propiedad, tal y como señaló en su día el profesor Moralejo, en la escultura de la seo jaquesa no existió una "voluntad de copia" directa del sarcófago ${ }^{1568}$. Sin embargo y creemos que más importante, podemos asegurar que se percibe una "voluntad de continuidad", que si no aparece concretada hacia los modelos del sarcófago de Husillos, si que está enfocada hacia otras piezas de índole diversa que debieron estar al alcance de estos escultores $^{1569}$.

\footnotetext{
${ }^{1567}$ Las figuras danzantes del frente del capitel no tienen paralelo en aquella pieza. Tampoco los monstruos laterales. Quizás, y con muchas concesiones, los putti en cuclillas puedan ser comparados con la figura del esclavo del sarcófago, aunque no creemos que se trate de una copia directa.

${ }^{1568}$ S. MORALEJO ÁLVAREZ, "Sobre la formación...", p. 432. Podemos afirmar que la escultura de cada centro no es una consecuencia de la realizada en el otro. A la hora de explicar las características esenciales que definen ambos talleres, ni Frómista va a depender directamente de Jaca, ni viceversa.

${ }^{1569}$ N. DACOS, "Sopravvivenza...", p. 731; A. GRABAR, Las vías de la creación..., p. 139 у E. PANOFSKY, Renacimiento y renacimientos..., pp. 169-170. En este sentido, Panofsky defendió la idea de una continuidad ininterrumpida desde la caída del mundo antiguo hasta la llegada del año mil.
} 
B. LA SERPIENTE: UN TEMA RECURRENTE DE LA ANTIGÜEDAD EN LA ESCULTURA ROMÁNICA HISPANA. EL EJEMPLO DE LA CATEDRAL DE JACA.

Uno de los temas iconográficos de mayor difusión que fueron utilizados dentro del repertorio icónico de la escultura de la catedral jacetana fue el de la serpiente ${ }^{1570}$. Su recurrencia dentro de las representaciones escultóricas llevaría, incluso, a que algunos autores intentasen definir tal peculiaridad. En relación con ello, F. García Romo sería uno de los especialistas que apostillaría la expresión de "maestro de las serpientes" para denominar al posible escultor románico activo en la seo y que tendría especial preferencia por este tema ${ }^{1571}$.

Pensamos que hablar de un "maestro" basándose en el hecho, nada genérico además, de utilizar la imagen de la serpiente de manera reiterada puede resultar problemático. Al contrario, imaginamos un taller donde el modelo era bien conocido y donde diferentes escultores podrían manejar a la par, una serie de modelos similares.

Parece claro, a juzgar por lo habitual de su utilización, que el tema de la serpiente gustó entre estos artífices. Sin embargo, debemos recordar que, por las mismas épocas, los escultores de Frómista estaban haciendo idéntico uso de esa misma imagen dentro del templo, lo que indica que no se trata de un rasgo excepcional que permita personalizar las supuestas preferencias estéticas de los artistas hasta el punto de atribuirles una nomenclatura.

En la órbita occidental, desde el siglo IV d. de C., el oficio jugó un papel primordial en la iconografía cristiana ${ }^{1572}$. Fue símbolo del mal y de la muerte, del diablo

${ }^{1570}$ M. DURLIAT, "Sculpture romane....", concretamente, pp. 388-389. El autor alude, además, en relación con el tema de la serpiente, al de la mujer y el hombre, ligados al pecado de la humanidad.

${ }^{1571}$ F. GARCÍA ROMO, "Orígenes y cronología...", pp. 34-35 y p. 45. García Romo habla de la actividad de este supuesto "maestro" y lo sitúa, además de en Jaca, en las partes más antiguas de San Isidoro de León, entre otros lugares. En relación con su cronología nos dice: "podemos suponer el comienzo de su tarea algo antes del 1080-1085". Resulta muy interesante que, el mismo experto, llega a aportar cronologías muy concretas, con el consiguiente problema que ello conlleva, llegando a escribir: "el maestro de las serpientes" experto en figuración, llega a Jaca quizás dos o tres años antes de Iguácel, pues allí lo copian". Ya hemos aludido a la crítica realizada en: I. G. BANGO TORVISO, "La arquitectura románica...", en particular, p. 125.

${ }^{1572}$ H. GONZÁLEZ ZYMLA, "La simbología de la serpiente en las religiones antiguas: en torno a las posibles causas biológicas que explican su sacralidad e importancia", Akros, 3, 2004, pp. 67-82; ID., "La iconografía de la serpiente", Revista de arqueología, 23, 255, 2002, pp. 44-51 y A. M. VÁZQUEZ HOYS, "La serpiente en la Antigüedad: ¿genio o demonio?", Héroes, semidioses y daimones (J. Álvarez Sánchez, C. Blázquez Domínguez, E. C. González Wagner, coords.), Madrid, 1992, pp. 81-134. Para su fortuna antes del cristianismo, consúltese: F. DÍEZ PLATAS, "Imaginando el agua: reflexiones sobre el significado iconográfico del motivo de la serpiente en ciertas escenas de la cerámica griega arcaica", Fronteras e identidad en el mundo griego antiguo (P. M. López Barja de Quiroga, S. Reboreda Morillo, coords.), 2001, pp. 281-301 y D. RODRÍGUEZ PÉREZ, Serpientes, dioses y héroes: el combate contra el monstruo en el arte y la literatura griega antigua, León, 2008. 
y del pecado. Acompañado de otros seres, como por ejemplo los batracios, representaba los espíritus inmundos y se le solía figurar saliendo de la boca de los endemoniados. No obstante, siguiendo con esa tónica habitual de la iconografía cristiana, tuvo también un carácter dual. Podía, ocupando lugares y acompañada de elementos iconográficos diferentes, ser símbolo de Cristo, de la resurrección y de la encarnación, ligado en este caso a la regeneración de la piel que lleva a cabo el ofidio ${ }^{1573}$.

Fue muy utilizado dentro de todo tipo de composiciones artísticas de las más variadas técnicas y es precisamente por ese éxito que tuvo dentro de la plástica artística por el que llegó con relativa facilidad a la época medieval, donde el ofidio fue sometido de manera reiterativa a los procesos ligados al spolium in $r e^{1574}$. Creemos, no obstante, que desviaría la línea expositiva del trabajo iniciar aquí un repaso extenso de la iconografía de este animal desde la época antigua. Es muy conocida la fortuna que tuvo dentro del mundo grecolatino, tanto en las manifestaciones plásticas, como dentro de las literarias y, así mismo, tanto desde la órbita pagana como luego en la paleocristiana ${ }^{1575}$. En relación con ello, los ejemplos escultóricos que vamos a presentar a continuación, continúan reforzando el conocimiento, más o menos acertado, de las fábulas clásicas grecolatinas en los ambientes medievales y que, concretamente, durante los siglos XI y XII serían conocidas principalmente a través de la copia y difusión de los textos de Esopo y Fedro ${ }^{1576}$. En este sentido, tal y como hemos visto y explicado anteriormente,

${ }^{1573}$ E. FERNÁNDEZ GONZÁLEZ, “Sobre la serpiente...”, particularmente, pp. 44-48. Véase también la aportación realizada en: E. FERNÁNDEZ GONZÁLEZ y F. GALVÁN FREILE, "Iconografía, ornamentación...", particularmente, p. 248. En dicho punto, se realiza una reflexión interesante para nuestro objetivo. A parte de todo el valor simbólico que vamos a explicar aquí en relación con el uso de la iconografía de la serpiente, también tuvo, en infinidad de ocasiones, un valor meramente decorativo. Los autores afirman: "Por las características propias de su cuerpo, el ofidio es un animal "decorativo" por excelencia. La sinuosidad que puede imprimir a su figura (...) motivó su uso reiterado con fines ornamentales". Debemos tener en cuenta este hecho pues, en algunas esculturas que analizaremos, la serpiente aparece más como un elemento decorativo heredado de la Antigüedad clásica, que como gran contenedor de simbolismo. En todo caso, resulta imposible poder afirmar si los escultores y, más concretamente los espectadores de tales símbolos, conocían todas las acepciones y significaciones que el reptil había tenido en el mundo antiguo.

${ }^{1574}$ F. SAXL, "Continuitá e variazione nel significato delle immagini”, Storia delle immagini, Bari, 1965, particularmente, pp. 12-13. Saxl alude al carácter amenazador que conservó tanto en la Antigüedad como durante los siglos medievales. A pesar de que en su doble variante iconológica también fue símbolo positivo. No podemos estar de acuerdo con la afirmación realizada en torno a esta iconografía, según la cual, "la imagen (de la mujer con serpientes) sobrevivió durante la Antigüedad (...) pero durante el primer milenio de la era cristiana casi llegó a extinguirse", tal y como afirma el autor.

1575 P. DOCAMPO ÁLVAREZ, J. MARTÍNEZ OSENDE y J. VILLAR VIDAL, Animales fabulosos del románico en Asturias, Gijón, 2000, en especial p. 13. Se trata de una obra enfocada a un ámbito local y concreto pero con reflexiones e introducciones interesantes sobre el tema. También véase: C. CID PRIEGO, "El caballero y la serpiente. Iconografía y origen remotos de una miniatura singular del Beato de Girona", Annals de l'Institut d'Estudis Gironins, 30, 1988-1989, pp. 99-139.

1576 S. SEBASTIÁN, Mensaje simbólico..., pp. 256-257. El autor ejemplifica la perduración y conservación de las fábulas clásicas durante la Edad Media, tomando como ejemplo la fábula del lobo, la 
dichos textos fueron los que inspirarían el capitel esculpido en Frómista con el tema de la fábula de la zorra y el cuervo, obra que habla, nuevamente, sobre esta perdurabilidad en el conocimiento de los textos antiguos ${ }^{1577}$.

Sin duda, han sido los trabajos de la profesora J. Leclercq-Kadaner, los que con mejor criterio han analizado esta contaminación de la imaginería de tradición clásica de la serpiente en la plástica de la Edad Media, así como sobre todas la resignificaciones sufridas por el icono en tal proceso ${ }^{1578}$.

A partir de la imagen de Cibeles, Ceres o Proserpina, deidades ctónicas del ámbito grecolatino, los autores cristianos, a veces erróneamente, formarían su propia idea del panteón romano, relacionándolo, ocasionalmente, con los principios de creación y fecundidad. Tellus, Gä̈a, Terra Mater son, desde Hesíodo hasta Isidoro de Sevilla, diosas y personificaciones recurrentes a la hora de hablar de la mitología vinculada con la naturaleza ${ }^{1579}$. La serpiente pronto apareció ligada a estas deidades, sobre todo, gracias a su recurrente unión con la personificación de la Tierra, con la renovación y con la procreación, que llevará, desde el arte romano mismo, a asociar su presencia con la figura alegórica de una mujer joven, con pechos desnudos, portando a veces el cuerno de la abundancia y rodeada de animales y niños a los que amamanta.

Según la citada especialista, tanto la imagen de Tierra como la de la serpiente, fueron asociadas con la idea de renacimiento corporal y del alma, de ahí que aparezca coligada a la iconografía de los sarcófagos paganos de la época romana. Le acompañará, en gran numero de ocasiones, la otra deidad masculina generadora de vida, Okeanos $^{1580}$.

grulla o la del asno. Ésta última, perteneciente a la obra de Fedro, habla sobre la figura de un asno y el hallazgo de una lira abandonada en un prado. Tras ensayar y probar a tocarla, la historia finaliza mediante una moraleja que insiste en el destino y sobre la imposibilidad de los genios para manifestarse en medios no adecuados. El tema del burro y la lira, tan difundido en la escultura románica, tomó como base relatos como estos.

1577 Dentro de los estudios de la escultura románica se trata de un tema al que se le prestado cierta atención, teniendo en cuenta, sobre todo, su traspaso desde la etapa antigua al románico. Vid.: F. A. FERRER GARCÍA, "El santo y la serpiente: leyenda y realidad en el cenotafio de los mártires Vicente, Sabina y Cristeta de Ávila”, Cuadernos abulenses, 29, 2000, pp. 11-60.

1578 J. LECLERCQ-KADANER, "De la Terre-Mére...", en concreto, pp. 37-41; ID., "Imágenes. La doble tradición medieval", Quintana, 4, 2005, pp. 13-53 e ID., La sirène dans la pensée et dans l'art de l'Antiquité et du Moyen Âge: du mythe païen au symbole chrétien, Bruxelles, 1997. La experta se centra en la representación de seres monstruosos dentro de la iconografía medieval, herederos, casi siempre, de los textos de la Antigüedad.

1579 J. LECLERCQ-KADANER, “De la Terre-Mére...”, sobre todo, p. 37.

${ }^{1580}$ Ibidem, p. 38. Consúltese el interesante estudio realizado en: M. DARAKI, Dionisio y la diosa Tierra, Madrid, 2005, en concreto, p. 66. La especialista incide en la relación privilegiada que la serpiente mantiene con Gea. Véase también: M. A. CASTIÑEIRAS GONZÁLEZ, "La ilustración del De naturis rerum de Beda en un manuscrito de la abadía de Santa María de Ripoll (Madrid, Biblioteca Nacional, ms. 19) y su arquetipo cassinese", Arte d'occidente. Temi e metodi. Studi in onore di Angiola Maria Romanini, vol. 2, Roma, 1999, pp. 791-801, en especial, p. 795. Castiñeiras alude a la representación del 
No en vano, el ofidio aparece siendo el centro de la composición iconográfica en uno de los frescos de la catacumba de Prétextat en Roma, donde, acompañando a una figura orante y en un ambiente funerario muy marcado, se pintó un gran árbol en cuyo tronco se enrolla el animal, mientras que la otra parte del cuerpo, que se arrastra por el suelo, es pisoteada por el Cordero ${ }^{1581}$.

En la difusión de este tipo de imágenes, tal y como ya hemos comentado en este mismo trabajo, debió tener cierta importancia aquella representada en el vestíbulo del palacio de Constantino en Constantinopla. Allí mandó pintar los retratos de él y de sus hijos, todos con el símbolo de la cruz sobre la cabeza y, bajo sus pies, la imagen de una serpiente o dragón atravesado por unas flechas ${ }^{1582}$.

A partir de estas primeras reconversiones del símbolo en el arte cristiano, la serpiente comenzó, poco a poco, a olvidar el carácter benefactor que un día había ostentado para pasar a representar la fecundidad, pero ya no espiritual, sino carnal. Ahora la figura de la serpiente deja de aludir a una naturaleza creciente para pasar a significar el pecado. Los putti lactantes dejan de representarse en los siglos de la Alta Edad Media para ser sustituidos por animales de varias condiciones, como quimeras, batracios o reptiles. Ahora Tierra es entendida como la mujer pecaminosa y lujuriosa, y,

tema de la Rosa de los Vientos dentro de una ilustración proveniente de la abadía de Ripoll. En concreto, se trata del manuscrito conservado en Madrid, Biblioteca Nacional, Ms. 19, fol. 120r. Al analizar la obra, estudia, así mismo, la imagen de similares características de la Biblia de Cava de Tirreni, donde los vientos personificados, perfectamente identificados por sus cartelas, flanquean una circunferencia central en las que fue representada Tierra, acompañada de Océano. Los atributos de ambas figuras se repiten. Mientras que Tierra aparece con un león y una serpiente, Océano lo hace con peces marinos.

${ }^{1581}$ F. CABROL y H. LECLERCQ, voz "Colombe", Op. cit., vol. 3-II, col. 2215. Se trata de un claro ejemplo de los inicios de la interpretación de la imagen de la serpiente. Este grupo representado en la catacumba romana refleja la creencia de que el difunto, tras haber vencido todos los peligros de los que su alma se había visto amenazada por el demonio, personificado en la serpiente, es recibido en la paz celeste del paraíso.

1582 J. DELGADO GÓMEZ, "El singularísimo tímpano de Betán (Orense)", Archivo Español de Arte, 235, 1986, pp. 257-276, en particular, p. 266. El autor, a propósito del tímpano conservado en esta iglesia gallega, alude al simbolismo de la serpiente tanto en época tardoantigua, como más allá del año mil. El tímpano de Betán, presenta una cruz con dos palomas, un dragón y una serpiente. En relación con su posible significado dentro de esta obra románica, dice el experto: "la serpiente es temida por su astucia, por su veneno, malignidad, por su peligro mortal y es tenida como símbolo de la falsedad, de maledicencia y difamación".

$\mathrm{Su}$ estudio, si bien hoy en día superado en ciertos puntos, aporta ejemplos fundamentales para entender dicha imagen. El estudioso alude a una moneda acuñada por Constantino entre el año 325-326 d. de C. donde fue representado el lábaro sobre una serpiente con la inscripción SPES PUBLIC(A), mientras que debajo del ofidio se lee CONS (TANTINUS).

Según recoge, la serpiente se ha considerado como símbolo del paganismo, de forma que, el emperador, habría fundamentado su imperio cristiano en la idea de una victoria del cristianismo sobre el mundo pagano, idea que aquí se materializa iconográficamente. La fortuna de éste tipo de imágenes ya ha sido puesta de relieve en nuestro trabajo, recogiendo, así mismo, la bibliografía pertinente sobre el tema, sobre todo, en relación con el conocido marfil carolingio de Harrach de la Escuela de la Corte de Carlomagno. 
lo más importante, las serpientes pasan a materializar el castigo que ésta debe pagar por tal seducción. El ofidio aparece ahora como la reencarnación del vicio ${ }^{1583}$.

El tema de la serpiente pasó así con toda su fuerza simbólica a la Edad Media románica. En el caso hispano, uno de los primeros recintos con escultura figurada de la Península Ibérica, la iglesia de San Pedro de Teverga presenta, entre sus ricos elementos simbólicos, la imagen de una serpiente sinuosa. El tema haría referencia a ese carácter renovador y de resurrección, aunque si bien, tampoco debemos descartar ciertas concomitancias con la iconografía acuática, de la que, tanto el pez como la serpiente, son imágenes habituales y que, en el caso de Teverga, también se hallan dentro mismo recinto $^{1584}$. Aquí parece que su contenido antiguo perduró, a pesar de la avanzada cronología del edificio, con respecto a los siglos de la Antigüedad tardía.

No lejos de tal construcción se encuentra la iglesia de San Pedro de Arrojo, datada en la segunda mitad del siglo XIII y que presenta esculpida, en uno de los elementos del alero, la imagen de dos serpientes sinuosas que muerden un pez. Según se ha defendido, parece que también aquí perdura la simbología del arte cristiano primitivo, haciendo claras alusiones a la eucaristía y al carácter regenerador de la serpiente $^{1585}$.

Estos ejemplos y otros muchos posibles, indican que la representación de la imagen del ofidio dentro de la iconografía cristiana de los siglos XI y XII, no fue nada excepcional. Ahora bien, en el caso de la escultura de la catedral de Jaca dichas

${ }^{1583}$ J. LECLERCQ-KADANER, "De la Terre-Mére..." p. 41. Sin duda, se trata de una de las iconografías clásicas más interesantes para realizar el estudio de su resignificación desde su entidad como símbolo pagano a cristiano. La autora estudia a fondo el conocido marfil carolingio de Munich, Bayerische Staatsbibliothek, en el que la Tierra aparece criando a la serpiente. Parece que dicha imagen debe relacionarse con la condena ejercida por Dios en el pasaje del Génesis, según la cual, el reptil es condenado a vivir en la tierra y a desplazarse sobre ella.

También se alude a ese carácter funerario y subterráneo del ofidio en: J. L. AVELLO ÁLVAREZ, "El gallo de la Torre de San Isidoro. Avance al estudio iconográfico", El Gallo de la Torre de San Isidoro, León, 2004, pp. 70-81, en particular, p. 79. El profesor J. L. Avello estudia, particularmente, la imagen de Abraxas, un ser híbrido del mundo antiguo que se solía representar mitad gallo, mitad serpiente. Llegados a este punto, quisiera expresar mi agradecimiento al profesor J. L. Avello por toda la ayuda prestada, así como por las numerosas sugerencias bibliográficas realizadas durante la elaboración de este estudio.

${ }^{1584}$ Ya hemos recogido anteriormente algunos de los trabajos más significativos que se han dedicado al edificio. Sobre una posible lectura simbólica de las serpientes en Teverga, consúltese: M. FERNÁNDEZ PARRADO, "Colegiata de San Pedro....", particularmente, pp. 970-972 y R. ALONSO ÁLVAREZ, "La Colegiata de San Pedro de Teverga...", pp. 225-242.

${ }^{1585}$ M. FERNÁNDEZ PARRADO "Iglesia de San Pedro de Arrojo", Enciclopedia del románico en Asturias, 2 vols., Palencia, 2006, vol. I, en particular, pp. 140-141. La autora conecta ambas iconografías, tanto la utilizada en la Colegiata de San Pedro de Teverga, como la de este edificio.

Consúltese también: M. P. GARCÍA CUETOS, "La iglesia románica de San Pedro de Arrojo, Quirós. Un repertorio escultórico al servicio de una comunidad rural", Boletín del Instituto de Estudios Asturianos, 149, 1997, pp. 55-82 y G. E. ADÁN ÁLVAREZ, "San Pedro de Arrojo (Quirós): avatares constructivos de un templo románico", Excavaciones arqueológicas en Asturias: 1999-2002, Oviedo, 2007, pp. 365370 . 
imágenes adquieren unas dimensiones e importancia desmesuradas. Son muchos los capiteles y, dentro de ellos, muchas las figuras, que aparecen asociadas y que integran en su desarrollo compositivo, la imagen de la serpiente, que va más allá del mero detalle decorativo.

Supuestamente, en una fecha ligeramente anterior al inicio de los trabajos escultóricos en Jaca y Frómista, la imagen de la Lujuria con los reptiles que le succionan los pechos o la de un personaje cuya cabeza es atacada por los ofidios, ya habían sido desarrolladas en formato monumental. Nos referimos, concretamente, a uno de los capiteles del Panteón de San Isidoro de León y a otro ubicado en la tribuna situada en la parte alta del conjunto ${ }^{1586}$ (fig 266).

El capitel de la Lujuria colocado en el conocido como Panteón de Infantes de San Isidoro de León ${ }^{1587}$, es un ejemplo claro de esta reinterpretación cristiana de la imagen antigua de la mujer con las serpientes ${ }^{1588}$. Los ejemplos, en relación con esta pieza, desde un punto de vista compositivo y simbólico, podrían ser numerosos, tal y como demuestra el capitel de la cabecera de la iglesia San Bartolomé de Rebordans en Tuy o el ubicado en la girola de la catedral de Santiago de Compostela ${ }^{1589}$.

La otra de las esculturas, es aquella que fue colocada en la parte occidental del conjunto funerario leonés, sobre el arco de la primitiva apertura desde la tribuna a la nave central de la iglesia, hoy cegada. En la actualidad, se pueden percibir los restos de un capitel embutido en el muro que ciega ese gran vano y en el que se representó el

\footnotetext{
${ }^{1586}$ No es nuestro objetivo adentrarnos en la problemática cronológica de las obras citadas en este ejemplo. Independientemente de la teoría seguida para datar los capiteles del Panteón de San Isidoro de León, parece claro que, desde el punto de vista estilístico, estas esculturas con la imagen de la serpiente son más toscas y menos desarrolladas que, por ejemplo, aquellos capiteles que flanquean el acceso primitivo desde el Panteón a la Basílica. En definitiva, que pertenecen a una tradición diferente a la desarrollada en Frómista o Jaca. No recogeremos aquí las principales investigaciones llevadas a cabo para la datación del conjunto por haberlo hecho ya en este estudio. Cf.: J. A. MORÁIS MORÁN, El retorno..., pp. 18-100.

${ }^{1587}$ Se trata del capitel número 1, si seguimos la numeración establecida en: M. DURLIAT, La sculpture romane..., p. 185 y p. 193. El Panteón de Infantes es una estructura de similares características arquitectónicas que las que encontramos en el núcleo original del Panteón.

${ }^{1588} \mathrm{Se}$ analiza el capitel, visto desde los ideales difundidos por la Reforma Gregoriana en: W. WEISWACH, Reforma religiosa ..., en particular, p. 125; M. DURLIAT, La sculpture romane..., p. 191 y J. LACOSTE, Les maîtres..., en concreto, p. 47. El último experto realiza una comparación iconográfica entre el valor de la serpiente de esta obra del Panteón de León con el programa icónico desarrollado en la catedral de Jaca, así como con un capitel de la iglesia de Iguácel que, según su criterio, posee un idéntico sistema compositivo de la cesta. La relación que establece entre ambas obras es interesante para nuestro estudio.

${ }^{1589}$ Se trata de dos piezas coetáneas desde un punto de vista cronológico. Se hace un análisis de ellas, emparentándolas con el ejemplo de León en: V. R. NODAR FERNÁNDEZ, Los inicios de la catedral..., en concreto, pp. 121-130.
} 
tema de las serpientes. Dos seres monstruosos de bocas feroces y cuerpo de reptil atacan la cabeza de un personaje ${ }^{1590}$.

El tema, tal y como vemos, no perdió su vigor desde los últimos siglos de la Antigüedad hasta la llegada del románico. Su continuidad queda atestiguada por el éxito que dicha imagen ostentará dentro de la colección de capiteles de la catedral jaquesa, así como en otros templos del norte peninsular.

Hemos visto de manera extensa en las páginas anteriores cómo la imagen romana de las Furias azuzando serpientes con sus manos del sarcófago de Husillos había sido copiada de manera bastante fiel en Frómista. También se ha aludido a lo complicado de poder esgrimir argumentos a favor de una interpretación correcta en plena Edad Media del mito de Orestes, por parte del escultor románico.

En el estado actual de nuestros conocimientos sobre el tema no podemos pronunciarnos sin contemplar la posibilidad de errar al teorizar sobre qué significó, exactamente, la imagen de varias figuras femeninas con serpientes en sus manos atormentando a un hombre, salvo la evidente intención de provocar miedo y castigo.

De la misma manera, no debemos presuponer que el sarcófago fuera la única fuente de inspiración para justificar el éxito que la imagen tendrá en muchos lugares a lo largo del Camino de Santiago y en otros centros alejados de él. Como veremos, el tema de las serpientes alcanzó gran difusión dentro de la decoración de los edificios románicos y ello hace imposible atribuir el origen del motivo a un único punto o foco de propagación.

En Jaca, y a pesar de la desaparición de fuentes antiguas que lo indiquen, se puede intuir la presencia de otros modelos romanos en los que la imagen de la serpiente debía estar presente. En la gran mayoría de los capiteles del templo hallamos dicha

${ }^{1590}$ J. M. BOUSQUET, 'L'homme attaque a la tête par deux dragons géographie et origines d'un motif de sculpture romane", Cahiers de Civilisation Médiévale, 14, 1983, s. p. El autor estudió las imágenes a las que nos venimos refiriendo en los capiteles de San Isidoro de León. Enlaza, desde un punto de vista estilístico y cronológico, dicha obra y otras pertenecientes al ámbito francés. En concreto, establece ciertos parentescos con un capitel de la puerta de Comptes de la basílica de Saint-Saturnin de Toulouse. Además, cita otra serie de obras que poseen la misma composición, es decir, un personaje colocado de frente, en ocasiones con gesto de orante o de dolor, que es atacado en la cabeza por dos dragones o serpientes.

El gesto orante, con las manos tendidas hacia el cielo, es bastante ambiguo en este tipo de representaciones. No obstante, más que un gesto de súplica, creemos que se trata de una muestra del dolor ante tal ataque. Los cuerpos de los dos reptiles, con cabeza monstruosa y que, difícilmente, pueden relacionarse con un intento de representa una serpiente, aparecen enroscados sobre si mismos. El escultor se detuvo en ciertos detalles, como las estrías de la piel, así como los dientes de ambos animales. No es de extrañar que J. Bousquet los identificase como dragones-serpiente. Consúltese igualmente: F. GARCÍA ROMO, "Los pórticos de San Isidoro...", en particular, p. 215. Este autor identifica el gesto que realiza la figura femenina del Panteón de Infantes, como la representación de un "atlante que levanta en sus brazos dos dragones, cuyos cuerpos siguen paralelamente la línea de las volutas". 
iconografía, sin embargo, no toda ella parece depender directamente de la imagen de Husillos.

Al contrario, la gran originalidad de algunas de esas imágenes, la diversidad compositiva, la importancia que dentro de la historia esculpida en dichas piezas se le va a otorgar, nos lleva a pensar en otro tipo de obras que, lejos de negar una conexión con el sarcófago de Husillos, reafirma la importancia de las fuentes clásicas en la formación de estos artífices, así como su multiplicidad.

En la seo jacetana, simplificando en exceso la problemática, hallaremos la imagen de la serpiente relacionada con la figura humana, ya sea portándola en sus brazos -en ocasiones azuzando con el animal en mano a otras figuras, tal y como observamos en el sarcófago de Husillos- o portándola, incluso, enroscada al cuello, enriqueciendo las posturas que en su día había ofrecido la pieza funeraria.

Una de las primeras imágenes donde llama especialmente la atención la presencia del ofidio es en el capitel número 64 del recinto, que presenta una composición compleja donde la serpiente juega un papel complicado en cuanto a su simbolismo $^{1591}$ (fig. 267). La parte frontal de la escultura aparece ocupada por dos grandes felinos que, colocados de manera simétrica, presentan sus partes traseras antepuestas, mientras que las cabezas se colocan en el ángulo del capitel que da paso a los lados cortos. En el centro, tres personajes vestidos con clámides, parecen desarrollar algún tipo de acción. El central y el de la derecha se miran, mientras éste último dirige su brazo hacia una gran máscara monstruosa, colocada sobre la cabeza del león. El personaje contrario que, a diferencia de su pareja, ha conservado íntegramente el brazo, realiza la misma acción, llegando a tocar la cabeza del felino opuesto, sobre el cual se colocó otra máscara de similares características que las que posee la del otro lado.

En los lados cortos, fueron representados dos hombres desnudos que, mediante una gruesa cuerda atada al cuello de las fieras, parecen apresarlas o aplacarlas ${ }^{1592}$. En

\footnotetext{
${ }^{1591}$ A grandes rasgos, las imágenes de serpientes más importantes, que juegan un papel destacado dentro de las composiciones de los capiteles, corresponden con los numerados con el 64 y 50 . A ellos debemos sumar las representaciones del reptil del capitel número 22, así como la presente en la imagen del tímpano occidental, es decir, el del crismón. Seguimos la numeración establecida en: M. DURLIAT, La sculpture romane de la route..., en concreto, pp. 222-249.

${ }^{1592}$ Estas características que describimos sirvieron para configurar otro tipo de imágenes durante la época medieval. Sobre ello, véase: F. ESPAÑOL BERTRÁN, "El sometimiento de los animales al hombre como paradigma moralizante de distinto signo: "la Ascensión de Alejandro" y "el Señor de los animales" en el románico español", Actas del V Congreso Español de Historia del Arte, vol. I, Barcelona, 1986, pp. 49-64. Para el caso asturiano, véase: E. FERNÁNDEZ GONZÁLEZ, "Problemática en torno a Santa María de Carzana...", pp. 205-238.
} 
conjunto la imagen del capitel que más nos interesa, es aquella que aparece en la parte central de la pieza y que porta en sus manos una serpiente.

La importancia de tal figura reside en su posible relación con respecto a determinadas iconografías arraigadas en la tradición clásica, sobre todo, aquellas que portaban serpientes en sus manos. El sarcófago de Husillos da prueba del tipo de repertorios que estos escultores están siguiendo. Sin embargo, no creemos que esta imagen, en concreto, derive de este prototipo en particular, habida cuenta de las grandes diferencias existentes entre las figuras con serpientes del sarcófago y las románicas.

Tras la consulta del corpus de obras antiguas de tradición romana, conservadas actualmente y factibles de poder poseer una relación con este entorno, no hemos hallado ninguna imagen que pueda asegurar una inspiración en el arte clásico. Con todo, creemos posible continuar defendiendo la presencia, en el entorno en el que trabajan estos artífices, de un sarcófago de tema dionisiaco. Ya en su día el profesor S. Moralejo apuntó la posibilidad de que la figura de un hombre desnudo agarrando o conduciendo un felino atado por el cuello, pudiera derivar de este tipo de iconografía ligada a la figura de Dionisos ${ }^{1593}$.

En relación con el capitel de los dos tocadores de aulos y los danzantes, hemos corroborado la importancia de las imágenes del repertorio báquico en la posible inspiración para el capitel, además, de la misma iconografía de las Ménades.

La desnudez de la figura que tira del cordón con el que se ata al felino por el cuello, no fue desconocida dentro de este tipo de representaciones (fig. 268). Un sarcófago conservado hoy en el pórtico de acceso de la iglesia de San Lorenzo Extramuros de Roma, puede dar idea de la índole de fuentes que, posiblemente, se pueden relacionar con el capitel de Jaca ${ }^{1594}$ (fig. 269).

${ }^{1593}$ S. MORALEJO ÁLVAREZ, “La sculpture romane...", en concreto, p. 89. En este punto, véase también: M. DURLIAT, La sculpture romane de la route..., sobre todo, p. 235.

${ }^{1594}$ F. HENRY TAYLOR, "The sarcophagus of San Lorenzo", The Art Bulletin, 10, 1, pp. 46-58, en concreto, pp. 53-54. El autor analiza algunos aspectos estilísticos que le permiten afirmar que se trata de una pieza de origen ático, datada en el siglo II. Además de proponer otras piezas de similares características, como la conservada en Letrán, concluye que, alguna de las partes, fueron reelaboradas en una época posterior a la realización inicial de la pieza. En todo caso, el sarcófago no deja de presentar problemas, pues el especialista acaba por concluir que se trataría de una falsificación medieval realizada en la ciudad de Roma durante el siglo XV y que tendría como objetivo emular las producciones artísticas romanas.

En su momento se recogió información sobre la escultura, sin dudar sobre su datación antigua, en: A. GARCÍA Y BELLIDO, Arte Romano..., en concreto, p. 568. El autor afirma que se trata de un producto ático, del tipo kliné, del que se conservan, además, otros ejemplares de similares características. La pieza remata en los extremos a través de unas patas con garra leoninas que le otorgan la forma de lecho. El investigador propone la hipótesis, a juzgar por los demás ejemplos que conservamos, de que la tapa de la 
Se trata de una pieza de mármol en la que se labró una compleja escena de putti vendimiadores, que llega a ocupar la cara central y las dos cortas del sarcófago. El relieve que muestra la escultura es muy plano pero, a pesar de ello, sirve para desarrollar una complicada escena de vendimia. En dicha viña "habitan" estos angelotes que, con todo tipo de utensilios, llevan a cabo la recolección del vino para la fiesta de Baco. A ello debemos sumar todo un amplio repertorio de seres y fauna que pueblan dicho ambiente, entre la que destacan, gallos, serpientes, una tortuga, así como otra serie de aves, gallináceos y, lo más importante, algunos felinos ${ }^{1595}$.

En concreto, en la cara izquierda del sarcófago se esculpió la imagen de un erote alado desnudo que cabalga sobre uno de estos animales leoninos que, en realidad, más que un león o tigre asemeja a una pantera, el animal por excelencia dentro del repertorio iconográfico báquico (fig. 270). Aunque las diferencias iconográficas y estilísticas entre esta imagen y la del capitel de Jaca son acusadas, podría ser factible el conocimiento remoto de algún tipo de repertorios similares a estos.

Al observar uno de los capiteles conservados en la iglesia dedicada a San Pedro, en el castillo de Loarre ${ }^{1596}$ (fig. 271), se puede conjeturar sobre tales hipótesis. El capitel presenta dos caras esculpidas y en cada una de ellas aparece la figura de un joven, quizás un niño desnudo, montando sobre los lomos de un felino de acusada melena rizada. Dicha imagen nos permite constatar el conocimiento, durante la etapa románica, del tema de los felinos y los putti dentro de los cortejos báquicos. El problema más

pieza, hoy perdida, en su día tuvo forma de cojín o almohadón sobre el que se reclinaría una posible imagen del difunto.

En la misma idea, se defiende la forma de lecho para la imago del difunto en: S. DE MARINIS, voz "Letto", Enciclopedia italina dell'arte..., vol. IV, Roma, 1961, pp. 601-607. Se trata de un sarcófago que no debemos olvidar, pues no es la primera vez que se ha utilizado para hablar de la posible influencia que su temática pudo ejercer sobre la escultura románica de la Península Ibérica. Sobre esta cuestión, consúltese: M. A. CASTIÑEIRAS GONZÁLEZ, "Roma e il programma reformatore...", particularmente, p. 219. Véase también, la aportación realizada, en: A. GIULIANO, Il commercio dei sarcofagi Attici, Roma, 1962, concretamente, p. 67. Este especialista insiste en la forma de kliné que presenta la pieza.

${ }^{1595}$ Sobre la pieza, se recogen una serie de menciones en: M. P. GARCÍA-GELABERT, "Relieves vegetales en Hispania durante la Antigüedad Tardía", La tradición en la Antigüedad Tardía, Murcia, 1997, pp. 457-470, en concreto, pp. 464-466. Data la pieza en el siglo III d. de C. y analiza el simbolismo de la representación de la vid que presente la cista, atribuyéndole un sentido funerario. Se recoge, además, otros ejemplos hispanos, como la estela de Gastiain en el Museo de Pamplona o el pilar de Gallipienzo. El ejemplo más interesante, en relación con esta obra, es el del sarcófago de la vendimia de Vila Franca de Xira, originario de la Lusitania. Por su parte, el profesor Maciel data la pieza en el siglo III d. de C. analizando las concomitancias que presenta, desde el punto de vista simbólico, con el de San Lorenzo de Roma. Cf.: M. JUSTINO MACIEL, Antiguidade Tardia..., Lisboa, 1996, en concreto, pp. 140-143. Este autor ha dedicado varios trabajos muy completos en los que se mencionan y se analizan algunos detalles de la pieza italiana. Vid. también: M. JUSTINO MACIEL, J. M. PEIXOTO CABRAL y D. NUNES, “Os sarcófagos tardo-romanos...", en particular, pp. 165-166.

${ }^{1596}$ En concreto, se trata del capitel número 22. Vid.: M. DURLIAT, La sculpture romane de la route..., en particular, p. 278. 
importante recae en poder llegar a discernir, realmente, si se trata de un traspaso iconográfico explicable a través del contacto con una pieza antigua o, por el contrario, se trata, simplemente, de una imagen que conserva su pasado clásico de una manera remota, sin que sus autores medievales conocieran sus orígenes antiguos ni mucho menos su significado ${ }^{1597}$.

Regresando al tema central del capitel de Jaca, sobre la figura con clámide que porta una serpiente en su mano, resulta complejo hacer una identificación segura. Sin embargo, podemos llegar a dilucidar algunas de las fuentes más seguras que los artistas pudieron tener ante sus ojos.

Es posible, atendiendo a todo lo expuestos hasta aquí, que el repertorio de temas tomados de la leyenda de Orestes del sarcófago de Husillos fuera enriquecido, además, con otra serie de imágenes provenientes de un sarcófago de temática báquico-dionisíaca o, en relación, tal vez con el thiasos.

Dentro de las imágenes relacionadas con Dionisio, nuevamente la dualidad vuelve a ser el elemento más destacado. Además de ser un dios ctónico, también podía aparecer ligado, tal y como ha señalado M. Daraki, con los mundos infernales, conociéndole en este caso con el nombre de Zagreo "que exige sacrificios nocturnos (...)" introduciéndose así "una figura muy compleja, la de Dionisio Zagréus, el diosserpiente". La estudiosa pone de relieve la especial importancia que la serpiente mantenía con este dios, sobre todo, porque a dichos seres se les ofrecían abundantes libaciones de vino, pues "como los muertos, las serpientes son, por lo general, seres sedientos, Dipsádes".

El ofidio se ligó, desde tiempos antiguos, a la iniciación dionisíaca, mostrándose de manera habitual dentro de los cortejos dedicados al dios. Por lo tanto, no podemos extrañarnos de la conexión que existe entre la imagen del capitel románico con la

\footnotetext{
${ }^{1597}$ Las similitudes existentes entre las esculturas de Jaca y la de Loarre han ocupado la atención de muchos autores. Llama la atención que también en Loarre aparezca el tema del hombre que tira de un gran cordel que, a su vez, está atado al cuello de un felino o animal monstruoso. Se trata del capitel número 67 de San Pedro de Loarre y es muy similar, desde el punto de vista compositivo, a la figura que encontramos en el capitel de Jaca. Sin embargo, existen algunas diferencias de peso, ya que, en el ejemplo de Loarre, la figura aparece completamente vestida. Sobre ella, véase: Ibidem, pp. 278-279.

El tema de los personajes cabalgando leones, ya fuesen niños o, en su defecto, todo tipo de hombres y mujeres, habría de tener una gran fortuna en la escultura románica posterior, si bien ello no quiere decir que tal difusión se explique mediante un contacto directo con las obras clásicas, pues bien pudiera tratarse de una interpretación románica de obras propiamente medievales pero que, a su vez, se pudieran inspirar en una romana. Sobre este aspecto y la difusión del motivo tendremos oportunidad de hablar más adelante. Cf.: J. A. MARTÍNEZ PRADES, "El castillo de Loarre (Huesca): sus orígenes, construcción y problemática artística", Artigrama, 8-9, 1991-1992, pp. 533-536 y V. LAMPÉREZ Y ROMEA, "La iglesia de Santa María en el castillo de Loarre", Boletín de la Sociedad Española de Excursiones, vol. 9, 105, 1901, pp. 221-224.
} 
serpiente y las máscaras monstruosas que aparecen en los laterales, pues en contextos báquicos, este animal se relacionó con los "habitantes de las profundidades, ópheis y drákontes" ${ }^{\prime 1598}$.

Sin embargo y siempre dentro del campo de la mera hipótesis, se han conservado, en el ámbito hispanorromano, otra serie de piezas y obras que pueden permitir arrojar más luz sobre las fuentes utilizadas por los artistas de Jaca.

La imagen de la serpiente, además de todo lo anteriormente alegado, se suele relacionar, de manera directa, con la figura de Asclepios, la divinidad ctónica ligada al mundo subterráneo. Desde los primeros momentos se le representó para aludir a las curaciones y a la misma medicina, de la que es patrón y, de igual manera, a lo mágico y a lo onírico.

Su imagen aparece, desde muy temprano, bien codificada, se le representa en forma de hombre, vestido a la manera antigua, por lo general barbado y de largos cabellos que acusan su ancestral sabiduría y portando algún tipo de objeto identificador como, por ejemplo, un bastón o cetro. El elemento más importante en relación con nuestro objeto es el de la serpiente sagrada que, en ocasiones, lleva en su mano o que, más habitualmente, se enrolla alrededor de la vara ${ }^{1599}$.

Ello llevará a que, durante mucho tiempo, la imagen de un hombre portando una serpiente en sus manos o sobre un cetro, aludiese a la figura de Asclepios. No debemos olvidar, tal y como recoge G. A. Mansuelli, que uno de los ejemplares más bellos en relación con la imagen de este dios, es el que fue hallado en Ampurias (fig. 272). Se trata de la imagen más antigua de esta deidad conservada en todo el Occidente y que en

\footnotetext{
${ }^{1598}$ M. DARAKI, Op. cit., en especial, pp. 64-69. La autora realiza una serie de interesantes reflexiones a la hora de establecer la importancia de la serpiente dentro de las escenas de temática báquica. Se centra en la polémica en torno a la asimilación de la serpiente con Baco y Dionisos, así como su desarrollo iconográfico y simbólico en el mundo griego y romano. Parece claro, en este sentido, que la frecuencia de aparición de la serpiente dentro de la escultura de la catedral de Jaca y de otra serie de núcleos, permite hablar de la existencia de una fuente de tipo báquico. Se puede teorizar sobre la presencia, ante los ojos de los artistas románicos, de una imagen de procesión, fiesta o ceremonia de tipo orgiástico, dedicada a Dionisio. La escena se podía resolver también a partir de la escenificación de un banquete sagrado, donde acompañando al difunto, se colocarían músicos, generalmente, flautistas. No es preciso incidir en la importancia que el aulos tiene dentro del capitel anteriormente analizado. Sobre este tipo de iconografía báquica, consúltese: P. ORLANDINI, voz "Baccanali", Enciclopedia dell'arte antica classica e orientale, vol. I, Roma, 1958, pp. 956-957.

${ }^{1599}$ Asclepio era el hijo de Apolo y Coronide, que aparece como su maestra en lo relativo a la medicina. Sus capacidades curativas le llevarán, incluso, a resucitar a un muerto fulminado por un rayo. Sobre su figura, véase: G. A. MANSUELLI, "Asklepios", Enciclopedia dell'arte antica classica e orientale, vol. I, Roma, 1958, pp. 719-724. Un ejemplo que destaca por su enorme belleza es el que se conserva en Roma, Musei Vaticani. En el conjunto escultórico se muestra la imagen de Asclepios sentado, con el cetro en la mano izquierda, mientras que, con la derecha, se dispone a recoger la víbora de manos de Igea. La imagen, aunque lejos del modelo románico, habla de la idea de manipulación del ofidio mediante las manos, como ocurre en esta escultura romana.
} 
palabras de Mansuelli destaca por su autoría, heredera de ciertos resabios de las obras esculpidas por Lisipo ${ }^{1600}$.

Otro capitel, esta vez en el exterior del templo, concretamente, aquel ubicado sobre una de las columnas del pórtico occidental de la catedral, presenta, nuevamente, el tema de un hombre blandiendo una serpiente que azuza contra otro ${ }^{1601}$ (fig. 273). Sobre él, ya en su día el profesor S. Moralejo defendió una dependencia directa de la imagen romana representada en el sarcófago de Husillos. En concreto, se refería a la figura que ocupa la parte central de la composición, donde fue representando un hombre que, vestido con clámide abierta y caída en cascada sobre el hombro derecho, ase una serpiente de gran tamaño con ambas manos.

El personaje central muestra el ofidio a las restantes figuras, lo cual provoca una reacción de terror en éstas marcada, claramente, a través de los gestos ${ }^{1602}$. Ambas se retiran hacia atrás sus cuerpos, sus brazos se levantan en señal de rechazo, mientras que sus rostros se giran mostrando repulsa ante el animal. El recuerdo de las figuras romanas de la Orestíada es evidente aunque, en ningún caso, se puede hablar de una copia exhaustiva del sarcófago, tal y como ocurría con el capitel de Frómista.

Hace ya algunos años que S. Moralejo planteó una hipótesis de interpretación de la escena. Al encontrarse el capitel formando pareja con otro que representa el tema de Daniel en el foso de los leones y el profeta Habacuc, explicó la escena a través del texto bíblico en el que se narraba la destrucción de la serpiente adorada por los babilónicos. En este caso, la figura con clámide clásica colocada en el centro de la cesta, sería el profeta que sujetaría el cuerpo de la serpiente con intención de matarla ${ }^{1603}$. Nuevamente encontramos en esta imagen una posible connotación maligna del animal, tal y como expuso en su día D. L. Simon ${ }^{1604}$.

Las fuentes que hemos aludido dentro de la estatuaria clásica, bien podrían haber inspirado, en parte, esta imagen. El repertorio icónico antiguo que utilizó este tipo de

\footnotetext{
${ }^{1600}$ Ibidem. La escultura, datada en torno al siglo III. d. de C., apareció dentro del recinto del templo dedicado al dios en la ciudad de Ampurias. Nuevamente sigue el prototipo en el que destaca el uso del himation para cubrir un torso semidesnudo. Lo más destacado, es la presencia de la serpiente que se enrosca en el suelo y que alude a las capacidades curativas que hemos explicado anteriormente.

${ }^{1601}$ Es el capitel número 22. Vid.: M. DURLIAT, La sculpture romane de la route..., particularmente, p. 246.

${ }^{1602} \mathrm{El}$ gesto de terror de estos personajes recuerda, marcadamente, al que presenta la figura de la nodriza en el sarcófago de Husillos. Una expresión de miedo y repugna que fue puesta de relieve por T. Aguirre. Vid.: T. AGUIRRE, Op. cit., sobre todo, p. 133. Lo volveremos a hallar dentro de la catedral jacetana en una de las metopas del ábside sur, tal y como veremos más adelante.

${ }^{1603}$ S. MORALEJO ÁLVAREZ, "La sculpture romane...", p. 56 y M. DURLIAT, La sculpture romane de la route..., en concreto, p. 242.

${ }^{1604}$ D. L. SIMON, "El tímpano de la catedral....", particularmente, p. 411.
} 
composición de un hombre asiendo una serpiente fue, en cierta medida, amplio. Recuérdese en este sentido, la imagen personificada de Marzo, dentro de los menologios, en las que, frecuentemente, se utilizó la imagen de un hombre con una serpiente entre sus manos, aludiendo al despertar de la naturaleza que caracteriza dicho periodo y en el que tanto ofidios, como toda suerte de reptiles y batracios, despiertan del aletargamiento $^{1605}$.

Sin embargo, fueron S. Moralejo y, a través de éste, M. Durliat, los dos autores que abrieron la posibilidad de interpretar las fuentes antiguas de los escultores románicos de Jaca a través de otra serie de iconografías. Se señaló la posibilidad de que la imagen de la constelación de Escorpión, personificada a través de Ophiucuchus o, comúnmente conocido como el Serpentario, hubiera tenido cierto peso en el proceso de configuración de estas imágenes. Más allá de poder probar tal hipótesis de una manera irrefutable, lo más interesante, es la aportación de nuevas vías en la búsqueda de los orígenes clásicos de la imagen ${ }^{1606}$.

La iconografía del Serpentario, perteneciente a la larga serie de personificaciones de las constelaciones, aparecía asiduamente durante la Antigüedad entre los signos del zodiaco, generalmente, emparentada con la imagen del escorpión ${ }^{1607}$.

La hipótesis nos parece acertada, en cuanto no limita las filiaciones o dependencias de la escultura de la catedral de Jaca nuevamente hacia el sarcófago de Husillos, sino que plantea la posibilidad de que tales imágenes se hubieran visto enriquecidas por nuevos repertorios. A ello debemos sumar la importancia que este tipo de representaciones cosmológicas van a tener en la formación de algunos de los programas más complejos del arte románico ${ }^{1608}$.

A parte de lo expuesto anteriormente, es lógico pensar que, de ser cierta la presencia de alguna pieza de tema báquico dentro del repertorio seguido por los escultores, también para la imagen del hombre con la serpiente en las manos, se pudo

\footnotetext{
${ }^{1605}$ M. A. CASTIÑEIRAS GONZÁLEZ, "Las fuentes antiguas...”, de manera especial, p. 95.

${ }^{1606}$ S. MORALEJO ÁLVAREZ, "Pour l'interprétation...”, sobre todo, p. 156.

${ }^{1607}$ M. DURLIAT, “Sculpture romane...”, p. 389. El autor francés sigue, en todo momento, lo expuesto por S. Moralejo en su conocido estudio sobre las placas del zodiaco de la Puerta del Cordero de San Isidoro de León.

${ }^{1608}$ M. A. CASTIÑEIRAS GONZÁLEZ, “El Programa Enciclopédico...”, p. 658; ID., La Iconografía de los planetas en la Cataluña de los siglos XI-XII", Annals de l'Institut d'Estudis Gironins, 35, 1995, pp. 97122; ID., "From Chaos to Cosmos: The Creation Iconography in the Catalan Romanesque Bibles", Arte medievale, 1, 2002, pp. 35-50 y C. CASAL CHICO, "Tralas pegadas da cultura bieita: debuxos e esquemas no Mosteiro de Samos”, Semata, 14, 2003, pp. 349-362.
} 
seguir algún modelo de la misma categoría. Por citar una obra de temática parecida, baste recordar la placa conservada en Roma y en la que fue representada la figura de una bacante en pleno ritual de danza orgiástica, acompañada de varios instrumentos que ella misma agita con las manos y con el cuerpo ${ }^{1609}$ (fig. 274). En pleno movimiento, agarra varias serpientes con sus manos, que se retuercen al compás del baile ${ }^{1610}$.

Para finalizar con este aspecto que venimos analizando, cabe recordar la gran difusión que el tema alcanzó dentro de la iconografía numismática. En concreto, es de destacar la pequeña moneda en la que se representó la figura de Hércules niño agarrando con sus manos dos serpientes que, en actitud de lucha, intentan atacar su cabeza $^{1611}$ (fig. 275). Nos encontramos ante una misma imagen que, desde un punto de vista morfológico, puede compararse con las que documentaremos más tarde dentro de la escultura románica. Sin embargo, la desaparición en el ámbito hispano de un ejemplar parecido, deja tal suposición en el campo de una mera hipótesis.

El tema del ofidio llegará a repetirse casi de manera obsesiva dentro del repertorio utilizado por los artífices jacetanos. Sin dejar el exterior del recinto, concretamente, en el ábside meridional de la catedral, encontramos otra vez la repetición del tema de la serpiente. Nos interesa ahora mencionar uno de los canecillos que articulan y sustentan el alero del conjunto (fig. 276). Se trata de una pieza en la que se esculpió una figura animal, quizás un león o, en todo caso, un felino, a juzgar por sus fauces y rasgos. Lo más interesente es el hecho de que todo su cuerpo aparece cubierto por una gran serpiente que se enrolla en forma de espiral alrededor del tronco del $\operatorname{animal}^{1612}$.

El motivo no es nuevo. Lo volveremos a encontrar en otros templos estrechamente ligados con las fórmulas manejadas en la seo jacetana y que hablan de una tradición común a la hora de crear los repertorios artísticos. La serpiente que con fuerza aprisiona el cuerpo de los animales, es una iconografía que reaparecerá con gran desarrollo, por ejemplo, en algunas de las placas con la representación del zodiaco de la

\footnotetext{
${ }^{1609}$ Città del Vaticano, Musei Vaticani.

${ }^{1610}$ P. ORLANDINI, Op. cit., p. 975.

1611 J. BOARDMAN, O. PALAGIA y S. WOODFORD, voz "Herakles", Lexicon..., vol. IV, 1, ZurichMünich, 1988, pp. 728-838. La imagen acuñada sobre la moneda refleja la leyenda surgida a propósito de la infancia de Hércules. Según se narra, cuando contaba con ocho meses, Hera envía varias serpientes con la tarea de matar al niño. Sin embargo, demostrando ya su capacidad de fortaleza y poder, combate con ellas agarrándolas y acabando con ellas.

Se recoge la leyenda y las representaciones más importantes sobre el tema, en: H. SICHTERMANN, voz "Heracle", Enciclopedia italiana dell'arte..., vol. III, Roma, 1960, pp. 378-387, en particular, se ocupa del pasaje descrito en la p. 379.

1612 M. DURLIAT, La sculpture romane de la route..., p. 229.
} 
citada Puerta del Cordero de San Isidoro de León y de las que tendremos oportunidad de hablar más adelante.

Estos ejemplos nos retrotraen a las imágenes de la Antigüedad. En concreto, resulta interesante establecer ciertas conexiones con la denominada escultura de Chronos-Mithras, aparecida en Emerita Augusta ${ }^{1613}$ (fig. 277). Se trata de una pieza que representa una figura mitraica en forma de un joven desnudo de tipo apolíneo. Se han destacado de ella su marcado hieratismo y, de una manera más importante, la gran serpiente que se ciñe helicoidalmente a su cuerpo. Los diversos especialistas han identificado la imagen como una representación de Aion-Chronos-Saturno, la divinidad del tiempo infinito y que fue una de las grandes deidades del panteón mitraico.

Su aparición dentro de los ejemplos escultóricos conservados en Mérida no debe sorprender, pues la veneración a Mitra naciente está bien documentada en esta parte del Imperio $^{1614}$. A ello debemos sumar la gran calidad técnica de la pieza quizás, tal y como se ha señalado, proveniente del taller griego de Demetrio, lo que, sin duda, la convierte en una de las obras claves para poder comprender la difusión del motivo de la serpiente en la Hispania romana ${ }^{1615}$.

A pesar de lo arriesgado de la afirmación, es posible que algún ejemplar de similares características pudiera haber sido observado por los escultores medievales que, fascinados por la belleza y perfección técnica de las esculturas romanas y, al mismo tiempo, conscientes del simbolismo de la serpiente, acabarían por asimilar el modelo. Nuevamente nos encontramos ante una conjetura difícil de demostrar, sin embargo, no encontramos otra explicación posible que clarifique las fuentes seguidas por estos escultores medievales. Es factible que alguna de estas imágenes ligadas al

\footnotetext{
${ }^{1613}$ Se trata de una pieza marmórea que, siguiendo con la tónica general que venimos apuntando, se ha datado en torno al siglo II d. de C. y que, por lo tanto, reitera la predilección que estos escultores tenían por las fuentes romanas de similares cronologías. Actualmente se conserva en el Museo de Arte Romano de Mérida tras ser hallada en las excavaciones llevadas a cabo en el templo de los dioses orientales. Sobre la obra, consúltese: A. GARCÍA Y BELLIDO, Les religions orientales dans l'Espagne romaine, Leiden, 1967, en particular, p. 26 y T. NOGALES, "Statua di Chronos-Mithras", Hispania ..., ficha 206, p. 404. Es muy conocida también la representación realizada sobre el mosaico de la Casa del Mitreo de Mérida y sobre la que incidió en su día Palol a la hora de hablar sobre la transmisión de modelos clásicos del arte romano hispano a determinadas piezas medievales. Vid.: P. DE PALOL, El Tapís de la Creació de la Catedral de Girona, Barcelona, 1986, p. 142.

${ }^{1614}$ I. CAMPOS MÉNDEZ, "La aparición de los misterios mitraicos en el marco religioso del imperio romano", Vector plus, 24, 2004, pp. 33-44 y T. BARRIENTOS VERA, "Nuevos datos para el estudio de las religiones orientales en Occidente: un espacio de culto mitraico en la zona Sur de Mérida", Mérida, excavaciones arqueológicas, 5, 1999, pp. 357-381.

${ }^{1615}$ T. NOGALES, Op. cit., p. 404.
} 
culto mitráico acabase por cristalizar y ser traspasadas a los repertorios artísticos posteriores $^{1616}$.

Las serpientes que hemos encontrado en las manos de algunos seres de estos capiteles, la hallada en el comentado canecillo del ábside sur de la catedral de Jaca y otros casos que hemos omitido, hablan de la perpetuación de tal iconografía desde la Antigüedad a la época medieval ${ }^{1617}$.

El innegable carácter "antiquizante" del canecillo con la imagen del león y la serpiente ceñida a su cuerpo, tiene en el caso hispano un ejemplo de cierta importancia con el que debe ser relacionado. Se trata del conocido sarcófago de la catedral de Gerona en el que fue representada la imagen de un león con un ofidio que le oprime y se enrosca alrededor de su cuerpo (fig. 278). Sobre ambos animales fue esculpida la figura de Cristo, simbolizando, en conjunto, la victoria o el triunfo sobre el mal ${ }^{1618}$.

El sarcófago pertenece ya a la plástica de la Antigüedad tardía de tradición cristiana y suele ser considerado como el "cabeza de serie" de los ejemplos que presentan dicha imagen ${ }^{1619}$. El felino adquiere una importancia esencial a la hora de realizar una lectura de la imagen esculpida sobre el sarcófago y permite, además, establecer unos precedentes directos con las obras medievales.

Con todo, si en este sentido se puede deducir la importancia que habrían de tener estas esculturas en piedra, no se deben descartar, tal y como ya se ha insistido, en lo fundamental que pudieron resultar otros objetos artísticos para el aprovisionamiento de

\footnotetext{
${ }^{1616}$ Sin duda, la imagen más conocida en relación con esta deidad, es aquella que se conserva, actualmente, en Roma, Musei Vaticani. El Mitra Tauroktonos de época antonina, no hace sino ejemplificar el arraigado culto a este dios persa que, generalmente, aparece tocado con el gorro frigio, en el momento de dar muerte al toro y de cuya sangre brotarán, transformadas, las especies que han de servir de alimento a la humanidad. En la imagen que comentamos aparece una serpiente arrastrándose por el suelo y que, finalmente, consigue ascender por el cuerpo del toro abatido, ya en tierra, para lamer la herida mortal del cuello que Mitra ha abierto con un cuchillo. Sobre ella, se hace un breve síntesis en: A. GARCÍA Y BELLIDO, Arte Romano..., en especial, p. 492 y p. 516. Este investigador recoge el ejemplo pintado del Mithra Tauroktonos, del mithraeum de Capua. Uno de los ejemplos más evidentes de traspaso iconográfico, desde el mundo antiguo a la Edad Media, lo ofrece la representación del dios que hallamos en un capitel románico del claustro de Monreale donde, según el autor, se copió la imagen sin entender su sentido, siendo tomada, tan sólo, por un simple y cruento sacrificio.

${ }^{1617}$ No es preciso insistir en la presencia del tema dentro de las obras antiguas que han llegado hasta nosotros. Los sarcófagos, cerámicas y pinturas en las que la divinidad griega ocupa el grueso de la escena son muy abundantes. Desde otro orden de cosas, parece que textos tan importantes como el de Eurípides y su obra Los Bacantes, datada tras el año 406 a. de C., pudieron ayudar a tal difusión. Sobre la fortuna del dios en el mundo griego y su traspaso al romano, véase: E. HOMANN-WEDEKING, voz "Dioniso", Enciclopedia italiana dell'arte..., vol. III, Roma, 1960, pp. 112-114.

${ }^{1618}$ Se analiza esta imagen del sarcófago en: J. DELGADO GÓMEZ, "El singularísimo...", de manera especial, pp. 259-263.

${ }^{1619}$ G. RIPOLL LÓPEZ, "Sarcófagos de la antigüedad tardía hispánica: importaciones y talleres locales", Antiquité tardive. Les sarcophages d'Aquitaine, 1, 1993, pp. 150-158.
} 
imágenes y fórmulas plásticas, a pesar de su menor importancia. Entre tales elementos, las monedas debieron tener un papel importante.

La pieza, anteriormente citada, en la que se representó la imagen de Hércules niño luchando contra las serpientes, tan sólo muestra la posibilidad de acudir a estas piezas en busca de posibles modelos antiguos ${ }^{1620}$. Del mismo modo, cabría mencionar, incluso, las diferentes ilustraciones de los códices miniados, donde la imagen de estas personificaciones aparece también de manera reiterativa. Sin embargo, ante la complejidad de un rastreo entre obras no tan fácilmente accesibles como la escultura monumental pétrea y, sobre todo, ante la carencia de modelos antiguos de este tipo conservados en la Hispania romana, creemos que podría tratarse de una vía menos fructífera que la que ofrecen los sarcófagos ${ }^{1621}$.

Así, a tenor de los paralelismos establecidos en su día por S. Moralejo entre este tipo de imágenes con serpientes de época románica y la iconografía de Ophiucuchus o el Serpentario de algunos códices, nuevamente, se vuelve a plantear la duda sobre lo complejo y confuso de indagar en el origen de tales representaciones ${ }^{1622}$.

Para finalizar este apartado dedicado a la asimilación de la iconografía clásica de la serpiente dentro de la escultura de los focos de Frómista y Jaca durante los años finales del siglo XI y principios del XII, queremos detenernos en dos obras importantes. La primera de ellas, es un capitel que se conserva en el interior de la catedral. En la composición de esta escultura que se desarrolla a lo largo de toda la parte frontal de la pieza, destaca una figura femenina colocada en la parte central (fig. 279). Aparece vestida con un manto de gran exhuberancia textil, característica que se acentúa gracias al gesto de salutación que realiza con la mano izquierda. Le acompañan dos figuras angélicas en pareja, colocadas a cada lado de la cesta del capitel, flanqueando a dicha mujer.

\footnotetext{
${ }^{1620}$ Otro ejemplo bien conocido es aquel que muestra al Hércules niño luchando contra los ofidios en presencia de Alcmena y Anfitrión, en una de las pinturas murales de la Casa de los Vettii de Pompeya, tal y como se recoge en: H. SICHTERMANN, Op. cit., en concreto, p. 384 y J. BOARDMAN, O. PALAGIA y S. WOODFORD, Op. cit., pp. 728-838.

${ }^{1621}$ Una miniatura de gran interés en este sentido es la que se conserva en Viena, Staatsbibliothek, Cod. Med. gr. fol. 3. En dicha imagen se representó la figura de Galeno, el famoso médico de la Antigüedad que las fuentes ubican en Pérgamo, entre el año 129 al 201 d. de C. En la ilustración se ha escenificado una reunión de médicos, entre los que se hallan, Cratevas, Dioscórides, Nicandro, Rufo, Andrea y Apollonio. La serpiente vuelve a convertirse aquí en un atributo fundamental dentro de la composición. Sobre la ilustración, véase: C. BERTELLI, voz "Galeno", Enciclopedia italiana dell'arte..., vol. III, Roma, 1960, pp. 759-760.

${ }^{1622}$ S. MORALEJO ÁLVAREZ, "Pour l'interprétation...", particularmente, p. 156. El investigador recogía el ejemplo de la imagen de la esfera celeste del códice conservado en Città del Vaticano, Biblioteca Vaticana, Vat. gr. 1087.
} 
En los lugares dispuestos para el nacimiento de las volutas del capitel corintio fueron colocadas dos figuras de gran tamaño. La de la izquierda, parece claramente una mujer que porta una serpiente enroscada al cuello, mientras que, la figura de la derecha, muy deteriorada, se caracteriza por su gran masa corpórea, además de por sus marcados rasgos simiescos. Parece que, en origen, pudo llevarse la pata a la boca en actitud, quizás, burlesca ${ }^{1623}$.

Nuevamente fue S. Moralejo quién, en su día, barajó una hipótesis de interpretación de la imagen, que otros autores, como M. Durliat, seguirían directamente. Según se ha venido aceptando, la figura central representaría a la Virgen María, mientras que los dos ángeles laterales aludirían al momento exacto en el que se produce la Anunciación, calificada por Durliat como "demoníaca"1624.

Desde otro punto de vista, la imagen de la mujer con la serpiente al cuello y la del simio fueron entendidas por los citados especialistas como el triunfo o la victoria de Cristo sobre la antigua serpiente quizás, la misma que Daniel destruía en uno de los capiteles del exterior, antes comentados ${ }^{1625}$.

Independientemente del problema iconográfico que envuelve no sólo a esta pieza, sino a todo el repertorio de la catedral, destacamos la presencia de la figura femenina con el ofidio al cuello, cuya cola, además, sujeta con una de sus manos ${ }^{1626}$. El tema, gozó de gran éxito en la escultura desarrollada, por los mismos años, en algunos centros adscritos a las vías de peregrinación que se dirigían a Santiago de Compostela. Baste con citar uno de los capiteles ubicado en el pequeño absidiolo que da paso a la cabecera tardogótica de la iglesia de San Isidoro de León, donde encontramos una imagen parecida (fig. 280). Aquí, la figura de la mujer ha sido sustituida por un águila, que despliega sus grandes alas a lo largo del capitel. A pesar del estado bastante deteriorado de la cabeza, se puede percibir su forma, así como las grandes patas del ave que se agarran al astrágalo del capitel. La serpiente se vuelve a enroscar sobre sí misma

${ }^{1623}$ Capitel número 50. Vid.: M. DURLIAT, La sculpture romane de la route..., en concreto, pp. 236-237 e ID., "Sculpture romane...", concretamente, p. 377. El mismo autor, a partir de la interpretación de Moralejo, llevó a cabo una equiparación iconográfica entre la escena de Jaca y otras de similar índole. Aludía, en particular, al portal de la abacial Conques y a las diversas escenas infernales, el anuncio de la venida de Cristo y la victoria sobre el diablo.

${ }^{1624}$ Resulta problemática la aparición en la escena de dos ángeles, ambos en actitud dinámica y que dirigen sus gestos hacia la figura femenina.

${ }^{1625}$ Sobre la lectura del mencionado capitel de Jaca, en relación con el pasaje Daniel y Habacuc, véase: S. MORALEJO ÁLVAREZ, “Aportaciones a la interpretación...”, en concreto, p. 93. Sobre la posibilidad del que tema esté, a su vez inspirado, en un sarcófago paleocristiano, consúltese: D. L. SIMON, “A Moses...", de manera especial, p. 219.

${ }^{1626} \mathrm{El}$ tema posee un origen, nuevamente, ligado a la Antigüedad. Sobre ello, véase.: A. GRABAR, "Le tiers monde de l'Antiquité...", en concreto, p. 15. 
alrededor del cuello hasta formar una suerte de collar que ella misma genera al morderse su propia cola ${ }^{1627}$.

El tema, de clara tradición clásica, fue estudiado en su día por el profesor C. Cid Priego, quién defendió un origen romano para tales imágenes y su traspaso a los siglos del románico ${ }^{1628}$. En relación con ello, resulta sugerente la imagen de la serpiente Ouroboros conservada en un manuscrito París ${ }^{1629}$. En la imagen se muestra al ofidio formando una especie de círculo que surge cuando, con su boca, éste muerde su propia cola, tal y como se muestra en la fórmula utilizada por el capitel leonés y que entronca con la manera en que se figuraba al reptil en algunas de estas piezas datadas en torno al siglo II d. de. $\mathrm{C}^{1630}$ (fig. 281).

En la misma línea se encuentra el espectacular mosaico conservado en el Gran Palacio de Constantinopla que, nuevamente, utiliza fuentes antiguas para gestar tal iconografía. En dicha obra se observa la imagen de una serpiente que es cazada por un águila en pleno vuelo, mientras que el ofidio se enrosca intentando escapar del pico que le dará muerte.

Por su parte, la relación de la serpiente con el mono, presente en el capitel que ahora analizamos, tiene su paralelo en la misma catedral jacetana, pues en uno de los canecillos exteriores se representó la figura de un mono que agarra con sus manos una serpiente que, retorciéndose hacia su rostro, parece acercarse a la oreja del animal ${ }^{1631}$.

${ }^{1627}$ J. ARCE, Funus Imperatorum..., de manera especial, pp. 131-135. El autor llama la atención sobre las connotaciones funerarias del águila en relación con los textos clásicos. Especialmente, cita los testimonios de Dion Casio y Herodiano, justo en el momento en que describen la presencia del águila dentro de la ceremonia fúnebre de algunos emperadores. El especialista analiza la problemática sobre la presencia real de tal animal en estos actos, sobre todo, tras la mención que los autores contemporáneos hacen del águila, supuestamente, soltada por los centuriones durante el funeral de Augusto.

${ }^{1628}$ C. CID PRIEGO, "La miniatura del águila y la serpiente en los Beatos", Boletín del Seminario de Estudios de Arte y Arqueología, LVI, 1990, pp. 335-350, en concreto, pp. 335-336.

${ }^{1629}$ Paris, Bibliothèque nationale de France, Ms. gr. 2327, fol. 196.

${ }^{1630}$ Y. BONNEFOY, Dictionnaire des mythologies et des religions des sociétés traditionnelles et du monde antique, vol. II, Paris, 1981, pp. 247-249. El autor explica la importancia de la serpiente Ouroboros dentro del culto realizado por los Pérates, gnósticos cristianos que otorgaron dentro de su movimiento un importante papel al ofidio. Conecta la iconografía con la constelación del Serpentario que, en ocasiones, se identifica también con la imagen de Ouroboros, inmóvil, cerrado en sí mismo, aprisionando con su mandíbula su cola.

${ }^{1631}$ Una pieza de cronología románica procedente de la ermita de San Miguel de Villatuerta en Navarra y hoy conservada en el Museo de Pamplona, muestra una figura con enormes orejas y rasgos que recuerdan a los de un simio. Tradicionalmente se ha venido considerando esta figura como la representación de un mono que cruza sus piernas. Recientemente se abordaron tales obras en: M. POZA YAGUE, "Espinario", Sancho el Mayor..., vol. II, ficha 176, pp. 102. La autora ha identificado la escultura como humana, aludiendo al gesto que presenta como una herencia de la Antigüedad. Afirma que se trata de la figura del espinario que "fue utilizado como icono condenatorio de la actividad sexual dado el absoluto descaro con el que estos personajes mostraban a la vista sus genitales al cruzar una de las piernas". Podría tratarse de una imagen del espinario, aunque su fisonomía no encaja totalmente con las características propias de tal iconografía. A pesar de que el rostro de la escultura, datada por M. Yagüe en el último tercio del siglo 
Por último debemos aludir a la imagen más monumental que hallamos en el templo en relación con la serpiente. Se trata de la presente en el tímpano occidental del recinto, en el que se esculpió el famoso crismón (fig. 282). Aquí se representó, a la izquierda del anagrama de Cristo y bajo las zarpas de un león, arrastrado por el suelo, un hombre que, con sus manos, sujeta una serpiente de línea sinuosa ${ }^{1632}$. El ofidio conserva aquí su marcado simbolismo, como en las mejores esculturas del arte antiguo tardío ${ }^{1633}$.

Sin adentrarnos ahora en la tradición paleocristiana presente en la imagen del tímpano, pues se trata de una tarea que realizaremos en las siguientes páginas, debe quedar patente la reiteración en el uso de la imagen del animal ${ }^{1634}$; así como su dependencia de la escultura funeraria de la Antigüedad ${ }^{1635}$.

$\mathrm{X}$, ha llegado a nosotros totalmente destruido, parece más segura una identificación con una figura simiesca que con la de un humano. En todo caso, de tratarse de un mono, la idea de que su presencia simbolice el pecado, encaja también con el supuesto significado del canecillo de la catedral de Jaca donde, al aparecer, la persuasión de la serpiente remarca, aún más, su carácter maléfico.

Sobre este aspecto, en relación con ciertos símbolos zoomórficos, véase, además: E. MARTÍNEZ DE LAGOS, “AAlegorías de la lucha entre el bien y el mal? Aportación al estudio de las fuentes escritas y visuales que sirven de inspiración a los enfrentamientos entre hombres y bestias en el arte medieval", Boletín del Museo e Instituto Camón Aznar de Ibercaja, XCVIII, 2006, pp. 257-289, en particular, pp. 257-260.

Por otra parte, esta iconografía, según apunta J. Adhémar, debió estar muy difundida en las provincias gracias a la presencia del tema en pequeñas piezas, especialmente terracotas. Cf.: J. ADHÉMAR, Influences antiques..., p. 190. Nuevamente se aborda el tema del espinario en: M. RUIZ MALDONADO, Escultura románica..., p. 126. La autora habla de la llegada del modelo desde la Antigüedad a la Edad Media a través de pequeñas producciones en materiales delebles. En relación con las imágenes clásicas deformes que exhiben los órganos sexuales, consúltese: M. A. CASTIÑEIRAS GONZÁLEZ, El calendario..., pp. 153-154 e ID., "Las fuentes...", pp. 78-81. En estos trabajos el experto estudia la fortuna de la imagen del espinario dentro de los menologios italianos.

${ }^{1632}$ D. L. SIMON, "A Moses...", sobre todo, pp. 216-217 e ID., "El tímpano de la catedral...", en particular, p. 411. Según el autor se trataría de una imagen de un hombre penitente, vestido con túnica corta y que debe ser considerada como un símbolo del postramiento ante Cristo. Véase también: S. MORALEJO ÁLVAREZ, "La sculpture romane....", particularmente, p. 152. El investigador había incidido en la tradición de llevar a cabo ritos y ceremonias de penitencia pública en el pórtico o narthex occidental donde se ubica el tímpano. Ambos coinciden en señalar la especial importancia que parecen tener los sarcófagos paleocristianos para la génesis de esta imagen.

${ }^{1633}$ Un ejemplo muy interesante, de cronología románica, es el de la fachada de Rheinau, en Alemania. Los especialistas, a pesar de tratarse de una producción medieval, han vinculado sus imágenes zoomórficas con la tradición simbólica paleocristiana. El tímpano posee tres registros, donde las aves se mezclan con la figura de un ciervo y de una liebre. Vid.: A. REINLE, "Les débuts de la sculpture romane dans la région du lac de Constance", Cahiers de Civilisation médiévale, XV, 3, Poitiers, 1972, pp. 179191, sobre todo, p. 180. El autor identifica cada una de estas figuras con un simbolismo antiguo, demostrando que tales tradiciones pasaron de manera, más o menos, intacta hasta los siglos del románico. El fuerte sustrato clásico del tímpano viene remarcado por la presencia de dos hipocampos de tradición antigua. Se incide en la importancia simbólica de las representaciones zoomórficas en el arte romano, en: A. GRABAR, Las vías de la creación..., de manera especial, pp. 127-128.

1634 Se tratará más adelante la complejidad iconográfica del tímpano, así como las diferentes interpretaciones que ha recibido por parte de los especialistas, no sólo por la presencia de la serpiente, sino además por el uso de iconos tan complejos como el del crismón, el basilisco o los dos leones afrontados. Todo ello, como es bien conocido, acompañado de una serie de inscripciones que, aún hoy en día, siguen presentando numerosos problemas de interpretación.

${ }^{1635}$ D. OCÓN ALONSO, "El sello de Dios...", en particular, p. 82. La profesora Dulce Ocón incide en la importancia de la escultura de sarcófagos antiguos relacionada con los temas dionisíacos-báquicos o 
Aceptando la tesis tradicional, la serpiente representada en el acceso occidental al templo debe ser entendida como un símbolo de humildad, de ahí que sea adecuada a la hora de acompañar al penitente que se encuentra bajo el cuerpo del felino ${ }^{1636}$. Resta entonces por demostrar si tal imagen fue generada de manera autónoma por el artífice románico gracias a su bagaje artístico o, por el contrario, su fuente de inspiración estaba en el pasado romano. Con todo, si tenemos en cuenta otras cuestiones ajenas al tema de la imagen parece que todo apunta a dar como válida la hipótesis de una puntual filiación con el arte antiguo. De hecho, al analizar el conjunto epigráfico que completa la lectura iconográfica del tímpano algunos autores no han dudado en hacer derivar determinados aspectos de estas inscripciones de los epitafios de cronología romana. Se trataría de un traspaso de fórmulas de los epitafios latinos, aquellos que, de manera metafórica, mantenían un diálogo imaginario con el viandante que se detenía a contemplar el mensaje escrito y, con él, la propia imagen ${ }^{1637}$.

En las páginas siguientes de este estudio se abordarán las posibles fuentes clásicas de este famoso tímpano occidental del templo jacetano. Sin embargo, a lo afirmado hasta aquí, cabe señalar la reciente comparación, de índole iconográfica, establecida por la profesora Licinia N. C. Wrench, quién señala las posibles relaciones existentes entre la composición de los dos leones afrontados románicos y algunas piezas datadas cronológicamente entre los años de la Antigüedad tardía y la Alta Edad Media.

La citada autora se refiere, por ejemplo, a la placa frontal conservada en la iglesia de San Juan Bautista de Tomar, en Santarém, que data entre los siglos VIII y $\mathrm{X}^{1638}$ (fig. 282 a). En relación con la placa alto medieval, esta posee forma de frontón

vinculados también con la figura de Cibeles. Resulta una tarea compleja y que desarrollaremos más adelante el poder asignar un carácter benefactor o negativo a la representación de la serpiente que hallamos en el tímpano, ya que si "habitualmente los eruditos han identificado a la serpiente como un símbolo del mal, abandonada por el penitente (...), en el caso del tímpano jacetano el ofidio rompe el sistema estrictamente bilateral de la composición, ya que la serpiente se encuentra situada en el lado del tímpano reservado para el Bien", tal y como escribe la mencionada investigadora. Véase también: D. L. SIMON, "El tímpano de la catedral...", p. 411.

${ }^{1636}$ Ibidem, p. 412. D. Simon desarrolla una serie de argumentos para poder relacionar la imagen de la serpiente con la liturgia penitencial y un simbolismo, hipotéticamente, apartado de lo maligno. Sobre lo problemático de realizar una lectura iconográfica segura sobre el animal y la imposibilidad de abarcar en un solo estudio un tema tan denso y complejo como este, ya llamó la atención en su día la profesora Etelvina Fernández, quién recoge un extenso corpus de ejemplos que van, desde la época paleocristiana hasta los siglos del románico. Vid.: E. FERNÁNDEZ GONZÁLEZ, "Sobre la serpiente...", especialmente, p. 43.

${ }^{1637}$ J. DEL HOYO, Op. cit., tomado de http://www.anmal.uma.es/numero6/Hoyo.htm, consultado el 10 de marzo de 2007.

1638 L. N. C. WRENCH, Decoração Arquitectónica na Antiguidade Tardia. Corpus de Escultura Arquitectónica, 2 vols. Lisboa, 2008, vol. II, en concreto, pp. 180-183. Reiteramos nuestro agradecimiento a la Dra. Licinia Wrench por habernos permitido, amablemente, la consulta de su Tesis Doctoral antes de haber realizado la publicación de la misma. Igualmente, el agradecimiento es extensible 
triangular. En el centro, sirviendo de eje compositivo a la escena, se esculpió un árbol de la vida entre dos leones afrontados. La estudiosa identifica uno de los animales con un león mientras, que el otro, sería una hembra. Lo más importante es que, el supuesto león, podría transportar en su boca una presa, quizás un basilisco como sugiere la citada investigadora. Resalta además, la postura en marcha que adquieren los animales.

Entre las relaciones que establece, destacan algunos mosaicos de las Islas Baleares, como los de Menorca de las basílicas de Illeta del Rei (Port de Maó) y la de Es Fornàs del Torelló. Además, el dato más interesante resulta de la comparación del tímpano románico de Jaca y el mosaico tardorromano proveniente de otro pórtico, esta vez, aquel construido alrededor del baptisterio paleocristiano de Mértola, datado entre los años finales del siglo V y el VI (fig. 282 b) ${ }^{1639}$.

A la vista de estos ejemplos, no es de extrañar que la citada investigadora señale, de manera insistente, que los modelos iconográficos de todas estas producciones fueran traspasados a la plástica de las etapas posteriores.

"Nas catedrais hispânicas, românicas, de Jaca e de Santa Cruz de la Serós (Huesca) as portadas ocidentais apresentam a mesma temática, com a substituição da árvore da vida pelo "círculo", Crísmon de oito braços. Em Jaca, além do basilisco e do urso sob as patas de um dos leões, é também introduzida uma figura humana a dominar uma serpente, sob as patas do outro leão"1640.

\footnotetext{
a la profesora Dra. Adelaide Miranda, por sus amables e interesantes sugerencias en relación con algunos puntos tratados en este trabajo.

${ }^{1639}$ Ibidem, pp. 182-183. Se señala que, en el caso del mosaico de Mértola, los leones se afrontan al árbol de la vida, siendo símbolo de los cristianos que acceden al paraíso y que, a veces, se materializa por la introducción de ciertas alusiones a la Tierra o el Mar.

${ }^{1640}$ Ibidem, p. 181 e ID., "Decoração arquitectónica litúrgica da antiguidade tardia nos grupos pacense e eborense", Arqueologia da Antiguidade na Península Ibérica, vol. VI, Porto, 2000, pp. 645-655.
} 

DECORATIVISMO DEL ROMÁNICO.

En el presente apartado se llevará a cabo el análisis de una serie de elementos que se muestran reiterativos dentro de la serie de modelos iconográficos de la escultura jaquesa. En concreto, nos referimos a la representación dentro de los capiteles y los canecillos del conjunto, de máscaras zoomórficas y rostros humanos, ya sean en forma de simples cabezas que nacen entre las volutas del capitel o en las esquinas de los cimacios. Se observará, por lo general, que fueron concebidas a modo de prótomos, en recuerdo de aquellos de aplique de la etapa clásica que aparecían en forma de falso mascarón y que, ocasionalmente, surgían de entre las manos de los personajes y la vegetación ${ }^{1641}$.

Se trata de un motivo universal y de gran difusión dentro del arte románico europeo, por lo que, teniendo en cuenta tal aspecto, no se podrá, en ningún caso, aportar ejemplos o conclusiones absolutas y cerradas. El motivo, por su cotidianidad, presenta unos orígenes difusos dentro de la evolución de las formas desde la Antigüedad, siendo igualmente complejo establecer las vías por las que tal repertorio de máscaras, prótomos cefálicos zoomórficos y cabezas humanas llegaron al ideario artístico de los escultores románicos ${ }^{1642}$.

En su publicación del año 1975, la profesora E. Fernández González, llevó a cabo una serie de interesantes reflexiones en torno a la problemática del motivo iconográfico de las cabezas rostradas, tan frecuente dentro de los edificios románicos asturianos. La autora señalaba la complejidad a la hora de poder analizar el origen del motivo y su larga difusión dentro de la escultura medieval, que permitían poder emparentar este tipo de imágenes románicas con ejemplos procedentes de cronologías dispares, tanto desde el punto de vista geográfico, como desde el cronológico y el estilístico $^{1643}$.

\footnotetext{
${ }^{1641}$ Véanse, por ejemplo, las máscaras y rostros conservados en la Lusitania que se recogen en: V. DE SOUZA, "Stierprotome", Corpus Signorum..., ficha catalográfica 18, pp. 15-16; ID., "Stierprotome", Ibidem, ficha catalográfica 19, p. 16 e ID., "Stierprotome", Ibidem, ficha catalográfica 20, p. 16. Se trata de una serie de pequeñas cabezas de toros y vacas realizadas en mármol y que, posiblemente, servirían como remates para los arcos de guerra.

${ }^{1642}$ Sobre su presencia en la Hispania romana, vid.: E. GONZÁLEZ FERNÁNDEZ, "Máscaras romanas en terracota halladas en la Ciudad de Lugo", Actas del XXII Congreso Nacional de Arqueología, vol. II, Vigo, 1993, pp. 279-282 y O. GARCÍA SANZ y D. BERNAL CASASOLA, "Iconografía dionisíaca en lucernas de la Hispania romana", Cuadernos de prehistoria y arqueología, 21, 1994, pp. 117-158.

${ }^{1643}$ E. FERNÁNDEZ GONZÁLEZ, "Las cabezas rostradas: un tema ornamental en el románico de Villaviciosa", Asturiensia Medievalia, 2, 1975, pp. 341-364; ID., La escultura románica..., pp. 302-322 e
} 
Las famosas cabezas rostradas o beak-heads, ya fuese en forma de pájaro o de monstruo, decorarían todo tipo de estructuras y darían la pauta para introducir toda una serie de variantes posibles. Las cabezas humanas serían una de ellas, aunque si bien es cierto que el tipo iconográfico original es aquel que presenta al animal agarrando con su pico determinadas molduras y elementos constructivos, pronto acabaría evolucionando hacia otra serie de repertorios de gran variedad y riqueza que, a parte de los lugares ya citados, acabaría por expandirse a determinados templos más alejados del foco asturiano, tal y como se puede constatar, por ejemplo, en la iglesia portuguesa de São Claudio de Nogueira, en Viana do Castelo ${ }^{1644}$ (fig. 283).

Tras los tempranos estudios de la autora, otros investigadores tomarían como base sus afirmaciones para continuar indagando en el tema, sin aportar grandes novedades al respecto ${ }^{1645}$.

Sin pretender, en ningún caso, emparentar de manera directa el desarrollo del tema de las cabezas humanas, zoomórficas y los mascarones con un único origen romano, creemos posible aportar, a través de esta serie de reflexiones, una hipotética vía de estudio para comprender la transmisión del tema hacia la escultura románica, centrándonos en el ejemplo concreto de la catedral de Jaca ${ }^{1646}$.

En un ambiente dominado por cierto recuerdo de la tradición iconográfica dionisíaca, no debe sorprender el uso de este tipo de máscaras y rostros ${ }^{1647}$. En este

ID., voz "Asturie. Età románica”, Enciclopedia dell'arte medievale, vol. II, Roma, 1991, pp. 681-685. El motivo, según la autora, se extiende desde la iglesia de San Juan de Amandi hasta producciones más alejadas del foco asturiano como, por ejemplo, en la iglesia de Santa María de Arbas, en León. Las "cabezas rostradas" suele presentar el motivo de un rostro, generalmente, de gran relieve y que, esculpido sobre capiteles, arquivoltas y aleros, alcanzó gran difusión como mero elemento ornamental. La investigadora utiliza el concepto de cabezas rostradas a través de la traducción de la expresión inglesa beak-heads, aunque alude a otras muchas acepciones bajo las que puede ser interpretado. Recoge, igualmente, la definición dada por A. Clapham, según la cual, las cabezas rostradas son "estos animales seductores, en forma de cabezas de pájaro o de animal monstruoso, cuyo pico inferior aparece agarrado a la moldura toral de las arquivoltas". Además, realiza un amplio estudio del motivo, desde su difusión en el ámbito anglosajón, así como en Francia y España. Señala que, incluso, se puede rastrear el motivo en el Peloponeso, concretamente, en Patras.

${ }^{1644}$ G. N. GRAF, Portugal Roman. Le Nord du Portugal, La-Pierre-qui-Vire, 1987, en particular, p. 198. El autor define tales motivos con la expresión beak-heads. Consúltese, sobre el tema de las máscaras, el capítulo que se dedica, en: C. ALBERTO FERREIRA DE ALMEIDA, Arquitectura Românica de entre Douro e Minho, 2 vols., Porto, 1978, vol. II, en particular, pp. 239-241 y J. M. DE OLIVEIRA RODRIGUES, Aspectos da ornamentação e representação na escultura do românico em Portugal, vol. I, Lisboa, 1987, en particular, pp. 110-115.

${ }^{1645}$ M. S. ÁLVAREZ MARTÍNEZ, "El Bestiario en la Plástica Monumental del Románico Asturiano”, El discurso artístico en oriente y occidente: semejanzas y contrastes (J. L. Caramés Lage, C. Escobedo de Tapia, J. L. Bueno Alonso, coords.), vol. 1, Oviedo, 1997, pp. 67-84; ID., El románico en Asturias, Oviedo, 1999 e ID., El románico en Asturias: monumentos y caminos, Oviedo, 1997.

${ }^{1646}$ E. FERNÁNDEZ GONZÁLEZ, La escultura románica..., p. 167. La autora aborda el tema de las máscaras grotescas, incidiendo en su valor puramente ornamental.

${ }^{1647}$ O. GARCÍA SANZ y D. BERNAL CASASOLA, Op. cit., pp. 117-118. 
sentido debemos traer nuevamente a colación un capitel del templo jaqués que ya hemos analizado y que presentaba tres figuras masculinas, la central con una serpiente en la mano. Según pensamos, esta pieza puede servir de base sobre la que iniciar nuestras reflexiones $^{1648}$.

Dentro de la composición ya hemos destacado el uso que se hizo de la imagen de los felinos, tal vez panteras, que amarradas mediante un cordón por el cuello, son guiadas por jóvenes efebos desnudos. En la misma obra y situadas en los extremos de la cesta del capitel, se esculpieron dos prótomos felinos que abren sus enormes fauces (fig. 284).

Dichas imágenes podrían permitir argumentar otra serie de razones para justificar la posibilidad de que el capitel hubiera tenido como objeto de inspiración una fuente clásica. Al observar la manera con la que fueron representados los animales de la escena siguiendo, por otra parte, los parámetros que tanta difusión van a tener dentro de la misma seo jaquesa, llama la atención el marcado interés que se le va a otorgar a las cabelleras, a las fauces y, sobre todo, a los ojos rasgados que van a presentar estos animales. Sin desviarnos de la línea argumental que estamos siguiendo, pues tal y como hemos explicado se le dedicará un apartado posteriormente, algunas de las esculturas más emblemáticas de ciertos templos coetáneos, desde el punto de vista cronológico, presentarán unas soluciones similares.

En relación con ello, una de las esculturas principales de la puerta del Cordero de San Isidoro de León, aquella que muestra la efigie de San Isidoro y que fue colocada en la albanega izquierda del arco de acceso al templo, presenta un elemento significativo al respecto. La figura sedente se sienta, presumiblemente, sobre un trono, cuyos remates presentan, como fue habitual desde mundo antiguo, forma de garra de león (fig. 285). Esta simplificación de mueble derivado de la silla curul romana, muy difundido en toda la etapa medieval, posee unos remates zoomórficos en la parte alta que, claramente, pueden identificarse con figuras felinas.

El motivo reaparece, nuevamente, en la imagen del rey David tocando la lira de la parte izquierda de la fachada de las Platerías, en la catedral de Santiago de Compostela (fig. 286). Allí observamos la imagen del mítico monarca sentado a la manera antigua sobre un mueble de idéntica ascendencia. Se repite la misma fórmula,

${ }^{1648}$ M. DURLIAT, La sculpture romane de la route..., p. 234. Se trata del capitel número 64. 
siguiendo la moda romana, con fuertes garras de león a modo de patas y apliques en forma de cabeza en las partes altas del mueble ${ }^{1649}$.

Son muchos los autores que han señalado una continuidad entre este tipo de representaciones muebles, desde la Antigüedad romana hasta la Edad Media. La silla curul, generalmente en forma de tijera plegable, gozó de gran éxito, no sólo en la época altomedieval, sino que la encontramos con cierto aire "antiquizante" romano dentro de las imágenes románicas. Un buen número de este tipo de representaciones aparecen recogidas en el llamado Tumbo $A$ de Santiago de Compostela, donde la galería de retratos regios, muchos de ellos sentados a la romana en sillas de este tipo, hablan de un traspaso de dicha iconografía ${ }^{1650}$ (fig. 287). Nuevamente los prótomos en forma de cabeza y las patas que simulan garras se repiten, tanto en el foco gallego como en el jacetano, atestiguándolo una ilustración realizada sobre el documento de las Actas del Concilio de Jaca (fig. 288), donde los obispos se muestran sentando en este tipo de sillas en forma de tijera ${ }^{1651}$.

En ocasiones, se ha defendido la poca veracidad de las representaciones medievales relacionadas con este tema, negando la posibilidad de utilizarlas con cierto rigor "arqueológico" a la hora de poder trazar un panorama sobre este tipo de mobiliario, la mayor parte hoy perdido. Sin embargo, tan sólo es necesario rastrear algunos ejemplos romanos para poder afirmar que, sí bien es poco posible demostrar de

${ }^{1649}$ Recordemos que un sarcófago ya tratado aquí, el conservado en el pórtico de la basílica de San Lorenzo Extramuros, presentaba dos remates en los extremos de la parte frontal de la caja en forma de gran pata felina con garras. Como hemos afirmado ya, parece que los especialistas creen que en origen la tapadera de la pieza, hoy perdida, poseía forma de almohadón sobre el que se recostaría la imagen del difunto. Sobre dicha obra, consúltese: S. DE MARINIS, Op. cit., en concreto, p. 605 y F. H. TAYLOR, Op. cit., p. 48, donde se relaciona el uso de tales prótomos con ejemplos helenísticos.

${ }^{1650}$ Santiago de Compostela, Archivo de la Catedral, cód. 1, fol. 29v. Cf.: M. C. DÍAZ Y DÍAZ, F. LÓPEZ ALSINA y S. MORALEJO ÁLVAREZ, Los Tumbos de Compostela, Madrid, 1985, en especial, pp. 27-41; S. MORALEJO ÁLVAREZ, “La miniatura en los Tumbos A y B”, Los Tumbos..., pp. 45-62; M. A. CASTIÑEIRAS GONZÁLEZ, "Poder, memoria y olvido: la galería de retratos regios en el Tumbo $A$ de la Catedral de Santiago (1129- 1134)", Quintana, 1, 2002, pp. 187-196 y E. FERNÁNDEZ GONZÁLEZ, "El retrato regio en los Tumbos de los tesoros catedralicios", Maravillas de la España Medieval. Tesoro sagrado y monarquía, León, 2001, pp. 41-54.

${ }^{1651}$ Huesca, Archivo de la Catedral (Sign. 2-47). La ilustración del supuesto Concilio de Jaca del año 1063, ha sido datada a mediados del siglo XII. Véase: C. BANGO GARCÍA, "Actas del Concilio de Jaca (Synodus nouem episcoporum in Jacca)", Sancho el Mayor..., vol. I, ficha catalográfica 36, p. 183. La autora señala que "por los motivos iconográficos (la imagen) responde a modelos más antiguos que el resto de actas de este Concilio que conocemos".

Desde otro orden de cosas, mencionamos en último lugar, la escultura de la Virgen sedente con el Niño, conservada en Madrid, Museo Arqueológico Nacional y que procede del monasterio de San Benito de Sahagún, en León. El trono sobre el que se sienta la Virgen presenta, nuevamente, estos prótomos, que algunos autores han querido enraizar con la tradición carolingia y que, tal y como sabemos, siempre presenta grandes deudas con las fórmulas clásicas. Véase, sobre esta escultura: A. FRANCO MATA, "Altorrelieve de la Virgen...", Los Caminos de Santiago. El arte en el periodo románico en Castilla y León, Valladolid, 2006, p. 250. 
una manera segura que dicho mobiliario fue traspasado y reutilizado durante las épocas posteriores a la caída del Imperio Romano, si que parece factible poder hablar de una cierta transmisión iconográfica desde la plástica romana hasta la medieval.

Entre los muchos casos posibles, citamos la pata en forma de zarpa de león de una mesa o, quizás, perteneciente a un trono que, actualmente, se conserva en el Museo de la Santa Cruz de Toledo y que permite imaginar una supuesta fuente para este tipo de representaciones, así como el pie de mesa con forma de prótomo de leona con remate de garra felina hallado en la villa romana de Can Bas en Lavern (Barcelona) ${ }^{1652}$.

Sin embargo, será a través de otra obra romana donde podemos hallar un hipotético origen del motivo románico. Nos referimos, concretamente, a un aplique de mármol con forma de cabeza de felino que proviene del sitio arqueológico de la villa de Quintanilla de la Cueza, en Palencia (fig. 289). De la pieza, tan sólo nos ha llegado parte del cráneo y aún a pesar su estado de deterioro, son muy visibles los ojos contorneados en relieve, además de un collar que el animal muestra alrededor del cuello ${ }^{1653}$.

No podemos, ni tampoco insinuamos, una relación directa entre esta pieza que, por lo demás, ha aparecido totalmente descontextualizada con respecto a su función originaria y toda la larga lista de imágenes de muebles medievales en las que las cabezas de felinos ocupaban los remates más visibles de estos elementos.

Sin embargo, el aplique del Museo Arqueológico de Palencia habla de una tradición decorativa muy difundida en el mundo hispanorromano y sobre la posibilidad de explicar, mediante este tipo de obras, ciertas deudas que mostrará el arte medieval. Además, dicho prótomo nos permite introducir un problema relacionado directamente con el capitel de la catedral de Jaca.

Rematando los ángulos de tal escultura, se colocaron sendas máscaras felinas. Se repiten cabelleras y ojos rasgados, así como grandes fauces abiertas. El motivo es de especial importancia para la escultura del foco jacetano, así como para otros centros que

${ }^{1652}$ La pieza proviene de Santa María de Abajo, en Carranque (Toledo) y está elaborada en un rico pórfido rojo. Sobre ella, vid.: B. PATÓN, "Gamba di tavolo a forma di zampa di leone", Hispania..., ficha 261, p. 432. Se ha datado dentro del siglo IV d. de C.

Del mismo tipo sería otra pieza de similar índole conservada en el Museo Monográfico de Ampurias. Para la escultura de Can Bas, conservada en el Museo de Villafranca del Penedés, véase: A. BALIL, Esculturas romanas de la Península Ibérica, Valladolid, 1980, en particular, p. 16. El especialista considera que este tipo de piezas no fueron raras en Hispania. Cita otros ejemplos, como el conservado en Ampurias y el de Mérida, donde el prótomo sirve de base para el nacimiento de un cáliz con hojas de acanto. Se trataría, en todo caso, de "un tipo de muebles muy bien documentado (...) y que se documenta bien en provincias occidentales".

${ }^{1653}$ Palencia, Museo Arqueológico. Se ha datado en el siglo IV a. de C. Sobre ella, la única mención que hemos encontrado se recoge en: M. DEL AMO Y DE LA HERA y F. J. PÉREZ RODRÍGUEZ, Op. cit., en concreto, p. 89. 
acabarán absorbiendo el modelo. Sin embargo, tras constatar su frecuente aparición decorando los ángulos de los capiteles, de los cimacios y toda una larga lista de elementos dispuestos a lo largo del espacio templario, cabe preguntarse por la posible función y simbolismos que tuvieron.

Es posible que las máscaras de felinos colocadas a modo de prótomo dentro de estas composiciones románicas sean una simple alusión a toda una larga nómina de obras muebles, de remates de objetos cotidianos o, incluso, de algunas partes de los templos clásicos como, por ejemplo, los aleros. Más aún, muchos sarcófagos datados entre los siglos I a. de. C. y el primer siglo de la nueva era, presentaban en los ángulos, así como en la base e, incluso, en la cornisa del tejaroz que, en ocasiones, servía de tapa de la cista, una serie de motivos en forma de prótomo zoomorfo y humano ${ }^{1654}$.

Lo que pretendemos mediante esta serie de ejemplos mencionados es, además de presumir un posible fin ornamental de las dos máscaras felinas colocadas sobre las cabezas de los animales que se representaron en la parte baja del capitel jaqués, conjeturar sobre el posible origen romano que dichas imágenes pudieran tener.

De aceptarse la presencia de modelos extraídos de los sarcófagos de temática dionisíaca dentro del taller románico activo en Jaca a finales del siglo XI, parece posible la contaminación con otros elementos que, de manera habitual, aparecen dentro de obras de este tipo. Resulta imposible poder hablar de una pieza concreta dentro del ambiente hispano que pudiera haber dado origen al modelo, por lo que, tan sólo, resta poder confirmar el uso de prótomos felinos y mascarones de diversa tipología dentro de los sarcófagos y obras vinculadas al dios Dionisio-Baco ${ }^{1655}$.

\footnotetext{
${ }^{1654}$ Recuérdese, por ejemplo, como se utilizó uno de estos remates de un sarcófago conservado en el Museo de l'Arles Antique para poder explicar ciertos rasgos fisonómicos de una de las figuras que componen el conocido relieve del Signo del León y el Cordero custodiado en Toulouse, Musée des Augustins. Tal hecho, habla de la importancia de estos elementos de la tradición romana en la formación de los repertorios de los escultores románicos. Sobre tal propuesta, vid.: TH. W. LYMAN, "La table d'autel de Bernard Gilduin et son ambiance originel", Les Cahiers de Saint Michel de Cuxa, 13, 1982, pp. 53-75.

${ }^{1655}$ El tema de las cabezas de león fue especialmente recurrente dentro de este tipo de sarcófagos. Creemos que no es necesario recoger todos aquellos que presentan este motivo, pues dicha tarea no esclarecería ni demostraría hasta que punto la iconografía romana acabó por influenciar un motivo tan estereotipado como el que hallamos en Jaca y, en concreto, dentro de este capitel que venimos estudiando. Para la importancia del tema dentro de algunos sarcófagos, véase: M. LAWRENCE, "The Pagan Themes in Christian Art", De Artibus Opuscula..., pp. 323-334, en particular, pp. 327-328. Se alude a la importancia de la temática dionisiaca dentro de algunas piezas utilizadas más tarde por el mundo cristiano. Publica, además, la imagen de un sarcófago con la historia de Endimión conservado en New York, Metropolitan Museum of Art, donde dos grandes cabezas leoninas con fauces abiertas interrumpen el desarrollo de la historia que se esculpió en la parte frontal de la pieza. Es posible que, algún modelo similar, fuera conocido por los escultores románicos, sobre todo, por la similitud a la hora de utilizar tal motivo como elemento de enmarque de las escenas, que presenta una misma solución, tanto dentro de la escultura antigua como en la románica.
} 
Con todo, el corpus de piezas halladas en la Península Ibérica es lo suficientemente rico como para presumir un conocimiento y la perdurabilidad de estas soluciones. El llamado sarcófago de los leones, encontrado en las cercanías de Évora, da buena prueba de ello ${ }^{1656}$ (fig. 290).

Se trata de una pieza que presenta un friso de estrígiles con una cratera en el centro que se remata en los extremos con dos cabezas de león ${ }^{1657}$. Los felinos, esculpidos con barrocas melenas y sendas argollas en las fauces, parecen evocar un arca transportable. A ello se suma, además, su claro simbolismo antiguo, según el cual, los leones eran considerados como representantes de la muerte y el dominio sobre la naturaleza. Además, tal y como se ha señalado, la presencia de las estrígiles sugiere, claramente, a sus connotaciones termales y a la idea de rejuvenecimiento y palingenesia que, acompañadas por la imagen del vaso central, no dejan de recordar ciertas corrientes de la imaginería dionisiaca ${ }^{1658}$.

Podemos concluir, en relación con el uso de estos temas dentro de la escultura clásica, debemos apuntar que las cabezas de león, tigre, pantera o cualquier tipo de felino, fueron habituales en cuanto a su utilización y que, generalmente, eran esculpidas dentro de las piezas funerarias a modo de apliques o prótomos de gran relieve. Además de estas, las máscaras humanas, ya sea a través de la utilización del modelo de mascarón teatral o en forma de simple cabeza rostrada, aparecen dentro de estas esculturas como elementos recurrentes y de gran importancia ${ }^{1659}$.

Las máscaras, motivo de gran alcance en cuanto a su difusión dentro del repertorio de obras románicas que manejamos, no dejaron durante los siglos medievales de preservar un ligero recuerdo de su origen clásico. Se mostrarían en todas sus variantes, del modo más imaginativo.

\footnotetext{
${ }^{1656}$ Belém, Museu Nacional de Arqueologia.

${ }^{1657}$ M. JUSTINO MACIEL, J. M. PEIXOTO CABRAL y D. NUNES, “Os sarcófagos tardo-romanos...", en particular, pp. 163-164. Los autores los definen con el término prótomo. También véase: J. L. MARTINS DE MATOS, "Sarcófago dos leões", Inventário do Museu Nacional..., ficha catalográfica 48, pp. 108-109.

${ }^{1658}$ M. JUSTINO MACIEL, J. M. PEIXOTO CABRAL y D. NUNES, “Os sarcófagos tardo-romanos...", p. 162 y M. JUSTINO MACIEL, Antiguidade Tardia..., pp. 125-128. Otros autores, por el contrario, han defendido que las cabezas de leones aquí esculpidas no estarían asociadas con la idea de cuba de vino o lenos, tal y como era habitual dentro de los sarcófagos romanos del siglo II d. de C. Estos datos, entre otros, llevaron al profesor Maciel a datarla en la época de los Antoninos. Sobre esta cuestión, véase: J. L. MARTINS DE MATOS, “Sarcófago dos leões...”, p. 108.

${ }^{1659}$ Por ejemplo y por citar uno de entre los muchos casos posibles, así aparece una gran máscara teatral apoyada sobre un pequeño pedestal, en un sarcófago conservado en Roma, Museo Nazionale Romano, en el que se representó una bacanal de tipo dionisiaco. Vid.: P. ORLANDINI, Op. cit., en concreto, p. 957 y F. BARETTE y C. METZGER, Musée du Louvre. Catalogue des sarcophages en Pierre d'époques romaine et paléochrétienne, Paris, 1985. Véase el capítulo titulado "thèmes dionysiaques", en las pp. 122151 , donde se recogen buenos ejemplos al respecto.
} 
Si la imaginería báquica puede ser una de las tipologías iconográficas a las que acudir para explicar la pervivencia de prótomos felinos dentro de estas composiciones románicas, la presencia, en la misma cronología medieval, de otra serie de tipologías de máscaras y prótomos, invitan a ampliar el campo de búsqueda.

En su día G. Krien-Kummrow señaló la importancia de aquellas de tipo teatral, considerándolas como unas de las más importantes en cuanto a su influencia dentro de la plástica románica. Tal hipótesis no sería impensable, pues sabemos, gracias a los ejemplos conservados en las artes plásticas y la literatura, que dichas máscaras aparecían de manera recurrente ligadas a las ceremonias dedicadas a Dioniso ${ }^{1660}$.

La importancia de tales objetos durante la Edad Media está fuera de toda duda. Parece que algunas llegaron incluso a influir, directamente, sobre piezas románicas, en las que se ha podido intuir un intento de copia, más o menos resuelto, tal y como señalara en su día V. Lasalle, para un capitel de la iglesia de Brioude ${ }^{1661}$ (fig. 291).

$\mathrm{Al}$ analizar algunos de estos rasgos de la escultura románica francesa, a parte de la posible influencia de las imágenes realizadas sobre lucernas romanas, es factible establecer otros paralelos similares, desde el punto de vista formal.

Un bronce hallado en la Lusitania muestra la utilización de algunos recursos análogos (fig. 292). La pieza de metalistería posee la forma de un rostro de bacante con una gran boca abierta, rasgo que, generalmente, fue muy utilizado por estas máscaras para expresar fácilmente diferentes tipos de sentimientos. La manera en que está tratada, así como el expresionismo del gesto facial y los ojos, habla de un mismo horizonte para ambas piezas ${ }^{1662}$. No en vano, todo parece señalar que este tipo de máscaras y prótomos optaron por soluciones similares a la hora de decorar los objetos de la vida cotidiana,

${ }^{1660}$ G. KRIEN-KUMMROW, voz "Maschera”, Enciclopedia italiana dell'arte..., vol. IV, Roma, 1960, pp. 900-918, de manera especial, p. 910. El autor diferencia algunos tipos de máscaras dentro del repertorio de la imaginería clásica, entre ellas, las de tipo funerario. En este sentido, debemos pensar que los materiales de los que estaban compuestas dichas obras era muy variado y con diferentes tipos de resistencias al paso del tiempo. Entre ellos, los más utilizados eran el mármol, la terracota o el metal y de las cuales, además, tenemos noticias bien documentadas a través de los mosaicos que, de una manera muy concreta, muestran detalladamente como eran este tipo de piezas. Sobre ello, véase también: P. LAVEDAN, voz "Masque Scénique”, Dictionnaire illustré de la mythologie..., pp. 627-629.

${ }^{1661}$ La escultura se realizó para la iglesia de Saint-Julien de Brioude (Haute Loire, Auvergne). Cf.: V. LASSALLE, "Imitation d'un masque scénique antique sur un chapiteau roman de Brioude", Revue Archéologique du Centre, 51-52, 1974, pp. 229-233. El autor analiza el capitel en el que fue representado un rostro cuya boca y rasgos faciales recuerdan a las máscaras teatrales de las que hablamos, emparentándola, en concreto, con una serie de imágenes realizadas sobre lámparas romanas.

1662 J. L. MARTINS DE MATOS, "Carranca de Valdevez", Subsídios para um catálogo da escultura Luso-romana, 2 vols, Lisboa, 1966, vol. II, pp. 257-258. El autor señala que la pieza apreció cuando se construía la carretera que unía las localidades de Arcos de Val de Vez y Monção. La boca abierta pudiera hacer pensar en que, en su día, pudo haber servido como surtidor de una fuente de algún jardín. El estudioso resalta ciertos rasgos del rostro, como la nariz saliente y el trabajo brillante de los cabellos. 
diversas partes de los templos o, por ejemplo, las salidas de las corrientes de agua o fuentes. La bella cabeza romana portuguesa ya citada, realizada en mármol y que presenta la efigie de un efebo con la boca abierta para poder expulsar el agua, posee algunas de estas mismas características ${ }^{1663}$ (fig. 293).

Su clara vinculación con la tradición pagana del mundo teatral, así como las conexiones que dichas piezas establecían con el mundo dionisiaco, no fueron causas suficientes como para que, en determinados centros cristianos, tales piezas gozaran de cierta consideración. Incluso, en ocasiones, se les otorgará cierto valor, tal y como atestigua, por ejemplo, la copa de los Ptolomeos de Saint-Denis o la conservada en Hildesheim $^{1664}$ (fig. 294).

Pero fue, sin duda, en el campo de la ilustración del libro, en concreto, a través de las miniaturas realizadas para decorar los códices que recogían las Comedias de Terencio, donde se puede llegar a entender la repercusión que el tema de la máscara teatral antigua tuvo en la Edad Media ${ }^{1665}$. En particular, la prueba más interesante al respecto es aquella imagen en la que se muestra una estructura arquitectónica de tradición clásica formada por dos columnas de capitel corintio esquematizado y un pequeño frontón. En cada una de las tres baldas en las que se divide el original armarium, fueron colocadas una serie de máscaras teatrales de diferentes tipos.

\footnotetext{
${ }^{1663}$ V. DE SOUZA, "Männliche...", pp. 32-33. La solución que presenta este brocal de fuente sigue los mismos parámetros, por ejemplo, que los prótomos en forma de máscaras que rematan las esquinas de la tapa del sarcófago de las Musas y los Filósofos de Chelas, custodiado en Belém, Museu Nacional de Arqueologia. Cf.: M. JUSTINO MACIEL, J. M. PEIXOTO CABRAL y D. NUNES, "Os sarcófagos tardo-romanos...", pp. 166-167; ID., "O sarcófago romano das Musas...", pp. 63-70 y J. L. MARTINS DE MATOS, "Carranca fontenária", Inventário do Museu Nacional de Arqueologia. Colecção de Escultura Romana, Lisboa, 1995, ficha catalográfica 114, pp. 182-183. Se identifica la figura como un personaje de raza negroide, bárbaro o esclavo. Martins de Matos atribuye la pieza a la natatio o tanque de agua de la villa romana de Santa Vitória do Ameixial y la data en siglo II d. de C.

También consúltese: F. BARETTE y C. METZGER, "Fragment de lénos: Ariane endormie", Musée du Louvre..., ficha catalográfica 53, pp. 124-125. Los expertos estudian un fragmento de sarcófago donde la cabeza de un enorme león emerge de entre la composición, de la misma forma que en alguno de los capiteles de Jaca.

${ }^{1664}$ Paris, Bibliothèque nationale de France, Cabinet des Médailles. La denominada copa de Ptolomeo, datada en torno al siglo I a. C, fue reempleada durante los siglos medievales. Se trata de un vaso alejandrino tallado en un bloque de ágata, que presenta un completo desarrollo de diversas escenas dionisíacas. Sin duda, destaca la importancia que en ella se le van a otorgar a la imagen de las máscaras escénicas. Resulta llamativo que, a pesar de tratarse de una pieza pagana, ello no supuso un impedimento que evitase su sacralización y reutilización en la abadía francesa de Saint-Denis. Cf.: E. PANOFSKY (ed.), El abad Suger..., pp. 225-226 y C. FRANZONI, "Presente del passato: la forme classiche nel Medioevo", Arti e storia nel Medioevo. Del construire: tecniche, artista, artigiani, committenti (a cura di E. Castelnuovo e G. Sergi), vol. II, Torino, 2003, pp. 329-359, en concreto, p. 348. Para la pieza de Hildesheim, véase: G. KRIEN-KUMMROW, Op. cit., en particular, p. 917.

${ }^{1665}$ J. ADHÉMAR, Influences antiques..., pp. 201-202. El autor dedica un apartado a valorar la ilustración de manuscritos con referencias a la Antigüedad. Sobre todo, incide en la importancia de la obra de Terencio y la copia de sus textos, desde el siglo II. d. de C hasta el final de la Edad Media.
} 
Creemos que dicha imagen ejemplifica, bien a las claras, la importancia que dichos modelos pudieron tener durante los siglos del medievo ${ }^{1666}$ (fig. 295).

Ejemplos como estos pueden ayudar a definir el papel que las máscaras jugaron a la hora de inspirar la escultura románica, pero no sólo en el propio templo de Jaca, sino, más allá de la misma cronología de la Plena Edad Media. En este sentido, sirva de ejemplo la pintura gótica realizada sobre tabla entre los años 1435 y 1440 por el pintor catalán Bernat Martorell sobre el tema del martirio de San Vicente. Al observar con detenimiento uno de los verdugos que dan muerte al Santo se puede advertir, claramente, el lejano recuerdo de una de estas máscaras teatrales ${ }^{1667}$.

Tomando como referencia el texto de Prudencio ${ }^{1668}$, el pintor logró una serie de recursos expresivos bien significativos. Sin embargo, lo más destacado para nuestro objeto es que, algunos de los elementos que presenta la pintura, son susceptibles de ser analizados teniendo en cuenta diversos modelos del mundo antiguo. Así, la representación del verdugo que tortura a San Vicente, por su gesto grotesco, calvo, de ojos demoníacos, perfil afilado y con prominente nariz aguileña, podría equiparase con el arquetipo del gesto satírico utilizado por los artistas griegos y romanos para elaborar las comentadas máscaras que, más tarde, utilizarían los actores en las representaciones teatrales ${ }^{1669}$. Al observar las características fisonómicas y gestuales de una de las máscaras de comedia griega reproducidas por P. Lavedan (fig. 296) y la representación de perfil del verdugo de San Vicente en la tabla catalana (fig. 297), encontramos paralelismos que nos hablan de cómo los artistas medievales no habían olvidado uno de

\footnotetext{
${ }^{1666}$ Città del Vaticano, Biblioteca Vaticana, Cod. Vat. Lat. 3868. Tal y como es sabido, la imagen sería muy difundida y copiada en diversos códices, datados la mayoría de ellos entre los siglos IX y XIII. Véase al respecto: M. D. REEVE, "Aratea et Terence", Texts and Transmission. A survey of Latin classics, Oxford, 1983, pp. 18-24 y G. KRIEN-KUMMROW, Op. cit., en particular, p. 916.

${ }^{1667}$ Barcelona, Museo Nacional de Arte de Cataluña. La pintura procede de la ermita de Santa Creu de Menàrguens (Noguera). Está compuesta por varias escenas, entre las cuales, destaca la Virgen de la Misericordia y las imágenes relativas al martirio de San Vicente. En la predela se representaron escenas de la vida de Cristo. Cf.: J. GUDIOL y S. ALCOLEA I BLANCH, Pintura gótica catalana, Barcelona, 1986, ficha catalográfica 385, pp. 126-127 y 246; F. P. VERRIÉ "La trajectòria artística de Bernat Martorell", Bernat Martorell i la tardor del gòtic català. El context artístic del retaule del Púbol, Museu d'art de Girona, (J. Molina i Figueras coord.), Girona, 2003, pp. 5-16 y E. CARBONELL y J. SUREDA, Tesoros Medievales del Museu Nacional d'art de Catalunya, Barcelona, 1997, particularmente, p. 287.

1668 AURELIO PRUDENCIO, Op. cit., pp. 559-565.

1669 Este tipo de máscaras, tal y como venimos afirmando, fueron usadas inicialmente en los cultos rituales y festejos dionisiacos, donde los celebrantes se pintaban la cara y se decoraban los cabellos y barbas con hojarasca de vid. Dentro de las tipologías que, generalmente, vienen aceptándose, debemos destacar varios tipos: la llamada máscara trágica, la máscara satírica y la máscara cómica. Nos interesa resaltar, especialmente, las máscaras cómicas, que reproducían la efigie de hombres viejos de perfil afilado, grandes ojos, nariz deforme y enorme boca. Cf.: P. LAVEDAN, voz "Masque Scénique...”, pp. 627-629 y T. WEBSTER, "Greek dramatic monuments from the Athenian Agora and Pnyx", Hesperia, 29, 1960, pp. 254-264. En estos trabajos se recogen los diferentes tipos de arquetipos gestuales usados en las máscaras antiguas.
} 
los arquetipos gestuales mejor definidos dentro de la plástica antigua: el gesto cómico del sátiro ${ }^{1670}$.

Los ejemplos que ofrece este tipo de iconografía, dentro del ámbito peninsular, poseen un buen representante en el pinax con máscaras de teatro afrontadas, de cierto tono arcaizante (fig. 298). En la cara principal se esculpió la efigie de Dioniso barbado acompañado de una ménade, mientras que, en bajo relieve, aparece otra vez el dios con un sátiro ${ }^{1671}$.

El recurso que analizamos, debatiéndose entre lo patético y lo satírico, fue una fuente inagotable para los artistas de la Edad Media que acabarían por crear una serie de arquetipos o un lenguaje gestual muy concreto que, usado de manera sistemática, perpetuaría unos modelos a los que recurrir de manera mecánica a la hora de representar diferentes sentimientos o estados de ánimo. El conocido trono episcopal de la catedral de Bari, elevada mediante la fuerza de unos atlantes sobre los que se apea la silla, parece que tampoco escapó a este fenómeno. El rostro de alguno de los personajes muestra un cierto recuerdo de estas máscaras del que, sin duda, el más característico y fácil de reconocer es el de la boca entreabierta, que no hace otra cosa que reafirmar el pathos satírico de la figura (fig. 299).

Sin embargo, a la vista de estos ejemplos, cabe preguntarse por la accesibilidad, por parte de los escultores románicos activos en la Hispania de los siglos XI y XII, a

${ }^{1670}$ F. GALVÁN FREILE, "Entre la diversión y la trasgresión: a propósito del humor en las artes plásticas medievales", Cuadernos del Cemyr, 12, 2004, pp. 37-68, en especial, pp. 40-41. El autor alude a la pervivencia de este determinado arquetipo gestual dentro de las artes medievales, especialmente, las del libro. Las diferentes versiones ilustradas de las Comedias de Terencio, ofrecían, tal y como hemos dicho, modelos que se caracterizan por el uso reiterativo del gesto cómico del sátiro. Es relativamente probable que las diferentes imágenes satíricas de este texto, acabaran influyendo en la creación de un arquetipo gestual, según el cual, el rostro de perfil, barbado, de ojos saltones rasgados, nariz aguileña y boca exhalante, representaba el modelo perfecto para aludir al gesto de ira, rabia, embriaguez y, finalmente, todas aquellas expresiones relacionadas con lo satírico.

A modo de ejemplo que atestigüe el uso de este arquetipo gestual más allá de la Edad Media, proponemos algunos dibujos de Alberto Durero, como el rostro agresivo de uno de los tritones del Combate de tritones de la Albertina de Viena, fechado en 1494. Cf.: H. WIDAUER, "Bacanal con Sileno. 1494", Durero. Obras Maestras de la Albertina, Madrid, 2005, ficha catalográfica 6, pp. 92-94.

Algunos de los aspectos aquí expuestos son fruto de un breve estudio que se presentó en forma de comunicación en el International Congress of the European Middle Ages (ca. 300-1500), celebrado en Leeds (Inglaterra), entre el 10 y el 13 de julio de 2006. En dicho evento científico, titulado "Gestures and emotions", presentamos el trabajo, aún hoy inédito, titulado "Gestures of pain in Spanish Romanesque sculpture. The Heroic Death: From Antiquity to the Middle Ages".

1671 V. DE SOUZA, "Pinax mit archaistischen, antithetisch argeordneten Theatermasken", Corpus Signorim..., ficha catalográfica 119, p. 42. El autor señala que la pieza pudo haber formado parte de un pilar que decoraría un jardín. Consúltese también: F. BARETTE y C. METZGER, "Fragment de couvercle: Dionysos et Ariane", Musée du Louvre..., ficha catalográfica 53, pp. 136-137. En este trabajo se estudia una pieza en la que se esculpió una gran máscara con los ojos y la boca vaciados, siguiendo el prototipo portugués y que se acompaña por dos figuras reclinadas semidesnudas. Se constata, nuevamente, la predilección por las máscaras, tanto felinas como de teatro, los cuerpos desnudos y la exposición de exuberantes drapeados dentro de estos repertorios. 
este tipo de repertorios antiguos. Resulta evidente que es problemático llegar a demostrar, de una manera más o menos segura, un contacto íntimo entre las máscaras antiguas y las que hallaremos en los repertorios románicos de estos territorios. En relación con ello, el arte hispanorromano nos ha legado dos piezas de un importante valor. Se trata de dos máscaras realizadas en estuco que, en un primer momento, hubieron de ser concebidas para decorar alguna de las estancias de la villa de Corral de Gil de Fuentes, en Palencia ${ }^{1672}$ (fig. 300).

A juzgar por tales imágenes, no sería de extrañar que, alguna de las más "antiquizantes" máscaras esculpidas en tiempos románicos, hayan tenido como modelo remoto, una pieza de similares características. Citamos, siendo conscientes de que se trata de una escultura de cronología más tardía que las que aquí analizamos, el mascarón barbado y colocado entre vegetales de un capitel de la iglesia de Santo Domingo de la Calzada $^{1673}$ (fig. 301). La utilización del recurso gestual de la boca entreabierta, vuelve a traer a la memoria los ejemplos romanos antes citados, es decir, desde el brocal de fuente portugués con el retrato de un nubio (fig. 293) a otros ejemplos ya de cronología románica relacionados con lo clásico, como el gesto del atlante de la cátedra de Bari (fig. 299).

Los modelos relacionados con el tema de las máscaras romanas debieron estar en boga dentro de la escultura románica. En la iglesia de San Isidoro de León, se esculpió un capitel vegetal, en cuyos lados laterales y asomando entre la vegetación, se colocaron dos mascarones humanos (fig. 302). Presentan rostros ciertamente intemporales, tal y como ocurre con algunas de las máscaras que venimos estudiando. A ello debemos sumar, la ausencia de cualquier expresión, tanto en la boca como en los ojos, que han sido esculpidos lisos, sin pupila y, por lo tanto, alejados de cualquier

\footnotetext{
${ }^{1672}$ Palencia, Museo Arqueológico. Las dos máscaras se encuentran en buen estado de conservación. Se trata de dos piezas de extraordinaria calidad, ambas de semejantes rasgos, que presentan la peculiaridad de mostrar el expresivo rictus bocal, típico de las máscaras de teatro. Cf.: M. DEL AMO Y DE LA HERA y F. J. PÉREZ RODRÍGUEZ, Op. cit., en especial, pp. 107-108.

Sobre la importancia de la técnica del estuco dentro de los siglos de la Antigüedad no es preciso incidir, así como de su paso a los siglos medievales, donde se utilizó con la misma frecuencia y calidad. Véase, al respecto, la interesante aportación colectiva publicada bajo el título de, Le Stuc. Visage oublié de l'art médiéval, Poitiers, 2005. Consúltese: CH. SAPIN, "Sculptures en stuc: continuité et renouveau", Le Stuc..., pp. 134-163. En el caso hispano hemos aludido ya a la importancia de tal técnica antigua dentro de la decoración de algunas partes de la iglesia de Santa María de Melque, claramente emparentadas con la manera de aplicarla en otros edificios de la Antigüedad tardía europea.

1673 J. LACOSTE, Les maîtres..., en particular, p. 126. Son interesantes las relaciones que establece el autor en torno a este capitel de Santo Domingo de la Calzada. Pues, a pesar de poseer una cronología posterior, lo emparienta con la tradición estilística del siglo XI, en concreto, con la presente en la basílica de Saint-Saturnin de Toulouse que, como veremos, fue uno de los focos más clasicistas del románico europeo.
} 
alusión natural. La máscara fue concebida, igualmente, sin cabellos lo que le otorga, junto con el tratamiento plano de la superficie de la piedra, un carácter artificial y mayestático, como si se tratase de un elemento inanimado ${ }^{1674}$. A pesar de que analizaremos, más adelante, los rasgos clásicos de la escultura de la iglesia leonesa, creemos que dicho elemento puede demostrar que el recuerdo de éste tipo de máscaras era común a muchos de los talleres románicos activos en este momento. Sin intención de establecer una relación directa entre el rostro de León y la máscara de estuco conservada en Palencia, podemos afirmar que, ésta última, puede ser uno de los pocos ejemplos que han llegado a nuestros días, de una larga lista de piezas, más que frecuentes, dentro de la decoración de muchos edificios hispanorromanos.

Nuevamente pensamos que las posibles fuentes que están utilizando los artistas medievales eran, preferentemente, obras halladas en los territorios de la Península. Se trataba de producciones que, si bien en la mayoría de las ocasiones habían sido trasladadas desde la metrópoli a la provincia, se mostraban como recurrentes dentro del panorama que los hombres medievales podían tener ante sus miradas.

La Hispania antigua nos ha legado piezas muy interesantes a la hora de poder demostrar la frecuencia con que la iconografía de las máscaras y los prótomos fueron utilizados. Por lo general, se trata de imágenes presentes en piezas aisladas que, algún día, decoraron edificios, tanto públicos como privados, y que han llegado hasta nosotros descontextualizadas de su función real ${ }^{1675}$.

Según pensamos, es posible continuar defendiendo la importancia de las producciones artísticas ligadas a la iconografía de Dionisos-Baco donde, tal y como hemos mencionado, el uso de tales imágenes estuvo muy arraigado. En este sentido, un fuste de columna, de muy buena calidad, proveniente de Beja, presenta una decoración

${ }^{1674}$ El capitel no fue estudiado por M. Durliat en la obra que venimos utilizando como referencia para poder situar las piezas dentro de los diferentes templos. Cf.: M. DURLIAT, La sculpture romane de la route...

Tampoco ha sido publicada en la reciente aportación de J. Lacoste. Por su fisonomía, los rasgos del supuesto mascarón que analizamos, pueden tener paralelos fiables, dentro, por ejemplo, de un capitel datado alrededor de 1095 y colocado en la ventana alta de la fachada norte del transepto de la iglesia de San Isidoro, que ha sido publicado y estudiado en: T. MARTIN, Queen as King..., en concreto, fig. 41. La autora publica el capitel del que venimos hablando identificándolo con la fig. 74.

1675 A ellas se deben sumar otros tipos de representaciones de menor tamaño realizadas en bronce o, por ejemplo, en piedra. El sarcófago de las Musas de Lisboa, Museo Arqueológico do Carmo, es una prueba de ello, pues en él, algunas de estas personificaciones portan como atributo una máscara. Cf.: M. JUSTINO MACIEL, Antiguidade Tardía..., pp. 134-139 y pp. 160-163. Este autor estudia un sarcófago de Tróia de Setúbal en el que fue representada la escena del banquete y viaje del difunto. Lo más interesante es que, en los extremos de la tapa, se colocaron dos mascarones simbolizando al Sol y la Luna. En la actualidad la obra está fragmentada pero ha pervivido uno de ellos. Las soluciones dadas por el escultor al rostro nos muestra una figura de gesto intemporal, donde las pupilas se han dejado sin trabajar en profundidad, siguiendo la solución usada por el escultor románico de San Isidoro. 
que recorre por completo la pieza (fig. 303). A través de diversos vegetales, entre los que se reconocen desiguales tipos de zarcillos, hojas de vid y algunos vástagos, fueron colocados los consabidos "habitantes", frecuentes dentro de este tipo de producciones. La iconografía más compleja viene definida por la presencia de dos palomas que fueron colocadas sobre una cratera de gran tamaño. Las aves picotean una serpiente que, de manera sinuosa, intenta escapar de la muerte mientras, otras aves, muerden los frutos de la viña ${ }^{1676}$.

Esta pieza del siglo IV ha sido estudiada por S. Vidal, considerando que "no posee ningún indicio iconográfico per se cristiano", por lo que forma parte de ese conjunto de piezas numeroso, donde la iconografía se presenta tan embebida dentro de los lenguajes clásicos, que no es posible discernir si se trata de una pieza clásica pagana o ya cristiana ${ }^{1677}$.

El autor, a través de diferentes elementos, como son la presencia de la cratera, posible alusión al vino báquico pero, sobre todo, a partir de la introducción en el conjunto de la serpiente, relaciona la pieza, nuevamente, con la iconografía báquica. Es digna de señalar la anomalía que aquí presenta el ofidio, al poseer un pico abierto y una cresta $^{1678}$. La representación de dos rostros o máscaras humanas de perfil con largas barbas puede arrojar luz sobre el tema que aquí tratamos ${ }^{1679}$. Concluye, por lo tanto, que no se debe dudar en vincular esta escultura a la tradición iconográfica dionisíaca, ciertamente frecuente dentro de piezas adscritas al arte romano funerario.

En relación con ello, baste citar el magnífico sarcófago de Constanza, hija del emperador Constantino y que hoy se conserva en Roma ${ }^{1680}$. La pieza, realizada en pórfido, originariamente se encontraba en el mausoleo que el emperador había

\footnotetext{
${ }^{1676}$ Beja, Museu Regional. La pieza que comentamos fue hallada en el Valle de Aguieiro a las afueras de la localidad portuguesa de Beja. Fue realizada en mármol blanco de tono rosado con vetas grises, que le otorgan una belleza y delicadeza muy marcada. Cf.: S. VIDAL, "Fuste de Beja", La escultura ..., ficha B23, pp. 78-82. El autor no se decanta por la posible función del fuste, aunque parece claro que formaría parte de algún edificio o estructura arquitectónica. Aquello que no permanece tan claro es si se trataba de una obra religiosa o civil. También véanse: G. GAMER, "Les colonnes ornées de Pampres et la colonne de Beja", Actas do III Congresso Nacional de Arqueologia, vol. II, Coimbra, 1971, pp. 487-493; C. TORRES y otros, Núcleo Visigótico, Museu Regional de Beja, Beja, 1993, ficha catalográfica 3 y L. N. C. WRENCH, Decoração Arquitectónica..., vol. II (Parte II), pp. 561-562.

${ }^{1677}$ M. JUSTINO MACIEL, "L'Art et l'expression de la foi", Pacien de Barcelone et l'Hispanie au IV siècle, Paris, 2004, pp. 207-218.

${ }^{1678}$ S. VIDAL, "Fuste de Beja...", p. 79. Se insiste en la importancia que los ofidios de este tipo van a tener dentro de la imaginería de los sarcófagos tardorromanos, especialmente, en obras del siglo IV, donde las serpientes se relacionaban con la imagen del gallo y el basilisco.

1679 Ibidem. El autor relaciona la iconografía de las máscaras del fuste con las imágenes del filósofo/pedagogo, habituales dentro de los sarcófagos romanos de los siglos II-IV d. de C. Menciona, en concreto, uno del siglo III, hallado en Tarraco.

${ }^{1680}$ Città del Vaticano, Musei Vaticani.
} 
levantado para dar cobijo a los restos de su primogénita, extra muros de la ciudad de Roma. El edificio de planta centralizada, posteriormente conocido como el Mausoleo de Santa Constanza, presentaba una estructura que permitía colocar en el interior del recinto, cobijado bajo la gran cúpula de la construcción y el anillo de columnas, un espléndido sarcófago en el que, nuevamente, se colocaron una serie de mascarones colgados de guirnaldas vegetales (fig. 304).

El edificio cristiano, identificado desde la Antigüedad con el sobrenombre del templo de Baco, fue concebido con una decoración absolutamente ligada a la tradición dionisíaca donde, las escenas de vendimia, la viña y toda una serie de vegetales entremezclados con objetos de la más diversa índole, llevaron a los hombres del medievo a caer en el error de considerarla una construcción con intenciones paganas ${ }^{1681}$.

La pieza en cuestión nos interesa por la presencia de una iconografía ciertamente ambigua y con unas claras dependencias del mundo clásico pagano. A parte de las imágenes de los putti vendimiadores en medio de una viña, repleta de alusiones báquicas, lo más significativo es como en la gran tapa del sarcófago fueron esculpidas unas guirnaldas vegetales, en cuyo centro parecen pender algunas máscaras.

No es nuestro objetivo estudiar aquí este tipo de representaciones ya que cuentan con trabajos muy importantes dedicados al tema y, sobre todo, por la lejanía del modelo con respecto al caso románico de Jaca. Algunos de estos especialistas han querido ver en las máscaras una suerte de retrato de la difunta insistiendo, además, en la gran difusión que los rostros/máscaras alcanzarían dentro de los programas icónicos más selectos de la Antigüedad.

En relación con el estudio de la fortuna de las éstas dentro de la iconografía románica hispana, nos interesa regresar ahora a un templo que, de manera generalizada, se ha puesto en relación con la escultura del foco de Frómista y el de la catedral de Jaca. Se trata de la iglesia de San Zoilo en Carrión de los Condes. La escultura del maltrecho templo cuenta con bastantes estudios dedicados a ella, especialmente, aquellos desarrollados por el profesor J. L. Senra Gabriel y Galán ${ }^{1682}$.

\footnotetext{
${ }^{1681}$ La bibliografía sobre la arquitectura y la decoración del mausoleo de Santa Constanza es abundante. Recogemos aquí aquellos trabajos que han hablado sobre la problemática de sus relaciones con lo dionisiaco para generar un mensaje cristiano. Cf.: A. GRABAR, Las vías de la creación..., p. 133. Sobre la iconografía de los famosos mosaicos del edificio, consúltese: ID., Le premier art..., en concreto, pp. 160-192 y A. AMADIO, I mosaici di Santa Constanza, Roma, 1984, pp. 20-24.

1682 J. L. SENRA GABRIEL Y GALÁN, "La Portada occidental recientemente descubierta...”, pp. 57-72; ID., "Algunas notas sobre la desaparecida iglesia...”, pp. 439-451; ID., "Nuevos hallazgos románicos en el monasterio...", pp. 88-95; ID., “Ángeles en Castilla: reflexiones en torno a renovación monástica y arquitectura en el siglo XI”, Patrimonio artístico de Galicia..., vol. III, pp. 261-274; ID., "La puerta
} 
En concreto, nos interesa destacar uno de los capiteles ubicados en la fachada occidental del recinto, sobre la columna del extremo derecho de la puerta ${ }^{1683}$ (fig. 305). Se trata de una pieza bien estudiada por los especialistas, pero que no ha recibido suficiente atención en algunos de sus detalles. Por nuestra parte, al abordarla, pudiera parecer que ello supondría alejarse de la línea de investigación seguida hasta el momento, sin embargo, creemos que ello ayudará a comprender el origen de algunos de los motivos presentes en la escultura de la catedral de Jaca, de la misma iglesia de Frómista y de todas aquellas que dependieron de éstas en algunos aspectos.

El capitel de la vendimia de Carrión de los Condes presenta la imagen de dos:

"hombres vendimiando y sobre ellos enigmáticas figuras reducidas a manos y cabeza dominado las viñas. El recurso compositivo basado en tallos vegetales enroscados y rematados en racimos, con o sin personajes, va a ser constante en la escultura de los principales focos escultóricos en torno a la primera década del siglo XII (...). La solución de representar las raíces del árbol encuentra paralelos en varios capiteles de Frómista"1684.

Por su parte, J. Castán Lanaspa describe la pieza en los siguientes términos:

como dogma: a propósito de un nuevo descubrimiento de la iglesia de san Zoilo de Carrión de los Condes", Archivo Español de Arte, vol. 81, 322, 2008, pp. 139-150 e ID., "Architecture et décor dans le contexte de la colonisation clunisienne des royaumes septentrionaux de la péninsule ibérique", Hauts lieux romans dans le sud de l'Europe (XI $-X I I^{e}$ siècles). Moissac, Saint-Jacques de Compostelle, Modène, Bari..., Cahors, 2008, pp. 11-70.

También véanse: J. CASTÁN LANASPA, "Una portada románica con capiteles historiados en Carrión de los Condes (Palencia)", Homenaje al profesor Martín González, Valladolid, 1995, pp. 305-310; J. L. HERNANDO GARRIDO, "La escultura románica en Palencia...", en concreto, p. 16; T. MARTIN, Queen as King..., en concreto, pp. 91-91 y J. LACOSTE, Les maitres..., en concreto, pp. 58-61. Resulta interesante señalar como, en su día, el profesor M. Durliat no recogió ninguna mención expresa y detallada del edificio ni de los pocos restos escultóricos conocidos hasta la fecha de publicación de su estudio. La nómina de ejemplos, como es sabido, ha aumentando extraordinariamente en los últimos años. ${ }^{1683}$ La portada fue descubierta en el año 1993 durante una serie de obras en el templo. Había permanecido oculta tras una serie de añadidos de época barroca que, tras su eliminación y gracias a las tendencias restauradoras de los años noventa del siglo XX, fue de nuevo puesta en funcionamiento. Cf.: J. L. HERNANDO GARRIDO, "La escultura en Palencia...", concretamente, p. 15.

La portada que comentamos, según se ha señalado, formaría parte de una supuesta galilea que se adosaba, por occidente, a una planta basilical de tres naves, cada una de ellas de cuatro tramos. El templo presentaría un transepto no destacado en planta. Todo este conjunto occidental fue rematado, hipotéticamente, por dos torres. El profesor J. L. Senra ha señalado que dicho conjunto daría acceso al templo desde el panteón funerario de la familia Banu-Gómez de Carrión, que se habrían de enterrar en el recinto. Cf.: J. L. SENRA GABRIEL Y GALÁN, "Nuevos hallazgos románicos...", sobre todo, p. 88; ID., "Architecture et décor...", pp. 46-47 e ID., "Mio Cid es de Bivar e nos de los Condes de Carrión: los Banu-Gómez de Carrión a la luz de sus epitafios", Quintana, 5, 2006, pp. 233-267.

${ }^{1684}$ J. L. SENRA GABRIEL Y GALÁN, "La portada occidental...", en concreto, p. 63. 
“(...) en el (capitel) de la derecha se simboliza la obra de los buenos cristianos en la viña del Señor mediante la representación de dos hombrecillos situados entre pitones angulares que trabajan un viñedo prolongado en la cara oculta. Sobre ellos y entre las volutas parecen observarlos con la serenidad de cariátides clásicas dos figuras de hermosas cabezas ovaladas y rostro pleno y suavemente modelado cuyo cabello se ordena en gruesos y rectos mechones"1685.

La mayoría de los estudiosos que han abordado la fachada han emparentado la obra, desde un punto de vista estilístico y cronológico, con la escultura realizada en la catedral de Jaca y en la iglesia de San Martín de Frómista, además de otra serie de obras coetáneas, como por ejemplo, los capiteles de la portada de San Isidro de Dueñas o la lauda sepulcral de Alfonso Ansúrez del monasterio de San Benito de Sahagún ${ }^{1686}$.

Acotando el campo de estudio y en lo que concierne a la posible influencia de las máscaras clásicas dentro de esta escultura románica, creemos posible poder exponer algunos argumentos que hablan de un conocimiento de este tipo fuentes.

El tema de la vendimia, que abordaremos de manera extensa más adelante al hablar de los fustes de la catedral de Santiago de Compostela, tuvo larga vida dentro de los siglos medievales. Muchos autores han defendido siempre las connotaciones paganas que posee el tema y como, en ocasiones, a pesar de haber recibido la frecuente reinterpretación cristiana, permanecieron intactos algunos rasgos que hablan de un pasado y unos modelos que, aunque lejanos y remotos, perdurarían en el imaginario de los hombres medievales.

Un capitel conservado en el Museo del Louvre y proveniente de la iglesia abacial de Notre-Dame et Saint-Jean en Moutiers-Saint-Jean (fig. 305 a), presenta una

\footnotetext{
1685 J. CASTÁN LANASPA, Op. cit., en particular, p. 310.

${ }^{1686}$ Para no desviar la atención de nuestro estudio hacia estas obras, nos limitamos, simplemente, a señalar que la escultura de la fachada occidental de San Zoilo y, en concreto, este capitel de la vendimia, han sido datados, casi de manera unánime por los especialistas, en torno año 1100. Desde un punto de vista temático, en lo referente a las escenas de vendimia, también se ha hablado de sus ligazones con la iconografía de la catedral de Santiago de Compostela, en concreto, con los famosos fustes que, hipotéticamente, proceden de la puerta norte, la llamada Puerta Francigena. No recogemos la bibliografía básica de estas piezas aquí, pues el presente trabajo contiene un apartado dedicado a ellas y en las que, puntualmente, se alude a los estudios consultados para realizar esta investigación. En relación con tales aspectos, véase: T. MARTIN, Queen as King..., en particular, p. 91. La autora vuelve a mencionar al "maestro de la Orestíada", a propósito de las concomitancias que la escultura de esta fachada de San Zoilo posee con los centros de Frómista y, según su criterio, San Isidoro de León.

Sobre las conexiones entre el capitel de Palencia y la lauda de Sahagún, véase: J. L. SENRA GRABRIEL Y GALÁN, “Architecture et décor...”, pp. 46-50.
} 
composición iconográfica que, aunque distante en muchos aspectos de la obra de San Zoilo, puede ayudar a clarificar algunos de sus aspectos ${ }^{1687}$.

En la pieza francesa desarrolla el tema de la vendimia, realizada por diferentes labriegos que, con sus aperos de labranza, recolectan el fruto, mientras otros lo cargan para su transporte. Las gruesas cepas se expanden por todo el capitel ofreciendo a la vista algunas hojas de vid y jugosos racimos de uva ${ }^{1688}$. En uno de los lados cortos observamos como un labriego, cuyo cuerpo no se ha llegado a representar completo, se agacha para poder recoger y cortar con un gran escalpelo los racimos. Se ha defendido que la fuente para este tipo de imagen estaría dentro de la escultura de los sarcófagos con el tema de la vendimia, muy habitual dentro de los monumentos funerarios de época antigua tardía. Incluso, el mismo gesto de llevarse unos granos de uva desde la cesta o desde la parra a la boca, está también documentado entre este tipo de repertorios.

En el caso del capitel de Carrión, el labriego porta ahora una pequeña azada, mientras toma la misma posición para trabajar la tierra. La relación que, desde un punto de vista iconográfico, podemos establecer entre ambas esculturas podría verse apoyada al argumentar las fuentes clásicas de similar tipo que ambas piezas parecen mostrar.

Como ocurre con muchas de estas obras de recuerdo clásico, centradas en el tema de la viña, no existe la certeza absoluta de poder llevar a cabo una lectura de la imagen en clave cristiana, tal y como había ocurrido, por ejemplo, con el fuste de Beja, del que S. Vidal mostraba sus dudas en relación con su simbolismo pagano.

En relación con el capitel de San Zoilo, J. Lacoste no ha dudado en otorgarle una intención cristiana ${ }^{1689}$. El autor, al abordar la imagen de las dos máscaras o, más correctamente, los dos bustos que, con sus manos, agarran los zarcillos de la viña, alude al texto bíblico:

“Yo soy la vid verdadera, y mi Padre es el labrador" (Juan, 15, 1-2).

\footnotetext{
${ }^{1687}$ Paris, Musée du Louvre. Cf.: J. R. G, "Chapiteau d'applique: scène de vendange", La France romane..., ficha 160 , pp. 218-219. Se trata de una pieza conservada en dicha iglesia hasta que fuera destruida en torno al año 1831. El autor relaciona la imagen con la iconografía de los menologios, en concreto, con algunos ejemplos de la zona borgoñona. La abacial benedictina de Notre-Dame de Moutiers fue, sin duda, después de Cluny y Vezelay, una de las más importantes de la región, tal y como indica el especialista.

${ }^{1688}$ No es preciso incidir en el tema, pero encontramos un idéntico interés por estos ciclos dentro de la escultura hispana de cronología románica. Recuérdense, en este sentido, los capiteles conservados, por ejemplo, en el Museo Arqueológico Nacional de Madrid, uno de ellos originario de la iglesia palentina de la Granja de Valdecal en Mave y el otro conservado in situ, en San Martín de Frómista, así como aquel de la iglesia cántabra de Santillana del Mar. Cf.: M. GARCÍA GUINEA, El románico..., en concreto, pp. 95-97.

${ }^{1689}$ J. LACOSTE, Les maîtres..., en concreto, p. 59.
} 
Desde nuestro punto de vista creemos que no existe ningún elemento dentro de la imagen que permita hablar de una lectura cristiana de la iconografía de manera indiscutible. Los dos labriegos trabajando la viña, bien pudieron ser tomados de un repertorio pagano aunque, como es sabido, su imagen se reconvirtió y pronto pasó a formar parte de los repertorios cristianos. Sin embargo, la presencia de los dos bustos/máscaras en la parte alta del conjunto habla de una posible lectura simbólica que no encaja plenamente dentro de los preceptos cristianos.

Más importante aún, al observar uno de los capiteles esculpidos en torno al año 1170 en la catedral de Santiago de Compostela, concretamente, en la denominada cripta que sirve de base arquitectónica para el Pórtico de la Gloria en el cierre occidental del buque del templo, se pueden constatar ciertas peculiaridades comunes entre ambas piezas $^{1690}$ (fig. 305 b).

Se trata de un capitel de gran calidad escultórica. Presenta un formato que fue concebido para recibir una doble columna en la parte inferior aunque, desde el punto de vista morfológico, este hecho no influyó excesivamente en su forma. En la parte frontal se representaron dos personajes arrodillados entre vegetales de factura muy carnosa, siguiendo la tónica general de este tipo de representaciones en las últimas etapas del siglo XII ${ }^{1691}$.

Destacan en la imagen la simetría con la que fue concebida la escena, la idéntica posición que toman los personajes entre zarcillos y, sobre todo, como en el eje central

\footnotetext{
${ }^{1690}$ Toda la estructura occidental que configura lo que hoy denominamos como Pórtico de la Gloria ha sido muy estudiada. Desde las investigaciones de S. Moralejo sobre la estructura, se ha venido aceptando que, de los tres niveles que forman este macizo occidental, se desprendía una posible lectura iconográfica no sólo de su escultura, sino también de la arquitectura.

Se ha defendido la existencia de una idea rectora en el conjunto, que exaltaría la Segunda Venida de Cristo, el Juicio Final y la posterior Gloria de la Jerusalén Celeste a partir de las visiones de Mateo. Cf.: S. MORALEJO ÁLVAREZ, "La imagen arquitectónica...", pp. 237-246, especialmente, pp. 242-244; M. A. CASTIÑEIRAS GONZÁLEZ, El Pórtico..., pp. 51-55 y W. WEISBACH, Reforma Religiosa...., p. 135. Este último autor habla de cómo el mundo del pecado y del infierno está "súper edificado" por el mundo divinal, corroborando la teoría de la lectura iconográfica de lo arquitectónico.

Recientemente se utilizó el mismo sistema de lectura iconográfica en altura, pero aplicado a la iglesia gallega de San Esteban, en: S. FERNÁNDEZ PÉREZ, "Para una nueva lectura de la portada occidental de Santo Estevo de Ribas de Miño", Compostellanum, vol. XLVI, 3 y 4, 2001, pp. 603-629 e ID., San Esteban de Ribas de Miño, Lugo, 2004, pp. 66-74.

Por último, debemos mencionar las nuevas teorías que, hoy en día, se están desarrollando en lo relativo a la cronología, fases constructivas y filiaciones del Pórtico compostelano. Cf.: H. KARGE, "De Santiago de Compostela a León...", pp. 165-198.

${ }^{1691}$ Somos conscientes de que este ejemplo se escapa, con mucho, de la cronología estudiada hasta el momento, sin embargo, creemos que la iconografía que presenta esta pieza puede aportar vías posibles para la interpretación de algunos aspectos de las producciones analizadas hasta el momento dentro de nuestro trabajo. El capitel fue estudiado en: R. SÁNCHEZ AMEIJEIRIAS, "Algunos aspectos de la cultura visual en la Galicia de Fernando II y Alfonso IX", El arte románico en Galicia y Portugal, Lisboa, 2001, pp.156-183, en concreto, p. 160.
} 
de la composición, en la parte alta, se esculpió un mascarón o busto de apariencia masculina. Resulta difícil poder describir con certeza la acción que estos dos hombres, de cabellos ondulantes y con cabeza cubierta, están llevando a cabo. En cualquier caso, su cuerpo queda enmarcado por un rico roleo rematado en jugosas hojas y dos frutos de grano quizás, dos racimos de uva, aunque no lo podamos asegurar. Ambos miran hacia la máscara de la parte alta e, incluso, parece que extienden sus manos intentando tocarla.

Un capitel conservado en el Museo Lapidario de Viena ${ }^{1692}$ (fig. 306), muestra la representación de un busto femenino tocado, naciendo del corintio de la escultura. Se trata de una pieza datada en el siglo I. d. de C., que porta una corona mural, mientras, tal y como señala F. Gury, muestra a la altura del pecho una serie de frutos, de entre los que destacan, los racimos de uvas. Lo más interesante del capitel es la identificación que se ha hecho de la figura como la diosa Rea, es decir, la hija de Gea y de Uranos, esposa de Khronos y madre de Zeus. Su postura, emergiendo de las hojas del corintio, no resulta nada extraña en el arte antiguo y, tal y como hemos señalado a lo largo del capitulo dedicado a estudiar la fortuna de este tipo de capitel en los siglos medievales, tal solución gozó de gran aceptación en durante el románico ${ }^{1693}$.

A pesar de ello, ya durante la Antigüedad tardía dicha imagen pronto fue confundida con la de Cibeles, la Gran Madre, tomando más tarde el nombre de Deméter. Así, tal y como defendiera el citado especialista, existen razones de peso que permiten relacionar tal personificación con la misma imagen de Dionisos, así como con las leyendas báquicas ${ }^{1694}$.

Sin embargo y en relación con la escultura hispana, no existe ningún elemento que aporte la suficiente fiabilidad como para poder identificar la imagen central en

\footnotetext{
${ }^{1692}$ Wien, Kunsthistorisches Museum.

${ }^{1693}$ Deben recordarse, en este sentido, algunas de las reflexiones realizadas por E. Vergnolle al respecto, sobre todo, en aquellas en las que insistía en la continuidad de esta fórmula desde lo romano hasta lo románico, especialmente en la Galia. Sobre algunas piezas con gran decoración vegetal de la que emergen bustos y seres figurados, consúltense los ejemplos recogidos en: G. BOVINNI, Corpus della scultura paleocristiana bizantina ed Altomedioevale di Ravenna, 3 vols., Roma, 1969, vol. III, p. 34. El experto analiza un capitel para pilastra con dos registros de hojas de acanto. La composición aparece dominada por el tipo de acanto "movido por el viento", que el investigador también define con esta expresión. Se trata de una pieza realizada en mármol. De la vegetación surgen una serie de figuras que identifica como el símbolo del evangelista Mateo y el de Lucas. Lo más interesante, en relación con esta escultura, es su fuerte carácter clásico que nos permite, además, recordar el capitel de Navarra, ya comentado, donde algunos autores también habían querido ver la representación de los evangelistas surgiendo de este mismo vegetal "antiquizante".

${ }^{1694}$ F. GURY, voz "Rhea”, Lexicon Iconographicum Mythologiae Classicae, vol. VII, 1, Zürich-Münich, 1994, pp. 628-632, en particular, pp. 628-629. El investigador recoge la leyenda que relaciona a Rea con Dioniso.
} 
forma de busto/máscara del capitel de San Zoilo o el de la cripta de Santiago de Compostela, con alguna deidad romana emparentada con el culto a la tierra, con sus frutos, con las labores agrícolas realizadas en ella o, en general, con la naturaleza. A pesar de ello, las manos del busto se aferran con fuerza a las cepas, como si surgiese del mismo ambiente vegetal, tal y como observamos en algunas de las personificaciones más conocidas de Rea o en aquellas deidades romanas ligadas con Tierra o Natura.

Sería arriesgado suponer un contacto directo entre algún modelo antiguo y los escultores románicos de Tierra de Campos; sin embargo, de la misma manera que se viene aceptando que los fustes marmóreos sobre los que se asienta el citado capitel provienen, claramente, de un edificio romano anterior, es decir, se trata de un spolium in $s e$, creemos que no sería disparatado poder suponer que tales máscaras reflejasen un hipotético spolium in re, basado en una pieza hoy desaparecida ${ }^{1695}$.

Por último, debemos señalar que el mismo tema agrícola de la vendimia, no sería, en ningún caso, extraño dentro de este supuesto recinto funerario. La iconografía de las estaciones del año o, en su lugar, las escenas que representaban los trabajos agrícolas realizados en cada época, eran colocadas en los recintos mortuorios cristianos, continuando con la tradición antigua de representar a los putti o a diversas personificaciones juveniles en plena faena agrícola. El tema "antiquizante" del capitel de Carrión continuaría igualmente con esta tradición antigua ${ }^{1696}$.

Para concluir con el apartado de las máscaras y los mascarones románicos y su hipotética filiación con la Antigüedad debemos recordar que, cuando los escultores de la catedral de Jaca llevaron a cabo la ejecución de un cimacio colocado sobre un capitel de la cabecera del edificio (fig. 307) y otro de una de las naves (fig. 308), ambos rematados mediante dos de estos prótomos, posiblemente el contacto directo con la obra clásica era ya inexistente. Sin embargo, tal aspecto no es suficiente como para negar un remoto recuerdo de la obra antigua ${ }^{1697}$.

Las máscaras en altorrelieve que sobresalen, casi exentas, en algunas piezas del exterior de la cabecera o del interior, así como otras con forma de felino vomitando

\footnotetext{
${ }^{1695}$ Sobre el spolium de los fustes, véase: J. L. SENRA GABRIEL Y GALÁN, "La portada occidental...", p. 59, nota 7.

${ }^{1696}$ P. DE PALOL, Arte Paleocristiano..., pp. 74-76. Según algunos autores, la imagen de la poda de la viña se relacionaría con la personificación del mes de marzo. Aunque la recolección de los frutos, específicamente la uva y la elaboración del vino, se ligaría a los meses del otoño. Sobre estos aspectos, véase: S. SEBASTIÁN, Mensaje simbólico..., en concreto, p. 237.

${ }^{1697}$ En concreto, se trata del capitel 46. Cf.: M. DURLIAT, La sculpture romane de la route..., en especial, p. 230. El otro capitel que recogemos en el anexo fotográfico no aparece numerado por el autor pues, en su día, no se detuvo en examinarlo ni estudiarlo.
} 
vegetales, no dejan de traer a la memoria algunos ejemplos del mundo antiguo. A modo de representación, citado, evidentemente, con intención de establecer una comparación lejana, sirva la galería de terracotas conservada en el Museo Nacional de Calabria ${ }^{1698}$, en Italia, donde una serie de cabezas felinas, con fauces abiertas, permitieron a los artífices clásicos poder decorar el alero del templo ${ }^{1699}$ (fig. 309).

Las cabezas sobresalen del tejaroz como si se tratase de apliques o prótomos, tal y como ocurre en los entablamentos de los templos etruscos y, tal y como sucede, igualmente, dentro de las piezas escultóricas romanas ${ }^{1700}$. Su presencia, tanto en los templos como en los sarcófagos clásicos, habla de una misma intencionalidad simbólica en su utilización, donde las cabezas de león y las máscaras pretendían un carácter apotropaico o profiláctico. Con tal intención fueron esculpidos los remates de varios sarcófagos conservados en el Museo del Louvre (fig. 310) ${ }^{1701}$.

En relación con algunas de estas obras, M. Barasch defendió un traspaso desde la Antigüedad hasta los siglos medievales de tales mascarones, sobre todo, con iconografía animal, pero centrándose también en la imagen del hombre-hoja, es decir, la versión medieval del dios Silvanus, tan habitual dentro de la imaginería antigua y que pasó casi intacta al arte románico y gótico ${ }^{1702}$.

Sobre la predilección de los artífices románicos por este tipo de máscaras, creemos haber incidido ya extensamente. Cuando el escultor de San Martín de Frómista sustituía, dentro del capitel románico, el nudo y las telas que decoraban la escena palatina del sarcófago de Husillos por una máscara de rasgos felinos vomitando textiles, demostraba varios comportamientos (fig. 311).

\footnotetext{
${ }^{1698}$ Calabria, Museo Nazionale di Reggio Calabria.

${ }^{1699}$ P. E. ARIAS, voz "Caulonia”, Enciclopedia italiana dell'arte ..., vol. II, Roma, 1959, pp. 443-444. Se trata de una serie de piezas conservadas en el citado museo, pertenecen a la colonia aquea situada en la costa jónica de Italia meridional, entre el cabo de Lacinio y el de Zefirio, cerca de Punta Stilo. Las terracotas arquitectónicas en cuestión, han sido datadas en el siglo VI. a. de C.

${ }^{1700}$ Aunque pudiera parecer desatinado establecer una relación entre la iconografía en terracota de determinados templos antiguos, en concreto, entre aquellas piezas colocadas en los entablamentos de los edificios clásicos y algunos elementos presentes en la arquitectura románica, la idea no es nueva y ya se ha intentado defender. De la misma manera que algunas de estas cabezas felinas pueden tener antecedentes en modelos en terracota de antefijas antiguas, la mayor parte de estudiosos del ábside sur de la catedral de Jaca, tal y como veremos en el apartado correspondiente, hablan de un repertorio decorativo que parece haber tenido como motivo de inspiración un templo romano, al menos, en cuanto a la solución con la que se ha resuelto el alero de la iglesia románica y donde se percibe un lejano recuerdo de los triglifos y las metopas. Cf.: A. KINGSLEY PORTER, "Spain or Toulouse?...", en concreto, pp. 10-13.

${ }^{1701}$ Paris, Musée du Louvre. Cf.: F. BARETTE y C. METZGER, "Fragment de couvercle", Musée du Louvre..., ficha catalográfica 141, p. 232 e ID., "Couvercle de sarcophage", Ibidem, ficha catalográfica 142, p. 233.

${ }^{1702}$ M. BARASCH, “Le beau ou le démoniaque...", en particular, pp. 105-109.
} 
En primer lugar, el escultor manifestaba que poseía una capacidad de reinterpretación y asimilación de los motivos que no se limitaba, simplemente, a copiar de forma mecánica aquello que tenía ante sus ojos, sino que reelaboraba las imágenes. Con todo, el artista, únicamente, suplantó el motivo romano por otro elemento asimilado por la plástica europea medieval y que, a su vez, tenía igualmente un lejano origen antiguo.

La máscara felina expulsando telas por sus fauces es un claro recuerdo de los prótomos de bronce que, habituales en ambientes cortesanos y palatinos, engalanaban las estancias en las que discurrían las historias mitológicas. Otro de los sarcófagos conservados en el Museo del Louvre en el que se narró una nueva versión del mito de Orestes, presenta un mismo interés por la utilización de estos cortinajes dentro de un ambiente áulico ${ }^{1703}$. No se debiera, por tanto, poder descartar la posibilidad de que en el capitel se hubiera fusionado, por un lado, la imagen de una de estas máscaras de león, con los textiles habituales dentro de estas composiciones, algunos de ellos, en forma de parapetasma $^{1704}$.

Paradójicamente es en la ilustración del libro, siempre abierta a nuevas vías de experimentación mucho más ricas e imaginativas, donde se nos presentan los referentes más factibles para tal motivo.

La famosa página miniada de los Evangelios de Saint-Medard de Soissons, en la que se representa la Jerusalén Celeste con el Tetramorfos y los Ancianos del Apocalipsis junto al Cordero, ha sido, insistentemente, relacionada con diversas fuentes clásicas. La utilización de una serie de microarquitecturas, la recreación de los muros de la ciudad a través de la imitación de un frons scenae o, el uso imitativo de mármoles de colores para las columnas y del capitel corintio clásico, son prueba de ello. Nos interesa señalar, para nuestro objetivo, la introducción en la imagen de los textiles, aquí colocados en forma de velum que penden y envuelven, en una solución no menos clásica, los fustes de las columnas, otorgando a la imagen cierto aire imperial ${ }^{1705}$.

\footnotetext{
${ }^{1703}$ Paris, Musée du Louvre. Se trata de una pieza perteneciente, antiguamente, a la colección de la Galería Borghese y presenta la historia de Orestes y Pílades sobre la tumba de Agamenón. Vid.: F. BARETTE y C. METZGER, "Face principale de sarcophage, fragment: meurtre de Clytemnestre", Le Musée du Louvre..., ficha catalográfica 102, pp. 102-103.

${ }_{1704}^{1704}$ M. D. DEL AMO, “El catapetasma en la plástica visigoda...", pp. 69-77.

${ }^{1705}$ Paris, Bibliothèque nationale de France, Evangéliaire de Charlemagne, nouv. acq. lat., Ms. 1203, fol. 3v. Consúltese al respecto: F. GALTIER MARTÍ, La iconografía arquitectónica..., pp. 134-135. El profesor Galtier insiste en estas fuentes clásicas para su iconografía. En la tradición pictórica asturiana los textiles alcanzaron gran éxito dentro de los ambientes palatinos, tal y como atestiguan, por ejemplo, las pinturas de San Julián de los Prados. Sobre la imagen carolingia, véase también: J. HUBERT, J. PORCHER y W. F. VOLBACH, L'Empire..., p. 86 y M-P. LAFFITTE, "Évangiles de Saint-Médard de
} 
En concreto, queremos centrar nuestra atención en el prótomo felino que sirve de eje central sobre el que se divide la composición (fig. 312). Aparentemente, se trata de una pieza de metal para aplicar, en forma de cabeza de león, que guarda, desde el punto de vista formal, algunos puntos en común con el motivo románico palentino. En la miniatura carolingia este prótomo sirve de sujeción o enganche para los textiles que parecen pender de la propia estructura cefálica. No los vomita por las fauces pero creemos que su origen podría estar en algunos ejemplos similares a este y heredados, claramente, del arte clásico.

No es preciso insistir en la importancia que tuvo tal elemento dentro de la ilustración del libro, durante todas las épocas, decorando todo tipo de márgenes y estructuras arquitectónicas. Citamos, como ejemplo representativo de esta tipología, la miniatura realizada para los Diálogos de Gregorio Magno donde, nuevamente, una máscara monstruosa, esta vez a medio camino entre el león y la personificación de Silvanus, expulsa todo tipo de elementos vegetales por la boca ${ }^{1706}$.

Llegados a este punto, queremos advertir que resulta complejo poder defender un origen seguro para tal motivo. Se trata de una imagen que se debate entre la realidad de ciertas piezas que ya hemos señalado y la inventiva del artista, siguiendo sistemas creativos bien constatados en la producción románica. La fusión de fuentes de la más diversa índole viene enriquecida, además, por la posibilidad de abrir los muestrarios comparativos a otro tipo de producciones como, por ejemplo, las carolingias.

En concreto, dentro de este ámbito, los capiteles que muestran muchas de las miniaturas, deben ser considerados como el eslabón intermedio que explicaría, en parte, el gran desarrollo que dentro de la escultura y la ilustración de época medieval van a tener las máscaras y los variados tipos de prótomos que aquí estudiamos. El escultor románico distorsionará todos estos repertorios, sirviéndose de ellos para la decoración de capiteles, cimacios, basas, cornisas, canecillos y otra serie de elementos ajenos a la escultura misma, como son los libros o las artes suntuarias.

En concreto, una de las imágenes del Evangeliario de Otón III presenta una serie de capiteles corintios, en los que dos rostros ocupan las partes centrales de la escultura. Además de todos aquellos modelos que se han propuesto como vía de inspiración para

Soissons", Trésors carolingiens. Livre manuscrits de Charlemagne à Charles le Chauve, Paris, 2007, ficha catalográfica 10, pp. 97-100.

${ }^{1706}$ Cambridge, Clare Collage, Ms. 30, fol. 45r. Se trata de un códice datado a finales del siglo XI pero, tal y como señalamos, este tipo de elemento decorativo estuvo ampliamente difundido. Cf.: M. KAUFFMANN, "Gregory the Great, Dialogues", English Romanesque Art 1066-1200, London, 1984, ficha catalográfica 10 , p. 90. 
estas piezas y la controversia en relación con la posibilidad de que se trate de obras inspiradas en modelos reales o, simplemente, fantaseados, queremos proponer algún ejemplo más que ayude a valorar tal cuestión ${ }^{1707}$ (fig. 313).

Los conocidos balsamarios decorados con dobles rostros, muy habituales en todas las Provincias del Imperio Romano, presentan una morfología que habla del gusto antiguo por los mascarones y los rostros de este tipo para decorar piezas muy variadas. En el Museo Arqueológico de Palencia se han conservado algunos ejemplos realizados en bronce, ciertamente interesantes, así como otros del Museo Arqueológico de Sevilla. En concreto, destacamos el pequeño incensario palentino decorado con tres rostros infantiles que se alternan con hojas vegetales (fig. 314). Se trata de una pieza importante desde varios puntos de vista ya que, por una parte, supone un buen modelo para indagar sobre la fortuna que dichas piezas tuvieron después de la caída del Imperio, pues dada su facilidad para el transporte y funcionalidad, acabarían por llegar a centros menos romanizados que las grandes urbes antiguas. Por otra parte, en el caso concreto de la pieza romana conservada en Palencia, los rostros de las figuras se han emparentado, por su factura, con el peinado de tirabuzones, muy característico, que presentan algunas imágenes de Gorgona Medusa ${ }^{1708}$.

Además, tal iconografía vuelve a poner de relieve la ductilidad del motivo de los rostros o máscaras que, fácilmente, podían adaptarse a todo tipo de producciones. En este sentido, su utilización desde el mundo romano para decorar diversos objetos muebles y escultóricos está sobradamente documentada, tal y como se observa en el Hermes del Museo Arqueológico de Portugal ${ }^{1709}$ (fig. 315).

Desde el motivo "inventando" por el escultor del capitel de la Orestíada de San Martín de Frómista, la imagen se difundiría a un gran número de centros, donde los escultores reproducían, de manera mecánica, el motivo, lejos de ser conscientes de su posible origen clásico. Los talleres de Jaca y San Isidoro de León, lo utilizarían en

\footnotetext{
${ }^{1707}$ Paris, Bibliothèque nationale de France, Evangéliaire de Otón III, Clm 4453, fol. 24 r.

${ }^{1708}$ Sobre la imagen de Gorgona Medusa hablaremos más adelante. Parece que dentro de los focos escultóricos hispanos de finales del siglo XI y principios del XII, es factible la posibilidad de que se conociese el modelo de la iconografía de Gorgona, sobre todo, teniendo en cuenta algunos rasgos que presentan diversas figuras. Sobre el balsamario de bronce, véase: M. DEL AMO Y DE LAHERA y F. J. PÉREZ RODRÍGUEZ, Op. cit., en concreto, p. 86.

${ }^{1709}$ Belém, Museu Arqueologico Nacional. Cf.: J. L. DE MATOS, "Hermes", Inventário do Museu..., ficha catalográfica 25, pp. 62-63. Procede de Quintana do Muro, en Faro. Se trata de dos cabezas unidas. Por un lado, la de un hombre barbado y, por el otro, una mujer joven. Formaban parte de una columna dedicada al dios, pues su efigie delimitaba los límites de caminos y encrucijadas, protegiendo a los pastores. Más tarde, se introducen en los jardines representando a Dionisos, relacionándose con los cultos a la naturaleza. El autor identifica la escultura cómo un Hermes báquico o dionisiaco, datado entre el siglo IV y I. a. d. C.
} 
algunas de sus composiciones, sin embargo, aquí ya no cabe hablar de una herencia directa de la Antigüedad romana sino de un lejano recuerdo que se disolvía en esta larga cadena de motivos estereotipados reproducidos inercialmente ${ }^{1710}$.

Finalizamos este apartado con una escultura conservada en el Museo Nacional de Arte Romano de Roma. Se trata de una figura de rasgos negroides que, en su día, pudo haber formado parte de un conjunto acuático quizás, para permitir la salida de un hilo de agua por su boca (fig. 316). La postura con la que fue ideada recuerda, en algunos aspectos, a las representaciones de danzantes y saltimbanquis que hallaremos tanto en el arte antiguo como en el medieval. En la misma línea, los rasgos esenciales del rostro, la manera con la que fueron trabajados los rasgos físicos y sus cabellos, permiten establecer paralelos dentro del mismo corpus de la escultura antigua. En concreto, con el surtidor de fuente portugués, que ya hemos citado en este estudio (fig. 293).

El mundo medieval tomaría los prototipos desarrollados en toda esta serie de prótomos, bustos, efigies, cabezas de aplique y remates de brocados de caballos, entre otros, para realizar la decoración de los templos cristianos. Así, con los mismos rasgos negroides se presenta, por ejemplo, el busto esculpido sobre una de las ménsulas que forman parte de un fragmento de cornisa conservado en el Museo de los Agustinos de Toulouse y que, supuestamente, formó parte de la decoración de la basílica (fig. 317) ${ }^{1711}$.

A la hora de analizar algunas de las esculturas de la catedral de Jaca como, por ejemplo, aquel canecillo de la zona sur del templo, en el que fue representado una suerte de saltimbanqui de rasgos negroides en una postura contorsionista, resulta complicado no recurrir a estos prototipos antiguos a la hora de establecer paralelismos (fig. 318).

La longevidad y cotidianeidad del motivo dentro de los repertorios románicos de este tipo de bustos y prótomos, queda manifestada por su utilización en alguno de los cimacios del templo (fig. 319) y su transmisión a otros talleres como, por ejemplo, en los posteriores trabajos en San Isidoro de León. La repetición del motivo habla de un uso inercial del tema antiguo, sin que, por el momento, se pueda explicar, a través de

\footnotetext{
${ }^{1710}$ En el caso concreto de Jaca, véase el capitel número 48. Cf.: M. DURLIAT, La sculpture romane de la route..., en concreto, p. 233. En el caso de San Isidoro de León, el capitel al que nos referimos se encuentra descontextualizado y, actualmente, reaprovechado como pie del altar norte de la basílica.

${ }^{1711}$ Toulouse, Musée des Augustins. Cf.: D. CAZES, "Toulouse, Musée des Augustins, acquisition d'un morceau de la corniche romane provenant de la basilique de Saint Sernin", Bulletin Monumental, 143, 1985, pp. 152-153. El autor insiste en las fuentes clásicas de esta pieza.
} 
una pieza antigua concreta, susceptible de ser copiada literalmente por estos artífices románicos (fig. 320) ${ }^{1712}$.

${ }^{1712}$ Por ejemplo, se puede observar la efigie de una figura de rasgos negroides en uno de los canecillos empotrados en la panda sur del claustro de la Real Colegiata de San Isidoro de León, hoy descontextualizado de su lugar original. 


\section{LA CONCEPCIÓN DEL CUERPO. EL USO DEL DESNUDO Y LOS TEXTILES EN LA ESCULTURA} JAQUESA.

Anteriormente, ya se ha hecho alusión a la obra de K. Clark sobre el desnudo y las escultura en época clásica y medieval, determinando que, algunas de las afirmaciones del autor, no tenían muy en cuenta algunos resurgimientos de las fórmulas de tradición antigua dentro de la Edad Media ${ }^{1713}$. La idea de que la captación del cuerpo y la atención que los escultores mostraban a la hora de representarlo era mínima, se ha convertido en un tópico sin fundamentos, debido a la manera con que la historiografía ha abordado el tema. Es cierto que, mayoritariamente, los escultores románicos prestaron una mayor atención a otra serie de intereses que a la reflexión sobre el cuerpo humano. Sin embargo, creemos que, dentro de la enorme variedad de escultores, talleres y movimientos estilísticos surgidos dentro de la escultura románica europea y la hispana, en particular, se debe atender a un conjunto de obras en las que parece que el cuerpo recobró la importancia que había tenido durante los siglos de la Antigüedad, donde los escultores lo concebían como objeto de belleza y de veneración, una excusa para captar la naturaleza y reflexionar sobre la capacidad de los hombres para emularla e imitarla ${ }^{1714}$.

Cuando el escultor del capitel de Jaca en el que se representa el sacrificio de Isaac decidió mostrar la figura del joven, completamente desnudo, seguramente tenía en mente la larga nómina de piezas medievales en las que Isaac, casi de manera canónica, se mostraba despojado de toda vestimenta (fig. 321). Sin embargo, parece igualmente factible poder pensar y, al menos parte de la historiografía especializada tiene una opinión unánime sobre esta cuestión, que la imagen desnuda del joven podría tener una serie de antecedentes lejanos dentro de la mejor escultura clásica de época romana.

Al observar este ejemplo, así como el ya comentado de las figuras danzantes al son de los dos tocadores de aulos, pensamos que no se puede mantener lo afirmado en su día por K. Clark:

\footnotetext{
${ }^{1713}$ K. CLARK, Op. cit., en particular, pp. 297-298. Sobre el problema del desnudo en el arte medieval, véanse las Actas del 25 Coloquio del CUERMA tituladas: Le Nu et le Vêtu au Moyen Age (XII - XIII ${ }^{e}$ siècles), Aix-en-Provence, 2001. En particular, consúltese: M-G. GROSSEL, "Suivre nu le Christ nu. L'idéal du dépouillement dans la Vie des Pères, traduction en prose offerte à Blanche de Champagne (ms. Lyon BM 0868)", Le Nu..., pp. 165-178.

${ }^{1714}$ N. ELIAS y E. DUNNING, Deporte y ocio en el proceso de la civilización, México 1992, pp. 3-40.
} 
"En los primeros siglos del cristianismo se había combinado múltiples causas para enterrar el desnudo (...) viendo en ellas una trasgresión del segundo mandamiento los ídolos paganos eran especialmente peligrosos porque (...) no sólo eran simples esculturas profanas, sino morada de los demonios que astutamente habían asumido figuras y nombres de seres humanos hermosos. El hecho de que estos dioses y diosas estuviesen desnudos en su mayoría confirió a la desnudez una asociación diabólica que se conservaría durante mucho tiempo" ${ }^{\text {1715. }}$.

Las afirmaciones del autor son acertadas pero, en cualquier caso, también demasiado simplificadas. Hemos visto cómo los hombres medievales profesaron un sentimiento contradictorio hacia la desnudez que mostraban algunas figuras del arte clásico. Recuérdese el caso del monje Bernardo y su viaje a Roma, donde tuvo la oportunidad de contemplar una de las esculturas de Venus y, posteriormente, legarnos sus reflexiones en torno a la obra.

Los individuos medievales fueron capaces de valorar la pericia y la calidad técnica de los escultores antiguos a la hora de captar las formas del cuerpo desnudo. No dudaron, tal y como venimos afirmando, en acercarse con ojos de admiración a las representaciones desnudas de los sarcófagos ${ }^{1716}$.

Por otra parte, como decimos, los cristianos presentaron una conducta confusa ante la desnudez. Dentro de los programas iconográficos salvíficos y de tono escatológico, las figuras desnudas aludían al estado de gracia e inocencia del alma de aquellos personajes, simbolizado a través del desnudo. Es la materialización plástica del cuerpo físicamente material, el cuerpo muerto, frente al alma que, abandonado la vida terrena, asciende al cielo ${ }^{1717}$.

Aunque alejado del periodo cronológico que estudiamos, una obra datada en época románica tardía, ejemplifica tales aspectos. Nos referimos al famoso cenotafio de la iglesia abulense de San Vicente, donde se realizaron una serie de relieves con un

\footnotetext{
1715 J. CLARK, Op. cit., p. 297.

${ }^{1716}$ F. DIEZ PLATAS, "Breviario de imágenes paganas: la iconografía de los dioses y el mito en la Galicia romana", Sémata, 14, 2002, pp. 207-251. La autora llama la atención sobre la importancia de la iconografía de las ninfas representadas, de una manera habitual, en actitud de danzantes. Las figuras, en ocasiones ataviadas con ricas telas, serán la base para muchas de las experiencias artísticas que, sobre el desnudo, se llevarán a cabo en etapas posteriores.

${ }^{1717}$ Se hacen algunas reflexiones sobre esta iconografía, en relación con el alma representada en el sarcófago de doña Blanca de Nájera, en: E. VALDÉZ DEL ÁLAMO, "Lament for a Lost Queen: The sarcophagus of Doña Blanca in Nájera", The Art Bulletin, 78, 2, 1996, pp. 311-333, en concreto, pp. 321322.
} 
tratamiento del desnudo muy interesante ${ }^{1718}$. Tal y como se ha estudiado, la obra conforma un monumento funerario levantado a finales del siglo XII para conmemorar y recordar el suplicio de los mártires San Vicente, Sabina y Cristera. Para generar tal ciclo parece que los escultores se inspiraron en la Passio de los santos, siguiendo un texto del siglo VIII ${ }^{1719}$. Sin duda, en conjunto, se trata de una de las escenas de martirio más interesantes del románico hispano tardío, donde el gesto y las aptitudes gestuales de los personajes quedan captados con total realismo.

Lo más interesante, en relación con el tema que nos ocupa, aparece relacionado con la factura y la forma con que ha sido representado el desnudo de las figuras martirizadas, despojadas de sus ropas, tal y como es habitual en este tipo de ciclos (fig. 322). En concreto, éstas reflejan un alarde técnico sin precedentes dentro de este tipo de representaciones que llevaron a Goldschmidt a afirmar, en su clásico estudio sobre la escultura del monumento:

"el esfuerzo de plasmar los movimientos de los miembros con cierta exactitud anatómica, no hubiera sido posible sin el conocimiento de modelos clásicos" ${ }^{, 1720}$.

Resulta interesante destacar la actitud gestual que poseen las figuras desnudas de los mártires a la hora de afrontar el tránsito vital del castigo y su posterior muerte. A pesar de recibir el trato más vejatorio al que, según la moral cristiana, podía ser sometido un santo, las figuras emanan una intención gestual llena de honestidad, templanza y fidelidad ante la promesa de redención divina, así como un cierto carácter heroico ante este trance de la desnudez pública y del martirio. El clasicismo del desnudo y el tratamiento gestual de las figuras, así como la manera de exhibir los cuerpos maltrechos, tienen como parangón la actitud gestual que ante la muerte tuvieron algunos personajes representados dentro del arte antiguo. Este es el caso, por ejemplo, de la heroína romana Lucrecia que, con similar desnudez, afrontará el tránsito mortuorio, concebido casi de manera heroica. No en vano, durante toda la Edad Media, la escena

\footnotetext{
${ }^{1718}$ No vamos a estudiar ahora la pieza con la profundidad que se merece, pues sólo nos detendremos en comentar algunos aspectos relacionados con el desnudo de ciertas figuras. Cf.: M. GÓMEZ-MORENO, Catálogo Monumental de la Provincia de Ávila..., pp. 145-146; W. GOLDSCHMIDT, "El sepulcro de San Vicente de Ávila...”, pp. 161-170; D. RICO CAMPS, El románico de San Vicente..., en especial, pp. 291-336 y S. SILVA Y VERÁSTEGUI, "Los sepulcros de los santos...”, pp. 199-214, en particular, pp. 204-205. Más recientemente, se abordó el tema, en: G. BOTO VARELA, "La integración...", p. 127.

${ }_{1719}$ Pasionario Hispánico (Introducción, edición, crítica y traducción de P. Priesco Chueca), Sevilla, 1995, pp. 214-225.

${ }^{1720}$ W. GOLDSCHMIDT, “El sepulcro de San Vicente de Ávila...”, p. 163.
} 
de Lucrecia desnuda, justo antes de recibir la daga que pondría fin a su vida, fue considerada como símbolo de la pudicitia, la honestidad inviolable o, lo que es lo mismo, una de las virtudes fundamentales de la mujer del medievo y de los albores del Renacimiento $^{1721}$. La actitud gestual de la desnudez de ambos personajes, tanto el medieval como el antiguo, puede englobarse, nuevamente, dentro del concepto de desnudo nacido en el seno de la sociedad antigua, donde las figuras despojadas de sus ropajes para ser conducidas a la muerte adquirían ciertas connotaciones heroicas. Los restos humanos del cenotafio de Ávila, decapitados, atados de manos y tirados por el suelo, dan buena prueba de estas vejaciones a las que hubieron de ser sometidos los mártires.

A pesar de ello, son varias las representaciones donde la desnudez de las figuras parece evocar un estado de pureza, pero también de heroicidad ante un tránsito forzado provocado por la defensa de la fe. Recuérdese, en este sentido uno de los capiteles más interesantes de los conservados en la iglesia zamorana de Santa Marta de Tera (fig. 323). Allí, fue figurada la ascensión del alma de la santa al cielo, enmarcada en una mandorla y asistida, siguiendo esquemas compositivos de gran clasicismo, por dos figuras angélicas.

Según palabras de M. Gómez-Moreno, “vense (...) una santa desnuda dentro de aureola y llevada por dos ángeles bien movidos, que será probablemente la santa titular ${ }^{1722}$, lo que permite poder afirmar que, a través del desnudo, se quiso aludir no

\footnotetext{
${ }^{1721}$ Lucrecia se suicidó después de ser violada por el hijo del Rey de Roma, Sextus Tarquinius. El tránsito de la muerte lo sobrellevó desnuda, en actitud digna y heroica. Es significativo como el uso del desnudo, tanto en esta escena del mundo antiguo como luego, en su reinterpretación del tema en el medievo, aparece ligado a la honestidad de un cuerpo indefenso, plasmado a través del desnudo, pero siempre en actitud serena y reflexiva. Sobre el tema de Lucrecia, especialmente dentro de la obra de Durero, véanse: A. SCHERBAUM, "Lucrecia. 1508", Durero. Obras Maestras de la Albertina, Madrid, 2005, ficha catalográfica 59, pp. 240-243 y F. CABROL y H. LECLERCQ, voz "Actes des martyrs", Op. cit., vol. I, Paris, 1907, cols. 373-446, en particular, col. 438. Los autores llaman la atención sobre la desnudez de Santa Perpetua a la hora de recibir el martirio, describiendo la manera de mostrar a la mártir con las siguientes palabras: "honorable manera de presentarla ante el pueblo", a pesar de las connotaciones moralizantes que este acto tenía en los primeros siglos del cristianismo.

${ }^{1722}$ M. GÓMEZ-MORENO, Catálogo Monumental de España. Provincia de Zamora, Zamora, 1927, pp. 182-185. Se abordó recientemente el tema en: C. COSMEN ALONSO, "Arte y liturgia en Santa Marta de Tera", Astórica, 25, 27, 2008, pp. 139-171. La especialista apoya la idea de que, posiblemente, se trate de Santa Marta ascendiendo al cielo en forma de ánima. La autora, además, utiliza textos de clara tradición clásica para poder someter la escultura a un análisis iconográfico. En concreto, recoge las fuentes escritas del Sermonario del Pseudo-Fulgencio, del siglo V ó VI. Desde un punto de vista estilístico, muchos autores han tendido a hacer depender la escultura de la iglesia de los talleres derivados de San Isidoro de León, además de otros, como los de la catedral de Santiago de Compostela o la misma basílica de SaintSaturnin de Toulouse. En este punto queremos mostrar nuestro agradecimiento a la Dra. Cosmen Alonso por la gentileza y atenciones prestadas durante la realización de este estudio.
} 
sólo al estado inmaterial y de ascensión del alma pura tras el martirio, sino a la dignidad de su muerte, donde las vejaciones y penurias del cuerpo ultrajado tras el martirio, eran superadas por la inmaterialidad del cuerpo bello y desnudo. La santa se mostraría victoriosa tras su degollamiento y su paso por la inmundicia donde fue arrojada tras la pasión a la que fue sometida por mandato del cónsul Paterno, en época del emperador Decio $^{1723}$.

No podemos asegurarlo, pues nos movemos en el campo de las meras hipótesis. Sin embargo, la manera de proyectar en el frente del capitel un cuerpo que muestra tan abiertamente la desnudez, puede equipararse al valor que éste tuvo dentro de la estatuaria clásica, en concreto, en relación con la iconografía de las Venus, de las que el arte hispanorromano nos ha legado varios ejemplos de alta calidad ${ }^{1724}$.

No debemos obviar que, el origen último de la iconografía del eidolon representante del alma cristiana, tiene su origen en las representaciones romanas y del arte paleocristiano, difundidas en todas sus variantes $\mathrm{y}$, de una manera frecuente, en algunos ejemplos de la escultura funeraria hispana ${ }^{1725}$. La presencia de estos personajes desnudos dentro de piezas mortuorias posee una importancia clara, tal y como se observa, por ejemplo, en el sarcófago portugués de Egas Moniz ${ }^{1726}$ (fig. 324).

Sobre el edificio zamorano, véase también: J. M. RODRÍGUEZ MONTAÑES, "Santa Marta de Tera", Enciclopedia del románico de Castilla y León. Zamora, Aguilar de Campoo, 2002, pp. 135-148, concretamente, p. 147.

${ }^{1723}$ C. COSMEN ALONSO, "Arte y Liturgia...", pp. 139-171 y J. M. RODRÍGUEZ MONTAÑÉS, "Santa Marta...", p. 144. El último autor alude a la representación de los estigmas que la santa presenta en los pies y los que, a través del visionado de la pieza y de las fotografías, no son visibles.

${ }^{1724}$ Por ejemplo, la bella Venus de Itálica, hoy en el Museo Arqueológico de Sevilla o la hallada en Ampurias y custodiada en el Museo Arqueológico de Barcelona. Cf.: J. M. BLAZQUEZ, "El comercio de obras de arte...", pp. 256-257.

${ }^{1725} \mathrm{~F}$. DÍEZ DE VELASCO, Los caminos de la muerte. Religión, rito e imágenes del paso al más allá en la Grecia antigua, Valladolid, 1995, p. 35 y pp. 73-76. Se trata del concepto con el que los antiguos griegos designaban al fantasma, es decir, a la sombra. El concepto aparece ya utilizado en los poemas homéricos, usado para designar, igualmente, a una efigie o cualquier elemento que pudiera ser entendido como un simulacro de la figura real del hombre. El eidolon, podía aparecer en forma de ave durante los primeros momentos para, con el tiempo, pasar a ser representado de forma antropomorfa, incluso emulando los rasgos físicos que la persona poseía en vida.

También se han dedicado excelentes reflexiones sobre el tema, siempre en relación con la escultura medieval, en: R. SÁNCHEZ AMEIJEIRAS, “¿Portada o relieve funerario? Una propuesta acerca de un tímpano leonés", Arte d'Occidente. Temi e metodi. Studi in onore di Angiola Maria Romanini, vol. I, Roma, 1999, pp. 519-535, en concreto, p. 522. La autora alude a una escultura de María conservada en la catedral de León y perteneciente a los pocos restos conservados de la fábrica románica tardía. La figura porta en las manos un alma niña, que habla, nuevamente, del papel psicopompo que adquiere aquí la figura. Véase también: E. VALDÉZ DEL ÁLAMO, "Lament for a lost...", p. 322.

${ }^{1726}$ La pieza se conserva en el Monasterio de Paço de Sousa y daría enterramiento a este personaje muerto en 1146. A pesar de ello, todo parece indicar que se trata de una obra fruto de una renovación del templo y de su escultura, datada por algunos autores ya en el siglo XIII. Cf.: C. A. FERREIRA DE ALMEIDA, "Escultura e iconografia...", pp. 160-162. 
A la presencia de la figura del difunto desnuda, elevada por dos ángeles mediante una especie de almendra mística debe sumarse la factura arcaizante de la pieza que acaba por dotar a la escultura un cierto resabio "antiquizante" aunque, ciertamente, ello tan sólo se deba a la incapacidad de unos escultores rústicos y no a la perduración de modelos antiguos propiamente ${ }^{1727}$.

La presencia del alma desnuda en esta pieza de Santa Marta de Tera vuelve a poner de relieve el aprecio que estos escultores de las etapas tardías del medievo tenían por las composiciones clásicas en las que, dos seres alados, sujetaban un clípeo o un elemento similar para materializar la ascensión. Todos estos aspectos han provocado que, piezas de cronología muy tardía, pero realizadas con medios, técnicas y destrezas muy escasas, hayan sido datadas en periodos muy tempranos que, quizás, no les correspondan. Los motivos clásicos de este tipo fueron una constante desde la Antigüedad tardía. De esta manera, su absorción por los artistas medievales, vuelve a poner de manifiesto la problemática de discernir si el pretendido sustrato clásico de estas esculturas fue obtenido por el contacto directo con piezas antiguas o, por el contrario, forman parte de un continuismo residual ${ }^{1728}$.

Es evidente que, en esta breve aportación a la problemática del desnudo, no pretendemos equiparar la atención que le prestaron los artistas antiguos con respecto a la mostrada por los medievales. Sin embargo, en algunos de los ejemplos aludidos, parece que el desnudo se presentó como un fenómeno estético vinculado, casi siempre, a la figura de los héroes o personajes míticos de la Antigüedad y su uso puede presentar lecturas ligadas con la idea de exaltar el comportamiento heroico que mostrarán, posteriormente, los mártires. Se trata de una conversión ideológica y teórica donde, los

\footnotetext{
${ }^{1727}$ A. DE LACERDA, História da Arte em Portugal, vol. I, Porto, 1942, pp. 320-323. Por otra parte, algunos autores señalaron, ya hace años, las pervivencias de algunos aspectos de la tradición visigoda dentro de la escultura del templo donde se conserva tal sepulcro, por lo que, el enriquecimiento de las fuentes que hubieron de manejar los artífices de la pieza también se pudo enriquecer con otros elementos hoy perdidos. Vid.: C. A. FERREIRA DE ALMEIDA, Arquitectura românica de entre-Douro-e-Minho, 2 vols., Porto, 1978, vol. II, pp. 163-167 y pp. 243-246.

${ }^{1728}$ Recientemente, se ha señalado que el sistema compositivo del famoso sarcófago de Dumio presenta una forma plenamente clásica, a pesar de su cronología tardía con respecto a los siglos de la Antigüedad. Ello mismo podría aplicarse a otra serie de piezas de tono "antiquizante" como, por ejemplo, los relieves de Cristo y la Virgen de la iglesia de Quintanilla de las Viñas, donde se repite el esquema de figuras elevadas o enmarcadas por ángeles, inmersas en la tradición romana pero, quizás, de manera residual. Cf.: E. FERNÁNDEZ GONZÁLEZ, "Hacia la renovación escultórica...", pp. 17-20. A pesar de ello, en algunas ocasiones y dentro de la iconografía funeraria, el tópico clásico del alma desnuda fue completamente obviado. Ello se constata al observar la iconografía de la lauda sepulcral de Alfonso Ansúrez del monasterio de San Benito de Sahagún. Recientemente, se ha vuelto a insistir en lo extraño de que "el párvulo aparezca vestido, en contraposición a la desnudez de los eidiloi, almas asexuadas ascendidas al cielo por ángeles", tal y como escribió el profesor Boto. Cf.: G. BOTO VARELA, "La integración...", p. 124.
} 
mecanismos ensalzadores de esas figuras míticas clásicas, servían ahora, para dignificar a los fieles muertos por Cristo.

Regresando al tema derivado de la representación esculpida del cuerpo desnudo de Isaac del capitel jacetano, parece que, su fisonomía y apariencia, recogen las enseñanzas anatómicas de la estatuaria clásica. En concreto, parece revivir algunos elementos del Orestes del sarcófago romano de Husillos, donde éste se presentaba mostrando la clásica posee de la "diagonal" heroica.

Los músculos, en el caso de las figuras desnudas del conjunto jacetano, se muestran tersos, marcados y bien modelados, mientras que, las actitudes son vivas y enérgicas, tal y como señaló la profesora D. Ocón Alonso en su estudio sobre la perduración de los modelos clásicos en el arte románico hispano ${ }^{1729}$.

Se advierte, en este tipo de producciones medievales, cierto gusto por la utilización de este recurso que, utilizado de manera mecánica, otorgaba a las figuras un aire clásico e inspirado en una serie de modelos de prestigio. Desde desnudez insinuada a través de las clámides en movimiento dentro del capitel de los danzantes, a la figura desvestida de Isaac, persiste aquí un primitivo estudio anatómico de las figuras y una intención de captar el desnudo atlético ${ }^{1730}$.

En este sentido, de la misma manera que la belleza de Afrodita suscitó incertidumbre en algunos de los espectadores medievales, otros ejemplos estatuarios de la misma tipología pudieron servir de modelos a la hora de concebir algunas de las figuras esculpidas en Jaca.

"En general, las figuras sin ropa de principios de la Edad Media están vergonzosamente desnudas, y soportan humillaciones, martirios y torturas. Sobre todo, fue así como el hombre sufrió su principal infortunio, la Expulsión del Paraíso; y ese fue el momento de la historia cristiana en el que tuvo conciencia de su cuerpo: Se dieron cuenta de que estaban desnudos. Mientras el desnudo griego había empezado exhibiendo orgullosamente el cuerpo heroico en la palestra, el desnudo cristiano empieza cubriéndose el cuerpo con conciencia de pecado" ${ }^{\text {1731. }}$.

\footnotetext{
${ }^{1729}$ D. OCÓN ALONSO, "Los modelos clásicos de la escultura monumental española: de fines del siglo XI a fines del siglo XII", Actas del X Congreso del CEHA, Los Clasicismos del Arte Español, Madrid, 1994, pp. 67-73. La autora ha señalado estas características de la escultura de los focos de Frómista y Jaca como un rasgo antiguo que habría de influir en la realizada durante la segunda mitad del siglo XII.

${ }^{1730}$ G. BECATTI, voz "Nudo", Enciclopedia italiana dell'arte antica ..., vol. V, Roma, 1963, pp. 576581, en particular, p. 579.

${ }^{1731}$ K. CLARK, Op. cit., p. 299.
} 
No creemos necesario volver a insistir en lo convencional de tales afirmaciones. En su estudio sobre el desnudo en el arte clásico, tanto griego como romano, G. Becatti señalaba cómo también durante las épocas etrusca y romana el desnudo presentó, en ciertas ocasiones, vinculaciones con la corrupción desde el punto de vista moral, flagiti principium, tal y como lo define el autor ${ }^{1732}$.

Igual que en la misma Antigüedad, durante la Edad Media el desnudo podía tener, dependiendo del contexto en el que se encontrase, connotaciones diversas. En relación con estas ideas, puede resultar estereotipado hablar de categorías similares al analizar el desnudo medieval, ya que, es evidente que no hubo el mismo interés por el cuerpo dentro de la escultura hispana de los siglos VI al X que, por ejemplo, y por citar el caso más clarificador, en las figuras desnudas de las portadas de la catedral gótica de Bourges (fig. 325).

A pesar de que ambos movimientos artísticos se han englobado dentro de un mismo periodo, el de los siglos medievales, la manera en que los artistas románicos y góticos abordaron la representación de los cuerpos desnudos presentó diferencias abismales. Por ejemplo, baste con citar el estudio del cuerpo desnudo que encontramos en la escultura de la citada catedral gótica. Así, dentro del ciclo dedicado al Juicio Final, las figuras desnudas se presentan bellas, naturales y vinculadas, de manera indisoluble, al arte clásico, hasta el punto de que la profesora N. Dacos ha hablado del uso de "posturas policletanas"1733.

Los modelos desnudos exhibidos durante la Antigüedad a través de las figuras de Hermes, Ares, Zeus, Afrodita o de Omphale, configurarían un corpus completado con las imágenes plásticas de todos aquellos deportistas y atletas que la imaginería ubicó en todo tipo de escenas de competición física y palestra.

1732 G. BECATTI, "Nudo...", p. 581.

${ }^{1733}$ N. DACOS, "Sopravvivenza...", pp. 731-732. La investigadora destaca el valor clásico de la escultura románica hispana, deudor, según señala, de algunos relieves romanos. Aunque no especifica cuales. Cita, en el mismo sentido, la escultura gótica de la catedral de León. En relación con el arte gótico apunta un regreso a la plasticidad en la representación del cuerpo humano.

Véase también: W. SAUERLÄNDER, "La escultura de la sede leonesa a la luz de los grandes talleres europeos", La Catedral de León en la Edad Media (J. Joaquín Yarza Luaces, M. V. Herráez Ortega, G. Boto Varela coords.), León, 2004, pp. 177-202; S. SEBASTIÁN, Mensaje simbólico..., p. 236 y K. CLARK, Op. cit., pp. 302-303. Sobre estas cuestiones, consúltese igualmente: M. L. TESTI CRISTIANI, "Magistra latinitas. La coscienza storica del mondo antico nelle opere di Nicola Pisano", Medioevo: $i$ modelli..., Parma, 2002, pp. 396-380, en concreto, p. 377. Resulta interesante lo concreto de los modelos utilizados por el artista italiano, si seguimos lo planteado por la autora. Parece que su escultura presenta claras dependencias con modelos de sarcófagos neoáticos, paleocristianos y de tipo alejandrino, además de referentes etruscos y bizantinos. En otra catedral gótica francesa, la de Reims, se ha localizado también la actividad del llamado "maestro de las figuras antiguas". Se caracteriza por el uso de cánones y pliegues de tipo romano. Su obra más famosa es el grupo de la Visitación, fechado en torno al año 1230 y que se ha relacionado con la Venus de los Médicis, tal y como veremos. 
A pesar de que el profesor Moralejo hizo derivar la figura de Isaac del capitel de Jaca, directamente, de la escultura de Husillos, actualmente, se tiende a buscar otros parentescos con obras tomadas del arte romano provincial. En concreto, J. Lacoste ha señalado una pieza custodiada en el Museo Arqueológico de Saintes (fig. 326), como una de las posibles vías de investigación para poder completar el conocimiento que, sobre los modelos romanos, pudieron tener los escultores de Jaca ${ }^{1734}$.

La figura de Isaac presenta una musculatura bien marcada. Las piernas formadas y en tensión, con gemelos muy definidos, le hacen poder emparentarse, lejanamente, con las figuras atléticas clásicas, en concreto, la del Diadoumenos. El interés que el arte clásico mostró hacia este tipo de temas, donde los atletas se presentaban en plena acción deportiva, exhibiendo libremente sus cuerpos, es bien conocido.

En el caso del Isaac de Jaca, la figura presenta cierta seguridad a la hora de representar el cuerpo, con una pierna extendida y la otra flexionada. Tan sólo la rotundidad de la masa muscular asegura la estabilidad de la pose, tal y como ocurre dentro de la representación del Diadoumenos de un ara del Museo Vaticano de Roma $^{1735}$. Dicho relieve, lejos de suponer un modelo directo con el que comparar la escultura románica, ofrece paralelismos lejanos con los que poder establecer estas relaciones ${ }^{1736}$ (fig. 327).

Debemos, según la comparación defendida por J. Lacoste, ser cautos en las afirmaciones. Todo parece indicar que la figura de Isaac del capitel románico tiene como fuente de inspiración última la imagen de Orestes del sarcófago palentino. Sin embargo, dicha pieza no puede explicar, ella sola, otra serie de esculturas que, de una manera más o menos evidente, se muestran derivadas de este prototipo.

Las figuras desnudas que hallamos dentro de los edificios que venimos citando se encuentran cercanas a diversos tópicos convencionalistas sobre la representación del cuerpo. Sin embargo, en ellas pervive cierto gusto "antiquizante".

\footnotetext{
${ }^{1734}$ Saintes, Musée Archéologique. Cf.: J. LACOSTE, Les maîtres..., p. 33. Desde otro orden de cosas, la ciudad de Saintes es, sin duda, una de las más importantes a la hora de buscar referentes artísticos que pudieran haber pasado al arte medieval, pues se trata de una zona extremadamente romanizada y con un conjunto de piezas conservadas y reutilizadas desde la época romana muy basto. Vid.: D. TARDY y F. SCHACH, Le décor architectonique de Saintes Antique. Les chapiteaux et bases, Paris, 1989, pp. 42-82. En dicho estudio se recogen algunos capiteles romanos comparados, frecuentemente, con los de otros centros medievales como, por ejemplo, los de la basílica de Saint-Saturnin de Toulouse.

${ }^{1735}$ Città del Vaticano, Musei Vaticani.

${ }^{1736}$ E. HOMANN-WEDEKING, "Diadumenos", Enciclopedia italiana dell'arte..., vol. III, Roma, 1960, pp. 89-90 y L. GUERRINI, "Diadoumenos", Ibidem, p. 89. Este último autor analiza la figura de este escultor de origen griego que se ha datado en torno a los siglos I y II d. de C. Se estudia, además, la escultura de los Museos Vaticanos, donde aparece, en forma genitiva, una inscripción con este nombre. En el relieve se figuró un diadoùmenos, claramente, derivado de las esculturas de Polícleto.
} 
El problema fundamental suele residir, normalmente, a la hora de buscar los referentes antiguos que, de manera hipotética, pudieron seguir los escultores medievales.

En relación con ello, citamos un importante sarcófago cercano, en cuanto a su conservación, al foco escultórico de la iglesia de San Isidoro de León. Aquí, tal y como veremos más adelante, parece que se encuentran las fuentes para algunos de los detalles presentes en las esculturas realizadas en Santa Marta de Tera, tan íntimamente ligada a la de la sede legionense.

Nos referimos al denominado como sarcófago de San Justo de la Vega y custodiado en la catedral de Astorga hasta su trasladado a Madrid ${ }^{1737}$.

La manera en que fue concebido el cuerpo de Eva dentro de la pieza funeraria, ciertamente mórbido y con unos senos apenas insinuados (fig. 328), recuerda el tratamiento que, durante la época románica, se le va a dar al cuerpo de algunas figuras (fig. 253 $)^{1738}$. Más allá de poder establecer una relación entre la obra paleocristiana y las representaciones desnudas localizadas en las iglesias leonesas de San Isidoro y Santa María del Mercado, así como en la zamorana de Santa Marta de Tera, proponemos hablar de una tradición común, de raíces antiguas, dentro de la representación iconográfica del ascenso del alma desnuda.

Del mismo modo, cabe destacara otra pieza de singular importancia en relación con el contexto escultórico de la catedral de Jaca. Se trata del conocido sarcófago de doña Sancha, procedente del monasterio de Santa Cruz de la Serós. En la parte frontal de la pieza, fue representada la ascensión de un alma al cielo. En el ascenso, realizado a través de una mandorla impulsada por ángeles, fue esculpido un eidolon en forma de personaje desnudo $^{1739}$ (fig. 329).

En este sentido, resulta complejo poder afirmar con seguridad que la figura de la mandorla sea, en realidad, una representación individualizada de la difunta en el momento del tránsito. Según pensamos, por el contrario se trataría de una iconografía totalmente estereotipada que podría seguir modelos ya establecidos y convencionales.

\footnotetext{
${ }_{1737}^{1738}$ Madrid, Museo Arqueológico Nacional.

${ }^{1738}$ Por ejemplo, se perciben algunos puntos en común entre esta escultura de San Justo de la Vega y la manera en que se concibió el cuerpo del danzante femenino del capitel jacetano.

${ }_{1739}$ Jaca, Convento de las Benedictinas. Cf.: D. L. SIMON, "Le sarcophage de Doña Sancha à Jaca", Les Cahiers de Saint-Michel de Cuxa, 10, 1979, pp. 107-124, en especial, p. 116; ID., "Sarcophagus of Doña Sancha”, The Art of Medieval Spain a. d. 500-1200, New York, 1993, ficha catalográfica 105, pp. 229232; J. MARTÍNEZ DE AGUIRRE, "La memoria de la piedra...", pp. 133-159 y X. DECTOT, Pierres tumbales..., pp. 32-35. Este último autor citado engloba la pieza hispana dentro de una lista de sepulcros que presentan diversas relaciones con lo antiguo.
} 
Sin embargo, la desnudez de la figura, con el tratamiento un tanto inexperto de la anatomía, parece heredar ciertas corrientes plásticas más antiguas, quizás, de índole paleocristiana, donde esta peculiaridad no fue ajena ${ }^{1740}$.

Tal y como enunciábamos en el inicio de este apartado, además de la cuestión del desnudo dentro de algunas esculturas de la catedral de Jaca y, por extensión, en otras localizadas en diversos conjuntos románicos hispanos, se reflexionará sobre otro tema importante para estas cuestiones.

En este contexto se nos presentan las asuntos relativos al tratamiento textil, tanto en las vestimentas como en otros elementos, que van a realizar estos escultores.

En la mayor parte de los capiteles conservados en la catedral, a pesar de mostrar, en algunos momentos, figuras completamente desvestidas, se percibe, de la misma manera, un interés absoluto por la reflexión entorno al cuerpo humano, el desnudo y, sobre todo, sobre su percepción a través de los elementos textiles.

Según pensamos, el tratamiento de las telas que mostrarán las figuras en sus vestimentas es un tema íntimamente derivado de las reflexiones resultantes de la manera de concebir el desnudo, ya que, en ocasiones, algunas partes del cuerpo de las figuras esculpidas serán insinuadas a través de ellos.

De manera tradicional, los especialistas de este tipo de escultura románica, han señalado como algunas de las soluciones tomadas por estos artífices pudieron haber tenido su modelo directo en determinadas producciones antiguas. Tal y como veremos en los apartados finales de este estudio, tal hipótesis se muestra más factible a la hora de reflexionar sobre determinadas esculturas de cronología más tardía y cercanas al año $1200^{1741}$.

\footnotetext{
${ }^{1740}$ El carácter "antiquizante" de la pieza llevó, en su día, a García Romo a insinuar una dependencia de este sepulcro con respecto a determinados talleres románicos en los que la influencia de la Antigüedad se había señalado de manera reiterada. Nos referimos, concretamente, a las conexiones que establecía entre la obra de Wiligelmo de Módena, activo en la catedral de dicha ciudad y la pieza del Monasterio de las Benedictinas de Jaca. El autor se valía de las alusiones al "arcaísmo helénico o griego" que algunos investigadores habían utilizado para poder explicar la escultura del foco jacetano y justificar así la dependencia con respecto a Módena. Cf.: F. GARCÍA ROMO, "Nota sobre los posibles contactos...", pp. 23-24.

Actualmente se tiende a minimizar dichas relaciones, argumentando que se trata, más bien, de ciertas concomitancias normales entre artistas de un mismo periodo cronológico y que utilizan medios mecánicos igualmente rústicos. Cf.: X. BARRAL I ALTET y N. DALMASES, Op. cit., p. 45 y F. REBECCHI, "Il reimpiego di materiale antico nel Duomo di Modena", Lanfranco e Wiligelmo. Il duomo di Modena, Milano, 1984, pp. 319-353. Estas teorías insisten en las relaciones entre la escultura de la seo y el sepulcro, además de atribuir al "maestro de Jaca" la serie de capiteles del pórtico sur en los que se narra la vida de San Sixto.

${ }^{1741}$ R. JULLIAN, “L'art de la draperie dans la sculpture romane...”, pp. 241-258.
} 
Los escultores, siguiendo modelos clásicos, parecen conocer y manejar la técnica que les permite captar el movimiento y la textura de los textiles. Los cuerpos muestran de manera parcial la desnudez, cubriendo otras partes con capas, clámides o piezas de indumentaria que recuerdan, lejanamente, a los paludamenta. Se trata de lienzos abundantes, que adquieren movimientos barrocos o que se deslizan por los brazos y piernas creando efectos plásticos de gran interés. Por lo tanto, el juego dual entre las partes desnudas y cubiertas por estos paños se convierte en un recurso muy socorrido.

Anteriormente, a propósito del capitel de los danzantes, se ha aludido al especial dominio que mostró el escultor en relación con el tratamiento de los textiles que aparecen en la imagen. Tanto la base de la escena, como las propias figuras, se envuelven en una serie de telas, quizás mojadas, que fluctúan en forma de onda.

En su obra clásica sobre la influencia de la Antigüedad en la Edad Media occidental, J. Adhémar aludía a un fenómeno interesante en relación con las telas de resabios clasicistas utilizadas por los escultores jacetanos. Según el mencionado autor, parece que fue una conducta habitual durante el siglo XII, que los artistas, a la hora de representar la imagen o figura de algún personaje clásico, mudasen y transformasen algunas de las piezas textiles con las que se solían representar las imágenes antiguas.

El fenómeno se definió como “evermerización” o, lo que es lo mismo, la pérdida de los ropajes antiguos sustituidos ahora por otros medievales. De esta manera se conseguía que los mitos y leyendas, así como aquellas iconografías legadas por la Antigüedad a los siglos posteriores, sufriesen un "revestimiento", de tal manera que sus indecorosos ropajes, fueran "moralizados" a través de la colocación de indumentarias más acordes con las modas medievales ${ }^{1742}$.

En el caso de las esculturas de la catedral de Jaca, si bien se observa una perfecta adecuación a la tradición medieval de vestir a las figuras, es igualmente verídico que otras muestran determinadas piezas textiles alejadas de tal costumbre, conservado, en parte, todo el esplendor del tratamiento clásico de las telas. Así, al analizar un capitel en el que algunas figuras desnudas se entremezclan y enredan con elementos vegetales y

\footnotetext{
${ }^{1742}$ J. ADHÉMAR, Influences antiques..., en concreto, p. 232. También se ha reflexionado sobre el término, dentro del contexto de la historiografía española, en: P. DÍEZ DEL CORRAL CORREDOIRA, “Al final del laberinto. Ariadna en los Ovidios ilustrados del siglo XVI”, Sémata, 2002, vol. 14, pp. 277289 , en concreto, p. 284. La autora lo aplica en relación con las fuentes literarias y el desarrollo de la mitología. En concreto, afirma que, a través de la "evermerización", la religión cristiana volvió inofensivos a los dioses paganos.
} 
máscaras felinas vomitando tallos, se deduce que el escultor no se molestó en adaptar las vestimentas de las figuras al pensamiento y la moda medievales ${ }^{1743}$ (fig. 330).

Los personajes aparecen completamente desnudos, con las piernas en forma de aspa, como las del Abraham del exterior del templo. La única pieza textil que portan aparece a la altura del pecho, dejándose caer en forma de cascada hacia abajo, resbalando por el cuerpo. Se trata de un elemento de clara tradición clásica, que recuerda la manera de colocarse las clámides de las figuras antiguas y en las que jugaban un papel fundamental las fíbulas o broches ${ }^{1744}$. Si a ello sumamos que la desnudez de ciertas figuras fue cubierta por la vegetación enmarañada que cubre algunas partes del cuerpo, la pieza, en rasgos generales, proyecta una mayor relación con los modelos clásicos.

El gusto por la materialización pétrea de los textiles clásicos, había quedado patente a través del caso del capitel de Frómista y la copia el sarcófago de Husillos. Allí, un simple cortinaje fue transformado por la mirada del escultor románico en una especie de fluido que vomitaba una máscara. La dificultad para poder discernir cuales de esos elementos son meros textiles y cuales ondas acuáticas es un tema que ya hemos abordado aquí ${ }^{1745}$.

Las modelos para la creación de telas y ropas en la escultura de Jaca atienden, posiblemente, a parámetros romanos. Si durante dicho periodo fue bien conocido el uso del desnudo dentro de la narración de las escenas en las que aparecían dioses y semidioses, así como escenas de ritual y, sobre todo, de sacrificio, parece que en el capitel de Isaac de Jaca se conservó tal actitud ${ }^{1746}$.

La figura de Abraham, rotunda y con ciertas soluciones que recuerdan la escultura en mármol, aparece en la escena íntegramente desnuda ${ }^{1747}$. Tan sólo una pieza

\footnotetext{
${ }^{1743}$ M. DURLIAT, La sculpture romane de la route..., p. 233. Se trata del capitel número 48.

1744 E. FERNÁNDEZ GONZÁLEZ, “Que los reyes vistiesen paños de seda, con oro, e con piedras preciosas. Indumentarias ricas en los reinos de León y Castilla (1180-1300): entre la tradición islámica y el Occidente cristiano", El Legado de Al-Andalus. El arte andalusí en los Reinos de Castilla y León durante la Edad Media, León, 2007, pp. 365-408.

1745 Véase el capítulo titulado "Cortèges marins" recogido en: F. BARETTE y C. METZGER, Op. cit., pp. 152-170. Los autores estudian gran cantidad sarcófagos donde los elementos textiles se entremezclan con los ambientes acuáticos hasta el punto de resultar imposible diferenciarlos.

${ }^{1746}$ E. LUCIE-SMITH, La sexualidad en el arte occidental, Barcelona, 1992, en particular, p. 26.

${ }^{1747}$ Este punto nos presenta ciertas dudas. Abraham aparecer sujetando esta especie de manto que se ciñe sobre su pierna derecha. Sin embargo, al analizarla detenidamente se percibe que el escultor ha realizado un trabajo muy fino y suave sobre otras partes del cuerpo como, por ejemplo, la zona del torso y el cuello. Pudiera parecer que, realmente, posee otra pieza textil muy fina con la que cubre su torso, pero esta ambigüedad responde, nuevamente, a planteamientos "antiquizantes". Los escultores romanos utilizaron frecuentemente esta solución, mediante la cual, las figuras vestían ropajes transparentes, ceñidos al cuerpo, claramente evocadores de la técnica de los paños mojados.
} 
textil recorre su brazo y desciende por una de las piernas hasta el suelo, generando un efecto de gran "barroquismo"1748 (fig. 331). Se podría alegar que muchas de estas soluciones fueron logradas por los escultores románicos a través de una experimentación casual, ya que también es muy posible que, artistas de épocas distintas y con medios técnicos similares, hubieran llegado a soluciones parecidas, sin tener la más mínima relación los unos con los otros.

Una esculturilla de un Sileno realizada en alabastro y conservada en el Museo Arqueológico de Lisboa presenta la imagen de un hombre fornido, erguido, con el cabello y la barba profusamente decorados ${ }^{1749}$ (fig. 332). Lleva un manto sobre sus espaldas, mientras que su expresión conserva ciertos rasgos patéticos ${ }^{1750}$. En líneas generales, pensamos que una pieza ligada a este tipo de repertorios puede ofrecer las vías para el análisis de la figura románica de Jaca.

El mismo fenómeno se percibe en la representación de una efigie femenina identificada por S. Moralejo como la Virgen María (fig. 333). La figura de este capitel, ya estudiado, porta un gran manto. El escultor se detuvo en recrear todos los pliegues que se forman en la tela cuando la figura intenta recoger su indumentaria con una de sus manos. El elemento textil se vuelve aquí más plástico si cabe, llegando a límites de gran complejidad que recuerdan, lejanamente, determinadas producciones realizadas en piezas escultóricas de materiales más fáciles de trabajar que la piedra.

Las palabras de E. Panofsky, en relación con la influencia de la escultura realizada en, por ejemplo, terracota o barro y otras materias más dúctiles, sobre la practicada en la piedra, nos parecen clarificadoras:

\footnotetext{
${ }^{1748}$ La escultura románica, por lo general, fue bastante proclive a utilizar como recurso expresivo el uso de drapeados. Las grandes capas, faldones y mantos permitían crear todo tipo de juegos visuales y de sombras, además, de otorgar monumentalidad a las figuras. Sin embargo, este tipo de composición no fue habitual. Las esculturas se muestran, por lo general, vestidas íntegramente y rara vez se detienen en este tipo de efectismos. Sobre el tema de los drapeados en la Edad Media y su conexión con lo clásico, vid.: R. JULLIAN, $O p$. cit., pp. 248-249.

Sobre el "olvido" o la pérdida de interés a la hora de representar tales vestimentas, véase.: $\mathrm{H}$. FOCILLON, La escultura románica..., en concreto, p. 58. El investigador se detiene, especialmente, en el caso español. Habla sobre el carácter geométrico y abstracto de las representaciones textiles de San Pedro de la Nave y Quintanilla de las Viñas, donde las vestimentas se transforman y forman pliegues tubulares. El autor alude a un "estilo tubular" que reaparece en San Miguel de Lillo y en otros ejemplos de cronología temprana, como la escultura de Saint Germingny-des-Prés. Aún con todo, el autor hace descender este tipo de tratamiento escultórico de la plática greco-romana.

${ }^{1749}$ Belém, Museu Arqueologico Nacional.

1750 J. L. DE MATOS, "Estatueta de Sileno”, Inventário do Museu..., ficha catalográfica 125, pp. 198-199 e ID., Subsídios para um catálogo..., vol. I, p. 47. El autor destaca el cuidado con el que fueron modelados los músculos del cuerpo. Por otra parte, no debemos olvidar que se trata, nuevamente, de una pieza ligada al repertorio báquico. Paradójicamente nos encontramos, otra vez, ante un aplique ideado para ser colocado sobre una fuente, pues las perforaciones del bajo vientre, la boca y la cabeza señalan los lugares para la salida de los hilos de agua. Su procedencia es desconocida.
} 
"Los más hábiles de estos escultores medievales habían llegado a dominar el lenguaje del arte clásico hasta el punto de no tener que recurrir ya al préstamo de frases o vocablos aislados. Y siempre habremos de contar con la posibilidad de que se inspirasen, más que en la escultura de gran tamaño en piedra, en esas graciosas estatuillas griegas y helenísticas en bronce o plata, que con frecuencia sólo conocemos a través de su débil eco en figuritas de terracota, que a menudo reflejaban los productos del arte monumental (...)"1751.

Un buen ejemplo del dinamismo y la rotundidad que podemos encontrar en este tipo de piezas, de pequeño tamaño, realizadas en bronce, lo representa la esculturilla de Genius Senatus de Mérida. La escultura muestra a un hombre anciano togado, siguiendo modelos helenísticos-romanos en relación con la representación de Zeus-Giove ${ }^{1752}$ (fig. 334).

Existen razones para poder creer que, algunas piezas realizas en materiales dúctiles, pudieron haber estado en la órbita de los escultores medievales de Jaca. Ya hemos aludido, y lo haremos de manera más concreta en las páginas siguientes, como algunos autores han señalado la importancia de las cornisas de terracota y las placas de de incrustación utilizadas durante la Antigüedad tardía para la decoración de muros, como elementos de vital importancia a la hora de explicar, por ejemplo, la articulación exterior del ábside sur de la catedral de Jaca.

Por otro lado, algunos de los rostros que encontramos en determinadas figuras como, por ejemplo, en uno de los hombres de un capitel exterior o, incluso, en el mismo capitel de la Virgen con clámide que ahora estudiamos (fig. 335), recuerdan, desde el punto de vista fisonómico, las soluciones plásticas que presentan algunas piezas en terracota $^{1753}$.

\footnotetext{
${ }^{1751}$ E. PANOFSKY, Renacimiento y renacimiento..., p. 110. Panofsky utiliza esta serie de pequeñas piezas para poder explicar el drapeado y la forma de vestir de algunas esculturas medievales. En concreto, alude a una Mater dolorosa conservada, en su tiempo, en el Instituto de Historia del Arte de la Universidad de Friburgo. Figuras de éste tipo están presentes en todos los Museos Arqueológicos Provinciales y Nacionales de la geografía española y europea, por lo que no se debería descartar su utilización como fuentes de inspiración durante el periodo medieval. Véase, por ejemplo, la pieza estudiada en: P. BARRACA DE RAMOS, "Applique. Soldato romano che lotta con un ispano", Hispania..., ficha catalográfica 59, p. 341. En dicha obra se utilizan, en parte, soluciones parecidas a las que observamos en la escultura románica.

${ }^{1752}$ Mérida, Museo Nacional de Arte Romano. Cf.: T. NOGALES, "Statuetta del Genius Senatus", Hispania..., ficha 116, p. 367.

${ }^{1753}$ El capitel exterior al que nos referimos es el número 25. Cf.: M. DURLIAT, La sculpture romane de la route...., p. 247.
} 
En concreto, nos referimos a algunas de las antefijas conservadas en el Museo Arqueológico de Palencia, que fueron realizadas con formas de máscaras y que se aplicaban como remate de las hileras de tejas curvas en los aleros de los edificios $^{1754}$ (fig. 336). De la comparación de ambas esculturas se perciben ciertas similitudes de índole formal. El rostro románico trasluce algunas pervivencias de un gusto por el trabajo de materiales fácilmente maleables, tales como el barro, el estuco o la mencionada terracota.

Estos rasgos hablan de ciertos contactos con la obra antigua, quizás extensibles, desde otro punto de vista, a una figura que fue esculpida en uno de los capiteles antes mencionados. Ya en su día D. L. Simon dedicó un estudio íntegro a analizar las formas e iconografía de la pieza, identificado las escenas narradas con la historia de Moisés y Aarón, con la vara y el libro ${ }^{1755}$ (fig. 337).

Desde nuestro punto de vista, las figuras que nos interesan son aquellas que portan el libro, según la identificación del investigador antes citado. Son dos personajes que, enfrentados, ayudan con sus manos a sostener un objeto. Lo más destacado son las clámides que portan y caen, suavemente, hacia el suelo deslizándose por sus cuerpos desnudos.

Un rasgo si cabe más "antiquizante" es el de hacer volar la pieza textil como movida por el viento. El personaje de la derecha, en la composición, recibe una ráfaga de aire que hace que su clámide se eleve y se mueva. Se trata de un recurso bien conocido dentro de la escultura antigua de época griega y romana y que, por lo general, ha sido identificado con las representaciones heroicas donde los mantos, capas y clámides, movidos por las corriente aéreas, otorgan un aire de magnificencia y trascendentalismo a las escenas ${ }^{1756}$.

El uso de las telas vaporosas en movimiento aparece, frecuentemente, dentro de la escultura hispanorromana. El famoso ara cilíndrica hallado en Itálica, cerca de la

\footnotetext{
${ }^{1754}$ M. DEL AMO Y DE LA HERA y F. J. PÉREZ RODRÍGUEZ, Op. cit., p. 108.

${ }^{1755}$ D. L. SIMON, “A Moses...”, pp. 211-213.

${ }^{1756}$ Ibidem, pp. 218-219. El especialista incidía en las posibles fuentes clásicas que tiene el capitel y, más concretamente, en las vinculadas a los sarcófagos paleocristianos. Es muy significativo como este tipo de recurso se utilizó, sobre todo, en escenas de marcada acción dramática o donde las figuras llevan a cabo movimientos violentos. Una placa conservada en la Galería Borghese de Roma, que representa el rapto de Casandra y que se ha datado en el siglo $\mathrm{V}$ a. de. $\mathrm{C}$, muestra al héroe homérico Aiace de Oileo agarrando bruscamente por los cabellos a la figura femenina. Es llamativo como la capa del personaje se eleva movida por el viento. El cuerpo de las figuras, en tensión, presenta un tratamiento anatómico donde la desnudez es el elemento más destacado. La pieza nos sirve para poder constatar la utilización de esta iconografía a la hora de narrar diversos acontecimientos tomados de la mitología. Sobre el relieve, véase: G. CRESSEDI, voz “Aiace di Oileo”, Enciclopedia dell'arte..., vol. I, Roma, 1958, pp. 164-165.
} 
actual Santiponce, muestra un cortejo de ménades bailando. Los textiles han sido esculpidos de manera magistral, insinuando las líneas de una desnudez que no llega a materializarse, pero que dotan a la composición de gran dinamismo ${ }^{1757}$.

El tipo que acabamos de describir, en relación con el tratamiento del drapeado, bien pudo pasar a las etapas posteriores del arte románico de la Península Ibérica a través de alguna pieza de similares características.

Así, a la hora de estudiar la iconografía del caballero victorioso, largamente difundida en el románico europeo, M. Ruiz Maldonado ha defendido el recuerdo continuo de las clámides romanas que posee la indumentaria medieval que portan dichas figuras. Tal hipótesis parece lógica, pues la mayor parte de estas imágenes tendría su modelo primigenio dentro de las esculturas tardoantiguas de los emperadores. Sin duda, el gesto clásico de aclamatio, salutatio o adlocutio que presentan la mayoría de estas obras, facilitó la tarea a la hora de poder representar, de manera efectista, tales textiles $^{1758}$.

Como observamos, la representación del desnudo, en primer lugar, y la reflexión y tratamiento de los elementos textiles que cubren determinadas partes de estas producciones románicas, en un segundo momento, parecen tener paralelismos posibles en el arte antiguo.

Todos los autores que, de manera puntual, han analizado estas clámides al aire, le otorgan un origen clásico, de recuerdo helenístico y que habrían de tener una gran difusión dentro del arte provincial romano ${ }^{1759}$.

Sin embargo, y a pesar de todo lo argumentado hasta el momento, nuevamente, surge la imposibilidad de demostrar una dependencia directa e indiscutible con respecto al arte antiguo debido, en parte, a la falta de piezas similares que puedan demostrar una copia inmediata. Las figuras nacidas dentro del taller de Jaca y las que luego fueron esculpidas bajo su influencia, presentarán todo tipo de clámides, tocados y mantos que, por lo general, insinúan un conocimiento de modelos romanos.

El uso de imágenes tocadas con velo, siguiendo el modelo iconográfico del capite velato, la utilización de túnicas cortas o todo tipo de togas, debe explicarse no sólo a través de la pieza romana de Husillos, sino en relación con el continuismo de una

\footnotetext{
${ }^{1757}$ Sevilla, Museo Provincial. Cf.: P. LEÓN, “Ara cilindrica da Italica”, Hispania..., ficha catalográficas 217, 218, 219, pp. 410-411. En relación con la iconografía de las Ménades y los ocho tipos identificados y aceptados por los especialistas, véase: J. J. POLLIT, Op. cit., p. 279.

${ }_{1758}$ M. RUIZ MALDONADO, Escultura románica ..., en concreto, p. 81.

1759 A. GRABAR, "Le tiers monde de l'Antiquité...,", p. 10 y G. A. MANSUELLI, voz "Provinciale, arte”, Enciclopedia dell'arte..., vol. VI, 1965, pp. 519-527.
} 
serie de tradiciones pláticas de mayor alcance. Creemos, tal y como hemos anunciado, que las figurillas de bronce o terracota, fácilmente transportables y algunas de ellas conservada a lo largo de los siglos como amuletos o exvotos, pueden ayudar a rastrear las posibles fuentes clásicas conocidas en la Edad Media.

La estatuilla de bronce conservada en el Museo de Cuenca, que representa un sacerdote, o la del Museo Arqueológico de Banyolas de Gerona, pueden ejemplificar el tipo de obras que, hipotéticamente, se podrían haber manejando. En dichas piezas se ha prestado gran importancia a la vestimenta, que llega a dominar el volumen de la composición, a pesar de tratarse de trabajos realizados en bronce. En concreto, la de Gerona aparece ataviada con una túnica corta y una toga anudada sobre el vientre que le otorga gran volumen, llegando a soluciones parecidas a las que presentan algunas esculturas románicas aquí analizadas ${ }^{1760}$.

La más interesante de la serie, es aquella que representa a Mercurio (fig. 337 a). Fue realizada en bronce y colocada sobre un pequeño plinto. A pesar de su desnudez, sobre un hombro se colocó una clámide deslizándose por el brazo izquierdo, así como sobre una de sus piernas ${ }^{1761}$. La manera en que este elemento textil fue colocado no deja de recordar a las soluciones que hallaremos, siglos más tarde, dentro ciertas esculturas del templo jaqués ${ }^{1762}$.

\footnotetext{
${ }^{1760}$ Sobre la pieza de Gerona, véase.: F. SALCEDO, "Lare", Hispania..., ficha catalográfica 253, p. 428. Se trata de una obra datada en el siglo III d. de C. y proveniente de la villa romana de Vilauba en Banyolas. Sobre la escultura de Cuenca, véase.: ID., "Stattueta di Sacerdote", Hispania..., ficha catalográfica 223, p. 413. Representa un sacerdote con el capite velato delante de un altar, antes de llevar a cabo un sacrificio. Se ha datado en el siglo I. d. de C.

${ }^{1761}$ F. SALCEDO, "Mercurio", Hispania..., ficha catalográfica 252, p. 427. El Mercurio de esta representación porta sandalias, además, del marsupium o bolsa de monedas. En su día, los ojos llevaban un relleno de plomo. Apareció, al igual que la estatuilla anterior, en la villa de Vilauba y se ha datado en el siglo III d. de C.

1762 J. L. MARTINS DE MATOS, Subsídios para um catálogo..., vol. II, pp. 214-277.
} 


\section{E. LA IMAGO CLIPEATA.}

El capitel identificado por M. Durliat en su estudio con el número 37 presenta una iconografía no menos "antiquizante" (fig. 338). La composición, de fuerte carácter simétrico, se desarrolla sobre la cesta de un capitel con grandes volutas en los extremos superiores. El centro de la imagen aparece ocupado por un clípeo o tondo que asen por los bordes dos personajes que, al mismo tiempo, giran su cuerpo en posición de tres cuartos para dirigirse a otras dos figuras que ocupan la cara corta de la escultura. Los dos hombres que sujetan el clypeus, señalan con sus dedos a los otros dos que presentan, como rasgo característico, sendos libros en las manos. El centro del tondo aparece ocupado por una figura vestida al modo clásico con una clámide que le cae sobre el pecho desde uno de los hombros. No posee barba ni porta nimbo, ni ningún otro rasgo específico que pueda ayudar a su interpretación ${ }^{1763}$.

Todos los autores que han abordado el capitel han aludido a las fuentes romanas que, hipotéticamente, lo pudieron inspirar. En concreto, la conocida composición de la imago clipetata, tan frecuente dentro de la escultura de sarcófagos, pudo tener un papel importante a la hora de componer la pieza.

Ya en su día, S. Moralejo estableció una posible relación entre esta obra románica y el sarcófago de San Pedro el Viejo de Huesca, cuyo frente fue decorado siguiendo el viejo esquema de la imago clipeata, un tondo elevado por dos putti o victorias $^{1764}$ (fig. 339).

Aportar alguna novedad al estudio de este tipo iconográfico antiguo y su traspaso a la escultura posterior resulta de gran complejidad, pues ha recibido gran atención por parte de los especialistas ${ }^{1765}$. Los retratos dentro de estructuras circulares, helicoidales o en forma de mandorla aparecen registrados desde el inicio de las

${ }^{1763}$ M. DURLIAT, La sculpture romane de la route..., p. 235 e ID., “Sculpture romane à Jaca...”, p. 375. El estudioso francés interpreta los gestos de las figuras como una sacra convensazione en la que las figuras se comunican y hablan.

${ }^{1764}$ S. MORALEJO ÁLVAREZ, “La sculpture romane...,", p. 147.

1765 A. GRABAR, "L'imago clipeata chrétienne", L'Art de la fin de l'Antiquité et du Moyen Age, vol. I, Paris, 1968, pp. 607-613; G. BECATTI, “Clipeate, immagini”, Enciclopedia dell'arte..., vol. II, 1959, pp. 718-721; A. GRABAR, Las vías de la creación..., p. 77 y E. PANOFSKY, Renacimiento y renacimientos..., p. 219. Este último autor alude, también, a la importancia que para el medievo tuvieron las piezas clásicas con representaciones de tondos. Pone el ejemplo concreto de un sarcófago romano conservado en el Campo Santo de Pisa y que hubo de influenciar la obra de Francesco Traini, datada en el año 1350.

Desde la perspectiva del arte hispanorromano, consúltese: A. BALIL ILLANA, "Un tondo de Fuentetojar y otros tondi hispanorromanos", Minerva, 1, 1987, pp. 169-184 
producciones artísticas, aunque se hace especialmente significativo en Grecia ${ }^{1766}$. Nuevamente, tales composiciones poseen un cierto tono heroico, otorgando cierta honorabilidad a aquellas figuras que aparecen circunscritas por tal elemento. La misma forma del clípeo permitirá representar, de una manera concreta, el busto o la cabeza de los personajes que en él se imbricaban, así como adaptarlo a muchas composiciones realizadas en todo tipo de materiales, desde el bronce al mármol o a la pintura ${ }^{1767}$.

Sin embargo, fue dentro de la iconografía realizada sobre los sarcófagos, donde la imagen del clípeo estuvo más difundida. Así, encontramos tales enmarques ocupando las caras más visibles de los frentes, formando bellas composiciones simétricas con los genios alados, putti, victorias o ángeles que, generalmente, aparecen rampantes elevando al aire dicha estructura ${ }^{1768}$.

En el mundo romano, aquel que nos interesa particularmente, la imagen del clípeo con la efigie del difunto en el interior significaba su "heroización" ${ }^{1769}$. Se trataba de un fácil mecanismo que permitía mostrar, de una manera pública, la imagen de quien generalmente se encontraba muerto en el sarcófago. El mismo clípeo, en ocasiones, podía ser sustituido por una venera, elemento que, tal y como veremos más adelante, alcanzó un gran desarrollo ${ }^{1770}$.

Con todo ello, la imagen del difunto esculpida dentro del clípeo tuvo como finalidad, desde los primeros tiempos, llevar a cabo una exposición pública de su efigie $^{1771}$. Sin duda, se trata de un elemento que alcanzó gran desarrollo dentro de la

\footnotetext{
${ }^{1766}$ Se habla del origen griego en: A. GRABAR, Las vías de la creación..., p. 77.

${ }^{1767}$ G. BECATTI, “Clipeate...", p. 720. El especialista recoge los ejemplos más famosos de este tipo de estructuras, en varios tipos de soportes.

${ }^{1768}$ D. HASSING, "He will make alive your mortal bodies: cluniac spirituality and the Tomb of Alfonso Ansúrez”, Gesta, XXX/ 2, 1991, 140-153, en particular, pp. 142-143. Al analizar la pieza románica, la autora expone la relación existente entre los ángeles de las esculturas cristianas con otra serie de deidades paganas, como las victorias.

${ }^{1769}$ F. CUMONT, Recherches sur le symbolisme funéraire..., pp. 338-339. Cumont recoge un sarcófago conservado en Roma, Museo Nazionale Romano alle Terme. En dicha escultura se desarrolla un programa "heroizador", siguiendo la expresión utilizada por el autor. En las escenas, una serie de amorcillos llevan a cabo diversas danzas realizadas entre dos mascarones de considerable tamaño.

${ }^{1770}$ A. GRABAR, Las vías de la creación..., p. 77 e I. RILLIET-MAILLARD, "Quelques remarques sur la production des sarcophages au IVe siècle", Artistes, Artisans et Production artistique au Moyen Âge, vol. III, Paris, 1990, pp. 175- 201, en particular, pp. 184-185. La autora citada en último lugar señala con el número de inventario 31427 un sarcófago donde el retrato del difunto aparece dentro de un clípeo, frente a otros conservados en la iglesia de San Sebastiano de Roma o en el Musée de l'Arles Antique, donde se utilizaron, preferentemente, las veneras. Este tipo de elementos serán muy significativos, pues a la hora de analizar, por ejemplo, la iconografía del thiasos marino, se han establecido dos tipologías en relación con el uso de la venera o del clípeo. Sobre tal cuestión, consúltese también: A. RUMPF, "Die Meerwesen auf den antiken Sarkophagreliefs", Antike Sarkophagreliefs, Berlin, 1939, pp. 19-28.

${ }^{1771} \mathrm{Al}$ fenómeno también se le ha definido con el término prothesis, tal y como se insiste en: F. DÍEZ DE VELASCO, Op. cit., p. 64. Véase el buen ejemplo que se recoge en : F. CUMONT, Recherches sur le
} 
escultura clásica, tanto de los ámbitos privados, como también aquella realizada al servicio de los emperadores, es decir, la puramente oficial. El uso del clípeo honorífico -clypeus virtutis-, de origen helenístico, pronto fue asumido por Roma, utilizándose para poder publicitar, abiertamente, las virtudes y méritos de los grandes mandatarios y personajes de relevancia ${ }^{1772}$.

Con todos estos antecedentes, la imagen de las victorias -nikés-o, en ocasiones, putti que elevaban al cielo un tondo con el retrato del difunto o portando una inscripción dedica al mismo, se hicieron habituales dentro del repertorio iconográfico de las piezas funerarias, sobre todo durante el siglo II. d. de C. Los seres alados, fundamentales en tales estructuras, se tornan indispensables a la hora de poder elevar y mostrar al público la imagen del difunto. Sin embargo, además de ello, tales figuras se convertirán en psycopompos, guías y protectoras del alma del muerto en el camino que le llevará hacia la morada de ultratumba ${ }^{1773}$.

La composición pasó, íntegramente, a las producciones artísticas de la Edad Media. Dentro del caso hispano en el que nos centramos, de una manera completa o, en ocasiones parcial, la ascensión de los personajes representados contará, habitualmente, con las figuras aladas antiguas, convertidas ahora en seres angélicos. A pesar de no poseer la estructura del clípeo, la posible ascensión de Cristo y de María representada en la iglesia de Quintanilla de las Viñas (Burgos) es muy representativa al respecto ${ }^{1774}$.

symbolisme funéraire..., p. 464. Se trata de la pintura realizada para la catacumba de Thrason (Roma) y en la que se figuró al difunto dentro de uno de estos tondos.

${ }_{1772}$ P. ZANKER, Augusto y el poder..., pp. 120-122. El autor recoge el caso del clypeus sobre el que el Senado de Roma mandó colocar una inscripción donde se destacaban las virtudes de Augusto, así como la creación de toda una serie de piezas seriadas que fueron repartidas por diferentes ciudades. La Curia fue el edificio donde se mostraba el tondo original. "En el futuro el clípeo aparecerá casi exclusivamente en combinación con la Victoria y en consecuencia llegará a ser un símbolo de carácter invicto dado por los dioses al gobernante", tal y como escribe el investigador.

${ }^{1773}$ M. CLAVERIA, "El sarcófago...", p. 56. También se habla sobre esta función protectora de determinadas figuras dentro de la escultura románica, en: R. SÁNCHEZ AMEIJEIRAS, “¿Portada o relieve...", en concreto, p. 521. La profesora Ameijeiras atribuye a los santos, obispos y mártires, funciones de intercesión y protección sobre el difunto en tránsito, es decir, un carácter psicopompo. En el mundo antiguo, dentro de las escenas de ascensión o apoteosis del emperador, tampoco faltarán personajes que sean testigos de la ascensión visual del divus, cuyo testimonio, además, era posteriormente requerido por la ley. Vid.: A. GRABAR, Las vías de la creación..., p. 111.

${ }^{1774}$ Se trata del tema de la elevatio animae, esculpido en formato de capitel-imposta. En concreto, la composición presenta a las figuras centrales flanqueadas por respectivas figuras angélicas que ayudan en el tránsito, impulsando el cuerpo de Cristo y el de la Virgen. La composición se repite, de manera clara, en la iconografía en forma de imagines clipeatae de SOL y LVNA, de la misma iglesia. Toda esta serie de esculturas, se han emparentado con algunas personificaciones romanas, llegando, incluso, a relacionarlas con el mismo sarcófago romano de San Pedro de Huesca. Cf.: P. DE PALOL y G. RIPOLL, Los godos en el Occidente Europeo. Ostrogodos y Visigodos en los siglos V-VIII, Madrid, 1988, p. 236; J. A. MORÁIS MORÁN, "Nuevas reflexiones...", p. 69; M. CRUZ VILLALÓN, "Quintanilla de las Viñas en el contexto...", pp. 101-135 e ID., "Quintanilla de las Viñas y el arte cordobés...", pp. 341-349. 
Nos parece interesante el análisis detenido del tipo de ascensión que se representó en estas esculturas. Siguiendo con las diferentes distinciones que se han hecho en relación con la iconografía de la ascensión de Cristo, parece evidente que, el ejemplo de las Viñas, correspondería al denominado tipo "latino" u "occidental".

Bajo tal nomenclatura se entiende aquella variante de la ascensión en la que la figura es impulsada, literalmente, hacia el cielo a través del contacto físico con los genios que le ayudan en el tránsito ${ }^{1775}$.

En el caso de Quintanilla de las Viñas, los seres alados tocan, directamente, a la figura en ascensión, de similar manera que, lo hacen, por ejemplo, los ángeles esculpidos en el tímpano de la puerta del Perdón de San Isidoro de León y que parecen descender de este tipo iconográfico de tradición clásica que hallamos en algunos dípticos romanos, como el denominado marfil de Symanchy ${ }^{1776}$.

El segundo tipo de ascensión identificada sería aquella conocida como "oriental" o "sirio-palestina". En ella, el movimiento ascensional se lleva a cabo a través de la presencia de varios ángeles que elevan al cielo un medallón, en el que aparecerá inscrita la figura en tránsito ${ }^{1777}$. El contacto con la figura divina es, por lo tanto, inexistente, perdiendo visos de realidad y adquiriendo, aparentemente, un carácter sobrenatural.

Parece claro que estas dos tipologías dependen, en mayor o menor medida, de la tradición pagano-romana, donde la iconografía nacida al amparo de los talleres imperiales fue utilizada para narrar la ceremonia de apoteosis de los grandes emperadores que, más tarde y bajo una reinterpretación cristiana, sería adaptada a la hora de materializar el tránsito de Cristo ${ }^{1778}$.

\footnotetext{
${ }^{1775}$ S. TSUJI, "Les Portes de Sainte Sabine. Particularités de l'Tconographie de l'Ascension", Cahiers Archéologiques, XIII, 1962, pp. 13-28, en especial, p. 16 y J. A. MORÁIS MORÁN, "Nuevas reflexiones...", pp. 68-69.

${ }^{1776}$ London, British Museum. Cf.: S. MORALEJO ÁLVAREZ, "Modelo, copia...”, particularmente, pp. 98-100. Se trata de una pieza datada en el siglo V. En ella se representó, con gran detalle, la apotheosis de un emperador que sirvió a S. Moralejo para hacer derivar las escenas de Ascensión esculpidas en las portadas de Miègeville de Toulouse y la del Perdón de San Isidoro de León de una pieza ebúrnea de este tipo. En el caso hispano esta variante de ascensión con contacto físico ya era conocida a través del sarcófago de Santa Engracia de la catedral de Zaragoza. P. Palol dató la pieza entre los años 340 y 350 . El personaje en cuestión, Floria, que se ha identificado mediante un epígrafe es, literalmente, empujada por la dextera domini a llevar a cabo el movimiento ascensional, tal y como, más tarde, se representará en las fachadas de finales del siglo XI. Para el sarcófago zaragozano, vid.: P. DE PALOL, Arqueología cristiana..., pp. 302-303. También se llama la atención sobre el sepulcro español en: S. TSUJI, Op. cit., p. 19. Sobre el díptico de Londres, véase: J. ARCE, Funus Imperatorum..., p. 151. Con todo, cabe destacar que, ya en el año 1942, F. Cumont había abordado la pieza de marfil apuntando algunos de estos aspectos. Cf.: F. CUMONT, Recherches sur le symbolisme funéraire ..., pp. 173-175.

${ }^{1777}$ S. TSUJI, Op. cit., p. 16. El ejemplo más característico de esta iconografía es el que se muestra esculpido sobre las puertas lígneas de la basílica romana de Santa Sabina.

${ }^{1778}$ A. GRABAR, Las vías de la creación..., pp. $42-43$ y p. 111 y S. TSUJI, Op. cit., p. 18.
} 
Aunque el ejemplo románico de la catedral de Jaca presenta ciertas variaciones, todo hace pensar que el modelo inspirador pudo estar relacionado con la iconografía de la elevatio ad sidera difundido en el mundo antiguo ${ }^{1779}$. Aquí se ha conservado, de manera íntegra, el clípeo, evocador del cielo, siguiendo los modelos de las "visiones científicas", si seguimos la tipología establecida por A. Grabar y que él mismo utiliza para definir ciertas imágenes realizadas sobre algunos manuscritos tardoantiguos ${ }^{1780}$.

Lo que parece claro, según lo dicho, es que en la escultura de la catedral de Jaca se podría haber tenido acceso a una fuente antigua en la que la imagen del clípeo estaba presente. Faltaría entonces poder concretar de qué tipo de piezas estaríamos hablando. Hemos hecho alusión, en páginas anteriores, a las relaciones que, recientemente, ha establecido M. Castiñeiras entre la escultura de la catedral, en concreto, en relación con el capitel de los danzantes y el sarcófago romano conservado en la iglesia de San Vicente de Àger (Lérida) ${ }^{1781}$ (fig. 258).

La pieza, de excelente calidad, representa en el frente una escena de thiasos marino. Además de destacar elementos sobre los que ya nos hemos detenido, tales como la desnudez de las figuras, el ambiente marino materializado a través de ondulaciones acuáticas y otra serie de características, nos interesa ahora la parte central de la composición. Un clípeo sobre el que se colocó la imagen del difunto es sustentado por dos tritones que giran su cuerpo, en posición de tres cuartos, para mirar a dos figuras femeninas.

La interpretación de este tipo de escenas, por parte de los especialistas, ha sido muy controvertida. Por un lado, la teoría tradicional ve en el thiasos una alegoría del "viaje venturoso y propicio hacia la isla de los bienaventurados"; mientras que, desde una segunda interpretación, este tipo de temas harían alusión al "estado dichoso y

\footnotetext{
${ }^{1779}$ M. DURLIAT, "Sculpture romane...", p. 375. En realidad, la imbricación de figuras dentro de estructuras circulares jugaría un papel de gran importancia dentro de la iconografía medieval. Muchas de las representaciones cósmicas y relacionadas con el menologio utilizarán esta fórmula. Véanse las reflexiones, sobre el uso de tondos, en el bordado de Gerona realizadas en: P. DE PALOL, El tapís..., p. 116 y M. A. CASTIÑEIRAS GONZÁLEZ, El calendario..., p. 119.

${ }^{1780}$ A. GRABAR, "L'iconographie du ciel...", p. 15. Grabar afirma que el origen de la mandorla medieval está en este tipo de composiciones. Un estudio importante sobre estas cuestiones, en: A. PUIGARNAU I TORRELLÓ, Imago Dei y Lux Mundi en el siglo XII: La recepción de la teología de la luz en la iconografía del Pantocrátor en Cataluña, Barcelona, 2005, sobre todo, pp. 219-279. El autor analiza, con enorme profundidad, las fuentes clásicas que los autores cristianos tomaron para reconfigurar la imagen de Cristo en mandorla.

${ }^{1781}$ M. A. CATIÑEIRAS GONZÁLEZ, “Verso Santiago?...”, p. 388.
} 
liberado de las cargas y preocupaciones de la vida al que se llega al final de ésta con la muerte ${ }^{1782}$.

Si aceptamos que una pieza de la misma índole pudo entrar en contacto con los escultores románicos a la hora de elaborar el capitel de los danzantes de la catedral de Jaca, del mismo modo, es factible poder defender una hipotética inspiración basada en el mismo sarcófago para la imagen de la figura masculina en clípeo.

Al igual que en el capitel jaqués, el difunto se muestra vestido a la moda romana, con la clámide recogida en uno de los hombros, dejando caer los pliegues de manera transversal. En el capitel, los dos tenantes giran sus cuerpos y se vuelven hacia las figuras de los lados cortos, de la misma manera que, en el sarcófago de Àger, los tritones lo hacen para dirigirse a las figuras femeninas.

Sin embargo, no podemos afirmar, con seguridad, que la pieza catalana pudo ser el modelo directo sobre el cual trabajaron los escultores románicos. La iconografía del clípeo estuvo muy difundida dentro de la escultura hispanorromana, por lo que, en este sentido, sería aconsejable ampliar el campo de búsqueda hacia otros ejemplos ${ }^{1783}$.

En relación con ello, es muy interesante el sarcófago de Asido, en Medinasidonia, Cádiz (fig. 340). La composición iconográfica que se desarrolla a lo largo del frente tiene muchos puntos en común con la que presenta el sarcófago de Àger. Nuevamente, nos encontramos ante una escena de thiasos, que tiene como eje central a los dos tritones sustentando el clípeo. Ésta vez dentro de él se esculpió la pareja de difuntos, siguiendo modelos bien conocidos dentro de este tipo de repertorios.

La pieza ha sido estudiada, de manera exhaustiva, por J. Beltrán Fortes, quién rastrea la procedencia y las circunstancias del hallazgo, así como su iconografía ${ }^{1784}$. En

\footnotetext{
1782 M. CLAVERIA NADAL, "El sarcófago romano...", p. 34 y F. CUMONT, Recherches sur le symbolisme..., pp. 167-170.

${ }_{1783}$ A. BALIL ILLANA, “Un tondo de Fuentetojar...”, pp. 169-184.

${ }^{1784}$ El sarcófago de Asido debió descubrirse en el siglo XVII. Su supuesto origen estaría en la ciudad romana del mismo nombre. La historiografía ha prestado gran atención a la pieza, por lo que se conoce bastante bien su historia. Fue reutilizada como aguamanil en la sacristía del convento de San Francisco de Medinasidonia hasta que, en el 1763, pasó a formar parte de la colección de Guillermo de Tyrry, marqués de la Cañada. En su traslado, la pieza comienza a sufrir los primeros desperfectos, dividiéndose en algunas partes que hoy se conservan en lugares diferentes. En la actualidad, se desconoce su paradero, sin embargo se conservan en la Biblioteca Capitular de la Catedral de Sevilla, varios dibujos de la pieza realizados para el Catálogo de la colección del marqués. Los diseños, de bastante calidad, permiten poder reconocer bien la iconografía de la obra. Vid.: J. BELTRÁN FORTES, Los sarcófagos romanos..., pp. 75-91; ID., "El retrato en los sarcófagos romanos. Ejemplos de la Bética", III Reunión sobre la Escultura Romana en Hispania, Córdoba, 1997, pp. 93-111; ID., "El uso del sarcófago en la Bética durante los siglos II-III d. C”, El sarcófago..., pp. 93-128, en concreto, pp. 95-96 y J. BELTRÁN FORTES, M. A. GARCÍA GARCÍA y P. RODRÍGUEZ OLIVA, Los sarcófagos romanos de Andalucía, (Corpus Signorum Imperii Romani - Corpus de Esculturas del Imperio Romano. España), vol. I, fasc. 3, Murcia, 2007.
} 
ella se representó un thiasos que tiene como eje compositivo el clípeo sustentado por los viejos tritones que se giran, nuevamente, hacia sus respectivas amazonas ${ }^{1785}$. Son destacar los elementos arquetípicos de este tipo de iconografía, como el ambiente acuático o el uso del velificatio, es decir, el manto volante que, a modo de arco, enmarca las cabezas de los personajes. De igual manera, sobresale la presencia de dos putti que fueron colocados formando parte de la composición y que, lejanamente, podrían ser utilizados como otra prueba más para relacionar la escultura jaquesa con estas producciones romanas, ya que dichos personajes tendrían su equivalente en los dos tañedores de aulos de la obra románica.

Según el mencionado autor, el esquema formado por la imagen del difunto en clípeo sustentado por tritones, adquirió gran difusión entre los siglos II y III. d. de C. De este modo, dicha datación reafirma la restricción cronológica que hemos llevado a cabo a la hora de poder señalar, de una manera más concreta, las fuentes utilizadas por los escultores medievales que aquí abordamos ${ }^{1786}$.

Nuevamente, la lectura correcta de la imagen habla de un interés por mostrar un cierto tono heroico en la escena, acentuado por el carácter cósmico del clípeo, así como por el uso de la velificata ${ }^{1787}$. Finalmente, podemos concluir que, cuando a finales del siglo XI se esculpe el capitel románico jacetano del que venimos hablando, se tuvieron bien en cuenta estos modelos, en los que, los emperadores y difuntos del mundo antiguo, eran circunscritos por el símbolo geométrico más perfecto: el círculo.

No podemos abordar el estudio de todas las lecturas simbólicas que se han hecho en relación con tal forma geométrica durante los siglos medievales, pero sabemos que se continuó utilizando, generalmente, bajo la variante de la mandorla o almendra mística, para enmarcar la figura de Cristo. Las lecturas relacionadas con la figura del Cosmócrator parecen claras, tal y como señaló, en su día, A. Grabar ${ }^{1788}$.

\footnotetext{
1785 J. BELTRÁN FORTES, Los sarcófagos romanos..., p. 78; ID., "El uso del sarcófago...", p. 95 y A. RECIO, "Sarcófago romano de Medina Sidonia", Actas del XIII Congreso Nacional de Arqueología, Zaragoza, 1975, p. 875. J. Beltrán identifica las dos figuras rodeadas por tal estructura como dos personajes femeninos con peinados y ropas diferentes. Rechaza, por lo tanto, la teoría de los dos difuntos o jóvenes esposos propuesta por otros autores.

${ }^{1786}$ J. BELTRÁN FORTES, Los sarcófagos romanos..., p. 82. El autor recoge las diferentes posiciones historiográficas en relación con la lectura iconográfica del tema del thiasos.

${ }^{1787}$ Ibidem, p. 83. Sobre el origen del clípeo y sus relaciones con las representaciones cósmicas, ya hemos hablado. La representación del cielo a través del círculo, ya sea completo o parcial, se traspasó, desde la Antigüedad a la Edad Media de manera evidente. Sobre esta cuestión, véase: A. GRABAR, "L'iconographie du Ciel...", p. 16.

${ }^{1788}$ A. GRABAR, Las vías de la creación..., p. 150; S. SEBASTIÁN, Mensaje simbólico..., p. 26 y P. DE PALOL, El tapís..., p. 24. El profesor Palol analiza el simbolismo del círculo o clípeo en relación con las representaciones de Annus o el Cosmócrator del bordado. El círculo, vinculado a diversos valores
} 
Sin ánimo de ser exhaustivos a la hora de aportar posibles ejemplos que presenten la misma iconografía ${ }^{1789}$, no sería descabellado presumir la existencia de otra serie de piezas antiguas al alcance de los escultores románicos de Jaca. Siguiendo con el rastreo de figuras infantiles, es decir, posibles putti, u otra serie de genios sustentando un tondo, llamamos la atención sobre un sarcófago conservado en la cripta de SaintVictor de Marsella. Conocido como el sarcófago de los compañeros de Santa Úrsula (fig. 341), aún posee la tapa, que es la que particularmente nos interesa. La parte central de tal pieza aparece ocupada por dos seres alados que asen una cartela sin inscripción. En su día, G. Drocourt-Dubreuil aludió, otra vez, al carácter psicopompo de los genios alados, significado que parece reforzarse con la presencia, sobre dicha cartela, de un crismón flanqueado por delfines. Todo el conjunto ha sido comparado por el autor con el esquema compositivo de la imago clipeata $^{1790}$.

El hecho que más nos interesa poner de relieve es que, el esquema compositivo de los tenantes con clípeo o, en su variante, de una cartela con inscripción, fue uno de los temas recurrentes utilizados por los escultores románicos del periodo que ahora tratamos. A ello debemos sumar la constatación de poder ofrecer un ejemplo funerario que, reuniendo tal iconografía, también incluye la imagen de un crismón, sin duda, uno de los elementos más trascendentales para el conjunto jaqués ${ }^{1791}$.

Con similares características se nos muestra otra pieza funeraria conservada en la iglesia de Saint-Caprais de Agen. Se trata de una cubierta de sarcófago, datada en los años finales del siglo IV d. de C. Además de la importancia que adquiere aquí el ciclo iconográfico de Jonás y la Ballena, destaca, sobre todo, la composición de los dos

cósmicos, fue reinterpretada por el cristianismo a la hora de representar la imagen de la Jerusalén Celeste, en relación con Cristo-Cronócrator. Sobre tales aspectos, vid. también: PH. VERDIER, "La colonne Colonia aelia et imago clipeata du Christ-Helios", Cahiers Archéologiques, XXIII, 1974, pp. 20-40. Véase también: M. L. LAHOZ, "Contribución al estudio de la Portada de Santa María La Real de Olite", Ondare, 18, 1999, pp. 77-112, en concreto, p. 101. La autora aplica dichas teorías a la arquitectura medieval, en especial, a los rosetones. También se analiza el tema del tondo acompañado por diversas personificaciones de los vientos, en: F. CUMONT, Recherches sur le symbolisme funéraire..., pp. 171172.

1789 Desde nuestro punto de vista, no podemos concretar más nuestras afirmaciones. El corpus de escultura antigua europea presenta tantas piezas con este tipo de imágenes que es complicado defender el contacto con una escultura en concreto.

${ }^{1790}$ G. DROCOURT-DUBREUIL, Saint-Victor de Marseille. Art funéraire et prière des morts aux temps paléochrétiens ( $I V^{e}-V^{e}$ siècles), Marseille, 1998, en concreto, pp. 47-57 y M. EDMOND LE BLANT, Les sarcophages..., en particular, p. 51. Se relaciona la pieza con otro ejemplar conservado en la iglesia de Saint-Caprais de Agen. La cartela se esculpió para poder inscribir el nombre del difunto, que nunca llegó a realizarse de manera incisa. Es de suponer que pudo ir pintada.

${ }^{1791}$ Dedicamos un apartado del trabajo al análisis de las fuentes utilizadas para la decoración del tímpano de la portada occidental de la catedral que, como es bien sabido, aparece ocupado por la imagen de un crismón. 
genios alados desnudos sosteniendo un crismón, que ocupa la parte central de la pieza (fig. 342). Por remarcar un rasgo específico de tal imagen, cabe mencionar la morfología que presenta el anagrama de Cristo, rodeado por una corona de laurel decorada con otra serie de elementos vegetales, elementos, todos ellos, que pasarán a la escultura románica ${ }^{1792}$.

El modelo de los tenantes de cartelas expositivas con mensajes fue bien conocido dentro del arte romano, tanto en la metrópoli como en las provincias ${ }^{1793}$. En Hispania, por aludir a un ejemplo menos conocido, destaca el fragmento de una cubierta de procedencia desconocida, pero relacionada con las localidades de Puente Genil o Estepa, en Córdoba y Sevilla, respectivamente (fig. 343). Dos figuras sustentan una cartela, girando su cuerpo en posición de tres cuartos hacia otros dos personajes, siguiendo los modelos ya mencionados ${ }^{1794}$.

Ante un número tan amplio de fuentes posibles, solamente resta pensar en la gran difusión que la imagen debió tener entre los siglos de la Antigüedad tardía y la Plena Edad Media. Una pieza expoliada, sobre la que ya hemos tratado aquí, el conocido sarcófago de la Colegiata de Covarrubias, da buena cuenta de cómo la fórmula de la imago clipeata estuvo al alcance de los hombres medievales de una manera bien documentada $^{1795}$ (fig. 344).

Si aceptamos la lectura propuesta por los especialistas que han abordado esta pieza, se trataría de una alusión al paraíso al que aspiran los difuntos, que se materializaría a través de la visión ideal de los pastores con sus rebaños. El carácter

\footnotetext{
${ }^{1792}$ Según la tradición, la pieza había formado parte de la tumba de un general de Gontran, el duque Regnovald. Cf.: M. EDMOND LE BLANT, Les sarcophages..., p. 92.

${ }^{1793}$ Sobre este punto, se realiza una buena síntesis del problema, en: F. CUMONT, Recherches sur le symbolisme funéraire..., pp. 484-498. En su estudio alude a algunos sarcófagos donde se esculpió el tema del clípeo con figuras en su interior, entre ellos, el famoso fragmento de sarcófago judeo-pagano de Roma, Museo Nazionale Romano alle Terme, el de las Estaciones del Campo Santo de Pisa y otro con el mismo tema de la colección Barberini de Roma.

${ }^{1794}$ Véase también, el ejemplo del sarcófago de San Pedro de Galligans, conservado en Gerona, Museo Arqueológico y que procede de Ampurias. Aquí la parte central de la cubierta fue decorada con dos ángeles tenantes que sujetan una cartela. Cf.: P. RODRÍGUEZ OLIVA, "Las últimas importaciones de sarcófagos paganos de talleres romanos en la Prouincia Baetica", El sarcófago..., pp. 107-128, en concreto, p. 111.

${ }^{1795}$ Ibidem, p. 108-111. La pieza, nuevamente, presenta dificultades en torno a su definición como pagana o como cristiana. Los dos paneles con el tema del hombre con su rebaño puede tener, tal y como hemos visto, una lectura en ambos sentidos. El citado autor afirma, en relación con ello: "no hay ninguna razón de peso en este ejemplar de sarcófago -si exceptuamos su avanzada cronología, época en la que el cristianismo estaba ya extendido en Hispania- para considerarlo paleocristiano. Esta pieza, de taller romano, por el contrario, es un buen ejemplo del uso todavía por estas fechas entre los paganos de esos temas pastoriles que tanto predicamento y simbolismo habrían de tener en la primitiva iconografía cristiana". Vid. también: J. A. MORÁIS MORÁN, "La «construcción» del pasado...", (en prensa) y A. BALIL ILLANA, "El arte de la época romana...”, pp. 88-90.
} 
bucólico de la escena simboliza la esperanza del difunto por el descanso en paz tras la muerte, algo que quedó plasmado, de manera sintética, con la colocación de un clípeo en el que se colocó a la pareja de esposos ${ }^{1796}$. Sobre la fortuna de la pieza en época medieval ya hemos dado cuenta en este trabajo ${ }^{1797}$. A través del spolium in se, la pieza, hipotéticamente, pasó a servir como tumba de Doña Sancha, la esposa del conde Fernán-González ${ }^{1798}$.

El repertorio de sarcófagos en los que se utilizó la imagen del tondo para circunscribir la efigie de los dos esposos es ciertamente numeroso. Sin duda, uno de los más conocidos es el conservado en el Palazzo Mattei de Roma. En el frente de la escultura se representó la personificación de las cuatro estaciones en forma de putti bailarines, portando, cada una, su atributo ${ }^{1799}$. Dos de estas deidades, las que se colocaron en el centro de la cista, además de sostener las uvas y las espigas que les sirven de emblema, sustentan un clípeo en el que, siguiendo la solución que hallamos en Covarrubias, se inscriben el magistrado acompañado por su esposa, ataviados con sendas túnicas y portando él un rollo ${ }^{1800}$.

En todo caso, resulta muy interesante la forma adoptada aquí por el clípeo pues, a partir de la circunferencia central que delimita el tondo, el escultor diseñó una serie de círculos concéntricos que surgen a partir de este. La utilización de una solución idéntica a esta en el clípeo del que surge la famosa mujer desmelenada de uno los canecillos de

\footnotetext{
1796 J. A. MORÁIS MORÁN, “La «construcción» del pasado..., (en prensa).

1797 Sobre la importancia de la pieza dentro del contexto hispano y la influencia sobre otras obras medievales ya insistió S. Moralejo, al hablar de la iconografía de Endimión y la imaginería pastoral de tipo helenístico. El autor defendió un traspaso del tema hacia el capitel de la Anunciación de los pastores del claustro de Santo Domingo de Silos. Vid.: S. MORALEJO ÁLVAREZ, “La reutilización...”, p. 199 y J. ADHÉMAR, Influences antiques..., pp. 162-163. Este último autor habla sobre la iconografía del pastor y el bucolismo de dichas escenas, ligadas a piezas funerarias en su mayor parte. Parece ser, según se ha indicado, que el sarcófago de Covarrubias, por haber sido utilizado por aristócratas, debe ser visto como una clara reminiscencia medieval del uso que, durante la Antigüedad tardía, habían tenido este tipo de piezas. La teoría se expone en: E. VALDÉZ DEL ALAMO, “Lament for a lost...”, p. 314.

${ }^{1798}$ A. GARCÍA Y BELLIDO, Arte romano..., p. 30. Sobre la posibilidad de una interpretación del retrato de los esposos romanos, durante la etapa medieval, como Fernán González y su esposa la condesa Sancha, véase: S. MORALEJO ÁLVAREZ, "La reutilización...”, p. 191.

1799 M. CLAVERIA, "Dos nuevos fragmentos de sarcófagos romanos con el tema de las estaciones", Locvs Amonvs, 2, 1996, pp. 7-14. La investigadora estudia los fragmentos del Museo Arqueológico de Tarragona y los compara con la pieza del palacio Mattei. Se engloba el ejemplar dentro del denominado grupo de sarcófagos con clipeus del ciclo Pisa/Ostia. En todo caso, se sigue aquí lo expuesto en su día por Cumont. Cf.: F. CUMONT, Recherches sur le symbolisme funéraire..., pp. 484-485.

${ }^{1800}$ Bajo la pareja fue colocada la personificación del mundo y, quizás, la de los vientos, tal y como se recoge en: E. VALDÉZ DEL ÁLAMO, “Lament for a lost...”, p. 314.
} 
la puerta Miègeville de Toulouse, vuelve a poner de relieve la utilización de fuentes clásicas en muchos de estos centros activos de manera paralela ${ }^{1801}$ (fig. 345).

De la gran difusión que alcanzó el motivo dentro de los repertorios de la Península Ibérica romana, incluso en zonas más periféricas, da buena cuenta el sarcófago de Reguegos conservado Oporto y donde, nuevamente, un clípeo, sujeto por genios alados, sirve de base para poder colocar la imagen del difunto, ataviada con túnica $^{1802}$.

Una vez hecho un repaso general del panorama de esculturas romanas susceptibles de presentar algunos puntos en común con el capitel románico, quisiéramos llamar la atención sobre otra serie de características que presenta dicha pieza y que pensamos se pueden explicar a través de una equiparación con las obras antiguas. En el capitel medieval llama la atención que la figura inscrita en el clípeo no tenga ningún rasgo distintivo que pueda llevarnos a identificarla certeramente. Se ha planteado la posibilidad de que el personaje imberbe, con clámide y sin nimbo, pudiera ser una representación de la figura de Cristo, mientras que, los dos personajes que sustentan el clípeo, configurasen una:

"vénération et l'acclamation du Christ par les apôtres, scène inspirée d'un décor de sarcophage, comme celui d'une petite face du sarcophage dit de Guillaume Taillefer dans l'enfeu des Comtes à Saint Sernin de Toulouse" ${ }^{, 1803 .}$

Mediante esta reflexión, M. Durliat exponía una hipotética lectura cristiana de la escena. En relación con ello, quizás estarían las figuras laterales que él identifica como apóstoles, pues las que se colocan en el lado corto del capitel portan dos objetos que podríamos entender como una representación de libros. Se trata de dos elementos rectangulares y finos, que recuerdan mucho al que portan las dos figuras masculinas de un capitel ya analizado, en relación con el uso de las clámides y mantos al viento.

\footnotetext{
${ }^{1801}$ No es necesario insistir en la influencia ejercida por las esculturas romanas sobre los escultores activos en la basílica tolosona. Recientemente se abordó el tema, analizando también el caso particular de esta figura, en: D. CAZES y Q. CAZES, "Saint-Sernin de Toulouse et l'Antique", dentro de las Jornadas de Arte Románico Actualité de l'art antique dans l'art roman celebradas durante el mes de julio del 2007 en la abadía de San Miguel de Cuxa. En el momento de la redacción de esta parte del estudio el volumen con dicho trabajo aún no ha visto la luz.

${ }^{1802}$ Oporto, Museu de Arte Sacra y Arqueologia. Cf.: A. GARCÍA BELLIDO, Arte Romano..., pp. 600604. Se data la pieza en el siglo III. d. de. C.

${ }^{1803}$ M. DURLIAT, La sculpture romane..., particularmente, p. 235.
} 
Ya en su día, D. L. Simon defendió la teoría de que dicho objeto podía ser identificado con el Decálogo portado por Moisés y Aarón ${ }^{1804}$. De aceptar la suposición de que dicho elemento fuese un libro, sería factible realizar la misma identificación para el objeto que portan las figuras del capitel.

Sin embargo, si bien defendemos una apropiación de un modelo romano por parte del escultor medieval, a la hora de realizar la composición del capitel, en concreto, de una imago clipeata, pensamos que es difícil poder argumentar de manera segura que la figura inscrita en él sea una representación de Cristo. Ningún rasgo justificaría tal atribución y pensamos que la ausencia de nimbo, sino absoluta, si es una razón de peso para negar tal identificación.

M. Durliat aludió, así mismo, al sarcófago tolosano de Taillefer (fig. 346), una pieza ya recogida en la monografía realizada por M. Edmond Le Blant sobre los sarcófagos romanos de la Galia. La escultura resulta muy interesante al respecto, pues muestra representado, en el lado corto derecho de la cista, la imagen de dos personajes no alados que sujetan un clípeo, por lo que, es poco probable poder, identificarlos como genios clásicos. Dentro del tondo se representó una figura masculina en busto, de perfil, barbada y con cabello rizado ${ }^{1805}$.

Teniendo en cuenta determinadas piezas de este tipo, creemos factible pensar que la obra que inspiró la composición románica hubiera sido una de este tipo. Los dos genios alados, típicos de la iconografía romana de entre los siglos I y IV d. de C, eran sustituidos ahora por dos hombres.

En Jaca, los dos personajes que sustentan el tondo aparecen sin alas por lo que, es posible pensar que, el escultor pudo acceder a un modelo similar al que ofrece el sarcófago de Toulouse. La apariencia de la figura inserta en el clípeo tolosano, sin

\footnotetext{
${ }^{1804}$ D. L. SIMON, “A Moses...”, p. 215. El autor identifica, así mismo, la figura en actitud reverencial arrodillada, que se coloca en el extremo de uno de los lados cortos del capitel, como una representación alegórica de los israelitas, que aparecen, según argumenta, justo en el momento en que Moisés recibe el Decálogo. El citado investigador conecta dicho capitel con el de Balaam y la burra del Panteón Real de San Isidoro.

${ }^{1805}$ M. EDMOND LE BLANT, Les sarcophages..., pp. 122-123. La pieza proviene del entorno de la famosa Puerta des Comtes de la basílica de Toulouse, donde aparecieron más piezas de este tipo en el siglo XVII. Desde siempre, se ha relacionado con la figura de Pons Taillefer, conde de Toulouse. Sin embargo, todo parece indicar, según se ha dicho, que, posiblemente, dio cobijo al cuerpo de Guillermo de Taillefer, nuevamente conde de la misma ciudad y que murió poco después del año 1037. La parte central muestra las figuras de Cristo acompañado por los apóstoles. Desde otro orden de cosas, también se analizó la importancia de la iconografía de la imago clipeata en la basílica de Toulouse, en: J. ADHÉMAR, Influences antiques..., pp. 165-166. Sobre el carácter funerario de la zona donde apareció el sarcófago, consúltese: M. DURLIAT, "Les origines...", p. 351.
} 
nimbo, habla, claramente, sobre la imposibilidad de identificar la efigie románica de Jaca como un retrato de Cristo.

Nos encontramos ante un posible motivo clásico tomado de un sarcófago romano. Sin embargo, restaría poder llegar a definir la intencionalidad con la que fue introducido entre el corpus de piezas que decorarían el recinto medieval. Atribuir a los escultores románicos la capacidad de poder realizar un análisis iconológico de las piezas romanas es algo que escapa a nuestras posibilidades, sobre todo, si pretendemos presentarlas bajo un método fiable ${ }^{1806}$.

Continuando con el sarcófago tolosano, en el lado corto izquierdo, tal y como describió M. Edmond, encontramos la imagen de un edículo cerrado junto a dos figuras masculinas. Una de ellas porta el típico volumen, siguiendo el mismo modelo compositivo que encontramos, por ejemplo, en el sarcófago de Béziers ${ }^{1807}$.

El uso del rollo o volumen, en manos del magister, del difunto, de los esposos o de algunas figuras representadas en este tipo de piezas estuvo muy difundido, tal y como apunta J. Beltrán Fortes ${ }^{1808}$. Deberíamos preguntarnos, en todo caso, si la imagen de los personajes laterales sustentando un libro en el capitel de Jaca no debe ser vista como una deuda de este tipo de iconografía ${ }^{1809}$. Y más aún, si su introducción dentro de la escena pudo tener, en algún momento, un sentido testimonial pues, algunos autores, tal y como hemos dicho, quisieron ver en estos personajes que rodean el clípeo una alusión a los testigos terrestres, que potencian el valor de autenticidad del suceso que acontece en la escena principal ${ }^{1810}$.

\footnotetext{
${ }^{1806}$ M. A. CASTIÑEIRAS GONZÁLEZ, Introducción al método..., pp. 86-87. En dicho estudio hace una síntesis de los niveles preiconográfico, iconográfico e iconológico que, según el criterio del autor, rigen las valoraciones de esta índole.

${ }_{1807}$ M. EDMOND LE BLANT, Les sarcophages..., p. 123. El estudioso expone la posibilidad de que se trate de la imagen del Santo Sepulcro con los apóstoles. Véase también: J. ADHÉMAR, Influences antiques..., pp. 78-80.

${ }^{1808}$ J. BELTRÁN FORTES, Los sarcófagos romanos..., p. 85 e ID., "El uso del sarcófago...”, p. 95.

${ }^{1809}$ Así lo muestra, por ejemplo, la composición del sarcófago de Maximino de Aix-en-Provence. En el centro de la tapa de la pieza se figuró la escena de los dos genios alados portando una cartela anepigráfica. En el lateral izquierdo aparecen dos personajes vestidos con clámide, en actitud dialogante, mientras que, el de la derecha, ofrece un rollo al de la izquierda. Cf.: M. EDMOND LE BLANT, Les sarcophages..., p. 51.

${ }^{1810}$ W. WEISBACH, Reforma religiosa..., p. 225. El autor otorga estas funciones a las cortes angélicas y a los apóstoles. Desde un punto de vista iconográfico, la imagen de los grupos o también definidas como "collegia funeraticia" fueron recurrentes dentro del arte romano. Se trataba de asociaciones de carácter funerario, regidas por el pago de una cuota y que aseguraban el control de determinados lugares de enterramientos, así como del mismo rito en memoria de los difuntos. Sobre este tema, véase: L. ABAD CASAL, El arte hispanorromano..., pp. 4-5 y M. JUSTINO MACIEL, "Banquete e Apotheosis en alguns signos artísticos da Antiguidade Tardia portuguesa", Propaganda y Poder. Congreso Peninsular de História da Arte, Lisboa, 1999, pp. 19-29. El profesor Maciel analiza los ritos del ágape, las oblationes y el refrigeria, ligados a este tipo de comunidades, sobre todo, las parentalias. Sobre el origen
} 
Para finalizar este apartado, quisiéramos apuntar, brevemente, una serie de reflexiones sobre la importancia que el fenómeno que acabamos de explicar va a tener dentro del arte románico hispano. Sin centrarnos directamente en este ejemplo, pues tendremos oportunidad de hacerlo más adelante, debemos aludir al tímpano de la Puerta del Cordero de la basílica de San Isidoro de León. En su parte alta se esculpió la imagen del triunfo del Cordero Pascual inscrito en un clípeo elevado por dos ángeles.

La mayoría de los autores que han analizado la escultura apuntaron, desde un punto de vista u otro, la importancia que, en la configuración de tal imagen, tuvo el arte romano tardío, especialmente, el de vertiente cristiana. No se puede afirmar con rotundidad, pero el marcado carácter clásico que muestra la composición, los rasgos "antiquizantes" de las vestimentas y las posturas de los ángeles, parecen hablar a favor de un supuesto conocimiento de las fuentes clásicas ${ }^{1811}$.

Si el modelo romano más directo para el capitel románico de Jaca hubo de estar en el sarcófago de San Pedro el Viejo de Huesca, tal y como apoya gran parte de la historiografía, creemos que no deben desecharse los contactos con otras piezas antiguas. La presencia continua y la transmisión inercial del motivo complica la tarea de apuntar un único modelo como fuente de inspiración.

En este sentido, la pieza romana habría sido objeto de múltiples reutilizaciones dentro de la etapa medieval. Desde su expoliación in se como tumba del monarca Ramiro II, tal y como apunta D. Ocón Alonso, hasta el otro tipo de reinterpretación. De aceptar una influencia sobre el capitel de Jaca se documentaría una primera expoliación, esta vez in se, que daría algunas pautas, más tarde, explotadas por estos escultores románicos. En un segundo momento más avanzado de la escultura románica, parece, según se ha dicho, que el sarcófago -u otro de similares características- volvió a ser examinado, influenciando, nuevamente, a los artesanos encargados de realizar la escultura románica del templo de San Pedro, aunque tal cuestión, aún permanece sin resolver $^{1812}$.

iconográfico de estas figuras flanqueando al difunto, dentro de este tipo de composiciones, en claro recuerdo de Hipnos y Thanatos, es decir, las deidades del Sueño y la Muerte, consúltese: E. PANOFSKY, Tomb sculpture, London, 1964, p. 35.

${ }^{1811}$ En el apartado correspondiente recogeremos toda la bibliografía relativa a tal cuestión.

${ }^{1812}$ D. OCÓN ALONSO, "Los maestros de San Pedro el Viejo de Huesca: un ensayo de aproximación a los procesos de creación artística en la escultura románica", El arte aragonés y sus relaciones con el hispánico e internacional, Huesca, 1983, pp. 87-100, en concreto, pp. 93-94, nota 21. La autora señala que, a pesar de ciertas relaciones entre el sarcófago y la escultura del edificio, "este no parece haber sido su fuente directa de inspiración". 
El estudio de tales piezas, fundamentado en meras hipótesis, provoca cierta inseguridad en nuestras afirmaciones. Baste con observar, por ejemplo, el sarcófago conservado en la iglesia de San Félix de Gerona (fig. 347). Se trata de un unicum en su género que muestra a dos ángeles extendiendo su cuerpo y sus alas a lo largo del formato rectangular de la cista. Con sus manos asen, nuevamente, una especie de clípeo o tondo en el que fue inscrita una estrella que, a su vez, alberga en su interior la imagen del Cordero con el lábaro.

La utilización de un relieve sin demasiado volumen, la simplicidad de formas y el hecho de que todo el fondo de la pieza se dejase sin esculpir, salvo la inserción de decenas de estrellas ciertamente esquemáticas, permitieron a M. C. Villalón relacionar la escultura con la misma plástica altomedieval de tradición tardoantigua, que tendría sus modelos más remotos en las imágenes clipeatae del Sol y la Luna realizadas para la iglesia de Quintanilla de las Viñas, con las que iniciábamos este apartado ${ }^{1813}$. Todo ello, a pesar de que, la pieza de Gerona, venga siendo datada en pleno siglo XIII.

\footnotetext{
${ }^{1813}$ M. C. VILLALÓN, "Quintanilla de las Viñas en el contexto...”, pp. 119-120. La autora se refiere a la pieza con las siguientes palabras: "Para la composición de los clípeos portados por ángeles, se han señalado ya antecedentes en la plástica clásica y bizantina, al igual que su presencia en la miniatura mozárabe. El Beato de Gerona, entre muchos otros ejemplos, muestra ángeles semejantes a los de Quintanilla y aún se pueden encontrar en el arte románico recurrencias que parecen continuar y reafirmar este esquema en las mandorlas teofánicas o en los clípeos con crismones o corderos, desde los primeros ensayos de los conocidos dinteles de Saint Genis-des-Fonts o San André de Sureda, hasta pervivencias retardatarias como la que recoge el sarcófago de la iglesia de San Feliù de Girona".
} 
El siguiente apartado, forzosamente más breve que los anteriores, debido a la poca información que nos ha llegado al respecto, se centra en el análisis de ciertos aspectos presentes en el ábside sur de la catedral de Jaca ${ }^{1814}$ (fig. 348).

No es nuestro objetivo analizar de manera detenida cada una de las piezas presentes en tal construcción, ni tampoco su iconografía, a la que se aludirá en casos puntuales. Tampoco pretendemos desarrollar un estado de la cuestión y una investigación sobre tales elementos, por otra parte, bien estudiados dentro de las investigaciones dedicadas a la arquitectura de la catedral.

Nuestro interés radica en el valor que las esculturas toman en dicho ábside, sobre todo, en cuanto son entendidas, no como meros elementos ornamentales que decoran las superficies de capiteles, metopas y canecillos, sino que, tales piezas, poseen, además, ciertas funciones arquitecturales y funcionales dentro de la misma construcción. La decoración de este ábside rememora la mejor "escultura arquitectónica" de la Antigüedad tardía y la Alta Edad Media y se presenta como uno de los mejores ejemplos que certifica su plena absorción, comprensión y utilización por parte de los $\operatorname{artífices~románicos~}^{1815}$.

En un primer contacto visual con el ábside sur del templo, llama poderosamente la atención el cuidado con el que fueron dispuestos los elementos ornamentales que

\footnotetext{
${ }^{1814}$ El ábside norte del templo está completamente alterado en relación con el del lado sur, casi íntegramente intacto. La parte central de la cabecera románica fue destruida para ser rehecha en torno al año 1970. A la hora de analizar algunos aspectos de tal construcción, no nos detendremos en examinar la iconografía de cada uno de los elementos que lo configuran. Se estudiará el ábside en general, desde su conjunto, prestando atención, sobre todo, a la manera en que fueron dispuestas las esculturas en relación con la arquitectura, pues creemos que es aquí donde, de manera más evidente, se pervive el recuerdo de lo antiguo. Véase al respecto: M. DURLIAT, La sculpture romane..., pp. 226-227; J. IÑíGUEZ ALMECH, "La catedral de Jaca y los orígenes del románico español", Actas del Quinto Congreso Internacional de Estudios Pirenaicos: Jaca-Pamplona, vol. 3, 1966, pp. 179-201; V. NAVARRO GONZÁLEZ, "IX centenario de la consagración de la catedral de Jaca y del concilio jacetano", Argensola, 47-48, 1961, pp. 285-302 y M. DURLIAT, "La Catedral de Jaca en el contexto del arte románico europeo", Signos: arte y cultura en el Alto Aragón medieval (T. Luesma coord.), Huesca, 1993, pp. 95-102.

${ }^{1815}$ La expresión "escultura arquitectónica" ha venido siendo utilizada por diferentes especialistas desde hace tiempo, generalmente, aplicada a las producciones arquitectónicas y escultóricas anteriores al año mil. Cf.: L. N. C. WRENCH, Decoração arquitectónica..., en concreto, vol. I, pp. 1-2. La profesora Wrench define el objeto de su estudio y las características de la "escultura arquitectónica". En el caso español, se utilizó un método similar para el estudio publicado hace años, en: M. C. VILLALÓN, Mérida visigoda. La escultura arquitectónica y liturgia, Mérida, 1985. Se utiliza la misma definición en: M. JUSTINO MACIEL, Antiguidade tardia..., p. 183.
} 
llegan a expandirse sobre todas aquellas piezas que, en un primer momento, fueron concebidas como estructuras participantes de la misma arquitectura del templo.

Los capiteles, basas, canecillos, metopas, ménsulas, así como todo tipo de molduras, fueron esculpidas con cuidado, mostrando imágenes bien definidas y complejas. Este tipo de solución, desarrollada tempranamente en el caso jaqués, habría de convertirse en recurrente dentro del románico ${ }^{1816}$. Aquí, ambas técnicas se unen y ofrecen una articulación del muro que no sería posible sin su combinación. Los elementos arquitectónicos se transforman, mostrando, de una manera muy preferente, un nuevo valor, el escultórico, rememorando algunos aspectos ideológicos y conceptuales albergados por el concepto clásico de decor ${ }^{1817}$.

La cornisa del ábside presenta una serie de canecillos que soportan el alero y que fueron ricamente decorados. Entre ellos y explotando un juego de luces y sombras muy interesante, se colocaron, en alternancia, una serie de placas cuadradas a modo de metopas antiguas que, según la disposición espacial que presenta la articulación del alero, pudieron, en origen, sobrepasar la decena. De igual modo, mientras que dichos elementos se alternan con los canecillos, en la parte baja del alero, también se dispusieron otras esculturas, haciendo doblete con las que se adosan, de manera parietal, al muro, a modo de sofitos.

Todo ello genera grandes efectos plásticos muy originales para una cronología que, a veces, se definido por su carácter prematuro. Tal novedad en el tratamiento de los paramentos y la misma escultura, pudo, tal y como intentaremos demostrar, tener su modelo último dentro de ciertas soluciones adoptadas por el arte antiguo de la etapa romana tardía y paleocristiana.

Con respecto a esta posibilidad, H. Focillon ya había defendido, en su día, la posibilidad de establecer ciertas dependencias entre este tipo de soluciones y las obras antiguas. Según el investigador francés, toda una serie de elementos habituales dentro de las construcciones medievales, tales como los relieves incrustados en el muro, los frisos, las esculturas colocadas bajo arquerías, las pilastras, canecillos, metopas y todo

\footnotetext{
1816 Sobre las cuestiones cronológicas del edificio y su construcción remitimos a los trabajos ya mencionados en el inicio de este bloque. Véase también: V. NAVARRO GONZÁLEZ, Op. cit., pp. 285302.

${ }^{1817}$ Desde un punto de vista arquitectónico, el ábside se ha datado en ese periodo que va, desde finales del siglo XI a principios del XII. Nuevamente, la estructura arquitectónica se emparentó con las existentes en suelo francés, especialmente, con los ábsides de Saint-Saturnin de Toulouse, además de otra serie de fábricas galas. Ya en suelo español, se pusieron como referentes, más o menos coetáneos, la iglesia de San Martín de Frómista o los ábsides laterales de San Isidoro de León. Sobre el concepto clásico de decor, véase: L. N. C. WRENCH, Decoração arquitectónica..., vol. I, p. 2.
} 
de tipo de elementos de similares características, tendrían una vinculación directa con el arte de la Antigüedad ${ }^{1818}$.

Así, su discípulo M. Durliat, basándose en sus argumentos, alegó una influencia de la articulación de los aleros y las cornisas de los templos romanos, a la hora de poder comprender el léxico de la parte alta del ábside de Jaca ${ }^{1819}$.

Tal hipótesis parecía lógica, pues los contactos entre la arquitectura antigua y la de época románica habían sido señalados de manera recurrente por parte de los especialistas ${ }^{1820}$. Recuérdese, por ejemplo, una pieza que ya hemos mencionado en este estudio. Se trata del fragmento de cornisa conservado, actualmente, en el Museo de los Agustinos de Toulouse y datada, posiblemente, no más allá del año $1100^{1821}$. D. Cazes ya relacionó su factura con la obra de condición "antiquizante" del escultor Bernardo Guilduino, del que nos ocuparemos más adelante (fig. 317).

La pieza presenta una alternancia de canecillos o ménsulas decoradas con placas dispuestas para recibir la decoración vegetal, en forma de rosetas clásicas. Creemos que el recuerdo antiguo de este tipo de esculturas es innegable ${ }^{1822}$.

Sobre el sustrato y los modelos clásicos seguidos por los artistas activos en el foco tolosano y, sobre todo, sobre las relaciones mantenidas con la escultura románica hispana, hablaremos en el apartado correspondiente. Simplemente insistimos en que los escultores que trabajaban en ambos centros parecen compartir unos modelos de índole similar e intereses comunes. En ambos casos, se percibe un interés desmesurado por ornamentar y dotar de una gran fuerza plática a aquellas piezas que, en origen, habrían sido ideadas para ser colocadas en la parte más alta de los edificios.

La supuesta dependencia entre este tipo de elementos escultórico-arquitectónicos románicos con respecto al arte romano, llevó a Th. Lyman a considerar que, algunas de las piezas dispuestas en las partes altas de la basílica francesa, entre ellas canecillos y metopas, podrían haber sido tomadas de la cinta muraria romana de la ciudad de Toulouse $^{1823}$.

\footnotetext{
${ }^{1818}$ H. FOCILLON, La escultura románica..., pp. 79-116.

${ }^{1819}$ M. DURLIAT, "Sculpture...”, pp. 369-370.

${ }^{1820}$ M. GREENHALGH, "Ipsa ruina docet...", pp. 123-124. Se insiste en la importancia de las piezas de mármol tomadas de la arquitectura clásica para comprender las fuentes sobre las que se asientan las realizadas en época románica.

${ }^{1821}$ Toulouse, Musée des Augustins.

1822 D. CAZES, “Toulouse, Musée des Augustins...", pp. 152-153.

${ }^{1823}$ Las fuentes clásicas del foco tolosano serán abordadas posteriormente. Cf.: TH. LYMAN, "Le style comme symbole chez les sculpteurs romans: essai d'interprétation de quelques inventions thématiques a la porte Miégéville de Saint-Sernin”, Les Cahiers de Saint-Michel de Cuxa, VI, 1975, pp. 161-178, particularmente, pp. 167-168. El autor se centra en otras piezas que pudieron haber inspirado la obra de
} 
Volviendo al modelo de Jaca, entre algunas de las placas incrustadas en el alero, se pueden identificar temas variados, entre los cuales, el repertorio zoomórfico es el más destacado. Entre las identificaciones seguras estaría la de un dromedario o camello, un león o felino pasante y un basilisco. También se incorporaron algunas placas con figuración humana donde, nuevamente, encontramos personajes desnudos con serpientes ${ }^{1824}$ (fig. 349).

Algunas de las más interesantes, como aquella que, posiblemente, representa un oso, se conservan el Museo Diocesano de la catedral, tal vez provenientes del ábside norte del edificio (fig. 350).

Con todo, aún viendo un origen clásico para la decoración del ábside sur del templo jacetano, M. Durliat alegó la imposibilidad de que se tratase de una influencia del mismo arte hispanorromano que, según el investigador, presentaba un panorama mucho más pobre y de menor alcance que la rica romanización uniforme de la Galia $^{1825}$. Sin embargo, el mismo autor y en la misma publicación escribía que, uno de los posibles orígenes para poder explicar la escultura de la cabecera jaquesa, estaría en algunas de las placas de tierra cocida que, en su día, habían decorado y articulado buena parte de las estructuras arquitectónicas de la edilicia antigua. Sin embargo, a pesar de ello, alegaba que la carencia de ejemplos de este tipo de piezas en la región española no permitiría hablar de un contacto directo o de primera mano con dichos modelos ${ }^{1826}$.

No es la primera vez que hemos hablado sobre la posibilidad de que determinadas piezas realizadas en terracota hubieran inspirado algunas de las soluciones adoptadas por los artífices medievales. Ya en su día, P. Deschamps utilizó los mismos argumentos para poder explicar, por ejemplo, el friso de la iglesia de Saint-Martin de Ainay, en Lyon, donde, nuevamente, se esculpieron diversas imágenes de animales adaptadas a este formato ${ }^{1827}$.

estos escultores medievales como, por ejemplo, una consola conservada en el Museo Nacional de Estambul, así como otra serie de esculturas romanas que dotarían a la plástica románica del edificio francés de un cierto aire helenístico, tal y como señala el investigador.

${ }^{1824}$ No creemos conveniente volver a insistir sobre la iconografía que muestra a diferentes hombres desnudos con serpientes, tema ya abordado, anteriormente, de manera extensa.

${ }^{1825}$ M. DURLIAT, La sculpture romane de la route..., pp. 13-14. El sustrato clásico del foco tolosano se explicaba, según el investigador francés, a través de la gran riqueza de restos romanos conservados en la zona y que facilitaron el acceso a tales piezas por parte de los artistas. Creemos que definir el legado romano conservado en Hispania como pobre es, cuanto menos, demostrar un mal conocimiento del tema. ${ }^{1826}$ Ibidem, p. 227. Durliat apuntaba la posibilidad de relacionar dichas obras con piezas marmóreas.

${ }^{1827}$ P. DESCHAMPS, Etude sur la renaissance..., en concreto, pp. 65-67. El autor también menciona otra serie de ejemplos, como los de Saint-Restitut de Drôme y otros de Ille-Barbe, en Rhône. 
Sabemos, gracias a los ejemplos conservados, de la existencia de edificios románicos que utilizaron estas mismas soluciones en el alero sin poder alegar dependencia ninguna con respecto a los modelos clásicos. Recuérdense, por ejemplo, el espectacular caso de la cabecera de Saint-Hilaire de Poitiers donde, nuevamente, encontramos una proliferación de la decoración de placas y canecillos muy parecida al caso de $\mathrm{Jaca}^{1828}$ (fig. 351).

En el caso hispano, es de destacar la cornisa que ofrece la iglesia de San Quirce de Burgos y donde los artífices se esmeraron en crear una estructura de gran complejidad, tanto desde el punto de vista escultórico como arquitectónico ${ }^{1829}$ (fig. 352). Otros ejemplos, como la posible cornisa, hoy desaparecida, de la Puerta del Cordero de San Isidoro de León o la también malograda Puerta de Francia de Santiago de Compostela, hablan de un marcado interés por invadir, a través de las imágenes, todo tipo de cornisas, canecillos y aleros, mediante complejos programas iconográficos ${ }^{1830}$. En otro orden de cosas y, concretamente, dentro de la escultura románica asturiana, la profesora E. Fernández González expuso la gran variedad de modelos vegetales dispuestos sobre metopas de algunas construcciones tan señeras, entre otras, como Santa Eulalia de la Lloraza o San Esteban de Aramil ${ }^{1831}$.

En relación con el formato de las placas de piedra recuerda, claramente, a las que se han conservado en la Galia. Nos referimos, concretamente, a varias piezas de terracota en las que se dispusieron diferentes iconografías como, por ejemplo, algunas rosáceas hexástilas (fig. 353) o, de una manera más desarrollada, temas cristianos, como

\footnotetext{
${ }^{1828}$ M. A. CASTIÑEIRAS, “A poética das marxes no románico galego: bestiario, fábulas e mundo ó revés”, Sémata, 14, 2002, pp. 239-334, en concreto, p. 314. El especialista se centra en la decoración de la cornisa y el alero de la fachada de Platerías, buscando paralelismos con la citada iglesia de Poitiers. Además, también señala una relación morfológica con las esculpidas en la puerta Miegèville de Toulouse. Ambas, tendrían su parentesco más evidente, según escribe el autor, con las de la catedral de Jaca.

1829 G. BOTO VARELA, "La integración...", pp. 103-106. El profesor Boto abordó el tema recientemente, defendiendo la posibilidad de explicar los relieves a través de textos de Aristóteles y Valerio, lo cual, no alejaría las esculturas de un pasado "antiguo". Por su parte, el profesor Rico ha publicado un estudio centrado en analizar algunos aspectos iconográficos de la escultura de este templo. Cf.: D. RICO CAMPS, Las voces del románico..., pp. 10-23.

${ }^{1830}$ M. A. CASTIÑEIRAS, "A poética das marxes...", pp. 239-334. El estudio se centra en los programas de Platerías o Santiago de Tabeirós, entre otros muchos. En lo referente a la portada del Cordero, el programa que decoró la cornisa debió ser complejo, sobre todo, al mostrar diferentes relieves con la representación de los signos del zodíaco. Hoy toda la cornisa se muestra desmantelada tras las reformas barrocas pero, según ha señalado Th. Martin, tales piezas fueron acompañadas, incluso, con diversos epígrafes identificativos. Vid.: T. MARTIN, Queen as King..., en concreto, pp. 92-93. En particular, publica las inscripciones incrustadas, a modo de sillares, en algunas de las partes de la basílica y sus dependencias. Hoy nos han llegado, más o menos legibles, las de ARIES y GEMINI: TAV.

${ }^{1831}$ E. FERNÁNDEZ GONZÁLEZ, La escultura románica..., pp. 289-291. La profesora Fernández recoge muchos de los modelos utilizados en el románico de la región que analiza.
} 
el del Pecado Original ${ }^{1832}$ (fig. 354). Tanto desde el punto de vista del formato, como desde el de su ubicación, dispuestas para presentarse entregas en el muro, las placas de la catedral de Jaca podrían tener un lejano precedente en dichos modelos.

Sin embargo, siguiendo la misma solución que el fragmento de cornisa conservado en el Museo de los Agustinos de Toulouse, son los elementos vegetales en los que mejor podemos encontrar esta perdurabilidad de modelos romanos.

Sobre la pervivencia en los siglos del románico del acanto y todos aquellos elementos vegetales asociados con él, ya hemos aludido anteriormente, pero resulta interesante mencionar el estudio realizado por R. Rey en relación con la utilización de un tipo de vegetal, muy común dentro de la plástica romana. A través de ejemplos de una cronología, levemente posterior, como la que se ha propuesto para el conocido dintel de la portada de la abadía de Saint-Pierre de Moissac (fig. 355) y otras piezas similares, como algunos de los elementos vegetales dispuestos en la fachada de la catedral de Cahors, el autor, ha podido poner de relieve la importancia de la decoración vegetal clásica en los edificios románicos. En concreto, se trataría de la carlina acanthifolia de grandes pétalos y derivada del mismo acanto, la que, desde las obras romanas, llegaría a formar parte del repertorio de modelos románicos ${ }^{1833}$. El mismo R. Rey defendió la posibilidad de que tales piezas marmóreas, de una calidad sorprendente, fuesen en realidad trabajos propiamente romanos, es decir spolia in se de un edificio más anciano ${ }^{1834}$.

Con todo, creemos que resulta muy problemático poder llegar a señalar el origen concreto del modelo que siguieron los escultores jaqueses, puesto que, tal y como es sabido, dentro del repertorio icónico románico, tampoco son descartables, en absoluto, otras vías de inspiración. Los marfiles y las obras en metal siempre ofrecieron

${ }^{1832}$ Nantes, Musée Th. Dobrée. Cf.: M-C. MAUFUS, "La Terre cuite", Naissance des arts chrétiens. Atlas des monuments paléochrétiens de la France (N. Duval coord.), Paris, 1991, pp. 232-237, en concreto, p. 223. La placa en la que se representó la iconografía del Pecado Original, se ha datado entre los siglos VI y VII. También se publica en el estudio citado otra pieza cuadrangular con una roseta inscrita en el interior, datada en el siglo VII y que se conserva en el mismo museo.

${ }^{1833}$ R. REY, "Quelques survivances antiques dans la sculpture méridionale", Gazette des Beaux-Arts, XVIII, 1928, pp. 173-191, en concreto, p. 182 ; M. DURLIAT, La sculpture romane de la route..., p. 227; ID., "L'apparition du grand...", p. 11 e ID., "Les origines de la sculpture...”, p. 360. Durliat habla de su utilización en la Puerta des Comtes de Toulouse, admitiendo, no obstante que, en Jaca, la variedad vegetal es más rica. El mismo autor insiste sobre la influencia de algunos de los sarcófagos romanos labrados en mármol de los Pirineos, como la fuente seguida por los escultores de Moissac y otros originarios de la antigua necrópolis, localizada en los alrededores de la iglesia de Saint-Martin, en la misma localidad. Para el problema del acanto en los siglos medievales, consúltese: E. PANOFSKY, Renacimiento y renacimientos..., p. 158.

${ }^{1834}$ R. REY, "Quelques survivances...", p. 180. Abordaremos el problema de la tradición clásica en el Languedoc y sus repercusiones sobre lo hispano posteriormente. 
excelentes ejemplos que imitar o copiar y que, además, se han señalado en numerosas ocasiones como posibles fuentes para este tipo de producciones ${ }^{1835}$.

Para finalizar estas breves reflexiones sobre la problemática de las fuentes seguidas para la realización de la cornisa del ábside sur de la catedral Jaca, haremos una breve alusión a la importancia que aquí cobra la iconografía zoomórfica. A parte del uso del tema de la serpiente, siempre en relación con figuras desnudas, también se incluyeron, entre otros, el tema del dromedario, el del león y el del basilisco ${ }^{1836}$.

Todos ellos gozaron de gran difusión dentro de la escultura románica, sin duda, a través del conocimiento que de tales seres se tenía desde el mundo antiguo. En concreto, para el caso del dromedario, ya M. Guardia señaló en su día, a propósito de la imagen pintada del animal en San Baudelio de Berlanga:

“(...) fue un animal muy conocido en el mundo antiguo por las numerosas funciones que cumplía, va a ser considerado en la Edad Media occidental como exótico (...) en el arte romano (se utilizaron) especialmente como animales de carga, incluso para la guerra" ${ }^{1837}$.

La misma autora insiste en la importancia del oso dentro de los programas iconográficos románicos, a pesar de su poca difusión dentro de los bestiarios. Ésta, estaría justificada por la gran propagación que el tema tuvo, desde la Antigüedad, en la Península Ibérica y que explicará la importancia del animal dentro del románico asturiano, por ejemplo, donde los osos aparecen junto a los leones, en plenas cacerías, tal y como muestra el capitel, de sabor clásico, realizado para la Cámara Santa de Oviedo y otro de San Pedro de Villanueva ${ }^{1838}$.

Por último, queremos mencionar que, en una de las metopas del alero se esculpió la imagen de un basilisco que, tal y como hemos señalado, se repitió dentro del mismo

\footnotetext{
${ }^{1835}$ Sobre la influencia de los metales y marfiles a la hora de configurar el motivo decorativo de las rosetas, véase: M. DURLIAT, "L'apparition du grand...", pp. 8-11. Véase el apartado que dedicamos en este trabajo a la problemática del acanto y otro tipo de vegetales dentro de la escultura románica, así como en relación con los modelos del pasado.

${ }^{1836}$ Sobre la desnudez de las figuras en el mundo clásico y medieval, véase: G. BECATTI, "Nudo...", pp. 576-579.

${ }^{1837}$ M. GUARDIA PONS, Las pinturas bajas..., pp. 142-143.

${ }^{1838}$ E. FERNÁNDEZ GONZÁLEZ, La escultura románica..., pp. 187-191 y M. GUARDIA PONS, Las pinturas bajas..., p. 148. La profesora M. Guardia señala el carácter negativo del animal durante la época medieval, sobre todo, ligado a la gula. El motivo del oso también fue representado en una de las ménsulas de la Puerta des Comtes de Toulouse, quizás, con un sentido negativo, tal y como se propone en: R. BARTAL, "La coexistencia de los signos apotropaicos cristianos y paganos en las entradas de las iglesias románicas", Archivo Español de Arte, 262, 1993, pp. 113-124, particularmente, p. 116, nota 10.
} 
tímpano occidental de la catedral. No es necesario incidir en las menciones que se realizaron en las fuentes antiguas de este ser, así como su relación con la serpiente, que huyen despavoridas al percibir su aliento venenoso ${ }^{1839}$.

Quizás, esta fue la razón de su inclusión dentro del conjunto, en relación con los hombres portando serpientes en sus manos, deudoras, en todo caso, del ideario romano al que tantas veces hemos aludido al hablar de este reptil.

La hipótesis ofrecida hasta el momento, vuelve a poner de relieve la complejidad de realizar un estudio serio asentado sobre el problemático método de las relaciones entre obras de espacios y tiempos muy alejados. Se presenta, además, el problema de aquello que se perdió, sin duda, ejemplos que podrían arrojar luz o incrementar el corpus de motivos susceptibles de ser comparados con la escultura medieval.

La imposibilidad de poder acercarnos, ni de lejos, a la manera en que estos artífices concebían la observación de la obra antigua, el panorama que pudieron conocer y la facilidad que poseían a la hora de reelaborar imágenes basándose en otras piezas materializadas en estilos, soportes y técnicas diversas, complica aún más la tarea.

Una solución coherente al respecto, debiera exprimir al máximo el método formalista, según el cual, se deduce el parentesco o una posible relación entre dos obras basándonos en los puntos en común que ambas comparten. La presencia de este tipo de placas y elementos para ser empotrados sobre los muros y los demás elementos arquitectónicos, pudo ser más rica en la Península Ibérica de lo que imaginamos ${ }^{1840}$.

Aunque fragmentados y conocidos mediante diseños, se nos presentaban algunos de los relieves de esta índole que decoraban los templos y basílicas romanas, de la época tardía, tal y como se constata en las piezas de la Lusitania recogidas por J. L. de Matos $^{1841}$.

Pero, más aún, su traspaso a la ornamentación de los nuevos edificios cristianos fue, tal vez, una mera continuación de soluciones. Este tipo de elementos, ahora con iconografía cristiana, continuaron presentando las mismas fórmulas en cuanto a su realización, el lugar para el que estaban destinadas y, sobre todo, en cuento piezas

\footnotetext{
${ }^{1839}$ I. MALAXECHEVERRÍA, El bestiario esculpido de Navarra, Pamplona, 1982, pp. 47-49.

${ }^{1840}$ El caso italiano conservó un corpus mucho más rico. Cf.: R. OLIVIERI FARIOLI, Corpus della scultura paleocristiana bizantina ed altomedioevale di Ravenna, III vols., Roma, 1969.

${ }^{1841}$ J. L. DE MATOS, "Placas decorativas com relevos de acantos e acroteras de máscara teatral e ave", Inventário do Museu..., ficha catalográfica 119, pp. 118-119 e ID., "Friso com relevos de bucrâneus e pateras de Évora", Subsídios para um catalogo..., vol. II, pp. 175-176. El investigador analiza una serie de relieves de granito provenientes del templo de Diana y que son un buen ejemplo sobre este tipo de articulación de las cornisas.
} 
necesarias para presentar una imagen arquitectónica de los templos basada en el concepto clásico de decor ${ }^{1842}$.

${ }^{1842}$ L. N. C. WRENCH, Decoração arquitectónica..., vol. II (parte 1), pp. 177-179. La autora analiza una placa para incrustación conservada en el convento de Santa Iria de Tomar, identificado la imagen allí esculpida como el evangelista Lucas en forma de toro. La pieza es un ejemplo, muy temprano, que señala la posibilidad de demostrar tal continuismo. 


\section{G. EL TÍMPANO OCCIDENTAL Y LA ANTIGÜEDAD ROMANA TARDÍA.}

Sin duda, es el tímpano del acceso por el occidente de la seo jaquesa la pieza más conocida de todo el conjunto, además de ser la escultura que más atención ha recibido por parte de los especialistas. En este apartado nos centraremos en algunos aspectos relativos a tal pieza, sin embargo, somos conscientes de la imposibilidad de aportar cualquier visión novedosa sobre el tema pues, tan sólo un mero y simple balance historiográfico se presenta complicado, sobre todo, si tenemos en cuenta la cantidad de opiniones, a veces controvertidas, que dicho tímpano ha suscitado ${ }^{1843}$ (fig. 356).

No pretendemos, en absoluto, iniciar aquí el estudio pormenorizado de la pieza, sino recoger todos aquellos aspectos que, a lo largo de la extensa literatura científica, han señalado la dependencia de la misma con respecto al arte de la Antigüedad para, poder corroborar así, la utilización de fuentes clásicas por parte de los escultores, además de intentar delimitarlas de una manera más precisa.

El tímpano al que nos referimos presenta una forma semicircular que no se llega a completar en el extremo superior de la pieza, al aparecer cortada, quizás, para su correcto engaste en el muro. La parte central está ocupada por una estructura circular en la que se inscribe el anagrama de Cristo, el crismón. A parte de todos los elementos consabidos que suelen aparecer en este tipo de representaciones, llaman la atención los ocho florones, con grandes pétalos, que se esculpieron entre los radios que lo configuran. Flanqueándolo, dos leones pasantes, de cuellos estilizados y patas en movimiento. Bajo ellos, aparece, en el lado izquierdo, un hombre postrado sobre el suelo. En su mano agarra una serpiente, mientras que, al otro lado, dos animales ocupan

\footnotetext{
${ }^{1843}$ L. TORRES BALBAS, "La escultura románica y el crismón de los tímpanos de las iglesias de la región pirenaica", Archivo Español de Arte y Arqueología, II, 6, 1926, pp. 287-291; G. GAILLARD, "Notes sur les tympans aragonais", Bulletin Hispanique, XXX, 1928, pp. 193-202; J. M. CAAMAÑO MARTÍNEZ, "En torno al tímpano...", pp. 200-207; M. DUARLIAT, La sculpture romane de la route..., en concreto, pp. 243-248; D. OCÓN ALONSO, "Problemática del crismón...", pp. 242-263; ID., Tímpanos románicos..., vol. II, en concreto, pp. 115-133; ID., "Ego sum ostium...", pp. 125-136 e ID., "El sello de dios...", pp. 75-101. Véanse también: D. OCÓN ALONSO y P. RODRÍGUEZ ESCUDERO, Op. cit., pp. 259-263; D. L. SIMON, "El tímpano de la Catedral...", pp. 405-419; H. S. CALDWELl, "Penance, Baptism...", pp. 23-35; M. C. LACARRA DUCAY, Catedral y Museo Diocesano de Jaca, Zaragoza, 1993, en concreto, pp. 20-25; C. B. KENDALL, Op. cit., pp. 122-138 y J. DEL HOYO, Op. cit., consultado en http://www.anmal.uma.es/numero6/Hoyo.htm, el día 8 de abril de 2009. Consúltese, igualmente, el inicio de este apartado donde recogíamos toda la bibliografía manejada para el estudio de la escultura de la catedral.
} 
la misma posición. Todo el conjunto se acompaña por un excepcional conjunto epigráfico que, a modo de explanatio, da cuenta del significado de la escena ${ }^{1844}$.

A pesar de todos los problemas existentes a la hora de poder datar las esculturas del templo, parece ser que, entre los años últimos años del siglo XI y los primeros del XII, la pieza pudo estar colocada en el acceso occidental al edificio ${ }^{1845}$.

Creemos realmente significativo que, D. Ocón, una de las investigadoras que más trabajos ha dedicado al tímpano, señale, siguiendo a otros muchos autores, el origen romano del monograma con el que se "marcó" el acceso al edificio ${ }^{1846}$. Conviene citar el estudio más importante al respecto, aún hoy en plena vigencia, realizado por $\mathrm{F}$. Cabrol y H. Leclercq, donde analizan, de una manera exhaustiva, el origen antiguo de tal símbolo, así como su traspaso y aceptación por la imaginería cristiana ${ }^{1847}$.

Tal fue la difusión del icono que, desde los primeros siglos del cristianismo, inundó todo tipo de producciones, desde aquellas de carácter monumental y público, hasta otras de carácter más privado, desde esculturas con mayores pretensiones, hasta otras más modestas ${ }^{1848}$. La importancia del símbolo le permitirá poder aparecer, de una manera autónoma e independiente, pero también, complementado con otra serie de elementos, tanto zoomórficos como antropomórficos ${ }^{1849}$.

Tal difusión no debe sorprender. Uno de los grandes momentos de la historia del icono aparece ligado al año 324, en el que, el emperador Constantino decide enfrentarse con sus ejércitos a las tropas del emperador Licinio. Según se viene afirmando, las

\footnotetext{
${ }^{1844}$ M. DOLÇ, "Tres inscripciones de la catedral de Jaca", Pirineos, IX, 1953, pp. 421-432; J. VIVES, "Las leyendas epigráficas del tímpano de Jaca", Hispania sacra, IX, 1956, pp. 391-394 y J. DURÁN GUDIOL, "Las inscripciones medievales de la provincia de Huesca", Estudios de Edad Media de la Corona de Aragón, VIII, Zaragoza, 1967, pp. 45-153.

${ }^{1845}$ S. MORALEJO ÁLVAREZ, "La sculpture romane...”, p. 145.

${ }^{1846}$ D. OCÓN ALONSO, "Problemática del crismón...,", p. 243.

${ }^{1847}$ F. CABROL y H. LECLERCQ, voz "Chrisme", Dictionnaire d'Archéologie, vol. 3-I, Paris, 1914, cols. 1481-1534 y R. REY, "Quelques survivances...”, pp. 184-185.

${ }^{1848}$ Pensemos, en este sentido y dentro del contexto hispano, en los pequeños arreos y frenos de carros de caballos que muestran este monograma. Un buen ejemplo se conserva en Madrid, Museo Arqueológico Nacional. Para el caso del área portuguesa, véase: M. JUSTINO MACIEL, Antiguidade tardia ..., p. 212.

1849 Por ejemplo, acompañado de palomas, siguiendo una solución muy frecuente dentro de ámbitos funerarios. En este sentido, aparecerá en todo tipo de piezas: laudas, cipos, urnas cinerarias, epitafios, etcétera. Véase al respecto : F. CABROL y H. LECLERCQ, voz "Colombe", Dictionnaire d'Archéologie Chrétienne et de Liturgie, vol. 3-II, Paris, 1914, cols. 2198-2231, en particular, col. 2218. Los autores aluden a la perdurabilidad en el uso del crismón acompañado de palomas dentro del mobiliario litúrgico de época merovingia. Citan también, el ejemplo del denominado "pupitre" de Santa Radegunda de Poitiers. Por otra parte, dentro de los posibles ejemplos hispanos, los autores señalaban una inscripción encontrada en Jerez de la Frontera donde, una paloma da paso al texto, rodeada por una corona y acompañada por dos estrellas. Cierran la composición otras dos palomas que sujetan, con sus picos, ramas de olivo. El crismón aparece grabado bajo la corona. Sobre la pieza conservada en el Musée Sainte-Croix de Poitiers, véase: P. SKUBISZEWSKI, "Pupitre dit de Sainte Radegonde", Le Supplice et la Gloire. La Croix en Poitou (R. Favreau dir.), Poitiers, 2000, pp. 30-31.
} 
tropas entraron en la batalla, precedidas del lábaro que mostraba expuesto un crismón, el anagrama de Cristo, mientras que, las del emperador pagano, lo hicieron amparadas bajo los emblemas de los antiguos dioses. La derrota de Licinio en Crisópolis, en la costa asiática, supuso el encumbramiento del símbolo, especialmente importante para las artes plásticas ${ }^{1850}$.

Creemos que no es necesario incidir ni citar la larga lista de ejemplos posibles en relación con tal imagen y su utilización entre los siglos IV y V d. de C. En el ámbito concreto de la Península Ibérica son muchos los casos posibles y susceptibles de ser nombrados, sin embargo, los reduciremos a los más significativos.

Ya en su día, P. de Palol expuso la importancia que había tenido el uso del crismón dentro de la Hispania tardoantigua, sobre todo, en relación con las famosas placas de ladrillo realizadas en serie a través de un molde ${ }^{1851}$. Este sistema de producción da buena idea de la importancia y cotidianeidad con la que el crismón fue utilizado. Se trata de piezas de idénticas medidas, en ocasiones, grabadas con epígrafes alusivos al nombre de algún individuo y halladas en todo tipo de núcleos importantes de fundación romana, como Emerita Augusta, Hispalis o Asta Regia ${ }^{1852}$.

Se trata, por lo tanto, de una iconografía muy difundida en la Península desde el siglo V, quizás, tras la influencia del ámbito norteafricano, tal y como, de manera reiterativa, defendió N. Duval ${ }^{1853}$. En este sentido, de entre las posibles vías para poder analizar las fuentes que llevaron a colocar en Jaca tal imagen, no cabe olvidar una de las piezas más interesantes conservadas en suelo hispano. Nos referimos al denominado

1850 J. BECKWITH, Arte Paleocristiano..., p. 83 y pp. 88-89. El autor recoge algunas piezas numismáticas de época de Constantino, donde el símbolo fue frecuente. También se analizan algunos ejemplos del uso del símbolo dentro de la escultura de sarcófagos.

Véase también: J. DOIGNON, "Le monogramme cruciforme du sarcophage paléochrétien de Metz représentant le passage de la mer Rouge: Un symbole du triomphe sur la mort dans le cadre d'une iconographie aulique d'inspiration constantinienne", Cahiers Archéologiques, XII, 1962, pp. 65-87, en concreto, pp. 74-76. El crismón ocupará, a partir de estos momentos, lugares de gran importancia como, por ejemplo, dentro de la columna de Arcadio, donde unas victorias aladas portan el crismón, que se eleva sobre la efigie de los hijos de Teodosio I. Sobre este aspecto en concreto, véase: Y. CHRISTE, "La colonne d'Arcadius...", particularmente, p. 31.

${ }^{1851}$ P. DE PALOL, Arqueología paleocristiana..., pp. 267-268. El autor descartaba que se tratase de ladrillos pensados para incrustarlos dentro de los muros de una tumba.

Por su parte, en el año 2003, D. Ocón seguía manteniendo que "los ladrillos hallados en la Betica, pudieran haber formado parte de recubrimiento de las paredes de alguna cámara funeraria". Cf.: D. OCÓN ALONSO, "El sello de Dios...", pp. 84-85.

${ }^{1852}$ Otros muchos ejemplos se conservaron fruto de la cristianización de la Galia. Sirva de ejemplo el ladrillo con crismón empotrado en la torre de Aubin de Nantes y hoy conservado en Angers, Musée des Beaux-Arts. La pieza, se ha datado entre los siglos IV y VII y fue estudiada en: M-C. MAUFUS, "La terre cuite...", en concreto, p. 233.

${ }^{1853}$ N. DUVAL, La mosä̈que funéraire dans l'art paléochrétien, Verona, 1976, en particular, p. 25. El autor señala los ejemplos de Tipasa y Tebessa, como prototipos de mosaicos o laudas funerarias con forma de altar y en las que, de manera habitual, se colocaba la imagen del crismón. 
lábaro o crismón de Quiroga, aparecido en 1925 y conservado en el Museo Arqueológico de Lugo (fig. 357). Se trata de una bella escultura en mármol blanco de forma circular, que presenta, así mismo, un segundo círculo interior decorado con perlado, tal vez, en una alusión a los modelos orfebres en los que se pudo inspirar ${ }^{1854}$. Este reborde creó un espacio donde se colocó una inscripción métrica que, según la traducción publicada por A. Rodríguez Colmenero, dice:

"Cristo, principio y fin de todo. El oro debe parecer vil; apártate de las riquezas. Vale más que el brillo de esos metales lo que desprende de tu propia felicidad ${ }^{, 1855}$.

El mensaje, creemos, habla bien a las claras de la conexión que presenta con el arte de los metales y de la que tampoco debemos separar al crismón de Jaca. En dicha obra, a través del reborde que cubre el círculo interior que, a su vez, circunscribe el monograma, es posible que, la cenefa en forma de ovas que presenta, aluda a unos modelos similares $^{1856}$.

Las hipótesis sobre su función han sido variadas. Desde considerarla como una pieza de aplique para encajarla en un muro, hasta imaginarla formando parte de una mesa de altar. Sin embargo, aún hoy en día, se sigue dudando en tal cuestión.

También hallamos otros paralelos dentro de la pintura. En Tróia de Setúbal, Portugal, se conservó, dentro del conocido aula cristiana, una representación pintada,

\footnotetext{
${ }^{1854}$ No fue algo extraordinario. Según ha señalado E. Chatel, las piezas de mármol se inspiran, en muchas ocasiones, en otro tipo de obras, generalmente, de orfebrería. En concreto, al estudiar la placa con la imagen del crismón de la iglesia de Chambornay-les-Bellevaux, insiste en este fenómeno. Además, cita otros ejemplos, como el conservado en el Musée du Cloître Saint-André-le-Bas, en Vienne, o el de la iglesia de Vérzeronce, en Isère. Lo más significativo es la comparación que hace de la pieza de Chambornay en relación con el monograma de Jaca. Cf.: E. CHATEL, "Plaque de marbre sculptée dans l'église de Chambornay-les-Bellevaux (Haute-Saône)", Cahiers Archéologiques, 32, 1984, pp. 31-38, sobre todo, pp. 31-32 y p. 35. El autor insiste en el carácter clásico de la inscripción que presenta la pieza francesa.

${ }^{1855}$ A. RODRÍGUEZ COLMENERO, "Lábaro de Quiroga", A Ribeira Sacra. Esencia de espiritualidade de Galicia, Lugo, 2004, pp. 337-339 y P. DE PALOL, Arqueología cristiana..., pp. 248-249. El profesor Palol transcribe la inscripción en los siguientes términos: AVRVUM VILE TIBI EST, ARGENTI PONDERA CEDANT PLVS EST QUOD PROPRIA FELICITATE NITES. Adviértase que, la inscripción del monograma de Jaca, fue colocada en un lugar idéntico. Se ha venido datando entre los siglos V y VI d. de C., admitiéndose, en gran medida, la posibilidad de su origen local, puesto que apareció en la ermita de Quiroga, junto con otra serie de mármoles expoliados de construcciones anteriores.

${ }^{1856}$ La solución estuvo muy difundida en otras piezas de las que hablaremos más tarde como, por ejemplo, dentro de los crismones de San Martín de Frómista o de San Isidoro de León.
} 
derivada, según P. de Palol, del arte tardorromano ${ }^{1857}$. Se trataría de una obra, posiblemente, realizada entre los siglos IV y V d. de C. ${ }^{1858}$.

En este breve periplo en el que el uso del crismón va recorriendo los siglos hasta llegar a la Alta Edad Media, merece una mención especial, sobre todo por el desarrollo que este tipo de piezas alcanzaron dentro de la Península, las conocidas "placas-nichos". Se trata de una serie de piezas, generalmente, de cronología visigoda y realizadas, en muchos casos, en mármol. En ellas, la imagen del crismón vuelve a ocupar un lugar predilecto, esta vez, incluso, enmarcadas por elementos arquitectónicos.

En el trabajo realizado ya hace años por S. Ordax Andrés, exponía la posibilidad de que se tratase de fondos de altar, cuya morfología habría derivado del altar familiar que presidía la casa romana. Más interesantes resultan las conexiones que este tipo de piezas pudieron tener con otro tipo de modelos en miniatura y en los que, de manera bien documentada, se representaba la Anástasis de Jerusalén. Aquí, según el mencionado autor, el crismón tendría sentido martirial, aludiendo a la Resurrección de Cristo $^{1859}$.

Pero fue, sin duda, dentro de la iconografía de los sarcófagos labrados durante la Antigüedad tardía donde el monograma gozó de mayor difusión ${ }^{1860}$. Sin ánimo de ser exhaustivo, en relación con este aspecto, simplemente constatamos la frecuencia con la que fue utilizado, para poder así apoyar la asimilación de fuentes romanas paganas y paleocristianas por parte de los escultores románicos. Con todo, se trata de una idea que, por otra parte, también señaló de manera contundente S. Moralejo, en relación, con el uso, en este tímpano románico, de la imagen del crismón ${ }^{1861}$.

\footnotetext{
${ }^{1857}$ Ibidem, pp. 236-237. La imagen aparece en una cámara funeraria que se adosa a otra serie de estancias, una de ellas, identificada como un mitreo donde, incluso, aparecieron restos de una escultura en la que se representó la imagen de Mitra. El crismón pintado, incompleto, también aparece asociado con la representación de aves y flores. Decía al respecto el autor: "es un caso único en la Península, bien fechado, creemos, por el conjunto pictórico y arqueológico que lo forma, en el siglo IV, posiblemente antes de la mitad, y con algunos paralelismos que podemos hallar en mosaicos del África cristiana, por ejemplo, en el pavimento del llamado oratorio cristiano de Timgad, donde el crismón, dentro de círculos que lo rodean a manera de corona, está flanqueado también por pájaros y flores".

${ }_{1858}$ M. JUSTINO MACIEL, Antiguidade tardia..., pp. 225-256.

1859 S. ANDRÉS ORDAX, "Simbolismo en la escultura altomedieval: la Anástasis y los relieves hispanovisigodos de nichos y placas-nicho", Actas del VII Congreso de Estudios Extremeños, vol. I, Cáceres, 1983, pp. 23-38, en concreto, pp. 32-37.

${ }_{1860}$ M. JUSTINO MACIEL, Antiguidade tardia..., pp. 167-171.

${ }^{1861}$ S. MORALEJO ÁLVAREZ, "San Martín de Frómista en los orígenes...", p. 63. Resultaría mucho más complejo poder llegar a abordar, de una manera sintética, la difusión que el tema alcanzó dentro de muchas portadas románicas. Frecuentemente, se ha querido ver en el tímpano de Jaca el modelo primigenio del que partirían las demás experiencias aunque, tales hipótesis, han sido sometidas a crítica en muchas ocasiones.
} 
Sin embargo, tal y como pasamos a explicar, todo parece indicar que las fuentes seguidas, nuevamente, deben rastrearse dentro de la iconografía de los sarcófagos. Más concretamente, se han propuesto diversas piezas de datación paleocristiana, aparecidas, mayormente, en la región de Aquitania. Desde finales del siglo IV y hasta bien avanzado el VII, los sarcófagos aquitanos habían usado, recurrentemente, el monograma cristológico para decorar el frente de las cistas.

En relación con ello, según la profesora D. Ocón Alonso, seguidora, a su vez, de las teorías desarrolladas por E. Demougeot, debemos ver en estas representaciones del crismón utilizadas dentro de las piezas halladas en las zonas de Aquitania y Narbona durante la Alta Edad Media, cierta perduración de una tradición anicónica ${ }^{1862}$.

La hipótesis nos parece acertada. Sabemos que la tradición iconográfica e iconológica del primer cristianismo estuvo, en muchas ocasiones, vinculada a esta tendencia ciertamente anicónica. Falta entonces por determinar en que grado influyeron, dentro de la Península Ibérica, las oleadas de aniconismo que, en ocasiones, impregnaron fuertemente las producciones artísticas de la etapa visigoda y asturiana. No sería desaconsejable ver en la utilización del crismón, en plenos años del románico, una pervivencia de tal tendencia tardoantigua ${ }^{1863}$.

Lo más significativo, al respecto, es advertir una transmisión hacia los siglos del románico de uno de los criptogramas más importantes de la primera cristiandad, recuperado en época románica para ser colocado en los lugares más preeminentes de los

\footnotetext{
${ }^{1862}$ D. OCÓN ALONSO, "Problemática del crismón...", pp. 260-262 y E. DEMOUGEOT, La formation de l'Europe et les invasions barbares, Paris, 1969, p. 100.

${ }_{1863}$ El problema es complejo y creemos que no es necesario, ni conveniente, tratar aquí de manera profunda el problema del aniconismo dentro de las artes plásticas de la Antigüedad tardía y la Alta Edad Media hispanas. Sintetizando mucho la cuestión, dicha tradición anicónica habría sido utilizada dentro de la tradición paleocristiana, recuperada, a través del mundo visigodo y traspasada a etapas posteriores, como, por ejemplo, el ámbito artístico asturiano.

El conjunto pictórico de la iglesia de San Julián de los Prados ha recibido diversas interpretaciones teniendo en cuenta dichos preceptos. Sin embargo, resulta problemático, para el caso altomedieval hispano, poder llegar a discernir en qué grado la ideología carolingia incidió sobre el pensamiento hispano o, por el contrario, fue la propia élite intelectual de tradición hispana la que acabó por inferir y transmitir dichos preceptos anicónicos hacia las artes carolingias. Sobre dicha cuestión, véase: I. G. BANGO TORVISO, "El ocaso de la Antigüedad...", en particular, p. 177. El profesor Bango insiste en el papel jugado por personajes como Teodulfo, Claudio o Agobardo, en la formación de la teoría anicónica del imperio. Remarca la educación recibida por estos autores y su marcado carácter hispano. "El arte europeo del siglo IX conserva dos obras excepcionales promovidas por hombres formados en la cultura hispanogoda, que estaba imbuida de estos principios: el oratorio de Germigny-des-Prés y la iglesia de San Julián de los Prados". Sobre esta cuestión, consúltese también.: J. DODDS, "Las pinturas de San Julián de los Prados. Arte, diplomacia y herejía”, Goya, 191, 1986, pp. 258-263 y J. A. MORÁIS MORÁN, "El valor clásico de la arquitectura asturiana...", pp. 242-244.
} 
edificios, es decir, los tímpanos ${ }^{1864}$. Desde otro punto de vista, se debe destacar cómo, en plenos siglos XI y XII, cuando los programas iconográficos adquirían un grado de desarrollo máximo, no importó publicitar una de las imágenes más sincréticas y anicónicas que los cristianos habían tomado del imaginario romano. Por último, no se puede olvidar que se trata de un símbolo utilizado, de manera recurrente, dentro de piezas funerarias, lo cual refrendaría nuestra hipótesis sobre el valor que los sarcófagos adquirieron dentro del taller jaqués.

En relación con ello, no es preciso incidir en la importancia que las piezas conservadas en la Galia van a tener en la formación de tal tradición, sobre todo, teniendo en cuenta la supuesta predisposición de estas obras para "viajar" y ser reutilizadas, a lo largo de los siglos, más allá de la misma época románica. Hispania cuenta con algunos ejemplos de estos sarcófagos aquitanos llegados a nuestro suelo en el periodo medieval y que presentan la iconografía del crismón tardoantiguo, tal y como sucede, por ejemplo, en el sarcófago del conde Santo de la iglesia de San Salvador de Lourenzá, ya estudiado en estas páginas ${ }^{1865}$ (fig. 159).

La nómina de piezas en las que el crismón ocupa lugares relevantes dentro del frente de los sarcófagos es numerosa, baste con citar, por ejemplo, la bella composición que presenta el conservado en la abadía de Saint-Pierre de Moissac, por cierto, un doble spolium in se que, además de albergar los restos de un personaje de los siglos IV o V, sirvió de tumba para el cuerpo de Raimond de Montpeçar, más allá del $1245^{1866}$.

En la misma línea se encuentra el excepcional sarcófago conservado en la llamada cripta de Saint-Seurin de Burdeos (fig. 358). Aquí el anagrama cristológico aparece en plena aparitio, descolgado por una mano que lo presenta en el centro de una galería de arcos de medio punto. Nuevamente, se repiten los elementos antes citados, como la pérgola sobre la que pende el vellum que, retirado, permite su visión ${ }^{1867}$.

Las composiciones se abstraen y los símbolos se hacen más sincréticos si cabe. Los círculos aparecen inscribiendo una serie de radios que surgen del centro y que forman el espacio necesario para ubicar todo tipo de elementos decorativos, especialmente rosáceas. Se trata de estructuras alejadas de la morfología estricta del

${ }^{1864}$ L. TORRES BALBAS, "La escultura románica aragonesa...”, pp. 287-291; G. GAILLARD, Les débuts..., en concreto, pp. 129-131 y D. OCÓN ALONSO, Tímpanos románicos..., vol. II, pp. 115-133. ${ }_{1865}$ M. A. CASTIÑEIRAS GONZÁLEZ, "La actividad artística...”, pp. 287-342.

${ }^{1866} \mathrm{La}$ pieza se halla en uno de los laterales de la iglesia de la abadía francesa. Se ha hablado de su posible datación merovingia, aunque en ello existe debate.

${ }^{1867}$ Llama la atención el horror vacui logrado por el escultor al colocar toda una serie de vegetales enmarañados que se desarrollan bajo las arquerías. Cf. : R. DURU, La crypte de l'église Saint-Seurin de Bordeaux, La sauvegarde de l'art français, Paris, 1982, p. 57-89. 
crismón, pero que hablan de una larga serie de motivos geométricos de lejano origen y de complicada lectura que, en todo caso, se remontan a la Antigüedad más remota. A título de muestra, baste con citar tan sólo, el magnífico conjunto de sarcófagos y lápidas conservadas en Poitiers y en los que este tipo de repertorios se repiten sin cesar ${ }^{1868}$.

La fortuna de las imágenes y motivos esculpidos en los sarcófagos antiguos conservados durante los siglos medievales en la Galia, ha sido señalada de manera reiterada. Por su parte, V. Lassalle incidió en el traspaso de diversos motivos vegetales, entre ellos, las foliáceas, desde las piezas romanas hasta algunos elementos escultóricos del claustro románico de la catedral de Elna, en los Pirineos Orientales ${ }^{1869}$.

El ejemplo de Jaca, quizás sometido, en reiteradas ocasiones, a una sobre lectura iconográfica, ha sido señalado por su carácter extraordinario. Sin embargo, los siglos XI y XII fueron prolijos en la reproducción del criptograma, tanto en los tímpanos más visibles de los accesos a los templos, como en aquellas partes más secundarias. En Galicia, a pesar de ser un motivo "que no arraigó especialmente", tal y como señala R. Sánchez Ameijeiras, aparece, tal y como veremos, inmerso dentro del ciclo escultórico de la fachada de Platerías de la sede compostelana.

En la segunda mitad del siglo XII, por concretar nuestras afirmaciones, lo encontramos en la iglesia lucense de San Martín de Foz, para acabar difundiéndose a otros edificios, como en la iglesia de Santa María de Leboreiro, la de Santa Cruz de Retorta, el templo de San Justo de Repostería o el de San Martín de Oleiros ${ }^{1870}$.

\footnotetext{
${ }^{1868}$ Dicha colección se distribuye entre el Musée Sainte-Croix y el baptisterio, ubicado a escasos metros. Sobre el tema, véase: J. HIERNAND y Y-J. RIOU, "Les sarcophages", Le Baptistère..., pp. 60-70. Nos interesa, especialmente, la pieza catalogada por los autores con el número 46. Proviene de Antigny y presenta una serie de rosetas en forma de tetrafolia ubicadas entre los radios que articulan el interior del círculo. El motivo de la escultura francesa no deja de recordar las soluciones románicas de Jaca.

${ }^{1869}$ V. LASSALLE, "Motifs inspirés par les sarcophages du Sud-Ouest dans le décor sculpté du cloître d'Elne (Pyrénées-Orientales)", Bulletin de la Société Nationale des Antiquaires de France, 85, 1997, pp. 198-205. En concreto, analiza algunos sarcófagos tallados en mármol del Rosellón y que, por diversas razones, acabaron conservados en el citado claustro. Llama la atención sobre una obra decorada con estrígilas, que presenta en el centro de uno de los lados cortos de la cista, una roseta inscrita en un tondo. El motivo fue copiado por los artífices románicos en una de las esculturas de la galería sur del recinto. Igualmente ocurre con otra pieza funeraria conservada en la iglesia de Saint-Vidian de Martres-Tolosane, que muestra el lado corto cubierto con un "tapiz" reticulado con foliáceas que inspiraría una composición similar en uno de los pilares de la galería sur del recinto de Elna. Todos estos motivos insisten en una tradición bien arraigada, dentro de la plástica románica, que llevó a los escultores medievales a admirar piezas de estas características y copiarlas dentro de sus producciones.

${ }^{1870}$ R. SÁNCHEZ AMEIJEIRAS, "Ritos, signos y visiones: El tímpano románico en Galicia (11571230)", El tímpano románico: imágenes, estructuras y audiencias, Santiago de Compostela, 2003, pp. 4971, en concreto, p. 50, nota 3 e I. G. BANGO TORVISO, "El espacio para enterramiento...", p. 123. El citado autor considera que, con un sentido claramente funerario debe ser leído el crismón invertido colocado en la cripta de San Lorenzo de Carboeiro.
} 
Más allá de toda la serie de edificios en los que la imagen fue incluida, cabe señalar su perdurabilidad dentro de las "artes funerarias". Así parece confirmarlo, por ejemplo, el lucillo sepulcral empotrado en uno de los muros de las dependencias para enterramientos del monasterio de San Juan de la Peña, donde fue esculpido el monograma ${ }^{1871}$; y ya dentro de la escultura de sepulcros, el ejemplo más conocido lo ofrece el sarcófago de doña Sancha de Santa Cruz de La Serós (fig. 359), que presenta, nuevamente, un crismón en uno de los lados cortos, posiblemente, otra vez emparentado con una tradición orfebre ${ }^{1872}$.

$\mathrm{Su}$ función dentro de los espacios funerarios románicos, claramente continuadora de una tradición cristiano-primitiva, hace que el símbolo aparezca "marcando los espacios funerarios durante los siglos, colocándose en lugares tan significativos como el Panteón de San Isidoro de León", tal y como advierte el profesor I. Bango Torviso (fig. 360) ${ }^{1873}$.

Sin embargo, tanto desde el punto de vista formal, como desde el iconográfico, el motivo aparece en gran cantidad de templos, no sólo en los derivados de la escultura de la catedral de Jaca, sino en otros lugares más periféricos y secundarios, sin relación con dicha construcción ${ }^{1874}$. Así, lo encontramos enmarcando una de las puertas interiores de la iglesia de San Martín de Frómista (fig. 361) ${ }^{1875}$. A esta lista debemos

${ }^{1871}$ Se analiza la problemática del Panteón regio y su ubicación, tras las remodelaciones del siglo XVIII en: J. MARTÍNEZ DE AGUIRRE, "La memoria de la piedra...”, pp. 138-139.

1872 Ibidem, pp. 145-146; D. L. SIMON, "Le sarcophage de Doña Sancha...", en especial, p. 116 e ID., "Sarcophagus of Doña Sancha...", pp. 229-232.

${ }^{1873}$ I. G. BANGO TORVISO, "El espacio para enterramientos...", p. 124, nota 172. Se trata de un pequeño tímpano colocado en una de las puertas del muro de poniente y que comunica la actual nave románica con algunas dependencias modernas. Véase también, sobre dicho tímpano: E. FERNÁNDEZ GONZÁLEZ, San Isidoro de León..., p. 28 y T. MARTIN, "The Art of...", p. 1152. La última autora apunta la hipótesis de que se trate de una puerta que daría acceso a las estancias privadas de palacio.

Sobre el mismo tema, véase: G. BOTO VARELA, "La integración...", p. 83. Este autor relaciona la representación del criptograma de San Isidoro de León con el ejemplo de la puerta de las Platerías de Santiago de Compostela. Además, expone la teoría, según la cual, dicho tímpano con el crismón permitía, originariamente, acceder a un desaparecido baptisterio. Se trata, evidentemente, de una mera hipótesis, aún por demostrar.

${ }^{1874}$ Es sobradamente conocida la gran difusión que el motivo alcanzó en muchas iglesias de Navarra y Aragón y más allá de los Pirineos. Creemos que no debemos abordar con detenimiento la problemática cronológica, en relación con la difusión de la imagen del crismón en esta serie de iglesias pues, de hacerlo, se desviaría el objetivo de nuestro trabajo. Sin embargo, el tema ha sido ampliamente tratado. Así, D. Ocón Alonso, insistió, hace años, en la imposibilidad de considerar el tímpano jaqués como el "cabeza de serie" para todos los ejemplos anteriores, de los que se han tenido serias dudas sobre su cronología. Consúltese, en relación con este tema: D. OCÓN ALONSO y P. RODRÍGUEZ ESCUDERO, Op. cit., pp. 259-263, sobre todo, p. 260. Las investigadoras escriben: "no hay razón para pensar que el artista de La Serós no sea contemporáneo del taller de Jaca (...) La imitación del tímpano de Jaca no puede explicar de ningún modo las formas de los leones de La Serós".

${ }^{1875}$ S. MORALEJO ÁLVAREZ, "San Martín de Frómista en los orígenes...", p. 63 e ID., "Cluny y los orígenes del románico...", p. 189. El profesor Moralejo relaciona el modelo seguido aquí con otros ultra pirenaicos, emparentándolo, nuevamente, con producciones antiguas. 
sumar el crismón recientemente aparecido en la iglesia de San Zoilo de Carrión de los Condes. Se trata de una pieza que, teniendo en cuenta las conexiones estilísticas ya explicadas, insiste en la utilización de modelos iconográficos similares (fig. 362).

Resulta evidente que las concomitancias que señalamos entre la imagen del crismón utilizada en las producciones artísticas tardoantiguas hispanas y aquellas datadas en el periodo románico son factibles. Sin embargo, debemos pensar, así mismo, que se trata de una dependencia normal dentro de un símbolo de tanta tradición y, sobre todo, que evolucionó de una manera muy poco drástica. Es posible que muchas de las esculturas que muestran tal símbolo, no deban ponerse en contacto con el arte paleocristiano y romano pues, a pesar de que guarden muchos puntos en común con éstas, se podría tratar de una serie de dependencias normales a la hora de copiar un símbolo tan marcadamente definido.

A la hora de analizar la pieza de Jaca creemos que resultaría de gran interés acotar el campo de estudio, lo que nos lleva a pasar por alto algunos aspectos que, en relación con ella, se han señalado de manera reiterativa por parte de los investigadores. Nos referimos, por ejemplo, a las diversas interpretaciones que se han dado sobre las imágenes del tímpano, en las que, se ha visto una alusión a la doble naturaleza de Cristo, donde palabra y concepto crearían un duplex, al mismo tiempo que, se ha buscado contextualizarlo dentro del ambiente histórico, político e ideológico del momento $^{1876}$.

Igualmente, se ha señalado una intención simbólica de representar la naturaleza trinitaria del monograma, siguiendo la misma exégesis cristiana ${ }^{1877}$. Tales intenciones simbólicas podrían haberse dado, según se ha señalado, en otros edificios románicos posteriores, aunque con importantes variantes estilísticas, ideológicas y, sobre todo, conceptuales $^{1878}$.

\footnotetext{
1876 D. L. SIMON, "El tímpano de la catedral...", p. 419. El autor defendió su utilización para "enfatizar la especial naturaleza de Jaca como capital del reino y sede episcopal, en un esfuerzo para resaltar la importancia real de Jaca", tanto desde un punto de vista histórico como político.

${ }^{1877}$ D. OCÓN ALONSO, "El sello de Dios...", pp. 77-79; D. L. SIMON, "El tímpano de la catedral...", p. 410 y M. DURLIAT, La sculpture romane de la route..., p. 244. En su día, al analizar la forma de las diferentes letras y grafías que configuran el crismón románico en la Península Ibérica, algunos autores hablaron de una tipología propia y definida en las iglesias pirenaicas españolas. Véase, por ejemplo: E. CHATEL, Op. cit., p. 33.

${ }^{1878}$ En la fachada de Nuestra Señora de la Peña, en Sepúlveda, (Segovia), fue esculpida la imagen del pantocrátor con el crismón trinitario ubicado en el dintel de la puerta. Cf.: M. POZA YAGÜE, "Símbolo y concepto. Visiones teofánicas y alegóricas de la Trinidad en el tímpano de Nuestra Señora de la Peña de Sepúlveda (Segovia)", El tímpano románico. Imágenes, estructuras y audiencias, Santiago de Compostela, 2003, pp. 131-151, sobre todo, p. 138. Aunque sin pretender una relación entre ambas obras y siendo conscientes de las diferencias, se debe recordar la imagen del crismón esculpida en la ermita de
} 
Teniendo en cuenta el objetivo de este estudio, debe quedar claro que, tal imagen, no hace sino retomar la tradición paleocristiana de señalar los accesos a determinados edificios.

En el ejemplo románico, la imagen conserva, claramente, toda su carga cristológica y, al igual que en los ejemplos conservados en la Hispania antigua, se muestra complementado y acompañado por otros símbolos zoomórficos ${ }^{1879}$.

Tal dependencia, sin duda, más ideológica que estilística, con los modelos romanos, queda patente a través del análisis del conjunto epigráfico que acompaña a las esculturas. La más interesante, en este sentido, es aquella que recorre el borde mismo del monograma de Cristo. Fue realizada, de manera continua, separando los hexámetros a través de dos puntos que se usan aquí como signos de puntuación. En ella se lee, siguiendo las versiones de los diferentes estudiosos del conjunto:

(Cruz) HAC IN SCVLPTVURA LECTOR SIC NOSCERE CVRA: P (e) PATER A GENITVS DVPLEX ES(t) SP(iritv)S ALMVS: HI(i) TRES IVRE QVIDEM DOMINVS SVNT VNVS ET IDEM.

La traducción aproximada que se ha dado para tal epígrafe, es la siguiente:

"En esta escultura, lector, debes interpretar lo siguiente: Pe (significa) el Padre; A el Engendrado (de) doble (naturaleza), S el Espíritu Vivificante. Estos tres son en verdad por derecho propio un único y mismo Señor" ${ }^{1880}$.

Por otra parte, se ha considerado dicho epígrafe como un hexámetro nacido de una littera elíptica en la que, lo más destacado, sería la utilización del vocativo lector. De esta manera, según J. del Hoyo, se trataría de:

\footnotetext{
San Bartolomé de Aguilar de Códes (Navarra), datada en el último tercio del siglo XII. Aquí aparece la iconografía del crismón rodeado por ángeles y que, nuevamente, se ha hecho derivar del esquema de la imago clipeata de los sarcófagos romanos, así como su relación con el fenómeno que venimos señalando en cuanto al desarrollo de tal iconografía en Navarra y Aragón. Cf.: M. MELERO MONEO, La escultura románica en Navarra, Madrid, 1991, ficha catalográfica 9.

${ }^{1879}$ A. FUENTES DOMÍNGUEZ, Arte Paleocristiano..., p. 11.

${ }^{1880}$ La problemática, en relación con el conjunto epigráfico del tímpano occidental de Jaca, ha generado abundante bibliografía al respecto. Debido a nuestro desconocimiento de la materia nos limitamos a recoger algunos de los estudios consultados sobre dicha cuestión. Cf.: J. VIVES, "Las leyendas epigráficas...", pp. 391-394; A. DURÁN GUDIOL, Op. cit., pp. 421-432 y W. WEISBACH, Reforma Religiosa..., p. 134. En especial, se abordó el tema, de una manera interesante para nuestro objeto en: J. M. CAAMAÑO MARTÍNEZ, "En torno al tímpano de Jaca...", pp. 200-201 y C. B. KEDALL, The Allegory..., p. 230.
} 


\begin{abstract}
“(...) herencia de tantos epitafios latinos en que el difunto o el propio epígrafe establecen un diálogo imaginario con el viandante -viator, praeteriens, lector-a quién mandan detenerse -asta, siste-, y leer detenidamente y hasta el finalpellege- para conocer-noscere, nosse-, quién está alli enterrado (...)"1881.
\end{abstract}

Esta deuda respecto a las inscripciones romanas o de la Antigüedad tardía, corroboraría, una vez más, la filiación clásica del conjunto que, nuevamente, parece inscribirse en el ámbito de las piezas funerarias. Si tal y como hemos visto se puede constatar la dependencia que presenta la escultura medieval en relación con la tradición iconográfica antigua, también, desde el punto de vista lingüístico y epigráfico, hallamos una dependencia con modelos funerarios, en concreto con los epitafia ${ }^{1882}$.

Nos parece que tal relación con este tipo de piezas no es desacertada, pues otro de los rasgos frecuentemente destacados de la portada es su intención simbólica de evocar, de manera constructiva y, sobre todo, iconográfica, la llamada Porta Coeli de la tradición cristiano primitiva. Los orígenes del tema, sin necesidad de remontarse a periodos más lejanos, aparecen dentro del arte romano, donde muchas piezas funerarias presentaban epígrafes que aludían al tránsito de los difuntos al más allá a través de la Puerta Sagrada ${ }^{1883}$. En relación con ello estarían los bellos ejemplos de sarcófagos con el tema de la Puerta del Hades y, en su versión cristianizada, de la Puerta del Cielo ${ }^{1884}$.

\footnotetext{
1881 J. DEL HOYO, Op. cit., consultado en http://www.anmal.uma.es/numero6/Hoyo.htm, consultado el 15 de noviembre de 2008. El trabajo de este investigador es una breve aportación a una problemática muy compleja. No podemos compartir, en ningún caso, la afirmación que realiza en relación con el tema, según la cual, la inscripción presenta una lectura difícil por estar adaptada al marco circular del crismón, así como por "el analfabetismo general de la sociedad en el siglo XI'. Igualmente escribe: "Ello parece indicar que lo que interesaba que el pueblo entendiera era la iconografía del tímpano ("la Biblia de los pobres" se llamó a todo el contenido catequético de las portadas en el románico), y la inscripción le debía servir al obispo, sacerdote o predicador para explicar el contenido al pueblo". Tal afirmación, creemos, se encuentra adscrita al tópico historiográfico, hoy en buena parte desmantelado y corregido, que forzaba a ver en todo tipo de imágenes acompañadas por inscripciones, un mecanismo de moralización y de enseñanza para los iletrados. En cualquier caso, de poder hacer una lectura en clave moralizante con la pieza y sus inscripciones, ésta debe ser más pausada y no asentada sobre los preceptos de la tan manida alusión a la Biblia pauperum.

1882 Véanse las inscripciones recogidas en: M. JUSTINO MACIEL, Antiguidade tardia ..., pp. 172-183.

${ }^{1883}$ M. JUSTINO MACIEL, “A arte da Antiguidade Tardia...”, en concreto, p. 127. El profesor Maciel habla sobre el simbolismo de este tipo de obras. Se trata, por lo general, de placas o inscripciones en los que se representaron, en perfecta sintonía con el mensaje epigráfico, una serie de elementos arquitectónicos, como arcos, columnas o capiteles, materializando, la mayoría de las ocasiones, la imagen de una puerta. Su lectura iconográfica aparecería relacionada con el acceso al Paraíso o al más allá. Señala, por ejemplo, la lápida funeraria de cronología paleocristiana custodiada en Mertola, Museu Arqueologico.

${ }^{1884}$ F. CUMONT, Recherches sur le symbolisme funéraire..., pp. 306-308. Señala el ejemplo del sarcófago de las Musas de Roma, Musei Vaticani. En el caso hispano, ya hemos citado el ejemplo más
} 
Tales piezas hablan de la tradición antigua que veía las puertas y los accesos como elementos constructivos a los que aplicar diversas lecturas simbólicas, siempre ligadas a la idea del tránsito y el acceso al paraíso. Con tales antecedentes, no es extraño que, en su día, D. L. Simon propusiese una interpretación similar para este tímpano occidental de la puerta de la catedral ${ }^{1885}$.

Si seguimos tal hipótesis, las posibles explicaciones de las inscripciones del tímpano, la lectura de sus imágenes a través de las mismas y, sobre todo, su ubicación en la puerta, podrían permitir establecer ciertas dependencias ideológicas con respecto a esta serie de obras de tradición clásica.

Sabemos la importancia que tuvo el material epigráfico expoliado de los edificios antiguos para los hombres medievales. En relación con ello, el profesor V. García Lobo ha recogido algunos interesantes ejemplos de epígrafes romano-paganos reutilizados en la iglesia de San Miguel de Escalada, tal y como ya hemos señalado en este estudio $^{1886}$ (fig. 143). Ello hace pensar que alguna pieza de esta índole pudiera haber entrado en contacto con el taller de Jaca, no sólo a la hora de inspirar el mensaje epigráfico, sino también, a la hora de concebir algunas de las simbologías que de él se desprenden ${ }^{1887}$.

conocido de este tipo. Se trata del sarcófago conservado en Córdoba, Alcázar de los Reyes Cristianos. Sobre la pieza, vid.: J. BELTRÁN FORTES, Los sarcófagos romanos..., pp. 93-111.

${ }^{1885}$ D. L. SIMON, "L'art roman, source...", p. 260. El profesor Simon pone en contacto las inscripciones de Jaca con otras conservadas en San Juan de la Peña y la Santa Cruz de la Serós y en las que el portal es comprendido, según su lectura, como la entrada al Paradisus cristiano.

También véase: M. JUSTINO MACIEL, "A arte da Antiguidade Tardia...”, p. 128. El estudioso portugués alude a las citaciones simbólicas del Paradisus, en relación con la placa de Mértola. La fuerte carga ideológica del conjunto de epígrafes conservados en la zona lusa se ve reforzado por las hipótesis de interpretación señaladas por el autor. Data las piezas en el siglo VI y alude al Tratado sobre el Apocalipsis realizado por el obispo Apríngio de Beja, sede de la diócesis a la que pertenecía la ciudad. Según M. Maciel, este autor cristiano hace una serie de comparaciones entre la figura de Cristo y algunos elementos arquitectónicos del templo, como las columnas. La idea se ve refrendada por las alusiones al laurel y a otros símbolos paganos de la época romana.

${ }^{1886}$ V. GARCÍA LOBO, Las inscripciones de San Miguel..., p. 15. El profesor García Lobo aborda una inscripción datada entre los siglos IV y $\mathrm{V}$, nuevamente, de tradición funeraria y de dos ladrillos provenientes de la Legio VII Gemina de tiempos de los Filipos y que el autor supone procedentes de Lancia. Las piezas fueron reutilizadas como material constructivo dentro del edificio.

${ }^{1887}$ Nos referimos a algún tipo de epígrafe romano de tradición cristiana que hubiera podido inspirar algunas características del conjunto epigráfico románico. Sin embargo, somos conscientes de la debilidad de tal hipótesis, pues parece claro que el traspaso de fórmulas textuales y literarias es un fenómeno mucho más complejo y que puede llevarse a cabo sin la necesidad de una transmisión material o una copia directa del modelo original. Con todo, muchos de estos epígrafes aparecen acompañados del crismón, la cruz o diversos animales, muy en la línea argumental del tímpano medieval de Jaca. Véanse los ejemplos recogidos en: A. DE LACERDA, História da Arte em Potugal..., pp. 102-105. Se señala la lápida fúnebre de Chantre Adreas conservada en Oporto, Museu Etnológico, la del presbiterio Satírio de Mértola o la lápida funeraria de Mannaria, en la misma localidad. Todas presentan el esquema de la puerta de acceso al paraíso cobijando el anagrama de Cristo. 
La simplicidad, un tanto "arcaizante", que presenta el mismo símbolo del crismón, así como otra serie de elementos a él adscritos, parecen tener su equivalente más directo en toda la larga serie de producciones tardoantiguas donde tales elementos se utilizaron de manera recurrente ${ }^{1888}$.

El simbolismo antiguo de la puerta como zona de tránsito, tan exitoso dentro de la imaginería pagana, tiene su mejor representación en la imagen de la Puerta del Hades. En relación con el tema, D. Ocón Alonso ha señalado, reiteradamente, este aspecto. Así, a propósito de la puerta de Jaca cita la inscripción colocada en la rosca del crismón del tímpano de la iglesia de la Santa Cruz de La Serós, donde se puede leer:

"Yo soy la puerta de entrada fácil, pasad por mí fieles. Yo soy la fuente de vida, tened más sed de mí que de vino todos los que penetréis en este bienaventurado templo de la Virgen" ${ }^{\prime 1889}$.

Se trata, claramente, de un interés muy marcado por destacar la importancia de los umbrales de las puertas y el sentido simbólico a la hora de flanquearlas. El tímpano con el crismón de Jaca insiste en tal aspecto ${ }^{1890}$.

Las posibles fuentes manejadas por los autores románicos a la hora de configurar la iconografía y el mismo mensaje epigráfico del tímpano medieval parecen fluctuar entre la misma tradición romano-pagana y aquella inmersa en la primera oleada de cristianismo. Si aceptamos la dependencia directa de alguno de los elementos epigráficos con respecto a las inscripciones de época romana y la posible pervivencia de una tradición paleocristiana en la utilización del crismón, solo restaría ofrecer una pieza, a ser posible hispana y dentro de la órbita de la misma catedral jacetana, que hubiera podido inspirar la composición.

Nuevamente tal tarea resulta compleja. El corpus de inscripciones susceptibles de ser equiparadas, desde un punto de vista simbólico, con la configuración del tímpano es abundante. El problema reside en la difusa línea de separación que divide aquellos ejemplares paganos de los ya cristianos.

En su día, A. de Lacerda estudio la vinculación de los epígrafes cristianos de Mértola con algunos ejemplares paganos hallados en la región de León refiriéndose,

\footnotetext{
1888 Véase, por ejemplo: M. J. BARROCA, Epigrafia medieval portuguesa (862-1422), 3. vols., Porto, 2000, vol. III, pp. 7-50. Se abordan aquellas piezas de cronología paleocristiana.

${ }_{1889}$ D. OCÓN ALONSO, “Ego sum Ostium...", p. 126.

${ }^{1890}$ M. DURLIAT, La sculpture romane de la route..., p. 245.
} 
sobre todo, a los ejemplares conservados en el Museo de la misma ciudad y que se han identificado como las laudas funerarias de Emilio Valente y otro personaje llamado Flavo $^{1891}$. En ellas, el autor, siguiendo a M. Gómez-Moreno, barajaba la posibilidad de entender las representaciones arquitectónicas como alusiones al tránsito y la Puerta del Hades. Evidentemente, al ser paganas, no existía aquí un desarrollo visible de la iconografía cristológica.

Sin embargo, con la multiplicación de los centros cristianos en la Península Ibérica, los modelos paganos fueron tomados y reutilizados. Ahora, a los antes mencionados se les añade, de manera bien visible, el crismón que, acompañado por toda una serie de mensajes epigráficos de tradición pagana, parecen continuar, claramente, con esta tradición ${ }^{1892}$.

Tras lo afirmando anteriormente, podría parecer un tanto desafortunado pretender ver el origen de ciertos aspectos presentes dentro del tímpano del crismón de Jaca en relación con una serie de producciones ligadas, por lo general, a los materiales lapidarios, como pudieran ser las placas de incrustación, aquellas realizadas como apliques, inscripciones o todo tipo de "escultura arquitectónica" y "utilitarista"1893.

Muy recientemente, la profesora Licinia N. C. Wrench, ha defendido la posibilidad de relacionar la composición e iconografía del tímpano de Jaca con una serie de producciones tardoantiguas de gran interés y que ya han sido mencionadas en nuestro estudio. En concreto, se trata de una placa frontal proveniente de la iglesia de São João Batista de Tomar, en Portugal (fig. 282 a). La pieza posee forma de frontón triangular y fue decorada con dos leones afrontados al árbol de la vida. Tal y como ya hemos

\footnotetext{
1891 A. DE LACERDA, História da Arte em Potugal..., p. 102.

1892 F. CABROL y H. LECLERCQ, voz “Chantres", Dictionnaire d'Archéologie, vol. 3-I, Paris, 1914, cols. 344-365, especialmente, col. 356. Los autores citaban ya el caso de Mértola. A ella podríamos sumar también la inscripción realizada con técnica musiva en la lauda sepulcral del obispo de Turín Ursicinus, muerto en torno al año 610, que destaca por la presencia de un gran crismón central rodeado por una bella inscripción.

Véase también: E. CHATEL, Op. cit., pp. 35-36 y P. DE PALOL, Arqueología cristiana..., pp. 252-253. Nuevamente, observamos la existencia de ejemplos antiguos en los que la figura del crismón aparece acompañada de inscripciones de manera casi explicativa.

${ }^{1893}$ Ya hemos realizado, anteriormente, la valoración sobre estas expresiones que pretenden abarcar todas aquellas esculturas concebidas como capiteles, ambones, cátedras o canceles, pero también, frisos, molduras o cornisas, por ejemplo. Cf.: G. BOVINI y P. ANGIOLINI MARTINELLI, Corpus della scultura paleocristiana bizantina ed altomedioevale di Ravenna. Altari, amboni, cibori, cornici, plutei con figure di animali e con intrecci, transenne e fragmmenti vari, vol. I, Roma, 1968; G. BOVINI, G. VALENTI ZUCCHINI y M. BUCCI, Corpus della scultura paleocristiana bizantina ed altomedioevale di Ravenna. I sarcofagi a figure e a carattere simbolico, vol. II, Roma, 1968 y G. BOVINI y R. OLIVIERI FARIOLLI, Corpus della scultura paleocristiana bizantina ed altomedioevale di Ravenna. Basi, capitelli, pietre d'imposta, pilastri, plutei, pulvini, vol. III, Roma, 1969.
} 
recogido, supuestamente el del lado derecho sería un macho mientras que, a la izquierda, fue representada una hembra con un hipotético basilisco en la boca.

La escultura ha sido datada en una época tardía, entre los siglos VIII y X. Lo más significativo es que, la misma estudiosa, haga derivar tal producción de toda una serie de obras plásticas inmersas en los últimos siglos de la Antigüedad pagana y los tiempos iniciales del cristianismo. Cita las similitudes que presenta la pieza de Tomar con los conocidos mosaicos de las Islas Baleares, como los de las basílicas de Illeta del Rei (Port de Maó) (fig. 363) y la de Es Fornàs del Torelló (fig. 364) ${ }^{1894}$. Con todo, el dato más interesante resulta de la comparación del tímpano románico de Jaca y el mosaico tardorromano aparecido en el baptisterio paleocristiano de Mértola y que se ha datado entre los años finales del siglo V y el VI (fig. 282 b) ${ }^{1895}$.

Sin embargo no nos referimos, únicamente, a la comparación formal entre ambas producciones. Lo más importante es que el citado mosaico paleocristiano fue encontrado en el área que envolvía, físicamente, en forma de pórtico, el baptisterio paleocristiano de Mértola ${ }^{1896}$. Es decir, se trata de un lugar que, tal y como hemos señalado en repetidas ocasiones, tuvo, durante este momento, fuertes connotaciones funerarias, penitenciales y salvíficas ${ }^{1897}$. La presencia de una iconografía similar en el pórtico de la catedral de Jaca, apoyaría todas aquellas hipótesis que citábamos en el inicio de este estudio sobre el posible valor penitencial del portal occidental y de su área circundante pues, tal y como se observa, existen ciertos antecedentes en el mundo antiguo que validarían algunos aspectos de tal teoría ${ }^{1898}$.

Para finalizar, queremos destacar que la presencia de los leones en los aledaños de las puertas desde la Antigüedad más remota, acabó por conferir a dichas zonas de tránsito un carácter profiláctico y apotropaico, que fue asumido, igualmente, por el arte

\footnotetext{
${ }^{1894}$ L. N. C. WRENCH, Decoração Arquitectónica..., vol. II (Parte 1), pp. 180-183. Reiteramos nuestro agradecimiento a la Dra. Licinia Wrench por habernos permitido el acceso a su Tesis Doctoral, aún inédita. Sobre los citados trabajos musivos, véase: P. DE PALOL, Arte Paleocristiano..., pp. 183-215.

${ }^{1895}$ L. N. C. WRENCH, Decoração Arquitectónica..., vol. II (Parte 1), pp. 182-183.

${ }^{1896}$ Ibidem, p. 181 y V. LOPES, Mértola na Antiguidade Tardia. A topografia histórica da cidade e do seu território nos alvores do cristianismo, Mértola, 2003, pp. 104-110.

${ }_{1897}$ J.-CH. PICARD, "Les origines du mot Paradisus parvis", Mélanges de l'École française de Rome. Moyen Âge, temps modernes, 83, 1971-1972, pp. 159-186 e ID., Évêques, saints et cités en Italie et en Gaule : Études d'archéologie et d'histoire, Rome, 1998, en particular, pp. 3-30.

${ }^{1898}$ L. N. C. WRENCH, Decoração Arquitectónica..., vol. II (Parte 1), p. 181 e ID., "Decoração arquitectónica litúrgica da antiguidade tardia nos grupos pacense e eborense", Arqueologia da Antiguidade na Península Ibérica, vol. VI, Porto, 2000, pp. 645-655. La citada investigadora escribirá: "Nas catedrais hispânicas, românicas, de Jaca e de Santa Cruz de la Serós (Huesca) as portadas ocidentais apresentam a mesma temática, com a substituição da árvore da vida pelo "círculo", Crísmon de oito braços. Em Jaca, além do basilisco e do urso sob as patas de um dos leões, é também introduzida uma figura humana a dominar uma serpente, sob as patas do outro leão".
} 
románico ${ }^{1899}$. S. Moralejo, al analizar su presencia en los salmeres y quicios de las puertas escribía:

“(...) constituyen por sí mismos -algunas veces con el concurso de otros motivos- un programa emblemático autónomo, destinado a recalcar el simbolismo elemental de la puerta- independientemente de cuál sea la iconografía particular que en ella se exponga -en cuento frontera entre el espacio sagrado y el profano (...) Hundiendo sus raíces en conocidas funciones apotropaicas precristianas, su significación puede precisarse en acepciones heráldicas, funerarias, judiciales, de custodia del templo (...)"1900.

Dicha lectura es extensible a todo el románico, donde siempre fueron vistos en un sentido dual, por una parte como protectores $\mathrm{y}$, por otra, relacionados con la administración de justicia ${ }^{1901}$. Su presencia dentro del programa jaqués insiste en el uso de fuentes de "ultratumba" y de tono fúnebre. Sin embargo, además de ello, no debemos olvidar que el animal aparece también presente, desde la etapa pagana, ligado al sueño eterno y embriagador de Dionisos. Ya en el ámbito cristiano, continuó estando asociado, de manera indisoluble, a la muerte, al triunfo sobre ésta y a la penitencia que, tal y como se ha venido afirmando, pudieron ser dos ideas claramente rectoras a la hora de planificar el conjunto románico ${ }^{1902}$.

${ }^{1899}$ P. ZANKER, Un'arte per l'impero..., p. 87.

Desde otro punto de vista, se insiste en el valor apotropaico del animal en: M. GREENHALGH, "Ipsa ruina docet...", p. 142. El autor citado señala su frecuente aparición dentro de las estelas funerarias romanas, de la misma manera que serán figuras habituales en los accesos de los templos cristianos. Alude a los ejemplos esculpidos por Nicola Pisano en el púlpito del Duomo de Siena y que, posiblemente, copian alguna escultura romana. En relación con el tema de los felinos decorando sarcófagos, consúltese: F. CUMON, Recherches sur le symbolisme funéraire..., p. 158.

${ }_{1900}$ S. MORALEJO ÁLVAREZ, Iconografía gallega de David y Salomón, Santiago de Compostela, 2004, concretamente, pp. 23-24.

1901 B. MARIÑO, "La portada de Santiago de Carrión de los Condes", Palencia en los siglos del románico, Aguilar de Campoo, 2002, pp. 51-69, en concreto, p. 67. La autora defiende la hipótesis de que, a la entrada de la iglesia, se celebrasen juicios reales, citando el caso de la catedral de Estrasburgo y la de León, donde se tiene constancia segura de tales prácticas. Se recoge, en este mismo sentido, los existentes en la catedral de Aquisgrán o Bari, que parecen identificarse como CVSTO (d) ES IUSTICIE. Véase también: G. CAVERO DOMÍNGUEZ, E. FERNÁNDEZ GONZÁLEZ y F. GALVÁN FREILE, Op. cit., tomado de http://e-spania.revues.org/index204.html, consultado el 1 de enero de 2009. Los autores abordan el tema de una manera más profunda, con nuevos ejemplos.

Sobre la relación entre la imagen del león y su deuda con respecto al arte clásico, en concreto, con los sarcófagos, véase: A. C. QUINTAVALLE, "Riforma Gregoriana...", pp. 265-266.

${ }^{1902}$ L. ABAD CASAL, El arte funerario..., p. 26. En relación con su vinculación con la imagen de la cruz, véase: A. GRABAR, "L'iconographie du Ciel...", p. 15. Sobre la lectura iconográfica e iconológica del ejemplo de Jaca, consúltese: D. L. SIMON, "El tímpano de la catedral...", p. 411 y p. 419; M. DURLIAT, La sculpture romane de la route..., pp. 244-245 y D. OCÓN ALONSO, "Problemática del crismón...", p. 255 y p. 260. D. Ocón insiste en la importancia de su lectura simbólica como exaltación de 
En Jaca el león se muestra, tal y como reza la inscripción, venciendo de manera simbólica al "imperio de la muerte", de ahí que aparezca pisoteando a las bestias, tema por otra parte repetido en el tímpano de la iglesia de Uncastillo donde, nuevamente, se muestra al felino ligado a un crismón central, pisoteando un pecador arrepentido que sujeta en su mano una serpiente ${ }^{1903}$.

Para finalizar este apartado dedicado a la imagen del crismón en la portada de Jaca, debemos realizar una serie de reflexiones finales. Parece claro que, si admitimos una serie de influencias de la estatuaria romana dentro de la escultura de los capiteles del templo medieval, concretamente, aquella realizada en los sarcófagos tardorromanos, no sería problemático, en principio, poder deducir que alguno de esos modelos pudiera haber aportado el referente para la realización del monograma cristológico.

Se trata de un modelo bien difundido dentro del área hispana, tal y como demuestra el conocido sarcófago llamado de la Pasión, del Museo de Bellas Artes de Valencia, donde reaparece el crismón acompañado por dos animales afrontados (fig. 365) ${ }^{1904}$.

Sin embargo, mientras que para el caso concreto de la escultura del resto del edificio se han señalado determinadas dependencias con respecto al mundo antiguo, el fenómeno parecía mostrarse ciertamente puntual, difuso y, hasta en cierto modo, superficial $^{1905}$. Por el contrario, a la hora de abordar el tímpano occidental de la catedral, determinados sectores de la historiografía, especializada en el tema, han aludido a que la presencia aquí del anagrama acompañado de un programa iconográfico tan complicado, quizás ayudase a definir un fenómeno artístico más complejo de recuperación de fórmulas tardoantiguas en la plástica medieval. En concreto, tal movimiento se denominó como "renacimiento paleocristiano" y vendría a etiquetar un supuesto resurgimiento de un determinado tipo de imágenes de tradición paleocristiana en torno a los últimos años del siglo XI y los primeros del siguiente ${ }^{1906}$.

ideales de victoria: "los dos grupos y las inscripciones aclaratorias sobre ellos hacen alusión a dos aspectos aparentemente contradictorios pero sin duda complementarios en el campo de la dialéctica de contrarios: la justicia divina, implacable para con el reino del mal y la misericordia que lleva implícita el perdón de los pecados para aquel que arrepentido escucha el mensaje de salvación, expuesto gráficamente por el crismón".

${ }_{1903}$ M. DURLIAT, La sculpture romane de la route..., p. 248.

${ }^{1904}$ P. DE PALOL, Arte Paleocristiano..., p. 16. Esta vez, quizás, se puedan interpretar como un ciervo y un cordero, además de dos aves.

${ }^{1905}$ En este punto del estudio queremos reiterar nuestro agradecimiento al profesor D. Fernando Galván Freile por toda la serie de sugerencias apuntadas en relación con estos aspectos que aquí tratamos.

1906 Véase el apartado posterior en el que analizamos, de manera más extensa, el término y donde se realiza un balance historiográfico sobre tal cuestión. 
Tal y como se abordará más adelante, la cuestión resulta muy compleja y, aún hoy, sigue planteando numerosos interrogantes. En palabras de D. Ocón Alonso:

“(...) la formulación plástica alcanzada en el tímpano de la catedral de Jaca erigida en la nueva sede vino a expresar de diversos modos el cambio religioso operado. En una primera lectura resulta evidente que su composición y sus imágenes vinieron a materializar la obsesión por el "renacimiento paleocristiano" de la Reforma Gregoriana" ${ }^{1907}$.

La utilización continúa de la expresión "renacimiento paleocristiano", realizada ya hace años por H. Toubert y E. Kitzinger, sería tomada como referente teórico, mediante el cual, justificar la utilización del crismón, así como otra serie de imágenes pertenecientes a la tradición visual tardoantigua, pero en su vertiente cristiana; que habrían de pasar con ligereas variantes a la iconografía de la Alta y Plena Edad Media $^{1908 .}$.

${ }^{1907}$ D. OCÓN ALONSO, “El sello de Dios...”, p. 93.

${ }^{1908}$ Para una reciente valoración de estos aspectos, véase: Roma e la riforma gregoriana: tradizioni e innovazioni artistiche (XI-XII secolo) (S. Romano y J. Enckell Julliard coord.), Roma, 2007. 


\section{ENTRE LA ASIMILACIÓN, LA REINTERPRETACIÓN Y LA DISOLUCIÓN DE LA CORRIENTE CLÁSICA JAQUESA. LOS TALLERES DE SANTIAGO DE COMPOSTELA Y SAN ISIDORO DE LEÓN (1075-1147).}

\section{1. INTRODUCCIÓN. ASPECTOS BIBLIOGRÁFICOS Y METODOLÓGICOS.}

En el presente apartado abordaremos la asimilación de modelos clásicos una vez superada, en parte, la corriente iniciada por los talleres de San Martín de Frómista y la catedral de San Pedro de Jaca ${ }^{1909}$.

La historiografía medieval viene aceptando de una manera consensuada que, a partir de las experiencias llevadas a cabo en los edificios anteriormente citados, se produjo un fenómeno bien definido de difusión de modelos, iconografías y formas que habían tenido su origen en las regiones de Aragón, Huesca y Palencia ${ }^{1910}$.

Así, partiendo de la escultura desarrollada en estos núcleos, parece lógico poder llegar a comprender algunos aspectos presentes en los trabajos que se iniciarán, en una cronología ligeramente posterior, dentro de los talleres de la catedral de Santiago de Compostela y San Isidoro de León.

Diversas cuestiones cronológicas, históricas y, lo que es más importante para nuestro estudio, de índole estilística y estética, permiten establecer relaciones directas entre la escultura desarrollada en torno a estos talleres antes estudiados y estos dos núcleos emergentes del norte de la Península Ibérica, en los que se comenzaba, ahora, a crear una serie de soluciones artísticas de gran importancia.

\footnotetext{
${ }^{1909}$ Aludimos a estos dos focos siendo conscientes de que su mención puede parecer demasiado simplista y un tanto parcial. Sin embargo, creemos que ambos centros representan los puntos más importantes, tanto desde un punto de vista cuantitativo como cualitativo, en la asimilación de los modelos antiguos dentro de la escultura románica de finales del siglo XI y principios del siglo XII. Señalamos, además, la importancia que, dentro de la órbita de éstos, tendrían otros templos coetáneos como, por ejemplo, la iglesia de Loarre, Iguacel, San Isidro de Dueñas o San Zoilo de Carrión de los Condes, por citar otros de los ejemplos más señeros donde la filiación con lo clásico, aunque constatada, no se presenta tan sistematizada y asimilada como en Frómista o Jaca.

${ }^{1910}$ Una prueba de ello la ofrece la reciente obra del profesor Lacoste. Cf.: J. LACOSTE, Les maîtres..., pp. 10-112. El autor desarrolla una serie de planteamientos herederos de los estudios de M. Durliat y, mediante los cuales, sigue considerando estas zonas como fundamentales en el surgimiento de este movimiento escultórico.
} 
Antes de comenzar el análisis pormenorizado de estas relaciones y la posible asimilación de fuentes clásicas en estos talleres, conviene justificar el encabezamiento de este apartado, así como su delimitación cronológica.

El enunciado con el que abrimos estas reflexiones, tan sólo alude a dos centros, la catedral compostelana y la iglesia de la Real Colegiata de San Isidoro de León. Resulta evidente que nuestro análisis no se centrará, exclusivamente, en ellos y lo utilizamos siendo conscientes de que tal epígrafe puede ofrecer una impresión muy simplificada de la espinosa cuestión del surgimiento de los diferentes talleres de escultores activos durante este periodo. Con todo, creemos que ello repercute, de manera positiva, a la hora de poder acotar el campo de estudio y en el momento de exponer determinadas conclusiones.

Será partirá del análisis de los rasgos clásicos presentes dentro de los talleres que trabajaron durante este periodo en la decoración de la catedral de Santiago de Compostela, claramente influenciados, en determinados aspectos, por los realizados en Jaca y Frómista para, posteriormente, centrarnos en el ejemplo concreto de San Isidoro de León. Dicho edificio es deudor, igualmente, de estas fórmulas, sin embargo, tal y como veremos, se percibe aquí una posible reinterpretación de algunos de los modelos originarios. Podríamos afirmar que los escultores accedieron entonces a una Antigüedad romana reinterpretada ya por una primera generación de artistas medievales. Su contacto con el mundo clásico ya no estará tan claro como habíamos observado en los ejemplos del apartado anterior. Las fuentes, los modelos y las formas a las que debieron acceder a través de la influencia de Jaca y Frómista, a pesar de tener un origen antiguo, no llegaban íntegras y "puras", sino vistas ya a través de una nueva mirada hacia el arte romano. Ahora la fuente de inspiración era el arte romano pero asimilado bajo el prisma del obrador románico.

Se trata de un arte con ciertos resabios clásicos, pero muy medievalizado ya. Parece una segunda generación de artífices que, a pesar de hallarse muy cercanos cronológicamente, no prestaron igual atención a los modelos antiguos, ni de la misma manera. Sus referentes eran ya románicos. La reinterpretación de una serie de obras medievales, cargadas de fuerte sustrato clásico, hacía que dicha influencia estuviese ahora doblemente tamizada. Era una Antigüedad conocida de manera indirecta.

Acotar el campo de estudio a sólo dos edificios, sería fragmentar una historia de la escultura ya de por sí dividida a causa de la desaparición de gran parte de las construcciones que debieron existir en el periodo que nos ocupa. 
En el caso concreto, de la catedral de Santiago es bien conocida la poca influencia que la escultura de la sede ejerció sobre otros edificios erigidos, posteriormente, en suelo gallego. Sin embargo, se ha demostrado que la irradiación de los talleres giróvagos acabaría por impregnar la escultura realizada para otra serie de iglesias más alejadas de su órbita como, por ejemplo, la de San Esteban de Corullón en el Bierzo, donde se observa el recuerdo de ciertos elementos clásicos, tan solo justificables a través de esta supuesta dependencia con respecto a lo santiagués ${ }^{1911}$.

Otros ejemplos, como los de las iglesias leonesas de Santa María del Mercado, San Julián de Ruiforco de Torío o, incluso algunas de las esculturas fragmentarias provenientes del monasterio de San Benito de Sahagún, hablan de un recuerdo y predilección por las fuentes clásicas fuera de los grandes centros con un mayor número de piezas esculpidas y que, actualmente, se conserven. Parece hasta cierto punto lógico, poder insinuar una dependencia de tales elementos con respecto a los trabajos excepcionales que se estaban realizando en San Isidoro de León ${ }^{1912}$.

Con ello intentamos explicar que, a pesar de que el enunciado de nuestro apartado presente una apariencia reducida y centrada, tan sólo, en dos ejemplos, éstos se han seleccionado teniendo en cuenta el elevado número de esculturas conservadas, algunos rasgos clásicos que éstas presentan y la importancia que sus talleres tuvieron en la formación de otros posteriores. No nos centraremos en ellos de manera exclusiva pues, al hablar sobre la fortuna de las fuentes clásicas en estos talleres de Santiago o León que pudiéramos denominar de la "segunda generación", será fundamental la mención y el estudio de otros más distantes y dispersos. Pensamos, por citar tan sólo un ejemplo bien representativo, en la iglesia de Santa Marta de Tera en Zamora que, alejada de ambos núcleos, conserva, en parte, el recuerdo clásico de la escultura leonesa ${ }^{1913}$. De igual manera se han señalado, correctamente, ciertos ecos de estos

1911 C. COSMEN ALONSO, El arte románico en León..., p. 30 e ID., Dos iglesias románicas del Bierzo..., pp. 69-77.

1912 Algunos de los motivos de tradición "antiquizante" que se observan en las esculturas procedentes de estos centros tendrían su origen o modelo principal en aquellos trabajos realizados para la iglesia de la Real Colegiata. Sobre estos aspectos, consúltese: J. A. MORÁIS MORÁN, "Modelo, copia...”, (en prensa).

${ }^{1913}$ La cuestión se presenta más compleja, si cabe, teniendo en cuenta las teorías defendidas por algunos investigadores. Según tales posturas, la perdurabilidad de la influencia de la escultura de Frómista, Jaca, Santiago de Compostela y San Isidoro de León, por citar los ejemplos mejor conservados, se observa en otros núcleos localizados más allá de las zonas geográficas lindantes con estos centros y de la serie de dataciones cronológicas propuestas. Sobre tal cuestión véase, por ejemplo: M. M. VILA DA VILA, Ávila Románica..., en particular, pp. 473-478. La autora se centra en el traspaso de ciertas fórmulas estilísticas e iconográficas desde los talleres de San Isidoro de León a diversos edificios construidos en Ávila. Se trataría, según su postura, de la asimilación de la escultura románica leonesa en una región más lejana y, 
talleres en otros lugares alejados de los núcleos que hemos propuesto como lugar de partida de algunas de estas reflexiones, tales y como son la portada de la iglesia de San Salvador de Leyre, la cripta de la iglesia de Sos del Rey Católico y, en última instancia, en los restos que nos han llegado de la primitiva catedral románica de Pamplona ${ }^{1914}$.

Una vez justificada la intención práctica de lo restrictivo de nuestro enunciado, consideramos importante aludir, brevemente, a la cuestión cronológica. De esta manera, en el apartado anterior delimitábamos la influencia de las obras clásicas sobre los escultores activos entre los años finales del siglo XI y los primeros del XII.

En el caso concreto de este apartado, se acusa, aún más, la complejidad de poder señalar una serie de cronologías cerradas y de años exactos a la hora de abordar el estudio.

Según se ha venido aceptando, no sin fuertes discrepancias entre los especialistas, las últimas décadas del siglo XI y buena parte del primer cuarto del siglo XII, deben ser consideradas como el periodo en el que se podrían datar los trabajos realizados en la catedral de Santiago y la iglesia de San Isidoro de León, refiriéndonos siempre, evidentemente, a la escultura.

En lo relativo a los años exactos utilizados para delimitar este apartado, habíamos tomado el año 1075 como fecha de referencia, pues fue en esta cronología cuando, hipotéticamente, se hubo de iniciar, materialmente, el proyecto del templo santiagués ${ }^{1915}$.

Con el mismo criterio se ha tomado el año 1147 como fecha límite de este apartado, por tratarse del año en el que se produce la última consagración de la iglesia de San Isidoro de León. Se trata de una elección de carácter formal y práctico que

sobre todo, en una serie de edificios más tardíos. Se deduce que, de existir ciertos motivos emparentados con la tradición clásica, éstos tendrían su posible origen en la escultura de San Isidoro.

1914 S. MORALEJO ÁLVAREZ, "La primitiva fachada norte de la Catedral de Santiago", Compostellanum, XIV, 1985, pp. 632-668, reeditado en, Patrimonio artístico de Galicia y otros estudios, A. Franco Mata (ed.), 3 vols., Santiago de Compostela, 2004, vol. I, pp. 21-46, en concreto, p. 45. El investigador señala a Navarra y el Alto Aragón como los lugares de difusión de tales tendencias escultóricas.

${ }^{1915}$ No recogemos, en este momento, toda la selección bibliográfica utilizada para realizar este estudio. En lo relativo a la fecha de inicio de las obras dentro del conjunto, se ha venido aceptando el año 1075, aproximadamente. Cf.: K. J. CONANT, Arquitectura románica de la Catedral de Santiago de Compostela, Santiago de Compostela, 1983, p. 196; S. MORALEJO ÁLVAREZ, "Notas para una revisión de la obra de K. J. Conant", Patrimonio..., vol. I, pp. 247-263; I. G. BANGO TORVISO, “Arquitectura románica en Galicia. Desde los orígenes hasta 1168”, Románico en Galicia y Portugal, La Coruña-Lisboa, 2001, pp. 12-29, en concreto, p. 18 y M. A. CASTIÑEIRAS GONZÁLEZ, "La catedral románica...", en concreto, p. 42. Este último autor, al abordar el estudio del templo, concreta las fechas de inicio y finalización de la obra entre los años 1075-1211. 
permite hablar, claramente, de una posible data de disolución o declive de la corriente escultórica surgida en el seno de la basílica leonesa ${ }^{1916}$.

Con todo, es indiscutible lo complicado que resulta iniciar una aportación al tema que ahora abordamos desde una óptica rigurosa, científica y en la que, además, se puedan introducir novedades con cierta solidez argumental.

Uno de los mayores problemas que se nos presentan en este sentido deriva de la basta producción bibliográfica que, desde los inicios del siglo XIX, ha terminado por generar una historiografía enormemente densa y que el investigador debe discriminar en busca de una mayor acotación del campo de estudio. Ello ha hecho necesario seleccionar, de una manera consciente, las fuentes, estudios y aportaciones realizadas por los diferentes expertos en relación con las cuestiones que aquí vamos a tratar.

Somos conscientes de que existen muchos trabajos que no aparecerán citados. Sin embargo, se han seleccionado aquellas contribuciones que, de una manera u otra, se han centrado en el asunto de la influencia de lo clásico en este tipo de escultura.

En este apartado se continua, en la medida de lo posible, la división utilizada en el desarrollo del bloque anterior, discriminando un conjunto de temas y motivos artísticos, lo suficientemente significativos, como para ofrecer una visión completa del fenómeno.

Resulta prácticamente imposible poder realizar, en este lugar, un balance historiográfico completo sobre las investigaciones llevadas a cabo en torno a la escultura de la catedral de Santiago de Compostela ${ }^{1917}$. A ello debemos sumar el

\footnotetext{
1916 Se ha tomado la fecha de la inscripción de la consecratio ubicada en el brazo sur del crucero del templo, donde señala el 6 de marzo del año 1147, como el año de la última consagración de la basílica. Dicha data no asegura que todos los trabajos estuvieran por entonces finalizados, pues es factible que restasen toda una serie de obras secundarias por realizar. Sin embargo, en lo referente a la escultura, podemos pensar y afirmar, con cierta seguridad, que ésta se encontraba totalmente realizada, al menos, en su mayoría. Sobre la inscripción y la citada fecha, véase: V. GARCÍA LOBO, "Las inscripciones medievales...", p. 386.

1917 Excluimos, conscientemente, todos aquellos trabajos centrados en el estudio de las cuestiones arquitectónicas, aunque se utilizarán siempre que sea necesario para poder explicar algunos aspectos relacionados con la escultura. Cf.: K. J. CONANT, Arquitectura románica de la Catedral..., pp. 27-57. Se trata de una obra, aún hoy, indispensable para comprender la fábrica catedralicia dentro del contexto europeo. También véase: S. MORALEJO ÁLVAREZ, "Notas para una revisión...", pp. 247-263. No podemos dejar de mencionar, aunque sus líneas de investigación se alejen de los temas relacionados con la escultura, los estudios metódicos aportados en: G. EDMUND STREET, Gothic Architecture in Spain, 2. vols., New York, 1914, vol. I, pp. 189-225; DUCHESNE, "Saint-Jacques en Galice", Annales du Midi, XII, 1900, pp. 145-179; M. CHAMOSO LAMAS, "Excavaciones en la catedral de Santiago de Compostela", Archivo Español de Arte, 106, 1954, pp. 183- 187; ID., "Noticia de las excavaciones arqueológicas que se realizan en la Catedral de Santiago", Compostellanum, 1, 1956, pp. 5-48; ID., "Una obra de Alfonso III el Magno: la basílica del Apóstol Santiago", Symposium sobre cultura asturiana de la alta Edad Media, Oviedo, 1967, pp. 27-35; E. LAMBERT, "La peregrinación a Compostela y la arquitectura románica”, Archivo Español de Arte, XVI, 1943, pp. 273-309. Igualmente, son de una
} 
aumento significativo de contribuciones que se han venido realizando en los últimos años y que, tanto desde la historiografía española como desde la europea, han convertido cualquier balance historiográfico en una tarea de gran dificultad.

Al contrario, el problema de la influencia del arte romano sobre la misma escultura románica del templo santiagués, no ha recibido una atención concreta por parte de los especialistas, a pesar que, desde los inicios, muchos autores intentaron emparentar algunos de estos elementos medievales con tales tradiciones ${ }^{1918}$.

Sin embargo, fue el profesor S. Moralejo quién dedicó los trabajos más detenidos a la hora de analizar la escultura de la catedral compostelana. Sin abordar nunca el tema de manera global, sus aportaciones muestran siempre datos importantes relacionados con el tema de las fuentes clásicas de la escultura románica ${ }^{1919}$.

Dentro de la misma corriente historiográfica, M. A. Castiñeiras González ha consagrado buena parte de sus investigaciones a estudiar, aunque de manera indirecta, el recuerdo clásico presente en algunas de las esculturas de la catedral, especialmente,

importancia crucial las aportaciones, más vinculadas a cuestiones arqueológicas, realizadas en: J. GUERRA CAMPOS, "La tumba apostólica de Santiago de Compostela a la luz de las excavaciones recientes. Crónica de una conferencia del P. Kirschbaum S. J., en Roma", Compostellanum, 1, 1956, pp. 370-380; ID., Excavaciones arqueológicas en torno al sepulcro del Apóstol Santiago, Santiago de Compostela, 1982; S. MORALEJO ÁLVAREZ, "Le Lieu Saint: le Tombeau et les basiliques médiévales", Europalia 85. Santiago de Compostela. 1000 ans de pélegrinage européen, Gante, 1985, pp. 41-52.

Más recientemente, se han realizado estudios relacionados con este tipo de arquitectura en: I. G. BANGO TORVISO, "Historia del arte cristiano (s. VIII al XII)", La Iglesia en la España de los siglos VIII al XIV (J. Fernández Conde ed.), Madrid, 1982, pp. 501-551; ID., "Las llamadas iglesias de peregrinación o el arquetipo de un estilo", El Camino de Santiago, camino de las estrellas..., Madrid, 1994, pp. 9-75; E. CARRERO SANTAMARÍA, "Le sanctuaire de la cathédrale de Saint-Jacques-de-Compostelle à l'épreuve de la liturgie", Saint-Martial de Limoges. Ambition politique et production culturelle $\left(X^{e}-X_{I I I}{ }^{e}\right.$ siècles), Poitiers-Limoges, 2005, pp. 295-307 y H. KARGE, “De Santiago de Compostela a León...”, pp. 165-198.

Posee una especial importancia, en aquellas cuestiones relacionadas con la historiografía, los estudios realizados en: J. GUERRA CAMPOS, "Bibliografía (1950-1969). Veinte años de estudios jacobeos", Compostellanum, XVI, 1971, pp. 575-732; M. VACCARO, "Le sculture de Platerías nella storiografia del XX secolo: I. Gli studi da López Ferreiro agli anni 60”, Compostellanum, 51, 3-4, 2006, pp. 565-622 e ID., "Le sculture di Platerías nella storiografia del XX secolo: II. Dagli studi iconografici alla valutazione funzionale", Compostellanum, 52, 3-4, 2007, pp. 471-510.

1918 A. KINGSLEY PORTER, "Spain or Toulouse?...”, pp. 2-25 y G. GAILLARD, Les débuts..., en concreto, pp. 156-219.

1919 Se observará que, para la redacción de este estudio, se han utilizado de una manera reiterativa los trabajos realizados por este autor. Recogemos algunos de los que consideramos más importantes, citándose otros a lo largo del texto y en momentos puntuales. Cf.: S. MORALEJO ÁLVAREZ, "Arte del Camino de Santiago y Arte de peregrinación (ss. XI- XIII), El Camino de Santiago, Poio, 1990, pp. 9-28, reeditado en, Patrimonio..., vol. II, pp. 137-144; ID., "El patronazgo artístico del arzobispo Gelmírez (1100- 1140): su reflejo en la obra e imagen de Santiago", Atti del Convengo Internazionale di Studi Pistoia e il Cammino di Santiago, Una dimensione europea nella Toscaza medioevale (L.Gai ed.), Nápoles, 1984, pp. 245-272, reeditado en, Patrimonio..., vol. II, pp. 289- 299; ID., "La imagen arquitectónica de la catedral...", pp. 37-62 e ID., "La primitiva fachada norte...”, pp. 21-46. 
aquellas que, en su día, se pensaron para decorar las fachadas sur y norte del transepto del edificio ${ }^{1920}$.

Sin embargo, aunque dichos expertos han enfocado el grueso de sus pesquisas a este tema, la historiografía cuenta con otras muchas aportaciones de interés que, igualmente, han aportado datos de relevancia para poder perfilar y definir las características del fenómeno de recuperación de lo clásico. Nos referimos, entre otras, a las contribuciones de investigadores como J. Mª de Azcárate y Ristori, M. Durliat, K. Matheus y otros autores ${ }^{1921}$.

${ }^{1920}$ M. A. CASTIÑEIRAS GONZÁLEZ, "Introitus pulcre refulget: alcune riflessioni sul programa iconografico dei frontespizi romanici del transetto della cattedrale", La meta del Camino di San Giacomo. La transformazione della cattedrale le attraverso i tempi, Santiago de Compostela, 1995, pp. 83-103; ID., "Un adro para un bispo...", pp. 231-264; ID., "La catedral románica: tipología arquitectónica...", pp. 3996; ID., "Platerías, función y decoración de un lugar sagrado", Actas del V Congreso Internacional de Estudios Jacobeos, Santiago de Compostela, 2001, pp. 289-311; ID., "Roma e il programma riformatore...", pp. 211-226; ID., "La meta del Camino: la catedral de Santiago de Compostela en tiempos de Diego Gelmírez", Los caminos de Santiago. Arte, Historia y Literatura (M. del C. Lacarra Ducay coord.), Zaragoza, 2005, pp. 213-252 e ID., "Verso Santiago?...", pp. 387-396.

${ }^{1921}$ J. M. DE AZCÁRATE Y RISTORI, "La portada de las Platerías y el programa iconográfico de la Catedral de Santiago", Archivo Español de Arte, 35, 1963, pp. 1-20; M. F. HEARN, Romanesque sculpture. The revival of Monumental Stone Sculpture in the Eleventh and Twelfth Centuries, Ithaca-New York, 1985, sobre todo, pp. 49-185; M. DURLIAT, La sculpture romane de la route..., en concreto, pp. 325-357; K. MATHEUS, "Reading Romanesque sculpture: the iconography and reception of the south portal sculpture at Santiago de Compostela", Gesta, XXXIX, 2000, pp. 3-12; J. L. SENRA GABRIEL Y GALÁN, "Los tímpanos de la catedral...", pp. 25-46 y S. FERNÁNDEZ PÉREZ y V. R. NODAR FERNÁNDEZ, "Un proyecto de reconstrucción hipotética de las portadas del transepto de la Catedral de Santiago en época de Diego Gelmírez", Compostellanum, XLVIII, 1-4, 2003, pp. 605- 613. 


\section{2. REPERTORIOS ORNAMENTALES E ICONOGRÁFICOS EN LA CATEDRAL DE SANTIAGO DE COMPOSTELA.}

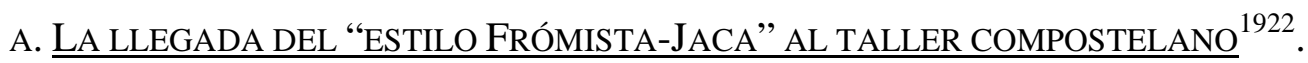

Desde los estudios más tempranos que abordaron la problemática en torno a la escultura del edificio, hasta los más recientes, muchos autores han incidido en la complejidad que presenta el conjunto santiagués, sobre todo, en lo relativo a las fuentes utilizadas por los artífices. Tal y como es sabido, fueron continuas las reformas y cambios a los que fue sometido el proyecto final, sobre todo, en relación con la decoración de las dos fachadas más importantes del templo que ya se encontraban en pie en las primeras décadas del siglo XII. En concreto, nos referimos a la fachada norte del brazo del transepto, también conocida como Puerta Francigena y a su pareja, en el lado sur, la denominada Puerta de Platerías.

Ambos espacios exhibieron las creaciones más originales y tempranas del templo, junto con la girola, donde fue proyectado un singular conjunto de capiteles, canecillos y otra serie de relieves, en los que la tradición clásica se muestra como una de las posibles fuentes definidoras de tales producciones ${ }^{1923}$. Las fachadas que cerraban el

${ }^{1922}$ Utilizamos la expresión "estilo Frómista-Jaca", siguiendo el uso que se le da en: S. MORALEJO ÁLVAREZ, "La sculpture romane...", p. 143.

${ }^{1923}$ En el apartado que ahora iniciamos no llevaremos a cabo un análisis de la escultura anterior a la erección de las fachadas de Platerías y la del brazo norte del crucero. Las razones son varias; en primer lugar, la escultura que encontramos en las partes iniciales proyectadas por el obispo Diego Peláez para el templo compostelano, es decir, lo que se viene considerando como una primera fase de la obra, presentan otra serie de filiaciones más alejadas del ámbito hispano.

Las primeras capillas de la girola, así como el conjunto de capiteles y canecillos del exterior, tienen su origen en el ámbito francés, a juzgar por las filiaciones defendidas por los especialistas. La cronología para este conjunto de esculturas parece estar entre los años 1075 y 1088. El estilo de tales obras ha de buscarse en suelo francés, sobre todo, a la vista del que fue utilizado en su día para realizar algunos de los capiteles de la girola de la abacial de Santa Fe de Conques, además de otras esculturas dispersas por la región de Auvernia.

La fecha del año 1075 coincide, además, con la del Concilio Magno, llevado a cabo con el fin de restaurar la liturgia romana. A pesar de que dicho repertorio presenta ciertos rasgos "antiquizantes", estos no pueden explicarse a través de las experiencias realizadas en la catedral de Jaca y la iglesia de Frómista, lo que obliga, por razones prácticas, a intentar limitar su estudio. Esta es la razón por la cual no analizaremos dichas obras.

Recogemos, tan sólo, los recientes estudios de V. Nodar, quién ha llevado a cabo un análisis pormenorizado de las filiaciones, cronología, iconografía y otra serie de problemáticas en un lugar tan concreto del templo. Cf.: V. R. NODAR FERNÁNDEZ, Los inicios de la catedral románica de Santiago: El ambicioso programa iconográfico de Diego Peláez, Santiago de Compostela, 2004, en concreto, pp. 60-70. Se trata de un estudio concreto sobre estos aspectos, sin adentrarse en las siguientes fases escultóricas y arquitectónicas de la catedral. Consúltese también: ID., "Alejandro, Alfonso VI y Diego Peláez: una nueva lectura del programa iconográfico de la Capilla del Salvador de la Catedral de Santiago", Compostellanum, XLV, 3-4, 2000, pp. 617-648; ID., "Capitel de Alejandro", Atlas de la 
transepto al norte y al sur, no han llegado a nuestros días intactas. Continuos cambios y modificaciones, muchos de ellos, realizadas ya en la época propiamente románica, nos han legado un conjunto de extrema complejidad, con piezas descontextualizadas, movidas desde su emplazamiento primigenio y, en ocasiones, no originales, fruto de remoces y acciones conservadoras, restauradoras o, simplemente, con intenciones renovadoras $^{1924}$.

El presente apartado se centrará en el obispado de Diego Gelmírez (1068-1140) y el patrocinio artístico que dicha personalidad eclesiástica desarrolló, atendiendo, sobre todo, a aquellas cuestiones importantes desde un punto de vista escultórico. Generalmente, la historiografía especializada ha englobado las obras llevadas a cabo por esta figura dentro de una supuesta "segunda fase" de la construcción del templo que duró hasta la muerte del prelado y que habría de dejar inconclusos los tramos occidentales del buque catedralicio ${ }^{1925}$. El momento exacto que más nos interesa es

Catedral..., (edición digital); ID., "Capitel con sirenas", Ibidem; ID., "La sirena: la metamorfosis de un tema en la catedral románica de Santiago de Compostela", Codex Aquilarensis, 21, 2005, pp. 33-47 e ID., "Sus cabelleras brillaban como plumas de pavor real: Los guerreros de Alejandro y las sirenas de un capitel de la catedral de Santiago de Compostela", Troianoalexandrina, 5, 2005, pp. 39-61. En todos estos trabajos se encontrará la compilación bibliográfica relativa a la primera fase del templo, antes de la llegada al poder del obispo Diego Gelmírez.

${ }^{1924}$ Entre las modificaciones que sufrirían las fachadas se hallan aquellas derivadas de los disturbios acontecidos ya en época románica, que acabarían con el incendió y deterioro de la Puerta de las Platerías. Muchas de las esculturas fueron sustituidas y parte de la fachada fue rehecha y remodelada. Igualmente, fue muy significativa la destrucción de la Puerta Francigena del brazo norte, desmontada completamente y sustituida por una fachada barroca. Parte de las piezas fueron reaprovechadas en la de Platerías, lo que ha complicado, aún más, el estudio del conjunto.

A modo de ejemplo reconstructivo, véase: K. J. CONANT, "The fire at Santiago de Compostela in 1117: a reconstruction drawing", Journal of the School of Architectural Historians, 15, 1, 1956, p. 3 y V. R. NODAR FERNÁNDEZ Y S. FERNÁNDEZ PÉREZ, “Un proyecto de reconstrucción...”, pp. 605-613.

${ }^{1925}$ No podemos ahondar en el complicado tema del cierre del templo a occidente y la conclusión del mismo a través de una supuesta portada. En relación con la escultura del entorno del año 1200 y el Pórtico de la Gloria, véase el capitulo correspondiente de este trabajo. Tan sólo aludimos a la descripción del Codex Calixtinus en relación con la supuesta existencia de esta portada que, según la fuente, habría de datarse en época de Gelmírez.

Sin embargo, la historiografía ha dudado siempre de su existencia. Cf.: J. M. AZCÁRATE Y RISTORI, "La portada de las Platerías...", p. 19. El autor apunta la posibilidad de que "como en las buenas guías, se diesen por terminadas obras no hechas", admitiendo que, es posible, que la fachada occidental nunca hubiese estado terminada hasta la época del "maestro" Mateo.

En la actualidad, son varios los especialistas que han recuperado viejas teorías sobre tal portada occidental, defendiendo su posible existencia y argumentando otra serie de reflexiones, no exentas de problemas. Véase, por ejemplo: H. KARGE, "De Santiago de Compostela a León...", pp. 184-185 e ID., "Der Pórtico de la Gloria und der ursprüngliche Westbau der Kathedrale von Santiago im Lichte neuer baugeschichtlicher Forschungen", en las Jornadas Internacionales tituladas: Neue Forschungen zur Bauskulptur in Frankreich und Spanien im Spannungsfeld des Portail Royal in Chartres und des Pórtico de la Gloria in Santiago de Compostela, celebradas en la Humboldt-Universität de Berlín, entre el 22-24 de febrero de 2007. Esta última aportación aún no había sido publicada en el momento de redactar esta parte del estudio.

Desde otro orden de cosas, la labor constructora y patrocinadora del obispo queda patente, de una manera reiterativa, en las continuas alusiones que a ellas se hacen dentro de la Historia Compostelana. Cf.: E. FALQUE REY, Op. cit., p. 345, nota 189. 
aquel en el que se produjo el cambio constructivo y decorativo, tanto del proyecto como de maestros que trabajaban dentro del taller.

S. Moralejo ya señaló en momento que era en la capilla de Santa Fe de dicha catedral gallega donde, más claramente, se podía advertir tal ruptura (fig. 366). Tanto su estructura arquitectónica como su escultura fueron tradicionalmente atribuidas al desconocido y problemático "maestro" Esteban que, en torno al año 1101, parece documentarse activo en la catedral de Pamplona ${ }^{1926}$. La monumentalidad de su proyecto en aquellas tierras convertiría a dicha catedral en el segundo templo hispano de mayores dimensiones, después de Santiago de Compostela, tal y como ha señalado J. Martínez de Aguirre a la hora de establecer determinadas relaciones entre ambas fábricas ${ }^{1927}$.

Lo más destacado, en relación con la figura de Esteban y su hipotética obra en Santiago es que, sería durante esta cronología cuando se produjo la introducción en la escultura del templo, de una corriente novedosa, si atendemos al resto de capiteles y elementos escultóricos realizados en la fase anterior del edificio ${ }^{1928}$. Se trata de la asimilación de ciertos aspectos presentes ya en la decoración realizada, anteriormente, en San Martín de Frómista y Jaca y que, ahora, parecía ser asimilada y utilizada por este taller.

La mayoría de los autores coinciden en concretar el arco temporal que va desde el año 1087 al 1088 como el final de la primera fase constructiva de la catedral y el inicio, coincidiendo con la llegada al obispado de Diego Gelmírez, de la segunda fase $^{1929}$. Anteriormente a dicha data, el conocido como "estilo" de Frómista-Jaca no se rastrea en ninguna de las producciones realizadas por los talleres que trabajaban en el

\footnotetext{
${ }^{1926}$ El problema de la existencia del "maestro" Esteban y la posibilidad de atribuirle, correctamente, algunas de las esculturas de la fábrica compostelana es un tema recurrente y reiterativo dentro de las investigaciones realizadas al respecto. Cf.: M. A. CASTIÑEIRAS GONZÁLEZ, "La catedral románica: tipología...", p. 49 y J. MARTÍNEZ DE AGUIRRE, "Catedral románica de Pamplona: el templo", Sancho el Mayor..., vol. II, pp. 873-874, en especial, p. 873. El autor destaca la siguiente secuencia cronológica, en relación con la catedral de Pamplona: en el año 1101 se le concede a Esteban, maestro de la obra compostelana, diversos bienes para la realización de obras en la iglesia. En el 1107 se incrementan estas donaciones para, finalmente, en el año 1127 llevar a cabo la consagración del templo.

${ }^{1927}$ Ibidem, pp. 837-838.

${ }^{1928}$ No es este un lugar indicado para detenernos en la espinosa figura del "maestro" Esteban. Remitimos al estudio realizado en: F. J. OCAÑA EIROA, "La controvertida personalidad del Maestro Esteban en las catedrales románicas de Pamplona y Santiago", Príncipe de Viana, 64, 228, 2003, pp. 7-58.

1929 S. MORALEJO ÁLVAREZ, "La sculpture romane...", pp. 144; J. YARZA, "Artes figurativas románicas en Galicia antes de 1150", El arte románico en Galicia y Portugal, La Coruña-Lisboa, 2001, pp. 57-87, en particular, p. 60 e I. G. BANGO TORVISO, “Arquitectura románica en Galicia...”, pp. 1925.
} 
espacio de la cabecera del templo, de un carácter mucho más arcaico, si aceptamos los análisis de S. Moralejo ${ }^{1930}$.

Las esculturas más representativas de esta fase que señalan, claramente, la introducción de ciertas corrientes renovadoras con respecto a las anteriores labores decorativas, son aquellas relacionadas con esta capilla de Santa Fe ${ }^{1931}$.

La interpretación de algunas de estas imágenes ha presentado dificultades a la hora de realizar una lectura iconográfica y un estudio formal fiables. Así, últimamente se defendió la posibilidad de que, en dicho conjunto esculpido, se pudiera haber desarrollado un ciclo dedicado a la mártir, que tendría como escena principal aquella en la que se narró la condena de la santa por Daciano ${ }^{1932}$ (fig. 255).

Por su parte, M. Durliat había señalado que, por primera, vez dentro de la escultura de la catedral, el estilo utilizado por los escultores introducía un elemento novedoso. Se trata del famoso "pitón", colocado en los ángulos del capitel y que el autor relacionaba con las fórmulas utilizadas, de manera reiterativa, en los capiteles de Jaca y Frómista. Desde la misma óptica, la introducción, nuevamente, en estas piezas de la imagen de los textiles o fluidos, según la interpretación que les diésemos, habla de un lejano recuerdo de las telas que decoraban el frente del sarcófago de Husillos de Palencia y que habían gozado de tanto éxito dentro de la escultura de finales del siglo $\mathrm{XI}^{1933}$.

Los dos capiteles en cuestión son aquellos que presentan una serie de personajes desarrollando diversas acciones a lo largo del cuerpo del capitel. El primero de ellos, ubicado en la capilla de Santa Fe, ha sido interpretado como la escena en la que se muestra el arresto de la santa que, velada, es aprisionada por un esbirro. Ya hemos

\footnotetext{
${ }^{1930}$ S. MORALEJO ÁLVAREZ, “La sculpture romane...”, p. 143.

${ }^{1931}$ Los capiteles que forman parte de esta capilla siempre han llamado la atención de los especialistas, dedicando investigaciones completas para abordar tal problemática. Véanse: J.-C. FAU, "À propos du chapiteau de la condamnation de Sainte Foy...", pp. 47-57; P. DESCHAMPS, "Étude sur les sculptures de Sainte-Foy de Conques...", pp. 239-264 y G. GAILLARD, "Une abbaye de pèlerinage; Sainte-Foy de Conques et ses rapports avec Saint-Jacques”, Compostellanum, X, 1965, pp. 335-347. El estilo de dichos capiteles es muy distinto, por ejemplo, al que presenta el capitel en el que se representó al rey Alfonso VI, en el arco toral del acceso a la capilla del Salvador y otro en el que se esculpió la efigie del obispo Peláez.

La concepción de dichas esculturas remite a los capiteles de la cabecera y las tribunas de la iglesia de Santa Fe de Conques. Sobre el tema, véase: P. DESCHAMPS, "Etudes sur les sculptures...", p. 248; G. GAILLARD, "Une abbaye...", pp. 335-347 y V. R. NODAR FERNÁNDEZ, Atlas de la Catedral..., (edición digital). Por su parte, el profesor Yarza se refiere a los capiteles de esta capilla como los "más finos de ejecución y más maduros", a pesar de que los engloba dentro de la primera etapa constructiva del edificio. Cf.: J. YARZA, “Artes figurativas...", p. 60.

${ }^{1932}$ M. A. CASTIÑEIRAS GONZÁLEZ, “Los santos viajan...”, pp. 63-90.

${ }^{1933}$ M. DURLIAT, La sculpture romane de la route..., pp. 215-216. El autor relacionaba el motivo con algunas de las ilustraciones realizadas en el scriptorium de la iglesia de Saint-Sever.
} 
señalado la narración continua e isocefálica que presentan las figuras, herederas, hipotéticamente, del sistema figurativo utilizado en los frentes de los sarcófagos ${ }^{1934}$.

Como rasgo significativo, debemos destacar el enorme volumen que adquieren en esta obra los citados "pitones" 1935.

El otro capitel, ciertamente más enigmático, se ubica en el brazo sur del transepto. Desde un punto de vista estilístico y morfológico debe compararse con la pieza anterior, aunque no parece haber sido realizado por la misma mano ejecutora. Ahora las figuras son más elegantes, los detalles más precisos y de calidad mayor. Se trata, posiblemente, de escultores diferentes, pero ambos poseen unos objetivos comunes. Recientemente, en relación con este capitel, J. Lacoste emparentaba este tipo de trabajos con las experiencias de los maestros jaqueses ${ }^{1936}$.

Nada nuevo podemos aportar al estudio de estas piezas tan complejas. Simplemente, atestiguamos una rápida asimilación de ciertos motivos presentes en la escultura de Jaca y, de entre los cuales, el más significativo es el uso que se le va a dar a los textiles, de cierto recuerdo clásico ${ }^{1937}$. La dificultad existente dentro del posicionamiento de los especialistas para poder discernir si la fuente para dichos capiteles está dentro del repertorio de la escultura de Conques o, por el contrario, imbuida ya en las experiencias hispánicas, sigue siendo un problema aún por resolver $^{1938}$.

En la misma capilla de Santa Fe compostelana, pero al exterior, se esculpieron unos elementos que han llamado, frecuentemente, la atención de los investigadores y que recogemos por su evidente carácter clásico. Se trata de una serie de esculturas realizadas en bulto redondo, de entre las cuales, destacamos una acrotera que remata el tejado de la capilla (fig. 367). La pieza representa la figura de una mujer semidesnuda, con cabellos agitados, que cabalga sobre un león de zarpas bien definidas. La mayoría

\footnotetext{
${ }^{1934}$ Ibidem, p. 315.

1935 J. LACOSTE, Les maîtres..., p. 14. El autor recoge la datación realizada en su día por M. Durliat, quién consideraba que la pieza se inscribía dentro de los trabajos llevados a cabo en una fase anterior a la llegada al obispado de Diego Gelmírez.

1936 Ibidem, p. 15 y M. DURLIAT, La sculpture romane de la route..., p. 315. El profesor Durliat relaciona el capitel con algunas de las esculturas de la iglesia de San-Caprais de Agen, en Francia. Además de ello, pesar de que, actualmente, se tiende a ligar estas esculturas con fuentes hispanas, el investigador francés las emparentó también con fórmulas francesas, especialmente, aquellas ligadas a la abacial de Conques. La pieza fue numerada por el autor como la 192.

${ }^{1937}$ Remitimos en este punto al apartado correspondiente en el que se abordó la utilización de este tipo de elementos dentro de la iconografía de los capiteles de la catedral de Jaca.

1938 J.-C. FAU, “À propos du chapiteau de la condamnation...”, pp. 48-49.
} 
de los autores que se han ocupado de la obra la han relacionado con modelos clásicos, concretamente, grecorromanos ${ }^{1939}$.

Por su parte T. Lyman, al estudiarla, remarcó su relación con las esculturas en bronce de época romana y en las que parece que estos tipos faciales fueron frecuentes. El referido autor, además, fue más lejos en su análisis, proponiendo una lectura de la acrótera a través de los textos de Prudencio y, sobre todo, aquellos en los que la mujer montada sobre un équido, convertido luego en león, debía ser vista como representante de la soberbia ${ }^{1940}$.

El carácter "antiquizante" de esta acrotera se refuerza gracias a otra escultura conservada en el mismo área del templo y que posee idéntica tipología. Se trata de una pieza en forma de esfinge que corona la cubierta de la capilla de San Juan de la dicha catedral de Santiago (fig. 368). Ya en su temprano estudio G. Gaillard reconocía el resabio clásico de esta figura, donde se formulan algunas de las características que se harán reiterativas dentro de los talleres de la catedral compostelana ${ }^{1941}$.

Creemos que las piezas que acabamos de analizar, de manera somera, pueden ser un buen punto de partida para iniciar el discurso que vamos a desarrollar a lo largo de estas páginas. Por una parte suponen, desde un punto de vista cronológico, las primeras experiencias, en Galicia, ligadas al movimiento que se había desarrollado en Jaca y Frómista. Además, desde otra óptica, reflejan el conocimiento de ciertas soluciones y

\footnotetext{
${ }^{1939}$ Sorprende el carácter exento de la pieza, su volumen y, sobre todo, el rostro de la figura. Insistimos en ello, pues habrá de convertirse en un tema recurrente dentro de la escultura del templo, donde los rostros ovalados, con mejillas voluptuosas, muy marcadas, y cabellos alborotados, serán soluciones recurrentes. A ello debemos sumar que, muchas de estas figuras, mostrarán desnudas algunas partes del cuerpo, sobre todo las piernas. Cf.: M. A. CASTIÑEIRAS GONZÁLEZ, "La catedral románica: tipología...”, pp. 75-77 e ID., "Sacro e profano nos programas monumentais do románico. I", Historia da arte galega, 36, pp. 130-144, en concreto, p. 142. El autor relaciona la escultura con algunas obras de la Península italiana, en concreto, con el románico de la Puglia. Nos parece más certero establecer las conexiones, tal y como él mismo señala, con las figuras cabalgando leones del capitel conservado en Palencia, Museo Arqueológico y proveniente de Frómista. Este capitel ya ha sido tratado en este estudio. Nos limitamos a recordar las conexiones establecidas con la iconográfica báquica de los cortejos orgiásticos y las imágenes de putti domando y cabalgando felinos. En otro trabajo, el mismo autor, apuntaba la hipótesis de que se tratase de una personificación de la lujuria, figurada a la manera en la que, años después, se haría en una de las consolas de la catedral de Auxerre, datada en torno al 1260.

1940 T. LYMAN, “Le style comme...", p. 175.

${ }^{1941}$ G. GAILLARD, Les débuts..., pp. 185-186. El investigador suponía que las demás capillas debían haber sido rematadas siguiendo la misma solución, aunque, hoy en día, tales piezas estén perdidas. Por otra parte, se ha constatado el uso de tales piezas en otras construcciones románicas de la Península, a través, por ejemplo, de las dos acróteras colocadas en los extremos de la Puerta del Obispo de la catedral de Zamora, una construcción donde el recuerdo de modelos clásicos han sido bien estudiados. Sobre este tema, véase.: E. FERNÁNDEZ GONÁLEZ, "Presencia de Oriente y Occidente...", pp. 225-2274 e ID., "Hacia la renovación del lenguaje arquitectónico en torno al reinado de Alfonso IX", Alfonso IX y su época. Pro utilitate regni mei, La Coruña, 2008, pp. 349-369, en particular, pp. 362-363.
} 
formalidades estilísticas que habrían de convertirse en características principales del taller santiagués.

Sin embargo y teniendo en cuenta nuestro objeto de estudio, lo más interesante es la evidente continuidad que los escultores de la catedral de Santiago ofrecieron, en cuento a su actitud, ante los modelos de prestigio. El arte clásico, nuevamente, parece ser una fuente a la que acudir a la hora de desarrollar la decoración de los espacios templarios. En una cronología temprana, las partes exteriores de estas capillas fueron rematadas, supuestamente, por estas acróteras, por lo que, su presencia sigue reafirmando el conocimiento del arte antiguo más allá de los centros de Jaca y Frómista.

Según se viene afirmando, tras las experiencias desarrolladas, una vez concluido el obispado de Diego Peláez, los nuevos obradores utilizaron algunas de las soluciones presentes en Jaca y Frómista para el establecimiento en Compostela de un taller que, compartiendo las mismas directrices estilísticas, llegaría a poder aportar toda una serie de novedades, y no sólo desde el punto de vista estilístico e iconográfico. También en el caso del manejo de los motivos clásico, los artífices de Galicia parecen acceder a otra serie de repertorios antiguos.

El primer problema al que nos enfrentamos es la disparidad de escultores que debieron trabajar en el edificio, algo normal, teniendo en cuenta las dimensiones del proyecto y su envergadura. Desde los estudiosos clásicos hasta los más actuales, todos convienen en identificar varias tendencias y diferentes orígenes para las esculturas de la cabecera y las realizadas para las dos fachadas del transepto. Una vez más, se nos presenta el tradicional problema del girovagismo y la itinerancia de los artífices medievales que, desde el campo a la ciudad, desde los centros de primer orden hasta otros más discretos, llegan a crear un mapa interminable de relaciones que se extienden más allá de la propia Península Ibérica ${ }^{1942}$.

La escultura de la catedral de Santiago, comparada frecuentemente, con un "palimpsesto" pétreo, presenta la complejidad de poder realizar un estudio sólido en relación con el origen de sus esculturas, su colocación original dentro del espacio de las fachadas y las diferentes reformas realizadas en ellas ${ }^{1943}$.

\footnotetext{
1942 C. GINZBURG y E. CASTELNUOVO, “Centro e periferia”, Storia dell'arte italiana, vol. I, Torino, 1979, pp. 283-352. Hemos insistido en estas cuestiones, a un nivel más provincial, en: J. A MORÁIS MORÁN, "Imitación, copia..." (en prensa). Sobre el problema del artista en los siglos medievales, véase: M. BARASH, Teorías del Arte..., p. 48.

1943 J. Ma DE AZCÁRATE Y RISTORI, "La Portada de las Platerías...”, p. 1; M. DURLIAT, "La Porte de France á la cathédrale de Compostelle”, Bulletin Monumental, CXXX, 1972, pp. 139-150 y M. A. CASTIÑEIRAS GONZÁLEZ, “Algunas reflexiones sobre el programa iconográfico de las portadas del
} 
La revuelta del año 1117 debió influir en la destrucción de algunas de estas piezas que, una vez renovadas, explicarían algunos de estos desajustes, así como la introducción de nuevas soluciones plásticas y la ampliación de las fuentes utilizadas.

"Cuando conocieron esto, bramaron los traidores y persiguiendo, por la iglesia a los mensajeros del obispo y de la reina que les habían dicho que depusieran las armas, se enfrentaron a ellos; huyen los legados a lo más alto de la iglesia (...) Los perversísimos atacantes pegan fuego a toda la iglesia de Santiago y la incendian por uno y otro lado; pues no poca parte de la iglesia estaba cubierta con tablas y paja (...). La llama de la iglesia del Apóstol sube a lo alto y por todas sus partes se ofrece un horrendo espectáculo (...) ${ }^{1944}$ (texto 71).

Al problema de la disparidad estilística, cronológica e iconográfica debemos sumar la existencia de un amplio fondo documental que, en lugar de esclarecer ciertos asuntos, ha enturbiado la problemática de adjudicar algunas de las realizaciones escultóricas a personajes determinados, valiéndose del método "atribucionista". En este sentido, se han perfilado, dentro de la historiografía, diferentes "estilemas", casi dogmáticos, que se empeñan en buscar una individualidad casi forzada de los artistas. Así como ocurrirá dentro del mismo templo jacobeo con la figura del "maestro" Mateo, las fuentes nos han hecho llegar, de manera muy fragmentaria, los nombres de personajes como el magister Bernardo o el ya mencionado Esteban ${ }^{1945}$.

Según se ha venido afirmando, hoy en día parece claro que no podemos seguir manteniendo que el citado "maestro" Mateo fue el escultor que, con su propio cincel, realizó todas las esculturas del Pórtico de la Gloria, además de levantar las cimbras ligneas necesarias para erigir la construcción y dirigir a los demás artesanos en las labores de estucado, pintado y decoración de otras partes secundarias como, por ejemplo, el coro pétreo del templo. Parece más lógico hablar de un administrador de la obra o, en todo caso, de un encargado del proyecto $^{1946}$.

transepto de la catedral de Santiago", La meta del Camino de Santiago. La transformación de la catedral a través de los tiempos, Santiago de Compostela, 1995, pp. 85-103.

${ }^{1944}$ Historia Compostelana..., pp. 272-273 y p. 345, nota 189.

${ }^{1945}$ F. J. OCAÑA EIROA, Op. cit., pp. 7-58.

${ }^{1946}$ No abordamos el tema por entender que desviaría nuestra línea de estudio, además de ser uno de los temas más recurrentes y complejos que existen en relación con el tema de los artistas. Vid.: M. RECUERO ASTRAY, P. ROMERO PORTILLA y A. RODRÍGUEZ PRIETO, Documentos Medievales del Reino de Galicia: Fernando II (1155-1188), A Coruña, 2000, documento número 88. El documento se refiere al llamado maestro Mateo en los siguientes términos: "Et ob reuerentiam sanctissimi apostoli Iacobi patroni nostri piisimi, pro munere dono et concedo tibi magistri Matheo, qui operis prefati 
En consonancia con ello, no nos pronunciaremos sobre las diferentes hipótesis vertidas sobre estos asuntos, a la hora de poder definir con nombres propios a los artífices responsables de las labores dentro del corpus escultórico del edificio. Baste citar, en relación con ello, uno de los estudios más completos realizados, recientemente, por M. Castiñeiras al abordar la escultura de las dos fachadas del transepto, donde llega a identificar hasta cinco manos diferentes trabajando, supuestamente, dentro de un mismo arco cronológico y espacial ${ }^{1947}$.

Sin duda, la denominación de "maestro" de Platerías ha sido la más socorrida en las investigaciones relacionadas con la fachada del mismo nombre. Sin embargo, casi de manera genérica, se han ido diferenciando otra serie de hipotéticos "maestros", a los cuales se les identificó, por lo general, con el nombre de la pieza o iconografía que, en principio, se les pretendía adjudicar. Surgirían así expresiones tales como la del llamado "maestro" de las Tentaciones o también denominado de Conques, el "maestro" de la Traición o el conocido como "maestro" de la Transfiguración 1948.

Con todo y a pesar de tal disparidad, se ha defendido una intención unificadora de todo el conjunto, donde la escultura fue proyectada teniendo muy en cuenta en que lugar del templo iba a ser colocada, así como su relación respecto al resto de piezas repartidas por todo el espacio catedralicio. A pesar de tratarse de un proyecto dilatado en el tiempo, tanto los capiteles de la primera fase de la girola, las dos fachadas que cerraban, al norte y al sur, los brazos del transepto e, incluso, el más tardío Pórtico de la Gloria, tuvieron siempre en mente una unidad compositiva, ideológica y, sobre todo, conceptual e iconográfica $^{1949}$.

apostoli primatum obtines et magisterium, in unoquoque anno, medietate me de moneta Sancti Iacobi (...)". También vid.: R. YZQUIERDO, El Maestro Mateo, Madrid, 1991, pp. 4-5 y M. A. CASTIÑEIRAS GONZÁLEZ, El Pórtico..., p. 7 y pp. 16-23.

${ }^{1947}$ La utilización del método estilístico a la hora de definir la diferenciación de escultores activos en las fachadas de la catedral ya fue utilizada en: S. MORALEJO ÁLVAREZ, "La primitiva fachada...”, p. 45.

${ }^{1948}$ Seguimos la diferenciación realizada en: M. A. CASTIÑEIRAS GONZÁLEZ, Atlas de la catedral..., (edición digital). El autor sintetiza las posturas desarrolladas por los diferentes investigadores hasta la fecha, así como las denominaciones utilizadas para diferenciar las manos de los escultores. Creemos que, tales distinciones, tan sólo pueden ser utilizadas para diferenciar ciertas maneras de trabajar y no para seguir fomentando el empeño de atribuir piezas a escultores individuales. Consúltese también: M. A. CASTIÑEIRAS GONZÁLEZ, "La catedral románica: tipología...”, pp. 50-55, en concreto. Véase el dibujo 1, donde se señala en color el origen diferente de las piezas, así como las diferencias de estilo entre las mismas.

${ }^{1949}$ J. M M DE AZCÁRTE Y RISTORI, "La portada de las Platerías...”, pp. 1-3 y p. 5. Con todo, creemos que, actualmente, no se pueden mantener ciertas lecturas pedagógicas y doctrinales que llevaron al autor a hablar de un "sermón pétreo", en relación con este conjunto escultórico. 
Tal y como veremos en los siguientes apartados, la supuesta figura del "maestro" de las Platerías tendría como uno de sus rasgos más individualistas y originales el gusto y la admiración por ciertas maneras de la tradición romana antigua. 


\section{B. LA FACHADA DE LAS PLATERÍAS Y LA PUERTA FRANCIGENA: DEUDAS CON LO ANTIGUO.}

En el estudio realizado por F. García Romo sobre la escultura del siglo XI en la Península Ibérica, a la hora de abordar la problemática de la escultura de las fachadas norte y sur de la catedral de Santiago de Compostela, el autor escribía:

"un mismo artista puede "evolucionar" varias veces, si su carrera ha sido de larga duración: ejemplos notables de ello: el maestro de Platerías (Portada del Perdón en León, Santiago, Pamplona, Toulouse, si es el mismo de la Portada Miégéville como piensa Gómez-Moreno)" ${ }^{\text {1950. }}$

El especialista defendía los rasgos propios y concretos de un escultor, al que, aceptando los planteamientos historiográficos del momento, acepta denominar como "maestro" de Platerías. Le atribuye una serie de obras realizadas en lugares muy distantes, pero conectadas a través de ciertas similitudes estilísticas que unen a todas aquellas que enumera. Ello le lleva a imaginar a un mismo artífice trabajando en los centros de Toulouse y Santiago, además, de en todo un sinfín de edificios y talleres ${ }^{1951}$.

En la actualidad parece resultar imposible poder demostrar, de manera absoluta, que el autor de tales esculturas fue una misma persona trabajando en tantos talleres, abiertos, todos ellos, a lo largo del Camino de Santiago. Las similitudes existentes entre obras tan dispersas vendrían justificadas por la proximidad cronológica entre ellas, los medios rudimentarios con que fueron realizadas y, desde el punto de vista intelectual, por el dominio absoluto que sobre estos artífices tendría la Iglesia, casi siempre, patrocinadora de los grandes conjuntos. Una iconografía muy marcada y dirigida, acabaría produciendo obras de gran similitud y características comunes, sin necesidad de haber sido esculpidas por una misma persona.

Tales hipótesis parecen justificar, igualmente, las palabras de S. Moralejo en relación con este anónimo escultor:

\footnotetext{
${ }^{1950}$ F. GARCÍA ROMO, “La escultura francesa...”, pp. 236-240.

${ }^{1951}$ La obra de García Romo es un estudio excepcional que, según pensamos, no ha sido valorado, de una manera justa, por parte de la historiografía posterior. Ciertos aspectos criticados de su investigación deben ser entendidos como reflejo de un momento concreto del desarrollo de la literatura científica española, donde el "atribucionismo" de obras concretas a maestros particulares pretendía ser la vía correcta para el estudio de la escultura románica. En este ambiente es donde debemos situar la obra de García Romo y excusar algunos de sus errores.
} 
"Dentro de una comunidad general de estilo, se acusa fuertemente, en la decoración de las fachadas del crucero compostelano, la personalidad de un escultor -llamado por antonomasia “maestro" de Platerías-al que Gómez-Moreno identifica con el Esteban magistro operis Sancti Iacobi citado en Pamplona en 1101 (...) Podemos citar obras seguras de Esteban en su etapa compostelana, los canecillos de la capilla de Santa Fe, las acróteras de la misma capilla y de la de San Juan, gran parte de los capiteles del crucero, la mujer del cráneo, el joven sobre un león, el San Andrés de la jamba, la mujer del cachorro de león, la figura con el gallo, la creación de Adán y Eva, el David y algunos fustes entorchados. Añadiríamos por nuestra parte, la mujer de las uvas y quizá, el mes de febrero" ${ }^{, 1952 .}$

El uso característico de unos tipos faciales de fuertes y marcados carrillos hinchados, con ojos abultados, labios gruesos y un cabello dividido en mechones estrangulados cayendo en puntas rítmicas, son algunos de los rasgos que mejor pueden definir la escultura, hipotéticamente, salida de sus manos ${ }^{1953}$. Sin embargo, si bien se trata de una serie de características bien definidas y que aparecen de forma reiterativa y, ciertamente, homogénea dentro del conjunto, creemos que no son pruebas suficientes que, de una manera segura, puedan demostrar que en su día fueron esculpidas por el mismo Esteban ${ }^{1954}$.

Sin embargo, no se trata de un dato importante poder atribuir un nombre propio a un escultor para demostrar que tales piezas salieron de sus manos. La escultura realizada para la fachada de las Platerías y la puerta Francigena presenta, a pesar de sus variantes, una cierta unidad estilística donde la disparidad de artistas trabajando se observa de manera clara. Es dicha definición de su estilo, además de las bases documentales, la que permite reafirmar una posible relación con las experiencias

${ }^{1952}$ S. MORALEJO ÁLVAREZ, "La primitiva fachada...", p. 44. El autor destaca como rasgos propios de su estilo, la sensación de vida y vigor, el equilibrio entre abstracción y realidad, un especial interés en remarcar las tibias, los tobillos, las muñecas, los torsos y las piernas, así como el uso vigoroso de los cuerpos escondidos bajo ceñidas vestimentas. Los investigadores posteriores han confirmado tal atribución, sobre todo, en relación con las esculturas de la mujer del cráneo, la creación de Adán, la imagen de David tocando la lira, los fustes entorchados, el mes de febrero y la mujer de las uvas. Vid.: M. A. CASTIÑEIRAS GONZÁLEZ, Altas de la catedral..., (edición digital).

${ }^{1953}$ S. MORALEJO ÁLVAREZ, "La primitiva fachada...”, p. 44 y J. A. MORÁIS MORÁN, “Autour du "style des joues gonflées..." (en prensa).

${ }^{1954}$ F. J. OCAÑA EIROA, Op. cit., pp. 6-17. En dicha aportación se intentan clarificar algunas nociones sobre la posible cronología de este "maestro", dentro de sus trabajos en la catedral de Pamplona, en torno al año 1100. Se insiste en el problema de llegar a determinar su presencia en la catedral de Santiago, dudando sobre su participación en la primera o segunda fase, tras la llegada de Gelmírez. También se pone de manifiesto la complejidad de discernir el alcance de sus trabajos como escultor o arquitecto, centrándose, concretamente, en su supuesta participación en la construcción y decoración de la puerta de las Platerías. 
coetáneas en la catedral de Pamplona, siempre analizada a través de los escasos y fragmentarios restos conservados ${ }^{1955}$.

En el caso de las fachadas del transepto de la catedral de Santiago de Compostela han sido hasta cinco los escultores identificados. Se ha supuesto la actividad de un taller formado por varios operarios trabajando, conjuntamente y de manera paralela, en las dos fachadas que cerraban los brazos del transepto. Sin embargo, para nuestro objetivo lo más destacado de todo lo afirmado hasta el momento es la fuerte impronta de lo clásico que parecen presentar algunas de las esculturas salidas de este taller, claro "heredero del gusto por la Antigüedad del maestro de Frómista-Jaca", si utilizamos las palabras de M. Castiñeiras ${ }^{1956}$.

A lo largo de las páginas siguientes y utilizando, en la medida de lo posible, el mismo esquema de estudio aplicado en el análisis del sustrato clásico de la escultura del los focos de Jaca y Frómista, se pretenderá concretar algunos aspectos de este supuesto clasicismo, intentando rastrear su origen, la manera en que fue absorbido por los talleres de Santiago, las fuentes en las que se inspira y su posterior difusión a otros edificios.

A pesar de que la discriminación de estos motivos, supuestamente clásicos, pueda generar un discurso simplificando en extremo, creemos que, tal segregación, puede ayudar a separar los rasgos propios de un taller de escultores románicos convencional, embebidos en el arte de su tiempo, de otra serie de características especiales, ligadas al mundo antiguo.

En este sentido, a continuación analizaremos, a modo de ejemplo, algunos aspectos que, según parece, se podrían hacer derivar de este conocimiento de las fórmulas clásicas. En primer lugar, tal cuestión se ejemplificará mediante el caso de la distribución bífora de las citadas puertas, derivadas, tal y como veremos, de fórmulas romanas. Mediante un segundo ejemplo, aludiremos a la combinación de diferentes materiales, dentro del conjunto compostelano, con la intención de generar efectos estéticos. Se aludirá, además, a diversas fuentes literarias y documentales que ponen de manifiesto el interés por la búsqueda y reempleo de este material. En tercer lugar, mediante el análisis del material marmóreo con el que fueron realizadas las columnas de la fachada de Platerías, se deducirán algunos aspectos que, nuevamente, ponen en contacto las soluciones empleadas en el arte romano con las fórmulas explotadas por los artífices hispanos activos en Galicia.

\footnotetext{
1955 Ibidem, pp. 20-26.

${ }^{1956}$ M. A. CASTIÑEIRAS GONZÁLEZ, Atlas de la catedral..., (edición digital).
} 
Desde un punto de vista arquitectónico, las fachadas de los brazos norte y sur del transepto de la catedral fueron proyectadas siguiendo soluciones conocidas dentro de la arquitectura coetánea. Anteriormente, hemos aludido al carácter clásico de algunas de las puertas románicas más importantes, en concreto, el que presenta la Puerta des Comtes de la basílica de Saint-Sernin de Toulouse. Su configuración y distribución parece recrear, tal y como han defendido recientemente D. Cazes y Q. Cazes, algunas puertas de acceso a las ciudades de época galorromana ${ }^{1957}$.

La estructura de dos vanos de medio punto formando un ACCESO BÍFORO que encontramos en la actual puerta de las Platerías, nos muestra el trazado que, originariamente, debió tener la destruida puerta Francigena o de Azabacherías ${ }^{1958}$.

Dicha morfología puede ser comprendida, además, a través de la aplicación de un método iconológico en el análisis de los elementos constructivos. Tal propuesta fue utilizada, por ejemplo, para poder definir la puerta románica de la catedral como "una especie de arco de triunfo que aúna regnum y sarcerdotium" y que tendría sus precedentes más remotos en la gran puerta del Chalké o Puerta de Bronce del Palacio del emperador Justiniano en Constantinopla ${ }^{1959}$.

El modelo de puerta bífora, enraizado en la tradición de las puertas de acceso a las ciudades romanas, debió tener una difusión más allá de Santiago de Compostela, pues se hallará, por los mismos momentos, en la fachada occidental de la catedral de Pamplona, si bien ello resulta más difícil de demostrar ante la ausencia de pruebas materiales en pie $^{1960}$ (fig. 369).

1957 Citamos, nuevamente, la conferencia impartida por los citados investigadores: D. CAZES y Q. CAZES, "Saint-Sernin de Toulouse et l'Antique", dentro de las Jornadas de Arte Románico Actualité de l'art antique dans l'art roman celebradas durante el mes de julio del 2007 en la abadía de San Miguel de Cuxa, a la espera de su publicación. Desde otro orden de cosas, hemos incidido en algunas estructuras romanas de la Galia y su relación con los monumentos medievales que, a veces, parecen inspirados en estos monumentos antiguos. Las estructuras defensivas de Nîmes, de Autun o de Orange parecen mantener estrechas vinculaciones con las construcciones románicas. Sobre tales aspectos, véase: J. MARIE ANETTE, Op. cit., en concreto, pp. 120-123.

1958 A. FERNÁNDEZ GONZÁLEZ, “Un viejo plano olvidado...”, pp. 701-743. Ya hemos aludido al estudio de este investigador que, a través del descubrimiento de un plano de la catedral, realiza una serie de puntualizaciones sobre la distribución arquitectónica y la morfología que, posiblemente, tuvo tal construcción.

${ }^{1959}$ M. A. CASTIÑEIRAS GONZÁLEZ, "La catedral románica: tipología...”, p. 59; ID., "Un passaggio al passato...", pp. 365-381 y M. MELERO MONEO, "La propagande politico-religieuse...", pp. 135157. En particular, Castiñeiras constata una función política, heredera de lo antiguo, tanto para la fachada del monasterio de Ripoll como para la de Compostela.

1960 J. MARTÍNEZ DE AGUIRRE, "Portada occidental de la catedral románica de Pamplona", Sancho el Mayor..., vol. II, ficha catalográfica 6. 2. 1. 1, pp. 875-877; E. CARRERO SANTAMARÍA, "La catedral románica. Hacia una interpretación funcional", Sancho el Mayor..., vol. II, ficha catalográfica 6. 2, pp. 856-866 e I. G. BANGO TORVISO, "La catedral románica”, Sancho el Mayor..., vol. II, pp. 835-839, en particular, sobre el diseño reconstructivo, véase la p. 838. Nuevamente, y a pesar de tratarse de un edificio 
A pesar de tratarse de una cuestión que no vamos a abordar aquí, parece que, incluso, presentando ciertas incoherencias constructivas, en general, ambas fachadas debieron ser algunas de las obras más importantes erigidas en suelo hispano por esta época ${ }^{1961}$.

Las referidas portadas de la catedral de Santiago de Compostela, por su monumentalidad, deben ser tenidas en cuenta como las representantes de la reactivación de la escultura a finales del siglo XI. El valor expositivo que adquieren sus imágenes, completamente insertas en un programa iconográfico de enorme complejidad que se expande e interactúa con otras partes del templo, permite hacerlas depender, en última instancia, de los arcos de triunfo romanos.

Tal relación no debe ser vista, tan sólo, de una manera simbólica. En las portadas medievales y, en concreto, en las que aquí analizamos, el arco se muestra como el lugar idóneo para la colocación de temas y escenas, alusivas a ciertas tendencias ideológicas relativas al triunfo del cristiano, como reflejo de la Jerusalén Celeste ${ }^{1962}$.

más tardío, se constata la utilización de tal estructura geminada en el acceso occidental de la iglesia de San Vicente de Ávila. Lo más interesante es que también se han defendido influencias antiguas del mundo clásico romano para los artistas que trabajaron en el edificio abulense. Cf.: J. LACOSTE, Les maîtres..., pp. 137-145 y M. M. VILA DA VILA, Ávila Románica..., pp. 89-90.

${ }^{1961}$ Siempre en relación con lo arquitectónico, véanse: J. L. SENRA GABRIEL Y GALÁN, "Los tímpanos de la catedral...", pp. 32-33. El investigador insiste en la problemática de unificar las soluciones arquitectónicas con la decoración escultórica en ambas fachadas.

Sobre la funcionalidad e importancia del transepto de la catedral gallega se insistió en: T. MARTIN, "The art of...”, p. 1157. La citada experta lo analiza en relación con el existente en San Isidoro de León.

Desde un punto de vista arquitectónico, la catedral de Santiago presenta ciertas concomitancias con otros edificios, generalmente, de la órbita romana. Sobre este aspecto, se ha incidido en: S. MORALEJO ÁLVAREZ, "La imagen arquitectónica...", pp. 237-246 y M. A. CASTIÑEIRAS GONZÁLEZ, "Topographie...", p. 33. Sobre todo, Castiñeiras insiste en el uso de la cripta anular, que relaciona, de manera simbólica, con la utilizada en el San Pedro del Vaticano medieval. Igualmente, cita el caso de San Crisógono de Roma (731-741) que, teniendo el ejemplo vaticano como modelo, parece ser otro de los edificios que pudieron haber inspirado algunos elementos constructivos en Santiago. El investigador cita otros ejemplos, como el de la iglesia de Santa María de Cosmedín de Roma (772-779), con igual distribución de la cripta.

${ }^{1962}$ El tema es complejo, tanto desde un punto de vista conceptual como artístico. Las portadas de la catedral de Santiago configuran un jalón que desembocará en el desarrollo de la portada historiada. Lo más significativo, y esta es una cuestión que ya hemos abordado aquí, es que muchas de ellas se han hecho derivar de modelos antiguos.

Para el caso de Ripoll, véase: Y. CHISTE, "La colonne d'Arcadius...", p. 40. En dicha aportación se la compara con un arco de triunfo romano. Le siguieron en esta idea otros autores. Cf.: M. A. CASTIÑEIRAS GONZÁLEZ, El calendario medieval..., p. 83 y p. 247, quién alude a las relaciones que presenta con la Porta Negra de Bensançon.

Consúltese igualmente: M. MELERO MONEO, "La propagande politico-religieuse...”, pp. 150-153. La autora apoya las teorías dadas, en su día, por el profesor Y. Chiste.

Véase también: E. TARRACO PLANAS, "El módulo de la Portada de Ripoll", España entre el Mediterráneo y el Atlántico, Granada, 1976, pp. 537-541. El autor, además de reiterar las semejanzas con los arcos de triunfo romanos, intenta demostrar la aplicación de leyes de simetría o proporción derivadas de los textos de Vitruvio. Sobre los mismos ejemplos, véase.: X. BARRAL I ALTET, "Propaganda eclesiástica...", p. 62 y A. GRABAR, "L'iconographie du Ciel...", p. 10. Éste último autor se centra en el arco de triunfo de Santa Práxedes de Roma y su filiación con los arcos de triunfo antiguos. En la misma 
Tal y como observamos, la misma distribución arquitectónica de las fachadas compostelanas, a través de su articulación bífora, refrendaría la teoría de una influencia antigua. Así, antes de comenzar a señalar los aspectos más relevantes de la escultura presente en dichos conjuntos y su vinculación con lo clásico, conviene destacar una característica muy llamativa que tales estructuras muestran. El MATERIAL por excelencia utilizado en el edificio, el granito, fue combinado, en la puerta de las Platerías, con el mármol.

La solución, muy conocida ya por estos momentos dentro de la arquitectura y la escultura peninsular, creemos que puede servir para contextualizar la obra en un supuesto ambiente conocedor de lo antiguo pues, en el caso de esta portada, el recurso adquiere un nivel estético preeminente.

De los restos conservados de la desaparecida Puerta Francigena y de aquellos transformados que presenta, en la actualidad, la Puerta de Platerías, se puede concluir que, el material empleado, no fue dispuesto, en ningún caso, de una manera $\operatorname{arbitraria}^{1963}$. Es cierto que, según los restos llegados hasta nosotros no se ha documentado ningún tipo de spolia in se dentro de la escultura de la catedral. Sin embargo, diversos aspectos indirectos nos hacen pensar en la utilización consciente del mármol como material de prestigio, riqueza y calidad quizás, siguiendo algunos mecanismos ideológicos similares a los explotados por los artistas de la Antigüiedad ${ }^{1964}$.

Esta solución plástica gozó de gran éxito dentro de la edilicia tardoantigua, tal y como atestigua el conocido ejemplo del arco de Constantino en Roma. Los relieves,

línea temática, véase: F. GALTIER MARTÍ, La iconografía arquitectónica..., p. 142. El profesor Galtier reafirma la dependencia de obras como el pórtico de Lorsch, el arco de Eginhardo o la portada de Ripoll con diversas construcciones romanas. Sobre el contenido simbólico de la puerta en la iglesia románica, consúltese: M-T. CAMUS, "Des images à lire...”, p. 279; R. SÁNCHEZ AMEIJEIRAS, "Ritos, signos y visiones...", p. 51 y P. DUBOURG-NOVES, “Des mausolées antiques...”, pp. 323-324.

${ }^{1963}$ La solución aquí tomada, en relación con la búsqueda de un efectismo a través de los materiales, tendría repercusiones en otros edificios como, por ejemplo, en la fachada del Cordero de San Isidoro de León. Cf.: M. A. CASTIÑEIRAS GONZÁLEZ, Atlas de la catedral..., (edición digital).

${ }^{1964}$ Ya hemos recogido la bibliografía relativa al uso de piezas antiguas durante los siglos medievales y el fenómeno del spolium in se. Son muchos los investigadores que han aplicado este razonamiento para explicar la utilización del mármol en partes muy visibles de los edificios, alternándose con materiales de otra índole y calidad. En el caso hispano, se han documentado, de manera más abundante, en los edificios prerrománicos. Cf.: F. A. MARÍN VALDÉS, “Observaciones sobre la adopción...”, p. 15. El investigador defiende que su uso buscó atribuir un valor de magnificentia a aquellas fábricas que no la tenían. Es decir, el mármol otorgaba prestigio y valor a las empresas en las que se utilizaba, dotándolas de cierta carga ideológica.

Consúltese también: P. ARAGUAS, “Spolia/contrefaçon, deux modalités d'appropriation du passé, pour quelles élites ?”, Élites y arquitectura en la Antigüedad Tardía, 2 vols., 2007, Zagrab, vol. I, pp. 110-140 y $\mathrm{M}^{\mathrm{a}}$ T. LÓPEZ DE GUEREÑO, "La cruz y el crucificado...", p. 373. En dicha aportación, la citada autora defiende un trasfondo ideológico en la expoliación de entalles antiguos en piezas orfebres medievales. 
tanto los expoliados de obras anteriores como los creados ex novo, fueron dispuestos generando efectos cromáticos y estéticos, alternando materiales y maneras de trabajo, tal y como ha señalado M. D’Onofrio ${ }^{1965}$.

En el caso hispano, donde no se documenta tan frecuentemente el uso del mármol dentro de las construcciones medievales y, menos aún, de origen antiguo, llama la atención que, en una zona dónde fue tan habitual y común la utilización del granito para la construcción y la escultura, se eligiera este material para esculpir algunas de las partes más significativas del conjunto. El uso de esta piedra en el periodo medieval ha servido a muchos autores para hablar de una alusión indirecta al arte antiguo ${ }^{1966}$.

En el caso de la fachada sur de Compostela, el granito fue el material dominante. Sin embargo, tres de las columnas de mayor calidad, poseedoras de un trabajo más detallista y perfecto, fueron elaboradas en un llamativo mármol blanco de vistosa pureza. Dos de estos fustes fueron colocados en los extremos del conjunto, cerrando la composición arquitectónica-escultórica; mientras que, el tercero, se colocó en el eje central de la fachada, soportando el volteo de los arcos que generan las arquivoltas. Se trata de un efecto, posiblemente, buscado y que tiene sus raíces dentro de las experiencias artísticas de la Antigüedad tardía ${ }^{1967}$. Sin embargo, no nos aventuramos a asegurar que su uso presente tanta carga simbólica, como para poder ser considerado un signo de preferencia por lo antiguo ${ }^{1968}$.

Estas columnas de los Apóstoles y de las Doce Tribus que presentan a las figuras bajo arcadas preciosistas elevadas por sinuosas y delicadas columnas de fuste torso, han recibido gran atención dentro de los estudios dedicados a la fachada. A parte de su material, se ha defendido una influencia de la orfebrería y de la escultura de sarcófagos romanos, tal y como veremos.

A pesar de que el mármol fue conocido en la factura de las iglesias del momento, no podemos dejar de aludir a la importancia que el material va a tomar dentro

\footnotetext{
${ }^{1965}$ M. D’ONOFRIO, Roma e Aquisgrana..., p. 61. Sobre la importancia del fenómeno, entre los siglos II y IV d. de C., véase: D. KINNEY, “The concept...”, pp. 233-234. El autor define, además, este tipo de spolia como "actos políticos".

${ }^{1966}$ E. CASTELNUOVO, "Indigeni sassi", Niveo de marmore. L'uso artistico del marmo di Carrara dall'XI al XV secolo (E. Castelnuovo ed.), Genova, 1992, pp. 5-20, en concreto, p. 15 у M. GREENHALGH, “Ipsa ruina docet...”, p. 116.

${ }^{1967}$ Por citar los ejemplos más conocidos, recordemos los trabajos marmóreos de la zona pirenaica, en concreto, los de la iglesia de Saint-André-de-Surede, donde las piezas de mármol, quizás provenientes de las labores de spolium, se alteran con materiales más pobres en la fachada. Su raigambre antigua se ha venido aceptando desde los primeros investigadores. Cf.: G. GAILLARD, Premiers essais..., pp. 50-100. ${ }^{1968}$ El concepto lo tomamos, según el sentido que se le otorga, en: M. GREENHALGH, "Ipsa ruina docet...", p. 128.
} 
de las fuentes documentales que hemos conservado en relación con la construcción del conjunto y de su patrocinador, el obispo Diego Gelmírez.

La búsqueda de materiales de calidad, supuestamente antiguos, fue señalada, de manera especial, por el profesor C. Cid Priego, en un trabajo de excepcional importancia en el estudio del fenómeno, tal y como hemos repetido en varias ocasiones $^{1969}$.

El autor señala la importancia que la alusión a este material tendría en las fuentes documentales y literarias, las cuales, acabarían por legar a los siglos posteriores noticias muy significativas sobre diversos monumentos importantes de la Galicia medieval. La problemática expresión de acaia marmarica, sobre la que ya hemos tratado aquí, sirvió para que, muchos autores, se hayan preguntado sobre la posibilidad de que el cuerpo del Apóstol hubiera sido inhumado en un sarcófago o arca de mármol, quizás de reempleo ${ }^{1970}$.

A este interés inicial por documentar un enterramiento tan importante en una pieza o una construcción relacionada con la materia marmórea, debemos sumar otra serie de referencias en las que, el mármol, se convirtió en un tópico recurrente. La ya mencionada Crónica de Sampiro, en su versión pelagiana, habla sobre la construcción de la basílica dedicada al apóstol por el monarca Alfonso III:

"Entonces este rey construyó en Galicia de Compostela la iglesia sobre el cuerpo del beato (...) la construyó muy hermosísima de cal y piedras cuadradas y columnas y basas marmóreas, en la era de 910"1971.

La noticia más interesante del texto, es aquella en la que se especifica como el rey hizo traer:

“(...) al santo lugar (...) las piedras de mármol que sacamos de la ciudad de Eabeca que nuestros antepasados transportaron por mar en naves y con la que edificaron bellas casas (...)"1972.

\footnotetext{
1969 C. CID PRIEGO, "Asturianos y mozárabes en los orígenes del culto jacobeo”, Las artes en los caminos de Santiago, Oviedo, 1993, pp. 39-90.

${ }^{1970}$ I. G. BANGO TORVISO, "El locus sanctus...", pp. 191-220 у C. CID PRIEGO, "Asturianos y mozárabes...", pp. 43-55.

1971 J. PÉREZ DE URBEL, Op. cit., p. 278.

1972 A. LÓPEZ FERREIRO, Historia de la Santa Iglesia..., pp. 46-53 y C. CID PRIEGO, “Asturianos y mozárabes...", p. 67.
} 
Tal y como defendió Cid Priego, es muy posible que se trate de piezas expoliadas de edificios romanos aunque, aún hoy, no se halla podido llegar a identificar con seguridad la enigmática ciudad de Eabeca. El transporte de piezas se documenta en las etapas anteriores a la erección del templo románico, sin embargo, atestigua, claramente, el comercio de obras $\mathrm{y}$, sobre todo, la importancia de los traslados marítimos de las mismas, posicionado la construcción de Alfonso III a la altura de las acciones emprendidas por algunos de los personajes más importantes de la Europa medieval. Ya hemos mencionado, anteriormente, el caso de Henry de Blois, el obispo de Winchester o el mismo abad Suger. En todos estos casos las naves y el mar fueron la vía idónea para permitir la llegada de estas piezas prestigiosas a las fábricas y talleres abiertos en torno a un templo ${ }^{1973}$.

No debemos olvidar que, la propia Historia Compostelana, insiste en varias ocasiones en la importancia que tuvieron, tanto el transporte marítimo como el tráfíco de navíos, durante la etapa medieval, en relación, sobre todo, con las prácticas bélicas.

"Por ello el mencionado arzobispo de Santiago y legado de la santa iglesia romana, conmovido por el dolor propio de un padre, puesto que no había en tierras de Galicia hombres diestros en el arte de la navegación, había enviado a sus mensajeros a Arles, Génova y Pisa, para que hicieran venir desde alli constructores de las naves muy expertos. Un genovés, de nombre Augerio, muy experto constructor de naves, hizo en Iria dos barcos de los que vulgarmente se llaman "galeras", en cuya construcción el arzobispo gastó mucho dinero e hizo muchos gastos”,1974.

\footnotetext{
${ }^{1973}$ Citamos, aún a pesar de haberlo hecho ya, el caso de las columnas de la Capilla de la Trinidad de la catedral de Canterbury, relacionadas con el mármol de Caen y Tournai y que se han explicado debido al interés que, en relación con el mundo clásico, surgió a finales del siglo XII y los primeros decenios del siguiente en la zona. Cf.: P. DRAPER, Op. cit., pp. 172-175. Es lógico pensar que las piezas pudieran haber llegado a través del transporte marítimo.

El ejemplo de Santiago de Compostela no sería especial, si se tiene en cuenta la larga lista de expoliaciones que se han documentado. Cf.: J. ADHÉMAR, Influences antiques..., pp. 96-97 у pp. 138140. El especialista recoge el traslado de columnas marmóreas desde Nîmes a Moissac, para utilizarlas como material de construcción. El mismo autor insiste en el permiso que el papa Adriano I otorgó a Carlomagno para poder tomar cualquier material de entre las ruinas de la ciudad de Roma y Rávena, lo que le permitió enriquecer las fábricas de Aix y Saint-Riquier con todo tipo de mármoles y columnas. El transporte, según se defiende, se realizó en navíos que surcaban cargados el Mediterráneo.

Sobre el traslado de piezas antiguas por mar a la abadía de Saint-Denis de París por Suger, consúltese: E. PANOFSKY (ed.), El abad Suger..., pp. 238-239. El investigador señala las fuentes clásicas utilizadas por los cronistas medievales de este topos típico de la literatura antigua, además de recoger el caso del abad Desiderio de Montecassino quién, en el 1066, hizo trasladar piezas de mármol para sus construcciones. Véase también: S. SETTIS, "Continuità, distanza...", pp. 386-388; B. BRENK, “Comittenza...", p. 6 y P. ZANKER, Un'arte per l'impero..., p. 29.

${ }^{1974}$ Historia Compostelana..., pp. 340-341.
} 
En otro lugar de la misma fuente se especifica:

“(...) viendo el arzobispo que la guerra de los amorreos (musulmanes) causaba anualmente muchos daños en las costas (...) mandó construir con gran gasto una birreme, que se llama vulgarmente "galera", y una vez construida la entregó a un joven llamado Frixón, oriundo de la ciudad de Pisa, de buenas costumbres y muy experto en artes náuticas, para que navegando con ella se dirigiera contra la tierra de los amorreos" 1975 .

Lo más llamativo de estos pasajes, a parte de demostrar un interesante desarrollo de la armada naval y de la industria de este sector, aparece vinculado a la idea del transporte marítimo en estas zonas tan ligadas al mar, así como los dos lugares con los que, según la Historia Compostelana, se mantenían dichas relaciones. Tanto la ciudad de Pisa como la de Génova fueron importantes centros de importación de sarcófagos y de otra serie de piezas marmóreas, lo que podría explicar algunos aspectos que aquí tratamos.

No pretendemos, en ningún caso, justificar la utilización del mármol en la puerta de Platerías a través de estos textos. No existen razones sólidas para poder hacerlo. Sin embargo, lo que si permiten es atestiguar un interés, desde la Alta Edad Media, por el material, por la búsqueda del mismo, aún encontrándose en lugares alejados, así como de su traslado por vía marítima y, en algunos casos, de su expoliación en edificios construidos ex novo.

Las piedras marmóreas mencionadas, en relación con el edificio de Alfonso III, fueron expoliadas para decorar la iglesia, siendo conscientes de que, al provenir de las pulcras domus, podían prestigiar el nuevo templo al que iban dirigidas ${ }^{1976}$. En tales circunstancias, tampoco debemos olvidar la importancia que hubieron de tener, durante el periodo, los núcleos urbanos antiguos que, expoliados desde la cimentación misma de las ciudades, sin duda, se convirtieron en grandes canteras abiertas ${ }^{1977}$.

\footnotetext{
1975 Ibidem, pp. 449-450.

${ }^{1976}$ Es bien significativa la expresión utilizada por S. Moralejo cuando define el fenómeno como "razzia arqueológica". Cf.: S. MORALEJO ÁLVAREZ, "La reutilización...”, pp. 188-189.

1977 V. MARTÍNEZ ENAMORADO, "Relaciones entre los omeyas y los núcleos cristianos", El esplendor de los Omeyas cordobeses. La civilización musulmana de Europa Occidental, Granada, 2001, pp. 310-319, en concreto p. 315. Sobre la importancia de dichos núcleos y sus infraestructuras durante los siglos posteriores a la Antigüedad, consúltese.: A. MARTÍNEZ TEJERA, "Arquitectura cristiana...", p. 110; C. COSMEN ALONSO, "Noticias sobre la arquitectura del siglo X...", pp. 83-90, concretamente, p. 84 e ID., "Noticias sobre la reconstrucción arquitectónica...", pp. 599-607. La profesora Cosmen insiste
} 
Algunas fuentes documentales insisten, de manera recurrente, en el valor que se le otorgó a este tipo de materiales e, incluso, la posibilidad de documentar piezas que hoy no han llegado hasta nosotros.

“En el año (...) 1102 el venerable Diego II de la sede compostelana (...) decidió visitar, como es debido, las iglesias, capillas y heredades que en tierras de Portugal pertenecían jurídicamente a la iglesia compostelana (...) Y así, aquel día, el obispo de Santiago recibió la hospitalidad del arzobispo de Braga. Al día siguiente, (...), el obispo se dirigió en compañía del arzobispo a la iglesia de San Víctor (...) Luego tras entrar en la iglesia de San Víctor y celebrar allí una misa, ordenó que se cavara en la parte derecha del altar mayor. Fue descubierta allí un arca marmórea, fabricada con finura y admirablemente y que estaba bajo tierra. Y al abrirla en presencia del señor obispo, encontraron dentro dos cajitas de plata"1978 (texto 2).

El pasaje es muy significativo, pues refleja la importancia que, por estos momentos tenían, no sólo las reliquias de los santos y mártires, hábilmente "custodiadas" y trasladas por el obispo a la sede compostelana, sino que, también, da cuenta del valor que poseían los lugares en los que descansaban, generalmente, piezas de mármol -arca marmorea mire ac subtiliter fabricata-, de las que todos los cronistas destacan la calidad de su labra y su antigüedad. No se puede defender que en todos los casos se trate de piezas antiguas pero sí resulta factible que, la mayoría, puedan responder a una cronología temprana ${ }^{1979}$.

Lo expuesto hasta el momento explicaría, de alguna manera, el interés mostrado por los artífices compostelanos, desde fechas tempranas, anteriores, incluso, a la erección del templo románico, por la utilización de piezas marmóreas en la fachada de Platerías, así como en otras partes preeminentes del edificio.

en la importancia de las zonas romanizadas para comprender el asentamiento de algunas fundaciones cristianas altomedievales.

${ }^{1978}$ Historia Compostelana..., pp. 94-97.

1979 Además de este tipo de expoliaciones de mármol, según se ha señalado, también es posible reflexionar sobre ciertos pasajes de la Historia Compostelana, en relación con la reutilización de piedras preciosas y engastes antiguos en las piezas orfebres patrocinadas por Diego Gelmírez. Nos referimos, concretamente, al retablo del altar mayor, cuya elaboración describe la citada fuente y en la que se utilizaron numerosas "antigüedades". Se trata del retablo que donaría el obispo a la catedral en el año 1135. Cf.: S. MORALEJO ÁLVAREZ, "La sculpture romane...", p. 150, nota 45 e ID., "La reutilización...", p. 191. El autor, además de recoger la noticia de expoliaciones de piedras romanas en este ejemplo, no duda en otorgar un origen antiguo al sarcófago hallado en Braga, al que se refiere la Historia Compostelana. Véase también: C. SASTRE PÉREZ, "La portada de las Platerías y la "mujer adúltera”. Una revisión”, Archivo Español de Arte, 79, 314, 2006, pp. 169-186, en concreto, p. 179. 
Los valores "colorísticos", si seguimos el calificativo dado por M. Núñez al reempleo de mármoles antiguos en la primitiva basílica de Alfonso III, parecen perpetuarse en el tiempo a través del uso de este material, en alternancia con el granito, ya en época románica, tal y como venimos explicando ${ }^{1980}$.

Todos estos argumentos sirven para poder explicar un fenómeno bien conocido en el arte antiguo, el de la varietas ${ }^{1981}$. Se trata de un recurso plástico que permitía, a través de la expoliación de materiales de diferente forma, color, textura, calidad, cronología y origen, crear juegos efectistas que diesen un valor suntuoso a la arquitectura. En el caso de las COLUMNAS DE PLATERÍAS, dicho valor se logra a través de la alternancia de materiales, a pesar de que, parece claro, que el mármol perteneció y fue esculpido en época medieval.

Por ejemplo, la variación de materiales, en este caso pétreos y latericios, había dominado la técnica constructiva de la cabecera de la basílica de Saint-Saturnin de Toulouse, siguiendo una técnica bien documentada en la edilicia romana y merovingia ${ }^{1982}$. Los precedentes de estos juegos cromáticos tienen referentes tan precisos y significativos como la articulación del paramento y el juego léxico del baptisterio de Saint-Jean de Poitiers, así como algunos edificios románicos del Languedoc ${ }^{1983}$.

\footnotetext{
1980 M. NUÑEZ, "La arquitectura como expresión de poder", Homenaje al profesor Martín González, Valladolid, 1995, pp. 205-212, en particular, p. 208. En el estudio se analiza el Acta de Consagración de la basílica de Alfonso III, así como la expresión petras marmoreas.

${ }^{1981}$ B. BRENK, "Spolia e il loro effetto...", especialmente, pp. 209-210. Ya hemos abordado el concepto anteriormente por lo que remitimos a dicho apartado. El fenómeno aparece documentado en el caso hispano, tal y como hemos señalado, a través de ejemplos como los capiteles de la cabecera de San Julián de los Prados. Cf.: G. CIOTTA, Op. cit., particularmente, p. 201 e ID., "La chiesa prerromanica...", p. 51. En estos estudios se insiste en el uso de capiteles datados en el siglo IX asturiano que coexistirían con otros de diferente procedencia como, por ejemplo, el ligado a la iglesia de Santa María de Bamba. A pesar de ello, seguimos manteniendo que algunas de estas hipótesis resultan difíciles de asegurar, sobre todo, teniendo en cuenta los enormes problemas que aún siguen teniendo los especialistas para poder crear un método fiable de estudio de los capiteles labrados en la Península Ibérica entre los siglos IV al VIII. Sobre ello, véase: J. L. DE LA BARRERA ANTON, Los capiteles romanos de Mérida, Badajoz, 1984, en concreto, pp. 17-23.

${ }^{1982}$ M. DURLIAT, "Les origines de la sculpture...", p. 350. Durliat reconocía la anterioridad de la cabecera de Santiago con respecto a la de la citada iglesia tolosana. El investigador daba como válido el año 1075 para el inicio de las obras en Galicia, mientras que, para el edificio francés, aceptaba la fecha de 1080. Sobre la utilización del ladrillo romano en construcciones medievales, particularmente en la Asturias del siglo IX, véase: F. MARÍN VALDÉS, "Observaciones sobre la adopción...", p. 15.

1983 A. BONNERY, "Matériaux et couleurs dans les églises romanes du Languedoc", Les Cahiers de Saint-Michel de Cuixà, XXVI, 1995, pp. 109-123. El autor analiza algunos ejemplos de cronología románica en los que, por influencia romana, se utilizó esta alternancia de materiales buscando efectos policromos a través de diferentes técnicas.
} 
Para finalizar estas breves líneas, queremos destacar una reflexión vertida por P. Cornelius Claussen, en relación con la utilización del mármol dentro de la arquitectura y los espacios templarios medievales de Roma.

El investigador ha defendido un interés premeditado en su uso, como una alusión al esplendor del pasado y, en concreto, considera que fueron las columnas marmóreas con incrustaciones de todo tipo de materiales, su policromía y fina labra, las que materializarían este aspecto. Sus fustes sinuosos, recordando constantemente las artes del metal y el trabajo orfebre, tiene en los candelabros romanos de fuste torso su mejor muestra, tal y como se constata mediante el espectacular ejemplo, con fines pascuales, conservado en la iglesia de San Pablo de Roma (fig. 370). Esta importante pieza ha sido datada en el siglo XIII, aunque se cree que, en realidad, puede sustituir otra más antigua $^{1984}$.

Las columnas de Platerías, por su dualidad retórica en la que el fuste salomónico establece un juego semántico con las pequeñas columnillas de igual forma, hablan del especial interés de sus escultores a la hora de planificar su labra y su colocación en el recinto de la fachada ${ }^{1985}$ (fig. 371).

Para concluir, debemos afirmar que, de la misma manera que en los edificios tardoantiguos y altomedievales hispanos, como por ejemplo, en San Juan de Baños o San Miguel de Escalada, se advierte un especial interés por utilizar fustes de gran calidad labrados en mármol, parece que, tal aspecto, tuvo su continuidad dentro de la etapa románica, si bien nunca de una manera tan acusada ${ }^{1986}$.

Las labores de expoliación de materiales romanos explican los desajustes entre los fustes reutilizados y los capiteles románicos de la portada occidental de San Zoilo en Carrión de los Condes y de la que, desde el Panteón, daba acceso a la iglesia de San

\footnotetext{
${ }^{1984}$ P. CORNELIUS CLAUSSEN, "Marmo e splendore. Architettura, arredi liturgici, spoliae", Arte e iconografía a Roma. Da Constantino a Cola di Rienzo, Milano, 2000, pp. 193-225, en particular, pp. 193197. Se trata de una pieza colocada en la schola cantorum del edificio, ubicada en el centro del espacio templario. Para su realización se reutilizaron piezas de todo tipo pero, sobre todo, destacan aquellas datables en el siglo IV. Véase también: M. L. TESTI, "Magistra latinitas...", p. 378. En dicha aportación, se habla de las diferentes variedades cromáticas logradas a través de la alternancia de materiales utilizada dentro de la obra de Nicola Pisano.

${ }^{1985}$ No debemos olvidar que, según se ha señalado, fueron unas columnas romanas expoliadas las que ocuparon un lugar preeminente dentro del pórtico o atrio de la basílica compostelana de Alfonso III. Cf.: C. CID PRIEGO, “Asturianos y mozárabes...", pp. 70-74.

${ }^{1986}$ M. L. REAL, "Inovação e Resistência...", pp. 17-68. Sobre las piezas expoliadas en la arquitectura asturiana, consúltese la aportación realizada en: L. ARIAS PÁRAMO, "La escultura arquitectónica en el área central del Reino de Asturias: tipos, tradiciones y tendencias", Escultura decorativa tardorromana y altomedieval en la Península Ibérica, Madrid, 2007, pp. 85-132.
} 
Isidoro de León. Ambas, por citar dos ejemplos bien conocidos, presentan fustes de mármol romano en lugares preeminentes del edificio ${ }^{1987}$.

Aunque en el caso de la fachada de Platerías no se haya detectado que el mármol pudiese provenir de las labores de expoliación, este dato es casi menos relevante que el valor que adquiere su color, su fina labra y su colocación premeditada dentro de la composición. Su efecto dentro del conjunto no deja de recordar ciertas reflexiones estéticas de algunos intelectuales del medievo, como Isidoro de Sevilla quién, a la hora de definir la venustas o belleza de los edificios dentro de sus Etimologías, destaca la función de las pinturas, los colores, los artesonados y los pavimentos pero, sobre todo, de los mármoles ${ }^{1988}$.

Pensamos que está fuera de toda duda la admiración que dicho material debió provocar a los ojos del hombre medieval. De la misma manera que Gregorio de Tours aludía en sus textos a la cualidad del mármol y su belleza y del mismo modo que los habitantes medievales de Soissons denominaron al palacio romano de la ciudad como Palacio de Alabastro, debido al brillo de sus mármoles; las columnas de Platerías debieron impactar al público medieval, casi más que por su iconografía, por el material con el que estaban realizadas ${ }^{1989}$.

El gusto, la valoración y una cierta predilección por los materiales bellos, caros y, en ocasiones, exóticos, fue lo que llevó a Pedro III de Aragón, muerto en el año 1285 , a elegir para su descanso eterno un sarcófago romano tardío de pórfido, hoy conservado en Santa María de Santes Creus. Tal ejemplo, tan sólo reitera la pasión que los hombres medievales mostraron hacia tales piezas ${ }^{1990}$.

\footnotetext{
1987 Sobre los fustes de San Zoilo, véase: S. GABRIEL Y GALÁN, “La portada occidental...”, p. 59, nota 7. Para el ejemplo de San Isidoro, consúltese: M. VALDÉS FERNÁNDEZ, "El Panteón Real...", p. 78. El profesor Valdés ve en la iglesia de San Juan Bautista de León, sobre la que se edificaría el actual San Isidoro, el lugar del que, posiblemente, provienen los fustes antiguos que, en la actualidad, se pueden observar en el Panteón Real. Además, es posible que algunos de los fustes del interior del templo también ofrezcan una cronología romana.

Para las piezas de la Cámara Santa, véase: A. ARBEITER, voz “Asturie...”, p. 675.

1988 Se reflexiona sobre el concepto y la definición dada por Isidoro en: I. VELÁZQUEZ, “Aedificiorum...", pp. 242-244.

1989 J. ADHÉMAR, Influences antiques..., p. 60 y p. 133. El autor señala el ejemplo del Palais d'Albâtre de Soissons como claro referente en el uso de mármoles blancos dentro de la arquitectura romana de la Galia y su influencia sobre el pensamiento de los hombres del medievo y el Renacimiento.

${ }^{1990}$ Se han localizado más lapides de este material dentro del monasterio catalán. Sobre el tema, véase: S. MORALEJO ÁLVAREZ, “La reutilización...”, p. 193 y p. 202, nota 22. El profesor Moralejo señaló, en su día, que el padre del monarca, el rey Jaime II de Aragón, ya había recurrido a Grecia para importar los lapides porfideos que servirían de sepultura a su esposa. También se abordó el tema en: M. CLAVERIA, "La reutilización...", pp. 244-246 y J. VIVES I MIRET, "Els sepulcres reials del Monestir de Santes Creus", Studia monastica, 6, 2, 1964, pp. 359-379; J. BAUCELLS I REIG, "Enterrament de Jaume II a Santes Creus l'any 1327", Acta historica et archaeologica mediaevalia, 20-21, 1999-2000, vol. 1, pp. 323-344 y L. FAEDO, Op. cit., p. 65. Éste último investigador analiza la importancia del pórfido en
} 
Se observará, por lo tanto, una cierta continuidad en tal fenómeno, desde estos ejemplos documentados en la catedral de Santiago de Compostela durante los primeros tiempos, desde la fundación del primer edificio, hasta más allá de la mitad del siglo XII. La misma preferencia estética que llevará, por ejemplo, al clasicista "maestro" de Cabestany, a alternar mármol y piedra en la fachada occidental de la iglesia de San Pedro de Rodas. La búsqueda de este efecto plástico, anclado absolutamente en las tradiciones constructivas y decorativas de la Antigüedad, no pudo pasar desapercibida a un escultor de tal categoría y habla, así mismo, de las fuentes que debieron conocer y de los materiales a los que tuvieron acceso los talleres vinculados a los grandes centros productores de obras artísticas, en la Edad Media hispana ${ }^{1991}$.

relación con el comercio del material desde Egipto y los valores de prestigio logrados a través de su uso. El pórfido acabó poseyendo, tal y como señala, valores imperiales, tanto en los mismos edificios civiles de Bizancio, como luego en aquellos de culto cristiano.

${ }^{1991}$ Dedicamos en este estudio un apartado íntegro a analizar la figura del escultor o maestro de Cabestany. En relación con el tema de la alternancia de materiales en la iglesia de Rodas, véase: J. BARRACHINA, "Las portadas de la iglesia de San Pere de Rodes", Locvs Amoenvs, 4, 1998-1999, en particular, p. 25. El autor escribe: "por mucho que se intentara cierta policromía alterando mármol y piedra, creemos que el motivo de fondo ha de ser la limitación en las posibilidades de conseguir mármol, tanto por el problema económico como por la premura en la finalización de la obra, si no es que porque sencillamente, se agotó el monumento antiguo de donde se expoliaban los mármoles". Aunque insistiremos en profundidad sobre esta cuestión en el apartado siguiente, una vez expuesto lo afirmado hasta el momento, no podemos compartir esta idea, tal y como intentaremos demostrar en las siguientes páginas. 


\section{ROMA, UN MODELO DE PRESTIGIO.}

Dentro de los estudios que han abordado la posibilidad de una influencia de la Antigüedad dentro de las producciones de cronología medieval, la ciudad de Roma se ha tenido siempre como un referente fundamental a la hora de establecer determinados paralelismos y relaciones. La hipótesis es verdaderamente sugestiva, en cuanto se trata de una de las grandes urbes del mundo antiguo y ofrece un rica "cantera" de obras bien conservadas a las que acudir en la búsqueda de posibles modelos inspiradores.

Suponer que el panorama monumental de la Roma de finales del Imperio y de la Antigüedad tardía pudo ejercer una influencia directa sobre algunos de los aspectos desarrollados en las artes románicas hispánicas es una tarea difícil de argumentar sólidamente.

En el presente apartado abordaremos la importancia que tuvieron algunos de estos monumentos de la ciudad de Roma, tanto antiguos como medievales, en la configuración de algunas de las soluciones, formas, funciones y preferencias estéticas atestiguadas dentro de los constructores y talleres escultores vinculados a la fábrica catedralicia de Santiago de Compostela. En concreto, nos centraremos en sus repercusiones dentro de las portadas de las Platerías y las Azabacherías, así como en aquellas áreas urbanas que éstas dominaban.

Se trata, nuevamente, de un tema complejo y en el que resulta problemático poder afirmar de una manera segura cualquier teoría. A ello debemos sumar la gran cantidad de estudios realizados por importantes especialistas, que han abordado el tema de las relaciones entre la sede apostólica hispana y aquella de la ciudad de Roma de una manera muy completa y científica. Se suman a tales problemas, las continuas modificaciones a las que han sido sometidos algunos de estos espacios y a la pérdida de muchos elementos escultóricos y arquitectónicos que no han llegado hasta nosotros. Igualmente, tal y como es habitual al utilizar un método comparativo, se presente el problema de llegar a discernir si realmente se trata de fórmulas traspasadas de una manera consciente e intencionada, a través de un contacto directo de los artistas con respecto a los modelos originales o, por el contrario, si se trata de meras soluciones estereotipadas que llegaron al románico hispano del siglo XII a través de un continuismo vacío y sin la carga ideológica que implica ser conscientes de participar de tal perpetuación de lo antiguo. 
En un apartado anterior de esta investigación hemos abordado la importancia que las obras paleocristianas tuvieron en la formación de muchas de las características del arte cristiano desarrollado en los siglos posteriores. Nos hemos centrado, de manera especial, en diversos aspectos del arte creado bajo el patrocinio del emperador Constantino, no sólo en la ciudad de Roma sino en otros grandes centros del cristianismo como, por ejemplo, Jerusalén o Bizancio.

Las grandes capitales de la religión cristiana asentaron sus fundamentos ideológicos y, más importante aún, sus cimientos materiales, sobre la base de un arte íntegramente pagano. Resta ahora por analizar que importancia tuvo el fenómeno dentro de las estructuras medievales conservadas en la Hispania románica y, sobre todo, si resulta factible, a través de los restos conservados, poder establecer unas líneas de influencias seguras y demostrables entre el arte tardoantiguo de época constantiniana y el arte románico realizado en la Península. 


\section{El PARADISUS DE LA CATEDRAL COMPOSTELANA Y LA ANTIGÜEDAD.}

Fue entre los años 1757 y 1770 cuando la originaria puerta románica denominada como Porta Francigena se sustituyó por otra estructura más acorde con la tendencia artística del momento. La primitiva fachada norte del templo compostelano fue suplantada por una fachada barroca que provocó una brutal modificación del plan original del edificio, así como de la distribución urbanística surgida en torno a esta parte concreta del templo ${ }^{1992}$.

La fachada, de la que tan sólo conservamos restos fragmentarios reempleados en la portada de las Platerías y otra serie de piezas descontextualizadas, ha recibido gran atención por parte de los investigadores. Se ha tratado de reconstruir su estado original a través de aquellas esculturas que, hipotéticamente, formaron parte de ella, surgiendo, incluso, algunos dibujos reconstructivos que han ofrecido hipotéticas teorías de cómo pudo ser su estado primitivo ${ }^{1993}$.

A pesar de ello, todos los autores que han abordado el tema se han servido, de una manera u otra, del famoso pasaje del Codex Calixtinus en el que se describe la portada y diversos aspectos urbanísticos relacionados con ella. El texto ha sido trascrito en multitud de ocasiones, pues resulta verdaderamente clarificador al respecto:

“Después de la fuente está el atrio o paraíso, según dijimos, pavimentado de piedra, donde entre los emblemas de Santiago se venden a los peregrinos las típicas conchas, y hay alli para vender botas de vino, zapatos, morrales de piel, bolsas, correas, cinturones y toda suerte de hierbas medicinales y además drogas, y otras muchas cosas. Los cambiadores, los hospederos y otros mercaderes están en el camino francés. El paraíso tiene dimensiones en ambos sentidos un tiro de piedra (...). Después del atrio se encuentra, pues, la puerta septentrional o Francesa de la misma basílica de Santiago, en la cual hay dos entradas bellamente esculpidas con las siguientes obras. En cada entrada se encuentran por el exterior seis columnas,

1992 R. OTERO TÚÑEZ, "La Edad Contemporánea”, La catedral..., pp. 381-422, en concreto, consúltense las pp. 382-383; K. J. CONANT, Arquitectura románica da catedral..., p. 56; F. LÓPEZ ALSINA, "Évolution urbaine de la Compostelle médiévale (IX ${ }^{\mathrm{e}}$ au XII" siècle)", Europalia 85..., pp. 230-232; S. MORALEJO ÁLVAREZ, "La primitiva fachada...", pp. 43-44 y S. FERNÁNDEZ PÉREZ y V. R. NODAR FERNÁNDEZ, "Un proyecto de reconstrucción...”, pp. 605-613.

${ }^{1993}$ A. VIGO TRASANCOS, La Catedral de Santiago y la Ilustración. Proyecto clásico y memoria histórica (1757-1808), Santiago de Compostela, 1999, pp. 126-130 y S. FERNÁNDEZ PÉREZ y V. R. NODAR FERNÁNDEZ, “Un proyecto de reconstrucción...", p. 610. 
unas de mármol y otras de piedra ${ }^{1994}$, tres a la derecha y tres a la izquierda, es decir, seis en una entrada y seis en la otra, de forma que hay doce columnas. Y sobre la columna que está entre los dos portales por fuera, en la pared, está el Señor sentado en un trono de majestad y con la mano derecha da la bendición y en la izquierda tiene un libro. $Y$ alrededor de su trono y como sosteniéndolo, están los cuatro evangelistas; y a su derecha está esculpido el paraíso y en él está representado el mismo Señor otra vez reconviniendo del pecado a Adán y Eva; y a la izquierda está también en otra figura arrojándolos del paraíso. Allí mismo, pues, hay talladas por todo alrededor muchas imágenes de santos, de bestias, de hombres, de ángeles, de mujeres, de flores y de otras criaturas, cuya esencia y calidad no podemos describir a causa de su gran cantidad. Sin embargo, sobre la puerta que está a la izquierda, según se entra a la catedral, está esculpida en el tímpano la Anunciación de la santísima Virgen María. Háblale también alli el ángel Gabriel. En cambio, a la izquierda de la entrada lateral sobre las puertas se ven relieves de los meses del año y otras muchas hermosas alegorías. En las paredes hay en la parte de afuera dos grandes y feroces leones, uno a la derecha y otro a la izquierda, que siempre miran hacia las puertas como si las vigilasen. Arriba, en las jambas, se ven cuatro apóstoles que llevan sendos libros en la mano izquierda y con las diestras levantadas bendicen a los que entran en la iglesia; Pedro está en la entrada de la izquierda, a la parte derecha, Pablo a la izquierda; y en la entrada derecha están el apóstol Juan a la derecha y Santiago a la izquierda. Y sobre las respectivas cabezas de los apóstoles hay esculpidas las de unos bueyes, que sobresalen de los dinteles"1995 (texto 72).

La fachada norte presentaría, si atendemos a esta descripción, un rico programa iconográfico desarrollado a lo largo de todo el conjunto, poniendo especial énfasis en las columnas, tímpanos y frisos que decoraban la parte alta de la misma. Las reconstrucciones y estudios realizados hasta el momento han ayudado a clarificar de una manera, más o menos segura, la forma que hubo de tener. Sin embargo, resulta problemático dar por sentadas las diversas teorías vertidas en relación con este aspecto, pues cualquier tipo de hallazgo documental, arqueológico o artístico, desmiente muchas de las afirmaciones dadas hasta el momento como válidas ${ }^{1996}$.

\footnotetext{
1994 Obsérvese como el propio autor del texto señala, como rasgo significativo, la utilización de esta técnica de alternancia de materiales y sobre la que ya hemos tratado en las páginas anteriores.

1995 Liber Sancti Iacobi..., pp. 595-596. Véase también: S. MORALEJO ÁLVAREZ, "La primitiva fachada...”, pp. 21-46 y K. J. CONANT, Arquitectura románica da catedral..., pp. 64-65.

1996 Por ejemplo, véase el plano de época moderna, datado en el año 1735, realizado por el arquitecto Simón Rodríguez y que fue descubierto en el Archivo de la Catedral de Santiago. Se trata de un diseño que reproduce la forma en planta que poseía la antigua fachada norte antes de su demolición. Gracias a
} 
Tal y como señaló en su día $\mathrm{S}$. Moralejo, la única fecha cierta en relación con el conjunto de la Puerta Francigena es la que aparece señala en el texto del Calixtinus. Según se nos dice, en el año 1122 fue colocada una fuente:

“Cuando nosotros los franceses queremos entrar en la basílica del Apóstol, lo hacemos por la parte septentrional, ante cuya entrada está junto al camino el hospital de peregrinos pobres de Santiago y después, más allá del Camino, se encuentran un atrio en donde hay nueve peldaños de bajada. Al pie de la escalera de este atrio existe una admirable fuente a la que en todo el mundo no le encuentra semejante. Tiene, pues, esta fuente al pie tres escalones de piedra sobre los que está colocada una hermosísima taza de piedra, redonda y cóncava, a manera de cubeta o cuenco, y que es tan grande que en ella me parece que pueden cómodamente bañarse quince hombres. En su centro se eleva una columna de bronce gruesa por abajo, de siete caras cuadradas y altura proporcionada, de cuyo remate surgen cuatro leones por cuyas bocas salen cuatro chorros de agua para mitigar la sed a los peregrinos de Santiago y a los habitantes de la ciudad. Y estos cuatro chorros, después que salen de la boca de los leones, caen seguida en la misma taza de abajo y saliendo de allí por un agujero de la misma taza escapan por debajo de la tierra. De la misma manera que no puede verse de dónde viene el agua, tampoco puede verse dónde va. Es luego el agua aquella dulce, nutritiva, sana, clara, muy buena, caliente en invierno y fresca en verano. En la citada columna se encuentra la siguiente inscripción grabada de esta forma en dos líneas por todo alrededor bajo los pies de los leones: $†$ Yo, Bernardo, Tesorero de Santiago, traje aquí esta agua y realicé la presente obra para remedio de mi alma y de las de mis padres en la era MCLX el tercero de los idus de abril"1997 (texto 73).

este tipo de hallazgos, se puede ir perfilando la forma que debió tener el conjunto. Sabemos que las similitudes arquitectónicas existentes entre las fachadas gallegas y la Puerta des Comtes de Saint-Sernin de Toulouse son claras.

Nuevamente, se reafirma la idea de que el acceso a través de dicha portada era bíforo, con un machón central a modo de contrafuerte, como el existente en Platerías, además del uso de columnas para el apeo de las arquivoltas, la primera de ellas, sobre sendas columnas y la segunda interna, sobre otras pareadas. Cf.: A. FERNÁNDEZ GONZÁLEZ, "Un viejo plano olvidado en el Archivo de la Catedral de Santiago: la Porta Francígena, su atrio y la Corticela en el año 1739", Compostellanum, XLVIII, 1-4, 2003, pp. 701742. Consúltese también: M. A. CASTIÑEIRAS GONZÁLEZ, "La meta del Camino...", p. 232. El investigador publica, nuevamente, los dibujos reconstructivos de S. Fernández Pérez y V. R. Nodar Fernández, ahora corregidos tras la aparición del plano descubierto por A. Fernández González.

${ }^{1997}$ Liber Sancti Iacobi..., pp. 593-594 y K. J. CONANT, Arquitectura románica da catedral..., pp. 6364. Los autores aclaran que la fuente tenía entonces, según se deduce del texto, una sección heptagonal, y que fue realizada por el tesorero Bernardo, tal vez, hijo de Bernardo el Viejo, que aparece citado como cantero en la fábrica catedralicia. Fue colaborador asiduo del obispo Gelmírez y el rey Alfonso VII. La fuente, indican los autores, quizás fue destruida en el siglo XV para ser sustituida por la actual de los 
Según la descripción, el Camino Francés terminaba, una vez accedido al entramado urbano de la ciudad, en un espacio que denomina adro (fig. 372). En él se encontraba la citada fuente (fig. 373). Lo más interesante es que, a partir de la descripción, se puede conjeturar sobre el valor urbanístico de tal recinto y su relevancia en relación con el acceso a la misma catedral, una vez finalizada la peregrinación, así como la datación segura para la colocación de tal fuente en este espacio urbano: el 11 de abril de 1122 .

Lejos de poder aportar ninguna novedad a un tema tan estudiado, nos limitaremos a indagar sobre las razones que llevaron a prestar tanta atención a este espacio norte de la catedral y al área circundante que permitía el acceso al templo.

Todos los autores que han investigado el tema no dudan en defender, con mayor o menor seguridad, la posible relación existente entre este espacio y otros recintos de la misma índole construidos en lugares cristianos de gran dignidad.

Para S. Moralejo, el espacio denominado por las fuentes como el Paradisus y su construcción hidráulica, manifiesta una clara voluntad de evocar uno de los espacios más visitados del Occidente cristiano desde época tardoantigua. Se refería al cuadripórtico de San Pedro del Vaticano que, al igual que el recinto compostelano, presentaba una fuente en el centro, interpretada aquí con un gran simbolismo ${ }^{1998}$.

Según escribe al respecto $M$. Castiñeiras:

“La plaza, denominada paradisus, no sólo era una emulación del Paraíso del antiguo San Pedro del Vaticano, sino que además intentaba evocar el Edén Bíblico. Dicho locvs amoenvs se significaba a través de una fuente -la fons vitae-coronada por cuatro leones, a la manera de los Ríos del Paraíso, así como por el empleo en el frontispicio de la fachada de hermosas lastras con decoración vegetal junto a relieves historiados con el ciclo de la Caída de Eva y Adán"1999.

Por su parte, también el profesor J. L. Senra apoyó la teoría de la evocación vaticana afirmando:

Caballos, en el lado opuesto en dónde se debió ubicar la del tesorero Bernardo, es decir, frente a la fachada de Platerías.

1998 S. MORALEJO ÁLVAREZ, "El patronazgo artístico del arzobispo...”, pp. 297-298. El profesor Moralejo alude a las expresiones romano more o romana consuetudine, utilizadas en otros lugares, para definir estructuras del mismo tipo que la existente en Compostela.

${ }^{1999}$ M. A. CASTIÑEIRAS GOZÁLEZ, “La meta del Camino...”, p. 233. 
“(...) existió una voluntad de dignificar esta conocida entrada al templo, pero tuvo como respuesta la inserción en 1122 de una "fons vitae" con resonancias simbólicas respecto a la pigna del atrio vaticano en un nuevo ejemplo de deliberada imitación visual de las formas" ${ }^{2000}$.

Incluso, este último investigador va más allá al considerar que, la puerta norte que analizamos, presenta "inevitables pero fortuitos parentescos en lo que se refiere a su topografía con el acceso a la basílica del Santo Sepulcro"2001.

Las posibles lecturas ideológicas y simbólicas del espacio y de la fuente, aunque imposibles, a la hora de darlas por seguras categóricamente, hablan de diferentes ritos de penitencia y bautismo, buscando, de alguna manera, otorgar al espacio urbanístico una importancia como marco para su celebración. La fachada cargada de imágenes que encuadraba dicho espacio se convertiría en el escenario perfecto de enmarque y su iconografía acompañaría, consecuentemente, a las ceremonias y ritos desarrollados delante de ella ${ }^{2002}$.

De la misma manera que en apartados anteriores nos hemos detenido en la importancia que los monumentos de época constantiniana tuvieron sobre determinados aspectos de la cultura visual de la Edad Media, pensamos que es interesante valorar estas afirmaciones que, de manera reiterativa, han conectado el paradisus compostelano con uno de los espacios más importantes de la arquitectura paleocristiana de la ciudad de Roma.

La idea del jardín paradisíaco, el locvs amoenvs de la literatura virgiliana y su traspaso al ideario cristiano a través de la evocación del Edén bíblico, es una cuestión suficientemente conocida como para detenerse en ella ${ }^{2003}$. Entre las más conocidas

\footnotetext{
2000 J. L. SENRA GABRIEL Y GALÁN, “Los tímpanos de la catedral...”, p. 29.

2001 Ibidem. Tal y como vemos, la teoría de las reminiscencias constantinianas es una hipótesis que, incluso, ha llevado a ligar el edificio hispano con el Santo Sepulcro.

${ }^{2002}$ S. MORALEJO ÁLVAREZ, "Le lieu Saint...", p. 44. El autor afirma que la comentada plaza supondría, no sólo el fin material de la peregrinación al templo, sino también, un fin espiritual. La fuente, así como el baptisterio, el anciano oratorio de San Juan Bautista, que se situaba en la capilla extrema opuesta al transepto de la catedral compostelana, permiten al autor desarrollar diversas teorías en relación con las hipotéticas funciones del recinto. La Puerta Francigena, acceso y comunicación del templo respecto al vicus novus, permitía al público acceder al edificio, una entrada física y simbólica realizada a través del bautismo.

${ }^{2003}$ A. GRABAR, Las vías de la creación..., p. 160. El autor señala que el paraíso descrito por los hagiógrafos bizantinos era el lugar donde se instalaban las almas, recibidas en el seno de Abraham, Isaac y Jacob. Fuera de la puerta del Paraíso se muestra a San Pedro recibiendo a los fieles, lo que permite comprender la carga simbólica que el Paradisus vaticano pudo representar, en cuanto a las infinitas posibilidades de realizar una lectura iconológica de la arquitectura. Desde otro orden de cosas, se analiza el pasaje de las Etimologías isidorianas donde se describe el Paraíso Terrenal del Oriente en: S.
} 
materializaciones arquitectónicas contenedoras y representantes de este simbolismo, estarían la de los pórticos, los atrios, los claustros, cementerios y plazas, es decir, gran cantidad de estructuras constructivas y arquitectónicas susceptibles de ser sometidas a una lectura ideológica de esta índole. Todas ellas, tal y como estudió J. C. Picard, fueron englobadas, durante los siglos medievales, bajo el término paradisus ${ }^{2004}$.

Más allá de esta definición, el concepto se utilizó también desde la Antigüedad de una manera arbitraría para designar los accesos a los templos y a los atrios e, incluso, como señala T. Lyman, para denominar las capillas altas de ciertos edificios ${ }^{2005}$.

Tales acepciones llevaron a que, desde bien temprano, los pórticos cerrados anexos a los edificios de culto fueran el lugar idóneo para la espera, zona de tránsito y espacio destinado a los catecúmenos, donde permanecían hasta recibir el ansiado sacramento del bautismo ${ }^{2006}$. Tal y como estudió J. A. Iñiguez, eran lugares donde los fieles permanecían separados de los catecúmenos, así como de aquellos que permanecían fuera de la iglesia debido a su situación jurídica de penitentes públicos ${ }^{2007}$.

Sin embargo, al leer con atención el pasaje del Codex Calixtinus en el que se describe con detenimiento la función y las características del espacio que antecedía el acceso a la basílica a través de la portada norte, queda claro que se trataba más bien de un espacio comercial que religioso, o al menos, así lo entendió el escritor medieval del texto. Un aspecto llamativo es que, en las breves líneas que dedica a describir el lugar, utilice el mayor espacio de texto para destacar los productos que allí se vendían y no para enumerar las supuestas funciones simbólicas y religiosas que, teóricamente, se realizaban en dicho recinto ${ }^{2008}$.

SEBASTIÁN, “La visión del cosmos medieval...”, pp. 73-74. En relación con la idea del Aurea Aetas o Edad de Oro Augusta, véase: P. ZANKER, Augusto y el poder..., p. 208.

${ }^{2004}$ J-C. PICARD, "Les origines du mot Paradisus...", pp. 159-186 e ID., Évêques, saints et cités..., en particular, pp. 3-30.

${ }^{2005}$ T. LYMAN, "Portails, portiques, paradis. Rapports iconologiques avec le cloîtres méridionaux", Les Cahiers de Saint-Michel de Cuxa, VII, 1976, pp. 35-43, concretamente, p. 37 y M. MIRABELLA ROBERTI, Op. cit., p. 102.

${ }^{2006}$ J. M. EGEA (ed.), Op. cit., p. 47.

2007 J. A. IÑíGUEZ, Síntesis de arqueología cristiana..., p. 120 y J. M. EGEA (ed.), Op. cit., p. 48. Dentro del caso hispano, son muchas las estructuras que se han entendido como espacios para las actuaciones penitenciales. Recuérdese, por ejemplo, la función que I. Bango atribuye al protyron. Se trata de una estructura colocada al occidente de algunos templos y que se considera de origen oriental. Señala las estructuras de San Juan de Baños, San Julián de los Prados, así como la destruida de Quintanilla de las Viñas o Santa Comba de Bande, como los mejores representantes de este elemento arquitectónico con valores penitenciales. No es este el lugar idóneo para abordar el extenso problema de las nomenclaturas derivadas del estudio de la arquitectura religiosa oriental y su aplicación sobre elementos constructivos hispanos. Cf.: I. G. BANGO TORVISO, "El espacio para enterramientos...," p. 98.

${ }^{2008}$ Ello ha llevado a que algunos autores hayan traducido el término latino paradisus como plaza o lonja, que, sin duda, se adecua mejor a los fines comerciales que, siguiendo el texto original, debió tener el lugar. Vid.: Liber Sancti Iacobi..., p. 594, nota 932. 
Por todo lo afirmado, creemos que, en principio, resulta arriesgado poder hacer depender, de una manera directa, dicha estructura y el enorme espacio construido a modo de narthex anticipando el ingreso a la basílica compostelana de aquel erigido en San Pedro del Vaticano ${ }^{2009}$.

En relación con el tema, creemos necesario recurrir al Liber Pontificalis o, lo que es lo mismo, la fuente más fiable para poder imaginar la morfología que debió tener el paradisus vaticano y observar las enormes diferencias que presentó, desde su origen, con el espacio compostelano ${ }^{2010}$.

${ }^{2009}$ No podemos recoger, ni tan siquiera sintetizando, los trabajos más importantes realizados sobre la iglesia de San Pedro del Vaticano erigida por Constantino en Roma. En las siguientes páginas de nuestro estudio se harán continuas alusiones a numerosas aportaciones centradas en cuestiones relacionadas con el edificio vaticano y su decoración. Citamos, tan sólo, las obras que hemos consultado para poder comprender mejor la problemática del espacio en Compostela. Véanse al respecto: F. CABROL y H. LECLERCQ, voz "Canthare...", vol. III, col. 1958 y cols. 1962-1963; W. SESTON, Op. cit., pp. 153159; S. GIANMARIA, "Tiberio Alfarano, Pianta dell'antica basilica di San Pietro in Vaticano", Romei \&..., ficha catalográfica 257, p. 437; H. L. KESSLER, "La decorazione della basilica medievale di San Pietro", Ibidem, pp. 263-270; P. SILVAN, "L'architettura della basilica...", pp. 249-262; S. MADDALO, "Roma terminus itineris multorum et laborum initium. Immagini di Roma tra devozione, archeologia e ideologia politica", Ibidem, pp. 241-248; R. SANTAGELI VALENZANI, Op. cit., pp. 195-198; L. GIAMPIETRO, "L'area vaticana nelle più antiche descrizioni medievali", Pellegrini alla tomba di Pietro (G. Morello ed.), Milano, 1999, pp. 144-151; V. LANZANI, "Ubi Petrus". L'antica immagine della Confessione vaticana", Ibidem, pp. 34-59; M. D’ONOFRIO, "La basilica costantiniana "reliquiario" delle spoglie di Pietro", Ibidem, pp. 11-31. A modo tan sólo ilustrativo, debido a las reconstrucciones que se publican: D. CASALINO, La basilica di San Pietro in Vaticano, Firenze, 1999, en particular, pp. 19-34; R. MENEGHINI y R. SANTAGELI VALENZANI, Roma nell'altomedioevo. Topografia e urbanistica della città dal $V$ al $X$ secolo, Roma, 2004, en concreto, pp. 54-57. En esta última obra se analiza la problemática de la muralla aureliana y su relación con el espacio vaticano.

En atención a la actividad constructiva del emperador Constantino y sus características, centrándonos en el caso concreto de San Pedro del Vaticano, nos han resultado útiles, los siguientes trabajos: G. H. FORSYTH, "The transept of old St. Peter's at Rome", Late classical and mediaeval studies in honor of Albert Mathias Friend, Jr. (K. Weitzmann ed.), Princeton, New Jersey, 1995, pp. 56-70; R. KRAUTHEIMER, St. Peter's and medieval Rome, Roma, 1985, en concreto, pp. 16-21; F. E. PETERS, Jerusalem. The Holy City in the Eyes of Chroniclers, Visitors, Pilgrims, and Prophets from the Days of Abraham to the Beginnings of Modern Times, Princeton, New Jersey, 1985, en particular, pp. 131-175, donde se recogen diversas fuentes en relación con el Santo Sepulcro y la arquitectura constantiniana. También véase: M. GRANT, The emperor Constantine, London, 1993, sobre todo, pp. 187-2007; S. DE BLAAUW, Cultus et Decor. Liturgia e architettura nella Roma tardoantica e Medievale. Basilica Salvatoris, Sanctae Mariae, Sancti Petri, vol. I, Città del Vaticano, 1994, en particular, sobre la iglesia de Constantino en el Vaticano, pp. 109-180; ID., "Architettura 312-600", Cultus et Decor..., pp. 109-116; V. SAXER, "Le culte des apportes Pierre et Paul à Rome", Les Cahiers de Saint-Michel de Cuixà, XXIX, 1998, pp. 15-27; M. ANDALORO y S. ROMANO, "L'immagine nell'abside", Arte e iconografia a Roma da Costantino a Cola di Rienzo: una premessa (M. Andaloro y S. Romano ed.), Milano, 2000, pp. 93132, en concreto, sobre el ábside vaticano, pp. 102-103; R. OUSTERHOUT, "Architecture as Relic and the Construction of Sanctity: The Stones of the Holy Sepulchre", The Journal of the Society of Architectural Historians, 62, 1, 2003, pp. 4-23; M. A. CRIPPA, "La primera architettura cristiana...", en particular, p. 189; G. LORENZONI, "Aspetti del tardoantico...", en concreto, pp. 23-38 y F. GUIDOBALDI, "Sull'originalità dell'architettura...., en concreto, pp. 433-437.

${ }^{2010}$ R. VALENTINI y G. ZUCCHETI, "Il Liber Pontificalis e le sue continuazioni”, Codice Topográfico della città di Roma, vol. II, Roma, 1942, pp. 209-329. Vid. también: J. CROQUISON, "L'iconographie chrétienne à Rome d'après le Liber Pontificalis", Byzantion, XXXIV, 2, 1964, pp. 535-606. El Liber Pontificalis, según se viene aceptando, fue realizado en dos momentos. El primero de ellos, finalizaría con el pontificado del papa Félix IV (470-530) y continuado, más tarde, por un clérigo romano bajo el pontificado de Bonifacio II (530-532). La redacción del mismo prosiguió en la Alta y Plena Edad Media, 
Según el texto, una especie de memorial histórico de la iglesia romana y de la política papal de la urbe, a pesar de que la basílica constantiniana se encontraba ya construida y en funcionamiento desde hacia años, tan sólo fue, a partir del pontificado del papa Simmaco (498-514) cuando el recinto abierto, colocado en el occidente de la basílica, pasó a denominarse, por parte de los peregrinos, con el término de paradisus $^{2011}$.

Al cotejar lo descrito en el Liber Pontificalis y las numerosas aportaciones historiográficas relacionadas con el tema, se advierte que el proceso debió ser el siguiente. Desde el año 396 se documenta la existencia de un espacio abierto precedente de la gran fachada de acceso al templo constantiniano. De este primer atrio que, según se ha venido aceptando, reutilizó, directamente, el peristilum de la casa romana, no han llegado restos arqueológicos hasta la actualidad, no conociendo ni tan siquiera sus dimensiones ni su planta.

A lo largo de sus estudios P. Silvan ha expuesto que, posiblemente, se trataría de un recinto tan grande como el templo. Sin embargo, se ha dudado que el espacio estuviese en origen porticado e, incluso, que la fuente central de este famoso paradisus hubiese estado prevista en el proyecto inicial ${ }^{2012}$. Se trataría, concretamente, del diseño espacial de los años 396-397, época en la que M. D’Onofrio ha señalado el final de las primeras labores de cierre del atrio ${ }^{2013}$.

Sin embargo, no será hasta el pontificado del papa Simplicio (468-483) y al del ya mencionado Simmaco (498-514), cuando se finalicen los trabajos en la estructura, ahora cerrada por un cuadripórtico ${ }^{2014}$. En relación con las obras acometidas por éste último pontífice, el Liber se muestra muy claro al respecto:

\footnotetext{
a través de las contribuciones de otros clérigos, como el romano Pandolfo (ca. 1137), Pedro Guillermo de San Pilles (ca. 1142) y otros, que continuarían el texto hasta la muerte de Martino V, en el año 1431. La primera edición del Liber vio la luz en el año 1602 en Maguncia.

2011 P. SILVAN, "L'architettura della basilica...", en concreto, p. 253. El autor apoya esta teoría basándose también en el Liber Pontificalis. En este mismo sentido, véase: M. D'ONOFRIO, "La basilica...”, p. 14. Este último investigador defiende que el edificio estaría prácticamente finalizado entre los años 352-356.

2012 Ibidem, p. 242.

${ }^{2013}$ M. D’ONOFRIO, “La basilica...”, pp. 14-15.

${ }^{2014}$ R. VALENTINI y G. ZUCCHETI, “Il Liber Pontificalis...”., pp. 242-243. De la lectura del texto se deduce la importancia de la figura del papa Simplicius en la organización de las peregrinaciones a los lugares más importantes de Roma. Llevó a cabo una reestructuración parroquial entre los servicios religiosos de las catacumbas y los oficiados en las grandes basílicas de la ciudad como, por ejemplo, en San Pedro o San Pablo y San Lorenzo extramuros.
} 
"Hic fecit basilicam Sancti Andreae apostoli apud Beatum Petrum, ubi fecit oraturium Sancti Thomae apostoli...; confessionem Sancti Cassiani et Sanctorum Proti et Yachinti...; oraturium Sancti Apollinaris...; oraturium Sancti Sossi...; Item ad fontem, in basilica Beati Petri apostoli, oraturium Sanctae Crucis... Fecit autem oraturia Sancti Iohannis Evangelistae et Sancti Iohannis Baptistae...; quas cubicula omnes a fundamento perfecta construxit. Basilicam vero Beati Petri marmoribus ornavit. Ad cantharum Beati Petri cum quadriporticum ex opere marmoribus ornavit et ex musivo agnos et cruces et palmas ornavit. Impsum vero atrium omnem conpaginavit; grados vero ante fores basilicae Beati Petri ampliavit et alios grados sub tigno dextra laevaque construxti. Item episcopia in eodem loco dextra laevaque fecit. Item sub grados in atrio alium cantharum foris in campo posuit, et usum necessitatis humanae fecit. Et alios grados ascendentibus ad Beatum Adream fecit et cantharum posuit. Hic fecit basilicam Sanctae martyris Agathae, via Aurelia, in fundum Lardarium; a fundamento cum fontem extruxit -fecit basilicam Sancti Pancrati...; fecit autem in eodem loco balneum. Item apud Beatum Paulum apostolum: in basilicam renovavit absidam, quae in ruina inminebat, et post confessionem picturam ornavit et cameram fecit et matroneum...; et ante fores basilicae grados fecit in atrium et cantharum; et post absidam aquam introduxit, ubi et balneum a fundamento fecit. Intra civitatem Romanam, basilicam Sanctorum Silvestre et Martini a fundamento cosntruxit iuxta Traianas... Ad Beatum Iohannem et Paulum fecit grados post absidam. Item ad Archangelum Michael basilicam ampliavit et grados fecit et introduxit aquam. Item ad Sanctam Mariam oratorium Sanctorum Cosmae et Damiani a fundamento construxit... Item ad Beatum Petrum et ad Beatum Paulum et ad Sanctum Laurentium pauperibus habitacula construxit...Hic reparavit basilicam Sanctae Felicitatis, quae in ruinam inminebat. Hic absidam Beatae Agnae, quae in ruinam inminebat, et omnen basilicam renovavit -Hic fecit cymiterium Iordanorum in melius, propter corpus sancti Alexandri- sepultus est in baslica Sancti Petri, ${ }^{2015}$.

Este fragmento tomado del Liber Pontificalis presenta una importancia fundamental en relación con el tema que aquí abordamos. Por una parte, nos informa de que el cuadripórtico o paradisus del edifico, iniciado quizás por Simplicio, debía estar por este momento terminado, a juzgar por las labores de ornamentación emprendidas

\footnotetext{
${ }^{2015}$ Ibidem, pp. 243-246. Recogemos el texto original en latín por no haber podido tener acceso a la edición traducida del mismo, limitándonos a transcribir el pasaje, según lo hicieran, en su día, en la edición del mismo los autores arriba citados.
} 
por Simmaco. De entre ellas, el cantharus es, sin duda, la pieza que más importancia ha cobrado para la posteridad.

A través de la mención recogida en el Liber y otras compiladas dentro de los Mirabilia, como aquel tan conocido de Pierre Mallius, parece que el papa mandó colocar en el centro del paradisus una fuente o cántaro formado por una gran piña de bronce perforada con agujeros que permitía manar los hilos de agua. Se tiene constancia de que, además, la estructura se cubría con un templete o baldaquino sustentado por columnas de pórfiro. El mismo papa acompañó la obra con una inscripción conmemorativa $^{2016}$.

Igualmente, y tal y como señala el Liber, el papa patrocinó, además, otras dos fuentes, la primera de ellas, fue colocada sobre la explanada que, a su vez, daba acceso al atrio. Tal construcción ha sido vista como el lugar donde los peregrinos del siglo IV se adecentaban para poder acceder al recinto sagrado. La segunda, vendría a sustituir a la que, en su tiempo, había colocado León I en la plaza anterior al ingreso occidental de la basílica de San Pablo de Roma ${ }^{2017}$.

Además del embellecimiento del recinto mediante mármoles y mosaicos, la estructura quedaba completada, en este momento, con la introducción del cantharus que habría de despertar gran interés entre los eruditos, viajeros, peregrinos y estudiosos de diferentes épocas.

En relación con ello, ya en su momento F. Cabrol y H. Leclercq publicaron el dibujo realizado, alrededor del año 1590, por el artista Philippe de Winghe (fig. 41). Gracias a este testimonio y a otros de diferente índole, se ha llegado a pensar que la fuente en forma de pinea aenea, estaba protegida por un baldaquino o ciborium apoyado en ocho columnas ${ }^{2018}$. También son los mismos investigadores los que recogen en su estudio la interesante noticia narrada en el ya citado Mirabilia urbis Romae de Pierre Mallius, en la que se describe la fuente vaticana en los siguientes términos:

\footnotetext{
${ }^{2016}$ Ibidem.

2017 Ibidem, p. 245, nota 2.

${ }^{2018}$ F. CABROL y H. LECLERCQ, voz “Canthare...”, cols. 1983-1986. Los autores hacen un análisis del comentado pasaje tomado del Liber Pontificalis. Véase también: F. ALTO BAUER, "Veduta dell'atrio dell'antica Basilica di San Pietro", Carlo Magno..., ficha catalográfica 43, pp. 196-197. Se publica un dibujo del paradisus vaticano datado entre los años 1574 y 1575 que se conserva en Firenze, Galleria degli Uffizi.
} 
"Cantarum columnis porphireticis ornatum, quae tabulis marmoreis cum griphonibus conexae, pretioso celo aureo coopertae (sunt) cum floribus et delfines aereis et deauratis aquas fundentibus: in medio cantari est pinea aerea (...),2019.

Pero es, si duda, el diseño anónimo, quizás realizado en el círculo de Baldassare Peruzzi en el año 1520, la prueba más temprana que nos ha llegado de cual fue la forma de tal obra (fig. 374). Según F. Alto Bauer, el cantharus en forma de piña representado en el dibujo sería, en líneas generales, el mismo que, en su día, patrocinara el papa Esteban II. Destaca la representación detallista que se ha hecho de la nueva cubierta de bronce, en la que advierte una decoración de escamas a modo de rejería, de clara tradición "antiquizante". Una pareja de pavos reales fue, claramente, identificada por el artista moderno, al igual que los defines, que refrendan los datos aportados por las fuentes documentales.

Con todo, es la gran piña de bronce el elemento que más destaca dentro de esta estructura hidráulica vaticana. El mismo autor, basándose igualmente en investigaciones anteriores, cree que, posiblemente, se trata de una pieza de expoliación procedente del Campo de Marte, en la misma ciudad de Roma ${ }^{2020}$.

Creemos, de igual manera, que no es preciso insistir en la importancia que la piña debió tener a los ojos de los visitantes del recinto. Siglos después, una piña de época romana, también expoliada, fue colocada coronando la fuente del atrio que antecedía el acceso a la capilla palatina de Aquisgrán, ya en tiempos del mismo Carlomagno (figs. 36 y 42). Tal objeto aparecía acompañado, como ya hemos

\footnotetext{
${ }^{2019}$ El texto se recoge en: F. CABROL y H. LECLERCQ, voz "Canthare...”, col. 1985. Los autores lo toman, a su vez, de la obra del siglo XI Mirabilia urbis Romae de Pierre Mallius. La propia fuente recibiría diferentes reparaciones y remodelaciones en épocas posteriores. La más significativa vendría patrocinada por el papa Esteban II (752-757) que sustituiría algunas de las columnas que elevaban el baldaquino de la fuente, además de colocar una cúpula de bronce sobre la estructura. El texto original del Liber recoge estos trabajos de la siguiente manera: “(...) renovavit in atrium ante fores Beati Petri apostoli, qui quadriporticos dicitur, columnas marmoreas. VIII., mirae pulchritudinis, sculptas, quae desuper quadris composuit et aereum desuper conlocavit tegumen". Cf.: R. VALENTINI y G. ZUCCHETI, "Il Liber Pontificalis...", concretamente, p. 269; P. SILVAN, "L'architettura della basilica...", p. 257 y L. GIAMPIETRO, "L'area vaticana...", pp. 147-148. El profesor P. Silvan liga el simbolismo de la piña vaticana al culto romano a Cibeles.

${ }^{2020}$ El autor estudió el dibujo al que nos referimos recientemente, a raíz de su aparición en la obra colectiva titulada Carlo Magno a Roma, publicada en el año 2001. Originariamente, el diseño fue atribuido a Cronoca, aunque el autor defiende en su estudio una nueva autoría. Cf.: F. ALTO BAUER, "Fontana delle Pigna nell'atrio dell'antica Basilica di San Pietro", Carlo Magno..., ficha catalográfica 44, pp. 198-199. En el mismo volumen mencionado, véase el otro diseño, ya citado, de cronología más tardía. Cf.: ID., "Veduta dell'atrio...", p. 196 y L. GIAMPIETRO, "L'area vaticana...", p. 147. Este último autor defiende que la pieza proviene del Panteón de Roma.
} 
comentado en este estudio, de otras obras expoliadas, como el retrato ecuestre de Teodorico, procedente de Rávena ${ }^{2021}$.

La especial atención prestada hasta el momento a la problemática en torno al paraíso vaticano, se justifica por la reiterativa opinión, por parte de ciertos investigadores, que han querido ver una relación entre la estructura compostelana y aquella romana ${ }^{2022}$.

Es cierto que ninguno ha hablado de una copia directa, ni tan siquiera de una derivación de la estructura tardoantigua de Roma y que, tal y como hemos visto, llegaría a la época pleno medieval no sin pocas reformas.

A través de los preceptos de lo que se ha dado en llamar "iconografía de la arquitectura", creemos que es posible comprender el carácter simbólico del paradisus vaticano. Sin embargo, aplicando tal método al ejemplo compostelano, resulta más complejo poder admitir, de una manera segura, aquellas concomitancias que se han defendido con respecto al espacio romano ${ }^{2023}$.

El fenómeno fue bien explicado, en su día, por R. Krautheimer, a propósito del estudio de las copias, imitaciones, evocaciones y ecos del Santo Sepulcro de Jerusalén sobre la arquitectura medieval occidental ${ }^{2024}$. En este sentido fueron muchos los

${ }^{2021}$ La escultura romana de bronce conservada en Aquisgrán, presenta una serie de perforaciones que demuestran, claramente, que se reutilizó como surtidor de agua para una fuente. Cf.: P. LASKO, Op. cit., pp. 36-37 y F. ALTO BAUER, "Fontana...", p. 198. Entre las otras piezas reutilizadas, cabe destacar, sobre todo, la denominada "loba", conservada, igualmente, en Aquisgrán. A pesar de tratarse de la representación de una osa, fue expoliada para colocarla en el atrio de la Capilla Palatina carolingia que, en escala reducida, imitaba el Foro de Augusto. Hoy se duda del lugar de procedencia de la pieza y se ha apuntado sobre la hipótesis de un supuesto traslado desde Italia por el propio Carlomagno. Lo que parece claro es que, todas estas esculturas, configuraron las bases materiales y estéticas de la emulación de la Nueva Roma en la capital carolingia. El Laterano, la basílica de San Pedro y los foros romanos fueron los modelos a los que se pretendía aludir. Véanse las reflexiones realizadas en: A. NESSELRATH, “L'orsa o cosiddetta lupa", Carlo Magno..., ficha catalográfica 2, pp. 103-105.

${ }^{2022}$ M. A. CASTIÑEIRAS GONZÁLEZ, "Roma e il programma riformatore di Gelmírez nella cattedrale di Santiago di Compostella", Medievo: Immagini e Ideologie, Milano, 2005, pp. 211-226.

${ }^{2023}$ R. KRAUTHEIMER, Introduction à une iconographie..., pp. 1-33. Para la comparación entre el paradisus de Santiago y el construido en el Vaticano, véase: M. A. CASTIÑEIRAS GONZÁLEZ, Atlas de la catedral..., (edición digital). El autor afirma que dicho espacio "no sólo era una emulación del paradisus del antiguo San Pedro del Vaticano, sino que además intentaba evocar el Edén Bíblico". Cf.: ID., "La catedral románica: tipología...", p. 59.

Uno de los primeros investigadores en plantear tal posibilidad fue el profesor Moralejo. Cf.: S. MORALEJO ÁLVAREZ, "La imagen arquitectónica...", p. 244, nota 35 e ID., "Arte del Camino de Santiago...", p. 139. En relación con el tema, el especialista afirmaba: "no faltan sin embargo argumentos a favor de la interpretación de ciertos paraísos o parvis medievales como alusivos al Génesis, y tal me parece ser el caso del compostelano si tenemos en cuenta la monumental fuente allí elevada por el tesorero Bernardo en 1122".

${ }^{2024}$ R. KRAUTHEIMER, Introduction à une iconographie..., pp. 7-11. Enumera diferentes ejemplos, entre los que destacamos, las iglesias de Saint-Germigny-des-Prés, Santa Sofía de Benevento, la rotonda de Lanleff, cerca de Caen o el Santo Sepulcro de Cambridge. Tales edificios fueron estudiados por el autor en relación con su dependencia, a veces directa y otras no tanto, respecto al Santo Sepulcro de Jerusalén. 
especialistas que, a la hora de poder analizar, simbólicamente, los espacios urbanos y arquitectónicos configurados en torno a la forma centralizada, recurrieron, casi de manera inercial y mecánica, al Santo Sepulcro de Jerusalén.

A veces, tales relaciones se justificaban más por razones de índole formal y estructural que meramente simbólicas. Dos edificios de planta centralizada se relacionaban entre sí, aunque la analogía entre el modelo original y el supuestamente inspirador no fuera estrecha.

No es el momento aquí de abordar tan compleja cuestión, pues ello supondría establecer los diferentes grados de asimilación de las obras de arte respecto a los modelos de los que dependen a través de sus diferentes variantes en forma de copia, imitación, emulación, evocación, eco, etcétera. Tal y como señaló el autor citado, dichas dependencias rara vez son completas o correctas y se suelen restringir a la alusión fragmentaria de algún elemento aislado, que caracterizaría, aún a pesar de su descontextualización, al monumento que representa ${ }^{2025}$.

En relación con ello, C. Péquignot ha demostrado que muchas de las supuestas evocaciones del Santo Sepulcro de época medieval, responden, en realidad, a una mera repetición mecánica que no implicaba ninguna relación material ni simbólica con el edificio que dignificaba la supuesta tumba de Cristo ${ }^{2026}$. Se trataría acaso de un remoto recuerdo, de un prototipo que acabaría derivando en un arquetipo, tal y como expone la investigadora.

Todos los problemas expuestos hasta aquí, sobre todo aquellos relativos a las posibles lecturas simbólicas e iconológicas que se pueden realizar sobre la misma arquitectura, permiten reflexionar sobre la posibilidad de aplicar tal método al caso del paradisus compostelano y sus fuentes romanas tardoantiguas.

Unos años antes de la construcción de la catedral de Santiago de Compostela se erigía, dentro de la Marca Hispánica, una iglesia de gran importancia para la historia de

\footnotetext{
${ }^{2025}$ Ibidem, p. 26. Cuando los artífices buscaban realizar una obra que se pareciese al Santo Sepulcro, bastaba con recrear una planta centralizada, un espacio a modo de deambulatorio columnado o, en los casos más concretos, un tegurium. Mediante tales elementos pretendían aludir, casi siempre a través de un conocimiento incompleto, al mencionado recinto hierosolimitano. Un simple arco apeado en una columna entorchada, podía, por sí solo, ser una alusión al Santo Sepulcro, tal y como se ha demostrado en relación con la imagen esculpida en el tímpano de la puerta del Perdón de San Isidoro de León. Cf.: E. FERNÁNDEZ GONZÁLEZ, "El arco...”, pp. 221-242.

${ }^{2026}$ C. PÉQUIGNOT, Op. cit., pp. 119-120. Para una lectura contraria a tales planteamientos, véase: G. SIEFFERT, $O p$. cit., pp. 29-39. El autor enumera multitud de edificios de planta centralizada defendiendo una derivación directa del modelo original. Véase también: W. E. KLEINBAUER, "Charlemagne's Palace Chapel at Aachen and Its Copies", International Center of Romanesque Art, 4, 1965, pp. 2-10, en concreto, pp. 2-6. En dicho estudio se aborda el problema de las copias medievales en materia arquitectónica.
} 
la arquitectura medieval hispana. Nos referimos a la abacial de San Miguel de Cuxá ${ }^{2027}$ (fig. 375).

En relación con tal edificio, nos interesa tan sólo señalar un aspecto que consideramos fundamental a la hora de profundizar en la influencia de la Roma tardoantigua dentro de las construcciones medievales hispanas. En concreto, dentro del conjunto que hoy conservamos, destaca una construcción datada, posiblemente, de mediados del siglo $\mathrm{X}$ y que, según parece, fue adosada en época del abad Oliba a la parte occidental de la iglesia preexistente ${ }^{2028}$. La fábrica a la que nos referimos se ha venido relacionando con las labores de ampliación llevadas a cabo por el abad entre los años 1030 y 1040. Esta nueva estructura, denominada como "iglesia" de la Trinidad, se caracterizó por ser una construcción de dos niveles flanqueada por dos pórticos que, además de servirle como acceso, englobaban la construcción dentro de una estructura de mayor tamaño, formada por un patio o atrio que se interponía entre el acceso occidental al templo y la misma construcción dedicada a la Trinidad.

Tal construcción se insertaba, de una manera funcional y perfecta, dentro del proyecto preexistente, salvando el desnivel del terreno a través de diversos elementos subterráneos que permitieron la creación de un espacio inferior, abovedado y con un característico y monumental pilar central. El recinto fue dedicado, doblemente, a la Virgen y a la Trinidad, mientras que el espacio inferior pasó a denominarse "cripta del Pesebre",2029 (fig. 376).

\footnotetext{
${ }^{2027}$ Se advertirá, en las páginas siguientes, una simplificación clara, tanto de las teorías expuestas como de la bibliografía seleccionada para tratar este tema. Nos hemos decantado por tal solución teniendo en cuenta que el presente estudio no se centra en cuestiones arquitectónicas y ni tan siquiera en una lectura simbólica de dichos espacios medievales a la luz de una posible influencia clásica. Los casos seleccionados, tomados del repertorio arquitectónico tardoantiguo y medieval, pretenden, tan sólo, aportar otra serie de ejemplos que ayuden a comprender esta posible influencia romana del paradisus vaticano sobre el espacio de Compostela. Tan sólo abordaremos el edificio a través de un aspecto arquitectónico muy concreto, de ahí que sólo recojamos las aportaciones más recientes sobre el tema. Véase, por ejemplo: G. BOTO VARELA, "Topografía de los monasterios de la marca de Hispania (ca. 800-1030), Monjes y monasterios hispanos en la Alta Edad Media, Aguilar de Campoo, 2006, pp. 149-203.

${ }^{2028}$ Actualmente se piensa que fue el abad Ponce el que inició el proyecto que hoy contemplamos, seguido, tras su muerte, por el abad Garín. Se cree que las obras del templo duraron desde el año 956 hasta el 997. Vid.: Ibidem, p. 172; A. BONNERY, "Le chevet de Saint-Michel de Cuxa. Nouvelles propositions", Études Roussillonnaises, XVIII, 2000-2001, pp. 97-106 y J. CAMPS I SÒRIA e I. LORÉS I OTZET, "Le patronage dans l'art roman catalan", Les Cahiers de Saint-Michel de Cuxa, XXXVI, 2005, pp. 209-223, en particular, p. 212.

${ }^{2029}$ C. HEIZ, "Saint-Michel de Cuxà et la tradition carolingienne", De la création..., pp. 53-67, en concreto, pp. 56-59. No podemos detenernos en la profunda y compleja problemática que, tanto desde un punto de vista arquitectónico como simbólico, presenta el edificio. La estructura, formada por la rotonda inferior y la capilla centralizada superior, además de los pórticos laterales y el mismo atrio abierto, ha sido estudiada por algunos investigadores en relación con una posible deuda con las estructuras occidentales o anteiglesias, también llamadas iglesias-torre. Sobre este punto, nuestros conocimientos no permiten pronunciarnos al respecto sobre tal problemática. Sobre la estructura, véase también: P.
} 
El ejemplo nos sirve para señalar lo problemático de poder asegurar una dependencia y establecer unas relaciones seguras entre construcciones, esculturas o determinado tipo de obras plásticas antiguas, con respecto a las medievales. Para el caso concreto de la estructura de Cuxá, algunos autores, entre ellos X. Barral i Altet, han defendido una transmisión de modelos directos entre prototipos romanos paleocristianos hacia la arquitectura patrocinada por el abad Oliba ${ }^{2030}$. Sus teorías han permitido englobar su morfología y su planta dentro de un grupo de edificios catalanes con características parecidas como, por ejemplo, los de San Miguel de la Pobla de Lillet, la capilla del castillo de Yuca, la capilla de Saldes, San Pedro el Gros de Cervera, Santiago de Vilanova, el Santo Sepulcro de Olèrdola o San Sebastián del Sull ${ }^{2031}$.

Tales casos ejemplifican bien lo problemático de poder aplicar, dentro de la "iconografía arquitectónica", el establecimiento de relaciones tan sólo basadas en criterios formales, antes que documentales, textuales o simbólicos. Si la estructura de San Miguel de Cuxa puede estar relacionada con el Panteón de Roma, uno de los edificios romanos más importantes conservados actualmente, es algo que la documentación y las fuentes no se han encargado de señalar. Su derivación arquitectural con respecto a la edilicia antigua se ha defendido a través de su marcado carácter centralizado, además de la dedicación de tal estructura a la Virgen María que, como es sabido, era también la que ostentó durante los siglos del medievo la construcción romana $^{2032}$.

PONSICH, "La pensée symbolique et les édifices de Cuxa du X $\mathrm{X}^{\mathrm{e}}$ au XIII $\mathrm{e}^{\mathrm{e}}$ siècle", Les Cahiers de SaintMichel de Cuxa, 12, 1981, pp. 7-27; B. UHDE-STAHL, "La chapelle circulaire de Saint Michel de Cuxà", Cahiers de Civilisation Médiévale, XX, 80, 1977, pp. 339-351; C. HEITZ, "Beata Maria Rotunda. À propos de la rotonde occidentale de Saint Michel de Cuixà", Études Roussillonnaises offertes à Pierre Ponsich, Perpinyà, 1987, pp. 273-277 e I. G. BANGO TORVISO, "La part oriental dels temples de l'abat-bisbe Oliba", Quaderns d'estudis Medievals, 22-23, 1988, pp. 51-66. Se abordó el tema, en relación con la producción manuscrita y la ilustración del libro en: A. ORRIOLS ALSINA, "Les imatges preliminars dels evangelis de Cuixà", Locvs amoenvs, 2, 1996, pp. 31-46.

${ }^{2030}$ X. BARRAL I ALTET, "Du Panthéon de Rome à Sainte-Marie la Rotonde de Vic: la transmission d'un modèle d'architecture mariale au début du $\mathrm{XI}^{\mathrm{e}}$ siècle et la politique "romaine" de l'abbé-évêque Oliba", Les Cahiers de Saint-Michel de Cuxa, XXXVII, 2006, pp. 63-75. Se centra, preferentemente, en la estructura centralizada de Vic, dedicada a Santa María. Fue construida delante de la catedral de San Pedro y destruida en el siglo XVIII. Se integraba dentro un conjunto episcopal formado por tres edificios, siguiendo una tradición atestiguada entre los siglos IX y X. El autor señala la función cementerial que tuvo la iglesia, llamada La Rotonda. En este caso particular se trata de un recinto con tan sólo una pequeña cripta en la parte central, lo que, además de todo lo dicho, ha permitido relacionarlo con la construcción dedicada a la Trinidad y la cripta del Pesebre de Cuxa.

${ }^{2031}$ Ibidem, p. 69.

2032 En este sentido, son bien significativas las relaciones establecidas por C. Heitz. Para el autor, la estructura de Cuxa dependería de los modelos carolingios, en concreto, de algunas partes de edificios tan señeros como Saint-Sauveur de Riquier. Por ejemplo, para la parte inferior del recinto de Cuxa establece ciertas conexiones con la cripta de San Miguel de Fulda donde, nuevamente, aparece este machón central 
El problema de poder definir la dependencia directa de ciertos espacios antiguos y algunas estructuras medievales, fue señalado en su día por C. Heitz en relación con esta "iglesia" occidental de Cuxa. Para el autor, más que una relación estrecha con la estructura pagana de Roma, la dedicación inferior al Pesebre es una clara referencia a Tierra Santa. Concretamente, su configuración en torno a un pilar central y su abovedamiento anular estarían emparentados con las soluciones arquitectónicas utilizadas en la misma iglesia del Santo Sepulcro y la rotonda de la Anástasis ${ }^{2033}$.

La problemática a la hora de utilizar este método para poder realizar una lectura simbólica de la arquitectura se muestra, más evidente aún, si tenemos en cuenta que, además de todo lo argumentado en las páginas anteriores, a la lista de edificios romanos que pudieron inspirar la fórmula arquitectónica de Cuxa, debemos sumar el caso de la cripta del Pesebre ubicada bajo el altar de la basílica romana de Santa Maria Maggiore y que, a su vez, evocaba el praesepe de la ciudad de Belén ${ }^{2034}$ (fig. 377).

"C'est vers ce modèle que regardait l'évêque Oliba quand il décida de construire la Rotonda de Vic. D'autres monuments de l'Antiquité, ou de l'Antiquité tardive, de plan centré, avaient au cours des siècles été dédiés à la Vierge Marie et avaient pris le nom de Sainte-Marie-de-la-Rotonde, comme le mausolée de Théodoric à Ravenne, par exemple (...) Autour de l'an Mil, cette tendance représente autant le prestige des souvenirs concrets de l'Antiquité tardive romaine qu'une affirmation d'identité collective. C'est surtout une orientation religieuse vers la Rome papale, symbole d'un pouvoir temporel et religieux, qui est à la fois un choix politique et idéologique ${ }^{\text {2035. }}$

que sirve, a través de un bello capitel jónico, de apeo a la bóveda. Vid.: C. HEIZ, "Saint-Michel de Cuxà....", p. 62.

${ }^{2033}$ Ibidem pp. 63-63. El investigador relaciona las soluciones seguidas en el Santo Sepulcro con otros grandes edificios medievales del Occidente, como por ejemplo la Beata Maria Rotunda de Dijon, de la que, a su vez, hace depender la estructura de la Trinidad de San Miguel de Cuxa. Sobre la arquitectura de San Benigno de Dijon, véase, además: C. HEITZ., "Un monument à la charnière des temps: SaintBénigne de Dijon", La France pré-romane. Archéologie et architecture religieuse du Haut Moyen Age du IV à l'an Mille, Paris, 1987, pp. 241-249 y C. MARINO MALONE, "Saint-Bénigne de Dijon: l'espace occidental et la contre-abside de l'an mil", Avant-nef..., pp. 424-437. Por su parte, X. Barral prefiere conectar la estructura de Cuxa con el Panteón de Roma antes que con el edificio de Jerusalén. Cf.: X. BARRAL I ALTET, "Du Panthéon de Rome...", p. 71.

${ }^{2034}$ Son muchos los investigadores que han explicado la parte inferior del recinto de Oliba en Cuxa a través de la estructura construida en la basílica romana. Entre ellos, véase: Ibidem, p. 71.

${ }^{2035}$ C. HEITZ, "Beata Maria Rotunda...", pp. 273-277; X. BARRAL I ALTET, "Du Panthéon de Rome...", p. 72 y A. ORRIOLS ALSINA, "Les imatges...", concretamente, p. 44. Esta última autora alude, nuevamente, al concepto utilizado por Krautheimer de "iconología de la arquitectura" a la hora de analizar el ejemplo arquitectónico que estamos estudiando. 
Resulta complejo poder llegar a definir, teniendo en cuenta el estado actual de las investigaciones, el grado de incidencia exacta que los monumentos antiguos y paleocristianos ejercieron sobre la doble estructura de Cuxa. Los dos viajes documentados que realizó el abad-obispo Oliba a Roma parecen poder apoyar dichas hipótesis.

Sin embargo, la cuestión es difícil de resolver en este sentido. Los grandes centros de peregrinación cristianos, de Oriente a Occidente, asentaron sus bases ideológicas y materiales sobre los cimientos del mundo pagano. Los santuarios erigidos en los primeros siglos, especialmente los constantinianos, se mostraban plagados de citas a aquel mundo clásico del que no se podían liberar. Las categorías de dependencia de los posteriores monumentos medievales con respecto a estos, son difíciles de establecer. A todo ello se suma lo complejo que resulta poder llegar a perfilar si la intención simbólica de los mismos también debe entenderse a través de esta supuesta preferencia con respecto al pasado.

Hacer derivar estos monumentos centralizados de época medieval justificando un conocimiento por parte de los arquitectos románicos de la arquitectura romana y, en concreto, la del Panteón de Roma, es una hipótesis sugestiva pero complicada. Las relaciones constatadas entre ambos casos son de largo alcance. Ambos monumentos comparten un horizonte común aún inmerso en la arquitectura de la Antigüedad, pero sin la necesidad de un contacto estrecho e íntimo entre monumentos y artistas.

Las fórmulas, originales en un primer momento, acabaron por convertirse en verdaderos arquetipos que, aún poseyendo profundos simbolismos, estos no pasaron de ser, en la mayoría de los casos, meros recuerdos de los monumentos que los inspiraron.

Son muchas las deudas que la arquitectura y, el arte medieval en general, muestran respecto a los grandes monumentos del pasado pagano y cristiano. Pensamos en ejemplos tan importantes como el de San Pedro del Vaticano que, con su paradisus, acabaría por generar un modelo arquitectónico digno de ser imitado y copiado, en mayor o menor escala y con los recursos propios de cada caso concreto.

Con todo, en estos momentos nos encontramos bien lejos del problema relativo al espacio denominado "paraíso" en Compostela. Sin confirmar, en ningún caso, una copia o un parentesco directo entre la gigantesca estructura vaticana y el espacio materializado en la Galicia de finales del siglo XI, pensamos en la posibilidad de afirmar la presencia de una serie de ecos en el recinto urbanístico románico. A pesar de estar ante un reducido área con funciones más vinculadas a la actividad comercial que a 
la espiritual, debemos someter dicha obra a una lectura desarrollada bajo los parámetros del método usado para los análisis de la "iconología arquitectónica".

El mismo escenario al que se abría el paradisus de Santiago de Compostela, más allá de los meros elementos urbanísticos, aparecía dominado por la puerta del brazo norte, la de Francia. Tal fachada presentaba en su articulación y composición arquitectónica una serie de elementos que permitirían, con mayor seguridad que en lo urbanístico, poder insinuar una hipotética relación entre el edificio romano vaticano de época constantiniana y este emblemático templo románico levantado en suelo hispano.

Nos referimos, concretamente, a las conocidas columnas helicoidales que, en su día, flanqueaban el acceso al recinto que custodiaba la tumba del Apóstol. Ellas mismas, indiscutiblemente apegadas a los modelos romanos y aún a pesar de su actual descontextualización, hablan de posibles relaciones entre ambas obras y periodos cronológicos, justificables a través de su misma conservación material que, al fin y al cabo, son el documento más fiable y verídico que nos permite hablar de ciertas resonancias antiguas en el recinto del paradisus compostelano. 


\section{LA COLUMNA HELICOIDAL EN LA CATEDRAL DE SANTIAGO.}

La reciente aparición de un plano conservado en el Archivo de la Catedral de Santiago en el que se dibujó, de manera bien definida, la cabecera y el transepto del templo, ha permitido poder conocer con mayor exactitud la forma que tenían algunas estructuras antes de las reformas barrocas ${ }^{2036}$ (fig. 372). En concreto, nos referimos a la nueva visión que, gracias al hallazgo, se puede tener de la desaparecida Porta Francigena, del atrio o paradisus y de otra serie de dependencias relacionadas con ambas estructuras $^{2037}$.

Sabemos que, según diseñara en su momento el arquitecto Simón Rodríguez (1697-1752), la fachada debía presentar, en cada portal, tres pares de soportes. La separación de dichos vanos se realizó a través de un contrafuerte estructural que marca el eje medio de la portada, reduciendo el radio de las arquivoltas exteriores ${ }^{2038}$. Sin embargo es, sin duda, la posición de las columnas interiores lo que más ha sorprendido. Se colocaron pareadas formando cuatro grupos de un total de ocho columnas ${ }^{2039}$.

En la actualidad, se tiende a considerar que tales columnas deben ser las que hoy se conservan en el Museo de la Catedral santiaguesa. Se trata de una serie de fustes de buena calidad material y escultórica, que han recibido gran atención por parte de la historiografía artística medieval. Ello se explica, no sólo a través de su rara descontextualización con respecto al lugar que ocuparon originariamente dentro del recinto catedralicio sino, sobre todo, por la bella ejecución con la que fueron realizadas, su compleja iconografía y el mármol en el que fueron esculpidas. El profesor J. Yarza llegó a escribir, en su día, en relación con dichas piezas: "nunca Toulouse tuvo nada semejante", aludiendo, claramente, a la calidad máxima que presentan, incluso dentro de las artes plásticas del románico europeo ${ }^{2040}$.

\footnotetext{
${ }^{2036}$ Santiago de Compostela, Archivo de la Catedral, Jurisdicción del Cabildo. Pleito con el cura de la Corticela, leg. 285, fol. 1.

${ }^{2037}$ El plano fue publicado por primera vez en: A. FERNÁNDEZ GONZÁLEZ, "Un viejo plano olvidado...”, pp. 701-742, concretamente, pp. 717-719.

${ }^{2038}$ Ibidem, p. 117.

${ }^{2039}$ Ibidem, p. 719. El autor señala lo extraño de este tipo de disposición pareada dentro de la arquitectura románica gallega, aludiendo, tan sólo, al ejemplo de la portada románica de Santa María de Cambre. La solución, desde un punto de vista formal, era conocida dentro de la arquitectura prerrománica gallega. Salvando las distancias, recuérdense, por ejemplo, las columnas pareadas que dan paso a la cabecera de Santa Comba de Bande, a través de cuatro bellos fustes romanos de mármol expoliados. Así mismo, también se localizan fórmulas parecidas, ya en el ámbito asturiano, dentro de la iglesia de Santa Cristina de Lena o en la capilla central de la Colegiata de Teverga, esta última, de cronología románica.

${ }^{2040}$ J. YARZA LUACES, “Artes figurativas románicas...”, p. 70.
} 
En los primeros estudios dedicados al estudio de la escultura del edificio gallego, se dudó sobre su origen primitivo, aunque investigadores de la importancia de G. Gaillard defendieron la posibilidad de que hubieran sido esculpidas para formar parte de la fachada occidental, supuestamente pensada dentro del proyecto original del templo ${ }^{2041}$ (figs. 378, 379, 380, 381).

El problema de estas piezas reside en la inseguridad a la hora de poder explicar las complejas imágenes que recorren, insertas en bandas helicoidales historiadas en alternancia con otras lisas, de arriba hacia abajo los fustes. Algunos autores, como M. Gómez-Moreno, insistieron en las razones decorativas para explicar su inclusión dentro del programa general de la fachada, aunque otros investigadores, más recientes, han negado, rotundamente, la posibilidad de su uso con un simple valor ornamental ${ }^{2042}$.

También parece que, otra vez, estas piezas marmóreas pudieron alternarse con otras realizadas en granito, siguiendo una tradición bien documentada desde la Antigüedad, tal y como hemos señalado reiteradamente ${ }^{2043}$.

En relación con el tema que venimos desarrollando, nos interesa destacar la dependencia y relación que se ha establecido entre dichos fustes y diversas obras de la Antigüedad romana, en concreto, de la tardoantiguedad. Muchos han sido los estudiosos que han aceptado una clara preservación, en estas piezas románicas, de una serie de formas e iconografías típicas del ambiente romano paleocristiano.

Las famosas columnas de fustes helicoidales colocadas, hipotéticamente, por el emperador Constantino en el área martirial vaticana, parecen ser el origen remoto que explicaría su inclusión dentro del programa escultórico de la basílica del Apóstol enterrado en Hispania ${ }^{2044}$.

${ }^{2041}$ G. GAILLARD, Les débuts de la sculpture..., pp. 218-219. El autor defendió su pertenencia a la primitiva fachada occidental, según él, destruida. No volveremos a insistir sobre los problemas que ha planteado la descripción realizada por el autor del Codex Calixtinus y las diferentes teorías vertidas en relación con dicho cierre a occidente. La bibliografía dedicada a las piezas es relativamente densa. Véase: A. LÓPEZ FERREIRO, El Pórtico de la Gloría, Platerías y el primitivo Altar Mayor, Santiago de Compostela, 1975, pp. 107-111; S. MORALEJO ÁLVAREZ, "La primitiva fachada...", pp. 42-45; ID., "Column shaft decorated with putti gathering grapes", The Art of the Medieval..., ficha catalográfica 92, pp. 212-214; M. DURLIAT, "L'apparition du grand...", p. 22; J. YARZA LUACES, "Fustes entorchados de la Azabachería", Galicia no tempo, Santiago de Compostela, 1991, ficha catalográfica 77, p. 187; M. A. CASTIÑEIRAS GONZÁLEZ, "Fragmento de fuste con putti vendimiadores", Luces de Peregrinación, Santiago de Compostela, 2004, pp. 150-154; ID., Atlas de la catedral..., (edición digital); ID., "La catedral románica: tipología...”, p. 83; ID., El calendario medieval..., p. 204, nota 346; ID., "La meta del camino...", p. 233 e ID., "Roma e il programma reformatore...", p. 218.

2042 J. YARZA LUACES, "Fustes entorchados...", p. 187.

${ }^{2043}$ G. GAILLARD, Les débuts de la sculpture..., p. 218. El autor ya incidió, en su día, sobre tal aspecto.

${ }^{2044}$ S. MORALEJO ÁLVAREZ, "Column shaft...", p. 212. Se retomaron tales filiaciones con el ambiente artístico de Roma, concretándolas, aún más, en: M. A. CASTIÑEIRAS GONZÁLEZ, "La 
Nuevamente debemos recurrir al Liber Pontificalis para poder entender las razones que llevaron a la colocación, sobre el lugar en el que, supuestamente, descansaban los restos de San Pedro, de esta serie de columnas que habrían de tener una vital importancia para la plástica de los siglos medievales y de la época moderna.

Exactamente, el texto dice:

“(...) fecit in urbe Roma ecclesiam in praedium cuiusdam presbiteri sui, qui cognominabatur Equitius, quem titulum Romanum constituit, iuxta termas Domitianas, qui usque in hodiernum diem appellatur titulus Equitii, ubi et haec dona constituit:... domum in urbe cum balneum, in Sicinini regione...; hortum intra urbem Roman, in regione ad Duo Amantes...; domum in regione Orfea, intra urbe- Huius temnporis fecit Constantinianam, ubi posuit ista dona:... cameram basilicae ex auro trimita in longum et in latum... Fontem sanctus, ubi baptizatus est Augustus Constantinus, ex lapide porfyretico et ex ovni parte coopertum intrinsecus et foris et desuper et quantum aquam continet ex argento purissimo... In medio fontis baptisterii agnum aurem fundentem aquam...; in laeva agni beatum Ionhannem Baptistam ex argento,...cervos argentos VII. Fundentes aquam -fecit basilicam beato Petro apostolo in templum Apollinis, cuius loculum cum corpus sancti Petri... recondit... Et exornavit supra columnis purfyreticis et alias columnas vitineas, quas de Graecias perduxit. Fecit autem et cameram basilicae ex trimma auri fulgentem- fecit... basilicam beato Paulo apostolo ex suggestione Silvestri episcopi-fecit... basilicam in palatio Sessoriano... ubi et nomem ecclesiae dedicavit, quae cognominatur usque in hodiernum diem Hierusalem- fecit basilicam sanctae martyris Agnae ex rogatu filiae suae et baptisterium, 2045 .

La serie de obras que describe la fuente fueron realizadas por el papa Silvestre I (314-335) y el mismo emperador Constantino (306-337). Dentro de tal actuación, se llevó a cabo la destrucción de toda una serie de tumbas que permanecían en la necrópolis pagana. Tan sólo el pequeño edículo en el que se creía que se conservaban los restos de San Pedro se salvo de las labores de demolición ${ }^{2046}$. Sobre dicho espacio, denominado posteriormente por la documentación como domus regalis, fue levantada la

catedral románica: tipología...”, p. 66 y M. A. CASTIÑEIRAS GONZÁLEZ, "Fragmento de fuste...”, p. 150.

${ }^{2045}$ R. VALENTINI y G. ZUCCHETI, “Il Liber Pontificalis...”, pp. 230-232. Las columnas a las que se refiere el texto, según E. Brandemburg, se conservan, actualmente, en los nichos colocados sobre los cuatro enormes pilares torales del crucero de la basílica de San Pedro del Vaticano. Cf.: E. BRANDEMBURG, Le prime chiese..., pp. 96-97.

${ }^{2046}$ F. W. DEICHMANN, Archeologia cristiana, Darmstadt, 1993, en concreto, sobre el edículo, p. 42. 
memoriae que otras fuentes han aclarado que se realizó con mármol blanco. Dicha estructura, colocada sobre la supuesta tumba del Apóstol, es la que más nos interesa. Alrededor de ella se colocaron las famosas columnas expoliadas y transportadas desde Grecia a la ciudad de Roma que tenían, como última función, definir, dignificar y embellecer el antiguo tropaion $^{2047}$ (fig. 382).

En conjunto y siguiendo la definición dada por M. D'Onofrio, se trataría de un "relicario" delimitado por cuatro columnas de pórfido que tenían como característica fundamental presentar una forma helicoidal decorada, íntegramente, a través de una iconografía de putti vendimiadores ${ }^{2048}$ (fig. 383). En relación con ello, creemos que es fundamental conocer estos datos para poder entender la fortuna que la columna torsa con el tema de vendimia habría de tener en los siglos posteriores y su perdurabilidad, no sólo en las piezas compostelanas, sino dentro del arte medieval en general.

En este sentido, una de las imágenes más interesantes que refleja de manera, más o menos verídica, el aspecto que dicho espacio debió tener en tiempos del emperador Constantino, y que sirve, de igual manera, para poder perfilar los orígenes de la iconografía de los fustes hispanos que analizamos, es la denominada arqueta de Samagher $^{2049}$ (figs. 384 y 385).

La imagen reproduce el aspecto de la confessio vaticana alrededor del año 440, tal y como ha señalado V. Lanzani donde, el sector central, aparece delimitado por cuatro columnas tortili que monumentalizaban el edículo de la memoria apostólica.

\footnotetext{
${ }^{2047}$ M. D'ONOFRIO, “La basilica...”, pp. 13-14; P. SILVAN, “L'architettura della basilica...”, pp. 250252 y V. LANZANI, "Ubi Petrus...", p. 37.

${ }^{2048}$ Las columnas medían 4, $75 \mathrm{~m}$ y se elevaban sobre una base de mármol frigio que, junto con las piezas de pórfido, darían una sensación de verdadero esplendor al recinto. Cf.: V. LANZANI, "Ubi Petrus...", p. 38. Sobre la decoración del resto del edificio, vid.: H. L. KESSLER, "La decorazione della basilica...", pp. 263-270 y L. FAEDO, Op. cit., p. 63.

${ }^{2049} \mathrm{Se}$ ha prestado especial atención a la pieza por su gran desarrollo iconográfico. Entre las muchas publicaciones que la han abordado, una de las más completas es la recogida en: T. BUDDENSIEG, "Le coffret en ivoire de Pola, Saint-Pierre et le Latran", Cahiers Archéologiques, X, 1959, pp. 157-195. También véase: A. TRIVELLONE, "Capsella di Samagher", Romeo \& ..., ficha catalográfica 256, p. 436. La pieza ebúrnea apareció, en estado fragmentado, entre las ruinas de la iglesia paleocristiana de San Ermagora, cerca de la localidad de Pola (Istria). Actualmente, se conserva en Venezia, Museo Archeologico, y se ha datado en torno a la segunda mitad del siglo V.

La arqueta desarrolla un programa iconográfico de gran complejidad. Además de la parte frontal, que ha recibido todo tipo de interpretaciones en relación con la presencia de la pareja de donantes ante el lugar funerario, cuenta con otras imágenes en las restantes caras. La parte superior muestra el tema de la traditio legis, deudor, en última instancia, de la decoración que presentó durante estos momentos el ábside la basílica vaticana. La parte posterior ofrece el tema iconográfico de la Etimasia, acompañado de algunas figuras apostólicas. La cara derecha, una de las más controvertidas, ofrece la imagen de un pequeño edículo poligonal entre columnas, que ha sido interpretado como el edículo del Santo Sepulcro, la imagen de la estructura que protegía la misma fuente del paradisus del atrio vaticano o, incluso, ha sido visto como el baptisterio de San Juan de Letrán.
} 
Dichos elementos, servían, además, de apoyo para una estructura arquitrabada que, a modo de baldaquino, enmarcaba la parte central de la confessio y se expandía hacia los laterales. Allí dos nuevas columnas, de igual factura, servían de apeo para toda la estructura. A partir de este momento nacía uno de los grandes iconos del arte occidental, que habría de impactar, de manera especial, sobre los artistas de la Edad Media y sobre otros de etapas posteriores ${ }^{2050}$.

La arqueta de Samagher, conservada en el Museo Arqueológico de Venecia, y otra serie de ejemplos han permitido, a diversos autores, llevar a cabo una reconstrucción del lugar durante la época constantiniana, centrándose, sobre todo, en la disposición de las columnas ${ }^{2051}$ (fig. 386).

Aunque parece factible que las causas que llevaron a realizar esta expoliación durante un primer momento fueran de tipo funcional, con el tiempo, tales piezas acabaron adquiriendo otra serie de connotaciones, entre las que se dio prioridad al valor material que poseían, su calidad técnica y, sobre todo, su apropiada iconografía ${ }^{2052}$.

Resta, por tanto, poder explicar cuales fueron las causas que llevaron a la reutilización de estas obras en un lugar tan importante para la cristiandad durante estos momentos y, sobre todo, intentar esclarecer el papel que jugaron en la difusión de este tipo de iconografía que, como vemos, perduraría hasta la etapa medieval.

En la actualidad, son muchos los problemas que plantean tales esculturas. Se duda sobre el momento exacto en el que el emperador Constantino mandó traerlas, de si se trataba, en realidad, de un expolio tomando de una construcción pagana o ya cristiana, así como de su función exacta en el recinto. Su iconografía, también presenta ciertas incertidumbres pues, tal y como veremos, durante estos primeros siglos del

\footnotetext{
${ }^{2050}$ No sólo el baldaquino de bronce realizado por G. L. Bernini para la basílica actual de San Pedro del Vaticano está influenciado por el modelo constantiniano. Son muchos otros los monumentos que siguieron tal imagen a la hora de engrandecer y monumentalizar los espacios funerarios en los que se conservaba el cuerpo o el recuerdo de algún santo cristiano.

La catedral de Santiago de Compostela parece reflejar un fenómeno paralelo en este sentido, pues también en época barroca las columnas torsas con fustes "habitados" por putti vendimiadores fueron el tema elegido para monumentalizar el lugar donde se conservaban los restos del Apóstol. Se ha insistido sobre este aspecto en: M. TAÍN GUZMÁN, "Fuentes romanas gráficas y literarias del baldaquino y la pérgola de la catedral de Santiago", Archivo Español de Arte, LXXIX, 314, 2006, pp. 139-155. El especialista se centra en la época barroca, pero teniendo en cuenta las obras medievales como posibles fuentes de inspiración.

${ }^{2051}$ G. H. FORSTH, Op. cit., en particular, pp. 62-63. Los restantes trabajos utilizados para realizar este estudio, también reproducen las recreaciones realizadas en la década de los años cincuenta y sesenta. Cf.: P. SILVAN, "L'architettura della basilica...", pp. 255-256 y V. LANZANI, "Ubi Petrus...", p. 38 у p. 43.

${ }^{2052}$ J. M. C. TOYNBEE y J. B. WARD PERKINS, The Shrine of S. Peter and the Vatican Excavations, London, 1956, en concreto, pp. 203-210.
} 
cristianismo la imagen de los putti se debatió entre ciertas interpretaciones ambiguas, que oscilarían entre lo pagano y lo propiamente cristiano.

Conocemos, claramente, sin necesidad de indagar exhaustivamente, ejemplos en los que tal iconografía fue utilizada dentro de recintos funerarios paganos. Las escenas de vendimiadores decoraron gran cantidad de monumentos de toda índole, aunque es cierto que se han conservado, en mayor número, aquellos con connotaciones funerarias $^{2053}$.

El mejor ejemplo a este respecto lo ofrecen los magníficos relieves que, en su día, configuraran la decoración de la llamada tumba de los Haterii (fig. 387). Creemos que esta pieza pagana puede ofrecer buenas claves para poder interpretar correctamente la transmisión del tema desde el ámbito pagano al cristiano y, de una manera más extensa, de la Antigüedad a los siglos del románico.

El monumento de los Haterii fue construido en la vía Labicana que salía desde Roma hasta la localidad de Centocelle y, actualmente, todos sus relieves decorativos han pasado a formar parte de la decoración lapidaria del Museo Lateranense. De entre ellos, son cuatro las esculturas que han recibido mayor atención, pues, además, presentan una narración iconográfica ciertamente unitaria, aunque para nuestro objetivo, tan sólo uno ofrece ciertas claves en este sentido ${ }^{2054}$.

Se trata de una de las piezas de mayor tamaño, en la que se esculpió la imagen micro-arquitectónica de un templo tetrástilo corintio, rematado por un frontón en la fachada. Dicha construcción ha hecho pensar que la pieza refleja las labores de comitencia de alguno de los difuntos en relación con la erección material del monumento funerario. La figuración de una hipotética grúa lígnea o máquina elevadora de cargas, presente en este relieve, parece ligada a las labores de construcción del templo. Entre otros muchos detalles iconográficos, imposibles de comentar en profundidad, cabe desatacar la prolija minuciosidad que el escultor ha utilizado para

\footnotetext{
${ }^{2053}$ H. WALTER, La colonne ciselée dans la Gaule romaine, Paris, 1970. La autora lleva a cabo un análisis, a modo de catálogo, de todas aquellas piezas de cronología romana, destacables por su calidad e iconografía. Del mismo modo, para una visión simbólica en relación con la utilización de la columna salomónica o torsa, con ejemplos tomados de diversas regiones y culturas, véase: V. CHAPOT, La colonne torse et le décor en hélice dans l'art antique, Paris, 1907.

${ }^{2054}$ No podemos detenernos en este trabajo sobre la hipotética reconstrucción arquitectónica del edificio y la distribución de las piezas en el mismo. Los relieves presentan un interés a la hora de exaltar y, hasta glorificar, todas aquellas acciones que los titulares de la tumba había realizado en la vida terrena. Dicha glorificación acaba por convertirse en una apotheosis de uno de los miembros de dicha familia. Cf.: G. AMBROSETTI, "Haterii, Monumento degli", Enciclopedia dell'arte antica..., vol. III, 1960, pp. 11121115 y J. PENNY SMALL, The parallel worlds of classical art and text, Cambridge, 2003, en concreto, pp. 128-129.
} 
representar la decoración misma del edificio donde, pilastras, muros, frisos, dinteles, puertas, entablamentos y columnas, entre otros, han sido captados con total atención ${ }^{2055}$.

Sobre la construcción se representó otro ambiente presidido por el propio difunto titular, reclinado sobre la kliné, siguiendo modelos bien conocidos dentro de esta imaginería de tipo fúnebre ${ }^{2056}$.

Sin embargo, a pesar de la profusa cantidad de imágenes presentes en la obra, tan sólo nos detendremos en las cuatro columnas colocadas en el frente del templo (fig. 388). Se trata de cuatro piezas rematadas por otros tantos capiteles corintios en los que reposan cuatro águilas. Sobre ellas y siguiendo unas soluciones ilusionísticas típicas de la escultura de tiempos flavios, reposa toda la estructura del entablamento del edificio y el frontón. Los fustes se han decorado con una serie de bandas helicoidales lisas que generan el espacio suficiente para asumir diversas escenas de "erotes" vendimiadores $^{2057}$.

Creemos que, a pesar de tratarse a primera vista de un mero detalle anecdótico dentro de la gran amalgama de imágenes, la misma pieza y sus elementos, demuestran un fuerte contenido simbólico y la necesidad de interpretar cada uno de estos detalles. En este sentido, los relieves juegan un papel primordial y demuestran la importancia que tuvo la columna historiada de tema dionisiaco ya dentro de los accesos a recintos funerarios de época romana pagana ${ }^{2058}$.

\footnotetext{
${ }^{2055}$ Muy importante es la representación inferior, esculpida en el mismo basamento sobre el que se eleva el templo. Se trata de la imagen de la puerta entreabierta, con las clásicas hojas fundidas en bronce y decoradas con cabezas felinas, auténtico símbolo de tránsito y materialización del mundo de ultratumba. Flanqueando dicha puerta, como era frecuente en los ambientes funerarios, fue colocada la imagen de Hércules, desnudo, presenciando el tránsito hacia el otro mundo.

Entre otros detalles, nos parecen importantes las imágenes de "erotes" desnudos sosteniendo guirnaldas vegetales, así como los candelieri que recorren frisos y pilastras. Se ha puesto de manifiesto, en este sentido, la fundamental presencia del retrato en este relieve pues, además de la imago del difunto, otras efigies fueron representadas en el templo, entre ellas, la de la mujer velada colocada en el frontón, así como las de los niños en busto inscritos en clípeos, quizás veneras, que se muestran entre los espacios libres generados por las pilastras. Véase: G. AMBROSETTI, "Haterii, Monumento...", p. 1114; J. ARCE, Funus imperatorum..., pp. 80-81 y pp. 131-140 e ID., "Imperatori divinizzati...", pp. 244-248.

${ }^{2056}$ Ibidem, p. 29. Así aparece en el denominado como relieve de Amiternum, hoy en Aquilea, Museo Archeologico. Se trata de una pieza de la primera mitad del siglo I a. de C. donde el difunto, vivo y reclinado o, quizás, una imago sustitutoria del mismo, es transportado sobre el lecho fúnebre.

${ }^{2057}$ V. CHAPOT, Op. cit., pp. 75-76. El autor recoge el ejemplo de este relieve, destacando la decoración vegetal de las pequeñas columnas.

${ }^{2058}$ F. CABROL y H. LECLERCQ, voz "Amours", Dictionnaire..., vol. I-II, col. 1612. Los autores escriben: "la antigüedad pagana había dado durante mucho tiempo un sentido fúnebre a las escenas de vendimia (...) Los amores clásicos se transforman en fieles, sobre todo a partir del siglo IV, cuando los cristianos introducen escenas de vendimias hechas por erotes".
} 
Otros ejemplos similares, localizados esta vez en algunas pinturas pompeyanas de época de Nerón, permiten atestiguar una difusión de dicha iconografía dentro de los ambientes funerarios paganos construidos en torno al siglo II d. de C.

Con todo, creemos que las palabras de G. Ambrosetti, en relación con las pequeñas columnas de la escultura, son muy significativas al respecto. La técnica que ofrecen recuerda la labor de los trabajos orfebres ${ }^{2059}$ que, junto con el naturalismo que presentan sus figuras, las convierten en un unicum $^{2060}$.

El arte pagano, origen del motivo, ofreció pronto su influencia sobre las primeras obras cristianas. El mausoleo de Santa Constanza de Roma, tantas veces mencionado, permite asegurar tal afirmación. Durante la época moderna el edificio fue conocido como el templo de Baco, debido a la decoración presente en los mosaicos del conjunto, además de la que mostraba el propio sarcófago de pórfido de Constantina, nuevamente decorado con el tema de los "erotes" vendimiadores. A pesar de ser una pieza totalmente cristiana, los festones y las máscaras dionisíacas de la pieza, recuerdan las fuentes paganas de todo el recinto ${ }^{2061}$.

A. Grabar defendió hace tiempo el origen del motivo y su continuidad durante los siglos del medievo, donde los putti eran representados en escenas desarrollando actividades típicas de los adultos, como vendimiar, cazar, escenas circenses o, incluso, de tipo religioso ${ }^{2062}$. El hecho de que dentro del mismo recinto vaticano, fuera hallado el conocido mausoleo pagano de la familia de los Julios, con una decoración musiva de temática vegetal de este tipo, es bien significativo al respecto. El mosaico ha presentado numerosos problemas de interpretación, debido a su marcada ambigüedad que se debate entre lo pagano y lo cristino. La supuesta figura de Helios, para otros Cristo, asciende a los cielos en su carro sobre un fondo de hojas de vid y racimos de uvas, incidiendo en lo problemático del paso de una tradición pagana a otra cristiana ${ }^{2063}$.

\footnotetext{
2059 Adelantamos que este tipo de pequeñas columnas, presentes en el sarcófago de Iulius Basso y otros ejemplos similares, han sido puestas en relación con las piezas conservadas en Santiago de Compostela. Ya en su día se señaló también las conexiones que las esculturas compostelanas mantenían con las artes suntuarias. Vid.: S. MORALEJO ÁLVAREZ, “Column shaft...”, p. 214.

${ }_{2060}$ Este relieve de los Haterii también ha sido puesto en relación con las columnas conservadas en Santiago de Compostela por otros autores. Véase al respecto: M. A. CASTIÑEIRAS GONZÁLEZ, "Roma e il programma rifomatore...", p. 218 e ID., El calendario medieval..., p. 203. El especialista insiste en la importancia del tema de la vendimia dentro de las obras patrocinadas por la aristocracia tardorromana, sobre todo, en la decoración de sarcófagos. El tema recreaba, de manera sintética, el ideal de la vida campestre de la Edad de Oro virgiliana.

${ }^{2061}$ J. BECKWITH, Arte paleocristiano..., pp. 33-35.

${ }^{2062}$ A. GRABAR, Las vías de la creación..., p. 41.

${ }^{2063}$ M. A. CRIPPA, J. RIES y M. ZIBAWI, El arte paleocristiano. Visión y espacio de los orígenes a Bizancio, Barcelona-Madrid, 1998, en concreto, p. 165 y M. P. GARCÍA-GELABERT, Op. cit., pp. 458-
} 
En relación con lo afirmado hasta el momento, el siguiente eslabón en la transmisión de tal iconografía, lo ofrece el denominado sarcófago de Iunius Basso, Prafectus Urbi, muerto el 24 de agosto del año $359^{2064}$ (fig. 389).

La pieza funeraria, tallada en mármol de Paros, presenta un frente altamente decorado a través de dos registros de cinco escenas cada uno, separados mediante columnas:

“minuciosamente decoradas. Unos genios de la vendimia aparecen sobre los nichos que cobijan las dos epifanías centrales (...) ideal de belleza propio de los romanos (...) los cánones del clasicismo triunfan" 2065 .

La iconografía presente en estas columnas, muy similar, desde un punto de vista formal, a la que acabamos de describir dentro del relieve de los Haterii, se muestra aquí ya dentro de un contexto cristiano. No sólo por su hallazgo en el mes de abril del año 1595 en una cripta próxima a la confessio vaticana, sino porqué la iconografía cristiana así lo demuestra.

F. Cabrol y H. Leclercq ya incluyeron la pieza en un hipotético movimiento de renacimiento artístico acaecido en la ciudad de Roma en torno al siglo IV d. de C. Según los autores, tal fenómeno tendría como característica fundamental retomar

460. Estos trabajos insisten en el simbolismo de la vid y las referencias a la figura de Baco. Fue símbolo de ultratumba, con fuertes connotaciones escatológicas. En ocasiones, puede ir acompañado por la hiedra, cuyo simbolismo se liga a la idea de perennidad. El investigador se detiene también en ciertas piezas hispanorromanas donde aparecen dichos elementos vegetales.

${ }^{2064}$ G. BOVINI, I sarcofagi paleocristiani della Spagna, Roma, 1954, p. 10; F. PIRANI, "Quando agli angeli spuntarono le ali”, Aurea Roma..., pp. 389-394, en particular, p. 392 y F. CABROL y H. LECLERCQ, voz "Amours...", vol. I-II, Paris, 1924, col. 1620. Véase, sobre todo, la aportación realizada por estos últimos autores en: ID., "Bassus (sarcophage de Junius)", Dictionnaire..., vol. II, Paris, 1910, cols. 608-614.

Las soluciones tomadas en esta pieza romana también tuvieron su eco en otras. Recuérdese, en este sentido, el sarcófago de Arles conocido como el de "Cristo Doctor", datado en el tercer cuarto del siglo IV y en el que la figura de Cristo, colocada en la parte central, aparece enmarcado por este tipo de columnas vegetales con escenas de viña. Otro ejemplo, esta vez en Saint-Maximilian, presenta la representación de la cruz entre dos fustes de columnas decoradas con el tema de la vid. Sobre estos temas, véase: Q. CAZES y D. CAZES, "Colonne à décor de vigne”, Le Stuc..., p. 109. Estos ejemplos siguen idénticas soluciones a las adoptadas por el de Iunius Basso en Roma.

2065 Ibidem, p. 140. Desde la escena superior izquierda, hacia abajo, el sarcófago de Basso presente los siguientes temas: sacrificio de Isaac, prendimiento de Pedro, Cristo como rey de reyes entronizado, Jesús prisionero seguido del Juicio ante Pilatos, Job refugiado en el estercolero, Adán y Eva, la entrada en Jerusalén, Daniel en el foso de los leones y Pablo ante el suplicio. La figura de Cristo aparece sedente sobre un trono, mientras que en la parte baja fue representado Caelum, siguiendo prototipos bien conocidos dentro de la estatuaria coetánea y que llegarían, incluso, a Hispania gracias a piezas como el sarcófago de Covarrubias, tal y como hemos señalado ya. 
diversos aspectos preciosistas de la decoración de los edificios públicos romanos paganos a la hora de inspirar diversas cuestiones iconográficas cristianas ${ }^{2066}$.

Este aspecto nos parece interesante, pues insiste en la complejidad de poder establecer las fuentes reales utilizadas por los artistas a la hora buscar inspiración. En los apartados anteriores señalamos la importancia de los sarcófagos romanos al hablar de las piezas que, con más frecuencia, influenciaron las composiciones de los artistas románicos. El ejemplo de la tumba de los Haterii o el mismo sarcófago de Basso tan sólo continúan reafirmando tal problema. Incluso, no sería improbable que el relieve funerario de la tumba de vía Labicana pudiera estar imitando un prototipo arquitectónico real a la hora de representar las columnas con putti de la parte frontal del templo.

A pesar de que anteriormente señalamos las concomitancias que existían entre la factura de las columnillas del sarcófago y diversas obras orfebres, creemos que resulta más factible atender a esta última hipótesis. El escultor del sarcófago de Basso pudo tomar el motivo de la misma escultura monumental. Es decir, a pesar de que los fustes con escenas de vendimias del frontal de la cista son de reducido tamaño, creemos que reproducen un modelo escultórico real que, posiblemente, decoraría alguna construcción de la ciudad de Roma.

Nuevamente F. Cabrol y H. Leclercq nos ofrecen un dato al respecto al señalar la importancia que el prefecto de Roma Junius Bassus tuvo en el patrocinio de edificios públicos. En concreto, hacia el año 317 había mandado erigir una basílica profana en el Esquilino $^{2067}$.

En un primer momento no parece problemático poder relacionar las pequeñas columnas de la pieza marmórea con los fragmentos de fustes helicoidales con decoración de "erotes" vendimiadores aparecidos, en torno al año 1877 y reutilizados como material de relleno en el muro perimetral que cerraba el área de Berlardi en el Esquilino de Roma, es decir, los antiguos Horti Liciniani ${ }^{2068}$ (figs. 390 y 391).

\footnotetext{
${ }^{2066}$ F. CABROL y H. LECLERCQ, voz "Bassus...”, cols. 608-611.

2067 Ibidem, col. 611.

${ }^{2068}$ Se trata de un fragmento conservado hoy en Roma, Musei Capitolini. Nuevamente se utilizó aquí una alternancia entre una banda lisa, tan sólo decorada con estriado, y otra que sirve de base para la colocación de las escenas de vendimia. En concreto, en la pieza conservada aparecen dos "erotes" desnudos, alados y con cestas de mimbre cargadas sobre el hombro derecho. Se cree que dicha columna formaría parte de un conjunto escultórico más amplio, del que se han conservado los capiteles que se alzarían sobre dichos fustes. Sobre las esculturas, véase: M. CIMA, "Lesena tortile figurata", Aurea Roma..., ficha catalográfica 15, p. 435 y V. CHAPOT, Op. cit., p. 147.
} 
Observamos, por lo tanto, que el motivo de la vendimia dispuesto sobre el fuste de una columna tiene, nuevamente, su continuidad en esta pieza datada en torno al siglo III d. de C. y que explota las fórmulas imperiales llegadas a Roma a través de corrientes orientales $^{2069}$. A ello debemos sumar que, su hallazgo dentro del área de los Horta Liciniani, no lejos del Templo de Minerva Médica, ha sido suficiente razón como para que, algún autor, conjeturase con la posibilidad de que estas columnas hubieran podido pertenecer a un pabellón centralizado, decorado, quizás, con un paramento articulado a través de fustes torsos rematados en bellos capiteles corintios decorados con figuras desnudas $^{2070}$. Las connotaciones paganas del conjunto, inmerso en el área de viñedos del Esquilino, insinúa una fuerte deuda con los ambientes báquicos ${ }^{2071}$.

Lo dicho hasta el momento habla de la importancia de la arquitectura monumental para la transmisión de modelos hacia la escultura, así como de lo complicado y lo extraño de poder llegar a conservar tanto el ejemplo monumental originador del motivo y aquella pieza esculpida que lo copia. Las columnas torsas con temática de vendimia del Esquilino romano pudieron haber inspirado otra serie de obras de pequeño formato que reprodujesen la forma y el simbolismo de aquellas monumentales. No parece arriesgado pensar que las pequeñas columnillas del sarcófago de Basso hayan tenido, como modelo, algún tipo de producción similar tomada de un edificio real.

El ejemplo permite suponer la importancia del tema en el arte romano y ayuda a definir también su difusión dentro del Imperio, lo que en parte explica el éxito que tendrá en el arte cristiano. Su uso en este tipo de espacios evocaba la autorictas,

\footnotetext{
${ }^{2069}$ Debemos recordar que, en el mismo Liber Pontificalis, tal y como hemos recogido, se señalaba que el origen de las piezas expoliadas en el Vaticano estaba en Grecia, además de compartir una cronología cercana. Véase: WARD-PERKINS, "The shrine of St. Peter and its twelve spiral columns", Journal of Roman studies, XLII, 1952, pp. 21-33. En este trabajo se adjudica a los fustes una cronología en torno al siglo II d. de C.

${ }^{2070}$ M. CIMA, "Lesena tortile...", p. 434; ID., "Capitello figurato di lesena", Aurea Roma..., ficha catalográfica 14, p. 434; ID., "Capitelo figurato di lesena", Aurea Roma..., ficha catalográfica 16, p. 435. Sobre la estructura centralizada del Horti Liciniani, también identificada como el Templo de Minerva Médica, véase: D. SCAGLIARINI CORLAITA, "Gli ambienti poligonali nell'architettura residenziale tardoantica", XLII Corso di cultura sull'arte ravennate bizantina, Ravenna, 1995, pp. 837-872, en particular p. 857. Se trata de una construcción decagonal articulada, en su perímetro interior, a través de nueve nichos y una parte columnada, de la que, posiblemente, proviene el fragmento de columna que aquí estudiamos.

${ }^{2071}$ Ya en su día, S. Moralejo apuntó las concomitancias formales existentes entre las piezas del Esquilino de Roma y los fustes de Compostela. Sobre tal cuestión, insistiremos en las páginas sucesivas. Cf.: S. MORALEJO ÁLVAREZ, “Column shaft...”, p. 212.
} 
siguiendo la expresión de B. Brenk, que el tema de la vendimia había tenido en los edificios paganos ${ }^{2072}$.

La problemática es más compleja si pensamos que muchas de estas piezas, incluso alguna de ellas hispanas, se presentan aún hoy ante el espectador con toda su ambigüedad. Recordemos, por ejemplo, el mencionado fuste portugués de Beja ${ }^{2073}$ (fig. 303). Lo más interesante es la decoración que presenta alrededor del fuste y que ha dado lugar a múltiples interpretaciones en cuanto a su función como a su simbolismo ${ }^{2074}$. La presencia de los racimos de uvas cubriendo la pieza podría hacer pensar en una intención pagana del uso de las formas, aunque la presencia de diversos animales como, por ejemplo, una serpiente que está siendo picoteada por dos palomas, ha servido para defender un origen cristiano.

Esta ambigüedad en cuanto a su función es muy significativa al compararla con las piezas halladas y conservadas en Roma a las que nos hemos referido en las páginas pasadas. A pesar de tratarse, desde un punto de vista temático y formal, de obras semejantes, unas han sido interpretadas en una vertiente contraría a la de las otras. Su iconografía no ha sido un dato relevante para su comprensión y sus supuestos usos paganos o cristianos han venido adjudicados, tan sólo, por el lugar en el que han aparecido o aquel en el que se han conservado ${ }^{2075}$.

\footnotetext{
${ }^{2072}$ Sobre las posibles razones simbólicas que justificarían la expoliación de las piezas de San Pedro de Roma, consúltese: B. BRENK, “Comittenza...”, p. 6 y H. BRANDENGURG, Le prime chiese ..., pp. $97-$ 96.

${ }^{2073}$ Hemos recogido, anteriormente, algunos datos en relación con la escultura. Cf.: S. VIDAL, "Fuste de Beja”, La escultura ..., ficha B23, pp. 78-82 y C. A. FERREIRA DE ALMEIDA, "Arte paleocristã...", p. 35.

${ }^{2074}$ C. TORRES, "Coluna", Núcleo Visigótico, Beja, 1993, ficha catalográfica 3, p. 32 у C. A. FERREIRA DE ALMEIDA, "Arte paleocristã...", p. 35. Este último investigador portugués lo data entre los siglos V y VI y ve en su iconografía un claro "mensaje paradisíaco".

${ }^{2075}$ S. VIDAL, "Fuste de Beja...", pp. 79-80. El autor se refería a la pieza en los siguientes términos: "el fuste de Beja no posee ningún indicio iconográfico per se cristiano, por lo que en este punto tan solo nos limitamos a constatar esta particularidad del animal representado y sus paralelos visuales más cercanos".

Un dato relevante al respecto es la presencia, dentro del conjunto, de diversas máscaras humanas o rostros que se distribuyen entre la vegetación. Este elemento ha sido interpretado por el autor como cabezas de filósofos/pedagogos que fueron habituales en los repertorios de un buen número de sarcófagos del taller romano de Tarraco, activo entre los siglos II-IV d. de C.

Sin embargo, también señala la importancia del motivo dentro de los temas mitológicos, pues la máscara podría aludir a la figura de Pan y la tradición iconográfica dionisíaca. Como paralelo más cercano alude a la pilastra de Amiadoso en Orense donde, nuevamente, aparece una máscara imberbe de perfil. Cf.: J. J. POLLIT, Op. cit., p. 344.

Con todo, la utilización de la iconografía de las máscaras dentro de fustes decorados con otros temas vegetales, no fue desconocida dentro del arte antiguo y del primer cristianismo. Véase, sobre ello: $\mathrm{H}$. WALTER, Op. cit., especialmente, fig. 107. Walter analiza un fuste decorado con elementos vegetales en forma de reticulado. Entre los espacios generados por el mismo se insertaron diversas máscaras teatrales, a veces aisladas y otras en parejas.
} 
S. Vidal, el autor que más recientemente ha estudiado la escultura de Beja, engloba el fuste dentro de la misma tradición que formaría el grupo:

“de las columnas salomónicas del siglo II reutilizadas en la basílica constantiniana de San Pedro del Vaticano y sus ejemplos homónimos de los siglos IIIII de geografías orientales (Éfeso), mostrando una destacada profusión por los temas dionisíacos, 2076 .

En relación con la pieza de Beja y otras puestas en paralelo con ella, destacamos ahora dos interesantes fustes con decoración vegetal conservados en la iglesia romana de San Clemente (fig. 392). Se trata de dos piezas reutilizadas dentro del monumento funerario del cardenal Venerio de Recanati, muerto en el año 1479. A pesar de la fecha tan tardía del sepulcro, no se dudó en reemplear estas dos obras marmóreas, posiblemente, realizadas en el siglo $\mathrm{VI}^{2077}$.

Las columnas presentan una decoración minuciosa basada en las hojas de hiedra, los zarcillos y los tallos abundantes, acompañados de diversos frutos granados. Entre la vegetación fueron esculpidas diversas aves que se apoyan sobre el ramaje de fina talla. Entre todas ellas, el autor ha destacado la presencia de un ave rapaz, un águila de pico curvo que, en lugar de picotear los frutos nacidos de la vegetación, se muestra estático con las alas abiertas, como si estuviese a punto de iniciar el vuelo ${ }^{2078}$.

Sin duda, lo más interesante, a parte de constatar el interés y el valor que durante el siglo XIV romano aún se le seguía otorgando a las piezas clásicas de temática vegetal, es que dicha expoliación se produjo a través del fondo escultórico conservado dentro de la misma iglesia de San Clemente de Roma. En relación con ello, se ha

\footnotetext{
${ }^{2076}$ S. VIDAL, "Fuste de Beja...", p. 80. Creemos que se trata de tradiciones diferentes, pues en el caso vaticano el tema principal es el de la vendimia de los putti, que no aparecen en la pieza de Beja. El citado autor analiza algunas producciones con el tema de Amor jugando con máscaras teatrales, exponiendo diversas teorías sobre la posibilidad de otorgarle un sentido cristiano.

Véase también: C. FRANZONI, "Presente del passato...", pp. 336-338 y p. 348. El investigador italiano señala la importancia del tema de la viña y las máscaras dionisíacas o teatrales dentro del imaginario cristiano.

${ }^{2077}$ F. GUIDOBALDI, "I capitelli e le colonnine riutilizzati nei monumento funebre del cardinal Venerio", San Clemente. La scultura del VI secolo, Roma, 1992, pp. 13-31 e ID., San Clemente..., pp. 15-16. El autor lleva a cabo un profundo estudio de los dos fustes, estableciendo los paralelos oportunos y analizando las causas de este spolium in se. También valora la problemática de las relaciones que se han defendido entre estas piezas y las producciones marmóreas bizantinas de carácter clásico, ligadas a la época justinianea.

${ }^{2078}$ Los ejemplos en los que la hiedra se desarrolla a lo largo de un fuste de columna son varios. Cita el fragmento conservado Roma, Museo Nazionale Romano alle Terme, además de otros procedentes de San Bartolomeo all'Isola Tiberina o el de la Villa Albani Torlonia.
} 
teorizado sobre la posibilidad de que las columnas hayan estado, originariamente, antes de pasar al sepulcro del cardenal, formando parte del ciborium del edificio durante el siglo $\mathrm{VI}^{2079}$.

Ello no hace sino corroborar una reinterpretación del simbolismo de todas estas piezas en época cristiana, a pesar de que, en su origen, su carga simbólica se asentó, totalmente, sobre preceptos paganos. Tal y como señala F. Guidobaldi, en la llamada Casa de los Vetii de Pompeya, algunas de las columnas de mármol que configuraban el peristilo y que circunscribían, además, el espacio ajardinado, estaban decoradas con esta misma solución de vegetales en forma de hiedra, tallos sinuosos y algunos vegetales $\operatorname{granados}^{2080}$ (fig. 393). La temática vegetal de estas columnas pompeyanas se adapta, consecuentemente, a la decoración del hortus o jardín romano ${ }^{2081}$. Se trata de un tipo de repertorio frecuente dentro de los llamados viridarii, es decir, pequeños espacios no edificados de la ciudad romana, generalmente, de las partes más antiguas de los recintos urbanísticos, que se utilizaban como lugar agradable de descanso y ocio y en los que se recogían las aguas pluviales para almacenarlas en cisternas subterráneas.

En estos recintos o viridarii se cultivaban todo tipo de plantas medicinales y decorativas, por lo que, las alusiones a la vegetación dentro de estas piezas escultóricas, estarían plenamente en consonancia con el ambiente general del espacio ${ }^{2082}$.

A través de los mecanismos de reinterpretación cristianos, el jardín o vergel fecundo en vegetación, pasó a formar parte de la lista de topoi clásicos utilizados por el cristianismo para representar el Locvs Amoenvs, el Edén o, incluso, el Hortus conclusus que rodea a la Virgen en infinidad de representaciones. Este paradisus, heredero de la tradición romana de decoración de jardines, tal y como se constata a través de los fustes pompeyanos, servía, en este caso, para delimitar la zona más importante de la iglesia de San Clemente de Roma: el ciborium, de la mima manera que, durante unos siglos antes,

\footnotetext{
${ }^{2079}$ Ibidem, pp. 15-17. El autor recoge una reconstrucción del ciborium realizada por Rohault de Flery, donde, además, se dibujaron con detalle sus capiteles.

${ }^{2080}$ Ibidem, pp. 23-24. Se publican fotografías de las piezas pompeyanas sobre el jardín original, tras su restablecimiento, en el año 1978.

${ }^{2081}$ E. DE CAROLIS, "La Casa Pompeyana", Pompeya. Historia, Vida y Arte de la ciudad sepultada (M. Ranieri Panetta, ed.), Barcelona, 2004, pp. 242-257, en particular, p. 245.

${ }^{2082}$ A. CIARALLO, "La flora y la fauna", Pompeya..., pp. 302-313, en especial, p. 310. Sobre la ornamentación de las villas de otium de la aristocracia tardorrepublicana, véase: S. ADAMO MUSCETTOLA, "El mobiliario doméstico", Pompeya..., pp. 258-285. La utilización de este tipo de piezas para la decoración de jardines viene abalada, además, por la aparición, señalada por V. Chapot como reciente en la publicación del año 1907, de una columna con fuste decorado con vegetales, similar al de la villa Vetii, y que tendría, según parece, idénticas funciones a las anteriormente mencionadas. Cf.: V. CHAPOT, Op. cit., p. 76.
} 
dentro de la basílica constantiniana, se había señalado el lugar en el que descansaban los restos del Apóstol a través de una pérgola marmórea con la imagen de la viña ${ }^{2083}$.

En Hispania, dentro del repertorio de piezas que nos han llegado, interesa señalar, por su concomitancia respecto a estas columnas de San Clemente, el fragmento de fuste proveniente de Elche, Ilici, y que ya publicó en su día A. García y Bellido (fig. 394). Se trata de una pieza que, nuevamente, desarrolla a lo largo del fuste un tema vegetal y que se ha relacionado con el estilo ilusionista desarrollado en tiempos flavios. En concreto, el autor relaciona la escultura con los relieves que ya hemos analizado de la tumba de los Haterii, sobre todo, en relación con lo jugoso y volumétrico de los vegetales. Tanto en los ejemplos romanos como en el hispano, tales elementos son picoteados por pajarillos, que aparecen con intenciones naturalistas ${ }^{2084}$.

Una vez constatada la difusión del tema de la viña durante los últimos siglos en los que se desarrolló el arte pagano y su traspaso a las primeras experiencias plásticas del arte cristiano, resta cerrar tal evolución con otra serie de ejemplos importantes.

Si aceptamos que las referencias al paraíso pagano, impregnadas de la literatura virgiliana y llenas de alusiones a la Edad de Oro, pasaron reinterpretadas a la iconografía cristiana a través de la representación de la viña y los vendimiadores; debemos aceptar que, tal repertorio antiguo acabó por transformarse en una referencia a la Iglesia, entendida a hora como la viña y los infatigables fieles trabajadores al servicio del Señor. La sangre derramada por Cristo, hecha visible a través del vino eucarístico, tenía en la viña su mejor representante. En relación con ello, debemos pensar que muchas de estas piezas sufrieron un relectura en clave cristiana, lo que, por otra parte, explicaría el gran éxito que llegaron a adquirir dentro de los edificios cristianos de los siglos V y VII.

Sin duda, fue el presbiterio de la iglesia de La Daurade de Toulouse, el ejemplo que mejor explica tal tradición iconográfica (fig. 395). Se trata de una construcción demolida alrededor del año 1765 y de la que tan sólo nos han llegado noticias documentales y restos muy fragmentados. El edificio cristiano se asentó sobre una

\footnotetext{
${ }^{2083}$ No debemos olvidar el importante éxito que habría de tener la imagen de la viña dentro del repertorio de modelos utilizados por los artistas musivos encargados de realizar la decoración del ábside del templo, aunque ésta se presentase en forma de acanto clásico o, a través, de otro tipo de elementos vegetales. En la misma línea se utilizaron las fuentes clásicas para la realización del mosaico del absidiolo del atrio del baptisterio de San Giovanni in Laterano, reconstruido por Sixto III (432-440). Cf.: G. MATTHIAE, Le chiese..., p. 138 y H. TOUBERT, "La renouveau paléochrétien...", p. 123. La autora considera este tipo de imágenes vegetales como una fórmula recurrente para aludir a la viña como símbolo de la Iglesia.

${ }^{2084}$ Las piezas pueden ser datadas en el siglo II. d. de C. Cf.: A. GARCÍA Y BELLIDO, Arte romano..., pp. 326-327.
} 
construcción antigua preexistente, situada cerca de una de las puertas romanas de la villa de Toulouse, en la parte final del decumanus ${ }^{2085}$. La parte que nos interesa resaltar es la de la cabecera, supuestamente, formada por una estructura de siete paños de muro, únicos vestigios expoliados de un anterior templo decagonal romano ${ }^{2086}$.

Durante el siglo VI para unos o, en torno al siglo XI para otros, el edificio recibe una remodelación completa, que lleva a transformar su morfología y su decoración. Ahora, la estructura centralizada pasa a utilizarse como presbiterio de una iglesia creada al añadir un cuerpo de nave a la construcción preexistente, adquiriendo una forma de polígono irregular ${ }^{2087}$.

Quizás, lo más interesante, dejando a un lado cuestiones de tipo arquitectónico, es la decoración que los artífices cristianos aplicaron sobre dicho edificio. Todo el perímetro interior del ábside fue articulado a través de tres niveles de nichos superpuestos. Cada nicho se decoró, así mismo, a través de dos columnas marmóreas que lo flanqueaban; solución que se aplicó a cada uno de ellos, originando tres galerías columnadas que, a juzgar por algunos grabados conservados, debieron generar una articulación del paramento muy espectacular ${ }^{2088}$.

${ }^{2085}$ Se trataría de un edificio que, cristianizado, formó parte de un grupo episcopal. La iglesia de SainteMarie, destruida entre el 1761 y el 1764, ha recibido gran atención por parte de los investigadores debido a la singularidad que parece debió ostentar el templo. Vid.: Q. CAZES, "Ancien église Sainte-Marie-laDaurade", Le Stuc..., pp. 117-118 y J. CAILLET, Sainte-Marie "La Daurade" à Toulouse. Du sanctuaire paléochrétien au grand prieuré clunisien médiéval, Paris, 2006. La obra incluye, además, otro estudio de la profesora Q. Cazes. Cf. : Q. CAZES, "Annexe VIII: Les éléments lapidaires provenant de l'abside détruite de la Daurade”, Sainte-Marie..., pp. 299-309.

${ }^{2086}$ N. DUVAL, "L'architecture cultuelle", Naissance des arts chrétiens. Atlas des monuments paléochrétiens de la France, Paris, 1991, pp. 186-220, especialmente, pp. 214-215. El autor recoge y analiza los grabados de Dom J. Martin, donde se representó la iglesia antes de su destrucción.

Sobre la función de la construcción anterior, a todas luces, de forma centralizada, se ha teorizado mucho. Parece claro que debió tener funciones funerarias o, quizás, residenciales, aunque la cuestión sigue planteando hoy numerosos interrogantes. Para otros autores, pudo ser un templo dedicado a Apolo, tal y como se defiende en: Q. CAZES, “Ancien église...", p. 117. La autora recoge la teoría planteada por J.-F. de Montagut. Véase también: C. HEITZ, "D'Aix-la-Chapelle à Saint-Benigne de Dijon, rotondes mariales carolingiennes et ottoniennes", Les Cahiers de Saint-Michel-de-Cuixà, XXV, 1994, pp. 5-11, en concreto, p. 5 y D. SCAGLIARINI CORLAITA, Op. cit., pp. 837-872.

${ }^{2087}$ Se trata de un fenómeno bastante frecuente dentro de la historia de la arquitectura, donde las estructuras anteriores son transformadas y reempleadas para adaptarlas a nuevas funciones. Sobre este tema, véase : J.-P- CAILLET, "La transformation en église d'édifices publics et de temples à la fin de l'Antiquité", La fin de la cité antique et le début de la cité médiévale de la fin du III siècle à l'avènement de Charlemagne (C. Lepelley ed.), Bari, 1996, pp. 191-211. Sin embargo, el especialista se centra en ejemplos del ambiento oriental, como los de Tipasa, Leptis Magna, Baalbek, Sabratha o Géresa.

${ }^{2088}$ Sin responder a la misma tipología, este tipo de galerías formadas por nichos y columnas eran conocidas desde la Antigüedad tardía. Recuérdese el caso de la decoración estucada del baptisterio de los Ortodoxos en Rávena o la menos conocida iglesia de Vouneuil-sous-Biard, en Vienne.

En el caso del templo francés, se trataba de una construcción que, en los primeros años del siglo VI, presentaba una decoración mural formada por este tipo de solución. En los nichos se colocaron, así mismo, diversas figuras realizadas en estuco vestidas con túnicas y sujetando libros con sus manos. Sobre 
Además de todo ello, el fondo de dicha estructura arquitectónica fue cubierto con un gran mosaico de teselas de oro que acabarían por otorgar al edificio el nombre de "La Daurade" "2089. Sin embargo, de toda esta decoración, son las columnas de mármol que flanqueaban los nichos las que, de una manera más completa, han llegado hasta nosotros. Según parece, aquellas de fustes estriados se alternarían con otras de fustes helicoidales decoradas con pámpanos de vid y racimos de uvas ${ }^{2090}$ (figs. 396 y 397).

Sin poder entrar en todas las interpretaciones que su arquitectura y su decoración han originado, parece claro que el sustrato clásico de la construcción es evidente. Las columnas de tema vegetal, alusivas a la viña, retoman aquí la iconografía del locvs amoenvs pagano, para dotarla de una nueva resignificación cristiana. Tal y como apuntara R. Krautheimer en su día, una dependencia con respecto a la temática decorativa de los mausoleos de la Antigüedad tardía vendría apoyada por la reutilización física del espacio centralizado romano, sobre el que se asentó el nuevo edificio cristiano $^{2091}$.

El recorrido realizado hasta aquí a través del estudio de algunas de las piezas más importantes, en relación con las columnas de fustes decorados con el tema de la viña, es ciertamente fragmentado e incompleto. Sin embargo, se han tomado tan sólo aquellas piezas significativas para perfilar un paisaje donde dichos productos parece que fueron frecuentes.

Su interés y continuidad, más allá de la Galia y la Hispania romanas, así como dentro del ambiente romano de los edificios constantinianos, queda puesto de

dicho edificio, véase: B. PALAZZO-BERTHOLON y C. SAPIN, "Les décors de stuc de Vouneuil-sousBiard", Le Stuc..., pp. 65-73.

${ }^{2089}$ Desviaría el objetivo del trabajo detenernos en otras cuestiones importantes del edificio como, por ejemplo, en el gran programa iconográfico que se aplicó sobre los nichos, también realizado en mosaico. Según se ha publicado recientemente, la parte superior de la galería estaría dedicada a la infancia de Cristo. La parte intermedia al Salvador y la Virgen, los cuatro arcángeles, los cuatro evangelistas y los apóstoles. Finalmente, la parte baja albergó la imagen de los profetas. De todo ello, tan sólo, se ha conservado un pequeño fragmento de mosaico de finas teselas doradas, hoy custodiado en Avignon, Musée Calvet. Consúltese sobre ello: Q. CAZES, "Ancien église...", p. 118 e ID., "Annexe VIII: Les éléments lapidaires...", en concreto, p. 299. La autora defiende que se trataría de catorce nichos ubicados en el nivel superior, veintidós en el intermedio y dieciséis o diecisiete en el inferior.

${ }^{2090}$ Diversas colecciones públicas y privadas de todo el mundo custodian hoy estas piezas. Por citar algunas, sirvan, a modo de ejemplo, las conservadas en Toulouse, Musée Saint-Raymond, Paris, Musée du Louvre, New York, Metropolitan Museum o en Harvard, Fogg Art Museum. Cf.: Ibidem, en concreto, pp. 302-303 y M. SCELLÈS, Inventaire de la sculpture monumentale du $I V^{e}$ au $X^{e}$ siècle en HauteGaronne, Toulouse, 1981.

${ }^{2091}$ R. KRAUTHEIMER, "Sancta Maria Rotunda”, Arte del primo millenio, Turín, 1950, pp. 21-27; A. M. JIMÉNEZ GARNICA, "El arte "oficial" de Toulouse bajo soberanía visigoda: La Daurade", Archivo Español de Arqueología, 61, 157-158, 1988, pp. 179-196 y J.-L. BOUDARTCHOUK, "Le souvenir antique de la Daurade (Toulouse) à travers légendes et traditions médiévales", Mémoires de la Société archéologique du Midi de la France, LXII, 2002, pp. 247-250. 
manifiesto con la noticia recogida, nuevamente, en el Liber Pontificalis. A las columnas traídas desde Grecia por el emperador Constantino para delimitar la tumba del Apóstol en el Vaticano, debemos sumar otros seis ejemplares donados por Gregorio III (731741) al mismo edificio:

"Hic concesass sibi columnas .VI. onichas volátiles ab Etychio exarcho, duxit eas in ecclesiam Beati Petri apostoli, quas statuit erga presbiterium, ante confessionem, tres a dextris et tres a sinistris, iuxta alias antiquas sex filopares. Super quas posuit trabes et vestivi eas argento muñidísimo, in quo sunt expressae ab uno latere efigies Salvatoris et apostolorum et ab alio latere Dei Genetricis et sanctarum virginum -Hic fecit oratorium intro eandem basilicam, iuxta arcum principales, parte virorum, in quo recondivit in honore Salvatoris sanctaeque eius Genetricis reliquias sanctorum apostolorum vel omnium sanctorum martyrum ac confesorum, perfectorum iustorum, toto in orbe terrarum requiescentium ${ }^{, 2092}$.

Se trata, sin duda, de una noticia interesante para poder atestiguar una voluntad, por parte de los papas, de mantener una línea coherente de continuidad estética e iconográfica en torno a la confessio vaticana, para la cual, no se duda en expoliar, tal y como señala V. Lanzani, unas piezas destinadas a cualquier edificio imperial o templo. Con todo, las seis nuevas columnas donadas por el exarca de Rávena Eutychio e iguales a las constantinianas, fueron alienadas por pares a las ya preexistentes, tal y como describe el Liber. Las piezas se unieron mediante un arquitrabe de plata pura y diversas lámparas e imágenes de Cristo, la Virgen y los apóstoles. El aspecto del recinto no varió mucho con la reforma, aunque la nueva pérgola se mantuvo intacta hasta el siglo XVI, quedando plasmada, por última vez, en la famosa escena pintada por Julio Romano en las estancias vaticanas de Rafael $^{2093}$ (fig. 398).

\footnotetext{
${ }^{2092}$ R. VALENTINI y G. ZUCCHETI, "Il Liber Pontificalis...”, p. 263.

${ }^{2093}$ V. LANZANI, "Ubi Petrus...", pp. 45-47. No podemos detenernos en analizar la remodelación realizada dentro de este espacio por el papa Gregorio Magno. Tan sólo, señalamos como el edículo de San Pedro permaneció inamovible mientras se añadió la pérgola y las nuevas columnas. Además, se crearon dos nuevas galerías subterráneas en forma de hemiciclo que permitían el acceso de los peregrinos al lugar donde se guardaba el cuerpo del apóstol, sin disturbar la celebración del rito litúrgico. Frente a lo novedoso de este hemiciclo subterráneo, la nueva distribución de la pérgola tenía sus referentes más directos entre otros ejemplos de Grecia, Constantinopla o Rávena, tal y como señala el investigador antes citado. Véase la reconstrucción recogida en: G. H. FORSYTH, Op. cit., p. 63; G. MATTHIAE, Le Chiese di Roma ..., p. 124; F. W. DEICHMANN, Archeologia ..., pp. 65-66 y P. SILVAN, "L'architettetura della basilica...”, p. 255. Estos estudios remarcan la importancia de la estructura como modelo a seguir por otras iglesias cristianas, entorno a la organización de sus presbiterios.
} 
El interés que presenta este spolium in se en pleno siglo VIII, remarca la importancia del conjunto y anuncia su impacto en el arte de los siglos posteriores. En relación con ello y cerrando este recorrido, debemos regresar ahora a las piezas con las iniciábamos este apartado.

A partir de las investigaciones realizadas por S. Moralejo, las columnas helicoidales conservadas en el Museo Diocesano de la catedral de Santiago (figs. 378371), fueron, durante mucho tiempo, relacionadas con la pérgola constantiniana, tanto desde un punto de vista formal como iconográfico ${ }^{2094}$. Sin embargo, de una manera más reciente se han concretado los supuestos modelos a los que pudieron acceder los marmolistas de Santiago a la hora de realizar la escultura en la catedral gallega. Nos referimos a los estudios de M. A. Castiñeiras que han permitido especificar más dichas fuentes.

Las columnas conservadas en las iglesias romanas de San Carlos a Cave y Santa Trininidad dei Monti retoman, nuevamente, el prototipo constantiniano de columna torsa decorada con putti vendimiadores, tal y como señalara, en su día, V. Chapot en su estudio del año $1907^{2095}$ (fig. 399).

Dichas piezas presentan escenas de vendimia que llevan a cabo "erotes" desnudos, donde el tratamiento del cuerpo y la musculatura se encuentra aún inmerso dentro de planteamientos antiguos. A ello se debe sumar la iconografía, claramente emparentada con las piezas romanas que acabamos de describir. Con todo, estas esculturas se han venido datando en época románica, concretamente, entre los años 1090 y 1130.

Tal cronología ha permitido poner en relación dichos fustes con las piezas románicas compostelanas, concretando, quizás, el modelo inspirador de una manera más certera, tanto desde un punto de vista compositivo, como desde las medidas de los fustes de las piezas románicas, casi iguales a las compostelanas y que las alejan del gran tamaño que presentan las constantinianas ${ }^{2096}$. A pesar de ello, actualmente se acepta un

\footnotetext{
${ }^{2094}$ S. MORALEJO ÁLVAREZ, "La sculpture romane...", p. 151. El experto no defendió nunca una dependencia directa de los modelos de Santiago con respecto a Italia, mostrando una cautela mayor que la que en su día habían tenido autores como Salvini o Francovich. Sus teorías fueron seguidas por otros investigadores, sin descartar un contacto por parte de los escultores hispanos con otra serie de repertorios como, por ejemplo, con los fragmentos ya comentados del Esquilino de Roma. Vid. también: M. DURLIAT, “L'apparition du grand...”, p. 22 y J. YARZA LUACES, “Artes figurativas...”, pp. 71-72.

${ }^{2095}$ V. CHAPOT, Op. cit., p. 144. El autor considera las columnas de la iglesia de la Trinidad del Monte como deudoras de la tradición constantiniana, analizando también la importancia que estas piezas tendrían para otros artistas posteriores como, por ejemplo, Piranessi.

${ }^{2096}$ M. A. CASTIÑEIRAS GONZÁLEZ, "Roma e il programma riformatore...", p. 218. Relaciona, además, la iconografía con otros modelos, como por ejemplo la pila de Grottaferrata, datada en torno al
} 
conocimiento por parte de los escultores hispanos de un modelo antiguo difundido desde los talleres de marmolistas de la ciudad de Roma a finales del siglo XI.

Sin embargo, S. Moralejo ya había advertido en su día la imposibilidad de poder afirmar con rotundidad la pieza original o el conjunto concreto que, en última instancia, inspiraría la supuesta "copia" realizada en Santiago de Compostela. El investigador defendía la posible disparidad de fuentes y las relaciones que las columnas helicoidales compostelanas presentaban con otra serie de piezas. Nos interesa este dato para nuestro objetivo, pues el autor señaló varios sarcófagos donde se repetía una temática similar a la de las columnas; entre ellos, el ya citado sarcófago de Iunius Basso y el sarcófago del Buen Pastor del Letrán, entre otros ${ }^{2097}$ (fig. 400). Dentro del territorio de la Península Ibérica, estos repertorios tampoco eran desconocidos, pues así lo atestigua otra pieza hallada en Castanheira do Ribatejo, Portugal (fig. 401).

La pieza está decorada con una gran vid que se expande ocupando todo el frente y en la cual aparecen, entre otros, putti vendimiadores, aves y otros animales, además de un retrato de la difunta ${ }^{2098}$.

A pesar de ello, aunque una de las fuentes más cercanas para las piezas de Santiago fueron, en primer lugar, las columnas torsas vaticanas que servirían de modelo, a su vez, a los escultores medievales de las otras piezas citadas; no debemos descartar,

año 1100 y donde, nuevamente, se representaron niños desnudos realizando todo tipo de actividades relacionadas con la pesca. Aquí el tratamiento del desnudo, con cierta sensación de morbidaza, clama un origen antiguo también para el modelo que inspiró al escultor de esta obra. Se aborda también la pila en: ID., El calendario medieval..., p. 204, nota 364; ID., "La meta del camino...", p. 233; ID., Atlas de la catedral..., (edición digital) y F. GANDOLFO, "Il romanico", L'arte..., pp. 330-331. Este último autor data la pieza en torno al año 1131, pero nunca posterior al año 1163. Lo más interesante son las relaciones que establece con otras piezas antiguas cristianas.

${ }^{2097}$ S. MORALEJO ÁLVAREZ, "La primitiva fachada...”, p. 42; F. CABROL, y H. LECLERCQ, voz “Amours...", vol. I, col. 1619 y M. ZIBAWI, "El auge del arte cristiano...", pp. 134-138. Todos los autores señalan lo problemático de someter las escenas de vendimia a una lectura en clave cristiana de una manera segura. El autor recoge también el ejemplar conservado en San Pablo Extramuros, donde las escenas de la vida de Cristo fueron colocadas bajo arcos en cuyas enjutas se colocaron putti vendimiando. Sobre el paso del tema a la Edad Media, véase: M. A. CASTIÑEIRAS GONZÁLEZ, El calendario medieval..., p. 161.

${ }^{2098}$ Se cree que proviene de la villa del Valle del Tejo, en la región portuguesa de Vila Franca de Xira, sirviendo, en el momento de su hallazgo, como pila para lavar la ropa. La parte central aparece ocupada por un clípeo en el que se inscribe una figura femenina joven, que ha permitido, a su vez, realizar una lectura de las escenas de vendimia en relación con el retrato de la difunta.

Los "erotes" representados aparecen alados y desnudos, trepando por las cepas y portando en las manos aperos para cortar el fruto. Nuevamente, se esculpieron aves que intentan picotear las frutas, además de otros seres que parecen esconderse entre la profusa vegetación y que se han identificado con jabalíes. La pieza se ha emparentado con el sarcófago de San Lorenzo Extramuros en Roma, por lo que parece que la cronología acertada estaría en torno al siglo III. Cf.: M. JUSTINO MACIEL, Antiguidade tardia..., pp. 140-143; ID., “A época clássica e a Antiguidade tardia...”, p. 109; M. JUSTINO MACIEL, J. M. PEIXOTO CABRAL y D. NUNES, “Os sarcófagos tardo-romanos...", 165-167 y A. GARCÍA Y BELLIDO, Arte romano..., pp. 568-569. Sobre el sarcófago de San Lorenzo, véase: F. H. TAYLOR, Op. cit., p. 48. 
tal y como veremos, que la iconografía de los fustes gallegos se enriqueciera con otra serie de temas que no aparecen en las columnas constantinianas ni en las romanas de datación románica. Los fustes de Santiago adoptan una serie de novedades que no se hallan en ninguno de los ejemplos antes citados, por lo que, la posibilidad de rastrear otras esculturas, susceptibles de ser equiparadas con los ejemplos de Santiago, parece factible ${ }^{2099}$.

$\mathrm{El}$ acceso de los escultores a otros repertorios viene ratificado por la presencia de temas más complejos dentro de los fustes. Recuérdese, por ejemplo, la identificación realizada, en su momento, por S. Moralejo del tema de la leyenda de Tristán e Isolda, que, según su criterio, inspiró las imágenes del supuesto caballero dormido a bordo de una barca acompañado por un équido ${ }^{2100}$.

Nuestros conocimientos no nos permiten pronunciarnos sobre un tema tan complejo y del que, por el momento, no podemos aportar una solución fiable. Sin embargo, más allá de ello, la disparidad de temas difíciles de interpretar por parte del espectador contemporáneo, habla, claramente, sobre el gran repertorio de fuentes que pudieron manejar los artífices de las columnas de Santiago y sobre lo erróneo de determinar y concretar, en exceso, el modelo "copiado".

Dentro de las mismas piezas se hallan otros elementos de difícil interpretación y cuya inclusión en el programa de las columnas no puede justificarse a través de un conocimiento de los prototipos romanos. La presencia de un posible fauno o demonio sujetando una serpiente, relaciona estas producciones con otra serie de esculturas de tradición "antiquizante" vinculadas al foco de Frómista, así como a la desarrollada, paralelamente, en la catedral de Jaca ${ }^{2101}$.

\footnotetext{
${ }^{2099}$ M. A. CASTIÑEIRAS GONZÁLEZ, "Fragmento de fuste...", p. 150. Se señala como una aportación novedosa de los escultores de las columnas españolas, la introducción de la alternancia de bandas figuradas y acanaladas, indicando la caída helicoidal del friso, "nunha fórmula moi diferente á tipoloxía do Vaticano e das súas copias medievais romanas".

${ }^{2100}$ S. MORALEJO ÁLVAREZ, "Column shaft...”, p. 214. El especialista defendió que se trataba de un pasaje épico relacionado con la leyenda de Tristán e Isolda, justo en el momento en el que el héroe emprende el viaje ultramar hacia Irlanda en busca del ungüento que le salvará de la muerte segura tras ser herido por la lanza envenenada de Morhot. El mismo autor señaló la problemática de poder defender estas ideas con argumentos sólidos, pues se trataría de un ejemplo muy temprano de la difusión sobre las artes plásticas del tema.

${ }_{2101}$ Reiteramos la complejidad iconográfica de las columnas, más allá del tema de los putti vendimiadores. Vid.: J. LECLERCQ-MARX, "Imágenes. La doble tradición medieval", Quintana, 4, 2005, pp. 13-53, en concreto, p. 15. La autora escribía al respecto: "El ejemplo más asombroso de escenas indescifrables pero manifiestamente cargadas de sobreentendidos novelescos se encuentra en una de las columnas historiadas provenientes de la antigua fachada norte de la catedral de Santiago de Compostela. Alli se ven dos mujeres pez entre varios caballeros. Uno lucha contra grandes aves de presa; el otro parece estar implorando de rodillas a un personaje sentado; el tercero yace muerto o dormido, con su caballo, en una pequeña embarcación. Parece claro que las tres escenas forman parte
} 
Independientemente de las cuestiones iconográficas, creemos que, tal y como se ha señalado reiterativamente, el conocimiento del mundo clásico que parecen tener los escultores de estas piezas deja entrever, en gran medida, la personalidad de su patrocinador.

El obispo Diego Gelmírez realizó dos viajes a Roma. El primero de ellos se llevó a cabo en el año 1100 cuando el obispo se desplazó a dicha ciudad para su nombramiento como diácono. El segundo, también documentado de una manera fiable a través de la Historia Compostela, fue en el año 1105 y vino motivado por la obtención del privilegio del pallium, que le fue impuesto en la basílica de San Lorenzo Extramuros de Roma.

"Y el 1 de julio siguiente, con la aprobación del Señor, el mencionado Diego fue elegido obispo, en la era 1138 (año 1100), y a la Pascua siguiente fue consagrado obispo el 22 de abril (...) Y tras dirigirse en compañía de muchas personas de esta iglesia después de su elección a Toledo (...), recuperó una parte del señorío que la iglesia de Santiago había perdido injustamente en tiempos de sus predecesores, y puesto que sabíamos que el electo según un privilegio de su predecesor don Dalmacio debía ser consagrado en Roma, profundamente nos afligimos con suspiros entrecortados, pensando que podría tal vez ser hecho prisionero en el camino de ida o de vuelta por las dolosas asechanzas de sus enemigos"2102 (texto 74).

Creemos que la trascripción de la narración recogida en la Historia Compostelana, es bien significativa al respecto:

"No mucho tiempo después, el venerable obispo (...), se presentó ante nuestro católico emperador, el rey don Alfonso, con humildísimo afecto, y expuso en sus discretos oídos lo que había proyectado (...) Y así, antes de salir de la región de tierra de Campos, le recibió honestamente con una gran procesión el obispo García de la iglesia de Burgos, quién no le dejó de obsequiarle y atenderle muy

de una misma historia cuyo carácter épico es evidente. En todo caso, al mirarlos, no podemos evitar pensar en temas célticos, en concreto en el del guerrero muerto, dormido o herido, como Arturo o Tristán en un barco encantado".

También se abordó el tema en: V. R. NODAR FERNÁNDEZ, "La sirena: la metamorfosis de un tema en la catedral románica de Santiago de Compostela", Codex Aquilarensis, 21, 2005, pp. 33-47, en concreto, pp. 42-43. El autor identifica la presencia de dos sirenas, una de ellas con la cola sujeta por un fauno, aunque señala, igualmente, lo complejo de poder demostrar un interés por narrar una historia coherente ligada a la figura de Tristán.

${ }^{2102}$ Historia Compostelana..., p. 86. 
especialmente en las parroquias de la diócesis (...) el arzobispo de la iglesia de Auch le salió al encuentro en la festividad de la Natividad de Santa María (...) Deteniéndose desde allí un poco en los asilos y señoríos de Santiago, entró en Tolosa rodeado de honores (...) llegó con la ayuda del Señor a través de caminos tortuosos al monasterio de San Pedro de Moissac como a puerto tranquilo; y después de ser recibido alli con toda dignidad y alabanzas con una sagrada procesión, se dirigió con algunos superiores de este monasterio a la ciudad de Cahors (...). Y cuando salió de allí, llegó al monasterio de San Pedro de Uzerche donde fue recibido no menos honrosamente por los monjes y el abad que allí vivían. Y así, según hemos narrado anteriormente, honrado por todos en todas partes, llegó felizmente a Limoges, donde se sabe con seguridad que está el cuerpo de San Marcial (...) Y al llegar a Cluny, capital de toda la religión monástica, el mencionado obispo, rodeado de tanta y tan grande y santa veneración, fue recibido familiarmente y de manera especial con diversas procesiones en la beatitud de aquella santísima congregación (...) Luego, fortalecido por las bendiciones de la sagrada congregación, llegó con el auxilio del Señor por los monasterios y posesiones de los cluniacenses hasta los valles de Soriana. Allí también el venerable conde Humberto le recibió (...) y le llevó hasta la ciudad de Susa (...) Se dirigió a Roma después de diversas visicitudes vestido de soldado. Y al entrar en el sagrado palacio, porque ninguno de los obispos de esta iglesia había ido a Roma voluntariamente, con tanto afecto y cordialísima consideración le recibió el Papa (...) el venerable obispo (...) pido la dignidad del palio por medio de sus clérigos al Papa (...) Por fin, con la ayuda de la divina gracia y confiando en la misericordia de Dios, recibió religiosamente el palio que tanto había deseado, en el altar de la iglesia de San Lorenzo según la costumbre romana, y lo entregó para siempre (...) a la iglesia de Santiago" ${ }^{2103}$ (texto 75).

La narración que acabamos de transcribir describe de manera meticulosa el recorrido llevado a cabo por Diego Gelmírez en su viaje a Roma. Se trata de un documento excepcional que permite reflexionar sobre la importancia y las consecuencias, dentro del campo artístico, de estos viajes realizados por insignes

\footnotetext{
${ }^{2103}$ Ibidem, pp. 99-106.

Desde otro orden de cosas, citamos, a título de ejemplo, la importancia que para M. Durliat tuvo una pieza conservada en la abadía de Auch. Se trata de un sarcófago paleocristiano proveniente de la iglesia de Saint-Orens que, según el citado investigador, podría haber influenciado la composición de determinadas imágenes de la catedral de Jaca como, por ejemplo, aquella en la que se muestra el sacrificio de Isaac. Tales teorías sugieren la importancia del contacto, a través de los viajes, de determinadas personalidades del ámbito cultural del momento con las piezas artísticas y sus repercusiones a la hora de definir las preferencias estéticas de las élites, en el patrocinio de las artes. Cf.: M. DURLIAT, La sculpture romane de la route..., pp. 239-242 e ID., "Sculpture romane...", p. 395.
} 
personalidades a otros centros importantes del cristianismo. En concreto, dentro del periplo del obispo desde Santiago a Roma, se mencionan centros de primer orden dentro del arte románico europeo, tales como Moissac, Cahors, Limoges o Cluny, antes de traspasar las fronteras naturales que le permitirían llegar a la península italiana.

Muchos autores, apoyándose en esta narración, han relacionado algunas de las características, reformas y obras patrocinadas por Gelmírez, con diversas producciones artísticas de estos lugares por los que transitó el obispo y su séquito. Así, por ejemplo, M. Castiñeiras llegará a escribir en relación con ello: "Por todo isto parece moi plausible que o mestre de Praterías formase parte do cortexo de Xelmírez nas viaxes de 1100 ó 1105 a Roma”.

Tales palabras demuestran, claramente, cómo el texto ha sido utilizado como argumento base para poder justificar las relaciones artísticas entre algunas partes de la basílica compostelana con respecto a Roma. Esta apertura de la sede compostelana de Gelmírez hacia la ciudad de los emperadores y hacia otros centros europeos de primer orden, debe ser vista como un paso más, inmerso dentro de un gran programa político, ideológico y, en última instancia, artístico, que buscaba equiparar muchas de las estructuras de la sede jacobea con respecto a las romanas ${ }^{2104}$.

Según esto, el recuerdo romano presente en ciertas partes y estructuras de la iglesia compostelana, tendría su explicación en estos dos viajes realizados por el obispo a Roma que, además, clarificarían otras partes complejas del programa iconográfico de las fachadas y de la misma arquitectura de época románica, tal y como se ha defendido recientemente ${ }^{2105}$.

\footnotetext{
${ }^{2104}$ M. A. CASTIÑEIRAS GONZÁLEZ, "Fragmento de fuste...", p. 152 y C. CID PRIEGO, “Asturianos y mozárabes...", p. 70. El fenómeno parece tener ciertos precedentes en los siglos anteriores al románico. Ya en su día, el profesor Cid intentó justificar la disposición y morfología de algunas partes de la basílica compostelana de Alfonso III, a través de un supuesto conocimiento de la arquitectura romana. Así, se defendió que el ábside de la primitiva basílica y las estructuras relacionadas con el famoso lugar donde se conservaban los restos del Apóstol, poseían una disposición similar a la utilizada en la basílica constantiniana de San Pedro de Roma, "que sin duda le sirvió de modelo, aunque se ignora como pudo conocerse en el reino asturiano".

${ }^{2105}$ M. A. CASTIÑEIRAS GONZÁLEZ, “Topographie...”, p. 32 e ID., "Un adro para un bispo...”, p. 264. El autor relaciona algunas soluciones de la catedral de Santiago con la iglesia de San Crisógono de Roma, así como con la realización de una colección de cantos gregorianos conocidos bajo el nombre de Polycarpus (1109-1111). Además, algunos de los temas iconográficos que hallamos en la escultura de la catedral gallega parecen derivar, según el investigador, de esta compilación que posee cierto tono "antiquizante" y parece basada en fuentes paganas.

También véase: V. R. NODAR FERNÁNDEZ, "La sirena...", p. 41. Se justifican ciertas iconografías clásicas de carácter pagano, a través de la lectura moralizante de algunas fuentes textuales. Desde otro orden de cosas, también se han establecido dependencias entre algunos aspectos de la escultura de la abacial de San Pedro de Moissac y la iglesia compostelana, basándose en este paso, por la abadía francesa, del obispo Gelmírez. Sobre ello, véase: S. MORALEJO ÁLVAREZ, "El patronazgo artístico...", p. 261 y M. A. CASTIÑEIRAS, "La catedral románica: tipología...", p. 90.
} 
El viaje de Diego Gelmírez a Roma, además de ser un hecho de vital importancia para el devenir de diversas cuestiones históricas y religiosas del momento, supone la plena apertura de la parte nordoccidental peninsular al ámbito europeo. Desde un punto de vista artístico, la excepcional personalidad del obispo debe ser equiparada, por su importancia y repercusión dentro de las artes plásticas, a otros personajes relevantes del panorama artístico de la Europa románica.

En concreto, pensamos en la figura del abad Bernardo de Hildesheim, por citar el caso más relevante y conocido. El tema ya ha sido abordado con cierta profundidad al tratar el problema de los "renacimientos medievales" en un apartado anterior, por lo que recordaremos, brevemente, algunos aspectos que consideramos esenciales.

El episcopado de esta importante figura se desarrolló entre los años 993 y 1022. El dato más importante aparece ligado al viaje que realizaría a la ciudad de Roma formando parte del séquito de Otón II y Teofano, en torno al año 980. De igual manera y por segunda vez, en noviembre del año 1000 regresa a la urbe ${ }^{2106}$.

Tal y como ha apuntado L. Castelfranchi Vegas, estas estancias del obispo en la ciudad le sirvieron para entrar en contacto con los vestigios artísticos del pasado imperial y para conocer, de primera mano, los grandes edificios antiguos y medievales romanos. La impronta clásica de las obras que el abad patrocinó y donó a la iglesia conventual de San Miguel de Hildesheim, han sido puestas de relieve frecuentemente.

En relación con el caso de las columnas de Compostela, interesa destacar el encargo que realizó el obispo germano en torno al año 1020. Se trata de la conocida columna helicoidal de relieve historiado, encargada, igualmente, a los mismos especialistas que años antes habían fundido las puertas de bronce para el mismo edificio en Hildesheim ${ }^{2107}$ (fig. 402).

La columna, de casi cuatro metros de altura, desarrolla a lo largo de la banda helicoidal que cae envolviendo, mediante siete pliegues, el fuste de la pieza, diversas historias relacionadas con la vida de Cristo. En las esquinas de la basa que eleva el fuste

Por último, debe recordarse como D. L. Simon, aludía a la influencia de Roma para explicar ciertos rasgos de la escultura de la catedral de Jaca, sobre todo, en época del rey Sancho Ramírez y de su esposa Felicia, cuando las relaciones con la sede romana se intensificaron. Cf.: D. L. SIMON, “A Moses...”, p. 219.

${ }^{2106}$ Sobre la figura del obispo de Hildesheim, véanse las siguientes obras: F. TSCHAN, Saint Bernward of Hildesheim. His Life and Times, vol. I, Indiana, 1942-1952; ID., Saint Bernward of Hildesheim. His Works of Art, vol. II, Indiana, 1942-1952; ID., Saint Bernward of Hildesheim. Album, vol. III, Indiana, 1942-1952 y Bernwardinische Kunst: Bericht über ein wissenschaftliches (A. Eggebrecht y M. Brandt, eds.), Göttingen, 1988.

${ }^{2107}$ L. CASTELFRANCHI VEGAS, "Hildesheim e Bernoardo...", pp. 59-60. Consúltese el apartado correspondiente dedicado al tema en este mismo estudio. 
se colocaron las personificaciones de los cuatro ríos del paraíso, lo que indica, de manera clara, una influencia clásica para la obra. Todos los autores han coincidido en afirmar, que se trata de una clara evocación de las columnas honorarias de relieve historiado romanas, tales como la de Trajano o Marco Aurelio. Sin embargo, la obra germana, en lugar de exaltar la grandeza de las campañas bélicas del divus, conmemoraría el triunfo de Cristo, es decir la "gloriosa gesta del Salvador",2108.

S. Settis, en su importante estudio sobre la influencia del arte clásico en la Edad Media, remarcaba las repercusiones que este prototipo de columna helicoidal historiada habría de ejercer sobre otros ejemplos medievales como, por ejemplo, la misma columna de Hildesheim o las columnas de Santiago de Compostela ${ }^{2109}$.

Según esto, parece factible pensar que, de la misma manera que el viaje a Roma realizado por el obispo germánico ha sido razón suficiente para que los especialistas justifiquen una evocación de las columnas historiadas romanas dentro de la pieza de Hildesheim; es posible también que, el viaje de Diego Gelmírez a la misma ciudad, sea la causa última que explique la presencia dentro del taller compostelano de un conocimiento de las fuentes y obras clásicas de la ciudad de los emperadores ${ }^{2110}$.

\footnotetext{
${ }^{2108}$ E. PANOFSKY, Renacimiento y renacimientos..., p. 99 . El autor proponía la hipótesis de que la obra conmemoraba el triunfo político del obispo Bernardo sobre su rival, el obispo Wiligis de Maguncia quién, exactamente después de seis años de la llegada del obispo de Hildesheim a Roma, se vio forzado a concederle los derechos, tanto tiempo disputados, sobre el convento de Gandersheim. Panofsky escribió al respecto: "quizá no sea demasiado atrevido suponer que este monumento único, trazado a imitación de las columnas triunfales de Roma, conmemore, además de la devoción de San Bernwardo, el éxito más resonante de su carrera administrativa".

Consúltese también: J. ADHÉMAR, Influences antiques..., pp. 90-94, donde se señala la importancia que, durante los siglos medievales, tuvo la columna trajana. Los abades de Saint-Benoît-sur-Loire, Cluny o Saint-Denis, tuvieron la oportunidad de viajar a Italia y contemplarla, gracias al decreto realizado por el Senado, en el año 1162, según el cual, se debía proteger la columna de la destrucción, con pena de fuerte sanción para quién hiciese lo contrario.

Sobre las fuentes clásicas de los trabajos en bronce patrocinados por el abad de Hildesheim, véase: B. GALLISTL, "Die Tür des Bischofs Bernward und ihr ikonographisches Programm", Le porte di bronzo..., pp. 145-181. Se señala la pervivencia medieval de determinadas iconografías habituales dentro del repertorio escultórico de los sarcófagos, sobre todo, a colación de la imagen de Adán y Eva siendo expulsados del Paraíso. El autor la relaciona con un sarcófago conservado en la iglesia de San Sebastiano de Roma. En relación con algunas piezas antiguas destruidas en los siglos medievales, véase: M. A. GARCÍA GARCÍA, "La reutilización y destrucción de los sarcófagos romanos de Baetica durante la Edad Media", Romula, 3, 2004, pp. 239-256.

${ }^{2109}$ S. SETTIS, "Continuità, distanza...", pp. 446-447. El especialista señala los ejemplos de la columna de Arcadio, la de Teodosio o la de San Poliuto de Constantinopla, como casos evidentes de una influencia posterior del prototipo romano.

${ }^{2110}$ M. A. CASTIÑEIRAS GONZÁLEZ, "Roma e il programma riformatore...”, pp. 219-220. En el estudio se menciona el sarcófago ático del siglo III conservado en la iglesia de San Lorenzo Extramuros de Roma y reempleado como tumba del papa Damaso II (†1048), como otra de las posibles fuentes conocidas por los escultores de las piezas hispanas. La temática de vendimia y la presencia de pájaros, así como el hecho de tratarse de una prestigiosa tumba papal, permiten suponer un conocimiento del modelo. También véase: F. H. TAYLOR, Op. cit., p. 56. En dicha aportación se señala lo problemático de una datación cronológica segura de la pieza, quizás reesculpida en época moderna.
} 
La complejidad espacial que presenta el hecho de desarrollar una historia ciñéndose al restringido marco de una banda helicoidal, no fue razón suficiente para que los artífices románicos enriqueciesen la fórmula con nuevas soluciones imaginativas alejadas de los ejemplos romanos. La utilización en la Hispania del siglo XII de tales modelos, señala la apertura artística de la Península hacia Europa pero, sobre todo, hacia aquellos lugares que, desde la Antigüedad, habían gozado de gran relevancia.

La utilización de la columna helicoidal con relieve de tipo dionisiaco en Santiago, demuestra un conocimiento de las fuentes romanas más allá de un ejemplo concreto. Participa dentro de un contexto más amplio y mucho más rico que una copia directa de una sola obra y permite otorgar al centro compostelano una importancia capital en la preservación de los valores clásicos en el arte románico hispano.

No en vano, en un excelente estudio realizado por E. Rosenbaum, se insistía en la importancia que durante los siglos medievales había tenido la utilización de la columna con relieve historiado, entendida ahora como una seña de prestigio. Su inclusión dentro de programas iconográficos de toda índole, dentro de las más variadas técnicas artísticas, así lo demuestra. La columna torsa aparecerá decorando ilustraciones de códices miniados, dotadas por los copistas de numerosos recursos ilusionistas evocadores de las mejores soluciones de la pintura romana. El uso fantástico del color, posible alusión a los ricos mármoles con el que estas piezas eran labradas, señala unas intenciones simbólicas y un conocimiento de las fuentes dentro del arte románico, más allá del conocimiento único del modelo arquetípico vaticano ${ }^{2111}$.

\footnotetext{
${ }^{2111}$ E. ROSENBAUM, “The Vine Columns of Old St. Peter's in Carolingian Canon Tables”, Journal of the Warburg and Courtauld Institutes, 18, 1-2, 1955, pp. 1-15. El estudio es una aportación ya clásica para el conocimiento del tema. Los conocidos Evangeliarios de Soissons, por citar el ejemplo más famoso, parecen influenciados, de manera clara, por este tipo de soluciones pictóricas de tradición clásica. Las columnas, ricamente representadas con todo tipo de colores alusivos a los mármoles con los que materialmente se realizaban, aparecen en buena parte de los ejemplos librarios de época carolingia. En concreto, cita la copia de dicho Evangelio conservado en Paris, Biblithèque nationale de France, Lat. 8850, f. 7 v. o, en la custodiada en London, British Museum, Harley Ms. 2788, f. 11v.

En ambos se utilizaron columnas torsas, algunas de ellas con pequeños "erotes" desnudos realizando labores de vendimia, siguiendo los modelos vaticanos. Insiste, además, en la leyenda que consideraba una de las columnas conservadas de la pérgola constantiniana, como procedentes del mismo templo de Salomón.

Véase también: W. WEISBACH, Reforma religiosa..., p. 66. Weisbach analiza algunos ejemplos de la utilización de los fustes preciosos dentro de construcciones medievales. En concreto, cita el ejemplo de Nicolás II que, en torno al año 1059, mandó colocar, dentro del baptisterio de Florencia, un sistema de apeos columnados totalmente decorados con incrustaciones de piedras policromadas, que dotaba de una solemne magnificencia a la construcción, renovando así "un uso practicado ya en las iglesias paleocristianas y bizantinas". En todo caso, esta tradición, ciertamente antigua, aparece atestiguada dentro de otras muchas piezas. Por ejemplo, recuérdese el baldquino que sirvió de tumba a Enrique el Liberal, muerto en el año 1181, en Chartres. La obra, hoy destruida, se conoce a través de un grabado y nos habla de una pieza de calidad exquisita donde se usó este gusto por la incrustación. Sobre ella,
} 
Para finalizar debemos centrarnos, brevemente, en las posibles causas que llevaron a elegir este tema para decorar unas piezas tan visibles dentro del conjunto escultórico del templo. Dichas columnas decoraban el acceso de los peregrinos al "relicario pétreo" en el que se custodian las reliquias corporales de un Apóstol. Así, de la misma manera que en la basílica vaticana las columnas de putti vendimiadores delimitaban y marcaban el lugar de la confessio donde se hallaban los restos de San Pedro, en el edifico románico hispano, una iconografía idéntica señalaba el acceso al recinto sagrado. Parece claro entonces que el tema de la viña pudo tener, a los ojos de aquellos que tuviesen la capacidad de comprender dichas imágenes, un claro sentido eucarístico.

Creemos que las columnas hispanas conservan la tradición cristiana primitiva de introducir el tema de la viña dentro de los recintos funerarios. En concreto, F. Cabrol y H. Leclercq han señalado la vinculación del tema con aquellos recintos destinados a custodiar las reliquias de los mártires, entendiendo que la viña y sus frutos aludirían, en última instancia, al sanguinem uvae, cuyo simbolismo se encuentra marcado por la propia liturgia romana, muy común en las celebraciones de época pascual ${ }^{2112}$.

No debe extrañar, por tanto, que las columnas adornadas con el tema de la viña fueran utilizadas con relativa frecuencia a la hora decorar frentes de altar, canceles, ciboria, retablos y toda suerte de mobiliario litúrgico. Incluso, tal y como señala la profesora S. Silva y Verástegui, la tradición no fue ajena dentro de la iconografía funeraria de los sepulcros de los santos durante la Edad Media ${ }^{2113}$. Su uso se perpetúa

consúltese: R. SÁNCHEZ AMEIJEIRAS, "La ritualización del camino de vuelta: Nuevos hallazgos sobre el sepulcro de Santo Domingo de La Calzada", Arte Medieval en La Rioja: prerrománico y románico (I. Gil Díez de Usandizaga ed.), Logroño, 2004, pp. 321-364, en particular, p. 357. La profesora Sánchez Ameijeiras señala que la pieza se debe incluir dentro de la tendencia de gusto "antiquizante" que dominó la corte Stauffen.

${ }^{2112}$ F. CABROL y H. LECLERCQ, voz "Vigne", Dictionnaire..., vol. XV, cols. 3114-3115. La uva es entendida, según estos autores, como la Viña del Señor, identificada, metafóricamente, a través de la cepa. Los fieles son, siguiendo este simbolismo, los ramajes y los pámpanos propiamente dichos. Como ejemplo bien significativo, citan el caso de la catacumba de Domitila, de época de los Flavios, donde se constata la utilización, dentro de un recinto funerario, del tema de la viña y los "erotes".

2113 S. SILVA Y VERÁSTEGUI, “Los sepulcros de los santos...”, p. 130. En muchas ocasiones, dichas columnas aparecen elevando el sepulcro debido a razones litúrgicas. Se han constatado algunos ejemplares donde tal elevación se realizó a través de piezas marmóreas expoliadas o, en otras ocasiones, donde el sepulcro que se eleva, es antiguo. Este último caso puede observarse, por ejemplo, dentro del sarcófago aquitano que sirvió de tumba al Conde Santo Osorio Gutiérrez en Villanueva de Lorenzana, Lugo. En relación con la pieza, véase: F. ESPAÑOL BERTRÁN, "Santo Domingo de la Calzada: el cuerpo santo y los escenarios de su culto", La cabecera de la Catedral calceatense y el Tardorrománico hispano, Santo Domingo de la Calzada, 2000, pp. 207-282, concretamente, pp. 259-260 y S. MORALEJO ÁLVAREZ, “La reutilización...", p. 189. Este último autor relaciona la pieza de Lorenzana con la representación del sepulcro de santa Eufemia en la catedral de Orense. Sobre esta imagen ya hemos 
además, en formato monumental, decorando los ábsides de los templos, como en el caso tantas veces aludido del mosaico San Clemente de Roma ${ }^{2114}$.

Por último cabe señalar que, la posible lectura, en clave eucarística, de algunas de las imágenes presentes en estos fustes tendría su referente en ciertos pasajes recogidos dentro del Codex Calixtinus:

"El, como un mayordomo de las viñas, plantó con gran trabajo la viña de la Iglesia, extirpando los abrojos de los vicios, cortando los espinos de las malas acciones, formando buenas cepas, poniendo alrededor el seto de los dogmas evangélicos contra las bestias salvajes, espantando lejos de ella a las zorras de la herejía que acostumbran destruir las viñas, y edificio también en ella el lagar del nuevo altar y la torre de la fe. El, a la manera de un labrador moderno, roturó inteligentemente la tierra antes inculta, con la cuchilla de su nueva predicación y el arado de la fe, a fin de que los venideros pudieran más fácilmente ararla predicando y la tierra, limpia de las malezas de los vicios, recibiese la semiente y produjese fruto más abundante, ya el ciento, ya el sesenta por uno (...)"2115 (texto 76).

Dentro de la misma fuente, las referencias a la viña y a la uva son frecuentes, siempre dentro de un leguaje metafórico y alusivo a la figura de Cristo:

"Extendióse la voz por todo el orbe, del compañero del Señor: no queda lugar donde se niegue su alta gloria. Noble de antiguo tronco descendiente, pero más noble con razón en Cristo. Rica luz, cima augusta, santo ornato, en cuyo elogio todo honor milita (...) En las ramas de la herejía injerta gérmenes píos de la fe, y lo que era acebuche, rebrota pingüe olivo. El árbol seco y deshojado nuevas galas ostenta que su fruta anuncian. La triste higuera destinada al fuego sin esperanza, su seno prepara a dar fruto, de abono bien nutrido. La uva hinchada en el pámpano, que pasto sería de los pájaros, con este guardián el buen lagar no ha de perderla. Viñador en las viñas apostólicas, puso en forma los liños, removiendo la tierra con la

hablado, pero se trata de una representación datada en torno al año 1500 , que presenta una clara decoración paleocristiana de escamas. De la misma forma, se eleva sobre columnas.

${ }^{2114}$ G. MATTHIAE, Mosaici medioevali..., pp. 279-304; F. BISCONTI, "Progetti decorativi dei primi edifici di culto romani: dalle assenze figurative ai grande scenari iconografici", Ecclesiae Urbis. Atti del Convegno Internazionale di Studi sulle Chiese di Roma (IV-X secolo) (F. Guidobaldi y A. Guiglia Guidobaldi ed.), III vols., Città del Vaticano, 2002, vol. I., pp. 1633-1658, en concreto, pp. 1640-1644 y W. TRONZO, "On the role...", p. 1090, nota 7. El profesor Tronzo justifica la introducción del tema de la viña en San Clemente y en el vestíbulo lateranense, a través de su difusión dentro de los ambientes funerarios antiguos de la ciudad como, por ejemplo, en la tumba de Pomponius Hylas.

${ }^{2115}$ Liber Sancti Jacobi..., pp. 70-71. 
azada y recortando los sarmientos con hábil podadera. Del campo del Señor la vid silvestre y estéril extirpó, y se ven ahora racimos en lo que antes fue matojo. Del sembrado de Dios la vil cizaña, y por igual las mies lozana crece (...),2116 (texto 77).

Estos pasajes demuestran la complejidad simbólica que se le otorgó, en el ambiente jacobeo, a todos aquellos aspectos relacionados con la viña, sus frutos y las actividades agrícolas ligadas a ella ${ }^{2117}$. Las fuentes documentales reiteran la importancia de preservar la viña lejos del ataque de los enemigos, mientras que, desde un punto de vista plástico, siguiendo una imagen bien conocida desde la Antigüedad, son los propios putti, encargados de recolectar los frutos, los que también evitan que las aves picoteen los racimos. Creemos que con esa función pudo haber sido representado uno de los "erotes" que agarra con fuerza a un ave por el cuello "para proteger su afanoso trabajo"2118 (fig. 403).

Con todo, este tema del vendimiador que protege la viña de las rapaces fue bien conocido dentro del arte pagano, tal y como se observa, por ejemplo, en el bello ejemplar marmóreo del niño ahogando una oca, conservado en Alemania ${ }^{2119}$ (fig. 404).

Se trata de una escultura de claros resabios helenísticos y hasta con cierto tono satírico, en la que, una figura infantil que muestra un desnudo mórbido, claramente, emparentado con la tradición escultórica helenística, ahoga al animal al agarrarlo por el cuello $^{2120}$.

Finalmente, podemos concluir que, aceptamos la utilización de un modelo romano como referente para los escultores medievales de Santiago, concretado, en primer lugar, por las columnas utilizadas en la pérgola constantiniana de San Pedro del

\footnotetext{
${ }^{2116}$ Ibidem, pp. 30-31 y pp. 77-83. Se trata de un centón de veintiocho dísticos elegíacos realizados, tal y como nos informa el texto, por San Fortunato. Dentro del mismo, véase el capítulo VII "25 de julio. Pasión de Santiago de Galicia" donde, nuevamente, se realiza una narración teniendo diversos elementos vegetales y frutales como elemento alegórico. Los textos ya fueron puestos en relación con la pieza por varios autores. Cf.: M. A. CASTIÑEIRAS GONZÁLEZ, "Fragmento de fuste...”, p. 152, nota 4.

${ }^{2117}$ Liber Sancti Iacobi..., pp. 204-206. El pasaje del texto ya ha sido trascrito anteriormente. Se trata de un fragmento del Libro de los Doce Sabios de San Basilio. Tal y como aclaran los autores encargados de realizar la edición crítica del Codex, este texto es una colección de advertencias a los monarcas, de todos aquellos saberes que debe tener un buen rey. Destacan la importancia que llegó a adquirir en Hispania el de Alfonso el Sabio, Tratado de la Nobleza y de la Lealtad.

${ }_{2118}$ Esta es la lectura que se propone en: M. A. CASTIÑEIRAS GONZÁLEZ, "Fragmento de fuste...”, p. 152.

${ }^{2119}$ München, Antikensammlung.

${ }^{2120}$ Sin pretender parentescos entre ambas obras, esta pieza constata la existencia del tema dentro de la escultura exenta de la Antigüedad. Cf.: L. LAURENZI, voz "Boethos I", Enciclopedia dell'arte antica..., vol. II, 1959, pp. 118-120.
} 
Vaticano. Sin embargo, la presencia de sarcófagos con el mismo tema en la Península Ibérica, como aquel de Castanheira de Ribatejo de Belém, Museo Arqueologico (fig. 401), permite suponer un enriquecimiento de la iconografía románica a través de otra serie de piezas, especialmente, las funerarias ${ }^{2121}$.

El sarcófago de la vendimia conservado en el pórtico de la iglesia de San Lorenzo Extramuros ya fue puesto en relación con el ejemplar anterior por el profesor M. Justino Maciel (fig. 405). Por su parte, M. Castiñeiras tomaría como referencia tal obra para explicar la presencia del tema en las columnas gallegas, tal y como ya hemos señalado $^{2122}$.

El horizonte común que comparten todas estas piezas tardoantiguas romanas es la razón última que puede explicar la reinterpretación que del tema hicieron los marmolistas románicos para las iglesias de San Carlos a Cave y Santa Trinidad dei Monti, ambas en Roma. Éstas, junto con los ejemplares hispanos, parecen probar la continuidad del motivo clásico en los siglos de la Edad Media ${ }^{2123}$.

La inseguridad argumental a la hora de señalar un único modelo inspirador para estas esculturas viene subrayada mediante el amplio corpus de piezas decoradas con este tema. Se trata de obras realizadas en el periodo romano, y conservadas en un estado fragmentario, tanto en suelo hispano como en la misma Galia. Cabe imaginar un panorama mucho más amplio donde se deduce la posible existencia de piezas, hoy posiblemente desaparecidas, que imposibilita concretar más la puntualización de potenciales modelos más exactos ${ }^{2124}$.

En este sentido sirva, a modo de ejemplo, el magnífico fuste de columna romana publicado, ya en su día, por H. Walter, donde se muestra el tema de los pámpanos y racimos de la viña que envuelve completamente el fuste de la pieza. Dentro de tal composición se incluyó, al menos teniendo en cuenta las partes fragmentarias que han llegado hasta nosotros de la pieza, la figura de un personaje desnudo que parece iniciar

\footnotetext{
2121 A. GARCÍA Y BELLIDO, "Sarcófagos romanos de tipo oriental hallados en la Península Ibérica", Archivo Español de Arqueología, 21, 71, 1948, pp. 95-109.

${ }^{2122}$ M. JUSTINO MACIEL, J. M. PEIXOTO CABRAL y D. NUNES, “Os sarcófagos tardo-romanos...”,

${ }_{2123}^{\text {p. } 166 .}$ A. SARTORIO, "Le colonne vitinee e le colonne tortili", Rasegna d'arte, XII, 1912, pp. 175-180 y H. WENTZEL, “Antiken-Imitationem des 12.u.13. Jahrhunderts in Italien”, Zeitschrift für Kunstwissenschaft, IX, 1955, pp. 29-72.

2124 G. CANTINO WATAGHIN, "Contributo allo estudio della città tardoantica", IV Reunió d'arqueologia Cristiana Hispànica, Barcelona, 1995, pp. 235-261.
} 
la vendimia. Nuevamente, aquí hallamos un idéntico tratamiento del desnudo, así como del tema vegetal ${ }^{2125}$.

Dentro del caso hispano, nos ha llegado la pilastra de Osuna, en Sevilla, y en la que se muestra la imagen de un personaje representado de perfil con un marcado ojo almendrado. S. Vidal ha identificado la figura como un "erote" vendimiando, pues coge, con una de sus manos, un racimo de uvas. De haberse conservado completa la escultura hubiera formado parte de una pieza de mayores dimensiones ${ }^{2126}$ (fig. 406).

Para finalizar, haremos alusión a una pieza que se ha datado en torno al año mil. Se trata de la placa ebúrnea de Adalbéron de Metz y presenta, como tema principal, una Crucifixión (fig. 407). Lo más interesante es que la cruz ha sido colocada sobre una columna con capitel corintio cuyo fuste fue decorado con diversos vegetales en forma de látigo, quizás cepas. Según D. Gaborit Chopin, tal imagen debe ser asociada con otra serie de obras cronológicamente coetáneas como, por ejemplo, la cruz que mandó hacer Bernardo de Hildesheim o aquella utilizada para la Virgen de Oro de Clermont ${ }^{2127}$.

La colocación de tal elemento bajo la cruz de Cristo insiste en el fuerte contenido simbólico que, con connotaciones martiriales y eucarísticas, adquirió el tema dentro de la tradición iconográfica cristiana. Creemos que la lectura simbólica del mismo tema en las columnas de la catedral debe ser encaminada en esta misma dirección.

Lejos quedaba ya la imagen de la viña y los "erotes" vendimiadores en ambientes báquicos, un tema que, desde la Antigüedad romana, llegaba hasta los talleres hispanos en los primeros años del siglo XII, aunque fuese enriquecido con un nuevo

\footnotetext{
${ }^{2125}$ H. WALTER, Op. cit., p. 100. Ocurre lo mismo con otro ejemplar en el que también se esculpió un personaje desnudo, con similar posición, que sujeta con su mano derecha un falx, con el que inicia la tarea agrícola en medio de un entramado vegetal en el que se llegaron a incluir diversos animales.

${ }^{2126}$ Se ha datado el relieve dentro del siglo IV y se ha puesto en relación con talleres romanos. Lo más interesante es que se trata de un ejemplo que permite afirmar que el tema fue conocido dentro de la Hispania antigua y no sólo a través de sarcófagos, tal y como se ha constatado. Su función de pilastra, elemento sustentante o decorativo, permite establecer ciertos precedentes anteriores a la Edad Media, en relación con la práctica de decorarlos con el tema de la vendimia. Cf.: S. VIDAL, "Fragmento de pilastra de Osuna (Sevilla)", La escultura ..., ficha catalográfica B14, p. 68.

2127 D. GABORIT CHOPIN, "Plaque de reliure: ivoire d'Adalbéron", La France romane..., ficha catalográfica 5, p. 55. Creemos que debe recordarse, en relación con esta imagen, la tradición antigua de conmemorar el lugar de descanso del difunto a través de una columna que también podía hacer las funciones de monumento funerario. Cf.: G. A. MANSUELLI, "Monumento funerario...", p. 196 у H. STERN, "Une mosaïque de pavement...", p. 88. Tal aspecto justifica la inclusión del tema dentro de los ábsides de los templos románicos, a través de cualquier tipo de técnica.
} 
significado, nuevas formas, temas y repertorios foráneos no estrictamente relacionados ya con el mundo clásico ${ }^{2128}$.

${ }^{2128}$ La distribución de los vegetales en forma de látigo del marfil tiene su paralelo en una columna romana de temática vegetal en el fuste. La escultura fue publicada en: H. WALTER, Op. cit., lámina IX. 


\section{3. OTROS ASPECTOS CLÁSICOS DE LOS ESCULTORES DE SANTIAGO DE COMPOSTELA.}

El apartado que ahora iniciamos está dedicado a otros elementos clásicos que parecen haber pervivido dentro de la escultura compostelana de los primeros años del siglo XII. Se trata de una serie de rasgos, generalmente descontextualizados y débiles, que permiten rastrear un cierto eco, ya difuso, y posiblemente deudor de una lejana absorción de fórmulas romanas.

Creemos que los aspectos más relevantes de la posible influencia del arte clásico dentro de la escultura románica de la catedral de Santiago han sido abordados en las páginas anteriores. Los que restan, se nos presentan como motivos aislados, de los que es muy difícil poder demostrar su origen y que, en ocasiones, por su uso concreto y discontinuo, resulta difícil catalogar como "clásicos".

Adelantamos aquí, que ello refleja un fenómeno natural y habitual dentro de la escultura románica europea con filiación clásica. Los artífices, conscientes de una Antigüedad que les ha llegado fragmentada, se enfrentan a ella con un conocimiento de la misma un tanto sesgado y disperso, lo que traducido dentro del campo de las artes plásticas se expresa mediante la utilización intermitente de dichos motivos "antiquizantes".

A pesar de que la mayor parte de los especialistas han señalado fuentes clásicas para esta escultura, se trata, más que de una presencia indiscutible, de ciertos ecos, lejanos y vagos, que nos permiten adelantar una de las conclusiones del presente apartado. A parte de las evidentes relaciones que presentan las esculturas anteriormente estudiadas con el arte romano, otra serie de piezas de la misma catedral parecen evidenciar un acceso, por parte de los artistas, a una Antigüedad que se muestra dispersa, inconexa y desperdigada.

A partir de la segunda y tercera década del siglo XII, en el momento de introducir ciertas novedades, los artistas las materializan en la plástica medieval mediante una forma muy cambiada y de la que, en ocasiones, tan sólo perduran lejanos recuerdos de aquellas. La introducción, en un momento determinado, de una iconografía muy concreta, la manera de tratar los pliegues de los textiles o, por ejemplo, ciertas innovaciones a la hora de materializar los nimbos de determinadas figuras, son rasgos muy imprecisos que atestiguan la reinterpretación de unas formas clásicas que les 
habían llegado ya sometidas a la interpretación de una primera generación de escultores románicos. Se trataba, quizás, de una Antigüedad doblemente expoliada. 


\section{A. LOS ELEMENTOS TEXTILES EN AMBIENTES ACUÁTICOS: UN PROBLEMA ICONOGRÁFICO} SIN RESOLVER.

En el bloque dedicado al análisis de algunos aspectos de la escultura de la catedral de Jaca, nos detuvimos, de manera especial, en el estudio de algunos elementos relacionados con la iconografía de los sarcófagos de temática báquica y aquellos que presentaban el tema del thiasos marino ${ }^{2129}$.

Concluíamos que algunos aspectos presentes dentro de las piezas romanas donde se había utilizado el tema, hipotéticamente, habían pasado a algunas de las esculturas románicas, a pesar de no poder concretar bien el significado último que les dieron los escultores medievales. En relación con ello, creemos que es significativo al respecto el capitel jacetano de los danzantes rodeados de ondulaciones, ya fuesen esculpidas con la intención de materializar, de manera plástica, un ambiente marino o, tal y como han interpretado otros especialistas, con el interés de aludir a diversos elementos textiles.

El problema, a pesar de no tener una importancia crucial para poder demostrar una pervivencia de modelos clásicos, ha recibido una atención especial por parte de los especialistas.

Tal y como hemos señalado anteriormente, esta complicada iconografía había aparecido ya en algunos capiteles de las iglesias de Loarre e Iguácel (fig. 408) donde, diversos personajes, aparentemente desnudos, surgían de una masa ondulante ${ }^{2130}$.

En el caso de San Pedro de Loarre, una solución similar reaparece en el friso superior que enmarca el acceso al edificio (fig. 409). Las relaciones con la escultura jaquesa han sido aceptadas por la mayoría de estudiosos que han abordado el tema, por lo que se podría deducir, hasta cierto punto, una herencia de algunos rasgos "antiquizantes" que presentaba la escultura de Jaca.

Con todo, nos interesa destacar una imagen que fue incluida en el desarrollo figurativo del malogrado friso. Entre una fragmentada Maiestas Domini acompañada por los símbolos Marcos y Lucas, "se vislumbran una serie de personajes que emergen

\footnotetext{
${ }^{2129}$ Se advertirá, en este sentido, una simplificación del aparato crítico, pues creemos que no es necesario citar nuevamente los trabajos utilizados para la documentación de nuestro estudio. A la hora de referirnos a algunos aspectos concretos y obras ya tratadas, en relación con la escultura de la catedral de Jaca o la de Santiago, remitimos a los referidos bloques.

${ }^{2130}$ J. LACOSTE, Les maîtres..., pp. 40-43.
} 
del agua o de una nube ${ }^{, 2131}$. La profesora F. Español, al realizar el estudio de tales imágenes, escribía:

"Los grupos de personajes emplazados a ambos extremos (...) constituyen el elemento más enigmático del friso (...) las figuras parecen sobresalir de una corriente de agua, pero las ondas admiten otras interpretaciones: que se trate de nubes, por ejemplo" 2132 .

En su día, M. Durliat interpretó la escena como unos personajes sujetando y mostrando al espectador las "telas lavadas" en la sangre del Cordero ${ }^{2133}$. Sin embargo, ya hemos señalado, anteriormente, y de manera reiterativa, como S. Moralejo relacionó el motivo con la plástica presente en los sarcófagos romanos con el tema del thiasos $^{2134}$.

Lo que parece claro es que el motivo jaqués y el presente en Loarre se muestran emparentados desde un punto de vista iconográfico y formal. La difusión de los motivos clásicos, tal y como venimos señalando, pronto habría de llegar a la catedral de Santiago de Compostela. En concreto, el capitel del brazo sur del transepto, tantas veces mencionado, presenta claros paralelismos con el elemento en cuestión (fig. 255). Nuevamente, aquí varias figuras parecen sujetar con sus manos un elemento ondulante que cuelga, además, cubriéndoles las piernas, mientras los pies asoman por la parte baja.

La mayor complejidad de la pieza no reside en su vinculación iconográfica con la escultura de Jaca, sino en la clara dependencia que muestra con respecto al estilo escultórico de la catedral de Conques, lo que, sin duda, difumina aún más cualquier conclusión sobre su estudio ${ }^{2135}$. Este último aspecto vendría apoyado mediante el supuesto tema que narra el capitel y que M. Castiñeiras ha interpretado, desde un punto de vista hagiográfico, en relación con el martirio de Santa $\mathrm{Fe}^{2136}$.

Bien se trate de textiles, los stoloe alboe, o bien de la imagen de unos personajes emergiendo del agua, ambos parecen tener su justificación a través de los textos

${ }^{2131}$ F. ESPAÑOL BERTRÁN, "El castillo de Loarre y su portada románica”, Locvs Amoenvs, 8, 20052006 , pp. 7-18, en concreto, p. 13. Creemos que se trata de un estudio fundamental por abordar, de una manera concreta, esta cuestión.

${ }^{2132}$ Ibidem, pp. 14-15. Donde se recogen las diferentes interpretaciones de algunos autores que van, desde identificar tal elemento como corrientes de fuego hasta como alusiones a las aguas del bautismo.

${ }^{2133}$ M. DURLIAT, "L'apparition...", p. 21.

${ }^{2134}$ S. MORALEJO ÁLVAREZ, “La sculpture romane...,", p. 88.

${ }^{2135}$ J.-C. FAU, “À propos du chapiteau de la condamnation...”, pp. 47-57.

${ }^{2136}$ M. A. CASTIÑEIRAS, "Los santos viajan....", p. 70. Sobre la teoría defendida por este autor se pronuncia la profesora Español que considera que se trata de "una interpretación hagiográfica, aunque no logramos ver los rasgos que permiten identificar a una santa mártir". Cf.: F. ESPAÑOL BERTRÁN, "El castillo de Loarre...”, p. 14, nota 56. 
apocalípticos, una de las fuentes más conocidas durante estos siglos. En este último caso se trataría de los seniores y la imagen del mar de cristal, tal y como señala la profesora F. Español, quién concluye sus reflexiones sobre el relieve afirmando:

“(...) las obras emprendidas en Loarre culminan con la ejecución de una portada monumental en la que pueden reconocerse ecos del programa desplegado en la fachada de San Pedro del Vaticano (...) y que aproxima el proyecto aragonés a una serie de monumentos occidentales que, desde época carolingia, han tomado como modelo la basílica constantiniana en sus propias remodelaciones, singularmente el sector oriental con el cuadripórtico conocido como Paraíso. Desde esta perspectiva, el texto de la inscripción que discurría a lo largo de la mandorla de la Maiestas de Loarre, FONS EGO SUM VITA, admite una asimilación a la corriente de agua que fluye del trono de Cristo-Sabiduría (...) quienes transitan por la puerta de Loarre acceden a la fuente de vida o, lo que es lo mismo, a la Jerusalén Celestial $^{, 2137}$.

Tal y como vemos, parece plausible que, dicho elemento, presente en Jaca, Loarre y Santiago, pudiera ser interpretado como una corriente acuática. Sin embargo, lo que es más importante para nuestro objeto es que, en opinión de la citada investigadora, podría tratarse de la pervivencia de algunos de los elementos iconográficos, nuevamente ligados a la basílica romana de San Pedro.

Sin embargo, aunque tal hipótesis resulta sugestiva creemos que es necesario continuar investigando sobre ella. Con todo y en relación con este motivo, quisiéramos finalizar estas breves reflexiones aludiendo, rápidamente, a una pieza muy citada en este estudio.

El capitel de la iglesia de San Martín de Frómista, que copia el frente del Sarcófago de Husillos, presenta un elemento que debe ser tenido en cuenta a la hora de valorar este tipo de iconografía. Ya hemos señalado, anteriormente, la ingeniosa reinterpretación llevada a cabo por el artista románico del motivo textil presente en la pieza romana. Mientras que en el sarcófago, el ambiente palatino se sugirió a través de ricos textiles colgando, a modo de cortinajes, en el capitel, el escultor copió el tema dotándolo de entidad propia. Recordemos como aquella parte que en la pieza clásica está ocupada por el pliegue que dobla el cortinaje, fue sustituida por un mascarón que

${ }^{2137}$ Ibidem, p. 17. 
parece vomitar una cascada de telas en la escultura románica. El problema, ya señalado, reside en saber si se trata de una representación textil o, por el contrario, tal máscara expulsa algún fluido.

Para concluir, lo que más nos importa destacar, es como un motivo de tradición clásica, es decir un cortinaje, fue representado libremente por el escultor románico de Frómista, aportando ciertas novedades e innovaciones, que acabarían por provocar, posteriormente, un debate en relación con las interpretaciones del mismo. Lo cierto es que, aquí, y por derivación, perfectamente demostrada, de una pieza romana, otra vez hallamos a varios personajes que cubren sus extremidades con el enigmático elemento. Nuevamente las piernas de las figuras asoman por la parte baja del supuesto textil, como en Loarre. Sin embargo, la presencia del mascarón y el hecho de que el cortinaje sea expulsado de su boca, vuelve a poner de manifiesto la ambigüedad de tal imagen. Creemos que después de haber señalado detenidamente las modificaciones "caprichosas", inventivas y fantásticas a las que el escultor medieval sometió al tema de Orestes, pocos serán los argumentos sólidos que permitan interpretar el motivo de una manera segura, más allá de una mera licencia del artista.

Sin embargo, la formula fue conocida dentro de los talleres compostelanos. Así, se repetirá, modificada, en las columnas de la fachada de Platerías (fig. 410). Allí se esculpieron una serie de figuras angélicas que, con sus manos, sujetan palmas y cortinajes. Éstos caen, finamente, cubriendo parte de sus cuerpos en una composición de innegables resabios clasicistas. A pesar de ello, parece que, en este caso, existe cierta unanimidad a la hora de poder explicar tales imágenes, pues han sido tenidas como diversas procesiones angélicas mostrando elementos ligados a la pasión de los mártires y su triunfo sobre el dolor y la muerte. La palma y los textiles que limpiarían la sangre derramada, parecen mostrarse aquí, nuevamente, herederos de ciertas influencias "romanistas" o, al menos, así lo ha explicado M. A. Castiñeiras.

El autor, que insiste en la vetustez del tema, no dudó en englobarlo dentro del supuesto "renacimiento paleocristiano" ${ }^{, 2138}$. La presencia de estos seres alados portando palmas martiriológicas, la inclusión de la iconografía de los pavos y el cáliz, así como

\footnotetext{
${ }^{2138}$ M. Castiñeiras utiliza el concepto al hablar de la iconografía de la fachada de Platerías, escribiendo: (...) "esta apostolicidad conecta con una de las obsesiones del renacimiento paleocristiano promovido por la reforma gregoriana, que veía a los discípulos de Cristo como modelo que debían seguir los obispos". Cf.: M. A. CASTIÑEIRAS GONZÁLEZ, "La catedral románica: tipología...", particularmente, p. 65 .
} 
otra serie de ornamentos eclesiásticos de la tradición paleocristiana, además de estos expresivos vela alexandrina, hacen dicha hipótesis ciertamente factible ${ }^{2139}$.

${ }^{2139}$ M. A. CASTIÑEIRAS GONZÁLEZ, “Un adro para un bispo...”, p. 242. 
B. LAS MÁSCARAS Y LOS ROSTROS DE TRADICIÓN ANTIGUA: ALGUNAS HIPÓTESIS A PROPÓSITO DE “MUJER DEL CRÁNEO” Y LA NUMISMÁTICA.

En el apartado relativo a la escultura del foco jacetano analizamos la fortuna que tuvieron diversos motivos emparentados con las máscaras teatrales y sus variantes, dentro del repertorio utilizado por los artífices. Es posible que, de la misma manera que se ha constatado una continuidad de tradiciones iconográficas en la utilización del motivo dentro, por ejemplo, de la miniatura y la ilustración del libro, el traspaso también pudiera haberse llevado a cabo hacia otras técnicas de la plástica medieval ${ }^{2140}$.

A ello debemos sumar la conservación, casi extraordinaria, de algunas de estas máscaras, tal y como hemos puesto de relieve a través de los ejemplares realizados en estuco y conservados en el Museo Arqueológico de Palencia, que parecen señalar algunos de los posibles modelos remotos que pudieron llegar a inspirar a los artífices románicos. En el caso gallego, la conservación de esculturas de índole similar no es tan afortunada.

Dentro de la plástica desarrollada en los inicios del siglo XII por los escultores compostelanos, parece probable poder señalar los ecos de una continuidad de tales tradiciones antiguas. Los rostros de algunas figuras y el recuerdo de las máscaras clásicas, pasaron de manera discontinua al repertorio de estos escultores, recuperados, casi de una manera indirecta, demostrando un conocimiento limitado de las fuentes originales.

Algunos estudiosos han señalado, consecuentemente, determinadas peculiaridades de la escultura de las fachadas de la puerta de Francia y la de Platerías en relación con el tratamiento del rostro de las figuras. Recuérdese, por ejemplo, como C. Sastre Vázquez ha insistido en la pervivencia de un sabor antiguo en el rostro de algunas figuras, como el "faunístico" San Andrés de Platerías o el mismo retrato del Santiago entre cipreses que, parecen recordar, según defiende, ciertos prótomos cefálicos que remataban los esquinales de los sarcófagos romanos ${ }^{2141}$.

\footnotetext{
${ }^{2140}$ Hemos aludido, anteriormente, a la fortuna del tema dentro de las diversas copias realizadas de las Comedias de Terencio durante los siglos medievales. En este mismo sentido, el profesor Fernando Galván Freile ha demostrado la utilización de este repertorio tomado de las artes clásicas, dentro de la ilustración de algunos manuscritos. Cita, en concreto, aquel conservado en Paris, Bibliothèque nationale de France, Ms. lat. 7899, f. 125 o el de Oxford, Bodleian Library, Ms. Auct. F.2.13, f. 3. Véase al respecto: F. GALVÁN FREILE, "Entre la diversión y la transgresión...", p. 40.

${ }^{2141}$ C. SASTRE VÁZZUEZ, "La portada de las Platerías y la "mujer adúltera". Una revisión", Archivo Español de Arte, LXXIX, 314, 2006, pp. 169-186, en particular, p. 179, nota 40.
} 
En relación con este aspecto queremos detenernos en una de las figuras más importantes del conjunto escultórico de la fachada de Platerías y que ha sido, sin duda, una de las representaciones que mayor atención ha recibido en los estudios dedicados al arte románico. La llamada "mujer de la calavera" o "mujer adúltera" es, por la bibliografía existente en relación con ella, uno de los temas más complicados e introvertidos del conjunto ${ }^{2142}$.

La mujer, que aparece descrita en el Codex Calixtinus, se muestra sentada en una silla de resabio clasicista, siguiendo un modelo bien conocido dentro de la escultura hispano-languedociana. Las patas en forma de garra y la decoración superior en forma de prótomos de leones, recuerdan soluciones utilizadas en la lastra con la imagen del rey David, hoy incrustada dentro del mismo conjunto.

De entre todos los aspectos que se han destacado, nos centramos en el rostro de la figura (fig. 411). Sin duda, se trata de una configuración fisonómica muy característica de la escultura desarrollada por los talleres compostelanos y que, paralelamente, se estaba desenvolviendo en otros lugares, tales como San Isidoro de León o la misma basílica de Saint-Sernin de Toulouse. A su vez, el tratamiento anatómico de la figura, con una pierna descubierta, no es tampoco desconocido dentro de las soluciones adoptadas por otros talleres, tal y como señalamos para el caso de los músculos de la atlética figura de Isaac en el capitel de Jaca, claramente deudor de formas romanas.

El rostro de la mujer del cráneo permite, por tratarse de un aspecto concreto de la figura, reflexionar sobre las soluciones adoptadas por los escultores románicos a la hora de materializar una figura en piedra. Si seguimos las ideas defendidas por muchos investigadores, los detalles de carácter "antiquizante" visibles en la fachada, permiten afirmar que el conocimiento del arte clásico que tenían estos artífices no era completo.

Se trata de una afirmación que ya realizó en su día E. Panofsky, tal y como hemos señalado, y que entendía que las tendencias recuperadoras de lo clásico durante los siglos medievales eran intermitentes. Esta recuperación no unitaria, sería lo que, a grandes rasgos, diferenciaría el gran número de renacimientos medievales del gran Renacimiento italiano.

${ }^{2142}$ Se trata de un tema muy estudiado. Por nuestra parte, no podemos aportar ninguna novedad al respecto, por lo que, tan sólo señalamos dos de los trabajos más recientes que a dicha escultura se han dedicado y donde, además, se recoge toda la bibliografía al respecto. Cf.: J. WILLIAMS, "La Mujer del cráneo y la simbología del románico", Quintana, 2, 2003, pp. 13-27 y C. SASTRE VÁZQUEZ, Op. cit., pp. 169-186. 
Al analizar el rostro de la mujer esculpida para el tímpano izquierdo de la fachada de Platerías, se pueden advertir algunos rasgos que, según pensamos, recuerdan las soluciones tomadas por cierto tipo de producciones plásticas de la Antigüedad.

Al contemplar algunas de los rostros femeninos que encontramos acuñados en determinadas monedas antiguas se advierten ciertas concomitancias con respecto a los rasgos de la figura románica, aunque, tan sólo se trate de igualdades factibles desde un punto de vista formal.

Dos monedas conservadas en Museo Nacional de Siracusa presentan, en una de sus caras, la imagen de una efigie femenina con facciones ovales bien marcadas, nariz ancha, boca pequeña y ojos almendrados saltones, junto con una característica melena alborotada. Una de esas representaciones se ha identificado como la imagen de Aretusa, una ninfa bien conocida en la Antigüedad $^{2143}$ (fig. 412). El tetradracma, acuñado probablemente en el año 410 a. de C. por Kymon en la ciudad de Siracusa, muestra a la ninfa con las facciones antes descritas y acompañada por dos delfines aunque, en todo caso, la identificación del personaje no haya sido mantenida con total seguridad ${ }^{2144}$.

El prototipo que señalamos en la moneda antigua se repite en otras dos acuñaciones, ahora con la imagen del dios Helios. Se trata de dos piezas que se han datado en el siglo III a. de C. y que, según los especialistas, pueden ser puestas en relación con algunos prototipos de las esculturas de Lisipo $^{2145}$ (fig. 413).

Sin proponer nunca una dependencia directa entre las piezas monetarias antiguas y esta escultura románica gallega, creemos que, desde un punto de vista figurativo,

${ }^{2143}$ L. BREGLIA, voz “Aretusa”, Enciclopedia dell'arte antica..., vol. I, 1958, pp. 616-617. El relato más conocido de esta ninfa llamada Aretusa la localiza junto a una fuente en Elide. La figura del dios fluvial Alfeo, también se ha ligado con ella, sobre todo, en relación con el amor que éste sentía hacia la ninfa. Aretusa, como ninfa acuática, no posee una imagen característica y codificada dentro de las artes plásticas, por lo que, tan sólo el nombre, colocado en relación con la figura, ha servido para poder identificarla. Véase también sobre la pieza monetaria: ID., voz "Kimon”, Enciclopedia dell'arte antica..., vol. IV, 1961, pp. 361-362. El autor señala a Kimon como un famoso caelator autor de varias obras, todas ellas datadas en los últimos años del siglo V a. de C. Según L. Breglia, llegaría a crear un prototipo característico de rostro femenino, del cual, la cabeza de Aretusa es una muestra. Los volúmenes mórbidos, el uso de una boca pequeña y la cabellera agitada son los rasgos más característicos de esta imagen clásica.

2144 Ibidem, p. 617. Recientemente, hemos aludido a estas y otras piezas relacionándolas con el tipo románico definido por H. Focillon como "carillos hinchados". Se trata de una solución escultórica que emparentamos con un prototipo facial muy difundido en la escultura antigua, tanto dentro de la numismática, como en la misma escultura de sarcófagos. Véase: J. A. MORÁIS MORÁN, "Problématique autour du "style des joues gonflées...", (en prensa).

${ }^{2145}$ L. LAURENZI, voz "Colosseo", Enciclopedia dell'arte..., vol. II, 1959, pp. 773-774. La imagen que aparece en esta moneda acuñada, según el autor, en el año 408 a. de C., debe ponerse en relación con la escultura monumental levantada en el puerto de la ciudad de Rodas y que habría de pasar a la historia como el Coloso de Rodas. El autor incluye una serie de reflexiones sobre la importancia que debió tener dicha escultura y la relación con la imagen de Helios. El otro ejemplar se conserva en Paris, Bibliothèque nationale de France. 
ambas guardan algunos puntos en común. Las relaciones entre estos prototipos, el medieval y el clásico, insisten en la complejidad y la inseguridad a la hora de poder hablar de dependencias entre obras de arte muy distantes en el tiempo y en la geografía. Es materialmente imposible que los escultores compostelanos accedieran a este tipo de repertorio o ejemplares ${ }^{2146}$.

Aunque parezca improbable poder establecer una dependencia directa entre las producciones monetarias señaladas y la manera en que fue esculpido el rostro de la "mujer del cráneo" de Compostela, no es descartable pensar en la importancia que dentro del taller gallego y, en el románico en general, habrían de tener objetos fácilmente transportables como, por ejemplo, las monedas, los textiles y las producciones de pequeño tamaño, como esculturillas de terracota o de bronce ${ }^{2147}$.

Sin embargo, ante tales comparaciones, vuelve a surgir el clásico problema que venimos planteando a lo largo de todo este trabajo. Resulta prácticamente inverosímil poder explicar tales relaciones a través de un contacto y conocimiento seguro de estas piezas por parte de los artistas románicos. Puede que estas similitudes respondan más a meras coincidencias formales. Es decir, el parecido entre ambas obras podría ser el resultado de una serie de coincidencias no ligadas precisamente al intercambio de modelos artísticos. Diferentes artistas en espacios y tiempos distintos pudieron obtener unos mismos resultados al trabajar con medios técnicos y materiales muy limitados, pudiendo tratarse de soluciones halladas sin relación las unas con las otras.

Este factor de casualidad y coincidencia es también mera conjetura pues, a lo anteriormente expuesto, debemos sumar las dudas que suelen presentar este tipo de producciones. Las monedas, al igual que los mosaicos y otro tipo de obras pudieron permanecer, ya desde la misma Antigüedad, ocultas bajo el suelo, enterradas a la espera de unas excavaciones que, tan sólo las sacarían a la luz durante los siglos XVIII, XIX y

\footnotetext{
${ }^{2146}$ No se ha constatado la existencia, que nosotros conozcamos, de la presencia de una acuñación similar dentro del corpus de monedas antiguas conservadas en suelo hispano. A pesar de ello, sabemos bien que este tipo de piezas viaja muy fácilmente.

${ }^{2147}$ E. PANOFSKY, Renacimiento y renacimientos..., p. 34 y J. ADHÉMAR, Influences antiques..., pp. 189-192. En ocasiones, el valor de estas piezas se ha menospreciado. Así, debemos recodar, a título de ejemplo, que uno de los primeros casos en el que se plasmó la iconografía de la traslatio del cuerpo del Apóstol Santiago, se realizó en una moneda procedente de la ceca de Fernando II, es decir, en los años que se estaba levantando el Pórtico de la Gloria. Ya en su día, M. Melero señaló que, a pesar de tratarse de un tema de fuerte contenido religioso, se utilizó un soporte esencialmente laico, así como lo extraño de que dicha iconografía no hubiera tenido el desarrollo que cabría esperar dentro de otras técnicas, como la escultura monumental. Véase al respecto: M. MELERO MONEO, "Traslatio Sancti Jacobi...", pp. 7374.
} 
XX y que hacen materialmente imposible que los escultores románicos las pudieran haber visto.

La "mujer del cráneo", "sucintamente cubierta con una túnica, dispuesta de tal manera que deja al descubierto un pecho y una pierna", presenta, además su característico rostro, una larga cabellera de rizos sueltos que, en palabras de J. Williams, "sugieren una belleza seductora y desenfrenada" ${ }^{2148}$. El posible recuerdo de la belleza clásica que en su día presentaran algunos personajes mitológicos parece asomar al analizar esta escultura $^{2149}$.

Tales nociones sobre las figuras femeninas y la belleza de tradición clásica, fueron explotadas por los escultores romanos a la hora de representar a las ninfas, tal y como hemos repetido constantemente. Tal hecho encaja, nuevamente, con la representación acuñada en una de las piezas monetarias de Siracusa, en concreto, aquella en la que se representó la imagen de la ninfa Aretusa. A través de ella se podría corroborar la hipótesis de un supuesto conocimiento, por parte de estos escultores medievales, de la iconografía del thiasos marino, las ninfas y las nereidas ${ }^{2150}$.

No vamos a insistir más en las particularidades del rostro de la mujer del cráneo y su participación dentro de la llamada tradición "hispano-languedociana"2151. En muchos de los templos situados en los anexos de las rutas de peregrinación hacia Santiago de Compostela y en otros más alejados, se constata la presencia del mismo motivo. El supuesto "estilo de los carrillos hinchados" tiene un buen representante, por ejemplo, en el capitel reempleado como pila bautismal en la iglesia de Santiago de $\mathrm{Jaca}^{2152}$ (fig. 414).

\footnotetext{
${ }^{2148}$ J. WILLIAMS, "La mujer del cráneo...", p. 17. Es muy significativo como el recurso de la pierna desnuda volvería a ser utilizado en la figura de una mujer amamantando a un niño de la misma fachada de las Platerías. Algunos autores defendieron, en su día, que se trataba de la imagen de la Virgen de la leche o Galactotrofusa, sin embargo, el hecho de que se presente con la cabeza descubierta, sin aureola, con las piernas cruzadas y desnudas desde las rodillas, no permite dar dicha interpretación como válida.

Según S. Moralejo, se trataría, más bien, de la imagen de Eva alimentando a uno de sus hijos. Cf.: S. MORALEJO ÁLVAREZ, "La primitiva fachada...", p. 40; K. CLARK, Op. cit., pp. 299-300. Sobre esta escultura de la posible Eva, véase: M. A. CASTIÑEIRAS GONZÁLEZ, Atlas de la catedral..., (edición digital).

${ }_{2149}$ M. BARASH, "Le Beau ou le démoniaque...", p. 105, nota 18 y p. 111. Barasch señala que los cabellos despeinados, en punta, desordenados o agitados, se han relacionado, frecuentemente, con la Psycomachia de Prudencio, aludiendo a los vicios. Cita el manuscrito De octo principalibus viciis et unde oriuntur, Paris, Bibliothèque nationale de France, Ms. 2077, fol. 163 r. Se ha datado en la primera mitad del siglo XI y, según se piensa, fue realizado en el escritorio del monasterio de Saint-Pierre de Moissac.

${ }_{2150}$ No es necesario recoger, nuevamente, los datos bibliográficos al respecto, pero recuérdese como ya lo advirtió y defendió con fuerza S. Moralejo.

${ }^{2151}$ J. A. MORÁIS MORÁN, "Problématique autour du "style des joues gonflées...", (en prensa).

${ }^{2152}$ L. DIEGO BARRADO, "Capitel de la iglesia de Santiago de Jaca", Sancho III el Mayor y sus herederos. El linaje que europeizó los reinos hispanos, vol. II, Pamplona, 2006, ficha catalográfica 208, pp. 698-699. La profesora L. Diego Barrado insiste en la posibilidad de que se trate de una pieza
} 
Las similitudes entre los rostros de las figuras del capitel jacetano, el de la "mujer del cráneo" y las monedas antes citadas, sino iguales, si que parecen presentar coincidencias indiscutibles. Lo más interesante reside en que, ya en su momento, S. Moralejo insistió en la posibilidad de que este tipo de soluciones fisonómicas de "ojos abultados y carrillos hinchados", presentes en algunas esculturas de la fachada de las Platerías de Compostela, pudiesen haber sido tomadas de las artes romanas ${ }^{2153}$.

El mismo autor, en otra de sus aportaciones, establecía otra serie de relaciones entre este tipo facial y la escultura del supuesto "estilo de Frómista y Jaca", concluyendo que, su origen se hallaba, nuevamente, en los sarcófagos de cronología romana, señalando el caso del sarcófago conservado en la iglesia de San Pedro el Viejo de Huesca, como una de las posibles vías de estudio de la formación estos rostros ${ }^{2154}$ (fig. 415).

La teoría de la filiación "antiquizante" de esta característica fisonomía fue retomada por otros especialistas como, por ejemplo, M. Durliat, quién no dudó en aludir a los tipos faciales presentes en el sarcófago paleocristiano proveniente de la abadía de Saint-Orens de Auch, como un posible modelo originario de estas fórmulas (fig. 416) ${ }^{2155}$.

Cabe, por último, señalar que, ante la imposibilidad de ofrecer otros paralelismos más fiables y semejantes a estas soluciones adoptadas por los escultores románicos, resta, en caso extremo, hacerlos depender de la tradición clásica, que es la que nos muestra soluciones de similar índole.

Sin embargo, las alusiones al arte de tradición romana dentro del taller compostelano no terminaron aquí. Dentro del estudio de los rostros y las máscaras que aparecen en el repertorio de estos talleres, existe otro elemento que ofrece menos dudas con respecto a su indiscutible origen antiguo. Se trata de una máscara vegetal representada sobre el incensario que porta uno de los ángeles del tímpano de las

proveniente del antiguo claustro desaparecido de la catedral jaquesa, además de señalar que la pátina oscura y brillante con la que lo vio S. Moralejo, hoy, tras la restauración, ha desaparecido. Actualmente sirve de base a una pila bautismal en la citada iglesia. La pieza ha sido datada siempre de manera poco concreta en el siglo XII.

${ }^{2153}$ S. MORALEJO ÁLVAREZ, "La primitiva fachada...”, en particular, p. 45. Sobre todo, comparaba los tipos faciales con algunas piezas de marfil de época bajo imperial.

${ }^{2154}$ S. MORALEJO ÁLVAREZ, "La reutilización...", en concreto, pp. 130-131 y T. AGUIRRE, "Arte romano...", pp. 11-179.

${ }^{2155}$ M. DURLIAT, La sculpture romane de la route..., pp. 241-242. El sarcófago se conserva, en la actualidad, en Toulouse, Musée des Augustins, aunque también ha llegado hasta nosotros otra pieza idéntica proveniente de Lucq-de-Béarn, cerca de Oloron-Sainte-Marie. 
Tentaciones de Cristo y que ofrece una correcta materialización del tema iconográfico de la masque feuillu (fig. 417).

La imagen presenta un rostro barbado de ojos grandes, con pupilas preparadas para recibir la incrustación habitual en estos casos. Sin duda, lo más interesante son los elementos vegetales que la máscara expulsa por su boca, y que, bifurcándose hacia ambos lados de la pieza litúrgica, representan el nacimiento de otra serie de brotes vegetales que acaban cubriendo el cuerpo del incensario ${ }^{2156}$.

No hemos hallado un modelo directo que explique la introducción de tal imagen ni la fuente seguida por los escultores compostelanos. En todo caso, el uso de este tipo de iconografía, muy conocida dentro de la Antigüedad clásica, permite relacionar el recurso con otra serie de centros europeos donde también se incluyó en la decoración de diversas obras. En concreto pensamos, por ejemplo, en la imagen de Silvano, la divinidad romana de los bosques por excelencia y relacionada también con las plantaciones, la vegetación y la naturaleza en estado salvaje. Su relativa frecuencia dentro de los programas musivos de época romana, incluso en Hispania, así como su éxito dentro de diversas narraciones mitológicas, permite intuir una cierta continuidad dentro de la iconografía románica ${ }^{2157}$.

En los siglos medievales se le dotó de cierto contenido negativo, aludiendo su presencia a la soledad de los bosques. En relación con ello, M. Barasch realizó un estudio de la imagen de tal personificación y su traspaso a la Edad Media, insistiendo en que, tal figura, no había sido representada jamás como una máscara vegetal durante los siglos de la Antigüedad. La imagen más frecuente dentro del arte romano lo presenta desnudo, con un cuerpo atlético, señalando su naturaleza rústica. Sin embargo, el artista medieval acabaría por reinterpretar la imagen, ligando su rostro a los bosques y las plantas que representaba, para, finalmente, pasar a retratarlo con un rostro en forma de hoja, una máscara vegetal ${ }^{2158}$.

\footnotetext{
${ }^{2156}$ M. A. CASTIÑEIRAS GONZÁLEZ, "La catedral románica: tipología...”, p. 70. El autor relaciona el modelo presente en Santiago con otros motivos escultóricos realizados en Francia, como el de la iglesia de Notre-Dame de Bernay, datada entre los años 1025-1040, así como con otros, nuevamente, vinculados con la iluminación anglonormanda de finales del siglo XI.

${ }^{2157}$ M. PASTOR MUÑOZ, "El culto al dios Silvano en Hispania ¿innovación o sincretismo?", Memorias de historia antigua. Paganismo y cristianismo en el occidente del Imperio Romano, 5, 1981, pp. 103-114 y J. M. BLÁZQUEZ MARTÍNEZ, "Máscaras humanas en roleos de mosaicos en Oriente, África e Hispania", L'Africa romana 15. Ai confini dell'Impero: contatti, scambi, conflitti. Atti del XV convegno di studio, Roma, 2004, vol. 2, pp. 1023-1038.

${ }^{2158}$ M. BARASH, “Le Beau ou le démoniaque...”, pp. 107-108.
} 
Uno de los ejemplos románicos más relevantes en el que la imagen de Silvano se incluyó dentro de un programa iconográfico, identificando su figura, además, mediante un titulus, es el de la famosa fuente realiza para la abacial de Saint-Denis en París. Se trata de una pieza esculpida en un bloque de calcárea que fue decorado con más de una treintena de cabezas de deidades mitológicas y héroes paganos de la Antigüedad, todos ellos, inscritos en medallones (fig. 418) ${ }^{2159}$.

Sin duda, merece especial atención la imagen de Silvanus, que aparece inscrito en un clípeo, formando conjunto con el resto de figuras que decoran el borde del gran vaso. Nuevamente, encontramos el rostro del dios coronado por una serie de hojas vegetales que, junto con la inscripción, permiten ofrecer una identificación segura. La fuente, de una calidad absoluta, ya llamó la atención del viajero Arnold van Buchel que realizó un diseño de ella en el año 1585. Se trata, concretamente, de un dibujo que muestra la estructura antes de su desmonte, formada por dos vasos, el de abajo de mayor tamaño y otro posterior, elevado sobre columnas de capiteles corintios. Es en el segundo de los cuerpos donde se representó la galería de tondos con los retratos de Faunus, Pan o Venus, entre otros ${ }^{2160}$ (fig. 419).

El ejemplo sirve para poder demostrar que la inclusión de las figuras de los dioses paganos dentro de piezas sacras, tales como un incensario, no fue algo extraño. La iconografía antigua que presenta la fuente francesa desentonaba fuertemente con el espacio sagrado para el cual fue diseñada y, sin embargo, ello no censuró su utilización. Lejos de olvidarse, la imagen de Silvano se conservó íntegramente más allá del cambio de siglo, manifestándose con fuerza dentro de la escultura gótica, tal y como observamos en infinidad de catedrales, entre ellas, la de Lyon, en Francia, o la de León, en $\operatorname{España}^{2161}$.

${ }^{2159}$ La pieza se ha venido datando en torno al año 1200 y se conserva, actualmente, en Saint-Denis, Depósito Lapidario. Sobre ella, véase: L. M. PARSONS, "Cleanliness with Godliness: A Discussion of Medieval Monastic Plumbing", Mélanges à la Mémoire du Père Anselme Dimie, Artois, 1982, pp. 123149 y W. SAUERLANDER, "Art antique et sculpture autour de 1200; Saint-Denis, Lisieux, Chartres", Art de France, I, 1961, pp. 47-56. En este punto, queremos agradecer a Maria Pellón Gómez-Calcerrada las sugerencias realizadas en relación con esta escultura.

${ }^{2160}$ Utrecht, University Library, Ms. 798 f. 181. Sobre la obra, véase: J. ADHÉMAR, Influences antiques..., pp. 265-266 e ID., "La Fontaine de Saint-Denis", Revue Archéologique, vol. I, 1936, pp. 224232. La obra sería encargada, aunque no hay consenso en este punto, por el abad Hugo de Milán, en los últimos años del siglo XII. Fue diseñada para ser colocada en el claustro de la abadía. En el momento en que publicó su trabajo, Adhémar situó la pieza en la Escuela de Bellas Artes de París. También se abordan algunos aspectos de esta iconografía en: L. PRESSOUYRE, "St. Bernard to St. Francis: Monastic Ideals and Iconographic Programs in the Cloister", Gesta, 12, 1/2, 1973, pp. 71-92.

${ }^{2161}$ J. ADHÉMAR, Influences antiques..., p. 286 y M. BARASH, "Le Beau ou le démoniaque...", p. 107. Debemos constatar, igualmente, que, sin duda, la inclusión de la imagen de la máscara vegetal dentro del repertorio de los libros de modelos de los artistas, debió ayudar en su difusión. El más conocido de 
Tras lo expuesto, podemos afirmar que el conocimiento del tema de la máscara vegetal, dentro del repertorio manejado por el taller compostelano, puede ponerse en relación con una práctica común en aquellas fábricas que, tradicionalmente, se han relacionado con modelos antiguos. Recuérdese, por ejemplo, el bello ejemplar atribuido al taller del famoso Wiligelmo de Módena, que muestra la figura del hombre-hoja vomitando carnosas hojas vegetales, mientras que, sus cabellos, adquieren idéntica forma $^{2162}$.

El principio de disyunción expuesto por E. Panofsky y seguido, dentro de la historiografía española, por otros autores, como H. Schlunk, parece tener en este elemento que decora el incensario compostelano su mejor materialización. La imagen del hombre-hoja antiguo, asociada en la Edad Media con la figura de Silvano, es reinterpretada por los artistas románicos y dotada de otras características. Un sentido distinto y diferente y que, dentro del caso concreto de la escultura que aquí analizamos, reafirma el conocimiento un tanto parcial y fragmentado que llevó al escultor medieval a decorar con un tema pagano una pieza litúrgica de tanto valor simbólico como un incensario $^{2163}$.

todos, el de Villard de Honnecourt, incluyó la imagen de esta figura. Cf.: R. BECHMANN, Villard de Honnecourt: la pensée technique au XIIIe siècle et sa communication, Paris, 1991.

${ }^{2162}$ A. PERONI, "Capitello con teste di green men, faccita", Lanfranco e Wiligelmo..., ficha catalográfica C.1 y R. SALVINI, Wiligelmo..., p. 93. En su día, se atribuyó la pieza, directamente, a la mano del escultor de Módena, aunque tales afirmaciones se toman con mayor cautela en la actualidad.

${ }^{2163}$ F. GARCÍA ROMO, La escultura románica..., pp. 238-240. El especialista realiza una serie de reflexiones en relación con el principio explicado por Panofsky. 
C. EL PRECIOSISMO DE LOS TRABAJOS ESCULPIDOS INFLUENCIADOS POR LA PLÁSTICA ROMANA: LOS EJEMPLOS DE LOS NIMBOS Y EL “ESCAMADO” DE ALGUNOS RELIEVES COMPOSTELANOS.

El conocimiento, un tanto disperso y simplificado que, de las obras de arte antiguas, tuvieron los escultores de las fachadas compostelanas, a excepción del repertorio utilizado dentro de los fustes de la Porta Francigena, aparece asegurado por otros detalles del conjunto.

A la hora de analizar las columnas marmóreas esculpidas para la fachada de Platerías, se han señalado diversos rasgos que, si bien de una manera poco segura, se pueden emparentar con la tradición artística paleocristiana. Sin embargo, del mismo modo, hemos de señalar de antemano que se trata de soluciones frecuentes dentro de otros focos románicos europeos.

Según M. Castiñeiras, las columnas de Platerías presentan determinados elementos iconográficos, tales como la imagen de las aves afrontadas a la crátera de la vida o la ya mencionada procesión de ángeles que portan en sus manos diversos objetos de suplicio, que parecen provenir de los repertorios típicos de la iconografía paleocristiana $^{2164}$ (fig. 410).

Desde un punto de vista formal, debido a la suntuosidad, el preciosismo y el detallismo de la escultura, dichas columnas se han emparentado con otros centros foráneos en los que, paralelamente, se estaban llevando a cabo obras de gran calidad y ciertamente emparentadas con fuentes romanas. En concreto, se ha hablado de las estrechas relaciones que estos trabajos mantienen con las esculturas de la segunda fase decorativa del monasterio de La Daurade de Toulouse o los realizados para la iglesia de Saint-Etienne de la misma ciudad.

Entre los aspectos más característicos que podemos señalar, caben destacar las representaciones que se han hecho sobre estas columnas de la imagen de los Apóstoles y de las Tribus de Israel. Los personajes se sitúan bajo arquitecturas ricamente labradas, presentando variadas posiciones de las manos, de los pies y de las cabezas. A parte de lo detallista de las vestimentas y de los libros que sujetan, debemos destacar la forma peculiar que adquieren aquí los NIMBOS de las figuras (fig. 420). Se trata de un prototipo bien conocido dentro de la escultura realizada en los sarcófagos antiguos,

${ }^{2164}$ M. A. CASTIÑEIRAS GONZÁLEZ, Atlas de la catedral..., (edición digital); ID., “Topographie...”, pp. 32-33 e ID., "La catedral románica: tipología...", p. 66. 
sobre todo, en aquellos de tradición cristiana. En el caso hispano, presentan una forma de perfil "avenerado" que "pudiera ser una interpretación de las conchas de las hornacinas de los sarcófagos antiguos, o de las veneras que en los mosaicos paleocristianos decoraban las concas absidiales" 2165 .

Aunque la forma "avenerada" fue utilizada, frecuentemente, durante los siglos de la Antigüedad clásica y la Alta Edad Media ${ }^{2166}$, creemos que, en el caso concreto de los nimbos de los apóstoles de la columna izquierda de la fachada, su origen puede acotarse al ámbito de la escultura de sarcófagos romanos ${ }^{2167}$.

El tema es complejo, pues algunos autores especialistas en escultura altomedieval señalan que, el origen de estos nimbos en forma de venera se encuentra dentro de la arquitectura monumental romana propiamente dicha. En concreto, el traspaso a las artes plásticas se produciría desde las concas absidiales en forma de concha.

"Su transformación en nimbo que expresa sacralización o santidad, o utilización como elemento de fondo al que se superpone la cabeza de Cristo o algún santo, indician un valor que alcanza la venera como signo sagrado",2168.

Tales aspectos, otorgaron a este elemento de un gran éxito dentro de los sarcófagos, los marfiles o, por ejemplo, dentro de los numerosos ejemplares de las “placas-nicho" de época visigoda ${ }^{2169}$.

\footnotetext{
${ }^{2165}$ M. A. CASTIÑEIRAS GONZÁLEZ, "La catedral románica: tipología...”, p. 90.

${ }^{2166}$ Por citar un ejemplo conocido, aludimos a la placa de cronología visigoda incrustada en los muros de la catedral de Lisboa y en la que se figuraron una serie de arcadas ultrapasadas con veneras que cobijan a diferentes animales. Vid.: C. A. FERREIRA DE ALMEIDA, "Arte da época visigótica", História da Arte..., pp. 37-72, en concreto, p. 60.

2167 J. BALTRUSAITIS, La Edad Media fantástica..., pp. 57-58. Su utilización dentro de las artes plásticas se documenta desde periodos remotos. La venera fue vista como representante de la figura de Afrodita, ya desde el mundo fenicio. En relación con ello, la iconografía utilizará sus valvas abiertas o cerradas, como símbolo de castidad o pecado. Su paso al mundo romano cristiano provocó una interpretación del tema, ahora entendido como imagen de la vida futura y la resurrección, de ahí que fuese habitual en los sarcófagos romanos, formando parte de todo tipo de decoraciones arquitectónicas. Su presencia sobre la cabeza de una escultura, tal y como señala Baltrusaitis, confería inmortalidad a la figura.

${ }^{2168}$ M. C. VILLALÓN y E. CERRILLO MARTÍN DE CÁCERES, "La iconografía arquitectónica desde la antigüedad a la época visigoda: ábsides, nichos, veneras y arcos”, Anas, I, 1988, pp. 187-203. Este estudio resulta interesante porque explica el paso de algunas formas constructivas a otras ramas de las artes plásticas. En origen, la venera decoraba la parte interior de los ábsides romanos, sobre todo, en tiempos helenísticos, tal y como atestiguan los estucos etruscos del siglo III a. de. C.

2169 A. GRABAR, Las vías de la creación..., pp. 111-112. El autor estudia el origen de tal elemento dentro de la iconografía cristiana, en concreto, en Santa Maria Maggiore de Roma. También véase: C. A. FERREIRA DE ALMEIDA, "Arte da época visigótica”, História da Arte..., p. 49. En dicho trabajo, al analizar la ventana avenerada de una de las capillas laterales de la iglesia de la Vera Cruz de Marmelar,
} 
En la Península Ibérica el prototipo aparece bien documentado dentro de la escultura visigoda, en concreto, en San Pedro de la Nave, donde "personalidades que debieron haber pertenecido al estado clerical" se muestran nimbadas por elementos en forma de concha (fig. 421). Según señalara el profesor H. Schlunk, la peculiaridad de estas piezas estriba en que las charnelas aparecen hacia abajo, perpetuando una tradición muy desarrollada en el ámbito oriental ${ }^{2170}$.

Para el caso hispano los modelos se reiteran, con idéntica función, en otros tipos de producciones tardoantiguas. El ejemplo de la lauda sepulcral de Ursicinus, hoy conservada en Madrid, Museo Arqueológico Nacional, demuestra la posibilidad de poder recurrir a obras de cronología romana tardía para explicar determinadas soluciones altomedievales (fig. 422) ${ }^{2171}$. Con todo, pensamos que los paralelos más próximos provendrían de otras técnicas diferentes a la del mosaico, como es la misma escultura en mármol o, incluso, el marfil. Numerosos investigadores han remarcado el carácter preciosista de la escultura de estas columnas de Platerías que, junto con la presencia de este tipo de nimbos, evocan las mejores soluciones tomadas por el arte tardoantiguo más selecto como, por ejemplo, las muestran que ofrecen algunas figuras de la cátedra ebúrnea de Maximiano de Rávena (fig. 423) o las que decoran la arqueta de Brescia (fig. 424).

A pesar de la abundancia de precedentes dentro de las manifestaciones artísticas realizadas durante los siglos pasados en Hispania, el motivo no gozó de gran éxito dentro del románico pues, a parte de los ejemplos de Compostela, su utilización fue concreta, sin continuidad ni difusión; revelando, quizás, un conocimiento vago de estos repertorios que, tan sólo, aparecen puntualmente en estas columnas para acabar desapareciendo gradualmente dentro de la escultura románica coetánea.

en Vidigueira, se defiende que ésta posee un sentido sagrado, por su orientación hacia el oriente. Desde otro orden de cosas, el motivo del arco con fondo avenerado también aparece, frecuentemente, ligado a la iconografía estampada sobre los ladrillos de barro de datación paleocristiana hallados en la Península. Cf.: R. CASTELO RUANO, "Placas decoradas paleocristianas y visigodas de la colección Alonso (Écija, Sevilla)", Espacio, Tiempo y Forma, Serie II, Historia Antigua, 9, 1996, pp. 467-536. La autora que ha llevado a cabo un estudio más reciente sobre el tema de la venera en la escultura tardoantigua lusitana es L. Wrench. Cf.: L. N. C. WRENCH, Decoração arquitectónica..., vol. I, pp. 157-158.

${ }^{2170}$ H. SCHLUNK, "Estudios iconográficos...", p. 258. Este autor también los hace depender del arte romano. Al respecto escribía: "Estas conchas las encontramos frecuentemente en sarcófagos o en tallas de marfil, llenando los arcos de una arquería, bajo los que se colocan las personas que se quieren destacar". También véase: M. T. SEPÚLVEDA GONZÁLEZ, "Reflexiones sobre el programa iconográfico de San Pedro de la Nave (Zamora) I", Cuadernos de arte e iconografía, 4, 7, 1991, pp. 135157 y R. CORONEO, "I capitelli di San Pedro de la Nave", Medioevo: immagine e racconto, Parma, 2003, pp. 130-141.

${ }^{2171}$ P. DE PALOL, Arte paleocristiano..., p. 300. 
Los nimbos "avenerados" que muestran los personajes pueden sugerir una relación con algún sarcófago, hoy perdido. Su desaparición hace imposible poder señalar la fuente que siguieron los escultores pero, en todo caso, parece claro que al tratarse de una solución tan original como extraña a la escultura románica de este contexto, la hipótesis de la copia de una obra romana que, en un momento determinado, estuvo al alcance de los artistas cobra fuerza.

Para el caso compostelano, cabría pensar que se trataría de una escultura única y en la que se incluyó este elemento. La noticia que justifique la existencia de esta desaparecida obra funeraria, quizás conservada en los aledaños de la catedral, tan sólo pervive, reinterpretada, a través de este elemento medieval. El motivo del nimbo "avenerado" fue copiado, ocasionalmente, en estas columnas, para acabar siendo olvidado $^{2172}$.

Es más, no debemos olvidar que, dentro de los sarcófagos con el tema del thiasos marino, la presencia de estos elementos en forma de concha marina fue frecuente, ya fuese en forma de venera completa, haciendo las veces del clípeo, o materializados mediante un nimbo ${ }^{2173}$.

En un artículo publicado en el año 1939, W. Goldschmidt ya recogía la peculiaridad de las aureolas que presentaban algunas de las esculturas conservadas en Toulouse, Musée des Augustins. En concreto, citaba la figura de Santo Tomás que el investigador atribuía al escultor Gilabertus ${ }^{2174}$ (fig. 425). El santo fue coronado por un nimbo "avenerado" que rememora soluciones romanas, en perfecta consonancia con los resabios clasicistas que, tradicionalmente, se vienen señalando para el foco escultórico tolosano.

Lo más destacable son las conexiones que establece con respecto a la escultura de la portada de Santa María de Ripoll donde, otra vez, observamos la presencia del elemento sobre la cabeza de San Pedro (fig. 426). Nuevamente, los prototipos antiguos resurgen en los principales centros del periodo románico, allí donde la escultura adquirió una calidad incomparable con respecto a la de los centros de menor abolengo y donde las pequeñas alusiones al mundo antiguo se convierten en meros ecos débiles de

\footnotetext{
${ }^{2172}$ Sobre la posibilidad de "deducir" la presencia de determinadas obras antiguas desaparecidas a través de su "recuerdo" dentro de la escultura románica, se insistió en: J. A. MORÁIS MORÁN, "Investigar sin corpus...", (en prensa).

${ }^{2173}$ F. BARETTE y C. METZGER, "Cuve de sarcophage: thiase marin", Musée du Louvre..., ficha catalográfica 77, pp. 158-159. La pieza proviene de la iglesia de Saint-Sulpice de París.

${ }^{2174}$ Databa la obra entre los años 1140 y 1150. Cf.: W. GOLDSCHMIDT, "Toulouse and Ripoll-The Origin of the Style of Gilabertus", The Burlington Magazine for Connoisseurs, 74, 432, 1939, pp. 104110 .
} 
un arte ya extinguido ${ }^{2175}$. El caso de Ripoll es verdaderamente importante ya que las fuentes antiguas están fuera de toda duda ${ }^{2176}$.

Una vez analizado, de manera sucinta, el posible origen de este tipo de nimbos, presentes en la escultura de la fachada de las Platerías de Compostela, queremos señalar, además, la presencia de otro motivo también vinculado al arte antiguo dentro del repertorio utilizado por los mismos obradores.

Al examinar algunas de las esculturas presentes en las dos fachadas del transepto del templo gallego, se detecta la utilización que se hizo del motivo decorativo del “ESCAMADO". Se trata de un sistema decorativo que, tal y como hemos señalado anteriormente, fue muy habitual dentro de las producciones artísticas romanas, en particular, dentro de los sarcófagos de la órbita aquitana ${ }^{2177}$.

Mediante una repetición mecánica de las escamas se logra un motivo muy dúctil y fácilmente aplicable sobre todo tipo de superficies. Ello permite al escultor medieval recurrir a él, de manera frecuente, para decorar diferentes partes del edificio, en concreto, molduras, elementos arquitectónicos y fondos ${ }^{2178}$.

Al contemplar tal motivo dentro de las fachadas compostelanas, se plantea la duda sobre su origen y el lugar de donde fue tomado. Diversas figuras esculpidas por estos talleres lo utilizan para decorar, por ejemplo, la base de la lastra en la que fue esculpida la "mujer del cráneo" (fig. 427), así como otras de idéntica solución, como el escamado sobre el que asientan los pies, por cierto, en una posición bastante inverosímil, los apóstoles de una de las columnas de Platerías ${ }^{2179}$ (fig. 428).

\footnotetext{
${ }^{2175}$ No insistiremos en la importancia de las fuentes clásicas para la portada de Ripoll, así como la que parecen presentar las esculturas del foco tolosano por ser una cuestión que, además, se abordará en las próximas páginas. Cf.: J. CAMPS, “À propos des sources toulousaines du Maître de Cabestany: l'exemple du portail de Sant Pere de Rodes (Catalogne)", Les Cahiers de Saint-Michel de Cuxa, XXVI, 1995, pp. 95-107 y M. MELERO MONEO, “La propagande politico-religieuse...”, pp. 135-157.

${ }^{2176}$ M. A. CASTIÑEIRAS GONZÁLEZ, "From Chaos to Cosmos: The Creation Iconography in the Catalan Romanesque Bibles", Arte medievale, 1, 2002, pp. 35-50.

${ }^{2177}$ F. BARETTE y C. METZGER, "Cuve de sarcophage: scène d'enseignement", Musée du Louvre..., ficha catalográfica 204, pp. 306-307 e ID., "Sarcophage avec couvercle: Christ, Apôtres et décor végétal", Musée du Louvre..., ficha catalográfica 219, pp. 323-324. Esta última pieza señalada proviene de Castelnau-de-Guers, en Hérault.

2178 Se trata de uno de los elementos formales más característicos de la escultura "hispano languedociana," que tuvo gran difusión en edificios franceses, como en Saint-Sernin de Toulouse. En el caso de las producciones esculpidas emeritenses se ha insistido en su utilización, ya fuese excavado en hueco relieve o mediante un prominente volumen, para decorar, sobre todo, canceles y barreras litúrgicas. Cf.: C. A. FERREIRA DE ALMEIDA, "Arte da época visigótica...", p. 63 y L. N. C. WRENCH, Decoração arquitectónica..., vol. II (Parte II), p. 362, p. 410 y p. 530.

${ }^{2179} \mathrm{Al}$ observar, detenidamente, el motivo se advierte que se trata de una variante del escamado de tipo clásico. En este caso en concreto se trata de unas escamas en forma alanceada, marcadas por un relieve exterior y que presentan una línea central que va desde la base hasta la punta, otorgándoles más la forma de hoja que de escama. La ductilidad del motivo permite utilizarlo sobre los ángeles sujetando textiles de
} 
En el caso de la Galia y, en concreto, dentro del ámbito aquitano, la frecuencia de su utilización en época medieval se puede explicar mediante una pervivencia del motivo del escamado desde las piezas romanas, modelo inspirador último que sería asimilado por los escultores.

Tal y como señalamos en el apartado en el que abordamos las expoliaciones de sarcófagos antiguos, la famosa pieza aquitana conservada en la capilla de Santa María de Valdeflores, perteneciente al conde Osorio Gutiérrez, presenta una decoración escamada que recorre toda la parte superior de la pieza siguiendo las soluciones de este tipo $^{2180}$ (fig. 159).

Faltaría ahora por concretar si ésta fue, en última instancia, la pieza que pudo ser tomada como base para inspirar el motivo, pues como decimos no es descartable la presencia en el mismo recinto catedralicio de estas piezas tan frecuentes en la Antigüedad tardía ${ }^{2181}$.

En un segundo lugar, faltaría, igualmente, por resolver el problema de esclarecer si el motivo fue asimilado a través de un conocimiento de piezas de esta índole o, por el contrario, el escamado románico deba explicarse a través de una reinterpretación del motivo tomado de la plástica coetánea francesa.

Nuevamente nos encontramos aquí con la incertidumbre de poder utilizar un método seguro para poder aclarar tales cuestiones. A través del método comparativo, se podría afirmar que, el motivo, bien pudo haberse tomado de la escultura romana y paleocristiana, sin embargo, más allá de las concomitancias formales, la frecuencia con la que apareció dentro de las artes plásticas de diversos periodos cronológicos desaconseja tal postura. Lo que parece seguro es que este sistema decorativo habría de tener repercusiones en otros edificios, tal y como veremos, posteriormente, en algunos detalles de las esculturas de la basílica de San Isidoro de León, donde, forzando el

otra de las columnas compostelanas, dando la sensación de un intento, por parte del escultor, de recrear nubes. Se repite en la base sobre la que se asientan las aves afrontadas y bebiendo de la crátera de la vida, así como en otra serie de piezas reempleadas en la fachada de Platerías, como aquella que muestra la escena de la curación del ciego, donde éste y Cristo asientan sus pies sobre un fondo escamado. En realidad, el motivo, con ligeras variantes, acaba generando en otras piezas una estructura en forma de hojas vegetales.

${ }^{2180}$ F. BARATTE y C. METZGER, "Sarcophage avec couvercle: Christ, Apôtres et décor végétal...", p. 324.

2181 El sarcófago presenta, además, otros motivos que han sido utilizados para poder contextualizar diversos motivos de la escultura tardoantigua hispana. En concreto, las sextifolias de los laterales han sido puestas en relación con la difusión del tema de las rosáceas de algunas obras visigodas. Igualmente, se defendió la conexión entre este sarcófago y la conocida placa esculpida de Saamasas, hoy en el Museo de Lugo. Cf.: M. CHAMOSO, "El Conde Santo Don Osorio Gutiérrez”, Cuadernos de Estudios Gallegos, 70, 1968, pp. 1-10; M. A. CASTIÑEIRAS GONZÁLEZ, "La actividad artística...”, pp. 296-297 y M. L. REAL, "Inovação e resistência...", p. 33. 
método, se puede defender la utilización de las mismas fuentes clásicas para la utilización del escamado ${ }^{2182}$.

Finalmente, aludiremos a un fragmento del Codex Calixtinus, ya mencionado, en el que queda patente la difusión que el motivo del "escamado" había alcanzado dentro de la vía de peregrinación hacia Compostela. A la hora de describir el sepulcro de San Gil, en la iglesia homónima de Saint-Gilles-du-Gard, se especifica:

“(...) las cubiertas del arca por arriba están labradas por ambas partes en forma de escamas de peces. En su ápice hay engarzados trece cristales de roca, unos a modo de escamado, otros en forma de manzanas o granadas"2183 (texto 64).

El texto induce a pensar que el motivo del "escamado" fue bien conocido dentro del arte paleocristiano y traspasado a la plástica medieval, a la que había llegado, en la mayoría de las ocasiones, a través de una contaminación de sistemas decorativos que hacen realmente difícil hacerlos depender de obras o esculturas concretas. Con todo, en los apartados anteriores hemos abordado la fortuna que la imagen de estos sepulcros decorados con escamas tendrían más allá de los siglos del románico y del que el "microsepulcro" representado en el altar renacentista de Santa Eufemia, de la catedral de Orense, es solo el ejemplo más significativo (fig. 160) ${ }^{2184}$.

Para finalizar queremos dejar claro que, según lo explicado, tanto la presencia de los nimbos "avenerados" esculpidos, de manera detallista, sobre las cabezas de los apóstoles de la fachada de Platerías y la utilización dentro del mismo ámbito catedralicio del motivo del "escamado", nos remite, una vez más, a los motivos de los sarcófagos romanos.

\footnotetext{
${ }^{2182}$ En el apartado siguiente analizaremos la difusión de ciertos motivos clásicos más allá de la escultura de la catedral de Santiago, a través de algunos edificios donde el grueso de los trabajos decorativos se extendería hasta las décadas de los años treinta y cuarenta del siglo XII.

${ }^{2183}$ Liber Sancti Jacobi..., p. 563.

2184 Véase el apartado correspondiente sobre la imagen de los sepulcros antiguos en la plástica románica.
} 


\section{EL PROBLEMA DE LA ASIMILACIÓN DE LO CLÁSICO EN LOS TALLERES COMPOSTELANOS.}

Para finalizar este apartado dedicado a la presencia de modelos y formas clásicas dentro de la escultura de la catedral de Santiago en los años finales del siglo XI y el inicio del nuevo siglo, creemos necesario realizar una serie de reflexiones sobre la manera en que la Antigüedad fue asimilada por estos artífices.

Tras el rastreo de las fuentes utilizadas a la hora de desarrollar los programas iconográficos del edificio, durante la cronología señalada, se advierte un mantenimiento inercial de ciertos temas de gran tradición antigua, pero que se encontraban totalmente asimilados por los escultores activos en el templo desde el inicio mismo de la construcción. En este sentido, creemos que no es necesario insistir en el origen del tema de las aves afrontadas a la crátera de la vida, por ejemplo, u otros de similar índole, como los grifos enfrentados, la sirena o algunos de los elementos más frecuentes dentro de la primera campaña del centro ${ }^{2185}$.

Con la llegada del obispo Diego Gelmírez a la sede, se produce una apertura, tanto política como artística. Ello se transmite en un enriquecimiento de las fuentes y los modelos que se habrían de utilizar en las obras realizadas bajo su mandato. Su intento por prestigiar la diócesis llevará a que los obradores activos en este momento recurran a determinados modelos de prestigio. En relación con ello, si durante los primeros trabajos escultóricos las iconografías utilizadas traslucían una continuidad en el uso de determinadas imágenes con respecto a las utilizadas durante la Alta Edad Media, ahora parece que las experiencias de Jaca y Frómista, tan ligadas a lo clásico, aportaron una serie de repertorios novedosos, tanto desde el punto de vista del estilo como desde la iconografía, en los que basarse para generar las nuevas composiciones artísticas.

Los modelos son ahora más concretos. Creemos que los contactos directos con Roma, materializados por los dos viajes de Gelmírez, son significativos y corroboran un

\footnotetext{
${ }^{2185}$ V. R. NODAR FERNÁNDEZ, "De la Tierra Madre...", pp. 335-347 e ID., Los inicios de la catedral..., pp. 5-30. La serie de estudios realizados por el autor se han centrado en el análisis de muchos de estos temas, concluyendo que se trata de iconografías de larga tradición dentro de la plástica antigua y altomedieval y que, en la mayoría de los casos, pasaron al edificio a través de modelos estereotipados y conectados con centros foráneos, sobre todo franceses. También véase: J. LECLERCQ-MARX, "De la Terre-Mére á la Luxure...", pp. 37-43; J. A. MORÁIS MORÁN, "De lo pagano...", pp. 383-391 y R. REY, "Quelques survivances...", pp. 173-179. El tema de las aves y la crátera reaparece en Platerías posteriormente, lo que reitera su continuidad desde la época antigua. Cf.: M. A. CASTIÑEIRAS GONZÁLEZ, "Roma e il programma riformatore...", p. 214 y p. 224, nota 19.
} 
conocimiento directo de otras fuentes, como las columnas de la pérgola constantiniana y sus derivaciones medievales ${ }^{2186}$.

Sin embargo, más allá de este ejemplo, el resto de elementos clásicos que presenta la escultura del periodo reaparecen de una manera debilitada en la mayoría de los casos. Se trata de una suma de modelos ligados a lo romano pero transmitidos a la plástica románica un tanto difuminados. Son elementos iconográficos y decorativos dispersos, pequeñas notas perdidas entre los grandes programas escultóricos de temática cristiana, como los dos tímpanos dedicados a las tentaciones y a las escenas de la vida de Cristo, en la misma sede compostelana. Entre tal desarrollo icónico, con ciertas concesiones a lo pagano, se intercalan motivos discretos, pero en todo caso presentes, como la imagen del hombre-hoja.

Sin embargo, su inclusión aquí no pasa de la mera anécdota. Existe un interés por conservar diversas tradiciones clásicas, como el uso de nimbos "avenerados" o la decoración en escamas, pero siempre como meros detalles dentro de un basto programa acorde con las fuentes bíblicas.

El estado fragmentario y desordenado del conjunto obliga a analizar las piezas de una manera disgregada, sin poseer una visión total que, quizás, hubiese ofrecido mayores datos con respecto a las fuentes antiguas utilizadas. En todo caso, a través de los relieves conservados, aquellos en las que se esculpió una sirena, una figura de un hombre al fuego que se ha interpretado como la alegoría del mes de febrero o un centauro, entre otros, hablan reiterativamente de los modelos "antiquizantes" seguidos $^{2187}$.

El conjunto compostelano, de haber permanecido intacto, posiblemente hubiera mostrado un mayor y mejor conocimiento de la Antigüedad que el que actualmente podemos llegar a comprender. Su parcial destrucción complica la tarea en exceso, al igual que lo hace el hecho de que, la mayor parte de las piezas antiguas que se habrían de hallar en suelo hispano, también se encuentren hoy perdidas.

Con esta evolución fragmentada y discontinua de la plástica desde los siglos de la Antigüedad hasta la época románica en el noreste peninsular, es complicado ofrecer datos más seguros al respecto.

\footnotetext{
2186 Ibidem, pp. 211-226.

${ }^{2187}$ D. L. SIMON, “Iconografía de un capitel...”, p. 432. El autor ya mencionaba la recuperación, en torno al año 1100, de este tipo de iconografía cósmica, en relación con las personificaciones del año, los meses y las estaciones.
} 
La figura malograda del personaje calentándose al fuego (fig. 59), único vestigio conservando del supuesto menologio que, a modo de friso, recorrería la parte superior de la fachada norte del transepto compostelano, es importante al respecto ${ }^{2188}$. La fortuna clásica del tema es sobradamente conocida, a pesar de que, al periodo románico llegase a través de una larga cadena de reinterpretaciones que hacen poco posible asegurar el origen de estos determinados ciclos en concreto $^{2189}$.

Exactamente el mismo fenómeno ocurre con las figuras del centauro arquero y la sirena atravesada por una flecha. Siguiendo un modelo bien conocido dentro de la escultura de la iglesia de Saint-Saturnin de Toulouse, el escultor traslada determinadas soluciones antiguas a las piezas, como el tratamiento de los volúmenes y el interés por la anatomía de las figuras ${ }^{2190}$. La asociación de ambas imágenes dentro de los programas iconográficos, puede vincularse a las relaciones que, ya en su día, establecía Virgilio en su obra, donde ambos seres aparecían luchando en pleno combate ${ }^{2191}$. El problema de poder diferenciar si el obrador compostelano pudo tener acceso directo a las fuentes antiguas $\mathrm{o}$, por el contrario, se trata de una asimilación mecánica y estereotipada de dicha imagen, vuelve a plantearnos serias dudas.

Otra serie de motivos, aislados en su mayor parte, y cuyo origen se muestra igualmente complicado de esclarecer, insisten en esta problemática. El hecho de que las columnas con tema vegetal de la puerta norte hayan sido puestas en contacto, de manera reiterativa, con el arte clásico, ha sido tenido en cuenta para explicar otra serie de elementos esculpidos en las mismas fachadas. Este es el caso de algunas lajas con representación de zarcillos, hojas de vid y racimos de uvas que hallamos hoy

\footnotetext{
${ }^{2188} \mathrm{La}$ escultura formaría parte del ciclo de los meses, configurando un menologio que, supuestamente, ostentaría la primicia dentro de las portadas monumentales del románico hispano. El tema de los meses encajaría, totalmente, dentro de un programa alusivo a los temas de la caída, condena, salvación y anuncio de la venida de Cristo, prefigurados en la fachada por las figuras Abrahán e Isaac. Cf.: S. MORALEJO ÁLVAREZ, "Lastra de febrero", The art of..., ficha catalográfica 94, pp. 215-216; M. A. CASTIÑEIRAS GONZÁLEZ, El calendario medieval..., p. 236; J. CAUCCI, "Maestro de las Platerías (Maestro Esteban?), L'inverno (Mese di Febbraio)", Romeo \&..., ficha catolográfica 178, p. 387 y J. C. VALLE PÉREZ, "Relieve del mes de febrero", Los Caminos de Santiago. El arte en el periodo románico en Castilla y León, Valladolid, 2006, p. 324. La pieza, nuevamente, se ha ligado, desde un punto de vista formal, al estilo utilizado dentro de la escultura de Saint-Saturnin de Toulouse y San Isidoro de León. Véanse también las ideas desarrolladas en: S. SCHRÖDER, "Tres sarcófagos de época romana en el Museo del Prado. Su iconografía y tipología”, El sarcófago romano..., pp. 157-174, en concreto, p. 160. En dicho trabajo se realiza la lectura del tema de las estaciones dentro de la escultura romana que era incluido dentro de las piezas funerarias, por creer que la vida del hombre podía ser entendida como una metáfora de aquellas.

${ }^{2189}$ M. TORRES CARRO, "El tiempo representado", Anas, 11-12, 1998-1999, pp. 93-102.

${ }^{2190}$ Ambos temas tenían larga tradición desde la Antigüedad remota. Cf.: J. ADHÉMAR, Influences antiques..., pp. 180-181; V. R. NODAR FERNÁNDEZ, "La sirena...", p. 39 y M. A. CASTIÑEIRAS GONZÁLEZ, El calendario medieval..., p. 67.

2191 J. ADHÉMAR, Influences antiques..., pp. 182-183.
} 
reempleadas en la fachada de Platerías (fig. 429). Los relieves aluden, claramente, a una tradición paleocristiana de relacionar el tema de la viña con la imagen de los apóstoles, costumbre que ofrecerá magníficos ejemplos en otros focos "antiquizantes" de la escultura europea. Recuérdense, en este sentido, los numerosos fragmentos marmóreos reaprovechados en diferentes partes de la catedral de Módena (fig. 430). Se trata de piezas expoliadas de edificios romanos del siglo I a. de C. y reempleadas como pilastras, como sillares e, incluso, como elementos arquitectónicos ${ }^{2192}$.

En el ejemplo concreto de las lastras decoradas con el tema de la viña de Platerías, colocadas junto a la figura de San Andrés, se han querido relacionar con el Sermón de la fiesta de Santiago recogido en el Liber Sancti Jacobi, donde el Apóstol es presentado como un racimo de la viña del Señor, tal y como se hizo, en torno al año 1130, en el mosaico de San Clemente de Roma ${ }^{2193}$.

Por otra parte, la figura de San Andrés o la de San Pedro, aparecen colocadas siguiendo un sistema compositivo que se ha ligado con el esquema tradicional de alineamiento de las figuras utilizado por el arte paleocristiano. En concreto, es una solución habitual en los frentes de sarcófagos, donde aparece el tema del colegio apostólico colocado frontalmente, con uso preferente de la isocefalia ${ }^{2194}$.

Con todo, aceptando las coincidencias que se han defendido entre estos aspectos y las fuentes clásicas a las que, posiblemente, se alude mediante estas soluciones, resulta difícil poder hablar de relaciones directas. En último caso, todas estas citas al mundo antiguo llegarían a través de diferentes estadios distribuidos durante toda la Alta Edad Media, siendo imposible poder llegar a discernir si se trata de un conocimiento directo

\footnotetext{
${ }^{2192}$ F. REBECCHI, "Frammenti architettonici con due succesive lavorazioni: come architrave nel I. Sec. a. C. (seconda metà), come pilastri nel secc. VIII-IX”, Lafranco e Wiligelmo..., ficha catalográfica R.8, p. 340; ID., "Blocchi con decorazione vegetale, I. Sec. a. C., seconda mità", Ibidem, ficha catalográfica R. 11, p. 342 e ID., "Plutei a cancello, V sec. d. C.", Ibidem, p. 345. El autor recoge diversas piezas antiguas que fueron reempleadas dentro del edificio. Destaca la predilección por las lastras de temática vegetal y otros motivos, perfectas para reutilizarse dentro de las construcciones medievales, en concreto, las fachadas.

${ }^{2193}$ M. A. CASTIÑEIRAS GONZÁLEZ, "Topographie...”, pp. 31-32 e ID., "Roma e il programma riformatore...”, pp. 211-214. Ya en su día S. Moralejo defendió interesantes teorías respecto a la inclusión de diversos motivos vegetales dentro del programa iconográfico de las fachadas debido a causas simbólicas y alegóricas. Cf.: S. MORALEJO ÁLVAREZ, "El patronazgo artístico...", p. 293, nota 20. Sobre la vinculación de este tipo de representaciones vegetales medievales con el mundo antiguo, véase: H. TOUBERT, "La renouveau paléochrétien...", p. 101; M. ALMAGRO y otros, Qusayr'Amra..., p. 55 y L. ABAD CASAL, El arte funerario..., p. 30.

${ }^{2194}$ M. A. CASTIÑEIRAS GONZÁLEZ, "Roma e il programma riformatore...", p. 211.
} 
de las piezas o asimilado a través de las consabidas reinterpretaciones realizadas durante los sucesivos siglos hasta la llegada del románico ${ }^{2195}$.

Al referirse al "maestro" de Platerías, S. Moralejo escribiría:

"Las fuentes de su arte están poco claras. Se ha insistido sobre la influencia de los marfiles, pero estos no resolvían todos los problemas que plantea la escultura monumental, 2196 .

Sus palabras reflejan bien la complejidad de analizar las fuentes de tradición tardorromana que parece evidenciar esta plástica medieval. Otros autores han señalado, paralelamente, la dependencia directa de estos mismos modelos de las Platerías con respecto a otros tipos de producciones artísticas, como por ejemplo, la ilustración del libro de época carolingia ${ }^{2197}$.

El recuerdo de fórmulas clásicas y el conocimiento, aunque parcial, del repertorio estilístico e iconográfico de determinadas obras de la órbita del arte romano, podría ser factible al analizar algunas de estas esculturas. Los talleres activos en la catedral durante el periodo cronológico que hemos abordado aquí, parecen evocar o rememorar, algunas de las soluciones más conocidas de este arte antiguo. Sin embargo, la mayor complejidad reside en poder discernir si su conocimiento de las fuentes y las piezas se produjo a través de un visionado directo de las mismas, a través de una serie de repertorios tomados del arte clásico y que, hipotéticamente, se encontraban circulando dentro de la Península Ibérica por estos momentos o, finalmente, si por el

\footnotetext{
${ }^{2195}$ En relación con los motivos vegetales, véase: L. N. C. WRENCH, Decoração arquitectónica ..., vol. I, pp. 123-145. No hemos podido tener acceso al estudio publicado en: A. M. QUIÑONES COSTA, La decoración vegetal en el arte español de la Alta Edad Media: su simbolismo, Universidad Complutense de Madrid, 2001. Sin embargo, creemos que, por su título, podría aportar datos interesantes sobre estos aspectos.

${ }^{2196}$ S. MORALEJO ÁLVAREZ, "La primitiva fachada...", p. 45. En este sentido también insistió en las relaciones existentes entre las artes del marfil y la escultura de los capiteles del Panteón Real de San Isidoro de León. Véase también: F. GARCÍA ROMO, La escultura del siglo XI..., pp. 254-255 e ID., "Los pórticos de San Isidoro...,", p. 216.

${ }^{2197}$ M. A. CASTIÑEIRAS GONZÁLEZ, Atlas de la catedral..., (edición digital). El autor afirma: "sus modelos estarían en las biblias carolingias de Tours", refiriéndose a las relaciones que presenta la imagen de la supuesta Eva amamantando a Caín de la fachada de Platerías con respecto a modelos germanos. El modelo también aparece, recordemos, en las puertas de bronce de Hildesheim. Es un dato interesante, pues tal y como hemos dicho, el sustrato clásico de estas obras germanas es muy marcado y las fuentes también se han puesto en relación con la miniatura. El hecho de que los artistas estén manejando estos modelos de prestigio se percibe en la famosa columna helicoidal de bronce de la iglesia de San Miguel, mientras que, en el caso hispano, el formato de la columna historiada romana se reinterpretó, mezclándose con la variante tipológica de temática dionisíaca, en las columnas helicoidales de la fachada norte de la catedral gallega. Actualmente la columna de metal se conserva en la catedral de Hildesheim.
} 
contrario, se trata de un conocimiento de la Antigüedad obtenido a través de segundas reversiones realizadas por otros escultores románicos coetáneos.

Creemos que el sustrato clásico que tantas veces se ha defendido para la escultura de Santiago de Compostela no puede ser comparado al fenómeno acaecido en Frómista y, mucho menos, en Jaca. Aquí, la Antigüedad parece materializarse a través de una reiterativa cita a sus modelos, mientras que, para el caso compostelano, estos parecen diluirse lentamente, manifestándose fragmentados y abreviados fruto, casi siempre, de un posible análisis marginal e indirecto de las piezas antiguas.

En contra de este argumento se podría aludir el caso de las columnas marmóreas de fuste helicoidal de la puerta norte del templo, claramente, deudoras de modelos constantinianos. Sin embargo, también aquí el referente de prestigio se ha tomado, de manera indirecta, a través de las reinterpretaciones realizadas por los escultores medievales de las grandes piezas colocadas, en su día, por Constantino en el templo vaticano. Los repertorios a los que tenían acceso los escultores hispanos eran, una vez más, obras "contaminadas" por una primera reinterpretación. La Antigüedad se transmitía, en este sentido, sesgada por una primera distorsión de sus modelos originales $\mathrm{y}$, tal vez, este sea el motivo por el que los elementos presentes en la escultura de la catedral parezcan enriquecidos por tan diversas fuentes.

Los escultores, a la larga lista de fuentes medievales que emplearon para la creación de un conjunto tan excepcional, sumaron los modelos antiguos como claro referente de prestigio. Muy a pesar de que, en ocasiones, tan sólo hubieran tenido acceso a ellos a través de las reinterpretaciones que otros artistas habían hecho ya de los mismos. 


\section{4. DIFUSIÓN Y DISOLUCIÓN DE LOS ELEMENTOS CLÁSICOS EN LA ESCULTURA ROMÁNICA HISPANA HASTA LA MITAD DEL SIGLO XII: EL EJEMPLO DE SAN ISIDORO DE LEÓN Y SUS ÁREAS DE IRRADIACIÓN.}

El breve apartado que ahora iniciamos supone, de alguna manera, el fin de una etapa dentro de la escultura románica hispana y la conclusión de uno de los apartados más importantes de este estudio. Hasta el momento, hemos abordado las características clásicas presentes dentro de la escultura de diversos focos, entre ellos, los más destacados, los de Jaca, Frómista y Santiago, así como algunos inscritos también en sus órbitas de influencias, con alusiones puntuales, entre otros, a los ejemplos de Loarre, Igúacel o Carrión de los Condes.

Durante las dos primeras décadas del siglo XII, tales centros habían resuelto la mayor parte de su actividad escultórica, por lo que, por estos momentos, existía una generación de escultores lo suficientemente preparados como para comenzar a emitir modelos que sobreviviesen al cierre de los talleres en los edificios ya finalizados.

En las siguientes páginas explicaremos lo hasta ahora defendido, en relación con la perduración de elementos clásicos dentro de la escultura románica española, tras las experiencias de Jaca y Santiago. La basílica de San Isidoro de León se nos presenta como otro de los templos que parecen retomar el relevo de la calidad de las obras compostelanas, así como el gusto por una compleja decoración esculpida ${ }^{2198}$.

Tal y como veremos, si el conocimiento de la obra antigua parecía, en ocasiones, lejano y fragmentando al examinar las esculturas de Santiago de Compostela, ahora, en San Isidoro de León, hasta cierto punto dependiente de los talleres gallegos, se observa un debilitamiento mayor de tal corriente "antiquizante". El conocimiento de las fuentes clásicas, salvo excepciones, se produce a través de meras reinterpretaciones medievales de los motivos que llegan apenas sin fuerza ni contenido. Son notas poco definidas, alusivas a un mundo antiguo que, iniciado con una fuerza inusitada en Jaca y Frómista,

\footnotetext{
${ }^{2198}$ No es preciso insistir en todas las investigaciones que han hablado de las relaciones entre la catedral de Santiago y la escultura del centro leonés. Véase, a modo de ejemplo, la reciente aportación realizada en: T. MARTIN, "Recasting the concept of the "Pilgrimage church": the case of san Isidoro de León", Corónica: A journal of medieval Spanish language and literature, 36, 2, 2008 pp. 165-190 e ID., Queen as King..., pp. 25-37. Se trata, por otra parte, de un tema ya abordado por los autores más clásicos de la historiografía. Cf.: A. KINGSLEY PORTER, "Leonesque Romanesque and Southern France", The Art Bulletin, 8, 4, 1926, pp. 235-250.
} 
parece diluirse, lentamente entre, los años 1120 y 1140, siempre teniendo en cuenta lo problemático de poder acotar tales fenómenos mediante una serie de años concretos ${ }^{2199}$.

Lo que podemos concluir al respecto, sin detenernos pormenorizadamente en las cuestiones cronológicas, es que, en torno a los años 1095 al 1100, parecen estar iniciadas las obras de construcción del nuevo templo románico de San Isidoro, elevado sobre el anterior, construido por el rey Fernando I y su cónyuge la reina Sancha ${ }^{2200}$. Una parte del patronazgo de dicha obra parece recaer sobre la hija de éstos, la infanta Urraca que, antes del año de su muerte en el 1101, habría de dejar iniciada la construcción de la primera cabecera del edificio, desaparecida al ser sustituida por la actual ${ }^{2201}$ (fig. 431).

Aceptando estas teorías, defendidas con fuerza por T. Martin:

\footnotetext{
${ }^{2199}$ El problema cronológico que presenta la datación correcta de la iglesia de San Isidoro de León, así como el del Panteón Real y otra serie de estructuras del conjunto, como la data del Palacio Real, son temas tangenciales a nuestro objeto de estudio. Al abordar, tan sólo, la escultura del templo, obviamos las referencias a las demás construcciones. La iglesia anterior al templo actual fue la de San Juan Bautista, construida por los reyes Fernando I y Sancha. Se podría tratar de una iglesia de mediados del siglo XI que sería destruida en los inicios del siglo XII para levantar el edificio que hoy conservamos.

La construcción del templo se inició con el patrocinio de la infanta Urraca, tal y como señala J. L. Senra y Galán, siempre antes del año 1101. Parece que la donación realizada por la reina Urraca en 1110 a la obra de San Isidoro, tal y como ha recogido la profesora E. Martín López, insinuaría tal año como fecha segura para poder datar el inicio de la actividad decorativa en el templo.

En relación con su finalización, el epígrafe conservado en el ábside norte del edificio, donde se grabó la fecha del 1124 "debe entenderse como una conmemoración del momento en el que la iglesia de San Isidoro estuvo terminada, hecha por un cantero que trabajaba en la fase final del edificio", según escribe T. Martin. Sin embargo, la consagración final debería esperar hasta el año 1149, cuando la basílica fue, nuevamente, consagrada. Sobre dichos aspectos hemos consultado los siguientes estudios: T. MARTIN, "Un nuevo contexto para el tímpano del Cordero en San Isidoro de León”, El tímpano románico..., en concreto, pp. 191-198; ID., "The art of...", p. 1136. En dichas obras la autora señala los años 1095-1124 como el arco temporal donde se llevó a cabo el grueso de las obras arquitectónicas y escultóricas en el edificio. Se trata de la investigadora que más publicaciones está realizando actualmente sobre el tema. Véase también: ID., "Recasting the concept of the "Pilgrimage church...", pp. 165-190.

En relación con las labores escultóricas, consúltese: M. POZA YAGÜE, "Entre la tradición...", p. 19; J. L. SENRA GABRIEL Y GALÁN, "Algunas notas...", p. 449, nota 41. Más importante, debido al análisis documental de las fuentes que realiza, es el estudio publicado en: E. MARTÍN LÓPEZ, "Las inscripciones del Panteón...”, en concreto, p. 946. La profesora Martín López señala el año 1126 como la fecha en la que se dejó de inhumar a los monarcas en el recinto funerario de San Isidoro, a excepción de los infantes, que continuaron haciéndolo.

En relación con el tema véase también: M. DURLIAT, La sculpture romane de la route..., p. 389; ID., "Les débuts...", p. 113; C. COSMEN ALONSO y M. V. HERRÁEZ ORTEGA, "Fernando II...", pp. 8283; G. BOTO VARELA, La memoria perdida..., p. 53. Con todo, los trabajos que mayor atención ha prestado al templo, teniendo en cuenta cuestiones de índole arquitectónica y escultórica son: I. G. BANGO TORVISO, "Arquitectura y escultura”, Historia del Arte en Castilla y León. Arte Románico, vol. II, Valladolid, 1994, pp. 9-212, especialmente, p. 68 y A. VIÑAYO GONZÁLEZ, "Real Colegiata de San Isidoro", Enciclopedia del románico en Castilla y León. León, Aguilar de Campoo, 2002, pp. $562-$ 564.

${ }^{2200}$ TH. MARTIN, “The Art of...”, p. 1136.

${ }^{2201}$ Se trataría de una cabecera románica datada alrededor del año 1100 que, posteriormente, y con el cambio de plan en las obras adscritas a la persona y al reinado de la reina Urraca (1109-1126), hija de Alfonso VI e Inés de Aquitania, se vería reformada. La figura de la reina Urraca ha sido recientemente puesta en relación con gran cantidad de obras dentro de la iglesia de San Isidoro. Este aspecto llevó a autores como D. Manuel Gómez-Moreno o G. Gaillard, a considerar el epígrafe del 1124 del edificio, como fecha de inicio de tal estructura. Cf.: T. MARTIN, Queen as King..., pp. 80-83 y J. L. SENRA GRABRIEL Y GALÁN, “Algunas notas...”, p. 449.
} 
"la escultura de la Puerta del Cordero y de los capiteles de los ábsides son los más antiguos de entre los varios estilos escultóricos que unen San Isidoro con la más sofisticada arquitectura románica en los albores del siglo XII,2202.

La autora data estos primeros capiteles del templo, los patrocinados por la infanta Urraca para la primera cabecera del edificio, entre los años 1095 y 1101. Tal y como hemos señalado, se trata de piezas emparentadas con la escultura coetánea de Santiago de Compostela, pero conocedora de las formas realizadas en Jaca y Frómista y, por lo tanto y más importante para nuestro objeto, susceptibles de poseer ciertos valores clásicos. Tales capiteles hubieron de ser conservados y reempleados en la nueva cabecera, la patrocinada por la reina Urraca, entre los años 1110-1124:

“al eliminarse los ábsides menores originales, se cuidó de conservar los capiteles para poder reutilizarlos en la nueva estructura" 2203 .

A pesar de que la fecha de 1124 inscrita en el ábside norte haya sido interpretada como el fin de las obras dentro de la basílica ${ }^{2204}$, tal y como han puntualizado, de una manera más concreta, las profesoras C. Cosmen y M. V. Herráez, deberíamos esperar al año 1168 para que se finalizasen completamente los trabajos en el templo ${ }^{2205}$.

En este sentido, aún en el año 1167 encontramos citados en algunos documentos del Archivo de la Real Colegiata de San Isidoro de León a pedreros y carpinteros que

\footnotetext{
${ }^{2202}$ TH. MARTIN, "Un nuevo contexto...", p. 198. La autora se imagina una rocambolesca historia del edificio, en la que la supuesta cabecera original, patrocinada por la infanta Urraca, es derribada pocos años después, siempre antes del 1124. Ésta construcción sería sustituida por otra mayor, con tres ábsides, que, al ser añadidos junto con un transepto, no proyectado inicialmente para el edificio, provocará que dichos ábsides quedasen descentrados con respecto a las naves anteriormente construidas del templo. Mientras, los escultores hubieron de conservar del derrumbe los capiteles de la anterior cabecera, todos ellos, desde un punto de vista estilístico, emparentados con el tipo de escultura que se realizaba en la Península en torno del año 1100, para, finalmente, como objetos relicarios, ser colocados sin destrucción alguna y una perfecta adaptación al marco arquitectónico en su nuevo emplazamiento.

${ }^{2203}$ Ibidem, p. 198.

${ }^{2204}$ TH. MARTIN, “The Art of...”, p. 1141 y G. BOTO VARELA, “Arquitectura medieval...”, pp. 50103- El profesor Boto ha realizado esta aportación recientemente, ofreciendo un análisis y datación del edificio leonés, a través de un trabajo de lectura de paramentos y documentación. De sus reflexiones se percibe un intento por cambiar algunas de las hipótesis tenidas, hasta hoy en día, como válidas.

${ }^{2205}$ C. COSMEN y M. V. HERRÁEZ, "Fernando II...", pp. 82-83. Según señalan, el 14 de noviembre de 1168 , el rey dictó un nuevo trazado en relación con la distribución del tejido urbano que rodeaba el templo de San Isidoro, desviando el Camino de Santiago, para conducir a los peregrinos hacia la basílica. Así dicen: "tras adorar las reliquias del patrón, rodearían la cabecera de la iglesia para continuar por la calzada...".
} 
nos indican la continuación de los trabajos en la fábrica ${ }^{2206}$. Cuatro años después de este hecho, aparece entre la documentación un operario llamado Cipriano, de Fenar, localidad cercana a León y conocida por poseer una cantera para la extracción de piedra. El citado obrero es donado por el rey Fernando II con el fin de trabajar en las obras de la basílica legionense $^{2207}$.

Por lo tanto, parece que, aunque de manera inercial, la basílica continuó desarrollando cierta actividad enfocada a rematar algunos aspectos inacabados del templo. A pesar de ello, la consagración final del edificio se había producido en el año 1147, en presencia del mismo Alfonso VII, hijo la reina Urraca y Raimundo de Borgoña, uno de los personajes de la corte más unidos a la figura del obispo Diego Gelmírez $^{2208}$.

Sin embargo, las relaciones con el obispo compostelano se remontaban ya al mandato de la misma reina Urraca, la cual, en un documento del año 1121 se dirige a él afirmando que será "una fiel señora y amiga, como un buen rey para su buen arzobispo, durante toda mi vida"2209.

Podemos concluir, dejando a un lado las cuestiones cronológicas, que la basílica de San Isidoro de León y sus respectivos patrocinadores, mantenían una larga trayectoria de relaciones con la sede compostelana. Creemos que, gracias a ellas, se pueden explicar algunos elementos de tradición clásica que, hipotéticamente, habrían de pasar desde las corrientes jaquesas y compostelanas, ya filtradas y reinterpretadas, a los mismos talleres activos en León.

Al examinar algunos de los capiteles conservados, actualmente, en los ábsides del edificio, se advierten varias filiaciones posibles. Algunos de ellos recuerdan soluciones ya adoptadas por los escultores encargados de decorar el mismo Panteón Real, tal y como señaló, hace tiempo, la profesora E. Fernández González ${ }^{2210}$.

\footnotetext{
${ }^{2206}$ Ibidem, en especial, p. 82 y J. A. MORÁIS MORÁN, “Imitación, copia y asimilación...”, (en prensa). ${ }^{2207}$ C. COSMEN y M. V. HERRÁEZ, "Fernando II...,", p. 82.

${ }^{2208}$ El rey Alfonso VII fue coronado dentro de otro templo leonés, la catedral de Santa María. Cf.: E. FERNÁNDEZ GONZÁLEZ, "Problemática en torno a Santa María...", pp. 220-221 y M. DURLIAT, La sculpture romane de la route..., p. 389. El documento epigráfico que nos ofrece el dato es la inscripción del 6 de marzo del año 1147, una consecratio empotrada en el brazo sur del crucero. Sobre el epígrafe, véase: V. GARCÍA LOBO, "Las inscripciones medievales...", en especial, p. 386. En relación con la continuidad de los trabajos en el edificio, se ha señalado la importante presencia de Petrus Deubstambem, al que se ha atribuido la construcción del Puente del Esla, en Benavente, fechado por documento en el 1166. Se insiste sobre esta cuestión en: M. DURLIAT, La sculpture romane de la route..., p. 389.

${ }^{2209}$ TH. MARTIN, "Un nuevo contexto...", p. 190. No podemos compartir la opinión de la autora que ve en este fragmento descontextualizado del documento, una declaración, por parte de la reina, de equipar su figura a la de su padre, desde un punto de vista político.

${ }^{2210}$ E. FERNÁNDEZ GONZÁLEZ, San Isidoro de León..., p. 24.
} 
Si diéramos como válida la hipótesis de la profesora T. Martin, el conjunto de piezas esculpidas de los ábsides actuales se integrarían dentro de una cronología cercana al año 1100. Este hecho nos parece factible, sobre todo, al tener en cuenta los diversos paralelismos que algunas de estas esculturas ofrecen con respecto a determinadas soluciones estilísticas e iconográficas adoptadas ya en las iglesias de Jaca y Frómista.

Sin embargo, se nos sigue planteando el problema de poder llegar a explicar porqué unos capiteles, presumiblemente pertenecientes a esta cronología, forman parte de una estructura arquitectónica atribuida al patronazgo de la reina Urraca y, por lo tanto, de una época más tardía. La teoría del reempleo intencionado de las piezas conservadas intactas para el nuevo ábside sigue sin poseer bases sólidas que la argumenten.

A pesar de ello, este es un problema tangencial para nuestro estudio. Nos interesa, tan sólo, centrarnos en un capitel presente en el ábside sur del edificio y que, actualmente, se presenta maltratado por el tiempo (fig. 432). Aquí se representaron cuatro figuras, tres de ellas ocupando la parte central de la cesta y la cuarta en el lado corto derecho. Según se puede advertir, incluso actualmente, al menos tres de ellas se muestran sentadas y con las piernas y los pies desnudos. Lo más destacado es la presencia de las serpientes que se enroscan y envuelven diversas partes del cuerpo de las figuras, rememorando uno de los temas de filiación clásica de mayor trascendencia, derivado, así mismo, del sarcófago de Husillos (fig. 433).

En la pieza se advierte también la utilización de un sistema decorativo que ocupa el lugar destinado a los caulículos del capitel corintio romano y donde se esculpió una especie de pliegues que descienden desde las partes altas. Pensamos que no existiría problema alguno en ver, en tal elemento, una derivación muy marginal del tema de los textiles del sarcófago romano, así como de aquellos esculpidos en el famoso capitel de Frómista.

A través de esta escultura y otras que pasaremos a analizar en breve, se perciben los ecos de las producciones realizadas por los talleres estudiados en las páginas anteriores, sin embargo, parecen llegar aquí tamizados por otras experiencias y enriquecidos por otros modelos. Lo que nos parece seguro es que se trata de escultores diferentes y ningún elemento nos puede llevar a pensar en unos mismos talleres trabajando en Jaca, Frómista, Santiago y León, de manera paralela. 
A. ALGUNAS REFLEXIONES SOBRE LA DISPERSIÓN DE LOS MOTIVOS CLÁSICOS EN LAS PRODUCCIONES ARTÍSTICAS DE LA REAL COLEGIATA DE SAN ISIDORO DE LEÓN.

En un breve estudio que recientemente hemos realizado sobre el famoso cáliz de Doña Urraca, conservado en el tesoro del Museo de la Real Colegiata de San Isidoro de León $^{2211}$, hemos puesto de manifiesto nuestras dudas con respecto a la autenticidad del supuesto camafeo tardoantiguo que la pieza presentaría en el frente ${ }^{2212}$.

En este estudio ofrecimos una serie de pruebas, casi todas ellas de carácter formal, surgidas al analizar la técnica y el estilo de la pieza, teóricamente romana, que presenta el cáliz. La teoría no es nueva pues, tal y como apuntaran en su día M. GómezMoreno o el profesor J. Williams, el supuesto camafeo del objeto litúrgico, una cabeza tallada en cierta pasta vítrea blanquecina, bien podría englobarse dentro de la plástica del periodo medieval. Algunos elementos destacados de la misma como, por ejemplo, la manera en que se han rematado los cabellos de la figura, recuerdan a otras piezas coetáneas, como el Cristo ebúrneo de Carrizo de la Rivera, hoy conservado en el Museo de León ${ }^{2213}$.

La pequeña máscara en forma de engaste, colocada sobre la parte alta del cáliz, es un buen ejemplo para poder explicar la actitud que hacia la Antigüedad y sus obras de arte tuvieron los artífices ligados al centro de San Isidoro. Muy a pesar, incluso, de que este ejemplo se aleje de la misma escultura monumental en piedra que aquí estudiamos.

De ser cierta la hipótesis planteada en su día por estos autores, los artistas que por estos momentos trabajaban realizando objetos suntuarios para la basílica, habrían tenido un acceso tan restringido a las piezas clásicas que hubieron de "inventarse" una, creando un falso spolium in se. Con un material medieval y en cronología románica, se realizó una réplica de un camafeo antiguo, siguiendo modelos bien conocidos dentro de

${ }^{2211}$ J. A. MORÁIS MORÁN, "Pervivencias de la Antigüedad clásica en la Edad Media hispana. El spolium in se: a propósito del cáliz de Doña Urraca", XII Congreso de la Sociedad Española de Estudios Clásicos (SEEC), Valencia, 2007, (en prensa).

${ }^{2212}$ A. VIÑAYO GONZÁLEZ, León y Asturias. Oviedo, León, Zamora y Salamanca, Madrid, 1979, en especial, pp. 144-145; J. W. WILLIAMS, "Chalice of Urraca", The Art of ..., ficha catalográfica 118, pp. 254-255; A. GARCÍA FLORES, "Cáliz de doña Urraca", Maravillas..., León, 2001, vol. I, ficha catalográfica 108, p. 335 y F. GALVÁN FREILE, "Arte y Monarquía en León", Enciclopedia del románico en Castilla y León, Aguilar de Campoo, 2002, pp. 53-65, en concreto, p. 56.

${ }^{2213}$ M. GÓMEZ-MORENO, Catálogo Monumental de España. Provincia de León (1906-1908), 1925 (reed. León, 1979), particularmente, p. 205 e ID., El arte románico español. Esquema de un libro, Madrid, 1934, particularmente, p. 32. Don Manuel Gómez-Moreno consideraba que se trataba de "un camafeo de pasta blanquecina remedando una cabeza humana, de carácter perfectamente románico y muy notable". 
la orfebrería anterior y coetánea, tanto de la órbita astur-leonesa como en la europea del momento. Se trata de un ficticio spolium in se que reinterpreta las formas y funciones de una pieza antigua, buscando otorgar al cáliz una antigüedad, un prestigio y unas raíces ancestrales que no posee, siguiendo idénticos mecanismos de legitimación visibles en los tesoros regios que, en su día, habían patrocinado monarcas como Alfonso II el Casto o Alfonso III el Magno, a través de piezas como la cruz de los Ángeles y de la Victoria $^{2214}$. En dichas obras orfebres la expoliación de verdaderos engastes y piedras preciosas romanas refleja una aproximación más directa y real a las piezas antiguas. Una facilidad a la hora de reintegrarlas en piezas medievales que, al contrario, no parece darse en los talleres de León.

La búsqueda de este tipo de soluciones para aludir al prestigio de la Antigüedad, refleja, finalmente, un mal conocimiento de la misma. El tesoro de la basílica y, tal y como veremos, también parte de su decoración pétrea, presenta ciertos detalles que recuerdan, vagamente, los modelos clásicos, pero jamás se trata de un conocimiento directo de los mismos y, mucho menos, de reutilizaciones reales. El hecho de que ninguna de las piezas utilizadas en tal conjunto sea verdaderamente antigua, habla de la dificultad para conseguirlas dentro de la Europa de los siglos XI y XII. En relación con ello, el texto de Suger donde se lamenta del elevado coste de estos spolia es bien significativo.

A pesar de ello, otros detalles del mismo tesoro reflejan este aspecto. La denominada como arqueta de los marfiles presenta una base o alma de madera en la que se adosaron diversas placas de marfil con la imagen de los apóstoles bajo arquerías. Lo más interesante es la inclusión, dentro del programa iconográfico, de la imagen de los cuatro ríos del paraíso que, junto con el cordero y otra serie de arcángeles, decoran la cubierta troncopiramidal de la cista ${ }^{2215}$ (fig. 434).

\footnotetext{
${ }^{2214}$ H. SCHLUNK, Las cruces de Oviedo. El culto de la Vera Cruz en el Reino Asturiano, Oviedo, 1985, en concreto, pp. 18-29. Dentro la cruz de los Ángeles, se han llegado a contabilizar hasta ocho entalles romanos, de los cuarenta y ocho que presenta la obra. También véase: I. G. BANGO TORVISO, Arte prerrománico..., en especial, pp. 296-297; ID., El prerrománico en Europa, Madrid, 1989, en concreto, p. 57. Sobre estas piezas dentro del contexto europeo, consúltese: P. SKUBISZEWSKI, L'art du Haut Moyen Âge. L'art européen du IV au IX siècle, Baume-les-Dames, 1998, en concreto, pp. 378-381.

${ }^{2215}$ A. VIÑAYO GONZÁLEZ, León y Asturias..., pp. 129-130. El autor apunta que la imagen de estos personajes recostados vertiendo el agua de un jarrón puede ser leída como la de los cuatro ángeles del Apocalipsis que derramaban las plagas sobre la tierra. También consúltense: E. FERNÁNDEZ GONZÁLEZ, "Arca relicario", Obras maestras recuperadas, Madrid, 1998, pp. 72-74 y C. COSMEN ALONSO, "Arca de San Pelayo", Maravillas de la España Medieval. Tesoro Sagrado y Monarquía, vol. I, Madrid, 2001, ficha catalográfica 87, p. 229.
} 
La introducción aquí del tema de los cuatro ríos del Paraíso, además de reflejar la capacidad interpretativa de los artífices medievales a la hora de relacionar estas imágenes antiguas con preceptos del ideario cristiano, permite integrar dichas soluciones dentro de otras desarrolladas en los mejores talleres del ámbito europeo ${ }^{2216}$. Recientemente, la profesora E. Fernández González ha puesto de manifiesto este aspecto, haciendo notar las deudas que diversas obras de los talleres leoneses presentan con respecto a otros foráneos. Lo más interesantes, es la relación que parece existir con el ámbito germano:

"Sobre la arqueta de San Isidoro se venía diciendo que parecía una pieza de importación. Sin embargo, teniendo en cuenta que hay otras piezas coetáneas con rasgos foráneos, parece más plausible que sea una obra de factura leonesa pero hecha por un artista extranjero; artista que conocía bien las obras señeras del momento, como las de la escuela renana y su área de difusión y, muy especialmente, las puertas de bronce de la catedral de Hildesheim, encargadas por el obispo Bernwald ${ }^{, 217}$.

Debemos recordar, así mismo que, otra obra, salida de los talleres de fundición del bronce ligados a la figura del obispo de Hildesheim, ya ha sido puesta en relación con el ámbito hispano a la hora de analizar las relaciones entre algunas obras romanas y otras de la etapa medieval. Nos referimos, a la columna de fuste helicoidal, con función de candelabro pascual, de la abadía de San Miguel de Hildesheim, tantas veces hemos mencionada aquí y que incluía, igualmente, dentro de su programa iconográfico la imagen de los ríos de Paraíso ${ }^{2218}$.

Las palabras de P. Lasko al estudiar la arqueta de los marfiles son bien significativas, ya que el autor relaciona dicha obra con la tradición carolingia:

"En una palabra, los elementos de la Antigüedad tardía transmitidos de la tradición carolingia y todavía tan visibles en las puertas de bronce de Hildesheim, han

\footnotetext{
${ }^{2216}$ En relación con algunas de las fuentes escritas a las que pudieron acceder los artífices de las piezas del tesoro, consúltese: C. COSMEN ALONSO, "La Arqueta de las Bienaventuranzas: fuentes iconográficas", De Arte, 1, 2002, pp. 21-30.

2217 E. FERNÁNDEZ GONZÁLEZ, "Reflexiones...", (en prensa) e ID., "Hacia la renovación escultórica...", p. 16.

${ }^{2218}$ Se realizan una serie de reflexiones sobre la columna de bronce, centrándose en el caso concreto de la iconografía de los ríos del Paraíso, en: R. KAHSNITZ, "Bernwardsäule", Bernward von Hildesheim..., vol. II, pp. 540-548.
} 
sido reemplazados por los duros y equilibrados modelos de un románico naciente y estilizado" 2219 .

Tanto en la arqueta de San Pelayo de San Isidoro de León como en la columna de bronce de Hildesheim (fig. 58), la imagen de las personificaciones de los ríos se inscriben en un programa ajustado a la ortodoxia cristiana y nos permite, desde otro orden de cosas, equiparar la importancia que las fuentes clásicas tendrían para estos dos centros tan distantes, desde el punto de vista geográfico, pero cercanos en cuento a las soluciones y técnicas utilizadas ${ }^{2220}$.

La iconografía de los ríos en forma de pequeños hombres reclinados, sujetando vasijas de las que mana la corriente acuática, y vestidos a la manera antigua, permite, igualmente, apoyar la idea que venimos defendiendo. Las diversas técnicas plásticas utilizadas para crear las piezas artísticas de San Isidoro de León traslucen un conocimiento del mundo antiguo, ciertamente intermitente y descontextualizado. El proceso que venimos explicando nos lleva a imaginar un contacto indirecto con estos modelos clásicos, con pocas posibilidades de figurarse un estudio y visionado directo de las piezas antiguas.

Tal recuerdo difuso de estos modelos se percibe dentro de algunos elementos de la escultura monumental. Si para el caso de Compostela parece claro el conocimiento profundo del tipo de columna helicoidal de tema dionisiaco, en León encontramos una referencia muy debilitada de tal elemento. Su uso, marginal, se rastrea tan sólo en la portada del Perdón del templo (fig. 235), aquella que cierra el brazo sur del transepto y donde fue esculpida una columna torsa decorada con un discreto perlado ${ }^{2221}$.

En numerosas ocasiones hemos señalado que, a través de la columna de fuste helicoidal de esta imagen del tímpano, se ha querido aludir, simbólicamente, al mismo Santo Sepulcro ${ }^{2222}$. En el caso concreto de la escultura realizada en el templo, nada permite afirmar que aquí se refleje un conocimiento real de fuentes clásicas relacionadas con esta tipología de columna, pues su modelo directo parece hallarse dentro de la misma arquitectura monumental del recinto. En concreto, una serie de fustes, actualmente reempleados formando parte del altar del ábside norte, muestran

\footnotetext{
${ }^{2219}$ P. LASKO, Op. cit., pp. 252-258.

${ }^{2220}$ E. FERNÁNDEZ GONZÁLEZ, "La imago regis y la jerarquía eclesiástica a través de las artes plásticas (ss. IX-XII)", Congreso Internacional. Monarquía y Sociedad en el Reino de León. De Alfonso III a Alfonso VIII, León, 2008, pp. 45-96.

${ }^{2221}$ J. A. MORÁIS MORÁN, "Nuevas reflexiones...", pp. 63-86.

${ }^{2222}$ E. FERNÁNDEZ GONZÁLEZ, “El arco...”, pp. 221-242.
} 
nuevamente, esta misma concepción del fuste, en forma helicoidal y decoradas con perlado (fig. 237).

Este carácter fragmentario que señalamos para el conocimiento medieval de los modelos antiguos, también se constata en otra serie de lugares ligados a la escultura de la basílica legionense.

En un trabajo ya citado en las páginas anteriores hemos insistido en la importancia que van a tener, dentro de otros centros más secundarios, aquellos modelos generados en los núcleos principales de la creación escultórica. En concreto, nos referimos a las derivaciones que vamos a encontrar en obras rurales y retardatarias del estilo y las soluciones adoptadas en San Isidoro de León.

Los tímpanos de Ruiforco y Matueca de Torío (fig. 435), ambos en la misma provincia de León, presentan una clara derivación con respecto al tímpano del Cordero de la fachada meridional de la basílica legionense (fig. 436). Son piezas significativas porque hablan de la utilización de determinados modelos de prestigio dentro del ámbito rural donde, a pesar de tratarse de piezas datadas a finales del siglo XII o muy posiblemente los primeros años del XIII, aún perduraron algunos detalles iconográficos derivados de dicha puerta, además de otros de índole estilística ${ }^{2223}$.

En relación con ello, queremos destacar que, estos ejemplos, reflejan bien el fenómeno que intentamos explicar. La iconografía de la puerta del Cordero, en la se que esculpió la imagen de dos ángeles elevando el clípeo con el óvido y el lábaro, ha sido entendida, de manera unánime, como una derivación de la iconografía de los sarcófagos paleocristianos $^{2224}$. Si pretender adentrarnos ahora en este tema, creemos que existen serias dudas para afirmar categóricamente que los escultores de San Isidoro hubieran tenido acceso directo a un frente de sarcófago antiguo donde el tema apareciese figurado. Más complejo, si cabe, es demostrar que tal pieza, de la que hoy no conservamos ni rastro, fuera copiada intencionadamente por los escultores medievales.

En el medio rural de donde salieron los tímpanos de Ruiforco y Matueca de Torío, es aún más complejo demostrar este hecho. La iconografía del clípeo se repite, nuevamente, con el cordero inscrito y los dos ángeles, sin embargo, a pesar de continuar manteniendo un modelo romano típico de los sarcófagos, la Antigüedad que reflejan

${ }^{2223}$ J. A. MORÁIS MORÁN, "Imitación, copia...", (en prensa). En el trabajo se recoge la bibliografía que las piezas han suscitado, además de analizar diversos aspectos políticos, documentales y artísticos, que llevan a pensar en un contacto directo entre las obras de estas zonas rurales del reino de León y el centro que había generado los modelos más importantes y prestigiosos, la basílica Real de San Isidoro.

${ }^{2224}$ F. PRADO-VILAR, “Saevum facinus...”., pp. 173-199. 
estas obras no fue conocida de primera mano sino, a través de sucesivas copias del arquetipo clásico $^{2225}$.

Tales ejemplos nos permiten afirmar que determinados modelos clásicos fueron copiados de manera reiterativa sin necesidad de haber tenido contacto directo con las piezas clásicas. Más aún, cuando tenemos constancia de la perdurabilidad de este tipo de composiciones en esculturas de datación bien tardía, como la que, por ejemplo, ofrece el ya citado sarcófago conservado en la iglesia de San Félix de Gerona realizado, posiblemente, en el siglo XIII (fig. 347) ${ }^{2226}$.

Regresando al problemático uso de la columna helicoidal en los talleres románicos de este momento, parece lógico aludir a un templo secundario donde este tipo de soluciones no fueron desconocidas. Nos referimos a la iglesia de San Esteban de Corullón, en el Bierzo ${ }^{2227}$. A pesar de que la cronología del edificio ha sido puesta en duda, recientemente, por G. Boto Varela, los modelos escultóricos que presenta el templo son deudores de la tradición artística compostelana. La fachada del edificio, compuesta por varios elementos escultóricos, destaca, sobre todo, por la presencia de un fuste helicoidal, claramente emparentado con las fórmulas clásicas de Platerías (fig. 437). Dicho elemento, labrado de una manera más burda, presenta una serie de estrías que recuerdan la distribución de los fustes compostelanos. Incluso se incorporaron, también aquí, las tetrafolias presentes en los fustes gallegos ${ }^{2228}$.

La columna es aquí mucho más rural y de poca calidad, lo que demuestra que se trata de una interpretación de modelos románicos de taller y no una evocación

${ }^{2225}$ Sobre el carácter arquetípico de esta iconografía en la Antigüedad, véase: E. FERNÁNDEZ GONZÁLEZ, "Hacia la renovación escultórica...", p. 19.

${ }^{2226}$ M. CRUZ VILLALÓN, “Quintanilla de las Viñas en el contexto...”, p. 120.

${ }^{2227}$ C. COSMEN ALONSO, Dos iglesias románicas..., pp. 69-74. Para la autora, la iglesia puede datarse entre los años finales del siglo XI y principios del XII, a pesar de las reformas a las que fue sometida en épocas posteriores. El elemento más interesante del templo, la fachada esculpida colocada en la puerta occidental de edificio, presenta una clara filiación con los modelos escultóricos de Platerías y la puerta de Francia.

Por su parte, G. Boto se ha pronunciado en relación con esta datación relacionada con el año 1100 , escribiendo, "resulta inverosímil sostener que en el primer año del XII los obradores de Azabacherías y Platerías estuviesen ya en condiciones de emitir motivos, por lo demás notoriamente degradados en su destino berciano. En otras palabras, sospecho que el epígrafe del año 1100 data la construcción de San Esteban de Corullón, pero no de sus labores escultóricas, posteriores y añadidas". Cf.: G. BOTO VARELA, "La integración...", p. 120.

Sobre la escultura de la fachada de Corullón también se pronunció en su día M. Poza, quién señaló que el epígrafe del templo en el que consta la fecha del 1100 debía considerarse como válido a la hora de datar estas obras. Así, al contrario que G. Boto, señalaba que la escultura de San Esteban de Corullón dataría de ese periodo y reflejaría, así mismo, el itinerario seguido por los escultores activos en la puerta del Cordero de León que, más tarde, pasarían a trabajar en el Bierzo para, finalmente, llegar a Santiago. Cf.: M. POZA YAGÜE, "Entre la tradición...", p. 19.

${ }^{2228}$ A. K. PORTER, Spanish Romanesque..., vol. I, p. 62. El autor hizo depender la facha de Corullón de la escultura de San Isidoro, aunque, igualmente, admitió las relaciones con la de las Platerías de Santiago. 
consciente de las piezas helicoidales antiguas. Era una Antigüedad conocida a través de segundas fuentes.

Ejemplos como este o como el del supuesto camafeo romano engarzado en el cáliz de Doña Urraca, traslucen bien el problema de las fuentes utilizadas en este centro. Las máscaras y cabezas antiguas, tema que ya hemos abordado, gozaron de importante éxito dentro de la escultura del edificio. Recordemos, una vez más, los rostros que se esculpieron en algunos de los capiteles del interior, a modo de máscaras y que, anteriormente, hemos puesto en relación con las máscaras romanas de estuco conservas en el Museo de Palencia (figs. 300 y 302).

Este tipo de mascarones, cuyo ejemplar más representativo lo había realizado el escultor del capitel de Frómista, se mimetizan y se modifican al antojo del escultor, generando composiciones imaginativas pero alejadas ya de los modelos clásicos.

A la utilización de estos temas debemos sumar el de las serpientes. En concreto, queremos mencionar un bello capitel esculpido para la puerta norte del templo ${ }^{2229}$ (fig. 438).

Se trata de una pieza bien conservada que muestra dos caras esculpidas ${ }^{2230}$. Mientras que en una hallamos la imagen de dos hombres desnudos, uno agachado y otro sosteniendo una serpiente en sus manos, en la otra, se representó la figura de un joven imberbe, con una clámide de innegable ascendencia clásica que también sujeta un ofidio entre sus manos. Dentro de la composición, sin duda, llama la atención, la gran máscara de ojos felinos y grandes fauces abiertas, por las cuales, salen dos grandes serpientes escamadas.

Esta pieza, de gran calidad, presenta muchos de los rasgos clásicos analizados en apartados anteriores y que no vamos a repetir. A la concepción clásica del desnudo de

\footnotetext{
${ }^{2229}$ M. DURLIAT, La sculpture romane de la route..., p. 367. El autor no numeró ninguno de los capiteles de la fachada sur del templo en su estudio.

${ }^{2230}$ A. VIÑAYO GONZÁLEZ, León y Asturias..., pp. 103-104. Se trata de una portada hoy envuelta en construcciones de época posterior. Entre ellas, la capilla del siglo XV adaptada como enterramiento de los Quiñones. Su descubrimiento en el siglo pasado le ha permitido llegar en muy buen estado de conservación hasta nosotros. La cronología de los capiteles, por sus rasgos formales, se ha venido datando entre los años finales del siglo XI y los primeros del XII, siguiendo soluciones, técnicas e iconográficas, bien conocidas dentro de la escultura de la catedral de Jaca y Compostela. Esta puerta norte de la basílica ha recibido recientemente atención por parte de los especialistas, sobre todo, a la hora de intentar reconstruir su estado original. En la actualidad no presenta tímpano y los muros que configuran el espacio en el que se inserta han recibido grandes remodelaciones. Cf.: M. POZA YAGÜE, "Entre la tradición...", p. 28, nota 84; J. WILLIAMS, "Saint John", The Art..., ficha catalográfica 89, pp. 209-210; M. DURLIAT, La sculpture romane de la route..., p. 388. En el año 2006 se publicó una hipotética reconstrucción de la fachada a través de algunos restos conservados en el claustro y en el propio Museo la Colegiata. Véase, sobre ella: T. MARTIN, Queen as King..., pp. 116-118; ID., "Un nuevo contexto...”, p. 200 e ID., "Una reconstrucción hipotética...", pp. 357-378. La profesora Martin cree que el tímpano presentaría la imagen central de una Maiestas Domini rodeada por los cuatro evangelistas.
} 
algunas figuras debemos sumar el tratamiento de la clámide del joven, además de la presencia del cabello ensortijado que recuerda modelos bien conocidos dentro de la escultura de sarcófagos. Nuevamente, se utilizan aquí los prótomos cefálicos de felinos, uno de ellos cortado por el escultor a la hora de adaptar el capitel a la portada, sino es, en realidad, una destrucción realizada en época moderna.

El tema de la serpiente reaparece en San Isidoro con fuerza y el capitel así lo demuestra. Sin embargo, a pesar de que se ha defendido una perdurabilidad del modelo nacido de la imitación del sarcófago de Husillos y, en concreto, de la figura de las Furias, éste se muestra aquí tan débil y difuso, así como enriquecido con otros elementos iconográficos, que resulta difícil establecer relaciones directas ${ }^{2231}$.

Para el caso concreto de las cabezas vomitando ofidios, el profesor M. Angheben ha señalado que se trata de una representación del pecado de la lengua, aludiendo a las referencias bíblicas que comparan las malas palabras con este animal. La metáfora habría de pasar, íntegramente, a la plástica medieval, donde la lengua pecaminosa es representada a través de la imagen de una boca de la que salen serpientes $^{2232}$.

Entre los ejemplos que señala el autor están el del capitel de Saint-Laurent-enBrionnais (Saône-et-Loire), el de Tournous y otro de Saint-André-de-Bâgé (RhôneAlpes) (fig. 439). En todos, una máscara humana escupe dos serpientes escamadas que se retuercen y se lanzan a morder las orejas de dicha cabeza.

En el caso hispano, el modelo también fue conocido. En su estudio sobre los ofidios la profesora E. Fernández González recogía el ejemplar de la iglesia de San Pedro de Villanueva, en Cangas de Onís ${ }^{2233}$ (fig. 440). Desde un punto de vista formal, la representación sigue los parámetros iconográficos de los ejemplos franceses antes mencionados. El motivo, nos permite, así mismo, señalar las concomitancias que dicha imagen posee con respecto al capitel esculpido de la puerta norte de la basílica de San Isidoro; aunque resulta difícil realizar una lectura iconográfica en conjunto de tal pieza, pues, a pesar de su factura ciertamente "antiquizante", las soluciones aquí tomadas parecen netamente medievales.

\footnotetext{
${ }^{2231}$ S. MORALEJO ÁLVAREZ, “La sculpture romane...", p. 143 y E. FERNÁNDEZ GONZÁLEZ, San Isidoro de León..., p. 24.

${ }^{2232}$ M. ANGHEBEN, Les chapiteaux romans de Bourgogne. Thèmes et programmes, Turnhout, 2003, en particular, pp. 236-239. Realiza un estudio de las fuentes bíblicas y otros textos para poder apoyar su interpretación.

${ }^{2233}$ E. FERNÁNDEZ GONZÁLEZ, “Sobre la serpiente...”, pp. 43-45.
} 
El modelo que se ha seguido ya no es clásico, pues parece que no se conoce directamente una pieza original del periodo antiguo. Se trata, una vez más, de la reinterpretación de un tema a través de la reversión realizada, tomando como base, una pieza medieval. Es decir, se estaba versionando, doblemente, la imagen clásica, no a través de las esculturas romanas, sino a partir de las sucesivas adaptaciones medievales. Tan sólo con este argumento podríamos explicar la importancia que adquirió la imagen de los hombres atacados por serpientes dentro de las iglesias románicas de la Península durante esta primera mitad del siglo XII. Creemos que su presencia en Jaca, Santiago, Frómista, León y otro gran número de templos, no puede justificarse, tan sólo, mediante un conocimiento directo de la imagen clásica de Husillos ${ }^{2234}$.

$\mathrm{Su}$ escultura presenta una comprensión de los modelos antiguos que por entonces gozaban de gran difusión a través de las vías de peregrinación. Sin embargo, no existe ningún rasgo o modelo clásico que, hasta la fecha, pueda justificarse a través de un contacto seguro con una pieza antigua que los obradores hubieran tenido a su alcance, a pesar de que, la ciudad de León y aquellas fundadas en su entorno, como la propia Asturica Augusta, legaron gran cantidad de obras romanas. Parece, a tenor de lo señalado, que muy pocas llamaron la atención de estos escultores hasta el punto de copiarlas literalmente ${ }^{2235}$.

Para finalizar, queremos llamar la atención sobre uno de los canecillos ubicados en el ábside norte del templo de San Isidoro y que presenta esculpida la imagen de un felino que despliega unas alas (fig. 441) ${ }^{2236}$. A pesar de las diferencias, la pieza no deja de señalar las relaciones que, desde un punto de vista formal, presenta con el bello ejemplar colocado, a modo de acrótera, en la capilla de San Juan de la catedral de Santiago de Compostela (figs. 367 y 368).

\footnotetext{
${ }^{2234}$ Es complejo poder atribuir, de manera segura, alguna de las esculturas de la iglesia de San Isidoro a la mano de la misma persona que esculpió el capitel de Frómista o alguno de los artistas activos en torno a él. Con todo, continuamente se sigue aplicando este método atribucionista dentro de la iglesia isidoriana. Creemos que debemos ser cautos a la hora de poder aplicar el concepto "maestro" o "taller" sobre piezas concretas, más aún, cuando todas fueron creadas en un ambiente estético e ideológico contemporáneo, con unas limitaciones técnicas provocadas por el uso de materiales de trabajo un tanto rudimentarios. En relación con este hecho, véase: T. MARTIN, "Escultura románica...", p. 78 e ID., "The Art of...", p. 1157. La investigadora identifica algunas piezas esculpidas en San Isidoro con el supuesto "taller que pudo trabajar con él", refiriéndose al "maestro" de la Orestíada, tal y como lo define.

${ }^{2235}$ Se podría también pensar en la hipótesis de la destrucción de muchas de ellas, tal y como se apunta en: M. A. GARCÍA GARCÍA, Op. cit., pp. 239-256.

${ }^{2236}$ Las fuentes para esta escultura son ciertamente complejas. A ello debemos sumar la imposibilidad de identificar, de manera segura, al animal. Con todo, aludimos a la primera visión de Daniel, en la que se menciona la presencia de un "león con alas de águila". Cf.: C. OLIVARES, "El león con alas de águila en Daniel 7:4: un resumen de la locura y la restauración de Nabuconodosor (Dn. 4)", DavarLogos 4.2, 2005, pp. 149-158.
} 
En la pieza gallega, un cuerpo felino y alado, presenta una cabeza femenina de cabellera voluminosa, además de gruesas zarpas. Posiblemente, se trate de una esfinge que, con su presencia, señala las fuentes clásicas del taller compostelano, más aún teniendo en cuenta que la pieza forma parte del excepcional conjunto de acróteras, tan raras dentro de la tradición románica ${ }^{2237}$.

La posibilidad de comparar tales esculturas con algunas de las esfinges de cronología romana conservadas en la Península Ibérica es sugestiva. Señalamos las piezas halladas en Herdade do Sargaçal y Silves, en la Lusitania (fig. 442). En ambas, se identifica un cuadrúpedo con cabeza de mujer, patas de león y alas de águila ${ }^{2238}$.

La escultura de San Isidoro de León muestra, tan sólo, un eco de tales composiciones $^{2239}$. La imagen señala un conocimiento marginal y fragmentado de lo antiguo y pocos datos nos permiten afirmar que su autor pudiera conocer, en el momento de ejecutar la escultura, las conexiones de tal iconografía con las visiones del profeta Daniel o con las más lejanas historias míticas que identificaban a la esfinge con el monstruo enviado por Hera para castigar los errores cometidos por la humanidad ${ }^{2240}$.

${ }^{2237}$ M. A. CASTIÑEIRAS GONZÁLEZ, "La catedral románica: tipología...”, p. 75. La pieza fue atribuida por el investigador al "maestro" de Platerías. Tal y como se ha dicho, se muestra en uno de estos ejemplares la figura de una mujer desnuda, de largos cabellos y montando un león. Además, se alude al Decretorum Libri de Burchard de Worms, en relación con la difusión de este motivo, quizás, ligado al mito de Diana como señora de los animales.

${ }^{2238}$ J. L. DE MATOS, Inventário do Museu Nacional de Arqueologia..., fichas catalográficas 33 y 34, pp. 76-77. La primera pieza, apareció en esta localidad cercana a Santiago de Cacém y se ha relacionado con un edifico romano. La segunda escultura, presenta dudas sobre su procedencia, creyéndose ligada a las localidades de Silves, Portimão o Faro.

${ }^{2239}$ F. C. FÉRNÁNDEZ, El libro de las maravillas y los monstruos en León, León, 1988, en particular, pp. 14-15. El autor identifica a esta escultura como un murciélago, aunque reconoce lo problemático de tal afirmación. La pieza se encuentra muy mutilada y deteriorada, lo que le permite plantear también la posibilidad de que se trate de un grifo o de un águila.

${ }^{2240}$ J. L. DE MATOS, Inventário do Museu Nacional de Arqueologia..., ficha catalográfica 33, pp. 7677. 
B. MultiPliCIDAD DE FUENTES CLÁSICAS E IMPOSIBILIDAD DE MODELOS ÚNICOS: A PROPÓSITO DE LA ICONOGRAFÍA DE LOS LICURGOS.

Dentro de la iconografía románica existió un tema que, de manera recurrente, fue incluido dentro de los conjuntos esculpidos que decoraban los templos. En este breve apartado que ahora iniciamos analizaremos la imagen de los hombres entre vegetales, un tema ampliamente difundido dentro del marco cronológico que estudiamos y que gozó de gran aceptación dentro de la llamada corriente "hispanolanguedociana".

En su día, G. Gaillard ya llamó la atención sobre el éxito de este tema, su carácter ciertamente ambiguo, su ductilidad a la hora de adaptarse al interior de los edificios, así como su facilidad para convivir con otros repertorios iconográficos ${ }^{2241}$.

En síntesis, se trata de la imagen de uno o varios hombres, a veces desnudos que, ocupando las partes más visibles de los capiteles, se muestran completamente rodeados por la vegetación ${ }^{2242}$. Tales soluciones ofrecen a la imagen una gran capacidad de variación y adaptación a las limitaciones impuestas por el mismo capitel, siguiendo principios bien conocidos dentro de la plástica románica europea ${ }^{2243}$.

Nos interesa señalar lo complicado que resulta poder llegar a concretar la actitud de estos personajes ante los vegetales pues, en ocasiones, parecen mostrarse atrapados por ellos, como si intentasen liberarse de las ramificaciones que los atan. En otros casos las figuras parecen convivir con este tipo de decoración, pudiendo llevar a cabo diversas tareas como, por ejemplo, vendimiar o, simplemente, esconderse en actitud traviesa dentro de la maraña.

Con independencia de las fuertes problemáticas de índole cronológica, para poder constatar el éxito de tal imagen basta con revisar algunas de las esculturas de los edificios levantados entre el final del siglo XI y los primeros años del siglo siguiente ${ }^{2244}$.

El clásico estudio de M. Durliat sobre la escultura de las rutas de peregrinación, ya recogía, en forma de catálogo, muchos de estos ejemplares, si bien sin prestar

${ }^{2241}$ G. GAILLARD, Les débuts..., pp. 48-66. El autor publicaba numerosos ejemplos de este tipo de iconografía, centrándose, sobre todo, en la imagen de los hombres desnudos entre vegetales.

${ }^{2242}$ J. LACOSTE, Les maîtres..., pp. 16-17.

${ }^{2243}$ H. FOCILLON, La escultura románica..., pp. 127-199. Tal hecho también había ocurrido ya durante los siglos de la Antigüedad, donde el capitel clásico modificaba sus formas para dar cabida a las figuras que, a su vez, también cambiaban sus proporciones y fisonomía para adaptarse a la forma de tal elemento. Sobre ello, véase: S. DONADONI, G. GARBINI y G. MATTHIAE, voz "Capitello. Mondo classico", Enciclopedia dell'arte antica..., vol. II, Roma, 1959, pp. 324-226.

2244 J. YARZA LUACES, "I grandi programmi iconografici...", pp. 102-110. 
excesiva atención a las cuestiones cronológicas y sin interesarse por el posible significado que tal tema pudo llegar a tener dentro de los edificios románicos ${ }^{2245}$.

En el caso hispano el prototipo aparece ya dentro de la iconografía de la catedral de Jaca (fig. 443), donde dos figuras masculinas, desnudas, se entremezclan con una serie de zarcillos. Se trata de una vegetación entrelazada sobre la que, además, se aplicó otra serie de elementos ya analizados, como leones de cuyas cabezas emergen algunos de estos ramajes, además de algunas aves ${ }^{2246}$.

Paralelamente en el tiempo y sin entrar en puntualizaciones cronológicas demasiado estrictas, el tema de varios personajes conviviendo con la vegetación reaparece en la iglesia del castillo de Loarre (fig. 444). Allí se nos muestran dos figuras, una desnuda y otra vistiendo una clámide de claro recuerdo jaqués ${ }^{2247}$.

Con ligeras variantes, idénticas soluciones aparecen dentro de uno de los capiteles de la catedral de Santiago de Compostela, donde varios personajes aparecen apresados por los vegetales que, además, decoran toda la estructura del capitel. En la misma línea, debemos recordar las imágenes de los putti desnudos esculpidos en los fustes helicoidales provenientes de la Puerta de Francia $^{2248}$ (fig. 445).

\footnotetext{
${ }^{2245} \mathrm{El}$ autor, tal y como haría en muchos de sus trabajos, defenderá la primacía de los edificios franceses con respecto a los hispanos. Siguiendo tal criterio, en su estudio aparecen recogidos antes los ejemplos de capiteles con hombres entre vegetación realizados para la iglesia de Saint-Sernin de Toulouse, por ejemplo, que otros hispanos, como los de la iglesia del castillo de Loarre. Tal y como es sabido, en la actualidad, tales planteamientos cronológicos vienen siendo revisados. Véase sobre ello: M. DURLIAT, La sculpture romane de la route..., pp. 261-268.

Ya en su momento, algunos autores criticaron el método seguido por el autor para desarrollar el planteamiento de la obra del citado autor francés, así como algunas incorrecciones cronológicas. Tal y como hemos señalado en este trabajo, en reiteradas ocasiones, no es nuestro objetivo centrarnos en tal cuestión. Cf.: I. G. BANGO TORVISO, "La peregrinación jacobea...", pp. 20-23. El profesor Bango escribía: "Libros como el de Marcel Durliat (...), no contribuyen a clarificar el tema. Con semejante título, en principio ingenuo, parece que se va a hablar del románico difundido por la peregrinación y sin embargo desde la primera página se nos dice que el románico del Camino no se debe a la peregrinación. Anunciado y vendido este libro como el estudio de un fenómeno de la peregrinación, poco importa lo que en realidad diga con más o menos ambigüedad, es utilizado a la manera de insignia de una tesis que nos muestra la ruta jacobea como principal difusora del románico en España".

${ }^{2246}$ M. DURLIAT, La sculpture romane de la route..., p. 233, capitel número 48. También debemos destacar el uso de pequeñas capas cortas que cuelgan del cuello y cubren, tan sólo, el torso de las figuras. El autor destacó en su día la "sinceridad" del desnudo dentro de esta pieza. También consúltese: G. GAILLARD, Les débuts..., pp. 101-102.

${ }^{2247}$ M. DURLIAT, La sculpture romane de la route..., p. 267, capitel 8, del portal meridional del edificio. La figura con clámide presenta los mismos modelos clásicos que, más tarde, se realizarán para la basílica de San Isidoro de León, recordando además, por el gesto, al Abraham esculpido en el famoso capitel de la catedral de Jaca. El autor francés emparentaba esta obra de Loarre con el estilo de las esculturas jacetanas. Se siguen fielmente estos planteamientos en: J. LACOSTE, Les maîtres..., pp. 4041.

${ }^{2248}$ M. DURLIAT, La sculpture romane de la route..., p. 324. Durliat identifica el capitel al que nos referimos con el número 105 . Se ubica en uno de los laterales del pilar central colocado justo en frente del acceso por la puerta norte del edificio, lo que, además, permite destacar cierta relación formal con las piezas de dicha fachada. Con todo, este capitel citado y las columnas no participan plenamente de unas
} 
En un estudio publicado recientemente, se intentó buscar una interpretación simbólica de este capitel, tanto desde la iconografía que contiene, como desde la presencia de los citados vegetales, además de su relación con otras esculturas del mismo contexto $^{2249}$.

A pesar de ello, la intención de demostrar un contenido simbólico para tales elementos continúa siendo un tema fundamental dentro de los estudios dedicados a la escultura románica y, sobre el cual, no siempre resulta seguro poder pronunciarse ${ }^{2250}$. Aunque en un sentido estricto las intenciones de los investigadores, a veces forzadas, por poder llegar a perfilar el sentido simbólico, si es que algún día lo tuvo, de estos vegetales, es una cuestión que también ha ocupado muchas páginas dedicadas a los estudios iconográficos del arte antiguo, especialmente, el romano ${ }^{2251}$.

Con todo, en el caso de las iglesias hispanas de este periodo, la presencia de tal tema en infinidad de espacios sagrados, a veces descontextualizado y aislado y, en otras ocasiones, inmerso en repertorios icónicos muy diferentes al compostelano, podría llevar a pensar que se trata más bien de un tema estereotipado y transmitido reiterativamente como un motivo decorativo, sin visos de una intencionalidad simbólica ${ }^{2252}$.

La transmisión del modelo de los hombres apresados o coexistiendo con los elementos vegetales fue una imagen tan arraigada y difundida en la escultura del periodo que es complejo rastrear su origen. En este mismo sentido, son innumerables los ejemplos en los que tal composición apareció decorando objetos artísticos realizados con otras técnicas, tales como el marfil o la ilustración del libro ${ }^{2253}$.

mismas soluciones estilísticas, pues creemos que el capitel se acerca más a las fórmulas de San Isidoro de León.

${ }^{2249}$ S. FERNÁNDEZ PÉREZ y V. R. NODAR FERNÁNDEZ, "Premio e castigo: o capitel historiado no transepto da catedral de Santiago", Porta da Aira, 11, 2006, pp. 291-310. Analizan la pieza sosteniendo una continuidad de tradiciones entre los fustes de la puerta norte y el resto de imágenes que parecen derivar del mismo tema. En este sentido, proponen una continuación iconográfica a través de los capiteles ubicados en el interior del templo, en el espacio que los autores definen como "pórtico interior" y la escultura desarrollada dicha puerta de Francia.

${ }^{2250}$ G. BOTO VARELA, Ornamento sin delito..., pp. 154-160.

${ }^{2251}$ G. SAURON, L'Histoire végétalisée..., pp. 28-29 y p. 228.

2252 Así se hizo con muchos de los motivos largamente difundidos dentro de los talleres románicos de estos ámbitos geográficos. Cf.: J. L. HERNANDO GARRIDO, "Los grandes talleres escultóricos en los monasterios románicos castellano-leoneses", Los Monasterios Románicos, Aguilar de Campoo, 2001, pp. 47-71, en especial, p. 49.

${ }^{2253}$ Recuérdese, por ejemplo, el caso paradigmático del Cristo ebúrneo de Fernando I y Sancha del Museo Arqueológico Nacional de Madrid, donde los vegetales se convierten en los protagonistas de unas soluciones decorativas en las que también se da cabida a la figura humana. Cf.: A. FRANCO MATA, "La eboraria de los reinos hispánicos durante los siglos XI y XII", Codex Aqvilarensis, 13, 1998, pp. 143-166, en particular, pp. 151-152. Los ejemplos susceptibles de ser mencionados al respecto son muy numerosos. 
El hecho de que el tema aparezca reproducido de manera prácticamente exacta en otros contextos e incluso a veces aislado, nos obliga a ser cautos a la hora de poder otorgarle un significado seguro dentro de estas piezas que hemos señalado, pudiendo tratarse de un tema dúctil que, dependiendo del lugar en el que se ubique, adquiriría diferentes connotaciones simbólicas.

Teniendo en cuenta tales premisas, resulta ciertamente interesante señalar el ejemplar esculpido para la iglesia de Santa Marta de Tera, en Zamora (fig. 446). Se trata de una pieza realizada para un templo alejado, en parte, de la principal vía del Camino de Santiago con la que, habitualmente, se han explicado los ejemplos hasta ahora citados, lo que vuelve a poner de relieve la imposibilidad de justificar las concomitancias que muestran estas obras con un argumento tan manido y débil como es el de la ruta de peregrinación ${ }^{2254}$.

En esta iglesia zamorana aparecen dos personajes desnudos enredados entre zarcillos, siguiendo modelos que recuerdan las soluciones del citado capitel de Santiago de Compostela, así como las llevadas a cabo por los escultores de San Isidoro de León $^{2255}$. Sin embargo, aquí ninguno de los capiteles que coexisten con este tema tiene su equivalente inmediato dentro de los templos de Galicia y León. Con ello intentamos señalar el carácter flexible de este tipo de representación, adaptable a cualquier contexto y con una posibilidad de lectura iconográfica ciertamente amplia. No se trata de un motivo estático e inamovible sino, más bien, de un tema habitual y cambiante, con un origen y unos horizontes de difusión infinitos, como otros tantos presentes dentro de los

Consúltese también: M. A. MIRANDA, "Imagens do sagrado na iluminura e ourivesaria românicas em Portugal”, Románico en Galicia y Portugal, Lisboa, 2001, pp. 185-213.

${ }^{2254}$ I. G. BANGO TORVISO, “La peregrinación jacobea...”, pp. 20-23.

${ }^{2255}$ Las relaciones entre la escultura de Tera y la de la Real Colegiata leonesa han sido señaladas frecuentemente. Cf.: M. GÓMEZ MORENO, "Santa Marta de Tera...", pp. 81-87; A. VIYAÑO, León y Asturias..., pp. 339-348 J. M. RODRÍGUEZ MONTAÑES, “Santa Marta de Tera...”, p. 145; G. BOTO VARELA, "La integración de las artes...", pp. 121-122. Este último autor escribió al respecto: "Para el presbiterio mayor de la colegial zamorana trabajó una cuadrilla de escultores adiestradas en el obrador que ejecutó los tramos medios de la nave de San Isidoro de León".

Véanse también las recientes publicaciones realizadas en: F. REGUERAS GRANDE, Santa Marta de Tera. Monasterio e iglesia, abadía y palacio, Benavente, 2005 y C. COSMEN ALONSO, "Arte y Liturgia..." pp. 139-171. En el caso de San Isidoro de León, el tema de los hombres y los vegetales aparece, al menos, en dos ocasiones. Por una parte, dentro de uno de los capiteles del ábside sur del edificio, donde dos hombres desnudos se muestran literalmente apresados por la gran amalgama vegetal. Sobre tal escultura, véase: G. GAILLARD, Les débuts..., pp. 43-44. Gaillard relacionó estas figuras, desde el punto de vista estilístico, con un capitel realizado para la iglesia de Santa María de Igúacel. En este sentido, se siguió tal teoría en: M. DURLIAT, La sculpture romane de la route..., pp. 363-372. Sin embargo, el modelo más interesante se muestra en uno de los capiteles del interior del templo, donde se esculpió, nuevamente, la imagen de dos efebos desnudos en los lados laterales del capitel, mientras que, la parte central de la cesta, se decoró con dos grandes aves que muerden dichos tallos vegetales. Se trata del capitel número 56, según la numeración dada por Durliat. 
innumerables corpus de imágenes que, en estos momentos, estaban siendo creados por los talleres activos en todo el norte peninsular hispano ${ }^{2256}$.

Lo expuesto hasta el momento, en relación con la presencia del tema de los hombres y los vegetales en las iglesias románicas del contexto cronológico que venimos manejando, permite extraer ciertas conclusiones.

Al analizar el capitel de los hombres apresados por la decoración vegetal ubicado en la ventana del ábside sur de San Isidoro de León (fig. 447), F. C. Fernández escribía:

“(...) Desde el arte copto, pasando por el irlandés, vikingo e islámico, llega hasta el románico e incluso el renacimiento, una corriente ornamental muy amplia acogida bajo el epígrafe común de lacerías (...). Este adorno tiene dos notaciones muy distintas. La una como representación de lo real y la imposibilidad de romper con ello, es la expresión de lo fatal, aludiendo a fenómenos insuperables, a cárceles de piedra que impiden la evasión de la pura materia, en este caso del cuerpo (...). La segunda significación, más positiva, muestra al entrelazo como definición del dinamismo por la movilidad de sus líneas, constituye la búsqueda de nuevos espacios de existencia que formen laberintos y marañas inextricables de signo geométrico (...) como representación del pecado según han creído ver algunos autores",2257.

A pesar de que las teorías vertidas en su estudio, actualmente, están superadas, queremos destacar que el autor enunciaba uno de los grandes problemas que nos encontramos a la hora de analizar la iconografía de los hombres desnudos apresados por la vegetación.

Por una parte, se constata que el origen del tema es completamente remoto. Numerosas culturas utilizaron la imagen con diferentes usos, no siempre claros. Desde otro punto de vista, el autor se ve persuadido por la necesidad de esclarecer el

\footnotetext{
${ }^{2256}$ En el caso de la iglesia de Tera se ha defendido una posible lectura en clave simbólica para esta imagen de los efebos apresados por la vegetación. Resulta bien factible que los escultores pudieran haber tenido un conocimiento de las fuentes textuales que se han utilizado para explicar tal imagen, sin embargo, parece claro que, tal solución, es tan sólo aplicable a esta iglesia en concreto pues, tanto en León como en Santiago, los capiteles que complementarían tal escena son muy diferentes desde un punto de vista iconográfico. Consúltese uno de los estudios más completos y convincentes realizados, hasta la fecha, sobre tal conjunto, centrado exclusivamente en cuestiones iconográficas en: C. COSMEN ALONSO, "Arte y Liturgia...", pp. 139-171. Sobre el problema de los talleres y la difusión de los modelos, véase: S. MORALEJO ÁLVAREZ, "Modelo, copia y originalidad...", pp. 92-93 y J. L. HERNANDO GARRIDO, "Los grandes talleres escultóricos...”, en particular, pp. 52-54.

${ }^{2257}$ F. C. FERNÁNDEZ, Op. cit., pp. 54-55.
} 
significado que, en su día, pudo tener este elemento decorativo ante los ojos de aquellos que eran sus espectadores ligándolo, preferentemente, con el mal y el pecado.

Tal y como hemos visto, posteriormente, otros autores aludieron a la selva de la tradición épica clásica para explicar la presencia de este tipo de elementos vegetales dentro de la escultura románica hispana, en concreto, en relación con el mencionado capitel de Compostela ${ }^{2258}$. Según se ha defendido, se trataría de una vegetación llena de peligros para el hombre, materializados, además, por la fauna que suele habitar este tipo de ambientes, a través de las aves de rapiña, los leones o las más diversas bestias salvajes $^{2259}$.

Volviendo al tema que nos ocupa, cabría preguntarse: ¿posee dicho motivo un origen antiguo susceptible de ser emparentado con la difusión que el tema alcanzará dentro de los talleres románicos? Al comparar todo este repertorio medieval sobre el que hemos venido insistiendo con determinadas iconografías clásicas, llama poderosamente la atención los puntos en común que las imágenes románicas mantienen con respecto a la iconografía de los Licurgos de la tradición antigua ${ }^{2260}$.

La imagen de estos personajes aparece, por lo general, vinculada a la selva de la tradición clásica que, en multitud de ocasiones, se materializa a través de la imagen de la viña. Las cepas y las hojas de vid se convierten en el lugar en el que se suele desarrollar esta narración mitológica, en la que los Licurgos disputan en combate contra Dionisos, representado a través de este tipo de vegetal ${ }^{2261}$.

Así aparece, por ejemplo, la imagen de un Licurgo en el impresionante vaso de vidrio conservado en Londres ${ }^{2262}$ (fig. 448). Se trata de una pieza datada en el siglo III o IV d. de C. que muestra en el centro a este personaje desnudo atrapado por la

\footnotetext{
${ }^{2258}$ S. FERNÁNDEZ PÉREZ y V. R. NODAR FERNÁNDEZ, "Premio e castigo...", pp. 291-310. Los mismos autores volvieron a tratar el tema más recientemente en: S. M. FERÁNDEZ PÉREZ y V. R. NODAR FERNÁNDEZ, "Vita peregrinatio est: reflexións sobre o capitel historiado no transepto norde da catedral de Santiago", El Camí de Sant Jaume i Catalunya, Barcelona, 2007, pp. 381-386, en concreto, p. 383.

${ }_{2259}$ Ibidem, p. 385. Los investigadores realizan siempre una lectura negativa de los motivos vegetales, ligados con la Tentación y el Juicio Final. Para otra serie de reflexiones relacionadas con lo maléfico durante los siglos medievales, a veces en relación con diversas pervivencias antiguas, vid.: E. FERNÁNDEZ GONZÁLEZ, "A propósito del mal: posesiones y exorcismos en la plástica del medievo", L'Espai del Mal (F. Sabaté i Curull ed.), Balaguer, 2005, pp. 117-142 y M. BARASH, "Le beau ou le démoniaque...", pp. 97-98.

2260 A. FARNOUX, "Lykourgos I", Lexicon iconographicum mythologiae classicae, vol. VI, 1, ZürichMünchen, 1992, pp. 309-319 y L. JONES ROCCOS, "Lykourgos II", Lexicon iconographicum mythologiae classicae, vol. VI, 1, Zürich-München, 1992, pp. 319-322.

${ }^{2261}$ A. FARNOUX, “Lykourgos I...", p. 315.

${ }^{2262}$ London, British Museum.
} 
vegetación, mientras que el hacha, atributo característico de esta iconografía, aparece tirada en el suelo ${ }^{2263}$.

Tal y como se puede constatar, las concomitancias de índole formal que presenta la imagen romana y aquellas románicas son significativas. Nuevamente, el problema reside en poder llegar a precisar el grado de asimilación de estas formulas antiguas por parte de los creadores medievales, si tales contactos fueron directos, si las piezas decoradas con tal iconografía pudieron estar a su alcance y, en última instancia, si la inspiración en estos motivos romanos vino acompañada por una resignificación del tema en la época medieval ${ }^{2264}$. Todas estas cuestiones son, en todo caso, difíciles de resolver.

Por el contrario, lo que sí nos atrevemos a defender es que la imagen del hombre apresado por la vegetación había sido bien conocida y asimilada en otros centros europeos, donde el conocimiento de las fuentes clásicas se ha demostrado de manera irrebatible. Baste con citar la escultura estudiada, en su momento, por J. Adhémar como perteneciente al triforio de la catedral de Langres (fig. 449). Se trata de dos capiteles ocupados por las figuras de Hércules y Sansón, el primero desnudo y con una maza y, el segundo, vestido con túnica y portando un hacha. Ambos personajes míticos parecen intentar liberarse de una serie de zarcillos vegetales, a la vez que, agarran una enorme máscara felina que ocupa la parte central de la composición ${ }^{2265}$.

Sin afirmar que las representaciones de hombres y vegetales dentro de la imaginería medieval puedan ser identificadas siempre en relación con estos temas de ascendencia clásica, llama poderosamente la atención que, otra escultura románica, realizada para la desaparecida iglesia de Sainte-Geneviève de París, nuevamente, recurra al mundo clásico en la búsqueda de soluciones icónicas (fig. 450) ${ }^{2266}$.

Se trata de un capitel en el que fueron figurados dos hombres que entrelazan sus brazos al tiempo que son apresados por la decoración vegetal. Lo más interesante es que, ambas figuras, han sido vistas como la representación de Géminis, hecho que, nuevamente, nos vuelve a poner sobre la pista de las fuentes clásicas que puede ofrecer el tema y sobre su difusión en los ambientes artísticos más selectos de la Europa medieval.

\footnotetext{
${ }^{2263}$ Ibidem.

${ }^{2264}$ Se trata, por otra parte, de preguntas habituales al trabajar sobre este tipo de cuestiones. Sobre ello, véase: J. WIRTH, “Copie en miroir...", pp. 265-277.

${ }_{2265}$ J. ADHÉMAR, Influences antiques..., pp. 222-223.

${ }^{2266}$ Paris, Musée National du Moyen Âge. Thermes et Hôtel de Cluny.
} 
Aludamos a un último ejemplo para finalizar. Las conocidas columnillas conservadas también en París, Musée National du Moyen Âge, ofrecen un interesante ejemplo al que apelar para poder apoyar las hipótesis vertidas en relación con este tema. Se trata de una serie de piezas provenientes de la basílica de Saint-Denis (fig. 451).

No es necesario insistir en la importancia de esta abacial en relación con la admiración, expoliación y difusión de obras de arte antiguas, entre los siglos XI y XIII. Ya hemos tratado, anteriormente, la importancia del abad Suger en relación con este tema y, creemos que, su figura puede explicar, por sí sola, la continuada preferencia por los modelos clásicos que este centro presentará de manera perpetuada ${ }^{2267}$. En relación con ello, estas descontextualizadas columnas fueron decoradas con una serie de elementos vegetales "habitados" por diversos personajes desnudos. Pensamos que no es necesario insistir en la importancia de la columna de tema vegetal como heredera de la tradición dionisíaca y su utilización dentro de los edificios medievales. Salvando las distancias, la factura preciosista de estas piezas, la importancia que adquiere el desnudo en ellas y su iconografía, no deja de traer a la memoria las lejanas columnas vaticanas y los más cercanos fustes de Santiago de Compostela ${ }^{2268}$.

Las posibles deudas con lo clásico que presentan todas estas producciones realizadas en los principales centros artísticos de la Europa medieval, insisten, de manera indirecta, en un fenómeno de mayor alcance.

La imagen mitológica de los Licurgos atrapados en la mortífera selva, en forma de viña, pudo ser el origen de una imagen que acabó contaminándose y reutilizándose de manera incesante durante toda la época románica ${ }^{2269}$. Es posible que su contenido simbólico primero se perdiese, que la voluntad primigenia con la que había nacido esta iconografía pasase de narrar la leyenda mitológica antigua para pasar a ser el ámbito en el que colocar otras iconografías ${ }^{2270}$. Sin embargo, los ejemplos en los que personajes desnudos parecen coexistir con esta decoración vegetal se suceden.

\footnotetext{
${ }^{2267}$ B. BRENK, "Sugers spolien...", pp. 101-107. Sobre diversos aspectos iconográficos de ascendencia romana, presentes en la escultura ligada a la abadía de Saint-Denis, consúltese también: M. BARASH, "Le beau ou le démoniaque...", pp. 106-107.

${ }^{2268}$ B. BRENK, "Sugers spolien...", pp. 101-107. Se analiza la importancia del traslado de materiales romanos, especialmente columnas, desde la ciudad de Roma hasta la citada abadía. Se trataría, según el autor, de unos actos cargados de intenciones políticas, donde tales piezas eran vistas como verdaderas reliquias. El dato más significativo es que, según Brenk, la Vita Ludovico Grissi Regis del abad Suger, datada aproximadamente en el año 1143, debe ser tenida en cuenta como un documento de excepcional importancia. Dicha obra narra la visita a la abacial parisina del Papa Pascual II, en el año 1107. En este mismo texto el abad llega a comparar, literalmente, su iglesia con la basílica de San Pedro del Vaticano. 2269 J. ADHÉMAR, Influences antiques..., pp. 17-22.

${ }^{2270}$ E. PANOFSKY, Renacimiento y renacimientos..., p. 164.
} 
No se trataba de un fenómeno nuevo. La iconografía alejada de los focos artísticos más sobresalientes presentaba variantes un tanto rústicas del tipo. El arte provincial, por su mismo carácter aislado, parece perpetuar, ocasionalmente, una serie de repertorios fuertemente ligados con la tradición clásica ${ }^{2271}$.

Derivado de tales premisas, citamos el capitel ubicado en la portada de la iglesia berciana de San Esteban de Corullón donde, nuevamente, dos hombres desnudos aparecen enredados entre este tipo de vegetales, destacando la presencia de algunos racimos de uvas de gran tamaño (fig. 452). Se trata de un modelo bien conocido y cuyas dependencias estilísticas con respecto a la escultura de la catedral de Santiago de Compostela fueron bien argumentadas en su día por la profesora C. Cosmen Alonso ${ }^{2272}$.

A pesar de no ser factible defender para este ejemplo concreto una pervivencia de los motivos clásicos relacionados con el tema de los licurgos aprisionados en la viña, tal y como ha defendido la citada estudiosa, nuevamente, son las fuentes antiguas las que explicarían tal imagen. Así, los dos instrumentos de viento que portan en sus manos dichas figuras y que parece que intentan hacer sonar, podrían señalar, una vez más, la perdurabilidad de ciertos ecos de una iconografía clásica ${ }^{2273}$.

En este sentido, se ha defendido la posibilidad de que los dos hombres aludan, posiblemente, a una personificación de los vientos, a la manera en que aparecían en el arte antiguo $^{2274}$. No debemos olvidar que, una representación románica de este tipo, posiblemente, coetánea en el tiempo, fue realizada ya dentro del programa pictórico del Panteón Real de San Isidoro de León. La colocación de la imagen de los vientos, personificados en el extradós de los arcos norte, sur y occidental del recinto, permiten asegurar un conocimiento de esta tradición iconográfica en el Reino de León, así como aventurar una posible contaminación de los repertorios y fórmulas.

En el caso del conjunto pictórico, los vientos fueron figurados inscritos en medallones, mostrando las personificaciones de Africus, Coros o Favonio. El más interesante es aquel clípeo en el que se colocó la figura de Auster, con forma humana bifronte, haciendo sonar dos de estos aerófonos (fig. 453). La misma composición se

\footnotetext{
${ }^{2271}$ Véanse las interesantes reflexiones que se realizan al respecto en: G. A. MANSUELI, voz "Provinciale, arte", Enciclopedia dell'arte antica ..., vol. VI, Roma, 1965, pp. 519-527.

${ }^{2272}$ C. COSMEN ALONSO, El Arte románico en León..., pp. 150-157.

${ }^{2273}$ Ibidem, p. 74.

${ }^{2274}$ Este tipo de personificaciones, entre las que se incluyen la imagen del tiempo o de los meses, aparecen, desde el arte romano, emparentadas con ambientes vegetales. Cf.: S. SEBASTIÁN, Mensaje simbólico..., p. 237.
} 
empleó para materializar a Bóreas, esta vez, con doble cabeza de monstruo soplando nuevamente los dos objetos ${ }^{2275}$.

Es evidente que, entre ambas imágenes, existen variantes formales importantes, tanto desde el punto de vista formal como desde el iconográfico. En Corullón encontramos dos personajes independientes con sendos instrumentos que acercan cada uno a su propia boca, mientras que, en el caso de la pintura, se trata de genios bifrontes. En todo caso, lo más interesante es constatar la transmisión de imágenes desde la Antiguiedad hasta los siglos medievales que, en el ejemplo concreto del corpus iconográfico presente en las artes realizadas para la basílica de San Isidoro, bien pudiera estar relacionado con la tradición clásica de la que surgieron los mismos textos isidorianos $^{2276}$.

Aceptando unas hipotéticas fuentes antiguas para el capitel de Corullón, faltaría por llegar a concretar el modelo exacto que se siguió para crear tal imagen y, sobre todo, llegar a perfilar el significado que, originariamente, tuvo esta iconografía ante los ojos de los hombres medievales. Nuevamente, resurge también el problema de la simbología vegetal que, en el caso de esta escultura, sigue planteando muchos interrogantes ${ }^{2277}$.

Según la profesora C. Cosmen Alonso, la utilización en esta portada berciana de algunos elementos, ya presentes en la escultura de las fachadas de la catedral de Santiago, como son, por ejemplo, las columnas helicoidales decoradas con florones, el manejo reiterativo de un volumen rotundo en las cabezas de las figuras y, sobre todo, la presencia del tema de la viñas cargada de frutos, son razones suficientes para sostener ciertas relaciones entre ambos centros.

${ }^{2275}$ M. A. CASTIÑEIRAS GONZÁLEZ, "El programa Enciclopédico...", pp. 661-662. El autor señala que el modelo seguido en estas pinturas puede estar en los cuatro vulti trifontes de la rota uentorum del Oracional visigodo datado en el año 700. Es una obra sobre la que se ha supuesto un posible origen hispano, tal vez Tarragona. Se trata del manuscrito custodiado en Venezia, Biblioteca Capitulare, cod. 89. ${ }^{2276}$ Ibidem, p. 663. Algunos trabajos han insistido, casi de manera monográfica, en la importancia de las fuentes clásicas en la configuración de los modelos utilizados por estos artistas. Véase, por ejemplo: G. LÓPEZ MONTEAGUDO, Op. cit., pp. 25-35. Estudios como el de esta autora permiten asegurar el conocimiento del arte antiguo que parecen dejar entrever estos artífices medievales.

Nuevamente, se insistió en la utilización de soluciones "antiquizantes" dentro de algunas piezas esculpidas en piedra y orfebres del conjunto, en: E. FERNÁNDEZ GONZÁLEZ, "Reflexiones sobre la evolución..." (en prensa).

${ }^{2277}$ La viña vuelve a ser el lugar idóneo en el que colocar la escena, mientras que, sus cepas, se tornan otra vez como el recurso ideal para ocultar ciertas partes del desnudo de las figuras, tal y como sucedía, por ejemplo, en las columnas de la catedral de Santiago de Compostela. En relación con la tendencia de atribuir un contenido simbólico a estos ambientes vegetales, apoyamos las palabras del profesor $\mathrm{J}$. Martínez de Aguirre cuando, a propósito de la decoración vegetal del Panteón Real de San Isidoro, escribía: "aún queda lejos de demostrar que palmetas, entrelazos y motivos semejantes hayan sido incorporados por su significado simbólico, en vez de pertenecer al repertorio ornamental propio de finales del siglo XI'. Cf.: J. MARTÍNEZ DE AGUIRRE Y ALDAZ, "La memoria de las piedras....", p. 152. 
Por nuestra parte, compartimos plenamente esta teoría que defiende parentescos directos entre las esculturas de Corullón y aquellas compostelanas pues, a los argumentos esgrimidos, debemos sumar que este taller provincial parece participar, igualmente, en el conocimiento de las fuentes clásicas que tantas veces parecieron resurgir dentro de la escultura dispuesta sobre la catedral de Compostela ${ }^{2278}$.

El tema de los sonadores de los aerófonos, estuvo muy difundido durante los siglos medievales. Por citar algunos ejemplos bien conocidos y alejados en el tiempo y en el espacio, recuérdense aquellos que aparecen en la parte superior del relieve ubicado en el claustro de Silos, donde se esculpió el tema de la Duda de Santo Tomás o el conocido capitel de la abacial de Conques ${ }^{2279}$.

A la hora de aludir a alguna pieza susceptible de ser comparada con la escultura de Corullón, baste con mencionar el capitel figurativo con escenas de caballería de la iglesia de Amorim, en Portugal (fig. 454). Se trata de una pieza en cuyo frente aparecen dos sonadores de este instrumento y cuya posición recuerda, lejanamente, la composición berciana ${ }^{2280}$.

A través de esta pieza y el establecimiento de una relación formalista con el citado capitel de Corullón pretendemos extraer algunas conclusiones del capítulo que ahora cerramos.

En primer lugar, es posible que la escultura desarrollada en los templos construidos durante los años finales del siglo XI y los primeros del siglo siguiente, presente una serie de rasgos susceptibles de ser emparentados con diversas tradiciones clásicas.

\footnotetext{
${ }^{2278}$ G. BOTO VARELA, "La integración de las artes...", p. 120. El profesor Boto escribió al respecto: "Sin embargo, resulta inverosímil sostener que en el primer año del siglo XII los obradores de Azabacherías y Platerías estuviesen ya en condiciones de emitir motivos, por lo demás notoriamente degradados en su destino berciano. En otras palabras, sospecho que el epígrafe del año 1100 data la construcción de San Esteban de Corullón, pero no sus labores escultóricas, posteriores y añadidas". Pensamos, en todo caso, que el aspecto un tanto rústico de esta escultura no es razón suficiente que permita retrasar su cronología, ya que, en relación con la iconografía del citado capitel que hemos estudiado, es un claro ejemplo de cómo los talleres marginales supieron asimilar imágenes de gran tradición "antiquizante", a pesar de materializarlas mediante lenguajes ciertamente "degradados". Véase también: E. FERNÁNDEZ GONZÁLEZ, "Consideraciones generales sobre el románico en la provincia de León”, Enciclopedia del Románico en Castilla y León, León, Aguilar de Campoo, 2002, pp. 35-52.

${ }^{2279}$ Sobre el relieve de Silos, véase: J. LACOSTE, "La sculpture à Silos autour de 1200", Bulletin Monumental, CXXXI, 1973, pp. 101-128 y S. MORALEJO ÁLVAREZ, "El claustro de Silos y el arte de los caminos de peregrinación", El románico en Silos. IX Centenario de la consagración de la iglesia y el claustro, Burgos, 1989, pp. 203- 223. Sobre el capitel de Conques, consúltese: J. LACOSTE, Les maîtres..., pp. 80-83.

${ }^{2280}$ Porto, Museu Nacional Soares dos Reis. En origen perteneció a la iglesia de Amorim, que ha sido datada en el siglo XII. Cf.: M. L. REAL, "O românico português na perspectiva das relações internacionais", Românico em Galicia y Portugal, Lisboa, 2001, pp. 31-55.
} 
El apartado que concluíamos anuncia el punto y final de una corriente artística. Se trata de la disolución de una vía de experimentación en la plástica escultórica románica caracterizada por una utilización de modelos comunes, reinterpretados y modificados por los diferentes talleres y que tuvo, en las vías de peregrinación, un excelente hilo conductor. Creemos que esta causa no es la única ni la más importante para poder justificar los parentescos estilísticos e iconográficos existentes entre los diversos talleres ${ }^{2281}$.

Teniendo en cuenta nuestros fines, creemos que una de las razones que explicarían estas correlaciones y analogías entre este tipo de plástica, pasaría por la importancia que adquirió la admiración y observación de las obras antiguas, elemento de gran prestigio y peso que, unificaría y homogenizaría, las diversas formas de trabajo utilizadas en los talleres de escultura. Los ejemplos de Jaca y Frómista representarían, a grandes rasgos, este primer estadio, donde el contacto con la obra clásica parece más directo y la reinterpretación de los modelos antiguos pudo haberse realizado, simplificando en exceso la cuestión, a través de una reflexión directa sobre la obra antigua.

En un segundo momento y con la proliferación de los edificios en construcción, hipotéticamente, se produjo un cambio. Ahora los talleres pasan de tomar los modelos directamente de las mismas piezas antiguas, para comenzar a emitir sus propias creaciones. Se trata de fórmulas de fuerte recuerdo clásico pero que parten, no ya de una obra antigua, sino de las versiones románicas realizadas por las sucesivas generaciones de nuevos escultores.

Ello conllevó la distorsión, la modificación y, en muchos casos, la incomprensión, de gran cantidad de estos modelos, reinterpretativos, a su vez, de los originales antiguos. Los repertorios "antiquizantes" se muestran contaminados, inconexos, fragmentados y alejados de su esencia original, aumentando, por tanto, la complejidad a la hora de señalar su puntual origen. Los grandes centros comenzaron entonces a formular y difundir unos motivos que, teniendo ciertos puntos en común con el arte romano, no llegaron a ser lo suficientemente fidedignos con aquellos como para poder señalar, claramente, la posible pieza antigua que llegó a inspirarlos.

Tales cuestiones se aprecian al estudiar el tema de los hombres y la vegetación cuya génesis parece estar en la plástica de la Antigüedad. Sin embargo, si para el caso

${ }^{2281}$ I. G. BANGO TORVISO, “El paisaje monumental...”, pp. 33-50. 
de las columnas con putti de Compostela había sido posible hablar de fuentes de inspiración concretas, nada permite sostener que las sucesivas variaciones del tema, presentes, por ejemplo, en los capiteles de la basílica de León, pudieran tener un mismo origen antiguo tan concreto. Esta afirmación se constata al evidenciar la utilización de las mismas fórmulas en otros centros más alejados, como es el caso, de la iglesia de Santa Marta de Tera. Aquí las notaciones "antiquizantes” existen, aunque se presente el problema de discernir si se trata de meras fórmulas estereotipadas y difundidas mecánicamente, sin la necesidad de que el escultor románico haya tenido acceso a repertorios antiguos originales ${ }^{2282}$.

Este fenómeno serviría para que, muchos autores, negaran la participación de algunos de estos artífices y sus obras en el conocimiento de las fuentes clásicas. El capitel de la iglesia de San Esteban de Corullón (fig. 452) y aquel de la de Amorim (fig. 454) ejemplifican bien esta cuestión. Además, en concreto, el segundo ejemplar, nos permitirá dar paso al siguiente bloque de este estudio.

En un primer análisis de estas esculturas y teniendo en cuenta su tosca factura, su carácter rural y su pertenencia a centros aislados, no resulta muy aconsejable poder defender, con seguridad, un conocimiento directo de las experiencias visuales y plásticas de la cultura clásica. Sin embargo, creemos que tales causas no son suficientes como para negar, rotundamente, su participación en tales corrientes.

El primero de los capiteles, el de la iglesia de Corullón, hace tiempo que fue justamente conectado con los talleres compostelanos, sobre los que, unánimemente, se han venido aceptando, sin dudas, sus relaciones con las obras clásicas ${ }^{2283}$.

El segundo ejemplar, nos sirve, así mismo, para presentar toda la serie de problemas que abordaremos en el apartado siguiente.

En un interesante trabajo, citado con anterioridad, el profesor M. L. Real explicaba las importantes dependencias que la escultura románica, del norte de Portugal, mostraba respecto a centros de tanta importancia como la basílica de Saint-Sernin, las diversas campañas decorativas de la iglesia y el claustro de La Daurade o con diversos restos provenientes de la iglesia de Saint-Étienne, todos ellos en la ciudad de Toulouse ${ }^{2284}$.

\footnotetext{
${ }^{2282}$ J. M. RODRÍGUEZ MONTAÑÉS, “Santa Marta de Tera...”, p. 145.

${ }^{2283}$ C. COSMEN ALONSO, Dos iglesias..., pp. 74-75 y J. YARZA, "Artes figurativas románicas...”, p. 70.

${ }^{2284}$ M. L. REAL, “O românico português...”, p. 48.
} 
El capitel en el que se figuraron los tañedores del instrumento musical de viento y que hemos citado a modo de ejemplo, parece aludir, lejanamente, a un arte de mayor calidad y de fuentes más complejas. En concreto, de ser cierta su posible relación con el foco tolosano, permitiría teorizar sobre la importancia de los principales talleres de la escultura románica europea a la hora de generar fórmulas que, más tarde, serían asimiladas por otros de menor importancia, incluso aquellos desligados por completo de las principales vías de comunicación del momento.

Tales hechos permiten certificar como las soluciones adoptadas por algunos de los más prestigiosos talleres de la Europa románica, tal y como fueron aquellos que estuvieron activos en la basílica tolosana, seguían fascinando a otros escultores de recursos y resultados más limitados. Finalmente, conviene señalar e insistir en el hecho de que, incluso, la Marca Hispánica y las regiones del sur francés, siempre se habían caracterizado por producir una escultura muy cercana a la tradición antigua, aspecto visible, sobre todo, en aquellas producciones realizadas entre los años finales del siglo XI y los primeros del XII ${ }^{2285}$.

En el caso concreto de las fuentes tolosanas seguidas por el escultor del capitel luso y, siempre que aceptemos como viables las hipótesis del profesor M. L. Real, sorprende que, aún en un periodo tan avanzado del siglo XII, se continuase teniendo como referente visual y estilístico algunas de las obras realizadas en el Languedoc y, particularmente, en el entorno de la basílica de Saint-Sernin de Toulouse. Lo más importante para nuestro objetivo es que, tanto en los templos levantados en la citada ciudad, así como en su área de influencia, habrían de ser el epicentro de uno de los momentos más fructíferos, dentro de la historia de la escultura europea, sobre todo, en relación con esta tendencia de recuperación y renacimiento del arte antiguo. Las soluciones de tradición clásica utilizadas, recurrentemente, en estos talleres del foco francés tendrían una perdurabilidad que llegaría a ser perceptible en producciones esculpidas, datadas más allá del último cuarto del siglo XII, tal y como veremos en las páginas siguientes.

\footnotetext{
2285 No recogemos en este momento puntual la bibliografía relacionada con el fenómeno del resurgimiento de las corrientes clasicistas dentro de la escultura ligada al área tolosona, por tratarse de un tema que desarrollaremos posteriormente.
} 
BLOQUE III 


\section{EN TORNO AL AÑO 1150. EL PROBLEMA CRONOLÓGICO Y LA SELECCIÓN DE LOS MONUMENTOS Y SUS VESTIGIOS.}

Desde un punto de vista meramente formal, el apartado anterior en el que analizábamos la fortuna de algunos motivos clásicos presentes en el repertorio de los talleres escultóricos de la catedral de Santiago de Compostela y la basílica de San Isidoro de León, tomábamos como fecha de referencia para su finalización, el arco cronológico contiguo al año $1147^{2286}$.

El presente bloque de nuevas reflexiones, tomará tal cronología como punto de partida. Se trata de un periodo temporal que configura una fase importante dentro del fenómeno que estudiamos, donde las producciones esculpidas alcanzarán un desarrollo y una calidad excepcionales, dentro de la historia de la escultura románica europea ${ }^{2287}$.

Sin embargo, antes de abordar las cuestiones fundamentales de ese momento, conviene realizar una serie de aclaraciones.

En un estudio como el que venimos realizando ha primado, de manera singular, el análisis de la escultura elaborada entre los primeros años del siglo XI y las primeras décadas del XII. Se pretende ahora evaluar la importancia que tuvo el periodo para la escultura posterior, una vez disueltos los trabajos salidos de los talleres que decoraron edificios como los de Jaca, Frómista o Carrión de los Condes, por citar algunos de los nombres más habituales en las páginas anteriores.

La historiografía reciente no ha dudado en asegurar que las esculturas realizadas para decorar tales edificios presentaban, de una manera u otra, algún tipo de conexión con el mundo clásico. Sin embargo, esta línea de recuperación de ciertas tradiciones antiguas, característica de la primera mitad del siglo XII, no se disolvió plenamente con la finalización de las obras en iglesias como la de San Isidoro de León o Santa Marta de Tera.

La estela dejada por los talleres que trabajaron en tales obras se advierte, a veces muy difusa, en las producciones que han sido datadas más allá de ese periodo cronológico.

\footnotetext{
${ }^{2286}$ Se trata de la fecha en la que, según muestra el epígrafe conservado en la basílica legionense, se produjo la última consagración del edificio. Remitimos al apartado anterior de este estudio donde se justificaba tal elección.

${ }_{2287}^{2}$ R. SALVINI, La escultura románica..., pp. 56-62.
} 
En este nuevo apartado temático se abordará la fortuna del movimiento "Frómista-Jaca" en la etapa más tardía de este siglo XII, donde, según algunos autores, parecen pervivir ciertos ecos de aquella manera de hacer resurgir determinadas soluciones "antiquizantes".

En relación con ello, conviene destacar una obra colectiva, de reciente aparición, que se nos muestra ciertamente reveladora en este sentido. El texto, titulado El románico y el Mediterráneo. Cataluña, Toulouse y Pisa. 1120-1180, se ha convertido en un referente fundamental sobre el que apoyarnos y partir para iniciar algunas de las reflexiones que aquí vamos a ofrecer ${ }^{2288}$. Entre los numerosos estudios, la profesora M. Melero Moneo publica una aportación titulada "Navarra y Aragón en las décadas centrales del siglo XII (de 1120 a 1180)" ${ }^{, 289}$. Se trata de una investigación que nos resultó considerablemente útil a la hora de iniciar el estudio de nuestro tema en los años centrales del siglo.

Al referirse a la construcción de la catedral de Pamplona, la citada experta alegaba:

“(...) suponemos que las obras de la catedral se iniciaron hacia 1100 (...) en la consagración de 1127 podía estar acabada una parte de la iglesia (...). Centrándonos ya en la escultura del claustro construido al sur de la iglesia, los capiteles que hemos conservado de este recinto funerario demuestran claramente una filiación en la escultura del sur de Francia, especialmente en esculturas cercanas a las del pórtico conservado en el monasterio de Saint-Pierre de Moissac y a las que formaron parte del pórtico que tuvo la iglesia de Sainte-Marie de Souillac. Desde el punto de vista de la cronología, puede situarse entre 1130 y 1140 (...). Es decir, unos años antes de mediados del siglo XII, en Navarra se estaba realizando la gran obra del claustro románico de la catedral de Pamplona"2290.

\footnotetext{
${ }^{2288}$ El románico y el Mediterráneo. Cataluña, Toulouse y Pisa. 1120-1180 (M. A. Castiñeiras González y J. Camps ed.), Barcelona, 2008. Se trata de un estudio colectivo con ocasión de la exposición celebrada en el Museo Nacional de Arte de Cataluña (MNAC) entre el 29 de febrero y el 18 de mayo de 2008.

El volumen profundiza, de una manera clara, sobre la pervivencia de ciertas corrientes clasicistas dentro de la escultura románica, poniendo especial énfasis en las relaciones que el arte medieval hispano de esta etapa mantuvo con respecto a otras regiones y países, donde los vestigios del arte antiguo, son ampliamente numerosos como, por ejemplo, en Italia.

${ }^{2289}$ M. MELERO MONEO, "Navarra y Aragón en las décadas centrales del siglo XII (de 1120 a 1180)", El románico y el Mediterráneo. Cataluña, Toulouse y Pisa. 1120-1180 (M. A. Castiñeiras González y J. Camps ed.), Barcelona, 2008, pp. 99-109.

${ }^{2290}$ Ibidem, p. 99.
} 
La autora defiende aquí una clara vinculación de esta serie de esculturas hispanas procedentes del entorno de la catedral de Pamplona, con respecto a determinados modelos languedocianos, a pesar de que las obras hayan sido ubicadas dentro de un marco cronológico que no debió sobrepasar nunca el año $1150^{2291}$.

Dejando a un lado los debates centrados en la datación de las piezas, nos interesa, sobre todo, insistir en las reflexiones realizadas a colación por el profesor $\mathrm{J}$. Martínez de Aguirre:

“(...) pronto fue señalada por Deschamps la proximidad de su arte con los capiteles tolosanos de la Daurade, reiterada por Lafargue y Mesplé, mientras Gaillard, que criticó lo endeble de ciertos argumentos protolosanos, sugirió una conexión con Jaca. (...) Vázquez de Parga (...) establecía un claro nexo con Tolosa (...). En la misma línea, Gudiol y Gaya recalcaron sus divergencias con los focos creativos franceses (Tolosa y Moissac) o españoles (Jaca-Compostela). (...). En los últimos años, Yarza y Melero han recuperado la conexión languedociana especialmente vinculada a Moissac, concretamente al grupo de artistas que trabajan en el pórtico, aunque no sea confundible con ellos (...). Entiendo que profundizar en la conexión languedociana sigue siendo el camino acertado y que es posible aportar argumentos que se me antojan concluyentes, mientras que el parangón con Jaca en ningún modo aporta paralelismos semejantes" 2292.

Tal y como se observa, a la hora de explicar la filiación estilística de los capiteles conservados del desaparecido claustro de la catedral de Pamplona, muchos de los autores insisten en la importancia del foco jaqués y el tolosano, a la hora de poder

\footnotetext{
${ }^{2291}$ No vamos a abordar aquí el clásico problema historiográfico sobre la datación de los capiteles del claustro de la catedral de Pamplona. Existe cierto consenso en aceptar el año 1116 como una posible fecha de inicio de las obras, en contra, de lo complejo que resulta señalar su finalización. Se habló del arco cronológico que comprendería los años 1135 al 1141-1142. Creemos que, para nuestro objetivo, tales disquisiciones no son excesivamente problemáticas. En relación con ello, consúltese: M. MELERO MONEO, La escultura románica..., pp. 7-8 y J. MARTÍNEZ DE AGUIRRE, "El segundo tercio del siglo XII...", pp. 117-164, particularmente, p. 117. En esta aportación, el profesor Martínez de Aguirre escribe: "Mientras Ubieto aproximaba este instrumento a las donaciones de 1141-1142, Goñi Gaztambide, a mi entender con buen criterio, prefirió acercarlo a la consagración de la catedral y fecharlo poco después de 1127. En resumen, la construcción quizá pudo ponerse en marcha en los primeros años del siglo XII, pero el impulso definitivo vino muy probablemente a partir de la consagración de la iglesia. El grueso de los trabajos se habría desarrollado durante los años treinta, período en que hemos de situar la labor del mejor de los escultores. Que estuviera terminado en 1137 o 1142 apenas tiene trascendencia para la conjunción con las restantes fechas del románico navarro y tolosano".

${ }^{2292}$ Recogemos las palabras del profesor Martínez de Aguirre y remitimos a su estudio donde se lleva a cabo un balance de todos estos aspectos historiográficos. Cf.: Ibidem, pp. 126-127.
} 
explicar muchas de las características de estas esculturas, independientemente, de la fuerza con la que algunos autores hayan defendido la influencia de Toulouse y negado la de Jaca, o viceversa.

Citamos ahora otro estudio realizado por la profesora I. Lorés i Otzet, centrado en la escultura románica hispana, esta vez, del ámbito catalán, datada más allá del segundo cuarto del siglo XII. Su aportación analiza obras que podrían haber sido realizadas, hipotéticamente, en etapas más tardías de este siglo, incluso, una vez superado el año $1150^{2293}$. Analiza ejemplos, tan importantes, como son los de la portada de Santa María de Ripoll ${ }^{2294}$ o la Virgen del claustro de Santa María de Solsona ${ }^{2295}$.

En el caso de la portada de Ripoll, generadora de grandes debates historiográficos, tanto en lo relativo a las cuestiones cronológicas como las estilísticas y las iconográficas, es considerada, por parte de los especialistas, como una obra posiblemente realizada entre los años 1150 y 1160 . I. Lorés, la investigadora que más recientemente abordó el tema escribe al respecto:

"Esta línea de interpretación lleva implícita una cronología para la realización de la portada a partir de 1150 (...). El análisis de su escultura, sin embargo, nos obliga a recuperar otra línea de trabajo establecida y argumentada por Goldschmidt en 1939: la extraordinaria proximidad que manifiesta la portada con la obra del escultor tolosano Gilabertus. (...) La valoración de esta proximidad con la escultura tolosana ha sido dejada un poco de lado (...).. Sin embargo una comparación atenta de pequeños detalles en partes con la superficie todavía bien conservada o de motivos geométricos y vegetales arroja unos resultados incontestables. Ello cuestiona seriamente una cronología de la portada a partir de 1150 y en torno a 1160 (...... En este sentido, una segunda interpretación iconográfica del conjunto, planteada recientemente por Castiñeiras, en la que retoma

\footnotetext{
${ }^{2293}$ I. LORÉS I OTZET, "Transmission de modèles toulousains dans la sculpture monumentale en Catalogne dans la première moitié du XII ${ }^{\mathrm{e}}$ siècle: anciennes et nouvelles problématiques", Les Cahiers de Saint-Michel de Cuxa, XXXVII, 2006, pp. 91-102.

${ }^{2294}$ La datación de la portada del monasterio de Santa María de Ripoll es un tema que sigue planteando fuertes debates. Sin tener criterio para poder pronunciarnos al respecto, nos limitamos, simplemente, a citar algunos de los estudios más importantes que a ella se han dedicado. Cf.: X. BARRAL I ALTET, "La sculpture à Ripoll...", pp. 311-359; ID., "Le portail de Ripoll...", pp. 139-161; J. YARZA LUACES, "Notes introductòries i aspectes generals sobre la portalada de Santa Maria de Ripoll. La portalada de Ripoll, confluència de corrents internacionals. Lectura iconogràfica", Catalunya Romànica, X, El Ripollès, Barcelona, 1987, pp. 241-252; M. L. MELERO MONEO, "La propagande politicoreligieuse...”, pp. 135-157; M. A. CASTIÑEIRAS GONZÁLEZ, "Un passagio al passato...”, pp. 365-381 e I. LORÉS I OTZET, “La decoración escultórica...”, pp. 169-189.

${ }^{2295}$ J. CAMPS I SÒRIA, "La Vierge du Cloître de Solsona (Catalogne), attribuée à Gilabertus: à propos de sa fonction et contexte d'origines", Les Cahiers de Saint-Michel de Cuxa, XXV, 1994, pp. 63-71 e I. LORÉS I OTZET, "Transmission de modèles toulousains...", p. 101.
} 
una vieja identificación de Joseph Gudiol (...) es más compatible con una datación más temprana, que nos parece más acertada. (...) El autor coincide en la revisión de la cronología de la escultura de la portada, hacia 1140, en unas fechas más acordes con la proximidad con la obra tolosana de Gilabertus (...),2296.

Para finalizar, aludiremos, en última instancia, a una de las figuras más emblemáticas que vendrían a representar este supuesto movimiento de perdurabilidad, durante los años centrales del siglo XII, de las fórmulas escultóricas desarrolladas por los maestros activos entre los últimos años del siglo XI y las primeras décadas del siguiente.

Nos referimos al conocido como "maestro" de Cabestany ${ }^{2297}$, figura hacia la que la historiografía actual ha revertido, nuevamente, su mirada, así como hacia al movimiento escultórico que de ella parece surgir ${ }^{2298}$.

Los trabajos de este supuesto "maestro" nos interesan por varios motivos que justifican su inclusión dentro de este estudio. Por una parte, las obras ligadas a su figura o, susceptibles de ser emparentadas con su manera de realizar escultura, presentan ciertos rasgos herederos de la tradición artística de la Antigüedad.

"La gran cantidad de obras relacionadas con él -Errondo en Navarra, San Pedro de Rodas en Cataluña, El Voló y Cabestany en el Rosellón, Saint-Hilaire d'Aude en el Languedoc, San Giovanni in Sugana o la abadía de Sant'Atimo en la Toscana- parecen recoger la originalidad de su arte escultórico, sin duda heredero de la lección de la Antigüedad romana que había cuajado en estas tierras latinas del Mediterráneo" 2299 .

Desde un segundo lugar, parece que sus intervenciones fueron desarrolladas dentro de un marco cronológico que va desde los decenios centrales del siglo XII a los

\footnotetext{
${ }^{2296}$ I. LORÉS I OTZET, “La decoración escultórica...”, pp. 178-179.

${ }^{2297}$ Utilizamos esta nomenclatura siendo plenamente conscientes de lo problemático que resulta poder hablar de un maestro concreto al que atribuir obras específicas. Remitimos a las páginas siguientes en las que se abordará tal cuestión.

2298 Las obras atribuidas a este "maestro" y a su círculo configuran el hilo argumental de la exposición organizada en el MNAC sobre el Románico y el Mediterráneo.

${ }^{2299}$ M. A. CASTIÑEIRAS GONZÁLEZ y J. CAMPS I SÒRIA, "El románico y el Mediterráneo. Cataluña, Toulouse y Pisa (1120-1180): idea de una exposición”, El románico y el Mediterráneo. Cataluña, Toulouse y Pisa. 1120-1180 (M. A. Castiñeiras González y J. Camps ed.), Barcelona, 2008, pp. 21-27, en concreto, p. 21.
} 
años sesenta, lo que las convierte en buenas representantes del periodo que queremos analizar $^{2300}$.

Sin embargo, es el tercer aspecto, y el más importante, el que justificaría su inserción en estas páginas. Se trata de la fuerte deuda que su escultura parece presentar respecto al movimiento escultórico desarrollado en la ciudad de Toulouse y aquellas áreas geográficas relacionadas con ella, dentro de un amplio marco cronológico que tendría su punto de partida en los últimos años del siglo $\mathrm{XI}^{2301}$.

El aspecto más llamativo es que, en la actualidad, cada vez se aceptan con mayor fuerza aquellas hipótesis que hablan de un traspaso hacia el arte de este "maestro", de los modelos y soluciones "antiquizantes" utilizados por los escultores encargados de decorar, por ejemplo, la basílica de Saint-Sernin de Toulouse a finales del siglo XI. En particular, lo más destacado sería la perdurabilidad de las fórmulas y repertorios utilizados por el "clasicista" Bernard Guilduin, el posible autor que firmó, en el año 1096, la tabla de altar de la basílica tolosana ${ }^{2302}$.

Se pretende poner de relieve la importancia de la escultura realizada en el área del Languedoc que, teniendo como epicentro la ciudad de Toulouse, se difundiría por todo el Midi francés a través de ejemplos tan relevantes como la abacial de Saint-Pierre de Moissac, la iglesia de Saint-Caprais de Agen o la de Saint-Michel de Lescure ${ }^{2303}$.

Se trata de claros ejemplos de escultura románica donde se advierten distintas pervivencias del arte clásico romano y que serían la base sobre cuyas experiencias asentarían su desarrollo los nuevos talleres activos, tanto en Francia, como en la zona de la Marca Hispánica, hasta bien traspasada la barrera artificial del año 1150.

Se insistirá en la importancia de este sustrato clásico, de sus fuentes, las principales producciones que lo configuraron y las razones por las que debió perdurar hasta fechas tan tardías. Creemos que el estudio del desarrollo paralelo que tuvo este tipo de escultura ligada al foco languedociano en relación con los movimientos hispanos

\footnotetext{
2300 A. MILONE, "El Maestro de Cabestany: notas para un replanteamiento", El románico y el Mediterráneo. Cataluña, Toulouse y Pisa. 1120-1180 (M. A. Castiñeiras González y J. Camps ed.), Barcelona, 2008, pp. 181-191, en particular, p. 185.

${ }^{2301}$ Ibidem, p. 184 e I. LORÉS I OTZET, "Transmission de modèles toulousains...", p. 92. La profesora Lorés señala, concretamente, los años 1090 y 1180, por tratarse de la datación de la mesa de altar firmada por Bernardo Guilduino y la otorgada al portal de la sala capitular del monasterio de La Daurade, respectivamente.

${ }^{2302}$ I. LORÉS I OTZET y J. CAMPS I SÒRIA, "L'artiste et son atelier, ses commanditaires", Le Maître..., pp. 147-154, en especial, p. 150. Sobre las relaciones entre las esculturas adscritas a la órbita de Cabestany y las obras tolosanas de la primera mitad del siglo XII, insistiremos en las páginas siguientes.

${ }^{2303}$ I. LORÉS I OTZET, “Transmission de modèles toulousains...,”, p. 92.
} 
que por estos mismos momentos se desenvolvían en Jaca o Frómista, puede ser interesante.

Sin embargo, nuevamente se nos presenta el problema del basto corpus de obras existentes en estos centros y la necesidad preeminente de realizar una discriminación, tanto de motivos iconográficos como de soluciones estilísticas. Parece imposible poder abordar seriamente cualquier indagación que se centre en la pervivencia de motivos clásicos en unos focos tan señeros y con tan alto número de piezas esculpidas, como los que presentan estos monumentos tan importantes. A ello debemos sumar todos aquellos vestigios surgidos de la órbita de estos edificios. Baste señalar el caso de la basílica de Saint-Saturnin con la conservación de restos muy descontextualizados, algunos capiteles pertenecientes a su desmantelado claustro y otros provenientes, posiblemente, de alguna de sus fachadas desaparecidas.

La misma premisa puede aplicarse para el caso de la catedral de Saint-Étienne de Toulouse y los supuestos relieves de su sala capitular o para las producciones escultóricas de las distintas fases que decoraron la iglesia y el claustro del monasterio de Notre-Dame de la Daurade, por citar los hitos más conocidos de la ciudad francesa ${ }^{2304}$.

La etapa que comprende el final de siglo XI y las primeras décadas del siguiente generará una escultura que tendrá un rasgo común y unificador en todas estas regiones y monumentos, tanto franceses como hispanos. Desde la catedral de Jaca hasta Frómista, desde la basílica Toulouse a Santiago de Compostela, desde los capiteles del claustro de la catedral de Pamplona a las esculturas del "maestro" de Cabestany; paralelamente, se adoptaron soluciones, a veces con mayor fuerza y otras, profundamente disipadas, encaminadas a hacer revivir la tradición de la Antigüiedad ${ }^{2305}$.

Más allá de todas la relaciones estilísticas demostradas entre estos centros, de la cercanía cronológica, de su asentamiento sobre las diferentes vías de peregrinación y de la utilización de unos lenguajes comunes -algo lógico al tratarse de producciones artísticas tan cercanas en el tiempo-, la herencia del arte clásico romano se presenta

\footnotetext{
${ }^{2304}$ Consúltese, a modo de catálogo fotográfico, el estudio titulado: Sculptures romanes (Musée des Augustins-Guide des collections), 2, Toulouse, 1998.

${ }^{2305}$ Iniciamos esta introducción aludiendo al ejemplo de los capiteles del claustro de la catedral de Pamplona. Son un claro ejemplo de piezas herederas de la tradición escultórica del pórtico de Moissac que, conservando algunas de las soluciones técnicas de aquel, se materializan en suelo hispano con apenas cualquier rasgo de la tradición clásica que, tan fuertemente, se había arraigado en el monasterio francés.
} 
como una de las bases más complejas sobre la que se desarrollaría esta escultura románica $^{2306}$.

\footnotetext{
${ }^{2306}$ Se advertirá, por lo tanto, una simplificación o, la exclusión directa, de algunos templos y esculturas que, en un primer momento, pudieran parecer imprescindibles en este estudio. Tanto para el caso francés como para el hispano, se omitirán aquellas obras que, aún pudiendo ser englobadas, por su datación cronológica, en este apartado, no presenten claramente unos parentescos y pervivencias con respecto a aquellos motivos escultóricos susceptibles de ser relacionados con las esculturas de tradición clásica relacionadas con el denominado movimiento de "Jaca-Frómista" y el presente en la órbita de Toulouse. Dicho en otras palabras, tan sólo tendrán cabida aquellos edificios en los que la "tradición hispanolanguedociana", aquella que definiera el profesor S. Moralejo, pudiera tener un peso relevante en la definición y configuración de la escultura románica.

A la hora de llevar a cabo un criterio de selección para el estudio de los ejemplos concretos que vamos a analizar, éste ha sido el principio básico de discriminación. El panorama artístico adscrito al periodo cronológico al que nos referimos es bastísimo y aquellos especialistas que lo han tratado han señalado, frecuentemente, pervivencias entroncadas con la tradición clásica, a pesar de que su vía de asimilación dentro del arte románico no esté relacionada, en absoluto, con la tradición "hispano-languedociana". Resulta evidente que, en multitud de templos y construcciones, pudieron persistir algunas tradiciones iconográficas y estilísticas derivadas del arte clásico, sin embargo, aquí solamente se tratarán aquellas que, en principio, pudieran presentar indicios suficientes como para relacionarlas con el fenómeno antes señalado. Cf.: M. MELERO MONEO, "La sculpture du cloître de la cathédrale de Pampelune et sa répercussion sur l'art roman navarrais", Cahiers de Civilisation Médiévale, Poitiers, 1992, 139, pp. 241246 e ID., "Navarra y Aragón en las décadas centrales...", p. 101. La autora menciona el caso de la iglesia de Santa María de Uncastillo y los capiteles del ábside del templo, posiblemente, realizados hacia 1140 y donde se percibiría la continuidad de ciertas soluciones procedentes de Moissac.
} 


\section{LA OBRA DEL “MAESTRO” DE CABESTANY.}

Entre las décadas que van desde los años cuarenta o cincuenta a los sesenta del siglo XII, existieron multitud de edificios en construcción que precisaron de escultores que los decorasen. Sin embargo, no en todas estas construcciones se puede señalar de una manera lógica, coherente y demostrable, determinados contactos con la tradición clásica, más allá de su utilización, a veces esporádica, y que llegó a ser conocida por los escultores, simplemente, a través de una transmisión estereotipada de los mismos.

En este sentido, creemos que el periodo que ahora iniciamos, tiene en la figura del denominado "maestro" de Cabestany un buen representante, de ahí que, a través de su figura, explicaremos el fenómeno de la asimilación de fórmulas clásicas en torno a esta cronología ${ }^{2307}$. No en vano, en el estudio realizado por M. Durliat sobre la figura de este escultor, aludía al espíritu completamente moderno que le envolvía y que explicaría, asimismo, el gran avance que mostrarán sus producciones. Quizás de manera desmesurada, el autor francés hacia alusión al "anuncio" de la escultura gótica que parece dejarse entrever en su obra, en particular, en aquella realizada en la zona del Rosellón francés ${ }^{2308}$.

La pasión que muestra el investigador francés al exponer las capacidades de este supuesto artista refleja bien el fenómeno de la "invención historiográfica" a la que ha sido expuesta su figura y en la que existen tantos puntos verídicos demostrados como mitificaciones alejadas de la realidad artística del periodo.

\footnotetext{
${ }^{2307}$ X. BARRAL I ALTET, "L'escultura romànica a Catalunya", Catalunya romànica..., vol. I, pp. 94110 , en concreto, p. 103. El autor realiza una división del panorama general del arte catalán de este momento, encuadrando la figura de este "maestro" en un capítulo que titula: "Entre el siglo XII y el siglo XIII: el románico tardío". Tal postura refleja la importancia de este escultor, desde el punto de vista metodológico, a la hora de poder perfilar un panorama general de la escultura románica en la segunda mitad del siglo.

Para la elaboración de este apartado relacionado con Cabestany hemos utilizado, de manera preferente, la última obra monográfica dedicada al escultor. Cf. : AA.VV, Le Maître de Cabestany, Pierre-qui-Vire, 2000.

${ }^{2308}$ M. DURLIAT, La sculpture romane en Roussillon. Le Maître de Cabestany-Coustouges-Le Monastir del Camp- Espira-de-l'Agly, Perpignan, 1954, en concreto, pp. 7-15.
} 


\section{1. EL PROBLEMA DEL ARTISTA Y SUS FUENTES.}

Dentro de la cronología que hemos acotado para el desarrollo de este apartado del estudio, hubiera cabido la posibilidad de abordar diversos aspectos en relación con la escultura que, por estos momentos, se realizaba en diversos centros de la Península. Sin embargo, creemos que es indiscutible que, en relación con el fenómeno de recuperación de lo clásico, el punto focal y más activo se traspasaba ahora desde el norte occidental peninsular a las zonas más orientales del territorio ${ }^{2309}$.

El caso de la escultura atribuida al "maestro" de Cabestany es complejo, sobre todo, si tenemos en cuenta la abundante bibliografía que se ha ocupado de esta materia. Con todo, aquí se abordarán, tan sólo, aquellos problemas relacionados con la influencia de la Antigüedad en dichas obras, dejando en un segundo plano otras cuestiones de índole cronológica e histórica.

El primer problema que se nos presenta es bien conocido, pues en torno a la figura del supuesto "maestro" se han realizado todo tipo de suposiciones. No es nuestro cometido indagar, profundamente, en torno a la aplicación del "método atribucionista" sobre las producciones ligadas a su persona y el supuesto círculo de artistas que con él trabajaron, pues se trata de cuestiones tangenciales al objetivo de este estudio ${ }^{2310}$.

Parece claro que todos estos asuntos relacionados con la correcta nomenclatura con la que se debe definir su obra o el esclarecimiento de su papel como artista individual, con nombre propio y concreto, dentro de un grupo de creadores, son cuestiones irrelevantes que nada nuevo aportarían en el desarrollo de estas páginas. A pesar de que, tales premisas, hayan marcado tradicionalmente las investigaciones dedicadas a esta escultura en detrimento de otros aspectos más interesantes ${ }^{2311}$.

\footnotetext{
${ }^{2309}$ X. BARRAL I ALTET y N. DE DALMASES, Op. cit., p. 43. Los investigadores insisten en la importancia del fenómeno a partir del año 1130.

${ }^{2310}$ O. POISSON, "Un sculpteur anonyme du XII" siècle", Le Maitre..., pp. 7-15. La aportación del autor aborda lo problemático de poder llegar a discernir todos estos aspectos, además de poner de relieve, una vez más, la complejidad en relación con el uso de conceptos como el de "maestro" o "taller". Véase también: A. MILONE, "El Maestro de Cabestany...", p. 181. Desde otro orden de cosas, en su día, la profesora D. Ocón ya criticó ciertos excesos "atribucionistas". Cf.: D. OCÓN ALONSO, "Cabestany: iglesia parroquial, portada sur", Tímpanos románicos, vol. I, Madrid, 1987, pp. 118-127, en concreto, p. 123.

${ }^{2311}$ En todo caso, es justo señalar a J. Gudiol como el autor que "inventó" en 1944 el nombre del supuesto "maestro". En lo consecutivo continuaremos aludiendo a la categoría del escultor mediante el entrecomillado, siendo conscientes de lo complejo del término y que, utilizado de una manera libre, puede llevar a error. Las esculturas que actualmente se relacionan con su autoría, han sido dividas, en la última publicación relevante sobre el artista, a través de las categorías de, obras atribuidas a él, obras atribuidas a su círculo de colaboradores y obras discutidas. Sobre la nomenclatura del escultor, véase: G. GUDIOL, "Los relieves de la portada de Errondo y el maestro de Cabestany", Príncipe de Viana, XIV, 1944, pp. 9-
} 
Lejos de estar capacitados para abordar el problema del taller y del sistema de trabajo utilizado por el supuesto "maestro", creemos que, una serie de datos bien conocidos, en torno a determinadas piezas relacionadas con el escultor pueden clarificar nuestra postura, con el fin de establecer ciertas premisas sobre las que partir en nuestro análisis.

En relación con la problemática de la ordenación del trabajo en el seno de la escultura atribuida al "maestro", cabe señalar que, por ejemplo, sobre uno de los fragmentos dispersos del antiguo portal esculpido de la abadía de Lagrasse, en Aude, se han podido identificar perfectamente los nombres de (WI) LLELMVS y ROBERTVS. Según A. Bonnery se trataría, posiblemente, de los nombres de los dos abades que ejercieron su mandato en la abadía, entre los años 1157 y 1167, aunque lo más interesante, en relación con tal cuestión, es la duda que el mismo autor muestra ante tal afirmación, preguntándose sí realmente se trata de otros personajes, quizás los nombres de dos de los escultores que, hipotéticamente, habrían trabajado en el portal ${ }^{2312}$.

También ligado a estos aspectos, la historiografía se ha centrado, tradicionalmente, en el esclarecimiento de los sistemas de trabajo utilizados por este taller relacionado con el "maestro"2313. Parece claro que el conjunto de obras habitualmente ligadas a esta tendencia escultórica, cuyos rasgos más característicos analizaremos más adelante, presenta la diversidad suficiente, tanto desde el punto de vista técnico, como material, iconográfico y geográfico, como para pensar que podría

14 y G. MALLET, "Un artiste itinérant? Géographie de l'oeuvre du Maître de Cabestany, Le Maitre..., pp. 16-23.

En relación con el problema de la utilización de conceptos tales como el de taller o círculo, creemos que se trata de un tema que aún está pendiente de clarificar, dentro del desarrollo de los trabajos de los artífices románicos, de los que tenemos siempre una información tan escasa y fragmentada. Véase también: S. BIAY, "Entre l'oeil et la main...", http://janua.blog4ever.com/blog/lirarticle-68850380168.html, consultado el 2 de febrero de 2008. El estudioso realiza una crítica sobre estos términos de tradición formalista.

${ }^{2312}$ A. BONNERY, "Les sculptures dispersées de l'abbaye de La Grasse (Aude)", Le Maitre..., pp. 109112. El profesor Bonnery duda, igualmente, hasta que punto se pueden atribuir tales restos de manera segura a la propia persona identificada como el "maestro" o a su círculo de trabajo. Según el investigador, el estilo de la pieza no es exactamente el del "maestro", pero sin llegar a plantear con seguridad que los epígrafes puedan ser identificados con los nombres de otros escultores. Más recientemente, se ha dado como seguro que los nombres pertenezcan a los abades Guillermo (1157-1161) y Roberto (1161-1167). Cf.: J. DURAN-PORTA, "Relieve de la abadía de Lagrasse", El Románico y el Mediterráneo..., ficha catalográfica 73, p. 342.

${ }^{2313}$ J. CAMPS I SÒRIA e I. LORÉS I OTZET, "Dos capitells del Museu Arqueològic de Narbona del cercle del Mestre de Cabestany", Lambard. Estudis d'art medieval, IV, 1985-1988, 1990, pp. 125-220, en especial, p. 127, nota 5. Los autores señalan la importancia del concepto "círculo" aplicado al sistema de organización de los talleres de escultura románicos, además, de analizar el sentido con el que es utilizado en relación con la escultura del "maestro" de Cabestany. Véase, sobre todo, la nota 1 de la p. 125, donde se aborda el problema de la nomenclatura del artista y la complejidad de la atribución de una obra tan dispersa. 
haberse tratado de varios escultores ${ }^{2314}$. Si aceptamos tal hipótesis, lo más lógico es imaginarlos trabajando en equipos de escultores, con una tendencia giróvaga que explicaría la dispersión de su supuesta obra, desde territorios tan distantes como los existentes entre la iglesia de San Pedro de Galligants, la abadía de Lagrasse, antes citada, el templo centralizado de Rieux-Minervois y otros lugares mucho más alejados de éstos como, por ejemplo, la iglesia de Sant'Atimo, en Italia ${ }^{2315}$.

La organización de talleres no sería, en ningún caso, extraña o ajena a la tradición de escultores de cronología tardoantigua y altomedieval activos en las regiones de los Pirineos o el Rosellón, así como en las ciudades de Toulouse y Narbona. En estos lugares, tal y como hemos señalado repetidas veces, se venía desarrollando una gran actividad escultórica, de cuyos talleres salieron importantes piezas, sobre todo, sarcófagos $^{2316}$.

Estos aspectos nos sitúan, de manera clara, ante una situación muy diferente a la vivida por los territorios anteriormente analizados. El contacto con los vestigios de la Antigüedad, por su mayor abundancia y riqueza, al menos, a juzgar por lo conservado, hacen de estas regiones orientales de la península un área especialmente propicia para el mantenimiento de ciertas corrientes clasicistas ${ }^{2317}$.

La parte norte del occidente peninsular nunca había asentado sus bases artísticas sobre una tradición continuada en el trabajo "industrializado" del mármol. En este sentido, la situación privilegiada de Cataluña y la Marca Hispánica, ofrecía todas las facilidades para perpetuar este tipo de sistemas productivos. Sin embargo, debemos ser cautos, pues actualmente se tiende a ser excesivamente críticos con la utilización de ciertas expresiones relacionadas con estos "talleres roselloneses" y con su hipotética actividad "industrial”. En concreto, en opinión de la profesora I. Lorés:

${ }^{2314}$ E. CARBONELL I ESTELLER, "Les relacions d'artistes, clients i consumidors de l'obra d'art", Catalunya romànica..., vol. I, Barcelona, 1994, pp. 54-58. En concreto, se dedica un apartado a analizar la vinculación entre los clientes y los artistas, señalando el caso del "maestro" de Cabestany y sus obras tan dispersas que, según el autor, "garantizan la movilidad de los artistas".

2315 J. CAMPS I SÒRIA e I. LORÉS I OTZET, "Dos capitells...”, p. 126. Los autores insistían sobre la importancia del marco geográfico tan vasto y la amplitud de la cronología propuesta para esta corriente escultórica, que abarcaría gran parte de la segunda mitad del siglo XII.

${ }^{2316}$ Por una parte, no se debe olvidar la importancia de la región catalana en relación con la romanización y sus contactos abiertos a todo el Mediterráneo. Tarraco, por ser capital provincial, importó todo tipo de producciones marmóreas de gran calidad. A ello debemos sumar otros centros, como Barcino y Gerunda que, tras la introducción del rito de la inhumación, entre los siglos II y III d. de C., tomarán el relevo en la producción de piezas. Sobre el tema, consúltese: M. CLAVERÍA, "El sarcófago...”, pp. 23-24.

${ }^{2317}$ Sobre los factores de la romanización de estas regiones como causas realmente favorecedoras para la perpetuación de la tradición clásica, durante los siglos del románico, se insistió recientemente en: X. BARRAL I ALTET, “Apropiación y recontextualización de lo antiguo...”, p. 177. 
“(...) estos talleres se han puesto a menudo como ejemplo de una determinada organización del trabajo, consistente en tallar las piezas a pie de cantera y transportarlas ya acabadas para ser montadas en la obra correspondiente. Quizás la existencia de capiteles casi idénticos en conjuntos diferentes o algunos desajustes no son del todo suficientes para suponer una producción mal denominada industrial. De hecho, la especialización en la talla de determinados tipos de elementos, como por ejemplo columnas, basas, etc., podía ser muy temprana por parte de algunos talleres. En cualquier caso, el lugar donde el artesano tallaba los capiteles, fuera la propia cantera o un lugar cercano a la obra al que iban destinados, es una cuestión muy diferente de la de una supuesta producción seriada, que, en el marco de la organización artesanal de la época, es difícil de imaginar, ${ }^{, 2318}$.

En todo caso, las palabras de la investigadora resultan muy representativas de la complejidad del fenómeno al que nos referimos.

\footnotetext{
${ }^{2318}$ I. LORÉS I OTZET, "Actualización de los edificios: nuevas construcciones e incorporación de la escultura”, El románico y el Mediterráneo. Cataluña, Toulouse y Pisa. 1120-1180 (M. A. Castiñeiras González y J. Camps ed.), Barcelona, 2008, pp. 121-131, en concreto, pp. 128-129. En nuestro estudio, al referirnos a un sistema de producción "industrial", hemos sido conscientes de estos aspectos, usándola como una expresión válida que define un sistema de trabajo continuado y mejor organizado. A pesar de ello, se trata de una producción mucho más "seriada" que la que encontremos en las áreas occidentales de la Península Ibérica.
} 


\section{2. LOS VESTIGIOS DE LA ANTIGÜEDAD COMO FUENTE MATERIAL (SPOLIUM IN SE).}

En el momento de iniciar este apartado, centrado en el fenómeno de la expoliación in se, parece obligado aludir a las reflexiones del profesor S. Moralejo. Según su criterio:

“(...) la reutilización medieval de sarcófagos presenta en España caracteres peculiares, determinados (...) por la radical peculiaridad resultante de la invasión islámica y la consiguiente (...) Reconquista cristiana” insistiendo de manera especial en "la aparentemente anómala distribución del conjunto de sarcófagos antiguos conservados en la Península, en proporción decisivamente favorable a su mitad norte, pese a la menor intensidad de su romanización" ${ }^{2319}$.

Tales deducciones dejan muy patente el problema de poder llegar a imaginar y "reconstruir" el paisaje monumental de aquellos edificios y su decoración, que los artesanos medievales pudieron llegar a tener ante $\operatorname{los} \operatorname{ojos}^{2320}$. Los hombres viajaban y con ellos las piezas, muy a pesar de que:

“(...) para explicar las indudables relaciones entre obras a menudo alejadas en el espacio, la historiografía tradicional ha obligado a los artesanos a "viajar". De hecho, se ha abusado de una realidad tan obvia como es la movilidad de los artesanos, de los picapedreros, de los pintores o mosaiquistas que debían trasladarse de un lugar a otro para hacer su trabajo. Y esto se ha hecho reconstruyendo trayectorias profesionales que al fin y al cabo resultan inverosímiles. Los conjuntos conservados, dispersos, a menudo aislados en sitios actualmente poco frecuentados han contribuido a inducir a pensar que eran el fruto de encargos puntuales que requerían la llegada de artesanos de otra procedencia. Bien, de eso no cabe duda: el modus operandi era la itinerancia. Sin embargo, según nos permiten deducir estudios recientes, esta itinerancia era limitada, se hacía en áreas reducidas" ${ }^{2321 .}$

\footnotetext{
${ }^{2319}$ S. MORALEJO ÁLVAREZ, “La reutilización...”, p. 187.

${ }^{2320}$ Con razón, el profesor Bango siempre ha insistido en muchos de sus trabajos sobre esta cuestión. Cf.: I. G. BANGO TORVISO, "El paisaje monumental...", p. 37.

${ }^{2321}$ M. GUARDIA PONS, "Una región meridional de la pintura románica", El románico y el Mediterráneo. Cataluña, Toulouse y Pisa. 1120-1180 (M. A. Castiñeiras González y J. Camps ed.), Barcelona, 2008, pp. 149-157, en concreto, p. 149.
} 
A la hora de poder analizar la importancia de las piezas antiguas con respecto a la formación de determinadas características de la escultura románica, se deberá tener muy en cuenta el valor que a estas se les otorgó. Tales vestigios eran vistos como restos de una pasado digno de recordar. Eran las representantes materiales de un recuerdo que se diluía a un ritmo, tan acelerado, como el devenir temporal de los mismos años y siglos.

El carácter giróvago de los artesanos encargados de decorar, mediante la piedra, los templos es, por lo tanto, uno de los aspectos fundamentales sobre los que centrarse a la hora de poder deducir el contacto que éstos tenían con piezas antiguas conservadas en las regiones más diversas ${ }^{2322}$. Además, a la frecuencia con que fustes, capiteles y sarcófagos fueron transportados desde unos lugares lejanos a otros más remotos, se debe sumar la facilidad para poder trasladar otro tipo de elementos, como entalles, piezas de orfebrería o marfiles.

En el caso de la figura del "maestro" de Cabestany, parece que sus horizontes culturales fueron amplios, tal y como se deduce, a través de la expresión utilizada por P. Ponsich, al referirse al escultor como "artista viajero",2323.

La historiografía más tradicional considera al "maestro" como representante de la tradición giróvaga clásica de los talleres de escultores románicos, independientemente, de la manera en que organizaba su trabajo. Se trataría de un continuador bien experimentado de los sistemas de producción arraigados en las zonas orientales de la Península, desde la misma Antigüedad. Los hipotéticos secuaces, alumnos, maestros, talleres o, simples artesanos, que colaboraban con él, conocían perfectamente el oficio, sobre todo, en relación con la escultura marmórea ${ }^{2324}$. Recientemente, A. Milone ha defendido en este sentido:

“(...) un taller que parte del acercamiento de un grupo de obras más o menos amplio que revela cierto aire familiar (...). Un artista que estaba al frente de un taller

\footnotetext{
${ }^{2322}$ R. SALVINI, "Spagna, Tolosa o Modena? Contributo alla preistoria di Nicholaus", Nicholaus e l'arte del suo tempo, Ferrara, 1985, pp. 29-49. El investigador insiste en estas cuestiones de las relaciones entre escultores y soluciones estilísticas con grandes áreas geográficas por el medio.

${ }^{2323}$ P. PONSICH, voz "Cabestany. Santa Maria de Cabestany", Catalunya romànica..., XIV, El Rosselló, Barcelona, 1993, pp. 161-163, en concreto, p. 162.

${ }^{2324}$ J. CAMPS I SÒRIA e I. LORÉS I OTZET, "L'artiste et son atelier, ses commanditaires", Les Maîtres..., pp. 147-155.
} 
reducido (...) creo que se puede pensar en un grupo de monjes o conversos benedictinos, especializados en la escultura y la decoración arquitectónica (...),2325.

Tal y como se ha señalado, es muy posible que, las esculturas que hoy contemplamos con tantas concomitancias, las unas con respecto a las otras y que se han atribuido a una misma persona o taller, pudieron ser realizadas siguiendo una tradición de trabajo basada en la organización de equipos de marmorii ${ }^{2326}$. Se trataría de talleres de escultores formados en la tradición antigua, sobre todo, en lo referente al trabajo en piedra de una manera organizada y que seguiría un sistema conocido en la zona del Rosellón, los Pirineos Orientales y Toulouse ${ }^{2327}$.

El análisis de algunos de estos materiales, especialmente, el mármol, ha permitido constatar la explotación de canteras ubicadas en lugares activos desde tiempos romanos, tal y como demuestra el supuesto uso del mármol de las explotaciones de Saint-Béat y que abasteció a buena parte de los talleres de tolosanos y narboneses, tanto para la decoración de monumentos romanos como medievales ${ }^{2328}$.

En relación con el tema, recientemente el profesor X. Barral escribió:

"A lo largo del siglo XII, las dos vertientes del extremo oriental de la cadena pirenaica se distinguen por una explotación masiva de varias canteras de mármol y

\footnotetext{
${ }^{2325}$ A. MILONE, "El Maestro de Cabestany...”, pp. 182-183.

${ }^{2326}$ Véase la crítica que realiza sobre la noción de "trabajos industrializados" realizada en: I. LORÉS I OTZET, "Actualización de los edificios...”, p. 129. Dentro de la historiografía, M. Durliat dedicó gran atención a la importancia de la actividad escultórica tardoantigua y su influencia sobre la románica. Consúltese al respecto : M. DURLIAT, "Les débuts de la sculpture romane dans le midi de la France et en Espagne", Les Cahiers de Saint-Michel de Cuxa, IX, 1978, pp. 101-113.

O. POISSON, "Le Maître de Cabestany, sculpteur et architecte?", Le Maître..., pp. 154-163, en concreto, p. 156. El profesor Poisson relaciona las obras del "maestro" con la tradición de marmolistas de los talleres del Rosellón del siglo XII, activos en la región y que se surtirían, en parte, de mármoles de gran belleza, como el de color rosa, típico de la zona de Villafranca de Conflent. Sobre estas zonas y la importancia del material antiguo como fuente de inspiración para las obras románicas, véase también: R. REY, "Quelques survivances antiques...", pp. 173-191.

${ }^{2328}$ M. BURRINI, "Le style du Maître de Cabestany", Le Maître..., pp. 125-146, en particular, p. 30. El profesor Burrini duda de la teoría expuesta por N. Kikuchi, en la que se defendía la posibilidad de un taller permanente instalado en la ciudad de Toulouse y desde donde se realizarían los encargos escultóricos para, más tarde, ser trasladados a los edificios en construcción. Sobre tal cuestión: N. KIKUCHI, "Study on the works of the Cabestany Master", Bulletin of the Study on Philosophy and History of Art in University of Tsukaba, 5, 1987, pp. 23-79.

Por otra parte, el origen del escultor fue un tema que también preocupó a los especialistas. En este sentido, la profesor D. Ocón señalaba que los argumentos que demostrasen su origen rosellonés no eran muy fuertes. En relación con ello, en la última aportación de A. Milone al tema, éste autor escribe: "Los elementos estilísticos con los que más frecuentemente dialogan los escultores que dependen del Maestro de Cabestany atañen justamente a esta fase de la tradición artística de la Cataluña histórica, la región de la que es originario el anónimo artista y en la que trabaja con mayor frecuencia". Cf.: A. MILONE, "El Maestro de Cabestany...", p. 185 y D. OCÓN ALONSO, "Cabestany...", p. 125.
} 
por la nueva talla de elementos de mármol clásicos. Varias generaciones de artesanos se especializan en una producción de mármol imitada ampliamente por los escultores que trabajan la piedra calcárea. La actividad de estos marmolistas se desarrolla muy tardíamente e incluso se prolonga hasta entrado el siglo siguiente. Entre los cultivadores de estas maneras de hacer tan apreciadas hay personalidades excepcionales (...). Un escultor anónimo, conocido como el Maestro de Cabestany, trabaja el mármol e imita la Antigüedad ${ }^{, 2329}$.

Es en este marco de la Europa románica y pluralista donde las personalidades fuertemente individualizadas y originales sobresalen. Estos artesanos han creado una forma de expresión propia, que tiene su origen en su genialidad enteramente individual y que nosotros percibimos, como lo general, de todas y cada una de sus obras individuales. Después, el estilo de un maestro individual puede ser adoptado por otros, convirtiéndose así en la propiedad de muchas personalidades artísticas. En esos otros expresa aquél su imposición como estilo, como algo que está por encima o que acompaña a la expresión de la personalidad ${ }^{2330}$.

La particularidad de las soluciones que adoptará, unidas a la brillantez a la hora de buscar inspiración en lo antiguo, serán las encargadas de generar una escultura de rasgos inconfundibles, muy a pesar de que, recientemente, algunos investigadores, como F. Gandolfo, argumenten otras teorías que intenten restar individualismo a la figura de este "maestro" 2331 .

A ello sumamos el trabajo del mármol que se convierte, según nuestra opinión, en un dato fundamental, sobre todo, si tenemos en cuenta que, dentro de las obras relacionadas con su figura o taller, la experimentación plástica y la combinación de diferentes materiales pétreos fueron recursos muy frecuentes.

Tal tradición ya ha sido señalada, a lo largo de este estudio, como un rasgo bien conocido de algunas de las construcciones más importantes de los siglos del románico donde, los artistas, recurriendo a un principio bien conocido dentro del arte y la arquitectura romana, utilizaban los materiales de distinta índole para generar efectos cromáticos y plásticos en los edificios. Nos referimos al tema, anteriormente abordado, de la varietas.

\footnotetext{
${ }^{2329}$ X. BARRAL I ALTET, “Apropiación y recontextualización de lo antiguo...”, p. 177.

${ }^{2330}$ G. SIMMEL, "El problema del estilo", Revista Española de Investigaciones Sociológicas, 84, 1998, pp. 319-326.

${ }^{2331}$ F. GANDOLFO, "Il sarcofago di Saint-Hilaire d'Aude, il Maestro di Cabestany e la Toscana", Medioevo: il tempo degli antichi, Milán, 2006, pp. 425-437.
} 
En relación con ello, J. Camps e I. Lorés i Otzet ya señalaron la posibilidad de que, en algunas de sus obras, el "maestro" o maestros, el taller o los talleres activos en estos edificios, hubieran utilizado el recurso de la no homogeneidad de los materiales para lograr ciertos efectos ${ }^{2332}$. Tales aspectos no deben sorprender pues, si aceptamos que las obras de Cabestany parecen partir de las experiencias plásticas y arquitectónicas desarrolladas en la ciudad de Toulouse, no sería extraño explicar algunas de estas soluciones a través de un conocimiento del sistema constructivo de la cabecera de la basílica de Saint-Sernin, por citar un caso conocido. En ella, la combinación de materiales pétreos y laterícios se muestra como una solución, claramente, heredera de las técnicas constructivas romanas ${ }^{2333}$.

A este respecto podríamos citar algunos ejemplos en los que el mármol juega un papel destacado pero, sobre todo, en lo que se refiere a su combinación cromática con otros materiales y a su colocación dentro de los propios edificios, en lugares de cierta relevancia, que se dignifican y embellecen gracias a su presencia.

Por citar un caso conocido, se muestra muy sugestiva la fachada de la iglesia prioral de Marcèvol (Pyrénées-Orientales), donde el mármol, tan solo se utilizó, para decorar la puerta de acceso y la ventana superior de la fachada occidental del edificio, enlazando con las experiencias artísticas y arquitectónicas del primer románico ${ }^{2334}$. Igualmente llamativas son otras construcciones relacionadas con la actividad de estos escultores. Así, en la iglesia de Monestir del Camp, en Passà, se proyectó un portal oeste donde la utilización de un tipo de mármol blanco, que destaca entre todo el resto de la construcción, facturada en materiales más discretos ${ }^{2335}$. Se trata de dos ejemplos bien expresivos en relación con la utilización de este material.

Tal y como observamos, estas soluciones adoptadas en el ámbito oriental de Hispania, más en contacto con la cultura mediterránea y la propia Galia, forman parte

\footnotetext{
2332 J. CAMPS e I. LORÉS I OTZET, "Le portail de Sant Pere de Rodes", Le Maître..., pp. 113-123, en concreto, p. 121. Los estudiosos realizan tales afirmaciones a propósito del portal desaparecido de la iglesia de San Pedro de Rodas y a través de ciertos vestigios conservados, entre ellos, el famoso capitel del Worcester Art Museum. Esta pieza fue realizada en caliza, frente a otros fragmentos de dicho portal que conservamos y que fueron esculpidos en mármol.

${ }^{2333}$ Q. CAZES, “La escultura en Toulouse entre 1120 y 1180", El románico y el Mediterráneo. Cataluña, Toulouse y Pisa. 1120-1180 (M. A. Castiñeiras González y J. Camps ed.), Barcelona, 2008, pp. 69-79, en concreto, p. 72.

${ }^{2334}$ P. PONSICH, "Santa Maria de Marcèvol”, Catalunya Romànica..., vol. VIII, Barcelona, 1995, pp. 309-310 y O. POISSON, "Le Maître de Cabestany...", pp. 157-158.

${ }^{2335}$ O. POISSON, "Le portail de l'église du Monastir del Camp à Passà", Le Maître..., pp. 169-175, en concreto, pp. 169-170.
} 
de una tendencia "antiquizante" paralela a la que hemos explicado para las regiones del norte occidental de la Península.

Sobre el uso de esta varietas romana o, lo que es lo mismo, las variaciones y juegos de materiales combinados en busca de efectos cromáticos, también habían sido insinuadas, de manera más discreta, por los obradores, por ejemplo, de Santiago de Compostela o San Isidoro de León.

A pesar de lo afirmado, J. Barrachina desarrolló otra serie de argumentos en los que no apoyaba esta teoría de la varietas o la explotación de los valores polícromos de la piedra dentro de la obra del "maestro" de Cabestany. Así decía:

“(...) La razón es muy extraña y, por mucho que se intentara cierta policromía alternando mármol y piedra, creemos que el motivo de fondo ha de ser de limitación en las posibilidades de conseguir mármol, tanto por problema económico como por premura en la finalización de la obra, si no es por que, sencillamente, se agotó el monumento antiguo de donde se expoliaban los mármoles",2336.

En relación con el uso del mármol queremos destacar otra posibilidad apuntada ya hace algunos años y, actualmente, puesta en duda. Según esta teoría, la dispersión de la obra del escultor podría explicarse también gracias a la exportación de piezas. La hipótesis, apuntada por L. Pressouyre, nuevamente, pondría en relación a los marmolistas de la segunda mitad del siglo XII con el gran sistema de importaciones,

\footnotetext{
${ }^{2336}$ J. BARRACHINA, "Las portadas de la iglesia...", p. 25; I. LORÉS I OTZET, El Monestir de Sant Pere..., sobre todo, pp. 19-23 e ID., "L'église de Sant Pere de Rodes...", pp. 34-35. La autora dedica un capítulo a los precedentes antiguos del monasterio. Señala la presencia de gran número de restos marmóreos, tales como la placa de mármol romana esculpida con bellos motivos vegetales y otros fragmentos, algunos realizados con roca procedentes de Carrara.

Lo más interesante para este aspecto es que, la autora, recoge toda una serie de piezas clásicas reutilizadas dentro de la construcción románica del monasterio, tanto en la primera portada datada en el año 1100, como en la segunda, realizada en torno al año 1160.

Los restos de mármol romano que se han relacionado con el edificio son muchos. Recuérdese, por ejemplo, el ara de mármol blanco, de gran tamaño, que vio Francisco de Zamora a finales del siglo XVIII sobre el altar de la iglesia de Rodas. Los argumentos ofrecidos por la investigadora hacen pensar en diversos focos romanizados en puntos próximos al momento. Tal hecho hace prácticamente imposible no poder llevar a cabo algún tipo de labor expoliadora en relación con los mismos.

Según nuestra opinión, resulta poco probable justificar esta alternancia de materiales a través de un agotamiento de las "canteras" abiertas en los ruinosos edificios romanos que abastecerían a estos escultores. Con todo, más recientemente, el mismo J. Barrachina insistió en su postura. Cf.: J. BARRACHINA, "Elementos de la portada de Sant Pere de Rodes", El románico y el Mediterráneo. Cataluña, Toulouse y Pisa. 1120-1180 (M. A. Castiñeiras González y J. Camps ed.), Barcelona, 2008, pp. 344-355, en concreto, p. 354. El autor señala: "Para la obra expolian mármoles romanos e incluso una escultura antigua. No hay, no obstante, mármol suficiente, y la portada se haría con un 10-20\% de piedra".
} 
exportaciones y traslados terrestres y por vía marítima, de numerosas piezas esculpidas en los talleres imperiales y tardoantiguos ${ }^{2337}$.

Sin embargo, la posibilidad es sugestiva, sobre todo, si tenemos en cuenta que, parte de estas obras, se encuentran repartidas, durante el siglo XII, a través de una de las principales vías de comunicación. Nos referimos, concretamente, a la vía Francigena que atravesaba, desde la ciudad de Roma, toda Italia del Norte para, finalmente, adentrarse en la Galia ${ }^{2338}$. El panorama de obras antiguas que debían permanecer desde época romana en todos estos lugares, hace factible la idea de que los artífices medievales tuviesen un contacto mucho mayor con estas piezas que el que hoy podamos imaginar.

En este mismo sentido cabe reflexionar sobre el papel jugado por estas obras y su influencia sobre la escultura que aquí abordamos. Si los restos romanos habían tenido un papel privilegiado en la configuración de determinadas tendencias escultóricas relacionadas con la decoración de la catedral de Jaca o Santiago de Compostela, parece que, una vez traspasado el año 1150, esta predilección por lo clásico se mantuvo.

Tales aspectos debieron influir en la formación del "maestro" de Cabestany y el círculo artístico en el que desarrolló su trabajo. La Antigüedad era vista, nuevamente, como una gran "cantera" abierta a la que acudir, primeramente, a la búsqueda de materiales con los que realizar las nuevas obras y, en segundo lugar, como fuente de inspiración intelectual, tal y como veremos más adelante.

El aspecto más importante de este apartado recae sobre la procedencia de algunos de los materiales presentes en los conjuntos en los que, parece que trabajó el escultor. Se trataría de materiales de acarreo, piezas romanas reutilizadas como soporte para las nuevas imágenes medievales, es decir, las denominadas expoliaciones in $s e^{2339}$.

\footnotetext{
${ }^{2337}$ L. PRESSOUYRE, "Une nouvelle oeuvre du maître de Cabestany en Toscane: le pilier sculpté de San Giovanni in Sugana", Bulletin de la Société nationale des Antiquaires de France, 1969, pp. 30-60. Recientemente, se ha dudado de tal teoría, sobre todo, después de los análisis petrográficos de las obras atribuidas al círculo del "maestro", donde queda patente la utilización de materiales propios de cada territorio, por lo que, parece poco probable, hablar de un traslado de obras o materiales desde el lugar de fabricación al lugar en el que, finalmente, acabarían decorando los edificios.

${ }^{2338}$ J. CAMPS I SÒRIA e I. LORÉS I OTZET, "L'artiste et son atelier...", p. 151 y M. BURRINI, "Sant'Atimo: le chapiteau de Daniel dans la fosse aux lions", Le Maître..., pp. 67-73, particularmente, p. 68.

${ }^{2339}$ S. SETTIS, “Continuità, distanza...”, pp. 391-393.
} 
El mismo tímpano de Cabestany, que daría nombre al "maestro", fue esculpido en una pieza de mármol que, según O. Poisson y otros autores, se trataría, realmente, de una tapa de sarcófago datada en época tardorromana ${ }^{2340}$ (fig. 455).

La posibilidad de llevar a cabo una reutilización de estas piezas de mármol romanas en la obra medieval del "maestro" cobra más fuerza al examinar otra de sus esculturas más conocidas. Se trata de la lastra marmórea conservada en el Museo Federico Marès de Barcelona, proveniente de San Pedro de Rodas y en la que fue esculpida la escena de la Aparición del Resucitado (fig. 456). Recientemente, se ha insistido en la vieja teoría de que tal pieza fue esculpida reaprovechando un bloque de mármol, "quizás antiguo" y en la que un escultor anterior habría realizado una escena que ha llegado hasta nosotros prácticamente mutilada ${ }^{2341}$ (fig. 457).

Sin embargo, dentro del repertorio escultórico y de las obras atribuidas a la influencia del "maestro", los ejemplos de reutilización de piezas antiguas parecen

${ }^{2340}$ O. POISSON, “Le tympan de Cabestany”, Catalunya Romànica, XIV, Barcelona, 1993, pp. 161-163. $\mathrm{El}$ autor insiste en la forma trapezoidal que presenta la pieza relacionada, posiblemente, con la tapa o el fondo de un sarcófago. Señala que tal fenómeno no sería extraño, tal y como se atestigua mediante otras reutilizaciones, en su mayor parte, llevadas a cabo mediante piezas salidas de la escuela de Aquitania, en estas zonas de los Pirineos. También véase: ID., "Le Maître de Cabestany", Terres Catalanes, 2, 1993, pp. 94-95; ID., “Gérone, Rieux, Cabestany, Saint-Papoul. Un premier groupe d'œuvres”, Le Maître..., pp. 27-28; ID., "Tímpano de Cabestany", El románico y el Mediterráneo. Cataluña, Toulouse y Pisa. 11201180 (M. A. Castiñeiras González y J. Camps ed.), Barcelona, 2008, ficha catalográfica 70, pp. 336-337; F. SAUNIER, "Le tympan de Cabestany”, Le Maître..., pp. 49-56 y X. BARRAL I ALTET, "L'escultura romànica a Catalunya”, Catalunya romànica..., vol. I, pp. 94-110, en concreto, p. 103.

${ }^{2341}$ J. CAMPS e I. LORÉS I OTZET, "Le portail de Sant Pere de Rodes...", en concreto, p. 116 y J. BARRACHINA, "Las portadas de la iglesia...", en particular, p. 14. J. Barrachina niega que se trate de una pieza de cronología romana, advirtiendo que, posiblemente, la escena hoy destruida y de la que restan tan sólo unos indicios complicados de analizar, represente realmente el pasaje bíblico de Eliezer y Rebeca.

El autor duda de que se trate de un sarcófago romano expoliado como material escultórico, basándose en el tamaño de la pieza de mármol que, según él, "tal relación de tamaños es impropia de un sarcófago antiguo". Véase la reconstrucción gráfica que realiza de la posible escena repicada de la parte trasera de esta lastra en la fig. 8 de la p. 15. A partir del análisis de ciertos detalles iconográficos, como los brazaletes, la presencia de una serie de perfiles en forma de trapecio invertido y otros elementos, identifica esta escultura maltrecha como las dos mujeres aguadoras de la Biblia. Sin embargo, la teoría según la cual esta pieza es fruto de un spolia in se, tiene larga tradición historiográfica y ha sido defendida frecuentemente. Consúltese también: J. AINAUD DE LASARTE, "Noticias de San Pedro de Roda", Revista de Gerona, V, 9, 1956, pp. 33-35; M. DURLIAT, "Le Maître de Cabestany...", concretamente, pp. 118-119 y D. L. SIMON, "Two sculptures attributed to the master of Cabestany", The Art of..., ficha catalográfica 161, pp. 313-314. Este último autor insistía en esta hipótesis.

Tal y como hemos señalado arriba, el último trabajo de Camps y Lorés, del año 2000, daba como válida la teoría del expolio de este mármol, supuestamente, antiguo. El trabajo más actualizado sobre esta escultura en: J. BARRACHINA, "Elementos de la portada...", p. 345. El investigador continúa defendiendo que esta escultura no es romana, sino más bien un "palimpsesto románico primitivo cuyo reverso representa a Eliezer y Rebeca".

En relación con las piezas atribuidas al "maestro" provenientes del monasterio de San Pedro de Rodas, véase: J. CAMPS I SÒRIA e I. LORÉS I OTZET, "L'escultura de Sant Pere de Rodes", Catalunya Romànica..., vol. IX, pp. 703-728, en concreto, pp. 711-717. Sobre el relieve en cuestión, consúltese también: J. CAMPS I SÒRIA, voz "Relleu figurat 3 de Sant Pere de Rodes", Catalunya romànica..., vol. XXIII, pp. 311-317. 
frecuentes. Se trata de un fenómeno más abundante de lo que se pudiera pensar en un primer momento, no sólo en el seno de su área de actuación, sino en las mismas zonas sobre las que, paralelamente, se realizaban otros tipos de trabajos escultóricos ajenos a su actividad $^{2342}$.

Parece, según recoge R. M. Comes, que uno de los restos pétreos conservados en el Museo del Castillo de Peralada y que, en su día, sirviera de base para formar parte de una cornisa del mismo monasterio románico es, en realidad, un fragmento de mármol romano originariamente utilizado como banco ${ }^{2343}$.

A la luz de estos datos resulta interesante reflexionar sobre la importancia que los edificios antiguos tuvieron en la construcción misma de los templos y la decoración encargada a estos artesanos. En relación con el enclave sobre el que fue levantada la iglesia de San Pedro de Rodas, se ha señalado la posibilidad de que, para su construcción, fueran reempleados mármoles cuyo origen, aunque no seguro, podría haber estado en los alrededores de la actual ubicación del templo.

Se trataría de un lugar importante en época romana y del que se conocen ciertas noticias de la posible existencia de algún resto dispuesto a ser recuperado por los artífices medievales $^{2344}$.

En este sentido, el caso concreto que hemos expuesto se podría enmarcar, perfectamente, en toda la serie de ejemplos citados a lo largo de este estudio y en los que la reutilización del mármol y las piezas clásicas permitían enriquecer, tanto visualmente como desde un punto de vista conceptual, las nuevas construcciones.

Para finalizar esta breve síntesis relacionada con las labores expoliadoras desarrolladas por el "maestro" de Cabestany y su círculo, queremos aludir a los bellos fragmentos marmóreos, de cronología romana, hallados en el área del mismo monasterio de Rodas. Se trata de una serie de piezas esculpidas con diversos motivos

\footnotetext{
${ }^{2342}$ M. MAYER, A. ÁLVAREZ e I. RODÀ, "Los materiales lapídeos reaprovechados en construcciones medievales en Cataluña. La ciudad de Barcelona y su entorno", Artistes, Artisans et production artistique au Moyen Age (X. Barral i Altet ed.), vol. II, Paris, 1987, pp. 529-558.

${ }^{2343}$ R. M. COMES, "Un banc romà reutilitzat pel Mestre de Cabestany, a Peralada", Sylloge Epigraphica Barcinonensis, III, 1999, pp. 39-41 y J. BARRACHINA NAVARRO, "Las portadas de la iglesia...", p. 25 , nota 49.

${ }^{2344}$ I. LORÉS I OTZET, El monestir de Sant Pere..., pp. 20-21. Respecto a la recuperación de piezas marmóreas esculpidas en épocas anteriores y reaprovechadas en otras construcciones es, verdaderamente llamativo, el ejemplo de la portada de la iglesia de Santa Maria del Castell de Ostrera, donde diversos elementos de la antigua iglesia del castillo, fueron reinsertados, a modo de "rompecabezas", dentro de una fachada posterior. Cf.: M.-D. PIÑERO I COSTA y P. PONSICH, "Santa Maria del Castell d'Oltrera", Catalunya romànica..., El Rosselló, vol. XIV, pp. 112-114 y X. BARRAL I ALTET, "Fragment de sarcophage antique de Torreilles (Pyrénées-Orientales), retaillé en table d'autel romane", Cahiers Archéologiques, XXVII, 1978, pp. 31-37.
} 
vegetales que "fueron reutilizados para formar parte de una arquivolta románica, muy probablemente en la portada del Maestro de Cabestany del siglo XII ${ }^{2345}$ (figs. 458 y 459).

Las piezas, en realidad fragmentos de una cornisa romana, insisten en el interés por el material antiguo de los escultores medievales y hacen patente su importancia dentro del monasterio de Rodas, como mínimo, desde el año 1000. Tal y como se ha apuntado, su reempleo parece indicar "claramente cómo en época románica se distinguían perfectamente los materiales y su antigüedad",2346.

El interés por las esculturas de cronología romana no cesaría con una simple apropiación de fragmentos recolocados en partes marginales de sus obras. Hace poco tiempo que J. Barrachina estudiaba diferentes hipótesis proyectadas a reconstruir la fachada de la iglesia de Rodas, tal y como hemos señalado. El dato más relevante es que, a raíz del análisis de la magnifica cabeza descontextualizada de San Pedro del Museo de Peralada, el autor citaba otra escultura recientemente descubierta (fig. 460).

Se trata de un fragmento que atribuye, hipotéticamente, a la cabeza anteriormente citada (fig. 461). Este cuerpo, una vez decapitado durante las agresivas expoliaciones que sufrió el monasterio, durante los primeros años del siglo XIX, pasó a ser reutilizado como mojón de término. El autor se refiere a la escultura en los siguientes términos:

"El formato marcadamente prismático del cuerpo, con arista lateral, demostraría indudablemente que se trata de una herma romana reutilizada y, por lo tanto, sin cabeza originariamente ${ }^{, 2347}$.

El escultor "románico-renacentista", tal y como lo denomina este investigador, demuestra su interés absoluto por el arte romano y paleocristiano de un arco temporal que iría, desde el siglo I d. de C. al IV ${ }^{2348}$. La reutilización de estos elementos revela la relativa facilidad con la que, los escultores medievales, accedían a los vestigios antiguos

\footnotetext{
${ }^{2345}$ I. LORÉS I OTZET, El monestir de Sant Pere..., p. 21. La profesora Lorés señala la importancia de la región en la que se ubica el monasterio de Rodas, muy romanizada, y donde los materiales podrían proceder de lugares tan importantes como Ampurias. Recoge, además, las teorías de Pere de Marca quién, basándose en un texto de Plinio, ubica un templo clásico en los aledaños de la desembocadura del río Ter. ${ }^{2346}$ M. GUARDIA PONS e I. LORÉS I OTZET, "La escultura tardorromana y altomedieval en Cataluña", Escultura decorativa tardorromana y altomedieval en la Península Ibérica (L. Caballero Zoreda y P. Mateos Cruz ed.), Madrid, 2007, pp. 191-219, en especial, pp. 210-211.

${ }^{2347}$ J. BARRACHINA, "Elementos de la portada...", p. 349.

${ }^{2348}$ Ibidem, p. 352.
} 
desperdigados por el paisaje monumental de las ciudades y núcleos poblaciones de la Hispania del siglo XII. El spolium de una herma romana, similar a la hallada en la casa número 2 de Ampurias (fig. 462), permite apoyar la hipótesis ${ }^{2349}$.

La reintegración de piezas antiguas, completamente reabsorbidas por las nuevas construcciones románicas o, ligeramente reelaboradas, habla de las intenciones utilitaristas del ahorro de materiales ${ }^{2350}$. Sin embargo, tal y como apuntó el profesor S. Moralejo, ello deja entrever también una voluntad por formar parte de la "autoridad" que estas podrían representar y cuya posesión ha sido visto, a veces, como un mecanismo de "legitimación política"2351.

Salvando las distancias, el anónimo "maestro" de Cabestany se muestra así como un claro continuador y heredero directo de su antepasado más "antiquizante", el "maestro" de Jaca. De esta manera, parece más factible, plantear un panorama de "renacimiento" de lo clásico un tanto lineal y coherente, desde los últimos años del siglo XI hasta una vez traspasada la década de los años sesenta del siguiente ${ }^{2352}$.

\footnotetext{
${ }^{2349}$ J. BARRACHINA, "L'expoli de Sant Pere de Rodes. De la col-lecció al museu”, La fortuna d'unes obres. Sant Pere de Rodes, del monestir al museu, Barcelona, 2006-2007, pp. 113-142.

2350 P. MATHIS, “Architrave”, Rilavorazione dell'antico nel Medioevo (M. D'Onofrio ed.), ficha catalográfica 18, Roma, 2003, pp. 56-60.

${ }^{2351}$ S. MORALEJO ÁLVAREZ, “La reutilización...”, pp. 188-189.

${ }^{2352}$ S. MORALEJO ÁLVAREZ, “Modelo, copia...”, pp. 99-100.
} 


\section{3. LOS VESTIGIOS DE LA ANTIGÜEDAD COMO FUENTE DE INSPIRACIÓN (SPOLIUM IN RE).}

La constatación de una voluntad utilitarista en el reempleo de piezas clásicas en la obra del "maestro" de Cabestany, el spolium in se, vino pareja con la expoliación y reinterpretación intelectual de los motivos antiguos que se mostraban representados sobre esas mismas obras.

En un entorno de gran riqueza artística como fue el área mediterránea ${ }^{2353}$, no es de extrañar que, M. Burrini haya ubicado estas experiencias artísticas, que ahora estudiamos, dentro de un fenómeno que él define como "renaissance méditerranéenne". El mismo autor, profundizando en las fuentes a las que los artistas pudieron tener acceso, señaló como importantes en la formación del estilo de este escultor, además de las antiguas, las orientales y las bizantinas ${ }^{2354}$.

Resulta llamativo como el investigador subraya la importancia que, según su criterio, habrían de tener otras fuentes artísticas. La ilustración del libro y lo que continúa denominando como "miniatura mozárabe" serían, en este sentido, algunos de los referentes utilizados para la concepción de determinadas imágenes ${ }^{2355}$.

El autor señala la gran riqueza de fuentes artísticas, sobre todo, en relación con la supervivencia de ciertos aspectos de la cultura helenístico-bizantina en toda la zona mediterránea y que pudieron perfilar el horizonte plástico sobre el que se desarrolló este tipo de escultura ${ }^{2356}$. A ellas se suman, evidentemente, las bien argumentadas hipótesis defendidas en su día por J. Camps, quién llamó la atención, de manera especial, sobre las experiencias tolosanas a la hora de valorar los recursos del anónimo "maestro",2357.

Sus afirmaciones son fundamentales para poder explicar el origen de algunos de los motivos, tanto de orden iconográfico como estilístico, que habrían de convertirse en una de las marcas características de estas esculturas ${ }^{2358}$.

\footnotetext{
${ }^{2353}$ X. BARRAL I ALTET, “Apropiación y recontextualización...”, p. 174.

${ }^{2354}$ M. BURRINI, “Le style du Maître...”, p. 126.

${ }^{2355}$ Ibidem, pp. 132-134. Burrini alude al ejemplo concreto del Beato de Gerona y, concretamente, a la miniatura de Daniel en el foso de los leones que compara, en cuanto a actitudes gestuales, con el capitel de la iglesia de Sant' Atimo.

${ }^{2356}$ D. OCÓN ALONSO, “Cabestany...”, p. 126. La autora ya defendía la importancia que pudieron tener los trabajos ebúrneos en su obra. En concreto, citaba algunos ejemplos bizantinos, como el cofre conservado en Roma, Palazzo Venezia.

2357 J. CAMPS I SÒRIA, “À propos des sources toulousaines du Maître de Cabestany: l'exemple du portail de Sant Pere de Rodes (Catalogne)", Les Cahiers de Saint-Michel de Cuxa, XXVI, 1995, pp. 95107.

${ }^{2358}$ F. GANDOLFO, "Il sarcofago di Saint-Hilaire d'Aude...”, pp. 425-437.
} 
El sur de la Galia romana había poseído un esplendoroso pasado, rico en vestigios artísticos que habrían proporcionado una base lo suficientemente abundante como para permitir a los escultores de una primera generación realizar obras de gran calidad y de fuerte sustrato clásico ${ }^{2359}$. Pensamos, en concreto, en la escultura y los artífices que trabajarían entre los años finales del siglo XI y las dos décadas siguientes en la basílica de Saint-Sernin de Toulouse ${ }^{2360}$.

Aceptando las fuentes tolosanas de la escultura del círculo de Cabestany, creemos que éstas se pudieron enriquecer más allá del establecimiento de relaciones con un determinado lugar concreto. La escultura del "maestro", tal y como señala M. Burrini, tiene sus fuentes en una obra mucho más variada y rica de lo que podamos pensar y que, en cierta medida, se debaten entre el clasicismo de origen romano occidental y aquel desarrollado en el Oriente ${ }^{2361}$.

A lo largo de la Europa románica, fueron muchas las personalidades activas en el campo escultórico que, tal y como hemos apuntado, se vieron seducidas por piezas antiguas de la más diversa índole. En el caso que nos ocupa tal hecho aparece igualmente constatado.

La importancia que habrían de tener los sarcófagos antiguos dentro de la obra de Cabestany es un hecho sobradamente demostrado. Con todo y sin negar en ningún caso otras vías de transmisión de la influencia de la Antigüedad a su obra, conviene señalar que, nuevamente, son los sarcófagos los que ofrecen el suficiente repertorio conservado y homogéneo como para poder establecer paralelismos lo suficientemente fiables.

Somos conscientes de la idéntica importancia que pudieron tener otro tipo de piezas, tales como las monedas, otras esculturas de formato monumental, las miniaturas o, incluso, los textiles de épocas antiguas. Sin embargo, la escasa conservación de este

2359 CH. LAURANSON-ROSAZ, "La romanité du Midi de l'an Mil; le point sur les sociétés méridionales", Catalunya i França meridional a l'entorn de l'any mil, Barcelona, 1991, pp. 45-58.

${ }^{2360}$ Q. CAZES, "La escultura en Toulouse...", p. 74.

${ }^{2361}$ M. BURRINI, "Le style du Maître...”, p. 141. En su exposición llega a la conclusión de que la escultura del "maestro" supone el punto de unión entre las experiencias escultóricas del arte de la Antigüedad clásica, enriquecidas en época medieval por unos escultores que toman la fuerza plástica de las piezas románicas de Toulouse y, además, conservan parte del gusto oriental de tradición "mozárabe". Estas fuentes de tipo oriental tenían en la zona del Rosellón un claro antecedente artístico, dentro de la escultura desarrollada por la denominada escuela narbonense.

Algunas de estas obras esculpidas entre el siglo X y el XI, entre ellas, las mesas de altar, presentan ciertos rasgos emparentados con este tipo de filiaciones orientales. Incluso muchas de ellas acabarían pasando a los mismos edificios románicos mediante la reutilización de estas piezas en otras partes de los templos. Cf.: P. PONSICH, voz "Sant Joan el Vell”, Catalunya Romànica..., vol. XIV, pp. 289-294, en concreto, p. 294. 
tipo de producciones, realizadas en la época antigua, impide la correcta aplicación de un método comparativo que nos ofrezca resultados viables.

El fenómeno no es nuevo en absoluto, pues en este estudio hemos venido señalando la importancia de estas piezas, desde diferentes puntos de vista, tanto estilísticos como iconográficos. Sin embargo, es el conocido como sarcófago de San Saturnino, conservado en la abadía benedictina de Saint-Hilaire, cerca de Carcassonne, el ejemplo más significativo al respecto (fig. 463). Se trata de una pieza que ha recibido gran atención por parte de los investigadores, no sólo por cuestiones estilísticas o iconográficas, sino por la misma forma que posee el receptáculo ${ }^{2362}$. Incluso, recientemente, el profesor F. Gandolfo la utilizó como base para desarrollar unos argumentos que defienden la imposibilidad de seguir apostando por la configuración de un itinerario del "maestro" partiendo de pruebas de índole estilística, lo que le lleva a dudar sobre este método "atribucionista", en relación con algunas de las piezas adjudicadas a su mano por la historiografía ${ }^{2363}$.

Se trata de una pieza con forma de sarcófago que, según se ha venido defendiendo, tendría una función de relicario, ya que su pequeño tamaño habría imposibilitado el hecho de depositar en su interior un cuerpo humano íntegro. Custodiaría, por tanto, alguna reliquia del obispo tolosano o, más probablemente, las brandae 2364 .

Más allá de todos los problemas iconográficos que la pieza ha podido suscitar derivados, en parte, del gran desarrollo de imágenes que presenta en el frente, nos interesa remarcar la importancia que adquiere aquí la imagen misma del sarcófago. Se trata de una obra que ha sido datada, en relación con otras esculturas del "maestro", en la segunda mitad del siglo XII, pero que conserva, esencialmente, la imagen misma de un sarcófago paleocristiano. Por una parte, la fuente textual sobre la que se basa, habla claramente de un alto grado de conocimiento de los textos paleocristianos en el ambiente en el que fue elaborada. Por la otra, cabe la posibilidad de que tal pieza

\footnotetext{
${ }^{2362}$ A. BONNERY, "Le sarcophage de Saint-Saturnin à Saint-Hilaire”, Le Maître..., pp. 100-108. En este estudio se recoge la bibliografía más importante sobre la pieza. También véase: M. DURLIAT, "Le Maître de Cabestany à Saint-Hilaire de l'Aude. Solutions à quelques problèmes archéologiques", Tramontane, 344, 1952, pp. 117-121; ID., "Saint-Hilaire d'Aude", Congrès Archéologique de France, 131, Paris, 1973, pp. 154-172; G.-J. MOT, "L'ossuaire de saint Saturnin à Saint-Hilaire d'Aude", Mémoires de la Société archéologique du Midi de la France, XXVII, 1961, pp. 41-47 y A. BONNERY, "Le sarcophage-reliquaire de saint Saturnin, à saint-Hilaire d'Aude", Les Cahiers de Saint-Michel de Cuxa, XXIX, 1998, pp. 53-62.

${ }^{2363}$ F. GANDOLFO, "Il sarcofago di Saint-Hilaire d'Aude...", pp. 425-437.

${ }^{2364}$ A. BONNERY, "Le sarcophage de Saint-Saturnin...", p. 100.
} 
hubiera formado parte, en realidad, del altar de mayor de la cabecera, a pesar de que, actualmente, se encuentre reutilizada como altar en un ábside del edificio donde se custodia. Tal hipótesis convertiría el sarcófago románico en una auténtica tumbarelicario, pero con funciones de mensa, siguiendo una tradición paleocristiana bien conocida, mediante la cual, este tipo de piezas, servían como altar en el que desarrollar diferentes oficios litúrgicos ${ }^{2365}$.

La tradición de concebir los altares en forma de sarcófagos para practicar el oficio sobre las cubiertas o tapas, tiene otros paralelos que se pueden relacionar con la solución aquí adoptada ${ }^{2366}$. En su día, M. Vallery-Radot citó, en relación con la escultura de Cabestany, un ejemplo conservado en la capilla de Saint-Serenus de Marseille. Aquella pieza había sido decorada con bajo relieves y, posiblemente, también debió tener funciones de $m e n s a^{2367}$.

Un paralelo similar, aunque muy tardío, lo hallamos en la catedral de SaintTrophime de Arles. Tras diversas remodelaciones, documentadas en el año 1819, un sarcófago paleocristiano, datado en torno al año 340 d. de C., acabaría formando la base para una pieza, ahora concebida como altar y sobre la que se asentaron dos columnas de orden corintio que, asimismo, permiten la elevación de un entablamento posterior que enmarca conjunto $^{2368}$.

Además de ello, los sarcófagos paleocristianos serían la fuente para otros aspectos de la pieza románica. El frente y los laterales del sepulcro presentan todo un desarrollo iconográfico que la relaciona, formalmente, con la tradición escultórica tardoantigua. En concreto, debido a su proximidad geográfica, se ha hablado de la escuela de Arles, de ciertas esculturas de Narbonne y, sobre todo, de aquellas conservadas en Gerona ${ }^{2369}$. En todos estos ámbitos geográficos se observan experiencias plásticas que muestran posibles modelos inspiradores.

\footnotetext{
2365 Ibidem, p. 101.

${ }^{2366}$ H. FOCILLON, La escultura románica..., pp. 69-76. Focillon ya abordaba algunas cuestiones relativas a la configuración del modelo de sarcófago cristiano a partir de la herencia romana. En concreto, aludía al sarcófago de Melfi custodiado en Napoli, Museo Archeologico Nazionale. Se trata de una obra del siglo II. d. C que, decorada mediante arquerías, le sirvió para explicar la contaminación ejercida entre obras paganas y cristianas de este tipo.

2367 J. VALLERY-RADOT, "Les dates des autels de la Major de Marseille et de Saint-Guilhem-leDésert", Gazette de Beaux-Arts, 1938, pp. 73-80.

2368 J.-P. CAILLET y H. N. LOOSE, Op. cit., pp. 7-8. Los autores señalaban que se trata de una pieza realizada en mármol, posiblemente, griego o del Proconeso y que fue recuperado alrededor del año 1724 de la necrópolis de Arles.

2369 S. MORALEJO ÁLVAREZ, "Modelo, copia...”, pp. 99-100. El investigador insistía en los ejemplares de la iglesia de San Félix de Gerona que "proporcionaron a Cabestany la fuente de su personalísima formosa deformitas con trascendencia de la misma Italia".
} 
Este tipo de sarcófagos tardoantiguos, datados entre los siglos II al IV d. de C. ofrecen, aunque sea de manera muy diluida, una mínima muestra del panorama real que debió existir ante los ojos de los creadores medievales. Es por ello, que no resulta extraño poder establecer una dependencia directa de la pieza conservada en la iglesia de Saint-Hilaire y otra serie de sarcófagos de cronología antigua.

En relación con estos temas, tal y como señalara en su día M. Durliat, la obra fue considerada propiamente romana en una época anterior al siglo XIX ${ }^{2370}$. Las claras concomitancias respecto a las tipologías de sarcófagos que muestra la obra del "maestro" de Cabestany y, sobre todo, los parentescos con las diferentes técnicas utilizadas por los escultores bajoimperiales, justifican claramente que, durante mucho tiempo, la obra fuese considerada un mero pastiche falsario ${ }^{2371}$.

Desde el punto de vista estilístico, M. Durliat señaló toda una serie de rasgos fácilmente explicables a través del contacto del escultor con piezas romanas. Resulta extremadamente evidente la importancia que adquieren aquí los planos del relieve, así como el interés por captar la profundidad del espacio mediante la colocación de ciertas figuras en isocefalia. Parece más que factible que, a través del análisis de este tipo de elementos formales, se pueda desprender una admiración de las piezas clásicas. Fue así, según creemos, cómo el escultor llegó a desarrollar un dominio y cierta predilección por la utilización del trepano, que aplica de manera reiterativa sobre ciertas partes de las esculturas. Sin duda, el prototipo del diseño ocular, de forma almendrada, con el uso del punzón en los bordes exteriores parece tener referentes bien claros dentro de la escultura antigua $^{2372}$ (fig. 464). En concreto, se trata de un recurso habitual dentro de las obras del

\footnotetext{
${ }^{2370}$ M. DURLIAT, La sculpture romane en Roussillon..., vol. IV, p. 29 y pp. 30-34. El autor expone las diferentes teorías, en relación con las reliquias, para las que fue esculpida la pieza, así como otra serie de problemas complejos que relacionan la misma abadía de Saint-Hilaire de Carcassonne, con el monasterio de San Miguel de Cuxa, por citar alguna de las cuestiones que aborda.

Sus conclusiones complican más los datos seguros que tenemos sobre la pieza. Parece ser, según afirma, que las reliquias de San Hilario habían sido colocadas en una tumba datada en el siglo X, mientras que, las de San Saturnino, debían permanecer, en el momento de la realización del sarcófago, aún enterradas, pues se tiene constancia de que, tan sólo fueron exhumadas en el año 1345.

Véase igualmente: O. POISSON, "Un sculpteur anonyme...", p. 15. El hecho de que algunas esculturas románicas de filiación "antiquizante" fueran consideradas por los eruditos y estudiosos de épocas pasadas como productos romanos y renacentistas, fue algo habitual. Recuérdese, por ejemplo el caso de las magnificas columnas de tema vegetal procedentes de la abadía de Saint-Denis de Paris y a las que ya nos hemos referido. Las piezas, datadas entre la campaña decorativa de los años 1137 y 1140, fueron consideradas, durante mucho tiempo, modernas. Véase, sobre estas esculturas: X. DECTOT, "Columna con decoración de roleos habitados", El románico y el Mediterráneo. Cataluña, Toulouse y Pisa. 11201180 (M. A. Castiñeiras González y J. Camps ed.), Barcelona, 2008, ficha catalográfica 28, pp. 268-269.

${ }^{2371}$ M. DURLIAT, La sculpture romane en Roussillon..., vol. IV, p. 29.

${ }^{2372}$ O. POISSON, “Un sculpteur anonyme...", pp. 7-12. Se señala que esta manera de representar los ojos de las figuras es una característica típicamente habitual de la escultura del "maestro". Insiste en la
} 
bajo imperio, caracterizadas por las profundas incisiones realizadas con este utensilio que acaban ofreciendo ciertos tonos de abstracción expresionista a las figuras ${ }^{2373}$.

Los estudios de los diferentes autores han buscado concretar, de una manera $\mathrm{u}$ otra, las piezas que, de forma más evidente, pudieron haber ejercido su influencia sobre este relicario-altar. Generalmente, se han venido citando, de manera reiterativa, los sarcófagos de la Narbonensis y los conservados en Gerona ${ }^{2374}$. De las piezas halladas en estos lugares resulta de especial importancia que las cistas presenten el típico desarrollo compositivo de las escenas a modo de friso ${ }^{2375}$. Ejemplos como el sarcófago de la caza del león de la iglesia de San Félix de Gerona podrían explicar la organización y distribución en friso que presentan algunos ejemplos atribuidos al "maestro" de Cabestany ${ }^{2376}$ (fig. 465).

La narración en banda, típica de los sarcófagos romanos reaparece, claramente, reproducida en esta pieza de pequeño formato, sin embargo, la volveremos a encontrar desarrollada de una manera monumental en el friso que recorre la parte alta de la iglesia del Voló (Languedoc-Roussillon) donde, nuevamente, se repite el prototipo compositivo $^{2377}$ (fig. 466). Aún así, resulta llamativo este tipo de ordenación de la escultura en una fachada ya que, según se ha señalado, es una solución extraña, tanto en el Laguedoc como en Cataluña ${ }^{2378}$.

importancia del trabajo mediante el trepano dentro de su obra, claramente, deudor de la escultura romana del bajoimperio.

${ }^{2373}$ M. BOCATTI, "Industria...”, pp. 59-60. Se cita, en concreto, la lastra de Pretestato del siglo III y ciertas producciones de la órbita temporal que va desde el emperador Diocleciano hasta Constantino.

${ }^{2374}$ I. RODÀ, "Producción...”, pp. 63-63.

2375 S. MORALEJO ÁLVAREZ, "Modelo, copia...", p. 100. El especialista aludía también a otros centros, como Toulouse y el Languedoc mediterráneo, así como la Toscana. Véase también: F. ESPAÑOL BERTRÁN, "Le sépulcre...", p. 184. La autora insiste en el prestigio de los mármoles durante la época románica, aludiendo al ejemplo del sarcófago de Saint-Hilaire.

${ }^{2376}$ A. BONNERY, "Le sarcophage...", p. 106. Se insiste en la importancia de esta pieza de Gerona, datada en el siglo II. Sobre todo, habla de la relación entre la figura del león perseguido por el cazador en la pieza romana y su recuerdo en la figura del toro del sarcófago románico. Los sarcófagos de la iglesia de San Félix ya habían sido utilizados por S. Moralejo a la hora de explicar ciertos rasgos clásicos de los capiteles, también relacionados con la figura de Cabestany, de la iglesia de San Pedro de Galligans. En concreto, aludía al ejemplo del Cristo Víctor de una de las piezas datadas en el siglo IV. Sobre ello, véase: S. MORALEJO ÁLVAREZ, "La Reutilización...”, pp. 197-203; ID., "Modelo, copia...”, pp. 89-112 y J. CAMPS I SÒRIA e I. LORÉS I OTZET, "Sant Pere de Galligants", Le Maître..., pp. 28-31.

${ }^{2377}$ F. SAUNIER, "Le portail de Sainte-Marie du Boulou (El Voló)", Le Maître..., pp. 88-99. Se trata del friso superior que enmarca la puerta occidental del edificio. Fue realizado en mármol blanco de Céret y desarrolla un amplio programa iconográfico relativo a la infancia de Cristo. Sobre dicha obra, consúltese también: P. PONSICH, voz "El Voló", Catalunya romànica..., vol. XIV, Barcelona, 1993, pp. 452-455. El autor relaciona este friso, desde el punto de vista estilístico, con algunos de los canecillos de la iglesia de San Papoul, la escultura de la iglesia de Cornellà de Conflent y la galería del claustro de Elna, datada entre los años 1175 y 1180.

${ }^{2378}$ M. DURLIAT, La sculpture romane en Roussillon..., vol. IV, p. 12. Durliat señalaba, igualmente, que se trata de una solución poco frecuente dentro de los trabajos tradicionales de los talleres del 
Debemos recordar no en vano que, en los ejemplos escultóricos analizados en el primer bloque de este estudio, se había seguido una solución lejanamente parecida en la iglesia del castillo de Loarre (fig. 409). Allí, nuevamente sobre la puerta, fue colocado un friso con diversos personajes en torno a la imagen de la Maiestas y para el que también se citaron algunas fuentes "antiquizantes",2379.

Lo más interesante en cuanto al manejo de estas soluciones por parte de dos escultores diferentes, separados desde un punto de vista cronológico y geográfico, es la posibilidad de remarcar que ambos llegan a fórmulas, ciertamente equiparables, a través de la utilización de unas posibles fuentes comunes. El conocimiento de la escultura en friso de tipo romano puede explicar, igualmente, algunas de las particularidades iconografías presentes en el friso de Loarre, claramente, emparentado con la tradición estilística y, sobre todo, iconográfica, de la catedral de Jaca ${ }^{2380}$. Allí analizamos detenidamente el capitel en el que dos personajes desnudos danzaban entre diversas olas acuáticas que parecían confundirse con piezas textiles. En el caso de Loarre, la iconografía seguía muy de cerca el capitel de Igúacel, donde los personajes parecían sujetar dichos textiles ondulantes ${ }^{2381}$ (fig. 408).

Lo que pretendemos señalar es que, dos artífices, en cierta manera inconexos y de cronologías bien diferentes, llegan a soluciones parecidas a través de un hipotético contacto con los sarcófagos conservados desde época romana. En ambos casos, tanto en la iconografía nacida en la órbita del movimiento de Jaca, como en la atribuida al "maestro" de Cabestany, el prototipo clásico les aporta una base para desarrollar sus propias variaciones sobre un mismo tema. Aunque en ambos ejemplos la pieza romana concreta que los inspiró esté perdida ${ }^{2382}$.

Los perfiles clásicos que muestra este tipo de escultura hacen necesaria una discriminación de los motivos. En este sentido, la presencia del tema de la imago clipeata en algunas de sus variantes más estandarizadas dentro del corpus de obras

Rosellón. Véase también: P. PONSICH, voz "Santa Maria del Voló", Catalunya Romànica..., vol. XIV, pp. 452-455, en concreto, p. 453.

${ }^{2379}$ F. ESPAÑOL BERTRÁN, "El castillo de Loarre...”, pp. 7-18.

${ }^{2380}$ Sobre los diferentes sistemas narrativos mediante la distribución de las imágenes en el arte romano y su traspaso a la plástica cristiana, véase: A. GRABAR, Las vías de la creación..., p. 85 y M. TORRES CARRO, "El tiempo representado...", pp. 101-102.

${ }^{2381}$ F. SAUNIER, "Le portail de Sainte-Marie du Boulou...", p. 98. El especialista llama también la atención sobre el friso de Loarre y su relación con este portal, conectado con el "maestro" de Cabestany. Véase también: F. ESPAÑOL BERTRÁN, "El castillo de Loarre...", pp. 7-18. En este caso, la autora, aporta toda una serie de argumentos que explican la iconografía del friso, incluida la de los personajes entre nubes, agua o telas, según las versiones de los diferentes autores.

${ }^{2382}$ Esto es lo que deducimos al no haber encontrado ningún modelo concreto con las suficientes concomitancias que permita ser comparado con estas obras románicas. 
relacionadas con el "maestro", permite obtener otra serie de conclusiones. Su frecuente aparición dentro de la escultura románica no debe ser ligada, de manera inercial, con prototipos clásicos. Sin embargo, llama la atención como el tema había logrado adquirir cierta importancia dentro de la escultura heredera de lo clásico desarrollada entre los años 1090 y 1120 .

El hecho de que dentro de la iconografía del "maestro" vuelvan a aparecer este tipo de figuras elevadas por ángeles dentro de mandorlas o, en su variante más clásica, a través de clípeos, habla del uso de fuentes comunes y de cierto apego a las fórmulas del pasado.

Uno de los ejemplos más significativos lo ofrece el capitel de la iglesia de Sainte-Marie Rieux-Minervois ${ }^{2383}$ (fig. 467). De los catorce capiteles estudiados en relación con la figura del "maestro" de Cabestany destaca, sobre todo, la utilización de este prototipo iconográfico de la Asunción de la Virgen María. Se trata de una composición figurativa distribuida alrededor de tal elemento que, a su vez, es elevado al cielo por cuatro ángeles. Lo más destacable de la pieza, más allá de ciertos detalles iconográficos, es la presencia, nuevamente, dentro del repertorio de un taller de resabios "antiquizantes", de este tema que se había desarrollado ampliamente en el seno de la escultura de la primera mitad del siglo $\mathrm{XII}^{2384}$. Los ejemplares presentes en la catedral de Jaca, allí en forma de clípeo, así como en la iglesia de Loarre, tal vez, por derivación de este tipo, permiten insistir en una posible derivación de fuentes clásicas. En concreto, se suele mencionar el prototipo presente en el sarcófago de San Pedro el Viejo de Huesca (fig. 164) ${ }^{2385}$.

La primera mitad de siglo había ofrecido modelos ligados a las artes funerarias, tal y como se puede observar en el sarcófago de doña Sancha de Jaca (fig. 359) ${ }^{2386}$. Allí, el personaje inscrito en la mandorla aparecía desnudo, formando parte de un nutrido

\footnotetext{
${ }^{2383}$ La iglesia, datada en el siglo XII, se consagró a la Asunción de María. Sigue una ordenación de planta central, aunque su estructura primitiva se vio alterada por reformas posteriores. Se trata de un ejemplo bien claro donde la arquitectura se complementa, extraordinariamente, con la escultura, dotando a cada parte de un simbolismo bien claro y marcado. Sobre ella, véase: A. BONNERY, "L'église SainteMarie...", pp. 32-45; ID., "L'église de Rieux-Minervois. Dimension symbolique de l'architecture et sculpture", Les Cahiers de Saint-Michel de Cuixa, 25, 1994, pp. 13-30 y G. HIDRIO, "L'église de RieuxMinervois: Marie et les sept colonnes de la Sagesse dans l'iconographie médiévale", Les Cahiers de Saint-Michel de Cuixa, XXV, 1994, pp. 87-97. En este último estudio se somete a una lectura iconográfica diversos elementos arquitectónicos del templo en relación con la iconografía de la Asunción de la Virgen y el motivo arquitectónico de la Domus Sapientiae, materializado, según la citada especialista, bajo la forma de tholos que presenta el templo.

${ }^{2384}$ M. DURLIAT, "Les origines...", p. 361. Se insistía en su presencia dentro de la escultura ligada a Moissac y Toulouse durante los primeros años del siglo XII.

${ }^{2385}$ S. MORALEJO ÁLVAREZ, "La reutilización...”, pp. 130-131.

${ }^{2386}$ Ibidem, p. 196. El autor nuevamente relacionaba este sarcófago con modelos clásicos.
} 
corpus de obras de una cronología similar en las que se volvería a repetir el modelo, más o menos reinterpretado. Los ejemplos del capitel de San Isidoro de León y el conservado sobre la puerta de acceso de la iglesia de Santa María del Mercado, en la misma localidad, ya fueron estudiados en su momento en relación con su posible relación con las fuentes clásicas. Por último, se debe citar la presencia, en la puerta meridional del templo dedicado a San Isidoro, de la imagen del clípeo elevado por ángeles que, en ocasiones, ha sido enlazada con diversas fórmulas romanas, pero de las cuales no se ha podido señalar, por el momento, el modelo original que la podría haber inspirado $^{2387}$ (fig. 436).

La utilización del clípeo o, en su defecto, de la mandorla elevada por los ángeles como lugar idóneo para colocar aquella imagen a exaltar pasaría, de manera completa, a la iglesia de Santa Marta de Tera donde se repite el modelo, allí con una figura femenina desnuda ${ }^{2388}$ (fig. 323).

El tipo iconográfico permite establecer ciertas relaciones entre talleres dispares $\mathrm{y}$, sobre todo, atestiguar una continuidad en el uso de determinados temas de la tradición clásica. Con todo, lejos de ser un elemento extraño a la iconografía románica, tampoco sería infrecuente dentro de las esculturas relacionadas con el "maestro" de Cabestany, ya que lo volvemos a encontrar en la pieza más conocida a él atribuida.

En el tímpano de la iglesia de Santa María de Cabestany (fig. 455), volvemos a observar esta composición de ángeles que elevan el cuerpo muerto de María, en mandorla, dentro de una escena de glorificación ${ }^{2389}$. Evidentemente, no se debe confundir la solución del clípeo con aquella de la mandorla, pues es sobradamente conocido que se trata de fórmulas diferentes. Sin embargo, los sistemas de distribución de las figuras en las escenas y la articulación de lo compositivo a su alrededor persiguen, por lo general, fines semejantes.

De la misma manera que en San Isidoro de León se ofrecía la imagen de los ángeles elevando la imagen del Agnus Dei dentro de un tondo o que en la catedral de Jaca una figura masculina se circunscribía al clípeo, siguiendo iguales soluciones antiguas, dentro de las esculturas adscritas a la órbita del "maestro", podemos constatar

\footnotetext{
${ }^{2387}$ J. WILLIAMS, “Generationes Abrahae...”, pp. 173-174 y F. PRADO-VILAR, “Saevum facinus...”, pp. 188-190.

${ }^{2388}$ No recogemos en este punto la bibliografía referida a estas piezas por haberlo hecho ya en el apartado en el que las hemos analizado.

${ }^{2389}$ F. SAUNIER, "Le tympan de Cabestany...", p. 52; M. DURLIAT, "Le Maître...”, pp. 116-117 y O. POISSON, "Tímpano de Cabestany...", pp. 336-337.
} 
una explotación de estas soluciones antiguas. En concreto, llama la atención su utilización en el dintel procedente de Errondo, en Navarra ${ }^{2390}$ (fig. 468).

En dicha pieza se esculpieron dos ángeles en las partes extremas y, otros dos, en la central, que agarran con sus manos un tondo en el que aparece la figura del Cordero. Sobre el animal, se superpuso un crismón en el que se observan, claramente, el alfa y la omega. Tal y como vemos se trata de símbolos todos ellos pertenecientes a la tradición paleocristiana de ascendencia romana y que, nuevamente, se vuelven a convertir en elementos continuadores de una tradición anterior.

En su día, el profesor M. Durliat aludió a la posible deuda de estas imágenes con respecto a las producciones artísticas de la escultura conservada en la región de los Pirineos Occidentales ${ }^{2391}$; mientras que, otros autores, defendieron la frecuencia del tema y su utilización dentro de un marco cronológico lo suficientemente amplio que, más bien, cabría hablar de una iconografía uniforme a todos los territorios de la Europa románica $^{2392}$.

El modelo directo con el que se ha emparentado esta escultura es la clave de una arquivolta conservada en el Museo Federico Marès de Barcelona y que proviene de la

\footnotetext{
${ }^{2390}$ New York, Metropolitan Museum of Art. The Cloisters. Cf.: G. MALLET, "Le tympan et le linteau d'Errondo (Navarre) conservés au Musée des Cloisters à New York", Le Maître..., pp. 165-168. Las piezas, hoy descontextualizadas de su lugar original, se han venido relacionando con la localidad de Errondo, cerca de Unciti. En la actualidad, se duda mucho de la unidad compositiva que, durante mucho tiempo, se defendió para el tímpano de las tentaciones y el dintel, sobre todo, debido a la descompensación de medidas existentes entre ambas esculturas.

También consúltese: D. OCÓN ALONSO, "Errondo: iglesia parroquial (hoy en The Cloisters; New York), Tímpanos románicos..., vol. I, pp. 185-186; ID., "Tímpano de Errondo", El románico y el Mediterráneo. Cataluña, Toulouse y Pisa. 1120-1180, (M. A. Castiñeiras González y J. Camps ed.), Barcelona, 2008, ficha catalográfica 80, pp. 356-357 y D. L. SIMON, "Romanesque Art in American Collections. XXI. The Metropolitan Museum of Art. Part I: Spain”, Gesta, XXIII/2, 1984, pp. 145-159, especialmente, p. 153.

${ }^{2391}$ M. DURLIAT, "Le Maître...", p. 124. Sobre la difusión del tema en el sudoeste francés y la zona de Arlés, véase: X. DECTOT, Pierres tumbales, pp. 18-19.

${ }^{2392}$ J. A. MORÁIS MORÁN, "Imitación, copia...", (en prensa). Se señala la importancia que tuvo la iconografía del clípeo elevado por ángeles, sobre todo, en relación con el tímpano del Cordero de San Isidoro de León. El modelo, finalmente convertido en arquetipo, acabaría por imitarse en dos obras provincianas, en una fecha muy tardía del siglo XII o, incluso, los primeros años del XIII. Se trata de los tímpanos de Ruiforco y Matueca de Torio de León, claros representantes de esta continuidad de tradiciones y de la perdurabilidad de la composición iconográfica de la imago clipeata. Desde el ámbito tolosano, la composición a través del clípeo elevado por ángeles había sido un elemento fundamental en la composición de la mesa de altar firmada por Guilduino en el año 1096. Las fuentes mediante las que se ha venido explicando esta pieza, nuevamente, se han relacionado con fórmulas clásicas. Sobre ello, véase también: M. DURLIAT, La sculpture romane de la route..., pp. 104-106.

En el claustro de Moissac la fórmula se utilizó para decorar algunos cimacios, apareciendo los dos ángeles elevando el clípeo sobre el que se inscribió también un Cordero. El motivo habría de tener gran difusión en otras artes, tales como la pintura. Los ángeles sujetando el clípeo, en el que se inscribe dicho animal, aparecen en gran cantidad de pinturas murales que van, desde la perfecta adecuación al marco de la escena del Panteón de San Isidoro de León, hasta ejemplos más modestos, de la parte oriental de la Península como, por ejemplo, el que encontramos en la iglesia de Santa María de Riquer. Cf.: P. PONSICH, "Santa Maria de Riquer", Catalunya Romànica..., vol. VIII, Barcelona, 1995, pp. 309-310.
} 
iglesia de San Pedro de Rodas (fig. 469). Según se ha venido manteniendo, el "maestro" de Cabestany o algún escultor emparentado con su figura, podría haber realizado esta figura del Cordero con el lábaro ${ }^{2393}$.

Se trata de una imagen bien conocida en el ámbito oriental de la Península Ibérica, sobre todo, en la zona catalana ${ }^{2394}$. Sin pretender hacer, en ningún caso, una historia detallada de la utilización del motivo en estos territorios, durante las últimas décadas del siglo XII, cabe destacar algunos ejemplos bien significativos, que reafirman la difusión del tema, por una parte y, en algunos casos, sus dependencias con respecto a la escultura paleocristiana.

Datada a finales del siglo XII, la iglesia de Santa María de Sant Feliu d'Amunt (Languedoc-Roussillon), presenta un tímpano de mármol en el que se esculpieron dos ángeles sustentando un clípeo que muestra inscrita, nuevamente, la imagen del Cordero $^{2395}$. En el mismo sentido, debe señalarse el clípeo del tímpano de la iglesia de San Pedro de Navata (Gerona) donde, el Agnus Dei sujetando el lábaro, reafirma la utilización del tema dentro de la escultura monumental catalana. Finalmente, se ha señalado un caso más dudoso. Se trata del fragmento conservado en el Museo Episcopal de Vic que, a pesar de su deteriorado estado, pudo tener, originariamente, una forma semicircular que ha permitido suponer su función como tímpano ${ }^{2396}$.

Tal y como hemos insistido anteriormente, los datos conocidos sobre la ubicación original de los diferentes fragmentos que han llegado hasta nosotros de la portada occidental de San Pedro de Rodas son problemáticos. Sin embargo, para el caso del relieve del Cordero, supuestamente esculpido por el "maestro" de Cabestany, se ha tomado como referente la ubicación que dicha imagen tuvo en otros edificios del ámbito catalán. En este sentido, la portada de Santa María de Ripoll presenta la misma imagen en la clave central de una de las arquivoltas, hecho que permite imaginar una función parecida para esta pieza ${ }^{2397}$.

${ }^{2393}$ J. CAMPS I SÒRIA, voz "Relleu figurat 1 de Sant Pere de Rodes", Catalunya romànica..., vol. XXIII, pp. 309-310 y J. CAMPS I SÒRIA e I. LORÉS I OTZET, "Le portail de Sant Pere de Rodes....", pp. 122-123. En particular, cuando J. Camps analiza la iconografía de esta pieza cita a colación el tímpano del Cordero de la basílica de San Isidoro, lo que implica, hasta cierto punto, poder hablar de una continuidad en el uso del tema que, por otra parte, fue general al románico.

${ }^{2394}$ I. RODÀ, "Producción...", p. 64.

${ }^{2395}$ M. DURLIAT, voz "Sant Feliu d'Amunt", Catalunya Romànica..., vol. XIV, Barcelona, 1993, pp. 348-351.

${ }^{2396}$ J. VIGUÉ I VIÑAS, voz “Relleu figurat 9”, Catalunya romànica..., vol. XXII, Barcelona, 1986, p. 26.

${ }^{2397}$ J. CAMPS I SÒRIA, voz "Sant Pere de Navata", Catalunya romànica..., vol. IX, Barcelona, 1990, pp. 575-579 y J. CAMPS I SÒRIA e I. LORÉS I OTZET, "L'escultura de Sant Pere de Rodes", Catalunya Romànica..., vol. IX, Barcelona, 1990, pp. 703-728, en concreto, p. 715. En estos estudios se analiza la 
La ductilidad del tema, a la hora de adaptarse a los ámbitos de la más diversa índole, hace posible que encontremos el motivo iconográfico esculpido sobre una pieza funeraria. Se trata de un sarcófago datado a finales del siglo XII o principios del XIII y proveniente de la iglesia de Santa María de Gualter, en Noguera (La Baronia de Rialb, Lérida). En su cista aparece, nuevamente, el clípeo con el Agnus Dei, acompañado de otros motivos que ofrecen un referente más a la hora de defender su proveniencia con respecto a las obras datadas dentro del primer arte cristiano de tipo funerario.

Lo más destacable al respecto es el parentesco iconográfico que se ha realizado de esta pieza medieval con respecto a otro sarcófago, este antiguo y conservado en el exterior de la iglesia de San Félix de Gerona y donde, de nuevo, se esculpió la imagen del Cordero ${ }^{2398}$.

La perdurabilidad de la utilización del clípeo y la mandorla dentro de las producciones románicas se justifica, simplemente, por el uso arquetípico que se hizo de este icono, derivado, en ocasiones, de prototipos antiguos $\mathrm{y}$, en otras, simplemente difundido a través de su manejo inercial por los artífices románicos. Llama especialmente la atención que el círculo del "maestro" conociese bien este tipo de fórmula, tanto para mostrar la resurrección y la asunción de diferentes personajes, como para circunscribir otra serie de elementos, tales como el Cordero o un crismón ${ }^{2399}$.

Es por ello que resulta complejo demostrar las fuentes de las que los artistas pudieron tomar este motivo de la imago clipeata y su variante en forma de mandorla ${ }^{2400}$. Recordemos al respecto que, aún en el siglo XIII, un sarcófago conservado en la iglesia de San Félix de Gerona reproducía la misma estructura e iconografía que un sarcófago romano, mostrando la glorificación del Cordero a través de la imagen de unos ángeles

pieza junto con otras obras atribuidas al "maestro" de Cabestany datándola, en la segunda mitad del siglo XII.

${ }^{2398}$ Urgell, Museu Diocesà. Cf.: J. CAMPS I SÒRIA, voz "Sarcòfag”, Catalunya romànica..., vol. XXIII, Barcelona, 1986, p. 212 y M. CLAVERIA, "La reutilización...”, p. 245. Esta autora relaciona estas piezas de Gerona con la escultura románica del "maestro" de Cabestany.

${ }^{2399}$ D. OCÓN ALONSO, "Problemática del crismón...”, p. 244.

${ }^{2400}$ Generalmente, se ha aludido a otras piezas esculpidas. Sin embargo, para el caso de la escultura con el mismo tema, realizada en el ámbito del reino castellano-leonés, las fuentes parecen ir más allá. Véase, en relación con ello: J. A. MORÁIS MORÁN, "Imitación, copia...", (en prensa). Hemos señalado el posible parentesco entre algunas piezas orfebres como, por ejemplo, la patena de la iglesia de Santiago de Peñalba con respecto a los tímpanos de San Isidoro de León, Ruiforco y Matueca de Torio. Para el caso catalán, entre los muchos ejemplos posibles, aludimos a la cruz de San Félix de Bagergue, en el Valle de Arán. La pieza se conserva en el Museo Federic Marès y se ha datado en el siglo XII. En el dorso de la pieza de metal se utilizó el nudo para colocar un clípeo en el que se inscribió la imagen del Agnus Dei. Sobre la obra, véase: R. BASTARDES I PARERA, voz "Creu de Bagergue", Catalunya romànica..., vol. XXIII, pp. 351-352. La misma posición ocupa el Cordero, esta vez pintado, en la cruz de procedencia desconocida conservada en el Museo Episcopal de Vic y que también se ha datado a finales del siglo XII. Cf.: M. G. SALVÀ I PICÓ, voz “Creu”, Catalunya romànica..., vol. XXII, pp. 192-193. 
elevándolo en clípeo hacia el cielo (fig. 347). Según ha señalado M. Cruz Villalón, se trata, posiblemente, de una obra de raíces clásicas que demuestra la continuidad de tradiciones artísticas romanas, incluso más allá de la misma disolución del románico ${ }^{2401}$.

Lo que si parece concluyente es que, de la misma forma que se ha podido demostrar, de una manera segura, la reutilización física de las piezas antiguas dentro de la obra del "maestro", también parece que, los ejemplos antes aludidos, responden claramente a una asimilación intelectual de este tipo de piezas ${ }^{2402}$. Las esculturas clásicas debieron servir a estos escultores de objeto de inspiración sobre el que basarse para generar sus nuevas creaciones.

Un fenómeno similar se percibe a la hora de analizar la utilización del capitel corintio de tradición romana dentro de este tipo de escultura. A lo largo de este trabajo se insistió en el traspaso de dicha tipología hacia los siglos medievales, así como en el enriquecimiento del tipo a través de una larga serie de variantes del mismo, gracias, en parte, a la introducción de figuras de diversa índole en las cestas ${ }^{2403}$.

Desde los inicios de la plástica altomedieval el capitel corintio ya había gozado de gran difusión, utilizándose, en algunas construcciones, como referente de prestigio y alusión al mundo antiguo ${ }^{2404}$. En el caso de la escultura desarrollada a finales del siglo XI y la primera mitad del XII, se señaló el interés por reproducir este orden de la arquitectura romana, a pesar de que, tal tarea, se lograse de manera desigual en los territorios de Hispania ${ }^{2405}$.

Así, sabemos con seguridad que, en las etapas anteriores al año mil, diversas construcciones datadas entre los siglos VIII al X, habían utilizado determinadas piezas de reempleo, rescatadas, en muchos casos, de los edificios romanos en estado de

${ }^{2401}$ M. CRUZ VILLALÓN, “Quintanilla de las Viñas en el contexto...”, pp. 101-135, en concreto, p. 120 e ID., "Quintanilla de las Viñas y el arte cordobés...", pp. 341-349. La investigadora señala la importancia de los dinteles de Saint Genis-des-Fonts o Saint-André-de-Surede, a la hora de marcar el itinerario iconográfico de esta imagen en la escultura románica. El sarcófago de la iglesia de San Félix de Gerona es un ejemplo retardatario que habla de la perdurabilidad de estas fuentes, sobre todo, en un ámbito tan importante para el estudio de la obra del "maestro" como fue éste.

${ }^{2402}$ M. CLAVERIA, "La reutilización...”, p. 244 e ID., "El sarcófago...", p. 25.

${ }^{2403}$ E. VERGNOLLE, Saint-Benoît-sur-Loire..., pp. 246-247.

${ }^{2404}$ Remitimos al apartado de este estudio donde se abordó la pervivencia del capitel corintio en los siglos medievales.

${ }^{2405}$ I. LORÉS I OTZET, "L'église de Sant Pere de Rodes...", pp. 34-35. Véase, igualmente, la importancia prestada a diversas piezas corintias romanas como configuradoras del prototipo de capitel medieval en: J. A. REMOLA, "Capitel corintio de la antigua Tarraco", El románico y el Mediterráneo. Cataluña, Toulouse y Pisa. 1120-1180 (M. A. Castiñeiras González y J. Camps ed.), Barcelona, 2008, ficha catalográfica 81, pp. 358-359 y J. DURAN-PORTA, "Capitel de Santa María de Ripoll", El románico y el Mediterráneo. Cataluña, Toulouse y Pisa. 1120-1180 (M. A. Castiñeiras González y J. Camps ed.), Barcelona, 2008, ficha catalográfica 82, pp. 360-361. 
ruina $^{2406}$. Sorprendentemente, la expoliación de capiteles dentro de la arquitectura románica hispana fue menos habitual, pudiéndose señalar, al respecto, muy pocos ejemplos seguros.

En el caso concreto que ahora estudiamos, parece que los artesanos ligados al "maestro" de Cabestany otorgaron un fuerte valor a la utilización del capitel corintio. En sus obras parece que cobró una fuerza destacable continuando, en cierta medida, el interés que, durante la etapa primera del siglo XII, había tenido en otros focos escultóricos, donde su utilización nunca cesó ${ }^{2407}$.

En el último estudio realizado por A. Bonnery sobre la escultura de la iglesia de Sainte-Marie de Rieux-Minervois, a la hora de analizar la escultura vegetal de los capiteles, el autor realizaba una división de tipo estilístico (fig. 470). El investigador llevaba a cabo un agrupamiento de los capiteles a través de diversos grupos que él mismo consideraba como pertenecientes a un "estilo pseudo-clásico", a un "estilo florido" o a un "estilo depurado",2408.

Esta distinción entre los capiteles se regía por el grado de aproximación formal al capitel corintio romano que, el citado autor, consideraba como el modelo original que se intentó seguir. Las piezas esculpidas para la iglesia revelan un profundo conocimiento de esta tradición, en la que se puede conjeturar con la posibilidad de que, los artífices, hubieran realizado un análisis de alguna pieza romana a la hora de concebir sus propias obras. A través del estudio de algunas de ellas, es posible afirmar que, se trataría de una visión, casi de índole "arqueológica", si es posible utilizar esta expresión en el sentido con el que, actualmente, lo hacemos ${ }^{2409}$.

En el apartado dedicado a la fortuna del capitel corintio dentro de los templos medievales, habíamos señalado el magnífico ejemplo de San Pedro de Rodas y la complejidad de filiaciones para la escultura de sus piezas ${ }^{2410}$. Aunque el factor islámico

\footnotetext{
${ }^{2406}$ M. L. REAL, “A escultura decorativa em Portugal: o grupo portucalense”, Escultura decorativa tardorromana y altomedieval en la Península Ibérica, Madrid, 2007, pp. 133-170 y M. GUARDIA PONS e I. LORÉS I OTZET, “La escultura tardorromana...”, en concreto, pp. 204-211. En tales aportaciones se analizan diversas piezas y capiteles antiguos reempleados en edificios medievales.

2407 A. MILONE, "Capitel con amorcillos y guirnaldas", El románico y el Mediterráneo. Cataluña, Toulouse y Pisa. 1120-1180 (M. A. Castiñeiras González y J. Camps ed.), Barcelona, 2008, ficha catalográfica 54, pp. 309 e ID., “Taller de Guglielmo (doc. 1158/1159-1165”, El románico y el Mediterráneo. Cataluña, Toulouse y Pisa. 1120-1180 (M. A. Castiñeiras González y J. Camps ed.), Barcelona, 2008, ficha catalográfica 52, p. 307.

${ }^{2408}$ A. BONNERY, "L’église Sainte-Marie...", en concreto, pp. 36-39.

2409 N. DACÓS, "Sopravivenza...", pp. 731-732. Por su parte, el profesor Durliat insistía en las conexiones con la escultura tolosana. Cf.: M. DURLIAT, “Le Maître...”, pp. 120-121.

${ }^{2410}$ P. DE PALOL, "Els precedents de l'art romànic a Catalunya", Catalunya romànica ..., vol. I, pp. 5968 , en concreto, p. 66; X. BARRAL I ALTET, "L'escultura romànica a Catalunya", Catalunya
} 
dominó los estudios durante largo tiempo ${ }^{2411}$, en la actualidad, se ha preferido ver una relación con otros casos, como los bellos ejemplares vegetales de la catedral de SaintPierre de Maguelone y la iglesia de Saint-Jacques de Béziers (ambos en el LanguedocRoussillon), los capiteles "antiquizantes" de la catedral de Carcassonne o la escultura de Sainte-Marie d'Alet (Midi-Pyrénées) (fig. 471). Su alta calidad técnica hace que puedan ser traídos nuevamente a colación, por encontrarse, todos ellos, en la órbita de trabajo de este círculo de artífices ${ }^{2412}$.

Sin embargo, de la misma manera que los capiteles clásicos de San Pedro de Rodas podían ser emparentados con un amplio número de fuentes romanas, de las que los artistas pudieron tomar los modelos, igualmente complejo, resulta aplicar el mismo método sobre las esculturas conservadas del monasterio y atribuidas al "maestro" de Cabestany.

A parte de los ejemplos señalados del templo galo de Rieux-Minervois, dentro de la órbita hispana, y adscritos al entorno de este escultor, encontramos un posible uso de los modelos romanos en algunos capiteles vegetales de la iglesia de San Pedro de Galligants $^{2413}$ (fig. 472).

No es de extrañar que este tratamiento e interés por lo vegetal, así como el parentesco que este tipo de elementos presenta con respecto a la escultura romana fueran relacionados, en su día, con las aras de altar marmóreas de la zona de los Pirineos

romànica..., vol. I, pp. 94-110, en concreto, p. 98. El profesor Barral defendía la tradición clásica del corintio de los capiteles de Rodas, datándolos a finales del siglo X o principios del XI, recordando que, en determinados momentos, se les atribuyó cierta filiación con la escultura cordobesa. Consúltese también: J.-A. ADELL I GISBERT y J. BADIA I HOMS, "San Pere de Rodes", Catalunya Romànica..., vol. IX, Barcelona, 1990, pp. 657-703 y J. CAMPS I SÒRIA e I. LORÉS I OTZET, "L'escultura de Sant Pere de Rodes", Catalunya Romànica..., vol. IX, pp. 703-728. Creemos que uno de los trabajos más importantes, realizado en relación con el estudio de las fórmulas corintias dentro de la escultura de la iglesia, es el publicado en: I. LORÉS I OTZET, El monestir de Sant Pere..., pp. 53-76.

${ }^{2411}$ G. GAILLARD, Premiers essais..., pp. 102-103 y P. DESCHAMPS, Etude sur la Renaissance..., pp. 26-35.

${ }^{2412}$ Ya en el año 1954 M. Durliat llamó la atención sobre la escultura de resabios clásicos que encontramos en estos edificios citados, así como a la posible imitación de estos modelos, por parte del escultor. Insistió, igualmente, en la importancia de contar con los precedentes escultóricos de San Pedro de Rodas y los capiteles de Santa María de Besalú. Señalaba, además, diversas cuestiones históricas, más allá de las artísticas, en relación con la figura de Raimundo Berenguer IV, así como el papel jugado por otros personajes como Guillermo V de Montpellier, que aportarían la prueba histórica que permite relacionar estos territorios. Cf.: M. DURLIAT, La sculpture romane en Roussillon..., vol. IV, pp. 36-37. Para unas aportaciones más recientes, consúltese: O. POISSON, "Un sculpteur anonyme...", p. 12 y A. BONNERY, "Sources de la sculpture romane en Languedoc. Les églises abbatiales de Caunes et d'Alet", Les Cahiers de Saint-Michel de Cuxa, XXIV, 1993, pp. 79-91.

${ }^{2413}$ El foco bien romanizado de Gerona pudo abastecer de modelos de gran calidad a estos escultores. Sobre la cuestión, véase: J. CAMPS I SÒRIA e I. LORÉS I OTZET, “San Pere de Galligants...”, p. 30. 
y el Rosellón ${ }^{2414}$. En ellas, el interés por los motivos vegetales, finamente labrados, se han emparentado también con tradiciones clásicas, si bien esta teoría ha convivido, de manera tradicional, con aquella que defendía su dependencia con lo musulmán ${ }^{2415}$.

Sin embargo, más allá de limitarse a reproducir estos modelos clásicos, el grupo de esculturas que analizamos muestran una gran riqueza, en cuanto a la manera de distribuir los elementos vegetales, dentro de las partes estructurales del edificio. Los ejemplos de la utilización del corintio que hallamos en la iglesia centralizada de Rieux, deben ser analizados teniendo en cuenta los escasos restos fragmentados de la arquivolta de la portada de la abadía de Lagrasse, ya citada.

Se trata de unas piezas finamente labradas en las que se representaron carnosos vegetales de diferentes tipos, de los que surgen algunos frutos de diferente naturaleza (fig. 473). Entre ellos y mostrando unos rasgos de clara ascendencia antigua, se colocaron pequeños rostros, casi a modo de mascarones. Sin duda, entre la amalgama vegetal llama poderosamente la atención la incorporación de una cabeza de rasgos negroides, con el cabello trabajado mediante el trépano y la boca abierta ${ }^{2416}$.

En anteriores apartados hemos insistido en la importancia de estas imágenes, muy difundidas entre las obras clásicas y donde, a través de diversos sistemas decorativos de vegetales, eran insertadas diferentes máscaras, generalmente, emparentadas con el tipo de rostros escénicos. En el caso que nos ocupa, este sistema debe ser vinculado con la pieza marmórea conservada, aún in situ, en la parte baja de la fachada del monasterio de Rodas, donde también se puede observar un mismo interés por el tratamiento de los vegetales y los rostros (fig. 474).

De esta manera, si la dependencia respecto a los talleres marmolistas del Rosellón parece clara, no se debe desdeñar el posible conocimiento de otras fuentes más alejadas geográficamente. Pensamos, especialmente, en el trabajo de los talleres de marmolistas de la ciudad de Roma, sobre todo, aquellos activos en la etapa final del siglo XII. Por citar un ejemplo bien conocido al respecto, recuérdese la decoración de la cornisa superior del claustro de San Giovanni in Laterano. Allí, nuevamente realizadas en mármol, se colocaron diversas máscaras teatralizantes entre una vegetación bien

\footnotetext{
${ }^{2414}$ G. BARRUOL y Y. CODOU, "Le mobilier liturgique", D'un monde à l'autre. Naissance d'une Chrétienté en Provence $I V^{e}-V I^{e}$ siècle (J. Guyon y M. Heijmans ed.), Arles, 2002, pp. 167-176.

${ }^{2415}$ M. DURLIAT, La sculpture romane en Roussillon..., vol. IV, p. 41.

2416 A. BONNERY, "Les sculptures dispersées...", p. 109 y M. DURLIAT, La sculpture romane en Roussillon..., vol. IV, pp. 42-43. Durlilat insistía en las concomitancias con la escultura marmórea del Rosellón, especialmente, los emparentaba, por ejemplo, con varios edificios que ya hemos analizado en este estudio, tales como la portada de la iglesia de Coustouges o Notre-Dame de Llado.
} 
clásica, mostrando una continuidad en la utilización de los modelos de tradición romana que, en el caso de Roma, estaban más presentes, si cabe, que en otros lugares. Según ha señalado P. Cornelius Claussen, este tipo de escultura presenta rostros con tendencia al pathos o al patetismo, con las bocas entreabiertas en actitudes de burla grotesca, derivadas de la iconografía de las máscaras escénicas ${ }^{2417}$.

Desde otro punto de vista, este tipo de decoración vegetal decorando los accesos, señala, de nuevo, el conocimiento de fuentes clásicas. Ejemplos muy conocidos, como las lastras marmóreas decoradas con zarcillos de acanto clásico como los que presentan las famosas puertas del Eumachie de Pompeya (fig. 139), permiten hacer depender la ubicación de las piezas medievales, labradas por el taller relacionado con este "maestro", con el arte de la Antigüedad ${ }^{2418}$.

Esta tradición, que tendrá paralelos, más o menos factibles, en otros edificios del norte de la Península Ibérica, es a la que parece pertenecer el fragmento conservado en Rodas $^{2419}$. A ello sumamos la utilización de elementos decorativos de tradición clásica, tales como las ovas, que permiten defender una perduración de motivos, desde la escultura tardorromana hasta las producciones muebles en piedra de la región y que, finalmente, acabarían siendo absorbidas por el "maestro" de Cabestany, en cuya obra también se introdujo este sistema decorativo antiguo ${ }^{2420}$.

La tradición vegetal que venimos comentando para el fragmento de la abadía de Lagrasse y para la placa inferior de Rodas, pudo tener unas fuentes clásicas. Aunque aún no se haya propuesto un modelo seguro que, hipotéticamente, hubiera sido copiado por los artífices, baste recordar que, el mismo grupo de escultores, había incluido, dentro del despiece de dovelas de la misma portada occidental, diversos restos

\footnotetext{
${ }^{2417}$ P. CORNELIUS CLAUSSEN, "Marmo e splendore...", pp. 193-225. Sin ser una solución idéntica, cabe destacar que se trata de una fórmula no desconocida dentro de la decoración en opus sectile del ámbito medieval romano, sobre todo, muy recurrente en los pavimentos realizados por la familia de artesanos Cosmati, tal y como señala el autor. Sobre esta misma cuestión, véase también: W. TRONZO, "On the role...", p. 1095.

${ }^{2418}$ P. KLEIN, "Les portails de Saint-Genis-des-Fontaines et de Saint-Andre-de-Sorede. I. Le linteau de Saint-Genis", Les Cahiers de Saint-Michel de Cuxa, 1989, XX, pp. 121-160 y J. CAMPS I SÒRIA e I. LORÉS I OTZET, "L'escultura de Sant Pere de Rodes", Catalunya Romànica..., vol. IX, pp. 703-728, en concreto, p. 708. Los autores aluden al caso de Saint-Genis y Surede para explicar la importancia de su escultura, a la hora de poder hablar de las fuentes que pudieron conocer estos escultores en el círculo del "maestro".

${ }^{2419}$ J. CAMPS I SÒRIA, "Le portail de Sant Pere...", p. 121.

${ }^{2420}$ P. BESARAN I RAMON, "Alguns capitells de Sant Pere de Galligants i el Mestre de Cabestany", Estudi General. Girona revisitada. Estudis d'art medieval i modern, 10, 1990, pp. 17-45, en especial, p. 36, nota 63. En concreto, se alude a su uso dentro del cimacio del capitel de la sirena de este templo, comparándola con la imposta de la iglesia de Rodas.
} 
expoliados de la cornisa de un templo romano ${ }^{2421}$ (figs. 458 y 459). El dato despeja cualquier duda sobre el interés y la admiración de estos escultores por los vestigios del arte antiguo.

Sin embargo, de entre todas las piezas con decoración vegetal, es el capitel procedente de la iglesia de Rodas y conservado en el Museo de Worcester, el que más llama la atención, en relación con los aspectos que venimos señalando ${ }^{2422}$ (fig. 475). La escultura del capitel, muy deteriorada, presenta una decoración de palmetas, mientras que, la parte frontal superior, la ocupa un personaje de rostro profundo y barbado. Se trata de una cabeza de gran volumen que rompe la propia línea de la pieza y que ocuparía el lugar destinado a la roseta, si seguimos la morfología del capitel clásico romano.

A pesar de que, debido a la destrucción de la obra, no se puede afirmar nada con rotundidad, según M. Durliat el personaje aparecería sujetando los restos de dos colas de aves. En nuestra opinión, nada impide que tales elementos puedan ser vistos como los restos de dos zarcillos vegetales pues, otras piezas procedentes del mismo monasterio de Rodas, parecen apoyar tal hipótesis.

En este sentido, cabe señalar un capitel conservado en el Museo de Arte de Gerona donde, el cuerpo de la escultura, fue decorado con elementos vegetales entrelazados en la parte frontal, mientras que, como rasgo bien antiguo, se decidió conservar las dos volutas típicas del orden jónico, no tan frecuentes dentro de la escultura románica. La superficie central de la pieza la ocupa el busto de un personaje que sujeta dos tallos vegetales con sus manos. Nuevamente, se repite aquí el tipo facial de rostro barbado.

La figura ha sido relacionada con la representación de Atlante aunque, tal y como hemos señalado, el motivo iconográfico estuvo muy difundido y es posible que se trate de una tradición clásica residual, transmitida a la iconografía románica de manera inercial, sin sentido simbólico y como mero motivo decorativo ${ }^{2423}$. Otro capitel, también

\footnotetext{
${ }^{2421}$ I. LORÉS I OTZET, El monestir..., pp. 20-21.

${ }^{2422}$ Worcester, Art Museum. El capitel se ha vinculado con la portada del templo. Está realizado en piedra caliza y no en mármol, tal y como se puede observar en algunas de las otras piezas que configuraban la fachada occidental esculpida por el "maestro" para el edificio. Este aspecto, podría responder a ciertas razones estéticas ligadas con los valores polícromos de los edificios antiguos. Cf.: J. CAMPS I SÒRIA e I. LORÉS I OTZET, “Le portail de Saint Pere...”, pp. 120-121. En relación con su estudio, tal aspecto les lleva a pensar que la pieza podría haber sido esculpida no para dicho portal, sino para otra parte de la abadía.

${ }^{2423}$ A. DIÉGUEZ, voz “Capitell 5 de Sant Pere de Rodes”, Catalunya romànica..., vol. XXIII, Barcelona, 1988, p. 28. El autor lo relaciona con el ámbito oriental y con el simbolismo del hombre luchando contra
} 
conservado en el Museo de Arte de Gerona y proveniente de la misma iglesia, presenta una repetición del tema de la máscara humana surgiendo de diversos elementos vegetales $^{2424}$.

Se trata de una pieza esencial a la hora de comprender las fuentes tan variadas que están utilizando estos escultores, pero que, de una manera más restrictiva, se muestran dependientes de la Antigüedad romana. En concreto, al detenerse en la imagen barbada del capitel, algunos detalles llaman la atención especialmente. Nos referimos a la manera en que ha sido concebido el rostro de la figura, con unos pómulos muy marcados, boca carnosa con labios cerrados y descendentes, así como los ojos almendrados trabajados con el trépano.

Este rasgo es muy significativo debido a las continuas conexiones que se han establecido entre la escultura del "maestro" y las soluciones desarrolladas en la plástica tetrárquica y constantiniana donde, los contrastes logrados a través de la aplicación del taladro generaron rostros de tendencia un tanto barroca ${ }^{2425}$. A ello se suma la atención que se ha prestado a la barba y al cabello, dividido en crenchas muy marcadas y que, nuevamente, se puede ligar con las fórmulas de tipo clásico romano ${ }^{2426}$.

En general, el efecto gestual logrado en el rostro de la figura románica parece recordar las actitudes satíricas de algunos personajes clásicos del ideario romano. En este sentido queremos citar dos piezas que creemos fundamentales para poder explicar algunas de las fuentes, hipotéticamente, seguidas para crear la imagen del capitel de Worcester.

El busto de un Sileno esculpido en mármol y conservado en el Museo Arqueológico de Ampurias (fig. 476), lejos de presentar relaciones indiscutibles con el busto del capitel románico, permite establecer una posible fuente lejana y común del motivo. El tratamiento cuidadoso que se le ha dado a la barba, el bigote y el cabello de la figura habla de unos intereses comunes, entre la pieza clásica y el personaje de San Pedro de Rodas.

\footnotetext{
la naturaleza, que aquí se representaría a través de los vegetales. Cita como posibles fuentes para la pieza, el arte carolingio, el oriental y el mundo clásico.

${ }^{2424}$ J. VIGUÉ I VIÑAS, voz "Capitell 13”, Catalunya romànica..., vol. XXIII, pp. 30-31.

${ }^{2425}$ M. CLAVERIA NADAL, "La reutilización...”, p. 245.

${ }^{2426}$ Por citar de manera resumida varios ejemplos, destacamos el tratamiento capilar que presenta la cabeza conservada en el Museo de Peralada. El trabajo detallado de la piel del Cordero esculpido en la clave proveniente de Rodas y las melenas complicadas que presentan algunos felinos de los capiteles de Rieux-Minervois o el rostro masculino del modillón de la iglesia de Saint-Papoul, por ejemplo. Véase: D. L. SIMON, "Capital attributed...", p. 315.
} 
Sin embargo, creemos mucho más factible la relación que se puede establecer entre esta figura y la pieza de mármol conservada en el Museo Arqueológico de Córdoba (fig. 477). De nuevo se trata de la imagen de un Sileno y, a nuestro juicio, guarda puntos en común más fuertes con la pieza que aquí estudiamos. La figura romana presenta un mismo tratamiento de las facciones del rostro. Los ojos nuevamente muestran un gesto agresivo que recuerda las soluciones seguidas en la pieza medieval. A pesar de ello, aunque en los detalles concretos pueden alegarse grandes diferencias entre ambas piezas, creemos que, en general, la máscara del capitel de Rodas pudo tener como motivo inspirador algún tipo de escultura similar.

A su vez, un ejemplo escultórico datado en la segunda mitad del siglo XII vuelve a ponernos en relación con las experiencias desarrolladas en las etapas anteriores del arte románico hispano. Tal y como hemos visto, la utilización de la imagen del hombrehoja o, en su defecto, a través de la personificación de Silvanus, fue continua durante la Edad Media.

Los personajes rodeados de un ambiente vegetal habían ofrecido, desde la Antigüedad, todo tipo de soluciones compositivas e iconográficas adaptables a multitud de escenas. Debe recordarse, en este sentido, el apartado en el que estudiamos el problemático capitel conservado en la portada occidental de la iglesia de San Zoilo de Carrión de los Condes, datado, recordémoslo, en los últimos años del siglo XI y los inicios del siguiente (fig. 305). Los dos bustos que surgían de la viña en aquella pieza podían, según justificamos en su momento, ser relacionados con piezas de tradición romana, así como con diversos temas iconográficos ligados a Ceres ${ }^{2427}$.

La continuidad en el uso de estas imágenes a lo largo del siglo XII se pudo constatar a través de un capitel más próximo a la cronología del que ahora analizamos. Se trataba de la pieza de la catedral de Santiago donde, nuevamente, un personaje con rasgos que recordaban la imagen de un fauno, parecía aferrarse, con sus manos, a las cepas que configuraban la viña en la que trabajaban los labriegos, reclinados en la parte baja de la escultura (fig. 305).

Desde el ámbito catalán, son varias las piezas susceptibles de ser relacionadas con filiaciones "antiquizantes" y que parecen seguir algunas de las fórmulas utilizadas para el capitel de Worcester. Por ejemplo, cabe destacar el capitel procedente de Santa María de Solsona, que muestra a dos hombres que agarran los tallos de la viña de la que,

${ }^{2427}$ Véase el apartado correspondiente del trabajo donde se señala la bibliografía consultada al respecto. 
a su vez, germina un racimo de uvas, colocado en la parte alta de la cesta y que, por cierto, J. Camps ha relacionado con fuentes de tradición clásica desarrolladas en la escultura tolosana ${ }^{2428}$ (fig. 478).

Los mismos aspectos pueden traerse a colación al analizar el capitel conservado en el Museo de Peralada (fig. 479).

Se trata de la "obra del único colaborador del Maestro de Cabestany reconocible (...). Es una pieza excepcional, que significa una formación románica a partir de elementos romanos. Se copió en Cataluña (la mejor versión en Lladó) y hay versiones más directas o simplificadas en el norte peninsular (Museo Diocesano de Jaca; Eyré, Lugo). Podría pensarse, por lo tanto, que todas derivan de una primera versión situada en un lugar central de irradiación, como Toulouse, por ejemplo ${ }^{, 2429}$.

Al observar la pieza se advierte el mismo interés de origen clásico por la utilización de los mascarones. La factura del rostro, de volúmenes rotundos, ojos grandes y la ausencia de cabellos, nos retrotraen a las soluciones utilizadas por los talleres de San Isidoro de León (fig. 302). Algunos de los capiteles ya comentados poseían unas máscaras de similares características que, en su momento, hicimos derivar de algunos prototipos que podrían haber estado ligados a la escultura en estuco, tales como las máscaras romanas conservadas en el Museo Arqueológico de Palencia ${ }^{2430}$ (fig. 300).

Creemos, por lo tanto, que tales antecedentes permiten apoyar la hipótesis de las fuentes clásicas utilizadas por estos escultores de las regiones más orientales de la Península Ibérica, en una cronología más tardía. Además, son muy expresivas las palabras, antes transcritas, de J. Barrachina al ligar el prototipo con otros ejemplos, de cronologías anteriores y vinculados, por ejemplo, al núcleo jaqués. Tal aspecto es llamativo pues, las fuentes tolosanas de matiz clásico convivieron con aquellas que, paralelamente, se desarrollaban en suelo hispano durante la primera mitad del siglo XII, llegando incluso a contaminarse entre ambas.

\footnotetext{
2428 Solsona, Museu Diocesà i Comarcal. Cf.: J. CAMPS I SÒRIA, voz "Capitell 4", Catalunya romànica..., vol. XXII, pp. 301-302. Recientemente, el mismo autor ha seguido indagando en las relaciones de la escultura procedente de esta iglesia de Santa María de Solsona y la escultura de Toulouse, sobre todo, aquella salida de los talleres activos en torno al año 1120. Cf.: J. CAMPS I SÒRIA, "Elementos de Santa María de Solsona", El románico y el Mediterráneo. Cataluña, Toulouse y Pisa. 1120-1180 (M. A. Castiñeiras González y J. Camps ed.), Barcelona, 2008, pp. 270-272.

2429 J. BARRACHINA, "Elementos de la portada...", ficha catalográfica 78, p. 353.

${ }^{2430}$ Remitimos al apartado de este estudio donde analizamos dichos aspectos.
} 
Volviendo al capitel catalán que estudiamos, además de la incorporación del mascarón central, lo más destacado es la colocación, en el lugar dispuesto para las volutas en los capiteles romanos, de dos remates a modo de prótomos cefálicos zoomórficos $^{2431}$. Podría tratarse de dos cabezas de carneros, de excelente calidad y que, en absoluto, fueron ajenos a la iconografía románica. En este sentido, hace tiempo que E. Vergnolle aludía a la posible influencia de la escultura bizantina al estudiar un capitel, con soluciones parecidas, del pórtico de Saint-Benoît-sur-Loire (fig. 480). En concreto, habrían sido las esculturas de época de Justiniano las que habrían ofrecido el modelo a los artesanos medievales activos en el pórtico francés ${ }^{2432}$ (fig. 481).

Sin negar este tipo de filiación, creemos que la fórmula había adquirido tanta difusión dentro de la escultura de sarcófagos de la época paleocristiana, que su traspaso a la iconografía románica no es descartable. A pesar de ello, la pieza mencionada por E. Vergnolle se ha venido datando en el siglo VI d. de C., hecho que remarca, con énfasis, la variedad de fuentes a las que podrían estar accediendo estos escultores ${ }^{2433}$. El enriquecimiento de motivos y piezas artísticas a los que tenían acceso se puede entrever, de manera clara, al observar ciertas soluciones que el "maestro" o su grupo de escultores parecen haber tenido en cuenta para la concepción de otras esculturas a ellos atribuidas. En relación con estos temas, queremos destacar la pieza procedente de la iglesia parroquial de San Giovanni de Sugana, en Italia ${ }^{2434}$ (fig. 482).

Para esta magnifica pieza se han defendido diferentes hipótesis en cuanto a su función primitiva, aunque parece que, lo más acertado, sería ver este fuste figurado los vestigios de un candelabro pascual. De hecho, M. Burrini, recientemente, ha apoyado tal teoría, afirmando que, posiblemente, pudo soportar un cirio, relacionado quizás con la liturgia del Sábado Santo ${ }^{2435}$.

\footnotetext{
${ }^{2431}$ Sobre la fortuna de este motivo clásico, en la época medieval, ya hemos tratado en algunas páginas de este estudio, a las que nos remitimos.

${ }^{2432}$ E. VERGNOLLE, Saint-Benoît-sur-Loire..., en particular, pp. 80-83.

${ }^{2433}$ Más allá de los propios sarcófagos, tal y como señala el profesor Poisson. Cf.: O. POISSON, "Un sculpteur anonyme...", p. 12.

${ }^{2434}$ Val di Pesa, Musei d'Arte Sacra di San Casciano. Sobre la obra, véase: M. BURRINI, "San Casiano Val di Pesa: colonne sculptée de l'église parossiale de San Giovanni in Sugana", Le Maître..., pp. 74-80 y F. SAUNIER, "Une oeuvre attribuée au maître de Cabestany: la colonne de San Giovanni in Sugana en Toscane", Les Cahiers de Saint-Michel de Cuxa, XXV, 1994, pp. 165-175. Desde el sigo XV o XVI, parece ser que formó parte de lo que, junto con un capitel vegetal, habría de ser una pila bautismal.

${ }^{2435} \mathrm{La}$ iconografía de la infancia de Cristo, con el tema de la Anunciación a los pastores, la Natividad y el Baño del Niño permiten corroborar tal función, desde el punto de vista iconológico. Cf.: A. MILONE, "Fuste de San Giovanni in Sugana", El románico y el Mediterráneo. Cataluña, Toulouse y Pisa. 11201180 (M. A. Castiñeiras González y J. Camps ed.), Barcelona, 2008, ficha catalográfica 72, pp. 340-341. $\mathrm{El}$ investigador también baraja la posibilidad de que, se pudiera tratar de la base para una pila bautismal o la de un púlpito.
} 
Dejando a un lado las cuestiones iconográficas, nos interesa destacar el formato en el que se esculpió tal elemento y, de la misma manera, la disposición de las imágenes, insinuando una espiral ${ }^{2436}$. Ello lleva a relacionar la pieza con otra serie de experiencias plásticas presentes en la Europa románica donde, tal y como hemos explicado, estuvo muy difundido el tipo de columna o fuste decorado con escenas iconográficas que se distribuyen a lo largo de su perímetro.

Sin tratarse de la misma solución, cabría mencionar los magníficos ejemplos de la columna del abad Bernward de Hildesheim o las columnas marmóreas de Santiago de Compostela, las cuales pueden ser vistas como una serie de jalones artísticos donde la utilización del prototipo se ha justificado por un contacto directo con las obras antiguas, concretamente, romanas $^{2437}$.

La utilización de la columna en espiral o de tradición constantiniana recuperaba, a su vez, el prototipo de la columna historiada romana pagana. Recuérdense, en este sentido, las interpretaciones medievales que los marmolistas romanos van a hacer de este tipo, sobre todo, en relación con la copia de los modelos conservados, durante la Edad Media, en San Pedro del Vaticano. Estos mismos marmolistas serían los que habrían de crear un prototipo de columna de fuste marmóreo sinuoso que serviría, por ejemplo, no sólo para decorar las pandas del claustro de San Juan de Letrán, sino que enriquecería los repertorios usados para crear diferentes muebles litúrgicos, sobre todo, cátedras y barreras litúrgicas. La comparación de esta estructura atribuida al "maestro" de Cabestany con el candelabro pascual de la basílica de San Pablo Extramuros de Roma podría parecer desacertada. Sin embargo, no debemos olvidar que la escultura de Sugana sería un simple remedo que recogería, pálidamente, tal tradición ${ }^{2438}$ (fig. 483).

Las columnas con de fuste salomónico, muy diferentes, en soluciones, al tipo usado para la escultura italiana, parece tener los mismos orígenes antiguos que la columna historiada. Entre estas tradiciones creemos que debe ser entendida la obra del "maestro" de Cabestany en Sugana donde quedaría patente, una vez más, el conocimiento de los diferentes sistemas de trabajo realizados por los talleres del Rosellón, tal y como se ha argumentado de manera reiterada. Restaría por determinar,

${ }^{2436}$ F. SAUNIER, “Une oeuvre...," pp. 171. En realidad, no se trata de una disposición helicoidal ni en espiral. Las figuras se adaptan, superpuestas en niveles, a la forma de la pieza, generando tal sensación.

${ }^{2437}$ Véase el apartado pertinente en el que se estudió el traspaso de la columna historiada romana a la Edad Media, a propósito de las piezas conservadas en el Museo de la Catedral de Santiago de Compostela.

${ }^{2438}$ V. PACE, "Nihil innovetur nisi quod traditum est. Sulla scultura romana del Medioevo", Diskurse zur Geschichte der Europäischen Bildhauerkunst. Skulptur des 12. und 13. Jahrhunderts, Frankfurt, 1994, vol. I, pp. 587-603. 
igualmente, la importancia que los talleres de marmolistas romanos tuvieron en la formación de estos escultores activos en la zona catalana y de los Pirineos y a los que se han atribuido otra larga serie de piezas, ubicadas dentro de las vías de comunicación más importantes, desde la Galia hacia Italia ${ }^{2439}$.

De esta forma, quedarían justificadas diversas peculiaridades narrativas presentes en la obra de Cabestany. Por una parte, la observación directa de los sarcófagos se percibe, claramente, en la escultura funeraria de Saint-Hilaire (Aude) o el friso de El Voló (Languedoc-Roussillon). Desde otro orden de cosas, tal observación de las piezas romanas permitiría, incluso, hablar de una continuidad en la utilización de diversas soluciones técnicas. El uso del trépano, tantas veces señalado y las diferentes concepciones del relieve son prueba de ello.

A propósito de tal aspecto, el Musée d'Arles Antique conserva varias piezas donde es posible observar algunas concomitancias con muchos de los rasgos más característicos de su escultura. En concreto, tradicionalmente se ha venido señalando la manera tan característica que presenta este grupo de escultores, a la hora de realizar los ojos de las figuras, con una marcada forma almendrada, la pupila esférica muy marcada $\mathrm{y}$, sobre todo, el trabajo mediante el trépano en las extremidades de la cavidad ocular $^{2440}$.

Mencionamos, en este sentido, el famoso sarcófago de Marcia Romania Celsa de dicho museo, que presenta los temas habituales dentro de este tipo de piezas ${ }^{2441}$. Nos interesa recalcar el tratamiento facial de algunas figuras, cuyos ojos, fueron esculpidos con gran profundidad. El trabajo con el cincel y el trépano, aún no siendo exactamente igual que el de las figuras atribuidas al "maestro", si parece responder a unas soluciones cercanas, desde el punto de vista técnico (fig. 484).

En la misma línea, cabría señalar el sarcófago denominado como "dogmático", conservado actualmente Roma ${ }^{2442}$. Lo más destacado de esta obra es el clípeo frontal presentado por dos genios alados que aparece dominando el centro de la composición, dividida en dos registros. Es en él se halla la clásica iconografía de los dos esposos, ella

${ }^{2439}$ G. MALLET, "Un artiste itinérant?...”, pp. 16-19 y J. CAMPS Y SÒRIA e I. LORÉS I OTZET, "L'artiste et son atelier...", p. 151. Se insiste en la importancia de la ubicación de algunas de sus esculturas en la vía de peregrinación a Roma.

${ }^{2440}$ O. POISSON, "Un sculpteur anonyme...”, p. 11.

${ }^{2441}$ El sarcófago pertenecía a la esposa de un cónsul y parece que fue realizado sobre el año 328 . Fue descubierto alrededor del 1974, en Trinquetaille, Arles, aunque parece que su origen debe atribuirse a los talleres romanos del segundo cuarto del siglo IV. Cf.: J.-P. CAILLET y H. NILS LOOSE, Op. cit., p. 9.

${ }^{2442}$ Città del Vaticano, Musei Vaticani. 
aferrada al brazo derecho de su marido mientras que, con el otro, le abraza ${ }^{2443}$. En este ejemplo los rostros vuelven a presentar soluciones equiparables a las que, más tarde, utilizarán los escultores en relación con la figura del "maestro" de Cabestany.

A pesar de todos estos aspectos, resulta imposible establecer un modelo concreto que permita afirmar, con rotundidad, el prototipo exacto que siguieron o inspiró a los escultores románicos. Desde nuestro punto de vista, creemos que la serie de rasgos faciales de origen antiguo que se perciben en las esculturas románicas de este área geográfica, aún presentando muchas variantes entre ellas, pueden emparentarse con estas producciones escultóricas romanas. Por ello pensamos que el modelo seguido no fue único y concreto, sino que, tales fisonomías, proceden de un conocimiento profundo de esta escultura romana, adquirido de la observación de piezas muy heterogéneas entre sí.

Sin embargo, parece que las similitudes más evidentes se mantienen con respecto a los sarcófagos llegados hasta nosotros del Arles romano. En este grupo de piezas se observa, igualmente, una cierta preferencia a exagerar el trabajo con el trépano, la concepción de los cabellos de un modo complejo y la tendencia a colocar las figuras de perfil, lo que acentúa, aún más, la imagen almendrada de los ojos ${ }^{2444}$. Dichos recursos, tal y como se ha visto, serían explotados por los escultores del siglo XII.

La importancia de las piezas romanas fue más allá de lo meramente estilístico. Sin adentrarnos, profundamente, en las cuestiones iconográficas, nos interesa destacar la comparación realizada entre el conocido relieve de la aparición de Cristo a sus discípulos en el mar, procedente del monasterio de Rodas y la iconografía presente en otro sarcófago conservado en Arles (fig. 456) ${ }^{2445}$. Mediante tal comparación, M. Burrini reafirmó, no sólo la deuda que presentan estas piezas respecto a la escultura romana paleocristiana, sino que, además, la concretó. La alegoría de Jonás y el barco representada en esta obra es un buen ejemplo que permite sugerir el ambiente artístico

${ }^{2443}$ Ibidem, p. 14. Los autores señalan que se trata de un sarcófago proveniente de la iglesia San Lorenzo Extramuros, en Roma. La cronología de la pieza estaría, nuevamente, centrada en torno a las primeras décadas del siglo IV, siempre dentro de los talleres romanos.

${ }^{2444}$ Ibidem, pp. $18-19$ y p. 66 . Se reafirma la importancia de los rostros de las figuras y la tendencia a mostrarlas de perfil, lo que otorga un mayor protagonismo a los ojos almendrados, aunque repetimos, no son soluciones idénticas a las que hallamos en la escultura románica de Cabestany. Desde el punto de vista de la factura de los cabellos, llama la atención el marcado interés preciosista, que muestra complejos peinados trabajados con fuertes volúmenes. Tales soluciones recuerdan, lejanamente, a los que encontramos, por ejemplo, en la figura de Daniel del capitel de Sant'Atimo o en algunas de las obras de la abadía de Sant-Papoul. Cf.: O. POISSON, "L'abbaye de Saint-Papoul", Le Maître..., pp. 56-63 y M. BURRINI, "Sant' Atimo: le chapiteau de Daniel dans la fosse aux lions", Le Maître..., pp. 67-73.

${ }^{2445}$ Arles, Musée d'Art Chrétien. Sobre la conocida pieza atribuida al "maestro", véase el trabajo más reciente, a ella dedicada, en: J. BARRACHINA, "Elementos de la portada...", p. 345. 
en el que se pudo inspirar el escultor de la pieza románica. Por otra parte, permite especificar, aún más, la deuda con la obra clásica que, generalmente, tal y como venimos apuntando, aparece ligada a los trabajos esculpidos sobre los sarcófagos de los siglos III y IV d. de $\mathrm{C}^{2446}$ (fig. 485).

Los pequeños detalles, aparentemente, sin importancia que presenta la escultura atribuida al "maestro", presentan sus equivalentes, más o menos acertados, dentro de la estatuaria antigua romana. Intentando apoyar tales hipótesis, señalamos el interés por aludir a los sarcófagos antiguos presente, a la hora de idear el sepulcro de la iglesia de Saint-Hilaire de Aude. Aquí, además de realizar una alusión, desde el punto de vista morfológico a las piezas romanas a través de la forma del sarcófago, otros detalles iconográficos hablan de un mismo interés por el arte romano.

Nos referimos, por ejemplo, a la representación microarquitectónica realizada en el frente de dicha pieza y que, según parece, podría aludir a un arco romano monumental $^{2447}$ (fig. 486). Se trataría de una práctica común de la que ya hemos tratado en este estudio. Los artífices medievales aludirían, de manera reiterativa, a las ciudades romanas de la Antigüedad a través de aquellos monumentos más emblemáticos que, aún durante los siglos medievales, permanecían en pie $^{2448}$.

En el caso concreto de esta estructura, así como el resto de elementos microarquitectónicos labrados en el sepulcro, se ha querido ver en ellos una alusión al famoso templo pagano del Capitolio de la Toulouse romana ${ }^{2449}$.

A pesar de tratarse de una visión fantaseada de este monumento de la Antigüedad, visto a través de los ojos de un escultor románico, lo más interesante es la intención que éste ha mostrado al identificar el suceso acontecido en época tardoantigua con un monumento clásico. Nuevamente, este tipo de construcciones romanas, en muchos casos llegadas al periodo románico maltrechas, servían para concretar el lugar

\footnotetext{
${ }^{2446}$ M. BURRINI, "Le style du Maître...”, pp. 138-139. Señala, concretamente, la importancia de la escultura tardorromana. En relación con la iconografía de la barca de la iglesia de Rodas indica que, parece continuar la tradición del tema de la barca mística, representado, frecuentemente, sobre los sarcófagos paleocristianos. El autor alude a un ejemplar fragmentando conservado en Roma, Musei Vaticani, también datado en el siglo IV. La escena de la barca, en relación con el desarrollo de la historia de Jonás, estuvo muy difundida dentro de la escultura paleocristiana. Así lo muestra, por ejemplo, una pieza conservada en Copenhague, Ny Carlsberg Glyptotek. La pieza fue adquirida en el año 1889, pero se ha relacionado con los talleres romanos activos a finales del siglo III. Cf.: J.-P. CAILLET y H. NILS LOOSE, Op. cit., p. 109.

${ }^{2447} \mathrm{Al}$ menos, así se identifica en: A. BONNERY, "Le sarcophage de saint Saturnin...”, p. 103.

${ }^{2448}$ X. BARRAL I ALTET, “Apropiación y recontextualización...”, pp. 174-175.

${ }^{2449}$ Esta estructura arquitectónica materializaría, visualmente, el lugar donde la Pasión del santo describe que aconteció su martirio. Cf.: A. BONNERY, "Le sarcophage-reliquaire...", pp. 54-55. El autor realiza en este estudio un completo análisis de la Passio antiqua que narra los hechos de la muerte del mártir, escrita entre los años 410-420.
} 
en el que habían ocurrido este tipo de sucesos. Se trataba de ubicar, desde un punto de vista geográfico, un hecho histórico. El santo había muerto en un tiempo lejano que ellos consideraban antiguo y pagano. Era el mismo paganismo que le había llevado a la muerte, por lo que, la manera más clara y sintética de concretar este espacio físico, para perpetuar un hecho histórico, pasaba por su identificación con un monumento antiguo emblemático $^{2450}$.

Sin embargo, el ejemplo permite incluir la imagen medieval dentro de la tradición iconográfica de los sarcófagos romanos y paleocristianos donde, las ciudades antiguas, eran representadas a través de arquitecturas ficticias y en las que, los estudiosos, han querido entrever ciertos visos de realismo. Los famosos sarcófagos denominados "a las puertas de la ciudad" y, de cuyo ejemplo más impresionante, es el conservado en la iglesia de San Ambrogio de Milán, permiten certificar esta costumbre (fig. 166). Las escenas critológicas o relativas a la vida de los mártires se desarrollaban enmarcadas entre arquerías y murallas que, ocasionalmente, se transformaban en verdaderas alusiones a los espacios urbanísticos de la Antigüedad tardía ${ }^{2451}$.

En el caso hispano, tales soluciones llegaron a alcanzar cierta complejidad en sarcófagos tan expresivos como el que se empotró en el portal sur de la fachada occidental de la catedral de Tarragona ${ }^{2452}$. En esta obra, las arquerías, las columnas y capiteles adquieren un desarrollo y morfología inmersos, plenamente, en una estética romana, por lo que, no se debe desdeñar una posible inspiración en alguna pieza de este tipo que hubiera servido de modelo a los artífices del sarcófago medieval conservado en Saint-Hilaire ${ }^{2453}$.

\footnotetext{
${ }^{2450}$ Ibidem, pp. 58-59. Se señala que el Capitolio era el templo más importante del que gozaron muchas de las ciudades romanas y que, generalmente, se dedicaba a la triada de Júpiter, Juno y Minerva. Sin duda, estos templos fueron el símbolo por excelencia del paganismo y de los sacrificios rituales romanos, así como el lugar en el que, de manera habitual, se llevaban a cabo las persecuciones y martirios de los primeros defensores de la fe. El mismo autor concluye que, tras las excavaciones llevadas a cabo en la plaza del Esquirol de Toulouse, no se puede defender la teoría de que la microarquitectura del sarcófago románico evoque de manera "arqueológica" el citado lugar. Poco tiene que ver este elemento con los templos greco-romanos pseudoperípteros, tal y como muestra, el Capitolio de Narbona o la MaisonCarrée de Nîmes.

${ }^{2451}$ Ya hemos aludido, anteriormente, a este tipo de piezas. Cf.: J.-P. CAILLET y H. NILS LOOSE, $O p$. cit., p. 121. Se confirma que la pieza fue reempleada en torno al año 1200, al ser englobada por una estructura arquitectónica románica en forma de púlpito.

${ }^{2452}$ Ibidem, p. 122 y p. 71. En esta pieza de Tarragona adquieren un gran desarrollo las microarquitecturas de la escena de la curación del sirviente del centurión y del hijo del funcionario real, al igual que en la configuración de la piscina probática de la escena de la curación del paralítico.

${ }^{2453}$ No pretendemos emparentar de una manera directa las piezas de Tarragona y Gerona con el sepulcro del "maestro" de Cabestany. Se trata, más bien, de reflexionar sobre los orígenes de este tipo de representaciones arquitectónicas. A pesar de que, para este ejemplo concreto, no tengamos pruebas fehacientes que permitan establecer conexiones entre la pieza románica y la escultura antigua conservada en la actual Cataluña, otros autores han utilizado dichos sarcófagos para buscar los posibles modelos
} 
La escultura desarrollada en el ámbito oriental de la Península Ibérica, durante una cronología posterior a la mitad del siglo XII, debe ser considerada con un hito importante dentro del estudio de la influencia de la Antigüedad en la plástica escultórica románica.

El caso del "maestro" de Cabestany ${ }^{2454}$ y aquella escultura vinculada a su personalísimo sello, parecen ofrecer una continuidad en el conocimiento exhaustivo de las fuentes clásicas, tanto desde el punto de vista de su expoliación física, como desde el intelectual. Se trata de una preferencia estética basada en el continuismo y que se retrotrae hasta los últimos años del siglo XI. En este sentido, sirvan a título explicativo las palabras del profesor Barral, con las que finalizamos este apartado:

"Poco después de 1100, asistimos al nacimiento de una escultura románica marcada por el signo de la reflexión sobre lo antiguo de forma contemporánea en el nordeste de la península Ibérica y en Toulouse o en Italia del norte. En Jaca, Santiago de Compostela o San Salvador de Leyre, la búsqueda de la monumentalidad queda reflejada en la proliferación de la ornamentación en toda la superficie de la fachada de la iglesia (...). A lo largo del siglo XII, los escultores románicos prosiguen esta conquista gradual de la Antigüedad en todas sus expresiones"2455.

Mediante esta reflexión final y pretendiendo anunciar los temas que se abordarán en las próximas páginas, debemos insistir en ese continuismo. La Antigüedad siguió interesando a los artistas. Variarán ligeramente sus intereses, la manera con que se enfrentarán a ella y sus vestigios, las soluciones con las que materializarán la influencia que esta les prodigó y, sobre todo, las piezas que tuvieron a su alcance.

Lejos de ello, ahora se percibe como un argumento lineal lo que, hasta este momento, hemos pretendido defender. Desde la etapa final del siglo XI hasta más allá

seguidos por los escultores del sarcófago medieval. Cf.: A. BONNERY, "Le sarcophage-reliquaire...", pp. 60-61. El experto afirma que es posible establecer ciertas relaciones entre el sarcófago de la caza del león de San Félix de Gerona y la escena del martirio del santo en el sepulcro románico de Cabestany. En concreto, habla de la postura utilizada para el león de la pieza catalana que, con gran realismo, salta impulsándose con las patas traseras. La postura del animal se podría relacionar, según el autor, con la que presenta el toro que arrastra el cuerpo de San Saturnino en el sarcófago románico.

${ }^{2454}$ Recordamos, finalmente, que a lo largo de este apartado hemos utilizado de una manera convencional el término "maestro", siendo conscientes de lo problemático de su uso y sobre todo, lo mucho que, actualmente, se debate y se duda sobre el mismo. Cf.: F. GANDOLFO, "Il sarcofago di Saint-Hilaire d'Aude...", pp. 425-437 y A. MILONE, "El Maestro de Cabestany...”, p. 184.

${ }^{2455}$ X. BARRAL I ALTET, “Apropiación y recontextualización...”, p. 176. 
de la década de los años sesenta del siglo XII, los escultores miraron hacia el arte clásico romano de manera recurrente. 


\section{BLOQUE IV}




\section{LAS ÚlTIMAS DÉCADAS DEL SIGLO XII Y EL AÑO 1200: LOS CRITERIOS DE DELIMITACIÓN CRONOLÓGICA Y EL PROBLEMA TERMINOLÓGICO.}

En el apartado que ahora iniciamos vuelven a surgir determinados problemas a los que nos habíamos enfrentado en las páginas anteriores. Se trata de una serie de temas, algunos de ellos ya abordados, que se presentan como condicionantes complejos en relación con la división metodológica de este estudio.

Anteriormente ya hemos aludido a las razones que nos llevaron a presentar la distribución temática que, hasta el momento, hemos seguido. Se trata de un trazado que parte de una necesaria discriminación de obras, periodos cronológicos, territorios y conceptos. Parece evidente que resultaría prácticamente imposible plantear un panorama de la asimilación de lo clásico dentro de la escultura románica hispana de una manera minuciosa, atendiendo a cada foco artístico específicamente, a cada construcción y a cada uno de los trabajos plásticos que embellecieron tales estructuras. Tal y como hemos expuesto, creemos que abordar nuestras reflexiones pretendiendo aproximarnos monográficamente a las obras es una tarea excesivamente ambiciosa ${ }^{2456}$. Es por ello, por lo que, desde un punto de vista metodológico, se hace necesaria una discriminación de estos aspectos.

El problema cronológico no escapa a estos parámetros. En el inicio de cada uno de los grandes bloques anteriores hemos intentado justificar, mediante los argumentos que nos han parecido más coherentes, las razones que nos llevaron a decantarnos por tal delimitación y acotación, tanto cronológica como de obras artísticas.

En este punto del estudio tal práctica parece nuevamente obligada. De esta forma, si anteriormente analizamos algunos aspectos "antiquizates" relacionados con la figura del "maestro" de Cabestany, partiendo de los supuestos cronológicos que los especialistas habían dado como válidos, parece coherente iniciar este nuevo bloque partiendo de aquel fin impuesto. A pesar de ello, somos plenamente conscientes de que se trata de un valor artificial, desde un punto de vista histórico o de una barrera delimitadora poco realista.

\footnotetext{
${ }^{2456}$ Hemos repetido numerosas veces que la línea principal de nuestro discurso pretende poner de relieve la herencia de un determinado tipo de clasicismo muy concreto sobre un momento determinado del desarrollo del movimiento románico, apartándonos de una visión diacrónica.
} 
Ya hemos expuesto la situación del fenómeno de recuperación e influencia del mundo antiguo sobre la escultura románica hispana en torno al año 1150. De ello da cuenta el apartado anterior.

Tras las últimas publicaciones realizadas sobre el tema, la mayoría de los autores han coincido en señalar una cronología cercana a los años 1160 y 1170 para concretar algunas de las realizaciones plásticas supuestamente realizadas por el "maestro" de Cabestany y su círculo ${ }^{2457}$.

Teniendo en cuenta que el movimiento ligado a la figura de Cabestany fue uno de los más importantes, en relación con la recuperación de diversas fórmulas clásicas, dentro de la escultura románica de mediados de siglo, a la hora de avanzar en el análisis, no parece ilógico decantarse por los años 1160 y 1170 para comenzar el estudio de la última etapa del románico en España.

Con todo, somos conscientes de la gran problemática que aquí se plantea. Siguiendo tal sistema metodológico es evidente que se observa la posibilidad de incluir aquí obras que, datadas cronológicamente por los estudiosos en periodos y años concretos, a través de diversos métodos que, a veces, no ofrecen una fiabilidad plena, podrían haber sido realizadas en otros años. Se trata, no en vano, de uno de los problemas más criticables en cuanto al estudio y la delimitación de las etapas en torno a las cuales, hipotéticamente, se desarrolló la estética de finales del románico ${ }^{2458}$.

El hecho de considerar estas décadas como punto de partida para nuestros próximos análisis puede acarrear otras consecuencias. Nos referimos no sólo a excluir obras que, pudiendo haber sido realizadas en años anteriores y que, aunque sea por un arco temporal mínimo, dejen por ello de ser incluidas en este apartado. Se trata de un hecho que no tiene fácil solución pues, como es sabido, los edificios medievales y sus esculturas, en muchas ocasiones, no se pueden datar con tanta exactitud.

Así, las características de este trabajo implican necesariamente una organización del método y de la exposición, por lo que consideramos obligado acotar los apartados que aquí presentamos, haciéndolo mediante una aceptación de las divisiones y

\footnotetext{
${ }^{2457}$ Nos referimos, concretamente, a los estudios recogidos en el catálogo de la exposición El románico y el Mediterráneo: Cataluña, Toulouse y Pisa, 1120-1180, organizada en el MNAC de Barcelona. Remitimos al apartado anterior de nuestro estudio en el que hemos recogido la bibliografía utilizada para realizar tales afirmaciones.

${ }^{2458}$ J. PLAZAOLA, Modelos y teorías..., pp. 47-48. El autor hace un breve análisis crítico de los diferentes teóricos y pensadores que gestaron la importante teoría de los estilos, que tan frecuentemente se aplicó sobre los estudios en Historia del Arte. El problema que se nos presenta en esta parte del estudio es, por otra parte, uno de los ejes fundamentales sobre el que se asienta buena parte de las producciones historiográficas.
} 
dataciones cronológicas aceptadas de manera tradicional por la historiografía más reconocida.

En su reciente publicación, el profesor J. Lacoste utilizaba idénticos criterios para organizar la división de su análisis del desarrollo de los trabajos escultóricos durante el siglo XII en la Península Ibérica. En uno de los capítulos de su citado estudio, el autor consideraba la década de los años 1160 al 1170 como un periodo fuertemente marcado por los cambios ${ }^{2459}$.

Además de ello, se debe hacer alusión, igualmente, al clásico estudio realizado por el profesor J. Yarza y publicado en la década de los años ochenta. En dicha obra el experto iniciaba su exposición aludiendo a la figura de Suger y su actividad, en torno al cuarto decenio del siglo XII, en la reconstrucción de la abacial de Saint-Denis de París. Según el citado autor, dichos trabajos artísticos reflejan los puntos más importantes de la ideología y estética de las nuevas producciones plásticas. El periodo que ahora estudiamos estuvo marcado por un cambio profundo de las formas artísticas, debiendo ser entendido menos como ruptura que como una acelerada evolución de las experiencias inmediatamente anteriores.

En el caso hispano, las novedades se implantaron con cierta lentitud, por lo que la elección de la fecha inicial que barajamos para el presente capítulo debe considerarse convencional. Es el momento en el que se perciben las mayores influencias francesas, presentándose ejemplos tan excepcionales como las obras realizadas en la órbita del "maestro" Mateo de Compostela ${ }^{2460}$.

Es importante mencionar que, tales ideas, fueron realizadas por el profesor Yarza en la introducción de un capítulo titulado "Hacia la disolución del románico". El especialista encerraba en este epígrafe las últimas obras arquitectónicas y plásticas realizadas en las décadas finales del siglo XII, frente al grueso de su investigación, englobado bajo el título "El Pleno románico (1075-1150)"2461.

Aunque se trata de una división ciertamente artificial y tópica, tal y como ocurre en la mayoría de las ocasiones con las líneas cronológicas establecidas por los historiadores, creemos que dicha fragmentación temporal puede aplicarse al discurso seguido en nuestro estudio.

${ }^{2459}$ J. LACOSTE, Les maîtres..., pp. 87-95.

2460 J. YARZA LUACES, Arte y Arquitectura..., p. 249 e ID., voz "Burgos", Enciclopedia dell'arte medievale, vol. IV, Roma, 1993, pp. 1-10 El autor justificaba, igualmente, la acotación cronológica que utiliza para la división de los capítulos de su estudio, entendiéndola como algo meramente convencional.

${ }^{2461}$ J. YARZA LUACES, Arte y Arquitectura ..., pp. 173-247. 
Una vez superada la mitad del siglo XII, la escultura románica hispana comienza a verse enriquecida y modificada por otras corrientes novedosas. Si aceptamos que el movimiento románico evolucionó de tal manera que es posible establecer ciertas fases de inicio (primer románico), desarrollo (románico pleno) y finalización (tardorrománico), creemos que, igualmente, se debe aceptar el hecho que las obras producidas tras los años 1150 y 1160 presentan características novedosas con respecto a la concepción estilística de las esculturas de la primera mitad de siglo ${ }^{2462}$.

Evidentemente, este problema que sugerimos aquí excede con mucho nuestra capacidad para abordarlo de una manera rigurosa y seria. Sin embargo, antes de iniciar ciertas reflexiones, parece necesario llamar la atención sobre estos aspectos e intentar clarificarlos.

En este sentido, son estas mismas producciones realizadas una vez traspasada la mitad del siglo XII las que comienzan a presentar ciertas fórmulas novedosas, abiertas a los contactos foráneos con Francia. Lejos quedaban las fuertes relaciones que el románico hispano había mantenido, durante la primera mitad del siglo, con el foco languedociano y la zona de Toulouse.

En este nuevo momento, tal y como apunta el profesor Yarza, el norte y la Isla de Francia se convierten en los nuevos catalizadores y filtradores de las influencias hacia la Península Ibérica. Ello tuvo fuertes consecuencias en la escultura que aquí vamos a tratar.

Creemos que no es necesario insistir en tal cuestión, por otra parte, tangencial al problema que nos atañe, pero parece que la mayoría de los especialistas coinciden en aceptar tales fechas como el inicio del fenómeno de enriquecimiento y evolución de la escultura románica a través de sus conexiones con este tipo de arte regional francés. Fruto de tales contactos, además de una larga serie de causas, parece que surgiría lo que tradicionalmente se viene considerando como arte gótico ${ }^{2463}$.

Por tanto, partimos de la base de que tales cambios se produjeron, de manera mayoritaria, entre los años 1150 al 1170, para continuar su evolución hasta la

\footnotetext{
${ }^{2462}$ I. G. BANGO, "Arquitectura y Escultura", Historia del Arte de Castilla y León. Arte Románico, vol. II, Valladolid, 1994, pp. 9-212, en concreto, pp. 62-152. El autor utiliza estos epígrafes para remarcar la evolución del movimiento románico. En la actualidad, parece claro que todos somos conscientes de que se trata de meras divisiones utilitaristas y, en ningún caso, con intenciones dogmáticas o academicistas.

${ }^{2463}$ J. ARA GIL, "Escultura", Historia del Arte de Castilla y León. Arte Gótico, vol. III, Valladolid, 1995, pp. 219-328. Insistimos en que nuestras palabras, en este estudio, son meramente introductorias, pues el problema que abordamos ha sido largamente discutido por los especialistas sin llegar a conclusiones cerradas al respecto. No en vano, se trata del vértice visible de la difundidísima teoría de los estilos que de manera tradicional rige la Historia del Arte.
} 
arquetípica fecha del año 1200. Estas datas son, tal y como es sabido, puntos fundamentales e hitos dentro de la evolución de la estética románica que, aceptando las propuestas defendidas por los expertos, hipotéticamente tuvieron en el ámbito francés su germen originario. De ahí se transmitiría al ámbito hispano.

Es por ello, por lo que las tomamos como punto de partida y de finalización para este apartado del estudio, aún a sabiendas de su fuerte carácter tópico.

Finalmente, al difícil problema de argumentar congruentemente la división cronológica adoptada, debemos sumar aquel que habla de la multiplicidad terminológica que los autores han venido señalando en relación con la definición de estos fenómenos ${ }^{2464}$.

Tal diversidad viene dada por la misma naturaleza del movimiento románico. De manera habitual se ha insistido en el carácter general y unificador que presentan algunos de sus rasgos que, sumados al enriquecimiento "regionalista", acabaron por gestar una estética plástica y arquitectónica muy singular. Las denominadas por algunos como escuelas regionales, "inventaron" una diversidad que se vio agudizada con la diferente manera de asimilar las evoluciones, cambios y novedades en los distintos territorios. Cada región y país absorbió las formas en diferentes cronologías y ello conllevó graves problemas a la hora de incluir tales formas artísticas bajo académicos epígrafes.

En un ambiente tan rico, abierto a las filiaciones diversas y los emergentes cambios que se estaban produciendo en el ámbito europeo, no es de extrañar que se encuentren numerosos problemas a la hora de limitar las características tan peculiares del románico finisecular.

Si aceptamos el desarrollo de un arte plenorománico durante una etapa de esplendor del "estilo", parece posible aplicar una terminología similar para la etapa final del mismo ${ }^{2465}$.

Desde la expresión "tardorrománico" a la más compleja de "estilo 1200", desde la de "primer gótico" a la más criticada de "protogótico", podríamos afirmar que todas ellas van dirigidas, evidentemente, a señalar un cambio brutal surgido en las artes desde las últimas etapas del siglo XII y los inicios del siguiente. Y eso, independientemente de

\footnotetext{
${ }^{2464}$ J. PLAZAOLA, Modelos y teorías..., p. 23.

${ }^{2465}$ No es preciso insistir, pues ya lo hemos hecho, en los problemas actuales que existen en torno al uso de dicho vocablo. Vid.: I. G. BANGO TORVISO, "Crisis de una historia del arte medieval...", pp. 15-28 e ID., "Arquitectura tardorrománica", I Curso de cultura medieval (F. J. Mingorance y Ricart coord.), Aguilar de Campoo, 1989, pp. 65-76. Lo más interesante es que, tras tomar consciencia de las limitaciones que tales divisiones conllevan, tales conceptos se han venido utilizando de forma habitual.
} 
las grandes diferencias que muestran entre ellas y la diversidad de sus objetivos a la hora de definir fenómenos muy plurales y diferentes.

La ambigüedad conceptual y la complejidad a la hora de definir las artes del periodo, tienen su representante más destacado, por ejemplo, en la corriente historiográfica inaugurada por el profesor J. $\mathrm{M}^{\mathrm{a}}$ de Azcárate Ristori, en torno a la década de los años sesenta y setenta del siglo $\mathrm{XX}^{2466}$. Dicho autor intentó definir y desgranar las características de un arte que él incluía bajo el epígrafe de "protogótico hispano", entendiendo que se trataba de uno de los periodos de mayor y más intensa actividad dentro del arte medieval. El marco cronológico sobre el que se basaba comprendía, aproximadamente, los años 1170 y 1225, un periodo histórico concreto que, según sus argumentos, no implicaba obligatoriamente el nacimiento de un "estilo" surgido de la evolución de los "estilos" anteriores. Según su criterio, el arte de este momento no fue una consecuencia de la evolución de las fórmulas románicas hacia el gótico, es decir, no existió una transición de un "estilo" a otro, por lo que, desde este punto de vista, el experto acabó por documentar la presencia de una fase "preclásica" del estilo, definiéndola mediante la aplicación del prefijo "proto", en su acepción inicial, entendido como una precedencia o prioridad ${ }^{2467}$.

El uso del término "protogótico", refleja la complejidad de abordar el estudio de la escultura del período que, según el citado autor, se caracterizaba por la introducción y predominio del carácter naturalista, la tendencia narrativa y la expresión de la belleza ideal. Igualmente, se aludió a la renovación y la ruptura con respecto al arte románico anterior, ejemplificando tales aspectos a través de la figura del "maestro" Mateo, si citamos el caso más conocido. Esta supuesta fase "protogótica" era claramente diferenciable respecto al "estilo" románico ya que pronto sumó la aportación de elementos tomados de las primeras obras góticas francesas del siglo XII. Finalmente, la defensa conceptual del "protogótico" realizada por el profesor Azcárate, llamaba la

\footnotetext{
${ }^{2466}$ Llegados a este punto debemos advertir que todas las reflexiones realizadas hasta el momento son extremadamente complejas y han sido muy debatidas por los especialistas. No es nuestro objetivo posicionarnos en estas controversias pues, tan sólo, abordamos aquí este tema de manera tangencial y a título de simple introducción para este capítulo final. De igual modo, se advertirá que la bibliografía citada al respecto es extremadamente básica, signo de que solamente pretendemos plantear un panorama general sobre esta cuestión. No estamos capacitados y carecemos de la formación necesaria para pronunciarnos sobre la correcta utilización de términos como "primer románico", "románico pleno", "tardorrománico", "protogótico", "estilo 1200", "estilo de transición" o "primer gótico". Insistimos en que nuestro objetivo simplemente reside en confrontar la manera de asimilar ciertas corrientes derivadas del arte antiguo en la escultura vinculada al ámbito que se ha dado en llamar "hispano-languedociano" con respecto a la realizada en la última etapa del siglo XII y que, a nuestro juicio, responden a dos actitudes bien diferentes.

${ }^{2467}$ J. M Ma AZCÁRATE RISTORI, El protogótico hispano, Madrid, 1974, pp. 12, 14 y 16.
} 
atención con respecto al lo que el consideraba un espléndido florecimiento la escultura. Así, conviviendo con las obras plenamente románicas, se crearon otras que, ni por su carácter, ni por el edificio al que fueron destinadas podían ser incluidas dentro del concepto de arte románico, tal como en la actualidad lo entendemos ${ }^{2468}$.

Las reflexiones del citado autor pueden ser consideradas como clásicas dentro de la historiografía hispana a la hora de estudiar los trabajos escultóricos de los años finales del siglo XII. Sin embargo, también resulta muy significativo que sus argumentos fueran puestos en duda por diversos autores o, al menos, matizados. Entre ellas, tomaron especial relevancia las afirmaciones del profesor Bango, quien entendía que el acto de intentar definir el "estilo protogótico" como tal, era un recurso muy útil para los que se ven obligados a explicar la sucesión de formas a lo largo de la historia, pretendiendo encerrar las creaciones artísticas en una serie de compartimentos contiguos.

Las críticas que el autor realizó sobre las expresiones de arte "hispanovisigodo", "arte imperial carolingio", "arte condal", "arte de repoblación" o "estilo 1200", insisten en el problema al que nos referimos y las dificultades a la hora de estudiar la escultura del periodo que aquí abordamos ${ }^{2469}$.

Hasta aquí se ha intentado esbozar una pequeña muestra de la complejidad del periodo que ahora comenzaremos a analizar, de lo problemático de poder definirlo bajo un epígrafe seguro, representante y del que se deduzcan, una serie de características escultóricas auténticas y exclusivas, así como de lo inseguro de su utilización de una manera fiable.

Derivado de este panorama de la escultura hispana a finales del siglo XII no es de extrañar que surgieran intentos, casi utópicos, de definir el fenómeno bajo el concepto de "protogótico". No en vano, en el seno de este cuestionado movimiento, cierto sector de la historiografía acabó por deslindar una corriente que, según sus criterios, poseía unas características exclusivas, diferenciables, a su vez, de este supuesto "estilo". Nos referimos al definido como "arte 1200" y que recibió no menos críticas.

\footnotetext{
${ }^{2468}$ Ibidem, pp. 54-57.

${ }^{2469}$ I. G. BANGO TORVISO, "Crisis de una historia del arte...", pp. 22-23 e ID., "Un gravísimo error en la historiografía española, el empleo equivocado del término mozárabe", El legado de Al-Andalus. El arte andalusí en los reinos de León y Castilla durante la Edad Media (M. Valdés Fernández coord.), 2007, León, pp. 73-88.
} 
Independientemente de las teorías que defendieron el correcto uso de tales vocablos como verídicos representantes de una realidad escultórica, parece claro que determinadas esculturas datables cronológicamente en las últimas décadas del siglo XII y principios del XIII, presentan unas características diferentes. Pero, ¿contaron estas obras con un determinado y particular sustrato clásico susceptible de análisis?, ¿de ser positiva tal afirmación, fue idéntica la relación que estos artífices románicos finiseculares mantuvieron con el arte clásico a la que mostraron aquellos artesanos activos desde finales del siglo XI?.

El siguiente apartado intentará arrojar, en la medida nuestras posibilidades, cierta luz sobre estas complejas cuestiones. 


\section{EL SUSTRATO CLÁSICO DE LA ESCULTURA TARDORROMÁNICA (1160-1200).}

\section{1. INTRODUCCIÓN.}

Una vez realizadas las oportunas reflexiones con el objetivo de manifestar la inseguridad de los conceptos con los que designar a estos movimientos renovadores de la escultura realizada a finales del siglo XII, finalmente, hemos intentado utilizar un concepto lo más neutral posible para el encabezamiento de este epígrafe.

Entendemos que la diferenciación terminológica basada sobre los criterios de datación cronológica puede ser un sistema que, sin ofrecer las garantías más seguras, muestra menor problemática que apostar por el uso de alguno de los términos analizados en el apartado anterior.

Pensamos que los argumentos defendidos en las páginas preliminares podrían avalar la división cronológica con la que completamos el epígrafe que encabeza este apartado, pues fue a partir de la década de los años sesenta, cuando cierta escultura románica hispana comenzó a coexistir con las primeras formas góticas. Al menos, en este sentido, se encuentran los argumentos defendidos por la profesora M. Melero, al referirse al caso de las producciones navarras y aragonesas, ya que, según sus teorías, es poco después de mediados del siglo XII y en los años posteriores, cuando en algunos centros del reino de Navarra se detecta la introducción de otras formas francesas relacionadas tanto con el románico pleno de Borgoña como con las primeras formas góticas de la Isla de Francia ${ }^{2470}$.

No es de extrañar que los argumentos expuestos por esta citada especialista, concuerden, igualmente, con otro de los investigadores que mejor conoce el desarrollo de la escultura en la Europa del periodo que aquí tratamos. Así, según P. Williamson será en los monumentos realizados en suelo hispano, entre los años 1160 y 1230, aproximadamente, los que mejor muestren el conocimiento de la escultura francesa ${ }^{2471}$.

La introducción de ciertos cambios una vez traspasado el ecuador del siglo XII, nos permite justificar tal elección. En este mismo sentido, pensamos que el año 1200,

\footnotetext{
${ }^{2470}$ M. MELERO MONEO, "Navarra y Aragón en las décadas centrales...”, p. 103.

${ }^{2471}$ P. WILLIAMSON, Escultura Gótica. 1140-1330, Madrid, 1997, p. 187. Obsérvese que, nuevamente, propone el año 1160 como fecha de partida para la introducción de tales innovaciones. Véase también: W. SAUERLÄNDER, "La escultura de la sede leonesa a la luz de los grandes talleres europeos", La catedral de León en la Edad Media, León, 2004, pp. 177-202, en particular, p. 179.
} 
por la importancia que la historiografía posterior le ha otorgado, permite poner un punto y final a nuestro estudio, siendo conscientes, en todo caso, de su carácter $\operatorname{artificial}^{2472}$.

${ }^{2472}$ E. FERNÁNDEZ GONZÁLEZ, “Santo Martino...”, en particular, p. 61. Sobre este tipo de cuestiones relativas a la teoría de los estilos, véase: J. PLAZAOLA, Modelos y teorías..., pp. 47-56. 


\section{2. CUANDO LAS FUENTES ANTIGUAS SE MULTIPLICAN.}

Tras abordar resumidamente y a título introductorio algunos de los problemas más significativos derivados del análisis de la escultura de finales del siglo XII, en este apartado se intentarán sintetizar las posibles vías de asimilación de tales fórmulas clásicas.

Este objetivo es considerablemente espinoso ya que intentar separar, de manera rotunda, estas vías "antiquizantes" puede llevar a ofrecer una visión demasiado simplista del panorama europeo en un momento convulso, tal y como venimos señalando.

Una vez más surge un tema que ya hemos abordado en capítulos anteriores y que radica en la complejidad de tratar este asunto a través de una forzada selección de obras. La discriminación de unas en favor de otras conlleva el error de ofrecer un panorama falsificado ya que, aún con todo, resultaría imposible poder analizar de manera monográfica todos los conjuntos hispanos datados en este periodo.

Tal objetivo no es la tarea que desarrollaremos aquí. Se pretenderán esquematizar, a través de una división compartimentada del fenómeno, algunas de las principales vías a través de las cuales el clasicismo acabó por ser asumido dentro de los planteamientos estéticos de la última escultura románica hispana. 


\section{A. LAS APORTACIONES DE LA ISLA DE FRANCIA Y EL TRASPASO DE FÓRMULAS ANTIGUAS. EL EJEMPLO DE LAS ESTATUAS-COLUMNA.}

De manera tradicional, la historiografía viene aceptando como válido el año 1140 para poder señalar el inicio del gran cambio que se produciría dentro de la escultura europea. Casi de manera canónica, se ha considerado el conjunto escultórico promovido por el abad Suger, en Saint-Denis, como uno de los reactivos más importantes que desencadenarían tal fenómeno. Todo ello, a pesar de las fuertes reformas y modificaciones sufridas por el conjunto desde la época moderna ${ }^{2473}$.

La Isla de Francia, y con ella, la citada abadía, preparaban el terreno para este cambio. El abad Suger, materializador de esta tendencia, había sido ordenado el 12 de marzo de 1122 y, desde el primer momento, dirigió todos sus esfuerzos a renovar las estructuras arquitectónicas, la decoración y el ambiente cultural que rodeaba la vieja basílica de finales del siglo VIII ${ }^{2474}$.

En relación con tales aspectos, la emergencia de nuevas corrientes focalizadas en la Isla de Francia, entre otros lugares, es uno de los fenómenos más interesantes a tener en cuenta por su temprana repercusión sobre la escultura románica española.

El primer estadio pasaría por reconocer la existencia de un sustrato clásico, hipotéticamente, tomado como base para la creación plástica de los artífices activos en el entorno de la basílica de Saint-Denis. Aceptando tales fuentes "antiquizantes", no sería extraño que este clasicismo se traspasase a la escultura realizada, poco después, en España.

Veamos un ejemplo al respecto. En el Museo de la catedral de Astorga se conservan dos excepcionales piezas que en su día formaron parte de la misma escultura (figs. 487 y 488). Se trata de una cabeza fragmentada perteneciente a una figura, cuyos cabellos se ciñen con una cinta siguiendo soluciones "clásicas". Según se ha defendido, tal escultura, junto con un brazo ricamente ataviado y los restos de un pie calzado con una sandalia de finísimas tiras cruzadas podrían haber formado parte de una estatuacolumna.

Estas y otras características han permitido concretar que dicha obra pudo haber sido esculpida en un momento anterior a la creación de las esculturas más señeras de finales del siglo XII, tales como las que decoran el pórtico de la Gloria santiagués, la

\footnotetext{
${ }^{2473}$ P. WILLIAMSON, Op. cit., p. 33.

${ }^{2474}$ F. CECCHINI, voz "Suger”, Enciclopedia dell'Arte Medievale, vol. XI, Roma, 2000, pp. 33-36.
} 
portada de la iglesia de Santiago de Carrión de los Condes o algunas de las figuras de la portada de San Vicente de Ávila o la Cámara Santa de la catedral de Oviedo pues, todas ellas presentan peculiaridades mucho más avanzadas.

La descontextualizada escultura de Astorga, muestra una concepción artística deudora de las experiencias europeas, en concreto, aquellas más vinculadas y próximas a las estatuas-columna de la abadía de Saint-Denis, que a otras esculturas del área borgoñona y del foco de Chartres, con las que también se ha querido relacionar la cabeza leonesa $^{2475}$.

Las reflexiones de la profesora C. Cosmen, la especialista que mejor ha estudiado estas piezas, son muy expresivas a la hora de plantear el problema que aquí tratamos. A través del análisis de los fragmentos leoneses, la mencionada autora entiende que nos encontramos con un nuevo tipo de escultura de resabios clásicos.

Nos interesa, sobre todo, insistir en la importancia que adquieren aquí estos recuerdos de tradición antigua, pues es realmente el punto focal sobre el que nos centraremos.

Teniendo en cuenta estas suposiciones, parece que la escultura desarrollada durante la segunda mitad del siglo XII presentará, incluso desde fechas tempranas, una vinculación con determinadas formas clásicas, pero, y ello es fundamental, que habían sido desarrolladas desde los talleres de la Isla de Francia y no en Hispania.

Se trata de un nuevo sustrato clásico muy diferente. La Península Ibérica vive ahora una renovación en este sentido, pues, enfrentado directamente a la actitud hacia la Antigüedad que habían mostrado los escultores de las etapas anteriormente analizadas, ahora se vislumbra el nacimiento de una nueva forma de mirar hacia el mundo antiguo. La escultura hispana estaba adoptando ciertas fórmulas clásicas muy complejas, pero que le son foráneas e importadas.

El sustrato clásico aquí adoptado es lejano, ha viajado desde el centro de Europa y parece que fue allí mismo donde se produjo su reelaboración. Se trata de un transplante de soluciones que tiene como resultado la implantación, en estos territorios,

2475 C. COSMEN ALONSO, "Las catedrales románicas de Astorga", Enciclopedia del románico en Castilla y León. León, Aguilar de Campoo, 2002, pp. 439-445, en particular, pp. 443-444. La bibliografía centrada en el estudio de estas piezas, rescatadas de la desaparecida catedral románica de Astorga, se ha visto incrementada en los últimos años. A parte del actualizado trabajo antes citado, véase también: $\mathrm{CH}$. T. LITTLE, "Head o fan old testament figure", The Medieval Art of..., ficha catalográfica 100, p. 221. Este último especialista, nuevamente, insiste en las filiaciones con Saint-Denis, datándola, con dudas, en torno al año 1170. En esta misma línea insinúa, igualmente, relaciones con las esculturas de Chartres, a pesar de que los estudios de la profesora Cosmen ya han puesto de manifiesto su mayor cercanía con la obra de Suger. 
de unas soluciones clásicas muy tamizadas a traves de ricos estadios con fuentes innumerables.

No podemos desgranar todas las relaciones con lo clásico que los especialistas han ido emparentando con la figura de Suger y su ámbito de acción, así como las repercusiones de algunas de las esculturas de su ámbito sobre lo hispano ${ }^{2476}$.

Anticipando algunas conclusiones que enunciaremos al final de este apartado, podemos adelantar que se trata de dos formas muy diversas de asimilar las formas antiguas, de dos "antigüedades" completamente diferentes y de dos procesos de reelaboración de lo antiguo muy dispares y alejados. No se trata ya de una observación del arte romano, no existe una reflexión continuada sobre las piezas, ni mucho menos una actitud dominada por la voluntad de copia de la obra clásica, tanto desde el punto de vista técnico como plástico e iconográfico. A ello debemos sumar otro aspecto más importante ya que, según creemos, la asimilación de lo clásico sobre el estilo escultórico románico no se producirá, tal y como intentaremos demostrar, a través del contacto con obras hispanorromanas, sino que el germen de tal fenómeno se localiza en el ámbito europeo y no en suelo hispano.

Volviendo a las ideas expuestas por la profesora Cosmen, tanto la cabeza como los restos inferiores de la escultura de Astorga presentan más deudas con algunas de las estatuas-columna de la abadía de Saint-Denis que con las presentes en la catedral de Chartes (fig. 489). A su vez, y dentro del mismo debate, otros autores han insistido, en repetidas ocasiones, en la dependencia que muestran las estatuas realizadas para la portada de la iglesia navarra de Santa María de Sangüesa con respecto a los trabajos efectuados para las jambas del Pórtico Real de Chartres ${ }^{2477}$ (fig. 490).

Sin embargo, aunque es evidente que los trabajos de Sangüesa presentan, en lo referente a las estatuas-columna, ciertas soluciones que recuerdan el caso de la pieza de Astorga, insistimos en que, según la profesora C. Cosmen, el caso astorgano se explicaría mejor a través de una conexión con Saint-Denis.

\footnotetext{
${ }^{2476}$ F. CECCHINI, voz "Suger...", pp. 35-36; W. R. LETHABY, "The Part of Suger in Creation of Medieval Iconography”, Burlington Magazine, 25, 1914-1915, pp. 206-207; C. RUDOLPH, Artistic Change at St-Denis. Abbot Suger's Program and the Early Twelfth-Century Controversy over Art, Princeton, 1990 y C. COSMEN ALONSO, El arte románico en León..., pp. 252-253.

${ }^{2477}$ M. P. ALONSO ABAD., "Estatua yacente de un obispo", Los Caminos de Santiago..., p. 315 ; J. YARZA LUACES, Arte y Arquitectura..., p. 290; X. BARRAL I ALTET y N. DE DALMASES, $O p$. cit., p. 53 y M. C. LACARRA DUCAY, voz "Navarra", Enciclopedia dell'arte medievale, vol. VIII, Roma, 1997, pp. 654-657, en concreto, p. 556. Todos los autores incluyen estas esculturas dentro de la nómina de obras que presentan ciertos aires renovadores. Sobre la catedral francesa, véase: A. PRACHE, voz "Chartres", Enciclopedia dell'arte medievale, vol. IV, Roma, 1993, pp. 653-659.
} 
El problema fundamental reside en poder llegar a concretar el papel que jugaron tanto Saint-Denis como Chartres en la configuración de las esculturas de Astorga y Sangüesa, ya que las importantes relaciones que estos talleres mantuvieron con el ámbito francés están fuera de toda duda.

Por otro lado, la vinculación de las esculturas navarras con la fachada occidental de la catedral francesa antes citada, es para la profesora C. Fernández-Ladreda la prueba más significativa que explicaría la presencia de los rasgos avanzados de las estatuascolumna del conjunto navarro ${ }^{2478}$.

Para finalizar, aludiremos al trabajo de la profesora M. Melero, sin duda, uno de los estudios más específicos publicados hasta la fecha sobre las esculturas de Sangüesa $^{2479}$. La autora volvía sobre la famosa teoría relacionada con el escultor que firmó una de las esculturas navarras bajo el nombre de Leodegarius. Por lo general, a él se atribuyeron, además, obras tales como las estatuas-columna de Uncastillo, el sarcófago de doña Blanca de Nájera y algunos capiteles de la iglesia de Santo Domingo de la Calzada ${ }^{2480}$.

La mayoría de los autores emparentaron los trabajos adscritos al hipotético escultor Leodegarius con los prototipos de Chartres. Sin embargo, sin negar en ningún caso la aportación "chartriana", la investigadora ha conseguido entrever el sustrato borgoñón que presentan dichas esculturas. Se trataría de modelos de ascendencia borgoñona pero, y ello es fundamental, con las aportaciones procedentes de la Isla de Francia, según apunta ${ }^{2481}$.

Es este uno de los aspectos más importantes y evidentes que diferencian las esculturas de Sangüesa con respecto a los restos conservados en la catedral de Astorga. Mientras que Navarra recibía un doble impacto desde lo borgoñón y Chartres, en el Reino de León, tal y como defendió la profesora Cosmen, se advierte una adhesión, tan sólo, al "estilo" derivado de las obras de la Isla de Francia.

\footnotetext{
${ }^{2478}$ C. FERNÁNDEZ LADREDA, "El último tercio del siglo XII...”, p. 329.

${ }^{2479}$ M. MELERO MONEO, "El sarcófago de doña Blanca de Navarra y el taller de Leodegarius: Sangüesa y San Martín de Uncastillo", I Encuentro Transpirenaico sobre Patrimonio Histórico Artístico: La Escultura Románica, Zaragoza, 2007, pp. 7-29.

${ }^{2480}$ C. FERNÁNDEZ LADREDA, "El último tercio del siglo XII...", en particular, p. 328; D. OCÓN ALONSO, voz "Uncastillo", Enciclopedia dell'Arte Medievale, vol. XI, Roma, 2000, pp. 428-431 y A. DE EGRY, "Esculturas románicas inéditas de San Martín de Uncastillo", Archivo Español de Arte, 36, 1963, pp. 181-187.

${ }^{2481}$ M. MELERO MONEO, “El sarcófago de doña Blanca...”, p. 20.
} 
Esta compleja problemática sería completamente ajena a nuestro estudio, de no ser por las fuertes reminiscencias hacia las obras antiguas que mostraron, tanto los artífices de la Isla de Francia como los de Borgoña.

Haciendo más concretas nuestras afirmaciones, es obligatorio mencionar el clásico estudio realizado por W. Oakeshott, en el que abordaba las repercusiones del mundo antiguo sobre el arte medieval. Dicho autor, planteaba una serie de reflexiones basadas en una metodología de tradición formalista y comparativa y, a través de las cuales, intentaba perfilar el supuesto origen de la morfología y estilo de las estatuascolumna de la citada portada de la catedral de Chartres ${ }^{2482}$ (fig. 491).

El autor aludía a la importancia que, hipotéticamente, había tenido para la formación de estos escultores la escultura griega arcaica. El ideal sobre el que supuestamente se hubieron de basar, según defendía, se fundamentó en el conocimiento de una tipología escultórica bien difundida dentro de la cultura griega ${ }^{2483}$. Según el autor, los difundidos kouros y kore de la tradición arcaizante helena herederos, a su vez, de los lejanos preceptos egipcios y asirios, pudieron ser tomados como lejana referencia para crear estos prototipos medievales ${ }^{2484}$ (fig. 492).

Según el autor, en torno al año 1150, algunas de las esculturas de la catedral de Chartres materializaron y recuperaron una tendencia arcaica derivada del arte griego. En concreto, aludía a diversas esculturas datadas entre los siglos VI y V a. de C. ${ }^{2485}$.

Se trataba de una teoría obtenida a través de la aplicación, sobre ambas obras escultóricas, de un método comparativo formalista y que, hoy en día, resulta complicado poder llegar a sostener de una manera absoluta.

De esta manera y teniendo en cuenta este punto, la utilización del carácter lineal de los plegados, la verticalidad, alargamiento y espiritualidad de las figuras y la rigidez de éstas son características bien llamativas que, según M. Melero, habrían de generar una estética escultórica de gran importancia artística y que hace a la escultura de la puerta Real de Chartres verdaderamente inconfundible ${ }^{2486}$.

\footnotetext{
${ }^{2482}$ W. OAKESHOTT, Classical Inspiration..., pp. 97-100.

${ }^{2483}$ E. H. GOMBRICH, La Historia del Arte, London, 2008, pp. 75-82.

${ }^{2484}$ E. PARIBENI, "Kouros e Kore", Enciclopedia dell'arte antica, classica e orientale, Roma, 1961, pp. 398-402. Creemos que no es preciso realizar un análisis exhaustivo de los aspectos relacionados con el arte clásico, por lo que, la selección bibliográfica que aquí vamos a mostrar es, de manera intencionada, selectiva. Según se viene aceptando, estos tipos escultóricos se documentan ya desde la mitad del siglo VII a. de C. en las regiones del Ática y el Peloponeso.

${ }^{2485}$ W. OAKESHOTT, Classical Inspiration..., p. 98 e ID., "Some New Initials by the Entangled Figures Master Source", The Burlington Magazine, vol. 126, 973, 1984, pp. 230-232 y E. PARIBENI, "Kouros...", p. 400.

${ }^{2486}$ M. MELERO MONEO, La escultura románica..., p. 17.
} 
De forma general, las características que los especialistas en escultura románica y gótica han deslindado como representantes de determinadas corrientes desarrolladas desde la mitad del siglo XII y hasta los inicios del siguiente, tendrían, si seguimos las teorías vertidas por Oakeshott, su claro correspondiente dentro de las producciones artísticas griegas que hemos citado ${ }^{2487}$.

De la comparación de ambas tipologías se observan claros puntos en común. Las obras griegas muestran idéntica rigidez en la concepción del cuerpo, cierta tendencia a desarrollar un canon alargado que otorga una forma descompensada y cilíndrica a las figuras, así como una concepción de los miembros, por lo general, adosados al tronco $^{2488}$. Igualmente llamativo resulta el caso de las vestimentas, pues éstas fueron esculpidas prestando gran atención al drapeado, explotando la técnica "de los paños mojados" y mostrándose, en ocasiones, en extremo rígidas, formando pliegues geometrizados y antinaturales, que caen adosados al cuerpo de las figuras.

No es preciso desgranar todas las características generales que presenta este tipo de escultura griega, tarea que, por otra parte, se aleja de nuestra línea argumental ${ }^{2489}$.

Con todo, resulta casi igual de sugestivo detenerse en los rasgos tan peculiares que presentan todas estas producciones a la hora de concebir el rostro. Tanto la escultura griega arcaica como algunos de los ejemplos medievales que aquí analizamos, presenta un rictus facial muy específico y sobre el que resulta interesante detenerse.

Tal y como es sabido, los especialistas y estudiosos de la escultura griega de los citados Kouros y Korai, han señalado que una de las particularidades más sobresalientes de estas figuras es aquella que muestra ciertos rasgos arcaicos sobre determinadas zonas faciales de las figuras (fig. 493). La utilización de algunas soluciones geometrizantes en la musculatura y el cabello, también acabó por aplicarse sobre la concepción de los inconfundibles ojos almendrados que presentan algunas de ellas. Los labios cerrados o, en otros casos, con el superior levantado, configuran una sonrisa que algunos autores definieron como "arcaica". Esta solución anacrónica acabó por difundirse dentro de las producciones griegas como uno de sus rasgos más señeros. En este sentido, Oakeshott también aplicó la expresión de "sonrisa arcaica" para definir algunos de los gestos presentes en las esculturas románicas francesas. Sus afirmaciones llegaban incluso a

\footnotetext{
${ }^{2487}$ E. PARIBENI, “Kouros...”, p. 401.

${ }^{2488}$ Por otra parte, el formato de las estatuas-columna ofrece una solución perfecta para que tales figuras se adapten al marco arquitectónico.

${ }^{2489}$ E. PARIBENI, “Kouros...”, p. 398.
} 
defender que tales obras medievales podrían ser equiparadas, sin problemas, con respecto a determinadas tallas griegas provenientes de Chipre $^{2490}$.

Sin embargo, Oakeshott no fue el último autor defensor del recuerdo de la plástica griega en el medievo. Algunos especialistas más actuales utilizaron argumentos parecidos para explicar ciertos rasgos tan peculiares de la escultura románica hispana. En este sentido, cuando el profesor M. Castiñeiras se refiere a la escultura del famoso profeta Daniel del Pórtico de la Gloria (fig. 494), no duda en comparar tal solución, aunque sea de manera casi metafórica, con las soluciones griegas adoptadas por los escultores de Kouroi $^{2491}$. Según su criterio, el rictus que presenta el rostro del profeta de dicho conjunto ofrece una tipología similar a la "sonrisa arcaica" de la tradición antigua $^{2492}$.

En relación con esta escultura del Pórtico de la Gloria de Santiago, no fue éste el único autor en realizar tal comparación. Otro especialista, J. Rutherford, también defendió que el gesto risueño de la escultura, según su criterio, único en el arte románico, podía ser emparentado con algunos ejemplares de kouroi de la escultura griega del siglo V a. De C. ${ }^{2493}$.

Tal y como se observa, a la hora de explicar la típica sonrisa "eginética" o arcaica de esta importante escultura medieval hispana, los autores aludieron a complejas y lejanas filiaciones. Por nuestra parte, somos conscientes de lo complicado que resulta posicionarse sobre tal aspecto, por lo que optamos por confrontar los datos.

Así las cosas, lo más interesante de tales afirmaciones es la proximidad de dichas postura con respecto a las teorías de W. Oakeshott. De tales tendencias derivó esta actitud a la hora de explicar las esculturas de la fachada de Chartres o la sonrisa del profeta Daniel en el Pórtico de la Gloria, a través de su potencial filiación o relación con respecto a las producciones griegas arcaicas. Tales teorías difícilmente podrán ser confrontadas y demostradas de manera plena, más allá de las meras concomitancias formales.

\footnotetext{
${ }^{2490}$ W. OAKESHOTT, Classical Inspiration..., pp. 98-99. Este investigador llega a concretar la existencia del llamado "Maestro de la Sonrisa Arcaica", al que cree trabajando en la catedral de Chartres. Sobre la importancia de las fuentes clásicas antiguas y su influencia sobre determinadas producciones de cronología medieval, véase: N. GENDLE, voz "Cipro", Enciclopedia dell'arte medievale, vol. IV, Roma, 1993, pp. 800-812.

${ }^{2491}$ M. A. CASTIÑ̃EIRAS GONZÁLEZ, El Pórtico..., pp. 56-57 e ID., "O profeta Daniel na arte europea", Galicia, o sorriso de Daniel (R. Villares dir.), Santiago de Compostela, 2004, pp. 31-45, en particular, p. 32.

${ }^{2492}$ M. A. CASTIÑEIRAS GONZÁLEZ, “O profeta Daniel...”, p. 31.

2493 J. RUTHERFORD, "O fermoso sorriso do profeta Daniel", Real Academia Galega, A Coruña, 2008, pp. 1-21, en concreto, p. 14.
} 
En esta misma línea, los autores que estudiaron la decoración del conjunto occidental compostelano, no dudan en considerar que el autor o ideador del programa del Pórtico era conocedor de las últimas innovaciones del románico en Francia, relacionables con el primer gótico de la Isla de Francia" ${ }^{2494}$.

Tomando como base todo lo afirmado hasta el momento, creemos que podemos concluir y trazar varias hipótesis. En primer lugar, parece que no existe problema en aceptar la introducción, sobre todo a partir de los años cuarenta y cincuenta del siglo XII, de una serie de novedosas corrientes escultóricas de origen francés en la Península Ibérica. Así, a partir del ejemplo de las estatuas-columna de la abadía de Saint-Denis y las del pórtico Real de la catedral de Chartres, hemos insistido en la importancia de ambos centros como catalizadores de tales innovaciones. Finalmente, hemos enunciado, además, las teorías "griegas" que defendieron el posible recuerdo de la estatuaria arcaica helénica en estos movimientos.

$\mathrm{Su}$ influencia sobre las esculturas creadas durante la segunda mitad de siglo en suelo hispano fue cambiante, acusándose una mayor conexión de Chartres en Sangüesa y de Saint-Denis sobre Astorga, si citamos los hitos artísticos que aquí hemos barajado.

Aceptando tales relaciones, resta por determinar qué papel jugó el arte antiguo en la formación de tales soluciones.

Resulta prácticamente imposible poder defender con seguridad un conocimiento de la escultura griega arcaica en la Francia del siglo XII y la asimilación de tales formas por parte de los escultores románicos, por lo que, en última instancia, tan solo nos resta la aplicación de un método comparativo entre ambas producciones.

Los resultados que se obtienen, nuevamente, perfilan una situación de extrema complejidad, además de unas similitudes sorprendentes.

No es necesario volver, otra vez, sobre la fuerte impronta ejercida por las artes del periodo antiguo sobre las obras patrocinadas por el abad Suger y otra serie de focos franceses. Se trata de un tema que aquí ya hemos tratado, pero baste con recordar las numerosas expoliaciones, tanto físicas como iconográficas, realizadas dentro del basto corpus de obras generadas bajo el patrocinio del abad en Saint-Denis ${ }^{2495}$.

Con tales antecedentes, no sería ilógico deducir un hipotético conocimiento de las esculturas griegas del periodo arcaico en la región central francesa. Aunque, tal y

\footnotetext{
${ }^{2494}$ M. A. CASTIÑEIRAS GONZÁLEZ, El Pórtico, p. 17 y p. 43.

${ }^{2495}$ B. BRENK, "Suger Spolien...”, pp. 101-107.
} 
como comentamos, esta suposición se antoja muy seductora pero carece de valores argumentales seguros.

Hasta aquí se ha intentado poner de manifiesto, a través de un ejemplo tan concreto como el de las estatuas-columna y la defensa de su dependencia con respecto a la escultura griega, la complejidad de las fuentes que pudieron utilizar los escultores románicos franceses en torno a la mitad del siglo XII y sus oportunas repercusiones en la plástica escultórica realizada en Hispania a partir de los años 1150 y 1160.

No podemos demostrar que las soluciones adoptadas en los conjuntos españoles anteriormente citados sean herederas de una corriente recuperadora de lo clásico cuyo origen estaría, aceptando la hipótesis defendida por Oakeshott, dentro de la escultura griega arcaica y tamizada, a su vez, por la escultura románica de la Isla de Francia. Mediante esta inestable hipótesis hemos querido poner de manifiesto la enorme complejidad de fuentes que se pudieron conocer y cuya repercusión sobre la escultura románica hispana no siempre es fácil de detectar.

El caso de las estatuas-columna de resabios "antiquizantes" prepara el camino para poder insistir en la gran multiplicidad de fuentes, a veces lejanas y difícilmente accesibles para los artífices románicos. Por otra parte, tales premisas nos llevan, otra vez, a incidir en lo complejo que resulta poder llegar a diferenciar las reinterpretaciones de las obras antiguas realizadas por los talleres medievales a través de la observación directa de las piezas antiguas que tenían a su alcance, en confrontación con una elaboración foránea de lo antiguo. Fue en Francia donde se reelaboraron este tipo de soluciones antiguas, desde allí se difundieron y, según creemos, acabaron llegando a la Península Ibérica como prototipos de “importación” ya elaborados ${ }^{2496}$.

\footnotetext{
${ }^{2496}$ Al final de este capítulo se realizarán las oportunas conclusiones en relación con estos temas, buscando una confrontación que ponga en evidencia las fuertes diferencias entre los modos de asimilar las fuentes clásicas por los escultores románicos de este periodo finisecular, con respecto a los de etapas anteriores.
} 


\section{B. EL PROBLEMA DEL LLAMADO “ESTILO 1200”, TRAZADO DE UN PANORAMA GENERAL.}

De manera paralela a las innovaciones introducidas por los escultores de la Isla de Francia a partir de los años 1140 y 1150 y sus consecuentes repercusiones dentro de la escultura europea hasta los inicios del siglo XIII, la historiografía ha querido defender la existencia de otro supuesto "estilo" que, hipotéticamente, habría coexistido con los movimientos anteriores.

Insistimos en que este "nuevo" arte, englobado por determinados especialistas bajo la "etiqueta" de "estilo 1200", se desarrolló, desde un punto de vista cronológico, de una manera paralela y coetánea a las innovadoras corrientes surgidas desde la Isla de Francia, si bien llegó a su máximo desarrollo entre las últimas décadas del siglo XII y los primeros años del XIII.

Aquí tan sólo nos centraremos en esbozar un panorama general de la importancia que, por lo general, los autores suelen dar a las fuentes clásicas como enriquecedoras de este supuesto "estilo". No se abordará el concepto de una manera internacional, ni tampoco se intentará llegar a conclusiones que clarifiquen el derecho o la imposibilidad de esta serie de producciones para ostentar la categoría de "estilo"2497.

El problema focal estriba en las numerosas y continuas referencias que los expertos han realizado hacia los modelos clásicos como factores explicativos de algunas de las características más genuinas de este tipo de arte.

Por último, debemos advertir que, para acotar más nuestra exposición, nos remitiremos, preferentemente, al ámbito hispano.

\footnotetext{
${ }^{2497}$ Evidentemente se acudirán a conceptos y obras del ámbito europeo cuando sea necesario, pues no se puede negar que, en sí mismo, tal movimiento se ha caracterizado siempre por su enorme carácter internacional. Cf.: E. FERNÁNDEZ GONZÁLEZ, "Santo Martino de León...”, pp. 49-74.
} 


\section{EL “ARTE 1200” Y SUS PROBLEMAS. UNA SÍNTESIS INTRODUCTORIA.}

Parece obligado iniciar este breve repaso al concepto que encabeza este apartado, a través de la alusión a la exposición y el congreso celebrados en el año 1970 en Nueva York y que fueron englobados bajo el título The Year $1200^{2498}$.

Tal evento científico supuso el inicio de una de las corrientes teóricas más difundidas dentro de la Historia del Arte, aquella que defendía la posibilidad de categorizar algunas de las características más llamativas de las artes realizadas en el entorno de este año bajo el epígrafe de "estilo 1200".

A partir de tales propuestas, los investigadores y estudiosos han intentado, por todos los medios, valorar la importancia del concepto, su validez y la posibilidad de continuar manejándolo de una manera correcta al aplicarlo a este tipo de arte, proponiéndose como tarea fundamental, la definición del mismo.

En relación con ello, desde sus numerosos estudios dedicados al tema, el profesor L. Grodecki mantenía:

"On peut remonter jusque vers 1170 pour en voir les premières manifestations du style 1200 ; après 1230, la poussée des formes proprement gothiques est déjà très forte, en France du Nord en particulier, sans que les survivances des styles antérieures disparaissent, 2499 .

El autor planteaba una supuesta definición formal del concepto, insistiendo en lo problemático de agrupar una serie de obras artísticas de características y naturalezas tan dispares bajo un mismo concepto estilístico. Además, remarcaba el incremento del problema en relación con el concepto de "arte de transición", sobre el cual parecía asentarse esta nueva "estética"2500.

La mayoría de los autores continuaron, hasta fechas muy recientes, haciendo suyas las palabras del autor francés. Así por ejemplo, en su estudio monográfico sobre el tema, el profesor F. Galván aducía que, entre los elementos que podían definir el "nuevo estilo", estarían el uso de colores vivos, la firmeza de los contornos o la

\footnotetext{
${ }^{2498}$ The Year 1200. A Symposium, New York, 1975 y The Year 1200. A Background Survey, New York, 1970.

${ }^{2499}$ L. GRODECKI, “Le Style 1200”, Encyclopedia Universalis, Suplément II, 1980, pp. 1337-1340.

${ }^{2500}$ Ibidem, p. 385. Debemos recordar también la importancia que en su día se dio a la problemática de la evolución de las formas dentro de la teoría de los estilos y la complejidad de los periodos de transición entre los mismos. Cf.: J. Ma AZCÁRATE RISTORI, El protogótico..., pp. 14-15.
} 
amplitud de los vestidos. Siguiendo al experto francés, el citado autor destacaba la cronología que iba desde los años 1170 al 1230, insistiendo en la no homogeneidad del "estilo" que se intentaba definir. De este modo, se localizaron los puntos fundamentales en los que, hipotéticamente, se desarrolló, en Inglaterra, Francia septentrional y París y las regiones renana y mosana. En este sentido, escribía:

“(...) En el sudeste inglés las formas se debatirán entre cierto carácter antiquizante o clasicista y la estilización que apunta hacia formas góticas; el papel más preponderante fue jugado por la miniatura y la vidriera. Francia será esencial en la configuración del nuevo lenguaje, destacando sus manifestaciones en vidrieras, esmaltes y miniaturas (...). Francia se convertirá en el principal foco del gótico. El tercer núcleo clave en el desarrollo del "estilo 1200” (...) fueron las regiones renana y mosana, con unas características ligeramente diferentes a las manifestadas en Inglaterra y Francia, pues es produce una continuación en el desarrollo de las formas románicas, que se barroquizan; en esta zona la influencia bizantina ser hará mucho más patente (...) Por tanto, bizantinismo, clasicismo, un marco cronológico entre 1170 y 1230, una preponderancia de Inglaterra, Francia y las regiones del Rhin y del Mosa vendrían a definir las líneas maestras de los planteamientos de L. Grodecki, que encontrarán su plasmación en las artes del color y en las suntuarias, quedando prácticamente excluidas las artes monumentales"2501.

Las palabras del profesor F. Galván sintetizan, de manera coherente, la complejidad del supuesto "estilo", sus características y el marco geográfico y cronológico en el que, supuestamente, se habría de desarrollar. Tal y como se podrá advertir, las palabras del autor, recogidas en los numerosos artículos y monografías publicadas en relación con el tema, se presentan como una base estable sobre la que partir para realizar nuestras propias reflexiones.

\footnotetext{
${ }^{2501}$ F. GALVÁN FREILE, La decoración de manuscritos en León en torno al año 1200, 3 vols., León, 1997, vol. I, pp. 64-65; L. GRODECKI, "Le Style 1200...", pp. 1337-1340; ID., Le vitrail roman, pp. 213-250 e ID., Le vitrail gothique au XIII ${ }^{e}$ siècle, pp. 10-100. Véase también: A. M. KOLDEWEIJ, voz "Mosana, arte", Enciclopedia dell'arte medievale, vol. VIII, Roma, 1997, pp. 578-582. El río Mosa, que nace sobre el Plateau de Langres, en la Francia oriental y desemboca en el Mar del Norte, en los Países Bajos, constituyó durante el medievo una importante vía de comunicación. No sólo se trataba de la conexión con la región renana y una posibilidad para acceder a Inglaterra, sino que, igualmente, acercaba lugares tan dispares como los de Verdun, Mezières, Dinant, Namur, Huy, Lieja, Maastricht, Roermond o Venlo. Se trata de reconocidos lugares en los que se gestarían obras teóricamente adscritas a este "arte 1200 ".
} 
Resulta evidente la complejidad de poder incluir todas las manifestaciones artísticas realizadas en el entorno del año 1200 bajo un mismo epígrafe de talante estilístico. El supuesto "estilo" se desarrolló en una problemática etapa, a medio camino entre las formas románicas y las góticas ${ }^{2502}$.

Son muchos los problemas surgidos en relación con el uso de este término, ya que, a las razones conceptuales, de índole geográfica y cronológica, se suman otras más extensas. Es incuestionable que la mayoría de los autores han insistido sobre el problema de poder aplicar el método estilístico y el término "arte 1200" sobre todas las artes con igual seguridad. En relación con ello, baste con señalar la desigual aceptación con que los diversos estudiosos entendieron la incidencia del supuesto "estilo" sobre la arquitectura o la escultura.

Al abordar esta cuestión, el profesor F. Galván aceptaba que la diversidad, amplitud, complejidad y calidad de las manifestaciones artísticas que tienen lugar en Europa, durante los años inmediatamente anteriores y posteriores al 1200, aumentaban equívocamente el problema de poder llegar a valorar el grado de incidencia del "estilo" sobre las diversas tipologías artísticas.

La teoría aceptada por éste y otros especialistas tenía su origen en las afirmaciones realizadas por L. Grodecki, quién consideraba que era sobre las denominadas "artes del color" y las artes suntuarias, es decir la miniatura, la pintura, la vidriera, el esmalte y la orfebrería, sobre las que con mayor incidencia habían incidido los nuevos preceptos estéticos del "1200" los autores que abordaron el tema en etapas posteriores ${ }^{2504}$.

\footnotetext{
${ }^{2502}$ Utilizamos tales calificativos derivados de la teoría de los estilos por ser los que, de una forma más o menos unánime, vienen utilizando los especialistas. Véanse las reflexiones realizadas en: $P$. WILLIAMSON, Op. cit., pp. 33-107; J. Ma AZCÁRATE, Arte Gótico..., pp. 139-151 y J. YARZA LUACES, Arte y Arquitectura..., en concreto, pp. 249-309. Es evidente que cuando hablamos de una evolución de las formas románicas hacia las góticas no nos referimos a una transición y evolución de las primeras hacia las segundas. Parece claro que la etapa final de románico no acabó evolucionando de manera natural hacia el gótico. Igualmente, somos conscientes de la peligrosidad que presenta tal afirmación, sin embargo, será un tema sobre el que volveremos en las páginas posteriores.

${ }^{2503}$ L. GRODECKI, "Le Style...”, p. 392; F. GALVÁN FREILE, La decoración miniada ..., pp. 16-18; ID., "Obras de Santo Martino", Maravillas de la España Medieval. Tesoro Sagrado y Monarquía, vol. I, León, 2001, ficha catalográfica 197, p. 474 e ID., "Los libros litúrgicos y espirituales en la Edad Media", Maravillas de la España Medieval. Tesoro Sagrado y Monarquía, vol. I, León, 2001, pp. 453-454 y F. GALVÁN FREILE y J. A. MORÁIS MORÁN, Op. cit., p. 479. En esta última aportación, los autores llamaban la atención sobre el carácter heterogéneo y variable de la presencia del "estilo 1200" sobre las diversas técnicas artísticas.

${ }^{2504}$ F. GALVÁN FREILE, La decoración de manuscritos..., p. 65 y F. GALVÁN FREILE y J. A. MORÁIS MORÁN, Op. cit., pp. 479-482. Los autores insistieron, recientemente, sobre la importancia de las artes del color como asimiladoras del nuevo "estilo", "quedando prácticamente excluidas las artes monumentales". Se pretendía poner de relieve su mayor asimilación sobre estas artes del color, por encima, por ejemplo, de la escultura. Para algunas reflexiones sobre el concepto de "artes del color",
} 
A pesar de tales tentativas y esfuerzos por definir el "estilo", no dejarán de surgir numerosas voces fuertemente críticas con tales planteamientos. Así, en el año 1996, el profesor I. Bango publicaba un estudio en el que se mostraba en desacuerdo con diversos aspectos que hasta el momento se habían defendido como configuradores teóricos de este "estilo"2505. El autor consideraba que la conocida exposición neoyorquina sobre el año 1200 buscaba un nuevo sistema de periodizar el arte, proponiendo un sistema que superase el corsé de los esquemas estilísticos convencionales mediante referentes más neutrales, como sería el meramente cronológico, y caracterizaciones formales más epidérmicas, brillantez de los colores y un cierto tratamiento manierista de las formas ${ }^{2506}$.

A través de las afirmaciones realizadas en sus trabajos, quedaba totalmente descartada, por ejemplo, la existencia de una arquitectura encuadrable dentro del término "1200", dejando abiertas las puertas hacia las artes suntuarias.

Así las cosas, ya fuese tomando una postura crítica a la hora de aceptar el término o, por el contrario, aceptando la existencia de una serie de características susceptibles de ser englobadas bajo esta nomenclatura estilística, lo que parece claro, es que la supuesta "estética 1200" no fue igualmente permeable a todas las artes y técnicas. Tal y como desarrollaremos en las páginas venideras, se percibe su mayor y más profunda presencia en aquellas producciones relacionadas con "el color", sin que por ello se niegue, en ningún caso, sus ecos sobre la escultura, por ejemplo ${ }^{2507}$.

Hasta aquí hemos intentado esbozar algunos de los problemas más significativos surgidos de la aplicación del término "1200". Con todo, resulta evidente la acusada síntesis y simplificación, tanto teórica como bibliográfica, que muestran las reflexiones anteriores, claro reflejo de nuestra preocupación por otro tema más cercano al estudio que aquí planteamos.

véase: J. YARZA LUACES, “Artes del color en el siglo XV en la catedral de León”, La catedral de León en la Edad Media, León, 2004, pp. 399-431 e ID., "La miniatura en Galicia, León y Castilla en tiempos del Maestro Mateo", O Pórtico da Gloria e a Arte do seu Tempo, A Coruña, 1991, pp. 319-355, en particular, p. 313, donde se utiliza el término "artes del color" para insistir de que se trata del tipo de producciones donde mejor se asimiló el "estilo 1200".

${ }_{2505}$ I. G. BANGO TORVISO, “Crisis de una Historia del Arte...", pp. 15-28.

2506 Ibidem, p. 21.

${ }^{2507}$ La profesora D. Ocón Alonso ha seguido una línea de investigación centrada en tales aspectos desde hace mucho tiempo. Tal y como se podrá comprobar, sus publicaciones han demostrado, en cierta medida, la asimilación de la "estética 1200" en determinados focos artísticos centrados en las producciones escultóricas. Más adelante se recogerán y valorarán algunas de sus aportaciones más clarificadoras. 
Partiendo de estas pautas, en el siguiente apartado nos centraremos, más concretamente, en la influencia ejercida por el arte antiguo dentro de la formación de este supuesto "estilo 1200", axioma central y objetivo básico del estudio. Aún con todo, creemos que tales preceptos demandaban, obligatoriamente, una serie de reflexiones preparatorias para abordar este asunto, que tendrá como hilo vertebral preferente el área geográfica hispana. 


\section{El PAPEL DE LO “CLÁSICO” EN LA FORMACIÓN DEL “ESTILO 1200”.}

Desde la publicación en el año 1961 del conocido artículo del profesor W. Sauerländer, quedaba patente la supuesta importancia que el arte antiguo había tenido en el desarrollo del "estilo 1200",2508.

Aceptando, aunque con cautela, la homogeneidad que presentan algunas de las características estéticas de las obras realizadas a finales del siglo XII y susceptibles de formar parte de este "arte 1200", parece obligado preguntarse también por el origen de las tan defendidas formas "clásicas" que este movimiento presenta.

A la hora de valorar la influencia ejercida por el arte antiguo sobre este tipo de producciones, son muchos los problemas que surgen. La mayoría de los autores se limitaron a insistir en tal aspecto, sin concretar exactamente de que tipo de clasicismo se trataba y su delimitación cronológica dentro de los siglos de la Antigüedad. Por lo general, se aludía a las fuentes clásicas de una manera vaga e ilimitada, sin decantarse ni localizar el tipo de arte antiguo que acabó por traspasarse hasta finales del siglo XII. En esta misma línea y dentro del caso hispano, tampoco se concretaron los mecanismos por los que se habría producido tal asimilación. Se advierte, por tanto, que el término "clásico", tal y como habíamos señalado para las etapas anteriores de nuestro estudio, acabó por usarse como un término vacío y carente de exactitud.

Decir que el supuesto “arte 1200" presenta fundamentos clásicos puede resultar una afirmación en exceso abstracta. Se necesitaba una mayor exactitud, la obligación de concretar el tipo de arte antiguo y los vestigios de este arte que pudieron llegar a entrar en contacto con los artífices de las últimas etapas del arte románico.

Surge entonces una incógnita ya familiar dentro de este trabajo. Nuevamente debemos plantearnos la posibilidad de reconstruir el paisaje monumental que aquellos hombres pudieron tener ante los ojos, las obras a las que tuvieron alcance y el grado de impacto que su observación produjo sobre el arte que estaban creando. Además de ello, la cuestión vértice reside en poder llegar a discernir si la filiación de estos motivos clásicos se puede explicar, dentro del caso hispano, mediante un conocimiento directo de las obras antiguas por parte de los escultores románicos activos en nuestro suelo. Tales interrogantes no poseen una respuesta fácil ${ }^{2509}$.

\footnotetext{
${ }^{2508}$ W. SAUERLÄNDER, “Art antique et sculpture autour de 1200”, Art de France, I, 1961, pp. 47-56.

${ }^{2509}$ I. G. BANGO TORVISO, "El paisaje monumental románico...”, pp. 33-50 e ID., "Los expolios del paisaje monumental...", pp. 7-50. El profesor Bango siempre ha tenido muy en cuenta, en estos y otros
} 
Tanto las construcciones como los restos escultóricos romanos, debían mostrarse al alcance de los nuevos constructores y artífices que, a modo de expoliadores, podían apoderarse libremente de dichos restos ${ }^{2510}$. Aunque en este sentido, somos conscientes de lo complicado o, casi imposible, que resulta poder llegar a concretar si existieron diferencias en la actitud que mostraron hacia esos vestigios los artistas de este momento con respecto a los activos durante las primeras décadas del siglo XII.

Como entonces, tal proceso debió pasar por varios estadios que iban, desde la apropiación íntegra de estos vestigios, hasta la reconversión o reabsorción parcial de los mismos dentro de los nuevos edificios. Se trataba de una costumbre que tan sólo continuaba perpetuando una tradición constatada durante la Antigüedad tardía y la Alta Edad Media europeas y, de manera paralela, también en el ámbito hispano ${ }^{2511}$. Un hábito que, según se ha defendido, se mantuvo más o menos vigente hasta los siglos finales del medievo ${ }^{2512}$.

Sin embargo, en la búsqueda de unos datos más exactos, aquellos que se encargaron de definir el "estilo 1200", se mostraron ciertamente ambiguos a la hora de especificar las características que compondrían tal estilo. Por lo general, los diferentes investigadores señalaron una serie de características comunes, que vendrían a definir el nuevo "estilo" y que, básicamente, se trataba de dos: fuerte impronta bizantina y cierto clasicismo en las formas" ${ }^{, 2513}$.

La complejidad de acotar el tipo de obras y periodos del arte antiguo, que fueron tomados como modelos para el surgimiento de la "estética 1200", se refleja, incluso, en algunos aspectos que nosotros mismos hemos apoyado en otras ocasiones ${ }^{2514}$.

Aún con las dudas que plantea el tema, todo parece indicar que las fuentes en las que ahora se basarán los artífices de finales de siglo son dispares, heterogéneas y de

estudios, la importancia de los vestigios de la Antigüedad, especialmente romanos y tardorromanos, para la formación de la arquitectura y la estética alto y pleno medievales.

${ }^{2510}$ S. SETTIS, "Continuità, distanza...”, pp. 372-486.

2511 C. COSMEN ALONSO, "Noticias sobre arquitectura...", pp. 83-90; ID., "Noticias sobre la reconstrucción arquitectónica...”, pp. 599-607 y A. M. MARTÍNEZ TEJERA, “Arquitectura cristiana en Hispania...”, pp. 109-187.

${ }^{2512}$ E. PANOFSKY, Renacimiento y renacimientos..., pp. 83-173.

${ }^{2513}$ F. GALVÁN FREILE, La decoración de manuscritos..., p. 63; W. OAKESHOTT, Classical Inspiration..., p. 102 y The Year 1200. A Centennial..., pp. 43-45 y pp. 235-294.

${ }^{2514}$ F. GALVÁN FREILE y J. A. MORÁIS MORÁN, Op. cit., p. 479. Según defendíamos, se trata de un arte de herencia clásica. En la actualidad, aún estando plenamente de acuerdo con tal afirmación, creemos que sigue siendo necesario matizar y puntualizar qué tipo de "clasicismo" impregnó el "arte 1200". 
orígenes diversos $^{2515}$. Ello conllevará la generación de una estética de talante "antiquizante", potenciada bajo el criterio rector derivado de los impulsos patrocinadores de las élites cortesanas de toda Europa, tanto la continental, como la de las regiones insulares.

Si se acepta, abiertamente, una dependencia de las artes realizadas en torno al 1200 con respecto a las producciones artísticas de la Antigüedad, las afirmaciones deben ser extremadamente precisas ${ }^{2516}$.

Ahora bien, ¿cómo podemos llegar a discernir, separar y valorar los diferentes clasicismos empleados por los escultores? ¿qué tipos de obras antiguas y de que cronologías pudieron acabar enriqueciendo sus lenguajes artísticos? y por último, ¿podemos continuar considerando el clasicismo de tipo bizantino como un elemento plenamente asimilado por los escultores activos en Hispania a finales del siglo XII?. De ser positiva la respuesta a tal interrogante, tendremos que cuestionarnos también si éste tuvo la fuerza suficiente como para transformar su valor foráneo en un componente autóctono de nuestros territorios.

De este modo, aceptando la fuerza que ejerció lo bizantino sobre esta tendencia del arte románico, no resulta fácil teorizar sobre la importancia del arte clásico, tanto griego como romano, a la hora de analizar los rasgos "antiquizantes" que mostró el arte producido en Bizancio a lo largo de los siglos en los que se desarrolló ${ }^{2517}$. A estos aspectos debemos sumar otros muy específicos, derivados de la pluralidad misma del arte bizantino. La importancia del arte antiguo dentro de la configuración de la plástica comnena es tan sólo uno de los vértices más complejos a los que nos referimos ${ }^{2518}$.

\footnotetext{
${ }^{2515}$ Podríamos afirmar incluso, que la cantidad de fuentes y su riqueza, fueron más abundantes y de orígenes más complejos que las utilizadas por el movimiento escultórico "hispano-languedociano" desarrollado hasta la primera mitad del siglo XII.

${ }^{2516}$ J. A. MORÁIS MORÁN, "El valor clásico de la arquitectura asturiana...”, (en prensa).

${ }^{2517}$ Además de las obras y estudios mencionados anteriormente en este apartado, véase: E. KITZINGER, "The Byzantine Contribution to Western Art $\mathrm{f}$ the Twelfth and Thirteenth Century", Dumbarton Oaks Papers, XX, 1966, pp. 27-47; ID., Byzantine Art in the making. Main lines of stylistic development in Mediterranean Art $3^{\text {rd }}$ - $7^{\text {th }}$ Century, Cambridge, 1995, pp. 22-44; O. DEMUS, Byzantine Art and the West, New York, 1970, pp. 5-20; K. WEITZMANN, "Various Aspects of Byzantine Influence on the Latin Countries from the Sixth to the Twelfth Centuries", Dumbarton Oaks Papers, XX, 1966, pp. 3-24 e E. PANOFSKY, Renacimiento y renacimientos..., pp. 85-98. Desde otro orden de cosas, resaltamos la importancia que el tema posee en la actualidad. Entre el mes de Octubre de 2008 y Marzo de 2009 se celebró en la Royal Academy of Arts de Londres una exposición de la que surgió un importante catálogo mediante el cual abordar tales cuestiones. Cf.: TH. F. MATHEWS, "The Beginnings of Christian Art", Byzantium 330-1453, London, 2008, pp. 46-63; H. MAGUIRE, "From Constantine to Iconoclasm", Byzantium 330-1453, London, 2008, pp. 66-109 y M. BACCI, "Byzantium and the West", Byzantium 330-1453, London, 2008, pp. 276-305.

${ }^{2518}$ Estos son, simplificadamente, los componentes de raíz clasicista antigua que pudieron acabar siendo absorbidos por el "estilo 1200". Vid.: F. GALVÁN FREILE, La decoración miniada ..., pp. 10-23 e ID., La decoración de manuscritos..., p. 50-68.
} 
No obstante, aceptando la influencia ejercida por el arte clásico sobre Bizancio, el problema reside en poder llegar a rastrear la naturaleza de tal "clasicismo" a lo largo de sus múltiples transformaciones, desde su presencia en la plástica bizantina, hasta su difusión a lo largo de los bastos territorios europeos ${ }^{2519}$.

Finalmente, el problema se agudiza al intentar definir los derroteros que ese tipo de filiaciones clásicas siguieron tras el momento en el que penetraron en Europa ${ }^{2520}$.

La tarea se complica al constatar que, con la llegada de estas corrientes bizantinizantes a los distintos territorios de la Europa medieval, estas filiaciones "clásicas" se tamizaron, fusionaron y mutaron al sumarse a otro tipo de "clasicismos" que habían sobrevivido en estos territorios. Nos referimos, en concreto, a la importancia que tuvieron las artes de época carolingia y otoniana, cuyas órbitas culturales se caracterizaron por una plena asimilación con los preceptos clásicos ${ }^{2521}$.

Concluimos entonces que, a la vista de lo expuesto, resultaría enormemente complejo poder llegar a concretar el lugar que ocupó cada uno de estos "estilemas clásicos" en la formación de este supuesto "estilo 1200".

Desde el ámbito de la historiografía española, junto con las publicaciones del profesor F. Galván, tendrían una importancia vital aquellas realizadas por la profesora E. Fernández quién, desde hace años, abordó la problemática de la llegada de corrientes bizantinizantes a la Península, sobre todo, dentro de las producciones librarias ${ }^{2522}$.

\footnotetext{
${ }^{2519}$ Los estudiosos más prestigiosos no han cesado de aludir al arte griego y romano en la formación de la estética que hoy denominamos bizantina. El problema, a parte de los apuntados arriba, reside en que dicho arte se extendió a lo largo de muchos siglos, en los cuales, suponemos, que las fuentes antiguas utilizadas fueron enormemente dispares. Desde el mismo arte tardoantiguo cristiano, hasta las producciones ravenantes de la época de Justiniano, las fuentes clásicas estuvieron presentes. Ahora bien, las producciones plásticas desarrolladas en el Bizancio de los siglos XI al XIV, continuarán presentando recuerdos de la tradición clásica griega y romana. La cuestión es de gran complejidad, pero suponemos que los modelos antiguos a los que recurrieron variarían a lo largo de este arco temporal. Para una síntesis clara de estos aspectos, véase: J. BECKWITH, Arte paleocristiano y bizantino..., pp. 113-158 y pp. 307370

${ }^{2520}$ O. DEMUS, “A Renascence of Early Christian Art in Thirteenth Century Venice", Late Classical and Mediaeval Studies in honor of Albert Mathias Friend, JR. (K. Weitzmann ed.), Princeton, 1955, pp. 348361; G. MATTHIAE, Pittura romana del Medioevo. Secoli IV-X, vol. I, Roma, 1987, en concreto, pp. 128-132, donde se incluye un capítulo titulado "Problemática Bizantina a Roma". Consúltese también: R. ALCOY, "Les pintures bizantinitzants de Sant Esteve d'Andorra La Vella en el món europeu del 1200", Lambard, V, 1989-1991, pp. 23-47 y M. GUARDIA PONS, "Una obra bizantina de Ciudad Real y el tema de la Anástasis”, D’Art, 12, 1986, pp. 86-112. Esta última autora confirma la importancia de la tradición bizantina dentro del ámbito peninsular hispano a lo largo de la Alta y Plena Edad Media. Véase igualmente: M. VALDÉS FERNÁNDEZ, "Las artes y sus promotores en la época de Fernando III (12171252)", Fernando III y su tiempo (1201-1252), León, 2003, pp. 235-258.

${ }^{2521}$ V. H. ELBERN, "Carolingia, Arte”, Enciclopedia dell'Arte Medievale, vol. IV, Roma, 1993, pp. 294304 y G. LORENZONI, "Carolingia, Arte. Roma", Enciclopedia dell'Arte Medievale, vol. IV, Roma, 1993, pp. 315-317.

${ }^{2522}$ E. FERNÁNDEZ GONZÁLEZ, “Las miniaturas de los Códices...”, pp. 515-549.
} 
Sin embargo, siguiendo la línea argumental de nuestro estudio, poseen mayor interés para nuestro tema, aquellos estudios que se centraron en analizar la llegada de estas corrientes clásicas bizantinas y su repercusión sobre la escultura. Son, sin duda, los trabajos de la profesora D. Ocón, los que más han insistido sobre el enriquecimiento de la "estética 1200" hispana y su aplicación sobre la escultura románica ${ }^{2523}$.

No vamos a insistir nuevamente en la cuestión, por otra parte ya tratada, de la desigual presencia del "movimiento 1200" sobre las artes. Mientras que algunos especialistas defendieron las supuestas repercusiones, incluso dentro de la escultura, otros autores, sin embargo, prefirieron minimizar sus consecuencias sobre la Península Ibérica. Así, por ejemplo, según el profesor M. Valdés Fernández, dentro del "1200 hispano" y, más concretamente, en las artes creadas en el Reino de León y Castilla, la repercusión de esta estética considerada internacional fue mínima ${ }^{2524}$.

Hasta aquí se ha intentado explicar de manera muy simplificada el problema terminológico y conceptual de la expresión “estilo 1200”, la difusión desigual que tuvo sobre las diferentes manifestaciones artísticas y la complejidad y peligrosidad de aplicarlo de manera segura sobre nuestro estudio. A ello se suma, además, el problema de poder utilizar el adjetivo "clásico", por otra parte, igualmente abstracto, sobre un concepto tan inseguro como artificial.

\footnotetext{
${ }^{2523}$ D. OCÓN ALONSO, "Los ecos del último taller de Silos en el románico navarro-aragonés y la influencia bizantina en la escultura española en torno al año 1200”, El románico en Silos, Santo Domingo de Silos, vol. I, Burgos, 1990, pp. 501-510; ID., "Bizantinismo y difusión de modelos en el románico periférico", Actas del VIII Congreso CEHA, Cáceres, 1990, pp. 95-102; ID., "Alfonso VII, la llegada de las corrientes artísticas de la corte inglesa y el bizantinismo en la escultura hispana de fines del siglo XII", II Curso de cultura medieval: Alfonso VIII y su época, Madrid, 1992, pp. 307-320; ID., "La recepción de las corrientes artísticas monumentales europeas en la escultura monumental castellana en torno a 1200", El arte español en épocas de transición, vol. I, León, 1994, pp. 17-26; ID., "El papel artístico de las reinas hispanas en la segunda mitad del siglo XII: Leonor de Castilla y Sancha de Aragón”, La mujer en el arte español, Madrid, 1997, pp. 27-39 e ID., "Castilla, León y Galicia en tiempos de Alfonso VII", El Románico y el Mediterráneo. Cataluña, Toulouse y Pisa. 1120-1180, Barcelona, 2008, pp. 111-119.

${ }^{2524}$ M. VALDÉS FERNÁNDEZ, "Las artes y sus promotores...", p. 244, nota 24 y D. OCÓN ALONSO, "Regnun et sacerdotium au monastère de Silos", Les Cahiers de Saint-Michel de Cuxa, XXXVI, 2005, pp. 195-208. En este estudio, la autora desarrolla una serie de argumentos encaminados a señalar la importancia de algunas regiones, tales como Sicilia, a la hora de explicar la introducción de ciertas soluciones bizantinas en España.
} 


\section{LA DIFUSIÓN DE FÓRMULAS CLÁSICAS EN TORNO AL AÑO 1200. DEL ÁMBITO EUROPEO} AL CASO HISPANO ${ }^{2525}$.

En el presente apartado se pondrá de relieve la diferente intensidad ejercida por este movimiento sobre las diversas manifestaciones artísticas. La "estética 1200" no caló por igual dentro de todas las técnicas, tal y como ya hemos expuesto. Este hecho queda plenamente demostrado a través de un simple repaso general del panorama europeo en los años anteriores y posteriores al año 1200.

Las artes realizadas en torno a esta cronología presentan ciertos rasgos en común, independientemente de la técnica con la que fueron realizadas, a excepción, de la propia arquitectura. En relación con ella, tal y como se expuso, no existe consenso en defender una asimilación de estos preceptos ${ }^{2526}$.

A lo largo de las páginas siguientes se realizará un rápido balance de la situación europea, citando, a título de ejemplo, las principales áreas geográficas y los centros en los que la asimilación del "estilo 1200” es más evidente.

A continuación, el análisis se centrará en el caso hispano, prestando especial atención a la escultura, en torno a la cual hemos centrado de manera preferente todo nuestro discurso.

Resulta difícil iniciar tales objetivos refiriéndonos a un lugar geográfico en concreto. El hecho de que aquí se analicen antes los territorios de la Península Itálica que los de centro Europa, por ejemplo, no indica una primacía de los primeros con respecto los segundos. La perpetuación de los modelos clásicos, heredados por la tradición bizantina, fue un fenómeno extendido a lo largo de toda la Edad Media europea, pero que, tal y como se ha afirmado, cobró especial fuerza en torno al año 1200 .

\footnotetext{
${ }^{2525}$ Para este apartado hemos tomado como referencia el completo estado de la cuestión planteado en: F. GALVÁN FREILE, La decoración de manuscritos..., pp. 62-77, dentro del capítulo que el autor tituló "El estilo 1200: planteamiento del concepto. Aproximación historiográfica. El caso hispano".

${ }^{2526}$ E. FERNÁNDEZ GONZÁLEZ, "Hacia la renovación del leguaje arquitectónico...", pp. 349-369. En este reciente estudio, la autora realiza una serie de reflexiones sobre la actividad edilicia de los territorios hispanos bajo el patrocinio del monarca Alfonso IX, es decir, en un arco temporal que iría desde los últimos años del siglo XII y los primeros del siguiente. En relación con ello, la investigadora escribe: “(...) consideramos que en las artes del Reino de León, en torno a 1200, se introducen una serie de cambios considerables, bien visibles en las estructuras arquitectónicas y en el campo de la microarquitectura y emparentables con formas y tradiciones diversas". Sus reflexiones participan de las teorías expuestas por otros especialistas que, a pesar de estar de acuerdo en defender ciertos cambios en torno al año 1200 dentro de la arquitectura, nunca llegaron a presentar rasgos tan diversos, peculiares y expresivos como los que se observarán en otras producciones plásticas. Partiendo de tales preceptos, se entiende bien que la expresión "arte 1200" no fuera aplicada sobre las obras arquitectónicas.
} 
Los análisis que se realizarán a continuación no responden a un orden cronológico ni pretenden otorgar mayor importancia a un territorio sobre el otro. Se trata, como se ha señalado, de un fenómeno de carácter internacional, cuyas consecuencias se dejaron sentir en gran parte de Europa, dentro de un marco temporal más o menos coetáneo ${ }^{2527}$.

La transmisión de fórmulas "antiquizantes" reinterpretadas en el seno del arte bizantino y traspasadas a territorios foráneos donde fueron reelaboradas, tendrá en el caso italiano una especial relevancia.

Ahora bien, debemos ser concisos, se trata de la absorción de prototipos clásicos ya asimilados por la órbita bizantina. De allí partieron hacia GRECIA e ITALIA, donde fueron otra vez reelaborados. Ello implica que el grado de disolución de las formas clásicas "puras" va a ser muy elevado. No se trataba de un clasicismo heredado a través de una simple transmisión, sino que contaba ya con muchos estadios de reelaboración.

El papel que posee el historiador del arte ante este fenómeno es complejo, pues la tarea de aislar dichos rasgos clásicos de todos los demás elementos añadidos y absorbidos a lo largo de estas reinterpretaciones es casi imposible.

Tanto el actual territorio correspondiente a Grecia como la misma Italia, sufrieron de manera desigual la absorción de prototipos bizantinos a lo largo de los muchos siglos de actividad artística ${ }^{2528}$.

El Mediterráneo se convertirá, nuevamente, en una de las vías de tránsito de estos modelos, inundando territorios dispares, desde la actual Turquía y el Mar Negro, hasta las regiones de Egipto y Siria, desde las antiguas colonias e islas del Hélade hasta la Península Itálica, sin olvidar, por ejemplo, otros lugares tan señeros como la Península del Sinaí2529.

Un panorama geográfico tan amplio fue bien ilustrado hace tiempo por la profesora E. Fernández, quién publicó un mapa en el que demarcaban, claramente, las áreas culturales determinantes en el desarrollo del "estilo 1200"2530(fig. 495).

\footnotetext{
${ }^{2527}$ E. FERNÁNDEZ GONZÁLEZ, “Santo Martino...,", pp. 49-74.

${ }^{2528}$ J. BECKWITH, Arte Paleocristiano y Bizantino..., en particular, pp. 195-218. El clásico trabajo de este investigador resume, de manera muy sintética y clara, la importancia del arte romano y el legado del clasicismo pagano al arte paleocristiano. Su importancia estriba en el tratamiento que hace del traspaso de esos elementos clásicos a la misma tradición bizantina, desde la época de Teodosio y Rávena, al seno del Imperio Bizantino y desde allí, a toda la Edad Media.

${ }^{2529}$ Ibidem, pp. 175-182.

${ }^{2530}$ E. FERNÁNDEZ GONZÁLEZ, “Santo Martino de León...”, lám. 2.
} 
Centrándonos más concretamente en el ámbito occidental, los territorios que actualmente definen Italia, no dejarían durante toda la Edad Media de sufrir continuas oleadas de bizantinismo y, con ellas, de asimilar las diversas formas de clasicismo.

A pesar de ello, ante la ausencia de estudios monográficos que se hayan detenido en esta cuestión, tan sólo podemos limitarnos a constatar el hecho de que las influencias de bizantinismo "antiquizante" llegaron a estos territorios para, al mismo tiempo, acabar fusionándose con las tradiciones antiguas de índole local, que durante siglos se habían conservado en aquellos territorios.

El caso italiano es bien significativo en este sentido. Allí se rastrean muchas vías diversas y muy complejas de asimilar lo "clásico". Así, si aceptamos la importancia de la tradición clásica bizantina, parece que también deberíamos plantearnos como ésta debió coexistir con otras formas más diversas.

No es preciso insistir en la fuerte importancia del sustrato griego y las obras artísticas conservadas en suelo itálico durante los siglos del medievo ${ }^{2531}$. Es lógico pensar que, a este clasicismo "autóctono", se sumaron otros igualmente importantes y, en el caso del tema que aquí tratamos, parece que lo bizantino acabó por fusionarse con otro tipo de tradiciones clasicistas.

Tantas vías de asumir lo "clásico" hacen que sea imposible discernir ante que tipo de "clasicismo" nos encontramos, si realmente se trata de rasgos transmitidos a través de lo bizantino o, por el contrario, heredados directamente del arte romano y griego conservado en estos territorios.

El ámbito sur de la Península Itálica presentó tal mestizaje de elementos externos a la cultura romana, por lo que, no es de extrañar que se plantee como uno de los principales generadores de la nueva "estética 1200".

La profesora M. Andaloro, una de las grandes conocedoras de estos temas, ha insistido, con frecuencia, en la importancia crucial del arte insular, concretamente Sicilia, con focos tan catalizadores del fenómeno como Cefalù, por citar un hito bien estudiado por la investigadora ${ }^{2532}$.

${ }^{2531}$ A. GUIGLIA GUIDOBALDI, voz "Dafni”, Enciclopedia dell'arte medievale, vol. V, Roma, 1994, pp. 609-612 y H. BORBUDAKIS, voz "Creta", Enciclopedia dell'arte medievale, vol. V, Roma, 1994, pp. 461-466.

${ }_{2532}$ M. ANDALORO, voz “Cefalù. Mosaici”, Enciclopedia dell'Arte Medievale, vol. IV, Roma, 1993, pp. 607-610 y TH. CREISSEN, "Architecture religieuse et politique: à propos des mosaïques des parties basses de l'abside dans la cathédrale de Cefalù", Cahiers de civilisation médiévale, vol. 46, 183, 2003, pp. 247-263. 
A título de ejemplo, debemos recordar la importancia de la tradición musivaria de estas zonas como un eficaz mecanismo materializador de la conexión entre las artes occidentales y las orientales, especialmente las bizantinas. Todos los autores coinciden en remarcar que esta técnica, habitual dentro del sistema decorativo de los edificios sículo-normandos, presentó tantos lazos de unión con respecto a la plástica bizantina que, a través de ella, se puede explicar, en parte, la transmisión de tales elementos orientales a las artes medievales europeas. Sin embargo y aún teniendo en cuenta la complejidad del fenómeno, faltaría por llegar a delimitar aquellos rasgos clásicos de herencia bizantina que, susceptiblemente, debieron fusionarse con el fuerte sustrato clásico del arte de los territorios islámicos ${ }^{2533}$. Por último, y para hacer más complejo el panorama, no debemos olvidar las tradiciones locales, fuertemente "antiquizantes" y que, sin duda, pudieron jugar un papel determinante a la hora de aumentar este rico acerbo de rasgos "clásicos".

Las decoraciones musivarias realizadas en la Capilla Palatina de Palermo o en la catedral de Monreale, si atendemos a dos de los conjuntos más señeros, poseen un papel determinante a la hora de evaluar las vías de difusión de los elementos clásicos ${ }^{2534}$.

La permeabilidad del sustrato clásico bizantino tenía, ya por entonces, una larga tradición en Italia. A modo de simple recordatorio, no debemos olvidar que, dentro de la política edilicia del emperador Justiniano, no sólo se elevaron y decoraron multitud de templos en la misma metrópoli constantinopolitana, sino que, aunque no hay testimonio

\footnotetext{
${ }^{2533}$ Resulta muy interesante el tratamiento que hacen de los temas relativos al "arte 1200" los profesores C. Cosmen, E. Fernández y M. Valdés. En su planteamiento de la problemática sobre la asimilación del movimiento por parte de la escultura románica de finales del siglo XII, afirman que el final de la duodécima centuria y en los primeros años del siglo XIII, se incorporan a las corrientes mencionadas los nuevos matices plásticos que se vienen denominando "arte 1200". Según apuntaban, este complejo término define, de forma global, las tendencias surgidas desde la segunda mitad del siglo XII a los primeros años de la centuria siguiente en: Inglaterra, Norte de Francia y las cuencas del Mosa y el Mosela. A este panorama general habría que añadir una serie de consideraciones específicas fruto de la singular circunstancia que se da en la Península Ibérica a lo largo del los siglos medievales. Nos referimos a la presencia musulmana en Al-Andalus, hecho que motivará que ciertos elementos que aparecen en la escultura tengan un sello islámico. Cf.: C. COSMEN ALONSO, E. FERNÁNDEZ GONZÁLEZ y M. VALDÉS FERNÁNDEZ, "La escultura románica", Historia del Arte en León, León, 1989, pp. 74-87, en particular, pp. 77-78. Nos interesa destacar que la Península Ibérica, al igual que el área siciliana, presentarán una situación, en cierta medida comparable, en cuanto a la asimilación de ciertas tradiciones islámicas que acabarán impregnando las artes realizadas en torno al año 1200.

${ }^{2534}$ M. ANDALORO, voz, "Cefalù...," p. 607. La autora insiste en la importancia de que muchas de las inscripciones que presentan dichos trabajos en mosaico aparecen realizadas con caracteres griegos, claro indicativo de la formación bizantinizante de los artesanos medievales.
} 
de patrocinio imperial directo en la edificación y decoración de las iglesias, Rávena fue el siguiente espejo importante de la época de Justiniano ${ }^{2535}$.

En realidad, y volviendo al arte musivo realizado en Italia durante la época medieval, tal y como ha demostrado la profesora M. Andaloro, no es que dichos mosaicos presenten tendencia a lo bizantino, sino que, en realidad, fueron realizadas por maestros que habían aprendido el oficio en Bizancio ${ }^{2536}$.

Este hecho, continuamente traído a colación por la historiografía, tiene en el abad Suger de Saint-Denis y el abad Desiderio de Montecassino sus más conocidos representantes. La documentación conservada insiste en la importancia que ambos centros mostraron hacia las producciones artísticas bizantinas $\mathrm{y}$, en el caso de las labores de decoración musiva, se ha demostrado, con seguridad, que algunos de los trabajos realizados en la órbita de estos personajes contaron con artistas de formación constantinopolitana ${ }^{2537}$. No es preciso elucubrar en exceso para suponer que, a través de estas acciones, el legado clásico de Bizancio tuvo aquí una nueva vía de acceso hacia Europa.

Volviendo al tema en cuestión, una rápida valoración de las diversas ciudades itálicas en las que se han conservado monumentos susceptibles de considerarse como trasmisores culturales de filiaciones artísticas de tamiz bizantino, ofrece resultados reveladores.

Con frecuencia, se suele aludir a la producción musiva de Monreale, cuyos mosaicos son herederos de ciertos aspectos formales del mundo bizantino cercanos al estilo elaborado en Constantinopla bajo el patrocinio de los últimos emperadores de la dinastía comnena, pero traspasados bajo el tamiz griego ${ }^{2538}$. Resulta evidente que, de existir ciertas herencias de la tradición clásica, éstas habrían de llegar a formar parte de

\footnotetext{
${ }^{2535}$ Por citar algunos de los conjuntos más importantes, baste recordar su intervención patrocinadora en la iglesia de los Santos Sergio y Baco, la iglesia de Santa Sofía o la de Santa Irene, todas ellas en Constantinopla. Cf.: J. BECKWITH, Op. cit., pp. 114-116 y pp. 121-134.

${ }^{2536}$ M. ANDALORO, "Maestri bizantini, 1145-1148. Mosaici dell'abside. Cefalù-Cattedrale", XI Catalogo di opere d'arte restaurate (1976-78), Palermo, 1980, pp. 19-25; ID., voz "Costantinopoli. Pittura", Enciclopedia dell'arte medievale, vol. V, Roma, 1994, pp. 406-421 y M. J. JOHNSON, "The Royal View at Cefalù: A Note on the Choice of Subjects and their Arrangement in the Mosaics of Norman Sicily", Abstracts of Papers. Byzantine Studies Conference, 4-6, 1983, pp. 12-13.

${ }^{2537}$ E. PANOFSKY, El abad Suger..., p. 81 y V. VON FALKENHAUSEN, "Montecassino e Bisanzio dal IX al XII secolo", L'età dell'abate desiderio (F. Avagliano y O. Pecere), vol. III, 1, Montecassino, 1992, pp. 69-107, en concreto, p. 91. Según esta última investigadora, el abad Desiderio no debió tener grandes problemas a la hora de poder beneficiarse del trabajo de alguna cuadrilla de artesanos venidos de Constantinopla para realizar la decoración de la nueva basílica en Montecassino.

${ }^{2538}$ M. ANDALORO, voz "Palermo. Mosaici", Enciclopedia dell'arte medievale, vol. VIII, Roma, 1997, pp. 528-530, en concreto, p. 529; L. CASTELFRANCHI VEGAS, L'Arte Medioevale..., en concreto, pp. 54-57 y J. M. BLÁZQUEZ MARTÍNEZ, "Arte bizantino antiguo de tradición clásica en el desierto jordano: los mosaicos de Um er-Rasas”, Goya, vol. 255, 1996, pp. 130-143.
} 
estos repertorios de forma muy diluida y mezclada con otros factores. Si a ello sumamos su posterior "exportación" al resto de Europa, la tarea de llegar a delimitar y concretar el tipo de fuentes clásicas utilizadas por estos artesanos es casi imposible ${ }^{2539}$. A ello debemos sumar la importante aportación "antiquizante", filtrada a través de lo islámico, que sufrirán estas áreas ${ }^{2540}$.

Hasta aquí, un esbozo de la situación itálica en relación con los trabajos en mosaico y la transmisión del legado clásico tamizado por lo bizantino. Así, siguiendo con el mismo discurso, al trazar un panorama que nos lleve de lo general a lo particular, cabe preguntarse por la influencia que estas experiencias ejercerán sobre el ámbito hispano.

La Península Ibérica no tuvo especial predilección por la decoración en mosaico durante los años finales del siglo XII, al menos, a juzgar por aquello que se ha conservado. Aún con este inexistente panorama, algunos autores defendieron la importancia del arte musivo de raíz clásico-bizantina realizado en Sicilia y sus repercusiones sobre la escultura hispana cercana al año $1200^{2541}$.

En concreto, al estudiar ciertos aspectos de la escultura del claustro de Santo Domingo de Silos, en Burgos, la profesora D. Ocón Alonso defendió la importancia de los modelos naturalistas y de gusto clásico a la hora de concebir, por ejemplo, el relieve de la Anunciación del citado claustro ${ }^{2542}$.

La mencionada investigadora relacionaba una representación en mosaico de San Pedro, presente dentro de la escena de la Transfiguración de la Capilla Palatina de Palermo (fig. 496), con la imagen en genuflexión del arcángel Gabriel en la escultura silense (fig. 497). Se trataría, siempre según esta especialista, de una fórmula habitual dentro de las artes de la segunda mitad del siglo XII y, sobre todo, en el seno de las realizaciones artísticas europeas de patrocinio aristocrático, donde la preferencia por fórmulas clásicas de reminiscencias bizantinas pudieron estar consideradas como "signo de distinción" 2543 .

\footnotetext{
${ }^{2539}$ Sobre algunos de estos trabajos musivos, una breve síntesis en: P. J. NORDHAGEN, voz "Mosaico", Enciclopedia dell'arte medievale, vol. VIII, Roma, 1997, pp. 563-574.

${ }^{2540}$ A. M. SCHMIDT, voz "Catania", Enciclopedia dell'Arte Medievale, vol. IV, Roma, 1993, pp. 483486 y J. M. BLÁZQUEZ MARTÍNEZ, "La herencia clásica en el Islam: Quesaur 'Amra y Quasrt al-Hayr al-Garbi”, Europa y el Islam (G. Anes Álvarez de Castrillón coord.), Madrid, 2003, pp. 45-142.

${ }^{2541}$ En las páginas siguientes abordaremos con detenimiento estos temas relacionados con la escultura hispana. El ejemplo que incluimos aquí es meramente clarificativo.

${ }^{2542}$ D. OCÓN ALONSO, “Regnun et sacerdotium...", en concreto, pp. 203-204.

${ }^{2543}$ Ibidem, p. 204. Recogemos entre comillas la expresión utilizada por la autora.
} 
A pesar de las similitudes formales que ofrecen ambas imágenes, continúa siendo complicado poder llegar a concretar la manera mediante la cual dicho modelo fue asimilado por el escultor de la pieza castellana y, sobre todo, si tal imagen fue concebida pretendiendo una participación dentro de este movimiento artístico ${ }^{2544}$.

Lo que parece claro es que las artes plásticas realizadas en el sur de la Península Itálica mostraron, de manera evidente, una plena asimilación de las fórmulas bizantinas, trasladadas hacia Occidente a través de ésta y otras múltiples vías ${ }^{2545}$.

Sin embargo, tal fenómeno no sólo afectó a los trabajos musivarios, ya que, si existió un arte íntimamente ligado al mosaico esas fueron las producciones pictóricas, una de las manifestaciones donde, más evidentemente, se perciben estas relaciones con el arte bizantino ${ }^{2546}$.

En esta síntesis general que aquí realizamos, no podemos detenernos de manera exhaustiva en examinar todos aquellos conjuntos en los que se han detectado filiaciones directas con el mundo bizantino. A título de ejemplo, deben recordarse las controvertidas pinturas de la iglesia de Santa María de Castelseprio, cerca de Milán.

Se trata de un temprano conjunto en el que, de manera tradicional, los especialistas vienen defendiendo herencias directas del ámbito oriental, fenómeno que, sumado al hecho de que se hallan en plena Península Itálica, permiten defender la importancia del arte bizantino a lo largo de los siglos.

\footnotetext{
${ }^{2544}$ A la hora de analizar la dependencia del San Gabriel de Silos con respecto al mosaico siciliano y la de ambos modelos con respecto al arte clásico, faltaría por concretar que tipo de obra antigua fue tomada como punto de partida para generar tal composición. La autora no llega a concretar si el modelo pudo provenir originariamente del arte griego, del romano o de otras producciones adscritas al ámbito constantinopolitano. Tales ausencias son plenamente justificables, sobre todo, si tenemos en cuenta la dificultad para mostrarse concisos en estos temas.

${ }^{2545}$ Entre otros aspectos, no debemos olvidar la conexión directa con Grecia, así como la importancia que lo bizantino había tomado en todos estos territorios. Baste con citar la aportación fundamental realizada por los "monjes basilios", tan íntimamente ligado a las prácticas litúrgicas orientales. Sin duda, tales preferencias acabaron por transmitirse a las artes que, reiteradamente, tomaron como modelo ciertas tendencias vinculadas a la órbita bizantina. La importancia del propio San Basilio el Grande (330-379) como fundador de varios monasterios adscritos a su regla y la difusión de los llamados "monjes basilios" ocupando centros tan importantes como el Monte Athos, son tan sólo los puntos más conocidos mediante los que, frecuentemente, se han explicado esta introducción de elementos bizantinos dentro de las artes europeas hasta fechas tardías. Vid.: H. VON CAMPENHAUSEN, Los Padres de la Iglesia. I Padres Griegos, Madrid, 1974, en particular, pp. 134-143; J. M. FLORISTÁN IMÍZCOZ, "Basilios ortodoxos y política mediterránea de España", Erytheia, vol. 28, 2007, pp. 139-196; Y. BOUDALIS, "Influencias islámicas en las encuadernaciones griegas de época post-bizantina", Erytheia, vol. 26, 2005, pp. 127-176 y S. FERNÁNDEZ ARDANAZ, "Monaquismo oriental en la Hispania de los siglos VI-X", Antigüedad y cristianismo: Monografías históricas sobre la Antigüedad tardía, vol. 16, 1999, pp. 203-216.

${ }^{2546}$ E. CHALYVOPOULOU, Relaciones entre la pintura románica y la pintura bizantina las pinturas murales del siglo XII en España y Grecia: un estudio comparativo e intercultural de las figuras de la iconografía religiosa (Tesis doctoral dirigida por M. T. Escohotado Ibor y M. Sánchez Cifuentes), Universidad Complutense de Madrid, 2005. Se trata de un reciente estudio donde se pone de manifiesto la importancia de los modelos bizantinos dentro de la pintura románica, concretamente, aquella realizada en España durante esta época.
} 
Así, a pesar de los problemas de datación que presenta el conjunto, algunos autores han insistido en la importancia de algunos aspectos técnicos e iconográficos que podrían derivar de obras constantinopolitanas emparentadas con el denominado "renacimiento macedónico" 2547 ; ya que, tal y como ha estudiado M. Andaloro, la cuestión vuelve a planear sobre la enigmática y problemática cuestión de llegar a valorar la deuda que el arte alto y pleno medieval europeo posee con respecto a Oriente $^{2548}$.

Nuevamente se pone de manifiesto la importancia de lo oriental y, sobre todo, las cruzadas, consideradas como uno de los fenómenos que mejor pueden justificar esta recuperación de tales criterios estéticos ${ }^{2549}$.

Dentro de las diversas características que los especialistas han señalado como definidoras del "estilo 1200", se insistió con fuerza en la evidencia con la que tales preceptos estéticos se mostraron dentro de los objetos de carácter cortesano ${ }^{2550}$. De entre ellos, parece que existe cierta unanimidad en afirmar que las producciones orfebres y los trabajos en metal fueron los que mejor supieron materializar la "estética 1200", además de presentarse como una de las vías más importantes de su difusión, gracias, sobre todo, a su facilidad para ser transportados ${ }^{2551}$.

El sur de Italia conserva numerosos ejemplos susceptibles de ser mencionados, sin embargo, dentro de la síntesis que desarrollamos, existieron además otras áreas geográficas donde el fenómeno también adquirió un gran desarrollo ${ }^{2552}$.

En concreto, se ha señalado el área CENTRO EUROPEA y las REGIONES SEPTENTRIONALES del continente como otros puntos focales donde se desarrolló

${ }^{2547}$ K. WEITZMANN, "The Fresco Cycle di Castelseprio", L'Arte, s. n., 18, 1951, pp. 12-19 y P. D. LEVETO, "The Marian Theme of the Frescoes in S. Maria at Castelseprio", The Art Bulletin, vol. 72, 3, 1990, pp. 393-413; F. POMARICI, "Classicismo...", en particular, p. 112; A. GRABAR, "Le succès des arts orientaux a la cour byzantine sous les macédoniens", L'Art de la fin de l'Antiquité et du Moyen Âge, vol. I, Paris, 1968, pp. 266-290 e ID., "L'Art religieux et l'Empire byzantin a l'époque des macédoniens", L'Art de la fin de l'Antiquité et du Moyen Âge, vol. I, Paris, pp. 151-168. Se insiste en la importancia del denominado "renacimiento macedónico" a la hora de realizar un balance sobre el traspaso de fórmulas bizantinas hacia el Occidente europeo.

${ }^{2548}$ M. ANDALORO, “Castelseprio. Affreschi”, Enciclopedia dell'Arte Medievale, vol. IV, Roma, 1993, pp. 453-459.

${ }^{2549}$ F. POMARICI, voz “Classicismo...”, p. 114. El autor alude a los cruzados y a la orfebrería realizada entre los siglos IV y VII, como potenciadores de la difusión de lo oriental en Europa. Sobre el tema, véase también: J. FOLDA, voz "Crociati. Pittura e miniatura”, Enciclopedia dell'arte medievale, vol. V, Roma, 1994, pp. 569-577.

${ }^{2550}$ M. VALDÉS FERNÁNDEZ, "Las artes y sus promotores...”, p. 244.

${ }^{2551}$ F. GALVÁN FREILE y J. A. MORÁIS MORÁN, Op. cit., pp. 488-490.

${ }^{2552}$ Debido al importante papel que jugaron los territorios griegos y la Península Itálica como principales focos de introducción y difusión de las formas bizantinas, parece lógico que, además del arte musivo y la pintura, también las artes suntuarias acusasen las repercusiones de estas "oleadas" de bizantinismo. El caso peculiar y fragrante de la miniatura, será objeto de atención en las páginas siguientes. 
este movimiento. En particular, se suele aludir a las cuencas del Mosa y el Mosela, la del Rin, así como la misma Isla de Francia, la Champagne o la Inglaterra meridional. Estos lugares, además de los ya citados, marcarán los puntos en los que se produjo tal renovación ${ }^{2553}$.

A la hora de estudiar la filiación clásica de los motivos y técnicas, se observa una disparidad tan amplia, que la nómina de bases susceptibles de ser mencionadas es enorme. A este respecto, debemos recordar la larga experiencia que tenían estos territorios, a finales del siglo XII, en las técnicas relacionadas con el trabajo del $\operatorname{metal}^{2554}$.

La especialización que alcanzaron durante los siglos de la Antigüedad los diversos pueblos que ocuparon estos territorios en el trabajo del metal, explicará también la importancia que los medievales otorgaron a estas producciones. No es preciso insistir más en la importancia que dicha tradición había tenido para los carolingios y los otonianos. Sin duda, todos estos aspectos ayudaron a perpetuarla ${ }^{2555}$.

Las fuentes decididamente clásicas utilizadas desde el siglo IX por estos pueblos, pudieron acabar enriqueciendo la estética "antiquizante" que mostrará la orfebrería realizada en los años finales del siglo XII ${ }^{2556}$.

\footnotetext{
${ }^{2553}$ Uno de los estudios más importantes que ha producido la historiografía especializada en el tema y, a la vez, hito bibliográfico sobre la repercusión de lo bizantino sobre las artes suntuarias en la Europa Septentrional, es el volumen titulado: Rhein und Maas. Kunst und Kultur. 800-1400, Köln, 1972, pp. 1025.

${ }^{2554}$ No es preciso remontarse a las épocas prehistóricas, pero recordemos que, desde Edad del Hierro, se ha localizado la que hoy denominamos cultura de "La Tène". Compuesta principalmente por un fuerte sustrato social proveniente de los pueblos celtas, acabó por desarrollarse dentro de un basto territorio, que llegó desde las regiones de los Alpes y centro Europa hasta difundirse por las Islas Británicas, entre otros territorios. Dentro de este movimiento, las producciones relacionadas con la metalistería generaron una amplia base que supuso la perpetuación, durante muchos siglos, de formas de trabajar, repertorios, técnicas y motivos ornamentales. Es lógico pensar que, incluso después de la fragmentación del Imperio Romano y la llegada de los siglos medievales, pudieron subsistir tales fórmulas de producción artística. Vid.: M. SZABÓ y J-P. GUILLAUMET, "Les fourreaux d'épées de La Tène dans la Vallée de la Saône au Musée de Chalon-sur-Saône", Acta Archaeologica Academiae Scientiarum Hungaricae, vol. 52, 1-3, 2001, pp. 63-102 y P. S. WELLS, "Manufactured objects and the construction of identities in late la Tène Europe", Eirene: studia graeca et latina, 31, 1995, pp. 129-150.

${ }^{2555}$ L. CASTELFRANCHI VEGAS, L'Arte Medioevale..., pp. 25-40; ID., L'Arte Ottoniana..., pp. 20-23 y D. OCÓN ALONSO, "La recepción de las corrientes...", p. 17.

${ }^{2556}$ A este respecto, resulta muy significativa la perpetuación de técnicas y modelos dentro de las producciones orfebres realizadas en la Europa de los siglos XI y XII. En el caso hispano, por citar un ejemplo importante, se ha destacado la posibilidad de que orfebres conocedores de las técnicas renanas del centro de Europa, pudieran haber realizado el arca de San Isidoro, en el Museo de la Real Colegiata. Estas noticias son bien significativas, pues tal y como veremos, de manera frecuente se ha aludido a estos territorios para justificar algunos motivos y técnicas presentes en determinadas piezas conservadas en la Real Colegiata de San Isidoro. Véase al respecto: F. GALTIER MARTíN, La iconografía arquitectónica..., p. 68; I. G. BANGO TORVISO, "Relicario de San Isidoro", Maravillas de la España Medieval. Tesoro sagrado y monarquía, vol. I, León, 2001, ficha catalográfica 86, pp. 228-229; E. FERNÁNDEZ GONZÁLEZ, "Relicario de San Isidoro", Sancho el Mayor y sus herederos. El linaje que
} 
El resultado producido sobre las artes suntuarias fue complejo, sobre todo, a la hora de estudiar su vinculación con lo clásico. La defensa de tales teorías a través del estudio de aquellas piezas más señeras y de mayor calidad, generó una visión del fenómeno un tanto simplificada y fragmentada. La nómina de objetos a los que se suele aludir, considerados tradicionalmente como representantes de una fase extrema del clasicismo áulico, no facilita la resolución del problema ${ }^{2557}$.

Así, la mayoría de los estudiosos suelen considerar, por ejemplo, la famosa pila bautismal de bronce de San Bartolomé de Lieja y el relicario con forma cefálica de San Alejandro del Musée Royaux d'Art et d'Histoire, como precursores de la futura asimilación del ideal clásico dentro de los trabajos en metal que dominaría la llamada “estética $1200 ", 2558$.

En relación con ello, en el estudio del año 1959 realizado por W. Oakeshott, se incluían este tipo de producciones dentro de la nómina de obras emparentadas con lo clásico y, sobre todo, se aludía a otro problema más importante, que se perfilará como una de las conclusiones de este apartado dedicado al "estilo 1200",2559. Las soluciones que planteaba y la metodología utilizada por el autor, así como lo concreto de sus afirmaciones, merecen ser tenidas en cuenta.

En su investigación se centraba en una pieza en concreto. Se trata de la pila bautismal que, según destacaba, había sido realizada en un primer momento para la iglesia de Nuestra Señora de las Fuentes por el artesano Renier de Huy, posiblemente entre los años 1107 y $1118^{2560}$. Destacaba el autor, que el tratamiento realizado por los

europeizó los reinos hispanos, vol. I, Pamplona, 2006, ficha catalográfica 22, pp. 136-141 e ID., "Hacia la renovación escultórica...”, pp. 15-16.

${ }^{2557}$ F. POMARICI, voz "Classicismo...", p. 114.

2558 J. LAFONTAINE-DOSOGNE, "La tradition byzantine des baptistères et leur décor, et les fonts de Saint-Barthélemy à Liège", Cahiers Archéologiques, 37, 1989, pp. 45-69; FR. BOUSSART, "Un chefd'œuvre médiéval de la fonderie mosane: les fonts baptismaux de l'église Saint-Barthélemy, à Liège", $L a$ fonderie belge, 9-10, 1958, pp. 280-281; A-M. BOUCHÉ, "Les fonts baptismaux de Saint-Barthélemy à Liège: Chef-d'oeuvre sans pareil et noeud de controverses", Speculum, vol. 2, 2005, pp. 548-550 y R. HALLEUX, "Le baptême du philosophe Craton. Origine et sens d'une image sur les fonts baptismaux dits de Saint-Barthélemy à Liège", Études sur les fonts baptismaux de Saint-Barthélemy à Liège, Liège, 2006, pp. 199-210. Se trata de un conjunto de piezas bautismales de excelente calidad, atribuidas a artesanos y cronologías diferentes.

${ }^{2559}$ W. OAKESHOTT, Classical Inspiration..., en particular, pp. 87-89.

${ }^{2560}$ J. LAFONTAINE-DOSOGNE, Op. cit., p. 45; D. KÖTZSCHE, “Taufbecken Des Reiner Von Huy", Rhein und Maas. Kunst und Kultur. 800-1400, Köln, 1972, ficha catalográfica 238-239 y L. CASTELFRANCHI, L'Arte Medioevale..., en particular, pp. 74-75. Se trata de una producción temprana desde el punto de vista cronológico. Ese mismo carácter precoz permite considerarla como un nexo de unión viable que relacione las producciones orfebres de tamiz clásico de época carolingia y otoniana y las futuras soluciones adoptadas por las artes suntuarias durante la segunda mitad del siglo XII. En relación con este aspecto, la profesora Castelfranchi alude en sus estudios a la posibilidad de comparar y 
orfebres sobre los drapeados, manifestaba una clara observación de obras antiguas (fig. 498). Se trataría de una asimilación de las experiencias carolingias y otonianas, pero enriquecidas, además, por la absorción de corrientes bizantinas. El clasicismo resultante de estas diversas vías de acercamiento a lo clásico es, según creemos, extremadamente diverso y tamizado.

W. Oakeshott profundizó en la localización exacta de las fuentes clásicas que pudieron haber utilizado los artistas bizantinos y, a través de éstos, los artífices ligados a la ciudad de Huy, en la región de Valonia. Según su criterio, se debieron tener en cuenta, para realizar la pila, algunos trabajos en metal y, en particular, determinados bronces de época griega (fig. 499). El autor se mostraba conciso al concretar que, posiblemente habían sido aquellas piezas realizadas entre los siglos VI al IV a. de C., las que proporcionaron los modelos a seguir ${ }^{2561}$. Además de ello, proponía ciertos intercambios y contaminaciones entre ambos momentos, mencionando una figurilla en bronce datada en el siglo III a. de C. y una escultura monumental en piedra, también perteneciente al siglo $\mathrm{V}$ griego, como referentes ideales que los artesanos medievales tuvieron en mente para solucionar ciertas fórmulas gestuales, prototipos en el peinado y tratamiento de la musculatura ${ }^{2562}$.

Sin embargo, al abordar estos temas, la historiografía se ha mostrado insistente en relación con otros temas derivados de tales teorías. Por lo general, se suele considerar al orfebre mosano Nicolás Verdun como uno de los máximos representantes de este movimiento. Definido por F. Pomarici como una "personalidad clave del neoclásico estilo 1200", la aplicación de ciertos aspectos derivados del método atribucionista, han supuesto un intento de los investigadores por apoyar la definición de tipo academicista sobre el que asentar las bases que explicasen la génesis de este "estilo 1200",2563.

Con frecuencia, este tipo de producciones en metal fueron consideradas como las mejores representantes de esta estética, aunque si bien su proyección parece más acusada dentro de las artes del libro. Los objetos suntuosos que, por lo general, se

considerar los trabajos realizados en el entorno de la ciudad de Huy con los facturados años después por el orfebre Nicolás Verdun.

${ }^{2561}$ W. OAKESHOTT, Classical Inspiration..., p. 88.

${ }^{2562}$ Ibidem, p. 89. Desde otro orden de cosas, queremos señalar que la fuente en cuestión ha sido utilizada como base argumental para poder explicar otra serie de producciones. En concreto, tal y como defiende la profesora E. Fernández, la iconografía que muestra la pieza de Lieja puede ser el último eslabón de un tema poco difundido durante los siglos medievales y que podría pertenecer a una serie de obras, algunas de ellas desaparecidas, que ayudarían a interpretar otras más antiguas. Cf.: E. FERNÁNDEZ GONZÁLEZ, "Hacia la renovación escultórica...”, pp. 27-28.

${ }^{2563}$ F. POMARICI, voz "Classicismo...”, p. 16. 
utilizan como representantes del "1200” parecen expresar mejor las características del citado fenómeno que las producciones en materiales pétreos de tipo monumental.

En relación con ello, E. Panfosky consideraba que cuando se produjo la llegada a Europa de esta nueva oleada de bizantinismo que invadió estos territorios durante veinticinco o treinta años, fue en las que él denominaba como "artes menores" de la ilustración del libro, la talla del marfil y la metalistería, donde mejor se percibió el fenómeno. A pesar de ello, también puntualizó que esta tendencia pronto se extendió a la escultura monumental en madera y piedra. Según defendió, fue en lo que había sido el corazón mismo del imperio carolingio y allí donde, tiempo después, acabarían por cristalizar las formas góticas, es decir, en la Lorena, la Ile-de-France y la Champagne, donde los artistas supieron aislar lo que aún había de helénico en el estilo bizantino.

Con Nicolás Verdún a la cabeza de este fenómeno, las escuelas de Laón, Senlis, Chartres y París volvieron a infundir a sus figuras una animación tan cercana a la humanitas grecorromana como era posible dentro del arte medieval ${ }^{2564}$.

Con tales ideas, el prestigioso estudioso intentaba defender el sustrato griego como uno de los horizontes rectores de las producciones que ahora se realizaban bajo la mano del orfebre de Verdun. De esta forma, según A. Tomei, un claro ejemplo de esta tendencia vendría representado a través de la orfebrería surgida en el entorno de la catedral de Colonia, parangonable, desde el punto de vista artístico y cronológico, a los trabajos localizados en el área mosana. De entre los ejemplos a los que alude citamos, a título de muestra, la famosa arqueta de los Reyes Magos conservada en este templo germano $^{2565}$. Según apunta el investigador, se trata de una obra maestra del "estilo 1200,2566 .

Así las cosas, creemos que teniendo en cuenta los objetivos de nuestro estudio, de poco serviría realizar aquí una lista extensa y exhaustiva de las obras que se han ligado, de una forma u otra, al movimiento “1200”. Desde el relicario de Saint Servatius

\footnotetext{
${ }^{2564}$ E. PANFOSKY, Renacimiento y renacimientos..., p. 109.

2565 A. TOMEI, voz "Colonia. Arti suntuarie", Enciclopedia dell'arte medievale, vol. V, Roma, 1994, pp. 197-203, en particular, p. 199. El autor data la arqueta de los Magos dentro de un arco temporal excesivamente amplio, entre lo años 1181-1230. Véase también: D. KÖTZSCHE, "Nikolaus von Verdun und die Kölner Goldschmiedekunst", Rhein und Maas. Kunst und Kultur. 800-1400, Köln, 1972, ficha catalográfica K, pp. 314-315 y F. CERVINI, voz "Nicola di Verdun”, Enciclopedia dell'arte medievale, vol. VIII, Roma, 1997, pp. 695-698. La lista de obras a él atribuidas es amplia. Destacamos la arquetarelicario de la Virgen de la catedral de Tournai o el ambón de la Colegiata de Klosterneuburg.

${ }^{2566}$ Ibidem, p. 200.
} 
de Maastricht hasta el de Saint-Remacle de Stavelot, en Bélgica, son muchas las obras del ámbito norte europeo que se han vinculado con esta tendencia ${ }^{2567}$.

Para concluir esta breve alusión a la orfebrería del norte de Europa como impulsora y difusora de la denominada "estética 1200", queremos remitir, en último lugar, a la pequeña aportación sobre el tema realizada por A. M. Koldeweij ${ }^{2568}$.

Según este autor, parece claro que si se acepta la existencia de un fuerte carácter bizantino en las producciones en metal creadas en estos ámbitos, éste debe explicarse teniendo en cuenta otros factores de índole histórica. Según defiende, el segundo cuarto del siglo XII apareció dominado en estos territorios por la figura del benedictino Vivaldo de Stavelot, quién "jugó un rol importante como elemento de contacto entre el Imperio germánico y Bizancio", a través del establecimiento de fuertes relaciones comerciales, sobre todo en el campo de la orfebrería e, indirectamente, en la miniatura $^{2569}$.

Teniendo en cuenta este factor, parece más fácilmente explicable el fuerte sustrato clásico de tamiz bizantino que acabó por inundar la orfebrería mosana ${ }^{2570}$.

En este ambiente es donde debemos localizar la "transformación lingüística sufrida por el arte occidental en torno al año 1200"2571.

A pesar de todo, hasta la fecha no se ha realizado ningún estudio profundo que se centre, específicamente, en desgranar las diferentes interpretaciones de las formas clásicas que estaban realizando estos artesanos inmersos en el movimiento "1200". Al menos teniendo como objetivo la concreción del tipo de arte antiguo que fue tomado como referencia.

2567 A. M. KOLDEWEIJ, voz "Maastricht”, Enciclopedia dell'arte medievale, vol. VIII, Roma, 1997, pp. 59-65. El autor insiste en las fuertes relaciones comerciales que dominaron estas regiones, desde la zona del Mosa hasta Verdun, desde Colonia a Brujas. Cf.: Rhein und Maas. Kunst und Kultur. 800-1400, Köln, 1972, en particular, p. 247, p. 317 y pp. 318-319.

2568 A. M. KOLDEWEIJ, voz "Mosana, arte...", pp. 578-582.

${ }^{2569}$ Ibidem, p. 579. Las cronologías que concretan su año de nacimiento y de fallecimiento oscilan entre los años 1098 y 1158. El autor recoge algunos datos bien reveladores sobre su figura. Desde su nombramiento como abad de Stavelot y de Malmédy en el año 1130, hasta su llegada a Montecassino en el 1137 o a Corvey en el 1146. Entre las obras artísticas que se han ligado a su persona se han destacado la cabeza-relicario del papa Alejandro I, del año 1145, realizada en oro y plata y que hoy se conserva en el Musée Royaux d'Art et d'Histoire de Bruxelles. Por otro lado, se han documentado algunos trabajos encargados por dicho personaje con la ayuda de Federico I Barbarroja y Manuel I Comneno.

${ }^{2570}$ V. H. ELBERN, voz "Oreficeria", Enciclopedia dell'arte medievale, vol. VIII, Roma, 1997, pp. 833849, en particular, pp. 843-847. El autor explica las diferentes vías por las que se produjo una asimilación de las formas bizantinas dentro de este tipo de producciones.

${ }^{2571}$ F. CERVINI, voz "Nicola...", pp. 697-698 y L. CASTELFRANCHI, L'Arte Medioevale..., en particular, pp. 64-65, dentro del capítulo titulado "Las artes del color en el siglo XII". 
Es por ello que no resultan extrañas las palabras escritas por F. Cervini al reflexionar sobre estos temas:

"La individualización de las fuentes de Nicolás de Verdun, oscila entre la tradición orfebre del ámbito áulico de las regiones del Rin y Lorena y la citación directa de la Antigüedad, entre la miniatura inglesa y franco-septentrional, a ciertas reminiscencias carolingias, de la pintura bizantina a la misma escultura de la Isla de Francia" $^{, 2572}$.

Un panorama tan complejo de filiaciones foráneas complica en exceso la tarea de concretar tales fuentes pues, a todo lo anteriormente argumentado, se suman todos aquellos aspectos derivados de la producción de libros manuscritos e ilustrados. Sin duda, una de las manifestaciones artísticas en los que tales preceptos se localizan con mayor claridad $^{2573}$.

La etapa final del románico y la llegada del siglo XIII provocaron en la miniatura una serie de transformaciones profundas, aunque no fueron repentinas o rápidas. Francia e Inglaterra son los países donde mejor se puede contemplar tal proceso y donde se elaboraron los códices más espléndidos ${ }^{2574}$.

A pesar de centrar su estudio en el ámbito hispano, las reflexiones del profesor Yarza ponen de manifiesto la importancia que adquirirá la ilustración del libro en el tránsito del siglo XII al XIII como difusora de la nueva "estética 1200".

Los territorios insulares de la Europa del norte, en concreto las ISLAS BRITÁNICAS, habían mostrado, a lo largo de la Alta Edad Media, un interés creciente por aquellos fenómenos renovadores. Las artes producidas en estos ámbitos geográficos propiciaron fructíferas relaciones con el continente y, en el caso del "estilo 1200", sin duda tendrán un papel absolutamente relevante.

Si bien las artes suntuarias y la pintura gozaron de gran desarrollo, tal y como se ha sostenido, será dentro del apartado de la ilustración del libro donde se localizará, de una manera más clara, la vinculación con el arte bizantino.

\footnotetext{
2572 Ibidem, p. 698.

${ }^{2573}$ E. CASTELNUOVO, Nicolas de Verdun, Milano, 1966, pp. 39-50.

${ }^{2574}$ F. YARZA LUACES, "La miniatura en los reinos peninsulares medievales", La miniatura medieval en la Península Ibérica (J. Yarza ed.), Murcia, 2007, pp. 25-94, en particular, p. 40.
} 
Ahora bien, nuevamente surge el problema de la multiplicidad de fuentes y obras, de toda índole, susceptibles de haber enriquecido el acerbo artístico de los diferentes núcleos productores de miniaturas y códices.

La importancia de los territorios ingleses dentro de este arte ha sido remarcada, continuamente, por los especialistas. En este sentido, el profesor M. Kauffmann ha señalado el papel de la ilustración de los códices como fuente primordial de la que beberían las demás artes, tanto aquellas vinculadas al "color", es decir la vidriera y la pintura, como otras realizadas en diferentes técnicas. Entre ellas, destaca la escultura monumental y las artes suntuarias, en continua relación con las manifestaciones realizadas desde los diferentes scriptoria ${ }^{2575}$.

El ambiente del que surgirán aquellas manifestaciones señaladas por los estudiosos como representantes del “estilo 1200" presentaba, desde la época altomedieval, una situación compleja. Según se ha indicado, dentro de esas intensas y ricas relaciones con el continente, ocuparon un lugar especial, aquellas establecidas con el imperio carolingio, de donde pudieron tomar diversas soluciones, tanto iconográficas como técnicas ${ }^{2576}$. El mismo fenómeno se observa en lo concerniente a las relaciones con las diversas dinastías otonianas.

Así, del mismo modo que en la Europa septentrional se había explicado el perfecto conocimiento de las técnicas de trabajo del metal a través de la influencia de los carolingios y otonianos, parece que también es posible destacar el papel que éstos jugaron con respecto al desarrollo de las artes del libro en estos territorios insulares ${ }^{2577}$.

Ante la imposibilidad de plantear un panorama resumido del arte insular en las postrimerías del siglo XII, nos resignamos a mencionar aquellas obras artísticas que los especialistas han considerado como hitos representantes del "estilo", además de mostrarse como claras continuadoras de los prototipos clásicos.

La exposición The Year 1200, ya prestó una atención primordial a los manuscritos ingleses cercanos a esta cronología, sobre todo, a través de la aportación de

\footnotetext{
${ }^{2575}$ M. KAUFFMANN, “Manuscripts. The $12^{\text {th }}$ century", English Romanesque Art 1066-1200, London, 1984, pp. 84-85. Se trata del volumen fruto de la exposición del mismo título llevada a cabo en la Hayward Gallery de Londres y, tal y como se observa en el catálogo, la miniatura fue abordada teniendo en cuenta su especial relevancia, por encima, incluso, de la arquitectura.

${ }^{2576}$ D. TALBOT RICE, English art. 871-1100, Oxford, 1952, en particular, pp. 9-12. El especialista insistía en la importancia de los carolingios como transmisores hacia las islas de ciertos aspectos heredados del arte clásico, los cuales, a su vez, poseían un perfecto conocimiento de las manifestaciones artísticas coetáneas realizadas en Bizancio e Italia, tal y como asegura. A ello debemos sumar la posibilidad de que las islas inglesas también pudieran haber accedido a diversos repertorios y soluciones artísticas tomadas de los contactos con los pueblos merovingios.

${ }^{2577}$ Ibidem, pp. 20-22.
} 
D. H. Turner ${ }^{2578}$. Tras este evento científico, la mayoría de los especialistas han venido insistiendo en torno a los mismos preceptos ${ }^{2579}$.

Nuevamente se observa que, para apoyar la existencia del "estilo", los autores se basaron en hitos u obras de gran calidad artística, sobre las que construir su discurso.

Son frecuentemente traídos a colación obras maestras de la miniatura inglesa tales como la Biblia de Winchester ${ }^{2580}$, el Bestiario de Oxford ${ }^{2581}$ o el Salterio de Westminster $^{2582}$.

Las características de estas obras, en ocasiones fuertemente innovadores y, en otras tantas, más conservadoras, aparecen en plena concordancia con los tópicos que los estudiosos han señalado como específicos de la "estética 1200”. El uso de colores vivos, la utilización frecuente de los fondos dorados, la proliferación de complejos ornamentos marginales, tanto vegetales como geométricos, la potenciación del canon naturalista de las figuras, así como la presencia de aparatosos drapeados en los textiles, son los rasgos supuestamente más definitorios de estas obras ${ }^{2583}$.

Sin embargo, serán finalmente, la impronta clásica y el fuerte carácter bizantino, los elementos presentes dentro de estos manuscritos que más nos interesan destacar ${ }^{2584}$.

Los núcleos artísticos en los que se estaba gestando tal movimiento, se localizan a lo largo de todo el territorio inglés. En este sentido, el profesor Kauffmann ha rastreado la asimilación de prototipos bizantinos a lo largo de infinidad de manuscritos

\footnotetext{
2578 D. H. TURNER, "Manuscript illumination", The Year 1200. A Background Survey, New York, 1970, pp. 133-168.

${ }^{2579}$ F. GALVÁN FREILE, La decoración de manuscritos..., p. 47. Resulta evidente que, paralelamente a la producción de obras miniadas insulares, también Europa continuó creando obras de especial relevancia. En este sentido, debe insistirse que, nuevamente, el norte de Francia o el sur de Bélgica alcanzaron cotas de gran calidad artística.

2580 Winchester, Cathedral Library, Ms. 17. Las publicaciones dedicadas a estos manuscritos son abundantes por lo que citaremos, tan sólo, aquellas que hemos consultado para elaborar estas páginas. Véase al respecto: W. OAKESHOTT, The Two Winchester Bibles, Oxford, 1981; C. DONOWAN, The Winchester Bible, Winchester, 1993 y M. KAUFFMANN, "Bible: the Winchester Bible, vol. II", English Romanesque Art 1066-1200, London, 1984, ficha catalográfica 64, pp. 120-121; ID., "Bible: the Winchester Bible, vol. III", English Romanesque Art 1066-1200, London, 1984, ficha catalográfica 64a, p. 121; ID., "Bible: the Winchester Bible, vol. IV", English Romanesque Art 1066-1200, London, 1984, ficha catalográfica 64b, p. 121 y ID., "Leaf related to the Winchester Bible", English Romanesque Art 1066-1200, London, 1984, ficha catalográfica 65, p. 122.

${ }^{2581}$ Oxford, Bodleian Library, Ms. Ashmole 1511.

${ }^{2582}$ London, British Library, Ms. Royal 2. A. XXII.

${ }^{2583}$ F. GALVÁN FREILE, La decoración de manuscritos..., p. 48.

${ }^{2584}$ W. OAKESHOTT, Classical Inspiration..., p. 77; ID., The Artist of the Winchester Bible, London, 1946, pp. 10-15; W. WEITZMANN, "Byzantium and the West around the Year", The Year 1200. A Symposium, New York, 1975, pp. 53-94 y A. WEYL, voz "Constatinopoli. Miniatura”, Enciclopedia dell'arte medievale, vol. V, Roma, 1994, pp. 412-428.
} 
producidos en Aberdeen ${ }^{2585}$, Cambridge ${ }^{2586}$, Westminster ${ }^{2587}$, Norwich ${ }^{2588}$, Durham $^{2589}$, Oxford $^{2590}$, Canterbury ${ }^{2591}$ y, sobre todo, Winchester.

Este último centro fue uno de los más destacables en relación con un panorama de tal riqueza. La biblioteca configurada en la catedral de Winchester conserva la excepcional Biblia del año 1160 que, a pesar de poseer varias fases de trabajo y elaboración, algunas de ellas se encuadran perfectamente bajo la "estética 1200"2592.

El círculo del que surgió esta pieza representa, casi de manera ideal, el ambiente artístico que los especialistas han descrito como característico del "arte 1200". A saber: se trataba de un centro episcopal absolutamente ligado a la realeza y del que sobresalieron, además, insignes personajes de la órbita religiosa.

Con frecuencia se suele citar al conocido Henry de Blois (1129-1171), obispo de la ciudad de Winchester y hermano del rey Stephen (1135-1154) ${ }^{2593}$. Recoger todos aquellos aspectos importantes en relación con el mecenazgo de este tipo de artes excede, con mucho, nuestros objetivos, pero baste recordar que, mucho antes de que el rey Federico II adquiriese bronces y mármoles clásicos para sus castillos, Henry de Blois, había importado de Roma y colocado en su palacio unos cuantos "ídolos" ejecutados por artistas paganos ${ }^{2594}$.

\footnotetext{
${ }^{2585}$ Alberdeen, University Library, Ms. 24. En las notas siguientes aludiremos a los ejemplares más representativos del movimiento, recogidos todos ellos en la exposición de la Hayward Gallery de Londres. Cf.: M. KAUFFMANN, "Bestiary", English Romanesque Art 1066-1200, London, 1984, ficha catalográfica 86, p. 133.

${ }^{2586}$ Evangeliario de Cambridge. Cambridge, Trinity Collage, Ms. B. 5. 3. Cf.: M. KAUFFMANN, "Glossed Gospels", English Romanesque Art 1066-1200, London, 1984, ficha catalográfica 83, p. 132.

${ }^{2587}$ Pslaterio de Westminster, London, British Library, Ms. Royal 2. A. XXII. Cf.: M. KAUFFMANN, "Psalter: the Westminster Psalter", English Romanesque Art 1066-1200, London, 1984, ficha catalográfica 82, p. 131.

${ }^{2588}$ Epístolas de San Pablo, Norwich, Iglesia de Saint Peter Mancroft. Cf.: M. KAUFFMANN, "Epistles of St. Paul, with gloss of Peter Lombard", English Romanesque Art 1066-1200, London, 1984, ficha catalográfica 78, p. 129.

${ }^{2589}$ Biblia, Durham Cathedral Library, Ms. A. II. I. Cf.: M. KAUFFMANN, "Bible: the Puiset Bible, vol. I, Genesis-2 Kings", English Romanesque Art 1066-1200, London, 1984, ficha catalográfica 77, p. 128.

${ }^{2590}$ Psalterio de Oxford, Oxford, Bodleian Library, Ms. Douce 293. Cf.: M. KAUFFMANN, "Psalter", English Romanesque Art 1066-1200, London, 1984, ficha catalográfica 74, p. 127.

${ }^{2591}$ Biblia Lambeth, London, Lambeth Palace Library, Ms. 3. Cf.: M. KAUFFMANN, "Bible: the Lambeth Bible, vol. I, Genesis-Job", English Romanesque Art 1066-1200, London, 1984, ficha catalográfica 53, p. 115 y C. R. DODWELL, voz "Canterbury. Miniatura", Enciclopedia dell'Arte Medievale, vol. IV, Roma, 1993, pp. 156-159.

${ }^{2592}$ Winchester, Cathedral Library, Ms. 17. Cf.: J. CROOK, voz "Winchester...", en particular, p. 797 y F. GALVÁN FREILE, La decoración de manuscritos..., p. 47, nota 35.

${ }^{2593}$ El obispo Henry de Blois fue uno de los personajes más sobresalientes de este ámbito, no sólo por sus capacidades intelectuales, sino también por su labor como patrocinador de las artes. De su mano corrió la reconstrucción y ampliación del palacio de Wolvesey (Winchester), destruido durante las guerras civiles del año 1141, además de ser fundador del Hospital de la Santa Cruz de Sparkford, al sur de Winchester. Consúltese al respecto: J. CROOK, voz "Winchester...", p. 797.

${ }^{2594}$ E. PANOFSKY, Renacimiento y renacimientos..., p. 122.
} 
En varias ocasiones, a lo largo de este estudio hemos mencionado la importancia de este prelado, ya que se trata una figura intelectualmente muy compleja que, según se ha demostrado, tuvo especial predilección por el arte antiguo. Adquirió estatuas romanas y participó del comercio local de antigüedades durante el siglo XII, aunque se tratase, evidentemente, de ventas ocasionales ${ }^{2595}$.

Según defendiera en su día J. B. Ross, en el año 1151, el obispo de Blois realizó un viaje a la ciudad de Roma y, a su vuelta, no dudó en transportar algunas piezas escultóricas de época clásica, así como diversos mármoles ${ }^{2596}$.

Estos y otros aspectos, nos revelan una compleja personalidad amante del arte antiguo, parangonable tan sólo a otras figuras de igual categoría dentro del contexto europeo $^{2597}$.

El caso de ciertos manuscritos producidos en Winchester ejemplifica de manera clara algunos aspectos relacionados con las vías de asimilación de los tipos clásicos dentro de la "ilustración 1200". De esta forma, según se ha mantenido, ciertos manuscritos datados en las etapas más tempranas de la producción miniada del entorno catedralicio presentaban ya una clara asimilación de fórmulas carolingias y bizantinas $^{2598}$.

Ello permite afirmar que el traspaso de elementos bizantinos sobre la primera miniatura de Winchester permitió preparar el terreno para experiencias posteriores ${ }^{2599}$. El profesor A. Lawrence insiste en poner de relieve los profundos cambios que sufrió la ilustración del libro con la llegada al obispado de Henry de Blois, quién pudo incluso llegar a elaborar algún códice él mismo. En concreto, alude al denominado Salterio de

2595 J. B. ROSS, "A Study of Twelfth-Century Interest in the Antiquities of Rome", Mediaeval and Historiographical Studies in Honor of J. W. Thompson, Chicago, 1938, pp. 302-321.

${ }^{2596}$ Ibidem, p. 309. Agradezco al profesor D. Mario D'Onofrio del Dipartimento di Storia dell'Arte de la Università di Roma La Sapienza, la ayuda prestada durante la elaboración de este estudio, sus orientaciones bibliográficas, así como la amable acogida que me prodigó durante la Estancia de Investigación del Ministerio de Educación y Ciencia que realicé bajo su tutela dentro de la mencionada institución, entre los meses de junio y octubre del año 2006.

${ }^{2597}$ W. OAKESHOTT, Classical Inspiration..., pp. 77-79 y N. E. STACEY, "Henry of Blois and the Lordship of Glantonbury", English historical review, vol. 114, 455, 1999, pp. 1-33.

${ }^{2598}$ Historia ecclesiastica gentis Anglorum de Beda, Oxford, Bodleian Library, Ms. 10 y el Salterio de Etelstano, London, British Library, Ms. XVIII. Estos dos ejemplares aparecen mencionados como buenos asimiladores de ciertos aspectos de la plástica bizantina, a pesar de datarse en el siglo X. Véase sobre el tema: A. LAWRENCE, voz "Winchester. Miniatura", Enciclopedia dell'Arte Medievale, vol. XI, Roma, 2000, pp. 798-801, en particular, p. 799.

${ }^{2599}$ Los autores siguen enfrentándose a grandes problemas para poder distinguir los manuscritos y las fuentes seguidas por los miniaturistas del denominado como "Old Minster" y "New Minster". Cf.: Ibidem. 
Winchester que, según añade el citado investigador, "parece inspirarse en un icono bizantino" 2600 .

Sin embargo, aún teniendo en cuenta estos precedentes, será la citada Biblia de Winchester la que mejor representó esta oleada bizantinizante que sacudió las "artes del color" de este área geográfica en concreto ${ }^{2601}$.

Hace años que, tanto O. Demus como W. Oakeshott, defendieron la fuerte impronta bizantina que manifestaba el códice. En concreto, se insinuó en la posibilidad de que el artista o artistas que trabajaron en él pudieran haber estado influenciados por el mosaico del ábside de la catedral de Cefalù, en Sicilia, antes de miniar algunas páginas del volumen ${ }^{2602}$ (fig. 500). En este sentido, los mosaicos del área sur italiana ofrecen imágenes susceptibles de ser equiparadas con algunos de los mejores folios de la Biblia inglesa. Se trata de elementos formales compartidos que permitieron a estos investigadores ligar de manera formal, por ejemplo, el Pantócrator del ábside de la citada catedral siciliana, realizado en torno al año 1148, con una inicial miniada de la Biblia inglesa ${ }^{2603}$ (fig. 501). En la misma línea, se aludió a la conocida escena de Creación de Eva y Adán en el mosaico de Palermo, claramente inspirador de otra de las ilustraciones del mismo códice ${ }^{2604}$.

La asimilación de ciertas fórmulas tendentes a lo clásico pero tamizadas bajo el influjo de la plástica bizantina, pudieron llegar a las Islas Británicas en la etapa final del siglo XII. La manifestación artística donde mejor se supo reflejar tal asimilación fue la ilustración del libro, si bien, las demás artes no fueron ajenas a los nuevos planteamientos $^{2605}$.

Según creemos, a través del ejemplo de los códices generados por el scriptorium de la catedral de Winchester se pueden llegar a visualizar bien tales planteamientos. Dichas obras dan buena cuenta de la influencia ejercida por el patronazgo artístico de la corte real y las élites intelectuales ligada a tales ámbitos. El nombre de Henry de Blois

2600 Salterio de Winchester, London, British Library, Cott. Nero C. IV. Cf.: F. WORMALD, The Winchester Psalter, London, 1973; A. LAWRENCE, voz "Winchester. Miniatura...”, p. 800 e ID., "Alfred, his Heirs and the Traditions of Manuscript Production in Tenth-Century in England", Reading Medieval Studies, 13, 1987, pp. 35-56.

${ }^{2601}$ Winchester, Catedral Library, Ms. 17.

${ }^{2602}$ Winchester, Cathedral Library, Ms. 17, f. 190r.

${ }^{2603}$ Winchester, Cathedral Library, Ms. 17, f. 169r.

${ }^{2604}$ Winchester, Cathedral Library, Ms. 17, f. 5r. Cf.: W. OAKESHOTT, Classical Inspiration..., p. 101; ID., The Artist of the Winchester..., pp. 10-19; O. DEMUS, Byzantine mosaic decoration: aspects of monumental art in Byzantium, London, 1976 y C. M. KAUFFMANN, "Winchester, Cathedral Library", A Survey of Manuscripts Illuminated in The British Isles. Romanesque Manuscripts. 1066-1190, London, 1975, ficha catalográfica 83, pp. 108-111.

${ }^{2605}$ M. GREENHALGH, The Survival of Roman..., en concreto, pp. 142-143. 
es tan sólo el eslabón más visible de la cadena, pero parece claro que su viaje a Roma pudo tener algo que ver en la aceleración de este proceso de asimilación de las formas bizantinas que, por otra parte, ya se rastrean en las primeras fases de desarrollo de la miniatura del centro catedralicio ${ }^{2606}$. La importancia de sus obras como referentes sintetizadores del fenómeno de asimilación de fórmulas bizantinizantes durante la etapa final del románico tendrá, como veremos, una importancia capital para el ámbito hispano. Así, cuando Lawrence lleva a cabo un análisis de alguna de las ilustraciones de la Biblia de Winchester, no duda en sostener la trascendencia que tendrán para el futuro, no sólo como asimiladoras perfectas del pasado -recuérdense las pinturas "estilo 1200" de la capilla del Santo Sepulcro de la catedral inglesa-, sino también para los ámbitos foráneos, tal y como se observa en la sala capitular de Sigena, en Huesca; sin duda, uno de los conjuntos hispanos donde mejor se percibe la asimilación de los preceptos derivados de las artes plásticas bizantinas ${ }^{2607}$.

${ }^{2606}$ Ibidem, p. 213.

2607 A. LAWRENCE, voz "Winchester. Miniatura...", p. 801. Esta problemática se abordará en el apartado siguiente, referido al problema del "estilo 1200" en el arte hispano. 


\section{EL PROBLEMA DEL “ESTILO 1200” Y LAS ARTES HISPANAS.}

Según defendió el profesor Galván a través de algunas investigaciones:

“(...) podemos concluir que, a nuestro entender, sí se puede hablar de un "estilo 1200" hispano, máxime si nos referimos a la decoración de manuscritos. Lo cual no quiere decir (...) que todas las obras realizadas en este momento puedan ser clasificadas dentro del nuevo lenguaje artístico que se impone en algunas regiones de Europa y en determinadas manifestaciones artísticas" 2608.

Partiendo de tales preceptos, la historiografía que abordó el impacto del fenómeno que aquí analizamos sobre la plástica hispana en torno al año 1200, ha venido aceptando tales planteamientos de manera desigual. Lo más interesante en este sentido es que, en el estado actual de las investigaciones, la producción bibliográfica enfocada a analizar el fenómeno cuenta con una buena nómina de estudios.

Debemos a los profesores J. Yarza ${ }^{2609}$, E. Fernández ${ }^{2610}$ y, especialmente, al profesor F. Galván ${ }^{2611}$, el mayor número de aportaciones al respecto, aunque si bien

${ }^{2608}$ F. GALVÁN FREILE, La decoración de manuscritos..., p. 76.

2609 J. YARZA LUACES, Arte y arquitectura..., pp. 282-287; ID., "Miniatura", Historia del Arte en Castilla y León. La Edad Media (J. J. Rivera Blanco, F. J. de la Plaza Santiago, S. Marchán Fiz, coords.), vol. II, Valladolid, 1994, pp. 263-292; ID., "La miniatura románica: Estado de la cuestión”, Anuario del Departamento de Historia y Teoría del Arte, 2, 1990, pp. 9-26; ID., "Códices iluminados en el Monasterio de Las Huelgas", Reales Sitios: Revista del Patrimonio Nacional, 107, 1991, pp. 49-56; ID., "La pintura española medieval: desde la cultura visigoda hasta finales del románico", La pintura en Europa. La pintura española (A. E. Pérez Sánchez ed.), vol. I, 1995, pp. 15-70; ID., "Miniatura y pintura: Siglos X-XV", Real Colegiata de San Isidoro: relicario de la monarquía leonesa (C. Robles García y F. Llamazares Rodríguez coords.), León, 2007, pp. 278-293 e ID., "La miniatura en los reinos peninsulares...", pp. 25-94.

2610 E. FERNÁNDEZ GONZÁLEZ, “Santo Martino de León...”, en particular, pp. 53-53; ID., "Las miniaturas de los códices...", pp. 511-58; ID., "Hagiografía e iconografía en torno a Santo Martino...", pp. 177-203 y E. FERNÁNDEZ GONZÁLEZ y A. VIÑAYO GONZÁLEZ, Abecedario-Bestiario..., por ejemplo, p. 42.

${ }^{2611}$ F. GALVÁN FREILE, La decoración de manuscritos..., pp. 62-77; ID., La decoración miniada..., pp. 11-18; ID., "Origen y difusión del modelo iconográfico de la Virgen Eleusa en la Península Ibérica", Imágenes y promotores en el arte medieval, Bellaterra, 2001, pp. 125-137; ID., "El proceso de internacionalización de la miniatura en torno al año 1200 en la Península Ibérica: el antifonario de Las Huelgas Reales de Burgos", El monacato en los reinos de León y Castilla (siglos VII-XIII), León, 2007, pp. 437-456; ID., "El Ms. 1513 de la Biblioteca Nacional de Madrid: primeros pasos en la miniatura gótica hispana", Anuario de estudios medievales, 27, 1, 1997, pp. 479-500; ID., "Miniaturas en fragmentos de códices del Archivo Diocesano de Astorga (c. 1200)", Astórica, vol. 17, 19, 2000, pp. 203222; ID., Fragmentos de manuscritos iluminados en el Archivo Histórico Provincial de León: (c. 1200), León, 2000; ID., "El Libro de las Estampas, modelo para algunas de las vidrieras de la Catedral de León", Memoria ecclesiae, 16, 2000, pp. 45-54; ID., "La producción de manuscritos iluminados en la Edad Media y su vinculación a las monarquías hispanas", Anuario del Departamento de Historia y Teoría del Arte, 13, 2001, pp. 37-52 e ID., "Manuscritos iluminados y monarquía en los siglos X y XI", Alfonso VI y 
afrontaron la problemática centrándose en la ilustración del libro. Estos aspectos, básicos dentro de la definición del supuesto “estilo 1200” dentro del ámbito hispano, serían tomados como base para autores posteriores. Así, en la actualidad se continúa prestando especial atención al fenómeno del llamado "arte 1200", sobre todo, a través de las “artes del color" y, generalmente, desde la óptica de la filiación bizantina ${ }^{2612}$.

Para finalizar, destacamos los estudios realizados por la profesora D. Ocón en los que, sobre todo, se tuvieron en cuenta las producciones escultóricas ${ }^{2613}$.

En este breve repaso historiográfico relativo al arte hispano relacionado con el año 1200, tienen especial relevancia los estudios centrados en analizar las artes suntuarias.

Si en el contexto europeo habíamos apuntado la importancia del arte objetual de filiación cortesana como uno de los generadores y difusores de la nueva "estética", para el caso hispano debemos afirmar que la situación fue también brillante.

Al respecto, merecen una mención especial los trabajos en esmalte, estudiados en profundidad por el profesor J. Yarza ${ }^{2614}$.

La nómina de objetos de gran calidad artística y susceptibles de enmarcarse dentro del ámbito cronológico del año 1200 es amplísima. Baste tan sólo con recordar, brevemente, piezas tan señeras como la Virgen de la Vega, en la catedral de

su época. I, Los precedentes del reinado (966-1065) (E. Fernández González y J. Pérez Gil ed.), León, 2007, pp. 209-233.

${ }^{2612}$ En la actualidad se continúa trabajando con grandes frutos sobre esta materia. Véanse los trabajos publicados en: R. ALCOY I PEDROS, "Las pinturas de Sant Pau...", pp. 107-134; A. MIGUÉLEZ CAVERO, "La iconografía de la Natividad: los contactos artísticos entre Oriente y Occidente en la época románica", La Multiculturalidad en las Artes y en la Arquitectura, 2 vols., Las Palmas de Gran Canaria, 2006, vol. I, pp. 359-365; E. LOZANO PÉREZ, "El Claustro de Monreale y el Tardorrománico hispano: relaciones formales", La Multiculturalidad..., vol. I, pp. 329-336; A. B. MUÑOZ MARTÍNEZ, "Presencia y evolución de una fórmula iconográfica bizantina en la pintura románica catalana: la Natividad", La Multiculturalidad..., vol. I, pp. 393-399 y L. DIEGO BARRADO, "Relaciones entre Oriente y Occidente...", pp. 213-221. Véase también la Tesis Doctoral recientemente publicada en: E. CHALYVOPOULOU, Op. cit.

${ }^{2613}$ La nómina de trabajos que han abordado la escultura tardorrománica encuadrada bajo el epígrafe "1200" no es tan amplia y no ha recibido tanta atención como las artes del libro. Véanse, entre otros: D. OCÓN ALONSO, "Alfonso VIII, la llegada de corrientes...", p. 311; ID., "Bizantinismo y difusión de modelos...", p. 98; ID., "Bizantinismo y difusión de modelos en el románico periférico", VIII Congreso Español de Historia del Arte, Cáceres, 1990, pp. 307-320; ID., "El renacimiento bizantinizante de la segunda mitad del siglo XII y la escultura monumental en España", Viajes y Viajeros en la España Medieval, Aguilar de Campoo, 1993, pp. 267-290.

2614 J. YARZA LUACES, "De Limoges a Silos", Esmaltes Medievales. De Limoges a Silos, Burgos, 2002, pp. 13-61. El autor dirigió el volumen resultado de la exposición del mismo título, organizada, entre otros lugares, en el monasterio de Santo Domingo de Silos. Remitimos a esta contribución, pues en ella se lleva a cabo el tratamiento más completo que se ha realizado sobre este tipo de técnica dentro de la Hispania medieval. 
Salamanca $^{2615}$, la llamada Virgen de las Batallas del monasterio de San Pedro de Arlanza $^{2616}$, la paloma eucarística de la catedral de Burgo de Osma ${ }^{2617}$, el espectacular Cristo de Nicomedo de la Cámara Santa de Oviedo ${ }^{2618}$, la espléndida arqueta de la Crucifixión de la Real Colegiata de San Isidoro de León ${ }^{2619}$, el frontal proveniente de San Miguel de Aralar ${ }^{2620}$ o la colección de piezas sueltas custodiadas en la catedral de Orense $\mathrm{e}^{2621}$.

Con todo, dentro de este rico panorama, la pieza que más interés ha suscitado es el llamado frontal de Silos, hoy en el Museo de Burgos y que reúne, de manera perfecta, algunos de los hipotéticos postulados conformadores del "estilo 1200",2622.

No queremos extendernos en estos aspectos, pero parece claro que la mayoría de los expertos han defendido el fuerte carácter bizantinizante que muestran estas piezas, sus conexiones con las regiones septentrionales de Europa, la relación que mantienen

2615 I. ARIAS SÁNCHEZ, "Silos y Limoges”, Boletín del Museo Arqueológico Nacional, XIII, 1995, pp. 75-84 y C. FERNÁNDEZ LADREDA, "Las imágenes de la Virgen en la escultura", Maravillas de la España Medieval. Tesoro sagrado y monarquía, vol. I, León, 2001, pp. 415-417 e ID., "Virgen de la Vega", Maravillas de la España Medieval. Tesoro sagrado y monarquía, vol. I, León, 2001, ficha catalográfica 178, pp. 434-435.

2616 J. NUÑO GONZÁLEZ, voz "Virgen de las Batallas (Museo de Burgos)", Enciclopedia del románico en Castilla y León. Burgos, vol. IV, Aguilar de Campoo, 2002, pp. 2378-2380; J. L. SENRA GABRIEL Y GALÁN, voz "Monasterio de San Pedro de Arlanza", Enciclopedia del románico en Castilla y León. Burgos, vol. IV, Aguilar de Campoo, 2002, pp. 2359-2377; ID., "La escultura románica y sus problemas...", pp. 25-38 y J. YARZA LUACES, “De Limoges...”, p. 17.

${ }^{2617}$ J. YARZA LUACES, "De Limoges...", p. 17.

2618 M. P. GARCÍA CUETOS, "Los Reyes de Asturias. La Cámara Santa de la Catedral de Oviedo", Maravillas de la España Medieval. Tesoro sagrado y monarquía, vol. I, León, 2001, pp. 205-214 y M. TERESA LÓPEZ DE GUEREÑO, "La cruz y el crucificado...”, en particular, p. 375.

${ }^{2619}$ M. L. MARTÍN ANSÓN, “Arca de los esmaltes”, Maravillas de la España Medieval. Tesoro sagrado y monarquía, vol. I, León, 2001, ficha catalográfica 164, pp. 404-405.

${ }^{2620}$ M. L. MARTÍN ANSÓN, Esmaltes en España, Madrid, 1984, pp. 11-12 y D. RICO CAMPS, "El retablo de San Miguel de Aralar", Sancho el Mayor de Navarra y sus herederos. El linaje que europeizó los reinos hispanos, vol. I, Pamplona, 2006, pp. 561-580.

${ }^{2621}$ I. G. BANGO TORVISO, "El tesoro de la Iglesia", Maravillas de la España Medieval. Tesoro sagrado y monarquía, vol. I, León, 2001, pp. 155-188; M. L. MARTÍN ANSÓN, "Panel de la urna de Santo Domingo de Silos", Maravillas de la España Medieval. Tesoro sagrado y monarquía, vol. I, León, 2001, ficha catalográfica 163, pp. 403-404 y J. GALLEGO LORENZO, "Placa de cubierta de Evangeliario con Crucifixión", Alfonso IX y su época. Pro utilitate mei, A Coruña, 2008, ficha catalográfica 92, pp. 425-426.

${ }^{2622}$ M-M. GAUTHIER, "L'atelier d'orfèvrerie de Silos à la époque romane”, El románico en Silos: IX Centenario de la consagración de la iglesia y claustro, Silos, 1990, pp. 377-395; I. ARIAS SÁNCHEZ, "La orfebrería y los esmaltes medievales de Silos", El Scriptorium silense y los orígenes de la lengua castellana, Valladolid, 1995, pp. 35-83; M. L. MARTÍN ANSÓN, Los esmaltes románicos de Silos, Madrid, 1998, pp. 10-11; C. DEL ÁLAMO, "Panel de la urna de Santo Domingo de Silos", Maravillas de la España Medieval. Tesoro sagrado y monarquía, vol. I, León, 2001, ficha catalográfica 161, pp. 400401 e ID., "Panel de la urna de Santo Domingo de Silos", Maravillas de la España Medieval. Tesoro sagrado y monarquía, vol. I, León, 2001, ficha catalográfica 162, pp. 401-402. 
con los ámbitos del Rin y el Mosa y el vital papel jugado como trasmisores de algunas soluciones derivadas del "movimiento 1200 ",2623.

Así por ejemplo, atendiendo a tales preceptos, no es de extrañar que la profesora M. L. Martínez Ansón, al estudiar el arca de los esmaltes de San Isidoro de León, recurriese a la expresión de "taller bizantinizante" para argumentar la posible factura de la pieza, vinculado, según defendió, con el gusto principesco reinante en el Mediterráneo $^{2624}$.

Dentro de este breve repaso dedicado a las artes suntuarias hispanas y a su perfecta participación del mismo movimiento que, por entonces, se desarrollaba en Europa, queremos aludir a las cubiertas del evangeliario custodiadas en la Real Colegiata de Roncesvalles, en Navarra (fig. 502).

Según la profesora M. V. Herráez, resulta difícil poder llegar a concretar si esta es una producción propiamente ejecutada por un taller hispano de índole local o, por el contrario, una obra realizada en Francia, posiblemente, entre los años finales del siglo XII y principios del XIII. Lo más interesante es que, aún en las fechas tardías que propone, 1220-1230, se percibe plenamente el mantenimiento de las soluciones técnicas e iconográficas de la tradición bizantina, repetidas frecuentemente por carolingios y otonianos.

Parece que el foco renano o, al menos el área delimitada entre París, Colonia y Tréveris, ofrecerían el marco perfecto en el que encuadrar esta pieza. En ella, aún se perciben los ecos de las soluciones dadas por los mismos talleres pocos años después del 1150 y que tendrán una pervivencia que se rastrea con facilidad más allá del año $1250^{2625}$.

${ }^{2623}$ F. GALVÁN FREILE, La decoración de manuscritos...", p. 54 y J. YARZA LUACES, "De Limoges...", p. 14. El profesor Yarza escribe al respecto: "Es muy antigua la fabricación de esmaltes con diferentes técnicas y utilizando diversos materiales como soportes. En los siglo XI y XII los más extraordinarios se hacen el oriental imperio bizantino, muchas veces sobre una base de oro. En Occidente trabajan diversos obradores y con preferencia por el cobre. Se ha distinguido la producción del norte de la llevada a cabo en el sur. El núcleo septentrional es el ámbito de los monasterios y centros religiosos extendidos en el entorno de los ríos Mosa y Rhin alto, pero incluye obras semejantes fabricadas en el norte de Francia".

${ }^{2624}$ M. L. MARTÍN ANSÓN, “Arca de los esmaltes...”, p. 405.

${ }^{2625}$ M. V. HERRÁEZ ORTEGA, "Contribución al estudio de la orfebrería en el siglo XIII en Navarra. El Evangeliario de Roncesvalles", Laboratorio de Arte, 18, 2005, pp. 57-72 e ID., "Cubiertas de evangeliario", Sancho el Mayor de Navarra y sus herederos. El linaje que europeizó los reinos hispanos, vol. I, Pamplona, 2006, ficha catalográfica 138, pp. 416-420. 
Sin embargo, será dentro de la pintura monumental y la ilustración del libro manuscrito donde, según los expertos, mejor se localice la incidencia del "estilo 1200,2626 .

No es este el lugar para detenerse en el importante conjunto pictórico que en su día decoró la sala capitular del monasterio de Sigena. Por unanimidad, todos los autores coinciden en defender tan emblemática obra, como la mejor representante del "estilo 1200 " dentro de la pintura hispana ${ }^{2627}$.

Mediante estas pinturas, queda perfectamente demostrado el hecho de que la Península Ibérica participaba plenamente de los preceptos estéticos del “arte 1200”. Los diversos autores, a través de sus trabajos concienzudos y minuciosos, han conseguido desenmarañar toda una red de filiaciones y relaciones con el arte contemporáneo a las pinturas. Así, según se viene aceptando, es posible que los pintores activos en el área aragonesa a finales del siglo XII se hubieran formado en una tradición cercana a los focos más importantes del movimiento que aquí analizamos, es decir, el sur del Península Itálica y Sicilia y la Europa Septentrional, con las Islas Británicas como foco preferencial $^{2628}$.

En el estudio realizado sobre el conjunto hispano antes citado, O. Pächt se atrevió incluso a concretar que los pintores que las habían realizado podían haber tenido pleno conocimiento de los mosaicos sicilianos, tanto de la Capilla Palatina de Palermo como de Cefalù ${ }^{2629}$. Más recientemente, la profesora D. Ocón retomó el tema, insistiendo en las fuentes inglesas conocidas a través de los manuscritos de Winchester y los vitrales de Canterbury, además de las estrechas relaciones que el conjunto de pinturas guardaría con el arte sículo-normando y el arte comneno. Finalmente, también

\footnotetext{
${ }^{2626}$ Dentro de la famosa exposición The Year 1200 la representación de obras adscritas a la Península Ibérica fue mínima. Sin embargo, es bien significativo que fueran algunos fragmentos pictóricos provenientes de la Sala Capitular de Sigena los seleccionados como mejores representantes del "estilo 1200" hispano. También se incluyeron algunos relieves del coro pétreo de la catedral de Santiago. Cf.: F. GALVÁN FREILE, La decoración de manuscritos..., p. 52, nota 15.

${ }^{2627}$ Ante la abundante bibliografía que tal obra ha suscitado, recogemos tan sólo aquellos estudios que hemos consultado. Creemos que la obra más señera es la realizada por W. Oakeshott, pues sintetiza bien la compleja formación que debieron tener los artistas que pintaron la cubierta de madera, además de dedicar algunos capítulos a la filiación de los motivos allí representados con respecto a la tradición clásica. Cf.: W. OKESHOTT, Sigena Romanesque Paintings in Spain and the Winchester Bible Artists, London, 1972. Véase también: G. ZARNECKI, "Prophets from the chapter house of Sigena", English Romanesque Art 1066-1200, London, 1984, ficha catalográfica 87, p. 134 y A. SICART, Las pinturas de Sigena, Madrid, 1992.

${ }^{2628}$ G. ZARNECKI, "Prophets...”, p. 134.

${ }^{2629}$ O. PÄCHT, “A Cycle of English Frescoes in Spain”, The Burlington Magazine, 1961, vol. 103, 698, 1961, pp. 166-175.
} 
insistió en ciertas producciones derivadas de los estrechos contactos de Occidente con la producción de iconos de Jerusalén o Chipre ${ }^{2630}$.

Nuevamente observamos como la elaboración y construcción historiográfica del “estilo 1200" se fundamentaba en la alusión directa a una serie de hitos, supuestamente perfiladores de algunos de sus planteamientos maestros.

Cuando Oakeshott publicó su estudio monográfico sobre Sigena, aceptó la importancia del foco siciliano y del sur itálico, pero defendió que aún había sido más significativa la observación de los manuscritos. Supuestamente, siempre según sus teorías, éstos debieron impregnarse de tales soluciones bizantinizantes a través de reinterpretaciones realizadas ya en suelo inglés. Concretamente, volvía a hacer referencia al foco catedralicio de Wichester ${ }^{2631}$.

La práctica mayoría de los expertos citan con frecuencia todas aquellas obras que aquí hemos mencionado, desde el bizantinismo altomedieval presente en el conjunto pictórico de la iglesia italiana de Castelseprio, a las representaciones de profetas del monasterio de Daphni, de la pinturas murales de la capilla del Santo Sepulcro de la catedral de Winchester, hasta numerosas obras miniadas salidas de los scriptoria vinculados a este centro catedralicio ${ }^{2632}$.

El bizantinismo de raíz helenística, fue traspasado hacia los territorios occidentales por diversas vías. Una de las más interesantes acabó llegando al ámbito griego y de allí, pasó al sur italiano. La situación histórica y política que conectó estos ámbitos con la Europa septentrional proporcionó las fuentes para que los artistas ingleses asimilasen tales modos. Aún así, tal y como apuntaremos, la forma con que tal bizantinismo alcanzó estos territorios estaba muy modificada, pues suponemos que en esos largos "viajes" de las fórmulas, las soluciones iconográficas e estilísticas y, en última instancia, los rasgos clásicos, acabaron por ser materializados de una manera extremadamente matizada.

Sin embargo, el conjunto aragonés no fue un unicum. A él deben añadirse otra serie de obras que los investigadores han ido incluyendo, a veces con seguridad y otras tantas, de manera más dubitativa, a la serie de hitos que ayudarían a formar, desde el punto de vista histórico-artístico, el supuesto "estilo".

${ }^{2630}$ D. OCÓN ALONSO, "Une salle capitulaire pour une reine: les peintures du chapitre de Sigena", Les Cahiers de Saint-Michel de Cuxa, 38, 2007, pp. 81-94.

${ }^{2631}$ W. OAKESHOTT, Sigena Romanesque..., pp. 80-88.

${ }^{2632}$ Sobre las pinturas de Wichester, véase: A. LAWRENCE, voz "Winchester. Miniatura...", p. 801. En relación con todos los paralelismos citados, consúltese.: W. OAKESHOTT, Sigena Romanesque..., pp. $79-118$. 
Según señalara en su momento la profesora F. Español, los frontales de Aviá y Lluça presentan ecos de estos preceptos, aunque considera arriesgado englobarlos dentro de la nomenclatura "estilo 1200", por ostentar un carácter vago e impreciso ${ }^{2633}$. También dentro del arte catalán, la profesora R. Alcoy encuadró dentro del bizantinismo imperante en torno al año 1200 las pinturas de San Esteban de Andorra, aumentando así la nómina de obras representantes del movimiento en Hispania ${ }^{2634}$.

Sin embargo, fueron las pinturas realizadas para la sala alta del monasterio de San Pedro de Arlanza las que, junto con las de Sigena, mayor importancia adquirieron dentro del movimiento ${ }^{2635}$. En relación con ellas, ya en su día W. Oakeshott relacionó la representación del grifo proveniente del monasterio burgalés con la imagen del mismo ser mitológico presente en Sigena (figs. 503 y 504), insistiendo además en la importancia de los frescos de Arlanza como herederos directos de los preceptos bizantinistas de tamiz clásico ${ }^{2636}$.

En relación con estas obras, el profesor S. Moralejo puso de relieve la importancia del año 1200 dentro del monasterio arlantino. En concreto, a parte de otra serie de obras acometidas en el cenobio, llamaba la atención sobre el singular ciclo de frescos proyectados para decorar un ambiente, hoy en día de función incierta, anexo al ábside meridional. Se trataba de un friso pintado con temática zoomorfa de seres afrontados.

En concreto, remarcaba la imagen de un ave, un grifo, un león y un cuadrúpedo, además de diversos elementos arquitectónicos, entre otras figuraciones.

De manera clásica, los frescos han sido considerados como representantes del “arte 1200" y, supuestamente, relacionables con otras obras hispanas, como el Tumbo A de Santiago de Compostela ${ }^{2637}$ y el Beato de las Huelgas de Burgos ${ }^{2638}$. A pesar de estas fuentes, nuevamente se defendió con fuerza la teoría de la influencia inglesa ${ }^{2639}$.

\footnotetext{
${ }^{2633}$ Barcelona, Museo Nacional de Arte de Cataluña. Cf.: F. ESPAÑOL BELTRÁN, El Arte Gótico I, Madrid, 1989, en particular, pp. 50-58 y p. 100.

${ }^{2634}$ R. ALCOY, "Les pintures bizantinitzants de Sant Esteve d'Andorra...", pp. 23-47.

${ }^{2635}$ El conjunto se encuentra hoy repartido entre el Museo Nacional de Arte de Cataluña, en Barcelona y el Metropolitan Museum of Art The Cloisters, de New York.

${ }^{2636}$ W. OAKESHOTT, Sigena Romanesque..., pp. 120-121.

${ }^{2637}$ Santiago de Compostela, Archivo de la Catedral, cód. 1.

${ }^{2638}$ New York, Pierpont Morgan Library, Ms. 429.

${ }^{2639}$ S. MORALEJO ÁLVAREZ, voz “Arlanza, San Pedro de", Enciclopedia dell'Arte Medievale, vol. II, Roma, 1991, pp. 453-454; M. GÓMEZ-MORENO, "Pinturas murales de San Pedro de Arlanza", Boletín de la Real Academia de la Historia, 86, 1925, pp. 13-16 y W. W. S. COOK y J. GUDIOL RICART, "Pintura e imaginería románicas", Ars Hispaniae, Madrid, 1950, pp. 127-174.
} 
La alusión a las artes del libro a la hora de buscar paralelismos con las pinturas de Sigena y Arlanza no debe sorprender. En el ámbito hispano, como en el europeo, la miniatura fue una de las manifestaciones artísticas donde mejor se materializaron los preceptos y soluciones propias del "arte 1200".

Las investigaciones llevadas a cabo por los historiadores del arte dedicados a estudiar el arte hispano, han puesto de manifiesto tales aspectos. Sin pretender realizar un profundo estado de la cuestión, remitimos a los estudios, ya mencionados, del profesor J. Yarza, además de los realizados por los profesores F. Galván y E. Fernández $^{2640}$.

La lista de manuscritos en los que se perciben tales preceptos artísticos es muy extensa y no sólo en relación con los producidos en Hispania, sino también aquellos realizados en la zona lusitana ${ }^{2641}$. Así, se suelen destacar obras importantes vinculadas nuevamente al ámbito burgalés, tales como el grupo de manuscritos custodiados en el monasterio de Las Huelgas de Burgos, ligados continuamente a soluciones inglesas de ascendencia bizantinizante, por una parte $\mathrm{y}$, desde la otra, a las producciones $\operatorname{lusitanas}^{2642}$.

Por citar otro de los focos bien conocidos, aludiremos al ámbito occidental peninsular y, concretamente, a los códices realizados en el escritorio de la Real Colegiata de San Isidoro de León. Tal y como ha estudiado la profesora E. Fernández, debemos a la figura de Santo Martino de León la introducción de ciertas soluciones propias del "arte 1200 ",2643.

Como otros personajes destacados de la etapa final del románico, este canónico realizó un viaje que le llevó hacia Tierra Santa, visitando lugares emblemáticos de la

\footnotetext{
${ }^{2640}$ Véase la selección bibliográfica recogida a lo largo de las páginas anteriores.

${ }^{2641}$ Desde hace algunos años han tomado un papel destacado los estudios dedicados a indagar en el papel que jugó el arte portugués y, sobre todo, la ilustración del libro, en relación con el contexto europeo. Véanse los estados de la cuestión realizados en: M. A. MIRANDA, "Iluminura românica em Portugal", La miniatura medieval en la península Ibérica (J. J. Yarza Luaces), Murcia, 2007, pp. 375-418; ID., "Imagens do sagrado na iluminura e ourivesaria românicas em Portugal", Románico en Galicia y Portugal, Santiago de Compostela, 2001, pp. 184-213 y M. L. REAL, voz "Alcobaça", Enciclopedia dell'arte medievale, vol. I, Roma, 1991, pp. 335-340. En este punto queremos agradecer a la profesora Adelaida Miranda del Departamento de História da Arte de la Universidade Nova de Lisboa, todas las observaciones y sugerencias realizadas sobre estos temas, así como su tutela durante la realización de una Estancia de Investigación del Ministerio de Educación y Ciencia en dicho centro, durante los meses de junio y agosto del año 2008.

${ }^{2642}$ F. GALVÁN FREILE, "El proceso de internacionalización de la miniatura en torno al año 1200...", en especial, pp. 437-456 e ID., La decoración de manuscritos..., p. 73.

${ }^{2643}$ E. FERNÁNDEZ GONZÁLEZ, "Santo Martino de León...", pp. 50-51; F. GALVÁN FREILE, La decoración de manuscritos..., p. 75 y A. VIÑAYO, Santo Martino de León, León 1984, pp. 53-55.
} 
cristiandad, tanto en Occidente como en Oriente ${ }^{2644}$ (fig. 495). Según se acepta hoy en día, tal peregrinación le proporcionó el bagaje cultural suficiente como para que, a su vuelta, la labor intelectual y de producción artística que llevó a cabo en el escritorio isidoriano, se viera impregnada plenamente de tales preceptos estéticos ${ }^{2645}$.

La serie de miniaturas que decoran sus códices presentan recuerdos de la tradición artística oriental, con alusiones lejanas a centros de la categoría, por ejemplo, de Santa Catalina del Sinaí. Su obra pictórica trasmite un conocimiento de las soluciones bizantinizantes conocidas en Europa desde hacia siglos, gracias a la influencia ejercida por otros núcleos preponderantes, como el de la ciudad de Ravenna. De igual modo, la obra miniada del citado clérigo, parece dejar entrever los ecos de ciertas soluciones conocidas en la órbita siciliana, como Moreale y, aquellas producciones ligadas al área septentrional europea.

En su publicación del año 1987, la profesora E. Fernández ya insistía en la importancia de lo que ella denominaba "el triángulo del norte de Europa" y que estaría formado por aquellos lugares que sirvieron de base para la formación visual y artística del canónigo isidoriano. Nuevamente citaba la importancia de las Islas Británicas, el norte de Francia y las tierras del Mosa, Mosela, norte del Rin y las regiones próximas del territorio germano ${ }^{2646}$.

La cuestión es demasiado compleja, pues más allá del traspaso de fórmulas "antiquizantes" orientales, recientemente se han aumentado las perspectivas artísticas del clérigo en cuanto a las posibles fuentes de inspiración para sus obras. En concreto, el profesor G. Boto ha llegado a insinuar, de manera hipotética, que la denominada Capilla de la Santísima Trinidad, patrocinada por Santo Martino y construida como un anexo de la basílica de San Isidoro, pudo haber tomado como referencia la arquitectura tardoantigua (fig. 505). Alude al caso de la basílica de Marialba de la Ribera, una de las construcciones más antiguas de la Hispania cristiana y en la que se utilizaron técnicas constructivas de tradición romana, mediante el uso de dobles hiladas de ladrillo a tizón en alternancia con secciones de calicantos (fig. 506). Sin embargo, como en otros

\footnotetext{
${ }^{2644}$ E. FERNÁNDEZ GONZÁLEZ, “Santo Martino de León...”, p. 51.

2645 Ibidem, p. 53.

2646 E. FERNÁNDEZ GONZÁLEZ, "Hagiografía e iconografía en torno a Santo Martino de León: tradición hispana y conexiones europeas", Memoria ecclesiae, 24, 2004, pp. 177-203; E. FERNÁNDEZ GONZÁLEZ y A. VIÑAYO GONZÁLEZ, Abecedario-Bestiario..., pp. 40-50. La autora especificaba y concretaba la importancia de diversos centros artísticos, como Winchester y su escuela de miniaturistas. Su estudio se acompañaba de sendos mapas. El primero representaba claramente los lugares visitados por Santo Martino a partir de los textos hagiográficos, mientras que el segundo recogía, de una manera muy visual, las áreas culturales más determinantes dentro del "estilo 1200”.
} 
muchos casos, la posibilidad de ver en las obras romanas y paleocristianas una posible fuente de inspiración para los artífices medievales, resulta meramente conjetural ${ }^{2647}$.

Volviendo al caso de las obras miniadas atribuidas a Santo Martino de León, otros investigadores ahondaron en la proyección del "estilo 1200" y su repercusión en otras manifestaciones artísticas coetáneas. Así, según apunta la profesora R. Sánchez Ameijeiras, al referirse a las esculturas de San Pedro y San Pablo del Museo Catedralicio y Diocesano de León, los escultores que las realizaron pudieron haber tomado como modelo algunas de las miniaturas realizadas por este clérigo. La citada experta mencionaba, concretamente, la efigie de San Isidoro en el volumen de las obras de Santo Martino de León ${ }^{2648}$.

Resultaría demasiado extenso referirnos a todos aquellos códices hispanos que, de una forma u otra, participaron de este "arte 1200"2649. En este sentido, y para finalizar este breve repaso general del fenómeno, debemos resaltar que tal movimiento acabó impregnando a otras manifestaciones artísticas, de entre las cuales, cabe destacar, la producción de vidrieras ${ }^{2650}$.

Este breve panorama de las artes hispanas pone de relieve la total interconexión que existió entre ellas, donde la adopción de modelos, soluciones y formulas cargadas de ciertos aspectos orientalizantes y de tradición bizantina fue la tónica más generalizada. Éstos, a su vez, presentaban una dependencia muy fuerte con respecto a la tradición greco-helenística. Sin embargo, el problema reside en poder llegar a valorar el

${ }^{2647}$ G. BOTO VARELA, "Arquitectura medieval: configuración espacial y aptitudes funcionales", Real Colegiata de San Isidoro: relicario de la monarquía leonesa (C. Robles García y F. Llamazares Rodríguez coords.), León, 2007, pp. 50-103, en particular, pp. 90-91.

${ }^{2648}$ R. SÁNCHEZ AMEIJEIRAS, "Una empresa olvidada del primer gótico hispano: la fachada de la sala capitular de la catedral de León”, Archivo Español de Arte, 276, 1996, pp. 389-406. En relación con estas y otras esculturas románicas leonesas cercanas al año 1200, véase: M. VALDÉS, C. COSMEN y M. V. HERRÁEZ, "La Edad Media. Del origen a la consolidación de un templo gótico", Una historia arquitectónica de la catedral de León, León, 1994, pp. 13-132, en particular, p. 50; G. BOTO VARELA, "1200 en León: Esculturas de la antigua catedral románica", Boletín del Museo e Instituto Camón Aznar, 59-60, 1995, pp. 83-118; ID., La memoria perdida..., pp. 112-113 e I. RUIZ DE LA PEÑA GONZÁLEZ, "Un tema iconográfico en torno al 1200...", pp. 435-468.

${ }^{2649}$ Baste con recordar, por ejemplo, la unanimidad que existe a la hora de conectar el "arte 1200" con obras tan señeras como el Libro de las Estampas de la catedral de León, la Biblia Antigua de las Huelgas de Burgos o parte del Tumbo A compostelano. Cf.: F. GALVÁN FREILE, La decoración de manuscritos..., p. 72; F. GALVÁN FREILE, Fragmentos de manuscritos iluminados..., en particular, pp. 73-74; ID., "La producción de manuscritos...", pp. 39-41; ID., "El Ms. 1513 de la Biblioteca Nacional de Madrid: primeros pasos en la miniatura gótica hispana", Anuario de Estudios Medievales, 27, 1997, pp. 479-496; ID., "Arte y monarquía en León...", pp. 53-65 e ID., "Rostros entre motivos vegetales. ¿Una travesura de miniaturistas?", Estudios Humanisticos, 17, 1995, pp. 163-177.

${ }^{2650}$ F. GALVÁN FREILE, "El Libro de las Estampas, modelo para algunas de las vidrieras...", pp. 4554; V. NIETO ALCAIDE, "Aspectos técnicos e iconográficos de las vidrieras de las capillas de la Catedral de León”, La Catedral de León en la Edad Media (J. J. Yarza Luaces, M. V. Herráez Ortega y G. Boto Varela coords.), León, 2004, pp. 297-303 y E. FERNÁNDEZ GONZÁLEZ, "Santo Martino de León...", p. 61. 
alcance que tuvo tal traspaso de los elementos clásicos. Ahora el sustrato clásico inundaba la Europa de los años finales del siglo XII, sin embargo, éste se encontraba tan tamizado y reinterpretado a través de múltiples variaciones obtenidas mediante su paso por diferentes fases, que resulta científicamente imposible poder llegar a ser más concreto en las afirmaciones ${ }^{2651}$.

${ }^{2651}$ F. GALVÁN FREILE, “Origen y difusión del modelo iconográfico...”, p. 137. 


\section{El “ARTE 1200” Y LA ESCUltura MONuMENTAL. PARTiCularidades DE LA PENÍNSULA IBÉRICA EN LOS PROCESOS DE ASIMILACIÓN DEL SUSTRATO CLÁSICO.}

En el último apartado de este bloque se abordarán una serie cuestiones de extrema complejidad. Las fuentes utilizadas por los escultores activos en la Península Ibérica en torno a los años 1160 y 1200, sigue planteando, aún hoy, multitud de interrogantes y opiniones enfrentadas.

Las causas de tales desacuerdos son innumerables. En primer lugar, se trata de un momento de máxima producción escultórica donde existen infinidad de corrientes, núcleos y obras en proceso de construcción. El panorama es excesivamente amplio, al igual que las soluciones seguidas por los escultores a la hora de practicar su oficio.

En el mismo sentido, al igual que había ocurrido durante las primeras etapas de la escultura románica hispana, frente a las nuevas corrientes estéticas que se introducían en estos territorios, se podrán detectar otros movimientos, paralelos, y que coexistirán con estas corrientes pioneras.

Los focos más pequeños o de menor importancia continuaron practicando una escultura ligada al pasado. Así, a pesar de que las cronologías tardías que presentarán algunos conjuntos escultóricos, las soluciones adoptadas mantendrán ciertos modos, prácticas o soluciones estilísticas ancladas en la tradición de las primeras décadas del siglo $\mathrm{XII}^{2652}$.

Así, a la hora de enumerar los conjuntos escultóricos hispanos en los que, de manera más clara, se pueden evidenciar las resonancias del "arte 1200", los historiadores del arte nuevamente recurrieron a un número de obras bastante reducido, configurándose una nómina de hitos que se han repetido de manera canónica.

En relación con estos aspectos, el profesor F. Galván consideraba que, entre los grandes grupos escultóricos del momento, cabían destacar los creados para la iglesia de San Vicente de Ávila, algunos de los grupos del claustro de Santo Domingo de Silos, el friso superior de la iglesia de Santiago en Carrión de los Condes, determinados relieves conservados en la León o el Pórtico de la Gloria de la catedral compostelana, así como gran parte de la escultura monumental gallega, incluido el desmantelado coro pétreo de la citada sede ${ }^{2653}$.

\footnotetext{
${ }^{2652}$ M. M. VILA DA VILA, Ávila románica: talleres escultóricos de filiación hispano-languedociana, Ávila, 1999, en especial, pp. 469-498.

${ }^{2653}$ F. GALVÁN FREILE, La decoración de manuscritos..., pp. 51-52.
} 
Sin embargo, aunque de manera unánime los especialistas reconocieron fácilmente la difusión de este tipo de fórmulas dentro de las artes suntuarias, la pintura y la miniatura, los estudios centrados en el análisis de la escultura no han sido tan $\operatorname{prolijos}^{2654}$.

La cuestión es ciertamente compleja. El hecho de que este tipo de soluciones tuvieran una desigual incidencia sobre las diversas artes, plantea el problema de no poder seguir aplicando metodologías formalistas derivadas de la teoría de los estilos sobre estas producciones. Se trata, por lo general, de conjuntos dispersos y muy diferentes los unos de los otros. También su cronología es excesivamente variable, así como las soluciones adoptadas por cada grupo de escultores. Tales hechos hacen imposible perfilar unas características generales en todos ellos, más allá de la lista de tópicos con los que, en ocasiones, se suele definir el desarrollo del "arte 1200" en la escultura $^{2655}$.

Además de este desigual impacto de las nuevas corrientes estéticas sobre la escultura hispana, también se observa la calidad desigual de las producciones. Finalmente, debemos destacar las complejas redes establecidas por los expertos en cuanto a las supuestas fuentes estilísticas a las que los escultores debieron tener acceso. Todos estos aspectos convierten este apartado en un conjunto de premisas de gran complejidad y cuyo tratamiento excede, con mucho, nuestro conocimiento en la materia.

Baste con citar tan sólo el famoso Pórtico de la Gloria de Santiago de Compostela, al que se dedicaron infinidad de estudios que han intentado esclarecer la ascendencia estilística de sus esculturas.

En relación con este importante conjunto compostelano, la mayor parte de los autores observaron ciertos rasgos "antiquizantes" en las soluciones dadas a las esculturas. Se buscaron sus orígenes dentro de la arquitectura y la escultura borgoñonas, en concreto, ligándolo con los trabajos escultóricos de la iglesia de Sainte-Madeleine de Vézelay, Saint-Benigne de Dijon, Paray-le-Monial, Saint-Lazare de Autun o la iglesia de Notre-Dame de Beaulieu ${ }^{2656}$.

\footnotetext{
${ }^{2654}$ Remitimos a los estudios, ya citados, de la profesora D. Ocón Alonso, una de las investigadoras que más insistió sobre el tema.

${ }^{2655}$ Este problema, tal y como hemos anotado ya, tuvo su reflejo en la exposición de Nueva York, donde tan sólo se recogieron apenas unos cuantos relieves susceptibles de ser englobados bajo el epígrafe de "escultura 1200" hispana. En concreto, tan sólo se mostraron algunas piezas pertenecientes al coro pétreo de Compostela.

${ }^{2656}$ M. WARD, Studies on the Pórtico de la Gloria at the Cathedral of Santiago de Compostela, New York, 1978, pp. 10-30; J. YARZA LUACES, Arte y Arquitectura..., p. 274 y M. CASTIÑEIRAS GONZÁLEZ, El Pórtico..., p. 17 y p. 41.
} 
Otros autores, encabezados por J. D'Emilio, ligaron la obra tanto a estructuras foráneas como propiamente hispanas, defendiendo las similitudes estilísticas y arquitecturales que el Pórtico compostelano guardaba con la iglesia de Saint-Lazare de Avallon o con la de San Vicente de Ávila ${ }^{2657}$.

La conexión con lo francés fue defendida con fuerza por todos ellos, aportando conexiones menos evidentes. En este sentido, P. Williamson llamaba la atención sobre los posibles paralelismos con la escultura realizada en Senlis y Mantes-la-Jolie, considerando al Pórtico y sus esculturas como un elemento preparador de las experiencias europeas que se vivirán en el hastial norte de Chartres, Reims o Bamberg $^{2658}$.

En esta misma línea que ampliaba el horizonte de posibles filiaciones, destaca igualmente la progenie apuntada por la profesora R. Sánchez Ameijeiras. Según la autora, es posible comparar algunas de las fórmulas arquitectónicas y escultóricas practicadas en el Pórtico compostelano con los conjuntos de Etampes, Soissons o Braine $^{2659}$.

Por su parte, el profesor S. Moralejo defendió ascendentes internacionales muy extensos, no sólo reafirmando las conexiones con Vézelay o Dijon, sino también desde su carácter bizantinizante, tal y como veremos. Desde el mismo autor se perfilaron teorías de gran interés que expondrán, por ejemplo, la relación de la columna marmórea con el Árbol de Jesé de Compostela y su posible dependencia con respecto a la escultura del mismo tema realizada para la catedral de San Martín de Lucca, en la Toscana italiana $^{2660}$.

En la misma línea e insistiendo en la relación con las fuentes itálicas, D. Ocón mencionaba la posibilidad de comparar esta tendencia recuperadora de ciertos modelos clásicos que se observa en Compostela, con las obras realizadas por el escultor Benedetto de Atelami ${ }^{2661}$.

Tanto Ward ${ }^{2662}$ como S. Moralejo ${ }^{2663}$ y D. Ocón, apuntaron conexiones bizantinas, sin explicar en profundidad como llegaron hasta el ámbito gallego ${ }^{2664}$. Ésta

${ }^{2657}$ J. D’EMILIO, “Tradición local y aportaciones foráneas en la escultura románica tardía: Compostela, Lugo y Carrión”, O Pórtico da Gloria e arte do seu tempo, A Coruña, 1991, pp. 83-101.

${ }^{2658}$ P. WILLAMSON, Op. cit., pp. 192-193.

${ }^{2659}$ R. SÁNCHEZ AMEIJEIRAS, “Algunos aspectos de la cultura visual...”, p. 165.

${ }^{2660}$ S. MORALEJO ÁLVAREZ, "Le Porche de la Gloire...”, en concreto, p. 310 y p. 316.

2661 D. OCÓN ALONSO, "El Maestro Mateo. Corrientes artísticas internacionales", Biblioteca Gonzalo de Berceo. Consultado en http://www.vallenajerilla.com/berceo/oconalonso/maestromateo.htm, el día 9 de febrero de 2009.

${ }^{2662}$ M. WARD, Studies on the Pórtico..., pp. 140-159. 
última investigadora, basándose en estudios anteriores, equiparó las soluciones compostelanas a las llevadas a cabo dentro del conjunto escultórico de la abadía de Saint-Denis y la Isla de Francia ${ }^{2665}$.

En concreto, el aspecto más llamativo es la importancia que algunos autores, entre ellos la experta anteriormente citada, darán al bizantinismo, como generador de ciertas soluciones del conjunto. En este sentido, nos interesan destacar las continuas citas "antiquizantes" que se realizaron dentro de la escultura del Pórtico, fruto de las corrientes que invadían las artes figurativas europeas de fines del siglo XII. El pórtico participa así del ensimismamiento general del arte de su tiempo con las fórmulas de un renovado bizantinismo que ofrecía la posibilidad de acercarse al arte de la Antigüedad $^{2666}$.

Las reflexiones que la estudiosa dedica a la progenie de los artífices escultores y los modelos que siguieron, no llegan a concretar ante que tipo de fuentes antiguas se pudieron encontrar, pues resulta poco concreto o inexacto argumentar que la escultura del Pórtico de la Gloria se nos presenta "cuajada de referencias al arte antiguo", sin llegar a concretarlas minuciosamente.

A la hora de buscar la ascendencia estilística e iconográfica del conjunto, continuamente se aludió a la importancia del arte antiguo y su reinterpretación en la etapa románica mediante la criba bizantina. Además, aún observando que buena parte de estos especialistas continuaron ratificando la adhesión a ciertas tendencias bizantinizantes, pocos son los autores que se arriesgaron a mencionar piezas concretas y cronologías específicas, a través de la utilización de unas argumentaciones que explicasen coherentemente el resultado final que provocaron en la Galicia finisecular.

Para explicar el manejo de fuentes "antiquizantes" dentro de la elaboración de algunos de los aspectos presentes en la escultura del Pórtico, nos interesa simplificar las teorías existentes mediante dos posturas bien desiguales.

Por una parte, la primera tendencia explicaba los rasgos "antiquizantes" de estas esculturas a través de la herencia bizantina, tal y como venimos explicando. La defensa

\footnotetext{
${ }^{2663}$ S. MORALEJO ÁLVAREZ, "Le Porche...”, p. 312.

2664 Sobre el bizantinismo de estas esculturas véase también: W. SAUERLANDER, “1188. Les contemporains du Maestro Mateo”, O Portico da Gloria e a arte do seu tempo, A Coruña, 1991, pp. 7-22 y M. STOKSTAD, "Forma y fórmula; reconsideraciones del Pórtico de la Gloria", O Portico da Gloria e a arte do seu tempo, A Coruña, 1991, pp. 181-191.

${ }^{2665}$ D. OCÓN ALONSO, "El Maestro..." y J. M. PITA ANDRADE, "Un capítulo para el estudio de la formación artística del maestro Mateo. La huella de Saint Denis", Cuadernos de Estudios Gallegos, VII, 1952, pp. 371-383.

${ }^{2666}$ D. OCÓN ALONSO, "El Maestro...".
} 
de tal teoría se debió a autores como H. Buschbeck y W. Ward, seguidos de cerca por S. Moralejo $^{2667}$.

Se aludió a la importancia que debieron jugar los mosaicos sicilianos, los manuscritos y los frescos de Nerezi, en Yugoslavia, así como algunos detalles presentes en las pinturas de la catedral de Trieste ${ }^{2668}$.

La otra postura fue la defendida, entre otros, por el profesor J. Lacoste ${ }^{2669}$. Para ser más exactos, en una de sus recientes aportaciones al tema, el especialista profundizaba en el análisis de los rasgos antiguos de la escultura del Pórtico de la Gloria.

Las palabras utilizadas por el autor en relación con estos aspectos son cruciales para comprender nuestra postura al respecto:

"Cependant, on constatera également que les choix fondamentaux de Mathieu, incompatibles avec une trop précise imitation de la sculpture antique telle que l'avaient souvent pratiquée des artistes comme le Maître de Carrión ou celui d'Ávila, ne l'ont pas empêché d'introduire dans sons ouvrage, à des fins que l'on précisera, des éléments de style excessifs par rapport à la représentation fidèle du réel empruntés aux reliefs romains -éléments dont les sculpteurs castillans avaient parfois fait usage. Au demeurant, on s'apercevra que Mathieu a de même utilisé d'autres traits de style, eux aussi marqués par une certaine exagération et également d'origine romaine, qui avaient déjà été recueillis par des sculpteurs d'Île-de-France comme ceux de Senlis" ${ }^{2670}$.

J. Lacoste aceptaba que la incidencia de la escultura romana había sido menor dentro del Pórtico de la Gloria que la que, según sus palabras, se localizaba sobre la

${ }^{2667}$ W. WARD, Op. cit., pp. 150-157; H. BUSCHBECK, Der Pórtico de la Gloria von Sant Jago de Compostela, Berlin-Vienne, 1919, en concreto, pp. 30-39 y S. MORALEJO ÁLVAREZ, "Le Porche...", pp. 317-318.

${ }^{2668}$ S. MORALEJO ÁLVAREZ, "Le Porche...”, p. 317.

${ }^{2669}$ Se trata de uno de los investigadores que con más profundidad ha insistido en las fuentes de raíz clásica utilizadas por los escultores hispanos en torno al año 1200. Cf.: J. LACOSTE, "La sculpture à Silos autour de 1200", Bulletin Monumental, 131, 1973, pp. 101-128; ID., Les grands sculpteurs romans du dernier tiers $d u$ XII siècle dans l'Espagne du Nord Ouest, Toulouse, 1986; ID., "El Maestro de Carrión de los Condes", La fortificación medieval en la Península Ibérica (P. L. Huerta coord.), Aguilar de Campoo, 2001, pp. 155-185; ID., "Nouvelles recherches a propos du second maître du cloître de Santo Domingo de Silos", El románico en Silos: IX centenario de la consagración de la iglesia y claustro, 1088-1988, Burgos, 1990, pp. 473-482; ID., "La escultura románica en Aragón en el siglo XII", Signos: arte y cultura en el Alto Aragón medieval (T. Luesma coord.), 1993, pp. 111-120; ID., Les Maîtres..., pp. 137-268.

${ }^{2670}$ J. LACOSTE, Les Maîtres..., p. 218. 
escultura de Carrión de los Condes o Ávila, por citar dos hitos bien conocidos. Según admitía la importancia de las obras antiguas de cronología romana debieron ser fundamentales dentro de la formación de estos escultores activos en Hispania ${ }^{2671}$.

Sin embargo, a pesar de tales afirmaciones y de confirmar repetidamente que, tanto los escultores compostelanos, como los activos en San Vicente de Ávila y Carrión de los Condes poseían el horizonte común de la estatuaria romana, para el caso gallego en concreto, el autor no llegó a ofrecer ningún paralelismo exacto ${ }^{2672}$.

Un punto destacado de sus teorías retomaba, en parte, la metodología y las afirmaciones vertidas hacia años por otros especialistas. Así, consideraba que, por ejemplo, el tratamiento facial y gestual de la conocida figura del profeta Daniel, presentaba claros ecos y alusiones directas a la estatuaria antigua (fig. 507). En concreto, mencionaba las repercusiones que pudieron haber tenido sobre esta figura las difundidas obras de la retratística de los emperadores romanos ${ }^{2673}$.

No es preciso insistir en tales posturas, pero ya W. Oakeshott había utilizado tales comparaciones para justificar, por ejemplo, la fisonomía de algunas de las representaciones de profetas realizadas para la catedral de Reims, aquellas supuestamente esculpidas, por el que él definía como el "antique master" (fig. 508). Según expuso, los prototipos antiguos de los que derivaría esta escultura estarían en la llamada cabeza de Odiseo del Museo Nacional de Roma, datada en el siglo II d. de C. y el fragmento de la conocida como cabeza de Zeus, conservada hasta el año 1914 en el entorno catedralicio de Reims y actualmente en paradero desconocido ${ }^{2674}$ (figs. 509 y 510).

Con iguales intenciones y volviendo a tomar como referencia la retratística romana, E. Panofsky comparó un busto del emperador Antonino, nuevamente del Museo Nacional romano (fig. 511), con la efigie de San Pedro situada en el pórtico izquierdo del crucero norte de la catedral francesa ${ }^{2675}$ (fig. 512). Según insistía, fue precisamente dentro de una atmósfera gótica temprana donde lo que definió como "clasicismo superficial" evolucionó hacia un "clasicismo intrínseco", ofreciendo

\footnotetext{
${ }^{2671} \mathrm{El}$ autor se refiere, concretamente, a la importancia que debieron tener las esculturas romanas como inspiradoras de la Maiestas del friso de la iglesia de Santiago en Carrión de los Condes y algunos de los aspectos ornamentales datados a finales del siglo XII en la iglesia de San Vicente de Ávila. Con todo, el autor no llega a especificar ninguna obra de cronología romana susceptible de emparentarse con la escultura "mateana".

2672 J. LACOSTE, Les Maîtres..., pp. 218-219.

2673 Ibidem, p. 219.

${ }^{2674}$ W. OAKESHOTT, Classical Inspiration ..., pp. 107-108.

${ }^{2675}$ E. PANOFSY, Renacimiento y renacimientos..., p. 109.
} 
ejemplos significativos como los de las efigies apostólicas del pórtico del Juicio Final de la catedral de Reims y, en concreto, las extraordinarias efigies de San Pedro y San Pablo, que presentan parecidos inequívocos con el retrato de Antonino Pío, antes citado $^{2676}$

Con tales relaciones, no debe extrañar la postura del profesor Lacoste con respecto al rostro del profeta Daniel, pues, y aún con todo, los autores más clásicos que llevaron a cabo sus investigaciones en los albores del siglo XX se mostraron más exactos a la hora de definir sus hipótesis, estuvieran o no en lo cierto.

En las páginas anteriores ya aludimos al, tantas veces mencionado, rictus del profeta compostelano y su ascendencia griega arcaica. En relación con estas suposiciones, no debemos pensar que tales teorías son un reflejo de posiciones decimonónicas y metodologías superadas.

Recientemente, el profesor F. Singul aludió a las fuentes plásticas de la estatuaria griega a la hora de explicar los complejos drapeados que ostenta una figura granítica conservada en el Museo de la Catedral de Santiago de Compostela ${ }^{2677}$ (fig. 513).

La serie de drapeados que muestra esta escultura, ligada tan cercanamente con las obras atribuidas al "maestro" Mateo, reflejan un conocimiento de la técnica de los "paños mojados". Ello, sumado al porte majestuoso que ostenta, permitió al estudioso equipararla con la mejor plástica griega de finales del siglo $\mathrm{V}$ a. de $\mathrm{C}$. $\mathrm{y}$, en concreto, con la Nikai del Templo de Atenea Niké (Atenas) o el conjunto de las Nereidas de Janto (Asia Menor, actual Turquía), además de establecer otros tipos de dependencias con la escultura helenística del período 200-150 a. C., y las célebres esculturas de Venus, el Poseidón de Melos, la Victoria de la Samotracia del Louvre de Paris o el friso del Altar de Zeus y Atenea en Pérgamo (Berlín, Pergamonmuseum).

\footnotetext{
${ }^{2676}$ Ibidem. El busto romano se conserva en Roma, Museo Nazionale.

2677 Se trataría, posiblemente, de una figura masculina datada entre los años 1170 y 1175 y que, hipotéticamente, procedería de la primitiva fachada de la cripta del Pórtico de la Gloria. Aunque se bien el autor duda de estos datos. Cf.: F. SINGUL, "Figura Masculina (¿Redentor?)", Luces de Peregrinación, Madrid-Santiago de Compostela, 2004, pp. 166-169. Las piezas fueron mostradas por primera vez en la exposición de arte románico del año 1961. Cf.: M. GIL, "Fragmento de escultura", El arte románico. Catálogo, Barcelona-Santiago de Compostela, 1961, ficha catalográfica 1798, p. 525 e ID., "Fragmento de escultura”, El arte románico. Catálogo, Barcelona-Santiago de Compostela, 1961, ficha catalográfica 1799 , p. 525. La serie de fichas catalográficas realizadas por este autor fueron algunas de las primeras aportaciones científicas publicadas sobre las citadas esculturas. En este momento se adscribieron a la "escuela compostelana" y se entendieron como "los vestigios del pórtico occidental de la catedral, destruido por Mateo para levantar el Pórtico de la Gloria".
} 
A través de tales ejemplos, el profesor Singul consideró que esta referencia a la Antigüedad clásica e helenística que parecen mostrar las esculturas gallegas, pueden probar que su autor, participaba de las corrientes internacionales de recuperación de las tendencias humanistas y de inspiración antigua, fruto de la llegada de las pertinentes influencias bizantinas a la Península ${ }^{2678}$.

Estas comparaciones permitieron al experto adivinar una suerte de "espíritu helenístico", tal y como define, a través de esta ambigua expresión, que no deja de recordar aquellas que, en su día, utilizaron Oakeshott y Panofsky.

Más allá de tales licencias poéticas, creemos que la comparación de esta escultura hispana con las producciones heládicas de la etapa clásica no resuelve el problema. Faltarían por concretar los mecanismos mediante los cuales los artífices pudieron acceder a estos repertorios tan remotos, pues creemos que resulta excesivo suponer un conocimiento directo de la estatuaria griega en la Galicia de este momento.

Más acertado, según creemos, sería conjeturar sobre la transmisión de una forma de hacer de tradición clásica, tamizada bajo reinterpretaciones medievales. El hecho de que los escultores compostelanos de este periodo accedieran a repertorios tan internacionales, vuelve a poner de relieve la participación de la decoración del Pórtico de la Gloria en el "movimiento 1200”. Sin embargo, el fenómeno fue más allá, tal y como se observa al analizar algunos de los vestigios del famoso coro pétreo levantado en el interior del buque catedralicio santiagués, hipotéticamente, entre los años 1188 y $1211^{2679}$.

En algunas de sus piezas se advierten los traspasos de ciertos matices de la tradición siciliana e inglesa, herederos, a su vez, de algunos aspectos de la plástica tardocomnena, tantas veces invocada en relación con estas esculturas del Pórtico de la Gloria. En concreto, una de las cabezas de un apóstol o patriarca, conservada en el

\footnotetext{
${ }^{2678}$ F. SINGUL, "Figura masculina...", p. 166. Ya dentro de la cronología medieval, el autor relaciona la pieza con los estilos presentes en Saint-Denis, Chartres, París y Senlis, además de insistir en las concomitancias con la escultura de la iglesia de Santiago de Carrión de los Condes. Todo ello le permite incluir dicha escultura dentro del "arte 1200", expresión que utiliza.

La pieza fue encontrada en unas excavaciones realizadas entre los años 1956 y 1957 en la catedral compostelana. Se trata, en realidad, de un conjunto excepcional que abrió las puertas a una serie de investigadores para intentar esclarecer el panorama de filiaciones entre centros tan distantes como Compostela, Carrión o Ávila. Se trata, no obstante, de un tema muy extenso para abordarlo aquí. Remitimos al completo estado de la cuestión planteado en: D. RICO CAMPS, El románico en San Vicente..., pp. 162-163.

${ }^{2679}$ Nuevamente remarcamos aquí el hecho de que, al tratarse de una serie de ejemplos que permitan conocer un fenómeno tan especifico y concreto como el de la recuperación de lo antiguo, hemos optado por una simplificación del aparto crítico y la omisión de los balances historiográficos, pues tal hecho no aportaría nada nuevo al tema. Cf.: R. OTERO TÚÑ̃EZ y R. YZQUIERDO PERRÍN, El coro del maestro Mateo, A Coruña, 1990, pp. 170-175.
} 
Museo de las Peregrinaciones de Santiago (fig. 514), parecería retomar prototipos existentes en las citadas pinturas murales de Nerezi, en Macedonia, y que, a su vez, presentaban relaciones estrechas con la decoración de la armadura de Sigena (fig. 515) y la miniatura realizada por el "Maestro de la Hoja Morgan" de la Biblia de Winchester $^{2680}$.

Hasta aquí quedaría definida la primera vía que, según parte de los especialistas, cimentó los caminos necesarios para permitir la llegada de estas corrientes bizantinistas de tono clásico a la Galicia de finales del siglo XII.

No obstante, tales hipótesis serían factibles si pensamos en las estrechas relaciones e intercambios que el norte de la Península Ibérica mantendrá con los territorios insulares del norte de Europa, especialmente las Islas Británicas ${ }^{2681}$.

Mediante esta vía, y con mayor frecuencia a través de un contacto directo con lo inglés, los artistas pudieron asimilar el "arte 1200" que venimos estudiando aquí. Algo fácilmente demostrable si pensamos, por ejemplo, que el culto al apóstol Santiago desde las Islas provocó un flujo constante de peregrinos ${ }^{2682}$.

Así por ejemplo, entre el año 1100 y 1104 llega a Compostela Richard Maulever de Yorkshire, así como Angost de la Haya (1094-1123), natural de Licolnshire. En este mismo sentido, la hija de Enrique I (1100-1135) y la nieta de Guillermo el Conquistador realizan el "Camino Inglés" por esos mismos años, mediante una travesía por mar ${ }^{2683}$.

Sin embargo, otros autores preferirán profundizar en otras vías de asimilación de lo clásico dentro de este tipo de escultura, más allá de los contactos con lo inglés.

Uno de los especialistas que más va a apoyar esta otra serie de hipótesis, es el anteriormente mencionado J. Lacoste. Según defiende, tanto la escultura del Pórtico de la Gloria, como otra serie de hitos que cita en relación con el estilo presente en Compostela en torno al año 1200, presentarían una asimilación de prototipos clásicos a

\footnotetext{
${ }^{2680}$ New York, Pierpont Morgan Library, Ms. 619. Cf.: C. M. KAUFFMANN, "New York, Pierpont Morgan Library Ms. 619", A Survey of Manuscripts Illuminated in The British Isles. Romanesque Manuscripts. 1066-1190, London, 1975, ficha catalográfica 84, pp. 111-112. Todos estos hitos artísticos son traídos a colación por M. Castiñeiras en relación con la escultura compostelana del Pórtico de la Gloria y el coro pétreo. Cf.: M. A. CASTIÑEIRAS, "Cabeza de apóstolo ou patriarca", Luces de Peregrinación, Madrid-Santiago de Compostela, 2004, pp. 180-181 e ID., El Pórtico..., pp. 43-44.

${ }^{2681}$ E. FERNÁNDEZ GONZÁLEZ, La escultura románica..., p. 90.

2682 R. PLÖTZ, "Peregrinando por mar: relatos de peregrinos", Rutas Atlánticas de peregrinación a Santiago de Compostela, Santiago de Compostela, 1998, pp. 57-58 y F. SINGUL, "Peregrinos ingleses a Santiago. A ruta marítima", Ate o Confín do mundo: diálogos entre Santiago e o mar, Vigo, 2004, pp. 143-144.

${ }^{2683}$ V. R. NODAR FERNÁNDEZ, "De Apóstol a Peregrino: la iconografia de Santiago en el Camino Inglés a Compostela", Abrente, 35-37, 2003-2005, pp. 103-116, en particular, pp. 103-104.
} 
través de un contacto directo con el arte romano, concretamente, con la escultura de formato monumental.

Sin negar la importancia del bizantinismo y la serie de hipótesis antes mencionadas, se decanta por argumentar que, tanto la obra del "maestro Mateo", como otras relacionadas con ésta, es decir, el friso de la iglesia de Carrión de los Condes, en Palencia o la escultura románica tardía de la iglesia de San Vicente de Ávila, tomaron algunas de sus características definidoras del arte romano ${ }^{2684}$.

La mayor parte de la historiografía coincide en incluir la magnífica figura de Cristo en Maiestas del friso que enmarca la puerta de la iglesia de Santiago de Carrión de los Condes, dentro de los preceptos plásticos del "arte 1200" (fig. 516). Más concretamente, se han insistido en el hecho de que este trabajo revela la evidencia de una observación del arte antiguo por parte del que, durante bastante tiempo, se denominó como "Maestro de Carrión"2685.

Este segundo método de análisis se centra en la búsqueda de tipos clásicos dentro del arte romano. Se trataría de piezas esculpidas, por lo general, de carácter monumental, y a las que los artífices debieron acceder directamente.

Se trata de un conocimiento del arte antiguo romano que, según J. Lacoste, oscilaría entre diversas producciones datadas en torno al siglo I a. de C. y IV. d. de C. A veces, incluso, con especial predilección por la escultura tardorromana ${ }^{2686}$.

Debemos al citado autor francés un gran número de referencias centradas en indagar sobre las fuentes clásicas que influenciaron al escultor de esta figura palentina. En concreto, aludió a un posible parentesco entre la solución tomada en el friso románico y algunas obras de cronología romana, especialmente la adoptada para la llamada Porta Marzia de Perugia (fig. 517). En dicha estructura, enraizada en la tradición de las grandes portadas monumentales de acceso a las ciudades romanas, se observa una disposición en sintonía de los elementos esculpidos y arquitectónicos ${ }^{2687}$.

Pero el autor fue más allá. En lo relativo a las fórmulas del drapeado que presenta la espléndida figura de Carrión, volvió a recurrir a tipos romanos, aportando

\footnotetext{
${ }^{2684}$ Resultaría imposible aludir a todos los estudiosos que han establecido toda una compleja red de intercambios y filiaciones entre estos importantes centros de la escultura de finales del siglo XII en España. Aquí se aborda un aspecto muy concreto, por lo que otra vez se omitirá la realización de un balance historiográfico sobre tal cuestión, por otra parte, bien estudiada y con una gran nómina de estudios a ella dedicados. Cf: J. LACOSTE, Les Maîtres..., pp. 180-186 y pp. 218-226.

${ }^{2685}$ J. LACOSTE, “El Maestro de Carrión...”, pp. 155-185.

${ }^{2686}$ J. LACOSTE, Les Maîtres..., pp. 182-184.

${ }^{2687}$ Ibidem, pp. 182-185. En esta estructura romana fueron representadas diversas deidades, como Júpiter y los Dióscuros.
} 
ejemplos concretos. La concepción del manto de la Maiestas, una de las obras más espectaculares de la escultura hispana finisecular, adquiere unas soluciones barrocas que, desde un punto de vista formal, recuerda prototipos romanos (fig. 518). Aludía a dos esculturas de época romana para realizar las comparaciones pertinentes. La primera de ellas era una pieza sedente vestida con una toga cuyos pliegues, fruncidos y formando líneas sinuosas como consecuencia de la apertura de las piernas recordaba, lejanamente, a la escultura románica de Palencia ${ }^{2688}$ (fig. 519).

Las segunda de las obras con la que establecía paralelismos era una escultura sin brazos ni piernas y decapitada, pero cuya vestimenta presenta un tratamiento textil de enorme calidad ${ }^{2689}$ (fig. 520).

Las equiparaciones realizadas le permitieron ampliar horizontes a la hora de valorar la aportación del arte clásico a los repertorios y soluciones románicas que aquí tratamos.

Así, en otra de sus publicaciones, el mismo autor se centraba en la posibilidad de que algunos de los escultores activos en la última etapa decorativa del claustro y la iglesia de Santo Domingo de Silos, aquellas cercanas al "estilo 1200", pudieran haber mantenido idénticas relaciones con el arte romano ${ }^{2690}$.

No podemos insistir en las complejas relaciones que la historiografía ha elaborado respecto a la decoración realizada para el Pórtico de la Gloria, el friso de Carrión de los Condes, la última fase de la iglesia de San Vicente de Ávila, el cenotafio conservado en el mismo templo y las esculturas de filiación "1200” de Silos.

Nuestra preocupación recae en el papel del arte clásico y su influencia sobre los escultores románicos. Así, mediante esta segunda vía de asimilación "antiquizante" que venimos exponiendo, ésta habría de llegar mediante un contacto directo con el arte romano y no mediante los estadios de transmisión de lo bizantino a través de las diversas áreas europeas.

Siguiendo tal método, J. Lacoste insistió en la posibilidad de que los artífices de algunos de los capiteles del claustro de Silos y, sobre todo, aquellos que realizaron el

\footnotetext{
${ }^{2688}$ Arles, Musée de l'Arles Antique. Cf. Ibidem, p. 182-184 y G. BOTO VARELA, "La integración de las artes...", p. 113. El profesor Boto recoge las teorías de Lacoste sobre tales filiaciones, dándolas como válidas.

${ }^{2689}$ Roma, Museo Palatino. Cf. J. LACOSTE, Les Maîtres..., p. 184.

${ }^{2690}$ Remitimos a los estudios de Lacoste, dada su preocupación por el tema del sustrato clásico sobre la escultura “1200”. Cf.: J. LACOSTE, "La sculpture à Silos...”, en concreto, pp. 110-111.
} 
tímpano conservado actualmente en el museo del monasterio, pudieran haber accedido a un modelo romano ${ }^{2691}$ (fig. 521).

Más exactamente, se refirió al sarcófago tardorromano conservado en la Colegiata de los Santos Cosme y Damián de Covarrubias, en Burgos y que, presuntamente, perteneció al monasterio de San Pedro de Arlanza ${ }^{2692}$ (fig. 522).

La pieza, posiblemente una producción de los talleres romanos activos en el siglo IV d. de C., fue tradicionalmente atribuida a la condesa castellana doña Sancha, esposa de Fernán González. Según estudió el profesor S. Moralejo, se trataría de un spolium in se que acabaría por custodiar los cuerpos de los nobles castellanos ${ }^{2693}$.

Por su parte, J. Lacoste se centró en el otro fenómeno, el definido como spolium in re. Según el autor, los dos paneles esculpidos que flanquean la composición decorada con estrígiles del sarcófago de Convarrubias, aquellas en las que se observan dos escenas pastoriles en plena naturaleza, fueron las que, ya a finales del siglo XII, serían tomadas como referencia por parte de los artífices románicos ${ }^{2694}$ (figs. 521 y 522).

Se trata de un esfuerzo más del estudioso galo por intentar precisar, mediante ejemplos concretos y cronologías exactas, la supuesta preferencia de los escultores participantes de la "escultura 1200" hacia la estatuaria tardorromana.

Sin embargo, la cuestión resulta más compleja, sobre todo si se tiene en cuenta que el profesor S. Moralejo no llegó a aprobar del todo tal hipótesis. Según su criterio, la supuesta influencia del sarcófago de Covarrubias sobre las dos versiones del Anuncio a los Pastores de Silos, debía ser matizada. La dependencia de este tema cristiano con respecto a la iconografía de Endimión -y en general, de la imaginería pastoral

\footnotetext{
${ }^{2691}$ Santo Domingo de Silos, Museo del Monasterio. Según han apuntado algunos investigadores este tímpano perteneció originariamente a la puerta norte del templo. Presenta diversas escenas del ciclo de la infancia de Cristo, tales como la Natividad, el Anuncio a los Pastores, la Adoración de los Magos y la Presentación en el Templo. Cf.: J. LACOSTE, Les Maîtres..., pp. 240241; ID., "La sculpture à Silos...", p. 110; E. VALDEZ DEL ÁLAMO, "Triumphal Visions and Monastic Devotion: The Annunciation Relief of Santo Domingo de Silos", Gesta, 19, 2, 1990, pp. 167-188; ID., "Visiones y Profecía: El árbol de Jesé en el Claustro de Silos", El románico en Silos. IX Centenario de la Consagración de la Iglesia y Claustro 1088-1988, Silos 1990, pp.173-202 e ID., "Relaciones artísticas entre Silos y Santiago de Compostela", O pórtico da Gloria e a Arte do seu Tempo, La Coruña 1992, pp. 199-212.

${ }^{2692}$ J. A. MORÁIS MORÁN, "La construcción del pasado..." (en prensa). Remitimos a nuestro estudio en el que recogemos las publicaciones más importantes que han abordado la fortuna de esta pieza que, a su vez, hace pareja con otro sarcófago también trasladado desde el monasterio arlantino.

${ }^{2693}$ S. MORALEJO ÁLVAREZ, "La reutilización...", p. 189. Remitimos, así mismo, al apartado de este trabajo donde definimos y abordamos tales cuestiones en relación con el caso hispano.

${ }^{2694}$ J. LACOSTE, "La sculptures à Silos...”, pp. 110-121. El autor consideraba que, en realidad, no se trataba de una simple copia del sarcófago sobre el capitel románico o el tímpano, sino de una reelaboración, una adaptación enriquecida.
} 
helenística- se rastrea ya desde muy antiguo, por lo que no es necesario recurrir, en un caso particular, a un modelo inmediato y preciso ${ }^{2695}$.

Aún con todo, defender que los escultores activos dentro del "movimiento 1200”, además de tomar las referencias al arte clásico que traía consigo plenamente absorbido el arte bizantino, lo hicieron a partir de las obras romanas, hace más compleja la cuestión.

Nos enfrentaríamos entonces ante dos referencias diferentes a la Antigüedad. Tal y como vemos, se trata de dos posturas en cierta medida antagónicas. La primera, defendía el papel del arte antiguo y el clasicismo traspasado a los territorios peninsulares a través de la tradición bizantina.

La segunda, por el contrario, admitía la observación directa de la estatuaria romana, concretando tales filiaciones en torno a la escultura de cronología tardía y, preferentemente, de formato monumental.

Si el caso de los relieves laterales del claustro, algunos capiteles y, sobre todo, el tímpano del museo del monasterio del Silos, presentan una cierta deuda con la estatuaria clásica, las relaciones que los autores enumeraron con respecto al arte europeo románico no fueron menos extensas ${ }^{2696}$.

A tales aspectos, nunca debemos olvidarlo, se deben sumar las pervivencias de la escultura de los años centrales del periodo románico, que, sin duda, coexistieron con las nuevas aportaciones ${ }^{2697}$.

Dentro de las filiaciones establecidas con la escultura borgoñona adquieren una importancia fundamental las realizaciones escultóricas proyectadas para decorar la iglesia de San Vicente de Ávila ${ }^{2698}$.

\footnotetext{
${ }^{2695}$ S. MORALEJO ÁLVAREZ, “La reutilización...”, p. 199.

${ }^{2696} \mathrm{El}$ tema de las filiaciones escultóricas es una cuestión que sobrepasa los objetivos de este estudio. Con todo, simplificando en exceso la cuestión, se aludió a la importancia de la escultura de Provenza, el valle de Rhône, la Toscana y el sur de Italia, concretamente, Sicilia. Además, se aludió a la importancia de los conjuntos franceses de Saint-Gilles, el claustro de la catedral de Aix-en-Provence o el apostolado de la iglesia de Saint-Jean-le-Vieux de Perpignan. Para hacer más compleja tal cuestión, incluso se rastreó la posible influencia con respecto a las esculturas de Antelami en Parma o Borgo, además de las obras del escultor Ramond de Bianya. Cf.: J. LACOSTE, "La sculpture à Silos...", pp. 121-124; ID., Les Maîtres..., pp. 238-251 y J. D’EMILIO, “Tradición local y aportaciones...”, pp. 88-89.

${ }^{2697}$ E. FERNÁNDEZ GONZÁLEZ, "Los sepulcros de la Sala Capitular del monasterio de San Andrés de Arroyo (Palencia)", Estudios Humanísticos, 1, 1979, pp. 83-98, en concreto, p. 94.

${ }^{2698}$ D. RICO CAMPS, El románico en San Vicente..., pp.184-202. A lo largo de estas páginas, en el momento de realizar cualquier tipo de citación sobre determinados aspectos de la escultura del templo, acudiremos a este trabajo monográfico, uno de los más completos realizados hasta la fecha.
} 
De manera clásica, la mayoría de los expertos fecharon algunas de estas realizaciones escultóricas en torno a las últimas décadas del siglo XII ${ }^{2699}$, emparentándolas, nuevamente, con el área borgoñona ${ }^{2700}$.

De nuevo volvió a ser el J. Lacoste el autor que más insistió en la importancia de las fuentes clásicas dentro de este tipo de escultura. De sus trabajos se desprenden ideas muy significativas, aunque en ocasiones, un tanto problemáticas.

Según afirma, el "estilo antiquizante" que muestran algunos ejemplares de la puerta occidental del edificio, será el catalizador que, finalmente, dotó al conjunto de una gran "unidad estilística", muy a pesar, de la lógica actuación de varias manos escultoras.

Tal afirmación resulta cardinal para comprender algunos aspectos de este tipo de escultura románica, pues se presume un conocimiento íntimo del arte antiguo, sobre todo, a la hora de concebir plegados y rostros, además de idear los repertorios ornamentales de índole vegetal, entre los que incluimos la morfología del capitel corintio.

El problema reside, una vez más, en que el autor no llega a concretar las piezas romanas que posibilitaron tales contactos con lo antiguo. En sus estudios se localizan apenas una serie de ejemplos concretos, todos ellos alejados de las áreas hispanas ${ }^{2701}$.

A ello debemos sumar la extensa bibliografía que el estudio de tales obras ha producido. Al tratarse de hitos bien reconocidos por su calidad artística, la nómina de publicaciones que han tenido como objetivo definir, concretar y desgranar la compleja

\footnotetext{
${ }^{2699}$ Por lo general, se solía hacer referencia al año 1192, en el que se produjo la muerte "de un arquitecto llamado Fruchel, al parecer extranjero, autor de la cabecera de la catedral de Ávila (...)”. Se trataría, según algunos autores, de la personalidad de un extraordinario escultor responsable de la obra esculpida de San Vicente de Ávila. En realidad, desde hace años, también se insistió en lo problemático de considerar a esta figura como un único artista. Cf.: M. A. GARCÍA GUINEA, El arte románico en Palencia..., pp. XI-XVIII, en particular p. XIII. Se trata, más concretamente, del prólogo realizado por M. Gómez-Moreno para este estudio y donde expuso algunas ideas relacionadas con el llamado "maestro Fruchel". Véase también: E, LAMBERT, L'art gothique en Espagne aux XII et XIII' siècles, Paris, 1931, concretamente, pp. 51-59, J. YARZA LUACES, Arte y arquitectura ..., p. 277; J. D’EMILIO, “Tradición local y aportaciones...", p. 89; G. RAMOS, "En torno a Fruchel", Boletín del Seminario de Estudios de Arte y Arqueología, 1975, 40-41, 1975, pp. 189-198 y D. RICO CAMPS, El románico de San Vicente de Ávila..., en particular, p. 147, nota 70. El profesor Camps realiza una fuerte crítica sobre la teoría que defiende la participación de Fruchel en la obra y la adjudicación a su mano de ciertas obras escultóricas. En concreto, valora la teoría expuesta en su día por G. Ramos, calificándola de inadmisible.

${ }^{2700}$ J. LACOSTE, Les Maîtres..., pp. 137-148. En concreto, se mencionan habitualmente edificios como Saint-Lazare de Autun, Saint-Lazare de Avallon, algunas esculturas de Saint-Benigne de Dijon o Vezelay. El autor también relaciona algunas de las esculturas de la iglesia abulense con producciones de la Isla de Francia.

${ }^{2701}$ J. LACOSTE, Les Maîtres..., pp. 154-160. Apenas hace alusión a una lastra de cronología romana en la que fue esculpido un centauro y que hoy se conserva en el Museo Provincial de Ávila. Resulta evidente que, ante un panorama tan vacío y que impide cualquier comparación de la obra románica con las producciones antiguas hispanas, la cautela debe regir tales hipótesis.
} 
red de filiaciones y relaciones entre los escultores, talleres y focos artísticos, es muy amplia.

En el año 2002 se publicó, por parte del profesor D. Rico Camps, el estado de la cuestión más completo que se ha realizado hasta la fecha sobre tema. Se centraba no sólo en la problemática de las fases escultóricas y los diversos talleres que actuaron sobre la iglesia de San Vicente de Ávila, sino que, además, contextualizaba tales trabajos dentro del mismo románico hispano ${ }^{2702}$.

Sin embargo, aún a pesar de tratarse de un estudio exhaustivo y completo, el autor tampoco llega a profundizar en el problema de las fuentes clásicas utilizadas por estos escultores, que habrían de impregnar los trabajos desde Ávila a Carrión, desde el Pórtico de la Gloria hasta el monasterio de Aguilar de Campoo. Teniendo en cuenta estos aspectos, fueron muchos los expertos que abordaron la escultura del templo abulense, sin embargo:

“(...) la investigación sigue abierta, quizá más que nunca: hace falta incidir en asuntos tradicionales pero que han sido rejuvenecidos con nuevas sugerencias como la relación Ávila-Compostela, continúa habiendo temas completamente desasistidos, como el papel de lo clásico en la formación del estilo escultórico, 2703 .

En realidad, en el estado actual de nuestros conocimientos, comprobamos que, actualmente, los estudios proyectados a esclarecer las fuentes clásicas que pudieron gestar las fórmulas estilísticas utilizadas, son prácticamente nulos, y tan sólo podemos excluir las menciones, vagas y esporádicas, realizadas por el profesor Lacoste.

El mismo razonamiento se aplicó a diversos conjuntos, tanto aquellos emparentados con el foco abulense, tal y como es el caso del cenotafio de los santos mártires Vicente, Sabina y Cristeta ${ }^{2704}$, como a otras obras inmersas dentro de la misma

\footnotetext{
${ }^{2702}$ D. RICO CAMPS, El románico de San Vicente..., pp. 130-180.

${ }^{2703}$ Ibidem, p. 141.

${ }^{2704}$ A lo largo de este estudio hemos mencionado diversos aspectos relacionados con el famoso cenotafio. Remitimos a los trabajos que hemos citado en su debido momento. La mayoría de los autores suelen establecer las consabidas relaciones con los monumentos funerarios de época romana y paleocristiana, sin concretar sus afirmaciones. Cf.: W. GOLDSCHIMIDT, "El sepulcro de San Vicente...”, pp. 161-170 y J. LACOSTE, Les Maîtres..., pp. 145-153. En concreto, este último autor relaciona su estructura con la forma de las basílicas paleocristianas y altomedievales, además de mencionar sus parentescos con el monumento erigido en Saint-Denis por Suger. También resulta bien significativo el establecimiento de relaciones con las obras suntuarias realizadas en la etapa final del siglo XII y principios del siguiente en las regiones del Rin y el Mosa, pues menciona la posible conexión con la arqueta de los Reyes Magos de Colonia, la caja de Santa María en Aix-la-Chapelle o la de Notre-Dame de Tournai. Además, J. Lacoste
} 
tendencia. En este sentido, cabe destacar el apostolado de la Cámara Santa de Oviedo, que abordaremos más tarde.

Resulta prácticamente inviable aludir a producciones escultóricas hispanorromanas susceptibles de emparentarse con la escultura y morfología del cenotafio de San Vicente. No obstante, se podría pensar que el conocimiento de tales productos nos fue privado debido a su desaparición ${ }^{2705}$.

Como mucho, deben valorarse las afirmaciones que relacionan la tipología microarquitectónica del cenotafio y algunos aspectos de la morfología del pórtico occidental de San Vicente, con algunas estructuras defensivas de época antigua (fig. 523). Más exactamente, se mencionó su lejana relación con la Puerta Soprana de Génova que presenta una fórmula equiparable a la Puerta de San Vicente, en la entrada a la ciudad de Ávila ${ }^{2706}$ (figs. 524 y 525).

En realidad, tales aspectos se podrían emparentar con una tradición bien conocida durante los siglos del románico y mediante la cual, los escultores parecen repetir una serie de "arquetipos arquitectónicos" tomados del panorama monumental que dominaba las regiones romanizadas. Dentro de este mismo fenómeno, se podría incluir, por ejemplo, la pila bautismal conservada en Nuestra Señora de la Calle y que ha sido puesta en relación con el lejano recuerdo de la Puerta Negra de Tréveris ${ }^{2707}$.

Volviendo a la problemática central de estas páginas, observamos que, al igual que en San Vicente de Ávila o el Pórtico de la Gloria, las fuentes clásicas reaparecen dentro de las esculturas románicas fruto de la remodelación de la Cámara Santa de Oviedo $^{2708}$.

Desde los estudios realizados por las profesoras E. Fernández e I. Ruiz de la Peña, parece que la reforma románica que acabó por embellecer el nivel superior de este

se centra, principalmente, en los parentescos borgoñones, aludiendo al sepulcro de Sainte-Magnance, custodiado en la iglesia del mismo nombre, cerca de Avallon.

${ }^{2705}$ Insistimos en este aspecto una vez más, pues es posible que muchas obras que, originariamente pudieron haber sido utilizadas como fuente de inspiración por parte de los artífices medievales, fueran destruidas en el transcurso de los siglos.

${ }^{2706}$ F. GALVÁN FREILE y J. A MORÁIS MORÁN, Op. cit., p. 487; D. RICO CAMPS, El románico de San Vicente..., pp. 216-218 y ID., "Clerici vero habeant...", p. 434.

${ }^{2707}$ Redecilla del Camino, Nuestra Señora de la Calle. Cf.: F. GALVÁN FREILE y J. A MORÁIS MORÁN, Op. cit., p. 488.

${ }^{2708}$ No es preciso insistir en la abundante nómina de publicaciones que han establecido conexiones de índole estilística entre las esculturas ovetenses y los grupos que aquí venimos analizando, desde Carrión hasta Compostela. Si bien es cierto, que este grupo es el que más se separa de tales filiaciones. Cf: J. D’EMILIO, “Tradición local y aportaciones...”, pp. 88-89; J. LACOSTE, Les Maîtres..., pp. 230-237; L. ARIAS PÁRAMO, La Cámara Santa de la Catedral de Oviedo, Gijón, 1998, p. 20 y M. S. ÁLVAREZ MARTÍNEZ, "Cámara Santa”, Enciclopedia del Románico en Asturias. Asturias, 2 vols., Aguilar de Campo, 2006, vol. II, pp. 607-622. Repetimos que no es el objetivo de este estudio diseccionar todas aquellas relaciones geográficas y estilísticas que se establecieron entre estos escultores. 
edificio del siglo IX, puede encuadrarse entre los años 1175 y 1188, coincidiendo con el reinado de Fernando II $^{2709}$.

Por lo general, a la hora de analizar la filiación estilística de las estatuascolumnas del conjunto, se suelen invocar con frecuencia las conexiones con el románico borgoñón, el tolosano o el de Normandía ${ }^{2710}$.

Dentro del ámbito hispano, la iglesia de San Vicente de Ávila y el Pórtico de la Gloria vuelven a ser los puntos referenciales a la hora de analizar los ejemplares ovetenses $^{2711}$.

Sin embargo, nos interesan destacar más las conexiones defendidas al emparentarlas, nuevamente, con las existentes en el pórtico real de Chartres, las hispanas de Santa María de Sangüesa o las de Uncastillo, todas ellas ya mencionadas en la primera parte de este apartado $^{2712}$.

Sin profundizar excesivamente en el tema las filiaciones entre estos focos artísticos coetáneos, creemos que no es posible hablar de la misma incidencia de los modelos clásicos para todos los conjuntos por igual.

En la Cámara Santa, más allá de la relativa frecuencia con la que lo "clásico" es invocado a la hora de ejecutar pliegues y drapeados, la absorción de fórmulas "antiquizantes" se nos muestra un tanto difusa y sectorial, casi, podríamos decir, marginal.

La concepción de los rostros y actitudes no llegan a presentar las cotas clasicistas del Cristo de Carrión y lo mismo cabe decir para el tratamiento textil.

Los detalles escultóricos marginales, tales como la utilización de la iconografía del Atlante y la inclusión en dicho conjunto de plintos acanalados de recuerdo clásico (fig. 526), se convierten tan sólo en pequeñas notaciones lejanas, quizás fruto de unas

\footnotetext{
${ }^{2709}$ E. FERNÁNDEZ GONZÁLEZ, “Estructura y simbolismo...”, pp. 335-397 e I. RUIZ DE LA PEÑA GONZÁLEZ, "La reforma románica de la Cámara Santa...", pp. 29-45. Los nexos estilísticos que, por lo general, se establecen entre el apostolado ovetense y el Pórtico de la Gloria y algunas esculturas de la catedral de Lugo, quedan esclarecidos a partir del detenido examen de la documentación que analiza la profesora I. Ruiz de la Peña. Llegados a este punto queremos agradecer a Isabel Ruiz de la Peña, del Departamento de Historia del Arte y Musicología de la Universidad de Oviedo, toda la ayuda prestada y la atención y solvencia con las que ha respondido a todas nuestras dudas a lo largo de la redacción de este estudio.

${ }^{2710}$ E. FERNÁNDEZ GONZÁLEZ, "Estructura y simbolismo...”, pp. 352-353.

${ }^{2711}$ Ibidem, p. 354.

${ }^{2712}$ Ibidem, p. 354 y L. ARIAS PÁRAMO, La Cámara Santa..., p. 20. El autor sintetiza, de manera muy didáctica, estos parentescos, aludiendo también a otros ejemplares, como los de Augers o Dijon.
} 
pervivencias inerciales y mecánicas, más que de una verdadera inspiración en modelos $\operatorname{concretos}^{2713}$.

Las estatuas-columna de la Cámara ovetense, aún con participar de los nuevos aires renovadores que invadían la escultura románica hispana desde hacia más de una década, conservan ciertos rasgos, que algunos autores definieron como "arcaizantes".

Con todo, el aspecto que más nos interesa destacar es la estrecha relación que el apostolado guarda, por una parte, con las esculturas adjudicadas a Leodegarius en Sangüesa y, por la otra, con las del portal occidental de San Vicente de Ávila.

Con tal comparación, bien comprobada por la crítica historiográfica, el bucle parece cerrarse. En el final de este apartado volvemos al lugar del que partimos, insistiendo en el papel que jugaron las regiones de la Isla de Francia y Borgoña, así como otra serie de componentes, en la introducción de ciertos rasgos derivados de la tradición clásica.

Para finalizar, intentaremos sintetizar las vías que, a nuestro juicio, pueden diferenciarse claramente, apuntando una serie de mecanismos transmisores del sustrato clásico hacia la escultura tardorrománica hispana ${ }^{2714}$. Evidentemente se trata de una simplificación que tan sólo pretende sintetizar y economizar las argumentaciones desarrolladas a lo largo de estas páginas, aún teniendo muy en cuenta que se trata tan sólo de una creación de tipologías hipotéticas, proyectadas a ofrecer un planteamiento inteligible de nuestras teorías.

De la afirmando hasta el momento a lo largo del presente capítulo podemos concluir la siguiente serie de premisas:

1) Desde las décadas de los años cuarenta y cincuenta se percibe la llegada de corrientes escultóricas ligadas con la Isla de Francia. En concreto, aceptando la cronología propuestas por la profesora C. Cosmen, un claro ejemplar de asimilación de este tipo de plástica vendría representado por los restos escultóricos de la catedral románica de Astorga. La cabeza y los pies de una fragmentada figura (figs. 587-588),

\footnotetext{
${ }^{2713}$ E. FERNÁNDEZ GONZÁLEZ, “Estructura y simbolismo...”, p. 353. Es bien expresiva la concreción de la autora, que señala que tales plintos fueron muy frecuentes dentro del ámbito borgoñón y provenzal.

${ }_{2714}$ Buscando una mayor síntesis, se omitirán las menciones bibliográficas y las notas en esta enumeración de vías que vamos a desarrollar, pues los datos que se ofrecen han sido tomados a partir de las publicaciones citadas a lo largo de este apartado. También se advertirá que, a pesar de aludir, en ocasiones, a la problemática cronológica, aclaramos que, en absoluto, se trata del principal objetivo de esta serie de conclusiones para este apartado, más aún teniendo en cuenta, las enormes disputas que se ciernen sobre algunas de estas dataciones.
} 
conservados en el museo catedralicio, presentan, a nuestro juicio, una buena prueba de la llegada de corrientes dependientes de Saint-Denis.

2) Por los mismos años, en torno al año 1141, el profesor Senra ha datado una paralela asimilación de la llegada de corrientes borgoñonas que afectaron a la escultura románica hispana ${ }^{2715}$. Se trataría de una filiación con los talleres activos en Cluny, entre otros centros. La relación que los arquitectos y escultores del ámbito cluniacense mantuvieron con el arte antiguo romano ha sido puesta de manifiesto y demostrada con cierta frecuencia $^{2716}$.

3) En un momento determinado posterior y, según apunta la profesora $M$. Melero Moneo, posiblemente circunscrito a los años 1156-1158, se realiza el sarcófago de Doña Blanca de Nájera. Su escultor o escultores se formaron dentro de la tradición borgoñona. Poco después, entre los años 1160-1170, se lleva a cabo la portada de la iglesia de Santa María de Sangüesa, con la creación de las estatuas-columnas, una de ellas firmada por Leodegarius ${ }^{2717}$. La investigadora insiste en afirmar que para la creación de este modelo se tomó como referencia la escultura de la Isla de Francia, es decir, Saint-Denis y Chartres, principalmente. Esta obra, a diferencia de la realizada en Astorga presenta, además, las aportaciones realizadas por el conocimiento de la escultura de Borgoña, por lo que se trata ya de dos filiaciones diferentes.

4) Por esas fechas, posiblemente a partir de los años sesenta y setenta del siglo XII, la Península Ibérica recibe el impacto de nuevos horizontes estéticos. Se trata de la llegada de las soluciones que algunos catalogaron como "arte 1200". Las obras realizadas en Hispania y susceptibles de ser encuadradas bajo este tipo de denominación, presentaban ciertos regustos clásicos o antiguos, pero tamizados bajo la plástica bizantina que se difundió, a través de Grecia, el sur de la Península Itálica y el área siciliana, las regiones de la Europa norte septentrional, las Islas Británicas y el norte de la Península Ibérica, principalmente.

\footnotetext{
2715 J. L. SENRA GABRIEL Y GALÁN, “La irrupción borgoñona...”, pp. 35-51. Concretamente localiza ciertas influencias de la escultura de Cluny sobre la decoración de los templos castellanos de San Salvador de Oña y San Pedro de Cardeña.

${ }^{2716}$ A. BAUD, Cluny: un grand chantier médiéval..., en particular, pp. 85-88.

${ }^{2717}$ M. MELERO, “El sarcófago de doña Blanca...”, pp. 12-14 y pp. 15-16.
} 
5) Coexistiendo en cierta medida, todas estas tendencias acabaron formulando un tipo de escultura indudablemente peculiar y con tendencia a lo clásico. Es el momento en el que se realizan obras como el friso de la iglesia de Santiago de Carrión de los Condes, la escultura tardorrománica de San Vicente de Ávila, la reforma románica de la Cámara Santa, las esculturas ya citadas de Santo Domingo de Silos, algunos capiteles provenientes del monasterio de Santa María de Aguilar de Campoo, así como el Pórtico de la Gloria de Compostela, entre otras ${ }^{2718}$.

Estos trabajos, tal y como hemos afirmado, han sido emparentados y se han hecho depender de varias fuentes. Por un lado, se relacionaron con las fórmulas borgoñonas y las derivadas de la Isla de Francia, mientras que, por el otro, se remarcó su participación en las corrientes bizantinizantes que conforman el supuesto "arte $1200 "$

Con ello, se materializaba el viejo problema de la historiografía francesa que pretendía discutir el papel de Borgoña como germen y campo de ensayo para las experiencias de la Isla de Francia, realizadas a partir de los años treinta y cuarenta del siglo XII. Según nuestra opinión, una premisa no es privativa de la otra. Como bien apuntó la profesora M. Melero, la corriente del centro de Francia pudo coexistir, fusionarse y enriquecerse con las experiencias borgoñonas, llegando a Hispania, veces de forma "pura"-véase el caso de Astorga- y en otras ocasiones, fusionadas con las formas de Borgoña, tal y como ocurre en Sangüiesa y Uncastillo ${ }^{2719}$.

El trazado de este forzado y sintético resumen, aún omitiendo hitos y estadios importantes de la evolución de las formas, nos lleva a concluir que podemos distinguir tal pluralidad de corrientes clásicas que su mera enumeración refleja bien el problema al que nos enfrentamos.

Según creemos, a partir de la segunda parte del siglo XII y partiendo siempre de las teorías sobre la recuperación de lo clásico expuestas por los expertos, pensamos que es posible distinguir, dentro de Hispania, los siguientes tipos de sustratos "antiquizantes":

\footnotetext{
${ }^{2718}$ La sucesión de obras aquí mencionadas no indica, en ningún caso, el seguimiento de una consecución cronológica de unas con respecto a las otras, ni mucho menos, una evolución estilística. Para las cronologías en las que, posiblemente, se facturaron estas esculturas y los debates historiográficos surgidos a raíz de este tema, nos remitimos a las publicaciones anteriormente mencionadas.

${ }^{2719}$ M. MELERO MONEO, "El sarcófago de doña Blanca...", p. 20. La autora escribe sobre la filiación estilística de las estatuas-columna de Sangüesa: "Un modelo de ascendencia borgoñona tamizada en la portada de Sangüesa por las novedades procedentes de Chartres u otra portada del mismo grupo".
} 
1) El sustrato hispanorromano. La teoría que defiende la importancia de las obras y productos artísticos realizados en la Hispania romana o, bien aquellos importados desde la metrópoli a la provincia, como fuentes de inspiración para los escultores románicos activos entre los años 1150 y 1200, no tuvo gran aceptación por parte de los expertos. A pesar de que J. Lacoste intentó ligar o defender una suerte de spolium in re desde el sarcófago de doña Sancha en Covarrubias hasta la escultura silense, tal y como hemos visto, la hipótesis no tuvo aprobación e, incluso, fue desestimada por el profesor S. Moralejo.

A parte de ello, no tenemos constancia de otros ejemplos en los que algún especialista haya defendido la importancia de las piezas hispanorromanas como abastecedoras intelectuales y formadoras del estilo de las esculturas vinculadas a las corrientes finiseculares.

$\mathrm{Al}$ respecto, sirvan de muestra las reflexiones realizadas por el profesor D. Rico Camps en relación con origen del estilo de las esculturas de San Vicente de Ávila, pues considera que, esencialmente, se trata de una manera de concebir las formas directamente importada desde Borgoña, particularmente, entre Vézelay, Autun y Avallon. La inspiración borgoñona aparece en San Vicente bruscamente y casi sin mezcla, siendo imposible, por el momento, defender para la iglesia de Ávila la existencia de rasgos que puedan considerarse verdaderamente hispanos, propios y privativo de las tradiciones locales ${ }^{2720}$.

De tales aspectos concluimos que, a la hora de rastrear la pervivencia del arte hispanorromano dentro de la escultura tardorrománica hispana, el panorama ha sido completamente infructuoso ${ }^{2721}$. Concluimos entonces, que la tendencia hacia determinadas formas clásicas perceptibles en esta escultura no posee un origen hispanorromano, es decir, los escultores ni visionaron, ni reelaboraron, ni se dejaron influir por las producciones que, hipotéticamente, nutrían el panorama monumental hispano.

\footnotetext{
${ }^{2720}$ D. RICO CAMPS, El románico en San Vicente..., p. 201.

${ }^{2721}$ J. L. HERNANDO GARRIDO, "Las Claustrillas de Las Huelgas, San Andrés de Arroyo y Aguilar de Campoo: los repertorios ornamentales y su eclecticismo en la escultura del tardorrománico castellano", Anuario del Departamento de Historia y Teoría del Arte, IV, 1992, pp. 53-74. El autor alude a la posibilidad de rastrear diversas influencias de la escultura hispanorromana sobre algunos detalles de las clámides, las palmetas y acantos de ciertas esculturas románicas. Sin embargo, él mismo expone que se trata de meras hipótesis, difíciles de demostrar.
} 


\section{2) El clasicismo de la Antigüedad bajo la criba bizantina y su asimilación en}

el entorno del año 1200. Nadie duda actualmente de la importancia del arte griego y el romano como precursores y fuentes incesantes para las producciones del Imperio Bizantino $^{2722}$.

Tal y como demostró la profesora E. Fernández ${ }^{2723}$, las vías de penetración hacia la Europa occidental de la influencia bizantina se localizaron en áreas geográficas de especial importancia, tales como los territorios mediterráneos, configuradores del imaginario "triángulo" que establecía entre Bizancio, la Península del Sinaí e Italia. El recuerdo de lo clásico, ciertamente modificado por la estética bizantina, además llegó a Europa por otras vías, mediante los contactos con Venecia, Roma o a través de una transmisión por el interior del mismo continente. Esta estética bizantinizante de tamiz clásico floreció espectacularmente en la Europa septentrional y las Islas Británicas, en Aquitania y en el norte hispano.

Por lo tanto, aceptamos y defendemos una vía diferente de asimilación de lo clásico a través de la expansión de la plástica bizantina. Pero, del mismo modo, intentamos esclarecer y defender que se trata de una vía muy diferente a la existente en la Hispania anterior al año 1150.

La mayor parte de los expertos argumentaron que la escultura tardorrománica hispana ligada al movimiento "1200" no tenía precedentes en Hispania, que no se explicaba mediante ninguna obra precedente ni poseía ningún elemento “indígena”. El caso de la iglesia de San Vicente de Ávila vuelve a reflejar bien este fenómeno.

El profesor D. Rico Camps, al hablar sobre este traslado directo e importado del románico desde Borgoña hacia Ávila, vuelve a afirmar:

"La escultura de San Vicente merece con seguridad el calificativo de sintética (...) por cuanto concilia y funde en una sola forma corrientes de cronología y vocaciones diversas, pero estas corrientes son básicamente borgoñonas. Mejor que una vena indígena, lo que si debió participar en el proceso de creación del estilo (o por lo

\footnotetext{
${ }^{2722}$ A lo largo de las páginas anteriores hemos criticado la ausencia de determinación por parte de los especialistas a la hora de concretar, exactamente, los periodos y las obras exactas que estuvieron al alcance los artífices bizantinos. También hemos hecho notar la ambigüedad que mostraron a la hora de valorar si el arte clásico tuvo un impacto continuado a lo largo de los siglos de productividad o sí existió preferencia por lo griego o por lo romano o por ambos a la vez. Los estudios acusan un lento avance en este campo, por lo demás, absolutamente complejo y lleno de problemáticas, suponemos, imposibles de solucionar.

${ }^{2723}$ Remitimos al mapa publicado por la autora sobre las áreas determinantes de las "artes 1200". Cf. E. FERNÁNDEZ GONZÁLEZ, "Santo Martino de León...”, lám. II.
} 
menos en el estadio de su maduración en la propia Castilla) es la más que esporádica inspiración en el arte antiguo y en especial tardorromano, que se ha demostrado tan activamente (...) Sin desechar un ligero impacto de la ventisca de helenismo que trajo consigo la lluvia de bizantinismo que tanto caló en el arte europeo de la segunda mitad del siglo XII, véase, por ejemplo, el atlante del sepulcro de San Vicente, o el rostro del ángel de la Anunciación (de la iglesia de San Vicente)"2724.

Es cierto que, en muchos de los detalles, especialmente en ciertas iconografías, en el tratamiento y la concepción fisonómica de algunas figuras y en la manera con la que abordan los plegados, estos escultores parecen acercarse a un pasado común, presente en la estatuaria clásica. Sin embargo, respecto a la opinión del citado investigador, tenemos algunas dudas al respecto.

Las diversas oleadas de bizantinismo que se produjeron sobre el territorio hispano en este momento, coexistieron con las experiencias borgoñonas que llegaban de la mano de los artífices que realizarían las portadas de, por ejemplo, Carrión o Ávila. Sin embargo, no podemos estar de acuerdo con que su "estilo antiquizante" fue reelaborado aquí y enriquecido con obras presentes en nuestros territorios.

Aceptando con plena seguridad que el arte que estaban realizando estos artesanos presentaba una indiscutible base borgoñona, creemos que debe ser allí donde se busque el momento y los mecanismos exactos que permitan concretar las fuentes clásicas que utilizaron los artífices. Desde luego, y a juzgar por los restos artísticos conservados en la Hispania romana, el enriquecimiento de las formas borgoñonas mediante las aportaciones del arte clásico debió realizarse en territorios franceses y no en los hispanos.

3) La influencia del arte galorromano. Desde un punto de vista cuantitativo, creemos que nadie puede negar que, aún aceptando la fuerte e indiscutible romanización que sufrió la Península Ibérica, no se debe subestimar la fuerza romanizadora que inundó la citada región francesa.

Partimos de la base de que los escultores que realizaron los trabajos en Santo Domingo de Silos, el Pórtico de la Gloria, la Cámara Santa de Oviedo o el friso de Carrión de los Condes, tenían bien asimilada una forma de realizar su escultura. Los fuertes lazos que unen tales producciones, más numerosos que las diferencias que

${ }^{2724}$ D. RICO CAMPS, El románico en San Vicente..., pp. 201-202. 
muestran entre ellos, nos hablan de un estilo bien asimilado, de un horizonte común para todos. Sólo así se explica la unicidad estilística que presentan estos conjuntos, no sólo dentro de sus propios focos escultóricos, sino también en las relaciones que mantuvieron entre ellos.

Ya hemos mencionado que, algunos autores, y entre ellos J. Lacoste, habían otorgado a este tipo de escultura una unicidad estilística que, según informaba, era fruto de una atenta observación de lo antiguo.

Si aceptamos que el germen de su manera de esculpir procede de Borgoña, también tendremos que aceptar que fue allí donde estos escultores recibieron el impacto del arte antiguo, que, a la vista de los resultados presentes en la escultura románica, debió ser romano.

Resulta prácticamente imposible que un "arte de importación" como el que practicaban, se hubiera visto reelaborado desde lo más profundo de su concepción estilística en suelo hispano a través del visionado de las obras romanas aquí conservadas. La manera con la que estos creadores impregnan su escultura de alusiones "antiquizantes" parece tan profunda y asimilada que no debe ser entendida como un mero enriquecimiento de su estilo. Es, en realidad, una de las bases más fuertes sobre las que se asienta su peculiar manera de entender la escultura y no un mero amaneramiento.

El tratamiento y los cánones de las figuras, la concepción de los tipos faciales y craneales, la manera que poseen de concebir los textiles, nos permiten ver que lo antiguo no se entiende como un mero motivo que imitar, sino que es el punto de partida para comprender la representación humana a través de la escultura.

En el hipotético caso de que estos escultores se hubieran dejado influenciar por las obras de arte hispanorromanas y hubieran reelaborado su estilo aquí, este no gozaría de la unicidad general que presenta el conjunto de esculturas que hemos analizado.

La observación de lo antiguo, por lo general, se produce de manera puntual dentro de un foco escultórico, con casos tan excepcionales como el de Husillos y otros, que no lo son tanto. Pero en todo caso, la seducción por lo antiguo dentro de los talleres románicos no fue un fenómeno tan fragante como para acabar contaminando todo el arte de una época.

Sin embargo, aquí lo antiguo está tan asimilado y posee tanta importancia como elemento sobre el cual asentar su arte que, en ocasiones, es imposible concretar el modelo y la fuente. Es lógico pensar que fue allí donde surgió esta tendencia, en los 
estados germinales de la misma y desde los inicios, donde lo clásico se convirtió en fuente primordial y profunda, no aislada y superficial.

De aceptar que fue en Hispania donde los escultores accedieron a los repertorios clásicos, no se podría explicar porqué de manera generalizada, desde la supuesta obra de "maestro" Mateo en Compostela al portal occidental de San Vicente de Ávila, subyacen siempre las filiaciones borgoñonas tamizadas bajo la influencia antigua de una manera tan generalizada y repetitiva. ¿Acaso se podría pensar que, una vez trasladados estos talleres de filiación borgoñona hacia la Península Ibérica fue aquí donde se empararon de lo clásico hasta el punto de que todos los escultores que comenzaron a trabajar obtuvieron los mismos resultados? Cuesta imaginarse a los escultores de Oviedo, Santiago, Carrión, Aguilar de Campoo y Ávila sintiendo una misma curiosidad por lo clásico, accediendo a las mismas esculturas y reaccionado, casi de manera similar, ante el estímulo de las producciones antiguas.

El estilo es tan unitario y presenta unas reacciones ante lo clásico tan homogéneas, que tales aspectos corresponden a la esencia misma de su manera de hacer, sin posibilidad, creemos, de poder defender un contacto esporádico con la materia clásica.

Su conocimiento de lo antiguo es tan profundo que se presenta como una norma general del estilo, del que aprendieron en Borgoña y no de una mera influencia epidérmica, fruto de una copia esporádica.

La teoría no es nueva. El experto que más ha trabajado la filiación clásica de este tipo de escultura, nuevamente el profesor J. Lacoste, ha defendido continuamente que los rasgos que el denomina "romano-helenísticos" y que se observan en las esculturas hispanas de ascendencia borgoñona realizadas en el último cuarto del siglo XII, presentan un claro conocimiento de los modelos romanos, pero, y ello es lo más importante, conocidos a través de las reinterpretaciones que los creadores del estilo habían hecho en la misma Borgoña ${ }^{2725}$.

No se trata de realizar ahora un balance de la importancia del arte romano para la germinación de la escultura románica borgoñona, tema que, por otra parte, no ha recibido una atención concentrada por parte de la historiografía.

Nos limitamos tan sólo a citar los estudios realizados por J. Adhémar, quién desde hace muchos planteó la importancia de las fuentes romanas para la formulación

${ }^{2725}$ J. LACOSTE, Les Maîtres..., p. 160 y p. 186. 
de algunas de las soluciones tomadas por los artífices románicos en centros de la importancia de Autun, Paray-le-Monial, Tournus, Vézelay, Saulieu o el mismo monasterio de Cluny $^{2726}$.

Según se ha demostrado, el románico borgoñón asimiló de una manera más fuerte y enraizada los vestigios romanos. No sólo los expolió intelectualmente a la hora de germinar el nuevo estilo escultórico medieval sino que, además, lo hizo desde una óptica material, a través de los numerosos spolia in se que tenemos documentados ${ }^{2727}$.

Fue en Borgoña, y no en Hispania, donde destacó la importancia de los manuscritos medievales copiados de obras antiguas, tal y como se observa en los ejemplares de las Comedias de Terencio que poseía el monasterio de Cluny. De allí, siempre según J. Adhémar, tomaron los escultores románicos de la Borgoña la concepción del cuerpo, ciertos cánones faciales y el tratamiento de los textiles ${ }^{2728}$.

El objetivo de nuestro trabajo no recae en poder llegar a dilucidar el papel que jugó el arte galorromano dentro de la formación de la escultura románica de la región de la que, presuntamente, surgió el estilo que luego reaparecería en Hispania. La tarea no es fácil, sobre todo si tenemos en cuenta las dificultades que han señalado autores de la categoría de F. Salet, E. Vergnolle o N. Stratford, para definir el rol que tuvo el arte clásico a la hora de inspirar a los $\operatorname{artistas}^{2729}$.

Por lo tanto, finalizamos en este punto considerando que la escultura de raigambre borgoñona localizada en el área hispana y realizada en las cronologías que aquí hemos manejado, presenta unos rasgos "antiquizantes" derivados de la reinterpretación que de esos lenguajes realizaron los escultores desde la misma Borgoña, descartando una reelaboración en suelo hispano ${ }^{2730}$.

\footnotetext{
${ }^{2726}$ J. ADHÉMAR, Influences antiques..., pp. 241-248. El autor realiza un sintético balance de los numerosos monumentos antiguos y esculturas romanas que se encontraban conformando el paisaje monumental de la región borgoñona. Por ejemplo, alude a la importancia de la puerta romana de Arroux y la influencia que ejerció sobre numerosos templos medievales a la hora de configurar sus triforios y en los que se percibe una articulación mediante pilastras acanaladas que perduraría hasta el siglo XIV. Siguiendo este mismo método explica las columnas decoradas con el tema de la viña a través del conocimiento de obras romanas, citando el caso de las columnas de Souvigny, o las del claustro de Saint André-le-Bas, así como las existentes en Saint-Lazare de Avallon.

${ }^{2727}$ Ibidem, p. 244. Menciona el caso del dintel de la iglesia de Saint-Maurice de Vienne, el friso de Puy, los relieves de Moutier d'Ahun, Saint-Saturnin des Bois y Autun. El estudioso insiste en que fue una región romanizada profundamente, a juzgar por los restos actuales que se han conservado en las cercanías del templo de Montmartre o en Saint-Pierre, un centro galorromano de primer orden.

${ }^{2728}$ Ibidem, p. 245.

${ }^{2729}$ F. SALET, Cluny et Vézelay..., pp. 35-40; E. VERGNOLLE, "Chapiteaux corinthisants...”, pp. 339350; ID., "Fortune et infortunes du chapiteau corinthien...", pp. 21-34 y N. STRATFORD, "Autun and Vienne", Romanesque and Gothic. Essays for George Zarnecki, Woodbridge, 1987, pp. 193-200.

${ }^{2730}$ S. MORALEJO ÁLVAREZ, "Esculturas compostelanas...", en particular, p. 55. El autor apoya la teoría de que fue en el ámbito borgoñón donde se produjo una asimilación de las formas clásicas y no
} 
Por tanto, corresponde a aquellos teóricos que defiendan la importancia de las fuentes clásicas ibéricas sobre la obra de los escultores del último tercio del siglo XII hispano, el esclarecer cuánto de importante fue la aportación de lo clásico hacia el románico borgoñón. El mismo que de una manera más fuerte y más evidente asimilaba, desde hacia años, el arte galorromano.

Hasta aquí hemos intentado definir algunas de las vías que trajeron aires clásicos hasta la escultura románica de finales del siglo XII. Se trata, como hemos visto, de un panorama complejo y lleno de interrogantes.

La situación de los mecanismos de asimilación de la influencia clásica en torno al año 1200, es muy diferente a aquella que habíamos perfilado para los escultores del entorno del año 1100 hispano. Se trata, según creemos, de dos maneras muy diversas y contrapuestas de afrontar las obras del pasado, dos maneras de observar, contemplar y entender los vestigios del mundo antiguo que se presentaban ante los ojos del creador románico.

aquí. Además, concluye que, en el caso de aceptarse que los escultores hispanos superaron y enriquecieron sus fuentes "antiquizantes" francesas, no fue a través de la observación del arte hispanorromano, sino a través "del impacto de los mismos ideales protohumanistas que inspiraban por entonces el primer gótico". 


\section{BLOQUE V}




\section{CONCLUSIONES}

La investigación que hemos realizado y que hoy presentamos para obtener el grado de Doctor, se ha centrado en el análisis de algunos de los rasgos "clasicistas" presentes dentro de la escultura románica de los reinos hispanos. En particular, nos ocupamos de las repercusiones que este fenómeno tuvo sobre los trabajos escultóricos desarrollados en tales territorios durante siglos XI y XII, destacando, principalmente, las deudas con respecto a la tradición plástica tardoantigua.

Teniendo en cuenta estos aspectos consideramos oportuno exponer las siguientes conclusiones:

\section{Primera.}

Hemos podido verificar la importancia que el arte antiguo tuvo sobre algunos de los rasgos más esenciales de las producciones plásticas de la Alta y Plena Edad Media y, al mismo tiempo, concretar determinadas vías, mediante las cuales, se produjo la transmisión de este legado "clásico".

A pesar de que la investigación se circunscribe al arte románico hispano, nos hemos aproximado al tema mediante de un buen conocimiento del contexto europeo en general; advirtiéndose el valor de los periodos altomedievales como canales fundamentales para el traspaso del sustrato "antiquizante" hacia los siglos XI y XII.

La cultura pagana y sus manifestaciones artísticas, claramente precursoras de las soluciones adoptadas por el emergente arte cristiano, fue parcialmente transferida, mediante múltiples formas, hacia la plástica románica. Concretamente, se pudo reafirmar la relevancia que para este hecho tuvo la cultura visual desarrollada en el seno del Imperio Romano, especialmente en época tardoantigua.

Aceptadas estas premisas, se concretó la naturaleza de los mecanismos o canales de transferencia de este tipo de herencia antigua. Las oleadas "clasicistas" documentadas entre los siglos IV al XII, verifican una "voluntad de continuidad" o el deseo de preservar y perpetuar una tradición materializada a través de los diferentes "renacimientos" de la Antigüedad, que el presente estudio ha intentado concretar. 


\section{Segunda.}

En segundo lugar, se logró profundizar en la importancia del fenómeno de la expoliación como una vía esencial para la adopción y reinterpretación de tales corrientes “clásicas" dentro del periodo románico.

Mediante las labores de expoliación de materiales antiguos, tanto en su vertiente física (spolium in se) como mediante su reinterpretación intelectual (spolium in re), el artífice románico entraba en contacto con los vestigios del arte antiguo. Así, se concluye que, en el ámbito hispano que nos ocupa, la utilización de estas dos vías podía documentarse de manera concluyente. En este sentido, hemos evidenciado cómo las expoliaciones in se, muy frecuentes durante todo el periodo altomedieval, fueron menos usuales en los siglos del románico hispano, aunque su reducción cuantitativa no implicó su inexistencia.

Por el contrario, la reinterpretación intelectual de las obras de la Antigüedad -spolium in re-fue continua en estos territorios desde la Alta a la Plena Edad Media, hecho que demuestra como los artistas románicos, así como las élites y patrocinadores de los ambientes más ilustrados y pujantes, mostraron una predilección por este tipo de variantes estéticas.

\section{Tercera.}

En tercer lugar, hemos logrado confirmar la perpetuación de modelos antiguos en algunos de los principales núcleos artísticos románicos, activos entre los años finales del siglo XI y las primeras décadas del siglo XII.

En particular, a través del análisis del corpus escultórico de la catedral de San Pedro de Jaca y de la iglesia de San Martín de Frómista, hemos indicado el papel que debieron tener los sarcófagos y la escultura funeraria antigua en la formación de los escultores que ornaban tales edificios.

Basándonos en la decoración de estos templos, hemos profundizado en los repertorios ornamentales románicos derivados de la escultura presente en los sarcófagos. La hipotética presencia de algunas de estas piezas en estos círculos de escultores, bajo ningún concepto, debe reducirse únicamente al ejemplo del sarcófago de Husillos.

Al contrario, hemos podido defender que ciertos temas emparentados con las escenas del thiasos marino o derivados de la tradición dionisíaca de la escultura de 
sarcófagos, hubieron de ocupar un lugar preeminente en la gestación de la escultura a finales del siglo XI y principios del XII.

Ello nos llevó a concluir que, si bien el caso del sarcófago de Husillos es uno de los mejores documentados, la primacía en cuanto a la utilización de fuentes "clásicas" en Frómista y Jaca debe reconsiderarse. Ambos edificios presentaban un horizonte común: el interés sobresaliente por la estatuaria romana y, particularmente, por aquella realizada en los periodos más tardíos de la Antigüedad. En menor medida, especificamos otro tipo de obras, tales como esculturas en estuco o pequeñas figurillas de bronce que, en la misma dirección, ampliaron el acerbo "clasicista" de estos escultores.

El beneficio de la observación de lo antiguo no sólo fue exclusivo de los ejemplos citados. Hemos confirmado la continuidad del fenómeno en otros templos como la catedral de Compostela y la basílica de San Isidoro de León.

En el caso de la sede compostelana percibimos la utilización de dos mecanismos de acercamiento al arte de la Antigüedad. Por una parte, la deuda con respecto a las reinterpretaciones realizadas desde el foco jaqués y palentino; desde el otro, se observaron reminiscencias puntuales con ciertos monumentos de la ciudad de Roma.

Para los ejemplos esculpidos en la iglesia leonesa concluimos, sin embargo, que aquí los modelos fueron absorbidos con tanta profundidad que acabaron por convertirse en meros arquetipos. Su origen era "clásico" pero, en realidad, ya habían asumido las tamizaciones de los talleres de Jaca, Frómista y Compostela.

La corriente escultórica definida por la historiografía como "hispanolanguedociana" mostraba una clara deuda con la tradición artística antigua. Las aportaciones de la región del Languedoc, con epicentro en la basílica de Saint-Sernin de Toulouse, ofrecieron una rica inspiración para las esculturas que, por esos momentos, se concebían en suelo hispano. Finalmente, hemos constatado que, a este sustrato de raíz galorromana, los escultores románicos hispanos pronto sumaron las enseñanzas adquiridas a través de la asimilación de fuentes propiamente hispanorromanas.

\section{Cuarta.}

Hemos verificado que, a partir de los años 1140 y 1150, se aprecian cambios en la manera de observar lo antiguo, frente al acercamiento a lo "clásico" documentado durante los últimos años del siglo XI y las primeras décadas de la centuria siguiente. 
Así mismo, advertimos que, en torno a la mitad del siglo XII, la predilección por los lenguajes "antiquizantes" se trasladaba desde los territorios occidentales y del noroeste hispano hacia las áreas más orientales de la Península Ibérica.

Las esculturas atribuidas al discutido "maestro" de Cabestany y su hipotético círculo de escultores evidencian una preferencia por el legado "clásico" y la valoración de las producciones de época romana, tanto paganas como de tradición cristiana. Ahora bien, en oposición al fenómeno señalado, por ejemplo para el caso de Jaca y Santiago, las posibles creaciones de este grupo de escultores revelan un acercamiento muy sensible a los sarcófagos y esculturas romanos. Podemos defender que la inspiración es más directa, documentándose aquí los reempleos de materiales antiguos más claros de todo el románico hispano. Se readaptan y expolian restos marmóreos de tradición "clásica", en contra de la escasez de esta práctica en los años anteriores.

Según se ha podido especificar, la escultura ligada a Cabestany aprovechaba el panorama de vestigios antiguos de la región languedociana, sumando ahora las enseñanzas adquiridas a través del paisaje monumental de la basta región mediterránea.

No se trataba solamente de una influencia antigua tomada del movimiento "hispanolanguedociano" o la ejercida por las piezas hispanorromanas. A diferencia de la situación anterior, su bagaje visual se enriquecía con fuentes pirenaicas, aquitanas y provenzales. En definitiva, una apertura a nuevas tradiciones antiguas que, según concluimos, no nos parecen tan claras en los escultores románicos de la primera etapa.

\section{Quinta.}

La escultura realizada durante las últimas etapas del románico hispano aparece nuevamente marcada por la huella "clásica". Sin embargo, este sustrato "antiquizante" posee una naturaleza muy diferente respecto a la tradición anteriormente especificada, fruto de las aportaciones foráneas legadas, principalmente, por el arte bizantino.

Los modelos que ahora comenzarán a introducirse, parece que provenían, en su gran mayoría, de los centros artísticos más sobresalientes de la Isla de Francia y Borgoña donde, posiblemente, existió una evocación de modelos griegos arcaicos. Así, fruto de la importación a Hispania de soluciones románicas francesas a partir de los años sesenta del siglo XII, se acreditó esta progenie "clásica" arcaizante para determinados tipos faciales presentes, por ejemplo, en algunas de las esculturas del Pórtico de la Gloria. 
Cercanos al año 1200, la multiplicación de fuentes "antiquizantes" era tan extensa que resultó difícil concretar el origen exacto de todas.

En este fenómeno jugó un papel relevante la introducción de corrientes bizantinizantes de ascendencia "clásica" en la Península Ibérica, ahora tamizadas bajo las aportaciones asumidas a través de algunas regiones de Grecia, Italia y Centro Europa. La presencia de recuerdos de la plástica griega, de la tradición helenística y del arte del Imperio Romano Oriental, provocó la gestación de una escultura enérgicamente "clasicista", pero que nada tenía que ver con el sustrato antiguo que, años atrás, había dominado la escultura románica hispana.

En conclusión y a nuestro modo de ver, a través de la presente investigación hemos podido llegar a diferenciar la existencia de dos movimientos recuperadores de lo antiguo muy diversos:

1. Por un lado, documentamos una práctica "antiquizante" heredera de las fórmulas de explotación de lo antiguo usadas en los núcleos relacionados con el románico languedociano. A su llegada a los reinos hispanos en la etapa final del siglo XI y las primeras décadas de la centuria siguiente, esta primera tradición se vio vigorosamente enriquecida por los escultores que aportaron, a su vez, las enseñazas adquiridas a través del arte hispanorromano.

2. Al contrario, una segunda vía de asimilación de los postulados del arte “clásico", llegaba a Hispania como un elemento importado y foráneo que desembarca aquí ya reelaborado y disipado por aportaciones muy distintas.

Los creadores de la escultura hispana a finales del siglo XII, cuando mostraron su conocimiento de las obras antiguas, lo hicieron mediante las experiencias adquiridas a través de la Isla de Francia y Borgoña. Fue allí donde se reelaboraron estos lenguajes para, poco después, implantarlos en la Península Ibérica, donde acabarían fusionándose con la ecléctica tradición "antiquizante" bizantina propia de la plástica cercana al año 1200 . 
BLOQUE VI 


\section{APÉNDICES.}

\section{1. APÉNDICE DE TEXTOS.}

El presente aparto recoge una selección de textos de diversa naturaleza. Entre ellos, se han incluido algunos fragmentos procedentes de obras literarias, cronísticas y epigráficas, sobre algunos aspectos históricos, biográficos, filosóficos y estéticos que, según hemos considerado, podían aportar importantes datos y noticias en las que apoyar las hipótesis vertidas a lo largo de las páginas precedentes.

La selección que presentamos a continuación se enmarca en un periodo cronológico muy amplio, que va desde la Antigüedad clásica hasta, prácticamente, la contemporaneidad. En este sentido, la aparente incoherencia que, en un primer momento, podría atribuirse a este criterio cronológico, se justifica a través de la misma índole de los fragmentos seleccionados.

Se buscaron aquellos ejemplos que consideramos más clarificadores sobre diversas cuestiones que aportaban interesantes datos sobre las relaciones históricas y artísticas de los periodos antiguo y medieval. En el mismo sentido, otros fueron incluidos por su fuerte valor testimonial, por ofrecer noticias relevantes sobre los fenómenos de la expoliación y traslado de materiales, por su fuerte carga teórica a la hora de reflexionar sobre la influencia del arte antiguo sobre el periodo románico o, en última instancia, porqué dichos textos fueron realizados por expertos en estos temas y cuyas reflexiones y palabras se han convertido, con el paso del tiempo, en obras ya ineludibles dentro de la historiografía.

El apéndice de textos se presenta en riguroso orden de aparición con respecto al aparato teórico de la Tesis Doctoral. De tal manera que, en el discurrir de nuestras explicaciones y cuando las bases teóricas lo requerían, se optó por transcribir parcialmente aquellos que consideramos más importantes para el tema que se trataba. Además de ello, también se llamó la atención, mediante la correspondiente numeración, del texto al que nos referíamos.

Por motivos de espacio dentro del cuerpo que configura la Tesis Doctoral dichos textos fueron, casi siempre, resumidos y abreviados. Sin embargo, debido a su importancia consideramos fundamental introducirlos casi completos en esta parte del estudio. 
No se trata de una nómina ordenada diacrónicamente pues, debido a las características del discurso que hemos elaborado, continuamente nos referíamos al periodo antiguo y al medieval de manera alterna. Esta es la razón por la que los textos se presentan ahora siguiendo su orden de aparición con respecto al texto principal y no a través una consecución cronológica basada en la datación otorgada a estas fuentes.

Las versiones que se ofrecen de cada uno de los fragmentos textuales recogidos a continuación fueron extraídas de las ediciones críticas realizadas por los autores más reconocidos. Uno de los objetos del estudio se centra en valorar las cuestiones artísticas que se pueden derivar de la lectura de tales textos, por lo que, en buena medida, se han aceptado las traducciones y las interpretaciones que sobre ellos han realizado los historiadores, paleógrafos y filólogos.

Por último, debemos señalar que, junto con el epígrafe que numera cada uno de ellos se colocó, entre paréntesis, la página exacta de la Tesis Doctoral en la que se hace mención a dicho texto. 


\section{TEXTO 1}

(p. 45)

"Sin embargo, por lo divino de su espíritu no consintió que ese recinto mismo que acaba de mostrarse siguiera soterrado por toda suerte de material inmundo, acopiado fraudulentamente por los enemigos, y entregado al olvido y la ignorancia; tampoco transigió con la maldad de los culpables, antes invocado a Dios como su valedor, dicta la orden de limpiar aquella área, en la idea de que aquella parte especialmente contaminada por los enemigos debía, por su intervención, disfrutar de la magnificencia divina. Nada más dictarse la orden, todos los armatostes de la confusión fueron derribados y destrozados con todas sus estatuas de divinidades. No se detuvo sólo en esto la muestra de su celo, sino que una vez más ordena que los materiales de derribo, de piedra y de madera, sean recogidos y arrojados lo más lejos posible de la comarca $(\ldots)$ ".

(E. DE CESAREA, Vida de Constantino (Introducción, traducción y notas de M. Gurruchaga, Madrid, 1994), Libro III, 27, p. 291).

\section{TEXTO 2}

(pp. 48 y 724)

"Y para no apartarse en su capacidad humana del refrán que dice: Lo que pueda hacer tu mano, hazlo enseguida, en la medida en que pudo, trabajó con diligencia para que su ánimo no fuera sepultado, poco a poco por el afán de la vida presente bajo el cúmulo de preocupaciones terrenas. Y así, inspirado por la divina gracia, después de marchar a Portugal, con la ayuda del Señor, realizó lo que a continuación se lee.

Traslado de San Fructuoso, San Silvestre, San Cucufate y Santa Susana, virgen y mártir, a Compostela.

En el año de la Encarnación del Señor 1102 el venerable padre Diego II de la sede compostelana de la iglesia de Santiago, con la ayuda de la divina gracia, en el segundo año de su episcopado decidió visitar, como es debido, las iglesias, capillas y heredades que en tierra de Portugal pertenecían jurídicamente a la iglesia compostelana, pues es propio del buen pastor velar por los bienes de dentro y de fuera de su iglesia por si encontrara en ellos algún detrimento o algún desorden, restaurarlos y arreglarlos por su providencia. Tomó a algunas de las personas más relevantes de su iglesia y se encaminó a Portugal, como había decidido. Y al aproximarse a la ciudad de Braga, envió por delante un mensajero al arzobispo de aquella ciudad para que le anunciara su llegada. Pero el arzobispo Giraldo, hombre sabio y religioso, cuando escuchó que el obispo de Santiago venía a su ciudad, se llenó de alegría y congregando a todos sus clérigos con las cruces y restantes ornamentos de su iglesia le salió al encuentro y lo recibió procesionalmente con gran veneración al obispo de Compostela y en medio de los cánticos del clero, llevándole a su diestra, le introdujo en la iglesia y le pidió con grandes ruegos que se dignara a celebrar una misa en aquel día. Después de la celebración de la misa, el arzobispo llevó al obispo a cenar y, después de la cena, le acompañó hasta su propio dormitorio con grandes honores, le ofreció su propio residencia y marchó él a dormir a otra mansión. Y así, aquel día, el obispo de Santiago recibió la hospitalidad del arzobispo de Braga. Al día siguiente, después de saludar a los hermanos de esta iglesia y confortarlos con su bendición, el obispo se dirigió en compañía del arzobispo a la iglesia de San Víctor, la que pertenece jurídicamente la mita a la ciudad de Braga, y fue recibido en sus palacios regios como señor. Pero entretanto, al dar la vuelta por sus iglesias, visitarlas y celebrar en ellas misas solemnes, 
cuando contemplaban los cuerpos de muchos santos que, semienterrados en ellas, carecían del honor debido, lloraba con piadoso sentimiento y daba vueltas en su corazón movido por esta misma piedad a lo que después con la ayuda divina llevó a cabo, pues pensaba con ansia de qué manera podía sacar aquellas preciosas perlas de lugares tan inconvenientes y llevarlas a la ciudad de Compostela. Tras convocar, pues, a los clérigos, personas de su confianza y de consejo probado, les hizo saber qué y de qué modo quería obrar, diciéndoles.

"Hermanos queridísimos, sabéis que hemos venido aquí para, si hubiera algo destruido o desordenado en estas iglesias y heredades, restaurarlo y ordenarlo con vuestra presencia y mejorar lo que está mal. Pero ahora no se oculta a vuestra diligencia lo que se encuentra en condiciones inconvenientes, pues veis que yacen en ellas muchos cuerpos de santos desgraciadamente sin que sean venerados por culto alguno, sino desnudos y a la vista pública, y no ignoráis que carecen de la debida veneración.

Y si vuestra prudencia nos aconsejara, procuraríamos enmendar esto e intentaríamos llevar a la sede compostelana los preciosos cuerpos de los santos a los que ningún culto se les rinde aquí. Pero convendrá hacer esto de manera oculta para la gente de esta tierra, indisciplinada y expoliada de este gran tesoro, no promueva contra nosotros una súbita sedición y no nos tengamos que arrepentir de haber intentado en vano lo que nos atrevemos a intentar".

Después de haber aprobado sus clérigos esta decisión, puesto que creían que era de inspiración divina y que no debían posponerlo, el venerable obispo, lleno de una gran alegría, respondió diciendo: "El Señor Jesucristo en cuya misericordia confiamos, por su piedad, cumpla lo que deseamos y se digne a llevar a buen fin nuestro devoto pronóstico". Luego tras entrar en la iglesia de San Víctor y celebrar allí una misa, ordenó que se cavara en la parte derecha del altar mayor. Fue descubierta allí un arca marmórea, fabricada con finura y admirablemente y que estaba bajo tierra. Al abrirla en presencia del señor obispo, encontraron dentro dos cajitas de plata. Y cuando las recibió el mencionado obispo con gran respeto, glorificando el nombre del Señor con salmos y oraciones, descubrió la de muchos santos. Tras cerrarlas y sellarlas con firmeza, las entregó a sus más fieles clérigos para guardarlas".

(Historia Compostelana, (E. Falque ed.), Madrid, 1994, XV. Viaje a Portugal, pp. 94-99).

\section{TEXTO 3}

(p. 55)

"Asimismo se ha de implorar en el cementerio de dicha ciudad la protección de San Honorato, obispo, cuya solemnidad se celebra el 16 de enero. En su venerable y magnífica iglesia descansa el cuerpo de San Ginés, mártir muy preclaro. Pues hay un arrabal junto a Arles, entre los dos brazos del Ródano, que se llama Trinquetaille, en donde existe detrás de la iglesia una columna de magnífico mármol, muy alta y elevada sobre la tierra, a la que, según se cuenta, ataron a San Ginés y lo degolló la plebe fiel; y aún hoy aparece enrojecida por su rosada sangre".

(Liber Sancti Jacobi Codex Calixtinus, Traducción al castellano de A. Moralejo, C. Torres y J. Feo, Santiago de Compostela, 2004, Libro V, cap. VIII, p. 559$560)$. 


\section{TEXTO 4}

(p. 64)

"En primer lugar, existen razones suficientes para afirmar que los llamados "hombres del Renacimiento" eran en realidad bastante medievales. Su comportamiento, postulados e ideales eran más tradicionales de lo que tendemos a creer y de lo que ellos mismos pensaban. Hindsight sugiere que incluso Petrarca, "uno de los primeros hombres realmente modernos", según Burckhardt, y un personaje del que nos volveremos a ocupar en estas páginas, por su creatividad tanto poética como intelectual, tenía muchos puntos en común con la época que él mismo describió como "oscura".

(P. BURKE, El Renacimiento, Barcelona, 1999, p. 12).

\section{TEXTO 5}

(p. 122)

"Rechazaba las indumentarias de otras naciones, aunque fueran bellísimas, y jamás consintió llevarlas excepto una vez, en Roma, a instancias del pontífice Adriano y una segunda vez porque se lo pedía su sucesor León; entonces se cubrió con una larga túnica y con una clámide y llevó también un calzado a la moda romana”.

(EGINHARDO, Vida de Carlomagno (A. De Riquer ed.), Barcelona, 1986, cap. XXIII, pp. 93).

\section{TEXTO 6}

(p. 123)

“(...) Yendo a Roma por este motivo, para restablecer la situación de la Iglesia, que estaba demasiado alterada, paso todo el invierno allí. Entonces fue cuando recibió el título de emperador y augusto; en un principio mostraba ante esto una actitud tan hostil que afirmaba que no habría entrado en la iglesia aquel día, aunque era una gran festividad, si hubiera podido saber de antemano la decisión del pontífice. Pero soportó con gran paciencia la envidia de los emperadores romanos que estaban indignados por el título que había asumido (....)".

(EGINHARDO, Vida de Carlomagno (A. De Riquer ed.), Barcelona, 1986, cap. XXVIII, pp. 103-104).

\section{TEXTO 7}

(p. 124)

"Practicó escrupulosamente y con la mayor devoción la religión cristiana, que le habían inculcado desde la infancia. Pero esto, hizo construir en Aquisgrán una basílica de excepcional belleza que decoró con oro, plata, candelabros y con balaustradas y puertas de bronce macizo. Y como no podía procurarse de otro sitio las columnas y los mármoles para la construcción de la basílica, mandó que se trajeran de Roma y Rávena”.

(EGINHARDO, Vida de Carlomagno (A. De Riquer ed.), Barcelona, 1986, cap. XXVI, pp. 99). 


\title{
TEXTO 8
}

(p. 127)

"Había decidido hacer un testamento para instituir herederos (...). Entre otros tesoros y riquezas consta que figura tres mesas de plata y de ellas de oro de gran tamaño y peso. Decidió y dispuso que una de ellas, la de forma cuadrangular y que lleva un trazado de la ciudad de Constantinopla, fuera enviada, entre otras ofrendas previstas para este fin, a Roma, a la basílica del bienaventurado apóstol Pedro: otra, de forma redonda, en la que está representada la ciudad de Roma, que fuera donada al episcopado de la iglesia de Rávena; la tercera, mucho más hermosa y más pesada que las otras, que lleva grabado en un dibujo fino y pequeño el mapa del mundo entero bajo la forma de tres círculos concéntricos, y la de oro -la que se designa como la cuarta- pasaran a aumentar aquella parte que había que dividirse entre los herederos y las limosnas".

(EGINHARDO, Vida de Carlomagno (A. De Riquer ed.), Barcelona, 1986, cap. XXXIII, p. 117).

\section{TEXTO 9}

(p. 129)

“(...) Más las estatuas de personas a cavallo son celebradas de los romanos, haviendo sin duda seguido el exemplo de los griegos. Pero ellos sólo las dedicavan esculpidas o cinceladas a aquellos que havían sido vencedores en cosas sagradas. Pero después también a los que huviesen vencido en carros de dos cavallos o de quatro (...)"

(C. PLINIO SEGUNDO, Historia Natural de Cayo Plinio Segundo, (Traslada y antoda por el doctor F. Hernández (Libros primero a vigésimoquinto) y por J. De Huerta (libros vigésimosexto a trigesimoséptimo), Madrid, 1998, Libro Trigésimocuarto, cap. $V$. De las estatuas togadas y de algunas otras, y a quiénes se pusieron estatuas sobre colunas y quánto primero públicamente y quáles fueron las primeras estatuas de Roma, p. 1072).

\section{TEXTO 10}

(p. 143)

"Su cuerpo fue lavado y compuesto según el rito solemne, fue llevado a la iglesia e inhumado en medio de la gran aflicción de todo el pueblo. Se dudó en un principio sobre el lugar en donde debía ser depositado porque él, en vida, no había dispuesto nada al respecto. Finalmente, todos decidieron que el sitio más digno de que fuera enterrado era la basílica que él mismo había hecho construir, a sus expensas, en este lugar, por amor a Dios y a Nuestro Señor Jesucristo y en honor a su santa Madre, siempre Virgen. Allí fue sepultado el mismo día de su muerte y sobre la tumba se construyó un arco dorado con su imagen y con una inscripción; el texto que fue grabado es el siguiente:

\author{
EN ESTE SEPULCRO YACE EL CUERPO \\ DE CARLOS, MAGNO Y ORTODOXO EMPERADOR \\ QUE NOBLEMENTE AMPLIÓ EL REINO DE LOS FRANCOS \\ Y LO QUE GOBERNÓ FELIZMENTE DURANTE XLVII AÑOS \\ MURIÓ SEPTUAGENARIO EN EL AÑO DEL SEÑOR DCCCXIV \\ EN LA VII INDICCIÓN EL DÍA V ANTES DE LAS CALENDAS
}




\title{
DE FEBRERO”.
}

(EGINHARDO, Vida de Carlomagno (A. De Riquer ed.), Barcelona, 1986, cap. XXXI, pp. 109).

\section{TEXTO 11}

\author{
(p. 160)
}

"Para adorar la cruz que da vida, estandarte salvador de la eterna victoria de nuestro Señor, (...) habríamos dedicado, de haber sido posible, toda la devoción de nuestro pensamiento a embellecerla con toda la gloria posible como el signo del Hijo del Hombre que aparecerá en el cielo en el último día (...). Pero porque no pudimos hacer lo que quisimos, quisimos hacerlo lo mejor que pudimos y conseguimos llevarlo a cabo con la generosidad de Dios. De ahí que buscamos nosotros mismos por nuestro entorno a través de nuestros mensajeros abundancia de perlas y piedras preciosas, y preparamos material de aderezo en oro y piedras preciosas lo más hermosos que pudimos hallar; mandamos venir de diversos lugares a expertos artesanos que trabajando con diligencia y cuidado levantaron la cruz. (...). No queremos callar un milagro jubiloso, pero honesto, que en relación con esto nos mostró el Señor. Pues encontrándome en dificultades por la carencia de piedras preciosas y no pudiendo sobre este particular proveerme lo suficiente (pues la escasez las encarece), he aquí que unos monjes de tres abadías de dos Órdenes -a saber, del Cister y de otra abadía de la misma Orden, y de Fontevrault- entraron en nuestro habitáculo contiguo a la iglesia y nos ofrecieron en venta una cantidad tal de piedras preciosas que no esperábamos encontrar ni en diez años, a saber, jacintos, zafiros, rubíes, esmeraldas y topacios".

(El abad Suger, Sobre la abadía de Saint-Denis y sus tesoros artísticos, (E. Panfosky ed.), Madrid, 2004, XXXII, Del crucifijo de oro, pp. 73-75).

\section{TEXTO 12}

\author{
(p. 172)
}

"El lugar de la su tumba está ahora en Mérida, colonia ilustre de de la Vetonia, por la que pasa el famoso río Ana (Guadiana) y cuyas bellas murallas baña raudo con sus verdeantes ondas. Aquí, donde el brillo de relucientes mármoles, traídos de fuera y del propio país, llena de esplendor su templo santo, el suelo venerable guarda en su seno sus reliquias y sagradas cenizas Los techos relucientes brillan, además, al rojo vivo desde los artesonados dorados, los mosaicos llenan de colorido el pavimento, de su suerte que podrías tenerlos por prados de rosas encendidos entre múltiple variedad de flores (...).

Así nos gusta venerar sus huesos y el altar que se ha levantado sobre ellos. Ella, colocada allí a los pies de Dios, mira bien estas cosas y, propicia por nuestro cántico, favorece a sus pueblos". 
(AURELIO PRUDENCIO, Obras completas de Aurelio Prudencio, (A. Ortega ed.), Madrid, 1981, Peristephanon, Hymnus 3. En honor de Santa Eulalia, pp. 539-540).

\title{
TEXTO 13
}

(p. 187)

"Una vez que el pueblo ha descansado, al empezar la hora segunda se reúnen todos en la iglesia mayor, que está en el Gólgota. Cuál sea el ornato aquel día en la Iglesia o en la Anástasis o en la Cruz o en el Belén, me ha parecido inútil escribíroslo. Allí no ves más que oro, piedras preciosas y seda; porque si miras los tapices, son de seda bordada de oro; si miras las cortinas, son también de seda bordada de oro. Todo el servicio de culto divino que se ve aquel día es de oro con piedras preciosas incrustadas. Y el número o valor de los cirios, candelabros o lámparas y de toda clase de objetos de culto, ¿puede acaso apreciarse o escribirse?. Y ¿qué diré de la ornamentación de la fábrica misma, que Constantino, bajo la vigilancia de su madre, en cuanto se lo permitieron las riquezas de su reino, decoró con oro, mosaicos y mármoles preciosos, tanto la iglesia mayor como la Anástasis y la Cruz y los demás lugares santos de Jerusalén?".

(Itinerario de la Virgen Egeria (381-384) (A. Arce ed.), Madrid, 1980, Liturgia del año. Epifanía y su octava, p. 269).

\section{TEXTO 14 \\ (pp. 188 y 470)}

"Los pórticos que daban a la fachada de la basílica gravitaban sobre columnas gigantescas; los interiores elevándose sobre pilastras cuyas superficies ostentaban una rica decoración. Tres poternas bien orientadas al levante daban recibimiento al gentío que penetraba en el interior. En frente de éstas, cual epicentro de todo el conjunto, hallábase el ábside, colocado en el extremo de la basílica; lo ceñían doce columnas, de cifra igual a los apóstoles del Salvador; tenían sus capiteles ornamentados con enormes cráteras de plata que el mismo emperador había donado (...)".

(EUSEBIO DE CESAREA, Vida de Constantino (Introducción, traducción y notas de M. Gurruchaga), Madrid, 1994, Libro III, 38-39, pp. 297-298).

\section{TEXTO 15}

\author{
(p. 196)
}

"Pero conveniente es pasar a contar las cosas admirables de nuestra ciudad (Roma) y hazer mención de los hombres que en novecientos años han sido de sutil ingenio (...) Algunas veces reciben las ondas del río Tibre, que infundido por ellos los haze bolver atrás, y pelean dentro los ímpetus de las aguas, y estrivando la firmeza de los conductos resiste. Llevan las aguas por dentro piedras grandes y de grande peso, sin quedar vencidas las causas de la obra. Reciben golpes de las ruinas que encima se hunden o se derriban con incendios".

(C. PLINIO SEGUNDO, Historia Natural de Cayo Plinio Segundo, (Traslada y antoda por el doctor F. Hernández (Libros primero a vigésimoquinto) y por J. De 
Huerta (libros vigésimosexto a trigesimoséptimo), Madrid, 1998, Libro Trigésisexto, cap. XV, Del templo de Cízico y de la piedra fugitiva y del eco que resuena siete veces y del edificio sin clavos y cosas admirables de edificios de Roma, p. 1115-1116).

\section{TEXTO 16}

(p. 197)

"Y así me llevó primero al palacio del rey Abgar, donde me mostró su estatua de mármol, grande y muy parecida a él, según ellos decían, tan brillante que parecía de perlas; en el rostro de Abgar, mirando de frente, se veía haber sido realmente varón muy sabio y honorable. Díjome el santo obispo: "Este es el rey Abgar, quien antes de haber visto al Señor creyó que él era verdaderamente Hijo de Dios".Cerca de allí había otra estatua también de mármol, que dijo ser la de Magno, hijo de Abgar, la cual también tenía un aspecto gracioso. Luego entramos en la parte interior del palacio. Había allí fuentes llenas de peces, cuales yo nunca había visto: tan grandes, tan lustrosos y de tan buen sabor. La ciudad no tiene actualmente más agua que la que sale del palacio, que es como un gran río de plata (....)".

(Itinerario de la Virgen Egeria (381-384) (A. Arce ed.), Madrid, 1980, En Mesopotamia, p. 237).

\section{TEXTO 17}

(p. 198)

"Palazo Maggiore et chuliseo erano nel mezo di Roma, et era palazo Maggiore ritondo, di giro oltre d'uno miglio, nel quale erano cinquanta altissime torri, chon cinquanta bellismi palazi, e di belleza l'uno simile a l'altro, et l'alteza delle mura erano sessanta braccia et grosse dieci: le quali torre altretanto disopra passavano, ornate di bellissimi porfido et marmi di diversi cholori, et nel mezo di dentro era un lacho, nel quale era ogni generazione di pesci, d'intorno al quale circundaba una strata di marmo biancho e seliciata da porfidi di diversi cholori, gl'intagli de liquali facevano memoria delle storie troyane e dello avvenimento d'Enea in Italia. Lo palazo aveva una entrata di altissime e belle porti di metallo, et chosì erano porte et finestre degli altri palazi li quali erano dentro di musayco tutti lavorati facendo memoria de fatti antichi del chominciamento del mondo. Le tetta erano coperte di pionbo in fortísima volta, sanza alcuno edifizio di legname, di chamere, sale, logge et camínate forniti, che la natura none aveva in ciò niente machato; citerne et fonti et pozi di dolcissime aque. L'aque del chondotto si chonducevano dal fiume di fogle sopra quasi i palagi, chadeva l'acqua in detto lacho, la quale veniva trenta miglia lontano. Nella sommità d'intorno s'andava a caballo et a pie, come altri voleva. Hordinato era d'intorno da uno de lati che infino a sommo si saliva quasi a piano. Nel detto palazo stavano tutti li rettori li quali avevano a dare sentencia, et anchora vi si teneva ragione a vedove et a pupulli et orfani. Furono certi imperatori ch'ordinarono loro stanze in certi luochi di Roma si chome fu dove era santo Yanni, che ivi si è Costantino, et a termo, dove'è ora santo Piero, che v'abitò Nerone, e dove santa María Trasperina, che ivi si è Adriano, el quale edifichò castel Santo Angnuolo; ma la Maggiore parte degli imperatori stavano in palazzo Maggiore".

(A. GRAF, Roma nella memoria e nelle immaginazioni del Medio Evo, Roma, 1923, pp. 90-92). 


\section{TEXTO 18}

(p. 214)

"Solberat antiquas moles ruinosa uetustas, Lapsum et senio ruptum pendebat opus. perdiderat usum suspensa uia $\mathrm{p}(\mathrm{er})$ amnem. et liberum pontis casus negabat iter. nunc tempore potentis Getarum Eruigii regis, quo deditas sibi precepit excoli terras, studuit magnanimus factis extendere $\mathrm{n}(\mathrm{o}) \mathrm{m}(\mathrm{e}) \mathrm{n}$, ueterum et titulis addit Salla suum. nam postquam eximiis nobabit moenib(us) urbem, hoc magis miraculum patrare non destitit . construxit arcos, penitus fundabit in undis et mirum auctoris imitans uicit opus.

nec non et patrie tantum cr(e)are munimen sumi sacerdotis Zenonis suasit amor. urbs Augustea felix mansura p(er) scla. longa nobate studio ducis et pontificis".

(J. VIVES, Inscripciones cristianas de la España romana y visigoda, Barcelona, 1969, pp. 126-127).

"La ruinosa antigüedad había deshecho las antiguas moles (de piedra). La obra se mantenía caída y rota por la vejez. El puente sobre el río había perdido su uso. En el tiempo actual del poderoso rey Eurico, a quién Dios ordenó conquistar tierras, éste, magnánimo, puso todo su empeño en dar a conocer su nombre; y el noble cortesano Salla también añadió honores a un antiguo nombre, puesto que después de renovar las fuertes murallas de la ciudad (de Mérida), no dudó en realizar otra obra prodigiosa.

Construyó los arcos del puente, los asentó con firmeza en lo profundo del río y remató una obra admirable, que imitaba la de un primer constructor. Además, el afecto de Zenón, obispo (de Mérida), le persuadió para fortificar en gran medida.

La ciudad augusta (de Mérida) permanecerá dichosa por los siglos gracias al empeño del citado noble y del citado obispo.

(Traducción al castellano de la inscripción anterior de J. A. Moráis Morán y S. Domínguez Sánchez).

\section{TEXTO 19}

(p. 226)

"En la otra parte, la vía Hóstiense conserva el sepulcro de Pablo, por donde el río lame el césped de la izquierda. Regia es la magnificencia del lugar; un príncipe bueno (¿Honorio?) dedicó esta mansión e hizo decorar el recinto con grandes riquezas.

Con planchas de oro recubrió las vigas, para que el interior fuese toda la luz dorada, como la del sol al amanecer. Hizo poner bajo los dorados artesonados columnas de mármol de Paros, que allí aparecen hermosas en cuatro filas. La arcadas de la bóveda ordenó exornar después variadamente 
con mosaicos de magnífico vidrio de color verde; de igual modo brillan los prados, esmaltados de flores primaverales".

(A. PRUDENCIO, Obras completas de Aurelio Prudencio, (A. Ortega ed.), Madrid, 1981, Peristephanon, Hymnus 12. Martirio de los apóstoles Pedro y Pablo, pp. 721-723).

\section{TEXTO 20}

(p. 228)

"Luego, pues, devastando las tierras de España, llegó a la villa que vulgarmente se llama Orniz (actual San Román de Hornija), en la que había una bellísima y muy buena basílica de San Román con riquísimos paños y códices, cruces de plata y telas bordadas de oro. Y al llegar a ella el inicuo Almanzor robó cuanto en ella encontró y de igual suerte devastó la villa. Y habiéndose albergado con sus ejércitos en esta villa, cierto capitán de sus huestes que entró en la iglesia vio las bellísimas columnas de piedra que sustentaban el techo de la iglesia y cuyos capiteles estaban plateados y dorados, y estimulando por su odio y crueldad, clavó una cuña de hierro entre una columna y su basa. Y al golpear fuertemente aquella cuña con un martillo de hierro, tratando de derrumbar toda la iglesia, el hombre se convirtió en piedra por providencia de Dios. Y esta piedra con forma humana subsiste hasta el día en la misma iglesia y tiene el mismo color que tenía la túnica del sarraceno entonces. También suelen contar los peregrinos que allá van a rezar, que la piedra hiede".

(Liber Sancti Jacobi Codex Calixtinus, Traducción al castellano de A. Moralejo, C. Torres y J. Feo, Santiago de Compostela, 2004, Libro IV, cap. XXV, p. 519).

\section{TEXTO 21}

(p. 229)

"Dagoberto, el rey glorioso y famoso rey de los francos, hombre prudente por su real generosidad en la administración del reino y no menos devoto de la iglesia de Dios (...). Ordenó en un impulso de amor digno de admiración que se construyera la basílica de los santos con real magnificencia. Una vez construida la basílica con una maravillosa variedad de columnas de mármol, la enriqueció de forma incalculable con tesoros abundantes en oro purísimo y plata, y mandó cubrir paredes, columnas y arcos con tapices tejidos en oro y adornados con abundantes perlas (...)".

(El abad Suger, Sobre la abadía de Saint-Denis y sus tesoros artísticos, (E. Panfosky ed.), Madrid, 2004, Segundo libro de la consagración de la iglesia de Saint-Denis, II, p. 103).

\section{TEXTO 22}

(p. 230)

“Alfonso el Magno reinó 51 años. (...) Este construyó en Oviedo el admirable templo de San Salvador y los Doce Apóstoles, de piedra y cal, y la iglesia de Santa María con sus tres altares. También erigió la basílica de San Tirso, admirable edificación, con numerosos ángulos; y todas estas casa del Señor las adornó con arcos y con columnas de mármol, y con oro y plata, con la mayor diligencia y junto con los 
regios palacios, las decoró con diversas pinturas; y todo el ceremonial de los godos, tal y como había sido en Toledo, lo restauró por entero en Oviedo, tanto en la Iglesia como en el Palacio".

(Crónicas asturianas (J. Gil Fernández, J. L. Moralejo y J. I. Ruiz de la Peña eds.), Oviedo, 1985, Crónica Albeldense, 9, p. 248-249).

\section{TEXTO 23}

(p. 232)

“(...) por las doce piedras preciosas engastadas en el pectoral de Aarón (Éx. 28, 15), por los doce panes de la proposición (Lev. 24, 5), por los doce exploradores enviados por Moisés a la tierra de promisión (Núm. 13, 2), por las doce piedras de que fue hecho el altar (Éx. 24, 4), por las doce piedras tomadas del Jordán (Jos. 4, 1), por los doce bueyes que sostenían el mar de bronce (III Rey. 7, 25), por las doce estrellas que se ponían en la corona de una esposa (Apoc. 12, 1), por los doce signos del zodiaco, por los doce meses del año, por los doce senadores romanos y por los doce sabios. También por el Nuevo Testamento (Mat. 14, 29; Marc. 6, 43; Juan 6, 13) están indicados en los doce cuévanos de los pedazos, en los doce nombres que vio San Juan en el Apocalipsis escritos sobre la puerta del Jerusalén celestial y en las doce hiladas del muro de la misma ciudad (Apoc. 21, 12-14 y 19-20). Y es de notar que el Señor eligió a los doce apóstoles conforme al número de los doce patriarcas o sea de los hijos de Israel, y conforme a los doce profetas".

(Liber Sancti Jacobi Codex Calixtinus, Traducción al castellano de A. Moralejo, C. Torres y J. Feo, Santiago de Compostela, 2004, cap. II, pp. 30-31).

\section{TEXTO 24}

(p. 239)

"Estas vigilias cuidadosamente se celebran allí; unos vienen, otros se retiran y ofrecen en su variedad diversos dones. Si alguno se acerca triste, se retira alegre. Allí se celebra continua solemnidad, la festividad se prepara cuidadosamente, ala esclarecida celebridad se rinde culto de día y de noche, alabanzas y gozos, alegría y contento, en común, se cantan. Todos los días y noches como en interrumpida solemnidad, en continuo alborozo, se celebran los cultos para la gloria del Señor y del Apóstol. Las puertas de esta basílica nunca se cierran, ni de día ni de noche; ni en modo alguno la oscuridad de la noche tiene lugar en ella; pues con la luz espléndida de las velas y cirios, brilla como el mediodía".

(Liber Sancti Jacobi Codex Calixtinus, Traducción al castellano de A. Moralejo, C. Torres y J. Feo, Santiago de Compostela, 2004, cap. XVII, p. 192).

\section{TEXTO 25}

$$
\text { (p. 241) }
$$

“Tal es en el Capitolio la estatua de Apollo, traída por Marco Lúculo desde Apollonia, ciudad del Ponto, que tiene treinta brazas de largo y costó de hechura ciento y cincuenta talentos. Tal es en el campo Marcio el Júpiter que dedicó el emperador Claudio, a quién llaman Pompeyano, por estar junto al teatro de Pompeyo; tal es 
también el de Tarento, el qual hizo Lisipo de quarenta brazas. Havía en él una cosa admirable, que, según dizen, se movía con una mano y ningunas tempestades le hazían perder su firmeza (tal era el orden con que estava fijado).

(C. PLINIO, Historia Natural de Cayo Plinio Segundo, (Traslada y antoda por el doctor F. Hernández (Libros primero a vigésimoquinto) y por J. De Huerta (libros vigésimosexto a trigesimoséptimo), Madrid, 1998, Libro Trigésimocuarto, cap. VII, De estatuarios antiguos y de los precios excesivos de retratos y de colosos celebradísimos en Roma, p. 1074).

\section{TEXTO 26}

(p. 243)

"En nuestra edad se vio en el Capitolio, antes que se quemase haviéndole puesto fuego los Vitelianos, que en la capilla de Juno havía un perro de bronce que se estava lamiendo su llaga, del qual su admirable figura y natural semejanza del verdadero, no sólo se entiende por haver sido dedicado a aquel lugar (...)".

(C. PLINIO, Historia Natural de Cayo Plinio Segundo, (Traslada y anotada por el doctor F. Hernández (Libros primero a vigésimoquinto) y por J. De Huerta (libros vigésimosexto a trigesimoséptimo), Madrid, 1998, Libro Trigésimocuarto, cap. VII, De estatuarios antiguos y de los precios excesivos de retratos y de colosos celebradísimos en Roma, p. 1074).

\section{TEXTO 27}

(p. 245)

"No te dejes de Venus vencer ni tampoco del vino, Pues de la misma forma Venus y el vino dañan.

Venus enerva las fuerzas y Baco a su vez, excesivo, Entorpece el paso, debilitando los pies.

Muchos, movidos de un ciego amor, descubrieron secretos,

Y la demente embriaguez nunca los supo guardar.

Muchas veces Cupido ha llevado a la guerra funesta;

Muchas las manos mueve Baco a la guerra también.

Venus fatal a Troya perdió con la lucha homicida, Y a los Lapitas tú, Baco, perdiste fatal.

Y cuando, en fin, por aquélla o por ésta enloquecen los hombres,

Toda vergüenza y bondad huyen con todo temor.

Ponle ferretes a Venus, con lazos sujeta a Lieo, Para que con sus dones ni ella te dañe ni él.

Cálmete el vino la sed y feliz creadora de hijos Venus te sea: saltar límites tales daña". 
(Liber Sancti Jacobi Codex Calixtinus, Traducción al castellano de A. Moralejo, C. Torres y J. Feo, Santiago de Compostela, 2004, cap. XVII, p. 205).

\title{
TEXTO 28
}

\author{
(p. 250)
}

"Nueva parte de tierra que tracto, la cual está como levantada del Océano que la cerca, tiene su mayor longitud desde oriente a occidente, conviene a saber, desde la India hasta las Columnas de Hércules, consagradas en Cádiz, de ocho cuentos y 578 mil pasos, según le parece a Artemidoro, y según, Isidoro, nueve cuentos y 818 mil. Añade más Artemidoro: desde Cádiz, en el circuito del cabo de San Vicente, hasta el de Finisterre, por donde se estiende más largamente la frente de Hespaña, 891 mil’”.

(C. PLINIO, Historia Natural de Cayo Plinio Segundo, (Traslada y anotada por el doctor F. Hernández (Libros primero a vigésimoquinto) y por J. De Huerta (libros vigésimosexto a trigesimoséptimo), Madrid, 1998, Libro II, cap. CVIII, De la medida de toda la Tierra en longitud y altitud, p. 134).

\section{TEXTO 29}

$$
\text { (p. 250) }
$$

"España se llamó antes Iberia por el río Ebro; luego fue denominada España por (H)íspalo. También es verdaderamente llamada $(\mathrm{H})$ esperia por el $(\mathrm{H})$ espero, la estrella de occidental. Está dividida entre África y Galia, cerrada al Septentrión por los montes Pirineos, y rodeada por todas las demás partes por el mar, igual en lo salubre de su clima, fecunda en todo género de frutos, riquísima en recursos de piedras y metales".

(Crónicas asturianas (J. Gil Fernández, J. L. Moralejo y J. I. Ruiz de la Peña ed.), Oviedo, 1985, Crónica Albeldense, II Sigue una descripción de España, p. 224).

\section{TEXTO 30}

(p. 251)

"La serie de canales que han abierto por doquier, ayudan al tráfico y a las relaciones, tanto entre ellos mismos como con los forasteros. Del mismo modo, también en la pleamar se utilizan los brazos confluentes cuando los istmos que los separan se hacen navegables al quedar anegados. Las naos pasan entonces de los ríos a los esteros, y viceversa. Todo el tráfico se hace con Italia y Rhóme”.

(A. GARCÍA Y BELLIDO, España y los españoles hace dos mil años según la geografía de Strábon, Madrid, 1945, Libro III, cap. 2, pp. 86).

\section{TEXTO 31}

(p. 252)

"Después de esto, unas gentes extrañas que se llamaban almonizos expulsaron a los griegos y reinaron en España durante cuarenta años. Después llegaron numerosos ejércitos desde Alemania y las islas cercanas y expulsaron a los almonizos y reinaron 
entre los hispanos durante mucho tiempo hasta que los cartagineses pasaron desde África y sometieron una gran parte de España. Como en un principio resultó muerto Amílcar mientras asediaba Sagunto, Aníbal, el más valeroso rey de los cartagineses, reanudó más tarde el asedio y conquisto la fortaleza de Sagunto, que no es Sigüenza sino que es Murviedro, es decir, Muro Viejo, cerca de Valencia, con la que los romanos, que ya llevaban largo tiempo de hegemonía, tenían un trato de amistad y por ello la llamaban Segunda Roma".

(B. MORER DE TORLA, Crónica (Additiones a De Rebvs Hispaniae de Rodrigo Jiménez de Rada (J. Fernández Valverde ed.), Zaragoza, 2002, I, VII, Sobre las obras del rey de Hispán, pp. 76-77).

\section{TEXTO 32}

(p. 253)

"La pureza del aire y la dulce influencia del zéphyros son, en efecto, caracteres propios de Ibería, que vuelta por completo al lado del Occidente, posee un clima verdaderamente templado. Además está situada en los últimos confines de la tierra habitada, es decir, en los mismos lugares donde la fábula -como hemos dicho- ha colocado el Háides (...)".

(A. GARCÍA Y BELLIDO, España y los españoles hace dos mil años según la geografía de Strábon, Madrid, 1945, Libro III, cap. 2, pp. 114).

\section{TEXTO 33}

(p. 254)

“Consagrado a Diana; Quinto Tulio Máximo, legado de Augusto de la legión VII Gemina Feliz.

Delimitó las llanuras del campo y las dedicó a las divinidades y te levantó un templo, Delia, Virgen Triforme, Tulio, natural de Libia, jefe de la legión íbera, para conseguir herir a las cabras veloces, a los ciervos, a los jabalíes de cerdas erizadas, a la progenie de caballos salvajes para competir en carrera y derribarlos con la lanza bien llevando a pie las armas o arrojándolas desde un caballo íbero.

Dedica a Diana los colmillos de los jabalíes que mató Máximo, como hermoso testimonio de su valor.

Dedica a Diana Tulio los cuernos de los ciervos de la elevada frente, a los que venció en la llanura del páramo, montando un fogoso caballo de cascos resonantes".

(M. A. RABANAL ALONSO y S. GARCÍA MARTÍNEZ, Epigrafía romana de la Provincia de León: Revisión y actualización, León, 2001, pp. 85-89).

\section{TEXTO 34}

$$
\text { (p. 255) }
$$

"Pariendo de la región del Kálpe, cruza la Bastetania y el país de los oretanoí una cordillera cubierta de densos bosques y corpulentos árboles (...). En la costa la primera ciudad es Málaka, que dista tanto de Kálpe como ésta de Gádeira; en ella hay un emporio, que usan los nómadas que viven en la costa opuesta, y grandes talleres de salazón. Algunos creen que es la misma Maináke, que la tradición dice haber sido la última de las ciudades de los phókaioi hacia el Occidente; pero no es así, pues ésta se 
halla más lejos de Kálpe, y los vestigios de sus ruinas demuestran ser una ciudad griega, mientras que Málaka está más cerca y presenta planta fenicia”.

(A. GARCÍA Y BELLIDO, España y los españoles hace dos mil años según la geografía de Strábon, Madrid, 1945, Libro III, cap. 2, p. 142).

\section{TEXTO 35}

(p. 255)

"Sigue el puerto llamado de Menestheús (...). Inmediatamente después se halla la desembocadura del Baítis, dividida en dos brazos (...). Allí es donde se encuentra el oráculo de Menstheús y donde se alza el Kaipíonos Pyrgos, construído sobre rocas a las que circundan las olas, obra admirablemente hecha y destinada, como el Pháros, a evitar la pérdida de los navegantes (...) sus proximidades están sembradas de escollos, se hizo necesaria una señal perceptible de lejos. De aquí remontando el Baítis, está la ciudad de Eboúra y el santuario de Phosphóros, llamado también Lux Divina".

(A. GARCÍA Y BELLIDO, España y los españoles hace dos mil años según la geografía de Strábon, Madrid, 1945, Libro III, cap. 1, pp. 70-72).

\section{TEXTO 36}

(p. 256)

"Por el mismo tiempo el pueblo de los normandos, antes desconocido para nosotros -un pueblo pagano e infinitamente cruel-, vino con una armada a nuestras tierras. Ante su llegada, el ya dicho rey Ramiro congregó un gran ejército, y en el lugar que se llama Faro de Brigancio les plantó batalla; allí dio muerte a gran cantidad de ellos y sus naves las aniquiló por el fuego".

(Crónicas asturianas (J. Gil Fernández, J. L. Moralejo y J. I. Ruiz de la Peña ed.), Oviedo, 1985, A. III Rotense, 23, p. 216).

\section{TEXTO 37}

(p. 262)

"Mientras se combatía asiduamente y casi sin descanso contra los sajones y ya estaban colocadas las guarniciones a lo largo de los puntos estratégicos de las fronteras, Carlos atacó España con el mayor contingente bélico que pudo. Atravesó el desfiladero de los Pirineos, aceptó la rendición de todas las fortalezas y castillos que encontró a su paso y volvió con el ejército sano y salvo si se exceptúa que, a su regreso, tuvo ocasión de experimentar algo la perfidia vasca en las mismas cumbres de los Pirineos".

(EGINHARDO, Vida de Carlomagno (A. De Riquer ed.), Barcelona, 1986, p. $65)$.

\section{TEXTO 38}

\section{(p. 263)}

"Pero a la honra del pueblo romano toca, y no a la de un hombre solo, nombrar en este lugar todas las victorias, los títulos y triumphos del Magno Pompeyo, con las cuales no solamente igualó la fama de las hazañas de Alexandro Magno, pero cuasi las 
de Hércules y del padre Libero. (...) entró en Roma en carro triunfal, lo que no havía hecho otro ninguno antes de él. Y después, pasado a occidente y levantados en el Pyrineo muchos tropheos, juntó a sus victorias 866 pueblos que ganó desde los Alpes hasta los fines de la Hespaña Ulterior".

(C. PLINIO, Historia Natural de Cayo Plinio Segundo, (Traslada y anotada por el doctor F. Hernández (Libros primero a vigésimoquinto) y por J. De Huerta (libros vigésimosexto a trigesimoséptimo), Madrid, 1998, Libro VII, cap. XXVI, Loores del gran Pompeyo, p. 327-328).

\section{TEXTO 39}

(p. 263)

"Para que esto más claramente se conozca, pondré abaxo las palabras de los mismos actos de los triunfos de Pompeyo. En el tercero triunfo, pues, el qual tuvo el día de su nacimiento y último de octubre (...) Y para que no pongan duda en esto, ninguna piedra preciosa ha llegado hasta hoy a esta grandeza y tamaño. Huvo en aquel triunfo una luna de oro de treinta libras y tres lechos triclinares para comer; vasos de oro y piedras preciosas para nueve aparadores; tres estatuas de oro, de Minerva, Marte y Apolo; coronas de perlas, treinta y tres; un monte de oro cuadrado con ciervos y leones $\mathrm{y}$ frutas de todos géneros, y rodeada una vida de oro; un muscho hecho de perlas, en cuyo capitel estava un relox; una estatua de Cn Pompeyo, de perlas (...). ¿Así quieren que parezcas prodigioso? ¿Por ventura no es más parecida a ti aquella imagen que pusiste sobre los montes Pirineos?".

(C. PLINIO, Historia Natural de Cayo Plinio Segundo, (Traslada y anotada por el doctor F. Hernández (Libros primero a vigésimoquinto) y por J. De Huerta (libros vigésimosexto a trigesimoséptimo), Madrid, 1998, Libro Trigesimosétimo, cap. II, De las piedras preciosas traídas en el triunfo de Pompeyo y de la naturaleza del cristal y sus medicinas y de los excesos acerca dello, y quándo se hallaron las murrhinas y la demasía acerca dellas y de la naturaleza de las murrhinas y qué mentiras han escrito los autores del succino, p. 1126).

\section{TEXTO 40}

(p. 264)

"La primera parte de ellas, es como decíamos, el Occidente; es decir, Ibería; ésta, en su mayor extensión, es poco habitable (...) La región septentrional es muy fría por ser accidentada en extremo (...). La meridional casi toda ella es fértil, principalmente la de fuera de las Stélai”.

(A. GARCÍA Y BELLIDO, España y los españoles hace dos mil años según la geografía de Strábon, Madrid, 1945, Libro III, cap. 1, pp. 54-56).

\section{TEXTO 41}

(p. 268)

"Eres feliz, porque en el clima eres semejante al Paraíso; pero eres más dichosa, porque has sido encomendada al paraninfo del cielo. En otro tiempo fuiste célebre por 
las columnas de Hércules, según vanas leyendas, más ahora con más felicidad te apoyas en la columna firmísima de Santiago".

(Liber Sancti Jacobi Codex Calixtinus, Traducción al castellano de A. Moralejo, C. Torres y J. Feo, Santiago de Compostela, 2004, cap. XV, p. 169.).

\section{TEXTO 42}

(p. 270)

"Los monumentos históricos son, por oposición a los intencionados, "no intencionados", pero des un principio está claro que todos los monumentos intencionados también pueden ser no intencionados, y representan sólo un pequeño fragmento de los no intencionados. Dado que los autores de estas obras, que hoy se nos presentan como monumentos históricos, en general sólo pretendían satisfacer ciertas necesidades prácticas o ideales propias, de sus contemporáneos o, como mucho, de sus sucesores más inmediatos, y que seguramente no pensaban en dejar a las generaciones de siglos posteriores testimonios de la vida y la creación artística y cultural propias, la denominación de "monumentos" que a pesar de ello solemos dar a estas obras no puede tener un sentido objetivo, sino solamente subjetivo. Pues el carácter y significado de monumentos no corresponde a estas obras en virtud de su destino originario, sino que somos nosotros, sujetos modernos, quienes se lo atribuimos".

(A. Riegl, El culto a los monumentos modernos, Madrid, 1999, pp. 28-29).

\section{TEXTO 43}

$$
\text { (p. 274) }
$$

"Actuando de este modo, me preocupaba en primer lugar la conveniencia y coherencia de la obra antigua y la nueva, a saber, de dónde íbamos a sacar columnas de mármol o parecidas al mármol, y de tanto pensar, preguntar, buscar por diversas regiones del remoto mundo y no encontrar nada, sólo un hecho ocupaba la mente y el espíritu de los trabajadores, a saber, que de la Ciudad (pues en Roma, en el palacio de Diocleciano y en otras termas, las habíamos visto a menudo admirables), cruzando el mar Mediterráneo con una flota segura, luego el mar de Inglaterra y el tortuoso recorrido del río Sena, las consiguiéramos con gran gasto por parte de los amigos e incluso con el pago a los enemigos sarracenos cercanos".

(El abad Suger, Sobre la abadía de Saint-Denis y sus tesoros artísticos, (E. Panfosky ed.), Madrid, 2004, Segundo libro de la consagración de la iglesia de Saint-Denis, II, p. 107).

\section{TEXTO 44}

(p. 280)

"En un tiempo en que no se concebía la existencia de monumentos no intencionados, los monumentos intencionados hubieron de sucumbir a los efectos de la erosión formal y la destrucción a partir del momento en que desaparecieron aquellos para los que estaban destinados y que habían tenido un interés constante y vivo en conservarlos. En el fondo, toda la Antigüedad Clásica y la Edad Media sólo han conocido los monumentos intencionados. Una descripción exacta del proceso evolutivo que tiene lugar durante este largo período nos llevaría aquí demasiado lejos; 
mencionaremos, pues, simplemente, que en la época del Antiguo Oriente los monumentos responderían por lo general a los designios de individuos (o familias), mientras que con los griegos y los romanos surge el monumento patriótico, que desde un principio se situaba bajo la protección de mayores grupos de interesados. Esta ampliación del círculo de interesados trajo consigo también la garantía de una mayor duración, aunque, por otra parte, también dio lugar a una disminución del anterior cuidado en la elección de materiales lo más imperecederos e indestructibles posibles. (...) Por lo demás, es evidente que en la Edad Media comienzan a darse manifestaciones de una transición paulatina hacia la concepción del monumento no intencionado.

Una obra como la columna de Trajano tenía que carecer por fuerza en la Edad Media de todo tipo de protección, una vez que había sido destruido el antiguo Imperio, cuya grandeza y poder invencible ésta había de mantener presente en la memoria de las generaciones venideras. Así, sufrió entonces numerosas mutilaciones, sin que nadie pensara nunca en su restauración. El que llegara a mantenerse en pie se debe fundamentalmente a la supervivencia de los restos del patriotismo de la antigua Roma, que los romanos medievales nunca llegaron a perder por completo, por lo que, en último extremo, podemos seguir considerando la columna de Trajano como un monumento intencionado, incluso durante la Edad Media, si bien en una medida muy limitada. De todos modos, hasta entrado el siglo XIV, siempre existió el peligro de que la columna fuese sacrificada sin el menor escrúpulo a cualquier tipo de necesidad práctica. Hasta el Renacimiento este peligro no quedó conjurado, con una provisionalidad que ha llegado hasta nuestros días y que previsiblemente alcanzará a un futuro, ciertamente no ilimitado.

Este cambio se debió a que a partir del siglo XV se vino configurando en Italia un nuevo valor rememorativo. Los monumentos de la Antigüedad Clásica comenzaron a valorarse de un modo nuevo, pero ya no sólo por el recuerdo patriótico que transmitían del poder y la grandeza del antiguo Imperio, y que el romano medieval, en una ficción llena de fantasía, se imaginaba como algo todavía existente o sólo esporádicamente interrumpido, sino también debido a su "valor histórico y artístico". El que ahora se encontraran dignos de consideración no sólo monumentos como la columna de Trajano, sino incluso fragmentos insignificantes de molduras y capiteles, demuestra que es el arte clásico como tal el que iba despertando interés. Del mismo modo, el que se comenzaran a coleccionar y a archivar incluso inscripciones intranscendentes, sólo por el hecho de que procedían de la época clásica, revela el despertado interés histórico".

(A. Riegl, El culto a los monumentos modernos, Madrid, 1999, pp. 32-34).

\section{TEXTO 45}

(p. 282)

"La ruinosa antigüedad había deshecho las antiguas moles (de piedra). La obra se mantenía caída y rota por la vejez. El puente sobre el río había perdido su uso. En el tiempo actual del poderoso rey Eurico, a quién Dios ordenó conquistar tierras, éste, magnánimo, puso todo su empeño en dar a conocer su nombre; y el noble cortesano Salla también añadió honores a un antiguo nombre, puesto que después de renovar las fuertes murallas de la ciudad (de Mérida), no dudó en realizar otra obra prodigiosa.

Construyó los arcos del puente, los asentó con firmeza en lo profundo del río y remató una obra admirable, que imitaba la de un primer constructor. Además, el afecto de Zenón, obispo (de Mérida), le persuadió para fortificar en gran medida. 
La ciudad augustea (de Mérida) permanecerá dichosa por los siglos gracias al empeño del citado noble y del citado obispo".

(Traducción al castellano de J. A. Moráis Morán y S. Domínguez Sánchez).

\title{
TEXTO 46
}

\author{
(p. 283)
}

"Sin embargo, por lo divino de su espíritu no consintió que ese recinto mismo que acaba de mostrarse siguiera soterrado por toda suerte de material inmundo, acopiado fraudulentamente por los enemigos, y entregado al olvido y la ignorancia; tampoco transigió con la maldad de los culpables, antes invocado a Dios como su valedor, dicta la orden de limpiar aquella área, en la idea de que aquella parte especialmente contaminada por los enemigos debía, por su intervención, disfrutar de la magnificencia divina. Nada más dictarse la orden, todos los armatostes de la confusión fueron derribados y destrozados con todas sus estatuas de divinidades. No se detuvo sólo en esto la muestra de su celo, sino que una vez más ordena que los materiales de derribo, de piedra y de madera, sean recogidos y arrojados lo más lejos posible de la comarca. La ejecución siguió inmediatamente a la orden. Y no le bastó tampoco haber llegado hasta ahí; de nuevo acuciado por la divinidad, sea transportado el mismo suelo con toda su tierra removida por la excavación al sitio más distante posible, por estar contaminado con los demoníacos sacrificios. También esto se ejecutó sin dilación (...)”.

(E. DE CESAREA, Vida de Constantino (Introducción, traducción y notas de M. Gurruchaga, Madrid, 1994), Libro III, 27, p. 291).

\section{TEXTO 47}

$$
\text { (p. 288) }
$$

"En el nombre de Nuestro Señor Jesucristo, fue edificado el templo de San Salvador y Santiago Apóstol en el lugar del Arca Mamórea en territorio de Galicia, por disposición del gloriosísimo príncipe Alfonso con su esposa Jimena, bajo el prelado de este mismo lugar el obispo Sisnando.

Hijo piadoso del egregio y eximio príncipe Ordoño, yo, el príncipe Alfonso, junto con el citado obispo, dispusimos edificar la casa del Señor y restaurar el templo que está en el túmulo del sepulcro del Apóstol, que en otro tiempo el señor Alfonso el Magno de excelentísimo recuerdo, había construido pobremente de piedra y barro. Nosotros, impulsados ciertamente por la inspiración divina, con nuestros súbditos y familia trajimos al santo lugar de España por entre las muchedumbres de los moros las piedras de mármol que sacamos de la ciudad de Eabaca, que nuestros antepasados transportaron por mar en naves y con las que edificaron bellas casas, que permanecían destruidas por los enemigos. Por ello también se restauró con estos mismos mármoles la puerta principal de la parte occidental, sin embargo encontramos los dinteles del asiento de la puerta tal como había sido en el antiguo asentamiento, esculpidos con admirable trabajo. Construimos la puerta de la izquierda junto al templo de Juan el Bautista y Mártir, a quien del mismo modo la dedicamos, y pusimos seis columnas enteramente de piedra con otros tantos basamentos donde fue construida la bóveda de la tribuna, incluso trajimos de una ciudad de Portugal, transportadas en naves, otras columnas esculpidas, sobre las que fueron levantadas dieciocho columnas, junto con otras columnitas de mármol traídas también por el mar". 
(A. LÓPEZ FERREIRO, Historia de la Santa Iglesia, Santiago de Compostela, 1978, vol. I, pp. 50-51).

\title{
TEXTO 48
}

\author{
(p. 294)
}

“Aquí está sepultada (Valeria) esposa de Montano; séate la tierra leve benigna. ¡O mi muy amada . Podías, si el tiempo no te hubiera vencido, educar a nuestros hijos al menos durante otros fecundos cinco años; pero la corriente del agua, cogiéndote, te llevó con toda facilidad (...)".

(V. GARCÍA LOBO, Las inscripciones de San Miguel de Escalada. Estudio crítico, Barcelona, 1982, p. 60).

\section{TEXTO 49}

(pp. 298, 301, 461)

"Luego se ha de visitar junto a la ciudad de Arles un cementerio en el lugar llamado Aliscamps, para rogar por los difuntos con rezos, salmos y limosnas, según costumbre. Su longitud y anchura es de una milla. Tantas y tan grandes tumbas de mármol colocadas sobre la tierra no pueden encontrarse en cementerio de parte alguna, excepto en éste. Tienen esculpidos diversos motivos e inscripciones latinas y son antiguas por su redacción ininteligible. Cuanto más lejos se mira, tanto más lejos se ven sarcófagos. En este mismo cementerio existen siete iglesias; si en cualquiera de ellas un sacerdote celebra la misa por los difuntos, o si un seglar la hace devotamente celebrar a algún sacerdote, o si un clérigo lee el salterio, tendrá, en verdad, a los piadosos difuntos que allí yacen como valedores de su salvación ante Dios en la resurrección final. Pues allí descansan los cuerpos de muchos santos mártires y confesores, cuyas almas gozan ya en la paradisíaca morada. Su conmemoración suele celebrarse el lunes después de la octava de Pascua".

(Liber Sancti Jacobi Codex Calixtinus, Traducción al castellano de A. Moralejo, C. Torres y J. Feo, Santiago de Compostela, 2004, Libro V, cap. VIII, p. 560$561)$.

\section{TEXTO 50}

(p. 300)

"No se solía usar antiguamente entre los romanos quemar los cuerpos de los hombres, sino enterrarlos. Más de que vieron que los que se havían, en tiempo de guerras prolixas, enterarado, se desenterravan, ordenaron que sirviese el fuego de la sepultura, aunque ciertos linajes guardaron la costumbre antigua, y ansí no se escribe haverse quemado hombre en la familia de los Cornelios antes de Sylla, dictador. El cual, porqué havía hecho desenterrar el cuerpo de Cayo Mario, temiendo que conforme a la ley del Talión no se hiziese con él, ansí quiso que le quemasen".

(C. PLINIO, Historia Natural de Cayo Plinio Segundo, (Traslada y anotada por el doctor F. Hernández (Libros primero a vigésimoquinto) y por J. De Huerta (libros vigésimosexto a trigesimoséptimo), Madrid, 1998, Apéndice, Libro séptimo, cap. LIV, De la sepultura, p. 348). 


\section{TEXTO 51}

(p. 302)

"Innumerables cenizas de santos he visto en la ciudad de Rómulo, ¡oh Valeriano, consagrado a Cristo;

Me preguntas las inscripciones grabadas en los sepulcros y los nombres grabados de cada uno de los santos: difícil es que yo pueda recorrer toda su lista.

Tantas fueron las muchedumbres de justos que arrebató el furor impío en los tiempos en que la Roma troyana adoraba los dioses de sus padres.

Muchísimos sepulcros con menudas inscripciones, proclaman el nombre del mártir, o algún epitafio;

también hay, sin embargo, muchas losas de mármol cubriendo tumbas silenciosas que sólo indican el número de mártires.

Se puede saber qué cantidad de cuerpos de héroes reposan en sepulcros comunes, aunque no puedes leer ninguno de sus nombres. Recuerdo haberme enterado de que bajo una misma piedra hay allí enterradas las reliquias de sesenta mártires, cuyos nombres Cristo solo tiene averiguados, ya que fue El quien los unió a su propia amistad.

Mientras voy recorriendo con mis ojos y busco entre los Sepulcros si acaso hay en alguna parte ocultas inscripciones de antiguas hazañas (...)".

(A. PRUDENCIO, Obras completas de Aurelio Prudencio, (A. Ortega ed.), Madrid, 1981, Peristephanon, Hymnus 11. Al obispo Valeriano, sobre la Pasión del Bienaventurado Mártir Hipólito, pp. 699).

\section{TEXTO 52}

(p. 309)

"Y así, tras haber llevado por cincuenta y dos años casta, sobria, inmaculada, piadosa y gloriosamente el gobernalle del reino, amable para Dios para los hombres, dejó marchar al cielo su glorioso espíritu. Más su cuerpo, sepultado con unas exequias llenas de veneración en la ya nombrada Iglesia de Santa María, por él fundada, en un túmulo de piedra, descansa en paz”.

Crónicas asturianas (J. Gil Fernández, J. L. Moralejo y J. I. Ruiz de la Peña eds.), Oviedo, 1985, A. III “A Sebastián”, 22, p. 215).

\section{TEXTO 53}

(pp. 316 y 317 )

"No en todos los países existe la misma especie de mármol; en ciertos lugares se encuentran bloques salpicados de granitos transparentes, como si fueran de sal, que mojados y molidos son de gran uso para el enlucido. Por el contrario, donde no se le encuentra, se mojan y se muelen los pedazos o astillas que saltan al trabajar el mármol, y después de cernidos se los emplea en las obras. Ahora bien, por efecto de este 
tamizado, resultan tres clases de polvo: la parte más granulosa sirve, como se ha dicho anteriormente, mezclada con la cal, para la primera capa; la segunda, para la siguiente, y el polvo más fino, para la tercera. Aplicadas estas materias y cuidadosamente alisadas con la llana, las capas están en condiciones de recibir los colores y para que éstos tengan en los enlucidos una tonalidad brillante. Ahora bien, he aquí su diferencia y su preparación".

(M. L. VITRUVIO, Los Diez Libros de Arquitectura, (A. Blázquez ed.), Barcelona, 2000, Libro VII, cap. VI, Del mármol y cómo se le ha de preparar para los enlucidos, pp. 185-186).

\section{TEXTO 54}

(p. 317)

"Pero tratemos ahora con verdadera estimación las no vencidas maravillas que hizo Q. Marcio, rey. Este, teniendo comisión del Senado para reparar los conductos de las aguas apias, anienas y tépulas, truxo otra nueva agua a Roma, llamada de su nombre, haziendo cuevas por los montes, y acabó esta obra antes que pasase el tiempo de su pretura. Pero Agripa, siendo edil, añadió a ésta el agua virgen, y haviendo dado corriente y enmendado las demás, hizo setecientos lagos, y fuera déstos ciento y cinco fuentes que corrían y ciento y treinta arcas y otras muchas obras magníficas; sobre estas obras puso trescientas estatuas de bronce, o de mármol y quatrocientas colunas de mármol, y todas estas en el espacio de un año".

(C. PLINIO, Historia Natural de Cayo Plinio Segundo, (Traslada y anotada por el doctor F. Hernández (Libros primero a vigésimo quinto) y por J. De Huerta (libros vigésimo sexto a trigésimo séptimo), Madrid, 1998, Libro Trigésisexto, cap. XV, Del templo de Cízico y de la piedra fugitiva y del eco que resuena siete veces y del edificio sin clavos y cosas admirables de edificios de Roma, p. 1117).

\section{TEXTO 55}

(pp. 317 y 318 )

"Partiendo de nuevo de allí, llegamos en nombre de Cristo nuestro Dios a Edesa; donde una vez llegados nos dirigimos inmediatamente a la iglesia y al sepulcro de Santo Tomás. La iglesia que hay allí es grande, muy hermosa y de nueva planta (...). Vi, pues, en esa ciudad muchos sepulcros y santos monjes, viviendo unos junto a los sepulcros, otros lejos de la ciudad en monasterios que tienen en los lugares más ocultos".

(Itinerario de la Virgen Egeria (381-384) (A. Arce ed.), Madrid, 1980, En Mesopotamia, p. 235).

\section{TEXTO 56 \\ (pp. 318 y 319)}

"Pero sus discípulos, a los que él había ordenado en vida que llevaran su cuerpo a Hispania para enterrarle, recogieron el cuerpo con la cabeza durante la noche, según atestigua el papa León, llegaron hasta la orilla del mar con paso apresurado y, al buscar allí un barco para hacer el viaje a Hispania, encontraron en la playa una nave que les había sido preparada por Dios, en la cual se hicieron a la mar llenos de gozos dando 
gracias a Dios de manera unánime tras embarcar el sacratísimo cuerpo, y después de evitar Escila y Caribdis junto con las peligrosas Sirtes, siguiendo el rumbo de la mano del Señor, arribaron a bordo del afortunado navío primero al puerto de Iria y luego llevaron el venerable cuerpo al lugar que entonces se llamaba Liberum donum y que ahora se llama Compostela, donde los sepultaron siguiendo el rito eclesiástico bajo unos arcos de mármol".

(Historia Compostelana, (Emma Falque ed.), Madrid, 1994, p. 68).

\title{
TEXTO 57
}

\author{
(p. 319)
}

"Unos hombres, personas de gran autoridad, refirieron al mencionado obispo que habían visto muchas veces unas luminarias, que brillaban de noche en el bosque que, por el mucho tiempo transcurrido, había crecido sobre la tumba de Santiago, y que allí se les habían aparecido ángeles con frecuencia. Cuando escuchó esto, él mismo se dirigió al lugar donde aquéllos aseguraban que habían visto tales cosas, y efectivamente contempló con sus propios ojos las luminarias que brillaban allí. Inspirado, pues por la divina gracia, se dirigió rápidamente al referido bosquecillo y mirando alrededor con cuidado encontró entre los arbustos y malezas una pequeña casa que tenía dentro una tumba de mármol. (...) Hemos escuchado a muchos que lo cuentan que esto sucedió en tiempos de Carlomagno".

(E. FLÓREZ, España Sagrada. Teatro geográfico-histórico de la iglesia de España, Madrid, 1953, vol. VIII, pp. 1754-1862).

\section{TEXTO 58}

\author{
(p. 319)
}

"En tiempos del serenísimo rey don Alfonso el Casto fue revelado por los ángeles a un anacoreta llamado Pelayo que muy cerca de donde él vivía se hallaba enterrado el cuerpo del Apóstol Santiago. Luego, muchos fieles de la vecina iglesia de San Félix de Lobio vieron luces en el sitio indicado. Avisan de ello al obispo de Iria Teodomiro, el cual, después de tres días de ayuno, encontró el sepulcro del bienaventurado Santiago cubierto de losas de mármol".

(Historia Compostelana, (Emma Falque ed.), Madrid, 1994, p. 70).

\section{TEXTO 59}

(p. 319)

"Pero puesto que aquí hemos tratado de las características de la iglesia, trataremos ahora del venerable altar del Apóstol. En la referida y venerable catedral yace honoríficamente según se dice el venerado cuerpo de Santiago, guardado en un arca de mármol, en un excelente sepulcro abovedado, trabajado admirablemente y de conveniente amplitud, bajo el altar mayor, que se levanta en su honor".

(Liber Sancti Jacobi Codex Calixtinus, Traducción al castellano de A. Moralejo, C. Torres y J. Feo, Santiago de Compostela, 2004, Libro V, cap. VIII, p. 600). 


\section{TEXTO 60}

(p. 320)

"Entonces este rey construyó en Galicia de Compostela la iglesia que sobre el cuerpo del beato apóstol Jacobo había contribuido el rey don Alfonso el Magno, pequeña, de piedras y obras de barro, y la construyó muy hermosísima de cal y piedras cuadradas y columnas y basas marmóreas, en la era de 910".

(J. PÉREZ DE URBEL, Sampiro, su Crónica y la Monarquía leonesa en el siglo $X$, Madrid, 1952, p. 278).

\section{TEXTO 61}

(p. 321)

"El príncipe Ramiro ya tantas veces nombrado se vio muchas veces acosado por las guerras civiles. (...). Después de que descansó de las guerras civiles, edificó muchos edificios de piedra y mármol, sin vigas, con obra de abovedado, en la falda del Monte Naranco, a sólo dos millas de Oviedo (...). Tras el séptimo año de reinado, murió de muerte natural y descansa en su tumba en Oviedo".

(Crónicas asturianas (Gil Fernández, J., Moralejo, J. L., y Ruiz de la Peña, J. I., ed.), Oviedo, 1985, A. III Rotense, 24, p. 216).

\section{TEXTO 62}

(p. 322)

"Igualmente depositamos en este lugar unas vinajeras de cristal que habíamos destinado en nuestra capilla privada al servicio diario del altar. E igualmente adaptamos al servicio del altar un vaso de pórfido, obra admirablemente labrada por la mano del escultor y el pulidor, el cual había permanecido durante muchos años en un baúl de papeles, transformando su forma inicial de un ánfora en la de un águila mediante la adición de oro y plata; en él hicimos inscribir estos versos:

Esta piedra merece ser incluida entre las piedras preciosas y el oro.

Era de mármol, pero en este marco es más valiosa que el mármol”.

(El abad Suger, Sobre la abadía de Saint-Denis y sus tesoros artísticos, (E. Panfosky ed.), Madrid, 2004, XXXXIV A, p. 95).

\section{TEXTO 63}

(pp. 322 y 323)

"Bajo este mármol sepultado está Esteban, abad egregio, eximio en las costumbres, varón verdadero del Señor, severo de materia de disciplina, discreto, sabio, sobrio y sufrido, de gran honestidad y también varó de grande piedad mientras le fue dado vivir. La nación francesa nos dio una guía para los jóvenes y un admirable modelo para los ancianos. Se rindió a la frágil senectud en la fiesta de San Gervasio, que el excelso poder de Dios le sea propicio. Toma cien años, añade siete veces diez, júntales mil y sabrás la era que fue. El diecinueve de junio murió el abad Esteban. Pelayo Fernández mandó hacer la inscripción y Pedro la grabo"

(M. GUARDIA PONS, "Scariphare et pingere en la Edad Media", Patrimonio, 33, 2008, pp. 51-58). 


\section{TEXTO 64}

(pp. 338 y 804)

"Las cubiertas del arca por arriba están labradas por ambas partes en forma de escamas de peces. En su ápice hay engarzados trece cristales de roca, unos a modo de escamado, otros en forma de manzanas o granadas. Hay in enorme cristal en forma de pez grande, de trucha seguramente, erguido, con la cola vuelta hacia arriba".

(Liber Sancti Jacobi Codex Calixtinus, Traducción al castellano de A. Moralejo, C. Torres y J. Feo, Santiago de Compostela, 2004, Libro V, cap. VIII, p. 563).

\section{TEXTO 65}

(p. 349)

"De género bien distinto es la joya que hoy se envanece la iglesia de Husillos; un sepulcro pagano de procedencia desconocida, de piedra compacta y pulida como el mármol, de primor comparable al de las más esquisitas antigüedades romanas. El significado de la escena, esculpida de más de medio relieve en la delantera de la urna, no se atina fácilmente: una joven difunta tendida en el centro y junto á ella de pié un robusto mancebo, á los estremos dos mujeres reclinadas, personas de ambos sexos con grandes tendidos como para cubrir el cadáver, revelan bien una ceremonia fúnebre, pero no es tan cierto que figuren el combate de los Horacios y la muerte de su hermana á manos del último, ni menos la paz entre Sabinos y Romanos por mediación de sus hijas y esposas. Siglos hace que artistas y viajeros admiran aquella obra maestra, sin que se sepa donde y cuándo fue hallada, ni como vino á tan escondida soledad: solo parece que el sepulcro, lo mismo que el del Rey Monge en Huesca, el de Itacio en el panteón real de Oviedo, el atribuido al rey Alfonso en la catedral de Astorga, encierra restos de algún personage muy distinto de aquel para quien se labró con mil años de anterioridad. Con la perfección del arca contrasta lo tosco de la cubierta, añadida sin duda al destinarla á su actual empleo; mas carece de epitafio que permita asegurar si yace allí el conde fundador ó alguno de sus descendientes.

(A. DE MORALES, Viaje a los reinos de León, y Galicia, y Principado de Asturias, Edición facsímil, Oviedo, 1977, pp. 119-110).

\section{TEXTO 66}

(p. 350)

"Por larga y minuciosa que sea la relación que de esta urna hace Morales, no sabemos abreviarla una línea, tan interesante es. "Y estando ella, dice en sus Anales, labrada como se dirá, tiene la cubierta tumbada de una piedra tosca y lisa y tan groseramente labrada que parece se hizo de aquella manera para que la labor de la caja de abajo pareciese mejor, aunque sin este opósito le basta sola su excelencia para mucho resplandecer. En la haz desta caja está esculpido de mas que medio relieve el fin de la historia de los Horacios y Curiacios, pues está al principio la hermana muerta y allí su esposo y otra gente llorosa sobre la hermana, y entre ellos uno que no se le pareciendo mas que el colodrillo con la mano puesta en él representa mas tristeza que ningún rostro de los muy tristes que se parecen; con esto se puede creer quiso el artífice fuese este el Agamenon de Timantes, que cubriendo su pesar el buril lo muestra mayor el arte. Sigue luego una manera de sacrifico, y parece el pasarlo el padre al matador por debajo del tigilo sororio y todo aquello que Tito Livio prosigue: porque también el un testero desta 
caja están dos que teniendo un asa en medio parece sacrifican, y en el otro testero asimismo están dos que encierran en un sepulcro la urna con las cenizas de la muerta. Esta es á mi juicio la historia: la excelencia de la escultura se pude sumar con lo que dijo el famoso Berruguete, después de haber estado gran rato como atónito mirándola: ninguna cosa mejor he visto en Italia. Lo que a mí me sucedió allí es que habiendo más de veinte figuras, cuando estaba mirando la una y pensaba que allí se había acabado la perfección del arte, en pasando á mirar la siguiente entendía como tuvo el artífice de nuevo mucho que añadir. Cada figura mirada toda junta tiene estraña lindeza, y en cada miembro por sí aunque sea muy pequeño hay otra particular, que sin ayudar al todo, ella por si sola tiene su estremado artificio. Toda la escultura está muy conservada sino es una sola figura al un lado, que a lo que yo creo por estar muy relevada quitó algún grande artífice para llevarse algo de aquella maravilla. Y no se espante nadie como me detengo tanto en celebrar una piedra, porque además de mi afición natural á la pintura y escultura, desta antigualla dijo el cardenal Poggio, á quién todos conocimos por hombre de lindo ingenio y alto juicio, que podía estar en Roma entre las mas estimadas por su igual. Y á lo que yo creo debe ser sepultura de aquel conde Fernando Ansurez fundador, que aviendo avido esta rica antigualla de romanos, quiso sirviese para su sepultura. De romanos digo que es, pues para sepultura de ningún cristiano cierto que no se hiciera con tan profana historia". En el Viaje Santo, donde se espresa casi en iguales términos, añade que es de ocho pies en largo y tres y medio de alto y otro tanto de ancho, que dentro hay huesos, y que tal vez tenga algunas letras el lado de la urna arrimado a la pared, que está liso según se juzga por lo que se puede tocar.

(J. M. QUADRADO, Recuerdos y bellezas de España. Palencia, (1865), Valladolid, 1989, (reedición 1865), pp. 109-111).

\section{TEXTO 67}

(pp. 377 y 485)

"El emperador Nerón havía mandado pintar un coloso o figura suya de ciento y veinte pies, en un lienzo incógnito hasta ese tiempo. Esta pintura, estando ya acabada en los huertos Laminados encendida con un rayo, se quemó con la mejor parte de los huertos. Un liberto suyo, queriendo hazer en Anthio los juegos de los gladiadores, cubrió de pintura las puertas públicas, como todos saben, puestos los retratos al natural de todos los gladiadores y ministros (...) Pero el que comenzó a pintar los premios de gladiadores y ponerlos en público fue C. Terencio Lucano".

(Historia Natural de Cayo Plinio Segundo, (Traslada y anotada por el doctor F. Hernández (Libros primero a vigésimoquinto) y por J. De Huerta (libros vigésimosexto a trigesimoséptimo), Madrid, 1998, Libro Trigésiquinto, cap. VII, Qué colores no se gastan al fresco y con qué colores pintaron los antiguos, y quánto se pintaron la primera vez batallas de gladiadores, p. 1092).

\section{TEXTO 68}

$$
\text { (p. 485) }
$$

"De otra manera, acerca de los antiguos, en los patios estavan estas cosas para que fuesen vistas, no estatuas de artífices estrangeros ni de bronce o mármol, sino retratados en cera se ponían los rostros cada uno en su caxa, para que huviese imágenes que acompañasen las honras funerales y mortuorios de la familia, y siempre en 
muriendo alguno estava presente todo el pueblo o personas que havía havido en algún tiempo de aquel linaje, y los epitafios de sus nombres, honras y hechos discurrían con líneas al rededor de las imágenes pintadas, y los caxones se llenavan de libros y de memorias de las cosas hechas en el Magistrado".

(Historia Natural de Cayo Plinio Segundo, (Traslada y anotada por el doctor F. Hernández (Libros primero a vigésimoquinto) y por J. De Huerta (libros vigésimosexto a trigesimoséptimo), Madrid, 1998, Libro Trigésiquinto, cap. II, Honra de imágenes, p. 1087).

\section{TEXTO 69}

(p. 349)

“(...) está esculpido de mas que medio relieve el fin de la historia de los Horacios y Curiacios, pues está al principio la hermana muerta y allí su esposo y otra gente llorosa sobre la hermana (...) con esto se puede creer quiso el artífice fuese este el Agamenón de Timantes (...)".

(A. DE MORALES, Viaje a los reinos de León, y Galicia, y Principado de Asturias, Edición facsímil, Oviedo, 1977, pp. 119-110).

\section{TEXTO 70}

(p. 521)

"Tampoco pertenece al Estado, el precioso Monumento que se conserva en una capilla, bastante obscura, de la Iglesia Parroquial de este pueblo. Consiste aquel en un antiguo sepulcro de mármol blanco, sin tapa alguna que lo cubra; su largo ocho pies, y tres de ancho y altura. En su frente está esculpida de más de bajo relieve, la terminación del Justo encono y deseos de venganza de Sabinos contra los Romanos; en el lado opuesto hay figuras en acción de sacrificio; y en otro lado están depositando en un sepulcro una urna dentro de la que se debían conservar las cenizas de algún héroe.

El célebre pintor escultor y arquitecto Alonso Berruguete, quedo admirado contemplando la excelencia de la ejecución, y los conocimientos profundos de la belleza ideal que rebelaba esta urna, asegurando que "competía con las mejores obras que había visto y estudiado en Italia y que ninguna había hallado mejor".

También el Cardenal Paggio habiéndola visto dijo al secretario Gracias Padre, "Esta urna merecía estar en Italia en medio de las más preciosas antigüedades que allí se conservan, pues que su mérito la hace digno rival de aquellas (...). Este singular monumento dejará de existir muy pronto, si nuestro ilustrado Gobierno no exige que sea trasladado a la Capital, depositándole y al cuidado de algún cuerpo facultativo, tal como la Sociedad económica. Es facilísima su total inexistencia; pues que estando colocado a la altura sobre el pavimento de la iglesia, llegan a él con gran facilidad los muchachos, y estos, no sólo en las noche de Miércoles y Jueves Santo con gruesas piedras, hacen gala de la fuerza de sus puños, sino que a competencia se proponen hacer amputaciones en las bellas figuras que aquella antigüedad presenta en sus tres lados; deshaciendo en un solo instante una preciosidad que costó muchas fatigas y estudios a su autor. El centro o interior de este sarcófago sirve en la actualidad de depósito a muebles inservibles de la Iglesia. ¡Qué ratos tan fatales para el viajero instruido, al hallar en estado tan triste y descuidado, preciosidades como esta que no tiene precio! (...)". 
"En cumplimiento de los dispuesto por S. A. el Regente del Reino en orden comunicada por el Excelentísimo Sr. Ministro de Fomento con fecha 8 de noviembre último, tengo el honor de acompañar adjunto el talón de consignación en el ferrocarril del Norte del Sepulcro Romano que existía en la Iglesia de Husillos en esta provincia, y la cuenta de los gastos ocasionados en la misma, esperando que V. S. se servirá acusarme recibo de dicho Sepulcro que va perfectamente encajonado y embalado y abonar el importe de la referida cuenta a cargo de los gastos de material del Museo que tan dignamente dirige, según está determinado en dicha disposición de S. A.

Dios guarde a V. S. muchos años. Palencia, 21 de diciembre de 1870”.

(Madrid, Archivo de la Real Academia de Bellas Artes de San Fernando, sig. 77/2, Monumentos en general, Informe de Justo María Velasco adjunto a oficio del Jefe Político de la Provincia de Palencia al Ministro de la Gobernación de la Península de 30 de junio de 1844).

\section{TEXTO 71}

(p. 711)

“Agradó al obispo y a los otros que estaban presentes al parecer de la reina y se les prohibió que tomaran las armas en la iglesia. Cuando conocieron esto, bramaron los traidores y persiguiendo, por la iglesia a los mensajeros del obispo y de la reina que les habían dicho que depusieran las armas, se enfrentaron a ellos; huyen los legados a lo más alto de la iglesia, vociferan los infames traidores gritos de guerra, sube el clamor a los oídos de todos, se descubre el ánimo de los traidores y hacen público lo que durante tanto tiempo habían intentado. Toda la ciudad resuena, corren a las armas y se apresuran a la lucha. La Fama, mal más veloz que ningún otro, propaga que los soldados del obispo y de la reina han atacado a los compostelanos. Intervinieron algunos, tanto canónigos como ciudadanos, ajenos a esta nefanda locura, los cuales quisieron calmar tan gran audacia de sus locos conciudadanos. Pero, ¿qué podían hacer unos pocos contra tantos miles? Corren los cómplices de la traición al combate y, atrayéndose a los conocidos y amigos, quieren acabar con el obispo y la reina que habían querido acabar con ellos. El obispo y la reina en los palacios de éste, después oyeron los clamores y el estrépito de la ciudad y de qué manera los compañeros del Iscariotes habían incitado a los ciudadanos contra ellos, tuvieron miedo, pues vieron que la audacia de los traidores se extendía y que se hacía más violeta la rebelión, que la iglesia de Santiago y los palacios eran asediados por grupos de gente armada y eran atacados con más fuerza. No saben qué decisión tomar contra tan nefanda audacia. Es tomada la iglesia del Apóstol con frecuentes asaltos, vuelan piedras, las flechas, los dardos sobre el altar y se llevan a cabo sacrílegos combates por parte de los traidores. ¿A qué no se atreverán manos infames? Los perversísimos atacantes pegan fuego a toda la iglesia de Santiago y la incendian por uno y otro lado; pues no poca parte de la iglesia estaba cubierta con tablas y paja. ¡Oh, maldad! La iglesia del Apóstol, tan venerada y tan digna, arde y ningún honor se le da a tan apreciado patrono. ¡Oh, dolor! La llama de la iglesia del Apóstol sube a lo alto y por todas sus partes se ofrece un horrendo espectáculo. Todos los que están presentes, tanto hombres como mujeres, temerosos de Dios, lloran y gimen y maldicen a los autores de tan gran crimen. ¡Oh! ¡Cuánto era el llanto de los peregrinos que desde diversas regiones habían venido a venerar el cuerpo del Apóstol!”.

(Historia Compostelana, (Emma Falque ed.), Madrid, 1994, pp. 272-273). 


\section{TEXTO 72}

(pp. 731 y 732)

"Después de la fuente está el atrio o paraíso, según dijimos, pavimentado de piedra, donde entre los emblemas de Santiago se venden a los peregrinos las típicas conchas, y hay allí para vender botas de vino, zapatos, morrales de piel, bolsas, correas, cinturones y toda suerte de hierbas medicinales y además drogas, y otras muchas cosas. Los cambiadores, los hospederos y otros mercaderes están en el camino francés. El paraíso tiene dimensiones en ambos sentidos un tiro de piedra (...). Después del atrio se encuentra, pues, la puerta septentrional o Francesa de la misma basílica de Santiago, en la cual hay dos entradas bellamente esculpidas con las siguientes obras. En cada entrada se encuentran por el exterior seis columnas, unas de mármol y otras de piedra, tres a la derecha y tres a la izquierda, es decir, seis en una entrada y seis en la otra, de forma que hay doce columnas. Y sobre la columna que está entre los dos portales por fuera, en la pared, está el Señor sentado en un trono de majestad y con la mano derecha da la bendición y en la izquierda tiene un libro. Y alrededor de su trono y como sosteniéndolo, están los cuatro evangelistas; y a su derecha está esculpido el paraíso y en él está representado el mismo Señor otra vez reconviniendo del pecado a Adán y Eva; y a la izquierda está también en otra figura arrojándolos del paraíso. Allí mismo, pues, hay talladas por todo alrededor muchas imágenes de santos, de bestias, de hombres, de ángeles, de mujeres, de flores y de otras criaturas, cuya esencia y calidad no podemos describir a causa de su gran cantidad. Sin embargo, sobre la puerta que está a la izquierda, según se entra a la catedral, está esculpida en el tímpano la Anunciación de la santísima Virgen María. Háblale también allí el ángel Gabriel. En cambio, a la izquierda de la entrada lateral sobre las puertas se ven relieves de los meses del año y otras muchas hermosas alegorías. En las paredes hay en la parte de afuera dos grandes y feroces leones, uno a la derecha y otro a la izquierda, que siempre miran hacia las puertas como si las vigilasen. Arriba, en las jambas, se ven cuatro apóstoles que llevan sendos libros en la mano izquierda y con las diestras levantadas bendicen a los que entran en la iglesia; Pedro está en la entrada de la izquierda, a la parte derecha, Pablo a la izquierda; y en la entrada derecha están el apóstol Juan a la derecha y Santiago a la izquierda. Y sobre las respectivas cabezas de los apóstoles hay esculpidas las de unos bueyes, que sobresalen de los dinteles".

(Liber Sancti Jacobi Codex Calixtinus, Traducción al castellano de A. Moralejo, C. Torres y J. Feo, Santiago de Compostela, 2004, pp. 595-596).

\section{TEXTO 73}

(p. 733)

"Cuando nosotros los franceses queremos entrar en la basílica del Apóstol, lo hacemos por la parte septentrional, ante cuya entrada está junto al camino el hospital de peregrinos pobres de Santiago y después, más allá del Camino, se encuentran un atrio en donde hay nueve peldaños de bajada. Al pie de la escalera de este atrio existe una admirable fuente a la que en todo el mundo no le encuentra semejante. Tiene, pues, esta fuente al pie tres escalones de piedra sobre los que está colocada una hermosísima taza de piedra, redonda y cóncava, a manera de cubeta o cuenco, y que es tan grande que en ella me parece que pueden cómodamente bañarse quince hombres. En su centro se eleva una columna de bronce gruesa por abajo, de siete caras cuadradas y altura proporcionada, de cuyo remate surgen cuatro leones por cuyas bocas salen cuatro 
chorros de agua para mitigar la sed a los peregrinos de Santiago y a los habitantes de la ciudad. Y estos cuatro chorros, después que salen de la boca de los leones, caen seguida en la misma taza de abajo y saliendo de allí por un agujero de la misma taza escapan por debajo de la tierra. De la misma manera que no puede verse de dónde viene el agua, tampoco puede verse dónde va. Es luego el agua aquella dulce, nutritiva, sana, clara, muy buena, caliente en invierno y fresca en verano. En la citada columna se encuentra la siguiente inscripción grabada de esta forma en dos líneas por todo alrededor bajo los pies de los leones: $\uparrow$ Yo, Bernardo, Tesorero de Santiago, traje aquí esta agua y realicé la presente obra para remedio de mi alma y de las de mis padres en la era MCLX el tercero de los idus de abril”.

(Liber Sancti Jacobi Codex Calixtinus, Traducción al castellano de A. Moralejo, C. Torres y J. Feo, Santiago de Compostela, 2004, De la Fuente de Santiago, pp. 593-594).

\section{TEXTO 74}

(p. 770)

"Y el 1 de julio siguiente, con la aprobación del Señor, el mencionado Diego fue elegido obispo, en la era 1138 (año 1100), y a la Pascua siguiente fue consagrado obispo el 22 de abril (...). Y tras dirigirse en compañía de muchas personas de esta iglesia después de su elección a Toledo (...), recuperó una parte del señorío que la iglesia de Santiago había perdido injustamente en tiempos de sus predecesores, y puesto que sabíamos que el electo según un privilegio de su predecesor don Dalmacio debía ser consagrado en Roma, profundamente nos afligimos con suspiros entrecortados, pensando que podría tal vez ser hecho prisionero en el camino de ida o de vuelta por las dolosas asechanzas de sus enemigos".

(Historia Compostelana, (Emma Falque ed.), Madrid, 1994, pp. 86).

\section{TEXTO 75 \\ (pp. 770 y 771)}

"No mucho tiempo después, el venerable obispo, con infinita solicitud hacia el ministerio y dignidad de la santa Iglesia, junto con los más nobles de esta iglesia, se presentó ante nuestro católico emperador, el rey don Alfonso, con humildísimo afecto, y expuso en sus discretos oídos lo que había proyectado y guardaba en su corazón para utilidad de su iglesia (...). Y así, antes de salir de la región de tierra de Campos, le recibió honestamente con una gran procesión el obispo García de la iglesia de Burgos, quién no le dejó de obsequiarle y atenderle muy especialmente en las parroquias de la diócesis (...) el arzobispo de la iglesia de Auch le salió al encuentro en la festividad de la Natividad de Santa María que se celebra cada año entre los naturales de aquel lugar (...). Deteniéndose desde allí un poco en los asilos y señoríos de Santiago, entró en Tolosa rodeado de honores (...) llegó con la ayuda del Señor a través de caminos tortuosos al monasterio de San Pedro de Moissac como a puerto tranquilo; y después de ser recibido allí con toda dignidad y alabanzas con una sagrada procesión, se dirigió con algunos superiores de este monasterio a la ciudad de Cahors (...). Y cuando salió de allí, llegó al monasterio de San Pedro de Uzerche donde fue recibido no menos honrosamente por los monjes y el abad que allí vivían. Y así, según hemos narrado anteriormente, honrado por todos en todas partes, llegó felizmente a Limoges, donde se sabe con seguridad que está el cuerpo de San Marcial (...). Y al llegar a Cluny, capital de toda la religión 
monástica, el mencionado obispo, rodeado de tanta y tan grande y santa veneración, fue recibido familiarmente y de manera especial con diversas procesiones en la beatitud de aquella santísima congregación (...). Luego, fortalecido por las bendiciones de la sagrada congregación, llegó con el auxilio del Señor por los monasterios y posesiones de los cluniacenses hasta los valles de Soriana. Allí también el venerable conde Humberto le recibió (...) y le llevó hasta la ciudad de Susa (...). Se dirigió a Roma después de diversas vicisitudes vestido de soldado. $\mathrm{Y}$ al entrar en el sagrado palacio, porque ninguno de los obispos de esta iglesia había ido a Roma voluntariamente, con tanto afecto y cordialísima consideración le recibió el Papa (...) el venerable obispo (...) pidió la dignidad del palio por medio de sus clérigos al Papa (...). Por fin, con la ayuda de la divina gracia y confiando en la misericordia de Dios, recibió religiosamente el palio que tanto había deseado, en el altar de la iglesia de San Lorenzo según la costumbre romana, y lo entregó para siempre (...) a la iglesia de Santiago".

(Historia Compostelana, (Emma Falque ed.), Madrid, 1994, pp. 99-106).

\section{TEXTO 76}

(p. 777)

"Y como el fiel administrador puesto por un señor al frente de su familia para que les dé el sustento en el momento necesario, así él se apresuraba a sustentar a los pueblos extraños con toda clase de alimentos espirituales, enseñando con clemencia, instruyendo con suma bondad esforzándose con todo su poder por apartar a todos de errores de los ídolos. ¡Oh vaso lleno de espíritu santo; que suministraba en abundancia a las gentes la sustancia del trigo de Cristo y la flor del aceite y la sobria embriaguez del vino. Porque fue ojo para el cielo y pie para el cojo, padre de los pobres y desgraciados, consolador de huérfanos y viudas. Él, como un piloto, condujo la nave de la Iglesia cargada con las riquezas de los pueblos al puerto de salvación, echando el ancla de la fe en el mar de este agitado mundo. Él, como un mayordomo de las viñas, plantó con gran trabajo la viña de la Iglesia, extirpando los abrojos de los vicios, corando los espinos de las malas acciones, formando buenas cepas, poniendo alrededor el seto de los dogmas evangélicos contra las bestias salvajes, espantando lejos de ella a las zorras de la herejía que acostumbran a destruir las viñas, y edificó también en ella el lagar del nuevo altar y la torre de la fe".

(Liber Sancti Jacobi Codex Calixtinus, Traducción al castellano de A. Moralejo, C. Torres y J. Feo, Santiago de Compostela, 2004, cap. VI, pp. 70-71).

\section{TEXTO 77}

(pp. 777 y 778 )

"Extendióse la voz por todo el orbe, del compañero del Señor: no queda lugar donde se niegue su alta gloria. Noble de antiguo tronco descendiente, pero más noble con razón en Cristo. Rica luz, cima augusta, santo ornato, en cuyo elogio todo honor milita (...). En las ramas de la herejía injerta gérmenes píos de la fe, y lo que era acebuche, rebrota pingüe olivo. El árbol seco y deshojado nuevas galas ostenta que su fruta anuncian. La triste higuera destinada al fuego sin esperanza, su seno prepara a dar fruto, de abono bien nutrido. La uva hinchada en el pámpano, que pasto sería de los pájaros, con este guardián el buen lagar no ha de perderla. Viñador en las viñas apostólicas, puso en forma los liños, removiendo la tierra con la azada y recortando los 
sarmientos con hábil podadera. Del campo del Señor la vid silvestre y estéril extirpó, y se ven ahora racimos en lo que antes fue matojo. Del sembrado de Dios la vil cizaña, y por igual las mies lozana crece (...)".

(Liber Sancti Jacobi Codex Calixtinus, Traducción al castellano de A. Moralejo, C. Torres y J. Feo, Santiago de Compostela, 2004, cap. VI, pp. 77-83). 


\section{2. FUENTES.}

\section{A. FUENTES NARRATIVAS.}

ALBERTUS AQUENSIS, "Historia Hierosolymitana", Itinera Hierosolvmitana Crucensignatorum (saec. XII-XIII) (S. de Sandoli ed.), vol. I, Jerusalem, 1978, pp. 270-307.

ANONYMUS, "Gesta Francorum Expugnantium Iherusalem", Itinera Hierosolvmitana Crucensignatorum (saec. XII-XIII) (S. de Sandoli ed.), vol. I, Jerusalem, 1978, pp. 133-167.

ANONYMUS, "Qualiter sita est civitas hierosolymitana", Itinera Hierosolvmitana Crucensignatorum (saec. XII-XIII) (S. de Sandoli ed.), vol. I, Jerusalem, 1978, pp. 1-5.

El abad Suger, Sobre la abadía de Saint-Denis y sus tesoros artísticos (E. Panfosky ed.), Madrid, 2004.

BENJAMÍN DE TUDELA, Libro de Viajes de Benjamín de Tudela (J. R. Magdalena Nom de Déu ed.), Barcelona, 1989.

ID., The Itinerary of Benjamin de Tudela (M. Nathan Adler ed.), London, 1909.

CAFARUS DE CASCHIFELONE, "De Liberatione Civitatum Orientis", Itinera Hierosolvmitana Crucensignatorum (saec. XII-XIII) (S. de Sandoli ed.), vol. I, Jerusalem, 1978, pp. 330-345.

CARTONENSIS, F., "Historia Hierosolymitana Gesta Francorum Iherysalem peregrinatium", Itinera Hierosolvmitana Crucensignatorum (saec. XII-XIII) (S. de Sandoli ed.), vol. I, Jerusalem, 1978, pp. 107-131.

CARVAllO, A. L. DE, Antigüedades y cosas memorables del Principado de Asturias, Oviedo, 1695, (reedición 1988).

CAYO PLINIO SEGUNDO, Historia Natural de Cayo Plinio Segundo, (Traslada y anotada por el doctor F. Hernández (Libros primero a vigésimoquinto) y por J. De Huerta (libros vigésimosexto a trigesimoséptimo), Madrid, 1998.

Concilios Visigóticos e Hispanorromanos, (J. Vives ed.), Barcelona, 1963

Crónicas Asturianas (J. Gil Fernández, J. L. Moralejo y J. I. Ruiz de la Peña, eds.), Oviedo, 1985.

Diccionario de la Real Academia de la Lengua Española, Madrid, 2001.

EGEA, J. M., Relato de cómo se construyó Santa Sofía. Según la descripción de varios códices y autores, Granada, 2003. 
EGINHARDO, Vida de Carlomagno (A. De Riquer ed.), Barcelona, 1986.

EUSEBIO DE CESAREA, Vida de Constantino, (introducción, traducción y notas de M. Gurruchaga), Madrid, 1994.

ID., Historia Eclesiástica, (texto, versión española, introducción y notas por A. Velasco-Delgado), Madrid, 2008.

Il fascino di Roma nel Medioevo. Le «Meraviglie di Roma» di Maestro Gregorio (C. Nardella ed.), Roma, 1998.

FRESNE DU CANGE, C., Glossarium mediae et infimae latinitatis, 8 vols., Graz, 1954.

FLEURY, A. DE Vie de Gauzlin, Abbé de Fleury. Vita Gauzlini Abatís Floriacensis Monasterio (R.-H. Bautier y G. Labory ed.), Paris, 1969.

FLÓREZ, E., España Sagrada. Teatro geográfico-histórico de la iglesia de España, 29 vols., Madrid, 1953.

GARCÍA Y BELLIDO, A., España y los españoles hace dos mil años según la geografía de Strábon, Madrid, 1945.

Hildeberti Cenomanensis Carmina minora (A. Brian Scott ed.), Leipzig, 1969.

Historia Compostelana, (Emma Falque ed.), Madrid, 1994.

Itinerario de la Virgen Egeria (381-384) (A. Arce ed.), Madrid, 1980.

ISIDORO DE SEVILLA, Etimologías, (Edición bilingüe preparada por J. Oroz Reta y M. A. Marcos Casquero), 2 vols., Madrid, 1983.

JANVIER, Y., La géographie d'Orose, Paris, 1982.

Liber Sancti Jacobi Codex Calixtinus (Traducción al castellano de A. Moralejo, C. Torres y J. Feo), Santiago de Compostela, 2004.

MOLINER, M., Diccionario del uso del español, Madrid, 2001.

MORALES, A. de, Crónica general de España que continuaba Ambrosio de Morales, Madrid, 1971.

ID., Viaje a los reinos de León, y Galicia, y Principado de Asturias, Oviedo, 1765, (reedición 1977).

MORER DE TORLA, B., Crónica (Additiones a De Rebvs Hispaniae de Rodrigo Jiménez de Rada (J. Fernández Valverde ed.), Zaragoza, 2002.

Obras completas de Aurelio Prudencio, (A. Ortega ed.), Madrid, 1981. 
Pasionario Hispánico, (Introducción, edición, crítica y traducción de P. Priesco Chueca), Sevilla, 1995.

PÉREZ DE URBEL, J., Sampiro, su Crónica y la Monarquía leonesa en el siglo X, Madrid, 1952.

Poema de Fernán González (J. Victorio, ed.), Madrid, 1981.

Poema de Fernán González e Hispano Diego García, (José Hernando Pérez, ed.), Salamanca, 2001.

QUADRADO, J. M., Recuerdos y bellezas de España. Palencia, (1865), Valladolid, 1989, (reedición 1865).

RADULFUS CADOMENSIS, "Gesta Tancredo in Expeditione Hierosolymitana", Itinera Hierosolvmitana Crucensignatorum (saec. XII-XIII) (S. de Sandoli ed.), vol. I, Jerusalem, 1978, pp. 182-233.

SAN BERNARDO, Obras completas de San Bernardo (ed. preparada por los monjes cistercienses), Madrid, 1986, vol. IV.

VITRUVIO, M. L., Los Diez Libros de Arquitectura, (A. Blázquez ed.), Barcelona, 2000 .

YEPES, A., Crónica General de la Orden de San Benito, 2 vols., Madrid, 1615, (reedición 1960). 


\section{B. FUENTES BIBLIOGRÁFICAS.}

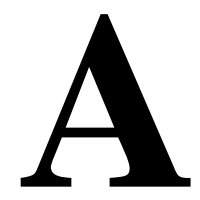

ABAD CASAL, L., La pintura romana en España, 2 vols., Cádiz, 1982.

ID., El arte funerario hispanorromano, Madrid, 1991.

ABAD CASTRO, C., "Espacios y capillas funerarias de carácter real", Maravillas de la España medieval: Tesoro sagrado y monarquía, 2 vols., Valladolid, 2001, vol. I, pp. 63-71.

ABÁSOLO, J. A., "Las comunicaciones", Hispania. El legado de Roma, Zaragoza, 1998, pp. 151-158.

ADAMO MUSCETTOLA, S., "El mobiliario doméstico", Pompeya. Historia, Vida y Arte de la ciudad sepultada (M. Ranieri Panetta, ed.), Barcelona, 2004, pp. 258285.

ADÁN ÁlVAREZ, G. E., "San Pedro de Arrojo (Quirós): avatares constructivos de un templo románico", Excavaciones arqueológicas en Asturias: 1999-2002, Oviedo, 2007, pp. 365-370.

ADELL I GISBERT, J.-A. y BADIA I HOMS, J., "San Pere de Rodes", Catalunya romànica. L'Empordà: 2, vol. IX, Barcelona, 1990, pp. 657-703.

ADHÉMAR, J., “La Fontaine de Saint-Denis”, Revue Archéologique, I, 1936, pp. 224232.

ID., Influences antiques dans l'art du Moyen Âge français; recherches sur les sources et les thèmes d'inspiration, London, 1939.

ID., Influences antiques dans l'art du Moyen Âge français, Paris, 1996.

AGUIRRE, T., “Arte Romano”, Ars Hispaniae, vol. II, Madrid, 1947, pp. 11-179.

AINAUD DE LASARTE, J., "Noticias de San Pedro de Roda", Revista de Gerona, V, 9, 1956, pp. 33-35.

AINI, S., "Mirabilia Urbis Romae", Romei \& Giubilei. Il pellegrinaggio medievale a San Pietro (350-1350) (M. D’Onofrio ed.), Milano, 1999, pp. 199-204.

ALCHERMES, J., "Spolia in Roman Cities of the Late Empire: Legislative Rationales and Architectural Reuse", Dumbarton Oaks Papers, 48, 1994, pp. 167-178. 
ALCOY, R., "Les pintures bizantinitzants de Sant Esteve d'Andorra La Vella en el món europeu del 1200", Lambard, V, 1989-1991, pp. 23-47.

ALMAGRO-GORREA, M., "Hispania a la llegada de Roma", Hispania. El legado de Roma, Zaragoza, 1998, pp. 37-50.

ALTO BAUER, F., Fontana delle Pigna nell'atrio dell'antica Basilica di San Pietro", Carlo Magno a Roma, Roma, 2001, ficha catalográfica 44, pp. 198-199.

ID., "Sarcofago paleocristiano riutilizzato per Leone III", Carlo Magno a Roma, Roma, 2001, ficha catalográfica 11, pp. 122-123.

ID., "Veduta dell'atrio dell' antica Basilica di San Pietro", Carlo Magno a Roma, Roma, 2001, ficha catalográfica 43, pp. 196-197.

ÁLVAREZ MARTÍNEZ, M. S., "El Bestiario en la Plástica Monumental del Románico Asturiano", El discurso artístico en oriente y occidente: semejanzas y contrastes (J. L. Caramés Lage, C. Escobedo de Tapia, J. L. Bueno Alonso, coords.), vol. 1, Oviedo, 1997, pp. 67-84.

ID., El románico en Asturias: monumentos y caminos, Oviedo, 1997.

ID., El románico en Asturias, Oviedo, 1999.

ID., "Cámara Santa", Enciclopedia del Románico en Asturias. Asturias, 2 vols., Aguilar de Campo, 2006, vol. II, pp. 607-622.

AMBROSETTI, G., "Haterii, Monumento degli", Enciclopedia dell'arte antica, classica, e orientale, vol. III, Roma, 1960, pp. 1112-1115.

ANNE ORR, B., The sculptural program of the Royal Collegiate Church of San Isidoro in Leon, The Ohio State University, 1988.

ARA GIL, J., "Escultura", Historia del Arte de Castilla y León. Arte Gótico, vol. III, Valladolid, 1995, pp. 219-328.

ARAGONÉS ESTELLA, M., "El desaparecido capitel de los Ríos del Paraíso de la catedral románica de Pamplona", Archivo Español de Arte, 68, 272, 1995, pp. 410-418.

ARBEITER, A., "Santiago de Compostela (Prov. A Coruña), Ausgrabungen unter der Kathedrale", Christliche Denkmäler des frühen Mittelalters vom 8. bis ins 11 . Jahrhundert, Mainz-Rheim, 1999, pp. 216-224.

ID., voz “Asturie”, Enciclopedia dell'arte medievale, vol. II, Roma, 1991, pp. 674-675.

ID., "Los edificios de culto cristiano: escenarios de la liturgia", Repertorio de arquitectura cristiana en Extremadura: época tardoantigua y altomedieval (P. Mateos Cruz y L. Caballero Zoreda ed.), Mérida, 2003, pp. 117-230. 
ARCE MARTÍNEZ, J., "La "crisis" del siglo III d. C. en Hispania y las invasiones bárbaras", Hispania antiqua, 8, 1978, pp. 257-270.

ID., Funus Imperatorum. Los funerales de los emperadores romanos, Madrid, 1988.

ID., "Missorium di Teodosio", Hispania Romana Da Terra di Conquista a Provincia dell'Impero, Roma, 1997, ficha catalográfica 285, p. 444.

ID., "El Missorium de Teodosio I: Problemas históricos y de iconografía", El disco de Teodosio (M. Almagro Gorbea coord.), Madrid, 2000, pp. 281-288.

ID., "Imparatori divinizzati”, Aurea Roma: dalla città pagana alla città cristiana (S. Ensoli y E. La Rocca eds.), Roma, 2000, pp. 244-248.

ID., “Arte romano en Hispania”, El arte de España. Altamira y los orígenes del arte español, vol. I, Barcelona, 2002, pp. 43-80.

ID., "Agusta Emerita en los siglos IV-V d. C.: la documentación escrita", Anejos de Archivo Español de Arte (P. Mateos Cruz y L. Caballero Zoreda ed.), XXIX, 2003, pp. 121-131.

ARIAS, P. E., voz "Caulonia", Enciclopedia dell'arte antica, classica, e orientale, vol. II, Roma, 1959, pp. 443-444.

ARIAS PÁRAMO, L., La Cámara Santa de la Catedral de Oviedo, Gijón, 1998.

ID., Prerrománico asturiano: el arte de la monarquía asturiana, Gijón, 1999.

ID., "La escultura arquitectónica en el área central del Reino de Asturias: tipos, tradiciones y tendencias", Escultura decorativa tardorromana y altomedieval en la Península Ibérica (L. Caballero Zoreda y P. Mateos Cruz ed.), Madrid, 2007, pp. 85-132.

ARIAS SÁNCHEZ, I., "La orfebrería y los esmaltes medievales de Silos", El Scriptorium silense y los orígenes de la lengua castellana, Valladolid, 1995, pp. 35-83.

ID., "Silos y Limoges", Boletín del Museo Arqueológico Nacional, XIII, 1995, pp. 7584.

ARMSTRONG, G. T., "Constantine's Churches: Symbol and Structure", The Journal of the Society of Architectural Historians, 33, 1, 1974, pp. 5-16.

ALMAGRO, M., et alii, Qusayr'Amra. Residencia y baños omeyas en el desierto de Jordania, Madrid, 1975.

ALONSO ABAD., M. P., "Estatua yacente de un obispo", Los Caminos de Santiago: el arte en el período románico en Castilla y León, España, siglos XI a XIII (J. C. Elorza Guinea dir.), Valladolid, 2006, p. 315. 
AlONSO ÁlvareZ, R., "La Colegiata de San Pedro de Teverga. La "imagen medieval" de un edificio reformado", Asturiensia Medievalia. Homenaje a Juan Uria, Oviedo, 1995, pp. 225-242.

ID., "De Carlomagno al Cid: la memoria de Fernando III en la Capilla Real de Sevilla", Actas del VIII Congreso de Estudios Medievales. Fernando III y su tiempo (1201-1251), León, 2003, pp. 471-488.

ID., "Los enterramientos de los reyes visigodos", Fundamentos medievales de los particularismos hispánicos. IX Congreso de Estudios Medievales Fundación Sánchez Albornoz, León, 2005, pp. 361-375.

ALTO BAUER, F., "Sarcofago paleocristiano riutilizzato per Leone III", Carlo Magno a Roma, Roma, 2001, ficha catalográfica 11, pp. 122-123.

AMADIO, A., I mosaici di Santa Constanza, Roma, 1984.

ANDALORO, M., "Maestri bizantini, 1145-1148. Mosaici dell'abside. CefalùCattedrale", XI Catalogo di opere d'arte restaurate (1976-78), Palermo, 1980, pp. 19-25.

ID., "I seculi della clandestinitá. Lo spazio del culto", L’Arte Medievale in Italia, Firenze, 1988, pp. 49-74.

ID., “Castelseprio. Affreschi”, Enciclopedia dell'Arte Medievale, vol. IV, Roma, 1993, pp. 453-459.

ID., voz “Cefalù. Mosaici”, Enciclopedia dell’Arte Medievale, vol. IV, Roma, 1993, pp. 607-610.

ID., voz "Costantinopoli. Pittura", Enciclopedia dell'arte medievale, vol. V, Roma, 1994, pp. 406-421.

ID., voz "Palermo. Mosaici", Enciclopedia dell'arte medievale, vol. VIII, Roma, 1997, pp. 528-530.

ID., La pittura medievale a Roma 312-1431. Corpus. L'Orizzonte tardoantico e le nuove immagini, vol. I, Roma, 2006.

ID., La pittura medievale a Roma 312-1431. Atlante Perocorsi Visivi. Suburbio, Vaticano, Rone Monti, vol. I, Milano, 2006.

ID., "Santa Prassede", La pintura medievale a Roma 312-1431. Atlante percorsi visivi, 6 vols., Roma, 2006, vol. I, pp. 295-306.

ANDALORO, M. y ROMANO, S., "L'immagine nell'abside", Arte e iconografia a Roma da Costantino a Cola di Rienzo: una premessa (M. Andaloro y S. Romano ed.), Milano, 2000, pp. 93-132. 
ANDRÉS ORDAX, S., "Simbolismo en la escultura altomedieval: la Anástasis y los relieves hispanovisigodos de nichos y placas-nicho", Actas del VII Congreso de Estudios Extremeños, vol. I, Cáceres, 1983, pp. 23-38.

ANETTE, J. M., The Porte des Comtes atelier of Saint-Sernin in Toulouse and the Romanesque sculpture of southwest France, University of North Carolina at Chapel Hill, 1992.

ANGHEBEN, M., Les chapiteaux romans de Bourgogne. Thèmes et programmes, Turnhout, 2003.

ANTÓN REMOLÀ, J., "Capitel corintio de la antigua Tarraco", El románico y el Mediterráneo: Cataluña, Toulouse y Pisa, 1120-1180 (M. A. Castiñeiras y J. Camps eds.), Barcelona, 2008, ficha catalográfica 81, p. 358.

ARAGUAS, P., "Spolia/contrefaçon, deux modalités d'appropriation du passé, pour quelles élites ?", Élites y arquitectura en la Antigüedad Tardía, 2 vols., 2007, Zagrab, vol. I, pp. 110-140.

ARBELlOT, A., Mémoire sur les statues équestres de Constantin placées dans les églises de l'Ouest de la France, Limoges, 1885.

ARGAN, G. C., "El revival", El pasado en el presente. El revival en las artes plásticas, la arquitectura, el cine y el teatro, Barcelona, 1977, pp. 7-66.

ARROYO PUERTAS, C., San Martín de Frómista, Palencia, 2002.

AVELlO ÁlVAREZ, J. L., "El gallo de la Torre de San Isidoro. Avance al estudio iconográfico", El Gallo de la Torre de San Isidoro, León, 2004, pp. 70-81.

AZCÁRATE RISTORI, J. M., El protogótico hispano, Madrid, 1974.

ID., "La portada de las Platerías y el programa iconográfico de la Catedral de Santiago", Archivo Español de Arte, 35, 1963, pp. 1-20.

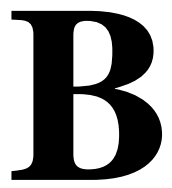

BACCI, M., "Byzantium and the West”, Byzantium 330-1453, London, 2008, pp. 276305.

BALIL ILLANA, A., "El códice de Beato de Liébana en Burgo de Osma: notas sobre su mapa y las representaciones de faros en el mismo", Celtiberia, 28, 1978, pp. 7-12. 
ID., Esculturas romanas de la Península Ibérica, Valladolid, 1980.

ID., "Un tondo de Fuentetojar y otros tondi hispanorromanos", Minerva, 1, 1987, pp. 169-184.

ID., "Arte de la época romana", Historia del Arte en Castilla y León. Prehistoria, Edad Antigua, Arte Prerrománico, 5 vols., Valladolid, 1994, vol. I, pp. 69-102.

BALSEMADA MUNCHARAZ, J. L., "Algunos problemas de la escultura visigoda toledana", Escultura decorativa tardorromana y altomedieval en la Península Ibérica (L. Caballero Zoreda y P. Mateos Cruz ed.), Madrid, 2007, pp. 275-300.

BANGO GARCÍA, C., "Actas del Concilio de Jaca (Synodus nouem episcoporum in Jacca)", Sancho el Mayor y sus herederos. El linaje que europeizó los reinos hispanos, 2 vols., Pamplona, 2006, vol. I, ficha catalográfica 36, p. 183.

ID., "Rodrigo Jiménez de Rada, arzobispo de Toledo", Sancho el Mayor y sus herederos. El linaje que europeizó los reinos hispanos, 2 vols., Pamplona, 2006, vol. I, pp. 231-233.

BANGO TORVISO, I. G., "Arquitectura de la décima centuria: ¿repoblación o mozárabe?”, Goya, 122, 1974, pp. 68-75.

ID., "El neovisigotismo artístico de los siglos IX y X: la restauración de las ciudades y templos", Revista de Ideas Estéticas, 1979, pp. 319-338.

ID., "Historia del arte cristiano (s. VIII al XII)", La Iglesia en la España de los siglos VIII al XIV (J. Fernández Conde ed.), Madrid, 1982, pp. 501-551.

ID., "L'Ordo Gothorum et sa survivance dans 1'Espagne du Haut Moyen Âge", Revue de l'art, LXX, 1985, pp. 9-20.

ID., "La part oriental dels temples de l'abat-bisbe Oliba", Quaderns d'estudis Medievals, 22-23, 1988, pp. 51-66.

ID., "Arquitectura tardorrománica", I Curso de cultura medieval (F. J. Mingorance y Ricart coord.), Aguilar de Campoo, 1989, pp. 65-76.

ID., El prerrománico en Europa, Madrid, 1989.

ID., "El espacio para enterramientos privilegiados en la arquitectura medieval española", Anuario del Departamento de Historia y Teoría del Arte, vol. IV, 1992, pp. 93-132.

ID., "Arquitectura y escultura", Historia del Arte en Castilla y León. Arte Románico, vol. II, Valladolid, 1994, pp. 9-212.

ID., "Las llamadas iglesias de peregrinación o el arquetipo de un estilo", El Camino de Santiago, Camino de las Estrellas, Madrid, 1994 Madrid, pp. 9-75. 
ID., "Crisis de una historia del arte medieval a partir de la teoría de los estilos. La problemática de la Alta Edad Media”, Revisión del arte medieval en Heuskal Herria, 15, 1995, pp. 15-28.

ID., "La cultura artística de la monarquía astur, la última manifestación de la antigüedad", Astures (pueblos y cultura en la frontera del Imperio Romano), Gijón, 1995, pp. 175- 187.

ID "La vieja liturgia hispana y la interpretación funcional del templo prerrománico", VII Semana de Estudios Medievales (J. I. de la Iglesia Duarte coord.), Logroño, 1997, pp. 61-120.

ID., "El ocaso de la Antigüedad. Arte y Arquitectura en la Alta Edad Media hispánica", Cataluña en la época carolingia. Arte y cultura antes del románico (siglos IX y X), Barcelona, 1999, pp. 175-185.

ID., "La peregrinación jacobea: algunos aspectos de una mistificación cultural", Cuenta y razón, 112, 1999, pp. 20-23.

ID., "Las imágenes en los templos medievales. Del aniconismo a la intención docente. Las tres posturas tradicionales de la Iglesia", La Enseñanza en la Edad Media (J. I. de la Iglesia Duarte ed.), Logroño, 2000, pp. 357-82.

ID., "Arquitectura románica en Galicia. Desde los orígenes hasta 1168”, Románico en Galicia y Portugal, La Coruña-Lisboa, 2001, pp. 12-29.

ID., Arte Prerrománico Hispano. El arte en la España cristiana de los siglos VI al XI, Madrid, 2001.

ID., "La creación artística como emblema de la teoría del estado en la monarquía visigoda y en la asturleonesa", Propaganda e poder. Congreso Peninsular de História da Arte, Lisboa, 2001, pp. 31-46.

ID., "Relicario de San Isidoro", Maravillas de la España medieval: Tesoro sagrado y monarquía, 2 vols., Valladolid, 2001, vol. I, ficha catalográfica 86, pp. 228-229.

ID., "El tesoro de la Iglesia", Maravillas de la España medieval: Tesoro sagrado y monarquía, 2 vols., Valladolid, 2001, pp. 155-188.

ID., "La arquitectura románica en Palencia", Enciclopedia del románico en Castilla y León. Palencia, vol. I, Aguilar de Campoo, 2002, pp. 115-136.

ID., "La cultura enciclopédica”, Sancho el Mayor y sus herederos. El linaje que europeizó los reinos hispanos, 2 vols., Pamplona, 2006, vol. I, pp. 96-107.

ID., "La catedral románica", Sancho el Mayor y sus herederos. El linaje que europeizó los reinos hispanos, 2 vols., Pamplona, 2006, vol. II, pp. 835-839.

ID., "La tradición (Prerrománico)", Sancho el Mayor y sus herederos. El linaje que europeizó los reinos hispanos, 2 vols., Pamplona, 2006, vol. II, pp. 586-587. 
ID., "Cuando los edificios eran de colores", Descubrir el arte, 100, 2007, pp. 196-200.

ID., "Un gravísimo error en la historiografía española, el empleo equivocado del término mozárabe", El legado de Al-Andalus. El arte andalusí en los reinos de León y Castilla durante la Edad Media (M. Valdés Fernández coord.), León, 2007, pp. 73-88.

ID., "El locus sanctus de Santiago de Compostela. Una nueva interpretación del escenario arquitectónico del santuario”, El Camí de Sant Jaume i Catalunya, Barcelona, 2007, pp. 191-220.

ID., "Los expolios del paisaje monumental y la arquitectura hispana de los siglos VII al XI. Reflexiones sobre el proceso constructivo de San Miguel de Escalada", De arte, 7, 2008, pp. 7-50.

BARASCH, M., "Le Beau ou le démoniaque: le regard du spectateur médiéval sur la statuaire classique", Histoire de l'histoire de l'Art de l'Antiquité au XVIIIe siècle, vol. I, Paris, 1995, pp. 97-117.

ID., Teorías del Arte. De Platón a Winckelmann, Madrid, 1999.

BARETTE, F., y C. METZGER, Musée du Louvre. Catalogue des sarcophages en Pierre d'époques romaine et paléochrétienne, Paris, 1985.

ID., "Cuve de sarcophage: scène d'enseignement", Musée du Louvre. Catalogue des sarcophages en Pierre d'époques romaine et paléochrétienne, Paris, 1985, ficha catalográfica 204, pp. 306-307.

ID., "Cuve de sarcophage: thiase marin", Musée du Louvre. Catalogue des sarcophages en Pierre d'époques romaine et paléochrétienne, Paris, 1985, ficha catalográfica 77, pp. 158-159.

ID., "Face principale de sarcophage, fragment: meurtre de Clytemnestre", Musée du Louvre. Catalogue des sarcophages en Pierre d'époques romaine et paléochrétienne, Paris, 1985, ficha catalográfica 102, pp. 102-103.

ID., "Fragment de couvercle", Musée du Louvre. Catalogue des sarcophages en Pierre d'époques romaine et paléochrétienne, Paris, 1985, ficha catalográfica 141, p. 232.

ID., "Fragment de couvercle: Dionysos et Ariane", Musée du Louvre. Catalogue des sarcophages en Pierre d'époques romaine et paléochrétienne, Paris, 1985, ficha catalográfica 53, pp. 136-137.

ID., "Fragment de lénos: Ariane endormie", Musée du Louvre. Catalogue des sarcophages en Pierre d'époques romaine et paléochrétienne, Paris, 1985, ficha catalográfica 53, pp. 124-125. 
ID., "Sarcophage avec couvercle: Christ, Apôtres et décor végétal", Musée du Louvre. Catalogue des sarcophages en Pierre d'époques romaine et paléochrétienne, Paris, 1985, ficha catalográfica 219, pp. 323-324.

BARRACA DE RAMOS, P., "Applique. Soldato romano che lotta con un ispano", Hispania Romana: da terra di conquista a provincia dell'imperio (a cura di J. Arce, S. Ensoli, E. La Rocca), Milano, 1997, ficha catalográfica 59, p. 341.

BARRACHINA, J., "Las portadas de la iglesia de Sant Pere de Rodes", Locvs Amoenvs, 4, 1998-1999, pp. 7-35.

ID., "L'expoli de Sant Pere de Rodes. De la col-lecció al museu", La fortuna d'unes obres. Sant Pere de Rodes, del monestir al museu, Barcelona, 2006-2007, pp. 113-142.

ID., "Elementos de la portada de Sant Pere de Rodes", El románico y el Mediterráneo. Cataluña, Toulouse y Pisa. 1120-1180 (M. A. Castiñeiras González y J. Camps ed.), Barcelona, 2008, pp. 344-355.

BARRAL I ALTET, X., "La representación del palacio en la pintura mural asturiana de la Alta Edad Media", Actas del XXIII Congreso Internacional de Historia del Arte, España entre el Mediterráneo y el Atlántico, Granada, 1973, pp. 293-301.

ID., "Fragment de sarcophage antique de Torreilles (Pyrénées-Orientales), retaillé en table d'autel romane", Cahiers Archéologiques, XXVII, 1978, pp. 31-37.

ID., L'art preromànic a Catalunya. Segles IX-X, Barcelona, 1981.

ID., "L'escultura romànica a Catalunya", Catalunya romànica. El Ripollès, vol. X, Barcelona, 1987.

ID., "Sant Fruitós de Bages: Sant Benet de Bages, El claustre", Catalunya romànica. Bages, vol. IX, Barcelona, 1984, pp. 431-438.

ID., "El mito de los terrores del año mil y el arte románico", Alfonso VIII y su época, Madrid, 1992, pp. 393-396.

ID., "L'escultura romànica a Catalunya", Catalunya romànic. Introducció a l'estudi de l'art romànic català; Fons d'art romànic del museu nacional d'art de Catalunya, vol. I, Barcelona, 1994, pp. 94-110.

ID., "Il mosaico parietale", Pittura in Italia. L'Altomedioevo, Roma, 1994, pp. 462-478.

ID., "Propaganda eclesiástica y poder feudal. El orden del mundo en las fachadas románicas", Propaganda y Poder, Congreso Peninsular de História da Arte, Lisboa, 1999, pp. 57-70.

ID., "The Roman World", Sculpture. From Antiquity to the Middle Ages, (G. Duby y JL. Daval eds.), Köln, 1999, pp. 147-237. 
ID., "Du Panthéon de Rome à Sainte-Marie la Rotonde de Vic: la transmission d'un modèle d'architecture mariale au début du $\mathrm{XI}^{\mathrm{e}}$ siècle et la politique "romaine" de l'abbé-évêque Oliba", Les Cahiers de Saint-Michel de Cuxa, XXXVII, 2006, pp. 63-75.

ID., "Apropiación y recontextualización de lo antiguo en la creación artística románica mediterránea", El románico y el Mediterráneo: Cataluña, Toulouse y Pisa, 1120-1180 (M. A. Castiñeiras y J. Camps ed.), Barcelona, 2008, pp. 171-179.

BARRAL I ALTET, X. y NAVARRO SÁEZ, R., "Las representaciones de murallas en los mosaicos romanos de Hispania: un motivo de orla itálico", Boletín del Seminario de Estudios de Arte y Arqueología, vol. 40-41, 1975, pp. 503-522.

BARRIENTOS VERA, T., "Nuevos datos para el estudio de las religiones orientales en Occidente: un espacio de culto mitraico en la zona Sur de Mérida", Mérida, excavaciones arqueológicas, 5, 1999, pp. 357-381.

BARROCA, M., Epigrafia medieval portuguesa (862-1422), 3 vols., Porto, 2000.

BARROSO CABRERA, R. y MORÍN DE PABLOS, J., "Fórmulas y temas iconográficos en la plástica hispanovisigoda (siglos VI-VIII). El problema de la influencia oriental en la cultura material de la España tardoantigua y altomedieval", Visigodos y Omeyas. Un debate entre la Antigüedad tardía y la Alta Edad Media, Madrid, 2002, pp. 279-306.

BARRUOL, G. y CODOU, Y., "Le mobilier liturgique", D'un monde à l'autre. Naissance d'une Chrétienté en Provence $I V^{e}-V I^{e}$ siècle (J. Guyon y M. Heijmans ed.), Arles, 2002, pp. 167-176.

BARTAL, R., "La coexistencia de los signos apotropaicos cristianos y paganos en las entradas de las iglesias románicas", Archivo Español de Arte, 262, 1993, pp. 113-124,

BARTL, F. X. y BOEHRINGER, J., Ravenna, San Vitale, Sant'Apollinare in Classe, Baden-Baden, 1959.

BASTARDES I PARERA, R., voz "Creu de Bagergue", Catalunya romànica. Museu d'art de Girona; Tresor de la Catedral de Girona; Museu diocesà d'Urgell; Museu Frederic Marès, vol. XXIII, Barcelona, 1988, pp. 351-352.

BATLLE HUGUET, P., "Arte Paleocristiano”, Ars Hispaniae, Madrid, 1947, pp. 183223.

BAUCELLS I REIG, J., “Enterrament de Jaume II a Santes Creus l'any 1327”, Acta historica et archaeologica mediaevalia, 20-21, 1999-2000, vol. 1, pp. 323-344.

BAUD, A., "La place des morts dans l'abbaye de Cluny. État de la question", Archéologie médiévale, vol. 29, 1999, pp. 99-114. 
ID., "La troisième église abbatiale de Cluny modèle ou prototype?", Paray-le-Monial, Brionnais-Charolais: le renouveau des études romanes en Bourgogne du Sud, Paray-le-Monial, 2000, pp. 337-345.

ID., Cluny. Un grand chantier médiéval au Coeur de l’Europe, Paris, 2003.

BECCATTI, G., "Clipeate, immagini”, Enciclopedia dell'arte antica, classica, e orientale, vol. II, 1959, pp. 718-721.

ID., voz "Nudo", Enciclopedia dell'arte antica, classica, e orientale, vol. V, Roma, 1963, pp. 576-581.

BECHMANN, R., Villard de Honnecourt: la pensée technique au XIIIe siècle et sa communication, Paris, 1991.

BECKWITH, J., Arte paleocristiano y bizantino, Madrid, 1997.

BREGLIA, L., voz “Aretusa”, Enciclopedia dell'arte antica, classica, e orientale, vol. I, Roma, 1958, pp. 616-617.

ID., voz "Kimon", Enciclopedia dell'arte antica, classica, e orientale, vol. IV, Roma, 1961, pp. 361-362.

BELTRÁN FORTES, J., "El retrato en los sarcófagos romanos. Ejemplos de la Bética", III Reunión sobre la Escultura Romana en Hispania, Córdoba, 1997, pp. 93-111.

ID., "El esplendor de un imperio: la época de Trajano", En el año de Trajano. Hispania. El legado de Roma, Zaragoza, 1998, pp. 225-238.

ID., Los sarcófagos romanos de la Bética con decoración de tema pagano, Málaga, 1994.

ID., "El uso del sarcófago en la Bética durante los siglos II-III d. C", El sarcófago romano. Contribuciones al estudio de su tipología, iconografía y centros de producción (J. M. Noguera Celdrán y E. Conde Guerri eds.) Murcia, 2001, pp. 93-128.

BELTRÁN FORTES, J., GARCÍA GARCÍA, M. A., y RODRÍGUEZ OLIVA, P., Los sarcófagos romanos de Andalucía (Corpus Signorum Imperii Romani-Corpus de Esculturas del Imperio Romano. España), vol. I, fasc. 3, Murcia, 2007.

BELTRÁN, J. y GASCÓ, F., La Antigüedad como argumento, 2 vols., Sevilla 19931995.

BELlO DIÉGUEZ, X., "La Torre de Hércules y la leyenda", Ciudad. Ciudad y Torre. Roma y la Ilustración, La Coruña, 1991, pp. 145-149.

BENDALA GALÁN, M., "La paz augustea y la romanización”, En el año de Trajano. Hispania. El legado de Roma, Zaragoza, 1998, pp. 127-138. 
BENITO RUANO, E., "El mito histórico del año mil", Revista de Estudios Humanísticos, 1, 1979, pp. 11-31.

BENSON, R. L. y CONSTABLE, C., Renaissance and Revewal in the Twelfth Century, Oxford, 1982.

BERENSON, B., The Arch of Constantine, or the Decline of Form, New York, 1954.

Bernwardinische Kunst: Bericht über ein wissenschaftliches (A. Eggebrecht y $\mathrm{M}$. Brandt eds.), Göttingen, 1988.

BERTEAUX, E., "La sculpture chrétienne en Espagne des origines au XIV siècle", Histoire de l'Art (A. Michel dir.), Paris, 1938, vol. I, pp. 214-295.

BERTELLI, C., voz "Aerobindo", Enciclopedia dell'arte antica classica e orientale, vol. I, Roma, 1958, pp. 601-603.

ID., voz "Anastasio I", Enciclopedia dell'arte antica classica e orientale, vol. I, Roma, 1958, p. 342.

ID., voz "Galeno", Enciclopedia dell'arte antica classica e orientale, vol. III, Roma, 1960, pp. 759-760.

ID., "La pintura medievale a Roma en el Lazio", La pittura in Italia. L'Altomedioevo, Milano, 1994, pp. 206-241.

BESARAN I RAMON, P., "Alguns capitells de Sant Pere de Galligants i el Mestre de Cabestany", Estudi General. Girona revisitada. Estudis d'art medieval i modern, 10, 1990, pp. 17-45.

BESSEYRE, M., "La fontaine de vie", Trésors carolingiens. Livres manuscrits de Charlemagne à Charles le Chauve, Paris, 2007, pp. 90-91.

BETTINI, S., Lo spazio architettonico da Roma a Bisanzio, Bari 1992.

BIAY, S., "Entre l'oeil et la main: le concept de maître sculpteur appliqué aux chapiteaux du rond-point de Cluny III et aux portails de la nef de Vézelay", $\grave{A}$ l'ombre des mots: dire et penser le Moyen Âge, Poitiers, 2007, http://janua.blog4ever.com/blog/lirarticle-68850-380168.html, consultado el 10 de agosto de 2008.

BILBAO LÓPEZ, G., Iconografía de las pilas bautismales del románico castellano. Burgos y Palencia, Burgos, 1996.

BINDING, G., "Bischof Bernward von Hildesheim -architectus et artifex?", Bernwardinische Kunst. Bericht über ein wissenschaftliches Symposium in Hildesheim vom 10.10 bis 13.10.1984, Göttingen, 1988, pp. 27-47.

BISCONTI, F., "Progetti decorativi dei primi edifici di culto romani: dalle assenze figurative ai grande scenari iconografici", Ecclesiae Urbis. Atti del Convegno 
Internazionale di Studi sulle Chiese di Roma (IV-X secolo) (F. Guidobaldi y A. Guiglia Guidobaldi ed.), III vols., Città del Vaticano, 2002, vol. I., pp. 16331658 .

BIURRUM Y SOTIL, T., El arte románico en Navarra o las órdenes monacales, sistemas constructivos y monumentos cluniacenses, sanjuanistas, agustinianos, cistercienses y templarios, Pamplona, 1936.

BLÁZQUEZ MARTÍNEZ, J. M., "Panorama general de la escultura romana en Cataluña", Problemas de la Prehistoria y de la Arqueología Catalanas. II Symposium de Prehistoria Peninsular, Barcelona, 1963, pp. 225-245.

ID., "El comercio de obras de arte en la Hispania romana", Goya, 143, 1978, pp. 254265.

ID., "Transformaciones sociales y descomposición de las formas artísticas en la Antigüedad clásica”, Imágenes de la Edad Media, Madrid, 1987, pp. 25-37.

ID., "El urbanismo en Occidente", Homenaje a Manuel de los Santos, Albacete, 1988, pp. 179-183.

ID., "Arte bizantino antiguo de tradición clásica en el desierto jordano: los mosaicos de Um er-Rasas", Goya, vol. 255, 1996, pp. 130-143.

ID., "Los productos de la tierra", Hispania. El legado de Roma, Zaragoza, 1998, pp. 95102.

ID., "La herencia clásica en el Islam: Quesaur 'Amra y Quasrt al-Hayr al-Garbi", Europa y el Islam (G. Anes Álvarez de Castrillón coord.), Madrid, 2003, pp. 45142.

ID., "Máscaras humanas en roleos de mosaicos en Oriente, África e Hispania", L'Africa romana 15. Ai confini dell'Impero: contatti, scambi, conflitti. Atti del XV convegno di studio, Roma, 2004, vol. 2, pp. 1023-1038.

BLOCH, H., "Monte Cassino, Byzantium and the West in the Earlier Middle Ages", Dumbarton Oaks Papers, 3, 1946, pp. 163-224.

ID., Monte Cassino in the Middle Ages, Rome, 1986.

BOARDMAN, J., PALAGIA, O. y WOODFORD, S., voz "Herakles", Lexicon iconographicum mythologiae classicae, vol. VI, 1, Zurich-Münich, 1988, pp. 728-838.

BOISSAVIT-CAMUS, B., "L'environnement du Baptistère”, Le Baptistère Saint-Jean de Poitiers, Poitiers, 2004, pp. 3-34.

BONNE, J.-C., "De l'ornement à l'ornamentalité: la mosaïque absidiale de SaintClément de Rome", Le rôle de l'ornement, Paris, 1997, pp. 103-119. 
BONNET, M. E., Les sarcophages chrétiens de l'église St-Félix de Gérone et l'école arlésienne de sépulture funéraire, Paris, 1911.

BONET CORREA, A., Arte prerrománico asturiano, Barcelona, 1967.

BONET Y SISÓ, J., Sarcófagos romano-cristianos esculturados que se conservan en Cataluña, Barcelona, 1895.

BONNEFOY, Y., Dictionnaire des mythologies et des religions des sociétés traditionnelles et du monde antique, vol. II, Paris, 1981.

BONNERY, A., "L'édicule du Saint-Sépulcre de Narbonne. Recherche sur l'iconographie de l'Anastasis", Les Cahiers de Saint-Michel-de-Cuxa, XXII, 1991, pp. 7-42.

ID., "Le thème de l'Ascension dans les ivoires du Moyen Âge", De la création à la restauration: Travaux d'histoire de l'art offerts à Marcel Durliat pour son $75 e$ anniversaire, Toulouse, 1992, pp. 293-304.

ID., "Sources de la sculpture romane en Languedoc. Les églises abbatiales de Caunes et d'Alet", Les Cahiers de Saint-Michel de Cuxa, XXIV, 1993, pp. 79-91.

ID., "L'église de Rieux-Minervois. Dimension symbolique de l'architecture et sculpture", Les Cahiers de Saint-Michel de Cuixa, 25, 1994, pp. 13-30.

ID., "Matériaux et couleurs dans les églises romanes du Languedoc", Les Cahiers de Saint-Michel de Cuixa, XXVI, 1995, pp. 109-123.

ID., "Le sarcophage-reliquaire de saint Saturnin, à Saint-Hilaire d'Aude", Les Cahiers de Saint-Michel de Cuxa, XXIX, 1998, pp. 53-62.

ID., "Le chevet de Saint-Michel de Cuxa. Nouvelles propositions", Études Roussillonnaises, XVIII, 2000-2001, pp. 97-106.

ID., "L'église Sainte-Marie de Rieux-Minervois", ID., "Les sculptures dispersées de l'abbaye de La Grasse (Aude)", Le Maître de Cabestany, Pierre-qui-Vire, 2000, pp. 32-47.

ID., "Le sarcophage de Saint-Saturnin à Saint-Hilaire", Le Maître de Cabestany, Pierrequi-Vire, 2000, pp. 100-108.

ID., "Les sculptures dispersées de l'abbaye de La Grasse (Aude)", Le Maître de Cabestany, Pierre-qui-Vire, 2000, pp. 109-112.

BORBUDAKIS, H., voz "Creta”, Enciclopedia dell'arte medievale, vol. V, Roma, 1994, pp. 461-466.

BOTO VARELA, G., "Seres teriomóficos en los claustros de Girona y Sant Cugat", Annals del Institut d'Etudis Gironins, XXXIII, 1994, pp. 291-320. 
ID., La memoria perdida. La catedral de León (917-1255), León, 1995.

ID., "1200 en León: Esculturas de la antigua catedral románica", Boletín del Museo e Instituto Camón Aznar, 59-60, 1995, pp. 83-118.

ID., "Ciudades escatológicas fortificadas. Usos perspectivos en los beatos de Girona y Saint-Sever", Locus Amoenus, 2, 1996, pp. 15-30.

ID., Ornamento sin delito. Los seres imaginarios del claustro de Silos y sus ecos en la escultura románica peninsular, Burgos, 2001.

ID., "Sobre reyes y tumbas en la catedral de León: discursos visuales de poder político y honra sacra”, La Catedral de León en la Edad Media (por J. J. Yarza Luaces, M. V. Herráez Ortega y G. Boto Varela coords.), León, 2004, pp. 305-365.

ID., “Topografía de los monasterios de la marca de Hispania (ca. 800-1030), Monjes y monasterios hispanos en la Alta Edad Media, Aguilar de Campoo, 2006, pp. 149-203.

ID., "Arquitectura medieval: configuración espacial y aptitudes funcionales", Real Colegiata de San Isidoro: relicario de la monarquía leonesa (C. Robles García y F. Llamazares Rodríguez), León, 2007, pp. 50-103.

BOUCHÉ, A-M., "Les fonts baptismaux de Saint-Barthélemy à Liège: Chef-d'oeuvre sans pareil et noeud de controverses", Speculum, vol. 2, 2005, pp. 548-550.

BOUDALIS, Y., "Influencias islámicas en las encuadernaciones griegas de época postbizantina", Erytheia, vol. 26, 2005, pp. 127-176.

BOUDARTCHOUK, J.-L., "Le souvenir antique de la Daurade (Toulouse) à travers légendes et traditions médiévales", Mémoires de la Société archéologique du Midi de la France, LXII, 2002, pp. 247-250.

BOUSQUET, J. M., "L'homme attaque a la tête par deux dragons géographie et origines d'un motif de sculpture romane", Cahiers de Civilisation Médiévale, 14, 1983, s. p.

BOUSSART, F., "Un chef-d'œuvre médiéval de la fonderie mosane: les fonts baptismaux de l'église Saint-Barthélemy, à Liège", La fonderie belge, Bruxelles, 1958, pp. 280-281.

BOUTEMY, M. A. y VERCAUTEREM, F., "Foulcoie de Beauvais, et l'intérêt pour l'archéologie antique au XI et au XII' siècle", Latomus, I, 3, 1937, pp. 173-186.

BOVINI, G., I sarcofagi paleocristiani della Spagna, Roma, 1954.

BOVINNI, G., Corpus della scultura paleocristiana bizantina ed Altomedioevale di Ravenna, 3 vols., Roma, 1969. 
BOVINI, G. y ANGIOLINI MARTINELLI, P., Corpus della scultura paleocristiana bizantina ed altomedioevale di Ravenna. Altari, amboni, cibori, cornici, plutei con figure di animali e con intrecci, transenne e fragmmenti vari, vol. I, Roma, 1968.

BOVINI, G. VALENTI ZUCCHINI, G., y BUCCI, M., Corpus della scultura paleocristiana bizantina ed altomedioevale di Ravenna. I sarcofagi a figure e a carattere simbolico, vol. II, Roma, 1968.

BOVINI, G. y OLIVIERI FARIOLLI, R., Corpus della scultura paleocristiana bizantina ed altomedioevale di Ravenna. Basi, capitelli, pietre d'imposta, pilastri, plutei, pulvini, vol. III, Roma, 1969.

BRANDEMBURG, H., L'abbaye de Cluny, Paris, 1981.

ID., “Iconography de Cluny III”, Bulletin Monumental, CXXVI, 1986, pp. 293-322.

ID., Le prime chiese di Roma. IV-VII secolo. L'inizio dell'architettura ecclesiastica occidentale, Milano, 2004.

BRAUNFELS, W., "L'arc de triomphe d'Eginhard", Charlemagne. Oeuvre, Rayonnement et Survivances, Aix-la-Chapelle, 1965, ficha catalográfica 9, pp. 29-30.

ID., "La cour d'Aix-la-Chapelle et sa culture", Charlemagne. Oeuvre, Rayonnement et Survivances, Aix-la-Chapelle, 1965, pp. 17-30.

ID., "Les huit grilles des tribunes de la chapelle palatine", Charlemagne. Oeuvre, Rayonnement et Survivances, Aix-la-Chapelle, 1965, ficha catalográfica 6, pp. 27-28.

ID., "Pomme de pin", Charlemagne. Oeuvre, Rayonnement et Survivances, Aix-laChapelle, 1965, ficha catalográfica 3, p. 25.

ID., "Le sarcophagi de Charlemagne", Charlemagne. Oeuvre, Rayonnement et Survivances, Aix-la-Chapelle, 1965, ficha catalográfica 7, p. 28.

ID., "Statue de Charlemagne de St-Johann de Mustiar", Charlemagne. Oeuvre, Rayonnement et Survivances, Aix-la-Chapelle, 1965, ficha catalográfica 30, p. 41.

ID., "La statuette équestre de Charlemagne", Charlemagne. Oeuvre, Rayonnement et Survivances, Aix-la-Chapelle, 1965, ficha catalográfica 29, pp. 39-40.

BRAVO, F., "Arte de enseñar, arte de contar. En torno al exemplum medieval”, La enseñanza en la Edad Media (J-I. de la Iglesia Duarte coord.), Nájera, 1999, pp. 303-327.

BRAVO GARCÍA, A., "El héroe bizantino", Los héroes medievales. Cuadernos del Cemyr, 1, 1994, pp. 101-142. 
BREDEKAMP, H., "Die nordspanische Hofskulptur und die Freiheit der Bildhauer", Studien Zur Geschichte der Europäischen Skulptur im 12./13. Jahrhundert, Frankfurt am Main, 1994, pp. 263-274.

ID., "Das Reliquiar als Staatsform. Das Reliquiar Isidors von Sevilla und der Beginn der Hofkunst in León”, Reliquiare im mittelalter, Berlin, 2005, pp. 139-164.

BRENK, B., "Suger Spolien”, Arte Medievale, I, 1983, pp. 101-107.

ID., "Spolia from Constantine to Charlemagne: Aesthetics versus ideology", Dumbarton Oaks papers, 1987, 41, pp. 103-109.

ID., voz “Architrave”, Enciclopedia dell'Arte Medievale, vol. II, Roma, 1994, pp. 411414.

ID., "Committenza e retorica", Arti e storia nel Medioevo. Del construire: tecniche, artista, artigiani, committenti, (a cura di E. Castelnuovo), vol. II, Torino, 2003, pp. 3-42.

ID., "Il luogo di culto, sua accessibilità e suoi visitatori. La retorica dell' architettura di pellegrinaggio", Architettura e immagini del sacro nella tarda antichità, Spoleto, 2005, pp. 119-142.

ID., "Spolia da Constantino a Carlomagno: estetica versus ideología", Architettura e immagini del sacro nella tarda antichità, Spoleto, 2005, pp. 197-203.

ID., "Spolia e il loro effetto sull'estetica della varietas. Attorno al problema dei capitelli alternati", Architettura e immagini del sacro nella tarda antichità, Spoleto, 2005, pp. 205-219.

BRUNEAU, P., "Greek Art", Sculpture. From Antiquity to Middle Ages (G. Duby y JL. Daval, edits.), Köln, 1999, pp. 11-113.

BUENACASA PÉREZ, C., "La instrumentalización económica del culto a las reliquias: una importante fuente de ingresos para las iglesias tardoantiguas occidentales (siglos IV-VIII)", Santos, obispos y reliquias, (A. L. García Moreno, M. E. Gil Egea, S. Rascón Márquez, M. Vallejo Girvés ed.), Alcalá de Henares, 2003, pp. 123-140.

BUDDENSIEG, T., "Le coffret en ivoire de Pola, Saint-Pierre et le Latran", Cahiers Archéologiques, X, 1959, pp. 157-195.

BURCKHARDT, J., La cultura del Renacimiento en Italia, Roma, 1860.

BURKE, P., El Renacimiento, Barcelona, 1999.

BURRINI, M., "Le style du Maître de Cabestany", Le Maître de Cabestany, Pierre-quiVire, 2000, pp. 125-146. 
ID., "Sant'Atimo: le chapiteau de Daniel dans la fosse aux lions", Le Maître de Cabestany, Pierre-qui-Vire, 2000, pp. 67-73.

ID., "San Casiano Val di Pesa: colonne sculptée de l'église parossiale de San Giovanni in Sugana", Le Maître de Cabestany, Pierre-qui-Vire, 2000, pp. 74-80

BUSCHBECK, H., Der Pórtico de la Gloria von Sant Jago de Compostela, BerlinVienne, 1919.

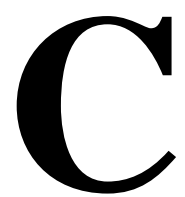

CAAMAÑO MARTÍNEZ, J. M., "En torno al tímpano de Jaca", Goya, 142, 1978, pp. 200-207.

ID., "Algunas consideraciones sobre arquitectura alto-medieval", Relaciones artísticas entre Portugal y España, Salamanca, 1986, pp. 65-69.

CABANOT, J., "Le décor sculpté de la basilique Saint-Sernin de Toulouse", Bulletin Monumental, 132-1, 1971, pp. 99-145.

ID., "La construction de l'abbatiale de Saint-Sever. État des questions", Saint-Sever Millénaire de l'abbaye, Mont-de-Marsan, 1986, pp. 145-161.

ID., "Constitution d'une banque de donnes sur les chapiteaux corinthiens et dérivés du corinthien: méthodes et perspective", L'Acanthe dans la sculpture monumentale de l'Antiquité à la Renaissance, Paris, 1993, pp. 9-25.

CABROL, F. y LECLERCQ, H., voz "Actes des martyrs", Dictionnaire d'Archéologie Chrétienne et de liturgie, vol. I, Paris, 1907, cols. 373-446.

ID., voz "Amours", Dictionnaire d'Archéologie Chrétienne et de liturgie, Paris, 1924, vol. I-II, cols. 1612-1619.

ID., voz "Bassus (sarcophage de Junius)", Dictionnaire d'Archéologie Chrétienne et de liturgie, vol. II, Paris, 1910, cols. 608-614.

ID., voz "Canthare", Dictionnaire d'Archéologie Chrétienne et de liturgie, vol. 2-II, Paris, 1914, cols. 1955-1969.

ID., voz "Chantres", Dictionnaire d'Archéologie Chrétienne et de liturgie, vol. 3-I, Paris, 1914, cols. 344-365. 
ID., voz "Charlemagne Dictionnaire d'Archéologie Chrétienne et de liturgie, vol. 2-II, Paris, 1914, cols. 656-803.

ID., voz "Chrisme", Dictionnaire d'Archéologie Chrétienne et de liturgie, vol. 3-I, Paris, 1914, cols. 1481-1534.

ID., voz "Colombe", Dictionnaire d'Archéologie Chrétienne et de Liturgie, vol. 3-II, Paris, 1914, cols. 2198-2231.

ID., voz "Vigne", Dictionnaire d'Archéologie Chrétienne et de liturgie, vol. 15, Paris, 1950-1953, cols. 3114-3115.

CAILLET, J.-P., "Groupe d'applique: Ariane, ménade, satyre et amours", L'antiquité classique, le haut moyen âge et Byzance au musée de Cluny, Paris, 1985, ficha catalográfica 50, pp. 110-111.

ID., "Metz et le travail de l'ivoire vers l'an mil", Religion et culture autour de l'an mil. Royaume capétien et Lotharingie, (D. Iogna-Prat y J-Ch. Picard ed.), Picard, 1990, pp. 315-337.

ID., "La transformation en église d'édifices publics et de temples à la fin de l'Antiquité", La fin de la cité antique et le début de la cité médiévale de la fin du III $e^{e}$ siècle à l'avènement de Charlemagne (C. Lepelley ed.), Bari, 1996, pp. 191211.

ID., “Architecture et décor monumental”, L'Europe de l'an mil (P. Riché dir.), La Pierre-qui-Vire, 2001, pp. 77-255.

ID., “Le pape et l'empereur en l'an mil", L'Europe de l'an mil (P. Riché dir.), La Pierrequi-Vire, 2001, pp. 80-100.

ID., L'art carolingien, Paris, 2005.

ID., Sainte-Marie La Daurade à Toulouse. Du sanctuaire paléochrétien au grand prieuré clunisien médiéval, Paris, 2006.

CAILLET, J.-P. y NILS LOOSE, H., La vie d'éternité. La sculpture funéraire dans l'Antiquité chrétienne, Paris, 1990.

CALDWELL, S. H., The Introduction and diffusion of the Romanesque projecting single-portal unit in northern Spain, Ann Arbor, 1979.

ID., "Penance, Baptism, Apocalypse: The Easter Context of Jaca Cathedral's West Tympanum", Art History, 3, 1980, pp. 23-35.

CAMES, G., "Otton III et ses hauts dignitaires sur les miniaturas de Bamberg et de Munich. Un essai d'identification”, Scriptorium, XVI, 2, 1962, pp. 231-238.

CAMPOS MÉNDEZ, I., "La aparición de los misterios mitraicos en el marco religioso del imperio romano", Vector plus, 24, 2004, pp. 33-44. 
CAMPOS SÁNCHEZ-BORDONA, M. D., El arte del renacimiento en León: las vías de difusión, León, 1992.

CAMPS I SÒRIA, J., voz "Capitell 4", Catalunya romànica. Museu episcopal de Vic; Museu diocesà i comarcal de Solsona, vol. XXII, Barcelona, 1986, pp. 301-302.

ID., voz "Relleu figurat 1 de Sant Pere de Rodes", Catalunya romànica. Museu d'art de Girona; Tresor de la Catedral de Girona; Museu diocesà d'Urgell; Museu Frederic Marès, vol. XXIII, 1988, pp. 309-310.

ID., voz "Relleu figurat 3 de Sant Pere de Rodes", Catalunya Romànica. Museu d'art de Girona; Tresor de la Catedral de Girona; Museu diocesà d'Urgell; Museu Frederic Marès, vol. XXIII, Barcelona, 1988, pp. 311-317.

ID., voz "Sarcòfag", Catalunya romànica. Museu d'art de Girona; Tresor de la Catedral de Girona; Museu diocesà d'Urgell; Museu Frederic Marès, vol. XXIII, 1988, p. 212.

ID., voz "Sant Pere de Navata”, Catalunya romànica. L'Empordà: 2, vol. IX, Barcelona, 1990, pp. 575-579.

ID., "La Vierge du Cloître de Solsona (Catalogne), attribuée à Gilabertus: à propos de sa fonction et contexte d'origines", Les Cahiers de Saint-Michel de Cuxa, XXV, 1994, pp. 63-71.

ID., “À propos des sources toulousaines du Maître de Cabestany: l'exemple du portail de Sant Pere de Rodes (Catalogne)", Les Cahiers de Saint-Michel de Cuxa, XXVI, 1995, pp. 95-107.

ID., "Elementos de Santa María de Solsona", El románico y el Mediterráneo. Cataluña, Toulouse y Pisa. 1120-1180 (M. A. Castiñeiras González y J. Camps ed.), Barcelona, 2008, pp. 270-272.

CAMPS I SÒRIA, J. y LORÉS I OTZET, I., "Dos capitells del Museu Arqueològic de Narbona del cercle del Mestre de Cabestany", Lambard. Estudis d'art medieval, IV, 1985-1988, 1990, pp. 125-220.

ID., "L'escultura de Sant Pere de Rodes", Catalunya Romànica. L'Empordà: 2, vol. IX, Barcelona, 1990, pp. 703-728.

ID., "L'artiste et son atelier, ses commanditaires", Le Maître de Cabestany, Pierre-quiVire, 2000, pp. 147-155.

ID., "Le portail de Sant Pere de Rodes", Le Maître de Cabestany, Pierre-qui-Vire, 2000, pp. 113-123.

ID., "Sant Pere de Galligants", Le Maître de Cabestany, Pierre-qui-Vire, 2000, pp. 2831. 
ID., "Le patronage dans l'art roman catalan", Les Cahiers de Saint-Michel de Cuxa, XXXVI, 2005, pp. 209-223.

CAMPS I SÒRIA, J., MANCHO, C. e LORÉS I OTZET, I., “L'escultura preromànica”, Del Romà al Romànic. Història, art i cultura de la Tarraconense Mediterrània entre els segles IV i X, Barcelona, 1999, pp. 416-423.

CAMUS, M-T., "L'Eglise: la construction romane", La vie de Sainte Radegonde par Fortunat (R. Favreau dir.), Poitiers, 1995, pp. 254-257.

ID., Sculpture romane du Poitou. Les grands chantiers du XI $I^{e}$ siècle, Paris, 1992.

ID., "Tours-porches et fonction d'accueil dans les églises du Poitou au XI $\mathrm{C}^{\mathrm{e}}$ siècle", Avant-nefs et les d'accueil dans l'église entre le IVe et le XIIe siècle, Auxerre, 1999, pp. 260-280.

ID., "Des Images à lire, méditer, admirer", Notre-Dame-la-Grande de Poitiers. L'ouvre romane, Paris, 2002, pp. 249-307.

CAMUS, M-T. y ANDRAULT-SCHMITT, C., Notre-Dame-la-Grande de Poitiers. L'euvre romane, Paris, 2002.

CANELlAS-LÓPEZ, A. y SAN VICENTE, A., Aragon roman, La-Pierre-qui-Vire, 1971.

CANTINO WATAGHIN, G., "Archeologia e «archeologie». Il raporto con l'antico fra mito, arte e ricerca", Memora dell'antico nell'arte italiana, L'uso dei classici, vol. I, Turín, 1984, pp. 171-217.

ID., "Contributo allo estudio della città tardoantica", IV Reunió d'arqueologia Cristiana Hispànica, Barcelona, 1995, pp. 235-261.

CANTO, A. M., "Saeculum Aelium, saeculum Hispanum: Poder y promoción de los hispanos en Roma", En el año de Trajano. Hispania. El legado de Roma, Zaragoza, 1998, pp. 209-224.

CAPITANI, O., "La Reforma gregoriana e la lotta per le Investiture nella recente storiografia", Cultura es Scuola, 6, 1962-1963, pp. 108-115.

CARBONELL I ESTELLER, E., "Les relacions d'artistes, clients i consumidors de l'obra d'art", Catalunya romànica. 1, Introducció a l'estudi de l'art romànic català; Fons d'art romànic del museu nacional d'art de Catalunya, vol. I, Barcelona, 1994, pp. 54-58.

ID., Tesoros Medievales del Museu Nacional d'art de Catalunya, Barcelona, 1997.

CARRIÈRE, L., "Les portails des églises et des chapelles du haut et du moyen Vallespir (XII'-XIII ${ }^{\mathrm{e}}$ siècles)", Les Cahiers de Saint-Michel de Cuxa, XXXII, 2001, pp. 207-217. 
CASALINO, D., La basilica di San Pietro in Vaticano, Firenze, 1999.

CASTÁN LANASPA, J., "Una portada románica con capiteles historiados en Carrión de los Condes (Palencia)", Homenaje al profesor Martín González, Valladolid, 1995, pp. 305-310.

CASTELFRANCHI VEGAS, L., "L'arte ottoniana e l'anno Mille", L'arte dell'anno mille in Europa 950-1050, Milano, 2000, pp. 13-34.

ID., "Corone e crocifissi”, L'arte dell'anno mille in Europa 950-1050, Milano, 2000, pp. 108-115.

ID., "Egberto, Treveri e la Lotaringia", L'arte dell'anno mille in Europa 950-1050, Milano, 2000, pp. 73-85.

ID., "Hildesheim e Bernoardo", L'arte dell'anno mille in Europa 950-1050, Milano, 2000, pp. 125-130.

ID., "Reichenau e la miniatura ottoniana", L'arte dell'anno mille in Europa 950-1050, Milano, 2000, pp. 49-64.

CASTELNUOVO, E., Nicolas de Verdun, Milano, 1966, pp. 39-50.

ID., "Indigeni sassi", Niveo de marmore. L'uso artistico del marmo di Carrara dall'XI al XV secolo (E. Castelnuovo ed.), Genova, 1992, pp. 5-20.

CASTELO RUANO, R., "Placas decoradas paleocristianas y visigodas de la colección Alonso (Écija, Sevilla)", Espacio, Tiempo y Forma, Serie II, Historia Antigua, 9, 1996, pp. 467-536.

CASTILLO MALDONADO, P., Los mártires hispanorromanos y su culto en la Hispania de la Antigüedad Tardía, Granada, 1999.

CASTIÑEIRAS GONZÁLEZ, M. A., "La reutilización de piezas romanas y medievales en Galicia", Brigantium, 6, 1989-1990, pp. 77-90.

ID., "Las fuentes antiguas en el menologio medieval hispano: la pervivencia literaria e iconográfica de las Etimologías de Isidoro y del Calendario de Filócalo", Boletín del Museo Arqueológico Nacional, XIII, 1-2, 1994, pp. 77-100.

ID., "Algunas reflexiones sobre el programa iconográfico de las portadas del transepto de la catedral de Santiago", La meta del Camino de Santiago. La transformación de la catedral a través de los tiempos, Santiago de Compostela, 1995, pp. 85103.

ID., "La iconografía de los planetas en la Cataluña de los siglos XI-XII", Annals de l'Institut d'Estudis Gironins, XXXV, 1995, pp. 97-122. 
ID., "Introitus pulcre refulget: alcune riflessioni sul programa iconografico dei frontespizi romanici del transetto della cattedrale", La meta del Camino di San Giacomo. La transformazione della cattedrale le attraverso i tempi, Santiago de Compostela, 1995, pp. 83-103.

ID., "Arte románico y reforma eclesiástica", Las religiones en la historia de Galicia (M. V. García Quintela), Santiago de Compostela, 1996, pp. 307-332.

ID., El calendario medieval hispano (s. XI- XIV), Salamanca, 1996.

ID., "Un adro para un bispo: modelos e intencions na fachada de Praterías", Sémata, Cultura, Poder y mecenazgo, 10, 1998, pp. 231-264.

ID., "La actividad artística en la antigua provincia de Mondoñedo: del Prerrománico al románico", Estudios Mindonienses, 15, 1999, pp. 287-342.

ID., "La ilustración del De naturis rerum de Beda en un manuscrito de la abadía de Santa María de Ripoll (Madrid, Biblioteca Nacional, ms. 19) y su arquetipo cassinese", Arte d'occidente. Temi e metodi. Studi in onore di Angiola Maria Romanini, vol. 2, Roma, 1999, pp. 791-801.

ID., El Pórtico de la Gloria, Madrid, 1999.

ID., "Sacro e profano nos programas monumentais do románico. I", Historia da arte galega, 36, Santiago de Compostela,1999, pp. 130-144.

ID., "La catedral románica: tipología arquitectónica y narración visual”, Santiago, la Catedral y la memoria del arte, Santiago de Compostela, 2000, pp. 39- 96.

ID., "Platerías, función y decoración de un lugar sagrado", Actas del V Congreso Internacional de Estudios Jacobeos, Santiago de Compostela, 2001, pp. 289311.

ID., "From Chaos to Cosmos: The Creation Iconography in the Catalan Romanesque Bibles", Arte medievale, 1, 2002, pp. 35-50.

ID., "A poética das marxes no románico galego: bestiario, fábulas e mundo ó revés", Sémata, 14, 2002, pp. 239-334.

ID., "Poder, memoria y olvido: la galería de retratos regios en el Tumbo A de la Catedral de Santiago (1129-1134)", Quintana, 1, 2002, pp. 187-196.

ID., "El Programa Enciclopédico de la Puerta del Cielo en San Isidoro", Compostellanum, vol. XLV, 3 y 4, 2002, pp. 657-694.

ID., "Topographie sacrée, liturgie pascale et reliques dans les centres de pèlerinage: Saint-Jacques-de-Compostelle, Saint-Isidore-de-León et Saint-Étienne-de-Ribasde-Sil", Les Cahiers de Saint-Michel de Cuxa, 34, 2003, pp. 27-49. 
ID., "Cabeza de apóstolo ou patriarca", Luces de Peregrinación, Madrid-Santiago de Compostela, 2004, pp. 180-181.

ID., "Capitel románico inspirado na Orestíada do sarcófago de Husillos", Luces de Peregrinación, Santiago de Compostela, 2004, pp. 252- 254.

ID., "Fragmento de fuste con putti vendimiadores", Luces de Peregrinación, Santiago de Compostela, 2004, pp. 150-154.

ID., "O profeta Daniel na arte europea", Galicia, o sorriso de Daniel (R. Villares dir.), Santiago de Compostela, 2004, pp. 31-45.

ID., "Sarcófago da Orestíada", Luces de Peregrinación, Santiago de Compostela, 2004, pp. 248-250.

ID., Introducción al método iconográfico, Barcelona, 2005.

ID., "La meta del Camino: la catedral de Santiago de Compostela en tiempos de Diego Gelmírez", Los caminos de Santiago. Arte, Historia y Literatura (M. del C. Lacarra Ducay coord.), Zaragoza, 2005, pp. 213-252.

ID., "Roma e il programma reformatore di Gelmírez nella Catedrale di Santiago di Compostella", Medioevo: Immagini e Ideologie, Milano, 2005 pp. 211-226.

ID., "Los santos viajan: la circulación de objetos y modelos artísticos en el camino", "Visitandum est": santos y cultos en el Codex Calixtinus (P. G. Caucci von Saucken coord.), Santiago de Compostela, 2005, pp. 63-90.

ID., "Un passaggio al passato: il portale di Ripoll”, Medioevo. Il tempo degli antichi, Parma, 2006, pp. 365-381.

ID., "Verso Santiago? La sculptura romanica de Jaca a Compostella", Medioevo: l'Europa delle catedrali, Milano, 2007, pp. 387-396.

CASTIÑEIRAS GONZÁLEZ, M. A., y CAMPS I SÒRIA, J., "El románico y el Mediterráneo. Cataluña, Toulouse y Pisa (1120-1180): idea de una exposición", El románico y el Mediterráneo. Cataluña, Toulouse y Pisa. 1120-1180 (M. A. Castiñeiras González y J. Camps ed.), Barcelona, 2008, pp. 21-27.

CASTRIOTA, D., The Ara Pacis Augustae and the imagery of abundance in later Greek and early Roman imperial art, Princeton, 1995.

CASSANELLI, R., "I resti di un grande patrimonio architettonico", L'arte dell'anno mille in Europa 950-1050, Milano, 2000, pp. 35-40.

CARRERO SANTAMARÍA, E., "El confuso recuerdo de la memoria", Maravillas de la España medieval: Tesoro sagrado y monarquía, 2 vols., Valladolid, 2001, vol. I, pp. 85-93. 
ID., "Le sanctuaire de la cathédrale de Saint-Jacques-de-Compostelle à l'épreuve de la liturgie", Saint-Martial de Limoges. Ambition politique et production culturelle ( $X^{e}$-XIII ${ }^{e}$ siècles), Poitiers-Limoges, 2005, pp. 295-307.

ID., "La catedral románica. Hacia una interpretación funcional", Sancho el Mayor y sus herederos. El linaje que europeizó los reinos hispanos, 2 vols., Pamplona, 2006, vol. II, ficha catalográfica 6. 2, pp. 856-866.

CASAL CHICO, C., "Tralas pegadas da cultura bieita: debuxos e esquemas no Mosteiro de Samos", Semata, 14, 2003, pp. 349-362.

CAUCCI, J., "Maestro de las Platerias (Maestro Esteban?), L'inverno (Mese di Febbraio), Romei \& Giubilei. Il pellegrinaggio medievale a San Pietro (3501350) (M. D’Onofrio ed.), Milano, 1999, ficha catalográfica 178, p. 387.

CAVERO DOMÍNGUEZ, G., FERNÁNDEZ GONZÁLEZ, E. y GALVÁN FREILE, F., "Imágenes reales, imágenes de justicia en la catedral de León”, e-Spania, Images du pouvoir, pouvoir des images dans l'Espagne médiévale (IX $-X V^{e}$ siècle), mis en ligne le 26 juin 2007. URL: http://espania.revues.org/document204.html. Consulté le 03 octobre 2007.

CAZES, D., "Sarcófago paleocristiano llamado de Saint-Clair", El románico y el Mediterráneo. Cataluña, Toulouse y Pisa. 1120-1180 (M. A. Castiñeiras González y J. Camps ed.), Barcelona, 2008 ficha catolográfica 67, pp. 330-331.

ID., "Toulouse, Musée des Augustins, acquisition d'un morceau de la corniche romane provenant de la basilique de Saint Sernin”, Bulletin Monumental, 143, 1985, pp. 152-153.

CAZES, Q., “Ancien église Sainte-Marie-la-Daurade”, Le stuc: visage oublié de l'art médiéval, Paris-Poitiers, 2004, pp. 117-118.

ID., "Colonne à décor de vigne", Le stuc: visage oublié de l'art médiéval, Paris-Poitiers, 2004, p. 109.

ID., "Annexe VIII: Les éléments lapidaires provenant de l'abside détruite de la Daurade", Sainte-Marie "La Daurade" à Toulouse : du sanctuaire paléochrétien au grand prieuré clunisien médiéval, Paris, 2006, pp. 299-309.

ID., "La escultura en Toulouse entre 1120 y 1180”, El románico y el Mediterráneo. Cataluña, Toulouse y Pisa. 1120-1180 (M. A. Castiñeiras González y J. Camps ed.), Barcelona, 2008, pp. 69-79.

CAZES, Q., SCELLES, M. y RENIE, G.-M., Le cloître de Moissac, Bordeaux, 2001.

CECCHINI, F., voz "Suger", Enciclopedia dell'Arte Medievale, vol. XI, Roma, 2000, pp. 33-36.

CERRILlO MARTÍN DE CÁCERES, E., "Los campos de Hispania”, Hispania. El legado de Roma, Zaragoza, 1998, pp. 343-352. 
CHALYVOPOULOU, E., Relaciones entre la pintura románica y la pintura bizantina las pinturas murales del siglo XII en España y Grecia: un estudio comparativo e intercultural de las figuras de la iconografía religiosa (Tesis doctoral dirigida por M. T. Escohotado Ibor y M. Sánchez Cifuentes), Universidad Complutense de Madrid, 2005.

CHAMOSO LAMAS, M., "Excavaciones en la catedral de Santiago de Compostela", Archivo Español de Arte, 106, 1954, pp. 183-187.

ID., "Noticia de las excavaciones arqueológicas que se realizan en la Catedral de Santiago”, Compostellanum, 1, 1956, pp. 5-48.

ID., "Excavaciones arqueológicas en la catedral de Santiago (tercera fase)", Compostellanum, II/4, 1957, pp. 575-624.

ID., "Una obra de Alfonso III el Magno: la basílica del Apóstol Santiago", Symposium sobre cultura asturiana de la alta Edad Media, Oviedo, 1967, pp. 27-35.

ID., "El Conde Santo Don Osorio Gutiérrez", Cuadernos de Estudios Gallegos, 70, 1968, pp. 1-10.

ID., "La Catedral de Orense", Catedrales de España., vol. 1, 1994, pp. 121-216.

CHAPOT, V., La colonne torse et le décor en hélice dans l'art antique, Paris, 1907.

CHATEL, E., "Plaque de marbre sculptée dans l'église de Chambornay-les-Bellevaux (Haute-Saône)", Cahiers Archéologiques, 32, 1984, pp. 31-38.

CHRISTIE, N., From Constantine to Charlemagne. An Archaeology of Italia A.D. 300800, Cornwall, 2006.

CHRISTE, Y., "La colonne d'Arcadius, Sainte-Pudentienne l'arc de Eginhard et le portail de Ripoll", Cahiers Archéologiques, XXI, 1971, pp. 31-42.

CERVINI, F., voz "Nicola di Verdun", Enciclopedia dell'arte medievale, vol. VIII, Roma, 1997, pp. 695-698.

Los clasicismos del Arte Español. Actas del X Congreso del CEHA, Madrid, 1994.

CIARAllO, A., "La flora y la fauna", Pompeya. Historia, Vida y Arte de la ciudad sepultada (M. Ranieri Panetta, ed.) Barcelona, 2004, pp. 302-313.

CID PRIEGO, C., "El caballero y la serpiente. Iconografía y origen remotos de una miniatura singular del Beato de Girona", Annals de l'Institut d'Estudis Gironins, 30, 1988-1989, pp. 99-139.

ID., "La miniatura del águila y la serpiente en los Beatos", Boletín del Seminario de Estudios de Arte y Arqueología, LVI, 1990, pp. 335-350. 
ID., "Asturianos y mozárabes en los orígenes del culto jacobeo", Las artes en los caminos de Santiago, Oviedo, 1993, pp. 39-90.

ID., Arte Prerrománico de la Monarquía Asturiana, Oviedo, 1995.

CILENTO, N., 'L'opera di Desiderio abate cassinese e pontífice peri il rinnovamento della chiesa dell'Italia meridionale nell'età gregoriana", L'età dell'abate Desiderio, (a cura di F. Avagliano y O. Pecere), Montecassino, 1992, pp. 120190.

CIMA, M., "Capitello figurato di lesena", Aurea Roma: dalla città pagana alla città cristiana (S. Ensoli y E. La Rocca eds.), Roma, 2000, ficha catalográfica 14, p. 434.

ID., "Capitelo figurato di lesena", Aurea Roma: dalla città pagana alla città cristiana (S. Ensoli y E. La Rocca eds.), Roma, 2000, ficha catalográfica 16, p. 435.

ID., "Lesena tortile figurata", Aurea Roma: dalla città pagana alla città cristiana (S. Ensoli y E. La Rocca eds.), Roma, 2000, ficha catalográfica 15, p. 435.

ID., "Lesena tortile", Aurea Roma: dalla città pagana alla città cristiana (S. Ensoli y E. La Rocca eds.), Roma, 2000, p. 434.

CIOTTA, G., "La chiesa prerrománica asturiana di San Julián de los Prados a Oviedo. Iconografía, sistemi construttivi e partiti decorativi", Arte d'occidente. Temi e metodi. Studi in onore di Angiola Maria Romanini, 3 vols., 1999, vol. I, pp. 4959.

CIRANNA, S., "La lectura architettonica degli spolia nelle chiese di Roma", Ecclesiae Urbis. Atti del Congresso Internazionale di Studi sulle chiese di Roma (IV-X secolo) (F. Guidobaldi y A. G. Guidobaldi), vol. II, Cittá del Vaticano, 2002, pp. 895-874.

CIRLOT, L., Nacional Gallery, Barcelona, 2005.

CITARELLA, A. O. y WILLARD, H. M., "Le relique e la loro disposizione nelle chiese di Montecassino nell'età di Desiderio e Odoresio I", L'età dell'abate Desiderio, (a cura di F. Avagliano y O. Pecere), Montecassino, 1992, pp. 441466.

CLARK, K., El desnudo. Un estudio de la forma ideal, Madrid, 1981.

CLAUSSEN, P. C., "Marmi antichi nel medioevo romano. L'arte dei Cosmati”, Marmi antichi (G. Borghini coord.), Roma, 1989, pp. 65-79.

ID., "The concept of spolia", A Companion to Medieval Art: Romanesque and gothic in Northern Europe (C. Rudolph ed.), Oxford, 2006, pp. 233-252.

CLAVERIA NADAL, M., "La reutilización de sarcófagos romanos en Cataluña", Anmurcia, 13-14, 1995 pp. 34-60. 
ID., "Dos nuevos fragmentos de sarcófagos romanos con el tema de las estaciones", Locvs Amonvs, 2, 1996, pp. 7-14.

ID., "El sarcófago romano. Cuestiones de tipología, iconografía y centros de producción”, El sarcófago romano: contribuciones al estudio de su tipología, iconografía y centros de producción (J. M. Noguera Celdrán y E. Conde Guerri eds.), Murcia, 2001, pp. 19-50.

ID., Los sarcófagos romanos de Cataluña, Murcia, 2001.

ID., "El sarcófago romano en la tarraconense", IV Reunión sobre escultura romana en Hispania, Madrid, 2004, pp. 273-306.

La colonne Aurélienne. Autour de la colonne Aurélienne. Geste et image sur la colonne de Marc Aurèle á Rome (J. Scheid et V. Huet eds.), Thurnhout, 2000.

Coloquio Internacional de Capiteles Corintios Prerrománicos e Islámicos (ss. VI-XII d. C.) (P. Cressier, Ch. Ewert y J. Zozaya ed.), Madrid, 1992.

COMES, R. M., "Un banc romà reutilitzat pel Mestre de Cabestany, a Peralada", Sylloge Epigraphica Barcinonensis, III, 1999, pp. 39-41.

CONANT, K. J., "The fire at Santiago de Compostela in 1117: a reconstruction drawing", Journal of the School of Architectural Historians, 15, 1, 1956, p. 3.

ID., Arquitectura románica de la Catedral de Santiago de Compostela, Santiago de Compostela, 1983.

CONDE GUERRI, E., "La iconografía de los milagros de Cristo en los sarcófagos paleocristianos como prototipo del "nuevo héroe", El sarcófago romano: contribuciones al estudio de su tipología, iconografía y centros de producción (J. M. Noguera Celdrán y E. Conde Guerri eds.), Murcia, 2001, pp. 273-281, en especial, pp. 274-275.

CONTI, A., "Giotto e la pittura italiana nella prima metà del Trecento", L'Arte Medioevale in Italia e nell'Occidetne europeo (L. Castelfranchi Vegas ed.), Milano, 1994, pp. 89-106.

ID., “Ampolla", Romei \& Giubilei. Il pellegrinaggio medievale a San Pietro (350-1350) (a cura di M. D’Onofrio), Milano, 1999, ficha 44, p. 309.

Constantinopla 1453. Mitos y Realidades (P. Bádenas, A. Bravo, I. Pérez Martín, E. Ayensa, J. S. Codoñer y M. Cortés Arrese eds.), Madrid, 2004.

COOK, W. W. S. y GUDIOL RICART, J., "Pintura e imaginería románicas", Ars Hispaniae, Madrid, 1950, pp. 127-174. 
CORNELIUS CLAUSSEN, P., "Marmo e splendore. Architettura, arredi liturgici, spoliae", Arte e iconografía a Roma. Da Constantino a Cola di Rienzo, Milano, 2000, pp. 193-225.

CORONEO, R., "I capitelli di San Pedro de la Nave", Medioevo: immagine e racconto. Atti del Convegno internazionale di studi, Parma, 2003, pp. 130-141.

CORTÉS ARRESE, M., “Acerca de la "invención” de Bizancio en el arte español: tres notas", Arte e Identidades Culturales, Oviedo, 1998, pp. 86-96.

COSMEN ALONSO, C. Dos iglesias románicas del Bierzo, San Miguel y San Esteban de Corullón, León, 1985.

ID., El arte románico en León: Diócesis de Astorga, León, 1987.

ID., "Noticias sobre arquitectura del siglo X en la diócesis de Astorga", Anales de Historia del Arte, 4, 1999, pp. 83-89.

ID., "Arca de San Pelayo", Maravillas de la España medieval: Tesoro sagrado y monarquía, 2 vols., Valladolid, 2001, vol. I, ficha catalográfica 87, p. 229.

ID., "La Arqueta de las Bienaventuranzas: fuentes iconográficas", De Arte, 1, 2002, pp. 21-30.

ID., "Las catedrales románicas de Astorga", Enciclopedia del románico en Castilla y León. León, Aguilar de Campoo, 2002, pp. 439-445.

ID., "Noticias sobre la reconstrucción arquitectónica en la Diócesis de León durante el siglo X", La Multiculturalidad en las Artes y en la Arquitectura, 2 vols. Las Palmas de Gran Canaria, 2006, vol. I, pp. 599-607.

ID., “Arte y Liturgia en Santa Marta de Tera”, Astórica, 27, 2008, pp. 139-171.

COSMEN ALONSO, C., FERNÁNDEZ GONZÁLEZ, E., HERRÁEZ ORTEGA, M. V. y VALDÉS FERNÁNDEZ, M., "La renovación del monasterio en el reinado de Alfonso VI", Esplendor y decadencia de un monasterio medieval. El patrimonio artístico de San Benito de Sahagún (M. V. Herráez coord.), León, 2000, pp. 67-62.

COSMEN ALONSO, C. y HERRÁEZ ORTEGA, M. V., "Fernando II: promotor del Camino de Santiago en León", Imágenes y promotores en el arte medieval: miscelánea en homenaje a Joaquín Yarza Luaces, Barcelona, 2001, pp. 79-87.

COSMEN ALONSO, C., FERNÁNDEZ GONZÁLEZ, E. y VALDÉS FERNÁNDEZ, M., "La escultura románica”, Historia del Arte en León, León, 1989, pp. 74-87.

COSMEN ALONSO, C., HERRÁEZ ORTEGA, M. V. y VALDÉS FERNÁNDEZ, M., "Alfonso VI y el monasterio de Sahagún. Nuevos testimonios sobre la construcción del templo monástico", De Arte, 5, 2006, pp. 29-41. 
CONSTABLE, C., The Reformation of the Twelfth Century, Cambridge, 1996.

COWDREY, H. E. J., The Age of Abbot Desiderius, Oxford, 1983.

ID., "Cluny et Rome”, Revue Mabillon, 66, 1994, pp. 258-264.

ID., "Desiderio abate di Montecassino", L'età dell'abate Desiderio, (a cura di F. Avagliano y O. Pecere), Montecassino, 1992, pp. 17-32.

ID., The Cluniacs and the Gregorian Reform, Oxford, 1970.

CRESSEDI, G., voz "Aiace di Oileo", Enciclopedia dell'arte antica, classica $e$ orientale, vol. I, Roma, 1958, pp. 164-165.

CREISSEN, T., "Architecture religieuse et politique: à propos des mosaïques des parties basses de l'abside dans la cathédrale de Cefalù", Cahiers de civilisation médiévale, vol. 46, 183, 2003, pp. 247-263.

CRESSIER, P., "Les chapiteaux de la grande mosquée de Cordoue (oratoire d' Abd-alRahmān I et d' Abd-al-Rahmān II) et la sculpture de chapiteaux à l'époque émirale. Première partie”, Madrider Mitteilungen, 25, 1984, pp. 216-281.

ID., "El renacimiento de la escultura de capiteles en la época emiral: entre Occidente y Oriente", Cuadernos de Madinat al-Zahra, 3, 1991, pp. 165-187.

ID., "Historias de capiteles ¿Hubo talleres califales provinciales?”, Cuadernos de Madinat al-Zahra, 5, 2004, pp. 355-375.

CRESSIER, P. y MARINETTO SÁNCHEZ, P., "Les chapiteaux islamiques de la Péninsule Ibérique et du Maroc de la renaissance émirale aux almohades", L'Acanthe dans la sculpture monumental de l'Antiquité à la Renaissance, Paris, 1993, pp. 211-246.

CRIPPA, M. A., "La primera arquitectura cristiana. Siglos IV y V", El arte paleocristiano. Visión y espacio de los orígenes a Bizancio, Barcelona- Madrid, 1998, pp. 183-216.

CRIPPA, M. A., RIES, R. y ZIBAWI, M., El arte paleocristiano. Visión y espacio de los orígenes a Bizancio, Barcelona-Madrid, 1998.

CRIVELLO, F., "Le opere: colori, materiali, artefici", Arti e storia nell Medioevo, vol. II, Torino, 2003, ficha catalográfica 16, p. 427.

CROISIER, J., "I mosaici dell' abside e dell' arco absidiale della Chiesa superiore di San Clemente. 1118 ca.", Riforma e Tradizione (S. Romano dir.), Roma, 2006, pp. 209-218.

CROQUISON, J., "L'iconographie chrétienne à Rome d'après le Liber Pontificalis", Byzantion, XXXIV, 2, 1964, pp. 535-606. 
CROZET, R., "Les survivances de la pensée et de l'art antique dans la peinture carolingienne”, Mélanges d'histoire du Moyen Âge dédiés à la mémoire de L. Halphen, Paris, 1951, pp. 165-168.

ID., "Survivances antiques dans l'architecture romane du Poitou, de l'Angoumois et la Saintonge", Mémoires de la société nationale des Antiquaires de France, 3, 1954, pp. 193-202.

ID., "Survivances antiques dans le décor roman du Poitou, de l'Angoumois et de la Saintonge, Bulletin Monumental, 114, I, 1956, pp. 7-33.

ID., "Le thème du cavalier victorieux dans l'art roman de France et d'Espagne", Príncipe de Viana, 124-125, 1958, pp. 125-143.

CUADRADO SÁNCHEZ, M., Arquitectura palatina del Naranco, Madrid, 1991.

CUCHERAT, M. F., Cluny au onzième siècle. Son influence religieuse, intellectuelle et politique, Paris, 1850.

CUÉLLAR LÁZARO, J., España romana: arquitectura romana en España, Madrid, 1998.

CUMONT, F., Recherches sur le symbolisme funéraire des romains, Paris, 1942.

ID., Lux perpetua, Paris, 1949.

CUTLER, A., "Reuse o use? Theoretical and practical attitudes toward objects in Early Middle Ages", Ideologie e pratiche del reimpiego nell'Alto Medioevo, XLVI, Spoleto, 1999, pp. 1055-1079.

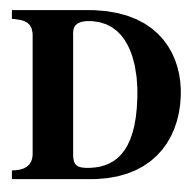

DACOS, N., La découverte de la Domus Aurea et la formation des grotesques dans la Renaissance, London, 1969.

ID., "Sopravvivenza dell'antico", Enciclopedia dell'arte antica, classica e orientale. Supplemento 1970, Roma, 1973, pp. 725-746.

DARAS, M. CH., "Réflexions sur les statues équestres représentant Constantin en Aquitaine", Bulletin de la Société des Antiquaires de l'Ouest, $2^{\circ}$ trimestre, 1969, pp. 151-157. 
DARAKI, M., Dionisio y la diosa Tierra, Madrid, 2005.

DEBIAIS, V., "Afficher pour convaincre: la construction et la promotion de la mémoire dans les inscriptions comme instrument de la propagande médiévale", Convaincre et persuader: communication et propagande aux XII et XIII siècles, Poitiers, 2007, pp. 649-702.

DECTOT, X., Pierres tombales médiévales: Sculptures de l'au-delà, Paris, 2006.

ID., "Columna con decoración de roleos habitados", El románico y el Mediterráneo. Cataluña, Toulouse y Pisa. 1120-1180 (M. A. Castiñeiras González y J. Camps ed.), Barcelona, 2008, ficha catalográfica 28, pp. 268-269.

DEICHMANN, F. W., Die Spolien in der spatantiken Architektur, Munich, 1975.

ID., Ravenna, Hauptsadt des spätantiken Abendlandes, Wiesbaden, 1969.

ID., Archeologia cristiana, Darmstadt, 1993.

DELGADO GÓMEZ, J., "El singularísimo tímpano de Betán (Orense)", Archivo Español de Arte, 235, 1986, pp. 257-276.

DEMOUGEOT, E., La formation de l'Europe et les invasions barbares, Paris, 1969.

DEMUS, O., Byzantine Art and the West, New York, 1970.

ID., Byzantine mosaic decoration: aspects of monumental art in Byzantium, London, 1976.

ID., "The First Romanesque Beatus Manuscripts and the Liturgy of Death", Estudio de los Códices del Comentario al Apocalipsis de Beato de Liébana, Madrid, 19791980, vol. I, pp. 320-328.

ID., "A Renascence of Early Christian Art in Thirteenth Century Venice", Late Classical and Mediaeval Studies in honor of Albert Mathias Friend, JR. (K. Weitzmann ed.), Princeton, 1955, pp. 348-361.

DE ALARCÃO, Roman Portugal, Warminster, 1988.

DE BLAAUW, S., "Architettura 312-600”, Cultus et Decor. Liturgia e architettura nella Roma tardoantica e Medievale. Basilica Salvatoris, Sanctae Mariae, Sancti Petri, vol. I, Città del Vaticano, 1994, pp. 109-116.

ID., Cultus et Decor. Liturgia e architettura nella Roma tardoantica e Medievale. Basilica Salvatoris, Sanctae Mariae, Sancti Petri, vol. I, Città del Vaticano, 1994.

DE CAROLIS, E., "La Casa Pompeyana", Pompeya. Historia, Vida y Arte de la ciudad sepultada (M. Ranieri Panetta, ed.), Barcelona, 2004, pp. 242-257. 
DE EGRY, A., "Esculturas románicas inéditas de San Martín de Uncastillo", Archivo Español de Arte, 36, 1963, pp. 181-187.

ID., "Símbolos funerarios en monumentos románicos españoles", Archivo Español de Arte, 4, 1971, pp. 9-15.

D’EMILIO, J., “Tradición local y aportaciones foráneas en la escultura románica tardía: Compostela, Lugo y Carrión", O Pórtico da Gloria e arte do seu tempo, A Coruña, 1991, pp. 83-101.

DE GARAY SUÁREZ-LLANOS, J., “Lo barroco, según E. D’Ors”, Comentarios de textos literarios hispánico: homenaje a Miguel Ángel Garrido Gallardo (J. L. García Barrientos y E. Torre coords.), Madrid, 1997, pp. 181-202.

DE GRIMOUARD DE SAINT-LAURENT, H. J. L., "Étude sur une série d'anciens sarcophages", Revue de l'Art chrétien, II, vol. IV, 1877, pp. 1-39.

DE LACERDA, A., História da Arte em Portugal, vol. I, Porto, 1942.

DE LACHENAL, L., Spolia. Uso e reimpiego dell'antico. Dal III al XIV secolo, Milano, 1995.

DE MATOS, J. L., Subsídios para um catálogo da escultura Luso-romana, 2 vols, Lisboa, 1966.

ID., "Carranca de Valdevez", Subsídios para um catálogo da escultura Luso-romana, 2 vols, Lisboa, 1966, vol. II, pp. 257-258.

ID., "Friso com relevos de bucrâneus e pateras de Évora", Subsídios para um catálogo da escultura Luso-romana, 2 vols., Lisboa, 1966, vol. II, pp. 175-176.

ID., "Carranca fontenária", Inventário do Museu Nacional de Arqueologia. Colecção de Escultura Romana, Lisboa, 1995, ficha catalográfica 114, pp. 182-183.

ID., "Estatueta de Sileno", Inventário do Museu Nacional de Arqueologia. Colecção de Escultura Romana, Lisboa, 1995, ficha catalográfica 125, pp. 198-199.

ID., "Hermes", Inventário do Museu Nacional de Arqueologia. Colecção de Escultura Romana, Lisboa, 1995, ficha catalográfica 25, pp. 62-63.

ID., Inventário do Museu Nacional de Arqueologia. Colecção de Escultura Romana, Lisboa, 1995.

ID., "Placas decorativas com relevos de acantos e acroteras de máscara teatral e ave", Inventário do Museu Nacional de Arqueologia. Colecção de Escultura Romana, Lisboa, 1995, ficha catalográfica 119, pp. 118-119.

ID., "Sarcófago dos leões", Inventário do Museu Nacional de Arqueologia. Colecção de Escultura Romana, Lisboa, 1995, ficha catalográfica 48, pp. 108-109. 
DEL AMO, M. D., "El catapetasma en la plástica visigoda", IV Reunió d'Arqueologia Cristiana Hispánica, Barcelona, 1995, pp. 69-77.

DEL AMO Y DE LA HERA, M., "Capitel com nú clássico", O Románico e o Douro, Lisboa-Porto, 1998, pp. 182-184.

DEL AMO Y DE LA ERA, M., y PÉREZ RODRÍGUEZ, F. J., Museo de Palencia, Palencia, 2006.

DEL HOYO, J., "El crismón de la catedral de Jaca y la pérdida de la conciencia lingüística", Analecta Malacitana, 6, 2000, consultado en http://www.anmal.uma.es/numero6/Hoyo.htm, el día 15 de noviembre de 2008.

DE MARINIS, S., voz "Letto", Enciclopedia dell'arte medievale, vol. IV, Roma, 1961, pp. 601-607.

DE NOBLE LALAUZIÈRE, J.-F., Abrégé chronologique de l'histoire d'Arles, Arles, 1808.

DE OLIVEIRA RODRIGUES, J. M., Aspectos da ornamentação e representação na escultura do românico em Portugal, vol. I, Lisboa, 1987.

DE PALOL, P., Arte paleocristiano en España, Barcelona, 1968.

ID., Arte hispánico de la época visigoda, Barcelona, 1968.

ID., "Elements clàssics en la iconografia del brodat de la Creació de la Catedral de Girona", Anals de d'institut d'estudis Gironins, XXII, 1974- 1975, pp. 427-438.

ID., El Tapís de la Creació de la Catedral de Girona, Barcelona, 1986.

ID., "Els precedents de l'art romànic a Catalunya", Catalunya romànica. Introducció a l'estudi de l'art romànic català; Fons d'art romànic del museu nacional d'art de Catalunya, vol. I, Barcelona, 1994, p. 66-79.

DE PALOL, P., y RIPOLL, G., Los godos en el Occidente Europeo. Ostrogodos y Visigodos en los siglos V-VIII, Madrid, 1988.

DE SOUZA, V., "Männliche Maske", Corpus Signorum Imperii Romani. Corpus der Skulpturen Der Römischen Welt. Portugal, Coimbra, 1990, ficha catalográfica 72, p. 32.

ID., "Pinax mit archaistischen, antithetisch argeordneten Theatermasken", Corpus Signorum Imperii Romani. Corpus der Skulpturen Der Römischen Welt. Portugal, Coimbra, 1990, ficha catalográfica 119, p. 42.

ID., “Stierprotome”, Corpus Signorum Imperii Romani. Corpus der Skulpturen Der Römischen Welt. Portugal, Coimbra, 1990, ficha catalográfica 18, pp. 15-16. 
ID., "Stierprotome", Corpus Signorum Imperii Romani. Corpus der Skulpturen Der Römischen Welt. Portugal, Coimbra, 1990, ficha catalográfica 19, p. 16.

ID., "Stierprotome", Corpus Signorum Imperii Romani. Corpus der Skulpturen Der Römischen Welt. Portugal, Coimbra, 1990, ficha catalográfica 20, p. 16.

ID., "Unterteil eines Mänadenreliefs", Corpus Signorum Imperii Romani. Corpus der Skulpturen Der Römischen Welt. Portugal, Coimbra, 1990, ficha catalográfica 4, p. 10.

DE LA BARRERA ANTON, J. L., Los capiteles romanos de Mérida, Badajoz, 1984.

DESCHAMPS, P., Étude sur la renaissance de la sculpture en France a l'époque romane, Paris, 1925.

ID., "Etudes sur les sculptures des Sainte-Foy de Conques et de Saint- Sernin de Toulouse et leurs relation avec celles de Saint-Isidore de León et Saint-Jacques de Compostelle”, Bulletin monumental, C, 1941, pp. 235-264.

DE VISSCHER, F., Le droit des tombeaux romains, Milano, 1963.

DÍAZ, P. C., "Urbes in rure: I pacieri della campagna e della natura", Hispania Romana. Da terra di conquista a Provincia dell'imperio (J. Arce, S. Ensoli, E. La Rocca coord.), Roma, 1997, pp. 283-294.

DÍEZ DE VELASCO, F., Los caminos de la muerte. Religión, rito e imágenes del paso al más allá en la Grecia antigua, Valladolid, 1995.

DÍEZ DEL CORRAL CORREDOIRA, P., "Al final del laberinto. Ariadna en los Ovidios ilustrados del siglo XVI”, Sémata, 2002, vol. 14, pp. 277-289.

DÍAZ-JÍMENEZ Y MOLLEDA, J. E., "San Isidoro de León”, Boletín de la Sociedad Española de Excursiones, vol. XXV, 1917, pp. 81-98.

DÍEZ PLATAS, F., "Imaginando el agua: reflexiones sobre el significado iconográfico del motivo de la serpiente en ciertas escenas de la cerámica griega arcaica", Fronteras e identidad en el mundo griego antiguo (P. M. López Barja de Quiroga, S. Reboreda Morillo, coords.), 2001, pp. 281-301.

ID., "Breviario de imágenes paganas: la iconografía de los dioses y el mito en la Galicia romana", Sémata, 14, 2002, pp. 207-251.

DÍAZ Y DÍAZ, M. C., Visiones del Más Allá en Galicia durante la alta edad media, Santiago de Compostela, 1985.

DÍAZ Y DÍAZ, M. C., LÓPEZ ALSINA, F. y MORALEJO ÁLVAREZ, S., Los Tumbos de Compostela, Madrid, 1985.

DIEGO BARRADO, L., Nacido del Fuego. El arte del hierro románico en torno al Camino de Santiago, Zaragoza, 1999. 
ID., "Capitel de la iglesia de Santiago de Jaca", Sancho III el Mayor y sus herederos. El linaje que europeizó los reinos hispanos, 2 vols., Pamplona, vol. II, 2006, ficha catalográfica 208, pp. 698-699.

ID., "Relaciones entre Oriente y Occidente en la Alta Edad Media: la cultura artística en la Roma bizantina", La Multiculturalidad en las Artes y en la Arquitectura, 2 vols., Las Palmas de Gran Canaria, 2006, vol. II, pp. 213-221.

DIEGO SANTOS, F., Inscripciones medievales de Asturias, Gijón, 1993.

DIÉGUEZ, D. A., voz "Capitell 5 de Sant Pere de Rodes", Catalunya romànica. Museu d'art de Girona; Tresor de la Catedral de Girona; Museu diocesà d'Urgell; Museu Frederic Marès, vol. XXIII, Barcelona, 1988, p. 28.

DIXON, PH., JONES, M., y MEIRION-JONES, G., "L'abbaye de Cluny", La ville de Cluny et ses maisons. $X I^{e}-X V^{e}$ siècles, Paris, 1997, pp. 55-75.

DOCAMPO ÁlVAREZ, P., MARTÍNEZ OSENDE, J. y VILLAR VIDAL, J., Animales fabulosos del románico en Asturias, Gijón, 2000.

DODDS, J., "Las pinturas de San Julián de los Prados. Arte, diplomacia y herejía", Goya, 191, 1986, pp. 258-263.

DODWELL, C. R., voz "Canterbury. Miniatura”, Enciclopedia dell'Arte Medievale, vol. IV, Roma, 1993, pp. 156-159.

DOIGNON, J., "Le monogramme cruciforme du sarcophage paléochrétien de Metz représentant le passage de la mer Rouge: Un symbole du triomphe sur la mort dans le cadre d'une iconographie aulique d'inspiration constantinienne", Cahiers Archéologiques, XII, 1962, pp. 65-87.

DOLÇ, M., “Tres inscripciones de la catedral de Jaca”, Pirineos, IX, 1953, pp. 421-432.

DOMINGO MAGAÑA, J. A., Capiteles Tardorromanos y Altomedievales de Hispania (ss. IV-VIII dC), Barcelona, 2007.

DOMÍNGUEZ PERELA, E., "Los capiteles del pórtico de Escalada, entre la tradición clásica y la bizantina, lo islámico y la creación local", V Congrés espanyol d'història de l'art, (F. Español Bertrán y J. Yarza Luaces), vol. 1, Barcelona, 1987, pp. 65-76.

DONADONI, S., GARBINI, G. y MATTHIAE, G., voz "Capitello", Enciclopedia dell'arte antica classica e orientale, vol. II, Roma, 1959, pp. 321-326.

D'ONOFRIO, M., “La königshalle di Lorsch presso Worms”, Roma e l'età carolingia, Roma, 1976, pp.131-138.

ID., Roma e Aquisgrana, Roma, 1983. 
ID., "La basilica costantiniana "reliquiario" delle spoglie di Pietro", Romei \& giubilei: il pellegrinaggio medievale a San Pietro, 350-1350 (M. D’Onofrio ed.), Milano, 1999, pp. 11-31.

D’ORS, E., Lo Barroco, Madrid, 2002.

DOPPELFELD, O., "More Romano. Die beiden Karolingischen Domgrundrisse von Köln”, Kölner Domblatt, VIII-IX, 1954, pp. 33-61.

DRAPER, D., "Canterbury Cathedral: Classical Columns in the Trinity Chapel?", Architectural History. Essays in Architectural History Presented to John Newman, 44, 2001, pp. 172-178.

DROCOURT-DUBREUIL, G., Saint-Victor de Marseille. Art funéraire et prière des morts aux temps paléochrétiens (IV $V^{e} V^{e}$ siècles), Marseille, 1998.

DUBOURG-NOVES, P., "Des mausolées antiques aux cimborios romans d'Espagne. Évolution d'une forme architecturale", Cahiers de Civilisation Médiévale, 4, 1980, pp. 323-359.

DUCHESNE, “Saint-Jacques en Galice”, Annales du Midi, XII, 1900, pp. 145-179.

DUFRENNE, S., Les illustrations du Psautier d'Utrecht. Sources et apport carolingien, Paris, 1978.

Du héros païen au saint chrétien, Paris, 1997.

DURÁN GUDIOL, "Las inscripciones medievales de la provincia de Huesca”, Estudios de Edad Media de la Corona de Aragón, VIII, Zaragoza, 1967, pp. 45-153.

DURÁN-PORTA, J., "Capitel de Santa María de Ripoll”, El románico y el Mediterráneo. Cataluña, Toulouse y Pisa. 1120-1180 (M. A. Castiñeiras González y J. Camps ed.), Barcelona, 2008, ficha catalográfica 82, pp. 360-361.

ID., "Relieve de la abadía de Lagrasse", El románico y el Mediterráneo: Cataluña, Toulouse y Pisa, 1120-1180, (M. Castiñeiras y J. Camps), Barcelona, 2008, ficha catalográfica 73, p. 342.

DURLIAT, M., "Influences antiques sur la sculpture romane du Languedoc méditerranéen et de Catalogne”, Congrès National des Sociétés Savantes, 1952, pp. 20-43.

ID., "Le Maître de Cabestany à Saint-Hilaire de l'Aude. Solutions à quelques problèmes archéologiques", Tramontane, 344, 1952, pp. 117-121.

ID., La sculpture romane en Roussillon. Le maître de Cabestany Coustouges. Le monastir del Camp. Espira-de-l'Agly, vol. IV, Perpignan, 1954.

ID., La sculpture romane en Roussillon. La sculpture romane en Cerdagne, vol. V, Perpignan, 1957. 
ID., La sculpture romane en Roussillon. Corneilla-de-Conflent, vol. II, Perpignan, 1958.

ID., La sculpture romane en Roussillon. Saint-Martin-du-Canigou. Le Roussillon et la Catalogne, vol. III, Perpignan, 1958.

ID., La sculpture romane en Roussillon. Les premiers essais du XIe siècle. Les ateliers de Saint-Michel-de-Cuxa et de Serrabonne, vol. I, Perpignan, 1959.

ID., "Les origines de la sculpture romane á Toulouse et á Moissac", Cahiers de civilisation médiévale, XII, 1969, pp. 349- 363.

ID., "La Porte de France á la cathédrale de Compostelle", Bulletin Monumental, CXXX, 1972, pp. 139-150.

ID., "Saint-Hilaire d'Aude", Congrès Archéologique de France, 131, Paris, 1973, pp. 154-172.

ID., "L'apparition du grand portail roman historié dans le Midi de la France et le Nord de 1’Espagne”, Les Cahiers de Saint-Michel de Cuxa, 8, 1977, pp. 7-24.

ID., "Les débuts de la sculpture romane dans le Midi", Cahiers de Saint-Michel de Cuxa, 1977, pp. 101-114.

ID., “Toulouse et Jaca”, Homenaje a don José María Lacarra de Miguel, vol. I, Zaragoza, 1977, pp. 199-207.

ID., "Les débuts de la sculpture romane dans le midi de la France et en Espagne", Cahiers de Saint-Michel de Cuxa, 1978, pp. 104-105.

ID., "Les origines de la sculpture romane à Jaca", Comptes redus de l'Académie des inscriptions et belles- lettres, 1978, pp. 222-235.

ID., "Les débuts de la sculpture romane dans le midi de la France et en Espagne", Les Cahiers de Saint-Michel de Cuxa, IX, 1978, pp. 101-113.

ID., "La Catalogne et le premier art roman", Bulletin Monumental, 147-I, 1989, pp. 209-238.

ID. La sculpture romane de la route de Saint- Jacques. De Conques à Compostelle, Mont-de-Marsan, 1990.

ID., "La Catedral de Jaca en el contexto del arte románico europeo", Signos: arte y cultura en el Alto Aragón medieval (T. Luesma coord.), Huesca, 1993, pp. 95102.

ID., voz "Sant Feliu d'Amunt", Catalunya romànica. El Rosselló, vol. XIV, Barcelona, 1993, pp. 348-351. 
ID., "La sculpture du XI ${ }^{\mathrm{e}}$ siècle en Occident", Bulletin Monumental, 125, II, 1994, pp. 129-213.

DURU, R., La crypte de l'église Saint-Seurin de Bordeaux, La sauvegarde de l'art français, Paris, 1982.

DUVAL, N., La mosaïque funéraire dans l'art paléochrétien, Verona, 1976,

ID., "L'architecture cultuelle", Naissance des arts chrétiens. Atlas des monuments paléochrétiens de la France (N. Duval coord.), Paris, 1991, pp. 186-220.

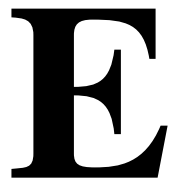

EDMOND LE BLANT, M., Les sarcophages chrétiens de la Gaule, Paris, 1886.

EDMUND STREET, G., Gothic Architecture in Spain, 2. vols., New York, 1914.

EHRENSPERGER-KATZ, M., "Les représentations de villes dans l'art Chrétien avant l'an mil', L'information d'Histoire de l'art, 3, 1964, pp. 130-132.

ELBERN, V. H., "L'Orfèvrerie”, Charlemagne. Oeuvre, Rayonnement et Survivances, Aix-la-Chapelle, 1965, pp. 357-362.

ID., "Carolingia, Arte", Enciclopedia dell'Arte Medievale, vol. IV, Roma, 1993, pp. 294-304.

ID., voz “Oreficeria", Enciclopedia dell'arte medievale, vol. VIII, Roma, 1997, pp. 833849.

ELIAS, N. y DUNNING, E., Deporte y ocio en el proceso de la civilización, México 1992.

ENRÍQUEZ DE SALAMANCA, C., Jaca y el románico, León, 1983.

ENSOLI, S., "I colossi di bronzo a Roma in età tardoantica: dal Colosso di Nerone al Colosso di Costantino. A proposito dei tre frammenti bronzei dei Musei Capitolini", Aurea Roma: dalla città pagana alla città cristiana (S. Ensoli y E. La Rocca eds.), Roma, 2000, pp. 66-90.

ESCH, A., "Reimpiego dell'antico nel Medioevo: la prospettiva dell'archeologo, la prospettiva dello storico", Ideologie e pratiche del reimpiego nell'alto medioevo, XLVI, vol. I, Spoleto, 1999, pp. 75-108. 
ID., "Zur Wiederverwendung antiker Baustucke und Skulpturen im mittelalterlichen Italien", Auchiu fur Kulturgeschichte, 51, 1969, pp. 1-33.

ESCUDERO NAVARRO, Z., GARCÍA ÁLVAREZ, J. y LEÓN LÓPEZ, A., "Milagro en color. El cenotafio de San Vicente, en la basílica de los Santos Mártires de Ávila", Patrimonio, 33, 2008, pp. 28-34.

ESPAÑOL BERTRÁN, F., "El sometimiento de los animales al hombre como paradigma moralizante de distinto signo: la "Ascensión de Alejandro" y el "Señor de los animales" en el románico español", Originalidad, modelo y copia en el arte medieval español (F. Español Bertrán y J. Yarza Luaces coord.), Barcelona, 1987, vol. 1, 1987, pp. 49-64.

ID., El Arte Gótico I, Madrid, 1989.

ID., "Santo Domingo de la Calzada: el cuerpo santo y los escenarios de su culto", La Cabecera de la Catedral Calceatense y el Tardorrománico Hispano: actas del Simposio en Santo Domingo de la Calzada, Santo Domingo de la Calzada, 2000, pp. 209-282.

ID., "Los Descendimientos hispanos", La Deposizione lignea in Europa. L'immagine, il culto, la forma, Milano-Perugia, 2004, pp. 511-554.

ID., "El escenario litúrgico de la catedral de Girona (s. XI-XIV)", Hortus Artium Medievalium, vol. 11, 2005, pp. 213-232.

ID., "El castillo de Loarre y su portada románica", Locvs Amoenvs, 8, 2005-2006, pp. 718.

ESTEBAN LLORENTE, F., "Las inscripciones del tímpano de la Catedral de Jaca", Artigrama, 10, 1993, pp. 143-161.

ID., "El tímpano de la catedral de Jaca (continuación)", Aragón en la Edad Media XIV$X V, 1999$, pp. 451-472.

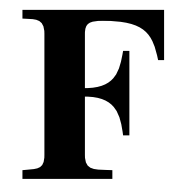

FAEDO, L., "I porfidi: imagines di potere", Aurea Roma: dalla città pagana alla città cristiana (S. Ensoli y E. La Rocca eds.), Roma, 2000, pp. 61-65.

FALKENSTEIN, L., "Charlemagne et Aix-la-Chapelle", Le souverain à Byzance et en Occident du VIIIe au Xe siècle (A. Dierkens et J. M. Sansterre), Bruxelles, 1991. 
ID., "Charlemagne et Aix-la-Chapelle", Byzantion, 61, 1991, pp. 230-289.

ID., Der Lateran der Karolingischen Pfalz zu Aachen, Köln, 1966.

FARNOUX, A., "Lykourgos I", Lexicon iconographicum mythologiae classicae, vol. VI, 1, Zürich-München, 1992, pp. 309-319.

FAU, J.-C., "Les chapiteaux de l'église et du cloître de Conques", Mémoire de la Société Archéologique du Midi, XXIV, 1956, pp. 33-312.

ID., "Un décor original: l'entrelacs épanoui en palmette sur les chapiteaux romans de l'ancienne Septimanie", Cahiers de Saint-Michel de Cuxa, 1979, pp. 129-139.

ID., "À propos du chapiteau de la condamnation de Sainte Foy, à Saint-Jacques de Compostelle et à Sainte-Foy de Conques", Les Cahiers de Saint-Michel-de Cuxa, XXXI, 2000, pp. 47-57.

FAVREAU, R., Corpus des inscriptions de la France médiévale. I, Poitou-Charentes. 1, Ville de Poitiers, Paris, 1974.

ID., "Peinture et épigraphie", Peintures romanes, Poitiers, 1988, pp. 41-49.

ID., "Le culte a Sainte Radegonde", La vie de Sainte Radegonde par Fortunat (R. Favreau dir.), Poitiers, 1995, pp. 5-20.

ID., "Les inscriptions du tympan de la Cathédrale de Jaca", Académie des Inscriptions et Belles-lettres, 1996, pp. 535-560.

FERBER, S., "Crucifixion Iconography in a Group of Carolingian Ivory Plaques", The Art Bulletin, 48, 1966, pp. 323-334.

FÉRNÁNDEZ, F. C., El libro de las maravillas y los monstruos en León, León, 1988.

FERNÁNDEZ, J. J., "Capitel inspirado en La Orestíada", Los Caminos de Santiago: el arte en el período románico en Castilla y León, España, siglos XI a XIII (J. C. Elorza Guinea dir.), Valladolid, 2006.

FERNÁNDEZ ARDANAZ, S., "Monaquismo oriental en la Hispania de los siglos VIX”, Antigüedad y cristianismo: Monografías históricas sobre la Antigüedad tardía, vol. 16, 1999, pp. 203-216.

FERNÁNDEZ BALBUENA, G., "La Colegiata de San Pedro de Teverga", Arquitectura, III, 1920, pp. 223-227.

FERNÁNDEZ CATÓN, J. M., San Mancio, culto, leyenda y reliquias. Ensayo de crítica hagiográfica, León, 1983.

FERNÁNDEZ CASADO, C., Acueductos romanos en España, s.1., 1972. 
FERNÁNDEZ GONZÁLEZ, A., "Un viejo plano olvidado en el Archivo de la Catedral de Santiago: la Porta Francigena, su atrio y la Corticela en el año 1739", Compostellanum, XLVIII, 1-4, 2003, pp. 701-742.

FERNÁNDEZ GONZÁLEZ, E., "Las cabezas rostradas: un tema ornamental en el románico de Villaviciosa", Asturiensia Medievalia, 2, 1975, pp. 341-364.

ID., "Los sepulcros de la Sala Capitular del monasterio de San Andrés de Arroyo (Palencia)", Estudios Humanísticos, 1, 1979, pp. 83-98.

ID., "El arco: tradición e influencias islámicas y orientales en el románico del reino de León”, Awrāq, 5-6, 1982-1983, pp. 221-242.

ID., "Escenas cinegéticas en el románico de Villaviciosa (Asturias)", Boletín del Instituto de Estudios Asturianos, 105-106, 1982, pp. 167-179.

ID., La escultura románica en la zona de Villaviciosa (Asturias), León, 1982.

ID., "Sobre la serpiente: aproximación a un tema iconográfico universal”, Ástura, 4, 1985, pp. 43-53.

ID., "Presencia de Oriente y Occidente en la Portada del Obispo de la Catedral de Zamora", Estudios Humanísticos, 1988, León, pp. 225-274.

ID., "Estructura y simbolismo de la Capilla Palatina y otros lugares de peregrinación: los ejemplos asturianos de la Cámara Santa y las Ermitas del Monsacro", Las peregrinaciones a Santiago de Compostela y San Salvador de Oviedo en la Edad Media, Oviedo, 1990, pp. 335-397.

ID., voz "Asturie. Età románica”, Enciclopedia dell'arte medievale, vol. II, Roma, 1991, pp. 681-685.

ID., San Isidoro de León, Madrid, 1991.

ID., "Héroes y arquetipos en la iconografía medieval", Los héroes medievales. Cuadernos del Cemyr, 1, 1994, pp. 13-52.

ID., "Problemática en torno a Santa María de Carzana en el Concejo asturiano de Teverga", Asturiensia medievalia, 8, 1995-1996, pp. 205-238

ID., "Arca relicario", Obras maestras recuperadas, Madrid, 1998, pp. 72-74.

ID., "El retrato regio en los Tumbos de los tesoros catedralicios", Maravillas de la España Medieval. Tesoro sagrado y monarquía, 2 vols. Valladolid, 2001, vol. I, pp. 41-54.

ID., "Consideraciones generales sobre el románico en la provincia de León", Enciclopedia del Románico en Castilla y León, León, Aguilar de Campoo, 2002, pp. 35-52. 
ID., "Hagiografía e iconografía en torno a Santo Martino de León: tradición hispana y conexiones europeas", Memoria ecclesiae, 24, 2004, pp. 177-203.

ID., "Reflexiones sobre la evolución hacia el románico de las fórmulas artísticas altomedievales, en el ámbito astur-leonés, en la undécima centuria", Internationale Tagung: Christliche Kunst im Umbruch Hispaniens Norden im 11. Jahrhundert, Göttingen, 27-29 de febrero de 2004, (en prensa).

ID., "A propósito del mal: posesiones y exorcismos en la plástica del medievo", L'Espai del Mal (F. Sabaté i Curull ed.), Balaguer, 2005, pp. 117-142.

ID., "Relicario de San Isidoro", Sancho el Mayor y sus herederos. El linaje que europeizó los reinos hispanos, 2 vols., Pamplona, 2006, vol. I, ficha catalográfica 22, pp. 136-141.

ID., "Hacia la renovación escultórica de la segunda mitad del siglo XI: Los ejemplos del sarcófago de San Martín de Dumio y de la pila bautismal de San Isidoro de León”, De arte, 6, 2007, pp. 5-36.

ID., "Que los reyes vistiesen paños de seda, con oro, e con piedras preciosas. Indumentarias ricas en los reinos de León y Castilla (1180-1300): entre la tradición islámica y el Occidente cristiano”, El Legado de Al-Andalus. El arte andalusí en los Reinos de Castilla y León durante la Edad Media (M. Valdés Fernández coord.), León, 2007, pp. 365-408.

ID., "Hacia la renovación del lenguaje arquitectónico en torno al reinado de Alfonso IX", Alfonso IX y su época. Pro utilitate regni mei, La Coruña, 2008, pp. 349369.

ID., "La imago regis y la jerarquía eclesiástica a través de las artes plásticas (ss. IXXII)", Congreso Internacional. Monarquía y Sociedad en el Reino de León. De Alfonso III a Alfonso VIII, León, 2008, pp. 45-96.

FERNÁNDEZ GONZÁLEZ, E. y GALVÁN FREILE, F., "Iconografía, ornamentación y valor simbólico de la imagen”, 976 Códice Albeldense, Madrid, 2002, pp. 205277.

ID., "Un ejemplo de topografía urbana en el siglo X: la visión de la ciudad de Sevilla en el códice Emilianense”, Homenaje a Joaquín González Vecín, León, 2005, pp. 137-147.

ID., "Pintando arquitecturas/arquitecturas pintadas: las construcciones figuradas en el Códice Albeldense", De arte, 7, 2008, pp. 51-60.

FERNÁNDEZ GONZÁLEZ, E. y MIGUÉLEZ CAVERO, A., "Die Mikroarchitekturen in den Darstellungen Der "Sieben Gemeinden Von Asien" in den Ikonographischen Zyklen der Apokalypse im Spanischen Mittelalter", Mikroarchitektur im Mittelalter. Ein gattungsübergreifendes Phänomen zwischen Realität und Imagination, Leipzig, 2008, pp. 455-476. 
FERNÁNDEZ GONZÁLEZ, E. y VIÑAYO GONZÁLEZ, A., Abecedario-bestiario de los códices de Santo Martino, León, 1985.

FERNÁNDEZ GUERRA Y ORBE, A., "Sarcófago pagano en la Colegiata de Husillos, recién traído al Museo Arqueológico Nacional", Museo Español de Antigüedades, I, 1872, pp. 43-60.

FERNÁNDEZ LADREDA, C., "Las imágenes de la Virgen en la escultura”, Maravillas de la España medieval: Tesoro sagrado y monarquía, 2 vols., Valladolid, vol. II, 2001, pp. 415-417.

ID., "Virgen de la Vega", Maravillas de la España medieval: Tesoro sagrado y monarquía, 2 vols., Valladolid, 2001, vol. II, ficha catalográfica 178, pp. 434435.

FERNÁNDEZ OCHOA, C., "Le terme di Gijón (Asturie)", Hispania Romana. Da terra di conquista a provincia dell'Impero, Milano, 1997, pp. 181-187.

FERNÁNDEZ PARRADO, M., "Colegiata de San Pedro de Teverga", Enciclopedia del románico en Asturias, 2 vols., Aguilar de Campoo, 2006, vol. II, pp. 960-972.

ID., "Iglesia de San Pedro de Arrojo", Enciclopedia del románico en Asturias, 2 vols., Aguilar de Campoo, 2006, vol. I, pp. 140-141.

FERNÁNDEZ PÉREZ, S., "Para una nueva lectura de la portada occidental de Santo Estevo de Ribas de Miño", Compostellanum, vol. XLVI, 3 y 4, 2001, pp. 603629.

ID., San Esteban de Ribas de Miño, Lugo, 2004.

FERNÁNDEZ PÉREZ, S. y NODAR, V. R., "Un proyecto de reconstrucción hipotética de las portadas del transepto de la Catedral de Santiago en época de Diego Gelmírez", Compostellanum, XLVIII, 1-4, 2003, pp. 605-613.

ID., "Premio e castigo: o capitel historiado no transepto da catedral de Santiago", Porta da Aira, 11, 2006, pp. 291-310.

ID., "Vita peregrinatio est: reflexións sobre o capitel historiado no transepto norde da catedral de Santiago", El Camí de Sant Jaume i Catalunya, Barcelona, 2007, pp. 381-386.

FERNÁNDEZ PUERTAS, A., "Mezquita de Córdoba: Abd al-Rahman I (169/785786). El trazado proporcional de la planta y alzado de las arquerías del oratorio. La qibla y el mihrab del siglo VIII", Archivo Español de Arte, 81, 324, 2008, pp. 333-356.

FERREIRA DE ALMEIDA, C. A., Arquitectura românica de entre-Douro-e-Minho, 2 vols., Porto, 1978. 
ID., "Arte da época visigótica", História da Arte em Portugal. Arte da Alta Idade Média, vol. II, Lisboa, 1986, pp. 37-72.

ID., "Arte paleocristã da época das invasões", História da Arte em Portugal. Arte da Alta Idade Média, vol. II, Lisboa, 1986, pp. 9-36.

FERRER GARCÍA, F. A., "El santo y la serpiente: leyenda y realidad en el cenotafio de los mártires Vicente, Sabina y Cristeta de Ávila", Cuadernos abulenses, 29, 2000, pp. 11-60.

FÉVRIER, P.-A., “Arles, Les Alyscamps. Nécropole orientale”, Les premiers monuments chrétiens de la France. 1. Sud-Est et Corse, Paris, 1995, pp. 118120.

FILLITZ, H., "Die Bronzetüren des Aachener Münsters", Le Porte di bronzo dall'antichità al secolo XIII (S. Salvatorino dir.), 2 vols., Roma, 1990, vol. I, pp. 139-144.

FLORISTÁN IMÍZCOZ, J. M., "Basilios ortodoxos y política mediterránea de España”, Erytheia, vol. 28, 2007, pp. 139-196.

FOCILlON, H., La escultura románica: investigaciones sobre la historia de las formas, Madrid, 1987.

FOLDA, J., voz "Crociati. Pittura e miniatura", Enciclopedia dell'arte medievale, vol. V, Roma, 1994, pp. 569-577.

FORSYTH, G. H., "The transept of old St. Peter's at Rome", Late classical and mediaeval studies in honor of Albert Mathias Friend Jr. (K. Weitzmann ed.), Princeton, New Jersey, 1995, pp. 56-70.

FRANCO MATA, A., "La eboraria de los reinos hispánicos durante los siglos XI y XII", Codex Aqvilarensis, 13, 1998, pp. 143-166,

ID., “Altorrelieve de la Virgen", Los Caminos de Santiago: el arte en el período románico en Castilla y León, España, siglos XI a XIII (J. C. Elorza Guinea dir.), Valladolid, 2006, p. 250.

FRANCOVICH, G., Il palatium di Teodorico a Ravenna e la cosiddetta "architettura di potenzo". Problema d'interpretazione di raffigurazioni architettoniche nell'arte tardoantica e altomedioevale, Roma, 1970.

FRANZONI, C., "Rimembranze d'infinite cose. Le collezioni rinascimentali di antichità", Memoria dell'antico nell'arte italiana. L'uso dei classici (a cura di S. Settis), 3 vols., Torino, 1984, vol. I, pp. 301-360.

ID., "Presente del passato: le forme classiche nel Medioevo", Arti e storia nel Medioevo, vol. II, Torino, 2003, pp. 329-359. 
ID., "Presente del passato: la forme classiche nel Medioevo", Arti e storia nel Medioevo. Del construire: tecniche, artista, artigiani, committenti (a cura di E. Castelnuovo e G. Sergi), vol. II, Torino, 2003, pp. 329-359,

FRUGONI, CH., Una lontana città. Sentimenti e immagini nel Medioevo, Torino, 1983.

ID., "La antichità: dai Mirabilia alla propaganda politica", Memoria dell'antico nell'arte italiana. L'uso dei classici (a cura de Salvatore Settis), 3 vols., Torino 1986, vol. I, pp. 5-72.

ID., "Alberi (in paradiso voluptatis)", L'ambiente vegetale nell'alto Medioevo (XXXVII settimana di studio del Centro italiano di studi sull'Alto Medioevo, Spoleto, 1990, pp. 725-762.

FRUTAZ, A. P., Le piante di Roma, 3 vols., Roma, 1962.

FUENTES DOMÍNGUEZ, A., Arte paleocristiano, Madrid, 1991.

FUENTES, A., "Aproximación a la ciudad hispana de los siglos IV y V d. C.", Congreso Internacional de la historia de Teodosio, Salamanca, 1997, pp. 477496.

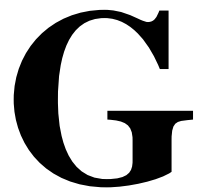

GABORIT, J.-R., Ivoires du Moyen Age, Fribourg, 1978.

ID., "Diptyque du Cónsul Aréobindus", Ivoires du Moyen Age, Fribourg, 1978, ficha 28, p. 182.

ID., Regalia. Les instruments du sacre des Rois de France. Les "Honneurs de Charlemagne”, Paris, 1987.

ID., "Dyptyque du cónsul Anastasius", Byzance. L'art bizantin dans les collections publiques françaises, Paris, 1992, ficha catalográfica 15, pp. 54-56.

ID. "Feuillet inférieur d'un diptyque du cónsul Areobindus", Byzance. L'art bizantin dans les collections publiques françaises, Paris, 1992, ficha catalográfica 12, pp. 49-50. 
ID., "Feuillet supérieur d'un diptyque du consul Areobindus", Byzance. L'art bizantin dans les collections publiques françaises, Paris, 1992, ficha catalográfica 13, pp. $50-51$.

ID., "Feuillet inférieur d'un diptyque du cónsul Magnus", Byzance. L'art bizantin dans les collections publiques françaises, Paris, 1992, ficha catalográfica 16, pp. 5658.

ID., "Les ivoires du $\mathrm{V}^{\mathrm{e}}$ au VIII ${ }^{\mathrm{e}}$ siècle", Byzance. L'art bizantin dans les collections publiques françaises, Paris, 1992, Paris, 1992, pp. 42-45.

ID., "Plaque: baptême du Christ", Byzance. L'art bizantin dans les collections publiques françaises, Paris, 1992, Paris, 1992, ficha catalográfica 25, p. 72.

ID., La statuette équestre de Charlemagne, Paris, 1999.

ID., “Les arts précieux en l'an mil”, L'Europe de l'an mil, (P. Riché dir.), La Pierre-quiVire, 2001, pp. 321-364.

ID., "Diptyque d'Areobindus", Ivoires médiévaux: $V^{e}-X V^{e}$ siècle, Paris, 2003, ficha 7, pp. 45-47.

ID., "Diptyque: Sénateur présidant les jeux du cirque", Ivoires médiévaux: $V^{e}-X V^{e}$ siècle, Paris, 2003, ficha 6, pp. 43-44.

ID., "Panneau central d'un triptyque: Crucifixion; Saintes Femmes au tombeau", Ivoires médiévaux: $V^{e}-X V^{e}$ siècle, Paris, 2003, ficha catalográfica 60, pp. 210-212.

ID., "Aigle de Suger", La France romane au temps des premiers capétiens (987-1152), Paris, 2005, p. 347.

ID., "Chapiteau d'applique: scène de vendange", La France romane au temps des premiers capétiens (987-1152), Paris, 2005, ficha 160, pp. 218-219.

ID., "Dalle funéraire de l'abbé Isarn", La France romane au temps des premiers capétiens (987-1152), Paris, 2005, ficha catalográfica 178, p. 240.

ID., "Plaque de reliure: ivoire d'Adalbéron", La France romane au temps des premiers capétiens (987-1152), Paris, 2005, ficha catalográfica 5, p. 55.

GABRIEL PÉREZ, I. M., "El Sarcófago de San Justo de la Vega (Astorga, León)", Revista de arqueología, 29, 327, 2008, pp. 24-33.

GAILLARD, G., "Notes sur les tympans aragonais", Bulletin Hispanique, XXX, 1928, pp. 193-202.

ID., Les débuts de la sculpture espagnole. León-Jaca-Compostelle, Paris, 1938.

ID., Premiers essais de sculpture monumental en Catalogne au $X^{e}$ et XI siècles, Paris, 1938. 
ID., "La sculpture du XI $\mathrm{I}^{\mathrm{e}}$ siècle en Navarre avant l'influence des pèlerinages", Bulletin Monumental, CXIII, 1955, pp. 237-249.

ID., "Éléments andalous et carolingiens dans l'architecture et la sculpture de SaintPierre de Roda", Cahiers de Saint-Michel de Cuixa, 1979, pp. 129-139.

ID., "Une abbaye de pèlerinage; Sainte-Foy de Conques et ses rapports avec SaintJacques", Compostellanum, X, 1965, pp. 335-347.

GALLEGO LORENZO, J., "Placa de cubierta de Evangeliario con Crucifixión", Alfonso IX y su época. Pro utilitate mei, A Coruña, 2008, ficha catalográfica 92, pp. 425-426.

GALLISTL, B., "Die Tür des Bischofs Bernward und ihr ikonographisches Programm", Le Porte di bronzo dall'antichità al secolo XIII (S. Salvatorino dir.), 2 vols., Roma, 1990, vol. I, pp. 145-181.

GALTIER MARTÍ, F., “Aproximación a un nuevo tema: la pintura de exteriores románicos", Actas del VII Congreso Internacional de Estudios Pirenaicos, Jaca, 1983, pp. 5-15.

ID., "Le corps occidental des églises dans l'art roman espagnol du XI $\mathrm{X}^{\mathrm{e}}$ siècle: problèmes de réception d'un modèle septentrional", Cahiers de Civilisation Médiévale, XXXIV, I, 1991, pp. 297-307.

ID., La iconografía cristiana en el arte cristiano del primer milenio. Perspectiva y convención; sueño y realidad. Huesca, 2001.

GALVÁN FREILE, F., "Rostros entre motivos vegetales. ¿Una travesura de miniaturistas?”, Estudios Humanísticos, 17, 1995, pp. 163-177.

ID., La decoración de manuscritos en León en torno al año 1200, 3 vols., León, 1997.

ID., "El Ms. 1513 de la Biblioteca Nacional de Madrid: primeros pasos en la miniatura gótica hispana", Anuario de estudios medievales, 27, 1, 1997, pp. 479-500.

ID., "Representaciones bélicas en el arte figurativo medieval: particularidades del caso hispano", Memoria y civilización. La violencia en la Historia, 2, 1999, pp. 5586.

ID., Fragmentos de manuscritos iluminados en el Archivo Histórico Provincial de León: (c. 1200), León, 2000.

ID., "El Libro de las Estampas, modelo para algunas de las vidrieras de la Catedral de León”, Memoria ecclesiae, 16, 2000, pp. 45-54.

ID., "Miniaturas en fragmentos de códices del Archivo Diocesano de Astorga (c. 1200)”, Astórica, vol. 17, 19, 2000, pp. 203-222. 
ID., "Los libros litúrgicos y espirituales en la Edad Media", Maravillas de la España medieval: Tesoro sagrado y monarquía, 2 vols., Valladolid, 2001, vol. II, pp. 453-454.

ID., "Obras de Santo Martino", Maravillas de la España medieval: Tesoro sagrado y monarquía, 2 vols., Valladolid, 2001, ficha catalográfica 197, p. 474.

ID., "Origen y difusión del modelo iconográfico de la Virgen Eleusa en la Península Ibérica”, Imágenes y promotores en el arte medieval, Barcelona, 2001, pp. 125137.

ID., "La producción de manuscritos iluminados en la Edad Media y su vinculación a las monarquías hispanas", Anuario del Departamento de Historia y Teoría del Arte, 13, 2001, pp. 37-52

ID., “Arte y Monarquía en León”, Enciclopedia del románico en Castilla y León. León, Aguilar de Campoo, 2002, pp. 53-65.

ID., "Entre las diversión y la transgresión: a propósito del humor en las artes plásticas medievales", Cuadernos del CEMYR, 12, 2004, pp. 37-68.

ID., "Manuscritos iluminados y monarquía en los siglos X y XI", Alfonso VI y su época. I, Los precedentes del reinado (966-1065) (E. Fernández González y J. Pérez Gil ed.), León, 2007, pp. 209-233.

ID., "El proceso de internacionalización de la miniatura en torno al año 1200 en la Península Ibérica: el antifonario de Las Huelgas Reales de Burgos", El monacato en los reinos de León y Castilla (siglos VII-XIII), León, 2007, pp. 437456.

ID., "Iconografía del soberano en la Alta Edad Media Hispana: Propaganda y Legitimación", Sacralités Royales en Péninsule Ibérique: formes, limites, modalités (VII-XV siècle), (en prensa).

GALVÁN FREILE, F. y MORÁIS MORÁN, J. A., "Microarchitectures dans les arts plastiques hispaniques autour de 1200 et leurs relations avec l'architecture monumentale", Mikroarchitektur im Mittelalter. Ein gattungsübergreifendes Phänomen zwischen Realität und Imagination, Leipzig, 2008, pp. 479-497.

GAMER, G., "Les colonnes ornées de Pampres et la colonne de Beja", Actas do III Congresso Nacional de Arqueologia, vol. II, Coimbra, 1971, pp. 487-493.

GANDOLFO, F., "Reimpiego di sculture antiche nei troni papali del 12 secolo", Atti della Pontificia Academia Romana di Archeologia: Rendiconti, 47, 1974-1975, pp. 203-218.

ID., "La pinttura romana tra XI e XII secolo e l'Antico", Roma, centro ideale dell cultura dell'Antico nei secoli XV e XVI. Da Martino V al Sacco di Roma 14171527, Milano, 1985, pp. 21-32. 
ID., "Il romanico in Alta Italia", L'Arte Medievale in Italia, Firenze, 1988, pp. 285-356.

ID., "Il sarcofago di Saint-Hilaire d'Aude, il Maestro di Cabestany e la Toscana", Medioevo: il tempo degli antichi, Milán, 2006, pp. 425-437.

GARCÍA Y BELLIDO, A., "Sarcófagos romanos de tipo oriental hallados en la Península Ibérica”, Archivo Español de Arqueología, 21, 71, 1948, pp. 95-109.

ID., Esculturas romanas de España y Portugal, Madrid, 1949.

ID., Les religions orientales dans l'Espagne romaine, Leiden, 1967.

ID., Arte Romano, Madrid, 1972.

ID., "La Hispania de Hadriano", Homenaje a Conchita Fernández Chicarro, Madrid, 1982, pp. 301-317.

ID., Arte Romano, Madrid, 2004.

GARCÍA-BELLIDO, M.-P.,"Dalla moneta iberica alla moneta ispanica”, Hispania Romana. Da terra di conquista a Provincia dell'imperio (J. Arce, S. Ensoli, E. La Rocca coord.), Roma, 1997, pp. 31-43.

GARCÍA CUETOS, M. P., "La iglesia románica de San Pedro de Arrojo, Quirós. Un repertorio escultórico al servicio de una comunidad rural", Boletín del Instituto de Estudios Asturianos, 149, 1997, pp. 55-82.

ID., "Los Reyes de Asturias. La Cámara Santa de la Catedral de Oviedo", Maravillas de la España medieval: Tesoro sagrado y monarquía, 2 vols., Valladolid, 2001, vol. I, pp. 205-214.

GARCÍA DE CASTRO VALDÉS, C., "San Miguel de Lillo: Campaña de excavaciones arqueológicas 1991: II análisis de materiales”, Boletín del Real Instituto de Estudios Asturianos, 51, 150, 1997, pp. 47-74.

GARCÍA FLORES, "Cáliz de doña Urraca”, Maravillas de la España medieval: Tesoro sagrado y monarquía, 2 vols., Valladolid, 2001, vol. I, ficha catalográfica 108, p. 335 .

GARCÍA GARCÍA, M. A., "La reutilización y destrucción de los sarcófagos romanos de Baetica durante la Edad Media”, Romula, 3, 2004, pp. 239-256.

GARCÍA-GELABERT, M. P., "Relieves vegetales en Hispania durante la Antigüedad Tardía”, La tradición en la Antigüedad Tardía, Murcia, 1997, pp. 457-470.

GARCÍA GUAL, C., "Roma y la herencia de la cultura griega", Roma. Senatus Populus Que Romanus, Madrid, 2007 pp. 363-371.

GARCÍA GUINEA, M. A., "El arte románico en Palencia", Ciclo de conferencias sobre el románico y el Camino de Santiago, Palencia, 1983, pp. 83-108. 
ID., "El arte románico en Palencia", Historia de Palencia. Edades Antigua y Media, vol. I, Palencia, 1984, pp. 217-243.

ID., "San Martín de Frómista, paradigma del románico hispano", Perfiles del arte románico, Aguilar de Campoo, 2002, pp. 11-25.

GARCÍA LANA, J. M., El concejo de Teverga y la insigne Colegiata de San Pedro, Palencia, 1952.

GARCÍA LOBO, V., Las inscripciones de San Miguel de Escalada. Estudio crítico, Barcelona, 1982.

ID., "Las inscripciones medievales de San Isidoro de León. Un ensayo de Paleografía epigráfica medieval", Santo Martino de León. Ponencias del I Congreso Internacional sobre Santo Martino en el VIII centenario de su obra literaria (1185-1985), León, 1985, pp. 373-397.

ID., Los medios de comunicación social en la Edad Media. La comunicación publicitaria, León, 1990.

GARCÍA LOBO, V. y MARTÍN LÓPEZ, E., "La escritura publicitaria en la Edad Media. Su funcionalidad”, Estudios Humanísticos, 18, 1996, pp. 125-145.

GARCÍA MARTÍNEZ, A., "El Panteón de S. Isidoro de León: Estado de la cuestión y crítica historiográfica", Anuario del Departamento de Historia y Teoría del Arte, vol. XVI, 2004, pp. 9-16.

ID., "Aproximación crítica a la historiografía de San Isidoro de León", Estudios Humanísticos. Historia, IV, 2005, pp. 53-93.

GARCÍA NISTAL, J., "La memoria de la Antigüedad en las armaduras de cubierta y sus diferentes vías de difusión. Reflexiones sobre la historia de los ornamentos", Art i Memoria, Barcelona, 2008, (en prensa).

GARCÍA ROMO, F., "Los pórticos de San Isidoro de León y de Saint-Benoît-sur-Loire y la iglesia de Sainte-Foy de Conques (Estudio comparativo de sus capiteles)", Archivo Español de Arte, 111, 1955, pp. 207-236.

ID., "El problema de la personalidad del escultor románico: el maestro de Jaca (Jaca, Loarre, Frómista, León)", Mélanges offerts à René Crozet, vol. II, Poitiers, 1966, pp. 359-363.

ID., "Nota sobre los posibles contactos entre la escultura de Jaca y la de Módena", Arte Lombarda, 1967, pp. 23-24.

ID., "Orígenes y cronología de nuestro románico", Revista de Ideas Estéticas, 117, 1972, pp. 23-47. 
ID., La escultura del siglo XI (Francia- España) y sus precedentes hispánicos, Barcelona, 1973.

GARCÍA SANZ, O. y BERNAL CASASOLA, D., "Iconografía dionisíaca en lucernas de la Hispania romana", Cuadernos de prehistoria y arqueología, 21, 1994, pp. 117-158.

GARCÍA TORAÑO, P., "Los dípticos consulares y el ramirense”, Boletín del Instituto de Estudios Asturianos, 35, 1981, pp. 837-848.

GARDELLES, J., "Recherches sur les origines des façades a étages d'arcatures des églises médiévales”, Bulletin Monumental, 136-I, 1978, pp. 143-133.

GARDNER, J., “Arnolfo di Cambio and Roman Tomb Design”, The Burlington Magazine, vol. 115, 844, 1973, pp. 422-439.

GARGIULO, M., "Sarcofago architettonico di un centurione", Rilavorazione dell'Antico nel Medioevo (a cura di M. D’Onofrio), Roma, 2003, ficha catalográfica 6, pp. 38-39.

GARRIGOU GRANDCHAMP, P., SALVÈQUE, J-D. y MAURICE-CHABARD, B., "La sculpture civile clunisoise", La ville de Cluny et ses maisons. XIe-XVe siècles, Paris, 1997, pp. 178-206.

GAUTHIER, M.-M., "L'atelier d'orfèvrerie de Silos à la époque romane”, El románico en Silos: IX Centenario de la consagración de la iglesia y claustro, Silos, 1990, pp. 377-395.

GAUTIER DALCHÉ, P. La descriptio mappe mundi de Hugues de Saint-Victor, Paris, 1988.

GENDLE, N., voz “Cipro”, Enciclopedia dell'arte medievale, vol. IV, Roma, 1993, pp. 800-812.

GERMAIN, M-O., "Genèse, dite Genèse de Cotton", Byzance. L'art bizantin dans les collections publiques françaises, Paris, 1992, ficha catalográfica 96, p. 142.

GHDINI, F. y SALVADORI, M., "Tradizione e innovazione nelle picture di vigne e giardini nel repertorio funerario romano", La peinture funéraire antique $I V^{e}$ siècle av. J.-C.-IV siècle apr. J.-C. (A. Barbet ed.), Paris, 2001, pp. 93-98.

GIANMARIA, S., "Isidoro di Siviglia, De natura rerum", Romei \& giubilei: il pellegrinaggio medievale a San Pietro, 350-1350 (M. D’Onofrio ed.), Milano, 1999, ficha catalográfica 11, p. 287.

ID., "Tiberio Alfarano, Pianta dell'antica basilica di San Pietro in Vaticano", Romei \& giubilei: il pellegrinaggio medievale a San Pietro, 350-1350 (M. D’Onofrio ed.), Milano, 1999, ficha catalográfica 257, p. 437. 
GIAMPIETRO, L., "L'area vaticana nelle più antiche descrizioni medievali”, Pellegrini alla tomba di Pietro (G. Morello ed.), Milano, 1999, pp. 144-151.

GIARDINA, B., "La rappresentazione del faro nelle emissioni numismatiche del mondo antico", Rivista italiana di numismatica e scienze affini, 108, 2007, pp. 145-168.

GIGLI, A. y VALENZANO, G., "Ampolla”, Romei \& Giubilei. Il pellegrinaggio medievale a San Pietro (350-1350) (a cura di M. D’Onofrio), Milano, 1999, ficha 47, p. 311.

GIULIANO, A., Il commercio dei sarcofagi Attici, Roma, 1962.

GIL, M., "Fragmento de escultura", El arte románico. Catálogo, Barcelona-Santiago de Compostela, 1961, ficha catalográfica 1798, p. 525.

ID., "Fragmento de escultura", El arte románico. Catálogo, Barcelona-Santiago de Compostela, 1961, ficha catalográfica 1799, p. 525.

GINZBURG, C. y CASTELNUOVO, E., "Centro e periferia", Storia dell'arte italiana, vol. I, Torino, 1979, pp. 283-352.

GINZO FERNÁNDEZ, A., El legado clásico, Alcalá de Henares, 2003.

GLASS, D., The Renaissance of the Twelfth Century, Rhode Island, 1969.

GODOY FERNÁNDEZ, C., "Calagurris, centro de culto martirial de los santos Emeterio y Celedonio. Observaciones sobre la restitución arquitectónica de la memoria martyrum a partir de Prudencio", Kalakorikos, 5, 200, pp. 87-102.

GOLDSCHMIDT, W., "El sepulcro de San Vicente de Ávila”, Archivo Español de Arte, 34, 1936, pp. 161-170.

ID., "Toulouse and Ripoll-The Origin of the Style of Gilabertus", The Burlington Magazine for Connoisseurs, 74, 432, 1939, pp. 104-110.

ID., "The West Portal of San Vicente at Ávila", The Burlington Magazine for Connoisseurs, 71, 414, 1937, pp. 110-123.

GOMBRICH, E. H., La Historia del Arte, London, 2008.

GÓMEZ GÓMEZ, A., "La escultura románica en Navarra; Álava y su entorno", Revisión del Arte Medieval en Euskal Herria, 15, 1996, pp. 83-101.

GÓMEZ-MORENO, M., "Santa Marta de Tera", Boletín de la Sociedad Española de Excursiones, 16, 3, 1908, pp. 81-87.

ID., Catálogo Monumental de España. Provincia de León (1906-1908), 2 vols., 1925 (reed. León, 1979). 
ID., "Pinturas murales de San Pedro de Arlanza", Boletín de la Real Academia de la Historia, 86, 1925, pp. 13-16.

ID., Catálogo Monumental. Provincia de Ávila (A. de la Morena y T. Pérez Higuera eds.), 3 vols., Ávila, 1983.

GONZÁLEZ FERNÁNDEZ, E., "Máscaras romanas en terracota halladas en la Ciudad de Lugo", Actas del XXII Congreso Nacional de Arqueología, vol. II, Vigo, 1993, pp. 279-282.

GONZÁLEZ FERNÁNDEZ, M. L., FERNÁNDEZ ORDÁS, R., ALVAREZ ORDÁS, J. C., RODRÍGUEZ GONZÁLEZ, P. y VIDAL ENCINAS, J. M., "Un asunto superficial: el revoco decorativo del recinto amurallado romano-medieval de León”, De arte, 1, 2002, pp. 11-20.

GONZÁLEZ HERNÁNDEZ, A., Los primeros renacimientos, Valencia, 1982.

GONZÁLEZ HÉRRANZ, R., "Representaciones musicales en la iconografía medieval", Anales de Historia del Arte, 8, 1998, pp. 67-96.

GONZÁLEZ ZYMLA, H., "La iconografía de la serpiente", Revista de arqueología, 23, 255, 2002, pp. 44-51.

ID., "La simbología de la serpiente en las religiones antiguas: en torno a las posibles causas biológicas que explican su sacralidad e importancia", Akros, 3, 2004, pp. 67-82.

GRABAR, A., Martyrium. Recherches sur le culte des reliques et l'art chrétien antique, 2 vols. Paris, 1946.

ID., Les ampoules de Terre Sainte (Monza-Bobbio), Paris, 1958.

ID., "L'Art religieux et l'Empire byzantin a l'époque des macédoniens", L'Art de la fin de l'Antiquité et du Moyen Âge, vol. I, Paris, 1968, pp. 151-168.

ID., "L'imago clipeata chrétienne", L'Art de la fin de l'Antiquité et du Moyen Age, vol. I, Paris, 1968, pp. 607-613.

ID., "A propos des mosaïques de la coupole de Saint-Georges a Salonique", Cahiers Archéologiques. Fin de l'Antiquité et Moyen Age, XVII, 1977, pp. 59-81.

ID., "Le succès des arts orientaux a la cour byzantine sous les macédoniens", L'Art de la fin de l'Antiquité et du Moyen Âge, vol. I, Paris, 1968, pp. 266-290.

ID., "Le tiers monde de l'Antiquité à l'école de l'art classique et son rôle dans la formation de l'art du Moyen Âge", L'art paléochrétien et l'art byzantin, London, 1979, pp. 1-59.

ID., "L'iconographie du Ciel dans l'art Chrétien de l'Antiquité et du Haut Moyen Âge", Cahiers Archéologiques, 30, Paris, 1982, pp. 5-24. 
ID., Las vías de la creación iconográfica cristiana, Madrid, 1985.

GRABINIER, E. y PRESSOUYRE, L., "Chapiteaux à feuilles d'acanthe fouettées par le vent", L'Acanthe dans la sculpture monumental de l'Antiquité à la Renaissance, Paris, 1993, pp. 357-392.

GRAF, A., Roma nella memoria e nelle immaginazioni del Medio Evo, Roma, 1923.

GRAF, G. N., Portugal Roman. Le Nord du Portugal, La-Pierre-qui-Vire, 1987.

GRANT, M., The emperor Constantine, London, 1993.

GREENHALGH, M., “Ipsa ruina docent: l'uso dell'antico nel Medioevo", Memoria dell'antico nell'arte italiana, L'uso dei classici (a cura di S. Settis), 3 vols., Torino 1984, vol. I, pp. 113-167.

ID. The survival of Roman Antiquities in the Middle Ages, London, 1989.

GRIMAL, E., Pompéi, Paris, 1992.

GRODECKI, L., Le vitrail roman, 1977.

ID., “Le Style 1200”, Encyclopedia Universalis, Suplément II, 1980, pp. 1337-1340.

ID., Le vitrail gothique au XIII ${ }^{\mathrm{e}}$ siècle, Paris, 1984.

GROS, P., L'architecture romaine: du début du IIIe siècle av. J.-C. à la fin du HautEmpire. Maisons, palais, villas et tombeaux, Paris, 2001.

ID., L'architecture romaine du début du IIIe siècle av. J.-C. à la fin du Haut-Empire. Les monuments publics, Paris, 2002.

ID., "Situation stylistique et chronologique du chapiteau corinthien de Vitruve", L'Acanthe dans la sculpture monumental de l'Antiquité à la Renaissance, Paris, 1993, pp. 27-37.

GROSSEL, M-G., "Suivre nu le Christ nu. L'idéal du dépouillement dans la Vie des Pères, traduction en prose offerte à Blanche de Champagne (ms. Lyon BM 0868)", Le Nu et le Vêtu au Moyen Age (XII'-XIII siècles), Aix-en-Provence, 2001, pp. 165-178.

GROUSSET, R. y AUROYER, J., voz “Oreste”, Enciclopedia dell'arte antica classica e orientale, vol. IV, Roma, 1960, pp. 741-750.

GUARDIA PONS, M., Las pinturas bajas de la Ermita de San Baudelio de Berlanga, Soria: problemas de orígenes e iconografía, Soria, 1982.

ID., "Una obra bizantina de Ciudad Real y el tema de la Anástasis", D’Art, 12, 1986, pp. 86-112. 
ID., "De Peñalba de Santiago a Berlanga de Duero: la pintura mural de los siglos X y XI en el reino de León y en Castilla. ¿Un espejo del al-Andalus?”, El legado de Al-Andalus. El arte andalusí en los reinos de León y Castilla durante la Edad Media (M. Valdés Fernández coord.), León, 2007, pp. 115-156.

ID., "Scariphare et pingere en la Edad Media", Patrimonio, 33, 2008, pp. 51-58.

ID., "Una región meridional de la pintura románica", El románico y el Mediterráneo. Cataluña, Toulouse y Pisa. 1120-1180 (M. A. Castiñeiras González y J. Camps ed.), Barcelona, 2008, pp. 149-157.

GUARDIA PONS, M. y LORÉS I OTZET, I., "La escultura tardorromana y altomedieval en Cataluña", Escultura decorativa tardorromana y altomedieval en la Península Ibérica (L. Caballero Zoreda y P. Mateos Cruz ed.), Madrid, 2007, pp. 191-219.

GUERRA CAMPOS, J., "La tumba Apostólica de Santiago de Compostela a la luz de las excavaciones recientes", Compostellanum, I/4, 1956, pp. 886-896.

ID., "La tumba apostólica de Santiago de Compostela a la luz de las excavaciones recientes. Crónica de una conferencia del P. Kirschbaum S. J., en Roma”, Compostellanum, 1, 1956, pp. 370-380.

ID., "El descubrimiento del cuerpo de Santiago en Compostela. Según la "Historia de España" dirigida por Menéndez Pidal. Nota bibliográfica", Compostellanum, I/2, 1965, pp. 513-551.

ID. "Bibliografía (1950-1969). Veinte años de estudios jacobeos", Compostellanum, XVI, 1971, pp. 575-732.

ID., "El sepulcro de Santiago", La Catedral de Santiago de Compostela: IX Centenario de la Catedral de Santiago de Compostela. Año Santo de 1976, Santiago de Compostela, 1977, pp. 13-86.

ID., Excavaciones arqueológicas en torno al sepulcro del Apóstol Santiago, Santiago de Compostela, 1982.

GUERRINI, L., voz "Clitennestra”, Enciclopedia dell'arte antica classica e orientale, vol. II, Roma, 1959, pp. 721-723.

ID., "Diadoumenos", Enciclopedia dell'arte antica classica e orientale, vol. II, Roma, 1959, p. 89.

GUDIOL, G., "Los relieves de la portada de Errondo y el maestro de Cabestany", Príncipe de Viana, XIV, 1944, pp. 9-14.

GUDIOL, G. y ALCOLEA I BLANCH, S., Pintura gótica catalana, Barcelona, 1986.

GUDIOL, M. J., Els primitius. La miniatura catalan, Barcelona, 1955. 
GUIDOBALDI, A. G., voz "Dafni”, Enciclopedia dell'arte medievale, vol. V, Roma, 1994, pp. 609-612.

GUIDOBALDI, F., "I capitelli e le colonnine riutilizzati nei monumento funebre del cardinal Venerio", San Clemente. La scultura del VI secolo, Roma, 1992, pp. 1331.

ID., San Clemente gli edifici romani, la basilica paleocristiana e le fasi altomedievali, Roma, 1992.

ID., "Sull'originalità dell'architettura di età costantiniana", XLII Corso di cultura sull'arte ravennate e bizantina. Seminario internazionale sul tema: Ricerca di Archeologia Cristiana e Bizantina, Ravenna, 1995, pp. 419-441.

ID., voz "Roma”, Enciclopedia dell'arte medieval, vol. X, Roma, 1999, pp. 63-77.

GURY, F., voz "Rhea", Lexicon Iconographicum Mythologiae Classicae, vol. VII, 1, Zürich-Münich, 1994, pp. 628-632.

GUTIÉRREZ BEHEMERID, M. A., "Sobre la sistematización del capitel corintio en la Península Ibérica", Boletín del Seminario de Estudios de Arte y Arqueología, 48, 1982, pp. 25-44.

GUZMÁN ARMARIO, F. J., “¿Germanismo o romanismo?: una espinosa cuestión en el tránsito del mundo antiguo a la Edad Media: el caso de los visigodos", Anuario de estudios medievales, 35, 1, 2005, pp. 3-24.

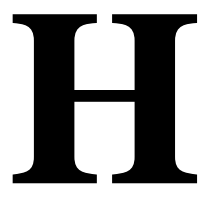

HALLEUX, R., "Le baptême du philosophe Craton. Origine et sens d'une image sur les fonts baptismaux dits de Saint-Barthélemy à Liège", Études sur les fonts baptismaux de Saint-Barthélemy à Liège, Liège, 2006, pp. 199-210.

HAMBLIN, W. J. y ROLPH SEELY, D., El Templo de Salomón: historia y mito, Madrid, 2008.

HARVEY, P. D. A., Medieval Maps, London, 1991.

HASKELL, F. y PENNY, N., El gusto y el arte de la Antigüedad. El atractivo de la escultura clásica (1500-1900), Madrid 1990. 
HASKINS, C. H., The Renaissance of the Twelfth Century, Cambridge, 1927.

HASSING, D., "He will make alive your mortal bodies: cluniac spirituality and the Tomb of Alfonso Ansúrez", Gesta, XXX/ 2, 1991, 140-153.

HAUSCHILD, TH., “Torre de Hércules (prov. La Coruña). Leuchtturm”, Denkmäler der Römerzeit, Hispania Antiqua, Maguncia, 1993, p. 300.

ID., "Arquitetura em Portugal sob o domino dos visigodos", XXXIX Corso di cultura sull'arte ravennate e bizantina. Aspetti e problemi di archeologia e storia dell'arte della Lusitania, Galicia, e Asturie tra Tardoantico e Medioevo, Ravenna, 1992, pp. 387-495.

HEARN, M. F., Romanesque sculpture. The revival of Monumental Stone Sculpture in the Eleventh and Twelfth Centuries, Ithaca-New York, 1985.

HEITZ, C., Recherches sur les rapports entre architecture et liturgie à l'époque carolingienne, Paris, 1963.

ID., "Mathématique et architecture. Proportions, dimensions systématiques et symboliques dans l'architecture du haut Moyen Âge", Musica e arte figurativa nei secoli X-XII, Todi, 1973, pp. 167-193.

ID., "Vitruve et l'architecture du Haut Moyen Âge", La cultura antica nell'Occidente latino dal VII all' XI secolo, XXII Settimana di Studio del Centro di Studio sull'Alto Medioevo, Spoleto, 1975, pp. 725-757.

ID., "More romano. Problèmes d'architecture et liturgie carolingiennes", Roma e l'età carolingia, Roma, 1976, pp. 27-37.

ID., "Sepulcrum Domini: Le sépulcre visité par les saintes Femmes (IX ${ }^{\mathrm{e}}-\mathrm{XI}$ e siècles)", Haut Moyen-Âge. Culture, Education et Société, Paris, 1981, pp. 389-400.

ID., "Beata Maria Rotunda. À propos de la rotonde occidentale de Saint Michel de Cuixà”, Études Roussillonnaises offertes à Pierre Ponsich, Perpinyà, 1987, pp. 273-277.

ID., La France pré-romane. Archéologie et architecture religieuse du Haut Moyen Âge, IV siècle- An Mille, Paris, 1987.

ID., "Un monument à la charnière des temps: Saint-Bénigne de Dijon", La France préromane. Archéologie et architecture religieuse du Haut Moyen Age du IV à l'an Mille, Paris, 1987, pp. 241-249.

ID., "Saint-Michel de Cuxà et la tradition carolingienne", De la création à la restauration: Travaux d'histoire de l'art offerts à Marcel Durliat pour son $75 e$ anniversaire, Toulouse, 1992, pp. 53-67. 
ID., "D'Aix-la-Chapelle à Saint-Benigne de Dijon, rotondes mariales carolingiennes et ottoniennes", Les Cahiers de Saint-Michel-de-Cuixà, XXV, 1994, pp. 5-11,

ID., "Bâtir et célébrer more romano", Les Cahiers de Saint-Michel de Cuixà, XXVI, 1995, pp. 57-66.

HENRIET, P., "Mille Formis Daemon. Usages et fonctions de la croix dans l'Hispania des IX ${ }^{\mathrm{e}}-\mathrm{XI}^{\mathrm{e}}$ siècles", Guerre, Pouvoirs et Idéologies dans l'Espagne Chrétienne aux alentours de l'an mil (T. Deswarte y Ph. Sénac dir.), Turnhout, 2005, pp. 163-18.

HENRY TAYLOR, F., "The sarcophagus of San Lorenzo", The Art Bulletin, 10, 1, pp. 46-58.

HERBER-SUFFRIN, F., "L'acanthe dans le décor architectural carolingien”, L'Acanthe dans la sculpture monumental de l'Antiquité à la Renaissance, Paris, 1993, pp. 189-210.

HERNÁNDEZ, F., "Un aspecto de la influencia del arte califal en Cataluña (Basas y capiteles del siglo XI)", Archivo Español de Arte y Arqueología, 1930, pp. 2149.

HERNANDO GARRIDO, J. L., "Las Claustrillas de Las Huelgas, San Andrés de Arroyo y Aguilar de Campoo: los repertorios ornamentales y su eclecticismo en la escultura del tardorrománico castellano", Anuario del Departamento de Historia y Teoría del Arte, IV, 1992, pp. 53-74.

ID., "Los grandes talleres escultóricos en los monasterios románicos castellanoleoneses", Los monasterios románicos, Aguilar de Campoo, 2001, pp. 45-72.

ID., "La escultura románica en Palencia: un balance historiográfico", Palencia en los siglos del románico, Aguilar de Campoo, 2002, pp. 11-35.

ID., "La restauración de la arquitectura románica en Castilla y León a finales del siglo XIX: el caso de San Martín de Frómista”, Perfiles del arte románico, Aguilar de Campoo, 2002, pp. 83-109.

HERRÁEZ ORTEGA, M. V., "Contribución al estudio de la orfebrería en el siglo XIII en Navarra. El Evangeliario de Roncesvalles", Laboratorio de Arte, 18, 2005, pp. 57-72

ID., "Cubiertas de evangeliario", Sancho el Mayor de Navarra y sus herederos. El linaje que europeizó los reinos hispanos, 2 vols., Pamplona, 2006, vol. I, ficha catalográfica 138, pp. 416-420.

HERRÁEZ ORTEGA, M. V. y TEIJEIRA PABLOS, M. D., "El cuerpo occidental de la iglesia de San Pedro de Arlanza. Propuesta de reconstrucción histórica”, De Arte, 2, 2003, pp. 7-27. 
HERRERO DE LA FUENTE, M. y FERNÁNDEZ FLÓREZ, J. A., "El códice albeldense (o Vigiliano) de la Biblioteca del Real Monasterio de El Escorial, Ms. D.I.2.", Los manuscritos visigóticos: estudio paleográfico y codicológico (C. García Turza coord.), 2002, pp. 117-174.

HERRMANN, L., Les fables antiques de la broderie de Bayeaux, Bruxelles, 1964.

HIERNAND, J., y RIOU, Y-J., "Les sarcophages", Le Baptistère Saint-Jean de Poitiers, Poitiers, 2004, pp. 60-70.

HIDRIO, G., "L'église de Rieux-Minervois: Marie et les sept colonnes de la Sagesse dans l'iconographie médiévale", Les Cahiers de Saint-Michel de Cuixa, XXV, 1994, pp. 87-97.

Hispania Romana. Da terra di conquista a provincia dell'impero (a cura di J. Arce, S. Ensoli y E. La Rocca), Roma, 1997.

HOMANN-WEDEKING, E., "Diadumenos", Enciclopedia dell'arte antica classica e orientale, vol. III, Roma, 1960, pp. 89-90.

ID., voz "Dioniso", Enciclopedia dell'arte antica classica e orientale, vol. III, Roma, 1960, pp. 112-114.

HOPPE, J. M., "Quelques observations personnelles sur le rencontre "escultura decorativa tardorromana y altomedieval en Hispania", Escultura decorativa tardorromana y altomedieval en la Península Ibérica (L. Caballero Zoreda y P. Mateos Cruz ed.), Madrid, 2007, pp. 415-420.

HUBERT, J., "Les prémisses de la Renaissance carolingienne au temps de Pépin III", Nouveau recueil d'études d'Archéologie et d'histoire. De la fin du monde antique au Moyen Age, Paris, 1985, pp. 225-234.

ID., "Rome et la Renaissance carolingienne", Nouveau recueil d'études d'Archeólogie et d'histoire. De la fin du monde antique au Moyen Age, Paris, 1985, pp. 235244.

HUBERT, J., PORCHER, J. y VOLBACH, F. W., L'Impero carolingio, Milano, 1968.

HUET, V., "La colonne Aurélienne: contexte spatial et historiographie", La colonne Aurélienne. Autour de la colonne Aurélienne. Geste et image sur la colonne de Marc Aurèle á Rome (J. Scheid et V. Huet eds.), Thurnhout, 2000, pp. 107-127.

HUICI, S., "Iglesia de templarios de Torres del Río (Navarra), Boletín de la Comisión de Monumentos Históricos y Artísticos de Navarra, XV, 1924, pp. 47-51.

HUNT, N., Cluny under Saint Hugh 1049-1109, London, 1967. 


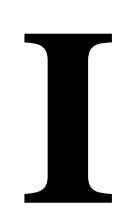

IBAÑEZ IBAÑEZ, J., y MENDOZA RUIZ, F., Melitón de Sardes, Homilía sobre la Pascua, Pamplona, 1975.

IBARBURU ASURMENDI, M. E., "La pervivencia de ilustraciones sobre temas astronómicos del mundo clásico, a través del ms. Vat. Reg. 123”, V Congreso Español de Historia del Arte, Barcelona, 1986, pp. 29-37.

ICARD-GIANOLIO, N., y VIOLAINE SZABADOS, A., voz "Nereides", Lexicon Iconographicum Mythologiae Classicae, vol. VI, 1, Zürich-München, 1992, pp. 785-824.

IELT, A., "Die Relikarium in Apsismosaik von San Clemente in Rom", Patrum Romanum, 1997, pp. 97-111.

INGLEBERT, H., "La mémoire de l'histoire de Rome chez les auteurs latins chrétiens de 410 à 480", La Mémoire de l'Antiquité dans l'Antiquité tardive et la Haut Moyen Âge, Paris, 2000, pp. 57-66.

IÑíGUEZ, J. A., "La catedral de Jaca y los orígenes del románico español”, Actas del Quinto Congreso Internacional de Estudios Pirenaicos: Jaca-Pamplona, vol. 3, 1966, pp. 179-201.

ID., Síntesis de Arqueología Cristiana, Ávila, 1977.

IÑíGUEZ, F., "La catedral de Jaca y los orígenes del románico", Pirineos, XXIII, 1967, pp. 179-200.

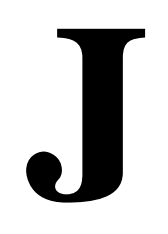

JIMÉNEZ GARNICA, A. M., "El arte "oficial" de Toulouse bajo soberanía visigoda: La Daurade", Archivo Español de Arqueología, 61, 157-158, 1988, pp. 179-196. 
JOHNSON, M. J., "The Royal View at Cefalù: A Note on the Choice of Subjects and their Arrangement in the Mosaics of Norman Sicily", Abstracts of Papers. Byzantine Studies Conference, 4-6, 1983, pp. 12-13.

JONES ROCCOS, L., "Lykourgos II", Lexicon iconographicum mythologiae classicae, vol. VI, 1, Zürich-München, 1992, pp. 319-322.

JULLIAN, M., "La lyre dans l'art roman. Transmission et diffusion par l'image d'un modèle antique à l'époque romane", Les Cahiers de Saint-Michel de Cuxa, XXXVII, 2006, pp. 43-58.

JULLIAN, R., "L'art de la draperie dans la sculpture romane de Provence", Gazette de Beaux-Arts, 1928, II, pp. 241-258.

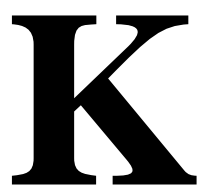

KAHSNITZ, R., "Bernwardsäule", Bernward von Hildesheim und das Zeitalter der Ottonen (A. Eggebrecht y M. Brandt ed.), Hildesheim, 1993, vol. II, pp. 540548.

KARGE, H., "De Santiago de Compostela a León: modelos de innovación en la arquitectura medieval española. Un intento historiográfico más allá de los conceptos de estilo", Anales de Historia del Arte, Cien años de investigación sobre arquitectura medieval española, 2009, pp. 165-198.

KARTSONIS, A. D., Anastasis. The making of a image, Princeton, 1986.

KAUFFMANN, C. M., "New York, Pierpont Morgan Library Ms. 619”, A Survey of Manuscripts Illuminated in The British Isles. Romanesque Manuscripts. 10661190, London, 1975, ficha catalográfica 84, pp. 111-112.

ID., "Winchester, Cathedral Library", A Survey of Manuscripts Illuminated in The British Isles. Romanesque Manuscripts. 1066-1190, London, 1975, ficha catalográfica 83, pp. 108-111.

ID., "Bestiary", English Romanesque Art 1066-1200, London, 1984, ficha catalográfica 86, p. 133.

ID., "Bible: the Lambeth Bible, vol. I, Genesis-Job", English Romanesque Art 10661200, London, 1984, ficha catalográfica 53, p. 115.

ID., "Bible: the Puiset Bible, vol. I, Genesis-2 Kings", English Romanesque Art 10661200, London, 1984, ficha catalográfica 77, p. 128. 
ID., "Bible: the Winchester Bible, vol. II", English Romanesque Art 1066-1200, London, 1984, ficha catalográfica 64, pp. 120-121.

ID., "Bible: the Winchester Bible, vol. III", English Romanesque Art 1066-1200, London, 1984, ficha catalográfica 64a, p. 121.

ID., "Bible: the Winchester Bible, vol. IV", English Romanesque Art 1066-1200, London, 1984, ficha catalográfica 64b, p. 121.

ID., "Epistles of St. Paul, with gloss of Peter Lombard", English Romanesque Art 10661200, London, 1984, ficha catalográfica 78, p. 129.

ID., "Glossed Gospels", English Romanesque Art 1066-1200, London, 1984, ficha catalográfica 83, p. 132.

ID., "Gregory the Great, Dialogues", English Romanesque Art 1066-1200, London, 1984, ficha catalográfica 10, p. 90.

ID., "Leaf related to the Winchester Bible", English Romanesque Art 1066-1200, London, 1984, ficha catalográfica 65, p. 122.

ID., "Manuscripts. The $12^{\text {th }}$ century", English Romanesque Art 1066-1200, London, 1984, pp. 84-85.

ID., "Psalter", English Romanesque Art 1066-1200, London, 1984, ficha catalográfica 74, p. 127.

ID., "Psalter: the Westminster Psalter", English Romanesque Art 1066-1200, London, 1984, ficha catalográfica 82, p. 131.

KENDALL, C. B., "The Verse Inscriptions of the tympanum of Jaca and PAX Anagram", Mediaevalia, 19, 1996, pp. 405-434;

ID., The Allegory of the Church. Romanesque and Portals and Their Verse Inscriptions, Toronto, 1998.

KESSLER, H. L., "Caput et speculum onmium ecclesiarum: Old St. Peter's and church decoration in medieval latium", Old St. Peter's and church decoration in medieval Italy, Spoleto, 2002, pp. 46-73.

ID., "La decorazione della basilica medievale di San Pietro", Old St. Peter's and church decoration in medieval Italy, Spoleto, 2002, pp. 263-270.

ID., "La decorazione della basilica medievale di San Pietro", Romei \& Giubilei. Il pellegrinaggio medievale a San Pietro (350-1350) (M. D’Onofrio ed.), Milano, 1999, pp. 263-270.

ID., "Pictures as scripture in fifth-century churches", Old St. Peter's and church decoration in medieval Italy, Spoleto, 2002, pp. 15-43. 
KIKUCHI, N., "Study on the works of the Cabestany Master", Bulletin of the Study on Philosophy and History of Art in University of Tsukaba, 5, 1987, pp. 23-79.

KINNEY, D., "Spolia from the Baths of Caracalla in Santa Maria in Trastevere", Art Bulletin, 68, 1986, pp. 379-397.

ID., "The concept of spolia", A Companion to Medieval Art: Romanesque and gothic in Northern Europe (C. Rudolph ed.), Oxford, 2006, pp. 233-252.

KITZINGER, E., Early Mediaeval Art in the British Museum, London, 1940.

ID., "The Byzantine Contribution to Western Art $\mathrm{f}$ the Twelfth and Thirteenth Century", Dumbarton Oaks Papers, XX, 1966, pp. 27-47.

ID., "The Gregorian Reform and the visual arts: a problem of method", Transactions of the Royal Historical Society, V, 22, 1972, pp. 87-102.

ID., Byzantine Art in the Making. Main lines of stylistic development in Mediterranean Art. $3^{\text {rd }}-7^{\text {th }}$ Century, Cambridge, 1995.

KLEIN, P., "Les portails de Saint-Genis-des-Fontaines et de Saint-Andre-de-Sorede. I. Le linteau de Saint-Genis", Les Cahiers de Saint-Michel de Cuxa, 1989, XX, pp. 121-160.

KLEINBAUER, W. E., "Charlemagne's Palace Chapel at Aachen and Its Copies", Gesta, vol. 4, 1965, pp. 2-11.

$\mathrm{KOCH}, \mathrm{G}$. , "Zu dem verschollenen attischen Sarkophag aus La Gayole", Imago Antiqvitatis. Religions et iconographie du monde romain, Mélanges offerts à Robert Turcan (N. Blanc y A. Buisson ed.), Paris, 1999, pp. 291-297.

KOLDEWEIJ, A. M., voz "Maastricht", Enciclopedia dell'arte medievale, vol. VIII, Roma, 1997, pp. 59-65.

ID., voz "Mosana, arte", Enciclopedia dell'arte medievale, vol. VIII, Roma, 1997, pp. 578-582.

KOPPEL, E., "Sarcófago con cortejo de cupidos", Locvs Amønvs, 3, 1997, pp. 7-14.

KÖTZSCHE, D.,"Nikolaus von Verdun und die Kölner Goldschmiedekunst", Rhein und Maas. Kunst und Kultur. 800-1400, Köln, 1972, ficha catalográfica K, pp. 314-315.

ID., "Platte Von Einen Buchdeckel", Rhein und Maas. Kunst und Kultur 800-1400, Köln, 1972, ficha catalográfica 20, p. 258.

ID., "Taufbecken Des Reiner Von Huy”, Rhein und Maas. Kunst und Kultur. 800-1400, Köln, 1972, ficha catalográfica 238-239. 
KRAUTHEIMER, R., Corpus Basilicarum Christianarum Romae. Le basiliche cristiane antiche di Roma (sec. IV-X), vol. I, 1937, Città del Vaticano.

ID., "The carolingian revival of early christian architecture", The Art Bulletin, XXIV, 1942, pp. 1-38.

ID., "Sancta Maria Rotunda", Arte del primo millenio, Torino, 1950, pp. 21-27.

ID., "The Architecture of Sixtus III: a fifth Century Renascence?", Essays in Honor of E. Panofsky (M. Meiss ed.), New York, 1961, pp. 291-302.

ID., The Constantinian Basilica”, Dumbarton Oaks Papers, 21, 1967, pp. 117-131.

ID., "Constantine's Church Foundations", Akten des VII. Internationalen Kongresses für christliche Archäologie, Vatican City-Berlin, 1969, pp. 237-255.

ID., Roma. Profilo di una città. 312-1308, Roma, 1981.

ID., Arquitectura paleocristiana y bizantina, Madrid, 1984.

ID., St. Peter's and medieval Rome, Roma, 1985.

ID., Introduction à une iconographie de l'architecture médiévale, Paris, 1993.

ID., "La fondation de Saint-Paul-hors-les-murs", Idéologie de l'art antique. Du IV au $X V^{e}$ siècle, Paris, 1995, pp. 11-24.

ID., "Le renouveau carolingien de l'architecture paléochrétienne", Idéologie de l'art antique. Du IV au XV siècle, Paris, 1995, pp. 27-83.

KRIEN-KUMMROW, G., voz "Maschera", Enciclopedia dell'arte antica classica e orientale, vol. IV, Roma, 1960, pp. 900-918.

KOSTOF, S., Historia de la arquitectura, 2 vols., Madrid, 1988.

KUSABA, Y., "Henry of Blois, Winchester, and the Twelfth-Century Renaissance", Winchester Cathedral: Nine Hundred Years (J. Cook ed.), 1993, pp. 69-80.

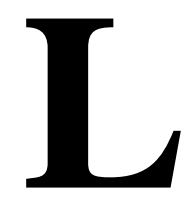

LABANDE-MAILFERT, Y., "Les peintures murales. Le programme roman", Le Baptistère Saint-Jean de Poitiers, Poitiers, 2004, pp. 45-53. 
LABBÉ, A., "La poétique des ruines dans quelques chansons de geste", Littératures, 36,1997, pp. 5-32.

LACARRA DUCAY, M. C., Catedral y Museo Diocesano de Jaca, Zaragoza, 1993.

ID., voz "Navarra", Enciclopedia dell'arte medievale, vol. VIII, Roma, 1997, pp. 654657.

LACOSTE, J., "La sculpture à Silos autour de 1200", Bulletin Monumental, 131, 1973, pp. 101-128.

ID., "Découvertes dans la cathédrale de Lérida", Bulletin Monumental, 132-1, 1974, pp. 231-234.

ID., Les grands sculpteurs romans du dernier tiers du XII siècle dans l'Espagne du Nord Ouest, Toulouse, 1986.

ID., "Nouvelles recherches a propos du second maître du cloître de Santo Domingo de Silos”, El románico en Silos: IX centenario de la consagración de la iglesia y claustro, 1088-1988, Burgos, 1990, pp. 473-482.

ID., "La escultura románica en Aragón en el siglo XII", Signos: arte y cultura en el Alto Aragón medieval (T. Luesma coord.), 1993, pp. 111-120.

ID., "El Maestro de Carrión de los Condes", La fortificación medieval en la Península Ibérica (P. L. Huerta coord.), Aguilar de Campoo, 2001, pp. 155-185.

ID., Les maîtres de la sculpture romane dans l'Espagne du pèlerinage à Compostelle, Bordeaux, 2006.

LAFFITTE, M-P., "Évangiles de Saint-Médard de Soissons", Trésors carolingiens. Livres manuscrits de Charlemagne à Charles le Chauve, Paris, 2007, ficha catalográfica 10, pp. 97-100.

ID., "Sacramentaire de Charles le Chauve (?), fragment", Trésors carolingiens. Livres manuscrits de Charlemagne à Charles le Chauve, Paris, 2007, ficha catalográfica 18, pp. 117-118.

LAFONTAINE-DOSOGNE, J., "La tradition byzantine des baptistères et leur décor, et les fonts de Saint-Barthélemy à Liège", Cahiers Archéologiques, 37, 1989, pp. 45-69.

LAGUNA PAÚL, T., "Memorias sepulcrales de las Sauninas", Laboratorio de Arte, 12, 1999, pp. 27-38.

LAHOZ, M. L., "Contribución al estudio de la Portada de Santa María La Real de Olite", Ondare, 18, 1999, pp. 77-112. 
LAMBERT, E., "Les chapelles octogonales d'Eunate et de Torres del Río", Mémorial Henri Basset. Nouvelles études nord-africaines et orientales, Paris, 1928, pp. 18.

ID., L'art gothique en Espagne aux XII et XIII siècles, Paris, 1931.

ID., "La peregrinación a Compostela y la arquitectura románica", Archivo Español de Arte, XVI, 1943, pp. 273-309.

LAMIA, S., "Souvenir, synaesthesia, and the sepulcrum Domini: sensory stimuli as memory stratagems", Memory and the Medieval Tomb, (E. Valdez del Álamo y C. Stamatis Pendergast), Cambridge, 2000, pp. 19-41.

LAMPÉREZ Y ROMEA, V., "La iglesia de Santa María en el castillo de Loarre", Boletín de la Sociedad Española de Excursiones, vol. 9, 105, 1901, pp. 221-224.

LANZANI, V., "Ubi Petrus". L'antica immagine della Confessione vaticana", Pellegrini alla tomba di Pietro (a cura di G. Morello), Milano, 1999 pp. 34-59.

LAPEÑA PAÚL, A. I., "Lauda sepulcral atribuida a la tumba de Pedro I de Aragón", Sancho III el Mayor y sus herederos. El linaje que europeizó los reinos hispanos, 2 vols., Pamplona, 2006, vol. I, ficha catalográfica 131, pp. 367-368.

LA ROCCA, E., "Le basiliche cristiane "a deambulatorio" e la sopravvivenza del culto eroico", Ecclesiae Urbis. Atti del Congresso Internazionale di Studi sulle chiese di Roma (IV-X secolo) (a cura di F. Guidobaldi e A. G. Guidobaldi), vol. II, Città del Vaticano, 2002, pp. 1109-1140.

LASKO, P., Arte sacro. 800- 1200, Madrid, 1999.

LASSALLE, V., "Imitation d'un masque scénique antique sur un chapiteau roman de Brioude", Revue Archéologique du Centre, 51-52, 1974, pp. 229-233.

ID., L'influence antique dans l'art roman provençal, Paris, 1983.

ID., "Les chapiteaux corinthiens de Sant Pere de Rodes et leurs semblables ou dérivés du Roussillon et du Languedoc", Le Roussillon de la Marca Hispanica aux Pyrénées-Orientales (VIII ${ }^{e}-X X^{e}$ siècles), Perpinyà, 1995, pp. 381-409.

ID., "Motifs inspirés par les sarcophages du Sud-Ouest dans le décor sculpté du cloître d'Elne (Pyrénées-Orientales)", Bulletin de la Société Nationale des Antiquaires de France, 85, 1997, pp. 198-205.

LATORRE GONZÁLEZ-MORO, P. y CABALLERO ZOREDA, L., "El faro de La Coruña, llamado la Torre de Hércules", Hispania. El legado de Roma en el año de Trajano, Zaragoza, 1998, pp. 453-457.

LAURANSON-ROSAZ, C., "La romanité du Midi de l'an Mil; le point sur les sociétés méridionales", Catalunya i França meridional a l'entorn de l'any mil, Barcelona, 1991, pp. 45-58. 
LAURENZI, L., voz "Boethos I", Enciclopedia dell'arte antica classica e orientale, vol. II, 1959, pp. 118-120.

ID., voz "Colosseo", Enciclopedia dell'arte antica classica e orientale, vol. II, 1959, pp. 773-774.

LAVAGNE, H., "Le sarcophage à représentation dionysiaque de Cadenet (Vaucluse). Historiographie et problèmes d'iconographie", Imago Antiqvitatis. Religions et iconographie du monde romain, Mélanges offerts à Robert Turcan (N. Blanc y A. Buisson ed.), Paris, 1999, pp. 297-313.

LAVEDAN, P., Représentation des villes dans l'art du Moye Âge, Paris, 1954.

ID., voz "Masque Scénique", Dictionnaire illustré de la mythologie et des antiquités grecques et romaines, Paris, 1964, pp. 627-629.

LAVERRET, M., "L'iconographie de Sainte Radegonde dans les manuscrits", Bulletin de la Société des Antiquaires de l'ouest et des Musées de Poitiers, 5, II, 1988, pp. 85-112.

LAWRENCE, A., "Alfred, his Heirs and the Traditions of Manuscript Production in Tenth-Century in England", Reading Medieval Studies, 13, 1987, pp. 35-56.

ID., voz "Winchester. Miniatura", Enciclopedia dell'Arte Medievale, vol. XI, Roma, 2000, pp. 798-801.

ID., "The Pagan Themes in Christian Art", De artibus opuscula XL. Essays in Honor of Erwin Panofsky, New York, 1961, pp. 323-334.

LAWRENCE, M., “City-Gate Sarcophagi”, The Art Bulletin, 10, 1, 1927, pp. 1-45.

LE BLANT, E., Étude sur les sarcophages chrétiens antiques de la ville d'Arles, Paris, 1878.

LECLERCQ-KADANER, J., "De la Terre-Mère à la Luxure. A propos de la "migration des symboles”, Cahiers de civilisation médiévale, 69, XVIII, 1975, pp. 37-43.

ID., La sirène dans la pensée et dans l'art de l'Antiquité et du Moyen Âge: du mythe païen au symbole chrétien, Bruxelles, 1997.

LECLERCQ-MARX, J., "Imágenes. La doble tradición medieval”, Quintana, 4, 2005, pp. 13-53.

LEÓN, P., "Ara cilindrica da Italica", Hispania Romana Da Terra di conquista a Provincia dell'Impero, Milano, 1997, fichas catalográficas 217, 218, 219, pp. 410-411.

LETHABY, W. R., "The Part of Suger in Creation of Medieval Iconography", Burlington Magazine, 25, 1914-1915, pp. 206-207. 
LEVETO, P. D., "The Marian Theme of the Frescoes in S. Maria at Castelseprio", The Art Bulletin, vol. 72, 3, 1990, pp. 393-413.

LÉVY-RUBIN, M., "The Crusader Maps of Jerusalem”, Knights of the Holy Lands, Crusader Kingdom of Jerusalem, Jérusalem, 1999, pp. 231-237.

LINAGE CONDE, A., Alfonso VI, el rey hispano y europeo de las tres religiones (1065-1109), Burgos, 1994.

LIPPOLD, G., voz "Copie e copista", Enciclopedia dell'arte antica classica e orientale, vol. II, Roma, 1959, pp. 804-810.

LITTLE, C. T., "Head o fan old testament figure", The Art of the medieval Spain. 5001200, New York, 1993, ficha catalográfica 100, p. 221.

LITTLE, C. T. y HUSBAND, T. B., “Two Italian Church Portals”, The Metropolitan Museum of Art. Europe in the Middle Ages, New York, 1987, pp.68-71.

LITTLE, C. T., y HUSBAND, T. B., "Early Christian Silver", The Metropolitan Museum of Art. Europe in the Middle Ages, New York, 1987, pp. 30-31.

LIVERANI, P., "L'immagini della Hispania", Hispania Romana Da Terra di conquista a Provincia dell'Impero, Milano, 1997, pp. 93-98.

LOFFREDA, S., Recovering Capharnaum, Jerusalem, 1985.

LOPES, V., Mértola na Antiguidade Tardia. A topografia histórica da cidade e do seu território nos alvores do cristianismo, Mértola, 2003.

LÓPEZ ALSINA, F., "Évolution urbaine de la Compostelle médiévale (IX ${ }^{\mathrm{e}}$ au XII siècle)", Europalia 85 España. Santiago de Compostela 1000 ans de Pèlerinage Européen, pp. 230-232.

ID., "Le Tumbo (cartulaire) A de la cathédrale de Saint-Jacques", Europalia 85 España. Santiago de Compostela 1000 ans de Pèlerinage Européen, Santiago de Compostela, 1985, ficha catalográfica 36, p. 235.

LÓPEZ DE GUEREÑO, M. T., "La cruz y el crucificado en la Edad Media hispana", Maravillas de la España medieval: Tesoro sagrado y monarquía, 2 vols., Valladolid, 2001, vol. I, pp. 371-381.

LÓPEZ FERREIRO, A., El Pórtico de la Gloría, Platerías y el primitivo Altar Mayor, Santiago de Compostela, 1975.

ID., Historia de la Santa Iglesia, vol. I, Santiago de Compostela, 1978.

LÓPEZ MONTEAGUDO, G., "Modelos clásicos para las pinturas de San Isidoro de León”, La visión del mundo clásico en el arte Español, Madrid, 1993, pp. 25-35. 
LÓPEZ DE OCARIZ Y ALZOLA, J. J., "El temor al infierno hacia 1200. Análisis iconográfico de la Anástasis de Armentia (Álava)", Alfonso VIII y su época, Madrid, 1992, pp. 253-269.

LORENZONI, G., "Aspetti del Tardoantico: Diocleziano e Constantino", Aspetti e problemi del Medioevo artistico. Le origini, Torino, 1969, pp. 1-39.

ID., "Carolingia, Arte. Roma", Enciclopedia dell'Arte Medievale, vol. IV, Roma, 1993, pp. 315-317.

ID., "Per una possibile lettura simbolica del presbiterio nell'architettura paleocristiana", Arte d'Occidente. Temi e Metodi, Studi in onore di Angiola Maria Romanini. Arte, 3 vols., Roma, vol. I, 1999, pp. 1-6.

LORÉS I OTZET, I., "Sant Pere de Rodes. Consideracions sobre la cronologia de l'església", Actes del congrés internacional Gerbert d'Orlhac, Vic, 1999, pp. 287-303.

ID., "L'église de Sant Pere de Rodes un exemple de renaissance de l'architecture du XI siècle en Catalogne", Les Cahiers-de-Saint-Michel de Cuxa, XXXII, 2001, pp. 21-39.

ID., El monestir de Sant Pere de Rodes, Barcelona, 2002.

ID., "Transmission de modèles toulousains dans la sculpture monumentale en Catalogne dans la première moitié du XII ${ }^{\mathrm{e}}$ siècle: anciennes et nouvelles problématiques", Les Cahiers de Saint-Michel de Cuxa, XXXVII, 2006, pp. 91-102.

ID., "La decoración escultórica en el monasterio de Santa María de Ripoll", Los grandes monasterios benedictinos hispanos de época románica (1050-1200) (J. A. García de Cortázar y R. Teja Casuso coords.), Aguilar de Campoo, 2007, pp. 167-190.

ID., "Actualización de los edificios: nuevas construcciones e incorporación de la escultura", El románico y el Mediterráneo. Cataluña, Toulouse y Pisa. 11201180 (M. A. Castiñeiras González y J. Camps ed.), Barcelona, 2008, pp. 121131 ,

LORÉS I OTZET, I. y CAMPS I SÒRIA, J., “El Port de la Selva. L'escultura de Sant Pere de Rodes", Catalunya Romànica. Empordà II, vol. IX, Barcelona, 1990, pp. 703-728.

ID., "L'artiste et son atelier, ses commanditaires", Le Maître de Cabestany, Pierre-quiVire, 2000, pp. 147-154.

L'ORANGE, H. P., Apotheosis in Ancient Portraiture, Oslo, 1947.

ID., Apotheosis in Ancient Portraiture, New York, 1982. 
LOZANO PÉREZ, "El Claustro de Monreale y el Tardorrománico hispano: relaciones formales", La Multiculturalidad en la Artes y la Arquitectura, 2 vols., Las Palmas de Gran Canaria, 2006, vol. I, pp. 329-336.

LUCIE-SMITH, E., La sexualidad en el arte occidental, Barcelona, 1992.

LUGLI, G., voz “Appia, Via”, Enciclopedia dell'arte antica classica e orientale, vol. I, Roma, 1958, pp. 499-501.

ID., voz "Lago di Nemo", Enciclopedia dell'arte antica classica e orientale, vol. VI, Roma, 1963, pp. 406-409.

LYMAN, T. W. "Le style comme symbole chez les sculpteurs romans: essai d'interprétation de quelques inventions thématiques a la porte Miégéville de Saint-Sernin”, Les Cahiers de Saint-Michel de Cuxa, VI, 1975, pp. 161-178.

ID., "Portails, portiques, paradis. Rapports iconologiques avec le cloîtres méridionaux", Les Cahiers de Saint-Michel de Cuxa, VII, 1976, pp. 35-43.

ID., "Arts somptuaires et art monumental. Bilan de influences appliques pré-romanes sur la sculpture romane dans le sud-ouest de la France et en Espagne", Les Cahiers de Saint-Michel de Cuxa, IX, 1978, pp. 115-124.

ID., "La table d'autel de Bernard Gilduin et son ambiance originelle", Les Cahiers de Saint-Michel de Cuxa, vol. 13, 1982, pp. 53-73.

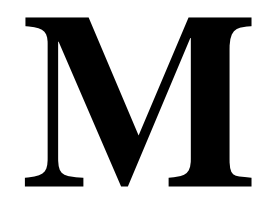

MACAULAY, R., Pleasure of Ruins, New York, 1967.

MACIEL, M. J., "Vectores da arte paleocrista em portugal nos contextos suévico e visigotico", XXXIX Corso di cultura sull'arte ravennate e bizantina, Ravenna, 1992, pp. 435-495.

ID., "A Arte de época classica (séculos II a. C.-II d. C), História da Arte Portuguesa, (P. Pereira dir.), Lisboa, 1995, vol. I, pp. 79-149.

ID., “A Arte da Antiguidade tardia (séculos III-VIII, ano de 711)", História da Arte Portuguesa, (P. Pereira dir.), Lisboa, 1995, vol. I, pp. 103-149.

ID., Antiguidade tardia e paleocristianismo em Portugal, Lisboa, 1996. 
ID., "Banquete e Apotheosis en alguns signos artísticos da Antiguidade Tardia portuguesa", Propaganda y Poder. Congreso Peninsular de História da Arte, Lisboa, 1999, pp. 19-29.

ID., "Do Paganismo ao Cristianismo: Interacçoes e continuidades nos comportamentos culturais e artísticos", Psicología, 30, 2002, pp. 241-249.

ID., "L'Art et l'expression de la foi", Pacien de Barcelone et l'Hispanie au IV siècle, Paris, 2004, pp. 207-218.

MACIEL, M. J., PEIXOTO CABRAL, J. M. y NUNES, D., "O sarcófago romano das Musas (Valado, Alfezeirão). Nova Leitura iconográfica e análise do mármore”, Arqueologia e História, 55, 2003, pp. 63-70.

ID., "Os sarcófagos tardo-romanos do Museo Nacional da Arqueología. Novos dados para a sua Interpretação”, O Arqueólogo Português, IV, 20, Lisboa, 2002, pp. 161-173.

MADDALO, S., In Figura Romae. Immagini di Roma nel libro medioevale, Roma, 1990.

ID., "Roma terminus itineris multorum et laborum initium. Immagini di Roma tra devozione, archeologia e ideologia politica", Romei e Giubilei. Il pellegrinaggio medievale a San Pietro (a cura di M. D’Onofrio), Milano 1999, pp. 241-249.

MAGUIRE, H., "From Constantine to Iconoclasm", Byzantium 330-1453, London, 2008, pp. 66-109.

Le Maître de Cabestany, Pierre-qui-Vire, 2000.

MALAXECHEVERRÍA, I., El bestiario esculpido de Navarra, Pamplona, 1982.

MÂLE, E., L'art religieux du XII en France, Paris, 1998.

MALLET, G., "La sculpture préromane en Catalogne: l'exemple des chapiteaux. État d'une question controversée", Saint-Guilhem-le-Desert dans l'Europe du Haut Moyen Age, Amis de Saint-Guilhem-le-Désert, 2000, pp. 175-181.

ID., "Un artiste itinérant? Géographie de l'oeuvre du Maître de Cabestany, Le Maître de Cabestany, Pierre-qui-Vire, 2000, pp. 16-23.

ID., "Le tympan et le linteau d'Errondo (Navarre) conservés au Musée des Cloisters à New York", Le Maître de Cabestany, Pierre-qui-Vire, 2000, pp. 165-168.

MANCHO I SUÁREZ, C., "La Anunciación de San Pere de Sorpe, un ejemplo matizado de continuidad", Los clasicismos del Arte Español, Madrid, 1994, pp. 59-66. 
ID., "Los grandes conjuntos de pintura mural del siglo XII", El románico y el Mediterráneo. Cataluña, Toulouse y Pisa. 1120-1180 (M. A. Castiñeiras González y J. Camps ed.), Barcelona, 2008, pp. 169-167,

ID., "La memòria artística I l'oblit del passat", Art i Memòria. Pre-Actes, Barcelona, 2008, pp. 20-22.

MANSUELI, G. A., “Asklepios”, Enciclopedia dell'arte antica classica e orientale, vol. I, Roma, 1958, pp. 719-724.

ID., voz "Provinciale, arte", Enciclopedia dell'arte antica, classica, e orientale, vol. VI, Roma, 1965, pp. 519-527.

MANSUELLI, G. A., "Monumento funerario", Enciclopedia dell'arte antica, classica y orientale, vol. V, Roma, 1963, p. 171.

ID., voz "Provinciale, arte", Enciclopedia dell'arte antica, classica, e orientale, vol. VI, 1965, pp. 519-527.

MAÑANES PÉREZ, T., "La escultura romana en la provincia de León", Butlletí de la Reial Acadèmia Catalana de Belles Arts de Sant Jordi, XVI, 2002, pp. 193-285.

MAÑE RODRÍGUEZ, M., "La época de los viajeros y el redescubrimiento: la memoria del Próximo Oriente y los primeros viajeros: Egeria. Cartas de una peregrina a Tierra Santa (381-384 d.C.): reseña bibliográfica", La aventura española en Oriente (1166-2006) (J. M. Córdoba Zoilo y M. C. Pérez Díez, coords.), vol. 1, 2006, pp. 53-54.

MARCHÁN FIZ, S., "La poética de las ruinas. Un capítulo casi olvidado en la historia del gusto", Fragmentos. Revista de Arte, 6, 1985, pp. 4-15.

MARFIL RUÍZ, P., “Arqueología. La Basílica de San Vicente: En la Catedral de Córdoba", Arte, arqueología e historia, 14, 2007, pp. 185-196.

MARÍN VALDÉS, F., "Los frontis de glorificación del prerrománico asturiano a la luz de algunas proyecciones de la Antigüedad Tardía", Cuadernos de arte e iconografía, VI, 1993, pp. 151-159.

ID., "Observaciones sobre la adopción de loci classici en el arte prerrománico asturiano: factures de continuidad", La Visión del Mundo clásico en el arte español, Madrid, 1993, pp. 30-59.

MARÍN VALDÉS, F. M. y GIL LÓPEZ, J., San Julián de los Prados o el discurso de las dos ciudades, Oviedo, 1989.

MARINO MALONE, C., "Saint-Bénigne de Dijon: l'espace occidental et la contreabside de l'an mil", Avant-nefs et espaces d'accueil dans l'église: entre le IV et le XII ${ }^{e}$ siècle (Ch. Sapin ed.), Paris, 2002, pp. 424-437. 
MARIÑO, B., "La portada de Santiago de Carrión de los Condes", Palencia en los siglos del románico, Aguilar de Campoo, 2002, pp. 51-69.

MARROU, H. I., Décadence romaine ou Antiquité tardive, Paris, 1977.

MARTIGNY, J. A., voz "Vasos sagrados", Diccionario de Antigüedades cristianas, Madrid, 1894, pp. 826-830.

MARTIN, T., "Un nuevo contexto para el tímpano del Cordero en San Isidoro de León”, El Tímpano románico: imágenes, estructuras y audiencias (R. Sánchez Ameijeiras y J. L. Senra Gabriel y Galán coords.), Santiago de Compostela, 2003, pp. 191-198.

ID., "The Art of a Reigning Queen as Dynastic Propaganda in Twelfth-Century Spain", Speculum, 80, 2005, pp.1134-1171.

ID., "Escultura románica para un público laico: El "maestro de la Orestíada" de Frómista y sus contemporáneos", San Martín de Frómista, ¿paradigma o historicismo?, Palencia, 2005, pp. 71-83.

ID., Queen as king: politics and architectural propaganda in twelfth-century Spain, Leiden-Boston, 2006.

ID., "Decorar, aleccionar, aterrorizar: escultura románica y gótica", Real Colegiata de San Isidoro: relicario de la monarquía leonesa (C. Robles García y F. Llamazares Rodríguez), León, 2007, pp. 104-143.

ID., "Recasting the concept of the "Pilgrimage church": the case of san Isidoro de León", Corónica: A journal of medieval Spanish language and literature, 36, 2, 2008, pp. 165-190.

ID., "Una reconstrucción hipotética de la portada norte de la Real Colegiata de San Isidoro, León”, Archivo Español de Arte, 81, 324, 2008, pp. 357-378.

MARTÍN ANSÓN, M. L., Esmaltes en España, Madrid, 1984.

ID., Los esmaltes románicos de Silos, Madrid, 1998.

ID., "Arca de los esmaltes", Maravillas de la España medieval: Tesoro sagrado y monarquía, 2 vols., Valladolid, 2001, vol. I, ficha catalográfica 164, pp. 404405.

ID., "Panel de la urna de Santo Domingo de Silos", Maravillas de la España medieval: Tesoro sagrado y monarquía, 2 vols., Valladolid, 2001, vol. I, ficha catalográfica 163, pp. 403-404.

MARTÍN LÓPEZ, E., "Las inscripciones del Panteón de San Isidoro de León. Particularidades epigráficas", Escritos dedicados a José María Fernández. Catón, León, 2004, pp. 941- 972. 
MARTÍNEZ DE AGUIRRE, J., “Aproximación iconográfica a la iglesia del Santo Sepulcro en Torres del Río (Navarra)", Imágenes y promotores medievales en el arte medieval (M. L. Melero Moneo, F. Español Bertrán, A. Orriols i Alsina, D. Rico Camps eds.), Barcelona, 2001, pp. 153-165.

ID., "La memoria de la piedra: sepulturas en los espacios monásticos hispanos (siglos X y XII)", Monasterios románicos y producción artística, Aguilar de Campoo, 2003, pp. 133-159.

ID., "Iglesias de plan central, encomiendas y otros templos del ámbito rural", El arte románico en Navarra (C. Fernández Ladreda dir.), Pamplona, 2004, pp. 270282.

ID., "El segundo tercio del siglo XII", El arte románico en Navarra (C. FernándezLadreda dir.), Pamplona, 2004, pp. 115-164.

ID., "Catedral románica de Pamplona: el templo", Sancho el Mayor y sus herederos. El linaje que europeizó los reinos hispanos, 2 vols., Pamplona, 2006, vol. II, pp. 873-874.

ID., "Portada occidental de la catedral románica de Pamplona", Sancho el Mayor y sus herederos. El linaje que europeizó los reinos hispanos, 2 vols., Pamplona, 2006, vol. II, ficha catalográfica 6. 2. 1. 1, pp. 875-877.

MARTÍNEZ DE AGUIRRE, J. y GIL CORNET, L., Torres del Río. Iglesia del Santo Sepulcro, Pamplona, 2004.

MARTÍNEZ ENAMORADO, V., "Relaciones entre los omeyas y los núcleos cristianos", El esplendor de los Omeyas cordobeses. La civilización musulmana de Europa Occidental, Granada, 2001, pp. 310-319.

MARTÍNEZ, M. L. y MARTÍNEZ, L. L., "Santa Elena y el hallazgo de La Cruz de Cristo", Comunicación y hombre: revista interdisciplinar de ciencias de la comunicación y humanidades, vol. 3, 2007, pp. 39-50.

MARTÍNEZ DE LAGOS, E., “¿Alegorías de la lucha entre el bien y el mal? Aportación al estudio de las fuentes escritas y visuales que sirven de inspiración a los enfrentamientos entre hombres y bestias en el arte medieval", Boletín del Museo e Instituto Camón Aznar de Ibercaja, XCVIII, 2006, pp. 257-289.

MARTÍNEZ PRADES, J. A., "El castillo de Loarre (Huesca): sus orígenes, construcción y problemática artística", Artigrama, 8-9, 1991-1992, pp. 533-536.

MARTÍNEZ TEJERA, A., "Arquitectura cristiana en Hispania durante la Antigüedad Tardía (siglos IV-VIII) (I)", Gallia e Hispania en el contexto de la presencia "germánica" (ss. V-VII): Balances y perspectivas: Actas de la Mesa Redonda hispano-francesca, Madrid, 2005, pp. 109-187.

ID., El templo del monasterium de San Miguel de Escalada: "arquitectura de fusión” en el reino de León (siglos X-XI), Madrid, 2005. 
ID., "El contraábside en la Arquitectura de Repoblación", Repoblación y Reconquista, Aguilar de Campoo, 1991, pp. 149-161.

MARTINS DE MATOS, J. L., Subsídios para um catálogo da escultura Luso-romana, 2 vols., Lisboa, 1966.

MASSIP BONET, F., Prerrománico y románico, Barcelona, 1997.

MATEO, I., "Temas paganos cristianizados", La Visión del Mundo clásico en el arte español, Madrid, 1993, pp. 37-48.

MATHEUS, K., "Reading Romanesque sculpture: the iconography and reception of the south portal sculpture at Santiago de Compostela", Gesta, XXXIX, 2000, pp. 312.

MATHEWS, T. F., “The Beginnings of Christian Art”, Byzantium 330-1453, London, 2008, pp. 46-63.

MATHIS, P., "Capitello con tre donne al sepulcro", Romei \& Giubilei. Il pellegrinaggio medievale a San Pietro (350-1350) (a cura di M. D’Onofrio), Milano, 1999, ficha catalográfica 179, p. 387.

ID., "Matthew Paris, Itinerario", Romei \& Giubilei. Il pellegrinaggio medievale a San Pietro (350-1350) (a cura di M. D’Onofrio), Milano, 1999, p. 289.

ID., "Architrave", Rilavorazione dell'antico nel Medioevo (M. D’Onofrio ed.), Roma, 2003, ficha catalográfica 182, pp. 56-60.

Matilde e il tesoro dei Canossa: tra castelli, monasteri e città (a cura di Arturo Calzona), Milano, 2008.

MATTHIAE, G., Le chiese di Roma dal IV al X secolo, Roma, 1962.

ID., Mosaici medioevali delle chiese di Roma, 2 vols., Roma, 1967.

ID., Pittura romana del Medioevo. Secoli IV-X, Roma, 1987.

MAUFUS, M-C., "La Terre cuite", Naissance des arts chrétiens. Atlas des monuments paléochrétiens de la France (N. Duval coord.), Paris, 1991, pp. 232-237.

MAYER I OLIVÉ, M., "Fuentes hispanas para los contactos con la iglesia de Roma", Ecclesiae Urbis. Atti del Congresso Internazionale di Studi sulle chiese di Roma (IV-X secolo) (F. Guidobaldi y A. G. Guidobaldi coords.), vol. I, Cittá del Vaticano, 2002, pp. 159-168.

MAYER, M., ÁLVAREZ, A. y RODÀ, I., "Los materiales lapídeos reaprovechados en construcciones medievales en Cataluña. La ciudad de Barcelona y su entorno", Artistes, Artisans et production artistique au Moyen Age (X. Barral i Altet ed.), vol. II, Paris, 1987, pp. 529-558. 
MEYER, E., “Antike Türzieher”, Festschrift E. V. Merckin, Waldsassen, 1964, pp. 8089.

MELERO MONEO, M. L., "Traslatio Santi Jacobi: Contribución al estudio de su iconografía", Los Caminos y el Arte. Caminos y Viajes en el Arte. Iconografía, vol. III, Santiago de Compostela, 1989, pp. 71-93.

ID., La escultura románica en Navarra, Madrid, 1991.

ID., "La sculpture du cloître de la cathédrale de Pampelune et sa répercussion sur l'art roman navarrais", Cahiers de Civilisation Médiévale, Poitiers, 1992, 139, pp. 241-246.

ID., El tímpano de la Iglesia de Sant Pol Joan de les Abadesses y la Traditio Legis, Anuario del Departamento de Historia y Teoría del Arte, 5, 1993, pp. 19-30

ID., "La propagande poitico-religeuse du programme iconographique de la façade de Sainte-Marie de Ripoll", Cahiers de Civilisation Médiévale, 182, 2003, pp. 135157.

ID., "La escultura del claustro de Pamplona", Sancho el Mayor y sus herederos. El linaje que europeizó los reinos hispanos, 2 vols., Pamplona, 2006, vol. II, pp. 911-920.

ID., "Capitel vegetal doble y exento con hojas, animales y cuatro personajes", Sancho el Mayor y sus herederos. El linaje que europeizó los reinos hispanos, 2 vols., Pamplona, 2006, vol. II, ficha catalográfica 272, p. 935.

ID., "El sarcófago de doña Blanca de Navarra y el taller de Leodegarius: Sangüesa y San Martín de Uncastillo", I Encuentro Transpirenaico sobre Patrimonio Histórico Artístico: La Escultura Románica, Zaragoza, 2007, pp. 7-29.

ID., "Navarra y Aragón en las décadas centrales del siglo XII (de 1120 a 1180)", El románico y el Mediterráneo. Cataluña, Toulouse y Pisa. 1120-1180 (M. A. Castiñeiras González y J. Camps ed.), Barcelona, 2008, pp. 99-109.

Memoria dell'antico nell'arte italiana. L'uso dei classici (a cura di S. Settis), vol. I, Torino, 1984.

Memoria dell'antico nell'arte italiana. Generi e i temi ritrovati (a cura di S. Settis), vol. II, Torino, 1985.

Memoria dell'antico nell'arte italiana. Dalla tradizione all'archeología, (a cura di S. Settis), vol. III, Torino, 1986.

MENCHON BES, J. J., "Tarragona, la antigua ciudad romana y la construcción de una ciudad medieval", El románico y el Mediterráneo. Cataluña, Toulouse y Pisa. 1120-1180 (M. A. Castiñeiras González y J. Camps ed.), Barcelona, 2008, pp. 47-53. 
MENEGHINI, R. y SANTAGELI VALENZANI, R., Roma nell'altomedioevo. Topografia e urbanistica della città dal V al X secolo, Roma, 2004.

MENÉNDEZ-PIDAL, G., Hacia una nueva imagen del mundo, Madrid, 2003.

METZGER, C., "Fragment de plaque de revêtement", Byzance. L'art byzantin dans les collections publiques françaises, Paris, 1992, ficha catalográfica 63, p. 116.

MICCOLI, G., “Ecclesiae Primitivae Forma”, Studi Medievali, II, 1960, pp. 470-498.

MIGLIO, M., "Roma dopo Avignone. La rinascita politica dell'antico", Memoria dell'antico nell'arte italiana. L'uso dei classici (a cura di S. Settis), Torino, 1984, vol. I, pp. 75-111.

MIGUÉLEZ CAVERO, A., "La iconografía de la Natividad: los contactos artísticos entre Oriente y Occidente en la época románica", La Multiculturalidad en las Artes y en la Arquitectura, 2 vols., Las Palmas de Gran Canaria, 2006, vol. I, pp. 359-365.

MILONE, A., "Capitel con amorcillos y guirnaldas", El románico y el Mediterráneo. Cataluña, Toulouse y Pisa. 1120-1180 (M. A. Castiñeiras González y J. Camps ed.), Barcelona, 2008, ficha catalográfica 54, pp. 309.

ID., "Fuste de San Giovanni in Sugana", El románico y el Mediterráneo. Cataluña, Toulouse y Pisa. 1120-1180 (M. A. Castiñeiras González y J. Camps ed.), Barcelona, 2008, ficha catalográfica 72, pp. 340-341.

ID., "El Maestro de Cabestany: notas para un replanteamiento", El románico y el Mediterráneo. Cataluña, Toulouse y Pisa. 1120-1180 (M. A. Castiñeiras González y J. Camps ed.), Barcelona, 2008, pp. 181-191.

ID., "Taller de Guglielmo (doc. 1158/ 1159-1165). Capitel compuesto", El románico y el Mediterráneo. Cataluña, Toulouse y Pisa. 1120-1180 (M. A. Castiñeiras González y J. Camps ed.), Barcelona, 2008, ficha catalográfica 51, p. 306.

ID., “Taller de Guglielmo (doc. 1158/1159-1165”, El románico y el Mediterráneo. Cataluña, Toulouse y Pisa. 1120-1180 (M. A. Castiñeiras González y J. Camps ed.), Barcelona, 2008, ficha catalográfica 52, p. 307.

ID., "Taller de Rainaldo. Capitel con amorcillos y guirnaldas", El románico y el Mediterráneo. Cataluña, Toulouse y Pisa. 1120-1180 (M. A. Castiñeiras González y J. Camps ed.), Barcelona, 2008, ficha catalográfica 54, p. 309.

MINER, D., The survival of Antiquity in the Middle Ages. The Greek tradition, Baltimore, 1939.

MIRABELLA ROBERTI, M., "La symbologie paléochrétienne prélude a la symbologie médiévale", Cahiers de Saint-Michel de Cuxa, 12, 1981, pp. 181-187. 
MIRANDA, M. A., "Imagens do sagrado na iluminura e ourivesaria românicas em Portugal”, Románico en Galicia y Portugal, Santiago de Compostela, 2001, pp. 184-213.

ID., "El Reino de Portugal, la promoción del conocimiento y de los viajes en la Edad Media a través del arte", El Mar de Portugal. Arte e Historia, La Laguna, 2002, pp. 17-39.

ID., "Iluminura românica em Portugal", La miniatura medieval en la península Ibérica (J. J. Yarza Luaces), Murcia, 2007, pp. 375-418

MOLINER, M., Diccionario de uso del español A-G, vol. I, Madrid, 1983.

ID., Diccionario de uso del español H-Z, vol. II, Madrid, 1983.

MONTERO FENOLLÓS, J. L., "De Gallaecia a Oriente: monumentos y lugares visitados por Egeria en su peregrinación por la Mesopotamia del siglo IV d.C.", Aulas no camiño: diálogos nun camiño da cultura europea (J. Leira LópezVizoso coord.), A Coruña, 2007, pp. 255-274.

MONTIJANO GARCÍA, J. M., "Iconografía y representación en Roma en el siglo XV: del emblema y la ruina a la figuración científica urbana", Boletín de arte, 15, 1994, pp. 9-32.

MORÁIS MORÁN, J. A., "Un arquetipo arquitectónico de la Antigüedad clásica en la edilicia Altomedieval astur-leonesa: el vano de triple arcada", Monarquía y sociedad en el Reino de León: de Alfonso III a Alfonso VII, 2 vols., León, 2007, vol. II, pp. 563-598.

ID., "Imitación, copia y asimilación de arquetipos. Algunas reflexiones sobre los procesos de creación artística en el arte románico español: los tímpanos de Ruiforco y Matueca de Torío (León)”, (en prensa).

ID., "De lo pagano a lo cristiano en el arte románico hispano: a propósito de la iconografía de las aves afrontadas a la crátera de la vida", La Multiculturalidad en las artes y en la arquitectura, 2 vols., Las Palmas de Gran Canaria, 2006, vol. I, pp. 383-391.

ID., "Nuevas reflexiones para la lectura iconográfica de la Portada del Perdón de San Isidoro de León: el impacto de la Reforma Gregoriana y el arte de la tardoantigüedad", De Arte, 5, 2006, pp. 63-86.

ID., "Pervivencias de la Antigüedad clásica en la Edad Media hispana. El spolium in se: a propósito del cáliz de Doña Urraca", XII Congreso de la Sociedad Española de Estudios Clásicos (SEEC), Valencia, 2007, (en prensa).

ID., La recuperación de la Ecclesiae Primitivae Forma en la escultura del Panteón Real de San Isidoro de León, León, 2008. 
ID., "El valor clásico de la arquitectura asturiana (s. IX): la iglesia de San Julián de los Prados. Entre la tradición "antiquizante" hispanovisigoda y la carolingia", Actas de las I Jornadas Complutenses de Arte Medieval "Cien años de investigación sobre arquitectura medieval española”, Madrid, 2009, pp. 233-246.

ID., "Autour du "style des joues gonflées" et de sa diffusion au sein de la sculpture romane hispano-languedocienne", Effets de style au Moyen Âge Colloque international et pluridisciplinaire organisé par le CUER MA/EA 2207, Aix-enProvence, 2008, (en prensa).

ID., La "construcción" del pasado a través de la memoria de los muertos: los sarcófagos antiguos de Fernán González y Doña Sancha”, Art i Memòria, 2008 (en prensa).

MORALEJO ÁLVAREZ, J. J., "De griegos en Galicia", Epieikeia. Homenaje al Profesor Jesús Lens Tuero (M. Alganza et alt. eds.), Granada, 2000, pp. 327358.

MORALEJO ÁLVAREZ, S., "Esculturas compostelanas del último tercio del siglo XII", Cuadernos de Estudios Gallegos, XXVIII, 84, 1973, pp. 294-310, consultado en Patrimonio artístico de Galicia y otros estudios: homenaje al Prof. Dr. Serafín Moralejo Álvarez (A. Franco Mata coord.), 3 vols., Santiago de Compostela, 2004, vol. I, pp. 47-56.

ID., "Sobre la formación del estilo escultórico de Frómista y Jaca", Actas del XXIII Congreso Internacional de Historia del Arte, vol. I, Granada, 1973, pp. 427-434, consultado en Patrimonio artístico de Galicia y otros estudios: homenaje al Prof. Dr. Serafín Moralejo Álvarez (A. Franco Mata coord.), 3 vols., Santiago de Compostela, 2004, vol. I, pp. 65-70.

ID. "Une sculpture du style de Bernard Gilduin á Jaca", Bulletin Monumental, 1973, pp. 7-16, consultado en Patrimonio artístico de Galicia y otros estudios: homenaje al Prof. Dr. Serafín Moralejo Álvarez (A. Franco Mata coord.), 3 vols., Santiago de Compostela, 2004, vol. I, pp. 57-64.

ID., "Pour l'interprétation iconographique du portail de l'Agneau à Saint-Isidore de León: les signes du zodiaque", Príncipe de Viana, 142-143, 1976, pp. 137-173, consultado en Patrimonio artístico de Galicia y otros estudios: homenaje al Prof. Dr. Serafín Moralejo Álvarez (A. Franco Mata coord.), 3 vols., Santiago de Compostela, 2004, vol. I, pp. 111-129.

ID., "Aportaciones a la interpretación del programa iconográfico de la catedral de Jaca", Homenaje a don José María Lacarra de Miguel, I, Zaragoza, 1977, pp. 173-198, consultado en consultado en Patrimonio artístico de Galicia y otros estudios: homenaje al Prof. Dr. Serafín Moralejo Álvarez (A. Franco Mata coord.), 3 vols., Santiago de Compostela, 2004, vol. I, pp. 89-100.

ID., "La lauda sepulcral de Alfonso Asúrez (†1093): su lugar en el desarrollo de la escultura románica hispánica y sus relaciones con el arte jaqués", Primer Coloquio de Arte Aragonés, Teruel, 1978, pp. 197-218, consultado en Patrimonio artístico de Galicia y otros estudios: homenaje al Prof. Dr. Serafín 
Moralejo Álvarez (A. Franco Mata coord.), 3 vols., Santiago de Compostela, 2004, vol. I, pp. 131-139.

ID., "La sculpture romane de la cathédrale de Jaca. Etat des questions", Les Cahiers de Saint-Michel de Cuxa, 10, 1979, pp. 79-106, consultado en Patrimonio artístico de Galicia y otros estudios: homenaje al Prof. Dr. Serafín Moralejo Álvarez. (A. Franco Mata coord.), 3 vols., Santiago de Compostela, 2004, vol. I, pp. 141-160.

ID., "La fachada de la sala capitular de la Daurade de Toulouse. Datos iconográficos para su reconstrucción”, Anuario de Estudios Medievales, 13, 1983, pp. 37-61, consultado en Patrimonio artístico de Galicia y otros estudios: homenaje al Prof. Dr. Serafín Moralejo Álvarez (A. Franco Mata coord.), 3 vols., Santiago de Compostela, 2004, vol. I, pp. 265-277.

ID., "El patronazgo artístico del arzobispo Gelmírez (1100- 1140): su reflejo en la obra e imagen de Santiago", L.Gai (ed.), Atti del Convengo Internazionale di Studi Pistoia e il Cammino di Santiago, Una dimensione europea nella Toscana medioevale, Nápoles, 1984, pp. 245-272, consultado en Patrimonio artístico de Galicia y otros estudios: homenaje al Prof. Dr. Serafín Moralejo Álvarez. (A. Franco Mata coord.), 3 vols., Santiago de Compostela, 2004, vol. I, pp. 289-300.

ID. "La reutilización e influencia de los sarcófagos antiguos en la España Medieval", Atti Colloquio sul reimpliego dei sarcofagi romani nel Medioevo, Marburger,1984, pp. 187-203, consultado en Patrimonio artístico de Galicia y otros estudios: homenaje al Prof. Dr. Serafín Moralejo Álvarez (A. Franco Mata coord.), 3 vols., Santiago de Compostela, 2004, vol. I, pp. 279-288.

ID., "La imagen arquitectónica de la catedral de Santiago de Compostela". Atti del Convengo Internazionale di Studi: Il pellegrinatio a Santiago de Compostela e la letteratura jacopea, Perugia, 1985, pp. 37-61, consultado en Patrimonio artístico de Galicia y otros estudios: homenaje al Prof. Dr. Serafín Moralejo Álvarez (A. Franco Mata coord.), 3 vols., Santiago de Compostela, 2004, vol. I, pp. 237-246.

ID., "Le Lieu Saint: le Tombeau et les basiliques médiévales", Europalia 85. Santiago de Compostela. 1000 ans de pélegrinage européen, Gante, 1985, pp. 41-52, consultado en Patrimonio artístico de Galicia y otros estudios: homenaje al Prof. Dr. Serafín Moralejo Álvarez (A. Franco Mata coord.), 3 vols., Santiago de Compostela, 2004, vol. II, pp. 11-19.

ID., "La miniatura en los Tumbos A y B", Los Tumbos de Compostela, Madrid, 1985, pp. 45-62, consultado en Patrimonio artístico de Galicia y otros estudios: homenaje al Prof. Dr. Serafín Moralejo Álvarez (A. Franco Mata coord.), 3 vols., Santiago de Compostela, 2004, vol. I, pp. 319-328.

ID., "San Martín de Frómista en los orígenes de la escultura románica europea", Jornadas sobre el Románico en la Provincia de Palencia, Palencia, 1985, pp. 28-37, consultado en Patrimonio artístico de Galicia y otros estudios: homenaje al Prof. Dr. Serafín Moralejo Álvarez (A. Franco Mata coord.), 3 vols., Santiago de Compostela, 2004, vol. II, pp. 61- 64. 
ID., "Le Porche de la Gloire de la Cathédrale de Compostelle: problèmes de la sources et d'interprétation", Les Cahiers de Saint-Michel de Cuxa, 1985, pp. 92-110, consultado en Patrimonio artístico de Galicia y otros estudios: homenaje al Prof. Dr. Serafín Moralejo Álvarez (A. Franco Mata coord.), 3 vols., Santiago de Compostela, 2004, vol. I, pp. 307-318.

ID., "La primitiva fachada norte de la Catedral de Santiago", Compostellanum, XIV, 1985, pp. 632-668, consultado en Patrimonio artístico de Galicia y otros estudios: homenaje al Prof. Dr. Serafín Moralejo Álvarez. (A. Franco Mata coord.), 3 vols., Santiago de Compostela, 2004, vol. I, pp. 21-46.

ID., "Modelo, copia y originalidad en el marco de las relaciones artísticas hispanofrancesas (siglos XI- XIII)", V Congreso Español de Historia del Arte, Barcelona, 1987, pp. 89-112, consultado en Patrimonio artístico de Galicia y otros estudios: homenaje al Prof. Dr. Serafín Moralejo Álvarez (A. Franco Mata coord.), 3 vols., Santiago de Compostela, 2004, vol. II, pp. 75-96.

ID., "Cluny et les débuts de la sculpture romane en Espagne", Le Gouvernement d'Hugues de Semur à Cluny, Cluny, 1988, pp. 405-422, consultado en Patrimonio artístico de Galicia y otros estudios: homenaje al Prof. Dr. Serafín Moralejo Álvarez. (A. Franco Mata coord.), 3 vols., Santiago de Compostela, 2004, vol. II, pp. 195-206.

ID., "Le origini del programma dei portali nel romanico spagnolo", Atti del Convengo: Wiligelmo e Lafranco nell'Europa romanica, Modena, 1989, pp. 35-51, consultado en Patrimonio artístico de Galicia y otros estudios: homenaje al Prof. Dr. Serafín Moralejo Álvarez (A. Franco Mata coord.), 3 vols., Santiago de Compostela, 2004, vol. II, pp. 121-136.

ID., "El claustro de Silos y el arte de los caminos de peregrinación", El románico en Silos. IX Centenario de la consagración de la iglesia y el claustro, Burgos, 1989, pp. 203- 223, consultado en Patrimonio artístico de Galicia y otros estudios: homenaje al Prof. Dr. Serafín Moralejo Álvarez. (A. Franco Mata coord.), 3 vols., Santiago de Compostela, 2004, vol. II, pp. 147-160.

ID., "Arte del Camino de Santiago y Arte de peregrinación (ss. XI- XIII), El Camino de Santiago, Poio, 1990, pp. 9-28, consultado en Patrimonio artístico de Galicia y otros estudios: homenaje al Prof. Dr. Serafín Moralejo Álvarez. (A. Franco Mata coord.), 3 vols., Santiago de Compostela, 2004, vol. II, pp. 137-144.

ID., "Cluny y los orígenes del románico palentino: el contexto de San Martín de Frómista", Jornadas sobre el arte de las Órdenes religiosas en Palencia, Palencia, 1990, consultado en Patrimonio artístico de Galicia y otros estudios: homenaje al Prof. Dr. Serafín Moralejo Álvarez (A. Franco Mata coord.), 3 vols., Santiago de Compostela, 2004, vol. II, pp. 183-194.

ID., voz "Arlanza, San Pedro de”, Enciclopedia dell'Arte Medievale, vol. II, Roma, 1991, pp. 453-454. 
ID., "El mundo y el tiempo en el Beato de Osma", El Beato de Osma. Estudios, Valencia, 1992, pp. 151-179, consultado en Patrimonio artístico de Galicia y otros estudios: homenaje al Prof. Dr. Serafín Moralejo Álvarez. (A. Franco Mata coord.), 3 vols., Santiago de Compostela, 2004, vol. II, pp. 237-260.

ID., "Altar support with Apostles Matthew, Simon, and Judas", The Art of the medieval Spain. 500-1200, New York, 1993, ficha catalográfica n 93, pp. 214-215.

ID., "Column shaft decorated with putti gathering grapes", The Art of the medieval Spain. 500-1200, New York, 1993, ficha catalográfica 92, pp. 212-214.

ID., "Lastra de febrero", The Art of the medieval Spain. 500-1200, New York, 1993, ficha catalográfica n 93, pp. 215-216.

ID., "Lid of Alfonso Ansúrez", The Art of the medieval Spain. 500-1200, New York, 1993, ficha catalográfica 90, pp. 210-211.

ID., "Notas para una revisión de la obra de K. J. Conant", Arquitectura románica da Catedral de Santiago de Compostela, 1983, pp. 221-236, consultado Patrimonio artístico de Galicia y otros estudios: homenaje al Prof. Dr. Serafín Moralejo Álvarez (A. Franco Mata coord.), 3 vols., Santiago de Compostela, 2004, vol. I, pp. 247-263.

ID., Iconografía gallega de David y Salomón, Santiago de Compostela, 2004.

MORENO, I.,"El tiempo como categoría histórica: la periodización y las Edades de Roma”, Minerva, 15, 2001, pp. 175-188.

MOT, G.-J., "L'ossuaire de saint Saturnin à Saint-Hilaire d'Aude", Mémoires de la Société archéologique du Midi de la France, XXVII, 1961, pp. 41-47.

MUNDÓ, A. M., Les Bíblies de Ripoll. Estudi dels Mss. Vaticà, Lat. 5729 I París, BNF, Lat. 6, Città del Vaticano, 2002.

MUÑOZ HERRERA, J. P., "Toledo ante la mirada romántica: reflexiones en torno a una imagen", Cuadernos de arte de la Universidad de Granada, 27, 1996, pp. 147-168.

MUÑOZ MARTÍNEZ, A. B., "Presencia y evolución de una fórmula iconográfica bizantina en la pintura románica catalana: la Natividad", La Multiculturalidad en la Artes y la Arquitectura, 2 vols., Las Palmas de Gran Canaria, 2006, vol. I, pp. 393-399.

MUÑOZ PÁRRAGA, M. C., "Las Capillas Palatinas", Maravillas de la España medieval: Tesoro sagrado y monarquía, 2 vols., Valladolid, 2001, vol. I, pp. 5561.

MÜTHERICH, F., "Die Bilder des Leidener Aratus", Studies in Carolingian Manuscript Illumination, London, 2004, pp. 147-265. 
ID., "Das Kaiserbild", Das Evangeliar Ottos III. Clm 4453 der Bayerischen Staatsbibliothek München (F. Mütherich y K. Dachs ed.), München, 2001, pp. 31-35.

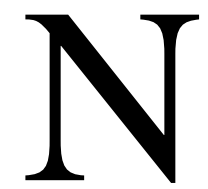

NASCIMENTO, A. A., "The iconography of the year: imagery and astrological dominance", The image of Time. European Manuscript Books, Lisboa, 2000, pp. 116-123.

ID., "The image of time: european manuscript books", The image of Time. European Manuscript Books, Lisboa, 2000, pp. 11-25.

NAVARRO GONZÁLEZ, V., "IX centenario de la consagración de la catedral de Jaca y del concilio jacetano", Argensola, 47-48, 1961, pp. 285-302.

NAVASCUÉS PALACIO, P., "La restauración monumental como proceso histórico: el caso español, 1800-1950", Curso de Mecánica y Tecnología de los edificios antiguos, Madrid, 1987, pp. 285-329.

NEUMAN DE VEGVAR, L., "The origin of the Genoels-Elderen ivories", Gesta, 1990, XXXIX/1, pp. 8-24.

NIETO ALCAIDE, V., "La imagen de la arquitectura asturiana de los siglos VIII y IX en las crónicas de Alfonso III", Espacio, Tiempo y Forma, VII, 2, 1989, pp. 1134.

ID., Arte Prerrománico Asturiano, Salinas, 1989.

ID., "Aspectos técnicos e iconográficos de las vidrieras de las capillas de la Catedral de León”, La Catedral de León en la Edad Media (J. J. Yarza Luaces, M. V. Herráez Ortega y G. Boto Varela coords.), León, 2004, pp. 297-303.

NIETO SORIA, J. M., Ceremonias de la realeza. Propaganda y legitimación en la Castilla Trastámara, Madrid, 1993.

NILGEN, U., "Texte et image dans les absides des $\mathrm{XI}^{\mathrm{e}}-\mathrm{XII}{ }^{\mathrm{e}}$ siècles en Italie", Epigraphie et iconographie (R. Fravreau dir.), Poitiers, 1996, pp. 153-165.

NOACK-HALEY, S., "Capiteles mozárabes", Coloquio internacional de capiteles prerrománicos e islámicos (s. VI-XII), Madrid, 1990, pp. 37-52. 
ID., "Tradición e innovación en la decoración plástica de los edificios asturianos", III Congreso de Arqueología Medieval Española, Oviedo, 1992, pp. 174-184.

ID., "Katalonien, Kapitelle: c. d. Ripoll (Prov. Girona), Kapitelle in der Kloster-kirche Santa Maria und im Arxiu-Museu Folklòric Parroquial. -Zweite Hälfte 10. Jh. e. Kapitell. -Zweite Hälfte 10. Jh. Aus Sant Mateu de Bages (Prov. Barcelona). Museu de Manresa. f. g. Cornellà de Llobregat (Prov. Barcelona), Kapitelle am Rathaus. -Zweite Hälfte 10. Jh.”, Christliche Denkmäler des frühen Mittelalters: vom 8. bis ins 11. Jahrhundert, Mainz, 1999, pp. 409-413.

ID., "San Miguel de Escalada (Prov. León) dreischiffige Basílika mit eingeschriebenem, dreigeteiltem Transept, drei Apsiden und Südportikus. -Weihe 913, Portikus um 930-940 und romanisch", Christliche Denkmäler des frühen Mittelalters: vom 8. bis ins 11. Jahrhundert, Mainz, 1999, pp. 262-270.

ID., "San Miguel de Liño bei Oviedo (Asturien), erhaltenes westliches Drittel der Basilika mit später angefügter Apsis. -848 geweiht", Christliche Denkmäler des frühen Mittelalters: vom 8. bis ins 11. Jahrhundert, Mainz, 1999, pp. 143-149.

ID., "San Miguel de Liño bei Oviedo (Asturien), Reliefplatten der Portallaibungen. Gegen 848", Christliche Denkmäler des frühen Mittelalters: vom 8. bis ins 11 . Jahrhundert, Mainz, 1999, pp. 152-153.

ID., "San Salvador de Valdediós (Asturien), Wand- und Gewölbemalereien des Mittelschiffes, der Hauptapsis und des südlichen Emporennebenraumes. Gergen 893", Christliche Denkmäler des frühen Mittelalters: vom 8. bis ins 11. Jahrhundert, Mainz, 1999, pp. 175-179.

ID., "Santa María de Bamba (Prov. Valladolid), Pilaster-kapitell und Kircheninneres. 2. Drittel 10. Jh.”, Christliche Denkmäler des frühen Mittelalters: vom 8. bis ins 11. Jahrhundert, Mainz, 1999, pp. 285-290.

ID., "Santa María de Melque (Prov. Toledo), Reliefs. -8. -9. Jh.?", Christliche Denkmäler des frühen Mittelalters: vom 8. bis ins 11. Jahrhundert, Mainz, 1999, pp. 92-94.

ID., "Oviedo (Asturien), San Julián de los Prados (Santullano), Pilaster der Hauptapsis. -8 Jh.?", Christliche Denkmäler des frühen Mittelalters: vom 8. bis ins 11. Jahrhundert, Mainz, 1999, p. 124.

ID., "Los capiteles de la mezquita de Madinat al-Zahra", Cuadernos de Madinat alZahra: 5, 2004, pp. 413-443.

NOBRE DE GUSMÃO, A., "Introduction", Portugal Roman. Le Nord du Portugal, La Pierre-Qui-Vire, 1987, pp. 15-18.

NODAR FERNÁNDEZ, V. R., “Alejandro, Alfonso VI y Diego Peláez: una nueva lectura del programa iconográfico de la Capilla del Salvador de la Catedral de Santiago", Compostellanum, XLV, 3-4, 2000, pp. 617-648. 
ID., "De Apóstol a Peregrino: la iconografia de Santiago en el Camino Inglés a Compostela", Abrente, 35-37, 2003-2005, pp. 103-116.

ID., "De la Tierra Madre a la Lujuria: a propósito de un capitel de la girola de la Catedral de Santiago", Sémata, 14, 2002, pp. 335-347.

ID., "Capitel de Alejandro", Atlas de la catedral románica de Santiago. Narración visual e interpretación artística (CDRom), Santiago de Compostela, 2004.

ID., "Capitel con sirenas", Atlas de la catedral románica de Santiago. Narración visual e interpretación artística (CDRom), Santiago de Compostela, 2004.

ID., Los inicios de la catedral románica de Santiago: El ambicioso programa iconográfico de Diego Peláez, Santiago de Compostela, 2004.

ID., "La sirena: la metamorfosis de un tema en la catedral románica de Santiago de Compostela", Codex Aquilarensis, 21, 2005, pp. 33-47.

ID., "Sus cabelleras brillaban como plumas de pavor real: Los guerreros de Alejandro y las sirenas de un capitel de la catedral de Santiago de Compostela", Troianoalexandrina, 5, 2005, pp. 39-61.

NOGALES BASARRATE, T., "Ritratti di provinciali. Immagini dei nuovi coloni nelle nuove colonie", Hispania Romana Da Terra di conquista a Provincia dell'Impero, Milano, 1997, pp. 112-115.

ID., "Statua di Chronos-Mithras", Hispania Romana Da Terra di conquista a Provincia dell'Impero, Milano, 1997, ficha 206, p. 404.

ID., "Statuetta del Genius Senatus", Hispania Romana. Da terra di conquista a provincia dell'Impero, Milano, 1997, ficha 116, p. 367.

NORDHAGEN, P. J., voz "Mosaico", Enciclopedia dell'arte medievale, vol. VIII, Roma, 1997, pp. 563-574.

NUÑEZ, M., "La arquitectura como expresión de poder", Homenaje al profesor Martín González, Valladolid, 1995, pp. 205-212.

NUÑO GONZÁLEZ, J., voz "Virgen de las Batallas (Museo de Burgos)", Enciclopedia del románico en Castilla y León. Burgos, vol. IV, Aguilar de Campoo, 2002, pp. 2378-2380. 


\section{$\mathbf{O}$}

OAKESHOTT, W., The Artist of the Winchester Bible, London, 1946.

ID., Classical inspiration in Medieval Art, London, 1959.

ID., Sigena Romanesque Paintings in Spain and the Winchester Bible Artists, London, 1972.

ID., The Two Winchester Bibles, Oxford, 1981.

ID., "Some New Initials by the Entangled Figures Master Source", The Burlington Magazine, vol. 126, 973, 1984, pp. 230-232.

OCAÑA EIROA, F. J., "La controvertida personalidad del Maestro Esteban en las catedrales románicas de Pamplona y Santiago", Príncipe de Viana, 64, 228, 2003, pp. 7-58.

OCÓN ALONSO, D., "Los maestros de San Pedro el Viejo de Huesca: un ensayo de aproximación a los procesos de creación artística en la escultura románica”, $E l$ arte aragonés y sus relaciones con el hispánico e internacional, Huesca, 1983, pp. 87-100.

ID., "Problemática del crismón trinitario", Archivo Español de Arte, 223, 1983, pp. 242263.

ID., "Cabestany: iglesia parroquial, portada sur", Tímpanos románicos, 2 vols., Madrid, 1987, vol. I, pp. 118-127.

ID., "Errondo: iglesia parroquial (hoy en The Cloisters; New York), Tímpanos románicos, 2 vols., Madrid, vol. I, 1987, pp. 185-186.

ID., Tímpanos románicos españoles: reinos de Navarra y Aragón, 2 vols, Madrid, 1987.

ID., Ego sum ostium, o la puerta del templo como la puerta del cielo en el románico navarro-aragonés", Cuadernos de Arte e Iconografía, vol. II, 3, 1989, pp. 125136.

ID., "Bizantinismo y difusión de modelos en el románico periférico", VIII Congreso Español de Historia del Arte, Cáceres, 1990, pp. 307-320.

ID., "Los ecos del último taller de Silos en el románico navarro-aragonés y la influencia bizantina en la escultura española en torno al año 1200”, El románico en Silos, Santo Domingo de Silos, vol. I, Burgos, 1990, pp. 501-510. 
ID., "Alfonso VII, la llegada de las corrientes artísticas de la corte inglesa y el bizantinismo en la escultura hispana de fines del siglo XII", II Curso de cultura medieval: Alfonso VIII y su época, Madrid, 1992, pp. 307-320.

ID., "El renacimiento bizantinizante de la segunda mitad del siglo XII y la escultura monumental en España", Viajes y Viajeros en la España Medieval, Aguilar de Campoo, 1993, pp. 267-290.

ID., Los modelos clásicos de la escultura monumental española: de fines del siglo XI a fines del siglo XII", Los Clasicismos del Arte Español, Madrid, 1994, pp. 67-73.

ID., "La recepción de las corrientes artísticas monumentales europeas en la escultura monumental castellana en torno a 1200", El arte español en épocas de transición, vol. I, León, 1994, pp. 17-26.

ID., “Aspectos musicales en el arte románico y protogótico", Musiker: cuadernos de música, 8, 1996, pp. 117-129.

ID., "El papel artístico de las reinas hispanas en la segunda mitad del siglo XII: Leonor de Castilla y Sancha de Aragón”, La mujer en el arte español, Madrid, 1997, pp. 27-39.

ID., voz "Uncastillo", Enciclopedia dell'Arte Medievale, vol. XI, Roma, 2000, pp. 428431.

ID., "El sello de Dios sobre la iglesia: tímpanos con crismón en Navarra y Aragón”, El tímpano románico. Imágenes, estructuras y audiencias (R. Sánchez Ameijeiras y J. L. Senra Gabriel y Galán coords.), Santiago de Compostela, 2003, pp. 75-101.

ID., "Regnun et sacerdotium au monastère de Silo", Les Cahiers de Saint-Michel de Cuxa, XXXVI, 2005, pp. 195-208.

ID., "Une salle capitulaire pour une reine: les peintures du chapitre de Sigena", Les Cahiers de Saint-Michel de Cuxa, 38, 2007, pp. 81-94.

ID., "Castilla, León y Galicia en tiempos de Alfonso VII", El Románico y el Mediterráneo. Cataluña, Toulouse y Pisa. 1120-1180 (M. A. Castiñeiras y J. Camps ed.), Barcelona, 2008, pp. 111-119.

ID., “Tímpano de Errondo", El románico y el Mediterráneo. Cataluña, Toulouse y Pisa. 1120-1180, (M. A. Castiñeiras y J. Camps ed.), Barcelona, 2008, ficha catalográfica 80, pp. 356-357.

ID., "El Maestro Mateo. Corrientes artísticas internacionales", Biblioteca Gonzalo de Berceo.

Consultado en http://www.vallenajerilla.com/berceo/oconalonso/maestromateo.htm, el día 9 de febrero de 2009. 
OCÓN ALONSO, D. y RODRÍGUEZ ESCUDERO, P., "Los tímpanos de Jaca y Santa Cruz de La Serós, una pretendida relación modelo-copia", Actas del V Congreso Español de Historia del Arte, Barcelona, 1984, pp. 259-263.

OEPEN, A., "Rasgos generales del sarcófago paleocristiano en Hispania. Bases para la redacción de un primer Corpus", El sarcófago romano: contribuciones al estudio de su tipología, iconografía y centros de producción (J. M. Noguera Celdrán y E. Conde Guerri eds.), Murcia, 2001, pp. 257-272.

OLIVARES, C., "El león con alas de águila en Daniel 7:4: un resumen de la locura y la restauración de Nabuconodosor (Dn. 4)”, DavarLogos 4.2, 2005, pp. 149-158.

ORDÓÑEZ AGULLA, S. M., "El Faro de Gades y las fuentes medievales", II Congreso peninsular de História antiga, Coimbra, 1993, pp. 247-278.

ORLANDINI, P., voz "Baccanali”, Enciclopedia dell'arte antica classica e orientale, vol. I, Roma, 1958, pp. 956-957.

OROFINO, G., "Montecassino", La pittura in Italia. L'Altomedioevo, Milano, 1994, pp. 441-461.

ORRIOLS ALSINA, A., "Les imatges preliminars dels evangelis de Cuixà", Locvs amoenvs, 2, 1996, pp. 31-46.

OTERO TÚÑEZ, R., "La Edad Contemporánea", La Catedral de Santiago de Compostela: IX Centenario de la Catedral de Santiago de Compostela. Año Santo de 1976, Santiago de Compostela, 1977, pp. 381-422.

OTERO TÚÑEZ, R. e YZQUIERDO PERRÍN, R., El coro del maestro Mateo, A Coruña, 1990.

OURSEL, R., La arquitectura románica, Madrid, 1987.

OUSTERHOUT, R., "Architecture as Relic and the Construction of Sanctity: The Stones of the Holy Sepulchre", The Journal of the Society of Architectural Historians, 62, 1, 2003, pp. 4-23. 


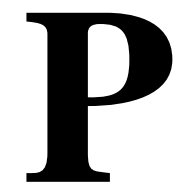

PACE, V., "Nihil innovetur nisi quod traditum est. Sulla scultura romana del Medioevo“, Diskurse zur Geschichte der Europäischen Bildhauerkunst. Skulptur des 12. und 13. Jahrhunderts, Frankfurt, 1994, vol. I, pp. 587-603.

PÄCHT, O., “A Cycle of English Frescoes in Spain”, The Burlington Magazine, 1961, vol. 103, 698, 1961, pp. 166-175.

ID., La miniatura medieval. Una introducción, Madrid, 1987.

ID., "The pre-Carolingian roots of early Romanesque art", Studies in Western Art. Romanesque and Gothic Art, Princeton, 1963, pp.67-75.

PAGÈS I PARETAS, M., voz "Santa María de Cornellà", Catalunya romànica. El Barcelonès, El Baix Llobregat, El Maresme, vol. XX, Barcelona, 1992, p. 354.

PAGLIARA, N. P., "Vitruvio da testo a canone", Memoria dell'antico nell'arte italiana, Dalla tradizione all'archeologia (a cura de S. Settis), vol. III, Torino, 1986, pp. 7-85.

PALAZZO, E., Les sacramentaires de Fulda. Étude sur l'iconographie et la liturgie à l'époque ottonienne, Münster, 1994.

PALAZZO-BERTHOLON, B. y SAPIN, C., "Les décors de stuc de Vouneuil-sousBiard”, Le Stuc. Visage oublié de l'art médiéval, Poitiers, 2005, pp. 65-73.

PALlOTTINO, M., voz "Arco onorario e trionfale", Enciclopedia dell'arte antica classica e orientale, vol. I, Roma, 1958, pp. 588-599.

PANERA CUEVAS, F. J., El retablo de la Catedral Vieja y la pintura gótica internacional en Salamanca, Salamanca, 1995.

ID., "El retablo y las pinturas murales de la Capilla Mayor de la Catedral Vieja de Salamanca", La restauración del Retablo de la Catedral Vieja de Salamanca, Valladolid, pp. 55-225.

PANOFSKY, E., Renaissance and Renascences in Western Art, Stockholm, 1960.

ID., Estudios sobre iconología, Madrid, 1972.

ID., Renacimiento y renacimientos en el arte occidental, Madrid, 1985.

ID., Renacimiento y renacimientos en el arte occidental, Madrid, 2004. 
PARIBENI, E., "Kouros e Kore”, Enciclopedia dell'arte antica, classica e orientale, Roma, 1961, pp. 398-402.

PARSONS, L. M., "Cleanliness with Godliness: A Discussion of Medieval Monastic Plumbing", Mélanges à la Mémoire du Père Anselme Dimie, Artois, 1982, pp. 123-149.

PASTOR MUÑÓZ, M., "El culto al dios Silvano en Hispania ¿innovación o sincretismo?", Memorias de historia antigua. Paganismo y cristianismo en el occidente del Imperio Romano, 5, 1981, pp. 103-114.

PATÓN, B., "Gamba di tavolo a forma di zampa di leone", Hispania Romana Da Terra di Conquista a Provincia dell'Impero, Roma, 1997, ficha 261, p. 432.

PEDREGAL, A., "El culto a los mártires: una herencia de la advocación mágica de los héroes", Héroes, semidioses y daimines, Madrid, 1992, pp. 345-359.

PENNY SMALL, J., The parallel worlds of classical art and text, Cambridge, 2003.

PENSABENE, A., "Contributo per una ricerca sul reimpiego e il "recupero" dell' antico nel Medioevo. Il rimpiego nell'età marmorea", Rivista dell'Istituto Nazionale d'Archeologia e Storia dell'Arte, III, XII, 1990, pp. 5-138.

ID., "La decorazione architettonica, l'impiego del marmo e l'importazione di manufatti orientali a Roma, in Italia e in Africa (II. d. C). Società romana e impero tardoantico", Le merci e l'insediamenti (A. Giardina coord.), Roma-Bari, vol. III, 1986, pp. 285-429.

ID., "Contributi per una ricerca sul reimpiego e il "recupero" dell' antico nel Medioevo. II. I portici cosmateschi a Roma", Rivista dell'Istituto Nazionale di Archeologia e Storia dell'Arte, 3, 14/15, 1991/1992, pp. 305-346.

ID., "Il reimpiego nell'età constantiniana a Roma", Constantino il grande dall'antichità all'umanesimo. Colloquio sul cristianesimo nel mondo antico, vol. II, Macerata, 1993, pp. 749-768.

ID., "Reimpiego dei marmi antichi nelle chiese altomedievali a Roma", Marmi Antichi (G. Borghini coord.), Roma, 1997, pp. 55-64.

PÉPIN, J., voz "Survivances mythiques dans le christianisme ancien", Dictionnaire des mythologies et des religions des sociétés traditionnelles et du monde antique $K$ Z, (Yves Bonnefoy coord.), 2 vols., Paris, 1981, vol. I, pp. 469-475.

PÉQUIGNOT, C., "Vraies ou fausses imitations de l'Anastasis de Jérusalem aux $\mathrm{XI}^{\mathrm{e}}$ et XII ${ }^{\mathrm{e}}$ siècles", Les Cahiers de Saint-Michel de Cuxa, XXXI, 2000, pp. 119-133.

PEREIRA, P., "O modo gótico (séculos XIII-XV). A Arquitectura (1250-1450), História da Arte Portuguesa (P. Pereira dir.), Lisboa, 1995, vol. I, 1995, pp. 332-433. 
PÉREZ DE URBEL, J., "La antiquísima iglesia de Santa María de las Viñas, monumento de gran interés", Enciclopedia Espasa-Calpe, Apéndice, 8, Madrid, 1978, pp. 1129-1130.

PÉREZ GIL, J. y RIVERA BLANCO, J. J., "Sahagún y Cluny: vidas paralelas”, Los grandes monasterios benedictinos hispanos de época románica (1050-1200), 2007, pp. 87-120.

PÉREZ RODRÍGUEZ, A. M., "Leyenda y realidad en dos textos cluniacenses sobre Alfonso VI", Memoria, mito y realidad en la historia medieval, Nájera, 2003, pp. 417-430.

PÉREZ VILATELA, L., Lusitania: Historia y Etnología, Madrid, 2000.

ID., "Los nombres del mar de más allá de las columnas de Hércules en la Antigüedad", El Estrecho de Gibraltar, Ceuta, 1995, pp. 165-178.

PERONI, A. "Capitello con teste di green men, faccita", Lanfranco e Wiligelmo: il duomo di Modena, Modena, 1984, ficha catalográfica C.1

ID., "Acanthe remployée et acanthe imitée dans les cathédrales de Modène, Ferrate et Pise", L'Acanthe dans la sculpture monumental de l'Antiquité à la Renaissance, Paris, 1993, pp. 313-326.

ID., "Architettura ottoniana e architettura romanica alla luce del reimpiego dell'antico", Mittellatenisches Jahrbuch, 35, 2000, pp. 205-225.

PETERS, F. E., Jerusalem. The Holy City in the Eyes of Chroniclers, Visitors, Pilgrims, and Prophets from the Days of Abraham to the Beginnings of Modern Times, Princeton-New Jersey, 1985.

PEYRE, R., Nîmes, Arles, Orange, Saint-Rémy, Paris, 1903.

PICARD, J.-C., "Les origines du mot Paradisus parvis", Mélanges de l'École française de Rome. Moyen Âge, temps modernes, 83, 1971-1972, pp. 159-186.

ID., Évêques, saints et cités en Italie et en Gaule: Études d'archéologie et d'histoire, Rome, 1998.

PICCIRILlO, M., "La città santa di Gerusalemme", Romei \& Giubilei. Il pellegrinaggio medievale a San Pietro (350-1350) (a cura di M. D’Onofrio), Milano, 1999, ficha catalográfica 17, p. 292.

ID., "Jérusalem et la basilique du Saint-Sépulcre", Les Croisades. L'Orient et l'Occident d'Urbain II à Saint Louis, 1096-1270, Milan, 1997, pp. 233-242.

PIGGOTT, S., Ruins in a Landscape. Essays in Antiquarianism, Edinburgh 1976.

PIÑERO I COSTA, M.-D. y PONSICH, P., "Santa Maria del Castell d'Oltrera", Catalunya Romànica. El Rosselló, vol. XIV, Barcelona, 1993, pp. 112-114. 
PIRANI, F., "Quando agli angeli spuntarono le ali", Aurea Roma: dalla città pagana alla città cristiana (S. Ensoli y E. La Rocca eds.), Roma, 2000, pp. 389-394.

PITA ANDRADE, J. M., "Un capítulo para el estudio de la formación artística del maestro Mateo. La huella de Saint Denis", Cuadernos de Estudios Gallegos, VII, 1952, pp. 371-383.

ID., Los maestros de Oviedo y Ávila, Madrid, 1955.

ID., "La arquitectura románica", La Catedral de Santiago de Compostela: IX Centenario de la Catedral de Santiago de Compostela. Año Santo de 1976, Santiago de Compostela, 1977, pp. 89-162.

PIVA, P., "Cluny: l'abbazia di Maiolo e Odilone (950-1050), L'arte dell'anno mille in Europa, 950-1050 (L. Catelfranchi Vegas ed.), Milano, 2000, pp. 152-160.

PLAULT, M., Les linternes des morts. Inventaire-Histoire et Liturgie, Poitiers, 1988.

PLAZAOLA, J., Modelos y teorías de la Historia del Arte, San Sebastián, 1987.

PLÖTZ, R., "Peregrinando por mar: relatos de peregrinos", Rutas Atlánticas de peregrinación a Santiago de Compostela, Santiago de Compostela, 1998, pp. $57-58$.

POISSON, O., “Le Maître de Cabestany”, Terres Catalanes, 2, 1993, pp. 94-95.

ID., "Le tympan de Cabestany", Catalunya Romànica. El Rosselló, vol. XIV, Barcelona, 1993, pp. 161-163.

ID., "L'abbaye de Saint-Papoul”, Le Maître de Cabestany, Pierre-qui-Vire, 2000, pp. 56-63.

ID., "Gérone, Rieux, Cabestany, Saint-Papoul. Un premier groupe d'œuvres", Le Maître de Cabestany, Pierre-qui-Vire, 2000, pp. 27-28.

ID., "Le Maître de Cabestany, sculpteur et architecte?", Le Maître de Cabestany, Pierrequi-Vire, 2000, pp. 154-163.

ID., "Le portail de l'église du Monastir del Camp à Passà", Le Maître de Cabestany, Pierre-qui-Vire, 2000, pp. 169-175.

ID., "Un sculpteur anonyme du XII siècle", Le Maître de Cabestany, Pierre-qui-Vire, 2000 , pp. 7-15.

ID., “Tímpano de Cabestany”, El románico y el Mediterráneo. Cataluña, Toulouse y Pisa. 1120-1180 (M. A. Castiñeiras González y J. Camps ed.), Barcelona, 2008, ficha catalográfica 70, pp. 336-337. 
Pompeya. Historia, Vida y Arte de la ciudad sepultada (M. Ranieri Panetta, ed.) Barcelona, 2004.

PONSICH, P., "La pensée symbolique et les édifices de Cuxa du X $\mathrm{X}^{\mathrm{e}}$ au XIII ${ }^{\mathrm{e}}$ siècle", Les Cahiers de Saint-Michel de Cuxa, 12, 1981, pp. 7-27.

ID., "Santa Maria de Riquer", Catalunya romànica. L'Empordà, vol. VIII, Barcelona, 1989, pp. 309-310.

ID., voz "Cabestany. Santa Maria de Cabestany", Catalunya romànica. El Rosselló, vol. XIV, Barcelona, 1993, pp. 161-163.

ID., voz "Sant Joan el Vell”, Catalunya romànica. El Rosselló, vol. XIV, Barcelona, 1993, pp. 289-294.

ID., voz "Santa María del Voló”, Catalunya romànica. El Rosselló, vol. XIV, Barcelona, 1993, pp. 452-455.

ID., "Santa Maria de Marcèvol", Catalunya Romànica. La Cerdanya . El Conflent, vol. VII, Barcelona, 1995, pp. 123-140.

PORRAS ROBLES, F., "La pervivencia del mito de Orfeo en la iconografía del rey David: origen, significación simbólica y aproximación organológica", Cuadernos de arte e iconografía, 16, 32, 2007, pp. 301-332.

PORTER, A. K., "Spain or Toulouse? and Other Questions", The Art Bulletin, VII, 1924, pp. 2-25.

ID., "Leonesque Romanesque and Southern France", The Art Bulletin, 8, 4, 1926, pp. 235-250.

ID., "The Tomb of Hincmar and Carolingian Sculpture", Burlington Magazine, 287, 1927, pp. 75-91.

ID., Spanish Romanesque Sculpture, New York, 1928, (reed. 1969).

ID., "The tomb of Doña Sancha and the Romanesque art of Aragón”, Burlington Magazine, 45, 1934, pp. 165-179.

POZA YAGÜE, M., "Entre la tradición y la reforma. A vueltas de nuevo con las portadas de San Isidoro de León", Anuario del Departamento de Historia y Teoría del Arte, XV, 2003, pp. 9-28.

ID., "Símbolo y concepto. Visiones teofánicas y alegóricas de la Trinidad en el tímpano de Nuestra Señora de la Peña de Sepúlveda (Segovia)", El Tímpano románico: imágenes, estructuras y audiencias (R. Sánchez Ameijeiras y J. L. Senra Gabriel y Galán coords.), Santiago de Compostela, 2003, pp. 131-151.

ID., "Espinario", Sancho el Mayor de Navarra y sus herederos. El linaje que europeizó los reinos hispanos, 2 vols., Pamplona, 2006, vol. II, ficha 176, pp. 102. 
PRACHE, A., voz "Chartres”, Enciclopedia dell'arte medievale, vol. IV, Roma, 1993, pp. 653-659.

PRADO-VILAR, F., "Saevum facinus: Estilo, genealogía y sacrificio en el arte románico español”, Goya, 324, 2008, pp. 173-199.

ID., "Lacrimae rerum: San Isidoro de León y la memoria del padre”, Goya, 328, 2009, pp. 195-221.

PRALONG, A., "Remarques sur les chapiteaux corinthiens tardifs en marbre de Proconnèse", L'Acanthe dans la sculpture monumental de l'Antiquité à la Renaissance, Paris, 1993, pp. 133-146.

PRESSOUYRE, L., "Une nouvelle oeuvre du maître de Cabestany en Toscane: le pilier sculpté de San Giovanni in Sugana", Bulletin de la Société nationale des Antiquaires de France, 1969, pp. 30-60.

ID., "St. Bernard to St. Francis: Monastic Ideals and Iconographic Programs in the Cloister", Gesta, 12, 1/2, 1973, pp. 71-92.

PUIGARNAU I TORRELlÓ, A., Imago Dei y Lux Mundi en el siglo XII: La recepción de la teología de la luz en la iconografía del Pantocrátor en Cataluña, Barcelona, 2005.

PUIG I CADAFALCH, J. Le premier art roman. L'architecture en Catalogne et dans l'occident méditerranéen aux $X^{e}$ et $X^{e}$ siècles, Paris, 1928.

ID., L'art wisigothique et ses survivances: recherches sur les origines et le développement de l'art en France et en la Espagne du IVe au XIIe siècle, Paris, 1961.

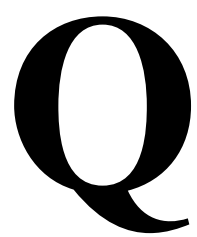

QUINTAVALLE, A. C., "L'antico ritrovato", Medioevo. Immagini e idelogie (a cura de A. C. Quintavale), Parma, 2002, pp. 23-45.

ID., "Medioevo: i modelli, un problema storico", Medioevo: i modelli, Milano, 2002, pp. 11-52.

ID., "Quei campi dei miracoli”, Rilavorazione dell'antico nel Medioevo (a cura di Mario D’Onofrio), Roma, 2003, pp. 15-28. 
QUIÑONES COSTA, A. M., La decoración vegetal en el arte español de la Alta Edad Media: su simbolismo, Madrid, 2001.

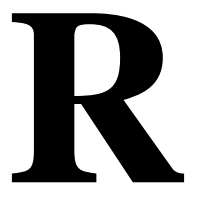

RABANAL ALONSO, M. A. y GARCÍA MARTÍNEZ, S., Epigrafía romana de la Provincia de León: Revisión y actualización, León, 2001.

RAMÍREZ, J. A., "De la ruina a la destrucción arquitectónica (para una iconografía del caos)", La Multiculturalidad en la Artes y la Arquitectura, 2 vols. Las Palmas de Gran Canaria, 2006, vol. I, pp. 526-553.

RAMOS DE CASTRO, G., "En torno a Fruchel", Boletín del Seminario de Arte y Arqueología de la Universidad de Valladolid, XL-XLI, 1975, pp. 189-199.

ID., El arte románico en la provincia de Zamora, Zamora, 1977.

RAMOS RUBIO, J. A., "La herencia del mundo antiguo. Aportaciones a la iconografía de la Edad Media en la Diócesis de Palencia", Hispania Sacra, LVII, 16, 2005, pp. 407-428.

RASPI-SERRA, J., "Le chapiteau d'acanthe en Italie entre le $\mathrm{V}^{\mathrm{e}}$ siècle et le $\mathrm{X}^{\mathrm{e}}$ siècle", L'Acanthe dans la sculpture monumental de l'Antiquité à la Renaissance, Paris, 1993, pp. 175-188.

REAL, M. L., voz "Alcobaça”, Enciclopedia dell'arte medievale, vol. I, Roma, 1991, pp. 335-340.

ID., "Inovação e resistência: dados recentes sobre a Antiguidade Cristã no Occidente Peninsular", IV Reunião de Arqueologia Cristã Hispânica, Barcelona, 1995, pp. $17-68$.

ID., "O românico português na perspectiva das relações internacionais", Românico em Galicia y Portugal, Lisboa, 2001, pp. 31-55.

ID., "A escultura decorativa em Portugal: o grupo portucalense", Escultura decorativa tardorromana y altomedieval en la Península Ibérica (L. Caballero Zoreda y P. Mateos Cruz ed.), Madrid, 2007, pp. 133-170.

REBECCHI, F., "Blocchi con decorazione vegetale, I. Sec. a. C., seconda mità", Lanfranco e Wiligelmo. Il duomo di Modena, Modena, 1984, ficha catalográfica R. 11, p. 342. 
ID., "Il reimpiego di materiali antico nel Duomo di Modena", Lanfranco e Wiligelmo. Il duomo di Modena, Modena, 1984, pp. 319-353.

ID., "Frammenti architettonici con due succesive lavorazioni: come architrave nel I. Sec. a. C. (seconda metà), come pilastri nel secc. VIII-IX", Lanfranco $e$ Wiligelmo. Il duomo di Modena, Modena, 1984, ficha catalográfica R.8, p. 340;

ID., "Plutei a cancello, V sec. d. C.", Lanfranco e Wiligelmo. Il duomo di Modena, Modena, 1984, p. 345.

RECIO, A., "Sarcófago romano de Medina Sidonia", Actas del XIII Congreso Nacional de Arqueología, Zaragoza, 1975, p. 875.

RECUERO ASTRAY, M., ROMERO PORTILLA, P. y RODRÍGUEZ PRIETO, A., Documentos Medievales del Reino de Galicia: Fernando II (1155-1188), A Coruña, 2000.

REDAZIONE voz "Heemskerck, Maarten Van”, Enciclopedia dell'arte antica classica e orientale, vol. III, Roma, 1960.

REEVE, M. D., "Aratea et Terence", Texts and Transmission. A survey of Latin classics, Oxford, 1983, pp. 18-24.

REGINA KNAUER, E., "Tribuerunt Sua Marmora Provinciae. Beobachtungen zu antiken Vorbildern Von Wiligelmus Genesis-Fries an der Domfassade in Modena und zu den sog. Metopen”, Zeitschrift für Kunstgeschichte, 50, 2, 1987, pp. 153-186.

REGUERAS GRANDE, F., Santa Marta de Tera. Monasterio e iglesia, abadía y palacio, Benavente, 2005.

REGUERAS GRANDE, F., YAGÜE HOYAL, P. y MARCOS FIERRO, R., Rapto y Rescate del Héroe. El mosaico de Hilas y las ninfas. Museo de León, León, 1994.

REINLE, A., "Les débuts de la sculpture romane dans la région du lac de Constance", Cahiers de Civilisation médiévale, XV, 3, Poitiers, 1972, pp. 179-191.

REMESAL RODRÍGUEZ, J., "Aspectos legales del mundo funerario romano", Espacios y usos funerarios en el Occidente Romano (D. Vaquerizo coord.), Córdoba, 2002, pp. 369-378.

REMOLA, J. A., "Capitel corintio de la antigua Tarraco", El románico y el Mediterráneo. Cataluña, Toulouse y Pisa. 1120-1180 (M. A. Castiñeiras González y J. Camps ed.), Barcelona, 2008, ficha catalográfica 81, pp. 358-359.

REY, R., "Quelques survivances antiques dans la sculpture romane du Midi de la France", Gazette des Beaux-Arts, II, 1928, pp. 173-191. 
Rhein und Maas. Kunst und Kultur. 800-1400, Köln, 1972.

RICCIONI, S., Il mosaico absidale di San Clemente a Roma. Exemplum della Chiesa riformata, Spoleto, 2006.

ID., "Signi epigrafici e sistema illustrativi alla greca nel mosaico di San Clemente a Roma", Medioevo mediterraneo: l'Occidente, Bisanzio e l'Islam dal tardoantico al secolo XII (a cura di A.Quintavalle), Parma, 2007, pp. 121-140.

RICO CAMPS, D., "El retablo de San Miguel de Aralar", Sancho el Mayor de Navarra y sus herederos. El linaje que europeizó los reinos hispanos, vol. I, Pamplona, 2006, pp. 561-580.

ID., El románico de San Vicente de Ávila (estructuras, imágenes, funciones), Murcia, 2002.

ID., Las voces del románico. Arte y epigrafía en San Quirce de Burgos, Murcia, 2008.

RICHÉ, P., "Quelques réflexions sur un nouveau grand siècle", $X^{e}$ siècle. Recherches Nouvelles. Contribution au Colloque Huges Capet 987-1987. La France de l'an mil, Paris, 1987, pp. 5-7.

RICHTER, G. M. A., El arte griego, Barcelona, 1990.

RIËGL, A., Spätrömische Kunstindustrie nach den Funden in Osterreich-Ungarn, Viena, 1901.

ID., Stilfragen. Grundlegungen zu einer Geschichte der Oranmentik, Viena, 1983.

ID., El culto a los monumentos modernos, Madrid, 1999.

RIGHETTI TOSTI-CROCE, M., voz "Roma. Secolo 12"”, Enciclopedia dell'arte medievale, vol. X, 1999, pp. 85-96.

ID., "Tra spolia e modelli altomedievali: note su alcuni episodi di scultura cistercense", Arte d'Occidente. Temi e Metodi, Studi in onore di Angiola Maria Romanini. Arte, 3 vols., Roma, 1999, vol. I, pp. 381-389.

Rilavorazione dell' antico nel medioevo (a cura di Mario D’Onofrio), Roma, 2003.

RILLIET-MAILLARD, I., "Quelques remarques sur la production des sarcophages au IVe siècle", Artistes, Artisans et Production artistique au Moyen Âge, vol. III, Paris, 1990, pp. 175- 201.

RIPOLL LÓPEZ, G., "Sarcófagos de la antigüedad tardía hispánica: importaciones y talleres locales", Antiquité tardive. Les sarcophages d'Aquitaine, 1, 1993, pp. 150-158.

RIVERA BLANCO, J., De Varia Restauratione. Teoría e Historia de la restauración arquitectónica, Valladolid, 2002. 
ID., "San Martín de Frómista y la restauración española en el cambio del siglo XIX al XX”, Frómista 1066-1094. San Martín, centenario de una restauración, Palencia, 2004, pp. 71-90.

ROCCHETTI, L., voz “Alessandria”, Enciclopedia dell'arte antica classica e orientale, vol. I, Roma, 1958, pp. 204-218.

RODRIGUES, J., “A Arquitetura românica”, História da Arte Portuguesa, (P. Pereira dir.), vol. I, Lisboa, 1995, pp. 183-263.

ID., "A escultura românica", História da Arte Portuguesa, (P. Pereira dir.), vol. I, Lisboa, 1995, pp. 264-331.

RODRÍGUEZ COLMENERO, A., "Lábaro de Quiroga", A Ribeira Sacra. Esencia de espiritualidade de Galicia, Lugo, 2004, pp. 337-339.

RODRÍGUEZ LÓPEZ, M. I., "Pervivencias iconográficas del mundo clásico en los códices prerrománicos: la personificación del mar", III Coloquio de Iconografía, vol. III, Madrid, 1993, pp. 218-224.

RODRÍGUEZ MONTAÑES, J. M., "Santa Marta de Tera”, Enciclopedia del románico de Castilla y León. Zamora, Aguilar de Campoo, 2002, pp. 135-148.

RODRÍGUEZ OLIVA, P., "Las últimas importaciones de sarcófagos paganos de talleres romanos en la Prouincia Baetica", El sarcófago romano: contribuciones al estudio de su tipología, iconografía y centros de producción (J. M. Noguera Celdrán y E. Conde Guerri eds.), Murcia, 2001, pp. 107-128.

RODRÍGUEZ PÉREZ, D., Serpientes, dioses y héroes: el combate contra el monstruo en el arte y la literatura griega antigua, León, 2008.

RODRÍGUEZ SUÁREZ, N., "La inscripción fundacional de San Miguel de Escalada. Un acercamiento atrevido", Paleografía I: la escritura en España hasta 1250 (J. A. Fernández Flórez y S. Serna Serna coords.), Burgos, 2008, pp. 173-187.

ID., "Multiculturalidad artística a través de la epigrafía", La Multiculturalidad en las Artes y en la Arquitectura, Las Palmas de Gran Canaria, 2 vols. 2006, vol. I, pp. 447-452.

Roma e la Riforma gregoriana. Tradizioni e innovazioni artistiche (S. Romano e J. Enckell Julliard ed.), Roma, 2007.

El románico y el Mediterráneo: Cataluña, Toulouse y Pisa, 1120-1180 (M. A. Castiñeiras y J. Camps eds.), Barcelona, 2008.

ROMANINI, A. M., L'Arte medievale in Italia, Firenze, 1988.

ID., “La caduta dell'impero", L'Arte Medievale in Italia, Firenze, 1988, pp. 77-114. 
ID., "Il concetto di classico e l'arte medievale", Romanobarbarica, I, 1976, pp. 203242.

ID., "Il concepto di classico e l'alto medieoevo", Arte Medievale. Interpretazioni storiografiche (a cura di A. Peroni e M. Righetti), Spoleto, 2005, pp. 129-142.

ROMANO, S., "La chiesa triunfante (1100-1143), Riforma e tradizione 1050-1198. La pintura medievale a Roma 312-1431 Corpus Atlante (M. Andaloro y S. Romano ed.), 6 vols., Roma, 2006, vol. IV, pp. 163-182.

Romei \& Giubilei. Il pellegrinaggio medievale a San Pietro (350-1350) (a cura di M. D’Onofrio), Milano, 1999.

RONK-VAANDRAGER, M., Tabernacle, temple et Jérusalem Céleste. Premier, Deuxième et Troisième Temple? Etude d'iconographie biblique de la peinture du IX $X^{e}$ au XII siècle, 2 vols., Paris, 1996.

ROOB, D., "The capitals of the Panteón de los Reyes de San Isidoro de León", The Art Bulletin, XXVIII, 3, 1945, pp. 165-174.

ROSENBAUM, E., "The Vine Columns of Old St. Peter's in Carolingian Canon Tables", Journal of the Warburg and Courtauld Institutes, 18, 1-2, 1955, pp. 115.

ROSS, J. B., "A Study of Twelfth-Century Interest in the Antiquities of Rome", Mediaeval and Historiographical Studies in Honor of J. W. Thompson, Chicago, 1938, pp. 302-321.

ROSSI PINELLI, O., "Chirugia della memoria: scultura antica e restauri storici", Memoria dell'antico nell'arte italiana. Dalla tradizione all'archeologia (S. Settis dir.), vol. III, Torino, 1986, pp. 181-250.

ROSSIGNOL, V., "Les débuts de la polychromie romane en Bourgogne", Edifices \& Peintures aux $I V^{e}-X I^{e}$ siècles (Ch. Sapin dir.), Auxerre, 1994, pp. 125-134.

RUDOLPH, C., Artistic Change at St-Denis. Abbot Suger's Program and the Early Twelfth-Century Controversy over Art, Princeton, 1990.

RUÍZ DE LA PEÑA GONZÁLEZ, I., "Un tema iconográfico en torno al 1200 la dama y el caballero", Actas del VIII Congreso de Estudios Medievales; Fernando III y su tiempo (1201-1252), León, 2003, pp. 437-467.

ID., "La reforma románica de la Cámara Santa de la Catedral de Oviedo en el contexto del patrocinio artístico de Fernando II", De arte, 2, 2003, pp. 29-46.

ID., "Arquetas musulmanas para mártires cristianos", Correspondencia e integración de las artes, Málaga, 2006, pp. 151-168.

ID., El Legado de Magín Berenguer (1918-2000), arte medieval asturiano, Oviedo, 2008. 
RUIZ MALDONADO, M., El caballero en la escultura románica de Castilla y León, Salamanca, 1986.

ID., Escultura románica alavesa: el foco de Armentia, Bilbao, 1991.

RUTHERFORD, J., “O fermoso sorriso do profeta Daniel”, Real Academia Galega, A Coruña, 2008, pp. 1-21.

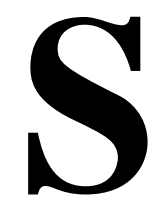

SALCEDO, F., "Lare", Hispania Romana Da Terra di conquista a Provincia dell'Impero, Milano, 1997, ficha catalográfica 253, p. 428.

ID., "Mercurio", Hispania Romana Da Terra di conquista a Provincia dell'Impero, Milano, 1997, ficha catalográfica 252, p. 427.

ID., "Stattueta di Sacerdote", Hispania Romana Da Terra di conquista a Provincia dell'Impero, Milano, 1997, ficha catalográfica 223, p. 413.

SALET, F. “Cluny III”, Bulletin Monumental, CXXXVI, 1968, pp. 235-292.

ID., Cluny et Vézelay. L'oeuvre des sculpteurs, Paris, 1995.

SALMI, M., "San Salvador di Spoleto, il tardo antico e l'Alto Medioevo", Actas IX Settimane di Studio del Centro Italiano di studi sull Alto Medioevo. Il passaggio dall'Antichità al Medieoevo in Occidente, Spoleto, 1962, pp. 497-520.

SALVÀ I PICÓ, M. G., voz "Creu”, Catalunya romànica. Museu episcopal de Vic; Museu diocesà i comarcal de Solsona, vol. XXII, Barcelona, 1986, pp. 192-193.

SALVINI, R., La escultura románica en Europa, México, 1965.

ID., "Il problema cronológico del portico de San Isidoro de León e le origine della Scultura romanica in Spagna", Actas del XXIII Congreso Internacional de Historia del Arte, vol. I, Granada, 1976, pp. 465-475.

ID., "Spagna, Tolosa o Modena? Contributo alla preistoria di Nicholaus", Nicholaus e l'arte del suo tempo, Ferrara, 1985, pp. 29-49. 
SALZA PRINA RICOTTI, E., "Peinture et vie quotidienne", Jeunesse de la beauté. La peinture romaine antique, Paris, 2001, pp. 43-49.

SÁNCHEZ-ALBORNOZ, C., Estudios críticos sobre la historia del Reino de Asturias: origen de la nación española, Oviedo, 1975.

SÁNCHEZ AMEIJEIRAS, R., "Una empresa olvidada del primer gótico hispano: la fachada de la sala capitular de la catedral de León", Archivo Español de Arte, 276, 1996, pp. 389-406.

ID., “¿Portada o relieve funerario? Una propuesta acerca de un tímpano leonés”, Arte d'Occidente. Temi e metodi. Studi in onore di Angiola Maria Romanini, 3 vols., Roma, 1999, vol. I, pp. 519-535.

ID., "Algunos aspectos de la cultura visual en la Galicia de Fernando II y Alfonso IX", El arte románico en Galicia y Portugal, Lisboa-A Coruña, 2001, pp.156-183.

ID., "Ritos, signos y visiones: El tímpano románico en Galicia (1157- 1230)", El Tímpano románico: imágenes, estructuras y audiencias (R. Sánchez Ameijeiras y J. L. Senra Gabriel y Galán coords.), Santiago de Compostela, 2003, pp. 4971.

ID., "La ritualización del camino de vuelta: Nuevos hallazgos sobre el sepulcro de Santo Domingo de La Calzada", Arte Medieval en La Rioja: prerrománico y románico (I. Gil Díez de Usandizaga ed.), Logroño, 2004, pp. 321-364.

ID., "The Eventful Life of the Royal Tombs of San Isidoro in León", Church, State, Velum and Stone. Essays on Medieval Spain in Honor of John Williams (T. Martin y J. Harris eds.), Leiden-Boston, 2005, pp. 489-530.

SÁNCHEZ LASSO DE LA VEGA, J., "Héroe griego y santo cristiano", Ideales de la formación griega, Madrid, 1966, pp. 181-272.

SÁNCHEZ-PALENCIA, F. J. y OREJAS, A., "Minería en la Hispania Romana", Hispania. El legado de Roma, Zaragoza, 1998, pp. 103-112.

SÁNCHEZ RAMOS, I., "La incidencia del cristianismo en el mundo funerario romano cordubense", Espacio y usos funerarios en el Occidente romano (D. Vaquerizo ed.), Córdoba, 2002, vol. II, pp. 325-342.

SANDRON, D., "Feuillet d'un diptyque du cónsul Areobindus", Musée national du Moyen Age Thermes de Cluny, Paris, 1993, ficha 130, p. 112.

ID., "Plaque d'une reliure: Crucifixion, avec Saintes Femmes au tombeau, Ascension et Parousie", Musée national du Moyen Age Thermes de Cluny, Paris, 1993, ficha 136, p. 116.

SANTAGELI VALENZANI, R., "Le più antiche guide romane e l'itinerario di Einsiedeln”, Romei \& Giubilei. Il pellegrinaggio medievale a San Pietro (3501350) (a cura di M. D’Onofrio), Milano, 1999, pp. 195-198. 
SAPIN, C., "Marseille (Bouches-du-Rhône). Abbaye Saint-Victor, Le Stuc. Visage oublié de l'art médiéval, Poitiers, 2005, p. 125.

ID., "Sculptures en stuc: continuité et renouveau", Le Stuc. Visage oublié de l'art médiéval, Poitiers, 2005, pp. 134-163.

ID., "Stucs et décors de l'Antiquité tardive", Le Stuc. Visage oublié de l'art médiéval, Poitiers, 2005, pp. 101-105.

SARTORIO, A., "Le colonne vitinee e le colonne tortili", Rasegna d'arte, XII, 1912, pp. 175-180.

SASTRE PÉREZ, C., "La portada de las Platerías y la "mujer adúltera”. Una revisión”, Archivo Español de Arte, 79, 314, 2006, pp. 169-186.

SAUERLÄNDER, W., “Art antique et sculpture autour de 1200”, Art de France, I, 1961, pp. 47-56.

ID., “1188. Les contemporains du Maestro Mateo", O Portico da Gloria e a arte do seu tempo, A Coruña, 1991, pp. 7-22.

ID., "La escultura de la sede leonesa a la luz de los grandes talleres europeos", La Catedral de León en la Edad Media (J. Joaquín Yarza Luaces, M. V. Herráez Ortega, G. Boto Varela coords.), León, 2004, pp. 177-202.

SAUNIER, F., "Une oeuvre attribuée au maître de Cabestany: la colonne de San Giovanni in Sugana en Toscane", Les Cahiers de Saint-Michel de Cuxa, XXV, 1994, pp. 165-175.

ID., "Le portail de Sainte-Marie du Boulou (El Voló)", Le Maître de Cabestany, Pierrequi-Vire, 2000, pp. 88-99.

ID., "Le tympan de Cabestany", Le Maître de Cabestany, Pierre-qui-Vire, 2000, pp. 4956.

SAURON, G., "La promotion apollinienne de l'acanthe et la définition d'une esthétique classique à l'époque d'Auguste", L'Acanthe dans la sculpture monumental de l'Antiquité à la Renaissance, Paris, 1993, pp. 75-97.

ID., L'Histoire végétalisée. Ornement et politique à Rome, Paris, 2000.

SAUVEL, T., "Le chapiteau dans les manuscrits carolingiens", Bulletin Monumental, 106, 1948, pp. 8-49.

SAXER, V., "Le culte des apportes Pierre et Paul à Rome", Les Cahiers de SaintMichel de Cuixa, XXIX, 1998, pp. 15-27.

SAXL, F., "Continuidad y variación en el significado de las imágenes", La vida de las imágenes, Madrid, 1989, pp. 11- 20. 
ID., "Continuitá e variazione nel significato delle immagini", Storia delle immagini, Bari, 1965, 12-23.

SAXL, F. y PANOFSKY, E., Classical Mythology in medieval art, New York, 1933.

SCAGLIARINI CORLAITA, D., "Gli ambienti poligonali nell'architettura residenziale tardoantica", XLII Corso di cultura sull'arte ravennate bizantina, Ravenna, 1995, pp. 837-872.

SCELLÈS, M., Inventaire de la sculpture monumentale du IV au $X^{e}$ siècle en HauteGaronne, Toulouse, 1981.

SCHALLER, D., "Poetic rivalries at the Court of Charlemagne", Classical influences on European Culture A. D. 500-1500, Cambridge, 1971.

SCHAPIRO, M., "Los frescos de Castelseprio (1952)", Estudios sobre el arte de la Antigüedad tardía, el cristianismo primitivo y la Edad Media, Madrid, 1987, pp. 69-110.

SCHEFERS, H., “Die „Köngshalle”, Weltkulturerbe Kloster Lorsch das Mittelalter erwacht, Regensburg, 2003, pp. 12-15.

SCHERBAUM, A., "Lucrecia. 1508", Durero. Obras Maestras de la Albertina, Madrid, 2005, ficha catalográfica 59, pp. 240-243.

SCHETTINI, F., "Nuovi elementi per lo studio del romanico pugliese", Scritti di Storia dell'Arte in onore di Mario Salmi, 3 vols., Roma, 1962, vol. I, pp. 263-286.

SCHLUNK, H., "La Iglesia de San Gião, cerca de Nazaré. Contribución al estudio de las influencias de la liturgia en la arquitectura de las iglesias prerrománicas de la Península Ibérica", Actas do II Congresso Nacional de Arqueología, Coimbra 1971, pp. 509-528.

ID., "Los monumentos paleocristianos en Gallaecia, especialmente en la provincia de Lugo", Actas del Coloquio Internacional sobre el Bimilenario de Lugo, Lugo, 1977, pp. 193-236.

ID., Las cruces de Oviedo. El culto de la Vera Cruz en el Reino Asturiano, Oviedo, 1985.

SCHLUNK, H. y BERENGUER, M., La pintura mural asturiana de los siglos IX y X, Oviedo, 1957.

SCHLUNK, H. y MAZANARES, J., "La iglesia de San Pedro de Teverga y los comienzos del arte románico en el Reino de Asturias y León", Archivo Español de Arte, 96, 1951, pp. 277-305

SCHMIDT, A. M., voz “Catania”, Enciclopedia dell'Arte Medievale, vol. IV, Roma, 1993, pp. 483-486 
SCHNAPP, A., La Conquête du passé. Aux origines de l'archéologie, Paris, 1993.

SCHNITZLER, H., "Diptyque de Genoels Elderen”, Charlemagne. Oeuvre, Rayonnement et Survivances, Aix-la-Chapelle, 1965, ficha catalográfica 534, pp. 345-346.

SCHRÖDER, S., "Tres sarcófagos de época romana en el Museo del Prado. Su iconografía y tipología”, El sarcófago romano: contribuciones al estudio de su tipología, iconografía y centros de producción (J. M. Noguera Celdrán y E. Conde Guerri eds.), Murcia, 2001, pp. 157-174.

Sculptures romanes (Musée des Augustins-Guide des collections), Toulouse, 1998.

SEBASTIÁN, S., Mensaje simbólico del arte medieval: arquitectura, iconografía, liturgia, Madrid, 1994.

ID., "La visión del cosmos medieval", Revista del Departamento de Historia del Arte, 6, 1986, pp. 73-81.

SENÉ, A., "Quelques remarques sur les tympans romans à chrisme en Aragón et Navarre”, Mélanges offerts à René Crozet, vol. I, Poitiers, 1966, pp. 365-381.

SÉNÉCHAL, P., "Originale e copia. Lo studio comparato delle statue antiche nel pensiero degli antiquari fino al 1170", Memoria dell'antico nell'arte italiana. Dalla tradizione all'archeologia (S. Settis dir.), vol. III, Torino, 1986, pp. 149180.

SENRA GABRIEL Y GALÁN, J. L., "La Portada occidental recientemente descubierta en el monasterio de San Zoilo de Carrión de los Condes", Archivo Español de Arte, 265, 1994, pp. 57-72.

ID., "Algunas notas sobre la desaparecida iglesia románica del priorato cluniacense de Carrión de los Condes", Actas del III Congreso de Historia de Palencia (M. V. Calleja González coord.), vol. IV, Palencia, 1995 pp. 439-452.

ID., "La iglesia de San Martín de Frómista en vísperas de su transformación decimonónica", Sautuola, VI Estudios homenaje al profesor Dr. García Guinea, 6, 1999, pp. 661-672.

ID., "Nuevos hallazgos románicos en el monasterio de San Zoilo de Carrión de los Condes (Palencia)", Archivo Español de Arte, 293, 2001, pp. 88-95.

ID., “¿Hércules versus Cristo? Una posible simbiosis iconográfica en el románico hispano", Quintana, 1, 2002, pp. 275-283.

ID., voz "Iglesia de San Martín (Frómista)", Enciclopedia del románico en Castilla y León. Palencia, vol. II, Aguilar de Campoo, 2002, pp. 1035-1050. 
ID., voz "Monasterio de San Pedro de Arlanza", Enciclopedia del románico en Castilla y León. Burgos, vol. IV, Aguilar de Campoo, 2002, pp. 2359-2377.

ID., "Los tímpanos de la catedral de Santiago en su contexto histórico artístico", El Tímpano románico: imágenes, estructuras y audiencias (R. Sánchez Ameijeiras y J. L. Senra Gabriel y Galán coords.), Santiago de Compostela, 2003, pp. 25-46.

ID., “Ángeles en Castilla: reflexiones en torno a renovación monástica y arquitectura en el siglo XI", Patrimonio artístico de Galicia y otros estudios, 3 vols., A. Franco Mata (dir.), Santiago de Compostela, 2004, vol. III, pp. 261-274.

ID., "Origen, muerte y resurrección de la iglesia de San Martín de Frómista", Frómista 1066-1094. San Martín, centenario de una restauración, Palencia, 2004, pp. 2137.

ID., "La realidad material de la iglesia de San Martín de Frómista en el siglo XII: de 1066-1904”, San Martín de Frómista, ¿paradigma o historicismo?, Palencia, 2005, pp. 39-68.

ID., "Mio Cid es de Bivar e nos de los Condes de Carrión: los Banu-Gómez de Carrión a la luz de sus epitafios", Quintana, 5, 2006, pp. 233-267.

ID., "Architecture et décor dans le contexte de la colonisation clunisienne des royaumes septentrionaux de la péninsule ibérique", Hauts lieux romans dans le sud de l'Europe (XI $-X I I^{e}$ siècles). Moissac, Saint-Jacques de Compostelle, Modène, Bari..., Cahors, 2008, pp. 11-70.

ID., "La puerta como dogma: a propósito de un nuevo descubrimiento de la iglesia de san Zoilo de Carrión de los Condes", Archivo Español de Arte, vol. 81, 322, 2008, pp. 139-150.

ID., "En torno a las estructuras occidentales de las iglesias románicas: formulación arquitectónica y funcional de las galileas (ca.1030-1150)", Espacios y estructuras singulares del edificio románico (P. L. Huerta Huerta coord.), Aguilar de Campoo, 2008, pp. 121-155.

SEPÚLVEDA GONZÁLEZ, M. A., "Los anagramas y el programa iconográfico de Quintanilla de las Viñas: una hipótesis de interpretación”, La España Medieval, Madrid, 1986, vol. V, pp. 1217-1248.

ID., "Reflexiones sobre el programa iconográfico de San Pedro de la Nave (Zamora) I", Cuadernos de arte e iconografía, 4, 7, 1991, pp. 135-157.

SERRANO FATIGATI, E., "Esculturas de los siglos IX al XIII. Astures, leonesas, castellanas y gallegas", Boletín de la Sociedad Española de Excursiones, IX, 1901, pp. 39-40.

SESTAN, E., "Tardo antico e alto Medievale: Difficoltá di una periodizzazione", Actas IX Settimane di Studio del Centro Italiano di studi sull'Alto Medioevo. Il passaggio dall'Antichità al Medieoevo in Occidente, Spoleto, 1962, pp. 15-37. 
SESTON, W., "Hypothèse sur la date de la basilique constantinienne de Saint-Pierre de Rome", Cahiers Archéologiques, II, 1972, pp. 153-159.

SETTIS, S., "Continuitá, distanza, conoscenza. Tre usi dell'antico", Memora dell'antico nell'arte italiana, Dalla tradizione all'archeología (a cura di S. Settis), vol. III, Turín, 1986, pp. 372-486.

ID., El futuro de lo clásico, Madrid, 2006.

ID., "Ineguaglianze e continuità: un'immagine dell'arte romana", Introduzione all'arte romana (J. Brendel ed.), Torino, 1982, pp. 161-200.

ID., "Tribuit sua marmora Roma: sul reimpiego di sculture antiche", Lanfranco $e$ Wiligelmo. Il duomo di Modena, Modena, 1984, pp. 309-317.

ID., "Les remplois", Patrimoine, temps, espace. Patrimoine en place, patrimoine déplacé. Actes des Entretiens du Patrimoine sous la présidence de F. Furet, Paris, 1997, pp. 67-86.

SEVCENKO, I., "A shadow Outline of Virtue. The Classical Heritage of Greek Christian Literature (Second to Seventh Century), Age of Spirituality: A Symposium (K. Weitzmann ed.), New York, 1980, pp. 15-33.

SICART, A., Las pinturas de Sigena, Madrid, 1992.

SICHTERMANN, H., voz "Heracle", Enciclopedia dell'arte antica classica e orientale, vol. III, Roma, 1960, pp. 378-387.

SIEFFERT, G., “A propos de l'église d'Ottmarsheim. Les imitations de la Chapelle palatine a Aix-la-Chapelle", Cahier de l'art médiéval, V, fascicule II, 1968 (1969), pp. 29-70.

SILVA, R., "Et domuncula, in qua sedebatur ad iudicantum, erat in media porticu. Alcune cosiderazioni sulla Königshalle di Lorsch", Arte d'occidente. Temi e metodi. Studi in onore di Angiola Maria Romanini, 3 vols., Roma, 1999, vol. I, pp. 41-47.

SILVA MAROTO, M. P., Pedro Berruguete, Valladolid, 1998.

ID., "Pedro de Berruguete", Álbum, letras, artes, 70, 2002, pp. 54-61.

ID., "La iconografía como clave para la comprensión de la personalidad de Pedro Berruguete", Cuadernos de arte e iconografía, vol. 2, 4, 1989, pp. 134-141.

SILVA Y VERÁSTEGUI, S., "Los sepulcros de los santos en la Alta Edad Media en España: aportaciones de la iconografía a la literatura hagiográfica", Memoria Ecclesiae, XXV, 2004, pp. 199-214. 
SILVAN, P. "L'architettura della basílica medievale di San Pietro", Romei \& Giubilei. Il pellegrinaggio medievale a San Pietro (350-1350) (a cura di M. D’Onofrio), Milano, 1999, pp. 249-261.

SIMMEL, G., "El problema del estilo", Revista Española de Investigaciones Sociológicas, 84, 1998, pp. 319-326.

SIMON, E., voz "Menadi”, Enciclopedia dell'arte antica classica e orientale, vol. IV, 1961, pp. 1002-1012.

SIMON, D. L., "Le sarcophage de Doña Sancha à Jaca", Les Cahiers de Saint-Michel de Cuxa, 10, 1979, pp. 107-124.

ID., "L'art roman, source de l'art roman", Les Cahiers de Saint-Michel de Cuxa, 11, 1980, pp. 249-268.

ID., "Un chapiteau de cloître de la cathédrale de Jaca, représentant la psychomachie", Cahiers de Saint-Michel de Cuxa, 12, 1981, pp. 151-159.

ID., "Romanesque Art in American Collections. XXI. The Metropolitan Museum of Art. Part I: Spain”, Gesta, XXIII/2, 1984, pp. 145-159.

ID., "Capital attributed to the master of Cabestany", The Art of Medieval Spain a. $d$. 500-1200, New York, 1993, ficha catalográfica 163, pp. p. 314-315.

ID., "Sarcophagus of Doña Sancha", The Art of Medieval Spain a. d. 500-1200, New York, 1993, ficha catalográfica 105, pp. 229-232.

ID., "Two sculptures attributed to the master of Cabestany", The Art of Medieval Spain 500-1200, New York, 1993, ficha catalográfica 161, pp. 313-314.

ID., "El tímpano de la Catedral de Jaca", Jaca en la Corona de Aragón (siglo XIIXVIII), vol. III, Zaragoza, 1994, pp. 405-419.

ID., "A Moses capital at Jaca", Imágenes y promotores en el arte medieval, Barcelona, 2001, pp. 209-219.

SIMON, S. C., "David et ses musiciennes: iconographie d'un chapiteau de Jaca", Les Cahiers de Saint-Michel de Cuxa, XI, 1980, pp. 239-248;

ID., "Iconografía de un capitel del claustro de la Catedral de Jaca", Actas del XV Congreso de Historia de la Corona de Aragón, Jaca en la Corona de Aragón (siglos XII-XVIII), vol. III, Zaragoza, 1994, pp. 223-436.

SINGUL, F., "Peregrinos ingleses a Santiago. A ruta marítima", Ate o Confín do mundo: diálogos entre Santiago e o mar, Vigo, 2004, pp. 143-144.

ID., "Figura Masculina (¿Redentor?)”, Luces de Peregrinación, Madrid-Santiago de Compostela, 2004, pp. 166-169. 
SKUBIZEWSKI, P., L'art du Haut Moyen Âge. L'art européen du IV $V^{e}$ au IX siècle, Baume-les-Dames, 1998.

ID., "Pupitre dit de Sainte Radegonde", Le Supplice et la Gloire. La Croix en Poitou (R. Favreau dir.), Poitiers, 2000, pp. 30-31.

ID., "Le tombeau de Sainte Radegonde et la croix de son sarcophage", Le Supplice et la Gloire. La Croix en Poitou (R. Favreau dir.), Poitiers, 2000, pp. 33-35.

SOARES PATROCÍNIO, M. F., Um lugar para o passado: A Arte e o Antigo, Évora, 1999.

SOLIER, Y., "Narbonne, Édifice à abside du cimentière Saint-Paul", Les premiers monuments chrétiens de la France. 1. Sud-Est et Corse, Paris, 1995, pp. 39-42.

SOT, M., "Mémoire, Antiquité, Renaissance, vues des $\mathrm{IX}^{\mathrm{e}}$ et $\mathrm{X}^{\mathrm{e}}$ siècles", La Mémoire de l'Antiquité dans l'Antiquité tardive et la Haut Moyen Âge, Paris, 2000, pp. 713.

SOTOMAYOR, M., Sarcófagos romano cristianos de España: estudio iconográfico, Granada, 1975.

SØREN KASPERSEN, V., "Cotton-Genesis, die Toursbibeln und die Bronzetüren Vorlage und Aktualität", Bernwardinische Kunst. Bericht über ein wissenschaftliches Symposium in Hildesheim vom 10.10 bis 13.10.1984, Göttingen, 1988, pp. 79-103.

SPRINGER, M., "Die Wiederverwendung Antiker Sarkophage", Kunst und Kultur der Karolingerzeit. Kart der Grobe und Papst Leo III in Paderborn, vol. II, Mainz, 1999, ficha catalográfica X. 41, pp. 758-763.

STACEY, N. E., "Henry of Blois and the Lordship of Glantonbury", English historical review, vol. 114, 455, 1999, pp. 1-33.

STAMM-SAURMA, L. E., "Die ,,autorictas” des Zitates in der bernwardinischen Kunst", Bernwardinische Kunst. Bericht über ein wissenschaftliches Symposium in Hildesheim vom 10.10 bis 13.10.1984, Göttingen, 1988, pp. 105-126.

STOKSTAD, M., "Forma y fórmula; reconsideraciones del Pórtico de la Gloria", $O$ Portico da Gloria e a arte do seu tempo, A Coruña, 1991, pp. 181-191.

STRATFORD, N., "Autun and Vienne", Romanesque and Gothic. Essays for George Zarnecki, Woodbridge, 1987, pp. 193-200.

STRINATI, T., Romei \& Giubilei. Il pellegrinaggio medievale a San Pietro (350-1350) (a cura di M. D’Onofrio), Milano, 1999, ficha catalográfica 190, p. 394.

SUÁREZ SARO, A., "Tapa del Sarcófago de Ithacio", Orígenes, arte y cultura en Asturias siglos VII-XV, Oviedo, 1993, ficha catalográfica 59, pp. 87-88. 
SUMPTION, J., Monaci suntuari pellegrini. La religione nel Medioevo, Roma, 1981.

SZABÓ, M. y GUILLAUMET, J-P., "Les fourreaux d'épées de La Tène dans la Vallée de la Saône au Musée de Chalon-sur-Saône", Acta Archaeologica Academiae Scientiarum Hungaricae, vol. 52, 1-3, 2001, pp. 63-102.

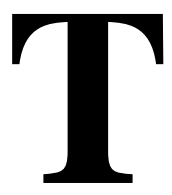

TAÍN GUZMÁN, M., "Fuentes romanas gráficas y literarias del baldaquino y la pérgola de la catedral de Santiago", Archivo Español de Arte, LXXIX, 314, 2006, pp. 139-155.

TALBOT RICE, D., English art. 871-1100, Oxford, 1952.

TARDY, D. y SCHACH, F., Le décor architectonique de Saintes Antique. Les chapiteaux et bases, Paris, 1989.

TARRACO PLANAS, E., "El módulo de la Portada de Ripoll", Actas del XXIII Congreso Internacional de Historia del Arte, España entre el Mediterráneo y el Atlántico, Granada, 1973, pp. 537-541.

TEDESCHI GRISANTI, G., "Capitel compuesto antiguo", El románico y el Mediterráneo: Cataluña, Toulouse y Pisa, 1120-1180 (M. A. Castiñeiras y J. Camps eds.), Barcelona, 2008, ficha catalográfica 56, p. 311.

TELESKO, W., "Ein Kreuzreliquiar in der Apsis? Überlegungen zum Konzept der mittelalterlichen Apsisdekoration von San Clemente in Rom", Römische historische Mitteilungen, 36, 1994, pp. 53-79.

TERRASE, H., "La reviviscence de l'acanthe dans l'art hispano-mauresque sous les almoravides", Al-Andalus, XXVI, 1961, pp. 426-435.

TESTI CRISTIANI, M. L., "Magistra latinitas. La coscienza storica del mondo antico nelle opere di Nicola Pisano”, Medioevo: $i$ modelli, Milano, 2002, pp. 396-380,

TINÉ BERTOCCHI, F., voz "Canosa di Puglia", Enciclopedia dell'arte antica classica e orientale. Supplemento 1970, Roma, 1973, p. 179.

TOMEI, A., voz “Colonia. Arti suntuarie”, Enciclopedia dell'arte medievale, vol. V, Roma, 1994, pp. 197-203. 
TORRES, C., “Coluna”, Núcleo Visigótico, Beja, 1993, ficha catalográfica 3, p. 32.

TORRES, C. et alii., Núcleo Visigótico, Museu Regional de Beja, Beja, 1993.

TORRES BALBAS, L., "La escultura románica aragonesa y el crismón de los tímpanos de las iglesias de la región pirenaica", Archivo Español de Arte y Arqueología, 6, II, 1926, pp. 287-291.

TORRES CARRO, M., "El tiempo representado”, Anas, 11-12, 1998-1999, pp. 93-102.

TORRES RODRÍGUEZ, C., “Arca Marmórea”, Compostellanum, II/2, 1957, pp. 323339.

TOUBERT, H., "Un fresque de San Pedro de Sorpe (Calalogne) et le thème iconographique de 1'Arbor Bona-Ecclesia, Arbor Mala-Sinagoga", Cahiers Archéologiques, XIX, 1969, pp. 167-189.

ID., "Le renouveau paléochrétien à Rome u début du XII $\mathrm{e}^{\mathrm{e}}$ siècle", Cahiers Archéologiques, XX, 1970, pp. 99-154.

ID., "Rome et le Mont-Cassin. Novelles remarques sur les fresques de l'église inférieure de Saint-Clement à Rome", Dumbarton Oaks Papers, 30, 1976, pp. 1-33.

ID., 'Le cycle de 1'Ancien Testament à Sant'Angelo in Formis. L'idéal de renovatio grégorienne et l'art du Mont-Cassin au temps de Didier", Un art dirigé. Réforme grégorienne et iconographie, Paris, 1990, pp. 94-148.

ID., "Rome et le Mont-Cassin: nouvelles remarques sur les fresques de l'église inférieure de Saint-Clément de Rome", Un art dirigé. Réforme grégorienne et iconographie, Paris, 1990, pp. 193-238.

ID., "Didier du Mont-Cassin et l'art de la Réforme Gregorienne", L'iconographie de l'Ancien Testament à Sant'Angelo in Formis", Desiderio di Montecassino e l'arte della Reforma Gregoriana (F. Avagliano ed.), Mont-Cassin, 1997, pp. 17105.

TOYNBEE, J. M. C. y WARD PERKINS, J. B., The Shrine of S. Peter and the Vatican Excavations, London, 1956.

TREFFORT, C., "Inscrire son nom dans l'espace liturgique à l'époque romane", Cahiers de Saint-Michel-de-Cuxa, XXXIV, 2003, pp. 147-160.

TRILLMICH, W., "Il modello della metropoli", Hispania Romana Da Terra di conquista a Provincia dell'Impero, Milano, 1997, pp. 131-141.

ID., "Las ciudades hispanorromanas: reflejos de la metrópoli", Hispania. El legado de Roma, Zaragoza, 1998, pp. 163-174. 
TRIVELlONE, A., "Beato di Liébana, Explanatio in Apocalipsim", Romei \& Giubilei. Il pellegrinaggio medievale a San Pietro (350-1350) (a cura di M. D’Onofrio), Milano, 1999, ficha catalográfica 12, p. 288.

ID., "Capsella di Samagher", Romei \& Giubilei. Il pellegrinaggio medievale a San Pietro (350-1350) (a cura di M. D’Onofrio), Milano, 1999, ficha catalográfica 256, p. 436.

ID., "Modelino del Santo Sepolcro di Gerusalemme", Romei \& Giubilei. Il pellegrinaggio medievale a San Pietro (350-1350) (a cura di M. D’Onofrio), Milano, 1999, ficha 18, p. 293.

TRONZO, W., "On the role of Antiquity in medieval art: Frames and framing devices", Ideologie e pratiche del reimpiego nell'Alto Medioevo, 2 vols, Spoleto, vol. II, pp. 1085-1111.

TSCHAN, F., Saint Bernward of Hildesheim. His Life and Times, vol. I, Indiana, 19421952.

ID., Saint Bernward of Hildesheim. His Works of Art, vol. II, Indiana, 1942-1952.

ID., Saint Bernward of Hildesheim. Album, vol. III, Indiana, 1942-1952.

TSUJI, S., "Les Portes de Sainte Sabine. Particularités de 1'Iconographie de 1'Ascension", Cahiers Archéologiques, XIII, 1962, pp. 13-28.

TURCAN, R., L'art romain dans l'histoire. Six siècles d'expressions de la romanité, Paris, 1995.

ID., Les sarcophages romains a représentations dionysiaques. Essai de chronologie et d'histoire religieuse, Paris, 1966.

TURNER, D. H., "Manuscript illumination", The Year 1200. A Background Survey, New York, 1970, pp. 133-168.

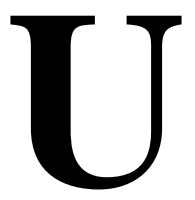

UBIETO ARTETA, A., "La catedral románica de Jaca. Problemas de cronología", Pirineos, 59-66, 1961-1962, pp. 125-137 
ID., "L'art roman en Aragon au XIe siècle", L'Information d'histoire de l'art, IX, 1964, 4, pp. 158-160.

ID., "El románico de la catedral jaquesa y su cronología", Príncipe de Viana, XXV, 1964, pp. 187-200.

UHDE-STAHL, B., "La chapelle circulaire de Saint Michel de Cuxà", Cahiers de Civilisation Médiévale, XX, 80, 1977, pp. 339-351.

ULBERT, T. y NOACK-HALEY, S., "Lid for the sarcophagus of Ithacius", The Art of Medieval Spain 500-1200, New York, 1993, ficha catalográfica 1, p. 45.

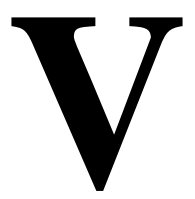

VACCARO, M., "Le sculture de Platerías nella storiografia del XX secolo: I. Gli studi da López Ferreiro agli anni 60”, Compostellanum, 51, 3-4, 2006, pp. 565-622

ID., "Le sculture di Platerías nella storiografia del XX secolo: II. Dagli studi iconografici alla valutazione funzionale", Compostellanum, vol. 52, 3-4, 2007, pp. 471-510.

VALDÉS FERNÁNDEZ, M., Arquitectura y escultura románicas en León (siglos XI y XII), Astorga, 1985.

ID., "El Panteón Real de la Colegiata de San Isidoro de León”, Maravillas de la España medieval: Tesoro sagrado y monarquía, 2 vols., Valladolid, 2001, vol. I, pp. 7384.

ID., "Las artes y sus promotores en la época de Fernando III (1217-1252)", Fernando III y su tiempo (1201-1252), León, 2003, pp. 235-258.

VALDÉS, M., COSMEN, C. y HERRÁEZ, M. V., "La Edad Media. Del origen a la consolidación de un templo gótico", Una historia arquitectónica de la catedral de León (M. Valdés coord.), León, 1994, pp. 13-132.

VALDEZ DEL ÁLAMO, E., "Triumphal Visions and Monastic Devotion: The Annunciation Relief of Santo Domingo de Silos", Gesta, 19, 2, 1990, pp. 167188. 
ID., "Visiones y Profecía: El árbol de Jesé en el Claustro de Silos", El románico en Silos. IX Centenario de la Consagración de la Iglesia y Claustro 1088-1988, Silos 1990, pp.173-202.

ID., "Relaciones artísticas entre Silos y Santiago de Compostela", O pórtico da Gloria e a Arte do seu Tempo, La Coruña, 1992, pp. 199-212.

ID., "Lament for a Lost Queen: The sarcophagus of Doña Blanca in Nájera", The Art Bulletin, 78, 2, 1996, pp. 311-333.

ID., "Panel de la urna de Santo Domingo de Silos", Maravillas de la España medieval: Tesoro sagrado y monarquía, 2 vols., Valladolid, 2001, vol. I, ficha catalográfica 161, pp. 400-401.

ID., "Panel de la urna de Santo Domingo de Silos", Maravillas de la España medieval: Tesoro sagrado y monarquía, 2 vols., Valladolid, 2001, vol. I, ficha catalográfica 162, pp. 401-402.

VALENTINI, R., y ZUCCHETTI, G., Codice Topografico della Città di Roma, 2 vols, Roma, 1940.

ID., "Il Liber Pontificalis e le sue continuazioni”, Codice Topográfico della città di Roma, vol. II, Roma, 1942, pp. 209-329.

VALLE PÉREZ, J. C., "Relieve del mes de febrero", Los Caminos de Santiago: el arte en el período románico en Castilla y León, España, siglos XI a XIII (J. C. Elorza Guinea coord.), Valladolid, 2006, p. 324.

VALLERY-RADOT, J., "Les dates des autels de la Major de Marseille et de SaintGuilhem-le-Désert", Gazette de Beaux-Arts, 1938, pp. 73-80.

VAN DER HORST, K., NOEL, W. y WÜSTEFELD, W. C. M., The Utrecht Psalter in Medieval Art. Picturing the Psalms of David, London, 1996.

VÁZQUEZ HOYS, A. M., "La serpiente en la Antigüedad: ¿genio o demonio?", Héroes, semidioses y daimones (J. Álvarez Sánchez, C. Blázquez Domínguez, E. C. González Wagner, coords.), Madrid, 1992, pp. 81-134.

VELÁZQUEZ SORIANO, I., "Aedificiorum Venustas: la recepción de un término clásico en Isidoro de Sevilla (Etym., XIX 11)", Antigüedad y cristianismo: Monografías históricas sobre la Antigüedad tardía, 14, 1997, pp. 229-248.

VELMANS, T., "Quelques versions rares du thème de la Fontaine de Vie dans l'art paléochrétien", Cahiers Archéologiques, XIX, 1969, pp. 29-43.

VERDIER, P., "La sculpture du clocher-porche de Saint-Benoît-sur-Loire dans ses rapports ave l'Espagne califale et mozarabe", Études Ligériennes, Auxerre, 1945, pp. 327-336 
ID., "La colonne Colonia aelia et imago clipeata du Christ-Helios", Cahiers Archéologiques, XXIII, 1974, pp. 20-40.

VERGER, J., La Renaissance du XIIe siècle, Paris, 1996.

VERGNOLLE, E., "Recherches sur quelques séries de chapiteaux romans", L'Information de l'histoire de l'art, 20, 1975, pp. 30-59.

ID., "Chapiteaux corinthisants de France et d'Italie (IX ${ }^{\mathrm{e}}-\mathrm{XI}^{\mathrm{e}}$ siècles)", Romanico padano. Romanico europeo, Parma, 1982, pp. 339-350.

ID., Saint-Benoît-sur-Loire et la sculpture du XI siècle, Paris, 1985.

ID., "Réflexions sur les chapiteaux à feuilles lisses à propos de Saint-Sever", SaintSever. Millénaire de l'abbaye, Mont-de-Marsan, 1986, pp. 184-197.

ID., "Fortune et infortunes du chapiteaux corinthien de le monde roman", Revue de l'art, 90, 1990, pp. 21-34.

ID., L’art roman en France, Paris, 1994.

ID., L'art Roman en France. Architecture-Sculpture-Peinture, Paris, 1994.

ID., "La colonne à l'époque romane. Réminiscences et nouveautés", Cahiers de Civilisation Médiévale, 41, 1998, pp. 141-174.

VERRIÉ, F. P., "La trajectòria artística de Bernat Martorell”, Bernat Martorell i la tardor del gòtic català. El context artístic del retaule del Púbol, Museu d'art de Girona, (J. Molina i Figueras coord.), Girona, 2003, pp. 5-16.

VICENT GARCÍA, J. M. y MARTÍNEZ NAVARRETE, M. I., "La periodización: un análisis histórico-crítico", Homenaje al prof. Martín Almagro Basch, vol. 4, 1983, pp. 343-352.

VIDAL ÁLVAREZ, S., "Fragmento de pilastra de Osuna (Sevilla)", La escultura hispana de la Antigüedad tardía, Murcia, 1995, ficha catalográfica B14, p. 68.

ID., "Fuste de Beja", La escultura hispana de la Antigüedad tardía, Murcia, 1995, ficha B23, pp. 78-82.

ID., "Tapa de sarcófago de Ithacius", La escultura hispana de la Antigüedad tardía, Murcia, 1995, ficha catalográfica B25, pp. 87-91.

ID., "La transmisión iconográfica en la escultura hispánica de la Antigüedad tardía. Vigencia y discontinuidad de modelos", Escultura tardorromana y altomedieval en la Península Ibérica, Madrid, 2007, pp. 11-46.

VIGO TRASANCOS, A., La Catedral de Santiago y la Ilustración. Proyecto clásico y memoria histórica (1757-1808), Santiago de Compostela, 1999. 
VIGUÉ I VIÑAS, J., voz "Relleu figurat 9", Catalunya romànica. Museu episcopal de Vic; Museu diocesà i comarcal de Solsona, vol. XXII, Barcelona, 1986, p. 26.

ID., voz "Capitell 13", Catalunya romànica. Museu d'art de Girona; Tresor de la Catedral de Girona; Museu diocesà d'Urgell ; Museu Frederic Marès, vol. XXIII, Barcelona, 1988, pp. 30-31.

VIGUERA MOLINS, M. J., "Esplendor y decadencia de al-Andalus: de la invasión musulmana a la toma de Granada", España Medieval y el legado de Occidente, Barcelona, 2005, pp. 37-60.

VILA DA VILA, M. M., Ávila Románica. Talleres Escultóricos de Filiación HispanoLanguedociana, Ávila, 1999.

VILLALÓN, M. C., "El taller de escultura de Mérida. Contradicciones de la escultura visigoda", Visigodos y omeyas. Un debate entre la Antigüedad tardía y la Alta Edad Media, Madrid, 2000, pp. 265-278.

ID., "Quintanilla de las Viñas y el arte cordobés", Norba-arte, XXII-XXIII, 2002-2003, pp. 341-349.

ID., "Quintanilla de las Viñas en el contexto del arte altomedieval: una revisión de su escultura", Antigüedad y cristianismo: Monografías históricas sobre la Antigüedad tardía (J. M. Blázquez Martínez y A. González Blanco coords.), vol. 21, Murcia, 2004 pp. 101-136.

ID., Mérida visigoda. La escultura arquitectónica y litúrgica, Badajoz, 1985.

VILLALÓN, M. C. y CERRILLO MARTÍN DE CÁCERES, E., "La iconografía arquitectónica desde la antiguiedad a la época visigoda: ábsides, nichos, veneras y arcos", Anas, I, 1988, pp. 187-203.

VIÑAYO, A., León roman. L'Ancien royaume de León roman, Saint-Léger-Vauban, 1972.

ID., Panteón de San Isidoro de León, León, 1979.

ID., León y Asturias. Oviedo, León, Zamora y Salamanca, Madrid, 1982.

ID., Santo Martino de León, León 1984.

ID., León y Asturias, La España románica, Madrid, 1987.

ID., San Isidoro de León. Panteón de los Reyes. Albores románicos: arquitectura, escultura y pintura, León, 1995.

ID., "Real Colegiata de San Isidoro de León", Enciclopedia del románico en Castilla y León. León, Aguilar de Campoo, 2002, pp. 534-566. 
VIVES, J., "Las leyendas epigráficas del tímpano de Jaca", Hispania Sacra, IX, 1956, pp. 391-394.

ID., Inscripciones cristianas de la España romana y visigoda, Barcelona, 1969.

VIVES I MIRET, J., "Els sepulcres reials del Monestir de Santes Creus", Studia monastica, 6, 2, 1964, pp. 359-379.

VLAD BORRELLI, L., "La porta romana", Le Porte di bronzo dall'antichità al secolo XIII (S. Salvatorino dir.), 2 vols., Roma, 1990, vol. I, pp. 1-18.

VON CAMPENHAUSEN, H. Los Padres de la Iglesia. I Padres Griegos, Madrid, 1974.

VON DER NAHMER, V. D., "Die Inschrift auf der Bernwardstür in Hildesheim im Rahmen Bernwardinischer Texte", Bernwardinische Kunst. Bericht über ein wissenschaftliches Symposium in Hildesheim vom 10.10 bis 13.10.1984, Göttingen, 1988, pp. 51-70.

VON FALKENHAUSEN, V., "Montecassino e Bisanzio dal IX al XII secolo", L'età dell'abate desiderio (F. Avagliano y O. Pecere), vol. III, 1, Montecassino, 1992, pp. 69-107.

VRANICH, S. B., "La evolución de la poesía de las ruinas en la literatura española de los siglos XVI y XVII", Ensayos sevillanos del Siglo de Oro, Valencia-ChapelHill, 1981, pp. 765-768, pp. 765-768.

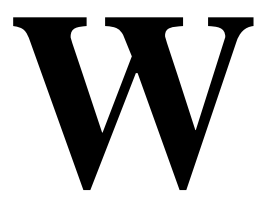

WALKER, R., "The Wall Paintings in the Panteón de los Reyes at León: A Cycle of Intercession", The Art Bulletin, 82, 2, 2000, pp. 200-225.

WALTER, H., La colonne ciselée dans la Gaule romaine, Paris, 1970.

WARD, M., Studies on the Pórtico de la Gloria at the Cathedral of Santiago de Compostela, New York, 1978.

WARD-PERKINS, B., "The shrine of St. Peter and its twelve spiral columns", Journal of Roman studies, XLII, 1952, pp. 21-33. 
ID., From Classical Antiquity to the Middle Ages: Urban Public Building in Northern and Central Italy, A.D. 300-850, Oxford, 1984.

ID., voz "Sarcofago. B) Commercio", Enciclopedia dell'arte antica, classica e orientale. Supplemento 1970, Roma, 1973, pp. 699-700.

WEBSTER, J. C., The labours of the months in antique and medieval art, Princeton, 1938.

WEBSTER, T., "Greek dramatic monuments from the Athenian Agora and Pnyx", Hesperia, 29, 1960, pp. 254-264.

WEISBACH, W., Reforma religiosa y arte medieval. La influencia de Cluny en el románico occidental, Madrid, 1949.

WEITZMANN, K., “The Fresco Cycle di Castelseprio”, L'Arte, s. n., 18, 1951, pp. 1219.

ID., "Various Aspects of Byzantine Influence on the Latin Countries from the Sixth to the Twelfth Centuries", Dumbarton Oaks Papers, XX, 1966, pp. 3-24.

WEITZMANN, W., "Byzantium and the West around the Year", The Year 1200. A Symposium, New York, 1975, pp. 53-94.

WELLS, P. S., "Manufactured objects and the construction of identities in late la Tène Europe", Eirene, 31, 1995, pp. 129-150.

WENTZEL, H., “Antiken-Imitationem des 12.u.13. Jahrhunderts in Italien”, Zeitschrift für Kunstwissenschaft, IX, 1955, pp. 29-72.

WESSEL, H., "Restauraciones decimonónicas en la iglesia de San Martín de Frómista", Compostellanum, XLVII, 3 y 4, 2002, pp. 605-632.

ID., "Neuere Erkenntnisse über die Kirche San Martín in Frómista und ihre Restaurierungen im 19. Jahrhundert, Mitteilungender Carl Justi Vereinigung e. $V .$, 14, Jahrgang, 2002, pp. 37-67.

WESTREM, S. D., The Hereford Map, Turnhout, 2001.

ID., "Lessons from Legends on the Hereford Mapamundi", Barber and Harvey, 91, 1991, pp. 30-67.

WETTSTEIN, J., La fresque romane. La route de Saint-Jacques, de Tours a León. Etudes comparatives II, Genève, 1978.

WEYL, A., voz "Constatinopoli. Miniatura", Enciclopedia dell'arte medievale, vol. V, Roma, 1994, pp. 412-428.

WIDAUER, H., "Bacanal con Sileno. 1494", Durero. Obras Maestras de la Albertina, Madrid, 2005, ficha catalográfica 6, pp. 92-94. 
WILLIAMS, J., "San Isidoro in León: Evidence for a New History", The Art Bulletin, 55, 2, 1973, pp. 171-184.

ID., Early Spanish Manuscript Illumination, New York, 1977.

ID., “Generationes Abrahae: Reconquest iconography in León”, Gesta, XVI/2, 1977, pp. 3-4.

ID., "A source for the capitel of the offering of Abraham in Panteón of the King in León", Scritti di Storia dell'Arte in onore di Roberto Salvini, Firenze, 1980, pp. $25-28$.

ID., "Chalice of Urraca", The Art of the medieval Spain. 500-1200, New York, 1993, ficha catalográfica 118, pp. 254-255.

ID., "Saint John", The Art of the medieval Spain. 500-1200, New York, 1993, ficha catalográfica 89, pp. 209-210.

ID., The illustrated Beatus: a corpus of the illustrations of the commentary on the Apocalypse. Introduction, vol. I, London, 1994.

ID., "Generationes Abrahae: iconografía de Reconquista en León", El Tímpano románico: imágenes, estructuras y audiencias (R. Sánchez Ameijeiras y J. L. Senra Gabriel y Galán coords.), Santiago de Compostela, 2003, pp. 155- 180.

ID., "La Mujer del cráneo y la simbología del románico", Quintana, 2, 2003, pp. 13-27

WILLIAMSON, P., Escultura Gótica. 1140-1330, Madrid, 1997.

WIRTH, J., "Copie en miroir: copie au miroir?", Materiam Superabat Opus. Hommage à Alain Erlande-Brandenburg, Paris, 2006, pp. 265-277.

WORMALD, F., The Winchester Psalter, London, 1973.

WRENCH, L. N. C., "Decoração arquitectónica litúrgica da antiguidade tardia nos grupos pacense e eborense", Arqueologia da Antiguidade na Península Ibérica, vol. VI, Porto, 2000, pp. 645-655.

ID., Decoração Arquitectónica na Antiguidade Tardia. Corpus de Escultura Arquitectónica, 2 vols. Lisboa, 2008,

WULFF ALONSO, F., "La Antigüedad en España en el siglo XIX”, Arqueología fin de siglo: la Arqueología Española de la segunda mitad del siglo XIX, (M. B. Deamos, J. Beltrán Fortes coords.), Sevilla, 2002, pp. 119-15.

WÜSTEFELD, W. C. M., NOEL, W. y VAN DER HORST, K., "Madrid AstronomicalComputistical Manual", The Utrecht Psalter in Medieval Art. Picturing the Psalms of David (K. van der Horst, W. Noel y W. C. M. Wüstefeld ed.), London, 1996. 
YARZA LUACES, J., "Notes introductòries i aspectes generals sobre la portalada de Santa Maria de Ripoll. La portalada de Ripoll, confluència de corrents internacionals. Lectura iconogràfica", Catalunya Romànica. El Ripollès, vol. X, Barcelona, 1987, pp. 241-252.

ID., "La miniatura románica: Estado de la cuestión", Anuario del Departamento de Historia y Teoría del Arte, 2, 1990, pp. 9-26.

ID., "Códices iluminados en el Monasterio de Las Huelgas", Reales Sitios: Revista del Patrimonio Nacional, 107, 1991, pp. 49-56.

ID., "Fustes entorchados de la Azabachería", Galicia no tempo, Santiago de Compostela, 1991, ficha catalográfica 77, p. 187.

ID., "La miniatura en Galicia, León y Castilla en tiempos del Maestro Mateo", $O$ Pórtico da Gloria e a Arte do seu Tempo, A Coruña, 1991, pp. 319-355.

ID., voz "Burgos", Enciclopedia dell'arte medievale, vol. IV, Roma, 1993, pp. 1-10.

ID., "Miniatura", Historia del Arte en Castilla y León. La Edad Media (J. J. Rivera Blanco, F. J. de la Plaza Santiago y S. Marchán Fiz coords.), vol. II, Valladolid, 1994, pp. 263-292.

ID., "La pintura española medieval: desde la cultura visigoda hasta finales del románico", La pintura en Europa. La pintura española (A. E. Pérez Sánchez ed.), vol. I, 1995, pp. 15-70.

ID., “Artes figurativas románicas en Galicia antes de 1150”, Románico en Galicia y Portugal, Lisboa-A Coruña, 2001, pp. 57-87.

ID., “De Limoges a Silos”, Esmaltes Medievales. De Limoges a Silos, Burgos, 2002, pp. $13-61$.

ID., "Artes del color en el siglo XV en la catedral de León", La catedral de León en la Edad Media (J. Yarza, G. Boto y M. Herráez coords.), León, 2004, pp. 399-431.

ID., "I grandi programmi iconografici", Arti e storia nel Medioevo (E. Castelnuovo e G. Sergi eds.), Del vedere: pubblici, forme e funzioni, vol. III, Torino, 2004, pp. 85143. 
ID., "Miniatura y pintura: Siglos X-XV", Real Colegiata de San Isidoro: relicario de la monarquía leonesa (C. Robles García y F. Llamazares Rodríguez coords.), León, 2007, pp. 278-293.

ID., "La miniatura en los reinos peninsulares medievales", La miniatura medieval en la Península Ibérica (J. Yarza ed.), Murcia, 2007, pp. 25-94.

The Year 1200. A Symposium, New York, 1975.

The Year 1200. A Background Survey, New York, 1970.

YZQUIERDO, R., El Maestro Mateo, Madrid, 1991.

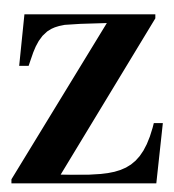

ZANKER, P., Augusto y el poder de las imágenes, Madrid, 1992.

ID., Un'arte per l'impero. Funzione e intenzione delle immagini nel mondo romano, Milano, 2002.

ID., Augusto e il potere delle immagini, Roma, 2006.

ID., "Las representaciones del soberano", Roma. Sentaus Populus Que Romanus, Madrid, 2007, pp. 373-383.

ZARNECKI, G., "Prophets from the chapter house of Sigena", English Romanesque Art 1066-1200, London, 1984, ficha catalográfica 87, p. 134.

ZEEGERS VAN DER VORST, N., Les citations des poètes chez les apologistes chrétiens du II siècle, Lovaina, 1972.

ZORRILLA, P. E., "Otra iglesia de templarios en Navarra. El Santo Sepulcro de la villa de Torres", Boletín de la Comisión de Monumentos Históricos y Artísticos de Navarra, 1914, pp. 129-139.

ZUCKER, P., Fascination of Decay, Ridgewood, 1968. 


\section{3. APÉNDICE FOTOGRÁFICO.}
A. ÍNDICE DEL APÉNDICE FOTOGRÁFICO.

Fig. 1. Pintura sobre tabla. La Verificacion de la Cruz.

Valencia, Museo de las Bellas Artes

Fig. 2. Miniatura. El descubrimeinto de la Cruz por Helena.

Paris, Bibliothèque nationale de France,

Ms. 244, fol. 146.

Fig. 3. Miniatura. Operario excavando en busca de la Vera Cruz.

Paris, Bibliothèque nationale de France,

Ms. lat. 12048, fol. 76v.

Fig. 4. Miniatura. La invención de la Cruz.

Vercelli, Biblioteca Capitulare,

Ms. CLXV

Fig. 5. Miniatura. Cristianos excavando en busca de reliquias.

Bruxelles, Bibliothèque royale Albert I,

Ms. 9428, fol. 158v.

Fig. 6. Cristianos excavando en busca de reliquias.

Bruxelles, Bibliothèque royale Albert I,

Ms. 9428 , fol. $159 \mathrm{v}$

Fig. 7. Miniatura. La invención del Sepulcro del Apóstol Santiago.

Santiago de Compostela, Archivo de la Catedral,

Cód. 1 , fol. $1 \mathrm{v}$

Fig. 8. Pintura. La exhumación de las reliquias de San Humberto.

Paris, Bibliothèque national de France,

Ms. 424, fol. 49 .

Fig. 9. Pintura. Exhumación de San Humberto, por Roger Van der Weiden.

London, National Gallery

Fig. 10. Pintura. San Silvestre curando a los dos magos, por Maso di Banco.

Firenze, Capilla Bardi, iglesia de la Santa Croce

Fig. 11. Pintura. San Sebastián, por Andrea Mantegna.

Paris, Musée du Louvre

Fig. 12. Pintura. Ángel portando la columna de la Flagelación, por los Hermanos Delli.

Salamanca, catedral vieja 1198 
Fig. 13. Escultura. Ángel portando la columna de la Flagelación.

Santiago de Compostela, catedral, Pórtico de la Gloria

Fig. 14. Escultura. Victoria con trofeo.

Roma, Foros imperiales, Arco de Septimio Severo

Fig. 15. Pintura. La Conversión al cristianismo de Recaredo, por A. Muñoz Degraín.

Madrid, Salón de Conferencias del Senado

Fig. 16. Pintura. La Conversión de Recaredo, capitel, por A. Muñoz Degrain.

Madrid, Salón de Conferencias del Senado

Fig. 17. Grabado. Visión del Puerto de Rodas y el Coloso, por M. van Heemskerck.

Earlangen, Universitätsbibliothek,

Ms. 115 , fol. $74 \mathrm{v}$.

Fig. 18. Dibujo. El área del Laterano, por P. de Venecia.

Roma, Biblioteca Marciana,

Ms. lat. Zan. 399 (1610), fol. 98r

Fig. 19. Planta. San Givanni in Laterano.

Roma.

(Según R. Krautheimer)

Fig. 20. Planta. San Pedro del Vaticano constantiniano.

Città del Vaticano.

(Según R. Krautheimer).

Fig. 21. Dibujo. Alzado reconstructivo de San Pedro de Vaticano.

Città del Vaticano, Biblioteca Apostólica,

Cod. A 64 ter., c 50r.

Fig. 22. Dibujo. Pantalla latericia formada por arcos de medio punto y muro.

Roma, San Giovanni in Laterano.

(Según F. Guidobaldi)

Fig. 23. Planta. San Julián de los Prados.

Oviedo.

(Según I. G. Bango Torviso).

Fig. 23a. Arco diafragma.

Oviedo, iglesia de San Julián de los Prados 1202

Fig. 24. Arco Romano.

Soria, Medinaceli.

Fig. 25. Arco diafragma.

Leiria, iglesia de San Gião de Nazaré. 
Fig. 26. Inscripción conmemorativa.

Roma, Arco de Constantino

Fig. 27. Diseño. Distribución del alzado del pórtico.

Santiago de Compostela, catedral, Pórtico de la Gloria.

(Según S. Moralejo)

Fig. 28. Diseño. Pantallas divisorias.

Roma, iglesia de la Santa Croce in Jerusalem.

(Según R. Krautheimer).

Fig. 29. Ara Pacis.

Roma.

Fig. 30. Relieves. Vegatales.

Roma, Ara Pacis.

Fig. 31. Fragmento de relieve. Espigas de la Edad de Oro.

Mérida, Museo Nacional de Arte Romano.

Fig. 32. Mosaico. Arquitecturas.

Ravenna, Baptisterio de los Ortodoxos.

Fig. 33. Mosaico. Palatium de Teodorico.

Ravenna, iglesia de San Apolinar.

Fig. 34. Pintura mural. Arquitecturas pintadas.

Oviedo, iglesia de San Julián de los Prados.

Fig. 35. Sistema de arquitrabado.

Roma, Baptisterio de San Giovanni in Laterano

Fig. 36. Capilla Palatina.

Aquisgrán

Fig. 36 a. Escultura. Loba u osa.

Aquisgrán, Capilla Palatina

Fig. 37. Escultura. Loba capitolina.

Roma, Musei Capitolini.

Fig. 38. Escultura ecuestre. Marco Aurelio.

Roma, Musei Capitolini. 1206

Fig. 39. Escultura. Carlomagno a caballo.

Paris, Musée du Louvre. 1206

Fig. 40. Dibujo. Caballero matando al dragón.

Paris, Musée du Louvre, Arco de Eginhardo. 1206 
Fig. 41. Grabado. Piña de bronce.

Città del Vaticano, basílica de San Pedro del Vaticano

(Según Philippe de Winghe)

Fig. 42. Escultura. Piña de bronce.

Aquisgrán, Capilla Palatina.

Fig. 43. Mosaico. Piñas y ramas de pino.

Roma, mausoleo de Santa Constanza.

Fig. 44. Planta de la abacial.

Fulda, iglesia de San Miguel.

(Según C. Heitz).

1208

Fig. 45. Dibujo. Arco de Eginhardo.

Paris, Bibliothèque nationale de France,

Ms. Franç. 10440, fol. 45r

Fig. 46. Arco de Tito.

Roma, Foros Imperiales 1208

Fig. 47. Torhalle Königshalle.

Lorsch 1208

Fig. 48. Arco de Constantino.

Roma, Foros Imperiales 1208

Fig. 49. Apliques decorativos.

Poitiers, Baptisterio de Saint-Jean

Fig. 50. Apliques pétreos sobre la muralla.

Le Mans 1209

Fig. 51. Pilastras.

Lorsch, pórtico

Fig. 52. Rejería. Vegetales y capitel corintio.

Aquisgrán, Capilla Palatina

Fig. 53. Sarcófago. Rapto de Proserpina.

Aquisgrán, Capilla Palatina 1209

Fig. 54. Miniatura. Cristo como señor del cosmos.

Sacramentario de Metz, Paris, Bibliothèque nationale de France,

Ms. Lat. 1141, fol. 6. 
Fig. 55. Miniatura. Río del Paraíso.

Sacramentario de Metz, Paris, Bibliothèque nationale de France,

Ms. Lat. 1141, fol. 6.

Fig. 56. Missorium. La Abundantia.

Madrid, Real Academia de la Historia

Fig. 57. La Tierra Madre.

Rollo Exultet, Bari, Museo della Cattedrale.

Ms. Lat. 6, III, fol. 83r.

Fig. 58. Escultura. Los ríos del Paraíso.

Hildesheim, iglesia de San Miguel, columna de bronce

Fig. 59. Escultura. Mes de Febrero.

Santiago de Compostela, Museo de la Catedral

Fig. 60. Bordado. Personificación de un Río del Paraíso.

Gerona, catedral, Bordado de la Creación

Fig. 61. Arqueta de los marfiles.

León, Museo de la Real Colegiata de San Isidoro

Fig. 62. Marfil. Personificación de un Río del Paraíso.

León, Real Colegiata de San Isidoro, arqueta de los marfiles

Fig. 63. Cubierta de códice. Los Ríos del Paraíso y el Agnus Dei.

Paris, Musée National du Moyen Age, Thermes de Cluny

Fig. 64. Planta.

Hildesheim, iglesia de San Miguel.

(Según C. Heitz).

Fig. 65. Planta.

Fulda, iglesia de San Bonafacio.

(Según C. Heitz).

Fig. 66. Planta.

Città del Vaticano, iglesia de San Pedro.

(Según R. Krautheimer)

Fig. 67. Puertas de bronce.

Hildesheim, iglesia de San Miguel

Fig. 68. Máscara de León.

Aquisgrán, Capilla Palatina

Fig. 69. Máscara de León.

Hildesheim, iglesia de San Miguel 
Fig. 70. Marfil. Crismón.

Ravenna, Museo Arzobispale, cátedra de Maximiano

Fig. 71. Cubierta de libro. Crismón.

Hildesheim, iglesia de San Miguel

Fig. 72. Columna de bronce.

Hildesheim, iglesia de San Miguel

Fig. 73. Escultura. Río del Paraíso.

Hildesheim, iglesia de San Miguel

Fig. 74. Diseño. Basas, molduras y capiteles.

Codice Magliabechiano, Firenze, Biblioteca Nazionale Centrale.

Ms. XVII, fol. 5v.

Fig. 75. Base de columna. Personificación del río Danubio.

Roma, Foros Imperiales, columna trajana

Fig. 76. Escultura. El río Jordán.

Hildesheim, iglesia de San Miguel, columna de bronce

Fig. 77. Cruz de Lothario.

Aquisgrán, Tesoro de la Catedral

Fig. 78. Diseño. Atrio vaticano.

Codex Grimaldi, Roma, Biblioteca Barberini.

Ms. Lat. 2733, fols. 133v-134r

Fig. 79. Diseño. Presbiterio vaticano.

Città del Vaticano, iglesia de San Pedro.

(Según M. Andaloro)

Fig. 80. Mosaico. Crucifixión.

Roma, iglesia de San Clemente

Fig. 81. Diseño reconstructivo. Monasterio de Montecassino.

(Según J. K. Conant)

Fig. 82. Mosaico. La Viña del Señor en forma de acanto.

Roma, iglesia de San Clemente

Fig. 83. Planta.

Iglesia de Cluny III

(Según K. J. Conant). 
Fig. 84. Planta.

Città del Vaticano, iglesia de San Pedro.

(Según R. Krautheimer).

Fig. 85. Pilastras acanaladas.

Cluny, iglesia de San Pedro

Fig. 86. Arco romano.

Autun

Fig. 87. Capitel. Músico.

Cluny, Musée Abatiale

Fig. 88. Capitel. Personificación de un viento.

Cluny, Musée Abatiale

Fig. 89. Bordado. Personificación de un viento.

Gerona, Museo de la Catedral, Bordado de Gerona

Fig. 90. Miniatura. Mappa Mundi.

De natura rerum, Città del Vaticano, Biblioteca Apostólica Vaticana.

Ms. Vat. Lat. 6018, fols. 63v-64r

Fig. 91. Grabado. Forma Urbis. Planta de Roma del templo de Septimio Severo.

Roma, Sovraintendenza ai Beni Culturali

Fig. 92. Miniatura. Mappa Mundi.

Explanatio in Apocalipsim, Madrid, Biblioteca Nacional.

Ms. vit. 14-2, fols. 63v-64r

Fig. 93. Mosaico. Representación cartográfica.

Madaba, iglesia de San Jorge.

Fig. 94. Miniatura. Orbe tripartito de Salustio.

De bello Iughurtino, Città del Vaticano, Biblioteca Apostólica Vaticana.

Ms. Reg. Lat. 571, fol. 71v

Fig. 95. Miniatura. El Orbe.

Münich, Bayerische Staatsbibliothek.

Clm. 10058, fol. 154v

Fig. 96. Miniatura. La ciudad de Roma atravesada por el Tiber.

Munich, Bayerische Staatsbibliothek.

Clm. 10058, fol. $154 \mathrm{v}$ 
Fig. 97. Miniatura. El Mundo.

Burgo de Osma, Biblioteca de la catedral.

Cod. 1, ff. 34v-35r .

Fig. 98. Miniatura. La ciudad de Roma.

Burgo de Osma, Biblioteca de la catedral.

Cod. 1, ff. 34v-35r

Fig. 99. Miniatura. Itinerario de Matthew Paris.

London, British Library,

Ms. Royal 14 C. VII.

Fig. 100. Escultura. Muralla y puerta de la ciudad.

Santiago de Compostela, catedral, portada de las Platerías.

Fig. 101. Muralla.

Ávila

Fig. 102. Cenotafio de los santos Vicente, Sabina y Cristeta.

Ávila, iglesia de San Vicente.

Fig. 102 a. Dibujo. Puerta Soprana.

Genova,

(Según D. Rico Camps)

1224

Fig. 103. Miniatura. Representación arquitectónica.

Corpus Agrimensorum Romanorum, Wolfenbüttel, Herzog August Bibliothek.

Cod. Guelf. 36.23A, fol. 56v

Fig. 104. Puerta Romana.

Trier

Fig. 105. Pila bautismal. Arquitecturas.

Redecilla del Camino, iglesia de Nuestra Señora de la Calle

Fig. 106. Miniatura. San Agustín y la Civitas Dei.

Paris, Bibliothèque de Sainte-Geneviève.

Ms. Lat. 218, fol. 2r

Fig. 107. Miniatura. La muralla de Toledo.

Codex Albeldense, El Escorial, Real Biblioteca del Monasterio.

Ms. d. 1.2, fol. 142r

Fig. 108. Pintura. Decoración pictórica en casetones.

Oviedo, iglesia de San Julián de los Prados

1226

Fig. 109. Cancel. Decoración geométrica.

Uclés, Monasterio, Caballerizas de la Orden de Santiago 1226 
Fig. 110. Mosaico. La ciudad de Ravenna.

Ravenna, iglesia de San Apolinar Nuevo

Fig. 111. Miniatura. La Jerusalén Celeste.

Liber Floridus, Wolfenbüttel, Braunschweigische Landesbibliothek,

Ms. Gud. Lat. I, fol. 43v

Fig. 112. Ilustración. Mapa de Jerusalén.

Expositio fratis Angelomi, Cambrai, Bibliothèque Municipale.

Ms. 437

Fig. 113. Portada de las Platerías.

Santiago de Compostela, catedral

1228

Fig. 114. Porte des Comtes.

Toulouse, iglesia de Saint-Sernin

Fig. 115. Diseño. Puerta de Augusto.

Nîmes.

(Según F. Germerd-Durand)

Fig. 116. Capitel y cimacio. Babilonia.

Moissac, iglesia de San Pedro, claustro.

Fig. 117. Capitel. El Santo Sepulcro.

Mozac, iglesia de San Pedro.

Fig. 118. El Santo Sepulcro.

Jerusalén

Fig. 119. Dibujo. Planta área de San Giovanni in Laterano.

Città del Vaticano, Biblioteca Apostólica Vaticana,

Ms. Vat. Lat. 1960, f. 270 v.

Fig. 120. Miniatura. Estatua de Venus.

Roma, Colección Particular.

Fig. 121. Miniatura. Venus saliendo del agua con una pizarra.

Copenhague, Det Kongelige Bibliotek.

Ms. Thott. 399, $2^{\circ}$, fol. 9v

Fig. 122. Pintura sobre tabla. La Encarnación de Cristo.

Sttutgart, Staatsgalerie

Fig. 123. Miniatura. El faro y la catedral de Santiago de Compostela.

Burgo de Osma, Biblioteca de la catedral.

Cod. 1, ff. 34v-35r 
Fig. 124. Mappamundi.

Hereford Map, Hereford, Cathedral Library ....

Fig. 125. Mappamundi. Hispania.

Hereford Map, Hereford, Cathedral Library

Fig. 126. Mappa Mundi. Catedral de Santiago de Compostela y faro de Perona.

Hereford Map, Hereford, Cathedral Library

Fig. 126 a. Mappa Mundi. Faro de Alejandría.

Hereford Map, Hereford, Cathedral Library

Fig. 127. Sarcófago. Faro con una personificación.

Roma, Museo Nazionale Romano

Fig. 128. Dibujo. Descriptio orbis térrea.

Città del Vaticano, Biblioteca Apostolica Vaticana.

Ms. Vat. Lat., 7318, fol. 3v

Fig. 129. Miniatura. Las Columnas de Hércules.

Munich, Bayerische Staatsbibliothek.

Clm 10058, f. 154 v

Fig. 130. Dibujo. Las Columnas de Hércules en el Gades.

Città del Vaticano, Biblioteca Apostolica Vaticana.

Ms. Vat. Lat. 7318, f. 3 v

Fig. 131. Miniatura. Las Columnas de Hércules.

Hereford Map, Hereford, Cathedral Library

Fig. 132. Miniatura. Las Columnas de Hércules.

London, British Library

Fig. 133. Mosaico. La Gran Columna.

Madaba, iglesia de San Jorge

Fig. 134. Placa de marfíl.Crucifixión y la Loba con Rómulo y Remo.

Città del Vaticano, Musei Vaticani

Fig. 135. Miniatura. Mujer judía condenada en Segovia.

El Escorial, Biblioteca del Real Monasterio de San Lorenzo.

Ms. 107, f. 154 r.

Fig. 136. Acueducto romano.

Segovia

Fig. 137. Mezquita.

Córdoba 
Fig. 138. Acueducto de los Milagros.

Mérida.

Fig. 139. Lastra. Vegetales.

Pompeya, Eumachie

Fig. 140. Lastras. Decoración vegetal.

Estíbaliz, Iglesia de Nuestra Señora

Fig. 141. Lastra. Vegetales y cabezas.

Rodas, iglesia de San Pedro

Fig. 142. Ara romana.

Santiago de Compostela, catedral, cimientos

Fig. 143. Ara romana.

León, iglesia de San Miguel de Escalada

Fig. 144. Sarcófago. Historia de Proserpina.

Aquisgrán, Capilla Palatina.

Fig. 145. Dibujo. Reconstrucción del sepulcro de Carlomagno.

(Según F. Carbrol y H. Leclercq).

Fig. 146. Sarcófago de Ithacio.

Oviedo, catedral.

Fig. 147. Pilastra. Decoración geométrica y vegetal.

Oviedo, San Julián de los Prados.

Fig. 148. Estuco. Tema vegetal.

Toledo, iglesia de Santa María de Melque

Fig. 149. Estuco. Tema vegetal.

Marsella, iglesia de Saint-Victor

Fig. 150. Diseño. Placas vegetales.

Oviedo, iglesia de San Miguel de Lillo.

(Según S. Noack-Haley).

Fig. 151. Vaso en forma de Águila.

Paris, Musée du Louvre

Fig. 152. Capitel. Escena de la traslatio del cuerpo del Apóstol.

Lérida, catedral.

Fig. 153. Conjunto escultórico. Santo Entierro.

Tarragona, catedral 
Fig. 154. Pintura sobre tabla. Cristo, de Bartolomeo Bonascia.

Modena, Galleria Estense.

Fig. 155. Marfil. Santo Sepulcro.

Salerno, Museo Diocesano

Fig. 156. Marfil. Marías visitando el sepulcro.

Salerno, Museo Diocesano

Fig. 157. Capitel. San Juan y el sepulcro vacío.

Toulouse, Musée des Augustins

Fig. 158. Sarcófago de doña Sancha.

Covarrubias, Colegiata de los santos Cosme y Damián

Fig. 159. Sarcófago del Conde Santo.

Vilanova de Lourenzá, monasterio de San Salvador,

Fig. 160. Retablo orfebre. Sepulcro de Santa Eufemia.

Orense, catedral

Fig. 161. Pintura. Peregrinos ante las reliquias de San Sebastián, por Josse Lieferinxe.

Roma, Galleria Nazionale d'Arte Antica di Palazzo Barberini.

Fig. 162. Capitel. Traslado de las reliquias de San Denis.

Paris, iglesia de Saint-Denis, cripta

Fig. 163. Sarcófago de Husillos.

Madrid, Museo Arqueológico Nacional

Fig. 164. Sarcófago romano.

Huesca, iglesia de San Pedro el Viejo

Fig. 165. Sarcófago de San Justo de la Vega.

Madrid, Museo Arqueológico Nacional

Fig. 166. Sarcófago paleocristiano.

Milán, iglesia de San Ambrosio

Fig. 167. Sarcófago. La Entrada en Jerusalén.

Tarragona, catedral

Fig. 168. Busto expoliado. Emperador romano.

Quintana del Marco, iglesia de San Pedro.

Fig. 169. Monumento funerario. Efigie del abad Isarn.

Marsella, iglesia de Saint-Victor

Fig. 170. Lauda funeraria romana.

Saulieu, Museé Municipale 
Fig. 171. Jamba. Tocado de magistrado.

Oviedo, iglesia de San Miguel de Lillo

Fig. 172. Marfil. Tocado de Adán.

Firenze, Museo Nazionale del Bargello

Fig. 173. Lauda de Ampelius.

Tarragona, Museo de la Necrópolis Paleocristiana

Fig. 174. Jamba. Cenefa vegetal.

Oviedo, iglesia de San Miguel de Lillo

Fig. 175. Díptico Symmanchy. Ascensión imperial.

London, British Museum.

Fig. 176. Tímpano. Cristo ascendiendo a los cielos.

León, Real Colegiata de San Isidoro, puerta del Perdón

Fig. 177. Pilastra. Decoración geométrica y vegetal.

Oviedo, San Julián de los Prados

Fig. 178. Friso corintio.

Braga, oratorio de San Fructuoso

Fig. 179. Capitel romano.

Oviedo, iglesia de San Tirso

Fig. 180. Capitel corintio.

Ripoll, iglesia de Santa María

Fig. 181. Capitel romano de hojas lisas.

Ostia.

Fig. 182. Capitel corintio.

Rodas, iglesia de San Pedro.

Fig. 183. Capitel corintio.

Nîmes, Maison Carré

Fig. 184. Interior de la iglesia.

Rodas, iglesia de San Pedro.

Fig. 185. Capiteles corintios.

Bande, iglesia de Santa Comba

Fig. 186. Capitel corintio.

Saint-Benoît-sur-Loire, iglesia de Saint-Benoît 
Fig. 187. Capitel corintio.

Poitiers, iglesia de Saint-Hilaire

Fig. 188. Capitel corintio.

León, Real Colegiata de San Isidoro, panteón

Fig. 189. Capitel corintio.

Toulouse, iglesia de Saint-Sernin

Fig. 190. Capitel compuesto.

Pisa, Museo del Duomo

Fig. 191. Capitel corintio.

Soria, Museo Numantino

Fig. 192. Capitel corintio. Detalle.

León, Real Colegiata de San Isidoro, Panteón

Fig. 193. Capitel corintio.

Ávila, iglesia de San Vicente.

Fig. 194. Mosaico. Acanto.

Roma, iglesia de San Clemente

Fig. 195. Mosaico. Vegetación.

Roma, oratorio de San Giovanni in Laterano

Fig. 196. Cáliz de Antioquia.

New York, The Metropolitan Museum of Art's. The Cloisters

Fig. 197. Pinturas. Tema vegetal.

Valdediós, iglesia de San Salvador.

Fig. 198. Pinturas. Tema vegetal.

Jordania, Baños de Qusayr ‘Amra

Fig. 199. Relieve. Guirnalda vegetal enmarcando a la Virgen y a los ángeles.

Zamora, catedral, Puerta del Obispo

Fig. 200. Tímpano. Decoración vegetal.

Coustouges, iglesia de Santa María

Fig. 201. Tímpano. Decoración vegetal y zoomórfica.

Cervatos, iglesia de Santa María.

Fig. 202. Capitel. Acanto, hombres y animales.

Pamplona, Museo de Navarra.

Fig. 203. Capitel. Los Evangelistas.

Córdoba, Museo Arqueológico 
Fig. 204. Capitel romano figurado.

Roma, Termas de Caracalla.

Fig. 205. Capitel romano figurado.

Roma, Termas de Caracalla

Fig. 206. Capitel. Anunciación.

Bages, iglesia de Sant Benet.

Fig. 207. Capitel. Inscripción.

Brevilla, iglesia de Notre-Dame

Fig. 208. Dibujo reconstructivo. El Santo Sepulcro.

(Según R. Krautheimer).

Fig. 209. Dibujo reconstructivo. La tumba de Cristo.

(Según F. Galtier Martí)

Fig. 210. Dibujo. El Tegurium rotundum.

(Según R. Krautheimer).

Fig. 211. Relieve. Templete funerario.

Città del Vaticano, Musei Vaticani.

Fig. 212. Dibujo. El Ptolemaion.

Lymira.

(Según P. Gros).

Fig. 213. Marfil. El Santo Sepulcro.

Munich, Staatsbibliothek

Fig. 214. Mausoleo de Boelmondo.

Altavilla, catedral de Canosa

Fig. 215. Marfíl. Las Marías ante el sepulcro.

London, British Museum.

Fig. 216. Sarcófago. Las Puertas del Hades.

Córdoba, Reales Alcázares

Fig. 217. Marfíl. Nichos y clípeos en el Santo Sepulcro.

Munich, Staatsbibliothek

Fig. 218. Dibujo. Tholos de Sestino.

Toscana.

(Según P. Gros). 
Fig. 219. Hebilla del obispo Cesáreo. El Santo Sepulcro.

Arles, Musée de l'Arles Antique

Fig. 220. Dibujo. El Santo Sepulcro.

Narbonne, Musée Archéologique.

(Según A. Bonnery).

Fig. 221. Dibujo. Ampolla con el Santo Sepulcro..

Bobbio, Museo del Duomo.

(Según R. Krautheimer).

Fig. 222. Situs Hierusalem.

Montpellier, Archive Municiapale, cod. H. 142, fol. 67 v.

Fig. 223. Planta. Iglesia de Santa María.

Riueux-Minervois.

(Según A. Bonnery)

Fig. 224. Capitel. Visitatio Sepulchri.

Torres del Río, iglesia del Santo Sepulcro 1260

Fig. 225. Marfil. Visitatio Sepulchri.

Firenze, Museo Nazionale del Bargello

Fig. 226. Puerta. El Santo Sepulcro.

Hildesheim, iglesia abacial de San Miguel

Fig. 227. Mausoleo de Punico-Libio.

Thugga 1260

Fig. 228. Torre de los Escipiones.

Tarragona.

Fig. 229. Mausoleo de los Julii.

Glanum

Fig. 230. Torre funeraria, Salterio de Utrecht.

Paris, Bibliothèque nationale de France,

Ms. 47, 13, fol. 27v

Fig. 231. Tímpano. El Sepulcro vacío.

León, iglesia de San Isidoro de León, puerta del Perdón 1261

Fig. 232. Tumba de Lázaro.

Alcaudete, Museo Arqueológico 1261 
Fig. 233. Representación del Santo Sepulcro. La Anástasis.

Paris, Bibliothèque nationale de France,

Cod. Ms. Turri, 2.

Fig. 234. Capitel. Santo Sepulcro.

Tarragona, catedral

Fig. 235. Tímpano. Columna del Santo Sepulcro.

León, iglesia de San Isidoro, puerta del Perdón

Fig. 236. Píxide. El Santo Sepulcro.

New York, The Metropolitan Museum of Art's. The Cloisters

Fig. 237. Columna torsa perlada.

León, iglesia de San Isidoro, altar del ábside norte

Fig. 238. Sarcófago de Husillos.

Madrid, Museo Arqueológico Nacional

Fig. 239. Capitel. Hombres y serpientes.

Frómista, iglesia de San Martín

Fig. 240. Planta con la situación del capitel.

Frómista, iglesia de San Martín,

(Según J. A. Moráis Morán).

Fig. 241. Capitel de restauración. Hombres y serpientes.

Frómista, iglesia de San Martín.

Fig. 242. Fotografía del capitel. Hombres y serpientes.

Palencia, Archivo de la Fundación Eugenio Fontaneda.

(Según J. Sanabria)

Fig. 243. Sarcófago. Orestes.

Madrid, Museo Arqueológico Nacional

Fig. 244. Capitel. Hombres y ofidios.

Palencia, Museo Arqueológico.

Fig. 245. Sarcófago. Orestes.

Città del Vaticano, Musei Vaticani 1266

Fig. 246. Sarcófago. Cortinajes. Madrid, Museo Arqueológico Nacional 1266

Fig. 247. Capitel. Máscara vomitando.

Frómista, iglesia de San Martín

Fig. 248. Capitel. Cara derecha.

Palencia, Museo Arqueológico 
Fig. 249. Capitel. Cara izquierda.

Palencia, Museo Arqueológico

Fig. 250. Capitel. Fábula de la zorra.

Frómista, iglesia de San Martín

Fig. 251. Capitel. Hombres con leones.

Palencia, Museo Arqueológico

Fig. 252. Capitel. Figura femenina.

Canosa, Museo Civico Archeologico. 1268

Fig. 253. Capitel. Danzantes, putti músicos y bestias Jaca, catedral de San Pedro

Fig. 254. Planta.

Jaca, Catedral,

(Según M. Durliat).

Fig. 255. Capitel. Martirio de Santa Fe.

Santiago de Compostela, catedral

Fig. 256. Capitel. Monstruo y textiles.

Jaca, catedral de San Pedro

Fig. 257. Capitel. Putti con aulos.

Jaca, catedral de San Pedro

Fig. 258. Sarcófago. Thiasos marino.

Àger, iglesia de San Vicente

Fig. 259. Dibujo. Sarcófago romano de Àger.

Madrid, Real Academia de la Historia, (CAIB/9/3930/02(07),

(Según F. Torres Amat).

Fig. 260. Sarcófago. Escenas de bacanal y máscara felina.

Vaucluse, Cadenet

Fig. 261. Sarcófago. Danza báquica.

Città del Vaticano, Musei Vaticani

Fig. 262. Sarcófago. Thiasos marino.

Città del Vaticano, Musei Vaticani

Fig. 263. Sarcófago. Figuras femeninas y tritón.

Città del Vaticano, Musei Vaticani

Fig. 264. Capitel. Danzantes.

Jaca, catedral de San Pedro 
Fig. 265. Sarcófago. Figuras.

Città del Vaticano, Musei Vaticani

Fig. 266. Capitel. Hombre atacado por serpientes.

León, iglesia de San Isidoro

Fig. 267. Capitel. Hombres, leones y serpientes.

Jaca, catedral de San Pedro...

Fig. 268. Capitel. Hombre desnudo con animal.

Jaca, catedral de San Pedro

Fig. 269. Sarcófago. Putti vendimiadores.

Roma, iglesia de San Lorenzo Extramuros

Fig. 270. Sarcófago. Putti cabalgando un felino.

Roma, iglesia de San Lorenzo Extramuros

Fig. 271. Capitel. Putti y felino.

Loarre, iglesia de San Pedro

Fig. 272. Escultura. Asclepios.

Ampurias, Museo Arqueológico

1275

Fig. 273. Capitel. Hombres y serpientes.

Jaca, catedral de San Pedro

Fig. 274. Placa. Danzante con serpientes.

Città del Vaticano, Musei Vaticani

Fig. 275. Moneda. Hércules niño con serpientes.

Philadelphia, University, Colection Stuempfli

1276

Fig. 276. Canecillo. Animal con serpientes.

Jaca, catedral de San Pedro

Fig. 277. Escultura. Chronos-Mithras.

Mérida, Museo de Arte Romano

Fig. 278. Sarcófago. El león y la serpiente.

Gerona, catedral.

Fig. 279. Capitel. Anunciación (?).

Jaca, catedral de San Pedro.

Fig. 280. Capitel. Figura con serpiente.

León, iglesia de San Isidoro 1278 
Fig. 281. Miniatura. Serpiente Ouroboros.

Paris, Bibliothèque nationale de France,

Ms. Gr. 2327, fol. 196.

Fig. 282. Tímpano. Crismón y leones afrontados.

Jaca, catedral de San Pedro.

Fig. 282 a. Placa de aplique. Leones afrontados.

Tomar, Santarém, iglesia de San Juan Bautista.

Fig. 282 b. Mosaico. Leones afrontados.

Mértola, baptisterio

Fig. 283. Arquivolta de ventana. Cabezas zoomórficas.

Viana do Castelo, Nogueira, iglesia de San Claudio

Fig. 284. Capitel. Máscara felina.

Jaca, catedral de San Pedro

Fig. 285. Escultura. Remate del trono.

León, iglesia de San Isidoro

Fig. 286. Escultura. Remate del trono.

Santiago de Compostela, catedral

Fig. 287. Miniatura. Remate del trono de Fruela II.

Santiago de Compostela, Archivo de la Catedral,

Tumbo A, Cód. 1, fol. 29v.

Fig. 288. Actas del Concilio de Jaca. Retrato de obispos entronizados.

Huesca, Archivo de la Catredral,

Sign. 2-47

1281

Fig. 289. Aplique. Prótomo animal.

Palencia, Museo Arqueológico.

Fig. 290. Sarcófago. Felinos y crátera.

Belém, Museu Nacional de Arqueologia.

Fig. 291. Capitel. Máscara teatral.

Brioude, iglesia de Saint-Julien

Fig. 292. Brocal. Máscara de Bacante. Belém, Museu Etnológico

Fig. 293. Surtidor de fuente. Nubio.

Belém, Museu Nacional de Arqueologia

Fig. 294. Copa. Escenas Dionisíacas.

Paris, Bibliothèque nationale de France, Cabinet des Médailles 1283 
Fig. 295. Miniatura. Comedias de Terencio. Armarium con máscaras.

Città del Vaticano, Biblioteca Apostolica Vaticana,

Cod. Vat. Lat. 3868, 3cr

Fig. 296. Máscara de teatro.

(Según P. Lavedan)

Fig. 297. Pintura sobre tabla. Verdugo de San Vicente, por Bernat Martorell.

Barcelona, Museo Nacional de Arte de Cataluña

Fig. 298. Pinax con máscaras.

Tavira, Museo Regional

Fig. 299. Cátedra. Máscara.

Bari, iglesia de San Nicolás

Fig. 300. Máscara romana de estuco.

Palencia, Museo Arqueológico

Fig. 301. Capitel. Máscara.

Santo Domingo de la Calzada, iglesia de Santo Domingo

Fig. 302. Capitel, Mascarón entre vegetales.

León, iglesia de San Isidoro

Fig. 303. Fuste. Aves, vegetales y una crátera.

Beja, Museu Regional

Fig. 304. Sarcófago de Constanza. Mascarón.

Città del Vaticano, Musei Vaticani 1286

Fig. 305. Capitel. Personajes vendimiando y máscaras.

Carrión de los Condes, iglesia de San Zoilo

Fig. 305 a. Capitel. Escenas de vendimia.

Paris, Musée du Louvre

Fig. 305 b. Capitel. Personajes entre vides.

Santiago de Compostela, catedral

Fig. 306. Capitel romano. Busto.

Wien, Kunsthistorisches Museum

Fig. 307. Capitel románico. Máscara.

Jaca, catedral de San Pedro 1288

Fig. 308. Cimacio. Máscara.

Jaca, catedral de San Pedro 1288 
Fig. 309. Antefija. Cabeza felina.

Calabria, Museo Nazionale di Reggio Calabria

Fig. 310. Cubierta de sarcófago. Máscaras.

Paris, Musée du Louvre

Fig. 311. Capitel románico. Máscara vomitando textiles.

Frómista, iglesia de San Martín.

Fig. 312. Miniatura. Prótomo de león vomitando textiles.

Paris, Bibliothèque nationale de France,

Evangéliaire de Charlemagne, nouv acq. lat. Ms. 1203, fol. 3v.

Fig. 313. Miniatura. Capitel con doble cara.

Paris, Bibliothèque nationale de France,

Evangéliaire de Otón III, Clm. 4453, fol. 24r. 1290

Fig. 314. Balsamario. Rostros.

Palencia, Museo Arqueológico

Fig. 315. Escultura. Hermes.

Belém, Museu Nacional de Arqueologia

Fig. 316. Surtidor de agua. Nubio.

Roma, Museo Nazionale Romano

Fig. 317. Fragmento de cornisa.

Toulouse, Musée des Augustins

Fig. 318. Canecillo. Posible nubio.

Jaca, catedral de San Pedro

Fig. 319. Cimacio. Cabeza.

Jaca, catedral de San Pedro

Fig. 320. Canecillo descontextualizado. Posible nubio.

León, iglesia de San Isidoro de León, claustro.

Fig. 321. Capitel. Sacrificio de Isaac.

Jaca, catedral de San Pedro

Fig. 322. Cenotafio. Cuerpos martirizados.

Ávila, iglesia de San Vicente.

Fig. 323. Capitel. Alma en mandorla.

Tera, iglesia de Santa Marta

Fig. 324. Sepulcro de E. Moniz. Alma desnuda en mandorla.

Paço de Sousa, iglesia de San Salvador 
Fig. 325. Relieve de la portada. Resurrección de los muertos.

Bourges, Catedral

Fig. 326. Relieve. Atleta.

Saintes, Musée Archélogique

Fig. 327. Relieve. Diadoúmenos.

Città del Vaticano, Musei Vaticani

Fig. 328. Sarcófago. Eva.

Madrid, Museo Arqueológico Nacional

Fig. 329. Sepulcro. Alma ascendiendo.

Jaca, Convento de las Benedictinas

1296

Fig. 330. Capitel. Personaje semidesnudo.

Jaca, catedral de San Pedro.

Fig. 331. Capitel. Abraham con clámide.

Jaca, catedral de San Pedro

Fig. 332. Esculturilla. Sileno.

Belém, Museu Arquelogico Nacional

Fig. 333. Capitel. La Virgen María.

Jaca, catedral de San Pedro.

Fig. 334. Estatua. Genius Senatus.

Mérida, Museo de Arte Romano

Fig. 335. Capitel. Rostro de María.

Jaca, catedral de San Pedro

Fig. 336. Antefija. Rostro.

Palencia, Museo Arqueológico

Fig. 337. Capitel. Aarón y Moisés.

Jaca, catedral de San Pedro.

Fig. 337 a. Mercurio.

Banyoles, Museo Arqueológico 1298

Fig. 338. Capitel. Figuras con clípeo.

Jaca, catedral de San Pedro.

Fig. 339. Sarcófago romano. Putti con clípeo.

Huesca, iglesia de San Pedro el Viejo 
Fig. 340. Sarcófago de Asido. Escena de thiasos marino.

Cádiz, Medinasidonia.

(Según A. Ponz).

Fig. 341. Sarcófago de los Compañeros de Santa Úrsula.

Marsella, cripta de Saint-Victor.

Fig. 342. Sarcófago.

Agen, iglesia de Saint-Caprais.

Fig. 343. Sarcófago. Retrato del difunto y deidades.

Gerona, Museu Arqueòlogic de San Pere de Galligans

Fig. 344. Sarcófago romano. Clípeo con retrato de difuntos.

Covarrubias, Colegiata de los Santos Come y Damián

Fig. 345. Canecillo. Busto de mujer en clípeo.

Toulouse, basílica de Saint-Sernin

Fig. 346. Sarcófago de Taillefer.

Toulouse, basílica de Saint-Sernin,

(Según M. Edmond Le Blant).

Fig. 347. Sarcófago. Ángeles con clípeo.

Gerona, iglesia de San Félix

Fig. 348. Ábside sur.

Jaca, catedral de San Pedro

Fig. 349. Placas figuradas.

Jaca, catedral de San Pedro

Fig. 350. Placa para aplicar. Oso. Jaca, Museo Diocesano.

Fig. 351. Cornisa. Placas decorativas.

Poitiers, iglesia de Saint-Hilaire

Fig. 352. Cornisa. Gallo.

Burgos, iglesia de San Quirce

Fig. 353. Terracota. Roseta.

Nantes, Musée Th. Dobrée

Fig. 354. Terracota. El Pecado Original.

Nantes, Musée Th. Dobrée

Fig. 355. Dintel. Decoración vegetal.

Moissac, iglesia de Saint-Pierre. 
Fig. 356. Tímpano. Crismón.

Jaca, catedral de San Pedro

Fig. 357. Placa. Crismón.

Lugo, Museo Arqueológico.

Fig. 358. Sarcófago. Crismón y decoración vegetal.

Burdeos, iglesia de Saint-Seurin, cripta.

Fig. 359. Sarcófago de doña Sancha. Crismón.

Jaca, Convento de las Benedictinas

Fig. 360. Tímpano. Crismón.

León, iglesia de San Isidoro

Fig. 361. Tímpano. Crismón.

Frómista, iglesia de San Martín.

Fig. 362. Tímpano. Crismón.

Carrión de los Condes, iglesia de San Zoilo

Fig. 363. Dibujo del mosaico. Leones afrontados.

Port de Maó, basílica de Illeta del Rei.

(Según P. de Palol)

Fig. 364. Dibujo del mosaico. Leones afrontados.

Menorca, Es Fornàs del Torelló.

(Según P. de Palol)

Fig. 365. Sarcófago de la Pasión. Cruz invicta y crismón.

Valencia, Museo de Bellas Artes

Fig. 366. Planta. Capilla de Santa Fe.

Santiago de Compostela, catedral.

(Según J. K. Conant).

Fig. 367. Acrotera. Mujer cabalgando al león.

Santiago de Compostela, catedral.

Fig. 368. Acrotera.

Santiago de Compostela, catedral.

Fig. 369. Dibujo reconstructivo. Alzado general y portada occidental.

Pamplona, catedral.

(Según I. G. Bango Torviso).

1308

Fig. 370. Candelabro Pascual.

Roma, iglesia de San Paolo Extramuros 1308 
Fig. 371. Escultura. Columnilla.

Santiago de Compostela, catedral

Fig. 372. Plano. El Paradisus y la Porta Francigena.

Santiago de Compostela, Archivo de la Catedral,

Leg. 285 .

Fig. 373. Dibujo reconstructivo. La Fuente del Paradisus.

Santiago de Compostela, catedral,

(Según S. Moralejo).

Fig. 374. Diseño. La Fuente vaticana, del círculo de B. Peruzzi.

Firenze, Galleria degli Uffizi.

Fig. 375. Planta.

Cuixá, abadía de San Miguel,

(Según G. Boto Varela)..

Fig. 376. Planta. La cripta del Pesebre.

Cuixá, abadía de San Miguel,

(Según O. Poisson).

Fig. 377. Cripta del Pesebre.

Roma, Santa Maria Maggiore,

(Según R. Krautheimer).

Fig. 378. Fustes entorchados. Escenas de vendimia.

Santiago de Compostela, Museo Catedralicio....

Fig. 379. Fuste entorchado.

Santiago de Compostela, Museo Catedralicio.

Fig. 380. Fuste entorchado.

Santiago de Compostela, Museo Catedralicio.

Fig. 381. Fuste entorchado. Putto vendimiando.

Santiago de Compostela, Museo Catedralicio.

Fig. 382. Dibujo reconstructivo. Trofeo.

Città del Vaticano, basilica de San Pedro,

(Según A. C. Carpiceci)

Fig. 383. Columna. Putti vendimiadores.

Città del Vaticano, basilica de San Pedro

Fig. 384. Arqueta de Samagher. Pérgola constantiniana.

Venezia, Museo Archeologico.

Fig. 385. Arqueta de Samagher.

Venezia, Museo Archeologico. 
Fig. 386. Dibujo. Ábside durante la época constantiniana.

Città del Vaticano, basilica de San Pedro,

(Según Kirschbaum).

Fig. 387. Relieve. Tumba de los Haterii.

Roma, Museo Lateranense.

Fig. 388. Relieve. Columnas con decoración de vides.

Roma, Museo Lateranense.

Fig. 389. Sarcófago de I. Basso. Columna vegetal.

Città del Vaticano, basilica de San Pedro

Fig. 390. Columna. Putti vendimiadores.

Roma, Musei Capitolini.

Fig. 391. Capitel. Personajes entre vegetales.

Roma, Musei Capitolini

Fig. 392. Fuste. Decoración vegetal.

Roma, iglesia de San Clemente.

Fig. 393. Fuste. Decoración vegetal.

Pompeya, Casa de los Vetii.

Fig. 394. Fuste. Decoración vegetal.

Elche, Museo Arqueológico.

Fig. 395. Dibujo reconstructivo. Ábside.

Toulouse, iglesia de La Daurade,

(Según Dom J. Martin).

Fig. 396. Columna. Decoración vegetal.

New York, The Metropolitan Museum of Art's. The Cloisters.

Fig. 397. Columna. Decoración vegetal.

Paris, Musée du Louvre.

Fig. 398. Pintura. La pérgola constantiniana.

Città del Vaticano, Estancias Papales

Fig. 399. Columna helicoidal. Escenas de vendimia.

Roma, iglesia de Santa Trinità dei Monti.

Fig. 400. Sarcófago. El Buen Pastor.

Roma, Musei de San Giovanni in Laterano.

Fig. 401. Sarcófago. Escenas de vendimia.

Belém, Museu Nacional de Arqueologia 
Fig. 402. Columna. Escenas de la vida de Cristo.

Hildesheim, iglesia de San Miguel....

Fig. 403. Columna. Putti agarrando un ave.

Santiago de Compostela, Museo de la Catedral.

Fig. 404. Escultura. Niño ahogando una oca.

München, Antikensammlung.

Fig. 405. Sarcófago. Escenas de vendimia.

Roma, San Lorenzo Extramuros.

Fig. 406. Relieve. Putto vendimiando.

Osuna, Museo Arqueológico Provincial.

Fig. 407. Cubierta ebúrnea. Crucifixión y columna con viña.

Metz, Musée de la Cour d'or.

Fig. 408. Capitel. Personajes entre ondas.

Igúacel, iglesia de Santa María.

Fig. 409. Friso esculpido. Personajes entre ondas.

Loarre, iglesia de Santa María

Fig. 410. Columna. Ángeles con textiles.

Santiago de Compostela, catedral, portada de Platerías.

Fig. 411. Escultura. Rostro de la mujer del cráneo.

Santiago de Compostela, catedral, portada de Platerías

Fig. 412. Moneda. Ninfa Aretusa.

Siracusa, Museo Nacional.

Fig. 413. Moneda. Helios.

Siracusa, Museo Nacional.

Fig. 414. Capitel. Personaje masculino.

Jaca, iglesia de Santiago.

Fig. 415. Sarcófago. Personaje en clípeo.

Huesca, iglesia de San Pedro del Viejo.

Fig. 416. Sarcófago de Saint-Orens.

Toulouse, Musée des Agustins.

Fig. 417. Incensario esculpido. La masque feuillu.

Santiago de Compostela, catedral, portada de Platerías. 
Fig. 418. Fuente. Personficación de Silvanus.

Paris, Deposite Lapidaire de Saint Denis

Fig. 419. Dibujo. Fuente.

Utrecht, University Library,

Ms. 798, fol. 181 .

Fig. 420. Columna. Figuras con nimbos.

Santiago de Compostela, catedral, portada de las Platerías

Fig. 421. Capitel. Figura con nimbo.

El Campillo, iglesia de San Pedro de la Nave

Fig. 422. Mosaico. Lauda Sepulcral de Ursicinius.

Madrid, Museo Arqueológico Nacional

Fig. 423. Cátedra del obispo Maximiano.

Ravenna, Museo Arcivescovile

Fig. 424. Arqueta. Personajes en clípeos avenerados.

Brescia, Museo Cristiano

Fig. 425. Escultura. Santo Tomás.

Toulouse, Musée des Augustins

Fig. 426. Escultura. Santo Pedro.

Ripoll, iglesia de Santa María

Fig. 427. Placa decorativa. Escamado.

Santiago de Compostela, catedral.

Fig. 428. Placa. Escamado.

Santiago de Compostela, catedral.

Fig. 429. Lajas con decoración vegetal.

Santiago de Compostela, catedral.

Fig. 430. Lajas esculpidas. Tema vegetal.

Modena, Duomo

Fig. 431. Planta.

León, iglesia de San Isidoro,

(Según M. Durliat)

Fig. 432. Capitel. Hombres y serpientes.

León, iglesia de San Isidoro.

Fig. 433. Dibujo. Hombres y serpientes.

León, iglesia de San Isidoro,

(Según J. A. Moráis Morán) 
Fig. 434. Arqueta de los marfiles. Río del Paraíso.

León, Museo de la Real Colegiata de San Isidoro

Fig. 435. Tímpano. Agnus Dei y ángeles.

Ruiforco de Torío, iglesia de los Santos Julián y Basilisa.

Fig. 436. Tímpano. Puerta del Cordero.

León, iglesia de San Isidoro.

Fig. 437. Fuste helicoidal. Banda y florones.

Corullón, iglesia de San Esteban..

Fig. 438. Capitel. Hombres y serpientes.

León, iglesia de San Isidoro, puerta norte.

Fig. 439. Capitel. Máscara vomitando serpientes.

Saint-André-de-Bâgé, iglesia de Saint-André..

Fig. 440. Capitel. Máscara vomitando serpientes.

Cangas de Onís, iglesia de San Pedro de Villanueva.

Fig. 441. Ménsula. Esfinge (?).

León, iglesia de San Isidoro.

Fig. 442. Escultura. Esfinge.

Belém, Museu Nacional de Arqueologia

Fig. 443. Capitel. Personaje desnudo y vegetación.

Jaca, catedral de San Pedro

Fig. 444. Capitel. Personajes y vegetales.

Loarre, iglesia de San Pedro

Fig. 445. Capitel. Hombres con vegetales.

Santiago de Compostela, catedral.

Fig. 446. Capitel. Hombres y vegetación.

Tera, iglesia de Santa Marta.

Fig. 447. Capitel. Hombres apresados por la vegetación.

León, iglesia de San Isidoro.

Fig. 448. Vaso. Licurgos.

London, British Museum.

Fig. 449. Capiteles. Hércules y Sansón.

Langres, catedral,

(Según J. Adhémar).. 
Fig. 450. Capitel-cimacio. Géminis.

Paris, Musée National du Moyen Age. Thermes et Hôtel de Cluny.

Fig. 451. Fuste de columna. Hombres y vegetales.

Paris, Musée National du Moyen Age. Thermes et Hôtel de Cluny.

Fig. 452. Capitel. Hombres y vegetales.

Corullón, iglesia de San Esteban.

Fig. 453. Pintura. Personificación de Auster.

León, Real Colegiata de San Isidoro de León, Panteón.

Fig. 454. Capitel. Hombres con cuernos.

Porto, Museu Nacional Soares dos Reis

Fig. 455. Tímpano. Cristo y la Asunción de la Virgen.

Villa de Cabestany, iglesia de Santa Maria.

Fig. 456. Relieve. Aparición de Cristo en el mar (anverso).

Barcelona, Museo Federico Marès.

Fig. 457. Relieve. Aparición de Cristo en el mar (reverso).

Barcelona, Museo Federico Marès.

Fig. 458. Escultura romana. Decoración vegetal.

Port de la Selva, monasterio de San Pedro de Rodas

Fig. 459. Cornisa romana. Decoración vegetal.

Port de la Selva, monasterio de San Pedro de Rodas

Fig. 460. Escultura. Cabeza de San Pedro.

Port de la Selva, Museo del Castillo de Peralada

Fig. 461. Escultura. Figura togada.

Port de la Selva, Ayuntamiento

Fig. 462. Herma romana. Togado.

Ampurias, Museo Arqueológico

Fig. 463. Sepulcro. Martirio de San Saturnino.

Carcassonne, abadía de Saint-Hilaire

Fig. 464. Relieve. Figura monstruosa.

Lagrasse, abadía de Santa María de Orbieu

Fig. 465. Sarcófago. Escenas de la caza del león.

Gerona, iglesia de San Félix

Fig. 466. Friso esculpido. Escenas de la vida de Cristo.

El Voló, iglesia de Santa María.... 
Fig. 467. Capitel. Asunción de María en mandorla.

Rieux-Minervois, iglesia de Santa Maria

Fig. 468. Tímpano y dintel de Errondo. Las tentaciones de Cristo.

New York, The Metropolitan Museum of Art's. The Cloisters

Fig. 469. Clave. Agnus Dei en clípeo.

Barcelona, Museo Federico Marès

Fig. 470. Capitel corintio.

Rieux-Minervois, iglesia de Santa Maria

Fig. 471. Capitel corintio.

Alet, iglesia de Santa Maria....

Fig. 472. Capitel corintio.

Gerona, San Pedro de Galligants

Fig. 473. Arquivolta. Decoración vegetal y máscaras.

Lagrasse, abadía de Santa María de Orbieu

Fig. 474. Placa decorativa. Decoración vegetal y máscaras.

Port de la Selva, monasterio de San Pedro de Rodas

Fig. 475. Capitel, Máscara y vegetales.

Worcester, Art Museum

Fig. 476. Busto. Sileno.

Ampurias, Museo Arqueológico

Fig. 477. Busto. Sileno.

Córdoba, Museo Arqueológico.

Fig. 478. Capitel. Escena de vendimia.

Solsona, Museu Diocesà i Comarcal

Fig. 479. Capitel. Máscara y prótomos.

Port de la Selva, Museo del Castillo de Peralada

Fig. 480. Capitel. Carneros y vegetales.

Saint-Benoît-sur-Loire, iglesia de Saint-Benoît

Fig. 481. Capitel. Carneros y vegetales.

İstanbul Arkeoloji Müzeleri.

Fig. 482. Candelabro o base. La infancia de Cristo.

San Casciano Val di Pesa, Museo di Arte Sacra di San Casciano 1348 
Fig. 483. Candelabro pascual.

Roma, iglesia de San Paolo Extramuros

Fig. 484. Sarcófago de Marcia.

Arles, Musée de l'Arles antique

Fig. 485. Sarcófago. La Barca Mística.

Città del Vaticano, Musei Vaticani,

(Según M. Burrini)..

Fig. 486. Sepulcro de San Hilario. Arco triunfal.

Carcassonne, abadía de Saint-Hilaire, sepulcro de Saint-Sernin

Fig. 487. Cabeza masculina.

Astorga, Museo Catedralicio

Fig. 488. Pie y pedestal.

Astorga, Museo Catedralicio

Fig. 489. Figura femenina.

Chartres, catedral

Fig. 490. Estatuas-columna.

Sangüesa, iglesia de Santa María

Fig. 491. Estatuas-columna.

Chartres, catedral

Fig. 492. Composición comparativa.

(Según W. Oakeshott)

Fig. 493. Retrato. Escultura griega arcaica.

Atenas, Nuevo Museo de la Acrópolis

Fig. 494. Escultura. Profeta Daniel.

Santiago de Compostela, catedral, Pórtico de la Gloria

Fig. 495. Mapa. Las artes en torno al año 1200.

(Según E. Fernández González)

Fig. 496. Mosaico. San Pedro.

Palermo, Cappella Palatina

Fig. 497. Relieve. Ángel Gabriel.

Silos, monasterio de Santo Domingo

Fig. 498. Pila bautismal. Bautismo de Cristo.

Liège, iglesia de Saint-Barthélemy. 
Fig. 499. Figura de Bronce

Atenas, Nuevo Museo de la Acrópolis

Fig. 500. Mosaico. Pantócrator.

Cefalù, catedral

Fig. 501. Miniatura. Inicial con la figura de Cristo.

Winchester, Cathedral Library,

Ms. 17, fol. 169r.

Fig. 502. Cubiertas de Evangeliario. La Crucifixión, el Sol y la Luna.

Roncesvalles, M. I. Cabildo de la Real Colegiata

Fig. 503. Pintura. Grifo.

Barcelona, Museo Nacional de Arte de Cataluña.

Fig. 504. Pintura. Grifo.

Barcelona, Museo Nacional de Arte de Cataluña

Fig. 505. Capilla de la Santísima Trinidad.

León, Real Colegiata de San Isidoro

Fig. 506. Restos del ábside y paramento.

León, basílica de Marialba de la Ribera

Fig. 507. Escultura. Profeta Daniel.

Santiago de Compostela, catedral, Pórtico de la Gloria

Fig. 508. Retrato. San Pedro.

Reims, catedral

Fig. 509. Retrato. Odiseo.

Roma, Museo Nazionale Romano 1356

Fig. 510. Retrato. Zeus.

Reims, catedral

Fig. 511. Retrato. Antonino Pio.

Roma, Museo Nazionale Romano

Fig. 512. Retrato. San Pedro.

Reims, catedral

Fig. 513. Fragmento de figura.

Santiago de Compostela, Museo de la Catedral

Fig. 514. Cabeza masculina.

Santiago de Compostela, Museo de la Catedral 1358 
Fig. 515. Retrato de un sacerdote.

Barcelona, Museo Nacional de Arte de Cataluña

Fig. 516. Escultura. Maiestas.

Carrión de los Condes, iglesia de Santiago

Fig. 517. Porta Marzia.

Perugia

Fig. 518. Escultura. Detalle del manto de Cristo.

Carrión de los Condes, iglesia de Santiago

Fig. 519. Figura femenina. Diana.

Roma, Museo del Palatino

Fig. 520. Fragmento de escultura.

Arles, Musée de l'Arles antique

Fig. 521. Tímpano. La Natividad y Anunciación a los pastores.

Silos, Museo del Monasterio

Fig. 522. Sarcófago. Escena de pastoreo.

Covarrubias, iglesia de los santos Cosme y Damián

Fig. 523. Pórtico occidental.

Ávila, iglesia de San Vicente.

Fig. 524. Puerta de muralla.

Genova.

Fig. 525. Puerta de muralla.

Ávila ..... 1362

Fig. 526. Plinto. Acanaladuras.

Oviedo, Cámara Santa 


\section{BLOQUE VII}


1. VERSION FRANÇAISE

1. 1. TABLE DES MATIÈRES

\section{LE SUBSTRAT DE L'ANTIQUITÉ CLASSIQUE DANS LA SCULPTURE ROMANE HISPANIQUE}

1. INTRODUCTION

2. MÉTHODOLOGIE 1

2. 1. JUSTIFICATION DU SUJET ...................................................................... 1

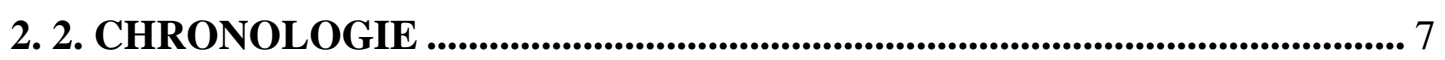

2. 3. LIMITES GÉOGRAPHIQUES........................................................................ 9

2. 4. MÉTHODE DE TRAVAIL........................................................................... 11

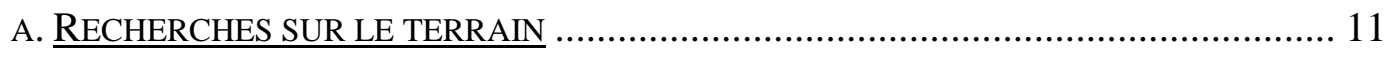

B. RECHERCHES EN ARCHIVES ET EN BIBLIOTHĖQUES............................................. 19

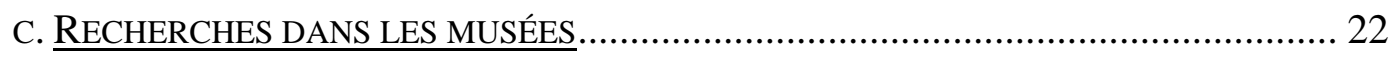

D. STAGES EN LABORATOIRES DE RECHERCHE ET PRÉSENCE LORS D'ÉVÉNEMENTS

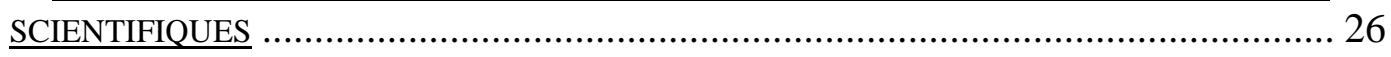

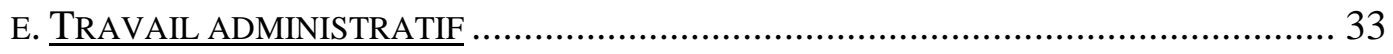

\section{PARTIE I}

1. 1. VERS UNE "ARCHÉOLOGIE" DU CLASSIQUE À PARTIR DE LA MÉMOIRE DE L'ANTIQUITÉ. INTRODUCTION.

1. 2. LES “RENAISSANCES” DANS L'ART MÉDIÉVAL. HISTORIOGRAPHIE 


\section{3. INFLUENCES, IMITATION, COPIE ET ARCHÉTYPE: À PROPOS}

DES RELATIONS ENTRE L'ART ANTIQUE ET L'ART MÉDIÉVAL ......... 75

1. 4. LA COMPRÉHENSION DE L'ANTIQUITÉ AU MOYEN ÂGE 89

A. LA “VOLONTÉ DE CONTINUITÉ" OU LE PASSAGE DE L'ANTIQUITÉ TARDIVE AU HAUT MOYEN ÂGE. ARTS “SUR-ANTIQUE" ET "PRÉ-ROMAN": LE PROBLÈME DE LA TERMINOLOGIE.

B. LES “RENAISSANCES”: DE L'ART ANTIQUE À L’ART MÉDIÉVAL 100

1. LE CLASSIQUE GREC CONSIDÉRÉ COMME ANTIQUITÉ CLASSIQUE PAR LES ROMAINS.

2. LA CONTINUITÉ DU PASSÉ GREC AU DÉBUT DU MOYEN ÂGE: LA

"RENAISSANCE GRECQUE" DU V V ${ }^{\text {ĖE }}$ SIÈCLE

3. LA "RENAISSANCE SIXTINE"

4. LA "RENAISSANCE CAROLINGIENNE"

5. LA "RENAISSANCE OTTONIENNE"

6. LA "RENAISSANCE PALÉOCHRÉTIENNE": ROME, LE MONT CASSIN ET

CLUNY SOUS L'EFFET DE L'ART CLASSIQUE.

C. ROME, L'IDÉE DE ROME ET SON LEGS AU MOYEN ÂGE

1. L'IMAGE DE L'URBIS ANTIQUE ET SON PASSAGE AU MOYEN ÂGE. 194

2. DE LA CIVITAS ANTIQUE À LA CIVITAS DEI: RÉUTILISATION CONCEPTUELLE ET ICONOGRAPHIQUE.

3. L' IMAGE DE LA ROME ANTIQUE DANS LE REGARD DES MÉDIÉVAUX ............. 240

4. L'IMAGE DE L'HISPANIA AU MOYEN ÂGE

\section{LE SPOLIUM DU CLASSIQUE À L'ÉPOQUE MÉDIÉVALE.....275}

2. 1. LE SPOLIUM IN SE ET L'APPROPRIATION DE MATÉRIAUX ANTIQUES. LES PRINCIPES D'AUTORITAS, VARIETAS ET VENUSTAS.

2. 2. LE TRANSPORT DES MATÉRIAUX ANTIQUES. 286

2. 3. LA SPOLIATION DES SARCOPHAGES ROMAINS DANS L'HISPANIA MÉDIÉVALE. 298

A. LE PRAETIOSO MARMORE: LE SARCOPHAGE D'ITHACIO À OVIEDO. 307

B. RENDRE HOMMAGE À LA MÉMOIRE DES DÉFUNTS: LES SÉPULCRES SPOLIÉS PAR FERNÁN GONZÁLEZ ET DOÑa SANCHA À COVARRUBIAS.

C. LA DIFFUSION DES RÉPERTOIRES ORNEMENTAUX. L' “ÉCAILLÉ” AQUITAIN ET LE SARCOPHAGE DU SAINT COMTE. 
D. LA SPOLIATION DE SARCOPHAGES À FRISE HISTORIÉE ET L'ADMIRATION POUR LES IMAGES ANTIQUES

3. L'ACANTHE ROMAINE ET LE CHAPITEAU CORINTHIEN. LE PASSAGE D'UN ORDRE ROMAIN VERS LE MOYEN ÂGE.......383

3. 1. LA CONTINUITÉ DU CHAPITEAU CORINTHIEN DANS LA SCULPTURE MÉDIÉVALE (VIII ${ }^{\text {èe }}$ - XII ${ }^{\text {ème }}$ s.)

3. 2. LA "VÉGÉTALITÉ POÉTIQUE" DE L'ACANTHE CLASSIQUE PENDANT LE MOYEN ÂGE 420

3. 3. LE CHAPITEAU HISTORIÉ ROMAN, UNE TYPOLOGIE 435

\section{PARTIE II}

1. SOUVENIRS CLASSIQUES DANS LA SCULPTURE ROMANE HISPANIQUE. INTRODUCTION 451

1. 1. L'IMPORTANCE DES SARCOPHAGES ANTIQUES DANS LA FORMATION D'UN NOUVEAU LANGAGE SCULPTÉ

1. 2. RÉFLEXIONS SUR LE SUCCÈS DANS L'ICONOGRAPHIE MÉDIÉVALE DE CERTAINS MONUMENTS FUNÉRAIRES ET SARCOPHAGES ANCIENS

1. 3. L'ANASTASIS DE JÉRUSALEM ET LA CHRISTIANISATION DES MONUMENTS FUNÉRAIRES ANTIQUES

1. 4. L'ÉDICULE SUR LE TOMBEAU DU CHRIST ET SES FILIATIONS "ANTIQUISANTES".

1. 5. L'IMAGE DU SAINT-SÉPULCRE AU MOYEN ÂGE 494

2. LE SUBSTRAT DE L'ANTIQUITÉ TARDIVE DANS LA SCULPTURE ROMANE PÉNINSULAIRE 
2. 1. LE SARCOPHAGE D'HUSILLOS: UN CAS PARADIGMATIQUE

DE L'INFLUENCE DE L'ANTIQUITÉ ROMAINE SUR LA

SCULPTURE ROMANE

A. LE SARCOPHAGE ROMAIN.

B. DU SARCOPHAGE ROMAIN AU CHAPITEAU ROMAN DE SAINT MARTÍN DE

FRÓMISTA

2. 2. LA PLACE DU SARCOPHAGE D'HUSILLOS DANS LA

SCULPTURE ROMANE HISPANIQUE.

A. LA QUESTION DE LA PERSONNALITÉ DE L'ARTISTE ET

L' "ATTRIBUTIONNISME"

B. IMAGE, SCULPTURE ET PUBLIQUE: À PROPOS DU CHAPITEAU DE

SAINT MARTÍN DE FRÓMISTA.

3. MOTIFS CLASSIQUES DANS LA SCULPTURE DE LA

CÁTHEDRALE DE JACA ET SON INTÉGRATION DANS

L'ART ROMAN ESPAGNOL (DERNIER QUART DU XI ${ }^{\text {ème }}$ SIĖCLE ET PREMIĖRE MOITIÉ DU XII ${ }^{\text {èe }}$ SIĖCLE).

3. 1. INTRODUCTION. BIBLIOGRAPHIE ET MÉTHODOLOGIE.

3. 2. RÉPERTOIRES ORNEMENTAUX ET ICONOGRAPHIQUES: LES PASSAGES DE L'ART ROMAIN VERS LA CATHÉDRALE ROMANE DE JACA

A. LE CHAPITEAU DES DANSEURS ET LES JOUEURS DU DOUBLE AULOS.

B. LA SERPENT: UN THÈME PRÉSENT DANS LA SCULPTURE ROMANE HISPANIQUE ET RÉCURRENT PENDANT L'ANTIQUITÉ. L'EXEMPLE DE LA CATHÉDRALE DE JACA .. 585

C. MASQUES ET PROTOMES CÉPHALIQUES: À MI-CHEMIN ENTRE LA TRADITION SYMBOLIQUE ANTIQUE ET LE GOÛT POUR LE DÉCOR DE L'ART TOMAN. 608

D. LA CONCEPTION DU CORPS. L'UTILISATION DU NU ET DES TEXTILES DANS LA SCULPTURE DE JACA...

E. L' IMAGO CLIPEATA

F. LES MODÈLES CLASSIQUES UITILISÉS DANS LA SCULPTURE DE L'ABSIDE SUD ET SA RÉ-INTERPRÉTATION DANS LA SCULPTURE ARCHITECTONIQUE TARDO-ANTIQUE . 668

G. LE TYMPAN OCCIDENTAL EL L'ANTIQUITÉ ROMAINE TARDIVE 677 


\section{ASSIMILATION, RÉ-INTERPRÉTATION ET DISSOLUTION}

DU COURANT CLASSIQUE DE JACA. LES ATELIERS DE SAINT-JACQUES-DE-COMPOSTELLE ET DE SAINT-ISIDORE-

4. 1. INTRODUCTION. BIBLIOGRAPHIE ET MÉTODOLOGIE 697

4. 2. LES RÉPERTOIRES ORNEMENTAUX ET ICONOGRAPHIQUES DE LA CÁTHEDRALE DE SAINT-JACQUES-DE-COMPOSTELLE ......... 704

A. L'ARRIVÉE DU “STYLE FRÓMISTA-JACA” À L’ ATELIER DE COMPOSTELLE ....... 704

B. LE PORTAIL DE PLATERÍAS ET LA PORTE FRANCIGENA: LA DETTE ENVERS

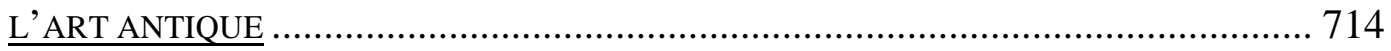

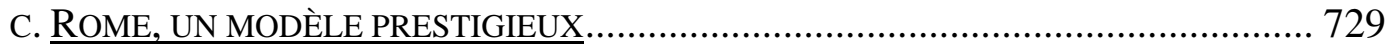

1. LE PARADISUS DE LA CATHÉDRALE DE COMPOSTELLE ET L'ANTIQUITÉ....... 731

2. LA COLONNE HÉLICOÏDALE DE LA CATHÉDRALE DE SAINT-JACQUES............ 749

4. 3. LES AUTRES CARACTÉRISTIQUES CLASSIQUES DES SCULPTEURS DE SAINT-JACQUES-DE-COMPOSTELLE.

A. LES TISSUS D'APPARENCE HUMIDE: UN PROBLÈME ICONOGRAPHIQUE SANS

SOLUTION

B. LES MASQUES ET LES VISAGES DE TRADITION ANTIQUE: QUELQUES HYPOTHÈSES À PROPOS DE LA "FEMME DU CRÂNE" ET LA NUMISMATIQUE.

C. LES TRAVAUX PRÉCIEUX D'INFLUENCE ROMAINE: LES EXEMPLES DES NIMBES ET “ÉCAILLÉS” DES RELIEFS DE COMPOSTELLE.

D. LE PROBLÈME DE L' ASSIMILATION DU CLASSIQUE AUX ATELIERS DE

COMPOSTELLE

4. 4. LA DIFFUSION ET LA DISSOLUTION DES ÉLÉMENTS CLASSIQUES DANS LA SCULPTURE ROMANE HISPANIQUE JUSQU'À LA MOITIÉ DU XII ${ }^{\text {ème }}$ SIÈCLE: LE CAS DE SAINT-ISIDORE ET DE SES ZONES D'INFLUENCE

A. QUELQUES RÉFLEXIONS SUR LA DISPERSION DES MOTIFS CLASSIQUES DANS LES PRODUCTIONS ARTISTIQUES DE LA COLLÉGIALE ROYALE DE SAINTISIDORE-DE- LEÓN

B. LA MULTIPLICITÉ DES SOURCES CLASSIQUES ET L'IMPOSSIBILITÉ DES MODĖLES UNIQUES: L'ICONOGRAPHIE DES LYCURGUE...... 


\section{AUTOUR DES ANNÉES 1150. LA QUESTION CHRONOLOGIQUE ET LA SÉLECTION DES MONUMENTS ET DE LEURS VESTIGES}

2. 2. LES VESTIGES DE L'ANTIQUITÉ COMME SOURCE

MATÉRIELLE (SPOLIUM IN SE)

2. 3. LES VESTIGES DE L'ANTIQUITÉ COMME SOURCE

D'INSPIRATION (SPOLIUM IN RE).

\section{PARTIE IV}

1. LES DERNIĖRES DÉCADES DU XII ème SIĖCLE ET L'ANNÉE 1200: LES CRITĖRES POUR LA LIMITATION CHRONOLOGIQUE ET LE PROBLĖME DE LA TERMINOLOGIE.

\section{LE SUBSTRAT CLASSIQUE DE LA SCULPTURE TARDO-} ROMANE (1160-1200).

2. 2. LA MULTIPLICATION DES SOURCES ANTIQUES .

A. LES CONTRIBUTIONS DE L'ÎLE-DE-FRANCE ET LE PASSAGE DES FORMULES ANTIQUES. L'EXEMPLE DES STATUES-COLONNES.

B. LE PROBLÈME GÉNÉRAL DU “STYLE 1200”

1. L' “ART 1200” ET SES PROBLÈMES. UNE SYNTHÈSE.

2. LE RÔLE DU “CLASSIQUE” DANS LA FORMATION DU "STYLE 1200"

3. LA DIFFUSION DES FORMULES CLASSIQUES AUTOUR DE L'ANNÉE 1200.

L'EUROPE ET LE CAS HISPANIQUE 
D. L' “ART 1200” ET LA SCULPTURE MONUMENTALE. LES PARTICULARITÉS DE LA PÉNINSULE IBÉRIQUE DANS LES PROCESSUS D' INTÉGRATION DU

\section{PARTIE V}

\section{PARTIE VI}

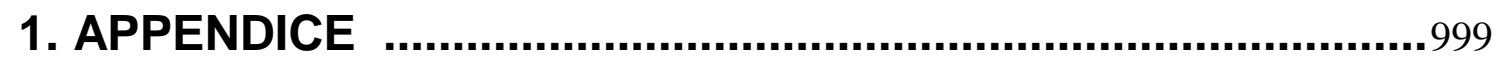

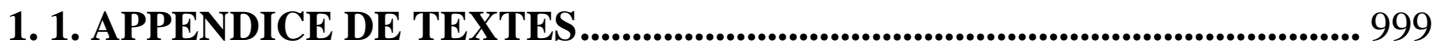

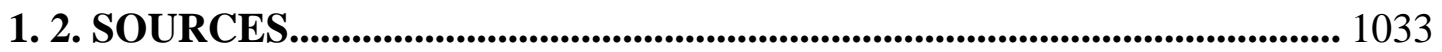

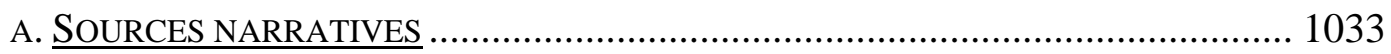

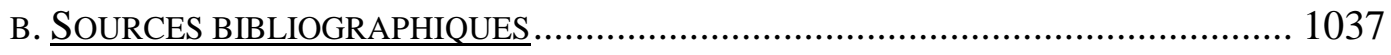

1. 3. APPENDICE PHOTOGRAPHIQUE .............................................................. 1159

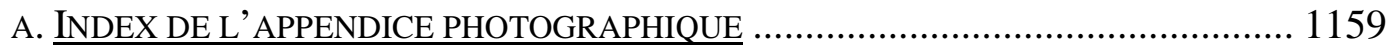

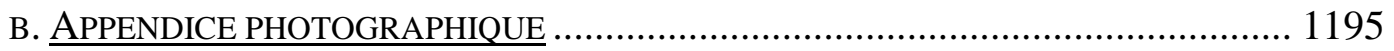

\section{PARTIE VII}

1. VERSION FRANÇAISE ...................................................... 1365

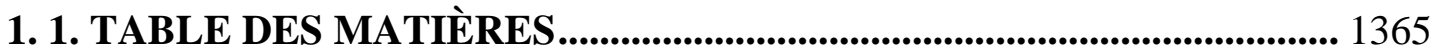

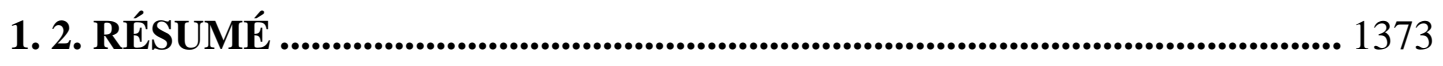

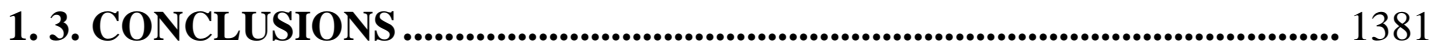




\section{2. RÉSUMÉ.}

La Thèse Doctorale présentée ici est le résultat des études de Doctorat du Département de Patrimoine Artistique et Documentaire de l'Université de Léon avec mention de qualité du Ministère de l' Éducation et de la Science d'Espagne, intitulées : Les relations artistiques comme voie d'échange culturel. Mécènes, artistes et clients. (Années 2003-2004).

La première étape de ce cycle d'études, le Diplôme d' Études Avancées (D.E.A.) et la Licence de Grade s'est accomplie lors de la soutenance d'un mémoire intitulé : La récupération de l'Ecclesiae Primitivae Forma dans la sculpture du Panthéon royal de Saint-Isidore de Léon. Dans cette première étude ont été abordés certains aspects de la récupération et de l'influence des arts de l'Antiquité classique et tardo-romane dans la sculpture romane. À cette occasion, nous avions étudié les concepts de spolium in re/in $s e$ et la ré-interprétation des oeuvres antiques par les créateurs médiévaux.

Par la suite, dans ce nouveau travail que nous présentons ici, nous avons voulu approfondir le sujet pour discerner la filiation «antiquisante » de la sculpture romane en lien avec la plastique de l'Antiquité classique et tardive.

Notre recherche porte chronologiquement sur les $\mathrm{XI}^{\text {éme }}$ et XII ${ }^{\text {ème }}$ siècles, période centrale du développement de la sculpture romane au sein des royaumes hispaniques. Malgré cela, l'approche par la filiation nous a obligé, évidemment, à élargir ce cadre chronologique. La limite proposée est l'année 1200, mais nous restons conscients que ce terminus ad quem établi sur des bases stylistiques demeure purement conventionnel.

En ce qui concerne l'aire géographique, l'étude se centre sur les royaumes hispaniques même si parfois il a été nécessaire de l'étendre ponctuellement aux territoires de l'ancienne Lusitania. Nous ne nous sommes pas limités aux frontières administratives et politiques- contemporaines des territoires de l'Espagne et du Portugal.

Parallèlement, la mise en contexte du mouvement de récupération du « classique» dans l'Hispania romaine doit se faire en prenant en compte un plus vaste territoire européen tel que les régions de la côte orientale du bassin méditerranéen, berceau de la tradition byzantine ou islamique. Méthodologiquement, l'étude s'organise en 6 grandes parties et leurs chapitres correspondants qui s'ouvrent par une introduction au sujet et à la méthode. 
Partie I : On trouve ici les réflexions concernant les questions conceptuelles et théoriques. Nous étudions les phénomènes de compréhension du «classique » au cours du Moyen Âge, le concept de mémoire et de récupération archéologique des arts de l'époque ancienne. Pour cela, ont été revisitées les notions d'influence, d'imitation et de copie. Dans cette partie, les phénomènes d'intégration des langages artistiques de tradition classique au haut Moyen Âge au Moyen Âge central ont été examinés.

Un chapitre a été dédié à l'analyse de l'idée que les médiévaux se faisaient de Rome et de ses arts. Ce dossier était nécessaire pour l'étude de l'image de l' Hispania antique et de son legs artistique aux yeux des créateurs du Moyen Âge. Le quatrième chapitre est consacré à la spoliation sous toutes ses formes, tant la spoliation de matériaux pour le remploi direct que pour le remploi intellectuel à partir de la réinterprétation des pièces classiques. Finalement nous étudions le chapiteau corinthien roman : cet élément fut utilisé dans toutes ses variantes pendant le Moyen Âge, comme matériel de remploi valorisé pour sa valeur décorative, ou comme porteur d'une nouvelle perspective symbolique dans l'imaginaire chrétien.

Partie II : Il s'agit d'une des parties les plus importantes tant par sa densité que par les sujets abordés. Au long de ces quatre chapitres, les traits classiques de la sculpture romane des royaumes hispaniques se font jour, tout en soulignant l'importance des sarcophages comme véhicules du nouveau langage. Sa durabilité et le respect dont ils ont été l'objet les ont sauvé de la destruction ; leur présence a ainsi contribué à l'enrichissement de l'imagination des sculpteurs romans.

A ce point il est important de remarquer l'actualisation historiographique du dossier autour du sarcophage d'Husillos et de ses répercussions sur la sculpture de l'église de Saint-Martin de Frómista (Palencia) parmi d'autres.

De la même façon nous avons repris l'étude de la sculpture de la cathédrale de Jaca, considérée comme un des principaux exemples de la présence de la tradition classique dans la sculpture romane. Après une critique bibliographique et une justification sur la méthode utilisée, nous avons analysé les principaux répertoires ornementaux de l'édifice en tentant d'établir le degré de dépendance avec les arts plastiques de l' Antiquité tardive.

De même nous avons repris l'étude d'autres monuments tels que la cathédrale de Saint-Jacques-de-Compostelle et l'église Saint-Isidore de Léon. Toutefois l'objectif n'était pas de réaliser les études monographiques des bâtiments mentionnés. Bien au 
contraire, nous les avons utilisés comme points de départ pour juger la variabilité de l'impact des sources classiques au cœur des différents territoires qui s'étendent de Huesca à Aragon, de Palencia aux Asturies et de Léon à la Galice.

Partie III : Cette partie devait être nécessairement différente parce qu'elle approfondit le cadre chronologique de la moitié du XIIème siècle. On insiste ici sur les différents points de vue concernant l'art antique et le mouvement de l'intérêt pour la tradition antiquisante d'un centre géographique à un autre. A cette période, -la moitié du XIIème siècle- l'admiration pour les oeuvres antiques passe des zones centrales et occidentales de l'Hispania aux territoires occidentaux, Catalogne et la « Marca Hispánica ». Le dit maître de Cabestany est la figure la plus représentative de ce phénomène.

Partie IV : Il s'agit de l'étude des oeuvres comprises entre le milieu du XIIème siècle et les dernières décennies de ce siècle. Le but est de dessiner les changements survenus au cours du siècle, dans les manières de percevoir l'Antiquité ainsi que dans la sculpture et les arts plastiques en général.

Les artistes du roman tardif ont une attitude très différente envers les oeuvres romaines et paléochrétiennes de celles de leurs prédécesseurs. Cependant, un réel changement s'opère dans le choix des sources, désormais plus diverses, riches et complexes. Cet enrichissement des sources est constaté dans toute la sculpture de la fin de l'époque romane. Il ne s'agit plus seulement de la pure observation de la plastique hispanoromane mais du travail à partir de modèles étrangers et dilués dans les traditions les plus diverses qui rendent difficile toute explication sur leur origine.

Partie V: Dernière partie théorique, elle comprend la synthèse des conclusions partielles.

Partie VI : Elle contient les appendices qui complètent les parties plus théoriques. Elle comprend aussi la bibliographie consultée pour cette étude. Ceci dit, il est évident que, vu la grande quantité de publications récentes sur les sujets abordés, certaines ont pu être oubliées, soit par méconnaissance, soit pour avoir été publiées une fois ce travail achevé. La partie finale est consacrée à l'appendice photographique et à son index. 
Ce travail n'aurait pas pu voir le jour sans l'aide de la Bourse de Formation du Professorat Universitaire (F.P.U.) du Ministère espagnol de l' Éducation et de la Science, dont nous avons profité de 2004 à 2008 au sein du Département de Patrimoine Artistique et Documentaire de l'Université de Léon. La dernière phase de rédaction a été rendue possible par la Bourse de la Fondation du Patrimoine Historique de Castille et Léon, accordée au mois de septembre de 2008.

Ces bourses nous ont permis de faire des stages de recherche dans des centres à l'étranger. Le premier a eu lieu au cours des mois de juin à octobre 2006 dans le Dipartamento di Storia dell'Arte della Universitá degli Studi di Roma "La Sapienza" (Italie) sous la tutelle du professeur M. Mario D’Onofrio.

Le deuxième pris place au sein du Centre d' Études Supérieures de Civilisation Médiévale de Poitiers (France) sous la tutelle du professeur M. Claudio Galderisi, de juin à octobre de 2007.

C'est au Departamento de Historia da Arte de l'Universidade Nova de Lisboa (Portugal) que le troisième stage a eu lieu, sous la tutelle du professeur Mme. Adelaide Miranda, entre juillet et août $2008^{1}$.

Enfin, en juillet et août 2009, le quatrième stage a été réalisé à l'Officina di Studi Medievali de la Universitá Degli Studi di Palermo (Italie), sous la tutelle du professeur M. Alessandro Musco ${ }^{2}$.

Au cours de ces stages, nous avons eu accès aux catalogues bibliographiques les plus complets nous permettant ainsi de consulter des ouvrages inexistants dans les fonds espagnols. En même temps que nous établissions des contacts avec des spécialistes prestigieux et reconnus, nous saisissions toute la valeur de l'interdisciplinarité.

Ainsi, les séances de travail à la Bibliothèque et aux Archives Vaticanes, à la Bibliothèque Nationale de France et à la Bibliothèque du CESCM de Poitiers ont été très importantes pour le bon développement de cette thèse.

De même, nous voudrions souligner la richesse des fonds de la Bibliothèque $G$. C. Argan du Dipartamento di Storia dell'Arte de la Università degli Studi « La Sapienza» di Roma et de tant d'autres en Espagne comme la Bibliothèque Nationale à

\footnotetext{
${ }^{1}$ Les stages réalisés à Rome, Poitiers et Lisbonne ont été inscrits au programme de Stages de Recherche du Ministère espagnol de l' Éducation et de la Science.

${ }^{2}$ Stage réalisé grâce à la bourse de la Fondation du patrimoine historique de Castille et Léon.
} 
Madrid, les fonds de la Casa de Velázquez ou la Bibliothèque Générale San Isidoro de Léon de l'Université de Léon.

Nous avons pu, par la même occasion, participer au développement d' activités scientifiques au sein de différents groupes de recherche, tels que le projet Imago de la Universidade Nova de Lisboa et en collaboration avec les membres du Centre d' Études Supérieures de Civilisation Médiévale de Poitiers.

Ainsi, les rapports personnels et scientifiques établis avec ce dernier nous ont permis de participer à l'organisation du Colloque de Jeunes Chercheurs organisé à l'Université de Léon en collaboration avec l'association JANUA (Association des Étudiants du Centre d’Études Supérieures de Civilisation Médiévale) le 16 et 17 avril de 2008 sur le sujet : Réflexions autour du corpus dans les études médiévales : série, composition, justification.

Nous voulons mettre aussi en valeur certains des travaux publiés par nous ces dernières années. Le travail : "Microarchitectures dans les arts plastiques en Espagne autour de 1200 et leurs relations avec l'architecture monumentale" a été publié en collaboration avec le professeur M. Fernando Galván dans le volume : Mikroarchitektur im Mittelalter. Ein gattungsübergreifendes Phänomen zwischen Realität und Imagination $^{3}$.

Nous pouvons aussi mentionner les articles: « Nuevas reflexiones para la lectura iconográfica de la Portada del Perdón de San Isidoro de León : el impacto de la Reforma Gregoriana y el arte de la tardoantigüedad » ${ }^{4}$; « El valor clásico de la arquitectura asturiana (s. IX): la iglesia de San Julián de los Prados. Entre la tradición «antiquizante», hispanovisigoda y la carolingia $~_{5}$ et la contribution au colloque international et pluridisciplinaire, Effets de style au Moyen Âge, où nous avons présenté une communication intitulée : «Problématique autour du «style des joues bouffies » et de sa diffusion au sein de la sculpture romane hispano-languedocienne $»^{6}$.

Finalement, nous ne saurions laisser de côté la recherche publiée sous le titre : La recuperación de la Ecclesiae Primitivae Forma en la escultura del Panteón Real de San Isidoro de León ${ }^{7}$.

\footnotetext{
${ }^{3}$ Leipzig, 2008, pp. 479-497.

${ }^{4}$ De Arte, 5, 2006, pp. 63-86.

${ }^{5}$ Cien años de investigación sobre arquitectura medieval española, Madrid, 2009, pp. 233-246.

${ }^{6}$ Aix-en-Provence, du 28 au 31 mai 2008.

${ }^{7}$ León, 2008
} 
Notre formation a été complétée par de nombreux séminaires, congrès et colloques notamment ceux abordant le cœur de notre sujet, les relations entre la sculpture romane et les sources classiques.

En ce sens, et sans vouloir être exhaustifs ${ }^{8}$, nous devons citer notre participation aux Journées Romanes de l' Association de l'Abbaye Saint- Michel de Cuxà sur "Actualité de l'art antique dans l'art roman"; le Séminaire « Modos de reutilización en la Edad Media en los países del Mediterráneo occidental (ss. X-XIII)" de la Casa de Velázquez à Madrid ${ }^{10}$ ou la participation au XII ${ }^{\text {ème }}$ Congrès Espagnol des Études Classiques, organisé à Valence par la Société Espagnole d' Études Classiques (SEEC) ${ }^{11}$.

Dans la même lignée nous avons participé à la LII Settimana internazionale di studio de la Fondazione Centro Italiano di studi sull'alto medioevo de Spoleto ${ }^{12}$ et aux Semaines d'Études Médiévales du CESCM de Poitiers ${ }^{13}$.

À côté de ce travail heuristique nous voulons mettre en avant la recherche faite sur le terrain en parallèle au travail de documentation. La bourse reçue nous a permis de faire de nombreux voyages intéressants qui ont complété notre connaissance soit des monuments soit des oeuvres conservées dans tel ou tel musée.

En Espagne nous avons parcouru les régions de la Catalogne, la Navarre, l'Aragon, La Rioja, la Cantabrie, la Castille et Léon et la Galice. Le travail de terrain mené à Tolède, à Valence et en Andalousie doit être mentionné car il s'agit de sites très riches en vestiges antiques dérivés de leur importante romanisation.

Hors du territoire espagnol nous voulons mentionner les sessions au Metropolitan Museum The Cloisters de New York où nous avons pu avoir accès aux oeuvres hispaniques conservées in situ. Notons aussi la visite au Musée de l'Hermitage à Saint Pétersbourg, importante car elle nous a permis d'avoir accès aux oeuvres en ivoire d'origine hispanique.

Dans cette lignée il fut incontournable de visiter certains des plus importants musées de Londres, Paris, Rome et Lisbonne afin d'observer les pièces directement. Sans oublier, bien sûr, l'enrichissant panorama des visites aux musées grecs et siciliens.

\footnotetext{
8 Un résumé des interventions principales lors de forums scientifiques peut être consulté dans l'introduction de ce travail.

${ }_{9}$ Abbaye de Saint-Michel-de-Cuxà entre le 6 et le 13 juillet 2007.

${ }^{10} 27$ et 26 mars 2006.

$1122-26$ octobre 2007.

${ }^{12} \mathrm{Du} 15$ au 20 avril 2004.

${ }^{13} \mathrm{Du} 25$ juin au 6 juillet 2007.
} 
En Grèce nous avons concentré notre attention sur la sculpture de Crète et sur les oeuvres conservées au Musée de l'Acropole d'Athènes. La visite de la région de l'Argolide, au cœur du Péloponnèse, s'est avérée fondamentale pour la compréhension la forte influence byzantine dans l'art médiéval de ces territoires. En ce qui concerne la Sicile, nous avons travaillé à la Chapelle Palatine de Palerme et au Musée Archéologique de la même ville ainsi qu'à la Villa del Casale de la Piazza Armerina, où nous avons pu voir les vestiges romains conservés.

Enfin, nous voulons faire valoir que les études faites à partir des visites et des activités qui en dérivent nous ont permis d'avoir un riche panorama du fait artistique romain et roman. Tout cela agrémenté par le travail bibliographique et la collaboration avec les centres d'études les plus divers nous ont permis de livrer aujourd'hui ce travail à votre considération. 


\subsection{CONCLUSIONS}

Au terme de cette recherche qui vise à l'obtention du grade de docteur, nous livrons les conclusions auxquelles nous sommes parvenus :

1. Premièrement, nous avons pu vérifier l'importance de l'art antique dans l'explication de certains traits des productions plastiques du haut Moyen Âge et du Moyen Âge central. En même temps, certaines voies empruntées pour cette transmission ont pu être mises en évidence. Bien que la recherche principale se concentre sur l'art roman hispanique, une approche plus générale du contexte européen s'avérait nécessaire. Cela nous permit d'affirmer l'importance de certaines périodes « antiquisantes » du haut Moyen Âge qui fonctionnèrent comme canaux de transmission vers les $\mathrm{XI}^{\text {ème }}$ et XII ${ }^{\text {ème }}$ siècles.

La culture païenne et ses manifestations artistiques fut transférée de manière partielle et sous différentes formules vers l'art roman chrétien. Concrètement cela revenait à confirmer l' Antiquité tardive de l'Empire romain comme une des principales sources d'inspiration pour cette période médiévale.

Sur ces bases, nous avons compris les mécanismes de transfert de l'héritage antique. Les vagues «classicistes » qui parcourent ces siècles (du IV ${ }^{\text {ème }}$ au XII ${ }^{\text {ème }}$ siècle) vérifient la «volonté de continuité » et le désir de préserver la tradition romaine. Comme preuve de tout cela nous signalons les différentes « Renaissances » de l'Antiquité telles que nous avons pu les mettre en lumière au cours de ce travail.

2. Dans un deuxième temps, nous pensons avoir approfondi l'importance du phénomène de la spoliation, comme biais essentiel pour l'adoption et la ré-interprétation des courants «classiques » au cours de la période romane. A partir de la spoliation des matériaux antiques, tant physiquement (spolium in se) qu' intellectuellement (spolium in re), l'artiste roman est entré en contact avec l'art antique. Nous pensons que, en ce qui concerne l'art hispanique et sur des bases largement documentées, il est possible de confirmer ces deux systèmes d'approche de l' Antiquité.

Malgré cela, les spoliations in se, très fréquentes au Moyen Âge, l'ont moins été dans le contexte hispanique, sans pour autant être inexistantes. 
Au contraire, la ré-interprétation des oeuvres de l'Antiquité -le spolium in re-fut très courant en nos territoires et nous avons pu constater qu'il fut le système de prédilection des artistes comme celui des mécènes et des élites éclairées.

3. Parallèlement, nous avons pu confirmer la perpétuation des modèles antiques dans certains des principaux sites romans, actifs entre la fin du $\mathrm{XI}^{\text {ème }}$ siècle et les premières décennies du XII ${ }^{\text {ème }}$ siècle. Plus concrètement nous avons analysé le corpus de la sculpture de la cathédrale San Pedro de Jaca et de l'église San Martin de Frómista remarquant aussi le rôle qu'ont certainement joué les sarcophages romains dans la formation des sculpteurs de ces sites.

Ainsi, à partir du décor de ces temples nous avons approfondi l'étude des répertoires ornementaux romans dérivés de la sculpture des sarcophages antiques. Ceci dit, nous ne pensons pas pouvoir réduire cette influence au sarcophage d'Husillos mais nous croyons en l'existence plus que probable d'autres oeuvres connues des cercles des ateliers de sculpture.

Ainsi, certains thèmes comme celui du thiasos marin ou ceux dérivés de la tradition dionysiaque ont dû jouer un rôle aussi important dans la création de la sculpture de la fin du XI ${ }^{\text {ème }}$ siècle et début du XII ${ }^{\text {ème }}$ siècle.

Tout cela nous permit d'affirmer que, même si le cas d'Husillos est un des mieux connus, son exclusivité comme source pour la sculpture de Jaca et Frómista devait être mise en question. Les deux monuments présentaient un horizon commun : celui de l'intérêt pour la statuaire romaine et tardo-romaine.

Même si son impact a été moins important, nous ne pouvons passer à coté de l'influence de certaines oeuvres «mineures » comme le stuc et les figures de bronze, qui ont élargi le goût « classiciste » de ces sculpteurs.

En même temps, cette observation de l'univers antique ne fut pas l'apanage exclusif des deux exemples cités auparavant. On retrouve ce phénomène à la cathédrale de Saint-Jacques-de-Compostelle et à la basilique San-Isidoro de Léon.

Pour Compostelle nous avons perçu deux mécanismes d'approche de l'art antique : d'un côté, on sentait la dette envers les ensembles de Jaca et Palencia issue de la ré-interprétation ; de l'autre, des réminiscences concrètes de certains monuments de Rome se laissaient observer.

Dans le cas de Léon, nous avons vu que les modèles ont été intégrés jusqu'à devenir des archétypes, sous les influences conjointes de Jaca, Frómista et Compostelle. 
Finalement, définir le courant « hispano-languedocien » se révélait essentiel car il admettait une dette considérable envers la tradition antique. Les influences du Languedoc, - notamment de Saint-Sernin de Toulouse-, ont été sûrement une bonne source d'inspiration pour les sculpteurs hispaniques mais ce substrat gallo-romain s'ajoutait aux sources hispano-romaines propres.

4. Un quatrième temps de notre réflexion nous permit de constater qu'à partir des années 1140- 1150 des changements apparaissaient dans la manière d'observer l'art antique par rapport aux époques antérieures. Le goût pour ce langage « antiquisant » est passé conjointement des territoires occidentaux et du Nord-Est vers des régions plus orientales de la péninsule ibérique. Les sculptures attribuées au cercle du dit «maître de Cabestany » montrent une préférence évidente pour le legs «classique » et les productions d'époque romaine, qu'elles fussent païennes ou chrétiennes. Mais cette approche est plus directe et plus sensible que celle décelée à Jaca et Saint-Jacques, car en ce cas les remplois des matériaux antiques sont particulièrement remarquables, les plus remarquables du territoire hispanique ; la spoliation et l'adaptation sont plus visibles qu'aux époques antérieures.

Nous avons pu vérifier que la sculpture du cercle de Cabestany profitait du panorama des vestiges anciens de la région du Languedoc ajouté à celui des monuments du pourtour méditerranéen. Il ne s'agit donc pas seulement d'une influence antique languedocienne ou hispano-romaine, mais d'un langage visuel enrichi des sources pyrénéennes, aquitaines et provençales.

En résumé, il s'agit d'une ouverture à de nouvelles traditions qui n'étaient pas aussi nettes pour les sculpteurs romans des époques antérieures.

5. Cinquième et dernier point, la sculpture des dernières étapes du roman hispanique apparaît aussi marquée par l'empreinte «classique ». Toutefois, ce substrat antiquisant a une nature très différente de la tradition vue auparavant, ceci étant dû principalement aux contributions de l'art byzantin.

Les modèles qui s' introduisent à ce moment sont originaires des centres artistiques importants d'Île-de-France et de Bourgogne, et ils présentent une évocation des types de la Grèce archaïque. Ainsi, dans les années soixante du XIIème siècle, l'importation en Hispania de ces solutions romanes françaises peut se voir dans certains types faciaux des sculptures de la Porte de la Gloire de Compostelle. Vers 1200, la 
multiplication de ces sources «archaïsantes » rendait impossible la détermination de leur origine.

Dans ce phénomène d'introduction, des courants byzantinisants «classiques » de Grèce, d'Italie et du centre de l'Europe ont joué un rôle important. La présence des « souvenirs » de la plastique grecque, de la tradition hellénistique et de l'art de l'Empire romain d'Orient ont provoqué la gestation d'une sculpture fortement «classiciste » qui n'avait rien à voir avec celle du substrat antique qui avait dominé le panorama de la sculpture romane hispanique aux siècles antérieurs.

En guise de conclusion, à partir de cette recherche nous avons pu définir l'existence de deux courants divers de récupération de l'art antique :

1. D’un côté, une pratique antiquisante héritière des formules d'exploit de l'Antiquité propre aux cercles languedociens romans. Ce courant arrivé dans les royaumes hispaniques à la fin $\mathrm{du} \mathrm{XI}^{\text {ème }}$ siècle et le début du XII ${ }^{\text {ème }}$ siècle a été enrichi par les contributions hispano-romaines des sculpteurs locaux.

2. Par contre, de l'autre côté, un deuxième courant d'assimilation des postulats de l'art «classique » est arrivé en Hispania de l'extérieur et il arrive déjà ré-élaboré et nuancé par des contributions diverses.

Quand les créateurs de la sculpture hispanique de la fin du XII ${ }^{\text {ème }}$ siècle ont montré leur connaissance des œuvres antiques, ils l'ont fait à partir de l'influence de l' Île-de- France et de la Bourgogne car c'est ici que ces langages se sont ré-élaborés. Plus tard, ces artistes ont implanté ces modèles dans la péninsule ibérique, où ils ont fusionné avec une tradition byzantine «antiquisante » très éclectique propre aux goûts de l'an 1200. 


\section{RESUMEN}

La Tesis Doctoral que presentamos a su consideración parte de la realización de los Estudios de Doctorado con Mención de Calidad del Ministerio de Educación y Ciencia de España, titulados: Las relaciones artísticas como vía de intercambio cultural. Mecenas, artistas y clientes e impartidos por el Departamento de Patrimonio Artístico y Documental de la Universidad de León durante los años 2003-2004.

Derivado de éstos, se presentó la Memoria de Licenciatura: La recuperación de la Ecclesiae Primativae Forma en la escultura del Panteón Real de San Isidoro de León, mediante la cual, se obtuvo el Diploma de Estudios Avanzados (D. E. A) y el título de Licenciado de Grado.

En este primer estudio se abordaron algunos aspectos relacionados con el fenómeno de recuperación e influencia de las artes de la Antigüedad clásica y tardorromana sobre la escultura románica. Fue el momento en el que estudiamos los conceptos de spolium in re/in se y la reinterpretación de las obras antiguas por parte de los creadores medievales.

Ahora ampliamos el tema con un trabajo más profundo centrado en el estudio de la filiación "antiquizante" de la escultura románica con respecto a la plástica realizada en la etapa clásica y tardía de la Antigüedad.

Nuestra investigación se acota temporalmente a los siglos XI y XII, aquellos en los que desarrolló la escultura románica en los reinos hispanos. No obstante, al tratarse de un trabajo basado en el establecimiento de filiaciones artísticas el arco cronológico es muy dilatado.

Como límite para nuestro estudio se propuso el año 1200, siendo conscientes de la problemática de esta barrera convencional para la delimitación simplemente estilística.

El estudio se circunscribe al ámbito de los reinos hispanos. No obstante, cuando fue necesario se acudió puntualmente a los territorios de la antigua Lusitania. En este sentido se huyó de la acotación de índole administrativa y política contemporánea de los actuales territorios de España y Portugal.

El marco europeo, tal y como se especifica en su debido momento, fue la base general en la que contextualizar el movimiento de recuperación de lo clásico en los trabajos escultóricos de la Hispania románica. Así, las regiones más orientales en las 
que se arraigó la tradición bizantina o islámica fueron examinadas de una manera más puntual.

Metodológicamente el estudio se organiza a través de seis grandes bloques que albergan sus respectivos capítulos. En las primeras páginas se dispone el capítulo introductorio y aquel dedicado a la metodología y justificación del tema.

El primer bloque reúne todas aquellas reflexiones derivadas de los aspectos conceptuales y teóricos. En él se estudian los diferentes fenómenos de comprensión de lo clásico durante la Edad Media, el concepto de memoria y de recuperación arqueológica de las artes de época antigua, así como las nociones de herencia, influencia, imitación y copia. En esta primera unidad temática también recogemos todos los principales fenómenos de asimilación de los lenguajes artísticos de tradición clásica a lo largo de los siglos de la Alta y Plena Edad Media. Por último, se dedica un capítulo que analiza la idea que poseían los hombres medievales de la ciudad de Roma y de sus artes, como marco introductorio para estudiar la imagen de la Hispania antigua y el legado artístico presentado ante los ojos de los creadores medievales.

Dentro de este primer bloque, el cuarto capítulo se consagra al fenómeno de la expoliación en sus múltiples variantes: expoliación física de materiales reempleados y reutilizaciones intelectuales o reinterpretaciones de las piezas clásicas por parte de los artesanos románicos.

El último capítulo del primer bloque se dedica al estudio del capitel corintio romano. Este elemento fue reutilizado en todas las variantes posibles durante los siglos medievales. Desde material de acarreo reintegrado en los nuevos edificios medievales hasta reconsiderado desde su significado decorativo.

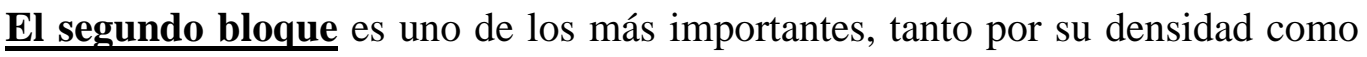
por los temas que en él se abordan.

A lo largo de cuatro capítulos se estudian los rasgos clásicos que muestra la escultura románica realizada en los reinos hispanos, subrayando la importancia de los sarcófagos como enriquecedores del nuevo lenguaje escultórico. Su perdurabilidad y respeto los libraron, frecuentemente, de una destrucción segura y su presencia contribuyó a enriquecer la imaginación y las soluciones adoptadas por los autores románicos.

En este punto toma especial relevancia para el estudio una actualización bibliográfica, crítica histórica y valoración del fenómeno surgido en torno al, ya célebre, 
sarcófago de Husillos y sus repercusiones sobre la escultura de la iglesia de San Martín de Frómista, en Palencia, entre otras.

Igualmente, las investigaciones se centran en la escultura de la catedral de Jaca, uno de los exponentes primordiales de la influencia de la tradición clásica sobre la escultura románica. Tras el consecuente balance bibliográfico y la concreción de los aspectos metodológicos, se analizan los repertorios ornamentales más destacados que presenta la decoración del templo, estableciendo su grado de dependencia con las artes plásticas de los siglos de la Antigüedad tardorromana.

El mismo esquema se utilizó para estudiar otros monumentos hispanos, tales como la catedral de Santiago de Compostela y la iglesia de San Isidoro de León.

No se trata de un estudio monográfico de los edificios que mencionamos. Al contrario, partiendo de ellos, establecimos y diferenciamos los diversos grados y la variabilidad del impacto de las fuentes clásicas en diferentes territorios, que iban desde Huesca a Aragón, de Palencia a Asturias o desde León a Galicia.

El bloque III debía ser, necesariamente, una parte diferenciadora del estudio porque coincide con un marco temporal cercano a la mitad del siglo XII.

En él se insiste en las diferencias radicales en cuanto a la observación del arte antiguo, así como el traslado geográfico de los principales centros sensibles a dicha tradición "antiquizante". Desde las regiones centrales y las áreas más occidentales de Hispania que se estudiaron anteriormente, ahora la admiración por este tipo de obra antigua se traslada a los territorios orientales, la zona catalana y de llamada Marca Hispánica. El conocido como "maestro" de Cabestany es el mejor representante de este fenómeno.

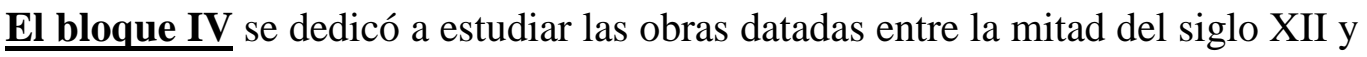
las últimas décadas cercanas al año 1200. El objetivo del apartado puso de relieve el cambio producido, tanto en la manera de observar la obra antigua como los cambios fundamentales que experimentaron las artes plásticas y, entre ellas, la escultura, durante este periodo.

Los creadores de la época tardorrománica, muestran una conducta muy diferente ante las obras romanas y paleocristianas a la que se pudo constatar para los artífices de los años anteriores. Sin embargo, el gran cambio vino propiciado por las fuentes artísticas que ahora manejaban que, siendo igualmente "antiquizantes", poseían un origen diverso, más rico y complejo. 
Parejo al complicado fenómeno definido como "estilo 1200", de cuya problemática damos cuenta en el lugar correspondiente, constatamos el enriquecimiento de las fuentes artísticas asimiladas en la escultura de la etapa final del románico. Ya no se trata de la observación e inspiración a partir de la plástica hispanorromana sino que los modelos sobre los que trabajan los artistas son foráneos, difusos y totalmente tamizados por tradiciones muy diversas, que apenas permiten explicar el origen concreto de esos ecos antiguos.

El último espacio teórico conforma el bloque $\mathbf{V}$. En él se han intentado sintetizar aquellas conclusiones derivadas de nuestras investigaciones, siguiendo las metodologías propias de este tipo de estudios.

El bloque VI contiene los apéndices y anexos que complementan lo defendido en los apartados teóricos. Siguiendo la coherencia metodológica se dispuso la consecuente selección bibliográfica de todos aquellos estudios consultados para elaborar el discurso. A pesar de ello, es lógico que, teniendo en cuenta la creciente nómina de publicaciones que estos temas vienen generando actualmente, algunos hayan quedado olvidados, ya por desconocimiento de los mismos o porque su reciente aparición imposibilitó su consulta.

Cierra la Tesis Doctoral el apéndice fotográfico precedido por su correspondiente índice.

Nuestra labor no podría haberse llevado a cabo sin la concesión de la Beca de Formación del Profesorado Universitario (F.P.U) del Ministerio de Educación y Ciencia de España, que disfrutamos durante los años 2004-2008 y que se aplicó en el Departamento de Patrimonio Artístico y Documental de la Universidad de León. Además de ello, la última fase de la misma se realizó mediante la continuación de nuestras investigaciones a través de la Beca de la Fundación del Patrimonio Histórico de Castilla y León, concedida el mes de septiembre de 2008.

Dichas becas han permitido realizar una serie de estancias de investigación en centros universitarios extranjeros. La primera de ellas se desarrolló en el Dipartamento di Storia dell'Arte della Universitá degli Studi di Roma "La Sapienza" (Italia), a cargo del Dr. Mario D’Onofrio y se prolongó entre los meses de junio y octubre de 2006.

La segunda estancia se llevó a cabo en el Centre d'Études Supérieures de Civilisation Médiévale de Poitiers (Francia), tutelada por el Dr. Claudio Galderisi. El desarrollo de dicha actividad se dilató entre los meses de junio y octubre de 2007. 
En un tercer periodo, realizamos otra de estas estancias en el Departamento de Historia da Arte de la Universidade Nova de Lisboa (Portugal), a cargo de la Dra. Adelaide Miranda, durante los meses de julio y agosto de $2008^{14}$.

Siguiendo el mismo proceso, durante los meses de julio y agosto de 2009 realizamos la cuarta estancia en la Officina di Studi Medievali. Palermo de la Universitá Degli Studi di Palermo (Italia), tutelada por el Prof. Dr. D. Alessandro Musco ${ }^{15}$.

A lo largo de estos periodos de estudio hemos podido acceder a los repertorios bibliográficos más completos. La bibliografía especializada sobre el tema, en ocasiones ausente en las bibliotecas españolas, pudo ser consultada y analizada. Así mismo, destacamos la importancia de dichas estancias a la hora de entrar en contacto con expertos de reconocido prestigio, además de poder comprender definitivamente el valor de la interdisciplinaridad que, actualmente, deben regir las investigaciones consagradas a estas materias.

Las sesiones de trabajo en la Biblioteca y Archivi Vaticani de la Ciudad del Vaticano, en la Bibliothèque nationale de Paris y en la Bibliothèque du Centre d'Etudes Supérieures de Civilisation Médiévale de Poitiers, aportaron valiosos datos a nuestra Tesis Doctoral.

Igualmente, debemos destacar la riqueza de los fondos consultados en la Biblioteca G. C. Argan del Dipartamento di Storia dell' Arte de la Università degli Studi La Sapieza di Roma y otras localizadas en territorio español, como la Biblioteca Nacional de Madrid, los fondos de la Biblioteca de la Casa Velázquez o la Biblioteca General San Isidoro de la Universidad de León.

Además, gracias a ello, pudimos conocer el desarrollo de actividades científicas desarrolladas por diversos grupos de investigación. En este sentido, queremos recordar, por ejemplo, el Grupo Investigador del Proyecto Imago de la Universidade Nova de Lisboa y los grupos adscritos al Centre d'Études Supérieures de Civilisation Médiévale de Poitiers.

Fruto del establecimiento de relaciones científicas con este último, pudimos intervenir en el Coloquio de Jóvenes Investigadores Reflexiones en torno al Corpus en los estudios medievales: serie, composición, justificación, organizado en la Universidad

\footnotetext{
${ }^{14}$ Las tres estancias realizadas en Roma, Poitiers y Lisboa se adscribieron al programa de Estancias de Investigación del Ministerio de Educación y Ciencia de España.

${ }^{15}$ Dicha estancia se realizó gracias a la Beca de la Fundación del Patrimonio Histórico de Castilla y León.
} 
de León en colaboración con JANUA (Association Étudiants du Centre d’études Supérieures de Civilisation Médiévale), entre el 16 y el 17 de abril de 2008.

En la misma línea y derivados de estas actividades, debemos destacar algunos estudios que hemos publicado en los últimos años. El trabajo titulado "Microarchitectures dans les arts plastiques en Espagne autour de 1200 et leurs relations avec l'architecture monumentale", fue publicado en colaboración con el Dr. Fernando Galván, dentro del volumen Mikroarchitektur im Mittelalter. Ein gattungsübergreifendes Phänomen zwischen Realität und Imagination ${ }^{16}$.

Igualmente, podemos mencionar algunos otros trabajos, publicados durante este periodo: "Nuevas reflexiones para la lectura iconográfica de la Portada del Perdón de San Isidoro de León: el impacto de la Reforma Gregoriana y el arte de la tardoantigüedad"17; "El valor clásico de la arquitectura asturiana (s. IX): la iglesia de San Julián de los Prados. Entre la tradición "antiquizante" hispanovisigoda y la carolingia" ${ }^{18}$ y la contribución al Colloque International et Pluridisciplinaire Effets de style au Moyen Âge, donde se presentó una comunicación que versó sobre la "Problématique autour du "style des joues bouffies" et de sa diffusion au sein de la sculpture romane hispano-languedocienne"19.

Finalmente, no podemos pasar por alto la investigación recogida en el libro que titulamos: La recuperación de la Ecclesiae Primitivae Forma en la escultura del Panteón Real de San Isidoro de León ${ }^{20}$.

La formación que se requería para poder realizar estas investigaciones que citamos y, así mismo, poder concluir nuestra Tesis Doctoral, se complementó ricamente gracias a la asistencia a congresos, cursos y simposios. Nos interesaban aquellos foros en los que se abordaban cuestiones relacionadas con la escultura románica y las fuentes clásicas utilizadas por los artífices.

Sin ánimo de ser exhaustivos ${ }^{21}$, debemos citar, por ejemplo, la participación en las Journées Romanes de la Association de Abbaye Saint-Michel de Cuxa sobre "Actualité de l'art antique dans l'art roman"22, la asistencia al Seminario "Modos de reutilización en la Edad Media en los países del Mediterráneo occidental (ss. X-XIII) de

\footnotetext{
${ }^{16}$ Leipzig, 2008, pp. 479-497.

${ }^{17}$ De Arte, 5, 2006, pp. 63-86.

${ }^{18}$ Cien años de investigación sobre arquitectura medieval española, Madrid, 2009, pp. 233-246.

${ }^{19}$ Fue celebrado en Aix-en-Provence, entre los días 28 y 31 de mayo de 2008.

${ }^{20}$ León, 2008.

${ }^{21}$ Un resumen de las principales intervenciones y participaciones dentro de foros científicos puede consultarse en la introducción de este trabajo.

${ }^{22}$ Celebradas en la Abadía de San Miguel de Cuxá entre el 6 y el 13 de julio de 2007.
} 
la Casa de Velázquez de Madrid ${ }^{23}$, o la participación en el XII Congreso Español de Estudios Clásicos, organizado en Valencia por la Sociedad Española de Estudios Clásicos $(\mathrm{SEEC})^{24}$.

En la misma línea destacamos nuestra participación en la LII Settimana internazionale di studio de la Fondazione Centro Italiano di studi sull'alto medioevo de Spoleto $^{25}$, o en la Semaine d'Études Médiévales, celebrada en el Centre d'Études Supérieures de Civilisation Médiévale de Poitiers ${ }^{26}$.

Además de lo descrito en relación con la labor heurística y el estudio de gabinete, debemos citar el trabajo de campo acometido paralelamente a la realización de las actividades investigadoras.

La beca disfrutada nos permitió realizar cuantiosos viajes para completar el conocimiento, tanto de los edificios que analizábamos, como de las piezas conservadas en los museos. Desde el ámbito hispano, se recorrieron las regiones de Cataluña, Navarra, Aragón, La Rioja, Asturias, Cantabria, Castilla y León y Galicia, donde se rastrearon, sobre todo, las obras de cronología antigua y románica.

Merecen una mención especial las labores de campo realizadas en la comunidad de Toledo, Valencia y Andalucía, muy ricas en restos antiguos derivados de su importante romanización.

Fuera de España la labor se desarrolló en diversos países. Destacamos las sesiones programadas en el Metropolitan Museum. The Cloisters de New York, donde pudimos acceder a muchas piezas hispanas conservadas en esta sede para analizarlas y fotografiarlas in situ. Destacamos, igualmente, la visita al Museo Ermitage de San Petersburgo, especialmente provechosa en cuanto a las piezas ebúrneas hispanas que custodia.

A tenor de lo expuesto, fueron indispensables las visitas a los museos más importantes localizados en Londres, Paris, Roma y Lisboa, donde se llevaron a cabo numerosas sesiones para cotejar datos y poder observar las piezas de primera mano. Por último, ponemos de relieve el enriquecedor panorama que ofreció el trabajo de campo desarrollado en Grecia y Sicilia.

En el primer país se prestó especial atención a los restos arqueológicos y escultóricos conservados en Creta, mientras que, en Atenas, nos centramos en algunas

\footnotetext{
${ }^{23}$ Celebrado entre el 27 y 28 de marzo de 2006.

${ }^{24}$ Celebrado entre el 22 y el 26 de octubre de 2007.

${ }^{25}$ Celebrada del 15 al 20 de Abril de 2004.

${ }^{26}$ Celebrada del 25 de junio al 6 de julio de 2007.
} 
piezas conservadas en el Nuevo Museo de la Acrópolis de Atenas. Igualmente, merece destacada mención las jornadas desarrolladas en la región de la Argolida, en el Peloponeso, fundamental para conocer el fuerte bizantinismo que impregna las producciones medievales de estos territorios.

En la región siciliana, resultaron notables las sesiones de estudio acometidas en la Capilla Palatina de Palermo, la visita al Museo Arqueológico de la misma ciudad, así como la posibilidad de conocer, directamente, los restos romanos de este territorio, como los conservados en la villa del Casale, en Piazza Armerina.

Finalmente, queremos destacar que, el estudio desarrollado en los lugares mencionados y la realización de las actividades descritas propició el conocimiento de un rico panorama artístico. La consulta bibliográfica y la colaboración con los centros académicos aludidos, fueron, en última instancia, elementos primordiales sin los cuales no se podría haber finalizado la Tesis Doctoral que hoy presentamos a su consideración. 